\title{
Dictionary of \\ World Biography
}

Ninth edition 



\title{
Dictionary of \\ World Biography \\ Barry Jones
}

\author{
** Australian \\ National \\ University \\ ANU PRESS
}

Ninth edition 


\section{Australian}

National

University

\section{ANU PRESS}

Published by ANU Press

The Australian National University

Acton ACT 2601, Australia

Email: anupress@anu.edu.au

Available to download for free at press.anu.edu.au

ISBN (print): 9781760465513

ISBN (online): 9781760465520

WorldCat (print): 1348968166

WorldCat (online): 1348968054

DOI: 10.22459/DWB.2022

This title is published under a Creative Commons Attribution-NonCommercial-NoDerivatives 4.0 International (CC BY-NC-ND 4.0) licence.

\section{(c) (i) () $\Theta_{\mathrm{BY}}$}

The full licence terms are available at

creativecommons.org/licenses/by-nc-nd/4.0/legalcode

Printed by Lightning Source

ingramcontent.com/publishers-page/environmental-responsibility

The ANU.Lives Series in Biography is an initiative of the National Centre of Biography at The Australian National University, ncb.anu.edu.au.

Cover design and layout by ANU Press

This book is published under the aegis of the ANU.Lives Editorial Board of ANU Press.

First edition (C) 2014 ANU Press

Second edition (C) 2015 ANU Press

Third edition () 2016 ANU Press

Fourth edition (C) 2017 ANU Press

Fifth edition (C) 2018 ANU Press

Sixth edition (c) 2019 ANU Press

Seventh edition (C) 2020 ANU Press

Eighth edition (C) 2021 ANU Press

Ninth edition () 2022 ANU Press 


\section{About the Author}

Jones, Barry Owen (1932- ). Australian politician, writer and lawyer, born in Geelong. Educated at Melbourne High School and Melbourne University, he was a public servant, high school teacher, television and radio performer, university lecturer and lawyer before serving as a Labor MP in the Victorian Parliament 1972-77 and the Australian House of Representatives 1977-98. He took a leading role in reviving the Australian film industry and abolishing the death penalty in Australia, and was the first politician to raise public awareness of global warming, the 'post-industrial' society, the IT revolution, biotechnology, the rise of 'the Third Age' and the need to preserve Antarctica as a wilderness. In the *Hawke Government, he was Minister for Science 1983-90, Prices and Consumer Affairs 1987, Small Business 1987-90 and Customs 1988-90. He became a member of the Executive Board of UNESCO, Paris 1991-95 and National President of the Australian Labor Party 1992-2000, 2005-06. He was Deputy Chairman of the Constitutional Convention 1998. His books include Decades of Decision 1860 - (1965), Joseph II (1968) and Age of Apocalypse (1975), and he edited The Penalty Is Death (1968, revised and expanded 2022). Sleepers, Wake! Technology and the Future of Work was published by Oxford University Press in 1982, became a bestseller and has been translated into Chinese, Japanese, Korean, Swedish and braille. The fourth edition was published in 1995. Knowledge Courage Leadership: Insights \& Reflections, a collection of speeches and essays, appeared in 2016.

He received a DSc in 1988 for his services to science and a DLitt in 1993 for his work on information theory. Elected FTSE (1992), FAHA (1993), FAA (1996) and FASSA (2003), he is the only person to have become a Fellow of four of Australia's five learned Academies. Awarded an AO in 1993, named as one of Australia's 100 'living national treasures' in 1997, he was elected a Visiting Fellow Commoner of Trinity College, Cambridge in 1999. His autobiography, $A$ Thinking Reed, was published in 2006 and The Shock of Recognition, about music and literature, in 2016. In 2014 he received an AC for services 'as a leading intellectual in Australian public life'.

What Is to Be Done was published by Scribe in 2020. 



\section{Abbreviations}

AC/AO Companion/Officer of the Order of Australia

ADC Aide de camp

AIDS Acquired Immune Deficiency Syndrome

a.k.a. also known as

ALP Australian Labor Party

BAFTA British Academy of Film and Television Arts

BBC British Broadcasting Corporation

BEF British Expeditionary Force

CC/OC Companion/Officer of the Order of Canada

CCP Chinese Communist Party

CERN Conseil Européen pour la Recherche Nucléaire

$\mathrm{CH}$ Companion of Honour

CIA Central Intelligence Agency

C-in-C Commander-in-Chief

CNRS Centre National de la Recherche Scientifique

CPSU Communist Party of the Soviet Union

DFC Distinguished Flying Cross

DSO Distinguished Service Order

EC European Community

EIC East India Company

EU European Union

FAA Fellow of the Australian Academy of Science

FBA Fellow of the British Academy

FBI Federal Bureau of Investigation

FRCP Fellow of the Royal College of Physicians

FRS Fellow of the Royal Society

FRSA Fellow of the Royal Society of Arts

GBE/ Grand Cross/Knight Commander/

$\mathrm{KBE} /$ Dame Commander/Companion of the

DBE/ Order of the British Empire

CBE

GCB/ Grand Cross/Knight Commander/

$\mathrm{KCB} / \mathrm{CB}$ Companion of the Order of the Bath
GCMG/ Grand Cross/Knight Commander/

KCMG/ Dame Commander/Companion of the

DCMG/ Order of St Michael and St George

$\mathrm{CMG}$

GCSI/ Grand Cross/Knight Commander/

KCSI/ Dame Commander/Companion of the

CSI Order of the Star of India

GCVO/ Grand Cross/Knight Commander/

KCVO/ Dame Commander/Companion of the

DCVO/ Royal Victorian Order

$\mathrm{CVO}$

GOC General Officer Commanding

ILO International Labour Organization

KC/QC King's/Queen's Counsel

KG/LG Knight/Lady of the Order of the Garter

KGB Committee of State Security (former USSR)

KP Knight of St Patrick

KT Knight of the Thistle

MEP Member of the European Parliament

MIT Massachusetts Institute of Technology

MP Member of Parliament

NASA National Aeronautics and Space Administration

NATO North Atlantic Treaty Organization

OM Order of Merit

PC Privy Counsellor

RA Royal Academician, London

RAF Royal Air Force

SDP Social Democratic Party

SI International System of Units (Système international d'unités)

SPD Sozialdemokratische Partei Deutschlands

UK United Kingdom

UN United Nations

UNESCO United Nations Educational, Scientific and Cultural Organization

US(A) United States (of America)

USSR Union of Soviet Socialist Republics

VC Victoria Cross

WHO World Health Organization 



\section{Introduction}

'I want to be there when everyone suddenly understands what it has all been for.'

— Fyodor Dostoevsky, The Brothers Karamazov (1881), Part II, Book 5, Chapter 4:

words spoken by Ivan Karamazov.

This is the ninth annual edition of my Dictionary of World Biography $(D W B)$ to be published by ANU Press, and possibly the last: after all, I will turn 90 before the end of 2022 and ANU Press may have different priorities in 2023.

The complicated story of the $D W B$ s evolution, and its frustrating publishing history, has been exhaustively treated in earlier editions and can be easily retrieved. This edition is appropriate for some reflective, even elegiac, observations.

Inevitably, the $D W B$, my magnum opus, is highly personal and opinionated, even semiautobiographical.

In The Republic, Plato describes a darkened cave, with a long entrance leading to daylight and the natural world. The cave's inhabitants are there for life, kept in by bars, but also conditioned through habit. Shadow plays seen on the walls constitute reality to them and they are unable to explore the world outside.

The cave metaphor seemed eerily prophetic in the era, first, of film, then television, then computing, computer games, smartphones and social media.

Getting people out of Plato's cave involves encouraging them to confront 'the shock of recognition' in unfamiliar, challenging phenomena, grasping the range of human diversity, trying to reconcile depth of understanding and breadth of experience, distinguishing between the macro and the micro.

'The shock of recognition', which I used as a book title (2016), examines the impact of self-discovery after exposure to, or immersion in, the uncanny, the challenging, the transcendental, relating the specific to the universal, the immediate to the timeless, the individual to all humanity.

I tried to pursue the concept of 'the abundant life', rattling the bars of the cave, escaping from a conceptual shoe box, by investing time and concentration, connecting with transcendental creativity, pursuing intellectual and aesthetic engagement-aiming to experience excitement, satisfaction, happiness, and often a sense of awe or the edge of danger. This involves taking risks. High culture, with all its complexity, can take us to places where we do not expect to go and has some aura of danger.

Tackling complexity is not just a matter of taste but an essential evolutionary developmental mechanism, which strengthens brain plasticity and capacity, wards off loss of cognition and the onset of dementia more effectively than computer games, Sudoku, crossword puzzles or jigsaws. 
This suggests an analogy with cathedrals, and their two axes, vertical and horizontal.

The vertical pulls our gaze upward, looking through the vault towards the stars, reaching out for the transcendental and numinous, rapture and the unattainable-for some, Heaven. Pursuing the vertical is difficult, complex, dangerous, involving travelling alone, coming to terms with the mysterious, the aspirational, the abstract, the unique.

The horizontal is comfortable, familiar, reassuring, earthbound, physical, less challenging and safer, with no fear of falling.

In a secular, technological, materialist and self-absorbed society, there may be risk in even mentioning the cathedral analogy, since so many have been deeply alienated, even traumatised, by childhood experience of religion.

When I become preoccupied with a subject, the urge to share experience becomes irresistible, even if my audience shows palpable reluctance.

I am hidden within the pages of the DWB.

I often feel like Odysseus on a long voyage of discovery, making a connection between mehere-now and everyone-everywhere-all time, balancing the sublime with the quotidian, recognising the tension between the unique and the universal. It helps me make sense of my own experience and reinforces a sense of connectedness ('we are not alone') with the unfamiliar and remote.

I could be accused, as an aged white male, of being unduly Europhile in my tastes. Proffering long, complex entries for Mozart, Beethoven, Wagner and Mahler and virtually ignoring practitioners of folk music or country and western may be seen, in a deconstructionist age, as condescending, hierarchical-even patriarchal.

I concede, at once, being far more familiar with the culture of Europe (including North America and Australia) than of other continents-but I have travelled extensively, and eagerly seek out the work of Asian, African and South American artists looking for achievement comparable, say, to that of Bach, Michelangelo or Shakespeare, just as I seek their equivalents in recent centuries, anywhere.

It was painful to observe that so many had no access to the unfamiliar and transcendental. If they knew nothing of Homer, Mozart, Darwin and Einstein they were missing something potentially life-changing. If the names of Lenin, Hitler, Stalin and Mao drew a blank, then fellow humans, especially the young, would fail to grasp the context in which their world evolved. And the $D W B$ gave opportunities for reappraisal of women, so often grossly underrepresented in reference works: Hatshepsut, Hildegard of Bingen, Emily Dickinson, Florence Nightingale, Marie Curie, Louise Bourgeois, Simone Weil, Margaret Thatcher, Julia Gillard.

Always a very rapid and-more important—efficient reader, over many decades I devoured thousands of books, including novels, biographies, plays and poetry, as well as being an assiduous visitor to archaeological sites and ruins, art galleries and museums, a modest collector of artworks and artefacts, and a concert hall habitué. Travel was also a very important 
factor, especially the periods I worked in Paris and Cambridge, and exploring France, Great Britain and Ireland, the United States, Italy, Spain, Germany, Austria, Finland, Russia, Egypt, Turkey, Iran, India, China, Japan, Brazil, Peru and Antarctica.

The $D W B$ projects my involvement in law, politics, teaching history, absorption in philosophy, ethics, religion up to a point, and decades of work with a disaster relief organisation and campaigns to reduce blindness.

The great French essayist Michel de Montaigne, a contemporary of Shakespeare and one of my heroes, had an extraordinary gift for making linkages-extracting from his own observations a sense of the universal, but also the infinite and inexplicable, examining the unpredictable ways his mind worked, then projecting his thoughts into speculation about the universe. And he was scrupulously undogmatic.

I don't hold myself out as a profoundly creative or original thinker, but I am good at linkages. I am gratified to have been the only person, so far, elected as a Fellow of four of Australia's five learned Academies. 'Only connect! Live in fragments no longer,' as E. M. Forster wrote.

I often see patterns and interactions long before others. In my head, from childhood, I constructed a framework of relationships between the living and the dead. This was like a sculptor's armature, a metal structure to which clay or wax is applied to produce a shape for casting as an artefact. Later, I built up similar frameworks about history, politics, geography, literature or music.

Children are often preoccupied with collecting and classifying, seashells, for example, as a way of making order out of chaos, exercising a degree of control over their environment. Trying to sort out family relations and sequences was my way of putting a complicated jigsaw together. To get a perfect fit at the end, to paraphrase the French novelist Georges Perec, if one needed an X-shaped piece, a Y would not do.

From the age of five or six, I tried to put family dates of birth in a global context, drawing on chronologies listed in Pears' Cyclopaedia. My great-aunt Edith Potter was born in 1878, the year that Pope Pius IX and Lord John Russell died and the car makers Chevrolet and Citroën were born. My grandmother Nana Black's birth year (1881) is shared by Kemal Atatürk, Anna Pavlova, Béla Bartók, Pablo Picasso, Alexander Fleming and Pope John XXIII. Thomas Carlyle, Benjamin Disraeli, Modest Mussorgsky and Fyodor Dostoevsky all died then. I was born in the year (1932) when Adolf Hitler challenged Paul von Hindenburg and Franklin Roosevelt was elected President of the US.

It was said of me, correctly, that I never met a piece of paper that I didn't like, and I collected books and documents from an early age.

Reading about the political history of Australia, Britain, the United States, France, Germany and Russia made me conscious of the changing relationships between the living and the dead, as time's arrow flies past the procession. This approach encouraged my abiding fascination with people and their connections to institutions and events. The results can be seen in my quiz successes and my writings and speeches. 
The uncomfortable truth is that my mind usually works as a giant memory bank. Getting access to material and disseminating it in a precise and comprehensive form is important and I can be unsettled by misquotations or confused dates or false attributions.

In 1950, as a student, I had been profoundly influenced by the philosopher Bertrand Russell, and observed him in Melbourne at close quarters. He said: 'Three passions, simple but overwhelmingly strong, have governed my life: the longing for love, the search for knowledge, and unbearable pity for the suffering of mankind.'

If I am remembered at all, I would like it to be for my role in abolishing the death penalty and for being a prophet without much honour in promoting linkages between science and politics.

I was the first Australian politician, long before I became Minister for Science, to argue that climate change was an existential threat to civilisation, and to campaign about the genetic revolution, the information revolution, post-industrialism and a post-carbon economy.

On the death penalty, I read very intensively-Cesare Beccaria, Samuel Romilly, Arthur Koestler-and this shaped entries in the DWB.

To be better informed about the genetic and information revolutions, I went to visit Francis Crick and Claude Shannon: who better?

I wrote to Igor Stravinsky, asking him to correct inconsistencies in his biography and he obliged. I spent time with Clement Attlee, Gough Whitlam, Macfarlane Burnet, Patrick White, Henry Moore, Karl Popper, David Hockney, Isaiah Berlin, Richard Feynman, Max Perutz, Benoît Mandelbrot, John Coetzee. I met many musicians, artists, writers, philosophers and historians, researchers on climate and economics, and my interactions are expressed in scores of entries. Gus Nossal, Peter Doherty and Fiona Stanley kept me up to date on medical advances.

I had begun work on the DWB as a history teacher at Dandenong High School and by May 1959 , at the age of 26 , I completed my first draft. I retain three bound volumes of text: 837 foolscap pages with about 430,000 words and 6,000 entries.

In January 1961 I signed a contract with Penguin Books in London. Then followed 16 frustrating years, due to internal divisions and changes in personnel and policy, until Penguin paid me off in 1977. Macmillan Publishing, London, somewhat unexpectedly took the work up and it appeared, with some deep flaws, as The Macmillan Dictionary of Biography, in October 1981. Two editions, of which I knew nothing, were also published by Routledge and St Martin's Press in New York. Then in 1986 Brian Stonier of Macmillan Australia took over publication and much improved editions appeared until 1989.

Michael Wilkinson, of Information Australia, later Wilkinson Publishing, published a much expanded and revised Dictionary of World Biography from 1994 until 1998.

After 1998 there was another long hiatus, when multi-volume or single-volume reference books such as Encyclopaedia Britannica or the Columbia Encyclopedia were going out of print because of the availability of millions of entries on Wikipedia. 
In 2011, Garry Sturgess helped to persuade the National Centre of Biography, which publishes the Australian Dictionary of Biography, at The Australian National University (ANU) to exhume, update and revise my obsession.

At ANU, Melanie Nolan and Tom Griffiths were enthusiasts and encouragers and proposed that the $D W B$ appear both as an ebook and in traditional printed form. Gareth Evans, ANU Chancellor at the time, was a benign influence.

In 2013 ANU E Press produced the work, revised and largely rewritten, in paperback and online. Michael Wilkinson published a handsome hardcover version in 2016 in conjunction with ANU Press.

The 2022 edition runs to nearly 1,000 pages in small print, about 9,000 entries and 930,000 words.

Four factors determined entry length: likelihood that the entries would be frequently consulted, availability of resource material, degree of influence that the subjects had on how we live (language, inventions, medicine, war, nutrition, religion, philosophy, exploration, education, communications, transport, economics, entertainment, the arts, architecture), and the extent of cross-referencing to other subjects in the $D W B$, indicated by *.

How tactful does an encyclopaedist have to be in writing about living subjects? Publishing serious entries on the living may inhibit discussion of sensitive issues such as sexuality, mental and physical health, addictions and obsessions, or financial links, and much primary source material will be inaccessible or embargoed. Postponing treatment of subjects still living, and presumably not eager to be eligible, gives future biographers space and time to reflect instead of rushing to judgment. I had no such inhibition with my $D W B$ and emphasised linkages between past and current subjects.

I included tightly compressed anecdotes and the occasional telling quotation, such as Artur *Schnabel's comment on *Mozart's piano sonatas: 'Too easy for amateurs: too hard for professionals.' I reported strongly critical views: 'Handsome, imaginative, but superficial and distrusted by his contemporaries (*Alanbrooke, *Montgomery, ${ }^{*}$ Templer, ${ }^{*}$ Ismay), *Mountbatten's reputation has declined since his death.' I wrote of Anton *Chekhov, 'His funeral was Chekhovian: the coffin was taken to Moscow by train in a refrigerated car intended for oysters, and the funeral procession was confused with a general's, accompanied by a military band.' Archbishop of Canterbury Cosmo *Lang 'developed an embarrassing passion for the actress Anne Todd'. In the entry on James *Joyce, I pointed to the long list of great writers who had failed to win the Nobel Prize for Literature: Ibsen, Tolstoy, Strindberg, James, Hardy, Conrad, Gorki, Proust, Rilke, Musil, Joyce, Woolf, Pound, Borges, Malraux, Greene and Auden (all with *).

Despite my long, and increasingly unhappy, career in politics, I tried to be clinically detached in my entries on public figures, and would immodestly point to entries on Harold Macmillan, Margaret Thatcher and Richard Nixon. However, I have not disguised my loathing of totalitarian systems, whether Left or Right, and entries on Hitler, Stalin, 
Mussolini and Mao are obvious examples. I felt that my explanation of ideologies was a strength and over many years I tried to cover my areas of weakness, such as sport, popular music, ballet, ornithology, gardening and 14th-century Islamic tiles.

If a serious attempt was made at a global biographical dictionary, with international participation, the first problem would be choosing authors to write on controversial figures such as Luther, Kim Il Sung, Mao Zedong, Hitler, Mussolini, Stalin, Churchill, Khomenei, Pius XII. Would editors necessarily choose a Korean scholar to write about Kim, a Chinese for Mao, a Catholic for a Pope or a Lutheran for Luther?

Who should write the entry on Jesus? A Jew, a Christian, a Palestinian, an agnostic, Catholic, Orthodox, Anglican, Protestant, fundamentalist, liberal, a sceptic, historian, philosopher, theologian? I could suggest possible authors, but the choice will not be mine and age alone would rule me out.

My co-worker on this project since 2013, Christine Fernon, from the National Centre of Biography at ANU, has been exemplary as an editor and encourager. I have been stunned at how much she achieves in a few days devoted each year to the $D W B$, noting slips and occasional sloppy writing and suggesting improvements-all delivered with patience (well, mostly), good humour and erudition.

The DWB is essentially 'our book' and Christine is a great asset for ANU.

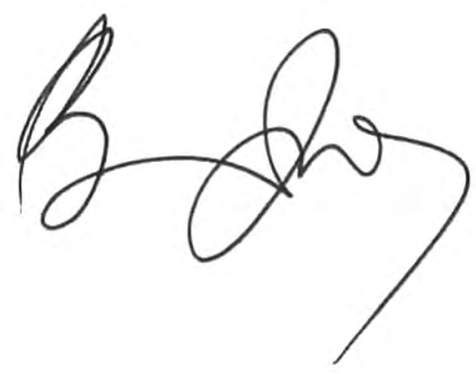




\section{Tributes}

\section{Phillip Adams AO FAHA FRSA, social commentator and broadcaster}

Ninety years ago the elders on Krypton, knowing their planet was doomed by runaway climate change, sent two rocket cribs to Earth. One, as is widely known, contained a baby who, adopted by a rural US couple, was raised as Clark Kent, later becoming a journalist at Rupert Moloch's Daily Planet. Given superpowers that included the power of flight and $\mathrm{x}$-ray vision he became famous as Superman. Less well known-the second child despatched to Earth. Raised in Geelong he is known as Barry Jones. His superpowers were mental rather than physical, as evidenced in his success in quiz shows and public life-but also in scholarship. Among his out-of-this-world efforts is his Dictionary of World Biography, published for many years by ANU Press. In this enterprise Barry has leapt tall volumes in a single bound and his late father on Krypton-Jor-el—would be proud of him. I know that I am.

\section{John Coetzee, winner of the Nobel Prize in Literature}

Back in the 1990s, as South Africa was emerging from under the grim weight of apartheid, I received a call from the Australian embassy in Cape Town: a man named Barry Jones, on a visit to the country, wanted to have lunch with me. Out of curiosity I accepted and met him at a restaurant. I knew nothing about him, but he seemed to know everything about me. 'Why not get away from all this and come and live in Australia?' he said. I thought: What a good idea! And I have never looked back. In the years since then I have had many occasions to chat with Barry, as well as to explore his manifold oeuvre, but not until today have I had a chance to express in public my gratitude for the invitation that, speaking for his country, he extended to me. Congratulations on the publication of your Dictionary of World Biography.

\section{Glyn Davis AC, Secretary, Department of the Prime Minister and Cabinet}

A coherent intellectual project, spanning six decades, is an astonishing feat. To combine such singular scholarship with engagement in every facet of public life, from politics to music, from poetry to human rights, is a sustained contribution rarely matched even in such a comprehensive dictionary of world biography. Barry Jones is our finest example of the best qualities extolled in the many editions of his extraordinary work.

\section{Professor Peter C. Doherty AC, immunologist and winner of the Nobel Prize in Physiology or Medicine}

Barry is extraordinary. I'm in the science business. I first met Barry when I was an obscure professor at ANU and he was Science Minister in the Hawke Government. His exhortation then that scientists were wimps and needed to get out on the public stage resonated later, when I was the 'touring' (from the USA) 1997 Australian of the Year and science communication suddenly became part of my job description. Barry practised what he preached. He has communicated in all regards, even the history of science and the biographies of scientists. The Dictionary of World Biography shows yet another facet of his being a polymath. His immense knowledge has genuine depth and real practical insight. This is a great contribution. Long may he continue! 


\section{Gareth Evans AC QC FASSA FAIIA, Distinguished Honorary Professor at ANU and former Foreign Minister}

Of the many contributions Barry Jones has made over his long and intensely active public life_-not only to decent public policy but to making us wiser, better informed and more appreciative of the richness of the world around us-the Dictionary of World Biography will stand as one of the most important and enduring of all his legacies. Already a standard reference text-becoming ever more comprehensive through the course of its nine editions - it is not only scholarly rigorous, demonstrating passionate attention to accuracy and detail, but written in a wonderfully lively, opinionated and distinctive style. The DWB is a marvellous smorgasbord of information and comment, not just a reference volume but one to be dipped into for the sheer pleasure of discovery on every page. There are many good reasons for bestowing on Barry, in his 91st year, the mantle of living national treasure, but he would earn it for the $D W B$ alone.

\section{The Hon. Julia Gillard AC, 27th Prime Minister of Australia}

Throughout his career, Barry Jones has garnered recognition and respect for his impressive intellect, exceptional perception, thoughtful nature, genuine compassion and willingness to pursue unfashionable causes. He is one of Australia's great thinkers and campaigners, and I am grateful to have the privilege of calling Barry a long-time mentor and friend. I have learnt so much from Barry. All these qualities come to bear in the DWB. I can hear his voice in the entries. Barry has himself acknowledged that he does not 'see many people around who look at things in quite the same way' as he does. I can't think of anyone else who could produce such a remarkable work as the Dictionary of World Biography. I know I am not alone in my affection towards Barry. He is much loved by the Australian community, a true national treasure. We are lucky to have the benefits of his fine mind.

\section{Emeritus Professor Tom Griffiths AO FAHA, chair of the editorial board of the Australian Dictionary of Biography}

Barry Jones is a learned connoisseur of the best (and worst) expressions of humanity. In collectively assessing whole lives he celebrates what is unique as well as universal in an individual's signature on the world. His own quest for meaning and transcendence shines through. Barry's constantly evolving Dictionary of World Biography represents his lifelong curation of extraordinary people, most of whom have achieved life after death through their influence. His portraits sparkle with flashes of opinion and wry judgement. This is a passionate, intensified world history with the literary power of lean prose poetry. ANU Press is blessed to be the publisher of this enduring gift of scholarship, not least because it speaks to the traditions of our own beloved Australian Dictionary of Biography, which has evolved through the same 60 -plus years.

\section{Janet Holmes à Court AC, company chair and philanthropist}

Barry Jones is a one-off-a unique individual. I have known and admired him for a very long time as a remarkable writer, thinker, politician, lover of music and compassionate supporter of human rights. No one I know has more knowledge of more subjects than Barry, and this he imparts generously and with great flair. Nothing could better illustrate Barry's huge intellect, knowledge and tenacity than his 60 years of scholarship involved in the production of the Dictionary of World Biography. 


\section{Professor Melanie Nolan FASSA, general editor of the Australian Dictionary of Biography}

As the general editor of the Australian Dictionary of Biography I know the hard work that goes into producing a biographical dictionary. I have the support of a team of working-party members, authors and research editors to choose subjects, write entries, and then research and edit them. Barry Jones' Dictionary of World Biography is all his own work. His voice is witty, ironic and sharp; it's a joy to read these beautifully crafted entries. The DWB is remarkable, amazing, impressive, breathtaking. I am in awe of Barry's achievement.

\section{Fiona Stanley AC FAA FASSA, child bealth epidemiologist}

Barry Jones' Dictionary of World Biography is a classic from many points of view: it is a personal journal of the people that Barry has known about and been influenced by since the age of 26, with thousands of additions of those who he felt were important-some even corrected by the subjects themselves (many famous and many now dead!). Hence not only is it a unique publication but it is incredibly useful to those of us who want to quickly check something about someone whom we have forgotten. I realise that such publications may become redundant as the internet takes over the role of dictionaries and published historical reviews, but let's cling to this wonderful creation for as long as we can. As this may be the last edition, I think we Australians need to acknowledge Barry Jones' amazing contributionnot only in giving us such information but also in the ways he has influenced our views. Thank you, Barry! 



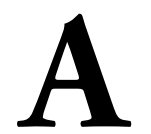

Aalto, (Hugo) Alvar (Henrick) (1898-1976). Finnish architect and designer. He set up practice in 1923 in central Finland, moving to Turku in 1927, then to Helsinki in 1933, collaborating with his wife Aino Marsio (1894-1949). He gained a national reputation with the Viipuri Municipal Library (1930 35), destroyed in World War II, and an international one with his Finnish pavilions at the World's Fairs at Paris (1937) and New York (1939-40). He made imaginative use of wood with brickwork, glass, copper and cement and also developed functional plywood furniture, mass-produced in his own factory. His range of commissions, including the Maison Carré in Paris, Baker House in Cambridge, Mass., and the Finlandia Concert Hall, Helsinki, was extensive: factories, museums, churches, theatres, department stores, private houses and public housing. He was professor of architecture at the Massachusetts Institute of Technology 1945-49.

Aaron (c.14th-13th centuries BCE). Hebrew High Priest. In the Bible story, with his brother *Moses, he led the Israelites from Egypt to Canaan (Palestine) and became their first high priest, but while Moses was receiving the Ten Commandments on Mount Sinai he made a golden calf for the people to worship (Exodus xxiii).

Abbado, Claudio (1933-2014). Italian conductor, born in Milan. He was principal conductor of La Scala, Milan 1971-86, the London Symphony Orchestra 1979-88, the Vienna State Opera 1986-91 and succeeded von *Karajan at the Berlin Philharmonic Orchestra 1990-2002. He won many awards for his recordings.

Abbas (566-653). Arab merchant. Uncle of *Muhammad, and a Hashemite member of the Quraysh clan in Mecca, he was ancestor of the Abbasid dynasty which overthrew the *Umayyads and held the caliphate 750-1258 until destroyed by the Mongols.

Abbās I (the Great) (1571-1629). Shah of Persia 1587-1629. Fifth ruler of the Safavid dynasty, son of Shah Mohammad Khodabanda, he inherited a weak and divided empire, but proved to be decisive, effective and brutal. He established Esfahan as his capital, commissioned magnificent buildings, and extended his rule into Mesopotamia, the Caucasus and eastern Anatolia.

Abbas II (Abbas Hilmi Pasha) (1874-1944). Ottoman khedive of Egypt 1892-1914. He supported the nationalist and Pan-Islamic cause and clashed with the British de facto rulers *Cromer and *Kitchener. When the Ottoman Empire entered
World War I in support of Germany and AustriaHungary he was deposed and succeeded by his uncle Hussein Kamil (brother of *Fuad I) who took the title of sultan. Exiled to Switzerland, he died in Geneva.

Abbas, Ferhat (1899-1985). Algerian politician. Trained as a pharmacist, he founded the Algerian Popular Union in 1938 and in 1943 sought political concessions from the Allied authorities who rejected his moderate demands and jailed him. In 1956, in Cairo, he became leader of the Front de Liberation Nationale (FLN) and was first president of the provisional government of the Algerian Republic 1958-63 until displaced by his rival Ahmed *Ben Bella and imprisoned 1963-64.

Abbas, Mahmoud (also known as Abu Mazen). (1935- ). Palestinian politician, born in Safan. Educated in Damascus, Cairo, and Moscow, he became active in the Fatah movement. Premier 2003, he succeeded Yasser *Arafat as President of the Palestine Liberation Organisation (PLO) 2004- and of the Palestine Authority 2005- . The last presidential election was held in January 2005.

\section{Abbasids see Abbas}

Abbott, Tony (Anthony John) (1957- ). Australian Liberal politician, born in London. Son of expatriate Australians who returned home in 1960, he was educated at Sydney University and won a Rhodes Scholarship to Oxford in 1981, graduating MA in politics and philosophy. He was active in sport and boxing, returned to study for the priesthood (1984-87) but turned to journalism instead. Deeply influenced at first by B. A. *Santamaria, he became active in the monarchist campaign to oppose Australia becoming a republic. Member of the House of Representatives 1994-2019, he served in the *Howard Government as Minister for Employment Services 1998-2001, for Employment and Workplace Relations 2001-03 and for Health and Ageing 2003-07. Leader of the Opposition 2009-13, he was an unrelenting critic of ${ }^{*}$ Rudd and ${ }^{*}$ Gillard, a climate-change sceptic but sympathetic to Indigenous Australians. In the September 2013 election the Liberal-National Party Coalition won a commanding victory and he became Prime Minister 2013-15. His pugilistic style, highly effective in opposition, proved counter-productive in government, and he was defeated by Malcolm *Turnbull in a party room ballot in September 2015. $\mathrm{He}$ campaigned passionately against recognition of same-sex marriage and against effective action to combat climate change and played a major role in forcing Turnbull from the prime ministership (August 2018).

Abboud, (El-Ferik) Ibrahim (1900-1983). Sudanese soldier and political leader. His military service was mostly spent with the Sudan Defence Force, serving with the Allies in World War II. He became Commander-in-Chief of the army of independent 
Sudan in 1956 and in November 1958 led a coup d'état to end anarchy, becoming both President and Prime Minister 1958-64. However, internal divisions in Sudan between the Muslim north and the non-Muslim south led to outbreaks of violence and Abboud was forced from power and retreated to England.

Abd al-Raḥmān I (Abd al-Raḥmān ibn Mu'awiya ibn Hishām ibn Abd al-Malik ibn Marwan) (c.730-788) Arab ruler in Spain (al-Andalus): Emir of Córdoba 756-88. Born in Damascus, he was a member of the *Umayyad dynasty which was overthrown and slaughtered by the Abbasids in 750 . He escaped to Islamic Iberia, built up alliances, defeated Abbasid fiefdoms and established his rule as Emir of Córdoba (756). There was religious tolerance for monotheistic religions and he built alliances against ${ }^{*}$ Charlemagne, the Abbasids and the Berbers. In 785 he began the great mosque (Mezquita) in Córdoba, extended by his son Hisham I, which became a World Heritage site in 1984.

Abd al-Raḥmān III (Abd al-Raḥmān ibn Muhammad ibn 'Abd Allāh ibn Muhammad ibn 'Abd al-Raḥmān ibn al-Hakam al-Rabdì ibn Hishām ibn 'Abd al-Raḥmān al-Dākhil) (c.891-961). Arab ruler in Spain (al-Andalus): first Caliph of Córdoba 929-61. Born in Córdoba, a seventh-generation descendent of *Abd al-Raḥmān I, he succeeded his grandfather as Emir of Cordoba 912-29. His mother was a Christian Frankish slave. The greatest ruler of the *Umayyad dynasty, he fought against the Fatimid (Muslim) dynasty and the Christian rulers of Leon and Navarre, capturing Seville (913) and Toledo (933). He promoted toleration for Christians and Jews and his reign was the golden age of Andalusian civilisation in architecture, the arts, education and science. From 936 he built the great palace Medinat al-Zahra, near Córdoba, a World Heritage site since 2018.

Abd el-Krim, Mohammed (1882-1963). Moroccan nationalist leader. A Berber, he was a teacher, editor and judge who organised the first liberation movement in North Africa against French and Spanish rule. He proclaimed the Republic of the Rif in 1921 and was its president until 1926 when his forces were defeated by a large Franco-Spanish army commanded by Marshal *Pétain. Exiled to the island of Reunion 1926-47, he went to Egypt to head the Maghrib Bureau and died in Cairo. He was a major influence not only on African nationalists but also on *Ho Chi Minh.

Furneaux, R., Abdel Krim: Emir of the Rif. 1967.

Abdulhamid II (1842-1918). Ottoman sultan and caliph 1876-1909. Son of Abdulmecid I (18231861), he was brought to power after the mental collapse of his brother Murad V (1840-1904) and appeared at first to be sympathetic to reform. He ruled as an absolute monarch from 1878. He lost Romania,
Bulgaria and parts of Serbia and Bosnia after the Russo-Turkish War (1877-78), was known as the Red' or 'the Damned' in Europe after the massacre of 200,000 Armenians (1894-95) and went to war with Greece (1896-97) over Cyprus. He used Germans to train his army and encouraged the completion of the Berlin to Baghdad railway. He encouraged PanIslamism as a counterbalance to Western influences and became obsessed with the fear of assassination. Deposed by the Young Turks, he was succeeded by his brother * Mehmed $\mathrm{V}$ and held as a prisoner in Istanbul until his death.

Abdullah I (Abdullah bin al-Hussein) (1882-1951). King of Jordan 1949-51, formerly Emir 1921-46 and King 1946-49 of Transjordan. Born in Mecca, son of ${ }^{*}$ Hussein, later King of the Hejaz, with the rest of his Hashemite family he actively supported Britain in World War I in bringing down the Ottoman Empire. Designated as king of the newly created Iraq in 1920, he declined the throne; it was taken up by his brother ${ }^{*}$ Faisal, who had been rejected in Syria. Abdullah took control of the Emirate of Transjordan instead, working closely with the British in Palestine, and showing some willingness to co-operate with Jewish settlement. The Hashemite Kingdom of Transjordan became fully independent in 1946 and was renamed as Jordan in 1949. On the creation of Israel (1948) and the partitioning of Palestine, Abdullah annexed the West Bank for Jordan and was assassinated by a Palestinian nationalist. His greatgrandson Abdullah II (1962- ) succeeded *Hussein as king in 1999.

Abdul Rahman Putra, Tunku (1903-1990). Malayan prince (Tunku) and politician. Educated at Cambridge University, he was called to the bar, and joined the public prosecutor's department of his state of Kedah in 1949 . In 1952 he was nominated to the federal executive and legislative councils, became Chief Minister (1955) and then first Prime Minister 1957-70 of the Malayan Federation (renamed Malaysia in 1963). Signapore was pushed out of the federation in 1964 and Sabah (British North Borneo) and Sarawak added. The UK awarded him a $\mathrm{CH}$ (1961) and Australia an AC (1987).

Abe Shinzō (1954-2022). Japanese politician, born in Nagato. Member of a political dynasty and grandson of *Kishi Nobusuku, he studied at Seikei University and in California. He worked for the steel industry, then as an organiser for the Liberal Democratic Party (LDP). Member of the House of Representatives 1993-2020, President of the LDP 2006-07, 201220; and Prime Minister 2006-07, 2012-20 (the first since ${ }^{*}$ Yoshida to hold non-consecutive terms). In 2013 the LDP won a majority in the upper house as well. Abe was an economic interventionist and rightwing nationalist who argued a revisionist position about Japan's role in World War II. His 'apology' for wartime excesses, given on the 70th anniversary of 
the Japanese surrender (August 2015) was regarded as grossly inadequate by China and the Republic of Korea. He was assassinated in Nara.

Abelard, Pierre [Peter in English usage] (10791142). French philosopher and theologian. Of a noble Breton family, he became a lecturer in Paris. He seduced and married a 17-year-old pupil, *Héloïse, whose uncle, Fulbert, canon of Notre Dame, eventually had him castrated. She became a nun and he a monk. Later his retreat at Nogent-surSeine, known as Le Paraclet, was visited by scores of disciples. Convicted of heresy, he was eventually absolved by the pope. His own account of his life and his correspondence with Héloïse have perpetuated one of the most famous love stories of the world. In 1817 the two were laid together in one tomb in the Père Lachaise cemetery in Paris. His contribution to the philosophical problem of universals was that a general word (e.g. 'pink') does not have meaning by standing for a single quality (e.g. pinkness) that somehow exists, but rather by being tied to a mental concept we acquire by noticing similarities between different things (e.g. pink ones). He extolled the use of reason in religion while giving a place to faith. One of his best known works is Sic et non (Yes and $N o$ ), which revealed the contradictions in the works of the early Christian Fathers.

Gibson, E., Hélö̈se and Abelard. 1953.

Abercrombie, Sir (Leslie) Patrick (1879-1957). British town planner. He first practised as an architect in Manchester and was professor of civil design at Liverpool 1915-35. During these years, plans for preserving Stratford-on-Avon and other English towns made him well known. He was professor of town planning at University College, London 1935-46. The 'Greater London Plan' 1943 was his major achievement.

Abercromby, Sir Ralph (1734-1801). Scottish soldier. After being trained for the law he was commissioned in the 3rd Dragoon Guards in 1756, and fought with distinction in the Seven Years War and the French wars at the close of the century. He was knighted in 1795 and, as leader of the West Indies campaign which immediately followed, received fresh acclaim. While Commander-in-Chief of British forces in the Mediterranean he made (June 1801) a successful choice of landing at Aboukir Bay, Alexandria. The French counter-attack was repulsed but Abercromby died of wounds.

Aberdeen, 4th Earl of, George Hamilton-Gordon (1784-1860). Scottish Peelite-Whig politician, born in Edinburgh. His family owned large estates, his parents died early and he succeeded his grandfather as earl in 1801. Educated at Harrow and Cambridge, he had a passion for the classics and archaeology. Originally a diplomat and a successful negotiator, as a youthful Ambassador to Vienna 1813-14 he organised the final coalition against *Napoléon and felt haunted by war. Originally a Tory, he was Foreign Secretary 1828-30 and again under *Peel 1841-46. He broke with the Conservatives over the Corn Laws and became leader of the Peelite faction in 1850 . Prime Minister 1852-55, he led a coalition between the Whigs and his own minority group. He cultivated good relations with the United States. He took Britain, reluctantly, into the Crimean War 1853-56 and military failure, coupled with internal tensions between *Palmerston and Russell, enfeebled his government and he was happy to resign. *Gladstone regarded him as 'lovable', a sentiment not widely shared: *Disraeli detested him.

\section{Aberhart, William (1878-1943). Canadian politician. Originally a clergyman, then a schoolteacher, he became Premier of Alberta 1935- 43 and attempted to implement in Canada the Social Credit policies of Major C. H. *Douglas. His scope of action was limited by the overriding authority of the Federal Government.}

Abraham (Abram) (c.2100-2000 BCE). Hebrew patriarch, born in Ur of the Chaldees (Mesopotamia). According to the biblical account (Genesis xi:26ff), by his wife Sarah (Sarai) he was ancestor of the Israelites, through *Isaac. The Qu'ran (Koran) claims him as progenitor of the Arabs by his wife Hagar (through his son Ishmael: *Muhammad was a descendant). Genesis describes how Abraham, at the call of God, migrated with Sarah and his whole household to Canaan (Palestine). His faith was tested when God commanded him to sacrifice his son Isaac. Only at the last moment, he was told to substitute a ram. According to tradition, Abraham was buried in Hebron.

Abu-Bakr (Abdullah ibn Abi Quhaafah) (c.573634). First caliph of Islam 632-34. Born to a merchant tribe in Mecca, he became the first male convert to Islam and *Muhammad's chief advisor in Medina (622-32). His daughter A'ishah (Ayesha) became one of Muhammad's wives. On his son-inlaw's death he assumed leadership of Islam as khalifa ('deputy or successor'). His claim was disputed by Muhammad's son-in-law *Ali, whose followers became known as Shi'ites. He was succeeded as caliph by *Umar. The first four caliphs, known as 'Rashidun' ('rightly guided'), were chosen by consensus among the imams.

Achebe, Chinua (1930-2013). Nigerian novelist, poet and critic. His Things Fall Apart (1958) was the biggest selling novel by an African writer: 10 million copies in 50 languages. He won the Man Booker Prize in 2007.

Acheson, Dean Gooderham (1893-1971). American lawyer, born in Connecticut. Educated at Yale and Harvard, he was a law clerk to Justice *Brandeis and became an attorney in 1921 . Undersecretary of the US 
Treasury 1933, he resigned over a matter of principle, worked as an international lawyer in Washington, then went to the State Department as Assistant Secretary 1941-45 and Undersecretary 1945-47. He formulated the *Truman Doctrine (1947), in which US aid was offered to countries under threat from the USSR. He was a major architect of the *Marshall Plan (1947) which provided support for the rebuilding of Western Europe. As Truman's Secretary of State 1949-53, despite his hard line in the Cold War in organising NATO (1949), he was attacked as a Communist sympathiser after *Mao's victory in China and the onset of the Korean War. Memoirs of his years at the State Department, Present at the Creation (1970), won the Pulitzer Prize for history.

Brinkley, D., Dean Acheson: The Cold War Years 195371. 1993.

Acton, John Emerich Edward Dalberg Acton, 1st Baron (1834-1902). English historian, born in Naples. Grandson of a former Prime Minister of the Kingdom of Naples, he was brought up in the household of the 2nd Earl Granville, who married his widowed mother. Excluded from Cambridge University as a Catholic, he studied in Munich with von ${ }^{*}$ Ranke, mastered historical analysis and travelled extensively. A Liberal MP 1859-66, he supported *Gladstone, who made him a peer in 1869. He strongly opposed *Pius IX's proclamation of the dogma of papal infallibility (1870). * Rosebery appointed him Regius Professor of Modern History at Cambridge 1895-1902, where he planned the original Cambridge Modern History. Fluent in several languages, he had a library of 60,000 volumes, now held at Cambridge. He published little but had a profound influence on his contemporaries. He coined the maxim (1887): 'Power tends to corrupt and absolute power corrupts absolutely.'

Mathew, D., Lord Acton and His Times. 1968; Mathew, D., Acton: The Formative Years. 1972; Chadwick, O., Acton and History. 2002.

Adam, Adolphe Charles (1803-1856). French composer. A professor at the Paris Conservatoire from 1848 , his best known work is the ballet Giselle (1841), but he also wrote popular operas, now forgotten, for the Opera-Comique.

Adam, Robert (1728-1792). Scottish architect, born in Kirkcaldy. Brought up on the family estate in Kinross-shire, in 1754 he was sent by his father (himself an architect of distinction in the Palladian tradition) to Italy, where, without neglecting the Renaissance masters, he made a special study of the antiquities of Rome, Pompeii and Herculaneum. Across the Adriatic the ruins of ${ }^{*}$ Diocletian's palace at Spalato (Split), much more complete than they are today, provided a theme for a book, fully illustrated by his own drawings; published in 1764 . In 1760 he set up in practice in London with his younger brother James Adam (1730-1794) who acted mostly as his assistant.

Out of his studies gradually emerged the so-called Adam style, based on the principle that exterior, interior and furnishings should form a harmonious whole. Details were largely elegant adaptations of Roman and Greek models. They designed and built the Adelphi (i.e. the brothers) Terrace (1768-72), an unfortunate financial speculation but an artistic triumph which was destroyed and replaced in 193638. Outstanding among the many Adam country houses are Harewood in Yorkshire, Kedleston in Derbyshire, Syon and Osterley near London. The famous town houses were a later phase. Robert, unmarried, a Member of Parliament 1768-74, elected FRS, was buried in Westminster Abbey.

Adams, Ansel Easton (1902-1984). American photographer. His richly textured, stark images of landscape, especially national parks in California and the southwest, established his reputation. He helped to secure recognition of photography as an academic subject and wrote technical manuals.

Adams, Gerry (Irish: Gearóid Mac Ádhaimh) (1948- ). Irish politician, born in Belfast. An active civil rights campaigner in Northern Ireland, he was interned 1971-76, and worked with the Provisional wing of the Irish Republican Army (IRA), but insisted that he was not a member. President of Sinn Féin 1983-2018, he was an abstentionist MP 198392; 1997-2011 in the UK House of Commons. He supported an end to terrorism after 1994, was a Member of the Northern Ireland Assembly 1998 2010, then transferred to the Dáil Éireann 2011- .

Adams, Sir Grantley Herbert (1898-1971). Barbadan Labour politician. Educated at Oxford University, he became a successful lawyer (and cricketer) in Barbados. He was premier of Barbados 1954-58 and the first and only Prime Minister of the West Indies Federation 1958-62.

Adams, Henry (Brooks) (1838-1918). American historian, born in Boston. Grandson of John Quincy *Adams and son of Charles Francis Adams (18071886), he was educated at Harvard and travelled extensively in Europe. His father became US Minister to Great Britain 1861-68 and Henry served as his private secretary throughout, returning to the US to find that his services and knowledge were rebuffed in *Grant's Washington. He taught history at Harvard 1870-77 and edited the North American Review 1870-76. He moved to Washington, opposite the White House, and there wrote his great History of the USA. During the Administrations of Thomas Jefferson and James Madison (9 volumes, 1889-91), which set new standards in documentation and was published at his own expense. Lesser historical work followed, but in later life Adams turned to general literature, having 
already written Democracy (1880), a slashing satirical novel of Washington society. He largely avoided the issues of race, slavery and the status of women. $\mathrm{He}$ toured the world (including Polynesia and Australia) with John *Hay 1890-92. Living in France in 1897, he became anti-Semitic and anti-Dreyfusard.

Mont-Saint-Michel and Chartres (privately published 1904 , commercially 1913) is a study of the unifying forces of medievalism symbolised by these great buildings. The Education of Henry Adams (privately published 1907, commercially 1918), is an ironic and deeply pessimistic autobiography, written in the third person, which speculates about the disintegrative forces of modern life. The Education posthumously won the Pulitzer Prize (1919), for all the wrong reasons.

Samuels, E., The Young Henry Adams. 1948, Henry Adams: The Middle Years. 1958, Henry Adams: The Major Phase. 1964, Henry Adams 1 vol. condensation 1989; Levenson, J. C., The Mind and Art of Henry Adams. 1957; Brown, D. S., The Last American Aristocrat: The Brilliant Life and Improbable Education of Henry Adams. 2020.

Adams, John (1735-1826). 2nd President of the US 1797-1801. Born in Braintree (Quincy), Massachusetts, and educated at Harvard College, he was cousin of Samuel *Adams. He became a leading lawyer and politically a strong supporter of the colonial cause, relying upon the argument 'No taxation without representation'. However, he revealed his fairness by defending British soldiers who had fired upon and killed some of a group of Boston citizens who had been baiting a sentry. He was prominent in the continental congresses, and signed the Declaration of Independence (1776) which he had helped to draft. He was appointed diplomatic representative to France (1778) and Holland (1781) and with ${ }^{*}$ Franklin and *Jay negotiated the treaty of Versailles (1783), which brought the War of Independence to an end. After serving as the first US minister to Great Britain 1785-88, he returned home, and as a leading member of *Washington's Federalist Party he became the first vice president of the US 1789-97, bewailing the lack of power of 'this most insignificant office'. When Washington announced his retirement in 1796 he was elected President of the US, narrowly defeating * Jefferson in the first contested poll but lost to Jefferson in the 1800 election. He returned to his home at Quincy, wrote several books analysing the machinery of American Government, and died on the 50th anniversary of the signing of the Declaration of Independence on the same day as Jefferson. Dying at 90 years 8 months, he was the longest lived US President until Ronald *Reagan.

McCullough, D., John Adams. 2001.

Adams, John (Coolidge) (1947- ). American composer, born in Massachusetts. A clarinettist, he studied composition at Harvard with Roger Sessions and Leon Kirchner, taught composition himself at the San Francisco Conservatory 1971-81 and was composer in residence with the San Francisco Symphony Orchestra 1982-85. His works include Shaker Loops (originally a string septet 1978, set for orchestra 1983), Grand Pianola Music (1982), Harmonium for large orchestra and chorus (*Donne and ${ }^{*}$ Dickinson, 1984), the successful opera Nixon in China (1987), the song cycles Fearful Symmetries (*Blake, 1988) and The Wound-Dresser (*Whitman, 1989). The opera The Death of Klinghoffer was premiered in 1991. Later works include Violin Concerto (1993), On the Transmigration of Souls (choral, 2002), Dr Atomic (opera, 2005), The Gospel According to the Other Mary (opera-oratorio, 2013), Scheherezade.2 (dramatic symphony, 2014) and Girls of the Golden West (opera, 2017). He describes himself as a 'post-style' composer.

Adams, John Couch (1819-1892). English astronomer and mathematician, born in Cornwall. Self-taught, then educated at Cambridge, in 1845 he predicted the existence of the planet Neptune from calculations on irregularities in the orbit of Uranus. Delay in publication resulted in his sharing credit for discovery of the planet with ${ }^{*}$ Le Verrier who, working independently, presented similar calculations to the Académie française in 1846 . Other notable work by Adams included researches on the moon's motion. Awarded the Copley Medal in 1846, he was professor of astronomy at Cambridge from 1859-92.

Adams, John Luther (1953- ). American composer, born in Mississippi. He played in rock bands, studied in California and lived in Alaska 19782014. Enormously prolific and experimental, his works, profoundly influenced by the environment and a sense of place, include Become Ocean (2013), Ten Thousand Birds (2014) and Become Desert (2018).

Adams, John Quincy (1767-1848). 6th President of the US 1825-29. Born in Braintree, eldest son of John *Adams, his natural precocity was increased by accompanying his father on diplomatic missions. At the age of 14 he was secretary to the American Ambassador in St Petersburg and at 16 to his father, Ambassador in Paris. He graduated at Harvard in 1787 , started work as a lawyer, but was soon recalled to diplomacy as minister to Holland 1794-96, to Portugal 1796 and Prussia 1797-1801. US Senator from Massachusetts 1803-08, he supported *Jefferson on the Louisiana Purchase, disagreeing with the Federalist Party. Minister to Russia 1809-14, he was appointed a justice of the United States Supreme Court in 1811 but declined this office. He negotiated the peace treaty of Ghent with England in 1814, and was Minister to Great Britain 1815-17. As Secretary of State under President *Monroe 1817-25, he negotiated a treaty with Spain (1819) which added Texas, California and the Oregon Territory to the US, fixed the border with Canada and formulated the 'Monroe Doctrine' (1823). There were four 
major candidates in the 1824 presidential election: Andrew *Jackson, Adams, Henry *Clay and William Crawford (1772-1834). As no candidate had a majority in the Electoral College, with Clay's support, Adams was elected by the House of Representatives. He imposed tariffs, promoted national infrastructure and encouraged education and science. Embittered by slander and defeat by Jackson in the presidential election of 1828, he retired to Quincy only to show his resilience by securing election to the House of Representatives. Here, from 1831 until his death he was known for his vehement attacks on slavery. In 1841 he argued before the Supreme Court to secure the freedom of slaves on the ship Amistad. The earliest surviving photograph of a US president was taken of Adams in 1843. Known as 'Old Man Eloquent', he died in the House after a vigorous speech.

Lipsky, G. A., John Quincy Adams: His Theory and Ideas. 1950; Bemis, S. F., John Quincy Adams. 2 vols, 1949, 1956; Nagel, P., John Quincy Adams: A Public Life, a Private Life. 1999; Remini, R. V., John Quincy Adams. 2002.

Adams, Phillip (Andrew Hedley) (1939-). Australian broadcaster, writer and film producer. He left school early, went into advertising, was central to the revival of the Australian feature film industry, produced 12 films and, from the 1980s, was an influential broadcaster, interviewing thousands of major figures and pursuing unpopular causes. He chaired the Commission for the Future 1985-90 and was a prodigious collector of artefacts. Author of 20 books, he became a 'living national treasure'. Minor planet 5133 Phillipadams was named for him in 1990.

Adams, Sam(uel) (1722-1803). American politician, born in Boston. The first distinguished member of the Massachusetts family which played such an important part in American history, Adams squandered his inheritance, mismanaged his post as a tax collector, but showed great talent as a political agitator and fiery propagandist. By fomenting and publishing the grievances of the American colonists as a radical leader in the state House of Representatives, he played a decisive part in the contrivance of events, such as the Boston Tea Party (1773), that led to the Declaration of Independence, of which he was a signatory.

Adams, William (1564-1620). English sailor. The first Englishman to settle in Japan (1600), he became the principal advisor on shipbuilding and trade: because of his usefulness he was not allowed to leave. He established a post there for the East India Company.

Addams, Charles Samuel (1912-1988). American cartoonist. A regular contributor to the New Yorker from 1940, his black humour, often featuring a family of grotesques, was the basis for the television series 'The Addams Family' (1964-66) and a film (1991).
Addams, Jane (1860-1935). American social reformer, born at Cedarville, Illinois. She founded (1889) the Hull House social settlement in Chicago and worked for female suffrage, social justice and the cause of peace. From 1916, she received 91 nominations for the Nobel Peace Prize, sharing it in 1931 with N. M. *Butler.

Tims, M., Jane Addams of Hull House. 1961.

Addington, Henry, 1st Viscount Sidmouth (17571844). English Tory politician. He entered parliament in 1784, was Speaker of the House of Commons 1789-1801 and Prime Minister and Chancellor of the Exchequer 1801-04, during *Pitt's temporary retirement. The Treaty of Amiens 1802 with *Napoléon was a brief respite, but war broke out again in 1803 . Pitt turned against him but after reconciliation took him into his own ministry. He received his peerage in 1805 and was almost continuously in office until 1824. As home secretary 1812-22 he was responsible for many repressive measures and incurred odium as a result of the 'Peterloo Massacre' of 1819. Minister without Portfolio 1822-24, his opposition to *Canning's policy of recognising the independence of the Spanish colonies in South America led to his final retirement. He opposed Roman Catholic emancipation and parliamentary reform.

Ziegler, P., Addington. 1962.

Addison, Joseph (1672-1719). English essayist. He was chiefly remembered as the founder of and chief contributor to the Spectator (first published 1711). A sickly, precocious child, he was educated at Charterhouse and Oxford. His poem The Campaign (1704), written to celebrate *Marlborough's victory at Blenheim, won him a post as Commissioner of Excise. Similar posts maintained him in comfort for the rest of his life. He became the main contributor to the Tatler, founded (1709) by his boyhood friend Richard *Steele, who later joined him on the Spectator. The declared aim of both men was to 'enliven morality with wit and to temper wit with morality', and it is likely that the influence of both on English manners in the 18th century was more profound than the elegance and sober good sense the papers would suggest. Addison's tragedy Cato (1713) was highly successful.

Smithers, P., The Life of Joseph Addison. 1954.

Addison, Thomas (1793-1860). English physician and pioneer endocrinologist. His early work was on the action of poisons on the human body, and in his Elements of the Practice of Medicine (1839) he printed an important account of appendicitis. But he is mostly remembered for his researches into the glands, and for his pioneering work on anaemia. On the basis of autopsies, he suggested in 1849 a connection between anaemia and diseases of the suprarenals. This work was extended in his book On the Constitutional and Local Effects of Disease of the Supra-Renal Capsules (1855), in which he identified 'idiopathic' anaemia 
(later known as Addisonian anaemia). He also identified what became known as 'Addison's disease', a condition of the suprarenal capsules which produced weakness, a bronze pigmentation of the skin, and fatality in the patient.

Singer, C. and Underwood, E. A. Short History of Medicine. 1962.

Adelaide (1792-1849). British queen consort 1830-37. Daughter of the Duke of Saxe-CoburgMeiningen, she married (1818) the Duke of Clarence, later *William IV of Great Britain. The capital of South Australia is named after her.

Hopkirk, M., Queen Adelaide. 1946.

Adenauer, Konrad (1876-1967). German Christian Democratic politician, born in Cologne (Köln). Son of a civil servant, he was educated at the universities of Freiburg, Munich and Bonn, became a lawyer in 1900, a Cologne councillor in 1906 and Lord Mayor (Oberburgermeister) 1917-33 until removed by the Nazis. Imprisoned briefly 1933 and 1944, he was inactive in politics until the end of World War II. Lord Mayor again 1945, in 1946 he founded the Christian Democratic Union (CDU), which although largely Catholic included Protestants and narrowly won the first post-war election of August 1949. He served as the first Chancellor of the Federal Republic of Germany 1949-63. At 73 his appointment was intended as provisional but 'Der Alte' kept hold until his unwilling retirement at the age of 87 . He was also Foreign Minister 1951-55. His shrewdness and stubbornness won him respect inside Germany and he established friendship with ${ }^{*}$ Churchill and ${ }^{*}$ de Gaulle. He negotiated the Federal Republic's entry into NATO, the Common Market and other international bodies and, with his successor Ludwig *Erhard, initiated Germany's 'economic miracle'.

Adès, Thomas (1971- ). English composer, pianist and conductor. He studied at King's College, Cambridge, with early successes paralleling Benjamin *Britten. His works include a piano quintet (2000); operas The Tempest (based on *Shakespeare, 2004) and The Exterminating Angel (based on *Bunuel's film, 2016); Todtentanz for mezzo and orchestra (2013) and Piano Concerto (2019).

Adler, Alfred (1870-1937). American psychologist. He was an eye specialist before taking up psychiatry and working with *Freud, from whom he finally broke in 1911 (mainly because he disagreed with Freud's undue emphasis on infantile sexuality), and established his own system. He stressed the link between hereditary physical defects and psychological states but is best known for the importance he ascribed to the will to dominate and its frustration. He coined the term 'inferiority complex'.

Bottome, P., Alfred Adler: Apostle of Freedom. 3rd ed. 1957.
Adler, Felix (1851-1933). American sociologist, born in Germany. Son of a rabbi, he established the first child-study group and the first free kindergarten in the US. He was a pioneer of the Ethical Culture movement aimed at providing ethical and moral teaching outside the churches.

Adler, Larry (1914-2001). American mouth organist. He toured constantly from the 1930s and commissioned works by ${ }^{*}$ Vaughan Williams, ${ }^{*}$ Milhaud and *Arnold. A political activist, he moved to England during the ${ }^{*}$ McCarthy period.

Adorno, Theodor W(iesengrund) (1903-1969). German philosopher and musicologist. He worked in the UK, US and Germany, attempting to explain modern music in the context of Marx and Freud and wrote extensively on ${ }^{*}$ Mahler, ${ }^{*}$ Schoenberg and ${ }^{*}$ Berg.

Adrian (Hadrianus) IV (Nicholas Breakspear) (c. 1100-1159). Pope 1154-59. The only English pope, born near St Albans, he became a canon of a monastery at Avignon in France and was cardinal bishop of Albano in Italy (1146-54). As Pope he reasserted papal power (*Arnold of Brescia), crowned *Friedrich I (Barbarossa) Emperor in 1155, but later opposed him on the basis of his theories of papal supremacy.

Adrian (Hadrianus) VI (Adriaan Florensz Boeyens) (1459-1523). Pope 1522-23. Born in Utrecht, he became a distinguished theologian. As tutor to the young Charles of Burgundy and the Low Countries (later King of Spain and emperor ${ }^{*}$ Charles V), he attained political and ecclesiastical preferment. Inquisitor-General of Aragon in 1516, cardinal in 1517, he became (1522) the last non-Italian pope until *John Paul II. Zeal for reform within the Church combined with opposition to all doctrinal change won him enemies both in Rome and among Luther's adherents. Moreover his inability to prevent the Turkish seizure (1522) of Rhodes from the Knights of St John marked his political failure.

Adrian, Edgar Douglas, 1st Baron Adrian (18891977). English physiologist, born in London. $\mathrm{He}$ was educated at Westminster and Trinity College, Cambridge, and trained for medicine at St Bartholomew's Hospital, London. Foulerton Research Professor at the Royal Society 1929-37, he discovered methods for measuring electrical signals in the nervous system and demonstrated the transmission, by nerve impulses, of sensation and muscular control. He shared the 1932 Nobel Prize for Medicine or Physiology with Sir Charles *Sherrington for their discoveries on the function of neurons. In Cambridge he became Professor of Physiology 1937-51, Master of Trinity College 1951-65 and Chancellor of the University 1967-75. Awarded the OM (1942), the Copley Medal (1946) and a peerage 
(1955), he was President of the Royal Society 195055 . His later research was on the electrical activity of the brain itself.

\section{A.E. (pen name of George William Russell) see Russell, George William}

Ælfric of Eynsham (c.955-1010). Anglo-Saxon scholar and writer. The best known scholar of his time, and the most prolific writer in Old English, he wrote homilies, sermons, a colloquy between the teacher, the pupil and such characters as ploughman, hunter, etc., a paraphrase of the early books of the Old Testament and Lives of the Saints.

Aeschines (389-314 BCE). Athenian orator. The great rival of *Demosthenes, the famous speech against Ctesiphon and only two others survive. He was important as chief spokesman of the party of appeasement in the face of the encroachments of *Philip II of Macedon and so delayed the resistance advocated by Demosthenes until too late.

Aeschylus (c.525-456/5 BCE). Greek tragic dramatist, born near Athens. A member of an old noble family, he was a soldier who fought against Persia at Marathon (490), Salamis (480) and Plataea (479). Comparatively little is known of his life, except that he was popular in Athens, acted in his plays, was regarded as impious and made three long visits to Gela in Sicily, where he died. The earliest Greek tragedian, and, with *Sophocles and *Euripides, one of the three greatest, he was the first dramatist to present two characters on stage simultaneously (additional to the chorus). He also developed the use of dialogue, costumes, music and scenery. (In the Oresteia trilogy he first presented three characters on stage.) Of about 80 plays, only seven survive. He competed in the Dionysia, an annual drama competition, more than 20 times, winning 13 of them (losing once to Sophocles). The Persians deals with the historic struggle of the Greeks against *Xerxes, the remainder are inspired by ancient legends of gods and heroes. Comprising the great trilogy of The Oresteia are Agamemnon, telling of the King's murder on his return from Troy by his wife Clytemnestra and her lover Aegisthus, The Choephoroe, in which Orestes and his sister Electra avenge their father, and The Eumenides, which relates the pursuit of Orestes by 'Furies', his trial and final acquittal by the goddess Athena. Other surviving plays are The Suppliants, Seven Against Thebes and Prometheus Unbound. All deal with the expiation of sin.

Murray, G. G. A., Aeschylus the Creator of Tragedy. 1940.

Aesop. Greek author of beast fables, probably legendary. He is supposed to have lived in the 6th century BCE but even his existence is uncertain. The first collection of Greek fables, now lost, was made in the 4th century BCE by Demetrius of Phaleron. century CE) contains the first Greek fables to survive. Clearly, the fables ascribed to Aesop originated in many countries and were the work of many hands.

Æthelberht (or Ethelbert) (c.560-616). King of Kent 560-616. Overlord of southern England, he married a Christian, the Frankish princess Bertha. which facilitated his own conversion (597) by St *Augustine of Canterbury. This link with the Franks probably stimulated him to issue a code of laws, the first known to have been written down in England.

Æthelred (or Ethelred) I (840-871). King of Wessex $865-71$, brother and predecessor of *Alfred (Ælfræd) the Great. The brothers worked in perfect harmony in their efforts to keep the Danes at bay, and, though the devout king was still at his prayers when the Battle of Asldown (871) began, the Danes sustained their first decisive defeat. He died soon afterwards at Merton.

Æthelred (or Ethelred) II (known as 'the Unready') (968-1016). King of England 987-1016. The son of *Edgar the Peaceful he succeeded his murdered halfbrother *Edward the Martyr. He was called 'Unraed' (lacking in counsel or good sense) because of his vacillating policy towards the Danes, sometimes bribing, sometimes fighting them. His reign was one of unrest and treachery to which he contributed, for example by a general massacre of Danes on St Brice's Day 1002. The Danish leader, *Sweyn Forkbeard, responded with fierce reprisals, defeated Ethelred and compelled him to flee to the court of the Duke of Normandy, the brother of Emma, Ethelred's second wife and mother of ${ }^{*}$ Edward the Confessor. $\mathrm{He}$ returned to England in 1014.

Roach, L., Athelred the Unready. 2016.

Æthelstan (or Athelstan) (c.895-939). King of the Anglo-Saxons 924-27, King of the English 927-39. Son of *Edward the Elder, and grandson of *Alfred the Great, he continued and extended their policy of unification by bringing the north of England and much of Wales under his rule. The marriages arranged for his sisters with the royal houses of France and Germany confirmed his position as one of the great medieval kings. He ruled England firmly but also addressed his efforts to the liberation of slaves, care of the destitute and improvement of the coinage. At the end of his reign (937) he defeated a confederacy of Scots, Welsh and Danes in a desperate encounter at Brunanburh (Bourne in Lincolnshire).

Æthelwulf (d. 858). King of Wessex 839-58. Son of *Egbert and father of *Alfred the Great, he was pious, judicious and absentee, but kept the Vikings at bay.

Aga Khan. Hereditary title held by the spiritual head of the Isma'ili (Shi' ite) Muslims, which claims descent from Fatimah, daughter of the prophet ${ }^{*}$ Muhammad. The first Aga Khan, Hasum Ali Shah (1800-1881), fled from Persia to India, where his services to the British won him recognition and the title 'His 
Highness'. His grandson, Aga Khan III (18771957), born in Karachi, who succeeded his father as 48th Imam of the Nizari-Isma'ili Muslims in 1885, was educated at Eton and Cambridge. He became first President of the All-India Muslim League 1912. A moderate reformer, he advocated ending purdah, represented India at international conferences and at the League of Nations 1932-38, and was President of the League of Nations Assembly 1937-38. He gained notoriety as a racing enthusiast whose horses won the Derby five times. He was buried in Egypt. His grandson Shah Karim al-Hussaini, Aga Khan IV (1936- ) campaigned to relieve global poverty and advance women's rights.

Agassiz, (Jean) Louis (Rodolphe) (1807-1873). Swiss-American biologist, born in Switzerland. A pupil of ${ }^{*}$ Cuvier and ${ }^{*}$ Humboldt, he graduated in medicine (1830), worked in Paris and in 1832 accepted a professorship at Neuchâtel. His early work on fossil fishes was followed by a systematic study of glaciers. In 1846 he went to America and in 1848 became professor of natural history at Harvard, and became an influential, and much admired, teacher. A vigorous critic of ${ }^{*}$ Darwin's theories of natural selection and the origin of species, he proposed 'polygenism'-the concept that human races had different origins. His ideas were used to provide a scientific justification for racism, unfairly, as Agassiz opposed slavery. A scientific expedition to Brazil 1865-66 led to the publication of A Journey in Brazil (1868). Only four volumes of his Contributions to the Natural History of the United States were issued before his death. His son Alexander Agassiz (1835-1910), who became curator of the Harvard Museum on his father's death, wrote much on oceanography, coral formations and the embryology of star fishes, etc.

Marcou, J., Life, Letters and Works of Louis Agassiz. 1972.

Agesilaus (c.444-360 BCE). King of Sparta. Famous for his military skill, his early successes were against the Persians in Ionia, but it was in the long war against an alliance of the other Greek states that he won his most famous victory, that of Coronea (394). In the Theban war, though defeated by ${ }^{*}$ Epaminondas at Mantinea (362), he maintained his country's defence.

Agnelli, Giovanni (1866-1945). Italian industrialist. Originally a soldier, in 1899 he founded FIAT (Fabbrica Italiana Automobili Torino) which became the biggest Italian car and weapons manufacturer. *Mussolini appointed him to the Senate in 1923 and he was a generous philanthropist.

Agnew, Spiro Theodore (1918-1996). American Republican politician. Son of a Greek migrant (the family name was Anagnostopoulos), he served in the forces, then became a supermarket manager. County executive in Baltimore 1962-67, he had a meteoric rise to become Governor of Maryland
1967-69 and Richard *Nixon's Vice President 196973 and seemed a likely nominee for president in 1976. When the Justice Department prosecuted him for receiving 'kickbacks' from Maryland contractors, he pleaded 'no contest' in court, was fined, placed on probation and resigned (October 1973) as Vice President. He then joined an international real estate investment firm.

\section{Agoult, Marie Catherine Sophie de Flavigny, Comtesse d' (1805-1876). French novelist. Her novel Nélida (1846), written under the pen name Daniel Stern, depicted her relations with the musician Franz Liszt. One of her daughters by *Liszt, Cosima, married Richard *Wagner.}

Agricola, Georgius (Georg Bauer) (1495-1555). German scholar. Trained as a humanist at Leipzig, and a friend of *Erasmus, he became a physician in the mining town of Joachimstal, Saxony (1527-33). His close observation led to the writing of his great work De re metallica (1533-53), posthumously published in Venice. Regarded as the foundation of systematic metallurgy, it was translated into English by Lou and Herbert *Hoover (1913).

Agricola, Gnaeus Julius (40-93 CE). Gallo-Roman soldier and administrator. Born to a senatorial family, Governor of Britannia (Britain) 78-85, he consolidated the Roman hold on Wales, pushed the frontier into Caledonia (Scotland), built a large fort at Inchtuthil (in modern Perthshire), and his fleet made the first circumnavigation of the British Isles since *Pytheas. Shortly after defeating the Caledonians at Mons Graupius (83) - although the scale of the battle was probably exaggerated-he was recalled by the jealous emperor *Domitian. His biography, written by his son-in-law *Tacitus, survives.

Agrippa, Marcus Vipsanius (63-12 BCE). Roman engineer, architect, commander and governor. As governor of Gaul (39), he crossed the Rhine and began colonising Germany. A strong supporter of Octavian, later known as *Augustus, he destroyed the navy of Sextus *Pompeius off Sicily (36). From 33 he enlarged and expanded Rome's water supply. His victory at Actium (31) over the fleets of *Antony and ${ }^{*}$ Cleopatra enabled Octavian to become the undisputed master of Rome. Augustus' daughter Julia became Agrippa's third wife and their daughter *Agrippina continued the imperial line. His Pantheon (27-25 BCE), originally rectangular, was destroyed by fire in 80 , rebuilt, first by ${ }^{*}$ Domitian, then $(126 \mathrm{CE})$ by *Hadrian, but Agrippa's portico remains. He also developed the Campus Martius (24 $\mathrm{BCE})$. The Pont du Gard, one of the greatest Roman aqueducts, originally regarded as Agrippas work, is now dated to $40-60 \mathrm{CE}$.

Agrippa von Nettesheim, Heinrich Cornelius (1486-1535). German physician, theologian, philosopher and courtier, born in Cologne. Educated 
at his birthplace, he had a stormy career, became court physician and astrologer to *François I, and was jailed as a heretic. His major work De occulta philosophia (1531) attempted to link scientific knowledge with magic, the occult and cabbalistic tradition. The Faust legend owes much to his reputation.

Agrippina (14 BCE-33 CE). Roman matron. Daughter of *Julia and *Agrippa, she became wife of Germanicus, nephew of *Augustus' successor, *Tiberius, whom she wrongly blamed for her husband's death. She died in exile. Of her children Gaius, nicknamed ${ }^{*}$ Caligula, became emperor, her daughter, the younger Agrippina (15-59), was the mother of the emperor *Nero by her first husband and probably poisoned her third, the emperor *Claudius. Notorious for her cruelty and depravity, she was eventually put to death by her son Nero.

Aguinaldo y Fama, Emilio (1869-1964). Filipino politician and insurgent. Born to a wealthy and influential family, he led guerrilla campaigns against the Spanish occupation, and, after invasion by US forces, became head of a revolutionary government 1898-99 and first President of the Philippines 18991901, the first head of a constitutional republic in Asia. Aguinaldo designed the national flag. When the United States invaded and defeated the Spanish, establishing direct rule in 1901, the first Filipino Republic ended and Aguinaldo retired to private life. In 1935 he contested the first election for the Presidency of the Commonwealth of the Philippines, losing heavily to his former supporter Manuel *Quezon. In 1945 he was accused of collaboration with the Japanese occupation and was jailed.

Ahab (d.c.853 BCE). King of Israel c.875-852 BCE. His confiscation of Naboth's vineyard earned him the wrath of the prophet Elisha. His evil genius was his wife ${ }^{*}$ Jezebel who persuaded him to introduce the worship of Baal. He was killed in battle with the Syrians by a man who 'drew his bow at a venture'. See I Kings xvi:29-xxii:40.

Ahasuerus. Biblical name of several Persian kings. The one who made ${ }^{*}$ Esther his queen has been questionably identified with *Xerxes I (reigned 485464 BCE). The name Ahasuerus was also attributed to the legendary Wandering Jew.

Ahern, Bertie (1951- ). Irish politician. He was Lord Mayor of Dublin 1986-87, Leader of Fianna Fail 1994-2008 and Prime Minister (Taoiseach) 19972008. He worked with Tony *Blair in negotiating peace in Northern Ireland (1998).

Ahmad Shah Durrani (1722-1772). Emir of Afghanistan 1747-72. At first a successful general in the service of ${ }^{*}$ Nadir Shah, on the latter's death he conquered extensive territories of which Afghanistan was the central part. This survived the collapse of his wider empire on his death and he is thus regarded as the founder of modern Afghanistan. He was also a poet.

Ahmadinejad, Mahmoud (1956- ). Iranian politician, born in Abadan. A Shi'ite, his father was a grocer and barber and his mother claimed direct descent from *Muhammad. Trained as an engineer and teacher, he held a series of appointed offices, including Mayor of Tehran 2003-05, and became a leader of the Alliance of Builders of Islamic Iran. Elected as President in 2005 (narrowly defeating Hashemi *Rafsanjani), he served 2005-13. As President, he directed domestic and economic policies, but was subordinate in religious and cultural areas, and foreign policy, to the supreme leader, Ali *Khamenei, and the Council of Guardians. An intransigent opponent of Israel, he clashed repeatedly with the United States, especially over Iran's nuclear program. There were massive protests against the conduct of the 2009 election.

Ahmed Khan, Sir Sayyid (1817-1898). Indian Muslim educator and jurist. He worked in the judicial department of the East India Co. 1841-76, was a major influence in the revival of Urdu as a literary language, and reformed the organisation of Muslim education. In 1875 he opened the Anglo-Oriental College, later called the Aligarh Muslim University.

Ahtisaari, Martti (1937- ). Finnish politician and diplomat. A professional diplomat who served with the UN, he was President of Finland 1994-2000 and received the Nobel Prize for Peace in 2008 for his work in negotiating settlements in Kossovo, Namibia, Indonesia and Iraq.

Ai Weiwei (1957- ). Chinese artist and political activist, born in Beijing. Son of a dissident poet, Ai Qing (1910-1996), he grew up in exile in Xinjiang, returning to Beijing in 1976 . He studied animation, cinematography and photography, lived in the US 1981-93, then became an architect (with the FAKE design group). He made many documentary films about urban and social problems, became an influential blogger in China from 2005, campaigning for human rights and exposing government failures in the Sichuan disaster relief. He was imprisoned and beaten up several times, and accused of fraud and plagiarism. He created powerful sculptural installations, for example Forever Bicycles (2011) and Tree (2013).

Aidan, St (d.651). Irish monk. Summoned by King *Oswald to become bishop of Northumbria, he left Iona in 635 and founded the monastery and see at the island of Lindisfarne. Thence his missionary journeys restored Christianity in northern England. 
Aiken, Conrad (Potter) (1889-1973). American poet, critic and novelist, born in Georgia. He lived in England for many years. His Selected Poems (1929) won the Pulitzer Prize for Poetry (1930). His novels include Great Circle (1933).

Hoffman, F. J., Conrad Aiken. 1963.

Ainsworth, William Harrison (1805-1882). English novelist, born in Manchester. Articled to a solicitor, and for a short time a publisher, he edited Ainsworth's Magazine (1842-53) and wrote over 40 historical novels, including The Tower of London (1840), Guy Fawkes (1841) and Old St Paul's (1841).

Airy, Sir George Biddell (1801-1892). English astronomer, born at Alnwick, Northumberland. Educated at Trinity College, Cambridge, in 1828 he became Plumian professor of astronomy at Cambridge and director of the new observatory there. As astronomer royal 1835-81 he reorganised Greenwich observatory, designed improved instruments and started meteorological and magnetic observations as well as solar photography and spectroscopy. He was elected FRS in 1836 and knighted in 1872 .

Akbar the Great (Abu'l-Fath Jalal-ud-din Muhammad Akbar) (1542-1605). Emperor of India 1556-1605. The third of the Mughals, he succeeded his father Humayun, and having gained the allegiance of the warlike Rajputs extended his rule over most of India. Fatehpur Sikri, $35 \mathrm{~km}$ from Agra, his wonderful new capital of red sandstone, symbolised the new era. He divided the country into provinces, each under a viceroy to secure law and order, promote trade and collect taxes, but Akbar himself maintained absolute central control. One of his aims was to establish a new religion containing all that was best in existing faiths and so abolishing the strife between the various sects. Among the religious leaders summoned for this purpose were Jesuit missionaries from Goa.

Smith, V., Akbar the Great Mogul, 1542-1605. 2nd ed. 1919; Giri, S., Akbar. 2009.

Akhenaten (or Ikhnaten: 'Servant of the Sun disc') (d.c.1336 BCE). Egyptian pharaoh of the XVIIIth dynasty. As Amenhotep (or Amenophis) IV, he succeeded his father Amenhotep III around 1379 BCE and may have been co-ruler with him. His mother was a commoner. He became a devotee of the sun disc ('Aten'), an entirely rational object of worship, changed his name, and is sometimes exaggeratedly claimed as the founder of monotheism. This new religious emphasis may have been aimed at the political power of priests devoted to Amun (or Amen)-Re, also a sun-god. Amun's name was replaced by Aten in the official religion, essentially optimistic nature worship. Weak physically, Akhenaten was no hunter, athlete or warrior but patronised the arts which flourished in his time. Some of his poems have survived. He moved his capital from Thebes to a new city Akhenaten, now Tell el Amarna. The beautiful sculptured head of his wife *Nefertiti, frequently reproduced, is in the Neues Museum, Berlin. The religion of Amun was restored by his son ${ }^{*}$ Tutankhamun.

Aldred, C., Akhenaten: Pharaoh of Egypt. 1972.

Akhmatova, Anna (pseudonym of Anna Andreyevna Gorenko) (1889- 1966). Russian poet. Her poems, in the style of Pushkin, were extremely popular and collections included The Rosary (1914) and The Willow Tree (1940). She was a leader of the Acmeist movement which was led by her husband Nikolai Gumilov and included *Mandelstam. Gumilov was executed in 1921 and Akhmatova was placed under ban 1923-40 and 1946-56. Her long Poem Without a Hero (1940-62) achieved international recognition and she is regarded as Russia's greatest woman poet.

Akihito (regnal name Heisei, i.e. 'achieving peace') (1933- ). Emperor of Japan 1989-2019. Son of *Hirohito, he was educated at the Gakushuin High School and Gakushuin University, graduating in political science. He travelled widely and married a commoner, Michiko Shoda, in 1959. He pursued interests in ichthyology, publishing 25 papers on a taxonomic study of the gobiid fish. In 1992 he became the first Japanese emperor to visit China, then went to the United States in 1994 and to the United Kingdom in 1998, where he was made an honorary KG. He abdicated in favour of his son *Naruhito in April 2019.

Aksakov, Sergei Timofeivich (1791-1859). Russian novelist. After retiring from the civil service, he wrote a notable autobiographical trilogy of Russian family life, Family Chronicle (1856), Years of Childhood (1858) and Reminiscences (1856).

Alain, Jehan (1911-1940). French composer and organist. Member of a distinguished musical family, he composed chamber, piano and vocal works but is remembered for his organ music, especially the powerful Litanies (1937). He was killed in action in World War II. His sister Marie-Claire Alain (19262013) was an organist and teacher who recorded more than 200 CDs.

Ālam II, Shah (né Ali Gohar) (1728-1806). Emperor of India 1760-1806. One of the last Moghul emperors, he ruled, in name only, under the domination of the Marathas whose army was run by skilled French mercenaries. In 1788 he was blinded by a Sikh insurgent. In 1803, the army of the British East India Company defeated the French and Alam Shah was placed under 'protection'. (Richard *Wellesley). He was a gifted poet.

Alanbrooke, Alan Francis Brooke, 1st Viscount (1883-1963). British field marshal, born in France. From a leading Ulster family (*Brookeborough) 
he joined the army in 1902. As GOC 2nd Army Corps, in France 1939-40, he showed great skill in extricating his troops at Dunkirk (May-June 1940), then became Commander-in-Chief of home forces 1940-41, succeeding Sir John ${ }^{*}$ Dill as Chief of the Imperial General Staff 1941-46 and Chairman of the Joint Chiefs of Staff. He had the best strategic mind of the British generals and ${ }^{*}$ Churchill wanted him to be Supreme Commander for the reconquest of Europe, although their relations were sometimes stormy. In 1946 he was created Viscount and given a KG and the OM.

Alarcón y Mendoza, Juan Ruiz de (1581-1639). Spanish dramatist, born in Mexico. He came to Spain and moved in the circle of Lope de *Vega. He is best known for his comedies of manners but also wrote heroic dramas. Interest in his work revived in modern times after a period of neglect.

Alaric (c.370-410). Visigoth chief 395-410. A nobleman, born in modern Romania in the reign of the emperor *Theodosius I, he commanded Gothic auxiliaries in the Roman army, but on the death of the emperor in 395 broke with Rome and invaded Greece. The eastern emperor *Arcadius tried to win him over by appointing him Governor of Illyricum 396-400. He invaded Upper Italy on behalf of the emperor but in 402 was defeated by * ${ }^{*}$ tilicho, the general of the western emperor Honorius. After another defeat (403) he changed sides but the bribe of huge sums of gold made by Stilicho was not paid by the emperor. When two advances upon Rome (408 and 409) had failed to secure a satisfactory settlement, Alaric entered the city as a conqueror and gave it over to pillage (410), though as an Arian Christian he forbade the desecration of religious buildings. A plan to reach Africa by way of Sicily to find a home for his people was foiled by his death in southern Italy.

Alba, Fernando Alvarez de Toledo, Duke of (15071582). Spanish soldier and administrator. Alba had already gained a military reputation with the armies of the emperor *Charles V in Italy, Tunisia, France and against Lutheran princes in Germany, but had equally incurred odium for intolerance and pride when Charles' son, *Philip II of Spain, sent him (1567) as Governor-General to the Netherlands to crush the independence movement and stamp out Protestantism. In the first task he began successfully by forcing *William the Silent (of Orange) to disband his army and take refuge in Germany. However, his subsequent cruelty (in five years 18,000 people were executed by his Council of Blood and 100,000 forced into exile) stirred up the antagonism that inspired William the Silent's subsequent leadership and led to the emergence of Holland as a separate state. Meanwhile in 1573, ill and exhausted, Alba had asked to be recalled.
Alban, St (d.209 or 251 or 304 CE). RomanBritish martyr. Alban's very existence is a matter of controversy, and his name may be drawn from 'Albion', or from 'alba' ('bright') with a feast day on the summer equinox. He may have been a soldier, possibly a Roman convert, condemned for giving shelter to a priest. Most early accounts agree that he was the first Christian martyr in Britain, beheaded in Verulamium, now St Albans. A church was built on the presumed site of his execution in 429. *Bede's account is the longest, but he sets the date too late, after Christianity was being tolerated in the Roman empire. Many shrines were devoted to St Alban in Britain and Europe, and he has been proposed as a replacement for St *George as England's patron saint.

Albanese, Anthony Norman (1963- ). Australian Labor politician, born in Sydney. Brought up by a single mother, he first met his father in Italy in 2009. Educated at St Mary's College and Sydney University, he became a ministerial staffer, party official and Federal MP 1996- . Under *Rudd and *Gillard he was Minister for Infrastructure and Transport 2007-13 and Deputy Prime Minister 2013. Defeated by Bill *Shorten in 2013, he was Leader of the ALP 2019- . He pursued a 'small target' campaign against the *Morrison government, but won the 2022 election, promising to act on climate change, an integrity commission and gender equality, and became the 31st Prime Minister of Australia 2022- .

Middleton, K., Albanese. Telling It Straight. 2017.

Albee, Edward Franklin (1928-2016). American dramatist. His early plays were influenced by *Jarry and *Ionesco but after Who's Afraid of Virginia Woolf: (1962) he returned to mainstream naturalism. He won Pulitzer Prizes with A Delicate Balance (1967) and Seascape (1975).

Albéniz (y Pascual), Isaac (Manuel Francisco) (18601909). Spanish composer. A prodigy as a pianist, he later studied under ${ }^{*}$ Liszt, and toured the US, South America and Europe. He worked in London 1890 93 and four of his six operas have English libretti. His greatest work was the piano suite Iberia (190609, later orchestrated by E. F. Arbos). He was a friend of *Debussy and a student of folk music.

Alberoni, Giulio (1664-1752). Italian cardinal. Son of a gardener, he went to Spain as secretary to the Duc de Vendôme. He soon gained ascendancy at court, which was strengthened when he brought about the marriage of *Felipe $\mathrm{V}$ with Elizabeth (or Isabella) Farnese, whose ambition to endow her sons with Spain's lost Italian duchies Alberoni (first minister 1714, cardinal 1717) fostered. The policy, which involved war (1718) with the Quadruple Alliance (Great Britain, France, Austria, Holland), failed and despite his sound internal administration Alberoni was dismissed.

Harcourt-Smith, S., Alberoni. 1963. 
Albers, Josef (1888-1976). German-American painter and designer. He worked at the Bauhaus, migrated to the US in 1933 and taught at Harvard and Yale. His famous series Homage to the Square influenced the development of op art and Minimalism.

Albert I (Albert Léopold Clément Marie Meinrad de Belgique) (1875-1934) King of the Belgians 1909-34. Studious, he married *Elisabeth, a Bavarian duchess, in 1900. An enthusiastic alpinist and pioneer conservationist, he succeeded his uncle *Léopold II and gained worldwide admiration for his defiance of German aggression in World War I and for leading the remains of his army throughout. In 1919 he made sensible suggestions at the Paris Peace Conference and became the first European monarch to visit the United States. In 1920 he changed the royal family's name from Saxe-Cobourg-Gotha (or Wettin) to de Belgique (French) or van België (in Dutch). He was killed in a mountaineering accident in the Ardennes, and was succeeded by *Léopold III. His grandson, Albert II (1934- ) was King of the Belgians 19932013, abdicating in favour of his son Philippe.

Albert of Saxe-Coburg-Gotha (Franz Albrecht August Karl Emmanuel von Wettin) (1819-1861). British Prince Consort, born in Coburg. The second son of Ernst, Duke of Saxe-Coburg-Gotha, he was educated in Brussels and Bonn and (after strenuous encouragement from their uncle *Leopold I of Belgium) married his cousin, Queen *Victoria in February 1840. The marriage was passionate and happy and they had nine children. For several years he was virtually the queen's private secretary, which aroused political mistrust although his judgment was good. Deeply interested in music, the fine arts, architecture, science and manufacturing, the Great Exhibition of 1851 at the Crystal Palace was a tribute to his organising skills. He became a field marshal, chancellor of Cambridge University 1847-61 and was created prince consort in 1857. His death, now thought to have been from Chrone's disease, devastated the queen who remained in seclusion for many years. London's Albert Hall (1867) is one of many memorials to him.

Weintraub, S., Albert: Uncrowned King. 1997.

Albert Victor Christian Edward (von Wettin), Duke of Clarence and Avondale (1864-1892). British prince, born in Windsor. Eldest son of the future ${ }^{*}$ Edward VII, he was second in the line of succession to Queen *Victoria. Known as 'Prince Eddie', he died of influenza. His fiancée *Mary of Teck married his brother, the future ${ }^{*}$ George $V$, in 1893 . A poor student, amiable but dim, he became, decades after his death, the subject of wild speculation, completely unsupported by evidence, that he was *Jack the Ripper.

Alberti, Leon Battista (1404-1472). Italian humanist and architect, born in Genoa. Son of an exiled Florentine nobleman, he was one of the most versatile figures of the Italian Renaissance. His 10 -volume treatise on architecture, De re aedificatoria (1485), was the first printed book on architecture and encouraged interest in classical forms. His buildings include churches at Mantua and the Rucellai palace at Florence. His plays, educational and moral treatises, and essays on law, politics and science reflect the extent of his interests.

\section{Gadol, J., Leon Battista Alberti. 1969.}

Albertus Magnus, St (Albrecht, Count of Bollstadt) (1193-1280). German philosopher. Renowned for the depth and breadth of his knowledge, he proved himself a great teacher of the Dominican order, his most famous pupil being St Thomas *Aquinas, with whom he contributed to the infusion of Aristotelianism into medieval theology. His work in natural science drew on many sources and he introduced the notion of affinity into chemistry. His work in these scientific fields gave him a reputation as a magician. Bishop of Regensburg 1260-62, he was canonised in 1931.

Albrecht of Magdeburg (Albrecht von Hohenzollern) (1490-1545). German prelate. Son of the elector of Brandenburg, he became Archbishop of Magdeburg 1513-45, Archbishop and Elector of Mainz 151445, Primate of Germany and a cardinal in 1518. Originally sympathetic to humanism, and influenced by *Erasmus, he spent extravagantly and borrowed heavily from the *Fuggers. His sale of indulgences, permitted by Pope ${ }^{*}$ Leo X, provoked *Luther to publish his 95 theses.

Albright, Madeleine Jana Korbel (née Korbelová) (1937-2022). American administrator, born in Prague. Daughter of a diplomat, her family migrated to the US in 1948. Educated at Wellesley and Columbia, she was US Ambassador to the UN 199397 and Secretary of State 1997-2001, the first woman so appointed. She became a professor at Georgetown University, rejecting bids to enter Czech politics, and wrote the memoir Madam Secretary (2003). She received the Presidential Medal of Freedom in 2012.

Albuquerque, Afonso de (1453-1515). Portuguese soldier. Raised at the court of King Alfonso V, he led an adventurous life, which included fighting against the Turks, before going to the East, where he succeeded (1507) Almeida as Viceroy. Goa, captured in 1510 , became his capital and he gradually asserted control over Malabar, Ceylon, Malacca and some of the Indonesian islands. Intrigues at home led to his dismissal and he died on the way home.

Alcaeus (620-after 580 BCE). Greek poet. He lived and worked on the island of Lesbos. Of his work, mainly battle songs, love songs and hymns, only fragments survive, but his Alcaic metre was used by others, especially by the Roman poet *Horace.

Page, D., Sappho and Alcaeus. 1955. 
Alcalá Zamora, Niceto (1877-1949). Spanish politician, born in Priego. A Catholic conservative, he was a Cortes member 1905-31, Minister for Works 1917 and for War 1922 and Prime Minister 1931, negotiating *Alfonso XIII's abdication. Elected as first president of the Spanish Republic 1931-36, he tried to reconcile all factions but showed little leadership and was distrusted by left and right. Removed in 1936, he went into exile in France, then Argentina, where he died.

Alcibiades (c.450-404 BCE). Athenian leader. Brought up in the household of *Pericles, he became a brilliant but wayward member of the group of talented young men who found inspiration in discussions with Socrates. In the Peloponnesian War between Athens and Sparta which began in 431, Alcibiades planned and jointly led the disastrous expedition to Syracuse. On the eve of departure all the statues of the god Hermes were mutilated. For this Alcibiades was blamed and to avoid prosecution took refuge with the Spartans, whom he helped by stirring up revolts among the allies of Athens in Asia Minor. Failing, however, to retain Spartan confidence he fled to the Persian satrap Tissaphernes, whom he tried to win over to the Athenian side in the hope of obtaining his own recall. He failed with Tissaphernes, but, chosen by the Athenian forces in Samos to lead them, he was so successful in the Hellespont (Dardanelles) that he returned home in triumph. But his command was not renewed and he withdrew to Thrace, where he was murdered.

Alcock, Sir John William (1892-1919). English aviator. With Arthur Whitten *Brown, he made the first aeroplane crossing of the Atlantic (14 June 1919) in a Vickers-Vimy, travelling about 3,154 km (1,960 miles) from Newfoundland to Clifden in Ireland in 16 hours 12 minutes. He died after an air accident in France.

Alcott, Louisa May (1832-1888). American novelist. Her stories of family life in America, especially Little Women (1868), had phenomenal sales. She served as a nurse in the American Civil War. She never married: as she wrote, 'I'd rather be a free spinster and paddle my own canoe.'

Stern, M., Louisa May Alcott. 1971.

Alcuin of York (né Ealhwine, in Latin Flaccus Albinus Alcuinus) (735-805). English scholar, born in York. From an Anglo-Saxon family attached to the nobility, he acquired his great learning at the cloister school in York, where he later taught and became head. He was a deacon, but not a priest. In 782 he accepted an invitation from ${ }^{*}$ Charlemagne to foster the revival of Latin language and literature throughout his empire. Master of the Palace School at Aachen 782-90; 792-96, he became Charlemagne's chief educational advisor and his pupils included the young princes and the emperor himself. He promoted the use of
Carolingian minuscule as lower case writing, and this became standard in Western Europe. He returned to England 790-92, and in 1796 became Abbot of Marmoutier, in Tours, where he taught and died.

Aldanov, Mark (né Mark Aleksandrovich Landau) (1886-1957). Russian-Jewish-French historical novelist, biographer and critic, born in Kiev. He studied chemistry, and left Russia after the Revolution, living in France 1919-41, 1946-57 and the US 1941-46. He wrote on the French and Russian Revolutions, ${ }^{*}$ Napoléon, ${ }^{*}$ Lenin and his once popular novels included The Key (1931). A hero to literary emigrés, he was nominated 13 times for the Nobel Prize.

Aldington, Richard (1892-1962). English poet, novelist and biographer. He wrote several volumes of Imagist and other poetry, the disillusioned war novel Death of a Hero (1929), and lively, controversial biographies of D. H. *Lawrence (Portrait of a Genius, but ... , 1950) and T. E. *Lawrence (Lawrence of Arabia, a Biographical Enquiry, 1954). He married (1913) the American poet Hilda *Doolittle.

Aldrovandi, Ulisse (1522-1605). Italian naturalist, born in Bologna. From a noble family, after studying medicine at Bologna University and travelling, he became professor in 1560 and later first director of the botanic garden. Like many Renaissance scholars, Aldrovandi's interests were wide ranging, and included archaeological remains and medicine. But his main passion was for natural history, especially the branches of botany, ornithology, embryology and the study of monsters. He observed the development of chicks by opening their eggs successively on each day of the incubation period, confirming that *Aristotle was correct in stating that the heart is formed prior to the liver in the embryo. Aldrovandi's work had lasting interest chiefly through his pioneer collecting activities. His museum of natural history was amongst the largest in Europe. He planned to catalogue his collections in 14 volumes, but lived to complete only four-one on insects, and three on birds. He bequeathed his collections and manuscripts to Bologna.

Bodenheimer, F. S., History of Biology. 1958.

\section{Aldus Manutius see Manutius, Aldus}

\section{Aleichem, Shalom see Shalom Aleichem}

Alekhine, Aleksandr Aleksandrovich (18921946). Russian-French chess master. He left Russia for France in 1921 and was world chess champion 1927-35 (defeating José *Capablanca, losing to Max Euwe) and 1937-46 (defeating Euwe). He joined the French army in 1940 but then collaborated with the Germans and held his title, without a rematch, until his sudden death in Portugal (possibly a murder).

Alekhine, A., My Best Games of Chess, 1924-1937. 1939. 
Aleksandr I (1777-1825). Tsar of Russia 180125 . He came to the throne after the murder of his father *Paul I. His education in humanitarian but abstract principles was directed by his grandmother, ${ }^{*}$ Catherine the Great, but though he was at first liberal in outlook and ordered the preparation of elaborate schemes of reform, he shrank from putting all but a very small part into effect. He joined the coalition against *Napoléon, but was forced to conclude the treaty of Tilsit (1807). There the two emperors met and Aleksandr conceived a hero worship for the conqueror which postponed a further clash for five years. However, in 1812 Napoléon made the disastrous invasion into Russia which brought about his downfall. Aleksandr, the hero of the hour, was thus a leading figure at the Congress of Vienna (1814-15). With Austria and Prussia he formed the 'Holy Alliance', intended to preserve the status quo, but under the influence of *Metternich became increasingly reactionary, though he gave Russian Poland a constitution under his sovereignty. He was succeeded by his brother, ${ }^{*}$ Nikolai I.

Palmer, A., Alexander I. 1974.

Aleksandr II (Aleksandr Nikolaievich Romanov, known as 'the Liberator') (1818-1881). Tsar of Russia 1855-81. Son of *Nikolai I, as Tsarevich he travelled extensively, from Siberia to England, succeeding to the throne after defeat in the Crimean War. Defeat created the atmosphere for reforms, the greatest of which was the emancipation of $10,000,000$ serfs and their families (1861). He sold Alaska to the US in 1867, reformed the judicial system, abolished corporal punishment in the military, created limited local self-government (zemstvo), built railways and was sympathetic to the Finns. He married his mistress in 1880. He survived assassination attempts in 1866, 1879,1880 but was killed by a bomb in St Petersburg.

Mosse, W. E., Alexander II and the Modernisation of Russia. 1958; Radzinsky, E., Alexander II: The Last Great Tsar. 2005.

Aleksandr III (Aleksandr Aleksandrovich Romanov) (1845-1894). Tsar of Russia 1881-94. He succeeded on the assassination of his father, *Aleksandr II. Under the influence of Konstantin *Pobedonostsev, he set out to reverse the liberalising reforms of his father, and was devoted to 'Orthodoxy, Autocracy and Nationality'. He married the Danish Princess Dagmar (1847-1928) in 1866. He survived an assassination attempt in 1887 for which *Lenin's brother was hanged. He died of nephritis.

Thomson, O., Romanovs: Europe's Most Obsessive Dynasty. 2008.

Aleksandr Nevsky (1220-1263). Russian hero. He gained his surname after defeating the Swedes on the River Neva (1240). In 1242 he overcame the Teutonic knights on the frozen Lake Peipus (on the Estonian border). Aleksandr, who ruled as grand prince in Novgorod 1236-52 and from 1252 in Vladimir, was canonised after his death. A knightly order named after him was founded by *Peter the Great and was revived by Soviet Russia in 1942 for deeds of valour.

Aleksandra Fyodorovna (1872-1918). Russian Tsarina 1894-1917. Born a princess of HesseDarmstadt, and a granddaughter of Queen *Victoria, she married *Nikolai II of Russia (1894). Belief in the power of *Rasputin to cure the young tsarevich Aleksei (1904-1918) of haemophilia brought her under his disastrous domination and led her to exert nefarious political influence. After the 1917 revolution she was murdered with her husband and children at Yekaterinberg.

Massie, R. K., Nicholas and Alexandra. 1969.

Aleksei Mikhailovich (1629-1676). Tsar of Russia 1645-76. Son of Mikhail Romanov, known as the 'quiet one', he gave Russia a new code of laws in 1649, favouring the landowners and confirming serfdom, which remained in force until the early 19 th century. He approved the Church reforms of Metropolitan Nikon which led to the dangerous schism in the Orthodox Church. He fought wars against Poland (1654-67) and Sweden (1656-61), and won Ukraine for Russia. A serious revolt by Cossacks under Stenka Razin was quelled in 1671.

Alemán (y Enero), Mateo (1547-c.1616). Spanish novelist, born in Seville. He was famous for his Guzmán de Alfarache (translated into English in 1622 as The Rogue), a vigorous story, with moralising digressions, of a boy who ran away from home and became involved with much sordid crime and vice before eventually being condemned to the galleys. Alemán, though a university graduate and for a short time in government service, spent much of his life in poverty, was twice in prison and in 1608 went to Mexico and died there.

Alembert, Jean Le Rond d' (1717-1783). French philosopher and mathematician, born in Paris. Illegitimate son of the Chevalier Destouches, he was abandoned on the steps of the Church St JeanLe-Rond, hence his name, and was later generously provided for by his father and brought up by a grazier's wife. Educated by Jansenists, he studied law, medicine, then mathematics. He expounded a positivist philosophy but it was in mathematics that his genius lay. He wrote a notable study of dynamics and threw light on the precession of the equinoxes. From 1746 to 1758 he worked with Denis *Diderot as an editor of the great Encyclopédie, then continued to write entries on science and mathematics. He became a friend of ${ }^{*}$ Voltaire, gained a great reputation for wit and wisdom in the Paris salons, but refused important offers from *Friedrich II ('the Great') of Prussia and Empress *Catherine of Russia. He was admitted to the Académie française in 1754.

Grimsey, R., Jean d'Alembert. 1963. 
Alexander (Aleksandar) (1876-1903). King of Serbia 1889-1903. A member of the *Obrenovíc dynasty, he became king after the abdication of his father King Milan. An unpopular marriage to Draga Mashin, a lady of the court, and his own pro-Austrian policy provoked a revolution during which he and his wife were murdered by a group of army officers. *Peter I of the rival Karageorgevic dynasty then took the throne.

Alexander (Aléxandros) (1893-1920). King of Greece 1917-20. He was chosen by the Allies to replace his father ${ }^{*}$ Constantine, who had been forced to abdicate because of his pro-German attitude in World War I, ruling as a puppet under the Prime Minister, *Venizelos. He married morganatically, and died of blood poisoning after a bite from a monkey in the palace grounds. Following a referendum, his father was restored to the throne.

\section{Alexander I, II, III Tsars of Russia see Aleksandr I, II, III}

Alexander I (1077-1124). King of Scots 1107-24. Son of ${ }^{*}$ Malcolm III (Canmore), he succeeded his brother Edgar. He ruled only north of the Forth. Clyde, his brother, and successor *David I governed the country to the south.

Alexander I (Aleksandar Karađorđević) (18881934). King of the Serbs, Croats and Slovenes 192129 and of Yugoslavia 1929-34. Born in Montenegro, educated in Switzerland and Russia, his father became King *Peter I of Serbia after a coup (1903). As regent for his father, he commanded Serbian forces through World War I and, after the Allied victory, the Slav lands in Austria-Hungary were joined with Serbia in a single state, which in 1929 was renamed 'Yugoslavia'. Violent conflicts between Serbs and Croats, the rise of Ustasha (fomented by *Mussolini), and a killing in Parliament led to Alexander suspending the Constitution (January 1929) and imposing a personal dictatorship. He was assassinated in Marseilles by a Romanian terrorist working for Ustasha, the French Foreign Minister Jean-Louis *Barthou becoming collatoral damage.

Alexander II (1198-1249). King of Scots 1214-49. He succeeded his father *William the Lion and was almost immediately excommunicated for helping the barons against the English king *John. Two years later the sentence was lifted and the liberties of the Scottish Church confirmed, while peace with England was secured by his marriage to a sister of *Henry III. Alexander extended his rule over much of the western Highlands but died while seeking to win the Hebrides from Norway.

Alexander (Aléxandros) III ('the Great') (356-323 BCE). King of Macedonia 337-323 BCE. Born in Pella, son of *Philip II, he was educated by *Aristotle, who had great influence over his mind and character. $\mathrm{He}$ first distinguished himself at the battle of
Chaeronea (338) against the Thebans, while his father was still king. He was only 19 when his father was murdered and he succeeded to the throne. He had still to put down rebellions in his own kingdom, and secure his rear in Greece before he could cross the Hellespont (334) to begin the war against Persia for which his father had long prepared by creating a magnificent army based on the supremacy of the Macedonian line of battle known as the phalanx. Alexander won his first victory on the River Granicus, and in 333 marched through Phrygia to Issus, where he defeated King *Darius III and captured his family and treasures. He now conquered Syria and Phoenicia and, rejecting offers of peace, reached Egypt (332) where the inhabitants, tired of the harsh Persian rule, welcomed him; in the following year he founded Alexandria, also visiting Luxor and Siwa. He returned to the east and fought Darius once more (331) near Arbela on the upper Tigris and inflicted on him an even heavier defeat than at Issus; from Arbela he marched to Babylon, Susa and Persepolis, all of which surrendered. Pursuit of Darius, whom he was too late to save from a rebellious satrap but whom he buried with full honours, took him northeastwards to the furthest corners of the empire in Sogdiana (Bukhara and Samarkand). It was on this campaign that he captured and married the beautiful Princess Roxana. In 327, starting from Balkh in Bactria, Alexander began his conquest of India. He crossed the Indus near Attock, and defeated Porus near the Hydaspes (it was here that he lost his famous charger, Bucephalus), and then went on through the Punjab. His troops, greatly depleted, would go no further. $\mathrm{He}$ returned to the ocean and having ordered one division to embark and sail to the Persian Gulf, he with the others marched back through Baluchistan and finally reached Persia in 325. At Susa he took a second wife, Barsine, daughter of Darius, and then remained in Babylon, ruling in great pomp until his death, from unknown causes - fever, complicated by alcohol and/or poison. His remains were entombed in Alexandria. *Augustus visited the tomb 300 years later, but it later disappeared. His posthumous son by Roxana, Alexander IV (323-310 BCE), ruled in name only and was murdered. Hailed as divine by many of his followers, he had already shown signs of megalomania. His judgment suffered and excesses had lost him the friendship of Clitus, whom he killed in a drunken brawl. But his achievement remains tremendous. With an army which probably never exceeded 35,000 fighting men he came to rule an empire stretching from Italy to India, although it was soon divided among his generals *Antigonus, *Ptolemy and ${ }^{*}$ Seleucus. Through them the civilising influence of late Greek culture, known as Hellenism, spread and left enduring effects.

Green, P., Alexander the Great. 1970, Alexander of Macedon. 1974; Everitt, A., Alexander the Great. 2019. 
Alexander (Alessandro) III (Orlando Bandinelli) (c.1100-1181). Pope 1159-81. Born in Siena and educated in Bologna, he became a canon lawyer, chief advisor of *Adrian IV, a cardinal in 1150 , but not a bishop. After his contested election as Pope, the Emperor *Friedrich I (Barbarossa) challenged his authority and recognised three successive 'antipopes', beginning with Victor IV. He was three times forced out of Rome and exiled for much of his pontificate. Equivocal in his support for ${ }^{*}$ Becket, after his murder he made him a saint and forced *Henry II to do public penance. Alexander canonised *Edward the Confessor, probably laid the foundation stone for Notre Dame, Paris, recognised an independent Portugal, and supported the growth of universities. Friedrich's forces were defeated at Legnano in 1176 by the Lombard League and in the Peace of Venice (1177) he accepted papal authority. At the Third Lateran Council (1179) Alexander established the rule for papal election by cardinals, which (with minor modifications) is still used. Even *Voltaire regarded him as one of the better popes.

Duggan, A. J. and Clarke, P. D., Pope Alexander III: The Art of Survival. 2012.

Alexander III (1241-1286). King of Scots 124986 . He succeeded his father *Alexander II at the age of 8 . He resumed his father's conflict with the Norwegians and by a decisive victory at Largs (1263) the Scots acquired the Hebrides and the Isle of Man. Alexander's children all died before him and his heiress was Margaret (Maid of Norway), whose mother, Alexander's daughter, had married Eric II of Norway.

Alexander VI (Rodrigo de Lanzol y Borja. Borgia in Italian) (1431-1503). Pope 1492-1503. Born in Játiva, near Valencia, he adopted the name of his maternal uncle Alonso de Borja, later Pope ${ }^{*}$ Callistus III. Created cardinal by his uncle in 1456 he became Vice Chancellor of the Curia and gained some reputation as an efficient financial administrator. But he was far more notorious for his profligacy, for his many mistresses, and for the complete lack of scruple with which he advanced the careers and fortunes of his numerous children, of whom the best known are Cesare and Lucrezia *Borgia. (Their mother was Vannozza Catanei.) The Florentine reformer *Savonarola, who denounced such evils, was excommunicated and executed (1498). Politically, Alexander made it his principal purpose to build up a strong, unified papal state in central Italy, making use of Cesare's military skill and not hesitating to invite help from ${ }^{*}$ Charles VIII and ${ }^{*}$ Louis XII of France. In 1493 he proposed dividing between Spain and Portugal those parts of the world not already under Christian rule. This principle was adopted in the Treaty of Tordesillas (June 1494) and confirmed by Pope *Julius II in 1506. (In modern maps, the 'Pope's line' is found between 48 and 49 degrees W of Greenwich, or 131 or 132 degrees E.) Alexander's patronage of the arts, especially by inviting *Bramante to the Vatican and commissioning Pintoricchio to decorate the Borgia apartments there, has at least proved of benefit to mankind. He died probably of a fever but, according to tradition, of poison intended for his guests at dinner. One of the most infamous figures in papal history, he reached the highest office through nepotism and bribery.

Alexander, Samuel (1859-1938). British-AustralianJewish philosopher, born in Sydney. Educated in Melbourne, he won a scholarship to Balliol College, Oxford, in 1877. Elected (1882) as a Fellow of Lincoln College, Oxford, he was the first practising Jew to hold a fellowship at Oxford or Cambridge. $\mathrm{He}$ was professor of philosophy at Manchester 1893-1924. His theory of 'emergent evolution' was that everything evolved, first things and then minds, from a beginning of pure motion or space-time. God, he held, is being evolved but does not actually exist. His Space, Time and Deity (1920) argues that there are three hierarchies of reality-matter, life, and mind - each striving towards perfection or deity. Alexander was the first Australian-born recipient of the OM (1930).

\section{Alexander of Tunis, Harold Rupert Leofric George} Alexander, 1st Earl (1891-1969). Anglo-Irish field marshal, born in London. Third son of the 4th Earl of Caledon, he was educated at Harrow and Sandhurst, joined the Irish Guards, served with distinction (MC and DSO) in World War I and (1934-38) on the Indian frontier. He commanded the 1st Division in France in World War II and was left in command on the beaches after Lord ${ }^{*}$ Gort had been recalled. When Japan entered the war Alexander was sent to Burma and conducted the retreat with such skill that when ${ }^{*}$ Rommel's victories (1942) threatened Egypt he was chosen for the supreme command in the Middle East and was thus General in Charge of *Montgomery's brilliant campaign which started at Alamein. Later he was *Eisenhower's deputy (and successor) in the campaign that cleared North Africa, Sicily and eventually Italy of the enemy. One of the most successful generals in World War II, he served as Governor-General of Canada 1946-52 and Minister of Defence in *Churchill's Government 1952-54. He was created Viscount in 1946, promoted to an earldom when he left Canada and given the OM in 1959.

Jackson. W. G. F., Alexander of Tunis. 1971, Nicolson, N., Alex: The Life of Field Marshal Earl Alexander of Tunis. 1973.

Alexander Severus (originally Marcus Julius Gessius Bassianus Alexianus) (208-235). Roman Emperor 222-35. Born in Syria (now in Lebanon), son of a magistrate and his Syrian wife, he succeeded on the murder of his cousin *Elagabalus. Weak, amiable and popular, he lacked the forcefulness necessary for imperial rule. A campaign against the Persians 
(231-33) had failed to achieve decisive results when he was forced to return to the west by German attacks. Here his caution and indecisiveness provoked an army mutiny and his murder.

Alexandra (Caroline Marie Charlotte Louise Julie) (1844-1925). British queen consort 1901-10. Daughter of ${ }^{*}$ Christian IX of Denmark, she went to England to marry the future king *Edward VII in 1863. Striking for her beauty (although lame and deaf in later years), she was very popular. ${ }^{*}$ George $\mathrm{V}$ was her second son.

Battiscombe, G., Queen Alexandra. 1972.

Alfieri, Vittorio, Conte (1749-1803). Italian dramatist. He inherited a fortune and his early life was occupied with travel and love affairs until the success of his first play, Cleopatra (1775), encouraged him to undertake a period of study. In Florence he fell in love with the Countess of Albany, wife of *Charles Edward Stuart (Bonnie Prince Charlie), and lived with her after the prince's death (1788) for the rest of his life. He wrote over 20 plays by which he hoped to arouse Italy's nationalist spirit and a hatred of tyranny.

Alfonsín, Raúl Ricardo (1926-2009). Argentinian politician. A lawyer, he served as councillor and congressman, opposed both Peronism and military rule and became leader of the Radical Civil Union in 1982. Elected President of Argentina (in the first free election for a decade) in 1983, he began to curb the military, normalised foreign relations, reformed trade unions and restored civil liberties. By the end of his term in 1989, the economy had deteriorated and Carlos *Menem was elected President.

Alfonso (or Alphonso). Name of two kings of Spain and of many kings of the constituent kingdoms of Aragon, León and Castile. For the kings of Portugal the form Afonso is used.

Alfonso X (known as 'the Wise') (1221-1284). King of Castile and León 1252-84. He engaged Arab and Jewish astronomers to prepare the 'Alfonsine Tables' of planetary movements and he codified the law by his fueroreal (c.1254). A notable poet himself, he made his court a great cultural centre, and by sponsoring works of learning (among them a general history and a history of Spain) written in Castilian (rather than Latin) he ensured that it became the literary language of Spain. Both his day-to-day administration and his foreign policy, however, suffered from a diffusion of energy. He had some success in bringing much of Moorish Spain under Castilian rule but had not the strength to pursue claims in Gascony, Portugal and Navarre to a successful conclusion. A vain attempt to obtain the imperial throne was most wasteful in money and energy as well as unwise. The raising of money for all these ventures absorbed much of the economic strength created by other reforms.

Proctor, E. S., Alfonso X of Castile. 1951.
Alfonso XII (Alfonso Francisco de Asís Fernando Pío Juan María de la Concepción Gregorio Pelayo de Borbón y Borbón) (1857-1885). King of Spain 1874-85. Son of Queen *Isabel II and possibly her husband, he studied in France and Vienna and married the Austrian archduchess Maria. Known as 'the peacemaker', his reign marked an end to the long period of civil war. He was the last Spanish king to die while still ruling.

Alfonso XIII (Alfonso León Fernando María Jaime Isidro Pascual Antonio de Borbón y HabsburgoLorena) (1886-1941). King of Spain 1886-1930. As a posthumous child of *Alfonso XII, he may be said to have been king before he was born. From the time that he took over the reins of government in 1902 his rule was threatened by revolutionary movements. In 1906 Alfonso married Victoria Eugénie, niece of King *Edward VII. The fall of *Primo de Rivera's dictatorship in 1930, with which the king was inextricably linked, led to his immediate abdication and exile. He died in Rome.

Alfred (Ælfræd) the Great (849-900). King of Wessex 871-900. Born at Wantage, son of King Æthelwulf, he twice visited Rome before succeeding his brother *Æthelred I. His reign began disastrously with invasions of armies from the Midlands which Alfred was forced to cut off. This won him only brief respite and early in 878 he was driven back into the Somerset marshes. (It is to this period that the legend of his letting the cakes burn belongs.) However, he won a decisive battle (almost certainly at Eddington in Wiltshire) in May of that year and was able to impose the treaty of Wedmore by which Guthrum, the Danish king, accepted baptism and a division of the country between himself and the Wessex king. He acknowledged Alfred's supremacy in East Anglia, much of Mercia and all England south of the Thames. London, too, was gained in 886. Having made his kingdom secure, partly by a network of forts (burhs), partly by building war vessels, Alfred turned to the tasks of peace. New codes of law and a fair, efficient administration restored stability after the wars, but his great love was education. He drew scholars to his court from other parts of England and from the Continent but, even more importantly, initiated a program of education far ahead of its time. To ensure the spread of the vernacular as a literary language he set his scholars to translating many religious, philosophical and historical works from Latin. He translated *Boethius, *Augustine and ${ }^{*}$ Gregory I and excelled as warrior, administrator and educator. Buried in Winchester, his remains have been lost.

Alger, Horatio (1834-1899). American author. His first story was Ragged Dick (1867). He wrote over 100 boys' books, all on the theme that, by hard work and honesty, adversities can be overcome and honour and riches won. His books had an astonishing popularity and influenced a generation of American youth. 
Algorithmi see Al-Khwārizmī, Muḥammad ibn Mūsā

Alhazen (abu-Ali al-Hasan ibn al-Haytham) (c.965-c.1038). Arab scientist, born in Basra. He spent most of his life in Egypt. His work on optics was remarkably percipient, including discussions of the propagation, reflection and refraction of light and the phenomenon of colour. This treatise was translated into Latin in the 13th century and published (1572) as Opticae Thesaurus Alhazeni. Alhazen opposed the theory of ${ }^{*}$ Euclid that the eye sends out visual rays and was the first to suggest that rays of light pass from an object to the eye.

Ali (Alī ibn Abī Tālib) (c.600-661). Fourth caliph of Islam 656-61. Born in Mecca, son of *Muhammad's uncle Abu Tālib, he grew up in the prophet's household, and married his daughter *Fatimah. According to Shi'ite tradition, he was the principal scribe to whom Muhammad dictated the Qu'ran. On Muhammad's death he contested the succession with *Abu-Bakr, father of the prophet's favourite widow A'ishah, who became the first caliph. However, on the death of ${ }^{*}$ Uthman, Ali was recognised as the fourth caliph. Murdered and buried in Kufa (modern Iraq), his son Hasan ibn Ali (625-670) succeeded briefly, but resigned and died in Medina, possibly by poison. The caliphate was taken by ${ }^{*}$ Mu'āwiyah, first of the *Umayyad dynasty. Supporters of Ali's descendants became known as Shi'ites, rivals of the Sunnis: comprising 90 per cent in Iran, 60 per cent in Iraq, a majority in Azerbaijan and Bahrain, but a minority elsewhere. In the Shi'ite tradition, pilgrimages are made to the tombs of Ali and his 11 successors as Imam, all descendants of Muhammad.

Ali, Muhammad (Cassius Marcellus Clay, Jr) (1942-2016). American heavyweight boxer, born in Louisville, Kentucky. After winning the light heavyweight gold medal at the Rome Olympics (1960) he turned professional, and in 1964 took the world heavyweight title from Sonny Liston. Following success he changed his name to Muhammad Ali and became a Black Muslim. In 1967 he refused to join the US army pleading conscientious objection and was convicted and deprived of his title. This decision was reversed on appeal (1971) and in 1974 he regained his pre-eminence, taking the title for the second time, on this occasion from George Foreman. Finally, having lost his title to Leon Spinks (February 1978) he made history when he became world heavyweight champion for the third time in September 1978, until his defeat in 1980 . He was identified with radical politics, but surprisingly endorsed *Reagan in 1984. Diagnosed with Parkinson's disease in 1984, he campaigned to raise levels of public awareness about it and received the Presidential Medal of Freedom (2005).

Remnick, D., King of the World: Muhammad Ali and the Rise of an American Hero. 1998.
Ali Pasha (known as 'the Lion') (1741-1822). Albanian ruler. Although nominally in the service of Turkey he came to exert despotic rule over most of Albania and Epirus and by 1820 was clearly intending to create an independent state. The sultan then ordered that he should be deposed and executed. His court at Yanina was visited by ${ }^{*}$ Byron, who described it in Childe Harold.

Alinsky, Saul (1909-1972). American social activist, born in Chicago. A brilliant tactician, he organised many successful campaigns on social issues, such as poverty and minority rights.

Alkan, Charles Henri Valentin (originally Morhange) (1813-1888). French pianist and composer. A friend of ${ }^{*}$ Chopin, he was an eccentric recluse who wrote extraordinarily demanding works for piano which, despite the admiration of ${ }^{*}$ Liszt and ${ }^{*}$ Busoni, were virtually ignored until the 20th century.

Al-Khwārīzmī (Abū Abdallāh) Muhammad ibn Mūsā (c.780-c.850). Persian mathematician, astronomer and geographer, born in Uzbekistan or Azerbaijan. Influenced by Greek, Babylonian and Indian mathematicians, including *Brahmagupta, he worked at 'The House of Wisdom' in Baghdad. He wrote On the Calculation with Hindu Numerals (c.825), which promoted use of Indian digits (1, 2, 3 , etc.) and the zero (0), adopted in Europe from the 12 th century $\mathrm{CE}$. The word 'algorithm' is derived from the Latin version (Algoritmi) of his name. He seems to have coined the word 'algebra' (from 'al-jabr', or 'completion') in his Compendious Book on Calculation by Completion and Balancing (c.830), published in Latin in 1145 . He edited and corrected the work of *Ptolemy in The Image of the Earth (c.833).

Allais, Maurice (1911-2010). French economist and engineer, born in Paris. He worked as an engineer in the Mines Department and the railways, taught at the University of Paris and directed research at CNRS. $\mathrm{He}$ was awarded the Nobel Prize for Economics in 1988 for his work on capital formation, resource allocation, operation of monopolies and factors influencing consumer choice.

Allbutt, Sir Thomas Clifford (1836-1925). English physician and medical historian, born at Dewsbury. He was educated at Cambridge and $\mathrm{St}$ George's Hospital, London. While a consultant in Leeds (1861-89) he introduced (1867) the clinical thermometer. He became Regius professor of medicine at Cambridge 1892-1925. His work on the use of the ophthalmoscope for nerve diseases and his Diseases of the Arteries (1915) are of lasting importance. He was knighted in 1907 and made a PC.

Allen, Ethan (1738-1789). American revolutionary patriot. A flamboyant personality, he raised a private army, 'The Green Mountain Boys', and captured Ticonderoga from the British. He was later taken 
prisoner on a rash expedition against Montréal. Vermont at this stage declared its independence. Allen engaged in devious negotiations with the British regarding its status, which was still unsettled when he died in 1789.

Allen, William (1532-1594). English Roman Catholic prelate. Principal of St Mary's Hall, Oxford, 1556-60, in 1568 he founded an English seminary at Douai, moved it to Reims in 1578 , remaining director until 1585. The Douai-Reims English translation of the Bible was prepared by Gregory Martin under Allen's supervision. He called on *Phillip II of Spain to assume the English throne and supported the Armada. Created cardinal in 1587, he died in Rome.

Allen, Woody (Allen Stewart Konigsberg) (1935- ). American writer, actor and director, born in Brooklyn. At high school he began writing jokes and scripts for television. He directed and wrote the films Bananas (1971), Everything You Always Wanted to Know About Sex But Were Afraid To Ask (1972), Sleeper (1973), Love and Death (1975), Annie Hall (Academy Award for Best Film, 1977), Interiors (1978), Manhattann (1980), Zelig (1983), Broadway Danny Rose (1984), The Purple Rose of Cairo (1985), Hannah and Her Sisters (1985), Radio Days (1986), Alice (1990), Husbands and Wives (1992), Manhattan Murder Mystery (1993), Scoop (2006), Vicky Cristina Barcelona (2007), Midnight in Paris (2011), To Rome with Love (2012) and Blue Jasmine (2013). In 1993 his former partner Mia Farrow raised allegations of child molestation against him, but criminal charges were not proceeded with.

Allenby, Edmund Henry Hynman Allenby, 1st Viscount (1861-1936). British field marshal. He commanded the 3rd Army in France 1915-17 and was then given command of the expeditionary force based on Egypt to fight the Turks. In the last great cavalry campaign in modern warfare he captured Jerusalem (December 1917) and Damascus (October 1918), freeing Palestine and Syria from Ottoman rule. A student of the Greek classics, he was notably sparing of lives in battle and worked closely with T. E. *Lawrence. Created a viscount (1919), he served as British High Commissioner in Egypt 1919-25, negotiating the transition to limited self-government (*Zaghlul).

Allende (Gossens), Salvador (1908-1973). Chilean socialist politician and physician. President of Chile 1970-73, he was the first Marxist elected in a free election in the western hemisphere, but lacked majority support in the electorate and in the Congress. On taking office he attempted to restructure Chile on socialist lines. Following considerable unrest mostly fomented from outside, the military demanded his resignation. In 1973 an attack was made on the presidential palace and his private residence and he was killed by machine-gun fire. The military dictatorship of General *Pinochet succeeded. His niece Isabel Allende (1942- ) was a successful novelist.

Alleyn, Edward (1566-1626). English actor and entrepreneur. He and Richard *Burbage were considered to be the finest actors in the ElizabethanJacobean theatre. He performed with The Admiral's Men, created the roles of Tamburlaine, Faustus and Barabbas in plays by *Marlowe, and *Shakespeare's Henry VI, and was actively involved in lion and bear-baiting, and theatre management. He married twice and his fathers-in-law were Philip ${ }^{*}$ Henslowe and John *Donne. He was the founder of Dulwich College (1619) and died rich.

Almagro, Diego de (1464 or 1475-1538). Spanish conquistador in South America. He served with *Pizarro in Peru and obtained a large share of the plunder. In 1535 he organised the expedition that invaded Chile but was disappointed by failure to find any precious metals. Back in Peru he attempted to seize the country, but was defeated, captured and strangled by Pizarro. He was avenged by the second Diego (his son born of an Indian mother), whose followers stormed Pizarro's palace and murdered him.

Alma-Tadema, Sir Lawrence (Lourens Tadema) (1836-1912). Anglo-Dutch painter, born in Dronrijp (Frisia). He lived in England from 1869, became the last person classified as a 'denizen' 1873, and was elected RA in 1879. His pictures interpret classical subject matter in a highly finished academic manner evocative of the Victorian epoch. He received the OM in 1905 but his reputation declined posthumously. Interest in his work revived in the 1970s. The Finding of Moses (1904) sold for $£ 252$ in 1960 , and was auctioned in New York for \$35.9 million in 2010.

Almeida Garrett, Joáo Baptista da Silva Leitào de (1799-1854). Portuguese novelist, poet and politician, born in Porto. He became famous with Camóes (1825), a long poetic tribute to Luis de ${ }^{*}$ Camoes as a prototype Romantic. A strong liberal, he was an exile in England 1823-25; 1828-32. He returned with the army supporting King *Pedro in 1832 and, having been ennobled, served as Minister of Foreign Affairs 1852.

Almodóvar Caballero, Pedro (1949- ). Spanish film director. Since making his first commercial film in the 1980s, he has written, directed, acted in and/or produced nearly 30 films. His films are characterised by elements of melodrama and high camp and he won Academy Awards for All about my Mother (1999) and Talk to Her (2002).

\section{Al-Razi see Razi, Al-}

Altdorfer, Albrecht (c.1480-1538). German painter, architect and engraver, born at Regensburg. Leader of the 'Danube school', a meticulous draughtsman and engraver, he was the first great landscape painter, in 
the sense that in his later works the landscape ceases to be merely a background to human figures and is granted an importance never before given to it. Major works include the St Florian Altar (Linz) and Alexander's Victory (Munich).

Altgeld, John Peter (1847-1902). American Democratic politician, born in Germany. He migrated, as a child, to Ohio with his very poor immigrant family. He became a lawyer and served as Governor of Illinois 1893-97. A champion of the poor and trade unionism he pardoned the anarchists who had been, on scanty evidence, convicted of taking part in the Chicago Haymarket riots (1886). He also opposed the use of federal troops in the Pullman strike (1894).

Althusser, Louis (1918-1990). French philosopher, born in Algiers. A leading theoretician of the French Communist Party, he argued that utopian and humanist elements in Marx should be disregarded and that the main stream of his teaching was a revolutionary science of history (i.e. class struggle), expressed through changes in production rather than by political operations per se (e.g. Leninism or Maoism). In 1980 Althusser murdered his wife and was certified insane.

Altman, Robert Bernard (1925-2006). American film director. Trained as an engineer, he was a pilot, documentary and feature producer and writer for television, then secured critical success with some major films, e.g. $M^{*} A^{*} S^{*} H$ (1970), Nashville (1975), A Wedding (1978), Health (1979), Popeye (1982), Fool for Love (1985), The Player (1991) and Pret-a-Porter (1994).

Alvarado, Pedro de (1485-1541). Spanish conquistador in Mexico. Left in command during the absence of *Cortés, by treacherously attacking the Mexicans he provoked an uprising which forced the Spaniards to retire from the city with disastrous losses. He became (1527) the first governor of Guatemala, and was killed fighting in Mexico.

Alvarez, Luis Walter (1911-1988). American physicist, born in San Francisco. Professor of physics at the University of California at Berkeley, he worked on the atomic bomb and won the 1968 Nobel Prize for Physics for his work in detecting short-lived 'resonance particles'. In 1979 with his son Walter Alvarez (1940- ) he proposed a theory (now generally accepted) that 'the Cretaceous-Teriary extinction' of dinosaurs and other species about 65,000,000 years ago was caused by the impact of a comet or asteroid.

Alvarez Quintero, Serafin (1871-1938) and Joaquin (1873-1944). Spanish dramatists. For 40 years they achieved success after success with light comedies mostly concerned with Andalusian life. Some, e.g. Pueblo de las mujeres (The Women have their Way) and El centenario (A Hundred Years Old), were translated into English by Harley and Helen Granville-Barker.
Alzheimer, Alois (1864-1915). German neurologist. In 1906 he described the symptoms of a form of cerebral atrophy, affecting all aspects of brain function, the most common cause of senile dementia, now called Alzheimer's disease (AD). It is irreversible, shortens life expectancy and, in 2020, sufferers were estimated to number 50 million.

Amadeo (1845-1890). King of Spain 1870-73. Second son of King *Vittorio Emanuele I of Italy, he accepted election as king by the Spanish Cortes after the 1868 revolution had forced Queen *Isabella II into exile. A liberal constitution had been drawn up but after further revolts he abdicated.

Amado, Jorge (1912-2001). Brazilian novelist. Son of a plantation owner, he studied law, became a reporter, identified himself with the Left and lived abroad for many years. His novels include Gabriela, Clove and Cinnamon (1958) and Dona Fler and her two Husbands (1966).

Amalrik, Andrei Alekseivich (1938-1980). Russian historian and playwright. He was expelled from Moscow University in 1963 for political reasons and in 1965 was sentenced to 21 years' exile for 'parasitism'. His experiences there formed the subject of his book Involuntary Journey to Siberia (1970). $\mathrm{He}$ also wrote Will the Soviet Union Survive until 1984? (1970). Expelled from the USSR in 1976, he was killed in a car accident.

Amanullah(Khan) (1892-1960). King of Afghanistan 1919-29. Immediately on his succession after the assassination of his father, Habibullah, Amanullah provoked a war with British India and sustained defeat. From later negotiations, however, Afghanistan emerged as a sovereign state with Amanullah as king. He lost his throne because he tried to modernise his backward state too quickly, his attempt to emancipate women being one of the most decisive causes of the revolution which overthrew him. He lived in exile after his dethronement and died in Zürich.

Amati. Italian family of violin-makers in Cremona. The most outstanding was Nicolo Amati (15961684), master of ${ }^{*}$ Stradivari and ${ }^{*}$ Guarneri. Others were Andrea Amati (c.1511-c.1580) and his sons Antonio (c.1540- 1638) and Girolamo, Nicolo's father (1561-1635). Another Girolamo (16491740) was Nicolo's son.

Ambrose, St (Ambrosius in Latin, Ambrogio in Italian) (c.339-397). Italian prelate and administrator, born in Trier. Trained as a lawyer, he was Governor of Liguria and Aemilia. When the Bishop of Milan died (371), rival factions being unable to agree on a successor, Ambrose was elected although not yet baptised. As bishop he proved to be a brilliant administrator and a courageous opponent of Arianism which the Emperor *'Theodosius supported. 
He probably wrote the Athanasian Creed. He insisted that the Church alone was guardian of moral and religious truth and even excommunicated Theodosius for his massacre of the Thessalonians. He had an important influence on *Augustine and helped to convert him. Augustine noted that he was a silent reader, a rare phenomenon at the time. He wrote many hymns and introduced the 'Ambrosian chant' and much ritual into church services. The aphorism 'When in Rome, do as the Romans do' is attributed to him. Ambrose, with Augustine, *Gregory and *Jerome, is regarded as one of the Four Doctors of the Latin Church. The Ambrosian library at Milan is named after him.

Amenhotep. Four Egyptian pharaohs of the XVIIIth dynasty, Amenhotep III built the avenue of ramheaded sphinxes at Thebes (Karnak). For Amenhotep IV see*Akhenaten.

\section{Amerigo Vespucci see Vespucci, Amerigo}

Amery, Leo(pold) Charles Maurice Stennett (18731955). English Conservative politician, born in India. Educated at Harrow and Balliol College, Oxford, he became a journalist on The Times, worked in *Milner's 'Kindergarten' in South Africa and wrote a history of the Boer War. A Conservative MP 1911-45, ardent imperialist and advocate of Imperial Preference, he served as Secretary 1924-29 and Secretary of State for India and Burma 1940-45. His son John Amery (1912-1945) became a fascist, went to Germany in 1942, proposing a British Free Corps and made propaganda broadcasts for the Nazis. He pleaded guilty to treason and was hanged.

Amherst, Jeffrey Amherst, 1st Baron (1717-1797). British field marshal. He was chosen (1758) by *Pitt to command the force sent against the French in Canada. The spectacular capture of Québec by *Wolfe has somewhat obscured Amherst's achievement in securing all Canada for Britain in the space of two years. His nephew and successor William Pitt Amherst, 1st Earl Amherst (1773-1857), a diplomat, gained notoriety by his refusal to 'kowtow' to the emperor Jiaqing while on an embassy to China (1816). He became Governor-General of Bengal 1823-28, won success in the first Burma War and was promoted to an earldom (1826).

Amin Dada, Idi (1925-2003). Ugandan soldier and politician. He joined the British army in 1946, served in Kenya against the Mau Mau, and became commander of the Ugandan army in 1964. In 1971 the army overthrew President Milton Obote and Idi Amin became President. An economic nationalist, he expelled Uganda's Asian minority, violently suppressed his opponents and identified himself with the Arab cause. In 1979 he fled the country following the invasion of Uganda by Ugandan exiles backed by Tanzania.
Amis, Sir Kingsley William (1922-1995). English novelist, born in London. After army service he graduated from Oxford, lectured in Wales and the US and was a Fellow of Peterhouse, Cambridge 1961-63. His first novel, Lucky Jim (1954), established his reputation as a comic-ironic observer of contemporary provincial life. He was also a poet and a staunch advocate of science fiction. Later novels include That Uncertain Feeling (1955), I Like It Here (1958), Jake's Thing (1978), Stanley and the Women (1984) and The Old Devils (1986, winner of the Booker Prize). He also edited The New Oxford Book of Light Verse (1978). His second wife was the novelist Elizabeth Jane Howard. After their divorce Amis boarded with her and her husband. With age he became notoriously reactionary and choleric. His son, Martin Amis (1949- ) was a novelist and essayist. His novels include Money (1984), Yellow Dog (2003), The Pregnant Widow (2010) and Lionel Asbo: State of England (2012).

Amos (fl. 780 BCE). Israelite prophet. Originally a shepherd or sheep-farmer, his denunciations of the Israelites for immorality and greed and oppression of the poor contain the implication that Jahweh (Jehovah) was not the God of Israel alone but of the whole world. The last part of the book of Amos, with its optimistic promises, is probably by another hand.

Ampère, André Marie (1775-1836). French mathematical physicist. A prodigy, largely tutored at home, he suffered profound depression after his father was guillotined in Lyon as a counter-revolutionary (1793). He later received *Napoléon's patronage and was a professor of physics at Bourg 1801-04, Lyon 1804-09, the Paris Polytechnique 1809-24 and the Collège de France 1824-36. Following *Oersted's discovery (1820) of the relationship between electricity and magnetism he became the virtual founder of electrodynamics, invented the solenoid and proposed Ampère's law. His work was taken even further by ${ }^{*}$ Faraday. In $1883{ }^{*}$ Kelvin named the unit of electric current (ampere, amp, A) for him.

Amundsen, Roald (1872-1928). Norwegian polar explorer. The first to reach the South Pole, he commanded (1903-06) the Gjoa, which was the first ship to navigate the Northwest Passage. In 1910 , in rivalry with the British expedition, which he informed of his intention, he set out for the Antarctic and in December 1911 he reached the Pole-one month before Captain *Scott. In 1926 he flew over the North Pole in a dirigible with the Italian explorer *Nobile. He lost his life in an air search for Nobile, two years later.

Partridge, B., Amundsen. 1953; Huntford, R., Scott and Amundsen. 1979.

Anacreon (d.c.485 BCE). Greek lyric poet. His work reflects the voluptuous refinement of Ionian life. Few poems survive and he is best remembered by 
the Anacreontic metre to which his name is attached and in which many imitations of his style, known as Anacreontea, were written from the 2 nd century CE.

Anastasia (1901-1918). Russian grand duchess. Daughter of Tsar ${ }^{*}$ Nikolai II, it was assumed that she had been murdered with the rest of the Russian royal family at Ekaterinburg until in 1929 a German citizen named Anna Anderson (d 1983) claimed to be Anastasia. Her claim provoked long-lasting controversy until DNA testing indicated that she was probably a Pole, Franziska Schanzkowska. However, the remains of the royal family found in 1993 are incomplete-either Anastasia or Maria is missing.

Anaxagoras (c.500-428 BCE). Greek philosopher, born in Clazamenae, Asia Minor (now Turkey). He lived in Athens and originated the idea that all things are composed of small particles, 'seeds' or atoms, the rearrangement of which was the cause of change, and he discovered the true cause of eclipses. He also believed that the world was flat and that the sun was a hot and glowing stone. He was prosecuted for the latter affront to the belief in the divinity of the heavenly bodies. The universe of 'seeds', he claimed, was organised into its apparent form by an all pervading mind, nous. He taught ${ }^{*}$ Pericles, *Euripides and other illustrious Greeks.

Anaximander (610-540? BCE). Greek philosopher, born in Melitus, Asia Minor (now Turkey). Known for his elaborate system of cosmology, he conceived the universe as a boundless mass separated into hot and cold masses from which land, sea and air were ultimately formed. Apertures in misty substances enveloping parts of the hot mass appear as sun, moon and stars. From a misunderstanding of his belief that the first human beings were born from huge fishes he has been credited with anticipating the theory of evolution.

Anaximenes of Miletus ( $f$ l. c.546 BCE). Greek philosopher, born in Miletus, Asia Minor (now Turkey). A follower of *Anaximander, he addressed himself to the question of the original nature of all things. He believed that origin to be air, for by processes of condensation and rarefaction air could be transformed into all other things. Condensation of air produces water, and eventually earth, rarefaction of air produces fire. *Plutarch tells us that Anaximenes demonstrated this truth by experiment. If we expel air from our mouths, it becomes cold if we exhale under pressure, whereas if we open our mouths wide, it is hot. Anaximenes probably thought of air as made up of small, separate particles. He believed in the infinity of worlds, and thought that each was formed by processes of condensation and rarefaction. He thought the earth was at the centre of things, and that both the sun and moon had been formed out of fire.
Anders, Wladislaw (1892-1970). Polish general. Captured by the Russians in their invasion of Poland in 1939, he later formed an army from the Polish prisoners in Russia to fight the common enemy. In 1943 he took command of the Polish troops in Italy. In 1946 he was deprived of his nationality by the Polish Communist Government and remained in Britain as a leader of the Free Polish community.

Andersen, Hans Christian (1805-1875). Danish author, born in Odense. Son of a poor shoemaker (although King Frederick VI could have been his father), as a boy he went to Copenhagen to seek his fortune but failed as an actor and, through lack of education, was equally unsuccessful as a playwright. At this time he came under the influence and patronage of Jonas Collin, a theatre director who sent him to school and later to the University of Copenhagen. His first important literary work was published in 1828-29. From 1835 to 1857 came that flow of stories whose titles have become household words all over the world-The Ugly Duckling, The Emperor's New Clothes, The Tinder Box, Thumbelina, The Red Shoes-about 160 in all. After 1840 he travelled in Europe and became a friend of Charles *Dickens (who found him a tedious house guest). Actively bisexual, he never married, and failed to win the love of the great singer Jenny *Lind.

Böök, F., Hans Christian Andersen, A Biography. 1962. Bredsdorff, E. Hans Christian Andersen. 1975.

Anderson, Carl David (1905-1991). American physicist. A student of R. A. *Millikan at Caltech, he specialised in the study of the cosmic rays first observed (1911-12) by V. F. *Hess. In 1932 Anderson discovered the positron (a positively charged particle of the same mass as the negatively charged electron), the existence of which had been predicted by P. A. M. *Dirac. In 1937 he established the existence of mesons (particles of mass between those of the electron and the proton), predicted in 1935 by *Yukawa Hideki. Anderson shared the 1936 Nobel Prize for Physics with Hess. He was professor of physics at Caltech 1939-76.

Anderson, Elizabeth (née Garrett) (1836-1917). English physician, born in Aldeburgh, Suffolk. A sister of Millicent ${ }^{*}$ Fawcett, she studied medicine privately, having being refused university admission, and was licensed to practise in 1865 by the Society of Apothecaries. She graduated MD from the University of Paris in 1870. She worked in London at the New Hospital for Women, renamed the Elizabeth Garrett Anderson Hospital in 1918. In 1908 she became England's first woman mayor, of Aldeburgh.

Manton, J., Elizabeth Garrett Anderson. 1965.

Anderson, John, 1st Viscount Waverley (18821958). British administrator. He joined the civil service and as Undersecretary for Ireland 1919-22 
was reputed to have created the 'Black and Tans'. He served as Undersecretary for Home Affairs 192232, Governor of Bengal 1932-37, then became a Conservative MP 1938-50. Home Secretary 193940 , under ${ }^{*}$ Churchill he was Lord President of the Council (with responsibility for research on atomic weapons) $1940-43$ and Chancellor of the Exchequer 1943-45. He received the OM in 1958.

Anderson, Marian (1897-1993). American contralto, born in Philadelphia. A notable interpreter of ${ }^{*}$ Brahms and *Sibelius and of African-American spirituals, it was not until 1955 that she was invited to sing at the Metropolitan Opera, New York. A delegate to the UN in 1958, she received the Congressional Medal of Honor and the Presidential Medal of Freedom.

Anderson, M., My Lord, What a Morning. 1957.

Anderson, Maxwell (1888-1959). American dramatist, born in Pennsylvania. Son of a Baptist minister, brought up in the Midwest, his first successful play, What Price Glory? (with Laurence Stallings, 1924), was concerned with front-line life in World War I. Other plays, many of which are in blank verse, include Saturday's Children (1927), Both Your Houses (Pulitzer Prize winner, 1932), Winterset (1935) and High Tor (1937).

Anderson, Sherwood (1876-1941). American writer. He held executive positions in advertising and in the paint industry, which he abandoned abruptly to devote himself to literature. His works reveal his disenchantment with the complexities of modern industrialised society. They include the short-story collection Winesburg, Ohio (1919) and the novels Poor White (1920) and Beyond Desire (1926).

Ando Tadao (1941- ). Japanese architect, born in Osaka. Essentially self-taught, from 1973 he designed houses, museums and churches that combined beauty of line, imagination and sensitivity to landscape. He won many international awards, including the Alvo *Aalto Medal (1985) and the Pritzker Prize (1995). Most of his buildings were in Japan, but also in Paris, New York, Chicago, Fort Worth, Milan, Venice and Manchester.

Andrássy (de Csíkszentkirály et Krasznahorka), Gyula, Count (1823-1890). Hungarian nobleman. He gained great influence with the emperor ${ }^{*}$ Franz Joseph and was Prime Minister of Hungary 1867-71 and Foreign Minister of Austria-Hungary during the critical years 1871-79. These included the Congress of Berlin (1878), one clause of which gave Austria the administration of Bosnia and Herzegovina, thus adding to the number of Slavs within the empire. It was the fear that Russia might at some time intervene to liberate these Slavs that guided Andrássy's entire policy. He put aside all thoughts of avenging the humiliating defeat of 1866 and did everything possible to build up and strengthen the German alliance. He did much therefore to create the political pattern that led to World War I. His son, also Gyula, Count Andrássy (1860-1929), was Foreign Minister (1918). He tried to negotiate a separate peace for Austria-Hungary, and after 1921 attempted to restore the Habsburgs.

André of Montréal, St (Alfred Bessette) (18451937). Canadian Catholic Brother, born in Québec. A barber and school porter in Montréal, known as Frère André, he claimed to have had a vision of St Joseph, established a reputation as a healer and campaigned tirelessly to build the huge Oratory of St Joseph. More than 1,000,000 people attended his funeral. He was canonised in October 2010.

André, John (1751-1780). British officer. In America during the War of Independence, he was caught while negotiating with Benedict *Arnold for the betrayal of West Point, and was hanged as a spy. In 1821 his grave was opened and his remains were later reinterred in Westminster Abbey.

Andrea del Sarto (Andrea d'Agnolo di Francesco) (1486-1531). Italian painter, born in Florence. Son of a tailor, as the name suggests, he was a master of the High Renaissance period. Some of his best work is to be found in the frescoes in the churches of the Annunciation and St Salvi in Florence. A fine example of his portraiture, A Sculptor, is in the National Gallery, London. Influenced by *Michelangelo, Fra *Bartolommeo and others, he had his own colour values and achieved striking effects by diffusion of light. The accuracy of his crayon drawings earned him the name of 'the faultless painter'. In 1518 he accepted an invitation to visit *François I in Paris and was commissioned to buy pictures in Italy. However, having squandered the money, he dared not return. He died of the plague. Robert *Browning's poem 'Andrea del Sarto' tells of his unhappy marriage with Lucrezia del Fede.

Andrée, Salomon Auguste (1854-1897). Swedish engineer and Polar explorer. In 1897 his second attempt (the first had been abandoned) to reach the North Pole by balloon failed. The finding of his body and those of his two companions in 1930, with diaries, revealed that the balloon had come down on the ice and that the men had reached White Island on foot.

Andreotti, Giulio (1919-2013). Italian Christian Democratic politician. A journalist, he served as a Deputy 1947-94, as a minister in innumerable governments and as Prime Minister 1972-73, 197679, 1989-91 and Foreign Minister 1983-89. He was attacked as symbolising the malaise of post-war Italian politics, a frequent recycling of ministers with little willingness to tackle difficult issues.

Andrew, Duke of York (Andrew Albert Christian Edward Mountbatten-Windsor) (1960- ) British prince. Second son of *Elizabeth II, he served in the Royal Navy as a helicopter pilot and captain. His 
marriage failed and he divorced in 1996. He later came under attack for his alleged sexual offences, and withdrew from his role as a functioning member of the royal family.

Andrew, St (Andreas in Greek and Latin: the name means 'manly') (d.c.60-70). Christian apostle. With his brother *Peter he was working as a fisherman on the Sea of Galilee when he received his call. According to tradition, after *Jesus' crucifixion he preached in Scythia and was crucified on an X-shaped cross, in Patra, Greece. Patron saint of Scotland and Russia, his feast day is 30 November.

Andrewes, Lancelot (1555-1626). English prelate. A favourite preacher of James I of England, he was one of the translators of the Authorised Version of the Bible. After being appointed bishop of Chichester (1605) and Ely (1609) he held the see of Winchester from 1618. He was the leading theologian of the High Church Party, and his Preces privatae (Private Prayers) witnesses his personal holiness. T. S. *Eliot drew attention to the remarkable originality and fine prose of his sermons.

Welsby, P. A., Lancelot Andrewes. 1958.

Andrews, Thomas (1813-1885). Irish physical chemist. He studied in Glasgow and Paris, graduated in medicine at Edinburgh but spent most of his life at his birthplace, Belfast, where he was professor of chemistry at Queen's University, from 1849 to 1879. His most important discovery was that every gas has a 'critical' temperature below which it must be cooled if it is to be liquefied by applying pressure. This discovery opened the way to the liquefaction of gases such as oxygen, nitrogen and hydrogen.

Andreyev, Leonid Nikolaivich (1871-1919). Russian short-story writer and dramatist. Originally a lawyer, he became a journalist, and was befriended by Maksim *Gorki, who influenced his style. Most of his works reveal his obsession with death, madness and sex, although he was capable of an almost surrealistic humour. His best known works are Anathema, The Red Laugh, Seven Who Were Hanged and He Who Gets Slapped. He fled to Finland after the Russian revolution (1917) and died in poverty.

Woodward, J. B., Leonid Andreyev. 1969; Newcombe, J., Leonid Andreyev. 1972.

Andric, Ivo (1892-1975). Bosnian (Yugoslav) author and diplomat. Son of an artisan family, educated in Zagreb, Krakow, Vienna and Graz, he was imprisoned by the Austrians as a nationalist and wrote his first novel, Ex Ponto (1918), in jail. He became a diplomat, serving in Rome and Berlin. During World War II, under German occupation, he wrote the trilogy The Bridge on the Drina, Bosnian Story and Young Miss, all published in 1945 but not translated into English until 1959. He was awarded the 1961 Nobel Prize for Literature for his 'epic power'.
Andropov, Yuri Vladimirovich (1914-1984). Russian Communist politician, born in Stavropol. The son of a railway worker, he was a Volga boatman briefly, rose through the Komsomol and joined the CPSU in 1939 to become a party functionary in Karelia and Moscow. He was Ambassador to Hungary 1953-57 (helping to suppress the 1956 revolt), Chairman of the KGB 1967-82, and a member of the Politburo 1973-84. On *Brezhnev's death (November 1982) he succeeded him as First Secretary of the CPSU and President of the USSR. Determined to reform the Soviet system, he was terminally ill and unable to effect major change before his death in January 1984. The succession went initially to a Brezhnev supporter, *Chernenko, instead of Andropov's protégé *Gorbachev.

Angelico, Fra (Guido di Pietri) (c.1387-1455). Italian painter. A Dominican friar (known as Giovanni da Fiesole) throughout his life, all his paintings, which are in a simple direct style, are of religious subjects. In 1443 he was summoned by the pope to work in the Vatican. The name by which he is now known comes from the unearthly beauty of his angelic figures. The largest collection is in the Museo di San Marco, Florence (his own convent).

Pope-Hennessy, J., Fra Angelico. 2nd ed. 1974.

Angell, Sir (Ralph) Norman (originally Lane) (1874-1967). English journalist and politician. His book The Great Illusion (1910), which showed that war was as disastrous for the victor as for the conquered, had an enormous influence, and won him the Nobel Prize for Peace (1933). He was a founder of the Union of Democratic Control (1914) and a Labour MP 1929-31.

Angell, N., After All. 1951.

Angerstein, John Julius (1735-1823). British merchant and philanthropist, born in Russia. A Lloyd's underwriter, his 38 paintings (including works by ${ }^{*}$ Raphael, *Rembrandt, *Rubens, *Claude, ${ }^{*}$ Hogarth) became, with the encouragement of ${ }^{*}$ George IV, the nucleus of the National Gallery collection.

Anglesey, 1st Marquess of, Henry William Paget (1768-1854). British field marshal, born in London. Son of the Earl of Uxbridge, he was an MP 1790-96, 1796-1804, 1806-10, served in the Peninsula War under *Wellington, commanded the Anglo-Belgian cavalry at Waterloo 1815 where he lost a leg, and became Master General of the Ordnance 1827-28, 1846-52. Twice Lord Lieutenant of Ireland 1828-29, 1830-33, he was a moderate reformer, sympathetic to Catholic emancipation.

Ångström, Anders Jonas (1814-1874). Swedish physicist. He studied, lectured and in 1858 became professor of physics at Uppsala University. He made extensive studies of the spectra of the sun's light and 
of the Aurora Borealis. In this work he expressed wavelengths of light in a unit equal to one hundred millionth of a centimetre. This unit, now called the 'angstrom', has been generally adopted for spectroscopic measurements.

Anna Ivanovna (1693-1740). Empress of Russia 1730-40. A niece of ${ }^{*}$ Peter the Great, she became Empress on the death of *Peter II. Having been a neglected and unloved child, she grew up to be a coarse and ignorant woman. On ascending the throne she gave herself up entirely to pleasure, leaving affairs of state to her lover, Ernst Johann von *Biron, who was detested by her subjects.

Longworth, P., Three Empresses. 1972.

Annan, Kofi Atta (1938-2018). Ghanaian administrator. Son of a chief, educated in the US and Switzerland, he joined the UN in 1962 and became Undersecretary for Peacekeeping Operations 1994-97. He married a niece of Raoul *Wallenberg and succeeded Boutros *Boutros-Ghali as SecretaryGeneral 1997-2006. In February 1998 he averted a second Gulf War by persuading *Saddam Hussein to accept closer UN inspection of weapon storage in Iraq. He shared the 2001 Nobel Peace Prize with the UN but failed to prevent the US invasion of Iraq in 2003. Appointed as UN mediator in Syria, he resigned in frustration in 2012 .

Anne (née Stuart, by marriage Oldenburg) (16651714). Queen of England, Scotland and Ireland 1702-14, from 1707 of Great Britain and Ireland. She was the first to rule over the United Kingdom of Great Britain, created by the Act of Union (with Scotland) in 1707 . The second daughter of the future *James II by his first wife Anne Hyde, she was born in Westminster and raised, with her sister *Mary, as an Anglican on instructions from her uncle ${ }^{*}$ Charles II. In 1683 she married Prince George (Jørgen) of Denmark (1653-1708) by whom she had 17 pregnancies: of five live births, only one child survived infancy, Prince William, Duke of Gloucester (1689-1700), who was hydrocephalic.

In 1701 the Act of Settlement provided that if Anne, the heir-presumptive to her brother-in-law *William III, died without heirs, the succession must pass to a non-Catholic; this excluded Anne's half brother James Edward *Stuart in favour of *Sophia, Electress of Hanover and her (Lutheran) descendants.

The earlier years of her reign, under Whig rule, were influenced by her favourite, Sarah Churchill, Duchess of Marlborough, enhanced by *Marlborough's victories in the War of the Spanish Succession. This period ended when Anne, whose natural affinity was with the Tories, having quarrelled with the Marlboroughs, appointed Robert *Harley to head her government in 1710. Anne was the last sovereign to veto an act of Parliament (the Scottish Militia
Her new favourite, Mrs Abigail Masham (née Hill) (c.1670-1730), was a cousin of both Sarah Churchill and Harley. An active promoter of the arts, Anne had been a patron of ${ }^{*}$ Purcell and, later, ${ }^{*}$ Händel, encouraged public gardens, and her reign was marked by distinguished architecture (*Vanburgh) and literature (*Pope, ${ }^{*}$ Addison, ${ }^{*}$ Swift, ${ }^{*}$ Defoe). Anne suffered agonies from gout, found it difficult to walk, became morbidly obese, drank heavily, and may also have had lupus and diabetes. She died of a stroke and was buried in a square coffin. She was succeeded by her second cousin *George I, Elector of Hanover, son of Sophia.

Gregg, E., Queen Anne. 1984; Somerset, A., Queen Anne: The Politics of Passion. 2012; Winn, J. A., Queen Anne. Patroness of Arts. 2014.

Anne (Anne Elizabeth Alice Louise MountbattenWindsor) (1950- ). British Princess Royal. Second child of Queen *Elizabeth II, she married Captain Mark Phillips in 1973 and, after a divorce, married Commander Timothy Laurence in 1992. One of the most active royals, she was an accomplished horse rider, member of the British Olympic team in 1976 and toured constantly in support of the Save the Children Fund.

Anne (Boleyn) (1501/7-1536). English queen consort 1533-36. Her father, Sir Thomas Boleyn, later 1st Earl of Wiltshire (c.1477-1539), was a diplomat, her mother daughter of the 2nd Duke of Norfolk. There is continuing controversy about her birth year. Educated in the Netherlands and France, her sister Mary Boleyn (c.1499/1500-1543), had been mistress both to ${ }^{*}$ François I and to ${ }^{*}$ Henry VIII. Following the failure of *Katherine of Aragon to produce a male heir, Henry began the process of having his marriage annulled and determined on Anne as his second wife. She married Henry in January 1533, was crowned Queen in June, and in September was created Marquess (sic) of Pembroke in her own right and gave birth to the future *Elizabeth I. She strongly supported Thomas ${ }^{*}$ Cranmer and evangelical reform in the church. Once Henry had determined to marry *Jane Seymour, Henry had her beheaded for adultery, incest (with her brother) and high treason. Five men, including her brother George Boleyn, 2nd Viscount Rochford (1504-1536), were also executed for adultery and treason. The trial and execution of all six was a travesty, driven by Henry's paranoia about gossip, and when her daughter Elizabeth became queen in 1558, Anne was regarded as a martyr.

Chapman, H., Anne Boleyn. 1974.

Anne of Austria (née Ana Maria Mauricia de Austria y Austria) (1601-1666). French queen consort 1615-43 and regent 1643-51. Daughter of *Felipe III of Spain, she was married to *Louis XIII of France. After her husband's death she became regent for her son *Louis XIV but allowed all power to rest with her lover (or even husband?) Cardinal ${ }^{*}$ Mazarin. 
*Dumas in his The Three Musketeers tells the story of the alleged romance between her and George Villiers, Duke of *Buckingham.

Anne of Brittany (Anne de Bretagne) (1477-1514). Duchess of Brittany 1488-1514 and French queen consort 1491-98, 1499-1514. She broke her betrothal to the future emperor ${ }^{*}$ Maximilian and married two successive French kings - ${ }^{*}$ Charles VIII (1491) and *Louis XII (1499). Her daughter Claude married the future *François I. She was a patron of artists and poets.

Anne of Cleves (Anna von Kleve) (1515-1557). English queen consort 1540. Born in Düsseldorf, her father, Johann, Duke of Cleves, was a Protestant follower of *Erasmus. Anne became the fourth wife of *Henry VIII of England in 1540. Henry had been guided by political reasons and encouraged by a flattering portrait, but they lacked a common language, he found her unattractive and the unconsummated marriage was annulled six months later. Henry blamed Thomas ${ }^{*}$ Cromwell, who had recommended the match. He was arrested and speedily executed. However, Anne was allowed to live in England in comfortable seclusion.

Annigoni, Pietro (1910-1988). Italian artist. His delicately flattering portraits of Queen *Elizabeth and others won him an important niche in British social life. This partly obscures work in other styles which can be seen, e.g. in the Modern Art Gallery in Milan. In his work he revived Renaissance techniques.

Anning, Mary (1799-1847). English fossil collector, born in Lyme Regis, Dorset. She collected, identified and sold fossils, from the Jurassic era, found near her birthplace, including the first ichthyosaur and plesiosaur, some marine reptiles and fossil fish. She identified the significance of coprolites. She was a lifelong friend of Henry *De La Beche, and William *Buckland organised a civil list pension. Women were excluded from the Geological Society until 1904. In 2010 the Royal Society recognised her as one of the 10 most significant women in British science.

\section{Annunzio, Gabriele d' see D'Annunzio, Gabriele}

Anouilh, Jean (1910-1987). French dramatist, born in Bordeaux. His plays vary from historical reconstruction e.g. L'Alouette (1953, The Lark), his version of the *Joan of Arc theme, and Becket (1959) to comedy or farce, e.g. L'Invitation au Chateau (1947, translated by Christopher Fry as Ring Round the Moon) and The Waltz of the Toreadors (1952). In 1949 his film M. Vincent was awarded the Grand Prix du Cinema Français. Anouilh, whose witty, sophisticated and elegant manner conceals a deep underlying pessimism, handles ingenious plots with a superb sense of stagecraft.

Marsh, E. G., Jean Anouilh, 1953; Pronco, L. C., The World of Jean Anouilh. 1961.
Anselm, St (c.1033-1109). Italian theologian and prelate, born at Aosta, northern Italy. As his father objected to his becoming a monk it was not until c.1059 that he reached Lanfranc's abbey at Bec, in Normandy, of which in 1078 he eventually became abbot. *Lanfranc, who had become Archbishop of Canterbury, died in 1089, and the see was left vacant until Anselm was appointed in 1093. His opposition to ${ }^{*}$ William Rufus' depredations of the church led to his exile in 1097 . He returned at the request of *Henry I in 1100 but while on the Continent he had become a convinced opponent of lay investiture and refused to do homage to Henry for his bishopric. This led to a further period of exile, but eventually in 1107 a compromise was reached. Anselm, the leading theologian of his age, put forward the theory that faith and reason are not incompatible, he also advanced the 'ontological argument' that the very fact that man can conceive the existence of a supreme omnipotent Being must mean that such a Being exists. He was canonised in 1494 .

Ansermet, Ernest (1883-1969). Swiss musician. He taught mathematics at the University of Lausanne, became a conductor with *Diaghilev's Ballets Russes 1915-23 and founded the Orchestre de la Suisse Romande (OSR) in Geneva (1918), remaining its chief conductor until 1967. He excelled in *Debussy, *Ravel, *Stravinsky, *Bartók and *Honegger and made many recordings. Suspected of anti-Semitism, he refused to perform *Schoenberg.

Anson, George Anson, 1st Baron (1697-1762). English sailor. On the outbreak of war with Spain (1740) he was sent in command of six ships, with orders to inflict as much damage on Spanish trade and colonies as possible. Nearly four years later he returned with only one ship but $£ 500,000$ of treasure, having sailed round the world. He received his peerage during the war of Austrian succession for a great victory (1747) over the French off Cape Finisterre. Coin worth $£ 300,000$ was found aboard the six prizes taken.

Anthony, (John) Doug(las) (1929-2020). Australian National Party politician, born in Murwillumbah. Three generations of the Anthony family were elected to the House of Representatives. He succeeded his father as MHR for Richmond 1957-84, became a minister in 1964, serving as Leader of the National Party 1971-84 and Deputy Prime Minister 1971-72 and $1975-83$. He received a $\mathrm{CH}$ in 1981 .

Anthony, Susan B(rownell) (1820-1906). American campaigner, born in Adams, Mass. From a Quaker abolitionist family, she became a teacher, working for temperance and against slavery. She devoted herself to the cause of female voting and founded the National American Women Suffrage Association in 1892. 
Antigonus I ('Monophthalmos' or 'Cyclops' i.e. oneeyed) (c.382-301 BCE). King of Macedonia 306301 BCE. One of*Alexander the Great's generals and successors (diadochi), he ruled first in Phrygia, then gained Lydia, Pamphilia and Asia Minor. He tried to unite Alexander's empire but was fought by a coalition of the other diadochi until his defeat and death at the battle of Ipsus.

Antiochus. Greek kings of the Seleucid (*Seleucus) dynasty which ruled Syria 312-64 BCE. Antiochus III ('the Great') (242-187 BCE), ruled 223-187, came into conflict with Rome, sheltered *Hannibal but was eventually forced to accept onerous terms. His son Antiochus IV ('Epiphanes' i.e. God Manifest) (c.215-164 BCE), ruled 175-164. By attempting to substitute the Greek gods for Judaism, he kindled the patriotic rising of the Maccabees (Maccabaeus). By defeating Antiochus XIII ('Asiaticus') (d.64 BCE), the last of the Seleucids, *Pompey was enabled to make Syria a Roman province.

Antipater (c.397-c.319 BCE). Macedonian general. Friend and advisor of *Alexander the Great, he was made regent of Macedonia (334) during Alexander's absence in Asia and after his death ruled all Greece, without claiming a kingdom for himself.

Antonello da Messina (c.1430-1479). Sicilian painter, born in Messina. He was greatly influenced by the techniques of the Flemish painters, especially the van ${ }^{*}$ Eycks. His surviving paintings are mostly portraits distinguished by a virtuoso style. His works influenced the Venetians, notably Giovanni *Bellini.

Antonescu, Ion (1882-1946). Romanian general and politician. After King ${ }^{*}$ Carol II had been forced to abdicate (1940), he assumed dictatorial powers. Under his rule Romania fought as Germany's ally against Russia in World War II with the result that after the Russian victory he was overthrown and two years later executed.

Antoninus Pius (Titus Fulvius Aelius Hadrianus Antoninus Augustus Pius) (86-161). Roman Emperor 138-61. One of the 'Five Good Emperors' in the *Nerva-Antonine dynasty, he succeeded *Hadrian, who had adopted him as his heir. He governed with ability and his reign was remarkably happy and peaceful. During his reign Roman control in Britain was extended northwards from Hadrian's Wall, and the Antonine Wall was constructed, from 142, between the Forth to the Clyde. His daughter, Faustina, married *Marcus Aurelius.

Antonioni, Michelangelo (1912-2007). Italian film director, born in Ferrara. He studied economics in Bologna, became a journalist, film critic, script writer and documentary film maker. His feature films include L'Avventura (1960), Blow-up (1967), Zabriskie Point (1969) and The Passenger (1974).
Antony (Abbot) ('the Great'), St (c.250-355). Egyptian hermit, born in Koman, Upper Egypt. His family was Christian and for 20 years he lived an ascetic life in the desert and is said to have been tormented by temptation, as depicted by Hieronymus ${ }^{*}$ Bosch, Matthias ${ }^{*}$ Grunewald and others. Many anchorites followed his example and in this sense he may be said to have initiated the monastic system. In the great theological controversy of the time he opposed Arianism.

Antony, Mark (Marcus Antonius) (c.82-30 BCE). Roman soldier and politician. An early supporter of ${ }^{*}$ Caesar, he fought under him with distinction in Gaul and against *Pompey, but it was after Caesar's death that, by exploiting the popular indignation, he was able to rise to greatness. With Caesar's heir Octavian and *Lepidus, a figure of comparatively minor importance, he formed a ruling triumvirate and it was mainly due to Antony's skill that the assassins, ${ }^{*}$ Brutus and ${ }^{*}$ Cassius, and their supporters, who had been forced to leave Italy, were decisively defeated at Philippi in Macedonia (42). After some dissension Octavian and Antony, Lepidus being tacitly ignored, agreed to separate their spheres of power, Octavian to rule Italy and the west, Antony over Asia and Africa, which included Egypt, where ${ }^{*}$ Cleopatra ruled in alliance with Rome. To cement the agreement Antony left Cleopatra to marry Octavian's sister Octavia. Unfortunately this marriage did not last. Egypt's resources were necessary for a war against Parthia and so, with self-interest and affection in convenient accord, Antony became openly the lover of Cleopatra and after the failure of the Parthian war lived with her in the state and style of an independent oriental monarch. His divorce of Octavia (32) immediately brought on the clash with Octavian which was in any case inevitable. A year of shapeless and indecisive struggle ended with the complete destruction of the fleets of Antony and Cleopatra at Actium (31). In the following year Octavian invaded Egypt. Defeated outside Alexandria, Antony committed suicide and Cleopatra, after the failure of negotiations, followed his example. The triumphant Octavian was to become the emperor *Augustus.

Tarn, W. and Charlesworth, M., Octavian, Antony and Cleopatra. 1965.

Antony of Padua, St (1195-1231). Portuguese religious, born in Lisbon. One of the most famous preachers of the Middle Ages, he was a Franciscan friar who spent most of his working life in Italy. It was said that he preached to the fishes when man refused to listen. Miracles at his tomb at Padua caused immediate canonisation. In art he often appears with a lily and the Christ Child in his arms.

Anwar (bin) Ibrahim (1947- ). Malaysian politician, born in Penang. He served in governments led by * Mahathir bin Mohamed, and was Education Minister 1986-91, Finance Minister 1991-98, Deputy Prime Minister 1993-98 and an absentee President of the 
UNESCO General Assembly 1989-91. Widely read and scholarly, he broke with Mahathir but was arrested and subjected to police brutality (1998), convicted of sedition and sodomy, after trials that attracted international condemnation, and jailed 1999-2004. He founded the Peoples' Justice Party and became Leader of the Opposition 2008-15, but was convicted of sodomy again and imprisoned. His party formed an unlikely alliance with Mahathir and their combined forces succeeded in defeating *Najib Razak, accusing him of corruption. Anwar was freed and pardoned (May 2018) on the understanding that he would succeed Mahathir as Prime Minister. Although this deal collapsed, Anwar ran for office in the next general election and became Prime Minister 2022- .

Apollinaire, Guillaume (Wilhelm Apollinaris de Kostrowitzky) (1880-1918). French poet, born in Rome. Of Polish descent, as a leader of the avant-garde, he helped to define Cubism, joined the Dadaists, and is said to have invented the term Surrealism. His volumes of poems Alcools (1913) and Calligrammes (1918), his play Les Mamelles de Tirésias (1918, later an opera by *Poulenc) and his novel Le Poète assassiné (1916) are among his best known works. He died of wounds in World War I.

Bates, S., Guillaume Apollinaire. 1967; Adema, M., Guillaume Apollinaire. 2nd ed. 1968.

Apollodorus of Damascus (d.c. 149). Greek architect. Chief architect and engineer of the Roman emperor, Trajan, he built the Odeum, Gymnasium and Forum in Rome. ${ }^{*}$ Trajan's Column, with its banded relief sculptures, was an architectural novelty planned by him. His bluntness of speech in professional matters is said to have led to his banishment and execution by Trajan's successor, *Hadrian.

Apollonius of Perga (c.262-190 BCE). Greek mathematician, born probably in Perga, Asia Minor. The greatest student of 'conic sections' in antiquity, almost nothing is known of his life, but several of his works survive. One of his main concerns was with generating curves. He pioneered new modes of generating curves which had the advantage of rendering it easier to solve traditional conic problems (e.g. calculating areas) by geometrical means. His work in this field became canonical. Apollonius also wrote a tract on applied optics and was apparently famous for his astronomical studies, where he used his rigorous geometrical approach to solve the problem of the motions of the planets. He may have produced solar and lunar tables, and seems to have calculated that the moon lies about 600,000 miles distant from the earth.

Apollonius of Rhodes (b.c.295 BCE). Greek poet and librarian. He composed the 6,000-line epic Argonautica, the story of Jason's voyage from Greece to Georgia in the Argo to retrieve the Golden Fleece. The story predates the Trojan War (about 1300 BCE). Apollonius was head of the library in Alexandria, then retired to Rhodes.
Appel, Karel Christian (1921-2006). Dutch painter. A co-founder (1948) of the CoBrA (Copenhagen, Brussels, Amsterdam) group of abstract expressionists, his powerful works were marked by vivid colour, and thick, almost sculptured, impasto. He won prizes at the Biennales in Venice 1953 and São Paulo 1959.

Appia, Adolphe (1862-1928). Swiss musician and theorist of scenic design. While studying music at Bayreuth he was struck by the disparity between the music and the stage settings. In his book Music and Staging (1899) he attacked the conventional painted scenery and suggested three-dimensional sets based on linear constructions, e.g. staircase, ramp. His theories and productions based on them (e.g. Tristan und Isolde at La Scala, Milan, in 1923) have, with those of Gordon ${ }^{*}$ Craig, had a revolutionary effect on theatrical design.

Appleton, Sir Edward Victor (1892-1965). English physicist, born in Bradford. He studied at the Cavendish Laboratory, Cambridge under *Thomson and ${ }^{*}$ Rutherford and specialised in the study of long distance radio waves and their reflections in the upper atmosphere. An ionised region which could cause this reflection had been predicted by *Heaviside, and in 1924 Appleton demonstrated the existence of such a region (the Heaviside Layer) at a height of about 60 miles. A higher reflecting region discovered later is called the Appleton Layer. Secretary of the Department of Scientific and Industrial Research (DSIR) 1939-49, he received the Nobel Prize for Physics in 1947 and was Vice Chancellor of Edinburgh University 1949-65.

Apuleius, Lucius (fl. c.160). Latin author, born in Africa. Educated at Carthage and Athens, he travelled widely in his youth and was able to put his experiences to good account in the most famous of his works, the scandalous and amusing novel The Golden Ass. The main theme concerns a young man turned into an ass for witchcraft, and among the episodes are the legend of Cupid and Psyche. The youth is restored to human shape by the Egyptian goddess, Isis, whose initiate Apuleius had probably become. In the light of his novel it is interesting that Apuleius himself was accused by the family of his wealthy wife, Pudentilla, of influencing her by magic. His successful defence (De magia) survives.

Aquaviva, Claudio (1543-1615). Italian cleric. As fifth general of the Society of Jesus (from 1581) he composed the Ratio studiorum, the basis of Jesuit education. He showed great diplomatic finesse especially in relation to the French Huguenots.

Aquinas, St Thomas (c.1225-1274). GermanSicilian theologian and philosopher, born near Aquino, Italy. He became a Dominican and, despite family opposition, left Italy to study theology in Paris and later under *Albertus Magnus at Cologne. Although nicknamed by fellow students 'The Dumb 
Ox', he is now considered to have been the greatest systematic theologian of the Catholic Church. Except for study in Italy (1259-68) he worked and taught in Paris (1252-72). Influenced by the philosophy of *Aristotle, he based his vast and clearly argued theology, now known as Thomism, upon it. He defended human reason as a source of knowledge of the natural world and also attempted to reconcile reason and faith. He opposed the claim that a belief could be philosophically false but theologically true, and set out five proofs of the existence of God. After his death his work was decried by the Franciscans for its debt to pagan Aristotle, but it remains today an enthusiastically studied theology. Aquinas died on his way to the Council of Lyon and was proclaimed a saint in 1323 and a doctor of the Church in 1567. His remains are in Toulouse. Of his many writings, Summa theologica is the most comprehensive exposition of his system.

Foster, K. (ed.), The Life of St Thomas Aquinas. 1959; Turner, D., Thomas Aquinas: A Portrait. 2013.

Aquino, (Maria) Corazon (Sumulong, née Cojuangco) (1933-2009). Filipina politician. Born to a wealthy and powerful family, she married Benigno Aquino (1932-1983) in 1964. A potential presidential candidate against Ferdinand *Marcos, he was arrested in 1972, sentenced to death and kept in prison for eight years. After his return from the US in August 1983 he was murdered at Manila airport. Officers accused of complicity in the assassination were later acquitted. In 1986 Corazon Aquino contested the presidential election against Marcos who was declared the winner after a fraudulent poll. The withdrawal of US, Church and military support from Marcos led to a virtually bloodless coup and Mrs Aquino took office (February 1986). In 1992 she was succeeded by Fidel *Ramos. Her son, Benigno Simeon Cojuangco Aquino III (1960-2021), known as Noynoy, was President 2010-16.

Arafat, Yasser (1929-2004). Palestinian politician, born in Jerusalem. Educated as an engineer at Cairo University, he became Chairman of the Palestine Student Federation, and in Kuwait trained Palestinian commandos. He rose to the leadership of the Al Fatah commando group and in 1968 was elected chairman of the Palestine Liberation Organisation, claiming credit for later acts of terrorism against Israel. Arafat's moderate wing of the PLO agreed to a peace settlement with Israel in the Gaza strip and the West Bank (September 1993). He shared the 1994 Nobel Peace Prize with Yitzhak *Rabin and Shimon *Peres. However, continuing acts of terrorism and interfada resistance to Jewish settlements on the West Bank led to a virtual war, and under Ariel *Sharon, Israeli troops occupied Palestinian cities (April 2002) and held Arafat in effective detention. He died in France and was buried in Egypt.
Arago, Dominique François Jean (1786-1853). French physicist and politician, born at Perpignan. He was educated at Toulouse and Paris, where he became (1804) secretary to the Observatory. Sent in 1806 to measure an arc of the meridian between Barcelona and the Balearics, he was arrested as a spy when war broke out between France and Spain. On his release he became a member of, and later secretary of, the Académie des Sciences and (1830-50) was director of the Observatory. He helped to confirm the wave theory of light and discovered several important electromagnetic effects. In politics he was a man of the left and took part in the revolution that deposed ${ }^{*}$ Charles $\mathrm{X}$ in 1830 . He was a deputy $1830-51$ and Minister of War in the government that in 1848 abolished slavery in the French empire. In 1852 he refused to take the oath of allegiance to ${ }^{*}$ Napoléon III.

Aragon, Louis (1897-1982). French poet, novelist and essayist. An early Dadaist and later a Surrealist he turned to political activities and joined the Communist Party (1930). He was decorated for war service (1940). Among the best known of his works are Les Beaux Quartiers (1936), for which he was awarded the Prix Renaudet, and Les Voyageurs de l'Imperiale (1943), published in English as Passengers of Destiny. He also wrote some notable war poems.

Roy, C., Aragon. 1945; Juin, H., Aragon. 1960.

Aram, Eugene (1704-1759). English philologist, teacher and murderer, born in Yorkshire. Largely self-educated, he ran his own school and pursued philological studies, arguing that Celtic was an IndoEuropean language. He was convicted of murdering a friend, Daniel Clark, and hanged at York. This murder and its discovery were the subject of Thomas Hood's poem The Dream of Eugene Aram and Bulwer *Lytton's novel Eugene Aram.

Arbatov, Georgiy Arkadyevich (1923-2010). Russian academician and administrator. He worked in publishing, the CPSU secretariat and the Academy of Sciences, and as Director of the Institute of US and Canadian Studies (ISKAN) 1967-95, played an important role in opening up Soviet political life and was an architect of perestroika. He advised Mikhail *Gorbachev and Boris *Yeltsin.

Arbuthnot, John (1667-1735). Scottish physician and author. After an Oxford education he became an MD at St Andrews (1696). Settling in London he was elected FRS in 1704. An urgent summons to attend the prince consort, George of Denmark, resulted in his becoming physician to Queen *Anne. With literary as well as scientific tastes he became a close friend of *Pope and *Swift, was the chief author of the Memoirs of Martinus Scriblerus and wrote the History of John Bull (1712). 
Arcadius (377-408). Eastern Roman Emperor 383408. Son of *Theodosius I, he inherited the eastern portion of the empire, while the western part was assigned to his younger brother Honorius. His reign at Constantinople marks the permanent separation of the two parts of the Roman world and so the beginning of what came to be known as the Byzantine Empire.

Archer, Jeffrey, Baron Archer of Weston-superMare (1940- ). English novelist and politician. Educated at Oxford and a Conservative MP 196974 , he wrote a series of successful novels to stave off bankruptcy, became a life peer in 1992 and was imprisoned for perjury 2001-03.

Archer, William (1856-1924). British journalist, critic and dramatist, born in Perth, Scotland. Educated at Edinburgh University, he worked in London, translated *Ibsen's plays and promoted Bernard *Shaw. His melodrama The Green Goddess (1921) was a great commercial success.

Archimedes of Syracuse (287-212 BCE). Greek mathematician and physicist, born in Syracuse, Sicily. He studied in Alexandria and made many discoveries, notably in mechanics and hydrostatics. He deduced the laws of levers, devised the compound pulley, and invented the Archimedian Screw still widely used in preindustrial societies for raising water. He is best known, however, for his statement of the principle (Archimedes' Principle) that a body immersed in a fluid appears to lose weight equal to the weight of the liquid it displaces. He thus discovered the property known as specific gravity. In mathematics he calculated the value of $\pi$ (pi) to a close approximation and discovered the correct formula for the area of a parabola. His ingenious war machines enabled Syracuse to hold out for three years against the Roman besiegers but on its fall (212) Archimedes was slain, in spite of orders by the Roman general that he should be spared. A moon crater and mountain range are named for him.

Dijksterhuis, E. J., Archimedes. 1956; Simms, D. L., Archimedes the Engineer. 1995; Gow, M., Archimedes. The Father of Mathematics. 2005.

Archipenko, Aleksandr Porfirievich (1887-1964). Russian sculptor. His technique followed the same trends as those set by the Cubist painters. A gradual simplification of human contours brought him to the point of expressing the nude figure entirely in geometrical shapes.

Archipenko, A., Archipenko: Fifty Creative Years, 1908-1958. 1960; Karshan, D. H. (ed.), Archipenko: International Visionary. 1970.

Arcimboldo, Giuseppe (1527-1593). Italian painter, born in Milan. He designed stained glass for Milan Cathedral, then became court painter to *Maximilian I and *Rudolf II in Prague. A Mannerist, his grotesque assemblages of faces and bodies made up of fruits, animals or objects influenced Surrealists in the 20th century.

\section{Ardashir see Artaxerxes}

Ardern, Jacinda Kate Laurell (1980- ). New Zealand Labour politician, born in Hamilton. Raised as a Mormon, educated at the University of Waikato, she was a protégé of, and staffer for, Helen *Clark. She was elected MP 2008-, Deputy Leader and, after six months, Leader of the Labour Party 2017- . With the support of the Greens and Winston *Peters' New Zealand First Party, she became Prime Minister 2017- . She gave birth in 2018, an exceptional event for a government leader. Her empathic and measured response to the massacre of 50 people at two mosques in Christchurch in March 2019 gained her international praise.

Duff, M., Jacinda Ardern. 2019.

Arendt, Hannah (1906-1975). American political philosopher, born in Germany. A student of Karl *Jaspers and lover of Martin *Heidegger (1924-28), she left Germany in 1933, working first in France, then the US from 1941. Her books included The Origins of Totalitarianism (1951), The Human Condition (1958), Eichmann in Jerusalem: A Report on the Banality of Evil (1963) and On Violence (1970).

Arensky, Anton Stepanovich (1861-1906). Russian composer and pianist. He is now mainly remembered for his Piano Trio in D minor (1894) and String Quartet No. 2, incorporating Variations on a Theme of Tchaikovsky, for violin, viola and two cellos (1894). He taught ${ }^{*}$ Scriabin and ${ }^{*}$ Rachmaninoff and drank himself to death in Finland. An Antarctic glacier is named for him.

Aretino, Pietro (1492-1556). Italian writer and wit, born at Arezzo. Living in Rome and Venice, he became known as 'the scourge of princes', and by a mixture of flattery and literary blackmail won patronage from such formidable characters as *François I of France and the emperor ${ }^{*}$ Charles V. His vivacious and satiric dialogues, plays and verses are of great value to the social historian.

Argerich, Martha (1941- ). Argentinian pianist, of Catalan-Jewish descent, born in Buenos Aires. A pupil of ${ }^{*}$ Michelangeli, she developed an extraordinarily powerful technique, toured extensively and made many recordings. Her extensive repertoire excluded the sonatas of ${ }^{*}$ Beethoven and ${ }^{*}$ Schubert. She preferred *Ravel to *Debussy and collaborative performances to solo recitals.

Argyll, 1st Marquess and 8th Earl of, Archibald Campbell (1607-1661). Scottish nobleman. The Campbells of Lochow were strong supporters of the Reformation and the Covenant. During the Civil War he raised an army against ${ }^{*}$ Charles I but after 
early defeats by the Royalist forces under *Montrose, became ruler of Scotland after 1645 . He collaborated with ${ }^{*}$ Cromwell, although opposing Charles' execution, then invited the future ${ }^{*}$ Charles II to Scotland and crowned him at Scone (1651). Never trusted, he was beheaded after the Restoration. His son Archibald Campbell, 9th Earl (1629-1685), was also sentenced to death in 1661 but worked with Charles II after his reprieve. He opposed *James II, sympathised with *Monmouth and the Rye House conspirators and was executed without trial. His son Archibald Campbell, 10th Earl and 1st Duke of Argyll (1658-1703), joined *William of Orange in Holland and was active in the Glorious Revolution in 1688. His son, John Campbell, 2nd Duke of Argyll and 1st Duke of Greenwich (1680-1743) helped to secure the union of 1707 , fought under *Marlborough, supported the Hanoverian succession and was created field marshal (1736).

Arias Sanchez, Oscar (1941- ). Costa Rican politician. Educated in England, he was President of Costa Rica 1986-90, 2006-10 and won the 1987 Nobel Peace Prize for his work in settling differences with El Salvador, Guatemala, Honduras and Nicaragua.

Ariès, Philippe (1914-1984). French historian. A public servant, he was essentially an amateur, who made original contributions to the study of attitudes to death and also to the study of childhood, a concept which, he argued, developed as late as the 17th century.

Arinze, Francis (1932- ). Nigerian cardinal. Baptised in 1941, he was ordained priest 1958, became a bishop in 1965 at the very early age of 32, Archbishop of Onitsha 1967-85 and became a cardinal in 1985 . He was Prefect of the Congregation for Divine Worship and the Discipline of the Sacraments, in Rome, 2002-08.

Ariosto, Ludovico (1474-1533). Italian epic poet, born in Reggio Emilia. He came of a good family of Ferrara and was intended for the law, but gained little from five years at the city's university. His father now secured employment for him with the d'Este family then ruling Ferrara. He served Cardinal Ippolito 1503-17 and his brother Duke Alfonso 1518-22. Here he found the literary background which helped inspire his great epic Orlando Furioso. Orlando is the Roland of the Charlemagne legends and in form the work is the continuation of (but far superior to) Boiardo's Orlando Innamorato. Ariosto's poem continues the story of Angelica, the beautiful princess of Cathay who has been carried off to the court of Charlemagne, then engaged in a war with the Saracens. In the new poem Angelica escapes, Orlando, who is in love with her, forgets his duties and pursues, but discovers her married to a Moorish youth, with whom she is idyllically in love. He becomes a raving madman (furioso) but eventually returns to sanity and duty and overcomes and kills the Saracen king. Nothing else of Ariosto's work compares with this great epic. Late in life he loved and married Alessandra Benucci and his last years were spent happily with her and in revising his poems.

Aristarchus of Samos (c.310-230 BCE). Greek astronomer. He taught at Alexandria and held the then unacceptable view that the earth and other planets revolve around the sun. Aristarchus was the first astronomer on record to estimate (crudely) the relative sizes of the sun and moon and their distance from earth.

Aristide, Jean-Bertrand (1953- ). Haitian politician and priest. Elected President of Haiti in a free election in October 1991, he was deposed by the army and restored only after a UN backed invasion by US forces (September 1994). In February 1996 he handed power over to his elected successor, René Préval.

Aristides (known as 'the Just') (c.530-468 BCE). Athenian leader. He distinguished himself against the Persians at the battle of Marathon (490) but was exiled by his fellow citizens (one of whom was alleged to have said that he was tired of hearing him called 'the Just'), probably for opposing the bold naval policy of ${ }^{*}$ Themistocles. He was allowed to return, held a command at Salamis (480), and led the Athenians to victory against the Persians at Phataea (479). He played a major part in the formation of the Delian league for united action against the Persians.

Aristophanes (c.448-c.388 BCE). Athenian dramatist. One of the greatest writers of comedy, his plays have remained popular and are still frequently revived. Little is known of his life and of his character only that which can be deduced from the plays. He was clearly a conservative, which then meant that he favoured the interests of the agricultural rather than the commercial classes, and, since it was the countryside that suffered from the annual incursions of the Spartans, he wanted peace in the apparently never ending Peloponnesian War. The earliest of his 11 plays to survive is The Acharnians (425), which tells of the efforts of the villagers of Acharnae to make a separate peace, and enables Aristophanes to ridicule the war party. In The Knights (424) a satiric presentation of the demagogic fire-eater Cleon provides a principal theme. The Clouds (423) is a satire on * Socrates. In The Wasps (422) the law is the target, and when a juryman is persuaded to try cases in his own home great fun is provided by the trial of a dog. The Birds (414) tells of how the birds in contest with the gods build Cloud-Cuckoo Land between earth and heaven, and starve the enemy into submission by preventing the smoke of sacrifice from reaching them. The Frogs (405), where the god Dionysus is asked to decide the rival merits of *Aeschylus and *Euripides, provides abundant opportunity for parody. Perhaps the most amusing to a modern audience is Lysistrata (411), where the women refuse intercourse with their 
husbands until peace is declared. The plays are written in verse, and in style are comparable with the greatest of the Greek tragedies.

Murray, G., Aristophanes. New ed. 1966.

Aristotle (384-322 BCE). Greek philosopher, born in Stagira, Northern Greece. Son of Nicomachus, a physician in the Macedonian court, he learned biology from his father and studied at the academy of *Plato from the age of 17 until Plato died, 20 years later. He then became tutor of Alexander, later *Alexander the Great. He came back to Athens and in 335 established his own school, the Lyceum, essentially a research institution, covering many disciplines. His followers became known as peripatetics after the peripatos (covered walk), where-perhaps pacing up and down-he taught. In 323, after the death of Alexander deprived him of the protection of his former pupil, Aristotle left Athens and took refuge on the island of Euboea, where he died. His work, known as Aristotelianism, covers many subjects, including philosophy, several sciences, poetry and drama. His influence on western civilisation has been immense, especially in establishing scientific method. In the Middle Ages his doctrines were combined with Christian theology, notably by St Thomas *Aquinas. In his philosophy, he set out a system of categories or basic classifications into which all things fall. Some things, for example, are classed as substances: those entities, if they are such, are the foundations or possessors of each ordinary thing's various properties but not properties themselves. In his Metaphysics (merely meaning that which comes after physics), he also elaborated doctrines on the distinction between form and matter, on the development of potentialities into actualities, and on various kinds of cause. At the bottom of an ascending scale was 'prime matter', with potentiality but no 'form' or function other than existence and therefore incomprehensible. At the top, and equally incomprehensible, was the equivalent of God, with potentiality fully realised and therefore no potency, but to be regarded as 'pure act' (in these terms the soul' is regarded as the 'act' of the body). In between, the terms 'form' and 'matter' may be sometimes interchangeable. A familiar example is that brick is 'form' when related to the clay of which it is made but 'matter' in relation to the building of which it forms a part. In logic Aristotle claimed to be the first to work out the theory of reasoning by syllogisms, arguments of a particular form whose conclusions follow necessarily or certainly from their premises. Aristotle's Ethics contains the doctrine that virtue consists in a mean between excess and deficiency, and in his Politics he argues for a form of government which is an oligarchy of merit, preferably with the consent of the governed. Of Aristotle's science, his biology was uneven. His system of classification was impressive, but his teaching that the brain was essentially a cooling mechanism for the blood, and not the centre of reason (which he located in the heart), although contrary to *Hippocrates and rejected by ${ }^{*}$ Galen, was dominant for nearly 2,000 years. In The Generation of Animals he taught that females were 'deformed males', a concept adopted by Galen and Aquinas. However, he seemed to have grasped the central feature of genetics, that encoded 'information' can be transmitted (and transformed). He dissected more than 50 species of animals and first identified the placenta. His view that the sun rotates round the earth, which is fixed in space, was one of a number of doctrines that were taken as unquestionable in the Middle Ages and had the effect of delaying scientific advance. His views on drama, contained in his Poetics, led to the 'rules' of the Renaissance, including those of the unities of time and place.

Green, M., A Portrait of Aristotle. 1963; Ross, W. D., Aristotle. 1964; Downey, G., Aristotle. 1965.

Arius (d.335). Greek theologian, born in Libya. He studied in Asia Minor and returned to Alexandria to work and teach. He gave his name to the great Arian controversy which rent Christendom during the 4th century. It related to the status of the members of the Trinity, whether God the Father was co-equal with God the Son or in some sense (as Arius maintained) his superior. At the Council of Nicaea (325) the dispute was dramatised as the battle of the iota (i), whether the Father and Son were of the same substance (bomoousioi) or of like substance (homoiousioi). The decision (formulated in the Nicene Creed) was against Arius, whose doctrines became heretical. Alexander, the bishop there, was a principal opponent. After Nicaea Arius was exiled to the Danube and died excommunicated, but the Arian controversy lived on.

MacCulloch, D., A History of Christianity. The First Three Thousand Years. 2009.

Arkwright, Sir Richard (1732-1792). English inventor, born in Preston. Originally a barber, by the late 1760s he was devoting his attention exclusively to improving cotton spinning processes and invented the water driven spinning frame in Preston in 1768. To escape Luddite antagonism he migrated to Nottingham and built (1771), in partnership with Jedediah Strutt, a factory with water power in Cromford, Derbyshire. His various inventions were copied, litigation went against him, and one of his factories was destroyed by a mob. However, his work was recognised by a knighthood (1786).

Arlen, Michael (Dikran Kouyoumdjian) (18951956). British novelist and short story writer of Armenian extraction. He became a British citizen in 1922, but spent most of his later life in New York, where he died. In an elegant but artificial style he portrayed in such novels as The Green Hat and These Charming People the sophisticated, amoral but highly decorative young people of the English upper classes in the years following World War I. 
Arlington, Henry Bennet, 1st Earl of (1618-1685). English politician. He gave great service to ${ }^{*}$ Charles II in procuring and managing his mistresses, and became one of the 'Cabal' (the clique that advised the king in the early years of his reign: see ${ }^{*}$ Clifford of Chudleigh). He was impeached (1674) by the House of Commons for his concealed advice in support of a return to Roman Catholicism, corruption and breach of trust, but was acquitted. Notorious for duplicity, superficiality and opportunism, he was a faithful husband (unusual in his cohort) and became a Catholic on his deathbed.

Arminius (Hermann) (c.18 BCE-19 CE). German chief. Educated in Rome, he served under *Tiberius in Germany and received Roman citizenship. Under his leadership his tribe, the Cherusci, annihilated three Roman legions under Varus in 9 CE, a defeat which led *Augustus to abandon the conquest of Germany north of the Elbe. He was killed in a feud with his own kinsmen.

Arminius, Jacobus (Jakob Hermandzoon), (15601609). Dutch theologian. Originally a Calvinist, he turned violently against *Calvin's doctrine of predestination and taught that any person who repents of his sins and accepts Christ as saviour is granted forgiveness by God and eternal life. These doctrines were violently assailed by Calvinists and in 1608 he asked that a synod should be convoked to decide the issue. However, worn out by anxiety and illness, he died before it was held. The controversy continued after his death but with decreasing bitterness as his views, with some modification, gained wider and wider acceptance notably by *Wesley and his Methodists.

Armitage, Simon Robert (1963- ). English poet, playwright and novelist, born in Yorkshire. Versatile and prolific, and a skilled photographer, he translated and dramatised *Homer's Odyssey; was lead singer with a band, LYR; Professor of Poetry at Oxford 2015-19; and Poet Laureate of the UK 2019- . He also wrote travelogues for the $\mathrm{BBC}$.

Armstrong, Edwin Howard (1890-1954). American electrical engineer. Educated at Columbia University, he used Lee *De Forest's triode vacuum tube to develop a regenerative or 'feedback' circuit which enabled (1912) radio signals to be amplified by 1,000 or more. (This led to unsuccessful litigation with De Forest.) In 1916 he invented the 'superheterodyne' circuit, still the basis of television and radio equipment. In 1933 he patented 'frequency modulation' (FM) as a means of overcoming natural static and set up the first FM transmitter in 1939. He committed suicide.

Armstrong, Lance Edward (originally Gunderson) (1971- ). American cyclist, born in Texas. After recovering from testicular cancer (1997), he returned to professional cycling with unparalleled zeal, assisted by performance enhancing drugs, and his seven consecutive wins in the Tour de France (1999-2005) established him in the international sporting pantheon. Revelations about drug use in cycling, and Armstrong's successful attempts to avoid detection, led to a major report in 2012 by the US Anti-Doping Agency, and all his victories since 1998 were annulled. Initially, Armstrong strongly denied the allegations, then conceded their accuracy, but without signs of repentance, in a television interview with Oprah *Winfrey.

Armstrong, Louis (1900-1971). American jazz trumpeter and singer, born in New Orleans. Known as 'Satchmo' (i.e. 'satchel mouth') he moved to Chicago to join King Oliver in 1922 and later formed the 'Hot Five' and the 'Hot Seven'. Apart from a period in the 1930s when he deserted ensemble playing to pursue a career as a virtuoso soloist, he and the groups he led remained in the forefront of the New Orleans style.

Jones, M. and Chilton, J., Louis. 1971.

Armstrong, Neil Alden (1930-2012). American astronaut and aeronautical engineer, born in Ohio. The first human to set foot on the moon, he was a licensed pilot from the age of 16 and studied aeronautics at Purdue University. He served in the Korean war and in 1962 joined the US National Aerospace Program, and was commander of Gemini 8 in which he completed the first manual space docking manoeuvre. In July 1969 he lifted off from Cape Kennedy US with Edwin Aldrin and Michael Collins in Apollo 11 and four days later, on 21 July, it landed on the moon. As he stepped on the moon's surface he said 'That's one small step for man, one giant leap for mankind'. He worked as a NASA executive and was professor of engineering at Cincinnati University 1971-79. He died in Cincinnati after failed heart surgery. He was awarded the Presidential Medal of Freedom and many other honours; a lunar crater and Asteroid 6469 Armstrong were named for him.

Armstrong, N. A., Change in the Space Age. 1973.

Armstrong, William George Armstrong, 1st Baron (1810-1900). English engineer and inventor, born at Newcastle upon Tyne. He turned from the law to engineering and devised a steam jet electric engine followed by a hydraulic crane and a hydraulic accumulator (1845-50). The Elswick works were built to make civil engineering machinery, but soon became better known for military guns, particularly heavy artillery. His first rifled gun was manufactured in 1854 . The wire wound barrel was another of Armstrong's improvements. An early advocate of renewable energy, particularly hydroelectricity and solar, he predicted an end to the use of coal. He received a peerage in 1887. His firm became Armstrong-Whitworth, later Vickers-Armstrong, and built battleships for the Japanese, which proved decisive in the defeat of the Russian fleet at Tsushima (1905). 
Arnau of Villanova (1240-1311). Catalan physician and astronomer. In the 1280s he was physician to Peter III of Aragon, and from 1291 taught medicine at Montpellier University. He seems to have been a successful medical practitioner curing Pope *Boniface VIII of a stone- but was chiefly important for his attempt to integrate empirical medicine with the medical philosophy of the Greeks and Arabs. Being familiar with Arabic, he translated works of *Galen and *Avicenna into Latin. Much of his medical teaching consisted of exposition of the works of *Hippocrates and Galen, and this pioneering approach was taken up and became the basis of 14 thcentury medical education. Arnau's chief theoretical medical interest was the attempt to conceptualise the body as being in a state of equilibrium between opposed forces (primarily those of hot and cold), which determines the resultant condition of health. Towards the end of his life, his interests took a more philosophical, mystical and theological turn. He investigated the occult world, wrote on astrology, and made a prophecy that the world would end in 1378. His theological heterodoxy involved him in difficulties with the Paris theologians.

Arne, Thomas Augustine (1710-1778). English composer. Educated at Eton, he worked in a lawyer's office before turning to music. He wrote Rule, Britannia (from his masque Alfred, Constant ${ }^{*}$ Lambert called it 'the best written of all national songs'), incidental music for plays (e.g. including *Shakespeare's song Where the Bee Sucks ... ) and many other songs in addition to oratorios, light operas and the serious opera Comus based on the poem by John *Milton.

Arnim, Elizabeth von (née Mary Annette Beauchamp, later Countess von Arnim, then Countess Russell) (1866-1941). English-Australian novelist, born in Sydney. Writing under the pen name 'Elizabeth', which she later adopted as her own, and a cousin of Katherine ${ }^{*}$ Mansfield, she was brought up in England. In 1891, she married Count Henning von Arnim-Schlagenthin (d.1910). While on his country estate, she wrote Elizabeth and her German Garden (1898) —ironic and charming, both a critical success and a bestseller. She returned to England in 1910, became a lover of H. G. *Wells and, in 1916, married Frank, 2nd Earl Russell, a disastrous union. (They separated in 1919 but never divorced.) Her later books include Vera (1921), The Enchanted April (1922, later a film and stage play) and Mr Skeffington (1940, later a film). She died of influenza, in the US.

Arno, Peter (Curtis Arnoux Peters) (1904-1968). American cartoonist. One of the earliest recruits to the New Yorker magazine, on whose staff he continued to work, his clever linear characterisation combined with metropolitan humour helped to establish the magazine's reputation.
Arnold, Benedict (1741-1801). American soldier. Eventually a traitor during the American War of Independence, he fought with gallantry first with Ethan *Allen's 'Green Mountain Boys', in Canada, and under ${ }^{*}$ Washington, and was an excellent officer. The Senate, ignoring Washington's recommendations, promoted several other officers ahead of him but he was soon breveted Major General and fought with distinction at Saratoga, where he received wounds which limited him to less active commands. In 1780, as Commander of West Point, he seemed embittered by lack of recognition and conspired with the British Major *André to surrender the post. The plot was discovered but Arnold escaped to the British, by whom he was given command of British troops. He lived in England after the war.

Arnold, Henry Harley (1886-1950). American airman, born in Pennsylvania. A pilot from 1911, 'Hap' Arnold was Commanding General of the US Army Air Force 1942-46 and promoted five-star General of the Army in 1944.

Arnold, Sir Malcolm (1921-2006). English composer. A trumpet player in the London Philharmonic and BBC Symphony orchestras, he wrote many orchestral compositions, including the ballet Homage to the Queen, English Dances (1953), nine symphonies and 18 concertos. He received an Oscar for music for the film Bridge on the River Kwai (1957).

Arnold, Matthew (1822-1888). English critic, educationist and poet, born at Laleham on Thames. Educated at Rugby under his father Thomas *Arnold, and at Balliol College, Oxford, he became a disciple of *Wordsworth. As an inspector of schools 1851-86, he was an important liberal influence in enriching the curriculum and pointing to the need for educating the working class. He became professor of poetry at Oxford 1857-67 and set high standards in his lectures on *Homer and his collected Essays in Criticism (1865) which emphasised the social function of the critic. His own poetry was criticised for its harshness, gloom and difficulty but his Dover Beach (1851—published 1867), is one of the greatest 19th-century poems, set to music in 1931 by Samuel *Barber. Arnold attacked middle class cultural values as 'philistine' (his own coinage) in Culture and Anarchy (1869). In his later years he was deeply troubled by his own spiritual restlessness and a fear of anarchy.

Rowse, A. L., Matthew Arnold. 1976; Honan, P. Matthew Arnold, a life. 1981; Collini, S., Arnold. 1988; Murray, N., A Life of Matthew Arnold. 1996.

Arnold, Thomas (1795-1842). English educator. Headmaster of Rugby School 1828-41, he created the educational pattern, followed by other British public schools, which encouraged the emergence of a class of capable and devoted administrators to meet the needs of the growing empire. To give older 
boys responsibility and self-discipline he introduced a prefectorial system while his own sermons and strict religious instruction supplied a moral background. The educational structure, based upon the classical form-master, had obvious limitations. A glowing picture of Rugby under Arnold is presented by Thomas *Hughes in Tom Brown's Schooldays.

Bamford, T. W., Thomas Arnold in Education. 1970.

Arnold of Brescia (c.1100-1155). Italian religious revolutionary. After studying under ${ }^{*}$ Abelard in France he returned to his birthplace, Brescia, where he entered an Augustinian monastery and eventually became Abbot. An embroilment with his bishop led to a period of exile, during which, after a quarrel with St *Bernard, he was banished from France. Meanwhile a revolution in Rome had suppressed the power of the pope and created a republic on the lines of that of ancient Rome. Returned from exile, Arnold threw himself into the fray (c.1147) as a violent supporter of the new regime and denouncer of the pope's temporal power. He accordingly had to flee when the new pope, *Adrian IV, brought about the republic's collapse. Arnold fell into the hands of the emperor *Friedrich I (Barbarossa), was delivered over to the papal prefect and hanged.

Arnolfo di Cambio (Arnolfo di Lapo) (c.12321302). Italian architect and sculptor. A pupil of Pisano, he designed Florence Cathedral (from 1296) and, also at Florence, built the Franciscan Church of S. Croce (1294 ff.) and the Palazzo Vecchio (also called the Palazzo della Signoria, 1298 ff.)

Aron, Raymond (Claude Ferdinand) (1905-1983). French political philosopher, teacher and journalist. He taught at Toulouse and Paris, worked in London for *de Gaulle (1940-44), broke with his friend *Sartre, and became the most prominent exponent of rationalist humanism. He was deeply opposed to all authoritarian regimes and supported Israel and Algerian independence.

Arp, Jean (Hans) (1886-1966). German-French sculptor, painter, poet, collage and woodcut artist, born in Strasbourg. He moved to Paris in 1904, studied in Weimar, then returned to Paris. In Zürich in 1916, with Tristan *Tzara, he was a founder of the Dada movement which later morphed into Surrealism. His versatility was immense, but he was known primarily as a sculptor, whose forms, though deriving largely from Surrealism, had an abstract purity of surface and contour. He also produced collages and wood-reliefs as well as works in more traditional media, and he wrote poetry.

Arp, J., Arp on Arp. Problems, Essays, Memories. 1972; Robertson, E., Arp: Painter, Poet, Sculptor. 2006.

Árpád (c.845-c.907). Hungarian prince. A leader of the Magyar tribes, he was invited by the Byzantine Emperor Leo VI 'the Wise' to drive out the Bulgarians and occupy the Carpathian basin. His dynasty reigned in Hungary from c.895 to 1301. The Hungarians, originally Tengriians, were Christianised in the 10th century.

Arrau (Léon), Claudio (1903-1991). Chilean pianist. After his Santiago debut (1908), he studied in Berlin, and emerged in the front rank of pianists during the 1940s. His performances and recordings of ${ }^{*}$ Beethoven, ${ }^{*}$ Chopin and ${ }^{*}$ Brahms were greatly admired.

Arrhenius, Svante August (1859-1927). Swedish physical chemist. He evolved a satisfactory explanation, published in 1887, of electrolytic dissociation from the many electrochemical observations of the 19th century. He put forward the idea, which is the basis of present-day 'Ionic Theory', that when salts are dissolved in water they split up almost completely into particles, which *Faraday had previously named 'ions'. In 1896 he made the first quantitative prediction of global warming due to increases of carbon dioxide in the atmosphere, calling it the 'hot-house' effect, renamed by his colleague Nils Gustaf Ekholm as the 'Greenhouse effect' in 1901. Much of his early work was done in Germany but he returned to Sweden in 1891 and served as director of the Nobel Institute at Stockholm 1905-27. He received the Nobel Prize for Chemistry in 1903 for his research on 'the electrolytic theory of dissociation'. He pioneered (1903) research on the concept of panspermia, first proposed by the ancient Greeks, the hypothesis that life forms arrived on earth in space debris.

Arrow, Kenneth Joseph (1921-2017). American economist, born in New York. Of Romanian-Jewish ancestry, he studied at Columbia University, worked in Chicago and was Professor of Economics at Harvard 1968-79 and Stanford 1979-91. He shared the Nobel Prize for Economics in 1972 with Sir John *Hicks 'for their pioneering contributions to general economic equilibrium theory and welfare theory'. Elected FRS in 2006, he taught five Nobel Laureates.

Arroyo, (Maria) Gloria Macapagal- (1947- ). Filipina politician. Daughter of Diosdado Macapagal (1910-1997) who was President 1961-65, she served as president herself 2001-10 and was arrested for electoral fraud in 2011.

Artaud, Antonin Marie Joseph (1896-1948). French actor, producer and theorist, born in Marseille. He advocated the 'theatre of cruelty', in which performances were ritualistic and cathartic for audiences and not mere expositions of a text. He gave an electrifying performance as Marat in Abel *Gance's film Napoléon (1927). He was confined to mental hospitals from 1936.

Artaxerxes. Name of several Persian kings, Artaxerxes I (reigned 464-424 BCE) brought the war with Greece to an end with the loss of Thrace and parts of 
Asia Minor. Artaxerxes II (d.358 BCE) defeated his rebellious brother ${ }^{*}$ Cyrus and gained the Greek cities of Asia Minor. A much later Artaxerxes or Ardashir (d.242 CE) overthrew the last of the Parthian kings (226 CE), conquered Media and, as founder of the Sassanian dynasty, restored the Persian monarchy.

Artemesia (fl. c.480 BCE). Queen of Halicarnassus. She fought with the Persians against the Greeks in the naval Battle of Salamis (480 BCE).

\section{Artemisia (Queen of Caria) see Mausolus}

Arthur (6th century). British legendary hero. He may represent the folk memory of one or more Romanised British chieftains who, after the departure of the legions, put up a heroic resistance to the invading Anglo-Saxons, in their westward advance. This would explain the number of places, from Astolat (Guildford) to the extreme Cornish west, associated with his name. The hero of romantic legend is first mentioned by the 9th-century ${ }^{*}$ Nennius, but the first long account was given (c.1135) by *Geoffrey of Monmouth. The legends were embellished by such medieval writers as Chretien de ${ }^{*}$ Troyes, and a great number of the stories were woven together by Sir Thomas *Malory in his vast Morte D'Arthur, printed by Caxton in 1485. Tennyson (Idylls of the King etc.) and others took up the tale and even in our own day the musical play Camelot is a reminder that the legends are still alive. Costume, armour and codes of conduct in the Arthurian stories are mainly those of the 12th-14th centuries.

White, T. H., The Once and Future King. 1958; Barber, R., King Arthur in Legend and History. 1973.

Arthur, Chester Alan (1830-1886). 21st President of the US 1881-85. Son of a Vermont clergyman, and a lawyer by profession, he held the lucrative post of collector of customs at the Port of New York 1871-78. During this period he became involved in the controversy within the Republican party over the use of patronage (i.e. the allocation of offices etc. to gain political support) and in opposition to President Rutherford *Hayes, a purist in such matters, who dismissed him for abuse of his official position. However, at the 1880 convention the choice of James A. ${ }^{*}$ Garfield for the presidential nomination was offset by that of Arthur, as a prominent supporter of patronage, for vice presidency. The Republicans won the 1880 election, and after Garfield's assassination, Arthur became President, but to the dismay of his former associates proved himself a determined enemy of corruption and patronage.

Reeves, T. C., Gentleman Boss, Chester Alan Arthur. 1975.

Arthur, Sir George, 1st Baronet (1784-1854). English soldier and administrator. As Lieutenant Governor 1823-25 and Governor 1825-36 of Van Diemen's Land (Tasmania), he organised the 'Black
Drive' and established Port Arthur, a large convict settlement (1830). He served as Lieutenant Governor of Upper Canada 1837-42 and Governor of Bombay $1842-46$.

Arthur of Brittany (1187-1203). Duke of Brittany. A grandson of *Henry II of England as his dead father, Geoffrey, was *John's elder brother, so, on *Richard I's death, Arthur had a claim to the throne which was supported by *Philippe II of France. The story of his imprisonment by his uncle and of his death is told with much poignancy (but considerable historical distortion) in *Shakespeare's King John.

Asbury, Francis (1745-1816). American prelate. The first Methodist bishop consecrated (1784) in America, John *Wesley sent him from England and in the course of his missionary journeys he is said to have travelled 270,000 miles.

Asch, Sholem (1880-1957). Polish-Jewish Yiddish writer, born in Poland. His first novel, an admitted masterpiece, Dos Shtetl (The Township) was published in 1904, but it was Max *Reinhardt's Berlin production (1907) of his play The God of Vengeance which brought him fame. He lived in the US (191456), moved to Israel and died in London. Among his books are The Mother, Mottke the Thief and East River.

Rosenberg, S., Sholem Asch at Close Quarters. 1959.

Ascham, Roger (1515-1568). English scholar, born near Thirsk, in Yorkshire. He received his early education in the family of Sir Anthony Wingfield, who sent him to Cambridge University, where he became reader in Greek at St John's College (c.1538). His Toxophilus (1545), an agreeable dialogue on archery, dedicated to *Henry VIII, as well as his growing reputation as a teacher, brought him wider recognition and in 1548 he became tutor to Princess *Elizabeth. After returning from a diplomatic mission (1550-53) he became Latin secretary to *Edward VI, an office which, though a Protestant, he was prudent enough to retain under ${ }^{*}$ Mary. He was still in office under Elizabeth when he died. The Scholemaster, published posthumously, is a humanist and humane treatise on education.

Ryan, L. V., Roger Ascham. 1963.

Ashbery, John Lawrence (1927-2017). American poet and art critic. Educated at Harvard, Columbia and New York 1974-90. He worked in publishing, lived in France 1955-65, became an art critic and was professor of creative writing at the City University of New York 1974-90. He won the 1975 Pulitzer Prize with Self-Portrait in a Convex Mirror. His Selected Poems (138 poems chosen from earlier volumes) appeared in 1985. Regarded as the greatest American poet since Robert *Lowell, Ashbery was relatively prolific. 
Ashcroft, Dame Peggy (Edith Margaret Emily) (1907-1991). English actor. She made her London debut in 1926 and played with outstanding success in ${ }^{*}$ Ibsen, ${ }^{*}$ Shakespeare and ${ }^{*}$ Chekhov. Her films include The Nun's Story (1959), Hullabaloo about George and Bonnie's Pictures (1976) and A Passage to India (1984), which won her an Academy Award. She was made a DBE in 1956. Her lovers included W. R. *Sickert, J. B. *Priestley and Paul *Robeson.

Ashdown, Paddy (Jeremy John Durham), Baron Ashdown (1941- ). English Liberal Democrat politician. After service as a Marine commando, diplomat and manager, he was MP 1983-2001, Leader of the Liberal Democrats 1988-99 and the international High Representative for Bosnia and Herzegovina 2002-06.

Ashford, Daisy (pen name of Margaret Mary Devlin) (1881-1972). English writer. She gained sudden and perhaps immortal fame by the publication in 1919, under Sir James *Barrie's sponsorship, of her book The Young Visiters, a remarkable and hilarious example of literary precocity, said to have been written when she was nine.

Ashkenazy, Vladimir Davidovich (1937- ). Russian-Icelandic pianist and conductor. He left the USSR in 1963, living first in Britain, then in Iceland, finally in Switzerland. He established an international reputation as an interpreter of ${ }^{*}$ Mozart, ${ }^{*}$ Beethoven, ${ }^{*}$ Chopin and the Romantics. He was conductor of the Sydney Symphony Orchestra 2009-13.

Ashmole, Elias (1617-1692). English antiquarian, born in Lichfield. He started work as a solicitor, joined the excise, but soon retired to studies extending from botany to alchemy. His book on the Order of the Garter revealed his antiquarian interest. The nucleus of the Ashmolean collection was formed by ethnological objects from America, Africa and the South Seas bequeathed to him by his friend, John Tradescant. His name is perpetuated by the Ashmolean Museum at Oxford.

Josten, C. H. (ed.), Elias Ashmole, 1617-92. 5 vols, 1967.

Ashton, Sir Frederick William Mallandine (19041988). English choreographer and dancer, born in Ecuador. After gaining prominence in creating ballets for and dancing with the Carmargo Society and the Rambert company he became in 1935 choreographer, and later associate director, of the Sadler's Wells Ballet (known as the Royal Ballet from 1956). He succeeded Ninette *de Valois as director 1963-70. His best known ballets were Cinderella (in which he took the role of one of the ugly sisters), Ondine, Daphnis and Chloe, La Fille mal gardee, Facade and Symphonic Variations. Ashton was knighted in 1962 and received both CH (1970) and OM (1977).
Ashur-bani-pal (or Assurbanipal) (d.626 BCE?). King of Assyria 668-627 BCE. The great-grandson of ${ }^{*}$ Sargon II, his half-brother Shamash-shum-ukin was an essentially subordinate king in Babylon who attempted to gain full independence, failed and suicided (648). Ashur-bani-pal was a scholar, athlete, soldier and administrator who created a great library of 22,000 cuneiform tablets in his capital at Nineveh, texts being collected from throughout the Near East and copies made. Deeply devout and a patron of the arts, his palaces and temples were notable for magnificent sculptured panels (many of which are in the British Museum and the Metropolitan Museum, New York). He lost Egypt (654) but conquered Phoenicia and Elam: however, the lavishness and expense of his rule created enmity in the provinces and his empire barely survived him. He was sometimes identified with the legendary ruler Sardanapalos.

Asimov, Isaac (1920-1992). American science fiction writer, biochemist and encyclopaedist, born in Russia. His family migrated to the US in 1923. Educated at Columbia University, he taught biochemistry at Boston University intermittently from 1949. The Foundation Trilogy (1951-53) and The Robot series (1954-85) established him as a pre-eminent science fiction writer. There are more than 500 books in his bibliography, including a biographical dictionary of scientists, histories of the US, Romans and Egyptians, the Bible, ${ }^{*}$ Shakespeare, ${ }^{*}$ Milton, astronomy and crime stories. He was a serial groper, a claustrophile with a phobia about flying. He coined the word 'robotics' and his 'Three Laws of Robotics' remain influential. Asteroid 5020 Asimov and a crater on Mars were named for him.

Aske, Robert (d.1537). English rebel. A lawyer who led the rising in the north of England known as the 'Pilgrimage of Grace' (1536) in protest against the dissolution of the monasteries by ${ }^{*}$ Henry VIII. Having received assurances, including a promise of his personal safety, he persuaded the rebels to disperse, but was immediately arrested, convicted of treason and hanged.

Prescott, H. F. M., The Man on the Donkey. 1952.

Asoka (c.300-232 BCE). Indian Emperor c.270-232 BCE. Grandson of the conquering Chandragupta Maurya, he became ruler of all India except the extreme South. Repentance for the bloodshed effected a conversion to Buddhism so violent and complete that (from c.257) the whole machinery of government was used as a propaganda machine for spreading the Buddhist faith, by such means as texts carved on walls (many of which survive) and officers sent out to ensure that the rules of piety were observed. His ambassadors became missionaries and so compelling was the impetus set in motion that within 20 years of his death the faith had reached China, whence it spread to Japan and Korea and elsewhere. Asoka sent his own son to Ceylon, which 
has been a stronghold of Buddhism ever since. The unfortunate result of these pious and peaceful exercises was that the country, having abandoned its means of self-defence, was quickly overrun after Asoka's death.

Moorkerji, R. K., Asoka. 3rd ed. 1962.

\section{Aspasia see Pericles}

Asperger, Hans (Johann Karl Friedrich) (19061980). Austrian pediatrician, born in Vienna. An enthusiastic supporter of the Nazi regime, he diagnosed autism spectrum disorder in children (1944), but his initial research paper was largely ignored until the 1980s when the condition, called 'Asperger's syndrome' (AS), became fashionable, and applied as a retrospective diagnosis (*Newton, ${ }^{*}$ Darwin, ${ }^{*}$ Einstein, Bill ${ }^{*}$ Gates). Since 2015 the name AS has been incorporated in broader definitions of autism.

Sheffer, E., Asperger's Children. 2018.

Asquith, Herbert Henry, 1st Earl of Oxford and Asquith (1858-1928). British Liberal politician, born at Morley, Yorkshire. Educated at the City of London School and Balliol College, Oxford, his impressive academic successes included the Craven Scholarship. He became a successful barrister (QC 1890) and first entered parliament in 1886 as Liberal Member for East Fife, serving 1892-95 as Home Secretary under ${ }^{*}$ Gladstone and Lord ${ }^{*}$ Rosebery. During the long spell of Conservative rule that followed, Asquith's standing so greatly increased that when at last the Liberals returned triumphantly in 1905 he became Chancellor of the Exchequer in *Campbell Bannerman's Government and, in April 1908, succeeded him as Prime Minister. His ministry, which contained ${ }^{*}$ Lloyd George, Winston *Churchill and Sir Edward ${ }^{*}$ Grey, put through a major program of reform including old age pensions, Welsh Church disestablishment and National Insurance, but the greatest parliamentary battles (in the course of which Asquith was confirmed in power by the two elections of 1910) were over a bill depriving the House of Lords of a final veto and over Irish Home Rule. Declaration of war in August 1914 seems to have come as a surprise to him, but the country was supportive, expecting rapid victory. However, early defeats and disappointments shook the faith of many in Asquith as a director of the war effort, brilliant though his peacetime administration had been. The formation of a coalition government in 1915 was temporarily reassuring, but in December 1916 popular unease and political intrigue brought about his displacement by Lloyd George. From this rift neither Asquith nor the Liberal Party (of which he remained the official leader) ever recovered. He lost his seat at East Fife in 1918 and, though re-elected at Paisley (1920), he was never able to bring his party back to a position of strength. He accepted a peerage in 1925. Asquith enjoyed great happiness in both his marriages. His children by the first, all of whom gained distinction in different fields, included Lady Violet Bonham Carter (1887-1969), later Baroness Asquith, who inherited much of her father's political talent. His second wife was the brilliant, witty Margot Tennant (1862-1945), whose son Anthony Asquith (19021968) became a distinguished film director.

Jenkins, R., Asquith, 1964; Coss, S., Asquith, 1976.

Assad, Hafez al- (1930-2000). Syrian politician and soldier. An Alawite, a minority Muslim sect, he joined the Arab Socialist Renaissance (Ba'ath) Party in 1946, served in the air force and became its commander. He was Minister for Defence 1966-70, and after a coup, Prime Minister 1970-71 and President of Syria 1971-2000. One of Israel's strongest opponents, he had an uneasy relationship with his fellow Bathist in Iraq ${ }^{*}$ Saddam Hussein. Hafez planned that his brother Rifaat Ali al-Assad (1937-) would succeed, but after a serious dynastic feud settled on his own son Bassel al-Assad (1962-1994), army officer, athlete and potential reformer. Bassel died in a car crash, and Hafez's second son, Bashar al-Assad (1965- ), an ophthalmologist, trained in London, succeeded as President 2000- . After promised political reforms failed to eventuate, and after the Arab Spring movement which toppled regimes in Egypt, Tunisia, Yemen and Libya, civil war broke out in Syria in 2011, with savage fighting and atrocities on both sides.

Assange, Julian Paul (1971- ). Australian publisher, editor and activist, born in Townsville. He was an early internet hacker, became a computer programmer and studied at Melbourne and Canberra universities. In 2006 he founded WikiLeaks which published material designated 'secret' to demonstrate discrepancies between what governments claimed and what they were actually doing. Assange, understandably apprehensive about being tried in the US for espionage, sought and received diplomatic asylum at the Embassy of Ecuador in London (2012). Expelled from the embassy in April 2019, he was imprisoned for having breached UK bail conditions. Extradition proceedings were initiated by the US (Sweden having withdrawn a similar application). In 2022, UK courts and the Home Secretary approved his extradition.

Astaire, Fred (né Frederick Austerlitz) (1899-1987). American dancer. He performed in a number of musical comedies in London and New York with his sister Adele (1898-1981) (who later married Lord Charles Cavendish), and made 37 films: he was partnered by Ginger Rogers (1911-1995) in 10 of them.

Aston, Francis William (1877-1945). English physicist. He extended the work of J. J. *Thomson on isotopes and developed the instrument known as the mass spectrograph to study them. Aston showed that 
almost all the natural elements consist of mixtures of isotopes. For this work he received the Nobel Prize for Chemistry in 1922. His original mass spectrograph is preserved in the Science Museum, London.

Astor. German-American-British family, with important social and business connections in Britain and America. John Jacob Astor (1763-1848), son of a German butcher from Waldorf, near Heidelberg, arrived in America in 1784 and made a vast fortune in the fur trade and in property speculation in New York. A great-grandson, William Waldorf Astor (1848-1919), was active in American politics and diplomacy before settling in England. In 1917 he was created Viscount Astor. The wife of the 2nd Viscount, Nancy Witcher Astor, née Langhorne (1879-1964), born in Virginia, was a Conservative MP 1919-45 and the first woman to actually sit in the Commons. She received the $\mathrm{CH}$ in 1937. Her brother-in-law, John Jacob Astor (1886-1971), was created Baron Astor of Hever in 1956. Among family interests were (elder branch) the Observer and (younger branch) The Times newspapers. Cliveden, with strong social and political associations, was the family seat.

Sykes, C., Nancy. Life of Lady Astor. 1972; Fort, A., Nancy: The Story of Lady Astor. 2012.

Atahualpa (c.1502-1533). Last independent Sapa Inca 1532-33. On the death of his father Huana Capac (d.1527) from smallpox, he became King of Quito while his older half-brother Huáscar (d.1532) received most of the Inca Empire, centred on Cuzco. In May 1532, during a five-year period of brutal civil war, the Spaniards invaded under Francisco *Pizarro. Atahualpa's troops defeated and seized Huáscar and he became Sapa (or supreme) Inca. When Atahualpa was ambushed and taken prisoner by Pizarro's men at Cajamarca in November 1532, he proffered a roomful of gold and silver objects (24 tonnes in total) as ransom. Having melted down the treasure, the Spaniards garrotted him to demonstrate their power and to crush possible rescue attempts.

Atatürk, (Mustafa) Kemal (1881-1938). Turkish soldier and politician, born in Thessalonika. Son of a customs official, he joined the Young Turk reform movement in 1908. He gained an army commission and won rapid promotion; he fought against the Italians in Tripoli (1911) and in World War I saved the situation at a critical moment (1915) in the Gallipoli campaign - a result that made him famous. He later served in the Caucasus and Syria. After the collapse of the Ottoman Empire, with Constantinople (Istanbul) under Allied occupation and sultan *Mehmed VI supine and powerless, he was in Anatolia and led the great movement of national resistance stirred by an invasion by Greece. He threw off allegiance to the sultan, and established a provisional government at Ankara (April 1920). He led the Turks to victory in the War of Independence which resulted, with eventual Allied acquiescence, in the expulsion of the Greeks, the deposition (1922) of the sultan, and the establishment (1923) of a republic with Kemal as first president 1923-38. He made no attempt to regain the Arab lands lost in the war and concentrated his activities on creating a strong modern state in the Turkish homelands of Anatolia and what remained of Turkey in Europe. Ankara became the new capital. His basic policies were 1 . maintaining territorial integrity, 2. secularism and 3 . democracy. The outward signs of his modernisation, e.g. the unveiling and emancipation of women, the replacing of the fez by western headgear, the adoption of surnames, the introduction of the Gregorian calendar and of Latin script, signalled a reawakening of a people dormant for centuries under corrupt and often oppressive rule. That these changes had taken place so quickly and with so little disturbance was due to the patriotic fervour, the military skill, the driving energy, the shrewd judgment and occasional restlessness of Mustafa Kemal, who auspiciously took the surname 'Father Turk' (Atatürk). He died of cirrhosis of the liver.

Kinross, J. P. D., Atatürk: The Rebirth of a Nation. 1964; Mango, A., Atatürk. 1999.

Athanasius of Alexandria, St (c.296-373). Egyptian (or Greek?) Christian theologian, born in Alexandria. His ethnicity remains controversial. One of the strongest opponents of the doctrines of *Arius at the council of Nicaea (the Athanasian Creed, though it expresses his orthodox views, was probably written by $\mathrm{St}{ }^{*}$ Ambrose), Athanasius succeeded to the see of Alexandria in 328 but was beset by controversy. Despite the presence of the emperor Constantine at Nicaea, the Arian cause gained increasing imperial support. Athanasius was forced five times into exile and in 356 a price was set on his head. In the last years of his life, however, he remained in peaceful occupation of his see. His early book $O n$ the Incarnation is the best known of his many works.

\section{Athelstan see Æthelstan}

Athlone, 1st Earl of, Alexander Augustus Frederick William Alfred George Cambridge (né von Hohenstein) (1874-1957). British soldier and courtier, born in London. Originally Prince Alexander of Teck, he was the younger brother of Queen *Mary, consort of ${ }^{*}$ George V, and married Princess Alice Mary Victoria Augusta Pauline of Albany (1883-1981), granddaughter of Queen *Victoria. He fought in the Boer War and World War I and was Governor-General of South Africa 1923-31 and Chancellor of the University of London 1932-55. Appointed Governor-General of Canada in 1914, he declined to serve during World War I but held the office 1940-45.

Atiyah, Sir Michael Francis (1929-2019). ScottishLebanese mathematician, born in London. He began school in Sudan and Egypt. Educated at 
Trinity College, Cambridge, he became professor of geometry at Oxford 1963-69, of mathematics at the Princeton Institute for Advanced Study 1969-72, Royal Society research professor at Oxford 1973-90, Master of Trinity College, Cambridge 1990-97 and President of the Royal Society 1990-95. He received the Copley Medal in 1988 for 'his fundamental contributions to geometry, topology, analysis and theoretical physics' and the OM in 1992.

Atkinson, Sir Harry Albert (1831-1892). New Zealand politician, born in England. He migrated to New Zealand in 1853, held several ministries and was Prime Minister 1876-77, 1883-84 and 1887-91. He took a leading role in abolishing the provincial governments. A convinced social reformer, he was forced to make financial stability his first concern.

Attenborough, Sir David Frederick (1926- ). English natural history broadcaster, television presenter and writer, born in Middlesex. Educated at Cambridge, he joined the BBC in 1952 and produced many acclaimed series of natural history programs for television, including Life on Earth (1979), The Living Planet (1984), The Life of Birds (1998), The Life of Mammals (2002), Madagascar (2011), Kingdom of Plants (2012) and Africa (2013), which emphasised the beauty and wonder of natural processes, and their vulnerability, from a deep perspective. Elected FRS in 1983, he was awarded a $\mathrm{CH}$ in 1996, the $\mathrm{OM}$ in 2005 and a GCMG in 2020. More than 50 species and genera have been named for him. His brother Richard Samuel Attenborough, Baron Attenborough (1923-2014) was an actor, producer and director. He turned to directing in 1969 and his greatest success was Gandhi (1982), which won eight Oscars in 1983.

Atterbury, Francis (1663-1732). English churchman. He rose to become Bishop of Rochester (1713). On the death of Queen *Anne he became involved in various Jacobite plots, was deprived of his offices and banished (1722). He died in Paris. *Pope, *Swift and ${ }^{*}$ Bolingbroke were among his friends.

Bennett, G. V., Tory Crisis in Church and State, 1688-1730: The Career of Francis Atterbury, Bishop of Rochester. 1976.

Attila (c.406-453). King of the Huns 433-453. Known as 'the Scourge of God', he became king, at first jointly with his brother Bleda, whom he murdered (445), of vast hordes living in lands from the Caspian to the Danube. He several times invaded the eastern empire and in 447 he devastated the Balkans as far as Constantinople and Thermopylae, forcing the emperor Theodosius to yield and pay tribute. In 451 he invaded Gaul and reached Orléans but was forced to return by Aetius, the Roman commander, who had opportunely won over Theodoric, King of the Visigoths. Attila's enormous army was decisively defeated near Chalons-sur-Marne but, though forced to retire into Hungary in 452, he invaded Italy and sacked Aquileia, Milan and Pavia. An advance to Rome was stayed only after a personal interview between the conqueror and Pope ${ }^{*}$ Leo I, although shortage of provisions in his army and plague in northern Italy may have suggested the same course. He was preparing a further invasion of the Balkans when he died of a heart attack on the night of his marriage to the lovely Ildico. His empire collapsed with his death. Attila is the Etzel of German legend, where, as in the Nibelungenlied, he appears as a just ruler and not a ruthless conqueror.

Thompson, E. A., A History of Attila and the Huns. 1948.

Attlee, Clement Richard, 1st Earl Attlee (18831967). English Labour politician, born in Putney. Son of a London solicitor, educated at Haileybury and Oxford, he was converted to socialism by his work as secretary of Toynbee Hall in the East End 1901-13 and lectured at the London School of Economics. In World War I he served in Gallipoli, Mesopotamia and France, rising to the rank of major. Mayor of Stepney 1919-20, he was elected MP for Limehouse in 1922-50, being the first Oxford graduate to represent Labour in the House of Commons. In Ramsay *MacDonald's governments he became Undersecretary for War 1924, Chancellor of the Duchy of Lancaster 1930-31 and Postmaster General 1931. When MacDonald formed a National Government with *Baldwin during the financial crisis of 1931, Attlee stayed with Labour and was Deputy Leader of the Opposition 1931-35 under George *Lansbury and Leader of the Labour Party for a record period, 1935-55. Until Munich he generally agreed with *Baldwin and ${ }^{*}$ Chamberlain on foreign policy, then supported stronger resistance to ${ }^{*}$ Hitler. He joined *Churchill's coalition government as Lord Privy Seal 1940-42 and Deputy Prime Minister 1942-45, taking increasing responsibility for domestic administration. The July 1945 election, the first for 10 years, swept the Conservatives out and Attlee became Prime Minister 1945-51 with an initial majority of 171 , reduced to six in the February 1950 election. His government introduced the National Health Act and the National Insurance Act, reduced the power of the House of Lords, nationalised railways, coal, gas and electricity, and promoted law reform and urban planning. Independence was granted to India and Pakistan (1947), Burma (1947) and Ceylon (1948). Attlee, with his Foreign Secretary Ernest ${ }^{*}$ Bevin, generally supported ${ }^{*}$ Truman in the Cold War (including Korea) and joined NATO; however he recognised ${ }^{*} \mathrm{Mao}$ in China. Although Labour led in the primary vote in the October 1951 election, Churchill won narrowly. Attlee was again Leader of the Opposition 1951-55 until he retired, ensuring that Hugh ${ }^{*}$ Gaitskell succeeded. Astonishingly laconic for a politician, he was a tough, shrewd administrator. As he wrote in a typically terse limerick: 
Few thought he was even a starter:

There were many who thought

themselves smarter

But he ended PM,

$\mathrm{CH}$ and $\mathrm{OM}$,

An earl and a knight of the garter.

Harris, K. Attlee, 1982; Beckett, C., Clem Attlee, 1997; Jago, M., Clement Attlee: the Inevitable Prime Minister, 2015; Bew, J., Citizen Clem. 2016; McKinstry, L., Attlee and Churchill. 2019.

Atwood, Margaret Eleanor (1939- ). Canadian novelist, poet, critic, environmentalist, born in Ottawa. Educated at Toronto and Harvard universities, she taught in Canada, Britain, the US and Australia and won awards for her poetry, novels and short stories. Her novels include Edible Woman (1969), The Handmaid's Tale (1986) and Catseye (1988). The Blind Assassin (2000) won the Booker Prize. She received many awards, including a $\mathrm{CH}$ in 2019. The Testaments (2019) was a long-awaited sequel to The Handmaid's Tale.

Auber, Daniel François Esprit (1782-1871). French composer, born at Caen. He wrote several vigorous 'comic operas', including Fra Diavolo (1830) and Les Diamants de la Couronne (1841). La Muette de Portici (1828) is a grand opera. He directed the Paris Conservatoire from 1842 to 1857.

Aubrey, John (1626-1697). English antiquary. Having lost through litigation his inherited estates in Wiltshire, Herefordshire and Wales, he had to depend upon the patronage of friends such as ${ }^{*}$ Hobbes and *Ashmole. He published a quaint collection of ghost stories and folk lore in Miscellanies (1696), but is best known for his incisive but somewhat malicious profiles of his contemporaries, collected after his death and edited as Brief Lives by Andrew Clark in 1898. The 'Aubrey holes' at Stonehenge were discovered by, and are named after him and he revived interest in megaliths in Avebury. His importance in preserving heritage sites has been lately recognised.

Powell, A., John Aubrey and his Friends. Rev. ed. 1963; Scurr, R., John Aubrey, My Own Life. 2015.

Auchinleck, Sir Claude John Eyre (1884-1981). British field marshal, born at Aldershot. Son of an officer, he served in the east, mostly India, until 1940 , returning to command the pointless but dramatic allied occupation of, and withdrawal from, Norway (May-June 1940). He was appointed GOC, Southern Command (July-November 1940), Commander in Chief, India (November 1940-June 1941), then replaced *Wavell as Commander in Charge, Middle East Command (June 1941-August 1942). He defeated the Germans in Libya and was then pushed back by ${ }^{*}$ Rommel, dismissed by ${ }^{*}$ Churchill and replaced by *Alexander. Again Commander in Chief, India (1943-47), he worked well with the Americans, providing the support for *Slim's success in Burma. He supervised partition in India 1947-48, refused a peerage and retired to Marrakech.

Connell, J., Auchinleck. 1959.

Auckland, 1st Earl of, George Eden (1784-1849). English politician and administrator. Educated at Oxford, he became a lawyer and a Whig MP, and was President of the Board of Trade 1830-35. His friend Lord *Melbourne appointed him Governor-General of India and he served 1836-42, being recalled after failure of the British campaign in Afghanistan. The New Zealand city was named for him.

Auden, W(ystan) H(ugh) (1907-1973). AngloAmerican poet, born in York. Brought up in Birmingham, he attended schools in Surrey and Norfolk, and while still at Christ Church, Oxford, he edited Oxford Poetry, and his own Poems appeared in 1930. He became a teacher and tutor, and spent time in Berlin. Auden was the most influential poet of his generation and one of the most prolific (about 400 poems), with strong left-wing sympathies. He was actively gay; his partners included the novelist Christopher ${ }^{*}$ Isherwood and the American poet Chester Kallman. In 1935 he married Erika Mann, daughter of Thomas *Mann, to provide her with a British passport; the union was unconsummated. In 1937 he observed the Spanish Civil War and wrote effective propaganda. In 1939, with Isherwood, he migrated to the United States and taught in universities, becoming a citizen in 1946 (a mirror image of T. S. *Eliot's experience.) He also rejoined the Anglican communion in 1940.

His works include The Orators (1932), The Dance of Death (1933), Look, Stranger (1935) and Another Time (1940). The Dog Beneath the Skin (1935) and The Ascent of F.6 (1936, with Isherwood) are verse plays, The Rake's Progress a libretto for a *Stravinsky opera (1951). He edited The Oxford Book of Light Verse (1938). Auden was professor of poetry at Oxford 1956-61. He was nominated for the Nobel Prize for Literature in 1961, 1963, 1964 and 1965. He died in Vienna and was buried in Kirchstettin.

His status as a poet was controversial, but Frank *Kermode regarded him as the greatest of his time. His most familiar poems include 'Funeral Blues', elegies to *Yeats and *Freud, 'Lullaby', 'Spain 1937', 'September 1, 1939', 'If I Could Tell You' and 'A Summer Night'. His wrinkled face has been described as 'a wedding cake left out in the rain'.

Spender, S. (ed.), W. H. Auden: A Tribute. 1975; Osborne, C., W. H. Auden. 1980; McCall Smith, A., What W. H. Auden Can Do for You. 2014.

Audubon, John James (1785?-1851). American ornithologist and artist. Of French descent, born either near New Orleans or in Haiti and educated in France, where he studied painting under *David, 
he spent most of his later life in Kentucky and on the Hudson devoting his time to the observation of birds. Between 1827 and 1838 he published Birds of America, with 435 remarkable coloured engravings. The Quadrupeds of North America was completed by his sons in 1854. The legend that he was the dauphin (Louis XVII), son of *Louis XVI, has no substance.

Herrick, F. H., Audubon the Naturalist. 1968.

Auerbach, Frank Helmut (1931- ). British painter, born in Berlin. Evacuated to England in 1939, his parents died in a concentration camp in 1942 . He was an actor, then a teacher and first exhibited in 1956 and won prizes at the Biennales in Venice 1982 and 1986 for his powerful depictions of urban life.

Hughes, R., The Art of Frank Auerbach. 1990; Lampert, C., Frank Auerbach. Speaking and Painting. 2015 .

August II 'the Strong' (Friedrich August von Wettin) (1670-1733). King of Poland 1697-1704, 1709-33, Grand Duke of Lithuania 1697-1704 and Elector of Saxony 1694-1733. On the death of Jan *Sobieski, he was elected from 18 candidates for the Polish throne, having pledged to become a Catholic. After being defeated by ${ }^{*}$ Charles XII of Sweden, the Diet deposed him (1704) in favour of Stanisław *Leszczyński, until his restoration after the Russian victory at Poltava. August, whose political schemes exceeded his power to achieve them, was far more successful in the artistic field and, under his inspiration, his two capitals, Dresden and Warsaw, achieved a spectacular baroque magnificence. August's nickname 'the Strong' referred to sexual rather than military prowess. He was notorious for the number of his mistresses and about 350 illegitimate children, of whom the best known was the French marshal, Maurice de *Saxe.

Augustine (or Austin) of Canterbury, St (d.604/5). Roman missionary bishop in England. Born to the Roman nobility, he was prior of a monastery at Rome until in 596 Pope *Gregory entrusted him with the mission to convert the English. With 40 priests he landed in Kent, and was received favourably by King * Æthelberth, whose wife Bertha, a Frankish princess, was already a Christian. Augustine was given land on which to build a church at Canterbury, and had soon converted and baptised the king. Before the end of 597 he was raised to episcopal rank. Early successes among the East Saxons were not maintained and Essex reverted to paganism. In 601 Augustine was given authority over the British by Pope Gregory, but they refused to recognise him as Archbishop. This may have been due to his own haughty temperament as well as to resentment at foreign interference. Augustine's mission was therefore only a partial success, but he must be recognised as a great missionary pioneer whose successors ensured the primacy of the Canterbury see.

Deansley, M., Augustine of Canterbury. 1964.
Augustine of Hippo, St (Aurelius Augustinus) (354430). Latin Father of the Church and theologian, born at Tagaste (Souk Arhas), Numidia (now Algeria). Son of a Roman officer, Patricius, a pagan, and a Christian mother, [St] Monica, he practised no religion as a youth but was attracted to Manichaen dualism (*Mani). He studied rhetoric and law in Carthage, lived with a mistress for 15 years and fathered Adeodatus. Professor of rhetoric at Milan 383-86, he experienced a sudden conversion in 386 and was baptised by [St] *Ambrose in 387 . He returned to Tagaste, living a monastic life until chosen as priest of the Christians at Hippo (Annaba, Algeria) in 391. Bishop of Hippo 395-430, he died there during a siege by the Vandals. His influence on Christian theology was enormous. The texts of 252 letters and more than 400 sermons survive, in addition to his books. In his Confessions (c.397), a literary masterpiece, strikingly modern in its psychological insights, he wrote frankly about his early life and feelings, leading to his conversion. De civitate Dei (The City of God), written after 412 is his view of society, and especially, at a time when the fall of the Roman Empire was attributed to its abandonment of its pagan gods, of the relationship between Church and State. On the Trinity is purely dogmatic, and a systematisation of the Christian doctrine on the subject. He also wrote energetically against the Donatist and Pelagian heresies and in doing so clarified and expounded his own convictions: that God's grace is offered independently of merit to those predestined for salvation and that it cannot be refused when offered, that man suffers from the burden of Adam's original sin unless through baptism he gains the redemption secured by Christ's passion, that only by the liberation of his will by God's grace from the enslavement of evil desires can man enjoy the vision and love of God. From his writings, which the above sentences summarise in barest outline, not only medieval Catholics but Calvin and Jansen derived their teaching on predestination. Indeed Augustine's thoughts as they developed over the years, contained inconsistencies, some of which were corrected in Retractationes (428). His feast is on 28 August. Diarmaid *MacCulloch argued that Augustine's impact on Western Christian thought 'can hardly be overstated, and Westerners have generally seen Paul through Augustine's eyes'. Outside the Catholic tradition, Augustine influenced *Schopenhauer, *Kierkegaard and *Nietzsche.

Brown, P., Augustine of Hippo. 1967; Matthews, G. B., Augustine. 2005; Pollman, K., Saint Augustine the Algerian. 2007; Ayres, L., Augustine and the Trinity. 2010; Lane Fox, R., Augustine. 2016; O’Collins, G., Augustine. 2017.

\section{Augustulus, Romulus see Romulus Augustulus}

Augustus (Gaius Octavius) (63 BCE-14 CE). First Roman Emperor 27 BCE-14 CE. Born near Rome, his father, Gaius Octavius, was rich but not patrician; 
his mother, Atia Balba Caesonia, was the daughter of Julia, sister of Julius *Caesar. He became close to Caesar, travelled with him, and was named as heir in his will. On Caesar's assassination in $44 \mathrm{BCE}$, he took the name Gaius Julius Caesar Octavianus. He formed the Second Triumvirate (sometimes called 'The Gang of Three') with Mark *Antony and *Lepidus, tracked down Caesar's assassins, their families and associates, and destroyed them brutally, then divided control of Roman territories (Octavian in the West, Antony in the East, Lepidus in North Africa). From 38 BCE, Octavian was known as Imperātor Caesar Divī Filius: as Commander-in-Chief he held the title of 'imperator', which evolved to mean 'emperor' or supreme ruler, and the other names pay tribute to his deified adoptive father. In $36 \mathrm{BCE}$, he destroyed the power of Lepidus, after a trial of strength in Sicily, spared his life, and sent him into contemptuous exile. By 32 BCE, with Antony obsessed with Egypt and *Cleopatra, Octavian decided to attack.

After Antony's defeat at Actium in 27 BCE the Senate conferred the additional name of 'Augustus', meaning 'great' or 'venerable'. The 'Empire' dates from that year, and he ceased using his birth name.

Augustus was the first ruler of what became known as the Julio-Claudian dynasty, which held power until $68 \mathrm{CE}$. He retained republican forms as a façade, lived comparatively austerely and called himself Princeps Civitatis, or 'first citizen of the state'. In theory his power rested on his possession of old republican offices, e.g. consul (an office he held 13 times), tribune, pontifex maximus. He retained the loyalty of a large, but physically dispersed, army with a generous retirement scheme. He claimed to have found Rome a city of brick and left it a city of marble. He directed the social, economic, political and military reforms which together created the imperial system of the next 400 years. In Italy and the older provinces he ruled through the Senate to which he left much of its dignity and at least some of its power. The outlying provinces were kept under his direct control through an agent (procurator), and the bulk of the army was kept there, with veterans settled in colonies near the frontiers to act as a first line of defence. His military policy was cautious: he did little to extend the limits of the empire except by advancing the frontier in the Danube area, which he held from Bavaria to the Black Sea. The loss of three legions which advanced in 9 CE fortified his cautious policy. It was a source of great pride to him that during his reign the doors of the temple of Janus were closed, indicating that the empire was everywhere at peace.

Economic progress followed: the construction of roads, aqueducts and fine buildings all witnessed to a steadily advancing prosperity. He also patronised the arts and in the 'Augustan Age' *Virgil, *Livy and *Horace all flourished (*Ovid was in exile).

He married three times: (1) Claudia, who had no children by him, (2) Scribonia, mother of his dissolute daughter *Julia, and (3) * Livia Drusilla, who had two sons by a former marriage, ${ }^{*}$ Tiberius and Drusus. Augustus had no sons, adopted Tiberius as his heir and married him to Julia. The month of Sextilis was renamed Augustus (August) for him in $8 \mathrm{CE}$.

He died, suddenly but peacefully, in Nola. He left a huge fortune: two-thirds to Tiberius, his heir, onethird to Livia.

In Rome he is commemorated by the Ara Pacis (dedicated in $9 \mathrm{BCE}$ ), now restored and reassembled on a different site, and his Mausoleum, which was sacked in 410. More statues and images of Augustus survive than all other Roman emperors combined, and he was very careful to promote his stereotypical image. After his brutal beginning, Augustus became a cool, enigmatic character who, for a time, adopted the sphinx as his emblem.

Hamond, M., The Augustan Principate. 1968; Grant, M., Augustus to Constantine. 1971; Goldsworthy, A., Augustus: From Revolutionary to Emperor, 2014.

Aung San (1914?-1947). Burmese nationalist politician. A prominent student leader, he worked with the Japanese during World War II, formed the Burma Independence Army and the AntiFascist People's Freedom League, then worked with the British to defeat the Japanese. He secured appointment to the provisional government, won the elections for a constituent assembly and became de facto Prime Minister. He was murdered together with seven other members of the Executive Council.

Aung San Suu Kyi (often referred to as Suu Kyi or ASSK) (1945-). Burmese (Myanmar) politician and activist, born in Yangon. Daughter of the nationalist leader *Aung San, she was educated in Delhi, Oxford and London, married the English historian Michael Aris (1946-1999), worked for the UN in New York and was exiled by the military government of ${ }^{*} \mathrm{Ne}$ Win. She returned to Burma (Myanmar) in 1988 and became leader of the National League for Democracy (NLD). Although she was placed under house arrest in 1989 her party won the May 1990 election, gaining 81 per cent of the seats. The army refused to cede power and she remained under house arrest until July 1995, attracting international support for her cause. Awarded the 1991 Nobel Peace Prize, she was under house arrest again 2000 02, 2003-10, then given some freedom of movement as part of a moderate reform process, continued by the new President of Myanmar, Thein Sein. In 2011 Suu Kyi visited Europe and the US, receiving her Nobel Prize in Oslo and the US Presidential Medal of Freedom from Barack *Obama. She delivered the 2011 BBC Reith Lectures on 'Securing Freedom'. In April 2012 she was elected to the House of Representatives, receiving 71 per cent of the vote, and became Opposition Leader. In November 2015, in a comparatively free election, the NLD won large majorities in both Houses of Parliament but the 
Constitution had been amended to prohibit any person who had married a foreign national from becoming President. Her nominee ${ }^{*}$ Htin Kyaw became President March 2016-18, with Suu Kyi as State Counsellor (in effect, Prime Minister) of Myanmar and Foreign Minister 2016-21. In 2016 she was criticised by other Nobel Laureates for her failure to prevent the 'ethnic cleansing' of the (Muslim) Rohingya population in Rakhine province. Despite attempting to accommodate pressure from the armed forces, her government was deposed by military coup in February 2021. In four separate secret trials she was sentenced to a total of 23 years in prison and four of her close associates were executed.

Aurangzeb (regnal name Alamgir; Muhi-ud-Din Muhammad) (1618-1707). Emperor of India 16581707. Sixth of the Mughals, he gained the throne by imprisoning his father ${ }^{*}$ Shah Jahan and overcoming the rivalry of his brothers by defeating them one by one and having them put to death. His puritanical Islamic rule alienated the Hindu majority, Sikhs and Rajputs, leading to revolts and building up of the hostile Maratha confederacy was hastened. Hopes of a strong united empire based on tolerance and justice were thus shattered and the way was opened for foreign intervention.

Sarkar, J., A Short History of Aurangzeb, 1618-1707. 1962.

Aurelian (Lucius Domitius Aurelianus) (212-275). Roman Emperor 270-75. Originally a common soldier, he was elected Emperor by the Danube army and consolidated the provinces in that area by evacuating Dacia. In Syria he overcame (271-72) the famous queen $*$ Zenobia. In the west he brought Gaul back to its allegiance by inducing the 'independent' ruler Tetricus to renounce his claims, by this and other successes fully deserving the title 'restorer of the Roman Empire'.

\section{Aurelius, Marcus see Marcus Aurelius}

Auric, Georges (1899-1983). French composer. One of the modernist group known as 'Les Six', much influenced by *Satie and *Stravinsky, he is best known for his colourful dramatic music for ballet (e.g. Les Matelots) and films (e.g. René *Clair's A Nous la liberté and *Shaw's Caesar and Cleopatra).

Auriol, Vincent (1884-1966). French Socialist politician. A lawyer, he was a Deputy 1914-42, secretary of the French Socialist Party 1918-22, and served under *Blum as Minister of Finance 1936-37 and Justice 1937-38. In 1940 he voted against giving full power to *Pétain and was imprisoned 1940-43, escaped to England and worked with the Free French. President of the Constituent Assembly 1946-47, he became the first President of the Fourth French Republic 1947-54.
Aurobindo, Sri (Sri Aurobindo Ghose) (1872-1950). Indian mystic and poet. Educated at Cambridge, he took an active part in the revival of political nationalism but after a term of imprisonment, withdrew to Pondicherry in 1910 . Here he set up an ashram devoted to his concept of a divine evolutionary force which would expand human capacity and lead to utopia. He was an active promoter of 'Integral Yoga and a prolific writer.

Austen, Jane (1775-1817). English novelist, born at Steventon, Hampshire. Daughter of a clergyman, George Austen (1731-1805) who held a family living, and Cassandra Austen, née Leigh (1739-1827), she had one sister, Cassandra (1773-1845), who like herself remained unmarried, and six brothers (two became clergymen, two became admirals). The quiet happy family life was varied by dancing, visiting and play-acting in the barn. In composing material for plays Jane found early opportunities for exercising her talents. She declined two proposals of marriage. Retiring in 1801 George Austen took his family to Bath where they lived until his death in 1805 . Four uncomfortable years at Southampton followed, before the sisters found themselves installed at Chawton Cottage near Alton, Hampshire, now a house museum. Here, with routine enlivened by visits from a growing number of nephews and nieces, she lived for all but the last few months of her life. She died, probably of Addison's disease (but possibly of typhus or bovine tuberculosis) in Winchester and is buried in the cathedral.

The order of publication of her novels is not always that of composition. First Impressions, refused by a publisher in 1797, was rewritten as Pride and Prejudice and published in 1813, after Sense and Sensibility (1811). Northanger Abbey, which began as a satire on the Gothic novel, was completed in 1803 but not published until 1818. She then wrote Mansfield Park (1814), Emma (1816) and Persuasion (1818). Lady Susan, The Watsons and Sanditon were unfinished when she died.

Her novels, published anonymously, were out of print 1820-32. After Richard Bentley republished them they gradually gained recognition with the assistance of Thomas Babington *Macaulay and George Henry ${ }^{*}$ Lewes (although Emily ${ }^{*}$ Brontë was a dissenter). They are remarkable for the beautifully poised satire with which she presents the tensions between individual ambition and social necessity among the 'middling classes' in English country towns in the late 18 th and early 19th centuries. Her dialogue is very witty, her characterisation shrewd and there is a deep vein of irony.

After reading Pride and Prejudice three times, Sir Walter ${ }^{*}$ Scott wrote in his journal (March 1826): 'That young lady has a talent for describing the involvements and feelings and characters of ordinary life which is to me the most wonderful I ever met with.' (By then she had been dead for almost nine years.) 
It is often asserted that events, such as the Napoléonic Wars then raging round her, had little or no influence in her absorbing but limited themes, but the Austen family were only one or two degrees of separation from conflicts in Europe and Asia. There was a family connection with Warren *Hastings in India, even some income from the opium trade, a cousin was married to a French aristocrat guillotined in 1794, an aunt was charged with stealing, and Jane's surviving letters indicate a keen observation of the world around her and a dark humour, sometimes using double entendre. James Edward Austen-Leigh's A Memoir of Jane Austen (1869) led to a sharp increase in interest and her novels were all republished. She has fallen in and out of fashion but is now recognised as one of the greatest writers in the language and (like Emily ${ }^{*}$ Dickinson) her self-imposed limitation in subject matter is seen as evidence of artistic mastery. Her fame has risen steadily since the 1940 s and her novels have been made into much admired films, television series and stage adaptations.

\section{W. H. *Auden wrote:}

You could not shock her more than she shocks me,

Beside her Joyce seems innocent as grass.

It makes me most uncomfortable to see

An English spinster of the middle class

Describe the amorous effects of 'brass',

Reveal so frankly and with such sobriety

The economic basis of society.

Cecil, D., Portrait of Jane Austen. 1978; Nokes, D., Jane Austen. A Life. 1997; Tomalin, C., Jane Austen. A Life. 1997; Byrne, P., The Real Jane Austen. A Life in Small Things. 2013.

Austin, Herbert, 1st Baron Austin of Longbridge (1866-1941). English motor car pioneer, born in Buckinghamshire. He migrated to Australia in 1884 and worked for the Wolseley Company in Melbourne. Back in England by 1890, he designed the first Wolseley car (a three-wheeler) in 1895, and a four-wheeler in 1900. He founded his own Austin Motor Company in 1905, and his highly successful 7 h.p. 'baby' Austin was the first of a line of small cars which revolutionised the pattern of car manufacture and ownership throughout Europe. A Conservative MP 1918-24, he received a peerage in 1936.

Austin, John (1790-1859). English legal philosopher, born in Suffolk. Known as 'the founder of the analytical school of jurisprudence in England', he became a barrister and was first professor of jurisprudence 1826-32 at the new University College, London. Much of his middle life he spent in Germany, often in bad health, and his last years (from 1848), at Weybridge, Surrey. Sound and subtle reasoning, which discerned errors in the traditional phraseology of legal writers, is a main characteristic of his work, much of which is summarised in his Province of Jurisprudence Determined (1832) and the posthumously published Lectures on Jurisprudence (1861-63).

Austin, John Langshaw (1911-1960). English philosopher. Educated at Shrewsbury and Balliol College, Oxford, he was a Fellow of All Souls College 1933-35 and taught at Magdalen from 1935. After service in army intelligence, he became White's professor of moral philosophy at Oxford 1952-60. Influenced by *Wittgenstein, he was, with *Ryle, leader of the 'Oxford school' of philosophy, published little, but had a powerful influence on the analysis of language, especially the need to formulate precise questions before satisfactory answers can be attempted.

Austin, Stephen Fuller (1793-1836). American pioneer. In 1823 he received permission to settle 200 American families in Texas (then in Mexican possession). The colony prospered, but friction developed with the Mexican Government and for a time Austin was imprisoned. After the revolution of 1835 caused by Mexico's abrogation of all states' rights, Austin served until his death as Secretary of State in the provisional government of an independent Texas.

Austral, Florence (Florence Mary Wilson, later Fawaz) (1892-1968). Australian soprano, born in Richmond. A protégé of ${ }^{*}$ Melba, much recorded, she appeared as a dramatic soprano, especially in Wagnerian roles in London and Berlin. She retired to Australia in 1946 and died virtually forgotten.

Avebury, 1st Baron. John Lubbock (1834-1913). English banker, social reformer, and amateur scientist, born in London. Educated at Eton and at home, he was a neighbour and young friend of Charles *Darwin at Downe, wrote many successful books on science, including anthropology, geology, botany, zoology, especially hymenoptera (ants, bees and wasps), and archaeology. In Pre-Historic Times (1865) he coined the terms Palaeolithic and Neolithic to describe distinct periods in the Stone Age. In 1871 he bought Avebury, Silbury Hill and the West Kennet long barrow to ensure their preservation. He was a Liberal MP 1870-1900, Vice-Chancellor of London University 1872-80, Chairman of the London County Council 1890-92 and held office in many professional bodies. After a long campaign, he secured passage of the Ancient Monuments Act (1882). Created a baron in 1900, he took his title from the stone circles in Wiltshire.

Averroës (Abu-al-Walid Muhammad ibn Ahmed ibn Rushd) (1126-1198). Arabic philosopher, jurist and medical writer, born in Córdoba, in Andalusia. He became 'cadi' (judge) in Córdoba, then in Seville, and wrote commentaries on the works of *Aristotle, 
which were widely influential in the Middle Ages. $\mathrm{He}$ attempted to reconcile the Muslim religion and Aristotelianism, and wrote an encyclopaedia of medicine which was widely diffused in Latin translations.

Avery, Oswald Theodore (1877-1955). AmericanCanadian molecular biologist, born in Nova Scotia. $\mathrm{He}$ worked at the Rockefeller Institute, New York, on influenza research. In 1944 his identification of deoxyribonucleic acid (DNA) as the genetic material of chromosomes-the building blocks of plant and animal life-was the foundation of molecular biology. He received the Copley Medal (1945), the Lasker Award (1947) and was nominated 38 times for a Nobel Prize, without success.

Dubos, R., The Professor, the Institute and DNA. 1976.

Avicenna (Latinised version of Ibn Sīnā: full name Abū 'Alī al-Husayn ibn 'Abd Allāh ibn al-Hasan ibn 'Alī ibn Sīnā) (980-1037). Persian polymath, philosopher, theologian and physician, born near Bukhara. His great Qanun (Canon), which codified medical knowledge, rivalled in importance the works of ${ }^{*}$ Galen. He translated ${ }^{*}$ Euclid and also wrote on mathematics, alchemy, music and science. In his philosophical writings, which influenced St Thomas *Aquinas, he attempted a synthesis of Islamic religious teaching and the work of ${ }^{*}$ Plato and *Aristotle. He accepted the view that matter has always existed and opposed the more orthodox belief that the universe was created from nothing.

Afnan, S. M., Avicenna, His Life and Works. 1958.

Avogadro, Amedeo (1776-1856). Italian physicist. A doctor of law, he taught physics in Turin from 1806 , eventually becoming professor of mathematical physics there. He is best known for the statement (Avogadro's hypothesis or law) that, under the same conditions, equal volumes of all gases contain an equal number of molecules (a word he coined). Although put forward in 1811, the importance of this hypothesis was not realised until 1858 when *Cannizzaro pointed out that it could be used to determine atomic weight. Thereafter it played a part in bringing order to chemical classification.

\section{Avon, 1st Earl of see Eden, Anthony}

Ay II (Kheperkheperure) (d.c.1319 BCE). Egyptian pharaoh of the XVIIIth dynasty 1323-19 BCE. High priest and possibly vizier during the reign of his grand-nephew ${ }^{*}$ Tutankhamun, he overturned the monotheism of ${ }^{*}$ Akhenaten.

Ayckbourn, Sir Alan (1939- ). British playwright and theatre director. He went straight from school to work in repertory companies and directed the Scarborough Theatre 1971-2009. From 1959 he wrote 76 plays, generally critical and popular successes, many of them adapted for television, including The Norman Conquests (1975), A Small Family Business (1987) and Henceforward ... (1989).

Ayer, Sir A(lfred) J(ules) (1910-1989). British philosopher. Educated at Eton and Oxford, he was originally known as an expounder of logical positivism. He was Grote professor of the philosophy of mind and logic at London University 1946-59 and Wykeham professor of logic at Oxford 1959-78. His books include Language, Truth and Logic (1936), where he expounded the theory that philosophic argument must be based on linguistic analysis, and The Problem of Knowledge (1956), an examination of the nature of philosophical skepticism and such problems as perception and memory. He was knighted in 1970. His frank autobiography revealed him as a serial philanderer.

Aylmer, Sir Felix (né Felix Edward Aylmer Jones) (1889-1979). English actor. He played upper-class type-cast characters, appeared in 137 films, was Polonius in *Olivier's Hamlet (1947), President of Actors' Equity 1950-69 and knighted in 1965.

Aylwin (Azócar), Patricio (1918-2016). Chilean politician. A lawyer and academic, he was a founder of the Christian Democratic Party (1952), became a senator 1964-73 and under the military rule of General *Pinochet continued cautious advocacy of democratic reform. In December 1989 he was elected President of Chile with 55.2 per cent of the vote and took office in March 1990, with Pinochet retaining command of the armed forces. He was succeeded by Eduardo *Frei in 1994.

Ayub Khan, Muhammad (1908-1974). Pakistani soldier and President. He entered the Indian army from the British military college at Sandhurst, served in Burma in World War II and became Commanderin-Chief of the Pakistani army (1951). He was Defence Minister 1954-55 and succeeded *Mirza as President 1958-69. To mitigate corruption and faction he abolished the 1947 constitution and used authoritarian methods, but prepared for a return to democracy by creating a large number of local councils known as Basic Democracy Units. In 1965 he won the presidential election against Fatima Jinnah, sister of Pakistan's creator, but resigned in 1969 after crop failures and political riots. Ayub's party was obliterated in the 1970 elections.

Azańa y Diaz, Manuel de (1880-1940). Spanish radical politician, born in Alcalá de Henares. A civil servant and writer, he was Prime Minister 1931-33 of the newly formed republic after *Alfonso XIII's fall. He became Prime Minister again (1936) and President 1936-39 during the Spanish Civil War. He fled to France on *Franco's victory. 
Azeglio, Marchese d', Massimo Taparelli (17981866). Italian author and politician. An aristocrat, he studied painting in Rome, married a daughter of Alessandro *Manzoni, wrote several political novels, became an ardent advocate of Italian unification and an opponent of papal rule in the Romagna. One of the pioneers of Risorgimento, he was premier of Sardinia-Piedmont under *Vittorio Emanuele II 1849-52, passed anti-clerical laws but had an uneasy relationship with *Cavour.

Azikiwe, Nnamdi (1904-1996). Nigerian politician. An Ibo, known generally as 'Zik', he lived in the United States 1925-34, lectured at Lincoln University, Pennsylvania, worked as an editor in the Gold Coast (now Ghana) 1934-37, then returned to Nigeria, where he acquired large banking and newspaper interests. Prime Minister of the Eastern region 1954-59, he was Governor-General in 196063 and, after Nigeria became a republic, the first president 1963-66, until deposed by an army coup.

Aznar, José Maria (1953- ). Spanish politician. Leader of the Partido Popular (PP) 1990-2004, he was Prime Minister of Spain 1996-2004. 


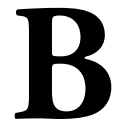

Baader, Andreas (1943-1977) and Meinhoff, Ulrike (1934-1976). German terrorists. They led the Baader-Meinhoff gang of West German leftwing terrorists, politically most active in the 1970s. Meinhoff was murdered in prison and Baader killed himself.

Babbage, Charles (1791-1871). English mathematician and computer pioneer, born in London. Educated at Trinity College and Peterhouse, Cambridge and elected FRS in 1816 (at the age of 25 ), he became a co-founder of the Analytical Society (1812), the Astronomical Society (1820) and the Statistical Society (1834). He held the Lucasian chair of mathematics at Cambridge 1828-39, but delivered no lectures. In On the Economy of Machinery and Manufactures (1832) he extended Adam *Smith's work on the 'division of labour' and proposed theories that F. W. *Taylor later called 'scientific management'. He proposed a machine for tabulating mathematical calculations for up to 20 decimal places and received government support 1823-42 for developing the first analytical computer, the programmed mechanical 'difference engine', but it was left incomplete. He then designed 'Difference Engine No. 2' (1846-49) but it was not built until 1991. (It is now displayed in the London Science Museum.) A small Swedish model, influenced by Babbage, was produced in 1854. From 1837, Babbage planned an 'analytical engine' to be fed by sets of Jacquard punch cards read by mechanical 'feelers', but it was never completed. It incorporated memory storage and anticipated modern computer techniques, such as 'conditional transfer', where intermediate calculations automatically direct the machine to modify its own program. He worked with Ada *Lovelace who published the first algorithm for a computer (1843).

Babbage's interests included theology, economics, dendrochronology and cryptography. $\mathrm{He}$ was a parliamentary candidate in 1832 and 1834, and declined a knighthood. He invented the speedometer, the cowcatcher for trains, and an ophthalmoscope.

Hyman, A., Charles Babbage. 1984.

Bab ed-Din (1821-1850). Persian religious leader. The name (Arabic: 'gate of faith') given to Mirza Ali Mohammed of Shiraz, who was recognised by one of the Shi'ite sects as a new prophet. The new religion he preached, Babism, was compounded from Sufism, Gnosticism and the Koran. He and his followers were persecuted and after an ineffectual rebellion in Tabriz the Bab was executed. His disciples took refuge in Turkey and Palestine and from the latter a new leader, Baha Ullah, emerged.
Babel, Isaak Emmanuilovich (1894-1940). Russian writer, born in Odessa. A friend of ${ }^{*}$ Gorki, he served with the Bolsheviks in the Civil War and was both appalled and exhilarated by the carnage. His works included Tales of Odessa (1923-24), the short story cycle Red Cavalry (1926) and the play Sunset (1928). Arrested in 1939, he was tortured and executed on *Stalin's orders and rehabilitated in 1954.

Babeuf, François Noël (1760-1797). French socialist and journalist. He found his original occupation as a collector of feudal dues highly distasteful and on the outbreak of the Revolution he immediately gave it enthusiastic support with popular and inflammatory articles. With the advent of the Directory his influence with the leaders waned. He believed strongly in economic as well as political equality and advocated a form of communism, i.e. the equal distribution of the products of labour. His paper and organisation were proscribed. His plan for an insurrection was betrayed and he and 30 of his followers were executed. His theories (known as Babeufism) inspired several later egalitarian movements.

Thomson, D., The Babeuf Plot: The Making of a Republican Legend. 1947.

Babington, Anthony (1561-1586). English conspirator. A wealthy Roman Catholic landowner in Derbyshire, he entered into a conspiracy to murder *Elizabeth I, free ${ }^{*}$ Mary and make her queen. But cipher correspondence was discovered by *Walsingham, Babington fled, and was caught and executed.

Babur (= lion. Zahīr ud-Dīn Muhammad) (14831530). Emperor (Padishah) of India 1626-30. First of the Mughals, born in Uzbekistan, great-greatgrandson of *Timur the Great (a.k.a. Tamerlane), he became ruler of Turkestan at the age of 12 but, troubled by constant revolts, he aimed at conquests to the south. After exploratory raids resulting in the occupation of much of Afghanistan he crossed the Indus in 1525 and in 1526 gained a decisive victory at Panipat over the Afghan Emperor of Delhi, confirmed by defeating the Rajputs the following year. In his short period of rule in northern India he improved communications and consolidated the administration of his realm.

Talbot, F. G., Memoirs of Babar. 1968.

Bach, Alexander, Freiherr von (1813-1893). Austrian bureaucrat. A lawyer, as Minister for the Interior 1849-59, he was the architect of a system of mildly reformist bureaucratic activism for the Austrian Empire, used to counter-balance nationalist populism.

Bach, Johann Sebastian (1685-1750). German composer, born at Eisenach. Since the early 16th century, more than 50 of his male relatives are listed as church or town musicians in Thuringia and 
neighbouring provinces. Youngest son of Johann Ambrosius Bach (1645-1695), who taught him the violin, both his parents died before he was 10 . Sebastian then lived with his eldest brother Johann Christoph Bach (1671-1721), from whom he learned organ and clavier playing. He sang in several church choirs, studied intensely and walked long distances to hear notable organists. He composed his first instrumental works about 1703 and played violin in the orchestra of Prince Johann-Ernst of Weimar and was organist at the Lutheran churches in Arnstadt 1703-07 and Mühlhausen 1707-08. In 1705 he walked from Arnstadt to Lübeck, more than 400 kilometres, to meet Dietrich *Buxtehude.

Bach wrote more than 1,100 works which were catalogued (1950) by Wolfgang Schmeider as BWV (Bach-Werke-Verzeichnis), grouped thematically and followed by a number. Some compositions have been lost and some attributions on the list are disputed.

In the years 1703-08 he composed many complex organ works, revealing his absolute mastery of counterpoint: these include the Toccata and fugue in D minor, BWV 565 (although the absence of an early MS has raised questions about its authorship), and the Passacaglia and fugue in C minor, BWV 582.

In 1707 he married his cousin, Maria Barbara Bach, who bore him seven children, and died in 1720 . Bach won a high reputation as an instrumentalist and was court organist to the Duke of Weimar 1708-17. The six 'Brandenburg' concertos for orchestra with various combinations of solo instruments are now thought to have been composed in Weimar, despite the publication date of 1721. As Prince Leopold of Anhalt-Cöthen's music director 1717-23, he composed much vivacious instrumental and orchestral music, including four orchestral suites, six suites for solo cello, three sonatas and three partitas for violin (including in No. 2, BWV 1004, the great 'Chaconne'), concertos for violin and clavier.

In 1722 he married Anna Magdalena Wilcken and they had 13 children. Of Bach's 20 children, 10 lived into adult life.

After two other musicians (including *Telemann) had refused the position, Bach became Cantor (musical director) and director of the Choir School at Thomaskirche (St Thomas Church), Leipzig, in 1723 and held the post until his death. He also directed music at the Nikolaikirche. To strengthen his position in the many disputes over administration which broke out within the Church, he sought, and gained, the honorary title of court composer to the Elector of Saxony (1736). At Leipzig, he wrote 295 Church cantatas at great speed, mostly in the years 1723-27, to provide variety for the church choir and congregation. The consistently high quality of his huge output is unparalleled. Of the 224 surviving cantatas attributed to him, a few are probably not authentic. His greatest religious works are the sublime Magnificat (1723), Passion according to St John (1724), Passion according to St Matthew (1727) and Easter Oratorio (1735). The Christmas Oratorio (1734) is a group of six cantatas written for the Christmas season. The Mass in B Minor, was a rarity in the Lutheran tradition: a complete mass, sung in Latin, but with impassioned orchestral parts. Of its 26 sections (one repeated), all but three are recycled from earlier works, the earliest composed in 1714. It took its final form in 1749 , but was not performed complete until 1859. Despite the spasmodic nature of its composition, it has great architectural strength and sublime expression. He also wrote about 30 'secular cantatas', cheerful works usually commemorating birthdays, weddings or ceremonies.

The 48 preludes and fugues for keyboard, usually known as Das Wohltemperierte Klavier (The WellTempered Clavier), in two books (I: BWV 846, 1722; II: BWV 893, 1742), demonstrate Bach's enthusiasm for 'equal temperament'-tuning the notes of an octave in keyboard instruments into 12 semitones (the chromatic scale) with equal frequency intervals between each note. Far from being a forbidding set of exercises, the work has an exceptional emotional range, coupled with increasingly complex, but fascinating, challenges to technique.

Bach was the greatest master of polyphonic form but also experimented with rich chordal harmonies in The Goldberg Variations (1742) and in many of his organ works. The great prelude and fugue in E Minor ('The Wedge') was written about 1730. The Musical Offering, a set of variations based on a theme given to Bach by *Friedrich II ('the Great') (1747) is an encyclopaedia of instrumental counterpoint.

In 1749 he became blind from cataracts. An operation by the English eye surgeon Sir John Taylor was unsuccessful (as he also was with ${ }^{*}$ Händel). Bach died of a stroke in the following year. Originally buried in the old cemetery at Johanniskirche, he was relocated in the church in 1894 , then reburied in the Thomaskirche in 1950.

Bach enjoyed only a modest fame compared to his contemporaries Telemann and Händel, and his music was seldom performed, although ${ }^{*}$ Mozart, *Beethoven and *Chopin admired him greatly. Bach's successor in Leipzig, Gottlob Harrer, did not perform his music.

In $1829{ }^{*}$ Mendelssohn revived the St Matthew Passion in Berlin. In 1850 Moritz Hauptmann founded the Bach Gesellschaft, which discovered many works thought to be lost and stimulated a great revival of interest in his life and music. Many critics rank him as the greatest of all composers.

A motif based on the notes B bA C B (in German notation, B A C H) was used by Bach himself in Art of the Fugue and, as a tribute, in about 400 works by composers including ${ }^{*}$ Schumann, ${ }^{*}$ Liszt, ${ }^{*}$ Brahms, 
${ }^{*}$ Rimsky-Korsakov, ${ }^{*}$ Busoni, ${ }^{*}$ Reger, ${ }^{*}$ Schoenberg, *Ives, *Webern, *Schnittke and *Pärt.

Albert *Schweitzer argued in his biography that Bach was not a composer of 'absolute' or abstract music, but a poet and mystic whose works were intensely dramatic and pictorial. Paradoxically, he considered that *Wagner's dramatic intensity had stimulated a fresh approach to Bach's emotional depth and power.

Three of Bach's sons were noted musicians (contemporaries ranked them higher than their father). Wilhelm Friedemann Bach (1710-1784), the greatest organist of his day, composed sonatas, concertos and fantasias for organ and clavier. Carl Philipp Emanuel Bach (1714-1788), a brilliant keyboard virtuoso who became chamber musician to Friedrich II in Potsdam (1740-67), then succeeded *Telemann as director of music at five Hamburg churches. He helped to establish sonata form, pioneered 'harmonic' music (in contrast to 'polyphonic') and wrote some of the earliest symphonies, which influenced *Haydn and *Mozart. He was a forerunner of romanticism and 'Sturm und Drang', his music being marked by sudden, unexpected modulations, pauses and emotional tension. He wrote 52 harpsichord concertos, many transcribed for other instruments, e.g. the amazing Flute Concerto in D Minor, H. 426 (1747). The first music by a European composer known to have been performed in Australia was by C. P. E. Bach. His youngest brother, Johann Christian Bach (17351782 ), lived and studied in Italy 1750-62, became a Catholic, then moved to London in 1762, taught music to Queen ${ }^{*}$ Charlotte and was known as 'the English Bach.' In the case of Bach v. Longman (1777), Lord *Mansfield ruled that copyright applied to musical scores. J. C. Bach wrote several operas, six symphonies, helped to develop sonata and symphonic form and influenced the young Mozart.

Schweitzer, A., J.S. Bach, 2 vols. 1905, revised 1966; Hofstadter, D.R., Gödel, Escher, Bach: An Eternal Golden Braid. 1980; Wolff, C., Johann Sebastian Bach: The Learned Musician. 2000; Gardiner, J. E., Bach: Music in the Castle of Heaven. 2013; Elie, P., Reinventing Bach. 2013.

Bachelard, Gaston (1884-1962). French historian and philosopher of science, born at Bar-sur-Aube. Some of his early work, such as La Formation de L'Esprit Scientifique (1938) was concerned with the obstacles which had traditionally hampered scientific thinking: metaphysics, anthropomorphism. He wanted to apply *Freud's work to understand the factors that had repressed scientific intelligence. Thus he saw alchemy as the projection of inner desires, whereas chemistry developed a body of formal experimental practices which took it out of the field of the subjective into the scientific. Bachelard also pioneered a 'structuralist' understanding of scientific thought. He tried to uncover the often hidden affinities which linked certain concepts. He believed that science progressed not by gradual evolution, but by sudden leaps from one framework of reference to another.

Dagognet, F., Gaston Bachelard. 1965.

Bachelet Jeria, (Verónica) Michelle (1951- ). Chilean politician, born in Santiago. Her father, an army administrator, was arrested, tortured and died in custody (1974). With her mother she was briefly a refugee in Australia (1975), then went to East Germany. A surgeon, pediatrician and epidemiologist, she was a Socialist moderate who served as Health Minister 2000-02, Defence Minister 2002-04, and became Chile's first female president 2006-10. She worked for a UN agency in New York, then ran for a second presidential term in 2013, winning 62 per cent of the vote in a second ballot. She became United Nations Commissioner for Human Rights 2018-.

Bacon, Francis, 1st Viscount St Alban, Baron Verulam (1561-1626). English lawyer, scientist, essayist and philosopher, born in London. His father, Sir Nicholas Bacon (1509-1579), was Keeper of the Great Seal to Queen *Elizabeth, his mother an aunt of William Cecil, Lord *Burghley. He attended Trinity College, Cambridge between the ages of 12 and 14, then studied at Gray's Inn, London, spent a few years in diplomacy and in 1586 became a bencher of Gray's Inn. He was a Member of Parliament 1584-1617. He became a protégé of the Earl of ${ }^{*}$ Essex but did not scruple to appear for the prosecution when Essex was tried for treason in 1601. Under *James I, Bacon advanced steadily: in 1613 he became AttorneyGeneral and in 1618 Lord Chancellor with the title Baron Verulam. In 1621 he became Viscount St Alban but in the same year was charged with bribery and corruption. He insisted that gifts received had not affected his judgments, but he was imprisoned briefly and banished from court and parliament. Side by side with his public life he followed his literary, scientific and philosophic pursuits. His Essays on such subjects as truth, adversity and death were first published in 1597 and issued in final form in 1625 . His philosophic and scientific work was intended to summarise the state of knowledge so far attained and outline a method by which this knowledge could be renewed and advanced. The latter purpose is the theme of Novum Organum, written in Latin, published in 1620 and intended to be part of a great all embracing work The Great Instauration. His method was a kind of tabular analysis of affinities and deviations by which he supposed scientific definition could be reached. The definition of heat arrived at by his method 'Heat is an expansive motion restrained and striving to exert itself in the smallest particles' is near the truth but the method in general has not proved useful to later scientists. His great significance in the history of science lies in the stress he gave to the value of experiment and to the failure of scholastic methods to arrive at a true understanding of nature. Other 
literary work includes The Advancement of Learning (1605) and The New Atlantis (1626), inspired by Sir Thomas *More's Utopia.

The theory that Bacon was the real author of the Shakespearian plays was first proposed in print in 1856 (independently) by Delia Bacon and William Henry Smith and has generated a vast, self-deluding, literature. *Pope's description of Bacon 'as the wisest, brightest, meanest of mankind' is probably unfair, but it is certain that a lack of moral fibre prevented him in times of crisis from living up to his best intentions.

Anderson, F. H., Francis Bacon: His Career and His Thought. 1962; Mathews, N., Francis Bacon. 1996.

Bacon, Francis (1909-1992). British painter, born in Dublin. Of English parentage, traumatised by his father, he had no formal training but spent two years in Berlin and Paris, then worked in London 1928-31 as an interior decorator and furniture designer. He exhibited in the 1930s but destroyed almost all of his early work. In 1945 his Three Studies for Figures at the Base of a Crucifixion (1944), now in the Tate Gallery, created violent controversy, showing figures of unrelieved horror, images evoking wartime concentration camps, far removed from serene landscapes or salon painting. Bacon's works were often inspired by other paintings, photographs or films, for example his Study after Velazquez's Portrait of Pope Innocent X (1953), sometimes called the screaming Pope', images from *Eisenstein's Battleship Potemkin and *Muybridge's photographs of 'animal locomotion'. Retrospectives were held at the Tate in 1962 and exhibited at the Tate, and in Paris and Washington in 1985. By then many critics considered him the greatest living painter. His Triptych May-June 1973 was sold for \$US6.27 million in New York in 1989. In 1983 he declined the OM. Robert *Hughes wrote (1985) that 'no other living painter has set forth with such pitiless clarity the tensions and paradoxes that surround all efforts to see, let alone paint, the human figure in an age of photography'. He died of asthma in Madrid. Three Studies of Lucien Freud (1969) was sold at auction in New York for \$US142.4 million, a record for any art work.

Leiris, M., Francis Bacon, 1987; Gowing, L. and Hunter, S., Francis Bacon 1989; Farson, D., The Gilded Gutter Life of Francis Bacon, 1993; Peppiatt, M., Francis Bacon: Anatomy of an Enigma, 1996; Stevens, M. and Swan, A., Francis Bacon: Revelations. 2021.

Bacon, Roger (c.1214-1292). English scientific philosopher, born according to one tradition near Ilchester, Somerset, and to another at Bilsey in Gloucestershire. Though probably educated in Oxford the first certain date in his career seems to be 1236 when he was studying in Paris. In or after 1251 he returned for a time to England and it may have been then that he joined the Franciscans. For 10 years from 1256 he seems to have been in France years of his life were spent at Oxford. Roger Bacon was a man of great learning and wrote much (e.g. the vast Opus Maius, 1267-68), on many subjects, but as a systematiser rather than an originator. In philosophy Aristotle provided the basis of his philosophical studies as he did for those of all medieval philosophers. His probings into more arcane subjects such as alchemy were in line with the thought of his time. Some of his opinions and speculations evidently incurred the disapproval of his superiors but of his actual imprisonment the evidence is insubstantial. His popular image was, however, that of a necromancer. It is in experimental science that he produced real achievement, especially in optics. $\mathrm{He}$ remains, however, one of the greatest expounders of medieval knowledge and thought.

Crowley, T., Roger Bacon. 1950; Clegg, B., Roger Bacon: The First Scientist. 2003.

Baden-Powell, Robert Stephenson Smyth BadenPowell, 1st Baron (1857-1941). English youth leader and general. Son of an Oxford professor of geometry, he was educated at Charterhouse School and joined the Indian Army in 1876. He campaigned in Afghanistan (1880-81), Zululand (1888), Ashanti (1895-96) and Matabeleland (1896) and became famous as the defender of Mafeking during the Boer War, when he was besieged with 1200 men for 215 days (1899-1900). In 1907 he founded the Boy Scouts movement which became established internationally and which he led as Chief Scout until his death. In 1910 he set up the Girl Guides with his sister Agnes, followed by Sea Scouts, Wolf Cubs and Rover Scouts. He wrote Aids to Scouting (1899), Scouting for Boys (1908) and 30 other books, all illustrated by himself. He received a peerage in 1929 and the OM in 1937. Although Scouts were banned by the Nazis in Germany in 1934, as late as 1939 Baden-Powell thought ${ }^{*}$ Hitler's Mein Kampf was 'a wonderful book'. His sexuality was controversial. He lived in Kenya from 1939, and died there. His wife Dame Olave St Clair Baden-Powell (née Soames) (1889-1977) became World Chief Guide in 1918.

Jeal, T., Baden-Powell. 1989.

Bader, Sir Douglas Robert Steuart (1910-1982). English aviator. Despite losing both legs in a flying accident in 1931, he rejoined the RAF, led a fighter squadron in the Battle of Britain, and had already brought down 22 opponents when (August 1941), after a collision with a German aircraft in France, he was captured and held in Colditz as a prisoner of war.

Brickhill, P., Reach for the Sky. 1954.

Badoglio, Pietro (1871-1956). Italian marshal. After distinguished service in World War I he was governor of Libya 1928-33 and was in command of the assault on Abyssinia in 1936. At the opening of World War II he was Chief of Staff but resigned in 1940 after Italian 
defeats in Albania. In 1943 he was made premier of an anti-Fascist government, on *Mussolini's fall, and at once negotiated an armistice with the Allies. He resigned in 1944 .

Baedeker, Karl (1801-1859). German publisher, born in Essen. Son of a printer and bookseller, he established his own business in Coblenz and from 1827 he published the famous Baedeker guidebooks. His son transferred the business to Leipzig.

Baekeland, Leo Hendrik (1863-1944). American chemist, born in Belgium. He migrated to the US in 1889, developed Velox photographic paper and sold it (1899) to George *Eastman. A pioneer of the plastics industry, he discovered (1905) the first thermosetting resin of practical importance named Bakelite. He was appointed an honorary professor of Columbia University.

Baer, Karl Ernst von (1792-1876). RussoGerman zoologist, embryologist, ethnographer, and geographer, born in Estonia. He studied at the universities of Tartu and Würzburg, and taught at Königsberg 1817-34, where he discovered the mammalian ovum and the notochord and wrote On the Development of Animals (2 vols, 1828, 1837) which established the basis of the science of embryology. He worked in the Russian Academy of Sciences in St Petersburg 1834-62, explored plant life in northern Siberia, and made discoveries in anthropology and geography. *Darwin used Baer's work in embryology to advance his evolutionary thesis, but Baer rejected the idea of a common ancestry for animals. He was awarded the Copley Medal in 1867.

Baeyer, (Johann Friedrich William) Adolf von (1835-1917). German organic chemist, born in Berlin. From a military family, Baeyer studied chemistry with *Bunsen at Heidelberg, and later with *Kekulé. He took up teaching positions at the Berlin technical institute and military academy 1860-72 and became professor of chemistry at Strasbourg 1872-75 and Munich 1875-1917. A superb experimenter in the field of organic chemistry, Baeyer devoted most of his life to solving problems of structure. After early work on uric acid, he investigated the carboxylic acids of benzene, and hoped to discover the structure of benzene itself. He isolated barbituric acid which led to the development of barbiturates. His main work, begun in 1865, was upon the synthesis of indigo. He successfully prepared indigo from other reagents, and by 1883 had unravelled the formula of its structure. He declined, however, to collaborate with the synthetic dye industry in making commercial use of his analysis. He turned his attention elsewhere, to studying polyacetylenes and other explosive compounds, and experimenting with oxonium compounds. Baeyer was chiefly an empirical chemist, but his work was of some theoretical interest in underlining the strength of ring structures, and investigating the direction of valence bonds. He was awarded the Nobel Prize for Chemistry in 1905.

Baffin, William (1584-1622). English Arctic explorer. A voyage to Greenland (1612) and whaling off Spitsbergen (1613-14) provided the experience for two vain attempts to find the Northwest Passage. In the second (1616) he discovered and named Smith's Sound and Lancaster Sound and explored what is now Baffin Bay and the shores of Baffin Island. In 1617 he abandoned the Arctic for the East and it was while helping the Shah of Persia at the siege of Ormuz that he was killed. He wrote accounts of several of his voyages.

Bagehot, Walter (1826-1877). English political economist, born at Langport, Somerset. After leaving London University he worked in his father's banking firm and, having married a daughter of its founder, James Wilson, was editor of The Economist 1860-77. He applied great scientific acumen to his rigorous analysis of 19th-century economics and politics. In The English Constitution (1867) he identified two distinct functions in the United Kingdom government, 'the dignified' (ceremonial, consensus, apolitical) and 'the efficient' (executive, decisionmaking, partisan, elected). Other books include Lombard Street (1873), Physics and Politics (1875), and Literary Studies (1879).

St John-Stevas, N., Walter Bagehot. 1959; Collected Works of Walter Bagehot. 1966.

Bagration, Piotr Ivanovich, Prince (1765-1812). Russian general. Of Georgian and Armenian descent, he served against the French revolutionary and Napoléonic armies in Italy, Switzerland and Austria and against Turkey in 1809 . He commanded an army against *Napoléon during the advance to Moscow in 1812, and was killed at Borodino.

Bahä’ al-Dīn Muhammad ibn Husayn al-'Āmilī (also known as Shaykh-i Bahā'ī) (1547-1621). Persian architect, astronomer, poet and philosopher, born in Lebanon. He was the architect of the Imam Mosque in Esfahan, begun in 1611, an important teacher and advocate of the heliocentric universe.

Bahadur Shah II, Zafar (Mirza Abu Zafar Sirajuddin Muhammad Bahadur Shah Zafar) (1775-1862). Emperor of India 1837-57, the last of the Mughals. Son of Akbar II, he succeeded when the empire was in decline, being completely controlled by the British East India Company. He was a gifted poet and calligrapher, promoting tolerance for all religions. The Indian Mutiny of 1857, although started by Hindus, was regarded as a treasonable attempt to restore the aged Emperor to power, and there were savage reprisals by British forces. Sentenced to life imprisonment, Zafar died in Rangoon (Yangon) and was secretly buried.

Dalrymple, W., The Last Mughal. 2006. 


\section{Baha-Ullah see under Bab ed-Din}

Bailey, Sir Donald Coleman (1901-1985). British engineer. His invention of a type of bridge which could be carried in sections and quickly erected solved many problems of military transport in World War II and was later adapted for civilian use.

Bailly, Jean Sylvain (1736-1793). French astronomer and politician. He became President of the National Assembly in the opening stages of the Revolution and was Mayor of Paris 1789-91, but retired into private life when blamed for allowing the National Guard to fire on a mob demonstrating against the king. He was later denounced, condemned and guillotined. His great Histoire d'astronomie appeared in five volumes (1775-87).

Bain, Alexander (1818-1803). Scottish philosopher, born in Aberdeen. Educated at Aberdeen, he was professor of logic 1860-81 at the university. His writings, e.g. The Senses and the Intellect (1855), The Emotions and the Will (1859), Mind and Body (1873), cover the borderland territory between physiology, psychology and philosophy. $\mathrm{He}$ also wrote textbooks on grammar and logic and a study of James and John Stuart *Mill (1882).

Baird, John Logie (1888-1946). Scottish electrical engineer, born in Helensburgh. A pioneer of mechanically scanned television, he was dogged by ill health and his early inventions failed, but from 1922 he devoted himself to studying the transmission of pictures by wireless waves. In 1924, at a house in Soho, he first transmitted a televised image over several feet, using a mechanical scanning device. This apparatus (now in the Science Museum, London) was publicly demonstrated in 1926 and Baird's system was given a prolonged test by the BBC. Electronic scanning (*Shoenberg, *Zworykin) was, however, eventually chosen for television systems. Later researches enabled Baird to produce three dimensional and coloured images (1944). In 1927 he also invented a method of direction-finding in total darkness by means of infra-red rays. He made the first ultrashort wave radio transmissions.

McArthur, C., and Waddell, P., Secret Life of John Logie Baird. 1986.

\section{Bajazet see Bayezid}

Baker, Sir Benjamin (1840-1907). English civil engineer. His long association with John *Fowler as consultant showed a record of remarkable achievement. They were responsible for the construction of London's Metropolitan Railway and Victoria Station. Later Baker designed the Central London and other sections of underground railway. Most spectacular was the Forth railway bridge (opened 1890); he was knighted (KCMG). Consultant on the old Aswan Dam (completed 1902), he received
Baker, Sir Herbert (1862-1946). English architect, born in Kent. A pupil of Ernest George, while still a young man he secured the patronage of Cecil ${ }^{*}$ Rhodes and a number of commissions for the design of South African houses, churches and public buildings, including the Anglican Cathedrals in Cape Town and Johannesburg. The Union Building, Pretoria, is the most grandiose example. His appointment as joint architect (with ${ }^{*}$ Lutyens) for the government buildings in New Delhi provided an even wider opportunity for him to display his talent for the magnificent. In London his best known works are the Bank of England and Church House, Westminster. Knighted in 1926, he became an RA in 1932 and wrote Architecture and Personalities (1944).

Baker, James Addison III (1930- ). American lawyer and administrator. Educated at Princeton and Texas universities, he was a lawyer in Houston from 1957 and a close political ally of George *Bush. He served Ronald *Reagan as White House Chief of Staff 198185 and Secretary of the Treasury 1985-88, and Bush as campaign director 1988, 1992 and Secretary of State 1989-92.

Baker, Dame Janet Abbott (1933- ). English mezzo soprano, born in Yorkshire. In 1956 she won the Daily Mail Kathleen *Ferrier Award, and in the same year made her stage debut at Oxford in *Smetana's The Secret. She sang throughout Europe and the US in recital, oratorio and opera, appearing at Covent Garden and Glyndebourne. She was particularly admired for stylish performances of *Monteverdi, ${ }^{*}$ Purcell, ${ }^{*}$ Händel, ${ }^{*}$ Mozart, ${ }^{*}$ Berlioz, ${ }^{*}$ Mahler, ${ }^{*}$ Elgar and ${ }^{*}$ Britten. She was made an honorary fellow of St Anne's College, Oxford in 1975 and received a CH in 1994.

Blyth, A., Janet Baker. 1973.

Baker, Josephine (1906-1975). African-American dancer and singer, born in St Louis. At the Folies Bergère, Paris from 1925 she became famous for her beauty (her lover *Simenon referred to the bottom that laughed') and memorable dress/undress, e.g. girdle of bananas. Like Paul *Robeson she was an important advocate of black rights and racial tolerance. She became a French citizen after World War II as a protest against racial discrimination in the US.

Baker, Sir Samuel White (1821-1893). British traveller, writer and hunter. He lived in Ceylon and wrote Rifle and Hound in Ceylon (1853), built railways in the Balkans and explored Asia Minor. $\mathrm{He}$ investigated tributaries of the Nile in Ethiopia (1861-62) and in 1864 discovered Albert Nyanza, which earned him a knighthood and election as FRS. The Ottoman khedive in Egypt appointed him as Governor-General of the Equatorial Nile basin 1869-73 with the rank of major general and pasha. He worked to suppress the slave trade. 
Bakewell, Robert (1725-1795). English agriculturalist, born at Dishley, Leicestershire. A pioneer of systematic breeding at Dishley, he greatly improved the standard of cattle, sheep and draught horses. He was best known for his breeding and improvement of Leicester sheep and Dishley cattle.

Pawson, H. C., Robert Bakewell: Pioneer Livestock Breeder. 1957.

Bakst, Léon (né Leyb-Khaim Samoylovich Rosenberg) (1866-1924). Russian-Jewish painter and designer. He studied in Paris from 1893, but, with Sergei ${ }^{*}$ Diaghilev and Alexandre ${ }^{*}$ Benois, was a co-founder of the World of Art group in St Petersburg 1899-1904 and taught Marc ${ }^{*}$ Chagall. In Paris from 1906, he designed sumptuous sets and costumes for Diaghilev's Ballets Russes.

Pruzhnan, I., Léon Bakst. 1988.

Bakunin, Mikhail Aleksandrovich (1814-1876). Russian anarchist. An aristocrat by birth and for a short time in the army, he left Russia in 1840, and was condemned in his absence. After taking part in a rising at Dresden during the revolutionary year of 1848 he was handed over to the Russian authorities and imprisoned. Later he was exiled to Siberia, but escaped and reached England in 1861. Most of the rest of his life was spent in a struggle with Karl *Marx to decide the form that socialist doctrine should take: Bakunin's anarchism or Marx's communism. Bakunin, defeated, was expelled from the International in 1872. His book God and the State, in which he called for militant atheism and the destruction of the State, had a great influence on the nihilist movement, especially in Spain and Italy.

Carr, E. H., Michael Bakunin. 1937.

Balakirev, Mili Alekseivich (1836-1910). Russian composer and pianist, born at Nizhny Novgorod. A pupil of *Glinka, he was a successful pianist, and later taught ${ }^{*}$ Mussorgsky and ${ }^{*} \mathrm{Cui}$. He became a leading member of 'The Five' (Cui, Mussorgsky, *Borodin, *Rimsky-Korsakov and Balakirev), a group which revived the nationalist tradition in Russian music. Balakirev, who had to support himself as a civil servant, wrote two symphonies, piano music, many songs and the symphonic poems Tamara (1882) and Russia (1884).

Garden, E., Balakirev. 1967.

Balanchine, George Melitonovich (1904-1983). Georgian-American choreographer, born in St Petersburg. He studied at the Maryinsky Theatre and danced with the Soviet State Dancers before joining *Diaghilev's Ballets Russes in Paris 1924-29 as ballet master. In the US he founded the School of American Ballet (1934) and the New York City Ballet (1948). He created 170 ballets, including Apollo, Firebird, Orpheus and Agon (Stravinsky), La Valse and Valses Nobleset Sentimentales (Ravel), Nutcracker and Ballet
Imperial (Tchaikovsky). He worked closely with Lincoln Kirstein (1907-1996), an art connoisseur, impresario and patron.

Balbo, Italo (1896-1940). Italian airman and politician. A leading Fascist, he was one of the quadrumvirs in *Mussolini's March on Rome (1922), later reputed to have devised the castor oil treatment to humiliate opponents. Minister for Aviation 192931 and a marshal 1931, he flew to Chicago and Rio to promote Italian aviation and his popularity rivalled Mussolini's. Sent as Governor of Libya 1933-40, he opposed the German alliance. His plane was shot down over Tobruk by Italian guns in unexplained circumstances.

Balboa, Vasco Nunez de (c.1475-1519). Spanish conquistador. In 1513 he became the first European to sight the Pacific when, having ousted his predecessor and made himself governor of Darien, he made an epic march across the isthmus of Panama. Meanwhile complaints at the Spanish court about his seizure of power had led to his being replaced by Pedro Arias de Avilla, who accused him of conspiracy and eventually had him beheaded.

Anderson, C. L. G., Life and Letters of Vasco Nunez de Balboa. 1941.

Baldwin (Baudouin). Name of five kings of Jerusalem. Baldwin I (1058-1118) accompanied his elder brother ${ }^{*}$ Godfrey de Bouillon on the first crusade and in 1100 succeeded him as 'defender of the holy sepulchre', immediately taking the title of King and so establishing the Latin kingdom of Jerusalem. He gradually asserted his authority over most of the coastal area of Palestine and Syria. His cousin Baldwin II (d.1131) was Lord of Edessa when chosen to succeed him in 1118 . He spent most of his reign defending the northern parts of the realm. His son-in-law *Fulk of Anjou succeeded him and his grandson, Fulk's heir, became Baldwin III (11311162) (reigned 1143-62). At the beginning of his reign the second crusade, launched to retake Edessa, was defeated in Asia Minor, but Baldwin was an able ruler who by expelling the Egyptians from Ascalon secured his kingdom in the south. Baldwin IV (1161-1185) (reigned 1173-85), 'the Leper', was incompetent. His nephew and successor Baldwin $\mathbf{V}$ (1177-1186) died as a child.

Baldwin, James (1924-1987). American writer, born in New York. Educated in Harlem, he began working in Greenwich Village. His novels, e.g. Go Tell it on the Mountain (1954) and Another Country (1963) are concerned with the position of African-Americans in American society, and his non-fiction works, e.g. Notes of a Native Son (1955) and Nobody Knows my Name (1961), contain several of the essays that made him famous in America. 
Baldwin, Stanley, 1st Earl Baldwin of Bewdley (1867-1947). British Conservative politician, born at Bewdley. Son of a rich steel manufacturer, educated at Harrow and Trinity College, Cambridge, he joined the family firm and it was not until 1908 that he entered parliament. After holding junior offices he was President of the Board of Trade when in 1922 leading members of the Conservative Party forced the resignation of *Lloyd George's coalition. Since most leading Conservatives refused office because of loyalty to Lloyd George, Baldwin gained rapid promotion as Chancellor of the Exchequer 1922-23 under Bonar Law. When fatal illness forced Law to retire, George $\mathrm{V}$ chose Baldwin as Prime Minister in preference to ${ }^{*}$ Curzon. He was Prime Minister three times 1923-24; 1924-29; 1935-37 and the all powerful Deputy to Ramsay *MacDonald in the 'National' government 1931-35 when he showed great skill in handling people and situations. The potentially disruptive General Strike of 1926 and *Edward VIII's abdication crisis of 1936 he overcame without bitterness. Although aware of the threat from *Hitler he shirked advocating a rearmament program that would risk electoral defeat. It is true that he knew that the Labour party was even less ready than he to face the military and political problems caused by the resurgence of Germany, but as the man in power he must be held largely responsible for the years of appeasement and their bitter consequences. Baldwin was a cousin of Rudyard *Kipling and his own tastes were contemplative and literary. For many years he was held to be the epitome of the true-blue middle class Englishman.

Middlemas, K. and Barnes, J., Baldwin. 1969; Young, K., Baldwin. 1976; Jenkins, R., Baldwin. 1987.

Balenciaga, Cristobal (1895-1972). Spanish (Basque) couturier. He became a tailor and dress maker, in Paris from 1936, celebrated for his elegance and simplicity in design.

Balfe, Michael William (1808-1870). Irish composer, violinist and baritone, born in Dublin. He moved to London in 1823, attracted the patronage of *Rossini and sang Figaro in The Barber of Seville in Paris (1828), performed with *Malibran, and was Papageno in the English premiere of The Magic Flute (1838). He composed 29 operas of which only The Bohemian Girl (1843) is still performed.

Balfour, Arthur James, 1st Earl of Balfour (18481930). British Conservative politician, born at Whittingehame, East Lothian. Member of an ancient Scottish family, educated at Eton and Trinity College, Cambridge, he was an MP 1874-1906 and 1906-22. At the opening of his career he was private secretary at the Berlin Conference of 1878 to his maternal uncle, Robert Cecil, 3rd Marquess of * Salisbury, and subsequently his promotion was rapid (whence the phrase 'Bob's your uncle!'). A ruthless but effective
First Lord of the Treasury (a position which, until then had always been held by the Prime Minister) and Leader of the House of Commons 1891-92, 1895-1902 while Salisbury, Prime Minister, sat in the House of Lords. When Salisbury retired in 1902 Balfour became Prime Minister, but his graceful balancing act between the factions of his party failed to convince the electorate of his ability to rule. He lost his seat when the government was defeated in the general election of 1905 . He resigned the party leadership in 1911 and was succeeded by Bonar *Law. The coalitions of World War I restored him to office. He was First Lord of the Admiralty in *Asquith's coalition, and Foreign Minister 1916-19 under Lloyd George. In 1917 he issued the 'Balfour Declaration', promising British support for a Jewish national home in Palestine. As Lord President of the Council 1919-22 and 1925-29, he created links between research and industry. Balfour's mind was too detached, said his detractors, and his charm too great for a successful politician. He could see both sides of a question too clearly to be decisive in action. This view of his character was reinforced by the title of his first book and a misconception of its contents: A Defence of Philosophic Doubt (1879). Later books were The Foundations of Belief (1900) and Theism and Humanism (1915). Awarded the OM in 1916, he was created Earl of Balfour and a KG in 1922, became Chancellor of Cambridge University 1919-30 and President of the British Academy 1921-30. He was unmarried.

Zebel, S. H., Balfour: A Political Biography. 1974; Adams, R. J. Q., Balfour: the Last Grandee. 2007.

Ball, John (d.1381). English rebel and priest. $\mathrm{He}$ preached social equality and his famous sermon at Blackheath on the theme "When Adam delved and Eve span, Who was then a gentleman?' helped to provoke the Peasants' Revolt of 1381 . He was executed at St Albans.

Balla, Giacomo (1871-1958). Italian painter and sculptor. Associated with the Futurists, his best known work Dynamism of a Dog on a Leash (1912) captures movement with wit and vivacity.

Balladur, Édouard (1929- ). French politician and administrator, born in Izmir. He was Georges *Pompidou's Chief of Staff 1974, Finance Minister 1986-88 under *Chirac's 'cohabitation' with *Mitterrand and Prime Minister 1993-1995. He broke with Chirac and in the 1995 presidential election ran third on the first ballot.

Ballantyne, James (1772-1833), and John (17741821). Scottish printers. They were close friends of Sir WaIter *Scott and printed his works. From 1805 he was a secret partner in the firm which, expanding into publishing and bookselling, was known from 1808 as James Ballantyne \& Co. The firm's bankruptcy 
(1826) involved Scott in a liability of $£ 130,000$ so to pay it off he made a heroic writing effort that hastened his death.

Ballantyne, Robert Michael (1825-1894). Scottish author. As a young man he served in Canada in the Hudson's Bay Company. From 1856 he wrote about 80 adventure books for boys, including Martin Rattler, The Dog Crusoe and Coral Island.

Quayle, E., Ballantyne the Brave. 1967.

Balliol, John de (1249-1315). King of Scotland 1292-96. Son of John de Balliol (d.1268/9), founder of Balliol College, Oxford, whose ancestors came from Bailleul in Normandy. His claim to the Scottish throne came through his mother, Devorgilla, a descendant of King *David I. In 1292 Balliol was chosen by ${ }^{*}$ Edward I of England from 13 contestants to reign as a vassal king, but in 1296 he threw off his fealty. Edward immediately invaded his kingdom and forced him to surrender. Known as 'Toom Tabard' ('Empty Jacket'), after three years' imprisonment he was permitted to go to Normandy, where he died. His son Edward de Balliol (c.1283-1364) was crowned at Scone in 1332 but could only maintain himself with English help and in 1356, after years of intermittent rule, surrendered all his claims to *Edward III.

Balthus (Balthazar Klossowski de Rola) (1912?2001). Polish-French painter, born in Paris. His paintings, often of adolescents, appear conventional, but are marked by a disturbing sexual tension, depicting loss of innocence.

Baltimore, David (1938- ). American biologist, born in New York City. Professor of Microbiology at MIT 1972-95 and President of CalTech 1995-2006, he shared the Nobel Prize for Medicine in 1975 for discovering the 'reverse transcriptase enzyme' which transcribes DNA into RNA.

Baltimore, George Calvert, 1st Baron (1580-1632). English coloniser. He was secretary of state from 1619 until 1625, when he announced himself a Catholic and on resigning received his Irish peerage. In 1627 he visited a colony which he had founded (1621) in Newfoundland, but after two years he decided to seek a warmer climate for his permanent home. He died while in England to obtain a grant for the selected territory. The grant passed to his son, the 2 nd Lord Baltimore, who governed the colony, now called Maryland, from England.

Balzac, Honoré de (1799-1850). French novelist, born in Tours. Author of the great novel sequence La Comedie Humaine, he was the son of an eccentric civil servant. His unhappy schooldays are described in the autobiographical Louis Lambert (1832). An attempt to turn him into a lawyer failed, and from 1820 he was in Paris trying to make a living as a writer. An unfortunate speculation in a printing firm involved him in debt which took years to settle. His industry, both in research and in the writing of his novels, was enormous; his eventual earnings equally so. In total his output amounted to about 100 novels, six plays, many pamphlets and a huge amount of correspondence. His first successful novel, Les Chouans (1829) describes, in the Romantic manner of Sir Walter *Scott, a rising in Brittany during the French Revolution. His Rabelaisian Contes drolatiques (1832-37) are medieval tales written in a pseudo 16th century idiom. His vast conception of linking under a single title, La Comedie Humaine, all the novels he had already written and those he planned to write, dates from 1842, his idea being to present an integrated picture of 19th-century France, with scenes of life in Paris, the country, the army, the family. The novels thus linked contain over 2,000 characters. He said of himself 'I penetrate the soul without neglecting the body', and this claim was vindicated by his genius for delineation of character, made possible by extraordinary powers of observation and imagination. Of the individual novels, the best known include Eugénie Grandet (1833), Le Père Goriot (1834), Cesar Birotteau (1837), Illusions perdues (1843) and La Cousine Bette (1846). His Lettres a l'Etrangere, published after his death, were written to a rich Polish countess, Evelina Hanska, who first wrote to him in 1832 and was soon promising marriage after her husband's death. This occurred in 1841 and thereafter they met regularly, but they were not married until 1850 , only five months before Balzac's death, which was hastened by travel in the bitter cold of a Polish winter.

Pritchett, V. S., Balzac. 1973.

Ban Ki-moon (1944- ). Korean diplomat and administrator. Educated at Seoul and Harvard universities, he served as a diplomat in India and the US and was Minister for Foreign Affairs and Trade 2004-06. Elected as Secretary-General of the United Nations 2007-16, he faced continued violence throughout the Middle East, failure to secure global action on climate change, and concerns about the administration on the UN itself. He was strong on gay rights, ambiguous about the death penalty.

Bancroft, George (1800-1891). American historian and diplomat. He studied history at Göttingen University and on his return started a school where he began writing his monumental History of the United States (10 volumes, 1834-74). Services to the Democratic party were rewarded with official posts ending with that of minister to Great Britain 184649. A strong supporter of Lincoln and Johnson, he was sent as minister to Berlin 1867-74.

Wolfe Howe, M. de, Life and Letters of George Bancroft. 1971.

Banda, Hastings Kamazu (1906-1997). Malawian politician. Educated at a mission school, he emigrated to the US, where, after 15 years' work, his savings 
allowed him to take degrees in philosophy and medicine. He moved to Britain and became an LRCP at Edinburgh and thereafter practised in England until 1953. From 1958 he led the independence movement in Nyasaland and headed the Malawi Congress party (founded in 1959), being imprisoned for a time by the British. When the country attained self-government in 1963 Banda became Prime Minister, an office which he retained when in July 1964 Malawi became independent. He was 'President for life' 1964-94, after reluctantly accepting international demands for free elections in 1993.

Bandaranaike, Solomon West Ridgeway Dias (1899-1959). Sri Lankan politician. Educated at Oxford University, he became a lawyer and after Ceylon's independence was minister of health 194751 in D. S. Senanayake's government. He resigned to form the Sri Lanka Freedom party, the basis of the People's United Front, the victory of which in the election of 1956 resulted in his becoming Prime Minister. He was assassinated by a Buddhist monk in 1959 but his policy of socialism at home (accompanied by expropriation of foreign interests) and neutralism abroad was continued by his widow Sirimavo Bandaranaike (1916-2000), who became the first woman Prime Minister. Her period of office was one of mounting financial difficulty, communal troubles and administrative chaos, some of it due to forces outside her control. She resigned after electoral defeat in 1965, but again became Prime Minister 1970-77, returning a third time 1994-2000, after the election of her daughter Chandrika Kumaratunga (1945-) as President of Sri Lanka.

Bandello, Matteo (c.1485-1561). Italian author, born in Piedmont. A Dominican friar, a diplomatist and (1550-54) Bishop of Agen in France, he wrote about 250 short stories (novelle) some of which were used as the basis of works by *Shakespeare (Romeo and Juliet), *Lope de Vega and *Byron.

Petrocchi, G., Matteo Bandello. 1949.

Bankhead, Tallulah Brockman (1903-1968). American actor. Famous in the 1920s and 1930s, the hysterical adulation aroused by her husky voice and vibrant personality was even more exuberantly expressed in London than in New York. She continued a successful career in America after World War II and made several films.

Gill, B., Tallulah Bankhead. 1973.

Banks, Sir Joseph, 1st Baronet (1743-1820). English botanist and patron of science, born at Isleworth, near London. Educated at Harrow, Eton and Christ Church, Oxford (which he left without a degree), he inherited a fortune from his father and used it to promote research and exploration for the advancement of botany. He collected plants in Newfoundland and Labrador which won him election as FRS (1766). He accompanied Captain James *Cook in his great voyage in the Endeavour (1768-71), paid for equipment and hired botanists. He became an important authority on, and promoter of, Australia, was the first to grasp that its mammals were mostly marsupials, more primitive than placental mammals, and campaigned for the establishment of a penal colony in New South Wales. He voyaged to the North Atlantic in 1772 and investigated geysers in Iceland. President of the Royal Society 1778-1820, he was created baronet in 1781, privy counsellor in 1797 and GCB in 1815. He encouraged international scientific exchanges, was a patron of ${ }^{*}$ Humboldt and created a major herbarium, where Robert *Brown was librarian and curator, and which became part of the Natural History Museum. Suffering acutely from gout, he could no longer walk after 1806. Preparation of Banks' Florilegium, a sumptuous edition of engravings of botanical drawings of Australian plants by Sydney Parkinson (1745-1771) cost him a fortune but was not published until 1983 .

Adams, P., The Flowering of the Pacific. 1986; O'Brian, P., Joseph Banks: a Life. 1987; Musgrave, T., The Multifarious Mr Banks: From Botany Bay to Kew, the Natural Historian Who Shaped the World. 2020; Kieza, G., Banks. 2020; Goodman, J., Planting the World: Joseph Banks and His Collectors. 2020.

Banksy (1974?- ). Pseudonym of British graffiti artist, thought to have been born in Bristol. He attracted international attention for his street art, marked by dark humour and political satire, which encouraged less gifted imitators around the world. He was also a documentary filmmaker. His works attracted high prices but it is not clear to whom the proceeds were paid.

Bannister, Sir Roger Gilbert (1929-2018). English athlete and neurologist. The first runner to achieve a four-minute mile (6 May 1954), he became a distinguished researcher in neurology, knighted in 1979 and Master of Pembroke College, Oxford, 1985-93.

Banting, Sir Frederick Grant (1891-1941). Canadian physiologist, born in Alliston, Ontario. $\mathrm{He}$ graduated in medicine at Toronto University and served with the Canadian Army Medical Corps in World War I. On returning to Toronto, he began research into diabetes in the laboratory of J. J. R. MacLeod. With C. H. *Best he first succeeded in preparing the hormone insulin from the pancreas of dogs (1922). In 1923 he was awarded the Nobel Prize for Medicine jointly with MacLeod who had merely provided laboratory space and suggested the name 'insulin'. Banting, furious, divided his share of the prize money with Best. He became foundation director of the Banting and Best Institute for Medical Research, Toronto 1930-41, was knighted (1934) and became an FRS (1935). He was killed while flying to England to conduct research into aviation medicine. 
Bantock, Sir Granville (1868-1946). English composer. He started his career as a conductor and was professor of music at Birmingham University 1908-34. His works include a setting for chorus and orchestra of Fitzgerald's Omar Khayyám, and Fifine at the Fair, an orchestral work based on a poem of Browning. He was knighted in 1930.

Banville, Theodore Faullin de (1832-1891). French poet and critic. He was an ingenious verse technician particularly in his use of medieval verse forms, which he revived. His works, including Les Cariatides (1941), Odes funambulesques (1857) and Les Exiles (1867), won him the admiration of his fellow poets and the title 'roi des rimes'. Baudelaire described him as the 'poet of the happy hours of life'; Swinburne as 'the French Tennyson'.

Bao Dai ('voice of authority': personal name Nguyen Vinh Thuy) (1913-1997). Last Emperor of Annam 1932-45. He was first head of state of Vietnam 1949-55, part of which had composed his former realm. In 1954, after the Geneva Conference which followed the French defeat in Indo-China, North Vietnam split off to form a separate Communist state. Bao Dai was still the nominal ruler in the south but showed little inclination for his task and spent much time on the French Riviera. He was deposed in 1955 in favour of *Ngo Dinh Diem.

Barabbas. (fl. c.30 CE). Jewish robber. All four Gospels record that he was freed in response to the acclamation of the mob by Pontius *Pilate during the trial of *Jesus. Pilate had hoped to save one whom he recognised as innocent by taking advantage of a supposed custom that a criminal, chosen by the people, should be released at the time of the Passover.

Baradei, Mohamed Mostafa el- (1942- ). Egyptian administrator and diplomat. Director-General of the International Atomic Energy Agency 1997-2009, he shared the 2005 Nobel Peace Prize with the IAEA.

Barak, Ehud (1942- ). Israeli soldier and politician. As Labour leader, he defeated *Netanyahu to become Prime Minister 1999-2001. After peace talks with the Palestinians stalled and communal violence returned, he called an early election (Feb. 2001) and lost heavily to Ariel *Sharon.

\section{Barbarossa see Friedrich I (Barbarossa)}

Barbarossa (= 'Redbeard'), Kheir ed-Din (Barbaros Kheir ed-Din Paşa, né Hızır Reis) (c. 1478-1546). Turkish-Albanian-Greek corsair and Grand Admiral, born in Lesbos. His elder brother, Oruç *Reis, the original 'Redbeard', established the family business of privateering in the Mediterranean on a grand scale, encouraged by the Sultanate. Kheir ed-Din succeeded Oruç as Pasha of Algiers in 1518. His navy raided Sicily and Sardinia, seizing control of Rhodes and the Ionic islands and he was appointed Grand Admiral of the Ottoman fleet in 1533. His forces captured Tunis in 1534 but were defeated next year by ${ }^{*}$ Charles V. Barbarossa attacked Naples in 1536, defeated the navies of Spain, the Habsburg empire and Venice at Preveza in September 1538 and established Ottoman dominance in the Mediterranean. In 1540, Charles V attempted to persuade him to change allegiances by offering him the lordship of North Africa. Barbarossa built a palace in Istanbul and dictated memoirs.

Barbarossa, Uruj (c.1482-1518), and Khaireddin (c.1482-1546). Turkish corsairs. Brothers of Greek parentage, their names inspired terror in the Mediterranean area. Uruj, having treacherously murdered the amir, seized Algiers but was soon captured and beheaded. Khaireddin, succeeding him in Algiers, for about 30 years preyed upon Mediterranean shipping and the almost defenceless coasts. He died in Constantinople where he had eventually returned with over 1,000 captives and laden with spoils.

Barber, Samuel (Osmond) (1910-1981). American composer, born at West Chester, Pennsylvania. A baritone, he set Matthew *Arnold's Dover Beach (1931) for voice and string quartet. He wrote some of the most popular of modern orchestral works, including Adagio for strings (1936), Essay for orchestra No. 1 (1937), Symphony No. 1 (1936), Cello concerto (1945), Symphony No. 2 (1944) and Piano Concerto (1963). His first full-size opera, Vanessa, was performed at Salzburg in 1958. Later works include Anthony and Cleopatra (opera, 1960) and The Lovers (1971). He lived with Gian Carlo *Menotti from 1930 to 1970.

Barbey d'Aurevilly, Jules Amédée (1808-1889). French novelist. He wrote La vielle maitresse (1851), L'Ensorcelée (1854) and Les Diaboliques (1874), which, despite the author's diatribes against the realists, recall ${ }^{*}$ Flaubert in their psychological realism. Barbey d'Aurevilly was an ultra-romantic and a monarchist, his output of polemics against democracy and materialism was enormous.

Canu, J., Barbey d'Aurevilly. 1945.

Barbirolli, Sir John (1899-1970). British orchestral conductor, born in London. Of Italian descent, he was a cellist in major string quartets for many years and conducted the British National Opera Company 1926-29 and the BBC Scottish Orchestra 1933-36. He unexpectedly succeeded ${ }^{*}$ Toscanini as conductor of the New York Philharmonic Symphony Orchestra 1936-43. He returned to England to conduct the Hallé Orchestra, Manchester 1943-70, made many recordings and received a $\mathrm{CH}$ in 1969.

Rigby, C., John Barbirolli: A Biographical Sketch. 1948.

Barbour, John (c.1320-1395). Scottish poet. He travelled and studied in England and France and held court appointments in Scotland under 
${ }^{*}$ Robert II. His only surviving work, The Brus, contains about 13,000 lines of eight-syllable couplets and tells the life-story of Scotland's hero-king Robert ${ }^{*}$ Bruce. The oldest major literary work written in Scots, it contains many vivid episodes and appears to be an accurate historical source.

Barbusse, Henri (1874-1935). French journalist and novelist. His novels are strongly reminiscent of *Zola's, but contain elements of existentialist thought. They include L'Enfer (1908) and Le Feu (1916), a grim study of life in the trenches during World War I, in which he served as a volunteer. Barbusse became a Communist sympathiser and a propagandist of internationalist ideas. He died in Moscow.

Barclay, Alexander (c.1476-1552). Scottish poet. He was chaplain of Ottery St Mary, Devon, and later became a monk. He wrote The Ship of Fools (1509), a long satirical poem based on a German original (Brant's Narrenschiff).

Bardeen, John (1908-1991). American physicist, born in Wisconsin. Educated at the University of Wisconsin, he carried out research in electrical engineering at Harvard and Princeton, working on magnetic mines during World War II. At the Bell Labs 1945-51, he was co-inventor, with W. H. *Brattain and W. B. *Shockley, of the germanium point-contact transistor (1947) for which they shared the Nobel Prize for Physics in 1956. He broke with the abrasive Shockley and was Professor of Electrical Engineering and Physics at the University of Illinois 1951-75. He investigated super-conductivity in metals at very low temperatures and in 1972 shared a second Nobel Prize for Physics with Leon Cooper and John Schrieffer for explaining the phenomenon. Bardeen was the first person to win two Nobel Prizes in the same discipline. He received the Presidential Medal of Freedom in 1977 and was elected FRS.

Bardot, Brigitte (1934- ). French actor, born in Paris. She started her career as a model and appeared as a 'cover girl' for the magazine Elle, but it was as a self-revealing star in such films as Et Dieu crea la femme and Babette's en va en guerre that she became the symbolic 'sex kitten' of the 1950s-60s. She married Roger Vadim, the film director, in 1952 and Jacques Charrier, the actor, in 1959.

Barebone, Praise-God (1596-1679). English clergyman. His odd name was applied in derision to the parliament set up by ${ }^{*}$ Cromwell (1653), of which he was a member. A London leather merchant, he became a noted preacher and a leader of the Fifth Monarchy Sect.

Barenboim, Daniel (1942- ). Argentinian-Israeli pianist and conductor, born in Buenos Aires. He toured internationally from 1954, recorded all the *Mozart piano concertos, and became a successful conductor as well. In 1967 he married the cellist
Jacqueline du Pré (1945-1987), who died of multiple sclerosis. He became chief conductor of the Orchestre de Paris 1975-89, the Chicago Symphony 19912006 (succeeding * ${ }^{*}$ Solti) and the Berlin Staatsoper 1992- . In 1999, with Palestinian writer Edward Said (1935-2003), he founded the West-Eastern Divan Orchestra. Parallels and Paradoxes (with Edward Said) was published in 2002 and he delivered the BBC's Reith Lectures in 2006, In the Beginning Was Sound. He held citizenship from Argentina, Israel, Spain and Palestine. He was awarded an honorary KBE (2011) and became general music director of La Scala, Milan 2011-

Barents, Willem (d.1597). Dutch navigator and explorer. He led three expeditions (1594-97) in an unsuccessful search for a north east sea passage to Asia, reaching Novaya Zemlya on the first two. On the third he accidentally discovered Spitsbergen and rounded the north point of Novaya Zemlya, the expedition was caught in the ice and forced to winter there. In the June he and his crew escaped in small boats but Barents died on the way. In 1871 his winter quarters were discovered undisturbed.

Barere, Simon (1896-1951). Russian American pianist, born in Odessa. He developed a prodigious technique, but his career languished and the quality of his recordings was only recognised in the 1980s.

Barère (de Vieuzac), Bertrand (1755-1841). French revolutionary politician, known for his eloquence as the 'Anacreon of the guillotine'. He attached himself to * Robespierre in the Convention and was a member of the Committee of Public Safety 1793-94. Under *Napoléon he became a secret-service agent.

Barham, Richard Harris (1788-1845). English writer. A clergyman who became minor canon at $\mathrm{St}$ Paul's, London, he wrote a series of burlesque verse tales under the pen name Thomas Ingoldsby, many of them based on medieval legends. They were published collectively as The Ingoldsby Legends (1840).

Baring family. German-British merchant bankers. The brothers John and Francis Baring, sons of a German immigrant, established Baring's Bank, in London, in 1762, and invested heavily in the slave trade, the Louisiana Purchase and the East India Company. It collapsed in 1995, due to fraud, and was sold for $£ 1$. Peerages held by the Baring family included Ashburton, *Howick, *Northbrook, Revelstoke and ${ }^{*}$ Cromer.

Baring, Evelyn, 1st Baron Howick of Glendale (1903-1973). English colonial administrator. Son of Evelyn Baring,1st Earl of *Cromer, he was Governor of Southern Rhodesia 1942-44 and Governor of Kenya 1952-59 at the time of the Mau Mau uprising, suppressed by extensive use of execution and torture. He was created KG in 1972. 
Baring-Gould, Sabine (1834-1924). English clergyman and writer, born in Devonshire. Member of an old county family, he held a quiet living at Lew Trenchard most of his life, allowing time for a large literary output. He is better remembered for his books on medieval lore and legends, e.g. The Book of Werewolves (1865), than for his many novels. 'Onward Christian Soldiers' is the best known of his hymns.

Purcell, W., Onward Christian Soldiers. 1957; Dickinson, B. H. C., Baring-Gould, Writer and Folklorist. 1970.

Barker, Sir Herbert Atkinson (1869-1950). English osteopath and bone-setter. A highly controversial figure, without formal qualifications, he was successful in treating injured joints without surgery. His knighthood (1922) irritated the medical profession.

Barklay de Tolly, Mikhail, Prince (1761-1818). Russian soldier, of Scottish descent. He commanded the Russian forces resisting *Napoléon's march to Moscow (1812). The unpopularity of his policy of continuous retreat into the heart of Russia caused him at last to make a stand and his defeat at Smolensk led to his being replaced by *Kutuzov. On Kutuzov's death in 1813, Barclay again became Commanderin-Chief. In the earlier part of his career he had lost an arm at Eylau in 1807 and in the same year led the army which invaded Finland and forced the Swedes to sue for peace.

Barkley, Alben William (1877-1956). American Democratic politician. A lawyer, he was a Member of the US House of Representatives 1913-27 and US Senator from Kentucky 1927-49, 1954-56. A loyal New Dealer, he became Harry *Truman's Vice President 1949-53.

Barmecides. Persian family of predominant influence at the court of the Abbasid caliphs at Baghdad. Their power was ended in 803 by the execution of one and the dismissal of the rest by *Harun al-Rashid. The term 'Barmecides feast' is derived from a story in the Arabian Nights telling of a practical joke which consisted of serving a dinner of elaborately named but empty dishes to a starving beggar. He, however, entered into the spirit of the occasion and was rewarded with real food.

Barnabas, St (Hebrew: son of encouragement. Personal name Joses) (d.c.70 CE). Christian apostle. Probably a Cypriot Jew and a cousin of *Mark, according to the Acts of the Apostles he introduced *Paul to the Christian community in Jerusalem and later accompanied him on a missionary journey until differences of opinion led to a parting of the ways. Barnabas went to Cyprus but accounts of his later movements and supposed martyrdom are apocryphal.

Barnard, Christiaan (Neethling) (1922-2001). South African surgeon, born in Beaufort West, Cape Province. Educated at the Universities of Cape Town and Minnesota, in 1958 he was appointed director of surgical research at the University of Cape Town and from 1961 was head of the cardiothoracic surgical unit at the Groote Schuur Hospital in Cape Town. Barnard introduced open-heart surgery to the Republic of South Africa, designed artificial heart valves and published much on congenital intestinal atresia. In December 1967 he performed the first human heart transplant operation on Louis Washkansky and became instantly famous. He later worked on arthritis.

Barnard, C. and Pepper, C. B., Christiaan Barnard: One Life. 1970; Barnard, C., Heart Attack: You Don't Have to Die. 1972.

Barnardo, Thomas John (1845-1905). British social reformer, born in Dublin. At the age of 17 he was an evangelist in the Dublin slums, went to London to study and practise medicine and at Stepney founded the first Dr Barnardo's Home for destitute boys. A home for girls at Barkingside followed in 1876 and by the time of his death more than 60,000 children had passed through his hands. In the intervening years the scope and scale of the work vastly increased.

Wymer, N., Father of Nobody's Children. 1954.

Barnato, Barney (originally Barnett Isaacs) (18521897). South African financier, born in London. Of Jewish parentage, he arrived in South Africa in 1873, made a fortune by buying up abandoned diamond mines and eventually linked his interests with those of his rival Cecil Rhodes by joining the control of the De Beers Mining Companies. He became a member of the Cape Colony legislature 1888-97. He committed suicide at sea after suffering heavy financial losses.

Barnes, Albert Coombs (1872-1951). American chemist and art collector. With Herman Hille he developed Argyrol, a silver nitrate solution used to prevent blindness in babies, made a fortune and created the Barnes Foundation in Merion, Pa. $\mathrm{He}$ amassed one of the greatest US collections of modern art and was a notable eccentric.

Schack, W., Art and Argyrol. 1960; Greenfield, H., The Devil and Dr. Barnes. 1987.

Barnes, Julian Patrick (1946- ). English novelist, lexicographer and critic. He worked on the Oxford English Dictionary and as a critic on the New Statesman, Sunday Times and Observer. His successful novels included Before She Met Me (1982), Flaubert's Parrot (1984), A History of the World in 101/2 Chapters (1989), Talking It Over (1991) and The Porcupine (1992). He also wrote several novels under the name Dan Kavanagh, including Duffy (1980) and Going to the Dogs (1987). Nothing to be Frightened Of (2008) was a memoir. The Sense of an Ending (2011), won the Man Booker Prize, and Levels of Life (2013), is a meditation on bereavement after the death of his wife Pat(ricia Olive) Kavanagh (1940-2008), an important literary agent. 
Barnes, Thomas (1785-1841). English journalist. Educated at Christ's Hospital, Horsham, and Cambridge, he became an unhappy lawyer and contributed to periodicals edited by his school-fellow Leigh *Hunt. He joined The Times (1809) as dramatic critic and in 1817 was appointed editor. During his 25 years of control The Times was the most formidable organ of opinion in Britain, and Barnes, who was independent of any political party, was the most powerful journalistic influence.

Barnes, William (1801-1886). English clergyman and poet. Having made a detailed study of local speech he became widely known as the author of three series $(1844,1859,1862)$ of idyllic and pastoral poetry in the Dorset dialect, collected as Poems of Rural Life in Dorset Dialect (1879). His Outline of English Speechcraft (1878) was an odd attempt to teach English by using only words of native origin.

Dugdale, G., William Barnes of Dorset. 1953.

Barnum, Phineas T(aylor) (1810-1891). American showman. Famed for his flamboyant publicity, in 1834 he entered show business as the exhibitor of such as a black slave whom he claimed to be the nurse of George *Washington and, later, the midget 'General Tom Thumb'. In 1847 he managed Jenny *Lind's American tour. His circus, 'The Greatest Show on Earth', was founded in 1871, being merged with that of his chief competitor, James Anthony Bailey (1847-1906). It soon became an American institution and continued for a generation after his death.

Baroja y Nessi, Pío (1872-1956). Spanish novelist, born in San Sebastian. Son of an engineer-composer, brother of a painter, he studied medicine, practised briefly, then became active in the 'Generation of 1898 ' radicals. He wrote three trilogies, notable for their forceful, rather bare style and their undertone of social discontent: La Tierra Vasca (The Basque Country, 1900-09), La lucha por la vida (The Struggle for Life: 1922-24) and El Mar (The Sea: 1923-30). ${ }^{*}$ Hemingway hailed his Memoirs of a Man of Action (1931), concerned with the 19th-century Carlist wars, as a masterpiece.

Barras, Paul François Jean Nicolas, Vicomte de Barras (1755-1829). French aristocrat and revolutionary politician. He wasted his inheritance and seized the opportunity of the Revolution to restore his fortunes. He was a member of the National Convention 1792-95, joined the Jacobins, and voted for the execution of *Louis XVI. After Bonaparte (*Napoléon) broke the siege of Toulon, a royalist stronghold, in December 1793, Barras massacred about 750 prisoners. However, he was wise enough to see when the people tired of bloodshed and, with *Fouché and *Tallien, organised Robespierre's overthrow in 1794. A leader of the Directorate 1795-99, he promoted Bonaparte and arranged his marriage to Josephine ${ }^{*}$ Beauharnais. He gained a reputation for avarice and corruption, and, after Bonaparte's coup d'état in 1799, he was imprisoned and exiled. Returning to France in 1814, he enjoyed wealth but not power.

Barrault, Jean-Louis (1910-1994). French actor and stage director. After training at a drama school and service in World War II he was producer-director at the Comedie Française (1940-47). With his wife Madeleine Renaud (1900-1994) he founded a new company, le Troupe Marigny (1947), which gained an international reputation. His own acting was influenced by his talents as a mime, demonstrated in Marcel *Carnés film Les Enfants du Paradis (1944). He was director of the Théâtre de France 1959-68 and the Théatre d'Orsay 1974-81.

Barrault, J. L., Memories for Tomorrow. 1971.

Barrès, Maurice (1862-1923). French novelist, journalist and politician. An extreme nationalist, he acquired notoriety by the fervour of his articles in L'Echo de Paris during World War I. His literary talents were admired even by those who deplored his politics. Among his best known works are Les Deracines (1897) and Les Amities Françaises (1903). He was a Deputy 1889-93; 1906-23 and fiercely anti-Dreyfusard.

\section{Barrett, Elizabeth see Browning, Elizabeth Barrett}

Barrie, Sir J(ames) M(atthew), 1st Baronet (1860 1937). Scottish playwright and novelist, born in Kirriemuir. Educated at Edinburgh University, he left Scotland in 1883 and worked as a journalist on the Nottingham Daily Journal before coming to London in 1885 . He began writing with novels (e.g. A Window in Thrums, 1889, The Little Minister, 1891), but from 1890 he turned to the theatre and achieved wealth and fame with Quality Street (1902), The Admirable Crichton (1902), Peter Pan (1904), Dear Brutus (1917), Mary Rose (1920) and Shall We Join the Ladies? (1921). He received a baronetcy in 1913, the OM in 1922 and was chancellor of Edinburgh University 1930-37. The whimsical humour of his works gradually lost much of its appeal, but Peter Pan is revived annually: he bequeathed its royalties to the Hospital for Sick Children, London. He had a happy relationship with children, an uneasy one with adults.

Dunbar J., J. M. Barrie. 1970.

Barrow, Isaac (1630-1677). English mathematician, born in London. Son of a merchant, he studied at Trinity College, Cambridge, where he became a fellow in 1652 and master 1672-77. His royalist sympathies made life uncomfortable for him, and he left in 1655 for a five year tour of the Continent. Returning at the Restoration in 1660, he became professor of Greek in Cambridge. He took the Lucasian chair of mathematics in Cambridge in 1663. Barrow was a first class teacher. He produced editions of *Euclid's 
Elements (1655) and Data (1657) and versions of works by ${ }^{*}$ Archimedes, ${ }^{*}$ Apollonius and ${ }^{*}$ Theodosius. He gave important optical lectures concerning a new method for finding the relationship of a sphere and a curve in a spherical interface. His geometrical lectures were not original, but did digest modern continental writers such as ${ }^{*}$ Descartes, ${ }^{*}$ Huygens and ${ }^{*}$ Pascal to his audiences. Isaac ${ }^{*}$ Newton was a student at Trinity during this period, and it is possible that Barrow's work made some impression on him. Newton succeeded Barrow as Lucasian professor of mathematics.

Osmond, H., Isaac Barrow: His Life and Times. 1944.

Barry, Sir Charles (1795-1860). English architect. The Travellers' Club (1829-31) and the Reform Club (1837) in London are good examples of his work in the Italian renaissance style. He won the commission to design the new Houses of Parliament (erected from 1839) to replace the old buildings destroyed by fire in 1834. It was stipulated that the work should be in Gothic style, and Barry, who was essentially a classic architect, therefore obtained some assistance in Gothic detail from A.W.N. *Pugin.

Barry, Sir Redmond (1813-1880). Irish-Australian colonial judge, born near Cork. Son of a general, and an Anglican, he studied in Dublin and migrated to Australia in 1839, settling in Melbourne in 1840. Justice of the Supreme Court of Victoria 1852-80, during the Gold Rush period he was exasperatingly energetic and was the driving force in establishing the Royal Melbourne Hospital, the University of Melbourne, the Public Library, the Art Gallery and the Royal Society of Victoria. He was the judge in the Eureka Stockade trials (1855), sentenced Ned *Kelly to death (1880) and is commemorated in paintings by Sidney *Nolan.

Barrymore. American theatrical family, children of the British actor Herbert Blythe (1847-1905) who adopted the stage name Maurice Barrymore and married the actor Georgina Drew. Lionel Barrymore (1878-1954), like his younger brother, John, was successful both on stage and screen but it was in character rather than romantic parts that he excelled. He became paralysed in 1940 but continued to act from a wheelchair. Their sister Ethel (1879-1959) was perhaps the most talented of the trio and in 1928 opened the New York theatre bearing her name. She is especially remembered for parts in plays by *Ibsen and *Shaw, later in Emlyn *Williams' The Corn is Green (1942-44). John (1882-1942) was the matinee idol of his time, achieving his greatest fame as a Shakespearian actor, particularly in Hamlet and Richard III. From 1925 onwards he was occupied almost exclusively with the cinema, in which he played romantic and dramatic roles in films such as Don Juan and Dr Jekyll and Mr Hyde. In his later years he was incapacitated by alcoholism.
Bart, Jean (1651-1702). French sailor. A hero of the French navy and a fisherman's son, he rose to command a squadron. He first served with the Dutch navy, and it was only after he had left that service and had achieved fame as a privateer that he was appointed lieutenant of a French man of war. In the War of the Grand Alliance his exploits were a constant menace to the English and Dutch by whom France was opposed. A raid was made near Newcastle. Many ships were sunk and on one occasion he captured a whole flotilla of Dutch corn ships. In 1697 he was received by ${ }^{*}$ Louis XIV and given command of a squadron.

Bart, Lionel (1930-1999). English composer and songwriter. He wrote several successful musicals, including Lock Up Your Daughters, Fings Ain't Wot They Used t'Be, Oliver!, and Maggie May.

Barth, Karl (1886-1968). Swiss Calvinist theologian, born in Basle. He was professor of theology at Göttingen 1923-25, at Munster 1925-30 and then at Bonn, until he was dismissed in 1934 for opposition to ${ }^{*}$ Hitler. He was appointed to a theological professorship at Basle in 1935, retiring in 1962. Barth's teaching insists that the word of God as revealed by Jesus Christ is the sole source of religious truth, and that consequently man is unable to solve his own problems by reason and is completely dependent on divine grace and the workings of the Holy Spirit within him. Barth's theology is systematically set out in his many volumed work Church Dogmatics, publication of which began in 1932.

Hartwell, H., The Theology of Karl Barth. 1964.

Barthes, Roland Gérard (1915-1980). French philosopher and critic, born in Cherbourg. Educated at the Sorbonne, he developed and updated the ideas of the Swiss linguist Ferdinand de *Saussure in promoting 'semiotics' (the sociology of signs, symbols and representations) and analysed the impact of film, radio, television and advertising in changing language, fashion and cultural iconography. His books include S/Z (1970), The Pleasure of the Text (1973), A Lover's Discourse (1977) and Camera Lucida (1980). He lived with his mother, was deeply interested in photography and held a chair at the Collège de France 1977-80. He was killed by a laundry van.

Bartholdi, Frederic Auguste (1834-1904). French monumental sculptor. He was best known for his Statue of Liberty presented to the US by the French Government in 1886 and set up on Bedloe's Island, New York harbour.

Bartholomew, St (Aramaic: 'son of Talmai') (d.c.50 CE). Christian apostle: usually identified with Nathaniel. Almost nothing is known of him but traditions tell of missionary journeys in Asia Minor and India and of being martyred by flaying in Armenia. 
Bartholomew, John George (1860-1920). Scottish cartographer and map and atlas publisher. $\mathrm{He}$ improved standards of British cartography and introduced into Great Britain the use of contours and systematic colour layering to show relief. His father was Edinburgh map publisher John Bartholomew (1831-1893). He published important atlases of Scotland (1895), England and Wales (1903), An Atlas of Meteorology (1899) and Atlas of Zoogeography (1911), the first two volumes of a major physical atlas. He began work on The Times Survey Atlas of the World, published 1921 by his son, John Bartholomew (1909-1962), also editor of the new Times Atlas of the World (1955).

Gardiner, L., Bartholomew 150 Years. 1976.

Barthou, Jean-Louis Firmin (1862-1934). French politician. He entered politics in 1889, was Minister for Justice 1909-10, 1913, 1922, 1926-29, Premier 1913, Foreign Minister 1917, 1934, and Minister for War 1921-22, 1930-31. He wrote biographies of *Mirabeau (1913) and *Lamartine (1916) and in 1918 was elected to the Académie française. In October 1934, when King *Alexander of Yugoslavia was assassinated in Marseilles, Barthou died after being shot in the police crossfire (evidence concealed until 1974).

Bartók, Béla (Viktor János) (1881-1945). Hungarian composer and pianist, born in Nagyszentmiklós (now part of Romania). He was taught music by his mother, studied under Laszlo Erkel before entering the Budapest Academy of Music in 1899, and in 1901 he won the *Liszt scholarship. His early works were influenced by Liszt, ${ }^{*}$ Brahms, *Wagner and Richard *Strauss. In 1905 he began to collect and publish Magyar folk songs with *Kodály which had an important influence on his own compositions. In 1907 he became professor of piano at the Academy. Of his earliest mature works, the ballet The Wooden Prince (1917) and opera Bluebeard's Castle (1918) were most successful. By 1923 he was commissioned to write an orchestral work for the fiftieth anniversary of the union of Buda and Pest (the Dance Suite). He visited Britain 20 times between 1904 and 1938 to give concerts. After tours in the US (1927) and the USSR (1929) he resigned the Academy post (1934) and returned to collecting folk songs for the Hungarian Academy of Arts and Sciences. He composed two violin concertos $(1908,1928)$, six string quartets (1909, 1917, 1927, 1928, 1934, 1939), among the greatest in the repertoire Mikrokosmos (1926-39), a set of 153 lively exercises for piano, three important piano concertos $(1926,1931,1945)$, the virtuosic music for strings, percussion and celesta (1936), sonata for two pianos and percussion (1937, also arranged as a concerto 1943) and divertimento for string orchestra (1939). In 1940 he emigrated to the US and became a research assistant in music at Columbia University continuing his work on folk music. There a study of Romanian folk music (3 volumes 1967). His most performed work, Concerto for Orchestra (1943-45), was commissioned by *Koussevitzky. $\mathrm{He}$ became a US citizen in 1945 . Financially precarious, but too proud to accept financial support from friends and too ill to work, he died of leukemia in New York. He left an unfinished viola concerto. $\mathrm{He}$ combined the essential characteristics of Hungarian folk music with traditional music and developed a national, yet individual, style. He was reburied in Budapest in 1988.

Stevens, H., The Life and Music of Bela Bartok. 2nd ed. 1964; Wilson, P., The Music of Béla Bartók. 1992; Gillies, G., The Bartók Companion. 1993; Chalmers, K., Béla Bartók. 1995.

Bartolommeo, Fra (né Baccio della Porta) (c.14721517). Italian painter. The son of a muleteer, he early found work in a Florentine studio, but under the influence of *Savonarola, whose portrait he painted, he burnt his drawings of nudes and in 1500 joined the Dominican order. Thenceforth all his work was of a religious character, and it was to reflect in turn the influences of *Raphael and *Michelangelo. But his treatment of figures and draperies and his grand static compositions assert his own instincts.

Bartolozzi, Francesco (1727-1815). Italian engraver, born in Florence. After working in Venice and Rome, he settled in London in 1764, became official engraver to King *George III, and a foundation member of the Royal Academy. Enormously prolific, and technically adventurous, he was director of the National Academy of Lisbon 1802-15.

Barton, Clara (1821-1912). American social worker. Originally a schoolteacher, she served as a nurse in the American Civil War and the Franco Prussian War. In 1877 she founded the American National Committee which later became the American Red Cross, of which she was president 1882-1904.

Barton, Sir Edmund (1849-1920). Australian lawyer, politician and judge, born in Sydney. Educated at Sydney University, he became a barrister and QC/ KC, had broken terms in both houses of the New South Wales Parliament 1879-99 and was Speaker 1883-87 and Attorney-General 1889, 1891-93. He became the most ardent advocate of federation in a state which showed little enthusiasm for it, was elected leader of the 1897-98 Federal Convention (Adelaide and Melbourne) where the constitution was drafted and led the delegation to London that persuaded Joseph ${ }^{*}$ Chamberlain and the British Government to accept it. In January 1901 he became the first Prime Minister of the Commonwealth of Australia and also served as Minister for External Affairs until his appointment as a justice of the High Court of Australia 1903-20.

Bolton, G., Edmund Barton: The One Man for the Job. 2000. 
Barton, Elizabeth (c.1506-1534). English mystic, known as 'the Maid of Kent'. She was a domestic servant who, after a period of illness, began to fall periodically into trance states, during which she uttered prophecies that were taken to be divinely inspired. Unfortunately the monk, Edward Bocking, sent by Archbishop Warham of Canterbury to examine her, tried to make use of her for political ends. In particular she was impelled to prophesy ${ }^{*}$ Henry VIII's death if he married *Anne Boleyn. Eventually she was arraigned before Cranmer, confessed her imposture and was executed, with Bocking and others.

Bartram, William (1739-1823). American naturalist and traveller. A Quaker, he wrote a well regarded account of Travels through North and South Carolina (1791). *Wordsworth and *Coleridge admired his descriptive powers.

Baruch, Bernard M(annes) (1870-1965). American financier. He made a fortune by speculation by the age of 30 and became a friend and economic advisor to Woodrow *Wilson and Franklin D. *Roosevelt during World Wars I and II, and was also a close friend of Winston ${ }^{*}$ Churchill. As US representative to the UN Atomic Energy Commission 1946-47 he devised the 'Baruch plan' for the international control of atomic energy. He coined the term 'Cold War' (1947).

Barwick, Sir Garfield Edward John (1903-1997). Australian lawyer, Liberal politician and judge, born in Sydney. An outstanding advocate, he became a KC in 1941, a Federal MP 1958-64, AttorneyGeneral 1958-64 and Minister for External Affairs 1961-64. A potential rival to ${ }^{*}$ Menzies, he was made Chief Justice of the High Court 1964-81 and played an important role in *Kerr's dismissal of *Whitlam (1975).

Baryshnikov, Mikhail Nikolayevich (1948- ). Russian-American-Latvian dancer and actor, born in Riga. He became a soloist with the Kirov Ballet, Leningrad 1966-74, defected to Canada in 1974 and became director of the American Ballet Theatre 1980-92. He ranked with Rudolf *Nureyev as the greatest male dancer of his time.

Bashkirtsev, Maria Konstantinovna (1860-1884). Russian diarist. Her correspondence (e.g. with de *Maupassant) is of great psychological interest but most remarkable are her diaries (published in 1885), a self study undertaken with a conscious effort to attain exact truth and as a revelation of the exultations and despairs of a talented and precocious girl. She lived in France from early childhood, studied painting, in which she achieved a limited success, and died of tuberculosis.
Bashō Matsuo (originally Matsuo Chūemon Munefusa) (1644-1694). Japanese poet, born near Ueno. From a landowning peasant family, he became servant to a noblemen, then a poetry teacher, contributing to collaborative poems, known as renga. He became the greatest master of haiku (then called hokku), three line poems with 17 syllables $(5+7+5)$. Bashō was deeply influenced by Zen Buddhism.

Basie, 'Count' (William) (1904-1984). American jazz pianist, composer and band leader. Influenced by 'Fats' *Waller, Basie's first band was founded in Kansas City (1935). He became one of the dominant figures of the 'swing' era, continuing as a successful performer with a series of bands for more than 40 years, appearing in films and touring internationally.

Basil I (the Macedonian) (c.812-886). Byzantine Emperor 867-886. Founder of the Macedonian dynasty, he gained the throne of the Eastern Roman Empire by murdering his patron Michael III, but raised the empire to the height of its power, codified its laws and beat back Muslim incursions.

Basil II (Bulgaroctonus) (958-1025). Byzantine Emperor 963-1025. Son of Romanus II, he emerged from his minority as a soldier-emperor, described as 'killer of Bulgars' from his victories in a long war (986-1018). He shared rule with his brother Constantine VIII but was always dominant and protected the peasants from encroachments by the nobles.

Basil, St (c.329-379). Cappodocian Father of the Church, born in Caesarea. From a noble family, he was a brother of St Gregory of Nyssa. Ordained in 364 and appointed bishop of Caesarea in 370, he succeeded Athanasius as one of the main upholders of Nicene orthodoxy over which he conflicted with emperor ${ }^{*}$ Valens. Monastic rules set out by him are still used with little alteration by communities within the Greek Orthodox Church.

Prestige, G. L., St Basil the Great and Apollinaris. 1956.

Baskerville, John (1706-1775). English typographer, born in Worcestershire. After working as footman, writing master and manager of a Birmingham japanning business, he rose to be one of the most influential designers of type in the history of printing. His editions of ${ }^{*}$ Virgil (1757) and *Milton (1758) followed years of experiments. As printer to Cambridge University (from 1758) he produced many magnificent editions, including the Bible and the Greek New Testament.

Gaskell, P., John Baskerville: A Bibliography. 1959.

Bass, George (1771-1803?). English surgeon and sailor. A 'surgeon second rate' in the navy (1789), he served in New South Wales from 1795, explored the coast and inland, finding coal in the Hunter Valley. 
With Matthew *Flinders he established (1798-99) that Van ${ }^{*}$ Diemen's Land (Tasmania) was a separate island. He was lost in the Pacific, possibly captured by pirates.

Bassano, Jacopo (or da Ponte) (c.1510-1592). Italian painter, born in Bassano. With his four sons, he developed a popular style of genre painting. His Last Supper (1546) in the Borghèse Gallery, Rome, has disconcerting images of exhausted, quarrelsome disciples.

\section{Bath, 1st Earl of see Pulteney, William}

Bathsheba (11th-10th centuries BCE). Israeli queen. Daughter of Eliam, she was seduced by *David who then contrived the death of her husband Uriah the Hittite, by placing him in the forefront of battle. She became David's queen and the mother of *Solomon.

Batista y Zaldivar, Fulgencio (1901-1973). Cuban soldier and politician. As an army sergeant he organised a 'sergeants' revolt' (1933) against the ruling oligarchy, became Commander-in-Chief of the Cuban forces 1933-40 and de facto ruler, serving as President 1940-44. He retired to Florida with his wealth after a period of stability, reform and corruption. He seized power again in 1952 and as President ruled as a dictator until his overthrow by Fidel Castro (December 1958). Thereafter he lived in the Dominican Republic, then Madeira and finally Portugal.

Batoni, Pompeo Girolamo (1708-1787). Italian painter, born in Lucca. A skilled, prolific and popular artist, he worked especially in portraiture, but also in landscape and was a forerunner of neo-classicism. Many of his portraits are of British subjects, but he also painted popes, emperors and kings.

Batten, Jean Gardner (1909-1982). New Zealand aviator. In 1935 she became the first woman to complete a return flight England-Australia-England. She broke the record for an Atlantic crossing (1936) and flew England-Australia in a record five days 18 hours (1937). She was active in promoting the war effort but did not fly during World War II, and gradually became reclusive, living with her mother. She died in Majorca as the result of a dog bite and was buried with the name 'Gardner'. Auckland airport is named for her.

Mackersey, I., Jean Batten: The Garbo of the Skies. 1990 .

Battenberg (later Mountbatten). Anglo-German family name. Descendants of the morganatic marriage of Prince Alexander of Hesse-Dessau were given the name Battenberg in 1851, which was anglicised to Mountbatten in 1917 when anti-German feeling ran high. Louis von Battenberg (*Mountbatten) married
(1857-1893) was Prince of Bulgaria 1879-86; Henry Maurice (1858-1896) married Victoria's daughter Princess Beatrice. Henry's daughter Victoria Eugenie (1887-1969) married *Alfonso XIII of Spain.

Batu Khan (1205-1255). Khan of the Golden Horde 1227-55. Grandson of ${ }^{*}$ Genghis Khan and son of Jochi (who predeceased his father). His Mongol army (or horde) of 130,000 invaded Europe in 1236, first conquered Kiev, and his realm ultimately extended from parts of Italy, up to Poland and east to the Caucasus.

Baudelaire, Charles Pierre (1821-1867). French poet, critic, essayist and translator, born in Paris. His elderly father, a civil servant, died in 1827 . His mother survived him and he never forgave her for remarrying. Educated first in Lyon, he studied law in Paris but never practiced. To keep him from dissipation in Paris, his stepfather sent him on a voyage to India, but the ship foundered and his travels ended at Mauritius (1841-42). After returning to Paris he soon spent half of his small inheritance: although the remainder was tied up he constantly struggled with poverty. He was passionate about his mother and his mistress, Jeanne Duval, a Haitian, with whom he lived intermittently 1842-62. He frequented the artistic circle of Eugène *Delacroix, and became known as an original critic. He began reading Edgar Allen *Poe in 1848, published an important essay on him in 1852 and devoted years to translating his prose and poetry. $\mathrm{He}$ took a minor role in the 1848 Revolution but soon adopted the authoritarian views of Joseph de *Maistre, rejecting 'the transitory, the fugitive, the contingent.' In 1857 he published a collection of poems, Les Fleurs du mal (Flowers of Evil), an extraordinary mixture of morbidity, eroticism, mysticism, and acute aesthetic perception, for which author, printer and publisher were prosecuted and fined for 'offending public morals' in 1864. (His conviction was reversed in 1949). Much of his reputation for immorality and decadence was due to misunderstanding. He insisted that the unity of all art is a manifestation of the divine essence, which includes the contrast between beauty, ugliness and evil: humanity should not shrink from the poor, the wicked or the tortured. Obsessed with human suffering, as an artist his words invoked colours, scents, sensations, sounds, with glowing imagination and mastery of poetic symbolism. Other works by Baudelaire include Petits Poèmes en prose and studies of ${ }^{*}$ Balzac, ${ }^{*}$ Flaubert and ${ }^{*}$ Gautier. In later life he became addicted to opium and alcohol. He suffered from paralysis with aphasia from 1866 and his condition progressively worsened until his death.

*Mallarmé, *Rimbaud, *Verlaine, *Proust and *Eliot admired his poetry. ${ }^{*}$ Debussy and ${ }^{*}$ Duparc set some poems, and his work was later adopted by hard rock bands.

Leakey, F. W., Baudelaire and Nature. 1968; Richardson, J., Baudelaire. 1994. 
Baudin, Nicolas Thomas (1754-1803). French explorer, cartographer and naturalist. After a series of extraordinary adventures in the navy and as a privateer, he led an expedition to Australia (New Holland) 1801-03, charting the western and southern coasts and Tasmania (Van Diemen's Land). He died on Mauritius.

Baudouin (Boudewijn) I (Baudouin Albert Charles Leopold Axel Marie Gustave de Saxe-Cobourg) (1930-1993). King of the Belgians 1951-93. Son of *Leopold III, he succeeded on his father's abdication, married Dona Fabiola Mora y Aragon in 1960, travelled extensively, was interested in astronomy and photography and was concerned about global poverty and the environment.

Baudrillard, Jean (1929-2007). French cultural theorist and philosopher, political commentator, and photographer. His work is frequently associated with Postmodernism and Post-structuralism.

Baum, L(yman) Frank (1856-1919). American author. His The Wonderful Wizard of $\mathrm{Oz}$ (1900), the popular children's story, the first of a long series, achieved great success on stage (1901) and was filmed as The Wizard of $O z$ in 1908, 1925 and 1939.

Baum, Vicki (née Hedwig) (1896-1960). Austrian novelist, born in Vienna. Her Grand Hotel (1930), which used the accidental isolation of a group of people in an artificial setting as the basis of the plot, set a pattern by many other novelists. Its immense success, reinforced by a film version, was never achieved by her later works. She lived in the US from 1931 .

Baur, Ferdinand Christian (1792-1860). German theologian. Professor of theology 1826-60 at Tübingen University and the leading Protestant historian of religious dogma, he adopted much of *Hegel's dialectical method and subjected the New Testament and Church tradition to a rigorous analysis. His followers became known as the 'Tübingen School'.

Bax, Sir Arnold Edward Trevor (1883-1953). English composer, born in London. He composed the symphonic poems In Faery Hills (1909) and Tintagel (1917) in addition to seven symphonies, concertos for piano, violin and cello, songs, piano works and the choral work Mater, ora Filium ... (1921). His richly romantic style is a musical reflection of the 'Celtic Twilight' movement in literature. Bax, who was knighted in 1937, was Master of the King's Musick 1942-53. He wrote an evocative memoir Farewell My Youth (1943).

Scott Sutherland, C., Arnold Bax. 1973.

Baxter, James Keir (1926-1972). New Zealand poet. His parents were radical pacifists, and after an unhappy schooling in the South Island and England, he published his first volume of poetry Beyond the Palisade at 18 (1944). After a sporadic education at three universities, he worked as a postman, teacher and public servant, and became a Catholic (1958). He struggled with alcoholism, was tormented by his linking of sexuality and death, and torn between radical and conservative instincts. His poetry collections included Pig Island Letters (1966), Jerusalem Sonnets (1970) and Autumn Testament (1972). He set up an unsuccessful commune for juvenile drug addicts, and malnutrition contributed to his early death.

Baxter, Richard (1615-1691). English Puritan divine, born in Shropshire. In 1638 he was ordained in the Church of England but never became a strong adherent of any particular denomination, though his pastoral work at Kidderminster (from 1641) is said to have 'transformed the town'. A chaplain in the parliamentary army in the Civil War, he opposed the King's execution and worked for the restoration of Charles II. Forced to leave the Church because he rejected episcopacy, he was persecuted as a dissenter and imprisoned (1685-86) after a brutal trial before Judge *Jeffreys. A prolific writer, his best known works are The Saints Everlasting Rest (1650) and an autobiography, Reliquiae Baxterianae.

Bayard, Pierre du Terrail, Seigneur de (c.14731524). French soldier, known as 'le chevalier sans peur et sans reproche'. When only 20 years old he went with ${ }^{*}$ Charles VIII to Italy and in battle after battle he was to be found wherever danger was greatest. His reputation for humanity and piety grew with the fame won by his courage. In the wars of ${ }^{*}$ Louis XII and *François I his exploits continued, but while returning from Italy in 1524 he was mortally wounded by an arquebus shot.

Bayes, Thomas (1702-1761). English mathematician and theologian. 'Bayes' theorem', unpublished in his lifetime, marks the beginning of probability theory.

Bayezid I Yilderim (= 'Thunderbolt': Bāyezīd Han bin Murad Han) (c.1360-1403). Fourth Sultan of the Ottoman Empire 1389-1402. He succeeded his father, Murad I, greatly extended his dominions in Anatolia and invested Constantinople. The threat to Europe provoked a crusade against him by the emperor Sigismund, but by his victory at Nicopolis on the Danube he was able to move into northern Greece. Meanwhile a threat was developing from the rear from the Mongol leader Timur the Lame (*Tamerlane) who entered Anatolia in 1400. Bayezid was defeated and captured at Ankara (1402); he died in captivity. He is a character in *Marlowe's Tamburlaine the Great.

Bāyezīd II Veli (= 'the Saint': Bāyezīd bin Mehmed) (1447-1512) Eighth Sultan of the Ottoman Empire 1481-1512. He was defeated in battle by his son *Selim I and soon died. 
Bayle, Pierre (1647-1706). French philosopher. Son of a Calvinist minister, he became a Catholic and then reverted to Protestantism. He was professor of philosophy at Sedan 1675-81, of philosophy and history at Rotterdam University 1681-93, and wrote a famous Dictionnaire historique et critique. This acute and urbane work questioned many of the precepts of orthodox religious teaching and influenced *Voltaire, *Diderot and the French Encyclopaedists.

Baylis, Lilian Mary (1874-1937). English theatrical manager. Trained as a violinist, she managed the Royal Victoria Hall, a music hall off Waterloo Road, London, for her aunt Emma Cons from 1898 to 1912. She ran it alone from 1912 and, as the 'Old Vic', it became a national institution, notable as 'the home of Shakespeare'. She received a CH in 1929 and in 1931 acquired the Sadler's Wells Theatre for opera and ballet.

Bazaine, Achille François (1811-1888). French marshal. Having gained distinction in the Crimean War and against the Austrians in the Italian unification campaign, he was sent to Mexico where, from 1863, he was in supreme command and the main prop of *Napoléon III's protégé, the ill fated emperor ${ }^{*}$ Maximilian. In the Franco Prussian War, he was forced to take refuge in the fortress of Metz after the defeat at Gravelotte. His surrender with over 150,000 men (October 1870) was a decisive disaster. In 1873 he was court martialled for failure of duty and given a death sentence (commuted to 20 years' imprisonment). In 1874 he escaped to Spain, where he died.

Bazalgette, Sir Joseph William (1819-1891). English civil engineer. On the recommendation of I. K. *Brunel, he was appointed chief engineer of London's Metropolitan Board of Works 1856-89 and organised a vast reorganisation of the city's sewers, regarded as an outstanding achievement in civil engineering.

\section{Beaconsfield, 1st Earl see Disraeli, Benjamin}

Beadle, George Wells (1903-1989). American geneticist. Professor at the California Institute of Technology, he shared the Nobel Prize for Medicine (I958) with Joshua *Lederberg and Edward Tatum, for discovering that genes act by regulating definite chemical events.

Beaglehole, John Cawte (1901-1971). New Zealand historian. After a slow climb up the academic ladder, he became professor of Commonwealth History at Victoria University, Wellington 1963-66 and received the OM (1970) in the Cook Bicentennial Year for his scholarly work, including editing the four volume Journals of Captain James Cook (1955-67).

Beale, Sir Simon Russell (1961- ). English actor, author and historian, born in Malaysia. Educated at Cambridge, he made his debut in comic roles but soon excelled on stage as Hamlet, Lear, Falstaff, Richard III and Prospero, in television series as Kenneth Widmerpool, and on radio as George Smiley. He became Professor of Contemporary Theatre at Oxford 2014- and was an outstanding *Beria in the film The Death of Stalin (2017).

Bean, C(harles) E(dwin) W(oodrow) (1879-1968). Australian war correspondent and historian. Born in Bathurst, but educated in England, he became an official war correspondent in 1914, reporting on Gallipoli and the Western Front. He edited The Official History of Australia in the War of 1914-18 (12 volumes, 1920-42), writing six volumes himself. He did much to promote the ANZAC legend but was not an enthusiast for Sir John ${ }^{*}$ Monash. A driving force for establishing the Australian War Memorial in Canberra (1941), he declined several offers of a knighthood.

Coulthart, R., Charles Bean. 2015; Rees, P., Bearing Witness. 2016.

Beard, Dame (Winifred) Mary (1955- ). English classical scholar. Professor of Classics at Cambridge 2004- , she was a prolific author, reviewer, blogger and television presenter whose programs on the classical world were highly praised. Her books include Pompeii (2008), SPQR: A History of Ancient Rome (2015) and Women \& Power (2017).

Beardsley, Aubrey (1872-1898). English illustrator, born in Brighton. Associated with the English Aesthetic movement which his work typifies, he early developed a highly individual two dimensional style, characterised by contrasts of fine richly detailed linework and solid blacks, and by all the preoccupations and morbid tendencies of the Decadents. Among his most famous illustrations are those to *Wilde's Salome, *Pope's Rape of the Lock and his own work Under the Hill (1904). He became a Roman Catholic shortly before his early death from tuberculosis.

Symons, A., Aubrey Beardsley. 1972.

Beatles, The (1960-1970). British pop group, born in Liverpool. The group comprised John ${ }^{*}$ Lennon, George Harrison (1943-2001), Sir Paul *McCartney and Ringo Starr (Sir Richard Starkey) (1940- ), and first became cult figures in Germany. From 1963-67 'Beatlemania' was the dominant feature of world pop culture. Lennon and McCartney composed much of the Beatles' most successful material which revealed a strong lyrical gift, and a yearning for new ideas (e.g. 'flower power', eastern religions). Sergeant Pepper's Lonely Hearts Club Band was released in 1967.

Beaton, Sir Cecil WaIter Hardy (1904-1980). English photographer and designer. Originally known for his portraits of the fashionable, he extended his range to include designs of sets and costumes for theatre and films. His costumes for the film Gigi 
and his colour compositions for the musical success My Fair Lady in both its stage and screen versions, were widely acclaimed. He was the friend and (briefly) lover of Greta *Garbo 1929-51.

Vickers, H., Cecil Beaton.1985.

Beaton (or Bethune), David (1494-1546). Scottish prelate and statesman. Equipped for the Church by studies at the universities of Glasgow, St Andrews and Paris, and qualified as a statesman by skilful diplomacy for ${ }^{*}$ James $\mathrm{V}$, he was created a cardinal in 1538 and became archbishop of St Andrews and therefore primate of Scotland. After the death of James V, when his widow Mary of Guise headed the regency for her young daughter, ${ }^{*}$ Mary Queen of Scots, Cardinal Beaton, though he had to contend with the Protestant faction and other rivals, attained almost supreme power, which he used in the Roman Catholic and French interest. He was murdered by Protestant conspirators in revenge for the execution of George Wishart, a Calvinist preacher. Beaton was a typical Renaissance figure, cultivated, able, brave, intensely individual but largely amoral.

Beatrix (Beatrix Wilhelmina Armgard) (1938- ). Queen of the Netherlands 1980-2013. Daughter of Queen *Juliana and Prince *Bernhard, she married Claus von Amsberg (created Prince Claus) in 1966 and succeeded on her mother's abdication. A gifted painter, she abdicated in favour of her son Willem-Alexander.

Beatty, Sir (Alfred) Chester (1875-1968). American-British-Irish mining magnate, art collector and philanthropist, born in New York. He used his geological knowledge to identify mining sites (few of which he visited), amassed a fortune, became a discriminating connoisseur and a generous patron of libraries, art galleries, museums and cancer research. The Chester Beatty Library in Dublin has the world's greatest collection of early Gospel fragments.

Beatty, David Richard Beatty, 1st Earl (18711936). British admiral of the fleet, born in Cheshire. He joined the Royal Navy in 1884, served with Nile gunboats in the Sudan (1896-98) and in the Boxer Rebellion in China (1900), was naval secretary to Winston ${ }^{*}$ Churchill (1912) and commanded the 1st Battle Cruiser Squadron (1912-16). He directed successful naval actions at Heligoland Bight (1914) and Dogger Bank (1915). At the Battle of Jutland (1916), he lost two of his ships, but escaped the criticism encountered by *Jellicoe. He succeeded Jellicoe as Commander-in-Chief of the Grand Fleet 1916-18 and received the surrender of the German fleet in November 1918. Beatty, a capable and flamboyant leader, received an earldom, the $\mathrm{OM}$, and a grant of $£ 100,000$ in 1919 and served as First Sea Lord 1919-27.

Chalmers, W. S., The Life and Letters of David, Earl Beatty. 1951.
Beaufort. Name taken by the children of *John of Gaunt and Catherine ${ }^{*}$ Swynford when they were legitimised (1397). One of them, Cardinal Henry Beaufort (1377-1447), bishop of Winchester, was the chief rival of his nephew Humphrey, Duke of *Gloucester, for control of the government of England during the early years of *Henry VI. The cardinal's brother, John, Duke of Somerset, was grandfather of Margaret Beaufort, mother of *Henry VII, who through her, inherited the claim to the throne of the Lancastrian house.

Beaufort, Sir Francis (1774-1857). British naval hydrographer. In 1805 he devised a scale of numbers (the Beaufort Scale) for expressing wind force. Originally the numbers ran from 0 (calm) to 12 (hurricane that no canvas can withstand) but they have now been given precise values in knots and the scale has been extended to Force 17. Beaufort also devised a system of letters, still in use, for denoting weather phenomena.

Beauharnais. French family that attained distinction during the Revolutionary and Napoléonic periods. Alexandre, Vicomte de Beauharnais (1760-1794), served in the American War of Independence and supported the Revolutionary cause in France, but was executed during the Terror. His widow, *Josephine, became the first wife of ${ }^{*}$ Napoléon Bonaparte. His son, Eugène de Beauharnais (1781-1824), with Napoléon in Italy and the East, was an able and popular viceroy of Italy $1805-14$. He was one of the few to gain fresh laurels during the Moscow campaign of 1812 , and returned to hold Italy loyally to the last. After Napoléon's downfall he lived in Munich as Duke of Leuchtenberg.

Beaumarchais, Pierre Augustin Caron de (17321799). French playwright, born in Paris. Son of a watchmaker called Caron, as a young man he invented an improved watch escapement and taught the harp to the daughters of *Louis XV. He made a fortune from investment, took the name Beaumarchais from the first of two wealthy widows whom he married, went on secret missions in the king's service, and supplied arms to the insurgents in the American War of Independence. As a comic playwright he is regarded as second only to *Molière. His plays The Barber of Seville (1775) and The Marriage of Figaro (1784) were sensationally successful and were used as operatic libretti by ${ }^{*}$ Rossini and ${ }^{*}$ Mozart respectively.

Beaumont, Francis (1584-1616). English playwright, born in Leicestershire. The son of a judge, he studied law but from 1603 he devoted himself to literature. From 1606 until his marriage to Ursula Isley in 1613, Beaumont lived with his collaborator and friend John *Fletcher. Beaumont's part was predominant in The Knight of the Burning Pestle (1609), but the partners can share equal credit for Philaster (1611) and The Maid's Tragedy (1611). Altogether Beaumont is believed to have had a 
hand in about 10 of the ingenious and sophisticated tragedies and tragi-comedies attributed to the joint authorship.

Macaulay, G. C., Francis Beaumont: A Critical Study. 1972.

Beaumont, William (1785-1853). American physiologist and surgeon, born in Lebanon, Connecticut. Son of a farmer, he became a village teacher and began to study medicine. After an apprenticeship with a surgeon, he became an assistant in the US Army in North Michigan. In July 1822 he began treating a French-Canadian fur trapper, Alexis St Martin, who had been badly wounded in the stomach by a shotgun accident. The patient recovered (living to the age of 82) but developed a fistula, $25 \mathrm{~mm}$ across, through which the operation of his digestion could be observed. Over 10 years Beaumont carried out 238 experiments on St Martin, publishing the results in his classic Experiments and Observations on the Gastric Juice (1833). Beaumont established the presence of free hydrochloric acid in the juice, thus confirming that its action was primarily chemical in nature. He noted that gastric juices were not to be found in the stomach in the absence of food, and that psychological factors could influence their secretion. He also carefully investigated the digestibility of different aspects of diet, and studied the action of stimulants, such as coffee and alcohol, on the workings of the digestive system. His work was highly influential, especially in Germany.

Miller, G., William Beaumont's Formative Years. 1946.

Beauregard, Pierre Gustave Toutant (1818-1893). American soldier, born in New Orleans. A West Point graduate, he joined the Confederate army on the outbreak of Civil War in 1861, and was appointed to a command at Charleston in South Carolina. His order to fire on Fort Sumter marked the opening of the war, throughout which he held high command with varying success.

Beauvoir, Simone (Lucie Ernestine Maria Bertrand) de (1908-1986). French philosopher and author, born in Paris. Daughter of a lawyer, she was brought up in a conventional Catholic household, studied at the Sorbonne, graduated in 1929, being placed second in the competitive examinations to Jean-Paul *Sartre, her lifelong collaborator (and exploiter). She taught philosophy and literature at lycées in Marseille 1931-32, Rouen 1932-36 and Paris 1936-43, then worked as scriptwriter and editor for Radiodiffusion Nationale 1943-44. She became an important exponent of existentialism. Long assumed to have been Sartre's disciple, the influence was two-way and her contribution was both original and profound. She joined the board of the review Les Temps Modernes in 1945 and wrote many articles for it. Her most important work was The Second Sex (2 vols, 1949), an encyclopaedic study of the human female and still the greatest feminist text, transforming debate about the role of women. Other books included The Mandarins (1954), a novel about Parisian literary circles which won the Prix Goncourt, The Long March (1958), a study of modern China, and the autobiographical Memoirs of a Dutiful Daughter (1959), The Prime of Life (1963), Force of Circumstance (1965), A Very Easy Death (1966), All Said and Done (1972) and Farewell to Sartre (1981). She was buried with him at Montparnasse Cemetery.

Bair, D., Simone de Beauvoir. 1990.

Beaverbrook, (William) Max(well) Aitken, 1st Baron (1879-1964). British newspaper proprietor and politician, born in Canada. A cement and timber millionaire when he went to England 1910, he was a Conservative MP 1910-16, and friend and protégé of Andrew Bonar * Law. Created a peer in 1916, he was Britain's first Minister of Information (1918). The Daily Express, almost derelict when he bought it in 1919, became his life's work. It became in a sense an enlargement of his own personality, energetic, exciting, entertaining, mischievous and sometimes brash. Later he founded the Sunday Express, and the Evening Standard was taken over in 1929. Beaverbrook's active interest in every detail and department of his newspaper was maintained throughout his life. He pursued Imperial preference with frantic zeal and clashed with *Baldwin. Under ${ }^{*}$ Churchill, with whom he had an uneasy friendship, he served as Minister for Aircraft Production 194041, Minister for Supply 1941-42 and Lord Privy Seal 1942-45. Churchill sent him to Moscow to negotiate with *Stalin (Sept. 1941) and he developed a rapport with ${ }^{*}$ Roosevelt. His great collection of political papers, as well as providing valuable source material for historians (notably his friend and biographer A.J.P. *Taylor), helped him with the writing of Men and Power, 1917-18 (1956) and The Decline and Fall of Lloyd George (1963).

Davie, M. and Chisholm, A., Beaverbrook. 1992.

Beazley, Kim Christian (1948- ). Australian Labor politician. His father Kim Edward Beazley (19172007) was *Whitlam's Education Minister 1972-75. A Rhodes Scholar, he was a Federal MP 1980-2007, Minister 1983-96, and succeeded Paul *Keating as Labor Leader 1996-2001 and (after Mark *Latham) 2005-06: he was then defeated by Kevin *Rudd. He served as Australian Ambassador to the US 200916 and Governor of Western Australia 2018-22.

FitzSimons, P., Beazley. 1998.

Bebel, (Ferdinand) August (1840-1913). German socialist politician. A founder of the German Social Democratic Party, he was a Member of the Federal German Legislature (Reichstag) 1871-81, 18831913, prominent in his opposition to Germany's nationalist policies, and several times imprisoned. He belonged to the Marxist wing of his party and with Wilhelm *Liebknecht founded the political 
journal Vorwarts (Forward). His Women under Socialism (1883) compared women to the proletariat and was highly praised by Simone de *Beauvoir.

Beccaria, Cesare Bonesana di, Marchese di Gualdrasco e Villareggio (1738-1794). Italian economist, philosopher and legal reformer, born in Milan. From an aristocratic family, he became an economist, anticipating Adam ${ }^{*}$ Smith, ${ }^{*}$ Bentham and *Malthus, and pioneered statistical analysis. In his work On Crimes and Punishment (Dei delitti e delle pene) published in 1764 he followed *Montesquieu's assertion that punishment is a function of civil society, not the expression of divine vengeance, advocating abolition of the death penalty and torture as being 'neither necessary nor useful'. He urged comparative statistical examination of crime rates, that the aims of punishment are reformation and deterrence, and that certainty of apprehension and conviction is a greater deterrent than severity of punishment. His book, widely translated, influenced *Leopold II (then Grand Duke of Tuscany) and *Joseph II and inspired criminal law reformers for more than a century. He adopted Francis *Hutcheson's concept of 'the greatest good for the greatest number' ('la massima felicità divisa nel maggior numero'). Alessandro *Manzoni was a grandson.

Hostetter, J., Cesare Beccaria: The Genius of 'On Crimes and Punishments'. 2010.

Becker, Gary Stanley (1930-2014). American economist. Educated at Princeton and Chicago, he taught at Chicago from 1954 and was interested in the relationship of economics and psychology, such as the determining of consumer preference, first set out in an essay 'A theory of the allocation of time' (1965). His books include The Allocation of Time and Goods over the Life Cycle (1975) and A Treatise on the Family (1976). He won the 1992 Nobel Prize for Economics.

Becket, St Thomas (or Thomas à Becket) (11181170). English archbishop and martyr, born in London. Son of a rich merchant of Norman descent, having been given a knightly training, he studied theology in Paris, and entered the household of *Theobald of Bec, Archbishop of Canterbury. Theobald sent him to Bologna and Auxerre to study canon law, and appointed him as Archdeacon of Canterbury in 1154 . Theobald persuaded *Henry II to appoint Becket as Lord Chancellor 1155-62, and he became the king's confidant and chief minister, offending many by his ostentation and pride. Henry was preoccupied with preventing what he regarded as the encroachments of Church courts upon secular jurisdiction. To achieve this, in 1162 he decided that the presumably compliant Becket would be the ideal successor to Theobald as Archbishop of Canterbury and Pope *Alexander III acquiesced. Before enthronement as Archbishop, Becket had to be ordained as a priest. Henry was soon bitterly disappointed: once appointed archbishop, Becket became as devoted to the pope's cause as he had been to the king's. Henry was furious and, to escape persecution, in 1164 Becket took refuge in Sens and Pontigny. Becket excommunicated many of his opponents, and there were bitter disputes about land ownership. The pope's role had been ambiguous but, at last, he supported Becket's threat to put England under an interdict (essentially withdrawing the right of priests to administer the sacraments). A settlement was negotiated and in December 1170 Becket returned to Canterbury. However, he continued to challenge royal authority, and within weeks Henry, holding court at Bur-le-Roi, near Bayeux, Normandy, reacted with the fatal words indicating his wish for 'deliverance from this turbulent priest', or something similar. Four of his knights eagerly took up the hint, proceeded to Canterbury and hacked Becket to death in his cathedral, near the entry to the crypt (29 December 1170). The dead martyr was far more powerful than the living priest. In 1173 the pope proclaimed Becket a saint and the king did public penance in 1174. After Rome and Compostella, Canterbury became one of the greatest European pilgrimage destinations. This was the context for *Chaucer's Canterbury Tales, written 200 years after the murder. In 1538, *Henry VIII ordered the destruction of Becket's tomb and his remains were scattered.

Barlow, F., Thomas Becket. 1986; Duggan, A., Thomas Becket. 2005; Guy, J., Thomas Becket: Warrior, Priest, Rebel. 2012.

Beckett, Dame Margaret Mary (née Jackson) (1943- ). British Labour politician. She qualified as a metallurgist, was MP 1974-79, 1983- ; Deputy Leader of the Labour Party 1992-94, acting as Leader after John ${ }^{*}$ Smith's sudden death in 1994. She became Secretary of State for the Environment, Food and Rural Affairs 2001-06, the first female Foreign Secretary 2006-07 and Lord President of the Council 1998-2001.

Beckett, Samuel (Barclay) (1906-1989). Irish dramatist, novelist and poet, born near Dublin. Educated at Trinity College, Dublin, he lectured in English in Paris (1928-30) and was James *Joyce's literary assistant and translator. He wrote a monograph on Marcel *Proust (1931) and had an obvious sympathy with Franz *Kafka. He lectured in French at Trinity College, Dublin 1930-32, then returned to Paris where he spent most of his life (1932-37; 1938-89). During World War II he was active in the Resistance.

His important early novel, Murphy (1938), written in English, shows the influence of Joyce, and a second comic novel Watt, completed in 1945, and later dramatised, was published in 1953. Molloy (1951, translated 1955), Malone meurt (1951; Malone dies 1956), and L'Innommable (1953; The Unnamable 1958), a trilogy, written in French and translated 
by Beckett, are interior monologues which can be read as plays, just as his plays can be read as novels. Beckett showed some affinity with existentialism and his spare, lucid style is minimalist. There is a bracing stoicism in Beckett's words (from The Unnamable):

'It will be I? It will be the silence, where I am? I don't know. I'll never know, in the silence you don't know. You must go on. I can't go on. I'll go on.'

Like Eugène ${ }^{*}$ Ionesco, Jean ${ }^{*}$ Genet, Edward *Albee and Harold *Pinter, Beckett was identified with the 'theatre of the absurd', in which humans exist in a moral vacuum, unable to communicate, hurtling towards death without the consolation of meaning, either religious or secular. His plays have the quality of chamber music with the beauty of the words (either in French or English) and significant pauses and silence. They include En Attendant Godot, 1952 (Waiting for Godot, 1955), Fin de Partie (1957; Endgame, 1957), All that Fall (1957), Krapp's Last Tape (1957; La Dernière Bande, 1959), Happy Days (1961; Oh les beaux jours, 1962), Comment c'est (1961; How It Is, 1964) and Quoi où (1983; What Where, 1983).

Waiting for Godot, his most famous work, is a 'tragicomedy in two acts'. Two men, Estragon and Vladimir, sit near a tree in the country waiting interminably for Godot to arrive. He never does. Later they are joined by the bullying Pozzo, who is trying to sell his slave, Lucky. A boy who seems to know Godot makes an enigmatic appearance. The play's ambiguities are challenging, even transcendental and it has been performed more than any other contemporary drama.

Beckett was awarded the Nobel Prize for Literature in 1969 'for his writing, which-in new forms for the novel and drama-in the destitution of modern man acquires its elevation'.

Bair, D., Samuel Beckett. 1978; Knowlson, J., Doomed to Fame: the Life of Samuel Beckett. 1996; Cronin, A., Samuel Beckett: the Last Modernist. 1997.

Beckford, William Thomas (1760-1844). English writer and collector. A large inherited fortune enabled him to lead an easy cultured life as a man of letters. His novel Vathek, a tragicomic oriental fantasy, was begun in 1782 and in French. 'Episodes' intended to be interpolated were not published until 1912 . From 1785 to 1798 , partly as the result of a scandal, he spent most of his time in France, Switzerland, Spain and Portugal. His Recollections of an Excursion to the Monasteries of Alcobaca and Batalha (1835), esteemed as his best book, recalls a Portuguese visit made in 1795. Much of his time was, however, spent in building up collections of books and pictures which were eventually housed at Fonthill, a Gothic extravaganza which he commissioned ${ }^{*}$ Wyatt to build for him in Wiltshire (1796-1807). He lived there in hermit-like seclusion.
Beckmann, Max (1884-1950). German painter. A figurative artist, he was associated with the Expressionists, working in Berlin, Frankfurt, Amsterdam and New York. His paintings were large, powerful and savage, reflecting despair at human cruelty.

Becquerel. French scientific family. Antoine César Becquerel (1788-1878) served as an engineer in the Peninsular War and in 1837 became professor of physics (working on animal heat, electrochemistry, etc.) at the Musée d'Histoire Naturelle. In this post he was succeeded by his son Alexandre Edmond (1820 1891), whose principal field of study was optics. The same chair was held by Alexandre's son (Antoine) Henri (1852-1908), who held it for three years before becoming professor of physics (1895) at the École Polytechnique. In 1896, while investigating the fluorescence produced by exposing uranium salts to $\mathrm{X}$-rays, Becquerel discovered that radiation was given off by the uranium salts even when they had not been exposed to X-rays. This 'radioactivity' he showed to be a fundamental property of salts of uranium, thorium and other heavy elements. His suggestion that Marie and Pierre ${ }^{*}$ Curie should investigate radioactivity in pitchblende led them to isolate the element radium. Becquerel and the Curies were jointly awarded the Nobel Prize for Physics in 1903.

Beddoes, Thomas Lovell (1803-1849). English poet. The son of a physician, he studied at Oxford (1820-24) and spent the rest of his life as a doctor in Germany and Switzerland with occasional visits to England. From 1825 he worked on his most important work, a drama called Death's Jest Book, or the Fool's Tragedy, which was published posthumously after his suicide in Basle. His morbidity and obsession with death (he described himself as a 'creeper into worm holes'), is reminiscent of the Jacobean dramatists, but occasionally his lyrics display a delicate and moving poignancy. His collected poems first appeared posthumously in 1851 .

Bede (or Baeda), St (c.673-735). English historian and theologian. Known as 'the Venerable Bede', he spent most of his life as a Benedictine monk at Jarrow, near Durham, became the greatest scholar in the English Church and a European figure, writing works on grammar, theology and history with standards of scholarship unusual for his time. In $O n$ the Reckoning of Time (c.725), he promoted the Christian chronology proposed by ${ }^{*}$ Dionysius Exiguus. He calculated that the creation of the universe occurred in 3952 BC, using Genesis as his source. His main work was The Ecclesiastical History of the English Nation, still an essential source for the period 597 to 731 . He died immediately after completing a vernacular translation of St John's Gospel and is buried in Durham Cathedral. His influence on the school at York was transmitted by *Alcuin to the court of ${ }^{*}$ Charlemagne. In 1899 , he was canonised and proclaimed as a Doctor of the Church by ${ }^{*}$ Leo XIII. 
Bedford, John of Lancaster, Duke of (1389-1435). English prince. On the death (1422) of his brother, *Henry V of England, Bedford was regent in France for the boy king *Henry VI. He proved himself able both as a soldier and administrator but found himself confronted by the French national spirit revived by *Joan of Arc.

Beebe, Charles William (1877-1962). American ornithologist and explorer. In 1934 he reached a record depth of $993 \mathrm{~m}$ (3,028 feet) in the sea off Bermuda in a bathysphere, a diving bell of his own design, in order to study marine life at intense pressures. He described the experience in Half a Mile Down (1934).

Beecham, Sir Thomas, 2nd Baronet (1879-1961). English conductor, born in St Helens, Lancashire. Son of a millionaire laxative (Beecham's Pills) manufacturer, educated at Rossall School, Fleetwood, and Oxford, he made his debut in 1905. In 1906 he founded the New Symphony Orchestra and in 1910 initiated a series of opera seasons at Covent Garden. The following year he introduced *Diaghilev's Ballets Russes to London. He strove to establish opera permanently in Britain and to improve operatic and orchestral performances. Admired for the verve and elegance of his interpretations, he was associated particularly with music by ${ }^{*}$ Haydn, ${ }^{*}$ Mozart, ${ }^{*}$ Delius, *Sibelius and Richard *Strauss. He founded the London Philharmonic Orchestra in 1932 and the Royal Philharmonic Orchestra in 1946, was artistic director at Covent Garden 1932-39, and lived in the US (1940-44). In 1916 he was knighted, succeeded to his father's baronetcy in the same year, and received a $\mathrm{CH}$ in 1957.

Cardus, N., Sir Thomas Beecham. 1961.

Beecher, Henry Ward (1813-1887). American preacher. The brother of Harriet Beecher *Stowe, the author of Uncle Tom's Cabin, as a Congregational minister he attracted 3,000 to Plymouth Church, Brooklyn (1847-87), where he won fame as a preacher of great eloquence and power. He denounced black slavery and advocated temperance and women's suffrage. A visit to Britain (1863) proved a triumph. In 1874 he was charged with having committed adultery with Mrs Elizabeth Tilton, the wife of prominent journalist, Theodore Tilton, but after a long trial the jury was unable to agree on a verdict.

Beethoven, Ludwig van (1770-1827). German composer, born in Bonn. Of Flemish descent, his father Johann (c.1740-1792), a tenor in the Electoral choir, was Beethoven's first teacher and took him from school at the age of 11 to exploit his musical talents. Beethoven studied composition (1781-87) with the organist Christian Neefe who stimulated his interest in *Bach. On a journey to Vienna (1787) he played for ${ }^{*}$ Mozart and perhaps had a few lessons from him. $\mathrm{He}$ was assistant conductor at the Electoral court
(1784-88) and also played the viola in the Bonn opera orchestra. With the financial support of the Elector Maximilian Franz and Count Ferdinand Waldstein, Beethoven was sent to Vienna where he studied with ${ }^{*}$ Haydn, J. G. Albrechtsberger and ${ }^{*}$ Salieri. Apart from short visits to Berlin and Budapest, he remained in Vienna until his death. His acceptance by the highest social circles showed the revolutionary change in the status of composers since Haydn and Mozart. Archduke Rudolph, Prince Lichnowsky, Prince Kinsky and Prince Lobkowitz were not only Beethoven's patrons but also friends and subscribed to a large annuity to keep him in Vienna, despite his rude manners, outbursts of temper and rough appearance.

Beethoven's works, 722 in total, are usually classified into three periods, although these classifications cannot be applied arbitrarily. His early music shows the extent of his debt to the Classical masters, especially Haydn and Mozart, with its restraint, balance, subtle emotion and strict observance of form. To this period belong the first two symphonies $(1800,1802)$, the first two piano concertos (1797, 1795-98), the first 12 piano sonatas, the first six string quartets and 13 trios.

From 1796 Beethoven suffered from acute tinnitus, and by 1798 there was serious hearing loss, a cause of profound personal and professional anguish for 30 years. After 1801 he became a highly functioning alcoholic, suffered from progressive cirrhosis of the liver and from lead poisoning, due to plumbing, complicated by a bad diet. He contemplated suicide in 1802. His deafness was almost certainly caused by osteosclerosis, abnormal growth of bone in the cochlea or the stirrup-shaped stapes. He tried various treatments including diet and even electric shock. He rarely performed on piano in public from 1808 and abandoned it in April 1814. However, a letter of 1823 indicated that he retained vestigial hearing in the left ear and last conducted, erratically, in May 1824.

Between 1802 and 1815 (the second period), Beethoven broke away from the Classical tradition and developed the new 'romantic' style, which had been hinted at in the late works of Haydn and Mozart. His symphonies and sonatas were longer than their Classical forebears, more vigorous, with a much greater range of dynamics, tempos, rhythms, key changes, syncopation and harmony. The music was much less predictable and much more emotional in both form and content. Beethoven's symphonies substituted the scherzo for the traditional minuet and trio movement and are scored for a substantially larger orchestra than Mozart's. An ardent democrat and republican, Beethoven originally dedicated his Symphony No. 3 in E flat, op. 55 (1804) to*Napoléon but, disillusioned when he proclaimed himself Emperor, changed the dedication and renamed it 'Eroica'. The longest symphony written to that time, it is marked by a driving urgency, exceptional 
dynamic range and unprecedented orchestration, leaving behind the world of Haydn and Mozart, just as the impact of the French Revolution and the long turmoil of the Napoléonic Wars transformed European society, its traditions and institutions. The symphony begins starkly with two fierce chords followed by a long powerful theme over a grinding bass. The slow movement is a long, unprecedented, funeral march, followed by a wild scherzo, concluding with a heaven storming set of variations on the theme of Prometheus. Its power and the obsessive repetition of dissonance shocked the Viennese audience. The hero, the creative artist challenging the world and defying death and infirmity, is Beethoven himself.

Other works of this period include the Piano Concertos Nos 3 (1803), 4 (1806), 5 (1809, nicknamed the 'Emperor', but not by Beethoven); his Symphony No. 4 in B flat, op. 60 (1806); 15 piano sonatas; the 'Kreutzer' (1803) and 'Spring' (1805) violin sonatas; much chamber music including five string quartets, string and piano trios including the 'Archduke' op. 97 (1811); the Violin Concerto in D major, op. 61(1806); several sets of variations; and the opera Fidelio. Originally titled Leonora, after the heroine, Fidelio was a failure when first performed in 1805. It succeeded in 1814 only after drastic revisions had been made. Four more symphonies were also composed during this period: No. 5 in C minor, op. 67 (1807) probably the most performed in the repertoire; No. 6 in F major, op. 68 (1808, 'Pastoral'); No. 7 in A major, op. 92 (1812, described by *Wagner as the apotheosis of the dance') and No. 8 in F major, op. 93 (1813).

His third period begins in 1815, but until 1824 there was a comparative hiatus in Beethoven's productivity, due to sickness, depression and family problems: no symphonies, concertos or string quartets. However, there were five superb piano sonatas, Nos. 28, 29 (the 'Hammerklavier', 1818), 30. 31 and 32, two cello sonatas, the Diabelli Variations (1823), the Missa Solemnis (1823) and many songs.

Symphony No. 9 in D minor, op. 125 (1823-24), the 'Choral' Symphony, his longest and most innovative, creates a completely new sound, introducing four soloists and a chorus in the last movement, singing *Schiller's 'Ode to Joy'. In November 1989 the 'Choral' Symphony was played in Berlin when the wall came down because it expresses, as Daniel *Barenboim wrote, 'a social affirmation of the human being, with promises of fulfilment, of liberation and brotherhood'. The last five string quartets and the Grosse Fuge (1824-27), are the greatest in the repertoire. His favourite among his works (Wagner's choice as well) was the String Quartet No. 14 in C sharp, op. 131 (1826). Quartet No. 15 in A minor, op. 132 (1825) contains his Heiliger Dankgesang ('Sacred Song of Thanksgiving'), a profound expression of personal experience and conviction, and a hint of belief in a personal God. The music begins with an attempt to grapple with the stress of existence, pain and uncertainty, moving through questioning to understanding, to resolution, to affirmation and finally to joy.

He never married, although he had several brief and pathetic love affairs; he never found his Leonora. $\mathrm{He}$ had wealthy patrons, a reasonable income, lived at a fashionable address, but in squalor and lacked all social graces. He lost savings in unwise investments and his later years were darkened by anxiety over his hapless nephew Karl (1806-1858). Associates tried to communicate through ear trumpets, then by correspondence books, of which 139, between 1818-27, survive. After questions were written out, Beethoven would reply, either by scrawling in the book or shouting. Raised as a Catholic, he was a deist with a profound reverence for nature. After a long illness he died of dropsy and jaundice at his lodgings in the Schwarzspanierhaus (demolished in 1904). His funeral was attended by 20,000 people. His will directed an autopsy.

Beethoven remains the most popular of the greatest composers perhaps because listeners feel that in his constant struggles with fate he never fails to win a victory.

Solomon, M., Beethoven. 1977; Cooper, B. (gen. ed.), The Beethoven Compendium. 1991; Kinderman, W., Beethoven. 1996; Swafford, J., Beethoven: Anguish and Triumph. 2014.

Beeton, Isabella Mary (née Mayson) (1836-1865). English author. Mrs Beeton's was a household name in British kitchens for over a century. Educated in Heidelberg and trained as a pianist, she married a publisher and began writing on cookery in his Englishwoman's Domestic Magazine. Her famous Book of Household Management (1861) originally appeared in three parts during 1859-60.

Begin, Menachem (1913-1992). Israeli politician, born in Poland. After working as a Jewish youth organiser in Poland he was deported to Siberia by the Russians, released and sent to Palestine. In 1943 he became leader of Irgun Zvai Leumi which adopted more militant tactics against the British than David *Ben Gurion's Zionists. He led the Likud party in the Knesset and defeated the Mapai to become Prime Minister 1977-83. He welcomed the visit of Egypt's President *Sadat to Jerusalem (November 1977) and in 1978, with assistance from President Jimmy ${ }^{*}$ Carter, concluded an Israeli Egyptian peace treaty at Camp David, Maryland. Begin and Sadat shared the 1978 Nobel Peace Prize.

Behan, Brendan (1923-1964). Irish playwright, born in Dublin. Son of a house painter, he was arrested in Liverpool for terrorist activities on behalf of the Irish Republican Army in the early days of World War II. His subsequent years in an institution were described in Borstal Boy (1958). His fame rests on two plays 
The Quare Fellow (1956) and The Hostage (1958), both owing much to Joan *Littlewood's production at the Theatre Workshop in East London, and his notorious conviviality and outspokenness.

O'Connor, V., Brendan Behan. 1970.

Behn, Aphra (née Amis) (1640-1689). English author. The first professional woman writer in English, she was brought up in Surinam before returning to England and marrying a merchant called Behn. An adventurous interlude as a spy in Holland followed her husband's death, and it was only then, after imprisonment for debt, that she took to writing as a career. She wrote two plays and 14 novels, including Oroonoko, or The Royal Slave, which anticipated Rousseau's 'noble savage'.

Hahn, H., Aphra Behn. 1951.

Behrens, Peter (1868-1940). German architect, born at Hamburg. He worked as an industrial designer in Munich before being appointed professor of architecture at Darmstadt in 1900. He became the principal architect of the Deutscher Werkbund, founded in 1907, an association of architects and designers formed to meet the needs of and take advantage of the new opportunities provided by industrial building and design. Among the earliest and best known of Behrens' functional buildings was his turbine factory (1909) in Berlin, built for the great electrical combine AEG, for whom he designed other major buildings and a number of industrial products. Both his architecture and his design are characterised by functional expression and geometric simplicity. *Le Corbusier, *Gropius and *Mies van der Rohe were influenced by his work.

Behring, Emil Adolf von (1854-1917). German bacteriologist. He graduated at Berlin and joined the Army Medical Corps, which he left (1888) to work on immunisation at Robert *Koch's Institute for Infectious Diseases. In 1890, with *Kitasato Shibasaburo, he produced an anti-toxin for use against tetanus. In 1892 he developed an anti-toxin for diphtheria. Paul *Ehrlich demonstrated how it could be produced in greater strength and volume by growing it in horses. In 1895 he became a professor at Marburg, where he set up his own laboratories for manufacturing anti-toxins. He won the first Nobel Prize for Medicine in 1901 for his 'work in serum therapy, especially diphtheria' (and Ehrlich never forgave his exclusion). He failed in attempts to find a vaccine for tuberculosis but his tetanus vaccine saved many lives in World War I.

Beiderbecke, Bix (né Leon Bismark) (1903-1931). American cornettist, pianist and composer, born in Davenport, Iowa, he was the first to attempt to incorporate concert hall harmonies into jazz improvisation, and the first white musician to be acknowledged an important innovator by AfricanAmerican contemporaries. He worked with various musicians, including Frank Trumbauer and Jean Goldkette, but died in comparative obscurity. His posthumous reputation grew and he was remembered for the purity of tone of his cornet style, and the impressionistic influences shown in his piano playing. A Beiderbecke cult was initiated with the publicity of Dorothy Baker's novel Young Man with a Horn (1938).

Béjart. French acting family, closely associated with the playwright ${ }^{*}$ Molière. Joseph Béjart (c.16171659) was a strolling player and he joined the Illustre Théatre and created the parts of Lelie and Eraste in Moliere's L'Etourdi and Depit amoureux. Louis Béjart (c.1630-1678), brother of Joseph, also a member of the Illustre Théatre, created the parts of Valere in Depit amoureux, Dubois in Le Misanthrope, Alcantor in Le Mariage force and others. Madeleine Béjart (1618-1672) was head of a company of strolling players to which her sister Geneviève and brothers, Joseph and Louis, originally belonged. It is said she persuaded Molière to enter upon a theatrical career, and her acting boosted the company's morale in their periods of financial difficulty. She was particularly convincing in the parts of soubrettes (coquettish maids or frivolous young women), several written specially for her by Molière, including Dorine in Tartufe. Her sister Geneviève was more successful as a tragedian. Armande Béjart (1642-1700), Madeleine's sister or daughter, joined the company at Lyons in 1653 and married Molière in 1662. In 1663 she made her debut as Elise in La Critique de l'École des femmes. In 1665 she and Molière parted, but were later reconciled (1671). She played many important Molière roles including Celimene (modelled on herself) in Le Misanthrope and Angelique in Le Malade Imaginaire. Following Molière's death in 1673 she kept the company together, and in 1679 it secured Marie Champmesle, an outstanding tragedienne, and subsequently became the Comédie Française, the French national theatre. In 1667 she married Isaac-François Guerin d'Etriche, a leading actor who headed the Comédie Française.

Belasco, David (1853-1931). American dramatist, theatre manager, and actor, born in San Francisco. From childhood he worked in stock touring companies, lived in San Francisco 1873-79 and moved to New York in 1880, becoming an independent producer from 1890. He established the Belasco Theatre in 1906. His lavish productions were marked by technical innovations and new standards of professionalism. However, his taste was conservative and he ignored the emerging major playwrights of Europe and the US. His own plays included Hearts of Oak (1880), The Heart of Maryland (1895), Madame Butterfly (1900) and The Girl of the Golden West (1905) - both used as libretti for *Puccini's operas, Du Barry (1901) and Lulu Belle (1926). He affected a clerical style of dress and was often called 'the Bishop of Broadway'. 
Belinsky, Vissarion Grigorievich (1811-1848). Russian literary and social critic, born in Helsinki. An associate of ${ }^{*}$ Herzen and ${ }^{*}$ Bakunin, he was attracted to the Western tradition of individualism and gave early support to ${ }^{*}$ Dostoevsky who soon broke with him.

Belisarius (c.505-565). Byzantine general. In the service of the emperor *Justinian, his most successful campaigns were fought when he was trying to win back the former territories of the Roman Empire in Africa and Italy. He defeated the Vandals in Africa (533-34) and in 535 occupied Sicily, whence he proceeded to his main task of expelling the Ostrogoths from Italy. Rome was triumphantly reoccupied in 536 but this was only a beginning and it was not until 540 that the Ostrogoths' capital at Ravenna was taken. Recalled to repel Persian attacks in the East, he returned to Italy (544) when the Ostrogoths had renewed the struggle. Mainly through lack of support by the emperor, he failed to achieve decisive results and in 549 he was again recalled. Justinian, indeed, found it difficult not to suspect the loyalty of so successful and popular a general and though in the case of Belisarius they were quite groundless, these suspicions continually hampered his career. Indeed in 562 he was even imprisoned for a short time, though only three years earlier the Huns had been driven back from the outskirts of Constantinople by his skill and courage. However, the legend that he was blinded and died a beggar is untrue.

Graves, R., Count Belisarius. 1938.

Bell, Alexander Graham (1847-1922). American inventor, born in Edinburgh. His father was an elocutionist, his mother became increasingly deaf. $\mathrm{He}$ attended classes at Edinburgh University and University College, London, and worked with his father as a teacher of the deaf. He migrated to Canada for his health (1870), then went to Boston where he taught 'deaf mutes' (as they were then called) and became professor of vocal physiology at Boston University (1873). (He married a deaf student in 1877 and Helen *Keller was one of his later protégés.) $\mathrm{He}$ opposed use of sign language and became preoccupied with the mechanical transmission of sound vibrations by wire. He invented the first practical telephone, submitting a patent application on 14 February 1876, only a few hours before Elisha ${ }^{*}$ Gray. (Both used a crude 'liquid transmitter', with a vibrating reed touching acidified water, instead of a microphone.) The telephone was an instant success at the Philadelphia Centennial Exposition (1876) and the Bell Telephone Company was founded in 1877. (Queen *Victoria had a telephone in 1877 and Melbourne a telephone exchange by 1880 .) *Edison's carbon microphone (1878) improved performance greatly. In return he improved Edison's phonograph (1880). France awarded him the Volta Prize in 1880 and he used the money to establish the Volta
Bell became a US citizen in 1882, was a co-founder of the magazines Science (1880) and the National Geographic (1898), supported experimentation in aviation, and invented the tetrahedral kite. He studied the genetic basis of deafness and sonar detection and was an advocate for eugenics. He died in Nova Scotia. The decibel (db: measure of intensity of sound) was named for him. His father, Alexander Melville Bell (1819-1905), who also went to America, settled in Washington, DC, in 1881. He invented a system of 'visible speech', his methods combining 'phonetic signs and graphs of the organs and motions of speech'.

Mackay, J., Alexander Graham Bell. 1998.

\section{Bell, Andrew see Lancaster, Joseph}

Bell, Clive Arthur Howard (1881-1964). English art and literary critic. He did much by his critical works, e.g. Art (1914) and Since Cezanne (1922), to explain and popularise the Post Impressionists and Fauves. Other works include Civilisation (1928) and Proust (1929). A member of the Bloomsbury group, Bell married Vanessa, daughter of Sir Leslie *Stephen, and sister of Virginia *Woolf.

Bell (né Bolotsky), Daniel (1919-2011). American sociologist. Originally a journalist, he became a socialist, then a liberal, finally a conservative, holding a chair in sociology at Harvard 1969-90. His major works were The End of Ideology (1960) and The Coming of Post-Industrial Society (1973).

Bell, George Kennedy Allen (1883-1958). Anglican prelate. Bishop of Chichester 1929-58, a pioneer of the ecumenical movement, he became close to Dietrich *Bonhoeffer and during World War II campaigned to draw attention to Nazi atrocities.

Bell, Gertrude Margaret Lowthian (1868-1926). English traveller, mountaineer, linguist, author and archaeologist. Educated at Oxford (but unable to take out a degree), her travels from 1892 in almost every part of the Middle East were of great importance to the British Government when these lands became battlefields or areas of political contention during and after World War I. She worked with T. E. *Lawrence and, as 'oriental secretary', largely drew the boundaries for the new state of Iraq in 1921. A strong supporter of the Hashemite interest, she pushed for the imposition of *Faisal as King of Iraq. She lived in Baghdad, worked at the museum and committed suicide there. She was anti-Zionist and also (oddly) strongly opposed to votes for women.

Meyer, K. E. and Brysac, S. B., Kingmakers. 2008.

Bell, John (1940- ). Australian actor and theatre director, born in Maitland. A Sydney University graduate, he worked with the Royal Shakespeare Company in England, acted, taught and directed in Sydney, and founded the Bell Shakespeare Company 
in 1990. In addition to *Shakespeare, his company was successful in plays by *Marlowe, *Webster, *Goldoni, *Strindberg and *Williamson.

Bell, J., The Time of My Life. 2002.

Bell, John Stewart (1928-1990). Irish physicist. Educated at Birmingham University, he worked at CERN (Conseil Européen pour la Recherche Nucléaire), Geneva, from 1960. 'Bell's theorem' (1964) argues that there is an interconnectedness between subatomic particles that raises fundamental questions about models of, and the nature of, causation.

Bell, Patrick (1801-1869). Scottish inventor, born in Angus. Son of a farmer, his agricultural machinery derived from a practical understanding of a farmer's needs rather than from specialised training. He invented the first practical reaper for cereal crops and machines for grinding oats and making wheat-flour, and devised equipment for extracting the sugar from sugar beet. He later became a minister in the Kirk.

Bell Burnell, Dame Jocelyn (née Susan Jocelyn Bell) (1943-). British astrophysicist, born in Northern Ireland. An active Quaker, she studied at Glasgow and Cambridge, where, as a graduate student, working (1967) with Antony ${ }^{*}$ Hewish, she identified the first four pulsars. Hewish, who initially dismissed her observation, went on to share a Nobel Physics Prize in 1974 from which Bell was excluded, one of the most egregious failures in the history of the Prize. She became FRS in 2003 and DBE in 2007.

Bellamy, Edward (1850-1898). American novelist and political writer. His most famous work was Looking Backward (1888), a Utopian romance which influenced socialist ideas of economic organisation and became a bestseller, ranking only behind Uncle Tom's Cabin and Ben-Hur. Other romances with similar aims were Equality (1897) and The Duke of Stockbridge (1900).

Morgan, A. E., Life of Edward Bellamy. 1944.

Bellarmino, St Roberto Francisco Romulo (15421621). Italian cardinal and theologian. He entered the Jesuit Order in 1560 and was ordained, after studying at Louvain and Padua, in 1570 and spent the rest of his life either teaching theology (at Louvain until 1576 and then in Rome) or engaged in theological controversy. Among the most persuasive supporters of the papacy and obliged to denounce the teachings of *Galileo Galilei, he was regarded as a moderating influence and praised for his tolerance and learning. Against his wishes, he was made a cardinal in 1599 and in 1602 Archbishop of Capua. He avoided election to the papacy on the death (1605) of *Clement VIII but was given high office at the Vatican. He was canonised in 1930 .

Brodnick, J., Robert Bellarmine: Saint and Scholar. 1961.
Bellingshausen, Faddei Faddeivich (1778-1852). Russian navigator. He led an expedition which, in January 1820, was the first to sight Antarctica, but did not land.

Bellini. Venetian family of painters, Jacopo (c.14001470) and his sons Gentile (c.1429-1507) and Giovanni (c.1430-1516). Few of Jacopo's paintings survive but his many drawings show his work covered a wide range of religious and secular themes and provided a link between the old Venetian style and its Byzantine traditions, and the art of the High Renaissance.

Both sons were probably trained in their father's studio. Gentile, the lesser of the two, won success as a portrait painter and, in his narrative works, (e.g. The Procession in the Piazza of San Marco) showed a taste for spectacular display. An interlude in Constantinople (1479-81) in response to a request by Sultan *Mohammed II resulted in a number of paintings with an oriental flavour, including a portrait of the Sultan himself (National Gallery, London). Giovanni, the greatest of the Bellini family, is justly regarded as the father of Venetian High Renaissance style, the most important influence on his work being clearly that of his brother-in-law Mantegna. His paintings are characterised by a sense of tragic pathos, quiet dignity and compassion: his masterpiece St Francis in Ecstasy (c.1480) hangs in the Frick Collection, New York. Although mostly a painter of religious subjects, Bellini also executed mythological works such as the famous Feast of the Gods, later completed by *Titian. As the teacher of Titian and *Giorgione, Bellini's influence upon the next generation was profound. In many of his paintings we see in embryo the mood, the pastoral setting and the soft, warm colours which were to typify the work of his pupils. The well known Doge Leonardo Loredano (National Gallery, London) is one of several fine portraits.

Robertson, G., Giovanni Bellini. 1968.

Bellini, Vincenzo (1801-1835). Italian operatic composer, born in Catania, Sicily. He studied in Naples and his operas, distinguished by their melodic sophistication include I Capuleti e I Montecchi (The Capulets and the Montagues, 1830), La sonnambula (The Sleepwalker, 1831), Norma (1832) and I Puritani (1834), performed with great success in Milan and Paris. His music had an important influence on ${ }^{*}$ Chopin and ${ }^{*}$ Verdi.

Belloc, (Joseph) Hilaire (Pierre) (1870-1953). English writer, born near Paris. Son of a French advocate and his English wife, he was educated at Oxford, became a Liberal MP 1906-10 and first gained fame with his nonsense verse in The Bad Child's Book of Beasts (1896), followed later by Cautionary Tales (1907). Versatile and prolific, he wrote essays; innumerable discursive travel books, historical studies, e.g. Marie Antoinette (1910), Richelieu (1929) and Napoleon (1932); fantastic or 
satirical novels, e.g. Mr Clutterbuck's Election, and serious political works such as The Servile State (1912). In World War I he gained a short-lived reputation as a military critic. He shared with his friend G. K. ${ }^{*}$ Chesterton his Roman Catholic religion, a hatred of the manipulations of finance, a gift for friendship and a romantic nostalgia for the Middle Ages. His sister Marie-Adelaide Belloc-Lowndes (1868-1947), wrote many detective stories and thrillers including The Lodger (1913, and later filmed), an imaginary reconstruction of the *Jack the Ripper murders.

Wilson, A. N., Hilaire Belloc. 1985.

Bellow, Saul (1915-2005). American novelist, born in Québec of Russian Jewish parents. His novels, some of which were filmed, include The Adventures of Augie March (1953), Henderson the Rain King (1959), Herzog (1964) and Humboldt's Gift (1975). He won the 1976 Nobel Prize for Literature.

Leader, Z., The Life of Saul Bellow. 2 vols, 2015, 2018.

Belshazzar (or Balthasar) (d.c.539 BCE). Babylonian prince. He was regent for his father king Nabonidus (Nabu-Na'id) when Babylon fell to ${ }^{*}$ Cyrus II of Persia (538). Daniel, Chapter 5, tells how the words 'mene, mene, tekel, upharsim' (that he had been 'weighed in the balance and found wanting') appeared on the walls of the banqueting room and were taken for a warning of the approaching disaster. Belshazzar seems to have been killed that night or shortly afterwards.

Belzoni, Giovanni Battista (1778-1823). Italian traveller and archaeologist. Of humble origins, he was gifted with enormous size and strength, which he exploited as a 'strong man' when he came to England in 1803 . He also devised a hydraulic engine. A visit to Egypt (1815) stirred his interest in archaeology, or rather, in tomb robbing. He discovered the sepulchre of *Seti I at Thebes (1817), cleared the rock temple of Abu Simbel and opened up the second pyramid at Giza. His clumsy practice and the adventurous circumstances of his Egyptian explorations are described in his Narrative of the Operations and Recent Discoveries within the Pyramids, Temples, Tombs, and Excavations in Egypt and Nubia (1820).

Bem, Józef Zachariasz (later, Murad Pasha) (17941850). Polish general, engineer and nationalist leader, born in Tarnów, now in Poland, then in Austrian Galicia. He was appointed by ${ }^{*}$ Kossuth to lead Hungarian nationalist forces against the Russians and Austrians during the revolution of 1848-49. On its failure, he fled to Turkey, became a Muslim, was given a command and died in Aleppo, Syria.

Bembo, Pietro (1470-1547). Italian poet and cardinal. He held a commanding position in Italian literature during his lifetime and was mainly instrumental in establishing *Petrarch's versification and Tuscan vocabulary as standard poetical practice.
His dialogue Gil Asolani (1505), which discusses platonic love, and his letters are well known. He was appointed historian to the republic of Venice in 1530.

Benavente y Martinez, Jacinto (1866-1954). Spanish dramatist. Son of a physician, he abandoned the study of law to become an actor and playwright. His very large output includes plays of many different styles and moods satirical, romantic or fantastic. The best known of them is perhaps Los intereses creados (Vested Interests, 1907). Others well known in translation include Saturday Night (1903) and Rose of Autumn (1905). He won the Nobel Prize for Literature in 1922.

Ben Ali, Zine El Abidene (Ben Haj Hamda Ben Haj Hassen) (1936-2019). Tunisian politician and soldier. Educated in France and the US, he was Minister for Defence and National Security 1977-80 and as Prime Minister 1987 peacefully deposed *Bourguiba, becoming President of Tunisia 1987-2011. He was forced into exile in Saudi Arabia in January 2011.

Ben Bella, Ahmed (1916-2012). Algerian politician. A former sergeant major in the French Army, he was among the early workers for Algerian independence from France and became the leader of the Algerian nationalists in exile. In 1956 an aeroplane in which he was travelling was brought down by the French and he remained in confinement until the cease-fire conference at Evian in 1962. His advance to power in Algeria now became rapid; he displaced Yusuf Ben Khedda to become Prime Minister in September of the same year. A year later (1963) the president Ferhat ${ }^{*}$ Abbas was also removed and, under a new constitution confirmed in a referendum by an overwhelming majority, Ben Bella occupied both offices. He was overthrown in a coup by his secondin-command, *Boumedienne, in 1965.

Merhe, R., Ahmed Ben Bella. 1967.

Benbow, John (1653-1702). English sailor. He first entered the navy (1678) as master's mate and had risen to be rear admiral at the time of his last and most famous exploit. This took place in August 1702 when he kept up a running fight for four days with a French squadron off St Marta in the West Indies. Virtually deserted by most of his squadron, probably because of his bullying temperament, he fought alone. With his leg smashed by a chain shot he still directed operations. In the following November he died of his wounds in Jamaica.

Benda, Julien (1867-1956). French author and philosopher. The work for which he is chiefly remembered is La Trahison des clercs (1927), published in England as The Great Betrayal. The treason is that of intellectuals who apply double standards, surrendering their analytical skills to promote an ideology. Other works are the novel The Yoke of Pity (1912) and La Jeunesse d'un clerc (1936), an intellectual autobiography. 
Benedict (Benedictus) of Nursia, St (c.480-547). Italian religious, born at Nursia, near Spoleto (Umbria). Founder of Western monasticism, as a boy of 14 he withdrew from the world, and lived alone in a cave near Subiaco. He became famous for his piety and was soon surrounded by a number of disciples. $\mathrm{He}$ founded 12 small monasteries from the most devout of these followers and in c.529 founded a monastery at Monte Cassino, between Rome and Naples, which later became one of the richest and most famous monasteries in Europe. His Regula Monachorum, in addition to the usual spiritual exercises, directs that the monks shall do manual labour by working in the fields, teaching the young and copying manuscripts, following the principle that 'to work is to pray' ('laborare est orare'). St Benedict did not found a particular order and the name Benedictines was applied to all who followed his rule. In 1964 *Paul VI proclaimed him patron saint of Europe.

Benedict XIV (Prospero Lambertini) (1675-1758). Pope 1740-58. Archbishop of Bologna 1731-40, he was one of the wisest and most conciliatory of popes and proved himself one of the most successful at reconciling the interests of the Church with those of the sovereigns. Thus he came to terms with *Friedrich II ('the Great') of Prussia concerning the Catholic minority, showed a tolerant attitude to the Jansenists in France, assented to nominations by the Spanish crown to nearly all benefices, and made concordats with Naples and Sardinia.

Benedict XV (Giacomo della Chiesa) (1854-1922). Pope 1914-22. He served in the papal diplomatic service for many years and was Archbishop of Bologna 1907-14, being appointed a cardinal only a few months before his election to the papacy. His attempts to settle World War I by negotiation failed but he did much to alleviate the lot of prisoners of war and other sufferers.

Benedict XVI (Joseph Alois Ratzinger, later known as Pope Emeritus Benedict XVI) (1927- ). Pope 200513. Born in Marktl, Bavaria, he was forced to join the Hitler Youth but deserted from military service. Educated at Munich University, and ordained in 1951, he became a professor of theology at Tübingen 1966-69 and Regensburg 1969-77, and Archbishop of Munich-Freising 1977-81. Although regarded as a progressive during Vatican II, as *John Paul II's Prefect of the Sacred Congregation of the Faith 1981-2005 he took a strongly conservative line. Elected as Pope on the fourth ballot, he was the oldest person to have been chosen since 1730 . He came under sustained attack for responding inadequately to charges of sexual abuse inside Church institutions. His encyclical Caritas in Veritate ('Love in Truth') was published in 2009. In February 2013, he resigned as Pope, the first to do since *Gregory XII in 1415 , pleading 'lack of strength in mind and body'.
Beneš, Eduard (1884-1948). Czechoslovak scholar and politician, born in Kozlány. Of peasant origin, he built up his position solely by his own abilities. Educated in Prague and Paris (where he supported himself by journalism) he returned to become professor of sociology in Prague. During World War I he worked abroad with his political mentor *Masaryk to secure recognition by the Allies of Czechoslovakia's right to nationhood. So successful were these efforts that the Allied victory in 1918 was followed by the creation of Czechoslovakia as a separate state with Masaryk as President and Beneš Foreign Minister 1918-35. He was the main architect of the Little Entente (Czechoslovakia, Romania and Yugoslavia), which in alliance with France was intended to sustain the postwar settlement. One of the strongest upholders of the League of Nations, he was President of the Assembly in 1935. He succeeded Masaryk as President of the Republic 1935-38. *Hitler demanded autonomy for Germans living in Sudetenland, the mountainous Czech border region. When Beneš mobilised forces to resist, a peace settlement was negotiated by Germany, Italy, France and the UK at Munich (September 1938). The result was imposed on Czechoslovakia without consultation and Beneš resigned. In London he became President of the provisional Czechoslovak Government in exile 1942-45. Restored as President in 1945, he resigned in June 1948, after the Communists seized power, and he died in September.

Beneš, E., Memoirs. 1954.

Benet, Stephen Vincent (1898-1943). American writer. He won the Pulitzer Prize for Poetry in 1929 for John Brown's Body, a ballad-epic of the Civil War, and in 1944 for his narrative poem Western Star. His story The Devil and Daniel Webster (1937) demonstrated his gift for re-interpreted American legends. His brother William Rose Benet (18861950) won the 1942 Pulitzer Prize for Poetry for his verse-novel The Dust Which is God.

Ben Gurion, David (1886-1973). Israeli politician, born in Poland. He migrated to Palestine in 1906 and in World War I, having been expelled by the Turks as a Zionist, he helped to organise, and served with, a Jewish force under *Allenby. An organiser of the Jewish Mapai (socialist) party, he became the first Prime Minister when Israel was established in 1948. He served as Prime Minister 1948-53 and 1955-63. He sanctioned the attack on Egypt in 1956.

Benjamin (Binyamin) (fl. c.1850 BCE). Hebrew patriarch. Youngest son of *Jacob and Rachel (who died giving him birth). The tribe named after him, with the tribe of Judah, remained loyal to the house of *David when, in the reign of Rehoboam, son of *Solomon, the other 10 tribes broke away to form a separate kingdom. 
Benjamin, Judah Phillip (1811-1884). American politician and lawyer, born in the West Indies. Educated at Yale, he was a lawyer in New Orleans, a US Senator from Louisiana 1853-61, serving as Attorney-General 1861, Secretary of War 1861-62 and Secretary of State 1862-65 in the Confederate Government of Jefferson *Davis. He then became a leading commercial lawyer in England, a QC and author of a classic textbook The Law of Sale (1868).

Benjamin, Walter (1892-1940). German-Jewish literary critic. He worked in Berlin as a literary journalist until 1933 and became a friend of *Brecht, then lived in Paris, committing suicide when refused entry to neutral Spain. He wrote on Marxism, *Baudelaire, the philosophy of history and the material, productive base of art.

Benn, Tony (Anthony Neil Wedgwood-Benn) (19252014). British Labour politician. Educated at Oxford, he worked for the BBC, was a Labour MP 1950-60, but had to leave the House of Commons when he became 2nd Viscount Stansgate on the death of his father. He refused to use the title and campaigned for the right to disclaim inherited peerages; this led to the passage of the Peerage Act (1963). Elected MP 196383, 1984-2001, he served as Postmaster General 1964-66, Minister of Technology 1966-70, Secretary of State for Industry 1974-75 and Energy 1975-79. In opposition he emerged as leader of Labour's left and wrote Arguments for Socialism (1979).

Bennett, Alan (1934-). English playwright and actor, born in Leeds. Son of a butcher, educated at Oxford University, he lectured in modern history at Magdalen College 1960-62 until his full time involvement as writer and performer in Beyond the Fringe, with Peter Cook, Dudley Moore and Jonathan *Miller. He wrote plays for the stage including Forty Years On (1968), The Old Country (1977), The Madness of George III (1991), The History Boys (2004), The Habit of Art (2009), People (2012), and television (Talking Heads 1982-88, 102 Boulevard Haussmann 1991, A Question of Attribution 1991).

Bennett, (Enoch) Arnold (1867-1931). English novelist, born near Hanley, Staffordshire. He grew up in one of the 'Five Towns' of the potteries, which inspired so many of his novels. He completed his education at London University and subsequently spent most of his working life in London, but the years (1902-10) which he spent in France provided him with a French wife, introduced him to European culture and awakened a taste for fine living. His novels belong to two groups: the first and most lastingly important gives a vivid and naturalistic account of life in the industrial society in which he was brought up, it includes Anna of the Five Towns (1902), The Old Wives' Tale (1908), Clayhanger (1910), and The Card (1911). To this genre, though with a different setting (Clerkenwell, London), belongs also Riceyman Steps entertainment than with character study and social comment, to it belong e.g. The Grand Babylon Hotel (1902) and Buried Alive (1908), dramatised (1913) as The Great Adventure. With Edward Knoblock he wrote the play Milestones (1912), which also proved popular. In his later years Bennett achieved a new reputation as literary critic on the London Evening Standard.

Drabble, M., Arnold Bennett. 1974.

Bennett, James Gordon (1795-1872). American journalist, born in Scotland. He emigrated in 1819 and in 1835 founded the New York Herald which was both successful and revolutionary. His son, also James Gordon Bennett (1841-1918), was a pioneer of modern journalism. He commissioned H. M. * Stanley to head the expedition that found Livingstone, and shared with the London Daily Telegraph the financing of Stanley's great journey in central Africa (1874-77). He established the New York Herald's reputation as one of the great newspapers of the world, with a brilliant team of reporters.

Bennett, Naftali (1972- ). Israeli politician, born in Haifa. Son of American immigrants, he became a software entrepreneur, joined Likud and worked closely with Benjamin *Netanyahu, then broke with him, forming the New Right. Minister for Diaspora Affairs 2013-19, he formed an alliance with Yair Lapid and displaced Netanyahu to become Prime Minister 2021-22 until his coalition lost its majority.

Bennett, Richard Bedford Bennett, 1st Viscount (1870-1947). Canadian politician, born in New Brunswick. Elected to the House of Commons from Alberta 1911-17, 1925-38, he was Leader of the Conservative Party 1927-38. He defeated Mackenzie *King in 1930, when the depression was deepening, serving as Prime Minister until 1935. A strong economic nationalist, he organised the Imperial Economic Conference in Ottawa (1932) which created a system of tariff preference for the British Empire. His government set up the Canadian Wheat Board, Air Canada and the Canadian Broadcasting Corporation, and legislated on minimum wages and maximum hours of work, pensions and health insurance. In 1938 he retired to Great Britain, receiving a peerage in 1941. He drowned in the bath.

Benois, Alexandre Nikolaievich (1870-1960). Russian artist, designer, historian and critic, born in St Petersburg. Of partly French descent and member of a distinguished artistic family, he studied law, then became, with Sergei *Diaghilev and Leon *Bakst, co-founder of the artistic movement and periodical Mir Iskusstva (World of Art, 1899-1904). His concept of décor, integrated with music and dancing, added a third dimension to ballet, and his work with Diaghilev's Ballets Russes, collaborating with Bakst and *Fokine, was transformative in Les Sylphides 
(1909), Giselle (1910) and Petrushka (1911). He was curator of old masters at the Hermitage, Petrograd/ Leningrad 1918-27, then returned to Paris.

Benson, E(dward) F(rederic) (1867-1940). English novelist, short story writer and biographer. Son of Edward White Benson, later Archbishop of Canterbury, and educated at Cambridge, he wrote more than 100 books, and is best known for his six lightly satirical 'Mapp and Lucia' novels, set in a fictitious town based on Rye in Sussex, later dramatised for radio and television. His brother, A(rthur) C(hristopher) Benson (1862-1925), poet, essayist and Master of Magdalene College, Cambridge, wrote the words to *Elgar's Land of Hope and Glory.

Masters, B., The Life of E.F. Benson. 1991; Goldhill, S., A Very Queer Family Indeed: Sex, Religion, and the Bensons in Victorian Britain. 2016.

Bentham, George (1800-1884). English botanist. $\mathrm{He}$ worked in France and for his uncle Jeremy *Bentham, then devoted himself to the taxonomy of plants and compiled the Genera Plantarum (3 vols, 1862-83) with Joseph *Hooker.

Bentham, Jeremy (1748-1832). English utilitarian philosopher, born in London. Son of a solicitor, he was a precocious and prodigious student. After graduating from Oxford in 1763, he studied law under *Blackstone but was dismayed by its anomalies and illogicalities and thus abandoned the idea of going into practice. The publication of his Fragment on Government in 1776 brought him to the friendly notice of Lord *Shelburne, at whose house, by meeting people from the social and political worlds, he was able to gain self-confidence. In 1789, after four fruitful years of travelling in Russia and elsewhere, he published An Introduction to the Principles of Morals and Legislation, which argues, following *Priestley, that all laws should work for the greatest happiness of the greatest number of people, and sets out a general doctrine of Utilitarianism, which inspired J. S. *Mill and others. He believed that all men seek only their own pleasure, and combined this psychological claim with the moral view that the right action is that one which seems likely to produce more happiness (pleasure or absence of pain) than any other possible action. Utilitarianism, modified by his followers, was the source of much social investigation and reform in the 19th century. In 1785-88, Bentham spent much money and time on a plan for a model prison, the 'Panopticon', in which all prisoners could be observed from a single point. Reform and codification of the law to accord with his utilitarian principles remained his chief interest, but in later life he campaigned for a number of specific reforms: the secret ballot, universal suffrage, abolition of capital and corporal punishment, a national system for registering births, deaths and marriages, the ending of transportation of criminals and imprisonment for debt, and the setting up of an international authority to prevent the outbreak of wars. He attacked the idea of 'natural' or 'universal' human rights as an abstraction ('nonsense on stilts'), insisting that rights and responsibilities had to be linked to specific structures and attitudes in societies. He founded the Westminster Review in 1823 , and was also a founder of University College, London, where, at his wish, his skeleton sits, dressed in his clothes and with a model head.

Mack, M., Jeremy Bentham 1748-1792. 1963.

Bentinck, Lord William Cavendish (1774-1839). English Whig politician. The son of the third Duke of Portland, he was an MP 1796-1803, Governor of Madras 1803-07 and served under Wellington in the Peninsular War. He became Governor-General of Bengal in 1828 and by statutory conferment became the first holder of the title Governor-General of India 1833-35. He abolished suttee (the religious custom of widow burning), suppressed the Thugs (a group of religious assassins), and introduced English as the language of higher education.

Bentley, Edmund Clerihew (1875-1956). English novelist and journalist. He originated the 'clerihew', a four-line humorous verse form, and wrote what is regarded as the first of the modern type of realistic detective novels, Trent's Last Case (1913). The clerihew can be illustrated by:

The Art of Biography

Is different from Geography,

Geography is about maps,

But Biography is about chaps.

Bentley, E. C., Those Days: An Autobiography. 1940.

Bentley, Richard (1662-1742). English classical scholar. Educated at Wakefield Grammar School and at Cambridge, he was master of Trinity College 1700-42. He established his reputation with the Dissertation upon the Epistles of Phalaris (1699), a brilliant contribution to a controversy concerning their authorship. This was followed by editions of ${ }^{*}$ Horace, ${ }^{*}$ Terence, ${ }^{*}$ Cicero and Manilius. A master of textual emendation, noted for his pedantic, quarrelsome and arrogant nature, he has maintained his reputation as one of the greatest of English classical scholars.

White, R. J., Dr Bentley. 1965.

Bentsen, Lloyd Millard (1921-2006). American Democratic politician. A Texas businessman and lawyer, he was a US Congressman 1948-54, defeated George*Bush in 1970 to become a US Senator, serving 1971-92, and ran as vice presidential candidate with Michael *Dukakis in 1988. He became Bill *Clinton's Secretary of the Treasury 1993-94. 
Benz, Karl (1844-1929). German motor car pioneer. He produced (1885) a three-wheeled, chain-driven vehicle with a watercooled internalcombustion engine using coal gas as fuel. It travelled at a maximum speed of $24 \mathrm{kph}$.

Berchtold (von und zu Ungarschitz), Leopold, Graf [Count] von (1863-1942). Austrian diplomat. He served as Ambassador in Paris 1894-99, London 1899-1906 and St Petersburg 1906-12 before his appointment as Imperial Foreign Minister 1912-15. Largely responsible for escalating the assassination of *Franz Ferdinand (1914) into a world war, Berchtold was not a war criminal but a vacillating lightweight: the wrong man in the wrong job at the wrong time.

Berdyaev, Nikolai Aleksandrovich (1874-1948). Russian religious and social thinker, born in Kiev. Originally a Marxist, he returned to the Orthodox Church in 1907, supported the Revolution but was expelled in 1922. He established the Academy of the Philosophy of Religion at Clamart near Paris. He insisted in his books, e.g. The Destiny of Man (Eng. tr.1937) and Spirit and Reality (1939), that history is subject to the control of God, and looked forward to a Christian society, by which term he designated a way of life rather than outward observance.

Vallon, M., Apostle of Freedom. 1960.

Béregovoy, Pierre Eugene (1925-1993). French Socialist politician. Of Russian descent, he became a lawyer and administrator, worked in the Socialist Party apparatus and was Minister for Economy, Finance and Budget 1984-86, 1988-92. He succeeded Edith *Cresson as Prime Minister 1992-93. He shot himself after the crushing Socialist defeat in the May 1993 elections for the Chamber of Deputies.

Berengario da Carpi, Giacomo (1460-1535). Italian anatomist, born in Carpi. He attended Bologna University, received his degree in 1489 and was appointed to the faculty in 1502 . He became consultant to famous men, and his attendance upon Lorenzo de'*Medici in 1517 , who had received a gunshot wound and a fracture of the skull, led to his book on the subject in 1518. Partly because of its first hand discussion of the different lesions, grouped according to symptoms, Berengario's book is a classic of neurosurgery. His interest in anatomy grew, and after performing several hundred dissections, he distilled his knowledge into his Commentaria (1521). His accounts of the reproductive organs were particularly important, as also of the greater capacity of the female pelvis. He described the pituitary and pineal glands and noted the corpus striatum. He could find no sign of *Galen's rete mirabile (the supposed source of animal spirit) though he was traditionalist enough not to dismiss the idea of animal spirit itself. Berengario's importance lies in his pioneering careful anatomising of the human body, and attempting to correlate his own observations with classical medical opinion. In this_-as in his use of medical illustrations - he was engaged in similar work to ${ }^{*}$ Vesalius.

Lind, L. R., Berengario: A Short Introduction to Anatomy. 1959.

Berenson, Bernard (Bernhard Valvrojenski) (18651959). American-Lithuanian-Jewish art historian and connoisseur, born in Lithuania. Brought up in Boston and educated at Harvard, he lived in Italy from 1900, became a great authority on Italian Renaissance art and, as advisor to the dealer Joseph *Duveen, enjoyed a position of unparalleled eminence in matters of attribution and connoisseurship. His disciples included Kenneth ${ }^{*}$ Clark. He left his art collection, library and villa I Tatti (near Florence) to Harvard University. His best known work is Italian Painters of the Renaissance (1932).

Secrest, M., Being Bernard Berenson. 1979.

Beresford, Charles Carr Beresford, 1st Viscount (1768-1854). British general. An illegitimate son of the 1st Marquess of Waterford, he played an adventurous part in the French Revolutionary and Napoléonic Wars. After distinguished service in Toulon and Corsica, in General David Baird's desert march from the Red Sea to Egypt (1801), at the Cape of Good Hope (1806), and at Buenos Aires (1807), he eventually found permanent fame as the successful organiser and commander of the Portuguese army in the Peninsular War. His later life was troubled by controversy over his generalship at Albuera. He bore the Spanish title of Duke of Elvas, and the Portuguese title of Conde de Trancoso and was master general of ordnance in *Wellington's cabinet 1828-30.

Berg, Alban (1885-1935). Austrian composer, born in Vienna. As a boy he composed many songs which reveal his deeply romantic temperament, but after studying composition with Arnold ${ }^{*}$ Schoenberg (1904-10) he developed his own modification of Schoenberg's 'atonal/atonic' or 'twelve-tone' system. His music is notable for its lyricism and dramatic intensity, especially the operas Wozzeck (completed 1921) and Lulu (unfinished). Among his other works are the Lyric Suite for string quartet (1926) and a violin concerto (1935) dedicated 'to the memory of an angel' (Manon Gropius). The tone row for the Violin Concerto is: G, B\#, D, F\#, A, C, E, G\#, B, C\#, $\mathrm{E} \#, \mathrm{~F}$. Berg died of blood poisoning from an abscess on his back caused by an insect bite.

Reich, W., The Life and Work of Alban Berg. 1982.

Berger, Hans (1873-1941). German physiologist. His early work concentrated mainly on the effect blood supply and pressure had on brain action, taking into account the influence of the heartbeat, respiration, and stimulants (e.g. caffeine, cocaine). He then moved on to the brain's electrical activity. Building on crude 19th-century recordings of 
electrical activity in animal brains, Berger pioneered the technique of planting needle electrodes under the scalp of patients. He pioneered the use of the electroencephalogram as a tool of diagnosis. His work was neglected in Germany, and shortly after his retirement he committed suicide in a fit of depression.

E. Adrian and B. Matthews, The Berger Rhythm', Brain, 57 (1934), 355-385.

Bergerac, (Savinien) Cyrano de (1619-1655). French soldier, satirical poet and dramatist. Famous as a duellist and for his enormously long nose, his best known works are two fantastic romances (translated by Richard *Aldington as Voyages to the Moon and the Sun), which influenced ${ }^{*}$ Swift and ${ }^{*}$ Voltaire. He is best remembered as the hero of a play (1897) by Edmond *Rostand.

Bergman, (Ernst) Ingmar (1918-2007). Swedish director and playwright, born in Uppsala. Son of a Lutheran pastor, he had a traumatic childhood, then studied literature at Stockholm University. One of the major influences on cinema since the 1950s, his films show an often uncomfortable psychological penetration, sometimes using symbolism and the grotesque. They include Smiles of a Summer Night (1955), The Seventh Seal (1956), Wild Strawberries (1957), The Devil's Eye (1961), The Silence (1963), Shame (1968), Scenes from a Marriage (1974), Face to Face (1976), Autumn Sonata (1978), Fanny and Alexander (1983) and Best Intentions (1992), most of which he wrote. He directed the Royal Dramatic Theatre, Stockholm 1963-66 and worked in Munich 1976-78. He won many international awards, but never an Oscar.

Wood, R., Ingmar Bergman. 1969.

Bergman, Ingrid (1915-1982). Swedish actor, born in Stockholm. She moved to Hollywood in 1938 and achieved immediate recognition in Intermezzo (1939), Casablanca (1942) and For Whom the Bell Tolls (1945). She appeared in three *Hitchcock films: Spellbound (1945), Notorious (1946) and Under Capricorn (1949) and won three Academy Awards for best actor, in Gaslight (1944), Anastasia (1956) and Murder on the Orient Express (1974). She made Stromboli (1949) in Italy and her affair and later marriage with its director Roberto *Rossellini damaged her box office appeal until Anastasia. She made many stage appearances in London, notably in a revival of Hedda Gabler. She appeared in opera (Honegger's Joan of Arc at the Stake, 1954) and television (as Golda *Meir, 1982). Her last (and possibly best) film was Autumn Sonata (1978), directed by her compatriot Ingmar *Bergman.

\section{Bergoglio, Jorge Mario see Francis}

Bergson, Henri Louis (1859-1941). French philosopher, born in Paris. Son of a Polish Jewish musician and an English mother, he studied and taught at the École Normale Supérieure, and became a professor at the Collège de France 1900-14. $\mathrm{He}$ married a cousin of Marcel ${ }^{*}$ Proust. He is best known for the theory set out in Time and Freewill (1889) and Creative Evolution (1907), which enjoyed considerable popularity despite its lack of clarity. It is opposed to the view that life evolves in a mechanical way subject to physical laws and thus towards ends that are already fixed. Evolution, rather, results from a life force ('elan vital') which is creative and unpredictable in its effects. This life-force, not adequately specified, is in conflict with 'matter', by which Bergson appeared to mean the regularity and repetitiveness of the natural world. This latter aspect of the universe is known by what Bergson calls Intelligence, which classifies reality into separate items and kinds, and tends to look upon natural change as a series of different fixed states. The faculty of Intuition, on the other hand, is related to the life-force and gives us knowledge of the kind of change which characterises it: a development not made up of separable stages but one in which past and present run together in an unbroken stream or flux. This was called duration ('la duree'). Other important works include Laughter (1900) and The Two Sources of Morality and Religion (1932). A member of the Académie française from 1914, he was awarded the Nobel Prize for Literature in 1928.

Jankelevitch, V., Henri Bergson. 1959.

Beria, Lavrenti Pavlovich (1899-1953). Russian (Georgian) commissar. Of peasant origin, and a confidant of * Stalin, he ran the NKVD (Commissariat of Internal Security) 1938-53 and became a Deputy Premier 1941-53, a Marshal of the USSR 1945 and Politburo member 1946-53. On Stalin's death (1953) he was (with *Malenkov and ${ }^{*}$ Molotov) one of the triumvirate that assumed power. Almost immediately, however, he was accused of treason, tried and shot, an action instigated by ${ }^{*}$ Khrushchev. Beria was mistrusted because he aimed at making his security organisation the ultimate power.

Williams, A., Beria Papers. 1973.

Bering, Vitus Jonassen (1681-1741). Danish navigator. He joined the Russian navy in 1704 and in 1725 was commissioned by Peter the Great to explore the eastern extremity of Siberia. In 1728 he sailed through the Strait (separating Asia from North America), later named after him, but did not then recognise its importance. On a later expedition he reached Alaska. He died after his ship was wrecked on what is now called Bering Island. The naturalist G. W. Steller, who escaped in a boat, wrote an account of the voyage.

Berio, Luciano (1925-2003). Italian composer, conductor and teacher. He was a serial composer (using 'tone rows' like *Schoenberg and ${ }^{*}$ Berg), also writing for electronic instruments and tape recorders, and he produced some 'indeterminate' or 'aleatory' music in which the players themselves determine 
in what order they play the notes. His best known work was Sinfonia (1968-69). He was married to the American soprano Cathy Berberian (1928-1983) from 1950 until 1966, and wrote virtuosic works for her, even after their marriage ended.

Berkeley, Busby (William Berkeley Enos) (18951976). American choreographer and director. After success as a Broadway dance director, he moved to Hollywood in 1930. His imaginative and extravagant mass choreography of young women used new film techniques and created kaleidoscopic imagery, often highly (but subliminally) erotic. His films include Whoopee! (1930), 42nd Street (1933), Gold Diggers of 1933 (1933) and The Gang's All Here (1943). He became a cult figure in the 1990s.

Berkeley, George (1685-1753). Irish philosopher and Anglican Bishop of Cloyne, born in Kilkenny. Educated at Trinity College, Dublin, he spent several years in London, where he knew ${ }^{*}$ Swift, ${ }^{*}$ Pope and *Addison. In 1728-31 he taught at Rhode Island in preparation for the carrying out of his ill-fated plan to found a missionary college in Bermuda, a government grant for which was later withdrawn. In 1734 he accepted the bishopric of Cloyne in Southern Ireland. There he lived until 1752 when he retired through ill health and went to Oxford, where he died. Berkeley's philosophy of idealism is centrally a denial of the existence of matter, in the ordinary sense of the word. *Locke had argued that the world of material objects gives rise to 'ideas' or subjective sense-impressions in our minds. We are directly aware of only these impressions. Berkeley held that there is no reason to suppose that anything lies behind these impressions: objects depend for their actuality on being perceived (esse est percipi-'to be is to be perceived'). This doctrine can be easily misunderstood and ridiculed as it appears to violate common sense, but Berkeley is leading the argument to the point that since such impressions must be had by someone if they are to exist at all, and since it is accepted that material objects continue to exist when unperceived by men, their existence must depend upon perception by reason and ultimately by that of Supreme Reason or God. His doctrine, he claimed, therefore refuted scepticism. This is a vast over simplification of the difficult series of arguments presented in his Principles of Human Knowledge (1710) and Three Dialogues between Mylas and Philonus (1713). On his return from Rhode Island he published Alciphron (1732), using the American background as a setting for more dialogues, Platonic in form.

Ritchie, A. D., George Berkeley: A Re-appraisal. 1967.

Berkeley, Sir Lennox (Randal) (1903-1989). English composer, born at Oxford. Educated at Oxford University, he studied under Nadia *Boulanger in Paris and shows the influence of such French composers as ${ }^{*}$ Bizet and ${ }^{*}$ Chabrier. Among his better known works are many songs, the Stabat Mater (1946), the operas Nelson (1954) and Ruth (1956). He tried most musical forms including incidental music for films, cantatas and works for unaccompanied choirs. He was President of the Composers' Guild and the Performing Right Society.

Berlichingen, Götz von (1480-1562). German (Swabian) knight and adventurer. He lost his right hand in battle and wore an iron one. He was one of the discontented nobles who led the rebellious peasants in the Peasants' War (1524-26) and later fought against the French and the Turks. His life is the basis of plays by ${ }^{*}$ Goethe (Götz von Berlichingen), * Sartre (Le Diable et le Bon Dieu) and John Arden (Ironhand).

Berlin, Irving (Israel Isidore Baline) (1888-1989). American songwriter, born in Russia. He wrote more than 1,000 popular songs, including Alexander's Ragtime Band (1911) and White Christmas, scores for several musicals (e.g. Annie Get Your Gun, 1946) and revues.

Berlin, Sir Isaiah (1909-1997). Russian-JewishBritish political philosopher, born in Riga. He went to England with his parents after the Russian revolution, gained a double first at Oxford and remained there, except during World War II (when he was attached to the British Embassies in Washington and Moscow). He succeeded G. D. H. *Cole as Chichele professor of social and political theory 1957-67 and was first President of Wolfson College 1966-75. His works include Karl Marx (1939), The Hedgehog and the Fox (a study of *Tolstoy's theory of history, 1953), Historical Inevitability (1954), Four Essays on Liberty (1969), Vico and Herder (1976) and The Crooked Timber of Humanity (1990). He received the OM in 1971 and was President of the British Academy 1974-78. Berlin argued for 'value pluralism' and against the rigidity of any system that asserted the right to compel belief.

Gray, J., Isaiah Berlin. 1995; Ignatieff, M., Isaiah Berlin. A Life. 1998.

Berliner, Emile (1851-1929). American inventor, born in Germany. In 1878 he invented the carbon microphone, simultaneously with David *Hughes, followed by a gramophone in 1887 . He was best known for his invention (1888) of the disc record for the gramophone, a word which he probably originated. In 1898 he founded The Gramophone Co. Like ${ }^{*}$ Edison and ${ }^{*}$ Bell he failed to grasp the significance of electric recording for music.

Berlioz, (Louis) Hector (1803-1869). French composer, born near Grenoble. Son of a physician, he studied medicine in Paris for some years but loathed it and, after a violent quarrel with his family, began to study music under Lesueur and entered the Paris Conservatoire in 1826. But again his emotional temperament brought him into conflict with his teachers. While a student he fell in love with the Irish 
actor Harriet Smithson, whom he married in 1833. The marriage was unsuccessful and they separated in 1842. Despite his genius for orchestration, Berlioz never completed his formal studies and was a poor instrumentalist, mastering only the guitar and flageolet. In 1830 his cantata Sardanapale won the Prix de Rome and then he studied in Italy for about a year. He won his first public success in 1832 with a performance of his Symphonie fantastique (1830, subtitled 'An episode in the life of an artist'), an extraordinarily vivid work describing five scenes (supposed to have been dreamt by Berlioz) in which the artist seeks out his beloved, kills her, is executed and then descends to hell. Berlioz composed most of his orchestral works to a definite literary program and most contemporary critics attacked his addiction to 'program music'. His later symphonies were Harold in Italy (1834, based on *Byron's Childe Harold), Romeo and Juliet (1838, with soloists and chorus) and Symphonie funèbre et triomphale (1840, written to commemorate victims of the 1830 Revolution). $\mathrm{He}$ also composed the concert overtures Waverley (1827), King Lear (1831), Le Carnaval romain (1844) and The Corsair (1855); the operas Benvenuto Cellini (1838), Beatrice and Benedict (1862, based on *Shakespeare's Much Ado About Nothing), and The Trojans (1862), an enormous work which Berlioz regarded as his masterpiece, rarely performed for a century, has received notable productions in the 21 st century and been much recorded. Among other works were the song cycle Nuits d'été (1842), the oratorio L'Enfance du Christ (1852) and the operatic cantata The Damnation of Faust (1846). He wrote a great Treatise on instrumentation (1844) and Memoirs (1865). He was a vigorous and vivacious music critic and his writings on his own music did much to attract attention to his genius. ${ }^{*}$ Paganini, ${ }^{*}$ Liszt, and, to a lesser degree, *Schumann were among the few of his contemporaries to acknowledge his place in 19thcentury music. His second wife was the singer Marie Recio (d.1862). He travelled widely, giving concerts in England and in Russia. He was appointed librarian of the Paris Conservatoire from 1852 and a member of the French Institute from 1856. There is debate about his place among the great composers, but the colour and originality of his orchestration have never been in dispute.

Elliot, J. N., Berlioz. 1967; Cairns, D., Berlioz. 2 vols, 1989, 1999.

Berlusconi, Silvio (1936- ). Italian businessman and politician. From 1969 he created a business empire which included commercial television, a cinema chain, department stores, real estate, insurance, publishing and the Milan A C Milan soccer club. He founded a conservative political party, Forza Italia, and in March 1994 his Freedom Alliance won the elections for the Chamber of Deputies. He became Prime Minister in a coalition government which included neo-Fascist ministers (May-Dec. 1994). He was charged with corruption and his party lost ground in the elections of April 1996. In July 1998 he was sentenced to a prison term but served no time. His party won the May 2001 election and he became Prime Minister again, losing narrowly in April 2006. Prime Minister for the third time 2008-11, he was forced out when his coalition fractured in the parliament, and Italy needed to take unpopular decisions following the 'Global Financial Crisis'. Convicted of tax evasion in 2012 and sentenced to four years' jail, he served no time. He led the People of Freedom alliance for the 2013 elections and during the campaign expressed sympathy for ${ }^{*}$ Mussolini's alliance with ${ }^{*}$ Hitler. His extravagant sexuality, and 'bunga bunga' parties, much publicised internationally, seems to have been discounted by Italian voters. His coalition polled 29.1 per cent of the primary vote for the Chamber of Deputies in 2013. In June 2013 he was convicted of abuse of power and paying for sex with an underaged prostitute, and sentenced to seven years jail, suspended while he appealed. His sentence was upheld on appeal, but then commuted in 2014 to 'community service'.

Bernadette, St (Marie-Bernard Soubirous) (18441879). French visionary, born in Lourdes. Daughter of a miller, in 1858 she claimed to have experienced 18 visions in which she saw and spoke with the Virgin Mary. The grotto at Lourdes where the visions occurred have become a major place of pilgrimage for Catholics. There was much controversy at the time and since concerning the event, its interpretation and the subsequent cures, and religious, national and local politics have been at various times involved; but no one has questioned the sincerity of the girl herself. She became a nun, served as a nurse in the Franco Prussian War and died of tuberculosis. She was canonised in 1933.

Bernadotte (af Wisborg), Folke, Count (18951948). Swedish diplomat. A nephew of King *Gustaf V of Sweden, in World War II he acted for the Swedish Red Cross in the exchange of wounded prisoners and was an intermediary in conveying an offer of surrender from Himmler to the US and British authorities. While serving as United Nations mediator between Jews and Arabs he was murdered by Jewish terrorists.

Bernadotte, Jean Baptiste Jules (1763-1844). French marshal and Swedish King (as Karl XIV Johan). Son of a lawyer at Pau, he enlisted when 17, was a sergeant when the Revolution broke out and seizing his chance rose (1792-94) from lieutenant to brigadier. He entered the *Bonaparte family circle by marrying Desirée Clary, Napoléon's first fiancee and a sister of Joseph Bonaparte's wife. He took part in several of Napoléon's campaigns and was prominent in Austerlitz, but it was his governorship of the Hanseatic cities (1807-09) that made him known and liked in northern Europe. This explains why in 1810 he was invited by the childless *Karl XIII of Sweden to become his crown prince and de facto 
ruler. Napoléon accepted on his behalf in the hope of having a faithful ally, but Bernadotte put the needs of his adopted country first and made an alliance with Russia. Accordingly, he was allowed to retain his position when Napoléon fell. As a reward for his services, Norway (acquired from the Danes in 1814) was confirmed by the Congress of Vienna as being in union with Sweden. In 1818 Bernadotte duly succeeded as Karl XIV Johan to the joint throne and proved a popular and successful ruler.

Bernal, John Desmond (1901-1971). British physicist and mathematician, born in Ireland, of Sephardic descent. He studied at Emmanuel College, Cambridge, worked with William *Bragg and became the great pioneer of X-ray crystallography. Disliked by ${ }^{*}$ Rutherford, and denied a Fellowship, he left Cambridge to become professor of physics at Birkbeck College, London, in 1937. His pupils included Dorothy *Hodgkin, Max *Perutz, Aaron *Klug and Rosalind *Franklin. During World War II he worked on mapping for the Normandy landings (1944). A Communist for some years, he won a Stalin Peace Prize (1953) but was overlooked for a Nobel Prize. A prolific writer, his books include the masterly Science in History (1954).

Swann, B. and Aprahanian, F., J. D. Bernal: A Life in Science and Politics. 1999; Brown, A., J. D. Bernal: The Sage of Science. 2005.

Bernanke, Ben Shalom (1953- ). American economist and banker, born in Georgia. A graduate of Harvard and MIT, he was a professor of economics at Princeton 1996-2002, and chair of the US Federal Reserve 2006- . Originally appointed by George W *Bush, he was reappointed by Barack *Obama.

Bernanos, Georges (1888-1948). French writer, born in Paris. He became one of the best known of the group of Catholic novelists of major importance in modern French literature. Among his best known works are Sous le soleil de Satan (1926, translated into English as The Star of Satan, 1940) and Journal d'un cure de campagne (1936, English version: The Diary of a Country Priest, 1940). His Les Grands Cimetieres sous la lune (1938) contains an unusually strong criticism (for a Roman Catholic) of *Franco's rule in Spain. During World War II he was in South America, where he wrote Lettre aux anglais (1940-42).

Speaight, R., Georges Bernanos. 1973.

Bernard, Claude (1813-1878). French physiologist, born near Villefranche. He worked in a Lyon pharmacy before studying medicine in Paris. He graduated in 1843 and worked for several years with François *Magendie, professor of medicine at the Collège de France, to whose chair he succeeded in 1855 . He is best known for his work on the function of the pancreas in digestion, and for the inference which he drew from his experiments that the production of sugar in the liver is controlled by the nervous system: he isolated and named the sugar-producing substance, 'glycogen'. He became a member of the Académie française 1868, a Senator in 1869 and received the Copley Medal (1876).

Holmes, F. L., Claude Bernard and Animal Chemistry. 1974.

Bernard of Clairvaux, St (1090-1153). French theologian and reformer, born near Dijon. A member of a noble family, in 1113 he entered the original Cistercian (White Monks) monastery at Citeaux, and in 1115 became the first Abbot of the newly founded monastery at Clairvaux, in Champagne. Clairvaux remained the centre of his activities for the rest of his life and during his tenure of office its numbers rose from 12 to 700 . From there he made the famous journeys which led to the foundation of 68 more Cistercian houses, and his reputation as the second founder of the Order. His ascetic and studious life made him one of the most influential men of his time. His stirring eloquence won him the name of 'Mellifluous Doctor', and his emphasis on spirituality and devotion still influences Catholicism. His practical achievements were also considerable. In 1131, by securing recognition for Pope Innocent II, he averted a schism, and his preaching before ${ }^{*}$ Louis VII at Vezelay in 1146 stirred support for the Second Crusade. He condemned the teachings of his great enemy, Peter *Abelard.

Bernard of Menthon, St (923-1008). Italian religious. He was founder of the Augustinian hospice near the crest of the Great St Bernard Pass, which bears his name, and is the patron of mountaineers.

Berners, 14th Baron, Gerald Hugh TyrwhittWilson (1883-1950). English composer, painter and novelist. Eccentric, gifted and versatile, his works include the ballet score The Triumph of Neptune (1926), the novel The Girls of Radcliff Hall (1937), an autobiography, and many paintings.

Zinovieff, S., The Mad Boy, Lord Berners, My Grandmother and Me. 2014.

Berners-Lee, Sir Tim(othy John) (1955- ). English physicist and computer scientist, born in London. Educated at Queens College, Oxford, he worked at CERN (Geneva) and there designed the World Wide Web (WWW, 1989), the gateway to the Internet, linking 'hypertext' documents together to form a 'web'. He also developed a web server, a web browser, the Hypertext Transfer Protocol (http://) and Hypertext Markup Language (html). The WWW was made available to the general public in August 1991. He campaigned to ensure that it remained 'open, non-proprietary and free'. He chaired the World Wide Web Consortium (W3C), held a chair at MIT, and became a professorial fellow at Oxford. He was elected FRS (2001) and awarded a KBE 
(2004) and the OM (2007). He wrote Weaving the Web: The Original Design and Ultimate Destiny of the World Wide Web (1999).

Bernhard (Bernhard Leopold Friedrich Eberhard Julius Kurt Karl Gottfried Peter Prinz zur LippeBiesterfeld) (1911-2004). German-Dutch prince. A prince of Lippe Biesterfeld, he joined the Nazi Party briefly, but left Germany to marry Princess *Juliana, the future Queen of the Netherlands, and was father of Queen *Beatrix. During World War II he served in the RAF as a pilot. He had many scientific, business and sporting interests. In 1976 Bernhard was accused of receiving a \$US 1 million bribe from the Lockheed Corporation but insisted that the money went to the World Wildlife Fund (WWF) which he chaired 1961-76.

\section{Fasseur, C., Juliana \& Bernhard. 2008.}

Bernhardi, Friedrich von (1849-1930). German general and military writer. His book Germany and The Next War (1912) advocated that, where necessary for victory or survival, treaties should be disregarded and battles fought without regard for humanitarian principles. His book, translated in cheap editions, did much to exacerbate anti-German feeling in Allied countries during World War I.

Bernhardt, Sarah (1844-1923). French actor, born in Paris. Daughter of a French father and a Dutch-Jewish mother, she became known as the divine Sarah', a description that gives an idea of the emotions inspired by her art. More than once she joined the company of the Comédie Française, but the restrictions of the national theatre irked her and she finally left in 1880 , formed her own company and from 1899 controlled her own theatre (Théâtre Sarah Bernhardt). She toured frequently and was as warmly acclaimed in London, America and elsewhere as in her own country. She triumphed in the great classical parts, such as in *Racine's Phedre, and equally in a romantic and tearful melodrama such as the younger *Dumas' La Dame aux camelias. *Sardou provided her with several parts: she could exploit a delicious comedy sense in ${ }^{*}$ Molière. She even achieved male impersonations as Hamlet or in the title part (*Napoléon I's young son) in Rostand's L'Aiglon. Despite the amputation of a leg in 1915, she continued to act.

Skinner, C. O., Madame Sarah. 1967.

Bernini, Gian (Giovanni) Lorenzo (1598-1680). Italian architect and sculptor, born in Naples. The greatest master of the Italian baroque, he went as a child to Rome, where his youthful skill, fostered and trained by his father, attracted the attention of Cardinal Scipione Borghese. The virtuosity and psychological subtlety of sculptures, such as Apollo and Daphne, Rape of Persephone, and David, commissioned by his patron brought him to the notice of the Vatican, and in 1629 he was appointed architect to St Peter's by Pope *Urban VIII. He did much work there during the next decades, notably the great bronze baldacchino, $29 \mathrm{~m}$ high (1663) and Cathedra Petri (a reliquary throne for St Peter's chair, with a Gloria above, 1666). It was not until 1667 that he completed his most ambitious and spectacular achievement, the enormous double colonnade which enclosed the piazza in front of the basilica. This consists of 640 columns, each 1.4 metres in diameter, so arranged that the enclosed space acts as an enormous stage in which pilgrims congregate to receive the papal blessing. In 1665 Bernini was invited to France by ${ }^{*}$ Louis XIV. He executed a magnificent bust of the king but his plans to redevelop the Louvre were rejected. Other great works include the statue The Ecstasy of St Teresa (1652) and the church Sant' Andrea Quirinale (called 'the Pearl of the Baroque', completed 1670). Passionate and sometimes violent, Bernini was also an occasional painter, caricaturist, stage designer, playwright and composer. Bernini and *Borromini detested each other.

Hibbard, H., Bernini. 1965; Avery, C., Bernini: Genius of the Baroque. 1997.

Bernouilli. Swiss family of mathematicians, originally from Antwerp. They are completely identified with Basle in Switzerland where they lived and worked (though not exclusively) during their period of fame. They include Jakob Bernouilli I (1645-1705), who wrote about the possibilities of the newly invented calculus; his brother Johann I (1667-1748), much of whose work was concerned with the mathematics of curves; Daniel (1700-1782), a son of Johann who contributed much to the study of hydrodynamics and held chairs in anatomy, botany and physics at Basle. He solved the differential equation now known as Bernouilli's Equation. Less famous members of the family were Nicolaus I (1687-1759), nephew of Jakob and Johann, Nicolaus II (1695-1726), a son of Johann, Johann II (1710-1790), Johann I's youngest son, Johann III (1744-1807) and Jakob II (1759-1789) both sons of Johann II. All taught mathematics.

Bernstein, Eduard (1850-1932). German socialist. During years of exile in London he became a close friend of Friedrich *Engels. Bernstein argued that the teaching of ${ }^{*}$ Marx and Engels needed drastic revision in view of the increasing wealth and size of the middle class and slowly improving working class conditions, concluding that class war was not inevitable. Known as the father of 'revisionism', he was elected to the Reichstag 1906-12, 1912-18, 1920-28 and, as a pacifist, opposed World War I.

Bernstein, Henri (1876-1953). French dramatist. $\mathrm{He}$ became a prolific playwright and theatrical manager in Paris and scored an enormous success with Israel (1906), Le Voleur (1906), Le Secret (1913) and Judith (1922). 
Bernstein, Leonard (1918-1990). American composer and conductor, born in Lawrence, Mass. He studied at Harvard and with *Reiner and became a protégé of ${ }^{*}$ Koussevitzky and ${ }^{*}$ Mitropoulos. He composed the ballet Fancy Free (1944), the symphony Jeremiah (1943) and the musicals Candide (1956) and West Side Story (1957). He succeeded Dimitri Mitropoulos as conductor of the New York Philharmonic Orchestra in 1958-69. He wrote several books including The Joy of Music (1959), and made many recordings and films. He toured extensively with the Israel and Vienna Philharmonic orchestras and was much admired for his *Mahler performances.

Burton, H., Leonard Bernstein. 1994; Secrest, M., Leonard Bernstein: A Life. 1995.

Berry. English publishing family, originating in Wales. William Ewert Berry, 1st Viscount Camrose (1879-1954) founded Advertising World (1901) and Boxing (1909), bought the Sunday Times in 1915 and the Daily Telegraph in 1928. With his brother (James) Gomer Berry, 1st Viscount Kemsley (18831968) he controlled many magazines and provincial newspapers. They divided the empire in 1937: Kemsley took the Daily Graphic and Sunday Times, Camrose the Daily Telegraph. Camrose's second son (William) Michael Berry, Baron Hartwell (19112001) was chairman and editor-in-chief of the Daily Telegraph until Conrad *Black bought it in 1987.

Berry, Charles Ferdinand, Duc de (1778-1820). French duke. Younger son of the Comte d'Artois (later *Charles X of France), he returned to France in 1814 and was assassinated in 1820 . His posthumous son was Henri, Comte de Chambord (1820-1883). His wife Caroline (1798-1870), a princess of Naples, attempted to raise a revolt in favour of her son, who was recognised by French royalists as Henri V. In 1832 she reached the Vendée, but was captured at Nantes and for a time imprisoned. She died at Palermo.

Berthelot, (Pierre Eugène) Marcellin (1827-1907). French chemist. He became professor at the École Supérieure de Pharmacie in 1859 and at the Collège de France in 1864 where he taught until his death. His career in chemistry was chiefly devoted to synthesis. Beginning with alcohol, he moved on to the synthesis of benzene, acetylene, and compounds of coal tar. He believed that organic compounds of great complexity could be built up out of simple elements and simple carbon compounds. Acetylene seemed to be the starting point in the investigation of hydrocarbons, since from it one could obtain ethylene, methane and benzene. The study of fatty acids interested him equally. Many of his experiments of the 1850s investigated the production of compounds of glycerin through heating it with hydrochloric acid and various fatty acids. These researches, together with similar analysis of sugars, led to studies of fermentation and the preparation of alcohol from ethylene. His work was extremely important in demonstrating the inter-relationship between organic and inorganic chemistry. He carried out important researches on explosives following the French defeat by Germany in the war of 1870 . He was a senator 1881-1907, Minister of Public Instruction 1886-87 and Foreign Minister 1895-96. On the political left, he attacked the influence of the Church, particularly in education.

Berthier, Louis Alexandre, Prince of Neuchâtel (1753-1815). French marshal. A soldier's son, he enlisted in 1770, fought against the British in the war of American Independence and rose to be Chief of Staff of the French army in Italy (1795). He was a friend of *Napoléon Bonaparte, both before and after he became Emperor, and acted as his chief of staff throughout his wars, as well as being Minister for War 1800-06. In 1814 he submitted to Louis XVIII, showed irresolution when he heard of Napoléon's return from Elba, and, as the Russian armies entered France after Waterloo, committed suicide.

Berthollet, Claude Louis, Comte (1748-1822). French chemist. He studied medicine at the University of Turin, graduating in 1768, then took up chemistry in Paris. During the Revolutionary period in particular he was deeply involved in practical chemistry, seeking improvements in soap, explosives and metals. His theoretical researches into chlorine led to his pioneering its use for bleaching purposes. Berthollet was one of the earliest supporters of *Lavoisier's anti-phlogiston chemistry. His understanding of oxygen helped in his analysis of ammonia, and in other researches in the chemistry of gases. In later life he became more involved in theoretical issues. In his Essai de Statique Chimique he claimed that the forces of chemical affinity were proportional to the masses of the reacting substances, a view seemingly undermined by *Dalton's law of definite proportions. Berthollet was a public figure in Revolutionary France. He taught at the École Polytechnique, was a friend of *Napoléon, and became a senator in 1804. At Napoléon's request he travelled to Egypt in 1796 to collect art treasures and help found the Institute of Egypt.

Bertillon, Alphonse (1853-1914). French criminologist. Son of an anthropologist, he introduced a system of identifying criminals by a series of body measurements (anthropometry). In 1892 nearly 700 French criminals were identified by this method, later replaced by fingerprinting.

Bertolucci, Bernardo (1940-2018). Italian film director, born in Parma. He gained international recognition with his films The Spider's Strategy (1970), The Conformist (1970), Last Tango in Paris (1972), 1900 (1975), La Luna (1979) and The Last Emperor (1986), which combined powerful, violent or sensual subjects with rich lyricism and elegant imagery. 
Bertrand, Henri Gratien, Comte (1773-1844). French general. He entered the army as an engineer and in that capacity fortified Alexandria in the Egyptian campaign. He was prominent at Austerlitz and his bridge-building skill helped to save the army at Aspern. He then became *Napoléon's adjutant, sharing his exile in Elba (1814-15) and St Helena (1815-21), and writing valuable diaries. After Napoléon's death, he returned to France, a death sentence imposed in 1817 having been annulled by *Louis XVIII. Elected Deputy in 1831, in 1840 he accompanied the expedition which brought back Napoléon's remains to France.

Berwald, Franz Adolf (1792-1868). Swedish composer, born in Stockholm. The son of a violinist, he played in orchestras until 1828, then travelled, devoting himself to composition, later managing a glassworks and sawmill. His music was virtually ignored for a century, but his four symphonies (1842-45), strongly influenced by *Beethoven, are now frequently played.

Berwick, James Fitz-James, 1st Duke of (1670 1734). English soldier in France. Illegitimate son of *James II and Arabella Churchill, the sister of the Duke of ${ }^{*}$ Marlborough, he received his title in 1687 from his father, whom he later accompanied into exile. Joining the French army he served with distinction under Marshal *Luxembourg. In 1706 he was created a marshal and by his victory at Almansa established *Louis XIV's grandson *Philip V on the throne of Spain. During the War of the Polish Succession he was killed at the siege of Philippsburg.

Berzelius, Jöns Jakob, Baron (1779-1848). Swedish chemist, born near Linköping. He studied medicine at Uppsala University, worked in Stockholm from 1802 and was professor of chemistry at the Carolinska Medical Surgical Institute 1815-32. He discovered selenium, thorium and cerium, and first isolated silicon, titanium and zirconium. By consolidating and extending John *Dalton's work on the atom and compiling the first accurate table of atomic weights he did much to make the advances of modern chemistry possible. He first suggested the modern system of chemical symbols (e.g. $\mathrm{H}^{2} 0$ for water, indicating that there are two atoms of hydrogen and one of oxygen in a molecule of water).

Besant, Annie (née Wood) (1847-1933). British theosophist. After separating from her husband, a clergyman, she became an active free-thinker closely associated with Charles ${ }^{*}$ Bradlaugh, with whom she was tried for immorality after reprinting a pamphlet on birth control, and then an ardent propagandist for socialism. G. B. *Shaw considered her the finest orator he had heard. In 1889 she met Madame *Blavatsky and turned to theosophy. She lived in India from 1895 , interested herself in the education of women and, having taken up nationalism, became president of the Indian National Congress in 1917. In later life, she identified a young Indian, Jiddu *Krishnamurti, as a new messiah.

Bessel, Friedrich Wilhelm (1784-1846). German astronomer and mathematician. By studying astronomy in his spare time as a merchant's clerk and at sea he eventually became director of Königsberg Observatory 1810-46. In 1804 he had recalculated the orbit of *Halley's Comet from observations that had been made in 1607, and in 1838 he made the first accurate measurement of the distance of a star (61 Cygni). His theory that irregularities in the motion of Sirius and Procyon were due to gravitational pull was confirmed when, as he predicted, 'dark' companion stars were subsequently discovered. At the time of his death Bessel was investigating the irregularities in the motion of Uranus that later enabled *Adams and *Leverrier to discover the existence of Neptune. His chief mathematical work was on the functions now known as Bessel functions.

Bessemer, Sir Henry (1813-1898). English metallurgist. Of Huguenot descent, in 1856 he invented the 'Bessemer Converter', in which some types of pig iron can be directly and economically converted into high grade steel by oxidising the impurities. This was originally achieved by passing air into the converter, but oxygen alone is now used. Bessemer also adapted the first composing machine invented by the Belgian printers Young and Delcambre in Lille. One of the founders of the Iron and Steel Institute in 1869, knighted and elected FRS in 1879, Bessemer wrote an autobiography. Eight US towns were named for him.

\section{Bessette, St André see André of Montréal, St}

Best, Charles Herbert (1899-1978). Canadian physiologist. With F. G. *Banting, he first succeeded in preparing insulin for the treatment of diabetes, and Banting shared his Nobel Prize money when Best was unfairly excluded from the award. He was professor of physiology at Toronto University 1929-67 and received many distinctions, including the US Legion of Merit (1947) the CC (1967) and a CH (1971).

Betancourt, Romulo (1908-1981). Venezuelan politician. He was driven into exile under the dictatorship of Juan Vicente *Gômez, and again in 1939 for his underground activities. On his return he organised the Accion Democratica and was largely responsible for the revolution of 1945 which resulted in his becoming provisional president. In 1948 a military coup d'etat once more forced him into exile, and this time he had to wait 10 years for the tide of fortune to turn and enable him to return in 1958. He was President 1959-64 and proceeded with his program of social and economic reform. 
Bethe, Hans Albrecht (1906-2005). GermanAmerican physicist, born in Strasbourg. He left Germany in 1933, worked in the US on quantum and solid state theory and won the Nobel Prize for Physics in 1967.

Bethmann-Hollweg, Theobald von (1856-1921). German politician. Prussian Minister of the Interior 1905-07 and Secretary of State 1907-09, he became a reluctant Imperial Chancellor 1909-17. He was alleged to be shocked and dismayed that Britain should enter the war just for a 'scrap of paper' (the treaty with Belgium), but he was considered too moderate by the militarists and was dismissed in 1917.

Betjeman, Sir John (1906-1984). English poet and journalist. Educated at Marlborough and Oxford, he wrote several architectural guidebooks, championed Victorian and Edwardian taste, and gained wide recognition for his light verse, mild satire and nostalgic descriptive pieces. His blank verse autobiography, Summoned by Bells (1960), was a popular success. His Collected Poems appeared in 1958. He was Poet Laureate 1972-84.

Bettelheim, Bruno (1903-1990). AustrianAmerican psychologist, born in Vienna. He worked in the US from 1939 and wrote extensively on child rearing, education and the problems of autism in children. His books include The Uses of Enchantment (1976). He committed suicide.

Betterton, Thomas (c.1635-1710). English actor. Despite disadvantages of face, voice and figure, he was esteemed by *Pepys to be the best actor in the world. All, including *Addison and *Dryden, speak well of him as an actor and man and, when speculation proved his undoing, a public benefit was arranged on his behalf. In 1705 he moved his company from his theatre in Lincoln's Inn Fields to the new Haymarket Theatre, designed for him by *Vanbrugh.

Gildon, C., Life of Mister Thomas Betterton, The Late Eminent Tragedian. 1970.

Betti, Ugo (1892-1953). Italian poet and playwright. A lawyer, he became a judge 1930-43 but had no involvement with Fascism. He wrote 25 plays on the theme of justice, notably Corruption in the Palace of Justice (1949), The Queen and the Rebels (1951) and The Fugitive (1953). They were translated and widely performed in the last years of his life.

Rizzo, G., Ugo Betti: Three Plays. 1966.

Beuys, Joseph (1921-1986). German sculptor, graphic and performance artist. A Luftwaffe pilot in World War II, he created his own personal mythology and was a pioneer of 'performance art', in which the artist him/herself creates an interaction with static art works. He taught at Dusseldorf, was involved in 'green' politics and became a major cult figure.
Bevan, Aneurin ('Nye') (1897-1960). British Labour politician, born in Tredegar, Monmouthshire (now Gwent). One of the great orators of the House of Commons, he was the son of a miner and worked in a mine as a boy. He had early experience of trade union organisation in the South Wales Miners Federation and gained a knowledge of politics and economics at the Central Labour College. He was elected MP for Ebbw Vale in 1929 and held the seat for the rest of his life. In World War II he often carried on a oneman opposition to the Winston *Churchill coalition government and afterwards in *Attlee's postwar Labour governments he was the life and soul of the left wing. As Minister of Health 1945-51 he gave the final shape to the National Health Service and secured the passing of the Act. His resignation in 1951 over what he regarded as excessive re-armament was soon followed by the Conservative return to office. In opposition his hostile attitude to the nuclear deterrent was almost as much an embarrassment to his own party leaders as to his opponents. However, as time went on, Bevan's views and those of his leader, *Gaitskell, tended to converge and Bevan became Deputy Leader of the Party 1959-60. In 1934 he married Jennie Lee (1904-1988). She was Minister for the Arts 1967-70 and became Baroness Lee. Tribune, a publication founded by Bevan, survived his death.

Foot, M., Aneurin Bevan. 2 vols, 1962, 1973.

Beveridge, William Henry Beveridge, 1st Baron (1879-1963). English economist, born in Bengal. Educated at Charterhouse and Oxford, he became a civil servant and Secretary of the Ministry of Food 1919. He directed the London School of Economics 1919-37 and was master of University College, Oxford 1937-44. Social Insurance and Allied Services (1942, usually called 'the Beveridge Report') recommended an extension of the 'welfare state'. His famous Full Employment in a Free Society (1944) was soon adopted as government policy in Britain, Australia and New Zealand and influenced ${ }^{*}$ Truman's 'Fair Deal' in the US. He became a Liberal MP 194445 and received a peerage in 1946.

Beveridge, W. H., Power and Influence. 1953.

Bevin, Ernest (1881-1951). English trade union leader and Labour politician, born in Somerset. Son of an unknown father and a hard-working but illiterate mother, he had a sporadic education until the age of 11 , then became a van boy and lorry driver in Bristol. An active trade unionist, then an organiser, at the age of 30 he was an official of the dockers' union, and the skill with which he put their case earned him the nickname of 'the dockers' KC'. But his greatest achievement and monument was the uniting (1922) of 32 separate unions into the huge Transport and General Workers Union; he became its General Secretary 1922-40. Strongly opposed to appeasement of fascism, and intolerant of pacifism, 
he supported Clement *Attlee as Labour leader. He served in Winston *Churchill's wartime coalition as Minister for Labour and National Service 1940-45, and proved an outstanding success in keeping industry going and meeting the demands of the services. In Attlee's postwar Labour Government, Bevin was an unexpected choice as Foreign Minister 1945-51 and his performance remains deeply controversial. He strongly opposed *Stalin's dictatorship and his totalitarian control of Eastern Europe, supported dismembering the British Empire, especially India, and Britain acquiring its own nuclear weapons. $\mathrm{He}$ encouraged the United States to play a major role in European reconstruction and was an architect of the Brussels treaty of 1948 (Western European Union) and NATO (1949). He was criticised for his pro-Arab outlook and lack of sympathy towards Israel.

Bullock, A., The Life and Times of Ernest Bevin. 3 vols, 1960, 1967, 1983; Adonis, A., Ernest Bevin. Labour's Churchill. 2020.

Bewick, Thomas (1753-1828). British wood engraver, born in Northumberland. $\mathrm{He}$ was apprenticed to a Newcastle engraver, Ralph Beilby, with whom he afterwards entered into partnership. His best work was in his History of Quadrupeds (1790) and History of British Birds (2 volumes, 1797 and 1804).

Bain, I., Thomas Bewick. 1975.

Beza (or de Béze), Theodore (1519-1605). French theologian, born in Vézelay. As a young man he led a dissipated life in Paris, but after a serious illness he changed his ways, and joined ${ }^{*}$ Calvin at Geneva. He was professor of Greek at Lausanne (1549-54) and, returning to Geneva (1559) to take up a theological professorship, he worked closely with Calvin, proving his skill as a diplomat by obtaining ${ }^{*}$ Henry of Navarre's help for the Huguenots. On Calvin's death (1564) much of the burden of leadership fell upon Beza and he presided at the Huguenot Synods at La Rochelle (1571) and at Nîmes (1572). He was also an important biblical scholar.

Bezos, Jeff (né Jeffrey Preston Jorgensen) (1964- ). American entrepreneur, born in New Mexico. Educated at Princeton, he became a computer scientist. He founded Amazon.com in 1994 and by 2017 had a net worth of \$US100 billion, greater than Bill *Gates. He also invested in newspapers and aerospace and was a major philanthropist.

Bhumibol Adulyadej (Rama IX) (1927-2016). King of Thailand 1946-2016. Born in Cambridge, Massachusetts (where his father studied medicine), he was partly educated in Switzerland and succeeded on the assassination of his brother Ananda Mahidol. $\mathrm{He}$ generally remained aloof from Thai politics but intervened twice (1973 and 1992) against military rule. He took an active interest in global environmental problems.
Bhutto, Zulfiqar Ali (1928-1979). Pakistani politician, born in Larkana, Sindh. From a wealthy family of Hindu origin, he studied at the University of California (Berkeley) and Oxford and became a barrister (1953). Minister of Commerce 1958-60 and Foreign Minister 1963-66, he founded the Pakistan Peoples' Party (PPP) in 1967 and described himself as a democratic socialist. Imprisoned 1968-69 by *Ayub Khan's Government, he won an election victory in West Pakistan in December 1970. Following the war of December 1971 which resulted in the secession of East Pakistan (Bengal) and the creation of Bangladesh, Bhutto became president of Pakistan 1971-73. After the adoption of a parliamentary constitution, Bhutto stepped down to become Prime Minister 1973-77 until his overthrow by a military coup led by General ${ }^{*} \mathrm{Zia}$ ul-Haq. Accused and convicted of a political murder, he refused to ask for clemency and was hanged. His daughter Benazir Bhutto (1953-2007), educated at Harvard and Oxford, became leaderin-exile (with her mother) of the PPP. She returned to Pakistan in 1986, was swept into office as Prime Minister 1988, but confronted the opposing forces until her dismissal in 1990 by President Ghulam Ishaq Khan who accused her of nepotism and corruption. Beaten decisively in the 1990 elections, she was re-elected Prime Minister in 1993. Following repeated accusations of corruption she was dismissed again by the president in November 1996. In 1998 she went into self-imposed exile in Dubai, returned in October 2007 to lead her party in the election and was assassinated (27 December 2007) in Rawalpindi, under mysterious circumstances that have never been explained. The PPP won the ensuing election and her husband Asif Ali Zardari (1955- ) became President of Pakistan 2008-13.

Taseer, S., Bhutto A Political Biography. 1979.

Biber, Heinrich Ignaz Franz von (1644-1704). Czech/Bohemian composer. A brilliant violinist, from 1670 he was Kapellmeister for the Archbishop of Salzburg. His Mystery Sonatas (1674), also known as the Rosary Sonatas, 15 works for violin and continuo, are virtuosic, experimental and profound. He was also a prolific composer of choral music, e.g. Plaudite tympana (1682), in 53 parts.

Bichat, Marie François Xavier (1771-1802). French physician, born in the Jura. He studied at Lyon and Paris and in 1797 began giving courses of instruction in anatomy and physiology. He gained his practical experience in some 600 postmortems. His work on body tissues (called by him 'membranes') earned him the distinction of being virtually the founder of morbid histology.

Bickerstaffe, Isaac (c.1735-1812). Irish playwright. He became an officer of marines but had to flee abroad in 1772 on a capital charge. The best known of his plays include Love in a Village (1762), The Maid 
of the Mill (1765) and Lionel and Clarissa (1768). The name 'Isaac Bickerstaff' was used as a pen name by both ${ }^{*}$ Swift and ${ }^{*}$ Steele.

Bidault, Georges (-Augustin) (1899-1983). French politician and journalist. A leader of the resistance movement during World War II, after the liberation he was appointed Foreign Minister by *de Gaulle 194446 and, as founder and leader of the Mouvement Republicain Populaire (Catholic Socialist party), he was Premier 1946, 1949, 1958 and Foreign Minister 1947-48, 1953-54. In 1962 he became head of the National Resistance Council, violently opposed to de Gaulle's granting of independence to Algeria. Associated with the OAS (Organisation de l'armée secrète) and deprived of parliamentary immunity, Bidault went into exile in Brazil in 1962, later in Belgium, but was amnestied in 1968 .

Bidault, G., Resistance. 1967.

Biden, Joe (in full Joseph Robinette Biden, Jr) (1942- ). 46th President of the US 2021- . Born in Scranton, Pennsylvania, of Irish descent, his father, Joe Biden, Sr, suffered financial setbacks and the family moved to Wilmington, Delaware. The younger Biden studied law at the University of Maryland and Syracuse University, became an attorney and a county councillor 1970-72. In November 1972, at the age of 29, he was elected as US Senator from Delaware, serving 1973-2009. (In December 1972 his wife and daughter were killed in a motor accident. $\mathrm{He}$ remarried in 1977.) $\mathrm{He}$ chaired the Senate Judiciary Committee 1987-95 and Foreign Relations Committee 2007-09.

He sought the Democratic Presidential nomination in 1988, 2008 and 2020. Elected on Barack *Obama's ticket in 2008, he served as Vice President of the United States 2009-17 and was the first Catholic to hold the office. He received the Presidential Medal of Freedom in January 2017.

Biden declared his candidature for the Democratic Presidential nomination for 2020. His son Hunter's business dealings led to Donald *Trump's application of pressure on Ukraine's President *Zelensky to obtain damaging material on the Bidens, and were central to the impeachment proceedings against Trump. After a shaky start, he polled well in the 'Super Tuesday' primaries, and the other candidates withdrew in his favour in April. The coronavirus pandemic transformed political campaigning, Biden was nominated at a 'virtual' Convention in August, and campaigned cautiously, avoiding crowds and wearing a mask at public appearances, in sharp contrast to Donald *Trump. Biden and his running mate Kamala *Harris, won a 7 million vote plurality on 3 November, and after narrow victories in 'swing states' gained a majority in the Electoral College. Trump refused to concede, claiming that postal voting had been fraudulent.
At 78 years 2 months, Biden was the oldest American President to be inaugurated.

Osnos, E., Joe Biden: American Dreamer. 2020.

Bierce, Ambrose Gwinnett (1842-1914?). American writer, born in Ohio. He served in the Union army 1861-64, was wounded and promoted major. Apart from journalism, he was the author of cynical, sardonic, often macabre short stories, published in collections such as Can Such Things Be? (1893), and In the Midst of Life (1898), a re-issue of Tales of Soldiers and Civilians (1891). He compiled The Cynic's Word Book (1906), later republished under the title of The Devil's Dictionary. He disappeared while on a journalistic assignment in Mexico to join the rebel leader *Villa.

O'Connor, R., Ambrose Bierce: A Biography. 1968.

Bildt, (Nils Daniel) Carl (1949- ). Swedish conservative politician. Member of the Riksdag 1979-2000, he was leader of the Moderate Party 1986-99 and Prime Minister of Sweden 1991-94, in the first centre-right government since 1930. He negotiated Sweden's entry into the EU (1994) and became Foreign Minister 2006-14. He was UN Special Envoy in the Balkans 1999-2001.

Billroth, (Christian Albert) Theodor (1829-1894). German surgeon, born in Prussia. From a wellconnected clerical family, he pursued extensive medical studies at Göttingen and Berlin, receiving his MD in 1852. Director of the Zürich surgical hospital 1860-67, he moved to Vienna in 1867 and there combined a career in pathological anatomy with brilliant innovations in practical surgery. $\mathrm{He}$ made extensive studies of wound fever (especially the chemical poisons that produced it). He pioneered the use of antisepsis in Europe, and developed important surgical techniques. He was the first to operate on the oesophagus (1872), the larynx (1872) and to perform stomach re-sections (1881). He was especially skilled in plastic surgery. An expert violin and viola player, he was a friend of ${ }^{*}$ Brahms, who dedicated two string quartets to him, but was deeply hostile to *Wagner. He developed ideas on the physiological basis of musical talent, which he wrote up in Wer ist Musikalisch?, published after his death by the music critic, Edouard Hanslick.

\section{bin Laden, Osama see Laden, Osama bin}

Bingham, Hiram (1875-1956). American explorer, historian and politician, born in Honolulu. Son and grandson of missionaries, he taught history at Yale 1909-24 and in July 1911 discovered a great Inca religious centre in the Peruvian Andes, abandoned for nearly 400 years, which he named Machu Picchu ('old peak'). A Republican, he became Governor of Connecticut 1924 and a US senator 1924-33. 
Binyon, Laurence (1869-1943). English poet, dramatist and art critic. During World War I he wrote the elegiac poem 'For the Fallen', which became enormously popular, especially for war memorials. His Collected Poems was published in 1931. His plays include Arthur (1923) and The Young King (1935). He joined the British Museum staff in 1893 and became keeper of prints and drawings with a special interest in Chinese and Japanese art. He received the $\mathrm{CH}$ in 1932 and was professor of poetry at Harvard 1933-34.

Birdseye, Clarence (1886-1956). American businessman and inventor, born in New York. His first employment was as a fur trader in Labrador, where he observed the method used of freezing food in winter when fresh supplies were unobtainable. Returning to the US, he began experiments. In 1924 he was co-founder of the General Seafoods Co. and developed a highly profitable and efficient method of freezing which aimed at preserving original taste.

Birdwood, William Riddell Birdwood, 1st Baron (1865-1951). English field marshal, born in India. Except during the South African War, when he was on *Kitchener's staff, most of his service had been in India. He commanded the Australian and New Zealand Army Corps (ANZAC) in World War I, leading them at the Gallipoli landing and after the evacuation (when he was in command of all troops) in France. He was promoted to command the 5th Army in 1918 in time to lead it to the final victory. In 1925 he was promoted to Field Marshal both in the British and the Australian armies (when John *Monash was only a retired Lieutenant General) and became Commander-in-Chief in India 1925-30. In 1930 he was *George V's choice as Governor-General of Australia, but *Scullin insisted on *Isaacs. He was Master of Peterhouse, Cambridge, 1930-38 and wrote his memoirs, Khaki and Gown (1941).

Birkbeck, George (1776-1841). English educationist, born in Settle, Yorkshire. He studied medicine at Leeds and Edinburgh. Birkbeck College, London University, founded in 1824, was originally one of the Mechanics Institutes for the education of the working classes, in the establishment of which he played a leading part.

Kelly, T., George Birkbeck, Pioneer of Adult Education. 1957.

Birkenhead, Frederick Edwin Smith, 1st Earl of (1872-1930). English lawyer and Conservative politician, born in Birkenhead. Educated at Oxford, he became a barrister in 1899 and soon acquired an enormous practice. As MP 1906-19 his wit and audacity soon marked him out, but as *Carson's chief lieutenant ('Galloper Smith' was his derisive nickname) he also won a reputation for reckless partisanship in support of the Ulster cause. In World War I coalitions he served as Solicitor-General 1915 and Attorney-General 1915-19; in the latter office he conducted the prosecution in the trial of Sir Roger ${ }^{*}$ Casement. He showed more generosity as an architect of the Irish settlement of 1921. As Lord Chancellor 1919-22 he was responsible for revising the Law of Property Act (1922) Created Earl in 1922, on the breakup of the coalition Birkenhead left office with *Lloyd George. He joined the second *Baldwin Government as Secretary of State for India 1924-28, but his performance was impaired by heavy drinking. His books include International Law (4th ed., 1911) Famous Trials of History (1927) and Law, Life and Letters (1927).

Campbell, J., F. E. Smith. 1983.

Biro, László Jozsef (1899-1985). Hungarian inventor. He patented a ballpoint pen in 1938, escaped to Argentina in 1943 and began manufacturing pens there.

Biron (Bühren), Ernst Johann von (1690-1772). German courtier. Son of a groom, he became Duke of Courland. As the lover of *Anna Ivanovna, Empress of Russia, he was hated for his insolence and greed, and Anna's death (1740) brought exile in Siberia and temporary eclipse. He was recalled by *Peter III in 1762 and restored to his dukedom by ${ }^{*}$ Catherine the Great.

Birtwistle, Sir Harrison Paul (1934-2022). British composer, born in Lancashire. Educated in Manchester and London, he taught in the US and in 1967 formed the Pierrot Players with (Sir) Peter Maxwell *Davies. His works include Silbury Air (1977), Secret Theatre (1984), Earth Dances (1985) and the operas The Mask of Orpheus (1981) and Gawain (1990). He was awarded a CH in 2001.

Bīrūnī, Abū Rayhāān Muhammad ibn Aḥmad Al(973-c.1050). Persian mathematician, astronomer, geographer and polymath. In the 'Golden Age of Islam', he had an extraordinary range of interests, made a reasonably accurate estimate of the Earth's circumference, mastered several languages, including Hebrew and Greek, challenged *Aristotle and ${ }^{*}$ Ptolemy on elliptical orbits, compiled a pharmacopoeia, studied comparative religion and wrote an encyclopaedia of India.

Bishop, Julie Isabel (1956- ). Australian lawyer and Liberal politician. Member of the House of Representatives 1998-2019, she was Minister for Education, Science and Training 2006-07, Deputy Leader of the Liberal Party 2007-18 and Minister for Foreign Affairs 2013-18. She became Chancellor of The Australian National University 2020- .

Bismarck(-Schönhausen), Otto Eduard Leopold, Prince von, Duke of Lauenburg (1815-1898). German statesman, born in Schönhausen, Brandenburg. From a Junker family, he was deeply influenced by his mother who encouraged him to 
study law at Göttingen and Berlin with a view to public service. At the university he was bored by the law but developed lifelong interests in history and literature. He entered the Prussian civil service in 1835, disliked his duties and was disapproved of for unpunctuality and the excessive demands of his social life. Resignation (1839) and a post as an estate manager in Pomerania followed. He engaged in country pursuits, read and corresponded much and entered into a happy marriage (1847) with Johanna von Puttkamer. He lost all religious belief but supported the Lutheran Church as a force for social stability, together with the monarchy and the army. As a member of the Prussian Landtag (Lower House) 1847-58, he was a crude advocate of royal absolutism, objecting to the lack of authoritative measures for dealing with the liberal risings of 184849. As Prussian Ambassador to the German Diet at Frankfurt 1851-59 he quickly acquired the arts of a diplomat and saw how assemblies of this kind could be used for his own ends, which more and more became clarified as the unity of Germany under Prussian leadership with the exclusion of Austria. After serving as Ambassador to Russia 1859-62, and to France 1862, appointments that enabled him to gain the confidence of one emperor (*Aleksandr II) and to study the weaknesses of another (*Napoléon III), Bismarck was called to head the Prussian Government in order to overcome parliamentary opposition to King *Wilhelm I's army plans. He achieved this by the dissolution of parliament over a legal quibble and at once proceeded with his plans to unify Germany. He was Minister-President (i.e. Premier) and Foreign Minister of Prussia 1862-71 and Chancellor of the North German Confederation 1867-71. A war with Denmark, over ownership of the duchies of Schleswig and Holstein, was provoked in 1864 and Prussia soon displaced Austria as Germany's natural leader. Next, Bismarck provoked war with Austria (1866) by claiming control of both Schleswig and Holstein. After seven weeks of savage fighting, in which Bismarck adopted techniques used in the US Civil War, Austria surrendered, but a generous settlement avoided the dangers of extreme bitterness and antagonising Germany's southern states. The North German Confederation was then set up and Bismarck became Chancellor 1867-71. His next step was to anticipate any possible resistance to his plans by France. By a series of adroit manoeuvres, such as support for the candidature of Prince Leopold of Hohenzollern for the vacant Spanish throne and 'editing' a telegram from Napoléon III to King Wilhelm, he created a situation which practically forced Napoléon to declare war in July 1870. Once more Bismarck had judged the military situation correctly: by August Napoléon's armies had been smashed at Sedan and he had been taken prisoner. In January 1871 in Versailles, Wilhelm I was proclaimed sovereign of the new German empire, and Bismarck became first Chancellor 1871-90. For the next 20 years the history of Bismarck was the history of Germany. In 1873, he initiated a campaign (Kulturkampf) to provide for secular education and limit the power of the Roman Catholic Church, provide for secular marriage and expel the Jesuits. In 1878 the new pope, ${ }^{*}$ Leo XIII, was able to negotiate an end to hostilities. His foreign policy was based on a friendly alliance between the three emperors of Germany, Austria, and Russia, and he was able to assert Germany's leadership in 1878 by getting Berlin chosen as the venue of a conference that successfully settled the Balkan problems created by the Russo-Turkish war. At home he tempered his conservatism with an opportunism which often shocked his friends as it disarmed his opponents. He accepted manhood suffrage and initiated such reforms as the Sickness Insurance Law, the Accident Insurance Law (both subsidised by the employers) and the Old Age and Invalidity Insurance Law (subsidised by the state). But his dictatorial methods were offensive to ${ }^{*}$ Friedrich III who soon died (1888) and to his successor ${ }^{*}$ Wilhelm II who wanted to assert royal authority. In 1890 Bismarck was dismissed. In retirement he was a constant and bitter critic of the emperor's policies, especially in his memoir Reflections and Reminiscences (1898)

An hysteric, he alternated between outbursts of rage and floods of tears. His personal charm disarmed opponents (e.g. Ferdinand *Lassalle) and he defined genius as 'knowing where to stop'.

Taylor, A. J. P., Bismarck: the Man and the Statesman. 1955; Steinberg, J., Bismarck. A Life. 2011.

Bizet, Georges (Alexandre César Léopold) (18381875). French composer, born in Paris. A pupil of *Gounod, he showed early brilliance but received late recognition. His lively Symphony in C major (1855) was unperformed until 1935. He won the Prix de Rome in 1857 and spent three years studying in Italy. His operas include the Pearl Fishers (1863), The Fair Maid of Perth (1867) and Carmen (1875), his last and greatest work, based on a story by Prosper *Mérimée. This was Bizet's first real success but he died a few months after its first performance. The incidental music to L'Arlesienne (1872) was written for a play by ${ }^{*}$ Daudet.

Dean, W., Bizet. 1965.

Bjelke-Petersen, Sir Joh(annes) (1911-2005). Australian politician, born in New Zealand of Danish descent. A peanut farmer, he was a Queensland MP 1950-87, a minister from 1963 and Premier 1968-87, a record term, leading the National (formerly Country) Party. He appealed to the traditional values of rural Australia, securing strong support from people who felt alienated from the complexities of modern urban society. In 1987 the abortive 'Joh for Canberra' campaign made him a national figure and split Coalition forces. 
Bjorling, Jussi (1911-1960). Swedish tenor. He sang with great success in London and New York, with sensitive phrasing, clear diction and a ringing tone, and made many recordings. His father, brothers and son were all accomplished singers.

Björnson, Björnstjerne (1832-1910). Norwegian poet, novelist and dramatist. Son of a Lutheran pastor, he was educated at Molde, Christiania and Copenhagen. He managed theatres in Bergen 185759, Christiania 1865-67, lived in Italy 1860-62 and travelled widely throughout Europe, while working as a newspaper editor and taking an active part in politics as an advocate of Norwegian nationalism and republicanism. His marriage to Karoline Reimers in 1858 was followed by one of his most creative periods to which belong the historical dramas King Sverre (1861) and the trilogy Sigurd the Bastard (1862) as well as the peasant novels Arne (1859) and A Happy Boy (1862). In 1874, influenced by his friend *Ibsen, he wrote the first of his modern plays, The Editor, followed by the successful A Bankruptcy (1875) and a political play called The King (1877) which caused considerable offence. The New System (1879) contrasted the honest quest for truth by the younger generation with the hypocrisy of the old. As the years went by Björnson continued to combine political agitation (the liberal victory of 1882 owed much to him) with writing, $A$ Gauntlet (1883) advocated sex equality and two plays under the title Beyond Our Power (1889) also dealt with such controversial topics as miracles and a strike. Also noted as a lyric poet, Björnson wrote 'Yes, we love this land' adopted as the Norwegian national anthem. With Ibsen he was one of the great figures of the Scandinavian literary renaissance. He won the Nobel Prize for Literature in 1903 .

Black, Conrad Moffat, Baron Black of Crossharbour (1944- ). Canadian investor and publisher, born in Montréal. Educated at Carleton, Laval and McGill universities, he had investments in newspapers, banks, railways, insurance, electronics and retailing. He controlled more than 260 newspapers, large and small, including the Daily Telegraph (London), the Jerusalem Post, the Sydney Morning Herald, and the Melbourne Age. He wrote biographies of the former Québec Premier Maurice Duplessis, Franklin D. *Roosevelt, Richard *Nixon and Donald *Trump. In December 2007, he was sentenced to 78 months' imprisonment for multiple counts of fraud. He received a Presidential pardon from Trump in 2019.

Black, Sir James Whyte (1924-2010). Scottish pharmacologist. A graduate of St Andrews, he held chairs at University College and Kings' College, London. A major pioneer in analytical pharmacology, he developed beta-blockers, to inhibit the effects of adrenalin on the heart, and propranolol was used to treat heart attack, angina, high blood pressure and migraine. He also developed the anti-peptic ulcer drug cimetidine (Tagamet), shared the Nobel Prize for Medicine in 1988 with George *Hitchings and Gertrude *Elion, and received the OM in 2000.

Black, Joseph (1728-1799). Scottish physician and chemist, born in Bordeaux. Educated in Belfast and at Glasgow University, he took a medical degree at Edinburgh in 1754. He realised that carbon dioxide is chemically distinct from air, and was the first to show the difference between mild and caustic alkalis. Black also propounded the theories of specific and latent heat (the latter was applied by James *Watt to the steam engine with historic consequences) and laid the foundations of calorimetry. He became professor of medicine at Glasgow 1756-66 and of medicine and chemistry at Edinburgh 1766-97.

\section{Black Prince see Edward the Black Prince}

Blackburn, Elizabeth Helen (1948- ). Australian molecular biologist, born in Hobart. Educated at the universities of Melbourne, Cambridge and Yale. Blackburn co-discovered telomerase, the enzyme that replenishes the telomere. For this work on the nucleotide sequence which protects the ends of chromosomes from deteriorating, she shared the 2009 Nobel Prize in Physiology or Medicine, with Carol W. Greider and Jack W. Szostak. She also worked in medical ethics, and was controversially dismissed from the President's Council on Bioethics in 2004 because of her support for stem cell research.

Blackett, Patrick Maynard Stewart, Baron Blackett (1897-1974). English physicist. He studied under *Rutherford at Cambridge and developed the use of C.T.R. *Wilson's cloud chamber in the study of atomic structure and cosmic rays. In his cosmic ray studies in 1933 he confirmed the existence of the positron previously discovered by C. D. *Anderson. He also confirmed (1935) the accuracy of *Einstein's $\mathrm{E}=\mathrm{mc}^{2}$ equation and worked on the atomic bomb project during World War II. He was professor of physics at Birkbeck College, University of London 1933-37, Manchester University 1937-53 and Imperial College, London 1953-74. In 1948 he was awarded the Nobel Prize for Physics, was President of the Royal Society 1965-70 and received a CH, an $\mathrm{OM}$ and a peerage.

Blackmore, Richard Doddridge (1825-1900). English novelist. Educated at Blundell's School, Tiverton, and at Exeter College, Oxford, he gave up the law because of epilepsy and took up writing and gardening. Of his 15 novels, Lorna Doone (1869) is best known. The story is set in Exmoor, with *Monmouth's rebellion against *James II as one of its episodes. The heroine herself and John Ridd, who rescues her from the Doone clan of robbers and murderers, are among the most romantic characters of fiction. 
Blackstone, Sir William (1723-1780). English jurist. Son of a silk mercer and educated at Charterhouse and Oxford, he practised at the bar until 1758, when he became the first Vinerian professor of law at Oxford. In this post he inaugurated courses in English law (only Roman law having been studied there until then). Blackstone was a Tory MP 176168, and a Justice of the Common Pleas 1770-80. His Commentaries on the Laws of England (1765-69), a lucid exposition of the whole of English law, exercised an immense influence upon succeeding generations of lawyers, and remains a standard work of reference.

Blackwell, Elizabeth (1821-1910). British woman doctor, born in Bristol. She was taken to America as a child, studied in New York and in 1849 became the first woman medical graduate. Having then come to London to study at St Bartholomew's Hospital she later (1859) became the first woman on the British medical register. Back in America she organised nursing services during the Civil War. In 1869 she settled in England, and in 1875 she became a professor at the London School of Medicine for Women, which she had helped to establish.

Fancourt, M. St J., They Dared to be Doctors: Elizabeth Blackwell and Elizabeth Garrett Anderson. 1966.

Blackwood, William (1776-1834). Scottish publisher. He became prominent by publishing the first series of Sir Walter *Scott's Tales of My Landlord. Later writers whose books bore the Blackwood imprint included George *Eliot, *Trollope and Charles *Reade. In 1817 Blackwood founded Blackwood's Magazine as a Tory rival to the Edinburgh Review. Under his descendants it grew to be a national institution.

Blaine, James Gillespie (1830-1893). American Republican politician, born in Pennsylvania. After working as a school teacher, lawyer and journalist he entered the Maine legislature and the US House of Representatives 1863-76, serving as Speaker 186975. Allegations of corruption were responsible for his loss of the presidential nomination in 1876 and 1880 , but he was US Senator 1876-81 and served as US Secretary of State under ${ }^{*}$ Garfield 1881 and under Harrison 1889-92. In 1884 he was narrowly beaten for the presidency by Grover *Cleveland.

Blainey, Geoffrey Norman (1930- ). Australian economic historian. Professor of history at Melbourne University 1968-88, he was a prolific author whose works include the influential The Tyranny of Distance (1966), Triumph of the Nomads (1977), A Shorter History of Australia (1994) and A History of the World (2000). An optimistic conservative, critical of 'the black armband' view of Australian history, he opposed becoming a Republic and was much admired by John *Howard.
Blair, Sir Tony (Anthony Charles Lynton) (1953- ). British Labour politician, born in Edinburgh. As a child he lived briefly in Adelaide, then attended Chorister School, Durham and Fettes College, Edinburgh, before studying law at Oxford. $\mathrm{He}$ became a barrister, MP 1983-2007, and a shadow minister 1984-94. After John *Smith died, he became Leader of the Opposition 1994-97. He continued Neil *Kinnock's revision of party policy, and, under the name New Labour, accepted many of the Thatcherite economic changes. He won the May 1997 election with 44.5 per cent of the vote and a record Labour majority of 179 seats and became Prime Minister. In June 2001 his government was reelected with a majority of 166 seats. Britain took a leading role in supporting the US invasion of Iraq in March 2003 and Blair emerged as *Bush's principal foreign supporter, a decision, based on faulty intelligence, which compromised his reputation for judgment. Nevertheless, in February 2005 he became the longest serving British Labour Prime Minister, winning a third election in May 2005. He supported strong action to combat global warming, urged debt relief for the Third World, and invested heavily in education and health. He resigned as Prime Minister in June 2007, when Gordon *Brown succeeded, and was appointed as Middle East Envoy for the UN, EU, US and Russia. In 2007, he became a Roman Catholic; oddly, no Catholic had ever been a serving British Prime Minister until Boris *Johnson. He was awarded a KG in 2022.

Blair, T., A Journey. 2010; Bower, T., Broken Vows. Tony Blair. The Tragedy of Power. 2016.

Blake, Robert (1599-1657). English admiral, born in Bridgewater, Somerset. Son of a merchant and educated at Oxford, he spent his early years at home occupied by business or country pursuits. Election to parliament in 1640 marked his entry into public life and during the Civil War he served with great distinction in the parliamentary land forces, his defence of Taunton for a year winning him great renown. In 1649 he was appointed to command (with two others) the Commonwealth navy. Although he had little naval training he managed to destroy Prince *Rupert's fleet (1650) and establish Britain's naval supremacy in the North Sea and English Channel after a series of encounters with the famous Dutch admirals ${ }^{*}$ Tromp and de *Ruyter. In 1654 he sailed to the Mediterranean and destroyed the power of the Tunisian and Algerian pirates. In 1657, having heard of the arrival of the Spanish West Indian Fleet at Vera Cruz, Tenerife, he immediately set sail and destroyed all 16 ships, but as his ship entered Plymouth harbour on its return Blake died suddenly.

Blake, William (1757-1827). English poet, artist and mystic, born in London. His father, a hosier, was a follower of Emanuel ${ }^{*}$ Swedenborg. From the very first he was a highly imaginative child who claimed to see angelic visions. Apprenticed to an engraver 
(1771-78), he studied briefly with the Royal Academy School and then set up shop in 1784 as a printseller and engraver. His first book of poems, Poetical Sketches (1783), was followed by Songs of Innocence (1789) and Songs of Experience which includes The Tyger (1794), illustrated like all his later books with his own hand-painted engravings. Poems such as The French Revolution (1791) and America (1793) express a temporary political fervour which he did not retain as his views became more and more imbued with mysticism. His mystical and prophetic works include the Marriage of Heaven and Hell (1791), The Book of Urizen (1794), The Book of Los (1795) and many others, printed from his own copper plates and illustrated with his visionary designs. Nearly all his works have a highly individual symbolism, but while his early poems are notable for their simple language and serene brightness, his later works, with their symbolic characters - Urizen, the author of restrictive moral law, Orc in rebellion against him and Los, the captive champion of light-create an atmosphere of gloom and mystery. However, despair is set aside and mutual love and forgiveness of sin offer revived hope of salvation in the epics the Four Zoas (1796-1804), Milton (1804-08) and Jerusalem (1804-20). Some of *Blake's finest artistic work went into the illustrations for the Book of Job (1820-26) and for *Dante's Divine Comedy (left unfinished at his death). His paintings were ignored by the public but he enjoyed the unfailing support and belief of his wife, the friendship and sometimes the financial help of other artists such as *Flaxman and Samuel *Palmer and he remained serenely happy until his death. Most modern critics have acknowledged him as a lyrical poet and visionary artist of supreme power.

Ackroyd, P., Blake. 1995.

Blamey, Sir Thomas Albert (1884-1951). Australian soldier, born in Wagga Wagga. He served as Chief of Staff to *Monash in World War I, was a controversial chief commissioner of police in Victoria 1925-36, commanded Australian troops in the Middle East and Greece 1940-41, and was Commander-inChief of Allied land forces in the southwest Pacific area 1942-45 under General Douglas *MacArthur. In 1950 he became the first Australian-born Field Marshal.

Hetherington, J., Blamey: Controversial Soldier. 1974; Horner, D., Blamey. The Commander-in-Chief. 1998.

Blanc, (Jean Joseph Charles) Louis (1811-1882). French socialist politician and author, born in Madrid. He was a dwarf and a twin. After studying law he became a journalist and was attracted to socialism by the utopian schemes of ${ }^{*}$ Saint-Simon and *Fourier. In his Organisation du Travail (1840) he advocated the nationalisation of property and the institution of co-operative workshops to be run by the workers themselves. He became a member of the revolutionary government formed in 1848 and when this collapsed took refuge first in Belgium and then in England. On returning to France after the fall of *Napoléon III (1871), he condemned the Commune, but served for the rest of his life as a leading deputy of the extreme left. He wrote a 12-volume Histoire de la Revolution Française while in exile (1847-64).

Vidalenc, J., Louis Blanc, 1811-1882. 1948.

Blanchett, Cate (Catherine Elise) (1969- ). Australian actor and director, born in Melbourne. Educated at Melbourne University, she gained early success both on stage and with films, taking the leading role in Elizabeth (1998), and received many awards, including an Academy Award (2004) for best supporting actress as Katharine *Hepburn in The Aviator. She and her husband, Andrew Upton, were joint directors of the Sydney Theatre Company 2009-13. She won the Academy Award (2013) for best actress for her performance in Woody *Allen's Blue Jasmine. She received an AC in 2017.

Blanqui, (Louis) Auguste (1805-1881). French revolutionary socialist. He took an active part in the political risings of 1830,1839 and 1848 and was exiled and imprisoned for sedition for much of his life. Blanqui coined the term 'industrial revolution' (1837), which was taken up by *Engels (1844) and later popularised (1882) by Arnold *Toynbee. He favoured dictatorship by a revolutionary leadership but never used the term 'dictatorship of the proletariat'. He organised several secret political societies in an attempt to gain power by force. Elected President (in absentia) of the Paris Commune 1870, he was amnestied from a life sentence imposed after the Commune and elected a deputy for Bordeaux but never took his seat.

Bernstein, S., Auguste Blanqui and the Art of Insurrection. 1971.

Blasco Ibáñez, Vicente (1867-1928). Spanish novelist, born in Valencia. An active republican, he was jailed several times, exiled twice and served in the Cortes 1901-07. His early novels deal realistically with provincial life and social change. Later he achieved world fame with Blood and Sand (1908), about a bullfighter's life, and the Four Horsemen of the Apocalypse (1916), a sensational novel of World War I, both successfully filmed.

Cardwell, R.A., Blasco Ibánez 'La Barraca'. 1973.

Blatchford, Robert (1851-1943). English journalist. A socialist and agnostic, he became a lively and prolific pamphleteer writing under the pen name 'Numquam'. His paper, The Clarion, and his books, e.g. Merrie England (1894), had a strong influence on British socialism.

Blavatsky, Helena Petrovna (née Hahn) (18311891). Russian American theosophist, born in the Ukraine. Little is known of her early life but she seems to have travelled widely in the East and even to 
have penetrated Tibet. She became a keen spiritualist and while living in New York (1873-78) founded, in 1875, the Theosophical Society. From New York she moved to India where the tenets of her mystical creed were said to have evolved. Despite the fact that her psychic powers failed to satisfy the Society for Psychical Research she had about 100,000 followers at the time of her death. Isis Unveiled (1877) was the first of several books. She was succeeded by Annie *Besant as leader of the Theosophists.

Symonds, J., Madame Blavatsky. 1959.

Blériot, Louis (1872-1936). French aviator and engineer. He devoted his personal fortune to the construction of monoplanes and in 1909 made the first aeroplane flight across the English Channel (Calais to Dover in 37 minutes), winning a prize of $£ 1,000$ offered by Lord *Northcliffe's Daily Mail.

Blessington, Marguerite Gardiner (née Power), Countess of (1789-1849). Irish writer. After a first marriage at the age of 14 , forced upon her by her father, a small Irish landowner, she married in 1818 the 1st Earl of Blessington. Their house in London became a social and literary centre. ${ }^{*}$ Byron was among the guests, and in 1834 she published A Journal of conversations with Lord Byron. Another friend was the notorious Count *d'Orsay, who was her lover for 12 years and with whom she fled to France in 1849 to avoid imprisonment for debt. Her writings included travel books and many forgotten novels.

Bligh, William (1754-1817). English sailor, navigator and administrator, born in Plymouth. Son of a customs officer, he was master of HMS Resolution (1776-80), during ${ }^{*}$ Cook's third exploration of the Pacific, and brought back news of his death. He commanded HMS Bounty on an expedition to Tahiti to collect breadfruit plants (1789), with the object of introducing them into the West Indies. On the return journey the ship's crew, led by Fletcher Christian, mutinied and cast Bligh and 18 of his men adrift in an open boat. The act was probably motivated more by the thought of wives left behind in Tahiti than Bligh's alleged harshness of discipline. Despite his lack of navigational aids, Bligh sailed $6,701 \mathrm{~km}$ (3,618 nautical miles) until picked up 47 days later at Timor. Ten mutineers were captured in Tahiti, and court martialled in 1792: four were acquitted, three pardoned and three hanged. (Christian had escaped to Pitcairn Island.) In 1793 he brought back breadfruit from Tahiti and ackee (Blighia sapida) from Jamaica and was elected FRS in 1801. He served under ${ }^{*}$ Nelson with distinction in the French wars. Bligh was Governor of New South Wales 1806-08, appointed, on the recommendation of Joseph *Banks, to succeed Philip Gidley *King. He clashed with the New South Wales Corps, largely over his attempt to control the traffic in rum, and in 1808 was imprisoned by rebels. After a year under house arrest he sailed for
Hobart on HMS Porpoise and remained there until 1810. He was promoted to rear admiral in 1811 and vice admiral in 1814.

Hough, R., Captain Bligh and Mr Christian. 1972; Dening, G., Mr Bligh's Bad Language. 1992; Salmond, A., Bligh. 2011.

Blinken, Antony John (1962- ). American diplomat and official. Of Hungarian-Jewish descent, educated at Harvard, he was Deputy Secretary of State 201517 and US Secretary of State 2021-.

Bliss, Sir Arthur Edward Drummond (18911975). English composer. Educated at Rugby and Cambridge, he served in the army during World War I and, after teaching in the US, was director of music for the BBC 1942-44. Among his vivid, somewhat astringent, works are A Colour Symphony (1922), Clarinet Quintet (1932), the music for the film of H. G. *Wells Things To Come (1935), Music for Strings (1935), the ballets Checkmate (1937), Miracle in the Gorbals (1944), and Adam Zero (1946), Piano Concerto (1939) and Violin Concerto (1955). Knighted in 1950, he was appointed Master of the Queen's Musick in 1953 and received a CH in 1971.

Bliss, A., As I Remember. 1970.

Blix, Hans Martin (1928- ). Swedish diplomat, lawyer and politician, born in Uppsala. Educated at Uppsala, Stockholm, Columbia and Cambridge universities, he was active in the Liberal Party, served as Foreign Minister 1978-79, and DirectorGeneral of the International Atomic Energy Agency 1981-97. As Executive Chair of the UN Monitoring, Verification and Inspection Commission for Iraq 2000-03, he pursued the issue of whether *Saddam Hussein had 'weapons of mass destruction' and an active nuclear program, but his work was truncated when the US made a pre-emptive strike in March 2003. Blix was bitterly attacked by George W. *Bush for his (understandable) failure to find WMDs. He published Disarming Iraq (2004).

Bloch, Ernest (1880-1959). American composer, born of Swiss-Jewish parents in Geneva. Educated in Switzerland and Germany, he studied the violin under Eugène *Ysäye, and became a teacher and conductor in Geneva. His opera Macbeth was produced in Paris in 1910. He lived in the US from 1916, teaching music in Cleveland 1920-25 and San Francisco 1925-30. He returned to Switzerland 1930-38, taught at the University of California 1939-52, but lived in Oregon. His works include the Israel Symphony (1916) and Schelomo ('Solomon'), a rhapsody for cello and orchestra (1936). He composed religious works and a large quantity of chamber music, reviving the Handelian form of the concerto grosso. Bloch was a thoughtful composer who never aimed at, or achieved, wide popularity. Many of his compositions have a Hebraic quality, while his violin concerto (1938) uses American Indian themes. 
Strassburg. R., Ernest Bloch: A Voice in the Wilderness. 1977; Kushner, D. Z., The Ernest Bloch Companion. 2002.

Blok, Aleksandr Aleksandrovich (1880-1921). Russian symbolist poet. Mysticism and romanticism distinguish his earlier poems, such as the cycle Verses about the Lady Beautiful (1904). He applauded the revolution of 1917, about which his poem The Twelve (1918) became famous. Later, his hopes of the new regime were disappointed. He died in poverty.

Kisch, C., Alexander Blok: Prophet of Revolution. 1960.

Blomstedt, Herbert Thorson (1927- ). Swedish conductor, born in Massachusetts. Still active at the age of 95, Blomstedt achieved cult status for his interpretations of *Beethoven, *Schubert, *Bruckner, ${ }^{*}$ Mahler, ${ }^{*}$ Nielsen and ${ }^{*}$ Sibelius, many downloadable on YouTube. He had been chief conductor of orchestras in Copenhagen, Dresden, San Francisco and Leipzig.

Blondel de Nesle (fl. c.1200). French troubadour. Tradition relates that when, in $1191,{ }^{*}$ Richard I ('Coeur de Lion'), returning from the First Crusade, was imprisoned by Leopold of Austria, Blondel discovered his whereabouts and so enabled his release to be secured by hearing the king responding to his song.

Blondin, Charles (né Jean François Gravelet) (1824-1897). French acrobat. In 1859 he crossed Niagara Falls on a tight rope, varying the act by being blindfolded, and pushing a man in a wheelbarrow.

Blood, Thomas (c.1618-1680). Irish adventurer. In 1671, dressed as a clergyman, he disabled the keeper and actually managed to escape with the crown under his arm while an accomplice carried off the orb. They were pursued, caught and imprisoned but later pardoned by ${ }^{*}$ Charles II.

Bloom, Claire (1931- ). English actor, born in London. She studied at the Guildhall School of Music and Drama, London and after working for the BBC, played Ophelia in Hamlet, Blanche in King John and Perdita in $A$ Winter's Tale at Stratford-upon-Avon in 1948. In 1952 she co-starred with Charles *Chaplin in the film Limelight and was highly praised. She then concentrated on stage and was noted for moving portrayals of Shakespearian heroines. She also acted in many films including Look Back in Anger, Alexander the Great, The Spy Who Came in From the Cold, A Severed Head, and in television series, A Legacy and Brideshead Revisited.

Bloomberg, Michael Rubens (1942- ). American businessman, philanthropist and politician, born in Boston. He amassed a fortune of \$US49 billion, was an independent and reforming Mayor of New York City 2002-13, was created an Hon. KBE, and contemplated a run for the Presidency in 2016, but withdrew in case his candidature helped to elect ${ }^{*}$ Trump or *Cruz. In 2020 he made a late entry into the Democratic contest.

Bloomer, Amelia (née Jenks) (1818-1894). American feminist, born in Homer, New York. She was remembered for her introduction of the 'rational' style of dressing for women originally a loose skirt and loose trousers gathered at the ankles. This costume and its later modifications came to bear her name. She was an ardent campaigner for temperance and female suffrage.

Blow, John (1648-1708). English musician. He composed the masque Venus and Adonis, in which Venus was played by Mary Davies before ${ }^{*}$ Charles II. He also wrote anthems and songs. For a time he was organist at Westminster Abbey. One of his pupils was *Purcell.

Clarke, H. L., John Blow. A Tercentenary Survey. 1949.

Blücher, Gebhard Leberecht von, Prince of Wahlstadt (1742-1819). Prussian general, born at Rostock, Mecklenburg-Schwerin. He joined the Swedish army in the Seven Years' War (1757), but having been immediately taken prisoner by the Prussians joined the army of his captors. Having resigned in 1772 he rejoined in 1793 to oppose the French revolutionary armies. In the ensuing campaigns he gained renown as a cavalry header. In 1806 , by then a lieutenant general, he was captured after the battle of Auerstadt, but was exchanged a fortnight later for the French general Claude VictorPerrin. When Prussia re-entered the war in 1813 he cleared Silesia and played an important part in *Napoléon's decisive defeat at Leipzig. Having fought his way through northern France in 1814 he entered Paris on 31 March. When Napoléon escaped from Elba, Blücher again took the field, was defeated at Ligny (16 June 1815), but rallied his troops and arrived at the decisive moment to complete *Wellington's victory at Waterloo.

\section{Bluetooth, Harald see Harald Bluetooth}

Blum, (André) Léon (1872-1950). French lawyer, writer and Socialist politician, born in Paris. From a secular Jewish family, he was shaken by the ${ }^{*}$ Dreyfus affair and inspired by Jean *Jaurès, who became a mentor. He worked in the civil service, edited Le Populaire 1921-42, 1946-50 and wrote a biography of *Stendahl. A deputy 1919-28, 1929-42, 1946-50, he was the main architect of the Popular Front of left-wing parties, including the Communists, between the wars and was Prime Minister for two short periods (1936-37,1938), the first Jew to head a ministry. For most of World War II he was interned in Germany. He was the foundation President of UNESCO 1946 and President of the Provisional Government of France and Minister 
of Foreign Affairs December 1946-January 1947, before the inauguration of the Fourth Republic (Vincent ${ }^{*}$ Auriol).

Blumenbach, Johann Friedrich (1752-1840). German physiologist and anthropologist, born in Gotha. He studied first in Jena, then in Göttingen, where he became professor of anatomy 1778-1835. One of the founders of physical anthropology and comparative anatomy, on the basis of measuring cranial angles and capacity, in 1779 he proposed the division of homo sapiens into five races: 'Caucasian' (a term he coined for 'white race'), Mongolian ('yellow'), Malayan ('brown'), Ethiopian ('black') and American ('red'). He believed that Adam and Eve had been Caucasian, and that this was the most beautiful race. Although his thesis was used as a scientific justification for racism, Blumenbach was a liberal who argued against slavery and recognised that racial differences were not innate but shaped by environment, diet and other physical factors. $\mathrm{He}$ influenced *Humboldt, was elected FRS and given honours in France, Sweden and the US.

Blunden, Edmund Charles (1896-1974). English poet and critic. His novel Undertones of War (1928) was based on his experiences in the Royal Sussex Regiment in World War I. His poetry, at first mainly pastoral, was issued in collected editions in 1930 and 1940. He also wrote a biography of Leigh ${ }^{*}$ Hunt and discovered and published works by John *Clare. Professor of English literature at Tokyo 1924-27 and at Hong Kong 1953-64, he was elected professor of poetry at Oxford in 1966.

Hardie, A. M., Blunden. 1958; Thorpe, M., The Poetry of Blunden. 1971.

Blunt, [Sir] Anthony Frederick (1907-1983). English art historian. Educated at Trinity College, Cambridge, recruited as an agent for the USSR, he served in the War Office 1940-45. Surveyor of the King's/Queen's Pictures 1945-72, Director of the Courtauld Institute of Art 1947-74, he held Slade chairs of fine art at Oxford 1962-63 and Cambridge 1965-66 and wrote books on Poussin and Blake. In 1979 he was revealed as the 'fourth man' (*Burgess and Maclean, *Philby) and stripped of his KCVO.

Blunt, Wilfred Scawen (1840-1922). English poet and traveller. He served in the diplomatic service (1859-70) but it is as a romantic figure that his memory survives - travelling in the Middle East, espousing the cause of Egyptian, Indian or Irish nationalism and writing passionate political verse or tender love poems. He married Baroness Wentworth, a granddaughter of *Byron. His Diaries appeared in 1922.

Lytton, E., Wilfred Scawen Blunt: A Memoir. 1961.
Blyton, Enid Mary (1897-1968). English writer for children. She trained as a nursery teacher, began publishing poetry (1917) and stories (1921), becoming enormously prolific in the 1930s. She published more than 400 titles, selling more than 200 million copies. Her characters, including Noddy and $\mathrm{Mr}$ Plod the policeman, were ubiquitous. Her plots were criticised, but not by her readers, as simple-minded, lacking in imagination and unduly conventional.

Boabdil (Abu Abdullah Mohammed XI) (14591527/8). Sultan of Granada 1482-92. He was the last Nasrid ruler of the Moorish sultanate of Granada in Spain before its capture (1492) by the troops of *Ferdinand and *Isabella.

Boadicea (or Boudicca) (d.62). Queen of the Iceni, a British tribe in East Anglia. On her husband's death (c.60) her territory was occupied by the Romans and, so it was said, her daughters ravished. In revenge she gathered an army, destroyed the Roman camp at Colchester and took St Albans and London before being defeated by the Roman governor, Suetonius Paulinus. She then committed suicide to avoid capture.

Dundley, D. R. and Webster. G., The Rebellion of Boudicca. 1962.

Boccaccio, Giovanni (1313-1375). Italian poet and author, born in Paris. Author of The Decameron, a famous collection of amusing, amatory and often bawdy tales, he was the illegitimate son of a Florentine merchant, sent for further study to Naples, where he began his literary career. The prosework Il Filicolo was followed by the verse romances Filostrato and Teseida (on the legends of Theseus, Palamon and Arcite), on which *Chaucer based his Troilus and Criseyde and his Knight's Tale respectively. It was in Naples, too, that he fell in love with Maria d'Aquino, an illegitimate daughter of King Robert. The title of his novel Faimena hides her identity. News of his father's threatened ruin brought him back to Florence in 1340 and there he became close friends with *Petrarch and *Dante, whose biography he wrote and whose poetry he expounded in his later years. The stories of the Decameron (finished in 1358) were ostensibly told by a group of young Florentines sheltering in the country during the plague of 1348 . Apart from its intrinsic interest, the Decameron was a stylistic model for future Italian writing, a source for countless other European writers, and a milestone in European literature, representing as it does a move towards realism and wholeheartedly secular themes. In 1362 * Petrarch restrained Boccaccio from destroying his works during a spiritual crisis; he then limited his writing to works of scholarship.

MacManus, F., Boccaccio. 1947. 
Boccherini, Luigi Rodolfo (1743-1805). Italian composer and cellist, born in Lucca. He studied in Rome, worked in Vienna, Paris, Madrid and Berlin, and wrote 90 string quartets and nine cello concertos. Although sometimes dismissed as '*Haydn's wife', he was an important innovator developing the string quartet and quintet and ${ }^{*}$ Mozart admired his concertos. He also wrote choral music and died in poverty in Madrid.

Rothschild, G. de, Luigi Boccherini. 1965.

Bodin, Jean (c.1530-1596). French political philosopher. Trained as a lawyer and appointed king's attorney by *Henri III, he accompanied the Duke of Alençon on his journey to England to request *Elizabeth I's hand in marriage. His books reveal views in advance of his time. In one, Les six livres de la république (1576), he introduces the idea of progress in history and anticipates *Hobbes in his statement of the need for a monarchy limited only by the laws of God and nature. His economic theories questioned much of the prevailing mercantilist doctrine.

Franklin, J. H., Jean Bodin and the Rise of Absolutist Theory. 1973.

Bodley, Sir Thomas (1545-1613). English bibliophile, born in Exeter. Brought up in Geneva, he became a fellow of Merton College, Oxford. On retirement from diplomatic work, which took him on several missions abroad, he offered to restore and re-equip *Humphrey, Duke of Gloucester's library at Oxford University. He devoted himself to this with great enthusiasm, buying books all over Europe and the name Bodleian Library acknowledged his work. $\mathrm{He}$ increased his benefaction by endowment and bequeathed the rest of his fortune to the university.

Boece, Hector (c.1465-1536). Scottish historian, born in Dundee. He completed his education at Paris University, where he met Erasmus and other humanist scholars. He was chosen (c.1500) to preside over the new university at Aberdeen. His vast and famous History of Scotland (written in Latin) appeared in 1527. Though it harbours a fair amount of fiction, the author makes some attempt to apply critical standards.

Boehme, Jakob (1575-1624). German mystic, born in Lusatia. Son of peasants, he became a cobbler, but spent much of his time in meditation and profound biblical study. His major works are Aurora, De signatura rerum and Mysterium magnum. In his theory, obscured by cloudy mystical language, all things come into existence by the separation of the original oneness, which is God, the nothing and the all, into discrete elements. Evil, in nature or in man, results from the efforts of single elements to become the whole. Boehme's works were studied in Holland and England (e.g. by Isaac *Newton) as well as in Germany, and interest in his work was revived in the 19th century, e.g. by ${ }^{*}$ Schelling, ${ }^{*}$ Hegel and *Schopenhauer.

Grunsky, H., Jacob Boehme. 1956.

Boeing, William Edward (1881-1956). American industrialist. A timber merchant in Seattle, he became an airmail contractor between Seattle and British Columbia and founded the Boeing Airplane Co. in 1917. He retired before the planes bearing his name-e.g. B-17 (Flying Fortress) and B-29 (Super Fortress) - became famous.

Boerhaave, Herman (1668-1738). Dutch physician. At Leyden University he studied the whole range of natural sciences, but then specialised in medicine, taking the chair of medicine and botany in 1709 . $\mathrm{He}$ was also professor of physics from 1714 and chemistry from 1718. The most famous medical and chemical teacher of the 18th century, he attracted students from many countries. The substance of his medical lectures appeared as the Institutiones medicae (1708), but his most important work was his Elementae chemiae (1732). Brought up in the rationalist tradition of *Descartes, Boerhaave was influential in introducing the English science of ${ }^{*}$ Boyle and ${ }^{*}$ Newton to the Continent. He accepted a corpuscular view of matter, and was deeply committed to the ideal of extensive experimentation, and strict quantification. The core of his system of medical ideas remained the mechanical theories of the 17th century, with their emphasis on the body as a system of hydraulics, pumps, physical pressures and devices such as levers and valves. But the nature of vital heat also preoccupied him, and his teachings on the nervous system look forward to the physiology developed by scientists, including ${ }^{*}$ Haller, later in the century.

King, L. S., The Medical World of the Eighteenth Century. 1958.

Boëthius, Anicius Manlius Severinus (c.480-525). Roman philosopher, theologian and administrator, born in Rome. From a patrician family, whose members included emperors and consuls, he was an administrator in the court of the Ostrogothic king *Theodoric the Great, and was appointed senator around 505. His first major work was De mathematica (c.500). His treatise De musica (c.510) was authoritative and many manuscript copies survive. Boëthius wrote extensively upon the corpus of Classical Greek texts, producing translations, commentaries, and fresh treatises in their own right. $\mathrm{He}$ was interested in *Aristotle's logical writings, and was a student of the Neo-Platonists. Most of his writings seem to be didactic in intention, and it is possible that he aimed to provide an encyclopaedic coverage of traditional learning. Boethius produced two works of philosophical theology, on the Trinity, and on the nature of Christ. He attempted to reconcile classical philosophy with Christian theology, using Greek logic to overcome the apparent paradox of the 
Trinity in which three persons were also one. Easily his most famous work is the Consolation of Philosophy written while in prison. This sets out, within a NeoPlatonic context, to prove that unaided reason can have certainty about the existence of an omnipotent God. He seeks to show that human free will is not incompatible with Divine foresight. It was one of the most popular books in the Middle Ages, and was translated into almost all the European languages. He was imprisoned from 522 and executed in Pavia, on a false charge of treachery.

Barret, H. M., Boethius, Some Aspects of his Times and Work. 1940; Chadwick, H., Boethius, the Consolations of Music, Logic, Theology and Philosophy. 1981; Manerton, J., Boethius. 2004.

Bogarde, Sir Dirk (Derek van den Bogaerde) (1921-1999). English actor and biographer. Between 1947 and 1980, he appeared in more than 60 films, graduating from light comedies to more serious roles, e.g. King and Country (1964), Death in Venice (1971) and The Night Porter (1975). He wrote a highly praised autobiography in six volumes.

Bogart, Humphrey (de Forest) (1899-1957). American film and stage actor. After several years of playing minor parts, his first big success came when he acted with Leslie Howard and Bette Davis as the gangster in The Petrified Forest (1934). This led to a long series of tough dramatic and romantic parts in 75 films including The Maltese Falcon, Casablanca, The Big Sleep, The Treasure of the Sierra Madre, Key Largo, The African Queen, Beat the Devil, Sabrina and The Caine Mutiny. In 1947 he married the actor Lauren Bacall.

Bohr, Niels Henrik David (1885-1962). Danish physicist, born in Copenhagen. Son of a professor of physiology, he studied at Copenhagen University and Trinity College, Cambridge, and was lecturer in physics at Manchester University (1914-16), where he worked with *Rutherford. In 1916 he became professor of physics at the University of Copenhagen, transferring to the Institute for Theoretical Physics when this was founded in Copenhagen (1922). Bohr also helped to develop quantum theory, applying it to the theory of atomic structure (1913), and he put forward the first theory of nuclear structure (1936). He won the Nobel Prize for Physics (1922) and the Copley Medal (1938). In September 1943, he escaped from German-occupied Denmark to neutral Sweden, then to Britain. He then flew to the US and advised on research that produced the atomic bomb. He was very influential in setting up CERN in Geneva (1957) and the International Atomic Energy Agency (1957). Asteroid 3948, a lunar crater and the element bohrium (No. 107) were named for him. His son, Aage Niels Bohr (1922-2009), was director of the Niels Bohr Institute for Theoretical Physics in Copenhagen and shared the 1975 Nobel Prize for Physics for work on investigating motion inside nuclei.

Moore. R. E., Niels Bohr, The Man and the Scientist. 1967; Frayne, M., Copenhagen. 1958.

Boileau, Nicolas (1636-1711). French poet and critic. In his satires and burlesques he gives a realistic first-hand portrayal of bourgeois life in the reign of ${ }^{*}$ Louis XIV. He was the friend of many well known writers and especially of ${ }^{*}$ Racine, with whom he shared the honour of being made historiographer royal. His verse treatise L'Art poétique (1674) won great contemporary esteem for its statement of classical literary principles. Renowned in his lifetime as the 'law-giver of Parnassus', his reputation did not survive the era of Romanticism, to which his views were anathema.

Brody, J., Boileau and Longinus. 1958.

Boito, Arrigo (1842-1918). Italian poet and composer, born in Padua. He studied in Milan and composed the opera, Mefistofele (1868). He wrote excellent libretti for *Verdi's Otello and Falstaff.

Bokassa, Jean-Bédel (1921-1996). Central African marshal and politician. He joined the French army in 1939 and was Commander-in-Chief of the Central African Republic's forces from 1963, seized power in a coup in 1965 and became President 1966-79. In 1976 he proclaimed himself as Emperor but was overthrown in 1979, went into French exile 1979-86, then returned to the CAR to face trial. Sentenced to death, he was reprieved and condemned to forced labour. He was released in 1993.

\section{Boleyn, Anne see Anne (Boleyn)}

Bolger, Jim (James Brendan) (1935- ). New Zealand National politician. A farmer, he was a Member of Parliament 1972-98, served as Minister for Labour 1978-84 and for Immigration 1978-81 under *Muldoon and on Labour's defeat became Prime Minister 1990-97. In 1996, after adoption of an MMP system, he formed a Coalition Government with Winston *Peters of the New Zealand First Party. Jenny *Shipley displaced him as Prime Minister in December 1997. He was Ambassador to the US 1998-2001 and then entered business.

\section{Bolingbroke, Henry of, Duke of Hereford and Duke of Lancaster see Henry IV}

Bolingbroke, Henry St John, 1st Viscount (16781751). English Tory politician. Entering parliament in 1701 as member for the family borough of Wootton Bassett, Wiltshire, he attached himself to Robert ${ }^{*}$ Harley and intrigued skilfully for the Tory cause. In the Tory Ministry which began in 1710 he became a Secretary of State and conducted the negotiations which led to the Treaty of Utrecht (1713). He became Viscount Bolingbroke in 1712 and, as Harley's power 
declined, rose to leadership. He had tried secretly to secure the succession of the Old Pretender (James *Stuart) and had openly dismissed Whig officers, replacing them with Tories. When ${ }^{*}$ George I became king on the death of Queen Anne, he fled to Paris, where he helped to plan the Jacobite rising of 1715 . In 1723 he was allowed to return. *Walpole denied him the right to sit in the House of Lords, but Bolingbroke led the opposition to him, particularly with the brilliant letters published in the Craftsman. In his later years he wrote the Idea of a Patriot King (1749), in which he envisaged the king standing above and removed from party faction and serving the interests of the nation as a whole. ${ }^{*}$ George III's attempt to put these ideas into practice disastrously failed. Bolingbroke is remembered as a brilliant orator, a profligate, and a skilful if unscrupulous intriguer and propagandist.

\section{Dickinson, H. T., Bolingbroke. 1970.}

Bolívar, Simón (1783-1830). South American revolutionary soldier, known as 'the Liberator', born in Caracas (Venezuela). He came from an ancient Basque family which had lived in Venezuela for 200 years. A tour of Europe during the early years of *Napoléon's power awakened a mind already inspired by the writings of*Voltaire and ${ }^{*}$ Rousseau to an interest in public affairs. It is said that it was in Rome (1805) that he determined to liberate South America from Spanish domination. He took part, under *Miranda's leadership, in the formation of the first Venezuelan republic and when that was overthrown was allowed to leave the country unharmed. Eventually, in 1813, in New Granada (Colombia) he was put in command of a force of 600 men and defeated the isolated Spanish detachments one by one to re-occupy Venezuela's capital at Caracas. But again the Spaniards rallied and restored the situation. Undismayed Bolívar collected a new army, secured Angostura in 1816 and by a daring winter march over the Andes drove the Spanish viceroy from Bogota (Colombia). Venezuela was finally gained after the battle of Carabobo in 1821; the liberation of Ecuador followed almost at once. This was linked with the republic of Gran Colombia (Colombia and Venezuela), already formed under Bolívar's presidency. Meanwhile General Jose de * San Martin had liberated the South with Chile and had entered Peru, which was Bolívar's next objective, but all possibility of a clash was avoided by San Martin's unselfish resignation in Bolívar's favour. Victories at Junin (August 1824) and the final triumph at Ayacucho (December) ended Spain's era of domination, and Upper Peru was named Bolivia in honour of its liberator. But faction and jealousy prevented his dream of a South American federation and the same influences turned against himself so that he was forced to resort to dictatorial methods which provoked hatred. He resigned from the presidency shortly before his death, but time has reinstated him as the greatest of South American heroes. He died poor in Santa Marta, Colombia and was buried in Caracas.

Masur, G., Simon Bolivar. 1969; Bushnell, D., The Liberator: Simon Bolivar. 1970; Arena, M., Bolivar. American Liberator. 2013.

Böll, Heinrich Theodor (1917-1985). German novelist, born in Cologne. He served in the German forces during World War II and became a full-time writer in 1947 . His works, pre-occupied with the implications of German war guilt, attack all forms of authoritarianism and bureaucracy and include The Unguarded House (1954), Billiards at Half-Past Nine (1961), The Clowns (1963), Group Portrait of a Lady (1973) and The Lost Honour of Katharina Blum (1974). He received the 1972 Nobel Prize for Literature and was President of International PEN 1971-74.

Reid, J. H., Heinrich Böll. 1973.

Bolsonaro, Jair Messias (1955- ). Brazilian politician, born near São Paulo. An army officer 197388, he represented Rio de Janeiro in the National Congress 1991-2018 as an outspoken conservative on social issues and a strong nationalist. Elected in October 2018 with 55 per cent of the vote, he served as President of Brazil 2019-23, the first conservative to win since 1990 . He promoted Trumpian, authoritarian policies, sceptical about climate change, the Covid pandemic and female liberation. He began stripping the Amazonian rainforest and Covid deaths were second only to the US. After a bitterly polarised campaign he was defeated narrowly ( 51 per cent to 49 per cent) in October 2022 by Luiz Ignácio *Lula da Silva.

Bolt, Robert Oxton (1924-1995). English dramatist, born in Manchester. Educated at Manchester Grammar School and Manchester University, he became a schoolmaster. Flowering Cherry (1957) was his first successful play, a 'Chekhovian study of failure and self-deception'. His third play $A$ Man for All Seasons (1960), a sympathetic study of Thomas *More, was also filmed (1966). Other plays included The Tiger and the Horse (1960), Gentle Jack (1963), Vivat! Vivat! Regina! (1970). He scripted the films Lawrence of Arabia, Doctor Zhivago, Ryan's Daughter, The Mission and Lady Caroline Lamb (which he directed).

Bolte, Sir Henry Edward (1908-1990). Australian Liberal politician, born in Ballarat. A farmer, he was an army sergeant in World War II and a Member of the Victorian Legislative Assembly 1947-72. An unexpected choice as Liberal leader, following the Labor split of 1954-55 he defeated John ${ }^{*}$ Cain and served as Premier of Victoria for a record term 195572. Authoritarian, but shrewd and often underrated, he retired at a time of his own choosing. 
Boltzmann, Ludwig Eduard (1844-1906). Austrian physicist, born in Vienna. He taught at Graz, Vienna, Munich and Leipzig, worked (independently from ${ }^{*}$ Maxwell) on the kinetic theory of gases and devised the 'Boltzmann constant' (the ratio of the mean total energy of a molecule to its absolute temperature). $\mathrm{He}$ modified the second law of thermodynamics to introduce the concept of probability; this led to statistical mechanics. He also grasped the significance of information theory and proposed (1894) that 'entropy is missing information'. Boltzmann hanged himself, feeling isolated over atomic theory.

Bonaparte (Buonaparte). Corsican-French family which migrated from Italy in the 16th century, made famous by *Napoléon I. His father, Carlo Buonaparte (1746-1785), was a lawyer. His mother, Letizia Ramolino (1750-1836), came of an old Corsican family. She was the Madame Mère of imperial history, a strong personality in her own right, who, however, eschewed political power. The fortunes of her other children were dependent upon their famous brother. Joseph (1768-1844), who married Julie Clary (*Bernadotte), was made king of Naples in 1806 and transferred to the throne of Spain in 1808. He was a competent administrator but the Peninsular War prevented effective rule. He abdicated in 1813. After Waterloo he farmed in the US until 1832 and finally settled in Florence. Lucien (1775-1840) was President of the Council of 500 in 1799 and played a decisive part in the coup d'état, which brought Napoléon to power. A republican by conviction he dissociated himself from his brother's policies but gained a large fortune by speculation. He was captured by the English army on the way to America in 1810 and imprisoned for the rest of the war. Louis (1778-1846), a soldier, married Hortense de Beauharnais, daughter of *Josephine, later Napoléon's empress, in 1802 and was father of the future *Napoléon III. Napoléon made him King of Holland in 1806 but forced him out in 1810 when he refused to join the Continental blockade against English trade. He lived in Switzerland, then in Italy, devoting himself to literature. The youngest of the brothers, Jerôme (1784-1860), married Elizabeth Patterson while in America as a young man. Later, as King of Westphalia 1806-13, he was forced to marry Princess Catherine of Württemberg, and their descendants maintained the Bonapartist claims. Jerôme returned to influence and office under Napoléon III. He was created a marshal of France in 1850. Of the sisters of this imperial brotherhood, Élisa (née Maria Anna Bonaparte, later Baciocchi Lévoy) (1777-1820), was created Princess of Piombino and Lucca in 1805, and Grand Duchess of Tuscany in 1809; after her first husband General Charles Leclerc died, the fascinating and frivolous Pauline (née Maria Paolo Bonaparte) (1780-1825) married Prince Camillo Borghese, was created Process of Guastalla, and became the subject of a semi-nude sculpture, Venus Victrix, by *Canova. Niccolo *Paganini was one of her lovers; Caroline (née Maria-Annonciata Carolina Bonaparte, later Murat) (1782-1839) married Joachim *Murat, Napoléon's dashing cavalry general and was queen consort of Naples 1808-15.

Markham, F., The Bonapartes. 1975.

\section{Bonar Law, Andrew see Law, Andrew Bonar}

Bonaventura, St (Giovanni di Fidenza) (12211274). Italian theologian, born near Orvieto. $\mathrm{He}$ studied in Paris and entered (1243) the Franciscan Order of friars of which he finally became general (1256). In 1274 he was appointed cardinal and Bishop of Albano. He died during the Council of Lyon, and was canonised in 1482. His mystical philosophy earned him the name 'seraphic doctor'. As general he did much by tact and personality to reconcile the differences between those who demanded strict adherence to the order of absolute poverty laid down by St *Francis and those who pointed out the impracticability of such rigour, as well as the evils of mendicancy. Bonaventura adopted a middle way: he enjoined the strictest simplicity of life but allowed certain departures from the letter of the rule, e.g. by defending the friars' right to receive offerings. In disputes between friars and regular clergy he strongly defended the friars' rights, e.g. to hear confession and preach without clerical permission. Bonaventura's theological writings remain important.

Bondarchuk, Sergei Fedorovich (1920-1994). Russian film actor and director, born in the Ukraine. A notable stage Othello (1956), his masterpiece was the four-part film War and Peace (1962-67) which he directed and in which he played the role of Pierre Bezukhov. This won the 1968 Oscar for best foreign film.

Bondfield, Margaret Grace (1873-1953). English Labour politician, born in Somerset. She became an organiser with the shop assistants' union, was a Member of Parliament 1923-24 and 1926-31 and the first British woman Cabinet member as Minister of Labour 1929-31. The first woman to be appointed a Privy Counsellor (1929), she was awarded a Companion of Honour (1948).

Bondi, Sir Hermann (1919-2005). Austrian-British mathematician and cosmologist, born in Vienna. With Fred *Hoyle and Thomas Gold he was a proponent of the now discredited 'steady state' theory of the universe. He was a professor at King's College, London, 1954-85 and Master of Churchill College, Cambridge, 1983-90.

Bonhoeffer, Dietrich (1906-1945). German Protestant pastor and theologian, born in Breslau, Prussia (now Wroclaw, Poland). He studied at the universities of Tübingen, Rome and Berlin 1923-27 and was then ordained a Lutheran minister. After working in Barcelona, New York and Britain, he became a lecturer at the University of Berlin in 1931, 
and from 1933 spoke for the German Protestant opposition to the Nazis. He left Germany in 1933 but returned in 1935 as head of the seminary at Finkenwalk, and as a member of the Military Intelligence Department worked secretly with the resistance. Arrested in April 1943, he was held at Tegel, briefly at Buchenwald, then at Flossenberg, where he was hanged, naked, in April 1945, together with Admiral *Canaris, a fortnight before US troops liberated the camp. His brother and brother-in-law were also executed, elsewhere, for their suspected involvement in the 1944 plot against ${ }^{*}$ Hitler. A radical theologian, Bonhoeffer rejected much of the apparatus of traditional Christianity. His posthumous published works include Letters and Papers from Prison (1953), The Cost of Discipleship (1959) and Acting and Being (1962).

Bethge, E., Dietrich Bonhoeffer. 1970.

Boniface, St (originally Wynfrith) (c.675-754). English missionary, born in Wessex. Educated in Benedictine monasteries at Exeter and Nursling, he became abbot of Nursling in 717. A preliminary mission to Germany failed, but in 718 he went to Rome and was commissioned by Pope Gregory II to resume his task of converting the heathen. His method was to follow up his preaching by building churches and monasteries and planting little colonies of monks and nuns. Successes in Hesse and Thuringia led to his appointment as bishop of a new German church east of the Rhine, which, having become an archbishop (c.732), he divided into the dioceses of Salzburg, Freising, Regensburg and Passau. Re-organisation of the Frankish Church followed and he is reputed to have anointed *Pepin as king. In 753 Boniface resumed his missionary work in Friesland, but in the following year he and 50 of his followers were killed in a pagan attack. He was buried at Fulda Abbey in Hesse, a future centre of learning which he had founded. His feast day is 5 June.

Reuter, T. A. (ed.), The Greatest Englishman. 1980.

Boniface (Bonifatius) VIII (Benedetto Caetani) (1235-1303). Pope 1294-1303. Trained in law and experienced in papal diplomacy he succeeded ${ }^{*}$ Celestine $\mathrm{V}$, whose resignation he helped to bring about. Despite his ability and energy he failed to maintain the temporal supremacy of the papacy against ${ }^{*}$ Edward I of England and *Philippe IV of France. He was attacked by ${ }^{*}$ Dante in the Commedia.

Bonington, Richard Parkes (1801-1828). English painter in France. He grew up in France, devoted himself to watercolours until 1824, then turned to oils. A friend of ${ }^{*}$ Delacroix, he greatly admired ${ }^{*}$ Constable, and his seascapes, landscapes and travel scenes were popular in London and Paris.

Bonnard, Pierre (1867-1947). French painter. From about 1890 to 1899 he belonged with *Vuillard and others to a Symbolist group of Post-Impressionist painters called the 'Nabis' (after a Hebrew word for prophet), mainly inspired by *Gauguin. Bonnard's particular circle was known as 'Intimists'. After 1900, Bonnard developed an individual style, not working, like the Impressionists, direct from nature but from memory. Subtle light and colour effects provide the main theme of subjects such as landscapes, gardens, sailing boats, and nudes in various outdoor and indoor settings.

Ferminger, A., Pierre Bonnard. 1969.

Bonnet, Georges-Etienne (1889-1973). French Radical politician. He served as a Deputy 1924-40 and 1956-68. As Foreign Minister 1938-39, he took part in the Munich Conference, supported 'appeasement' and was equivocal under *Pétain.

Boole, George (1815-1864). English mathematician and logician, born in Lincoln. Son of a shoemaker, he was largely self-educated, became a schoolteacher and professor of mathematics at Queen's College, Cork 1849-64. Boole pioneered modern symbolic logic and his 'algebra of logic' is one of the basic principles used in modern computer design, especially in 'binary switching', where quantities can be expressed by using only two symbols (0 and 1$)$. 'Binary logic' led to the creation of the NOT, AND and OR gates in computers.

Boone, Daniel (1735-1820). American pioneer, born in Pennsylvania. In 1750 his family moved to the frontier of North Carolina. He gained his first experiences of frontier wars as blacksmith and teamster in General Edward Braddock's campaign of 1755, but the heroic legends that have attached themselves to his name date from when he first entered Kentucky in 1767 and subsequently colonised and opened up the country, hunting, exploring and fighting Indians the while.

Boot, Jesse, 1st Baron Trent (1850-1931). English pharmacist and manufacturer, born in Nottingham. His father bought a herbal medicine shop in 1849 , and after he died, Jesse Boot assisted his mother from the age of 10 , opening his own business in 1877 . He founded Boots Pure Drug Co. in 1888. The Boots chain, calling itself 'Chemists to the Nation', both manufactured and retailed drugs, and diversified into libraries and bicycles. Jesse Boot was an active Liberal and a generous donor to the University of Nottingham. Boots was sold to American investors in 1920, returned to UK ownership in 1933, moved to Switzerland in 2007 and Walgreen's bought it in 2012 .

Booth, John Wilkes (1838-1865). American actor, born in Maryland. He assassinated Abraham ${ }^{*}$ Lincoln in Washington in April 1865 as an act of revenge for the Union's defeat of the Confederacy. He escaped to Virginia, where he was shot by troops. His father, Junius Brutus Booth (1796-1852) was an actor who, having made successes in Shakespearian 
parts, especially Richard III, emigrated to America in 1821 and there enjoyed a successful career, but, owing to alcoholism and melancholia, died insane. Edwin Thomas Booth (1833-1893), the assassin's brother, acted with his father for some years. He also acted in Australia in 1854. The success of his Hamlet in New York in 1864 marked him out as one of the foremost actors of the day. During a European tour (1880-82) his Othello, played to *Irving's Iago, was enthusiastically received. His 1890 recording of a speech from Othello can be heard on YouTube.

Smith, G., American Gothic. 1988.

Booth, William (1829-1912). English religious leader, born in Nottingham. Founder of the Salvation Army, he was an evangelist with the Methodist New Connexion for many years. Having left them to act independently, he founded, in 1865, a mission in Whitechapel, London, which proved to be the forerunner of the Salvation Army, established in 1878. He introduced military methods, uniform and discipline into evangelising work, 'General' Booth himself being in supreme command. The organisation, which spread over the world, became known for the rousing music of its open-air services, its shelters for the down-and-out and the courage with which its members penetrated the most degraded districts of the great cities. His son (William) Bramwell Booth (1856-1929), a capable organiser, succeeded his father as 'General' 1912-29 and was awarded the CH. Bramwell's sister, (Cory) Evangeline Booth (1865-1950), directed the Salvation Army in the US 1904-34 and became 'General' 1934-39. Bramwell's daughter, Catherine Bramwell Booth (1883-1985) was an effective publicist for the Army.

Collier, R., The General Next to God. 1965.

Boothroyd, Betty, Baroness Boothroyd (1929- ). English Labour politician. She worked as a political secretary, became an MP 1973-2000 and the first woman to be elected Speaker of the House of Commons 1992-2000. She received the OM in 2005 .

Borden, Lizzie Andrew (1860-1927). American accused murderer. She was 'heroine' of one of the most famous of American trials and of a rhyme commemorating it. In 1892 her stepmother and father were hacked to death with an axe at their home at Fall River, Massachusetts. She was tried for their murder and acquitted.

Borden, Sir Robert Laird (1854-1937). Canadian politician, born in Nova Scotia. Distantly related to Lizzie *Borden, he became prominent as a lawyer before his election to the Canadian Parliament 1896-1904; 1905-20. He led the Conservative Party 1901-20, won the election of 1911 and, as Prime Minister 1911-20, guided the country through World War I. By insisting upon Canada's signing the treaty of Versailles separately from Great Britain he confirmed its status as a sovereign independent state. He resigned in 1920 and was succeeded by Arthur *Meighen.

Wilson, H. A., The Imperial Policy of Sir Robert Borden. 1966.

Bordet, Jules (1870-1961). Belgian bacteriologist. He won the Nobel Prize for Medicine (1919) for discovering the bacillus of whooping cough.

Borelli, Giovanni Alfonso (1608-1679). Italian scientist. In his early career he was chiefly a mathematician, becoming professor of mathematics at Messina in 1640 and professor at Pisa in 1656. He examined the mechanical basis of respiration, circulation, nerves, and above all muscular activities. He closely studied the processes whereby the brain communicated physical impulses to muscles via the nervous system, and tried to calculate the quantity of force involved. He was interested in the physical force required to pump blood round the body, and studied digestive processes (which he believed were chiefly mechanical rather than chemical). He made accurate observations of Jupiter's satellites and studied volcanic eruptions on Etna.

Borges, Jorge Luis (1899-1986). Argentinan poet, critic, short story writer and essayist, born in Buenos Aires. He learned English at home (his mother was a translator), was educated in Buenos Aires and Geneva, lived in Spain 1920-21 and became associated with the ultraismo movement in poetry, which he introduced to Argentina. His volumes of poetry include Ferver de Buenos Aires (1923) and Luna de enfrente (1925). His tales, revealing a baroque imagination, a taste for the arcane and an interest in metaphysical problems, appear in such collections as Ficciones 1935-44 (1944, English translation 1962). Other important works include El Aleph (1949), Extraordinary Tales (1955), Labyrinths (1962) and The Book of Imaginary Beings (1967). He was librarian 1938-47, demoted to market inspector by *Perón, but appointed director of the National Library in 1955 just as he became totally blind.

Borghese. Italian noble family, originally from Siena, then Rome. Camillo Borghese became Pope ${ }^{*}$ Paul V. His nephew, Cardinal Scipio Borghese (1577-1633), a patron of ${ }^{*}$ Bernini, built the Villa Borghese to house his treasures. It was rebuilt and extended in 1782 and remains one of Rome's greatest galleries. The existing collection (now state property) was mainly brought together by Prince Camillo Borghese (1775-1832), husband of *Napoléon's sister, Pauline. The Borghese palace is one of the most magnificent in Rome.

Borgia, Cesare (1476-1507). Italian soldier. Son of Pope *Alexander VI, he was made a cardinal by his father in 1493 but gave up the office five years later. A mission to France in 1498 carrying papal dispensation for ${ }^{*}$ Louis XII to marry *Anne of 
Brittany was rewarded with the duchy of Valentinois and the promise of help in the Romagna, which it was Alexander VI's policy to unite and rule. This aim was achieved by Cesare in three campaigns in which guile and military skill were artfully combined. His father's death in 1503 caught him ill and unprepared to meet his enemies. Arrested in Neapolitan territory he escaped from a prison to die fighting at last in the cause of his brother-in-law, the King of Navarre. His political tactics, often treacherous, were described with a mixture of horror and fascination in *Machiavelli's The Prince.

Sacerdote, G., Cesare Borgia. 1950.

Borgia, Lucrezia, Duchess of Ferrara (1480-1519). Italian noblewoman, born in Rome. Daughter of the Spanish cardinal Rodrigo Borgia, later Pope *Alexander VI, and sister of Cesare, she married first Giovanni Sforza, second the Duke of Biscelgie, and third the Duke of Ferrara. She was often accused of complicity in her family's crimes and moral excesses, though there is no evidence to support her active participation. In fact, she left a reputation for learning, beauty and charity, and was said to have enjoyed the respect of her subjects. In 1501 she appeared with the mysterious Roman Infant, Giovanni, her supposed natural son. Two papal bulls recognised him first as Cesare's illegitimate son, then Alexander's. The latter was probably the true father. This and Lucrezia's attendance at an infamous orgy held at the Vatican led to rumours of incest. On Alexander's death in 1503 Lucrezia ceased to be a political pawn and led a more normal life at the court of Ferrara, which became a cultural centre of the Italian Renaissance.

Borglum, (John) Gutzon (de la Mothe) (18671941). American sculptor. Obsessed by the monumental sculptures of ancient Egypt, his works include the huge bust of ${ }^{*}$ Lincoln in the Capitol Rotunda, Washington DC, and the heads of *Washington, *Jefferson, *Lincoln and Theodore *Roosevelt carved on Mt Rushmore, South Dakota (memorably featured in *Hitchcock's film North by North-West). He supported the Ku Klux Klan.

Borg Olivier, Giorgio (1911-1980). Maltese Nationalist politician. The political history of Malta in the years preceding independence (September 1964) were largely struggles for power between Borg Olivier's party, with strong clerical backing, and Dom *Mintoff's Labour Party. He was Prime Minister 1950-55 (under British rule) and 1962-71.

Boris I (?d.907). Prince of Bulgaria 853-88. Regarded as a national saint, he succeeded his father, and was baptised (865) into the Greek Church, to which he confirmed his allegiance in 870 , though in the intervening year he had addressed a questionnaire to Pope Nicholas II, obviously with a view to change. He abdicated in favour of his son Vladimir (888), but four years later left the monastery to which he had withdrawn to blind and depose the new king and substitute his second son, Symeon.

Boris III (né Boris Klemens Robert Maria Pius Ludwig Stanislaus Xaver von Saxe-Coburg-Gotha) (18941943). Tsar of Bulgaria 1918-43. He succeeded his father *Ferdinand, who had been forced to abdicate after World War I and, despite a strange passion for driving steam trains, was generally regarded as a well-meaning monarch with considerable skill at balancing opposing factions. Willingly or unwillingly, he became *Hitler's ally in World War II, but courageously refused to deport Bulgarian Jews or send troops to fight the USSR. After being summoned to visit Hitler in August 1943, three weeks later he died mysteriously: either a heart attack or poisoning. His son *Simeon II succeeded him.

\section{Boris Godunov see Godunov, Boris}

Borlaug, Norman Ernest (1914-2009). American agronomist. Working in Mexico on wheat and maize improvement from 1944, he became the most important figure in the 'Green Revolution', receiving the Nobel Peace Prize in 1970.

Bormann, Martin (1900-1945). German Nazi functionary. He joined the Nazi Party in 1927 and was personal secretary to Rudolf ${ }^{*}$ Hess 1933-41. After Hess' eccentric flight to Scotland, Bormann became *Hitler's deputy 1941-45, and remained with him until his death. He disappeared at the end of the war, and was tried and condemned to death in absentia at the Nuremberg War Crimes Tribunal. There was much speculation that he had escaped to South America, but the discovery of his remains in 1972 confirmed that he died in Berlin.

Trevor Roper, H. (ed.), Bormann Letters. 1954.

Borodin, Aleksandr Porfirievich (1833-1887). Russian composer, born at St Petersburg. Illegitimate son of a prince, he first trained as a chemist and his musical studies began in 1862 under *Balakirev. His works include three symphonies (one unfinished), the unfinished opera, Prince Igor and In the Steppes of Central Asia.

Dianin, S., Borodin. 1963.

Borotra, Jean (1898-1994). French tennis player. Known as 'the Bounding Basque', he won the men's singles at Wimbledon in 1924 and 1926 and the men's doubles with Jacques Brugnon in 1932 and 1933. Borotra, Cochet and *Lacoste, who dominated French lawn tennis for many years, were known as 'The Three Musketeers'.

Borromeo, St Carlo (1538-1584). Italian prelate, born in Arona. From a noble Milanese family, and a nephew of Pope Pius IV, he was made a cardinal before he was a priest. His ordination took place in 1563 and enabled him to become Archbishop of 
the See of Milan, of which he had so far been only the administrator. Meanwhile as Papal Secretary of State he was attending the final sessions (1563-64) of the Council of Trent and took the leading part in its success by formulating the decisions by which the Roman Church put its house in order and was so enabled to resist the spread of Protestantism. Later in his own diocese he put the reforms into practice, himself setting an example by his austere and simple life. Canonised in 1610, his biography was written by Pope *John XXIII. A kinsman, Federico Borromeo (1564-1631), also Cardinal-Archbishop of Milan, founded the Ambrosian Library there.

Borromini, Francesco (Francesco Castelli) (15991667). Italian architect and sculptor, born in Ticino. He worked in Rome with *Bernini, then became his rival, and was noted for his use of spectacular effects and pioneered the Baroque style. He designed three masterpieces in Rome. San Carlo alle Quattro Fontane (1638-41), appears weightless, with its beehive dome and interplay between concave and convex shapes. Sant'Ivo alla Sapienza (1642-50) has an interior marked by tension between concave and convex elements and has a surging quality, in constant movement. The Re Magi chapel in the Collegio di Propaganda Fide (1660-65), is small, restrained, contemplative and soothing. Borromini was melancholic, probably bipolar, and committed suicide by falling on his sword.

Morrissey, Jake, The Genius in the Design. Bernini, Borromini and the Rivalry that Transformed Rome. 2005.

Borrow, George (Henry) (1803-1881). English author and traveller. Son of a Cornish army captain, he was educated at the Royal Grammar School, Norwich, but studied languages in preference to law. In London he helped compile the Newgate Calendar but soon left (1825) to take up a wandering life, either alone or with gypsies, describing them in Lavengro (1851) and Romany Rye (1857). He worked for the British and Foreign Bible Society in Russia and Spain (1832-40) and wrote The Bible in Spain (1843). Spanish gypsies are the theme of The Zineali (1841). Wild Wales appeared in 1862 and in 1874 Romano Lavo-Lil, a much criticised book on the gypsy language.

Myers, R. R., George Borrow. 1966.

Bosch, Carl (1874-1940). German chemist and engineer, born in Köln. Nephew of Robert Bosch, who produced the first successful spark plug, he studied at Leipzig. Pioneering high pressure chemistry to synthesise nitrates, with Fritz ${ }^{*}$ Haber he developed the Haber-Bosch nitrogen fixation process (190809), enabling large-scale production of ammonia and fertiliser. In 1925 he organised the merger of six large German chemical companies to become IG Farben.
He shared the 1931 Nobel Prize for Chemistry, was hostile to the Nazis, denied work and became an alcoholic. Asteroid 7414 Bosch was named for him.

Bosch, Hieronymus (originally van Aeken) (c.1450-1516). Dutch painter, born probably at Hertogenbosch. He spent his life in his presumed birthplace and adopted its name. His paintings, strongly imbued with the fantastic and full of bizarre composite figures and grotesques, are perhaps the most extreme expression of the haunted mood of the late Middle Ages; the significance of his symbolism is now largely lost. Among the best known of his works are the Seven Deadly Sins, The Hay Wain, The Earthly Paradise and The Temptation of St Anthony. He was regarded by the Surrealists as an important precursor. His earlier work (e.g. The Adoration of the Kings) follows the tradition of Flemish religious art.

Combe, J., Bosch. 1957.

Bose, Amar Gopal (1929-2013). American-Bengali inventor, born in Philadelphia. Educated at the Massachusetts Institute of Technology, he founded the Bose Corporation in 1964, manufacturing outstanding home audio equipment and was a major benefactor to MIT.

Bose, (Sir) Jagadish Chandra (1858-1937). Indian (Bengali) polymath, born in Bikrampur. Educated in Calcutta (Kolkata), London and Cambridge, he experimented in an extraordinary diversity of fields: radio and microwave optics, discovery of millimetre length electro-magnetic waves, plant physiology (inventing the crescograph, which measured comparable electrical responses to stimuli by animal and plant tissues), the polarisation of rays by crystals, the first use of semiconductor crystals as detectors for radio waves, then analysed electrical responses in metals. He was also the first Bengali writer of science fiction and took a deep interest in archaeology. Knighted (1917) and elected FRS (1920), he never received a Nobel Prize but is now regarded as having been (as Sir Nevill Mott said) 'at least 60 years ahead of his time'. He refused to patent his discoveries and his working conditions at the University of Calcutta were very primitive.

Bose, Satyendra Nath (1894-1974). Indian (Bengali) mathematician and physicist, born in Calcutta (Kolkata). Educated at Calcutta, where he was inspired by (but not related to) J. C. *Bose, he taught at Calcutta and Dhaka Universities, working on $\mathrm{X}$-ray crystallography, relativity and quantum theory. He was also a linguist with profound knowledge of anthropology, zoology, geology and engineering. A pioneer of 'particle statistics' (1922), his methodology was adopted by *Einstein, and is now called 'BoseEinstein statistics'. He also proposed (1925) what are now called 'Bose-Einstein condensates', proposing the clumping together of elementary particles, a concept that was theoretically attractive, but not able 
to be proven until 2012. The 'boson', defined as 'any of a class of particles, such as the photon, pion, or alpha particle, that have zero or integral spin and obey statistical rules permitting any number of identical particles to occupy the same quantum state', was named for him by Paul ${ }^{*}$ Dirac. He never received a Nobel Prize but was elected FRS in 1958.

Bose, Subhas Chandra (1897-1945). Indian nationalist leader, born in Orissa. Educated at Calcutta and Cambridge universities, he opposed *Gandhi's policy of non-violent resistance to the British. In World War II he escaped to Germany and later became head of a provisional government of India under Japanese sponsorship. He is said to have met his death in an air crash. The Kolkata/Calcutta international airport is named after him.

Bossuet, Jacques Bénigne (1627-1704). French bishop, historian, and rhetorician, born in Dijon. Precocious, he was tonsured at the age of 10 and after instruction from $(\mathrm{St}){ }^{*}$ Vincent de Paul became a priest. A master of baroque rhetoric, he was famous for his funeral orations, including those for ${ }^{*}$ Henrietta Maria, widow of ${ }^{*}$ Charles I, and the great *Condé. Bishop of Condom 1669-70, he became tutor to the Dauphin Louis (1661-1711), was elected to the Académie française and had great influence at court until his appointment as Bishop of Meaux 1681-1704. He supported Gallicanism, asserting that the king could exercise jurisdiction over the French Church, approved the revocation (1685) of the Edict of Nantes, removing legal protection for Protestantism (but then urged moderation), and obtained Rome's condemnation of *Fenelon's doctrine of Quietism (a passive form of religious mysticism). He wrote Discours sur l'histoire universelle (1681) and corresponded with *Leibniz.

Calvet, J., Bossuet. 1968.

Boswell, James (1740-1795). Scottish author and biographer, born in Edinburgh. Son of Lord Auchinleck, a judge, he was called to the bar but found his main interest in literature. In 1760 he went to London, living as an energetic libertine, and in May 1763 first met Dr Samuel *Johnson, taking notes of the conversations and opinions of the famous lexicographer until his death in 1784 . Between 1764 and 1766 he toured the Continent, introduced himself to ${ }^{*}$ Voltaire and ${ }^{*}$ Rousseau and had numerous love affairs. His Account of Corsica (1768) commemorated a visit to the island's hero, Pasquale di *Paoli. In 1773 he took Johnson to the Hebrides but it was 12 years before the appearance of Journal of a Tour of the Hebrides (1785). In 1791 he published the Life of Samuel Johnson, which has become the most famous biography in the English language. It was the product of careful research as well as being an eyewitness-it has been calculated that Boswell met Johnson on 276 occasions (about 425 days). Yale University Press began publishing his journals in 1950, the private papers in 1993 . He had 17 bouts of venereal disease, periods of alcoholism, bipolar mood swings and gambling addiction. His letters to his great friend William Johnson Temple provide biographical detail covering nearly 40 years. After initial support for the anti-slavery movement, he became a partisan of the slave trade.

Pottle, F. A., The Literary Career of James Boswell. 1966; James Boswell, the Earlier Years. 1966; Wain, J., The Journals of James Boswell 1762-95. 1994.

Botha, Louis (1862-1919). South African general and politician, born in Natal. Though an opponent of *Kruger's Uitlander policies he joined the Transvaal forces as a volunteer in the Boer War, and later captured Winston ${ }^{*}$ Churchill. Later, having been given command, he defeated the British at Colenso and Spion Kop. After the peace of Vereeniging (1902) he bore no bitterness and when Transvaal was given a constitution (1906) became its first premier 1907-10. As first Prime Minister of the Union of South Africa, and Commander-in-Chief, 1910-19, his main policy was restoring harmony between white South Africans of British and Afrikaner descent. (The role of black South Africans was given lower priority.) On the outbreak of World War I in 1914, Botha, strongly supported by his deputy, Jan *Smuts, immediately brought in South Africa on the British side, defeated an Afrikaner rebellion led by Christiaan de Wet and led the troops who occupied (1915) German South West Africa (now Namibia). He attended the Versailles Conference (1919), signed the treaty reluctantly and returned home to die.

Botha, Pieter Willem (1916-2006). South African Nationalist politician. He served as Minister of Defence 1965-78 and succeeded B. J. *Vorster as Prime Minister of South Africa 1978-84. He became the first executive state president under the new constitution 1984-89. Secret negotiations with Nelson *Mandela and the ANC began in 1989 but Botha suffered a stroke and was replaced as party leader by F. W. *de Klerk.

Bothwell, James Hepburn, 4th Earl of (c.15351578). Scottish nobleman. After the murder of *Rizzio (1566), he became one of the chief advisors of *Mary Queen of Scots, who had probably first met him when he came to France on a mission to ask help for her mother and regent, Mary of Guise, widow of *James V. When *Darnley, the queen's second husband, was killed in an explosion (1567), Bothwell was charged with the murder and acquitted, although most historians believe him to have been guilty (and probably Mary as well). Bothwell then abducted the queen (almost certainly with her connivance) and married her, after divorcing his wife. The nobles rose in revolt, and the queen was captured and deposed. Bothwell escaped to Norway. He later became prisoner of the King of Denmark and died in captivity, insane. The popular belief that Bothwell 
was a boorish, unmannered brute is not borne out by fact: he was reckless, pitiless and unscrupulous but he had the graces of a courtier and was fond of poetry as well as of dancing and dress.

Botticelli, Sandro (Alessandro di Mariano dei Filipepi) (c.1445-1510). Florentine painter. A pupil of Fra Filippo *Lippi, he was patronised by the *Medici family. His early works (e.g. his Birth of Venus, Primavera and Mars and Venus) have a great delicacy, freshness and poignancy coupled with a rare linear subtlety of design. The iconography of the major mythological pieces is highly complex. Although a product of Renaissance humanism as regards content, his painting represents, in its essentially linear manner, the persistence of a 'Gothic' tradition which was in slightly archaic contrast to the strongly plastic High Renaissance style evolved by *Leonardo, *Raphael and *Michelangelo, and he declined in popularity after about 1500 . Most of his work was done in Florence but in 1481 he was in Rome helping to decorate the Sistine Chapel for Pope *Sixtus IV. After 1497 he became a follower of *Savonarola and most of his later works are religious, ecstatic and anti-naturalistic, like The Adoration of the Magi and The Coronation of the Virgin. He also illustrated Dante's Divine Comedy with sensitive outline drawings (1492-97). His work was much loved (and extensively forged) in the 19th century.

Argan, G. C., Botticelli. 1957.

Botvinnik, Mikhail Moiseyevich (1911-1995). Russian chess player. He was world champion 194857, 1958-60, 1961-63.

Bouchard, Lucien (1938- ). Canadian politician. He was Ambassador to France 1985-88, Minister for the Environment 1989-90 and Leader of the Opposition in the Canadian Parliament 1993-96 after the Bloc Québécois ran second to ${ }^{*}$ Chrétien's Liberals. His leg was amputated in 1994 . He led the campaign for Québec independence in the 1995 referendum and was Premier of Québec 1996-2001.

Boucher, François (1703-1770). French artist. The most typical of the rococo decorators, he was a protégé of Madame de *Pompadour (*Louis XV's favourite) and was noted for tapestry designs, panelled interiors and gay, slightly improper mythological paintings. Fine examples of his work can be seen in the Wallace Collection, London, and the Frick Collection, New York.

Boucher de Crèvecoeur de Perthes, Jacques (17881868). French prehistorian. A customs official at Abbeville, he became an amateur archaeologist and was one of the first to declare that man had existed in the Pleistocene epoch. In 1837 he began collecting roughly worked flints in the Somme gravels and declared them to be of 'antediluvian' origin because of their association with extinct Ice Age animals. but they began to win acceptance after Charles *Lyell pronounced in their favour before the Royal Society in 1859 .

Boucicaut, Jean II le Meingre de (c.1366-1421). French nobleman and soldier. He fought in Prussia, Spain and France, and was created Maréchal de France. Captured in the catastrophic Crusade of Nicopolis (1396), now in Greece, and ransomed, he later defended Constantinople. He fought at Agincourt (1415), was taken by the English and died in Yorkshire. Famous as a jouster, he created a chivalric order and commissioned magnificent illuminated manuscripts.

Bougainville, Louis Antoine de (1729-1811). French navigator and scientist. After the end of the Seven Years' War, during which he served with ${ }^{*}$ Montcalm in Canada, he joined the navy and established a French colony in the Falkland Islands. He sailed round the world (1766-79) and rediscovered the Solomon Islands, one of which is named after him. He served with distinction in the War of American Independence but then occupied himself entirely with science. Bougainville was an expert mathematician and a friend of ${ }^{*}$ Diderot and *Rousseau. His membership of the Legion d'honneur was one of several distinctions conferred on him by *Napoléon.

Boulanger, Georges Ernest Jean Marie (18371891). French general, born in Rennes. After service in Algeria, Italy and Indochina, he was wounded in suppressing the Paris Commune in 1871. In 1884 he commanded in Tunisia, and was Minister of War 1886-87, attaining immense popularity by his jingoistic policy and unwavering attitude to Germany over an incident involving a frontier arrest. Fears, perhaps exaggerated, of a coup d'etat, caused the removal of his name from the army list. This enabled him to seek election. With a somewhat vague program of parliamentary dissolution and constitutional revision he drew support not only from militarists and monarchists but also from radicals. However, the government and its supporters reacted strongly. Boulanger was defeated in the Marne election (1888) and fearing arrest for treason he went to Brussels where, after the death of his mistress, he committed suicide. The term 'boulangisme' was later used to decry any such movement towards military dictatorship.

Boulanger, Nadia Juliette (1887-1979). French teacher, conductor, composer and pianist. She worked in France and the US, took a leading role in the revival of ${ }^{*}$ Monteverdi and her pupils included Lennox *Berkeley, Aaron *Copland, Jean Francaix, Igor Markevitch, Dinu *Lipatti, Elliot ${ }^{*}$ Carter, Philip *Glass and her sister Lili Boulanger (1893-1918), an able composer. 
Boulez, Pierre (1925-2016). French composer and conductor, born in Montbrison. He studied mathematics, engineering and music at Lyon, composition with Olivier ${ }^{*}$ Messiaen at the Paris Conservatoire (1944-45) and conducting under René Leibowitz. In 1947 he became musical director of *Barrault's theatre company, the Marigny. In 1954 he founded the Concerts Marigny, avant-garde concerts later known as Domaine Musical. Influenced by Debussy and Stravinsky, his early compositions included Flute Sonatina (1946) and La Visage Nuptial (1946-52). His Structures (1952 and 1961) for two pianos were a turning point in his musical development. His work has produced interesting and sometimes violent criticism and is extremely difficult to perform. By the 1960s he had an international reputation as a composer and conductor, and was musical director of the New York Philharmonic (1971-77) and the BBC Symphony Orchestra (1971-75). He directed Wagner's Ring cycle at Bayreuth (1976-80) in Patrice Chereau's production. Georges *Pompidou invited Boulez, after a decade of self-imposed exile from France, to organise IRCAM (Institut de Recherches et Coordination Acoustiquel Musique) which he directed 1977-91. He also wrote extensively, including musical theory, aesthetics and on Paul *Klee.

Boulle (or Buhl), André Charles (1642-1732). French cabinet maker. His elaborate marque-tried furniture was in great demand in the reign of *Louis XIV. The description 'boulle' is often applied not only to his own work and that of his sons, who worked with him, but to the many imitations of later years. There are examples in the Louvre, in Windsor Castle and the Wallace Collection, London.

Boullée, Etienne-Louis (1728-1799). French architect, born in Paris. After 1780 he planned vast futuristic structures (none actually built) which anticipate 20th-century architectural megalomania. His work was featured in Peter Greenaway's film The Belly of an Architect (1987).

Boult, Sir Adrian Cedric (1889-1983). English conductor, born in Chester. He received his musical training at Oxford and with ${ }^{*}$ Nikisch in Leipzig. $\mathrm{He}$ conducted the City of Birmingham Orchestra 1924-30 (and again 1959-60) but won international recognition as the first chief conductor of the $\mathrm{BBC}$ Symphony Orchestra 1930-50, admired as one of the world's greatest ensembles. He made many recordings, became principal conductor of the London Philharmonic Orchestra 1951-57 and received a CH in 1969.

Boult, A., My Own Trumpet. 1973.

Boulton, Matthew (1728-1809). English engineer, born in Birmingham. Best known for his partnership with James *Watt for the construction of steam engines, his main interest lay in the provision of power for the factory in Soho (near Birmingham), where a variety of metal articles, useful or ornamental, were produced. Later Boulton applied steam power to the manufacture of coins. Many scientists and writers (e.g. ${ }^{*}$ Boswell) were among his friends. He was a founder of the Lunar Society (Erasmus * Darwin) and an FRS.

Clay, R., Matthew Boulton and the Art of Making Money. 2009.

Boumédienne, Houari (Mohammed Boukharraba) (1927-1978). Algerian politician, born in Bône. From a poor peasant family, he became a schoolteacher. He joined the National Liberal Front (1954) and became friend and confidant of *Ben Bella whom he supported in becoming the first president of independent Algeria. In 1965 he organised a coup, which deposed Ben Bella and he became the new president. He died in office in December 1978.

Bourassa, Robert (1933-1996). Canadian politician. Educated at Montréal, Oxford and Harvard universities, he became a lawyer, then a bureaucrat and a professor of public finances at Montréal and Laval universities. A moderate on the secession issue, he led the Québec Liberal Party 1970-77, 19831994 and was Premier 1970-76, 1985-94.

Bourbon. French noble family that provided dynasties for France, Spain, Naples and Parma. The line, named after a village in central France, was founded when in 1276 Robert de Clermont, a son of King *Louis IX, married Beatrice de Bourbon. The direct line died out but the name and title passed in 1527 to Charles, Duke of Vendôme, whose son married Jeanne d'Albret, Queen of Navarre. Their son *Henri IV became the first of the Bourbon kings. The last of the senior line was ${ }^{*}$ Charles $\mathrm{X}$, though ${ }^{*}$ Louis Philippe of the Orléanist branch reigned 1830-48, and his descendants are the present pretenders. The Spanish Bourbons replaced the Habsburgs after Charles II had died childless and left his kingdom to Louis XIV's grandson *Philip V. Members of the dynasty continued to reign until *Alfonso XIII left the country in 1930. The Neapolitan Bourbons and the Parma branch stemmed from the Spanish line.

Bourgeois, Léon Victor Auguste (1851-1925). French Radical politician. He defeated ${ }^{*}$ Boulanger in the Marne election of 1888 and subsequently held a long series of ministerial posts. He was prominent internationally at The Hague conferences and in the League of Nations which he helped to found. He won the Nobel Peace Prize in 1920.

Bourgeois, Louise (1911-2010). French-American sculptor and graphic artist, born in Paris. A pupil of ${ }^{*}$ Leger, she lived in the US from 1938 and became a citizen in 1953. Her works were powerful and sexually ambiguous, and include the nine-metre-high metal sculpture of a spider Maman (2000) (at the Guggenheim in Bilbao and in Qatar). 
Bourget, Paul (1852-1935). French writer. His novels at first concentrated on the psychological analysis of characters but after his conversion to Catholicism in 1901 they tended to become vehicles for the transmission of traditionalist views. L'Etape (1902) marks the culmination of the first period, during which his best known books include L'Irréparable (1884). On Crime d'amour (1886) and André Cornélis (1887). Le Démon de Midi (1914) is typical of the later period.

Bourguiba, Habib Ben Ali (1903-2000). Tunisian politician. Son of an officer, he studied law in Paris, became a journalist and founded the Neo-Destour party in 1934. Imprisoned 1934-36, 1938-43, he escaped and travelled for years promoting the cause of Tunisian independence. He was interned again 1952-54 and 1954-55, then after negotiations with the French became Prime Minister under the Bey of Tunis 1955-57. After the proclamation of a Republic, Bourguiba became President 1957-87 until his peaceful overthrow. He was then kept under house arrest.

Boutros-Ghali, Boutros (1922-2016). Egyptian politician and diplomat, born in Cairo. A Copt, educated at Cairo, Sorbonne and Columbia universities, he was professor of international law at Cairo 1949-77 and a prolific author. As Minister of State (i.e. undersecretary) for Foreign Affairs 197791, he was an architect of the Camp David accords (*Sadat) leading to the resumption of diplomatic relations between Egypt and Israel. After a brief period as Foreign Minister 1991-92, he became Secretary-General of the United Nations 1992-97. The US vetoed his candidature for a second term.

Bouts, Dirk (or Deiric) (c.1415-1475). Dutch painter, born in Haarlem. One of the most powerful of the Early Netherlandish school, his deeply emotional religious scenes are highly prized. He worked mostly in Louvain and died there.

Boyce, William (1710-1779). English composer and organist. Master of the King's Musick 1735-79, he also wrote Church music, stage music, chamber and orchestral works and several songs, including 'Hearts of Oak'. He made a compilation of Church music entitled Cathedral Music (1760-78).

Boycott, Charles Cunningham (1832-1897). English land agent. As agent for Lord Erne in Co. Mayo, Ireland his refusal to lower rents in times of hardship was punished (1880) by complete social and business isolation. This form of protest, invented by the Irish Land League, came to be known as a 'boycott'.

Boyd, Arthur Merric Bloomfield (1920-1999). Australian painter, born in Melbourne. The most prominent of a distinguished artistic family, he worked in London for many years, and turned from landscape to figurative works, many with literary, biblical or mythological themes, e.g. the Nebuchadnezzar series.

Niall, B., The Boyds. 2002; Bungey, D., Arthur Boyd: A Life 2007.

Boyd-Orr, John Boyd Orr, 1st Baron (1880-1971). Scottish agricultural scientist and dietetic expert. Educated at Glasgow University, he was director of the Rowett Research Institute, Aberdeen 1914-45, won a DSO and MC in World War and discovered many of the causes (e.g. lack of minerals) of nutritional deficiency in animals and human beings. These he subsequently expounded before many national and international bodies. His report Food, Health and Income (1936) made him famous. An independent MP 1944-45 and Chancellor of Glasgow University 1946-71, he became first Director-General of the UN Food and Agriculture Organisation (FAO) 1945-48 and in 1949 received the Nobel Prize for Peace and a peerage. He was awarded a CH in 1968.

Boyer, Charles (1899-1978). French actor, in the US from 1934. He played romantic leads with such actors as Greta ${ }^{*}$ Garbo, Marlene *Dietrich and Ingrid *Bergman, later gaining a second reputation as a skilful character actor, e.g. in Stavisky (1972).

Boyle, Robert (1627-1691). Irish physicist and chemist, born at Lismore Castle, Munster. As his tombstone in Westminster recorded, Boyle was 'father of chemistry and brother of the Earl of Cork'. Educated at Eton, and by tutors, he travelled extensively in Europe, mastered Latin, French, Italian, Hebrew and Greek, became deeply devout and never married.

His book Sceptical Chymist (sic, 1661), demolished the concept of 'the four elements', transforming alchemy into a new discipline (although he kept an open mind on the transmutation of gold), and developed the art of experimentation. He was the first clearly to define an element in the terms we accept today (i.e. as a substance that cannot be split into simpler substances by chemical analysis), and explained that all matter consists of atoms or combinations of atoms in motion. His widely ranging studies included pneumatics and crystallography. He is probably best known for his statement of the law (now known as Boyle's Law) that, at constant temperature, the volume of a gas varies inversely with the pressure. $\mathrm{He}$ founded a series of lectures to prove the existence of God. An original fellow of the Royal Society (1662), he was elected President (1680) but refused to take the oath and declined a peerage.

Maddison, R. E. W., Life of the Honourable Robert Boyle. 1969.

Bracken, Brendan Rendall Bracken, 1st Viscount (1901-1958). British Conservative politician, born in Ireland. Educated in Australia and at Sedbergh, he 
entered publishing and helped to build up the group of periodicals which centred on the Financial News. A Tory MP 1929-45, 1945-51, and devoted follower of Winston ${ }^{*}$ Churchill, he succeeded Duff ${ }^{*}$ Cooper as Minister of Information 1941-45 and was briefly First Lord of the Admiralty 1945.

Boyle, A., Poor, Dear Brendan. 1974; Lysaght, C. E., Brendan Bracken. 1979.

Bracton, Henry de (d.1268). English ecclesiastic and lawyer. He was an itinerant justice, who eventually became Chancellor of Exeter Cathedral, but his fame arises from his great treatise On the Laws and Customs of England, the first printed edition of which appeared in 1569 .

Bradbury, Sir Malcolm (Stanley) (1932-2000). English novelist and critic, born in Sheffield. He held a chair at the University of East Anglia from 1970, and had a profound influence on Ian ${ }^{*}$ McEwan, Kazuo *Ishiguro and W. G. *Sebald. His novels include The History Man (1975) and To the Hermitage (2000).

Bradlaugh, Charles (1833-1891). English radical politician. After working as a soldier and solicitor's clerk, he became an active pamphleteer under the name of 'Iconoclast' and ran the journal National Reformer from 1862. He worked with Annie *Besant 1874-85. Elected as MP for Northampton in 1880, he asked, as an atheist, to be permitted to take an affirmation instead of a religious oath. He was required to take an oath which he did not believe and was unseated following a petition from a common informer. Three by-elections followed and Bradlaugh won them all, only to be refused his seat. He won a fourth in 1885 and was permitted to take his seat in 1886. In 1888 he secured passage of the Affirmation Act.

Bradley, Francis Herbert (1846-1924). English philosopher. A research fellow of Merton College, Oxford 1867-1924, his philosophy of idealism was inspired by ${ }^{*}$ Hegel and yet quite individual. In Appearance and Reality (1893) he argued that the ordinary world of qualities, relations, space, time and selves is in some sense 'unreal' and only 'appearance'. True reality is 'The Absolute', which is all encompassing and mental or spiritual in nature. Bradley was a vigorous critic of utilitarianism and his best known writing in ethics is an essay called 'My Station and Its Duties', contained in his Ethical Studies (1876). Essays on Truth and Reality appeared in 1914 . He received the OM in 1924. His brother Andrew Cecil Bradley (1851-1935), literary critic, was professor of poetry at Oxford 1901-06. He wrote the influential Shakespearian Tragedy (1904) and Oxford Lectures in Poetry (1909).

Wollheim, R., F. H. Bradley. 1959.

Bradley, James (1693-1762). English astronomer, born at Sherborne, Dorset. Educated at Oxford he became vicar of Bridstow in 1719. Even earlier a remarkable talent for astronomy and mathematics had led to his election as FRS (1718). He was a professor of astronomy at Oxford from 1721 until he became astronomer royal in 1742 . While attempting to measure stellar parallax he discovered the aberration of light, thus providing the first confirmation by observation of the theory that the earth moved round the sun (*Copernicus). Bradley also discovered nutation (oscillation of the earth's axis about its mean position).

Bradley, Omar Nelson (1893-1981). American General of the Army, born in Missouri. He served in North Africa 1942-43 and became Commanderin-Chief of US land forces in Europe 1944-45. He succeeded *Eisenhower as US Army Chief of Staff 1948-49 and became the first Chairman of the US Joint Chiefs of Staff 1949-53. He backed *Truman on the *MacArthur issue and wrote the memoirs A Soldier's Story (1951).

Bradman, Sir Donald George (1908-2001). Australian cricketer, born in Cootamundra. He grew up in Bowral, New South Wales. Perhaps the most brilliant and consistent batsman ever known, he first played for New South Wales in 1927 and for Australia in 1928, making the record score for firstclass cricket of 452 runs, not out, in a state match against Queensland in 1930. (This stood until Hanif Mohammed scored 499 for Karachi in 1959). His Test batting average was 99.94 runs. He was Australian cricket captain 1936-49, receiving a knighthood in 1949 and an AC in 1979. He became a stockbroker in Adelaide, retiring in 1954.

Bradman, D. G., Farewell to Cricket. 1950; Williams, C., Bradman. 1996.

Bradshaw, John (1602-1659). English lawyer and regicide. The culmination of his career came when he was selected to preside over the trial of King ${ }^{*}$ Charles I, on whom he passed sentence of death in 1649. After the Restoration, his body, buried in Westminster Abbey, was disinterred and hanged.

Bradstreet, Anne (c.1612-1672). American poet. She emigrated to Massachusetts in 1630. Her The Tenth Muse Lately Sprung Up in America was published in London in 1650 (second ed., Boston 1678). Her poems represent the first work of literary value to have been produced in New England. She left her Meditations in manuscript.

Bradwardine, Thomas (c.1290/1300-1349). English mathematician. At Oxford University he became a fellow of Balliol in 1321 and Merton in 1323, was later chaplain to ${ }^{*}$ Edward III and died of the plague. His philosophical and mathematical works were probably all composed while he was in Oxford. The range of problems that occupied him concerned the physical and mathematical understanding of motion. $\mathrm{He}$ was searching for some general formula for understanding speed of motion in terms of the forces 
which produced and hindered it. His conclusion was that the ratio of speeds of motions follows the ratio of the motive powers to the resistive powers. In some ways, this is a confused notion, but his attempt to study speed in its own right was an important influence upon later medieval writers on physics such as Richard ${ }^{*}$ Swineshead and Nicole Oresme. Bradwardine also wrote on theological subjects. He was concerned to reduce the role of human free will in favour of the Divine Will. In his view, God was free to create whatever kind of world he wished, including one of infinite space.

Obermann, H. A., Thomas Bradwardine. 1958.

Braga, (Joaquim) Teofilo Fernandes (18431924). Portuguese writer and politician. Though a leader of the anti-clericals in politics, he was better known as a poet, collector of folklore and author of a monumental history of Portuguese literature. He became provisional president 1910-11 on the deposition of King *Manoel II. He was provisional president again in 1915 .

Bragança (or Braganza). Dynasty that ruled Portugal 1640-1910, beginning with *João (John) IV, and Brazil 1822-89, when *Pedro I became emperor.

Bragg, Sir William Henry (1862-1942). British physicist, born in Cumberland. Educated on the Isle of Man and at Cambridge, he became professor of mathematics and physics at Adelaide University 1886-1909 (carrying out Australia's first X-ray procedure, on his son, in 1895) and held the chair of physics at Leeds University 1909-15 and University College, London 1915-23. He designed the X-ray spectrometer which permitted exact measurement of X-ray wavelengths and crystal structure. His son, Sir (William) Lawrence Bragg (1890-1971) was born in Adelaide and educated there and at Cambridge. He formulated Bragg's Law which helped to explain and measure the lattice arrangements in crystals and became the basis of X-ray crystallography. He shared the 1915 Nobel Prize for Physics with his father and, at 25, was the youngest Nobel laureate. Bragg senior received a KBE in 1920, the Copley Medal in 1930 and the OM in 1931, was director and professor of chemistry at the Royal Institution, London 1923-40 and president of the Royal Society 1935-40. The younger Bragg was technical advisor on sound-ranging at the British GHQ in France 1915-19, and succeeded *Rutherford both as professor of physics at Manchester University 191937 and Cavendish professor of experimental physics at Cambridge 1938-53. Like his father, he directed the Royal Institution 1954-66. His interests were unusually wide: silicates, metals, alloys and proteins and he was a founding father of two disciplines, X-ray crystallography and molecular biology. He received the Copley Medal in 1966 and a CH in 1967. Both Braggs promoted scientific programs for children.
Brahe, Tycho (or Tyge) (1546-1601). Danish astronomer, born in Scania (southern Sweden). At 19 he lost his nose in a duel and wore a silver replacement. The last great astronomer before the use of telescopes, he was attracted to the study of the stars by an eclipse that occurred during his student days at Copenhagen University. In 1572 he identified a supernova ('Tycho's star'). Between 1576 and 1580, under the patronage of King Frederik II, he established Uraniberg, a large and well-equipped observatory on the island of Ven (Hveen). There he made a series of astronomical observations more comprehensive and accurate than any previously recorded. Brahe did not accept in full the astronomical system of ${ }^{*}$ Copernicus, for though he believed that the five known planets revolved around the sun he still affirmed that the sun itself, as well as the moon, revolved around the earth. So accurate were his observation, however, that *Kepler was later able to deduce the laws of planetary motion from them. Frederik's death in 1588 exposed Brahe to the hostility of his fellow nobles, prejudiced against him because of his work and the king's favour. He went to Prague, where the emperor ${ }^{*}$ Rudolf II provided an observatory for him, and Kepler joined him as an assistant.

Brahmagupta (598-670). Indian mathematician and astronomer, born in Bhinmal (or Ujjain), Rajasthan. $\mathrm{He}$ is credited with being the first to use negative and positive numbers and zero (0) as a number, not a placeholder. He worked at an observatory in Ujjain, which now bears his name. He denied the rotation of the earth.

Brahms, Johannes (1833-1897). German composer, born in Hamburg. He was taught first by his father, a double bass player in the Hamburg State Theatre Orchestra, and then studied in Hamburg under Eduard Marxsen (1806-1887). From the age of 15 he appeared in public as a pianist until 1853 when he accompanied the Hungarian violinist Ede Remenyi (1828-1898) on a concert tour, after which he became friendly with Robert *Schumann. Largely because of Schumann's efforts to promote his music, Brahms began to gain recognition, and was a parttime musician in residence at the court of Detmold. His Piano Concerto No. 1 in D Minor (1858), conceived on a heroic scale, was initially a failure, later popularised by Clara *Schumann. Brahms remained a close friend of Clara's. Though he was in love with her, they did not marry after Schumann's death in 1856. His Quintet in F Minor for Piano and strings (1864) was hailed by Joseph *Joachim as the greatest piece of chamber music since ${ }^{*}$ Schubert.

Brahms settled in Vienna in 1863, where he directed the Wiener Singakademie from 1863 and the concerts of the Gesellschaft der Musikfreunde 1872-75. Among the great works of his full maturity were The German Requiem (1857-68), the four symphonies (1877, 1878, 1884, 1886), the Violin Concerto in D (1878), the Piano Concerto No. 2 in B Flat (1881), 
the Double Concerto for Violin and Cello (1887), the Clarinet Quintet (1891), 180 songs, three piano sonatas, ballades, capriccios and intermezzi, three violin sonatas and two sets of 'Liebeslieder' waltzes for chorus and piano. Brahms preserved the great musical traditions of the past in a period in which such composers as ${ }^{*}$ Liszt and *Wagner were advocating 'revolution and progress' in art; he had a long feud with Wagner on this account. Notwithstanding, the highly personal style he created was influenced by the Romanticism of the time, as in many of his Lieder where he combined lyricism and nostalgia with a striking simplicity. He was a solitary, somewhat antisocial figure, politically conservative (an admirer of *Bismarck), an indifferent Lutheran, and a collector of books and manuscripts, including *Mozart's Symphony No. 40, *Haydn quartets and Schubert songs. He died of liver cancer and was buried near Beethoven and Schubert. His stature suffered in the late 20th century because of the revival of *Bruckner and *Mahler who took Romanticism far beyond Brahms' classical restraint. Intensely self-critical, he destroyed much of his output. He was much admired by ${ }^{*}$ Schoenberg.

James, B., Brahms: A Critical Study. 1972; Geiringer, K., Brahms: His Life and Works. 1984; Swafford, J., Johannes Brahms. 1997.

Braid, James (1870-1950). Scottish golfer, born in Fife. He won the British Open championship five times $(1901,1905,1906,1908,1910)$ and was French champion in 1910. He, Harry Vardon and J. H. Taylor were known among golfers as 'the great triumvirate'.

Braille, Louis (1809-1852). French teacher of the blind. He became blind after an accident at the age of three. He spent most of his life, as pupil and professor, at the Paris Institution des Jeunes Aveugles. From 1825 he developed the system of 'raised point' writing, which is named after him.

Bramah, Joseph (1748-1814). English inventor, born in Yorkshire. He became a carpenter and cabinet maker and moved to London, where he invented or perfected many useful devices. His hydraulic press and security lock were of great value, but his water closet, beer pump and machine for printing serial numbers on bank notes also bear witness to his ingenious and versatile mind.

Bramante, Donato (c.1444-1514). Italian architect. Usually considered the greatest architect of the High Renaissance, he is lastingly famous as the designer of the initial, centralised, plan for St Peter's Basilica, Rome. His plan, which was commissioned by Pope *Julius II and upon which work began in 1506, was somewhat altered by ${ }^{*}$ Michelangelo and ${ }^{*}$ Raphael, but the original conception remains Bramante's (except for the nave, which was an extension by Maderna). Other work in Rome includes the Tempietto (1502) in the courtyard of S. Pietro in Montorio as well as parts of the Vatican palace (notably the Belvedere). Before he went to Rome in 1499, Bramante, who was humbly born, had worked mostly in Milan, as a painter. His architectural work there includes the chancel of San Satiro and the domed church of Santa Maria delle Grazie (1492-98). Bramante's mature work is in a severe, pure Roman classical style.

Foster, O., Bramante. 1956.

Branagh, Sir Kenneth Charles (1960- ). British actor and director, born in Belfast. He trained at the Royal Academy of Dramatic Art (RADA) in London and founded the Renaissance Theatre Co. in 1987. His first successful stage production, Another Country (1982) was followed by plays by *Shakespeare, *Ibsen, ${ }^{*}$ Chekhov and later dramatists. His film Henry $V(1989)$, in which, like *Olivier, he directed and played the leading role, was both moving and austere. Dead Again (1990) and Peter's Friends (1992), both written and directed by Branagh, co-starred his wife Emma *Thompson, who won an Oscar for her role in Howard's End (1993). They both acted in his film of Shakespeare's Much Ado about Nothing (1993), but separated in 1995. His epic film Hamlet (1996) running for four hours, was a critical success and box office failure. Other Shakespearean films include Othello (1995), Love's Labour's Lost (2000), and As You Like It (2006). He directed and starred in a memorable Macbeth (2013), making his New York debut with it in 2014.

Brancusi, Constantin (1876-1957). Romanian sculptor. Having been trained in art in Bucharest he went in 1904 to Paris, where he lived for the rest of his life. His work has been described as abstract, but his sculptures are rather symbolic reductions of objects to their essential form, as in his Egg (called by him The Beginning of the World) and Seal. The Musee de l'Art Moderne. Paris, has good examples of his work and a reproduction of his studio. Brancusi has been one of the most important influences on modern sculpture.

Geist, S., Brancusi. 1968.

Brand, Sir Johannes Hendricus (1826-1888). South African politician. A barrister, he was elected to succeed M.W. *Pretorius as President of the Orange Free State 1864-88. His chief aim being to maintain the state's independence, he refused all British attempts at federation. The Basutos were defeated by him (1865-66) but their territory was safeguarded (at their request) by British annexation. He maintained a cautious neutrality between the Transvaal and Cape Colony. The development of diamond mining underpinned the OFS's prosperity.

Brandauer, Klaus Maria (1944- ). Austrian actor. $\mathrm{He}$ won international recognition for his roles in the films Mephisto (Academy Award for Best Foreign Film, 1981), Colonel Redl (1985), Out of Africa (1985), Druids (2001) and Tetro (2009). 
Brandeis, Louis Dembitz (1856-1941). American lawyer and judge. Woodrow *Wilson appointed him as a justice of the US Supreme Court 1916-39, which generated controversy: he was the first Jewish member of the Court and had been a radical advocate of unpopular causes, such as civil liberties and rights for unions, a line he maintained on the bench.

Brandes, Georg Morris Cohen (1842-1927). Danish literary critic. After a tour of Europe, on which he met ${ }^{*}$ Taine, ${ }^{*}$ Renan and J. S.* Mill, he wrote Main Currents in Nineteenth-century Literature (6 volumes, 1872-90), which proclaimed him as a leading supporter of realistic literature, in which problems of everyday life should be discussed. Such views and his belief in free thought roused opposition which affected his career. Later he came to know ${ }^{*}$ Nietzsche whose influence can be seen in his studies of *Shakespeare (1896), *Goethe (1915),* Voltaire (1916) and others. In 1925 he wrote Jesus, a Myth.

Brando, Marlon (1924-2004). American actor, born in Omaha, Nebraska. His naturalistic style of acting, acquired largely at Lee Strasberg's Actors Studio, achieved great popular success in the play and film of Tennessee *Williams' A Streetcar Named Desire and such films as The Wild One, Julius Caesar (where he played Antony), On the Waterfront (for which he obtained an Academy award in 1954), The Young Lions, The Ugly American, Last Tango in Paris and The Godfather.

Mizruchi, S., Brando's Smile. 2014.

Brandt, Willy (Karl Herbert Frahm) (1913-1992). German Social Democratic politician, born in Lübeck. Educated at Lübeck, he made an early mark as a socialist propagandist. After ${ }^{*}$ Hitler came to power he went to Norway to become a Norwegian citizen and during the German occupation in World War II he worked with the Norwegian underground movement. After the war he re-entered German politics and became a member of the Bundestag in 1949. In 1957 he became Oberbürgermeister (Governing Mayor) of Berlin 1957-66 and in 1960 succeeded Erich *Ollenhauer as leader of the West German Social Democratic Party (SPD). He was Chancellor 1969-74, resigning after the arrest of one of his secretaries as a Communist spy. As Chancellor he improved relations with Eastern Europe and was awarded the Nobel Peace Prize in 1971. He chaired the Independent Commission on Development Issues 1977-79, and the Brandt Report (1980) asserted that East-West (communist v. capitalist) issues would decline in significance and North-South (development v. under-development) problems would increase. He was a member of the European Parliament 1979-83. His books include The Ordeal of Co-existence (1963), Reflections and Letters (1971), People and Politics 1960-75 (1978) and My Life in Politics (1992).

Harprecht K., Willy Brandt: Portrait and Self Portrait. 1972.
Brangwyn, Sir Frank (1867-1956). Welsh artist, born in Bruges, Belgium. As a boy he was apprenticed to William *Morris, ran away to sea at the age of 17 , and exhibited at the Royal Academy the following year. He achieved his greatest success in mural paintings of great size and rich colouring. Among the finest examples are those in the Skinners' Hall, London, and the parliament buildings, Winnipeg, Canada. Among other forms of art in which Brangwyn excelled were tapestry and furniture design. He was knighted in 1941.

Branson, Sir Richard Charles Nicholas (1950- ). English entrepreneur, born in Greenwich. $\mathrm{He}$ founded the first Virgin store in 1969 and developed interests in aviation, travel, entertainment, film and music.

Branting, Hjalmar (1860-1925). Swedish politician. The virtual creator of the Swedish Social Democratic party, he was its only member in the Riksdag of 1896. Though the party never attained an independent majority in his lifetime Branting was able to form the first socialist government in 1920 and was Prime Minister in 1920, 1921-23 and 1924-25. He had been a strong supporter of the Allies in World War I and as Prime Minister he represented his country at the League of Nations, of which he was a vigorous upholder. He won the 1921 Nobel Prize for Peace.

Brantôme, Pierre de Bourdeille, Seigneur and Abbé de (c.1534-1614). French writer and courtier. In 1561 he accompanied *Mary, Queen of Scots to Scotland and later took part in military expeditions throughout Europe and in Africa. His works, particularly the Vies de dames galantes, are collections of anecdotes, mainly scandalous, that reflect the gay and immoral life of the Valois court.

Braque, Georges (1882-1963). French painter. Son of a decorator, he joined the group known as the 'Fauves' ('wild beasts') in 1905, then in 1908 began an association with Pablo *Picasso which was to lead first to a monumental, brutal 'African' phase (Nude, 1908) and then to the development (about 1910) of the analytical style known as Cubism. In subsequent still lifes' Braque introduced elements of 'reality' into a pictorial context newsprint, stencilled letters etc. After World War I he developed a less revolutionary but highly personal two-dimensional semi-abstract style, mainly in a still-life idiom, to which he brought a remarkable sense of design and significant shape. $\mathrm{He}$ also designed ballet settings and jewellery.

Mullins, E. B., Braque. 1969; Danchev, A., Georges Braque: A Life. 2005.

Brasidas (d.422 BCE). Spartan commander in the Peloponnesian War. By a brilliant diversionary campaign in Thrace (424 BCE) he may have saved his country from defeat. In 422 BCE he overtook 
and defeated the Athenians withdrawing from Amphipohis but both he and his opponent Cheon were killed.

Bratby, John (1928-1992). English painter. A vigorous and colourful artist, his concern was with the immediate environment of daily life, into which he projected both religious and mundane themes. His pictures gained wider recognition after being used in the film of Joyce *Cary's book The Horse's Mouth (1958). His writings included novels, a play and a study of Stanley *Spencer (1969).

Bratianu, Ion Constantin (1821-1891). Romanian politician. After the failure of the revolutionary movement of 1848 , in which he had been a leading spirit, he lived in exile in Paris but continued to work underground for the unity of the Romanian principalities. He returned to Romania in 1856 and was mainly instrumental in securing the throne for Prince Karl of Hohenzollern (*Carol I). From 1876 to 1888 , as leader of the Liberal Party he was seldom out of office. His son, I. C. Bratianu (1864-1927), his party successor, held a comparable position in Romanian politics and was largely responsible for bringing Romania into World War I on the Allied side. A grandson, Constantin (Dinu) Bratianu (1889-1950?), led the liberal opposition to Ion *Antonescu before World War II and, briefly, to the Communist regime that followed it.

Brattain, Walter Houser (1902-1987). American physicist, born in China. Educated at the universities of Oregon and Minnesota, he carried out research at the Bell Labs 1929-67. With William *Shockley and John *Bardeen he invented the point-contact transistor 1947-48. They shared the Nobel Prize for Physics in 1956 for their investigations.

Brauchitsch, (Heinrich Alfred Hermann) Walther von (1881-1948). German field marshal, born in Berlin. He had a complicated relationship with *Hitler, borrowed money from him, but despised him, contemplated leading a coup, but accepted appointment as Commander-in-Chief of the German Army 1938-41. He directed the conquest of France and planned the abortive invasion of Great Britain. He was dismissed for the failure of the attack on Moscow in 1941, undertaken against his advice, with the Führer becoming Commander-in-Chief himself. Brauchitsch was harsh to civilians in Poland and spineless with Hitler. He died before he could be tried as a war criminal.

Braudel, Fernand (1902-1985). French historian. Educated at the Sorbonne, he taught in Algeria and Brazil, was a prisoner of war (1940-45), held a chair at the Collège de France 1949-72, and edited the periodical Annales 1957-68. Often described as the greatest modern historian (although not in Britain), his major works include The Mediterranean and the Mediterranean World in the Age of Philip II (1949) and Civilisation and Capitalism 15th-18th Century (3 vols, 1967-79). He was elected to the Académie française in 1984 .

Braun, Eva (1912-1945). German model. After some years as a model for Hitler's friend and photographer Heinrich Hoffman she became *Hitler's mistress. They were married in the moment of defeat in the bunker headquarters of Hitler in Berlin on 29 April 1945, and both committed suicide the next day.

Braun, Wernher Magnus Maximilian von (19121977). German-American rocket scientist, born in Poland. He joined the Nazi Party in 1937, became technical director of the missile establishment at Peenemünde 1937-45, a major in the SS and the driving force for the development of the V2 rocket weapon, using slave labour. In the US from 1945, he claimed to have experienced a religious conversion in 1946, and became an American citizen in 1955. $\mathrm{He}$ worked on rockets for launching missiles and satellites and his Saturn V rocket was used in the first moon landing (1969).

Goodrum, J. C., Wernher von Braun: Space Pioneer. 1969.

Brazza, Pierre Savorgnan de (1852-1905). French explorer, born in Rome. He joined the French navy in 1868 and was naturalised in 1874. He explored West Africa 1875-78 and 1879-82, established the course of the Ogoove River 1883-85, became Commissioner-General in the (French) Congo 188697 and founded Brazzaville. He died at Dakar.

\section{Breakspear, Nicholas see Adrian IV}

Brecht, Bertolt (1898-1956). German dramatist, poet and director, born in Augsburg. Of middle-class parentage, in 1916 he went to Munich University to study medicine, but his studies were interrupted by World War I in which he served as a medical orderly. His first play, Baal, was written in 1918 and was shortly followed by Drums in the Night. In 1921 he became Dramaturg (resident playwright and advisor) in a Munich theatre, his first plays were produced and brought their author immediate recognition as a powerful new presence in the German theatre. From the first the special character of the Brechtian theatre began to emerge. Brecht demanded, and tried to achieve, both by his writing and by the styles of acting and direction that he developed, a theatre that would deny its audience the satisfaction of emotional involvement, instead they were to be fully aware that they were in a theatre, alert, conscious and 'ready for action'. In 1924 Brecht went to Berlin, where, under the influence of Erwin Piscator's revolutionary epic theatre, his work became even more directly propagandist. He was by now a confirmed, if highly independent, Marxist, as he was to remain for the rest of his life. In 1926 he published the first major collection of his poems (Taschenpostille) and met the composer Kurt ${ }^{*}$ Weill, who was to collaborate 
with him in his most famous musical works, The Threepenny Opera (1928), Rise and Fall of the City of Mahagonny (1930) and Happy End (1929). $\mathrm{He}$ ruthlessly exploited his mistress-collaborators Elizabeth Hauptmann and Margarete Steffin and his major plays were essentially collective works. The series of didactic plays, the Lehrstücke, aimed at educating the social attitudes of his audience; St Joan of the Stockyards (1929-30) stands out in this period. In $1933{ }^{*}$ Hitler came to power and Brecht, now a prominent writer in Germany, went into exile and semi-oblivion with his wife, the actor Helene Weigel. Living mainly in Denmark, Brecht produced some anti-Nazi propaganda plays, The Threepenny Novel, and some of his finest poetry. Then, between 1938 and 194l, he wrote the great and mature works for which he is mainly remembered: The Life of Galileo (1938-39), Mother Courage and Her Children (1939), The Trial of Lucullus (1939), The Good Woman of Setzuan (1938-40), Herr Puntila and his Man Matti (1940-41) and The Resistible Rise of Arturo Ui (1941). In 1941 he went to the US and settled in Hollywood. There he wrote Schweik in the Second World War (1941-44) and The Caucasian Chalk Circle (1944-45), but failed properly to re-establish himself as a dramatist. In 1947 he was summoned to appear before the Committee on Un-American Activities, which was investigating Communist infiltration of the film industry. Adopting the Schweikian philosophy of self-interest and survival, Brecht denied his Marxist sympathies and emerged unscathed. He was, in fact, never a member of the Communist Party. Soon after, however, he left the US, and went to Switzerland, where he wrote his last complete play The Days of the Commune (1948-49). In 1949 he returned to East Germany and settled in Berlin. His relations with the East German authorities were uneasy, but his reputation was immense, and he was granted almost unlimited facilities for the production of plays. With these he created the Berliner Ensemble, a theatre company which could at last put into practice the dramatic theories he had spent a lifetime in developing. At the time of his death he was beginning to be recognised in western countries as one of the major figures in 20th-century theatre.

Fuegi, J., Brecht and Company. 1994.

Breckinridge, John C(abell) (1821-1875). American politician, born in Kentucky. A lawyer, he served in the US Congress 1851-55, was Vice President of the US 1857-61, and a strong supporter of states' rights on the slavery issue. As the presidential candidate of the southern Democrats in 1860, he won 10 states. Briefly a Senator (1861), although uneasy about secession, he became a heavy-drinking general in the Confederate army, with mixed success, and Jefferson *Davis appointed him as Secretary of War (1865). He spent three years of exile in Canada and Europe 186568, denounced the Ku Klux Klan and showed some sympathy for the legal rights of African-Americans.
Breivik, Anders Behring (later adopted name Fjotolf Hansen, pen name Andrew Berwick) (1979- ). Norwegian terrorist. A far-right race supremacist, he was fanatically anti-Muslim and anti-immigrant. He compiled 2083: A European Declaration of Independence, 1518 pages long, under the name Andrew Berwick and published it, by email, on 22 July 2011. On the same day he killed eight people by detonating a fertiliser bomb in Oslo, then fatally shot 69 Labour Party members and teenagers at a summer camp on the island of Utøya, injuring 319 more. Convicted of mass murder and terrorism in July 2011, he was sentenced to 21 years imprisonment, the maximum sentence under Norwegian law. He has repeatedly litigated, without success, claiming illtreatment in prison. In his manifesto he applauded conservatives, including five Australians, whom he regarded as anti-Muslim, and committed to European cultural hegemony.

Brendel, Alfred (1931- ). Austrian-British pianist. He made his debut in 1948, toured extensively and relocated to London in 1972 . He was regarded as a great ${ }^{*}$ Mozart specialist and recorded all the keyboard music of *Beethoven and *Schubert. He also wrote extensively on aesthetics. He was awarded an Hon. $\mathrm{KBE}$ in 1989.

Brennan, William Joseph, Jr (1906-1997). American jurist. A justice of the US Supreme Court 1956-90, he was regarded as leader of the liberal wing.

Brenner, Sydney (1927-2019). British biologist, born in South Africa. Of Jewish-Lithuanian descent, he studied at Witwatersrand and Oxford. $\mathrm{He}$ developed the use of the roundworm Caenorhabditis elegans for genetic analysis and succeeded Max *Perutz as director of the Medical Research Laboratory, Cambridge 1979-86. He received a CH in 1986, the Copley Medal in 1991 and shared the Nobel Prize for Medicine in 2002 with Robert Horvitz and John Sulston for 'discoveries concerning genetic regulation of organ development and programmed cell death'.

Brentano, Franz (1838-1917). Austrian philosopher. Known as 'the Austrian Socrates' because his influence depended more upon the spoken than the written word, he taught at Würzburg and Vienna 1866-80. He had a major influence on Tomas *Masaryk, the future president of Czechoslovakia. Through inability to accept papal infallibility he gave up his priesthood in 1873. Much of his work consisted of reviewing and revising *Aristotle's conceptions of logic and psychology. Parallels between right thinking and right living are discussed in Origin of the Knowledge of Right and Wrong (Eng. tr. 1902).

Breton, André (1896-1966). French poet and critic. $\mathrm{He}$ was the pioneer and ideologist of Surrealism, defining it as 'pure psychic automatism' and wrote The Surrealist Manifesto (1924). He worked with Louis 
*Aragon and Tristan *Tzara, was active as an anarchist and was a discriminating collector of paintings and ethnographic art.

Breuer, Josef (1842-1925). German Jewish physician, born in Vienna. A formative influence on the development of psychoanalysis, he undertook medical studies at the University of Vienna. He kept up contacts with the university, but made a living through private practice. Breuer's main early scientific research lay in the field of physiology, but his fame chiefly rests upon his studies of hysteria, particularly one of his patients, 'Anna O'. She suffered from severe classic hysteria, including paralysis and aphasia. But Breuer found that, over a long period, by getting her to talk about her distant past, particularly when under hypnosis, a state of catharsis was induced and the symptoms gradually ceased. Thus Breuer had hit upon the 'talking cure' which became central to Freudian analytic therapy. *Freud and Breuer collaborated closely in the 1880 s on a technique of curing by bringing into consciousness repressed phobias and wishes long consigned to the unconscious. After a series of quarrels their relationship ended in 1896, when Breuer refused to accept Freud's belief that infantile sexuality was a product of seduction by adults. (Freud himself later abandoned that belief.)

Sulloway, F., Sigmund Freud, Beyond the Psychoanalytic Myth. 1979.

Breuer, Marcel Lajos (1902-1981). American architect, born in Hungary. He studied at the Bauhaus in Germany and designed the first tubular steel chair in 1925. In 1937 he went to the US to teach at Harvard, where *Gropius, the German architect, whose pupil he had been, also came to work. They carried out some schemes in partnership. Breuer was a co-architect of the UNESCO building in Paris (1953-59).

\section{Breughel, Pieter see Bruegel, Pieter}

Breuil, Henri Edouard Prosper (1877-1961). French abbé and archaeologist. He was ordained in 1900 but from the first devoted himself to the study of prehistory and became recognised especially as the greatest authority on cave art. He studied and traced the figures of animals etc. in the caves of northern Spain (Altamira etc.) and France (the Dordogne and elsewhere), and by assigning them to the upper Palaeolithic enabled them to be dated approximately between 25,000 and 10,000 BCE. Breuil was professor of prehistory at the Collège de France (1929-17) and wrote many books, including Four Hundred Centuries of Cave Art (1952) and The Painted Rocks of the Sahara (1955).

Brodrick, A. H., The Abbe Brevil. 1963.

Brewer, E(benezer) Cobham (1810-1897). English clergyman and teacher, born in Norwich. His Dictionary of Phrase and Fable (1870), generally known as Brewer's, was a popular reference work, last revised in 2012.
Brewster, Sir David (1781-1868). Scottish physicist, born at Jedburgh. He worked mainly in the field of physical optics, and discovered the law (now known as Brewster's Law) that when polarisation occurs in a reflected beam of light, the tangent of the angle of polarisation is equal to the refractive index of the reflecting medium. Brewster invented the kaleidoscope, improved the stereoscope and devised a polyzonal lens still used in lighthouses. He received the Copley Medal in 1815. He helped to found the British Association for the Advancement of Science in 1831 and was knighted in that year. He wrote an authoritative life of ${ }^{*}$ Newton and many encyclopaedia articles.

Breytenbach, Breyten (1939- ). South African novelist, poet and painter. Writing in Afrikaans, he became deeply opposed to the Nationalist regime and was imprisoned 1975-82. His books included $A$ Season in Paradise (1973), The True Confessions of an Albino Terrorist (1984) and Return to Paradise (1993).

Brezhnev, Leonid Ilyich (1906-1982). Russian Communist politician, born in Ukraine. He worked as a surveyor, then as a metallurgist, joining the CPSU in 1931. He met ${ }^{*}$ Khrushchev during the Great Purges and became a senior political officer during World War II. As Party Secretary in the Kazahk Republic 1954-60, he directed the (largely unsuccessful) 'Virgin Lands' campaign. He was a candidate member of the Politburo 1952-53, 1956-57 and, after the expulsion of the 'anti-Party group', a full member 1957-82. He succeeded Marshal *Voroshilov as Chairman of the Presidium of the Supreme Soviet (i.e. President of the USSR) 1960-64 and again 1977-82. When *Khrushchev fell from power (1964) Brezhnev succeeded him as First Secretary of the Central Committee of the Communist Party, and so with *Kosygin became one of the two most powerful men in the government. He was awarded the Lenin Peace Prize in 1972, became a marshal of the Soviet Union in 1976 and his resumption of the Soviet presidency in 1977, an office he held with the post of first secretary, was regarded as the end of an era of collegiate leadership. Brezhnev's name became proverbial for corruption and nepotism.

Dornberg J., Brezhnev. 1974.

Brian, (William) Havergal (1876-1972). British composer, born in Staffordshire. Largely self-taught, he worked as a clerk, copyist, occasional critic and organist, devoting himself to a frenzy of composition, little of it played in his lifetime, including 32 symphonies and four operas. Symphony No. 1 in D Minor ('the Gothic', 1919-27), for an orchestra of 150 and a choir of 400, probably the longest symphony ever performed (about 107 minutes), is available on CD. The film The Curse of the Gothic Symphony (2012) describes the herculean task of organising its Australian première. 
Brian Boru (or Bóroimhe) (d.1014). Irish King. Having succeeded his brother as King of Munster in 976, he disputed the authority of Malachy II, the High King, gained supremacy over southern Ireland (997) and eventually (1002) expelled Malachy and usurped his power. The end came when in 1014 he found himself confronted with an alliance between the King of Leinster and the Vikings then holding Dublin. At Clontarf Brian Boru won a complete victory but was himself murdered after the battle. The many O'Briens perpetuate his name.

Briand, Aristide (1862-1932). French radical politician, born at Nantes, he became an advocate, co-founder of L'Humanité with his friend Jean *Jaurès, and a Socialist deputy 1902-32. He was Premier of France for six periods 1909-11, 1913, 1915-16, 1921-22, 1925-26, 1929 and Foreign Minister four times 1915-17, 1921-22, 1925, 192632. After World War I he advocated reconciliation with Germany and after the Locarno Treaty of 1925 he shared the Nobel Peace Prize (1926) with Gustav *Stresemann. The Briand-*Kellogg Pact outlawing war followed in 1928 . He was defeated by Paul *Doumer in a parliamentary vote to elect the President in 1931.

Bridge, Frank (1879-1941). English composer, conductor, violist and teacher, born in Brighton. He studied at the Royal College of Music under Sir Charles * Stanford, played in the English String Quartet and assisted Sir Henry* Wood as a conductor. He set many poems, and wrote an ambitious Piano Quintet in D Minor (1904-05; revised 1912), a symphonic suite The Sea (1911) and a tone poem Summer (1916). Deeply affected by World War I, his style, at first romantic, became astringent and radical in his later years in such works as the second and third string quartets (1920, 1937), Oration: Concerto elegiaco (for cello, 1930), Phantasia for piano and orchestra (1931) and many songs. He taught Benjamin *Britten from 1927. Variations on a Theme by Frank Bridge (1937) was one of Britten's earliest successes.

Bray, T., Frank Bridge. 1977.

Bridges, Harry (Alfred Bryant Renton) (19011990). American trade unionist, born in Melbourne. He worked in San Francisco from 1920, formed the International Longshoremen's Association and organised a general strike in 1934. He became President of the International Longshoremen's and Warehousemen's Union (ILWU) in 1937, and resisted many attempts to have him deported.

Bridges, Robert Seymour (1844-1930). English poet, born at Walmer. Educated at Eton and Oxford, he became a physician in London but was rich enough to be able to retire in 1882 . Three volumes of graceful lyrics had already won him recognition as a poet. Later he wrote several plays and the narrative poem Eros and Psyche, now largely forgotten. A collected edition of 1912 , followed by a more complete collection in 1936, introduced him as a major poet to a wider world. Bridges was a great friend of Gerard Manley ${ }^{*}$ Hopkins, whose poems he collected and published posthumously in 1918. The two shared a great interest in metrical and rhythmic experiments. Bridges also wrote critical studies of ${ }^{*}$ Keats and ${ }^{*}$ Milton and succeeded Alfred *Austin as Poet Laureate 1913-30. He expressed his philosophical and aesthetic ideas in his last long poem The Testament of Beauty (1929) and received the OM in 1929.

Sparrow, J., Bridges. 1962.

Bridget (or Brigid or Bride), St (c.450-c.525). Irish religious. Little is known of her life except that she founded the first Irish convent, in Kildare.

Bridget, St (c.1303-1373). Swedish visionary. Born of an aristocratic family, she became absorbed in religion only after the death (1344) of her husband by whom she had eight children. For the rest of her life she was seeing and recording visions. Her revelations concerned not only spiritual matters but also political questions. In 1349 she left Sweden after a disagreement with the king and settled in Rome. In 1370, with papal consent, she founded the Augustinian Order of Bridgettines.

Bridgewater, Francis Egerton, 3rd Duke of (17361803). English nobleman. Responsible for the first canal in England, he commissioned James *Bindley to build a canal from his Worsley coalmines to Manchester. This, later extended to join the Mersey at Runcorn, and subsequent canals, forestalled the railways in providing cheap transport for heavy industrial loads. Bridgewater died unmarried and the dukedom became extinct.

Bridgman, Percy Williams (1882-1961). American physicist. He held professorships at Harvard 1926-54. In 1946 he was awarded the Nobel Prize for Physics for his pioneering studies in the physics of very high pressures. He also made valuable contributions to the philosophy of science.

Bridie, James (Osborne Henry Mavor) (1888-1951). Scottish playwright. A physician in Glasgow for many years, he achieved great success with his plays, some whimsical, some pleasantly macabre. They include Tobias and the Angel (1930), The Anatomist (1931), Mr Bolfry (1943), Dr Angelus (1947) and Daphne Laureola (1949). He was one of the founders of the Glasgow Citizens' Theatre.

Luyben, H. L., James Bridie: Clown and Philosopher. 1965.

Brieux, Eugène (1858-1932). French dramatist. Originally a journalist, he wrote many didactic plays aimed at the exposure of social evils and middle-class hypocrisy. His works include the play Les Avariés (Damaged Goods, 1901), dealing with venereal disease. 
Briggs, Henry (1561-1630). English mathematician, born in Halifax. His life was spent in the academic world and his fame rests on his simplification of logarithms (invented by Napier in 1614) and his extension of their use. He originated the use of 10 as the most practical base for tables and in his Arithmetica Logarithmica (1624) published logarithms for 30,000 natural numbers, calculated to 14 decimal places. In his Trigonometria Britannica (1633) he gave tables of logarithms of sines and tangents to a hundredth of a degree, calculated to 15 decimal places.

Bright, John (1811-1889). English Radical and Quaker politician, born in Rochdale, Lancashire. The son of a cotton manufacturer he left school at 16 to enter the family business. He already had a reputation for speaking on such subjects as temperance when, in 1841, he joined the Anti-Corn Law League and with his lifelong friend Richard ${ }^{*}$ Cobden campaigned ardently for the repeal of taxes on imported grain. The Corn Laws were repealed under Sir Robert ${ }^{*}$ Peel in 1846. Bright's parliamentary career began in 1843 when he was elected for Durham, and he represented this and later constituencies, Manchester and Birmingham, until 1889 (apart from 185758). He campaigned for electoral reform, opposed *Palmerston's aggressive foreign policy, especially the Crimean War ('The angel of death has been abroad throughout the land; you may almost hear the beating of his wings'), and, despite Lancashire's cotton interests, supported the Union cause in the American Civil War. He served under *Gladstone as President of the Board of Trade 1868-70 and Chancellor of the Duchy of Lancaster 1873-74, 1880-82, but resigned over the government's Egyptian policy and finally broke with Gladstone in 1885-86 on the issue of Home Rule for Ireland. A supporter of laissez faire and an opponent of trades unions and factory legislation, he was one of the greatest parliamentary orators. He died of Bright's disease (not named for him: see Richard *Bright).

Ausbel, H., John Bright: Victorian Reformer. 1966.

Bright, Richard (1789-1858). English physician, born in Bristol. In 1812 he graduated in Edinburgh after studying at Guy's Hospital in London. He became a leading London consultant and on the accession of Queen *Victoria became her 'physicianextraordinary'. His name is perpetuated by the term Bright's disease, still applied collectively to a number of kidney disorders.

Brillat-Savarin, Anthelme (1755-1826). French lawyer. Famous for his La Physiologie du Goût (1825), a witty treatise on gastronomy, he was mayor of his native Belley near Chambery in 1793, but then took refuge from revolutionary excesses in Switzerland and America. On his return (1796) he became a member of the court of appeals.
Brin, Sergey Mikhailovich (1973- ). RussianAmerican internet entrepreneur, born in Moscow. His family migrated to the US in 1979, and he studied at the universities of Maryland and Stanford. With Larry *Page he was the co-founder of Google Inc. in 1998 which was floated as a public company in 2004. Brin had a net worth of \$US20 billion by 2012 .

Brindley, James (1716-1772). English engineer, born in Thornsett, Derbyshire. Apprenticed to a millwright, he set up on his own at Leek (1742) but was still almost illiterate when he was commissioned to design and supervise important canal systems by the Duke of *Bridgewater. Brindley built about 600 kilometres of canals, the longest being the Grand Trunk Canal linking the Mersey with the Potteries, Derby and Birmingham.

Brink, André (Philippus) (1935-2015). South African writer. He wrote both in Afrikaans and English, and taught at the University of Cape Town. Looking on Darkness (1974) was the first novel by an Afrikaaner to be banned in South Africa. A Dry White Season (1979) was successfully filmed.

Brinvilliers, Marie-Madeleine d'Aubray, Marquise de (1630-1676). French murderer. She and her lover, Godin de Sainte-Croix, poisoned her husband and all his family to obtain their fortune and avenge her lover's imprisonment. The crime remained undiscovered until after Sainte-Croix's death, when incriminating papers were discovered. The marquise was arrested, tortured and beheaded.

Brisbane, Sir Thomas Makdougall, 1st Baronet (1773-1860). Scottish administrator and astronomer. After distinguished army service, close to *Wellington, he was appointed Governor of New South Wales 1821-25. During his term of office the penal code was reformed and a constitution given to the colony. The Brisbane River, observed in 1823, and the city which was built on its banks were named after him. While in Australia he catalogued over 7,000 stars, receiving the Copley Medal of the Royal Society. In 1836 he was made a baronet, and in 1837 a GCB.

Brissot, Jacques Pierre (known as de Warville) (1754-1793). French revolutionary politician, born at Chartres. Son of an innkeeper, he became a lawyer and campaigned for penal reform, abolition of slavery and other liberal causes. In the revolutionary period he was a member of the Legislative Assembly 179192 and of the Convention 1792-93 and became a leader of the Girondists, the more moderate faction which was overcome and destroyed by *Robespierre's extremist Jacobins. Brissot attempted to flee but was caught and guillotined.

Brittain, Vera (Mary) (1893-1970). English writer and pacifist. Her family was prosperous and she read English at Oxford, breaking off study to become a nurse during World War I, in which her brother, 
fiancé and two close friends were killed. She devoted her life to pacifism and feminism. Her memoir Testament of Youth (1933) was adapted for television (1979) and as a feature film (2014). She married the philosopher (Sir) George Catlin. Shirley *Williams was their daughter.

Bostridge, M., Vera Brittain and the First World War. 2014.

Brittan, Leon, Baron Brittan (1939-2015). British Conservative politician and bureaucrat. Educated at Cambridge and Yale, he became a barrister, MP 1974-88, Home Secretary 1983-85, Secretary of State for Industry 1985-86 and Vice President of the European Commission 1989-99.

Britten, (Edward) Benjamin, Baron Britten of Aldeburgh (1913-1976). English composer, born in Lowestoft. Son of a dentist, educated at Gresham's School, Holt, he began composing from the age of nine (some early work being preserved in Simple Symphony, 1934), studied under Frank *Bridge and at the Royal College of Music. ${ }^{*}$ Mahler, ${ }^{*}$ Berg and *Shostakovich were important early influences. His first international success was Variations on a Theme of Frank Bridge (1937), followed by Les Illuminations (song cycle to poems by *Rimbaud, 1939). A conscientious objector, he lived in the US 1939-42 with his lifelong partner (Sir) Peter *Pears, for whom many works were written, including the Seven Sonnets of Michelangelo (1940), Serenade for tenor, horn and strings (1943), The Holy Sonnets of John Donne (1945), Winter Words (*Hardy, 1953), Nocturne (1958) and Five Canticles (Francis *Quarles, Chester Mystery Play, Edith *Sitwell, two by T. S. *Eliot, 1947-74). His opera Peter Grimes (based on The Borough, by George *Crabbe, 1945), commissioned by ${ }^{*}$ Koussevitzky, with Pears in the title role, was an immediate success and remains in the international repertoire. Other operas include The Rape of Lucretia (after André Obey, 1946), Billy Budd (libretto by E M*Forster and Eric Crozier, 1951), Gloriana (after Lytton *Strachey, 1953), The Turn of the Screw (after Henry *James, 1954), A Midsummer Night's Dream (after *Shakespeare, 1960), Curlew River (1962) and Death in Venice (adaptation of Thomas *Mann, 1973). The Young Person's Guide to the Orchestra (Variations on a Theme by Purcell, with commentary, 1945) has been much recorded. In 1947 he founded the Aldeburgh Festival which became the centre of his musical activities and made many recordings as pianist and conductor, including music by ${ }^{*}$ Bach, ${ }^{*}$ Haydn, *Mozart and ${ }^{*}$ Schubert. Among other works were Violin Concerto (1939), Spring Symphony (1949), The War Requiem (1962) and the Cello Symphony (1963, written for *Rostropovich). He also recorded with ${ }^{*}$ Richter and ${ }^{*}$ Arrau. Britten received the CH (1953), the Aspen Award (1964), the OM (1965) and in 1976 became the first musician created a peer. Shostakovich dedicated his Symphony No. 14 to Britten but * Stravinsky disparaged him. He died of congestive heart failure.

Carpenter, H., Benjamin Britten. 1993; Kildea, P., Benjamin Britten: A Life in the Twentieth Century. 2013.

Brockhaus, Friedrich Arnold (1772-1823). German publisher. Founder of the firm in Leipzig which has borne his name, he published the encyclopaedic Konversations Lexikon (completed 1811), which has been followed by many encyclopaedias during the history of the family firm.

Brodkey, Harold (1930-1996). American novelist and short story writer, born in Illinois. Educated at Harvard, he taught at Cornell and CCNY and contributed to the New Yorker. His novels included The Runaway Soul (1991) and Profane Friendship (1994). He died of AIDS.

Brodsky, Joseph Aleksandrovich (1940-1996). Russian-Jewish poet, born in St Petersburg. After leaving school, he began writing poetry and was sentenced to hard labour in Arkhangelsk for 'social parasitism' 1964-65. He lived in the US from 1972, teaching at the universities of Michigan, Queen's College, New York, and Mt Holyoake College 1981-96. He was awarded the 1987 Nobel Prize for Literature in 1987 and named as the Poet Laureate of the US in 1991. His poems were translated into English, German and French.

Broglie, Maurice, Duc de (1875-1960). French physicist. As a young man and again in World War I he served in the French navy, but was known for his work on the ionisation of gases, radioactivity and $\mathrm{X}$-rays, of which he obtained the first spectra. He became a member of the Académie française in 1934. His younger brother Louis Victor Pierre Raymond, Duc de Broglie (1892-1987), studied history for a diplomatic career, became a radio engineer in World War I, then took up physics at the University of Paris. He laid the foundations of wave mechanics and his prediction of the diffraction of electrons was confirmed in 1927 by C. J. *Davisson and G. P. *Thomson. Awarded the Nobel Prize for Physics in 1929, he was professor of physics at the University of Paris 1932-62, a member of the Académie française 1943-87, and a prolific writer. His publications include New Perspectives in Physics (1962).

Bromfield, Louis (1896-1956). American novelist and short-story writer. He won the Pulitzer Prize for 1926 with Early Autumn, his other novels include The Rains Came (1937), Night in Bombay (1940), and Mrs Parkington (1943).

Brown, M., Louis Bromfield and His Books. 1956. 
Bronowski, Jacob (1908-1974). British mathematician, humanist and poet, born in Łódz. In England from 1920, educated at Cambridge, he had an encyclopaedic range of interests, worked for government, wrote books on *Blake, broadcast for the $\mathrm{BBC}$ and researched in California. With Bruce Mazlish he wrote The Western Intellectual Tradition (1960) and presented an inspiring television series The Ascent of Man (1971-72).

Brontë (originally Brunty or Prunty, the familiar form was adopted after ${ }^{*}$ Nelson was made Duke of Brontë). Anglo-Irish literary family, resident in Yorkshire. Patrick Brontë (1777-1861), born in County Down, was educated in Cambridge and, despite Methodist leanings, ordained as an Anglican clergyman in 1806, serving parishes in West Yorkshire until his death, first Hartshead (1811), then Thornton (1815) and as perpetual curate of Haworth (1820). In 1812 he married Maria Branwell (d.1821). Two daughters, Maria (1813-1825) and Elizabeth (1814-1825), were born in Hartshead; Charlotte, Branwell, Emily and Anne in Thornton. Originally educated at home, after their mother's death the girls were cared for by their kindly but austere aunt Elizabeth Branwell. Their father became increasingly eccentric and in 1824 they were sent to a hated school for the daughters of the clergy at Cowan Bridge (the Lowood of Jane Eyre). The two older girls were sent home to die of tuberculosis and the younger three soon returned as well. The four surviving children, ardent readers of ${ }^{*}$ Shakespeare, Walter ${ }^{*}$ Scott and *Byron, created literary worlds of their own: Charlotte and Branwell wrote a cycle of plays, stories and poems about the imaginary kingdom of Angria (about 1500 pages of which survive), while Emily and Anne produced the island kingdom of Gondal (only a few fine poems remaining). To avoid personal publicity, scarcely necessary as it happened, the sisters adopted masculine names for their first publication, Poems by Currer, Ellis and Acton Bell, which appeared in 1846 and sold only two copies.

Charlotte Brontë (Currer Bell) (1816-1855) attended Miss Wooler's school at Roe Head (1831-32), made lasting friendships, returning to teach her siblings. She then taught at Roe Head (1835-38), became a private governess, and a pupil teacher at Constantin Heger's boarding school in Brussels (1842 and 1843). Her first novel The Professor, set in Brussels, completed in 1846, was rejected and published posthumously (1857). Jane Eyre: An Autobiography, edited by Currer Bell, appeared in 1847 . With its romantic intensity, the vividly Byronic Mr Rochester, and the rejection of love through moral conviction, it won immediate success. Shirley (1849) and Villette (1853), also set in Brussels, followed. In 1849 the sisters' authorship was revealed. Charlotte visited London three times in 1850 , meeting *Thackeray, then went to the Lake District, Scotland and Manchester (1851-52). In 1854 she married Arthur Bell Nicholls (18171906), her father's curate, and died nine months later of pregnancy toxaemia, complicated by tuberculosis. Elizabeth ${ }^{*}$ Gaskell became her first biographer (1857).

(Patrick) Branwell Brontë (1817-1848) showed youthful gifts and is remembered only for a striking but incomplete portrait of his sisters. Dismissed as a railway clerk and tutor, he was wayward and unstable. Addiction to alcohol and opium contributed to his early death.

Emily (Jane) Brontë (Ellis Bell) (1818-1848), the most gifted of the family, was the best poet, as Charlotte conceded, and the most powerful novelist. She was a governess in Halifax, taught English and piano in Brussels (1842) while learning French and German, then kept house at Haworth. Emily's poems are by far the best in the 1846 collection. Her only novel, Wuthering Heights (1847), set on the Yorkshire moors, is a work of great passion and power, suggesting elemental conflict between nature and civilisation, masterfully complex in structure, using time shifts and marked by touches of cruelty. The central character is the passionate Heathcliff, and Catherine Earnshaw is a self-portrait. Criticised for morbidity on publication, it was later recognised as a masterpiece. Emily died of tuberculosis after refusing all medical assistance.

Anne Brontë (Acton Bell) (1820-1849) was most influenced by her aunt and Emily, with whom she created Gondal. Gentle and submissive in character, she worked as a governess and died at Scarborough. Her novels were the autobiographical Agnes Grey (1847) and The Tenant of Wildfell Hall (1848), the story of a violent drunkard, partly modelled on Branwell.

Gerin, W., Anne Brontë. 1959; Charlotte Brontë. 1967; Emily Brontë. 1971; Winnifrith, T., The Brontës and Their Background. 1973; Barker, J., The Brontës. 1988.

Brook, Peter Stephen Paul (1925-2022). English stage producer and film director. After student productions at Oxford, he worked for the Royal Shakespeare Company, becoming co-director 196270. He also produced drama, ballet and opera at Covent Garden, the New York Metropolitan, in Iran and West Africa and (from 1970) in Paris. His films include The Beggar's Opera, The Lord of the Flies, King Lear, A Midsummer Night's Dream, Marat/ Sade, The Conference of the Birds and Meetings with Remarkable Men. From 1985 until 1989 he toured the world with his production of a Sanskrit epic The Mahabharata, which was then adapted for television and film. He received a CH in 1998.

Brook, P. S. P., The Empty Space. 1968.

\section{Brooke, Sir Alan Francis see Alanbrooke}

Brooke, Sir Basil Stanlake see Brookeborough 
Brooke, Rupert Chawner (1887-1915). English poet, born at Rugby. Educated at Rugby School, where his father was a master, he studied at King's College, Cambridge. He epitomised the golden youth of the Edwardian era: beautiful, sexually ambiguous, a questing Fabian. After travelling in Germany, the US and the Pacific he was commissioned in the Royal Naval Division in the early days of World War I and died of blood poisoning caused by an insect bite in Skyros on his way to the Dardanelles. He was the 'gifted and golden youth', the poignancy of whose early death typified the tragedy of his generation.

If I should die think only this of me

That there's some corner of a foreign field

That is for ever England ...

are the most famous lines from his two slim volumes of poetry (1911 and 1915).

Hassal, C., Rupert Brooke: A Biography. 1972; Jones, N., Rupert Brooke: Life, Death and Myth. 2016; Delany, P., Fatal Glamour: The Life of Rupert Brooke. 2016.

Brookeborough, Basil Stanlake Brooke, 1st Viscount (1888-1973). Northern Ireland politician, born near Brookeborough. A nephew of Viscount *Alanbrooke, he inherited a baronetcy, served in World War I (CBE, MC), and was a Senator 1921-22. A Member of the Northern Ireland parliament at Stormont 1929-69, he became a minister in 1933 and succeeded J. M. Andrews as Prime Minister 1943-63. Deeply anti-Catholic, he worsened Catholic v. Protestant divisions in Northern Ireland. He received a viscountcy in 1952 and a KG in 1965.

Brooks, Van Wyck (1886-1963). American essayist, literary critic and translator. He wrote much on the influence of Puritanism on American culture, e.g. in America's Coming-of-Age (1915). Other works include notable biographies of Henry *James (1925) and *Emerson (1932) and The Flowering of New England (Pulitzer Prize for History, 1936).

Brougham, Henry Peter, 1st Baron Brougham and Vaux (1778-1868). British lawyer and politician. Born and educated in Edinburgh, he was admitted to the Scottish bar and became active in journalism, helping to found the Edinburgh Review (1802). In 1805 he moved to London and in 1808 was called to the English bar, and was a Whig MP 1810-12, 181630 . He won notoriety and popularity as counsel for Queen *Caroline when the 'bill of divorcement' brought against her in 1820 by *George IV was withdrawn by the government. A prolific writer, Brougham founded the Society for the Diffusion of Useful Knowledge (1825) and, with others, London University (1828). In parliamentary opposition, he became an advocate for public education and the abolition of slavery (1833). In February 1828 he
House of Commons-six hours. When the Whigs returned to office (1830) he became Lord Chancellor and was prominent in the Reform Bill debates. His eccentricities became so marked that after the defeat of the government (1834) he never held office again. His most important work, if least known, was in law reform, where he followed the principles of Jeremy *Bentham. A carriage built to his design became the prototype of the brougham. He popularised Cannes as a resort, and died there.

Stewart, R., Henry Brougham. 1986.

Brouncker, William Brouncker, 2nd Viscount (1620-1684). English mathematician, born in Ireland. Educated at Oxford, he developed 'Brouncker's formula', which involves 'generalized continued fractions of $\pi^{\prime}$. He was the first President of the Royal Society 1662-77 and a Commissioner of the Navy 1681-84.

Brouwer (or Brauwer), Adriaen (1606-1638). Flemish painter, born at Oudenaarde. A pupil of Frans ${ }^{*} \mathrm{Hals}$, his pictures of brawls and taverns, in which he displays a strong sense of character, reflect the dissipation of his own life. He died of the plague in Antwerp.

Brown, Sir Arthur Whitten (1886-1948). British engineer and aviator. He was navigator to Sir John William *Alcock on the first non-stop Atlantic flight (June 1919) and received a knighthood.

Brown, Edmund G(eorge: 'Pat') (1905-1996). American lawyer and Democratic politician. Governor of California 1959-66, he defeated Richard *Nixon in 1962 and lost to Ronald *Reagan in 1966. His son Edmund Gerald ('Jerry') Brown, Jr (1938- ), formerly a priest, then a lawyer, was Governor of California $1975-83$ and a liberal contender for the presidential nomination in 1976, 1980 and 1992; his sister Kathleen Brown (1946- ) was the unsuccessful Democratic candidate for Governor 1994. Jerry Brown was Attorney-General 2007-11 and again Governor of California 2011-19 (the youngest, longest-serving and oldest to hold the office).

Brown, Ford Madox (1821-1893). English painter, born in Calais. Though closely associated with the Pre-Raphaelite Brotherhood by style and personal contact he never became a member. Christ Washing St Peter's Feet, in the National Gallery, London, is a fine example of his mature style, but more characteristic are pictures of historical subjects, such as the murals for Manchester Town Hall which occupied the last years of his life.

Hilton, T., The Pre-Raphaelites. 1970.

Brown, George Alfred, Baron George-Brown, (1914-1985). British politician. He became a local official of the Transport and General Workers Union and was elected as Labour MP for Belper in 1945. 
In the faction fights of the Labour opposition period he was a loyal supporter of *Gaitskell's defence policy and was deputy leader of the parliamentary party 1960-70. *Wilson beat him for the leadership in 1963 after Gaitskell died. After Labour won in 1964 he was given the new post of Secretary of State for Economic Affairs 1964-66, but clashed with Treasury and had little influence. He was Foreign Secretary 1966-68, was created a life peer in 1970 and left the Labour Party. He had superior natural gifts, but heavy drinking and an erratic style prevented his rise to the top.

Paterson, P., Tired and Emotional: The Life of Lord George-Brown. 1993.

Brown, (James) Gordon (1951- ). British Labour politician, born in Glasgow. Son of a clergyman, he studied at Edinburgh University, and, after being blinded in the left eye after a football accident, became a lecturer and television journalist, gaining a PhD in 1982 for a thesis on James *Maxton. A Labour MP 1983-2015, he supported Tony *Blair for Labour's leadership in 1994, in return for a promise that he would control economic policy in a future government. Brown served as Chancellor of the Exchequer 1997-2007, the longest continuous tenure since 1823, working closely with Blair despite constant speculation about tensions between them, especially over Iraq. He succeeded Blair as Prime Minister in June 2007 and had to cope with the impact of bank collapses in the global financial crisis of 2008-09. The election of May 2010 resulted in a comparatively narrow defeat for Labour, and a Conservative-Liberal Democrat coalition.

Brown, G., My Life, Our Times. 2017.

Brown, John (1800-1859). American abolitionist, born in Connecticut. Attempts to gain a living by cattle trading and land speculation in Kansas proved largely abortive, but as the years went by he developed a fanatical belief in his personal mission to carry out, by force if necessary, the liberation of slaves. For this object he collected considerable sums from well-meaning sympathisers. His plan was to establish places of refuge first in one state and then in another where slaves would gather or be brought, in the belief that such insurrections would force antislavery legislation. Virginia was his first choice, but his raid on the US arsenal and rifle factory at Harper's Ferry proved a fiasco. No one rose in his favour and all 20 members of his tiny force were killed or captured. Brown was condemned for treason and hanged. The emotional fires lit by this futile attempt did much to precipitate the Civil War, during which the song John Brown's Body became a marching song of the Northern troops.

Baird, J., Victoria the Queen. 2016; Oates, S. B., 'To Purge this Land of Blood': Biography of John Brown. 1972.
Brown, John (1826-1883). Scottish servant. Queen *Victoria's faithful retainer at her Scottish estate of Balmoral was not only a servant but a privileged friend whose pungent remarks to the sovereign herself and her visitors became legendary. Mementos of Brown were buried with the Queen but *Edward VII removed his statue.

Cullen, T., The Empress Brown. 1969; Baird, J., Victoria the Queen. 2016.

Brown, Lancelot ('Capability') (1716-1783). English landscape gardener. His nickname referred to his custom of assessing the 'capabilities' of a landscape. As a gardener at Stowe he learnt much from William ${ }^{*}$ Kent, who worked there. Kent's ideas, improved upon by Brown, involved the abandonment of the formal symmetrical beds and walks of earlier gardens and the laying out of gardens and parks by adapting or simulating the natural features of a landscape. The surroundings of many great country houses, e.g. Harewood and Blenheim, bear witness to his skill. He also designed houses himself, mainly in the Palladian style.

Stroud, D., Capability Brown. 1957.

Brown, Robert (1773-1858). Scottish botanist, born at Montrose. Educated at Edinburgh University, he collected many specimens while surveying the Australian coasts for the *Flinders expedition (from 1801), worked for Joseph *Banks, then became keeper of the botanical department at the British Museum from 1827 until his death. He was awarded the Copley Medal in 1839. The behaviour of pollen grains in water led him to discover and investigate a random movement to which particles in suspension are subjected. *Einstein explained (1905) this movement, known as 'Brownian motion', as being due to molecular bombardment.

Browne, Hablot Knight (known as 'Phiz') (18151882). English artist. He is best known for his illustrations to Pickwick Papers (in succession to Seymour and Bass) and several of Dickens' later works. He also illustrated books by Charles Lever, Harrison *Ainsworth and *Surtees.

Browne, Robert (1550-1633). English religious leader. He gave his name to the Brownists, afterwards known as 'independents' and 'Congregationalists'. He was related to Queen *Elizabeth's minister *Burghley, who obtained his release when he was imprisoned for his views. Later he moved with his congregation to Middleburg in Holland but his quarrelsome nature brought disruption, as it did wherever he went. Eventually he accepted Anglican orders but as a rector of Achurch from 1589-1631 he seems to have organised his church on Congregational lines. He died in Northampton gaol where he was incarcerated for an assault. 
Browne, Sir Thomas (1605-1682). English scholar, physician and author, born in London. Educated at Winchester and Oxford, he studied medicine at Montpellier, Padua and Leyden Universities, and settled as a physician in Norwich. His famous Religio Medici (published 1642-43) is self-revealing but leaves his actual religion in doubt. In his Pseudoxia Epidemica or Vulgar Errors (1646) he speculates widely on new and old beliefs. His Hydrotaphia or Urn Burial (1658), with which was printed The Garden of Cyrus, was inspired by the discovery of some sepulchral urns in Norfolk. All of his works display vast and curious learning and are couched in a rhythmic, exotic style, rich in imagery.

Keynes, G., A Bibliography of Sir Thomas Browne. 1968.

Browning, Elizabeth Barrett (née Moulton-Barrett) (1806-1861). English poet. Her father, Edward Moulton of Coxhoe Hall, Durham, where she was born, took the name Barrett on inheriting estates in Jamaica. Most of her childhood was spent among the Malvern Hills, but, injured by a fall from a horse at the age of 15 , she became a semi-invalid. After her mother's death (1832) the family moved more than once until in 1838 Elizabeth was living in seclusion with her father in Wimpole Street, London. She had been a precocious child and her poems had long been published and known when, in 1846, Robert ${ }^{*}$ Browning rescued her by an elopement and secret marriage from her father's jealous affection and from an invalidism continued through habit and nerves. She and Robert lived in great happiness in Florence where their only child Robert (1849-1912), was born. Her works published after her marriage included Sonnets from the Portuguese (1850)_misleading title as they are her own-and Aurora Leigh (1856), a verse-novel. Her elopement is the theme of a play, The Barretts of Wimpole Street, by Rudolf Besier (1930).

Hayter, A., Elizabeth Barrett Browning. 1965.

Browning, Robert (1812-1889). English poet, born in London. Education by private tutors and a background of taste and learning provided by cultured and sufficiently wealthy parents offered the opportunity and inducement to a life of travel and poetry. He visited Russia and Italy, a country which thenceforth dominated his imagination and in which he spent his married life with Elizabeth Barrett*Browning. His first important publication, Paracelsus (1835) brought him the friendship of ${ }^{*}$ Landor, ${ }^{*}$ Dickens and other literary men, but though Men and Women (1855) attracted wider attention, for renown he had to await the issue of his masterpiece The Ring and the Book (1868-69), based on a murder story of Renaissance Italy. Other works include Strafford (1837) and other verse plays now largely forgotten, Sordello (1840), a narrative poem of the Guelph and Ghibelline feuds but described by Browning himself as the 'development of a soul', and several dramatic monologues My Last Duchess, Andrea del Sarto, The Bishop Orders his Tomb for which he is now particularly remembered. Of his narrative poems, Pippa Passes, How They Carried the Good News From Ghent to Aix and The Pied Piper of Hamelin are among the best known. Browning obtained much of his story material from books, but his characterisation was based on a close observation of ordinary people moving round him or doing their ordinary work and he approached moral questions unprejudiced by preconceived Victorian ideas. His verse has not the limpid flow or musical rhythm of that of some of his contemporaries. His idioms are sometimes obscure, and his eye often seems more widely open to the grotesque than to the beautiful but these qualities emphasise an individuality which, with his mastery of verse forms, has ensured the survival and enjoyment of his work. He died in Venice and was buried in Westminster Abbey.

Griffin, W. H., The Life of Robert Browning. 1966.

Brubeck, Dave (David Warren) (1920-2012). American composer and jazz pianist, born in California. He formed the Dave Brubeck Quartet in 1951 and was a prolific composer of complex and sophisticated music in a variety of styles, including 'cool jazz'. Asteroid 5079 Brubeck was named for him.

Bruce, Sir David (1855-1931). Scottish parasitologist and microbiologist, born in Melbourne, Australia. Having graduated at Edinburgh he became a British army surgeon, rising to the rank of major-general. He discovered the bacterial cause of Malta (undulant) fever, which was renamed brucellosis. In Zululand in 1894 he identified a protozoan parasite, later named Trypanosoma brucei for him, transmitted by tsetse flies to cause sleeping sickness in humans, nagana in cattle. He collaborated with his wife, Mary Elizabeth Bruce (née Steele) (1849-1931), a microbiologist, and died during her funeral service.

Bruce, James (1730-1794). Scottish explorer. Having originally studied law, he became a wine merchant, entered the consular service and acquired enough medical knowledge to enable him to travel as a physician in North Africa and the Middle East. In 1768 he went to Egypt, whence he set out on his famous journey to Abyssinia (Ethiopia). He arrived at Gondar, then the capital, early in 1770; in November he reached the source of the Blue Nile, then considered the main stream. Back in Scotland he married Mary Dundas (1776). It was not until 1790 that his five-volume account of his journey appeared.

Bruce, Robert (1274-1329). King of Scotland (as Robert I) 1306-29. A Scottish national hero, his family was of Norman descent (from Bruis) and his grandfather Robert Bruce contended for the throne in 1291 when John de *Balliol was ultimately chosen. It was his murder of the Red (John) Comyn in the Greyfriars Church, Dumfries, an act for which he was excommunicated, that brought him into the open 
as national leader against England. He was crowned in 1306 at Scone and was fortunate that England's warrior King ${ }^{*}$ Edward I died the following year, for though Bruce still had to face some years of varying fortune he gradually asserted his mastery over the country and by his great victory over the English at Bannockburn (1314) assured Scotland's independence (finally recognised in 1328). He was succeeded by his son (by his first wife) ${ }^{*}$ David II. From his daughter Marjorie (by his second wife) was descended the Stewart (Stuart) dynasty. His brother Edward Bruce crossed with a Scottish force to Ulster in 1315 and succeeded in having himself crowned King of Ireland. He failed, however, to maintain his power, was driven back into Ulster and was killed in 1318 near Dundalk.

\section{Barrow, G. W. S., Robert Bruce. 1965.}

\section{Bruce, Stanley Melbourne, 1st Viscount Bruce} of Melbourne (1883-1967). Australian politician, born in Melbourne. He spent only 34 of his 84 years in Australia, was educated at Trinity Hall, Cambridge, called to the English bar, served with the Royal Fusiliers in World War I, winning the MC at Gallipoli and a Croix de guerre avec palme. A Member of the House of Representatives 1918-29, 193133, he was Treasurer 1921-23. He displaced W.M. *Hughes to become Prime Minister and Minister for External Affairs 1923-29, in a NationalistCountry Party coalition, with Earle *Page as his deputy. The coalition was overwhelmingly defeated in 1929 over a proposal that the states should in future control industrial arbitration and Bruce lost his seat. He lived in London from 1932, was High Commissioner 1932-45 and President of the League of Nations Council 1936. An arch-appeaser, he made constant excuses about why the Empire should avoid war with *Hitler's Germany. He represented Australia in Britain's War Cabinet 1942-45, received a CH in 1927 and a peerage in 1947. Elected FRS in 1944, he was foundation Chairman of the World Food Council (forerunner of the Food and Agriculture Organisation) 1947-51 and first Chancellor of The Australian National University, Canberra 1951-61.

Lee, D., Stanley Melbourne Bruce: Australian Internationalist. 2010.

Bruch, Max (Karl August) (1838-1920). German composer, born in Cologne. He conducted and taught composition in Germany and in England directed the Liverpool Philharmonic Society 1880-83. He was a close friend of ${ }^{*}$ Brahms. Prolific, including three symphonies, six string quartets, six concertos, and many choral works, he is now remembered only for his Violin Concerto No. 1 in G minor (1866), the virtuosic Scottish Fantasy for violin and orchestra (1880), and the Kol Nidrei variations for cello and orchestra (1881).

Bruckner, Anton (1824-1896). Austrian composer, born in Ansfelden, Upper Austria. He studied Bach's organ works intensively and in 1856 became organist at Linz Cathedral. He was highly regarded as an organist, giving concert performances in Paris (1868) and London (1871). In Vienna, where he settled in 1868, he became organist at St Stephen's Cathedral and was for many years a revered teacher at the Conservatoire. He never married. In his early life, Bruckner's musical idols had been *Bach and ${ }^{*}$ Beethoven; at Vienna he became a devotee of *Wagner. He was painfully naive and often ridiculed by his more sophisticated musical contemporaries, but his piety and sincerity emerge from his music. His best known symphonies are No. 3, dedicated to Wagner (1873), No. 4, the Romantic (1874), No. 5 (1877), No. 6 (1881), No. 7 (1883) the best known of the series; its slow movement, intended to commemorate Wagner's death, incorporates an inversion of themes from Tannhäuser, No. 8 (1886) and No. 9 (1894), dedicated to 'Our dear God', and left unfinished.

Watson, D., Bruckner. 1975.

Bruegel (or Brueghel or Breughel), Pieter (c.15261569). Flemish painter, born in Breda. He studied at the Antwerp Guild and in 1552-53 travelled through France, Switzerland and Italy making scores of landscape drawings, ancestral to the landscapes of his mature work. In fact, the influence of the Alpine landscape was of infinitely greater significance than that of Italian art, even in the time of ${ }^{*}$ Michelangelo and *Titian. Bruegel's early grotesque fantasies such as The Fall of The Rebel Angels clearly display the influence of Hieronymus *Bosch, but in his mature works Bruegel shows himself a painter of greater subtlety and humanity than Bosch. Ugly, squat, puppetlike, Bruegel's tragi-comic characters constitute a teeming and toil-ridden humanity in uneasy truce with their natural environment, but at the same time give a fascinating representation of the peasant life and lore of his time (as in The Peasant Wedding and Children's Games). The cosmic perspective of Bruegel's landscapes, the villages crouched at the bottom or teetering on the slopes of huge mountain formations, are a comment on the human condition which contrasts with the anthropocentric world of Italian painting. Bruegel moved from Antwerp to Brussels in 1563 and there spent the rest of his life. His work was well received by his contemporaries and is still greatly admired. Most of his finest works are in Vienna; they include the superb landscape sequence known as The Seasons. Two of his sons achieved a lesser reputation. Pieter II (c.1564-1636/8) became known as 'Hell Bruegel' for his nightmare scenes; Jan (1568-1625), known as 'Velvet Bruegel', became a court painter at Brussels and was a friend of *Rubens with whom he collaborated. He is best known for his artificial landscapes and flower pictures.

Grossmann. F. (ed.), Pieter Brueghel: Complete Paintings. 1973; Schama, S., Landscape and Memory. 1996; Orenstein, N. M., Pieter Bruegel the Elder. 2001 . 
Brummell, George Bryan (known as 'Beau Brummell') (1778-1840). English wit and dandy. Educated at Eton and Oxford, he became an intimate of the Prince of Wales (later ${ }^{*}$ George IV) and the leader of fashion in London. In 1813 he insulted the Prince ('Who's your fat friend?'), lost his fortune through gambling and fled to France in 1816 to escape his creditors, living in Calais, then Caen. He died in madness and poverty.

Franzero, C. M., The Life and Times of Beau Brummell. 1958.

Brundtland, Gro Harlem (1939- ). Norwegian Labour politician. Educated at Oslo and Harvard universities, she became a physician and a medical administrator. She was Minister for the Environment 1974-79, Leader of the Labour Party 1981-92, and Prime Minister of Norway 1981, 1986-89, 1990-96. She chaired the World Commission on Environment and Development which produced Our Common Future (1987), an important analysis of global poverty and the widening economic gap between North and South, known as the Brundtland Report. She was Director-General of the World Health Organisation (WHO) 1998-2003.

\section{Brunei, Sultan of see Hassanal Bolkiah}

Brunel, Isambard Kingdom (1805-1859). British engineer, born in Portsmouth. Son of Sir Marc Isambard *Brunel, he studied at the Lycée-Henri IV, Paris, and the university in Caen. In 1823 he entered his father's firm, working on the Thames Tunnel project until 1828, when it was incomplete (but is still in use). His plans for the Clifton Suspension Bridge, 214 metres span, over the Avon Gorge, near Bristol, were adopted in 1831 and he directed work on it. However, owing to insufficient funds it was not completed until 1864. As chief engineer of the Great Western Railway 1833-46, he introduced the broad gauge $(2.14 \mathrm{~m})$ railway, constructed more than $1,900 \mathrm{~km}$ (1,200 miles) of track and many canals. In 1837 he designed the first transatlantic steamer, the Great Western, later improving on this design with the Great Britain (1843) and the Great Eastern (1858), each the world's largest at the time of launching. The Great Britain, the first large vessel driven by a screw propeller, is on display in Bristol. The Great Eastern, 211 metres long, and the first to have a double iron hull, was designed for voyages to India and Australia; it also laid the first successful transatlantic cable. Inspired by *Paxton's Crystal Palace, he designed the London Paddington railway station (1854). Brunel also carried out extensive improvements at docks, including at Bristol and Plymouth, and worked on large guns. For the Crimean War he designed a floating armoured barge and a prefabricated hospital, erected in 1855 at Renkioi. He was an FRS, and Hon. DCL of Oxford. In a BBC public poll '100 Greatest Britons' (2001), Brunel came second to Winston ${ }^{*}$ Churchill. At the opening of the London Olympics in 2012, Brunel (played by Kenneth *Branagh) appeared as a central figure in the creation of modern Britain.

Rolt, L. T. C., Isambard Kingdom Brunel. 1974, rev. 1989; Vaughan, A., Isambard Kingdom Brunel. 1991; Beckett, D., Brunel's Britain. 2006; Buchanan, R. A., Brunel: The life and times of Isambard Kingdom Brunel. 2006; Gillings, A., Brunel. 2006.

Brunel, Sir Marc Isambard (1769-1849). British engineer, born in France. During the Revolution he took refuge in America, worked there as an engineer and came to England in 1799. He had gained a great reputation for constructional work in dockyards etc. before embarking on his most ambitious and anxious task, the building of the Thames tunnel (1825-43). His son, Isambard Kingdom *Brunel, worked with his father on the tunnel.

Clements, P., Marc Isambard Brunel. 1970.

Brunelleschi, Filippo (1377-1446). Italian Renaissance architect, born in Florence. Originally a sculptor, he turned to architecture after *Ghiberti's design for the bronze doors of the Florence baptistery was preferred to his own. He studied the classical buildings still existing in Rome. His theories of perspective were influential in Renaissance art. In the Ospedale degli Innocenti (begun in 1419) he introduced the device of supporting arches on the top of columns, a practice subsequently much imitated. His most spectacular achievement was the construction of the remarkable octagonal dome surmounting the cathedral in Florence. Built as a double-shelled cupola, the dome was erected entirely without scaffolding. He also built the churches of S. Lorenzo and S. Spirito.

Manetti, A., Brunelleschi. Eng. trans. 1970.

Brunhilda (Brynhildr) of Austrasia. (d.613). Visigoth princes. She married Sigbert I, ruler of the Frankish kingdom of Austrasia in 566. As regent for her grandchildren (from 595) she exercised power until she was expelled in 599 and finally defeated and captured in 613. She was put to death by being dragged at the heels of a wild horse. She is often confused with the legendary Brünnhilde whose story is told in *Wagner's opera-cycle The Ring.

Brüning, Heinrich (1885-1970). German politician. An organisor of the Catholic trade union movement, he was a Reichstag member 1924-33 and leader of the Centre Party 1929-33. Chancellor April 1930-June 1932, in a coalition, he introduced stringent economies during the Depression. After the Reichstag election of September 1930, the size of the Nazi and Communist blocs made parliamentary rule impossible, forcing Brüning to rule by presidential decree, a precedent later used by ${ }^{*}$ Hitler. ${ }^{*}$ Hindenburg replaced Brüning with von *Papen in June 1932. Escaping murder attempts by Nazis he 
took refuge abroad and was a professor at Harvard 1937-52. After returning to Germany he held the chair of political science at Cologne 1952-55 but never entered politics again.

Brunner, (Heinrich) Emil (1889-1966). Swiss theologian. After pastoral work as a minister in the Swiss Reformed Church he eventually became (1924) professor of theology at Zürich University. His views were formed in close association with Karl *Barth, with whom, however, he was in controversy (from 1933) concerning the nature of man. His pamphlet Nature and Grace gives his side of the argument. Among his many other works are Revelation and Reason (Eng. tr. 1943) and Communism, Capitalism and Christianity (1949).

Kegley, C., The Theology of Emil Brunner. 1962.

Bruno, St (c.1030-1101). German monk, founder of the Carthusian order, born in Cologne. Educated in his birthplace, he became rector of the cathedral schools at Rheims. In 1084 he withdrew to found an austere religious order at Chartreuse (Cartusia) in the French Alps. He died in Calabria where he had founded a second monastery. London's Charterhouse on the site of a Carthusian monastery, recalls the name of St Bruno's original foundation.

Bruno, Giordano (1548-1600). Italian philosopher, born in Campania. He became a Dominican monk in 1565, but was expelled for scepticism. Put on trial, he fled and led the life of a wandering teacher until in 1581 he obtained protection from ${ }^{*}$ Henri III of France. By 1586, after a vain attempt to obtain employment at Oxford, he was on the move again, and after finding temporary refuge in Wittenberg and Prague returned in 1591 to Italy, where he was handed over to the papal authorities, condemned after a seven-year trial by the Inquisition for his heretical pantheism and burned at the stake in Rome. As well as books on philosophy, he wrote poetry and a play. His philosophy had a profound effect on later thinkers, especially ${ }^{*}$ Spinoza and ${ }^{*}$ Leibniz.

Aquilecchia, G., Giordano Bruno. 1971; Rowland, I. D., Giordano Bruno: Philosopher/Heretic. 2008.

Brusilov, Aleksei Alekseivich (1856-1926). Russian general. In World War I his great drives through Galicia achieved spectacular if temporary success, but the last, undertaken in 1917 when he was Commander-in-Chief under the revolutionary provisional government, was halted by desertions of his troops. In 1920 he joined the Red Army in the war against Poland.

Bruton, John Gerard (1947- ). Irish politician. Minister for Industry 1982-86, he promoted Ireland's technological revolution, becoming Leader of Fine Gael 1990-2001 and Prime Minister 1994-97.
Brutus, Lucius Junius (fl. 509 BCE). Roman consul. $\mathrm{He}$ is said to have led the revolt which after the rape of Lucrece caused the expulsion of the last king of Rome, ${ }^{*}$ Tarquinius Superbus, and so was honoured as a founder of the republic. Another legend (for even his existence has been doubted) relates how he sentenced his two sons to death for trying to restore the monarchy.

Brutus, Marcus Junius (85?-2 BCE). Roman soldier and conspirator. Though his interest in philosophy had implanted a distaste for public life, he supported *Pompey in the struggle for power which resulted in *Caesar's victory at Pharsalus (48), but was pardoned, made governor of Cisalpine Gaul in 46 and praetor of the city of Rome in 44. Persuaded that Caesar planned to make himself king, Brutus reluctantly led the conspirators who murdered him (44). Later he fled from Rome to Macedonia and committed suicide, after his army was defeated at Philippi (*Antony, *Augustus).

Bryan, William Jennings (1860-1925). American Democratic politician, born in Illinois. He became a lawyer in Nebraska, and was a Member of the House of Representatives (1891-95), identifying himself with the 'free silver' policy. A famous speech ('You shall not crucify mankind upon a cross of gold') won him the Democratic nomination for president at the Chicago convention of 1896 , but in the election, as again in 1900 and 1908, he was crushingly defeated. Secretary of State under Woodrow *Wilson 191315 , he resigned during World War I because of his pacifist views. A strong fundamentalist, in 1925 in the notorious 'Monkey Trial' in Dayton, Tennessee he led the prosecution against John $\mathrm{T}$. ${ }^{*}$ Scopes for teaching *Darwin's evolutionary theories, contrary to state law. He also opposed Darwinism because he considered 'natural selection' to be anti-social, justifying domination of the weak by the strong.

Koenig, L. W., Bryan: A Political Biography. 1971.

Bryant, Sir Arthur Wynne Morgan (1899-1985). English historian. Until 1942 he was sympathetic to ${ }^{*}$ Hitler and closer ties with Germany, then wrote 30 popular books which were intensely patriotic and romanticised. These include works on the Napoléonic and Regency periods: The Years of Endurance, The Years of Victory, The Age of Elegance. Restoration England takes the story further back and the field is widened still further by Makers of the Realm and The Age of Chivalry. Subjects of his biographies include *Pepys, ${ }^{*}$ Baldwin, ${ }^{*}$ Nelson and ${ }^{*}$ George V. The Turn of the Tide (1957) and Triumph in the West (1959) are based on the diaries of Lord *Alanbrooke. He received the $\mathrm{CH}$ in 1967.

Bryant, William Cullen (1794-1878). American poet and journalist. While practising at the bar he became editor of the New York Evening Post 182978 , in which capacity he supported liberal causes. 
including the abolition of slavery, and helped to promote *Lincoln's election to the presidency. His poetry consists mainly of meditations on nature in the manner of *Wordsworth, but also includes translations of the Iliad and Odyssey. His best known poem is 'Thanatopsis' (1817).

McLean, A. F., William Cullen Bryant. 1965.

Bryce, James Bryce, 1st Viscount (1838-1922). British historian and Liberal politician. Educated at Glasgow and Oxford Universities he was Regius professor of civil law at Oxford 1870-93 and an MP 1880-1907. After having held minor offices 1886, 1892-95 he was, as a strong Home-Ruler, a popular Chief Secretary for Ireland 1905-07. His most important political role was as Ambassador to the US 1907-13. After World War I he headed a commission to inquire into German atrocities. He was a staunch supporter of the League of Nations. His many works include The Holy Roman Empire (1864), The American Commonwealth (1888, a major influence on the framers of Australia's Constitution) and Modern Democracies (1921). He received the OM in 1907.

Bryce, Dame Quentin Alice Louise (née Strachan) (1942- ). Australian official, born in Brisbane. A law graduate, she was an active advocate for affirmative action, serving as Federal Sex Discrimination Commissioner 1988-93, Governor of Queensland 2003-08 and the first female Governor-General of Australia 2008-14.

Buber, Martin (né Mordechai) (1878-1965). Austrian-Jewish-Israeli philosopher, born in Vienna. Distantly related to Karl *Marx, he lived in Lviv as a youth, later attended German universities and became deeply influenced by ${ }^{*}$ Kierkegaard and ${ }^{*}$ Nietzsche. He joined the Zionist movement in 1898 and during World War I organised the Jewish National Council in Berlin. An honorary professor at the University of Frankfurt-am-Main 1930-33, he left Germany in 1935 and in 1938 became professor of social philosophy at the Hebrew University, Jerusalem.

In his most important book, Ich und Du (1923: published in English as I and Thou, 1937), he argued that human existence is an oscillation between Ich$D u$ (I-You), an unstructured dialogue between man/ woman and God, between lovers, or with nature and Ich-Es (I-It), which is material, analytical and a monologue. Religious faith can only be subjective, a yearning form of $I c h-D u$. Ich-Es is common, Ich$\mathrm{Du}$ is rare.

The history of Israel, as recorded in the Bible, can be interpreted as a dialogue between God and the nation, and here Buber found inspiration for his insistence that the aim of Zionism should be to create a society in direct relationship with God. From 1925 he worked with Franz Rosenzweig (1886-1929) on a German translation of the Hebrew Bible but it was only completed in 1961 .
Kohn, H., Martin Buber. 1961; Mendes-Flohr, P., Martin Buber: A Life of Faith and Dissent. 2019.

Bucer (or Butzer), Martin (1491-1551). German religious reformer, born in Alsace. He became a Dominican friar at the age of 14 , but, influenced by ${ }^{*}$ Luther and ${ }^{*}$ Erasmus, left the order (1521), married a former nun and settled in Strasbourg, where he became a powerful influence among those preaching reform. He took a middle course in the disputes between Luther and *Zwingli, but found himself unable to sign the Augsburg Confession of 1530 . Attempts to reach agreement between the groups of reformers continued with varying success, but Bucer finally found his position in Germany so irksome that in 1549 he accepted *Cranmer's invitation and went to England. He lectured in theology at Cambridge, where he died.

Hopf, C., Martin Bucer and the English Reformation. 1946.

Buchan, John, 1st Baron Tweedsmuir (1875-1940). Scottish author and politician, born in Perth. Son of a Free Church minister, educated at Oxford, he became one of Lord *Milner's assistants in South Africa, held staff and administrative posts in World War I, was a director of Thomas Nelsons, publishers, until 1929, and a Conservative MP 1927-35, receiving a $\mathrm{CH}$ in 1932. Governor-General of Canada 1935-40, he suffered a stroke and died in Ottawa after a brain operation by Wilder *Penfield failed. He wrote about 50 books including biographies (e.g. of Sir Walter ${ }^{*}$ Scott, Julius *Caesar, and Oliver ${ }^{*}$ Cromwell), and novels, of which the most famous, The Thirty Nine Steps (1915), Greenmantle (1916) and The Three Hostages (1924), were about the spy-hunting exploits of Captain Richard Hannay (based in part on Edmund *Ironside), with strong characterisation and a hint of anti-Semitism.

Smith, J., John Buchan. 1965; Lownie, A., John Buchan: The Presbyterian Cavalier. 2003; Buchan, U., Beyond the Thirty-Nine Steps: A Life of John Buchan. 2019.

Buchanan, George (1506-1582). Scottish humanist and Latin poet. Educated at Paris University, his Franciscanus, a religious satire on the friars, caused his arrest by Cardinal *Beaton and imprisonment at St Andrews. He escaped in 1539 and taught Latin in Bordeaux, where ${ }^{*}$ Montaigne was among his pupils, and Coimbra (Portugal), where he was imprisoned for a time by the Inquisition. He returned to Scotland in 1561 and became a leading member of the Reformed Church. Though he had been for a time tutor to *Mary Queen of Scots, his Detectio Mariae Reginae (157l) exposed her allegedly guilty part in *Darnley's death. For the last years of his life he was tutor to * James VI. Among many other Latin works was a history of Scotland (1582).

McFarlane, I. D., Buchanan. 1981. 
Buchanan, James (1791-1868). 15th President of the US 1857-61. Born in Pennsylvania, he was a lawyer, served as a Democratic member of Congress 182131, and as a minister to Russia 1832-34. Elected as US Senator 1834-45, he sought nomination for the presidency in 1844, 1848 and 1852 . He served as *Polk's Secretary of State 1845-49. His absence as minister to Great Britain 1853-56 during critical debates on slavery and states' rights gave him an appearance of remote neutrality and secured him the presidential nomination at Cincinnati in 1856, defeating Franklin *Pierce, the incumbent. He was elected in November 1856, winning 19 states, over the Republican J. C. *Frémont and former President Millard *Fillmore. As President he adopted a policy of peace at any price. The first seven states left the Union, to form a Confederacy, after *Lincoln's election in 1860, while Buchanan was still in the White House. He supported the Union cause during the Civil War. 'Old Buck' was the only unmarried president, and probably the only gay. In 20 Presidential ranking lists by US historians and political scientists, Buchanan scored No. 39 in the aggregate.

Klein, P. S., President James Buchanan, A Biography. 1962; Baker, J. H., James Buchanan. 2004; Boulard, G., The Worst President— the Story of James Buchanan. 2015.

Buchanan, Pat(rick Joseph) (1938- ). American publicist. He worked in *Nixon's White House 196974, revived the term 'silent majority' and devised the Republican Party's 'Southern strategy', became assistant to *Reagan 1985-87. He emerged as a spokesman for the Christian Coalition, a presidential aspirant in 1992, challenging George H. W. *Bush, and again in 1996, and was an advocate for the radical Right.

Buchman, Frank Nathan Daniel (1878-1961). American evangelist, born in Pennsburg, PA. He entered the Lutheran ministry in 1902, then worked for the YMCA, and was a missionary in China. In 1921, he visited England and set up 'A First Century Christian Fellowship', renamed (somewhat misleadingly) 'The Oxford Group' in 1931 and 'Moral Re-Armament' (MRA) in 1938. He preached a doctrine of 'world-changing through life-changing', mainly among undergraduates. One method for helping the achievement of these aims was through gatherings, such as house parties, where young men and women were encouraged publicly to confess their difficulties and misdemeanours (often sexual). However, MRA was a significant influence in elements of the anti-*Hitler resistance in Germany. MRA adopted the name 'Initiatives of Change' in 2001.

Driberg, T., The Mystery of Moral Rearmament. 1964.

Büchner, Eduard (1860-1917). German organic chemist. His major discovery was the reality of cell-free fermentation, which he demonstrated by obtaining supplies of cell fluid through a complicated process of pulverising yeast. This extract, he showed, would ferment sucrose to ethanol. He attributed this property to a hypothetical enzyme which he termed 'zymase'. The importance of Buchner's researches was to show that living cells are not necessary for fermentation. He thus opened up the modern field of enzyme chemistry. Büchner worked on the fermentation processes of many microorganisms e.g. citrous fermentation and acetous fermentation. The general tendency of his work was to show that key life phenomena can be explained in terms of enzymecatalysed chemical reactions. A strong Bismarckian patriot, he volunteered for service in World War I and died of a shrapnel wound on the front in Romania.

Delbrück, M. and Schrohe, A., Hefe, Gärung und Fäulnis. 1904.

Büchner, Georg (1813-1837). German dramatist, born in Godelau. Influenced by *Shakespeare and the Sturm und Drang movement, he wrote three plays that anticipate the Expressionist movement. Dantons Tod (Danton's Death, 1835) was first performed in 1902, Leone und Lena (1836) satirised Romanticism and Woyzeck (1836, published 1879) was the basis of Alban *Berg's opera Wozzeck (1925). A political radical, he died in exile in Zürich.

Mayer, H., Georg Büchner und seine Zeit. 1946.

Buck, Pearl S(ydenstricker) (née Sydenstricker, later Walsh) (1892-1973). American novelist, born in West Virginia. Daughter of Presbyterian missionaries in China, she drew on her long experience of that country to write many novels, several of which, e.g. The Good Earth (1931) and Dragon Seed (1942), became very popular. She won the Pulitzer Prize in 1932 and the Nobel Prize for Literature in 1938. She campaigned actively for feminism, wartime support for China, breaking down Cold War tensions, nuclear disarmament, orphaned children and open recognition of the problems of mental retardation.

Buck, P., My Several Worlds. 1955; Conn, P., Pearl S. Buck: a cultural biography. 1996.

Buckingham, 1st Duke of, George Villiers (15921628). English courtier. Son of a Leicestershire knight, he was for many years the favourite ('Steenie': 'my sweet child and wife') of *James I, and wealth was showered upon him. When a Spanish marriage was proposed for the future *Charles I, Buckingham took the prince on the much ridiculed and unsuccessful visit to Madrid to woo the Infanta Maria in person. When Charles came to the throne (1625), Buckingham remained in power but became increasingly unpopular; after the failure of his expedition to Cadiz only Charles' dissolution of parliament (1626) saved him from the consequences of impeachment. Attempts to aid the French Huguenots proved equally futile and it was when he was about to embark at Portsmouth on a second expedition to La Rochelle that he was killed by 
a discontented soldier, John Felton. His son, George Villiers, 2nd Duke of Buckingham (1628-1687), was brought up with the royal family after his father's death and became an intimate of the future ${ }^{*}$ Charles II. He attended Trinity College, Cambridge and was taught by Thomas *Hobbes. He fought with Charles at the Battle of Worcester (1651), then escaped to Rotterdam, returning in 1657 . Suspected by both royalists and anti-royalists, he was imprisoned several times. After the Restoration, Charles was cool at first and *Clarendon a powerful enemy. Elected FRS (1661), he was soon back in favour at court and after Clarendon's fall became the leading minister in the powerful group known by the acronym 'cabal' (or CABAL): *Clifford, Arlington, Buckingham, Ashley (later ${ }^{*}$ Shaftesbury), ${ }^{*}$ Lauderdale, who were dominant 1668-74. He was Chancellor of Cambridge University 1671-74. Parliament denounced him for improper use of government funds and for his open liaison with the Countess of Shrewsbury (who had witnessed the duel in which Buckingham killed her husband), and he was out of favour with the king from 1674 until 1684, when he retired from politics. Remembered as a debauchee and wit, he was one of the most brilliant of the men of the Restoration, partauthor of the celebrated satire The Rehearsal (1671) and the 'Zimri' of *Dryden's Absalom and Achitophel. The dukedom became extinct on his death.

Lockyer, R., Buckingham. 1981.

Buckingham and Normanby, 1st Duke of, John Sheffield (1647-1721). English nobleman. He held office under ${ }^{*}$ William and ${ }^{*}$ Mary, and *Anne, wrote indifferent verse and tried to improve ${ }^{*}$ Shakespeare. His townhouse, Buckingham House, completed in 1703 , was sold to ${ }^{*}$ George III in 1761 , then converted and enlarged from 1825 to become Buckingham Palace.

Buckland, William (1784-1856). English clergyman and palaeontologist. Awarded the Copley Medal in 1822 for pioneering discoveries of fossils, he found the remains of a giant reptile naming it Megalosaurus ('great lizard')_-later renamed Dinosaurus ('terrible lizard') by Richard *Owen. He was Dean of Westminster 1845-56.

Buckle, Henry Thomas (1821-1862). English historian. He wrote two volumes of his History of Civilisation in England (1857-61) intended to be introductory to a much larger work. His new scientific method of history concentrated on mankind as a whole rather than 'great' individuals, linked the activities of man with natural conditions such as climate and soil, and had considerable influence on later historians.

Buckley, William F(rank), Jr (1925-2008). American conservative writer. Educated at Yale, he came from a rich Catholic family, wrote well and became a leading figure in the conservative revival in US politics, founding the National Review in 1955 and hosting the television program Firing Line 1966-99. He changed his mind on several issuescivil rights, the war in Iraq and marijuana. He wrote several spy novels.

Buddha, The (i.e. 'the enlightened one'. His personal name was Siddharta and his family name Gautama) (c.563-483 BCE). Indian religious teacher, born in Kapilavastu (Rummindei), Nepal. Son of Prince Suddhodana of Kappihavastu and a member of the Sakya clan, he was brought up in the luxury and dissipations of an eastern court but his father, already fearing that his contemplative nature might lead him to renounce the world, arranged for him to marry young. But what the father had feared took place some years later. He left his wife and son, Rahula, and became a wandering seeker after truth. Six years of extreme asceticism, which he came to regard as futile, were followed by a mystical experience known as 'the enlightenment', said to have come to him while sitting under a Bo or Bode (pipal or wild fig) tree. It was borne in upon him that sorrow and suffering resulted from the craving for life and it was only by abolishing this craving that the cycle of birth and rebirth (i.e. reincarnation) could be broken and a state of nirvana (usually understood as a complete cessation of suffering and craving) attained. Buddha, as he was henceforth called, began the task of spreading the new faith in Benares. Five men who had been his original disciples but had left him were first converted, others soon followed and formed a mendicant order of brethren. Three months each year were spent with the brethren in a monastery in contemplation and discussion, the remainder of the year in wandering about the country, begging bowl in hand, gathering adherents. To attain the cessation of craving, eight 'steps' were prescribed: (1) understanding, (2) intention, (3) speech, (4) action and rightness of morals, (5) livelihood, (6) mental control, (7) clearness of thought, (8) concentration. Buddha died after about 45 years of such missionary work. After the 4th century CE Buddhism gradually declined in India but spread as far as China, Korea and Japan. There are about 350 million Buddhists worldwide. Buddhism is the dominant religion in Thailand, Burma, Tibet, Korea, Vietnam, Laos, Cambodia and Sri Lanka. About 100 million Chinese are Buddhists and a similar number in Japan are adherents of Buddhism and Shinto.

Carrithers, M. M., The Buddha. 1983.

\section{'Buffalo Bill' see Cody, William Frederick}

Buffet, Bernard (1928-1999). French artist. He suffered poverty and sickness in his youth but from 1948, when he shared the Grand Prix de La Critique, he won success and fame. His pictures are often carried out in a gaunt linear style depicting human misery, but he also achieved success with murals, book 
illustrations and stage decor. He fell out of fashion in the 1970s. Suffering from Parkinson's disease, he committed suicide with a plastic bag.

Buffett, Warren Edward (1930- ). American investor and banker, born in Omaha. His company Berkshire Hathaway became the centre of a diversified empire and Buffett was one of the world's richest people, worth \$US101 billion in 2021.

Buffon, Georges Louis Leclerc, Comte de (17071788). French naturalist, born in Burgundy. Educated at the Jesuit college at Dijon, he spent his early manhood in travel and scientific writings. In 1739 he was appointed director of the Jardin du Roi in Paris (now the Jardin des Plantes, which houses the Zoo). From 1749 onwards he was engaged in publishing a vast Histoire naturelle. In some of his conjectures on the development of animal species he anticipated ${ }^{*}$ Darwin's theories. His speech on admission to the Académie française included the famous phrase 'le style est l'homme'.

Fellows, O. E. and Milliken, S. F., Buffon. 1972.

Bugatti, Ettore Arco Isidoro (1881-1947). Italian engineer and designer. He built his first motor car in 1909, designed racing cars and the luxurious Type 41, the 'Golden Bugatti' (La Royale) (1920).

\section{Buhl see Boulle, André Charles}

Buick, David Dunbar (1855-1929). American automobile manufacturer, born in Scotland. His Detroit company failed and was taken over by General Motors in 1908. He became a bookkeeper and died in poverty.

Bukharin, Nikolai Ivanovich (1888-1938). Russian Communist politician and theoretician, born in Moscow. He joined the Bolsheviks in 1906, lived in Oregon and New York 1911-13, then worked with *Lenin in Germany. He returned to Russia to become editor of Pravda 1917-29 and was a member of the Politburo 1924-29. He was editor of Izvestia 1934-37 but, as a prominent member of the 'right opposition', became one of the victims of Stalin's purge and was convicted and shot. Bukharin's widow Anna Mikhailovna Larina (1914-1996), imprisoned and exiled 1939-59, secured his rehabilitation under *Gorbachev (February 1988). His books, including The ABC of Communism (1921), became freely available.

Cohen, S., Bukharin and the Bolshevik Revolution. 1973.

Bulfinch, Charles (1763-1844). American architect. The first professional American architect, he built the state capitols in Massachusetts, Connecticut and Maine and designed the dome for the Capitol in Washington DC.
Bulgakov, Mikhail Afanasievich (1891-1940). Russian playwright, novelist and short story writer, born in Kiev. He graduated as a doctor from the University of Kiev in 1916 but left medicine for writing. His first comedies were staged in 1919, but he did not become really successful until the publication of his two satirical stories Deviltry (1923) and The Fatal Eggs (1924). His humour and penetrating satire are also much in evidence in the two comedies Zoyka's Apartment (1920) and The Crimson Island (1927). In 1925 he published his most successful novel White Guards, later dramatised as Days of the Turbins. Realistic and humorous, his works were extremely popular but his plea for artistic freedom expressed in later works, especially in The Master and Margarita, begun in 1928 but not published until 1966, led to government prohibition from publishing in 1930 . This official disapproval ensured 25 years' neglect of his work after his death in relative obscurity. Publication of his works was resumed in the Soviet Union and abroad in the late 1960s.

Bulganin, Nikolai Aleksandrovich (1895-1975). Russian Communist politician and marshal. He made his reputation as Chairman of the Moscow Soviet (i.e. Mayor) 1931-37 when he directed construction of the underground Metro. He was Premier of the RSFSR 1937-38, ran the State Bank 1938-41 and became* Stalin's Deputy Commissar for Defence 1944-47 and Minister for the Armed Forces 1947-53. On Stalin's death he backed *Khrushchev against *Malenkov for CPSU leadership, becoming Minister for Defence 1953-55 and Premier of the USSR 1955-58. He visited Britain, China and India. In 1957 he joined the 'anti-party group' against Khrushchev, was soon sacked and given an obscure posting in Stavropol.

Bull, John (1562/3-1628). English composer and organist. Organist of the Chapel Royal London 15911607, he left England in 1613 after a mysterious scandal and was organist of Antwerp Cathedral from 1617 to the end of his life. He is highly regarded as a brilliant technical innovator and as one of the founders of the English keyboard repertory. One of his pieces for virginals may be the source of God Save the Queen.

Caldwell. J., English Keyboard Music. 1973.

Bülow, Bernhard Karl Martin, Prince von (1849-1929). German politician and diplomat. A distinguished diplomatic career culminated in his serving as foreign minister 1897-1900 and chancellor 1900-09, his wit, culture and charm winning the support and friendship of Kaiser *Wilhelm II more effectively than his political skill. His ill-judged threats (e.g. to France in the Morocco crisis of 1905) exacerbated the international situation, and his denial that he had read an indiscreet interview given in 1908 by the emperor to the Daily Telegraph (though it had in fact been submitted to the German foreign office) 
lost him his ruler's support. His Memoirs (published 1932) are full of interest, but are basically an attempt at justifying his policies and denying responsibility for failure.

Bülow, Hans Guido von (1830-1894). German pianist and conductor. He studied music and law, took up conducting on *Wagner's advice, then studied piano with ${ }^{*}$ Liszt whose daughter Cosima he married in 1857. (She left him for Wagner in 1869.) He premiered Tristan und Isolde and Die Meistersinger, conducted the Munich Court Opera 1864-69 and the Meiningen Orchestra 1880-85. He toured the US three times and gave the premiere of *Tchaikovsky's Piano Concerto No. 1 in Boston in 1875 . He had an enormous repertoire, specialising in *Beethoven, but many good judges thought his playing cold and pedantic. He was also a composer and edited keyboard works by ${ }^{*}$ Bach, ${ }^{*}$ Beethoven and *Chopin.

Bultmann, Rudolf Karl (1884-1976). German Lutheran theologian. Professor of New Testament studies at Marburg University (1921-51), he was the most influential pioneer of 'form criticism' applied to the Gospels. Much of his work involved 'demythologising' traditional teachings. $\mathrm{He}$ emphasised what he called the 'existential' elements in Christ's teaching.

\section{Bulwer-Lytton, Edward see Lytton, Edward George Earle Bulwer-}

Bunche, Ralph Johnson (1904-1971). American United Nations official. Formerly a lecturer in political science at Howard University, Washington, he became the first African-American to be a division head at the State Department in 1945. In 1946 he became director of the UN Trusteeship Division. He succeeded Count ${ }^{*}$ Bernadotte as UN mediator in Palestine in 1948 and, for his work, won the Nobel Prize for Peace in 1950. Later, he worked for the United Nations in Congo, Yemen, Kashmir and Cyprus, receiving the US Presidential Medal of Freedom in 1963.

Bunin, Ivan Alekseivich (1870-1953). Russian writer. Born of an old but impoverished family, he first worked in an Odessa bookshop then travelled widely in Europe and the East, eventually settling down for three years with Maksim ${ }^{*}$ Gorki in Capri. After the Russian revolution he lived in France. Of his novels the best known is The Village (1910) which gives a gloomy picture of Russian peasant life. However, his short stories The Gentleman from San Francisco (1915), Mitya's Love (1925) and The Well of Days (1930) provide more scope for the lyric vitality of his style. In 1933 he became the first Russian to win the Nobel Prize for Literature, a distinction which eluded ${ }^{*}$ Tolstoy, ${ }^{*}$ Chekhov and Gorki. Although admired in his time, Bunin's works have sunk without trace.
Bunsen, Robert Wilhelm (1811-1899). German chemist, born in Göttingen. Professor of chemistry at Heidelberg 1852-89, in collaboration with *Kirchhoff he developed the new science of spectrum analysis by which elements can be identified from the spectra they emit when heated. This led to the discovery of caesium in 1860 and rubidium in 1861 . Bunsen invented several scientific instruments but is best remembered for the simple laboratory burner which bears his name.

Buñuel, Luis (1900-1983). Spanish film director. Noted for the 'black' character of his work, his films include the surrealist work Un Chien Andalou (1928) in which Salvador *Dali was his associate, L'Age d'Or (1930), Los Olvidados (1951), Viridiana (1961), El ángel exterminador (1962), Belle de Jour (1966), La voie lactée (1969) and Le Charme discret de la bourgeoisie (1972).

Buache, F., The Cinema of Luis Buñul. 1973.

Bunyan, John (1628-1688). English preacher and author, born near Bedford. Son of a tinker, he became a tinker himself, and served in the parliamentary army in the Civil War. After his marriage (about 1649) he began to undergo profound spiritual experiences and a deep sense of guilt. He was converted, joined the Puritan community of John Gifford ('Evangelist' in The Pilgrim's Progress) in 1653 and became an active preacher. After the Restoration he was arrested for preaching without a licence, refused to give up his activities and was imprisoned at Bedford (1660 72 ). During his not very arduous confinement-he was even allowed to visit London-he wrote his autobiography Grace Abounding, and several other works. Release followed the Declaration of Indulgence in 1672 but he was again in prison for two years from 1675, during which time he wrote the first part of The Pilgrim's Progress, The Life and Death of Mr Badman and The Holy War followed in 1680 and 1682. Bunyan's considerable gifts as a realistic storyteller in plain but vigorous prose reveal themselves almost in spite of the narrow religious doctrines expressed. The second part of The Pilgrim's Progress (published 1678 ) is the most serene and humane of his works; it enjoyed contemporary popularity but had to await the Victorian age for universal esteem.

Sharrock, R., John Bunyan. 1968.

\section{Buonaparte see Bonaparte}

\section{Buonarroti, Michelangelo see Michelangelo Buonarroti}

Burbage, James (1530/5-1597). English actor, theatrical impresario and builder. In 1576 he built 'The Theatre', in Shoreditch, the first permanent theatre in London since the Romans left, and there he directed Lord *Strange's Men, later The Lord Chamberlain's Men, an acting troupe for whom *Shakespeare wrote and performed. In 1596 Burbage 
bought 'The Blackfriars Theatre'. His son Richard Burbage (c.1567-1619) became the pre-eminent actor of his time. He won early fame on the stage but his period of greatest achievement began when he inherited a share of his father's theatres. In 1598 'The Theatre' was dismantled and its building material used in the first version of 'The Globe Theatre'. In this enterprise Shakespeare was one of Burbage's partners and provided him with several of his greatest parts (e.g. Hamlet, Lear, Othello and Richard III). The Lord Chamberlain's Men became The King's Men in 1603.

Stopes, C., Burbage and Shakespeare's Stage. 1973.

Burbank, Luther (1849-1926). American horticulturist, born in Lancaster, Mass. Son of a farmer, he left school early, read *Darwin avidly, began experimenting with plant breeding at 21 and soon developed the Burbank potato. He moved to Santa Rosa in California in 1875. By grafting and cross-pollination he produced 800 improved varieties of plants, including plums, prunes, berries and tomatoes. He produced the nectarine (a peach-plum cross); the spineless cactus, a useful cattle food in desert areas, the Shasta daisy, many lilies and the Fire poppy. He followed *Lamarck's ideas, knew nothing of *Mendel's work and influenced *Lysenko.

Burckhardt, Jacob (Christoph) (1818-1897). Swiss historian, born in Basle. After studying history at Basle University and in Berlin under von *Ranke, he taught, became a journalist and editor, travelled extensively in Italy and was professor of history at Zürich 1855-58 and Basle 1858-97. His great interest was the Renaissance, which he interpreted in terms of political and cultural developments. His major work was The Civilization of the Renaissance in Italy (1860, published in English 1878). He was extremely influential, especially on his friend *Nietzsche and his disciple Heinrich Wölfflin.

Ferguson, W. K., The Renaissance in Historical Thought. 1948; Ferguson, W. K., Jacob Burckhardt and the Renaissance, 100 Years After. 1960.

Burdett-Coutts, Angela Georgina Burdett Coutts, 1st Baroness (1814-1906). English philanthropist. She was the daughter of the radical MP Sir Francis Burdett (1770-1844), granddaughter of the banker Thomas Coutts (1735-1822), and the richest woman in England. She endowed schools, Anglican churches (including St Peter's Cathedral, Adelaide), three Anglican bishoprics, and financed the establishment of the National Society for the Prevention of Cruelty to Children (NSPCC) and the Royal Society for Prevention of Cruelty to Animals (RSPCA), social housing, training for women and Irish immigration to Canada. She was a close friend of *Wellington (to whom she proposed), *Disraeli, *Napoléon III, ${ }^{*}$ Gladstone and ${ }^{*}$ Dickens. In 1871 , she became the first woman raised to the peerage for public services and in 1881 she married her young American-born secretary.

Burger, Warren Earl (1907-1995). American judge. Educated at the University of Minnesota, he became Assistant Attorney-General 1953-56 and a judge of the US Court of Appeals 1956-69. President *Nixon appointed him as Chief Justice of the Supreme Court 1969-86. He attempted to curb the liberal tendencies established in the court by his predecessor, Earl *Warren.

Burgess and Maclean. Guy (Francis de Money) Burgess (1911-1965) and Donald (Duart) Maclean (1913-1983), British diplomats and Soviet agents. Burgess, educated at Trinity College, Cambridge joined the Communist Party in the 1930s, worked for the BBC, MI5, and the Foreign Office, serving in Washington. Maclean, educated at Trinity Hall, Cambridge, also became a Communist in the 1930 s and worked for the Foreign Office in Paris, Washington and Cairo. In 1951 they defected to the USSR having been warned by a 'third man', later identified as Kim *Philby, that they faced arrest. This episode led to an intense security hunt for the 'third', 'fourth' and 'fifth' men involved in their activities. Philby revealed himself as a KGB officer in 1963 and the 'fourth man' was identified in 1979 as the art historian [Sir] Anthony *Blunt. The 'fifth man', John Cairncross (1913-1995), linguist, literary scholar, public servant and spy was never prosecuted.

Boyle, A., The Climate of Treason. 1979.

Burgess, Anthony (John Anthony Burgess Wilson) (1917-1993). British novelist and critic, born in Manchester. He taught in England and Malaya, but his work as a serious writer only began in 1959 after he was diagnosed as incurably ill. He then wrote five novels in 12 months. His books include A Clockwork Orange (1962-also filmed), Shakespeare (1971), Napoleon Symphony (1974), 1985 (1978), Earthly Powers (1980), Enderby's Dark Lady (1984) and Mozart and the Wolf Gang (1991). He was an enthusiastic composer who wrote a symphony and two ballets, translated Cyrano de Bergerac and Oedipus the King, and published much criticism. Despite the quality of his huge output, he won no awards and received no honours (in striking contrast to E. M. *Forster).

Burgess, A., Little Wilson and Big God. 1987; Burgess, A., You've Had your Time. 1990.

Burghley, William Cecil, 1st Baron (1520-1598). English statesman. Grandson of David Cecil, a favourite of ${ }^{*}$ Henry VII who raised the family to prominence, he was educated at Cambridge and Gray's Inn. He held legal office under ${ }^{*}$ Henry VIII. In *Edward VI's reign he became secretary to the Lord Protector *Somerset, on whose overthrow he was briefly imprisoned, but emerged to become 
Secretary of State 1550-53. Under *Mary he nominally conformed to Roman Catholicism but was without office. On her death, however, he drafted the proclamation of the accession of *Elizabeth, with whom he had maintained secret contact. As Secretary of State 1558-72 and Lord High Treasurer he guided the queen's affairs with prudence, loyalty, wisdom and courage for the rest of his life. He became a baron in 1571. Only when he anticipated Elizabeth's secret wishes by hastening the execution of Mary Queen of Scots, in 1587, did he suffer the full force of her venomous (but politic) rage. Burghley was incorruptible, but the various emoluments and perquisites of office enabled him to build and maintain great houses, where he proved a generous host to his many friends and clients. He was succeeded as chief advisor to the queen by his second son, Robert Cecil, later Earl of *Salisbury.

Beckinsale, B. W., Burghley: Tudor Statesman 1520 1598. 1967.

Burgoyne, John (1722-1797). English general and dramatist. In the American War of Independence, sent to lead an army from Canada against the rebels of the south, he was severely censured for his surrender at Saratoga (1777). He wrote several successful plays including The Maid of the Oaks (1775) and The Heiress (1786). He appears in G. B. *Shaw's The Devil's Disciple.

Paire, L., Gentleman Johnny. 1973.

Buridan, Jean (1295-1358). French philosopher. He studied at Paris University, obtained his MA soon after 1320, and became a teacher, and twice rector, there. His death was probably due to plague. Most of the works of his which survive comprise his lecture notes. His writings defend the autonomy of natural philosophy (= science) as a field of study, independent of metaphysics or theology. Buridan saw the characteristic method of science as being that of establishing empirically well-founded generalisations (rather than necessary truths). He did not believe that truths about the physical world could be shown to be rationally necessary, since thereby God's own infinite freedom would be at risk. Many of his writings about physics are a set of queries around the work of Aristotle. He gave particular attention to the problem of why projectiles continued in motion after they had ceased to be in contact with a source of motion such as a thrower. He formulated a concept that the projectile possessed 'impetus' in proportion to the quantity of matter it contained. Such an idea contains within it the seeds of the modern concept of inertia. Buridan speculated upon the possibility of the motion of the earth, believing that for the earth to move might be a simpler explanation of our observations of the heavens, than believing that all other bodies rotated round the earth.
Burke, Edmund (1729-1797). Anglo-Irish politician and political philosopher, born in Dublin. Son of a Protestant solicitor and a Catholic mother, he studied at Trinity College, Dublin, went to London to read law at the Middle Temple, but was mainly occupied by literature. He published $A$ Vindication of Natural Society (1756) and The Sublime and Beautiful (1757) and was an intimate of Dr *Johnson. His political career began in earnest when in 1765 he became secretary to the Whig leader Lord *Rockingham, whose government fell, however, a year later. Burke (who had been MP for Wendover from 1765, and was returned for Bristol in 1774) became the chief organiser of the Whig opposition and in 1770 produced his famous Thoughts on the Cause of the Present Discontents, an attack on the 'King's friends' and a defence of party government. His speeches in favour of conciliating the American colonists were also published and are among the finest examples of his oratory. In a famous speech to the electors of Bristol (1774) he insisted that a member of Parliament was a representative, not a delegate: 'Your representative owes you, not his industry only, but his judgment, and he betrays instead of serving you if he sacrifices it to your opinion.' Denunciation of discrimination against Roman Catholics and of the slave trade gave further evidence of his liberal and generous mind. Under the malign influence of Philip *Francis, Burke was persuaded that the brutality and corruption of the East India Company had been directed by Warren *Hastings, the Governor-General, and he moved for his impeachment (1788), at the onset of a long trial before the House of Lords. A turning point in Burke's political life came with the publication (1790) of his Reflections on the Revolution in France. Here, urging the necessity of political continuity, he found himself revolted by the excesses of violent change. Equally was he estranged from the progressive Whigs and especially Charles James *Fox, with whom he had been so closely allied. He crossed the floor of the house and sat next to his old opponent ${ }^{*}$ Pitt. Thus his political life ended in sorrow and disillusion, but the inspiration of his wonderful eloquence, more effective in the written than the spoken word, survives. 'Magnanimity in politics is not seldom the truest wisdom, and a great empire and little minds go ill together.'

O'Gorman, F., Edmund Burke: His Political Philosophy. 1973; O'Brien, C. C., The Great Melody: A Thematic Biography and Commentated Anthology of Edmund Burke. 1992; Norman, J., Edmund Burke. Philosopher, Politician, Prophet. 2013; Bourke, R., Empire and Revolution: The Political Life of Edmund Burke. 2017.

Burke, Robert O'Hara (1820-1861). Irish-Australian explorer, born in Co. Galway, Ireland. Early episodes in his life included periods of service in the Austrian army and the Irish constabulary before he emigrated (1853) to Australia, where he became an inspector of police, first in Beechworth, then Castlemaine. In August 1860 he set out from Melbourne as leader 
of an expedition (19 men, 27 camels and 23 horses) to cross Australia from south to north. He succeeded in his purpose by reaching the estuary of the Flinders River on the Gulf of Carpentaria with William John Wills (1834-1861) but both men died of starvation (June 1861) at Cooper Creek, South Australia, on the way back. The expedition was elaborately equipped, but mismanagement and confusion of purpose in the rear, and Burke's impetuous character, which induced him to press forward without adequate attention to his chain of supplies, or taking advantage of Aboriginal knowledge, brought about disaster. Sidney *Nolan painted two series of works (1949-50; 1961$62)$ on the Burke and Wills expedition.

Moorehead, A., Cooper's Creek. 1963; Wilcox, D., Explorers. 1975; Bonyhady, T., Burke and Wills. Melbourne to Myth. 1991; Joyce, E. B., and McCann, D. A. (eds), Burke of Wills: The scientific legacy of the Victorian Exploring Expedition. 2011.

Burke, William (1792-1829). Irish labourer. With another Irishman, William Hare, he found an easy way of making a living by enticing the unwary to enter their Edinburgh lodging house, suffocating them and selling their bodies for dissection. The unsuspecting doctor, Robert Knox, had paid from $£ 8$ to $£ 14$ each for 15 corpses before inquisitive neighbours summoned the police. Hare saved himself by turning King's Evidence but Burke was hanged.

Boyle, H., Burke and Hare: The True Story. 1973.

Burlington, 3rd Earl of, and 4th Earl of Cork, Richard Boyle, (1694-1753). Anglo-Irish art patron. His influence was largely employed to further the use of the Palladian style in architecture, of which he had become a great admirer while travelling in Italy as a young man. He often acted as architect, e.g. for his own villa at Chiswick. Burlington House, London, the home of the Royal Academy, stands on the site of his former townhouse.

Burne-Jones (né Jones), Sir Edward Coley, 1st Baronet (1833-1898). Anglo-Welsh painter, designer, illustrator, born in Birmingham. Of Welsh descent, he befriended William *Morris at Exeter College, Oxford, and when they both decided to take up art, they were attracted to *Rossetti and the PreRaphaelites. His subjects were mainly legendary or mythological scenes such as The Rose Bower, The Star of Bethlehem, King Cophetua and the Beggar Maid (Tate Gallery, London) and episodes from the Arthurian cycle. Fine draughtsmanship, brilliant colours and romantic treatment are characteristics of his style. With Morris he also designed stained-glass windows, tapestries, mosaics and book illustrations. Long out of fashion, there was a revival of interest from the 1970 s and he influenced symbolists in England and France.

Harrison, M. and Waters, B., Burne-Jones. 1973; Wildman, S., Edward Burne-Jones. 1998; Wood, C., Burne-Jones. 1999.
Burnet, Gilbert (1643-1715). Anglo-Scottish prelate and historian, born in Edinburgh. Educated at Marishal College, Aberdeen, he was professor of divinity at Glasgow 1669-74, then came to London to take up a royal chaplaincy. In 1683 , having earned disfavour by his condemnation of King *Charles II's immorality and by his staunch Whiggery, he went to Holland, where he became friend and advisor of the Prince of Orange and chaplain to his wife. When the couple became ${ }^{*}$ William III and *Mary II of Great Britain, he became Bishop of Salisbury. The consummation of his life work was his great History of My Own Time, which appeared posthumously (1724-34), and in which his tolerance, enthusiasm and innocent indiscretions were revealed.

Burnet, Sir (Frank) Macfarlane (1899-1985). Australian medical scientist, born in Traralgon. Educated at Geelong College and Melbourne University, he worked in London at the Lister Institute 1926-27 and the National Institute for Medical Research 1932-33 and became a world authority on $\mathrm{Q}$ fever, herpes simplex, influenza and diphtheria. He was assistant director of the Walter and Eliza Hall Institute for Medical Research, Melbourne 1934-44 and director $1944-65$. He published 528 papers, more than 400 on his research. Burnet, essentially an old fashioned, solitary, intuitive researcher, had few collaborators, mostly women, other than Frank *Fenner, Ian Mackay, Gordon Ada and Gus *Nossal. He was rather suspicious of 'big science', heavy investment in equipment and setting up research teams, and wary of clinical or applied research. Knighted in 1951, he received the Lasker Award in 1952, the OM in 1958 and the Copley Medal in 1959.

He developed two international reputations, until 1957 as a virologist, then, as perhaps the world's most distinguished theoretician of immunology. Burnet worked with Fenner on 'acquired immunological tolerance', the capacity of organisms to distinguish between 'self' and 'not self', confirmed experimentally in England by Peter *Medawar and Rupert Billingham. Burnet and Medawar shared the 1960 Nobel Prize for Medicine for this work. (Fenner and Billingham were very unlucky not to have shared the award because Nobel Prizes can be split into two or three, but not four.) In 1957 Burnet published an important paper on 'clonal selection theory', a microevolutionary explanation of the adaptive nature of antibody production.

In 1961 Burnet became the first 'Australian of the Year' and was President of the Australian Academy of Science 1965-69. He had some significant nearmisses: he abandoned his work on poliomyelitis although it closely paralleled John *Enders' Nobel Prize-winning discovery; he failed to explore the phenomenon of haemagglutination (clumping of red blood cells) following attacks of influenza; he demonstrated interferon in action in 1951 but its 
significance was only recognised by his former coworker Alick Isaacs in 1957 and he had a notorious blind spot about molecular biology. His books include Viruses and Man (1953), Changing Patterns: An Atypical Autobiography (1968), and Credo and Comment: A Scientist Reflects (1979).

Fenner, F., Frank Macfarlane Burnet 1899-1985. 1987; Sexton, C., Burnet: A Life. rev. 1999.

Burnett, Frances (Eliza) (née Hodgson) (18491924). American writer, born in Manchester. Her family emigrated to Tennessee in 1865. She is remembered for Little Lord Fauntleroy (1886) and The Secret Garden (1911).

Thwaite, A., Waiting for the Party: A life of Frances Hodgson Burnett. 1974.

Burney, Fanny (Frances, later Madame d'Arblay) (1752-1840). English novelist and diarist. She married a French officer and lived in Paris (180215), then returned to England. Her husband died in 1818. She began to write quite early in life. Evelina, the story of a young girl's entry into society, had to be published under a pseudonym (1778). It was enormously popular. On her authorship being disclosed she became a friend of Samuel *Johnson. Her second novel, Cecilia (1782), was also a success, but her later works did not prove popular. Her Letters and Diaries (published posthumously) give lively accounts of Dr Johnson, *Garrick and their circle, and of her life at court.

White, E., Fanny Burney, Novelist. 1960.

Burnham, James (1905-1987). American political philosopher. Educated at Princeton and Oxford, he was a Trotskyist who moved steadily to the right, and became an important influence for neoconservatives. The Managerial Revolution (1941) accurately predicted that managerialism would displace ideology/politics in government, and influenced George *Orwell's Nineteen Eighty-four.

Burns, John Elliot (1858-1943). English radical politician. He was an active trade unionist, several times jailed, who founded the Battersea Labour League in 1889 and became a London County Councillor 1889-1907 and MP 1892-1918. He refused to join the Independent Labour Party, worked with the Liberals and became the first Cabinet minister drawn from the working class, as President of the Board of Local Government 1905-14. A pacifist, he opposed World War I and resigned as President of the Board of Trade (1914).

Burns, Ken(neth Lauren) (1953- ). American filmmaker, born in Brooklyn. He made a series of documentary films, characterised by the creative use of still photographs, including The Civil War (1990), Baseball (1994), Jazz (2001), Prohibition (2011), The Roosevelts (2014) and The Vietnam War (2017).
Burns, Robert ('Rabbie') (1759-1796). Scottish national poet, born near Alloway, Ayrshire. His father, a self-educated tenant farmer, gave him his first lessons and inspired a love of reading encouraged later by John Murdoch, a village schoolmaster. From the age of 14 Burns wrote poems in dialect, but it was only while he and his brother were farming unsuccessfully at Mossgiel 1784-88 that, to obtain money for contemplated emigration to Jamaica, he listened to suggestions for publication. In the meantime he continued a life of hard work, varied by wide reading, and bouts of dissipation, and complicated by his many love affairs. The first edition of his poems (the Kilmarnock edition) appeared in 1786 and its immediate success caused him to be lionised in Edinburgh, where he won popularity by his modesty, intelligence and charm. But he soon tired of patronage and flattery, and having acquired $£ 400$ from a second edition he was encouraged to settle on a small farm at Ellisland and marry Jean Armour, one of his many loves. The failure of the farm caused him to accept a post as exciseman at Dumfries. His first generous sympathy with the French Revolution might have threatened this government post, but he was quickly disillusioned and, in 1794 , on a patriotic impulse, joined the Dumfriesshire Volunteers. Overwork, alcohol and (probably) endocarditis induced by rheumatic fever combined to bring about his early death. The last years of his life as a writer were mainly spent in composing, collecting and adapting song lyrics. In Edinburgh he had met James Johnson, collector and publisher of Scottish songs, and it is to Burns' cooperation with him (and others) that we owe that wonderful abundance of songs that immortalise his name. They include Auld Lang Syne, My love is like a red red rose, Comin 'Thro' the Rye, John Anderson my Jo, Ye Banks and Braes o'Bonny Doon and many just as famous. Burns' lyrics have been set by many composers, among them *Haydn, *Beethoven ('The Lovely Lass of Inverness', 1794), *Mendelssohn, *Schumann, *Ravel ('Ye banks and braes o' Bonnie Doon...', 1909) and *Shostakovich. Burns also achieved success with such masterly satires as Holy Willie's Prayer and The Holy Fair, and long narrative poems such as The Jolly Beggars, Death and Dr Hornbrook and Tam o'Shanter, all except for the last named belonging to the earlier part of his life. Burns is unique among the great poets (except Shakespeare) in having universal and enduring appeal. He is much admired in Russia.

Daiches, D., Robert Burns and His World. 1971; Douglas, H., Robert Burns. A Life. 1977; McIntyre, I., Robert Burns. A Life. 2009; Crawford, R., The Bard: Robert Burns. 2010.

Burnside, Ambrose Everett (1824-1881). American soldier, politician and industrialist. Famous for having been jilted at the altar by a Confederate spy, and for his side whiskers, he was a popular but not very competent officer in the US Civil War. Commander of the Army of the Potomac 1862-63, he lost the 
Battle of Fredericksburg, but was given the command in Ohio. Governor of Rhode Island 1866-69, he became a US Senator 1875-81.

Burr, Aaron (1756-1836). American politician, born in Newark, New Jersey. Educated at Princeton College, he served on *Washington's staff and rose to the rank of Lieutenant Colonel in the War of Independence, became a successful lawyer in New York and was a US senator 1791-97. In the 1800 presidential election, in which *Adams was defeated, he tied with *Jefferson in the Electoral College and after 36 ballots the result was determined by the House of Representatives, where Alexander *Hamilton ensured Jefferson's victory and Burr became Vice President of the US 1801-05. In 1804 Hamilton also blocked Burr's nomination as Governor of New York State. In July 1804 Burr killed Hamilton in a duel in Weehawken, New Jersey, was indicted on a murder charge and fled. He tried to set up an independent state comprising the south-western states and part of Mexico. A small expedition was equipped and sailed down the Mississippi but Burr was arrested, tried for treason (1807) and acquitted, mainly on technical grounds. He continued his intrigues abroad (1808-12), but later resumed his law practice in New York City.

Vidal, G., Burr. 1973.

Burroughs, Edgar Rice (1875-1950). American author, born in Chicago. After indifferent success in business, he devoted himself to writing, including science fiction and adventure stories. Beginning with Tarzan of the Apes (1912), he produced 26 books about a feral white child (John Clayton III, Earl of Greystoke) brought up by apes, who became a sophisticated adult. They were bestsellers, the subject of many films, television series and comics. (Even Rudyard *Kipling read them.)

Burroughs, William Seward (1914-1997). American writer, born in St Louis. Educated at Harvard, he worked in advertising, as a detective, bartender, reporter and pest-exterminator, was a heroin addict 1944-58 and lived in France 1959-64 and Britain 1964-73. One of the gurus of the Beat generation, he developed a deliberately disjointed 'collage' style in his writing. His books include Junkie (1953), The Naked Lunch (1959, also filmed), Nova Express (1964), Queer (1985) and The Western Lands (1988).

Morgan, T., Literary Outlaw. 1988.

Burton (né Jenkins), Richard (1925-1984). Welsh stage and film actor, born in Pontrhydfen. Educated at Port Talbot Secondary School and Exeter College, Oxford, he served with the RAF, then acted with the Old Vic in London and New York and was a successful Hamlet and Henry V. His films include Alexander the Great (1956), Look Back in Anger (1959), Cleopatra (1963), Becket (1964), The Spy Who Came in From the Cold (1965), Who's Afraid of Virginia Woolf (1966),
Exorcist II (1977), Equus (1977) and The Heretic (1977). He produced a film version of Dylan Thomas' Under Milk Wood (1971). He married four times, twice to the actor Elizabeth *Taylor.

Bragg, M., Richard Burton: A Life. 1989.

Burton, Sir Richard Francis (1821-1890). English explorer and writer. While in the Indian army (1843-49), he served with Napier in Sind. In 1853 he became the first Western European to visit the holy places of Mecca when he went on a pilgrimage there disguised as a Pathan Muslim. After exploring Somaliland he discovered Lake Tanganyika with J. H. *Speke in 1858. Speke's discovery of Lake Nyanza and his claim that it was the main source of the Nile led to a prolonged controversy with Burton, only settled when H. M. * Stanley proved Speke right. Later he was British consul at Fernando Po, Santos, Damascus and Trieste. He described his travels in a long series of vividly written books, but by far his greatest literary achievement, both in size and fame, was his translation of The Arabian Nights (1885-88). $\mathrm{He}$ is said to have mastered more than 30 languages.

Wright, T., The Life of Sir Richard Burton. 2 vols, 1968; McLynn, F., Burton: Snow upon the Desert. 1992.

Burton, Robert (1577-1640). English clergyman. Famed as the author of The Anatomy of Melancholy, he spent nearly all his life at Christ Church, Oxford, first as a student and then, having taken orders, as tutor. The work upon which his fame entirely rests first appeared in 1621 and was strongly influenced by *Montaigne's Essays. The name 'Democritus Junior' which appeared on the title page was a reference to *Democritus, 'the laughing philosopher' of the ancient Greeks. The book is a whimsical and immensely learned analysis of the various types of melancholia but contains stories of celebrated lovers and is illustrated by quotations from the classical and medieval authors then known.

Busch, Fritz (1890-1951). German conductor and pianist. He directed the Dresden State Opera 1922 33, left Germany when *Hitler took power, went to Denmark and Argentina and became first director of the Glyndebourne Opera (John ${ }^{*}$ Christie) in 1934. He worked in New York 1945-50. His brother Adolf Busch (1891-1952), violinist, conductor and composer, founded the Busch String Quartet in 1919 and the Busch Chamber Players in 1935, performed in Switzerland, England and the US and made many outstanding recordings.

Bush, George Herbert Walker (1924-2018). 41st President of the US 1989-93. Son of Prescott Bush, a US senator from Connecticut, he was educated at Andover and Yale, became a very young naval carrier pilot in World War II, founded the Zapata Petroleum Corporation (1953) in Texas, and then entered politics. He served as a congressman 1967-70, 
Ambassador to the UN 1970-73, head of the US liaison office to Peking 1974-75, and Director of the Central Intelligence Agency 1975-76. He became Vice President of the US under Ronald *Reagan 1981-89. Elected President in 1988, defeating Michael *Dukakis, he was most comfortable in foreign affairs, claimed credit for ending the Cold War and, through the UN, he organised in 1990 an international coalition against Iraq (Saddam *Hussein), after its invasion of Kuwait. After Iraq's defeat in 'Operation Desert Storm' in February 1991, he enjoyed an approval rating of 91 per cent. However, the economy appeared to be sluggish and Bush was perceived to lack what he called the vision thing' in domestic policy. In November 1992 he was defeated by Bill ${ }^{*}$ Clinton, largely because H. Ross *Perot's intervention took away many conservative votes. Bush was uncomfortable with the fundamentalist Right in his party but, as the inheritor of Reagan's political legacy, seemed unable or unwilling to identify or articulate moderate or liberal domestic policies. In the week he left office he resumed bombing Iraq after Saddam failed to meet $\mathrm{UN}$ inspection requirements. He was awarded an Hon. GCB in 1997. His sons included George W. *Bush and John Ellis ('Jeb') *Bush. He celebrated his 90th birthday with a parachute jump and was, at the time of his death, the longest-lived US President (94 years 6 months 18 days).

Bush, George W(alker) (1946- ). 43rd President of the US 2001-09. Son of George Herbert Walker *Bush, he was born in New Haven, Conn., educated at Andover, Yale and Harvard (where he gained an MBA), then moved with his family to Texas. He worked in the oil business, managed the Texas Rangers baseball team and was governor of Texas 1993-2000. He defeated John ${ }^{*}$ McCain to win the 2000 Republican nomination for president, and, although losing the popular vote nationally by 540,000 , defeated $\mathrm{Al} *$ Gore narrowly in the Electoral College. (Ralph ${ }^{*}$ Nader ran as a Green candidate.) This followed a fiercely disputed return in Florida, in which the US Supreme Court voted 5-4 against a hand recount of votes in certain counties. This was the first election since 1888 (Benjamin *Harrison) when the winner did not lead in the popular vote. $\mathrm{He}$ organised an international coalition against terrorism following the 11 September 2001 terrorist attacks attributed to Osama bin ${ }^{*}$ Laden and his alQaeda group, but gave priority to regime change in Iraq, claiming that Saddam *Hussein's 'weapons of mass destruction' (WMD) threatened world peace. The 'coalition of the willing' invaded Iraq in March 2003 , claimed victory after 28 days, installed an occupation authority but failed to locate any WMDs and insurrection continued. In 2004, Bush won a second term, defeating Senator John *Kerry. His failure to act decisively after the impact of Hurricane Katrina (2005) and the 'global financial crisis' (2008), increased defence spending for Afghanistan, made him deeply unpopular towards the end of his term, even in his own party. In nine Presidential rankings by US historians and political scientists, Bush scored No. 31 in the aggregate.

Smith, J. E., Bush. 2016.

Bush, John Ellis ('Jeb') (1953- ). American businessman and Republican politician, born in Texas. Son and brother of US Presidents, educated at the University of Texas, Austin, he became a banker, consultant and real estate developer. $\mathrm{He}$ married Columba Garnica de Gallo, a Mexican, in 1974, became fluent in Spanish and converted to Catholicism in 1995. Governor of Florida 19992007, he was the preferred choice of the Republican establishment for the 2016 Presidential nomination but failed with voters.

Bush, Vannevar (1890-1974). American electrical engineer, born in Massachusetts. Educated at Tufts and the Massachusetts Institute of Technology, he taught at MIT 1919-38 and in 1925 devised the first analogue computer, used in solving differential equations. President of the Carnegie Institution, Washington 1939-56, he became Director of the US Office of Scientific Research and Development 1941-46 and Chairman of the Joint Research and Development Board 1946-47. Reporting to President Franklin *Roosevelt, he played a unique role in coordinating all major wartime scientific, technological and engineering projects, became the architect of science policy, set priorities and showed superb judgment. He took scientific responsibility for the atomic bomb project (*Oppenheimer), for the development of computing (*Eckert) and even the commercial development of penicillin ( ${ }^{*}$ Florey). He became an honorary KBE (1948), was Chairman of MIT 1957-59 and wrote Science Is Not Enough (1967).

Busoni, Ferruccio (Dante Michelangelo Benvenuto) (1866-1924). Italian composer, pianist and conductor, born in Florence. His father was a clarinet virtuoso, his German mother a pianist. He gave his piano debut in Trieste in 1874 and came to be recognised as one of the greatest performers. He made elaborate transcriptions of *Bach's organ works and the famous Chaconne for solo violin. He wrote a massive piano concerto, including a male chorus (1903-04), and the operas Turandot (1917, not to be confused with *Puccini's) and Doktor Faust (191624), left incomplete, rarely performed but important.

Bustamente, Sir (William) Alexander (1884-1977). Jamaican Labour politician. He studied in the US and worked in Havana and New York, returning to Jamaica in 1934. He established his own trade union and founded the Labour Party in 1943, having left the People's National party led by his cousin Norman ${ }^{*}$ Manley. He was Chief Minister 1953-55. 
After the formation of the West Indian Federation in 1958 he worked for the secession of Jamaica and was supported by a referendum held in 1961 and subsequent elections. Jamaica accordingly withdrew and Bustamente became first Prime Minister 196267 under independence.

Bute, 3rd Earl of, John Stuart (1713-1792). Scottish aristocrat and royal favourite, born in Edinburgh. Educated at Eton and Leyden University (Netherlands), he divided his time between his Scottish estates, London, and the mansion Luton Hoo, Bedfordshire. He had a passion for botany and antiquities. He became a close friend of ${ }^{*}$ Frederick, Prince of Wales, and his wife, the princess. The friendship with the family survived the prince's death in 1751 . Bute gained a position in the household and became virtually the tutor of the young prince, the future ${ }^{*}$ George III, whose warm affection he won. Unfortunately he instilled into him the doctrines of *Bolingbroke's Patriot King which claimed for the sovereign a much more active part than George's abilities could sustain or recent constitutional practice could allow. The test came when ${ }^{*}$ George II died. Bute was brought into the government in 1761, manoeuvred *Newcastle and *Pitt out of office and became First Lord of the Treasury (i.e. Prime Minister) 1762-63. He ended the Seven Years' War, but was forced to resign due to lack of political support and personal unpopularity. He was the last royal 'favourite' in government, but for several years the influence of 'the minister behind the curtain' survived. He was a patron of Dr *Johnson, contributing up to $£ 300$ p.a., and of Robert *Adam and Tobias *Smollett.

McKelvey, J. L., George III and Lord Bute. 1973.

Buthelezi, Mangosuthu Gatsha (1928- ). Zulu chief and politician. He played the role of his greatgrandfather ${ }^{*}$ Cetewayo in the film Zulu (1963) The most powerful Zulu chief, he founded the tribally based Inkatha movement, became Chief Minister of KwaZulu 1976-94, collaborated with Pretoria in return for economic concessions and was a strong critic of the African National Congress. He made the longest recorded speech, lasting for five days. He opposed creation of a unified South Africa under black rule, as this would destroy Zulu autonomy and his own power base. In 1993 he formed an alliance with white extremists against the power sharing arrangements of *de Klerk and *Mandela. He reluctantly took part in the election of April 1994 where his Inkatha Freedom Party won 10 per cent of the vote. He became Minister for Home Affairs 1994-2004.

Butler, Josephine Elizabeth (1828-1906). English social reformer. A fervent supporter of education for women. Between 1883 and 1886, working with Florence ${ }^{*}$ Nightingale, Harriet ${ }^{*}$ Martineau and others, she secured the repeal of acts that discriminated against prostitutes. She also established a pioneer organisation for suppression of the white slave trade.

Bell, E. M., Josephine Butler. 1963.

Butler, Nicholas Murray (1862-1947). American educator. After graduating at Columbia University he studied further in Berlin and Paris. He returned to become professor of education 1890-1901 and president 1901-45 of Columbia University, New York. From 1907 he worked incessantly for international goodwill, and was President of the Carnegie Endowment for International Peace 192545, sharing the 1931 Nobel Peace Prize with Jane *Addams. His many books included The Meaning of Education (1898 and 1915), Scholarship and Service (1921) and The Path to Peace (1930).

Butler, Reg(inald Cotterell) (1910-1981). British sculptor. He made his name by his linear wrought iron sculpture, such as his Unknown Political Prisoner, which won first prize in an international competition held in London in 1953. He then resumed his interest in modelling. He wrote Creative Development (1962).

Butler, Richard Austen ('Rab'), Baron Butler of Saffron Walden (1902-1982). English Conservative politician, born in India. Educated at Marlborough and Pembroke College, Cambridge, he was MP for Saffron Walden 1929-65. As a progressive undersecretary for India 1932-37 and an appeasing undersecretary for Foreign Affairs 1938-41 he earned the undying suspicion of Winston ${ }^{*}$ Churchill on two counts. As Minister for Education 1941-45, he initiated the famous Education Act (1944) providing for massive expansion of post-war secondary schooling. In Opposition (1945-51), Butler created the Conservative Research Department which developed new policies essential for re-election. He served as Chancellor of the Exchequer 1951-55, Lord Privy Seal 1955-57, Home Secretary 1957-62, Minister for Central Africa 1962-63 and Foreign Secretary 1963-64, all with great distinction, but was denied the prime ministership in 1957 and 1963. He declined an earldom but accepted a life peerage, with a KG and $\mathrm{CH}$, became Master of Trinity College, Cambridge 1965-77 and wrote understandably waspish memoirs The Art of Memory (1982).

Butler, Samuel (1612-1680). English poet, born in Worcestershire. Son of a farmer, he acted as clerk to several of the land owning gentry before he became, in 1661, secretary to Lord Carbery, who appointed him steward of Ludlow Castle. He wrote the long satirical poem Hudibras (1663-78), much admired by ${ }^{*}$ Charles II who seems to have promised him much but delivered little. (Butler later worked for the Duke of ${ }^{*}$ Buckingham.) Hudibrus strings together into a connected whole, burlesques of hypocritical and more or less disreputable, Puritan characters of the Civil War period. 
Butler, Samuel (1835-1902). English author, painter and musician, born in Nottinghamshire. Son of a clergyman, he was educated at Shrewsbury (where his grandfather had been a great headmaster) and Cambridge. He refused to enter the Church because of religious doubts, and became a successful sheep farmer at Mesopotamia, South Canterbury, New Zealand (1860-64) instead. On his return to England, he lived alone in London, devoting himself to painting, writing and music, one of his paintings hangs in the Tate Gallery. In 1872 he published the Utopian satire Erewhon. 'Erewhon' (an anagram of 'nowhere') is a land of' paradox where, for example, crime is regarded as an illness and illness as a crime. A sequel, Erewhon Revisited, appeared in 1901. Erewhon was followed by a number of semiscientific works in which he examined the theories of ${ }^{*}$ Darwin, accepting evolution, while giving the credit for it to Darwin's predecessors, and rejecting natural selection. In its place he offered his own creative view of evolution. In Unconscious Memory (1880) he anticipates the theories of C. G. *Jung. In his later years he became absorbed by ${ }^{*} \mathrm{Homer}$. He translated the Iliad (1898) and the Odyssey (1900) while The Humour of Homer (1892) is a notable piece of literary criticism. The Authoress of the Odyssey proposes the ingenious theory that the Odyssey was written by a Sicilian woman from Trapani. Possibly his best known work, however, is The Way of All Flesh (published in 1903 but written 1873-85), an autobiographical novel in which, through a thinly disguised portrait of his own childhood and youth, he demonstrates the conflict of the generations and the deleterious effects of a typical Victorian upbringing.

Harkness, S. B. The Career of Butler: A Bibliography. 1955.

Butt, Dame Clara Ellen (1872-1936). English contralto. Dedicatee of *Elgar's Sea Pictures. She toured extensively, often with her husband, the baritone Kennerly Rumford, had a voice of great power and depth (well captured on recordings) and was 6 feet 2 inches $(1.88 \mathrm{~m})$ tall.

Butterfield, William (1814-1900). English architect. A leading practitioner of the revived Gothic style, he designed churches in a brilliant polychrome style, including All Saints, Margaret Street, London; Keble College, Oxford, and the more subdued St Paul's Cathedral, Melbourne and St Peter's Cathedral, Adelaide.

Thompson, P., William Butterfield. 1971.

Butterworth, George Sainton Kaye (1885-1916). English composer. He collected and was strongly influenced by English folk songs. He composed two song cycles based on poems from *Housman's A Shropshire Lad and The Banks of Green Willow. He was killed on the Somme in World War I after winning an MC.
Buttigieg, Pete(r Paul Montgomery) (1982- ). American Democratic politician, born in South Bend, Indiana. Of Maltese descent, his father was a professor of literature. Educated at a Catholic school, he studied at Harvard University, won a Rhodes Scholarship to Oxford, then worked as a consultant for McKinsey's. Elected Mayor of South Bend 2012-20, he served as a naval intelligence officer in Afghanistan and outed himself as gay (2015). He announced his candidature for President in 2019 but despite polling well in early Democratic Party primaries in 2020, dropped out and urged support for Joe *Biden. A moderate on economic issues, he was against the death penalty and committed to strong action on climate change. $\mathrm{He}$ became US Secretary of Transportation 2021- .

Buxtehude, Dietrich (or Diderik) (1637-1707). Danish musician. Organist at the Marienkirke in Lübeck from 1668, in $1703{ }^{*}$ Händel came to hear his celebrated evening concerts and in $1705 \mathrm{~J} . \mathrm{S} .{ }^{*}$ Bach walked more than 400 kilometres to hear him play. He was a prolific composer of organ, harpsichord and Church music. Much has been lost but 114 cantatas survive.

Buxton, Sir Thomas Fowell, 1st Baronet (17861845). English reformer. On election to parliament 1818-37 he instituted a private inquiry into the administration of prisons, which led to the formation of a prison reform society. He opposed the slave trade and, as leader of the abolitionist group in succession to William *Wilberforce, was instrumental in securing the passage of the 1833 act for the ending of slavery in British possessions.

Byatt, Dame Antonia Susan (née Drabble) (pen name A. S. Byatt) (1936- ). English novelist and academic. Educated at Cambridge, Bryn Mawr and Oxford, she is a sister of Margaret *Drabble. Her novels include Possession (1990), which won the Booker Prize, and Angels and Insects (1992). She also wrote studies of George *Eliot and Iris *Murdoch.

Byng, John (1704-1757). English admiral. Son of Viscount Torrington, and MP 1751-57, at the outset of the Seven Years War (1756), he was sent to prevent French occupation of Minorca, handled his ships badly, was defeated and withdrew to Gibraltar (as he had been instructed). However, as *Voltaire aptly put it, 'pour encourager les autres', he was charged with 'neglect of duty', court-martialled and shot to death at Portsmouth, despite a strong recommendation to mercy which *George II ignored.

Pope, D., At Twelve Mr Byng was Shot. 1962.

Byng of Vimy, Julian Hedworth Byng, 1st Viscount (1862-1935). English field marshal. Son of the Earl of Strafford, he commanded the IX Corps at the Dardanelles 1915-16 and the Canadian Corps 191617, capturing Vimy Ridge in April 1917. He became GOC of the British 3rd Army 1917-19 and led the 
Cambrai offensive. In the final victorious operations his army captured 67,000 Germans. As GovernorGeneral of Canada 1921-26, Byng controversially refused a dissolution of Parliament to Prime Minister Mackenzie *King in June 1926 and when King resigned appointed a Conservative, *Arthur Meighen, to take office. Promoted to viscount in 1928 and field marshal in 1932, Byng served as Commissioner of the London Metropolitan Police 1928-31.

Byrd, Richard Evelyn (1888-1957). American Arctic and Antarctic explorer. He was the first to fly over the North Pole (1926) and the South Pole (1929), the latter as leader of an expedition (1928-30) in the course of which Marie Byrd Land and other areas were discovered. He led further expeditions to the Antarctic in 1933-35, 1946-47 and 1955-56. Byrd, a naval officer, became a rear-admiral in 1930 .

Montague, R., Oceans, Poles and Airmen. 1971.

Byrd, Robert Carlyle (1917-2010). American Democratic politician. He was a welder during World War II, and briefly joined the Ku Klux Klan, which he later repudiated. He served in the West Virginia Legislature 1947-53, the US House of Representatives 1953-59 and the US Senate 19592010 , setting a world record for length of service as a legislator.

Byrd, William (1539/40-1623). English composer, born in Lincolnshire. A pupil of Thomas *Tallis, although a Roman Catholic he accepted positions in the Anglican Church as organist of Lincoln Cathedral 1563-75, and joint organist (with Tallis) of the Chapel Royal 1575-1623. He also shared with Tallis a monopoly for the printing and selling of music and was often engaged in litigation, much of it concerned with a disputed estate. He composed Masses and motets for the Catholic Church as well as music for the Anglican liturgy, in addition to his great output of madrigals and instrumental pieces (mainly for the virginal). The power of his music and the extraordinary skill of his contrapuntal writing gained him great fame in Europe during his lifetime.

Andrews, H. K., The Technique of Byrd. 1966; McCarthy, K., Byrd. 2013.

Byrnes, James Francis (1882-1972). American lawyer and politician, born in Charleston. He represented South Carolina as a Democratic congressman 1911-25 and US Senator 1931-41, and has been described as the most influential Southerner in the US Congress between John ${ }^{*}$ Calhoun and Lyndon *Johnson. Justice of the US Supreme Court 1941-42, he resigned to take up appointment as Director of the Office of Economic Stabilization 1942-43 and War Mobilization 1943-45 and was often described as *Roosevelt's 'Assistant President'. However, his support for the New Deal had cooled and opposition by labour unions cost him the
Democratic nomination for Vice President in 1944. As President *Truman's Secretary of State 1945-47, he became an architect of the Cold War and was elected as a segregationist governor of South Carolina 1951-55. He endorsed *Eisenhower, *Nixon and ${ }^{*}$ Goldwater for the presidency and joined the Republicans in 1964.

Byrnes, J. F., Speaking Frankly. 1947.

Byron, George Gordon Noel Byron, 6th Baron (1788-1824). English poet, born in London. He spent his first 10 years in Aberdeen lodgings with his mother, whose fortune had been frittered away by her husband, 'mad Jack' Byron. Much of his childhood was made unhappy by unsuccessful attempts to cure a lame foot, of which he remained painfully conscious. He inherited the title in 1798 and went to live in the family home, Newstead Abbey, Nottinghamshire. At Harrow and Trinity College, Cambridge, he not only read eagerly but took pride in overcoming his lameness by boxing, playing cricket and becoming a powerful swimmer. In 1807 he published Hours of Idleness, which was savagely criticised in the Edinburgh Review. He withdrew it and replied with the satire English Bards and Scotch Reviewers. After leaving Cambridge he travelled to Greece and Albania with his friend J. C. Hobhouse (he swam the Hellespont in May 1810), and his tour was described in the first two cantos of the semi-autobiographical Childe Harold's Pilgrimage (published 1812). The Giaour (1813), The Bride of Abydos (1813) and Lara (1814) also reflect the romantic moods inspired by his travels. He had become famous overnight, was lionised in society, made a few radical speeches in the House of Lords, and engaged in a series of love affairs, not always by his own choice. The half-mad Lady Caroline *Lamb, for example, fell in love with him and pestered him almost to distraction. In 1815, he married an heiress, Annabella Milbanke, but the marriage was unhappy from the start. Conjectures about his incestuous relationship with his half-sister Augusta Leigh, combined with his wife's complaints of his dark moods of cruelty and despair, made separation inevitable. (His daughter Ada became Countess of *Lovelace.) Ostracised by many of his former admirers, Byron left England for good in 1816 and moved to Switzerland, where he spent happy weeks with the Shelleys. From a life of dissipation and promiscuous love affairs in Venice (1817-19), Byron was rescued by Teresa, Countess Guiccioli, a woman of cultivated tastes who became his mistress. In this Italian period he finished Childe Harold and among other writings produced the drama Manfred (1817), Beppo (1818) and A Vision of Judgement (1822). He also began Don Juan (1819-24), that extraordinary medley of satire, adventure and self-revelation which remained unfinished at his death. Byron's interest in the cause of freeing Greece from Turkish rule led him to join the liberation committee in 1823 . He set out for Greece later in the year; the following April he died 
of fever at Missolonghi. For much of the 19th century he was regarded as the epitome of the romantic hero, a noble, melancholy wanderer and a passionate lover of freedom, but this judgement, based on his early poems, is largely the creation of his admirers (and in some moods of himself). The truer Byron, repressed in youth and always aware of his deformity, was much more of a satirist in the tradition of *Voltaire, an ironical realist as little blind to his own failings as to those of others, as aware of the savagery, squalor and tedium of life as of its beauty and glory.

Marchand, L. A., Byron: A Biography. 3 vols, 1957; Byron. A Portrait. 1970. 


\section{C}

\section{Caballero, Francisco Largo see Largo Caballero,} Francisco

Cabot, John (Giovanni Caboto) (c.1450-c.1498). Italian navigator, probably born in Genoa. He lived in Venice from about 1461 and became a citizen in 1476. Between 1484 and 1490 he came to England and lived in Bristol. Commissioned by *Henry VII, in May 1497 he sailed westward in the Mathew, reached Nova Scotia in June, explored the coast of Newfoundland and returned in August, claiming to have reached China (Cathay). He began a second voyage with four ships in May 1498 and disappeared.

His son, Sebastian Cabot (?1476-1557), was born in Venice. He probably accompanied his father on the 1497 voyage and later became map maker to *Henry VIII and Ferdinand V of Spain. An attempt to find the Northwest Passage (1509) failed owing to a mutiny of the crew. In 1518 he was appointed pilot major by the emperor ${ }^{*}$ Charles V (Carlos I of Spain). He led an expedition that explored the coast of South America (1526-30), seeking a passage to the Pacific. In 1548 he returned to England and founded a company of merchant venturers, for which he organised an expedition (1553) under Willoughby and ${ }^{*}$ Chancellor to search for a northeast passage from the Arctic Ocean to the China coast. In 1544 Cabot published a map showing his own and his father's discoveries.

Williamson, J. A. (ed.), Cabot Voyages and Bristol Discovery under Henry VII. 1962.

Cabral, Pedro Alvares (c.1460-c.1520). Portuguese navigator. In 1500 he was made leader of an expedition to the East Indies with 13 ships, but while on the way he was forced westward by adverse currents (some say he deliberately altered course) and landed on the north east coast of Brazil, in Bahia, near Monte Pascoal, and he formally claimed possession on behalf of Portugal. During his resumed voyage to the east he lost seven ships with their crews (including the famous navigator Bartolomeo ${ }^{*}$ Diaz) before reaching Mozambique and eventually Calient (near Madras) in India. Having made the first commercial treaty between India and Portugal, he returned to Lisbon in July 1501 with much booty.

Amado, J. C., Pedro Alvares Cabral. 1968.

Cabrini, St Frances Xavier (1850-1917). American religious, born in Lodigiano, Italy. She lived in the US from 1889 and was naturalised in 1909. She founded the Missionary Sisters of the Sacred Heart, and schools, hospitals and orphanages. She became the first saint of the US when Pope *Pius XII canonised her in 1946.
Cadbury, George (1839-1922). English manufacturer and social reformer. With his brother Richard (1835-1899) he assumed control of his father's Birmingham cocoa business in 1867, and when it expanded in 1879 he transferred the enterprise to Bournville. Being greatly interested in housing, he integrated the factory in a planned housing project and so organised the first modern 'model' village. A Quaker and a liberal, George Cadbury owned two London newspapers, the Daily News and the Star, which were active in all campaigns for social reform.

Cade, Jack (d.1450). English rebel. He led the Kentish rebellion of 1450 during the reign of *Henry VI. Misgovernment and financial oppression were the main causes of the rising which soon became formidable. Cade headed and managed to keep together a host which swelled to many thousands as it moved towards London, overcoming such resistance as it met on the way. Once they had reached the city the authorities induced them to disperse, partly by a show of force but mainly by concessions and promises. Cade was hunted down and killed at Heathfield in Sussex while resisting arrest.

Cadillac, Antoine de la Mothe, Sieur (16561730). French administrator and soldier. He settled a colony on the site of modern Detroit (1701) and later governed Louisiana 1713-16 before retiring to Gascony.

Cadogan, Sir Alexander Montague George (1884-1968). English diplomat. Son of the 8th Earl Cadogan, educated at Eton and Oxford, he joined the diplomatic service in 1908 and became Permanent Undersecretary for Foreign Affairs 1938-46. A strong opponent of appeasement, he worked closely with Winston ${ }^{*}$ Churchill and wrote important diaries. British Ambassador to the United Nations 1946-50 and awarded the OM in 1951, he was Chair of the BBC 1952-57. The Diaries of Sir Alexander Cadogan, 1938-45 (1972) are a valuable research tool.

Cadogan, William Cadogan, 1st Earl (1675-1726). Anglo-Irish general, born in Meath. The Duke of *Marlborough's most trusted subordinate in the campaigns of the War of the Spanish Succession, he was known as his 'maid of work' from the variety of tasks he undertook. At Oudenarde (1708) he commanded the Allied vanguard. He was ennobled for his success in suppressing the Jacobite rising of 1715 .

Churchill, W. S., Marlborough. 1933-38.

Cadorna, Luigi (1850-1928). Italian soldier. Commander-in-Chief of the Italian armies in World War I from 1915 to November 1917. After the disaster at Caporetto he ordered summary executions of 750 of his own soldiers, and was replaced by Armando *Diaz. Nevertheless, Britain made him a GCB and ${ }^{*}$ Mussolini promoted him to Marshal in 1924. 
Cædmon (d.c.680). Anglo-Saxon poet. According to ${ }^{*}$ Bede he was a herdsman who was granted a vision and received the gift of song. Of his poems, most of which were said to be metrical paraphrases of the Bible, only a single hymn ('Nu scylun hergan hefaenricaes uard / Now [we] must honour the guardian of heaven'), translated into Latin by Bede is regarded as an authentic survival. Cædmon spent the last years of his life as a lay brother in Whitby Abbey, Yorkshire.

Caesar, (Caius) Julius (c.100-44 BCE). Roman soldier and statesman, born in Rome. Although born into one of the oldest and noblest Roman families he supported the democratic faction of *Marius (who had married his aunt) against the senatorial oligarchy under *Sulla. Sulla's triumph in 81 threatened his life and forced him to live abroad until 78, when, Sulla having died, he returned to Rome and resumed his political career as a leader of the democratic party, greatly increasing his popularity by lavish expenditure during his year (65) as aedile (organiser of games and festivals). A new political situation was now taking shape. Caesar, back from a year's campaigning in Spain, had formed a political association with Marcus ${ }^{*}$ Crassus, an ambitious intriguer and the richest man in Rome; *Pompey had returned a national hero and was seeking political support for the terms of his settlement of Asia and especially for the provision of land for his returning veterans. The possibility of a bargain was evident, and in 60 the first 'triumvirate' between the three men was formed. It was in effect an unofficial division of spoils. Caesar, as Consul in 59, was able to meet Pompey's demands and obtained what he most wanted for himself-a great military command in Gaul covering northern Italy and the conquered lands beyond the Alps. During the next eight years (58-50) Caesar in a series of brilliant campaigns raided Britain twice (55 and 54), conquered much of Gaul, defeating Vercingetorix (52) with savage killings, and advanced the Roman frontiers to the Rhine. Meanwhile a rift between Crassus and Pompey threatened not only stability in Rome but the survival of the triumvirate. Caesar made a hasty return in 56 to meet his partners at Luca; he patched up the quarrel and renewed the triumvirate on fresh terms. This time each was to have a military command. Pompey's was in Spain, but he exercised control from Rome, through deputies. Crassus commanded the east where he started a war against Parthians and was killed in battle in 53. Caesar's command in Gaul was extended and his relationship with Pompey became increasingly strained. Pompey, having few troops in Italy to oppose him, withdrew with the government to Epirus (Albania). This gave Caesar time to enforce the surrender of Pompey's troops in Spain and consolidate his own position in Rome, before crossing the Adriatic, luring Pompey out of his entrenched camp by marching into Thessaly. The issue was finally decided by his great victory at Pharsalus (48), and he was given the title of Imperator the king of Pontus at the battle of Zela (in Anatolia), with the famous words 'Veni, vidi, vici' (II came, I saw, I conquered'). Pompey fled to Egypt and was murdered on landing. Caesar then landed in Egypt and in 47 confirmed *Cleopatra, on the disputed throne. She soon became his mistress and bore him a son. *Plutarch blamed Caesar for burning the library of Alexandria, but ${ }^{*}$ Gibbon thought the charge was groundless. In 46 in North Africa Caesar crushed the remaining leaders of Pompey's faction at Thapsus. He returned to Rome, now dictator and tribune for life, to celebrate four triumphs and distribute gifts. In January 45 BCE he introduced a 3651/4 day calendar, based on Egypt's. The Julian calendar was further modified by *Augustus in $8 \mathrm{CE}$, with the month of Caesar's birth, Quintilis, renamed 'Julius' (July), Caesar extended eligibility for citizenship and made other liberal reforms. In 44 he was at the peak of his power and appointed dictator for life. Republican senators who feared (probably wrongly) that he intended to proclaim a monarchy, organised a conspiracy against him. He was assassinated on the Ides (15th) of March 44, at the Senate, meeting temporarily in the Hall of Pompey in the Campus Martius (now lying under the via di Torre Argentina, just south of the Pantheon). The conspirators were headed by *Brutus and ${ }^{*}$ Cassius, his erstwhile friends. His will left all he possessed to his grandnephew Octavian, later to become *Augustus.

Though motivated by great personal ambition, Caesar was more than a self-seeking demagogue. $\mathrm{He}$ succeeded in winning stability for Rome and the provinces, and his dictatorship represented the crushing of an oligarchy and paved the way for the empire. He was among the greatest generals of history, a superb military narrator and commentator (his De bello Gallico stands supreme), a statesman of liberal thought and instantaneous and perfectly executed action, and a man of great personal charm. He was epileptic.

Gelzer, M., Caesar: Politician and Statesman. 1968; Meier, C., Caesar. 1982; McCullough, C., Caesar: a novel. 1998.

Caesarion (Ptolemy XIV or XV Caesar) (47-30 BCE). Egyptian pharaoh. The son of ${ }^{*}$ Cleopatra and Julius ${ }^{*}$ Caesar, he was nominal co-ruler with his mother. After her death he was lured from refuge by agents of Octavian ( ${ }^{*}$ Augustus) and murdered.

Caesarius, St (c.470-543). Gallic prelate. Bishop of Arles (now in Provence), France (from 502), at a time when Visigoths, Ostrogoths and Franks were contending for mastery of the old Roman province, he gained a great reputation not only for his sermons and for his staunch support of orthodox doctrines but for the statesman like qualities that enabled him to safeguard the communities of monks and nuns under his care. 
Cage, John (1912-1992). American composer, philosopher, poet, music theorist and print maker, born in Los Angeles. A pioneer of 'indeterminism' in music, he studied with ${ }^{*}$ Schoenberg and *Varèse, and began to experiment in composition in the late 1930s. Influenced by Zen Buddhism and I Ching, he became a pioneer of chance music (that is, with random, unexpected outcomes) and non-standard use of musical instruments. He used sounds of indeterminate notation and duration, produced by a variety of means (including, but not limited to, musical instruments). $\mathrm{He}$ aimed to encourage audience response to all sound; he did not intend to present a selected musical structure as a personal expression. His most discussed work was 4' 33" (1952), catalogued as 'tacet [i.e. silent] for any instrument'. His impact on other creative artists was exceptional, and he experimented with percussion, electronics and the 'prepared piano' in which extraneous objects are placed between the strings. Because no two performances were to be alike, relatively little of Cage's work is available on CD. Roaratorio: An Irish Circus on Finnegans Wake (1976-79) is published on the Wergo label. He had an encyclopaedic knowledge of mushrooms.

Cagliostro, Alessandro, Count de (1743-1795). Italian adventurer (possibly Giuseppe Balsamo of Palermo). He travelled widely in the east, picked up some knowledge of chemistry and occult science. He claimed to be able to transmute base metals into gold and made a fortune in Europe selling love philtres and elixirs of youth. In 1776 he came to England. In Paris he was involved (1784-85) in the affair of the diamond necklace (*Marie Antoinette) and briefly imprisoned in the Bastille. Throughout this period his reputation as a man of mystery who could foretell the future (e.g. the execution of *Louis $\mathrm{XVI}$ ) was immense. He was condemned by the Inquisition and died in a Roman prison while serving a life sentence for founding a Masonic lodge.

Cai Lun (50?-118?). Chinese inventor, born in Guizhou. A eunuch and official at the court of the Han emperor Hodi, he is credited as the inventor of paper (about 105), and was an actual rather than legendary figure. Paper remained a Chinese monopoly until about 750 when the Arabs began manufacturing it in Baghdad and Samarkand.

Caillaux, Joseph (1863-1944). French radical politician. A deputy from 1898, he was Finance Minister 1899-1902, 1906-09, 1911, 1925, 1935 and campaigned for a progressive income tax. As Premier 1911-12 he negotiated with Germany a settlement of the Moroccan crisis, but his political life was abruptly interrupted when in 1913 his wife shot and killed Gaston Calmette, editor of Le Figaro, who had made various accusations against her husband (she was later acquitted of murder). Caillaux favoured the ending of World War I by a peace of negotiation, and in 1918 he was imprisoned after being convicted of corresponding with the Germans. Amnestied in 1924, he played an important part in war debt negotiations.

Caillaux J., Mémoires. 1942-48.

Caillebotte, Gustave (1848-1894). French painter and collector. A naval architect, he became a significant patron and collector and organised the first Impressionist exhibition in Paris in 1877. His best known work, Paris, a Rainy Day (1877), now in Chicago, combines Impressionist techniques with the classical tradition.

Cain, James M(allahan) (1892-1977). American author and journalist. He achieved great success with his novels The Postman Always Rings Twice (1934) and Mildred Pierce (1946), both filmed.

Cain, John (1882-1957). Australian Labor politician. With little formal education, he became a union organiser and municipal councillor, then a Member of the Victorian Legislative Assembly 1917-57 and Leader of the ALP 1937-57. In a gerrymandered parliament, Labor supported a minority Country Party Government in office 1935-43, 1943-47, 1950-52. Cain was Premier three times, for four days in 1943, in a minority government supported by Independents 1945-47, then with a massive majority in its own right 1952-55. However, a major split within the ALP over attitudes to Communism (H. V. *Evatt) began in 1954 and forced Cain from office. The Party remained in opposition until 1982. His son, John Cain (1931-2019), a lawyer and Law Reform Commissioner 1975-77, was MP 1976-92, and Premier of Victoria 1982-90, initiating many reforms, including freedom of information and equal opportunity legislation, development of the Melbourne Docklands, and increased investment in education and the environment.

Caine, Sir (Thomas Henry) Hall (1853-1931). English novelist. He was best known for a series of romantic, religious and melodramatic novels, one of which, The Deemster (1887), sold over 1,000,000 copies. Others include The Bondman (1890), The Manxman (1894), The Prodigal Son (1904) and The Woman Thou Gavest Me (1913). His Recollections of Rossetti (1882) was inspired by a friendship with the poet from 1881 until his death (1882).

Cairns, Jim (James Ford) (1914-2003). Australian Labor politician, born in Melbourne. An athlete and policeman, he took up a late vocation as an academic economist, and was a Member of the House of Representatives 1955-77. Handsome and charismatic, he led the anti-Vietnam War campaign and challenged Gough *Whitlam for the Labor leadership in 1968. In Whitlam's Government he served as Minister for Trade 1972-74, Deputy Prime Minister and Treasurer 1974-75, and Minister for the Environment 1975. Dismissed for careless handling 
of sensitive overseas loans and for misleading the House, after politics he became a prolific author, promoting non-violence and alternative life styles.

Ormonde, P., A Foolish Passionate Man. 1981; Strangio, P., Keeper of the Faith. 2002.

Caius (or Keys), John (1510-1573). English physician. He obtained his medical doctorate at Padua, returning in 1544 to England, where he lectured on anatomy in London. He became a fellow of the College of Physicians in 1547 and later was nine times president. He was in turn physician to ${ }^{*}$ Edward VI, *Mary and *Elizabeth and in 1557 endowed and enlarged Gonville Hall, Cambridge, where he had been a student, renaming it Gonville and Caius (pronounced 'Keys') College. He published A Boke of Counseill against the Sweating Sickness (1552) and wrote on a range of medical, scientific and antiquarian topics.

Cajal, Santiago Ramón y (1852-1934). Spanish neurologist, pathologist and histologist, born in Navarre. Son of a surgeon and anatomist, he studied at Zarazoga University and after a year as an army surgeon in Cuba (where he contracted malaria), he decided on an academic career in anatomy. He taught himself to become an expert histologist and miscroscopist and became professor of anatomy at Valencia 1883-1887 and of histology at Barcelona 1887-92 and Madrid 1892-1922. He used the silver staining techniques of Camillo Golgi (1843-1926) to investigate cell structure. He devoted the creative period of his life to the study of the fine structure of the nervous system, concerned above all to discover the functional pathways of the transmission of stimuli. He was acutely aware of the problem of understanding how neural information is passed across anatomical gaps. In 1888 he identified (but did not name) the neuron as the basic unit of the nervous system. His researches were published in his massive and highly influential Textura del Sistema Nervioso del Hombre $y$ de los Vertebrados (1904). For this work, he shared the Nobel Prize for Medicine (1906) with Golgi, who, ironically, completely rejected the neuron doctrine, proposing an alternative 'reticular theory' of the nervous system as a single continuous network. Cajal's later work focused more on the degeneration and regeneration of nervous structures. His researches confirmed the correctness of the 'monogenesist' school which believed that the regeneration of fibres came from the sprouting of the cylinders of the central stump. The first Spanish scientist to be awarded a Nobel Prize, Cajal devoted himself to promoting research in education and administration. His exquisite drawings of neural networks were inscribed by UNESCO in 2017.

Ehrlich, B., The Brain in Search of Itself: Santiago Ramón y Cajal and the Story of the Neuron. 2022.
Calas, Jean (1698-1762). French merchant. A Huguenot, victim of a notorious French miscarriage of justice exposed by ${ }^{*}$ Voltaire, he was a clothier in Toulouse. He was falsely accused of hanging one of his sons, who had committed suicide, to prevent his conversion to Roman Catholicism. The father was tried, tortured and executed, but Voltaire, suspecting priestly and official prejudice, took up the case and in 1765 the verdict was reversed.

Calder, Alexander (Stirling) (1898-1976). American sculptor, born in Philadelphia. He studied engineering in New Jersey and art in New York, moved to Paris (1926) and was influenced by *Miró and (after 1930) *Mondrian. After making sculptures and models of wood and wire, in 1931 he began to design and construct 'mobiles', moving abstract shapes (originally motor driven) of metal, plastic or wood, connected by wires, depending on air currents for movement, and (from 1933) 'stabiles', which were fixtures. He also worked as a painter, lithographer and jewellery designer. His mobiles and stabiles, many of them monumental, were exhibited in open spaces in New York, Washington, Los Angeles, Paris, Madrid, Stockholm, Spoleto and Jerusalem.

Calder, A., An Autobiography with Pictures. 1966.

Calderón de la Barca, Pedro (1600-1681). Spanish dramatist and poet, born in Madrid. He was educated at Alcalå and Salamanca universities, and was soon writing plays so successfully that after the death of Lope de *Vega in 1635 his position as leading dramatist was undisputed. He was made a knight of the Order of Santiago in 1636. After a period of distinguished army service (1640-42) he took holy orders (1651) on the command of King Philip IV, but he continued to write religious plays. He wrote in verse and, like *Shakespeare, with whom he has been compared, wrote both comedies and tragedies. His plays were concerned with themes of marital honour and with religious and philosophical ideas. They suffer, however, from the stylised conventions of the period, and are seldom now produced outside Spain. Over 100 have survived, one of the best known, El magico prodigioso (The Prodigious Magician), in some respects anticipating Goethe's Faust, others are El alcalde de Zalamea (The Mayor of Zalamea), La vida es sueno (Life is A Dream) and El gran teatro del mundo (The Great Theatre of the World). In addition there are some 70 of the so-called autos saeramentales, a special form of religious drama concerned with the mysteries of the Holy Eucharist.

Parker, A. A., The Allegorical Drama of Calderón. Repr. 1968.

Caldwell, Erskine Preston (1903-1987). American novelist and screenwriter. His Tobacco Road (1932) and God's Little Acre (1933) are the two best known of a series in which the degraded conditions of 'poor whites' in the southern states are described with 
humour and indignation; both were successfully filmed. He also wrote works of autobiography, criticism and travel.

Calhoun, John Caldwell (1782-1850). American politician, born in South Carolina. A lawyer, he served in the state legislature 1808-10 and in the US House of Representatives 1811-17. A 'War Hawk' (ultranationalist) during the War of 1812, he also campaigned for protective tariffs. *Madison's Secretary of War 1817-25, he was twice elected as Vice President, first with J.Q. *Adams (1824), then with Andrew *Jackson (1828), serving 1825-32, resigning (the first vice president to do so) in order to serve as a Senator. He broke with Jackson, a strong nationalist, on the issue of 'nullification', the doctrine that states could declare federal laws (e.g. on slavery or tariffs) unconstitutional where they felt themselves fundamentally threatened. Calhoun argued that slavery was 'a positive good'. As US Senator from South Carolina 1832-43; 1845-50, he developed the 'filibuster' (1841) as a method to prevent measures to which a minority were opposed from being brought to a vote. Secretary of State 1844-45, under *Tyler and Polk, he brought Texas into the Union as a slave state. He sought the Democratic nomination for president in 1844 and 1848, but failed badly. Calhoun is regarded as one of the greatest American orators.

Current, R. N., John C. Calhoun. 1966; Niven, J., John C. Calhoun and the Price of Union. 1988; Bartlett, I., John C. Calhoun: A Biography. 1994.

Caligula (Gaius Julius Caesar Augustus Germanicus) (12-41 CE). Roman Emperor 37-41. Son of Germanicus Caesar and *Agrippina, he owed his nickname Caligula (Little Boots) to his popularity as a child with his father's soldiers. At first he ruled with moderation but a serious illness, possibly epilepsy, a few months after his accession is believed to have affected his sanity. Thenceforth he behaved as an increasingly bloodthirsty and vicious tyrant. The story that he made his horse 'Incitatus' a consul is typical of many anecdotes indicating his irresponsibility. After only four years' rule, and having declared himself a god, a palace conspiracy brought about his assassination.

\section{Calixtus III see Callistus III}

Callaghan, (Leonard) James, Baron Callaghan (1912-2005). British Labour politician, born in Portsmouth. Son of a naval chief petty officer, he joined the Inland Revenue in 1929. He served in the navy, became MP for South Cardiff 1945-87, was Parliamentary Secretary in the Ministry of Transport 1947-50 and Parliamentary and Financial Secretary to the Admiralty 1950-51. He was Chancellor of the Exchequer 1964-67 and Home Secretary 1967-70 under Harold *Wilson, and when Labour was reelected he was Foreign and Commonwealth Secretary
1974-76. When Wilson retired, he was elected Leader of the Labour Party, defeating Michael *Foot in the third ballot, serving as Prime Minister 197679. His small majority depended on continuous support from the Liberals and the minority groups. After the notorious 'winter of discontent', marked by economic stagnation, strikes and a savage freeze, he lost the 1979 election to Margaret *Thatcher and the Conservatives, but continued as leader of the Labour Party until 1980. He retired with a KG and peerage (1987). He was the longest lived British Prime Minister.

Callas (née Kalogeropolous, later Kalos), Maria (Anna Cecilia) (1923-1977). Greek-American dramatic soprano, born in New York. She studied in Athens and made her debut there in 1941. In 1949 she married Giovanni Battista Meneghini, appeared at La Scala, Milan, in 1950, at Covent Garden in 1952 and at the Metropolitan Opera, New York, in 1956. Among her most famous roles were *Bellini's Norma, and Amina in his La Sonnambula, while her magnetic stage presence and great gifts as an operatic actor yielded memorable portrayals of Violetta in *Verdi's La Traviata and in the title role in *Puccini's Tosca. From 1959 until her death she had an intense relationship with Aristotle ${ }^{*}$ Onassis.

Calles, Plutarco Elias (1877-1945). Mexican soldier and politician. He took an active part in the revolution which in 1911 overthrew President *Diaz, and later served under ${ }^{*}$ Carranza and ${ }^{*}$ Obregón. He was President of Mexico 1924-28. He continued to control events from behind the scenes until in 1936 President ${ }^{*}$ Cárdenas asserted himself and had him deported. By the vigour with which he carried out the policy of land distribution and other reforms Calles did much to benefit the peasants, and his attacks on the Church and the oil companies were in line with revolutionary tradition, but as his rule proceeded he became increasingly dictatorial and conservative. He thus alienated many of his former supporters, and his deposition was popular.

Callimachus of Cyrene (c.310-240 BCE). Greek poet and librarian, born in North Africa. Working in the Alexandrian Library at the time of *Ptolemy II, his most important work, Aetia (Causes), which survives in fragmentary form, tells a series of episodes purporting to reveal the origins of ancient customs. He began a systematic catalogue of the library's holdings and originated alphabetical listing.

Callisthenes (c.360-327 BCE). Greek historian. Said to have been *Aristotle's nephew, he accompanied *Alexander the Great on his campaigns but was put to death for allegedly being involved in a plot. The real reason may have been his opposition to Alexander's assumption of divine honours. Only fragments of his writings survive. 
Callistus (or Callixtus) II. (Gui de Bourgogne) (c.1065-1124). Pope 1119-24. Born to a powerful French noble family, and archbishop of Vienne 1088-1119, his papal bull Sicut Judaeis (1120) was tolerant of the Jews. The First Lateran Council (1123) prescribed a celibate clergy.

Callistus (or Callixtus) III (Alonso de Borja. Borgia in Italian) (1378-1458). Pope 1455-58. Born in Valencia, he was a papal lawyer and diplomat. After the fall of Constantinople (1453), he attempted to organise a crusade against the Turks, aided *Hunyadi and ${ }^{*}$ Skanderbeg but had little support from France and Germany. He was deeply anti-Jewish and inclined to nepotism-Rodrigo Borgia, later *Alexander VI, being the main beneficiary. $\mathrm{He}$ annulled (posthumously) the sentence of excommunication passed on *Joan of Arc.

Calment, Jeanne Louise (1875-1997). French centenarian, born in Arles. She married a cousin, never worked and smoked until she was 117. In October 1995 she became the oldest person in geriatric records.

Calmette, (Léon Charles) Albert (1863-1933). French bacteriologist, born in Nice. Educated in Paris, he worked with Patrick *Manson, and Louis *Pasteur sent him to Saigon (1891-94). He developed the first anti-venin against snakebite and directed the Pasteur Institute in Lille 1895-1920. Between 1908 and 1921, with Camille Guérin (1872-1961), he developed the BCG (Bacillus Calmette-Guérin) vaccine, administered to infants to develop immunity against tuberculosis, but it was only adopted generally after Calmette's death. He received 77 nominations for the Nobel Prize for Medicine, all failed.

Calonne, Charles Alexandre de (1734-1802). French financier. An administrator of wide experience, he was one of the ablest of those who, in the hectic years of unrest before the French Revolution, were called in by *Louis XVI to try to rescue French finances from the chaos that threatened disaster. Appointed Controller General of Finance in 1783, he was at first successful in raising loans to meet immediate needs, but his proposals for taxing the privileged classes put before the Assembly of Notables in 1787 roused such indignation among those affected that Louis felt himself forced to dismiss his advisor. Calonne spent the revolutionary years in England as Finance Minister to the emigré government. He returned to France, poverty stricken, in the year of his death.

Calvé, Emma (Rosa Calvet) (1858?-1942). French operatic soprano. She performed with great success in France, England and America. Her greatest role was Carmen in *Bizet's opera.

Calvin, John (English form of Jean Cauvin) (15091564). French religious reformer, born at Noyon in Picardy. The son of an ecclesiastical lawyer, he went at the age of 14 to Paris University. Originally intended for the priesthood, he was attracted by the new humanism. Acting on his father's advice he began legal training at Orléans, and later at Bourges. His aptitude proving greater than his interest, so in 1531, after his father's death, he returned to Paris and devoted himself to classical scholarship, also beginning Hebrew. Already sympathetic to the attacks made on traditional theology by *Luther and ${ }^{*}$ Bucer, Calvin experienced what he called 'instant conversion' about 1533. Under threat of arrest as a Protestant, he spent the next two years constantly on the move, but at last took refuge in Basle, Switzerland, where he continued his Hebrew studies and worked on Institutes of the Christian Religion, completed in 1536 with a prefatory letter to King *François I of France in which he foresaw the destruction of any kingdom 'not ruled by the sceptre of God'. This, his greatest work, bears the imprint of St *Augustine's teaching, especially in its emphasis on the doctrine of predestination and the supreme sovereignty of God. Calvin taught that certain souls ('the elect') are predestined for eternal life and the remainder are damned, salvation being the free gift of God and good works being the sign of salvation, not its cause. Whether Christ's death was an act of atonement for the benefit of all or only of the elect is not always clear and was a subject of much controversy in the Reformed Churches. When passing through Geneva in 1536 Calvin accepted what was virtually a challenge from Guillaume *Farel to take over his work of directing the religious and political life of the city and he used his organising ability to create a system of theocratic government. He prescribed a profession of faith, banned all public entertainment, emphasised the need for unbending puritanism in private life and even issued regulations on dress. Such austerity soon proved unpopular and Calvin was expelled from the city in 1538 after riots organised by a faction called the Libertines. The three years that elapsed before he was recalled were spent mainly at Strasbourg where he entered upon a brief but happy marriage (his wife died in 1549 , their son having already died in infancy), continued his studies and renewed contact with Bucer and other reformers. Back in Geneva he resumed where he had left off and organised a Presbyterian system of government. He wanted Geneva to be a 'city of glass', and many informers helped to enforce his imposition of social discipline and puritan morality. The burning of *Servetus demonstrated his rigid intolerance in religious matters. The regime lasted during his lifetime and at least the hard work, thrift and sobriety enjoined brought trade and wealth to the city. The college which later became Geneva University was founded to provide an educated clergy. Calvinism spread before and after its founder's death and shared with Lutheranism the allegiance of the greatest part of the Protestant world. It provided a pattern for Presbyterian Churches in Scotland and elsewhere: it was the faith of the Huguenots in France, of the Dutch Reformed Church and of several German 
states. The relationship (if any) of Calvinism to the rise of capitalism has been a matter of considerable historical controversy, as has the suggestion that Calvinism encouraged rebellion.

Wendel, F., Calvin: The Origin and Development of his Religious Thought. 1963; Parker, T. M., Calvin. 1976.

Calvino, Italo (1923-1985). Italian writer, born in Cuba. He began work in Turin, on the magazine L'Unita, and from 1959 he was co-editor of Il Menabo di letteratura. He began to write realistic stories of the Italian Resistance (in which he had served), but during the 1950s turned to fantasy, some of it allegorical. He gained a wide reputation with Il visconte dimezzato (1952), Il barone rampante (1957), and Il cavaliere inesistente (1959). All his work shows a concern with what he considers to be the dehumanising influence of contemporary society. His If on a winter's night a traveller ... (1979) was widely acclaimed in translation.

Woodhouse, J. R., Italo Calvino: A Reappraisal and an Appreciation of the Trilogy. 1968.

Calwell, Arthur Augustus (1896-1973). Australian politician. As Minister of Immigration 1945-49 he initiated a scheme which brought 1,000,000 Europeans to Australia within a decade. He succeeded H. V. *Evatt as Leader of the Labor opposition 1960-67.

Camargo, Marie Anne de Cupis de (1710-1770). French dancer, born in Brussels. One of the most famous figures in the early history of ballet, she came from an influential family and received early encouragement. Her whole career from her first appearance in Paris in 1726 to her retirement in 1751 was a series of triumphs. She appeared in about 80 ballets and her fame was perpetuated by the celebrated artists and writers (including *Voltaire) of her time. She is said to have introduced the characteristic short ballet skirt. The Camargo Society was founded in London in 1930 (*Ashton, *Lambert).

Cambacérès, Jean Jacques Regis de, Duc de Parma (1753-1824). French politician. In the violent phase of the Revolution, he played a placatory role. In November 1799, he helped to organise the 'coup of 18 Brumaire' which overthrew the Directory and installed *Napoléon Bonaparte as First Consul. Cambacérès became Second Consul in 1800. His great interest was jurisprudence and he became principal architect of the Code Napoléon. Under the empire he was Archchancellor 1804-14, holding second place in the state hierarchy, receiving a dukedom in 1808 . After the restoration of *Louis XVIII he was expelled but allowed to return in 1818 .

Cambridge, George William Frederick Charles, 2nd Duke of (1819-1904). British prince and field marshal, born in Hanover. A grandson of *George III, and briefly (1819) heir presumptive to the throne, he married morganatically in 1847 but was also loyal to his mistress. He devoted his life to the army and served in the Crimean War. Having been mildly sympathetic to reform, as Commander-in-Chief 1856-95 he became increasingly hostile and the army became ossified until, despite loyal support from his cousin, Queen *Victoria, he was forced out by Henry *Campbell-Bannerman.

Cambyses I (Old Persian: Kabūjiya) (c.600-559 BCE). King of Persia (Ashan) 580-559 BCE. Son of Cyrus I and father of ${ }^{*}$ Cyrus II, head of the Achaemenid dynasty and a Zoroastrian, he died in battle against the Medes.

Cambyses II (Kabūjiya) (d.522 BCE). Shahanshah (King of Kings) of the Achaemenid Empire 530-522, Pharoah of Egypt 525-522 BCE. Son of *Cyrus the Great, he ruled Babylon jointly with his father. He added Phoenicia, Cyprus, and Egypt to the Persian empire but his subsequent expeditions to the south (Nubia) and west were partial or total failures. ${ }^{*}$ Herodotus, a hostile source, asserted that Cambyses became a cruel, drunken and capricious tyrant. He died while returning to Persia to deal with a usurper, Gaumata, who claimed to be his murdered brother Bardiya.

Olmstead, A. T., History of the Persian Empire. 1948.

Camden, Charles Pratt, 1st Earl (1713-1794). English judge. As Chief Justice of the Common Pleas 1762-66 he pronounced against the legality of 'general warrants' in the case of John *Wilkes and became extraordinarily popular. He became Lord Chancellor in 1766, but his support of Wilkes and opposition to the government's unyielding American policy caused him to resign in 1770 . He served under ${ }^{*}$ Rockingham and ${ }^{*}$ Pitt as Lord President of the Council 1782-94 and was created an ear1 in 1786.

Camden, William (1551-1623). English antiquarian, historian and schoolmaster. Educated at Christ's Hospital, St Paul's School and Oxford, he became a master at Westminster in 1575 and was headmaster 1593-97. His professional occupation allowed him time to travel up and down England and collect material for his great antiquarian survey Britannia, the original Latin version of which appeared in 1586. His Annals of Queen *Elizabeth's reign were published posthumously. Most of his many works, which include an account of the trial of the Gunpowder Plotters (*Fawkes) are in Latin. His name is commemorated by the Camden professorship at Oxford.

Trevor-Roper. H., Queen Elizabeth's First Historian. 1971.

Cameron, David William Donald (1966- ). English Conservative politician, born in London. Son of a stockbroker, descendent of *William IV, educated at Eton and Oxford, he worked in the 
Conservative Party's Research Department, then for a public relations firm. He was MP 2001-16, Shadow Minister for Education 2005 and Leader of the Opposition 2005-10. He became Prime Minister May 2010 as head of a ConservativeLiberal Democrat Coalition. Conservatives won an outright majority in May 2015 and the Coalition ended. Under pressure from anti-EU Conservatives, he imprudently called a referendum (June 2016) to decide on Britain's continued membership. The vote to leave ('Brexit') was unexpected, and Cameron, who had led the 'Remain' campaign, felt obliged to resign as Prime Minister. Theresa *May succeeded him.

Cameron, D., For the Record. 2019.

Cameron, Julia Margaret (née Pattle) (1815-1879). English photographer, born in Calcutta. Influenced by G.F. *Watts, after 1864 she made remarkable portraits of ${ }^{*}$ Tennyson, ${ }^{*}$ Darwin, ${ }^{*}$ Herschel, *Carlyle, ${ }^{*}$ Browning, ${ }^{*}$ Hooker and ${ }^{*}$ Eyre. A great-aunt of Virginia *Woolf, she died in Ceylon (Sri Lanka).

Cameron, Verney Lovett (1844-1894). British naval officer and explorer. Much of his service was spent in African waters in the suppression of the slave trade. Sent in 1873 to relieve *Livingstone, he met the party carrying his body to the coast. Proceeding westwards, he found some of Livingstone's papers and then surveyed Lake Tanganyika, arriving at the correct conclusion that its outlet flowed to the Congo. He eventually reached Portuguese Benguela (1875) and so was the first European to cross equatorial Africa from east to west. He wrote accounts of his travels and adventure stories for boys, including Across Africa (1877).

Camilleri, Andrea Calogero (1925-2019). Italian (Sicilian) novelist and director, born in Porto Empedocle. After a successful career writing and directing in film and theatre he wrote 27 crime novels about Inspector Salvo Montalbano, which were brilliantly translated, became a television series, transformed Sicily's tourism potential and, apparently, weakened Mafia influence.

Camóes (or Camoens), Luis de (1524-1580). Portuguese poet, born in Lisbon. From a poor family of the minor nobility, he received his education at Coimbra University and gained early recognition for his gifts as a lyric poet and dramatist. After he left the university it is surmised that he had many love affairs and that he was exiled from Lisbon as a result of one of these (supposedly with Caterina de Ataide, a lady of the court). He served in the army in North Africa (1547-49) and lost his right eye there, returned to Lisbon, was again exiled and went to Goa in India, where he served with military expeditions in the Far East. After further adventures and misadventures he left Goa in 1567 for Mozambique, but it was not until 1570, after his debts and passage money had been paid by friends, that he reached home. He lived in poverty on a small pension from the king until he died in hospital of the plague. While in the East he worked on his masterpiece, As Lusiadas (The Lusiads i.e. the Portuguese), a national epic, broadly modelled on *Virgil's Aeneid, and largely inspired by the discoveries and heroic exploits of da ${ }^{*}$ Gama and his fellow navigators and soldiers in the East. The work was published in 1572 and was an immediate success, with 36 editions published between 1580 and 1640 . Camóes also wrote three verse comedies, many lyric poems of great poignancy (some to a favourite Chinese slave girl) and philosophical sonnets.

Freitas, W., Camóes and his Epic. 1963.

Campanella, Tommaso (1568-1639). Italian astronomer and philosopher, born at Stilo in Calabria. He entered the Dominican order and early intellectual influences on him included the writings of Telesio (who advanced atomistic views of nature). In 1592 he was denounced to the Inquisition for heresy. Between then and 1629 he spent much of his time in internment. He passed his last few years in safety in France. Campanella was one of the foremost champions of the Copernican view that the sun was the centre of the planetary system. He may have held such views because of his independent conviction of the truth of natural magic and astrology, which led him to see the sun as the source of great spiritual powers. Throughout his life he defended the right of philosophers and scientists to speculate freely in matters relating to the natural world. In his view, Scripture did not pronounce on such matters and the Church should not dogmatise. Of importance as a political utopian, he conceived of a perfect state (the Civitas solis, the Commonwealth of the Sun) in which work and wealth were equally shared, and men perfected themselves by coming to a spiritual understanding of God through his creation.

Campbell. Scottish noble family, the heads of which have been earls (from 1457) and dukes (from 1701) of *Argyll.

Campbell, Alexander (1788-1866). American religious leader, born in Ireland. He was a Presbyterian then a Baptist preacher, before forming his own group, which, merged with others, became the 'Disciples of Christ', a body with over 1,000,000 members in the US. Campbell, who founded Bethany College in 1840 , believed that Christianity should rest solely on biblical authority and that forms of worship should resume the simplicity of New Testament times. He produced his own translation of the New Testament and was a prolific writer.

Campbell (originally Macliver), Colin, 1st Baron Clyde (1792-1863). British field marshal. Son of a carpenter, he adopted his mother's family name, and as a young man served in the Peninsular War. Fame, knighthood (KCB) and experience of Indian conditions came in the second Sikh War (1848-49), 
followed by much frontier fighting. In the Crimea (at Alma and Balaclava) he proved himself the most effective of the British generals and when the Indian Mutiny broke out (1857) he became Commander-inChief 1857-60. He relieved Lucknow and suppressed the rising.

Campbell, Joseph (1904-1987). American author, born in New York. Educated at Columbia University, he taught at the Sarah Lawrence College, Bronxville 1934-72 and became a prolific (and controversial) author of books on mythology and folklore, including The Masks of God (4 volumes: 1959-67) and The Historical Atlas of World Mythology (198387). Television and radio programs with Bill Moyers helped to popularise his ideas.

Campbell, Kim (Avril Thaedra) (1947-). Canadian Progressive Conservative politician. Educated at the University of British Columbia, she became a lawyer and academic, was elected MP 1988-93, and served as Attorney-General 1990-92 and Minister for Defence 1992-93. She succeeded Brian *Mulroney as party leader and Prime Minister of Canada 1993. In October 1993 her Conservative Party was overwhelmingly defeated. She became ConsulGeneral in California and also taught at Harvard.

Campbell, Sir Malcolm (1885-1948). British sportsman. In 1935 his famous car Bluebird reached $301 \mathrm{mph}$ (484 kph), on Bonneville Flats, Utah, US. In 1939 he captured the world water speed record on Coniston Water, in the English Lake District, by reaching $141.7 \mathrm{mph}$ (228 kph) in his motor boat, also named Bluebird. His son, Donald Malcolm Campbell (1921-1967), broke the world water speed record again at Coniston in 1955 by travelling at $202 \mathrm{mph}(325 \mathrm{kph})$, a speed which he had raised to $260 \mathrm{mph}$ (418 kph) by 1959 . In 1964 he also established a land speed record of $403 \mathrm{mph}$ (648 kph) at Lake Dumbleyung, Western Australia. His boats and cars were also named Bluebird. In an attempt to attain a water speed of $300 \mathrm{mph}$ ( $483 \mathrm{kph}$ ) his boat disintegrated and he was killed.

Campbell, Mrs Patrick (née Beatrice Rose Stella Tanner) (1865-1940). English actor, born in London. Her father was English and her mother Italian. In 1884 she eloped with Patrick Campbell (d. 1900) and thereafter invariably used his name as a performer. Her stage debut in 1888 was followed by great success in the plays of *Pinero, notably in the title role of The Second Mrs Tanqueray (1893), *Shakespeare and *Ibsen. In 1914 she created the role of Eliza Doolittle in Bernard *Shaw's Pygmalion, which was written for her. She married Winston *Churchill's youthful step-father George Cornwallis-West in 1914. She appeared in six films. Her friendship with Shaw led to a fascinating correspondence, first published in 1952 .
Campbell, (Ignatius) Roy (Dunnachie) (19011957). South African poet, born in Durban. His poems have a vigorous 'outdoor' quality, often mixed with sharp satire, and reflect the interests of Campbell himself, who was accomplished at bull tossing, jousting and steer throwing. He fought for General ${ }^{*}$ Franco in the Spanish Civil War. His poetic works include The Flaming Terrapin (1924), Wayzgoose (1928), Adamaster (1930) and Flowering Rifle (1939), which was inspired by his experiences in the Spanish war. Light on a Dark Horse (1951) is autobiographical. He was killed in a motor accident in Portugal, where he had lived since 1947.

Campbell-Bannerman, Sir Henry (1836-1908). British Liberal politician. Son of a lord provost of Glasgow, he was educated at Glasgow University and Trinity College, Cambridge and sat as MP 1868-1908. A strong supporter of *Gladstone's Irish policy, he became Chief Secretary for Ireland 1884-85. As Secretary for War 1886; 1894-95 he reformed the army and managed to remove the apparently immovable George, Duke of Cambridge (1819-1904) as Commander-in-Chief in 1895 . He succeeded Sir William *Harcourt as party leader in 1899. He read widely, supported votes for women and had a gift for languages. Prime Minister 190508 , his ministry was outstanding, including *Asquith, ${ }^{*}$ Grey, ${ }^{*}$ Haldane, ${ }^{*}$ Lloyd George and ${ }^{*}$ Churchill, and was one of the most brilliant in history. The Prime Minister was responsible for granting self-government to the defeated Boer republics, the Transvaal and the Orange Free State, from which stemmed the Union of South Africa. Heart disease forced his resignation and he died in 10 Downing Street 17 days later.

Wilson, J., CB: A Life of Sir Henry CampbellBannerman. 1974.

Campin, Robert (c.1378-1444). Flemish painter. Active in Tournai, he is now identified as the previously misdescribed 'Master of Flémalle', regarded as the founder of Flemish Realism and a major influence on Jan van ${ }^{*}$ Eyck and Rogier van der ${ }^{*}$ Weyden.

Campion, Edmund (c.1540-1581). English priest, born in London. He was educated at Christ's Hospital and Oxford, and later studied for the Roman Catholic priesthood at Douai and Rome. He joined the Jesuits (1573) and in 1580 returned to England on a mission to revive the spirit of the Roman Catholics suffering under Queen *Elizabeth's Anglican rule. With his eloquence and the qualities of a brilliant mind he was proving most successful when within a year he was captured. Despite torture he refused to recant and argued persuasively with his accusers. Nevertheless he was condemned on charges of sedition and hanged, drawn and quartered. Campion was beatified in 1886 .

Waugh, E., Edmund Campion. 1936.

Peters, M., Mrs Pat. 1984. 
Campion, Thomas (1567-1620). English poet and musician. By profession a physician, he is best known for his books of 'ayres' containing lyrics, some set to music (for the flute) by himself, he also wrote masques for court performances and a treatise on harmony. In his Observations in the Art of Poesie (1602) he attacked the practice of rhyming.

\section{Camrose, William Ewart Berry, 1st Viscount see Berry, William Ewart}

Camus, Albert (1913-1960). French writer, born in Algeria. He became a journalist and an actor and managed a theatrical company (1935-38). He went to Paris in 1939. Towards the end of World War II he worked for the resistance movement and was editor of the left wing newspaper Combat (1944-47). For a time he belonged to the Communist Party, but became disillusioned, and after breaking with *Sartre abandoned public activities. In his later works he revealed himself as a humanist, discouraged by the failure of contemporary civilisation to cope with major moral issues, and unable to accept the existence of God, but constantly trying to find significant values in a meaningless world. Most of his thought is centred on the concept of the 'absurd' - that man's predicament in the world is absurd. He is often termed an existentialist- to which he laid no claim. Among his works are the philosophical essays in Le Mythe de Sisyphe (1942), L'Homme révolté (1951), a declaration of his own attitude to life, novels such as L'Étranger (1942) and La Peste (1947), short stories, as L'Exil et la Royaume (1957), and plays such as Le Malentendu (1944). He won the Nobel Prize for Literature in 1957. He was killed in a motor accident.

Todd, O., Albert Camus. 1996; Lottman, H. R., Albert Camus. 1996.

Canaletto (né Giovanni Antonio Canal) (16971768). Italian painter, born in Venice. Originally trained in Venice by his father, a scene painter, he later studied in Rome. His best pictures combine exact topographical detail with a remarkably subtle feeling for light. An English connoisseur, Joseph Smith, whose collection of over 50 Canalettos was bought by *George III, persuaded him to come to England, where he lived between 1746 and 1756, but though some of his London scenes are as skilful as the Venetian ones in reproducing detail and conveying atmosphere, it is upon the latter that his reputation finally rests.

Constable, W. G., Canaletto. 1962.

Canaris, Wilhelm Franz (1887-1945). German admiral and spy. After long naval service, he became head of the Abwehr (German military intelligence) 1935-44, became convinced that *Hitler might destroy Germany and was involved in plots to remove him. He was hanged, naked, at Flossenbürg, on the same day as ${ }^{*}$ Bonhoeffer.
Candolle, Augustin Pyrame de (1778-1841). French botanist, born at Geneva. After working in Paris, he was professor at Montpellier from 1807-16, when he returned to Geneva. He is best known for his system for classifying plants in natural categories rather than in what he held to be the artificial ones in the system of *Linnaeus.

Canetti, Elias (1905-1994). German-Jewish writer, born in Bulgaria. From a Sephardic family, he was educated in Manchester, Vienna, Zürich and Frankfurt, and became a British subject in 1935. He was awarded the 1981 Nobel Prize for Literature for a lifetime's work, including the novel Auto da Fé (1935, originally Die Blendung), Crowds and Power (1960) and two volumes of autobiography.

Cannadine, Sir David (1950- ). English historian, born in Birmingham. He studied at Cambridge, Oxford and Princeton, held chairs at Columbia, London and Princeton, and became editor of the Oxford Dictionary of National Biography 2014- . His works include Decline and Fall of the British Aristocracy (1990), G. M. Trevelyan (1992), Orientalism (2001), In Churchill's Shadow (2002), Mellon (2006) and George V(2014).

Canning, Charles John Canning, 1st Earl (18121862). English politician and administrator, born in London. Son of George *Canning, he was educated at Eton and Oxford, became a protégé of Robert *Peel and served as Undersecretary for Foreign Affairs 1841-46 and Postmaster General 1853-55. *Palmerston appointed him as Governor-General of India 1856-62, and his early attempts at reform coincided with the outbreak of the Indian Mutiny (1857). Exhausted by overwork, his attempts to restrain mass executions of mutineers were largely ignored; the soubriquet 'Clemency Canning' was coined by his enemies. When rule in India was taken from the East India Company and vested in the Crown, Canning became the first to use the title Viceroy of India 1858-62. His wife died of malaria in 1861 and Canning soon followed.

Canning, George (1770-1827). English Tory politician, born in London. His father, a failed businessman, died in 1771 and his mother became an actor. Relatives saved him from destitution and paid for his education at Winchester, Eton and Oxford, where his brilliance soon attracted attention. ${ }^{*}$ Pitt found him a seat in Parliament, and he was MP 17931827. In 1797 he founded the satirical Anti-Jacobin, in which Tories less extreme than himself, especially Pitt's successor, *Addington, were violently attacked. The other side of his political nature was shown when, after holding minor office, he first became foreign secretary, in the Portland administration of 1807. Expert and liberal statesmanship abroad and reactionary politics at home were characteristics of his policies. In his first term as foreign secretary his promptness in obtaining control of the Danish and Portuguese fleets after 
*Napoléon's reconciliation with Tsar *Aleksandr at Tilsit and his support for the Spanish insurgents against Joseph *Bonaparte's rule had decisive effects in the struggle against Napoléon. A duel with his rival ${ }^{*}$ Castlereagh in 1809 , in which he was shot and wounded, caused a long interruption in his political career, during which he occupied important posts (Ambassador to Portugal, 1814-16, President of the Indian Board of Control 1816-21). Appointed to be Governor-General of Bengal, he was recalled to the government after Castlereagh's suicide (1822), and became Foreign Secretary once more. It was during this second term that his recognition and support of the South American colonists in revolt against Spanish rule evoked the phrase 'I called the New World into existence, to redress the balance of the Old'. His support for the Greek independence movement also proved decisive. He succeeded ${ }^{*}$ Liverpool as Prime Minister in April 1827 but died of emphysema in August, after 119 days in office, the shortest tenure of any British Prime Minister, until Liz *Truss.

Petrie, C., George Canning. 2nd ed. 1946; Hinde, W., George Canning. 1973.

Cannizzaro, Stanislao (1826-1910). Italian chemist. He was appointed to academic posts at Genoa (1855), Palermo (1861), and Rome (1870). He was the first to appreciate the importance of the hypothesis of *Avogadro as a means of introducing order into chemical classification, and brought it to general attention in his Sketch of a Course of Chemical Philosophy (1858). Cannizzaro also did important work in organic chemistry. The reaction of benzaldehyde with potassium hydroxide to form benzylalcohol was discovered by him and is often referred to as 'Cannizzaro's reaction'.

Canning, Stratford, 1st Viscount Stratford de Redcliffe (1786-1880). English diplomat. First cousin of George *Canning, most of his career was spent in Constantinople. He was First Secretary in the Embassy to the Ottoman Empire 1808-10 and Minister Plenipotentiary 1810-58. During his last period (from 1841), he exercised a very powerful influence over the Sultan's foreign policy. He aimed to secure Turkey's independence of Russia without war, and though he failed to avert the Crimean War he obtained enough external support for Turkey to ensure Russia's defeat. He was also largely responsible for many internal reforms. Throughout his career he acted as a proconsul almost entirely independently of the British Government.

Cannon, Walter Bradford (1871-1945). American physiologist, born in Wisconsin. Son of a poor railroad worker, he gained admission to Harvard, and graduated in 1896. He had already developed interests in neurology and psychology, and proceeded to study at Harvard Medical School. From 1902-42 he was in the Harvard Physiology Department. Cannon's early research was on digestion. He made pioneer use of X-rays to examine gastrointestinal action and the mechanisms of swallowing. He then directed his research to a study of the sympathetic nervous system, and developed the notion that the autonomic nervous system aims to keep the internal environment of the body in a state of constant equilibrium (homeostasis). These views he expounded in his Wisdom of the Body (1932). His later work on digestion shared many similarities with the researches of *Pavlov in Russia. During World War I he had made deep studies of the new phenomenon of shell shock. All the ways in which the nervous system operated to some degree autonomously from mental consciousness were of deep interest to him. Cannon had strong civic and political convictions, sympathised with the Russian Revolution and campaigned for the Republican cause in the Spanish Civil War. He was nominated 27 times for the Nobel Prize for Physiology or Medicine.

Cano, Juan Sebastian del (d.1526). Spanish navigator. He commanded one of the five ships in *Magellan's great expedition of 1519 , and when Magellan was killed in the Philippines (1521) Cano took command. On returning to Spain (1522) he was acclaimed as the first man to circumnavigate the world.

Canova, Antonio (1757-1822). Italian sculptor, born near Venice. Trained as a sculptor from the age of 11 , he settled in Rome at 24 and Vatican patronage soon made him prominent. He led the Italian neo-classical movement, famous for his idealised and sometimes sentimentalised representations of the human form. His monuments to popes Clement XIII and XIV belong to this period. Later he was patronised by the *Bonaparte family and especially *Napoléon's sister, Pauline, Princess Borghese, presented semi-naked on a couch. In 1815 he was sent to Paris to negotiate for the return of works of art looted by Napoléon. Among his best known classical works are several versions of Cupid and Psyche and the Perseus in the Vatican.

Munoz, A., Canova. 1957.

Canrobert, (François) Certain (1809-1895). French marshal. After long and distinguished service in Algeria he succeeded Marshal *St Arnaud as French Commander-in-Chief in the Crimean War. In 1859 he commanded a division against the Austrians at Magenta and Solferino in the war for Italian independence. In the Franco-Prussian War of 1870 he was taken prisoner with his troops when Metz surrendered.

Cantor, Georg (Ferdinand Ludwig Philipp) (18451918). German mathematician, born in St Petersburg. Following studies in Berlin and Göttingen, he became a lecturer at the University of Halle in 1969 and professor in 1879. In 1874 he published a revolutionary paper explaining that there were at least two different kinds of infinities, the countable 
infinity, the common numbers of elements ('cardinal numbers') in the sets $\{1,2,3,4,5 \ldots\}$ and $\{2,4,6$, $8,10, \ldots\}$, both of which go on ad infinitum, but can ultimately be counted to include every element, and the uncountable infinity of elements in sets such as all real numbers - the continuum-which cannot be counted. In later work, Cantor called the countable infinity $\boldsymbol{\aleph}_{0}$, and defined and studied an infinity of distinct infinities $\aleph_{0}, \aleph_{1}$, etc. He hypothesised, but could not prove, that the cardinality of the continuum was the next largest infinity after $\boldsymbol{S}_{0}$, indeed that $\boldsymbol{K}_{1}=2 \mathrm{~N}_{0}$. His transfinite set theory was the first careful and precise mathematical theory of the infinite. He became obsessed with the hypothesis that Francis *Bacon wrote ${ }^{*}$ Shakespeare's plays. From 1884 he experienced periods of extreme depression and was often hospitalised.

Bell, E. T., Development of Mathematics. 1945.

\section{Canute see Cnut}

Cáo Xuěqín (originally Cáo Zhān or Mèngruǎn) (c.1715-c.1763). Chinese novelist, poet and painter, born in Nanjing. His family served the ${ }^{*}$ Qing (Manchu) court, then fell from wealth and power. His novel Dream of the Red Chamber (or The Story of the Stone), circulated in manuscript from the 1760s, and first printed in 1791, is regarded as the greatest novel in the classical Chinese tradition.

Capablanca y Graupera, Jose Raúl (1888-1942). Cuban chess master. A diplomat by profession, he was the world chess champion from 1921, when he defeated Emanuel *Lasker, until he lost the title in 1927 to Aleksandr *Alekhine.

Čapek, Karel (1890-1938). Czech playwright and novelist, born in Malé Svatosnovice. He was best known as the author of the very successful satirical plays R.U.R. (Rossum's Universal Robots) (1920) which gave the word 'robot' to the languages of the world and (with his brother Joseph) The Insect Play (1921), a terrifying satire on a hedonistic, acquisitive and regimented society. His play The Makropulos Case (1922) was the basis of *Janáček's opera. His novels include the satires on misused science Krakatit (1924) and War With the Newts (1938). He also wrote books on travel, on gardening, many essays and a biography of President *Masaryk (1928).

Harkins, W. E., Karel Čapek. 1962.

Capet. French dynasty which ruled from 987 to 1328 when *Philippe IV died without male issue. Succeeding dynasties (*Valois, *Bourbon) were remote descendants of ${ }^{*}$ Hugues Capet through the female line. In 1992 *Louis XVI was tried and executed as 'Louis Capet', a derisive name.

\section{Capet, Hugues see Hugues Capet}

Capodistrias, Ioannes, Count (1776-1831). Greek politician, born in Corfu. After service in the administration of the Ionian Islands, he went to Russia, where eventually he became Foreign Minister 1815-18. He returned to Greece in 1822 to devote himself to the national cause, and after independence from Turkey had been won was elected first president of Greece (1827), but his autocratic measures were unpopular, and he was murdered.

Capone, Al(phonse Gabriel) (1899-1947). American criminal, born in Brooklyn. His parents migrated from Salerno to New York in 1893. He became a New York gangster, and in 1920 went to Chicago, where, during the Prohibition years, he became the head of a gang controlling the gambling, vice and supply of illegal liquor of Cook County. The gang's earnings were estimated to be in the region of \$US105 million. $\mathrm{He}$ was responsible for numerous brutal murders, but avoided prosecution by bribery and coercion of Chicago law officers. He was eventually prosecuted by Federal authorities, but could be convicted only for tax evasion (1931). He was released in 1939 following mental and physical collapse due to syphilis.

Capote, Truman (né Truman Streckfuss Persons) (1924-1984). American novelist, born in New Orleans. He wrote much about social decay in the southern states of the US and his novels include Other Voices, Other Rooms (1948), The Grass Harp (1951) and Breakfast at Tiffany's (1958). He wrote the dialogue for the film Beat the Devil (1953). In Cold Blood (1966), a powerful 'non-fiction novel', described the murder of a farming family in Kansas, and the trial and hanging of two young men. It was his last major work but collected essays appeared in Music for Chameleons (1980). He conducted bitter and protracted literary feuds with *Mailer and ${ }^{*}$ Vidal.

Clarke, G., Capote. 1986.

Capra, Frank (1897-1991). American film producer and director. Of Italian parentage, among his many successes were It Happened One Night (1934), Mr Deeds Goes to Town (1936) and Lost Horizon (1937).

Capra, F., Frank Capra: The Name Above the Title. 1971.

Caprivi, Georg Leo, Graf von (1831-1899). German soldier and politician, born in Berlin. A successful chief of staff in the Franco-Prussian War (1870-71), he then directed the administration of the German navy 1883-88 until *William II appointed him Chancellor and Foreign Minister 1890-94, after the dismissal of ${ }^{*}$ Bismarck. He negotiated the treaty with Britain (1890) under which German claims in Zanzibar were abandoned in return for the cession of Heligoland. He was dismissed in 1894 after negotiating a commercial treaty with Russia. 
Caracalla (popular name of Marcus Aurelius Severus Antoninus Augustus) (188-217). Roman Emperor 211-17. Born in Lyon, of mixed Punic and Syrian descent, son of the emperor *Septimius Severus, he was given the nickname Caracalla from the longhooded Gaulish tunic he wore. On his father's death, he and his brother Geta became joint rulers but Caracalla seized power by murdering Geta and his supporters. He secured his popularity with the troops by a 50 per cent increase in pay. His reign was notorious for cruelty, assassination and extravagance. He pacified the German frontiers and was unsuccessfully attempting to emulate the achievements of *Alexander the Great in the East when his assassination in (modern) Turkey was contrived by the prefect of his praetorian guards. During his reign Roman citizenship was extended to all free men in the empire (probably to increase the number of taxpaying citizens) and the colossal baths of Caracalla were constructed at Rome.

Mackenzie, D. C., The Reign of Caracalla. 1949.

Caratacus (known also as Caractacus/Caratācos/ Caradog/Karadeg) (d.c.54 CE). British chieftain of the Catuvellauni tribe. Son of ${ }^{*}$ Cunobelinus, after fighting bravely against the Romans, he was defeated and in 51 handed over by Cartismandua, queen of the Brigantes, and taken to Rome, where his bravery before the emperor ${ }^{*}$ Claudius secured him honourable treatment.

Caravaggio, Michelangelo Merisi da (15731610). Italian painter, born in Milan. His break with the conventions of the Mannerists created a resurgence of art in the 17th century and exercised enormous influence on e.g., *Rubens, *Velázquez and ${ }^{*}$ Rembrandt. A revolutionary technique was the setting of brightly lit figures against a dark background (e.g. in his St Matthew series in the church of San Luigi dei Francesi, Rome). Moreover he offended against accepted convention in his sacred pictures by depicting ordinary people in everyday surroundings. Another innovation was the introduction of 'still life' as a separate branch of painting. The dramatic nature of his painting may have reflected the violence of his own life. In 1606 he was banished from Rome after killing a man in a fight. From Naples he reached Malta, where he insulted a knight, was imprisoned but escaped to Sicily. When disembarking in Italy on his way to Naples he was arrested in error but on release found that his boat with all his belongings had sailed away. There was an attempt on his life in Naples and his death was prematurely reported three times. On his way to Rome to receive a papal amnesty, he seems to have died in Porto Ercole, Tuscany, and in 2010 remains found there were identified as Caravaggio's.

Famous in his lifetime, he was forgotten soon after and interest was revived only in the 1920s. About 80 works can be safely attributed to him. Some of his greatest masterpieces are in Rome: Boy with a Bowl of Fruit (1593), St Jerome Writing (1605-06), David with the Head of Goliath (1609-10) at the Borghese, Rest on the Flight into Egypt (1597) at the Doria Pamphilj, Judith Beheading Holofernes (c.1598) and Narcissus (c.1599) at the Barberini. Three Martyrdoms of John the Baptist at the Pro-Cathedral of St John, Valletta, Malta, are also outstanding. Caravaggio is now in the highest rank of Renaissance painters.

Berenson, B., Caravaggio: His Incongruity and his Fame. 1953; Jullian, R., Caravage. 1961; Robb, P., M. 1999; Langdon, D., Caravaggio: A Life. 1999.

Cardano, Geronimo (also known as Jerome Cardan or Hieronymus Cardanus) (1501-1576). Italian mathematician and physician. Although professor of medicine at Pavia 1543-59 and Bologna 156270 , he is best known for his work in mathematics, particularly algebra. His Ars Magna (1545) was the first algebraic text to be printed. His academic career at Bologna ended with imprisonment for heresy (astrology was one of his interests). He spent his last years in Rome and is said to have starved himself to death to prove the accuracy of a prediction. He was a polymath who wrote prolifically in science, history and music.

Cárdenas, Lazaro (1895-1970). Mexican general and politician. Of mixed Tarascan and Spanish descent, he was a follower of *Carranza and ${ }^{*}$ Calles and became Minister of War 1933-34. President of Mexico 1934-40, he expanded Calles' revolutionary policy of breaking up large estates and redistributing the land among the peasants. He was strongly anticlerical. A temporary breach with the US and Great Britain was caused by his nationalisation of the oil fields in 1938. He served as Secretary for Defence 1943-45 and later supported *Castro's rule in Cuba.

Scott, R. E., Mexican Government in Transition. Rev. ed. 1964.

Cardigan, James Thomas Brudenell, 7th Earl of (1797-1868). English soldier, born in Buckinghamshire. He sat in the House of Commons 1818-29, first representing a rotten borough, and then 1832-37, after the Reform Bill, when he spent a fortune to win the seat. He was leader and survivor of the famous charge of the Light Brigade at the Battle of Balaclava (October 1854) during the Crimean War.

Woodham-Smith, C., The Reason Why. 1953.

Cardin, Pierre (1922-2020). French couturier, born in Italy. He worked with Christian *Dior, established his own fashion house in 1949, extending his brand name to men's and women's clothing and accessories. He bought Maxim's and established it as a worldwide restaurant chain. 
Cardoso, Fernando Henrique (1931- ). Brazilian sociologist and politician. He taught in France, became Minister for Foreign Affairs 1992-93, Minister for Finance 1993-94 and President of Brazil 1995-2003.

Cardozo, Benjamin Nathan (1870-1938). American judge, born in New York. From a Sephardic Jewish family, he was a judge from 1913 and Chief Justice of the New York Court of Appeals 1927-32. President ${ }^{*}$ Hoover appointed him to succeed $\mathrm{Mr}$ Justice *Holmes on the US Supreme Court 193238. A liberal, he supported *Roosevelt's New Deal legislation and his views on law as a force in effecting social changes were highly influential. As well as several authoritative legal works Cardozo wrote Law and Literature and Other Essays (1931).

Carducci, Giosuè (1835-1907). Italian poet. Son of a physician, educated at Pisa University, he became a school teacher until appointment as professor of Italian literature at Bologna (1860). Elected to the Italian parliament as a Republican in 1876, in 1890 he became a senator. His poems, representing a reaction from Romanticism, were written in strict classical form in a style and language of great distinction. His main works include Rime (1857), Nuove poesie (1873) and Rime e ritmi (1898). He won the Nobel Prize for Literature in 1906.

Cardus, Sir (John Frederick) Neville (1888-1975). English cricket and music critic. Brought up in poverty and essentially self-educated, he wrote on music and cricket for the Manchester Guardian, then lived, wrote and broadcast in Australia 1940-47. He wrote many books on cricket and music and an Autobiography (1947).

Cardwell, Edward Cardwell, 1st Viscount (18131886). British politician. A Liberal MP 1842-74, he carried out important army reforms as Secretary of State for War 1869-74 under *Gladstone. These included the abolition of the purchase of commissions (1870), the reorganisation of the regiments of the line on a county basis, and the system by which one battalion of a regiment served abroad while the other remained in support and reserve at home. He also established the supremacy of the minister over the Commander-in-Chief.

Carew, Thomas (c.1594-1639). English poet. Having left Oxford without a degree, he accompanied diplomatic missions abroad. On his return his wit and pleasant manner made him a favourite of ${ }^{*}$ Charles I, before whom his masque Coelum ritannicum was produced in 1633. A friend and admirer of *Donne and ${ }^{*}$ Jonson, he also wrote short, polished lyrics in the Cavalier tradition, the well known Elegy on the Death of Dr Donne, and The Rapture.
Carey, George Leonard, Baron Carey of Clifton (1935- ). English cleric. Educated at a secondary modern school, and at King's College, London University, he served in the RAF, then lectured in theology in London, Nottingham and Bristol. He was Bishop of Bath and Wells 1987-91 and Archbishop of Canterbury 1991-2002.

Carey, Peter (1943- ). Australian novelist, born in Bacchus Marsh. He dropped out of Monash University and worked in advertising. His novels included Bliss (1981), Illywhacker (1985), Oscar and Lucinda (1988, which won the Booker Prize over Salman *Rushdie's Satanic Verses), The Tax Inspector (1991), Jack Maggs (1997), True History of the Kelly Gang (2000, which won him a second Booker Prize in 2001), My Life as a Fake (2003), Theft: A Love Story (2006) and Parrot and Olivier in America (2010).

Carey, William (1761-1834). English Baptist missionary and scholar. One of the first Baptist missionaries to go to India (1793), he began, almost at once, the translation of the Bible into Bengali. In 1799 he set up at Serampore not only a church and school but also an establishment for printing and publishing the Bible and other educational books in many Indian languages. In 1801 he became professor of Indian languages at Fort William College, and produced dictionaries of Sanskrit, Bengali, Marathi etc.

Carl XVI Gustaf (Carl Gustaf Folke Hubertus Bernadotte) (1946- ). King of Sweden 1973- . He succeeded his grandfather ${ }^{*}$ Gustaf VI Adolf, becoming the first Swedish monarch with purely symbolic duties, without Constitutional responsibilities, and the longest reigning. Deeply interested in science and the environment, he received more foreign honours than any person living or dead.

Carleton, Guy, 1st Baron Dorchester (1724-1808). Anglo-Irish soldier and administrator. He was first appointed to a command in America in 1758 where he served in the French and Indian Wars. As Governor of Québec 1766-77 he worked for the Quebec Act (1774) to better relations between English and French Canadians. He successfully defended Canada against American attacks during the American Revolution, he was briefly in command (1782) of the British forces towards the end of the fighting and was skilful in helping Loyalists to withdraw safely to Canada. He had a second term as Governor of Québec 178696. Many places in Canada and Britain are named 'Carleton' or 'Dorchester' after him.

Carlo Alberto (Charles Albert: Carlo Alberto Emanuele Vittorio Maria Clemente Saverio di Savoia) (1798-1849). King of Sardinia and Piedmont 183149. Born in Turin, son of the Prince of Carignano, who was sympathetic to *Napoléon, and brought up in France, as a young man he supported Italian unification but was no crusader. He inherited the 
throne from a distant cousin. He shrank from *Mazzini's extremism and harshly punished those of his followers who had taken part in a revolt. In 1848, 'the year of revolutions', however, having given the country a liberal constitution, he marched against the Austrians then ruling much of northern Italy. Defeated at Custozza and Novara he abdicated in favour of his son, *Vittorio Emanuele II, he died in Portugal.

Carlos I (Carlos Fernando Luís Maria Victor Miguel Rafael Gabriel Gonzaga Xavier Francisco de Assis José Simão de Savoia e Bragança) (1863-1908) King of Portugal and the Argives 1889-1908. Son of Luís I, he travelled extensively, was deeply interested in science and exploration, an able painter and accepted constitutional restraints on his powers. After a series of economic crises, Carlos was blamed for the actions of his government, and reluctantly signed a proclamation of martial law. He was assassinated, with his eldest son, by two conspirators who were then shot dead by police. Succeeded by his younger son *Manoel II, he was known as 'the Diplomat', 'the Martyr' and 'the Obese'.

Carlos (Charles) I. King of Spain see Charles (Karl) V, Holy Roman Emperor and King of Spain.

Carlos (Carlos de Habsburgo y Austria: known as El Hechizado, 'the Bewitched') II (1661-1700). King of Spain 1665-1700. Son of *Felipe IV and Maria Anna of Austria (1634-1696), uncle and niece, and severely inbred, he was hydrocephalic and possibly a hermaphrodite, suffered from rickets and an extreme Habsburg jaw which made speaking and eating difficult. He succeeded his father at the age of four and spent years of his reign under his mother's regency. But he did not lack intelligence. Married twice, and childless, he was induced to name in his will Philippe, grandson of *Louis XIV of France, as his successor (as *Felipe). This provoked the War of the Spanish Succession (1700-13).

Carlos (Charles) III (Carlos Sebastián de Borbón y Farnesio) (1716-1788). King of Spain 1759-88 and of Naples and Sicily 1735-59. Son of *Felipe $\mathrm{V}$ by his second wife Elizabeth (Isabella) Farnese, by her intrigues he secured the throne (as Carlo IV) of Naples and Sicily (1734). When he succeeded to the Spanish throne on the death of his half-brother Fernando (Ferdinand) VI, since his eldest son (Felipe) was incompetent to rule, he proclaimed his second son (*Carlos IV) his Spanish heir, and the third (Ferdinando) king of Naples. Carlos III was an able administrator and is considered the most successful Bourbon ruler of Spain, and showed some interest in education and science.

Herr, R., The Eighteenth Century Revolution in Spain. 1958.
Carlos (Charles) IV (Carlos Antonio Pascual Francisco Javier Juan Nepomuceno José Januario Serafín Diego de Borbón y Sajonia) (1748-1819). King of Spain 1788-1808. Son of *Carlos III, during most of his disastrous reign he was dominated by Manuel ${ }^{*}$ Godoy, lover and favourite of his queen, Maria Luisa. ${ }^{*}$ Goya made unforgettable portraits of his family. Induced to abdicate (and suitably pensioned) by *Napoléon in 1808 he was replaced as king of Spain by the Emperor's brother Joseph *Bonaparte. After four years in France, Carlos spent his last years in Rome.

Carlos, Don (Carlos de Habsburgo y Aviz) (15451568). Spanish Prince of the Asturias. Eldest son of *Felipe II and Maria Manuela of Portugal, who died four days after his birth. He was a victim of inbreeding, with only four great grandparents and six great great grandparents, and showed early evidence of sadism and insanity. Two princesses he was betrothed to later married his father. In 1567 he planned to escape from Spain and flee to the Netherlands and establish himself as king, but, increasingly manic and violent, he was imprisoned by his father in 1568 and soon died. His death was almost certainly not murder, but it contributed to the anti-Spanish Black Legend in the Netherlands and the rising by *William the Silent. Foxe's Book of Martyrs treats him generously and he was the subject of a tragedy by ${ }^{*}$ Schiller and an opera by *Verdi.

Carlos, Don, Count of Molina (Carlos María Isidro Benito de Borbón y Borbón-Parma) (1788-1855). Spanish prince. Son of ${ }^{*}$ Carlos IV of Spain, he was deprived of the right of succession to the throne when the Salic Law was revoked in 1833 and *Isabella, the daughter of his brother ${ }^{*}$ Ferdinand (Fernando) VII, became queen. The first Carlist War then broke out and lasted until 1840. A second Carlist revolt (187376) was equally unsuccessful and the last pretender in the direct line died in 1936.

Carlos 'the Jackal' (Ilich Ramírez Sánchez) (1949- ). Venezuelan mercenary and terrorist. Believed to have executed many assassinations in the Middle East and Europe, he was arrested in 1994 and taken to France for trial. In December 1997 he was convicted of murder and sentenced to life imprisonment. In 2011 and 2017, he received two more life sentences for assassinations. He wrote Revolutionary Islam (2003).

Carlota (née Marie Charlotte Amélie Augustine Victoire Clémentine Léopoldine von Wettin, later Habsburg-Lothringen) (1840-1927). Empress of Mexico 1864-67. Daughter of*Leopold I of Belgium, she married the Austrian Archduke ${ }^{*}$ Maximilian in 1857. When he became Mexican emperor in 1864, she accompanied him, but suffered a breakdown, and returned to Europe in 1866 seeking help from *Napoleon III and Pope *Pius IX for his doomed 
empire. She became paranoid (possibly compounded by psychotropic drugs) and was confined for the remainder of her life.

Carlson, Chester Floyd (1906-1968). American inventor. A patent attorney, he invented the process of dry photocopying known as xerography (1938). The first copier was not marketed until 1959.

Carlsson, Ingvar Gösta (1934- ). Swedish Social Democratic politician. Educated at Lund University and in the US, he worked in the party machine and entered the Riksdag in 1964. He was a minister 196976, Deputy Prime Minister and Minister for Research 1982-86. On Olof *Palme's murder he succeeded as Prime Minister 1986-91 and served again 1994-96.

Carlstadt (or Karlstadt) (Andreas Rudolf Bodenstein) (c.1480-1541). German religious reformer. A professor at Wittenberg University, he became an adherent of ${ }^{*}$ Luther (1517), until Luther repudiated his extreme iconoclasm. Accused of being involved in the Peasants' War, he fled to Switzerland and from 1534 preached and taught in Basle.

Carlyle, Thomas (1795-1881). Scottish essayist and historian, born in Ecclefechan, Dumfriesshire. Son of a stonemason, at the age of 15 he went to Edinburgh University, intending to be a clergyman. Religious doubts ended this ambition, and after some years as a schoolmaster and private tutor (during which time he formed a close friendship with and was much influenced by Edward Irving, later the founder of the Irvingite sect) his true vocation had become manifest. His earliest works stemmed from his interest in German literature-a Life of Schiller (1825), and a translation of *Goethe's Wilhelm Meister (1824), which won the author's praise. In 1826 he married Jane Welsh, whose wit could wound as well as delight, and whose letters still sparkle as brightly as when they were written. Her strong personality and her husband's produced one of the strangest love stories, a blend of irritation and mutual dependence, in literary history.

In 1828 the Carlyles withdrew to Craigenputtock where he set to work on Sartor Resartus (The tailor retailored), which appeared in Fraser's Magazine in 1833-34. It purports to reveal the philosophical speculations of a Professor Teufelsdrockh, and concludes that all institutions, political, religious etc., are in fact clothes constantly in need of repair and renewal. The life of the professor, which forms the second part, is based on that of Carlyle himself. He had already begun his most famous work, The History of the French Revolution, when he and his wife moved in 1834 to Cheyne Row, Chelsea, their permanent home. Disaster came when the manuscript was accidentally burnt in the flat of his friend J. S. *Mill'we must try and hide from him how very serious this business is' was Carlyle's generous comment. He rewrote the book and it was published in 1837 . It is not strictly factual history but an inspired interpretation: its rhetorical style is highly eccentric but the sheer dynamism of the work is inescapable and the character descriptions (e.g. the 'seagreen Incorruptible' *Robespierre) memorable. From the point of view of Carlyle's development it is interesting that he, who believed himself a radical and welcomed revolutionaries such as ${ }^{*}$ Mazzini to his home, was beginning to feel and see history in terms of the hero or superman. In The French Revolution (3 vols, 1837), the chief characters, *Danton especially, are already larger than life, and in On Heroes, Hero Worship and the Heroic in History (1841) he expands the theme, which is implicit also in Oliver Cromwell's Letters and Speeches (1845) and his great biography Frederick the Great (1858-65). He appears to disregard the corruption of character by power. Past and Present (1843) contrasts the ordered society of feudalism with the unordered confusion of modern times. The death of his wife in 1865 virtually ended his creative period. His influence on contemporary thought in many fields_-religious and political especially-was immense. Carlyle should be seen as more of a prophet than a historian or commentator.

Kaplan, F., Thomas Carlyle. 1983; Heffer, S., Moral Desperado. 1995.

Carmichael, Hoagy (né Hoagland Howard Carmichael) (1899-1981). American songwriter, singer and actor, born in Indiana. Originally a lawyer, his many songs include Stardust (1931) and he appeared in 14 films, sometimes playing himself.

Carmona, (António) Óscar de Fragoso (18691951). Portuguese soldier and politician. A general with distinguished military service, he had almost no political experience when called upon in 1926 to join the ruling triumvirate. He was Premier 1926-28 and President 1928-51, with all effective power held by Antonio *Salazar.

Carnap, Rudolf (1891-1970). German-American philosopher. A pupil of ${ }^{*}$ Frege at Jena, he was an original member of the 'Vienna circle' which expounded and developed logical positivism, and he concerned himself with such problems as the structure and meaning of utterances and the nature of statements of probability. He was professor of philosophy at Chicago University 1936-52 and UCLA 1954-62.

Schilpp, P. A. (ed.), The Philosophy of Rudolf Carnap. 1963.

Carnarvon, George Edward Stanhope Molyneux Herbert, 5th Earl of (1866-1923). English aristocrat. An enthusiastic amateur Egyptologist, from 1906 he financed Howard *Carter's excavations in the Valley of Kings near Thebes, culminating in Carter's discovery of the tomb of ${ }^{*}$ Tutankhamun (1922). He died in Cairo from the effects of a mosquito bite. 
Carné, Marcel Albert (1906-1996). French film director. Trained as a technician, his 19 films include Quai des Brumes (Port of Shadows, 1938) and Le Jour se leve (Daybreak, 1939) both typical of romantic pessimism in French cinema in the late 1930s. The latter had a strong influence on Hollywood direction in the 1940s. His masterpiece was Les Enfants du Paradis (Children of the Gods, 1943-44) starring JeanLouis *Barrault and Arletty, shot during the German occupation. He was elected to the Académie française in 1980 .

Carnegie, Andrew (1835-1918). American industrialist and philanthropist, born in Dunfermline, Scotland. The family emigrated to Pittsburgh in 1848 and Andrew then began work as a bobbin-boy in a cotton mill, was a messenger for Ohio Telegraph from 1850 and in 1853 a secretary/telegrapher for the Pennsylvania Railway. He started to invest in oil in 1864 and a year later entered the iron and steel industry. By the judicious merging of companies, he gradually built up a chain of interests not as a financier but as an industrialist mainly concerned with steel (but also with coal and iron fields, rail and steamship lines). Carnegie Hall in New York (1891) remains an outstanding monument to his philanthropy and music. In 1901 he sold his vast interests to the US Steel Corporation for $\$ 250$ million. He asserted, 'To die rich is to die disgraced.' His remaining years, most of which were spent in Scotland in retirement, he devoted to philanthropic ends to which he gave more than $\$ 300$ million, e.g. the Carnegie Endowment for International Peace, the endowment of libraries in Britain and the US, and gifts to Scottish and American universities. His Autobiography appeared in 1920.

Wall, J. F., Andrew Carnegie. 1971; Nasov, D., Andrew Carnegie. 2007.

Carnot, Lazare Nicolas Marguerite (1753-1823). French military engineer and politician, born in Burgundy. An army captain in 1789, he was elected to the Legislative Assembly 1791-92 and the National Convention 1792-95, becoming one of the 12 members of the Committee of Public Safety 179395. As de facto minister of war 1793-95 he received the title 'Organiser of Victories' for his achievement in raising, clothing, feeding, and training 14 armiesmore than $1,100,000$ men - to defend revolutionary France against intervention by foreign troops, also proving a resourceful and original strategist. (Claude Antoine *Prieur de la Cote d'Or shares credit for producing the armaments.) He served on the Directory 1795-97 after *Robespierre's overthrow, fleeing to Nuremberg in 1797 under an accusation of royalist sympathies. He returned after *Bonaparte's seizure of power and as Minister of War 1799-1800 provided the organisational skill necessary for the success of the Italian and Rhineland campaigns. He remained, however, a sincere republican, and retired when he understood *Napoléon's aims. The disasters that followed the retreat from Moscow induced him to offer his services once more. Napoléon made him Governor of Antwerp in 1814 and he defended it bravely against Allied attack. He was Minister of the Interior during the Hundred Days. $\mathrm{He}$ ended his days in exile and died at Magdeburg. He wrote mathematical treatises as well as The Defence of Fortified Places (1810).

His son (Nicolas Leonard) Sadi Carnot (1796-1832), named in honour of the Persian poet, was born and educated in Paris, became an army officer and after 1819 devoted himself to the study of the steam engine. Regarded as the founder of thermodynamics, his book Reflections on the Motive Power of Fire (1824) first stated the principle that the efficiency of a heatengine in operating a thermal cycle depended on the relative temperature of its hottest and coldest parts. This led to the formulation of the Second Law of Thermodynamics by *Clausius and *Kelvin nearly 20 years after he died of cholera. Lazare Hippolyte Carnot (1801-1888), his brother, was a journalist and radical politician, a consistent opponent of *Napoléon III, his son (grandson of the Revolutionary leader), (Marie François) Sadi Carnot (1837-1894), was an engineer and local administrator before being elected deputy in 1871. Minister of Public Works 1880 and Finance 1880-81, 1885-86, regarded as notably free from corruption, he was elected as President of the Republic 1887-94. An Italian anarchist, Sante Caserio, stabbed him to death in Lyon.

Caro, Sir Anthony (1924-2013). English sculptor, born in London. Educated at Charterhouse, Cambridge, the Regent St Polytechnic and the Royal Academy School, he worked with Henry *Moore 1951-53 but was heavily influenced by the American David *Smith. He lectured at St Martin's College 1953-79 and in Vermont 1963-65. His large, ground-based metal sculptures, often using prefabricated materials, then painted, were intended to create a new aesthetic and he was recognised as the most important sculptor of his generation. He won prizes at the Biennales in Paris 1959, Venice 1967 and Sáo Paulo 1969. He received the OM in 2000.

Carol I (Karl Eitel Friedrich von HohenzollernSigmaringen) (1839-1914). First king of Romania 1866-1914. A minor German prince, he was invited by the major European powers in 1866 to become ruler of the United Principalities of Moldavia and Wallachia, still under the nominal suzerainty of Turkey. The Congress of Berlin (1878) made these territories independent (1881) under the name of Romania. In 1869 he married Princess Elizabeth of Wied (1843-1916), a well-known novelist and poet under the pen name Carmen Sylva. He was succeeded by his nephew *Ferdinand II.

Carol II (Karl von Hohenzollern-Sigmaringen) (1893-1953). King of Romania 1930-40. Son of ${ }^{*}$ Ferdinand I, after divorcing Zizi Lambrino, he 
married (1921) Princess Helen of Greece, mother of his son ${ }^{*}$ Michael. His association with Magda *Lupescu created a scandal which forced his renunciation of the throne and when Ferdinand died in 1927, Michael succeeded. In 1930 Carol supplanted his son and became king. In 1938, he was torn between Romania's long-standing alliance with France and the prospect of economic support from Germany, and he faced the rising power of the authoritarian, xenophobic and populist 'Iron Guard' led by Ion *Antonescu. Carol proclaimed Romania’s neutrality in World War II, then signed a treaty with ${ }^{*}$ Hitler, after the USSR occupied Bessarabia. Antonescu forced his abdication in September 1940. He went into exile in Mexico, then Brazil, where he married Lupescu in 1947, and, finally, to Estoril, Portugal, where he died.

Caroline of Anspach (1683-1737). British queen consort 1727-37. Daughter of the Margrave of Brandenburg-Anspach, she married the future ${ }^{*}$ George II of Britain in 1705 . Her skill in managing an often obstinate king was a factor in maintaining Sir Robert *Walpole in power. She befriended *Pope, ${ }^{*}$ Gay, and ${ }^{*}$ Chesterfield, was a patron of ${ }^{*}$ Händel, took a keen interest in ecclesiastical patronage and was an amateur botanist and gardener.

Caroline of Brunswick (1768-1821). British queen consort 1820-21. Daughter of the Duke of Brunswick, she married the future ${ }^{*}$ George IV of Britain in 1795. After the birth of Princess Charlotte (1796) he deserted her and went to live with Mrs Maria *Fitzherbert. Caroline's indiscretions and eccentricities in Italy provided George with an excuse to seek divorce as soon as he became king, but when, in 1820, a bill was introduced into the House of Lords, a brilliant defence by the queen's counsel Henry (later Lord) *Brougham caused the bill to be dropped. Her forcible exclusion from Westminster Abbey at the coronation (1821) caused much resentment among the populace of London, and when she died a month later her funeral procession was accompanied by rioting in the London streets.

Carothers, Wallace Hume (1896-1937). American polymer chemist. Educated at the University of Illinois, he worked for Du Pont, and in 1930 developed a synthetic rubber, patented as Neoprene. In 1935 he found that adipic acid and hexamethylene diamine would condense together to form a tough polymer that could be drawn into a fibre. This plastic, which was called nylon, could be made into tough fabrics, cords and mouldings. There is now a family of nylons derived from slightly different starting materials. A depressive (and heavy drinker), he committed suicide.

Carpaccio, Vittore (c.1460-1526). Italian painter, born in Venice. A follower of Gentile *Bellini, his subtle treatment of light and the warm humanity of painters of the Venetian High Renaissance. He is a painter of pageantry, of architectural vistas and of details of contemporary life. His major achievement is the illustration of the story of St Ursula in a series of large, teeming and charmingly decorative compositions. Another cycle illustrates the lives of St George and St Jerome. The Presentation in the Temple is his outstanding altar-piece. All the above are in Venice. He was much admired by *Proust.

Carpenter, Edward (1844-1929). English writer. He gave up Anglican orders in 1874 to become a socialist follower of William *Morris and a literary disciple of Walt *Whitman. He rejected all existing norms of Victorian, Edwardian and Georgian society, lived by writing and craft work and deeply influenced E. M. * Forster.

Carpentier y Valmont, Alejo (1904-1980). Cuban novelist. Of French descent, he was an architect, journalist, professor of literature and composer, whose passionate novels include The Lost Steps (1953), Explosion in a Cathedral (1962) and Reasons of State (1974).

Carpentier, Georges (1894-1975). French boxer. $\mathrm{He}$ was light heavyweight champion of the world (1919-22), and in 1921 an unsuccessful contender with Jack *Dempsey for the world heavyweight title.

Carpini, Giovanni de Piano (c.1182?-1252). Italian friar, born in Perugia. He entered the Franciscan order, taught in Germany for many years and was sent by Pope Innocent IV as missionary and explorer to the Mongols. He set out from Lyon in April 1245, reaching Karakoram in July 1246 . On his return, he wrote an account of the journey, Liber Tartarorum.

Carr, Bob (Robert John) (1947- ). Australian Labor politician, born in Sydney. After graduating in history, he became a journalist, with a passionate interest in political science, foreign affairs and the environment, reluctantly entering the New South Wales Parliament in 1983, serving as Premier 1985-95. A Senator 2012-13, he was Minister for Foreign Affairs. He wrote several books, including Thoughtlines (2002), My Reading Life (2008) and Diary of a Foreign Minister (2014).

West, A., and R. Morris. Bob Carr: A Self-Made Man. 2003.

Carracci, Annibale (1560-1609). Italian painter, born in Bologna. With his brother Agostino (15571602) and cousin Ludovico (1555-1619), Annibale led a reaction against the prevailing exaggerated Mannerism and worked in the style of the High Renaissance masters ${ }^{*}$ Michelangelo, ${ }^{*}$ Raphael and *Titian. In Bologna they decorated the Palazzo Fava and founded an academy of fine arts: pupils included ${ }^{*}$ Domenichino and Guido ${ }^{*}$ Reni. From 1595 Annibale worked in Rome, painting frescos for the Farnese Palace. The ceiling of the great gallery, with its mythological scenes in settings painted to 
imitate architectural or sculptured work, became famous throughout Europe and greatly influenced the development of the Baroque decorative style. His most famous paintings include The Butcher's Shop (1583), Domine, Quo Vadis? (1601), Flight into Egypt (1604) and Pietà (1607). Annibale was buried near ${ }^{*}$ Raphael and became a major influence on ${ }^{*}$ Poussin and ${ }^{*}$ Claude.

Agostino was a masterly engraver, famous for his anatomical studies and portraits. Ludovico anticipated the Expressionists. ${ }^{*}$ Ruskin deeply disliked the work of the Carraccis.

Carranza, Venustiano (1859-1920). Mexican politician. As Governor of Coahuila 1910-15, he supported Francisco *Madera's overthrow of Porfirio *Diaz's long dictatorship (1911), and opposed Victoriano de la *Huerta who murdered Madera and seized power himself. Carranza led the 'Constitutionalists' who favoured political but not economic reform. In 1915 he became provisional president. As President under the Constitution 1917-20, he accepted some measures of land and labour reform, was anti-American and kept Mexico out of World War I. In 1923 Alvaro *Obregón led a revolt and Carranza was murdered while escaping to Vera Cruz.

Carrel, Alexis (1873-1944). French biologist and surgeon, born in Lyon. From 1904 he worked in Montréal, Chicago and New York (at the Rockefeller Institute for Medical Research 1912-14, 1919-39) and was an army surgeon in France during World War I. He won the 1912 Nobel Prize for Medicine for his work on the surgery of blood vessels and his techniques for transplanting arteries and suturing (i.e. joining) veins which during World War I reduced the number of amputations. Carrel devised equipment for keeping animal organs alive outside the body and he was able to keep a chicken heart alive for 32 years. Later he devoted himself to cancer research. He wrote Man the Unknown (1935), The Culture of Organs (1938) with Charles A. *Lindbergh, a close friend, and Reflections of Life (1943). He returned to France in 1939, had links to Jacques *Doriot, and worked for the Vichy regime. He supported eugenics, proposed gassing of the criminally insane, and was successively Catholic > agnostic > Catholic. He won awards from the USSR but not Britain.

Carreńo (García de Sena), (Maria) Teresa (18531917). Venezuelan pianist, singer, composer and conductor, born in Caracas. Her family migrated to New York in 1862. She had a phenomenal technique and declined an offer of tuition from ${ }^{*}$ Liszt. She recorded player piano rolls in 1905 and toured Australia and New Zealand 1907-08. A crater on Venus is named for her.
Carreras, José (1947- ). Spanish tenor, born in Barcelona. He made his operatic debut in Spain in 1970 and in the US in 1972 . He sang all the great *Verdi and *Puccini tenor roles and appeared in the films Don Carlos (1980) and West Side Story (1985). He founded a leukaemia research foundation in Melbourne (1992).

Carrier, Willis Haviland (1876-1950). American engineer, born in Angola, New York. He designed the first air-conditioning system in 1902, published an important paper on internal climate control in 1911 and founded the Carrier Corporation (1915).

Carrington, 6th Baron, Peter Alexander Rupert Carington, Baron Carington of Upton (19192018). English Conservative politician. Educated at Eton and Sandhurst, he served as High Commissioner to Australia 1956-59, First Lord of the Admiralty 1959-63, Secretary of State for Defence 1970-74 and Foreign Secretary 1979-82, resigning over criticism that the Foreign Office had not anticipated the invasion of the Falkland Islands by Argentina. He was chairman of General Electric 1983-84, SecretaryGeneral of NATO 1984-88 and received a KG and $\mathrm{CH}$. He was created a life peer in 1999.

Carroll, Lewis (pen name of Charles Lutwidge Dodgson) (1832-1898). English author and mathematician, born in Daresbury, Cheshire. The son of a clergyman, he was educated at Rugby and Oxford, and lectured in mathematics at Oxford 1855-81. His life was generally uneventful and he never married. His most famous children's books Alice's Adventures In Wonderland (1865) and Through the Looking Class (1872) both written for Alice Liddell, the daughter of Carroll's friend, the Dean of Christ Church, are full of subtle and almost surrealist humour, and the many fantastic characters have become familiar to millions of readers. Both books were illustrated by *Tenniel. Other favourites were The Hunting of the Snark (1876) and Sylvie and Bruno (1889 and 1893). Among his mathematical studies (written under his real name) was Euclid and His Modern Rivals (1879). He was also a skilful photographer.

Cohen, M. N., Lewis Carroll. 1995.

Carson, Ben(jamin Solomon) (1951- ). American neurosurgeon and Republican activist, born in Michigan. An African-American, educated at Yale, he became a surgeon at Johns Hopkins Hospital, Baltimore, and in 1987 was the first to successfully separate twins joined at the back of the head. After initial strong support from evangelicals and conservatives in the Republican contest for the 2016 Presidential nomination, his campaign collapsed. He was *Trump's Secretary of Housing and Urban Development 2017-21.

Carson, Edward Henry Carson, 1st Baron (1854-1935). Anglo-Irish lawyer and Conservative politician. Educated in Dublin, he became a barrister 
and won fame as the defender of the Marquess of ${ }^{*}$ Queensberry in the action for criminal libel brought by Oscar *Wilde. In parliament, where he sat as Unionist MP 1892-1918 he bitterly fought Liberal proposals to grant Irish Home Rule and organised the Ulster Volunteers, a military group which planned to oppose home rule by force and was diverted from this by the outbreak of World War I during which Carson was Attorney-General in the first coalition and in *Lloyd George's war cabinet was First Lord of the Admiralty 1916-17 and Minister without Portfolio 1917-18. He was a Lord of Appeal in Ordinary 1921-29.

Carson, Kit (Christopher) (1809-1868). American trapper, guide and scout, born in Kentucky. He acted as a guide for J. C. *Fremont 1842-44 and helped to settle and explore California 1845-46. Although almost illiterate, he became a prominent and effective Indian agent 1853-61 and served as a brigadier of volunteers in the American Civil War.

Carson, Rachel Louise (1907-1964). American biologist, writer and environmental activist. Working for the US Fish and Wildlife Service, she wrote Silent Spring (1962), an apocalyptic warning about the contamination of the environment by fertiliser, pesticides and insecticides, especially DDT. The book was extremely influential.

Carte, Richard D’Oyly (1844-1901). English impresario. He won fame by staging the Gilbert and Sullivan operas. His background was a family musicpublishing and instrument-making business, from which he progressed to become a concert agent and impresario. His success with Gilbert and Sullivan's Trial by Jury in 1875 inspired him to form a syndicate for the performance of future productions. In 1881 he built the Savoy Theatre for this purpose. His later venture the building of the Palace Theatre for serious opera, was not a success. The rights of the D'Oyly Carte family over the Gilbert and Sullivan operas ended only in 1961, when the libretto contract expired.

Carter, Elliott Cook (1908-2012). American composer, born in New York. Educated at Harvard and in Paris with Nadia *Boulanger, he worked with Charles *Ives and taught at Columbia, Yale, the Juilliard School and Cornell. His works include concertos for piano, violin, oboe, cello, horn, clarinet and flute, Concerto for Orchestra (1969), Symphony for Three Orchestras (1977), quintets for brass and woodwind and five string quartets. He was the longest-lived major composer in musical history.

Schiff, D., Carter. 2019.

Carter, Howard (1873-1939). English Egyptologist. A pupil of Sir Flinders *Petrie, he worked in Egypt for many years, and in 1922, when working with Lord ${ }^{*}$ Carnarvon, found the tomb of ${ }^{*}$ Tutankhamen in the Valley of the Kings, near Luxor.
Carter, Jimmy (James Earl Carter, Jr) (1924- ). 39th President of the US 1977-81. He was born in Plains, Georgia, and educated at public schools and Georgia Southwestern College. He graduated from the US Naval Academy in Annapolis (1946) and served as an electronics instructor and engineering officer in Hyman *Rickover's atomic submarine project. In 1953 he left the navy and returned home to manage the family peanut business. He became involved in community and church affairs and was elected to the Georgia State Senate 1963-67. In 1970 he won the Democratic primary for Governor as a moderate conservative by defeating the liberal ex-governor Carl Sanders. As Governor of Georgia 1971-75 Carter introduced 'zero base budgeting', urged reforms in environmental controls, schools and prisons and tried to ease racial tensions. In July 1976 he won the Democratic presidential nomination and was elected President in November. During his term of office he failed to work with his Democratic Congress and his only significant success was in negotiating the Egyptian-Israeli accord between *Sadat and *Begin. The continued captivity of 52 hostages in the US Embassy in Teheran (kept for 444 days and not released until he had left office) was politically very damaging, because Carter's extraordinary restraint was attacked as weakness by his opponents and he lost heavily in 1980 to Ronald *Reagan. Out of office, he devoted himself to the problems of urban poverty and housing, world peace and observing elections in the Third World. In 1994 he was a peace negotiator in Korea, Haiti and Bosnia-Herzegovina. He received the Nobel Prize for Peace in 2002 and became the longest-lived US President.

\section{Carteret, John see Granville, John Carteret, 2nd Earl}

Cartier, Jacques (1491-1557). French explorer, born at St Malo, Brittany. He made three voyages to North America in search of a northwest passage linking the Atlantic to the Pacific. On his first voyage (1534) he explored and claimed for France the coasts of Newfoundland and Labrador and the gulf of the St Lawrence, on his second (1535) he ascended that river (hoping it was a passage to China) and reached the site of Montréal. The third voyage (1541), also to the St Lawrence, provided much information but brought no new discoveries.

Cartier-Bresson, Henri (1908-2004). French photographer. He worked as an assistant to the film director Jean *Renoir, was a prisoner of war, escaped to the US and founded Magnum Photos. His evocative compositions, loaded with context and history, were exhibited internationally and he published books of photographs, including The Decisive Moment (1952), and studies of China, Russia, France and the US.

Cartland, Dame (Mary) Barbara Hamilton (19012000). English author. She wrote popular romantic fiction, and according to The Guinness Book of Records 
her 723 books had global sales of 600 million, translated into 25 languages. Her books also include poetry, biography and an autobiography.

Cartwright, Edmund (1743-1823). English inventor. Educated at Wakefield Grammar School and Oxford, he became a clergyman but having married a rich woman was able to give time and money to his inventions. In 1785 he invented a power loom which became the parent of the modern loom. He also invented rope-making and wool-combing machinery. In 1793, having been forced by debt to sell a mill he had set up in Doncaster, he went to London and worked with Robert *Fulton on steam engines. His money troubles were eased when in 1809 , in response to a petition to Parliament from 50 firms which had benefited by his inventions, he was awarded $£ 10,000$. He was elected FRS in 1821.

Caruso, Enrico (1873-1921). Italian operatic tenor, born in Naples. He came from a poor family, sang in church choirs and had a relatively late debut in Naples in 1894, appearing in Milan (1898), Buenos Aires (1899), Rome (1899), London (1902) and New York (1903). His voice had unusual range, power and flexibility, he became a pioneer recording artist and was acclaimed as the greatest tenor of his time. Leading tenor at the Metropolitan Opera, New York 1903-20, he retired after bursting a blood vessel in a performance of Halévy's La Juive.

Carver, George Washington (1864-1943). American agricultural chemist, born in Missouri. Son of slaves, he was kidnapped with his mother by slave raiders and redeemed with the exchange of a racehorse by his owner, Moses Carver, who then adopted him. He became the first black student at Simpson College, Iowa (1889) and from 1896 taught at the Tuskegee Institute, Alabama, where he gained a PhD and directed agricultural research. He promoted the planting of sweet potatoes and peanuts to replenish the soil, denuded of minerals by cotton and tobacco farming, developing 300 new products from peanuts, including fibres, dyes and soap. He declined offers to work for ${ }^{*}$ Edison and ${ }^{*}$ Ford.

Holt, R., George Washington Carver: An American Biography. Rev. ed. 1963.

Carver, John (c.1576-1621). English merchant, born in Nottinghamshire. Organiser of the London contingent of the Pilgrim Fathers, he emigrated to Holland in 1609. His preparations for the voyage to America included the hiring of the Mayflower, on which he sailed in 1620 with his wife and members of his household. He was chosen as governor of the Plymouth plantation but died the following year.

Carver, (Richard) Michael Power, Baron Carver (1915-2001). English field marshal. Educated at Winchester and Sandhurst, he was Chief of the
General Staff 1971-73 and Chief of Defence Staff 1973-76 and achieved a new reputation as an incisive writer on military and geopolitical affairs.

Carver, Raymond (1938-1988). American writer, born in Oregon. He fought alcoholism, poverty and cancer, producing magnificent short stories, in the Chekhovian vein, including Cathedral (1984) and Where I'm Calling From (1988).

Cary, (Arthur) Joyce (Lunel) (1888-1957). British novelist, born in Ireland. Educated at Oxford, he fought in the Balkan Wars (1912-13) and World War I and was for a time in the colonial service in Africa, where he found inspiration for Mr Johnson (1939). His best-known novel, The Horse's Mouth (1944), successfully filmed in 1958, is part of a trilogy with Herself Surprised (1941) and To be a Pilgrim (1942). Rich characterisation and feeling for the complexities of human emotions distinguish his work.

Wright, A., Joyce Cary. 1958.

Casabianca, Louis (1762-1798). Corsican French sailor. As commander of the French ship Orient, he was burnt to death when his ship was destroyed at the Battle of the Nile. The heroism of his young son, who perished with him, is the theme of a poem by Mrs Felicia Hemans ('Casabianca').

Casadesus, Robert (Marcel) (1899-1972). French pianist, born in Paris. Of Catalan descent, he was a great ${ }^{*}$ Mozart, ${ }^{*}$ Chopin and ${ }^{*}$ Ravel interpreter, often appearing in concerts with his wife Gaby and son Jean.

Casals, Pablo (or Pau) (1876-1973). Spanish (Catalan) cellist and conductor, born in Vedrell. Son of an organist, he studied music at Barcelona and Madrid, and made his concert debut as a cellist in Paris in 1899 . He revived interest in *Bach's works for unaccompanied cello, and developed improved cello techniques, gaining great popularity for this instrument with concert audiences. Active in his support of the government in the Spanish Civil War, he left Spain after *Franco's victory (1939). From 1950 he organised a series of music festivals at Prades, in the French Pyrenees, and he continued these from 1956 at San Juan in Puerto Rico.

Casanova de Seingalt, Giovanni Giacomo (17251798). Italian adventurer, born in Venice. He spent most of his life travelling through Europe in the varying capacities of preacher, gambler, journalist, violinist, lottery director, police spy, alchemist and cabbalist and met most of the famous men and women of his time. He was a man of intelligence and learning, his famous Memoirs-12 volumes written in the last years of his life, when (from 1785) he was secretary and librarian to Count Waldstein in Bohemia, though largely concerned with his love affairs, throw much light on the manners and morals of the time. 
Casaubon, Isaac (1559-1614). French-Swiss scholar, born in Geneva. He became professor of Greek at Geneva (1581), at Montpellier (1596) and royal librarian in Paris (1604). As a Protestant he felt unsafe after the death of ${ }^{*}$ Henri IV and came to England, where he found himself in sympathy with the middle position of the established Church and able to be of help in matters both of religion and scholarship. His religious writings display his tolerance, and his gifts as a classical commentator are shown by his editions of *Aristotle, *Theophrastus, *Suetonius etc. His son, Méric Casaubon (1599-1671), also a classical scholar and controversialist, settled into a living in the Church of England.

Casella, Alfredo (1883-1947). Italian composer, conductor and music critic, born in Turin. A pupil of ${ }^{*}$ Fauré in Paris, he worked there until World War I when he went to Rome. In 1924 he joined *D'Annunzio and others in founding a society to encourage contemporary Italian music, but he was a notable experimenter and retained an international outlook. His range of composition was wide and included two symphonies, concertos, songs, chamber music and lesser pieces.

Casement, [Sir] Roger David (1864-1916). Irish nationalist and diplomat, born in Dublin. He worked for H. M. * Stanley in the Congo, joined the British foreign service in 1901, exposed the exploitation of indigenous people in the Congo and Brazil, and was knighted (1911) for his investigation on slavery in Peru. He retired in 1913 and became active in promoting Irish nationalism and culture. In Germany during World War I he attempted to form an 'Irish Brigade' of Irish prisoners of war which he hoped would invade Ireland and free it from British rule. On his return to Ireland by submarine (1916) he was captured by the British and tried for treason. He was convicted, deprived of his knighthood, and hanged at Pentonville. In 1960 his 'black diaries' revealing homosexual practices were made available for study in the Public Records Office in London. Casement's remains were restored to Ireland in 1965.

MacColl, R., Roger Casement. 1956; Lacey, B., Terrible Queer Creatures. 2008; Mitchell, A., Roger Casement. 2013; Dudgeon, J., Roger Casement's German Diary. 2016.

Casey, Richard (Gavin) Gardiner, Baron Casey of Berwick (1890-1976). Australian Liberal politician, born in Brisbane. Son of a mining magnate, educated at Melbourne University and Trinity College, Cambridge, he served in World War I, winning a DSO and MC. His wife Maie Casey (Ethel Marian Sumner; 1892-1983) was a poet, librettist, aviator and patron of the arts. Casey was a Member of the Australian House of Representatives 1931-40 and 1949-60, was Commonwealth Treasurer 1935-39, a strong supporter of appeasement, and first Australian minister to the US $1940-42$. Winston ${ }^{*}$ Churchill appointed him Minister of State in the Middle East 1942-43, with a seat in the War Cabinet, and Governor of Bengal 1944-46, at a time of famine. In Australia after the war, under ${ }^{*}$ Menzies, he was Minister of National Development 1949-51, Minister in charge of CSIRO 1950-60 and Minister for External Affairs 1951-60. Patronised by Menzies (and disparaged by ${ }^{*}$ Hasluck), he became the first Australian life peer (1960), was Governor-General 1965-69 and the first Australian Knight of the Garter $(\mathrm{KG})$ in 1969 .

Hudson, W. J., Casey. 1986.

Casimir III (Kazimierz) (the Great) (c.1310-1370). King of Poland 1333-70. Knowing that his first task would be to unify Poland he learned western politics and secured help from his brother-in-law, Charles Robert, the Angevin King of Hungary, to whose son, Louis, he promised the Polish throne. He also came to terms with Bohemia and the Teutonic Knights. Later he enlarged his kingdom in the east and, thus secured, could concentrate upon internal reforms. Brigandage was suppressed, the liberty of the peasants protected and the nobles curbed. Jews were tolerated and encouraged to settle. In 1364, he founded the University of Kraków (later renamed Jagiellonian), which made the city not only an administrative and commercial centre but one of the great cultural centres of Europe.

Casimir (Kazimierz) IV Jagiełłon (1427-1492). Grand Duke of Lithuania 1440-92, King of Poland 1447-92. Son of *Władysław II, he belonged to the Lithuanian *Jagiellon dynasty which, linked by marriage with the Polish royal family, had brought the two countries under one ruler. He reigned during one of Poland's greatest periods. After failure against Turkey he turned against the old enemy, the Teutonic Knights in the north. After 13 years of war he destroyed their power and in 1466 by the peace of Thorn (or Torun) he annexed Pomerania with Danzig and much of south and west Prussia. To achieve these successes Casimir conceded representative government to the lesser gentry and so a parliament (Sejm) was created. $\mathrm{He}$ encouraged the growth and influence of the Jagellonian University in Kraków and was made a KG in 1450. In 1973, his tomb was opened by 12 researchers, of whom 10 died prematurely due to exposure to fungi, which produced deadly aflatoxins.

Casimir-Périer, Jean-Paul-Pierre (1847-1907). French politician. He served as a deputy 1876-83; 1885-94, was President of the Chamber 1893 and 1894, and, briefly, Premier and Foreign Minister December 1893-May 1894. After the assassination of Sadi *Carnot, he was elected as President of the Third Republic in June 1894 but resigned in January 1895, after a breakdown in relations with the Ministry; his six months as head of state is the shortest in French history. Alfred *Dreyfus was convicted in December 1894 and although Casimir-Périer was sceptical of his 
guilt, he remained passive. He left politics to become chair of the Anzin Mining Company, Europe's largest mine.

Caslon, William (1692-1766). English type founder. A broadsheet of 1734 gave examples of 12 different sizes of his roman and italic types, which at the time were recognised as the best in Europe. Caslon Old Face (1726), revived in 1840 after a temporary decline in fashion, remained among the most popular types in the first half of the 20th century, being favoured by printers because of its simplicity and legibility.

Cass, Lewis (1782-1866). American Democratic politician, born in New Hampshire. He became a lawyer, served in the 1812 war and as Governor of Michigan Territory 1813-31 opened new territories in the west for settlement. He was US Secretary of War under President *Jackson 1831-36, US Minister to France 1836-42, and a US senator 1845-48, 1849-57. Democratic candidate for the presidency in 1848 , he was defeated by Zachary *Taylor when he lost the support of the Free-Soil wing of his party. He resumed his work in the Senate, but was too old to be effective when Secretary of State under President *Buchanan 1857-60.

Cassatt, Mary (1844-1926). American artist. Whilst young she went to Paris, and under the influence of Camille *Pissarro, her teacher, *Degas and *Manet, joined the Impressionists. Neglected at first in America, her pictures, which show the Impressionist techniques applied to domestic subjects such as mothers with children or ladies at the tea table, have won her posthumous fame. She was an ardent campaigner for women's rights.

Watson, F., Mary Cassatt. 1932; Matthews, N. M. Mary Cassatt. 1998.

Cassel, Sir Ernest Joseph (1852-1921). AngloGerman financier, born in Cologne. He lived in London from 1870, and raised state loans for China, Egypt and South American governments. From an immense fortune he gave away about $£ 2$ million to hospitals, educational institutions etc. He became a friend of ${ }^{*}$ Edward VII, and his granddaughter, Edwina Ashley, married Lord Louis *Mountbatten.

Cassin, René Samuel (1887-1976). French jurist, born in Bayonne. Educated in Aix and Paris, he became a law professor and French delegate to the League of Nations. He escaped to London to work with *de Gaulle and in 1942 was sentenced to death in absentia by the Vichy regime. He drafted the UN Universal Declaration of Human Rights (adopted in 1948), became President of the European Court of Human Rights 1965-68 and received the 1968 Nobel Peace Prize. He was an active Zionist.

Cassiodorus, Flavius Magnus Aurelius (c.477570). Roman writer and administrator. Only about 20 years old when he joined the secretariat of the emperor *Theodoric, he rose to high office, in which he continued after Theodoric's death. In 540 he retired from the Ravenna court to a monastery he had built on the Calabrian coast, and there set himself the task of creating a compendium of learning, pagan and Christian alike, almost encyclopaedic in its scope. This he achieved by getting his monks to copy and amend ancient manuscripts and by his own voluminous works on history, theology and grammar. His Variae, collections of edicts, documents, etc., issued during his period of office, are of great importance for the study of the history of the Ostrogothic empire.

Cassius (Gaius Cassius Longinus) (d.42 BCE). Roman soldier and politician. An adherent of *Pompey, he became reconciled to ${ }^{*}$ Caesar but was a principal in the conspiracy to assassinate him. $\mathrm{He}$ left Italy with *Brutus and after their defeat by Mark *Antony at Philippi ordered one of his freedmen to kill him.

Cassivellaunus (fl. 54 BCE). British ruler. As chief of the Catuvellauni he offered strong resistance to *Caesar's advance across the Thames during his second invasion (54). The loss of his capital (now Wheathampstead, Herts.), forced him to make peace. His later history is unknown.

Casson, Sir Hugh Maxwell (1914-1999). English architect. One of the leading exponents in Britain of the contemporary style, he was chief designer (1951) for the Festival of Britain exhibition buildings on the south bank of the Thames in London and knighted in 1952. He wrote Homes by the Million (1947). He was President of the Royal Academy 1976-84 and made a CH (1984).

Castiglione, Baldassare, Conte (1478-1529). Italian humanist writer, born near Mantua. The son of a nobleman, he served more than one Italian duke, but it was the court of Urbino that provided the background for his great book, the Libro del cortegiano (The Courtier, 1518), a prose dialogue defining the attributes of the 'perfect gentleman', and discussing etiquette, hunting, social problems, the significance of the arts and Platonic love. It was translated into English in 1561 and widely read in Europe.

Castle, Barbara Anne (née Betts), Baroness Castle (1910-2002). English Labour politician. Married to a journalist, she was MP for Blackburn 1945-79 and a member of the Labour Party's National Executive 1950-79. She was Minister of Overseas Development 1964-65, of Transport 1965-68, Secretary of State for Employment and Productivity 1968-70, and for Social Services 1974-76. She was a member of the European Parliament 1979-89.

Castlemaine, Countess of see Cleveland, Barbara Villiers, 1st Duchess of 
Castlereagh, Robert Stewart, Viscount (afterwards 2nd Marquess of Londonderry) (1769-1822). Anglo-Irish politician, born in Dublin. Son of a landowner, he entered the Irish parliament (then separate) as a Whig (1790), but turned Tory in 1795 . As Chief Secretary for Ireland 1799-1801, he was instrumental in securing the passage of the Act of Union of Ireland with England, which, as he realised, was likely to fail unless Catholic emancipation was granted. *George III's veto on such concessions was crippling. He became Secretary of State for War and the Colonies 1805-06, 1807-09, being responsible for choosing Sir Arthur Wellesley, the future Duke of *Wellington, for the peninsular command. But equally he must take some responsibility for the selection of the incompetent Earl of Chatham for the disastrous Walcheren campaign. In 1809 Castlereagh fought a duel with and slightly wounded his political rival George ${ }^{*}$ Canning, who had been intriguing against him. He left office but returned in 1812 to begin his great period as Foreign Secretary 1812-22, when he was responsible for forming and holding together the anti-French alliance in the late stages of the Napoléonic Wars. After the French defeat he represented England at the Congress of Vienna and the signing of the Treaty of Paris (1815). He opposed vindictive peace terms and was instrumental in keeping Alsace-Lorraine French. Later he was opposed to the Holy Alliance being exploited as a means of suppressing all liberal movements in Europe. Little interested in domestic politics, he had to defend and bear censure for the government's repressive policies. This, combined with strain and overwork, and threats of blackmail about his homosexuality caused him to cut his throat. One of the ablest statesmen of his time and a man of character, he did not deserve the great unpopularity of his last years, expressed in the cheering which broke out at his burial in Westminster Abbey.

Bew, J., Castlereagh. 2013.

Castro Ruz, Fidel (1926-2016). Cuban politician. The son of a rich sugar planter, he studied law at Havana University and became a violent opponent of the repressive and dictatorial *Batista regime. Sentenced to five years' imprisonment for an attack on an army barracks in 1953 he was released under an amnesty two years later and went into exile. He returned in 1956, landing secretly in the Oriente province, where he gradually built up a guerrilla force which, by January 1959, proved strong enough to overthrow Batista. He was Prime Minister 1959-76. The US refused to recognise his government and supported the abortive 'Bay of Pigs' invasion by Cuban exiles (April 1961). Construction of a Russian missile base in Cuba led to a confrontation between *Kennedy and *Khrushchev in October 1962 and the base was dismantled. He was First Secretary of the Communist Party (based on his United Revolutionary Socialist Party) 1965-2011 and President of Cuba 1976-2008, President 2008-18
Cuba became increasingly dependent on Soviet aid which declined under *Gorbachev. Castro's regime actively intervened in Angola and Central America. He maintained his ideology despite the collapse of the USSR without making any concessions to political freedom or democratic practice. Pope *John Paul II visited Castro in January 1998. His brother, Raúl Modesto Castro Ruz (1931- ) was first vice president of Cuba 1976-2008 and President 2008-18, and First Secretary of the Communist Party 2011-21.

Matthews, H. L., Castro: A Political Biography. 1969.

Catalani, Alfredo (1854-1893). Italian operatic composer. Born in Lucca, like *Puccini, he composed five operas, the most performed being La Wally (1892).

Catesby, Robert (1573-1605). English conspirator. A Roman Catholic gentleman, embittered by a fine imposed for joining the rebellion by the 2nd Earl of ${ }^{*}$ Essex, he took a leading part in the gun powder plot. After the arrest of Guy *Fawkes he fled to Warwickshire but was pursued and killed.

Cather, Willa Sibert (1876-1947). American novelist, born in Virginia. She grew up in Nebraska, where she was taken at the age of nine, and whose pioneering history is the subject of some of her best books. After graduating at the University of Nebraska, she went to Pittsburgh as a teacher and journalist. In 1904 she moved to New York, where her career as a professional writer began. Her first major success was $O$ Pioneers (1913). Other major works include One of Ours (Pulitzer Prize, 1922), Death comes for the Archbishop (1927) and Shadows on the Rock (1933).

Catherine (Yekaterina) I (1684-1727). Tsarina (Empress) of Russia 1725-27. Marta Skowronska was born in Poland to a Lithuanian peasant family, became a servant and the mistress first of Prince ${ }^{*}$ Menshikov, then of *Peter the Great. She married Peter in 1712, became Empress Consort in 1724 and succeeded to the throne on his death.

Catherine (Yekaterina) II (known as 'the Great') (née Sophie Friederike Auguste von Anhalt-ZerbstDornburg, later Yekaterina Aleksayevna von Holstein-Gottorp-Romanov) (1729-1796). Tsarina of Russia 1762-96. Born in Stettin (now Szczecin, Poland), daughter of Prince Christian of AnhaltZerbst, and a cousin of two Swedish kings, * Gustav III and Karl XIII, her family life was relatively frugal but she was lively and curious, encouraged by a French governess. In 1744 she joined the Orthodox Church and in 1745 married a distant cousin, the future Tsar *Peter (Pyotr) III. Their only child, later *Paul (Pavel) I was born in 1754. Catherine hated her degenerate and feeble-minded husband but realised that marriage could be a path to power. Peter became tsar in 1762 but six months later a military coup led by two of Catherine's many lovers, Count Grigori *Orlov and Prince Grigori *Potemkin, deposed him, 
and he was murdered some days later. In taking the throne Catherine supplanted her own son. Though in her zeal for self-education she read and corresponded with *Voltaire and others and practised and patronised art and literature, she ruled as an autocrat. She appointed *Diderot as her (absentee) librarian in 1766 and he visited her in St Petersburg in 1773-74. She was variolated against smallpox in 1769, together with her family, and encouraged the practice. Catherine bought most of Robert *Walpole's collection of paintings for the Hermitage Museum in 1779. An enlightened despot she may have been, but a despot none the less, and she never forgot her political dependence on the nobility and gentry who had set her on the throne. Although she abolished capital punishment (except for political crimes), and prepared comprehensive schemes of educational, legal and administrative reform, little was actually accomplished. The number of serfs increased and the military and economic burdens on the peasantry grew worse. Following the revolt (1773-75) led by Emelian *Pugachev, a pretender who claimed to be her dead husband, her domestic policy became increasingly repressive. She pursued an imperialist foreign policy and in two wars with Turkey (1768-72 and 1787-92) expanded her territories near the Black Sea and annexed the Crimea. The Ukraine was fully absorbed and when Poland was obliterated by the three partitions of 1772,1793 and 1795 Russia took the largest share.

Grey, I., Catherine the Great: Autocrat and Empress of all Russia. 1961; Troyat, H., Catherine the Great. 1977; Massie, R.K., Catherine the Great: Portrait of a Woman. 2012.

Catherine de'Medici (de Medicis) (1519-1589). French queen consort 1547-59. Born in Florence, daughter of Lorenzo de'*Medici, she married ${ }^{*}$ Henri II of France in 1533 and was the mother of three kings *François II (first husband of *Mary, Queen of Scots), ${ }^{*}$ Charles IX and ${ }^{*}$ Henri III. She became regent in the reign of Charles IX, her aim was to increase the independence and power of the crown by maintaining a balance between the Roman Catholic extremists (under the Guises) and the Huguenots (Protestants). It was because the balance appeared to be endangered by the marriage of her daughter, Marguerite de Valois, to the Protestant leader ${ }^{*}$ Henri of Navarre that she obtained the agreement of Charles IX to the 'massacre of St Bartholomew' of the Huguenot guests gathered in Paris for the wedding. Under Henri III, Catherine's influence waned. She was much hated and traduced, but stood for a policy of moderation in general, in the interests of the survival of the monarchy which she saw as the basis of French stability.

Sutherland, N. M., Catherine de'Medici and the Ancien Regime. 1986.

Catherine (Catalina) of Aragon see Katherine of Aragon
Catherine of Braganza (Catarina de Bragança) (1638-1705). Queen consort of England, Scotland and Ireland 1660-85. Daughter of *João IV of Portugal, she married ${ }^{*}$ Charles II in 1662. She brought Bombay and Tangier to England as her dowry. No children survived, but, though he was notoriously unfaithful, Charles treated her with dignity and kindness. She finally returned to Portugal in 1692 .

Catherine (or Katherine) (Howard) (1521-1542). Queen consort of England and Ireland 1540-42. A granddaughter of the 2nd Duke of Norfolk and related to Anne *Boleyn, she married *Henry VIII as his fifth wife in 1540 . Less than two years later she was beheaded for adultery with Thomas Culpeper and young kinsman, Francis Dereham.

Catherine (or Katherine) (Parr) (1512-1548). Queen consort of England and Ireland 1544-47. Sixth and last wife of ${ }^{*}$ Henry VIII, and daughter of a controller of the royal household, she had been widowed twice before marrying the king in 1544. After his death in 1547 she soon married Lord Thomas Seymour, a brother of ${ }^{*}$ Jane Seymour, the mother of ${ }^{*}$ Edward VI. The young Princess *Elizabeth lived briefly with Catherine, but Thomas' attentions were unwelcome. She died in childbirth and her funeral was the first conducted in Protestant forms.

Catherine of Siena, St (Caterina Benincasa) (c.1347-1380). Italian nun and mystic, born in Siena. Daughter of a dyer, she became a Dominican tertiary and attracted a group of followers, nursing and healing the sick. Although illiterate, she dictated hundreds of letters and the famous Dialogue or Treatise on Divine Providence. She helped to persuade Pope Gregory XI to return from Avignon to Rome in 1376. She negotiated peace between Florence and the papacy and supported Rome in the Great Schism. A stigmatic, she was canonised in 1461, became patron saint of Italy in 1939 and a doctor of the Church in 1970.

Catherine of Valois (1401-1437). Queen consort of England 1420-22. Daughter of ${ }^{*}$ Charles VI of France, and younger sister of Isabella, *Richard II's queen, in 1420 she married *Henry V of England. After his death (1422) and the accession of their baby son *Henry VI, she married Owen *Tudor, a Welsh landowner. Her grandson, Henry Tudor, became King *Henry VII in 1485.

\section{Catherine Swynford see Swynford, Catherine}

Catiline (Lucius Sergius Catilina) (c.108-62 BCE). Roman conspirator. A supporter of ${ }^{*}$ Sulla as a young man, he later professed extreme democratic opinions to further his interests. The events that brought about his ruin originated from his belief that he was being unfairly deprived of the consulship, which he felt was his due. Thus his first conspiracy (65) was intended 
to help his own candidacy for 64. The plot was mismanaged and Catiline escaped conviction, but when he again sought election in 63 , it was ${ }^{*}$ Cicero, a man of lower rank than himself but with conservative backing, who was preferred. A second plot was then contrived to bring about the death of Cicero and other hostile senators. News of it had reached Cicero, who took emergency measures and in one of his most famous orations denounced Catiline in the Senate. Catiline himself gained a short respite by flight, but in January 62, he was hunted down and killed, with many of his followers, at Pistoia, while those conspirators who had stayed in Rome were arrested and executed.

Cato, Marcus Porcius (known as Cato the Elder) (234-149 BCE). Roman politician. As a young man he served against the Carthaginians in the second Punic War. As Consul (195) he fought in Spain, but it was as 'censor' (184) that he showed the zeal for moral reform by which he is best remembered. He denounced extravagance, tried to restore a sense of high moral values in public life, and strongly resisted Greek cultural influences, which he regarded as corrupting. His visit to Africa in 153 convinced him that Carthage could still be dangerous and for many years he ended every speech in the Senate with the words 'Carthage must be destroyed'. He wrote books on the history of Roman towns (Origines) and on farming. His great-grandson, also named Marcus Porcius Cato (Cato the Younger) (95-46 BCE), supported *Pompey against Julius *Caesar in the Civil Wars, and after Pompey's defeat at Pharsalus (48) escaped to Africa, where he defended Utica. When news of Caesar's victory at Thapsus (46) reached him he committed suicide. His daughter, Portia, married *Brutus. As a patron of the Stoic school of philosophers Cato was famed for his unbending rectitude. He was seen by his enemies as an obstructive, old fashioned and inflexibly doctrinaire politician; his admirers saw him as upholding the ancient Roman virtues in a corrupt age.

Catullus, Gaius Valerius (c.84-c.54 BCE). Roman lyric poet, born in Verona. He lived mainly at Rome and at his villas at Tibur and Sirmio. His surviving works consist mainly of love poems, some passionate, some playful, and scurrilous, witty or satirical verses written probably in the last years of his short life. They show his command of lyric metres and ability to express the tenderest and most personal emotions. His poems were lost until an early manuscript was found in Verona in 1305.

Wiseman, T. P., Catullan Questions. 1969; Quinn, K., Catullus: The Poems, edited with Commentary. 1970.

Cavafy, C. P. (Constantinos Petrou Kavaphes) (1863-1933). Greek poet, born in Alexandria. He lived in Liverpool 1870-77, then his family returned to Egypt where he worked as a minor civil servant and journalist in Alexandria, rarely visited Greece and wrote 154 poems, terse, ironic and pessimistic, skilfully evoking the past. The first publication in book form (1935) was posthumous. An English translation by John Mavrogordata (1951) led to international critical acclaim, aided by the advocacy of his friend E. M. *Forster, and he was admired by W. H. ${ }^{*}$ Auden, Leonard ${ }^{*}$ Cohen and Marguerite *Yourcenar. Among his greatest poems are 'Waiting for the Barbarians' (1904) and 'Ithaca' (1911). The translations by George Barbanis are particularly effective.

Cavaignac, Louis-Eugène (1802-1857). French soldier and politician. Son of a revolutionary lawyer, when *Louis Philippe was deposed (1848) he became Minister of War in the provisional government, and armed with dictatorial powers suppressed a rising by Parisian workers, protesting against the closure of 'national workshops'. 3,000 workers were killed and 4,000 were transported. However, Cavaignac was a committed republican and introduced some reforms as Chief of the Executive Power May-December 1848. A new constitution was promulgated under which Louis-Napoléon Bonaparte (later ${ }^{*}$ Napoléon III) was elected president with about 5,500,000 votes, against less than 1,500,000 for Cavaignac. A member of the National Assembly 1848-51, he was arrested when Bonaparte staged a coup-d'etat, and although re-elected in 1852 and 1857 refused to take an oath to the Second Empire.

Cavaillé-Coll, Aristide (1811-1899). French organ builder. He belonged to a dynasty of organ builders in France and Spain, and his company made nearly 500, noted for their astringent but exhilarating timbre, including Notre Dame, La Madeleine, La Trinité, St Sulpice and Ste Clotilde in Paris, the basilica of St Denis and cathedrals in Caen, Rouen, Bayeux and Toulouse. *Franck, *Saint-Saëns, *Fauré, *Widor and ${ }^{*}$ Messaien wrote specifically for Cavaillé-Coll organs. Asteroid 5184 Cavaillé-Coll was named for him.

Cavalcanti, Guido (c.1255-1300). Florentine poet. A friend of ${ }^{*}$ Dante, his sonnets and other poems reveal a philosophic and introspective temperament. His active support of the Ghibelline (imperial) cause led to his exile in the last year of his life. English translations were made by ${ }^{*}$ Rossetti and Ezra ${ }^{*}$ Pound.

Cavalli, Francesco (Pietro Francesco Caletti di Bruno) (1602-1676). Italian operatic composer, born at Crema. Son of Gian Battista Calettidi Bruno, he later took the name of his Venetian patron Federico Cavalli. At 15 he became a singer in the choir of St Mark's, Venice, where he was trained by Claudio ${ }^{*}$ Monteverdi. He became maestro di cappella at St Mark's in 1668. He wrote 42 musical dramas, of which 27 survive. They use a small orchestra and show the beginnings of the use of recitative and aria, the music complemented extravagant sets and costumes.

Worsthorne, S. T., Venetian Opera in the Seventeenth Century. 1954. 
Cavallini, Pietro (c.1250-c.1330). Italian fresco painter and mosaic artist. Working mainly in Rome, his first authenticated work is known to have been painted over a fifth century Christian fresco in which the Roman classical tradition had survived. It is this tradition which seems to have influenced him in his departures from the contemporary Byzantine style. His paintings reject the stiffness of Byzantine art, and they re-introduce sculptural modelling of figures and drapery, assisted by directed light. His best known works are probably The Last Judgment (fresco) in Sta. Cecilia in Trastevere, Rome, and Six Scenes from the Life of Mary (mosaics) at Sta Maria in Trastevere. He strongly influenced ${ }^{*}$ Giotto.

Toesca, P., Pietro Cavallini. 1960.

Cavell, Edith Louisa (1865-1915). English nurse, born near Norwich. A clergyman's daughter, she was a governess, then had a late vocation for nursing. She worked in Brussels from 1907. When Belgium was overrun by the Germans during World War I, she remained in Brussels to nurse the wounded of both sides and assisted over 200 Allied soldiers to escape into neutral Holland, an act of treason in the German military code, for which she was condemned and shot. Her execution caused widespread outrage, especially in Britain, the US, Canada and Australia. She was widely memorialised, with statues, coins, a mountain in Canada and in plays, early films and music. She was reburied at Norwich Cathedral. Her statue in St Martin's Lane, London, carries her words: 'Patriotism is not enough. I must have no hatred or bitterness towards anyone.'

Hochling, A. A., Edith Cavell. 1958; Souhami, D., Edith Cavell. 2010.

Cavendish, Henry (1731-1810). English scientist, born in Nice. Son of Lord Charles Cavendish, an able experimenter, Henry's elder brother became 3rd Duke of Devonshire, and he inherited two large fortunes, making him one of England's richest men. Educated at Peterhouse, Cambridge, unmarried, and devoid of any passion but science, he lived in London, either in Bloomsbury or at a villa at Clapham, in eccentric seclusion. His waking hours were devoted to scientific research. In 1766 he isolated hydrogen, realised that it was an element, and investigated many of its properties and received the Copley Medal of the Royal Society. He was the first to determine accurately the chemical composition of water and air. Like *Priestley, he supported the phlogiston theory later disproved by *Lavoisier. He also conducted many experiments in heat and electricity, and measured the constant of gravitation, from which he estimated the mean density of the earth (accurate to within 1 per cent). The Cavendish Laboratory at Cambridge is named after him.

Berry, A. J., Henry Cavendish: His Life and Scientific Work. 1960; Jungnickel, C. and McCormmach, R., Cavendish. The Experimental Life. 2016.
Cavour, Camillo Benso di, Conte (1810-1861). Italian politician, born in Turin. The main architect of Italian unity and independence, he was the son of a nobleman. He found army life alien to his liberal ideas and turned to scientific agriculture as a means of showing that, to prepare a country for freedom, practical improvements were more important than political agitation. His search for the newest techniques, which eventually brought him a fortune, took him abroad and introduced him to many influential people who shared his liberal views and moderate approach. In 1847 he founded Il Risorgimento, a liberal journal aimed at securing the political unification of Italy but at the same time advocating such steps as the construction of railways, free trade, and democratic constitutions, which would tend to bring unity naturally about. Meanwhile, political events were helping him. In $1848{ }^{*}$ Carlo Alberto, the king of Sardinia (and ruler of Piedmont) went to war with Austria (which then held the rest of northern Italy), and, though defeated, he was prepared to grant a democratic constitution, which provided a means by which Cavour could bring about his aims. In 1852 under the new king, *Vittorio Emanuele, he became Premier of PiedmontSardinia. By reforms of the army and administration, expanding the economy and strengthening the financial situation by reducing debt, he steadily built up the idea in Europe that the supporters of Italian unification were no longer reckless revolutionaries but sober serious politicians. He gained further goodwill by sending Sardinian troops to aid the British and French in the Crimea. Finally in 1858, accord with ${ }^{*}$ Garibaldi having already been reached, came the secret deal with *Napoléon III by which Nice and the Savoy duchy were promised to France in return for French aid. When war broke out with Austria in 1859 the French victories at Magenta and Solferino secured northern Italy (except Venice). Garibaldi landed in Sicily in May 1860 and a few weeks later he and Vittorio Emanuele rode through Naples together. In March 1861 Cavour became first Prime Minister of the almost united Italy. He died in June.

Mack Smith, D., Cavour. 1985.

Caxton, William (c.1422-1491). English printer, born in Kent. He became a prosperous silk merchant, and was a prominent member of the English commercial community at Bruges (1463-69). From 1471 to 1476 he was attached to the court of Margaret, Duchess of Burgundy, sister of England's *Edward IV. During this time he learned the art of printing, probably at Cologne, and began printing at Bruges, where he published the Recuyell of the Historyes of Troye, which he had translated from the French. This is the first known book to have been printed in the English language. In 1476 he set up the first English press, at Westminster. His first publication there was The Dictes or Sayengis of the Philosophers (1477), a translation from the French by the 2 nd Earl Rivers. He also printed the works of 
${ }^{*}$ Chaucer, ${ }^{*}$ Malory and ${ }^{*}$ Gower and was active until his death as translator and editor. His first illustrated work was the Myrrour of the World (1481) and his most elaborate the Golden Legend, lives of the saints illustrated with woodcuts. In all he published about 100 volumes, of which roughly one third survive.

Cayley, Arthur (1821-1895). English mathematician. Educated at Trinity College, Cambridge, he supported his research by practising as a barrister for 14 years. Elected FRS at the age of 31, he became first Sadleiran professor of mathematics at Cambridge 1863-95. He published 300 papers, received the Copley Medal in 1882 and became President of the British Association 1883. He made important contributions to abstract geometry and theoretical dynamics, his best known book (his collected papers alone fill 13 volumes) being Elementary Treatise on Elliptic Functions (1876).

Bell, E. T., Men of Mathematics. Repr. 1961.

Cayley, Sir George, 6th Baronet (1773-1857). English engineer, inventor and aviation pioneer, born in Scarborough, Yorkshire. Privately educated, as early as 1799 he proposed an aircraft with a fuselage, fixed cambered (i.e. asymmetrical) wings, a rudder and separate power source. He experimented with model balloons, then built a series of large gliders, and in 1810 published a paper identifying the four aerodynamic forces in flight: weight, lift, drag and thrust, rejecting *Leonardo da Vinci's concept of bird-like flight for humans. Now often described as 'the Father of Aviation', he was the first to explain the problems of flight mathematically. He invented a hot air engine in 1807 , forerunner of the internal combustion engine, improving it in 1837 . He also invented an artificial limb, a tension spoke wheel, safety belts and self-righting lifeboats. He was a Whig MP 1832-34 and was elected FRS. In 1853 he built a large glider, claiming 'steadiness, safety and steerage', which carried a passenger.

Fairlie, G. and Cayley, E., The Life of a Genius. 1965; Dee, R., The Man who Invented Flight. 2007.

Ceauşescu, Nicolae (1918-1989). Romanian Communist politician. He was imprisoned for political offences 1936-38, 1940-44, and became Minister of Agriculture 1947-50 in the first Communist Government, Deputy Minister of the Armed Forces 1950-54 and a Politburo member 1955-89. On the death of his patron Gheorge Gheorghiu-Dej (1901-1965), he succeeded as Secretary-General of the Romanian Communist Party 1965-89. With his wife Elena Petrescu (1919-1989), he built up a powerful family network and was President of the Romanian State Council 1967-74 and President of the Socialist Republic of Romania 1974-89. While pursuing a repressive policy at home, marked by extravagant expenditure on public buildings, he won international support by pursuing a foreign policy independent of Moscow, cultivating good relations with China, Israel, the US. With the collapse of Communism in eastern Europe, Ceauşescu's use of force in Timisoara led to an army revolt and in December he was overthrown and executed with his wife.

Cecchetti, Enrico (1850-1928). Italian ballet dancer and trainer. One of the strongest influences in the development of modern ballet, both his father and his mother were dancers, and he, by a blend of vigour and precision with French grace, produced the style of male dancing which came to be known as Russian. In 1902 he became Director of the Imperial School at Warsaw, but later took *Pavlova, at her special request, as his sole pupil. A long association with *Diaghilev followed, and in 1919 he started his own school in London, where Ninette ${ }^{*}$ de Valois and Marie *Rambert were among his pupils.

Cecil. For members of this family other than those below, see Burghley, 1st Baron, Salisbury, 3rd Marquess of, and Salisbury, 1st Earl of

Cecil, Lord (Edward Christian) David (Gascoyne) (1902-1986). English literary critic and biographer. Son of the 4th Marquess of Salisbury, he was professor of English literature at Oxford University 1948-69. He wrote biographies and studies of Walter ${ }^{*}$ Scott, Lord *Melbourne, Jane *Austen, William *Cowper and Thomas *Hardy, and a critical study, Early Victorian Novelists (1964).

Cecil of Chelwood, 1st Viscount, (Edgar Algernon) Robert Gascoyne Cecil (1864-1958). British politician. A son of the 3rd Marquess of *Salisbury, educated at Eton and Oxford, he became a barrister and QC (1889). After World War I, although a minister in *Baldwin's Government 1923-24, 1924-27, his main preoccupation was the League of Nations, where he represented Britain 1919-32 and at its last session in 1946. He served as President of the League of Nations Union 1923-45 and later of the United Nations Association. He was awarded the Nobel Peace Prize in 1937 and a CH in 1956.

Celan, Paul (né Pavel Antschel) (1920-1970). Romanian-Jewish -French poet and translator, born Czernowitz (now in Ukraine). His parents died in the Holocaust, and Celan survived a labour camp in Romania. He translated *Shakespeare's Sonnets into German and wrote 'Todesfuge' ('Death Tango') in 1944-45. He lived in Paris from 1948, and translated poetry by ${ }^{*}$ Donne, ${ }^{*}$ Dickinson, ${ }^{*}$ Baudelaire, ${ }^{*}$ Rimbaud, *Valery, ${ }^{*}$ Frost and ${ }^{*}$ Yevtushenko. He drowned himself in the Seine on *Hitler's birthday. His poems are short and compressed ('microliths') and have been compared to the music of *Webern. Neglected in his lifetime, Celan is now regarded as being in the front rank of modern German poets. There are eight English translations of his poems and an extensive bibliography.

Chalfen, I., Paul Celan. 1991; Felstiner, J., Paul Celan. 1995. 
Celestine I, St (d.432). Pope (from 422). A Roman deacon, as Pope he attacked the teachings of ${ }^{*}$ Nestorius, which argued that the human and divine natures of Jesus were independent, and of *Pehagius, who rejected predestination and the doctrine of original sin. He sent Palladius (431) as the first bishop to Ireland.

Celestine III (Giacinto Bobo-Orsini) (c.11061198). Pope 1191-98. A student and friend of *Abelard, sympathetic to *Becket, he was a diplomat until election to the papacy at the age of 85 . His attempts to restore papal influence were thwarted by the emperor ${ }^{*}$ Henry VI.

Celestine V, St (Pietro di Morrone) (c.1215-1296). Pope 1294. He lived for many years as a hermit in the Abruzzi and gathered round him an ascetic group, later known as the Celestines. After the death of Nicholas IV in 1292 the cardinals were unable to agree on a new pope, and after a two-year delay Celestine, now old and incompetent, was elected. Finding himself a political pawn he abdicated after five months, but was kept in captivity by his successor, ${ }^{*}$ Boniface VIII, to prevent him becoming a centre of faction. He was canonised in 1313 , though ${ }^{*}$ Dante sets him at the gateway of Hell.

Celibidache, Sergiu (1912-1996). Romanian conductor. He studied in Paris and Berlin and was Chief Conductor of the Berlin Philharmonic Orchestra 1948-52 during its post-war rebirth. $\mathrm{He}$ made a few recordings $1945-50$, but his international reputation depended exclusively on concerts. Like the pianist *Michelangeli, he remained an intensely controversial figure. He was musical director of the Munich Philharmonic Orchestra 1979-96.

Céline, Louis-Ferdinand (né Louis Ferdinand Destouches) (1894-1961). French novelist. His major novels, Journey to the End of the Night (1932) and Death on the Instalment Plan (1936), are autobiographical, describing his experiences during World War I, his work as a doctor in Paris slums, and his childhood and youth. Born a petit bourgeois, his writings reveal a pathological loathing for capitalist society and its products. Céline, assumed to be a leftist, was invited to the USSR in 1936 but hated what he saw. His visit made him first an anarchist and soon after a fascist. From 1937 his anti-Semitism became so virulent that even the French fascist press rejected his writings. To Germany in 1944, he fled to Denmark (1945), was briefly imprisoned, then began writing again. Tried in absentia in February 1951 and sentenced to a year in prison, he was soon amnestied and returned to France, broken in health.

Cellini, Benvenuto (1500-1571). Italian artist, born in Florence. His life, according to himself, was as colourful as his work. His father was a musician and he studied music until the age of 15 . Later he was apprenticed to a goldsmith, and it was during his apprenticeship that he was banished after fighting a duel. Making his way to Rome, he was employed by Pope ${ }^{*}$ Clement VII as a musician, but soon attracted notice by his gold and silver craftsmanship. $\mathrm{He}$ claimed, too, to have killed the Constable of Bourbon and the Prince of Orange during the sack of Rome by the imperial forces in 1527 . After a short absence he was back in Rome in 1529, designing coins for the papal mint. Pardoned by Pope *Paul III for the murder of a rival goldsmith, he was again in trouble in 1538 when he was charged (falsely, it is said) with having stolen papal jewels during the sack. After escaping from prison, he served *Francois I of France until 1545, when he returned to Florence, where he enjoyed the patronage of Duke Cosimo de'*Medici for the rest of his life. Cellini's Autobiography (155862), a lively and boastful account of his adventurous life, also gives much valuable information about the goldsmith's craft. It is indeed for their intricate and ingenious craftsmanship rather than for their artistic sensibility that his works, such as his statue of Perseus in Florence, are most praised.

Parker, D., Cellini. 2004.

Celsius, Anders (1701-1744). Swedish astronomer. Nephew of Olaf Celsius (1670-1756), the botanist and patron of *Linnaeus, and grandson of Magnus Celsius who deciphered the Helsing runes, he was professor of astronomy at the University of Uppsala 1730-44 and was a member of the expedition which, in 1736, visited Lapland to measure an arc of the meridian and investigate the Aurora Borealis. In 1742 he introduced the Celsius, or centigrade, temperature scale.

Cenci, Beatrice (1577-1599). Italian noblewoman. To escape the cruelty and the incestuous attentions of her father, she arranged with her stepmother and brother to have him assassinated. Put on trial with her accomplices, she confessed under torture and was beheaded. Her story was the basis of *Shelley's verse tragedy The Cenci.

Cerdic (Ceretic?/Caraticos?) (d.c.534). King of the West Saxons (Wessex) 519-34. Everything about his antecedents is contested, and his claimed descent from Wotan is unlikely. The Anglo-Saxon Chronicle describes him as a Saxon adventurer who defeated the Britons, but the name is not Germanic, and he may have been a Roman-Briton. He established a line that included *Egbert and *Alfred (the Great).

Cernuda (y Bidón), Luis (1902-1963). Spanish poet, born in Seville. A member of the 'Generation of 1927', he was a friend of *Lorca. He left Spain in 1938 during the Civil War and remained an exile until his death in Mexico City. His reputation has grown since his death with two collections of translations in English, The Poetry of Luis Cernuda (1977) and Selected Poems of Luis Cernuda (1999). 
Cervantes Saavedra, Miguel de (1547-1616). Spanish novelist, born in Alcalá de Hernares, near Madrid. Fourth child of Rodrigo Cervantes, a barbersurgeon from Córdoba, and Leonor Cortinas, little is known of his childhood or education but he was an avid reader and a lover of the theatre. He borrowed the name of Saavedra from a relative.

He may have fled after wounding a man in a duel, and in Rome became chamber assistant in the household of Giulio Acquaviva, later cardinal, 1569-70.

In 1571 he served at the Battle of Lepanto, suffering three gunshot wounds, one of which crippled his left hand. Later he rejoined his regiment and served in Corfu and Tunis. While returning to Spain with his brother Rodrigo, Moorish pirates captured his ship and he was imprisoned as a slave in Algiers (157580), finally ransomed after several abortive attempts to escape. In Madrid he tried to support himself by writing plays, poems, and a pastoral novel, $L a$ Galatea (1585). In 1584 he married Catalina de Palacios Salazar y Vozmediano (1565-1626). The marriage was unhappy and they had no children, though Cervantes had a daughter, Isabel, from an earlier liaison. Employed (1587) in raising provisions for the Armada, he was confirmed as a civil servant (1588), but was finally dismissed (1597) and imprisoned for three months because of discrepancies in his accounts.

He lived in Seville, in great poverty, from 1595 to 1603 , and occupied himself with poetry, unsuccessful plays and writing the first part of his masterpiece, Don Quixote, in full El ingenioso hidalgo Don Quixote de la Mancha (The Ingenious Gentleman Don Quixote of La Mancha). A satire on medieval romances of chivalry, Don Quixote recounts the adventures of an elderly and confused hidalgo, Alonso Quixano, who reinvents himself as Don Quixote, a knight ('The knight of the doleful countenance'), who tours the countryside on his steed Rocinante (just a nag), with his princess Dulcinea del Toboso (in reality a peasant girl) in his heart and his faithful squire Sancho Panza (a peasant) in his wake, 'to defend the oppressed and to undo wrongs'. Part I of Don Quixote was published in 1605 and won immediate success, being reprinted four times in the same year.

Translated into English by John Shelton in 1612, there were early versions in French, German and Italian.

Don Quixote is built around a long-running jokethe absurd obsolescence of romantic fiction with its implausible events, exaggerated emotions and self-delusion, and also has the characteristics of the 'buddy' story, very familiar in modern novels and films. Simon *Leys (Pierre Ryckmans) wrote: 'It is bizarre to observe how a literary masterpiece which was to exert such universal appeal-transcending all barriers of language, culture and time-could, from the start, have been entirely predicated upon such a narrow, tedious and pointless literary quarrel.'
In 1605, Cervantes was arrested on suspicion of conspiracy to murder, when the body of a notorious rake, believed to be a lover of his daughter, Isabel, was found in his house; the charge was, however, dropped. Isabel was again mixed up in some sort of mysterious imbroglio (1608-12). Fame seems, however, to have brought him some happiness, though he remained poor. Among Cervantes' last works were some short plays, a collection of Exemplary Novels (1613) in the manner of *Boccaccio, and The Trials and Peregrinations of Persiles and Sigismunda, a linked series of about 20 short novels, published posthumously.

In 1614, a spurious Part II was published over the name of Alonso Fernández de Avellaneda-the author has never been identified but the successful playwright Lope de *Vega may have organised the deception. The effect was catalytic and provoked Cervantes to complete an authentic Part II in 1615.

Cervantes became a member of the Order of San Francisco in 1613 and died, aged 68, probably of dropsy (edema, leading to chronic heart failure) in Madrid on 23 April 1616, the same date as *Shakespeare (but 10 days earlier in the Gregorian calendar). In March 2015, it was claimed that his remains, long lost, were found at the Convent of the Barefoot Trinitarians, Madrid.

Don Quixote is repeatedly listed as one of the world's greatest novels; many critics place it first. The lost play Cardenio (1613?) by *Shakespeare and *Fletcher is based on a character in Part I of Don Quixote. *Telemann wrote an opera (1761), as did *Salieri (1771), ${ }^{*}$ Mendelssohn (1825), *Massenet (1910) and de *Falla (1923). Several ballets have been based on Don Quixote, the first in 1719, the most performed version (1869) to music composed by Ludwig Minkus; but at least four more are in the repertoire. Richard *Strauss wrote a memorable tone-poem Don Quixote (1898), for cello and orchestra. The novel has been dramatised many times. There have been 24 films or television series based on Don Quixote: the Russian version (1957) directed by Grigori ${ }^{*}$ Kozintsev is the best. Orson *Welles tried and only partly succeeded. Terry Gilliam's attempt in 2000 was a magnificent failure, as recorded in the documentary Lost in La Mancha (2002), available online. From 1965 the musical Man of La Mancha was immensely successful internationally.

Grismer, R. L., Cervantes: A Bibliography. 1946-63; Byron, W., Cervantes, a biography. 1978; Canavaggio, J., Cervantes. 1991; McCrory, D. P., No Ordinary Man. 2006.

Cetewayo (Cetshwayo) (c.1836-1884). Zulu king. After he had gained the throne by killing his brother his hostile attitude to the British settlers in Natal brought on the Zulu War of 1879. The results of early successes, including the victory of Isandllwana, were wiped out by the decisive defeat of Ulundi. After 
imprisonment he was restored to part of his kingdom in 1883 but failed to secure the allegiance of his subjects, and was driven out.

Cézanne, Paul (1839-1906). French post impressionist painter, born in Aix-en-Provence. Son of a rich banker, he wrote poetry, and had as one of his boyhood friends Émile *Zola, who persuaded him, against his father's wishes, to take up art in Paris. From 1863 he joined the group round *Manet, and his earliest works, influenced by ${ }^{*}$ Delacroix, were often erotic or mythological scenes executed with violent strokes of the palette knife. The Franco-Prussian War having broken up the group, Cézanne became more closely associated with the Impressionists, and through Camille *Pissarro (187273) became friendly with ${ }^{*}$ Monet and ${ }^{*}$ Renoir. He soon developed an original and personal style. He saw natural objects as made up of basic geometrical forms, such as the cylinder, sphere or cone, and his aim was to represent them by colour alone without shadows or perspective, space being suggested by a series of receding planes. Cézanne achieved his effects with a limited colour range: blue, green and tan predominantly, and brush-work as distinctive as it is difficult to describe. From about 1876 he gave up small brush strokes and painted in masses. His subjects, repeated over and over again, were few: landscapes, still life (mainly fruit and flowers), a few local portraits (and some of himself) and groups of card players and bathers. The enormous prices now paid for his works make it hard to credit that, until he was over 50, Cézanne's talent went almost unrecognised. He became embittered and eccentric, withdrew to Provence in 1878 and except for short intervals lived there in seclusion for the rest of his life. When his father died (1886), leaving him enough to live in comfort, he married Hortense Figuet, a model with whom he had previously lived, and his work of the next 10 years is his most serene and assured. His last works are more violent and lyrical, e.g. the wonderful variants of Le Chateatu noir and Mont St Victoire. In 1895 Ambroise Vollard (1865-1939), a leading art dealer in Paris, mounted his first exhibition and thereafter Cézanne enjoyed at least moderate fame. A diabetic, he died from exposure after a fall. He had a profound influence on *Matisse, *Picasso and ${ }^{*}$ Braque. Cubism was the obvious development of his geometrical theories but his influence extended far more widely and his works led from the traditional schools to the revolutionary theories and techniques of today. The Card Players (1893) was bought by the royal family of Qatar in 2011 for \$US250 million, making it, at that time, the most expensive painting in the history of art.

Rewald, J., Cézanne. 1986; Callow, P., Lost Earth: A Life of Cézanne. 1995; Danchev, A., Cézanne. 2012.

Chabrier, (Alexis) Emmanuel (1841-1894). French composer. He was largely self-taught. At first a civil servant, he did not become a professional musician until 1880. His first successful work, the orchestral rhapsody Espana (1883), shows the gaiety and orchestral flair that characterise his music: other examples are the Marche slave and Marche joyeuse. He also wrote the light operas Gwendoline (1886) and Le Roi malgré lui (1887). His influence on later French composers was notable, and his songs, piano music and the orchestral Suite pastorale were much admired by Ravel and Debussy.

Chabrol, Claude (1930-2010). French film director. Educated at the University of Paris, he became a critic, coauthored a book on Alfred ${ }^{*}$ Hitchcock, and directed a series of films, many featuring his wife Stephane Audran, about crime, passion and family life among the bourgeoisie.

Chad (Ceadda), St (d.672). Anglo-Saxon missionary, born in Northumbria. Educated at Lindisfarne, he succeeded his brother, Saint Cedd, as abbot of their joint foundation at Lastingham in 664. He was consecrated Bishop of the Northumbrians with York as his see, but the appointment gave rise to a dispute and he resigned in 669 in favour of St Wilfrid. He was then made bishop of Mercia, with his see at Lichfield, and is credited with the conversion of the Kingdom of Mercia. He died of the plague. His remains are in St Chad's Cathedral, Birmingham.

Chadwick, Sir Edwin (1801-1890). English social reformer. Originally a lawyer, he became a friend and disciple of Jeremy *Bentham. He worked (183246) for the Poor Law Commission and played an important part in the drafting of the Factory Act (1833) and the Poor Law Amendment Act (1834). $\mathrm{He}$ was the leading public-health reformer of the 19th century. He wrote The Sanitary Condition of the Labouring Population (1842) and advocated the introduction of comprehensive drainage and sewerage systems in English cities. This and other reports, e.g. that on The Practice of Interment in Towns, led to important reforms.

Chadwick, Sir James (1891-1974). English physicist. He studied at Manchester, and under *Rutherford at Cambridge, and was appointed professor of physics at Liverpool in 1935. Chadwick investigated highly penetrating radiation which in 1930 had been observed by Bothe and Becker when certain light atoms, such as those of beryllium, were bombarded with alpha-particles. By analysing the masses and speeds of the particles involved, he showed in 1932 that neutrons, uncharged sub-atomic particles whose existence had been predicted by Rutherford, were being produced. Chadwick is thus generally credited with the discovery of the neutron, and was awarded the Nobel Prize for Physics in 1935. He worked on atomic energy research during World War II, was knighted in 1945 and became Master of Gonville and Caius College, Cambridge 1948-58. 
Chadwick, (William) Owen (1916-2015). English historian. Educated at St John's College, Cambridge, he was ordained as an Anglican priest and at Cambridge became Master of Selwyn College 195683, Regius Professor of Modern History 1968-83 and Vice Chancellor 1969-71. His books included The Reformation (1964), The Victorian Church (1966-70), The Secularization of the European Mind (1976), Michael Ramsey: A Life (1990), A History of Christianity (1995) and $A$ History of the Popes 18301914 (1998). He received the OM in 1983.

Chagall, Marc (1887-1985). Russian-Jewish artist, born in Vitebsk. He worked as a stage designer under *Bakst, lived in Paris (1910-14) and was there influenced by the Cubists. He returned to Russia, served in World War I and became a commissar of fine arts after the revolution. In 1922 he returned to Paris. He lived in the US 1941-47, returning to France in 1948. His style, though it links up with that of the Surrealists, is highly personal. His dreamlike pictures are made up of Jewish and Russian folk fantasies and symbols and childhood memories. His first wife, Bella, appears in many of them. He also designed stained glass, sets for ballet, e.g. Firebird (1945) and Daphnis and Chloe (1958) and opera, e.g. Magic Flute (1967), illustrated books, e.g. La Fontaine's Fables, and painted the ceiling of the Paris Opera (1964).

Alexander, S., Marc Chagall. 1979.

Chailly, Riccardo (1953- ). Italian conductor, born in Milan. He was principal conductor of the Berlin Radio Symphony Orchestra 1982-88, the Royal Concertgebouw Orchestra, Amsterdam 1988-2004 and the Gewandhaus Orchestra, Leipzig 2005-16. He made powerful recordings of *Mahler. He was appointed director of La Scala, Milan 2015- .

Chain, Sir Ernst Boris (1906-1979). AngloGerman biochemist, born in Berlin. He lectured at Oxford from 1935 and with *Florey devised methods of producing penicillin in commercial quantities. He shared the 1945 Nobel Prize for Medicine with Florey and ${ }^{*}$ Fleming.

Chaitanya Mahaprabu (né Visambhar Mishra) (1485-1533). Bengali Hindu mystic, also called Gauranga. His worship of Krishna in ecstatic dancing and singing inspired a form of Hinduism named after him. In 1510 he was initiated as an ascetic and afterwards settled in Puri, where a school of disciples grew up around him. His ecstatic trances and frenzies are thought to have undermined his health and hastened his death. His followers continued to follow his practices until the present day. They held that pure religious ecstasy was superior to all other forms of worship. An articulate theology, never established by Caitanya himself, who was not a teacher and did not intentionally establish an organised sect, was worked out by six of his disciples.
Chaliapin (Shalyapin), Fyodor Ivanovich (18731938). Russian singer, born in Kazan. His family was desperately poor and he had little formal education, but after working at a variety of odd jobs he joined a touring opera company at the age of 17 . His powerful bass voice and his great dramatic gifts soon brought him to St Petersburg and fame. He appeared at La Scala in 1901, New York 1907 and London in 1913. He left Russia in 1921. The title roles in the operas Boris Godunov and Prince Igor provided ideal opportunities for his talents. He acted in the silent film Ivan the Terrible (1915), and acted and sang in the film Don Quixote (1932). He made 200 recordings and toured Australia in 1926.

Challoner, Richard (1691-1781). English Roman Catholic bishop. Leader of the English Catholics, he was made apostolic vicar of the London Catholics in 1758, increased their numbers, strengthened their resistance to hostility and founded a charitable institution for the poor and aged. He revised the Reims Douai Bible (an English translation of the Vulgate for Roman Catholic use) and wrote many devotional works.

Chamberlain, Sir (Joseph) Austen (1863-1937). English Conservative politician. Son of Joseph ${ }^{*}$ Chamberlain by his first wife, and educated at Rugby and Cambridge, he was a Conservative MP 18921937 and a junior minister from 1895, becoming Chancellor of the Exchequer 1903-05 under *Balfour, and again 1919-21 under *Lloyd George. He led the Conservative party 1921-22, but his adherence to Lloyd George and the coalition deprived him of the opportunity to become Prime Minister himself. Under *Baldwin he was Foreign Minister 1924-29, and crowned his work for European conciliation by negotiating and signing the Locarno Pact (1925) on which high and vain hopes were set, and for which he shared a Nobel Peace Prize with Charles Gates *Dawes and received the KG.

Chamberlain, Houston Stewart (1855-1927). Anglo-German racial theorist. He was educated in Paris, Geneva and Vienna and eventually (1908) settled in Bayreuth and married Richard *Wagner's daughter Eva. He remained in Germany when World War I broke out and in 1916 became a German citizen. He wrote on Wagner and on aesthetic and philosophic themes, but the main work of his life, The Foundations of the Nineteenth Century (1899), was based on ${ }^{*}$ Gobineau and expounded a racial theory of history which provided arguments for Aryan and German racial supremacy repeated by Hitler to justify anti-Semitism.

Chamberlain, Joseph (1836-1914). English politician, born in London. Son of a screw manufacturer, he studied at University College School, London, then, to further his father's interests, entered a firm of screw manufacturers at Birmingham and remained closely identified with the city. $\mathrm{He}$ 
retired from business in 1874 , with a fortune of $£ 100,000$, was a reforming mayor of Birmingham 1873-76 and MP 1876-1914. During his first years in parliament he was an advanced radical and even a republican, but after serving under ${ }^{*}$ Gladstone as President of the Board of Trade 1880-85 and President of the Local Government Board 1886, he disagreed with the proposal to grant Home Rule to Ireland and resigned to become a Liberal Unionist in alliance with the Conservatives. Always a staunch imperialist, he was Colonial Secretary 1895-1903 in the ministries of ${ }^{*}$ Salisbury and ${ }^{*}$ Balfour. He was a strong supporter of the Workmen's Compensation Act (1897). He encouraged *Rhodes in his antiBoer policies and was partly responsible for the South African War (1899-1902). His support for the creation of the Commonwealth of Australia (1901) was more constructive. In 1903 he resigned as a minister to promote 'imperial preference', in opposition to free trade. He became first chancellor of Birmingham University 1901-14 and actively promoted its development. Crippled by a stroke in 1906, he remained MP until his death.

Amery, J., and Garvin, J. L., The Life of Joseph Chamberlain. 6 vols, 1932-69.

Chamberlain, (Arthur) Neville (1869-1940). English Conservative politician, born in Birmingham. Son of Joseph ${ }^{*}$ Chamberlain by his second wife and half-brother of Austen, he was educated at Rugby and Birmingham, ran the family's banana and sisal plantation in the Bahamas 1890-97, then returned to Birmingham where he became a leading industrialist and a reforming lord mayor 1915-16. It was not until he was appointed Director of National Service 1916-17 during World War I that he became closely associated with national politics. Elected Conservative MP for the Ladywood division of Birmingham in 1918, he rose rapidly to become Minister for Health 1923, 1924-29 and Chancellor of the Exchequer 1923-24, 1931-37. His energy, despite an abrasive vanity, made him the natural successor to *Baldwin as Prime Minister in 1937. His government followed a policy of appeasement towards Hitler, for which he must bear the main responsibility, although the policy had wide political and popular support as the reception of the Munich Agreement of 1938 indicated. After Munich, Chamberlain turned to preparations for war, but lacked the powers of inspiration required of a political leader in time of war. Labour refused to join a Coalition government under Chamberlain and in a no-confidence motion in the House of Commons, the Conservative nominal majority of 200 shrank to 81 . Chamberlain resigned (10 May 1940), ${ }^{*}$ Halifax took himself out of contention and Winston *Churchill became Prime Minister. Chamberlain served as Lord President of the Council in the War Cabinet and supported Churchill in rejecting *Halifax's proposal to involve Italy in pursuing a negotiated peace with Germany. Diagnosed with terminal cancer in October, he declined an earldom and a $\mathrm{KG}$ on his resignation and died in November. Historians have judged him harshly, but Chamberlain was an extremely able man, widely read, a gifted naturalist and amateur musician.

Dilkes, D., Neville Chamberlain. Vols 1 \& 2. 1984 86; Smart, N., Neville Chamberlain. 2010.

Chambers, Ephraim (c.1680-1740). English editor. His two-volume Cyclopaedia (1728) was translated into French and provided the foundations for *Diderot's famous Encyclopédie (1751-80).

Chambers, (Jay David) Whittaker (1901-1961). American journalist. A member of the Communist Party 1925-38, he later worked for Time magazine and in evidence before the House Un-American Activities Committee (HUAC) identified Alger *Hiss and other officials within *Roosevelt's administration as having been part of a Communist spy ring. This led to furious debate (in which Chambers' main supporter was Richard *Nixon) and strenuous denial. After two trials Hiss was convicted (1950) of perjury. Chambers wrote an autobiography, Witness (1952). $\mathrm{He}$ was posthumously awarded the Presidential Medal of Freedom in 1984.

Tanenhaus, S., Whittaker Chambers; A Biography. 1997.

Chambers, Sir Edmund Kerchever (1866-1954). English civil servant and stage historian. Educated at Oxford, he was a civil servant in the Board of Education, devoting his free time to the study of *Shakespeare. He wrote The Elizabethan Stage (4 vols, 1923 ) and William Shakespeare (2 vols, 1930).

Chambers, Sir William (1726-1796). British architect, born in Gothenberg. A voyage to China in his youth inspired his book Designs of Chinese Buildings (1757) and the pagoda at Kew Gardens. He designed Somerset House, London, in which he most successfully used and modified the English Palladian style. Chambers played an important part in the founding of the Royal Academy (1768) and helped to raise the status of the architectural profession.

Chambers, William (1800-1883) and Robert (1802-1871). Scottish publishers. The brothers founded the Edinburgh firm of W. and R. Chambers. William Chambers started Chambers's Journal in 1832, and the well known Chambers's Encyclopaedia (1859-68). Robert also wrote a number of books, including Traditions of Edinburgh (1823) and Vestiges of the Natural History of Creation (1844), published anonymously, an ambitious and influential speculation about evolutionary theory, applying it to biology, geology and cosmology.

Chambord, Comte de, Henri see Berry, Charles Ferdinand, Duc de 
Chamfort, (Sebastien-Roch) Nicolas (1740-1794). French playwright and cynic. He won an early reputation for his plays and for conversation and was elected to the Académie française. During the Revolution he worked with ${ }^{*}$ Mirabeau and as a secretary to the Jacobin Club. He became a moderate during the Terror, was imprisoned, attempted suicide and died of his wounds. Among his famous remarks were: 'Be my brother or I'll kill you' [said of the Jacobins] and 'One would have to eat a toad every morning to be certain of doing nothing more disgusting for the rest of the day'.

Chamisso, Adelbert von (1781-1838). FrancoGerman writer and botanist, born in Champagne. His parents fled to Germany during the French Revolution and he worked as a botanist and editor. His novella Peter Schlemibils wundersame Geschichte (Peter Schlemihil's Magic Story, 1814) about a man who sells his shadow to the Devil, became famous. His poems Frauen-Liebe und Leben (A Woman's Love and Life, 1830) were set by *Schumann. He took part in a Russian round-the-world expedition and became keeper of the Berlin Botanical Gardens.

Champaigne, Philippe de (1602-1674). French painter, born in Brussels. An outstanding portraitist, e.g. of *Richelieu, he modified the style of *Rubens with classical restraint, was influenced by Jansenism and devoted himself to religious subjects.

Champlain, Samuel de (1567-1635). French explorer. After an expedition to the West Indies (1599) he made three voyages (1603-08) to Canada and founded Québec (1608). He was prime mover for the founding of New France (i.e. Canada) and became its Lieutenant-Governor 1613-29. In 1615 he discovered and explored the Great Lakes, repelled lroquois Indians and opened up the fur trade. In 1629 he was captured and taken to England but returned to Canada in 1613.

Bishop, M., Champlain: the Life of Fortitude. 1948.

Champollion, Jean François (1790-1832). French scholar. In 1822, he found the key to Egyptian hieroglyphics by deciphering the inscriptions on the Rosetta stone, a basalt slab discovered in 1799 during *Napoléon's Egyptian expedition. Champollion was educated at Grenoble, where he was professor of history (1809-16), and was attracted to Egyptology at a very early age. He was still only 21 when he began publication of his Egypt Under the Pharaohs. In 1826 he became Director of Egyptian Antiquities at the Louvre, and a chair of Egyptology was founded for him at the College de France four years later.

Chancellor, Richard (c.1521-1556). English navigator, born in Bristol. In 1553 he commanded the Edward Bonaventure on the expedition of Sir Hugh Willoughby to find a northeast sea passage to China. Separated from his leader in a storm off the Lofoten Islands, he went alone into the White
Sea, and travelled overland to Moscow, where he negotiated a trade with the tsar Ivan the Terrible. On his return to England his reports encouraged the foundation (1554) of the Muscovy Company. He went to Moscow again (1555-56) and lost his life in a shipwreck on the way home.

Chandler, Raymond Thornton (1888-1959). American detective story writer. Educated in England at Dulwich College, he followed a variety of occupations before winning fame as an author. He brought to the 'tough' school of thriller-writing a more sophisticated technique. His novels introduced the cynical, laconic private detective with moral standards, Philip Marlowe. Some of the best known were filmed, e.g. The Big Sleep (1939), The Lady in the Lake (1943) and The Long Goodbye (1953).

Chandragupta Maurya (d.c.298 BCE). Indian King c.320-297 BCE. He conquered the Magadha kingdom, and in 305 defeated *Seleucus' attempt to regain the Indian territories conquered by ${ }^{*}$ Alexander the Great. His spacious capital, Patahiptura (Patna), was linked to the northwest frontier by a good road with rest houses. He abdicated, became a Jain monk and fasted to death. *Asoka was his grandson.

Nilakanta Sastri, K. A. (ed.), The Age of Nandas and Mauryas. 1952.

Chandrasekhar, Subrahmanyan (1910-1995). Indian-American astrophysicist, born in Lahore. $\mathrm{He}$ studied at Cambridge, had a tense relationship with *Eddington but admired *Dirac, lived in the US from 1936 and taught at Chicago from 1937. He was the greatest theoretician of black holes and white dwarf stars. He determined 'Chandrasekhar's limit', i.e. that stars with a mass more than 1.5 times that of the sun will collapse. He shared the 1983 Nobel Prize for Physics with William Alfred Fowler (1911-1995) and received the Copley Medal in 1984.

Miller, A. I., Empire of the Stars. 2005.

Chanel, Coco (née Gabrielle Bonheur-Chanel) (1883-1971). French fashion designer. She was a dominant influence in world fashion 1925-38, and her loose, comfortable designs were widely copied, making haute couture accessible to women generally. She introduced the perfume Chanel No. 5 in 1922, and designed jewellery and hair styles. For a decade she was the mistress of the Duke of *Westminster. She collaborated with the Nazi occupation in France and left for Switzerland in 1944. The musical Coco (1969), later filmed, was based on her life.

Chaney, Lon (Leonidas Frank) (1883-1930). American film actor. Well known for his horror roles, (e.g. in The Hunchback of Notre Dame), it is said that his skill in miming originated with attempts to communicate with deaf-mute parents. His son, Lon Chaney Jr (1906-1973) played Lennie in Of Mice and Men (1940). 
Chang Tsolin and Chang Xuehliang see Zhang Zuolin and Zhang Xueliang

Channon, Sir Henry ('Chips') (1897-1958). AngloAmerican politician and diarist, born in Chicago. In 1933 he married into the * Guinness family, became a Conservative MP 1935-58, was an assiduous social climber and wrote sharp and malicious diaries, published, in bowdlerised form, as Chips: The Diaries of Sir Henry Channon (1967). The unexpurgated version, edited by Simon Heffer, Henry 'Chips' Channon: The Diaries, runs to three volumes, the first (1918-38), published in 2021, the second (1938-43) and third (1943-57), in 2022.

Chaplin, 'Charlie' (Sir Charles Spencer) (18891977). British film actor and director, born in Kennington, London. From a poor family of musichall artistes in Kennington, London, he went on the stage aged 8 and from 1906 acted with his brother Sidney in one of Fred Karno's troupes, touring the US in 1910 and 1912. In 1913 he joined Mack *Sennett's Keystone Company in Los Angeles and in 1914 appeared in 35 films, mostly short slapsticks. Chaplin gradually evolved his character of the tramp or 'little man', with the costume, make-up and shuffling walk becoming universally recognisable after The Tramp (1915) which he wrote and directed for Essanay. He took artistic control of all his films from 1915, rejected slapstick, using the magnifying power of cinema to develop an individual style as a mime, mixing pathos and satire. By 1917 he had a salary of more than \$US1 million and was an international cult figure. With D. W. *Griffith, Mary *Pickford and Douglas ${ }^{*}$ Fairbanks he formed the United Artists Corporation in 1919. His best films were silent and include The Immigrant (1917), Shoulder Arms (1918), The Kid (1921), The Gold Rush (1925), The Circus (1928), City Lights (1931) and Modern Times (1936), defiantly rejected speech but used Chaplin's own music. His first talking film was The Great Dictator (1940), a satire on *Hitler, his exact contemporary. (They were born in the same week and Hitler resembled Chaplin's 'little man'.) After World War II Chaplin's radical views came under increasing political attack and in 1952 he left the US, living mainly in Switzerland. The last of his 82 films were Monsieur Verdoux (1947), Limelight (1952), A King in New York (1957) and The Countess from Hong Kong (1967). He married four times: his second wife was the actor Paulette Goddard, his fourth Oona O'Neill (the playwright's daughter), by whom he had eight children, including the actor Geraldine Chaplin (1944-).

Robinson, D., Chaplin: His Life and Art. 1985.

Chapman, George (1559-1634). English poet and translator. A prolific and popular playwright, he was admired by *Webster and *Jonson, his best known plays being the comedy, written with Jonson and *Marston, Eastward Ho! (1605), and the tragedy Bussy d'Ambois (1607), the story of a swashbuckling swordsman at the French court. But it is his translations of ${ }^{*}$ Homer that have ensured his immortality (reinforced by John *Keats' famous sonnet). The Iliad began to appear in 1598 and was continued under the patronage of Henry, Prince of Wales (1609-11). The Odyssey was completed in 1614, and The Whole Works of Homer (1616) comprised both works. Though often inaccurate as a translation, since Chapman tended to expand the text to stress a moral issue, the work introduced Homer to many generations and so exercised enormous influence.

Spivack, C. K., George Chapman. 1967.

Char, René (1907-1988) French poet. Originally a Surrealist, and friend of ${ }^{*}$ Camus and of ${ }^{*}$ Picasso, *Braque and *Miró who illustrated his work, he wrote Le Marteau sans maître (1934), later set to music by *Boulez. He served in the Resistance 1942-45 and his Oeuvres completes appeared in 1983.

Charcot, Jean-Martin (1825-1893). French neurologist. He studied medicine in Paris, and became an intern at the Salpêtrière, Paris' largest hospital, in 1848 . He became interested in the diseases of long-stay patients, such as arthritis, sclerosis, and other chronic nervous conditions. His medical interests ranged widely. He studied poliomyelitis and investigated liver and thyroid diseases. Later in his career he became more interested in the physiological roots of psychic behaviour. He supported the ideas of Hughlings *Jackson who believed that specific aspects of behaviour were controlled from particular local centres of the brain. His lectures on hysteria attracted wide attention, since, partly through the use of hypnosis, he was able to control the behaviour of hysterics by gesture and suggestion. *Freud was one of many who were highly impressed by Charcot's demonstrations of hysteria, for they suggested a world of the unconscious beyond the rational control of the subject. His son Jean Baptiste Charcot (1867-1936) led two major explorations of Antarctica.

Guillain, G., J. M.Charcot. 1959.

Chardin, Jean Baptiste Simeon (1699-1779). French painter. His still life pictures and domestic scenes follow the Dutch tradition and are notable for detail and simplicity and for the skill with which the natural appearance and texture of familiar objects, bread, fruit, an apron etc. are portrayed.

Rosenberg, P., Chardin 1699-1779. 1979.

Chardonnet, Hilaire Bernigaud, Comte de (18391924). French industrial chemist. He patented a cellulose nitrate-based fibre in 1884, and first exhibited rayon at the Paris Exposition of 1889.

Charlemagne (Karl der Grosse, Carolus Magnus, Charles the Great) (c.742-814). King of the Franks 768-814, King of the Lombards 781-814 and Emperor of the Romans 800-14. Grandson of 
${ }^{*}$ Charles Martel, probably born in Aachen, he and his brother, Carloman, jointly succeeded their father, *Pepin III ('the Short'). On his brother's death in 771, Charlemagne became sole ruler of the Franks and launched a vast expansion. $\mathrm{He}$ is regarded as the founder of the Carolingian dynasty. Germany, Bavaria and Saxony had been conquered by 808 and Christianity forced upon the people. At the request of Pope *Adrian I he took his army over the Alps to Italy, conquered Lombardy (773-74) and his son Pepin (777-810) was crowned as 'King of Italy' in 781. His first expedition to Spain, however, ended in failure and the death of his commander *Roland (the hero of romantic legend). But from 785 he systematically subdued north east Spain and in 801 captured Barcelona. He accomplished the conquest and forced conversion (791-96) of Pannonia and the kingdom of the Avars (barbarian tribes in Hungary). By 800, Charlemagne was the supreme power in western Europe, and he and his counsellors, such as the English *Alcuin, wishing to emphasise an imaginary continuity between Charles, his empire and that of Rome, argued that the imperial throne was vacant owing to the crimes of the Byzantine empress *Irene. Having obtained the assent of Pope *Leo III he went to Rome, and on Christmas Day 800, was crowned as Emperor of the Romans (Imperator Romanorum) in the old St Peter's basilica. This definition linked the Roman empire of antiquity with a Christian community, but while it thus created a focus of loyalty it soon led to a struggle between empire and papacy as well as conflicts between imperial claims and feudal states and thus eventually impeded the national development of Germany and Italy such as was gradually taking place elsewhere. To rule his vast empire Charlemagne retained the old system of local government 'counties' governed by counts (comtes) but exercised control and secured a degree of uniformity through the famous 'Missi Dominici', palace officials sent on circuit, a system which became a feature of later medieval administration. Many legal reforms were effected by the issuing of ordinances, while the use of writing was encouraged to secure uniformity of administration. Although Charlemagne read little and never learned to write, he encouraged the foundation of monastic and episcopal schools, and from his court at Aachen (Aix-la-Chapelle) he stimulated the revival of arts and of letters known as the Carolingian Renaissance. His octagonal Palatinate Chapel in Aachen Cathedral, built in Byzantine style 796-805, became his burial place. His biographer, Einhard, gives a picture of a large, robust man, of great industry and natural talent. Though he lived simply he fully enjoyed the pleasures of the senses with a succession of three wives and many mistresses. His empire fell apart soon after his death and with it his dream of a united Europe.

The name 'Holy Roman Empire of the German Nation' was first used in 1254 but only formally adopted in 1512. Nevertheless, Charlemagne is usually listed as the first 'Holy Roman Emperor', although he never used the title and preferred to style himself 'most serene Augustus'. The word for 'king' in a number of languages (including Hungarian, Polish, Czech, Lithuanian, and Bulgarian) is derived from the name Karl.

Bullough, D. A., The Age of Charlemagne. 1965; Fried, J., Charlemagne. 2016; Nelson, J. L., King and Emperor. A New Life of Charlemagne. 2019.

Charles (1226-1285). Count of Anjou, and King of Sicily 1265-83. This ambitious ruler, the youngest son of *Louis VIII of France, became Count of Anjou in 1246, acquired Provence by marriage, supported the papal party in Italy against the imperialists and by his victories was able to accept the throne of Sicily (1265). He was planning to invade the Balkan peninsula, with a view to reviving the Latin empire of Constantinople, when in 1282 his Sicilian subjects signalled their revolt by the massacre of Frenchmen known as the Sicilian Vespers and by offering the throne to Peter of Aragon. Charles failed to reestablish himself though his descendants remained kings of Naples until 1435.

Charles (known as 'the Bold' or 'le Téméraire') (1433-1477). Duke of Burgundy. Son of *Philippe 'the Good', on his succession in 1467 he ruled extensive but scattered territories in France and the Low Countries and set out to unite them under a single form of rule. This brought him into collision with *Louis XI, King of France, the feudal overlord of his French lands. Charles, having supported a baronial revolt against Louis, induced him (1468) to come to an interview, imprisoned him at Peronne and exacted a crippling treaty. He then annexed the prince bishopric of Liege, and by peaceful or warlike means extended his power in Guelders, Alsace and elsewhere. Meanwhile by subsidy and subtle diplomacy Louis XI continued to oppose him, especially by inflaming Swiss fears. War followed and in 1476 Charles was totally defeated at Granson on Lake Neuchâtel. In the following year the Burgundians were again defeated by the Swiss outside Nancy and Charles was killed. He left no male heir and the bulk of the Burgundian inheritance passed, through his daughter Mary, who had married the emperor Maximilian, to the Habsburgs.

\section{Charles (Carlos) I King of Spain see Charles V}

Charles I (Charles Stuart) (1600-1649). King of England, Scotland and Ireland 1625-49. Born in Dumferline, Fife, son of James VI of Scotland (later *James I of England) and Anne of Denmark, in 1616, on the death of his elder brother, Henry, he became Prince of Wales and heir to the throne. Charles, like his father, was firmly under the influence of the Duke of ${ }^{*}$ Buckingham, with whom in 1623 he made an undignified and futile expedition to Madrid to woo a Spanish princess. After his accession he married 
${ }^{*}$ Henrietta Maria, daughter of *Henri IV of France, a union which introduced a Roman Catholic influence at court, deeply alienating the growing body of Puritans. Buckingham's influence ended with his murder in 1628, but his last venture, an attempt to relieve the French Protestants in La Rochelle, was a fiasco that further discredited the king. Thus antagonised, Charles' first three parliaments failed to vote him adequate revenues and he attempted to raise money by an intensive and dubious use of the royal prerogative. In 1628, however, in return for a promise of funds, he assented to parliament's 'Petition of Right', which denounced the levying of forced loans and illegal taxes.

The greatest of royal art collectors and connoisseurs, he bought about 1500 pictures, including the Gonzaga collection from Mantua (1628-29) and was a patron of ${ }^{*}$ Rubens and ${ }^{*}$ Van Dyck. His collection, sold after his execution, included paintings by ${ }^{*}$ Leonardo, ${ }^{*}$ Raphael, ${ }^{*}$ Titian, *Mantegna and *Rembrandt. In 1629 Charles, still unable to work with parliament, dissolved it, and until 1640, ruled England with the help of Thomas Wentworth, Earl of ${ }^{*}$ Strafford, an efficient but stern administrator, and William *Laud, Archbishop of Canterbury, whose attempt to impose a uniform liturgy roused even greater hostility than the forced exactions of the civil government. Indeed, it was the need to finance an unsuccessful war undertaken to impose a uniform prayer book on Presbyterian Scotland that forced Charles in 1640 to summon first the 'Short' and then the 'Long' parliaments. In an attempt at conciliation he even allowed the impeachment and execution of his loyal minister Strafford (1641), an act of treachery which brought him no respite. In January 1642, now desperate, he tried to arrest five of the leading opposition members in the House of Commons (*Pym, ${ }^{*}$ Hampden, Holles, Strode and Haselrig). This act contributed to a complex situation which produced, in August 1642, a civil war. In the beginning the royalists (Cavaliers) had some successes but the possession of London by the parliamentarians (Roundheads) and the training of a New Model Army by ${ }^{*}$ Cromwell turned the scales. After his last crushing defeat at Naseby, Charles surrendered to the Scots (1646) and in the following January was handed over by them to the English parliament, soon to fall into the lands of the army leaders. At first his captivity was not strict and he was able to communicate with his friends abroad and even to negotiate a treaty with the Scots, which brought about the second Civil War. But the royalists' defeat strengthened the extremists. Charged with 'high treason and other high crimes', he was tried in Westminster Hall (20 January) before a specially constituted court, refusing to recognise its jurisdiction or defend himself. Beheaded in Whitehall (30 January), he was remembered for his courage as 'the martyr king'.

Hibbert, C., Charles I. 1968; Reeve, L. J., Charles I and the Road to Personal Rule. 1989.
Charles I. Emperor of Austria-Hungary see Karl I

Charles I and II. Kings of Romania see Carol I and II

Charles I, II, III and IV. Spanish Kings see Carlos I, II, III and IV

Charles II (known as 'the Bald') (823-877). King of the west Franks (Francia, later France) and Emperor 875-877. The death of his father, *Louis I ('the Pious'), son and successor of ${ }^{*}$ Charlemagne, was followed by a prolonged struggle for power with Charles' elder brother, *Lothair, ended by the Treaty of Verdun (843), by which Charles became the ruler of the western part of the empire. On the death (875) of his nephew Louis II he invaded Italy and was crowned king and emperor by Pope John VIII. The disorders of his reign were increased by the Normans, who sacked Paris and Bordeaux.

Charles II (1630-1685). King of England, Scotland and Ireland 1660-85. Son of ${ }^{*}$ Charles I, born in London, he took some part in the Civil War but in 1646 made an adventurous escape first to Jersey and then to France. After his father's execution he came to terms with the Scots and was crowned at Scone in 1651, but his invasion of England, with Scottish troops, was routed at Worcester by ${ }^{*}$ Cromwell (1651). Charles, after hiding in an oak tree at Boscobel, escaped to the Continent, and established a makeshift court first in France and then in Cologne, Bruges, Antwerp and Brussels. In 1658 Cromwell died and the protectorate soon collapsed. Early in 1660 General George * Monck intervened from Scotland and eventually a convention parliament, called under his auspices, invited Charles to return to England on the basis of his Declaration of Breda. This offered assurances of a settlement generally acceptable to 'the political nation'. In May 1660 Charles landed at Dover and, to the joy of almost all, the monarchy was restored. Charles' main preoccupation was to retain the throne and 'never go on his travels again'. He never therefore pressed a point at issue to extremes and used his very considerable intelligence to evade a direct challenge. Thus he tried to thwart the 'Clarendon Code' (named for his chief minister Edward Hyde, Earl of ${ }^{*}$ Clarendon), which imposed restrictions on dissenters and Protestants and was opposed to his natural tolerance, by a Declaration of Indulgence; this, however, he had to withdraw. But he welcomed the war with the Dutch (whom he disliked) by which the English acquired New Holland, including New York, and much trade. The plan of his next ministry, the Cabal (*Clifford, *Arlington, *Buckingham, Ashley—see ${ }^{*}$ Shaftesbury, ${ }^{*}$ Lauderdale), to create a Protestant alliance in northern Europe against the French, he evaded by a secret treaty (1670) with ${ }^{*}$ Louis XIV. In return for subsidies Charles helped France against Holland but failed to fulfil a clause that he should declare himself a Roman Catholic. This discretion was the more necessary because alarm was caused in the late 1670 s by the 'discovery' by Titus 
${ }^{*}$ Oates of an alleged Roman Catholic plot. Having with patience and ingenuity discredited Oates, and defeating an attempt to have his Catholic brother and heir James, Duke of York (*James II) excluded from the throne, Charles came into calmer waters. The French subsidies had eased his financial necessities, but the proceeds of customs and excise granted by parliament and swollen by increasing trade enabled him to rule without summoning parliament, which he had dissolved in 1681 . Thus by tortuous methods Charles contrived to guide the country in the way he thought it should go, also encouraging science (the Royal Society dates from 1662) and interesting himself in the navy, the growth of the colonies and cultural activities. His main pursuit, however, was pleasure. His wife *Catherine of Braganza, brought him as a dowry Tangier and Bombay, but none of her children survived. In his gay and licentious court there were at least 12 children by eight colourful mistresses, including Lucy Walters, mother of the Duke of *Monmouth; Barbara Villiers, who became Lady Castlemaine and Duchess of ${ }^{*}$ Cleveland; Nell ${ }^{*}$ Gwyn the actor; and the fascinating intriguer Louise de Keroualle, Duchess of *Portsmouth. His intelligence, wit and amoral nature set the tone of the Restoration period as a whole. After an apoplectic fit, probably due to uraemia, he became a Catholic, although his fervour may be doubted, urged his successor to look after his mistresses ('Let not poor Nelly starve') and died.

Kenyon, J. P., The Stuarts: A Study in English Kingship. 2nd ed. 1967; Fraser, A., King Charles II. 1979.

Charles III ('le Gros' or 'the Fat') (839-888). Emperor of the West 881-87, King of the Franks 881-88. Great-grandson of ${ }^{*}$ Charlemagne, an epileptic, thought to be subject to demonic possession, he ruled, in theory, much of France, Germany and northern Italy. Deposed, his empire was broken up, never to be restored and he soon died.

Herr, R., The Eighteenth Century Revolution in Spain. 1958.

Charles III (Charles Philip Arthur George Mountbatten-Windsor) (1948-). King of the United Kingdom and Head of the Commonwealth 2022- . Born in London and the eldest son of Queen *Elizabeth II of Great Britain and the Duke of *Edinburgh, he was educated at Cheam School, Gordonstoun, Geelong Grammar ('Timbertop') and Trinity College, Cambridge (MA), being the first British royal with a degree. Prince of Wales 1958-2022, he served briefly in the Royal Navy, then pursued active and controversial views on the environment, climate change, farming, architecture and urban planning. In July 1981 he married Lady Diana Spencer (*Diana) and the couple had two sons, *William (1982- ) and *Harry (1984-). They separated in December 1992 and after an increasingly public, and bitter, controversy agreed on a divorce (1996). The situation was complicated by
Diana's sudden death in an accident in Paris (1997). In her Jubilee year (2002), his mother awarded him the OM. In April 2005 he married Camilla Rosemary Parker-Bowles (née Shand) (1947- ) who took the title of Duchess of Cornwall, became LG in January 2022, and Camilla, Queen consort, in September 2022. Charles, at 73, was the oldest British sovereign to succeed.

Dimbleby, J. The Prince of Wales. 1994; Holden, A., Prince Charles. 1999; Bower, T., Rebel Prince: The Power, Passion and Defiance of Prince Charles. 2018.

Charles V (known as 'the Wise') (1338-1380). King of France 1364-80. He was regent from 1356 during the English captivity of his father, John II, and in 1358 suppressed the Jacquerie, a peasant revolt. By the reorganisation of the army, the administration and finances, he was able to achieve his ambition of restoring his kingdom after its defeats by the English under *Edward III. So successful were his military efforts that by the end of his reign the English had been driven out of all but a few fortresses and their ancient patrimony Guienne, around Bordeaux.

Charles V (Karl von Habsburg y Trastámara, Carlos in Spain) (1500-1558). King of Spain (as Carlos I) 1516-56 and Holy Roman Emperor (as Karl V) 1519-56. Son of the Austrian archduke *Felipe (Philipp), later king of Castile, and Juana, daughter of *Ferdinand and *Isabella, he was born in Ghent and brought up in Flanders by his aunt Margaret of Savoy, daughter of his grandfather, the emperor *Maximilian (*Katherine of Aragon was his aunt). His happy boyhood owed much to his tutor, Adriaan Boeyens, later Pope *Adrian VI. Charles was declared of age in 1515, and on the death of Maximilian (1519), elected emperor, defeating *François I of France, after heavy bribes (largely financed by the *Fuggers) which included the Spanish conquests in the New World and the Aragonese possessions in southern Italy. $\mathrm{He}$ kept his mother, nominally Queen of Castile and Leon, confined until her death in 1555. At the Battle of Pavia (1525), imperial forces decisively defeated a French army and François was taken prisoner. Charles was a constant traveller, visiting England twice, France four times, but spent most time in the Low Countries. In 1526 he married Isabella of Portugal. In his wars with France, although Charles was on the whole victorious, the final result (by the Treaty of Crepy, 1544, Burgundy remained in French lands while France relinquished its claims in Italy) was hardly worth nearly 25 years of struggle. A more vital matter with which Charles had to contend was the Reformation in Germany. Charles was a devout Catholic but in this matter his aim and interest was to come to some sort of terms with *Luther's movement to prevent the weakening of the empire by a prolonged religious struggle. The Peace of Augsburg (1555), though it satisfied neither side, was probably the best that could be obtained: it adopted the compromise formula cuius regio eius religio (i.e. each state was to 
adopt the religion of its ruler). Charles was a patron of *Titian and the father of Don *Juan (John) of Austria. After early difficulties Charles consolidated his rule in Spain and the conquests in the New World were among the many signs of the country's advance to greatness. To him in his last years it proved a place of refuge. He spent only 18 years of his life in Spain and never mastered the language. In the autumn of 1555 he astonished all by announcing the abdication of his powers. The imperial crown and the Habsburg lands in east Europe were to pass to his brother *Ferdinand, and the Netherlands and the Spanish throne to his son *Felipe, the husband of Queen *Mary of England. Crippled by gout, he retired to a monastery at Yuste in the north of Spain.

Parker, G., Emperor: A New Life of Charles V. 2019.

Charles VI (1368-1422). King of France 1380-1422. His reign, during most of which he was either a minor or insane, saw a continuous struggle for power, at first in council and (from 1411) in the field, between factions (Burgundians and Annagnacs) headed by the royal dukes of Burgundy and Orléans. ${ }^{*}$ Henry $\mathrm{V}$ of England seized the opportunity to resume the Hundred Years War, won the Battle of Agincourt (1415), and in 1420 was able to secure the Treaty of Troyes, by which Charles' daughter ${ }^{*}$ Catherine was to marry Henry $\mathrm{V}$ and their son was to succeed to the French throne. Meanwhile Henry was the virtual ruler of France.

\section{Charles (Karl) VI see Karl (Charles) VI}

Charles VII (Karl Albrecht) (1697-1745). Holy Roman Emperor 1742-45. Head of the Wittelsbach dynasty, he was Duke of Bavaria 1720-45. When *Charles VI died without male heirs he claimed the Habsburg lands, provoking the War of the Austrian Succession (1740-48). He was elected Emperor as a puppet of France and Prussia.

Charles VII (1403-1461). King of France 1422-61. On the death of his father, ${ }^{*}$ Charles VI, he had to contest the right to the throne with ${ }^{*}$ Henry VI of England, the legal successor under the Treaty of Troyes. He fought half-heartedly against the English in France from his own limited territory in the centre and south until the heroic efforts of Joan of Arc stirred him to greater action. After her capture of Orléans (1429) he was crowned at Reims and secured recognition as national leader. After the Burgundians joined Charles' cause in 1435, Paris was recaptured. By 1450 the English had been driven out of Normandy, and by 1453 nothing but Calais remained of their vast possessions in France. Charles was not a heroic figure, but for the thorough administrative reorganisation which made these successes possible much credit was due to the king himself.

Charles VIII (1470-1498). King of France 1483-98. Son of *Louis XI, the reign began with the regency of his sister Anne of Beaujeu, who secured his marriage
(1491) to *Anne of Brittany to ensure the acquisition of that duchy. Charles revived the Anjou claim to Naples ( ${ }^{*}$ Charles, Count of Anjou) and, allied with the Sforzas of Milan, invaded Italy. Although he captured Naples easily (1495) he was forced to retreat to France after a few weeks by the forces of the League of Venice (the papacy, Venice, Spain and the Empire). He died at Amboise after striking his head on a beam.

Charles IX (1550-1574). King of France 156074. The weak and indecisive son of ${ }^{*}$ Henri II and *Catherine de'Medici, the effective ruler throughout, his reign was marked by a fierce religious struggle between the Roman Catholics and Huguenots that culminated in the massacre of St Bartholomew's Day, 1572.

Charles X (Charles Philippe) (1757-1836). King of France 1824-30. Younger brother of *Louis XVI and ${ }^{*}$ Louis XVIII, he was known as the Comte d'Artois, left France in 1789 on the outbreak of the Revolution, living in Savoy, Turin, Trier, then Koblenz. He escaped to Great Britain in 1792 and lived in Edinburgh and London with his mistress until *Napoléon's first abdication in 1814. After the Bourbon restoration he led the ultra-royalists and, becoming king on the death of Louis XVIII, tried to revive absolutism. The result was the Revolution of 1830 after which he came once more to England, his cousin *Louis Philippe displaced him, with the new title of 'King of the French'. Charles then lived in exile in Dorset, Edinburgh and Prague. He died of cholera in Gorizia (then in Austria-Hungary, now in Italy) and was buried there. His son, Louis Antoine, Duc d'Angouleme (1775-1844) married Marie Therese, daughter of ${ }^{*}$ Louis XVI and claimed the throne himself as Louis XIX.

\section{Charles IX, X, XI and XII, Kings of Sweden see Karl} IX, X, XI and XII

Charles XIV John (Karl Johan) (King of Sweden) see Bernadotte, Jean Baptiste Jules

Charles, Jacques Alexandre César (1746-1823). French physicist. He gave public demonstrations of *Franklin's electrical experiments and eventually became professor of physics at the Conservatoire des Arts et Metiers, Paris. Data obtained by him on the expansion of gases were added to by ${ }^{*}$ Gay Lussac, who devised the law (called Charles' Law) which states that the volume of gas at constant pressure is directly proportional to its absolute temperature. Charles was also the first to use hydrogen instead of hot air to lift balloons.

\section{Charles Albert see Carlo Alberto}

\section{Charles Edward Stuart see Stuart}

Charles Martel (c.688-741). Frankish soldier and administrator. As 'mayor of the palace' under the decadent Merovingian kings of Austrasia (Rhineland) 
and Neustria (northern France), he became de facto ruler of the Franks. He extended his authority over lands now France, the Netherlands and the Rhineland and intervened in Bavaria. He gained his nickname Martel ('the hammer') by his great victory at Poitiers (732), the first decisive check to the Muslim advance into Europe. His rule marked the beginning of Carolingian power: his grandson was ${ }^{*}$ Charlemagne.

\section{Charles ('the Young Pretender') see Stuart, Charles Edward}

Charlotte Augusta (1796-1817). British princess. Only child of the future ${ }^{*}$ George IV, she married in $1816^{*}$ Leopold of Saxe-Coburg, later king of the Belgians. Her death in childbirth re-opened the question of succession to the English throne and her unmarried uncles were persuaded to marry. Her uncle Edward, Duke of ${ }^{*}$ Kent became the father of the future Queen *Victoria.

Charlotte (Sophia) (1744-1818). British queen consort 1761-1818. Daughter of the Duke of Mecklenburg-Strelitz, she arrived in London on 8 September 1761 , met ${ }^{*}$ George III for the first time and married him six hours later. She gave birth to 15 children, 13 of them surviving into adulthood, including ${ }^{*}$ George IV, ${ }^{*}$ William IV and Edward, Duke of ${ }^{*}$ Kent (whose daughter became Queen Victoria). She was a devoted, but reclusive, consort, passive about things she could not change, but widely read, an enthusiast for gardens and a pupil of J. C. *Bach.

Charpentier, Gustave (1860-1956). French composer. Encouraged by ${ }^{*}$ Massenet to take up composition he won the Prix de Rome in 1887. He is best known for his opera Louise (1900), for which he also wrote the libretto, and the orchestral work Impressions of Italy.

Charteris, Leslie (Leslie Bowyer Yin) (1907-1993). American thriller writer, born in Singapore, resident in Britain. He created 'the Saint', a charmingly ruthless detective called Simon Templar, the hero of most of his books and of film, television, radio and comic strip series based on them.

Chase, Salmon Portland (1808-1873). American lawyer and politician. He gained his reputation as an attorney for fugitive slaves, was US senator from Ohio 1849-55 and 1861 and Governor of Ohio 1855-59. He sought the 1860 Republican nomination for president, but was regarded as too extreme on the slavery issue and lost to ${ }^{*}$ Lincoln. As US Secretary of the Treasury 1861-64 he raised unprecedented taxes and established a national banking system. He resigned to pursue the presidency again, failed, and Lincoln made him Chief Justice of the US Supreme Court 1864-73. He presided with notable fairness at Andrew *Johnson's impeachment (MarchMay 1868).
Chase, Stuart (1888-1985). American social scientist. Educated at the Massachusetts Institute of Technology and at Harvard, he worked as a research economist in the ${ }^{*}$ Wilson and ${ }^{*}$ Roosevelt administrations. He wrote many books and articles on the 'economics of plenty' and was in a sense a precursor to ${ }^{*}$ Galbraith. Among his works are The Economy of Abundance (1934), Live and Let Live (1960) and The Most Probable World (1968).

Chastelard, Pierre de Boscosel de (1540-1564). French poet. Grandson of the Chevalier *Bayard, at the French court of ${ }^{*}$ François II he fell romantically in love with * Mary, the future Queen of Scots, and accompanied her to Scotland. Many of his poems were addressed to her. Found once hiding in her bedchamber he was forgiven, but later he repeated the offence and was hanged. The story was dramatised by *Swinburne.

Chateaubriand, François René, Vicomte de (17681848). French author, soldier and diplomat, born at St Malo. He spent most of his lonely childhood in Brittany, was a cavalry officer at the age of 18 and in 1791 went to North America which he described in his Voyage en Amerique (1827). Opposed to the Revolution he joined the emigrant army on the frontier, was wounded and lived in poverty in England (1794-99). He returned to France to hold minor diplomatic posts under ${ }^{*}$ Napoléon but soon became anti-Bonapartist. After the restoration of ${ }^{*}$ Louis XVIII he held ambassadorial posts in Berlin (1821) and London (1822) and was Foreign Minister 182324. After the revolution of 1830 , which replaced ${ }^{*}$ Charles X by ${ }^{*}$ Louis Philippe, he played little part in public life. About the time of his return to France he abandoned his scepticism and wrote his great apologia Le Cenie du Christianisme (1802), which not only defended the religious aspects of Christianity but also its effects on art and architecture, literature and institutions. In advance he published with great success an episode intended for the book Atala (1801), a highly coloured story of a Native American girl convert and her tragic love. René, extracted from the great work and published separately (1805), presents a passionate, disillusioned, egotistical Byronic young man (in fact Chateaubriand himself), irresistible to those who initiated the French Romantic movement. Perhaps his greatest work was the autobiographical Memoires $d$ 'Outre Tombe (published in six volumes between 1848 and 1902). Madame *Récamier was the best known of his many mistresses.

Châtelet-Lomont, Gabrielle Émilie (née Le Tonnelier de Breteuil), Marquise de (1706-1749). French mathematician, philosopher and translator. Educated at home, possibly by ${ }^{*}$ Fontenelle, she translated *Newton's Principia, corresponded with *Leibniz, *Euler and *Bernoulli. *Voltaire lived with her 1733-38. She proposed the hypothesis of the conservation of total energy. 


\section{Chatham, 1st Earl of see Pitt, William ('the Elder')}

Chatterji, Bambin Chandza (1838-1894). Indian author. He revolutionised Indian literature by being the first to write novels following the European pattern devoted to Indian themes and in a native language (Bengali). The song Bande Mataram originally a poem in his novel Amanda Math (1882) was adopted as the national anthem of the Republic of India.

Chatterton, Thomas (1752-1770). English poet, born in Bristol. Posthumous son of a schoolmaster, he read voraciously as a boy and began concocting pseudo-antique poetry. At the age of 17 he sent to Horace *Walpole manuscripts purported to be the work of a 15th-century monk, Thomas Rowley. Walpole accepted them as genuine at first but later rejected them, and they are now known to have been invented by Chatterton. In 1770 he went to London and in a few months produced an amazing amount of work, including satires, political essays, and the Ballade of Charatie. The death of his patron, the Lord Mayor William Beckford, and the increasingly frequent rejection of his manuscripts brought him to despair. At last, penniless and starving, he poisoned himself in his lodgings. The mock antique was regarded in that age not as forgery but as a semilegitimate literary form (cf. * Macpherson's Ossianic poems) and his rhythms and general approach to poetry were remarkably modern. The tragic boy poet became a literary hero romanticised by *Keats, *Wordsworth, ${ }^{*}$ Coleridge, *Shelley and *Rossetti, and controversy about the genuineness of the Rowley poems continued well into the 19th century.

Chatwin, (Charles) Bruce (1940-1989). British travel writer, novelist and photographer. He worked for Sotheby's in London until 1966, then studied archaeology in Edinburgh and joined the Sunday Times as a travel writer. His travel books were In Patagonia (1977), The Songlines (1987), a study of Australian Indigenous creation myths, and a posthumous collection What Am I Doing Here? (1990). His novels include On the Black Hill (1982, later filmed) and Utz (1988). He died of AIDS.

Chaucer, Geoffrey (c.1340-c.1400). English poet, courtier, bureaucrat, diplomat and scrap metal collector, probably born in London. Son of a rich vintner, the Black Death occurred during his early childhood. About 1356 he became a page in the household of Lionel, Duke of Clarence. He fought in what became known as 'the Hundred Years' War' in France (1359-60), in which he was captured in Rheims and ransomed for $£ 16$. In 1366 he married Philippa de Roet, a lady-in-waiting to Philippa of Hainault, King *Edward III's queen, and sister of Catherine Swynford who became *John of Gaunt's third wife. He entered the king's household in 1367.

After Edward's death in 1377, Chaucer served in the court of *Richard II until the king's deposition in 1399 (and, later, murder) by Bolingbroke (*Henry IV), John of Gaunt's son. His wife had died in 1387. He travelled to France and Italy on seven diplomatic or commercial missions, may have met *Boccaccio and ${ }^{*}$ Petrarch, and also visited Spain and Flanders. He was comptroller of customs in London (1374-86), a knight of the shire (that is, Member of Parliament) for Kent (1386) and clerk of works at the royal palaces (1389-91). On the accession of Henry IV, after some delay, his pension was renewed and he spent the remaining months of his life in comparative comfort. He had a deep interest in science, especially astronomy.

It is assumed that Chaucer died suddenly because the final editing of The Canterbury Tales is incomplete, the text is sometimes inconsistent and no contemporary record of his death has survived. Claimed to have been originally buried in Westminster Abbey because he lived in the close, in 1556 his remains were said to have been transferred to a larger tomb in the centre of what is now called 'Poet's Corner' and the new gravestone is the earliest record of a date of death. Its cause is unknown and murder has been suggested. He left no will and there is no evidence of what happened to his estate. However, his son Thomas Chaucer (c.1367-1434) was appointed Chief Butler by Henry IV, sat in 14 Parliaments, was five times Speaker of the House of Commons and died rich.

Chaucer is regarded as one of the greatest English poets.

His works may be divided into three periods. In the first, contemporary French influence was strong: The Book of the Duchess, and his part of the translation entitled The Romaunt of the Rose. In the second (c.1372$86)$, the Italian influence of $*$ Dante and Boccaccio was apparent: Troilus and Criseyde, The Parlement of Foules, The Legend of Good Women and The House of Fame. To the final period belongs his last and greatest work The Canterbury Tales, stories told by a party of 30 pilgrims, of all social classes_-knight, miller, cook, wife of Bath, friar, merchant, doctor etc.- -journeying to the tomb of Thomas *Becket at Canterbury. 'Here is God's plenty', *Dryden wrote of the work. Written in rhyming couplets, 17,000 lines in total, the stories present a vivid picture of life in the Middle Ages. A masterpiece by any standard, though incomplete, The Canterbury Tales is also the first major work written in the vernacular (Middle English), and one of the first to be printed, by William *Caxton, in 1478 and 1483 .

While other contemporaries (*Langland, ${ }^{*}$ Gower) wrote major works in English, Chaucer's influence was far greater and he made the first recorded use of about 2,000 words, including 'significant', 'session', 'superstitious', 'universe', 'galaxy', 'funeral', 'humiliation', 'moral', 'outrageous' and 'householder.'

Robinson, F. N. (ed.), Chaucer: Complete Works. 2nd ed. 1959; Rowland, B. (ed.), Companion to Chaucer Studies. 1968; Jones, T. et al., Who Murdered Chaucer?: A Medieval Mystery. 2003; Turner, M., Chaucer: A European Life. 2019. 
Chausson, (Amédée) Ernest (1855-1899). French composer. Trained as a lawyer, he became a pupil of ${ }^{*}$ Franck and ${ }^{*}$ Massenet. His romantic but melancholy works include a symphony (1890), Poème for violin and orchestra (1896), chamber works and songs. He was killed in a bicycle accident.

Chauvel, Sir Harry (Henry George) (1865-1945). Australian soldier, born in New South Wales. In World War I, he served in Egypt, Gallipoli, and his Light Horse Brigade defeated the Turks at Beersheba (October 1917) in the last great cavalry charge in history. Chief of the General Staff 1923-30, he was promoted to full general, together with John *Monash, in November 1929.

\section{Hill, A., Chauvel of the Light Horse. 1978.}

Chauvin, Nicholas (c.1770-1820?). French soldier. His exaggerated expressions of loyalty to *Napoléon and vain-glorious patriotism resulted in the coining of the word 'chauvinism'.

Chávez (y Ramírez), Carlos (Antonio de Padua) (1899-1978). Mexican composer, conductor and teacher. Founder of the Mexican Symphony Orchestra (1928), his works include five symphonies and several operas. He was much influenced by Mexican folk music but also followed contemporary trends, e.g. abstract music. He was Norton Professor of Poetics at Harvard 1958-59.

Chávez Frias, Hugo Rafael (1954-2013). Venezuelan politician. He served as an army officer and was imprisoned 1992-94 for leading an armed coup. He founded the United Socialist Party and was President of Venezuela 1999-2013, working closely with Cuba and attracting US suspicion for his radical measures, including land reform. In 2012 he had eight months' treatment for cancer in Cuba.

Cheever, John (1912-1982). American novelist and short-story writer. Many of his stories appeared in the New Yorker, and his highly praised novels include The Wapshot Chronicle (1958), Bullet Park (1969) and Falconer (1977).

Chekhov, Anton Pavlovich (1860-1904). Russian dramatist and short-story writer, born in Taganrog. Grandson of a liberated serf and son of a shopkeeper, he studied medicine at Moscow University (supporting himself by writing about 600 comic sketches), but later he practised little. Through the help of the publisher Aleksei Suvorin, with whom he travelled in Italy, he achieved early success with his stories and in 1887 his first play Ivanov was produced. In 1892 he went to live with his family at Malikhovo near Moscow and helped in the cholera outbreak of 1892-93. In 1897, threatened by tuberculosis, he went to the Crimea, and from 1900 lived mostly at Yalta, where he became friends with ${ }^{*}$ Tolstoy and ${ }^{*}$ Gorki. After several false starts as a dramatist, he
(1898) of The Seagull (1895), which had previously failed. His masterpieces Uncle Vanya (1901), The Three Sisters (1901) and The Cherry Orchard (1904) followed. In the last two, leading parts were played by Olga Knipper (1868-1959), whom he married in 1901. In his plays, as in his short stories, he used an impressionistic technique, eschewing the dramatic and the obvious and, while portraying the lives of ordinary people, hinting always at the absurdity, beauty and tragedy of life. He died in Badenweiler, Germany. His funeral was Chekhovian: the coffin was taken to Moscow by train in a refrigerated car intended for oysters, and the funeral procession was confused with a general's, accompanied by a military band. His heroes are almost always the gentle and the sensitive, at the mercy of forces which are too strong for them. His influence on European short-story writers has been immense.

Troyat, H., Chekhov. 1986; Rayfield, D., Anton Chekhov: A Life. 2000; Malcolm, J., Reading Chekhov. A Critical Journey. 2002; Bartlett, R., Chekhov. Scenes from a Life. 2004.

\section{Chelmsford, 1st Viscount, Frederic John Napier} Thesiger (1868-1933). English administrator. Educated at Oxford, he became a barrister, inherited a barony in 1905 and served as Governor of Queensland 1905-09 and New South Wales 1909-13. A captain in his regiment in India when unexpectedly appointed as Viceroy 1916-21, he was identified with the 'Montagu-Chelmsford' reforms (1918), under which dyarchy (i.e. a division of the functions and instruments of government between the centre and the provinces) was adopted as a limited constitutional reform for India, but opposed by *Gandhi. In April 1919, British troops under R. E. H. *Dyer massacred civilians at Amritsar (Jallianwala Bagh) but Chelmsford was slow to respond. In 1924, although a Conservative, he accepted appointment as First Lord of the Admiralty in the first Labour Government. He was Warden of All Souls, Oxford 1932-33.

Chen Duxiu (Ch'en Tu-hsiu) (1879-1942). Chinese Communist politician. In 1915 he became first editor of the periodical New Youth which launched a violent attack on traditional Chinese government and society, and promoted Western philosophies. He is regarded as the main inspiration of the May Fourth Movement, a social and intellectual revolution sparked off by a students' rising on 4 May 1919, resulting in his imprisonment. On his release, greatly impressed by the Soviet revolution in Russia he became a Marxist. $\mathrm{He}$ founded the Chinese Communist Party in Shanghai in July 1921 and became its first SecretaryGeneral. He was dismissed at the instigation of the international Comintern in 1927 because he opposed its insistence that the CCP cooperate with the Nationalist Guomintang. Expelled from the CCP in 1927, his direct influence came to an end, but he 
continued to teach a highly individual version of Marxism which incorporated some democratic ideas. The Nationalists jailed him 1932-37.

Chow Tse-tsung, D., The May Fourth Movement. Intellectual Revolution in Modern China. 1960; Feigon, L., Chen Duxiu, Founder of the Chinese Communist Party. 1983.

Cheney, Dick (Richard Bruce) (1941- ). American Republican politician, born in Nebraska. A Congressman from Wyoming 1978-89, he served as US Secretary of Defense 1989-93 under George H. *Bush and Vice President of the US 2001-09 under George W. *Bush. His daughter Liz (Elizabeth Lynne) Cheney (1966- ), a Member of the US Congress 2017- , voted for *Trump's impeachment and lost her position as Chair of the House Republican Conference in 2021. Vice chair of the Congressional committee to investigate the 6 January 2021 attack on the Capitol, she was defeated for Republican reendorsement in August 2022.

Gellman, B., Angler: The Cheney Vice Presidency. 2014.

Chénier, André Marie de (1762-1794). French poet, born in Constantinople. The son of a diplomat, he hailed the French Revolution on its outbreak, but became disgusted with its excesses and in one ode extolled Charlotte ${ }^{*}$ Corday. He was arrested in 1794 and guillotined on *Robespierre's order only two days before the Terror ended. His poems, Élégies, Bucoliques, Odes, Hymnes and Iambes, all follow classical models. Umberto Giordano wrote an opera based on his life. His brother, Marie Joseph Chénier (1764-1811), was a poet and dramatist. Fully committed to the Revolution he obtained fame for his revolutionary poetry, especially the Chant du départ.

\section{Cheops see Khufu}

Cherenkov, Pavel Alekseivich (1904-1990). Russian physicist. In 1958 he shared the Nobel Prize for Physics (with Tamm and Frank) for the discovery that light waves radiate from a charged particle passing through a transparent material at speeds greater than the speed of light through such material. This 'Cherenkov radiation' is used to detect charged particles and plot their course and speed.

Chernenko, Konstantin Ustinovich (1911-1985). Russian Communist politician. Son of a peasant, he joined the CPSU in 1931, became an official in Moldavia, worked for the Central Committee 1956-65 and for the presidium 1965-84. He was a Central Committee member 1971-85, joining the Politburo in 1978 . On the death of Yuri *Andropov (Jan. 1984) he was elected to succeed him as nominee of the Brehzhnevite anti-reform group, defeating M.S. ${ }^{*}$ Gorbachev. He died after 13 months as First Secretary of the CPSU and President of the USSR.
Chernomyrdin, Viktor Stepanovich (1938-2010). Russian politician. He worked in the oil and gas industry until 1985, became a minister 1985-92, Deputy Prime Minister 1992, and Prime Minister 1992-98.

Chernyshevsky, Nikolai Gavrilovich (1828-1889). Russian political philosopher and utopian socialist, born in Saratov. Son of a priest and educated in St Petersburg, he was influenced by ${ }^{*}$ Herzen, ${ }^{*}$ Belinsky and ${ }^{*}$ Feuerbach, and in turn influenced *Lenin, especially with his novel What Is To Be Done? (1863). He spent years in prison and Siberian exile and inspired the Russian populist (Narodnik) movement. *Dostoevsky attacked him.

Cherubini, (Maria) Luigi Carlo Zenobio Salvatore (1760-1842). Italian composer, born in Florence. He lived in Paris from 1788, wrote much religious music in his early life and this, with chamber music, occupied him almost exclusively during his later years. His reputation rests upon his operatic work, and ${ }^{*}$ Beethoven (oddly) thought him the greatest of his contemporaries in this field. He wrote 29 operas including Medée (1797) and Anacreon (1803). To the opera comique he introduced a romantic interest and an exciting plot, though the music itself remained classical in form and rather austere. Cherubini directed the Paris Conservatoire 1821-42, and influenced many French composers, although infuriating ${ }^{*}$ Berlioz. His friend ${ }^{*}$ Ingres painted an outstanding portrait (1841).

Deane, B., Cherubini. 1965.

Cherwell, Frederick Alexander Lindemann, 1st Viscount (1886-1957). British physicist and scientific advisor, born in Baden-Baden. His father was German (naturalised as British), his mother American. He studied in Germany and worked on low temperature physics with *Nernst. In World War I, as director of the experimental laboratory at Farnborough, he made a personal and practical test in the air of his theory of how to bring an aeroplane out of a spin. Professor of experimental philosophy at Oxford 1919-57, he upgraded the Clarendon Laboratory. The close friend and scientific advisor of Winston ${ }^{*}$ Churchill, he was reactionary on social policy, strongly supporting eugenics, but acute on German rearmament. Churchill loaded him with honours: baron (1941), PC (1943), CH (1953), viscount (1956) and he served in government as Paymaster-General 1942 45 and 1951-53. He advocated mass bombings of German working class houses, asserting that it would destroy morale, and was central to failure to relieve the 1943 famine in Bengal. Sceptical about radar and German V1 and V2 rockets, he was loathed by his scientific contemporaries.

Hastings, M., Bomber Command. 1999. 
Cheshire, (Geoffrey) Leonard, Baron Cheshire (1917-1992). British airman and social worker. The son of an Oxford don, he joined the RAF in World War II, flew bombers in over 100 missions, was promoted to group captain and awarded the VC, DSO (2 bars) and DFC. In August 1945 he was an official observer when the US Air Force dropped an atomic bomb on Nagasaki. After retiring from the RAF in 1946 he devoted himself to establishing the Leonard Cheshire Foundation homes for the sick and incurable, aided by his wife Sue Ryder (1923-2000), later Baroness Ryder of Warsaw. By 1990 there were 270 homes in 50 countries. He received the OM in 1981 and a peerage in 1991.

Braddon, R. Cheshire VC. 1954.

Chesterfield, Philip Dormer Stanhope, 4th Earl of (1694-1773). English statesman and man of letters. As Lord Stanhope he was an MP 1715-23. After inheriting the earldom (1726) he was Ambassador to the Netherlands 1728-32 and later held a succession of high offices. A friend of ${ }^{*}$ Pope, ${ }^{*}$ Swift, ${ }^{*}$ Bolingbroke and ${ }^{*}$ Voltaire, he took an active interest in scientific matters, but is best remembered for his letters to his illegitimate son Philip Stanhope (1732-1768). They are witty, elegant and cynical, and are marked by great shrewdness of observation-women, manners and education being the constantly recurring themes.

Chesterton, G(ilbert) K(eith) (1874-1936). English author and literary critic, born in London. He was educated at St Paul's School before studying art at the Slade. But art was always secondary to letters. He wrote regular articles for many newspapers and magazines, took over the New Witness on the death of his brother, Cecil, in 1918 and revived it as G.K.'s Weekly in 1924. He was a man of much geniality but he had a strong antipathy for the squalor of industrialism and disliked both capitalism and socialism, yearning, like his great friend Hilaire *Belloc (whose books he amusingly illustrated), for a return to the distributivist economics of the Middle Ages. All his work, which includes essays, poetry, novels, and literary, social and religious studies (he was converted to Roman Catholicism in 1922), reveals his tremendous energy, robust humour and mastery of paradox. He is probably best known as the creator of the detective priest Father Brown, who figured in several collections of semi-philosophical detective stories beginning with The Innocence of Father Brown (1911). His novels, The Napoleon of Notting Hill (1904), The Man Who Was Thursday (1908) and The Flying Inn (1914), combine fantasy with social comment. He also wrote biographies of *Browning, *Dickens and G. B. *Shaw. Chesterton was enormously fat.

Pearce, J., Wisdom and Innocence. 1996; Barker, D., G. K. Chesterton. 1973.

Chevalier, Maurice (1888-1972). French musichall singer and film star. His engaging smile and charm won him fame not only in Paris music halls (where he was long a co-star with ${ }^{*}$ Mistinguett) but internationally. He appeared in several films, notably Le Roi (1949) and Gigi (1958).

Chevreul, Michel-Eugène (1786-1889). French chemist, born in Angers. He worked at the Museum d'Histoire Naturelle and the Jardin des Plantes in Paris and became the director of both. He began a major study of the chemistry of oils and fats which led to soap-making becoming an exact science and to greatly improved candles. Elected FRS in 1826, he received the Copley Medal in 1857. A director of the Gobelins tapestry works, he became interested in the chemistry of dyes and in colour contrast. His ideas influenced neo-impressionist painters, e.g. *Seurat. The first to grasp the significance of sugar in the urine of diabetics, he was also a pioneer in gerontology and his 100th birthday was commemorated in the first photographic interview (by Felix and Paul *Nadar).

Chevrolet, Louis (1879-1941). American racing car driver and designer, born in Switzerland. In 1911 he founded his own automobile company, but in 1917 sold out to General Motors which retained his name for a popular model. He continued his career as a driver but died in poverty.

\section{Chiang Ch'ing (Jiang Qing) see Mao Zedong}

Chiang Kaishek (Wade-Giles: Jiang Jieshi in pinyin). (1887-1975). Chinese marshal and politician, born in Zhejiang. Son of a farmer, as an officer cadet he became involved in the successful revolution (1911) against the last Manchu emperor and was from then onwards a loyal adherent of *Sun Yat-sen who, in 1921, established himself as President of the republican government centred on Canton. The north was still in the lands of self-appointed warlords and after Sun's death in 1925 Chiang was chosen to command an expedition to bring them under control. This was delayed by a split between the Communist and Nationalist wings of Sun's revolutionary party, the Guomintang. Appointed leader of the Nationalists, Chiang, as generalissimo, resumed the delayed northern drive and by 1928 overcame the warlords and occupied Beijing (Peking). He then broke with the Communists. He was Commander-in-Chief of all forces under Guomintang control 1928-46 and held the titles of President of China 1928-31, 1943-49 and Premier 1930-31, 1935-37, 1939-45, 1947.

In 1931 the Japanese invaded Manchuria. Chiang was torn between wanting to resist the Japanese and defeating the Communists who ruled in Kiangsi province, settling for appeasement of the invaders. In the great 'Long March' (October 1934-January 1936), *Mao Zedong led his followers from Kiangsi to the remote Shensi province. In 1936 Chiang was kidnapped at Xi'an by *Zhang Xueliang and released on promising to make a truce with the Communists and stop appeasing the Japanese. This led to an intensification of the war, with the Japanese occupying Shanghai, forcing Chiang's government to 
move from Nanjing progressively up the Yangtze river until it found refuge above the rapids at Chungking. Pressure eased when, in 1941, the US entered World War II and in 1945 Chiang emerged as president of a stricken and impoverished country.

But immediately the old struggle with the Communists broke out, and political manoeuvre was followed by civil war in which the Communists finally triumphed. Chiang withdrew to Taiwan in 1950 and continued to lead a Guomintang administration, which occupied the seat of China in the Security Council of the United Nations until 1971.

Chiang obtained help and encouragement at every stage of his career from his American-educated second wife Song Meiling (1898-2003), sister of Sun Yat-sen's widow. His son Chiang Chingkuo (Jiang Jingguo) (1910-1988), was Premier of the 'Republic of China' (i.e. Taiwan) $1972-78$ and President 1978-88.

Fenby, J., Generalissimo Chiang Kai-Shek and the China He Lost. 2003; Crozier, B., The Man Who Lost China. 2009; Pakula, H., The Last Empress. 2009.

Chichele, Henry (1362-1443). English prelate and patron of learning. Educated at Winchester and New College, Oxford, he soon became prominent in Church and state, and after serving on embassies abroad became Bishop of St David's in 1408 and Archbishop of Canterbury 1414-43. He strongly supported *Henry V's war policy in France and his resistance to the encroachments of papal power at home. In 1437 he founded two Oxford colleges, All Souls and St John's (originally called St Bernard's).

Chicherin, Georgi Vasilievich (1872-1936). Russian diplomat. Of noble origin, he served in the Russian foreign office but resigned on joining the Social Democrat party; from 1904 he lived with revolutionaries abroad. In 1917 he was arrested in England and exchanged for Sir George Buchanan, British Ambassador. He became Peoples' Commissar for Foreign Affairs 1918-30. He signed the BrestLitovsk Treaty which ended the German war. While attending the Genoa Conference (1922) he secretly negotiated the Rapallo Treaty, securing recognition and trade agreements from Germany. Illness led to his resignation (1930).

Chichester, Sir Francis Charles (1901-1972). English aviator and yachtsman. In 1929-30 he made a solo flight from England to Australia in a Gipsy Moth bi-plane; in 1931 he made the first east-west flight between New Zealand and Australia. He began ocean sailing in 1953. In 1960 he won the first transatlantic race for solo yachtsmen. In 1966-67 he sailed round the world single-handed in Gipsy Moth IV.

Chichester, F., The Lonely Sea and the Sky. 1964.
Chifley, (Joseph) Ben(edict) (1885-1951). Australian Labor politician, born in Bathurst. Chifley's family suffered in the 1890s Depression. Separated from his parents and two younger brothers at the age of five, he rarely saw his mother for the next nine years, and lived with his grandparents at Limekilns until 1899, where he slept on a chaff-bag. He attended the Patrician Brothers' High School in Bathurst for two years (1899-1901) and became a voracious reader, including *Gibbon and *Plutarch. In 1902 he joined the New South Wales Railways as a shop-boy, then became a cleaner and fireman. He studied at the Workers' Educational Association and the Bathurst Technical School, and became an industrial advocate for the Locomotive Engine-drivers', Firemen's and Cleaners' Association. Promoted to first-class locomotive engine driver, he was later demoted because of his role as a trade union activist. He was a Member of the House of Representatives 1928-31 and 1940-51, and served as Minister of Defence 1931-32 under James *Scullin. When the ALP split in New South Wales, during the Depression, he supported the Federal leadership and strongly opposed J. T. *Lang.

Ben Chifley held the key position of Commonwealth Treasurer 1941-49 under ${ }^{*}$ Curtin when war with Japan broke out. After Curtin died, Frank *Forde succeeded for a week but Chifley won the Labor leadership overwhelmingly and became Prime Minister 1945-49. He was the architect of post-war reconstruction, including full employment and the welfare state, supported ${ }^{*}$ Evatt on foreign policy and ${ }^{*}$ Calwell in the post-war mass migration program. $\mathrm{He}$ was strongly committed to Bretton Woods, the World Bank and early elements of the global economy, but had to use all his political skills to win Caucus' reluctant approval. He aided the CSIRO and the ABC, created The Australian National University but ran aground with his preoccupation with banking and excessive regulation. The long coal strike of 1949 was no help either. However, there were significant gaps in his political repertoire: White Australia Policy, Aboriginal people, women's issues and schools, the last regarded as a state responsibility. On these issues, Chifley was a man of his times.

Day, D., Chifley. 2001.

Chikamatsu Monzaemon (Sugimori Nobumori) (1653-1724). Japanese dramatist. He wrote about 160 plays for the Bunraku puppet theatre. He was the first playwright to introduce true drama to the puppet theatre, previously a display of virtuoso skill by the puppeteers. Many of his plays were adapted for the Kabuki theatre and remain in the repertoire. He wrote historical melodramas such as The Battles of Kokusenya (1715) and realistic domestic tragedies such as The Love Suicides at Amijima (1720). 
Childe, V(ere) Gordon (1892-1957). Australian archaeologist, born in Sydney. Educated in Sydney and Oxford, he became secretary to John Storey, Premier of New South Wales 1920-21, and his How Labour Governs (1923) was a pioneering analysis. He wrote several important books on archaeology, including The Dawn of European Civilization (1925), providing a theory of social structures in prehistory, still widely supported, and the popular What Happened in History (1942). He excavated Skara Brae, Orkney, and held chairs in archaeology at Edinburgh 1927-46 and London 1946-56. He coined the term 'Neolithic Revolution' in 1935. He jumped to his death in the Blue Mountains, New South Wales.

Irving, T., The Fatal Lure of Politics: The life and thought of Vere Gordon Childe. 2020.

Childeric III (735-755). King of the Franks 74351. Last of the Merovingians, he was deposed by *Pepin III.

Childers, (Robert) Erskine (1870-1922). AngloIrish author and nationalist, born in London. A clerk in the House of Commons, he won a sensational success with his novel, The Riddle of the Sands (1903), dealing with secret preparations for a German invasion of Britain. Later he became a strong Irish nationalist. He was a leader of the Sinn Féin resistance to the Irish Free State, condemned by an Irish military court and executed. His son Erskine (Hamilton) Childers (1905-1974), born in London, educated at Trinity College Cambridge, became a Fianna Faíl MP 1938-73, Deputy Prime Minister 1969-73 and was President of the Irish Republic 1973-74.

Wilkinson, B., The Zeal of the Convert. 1978.

Ch'in. Chinese dynasty, now called ${ }^{*}$ Qin (pinyin), which ruled 221-205 BCE.

Ch'ing. Chinese dynasty, in pinyin ${ }^{*}$ Qing, which ruled 1644-1912.

Chippendale, Thomas (c.1718-1779). English furniture maker and designer. The son of a Yorkshire joiner, he moved from Worcestershire to London where, by 1755 , he and his firm were occupying three houses in St Martin's Lane. Furniture still surviving in Harewood House and elsewhere is mentioned in his accounts. His own best work, almost exclusively in mahogany, is in the neo-classical style, the association of his name with an Anglicised rococo style (with Gothic and oriental variants) being due to the fact that it was to that particular style that the designs of his publication The Director (The Gentleman and Cabinet Maker's Director, 1754) were devoted. Most so-called Chippendale furniture is the work of other craftsmen taken from The Director, designs inspired, but not actually drawn, by Chippendale himself.

Coleridge, A., Chippendale Furniture. 1968.
Chirac, Jacques René (1932-2019). French politician, born in Paris. As a student activist, he was briefly in the Communist Party, graduated from Sciences Po and the ENA, served as an army officer, then worked as public servant and a staffer for Georges *Pompidou. A Member of the National Assembly 1967-74, Minister for Agriculture 197274, and the Interior 1974, he became Prime Minister 1974-76, under ${ }^{*}$ Giscard d'Estaing. He led the RPR (Rassemblement pour la République) 1976-94. After the revival of the office of Mayor of Paris (in abeyance since 1871), he was elected, serving 1977-95. In 1981, he was a candidate for president, ran third in the first round of voting but contributed to Giscard's defeat by splitting the conservative vote. He was Prime Minister again 1986-88, in 'cohabitation' with *Mitterrand, but ran against him in 1988. President of France 1995-2007, his resumption of nuclear tests in the Pacific (1995-96) drew international protests. In 1997, he apologised to the descendants of ${ }^{*}$ Dreyfus and *Zola. He was frank in his condemnation of the French regime during the German occupation, and its role in the Holocaust. He was re-elected President in 2002, defeating Jean-Marie ${ }^{*}$ Le Pen, with 82 per cent of the vote in the second ballot. In 2011, he was found guilty of diverting public funds and abusing public confidence as Mayor of Paris and given a twoyear suspended prison sentence.

Chirico, Giorgio De' (1888-1978). Italian painter, born in Greece. One of the most important precursors of Surrealism, he painted objects and landscapes in unexpected juxtaposition with no regard to reality. Thus window dummies, plaster busts, abstract shapes or bits of machinery might be grouped against a background of classical architecture. From this he developed a style which came to be known as metaphysical painting in which there was a greater symbolic content. In the 1920 s he abandoned his earlier style and turned to more conventional styles and subjects, but the galleries of the world have chosen to show his earlier idiosyncratic paintings.

Chirico, G. de', Memorie della mia vita. 1945.

Chisholm, Caroline (née Jones) (1808-1877). English social reformer, born near Northhampton. She married an officer in the Indian army, and campaigned for migration and employment opportunities of young women to Australia as an essential precondition to a civilian society, and lived near Sydney 1838-46, 1859-66 and in Victoria 1854-59. *Dickens satirised her, unfairly, as Mrs Jellyby in Bleak House.

Chisholm, George Brock (1896-1971). Canadian psychiatrist. After a distinguished career he was Director General of the World Health Organisation 1948-53. His Can People Learn to Learn? (1958) was a bestseller. 
Choiseul, Etienne François, Duc de (1719-1785). French diplomat. Through the patronage of Madame de *Pompadour, he became ambassador to Rome 1753-57 and Vienna 1757-58, returning to take office as Foreign Minister 1758-70. He was thus at the heart of affairs during the Seven Years' War and signed the Treaty of Paris (1763), which confirmed the losses, e.g. in Canada and India, of the preceding years. He was also responsible for popular reforms in the services, supported the publication of the Encyclopédie, and assisted in the suppression of the Jesuits. Madame du *Barry's party at court was responsible for his downfall (1770) and he lived in retirement until his death.

Chomsky, (Avram) Noam (1928- ). American theoretical linguist and political activist, born in Philadelphia. Educated at Pennsylvania and Harvard Universities, he taught linguistics at the Massachusetts Institute of Technology from 1955 and held chairs in modern languages and linguistics from 1961. His principal thesis was first defined in Syntactic Structures (1957) and developed further in Aspects of the Theory of Syntax (1965), Language and Mind (1968), Reflections on Language (1975) and Essays on Form and Interpretation (1977). He argued for the existence of a universal grammar that underlies all languages, and that the structural principles of language are innate, biologically determined and capable of genetic transmission. He regarded linguistics as a branch of cognitive psychology. He was a vigorous polemicist, opponent of US foreign policy, especially in Vietnam, Iraq and with Cuba. He vigorously denied charges that he was an apologist for ${ }^{*}$ Pol Pot in Cambodia and described himself as a libertarian socialist. His political books include Manufacturing Consent (1988) and Deterring Democracy (1991). Between 1980 and 1992, according to the Arts and Humanities Citation Index, Chomsky was cited more often than any other living scholar.

Chopin, Frédéric François (Fryderyk Franciszek) (1810-1849). Polish-French composer, born near Warsaw. From boyhood Chopin suffered from ill health, but early displayed musical gifts. His music teacher in Warsaw encouraged him to develop in his own way and by 21 Chopin was already an accomplished pianist and composer for the piano. He made his debut as a concert pianist in Vienna in 1829, and from 1831 lived mainly in Paris and did not return to Poland. His recitals were successful and he became the friend of *Bellini (who, like ${ }^{*}$ Donizetti, influenced his melodic style) and *Mendelssohn. Catholic, conservative and royalist, he admired ${ }^{*}$ Bach, ${ }^{*}$ Haydn and ${ }^{*}$ Mozart but had grave doubts about ${ }^{*}$ Beethoven. He gave few concerts after 1831 . His compositions established the piano as a solo concert instrument. No other composer has surpassed him in this field which he explored more fully than any of his predecessors. His individual lyric and harmonic sense and his innovations in the technique of playing the piano were profoundly influential. His fame rests upon the wide range of his piano compositions, including three sonatas (1828, $1839,1844)$, two concertos (both 1830), 24 preludes (1836-39), four ballades $(1835,1839,1841$, 1842), four scherzos $(1835,1837,1839,1842), 15$ polonaises, 60 mazurkas, 21 nocturnes and many etudes and waltzes. In Paris he fell in love with the woman novelist George *Sand, an affair which began in 1838 , survived a horribly uncomfortable winter in Majorca (1838-39), before ending in a quarrel in 1847 due to her children's jealousy. Chopin's health deteriorated over many years but the cause is uncertain: tuberculosis, bronchiectasis or cystic fibrosis of the lungs have been suggested. In 1848 he visited England and Scotland, giving several concerts. He died in Paris and was buried in the Père-Lachaise cemetery.

Hedley, A., Chopin. 1947; Rosen, C., The Romantic Generation. 1995.

\section{Chou En-lai see Zhou Enlai}

Chrétien, (Joseph Jacques) Jean (1934- ). Canadian Liberal politician. Educated at Laval University, he became a lawyer and was a Liberal MP 1963-86, 1990-2003, serving under *Trudeau and *Turner as Minister for Industry, Trade and Commerce 197677, for Finance 1977-79, Attorney-General 1980 82, External Affairs Minister and Deputy Prime Minister 1984. Leader of the National Liberal Party 1990-2003, and Prime Minister 1993-2003, he was awarded the Order of Merit in 2009.

Chrétien de Troyes (fl. 1166-1190). French trouviere. A poet at the court of Champagne, he developed many of the legends which were later incorporated into Arthurian romances (*Malory) and also the Holy Grail and Parsifal (*Wolfram von Eschenbach, *Wagner). Perceval, left unfinished at his death, is the first in which the story of the Holy Grail is associated with Arthurian material. His claim that material for the epic Guillaume d'Angleterre was found at Bury St Edmunds suggests that he may have visited England. He was one of the most influential of medieval poets and many translations and imitations of his work appeared.

\section{Christ, Jesus see Jesus Christ}

Christian IX (Christian of Schleswig-HolsteinSonderburg-Glücksburg) (1818-1906). King of Denmark 1863-1906. Born in Schleswig to a junior branch of the *Oldenburg family, he was recognised as heir to the throne (1852) because Frederik VII (1808-1863), despite three marriages, had no legitimate heir. Immediately after succeeding his distant cousin, he had to face war with *Bismarck's Prussia and surrender the duchies of Schleswig and Holstein to overwhelming force. He was resistant to democratic change and, with his wife's strong encouragement, gained a special notoriety by the way in which he extended his family connexions. 
His children included his successor Frederik VIII, *Alexandra, wife of Edward VII of Great Britain, ${ }^{*}$ George I of Greece, and Dagmar, wife of the Russian emperor *Aleksandr III. His grandson became *Haakon VII of Norway. In the next generation this dynastic network spread further still, and, not only through Queen Alexandra but through its Greek connexions, including Prince *Philip, Duke of *Edinburgh, and Princess Marina, Duchess of Kent.

Christian X (Christian Carl Frederik Albert Alexander Vilhelm) (1870-1947). King of Denmark 1912-47. Son and successor of Frederik VIII and the elder brother of *Haakon VII of Norway, in 1920 he reluctantly accepted constitutional restraints on his authority to choose ministers. He achieved great popularity by his courageous bearing and behaviour during the German occupation in World War II.

Christie, Dame Agatha Mary Clarissa (née Miller, later Mallowan) (1890-1976). English crime novelist and playwright, born in Torquay. After limited schooling, although she read widely, she married Colonel Archibald Christie in 1914, became a nurse in World War I, published The Mysterious Affair at Styles in 1920, disappeared equally mysteriously in 1926, and in 1930 married the archaeologist (Sir) Max Mallowan (1904-1978). She published 66 detective novels, and 15 collections of short stories, translated into 103 languages, with total sales estimated at 4 billion books. Her plots were ingenious but hardly more baffling for her devoted readers than for her two most famous sleuths, the Belgian Hercule Poirot and the homely Englishwoman Miss Jane Marple. Her best known play, The Mousetrap, had an unbroken run in London from its premiere on 25 November 1952, until 16 March 2020, when it was closed due to COVID-19, after 28,000 performances, the longest run in theatrical history. (It reopened in May 2021).

Worsley, L., Agatha Christie: A Very Elusive Woman. 2022.

Christie, John (1882-1962). English opera promoter. Born to a rich landed family, educated at Eton and Trinity College, Cambridge, he taught at Eton for seven years. He won an MC fighting in France, and decided to turn his family home at Glyndebourne, Sussex, into an opera house, supported by his wife Audrey Mildmay (1900-1953), a Canadian operatic soprano. The Glyndebourne Opera began in 1934 (Fritz ${ }^{*}$ Busch) and was revived in 1950 . He received a CH in 1954. His son, Sir George Christie (19342014), was chair of Glyndebourne Opera 1962 2014, built a new opera house (1994) and received a CH (2001).

Christie, John Reginald Halliday (1899-1953). English murderer. He was convicted and hanged for the murder of his wife but also confessed to the murder of five other women whose bodies were found at his home. Among those whom he claimed to have killed was the wife of Timothy John Evans, an illiterate truck driver. When Evans was tried in 1950 for murdering his wife and daughter, Christie had been the principal witness for the prosecution. Evans was hanged for the murder of the child but received the consolation of a posthumous pardon in 1966.

Christie, William Lincoln (1944- ). AmericanFrench harpsichordist and conductor, born in Buffalo. Educated at Yale and Harvard, he lived in France from 1971 and in 1979 founded the baroque group Les Arts Florissantes, directing outstanding performances of baroque operas and making many recordings. Also an expert gardener, he became a French national in 1996.

Christina (Kristina Augusta Vasa) (1626-1689). Queen of Sweden 1632-54. Daughter of *Gustaf II (Gustavus Adolphus), during her minority, until 1644, the country was effectively governed by the great chancellor Axel *Oxenstierna, but their relationship was cool and he despaired at her extravagence. After the Thirty Years' War ended she acquired (1649) the collection of the Emperor*Rudolf II and commisioned many paintings and statues. Her sexuality is ambiguous, she had androgynous characteristics, but insisted that she was 'neither male nor hermaphrodite'. She probably suffered from a multi-endocrine disorder. She indicated abhorrance of marriage and secured recognition of her cousin, the future *Karl X Gustaf, as heir. She was fascinated by literature, theatre, art, music, theology, science, mathematics and philosophy and had a great library. (*Descartes came to Sweden at her invitation.) In 1652 she indicated her wish to abdicate but was persuaded to delay until 1654. She left Sweden, disguised as a man, and in Brussels in December 1654 became a Roman Catholic. She lived in Rome from 1655. In 1656, Cardinal *Mazarin toyed with making her Queen of Naples. She returned to Sweden briefly in 1660 after Karl X died but was barred from resuming her rule and in 1668 offered herself as a candidate for the Polish throne. She wrote an autobiography in 1681. In Rome she ruled a brilliant artistic and literary circle. She had an intense relationship with Cardinal Decio Azzolini (1623-1689) and left her collections to him. Pope Alexander VII called her 'a queen without a realm, a Christian without faith, and a woman without shame'.

Buried in St Peter's Basílica, she was the subject of August *Strindberg's play Kristina (1901), the films Queen Christina (1933, Greta ${ }^{*}$ Garbo), The Abdication (1974, Liv Ullmann) and The Girl King (2015, Malin Buska), an opera and several novels.

Weibull, C., Christina of Sweden. 1966; Meyer, C., Kristina, Queen of Sweden. 2003; Buckley, V., Christina, Queen of Sweden. 2004. 
Christo (Christo Vladimirovich Javacheff) (19352020). Bulgarian-American artist. Educated in Sofia and Paris, he gained early recognition for his 'wrapped objects', temporary public sculptures in which buildings, walls, bridges or coastlines were wrapped up. His wife Jeanne-Claude Denat de Guillebon (1935-2009), born in Morocco on the same day, was his collaborator.

Christoff, Boris (Kirilovich) (1918-1993). Bulgarian singer, born in Sofia. The greatest operatic bass since ${ }^{*}$ Chaliapin, and a powerful actor, he was a notable Boris ${ }^{*}$ Godunov, Prince Igor and ${ }^{*}$ Philip II (in *Verdi's Don Carlos).

Christophe, Henri (1767-1820). King of Haiti 1811-20. Originally a black slave, he became *Toussaint l'Ouverture's most successful general in his struggle against the French. After the death (1806) of *Dessalines he was elected President but, impatient of constitutional control, he set up an independent state in the north. After he was proclaimed King (1811), he built a palace on the model of St Cloud and created a nobility to provide a court. Though ruthless and capricious he showed an extraordinary willingness to learn and to introduce laws, educational methods, agricultural machinery indeed anything he thought useful from abroad. A stroke left him helpless in the face of a military revolt and he shot himself.

Christopher, Warren (1925-2011). American lawyer and administrator, born in North Dakota. Educated at Stanford, he became a Los Angeles lawyer, served as Deputy Secretary of State under President *Carter 1977-81 and was President ${ }^{*}$ Clinton's Secretary of State 1993-97.

Christus (Cristus), Petrus (c.1420-1473). Flemish painter, born near Antwerp. Active in Bruges from 1444, he was strongly influenced by the van *Eycks and is best known for his altarpieces and portraits, of which about 30 survive. He may have visited Milan in 1457.

Chrysler, Walter Percy (1875-1940). American motor manufacturer, born in Kansas. He left the Buick company, of which he was president (191619), to form the Chrysler Corporation, which he ran until 1938. Chrysler produced the Jeep and the Dodge. In 2009, to avoid bankruptcy, it formed a strategic alliance with Fiat.

\section{Chrysostom, St John see John Chrysostom, St}

Chu, Steven (1948- ). American physicist, born in St Louis. Professor of physics at Stanford 19872001, he shared the 1997 Nobel Prize for Physics for 'development of methods to cool and trap atoms with laser light' and directed the Lawrence Berkeley National Laboratory 2004-09, and in Houston Superconductivity. US Secretary of Energy 200913 , he was an effective advocate for climate change mitigation.

\section{Chu Hsi see Zhu Xi}

Chun Doo-hwan (1931-2021). Korean soldier and politician. He commanded the defence security unit in the South Korea army (1979-80), organised a coup that took over the army leadership in 1980, and became President of the Republic of Korea 198188. In 1996 he was tried for his involvement in the murder of President *Park Chung Hee (1979), was sentenced to death and amnestied in 1997.

Church, Alonzo (1903-1995). American mathematician and logician, born in Washington DC. A pioneer of symbolic logic, he taught at Princeton and UCLA. His students and collaborators included Alan *Turing.

Churchill, Arabella (1648-1730). English mistress. Sister of the 1st Duke of *Marlborough and mistress of James, Duke of York (later *James II), their son, the Duke of *Berwick, became a distinguished soldier in the French armies.

Churchill, Charles (1731-1764). English satirical poet. Ordained in 1756 he was briefly a curate but soon turned to writing satirical and political verse. He led a dissipated life, and left the Church in 1763. He was a vigorous supporter of John *Wilkes and wrote much of his famous political polemic in The North Briton.

Laver, J., Poems of Charles Churchill. 1970.

Churchill, Lord Randolph Henry Spencer (18491895). English politician. The third son of the 7th Duke of Marlborough, he was educated at Eton and Oxford and became a Conservative MP in 1874 . $\mathrm{He}$ developed a policy of progressive conservatism, known as Tory Democracy, and attacked both Liberal and Conservative leaders. He was Secretary for India 1885-86 and Chancellor of the Exchequer 1886, resigning the latter office after six months as a protest against the excessive financial demands of the army and navy. Then 37, he never held a Cabinet post again and was crippled by syphilis in his later years. In 1874 he married Jenny Jerome (1854-1921), daughter of a New York newspaper proprietor.

Churchill, W. L. S., Lord Randolph Churchill. Rev. ed. 1952.

Churchill, Winston (1871-1947). American novelist, born in Missouri. Among his successful romantic novels were Richard Carvel (1899, also a play), The Crisis (1901) and The Crossing (1904). He was also a poet, essayist and landscape painter. Active in Theodore *Roosevelt's Progressive Party, he was sometimes confused with his namesake, the English politician.

Churchill, Sir Winston Leonard Spencer (18741965). English politician, soldier and author, born at Blenheim Palace. An adoring son of a bullying remote father and a vivacious remote mother, his 
parents were Lord Randolph ${ }^{*}$ Churchill, a seventh generation descendent of the Duke of *Marlborough, and Jenny Jerome, an American. He was educated (patchily) at Harrow and Sandhurst. He served with the Spanish forces in Cuba (1895) then joined the British army in India, where he began to take an intense interest in history and literature. He was sent to the Sudan in 1898 and took part in the battle of Omdurman. A correspondent of the London Morning Post during the Boer War, he was captured by the Boers, escaped and returned to England as a hero. In 1900 he published a novel, Savrola, and was elected to the House of Commons, serving as MP 1900-22 and 1924-64 (Conservative 1900-04, 1924-64, Liberal 1904-22). His dreadful relatives and friends caused deep seated suspicion. Although a devoted monarchist, he was mistrusted by *Edward VII, *George V and (at first) ${ }^{*}$ George VI.

In the Liberal ministry of ${ }^{*}$ Campbell Bannerman he was Undersecretary for the Colonies 1906-08, President of the Board of Trade 1908-10 and Home Secretary 1910-11. As First Lord of the Admiralty 1911-15, he was responsible for the mobilisation of the fleet on the outbreak of World War I. He planned the Allied landing at Gallipoli (1915) and when this failed he was subject to severe criticism and resigned. In 1916 he served in France with the 6th Royal Scots Fusiliers, but when *Lloyd George displaced *Asquith he recalled Churchill to office as Minister of Munitions 1917-19. He was Secretary of State for War and for Air 1919-21 and Colonial Secretary 1921-22. When the war ended he was prominent in organising armies of intervention to overthrow the Soviet Government in Russia. He saw the futility of continued violence in Ireland and supported the establishment of the Irish Free State. After the dissolution of the Turkish Empire he was responsible for creating the new states of Jordan and Iraq (suggesting the last name himself as a substitute for Mesopotamia) which became British mandates.

He opposed breaking up Lloyd George's coalition government and was defeated in the 1922 and 1923 general elections. Returned in the October 1924 election, he served as Chancellor of the Exchequer 1924-29, under Stanley*Baldwin. In 1925 he pegged sterling to the Gold Standard, at the 1914 exchange rate, leading to an overvaluation which made exporting harder. He took an extremist line against the General Strike of 1926, calling it 'revolutionary' and had to be calmed down by Baldwin. He also showed some sympathy for ${ }^{*}$ Mussolini. He was not offered a place in the ${ }^{*}$ MacDonald-Baldwin National Government (1931), flirted briefly with Lloyd George and Oswald *Mosley and took an extreme view in opposing all moves towards self-government in India. He denounced *Gandhi in 1931 as 'this seditious ... fakir of a type well known in the east ... half-naked'. He remained deeply anti-Indian. In 1936 he reached his political nadir, supporting King ${ }^{*}$ Edward VIII lamentable judgment in other areas, he was correct in his consistent opposition to ${ }^{*}$ Hitler, although silent on Ethiopia and Spain. After ${ }^{*}$ Chamberlain became Prime Minister (1937) he bitterly attacked the policy of appeasing Germany and, on the outbreak of World War II (1939), became First Lord of the Admiralty. Chamberlain resigned after widespread criticism of his wartime government.

In May 1940 Churchill was made Prime Minister in a coalition government. He told the nation: 'I have nothing to offer but blood, toil, tears and sweat.' As Prime Minister and Minister of Defence he led a coalition government with Labour and Liberal support. He worked in close cooperation with *Roosevelt, whom he met in August 1941 in the Atlantic, near Newfoundland, and other world leaders including Josef ${ }^{*}$ Stalin (August 1942, Moscow), General *de Gaulle and ${ }^{*}$ Chiang Kaishek. He took little interest in the Pacific War and Asia (other than India: he had never visited Australia or New Zealand). His strategic judgment was often erratic and he treated some able generals (*Dill, *Wavell, *Auchinleck) harshly. Apart from his opposition to Hitler, his war aims were ill-defined apart from a determination to maintain the British Empire. In October 1944 at Moscow he conceded Stalin's claim to dominate Eastern Europe and the Balkans, and Roosevelt acquiesced at Yalta (February 1945).

At the post war general election of July 1945 his party was heavily defeated by Labour and *Attlee replaced him at the Potsdam Conference. Churchill continued as Conservative leader and Leader of the Opposition. In March 1946 his famous speech at Fulton, Missouri helped to define the 'Cold War'. He led the Conservatives to a narrow victory (his only one) in October 1951 and resumed office as Prime Minister 1951-55 and Minister of Defence 1951-52. His relationship with *Elizabeth II had embarrassing parallels with Lord *Melbourne and Queen *Victoria. He maintained his close relations with the US under Presidents *Truman and *Eisenhower. In April 1955, past 80 , he gave up as Prime Minister very reluctantly, although he had suffered two serious strokes and his memory was failing. Anthony ${ }^{*}$ Eden replaced him. He declined a dukedom in 1955, wishing to continue as a member of the House of Commons. Always a colourful and controversial figure, he earned the gratitude of the democratic world for his dynamic leadership in the wartime years. He was an enthusiast for Franco-German reconciliation and some form of European union.

A gifted amateur painter, he was made an honorary Royal Academician in 1948. His literary work reflects the stylistic influence of ${ }^{*}$ Gibbon and ${ }^{*}$ Macaulay. Among his books were Lord Randolph Churchill (1906), The World Crisis (1923-29, a history of World War I), My Early Life (1930), Life of the Duke of Marlborough (1933-38), Great Contemporaries (1937). He published The Second World War (6 vols, 
1948-54) and A History of the English Speaking Peoples (4 vols, 1956-58). He won the Nobel Prize for Literature in 1953 'for his mastery in historical and biographical presentation and for his brilliant oratory, in which he has always stood forth as the defender of eternal human values'. He suffered from periods of depression which he called the 'black dog'.

He was awarded the CH (1922) and OM (1946), made a Knight of the Garter in 1953, and received innumerable awards, degrees and fellowships, including FRS and RA.

He married Clementine Ogilvy Hozier (1885-1977) in 1908. She was created GBE in 1946 and Baroness Spencer-Churchill in 1965. Their son, Randolph Frederick Edward Spencer Churchill (1911-1968) was a notoriously erratic writer and journalist. He served in the army in World War II and was a Conservative MP 1940-45. Among his books were The Story of the Coronation (1953) and The Rise and Fall of Sir Anthony Eden (1959). Their daughter Mary Spencer-Churchill, Baroness Soames (1922-2014) married Christopher Soames, wrote Clementine Churchill's biography (1979) and was created LG in 2005. Randolph's son Winston (Spencer) Churchill (1940-2010) was a Conservative MP 1970-97.

Churchill, R. S. Winston S. Churchill 2 vols (and companions) 1966-67, continued by Gilbert, M. 6 vols (and companions) 1971-88; Soames, M., Clementine Churchill 1979; Charmley, J., Churchill: The End of Glory. 1992; Jenkins, R. Churchill. 2001; Roberts, A., Churchill. Walking with Destiny. 2018.

\section{Chu Teh see Zhu De}

Ciano, (Gian) Galeazzo, 2nd Conte di Cortellazzo e Buccari (1903-1944). Italian Fascist politician, born in Livorno. Son of a naval hero who became a minister in the first Fascist Government, in 1930 he married Edda Mussolini (1910-1995), daughter of il Duce. He served as Minister for Foreign Affairs 1936-43 but voted for *Mussolini's deposition at the Grand Council (1943). He was later captured by Mussolini's supporters, tried in Verona and shot as a traitor.

Mazzeo, T. J., Sisters in Resistance. 2022.

Cibber, Colley (1671-1757). English actor, playwright and poet. The author of about 30 plays, the best known being She Would and She Would Not, he was denounced by *Pope, *Fielding and ${ }^{*}$ Johnson, and his appointment as Poet Laureate in 1730 was the subject of much derision. He achieved varying success on the London stage as an eccentric comedian. He wrote the autobiographical Apology for the Life of $\mathrm{Mr}$ Colley Cibber, Comedian (1740).

Cicero, Marcus Tullius (106-43 BCE). Roman orator, politician and philosopher, born in Arpinum. Educated in Rome, Rhodes and Athens, he achieved early fame as an orator, served as quaestor of Sicily (75) and praetor of Rome (66). Although he was not of noble birth his ability won him the support of the senatorial party. As Consul (63) he exposed and suppressed the conspiracy of ${ }^{*}$ Catiline but was later exiled, and deprived of his property for having illegally passed death sentences on some of the conspirators. He served as Governor of Cilicia (52-51). He supported ${ }^{*}$ Pompey against ${ }^{*}$ Caesar during the civil war (49-48) and only returned to Rome on Caesar's invitation in 47. He supported the conspiracy against Caesar but did not take part in his murder. He led the republicans in opposition to the Second Triumvirate (Mark *Antony, ${ }^{*}$ Octavianus and *Lepidus) and was exiled and ultimately murdered on Antony's orders. His severed head and hands were displayed to the mob.

Vain but sincere, he proved an inept politician. Regarded as the greatest of Roman orators, 57 of his major speeches have survived. His vivacious letters and his books on law and philosophy (On Oratory, On the Republic, On Old Age, On Friendship) were of great historical significance and affected the development of Latin style. His writings were a major influence on the literature of the Renaissance, and *Petrarch wrote commentaries on his works.

Stockton, D., Cicero: A Political Biography. 1971.

Cid, El (Rodrigo Diaz de Vivar) (c.1040-1099). Spanish soldier. The name 'El Cid' is Arabic: 'seyyid' means 'lord'. He was also called 'El Cid Campeador': 'the lord champion'. So many legends have been told about him that it is difficult to determine the truth. He seems to have been a soldier of fortune who sold his services from time to time to both the Christians and the Moors. Noted for his skill in guerrilla warfare, he conquered and ruled Valencia 1094-99. Medieval legends incorrectly described him as a valiant champion of Christianity against the Moors.

Ciller, Tansu (1946- ). Turkish economist and politician. Educated in the US, she became an academic, wrote textbooks, succeeded ${ }^{*}$ Demirel as leader of the True Path party and was Prime Minister 1993-96.

Cimabue (= 'bull headed'), Giovanni (né Ceni de Pepo or Pepi) (c.1240-1302). Italian painter, born in Florence. Little has survived of his work apart from some mosaics in Pisa, and panel paintings and frescoes attributed to him in Florence and Assisi. His use of a golden background reveals the extent of Byzantine influence, but his figures are more natural than those of his predecessors. He was the teacher of ${ }^{*}$ Giotto according to *Vasari but there is hardly any documentary evidence of his life and work. ${ }^{*}$ Dante, his contemporary, refers to him as enjoying a fame that was overtaken by that of Giotto.

Battisti, E., Cimabue. 1967. 
Cimarosa, Domenico (1749-1801). Italian composer, born in Naples. He wrote about 60 operas, few of which are still performed; the best known is The Secret Marriage (1792), a comic opera. He became court conductor for ${ }^{*}$ Catherine the Great at St Petersburg. A popular oboe concerto was arranged by Sir John *Barbirolli from Cimarosa's music.

Cincinnatus, Lucius Quinctius (519-435 BCE). Roman politician and soldier. He was twice appointed dictator by the Senate to deal with invasions by the Aequians. On each occasion he returned to retirement in the country as soon as the military emergency was over. He was famous as a model of devotion to duty and the unselfish renunciation of power.

Cinna, Lucius Cornelius (d.84 BCE). Roman politician. A leader of the democratic party, he was Consul in 87 and in 86-84, and supported *Marius in the civil war against ${ }^{*}$ Sulla. His daughter Cornelia became the second wife of Julius ${ }^{*}$ Caesar, whose ambitions Cinna encouraged. He was killed during a mutiny of his own troops. His son Lucius Cornelius Cinna (d.44 BCE) was one of Caesar's assassins.

Cinthio (name used by Giovanni Battista Giraldi) (1504-1573). Italian novelist and poet, born in Ferrara. *Shakespeare's Othello is almost certainly drawn from a story in Cinthio's Hecatommithi (1565).

Cipriani, Amilcare (1844-1918). Italian revolutionary politician. A friend of ${ }^{*}$ Garibaldi, he fought for Italian unification, then served in the Paris Commune (1870-71). He spent many years in prison or in exile. He raised a battalion to fight for Greek independence from the Turks, and supported the Allied cause in World War I.

Citroën, André Gustave (1878-1935). French motorcar manufacturer. After World War I he began to produce small, low-priced cars, but in 1934 he went bankrupt and lost control of the company that still carries his name.

Cixi (pinyin: Tz’u Hsi in Wade-Giles) (1835-1908). Dowager empress of China 1861-1908. Daughter of an army officer, her personal name was Yehonala. A striking beauty who became the concubine of the weak and dissolute emperor Xianfeng (18311861) she achieved personal domination over him, bore his only son, Tongzhi (1856) and became regent when he succeeded at the age of five. She was probably responsible for the death of Tong and his wife (1875). She gained a new term of regency by placing her sister's four-year-old son Guangxu (né Zaitian) (1871-1908) on the throne. When he came of age (1889), she continued to rule in his name, maintaining authority with diplomatic skill to prevent further foreign encroachments. But there were major blows. China was defeated in a war with Japan (1894). In 1898 the emperor encouraged the 'Hundred Days' Reform movement (*Kang Yuwei) but the empress rallied reactionary forces, regained power and imprisoned Guangxu. There were even more disastrous effects from reprisals for the antiforeign Boxer Rebellion of 1900 (secretly encouraged by Cixi) which left the * Qing (Manchu) dynasty thoroughly discredited. She introduced some modest reforms including the abolition of footbinding for women (1905), which had never been part of Manchu custom. Guangxu died of arsenic poisoning, a day before Cixi, and the likeliest culprits were either the empress herself, despite her fragile health, or *Yüan Shikai. On the death of 'the Old Buddha', a two-year-old child (*Pu'yi, or Xuantong) was left to succeed. The revolution was in sight. She liked to be designated 'Motherly Auspicious Orthodox HeavenBlest Prosperous All-Nourishing Brightly Manifest Calm Sedate Perfect Long-Lived Respectful Reverend Worshipful Illustrious Exalted Empress Dowager'.

Chang, J., Empress Dowager Cixi. 2013.

Clair, René (né René-Lucien Chomotte) (18981981). French film director, born in Paris. Noted for developing a cinematic equivalent of the verbal cut and thrust of stage comedy, and for his poetic originality, his best known films are An Italian Straw Hat (1928), Le Million (1931), À nous la Liberté (1931), The Ghost Goes West (1935), And Then There Were None (1945) and La Beauté du Diable (1950). In 1960 he became the first film director to be elected to the Académie française.

Clarensol, G., and Regent, R., René Clair: Un Maître du Cinéma. 1952.

Clare, John (1793-1864). English poet. Called 'the Northamptonshire peasant poet', he became a farm boy at the age of seven, then worked as a gardener until he joined the local militia. He was a vagrant for some years, lived with gypsies and, after an unhappy love affair, became insane. He was confined in an asylum from 1837 . His simple and direct lyrics have an unusual purity of style and he published The Village Minstrel (1821) and Rural Muse (1827) which were well received. His best known lyric, written in the asylum, was: 'I am: yet what I am, who knows or cares?'.

Storey, E., A Right to Song: The Life of John Clare. 1982.

Clarence, George Plantagenet, Duke of (14491478). English prince. Son of Richard, Duke of *York, and brother of *Edward IV and *Richard III, he was also the son-in-law of the Earl of *Warwick ('The Kingmaker'). A vacillating character, he first supported Warwick against Edward, then changed sides and was ultimately imprisoned in the Tower on a charge of necromancy. He died in the Tower, traditionally having been 'drowned in a butt of Malmsey', presumably meaning that he drank himself to death. 


\section{Clarence, William Henry, Duke of see William IV}

Clarendon, 1st Earl of, Edward Hyde (1609-1674). English lawyer, politician and historian, born near Salisbury. The son of a squire, he was educated at Oxford, became a successful barrister and sat in the House of Commons 1640-42. Although he had criticised the practice of the monarchy of 'the personal government of *Charles I', he joined the King before the outbreak of the Civil War (1642) and tried to exert a moderating influence on him. Chancellor of the Exchequer 1642-43, he was the chief advisor to the future ${ }^{*}$ Charles II from 1646. After the Restoration he served as Chancellor of the Exchequer 1660-61 and Lord High Chancellor 1660-67, being the effective head of the government. His daughter, Anne Hyde (1637-1671) married the future *James II in 1660 and was the mother of queens ${ }^{*}$ Mary and ${ }^{*}$ Anne. $\mathrm{He}$ became Chancellor of Oxford University 1660-67 and received an earldom in 1661. The Clarendon Code which aimed at maintaining supremacy for the Church of England and denied toleration to Catholics and Dissenters was somewhat erroneously ascribed to him. King Charles began unjustly to blame him for every failure of national policy and dismissed him in 1667, the 'Cabal' ministry then taking office. Clarendon was impeached and fled to France, where he remained for the rest of his life. $\mathrm{He}$ wrote an important History of the Rebellion, published posthumously in 1704 , with a perpetual copyright to the University of Oxford, which became the basis of the Clarendon Press. He also wrote against *Hobbes. He died in Rouen.

Wormwald, B. H. G., Clarendon: Politics, History and Religion, 1640-1660. 1951; Ollard, R., Clarendon and His Friends. 1988.

Clark, Champ (né James Beauchamp Clark) (18501921). American Democratic politician, born in Kentucky. He represented Missouri in Congress 1893-95; 1897-1921 and was Speaker of the House of Representatives 1911-19. At the 1912 Democratic Convention he led on 30 ballots for the Presidential nomination but failed to win the two-thirds majority required, losing to Woodrow *Wilson on the 46th.

Clark, Colin Grant (1905-1989). English-Australian economist and statistician, born in London. Educated at Oxford, he worked with *Beveridge and *Keynes, developed 'gross national product' (GNP) as an economic indicator, divided his time between Britain and Australia and popularised (1940) A.G.B. Fisher's analysis of the labour force into primary, secondary and tertiary sectors.

Clark, George Rogers (1752-1818). American surveyor, soldier and frontiersman. He led successful military expeditions defending Kentucky during the War of Independence. He attacked the Shawnee Indians as well as the British, his aim being the extension of American settlement. After the war he was appointed an Indian commissioner, and helped to negotiate a treaty with the Shawnee tribe in 1786 . He lost his position as the result of intrigues, and in 1793 was part of an intrigue against Washington to persuade the US to join France in a war against Britain. He returned to Louisville on the Ohio River (which as Fort Nelson, had been one of his main war time bases) and lived in retirement.

Clark, Graeme Milbourne (1935- ). Australian medical scientist. Educated at Sydney University, he was Professor of Otolaryngology at Melbourne University 1970-2000 and developed a cochlear implant, known as the bionic ear, which restored hearing to the profoundly deaf. He was awarded an AC, FAA, FRS, the Lister Medal (2010) and the Lasker DeBakey Prize (2013).

Clark, Helen Elizabeth (1950- ). New Zealand Labour politician. She lectured at Auckland University, became an MP 1981-2009, Minister for Health 1989-90, Leader of the Opposition 1993-99 and Prime Minister 1999-2008. She was Director of the UN Development Programme 2009-17.

Clark, Joe (Charles Joseph) (1939- ). Canadian politician. A journalist and academic in Alberta, he was a Progressive Conservative MP 1972-93, Leader of the Opposition 1976-79 and 1980-83, and Prime Minister 1979-80. He became Minister for External Affairs 1984-91 and Minister for Constitutional Affairs 1991-93, under *Mulroney.

Clark, Kenneth Mackenzie Clark, Baron (19031983). English art historian, museum director and broadcaster, born in London. Educated at Oxford, he worked with Bernard *Berenson in Florence for two years, and became Director of the National Gallery, London 1934-45. He was Slade Professor of Fine Arts at Oxford University 1946-50 and 1961-62, Chairman of the Arts Council of Great Britain 1953-60 and of the Independent Television Authority 1954-57. His books included Leonardo da Vinci (1939), Landscape into Art (1949), Piero della Francesca (1951), The Nude (1956) and Rembrandt and the Italian Renaissance (1966). His television series and later book Civilisation (1969) were extremely popular. He received a $\mathrm{KCB}$ in 1938, the $\mathrm{CH}$ in 1959, a peerage in 1969 and the OM in 1976. His son Alan Kenneth Mackenzie Clark (1928-1999) was a controversial military historian and diarist, Conservative MP 1974-92, 1997-99, and a junior minister.

Secrest, M., Kenneth Clark. 1984.

Clark, (Charles) Manning (Hope) (1915-1991). Australian historian. Educated at Melbourne and Oxford, he was professor of Australian history at The Australian National University 1949-80, writing the massive but controversial $A$ History of Australia (1962-87, 6 vols). He was one of the original recipients of the AC (1973). 
Clark, Mark Wayne (1896-1984). American soldier. He served in World War I and was wounded, and in World War II became GOC of the US Fifth Army in the invasion of Italy (1943), later commanding all US troops in Italy 1944-45 and Austria 1945-47. He succeeded General M. B. *Ridgway as Supreme Commander of Allied Powers in the Far East and UN Commander-in-Chief in Korea 1952-53. He was in charge of the allied armies at the end of the Korean War. He wrote From the Danube to the Yalu (1954).

Clark, Sir Wilfred Edward Le Gros (1895-1971). English anatomist. Professor of Anatomy at Oxford University 1934-62, he wrote History of the Primates (1949) and The Fossil Evidence of Human Evolution (1955).

Clark, William (1770-1838). American explorer, born in Virginia. He joined the army in 1792 and fought against the Native Americans. With Meriwether *Lewis he went on an expedition to the northwest of the United States (1804-06). Leaving from St Louis, they explored the Missouri River to its source, crossed the Rocky Mountains and followed the Columbia River to the Pacific. They returned to St Louis and published a valuable scientific record of their expedition. Clark was Governor of Missouri Territory 1813-20 and Superintendent of Indian Affairs 1822-38.

Clarke, Sir Arthur C(harles) (1917-2008). British novelist and science writer. His predictions of future technological developments scored well for accuracy, including the communications satellite (1945). With Stanley *Kubrick he wrote 2001: A Space Odyssey (1968) as a novel and script for an important film. He published more than 50 books. He lived in Sri Lanka from 1956.

Clarke, John Morrison (1948-2017). AustralianNew Zealand satirist, actor, writer and film producer. A penetrating satirist in the tradition of * $\mathrm{S} w i f t$ and a master of language, he punctured political absurdity and pomposity on film, television, radio, books and journals.

Clarke, Kenneth Harry, Baron Clarke of Nottingham (1940- ). English Conservative politician. A barrister (QC), he was a Member of Parliament 1970-2019, Secretary of State for Health 1988-90, for Education and Science 1990-92, for Home Affairs 1992-93 and Chancellor of the Exchequer 1993-97. Under David ${ }^{*}$ Cameron, he served as Minister for Justice and Lord Chancellor 2010-12, then as Minister without Portfolio 201214 , then forced out, was consoled by the award of a $\mathrm{CH}$. His ministerial service was the fifth longest since *Palmerston.

Clarke, Marcus Andrew Hislop (1846-1881). Australian novelist, born in London. He became a journalist in Melbourne and wrote a powerful (but not completely accurate) novel about the convict settlement at Port Arthur (Tasmania), For the Term of His Natural Life (1874).

Claude, Georges (1870-1960). French chemist. He invented neon lighting and founded a company to exploit this invention. Among his other achievements was the invention of processes for the production of liquid air and of synthetic nitrates.

Claude Lorrain(e) (Claude Gellée) (1600-1662). French landscape painter, born in Nancy. Originally a pastrycook, he was trained in Rome and lived there from 1627. Most of his paintings were based on biblical, classical or medieval themes, for example The Judgment of Paris (1646), Seaport: The Embarkation of the Queen of Sheba (1648) and Landscape with the Marriage of Isaac and Rebekah (1648). He made thousands of fluent, almost impressionistic, drawings and was also an etcher. He died rich and about 250 of his paintings survive, most in England, where his idealised landscapes were much admired, especially by ${ }^{*}$ Turner

Claudel, Paul Louis Charles Marie (1868-1955). French poet, playwright and diplomat. He studied law, joined the diplomatic service in 1890 and spent most of his adult life abroad. He served as Minister to Brazil 1917-19, and Ambassador to Japan 1921-25, to the US 1926-33, and to Belgium 1933-35. He called himself a follower of *Rimbaud and it was the influence of the Symbolists which turned him away from materialism and the acceptance of a mechanical universe; however, he reacted against the decadence of the symbolists and his work reflects his devotion to Catholicism. His plays include Break of Noon (1908), The Tidings Brought to Mary (1916) and The Book of Christopher Columbus (1930). He was elected to the Académie française in 1946. He is important in the history of the theatre because of his use, in his later plays, of 'total theatre' stage presentation. His sister Camille Claudel (1864-1943) was a sculptor, mistress and model of *Rodin, and was confined in an asylum from 1913. The film Camille Claudel appeared in 1989.

Fowlie, W., Claudel. 1958.

Claudius I (Tiberius Claudius Drusus Nero Germanicus) (10 BCE-54 CE). Fourth Roman Emperor 41-54 CE. Born in Lugdunum (modern Lyon), son of Drusus, the brother of the Emperor *Tiberius, his supposed, or assumed, imbecility and physical incapacity saved him from the fate of many of his relatives. He wrote and studied history although his works (in Latin and Greek) are now lost. He became Emperor after *Caligula's assassination in 41. He built the Claudian aqueduct, commenced the conquest of Britain and was present for part of the campaign. He appeared to condone the viciousness and profligacy of his wife *Messalina, but when she publicly married a lover he had her executed. 
*Suetonius makes a confused reference to Claudius' attempt to expel Jews from Rome in $49 \mathrm{CE}$, because they had been 'causing disturbances at the instigation of Chrestus (sic)'. His second wife *Agrippina, who is believed to have poisoned him, was the mother of the next emperor, ${ }^{*}$ Nero.

Graves, R., I Claudius, Claudius the God. 1934.

Claudius II (Marcus Aurelius Claudius Gothicus) (d.270). Roman Emperor 268-70. Born in Sirmium, Pannonia (now in Serbia). A career soldier, he was Governor of Illyria, and was then appointed by the Emperor ${ }^{*}$ Gallienus as his military deputy. After senior officers murdered Gallienus, troops outside Milan proclaimed Claudius as emperor. He defeated the Goths at Naissus (269) and died of the plague in his birthplace.

Clausewitz, Carl Philipp Gottleib von (1780-1831). Prussian soldier and military strategist. Of Polish origin, he served as a staff officer under ${ }^{*}$ Scharnhorst and ${ }^{*}$ Gneisenau, and directed the Prussian army school at Berlin 1818-30. His famous book On War (Von Kriege, published posthumously by his widow in 1832-37) dealt with military strategy in an analytical manner and remained of major importance until World War I. He coined the aphorism 'War is the continuation of politics by other means'.

Parkinson, R., Clausewitz. 1971; Howard, M., Clausewitz. 1983; Strachan, H., Clausewitz, 2007.

Clausius, Rudolf Julius Emanuel (1822-1888). German mathematical physicist, born in Pomerania (now in Poland). He was educated in Berlin and Halle, and became a professor of physics at the Artillery and Engineering School, Berlin 1850-55. In 1850 he enunciated the First and Second Laws of Thermodynamics ('Work and heat are equivalent', 'Heat cannot of itself pass from a colder to a hotter body') precise formulations of discoveries by J. R. *Mayer, *Joule and ${ }^{*}$ Helmholtz, and of Sadi *Carnot respectively, just anticipating *Kelvin with the Second Law. In 1857 Clausius provided explanations of how electrolysis works and the kinetic theory of gases. He held professorships at Zürich 1855-67, Würzburg 1867-69 and Bonn 1869-88. In 1865 he proposed the concept of 'entropy', the measure of unavailability of energy for work within a system: with any change in the system, entropy increases (from order to disorder). Elected FRS, he was awarded the Copley Medal in 1879. A lunar crater is named for him.

Clay, Henry (1777-1852). American Whig politician, born in Virginia. He became a lawyer, lived in Kentucky from 1797, achieved great success as an advocate and served in the state legislature. He was a US senator 1806-07, 1810-11, 1831-42 and 1849-52, a Member of the House of Representatives 1811-14, 1815-21 and 1823-25, and three times Speaker 1811-14, 1815-20 and 1823-25. He was defeated each time he tried for the presidency, in
1824, 1832, 1840 and 1844. He insisted 'I would rather be right than President', and proved his point. When no candidate secured a majority in the 1824 poll, he urged his supporters in the House of Representatives to vote for J.Q. *Adams, rather than Andrew *Jackson who had led on the popular vote. Adams was elected and appointed Clay as US Secretary of State 1825-29. A great orator and magnetic personality, Clay was called 'The Great Pacificator' for his ability to effect compromises on issues that seemed likely to split the Union, e.g. the Tariff Bill of 1833, in which as an ardent protectionist he proposed that tariffs be lowered in order to appease the south. He also arranged the 1850 compromise, by which California was admitted to the Union as a nonslave state, and the Fugitive Slave Law was passed. His nephew Cassius Marcellus Clay (1810-1903) was an ardent abolitionist who edited an anti-slavery newspaper in Lexington.

van Deusen, G.G. The Life of Henry Clay. Repr. 1967.

Cleanthes (fl. c.300 BCE). Greek philosopher. A Stoic, he was the pupil of ${ }^{*}$ Zeno of Citium, and became a great teacher. St ${ }^{*}$ Paul quoted from one of his poems in the Acts of the Apostles.

Clegg, Sir Nick (Nicholas William Peter) (1967- ). English Liberal Democrat politician. Educated at Westminster School and Cambridge, he was MEP 1999-2004, MP 2005-17. He served as Deputy Prime Minister and Lord President of the Council 2010-15, in coalition with David *Cameron's Conservatives. In the elections of May 2015, the Liberals suffered a catastrophic loss, falling from 56 seats to 8 .

Clemenceau, Georges Benjamin (1841-1929).

French Radical politician, born in the Vendée. Son of a physician, he studied medicine in Paris, but went to the US as a journalist (1865-68) and taught for a time at a school in Connecticut. He was Mayor of Montmartre 1870-71 and a Member of the Chamber of Deputies 1876-93. He founded a radical newspaper in Paris, La Justice, in 1880, and became a remorseless critic of ministerial ineptitude. He forced the resignation of President *Grévy over an honours scandal (1887). He was defeated as a deputy in 1893 . The ferocity of his journalistic attacks earned him the soubriquet of 'The Tiger' and his revelations caused the fall of several ministries. He was a strong supporter of Captain *Dreyfus, unjustly charged with espionage. A senator 1902-20, he served as Minister of the Interior 1906, and Premier 1906-09, completing the separation of Church and State, but losing the support of the Socialists by using troops to break several strikes. During World War I he flayed government inefficiency in his newspapers, L'Homme Libré (suppressed by the censor in 1914) and L'Homme enchainé. At a critical moment in the war, when resistance was low (November 1917), President ${ }^{*}$ Poincaré appointed him as Premier and 
Minister of War, and he held these posts 1917-20. He proved a vigorous leader, mobilised all available resources, and crushed defeatism, but ruled as a virtual dictator, ignoring the legislature. $\mathrm{He}$ was responsible for the appointment of Marshal *Foch as Allied Generalissimo in March 1918. He was elected to the Académie française in 1918. After the war had been won he became President of the Paris Peace Conference (1919) and trenchantly criticised President *Wilson's proposals as impracticably idealistic. In January 1920 he was a candidate for President of the Republic, but received a derisory vote $(6 \%)$ from the French legislature, which chose the feeble Paul ${ }^{*}$ Deschanel. This was a left-handed compliment as his cynical advice at previous presidential elections had always been 'Vote for the stupidest'. He retired from public life, visited India and the US, and devoted himself to literature.

Monnerville, C., Clemenceau. 1968; Watson, D.R., Georges Clemenceau. 1974.

\section{Clemens, Samuel Langhorne see Twain, Mark}

Clement I, St (Clement of Rome) (c.30-100? CE). Pope 90-100? Thought to have been the fourth Bishop of Rome (i.e. Pope), assuming St *Peter to have been the first, an old tradition claims that he was consecrated by St Peter himself. He wrote an Epistle to the Church of Corinth (c.95) which has survived and demonstrates that the Roman see was exercising authority outside the boundaries of Italy. $\mathrm{He}$ is thought to have died in exile, perhaps in the Crimea.

Clement VII (Giulio de'Medici) (1478-1534). Pope 1523-34. Posthumous son of the murdered Giuliano de ${ }^{*}$ Medici, and a cousin of Pope ${ }^{*}$ Leo X, he was Archbishop of Florence 1512-34. He proved an indecisive pope and failed to cope with the problems raised by the Reformation. In 1527 Rome was sacked by the Imperial troops of ${ }^{*}$ Charles $\mathrm{V}$ but by 1529 Clement had become reconciled with Charles, and begged him to solve the problem of Lutheranism. He refused *Henry VIII's request for an annulment of his marriage to *Katherine of Aragon, the aunt of Charles $\mathrm{V}(1534)$.

Clementi, Muzio (1752-1832). Italian pianist and composer. He lived in England 1766-80, 1782$1804,1810-32$, and achieved great fame, first as a pianist and composer, later as a publisher, teacher and piano manufacturer. He was one of the founders of the modern school of piano playing, and composed 70 sonatas and a famous collection of studies Gradus ad Parnassum.

Cleopatra VII (Thea Philopater) (69-30 BCE). Queen of Egypt 51-30 BCE. Born in Alexandria, daughter of Ptolemy XII Auletes, she was a member of a Macedonian-Greek dynasty, but spoke Egyptian as well. She married her younger brother, Ptolemy Dionysus, in 51 but was forced into exile by her attracted the interest and attention of Julius *Caesar, and after he conquered Egypt in 48 she was restored to power. She became Caesar's mistress, bore him a son (Caesarion, $47 \mathrm{BCE}$ ) and lived with him in Rome 46-44. On returning to Egypt she married Ptolemy XIV, another of her brothers, but he was soon poisoned on her orders. In 42, she met Mark *Antony, they lived together for 12 years and had three children. Cleopatra's union with Mark Antony cost him much support in Rome, and after his heavy defeat at the battle of Actium (31) he committed suicide. Cleopatra tried to win the love of the victorious Octavian (*Augustus) but failed, and killed herself (according to tradition) by applying an asp to her breast. She was intelligent and widely read but subject to an overmastering ambition and sensuality. She is a major character in plays by ${ }^{*}$ Shakespeare and *Shaw, operas by *Händel and *Massenet and several films.

Volkmann, H., Cleopatra. 1958.

\section{Clerk Maxwell, James see Maxwell, James Clerk}

Cleveland, Barbara Villiers, 1st Duchess of (1641-1709). English noblewoman. The daughter of Viscount Grandison, she was the mistress of *Charles II from 1660-74 and her sons became Duke of Cleveland, Duke of Grafton and Duke of Northumberland. She became a Roman Catholic and her influence over Charles contributed to the fall of ${ }^{*}$ Clarendon. Among her other lovers was the future Duke of ${ }^{*}$ Marlborough.

Cleveland, (Stephen) Grover (1837-1908). 22nd and 24th President of the US 1885-89; 189397. Born at Caldwell, New Jersey, the son of a Presbyterian clergyman, he worked in a lawyer's office from the age of 17 and became an attorney in 1859. He served as Assistant District Attorney of Erie County, New York State, 1863-65, sheriff (and hangman, three times) of Erie County 1871-73, then returned to his law practice. In 1881 he began his extraordinary political career which took him in four years from a law office to the White House. As mayor of Buffalo 1881-82 he proved a notable reformer and gained the Democratic nomination for Governor of New York State, serving 1883-85. He was Democratic candidate for the presidency in 1884 , 1888 and 1892 . In the 1884 election he was narrowly elected and served as 22nd President 1885-89. In 1888 , although he gained a majority of the popular vote, he was defeated in the Electoral College and Benjamin *Harrison became President. In 1892 he won renomination at the Chicago Convention on the first ballot, despite fierce opposition from Tammany Hall in New York, defeated Harrison comfortably in the popular vote and the Electoral College (277 votes to 145) and became the only former President to serve non-consecutive terms. Extremely conservative on economic issues, he favoured a laissez-faire policy. He reformed the civil service, vetoed about 
300 Civil War pension bills, urged a policy of free trade (believing that protection was 'pampering employers'), and instituted the Interstate Commerce Commission (1887). His second term was marked by an economic depression. He secured the repeal of the Sherman Silver Purchase Bill and was anxious to maintain the gold standard. He used Federal troops to suppress the Pullman strike in Illinois (1894), despite the protests of J. P. *Altgeld, and invoked the *Monroe Doctrine against Great Britain in a dispute over the Venezuelan border (1895). He was virtually repudiated by his party in 1896 when W. J. *Bryan was nominated on a free-silver policy. He strongly opposed female suffrage. He retired to New Jersey, became a Trustee of Princeton University 1901-08 and of the Equitable Life Insurance Company, New York, 1905-08.

Cleveland, John (1613-1658). English poet. Champion of the Royalist cause during the Civil War, his best-known work is a series of political poems in heroic couplet: Rupertismus, The Rebel Scot and The King's Disguise.

Cliburn, Van (Harvey Lavan Cliburn, Jr) (19342013). American pianist, born in Louisiana. Brought up in Texas, he studied in New York, specialising in the Russian romantic tradition. Winning the first International Tchaikovsky Competition in Moscow (September 1958) made him an instant celebrity, highly honoured in the US and USSR. However, he kept playing the same repertoire that made him famous, suffered a 'burnout' in 1978 and withdrew from concerts until 1994.

Cliff, N., Moscow Nights. The Van Cliburn Story. 2017.

Clifford, Clark McAdams (1906-1998). American lawyer. Practising in Washington, he was an advisor to Presidents ${ }^{*}$ Truman, *Kennedy and ${ }^{*}$ Johnson, chair of the Foreign Intelligence Advisory Board 1963-68 and was Secretary of Defense 1968-69, when the US began to retract its military action in Vietnam. He was accused of conflict of interest in banking in 1991 which destroyed much of his reputation.

Clifford of Chudleigh, Thomas Clifford, 1st Baron (1630-1673). English politician and courtier. Educated at Oxford, he was MP 1660-72, served on several diplomatic missions for ${ }^{*}$ Charles II, and became a member of the 'Cabal' (Clifford, Arlington, Buckingham, Ashley, Lauderdale) ministry, as Commissioner for the Treasury 1667-72 and Lord Treasurer 1672-73. He became a Roman Catholic about 1670 . He was a sincere but ineffective minister.

Clinton, Bill (William Jefferson Blythe, Jr) (1946- ). 42nd President of the US 1993-2001. Born in Hope, Arkansas, he took his step-father's name after his widowed mother remarried. Educated at Hot Springs High School and Georgetown University, he won a Rhodes scholarship to Oxford (where he campaigned against the Vietnam war) and completed legal studies at Yale. In November 1975, he married Hillary Diane Rodham (Hillary ${ }^{*}$ Clinton). He was a professor at the University of Arkansas Law School 1974-76, Attorney-General of Arkansas 1977-79 and Governor of Arkansas 1979-81, 1983-93. In 1992 he won the Democratic nomination for president against a weak field, at a time when George ${ }^{*}$ Bush was thought to be unbeatable. In November, he defeated Bush 43 to 38 per cent in the popular vote, with $\mathrm{H}$. Ross *Perot on 19 per cent, after a vigorous campaign marked by strong personal attacks. Clinton concentrated on the US economy and promised an era of 'hope and change'. After a shaky start as President, he achieved some successes in foreign policy, backed the Middle East peace and supported Boris *Yeltsin. The Republicans won control of Congress in 1994 with a hard Right agenda, but this victory soon caused a political reaction, Clinton moved to the centre on policy issues and recovered lost popularity. In November 1996 he became the first Democrat since Franklin *Roosevelt to be elected for a second term, winning 49 per cent of the vote, in a low turnout, against Bob ${ }^{*}$ Dole and Perot. His second term was distracted by allegations of sexual impropriety ('Zippergate') by Paula Jones, Monica Lewinsky, Kathleen Willey and others. Fears of a second Gulf War in February 1998 were averted (or postponed) by the intervention of Kofi *Annan. Clinton, pursued by special prosecutor Kenneth Starr, gave evidence to a grand jury (August 1998) and made damaging admissions about sexual relations with Lewinsky. Starr's report alleged 15 offences by Clinton, and the House of Representatives decided to conduct impeachment hearings. Despite Democrat gains in the 1998 Congressional elections, in December the House, voting on party lines, impeached Clinton on two counts, perjury and obstruction of justice. (Air attacks on Baghdad at this time consolidated Saddam's position.) After trial in the Senate JanuaryFebruary 1999, the prosecution failed on both counts, but Clinton suffered heavy personal damage. NATO missile attacks and bombing of Serbia (AprilJune 1999) following 'ethnic cleansing' in Kosovo appeared at first to strengthen ${ }^{*}$ Milosevic, but led to a peace agreement in which NATO and Russian troops occupied Kosovo under UN auspices. The Clinton Foundation was founded in 2001 and has developed programs for tackling problems of global health, education and exposure to climate change. In 2008, the Clintons campaigned for Barack *Obama after Hillary failed to win the Democratic nomintion, and used networking skills to promote her candidacy in 2016. In 14 Presidential rankings by US historians and political scientists, Clinton scored No. 17 in the aggregate.

Clinton, B., My Life. 2004; Branch, T., The Clinton Tapes. 2009.

Clinton, De Witt (1769-1828). American lawyer. US Senator from New York 1802-03, Mayor of New York City 1803-07, 1808-10, 1811-15, and 
State Governor 1817-23, 1825-28, he was Federalist candidate for president in 1812, against *Madison. He first put forward the idea of a canal linking the northeast coast with the Great Lakes through Lake Erie. The State Legislature accepted a scheme in 1816 and Clinton supervised the project himself and opened the Erie Canal in 1825 . He was also noted for his interest in education and the dissemination of the arts and sciences.

Clinton, George (1739-1812). American politician, born in New York. Lawyer and soldier, he was Governor of New York 1777-95; 1801-04 (a record period), opposed ratification of the US Constitution and became a founder of the emerging DemocraticRepublican Party. In 1792, he was a candidate for Vice President (losing to John *Adams), but won in 1804 and 1808, serving under *Jefferson and *Madison 1805-12, and dying in office. De Witt ${ }^{*}$ Clinton was a nephew.

Clinton, Sir Henry (c.1738-1795). English soldier. A Member of Parliament 1772-84 and 1790-94, he was an indecisive Commander-in-Chief of British Forces in North America 1778-81, and wrote a narrative of the campaign.

Clinton, Hillary (Diane) (née Rodham) (1947- ). American lawyer and Democratic politician, born in Chicago. Educated at Wellesley College (Mass.) and Yale, in 1964 she campaigned for Barry *Goldwater, but became a Democrat and a lawyer for the Senate's *Nixon impeachment team. She married Bill ${ }^{*}$ Clinton in 1975. After her husband's election as President (1992), as First Lady she proposed comprehensive changes in health insurance which were blocked in Congress and she came under bitter personal attack about property dealings in Arkansas in the 1970s ('Whitewater'), which intensified after the Republican victory in mid-term elections in 1994. At the end of her husband's term, she was elected as US Senator from New York, serving 2001-09. She campaigned for the Democratic presidential nomination in 2008, and although initially regarded as a clear favourite, lost to Barack *Obama. She then served as his effective but controversial Secretary of State 2009-13, declining reappointment. In April 2015 she launched her campaign for the Democratic Party Presidential nomination. Overwhelmingly supported by the party establishment and in the Southern States, she was challenged by Senator Bernie *Sanders who appealed to the 'outsider' vote and young people. By June 2016 she had enough pledged delegates to secure the nomination-the first woman endorsed for President by a major party. In November, despite a popular vote of 65.8 million, the second highest figure in US history, a 2.1 per cent plurality, winning 20 states and the District of Columbia, she was defeated by Donald *Trump in the Electoral College.

Clinton, H. R., Living History. 2003, Hard Choices. 2014; Aller, J., and Parnes, A., HRC. 2014.
Clive, Robert, 1st Baron Clive of Plassey (Irish peerage) (1725-1774). English soldier and administrator, born near Market Drayton, Shropshire. Son of a squire, and MP, he was educated at the Merchant Taylors' School, became extremely unhappy there, and in 1743 joined the East India Company as a 'writer' (i.e. clerk administrator). He worked in Madras 1743-46 but obtained an ensign's commission in the Indian army after fighting began with *Dupleix' French troops. After training a large force of sepoys he defeated 10,000 French and Indian troops at Arcot in 1751 in a clash that resulted from a dispute over the control of the Carnatic. He returned to England in 1753.

When the Seven Years' War began in Europe, fighting between the British and French soon resumed in India. Clive was Lieutenant Governor of Fort St David (near Chennai) 1755-57. In June 1756, 64 British civilians were locked in the tiny 'Black Hole of Calcutta' and only 21 survived. Clive was ordered to remove the psychopathic Nawab of Bengal, Siraj udDaula (1733-1757) who was probably responsible. Clive's troops defeated the Nawab at Palashi (Plassey) in June 1757, after Siraj's commander Mir Jafar (c.1691-1765) was bribed to change allegiance: the large state of Bengal then came under EIC control, Mir Jafa became Nawab and Siraj was murdered. Clive became Commander-in-Chief in India 1756-60.

He returned to England in 1760, with about $£ 48,000,000$ in 2021 values (Horace *Walpole called him 'a Croesus'), and bought several estates. He had been a Member of Parliament 1754-55, was soon re-elected 1761-74 and awarded an Irish peerage in 1762.

In India for the third time, he was Commander-inChief and Governor of Bengal (technically, Governor of the Presidency of Fort William) 1765-67. He expanded British control over Bengal, Bihar and Orissa, proposed reforms in administration, reducing the role of the EIC and prohibiting corruption, on which he had expert knowledge. Oddly, he never liked India, made no attempt to learn its languages and was profoundly incurious about its history and culture. But he was a brilliant fighter with an exceptional grasp of strategy and human weakness.

He was attacked, somewhat unfairly, for the EIC's role in the catastrophic famine in Bengal in 1780 in which one-fifth of the population died but defended himself brilliantly before a Parliamentary Select Committee ('Mr. Chairman, at this moment I stand astonished by my own moderation'). A motion to censure Clive was defeated 155 votes to 95 .

Suffering from depression and gout, addicted to opium for pain relief, he travelled through Europe, collected artworks. Back in London he committed suicide by cutting his throat with a pen-knife. (He had twice attempted suicide years earlier). 
'Clive' became a popular given name, he was commemorated in Westminster Abbey, the subject of a poem by ${ }^{*}$ Browning, plays and films (generally admiring). Many statues were erected, now under threat. His giant tortoise Adwaita, died in 2006.

His son, Edward Clive, 1st Earl of Powis (17541839) was Governor of Madras 1798-1803, raised to an earldom in 1804 . His wife's inheritance, Powis Castle, Wales, housed a unique collection of artefacts looted from India. He voted against the Reform Bill (1832).

Harvey, R., Clive: The Life and Death of a British Emperor. 1998.

Clodius (Pulcher), Publius (c.93-52 BCE). Roman politician. A leader of the democratic party, he became a supporter of ${ }^{*}$ Caesar and an opponent of *Pompey and *Cicero. As Tribune of the People 5957 , he proved to be a capable demagogue, revived the guilds, ordered free gifts of corn for the people, and sent Cicero into exile. He organised street gangs to help him in his campaign for the Consulate but was killed by the rival gang of Milo.

Cloete, (Edward Fairly) Stuart (Graham) (18971976). South African novelist. His novels include Turning Wheels (1937), The Hill of Doves (1941), The African Giant (1955), The Mask (1957), Rags of Glory (1963) and The Abductors (1966). He was a strong critic of apartheid and the Boer tradition.

Cloete, S., Victorian Son. 1972.

Close, 'Chuck' (Charles Thomas) (1940- ). American painter and photographer, born in Washington State. Working in a variety of forms, including collage, woodcuts, lithographs, etchings, finger paintings, tapestry and mosaics, he was known for his massive portraits (e.g. Philip *Glass, Barack *Obama) and there were many international exhibitions.

Clough, Arthur Hugh (1819-1861). English poet. Brought up in the US, he was educated at Rugby and Oxford, and became the friend of *Carlyle, *Emerson and Matthew *Arnold. A civil servant, he was a melancholy sceptic whose verse reveals his preoccupation with ethical questions. He revised *Dryden's translation of Plutarch's Lives. His sister, Anne Jemima Clough (1820-1892) became the first Principal of Newnham College, Cambridge 1871-92.

Chorley, K., Arthur Hugh Clough. 1962.

Clovis I (Germanic form Hlodwig, Latinised as Louis) (466-511). King of the Franks c.481-511. Born in Tournai (modern Belgium), son of Childéric I, ruler of the Salian Franks, he murdered rivals to the succession, defeated the Gallo-Roman rulers of the Kingdom of Soissons in 486, made Paris his capital and won territory from the Alemanni, Burgundians and Visigoths. He married Clothilde, a Christian, and was baptised himself in Reims in 496. (This event led to a controversial commemoration in 1996 when Clovis was hailed by the ultra-Right as the founder of Christian France.) He opposed the Arians and convened a Church council at Orléans (511).

Verseuil, J., Clovis. 1992.

\section{Clyde, 1st Baron see Campbell, Colin}

Clynes, J(ohn) R(obert) (1869-1949). English Labour politician. Son of an Irish labourer, he worked in cotton mills from the age of 10 , self-educated but a great reader, he became a union organiser and a Labour MP 1906-31, 1935-45. He led the Labour Party 1921-22, during Ramsay *MacDonald's absence from Parliament, but stood down to become deputy Leader 1922-32. Lord Privy Seal 1924 and Home Secretary 1929-31, he died in poverty.

Cnut (or Knud = 'knot', also written as Canute) (c.995-1035). King of England 1016-35, Denmark 1018-35 and Norway 1028-35. Son of *Sweyn Forkbeard, King of Denmark, and a Polish mother, he invaded England in 1015, divided the kingdom with *Edmund Ironside and on his death became sole king. He codified law, encouraged the Church and (bigamously) married *Æthelred's widow Emma. He occupied Norway after a civil war in 1028. The legend of him attempting to command the tide to turn back has been misunderstood: he was ironically pointing out to fawning courtiers that there were limits to his power.

Bolton, T., Cnut the Great. 2017.

Coates, Albert (1882-1953). English conductor, born in St Petersburg. He worked in business and studied in both England and Russia, then became a pupil of *Nikisch in Germany. He conducted the St Petersburg Opera 1910-19, toured Europe and the US and made many recordings of *Wagner and the great Russians. He lived in South Africa 1947-53. His disappearance from recording catalogues is hard to fathom.

Coates, Eric (1886-1957). English composer. His light music gained wide popularity and included the London Suite, London Again, The Three Elizabeths and The Three Bears Suite.

Coates, (Joseph) Gordon (1878-1943). New Zealand politician. A Member of Parliament 191143, decorated in World War I, he became Leader of the Reform Party and Prime Minister 1925-28, the first born in New Zealand. As Minister for Finance 1933-35 he attempted to tackle the Depression's impact and during World War II served under Labour as a non-party minister 1940-43.

Cobb, John (1899-1952). English racing motorist. He broke the world land speed record, 1947, by travelling at $634.4 \mathrm{~km}$ p.h.in a Napier-Railton. He was killed in a motor boat accident on Loch Ness, Scotland. 
Cobbett, William (1763-1835). English pamphleteer and Radical politician. After service in the army in Canada 1783-91, he became a Tory propagandist, under the pen name of Peter Porcupine, and attacked all forms of radicalism and democracy. After 1804, he joined the radical cause, was imprisoned for denouncing flogging in the army and was later acquitted on a charge of sedition. A Member in the first reformed Parliament 1832-35 he wrote extensively on political and agricultural subjects. Rural Rides (1822-28), published as a series of pamphlets, is masterly.

Cole, G. D. H., The Life of William Cobbett. 3rd ed. 1947.

Cobden, Richard (1804-1865). English Liberal politician. A Member of Parliament 1841-65, the co-founder, with John ${ }^{*}$ Bright, of the Anti-Corn Law League, he became known as 'The Apostle of Free Trade'. Prominent in opposing the Crimean War (which brought him much unpopularity), he was an active worker for international peace and disarmament. Although he regarded himself as a radical, he firmly believed in 'laissez faire' and opposed trade unions and factory legislation, which he thought were opposed to liberty of contract. He supported the North in the US Civil War.

Hinde, W., Richard Cobden. 1987.

Cobham, Sir Alan John (1894-1973). English aviator. After serving in the Royal Flying Corps during World War I, he entered civil aviation, took part in many notable long distance flights and won the Britannia Trophy in 1926 for his flight to Australia and back. He pioneered the London-Cape Town route and devised a system for refuelling planes in the air.

Cochrane, Thomas, 10th Earl of Dundonald (17751860). Scottish sailor. After many brilliant exploits in which he captured over 50 French and Spanish ships, he became a Whig Member of Parliament 1805-16. Deprived of his naval command in 1816, after being tried for fraud he was imprisoned for one year. On his release he went to South America, where the struggle against Spanish domination was in progress, and served as Commander of the Chilean Navy 1818-22, and of the Brazilian Navy 1823-25, contributing much to the success of the nationalist risings. On returning to Europe he became Commander of the Greek Navy 1827-28, but when the Whigs came to power in England he was reinstated in the British Navy (1832) and served as Commander-in-Chief of the North American Station 1848-51.

Cockcroft, Sir John Douglas (1897-1967). English physicist. Educated at Manchester and St John's College, Cambridge, he worked with *Rutherford at the Cavendish Laboratory. In 1932, with E. T. S. Walton, he succeeded in splitting the nucleus
Cambridge 1939-46, during the war he worked on the production of the atomic bomb in the US. He was director of the UK Atomic Energy Establishment at Harwell 1946-59 and first Master of Churchill College, Cambridge 1959-67. He shared the Nobel Prize for Physics in 1951 with Walton, received the $\mathrm{OM}$ in 1957, and won the Ford 'Atoms for Peace' Award of \$US75,000 in 1961. He was Chancellor of The Australian National University, Canberra 1961-65.

Cockerell, Sir Christopher Sydney (1910-1999). English engineer. He was a pioneer of the amphibious hovercraft that can travel across a variety of surfaces on a cushion of air. The air is produced by jets. Cockerell was knighted in 1969, 10 years after a prototype hovercraft crossed the English Channel.

Cocteau, Jean (1889-1963). French poet, ballet designer, novelist, playwright, actor, film producer and graphic artist, born near Paris. He published his first volume of poetry La Lampe d'Aladin in 1908, was associated with *Diaghilev's Ballets Russes and served as an ambulance driver in World War I. His ballets include Parade (1917), with music by Erik *Satie, sets by Pablo ${ }^{*}$ Picasso and staged by ${ }^{*}$ Diaghilev, Le Boeuf sur le toit $\left(1920,{ }^{*}\right.$ Milhaud/ ${ }^{*}$ Dufy) and Les Biches (1924, *Poulenc). He wrote eight novels of which Thomas l'imposteur (1923) and Les Enfants Terribles (1929, filmed 1950) are the best known. His opera-oratorio Oedipus Rex (1927) was set to music by ${ }^{*}$ Stravinsky and remains in the repertoire. Several of his plays were filmed under his own direction e.g. Orphée (1926, 1950), and Les Parents terribles (1938, 1948), while others were successful on television and radio, e.g. La Voix Humaine (1930) and La Machine á écrire (The Typewriter, 1941). His beautiful but obscure films were based on a private mythology not always shared with the audience. The best known were Le Sang d'un poete (1932), L 'Eternal retour (1944) and La Belle et la bete (1945). In the 1950s he was active as a graphic artist and fresco painter. After decades as an 'enfant terrible' and foe of artistic orthodoxy, Cocteau accepted immortalisation by election to the Académie française (1955).

Cody, William F(rederick) (1846-1917). American showman, known as 'Buffalo Bill'. Originally an Indian scout, he gained his title by supplying buffalo meat to railway workers. From 1883 he organised a 'Wild West Show' which stimulated wide interest in 'Cowboys and Indians'.

Coen, Jan Pieterszoon (1587-1629). Dutch colonialist. He worked for the Dutch East India Company (Vereenigde Oostindische Compagnie: VOC) and was twice Governor-General of the Dutch East Indies 1618-23; 1627-29. He founded the capital, Batavia, established monopolies in nutmeg and cloves, and, using Japanese mercenaries, massacred 15,000 people in the conquest of the Banda Islands. 
Coen, Joel (1954- ) and Ethan Coen (1957- ). American film directors, born in Minneapolis. Their films include Raising Arizona (1987), Barton Fink (1991), Fargo (1996) and O Brother, Where Art Thou? (2000). They won the Academy Award for No Country for Old Men in 2008.

Coetzee, J(ohn) M(axwell) (1940- ). South AfricanAustralian novelist and critic, born in Cape Town. Educated at the University of Cape Town and in Texas, he worked in London and for IBM as a computer programmer. He taught English at Buffalo, New York and in Cape Town and held a chair in Chicago. He won the Booker Prize twice, for Life \& Times of Michael K (1983) and for Disgrace (1999). Other novels include Waiting for the Barbarians (1980), Master of Petersburg (1994), Elizabeth Costello (2003), Slow Man (2005), Diary of a Bad Year (2007) and The Childhood of Jesus (2013). He relocated to Adelaide in 2002 and became an Australian citizen in 2006. Awarded the Nobel Prize for Literature in 2003, the citation calls him 'a scrupulous doubter, ruthless in his criticism of the cruel rationalism and cosmetic morality of western civilisation'. He has published outstanding volumes of essays and literary criticism.

Kannemeyer, J. C., J. M. Coetzee. 2012; Attwell, J.C., J. M. Coetzee and the Life of Writing. 2015.

Coeur, Jacques (c.1395-1456). French merchant and pioneer capitalist, born in Bourges. Son of a merchant, he travelled through the Mediterranean and the Levant. His investments included ship-owning, salt, tax collecting, mining, shipping, arms, money changing, importing furs, silk, jewels and artefacts, and property in Paris, Marseille, Montpellier, Lyon and Tours. He was a minister to ${ }^{*}$ Charles VII, then accused of disloyalty, tortured and imprisoned. $\mathrm{He}$ escaped and died on the Greek island of Chios. His palace in Bourges, begun in 1444, is the finest surviving example of medieval domestic architecture, and a mansion in Paris (4e arrondissment) is still in use.

Coggan, (Frederick) Donald, Baron Coggan (1909-2000). English prelate. He was Principal of the London School of Divinity 1944-56, Bishop of Bradford 1956-61, Archbishop of York 1961-74 and Archbishop of Canterbury 1974-80. His theology was evangelical, and, although concerned with social issues, he stressed that a changed society can only come from the conversion of the individual to the service of God. His works include Sinews of Faith (1969) and The Heart of the Christian Faith (1978).

Cohan, George M(ichael) (1878-1942). American songwriter, producer and performer, born in Rhode Island. Of Irish Catholic descent, he worked in Tin Pan Alley and composed more than 150 songs, including Over There and I'm a Yankee Doodle Dandy.
Cohen, Leonard (1934-2016). Canadian singer, novelist and poet, born in Montréal. Relatively late in securing recognition, he recorded and toured for the first time in 1970 but soon had a great reputation in a variety of art forms and received many honours including the Canadian CC (2003). His novels include The Favourite Game (1963) and Beautiful Losers (1966).

Coke, Sir Edward (1552-1634). English lawyer and politician. A Member of Parliament 1580-1606, he was Speaker of the House of Commons 1593-94 and Attorney-General 1594-1606, proving to be a zealous supporter of the royal prerogative and being responsible for the prosecution of ${ }^{*}$ Essex, *Raleigh and the Gunpowder Plot conspirators. However, on his appointment as Chief Justice of the Court of Common Pleas, in 1606, he became the champion of the Common Law in opposition to the exercise of the Crown's prerogative rights. In 1610 he decided that the king's proclamations could not override laws made by Parliament and that ecclesiastical causes must be subject to the jurisdiction of the secular courts. He was promoted to the office of Chief Justice of the King's Bench Division 1613-16 where it was hoped that he would, prove less troublesome to *James I and his advisors. His fearless defiance of those orders of the king which he regarded as illegal made the supporters of the Divine Right determined to secure his removal from office. In 1616 several trivial charges prepared by ${ }^{*}$ Bacon, the Attorney-General, were brought against him and he was dismissed. A leading member of Parliament 1621-29, he denounced interference with the liberty of the House of Commons. In 1622 he was seized and imprisoned as a result of his attacks. He vigorously opposed the Duke of *Buckingham's monopoly of office and favour, describing him as the grievance of grievances'. Coke's law reports helped to systematise and consolidate the Common Law of England and his writings on jurisprudence, such as the four Institutes are well known, especially Coke on Littleton.

Holdsworth, W. S., A History of English Law. 2nd ed. Vol. 5. 1937; Throne, S. E., Sir Edward Coke. 1957.

Coke, Thomas William, 1st Earl of Leicester of Holkham (1752-1842). English agricultural innovator. He represented Norfolk as a Whig MP 1776-84, 1790-1832, but is much better known for the many farming improvements he introduced on his Norfolk estate of Holkham. By use of bone meal and fertilisers, by sowing seeds in drills, by planting sainfoin and clover to enable larger numbers of livestock to be maintained, by many other new or improved methods, he so increased the value of his estate that in 40 years from 1776 the rents are said to have risen from about $£ 2,000$ to $£ 20,000$. His example, propagated through 'open days' and tours of inspection, led to a general improvement in British farming. He was a Radical, and was denied a peerage until *William IV died. 
Colbert, Jean Baptiste (1619-1683). French administrator. After the death of *Mazarin he became the Chief Minister of *Louis XIV. As Controller General of Finance 1665-83, he repaid most of the national debt, reorganised the French Navy, established new colonies in Africa and America, encouraged shipbuilding and foreign trade and reformed the French administrative service. To finance these reforms he had to introduce higher taxation which made him unpopular.

Mongredien, G., Colbert, 1619-1683. 1963.

Cole, G(eorge) D(ouglas) H(oward) (1889-1959). English economist. The author of The Common People (with Raymond Postgate) (1938) and The Intelligent Man's Guide to the Post War World (1947), he became professor of social and political theory at Oxford University in 1944 and was active in the Labour Party and the Fabian Society. With his wife Dame Margaret Isabel Cole (née Postgate) (1893-1980) he wrote 29 detective novels (1923-42).

Cole, Nat(haniel Adams) 'King' (1919-1965). American singer and jazz pianist, born in Montgomery, Alabama. He first gained recognition as the leader of a jazz trio in the 1930s. Later he performed mainly as a singer. He had wide popular success with his more sentimental songs.

Coleridge, Samuel Taylor (1772-1834). English poet and philosopher, born in Devonshire. After leaving Jesus College, Cambridge, he became a friend of Robert *Southey and William *Wordsworth. Keenly interested in religion and philosophy, between 1794 and 1804 he was attracted by Unitarianism, preached for a time, planned to become a minister, then became agnostic. Involved in plans to set up a utopian community, a Pantisocracy, in Pennsylvania, his enthusiasm soon waned.

With Wordsworth he published Lyrical Ballads (1798) and the volume was a major contribution to the Romantic revival in English literature. All Coleridge's great poems were written in an 18-month burst: 'Kubla Khan' (1797-98), 'The Rime of the Ancient Mariner' (1797-98), 'Christabel' (1797; 1800), 'Frost at Midnight' (1798) and 'The Nightingale' (1798). He claimed that 'Kubla Khan' was part of a longer poem that he heard in an opium dream.

After 1800 he was completely addicted to opium and was dependent on the charity of friends. He spent time in Malta and Italy (1804-06) attempting to recover.

At his height he was celebrated as a dazzling conversationalist but later, because of debt and increasing ill-health, he became a melancholic. His principles of literary criticism are to be found in his Biographia Literaria (1817) and he is regarded as the founder of the modern school of Shakespearian criticism. He was also interested in metaphysics and translated works by ${ }^{*}$ Schiller, ${ }^{*}$ Kant and ${ }^{*}$ Lessing. $\mathrm{He}$ popularised the word 'psychology' (1800). Although most of his poetry is of uneven quality, his masterpieces have a mysterious and magical beauty that echoes the music of a visionary world.

Bate, W. J., Coleridge. 1968; Wilson Knight, G., The Starlit Dome. Repr. 1971; Holmes, R., Coleridge: Early Visions. 1989; Holmes, R., Darker Reflections. 1998.

Coleridge-Taylor, Samuel (1875-1912). English composer, of West African descent. His cantata Hiawatha achieved great success and his Little Concert Suite is often performed.

Colet, John (1466-1519). English theologian. A friend of *Erasmus and Thomas *More, he revived the humanist tradition in the English Church and his liberal opinions influenced the Reformation in England. He was Dean of St Paul's Cathedral 150519, and founder of St Paul's School, London.

Colette, Sidonie Gabrielle Claudine (1873-1954). French novelist. She began her working life as a music hall actor. Her first husband, Henry GauthierVillars (1859-1931), discovered her talent for writing and, by keeping her prisoner, forced her to produce novels which he published under his pen name of 'Willy'. After their divorce she continued to write and the semi-autobiographical 'Claudine' novels became very popular. A brilliant observer, she wrote always of love, with a masterly understanding of human motives. Her books include The Vagrant (1912), Chéri (1929), Claudine in Paris (1931), and The Cat (1936). Gigi (1951) was the basis of a highly successful musical film.

Richardson, J., Colette. 1982; Gilmour, J., Colette's France. Her lives, her loves. 2013.

Colfax, Schuyler (1823-1885). American Republican politician, born in New York City. He became a journalist, Congressman from Indiana 1855-69 and Speaker of the House of Representatives 1863-69. He was Vice President of the US 1869-73, serving with Ulysses $S .{ }^{*}$ Grant.

Coligny, Gaspard de (1519-1572). French soldier, admiral and Huguenot leader. Brother of a cardinal, noted as a fearless leader and imprisoned in Spain 1557-59, he became a Calvinist convert. From 1560 he was joint leader of the Huguenots with Louis I, Prince of *Condé, and actively promoted the Protestant cause. Although he was a favourite of *Charles IX, he was murdered by servants of the Duc de Guise at the St Bartholomew's Day massacre.

Colijn, Hendrikus (1869-1944). Dutch Christian Democratic politician. Prime Minister 1925-26 and 1933-39, he died in German captivity. 
Collingwood, Cuthbert Collingwood, Ist Baron (1750-1810). English sailor. After *Nelson's death he became Commander-in-Chief of the Mediterranean Fleet 1805-10.

Collins, Michael (1890-1922). Irish nationalist politician. He worked in London 1906-16 as a clerk in the post office and a bank, returning to Ireland to take part in the Dublin rising and was interned briefly. Elected to the House of Commons (1918) as a Sinn Féin MP, he refused to sit in Westminster but, with other Irish Nationalists, set up the Dáil Éireann (1919) and proclaimed the Republic. Under *de Valera, he became Minister for Home Affairs 1919 and Finance 1919-22, general of the Irish volunteer army and director of intelligence for the Irish Republican Army (IRA). In December 1921, with Arthur * Griffith, he negotiated a treaty with *Lloyd George that partitioned Ireland and set up the Irish Free State, with Dominion status. When de Valera repudiated the treaty, demanding full independence and the formation of a Republic, civil war broke out between the two Irish factions and Collins commanded the Free State forces. On the death of Griffith, he became head of the Free State Government but only 10 days later he was ambushed by soldiers of the Irish Republican Army and murdered.

Taylor, R. Michael Collins. 1958; Coogan, T. P., Michael Collins. 1996.

Collins, (William) Wilkie (1824-1889). English novelist, born in London. Son of a successful painter, he was trained for the law, but worked in publishing and was befriended by *Dickens, who (with ${ }^{*}$ Poe) became a major influence. His melodramatic novels were great successes. The Woman in White (1860) is based on a personal experience: while he was walking with Dickens one night a distraught young woman, dressed in white, begged him for help, claiming that her life was threatened. On this theme he wrote a dramatic story, featuring the memorable villain, Count Fosco. The Moonstone (1868) has been described by T. S. *Eliot as 'the first, the longest and the best of modern English detective novels'.

Peters, C., The King of Inventors: A Life of Wilkie Collins. 2017; Ackroyd, P., Wilkie Collins. 2017.

Collor de Mello, Fernando (1949- ). Brazilian politician, born in Rio de Janeiro. His family owned newspapers and magazines, and he entered politics in Alagoas State, as a mayor 1979-82, Federal Deputy 1982-86 and Governor 1986-89. He formed the National Reconstruction Party and after a sophisticated media campaign was elected President November-December 1989 in Brazil's first free direct election since 1960. Collor appeared to have cast off his playboy image, but serious accusations of corruption were raised in the Congress and in December 1992 he resigned to avoid impeachment.
Colman, Ronald (1891-1958). English actor, resident in Hollywood. He was well known for his romantic roles in films such as Beau Geste, Random Harvest and The Prisoner of Zenda.

Colombo, Matteo Realdo (1510-1559). Italian anatomist, born in Cremona. Son of an apothecary, he studied medicine under *Vesalius in Padua, succeeded him there in 1544 , then moved to Pisa (1546). In 1549 he established himself in Rome, where he spent the rest of his life. His fame rests on his great skill and experience in dissection, vivisection and autopsy. In his only book, the De Re Anatomica (published posthumously in 1559) he offered excellent descriptions of the eye, the pleura, and the peritoneum. But he is best known for his discovery of the course of the passage of blood from the right cardiac ventricle to the left through the lungs ('the pulmonary circuit'). From this he drew the important conclusion that it is not in the heart, but in the lungs, that venous blood is mixed with air to become arterial blood. He thus switched the focus of attention away from the heart to the lungs. His vivisections also led him to understanding the heartbeat. He emphasised the contraction of the heart, and the importance of its expulsion of materials. Such views were later taken up by *Harvey.

Colt, Samuel (1814-1862). American inventor. In 1835 he produced the famous revolver named after him and adopted by the US Army.

Coltrane, John (William) (1926-1967). American jazz saxophonist, born in North Carolina. He made his professional debut in 1945 and worked with Dizzy ${ }^{*}$ Gillespie (1949-51) and Miles *Davis (1955-57). He was already regarded as a leader of modern jazz in the late 1950s. From then on he became increasingly interested in experimental jazz and free form.

Colum, Padraic (1881-1972). Irish playwright and poet. He helped to found the Abbey Theatre and wrote the plays The Land and The Betrayal. He was also the author of several books of verse and stories for children.

Columba (Colm Cille), St (c.521-597). Irish missionary. He established a monastery at Iona (563) and was responsible for the conversion of much of Scotland. He illuminated 300 books himself and established a scriptorium which produced the Book of Kells (c.800).

Columbus, Christopher (Cristóbal Colón in Spanish, Cristoforo Colombo in Italian) (1451?1506). Spanish navigator and explorer, born in Genoa (Liguria). Probably of Castilian descent (but not Jewish, as sometimes suggested), and writing no Italian, son of a master weaver, went to sea at 14, and claimed to have sailed to Iceland, Ireland, England, Tunisia, the Greek islands and West Africa. He lived in Lisbon in the 1470 s, possibly as 
a chartmaker, sailor and sugar buyer, trading with Madeira, the Canaries and the Azores. He married in 1479. His wife, who owned property in Madeira, died about 1484. Columbus became convinced that the shortest trade route to Asia was by sailing west, contrary to the prevailing Portuguese belief that the eastern (African) route would be quicker. (He assumed the earth had a circumference of about 25,000 kilometres; the true figure is 40,000.) With his brother Bartoloméu Columbus (1445?-1515) he sought patrons for a voyage of exploration. * João II refused him and ${ }^{*}$ Henry VII of England and ${ }^{*}$ Charles VIII of France turned his brother down. After eight years of pleading, assisted by Genoese bankers and the Franciscans, he attracted the patronage of ${ }^{*}$ Ferdinand and *Isabella, rulers of the newly united Spain. On 3 August 1492, he set off from Palos with 87 men and three old ships (Nina, Pinta, Santa Maria), sailing via the Canaries. On 12 October 1492 he sighted an island, probably Watling Island in the Bahamas, naming it San Salvador. He assumed it to be part of India, describing the inhabitants as Indians, a term which has stuck. He then sailed by the north coast of Cuba (which he thought was China) and an island he named Hispaniola (Española), leaving a party to set up a fort in Villa de la Navidad (now in Haiti). The Santa Maria was wrecked on a reef in Santo Domingo (now the Dominican Republic), the Pinta lost in a storm and Columbus left for Spain in the Nina on 18 January 1493. On his return in March his discoveries were acclaimed, he was made Admiral of the Ocean Sea and Viceroy of the Indies, including all present and future discoveries. The impact was immediate. In 1494 Pope *Alexander VI divided the world between Spain and Portugal in the Treaty of Tordesillas. In his second expedition (1493-96) Columbus had 17 ships and 1500 men. He discovered the islands of Dominica and Jamaica and established the first European town in the New World on Haiti, at Isabella. Because he was unable to secure financial advantage to Spain from his discoveries he had difficulty in gaining support for a third expedition. However, in May 1498 he sailed again, discovered Trinidad, and on 5 August made his first landfall on the South American continent, on the Paria peninsula in Venezuela, then found the mouth of the Orinoco. Columbus was now convinced that he had discovered 'an Other World' (otro mundo), a continent to the south of China, concluding (oddly) that the world was pear-or breast-shaped. Meanwhile, John ${ }^{*}$ Cabot had already landed in North America (June 1497) and Vasco da *Gama had found the eastern sea route to India (May 1498). Columbus was a poor administrator and after clashes with the colonists he lost his position of Viceroy of the Indies. In 1499 he was arrested by his successor, Francesco de Bobadilla, and sent back to Spain in chains. Soon released, although still in disfavour, he was later reinstated to his former position of honour. In his fourth expedition (1502-04), he sailed along the coast of Honduras and Nicaragua, spending four months in Panama (Jan.-Apr. 1503) without realising that the Pacific was barely 70 kilometres away. When he returned empty handed once more, his reputation suffered, his patron Isabella was dead, and he was ill and neglected. But he did not die in poverty and received regular payments of gold from Hispaniola. He died in Valladolid, was later buried in Seville, then reburied (1542) in Santo Domingo, transferred to Havana (1795) and back to Seville in 1898. However, in 1877 a casket labelled with his name was found in Santo Domingo. It is probable that his remains never left Santo Domingo and that the tomb in Seville contains his son. Diego Columbus (1480-1526), appointed Viceroy of the Indies (1511) and created a duke, was refused authority over the mainland, although the Columbus estate received the gift of Jamaica and land in Panama. Ironically, adoption of the name America celebrates a relatively minor figure, Amerigo *Vespucci. Nevertheless, Columbus is widely commemorated-in Colombia, British Columbia, cities, rivers, mountains and universities. The towns at either end of the Panama Canal are Cristóbal and Colón.

The 1992 Quincentennial, The Encounter of Two Worlds, revived much controversy about Columbus. Some biographers saw him as a scientific, rational Renaissance explorer, most as an obsessed, medieval crusader who brought disease and slavery to the New World.

Fernandez-Armesto, F., Columbus. 1991; Henige, D., In Search of Columbus: The Sources for the First Voyage. 1991.

Combes, (Justin Louis) Emile (1835-1921). French Radical-Socialist politician. He was trained for the priesthood but became a physician. A senator from 1885, he became Minister of Education 1895-1906, and as Premier 1902-05 introduced anti-clerical legislation (1905) that ended the Concordat of 1801 and completed the separation of Church and state.

Comenius, Johannes Amos (Jan Amos Komensky) (1592-1670). Czech educationist. A pastor of the Moravian Church, he is famous for his innovations in the methods of teachings, especially of languages, and wrote the first pictorial text book for children Orbis sensualism pictus (1658). He was invited to England by the parliament in 1641 to advise on education and also assisted in reforming education in Sweden and Hungary.

Spinka, M., John Amos Comenius: that Incomparable Moravian. 1943.

Commodus, Lucius Aelius Aurelius (161-192). Roman Emperor 180-92. Son of *Marcus Aurelius, he was co-Emperor from 177. He ended the persecution of Christians but his rule was marked by extravagance, cruelty and corruption. He identified himself with Hercules and had all the months of the 
year renamed in his honour. He was strangled in his bath by the wrestler Narcissus, at the orders of his mistress, Marcia.

Compton, Arthur Holly (1892-1962). American physicist. He shared the Nobel Prize for Physics in 1927 (with C.T.R. *Wilson) for their research on $\mathrm{X}$-rays. He was Chancellor of Washington University 1945-53. His brother Karl Taylor Compton (18871954) was President of the Massachusetts Institute of Technology 1930-49. Both brothers were associated with the development of the atomic bomb.

Compton, Dennis Charles Scott (1918-1997). English sportsman. He was a noted Test cricket batsman and soccer player and wrote The End of an Innings (1958).

Compton-Burnett, Dame Ivy (1884-1969). English novelist, born in London. Her first two novels Dolores (1911) and Pastors and Masters (1925) were followed by a sequence of 17 more, including Men and Wives (1931), A House and its Head (1935), Parents and Children (1941), Mother and Son (1955) and A Cod and his Gifts (1963) in which she examines the complexities of lives in middle-class families in the period around 1900. Her novels consist mostly of dialogue.

Baldanaza, F., Ivy Compton-Burnett. 1964.

Comstock, Anthony (1844-1915). American reformer. Secretary of the Society for the Supression of Vice in New York 1873-1915, his name has been used in the word 'Comstockery', meaning prudery.

Comte, Auguste Isidore Marie François (17981857). French philosopher and mathematician. At first strongly influenced by *Saint-Simon, he was a lecturer at the École Polytechnique (1833-51) until periodic attacks of insanity compelled his retirement. He was financially assisted by J. S. *Mill in his later years. In The Course of Positive Philosophy (6 vols, 1830-42) he preached 'humanism' in its most extreme form, stating that mankind in general (and the individual also) passes through intellectual stages, the Theological (dominant in Europe until the 13th century) and the Positive (which he hoped would dominate Europe in the future, science taking the place of theology and philosophy). He theorised that because nothing can be ascertained beyond physical facts, it is useless to enquire into the origin of physical phenomena. Human knowledge is relative and not absolute, therefore mankind must seek moral values not in God, who is unknowable, but in the perfecting of human society on a scientific basis. This system is known as Logical Positivism. There are small Positivist Churches in several countries and these follow 'The Religion of Humanity' by worshipping the personification of man as an ideal. Comte was finally excommunicated by the Roman Catholic Church, and he died of cancer after a long illness.
Conant, James Bryant (1893-1978). American chemist, administrator and educationist. He was assistant professor 1919-27 and professor of organic chemistry 1928-33 at Harvard University, becoming president of the university 1933-53. He became High Commissioner 1953-55, then Ambassador, to West Germany 1955-57, and undertook a survey of American secondary education. Among his books are Organic Chemistry (1942), Education is a Divided World (1948), Education and Liberty (1953) and The American High School Today (1958).

Hershberg, J. G., James B. Conant. 1994.

Condé, de. French noble family, members of which include Louis I de Bourbon, Prince de Condé (1530-1569). French soldier. He was, with Gaspard de *Coligny, a leader of the Huguenot faction in the religious struggle against the party of the duc de Guise. After his defeat at the battle of Jarnac he surrendered but was treacherously slain by a Catholic officer. Louis II de Bourbon, Prince de Condé (1621-1686), was the great-grandson of the preceding. As duc d'Enghien he defeated the forces of the Spaniards and of the Holy Roman Empire in many notable battles (1643-46). After a bitter dispute with Cardinal *Mazarin he defected to Spain and later led the Spanish forces in several battles against the French. However, in 1659, he returned to France where he was pardoned and later commanded the armies of ${ }^{*}$ Louis XIV in succession to ${ }^{*}$ Turenne. $\mathrm{He}$ is commonly known as the Great Condé.

Mongredien, G., Le Grand Condé. 1959.

Condillac, Etienne Bonnot, Abbé de (17141780). French philosopher. Son of a vicomte, he took orders essentially as a means of establishing a career and income. He became one of the leading Paris philosophes of the mid-18th century, a friend of ${ }^{*}$ Rousseau and ${ }^{*}$ Diderot. One of his major undertakings was to make the empirical approach to epistemology developed by *Locke thoroughly familiar in France. Condillac, however, pursued a more reductionist analysis. Locke believed that all human information came into the mind through the senses, but that the mind possessed innate powers of reflection on those sense-data. Condillac argued that the powers of judgment themselves were associations which had been formed on the basis of previous sensations. In this regard, Condillac in particular insisted that language itself was not innate, but was learnt through individual experience. For this reason, he was an advocate of the reform and systematisation of scientific language, in order to purify thought. This idea played an important role in *Lavoisier's reforms of the language of chemistry.

Condorcet, Marie Jean Antoine Nicolas Caritat, Marquis de (1743-1794). French philosopher, mathematician and politician. Elected to the Académie française in 1782 , he was a protégé of d'*Alembert, a contributor to the Encyclopédie, biographer of *'Turgot 
and ${ }^{*}$ Voltaire and a pioneer of probability analysis. He supported the Revolution and served in the Legislative Assembly 1791-92 and the Convention 1792-94. A devotee of reason, he remained naively convinced about human perfectibility. Proscribed by Robespierre as a Girondin, he was captured and died in prison, perhaps by suicide. He was strongly anticlerical and anti-Imperialist. He supported pacifism, birth control, legal equality for both sexes, and the establishment of social services. His optimistic essay on population, published posthumously, urged active social choices, especially education for women and family planning (*Malthus' Essay on Population was written as a response).

Baker, K. M., Condorcet: From Natural Philosophy to Social Mathematics. 1982; Badinter, E. and R., Condorcet. 1988.

Confucius (Latinised form of Kongfuzi, i.e. 'Master Kung', personal name Kong Qiu in pinyin or K'ung Ch'iu in Wade-Giles) (551-479 BCE). Chinese philosopher and teacher, born in Ch'ü-fu, state of $\mathrm{Lu}$ (modern Shandong). Little is known of his life, but according to legend he was the son of a soldier who belonged to an impoverished noble family. His early years were spent in poverty and after some years of manual work he became an accountant and then a teacher c.531-517, wandering through the countryside discussing ethical problems. During his travels he is thought to have met ${ }^{*} \mathrm{Lao} \mathrm{Zi}$, the founder of Daoism. He married at an early age but the marriage soon ended in divorce and women are seldom mentioned in the Confucian writings. During a period of civil war Confucius fled to the neighbouring province of $\mathrm{Chi}$ and his fame spread throughout China. Duke Ting of Lu made him Governor of the city of Chungtu. He was Minister of Works and Justice 501-498 and Prime Minister of the province 498-495 until he was forced to resign by the pleasure-seeking duke. For 13 years he was an itinerant teacher. In 482 a new duke of $\mathrm{Lu}$ invited him to return and his three remaining years were devoted to collating and revising the ancient Chinese scriptures. He was buried with great ceremony at Qufu where his grave still attracts pilgrims. The term Confucianism is an 18th-century European coinage and characterising it as a religion is misconceived. Confucius was no more a religious teacher than *Socrates or *Plato: he was an ethical philosopher and none of his teachings deals with the nature of God or prospects of future life. He stressed that society depends on the observance of natural relationships of authority, obedience and mutual respect, both within the family and between ruler and subject, and he urged strict observance of loyalty, submission and benevolence. Many of his sayings are included in the famous Analects copied down by his disciples: they include Confucius' 'golden rule': 'What you do not like when done to yourself do not do to others.' Although he was never deified he has been the object of prayers and sacrifices by the Chinese and ancestor worship is inextricably linked to his teachings. Confucius was an exact contemporary of the ${ }^{*}$ Buddha. Until World War II, knowledge of the Confucian scriptures (The Five Kings, The Four Books and the Analects) was compulsory for Chinese university students and civil servants. Confucian teaching was also influential in Japan and Korea. H. H. Kung (1881-1967), one of ${ }^{*}$ Chiang Kaishek's ministers, was a direct descendant of Confucius, in the 75th generation.

Creel, H. G., Confucius and the Chinese Way. 1960; Dawson, R., Confucius. 1981; Leys, S., The Analects of Confucius. 1997.

Congreve, William (1670-1729). English dramatist. Brought up in Ireland and originally for the law he went to London in 1692, and became a novelist and playwright. Double Dealer (1694) and Love for Love (1695) show his mastery of construction and style. He was a friend of ${ }^{*}$ Dryden and ${ }^{*}$ Swift. His best known play, The Way of the World (1700), regarded as one of the best English comedies of manners, was a failure at first and Congreve, disappointed, abandoned writing for the stage.

Lynch, K. M., A Congreve Gallery. 1951.

Conkling, Roscoe (1829-1888). American Republican politician. US Congressman 1859-63, 1865-67, US Senator from New York 1867-81, he was progressive on slavery, a supporter of *Lincoln and ${ }^{*}$ Grant, and the Civil Rights Act (1875). However, as leader of the 'Stalwart' faction, he was corrupt and strongly opposed to civil service reform. He declined appointment as Chief Justice of the Supreme Court in 1873 and as an Associate Justice in 1881.

Connally, John Bowden, Jr (1917-1993). American politician. Originally a Democrat and protégé of L. B. *Johnson, he became Secretary of the Navy 1961, and Governor of Texas 1963-69, being shot and injured in Dallas when President Kennedy was assassinated. He was *Nixon's Secretary of the Treasury 1971-72 and joined the Republicans in 1973.

Connaught and Strathearn, Prince Arthur William Patrick Albert, 1st Duke of (1850-1942). English soldier and prince. The son of Queen *Victoria, he served for many years in the British Army and was Commander-in-Chief in the Mediterranean 190710 and Governor-General of Canada 1911-16. His son, Prince Arthur of Connaught (1883-1938), was Governor-General of South Africa 1920-23, his daughter Princess Margaret of Connaught (18821920) married the future * Gustaf VI Adolf of Sweden.

Connelly, Marc(us Cook) (1890-1980). American playwright. He wrote the plays The Wisdom Tooth and Green Pastures and won the Pulitzer Prize in 1930. 
Connery, Sir Sean Thomas (1930-2020). Scottish film actor. He worked in many casual jobs, including coffin polisher. He was the original James Bond in seven films based on Ian *Fleming's novels (from Dr No, 1962 to Never Say Never Again, 1983). He won an Academy Award for best supporting actor for The Untouchables. Other films included The Russia House (1990) and The Rock (1996).

Connolly, Cyril (Vernon) (1903-1974). English critic and editor. He edited Horizon 1939-50 and his books include Enemies of Promise (1938) and Condemned Playground (1944).

Connolly, James (1870-1916). Irish socialist politician. After joining the Sinn Féin movement, he became Commander-in-Chief of the Easter Rising in 1916. He was captured by the British and shot.

Conrad, Joseph (Jozef Teodor Konrad Nalecz Korzeniowski) (1857-1924). British novelist, born in Berdichev, Poland (now in Ukraine). From 1874 he worked as a seaman on French ships, joining the British merchant marine in 1880 . He sailed round the world and qualified as a master in 1886 . He became a naturalised British subject in 1886, explored the Congo on foot in 1890, retired from sea life in 1894 and devoted himself to writing. His novels, all written in English, include Almayer's Folly (1895), An Outcast of the Islands (1896), The Nigger of the Narcissus (1898), Lord Jim (1900), Nostromo (1904), The Secret Agent (1907), Under Western Eyes (1911), Chance (1913), Victory (1915), The Shadow Line (1917), The Rescue (1920) and The Rover (1923). His novella, Heart of Darkness appeared in the collection Youth (1902). Orson *Welles planned a feature film and it inspired Francis Ford *Coppola's Apocalypse Now (1979). Conrad worked with Ford Madox *Ford and was befriended by Henry *James and John *Galsworthy. His novels show a real mastery of narrative style and great psychological insight. There is also a strong sense of the mystery of nature, especially of the sea, and of the forces summoned up in human nature in order to fight it. The critic F. R. *Leavis placed him (1941) in 'the great tradition'.

Baines, J., Joseph Conrad: A Critical Biography. 1960.

Conrad von Hotzendorff, Franz, Graf [Count] (1852-1925). Austrian field marshal. Chief of Staff of the Imperial Army 1906-17, he was the leading Austrian advocate for war in 1914, anti-Serb and antiItalian and persuaded the foreign minister *Berchtold to support a punitive war against Serbia.

Conran, Sir Terence Orby (1931- ). English designer. He had a major influence in designing shops, restaurants, furniture, gardens and toys, was a prolific writer, able publicist, effective entrepreneur and company director.
Consalvi, Ercole (1757-1824). Italian cardinal and diplomat. As Papal Secretary of State 1800-23 he proved to be a masterly diplomat, took part in the Paris Peace Conference of 1814 and secured the restoration of the Papal States. He followed a relatively liberal domestic policy.

Constable, John (1776-1837). English painter. His landscape paintings have received recognition for their spontaneity and freshness, and greatly influenced the techniques of many 19th-century artists, notably the Barbizon school in France. He first exhibited at the Royal Academy in 1802, but he did not gain general recognition until about 1824, when his View on the Stour and The Hay Wain were exhibited in Paris, won gold medals and aroused great admiration. His work was rooted in a deep love of the East Anglian landscape, and characterised by his ability to convey atmosphere, weather and changing light. $\mathrm{He}$ is considered, with ${ }^{*}$ Turner, the greatest English landscape painter.

Gadney, R., Constable and His World. 1976.

Constant (de Rebecque), (Henri) Benjamin (17611830). French-Swiss writer and politician, born in Lausanne. A member of the Tribunate 1799-1802, he later opposed *Napoléon and was banished and after the Bourbon Restoration supported constitutional liberalism. He published the psychological novel Adolphe in 1816 and later wrote the monumental study On Religion. In 1951 Cecile, another of his novels, was discovered and published.

Nicolson, H., Benjamin Constant. 1949; Wood, D., Benjamin Constant. A Life. 1993.

Constantine I ('the Great') (Flavius Valerius Aurelius Constantinus) (c.280-337 CE). Roman Emperor 306-37. Born at Kis (now in Serbia), the illegitimate son of *Constantius Chlorus (250-306) and ${ }^{*}$ Helena, he served as a soldier under ${ }^{*}$ Diocletian and ${ }^{*}$ Galerius, and in 305 accompanied his father to Britain. After his father's sudden death, Constantine was proclaimed as Emperor by his troops. There were several years of struggle before his authority was fully recognised throughout the empire. Between 306 and 316 his capital was at Augusta Treverorum (modern Trier), where he built a great basilica, which largely survives, and imperial baths. In 312 he finally defeated the general *Maxentius (who had been proclaimed Emperor in Rome by his troops) at the battle of Milvian Bridge. At this battle he saw a vision of the cross in the Heavens accompanied by the words 'in hoc signo vinces' ('In this sign shalt thou conquer'). In the Edict of Milan (313), he and Licinius officially granted toleration 'for Christians and all others'. In 324 he became sole ruler of both the Eastern and Western Empires, and after gaining the support of the Christian Church for this administration, he established an absolute monarchy. Although he did not become a baptised Christian until shortly before his death, he took an active 
interest in Church affairs and convened (325) the first General Council of the Church at Nicaea (modern Iznik) at which the Athanasian (or Nicene) Creed was adopted and toleration, in effect, withdrawn from other religions. In 325 he chose Byzantium as the capital of the Roman Empire ('Roma Nova'), in 330 renamed Constantinopolis in his honour. He then made Christianity the state religion and improved the administration throughout the empire. His son, Flavius Claudius Constantinus (317-340), ruled as Constantine II 337-40. He shared the government of the Empire with his brothers, taking Britain and Gaul as his personal responsibility. He was killed in a battle against his brother Constans.

McMullen, R., Constantine. 1969; Fletcher, J., Life of Constantine the Great. 2008; Stephenson, P., Constantine. Roman Emperor, Christian Victor. 2010; Potter, D., Constantine the Great. 2013.

Constantine (Konstantinos) I (1868-1923). King of the Hellenes (Greece) 1913-17; 1920-22. Son of *George I of Greece, and brother-in-law of Kaiser *Wilhelm II, he supported Germany during World War I and was forced to abdicate by the pro-British Prime Minister Eleutherios *Venizelos. After the war he was recalled by a plebiscite but abdicated once more on the failure of the Greek campaign against the Turks in Asia Minor. He was the father of three Greek kings: *Alexander, *George II and *Paul I.

Constantine II (c.879-953). King of Alba (Scotland) 900-43. Grandson of Kenneth MacAlpine, and son of Aed, after a long reign he abdicated and died as a hermit in St Andrews.

Constantine II (1940- ). King of the Hellenes (Greece) 1964-67. Grandson of *Constantine I and son of *Paul I, he grew up in Egypt and South Africa. He won an Olympic Gold Medal for yachting in 1960. He toyed with adopting the numeral XIII to assert his continuity with the Byzantine (Greek) emperors before 1453. Following a military coup in April 1967, the king attempted a counter-coup in December in order to restore his personal authority. This failed and Constantine retreated to exile, settling in Hampstead. He was stripped of Greek citizenship in 1994.

Constantine IX (Kōnstantinos Monomarkhos) (c.1000-1055). Byzantine Emperor 1042-1055. Son of a Macedonian official, he was chosen to be husband and co-ruler by the Empress *Zoë. After her death (1050) he ruled with her sister Theodora. He revived the university in Constantinople and promoted arts, architecture and literature. However, he lost territory to the Normans in the West, to a rebellion in Thrace and the Seljuk Turks were about to invade Anatolia. The 'Great Schism' of 1054 between the Latin and Greek churches occurred during his reign but he was not involved.
Constantine XI Palaeologus (1404-1453). Byzantine Emperor 1448-53. Last Emperor of the East, he was killed by the Turks after the capture of Constantinople, and was buried without a trace.

Constantius I Chlorus (Gaius Flavius Valerius Constantius) (250-306). Roman Emperor 305-306. Born in Dardania (modern Kosova), his partner (or wife) was ${ }^{*}$ Helena. Their son was ${ }^{*}$ Constantine I. He left her and married the daughter of emperor *Maximian who promoted Constantius to be 'Caesar' in 293 , under the tetrarchy created by ${ }^{*}$ Diocletian, and on his abdication became joint Emperor with *Galerius, ruling as 'Augustus' in the west. He defeated a rising in Britain and died suddenly at Eboracum (York).

Constantius II (Flavius Julius Constantius Augustus) (317-361). Roman Emperor 337-61. Born in Serbia, third son of ${ }^{*}$ Constantine, he shared the throne with his brothers *Constantine II and Constans, but in the ensuing conflict, Constantine II was killed and the empire was divided, with Constantius taking the east. He engaged in inconclusive warfare with the Persians, continued his father's promotion of Christianity and attempted to find a compromise between the supporters of the Nicene Creed and Arianism. Baptised on his deathbed, he was succeeded by his cousin *Julian the Apostate.

Cook, Frederick Albert (1865-1940). American physician and explorer. In 1908 he claimed to have reached the North Pole but R. E. *Peary challenged this and Cook was greatly discredited. To the end of his life he still maintained that he was the first man to reach the Pole. He died in poverty after having been jailed for five years for mail frauds.

Cook, James (1728-1779). English explorer, navigator and scientist, born in Marton-inCleveland, Yorkshire. Son of an agricultural labourer, he joined the Royal Navy in 1755 and received rapid promotion, largely because of his skill at navigation. His detailed charts of the St Lawrence River assisted *Wolfe's victory on the Heights of Abraham, Québec (1759) and he was stationed in Newfoundland and Labrador waters 1763-67. In 1768 he was appointed commander of the barque Endeavour which was to take an expedition of scientists, headed by Joseph *Banks, to observe the transit of Venus, at Tahiti. On his return he circumnavigated the two islands of New Zealand and explored the eastern coast of Australia, north of $38^{\circ}$. On 29 April 1770, after Cook fired three shots at Indigenous people in canoes, his party landed at Botany Bay (originally called Stingray Bay), raised the Union Flag and stayed for eight days, collecting novel flora and fauna. Inexplicably, although Cook observed (and named) the entrance to Port Jackson, the future site of Sydney, just to the north, he failed to explore it. Endeavour was breached on a shoal of the Great Barrier Reef in June and repaired near the site of modern Cooktown. Having charted 
the whole eastern coastline, on 22 August 1770, at Possession Island, in the Torres Strait, he claimed possession of the whole eastern coast, naming it New South Wales, for King *George III. This exploration was acclaimed on his return to England in 1771. On a second expedition (1772-75), in the Resolution, he charted the coast of New Zealand, crossed the Antarctic Circle (January 1773) and reached $71^{\circ} 10^{\prime} \mathrm{S}$, explored (and re-named) New Caledonia and named the New Hebrides (now Vanuatu). He experimented with diet, including malt and wort (by-products of making beer), sauerkraut and fresh vegetables and no sailor on the Resolution died of scurvy; for this he received the Copley Medal of the Royal Society (1775) and was elected FRS (1776). On his third voyage to the Pacific (1776-79), again on HMS Resolution, he landed at Bruny Island (Tasmania) in January 1777, circumnavigated New Zealand, made the first European landing on the Hawaiian islands (which he named the Sandwich Islands) and charted the Pacific coast of North America up to the Arctic regions in an unsuccessful attempt to find a north-east passage through North America from the Pacific. On returning to Hawaii he was involved in a scuffle with indigenous people over a stolen boat, was clubbed on the head and fatally stabbed in the neck. He was ceremonially cooked, but not eaten: the bones were extracted and returned to his crew who deposited them at sea. Minor planet 3061 Cook, a Moon crater and places in Australia, New Zealand, Canada, Alaska, Hawaii, Antarctica, Chile, French Polynesia and the Cook Islands are named for him.

His widow, Elizabeth Cook (née Batts) (17431835), burnt all his letters before she died.

Beaglehole, J. C. (ed.), The Journals of Captain James Cook. 1955-67; Frame, W. and Walker, L., James Cook. The Voyages. 2018.

Cook, Sir Joseph (1860-1947). Australian politician, born in Staffordshire. Originally a coal miner, he emigrated to Australia in 1885 , becoming a union organiser, fervent Methodist and Member of the New South Wales Legislative Assembly 1894-1901. He broke with Labor on the solidarity pledge in 1894 , serving as a minister under George * Reid. Elected as a Free Trader to the House of Representatives 1901-21, he later became a Liberal, then Nationalist. Minister for Defence 1909-10, he succeeded *Deakin as Leader of the Opposition 1913, narrowly defeating *Forrest. He was Prime Minister 1913-14, Minister of the Navy 1917-20 and High Commissioner in England 1921-27.

Cook, Robin (Robert Finlayson) (1946-2005). British Labour politician. He was a tutor and racing journalist, Edinburgh councillor, MP 1974-2005, Foreign Secretary 1997-2001 and Leader of the House of Commons 2001-03. He broke with Tony *Blair over the Iraq war.
Cook, Thomas (1808-1892). English tourist agent. His firm pioneered the organisation of international tourist services which greatly encouraged European travel. Faced with online bookings, fierce competition, and an ageing clientele, the Thomas Cook Group ceased trading in September 2019.

Swinglehurst, E., Romantic Journey: Story of Thomas Cook and Victorian Travel. 1974.

Cooke, Robin Brunskill, Baron Cooke (19262006). New Zealand judge. A judge from 1972 and President of the Court of Appeal 1986-96, in 1995 he became New Zealand's last life peer.

Coolidge, (John) Calvin (1872-1933). 30th President of the US 1923-29. Born in Plymouth, Vermont, son of a storekeeper, he was educated at Amherst College, became an attorney, city councillor, Mayor of Northampton, State Senator 1912-15 and Lieutenant-Governor of Massachusetts 1916-18. As Governor 1919-20, he won fame by his firm handling of a police strike in Boston, 1919. In 1920 he was the successful Republican candidate for the vice presidency and served 1921-23. On the death of Warren *Harding, he succeeded to the presidency. Although re-elected overwhelmingly in 1924, he declined to stand again in 1928. He believed 'That the best government is the least government', and exercised little executive authority as president. A cold, somewhat introverted personality, he was notorious for his laconic utterances. When told that Coolidge had died, Dorothy *Parker commented: 'How can they tell?'

White, W. A., A Puritan in Babylon. 1938; Shlaes, A., Coolidge. 2013.

Coombs, H(erbert) C(ole) ('Nugget') (1906-1997). Australian economist, banker and public servant, born in Western Australia. Educated at the University of WA and the London School of Economics, he became Director of Rationing 1942-43 and Director-General of Post War Reconstruction 1943 49. For more than 40 years he played a decisive role in economic and social policy formulation, including central banking as Governor of the Commonwealth Bank 1949-60 and the Reserve Bank 1960-68, education, was Chairman of the Australian Council for the Arts 1968-74, the Council for Aboriginal Affairs 1968-76 and Chancellor of The Australian National University 1968-76. From 1972 he had an intense, touching relationship with the poet Judith *Wright and they were prolific correspondents. An original recipient of an AC in 1975, he resigned in protest when, in 1976, the Order of Australia was expanded (for some years) to include knighthoods.

Coombs, H. C, Trial Balance. 1981; Rowse, T., Nugget Coombs. A Reforming Life. 2002. 
Cooper, (Alfred) Duff, 1st Viscount Norwich (1890-1954). English Conservative politician and writer. A descendent of ${ }^{*}$ William IV, educated at Eton and Oxford, he entered the Foreign Office and won a DSO in World War I. Member of Parliament 1924-29, 1931-45, he was Secretary of State for War 1935-37, First Lord of the Admiralty 1937-38 (resigning as a protest against *Chamberlain's appeasement policy), Minister of Information 1940-41, and Ambassador to France 1944-47. A skilful author, he wrote biographies of ${ }^{*}$ Haig, ${ }^{*}$ Foch and *Talleyrand. In 1919 he married Lady Diana Manners (1892-1986), a daughter of the Duke of Rutland, a famous beauty and actor. For his son, see John Julius *Norwich.

Cooper, D., Old Men Forget. 1953. 1986; Charmley, J., Duff Cooper. 1986.

Cooper, Gary (Frank James) (1901-1961). American film actor. He appeared in 91 films as a vigorous man of action. The best known are For Whom the Bell Tolls, Sergeant York and High Noon.

Cooper, James Fenimore (1789-1851). American writer. His dramatic stories of the adventures of the pioneers with Native Americans include The Last of the Mohicans (1826), The Pathfinder (1840), and The Deer Slayer (1841). He lived in Europe 1826-33, where his novels were very popular and praised by Franz *Schubert, Victor *Hugo and *Balzac.

Grossman, J., James Fenimore Cooper. 1949.

Cooper, William (1860-1941). Australian Indigenous leader, born near Lake Moira. A Yorta Yorta man, whose tribal name was Yelgaborrnya, he became a Christian in 1884 , worked as a shearer, was active in the AWU and campaigned for the recognition of Indigenous rights. Founder and secretary of the Australian Aborigines' League, based in Melbourne, 1933-40, he organised petitions and led deputations to ministers. In December 1938 he led a protest in Melbourne about Nazi persecution of Jews in Germany, which has been commemorated in Israel.

Atwood, B., William Cooper: An Aboriginal Life Story. 2021; Miller, B., Shattered Lives Broken Dreams. 2022

Coote, Sir Eyre (1726-1783). English soldier. He served under ${ }^{*}$ Clive at the battle of Plassey (1757). As Commander-in-Chief in India, 1779-83, he allied himself with Warren ${ }^{*}$ Hastings and helped to complete the conquest of the subcontinent.

Copernicus Nicolaus (Mikolaj Koppernigk) (14731543). Polish astronomer born in Torun. He studied astronomy, mathematics and medicine in Cracow and Padua and was physician to his uncle, the Bishop of Ermeland, 1506-12. Although not in holy orders, his uncle appointed him to the office of Canon of Frauenburg in 1513 and he held this position until his death. For over 30 years he studied the theory, first enunciated by ${ }^{*}$ Pythagoras, that the earth is not the centre of the solar system, but his great work which lays down his final conclusions was not published until shortly before his death. In this book De revolutionibus orbium coelestium, he argued that the sun is the centre of the solar system, the earth rotates daily on its axis and that other planets also revolve around the sun in orbits. He is regarded as the founder of modern astronomy. His theories were adopted by ${ }^{*}$ Galileo and ${ }^{*}$ Kepler, but rejected by Tycho ${ }^{*}$ Brahe. He also advocated monetary reform and anticipated ${ }^{*}$ Gresham's Law.

Banville, J., Doctor Copernicus. 1977.

Copland, Aaron (1900-1990). American composer, born in New York. His parents came from Russia, where the family name was Kaplan. A pupil of Nadia *Boulanger, his works, mostly for orchestra, have great rhythmic vitality and many critics consider him the leading contemporary American composer. His music includes the ballets El Salon Mexico, Appalachian Spring, Billy the Kid and The Tender Land (an opera). He was awarded a Pulitzer Prize (1944), an Oscar (1950) and the Presidential Medal of Freedom (1964).

Smith, J., Aaron Copland. 1955.

Copley, Sir Godfrey, 2nd Baronet (c.1653-1709). English official. MP 1678-81, 1695-1705, he endowed the Royal Society's Copley Medal, its highest award, first conferred in 1736.

Copley, John Singleton (1738-1815). American portrait painter. Noted for his 'Boston portraits' of New England families, he moved to England in 1774 and extended his work into the genre of historical paintings. These were technically sophisticated but they lacked the vigour of his early work and his reputation suffered. His son, John Singleton Copley, 1st Baron Lyndhurst (1772-1863), born in Boston, was a Tory MP 1818-27, Attorney-General 182426, Lord Chancellor 1827-30, 1834-35 and 184146 and Chief Baron of the Exchequer 1831-34. He opposed Catholic emancipation and the Reform Bill (1832) and prosecuted Queen ${ }^{*}$ Caroline, but supported Jewish emancipation, divorce reform and was admired by his rival Henry *Brougham.

Coppola, Francis Ford (1939- ). American film director and writer. The son of a musician, educated at UCLA, his extremely successful films include The Godfather (1972), Godfather II (1974), The Conversation (1974), Apocalypse Now (1979), Godfather III (1990) and The Rainmaker (1997). He won five Academy Awards.

Coquelin, Benoît-Constant (1841-1909). French actor. He made his debut at the Comédie Française in 1860 , and became a full member of the company at 23. His range was exceptionally wide, and he excelled at the broadest comedy and most delicate pathos. $\mathrm{He}$ 
formed his own company in 1892. In 1895-97 he worked at the Renaissance Théâtre, Paris. In 1897 he was a director of the Théâtre de la Porte-Saint-Martin, where he created the part of Cyrano de Bergerac in *Rostand's play. In 1900 he toured with Sarah ${ }^{*}$ Bernhardt and acted at her theatre during the last years of his career.

Corbett, James John (1866-1933). American boxer, born in San Francisco. Known as 'Gentleman Jim', he defeated John L. *Sullivan to become world heavyweight boxing champion in 1892 , losing to Bob *Fitzsimmons in 1897 . He retired from boxing in 1903 and became an actor, appearing in 12 films. Errol *Flynn played Corbett in the film Gentleman $\operatorname{Jim}(1942)$.

\section{Corbusier, Le see Le Corbusier}

Corbyn, Jeremy Bernard (1949- ). British Labour politician. MP 1983-, but never a minister, strongly opposed to many policies advanced by Tony *Blair, often voting against the Labour Government (or abstaining), especially on Iraq and national security. In September 2015 he won Labour's leadership with strong votes from trade unions and branch members, despite only minuscule support from fellow MPs. Despite low expectations, Corbyn campaigned well in the June 2017 election, reviving many pre-Blair policies, securing a 9.5 per cent swing to Labour and denying a Tory majority to Theresa *May. Corbyn seemed unable, or unwilling, to shake off accusations of anti-Semitism. In the campaign for the December 2019 election, his position on a second referendum about the UK's relationship with the EU was equivocal and Labour suffered its worst result since 1935 , with a primary vote of 32.2 per cent. Corbyn left the Leadership in April 2020 on the election of his successor, Sir Keir *Starmer.

Corday, Charlotte (Marie Anne Charlotte Corday d'Armont) (1768-1793). French assassin and revolutionary. A member of an old Norman family, she supported the principles of the French Revolution, but, horrified by the Reign of Terror, she murdered one of the Jacobin leaders, Jean Paul *Marat, by stabbing him in his bath. She was guillotined four days later.

Corelli, Arcangelo (1653-1713). Italian composer and violinist, born in Fusignano. Educated in Bologna, he lived in Rome from 1675, enjoying the patronage of Queen ${ }^{*}$ Christina and Cardinals Pamphili and *Ottoboni, and composed orchestral music for great occasions. He created the Concerto Grosso form, wrote 60 of them, was extensively published, influenced *Scarlatti, *Händel and ${ }^{*}$ Bach and became the first composer known exclusively for instrumental works. Corelli was an outstanding teacher, ensemble trainer and one of the earliest conductors.

Pincherle, M., Corelli et son temps. 1954; Allsop, P., Arcangelo Corelli. New Orpheus of Our Times. 1999.
Corelli, Marie (Mary Mackay) (1855-1924). English novelist. She enjoyed a decade of sensational success with her novels $A$ Romance of Two Worlds (1886), Barabbas (1893), The Sorrows of Satan (1895) and The Mighty Atom (1896), followed by a critical reaction and oblivion.

Cori, Carl Ferdinand (1896-1984). American biochemist, born in Czechoslovakia. Professor of Biochemistry at Washington University, St Louis 1931-67, he and his wife Gerty Theresa Cori (née Radnitz) (1896-1957) shared the Nobel Prize for Medicine in 1947 for their studies in carbohydrate metabolism.

Coriolanus, Gaius Marcius (fl. 490 BCE). Roman hero. After being exiled from Rome he became Commander of the Volscian army, heading it against Rome. He stopped his forces outside the city in response to the pleas of his wife and mother, and was killed by the Volsces as a result. *Shakespeare wrote a tragic play on this theme.

Cormann, Mathias Hubert Paul (1970- ). Australian-Belgian politician. He migrated to Australia in 1996 and became a Liberal Party official, Senator from Western Australia 2007-20 and Minister for Finance 2013-20. Elected as Secretary-General of the OECD 2021-, he became a passionate advocate of stronger action to mitigate climate change, having been a firm opponent in domestic politics.

Corneille, Pierre (1606-1684). French playwright, born in Rouen. Of a middle-class family, educated by the Jesuits, he became a lawyer and was Crown Counsel in Rouen until 1650. Between 1631 and 1635 he had written seven successful comedies, was awarded a pension by Cardinal *Richelieu and became nationally famous with his drama El Cid (1637?) which led to an obscure quarrel over royalties and the loss of the Cardinal's favour. Corneille's later plays were mostly tragedies, dramatic rather than cathartic, written in Alexandrine verse, physically static but emotionally vigorous and brilliantly characterised, generally turning on the conflict between two duties, and mostly based on classical subjects. They include Médée (1637), Horace (1640), Cinna (1641), Polyeucte (1643), Oedipe (1659), Othon (1664) and Suréna (1674). He was greatly admired by ${ }^{*}$ Molière, ${ }^{*}$ Voltaire, ${ }^{*}$ Napoléon and ${ }^{*}$ Balzac. He became a member of the Académie française in 1647. His brother Thomas Corneille (1625-1709) was the author of two very successful plays, Timocrate (1656) and Ariane (1672).

Yarrow, P., Corneille. 1963; Stegmann, A. (ed.), Oeuvres complètes de Pierre Corneille. 1963.

Cornforth, Sir John Warcup (1917-2013). Australian organic chemist, born in Sydney. Educated at Sydney and Oxford universities, and completely deaf from the age of 20, he worked for the UK Medical Research Council 1946-62, directed the 
Shell chemical enzyme laboratory 1962-75, and shared the Nobel Prize for Chemistry in 1975 for work on the stereochemistry of organic molecules and reactions. He was Australian of the Year in 1975, received the Copley Medal in 1982 and an AC in 1991.

\section{Cornwall, Earl of see Richard, Earl of Cornwall}

Cornwallis, Charles Cornwallis, 1st Marquess (1738-1805). English general and politician, born in London. Son of the 1st Earl Cornwallis, educated at Eton and Cambridge, he was a Member of Parliament 1760-62. An able soldier, he served in British forces in the American War of Independence from 1776, under William *Howe and the incompetent Henry ${ }^{*}$ Clinton, until forced to surrender to George *Washington in Yorktown, Va. (October 1781), after defeat by American and French troops.

As Governor-General of Bengal and Commander-inChief in the East Indies 1786-93, he consolidated and simplified the legal system, imposing the English model. Master-General of the Ordnance 17951801, he was a signatory of the Treaty of Amiens (1802). Lord Lieutenant of Ireland 1798-1801, he imposed executions and brutal punishments after the 1798 Young Ireland rising (and an abortive French invasion), but detested the corruption involved securing the Act of Union (1801), which absorbed Ireland into the United Kingdom. Sympathetic to Catholic emancipation, he resigned, with William ${ }^{*}$ Pitt when reform was blocked by ${ }^{*}$ George III. On Pitt's return as Prime Minister, Cornwallis was reappointed as Governor-General of Bengal 1805, but nine weeks after his arrival he died of fever in Ghazipur and was buried there.

Corot, (Jean-Baptiste) Camille (1796-1875). French landscape and figurative artist, born in Paris. Son of prosperous shopkeepers, he was largely self-trained and apart from three years in Rome (1825-28) spent most of his life uneventfully in Paris, often visiting the country to sketch and paint. He never married. He began painting in the classical * Poussin tradition but evolved a subtle and original style that influenced and anticipated the Impressionists. He was a friend, but not a member, of the Barbizon school (*Millet). He was extremely prolific, much imitated (and forged): cynics observed that of Corot's 3,000 paintings, 5,000 were in the United States.

Correggio, Antonio Allegri da (c.1494-1534). Italian painter. His works are mostly on religious subjects and show great mastery of the art of composition. One of the best known is The Ascension of the Virgin in Parma Cathedral.

Cortés (de Monroy y Pizarro Altamirano), Hernán (1484-1547). Spanish (Castilian) conquistador, born in Medellin, Extremadura. Son of an impoverished hidalgo, he attended university at Salamanca, went to the New World in 1506 and became an administrator in Hispaniola (Santa Domingo) and Cuba. He led an expedition of 508 soldiers, 100 sailors and 16 horses which landed in Yucatan in February 1519, and soon formed alliances with some Mexican kingdoms hostile to Aztec domination. He arrived in Tenochtitlan (Mexico) in November 1519. The superstitious emperor *Moctezuma II may have identified Cortés with the god Quetzalcoatl and became a pliant hostage of the Spaniards until he died in June 1520, either as a result of stoning by his own people or Spanish murder. During Cortés' absence, the Aztecs drove the Spanish out of Tenochtitlan. He returned with a larger army in August 1521 assisted by horses, cannon and the devastating pandemic of smallpox to which the Spaniards were immune. Tenochtitlan was destroyed. Cortés established control of the whole Aztec empire and was made Governor of New Spain 1523-26. He explored Honduras 1524-26. Cortés was subject to violent attack by rival Spaniards and had powerful enemies at the court of ${ }^{*}$ Charles V. However, in 1529 he was created marques del Valle de Oaxaca, married a duke's niece and was confirmed as Captain General of New Spain. In 1536 he explored (and named) Lower California. He returned to Spain in 1540, claimed poverty and neglect but was enormously rich and died on his estate near Seville. He is now buried in Mexico.

Madariaga, S. de, Hernån Cortéz, Conqueror of Mexico. 1941.

Cortot, Alfred (Denis) (1877-1962). French pianist and conductor, born in Nyon, Switzerland. He began his career as a ${ }^{*}$ Beethoven pianist, then studied *Wagner's operas in Bayreuth and premiered Parsifal and Götterdämmerung in Paris (1902). In 1905 he formed a trio with Jacques Thibaud and Pablo ${ }^{*}$ Casals and toured extensively. He became a noted interpreter of ${ }^{*}$ Chopin, made many recordings and was an important teacher (*Lipatti was a pupil). He collaborated with the German occupation and *Petain's government and in 1945 was suspended from performing for a year.

\section{Corvo, Baron see Rolfe, Frederick William}

Cosgrave, William Thomas (1888-1965). Irish politician. Originally a grocer, he became active in the Irish Nationalist Movement and was a member of the House of Commons 1918-22, although he did not take his seat. Following the sudden deaths of Arthur ${ }^{*}$ Griffith and Michael ${ }^{*}$ Collins, he became the first Prime Minister (President of the Executive Council) of the Irish Free State 1922-32. He crushed *de Valera's rebellion far more harshly than the British had ever acted and, by 1923, 11,000 Republicans were in prison and more than 50 had been executed. His son, Liam Cosgrave (1920-2017) was Minister for External Affairs 1954-57, and Prime Minister 1973-77. 
Cosgrove, Sir Peter John (1947- ). Australian general, born in Sydney. Educated at Duntroon, he was Chief of the Army 2000-02, Chief of the Defence Force 2002-05 and Governor-General 2014-19. He wrote My Story (2006).

Cossa, Baldassarre (c.1370-1419). Italian prelate and anti-Pope, known as John XXIII, born in the kingdom of Naples. Educated at Bologna, he rose in the church bureaucracy at a time of 'the Great Schism', with rival popes in Rome ( ${ }^{*}$ Gregory XII) and Avignon (Benedict XIII). In Pisa, he was elected as 'pope' by a group of cardinals and was recognised by France, England, Portugal, Florence and Venice. He appointed the *Medici as bankers to the papacy. Cossa was deposed by the Council of Constance (1413), imprisoned in Germany, then ransomed by Florence. *Gibbon wrote of him, "The more scandalous charges were suppressed; the vicar of Christ was accused only of piracy, rape, sodomy, murder and incest'.

Costa, Lúcio Marçal Ferreira Ribeiro Lima (19021998). French-Brazilian architect, born in Toulouse. A follower of *Le Corbusier, appointed as Director of the School of Fine Arts in 1931, he was one of a team responsible for the Ministry of Education and Health building in Rio de Janeiro 1937-43 which is regarded as pioneering modern architecture in Brazil. He designed the plan for the city of Brasilia in 1956.

Costello, John A(loysius) (1891-1976). Irish politician. Leader of Fine Gael, he was an opponent of *de Valera, served as Prime Minister 1948-51, 1954-57 and took Ireland out of the British Commonwealth (1949).

Costello, Peter Howard (1957- ). Australian Liberal politician, born in Melbourne. Educated at Monash University, he became a barrister and was a Member of the House of Representatives 1990-2007 and Deputy Leader of the Liberal Party 1994-2007. In John *Howard's Government, despite some tensions on the issue of succession, he became Australia's longest serving Commonwealth Treasurer 1996-2007.

Coster, Laurens Janszoon (c.1370-1440?). Dutch inventor. He worked in Haarlem and is sometimes claimed to have preceded ${ }^{*}$ Gutenberg in the development of movable, metal type.

Cotman, John Sell (1782-1842). English landscape painter and etcher. With *Crome he is considered the leading member of the Norwich School. He had a deep interest in architecture, and painted landscapes with a strong structural form, emphasised by flat washes. His Liber Studorium of 1838 consists of 48 soft-ground etchings, and is considered a landmark in etching technique.

Cotton, Charles (1630-1687). English poet. He was a country gentleman who wrote some beautiful short lyrics, admired by Wordsworth. He translated the
Essays of Montaigne, and became the friend of Izaak Walton, to whose Compleat Angler he contributed. $\mathrm{He}$ wrote many parodies of the works of classical authors.

Coty, René Jules Gustave (1882-1962). French conservative politician. Originally a lawyer, he was active in local government and served as Deputy 1923-35 and Senator 1935-42. He took no part in politics during the war, but after the Liberation was re-elected as Deputy (1945) and Senator (1948). He became Minister of Reconstruction 1947 and was Vice President of the Senate 1949-53. In December 1953 on the 13th ballot he was elected as President of the Fourth Republic as a compromise candidate and served Jan. 1954-Jan. 1959. In May 1958, he installed General *de Gaulle as Premier, retiring on the inauguration of the Fifth Republic.

Coubertin, Pierre, Baron de (1863-1937). French publicist and educator. He was responsible for the revival of the Olympic Games and presided at the first modern Olympiad in Athens in 1896. He served as President of the International Olympic Federation 1894-1925.

Coué, Emile (1857-1926). French psychotherapist. He believed that auto-suggestion has a powerful effect on sickness (even organic disease) and his slogan 'Every day, in every way, 1 am getting better and better' became extraordinarily popular in the 1920 s.

Coughlin, Charles Edward (1891-1979). American priest, born in Canada. He began broadcasting from Detroit, Michigan, in the 1920s, originally in opposition to the Ku Klux Klan. In the period 1930-36 he had a weekly audience of more than 10 million. Originally a supporter of the New Deal, he turned strongly against Roosevelt and in 1935 formed the National Union of Social Justice which had anti-Semitic and pro-Fascist tendencies. In 1942 his broadcasts were banned and he quickly lost influence. Joseph P. * Kennedy was a strong supporter of Father Coughlin.

Coulomb, Charles Augustin de (1736-1806). French physicist. Noted for his work on electricity and magnetism, he was a military engineer by profession, and invented a magnetoscope, a magnometer and a torsion balance. He proved that the force of attraction between two electrical charges is inversely proportional to the square of their distance: this is known as 'Coulomb's Law'. A 'coulomb' is the standard unit of electrical quantity, a current of one ampere per second. In 1802 *Napoléon appointed him as inspector of schools.

Couperin, François (1668-1733). French composer, harpsichordist and organist, known as 'Couperin le Grand'. His family produced many notable musicians. He studied the works of ${ }^{*}$ Corelli and *Lully, becoming a church organist at St Gervais in Paris (from 1683) and music master at the Royal 
Court 1717-33. He was a great keyboard virtuoso and composed more than 300 vivacious and graceful harpsichord works that greatly influenced J. S. *Bach and ${ }^{*}$ Händel. He also wrote chamber music, songs and religious works.

Mellers, W., François Couperin and the French Classical Tradition. 1950.

Courbet, (Jean Desiré) Gustave (1819-1877). French realist painter, born in Ornans. Originally a student of theology, he taught himself painting by copying the works exhibited in the Louvre and ultimately became one of the most prolific of all French artists. His realism in painting made him the enemy of the traditionalists, and his original technique influenced later French schools. An atheist and socialist, he was active in the Paris Commune, sitting as a member of the revolutionary assembly (1871). He later served six months in jail, and in 1873 exiled himself to Switzerland, where he died of dropsy. His best works include The Burial at Ornans (1850), Bonjour, Monsieur Courbet (1854), The Painter's Studio (1855) and the powerful nude The Origin of the World (L'Origine du monde, 1866). His work had a powerful influence on the Cubists.

Zahar, M., Gustave Courbet. 1950; Rubin, J. H., Courbet. 1997.

Courtauld, Samuel (1876-1947). British industrialist and patron of the arts. As chairman of Courtauld's textile company he pioneered the commercial development of man-made fibres. His collection of French paintings became the nucleus of the collection at Home House, where he also set up the Courtauld Institute for the study of art history.

Cousin, Victor (1792-1867). French philosopher and educationist. A popular lecturer at the Sorbonne, he developed what he termed 'eclectic' philosophy, insisting that truth can be discerned by 'intuition'. As Minister of Education 1840-51, he introduced many reforms into French primary education, most of them derived from Germany. He translated *Plato's works and wrote studies on *Pascal and *Kant.

Cousteau, Jacques Yves (1910-1997). French marine explorer, conservationist, author and filmmaker. A French naval officer, with Emil Gagnan he invented the aqualung (1943) which permitted much underwater exploration and popularised scubadiving. In the Calypso, he conducted experiments to extend the period divers could spend underwater. With specially designed submarines, he made many underwater films: three won Academy Awards in 1957, 1959 and 1965. He directed the Oceanographic Museum, Monaco from 1957. The Cousteau Society (established in 1973) was a prolific producer of books and a 21-volume encyclopaedia. A member of the Académie française 1988-97, he played a central role, with Bob ${ }^{*}$ Hawke, in securing international agreement (1991) to preserve Antarctica from mining for 50 years.

Cousteau, J. Y., The Ocean World of Jacques Cousteau. 20 vols, 1973; Matsen, B., Jacques Cousteau. The Sea King. 2009.

Couthon, Georges (1755-1794). French revolutionary. A cripple, trained as a lawyer, he was a Member of the Legislative Assembly 1791-92, a Member of the Convention 1792-94 and of the Committee of Public Safety 1793-94. He was guillotined with *Robespierre.

Couve de Murville, Maurice (1907-1999). French diplomat and politician. He served as French Ambassador to Egypt 1950-54, to NATO 1954-55, to the United States 1955-56 and to West Germany 1956-58. President *de Gaulle appointed him Minister for Foreign Affairs 1958-68, in 1968 he was Minister of Finance and Economy (June and July) and then Prime Minister 1968-69. He was Chairman of the Foreign Affairs Committee of the National Assembly 1973-81.

Couve de Murville. M., Une politique étrangère, 1958-1969. 1973.

Coverdale, Miles (1488-1569). English prelate and translator, born in Yorkshire. Educated at Cambridge, he joined the Augustinian order, later becoming an ardent Protestant. In 1535, in Antwerp, he published the first printed, complete English translation of the Bible, including the Apocrypha. Having no Hebrew or Greek, he worked from the Latin Vulgate and *Luther's German translation, and incorporated *Tyndale's translations of the Pentateuch and New Testament. Coverdale's edition formed the basis of the so-called 'Matthew's Bible' of 1537, the first to be licensed for sale in England, and he worked on 'The Great Bible' of 1539 (also retaining Tyndale's material). Coverdale's Psalms were preserved in the Authorised (King James) Version. He was a Puritan and, because of his extreme views, spent several years in European exile, mostly in Germany 1543-48 and 1555-59. A notable preacher, he was Bishop of Exeter 1551-53 but lost this office on the accession of Queen *Mary.

Cowan, Edith Dircksey (née Brown) (1861-1932). Australian social reformer, born in Geraldton. In 1876 her father was hanged for shooting her stepmother. A prominent suffragist, she became an active campaigner on issues relating to women and children. A Nationalist MP in Western Australia 1921-24, and the first woman elected to an Australian Parliament, she was commemorated by the Edith Cowan University, a federal electoral division and appearing on the $\$ 50$ banknote. 
Coward, Sir Noël (Pierce) (1899-1973). English playwright, actor, producer and composer, born in Teddington. He made his stage debut as a boy and became a popular performer in light comedies. His first play The Vortex, portrayal of decadence, caused a sensation when produced in London in 1923. It was followed by many sophisticated comedies including Hay Fever (1925), Private Lives (1930), Blithe Spirit (1931), Present Laughter (1943) and Nude with Violin (1956). He composed the music and wrote the dialogue for the musical comedies Bitter Sweet (1929) and Words and Music (1934). He wrote and produced the successful films Cavalcade (1938), In Which We Serve (1942), This Happy Breed (1944), Blithe Spirit (1945) and Brief Encounter (1947). Among his other works were several volumes of autobiography, e.g. Future Indefinite (1954) and a number of witty songs, e.g. Mad Dogs and Englishmen. He was an accomplished actor who appeared in a number of films, e.g. In Which We Serve and Our Man in Havana. After World War II he lived in Bermuda. He was knighted in 1970.

Morley, S., Noël Coward. 1969; Hoare, P., Noël Coward. 1995.

Cowen, Sir Zelman (1919-2011). Australian lawyer, academic and administrator, born in Melbourne. Educated at Melbourne and Oxford, he was Dean of Melbourne University's law school 1951-66, and a prolific textbook writer, Vice Chancellor of the University of New England 1967-70 and of Queensland 1970-77. As Governor-General of Australia 1977-82 he brought a 'touch of healing' after the controversial Sir John *Kerr. He became Provost of Oriel College, Oxford 1982-90 and Chairman of the UK Press Council 1983-88, then returned to Australia.

Cowen, Z., A Public Life. The Memoirs of Zelman Cowen. 2006.

Cowley, Abraham (1618-1667). English essayist and metaphysical poet. Educated at Cambridge, he wrote a series of pastoral comedies as a young man but was expelled from university in 1643 on account of his Royalist sympathies during the Civil War. He lived on the Continent 1646-56 and undertook confidential missions for the royal family. Later he became a physician and actively engaged in botanical experiments. His poems include The Mistress and Pindaresque Odes.

Cowper, William (1731-1800). English poet. Trained as a lawyer, his verse was popular in his lifetime because of its directness and the natural sympathy he expressed towards everyday scenes and events. His life was characterised by evangelical religious fervour and periods of melancholia and mental instability. $\mathrm{He}$ collaborated with the evangelical divine John Newton in writing Olney Hymns (1779). He made an effective blank verse translation of The Iliad (1791).

Ryscamp, C., William Cowper. 1959.
Cox, James Middleton (1870-1957). American newspaper publisher and politician. $\mathrm{He}$ was Governor of Ohio 1913-15 and 1917-21, and became Democratic candidate for president in 1920, campaigning in support of *Wilson's policies with Franklin D. *Roosevelt as his running mate. He was heavily defeated by Warren *Harding.

Coypel, Charles-Antoine (1694-1752). French painter. Court painter to *Louis XV, he also designed tapestries, woven by the Gobelins manufactory, illustrating *Cervantes' Don Quixote. He wrote several plays.

Cozens, Alexander (c.1715-1786). English landscape painter, born in Russia. He settled in England (1746) and from 1763 to 1768 was drawing master at Eton. His watercolour landscapes are mainly in monochrome and are sometimes almost impressionistic in technique. His son John Robert Cozens (1752-c.1799), whom he taught, started to work in monochrome but later used a fuller range of colour.

Oppé, A. P., Alexander and John Cozens. 1954.

Cozzens, James Gould (1903-1978). American novelist. Educated at Harvard, his novels were conservative accounts of people operating within organisational or professional constraints, highly praised on publication, now undervalued. They included The S.S. San Pedro (1931), The Last Adam (1933), Men and Brethren (1936), The Just and the Unjust (1943), Guard of Honour (1948) and By Love Possessed (1958). He won the Pulitzer Prize in 1949.

Crabbe, George (1754-1832). English poet, born at Aldeburgh, Suffolk. He went to London to seek success as a writer. Edmund *Burke, to whom he had sent some poems, gave him encouragement, as did $\mathrm{Dr}$ *Johnson. In The Library (1781), The Village (1783) and The Newspaper (1783), he showed that stark but vivid realism which is his predominant characteristic. He took holy orders and in the following years, when he was chaplain to the Duke of Rutland (1783-85) and then a parish priest, he published nothing further. In 1807 came The Parish Register, and The Borough in 1810. A tale in the latter inspired Benjamin *Britten's opera Peter Grimes. (Britten later moved to Aldeburgh.) Crabbe's Tales (1812) and Tales of the Hall (1819) again show his realistic appreciation of character and somewhat grim sense of humour. Crabbe's main contribution to English poetry was his skill in telling a short story in verse.

Blunden, E. (ed.), The Complete Works of George Crabbe. 1947.

Craig, (Edward) Gordon (1872-1966). English theatrical designer, producer and actor. Son of Ellen *Terry and the architect Edward Godwin, he acted on the London stage for some years under Henry *Irving, but after 1900 he devoted himself to stage design and 
production. His first production (1900) was *Purcell's Dido and Aeneas, at the Hampstead Conservatoire, London. He lived with Isadora *Duncan 1905-07, then worked in Berlin, Florence and Rome. He produced a notable Hamlet in Moscow (1912) with Konstantin *Stanislavsky. His outstanding influence upon modern stage production was conveyed through his books, The Art of the Theatre (1905), Towards a New Theatre (1913), Scene (1923) and his magazine Mask (1908-14, 1919-29). By simplifying three dimensional scenery with costumes and lighting effects in harmony, he conceived a production as a unified and complete work of art. He spent several years in Florence, where he started a school of stage design. He received a CH in 1958 and died in Vence. Craig, E. G., Gordon Craig: The Story of his Life. 1968.

Craigavon, James Craig, 1st Viscount (1871-1940). Ulster politician. In the House of Commons 190621 he made his name as a bitter opponent of Home Rule for Ireland. After the partition of the country he became the first Prime Minister of Northern Ireland (Ulster) 1921-40.

Cram, Ralph Adams (1863-1942). American architect. Practising in Boston, and teaching at MIT, he was exceptionally productive in designing 54 cathedrals, churches and chapels, mostly in the 'collegiate Gothic' style. The huge Cathedral of St John the Divine, New York, was begun in 1892: Cram became its chief architect in 1912 and designed the nave. Other works include buildings at Princeton University, including the chapel.

Cranach, Lucas (1472-1553). German painter and engraver, born in Kronach, Franconia. His name was derived from his birthplace. His earlier work included religious subjects (e.g. Rest on the Flight to Egypt) with idyllic backgrounds and remarkable for their fresh colouring. He also executed many woodcuts. In 1505 he became a painter to the Saxon court at Wittenberg. He became an ardent Protestant and among his many portraits in which he is inclined to over-concentrate on the accessories of dress is one of *Luther. Two of his sons were trained by him, Lucas Cranach (15151586), whose work is often indistinguishable from that of his father, and Hans Cranach (d.1537).

Crane, (Harold) Hart (1899-1932). American poet. After working as a reporter in New York, he drifted unhappily through a succession of odd jobs. Most of his poetry, which shows the influence of ${ }^{*}$ Rimbaud and *Whitman, was published in two volumes, White Buildings (1926) and The Bridge (1930), which has been called 'a mystical interpretation of the past, present and future of America'. He jumped over the side of a ship in despair at his homosexuality and alcoholism.

Crane, Stephen (1871-1900). American writer and war correspondent. He wrote two novels, the stark and powerful Maggie, A Girl of the Streets
(1892), ignored at the time of publication, and The Red Badge of Courage (1895), a sensitive account of heroism under fire in the American Civil War. Its success led to his appointment as war correspondent in the Greco-Turkish and Spanish-American Wars. He also wrote poetry and realistic short stories. From 1898 he lived in England and came to know Joseph ${ }^{*}$ Conrad, Henry ${ }^{*}$ James and other writers. He died of tuberculosis in Germany.

Stallman, R. W., Stephen Crane: a Critical Bibliography. 1972.

Crane, Walter (1845-1915). English artist. He is best known as an illustrator (e.g. of the Toy-book series). Like William *Morris he sought to ally art to industry and everyday objects.

Cranmer, Thomas (1489-1556). English prelate, born in Nottinghamshire. Educated at Cambridge University, he became a Fellow of Jesus College and lectured in divinity, at the same time studying *Luther's works critically. (Martin *Bucer was a more important influence than Luther.) A widower, he also served as a diplomat. In 1529 he attracted the attention of *Henry VIII by expressing his opinion that Henry's reasons for divorcing ${ }^{*}$ Katherine of Aragon were valid, and that views from European universities should be sought. Cranmer was sent on missions abroad to rally support and in 1530 arrived in Rome to present the case for annulment of the marriage to Pope ${ }^{*}$ Clement VII. He became envoy to Emperor ${ }^{*}$ Charles V in 1532 and in Nuremberg married Margarete Osiander. In January 1533 he was raised from Archdeacon of Taunton to become Archbishop of Canterbury, working with, and to a large degree under the direction of, Thomas ${ }^{*}$ Cromwell. He declared the king's marriage to Katherine null and void (1533). In 1536 he annulled Henry's marriage to *Anne Boleyn but gave no detailed explanation and he pleaded against her execution. He supported too, the Act of Supremacy (1534) which asserted the royal headship of the Church of England. He also encouraged the English translations of the Bible but failed to reach doctrinal agreement with the German reformers, with the result that little change in doctrine was made in Henry's reign. The two prayer books of *Edward VI's reign, the latter little different from the Book of Common Prayer (of *Charles II's reign) still used, were, however, largely due to Cranmer's work and inspiration, and his gift for noble and sonorous expression is fully displayed. The words of the marriage ceremony are his. When *Mary came to the throne his Protestantism, combined with his support for Lady Jane *Grey, made his fate inevitable. He tried to save his life by a recantation of his opinions, but this he afterwards withdrew and met his death at the stake at Oxford with the same courage as his fellow martyrs, *Ridley and *Latimer.

MacCulloch, D., Thomas Cranmer: A Life. 1996. 
Crashaw, Richard (1613-1649). English poet. The son of a Puritan clergyman, he was educated at Charterhouse and Cambridge University. While at Peterhouse, he became a Roman Catholic and in 1643 fled abroad. He eventually obtained a benefice at Loreto, where he died soon after his arrival. His gentle character made him much loved. He wrote secular and religious poems in both Latin and English, and his fame mainly rests on those in which devotion and mystical experience are expressed in ardent, almost sensual, terms.

Crassus, Marcus Licinius (c.110-53 BCE). Roman magnate. Considered the wealthiest Roman of his time, he was also an able politician and a skilled but brutal general, who destroyed the slave revolt (73-71 BCE) led by ${ }^{*}$ Spartacus. He used his money for political ends and so was able to form with ${ }^{*}$ Caesar and *Pompey the first triumvirate which dominated Roman politics from $60 \mathrm{BCE}$. He held the office of consul twice (70 and 55) and as part of the bargain made with his associates at Luca became Governor of Syria in 54. His campaign to subdue the Parthians (53) ended in disaster in Mesopotamia and his own death.

Craxi, Bettino (1934-2000). Italian Socialist politician, born in Milan. He became a journalist and party organiser, Deputy 1968-94, party leader 197693 and Prime Minister 1983-87. He was charged with corruption in 1993, retired to Tunisia and was sentenced in absentia (1994) to $8 \frac{1}{1} 2$ years jail.

Cray, Seymour R(oger) (1925-1996). American computer designer. Educated at the University of Minnesota, he worked for Remington Rand and UNIVAC, and became the co-founder of Control Data in 1957. In 1972 he established Cray Research Inc. and designed a series of supercomputers, leading to the Y-MP C90 of 1990. Supercomputers were soon challenged by 'massively parallel' computing, where a network of smaller computers was linked synergistically to create greater computing capacity.

Crean, Simon Findlay (1949- ). Australian Labor politician. Son of Frank (Francis Daniel) Crean (1916-2008), a minister under Gough *Whitlam 1972-75, he was President of the Australian Council of Trade Unions 1985-90, a Federal MP 1990-2013, Minister 1990-96; 2007-13 and Leader of the Opposition 2001-03.

Crébillon, Claude Prosper Jolyot de (1707-1777). French novelist. A gay and witty man of the world, he chose elegant, sophisticated and licentious themes. In his most famous work, Le Sopha (1745), an oriental prince transformed into a sofa is titillated by overhearing the amorous conversations of those who choose him for a resting place. His father, Prosper Jolyot de Crébillon (1674-1762), a playwright, was regarded as a rival to ${ }^{*}$ Voltaire; his sensational tragedies, e.g. Atrée et Thyeste (1707), were based on unnatural crimes.

Creevy, Thomas (1768-1838). English diarist. His letters and journal, covering more than 40 years, give a sometimes prejudiced but always vivid account of the political and social events and gossip of his time. He married a rich widow, was an often absentee Whig MP 1802-26, 1831-32, always representing 'rotten boroughs', but regarded himself as a disciple of Charles James *Fox.

Cremer, Sir (William) Randal (1836-1908). English politician. Originally a carpenter and trade union leader, he was a friend of *Mazzini and ${ }^{*}$ Garibaldi and general secretary of the International Workingmen's Association 1864-67 and secretary of the Workmen's Peace Association 1871-1908. Elected as a Liberal MP 1885-95; 1900-08, he founded the InterParliamentary Union (IPU) in 1889 and was a strong advocate of international arbitration. In 1903 he received the Nobel Peace Prize. A pacifist, he became a passionate opponent of female suffrage (asserting that women voters were likely to be influenced by religion).

Crerar, Harry (Henry Duncan Graham) (18881965). Canadian soldier. After having commanded the Canadians in Italy and the Mediterranean area (1943-44) he was GOC of the Canadian 1st Corps, which formed (1944-45) the left wing of the great Allied liberating drive from Normandy to the German frontier. An excellent staff officer, less successful in the field, he was one of many generals scorned by *Montgomery. He received a CH in 1945.

Cressent, Charles (1685-1768). French cabinetmaker. Considered the greatest in the Regency style and one of the finest in the 18th century, he began his career in the studios of *Boulle, and was appointed official cabinet maker to the Duke of Orléans, Regent of France, in 1715. He was a skilled metalworker, not only designing and making his pieces but casting and carving their characteristic gilded bronze ornaments himself.

Cresson, Edith (née Campion). (1934- ). French Socialist politician. She served under ${ }^{*}$ Mitterrand and was Minister for Foreign Trade 1983-86 and for European Affairs 1988-90. She was France's first woman Prime Minister 1991-92 and became European Commissioner for Research, Science and Technology 1995-99.

Crewe, Robert Offley Ashburton Crewe-Milnes, 1st Marquess of (1858-1945). English Liberal politician, born in London. Son of Richard Monckton ${ }^{*}$ Milnes (Lord Houghton), educated at Harrow and Cambridge, he became Lord Lieutenant of Ireland 1892-95. Created earl in 1895, he served as a minister under ${ }^{*}$ Campbell-Bannerman and ${ }^{*}$ Asquith 1905-16 
and was Secretary of State for India 1910-15. Liberal Leader in the House of Lords 1908-23 and 193644 , he played a key role in securing passage of the Parliament Act 1911, which ended the veto power of the House of Lords. Promoted to marquess in 1911, he served as Ambassador to France 1922-28 and Secretary of State for War 1931. The last Whig, he was the son-in-law of *Rosebery and wrote a boring official biography (1931).

Crichton, James (1560-1582). Scottish scholar. Known as 'the Admirable Crichton' for his skill as a poet, linguist, mathematician and athlete, he graduated from St Andrew's University at the age of 15, left Scotland in 1577 and in the course of his continental travels gained fame by his ability to carry out disputations in 12 languages. He was killed in Mantua in a street brawl. (The play The Admirable Crichton by ${ }^{*}$ Barrie is wholly unrelated.)

Crick, Francis Harry Compton (1916-2004). British molecular biologist, born in Northampton. Educated at Mill Hill School, he graduated in physics from University College, London and worked for the Admiralty developing magnetic mines during World War II. From 1947 he worked at Cambridge, first at the Strangeways research laboratory 1947-49, then at the Medical Research Council's molecular biology laboratory 1949-77, where he studied under Max *Perutz. At the Cavendish laboratories he worked with J. D. *Watson on the molecular structure of DNA (deoxyribonucleic acid), partly basing their work on the X-ray diffraction studies of M. H. F. *Wilkins and Rosalind ${ }^{*}$ Franklin. Crick and Watson published a joint paper in Nature (25 April 1953) explaining the double helical structure of DNA, the chemical bases joining the helixes (like steps on spiral staircases) and the replication mechanism. This was regarded as one of the greatest scientific discoveries in all biology, in the face of fierce competition e.g. from Linus *Pauling and many others. In 1962 Crick, Watson and Wilkins shared the Nobel Prize for Physiology or Medicine. Crick was a fellow at the Salk Institute at San Diego 1962-73 and a research professor there 1977-2004. He proposed what he called the 'central dogma of molecular biology' (1970)_that DNA determines how cells will grow, that RNA (ribonucleic acid) acts as a transmission line, and 'information' is passed on to the protein which changes as directed. He wrote OfMolecules and Men (1966) and in the controversial Life Itself (1981) proposed the concept of 'directed panspermia'-that bacteria were introduced to earth from other planets. He received the Royal Society's Royal Medal (1972) and Copley Medal (1975) and the OM in 1991. What Mad Pursuit: A Personal View of Scientific Discovery (1990) was a memoir. His last great area for investigation was theoretical neuroscience and he attempted to explain the physical basis for consciousness. The Astonishing Hypothesis (1994) described the soul as 'no more than the behaviour of a vast assembly of nerve cells and their associated molecules'. The Francis Crick Institute, Europe's largest biomedical research centre, was opened in 2016.

Judson, H. F., The Eighth Day of Creation. 1979; Edelson, E., Francis Crick and James Watson: And the Building Blocks of Life. 2000; Ridley, M., Francis Crick: discoverer of the genetic code. 2006.

Crippen, Hawley Harvey (1865-1910). American homeopath and convicted murderer, born in Michigan. He lived in London from 1897 and in 1910 he poisoned his wife, a music-hall actor known as Belle Elmore, and concealed her dismembered body beneath the floor of his house. With his mistress, Ethel Le Neve (1883-1967), who was dressed as a boy, 'Dr' Crippen sailed for America but was arrested on the ship as the result of a wireless signal-the first time this new invention had been used to bring a criminal to justice. He was found guilty and hanged; Ethel Le Neve was acquitted.

Cripps, Sir (Richard) Stafford (1889-1952). British politician. Son of the ecclesiastical lawyer Charles Alfred Cripps, 1st Baron Parmoor (1852-1941) who served in the Labour governments of 1924 and 1929-31, Cripps, educated at Winchester and London University, was already one of the most successful KCs in the country when he became immersed in politics. MP 1931-50, and Ramsay *MacDonald's Solicitor General 1931, he was expelled from the Labour party (1939) for supporting a 'Popular Front' with the Communists. In World War II he was Ambassador to Russia 1940-42, Lord Privy Seal 1942 and Minister for Aircraft Production 1942-45. In 1942 he failed in a mission to India to secure agreement among Indians on the terms on which a promise to give dominion status to India after the war could be fulfilled. In Attlee's postwar Labour government, Cripps, as President of the Board of Trade 1945-47 and Chancellor of the Exchequer 1947-50, was especially associated with the austerity policy of rationing and controls. (Churchill called him 'Christ and carrots'.) Cancer forced his retirement (1950).

Cripps, S., Towards a Christian Democracy. 1945.

Crispi, Francesco (1819-1901). Italian politician, born in Sicily. A republican, inspired by *Mazzini, he took refuge in France after the collapse of the 1848 revolution. He landed in Sicily with *Garibaldi's Thousand in 1860 . He accepted the monarchy of *Vittorio Emmanuele as a unifying force, and in the Chamber of Deputies gained a great reputation for independence and his support of a nationalism based on moral unity. As Prime Minister 1887-91, 189396 he abandoned Italy's traditional amity with France by strengthening the Triple Alliance with Germany and Austria. He also developed the Italian settlements in East Africa, Somalia and Eritrea. The crushing defeat of the Italians at Adowa (1896) forced his resignation and had a demoralising effect on Italian politics for decades. 
Cristofori di Francesco, Bartolomeo (1655-1731). Italian harpsichord maker, born in Padua. Under Medici patronage, in 1700 there is the first reference to an 'arpicembalo', a harpsichord that could produce a soft or loud note according to the pressure on the keys. This he did by introducing a hammer action in place of the former plucking of the strings. The instrument was the first 'piano forte' ('soft loud') and the forerunner of the present pianoforte. He died in Florence.

Crivelli, Carlo (c.1430-c.1495). Venetian painter. His many altarpieces and pictures illustrate the life of the Madonna. His Annunciation in the National Gallery, London, is remarkable for its background ornamentation (which includes a peacock, a hanging carpet and many other decorative objects) and the mathematical precision of its perspective.

Croce, Benedetto (1866-1952). Italian philosopher, historian and critic, born in the Abruzzi region. Son of a landowner, he lost both parents and his sister in an earthquake at Ischia (1883) from which he narrowly escaped. Educated in Rome, he abandoned law for history and aesthetics. In Naples, he founded the journal La Critica in 1903 and edited it until 1944. Early formulations of his views on literature, philosophy and history appeared there and he also held an honorary chair in philosophy at Naples University 1903-44. His philosophy, influenced by Hegel, is an idealism that holds that the only reality is mind or spirit. This is not a transcendent entity, however, but rather to be identified with human experience and includes works of art. Croce's discussion of this area, which in a rather wide sense of the word he calls aesthetics, has been the most influential part of his philosophy. Actual works of art, according to Croce, are expressions of sensuous insights of artists. The insights, it is claimed, are the 'real' works of art, and the actual paintings, for example, are merely means of communicating them to others. Croce's greatest work is the Philosophy of the Spirit (1902-17) but his views on aesthetics are also presented in Aesthetic (1902). He was a Senator 1910-44 and Minister of Education 1920-21, withdrawing from politics when ${ }^{*}$ Mussolini came to power. He wrote $A n$ Autobiography (1927) and returned to public life as Leader of the Liberal Party 1944-47.

Crockett, David ('Davy') (1786-1836). American hero. This semi-legendary figure of the pioneer days ('cradled in a sap trough, clouted in a coonskin ...') was a lawyer, active in the development of Tennessee, Member of the House of Representatives for much of the period 1817-35, and killed at the Battle of Alamo, fighting against the Mexicans.

Croesus (d.546 BCE). Last king of Lydia (Asia Minor) 560-546 BCE. He extended his kingdom eastwards but when opposed by Cyrus, the Persian king, he was quickly overthrown and his realm annexed. It is for his proverbial wealth that he is remembered. His help in the rebuilding of the temple at Ephesus is commemorated by a column inscribed with his name, now in the British Museum.

Croker, John Wilson (1780-1857). British literary critic and politician, born in Ireland. An MP 180752 , he was a vitriolic opponent of parliamentary reform and coined the political name 'Conservative'. In 1809, he helped to found the Quarterly Review, in which appeared his attack on Endymion that, in Byron's words, 'killed John Keats'. Macaulay detested him 'more than cold boiled veal'. He was one of the founders of the Athenaeum Club, London, in 1824.

Crome, John (1768-1821). English painter. A leading member (with ${ }^{*}$ Cotman) of the Norwich School, he began as a sign painter and educated himself in art mainly by copying works owned by a friendly local collector. Most of his life was spent in and around Norwich (where he was a drawing master) and his pictures, e.g. The Poringland Oak, and Mousehold Heath, both in the National Gallery, London, which show the serenity and spatial quality of the Dutch landscapists, are mainly of local scenes. River and windmill, skies drenched in light, meadows and storm-wrecked trees are typical subjects.

Clifford, D., and Clifford, T., John Crome. 1968.

Cromer, 1st Earl of, Evelyn Baring (1841-1917). English administrator, born in Cromer. Member of a merchant banking family ( ${ }^{*}$ Baring), he was educated at Woolwich, served as a staff officer in Malta and Jamaica and became private secretary $1872-76$ to his cousin Lord *Northbrook, Viceroy of India. One of the European commissioners of the Egyptian public debt 1877-79 and Comptroller-General 1879-80, he returned to India as Finance Member of the Viceroy's Council 1880-83. As British Consul-General and Agent to Egypt 1883-1907, he was the de facto ruler of 'the veiled protectorate', with responsibility for finance, foreign affairs, defence, education and public works, although the country was nominally part of the Ottoman Empire. He was a Latin and Greek scholar but never attempted Arabic. He saw himself as ruling in an enlightened Whig tradition and was showered with British honours including an earldom in 1901, the OM in 1906, the Albert Medal, a FRS and $£ 50,000$ from parliament. He led the Unionist free traders in the House of Lords and was a vigorous opponent of votes for women. He chaired the Dardenelles Commission 1916-17, enquiring into the Gallipoli fiasco, where his exertions contributed to his death. His grandson, (George) Rowland Stanley Baring (1918-1991), 3rd Earl of Cromer, managing director of Baring Brothers (from 1947), headed the British Treasury's delegation in the US (1959-61), became a Director of the International Monetary Fund and the World Bank, Governor of the Bank of England 1961-66 and Ambassador to the US 1971-74, receiving a KG in 1977. 
Crompton, Richmal (pen name of Richmal Crompton Lamburn) (1890-1969). English writer. Originally a classics teacher, beginning with Just William (1922) she wrote 37 children's books about William Brown, a mischievous but endearing middleclass schoolboy and his friends (and enemies). By 1977, nine million of her books had been sold.

Crompton, Samuel (1753-1827). English inventor, born near Bolton, Lancashire. He was working in a spinning mill when he invented the 'spinning mule', which combined the virtues of *Hargreaves' 'spinning jenny' and *Arkwright's waterframe. In 1812 Crompton received a grant of $£ 5,000$, but his business ventures failed and he died in poverty only mitigated by secret gifts from friends.

Cromwell, Oliver (1599-1658). English soldier, statesman and Lord Protector of the Commonwealth, born in Huntingdon. Of yeoman stock (the original family name was Williams), related by marriage to Thomas ${ }^{*}$ Cromwell, he attended grammar school, spent a year at Sidney Sussex College, Cambridge, and may have studied law at Lincoln's Inn, London. In 1620 he married Elizabeth Bourchier, the daughter of a London merchant. He represented Huntingdon in Parliament 1628-29, but during the 11 years of *Charles I's absolute rule (1629-40) he was active only in local affairs, though he became a fervent, but not bigoted, Puritan. In 1638 he inherited property at Ely from an uncle, but suffered a nervous breakdown, leading to 'reconversion' and a burst of religious fervour. He was MP for Cambridge in the Short and Long Parliaments 1640-53. Soon after the Civil War broke out (1642) he was serving under ${ }^{*}$ Essex and won distinction as a cavalry officer at Edgehill. His military skill became more and more evident, his tactics being especially effective at the great parliamentary victory (1644) at Marston Moor near York. He played a principal part in the creation of the New Model Army (known as the 'Ironsides'), who were subjected to rigid discipline and stern morality. Cromwell emerged as the leader of this body and it became devoted to his interests. He was helped too by the passing of the Self Denying Ordinance (1645) under which the parliamentary generals (Cromwell himself excepted) gave up their commands. This left *Fairfax and Cromwell to lead the New Model Army to victory at Naseby. This was the beginning of the end: the west country and other royalist held areas were gradually overrun, the towns were stormed or surrendered. Charles himself was harried and chased until at last he surrendered to the Scots near Newark, only to be handed over after a year of haggling to the English parliament. In 1647 parliament and army quarrelled, Charles was seized in the name of the army and thenceforth, Fairfax being in favour of conciliation and no longer able to influence events, Charles depended for his life on Cromwell's mercy. Probably the king's intrigues with the Scots, which brought them into a war against him, made Cromwell decide that he must die. Having crushed the Scots at Preston, he caused Charles to be brought to trial and his execution followed (January 1649). With the formation of the Commonwealth, Cromwell's only official position was his army leadership, but he gradually gathered the executive reins into his hands. First a rising of the extremist 'Levellers' had to be suppressed (1649), then he went to Ireland, still in royalist hands, and achieved a conquest by cruelties, such as the massacres of the garrisons of Drogheda and Wexford, which provoked bitter memories that still survive. His settlement, based largely on dispossessing Roman Catholic Irish and replacing them by English ex-soldiers or land speculators, was equally disastrous. In contrast, after he had crushed, at Worcester, a Scottish invasion headed by Prince Charles (the future ${ }^{*}$ Charles II) he brought to Scotland the advantage of union and free trade with the more prosperous and advanced England. Meanwhile he was in trouble with the surviving members of the old parliament, known as the Rump, who had little relish for a new autocrat. Cromwell dissolved them by a show of force and called a Puritan convention, nicknamed the 'Barebones Parliament', which proved equally intractable and was also dismissed. Supreme power now rested with Cromwell and his officers. In 1653 under an 'Instrument of Government' he was declared Protector, a council of state assisted him in his executive functions and a single-chamber parliament dealt with legislation and taxation. His ordinances had the effect of law when parliament was not in session. The members varied from the sycophants to the querulous, but Cromwell never succeeded in working with assemblies and had to rule as a virtual dictator with 'major-generals' acting as regional administrators. He was offered the crown but would have forfeited the support of the army had he accepted. Cromwell proved as good an administrator as he had been soldier. In his religious reforms he took measures to improve the quality of the ministry but showed tolerance to all denominations other than Roman Catholicism and Anglican episcopalianism. His legal ordinances aimed at the suppression of corrupt practices swept away many barbarous punishments and provided relief for debtors. His foreign policy was designed to strengthen English trade. Although the 1651 Navigation Act precipitated the first Dutch War (1652-54), *Tromp found a match in *Blake, whose successes brought the Commonwealth much prestige. In the war with Spain (1655-58), in which Jamaica was won, Cromwell even managed to gain the alliance of Catholic France. He suffered from gout, malaria and stones in the bladder. He died on 3 September 1658, the anniversary of his victories at Dunbar and Worcester. His body was buried in Westminster Abbey, but in January 1661, after the Restoration, his embalmed body was exhumed, hanged at Tyburn, then decapitated and his head exposed on a pole outside Westminster Hall until 1684. (In 1960 his head was buried at Sidney Sussex College.)

Cromwell believed in, and found biblical justification for, all that he did and was unquestionably among the greatest of all English rulers, but that his system struck no deep roots was proved by the fact that within two 
years of his death the people were cheering the return of the monarchy. His third son, Richard Cromwell (1626-1712), succeeded him briefly as Lord Protector (1658-59), becoming virtually a prisoner of the army which deposed him. Known as 'Tumbledown Dick', he lived in exile in Paris until 1680.

Ashley, M., The Greatness of Oliver Cromwell. 1966; Fraser, A., Cromwell: Our Chief of Men. 1973.

Cromwell, Thomas, 1st Earl of Essex (c. 1485-1540). English lawyer and administrator, born in Putney. Son of a brewer and a gentlewoman, he did not attend university but left home, led an adventurous life on the Continent and became fluent in Italian, French and Latin. He became established (c.1513) in London as a trader. He attached himself (1514) to *Wolsey and, though elected to parliament (1523), continued to serve him as an assistant and secretary until his downfall. This he survived and soon proved as useful to King ${ }^{*}$ Henry VIII as he had been to Wolsey. MP again 1529-36, he became Chancellor of the Exchequer 1533-40, Principal Secretary to the King 1533-40, Master of the Rolls 1534-36 and Lord Privy Seal 1536-40. Sympathetic to the religious reformers in Zürich, Geneva and Strasbourg, and strongly opposed to papal supremacy, after Henry's position as head of the church was secured by the Act of Supremacy (1534), he was given the rather odd title of Vice-Gerent 1535-40, in which, as the king's deputy in religious affairs, he carried out the dissolution of the monasteries and secured a large part of their revenues for the crown. He played a significant role in the execution of John *Fisher and *Anne Boleyn (not so much with Thomas *More), succeeding Fisher as Chancellor of Cambridge University 1535-40 and attending Anne's beheading.

He continued to support Henry's personal ambitions and, by centralising the administration and making it more efficient, added to his power. For his services he was created a baron 1536 and KG 1537.

He secured publication of the 'Matthew Bible' (1537) and the 'Great Bible' (1539), most of it translated by the unnamed (and unnameable) William *Tyndale, with the remainder by Miles *Coverdale and John Rogers.

In April 1540, he was created Earl for arranging Henry's marriage with *Anne of Cleves. It was this service that proved his undoing. As the king's agent he made many powerful enemies and so, when the marriage failed, Henry could vent his anger in the certainty of public approval. Cromwell was arrested, condemned by bill of attainder for heresy and treason, and executed, without trial, in July 1540. However, in December 1540 Henry created Gregory Cromwell (c.1520-1555) a baron, apparently claiming to have been misled about his father's guilt.

The three novels of Hilary *Mantel (two winning the Man Booker Prize) were persuasive rehabilitations of his reputation, arguing that he was a practical reformer, remote from religious fanaticism and a restraint on Henry. Diarmaid *MacCulloch's biography is a powerful reinforcement.

Dickens, A. G., Thomas Cromwell and the English Reformation. 1959; Mantel, H., Wolf Hall. 2009; Bring Up the Bodies. 2011; The Mirror and the Light. 2020; MacCulloch, D., Thomas Cromwell. A Life. 2018.

Cronje, Piet (1835-1911). South African soldier. He was a leading figure of the Transvaal army in the first and second Boer Wars. In the early stages of the latter he had a striking success at Magersfontein when he repulsed Lord Methuen's attempt to relieve Kimberley. In the following February, however, at Paardeberg he was forced to surrender with 4,000 men to Lord *Roberts. He was confined at St Helena for the rest of the war.

Crookes, Sir William (1832-1919). English chemist and physicist, born in London. Educated at the Royal College of Chemistry, like *Huggins, *Joule and ${ }^{*}$ Rayleigh he inherited wealth and was able to pursue independent research without having to teach. He discovered (1861) the element thallium from spectroscopic investigation of selenium residues from a sulphuric acid plant. He invented the radiometer and a vastly improved vacuum tube, leading to the development of the cathode ray tube. In 1879 he discovered a 'fourth state of matter' (after solids, liquids and gases), which he called 'radiant matter', now known as 'plasma'. He correctly concluded that cathode rays consisted of streams of particles, later called electrons. He was unlucky not to have beaten *Röntgen to the discovery of X-rays. He designed 'Crookes glass' to protect the eyes of industrial workers from strong radiation which is now also widely used for protection against bright sunlight. He became a naive and credulous President of the Society for Psychical Research 1896-99. Awarded a knighthood (1897), the Copley Medal (1904) and the OM (1910), he was President of the Royal Society 1913-15. Nominated for the Nobel Prize for Physics five times and for Chemistry six-all failed.

Crosby, Bing (Harry Lillis) (1903-1977). American singer and actor, born in Tacoma, Washington. $\mathrm{He}$ began singing professionally in the 1920s, working 1926-30 with Paul *Whiteman's band. A baritone, Crosby was a pioneer of 'crooning', a soft, murmuring style, ideal for singing into a microphone. He made his film debut in 1930 and began his radio career as a soloist in 1931. His 84 films, some as narrator, included Pennies from Heaven (1936), Road to Singapore (1940, first of a Road series with Bob *Hope), Going My Way (1944, Academy Award), The Bells of St Mary's (1945), White Christmas (1954) and High Society (1956). He won many awards, invested in technology, died suddenly on a golf course in Spain and left a large fortune. 
Crosland, (Charles) Anthony Raven (1918-1977). British politician. After war service in North Africa and Italy, he resumed his studies at Oxford and lectured in economics there 1947-50. He was a Labour MP 1950-77, serving under Harold *Wilson in a variety of ministries 1964-70, and as Minister for Environment 1974-76. He contested the party leadership in 1976, polling badly, but James *Callaghan appointed him Foreign and Commonwealth Secretary, a post he held until his sudden death. Crosland will be best remembered for his writings on political philosophy, especially for his advocacy of democratic socialism in a mixed economy in The Future of Socialism (1956) and The Conservative Enemy (1962).

Crosland, S., Tony Crosland. 1982.

Crossman, Richard Howard Stafford (1907-1974). British Labour politician. Son of a judge, he was educated at Winchester and Oxford, becoming a don at New College and Deputy Editor of the New Statesman 1938-44. A Labour MP 1945-74, as an intellectual he aroused deep suspicion and *Attlee excluded him from office. He was party chairman 1960-64, serving under Harold *Wilson as Minister for Housing and Local Government 1964-66, Lord President of the Council 1966-69 and Secretary of State for Social Security 1968-70. He edited the New Statesman 1970-72. His Diaries, published posthumously (1975-77), although largely selfserving, give vivid insights into the workings of cabinet government.

Crowley, Aleister (1875-1947). British charlatan. He liked to be known as the wickedest man in the world'. He devised a form of Satanism, which involved many obscure and repugnant rituals, and attracted a small number of eccentric disciples.

Cruden, Alexander (1701-1770). Scottish bookseller in London. He compiled the Concordance of the Holy Scriptures (1737). He became insane soon afterwards and was subsequently subject to periods of madness in which he called himself 'Alexander the Corrector'.

Cruikshank, George (1792-1878). English caricaturist. Both his father and his elder brother were caricaturists. His cartoons, especially those ridiculing participants in Queen ${ }^{*}$ Caroline's trial, created his reputation but he is now best known for his book illustrations, especially those for ${ }^{*}$ Grimm's fairy tales, *Dickens' Oliver Twist and some of Harrison *Ainsworth's novels.

Crumb, George Henry (1929-2022). American composer, born in West Virginia. He studied in Berlin, and was influenced by ${ }^{*}$ Webern. His output was small, but intense and deeply emotional, including Black Angels (1970) for amplified string quartet, Vox Balaenae (Voice of the Whale) (1971), for electric flute, electric cello, and amplified piano, Music for a Summer Evening (Makrokosmos III) (1974), for two amplified pianos
Crusell, Bernhard Henrik (1775-1838). Finnish composer, conductor and clarinettist. He worked in Stockholm from 1791, composed three vivacious concertos for clarinet, a Sinfonia concertante for clarinet, horn, bassoon and orchestra (1808), much chamber music, and translated the libretti of Figaro and Fidelio into Swedish.

Crutzen, Paul Jozef (1933-2021). Dutch atmospheric chemist, born in Amsterdam. He shared the 1995 Nobel Prize for Chemistry with Mario Molina and Sherwood *Rowland 'for their work in atmospheric chemistry, particularly concerning the formation and decomposition of ozone'. $\mathrm{He}$ promoted the use of the term 'anthropocene' to define a new era in geology and ecology.

Cruz, Ted (Rafael Edward) (1970- ). American Republican politician, born in Canada. His father was Cuban born. Educated at Princeton and Harvard, he became a lawyer and administrator. US Senator from Texas 2013- , he was a strong conservative contender for the Republican Presidential nomination in 2016.

Cudworth, Ralph (1617-1688). English philosopher. The best known of the group of philosophers generally called the 'Cambridge Platonists', he summed up his philosophy in his The True Intellectual System of the Universe, a rambling uncompleted work intended to counteract materialism by proving the existence of a supreme divine intelligence. The learning displayed was immense, the presentation of his opponents' case was so fair and their arguments against the existence of God so strongly put forward that *Dryden could doubt whether he had successfully demolished them.

Passmore, J. A., Ralph Cudworth. 1950.

Cuénod, Hugues (-Adhémer) (1902-2010). Swiss tenor. His mother was of English descent, distantly related to the ${ }^{*}$ Churchills. His voice was small, but beautifully managed, with outstanding diction and a repertoire which extended from ${ }^{*}$ Monteverdi to *Stravinsky. He recorded selectively over a longer period than any other singer, and was an admired teacher, who continued his career well into his 90s.

Cugnot, Nicolas-Joseph (1725-1804). French military engineer. In 1769-70 he designed and built two steam-propelled vehicles for hauling heavy guns. The vehicles had three wheels, the single front wheel steering and driving. Cugnot had not solved the problems of water supply and of maintaining steam pressure, but his invention pioneered steam traction vehicles.

Cui, Cesar Antonovich (1835-1918). Russian composer of French-Lithuanian origin. He was associated with the group of composers known as 'The Five' (*Balakirev), and composed operas, piano pieces and orchestral works. By profession he was a military engineer and became a lieutenant general. 
Cuitlahuac (or Quetlavaca) (d.1520). Mexican (Aztec) Emperor 1520. He replaced his brother *Moctezuma, who was under Spanish control, rebelled against ${ }^{*}$ Cortés and died of smallpox during the siege of Tenochtitlan.

Cullen, Paul (1803-1878). Irish prelate. He worked in Rome for 20 years, became Archbishop of Armagh 1849-52 and Dublin 1852-78, and was the first Irish cardinal (1866). Because of his Vatican links, he was able to shape the Catholic Church not only in Ireland but in the US, Canada and Australia.

Cumberland, Ernest Augustus, Duke of (17711851). British prince and, as Ernst August, King of Hanover 1837-51. Born in London, the fifth son of *George III, also King of Hanover, he fought the French in the Hanoverian army (1792-93) and was severely wounded. An extreme reactionary in the House of Lords, and rumoured to have murdered his valet, he succeeded *William IV as King of Hanover, because the Salic Law excluded Queen *Victoria.

Cumberland, William Augustus, Duke of (17211765). British prince and Field Marshal. Known as 'Butcher', son of *George II, in the War of Austrian Succession he distinguished himself at the battles of Dettingen (1743) and Fontenoy (1745). He was then recalled to meet the threat of the Jacobite invasion from Scotland under Charles Edward *Stuart (the Young Pretender). Having reached Derby the Scots retreated to their own country where Cumberland gained a decisive victory at Culloden (1746). It was his severity after this battle that earned him his nickname. He commanded the Hanoverian army in the Seven Years War but, hopelessly outnumbered by the French, was defeated at Hastenberg (1757) and signed the convention of Kloster Zeven (later repudiated by George II) which left Hanover and Westphalia in French hands.

cummings, e e (Edward Estlin Cummings) (18941962). American poet and painter, educated at Harvard. He was imprisoned for six months during World War I by the French who mistakenly believed him to be a spy. He wrote about this experience in The Enormous Room (1922). His volumes of poetry are notable for their unorthodox form and abandonment of punctuation and capital letters.

Cunard, Sir Samuel, 1st Baronet (1787-1865). English ship owner, born in Nova Scotia. Having acquired experience of coastal shipping by carrying the mails from Halifax to Boston he came to England in 1838 and in 1840, in association with Robert Napier and others, started a fortnightly trans-Atlantic service. The first vessel used was the Britannia, a wooden paddle steamer of 1156 tons, but iron and screw propelled ships of much greater speed and tonnage were gradually introduced.
Cunningham of Hyndhope, Andrew Browne Cunningham, 1st Viscount (1883-1963). British sailor. In World War I he distinguished himself (DSO with two bars) in the Dardanelles campaign and the Dover patrol. In May 1939 he was appointed Commander-in-Chief in the Mediterranean where he had to face the much more numerous enemy squadrons. In September 1940 a brilliantly planned and executed naval air attack on the ships in Taranto harbour crippled the Italian battle fleet. Three more cruisers and two destroyers were eliminated at the battle of Cape Matapan in the following March. Cunningham had to organise the evacuations from Greece and Crete, to contain and attack when possible the Italian fleet and above all to protect the passage of convoys to Malta and the armies in North Africa in the face of almost continuous German and Italian air attack. In 1943 he succeeded Sir Dudley *Pound as First Sea Lord. Created a baronet in 1942, he received the KT in 1945 and a viscountcy and the OM in 1946. His brother, Sir Alan Gordon Cunningham (1887-1983), commanded the brilliant and successful attack from the south (1940) against the Italians in Ethiopia. His later appointment (1941) as Commander of the 8th Army in the western desert ended when he was superseded while an offensive which he had launched was still in progress. He was later High Commissioner in Palestine 1945-48.

Cunningham, A. B., A Sailor's Odyssey. 1951; Winton, J., Cunningham. 1998.

Cunobelinus (d.c.40). British ruler. From Verulamium (St Albans) he extended his power to cover most of southeast England. The legends preserved in *Shakespeare's Cymbeline are of no historical value.

Cuomo, Mario Matthew (1932-2015). American Democratic politician. He served as Secretary of State of New York 1975-79, Lieutenant-Governor 197982, and Governor 1983-95. An outspoken liberal, he declined to run for the presidential nomination in 1992 and was dubbed 'Hamlet on the Hudson'. His son, Andrew Mark Cuomo (1957- ) was US Secretary for Housing and Urban Development 1997-2001, Attorney General 2007-10 and Governor 2011-21 of New York State. He handled the COVID-19 crisis decisively, but was then accused of suppressing information. Facing impeachment, he resigned after accusations of sexual harassment.

Curie, Marie (née Manja Sklodowska) (18671934). Polish-French physicist, born in Warsaw. The youngest of five children, her father was a teacher of mathematics and physics, her mother principal of a girls' school. She taught briefly, then studied at an underground nationalist university. (Poland was then under Russian rule.) In 1891 she followed her sister Bronja to Paris, where she enrolled at the Sorbonne, living in great poverty. She became the assistant of Pierre *Curie and married him in 1895. 
Following *Becquerel's discovery of radioactivity (1896), the Curies in 1898 identified two new elements, polonium and radium, in pitchblende (a form of uranium oxide found in pitch-like substances), and after processing eight tonnes of it, isolated a gram of radium salts. She shared the 1903 Nobel Physics Prize with *Becquerel and Pierre *Curie for their work on radioactivity, becoming the first woman Nobel Laureate, and, at 36, still the youngest. On her husband's death in an accident, she succeeded him as professor of physics at the University of Paris until 1919, being the first woman ever appointed. She investigated the medical effects of radioactivity, and in 1910 isolated metallic radium. In 1911 she was awarded the Nobel Prize for Chemistry for the discovery and isolation of radium and polonium, becoming the first person (and only woman) to win two Nobel Prizes in the sciences. Her gender precluded election as FRS or award of the Copley Medal. She had a close relationship in 1911 with the physicist Paul *Langevin, but gave him up to devote herself to research. She founded and directed the Radium Institute in Paris and in World War I took a mobile treatment unit to the battlefields.

Professor of radiology at the University of Warsaw 1919-34, she continued her intensive research and also wrote a biography of her husband (1923). In 1921 she visited the US, met President *Harding and was publicly acclaimed. She died of leukaemia, induced by her years of working with radioactive materials, near Sallanches in Haute-Savoie. The film Marie Curie (1943) featured Greer Garson in the title role. The element 'curie' was named for her in 1944 by Glenn *Seaborg. In 1995 she was reburied with her husband in the Panthéon, the first woman so honoured.

She had two daughters. Irène Curie (1897-1956), worked with her mother, married another assistant, Jean Frédéric Joliot (later *Joliot Curie), sharing the 1935 Nobel Prize for Chemistry with him for the creation of artificial radiactivity. They both joined the Communist Party. Eve Curie (1904-2007) wrote her mother's biography (1937) and Journey among Warriors (1943).

Cotton, E., Les Curies. 1963; Quinn, S., Marie Curie: A Life 1995.

Curie, Pierre (1859-1906). French physicist. In 1880, with his brother (Paul) Jacques Curie (18551941), he discovered piezoelectricity (electricity produced by pressure in certain crystals). He also investigated the magnetic properties of materials and established 'Curie's Law' which relates magnetic properties and temperature. He was director of the laboratories 1882-95 and professor of physics 18951906 at the University of Paris. In 1895 he married Manja Sklodowska (Marie ${ }^{*}$ Curie) and thereafter they devoted themselves to the study of radioactive minerals. Jointly with his wife and ${ }^{*}$ Becquerel, he was awarded the Nobel Prize for Physics (1903). He was run over by a truck and killed.

Cotton, E., Les Curies. 1963.

Curnow, (Thomas) Allen (Munro) (1911-2001). New Zealand poet. Some of his best poems were collected in At Dead Low Water and Sonnets (1949), while his satiric verses, written under the pen name 'Whim Wham', proved popular. He edited the much praised A Book of New Zealand Verse (1945; expanded 1960).

Currier and Ives. American printers. Nathaniel Currier (1813-1888) founded a lithographic and publishing business, engaging James Merritt Ives (1824-1895) as designer. The prints, which represent many aspects of the US of their time-houses, coaches, railway and outdoor scenes in generalwere popular in their day and have become valued collectors' pieces.

Curtin, John (Joseph Ambrose) (1885-1945). Australian politician, born in Creswick, Victoria. After being secretary of the Victorian timberworkers' union 1911-15 and editor of the Westralian Worker 1917-28, he was a Labor MP 1928-31 and 1934-45. Leader of the ALP 1935-45, having been a determined isolationist and supporter of appeasement, from the outbreak of World War II he urged the strongest support of Britain in the struggle against ${ }^{*}$ Hitler. In the deeply divided parliament elected in 1940, *Menzies was forced out by colleagues, *Fadden was dogged but inadequate and two Independents decided to support Labor. Curtin became Prime Minister in October 1941. When Japan's conquest of Southeast Asia and invasion of the East Indies threatened Australia he appealed to ${ }^{*}$ Roosevelt for US aid. Joint defence was set up under the supreme command of General Douglas *MacArthur. Curtin was fortunate to be supported by a strong Treasurer, J. B. ${ }^{*}$ Chifley, and in the election of 1943 he won a massive majority. He died in office and many historians regard him as Australia's greatest Prime Minister.

Serle, A. G. For Australia and Labor. 1998; Day, D., John Curtin: a life. 1999; Edwards, J., John Curtin's War. 2 vols, 2017, 2018.

Curtis, Charles (1860-1936). Republican politician, born in Kansas. A member of the Kaw nation, he became the first Native American to achieve high political office. A lawyer, and US Senator 1907-13; 1915-29, he served as Vice President 1929-33 under Herbert *Hoover.

Curzon, Sir Clifford (Michael) (1907-1982). English pianist. He was noted as an exponent of *Mozart, *Beethoven and ${ }^{*}$ Brahms, and toured widely. 
Curzon of Kedleston, George Nathaniel Curzon, 1st Marquess (1859-1925). English Conservative politician, born in Kedleston, Derbyshire. Son of a peer, he showed brilliance at Oxford, was an MP 1886-99 and equipped himself by travel in Russia and the East and by extensive study to become Undersecretary for Foreign Affairs 1895-99. In 1899 he was appointed Viceroy of India, the youngest ever, and accepted an Irish barony, hoping to return to the Commons. He effected major reforms in Indian administration and his term was extended in 1904. However, in 1905 he resigned over a quarrel with the Commander-in-Chief, India, Lord *Kitchener, as much a clash of two autocratic temperaments as a real difference concerning the relation between army and civil authority. Curzon was an activist Chancellor of Oxford University 1907-25, accepted an earldom in 1911 and was raised to a marquessate in 1921. In World War I he was a member of *Lloyd George's war cabinet as Lord President of the Council 191619, later as Foreign Secretary 1919-24, continuing after the coalition broke up (1922). On Bonar *Law's resignation (1923), Curzon was bitterly disappointed to be passed over, when ${ }^{*}$ George $\mathrm{V}$, acting on advice from ${ }^{*}$ Balfour and others, chose Stanley *Baldwin as Prime Minister, partly because Labour, having become the major opposition party, was virtually unrepresented in the Lords. Curzon's temperament was as much his enemy as circumstances. His attempts to conceal his intense sensitivity, combined with a real love of, and skill at, organising pageantry, gave him a reputation for arrogance, hauteur and even bombast, which had a most damaging effect on his career. After Labour's 10 months in power, Curzon became Lord President of the Council 1924-25, but without departmental responsibilities. He was a pioneer conservationist and donated Bodiam Castle and Tattershall Castle to the National Trust.

His daughter, Lady Cynthia Blanche Curzon (1898-1933) married Oswald *Mosley, was a Labour MP 1929-31 and died of peritonitis: her sister Lady Alexandra Naldera Curzon, later Metcalfe (1904-1995), known as 'Baba Blackshirt', had an early enthusiasm for ${ }^{*}$ Hitler, and many prominent lovers, including Lord ${ }^{*}$ Halifax, but redeemed herself after World War II as a campaigner for the Save the Children Fund.

Gilmour, D., Curzon: Imperial Statesman. 1994.

Cushing, Harvey Williams (1869-1939). American surgeon. An early pioneer in brain surgery, he made valuable contributions, both technical and as teacher and writer. His The Life of Sir William Osler (1925) won the Pulitzer Prize. He held chairs at Harvard and Yale, was nominated 38 times for the Nobel Prize (without success) but was elected FRS.

Custer, George Armstrong (1839-1876). American soldier, born in Ohio. A dashing cavalry leader in the Civil War, he served in many campaigns against the Indians and is especially famous for 'Custer's last stand' (1876), at Little Bighorn River, Montana, when he led 200 cavalry into a Sioux Indian ambush (*Sitting Bull) in which all were killed. This tragic exploit has made him the subject of much controversy.

Goble, P. and D., Custer's Last Battle. 1970.

Cuthbert, St (c.634-687). Anglo-Saxon monk, possibly born in Scotland. He lived as a hermit, was faithful to the Roman tradition and became Bishop of Lindisfarne in 686. *Alfred the Great was inspired by Cuthbert who became regarded as the patron saint of northern England and was reburied at Durham Cathedral in 1104 . Buried with him was a tiny Gospel of St John, described as 'the earliest surviving intact European book and one of the world's most significant books', bought by the British Library in 2012 for $£ 9$ million.

Cuvier, Georges (né Jean Léopold Nicolas Frédéric Cuvier), Baron Cuvier (1769-1832). French zoologist, anatomist and palaeontologist, born in Montbéliard. A Lutheran, as a youth he assumed the name of his dead brother Georges. Educated at Stuttgart, where he began his animal studies, he became a tutor near Caen, Normandy, where he could study fossils and the animal life of the seashore at first hand. His abilities were recognised by a visiting savant and he was invited to Paris. He was the first scientist to recognise the extinction of species, named the Megatherium and Mastodon (1800) and became professor of comparative anatomy at the Jardin des Plantes 1802-32. He pioneered the study of fossils and is regarded as the founder of comparative anatomy. Cuvier asserted that species are fixed and strongly opposed the concept of evolution. His Le Regne animal (1817) contained a systematic classification of all animal life, based on structural similarities, and these theories led him to modify the Linnean system of animal classification. He was active in public life under successive regimes, a university chancellor, member of the Council of State and secretary of the National Institute. A beaked whale, gazelle, toucan, tiger shark and extinct giant sloth are named for him.

Coleman, W., Georges Cuvier, Zoologist. 1964.

Cuyp, Aelbert (1620-1691). Dutch landscape painter. He was the son of Jacob Cuyp (1575-1649), also an artist, best known for animal subjects and military scenes. Aelbert, though he also painted portraits, military and hunting scenes, is famous for idyllic scenes near his native Dordrecht (e g. Landscape with Cattle at the National Gallery, London) in tones warm and golden with sunshine. He greatly influenced English landscapists of succeeding generations.

\section{Cymbeline see Cunobelinus}


Cyprian, St (Thascius Caecilius Cyprianus) (c.200258). Latin bishop and martyr, born in Carthage. Trained as a rhetorician, he was past middle life when (c.246) he was converted to Christianity. As Bishop of Carthage he proved to have great powers of organisation, especially during the persecutions of the emperor Decius when he had to direct the affairs of the see from hiding. Later he showed moderation and humanity in dealing with the lapsed, those who for one reason or another had abandoned their faith. He was martyred during the persecutions of the emperor Valerian.

Cyril (Kyrill, né Konstantinos), St (c.827-869) and his brother St Methodius (né Mikhaël) (c.825-885). Greek missionaries in Russia, born in Thessalonica. In c.860 Cyril went to preach among the Tartar Khazars to the north of the Black Sea. Meanwhile Methodius had been working among the Bulgarians but in c.863 the two brothers went together to Moravia, where their knowledge of the Slav language of the people and their ability to transcribe the Bible and other liturgical works made them more influential than the missionaries already there who knew only Latin or German. Summoned to Rome, they received papal sanction for their use of the Slavonic language. Cyril died there (869) but Methodius, now Bishop of Moravia, returned to complete their work. Cyril devised the Glagolitic alphabet, a modification of the Greek with symbols for additional elements in spoken Slavonic. A later modification, developed in Bulgaria, now called Cyrillic, is the basis of written Russian, Ukrainian, Bulgarian and Serbian.

Cyrus (Ku’rash) (d.401 BCE). Persian prince. He was pardoned for conspiracy against his brother, King *Artaxerxes II, and became satrap of Asia Minor, he then raised a rebel army, many of them Greeks, but was met, defeated and killed at Cunaxa in Babylonia. The epic homeward march of the Greeks, the dangers they encountered, including the snows of Asia Minor, is described in the Anabasis of *Xenophon, who was with them.

Cyrus II ('the Great': Greek form of Ku'rash) (c.585529 BCE). King of Persia 559-529 BCE, Shahanshah (King of Kings) of Iran 550-529. Son of ${ }^{*}$ Cambyses I, of the Achaemenid dynasty, he conquered Media, Lydia (where he overcame *Croesus) and Babylon (*Belshazzar), and founded the Achaemenid Empire, the greatest to that time. Notably tolerant, he allowed the Jews to return from captivity in Babylon (539) and rebuild the temple in Jerusalem. He is often credited with promoting the first 'charter of human rights', and abolishing slavery, but this is contested. He had an enthusiasm for gardens. Killed fighting a nomadic tribe, the Massagetai, at his death Cyrus' empire spread from Afghanistan to the Bosphorus. His reign was described by *Xenophon, *Herodotus and the Book of Daniel. His son ${ }^{*}$ Cambyses II added Egypt, Libya and Thrace to the empire.
Frye, R. N., The Heritage of Persia. 1963; Potts, D.T., Cyrus the Great and the Kingdom of Anshan. 2005; Jovy, A., Cyrus the Great. 2011.

Czerny, Karl (1791-1857). Austrian pianist and teacher. Noted for his studies and exercises designed to improve technique, he studied with *Beethoven, and his pupils included ${ }^{*}$ Liszt and ${ }^{*}$ Leschetizky.

Cziffra, György (Georges) (1921-1994). HungarianFrench pianist. A phenomenal technician, he left Hungary in 1956 and made many recordings. 


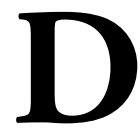

Dagobert (Dagobertus) I (605-639). King of Austrasia 623-29, of the Franks 629-39, of Neustria and Burgundy 634-39. He succeeded his father Chlothar II, was the last powerful Merovingian king, and the first to be buried at St Denis. He briefly reunited the whole kingdom of the Franks. St Eloi, a goldsmith and patron saint of craftsmen, was his treasurer.

Daguerre, Louis-Jacques-Mandé (1787-1851). French painter and physicist, born at Cormeilles, Seine-et-Oise. He invented the daguerreotype, the first practical process of photography. He worked first as an officer for inland revenue, then as a scene painter for the opera. He opened the Diorama in Paris (1822), an exhibition of panoramic views, different effects achieved by changes in lighting. In the same year J. N. *Niepce produced the first permanent photograph, though it was of poor quality and required eight hours' exposure time. Learning of Daguerre's experiments in the same field, he joined him in 1829. After Niepce's death in 1833, Daguerre continued with their work and in 1839 was able to publish his daguerreotype process, which required only 20-30 minutes exposure time. By this process permanent pictures (single images) were produced on an iodised silver plate, called a daguerreotype. His publications include Historie et description des procédés de daguerréotypie (1839). Made an officer of the Legion of Honour, he and Niepce's heir were granted annuities in 1839 .

Gernsheim, H. and A., L. J. M. Daguerre. Rev. ed. 1968.

Daimler, Gottlieb Wilhelm (1834-1900). German pioneer motor manufacturer, born in Württemberg. His success rested on his production (after earlier experiments with coal gas as a fuel) of a light, petrol-driven combustion engine, patented in 1883 . He founded (1890) the Daimler car company at Cannstatt and in 1900 produced the first Mercédès cars (named after the daughter of his financial backer Emil Jellinek). The Daimler and *Benz companies merged in 1926.

Daladier, Édouard (1884-1970). French politician, born in Carpentras, Provence. Son of a baker, he taught history at Grenoble and elsewhere before moving to Paris. After fighting in World War I, he was elected to the Chamber of Deputies (1919) and eventually succeeded Herriot as leader of the Radical Socialist party. He was Prime Minister 1934 and 1938-40 and negotiated the Munich agreement (1938) with *Hitler, *Mussolini and Neville
${ }^{*}$ Chamberlain. He was arrested (1940) by the Vichy Government, interned by the Germans (1942-45) and became a deputy again 1946-58.

Dalai Lama, The (Tenzin Gyatso) (1935- ). Tibetan religious leader, born in Taktser in Ando province. From a peasant family, he was identified as the 14th Incarnation as a child and enthroned at Lhasa in 1940 . He assumed political power in 1950 just after *Mao's victory in China, asserted Tibet's claim to autonomy, attempted to negotiate with Beijing, but withdrew to India after Chinese military action (1959). He campaigned for Tibetan independence but took up human rights and humanitarian causes generally and received the 1989 Nobel Peace Prize.

\section{Dalcroze, Émile Jaques see Jaques-Dalcroze, Émile}

Dale, Sir Henry Hallett (1875-1968). English physiologist, born in London. Educated at Trinity College, Cambridge, he was Secretary of the Royal Society 1925-35, Director of the National Institute for Medical Research 1928-42, Director of the Royal Institution, London 1942-46, and President of the Royal Society 1940-45. He shared the Nobel Prize for Medicine (1936) for his work on the chemical transmission of nerve impulses. He was awarded the Copley Medal (1937) and the OM (1944).

Dalén, (Nils) Gustav (1869-1937). Swedish engineer, born in Stenstorp. In 1906 he was appointed chief engineer of the AB Gas Accumulator (AGA) company which marketed acetylene gas. $\mathrm{He}$ researched into gases and turbines, improved hot-air turbine engines and the Laval steam turbine. By 1909 he was appointed managing director and invented Agamassan, the substance which absorbs acetylene with no risk of explosion. In 1912 he won the Nobel Prize for Physics for inventing the automatic sun valve ('solventil' in Swedish), regulating the flow of gas according to the intensity of light. It was widely used (as 'the Dalén light') in bouys and unmanned lighthouses. He was blinded by an explosion during an experiment (1913) but continued his research until his death. He patented the AGA cooker in 1922.

Dalhousie, James Andrew Broun-Ramsay, 1st Marquess of (1812-1860). Scottish administrator. Son of the 9th Earl of Dalhousie, a general, he lived in Canada as a child, was educated at Harrow and Oxford and elected MP in 1837. After being President of the Board of Trade 1845-46, he became Governor-General of India 1848-56. His first years were marked by the Second Burmese and the Sikh Wars, as a result more of Lower Burma and the Punjab were annexed. The annexation of Oudh, however, was much criticised. Dalhousie initiated a system of primary education, introduced railways and the telegraph, developed roads, trade and the postal service, and inaugurated major irrigation schemes. Created marquess in 1849 , he succeeded *Wellington as lord warden of the Cinque Ports 1853-60. 
Dali, Salvador Felipe Jacinto (1904-1989). Spanish painter and sculptor. Through the influence of ${ }^{*}$ De'Chirico and Max *Ernst, he became (from 1929) one of the principal exponents of Surrealism, a form of irrational art, deeply influenced by *Freud's work on the unconscious mind. Dali's paintings of nightmares or hallucinations often include figures drawn and painted with extreme realism. In addition to his paintings he made films (notably Un Chien Andalou, with *Buñuel, 1928), designed ballets, wrote an autobiography and other books. A retrospective exhibition of his work was held in Paris in 1980.

Gerard, M., Salvador Dali. 1974.

Dalton, (Edward) Hugh (John Neale) Dalton, Baron (1887-1962). British Labour politician. Educated at Eton and King's College, Cambridge he taught economics and worked with his close friend J. M. *Keynes before becoming a Labour MP 1924-31, 1935-59. Undersecretary for Foreign Affairs 1929-31, in *Churchill's wartime coalition he became minister. In 1945 he was Chancellor of the Exchequer in *Attlee's Labour Government, but resigned (1947) after a leakage of his budget proposals. He was Minister of Town and Country Planning 1950-51, and in 1960 became a life peer.

Dalton, John (1766-1844). English chemist, born in Cumberland. Son of a Quaker weaver, he spent most of his adult life in Manchester as a teacher and private tutor. Earlier, while teaching at Kendal (from 1781), he began a series of 200,000 meteorological observations which he continued throughout his life. He revived the theory, originating in ancient Greece, that matter is not continuous but made up of atoms, and he showed that such an atomic theory is consistent with the observed laws of constant, multiple and reciprocal proportions. He published these ideas, with a table of atomic weights and a list of chemical symbols, in A New System of Chemical Philosophy (1808). In the physical field he did much research into the constitution of gases and their expansion when heated, and into the force of steam. Dalton and his brother were colour-blind, and he was the first to give a detailed description of this deficiency.

Thackray, A., John Dalton: Critical Assessment of His Life and Science. 1973.

Damasus I, St (c.305-384). Pope 366-84. Born in Rome, son of a priest and deaconess from Lusitania, he was sometimes violent in his methods, overcame a rival pope, made many enemies and asserted papal primacy. He changed the liturgical language of the Church from Greek to Latin. The Council of Rome (382) settled the contents of the Bible and he commissioned his secretary *Jerome to produce the Latin 'Vulgate' translation.

Damien, Father (Joseph de Veuster) (1840-1889). Belgian Catholic missionary. A member of the Picpus
Mary), he went to the Hawaiian Islands in 1864 and from 1873 served at the leper colony at Molokai. After 16 years of selfless devotion he contracted leprosy and died on the island.

Farrow, J., Damien the Leper. 1955.

Damocles (4th century BCE). Syracusan courtier. Having expressed his envy of *Dionysius' power, the ruler then seated him at a banquet beneath a sword suspended by a single hair. The story was popularised by ${ }^{*}$ Cicero and ${ }^{*}$ Horace and quoted by ${ }^{*}$ Chaucer.

Dampier, William (1652-1715). English navigator, born in Somerset. He went early to sea and had taken part in several voyages before he became engaged (from 1679) in buccaneering along the South American coasts and further afield. On one such expedition (from 1683) he crossed the Pacific, touching on the Philippines, China and (in January 1688) King Sound, Western Australia. This brought him government employment. In 1699 he was commissioned to chart the east coast of New Holland in HMS Roebuck, and while failing in this, explored the coasts of northwest Australia, New Guinea and New Britain. When wrecked off Ascension Island on the return voyage, goats and turtles provided his diet for five weeks. He was soon at sea again, once more a privateer. The sailing master of one of his two ships was the prototype of Robinson Crusoe, Alexander *Selkirk, who was marooned (1704) on one of the islands of Juan Fernández. Dampier sailed with Woodes Rogers on the expedition that found and rescued him (1709). Dampier wrote vivid accounts of his voyages. He was probably the first navigator to have explored every continent except Antarctica.

Lloyd, C., William Dampier. 1966; Rutherford, A., and Preston, M.J., A Pirate of Exquisite Mind. 2004.

Danby, Thomas Osborne, 1st Earl of (later 1st Duke of Leeds) (1631-1712). English politician. He entered parliament (1665) and as a strong supporter of the king and the established Church was quickly promoted. In 1674 he became Chief Minister to ${ }^{*}$ Charles II, but was impeached (1678) by the Commons on a number of charges, the worst of which were concerned with secret negotiations, on Charles' behalf, with *Louis XIV and accepting bribes. The Commons rejected the king's immediate pardon, and Danby was imprisoned until 1684. After *James II's accession his zeal for the established Church led him to take an active part in promoting the revolution (1688) that placed *William and * Mary on the throne. He was virtually Prime Minister 1688-99 but lost his influence after being charged with bribery (1695) and retired.

Browning, A., Danby. 3 vols, 1944-51.

Dance, George (?1695-1768). English architect. Son of a London merchant, he started his career as a mason and in 1735 became surveyor to the City 
of London. Among the buildings he designed were the Mansion House (1739-53), St Botolph's, Aldgate (1741-44), and the facade of Guy's Hospital (1764). His son, also George Dance (1741-1825), who succeeded his father as city surveyor, was responsible for many London buildings and churches, e.g. Newgate Prison (1770-78, demolished 1902), All Hallows London Wall (1765-67), and the Royal College of Surgeons in Lincoln's Inn (1806-13, later reconstructed). As designer of country houses he was also in great vogue. He was an original member of the Royal Academy, where he became professor of architecture (1798).

Stroud, D., George Dance, Architect. 1971.

Dandolo, Enrico (c.1107-1205). Venetian patrician. Elected as Doge of Venice in 1192, when he was blind and about 85 , he provided transport for and accompanied the 4th Crusade, which he successfully diverted to the capture of Constantinople (1204). The islands and territories acquired by Venice were the foundations of its power in the Near East. Among the spoils were the four bronze horses which now surmount the doorway of St Mark's Cathedral (Venice).

Daniel (6th century BCE). Jewish exile in Babylon. He gave his name to a book in the Bible. He is said to have won favour with King Nebuchadnezzar for his ability to foretell the future, for interpreting the words that presaged Belshazzar's doom and, finally, for his miraculous preservation when he was thrown into a lion's den for refusing to obey a royal decree that conflicted with his religion.

D'Annunzio, Gabriele (1863-1938). Italian poet, novelist, dramatist, politician, born in Pescara. Son of an influential landowner, educated at the University of Rome, his first poems, Primo vere, were published in 1879 and a prose continuation Terra Vergine appeared in 1882, as did Canto Nuovo, followed in 1889 by an autobiographical novel Il Piacere. In 1892 he began reading ${ }^{*}$ Nietzsche who influenced his later works, several of which featured grasping, completely amoral Nietzschean heroes. He served as Deputy 18971900, supported the Allies in World War I, became an aviator and lost an eye. After the war he occupied Fiume with a force of volunteers, ruled as dictator from 1919-21, and became a national hero. Later he became an ardent fascist. He retired to Gardone Riviera and devoted himself to writing memoirs and confessions. His other important works include the two plays La figliadi Jorio (1904) and Le Martyre de Saint Sébastien (1911) the poetic works Laudi del cielo, del mare, della terra e degli eroi (1899), Alcyone (1904) and the novel Il trionfo della morte (1894). A prolific writer, he produced work of great passion and exuberance, and showed an individual and skilful use of language which influenced subsequent Italian literature. In his style of writing he broke away from the intellectualism of the 19th century, for which he was much criticised.

Julian, P., D’Annunzio. 1973; Hughes-Hallett, L., The Pike. 2013.

Dante Alighieri (or Durante degli Alighieri) (1265-1321). Italian poet, born in Florence. His prominent family belonged to the ${ }^{*}$ Guelf (pro-papal) faction in Florentine politics. Nothing certain is known about his education but he was formidably learned. In his first major work, La Vita Nuova (1283-92), a sequence of 31 love poems, we are introduced to 'Beatrice', the love of his life. The poet met her when he was nine and she was eight, and became enchanted. They met again when she was 18 and occasionally afterwards. Her death (1290) left him utterly forlorn. Her identity is a famous literary puzzle. The accepted version is that the glorious lady of his mind', as he describes her, was Bice (or Beatrice) Portinari, who married Simone de Bardi, a banker. Others suggest that the name merely masks an unknown lady, while a third theory argues that she personifies his ideal of love. In his sorrow he turned to theology and became interested in politics. In 1291 he married Gemma Donati, by whom he had three sons and two daughters.

His political ventures were disastrous. Florence was a Guelf city but the party was divided into two factions, the moderate 'Whites' (Guelfi Bianchi) and the extreme papal supporters, the 'Blacks' (Guelfi Neri). Dante, a 'White', rose to be on the Supreme Council of One Hundred. He joined the Apothecaries Guild, was elected a prior (senior magistrate) in 1301 and joined diplomatic missions to San Gemignano and possibly Paris. In Rome, on a mission to Pope *Boniface VIII, when the 'Blacks' seized power, he was convicted in absentia (1302) of barratry (selling political offices), and was sentenced to two years exile and an enormous fine. He remained in exile for the rest of his life having refused to pay the fine, with a sentence of burning at the stake if he returned to Florentine territory. He refused a conditional pardon in 1316. (The city council of Florence, not wanting to be too hasty, rescinded his conviction in June 2008.) His years of exile were in Lucca, Verona and, after 1318, Ravenna.

About 1307, he began Commedia (the word originally means a transition from confusion to certainty, or misery to joy), which *Boccaccio renamed La Divina Commedia.

Set in Easter (or the week before) 1300, over seven days (Thursday to Wednesday), The Divine Comedy consists of three books (canticas) - Inferno, Purgatorio and Paradiso-divided into 'cantos' $(34+33+33)$, 100 cantos in total, 14,233 lines, written in tercets (terza rima in Italian, units of three lines), with the rhyming scheme $\mathrm{aba} / \mathrm{bcd} / \mathrm{cdc}$ and so on, running to about $430 / 500$ printed pages. 
The Divine Comedy describes Dante's own spiritual development as he overcomes a mid-life crisis, presenting a vivid account of the mediaeval view of hell, purgatory and heaven, and life as a journey.

It is encyclopaedic in range, Michelangelesque in ambition, and draws heavily on many sources, including *Homer, *Virgil, Greek and Roman mythology, Old and New Testament, Ptolemaic cosmology and the theology of St *Augustine and St Thomas *Aquinas.

This epic poem, completed in 1321, written in the Tuscan dialect, was immediately recognised as a masterpiece, and helped to standardise the Italian language. Dante's Italian is closer to the modern language than Shakespeare's English is to ours.

It was translated into Spanish in 1428, French in 1596, and the complete version in English as late as 1802, due to Anglican resistance to Catholic orthodoxy. (At least 60 English translations of the complete work have been published and perhaps 100 of Inferno.)

The Divine Comedy has been memorably illustrated by Domenico di Michelino, Sandro *Botticelli, William *Blake, Gustave *Doré and Salvador *Dali, and inspired music by ${ }^{*}$ Liszt and ${ }^{*}$ Tchaikovsky.

The poet is guided through Hell and Purgatory (and Limbo) by *Virgil who has been sent by Beatrice. Ultimately, Beatrice leads him to Heaven. The Divine Comedy is written with extraordinary passion, obsessed with sin and punishment, often violent and scatological but also musical and serene. In the nine Circles of Hell, he assigns many personalities of his own and other times, judging them on political and moral grounds.

Colin Burrow refers to Dante's 'delicacy, his violence, his irony, his ability to soar into the divine abstraction of desire, his combination of physical immediacy and metaphysical urgency, his material weight and his spiritual profundity'.

Among Dante's lesser works, the Latin De Vulgari Eloquentia (1303-04) includes a classification of dialects and reveals his aim to secure a unified Italian tongue. Convivio (Feast, 1304-07), in which he discusses his moral and philosophic ideas, is the first important treatise written in Italian rather than Latin. De Monarchia (c.1313) discusses the relations of emperor and pope and the concept of a universal empire, and by then he was probably in the ${ }^{*}$ Ghibelline faction.

By using the vernacular in a major work, Dante is considered as the father of European literature, not only Italian. Dante died in Ravenna and is buried there, but Florence is eager for the remains to be returned.

T. S. *Eliot wrote: '[T]ake the Comedy as a whole, you can compare it to nothing but the entire dramatic work of Shakespeare ... Dante and Shakespeare divide the modern world between them; there is no third.' Dante was much admired by Ezra *Pound, James *Joyce, Samuel *Beckett and Leon *Trotsky.

Moore, E., Studies in Dante. 1969; Hawkins, P. S., Dante: A Brief History. 2007; Bemrose, S., A New Life of Dante. 2009; Santagata, M., Dante: The Story of His Life. 2016.

Danton, Georges Jacques (1759-1794). French revolutionary politician, born in Champagne. Originally an advocate in Paris, he was one of the founders of the radical Cordeliers' club (1790) but later identified himself with the moderate Jacobins, although he claimed credit for the revolt of the Paris sections (10 August 1792) which led to the overthrow of the Legislative Assembly and suspension of the monarchy. For two brief periods he was the most powerful leader in France, first as Minister of Justice (but de facto Minister of War) from August to October 1792 and President of the Jacobin club (1793) and the leading spirit in promoting national resistance as Prussian troops neared Paris with his bold challenge: 'De l'audace, encore l'audace, et toujours l'audace!'. He proclaimed that the revolutionaries had the moral right to initiate wars of national liberation outside France. He was a member of the Convention 1792-94. His second term in power was as virtual leader of the Committee of Public Safety from April to July 1793 , but when his moderate policies failed he was displaced by the extremist leader * Robespierre, who had long been his rival. Danton and his friend Camille ${ }^{*}$ Desmoulins were denounced and guillotined. A great orator, known as 'the *Mirabeau of the mob', he was susceptible to bribery, flattery and friendship and died rich.

Hampson, N., Danton. 1978.

Da Ponte, Lorenzo (original name Emanuele Conegliano) (1749-1838). Italian librettist, born in Vittorio Veneto. Of Jewish parentage, he was converted to Roman Catholicism by the Bishop of Cendea, whose name he took. He moved to Vienna (1780), became a friend of *Mozart and wrote the libretti for his operas The Marriage of Figaro, Don Giovanni and Cosi fan tutte. He lived in London 1793-1805 and in 1805 moved to the US where he became a storekeeper in New Jersey for a time. He was the first professor of Italian at Columbia University 1825-38.

Darby, Abraham (1677-1717). English iron-master and inventor, born near Dudley, Worcestershire. He patented (1707) a method of casting iron pots in sand moulds. Having taken over a blast furnace at Coalbrookdale, Shropshire, he brought about Britain's supremacy as an iron producing country by discovering (1709) a method of using coke instead of charcoal for the smelting of iron ore. A further development came when his son, the second Abraham Darby (1711-1763), successfully produced malleable 
iron from coke smelted pig iron. His son, the third Abraham Darby (1750-1791), helped to construct the cast-iron bridge over the Severn at Coalbrookdale, the first of its kind.

Raistrick, A., Dynasty of Ironfounders. 1953.

Darius I ('the Great', Greek form of Darayavaush) (548-486 BCE). King of Persia 521-486 BCE. The death (522) of *Cambyses found Persia in the midst of civil war and Darius, who belonged to a junior branch of the royal line, had to fight hard for his throne. Gradually he restored order to the empire, continued the reorganisation of the administration begun by ${ }^{*}$ Cyrus, and linked the provinces with the capital by highways of which the royal road from Sardis to Susa was the most famous. The Achaemenid Empire extended from Egypt to India and included part of the Balkans. He was tolerant towards the Jews, who were permitted and assisted to rebuild the temple at Jerusalem. After successful invasions of northwest India, Thrace and Macedon, Darius sent three expeditions that failed to conquer Greece: in the second his armies were defeated by the Athenians at Marathon (490), and the third was foiled by a rebellion in Egypt. He was succeeded by his son, *Xerxes. Darius is mentioned in Daniel v. 31, and subsequently.

Darius III (d.330 BCE). King of Persia 336-330 $\mathrm{BCE}$. His reign was marked by the conquest of his empire by *Alexander the Great, who inflicted a series of defeats, culminating with Arbela (331) in the Tigris valley. Darius fled but was murdered by the Bactrian satrap Bessus, in the belief that his death would appease Alexander. Barsine, Darius' daughter, was taken by Alexander as a second wife.

Darlan, (Jean Louis Xavier) François (1881-1942). French admiral. He joined the navy in 1902 and was Commander-in-Chief of the French fleet 1939-40. Strongly anti-British, he joined *Pétain's Government as Minister for Marine 1940-41, becoming Premier and Foreign Minister 1941-42, then, after the Germans insisted that *Laval return to government, Commander-in-Chief of all Vichy forces. However, after *Eisenhower's invasion in November 1942, Darlan negotiated to surrender North Africa to the allies, in return for being recognised as Chief of State. Enigmatic and ambiguous, he was assassinated in Algiers on Christmas Eve by a young monarchist who was executed two days later.

Smith, F., The Ship Aground. 1940.

Darnley, Henry Stuart, Lord (1545-1567). Scottish nobleman. Consort of *Mary Queen of Scots, he was the son of the 4th Earl of Lennox, whose mother, Margaret, sister of England's *Henry VIII, had married the Earl of Angus after the death of her husband *James IV. Darnley was therefore a cousin of Mary, whose second husband he became in 1565 . Their son, the future James VI of Scotland (later
*James I of England), was born the following year. After the murder of her favourite *Rizzio, in which Darnley played a leading part, the queen came to hate her husband, but when he became ill there was an apparent reconciliation. He was brought from Glasgow to Edinburgh, but was almost immediately killed when the house where he was staying, at Kirk o'Field, was blown up with gunpowder. The Earl of *Bothwell, already aspiring to take Darnley's position, was clearly guilty despite the show of a trial, at which he was acquitted. The strong probability of Mary's complicity has been the subject of continued controversy. Darnley, a gay man of cultivated tastes, was politically inept.

Darrow, Clarence Seward (1857-1938). American lawyer. He appeared for the defence in many controversial cases, notably for Eugene *Debs in the railway strike case (1894), for Loeb and Leopold in the 'thrill-murder' case in Chicago (1924) and for John T. *Scopes in the Dayton, Tennessee, 'Monkey Trial' (1925), where he battled with W. J. *Bryan. He strongly opposed capital punishment, and none of his clients was ever sentenced to death.

Darwin, Charles Robert (1809-1882). English naturalist, born in Shrewsbury (on the same day as Abraham *Lincoln). His father Robert Waring Darwin, a physician, was the son of Erasmus ${ }^{*}$ Darwin and his mother, Susannah Wedgwood, the daughter of Josiah *Wedgwood. After attending Shrewsbury Grammar School he studied medicine at Edinburgh and divinity at Christ's College, Cambridge, but his inclinations turned him to botany and geology. He had a profound, lifelong admiration for Alexander von *Humboldt. As naturalist on the naval survey ship, HMS Beagle (commanded by Robert *FitzRoy), making a voyage round the world, he investigated (1831-36) the fauna, flora and geological formations of many areas, including Brazil, Argentina, the Galapágos Islands, New Zealand, New South Wales, Tasmania and Western Australia. He never left Britain again. He became Secretary of the Geological Society of London 1838-41 and was elected FRS (1839). In the same year he married his cousin Emma Wedgwood (1808-1896) who bore him 10 children. He and his wife inherited a fortune and he was a shrewd investor leaving an estate of $£ 146,911$ (the equivalent of $£ 18.1$ million in 2021 values). By 1838 he had become convinced of the mutability of species and *Malthus' Essay on the Principle of Population helped him to grasp the mechanism of his famous theory of 'natural selection'. However, he treated his discovery as a deadly secret for 20 years. Darwin lived and worked in secure seclusion at his home at Down House, Kent, and had long periods of debilitating illness, probably Chrone's disease (inflammatory bowel syndrome), compounded by chronic depression. In 1842 he published The Structures and Distribution of Coral Reefs, which contains the now generally accepted theory of the origin of coral formations. From observations made during the Beagle expedition, he had become convinced that species had gradually 
evolved from earlier, simpler life forms in an unbroken descent from monocellular life instead of being immutable as was generally held (although *'Thales, *Empedocles, *Aristotle, *Montesquieu, *Buffon, Erasmus ${ }^{*}$ Darwin, ${ }^{*}$ Lamarck and others speculated otherwise). Darwin's great achievement was to propose a scientific explanation of how this transformation takes place. The most important factor, he considered, was 'natural selection': because of slight differences (many of them heritable) in their characteristics, some members of a species are better fitted than others for survival under the conditions of their environment and are therefore the most likely to live long enough to reproduce. In this way the variations passed on to the next generation tend to be those that favour the survival of the fittest. Although communicated privately to several colleagues, including Joseph ${ }^{*}$ Hooker, this theory remained unpublished until 1858 when A. R. *Wallace sent to Darwin from Malaya a manuscript putting forward a similar theory which he had worked out independently. Darwin then, in a paper before the Linnaean Society, announced their joint conclusions and in 1859 published his major work, On the Origin of Species by Means of Natural Selection. The work provoked furious opposition from clergy and others who saw it as an attack on the doctrine of the special creation of man, but with the support of T. $\mathrm{H}$. ${ }^{*}$ Huxley and many other eminent scientists the theory of evolution (although Darwin did not use the word in his text) gained widespread acceptance. He received the Copley Medal of the Royal Society in 1864, for 'his important researches in geology, zoology, and botanical physiology', not for his work on evolution. In 1871 Darwin published The Descent of Man, which provoked fresh controversy by its insistence that man and the anthropoid apes must have a common ancestor. In an unpublished letter to Hooker (1871) he hypothesised about the preconditions needed for the first cellular life.

The Expression of the Emotions in Man and Animals (1872), his third work on evolutionary theory, explores biological factors in human behaviour.

The concept of 'the survival of the fittest' (later described as 'social Darwinism') was proposed by Herbert ${ }^{*}$ Spencer, whom Darwin detested. By contrast, Darwin argued that humans had essentially similar physical and intellectual potential.

He was buried in Westminster Abbey (against his wishes). Darwin had a profound influence on Karl ${ }^{*}$ Marx and the science of genetics (*Mendel) later developed many of his ideas.

About 250 species including finches, frogs, shrimps, insects (mostly beetles), barnacles, an extinct primate (Darwinius), dinosaur (Darwinsaurus) and pterosaur (Darwinopterus), craters on the Moon and Mars, asteroid 1991 Darwin, an Australian city, and mountains in the Andes, Antarctica, Canada and the US were named for him.
Desmond, A. and Moore, J. Darwin. 1991; Browne, J., Charles Darwin: Voyaging. 1996; Browne, J., The Power of Place. 2002; Gopnik, N., Angels and Ages. 2009.

Darwin, Erasmus (1731-1802). English medical practitioner and philosopher of science, born at Elton Hall, Nottinghamshire. Best remembered as a forerunner of his grandson Charles *Darwin in developing evolutionary theories, his conclusions were essentially reached by philosophic speculation rather than scientific observation. He studied medicine at Edinburgh and took his degree at Cambridge. He practised as a doctor in Nottingham and with increasing success at Lichfield, when his fame even reached ${ }^{*}$ George III. Meetings of Lichfield's Lunar Society were attended by Matthew *Boulton, James *Watt, Josiah *Wedgwood, and Joseph *Priestley. Darwin moved from this congenial environment to Derby (1802). The Botanic Garden (1789-91) is an odd work written in rhyming couplets and, among other eccentricities, personifying the forces of nature, but it contains, especially in the notes, a mass of miscellaneous information. His immense range of interests included sewerage, flying machines, temperance, canals, and female education in boarding schools. His Zoonomia or the Laws of Organic Life (1794-96) anticipates evolutionary theory. He envisages the possibility of an animal having the faculty of self-improvement and able to pass on 'those improvements by generation to its posterity world without end'.

Hele, D., Erasmus Darwin. 1963.

Darwin, Sir George Howard (1845-1912). English astronomer, born in Down, Kent. The fifth child of Emma and Charles *Darwin, he studied law at Cambridge for six years, then returned to Trinity College to pursue his interests in mathematics and astronomy. Elected FRS in 1879, he became Plumian professor of astronomy and experimental philosophy, Cambridge 1883-1912. Essentially a mathematical cosmologist, his major work was on the origin of the Moon, which he argued had been drawn from planet Earth, when it was still molten, by solar tides, estimating this to have occurred about 50 million years ago. Neither hypothesis is now accepted. Recent research concludes that the Moon was fractured from Earth by a giant impact about 4.5 billion years ago. Darwin received the Copley Medal in 1911.

Darzi, Ara Warkes, Baron Darzi of Denham (1960- ). Armenian-British medical specialist, born in Baghdad. His family relocated to Ireland as refugees and, after training in Dublin, he moved to London in 1990, and became an outstanding surgeon, developing keyhole and robotic techniques. Professor of Surgery at Imperial College, London, 1996- , he was Under-Secretary for Health 2007-09 and proposed major reforms to the National Health Service. He received a peerage in 2007 and the OM in 2016. 
D'Aubigny, Charles François (1817-1878). French landscape painter. After a residence of a few years in Italy he lived mainly near Paris (the last 20 years on a houseboat on the Seine). Associated with the Barbizon school, he is noted for his successful impression of atmosphere and half-light.

Daudet, Alphonse (1840-1897). French novelist, born at Nîmes. He went to Paris at the age of 17 and became a secretary to the Duc de *Morny, publishing his first work, Les Amoureuses, a book of poems, in 1857. He confirmed his reputation with the collection of short stories Lettres de mon moulin (1866) and Contes du lundi (1873), and many novels which include Le petit chose (1868), with its memories of his own childhood. Best known of all is Tartarin de Tarascon (1872), first of a series centred on this delightful Provençal character. *Bizet wrote the music for his only play L'Arlésienne (1872). Daudet's ironic and sensitive work is notable for its realism. His son, Leon Daudet (1867-1942), editor of L'Action Française, was an unscrupulous but brilliant propagandist for the royalist cause.

Sachs, M., The Career of Alphonse Daudet. 1965.

Daumier, Honoré-Victorin (1808-1879). French painter, sculptor, lithographer and caricaturist, born in Marseille. Of poor parentage, in 1832 he drew a cartoon of King *Louis Philippe which earned him six months' imprisonment. Throughout his life Daumier was a victim of poverty and a savage critic of social injustice, he especially satirised the malpractices and foibles of lawyers and other members of the rich bourgeoisie, and the regime of *Napoléon III provided some excellent targets. The effectiveness of his lithographs derives from bold silhouettes defined by an energetic line and strongly marked lights and darks. In his paintings, whose near uniformity of style renders them difficult to date, Daumier made a still more imaginative play with strong shapes. His Don Quixote series constitutes a revolutionary reduction of form and narrative to the barest essentials. Daumier's paintings range between this extreme of modernism and a wholly romantic treatment of the commonplace (e.g. Tireur de Bateau).

Rey, R., Daumier. 1966; Roy, C., Daumier. 1971; Laughton, B., Honoré Daumier. 1996.

Davenant, Sir William (1606-1668). English poet and playwright, born in Oxford. Son of a tavern keeper, gossip, repeated by John *Aubrey, that he was *Shakespeare's illegitimate son lacks supporting evidence. His first play The Cruel Brother was produced in 1627. For the next 11 years he entertained the court of *Charles I with a series of tragedies, comedies and masques, and became Poet Laureate in 1638. During the Civil War he was knighted (1643) by Charles for his military services. He followed Queen Henrietta Maria into exile and in 1650 , while on the way to America, was captured by a parliamentary frigate and briefly imprisoned. His best known works are the tedious epic Gondibert (1651) and The Siege of Rhodes (1656), said to have been the first English opera. After the Restoration he was active in the London theatre, and collaborated with *Dryden on a new version of The Tempest (1667).

Nethercot, A. H., Sir William D'Avenant: Poet Laureate and Playwright Manager. 1967.

Davenport, Thomas (1802-1851). American inventor. A blacksmith from Rutland, Vermont, in 1835 he built the first successful rotary electric motor, later adapting it for use in a drill and printing press.

David (Dawid) (d.c.970 BCE). King of Israel and Judah c.1010-970 BCE. According to 1 Samuel, he was born in Bethlehem, the eighth son of Jesse, a farmer. Originally a shepherd, he became a gifted singer and lyre player, winning King *Saul's favour by assuaging his melancholy. He became an intimate of his son Jonathan and married Saul's daughters Michal (but without issue) and, later, Merab. He became the object of Saul's obsessions, especially after the prophet * Samuel anointed David as his successor. In the war against the Philistines, David killed the giant, Goliath. Forced into exile, after Saul and Jonathan were killed by the Philistines, he was proclaimed king, set up his court at Hebron and later built a new capital at Jerusalem, where he brought the Ark of the Covenant, and from which he ruled all Israel. Stories of his later life include the revolt of his favourite son Absalom, whose death he lamented so deeply. Overcome by lust, cruelty and his desire for Bathsheba, wife of Uriah the Hittite, he sent her husband into certain death in battle. He had eight wives and many children. The 'Psalms of David' are attributed to him; some may be authentic, for example the beautiful lament for Saul and Jonathan. The Messianic hopes of the Jews were fixed upon the royal line of David and the New Testament emphasises the genealogical links between him and *Jesus Christ. David was succeeded by his son *Solomon.

David (Dewi), St (d.c.589). Welsh monk and bishop. The details of his life are clouded by legend but he seems to have been a leading figure in the monastic revival in Wales, Cornwall, Ireland and Brittany during the 6th century. His bishopric of Mynyw (Menevia) was renamed St David's (in Pembrokeshire) in his honour, and his shrine was a famous place of pilgrimage in the Middle Ages (from c.1000). Canonised in 1120, he is the patron saint of Wales. St David's Day is 1 March.

David I, St (Daibhidh mac Chaluim) (c.1084-1153). King of Scotland 1124-53. Younger son of *Malcolm III, of the House of Dunkeld, and Margaret of Wessex, on his father's death he was sent for safety to the English court where he befriended the future *Henry I, who married his sister Matilda. David married (1113) Maud, Countess of Huntington, heiress of daughter of Waltheof (d. 1076), and acquired the earldoms of Huntington and Northumberland. After succeeding 
his brother *Alexander as king, he supported his niece *Matilda in her struggle for the English throne against ${ }^{*}$ Stephen. He introduced the Norman style of governing and feudalism. Though defeated at Northallerton he secured terms that allowed him to extend his kingdom to the Tees and Eden. He completed the alignment of the Scottish Church with that of the rest of western Christendom by increasing the number of bishoprics and founding many monasteries, e.g. Holyrood and Melrose, and was venerated as a saint. During his reign he introduced important changes in law and administration.

David II (1324-1371). King of Scotland 1329-71. He succeeded his father, Robert ${ }^{*}$ Bruce, as a child, but owing to the confused state of his country was sent to France in 1334. Returning in 1341, he invaded England in 1346 but was captured at Neville's Cross (by *Edward III's troops). After an imprisonment in England lasting 11 years, he was ransomed for a huge sum of which only half had been paid when he died childless.

David, Jacques Louis (1748-1825). French painter. He worked under Joseph-Marie Vien from 1765. After winning the first prize of the Académie des Beaux Arts he went to Italy, where he studied for some years. With the exhibition (1785) in Paris of his picture The Oath of the Horatii David became the leader of the neo-classical movement. It is a painting of great austerity and dramatic clarity with serious political undertones. During the Revolution David served as a member of the Convention 1792-95, and was briefly its president. From this period date some of his finest portraits and a haunting drawing of * Marie Antoinette on the way to the guillotine. Under the Consulate and Empire David's paintings embraced stilted, antiquarian interpretations of classical subjects (Leonidas at Thermopylae), huge compositions of great occasions such as The Coronation of Napoleon, and excellent, if sometimes over-romanticised, portraiture (e.g. Madame Récamier and Napoleon on Horseback). With the return of the monarchy David lived as an exile in Brussels. From this period dates the wonderful, compassionate yet severely realistic portrait of The Three Ladies of Ghent. Conflicting trends appear in David's paintings. He moves from pure neo-classicism to freer use of light and colour, reverts to a stilted classicism albeit with a relaxation in its style. He exerted considerable influence as the teacher of, among others, *Ingres, Gérard and Gros.

Hautecoeur, L., Louis David. 1954.

Davies, Sir John (1569-1626). English poet and lawyer. Attorney-General for Ireland and later Lord Chief Justice of England (though he died before he could take up office), his poetry is 'philosophical' in approach: Orchestra (1596) sees nature through a sustained metaphor of dancing and Nosce Teipsum (1599) considers the nature of man and his soul.
(1599), a series of nimble acrostics on the name Elizabeth Regina. T. S. *Eliot praised his poetry. $\mathrm{He}$ also wrote in prose on Irish history. His wife, Eleanor Touchet (d.1652), generally regarded as insane, became a prophetess, foretold the death of *Charles I and produced a series of cryptic pamphlets during the 1640 s and early 1650 s.

Davies, Sir (Peter) Maxwell (1934-2016). British composer and conductor. Educated at the Royal Manchester College of Music (where he was professor of composition 1965-80), and Manchester University, he also studied in Rome and Princeton. He directed the Pierrot Players 1967-71 with (Sir) Harrison *Birtwistle, and the Fires of London 1971-87, and won many awards for his recordings. A prolific composer, his works include the opera The Martyrdom of St Magnus (1976), four symphonies, concertos for violin, oboe, trumpet, cello and guitar, chamber music, songs and film scores. He lived in Orkney from 1971, became Master of the Queen's Music 2004-2014, and wrote 10 string quartets for Naxos. He received a CH in 2014.

Davies, (William) Robertson (1913-1995). Canadian novelist, playwright, poet, critic, essayist, editor and academic, born in Ontario. He edited The Examiner, which his family owned, 1942-55, taught at Toronto University and was Master of Massey College, 1963-81. His masterpiece, known collectively as The Deptford Trilogy, comprises three novels, Fifth Business (1970), The Manticore (1972) and World of Wonders (1975). He was extremely prolific, diverse in his interests, with a passionate interest in theatre, and won many awards.

Davies, William Henry (1871-1940). British poet, born in Monmouthshire. For a time apprenticed to a picture-framer, in his early twenties he went to America. He lived as a tramp for many years, lost his right leg while jumping a train and returned to England. He described his early life in Autobiography of a Supertramp (1908). The first volume of his poems, printed privately in 1905 , attracted the attention of Bernard *Shaw, who did much to help him.

Hockey, L., W. H. Davies. 1971.

Davis, Sir Andrew Frank (1944- ). English conductor. He was organ scholar at King's College, Cambridge, conductor of the Toronto Symphony 1975-88, the Glyndebourne Opera 1988-2000, the BBC Symphony Orchestra 1989-2000, the Lyric Opera of Chicago 2000- and the Melbourne Symphony Orchestra 2013-19.

Davis, Bette (1908-1989). American film actor. Famous for the dramatic intensity with which she entered into her parts, she made 88 films between 1931 and 1989, won Academy Awards for Dangerous (1933) and Jezebel (1938) and received eight more nominations, a record. Her best films include The Petrified Forest, Dark Victory, All This and 
Heaven Too, The Little Foxes, All About Eve, Wedding Breakfast and Whatever Happened to Baby Jane? Her autobiography, The Lonely Life, was published in 1963.

Davis, Sir Colin Rex (1927-2013). English conductor. He was chief conductor of the BBC Symphony Orchestra 1967-71, Royal Opera House Covent Garden 1971-86, the Bavarian State Radio Orchestra 1983-95 and the London Symphony Orchestra 1995-2006 and received a $\mathrm{CH}$ in 2001. $\mathrm{He}$ made outstanding recordings of *Sibelius, *Berlioz, ${ }^{*}$ Bruckner, ${ }^{*}$ Mozart and ${ }^{*}$ Elgar.

Davis, Dwight Filley (1879-1945). American official. A national doubles lawn tennis champion (1899-1901), as an enthusiastic Harvard law undergraduate he was donor (1900) of the Davis Cup, an international award for national teams, competed for annually (except for 12, mostly wartime, years). He served as Secretary of War 1925-29 and GovernorGeneral of the Philippines 1929-32.

Davis, Glyn Conrad (1959- ). Australian political scientist and administrator, born in Sydney. $\mathrm{He}$ directed the Premier and Cabinet office in Queensland 1995-96; 1998-2002, was Vice Chancellor of Griffith University 2002-04 and the University of Melbourne 2005-18, ranked first in Australia. Charismatic, deeply analytical and prolific, he became Secretary of the Department of Prime Minister and Cabinet 2022- . His wife, Margaret Elaine Gardner (1954- ), an economist, was Vice Chancellor of Monash University 2014- .

Davis, Jefferson (1808-1889). American politician, President of the Confederate States of America 186165. Born in Kentucky, he lived in Mississippi from childhood, became an officer in the US army, but resigned in 1835 after eloping with his commander's daughter. Returning to Mississippi, he became a cotton planter. He was elected to the US House of Representatives in 1845, but resigned (1846) to serve in the Mexican War. Afterwards he returned to politics as a senator 1847-51, 1857-61 and was Secretary of War 1853-57 under President *Pierce. When Mississippi seceded from the Union (1861) Davis withdrew from the Senate, and in February was chosen by the Congress of seceding states as President of the Confederacy. In the ensuing Civil War 186165 Davis failed to adequately coordinate the civil and military administrations, and was regarded by many as unduly hesitant and moderate. At the end of the war treason charges against him were dropped. He returned home to live in obscurity and wrote The Rise and Fall of the Confederate Government (1878-81).

Davis, John William (1873-1955). American lawyer. He was a congressman 1911-13, Solicitor General 1913-18 and Ambassador to the UK 191821. At the 1924 Democratic convention the party was hopelessly deadlocked between $\mathrm{Al}{ }^{*}$ Smith and W. G. *McAdoo (a 'dry' supported by the Klan) and on the 103rd ballot Davis was chosen. In the following campaign against ${ }^{*}$ Coolidge he seemed to avoid major issues (e.g. prohibition) and as a corporation lawyer for the Morgan banking interests he lost union voters, carrying only 12 states in the South. In 1953 he emerged from retirement to argue against the compulsory integration of African-American children in schools in the Deep South.

Davis, Miles Dewey (1926-1991). American bandleader, trumpeter and composer, born in Illinois. Son of a dentist and a teacher, he studied at the Juilliard School of Music in New York. He was a pioneer of 'cool jazz', attempted to combine elements of jazz and rock, and experimented with electronic effects.

Davis, Sammy, Jr (1925-1990). American actor, singer, dancer, born in New York City. He appeared in his uncle's all-black family troupe at the age of four and developed an extraordinary range of skills, including instrumentalist and mimic. He appeared on Broadway from 1956, in 26 films and countless nightclubs, often working with Frank ${ }^{*}$ Sinatra. He lost an eye and a hip, converted to Judaism and the Republican Party.

Davisson, Clinton Joseph (1881-1958). American physicist. In 1937 he shared, with Sir George *Thomson, the Nobel Prize for Physics for his work on the diffraction of electrons by crystals. He showed that electrons reveal wave-like, as well as corpuscular, properties.

Davitt, Michael (1846-1906). Irish nationalist politician. He joined the Fenians in 1865 and served seven years in jail (1870-77) for his revolutionary activities. He migrated to the US and was influenced by the ideas of Henry *George. He became the cofounder, with C. S. *Parnell, of the Land League, and campaigned for reduced rents and peasant ownership of the land. The League was suppressed in 1880 and Davitt was jailed for sedition 1881-82, 1883. $\mathrm{He}$ advocated secularism, socialism, collectivism and land nationalisation for Ireland, but denounced terrorism, adopting a policy of passive resistance. Elected in 1882, but unseated, he was an antiParnellite MP 1892-93, 1895-99. He founded the Irish Land League (1898), toured Australia in 1899 and Russia in 1903.

Davout, (sometimes spelled d'Avout or Davoust), Louis-Nicolas, Duke of Auerstädt, Prince d'Eckmühl (1770-1823). French marshal. One of *Napoléon's ablest commanders, known as 'the iron marshal', he fought under him in Egypt, at Austerlitz (1805), Auerstädt (1806), after which he received his dukedom, and at Eckmühl and Wagram in 1809. He was a despotic governor of Warsaw 1807-10, accompanied Napoléon to Moscow and, after the return from Elba, 
was Minister of War. He lost all his titles and rank after the Bourbon restoration, but was later pardoned and, in 1819 , was made a peer of France.

Davy, Sir Humphry, 1st Baronet (1778-1829). English chemist, born in Penzance. Son of a woodcarver, educated at a local grammar school, he became apprenticed to a surgeon-apothecary and was influenced by the writings of *Boyle and *Lavoisier. He became superintendent (1798) of the laboratory in the Pneumatic Institute, Bristol, established to investigate the medical effects of inhaling gases. He discovered (1799) the anaesthetic properties of laughing gas. He was a friend of ${ }^{*}$ Coleridge, and was deeply imbued with Romanticism. As professor of chemistry at the newly established Royal Institution in London 1802-13, he isolated sodium, potassium, calcium, magnesium, barium and strontium by using an electric current to decompose their fused salts. He formulated a theory of the electrical nature of chemical affinity (not verified for more than a century) and analysed many substances such as metallic oxides and acids, suggesting what elements were responsible for their properties. He recognised iodine, chlorine and fluorine as elements, but failed to isolate the last two. In 1812 he took on Michael *Faraday as his assistant, received a knighthood, married and went on a honeymoon tour of Europe with his wife and Faraday. His name was given to the miner's safety lamp he invented (1815) to meet the problem of firedamp. He received a baronetcy in 1818. Davy was President of the Royal Society 1820-27, succeeding Joseph *Banks, but he found the job frustrating, did no more experimental work and developed a deep resentment of Faraday. He died of a stroke.

Knight, D., Humphry Davy: Science and Power. 1993.

Dawes, Charles Gates (1865-1951). American banker, administrator and Republican politician, born in Ohio. A Chicago banker, he was a Brigadier in World War I, and first Director of the Bureau of the Budget 1921-22. As Director of the Allied Reparations Commission 1923-24 he proposed the 'Dawes Plan' for securing German repayment of war debts to the Allies. He served as Vice President of the US 1925-29, shared the Nobel Peace Prize for 1925 with Austen ${ }^{*}$ Chamberlain, and was Ambassador to Great Britain 1929-32.

Dawson, Peter (1882-1961). Australian singer, born in Adelaide. A baritone, notable for his diction, he recorded for almost 50 years and composed many successful ballads under the name J. P. McCall.

Day, Dorothy (1897-1980). American social activist. She became a socialist, a supporter of the Industrial Workers of the World (IWW) and a journalist on The Masses. Converted to Catholicism, she was co-founder of The Catholic Worker (1933) and a devoted supporter of many radical causes, but came to support Catholic teaching on birth control and was critical of the welfare state. She has been proposed as a candidate for sainthood.

Loughery, J. and Randolph, B., Dorothy Day: Dissenting Voice of the American Century. 2020.

Day Lewis, Cecil (1904-1972). British poet, born in Ireland. Regarded with W. H. *Auden and Stephen *Spender as one of the 'Thirties group' of poets, his work includes A Hope of Poetry (1934), The Friendly Tree (1936), Overtures to Death (1938) Collected Poems (1954) and an autobiography, The Buried Day (1960). Created CBE in 1950, he was professor of poetry at Oxford 1951-56 and Poet Laureate 1968-72. Under the pseudonym Nicholas Blake he wrote several accomplished detective stories. His son Daniel (Michael) Day Lewis (1957-), an actor, won an Oscar for My Left Foot (1989) and starred in The Last of the Mohicans (1993) and In the Name of the Father (1993).

Dayan, Moshe (1915-1981). Israeli soldier and statesman, born Deganya, Palestine (now Israel). In 1937 he was a member of the guerrilla force under British Captain Orde *Wingate, organised to fight Arab rebels in Palestine and to form the nucleus of a Jewish army. Dayan formed the Haganah (Jewish militia) but the band was declared illegal and Dayan imprisoned 1939-41. Freed to serve in World War II, he led a Palestinian Jewish company against the Vichy French in Syria, and lost an eye. His black patch became his trademark.

He commanded the Jerusalem area in the Israeli war of independence (1948), and later headed the delegation in armistice negotiations. From 1953-58 he was Chief of Staff, and planned and led the 1956 invasion of Sinai Peninsula, which gained him the reputation of an outstanding military commander. In 1966 he published Diary of the Sinai Campaign. Retired as chief of staff, he was elected to the Knesset (parliament) as a member of the Labour Party. In 1959 he was appointed Minister of Agriculture by Prime Minister *Ben Gurion, and served until 1964. In 1967 when war with the Arabs was imminent, Dayan was appointed Minister of Defence by popular demand. He directed the extremely successful attack on Egypt, Jordan and Syria in the Six-Day War. A symbol of security to the Israelis, he played a large part in the post-war period in determining policy in Arab territory occupied by Israeli forces.

Teveth, S., Moshe Dayan. 1973.

Deák de Kehida, Ferenc (1802-1876). Hungarian politician. He entered parliament in 1833 , liberated his serfs and supported progressive taxation. He was minister for justice after the rising in 1848 against rule by Austria, but resigned when *Kossuth seized power, and after his overthrow retired to his estates for six years. On Austria’s defeat by Prussia (1866) he conducted the negotiations by which Hungary 
became an equal partner with Austria in the Habsburg Empire. Hungary was granted a constitution in 1867 and Deák was the leading figure in the Hungarian Assembly until his death.

Kiraly, B. K., Ferencz Deák. 1975.

Deakin, Alfred (1856-1919). Australian politician, born in Melbourne. A barrister and a journalist, he was a Member of the Victorian Legislative Assembly 1879; 1880-89; 1889-1900 and soon became one of the leaders of the Liberal party. In 1883 he joined a coalition ministry, and as Minister of Public Works and Water Supply won international repute for his irrigation plans. He then became one of the most persuasive advocates of Australian federation. He was Attorney-General in *Barton's first Commonwealth Government and Prime Minister three times 190304, 1905-08, 1909-10, for a total of four years 10 months and 10 days, winning elections in 1903 and 1906 but without an outright majority. His first two governments were protectionist, the third was a protectionist-free trade coalition. Member of the House of Representatives 1901-13, he undertook a mission to the United States in 1915 but soon sank into dementia.

An idealist and intellectual with a deep interest in spiritualism, he created what has been called 'The Australian Settlement', five principles that dominated politics until the 1960s: White Australia, Industry Protection, Wage Arbitration, State Paternalism and Imperial Benevolence. (All have disappeared.) He secured passage of the Invalid and Old Age Pensions Act (1908) but resigned before its proclamation. He speech on the Judiciary Act (1903), creating the High Court, against strong state objections, promoted a strong national vision. He also supported imperial preference and compulsory military training.

He declined all honours. His The Federal Story was published in 1944.

Brett, J., The Enigmatic Mr Deakin. 2017.

Dean, Brett (1961- ). Australian composer, born in Brisbane. He played the viola in the Berlin Philharmonic Orchestra 1985-99, composed a viola concerto (2004) and won the Grawemeyer Award for Composition in 2009 for his violin concerto The Lost Art of Letter Writing, featuring letters by *Brahms, van ${ }^{*}$ Gogh, Hugo *Wolf and Ned *Kelly. His opera Bliss, based on Peter *Carey's novel, was premiered in Sydney in March 2010. Hamlet (2017) premiered at Glyndebourne Opera to great acclaim.

Dean, James (Byron) (1931-1955). American actor. Despite the brevity of his career, he was a spectacular screen success, embodying the restlessness of mid50s American youth with his performance in Rebel Without a Cause (1955). His two other major films were East of Eden (1955) and Giant (released 1956). After his death in a car accident he acquired international cult status.
Deane, Sir William Patrick (1931- ). Australian jurist, born in Melbourne. Educated in Sydney and a Federal Court Judge 1977-82, he was a judicial activist as a Justice of the High Court 1982-95. He became Governor-General of Australia 1996-2001 and expressed passionate concern on many social issues, including global poverty and Indigenous welfare.

DeBakey, Michael Ellis (1908-2008). American surgeon, born in Louisiana. He developed new techniques in cardio-vascular surgery, taught at Baylor College of Medicine, Houston and published 1500 articles.

de Bono, Edward (Francis Charles Publius) (19332021). British academic and author, born in Malta. Educated in Malta and at Oxford, he lectured in medicine at Oxford, Cambridge and Harvard. He established the Cognitive Research Trust in 1971, promoted the concept of 'lateral thinking' and urged the teaching of thinking as a discrete part of formal education. His many popular books included: Lateral Thinking (1970), The Greatest Thinkers (1976), Wordpower (1977), and de Bono's Thinking Course (1982).

Deborah (fl. c.1125 BCE). Hebrew prophet. Wife of Lapidoth, and the only woman judge in Israel, she persuaded Barak to free her people from Canaanite oppression. With him she led an army against Sisera and the Canaanites, and soundly defeated them at the Battle of Esdraelon. A long period of peace ensued. Scholars generally accept the 'Song of Deborah' (Judges v) as a genuine contemporary document, one of the oldest biblical records and one of the most brilliant poems in the Bible.

De Botton, Alain (1969- ). Swiss-British writer, philosopher and documentary maker, born in Zürich. He came from a rich Sephardic family in Switzerland but was educated at a school in Oxford and at Cambridge University. He wrote a series of lucid and engaging books which sold prodigiously, including How Proust Can Change Your Life (1997), The Consolations of Philosophy (2000), The Art of Travel (2002), Status Anxiety (2004) and The Architecture of Happiness (2006). His interests turned towards architecture and filming.

Debré, Michel Jean Pierre (1912-1996). French politician. A senator 1948-58, he backed General *de Gaulle's resumption of power (1958) and was appointed Minister of Justice. He drafted the new constitution which was adopted by a referendum in December 1958, and in January 1959 he became the first premier of the Fifth French Republic until replaced by *Pompidou in 1962 . He served as Minister for Finance 1966-68, Foreign Affairs 196869 and Defence 1969-73. 
Debs, Eugene Victor (1855-1926). American union leader and Socialist. He was active in the organisation of railway workers from 1875, and in 1893 became President of the American Railway Union. For his part in the Pullman strike (1894) he was imprisoned for contempt of court. He founded the US Social Democratic Party (1897) and was Socialist candidate for the presidency in 1900,1904, 1908, 1912 and 1920. He was again imprisoned (1918-21) for alleged sedition in World War I. He advocated organising trade unions on an industry-wide basis.

Ginger, R., The Bending Cross: A Biography of Eugene Victor Debs. 1949.

Debussy, (Achille-) Claude (1862-1918). French composer, born at St-Germain-en-Laye. He entered the Paris Conservatoire when he was 10 and studied composition for a time under ${ }^{*}$ Massenet. He was pianist in the household of Nadezhda von Meck, who had been *Tchaikovsky's patron, and travelled with her (1880-82) in Italy, Switzerland and Russia. He won the Prix de Rome with L'Enfant prodigue (1884) and studied in Italy until 1887. Both drawn to and repelled by *Wagner, he was influenced by *Berlioz, *Mussorgsky and *Fauré, exposure to Javanese music, by Symbolist poets, ${ }^{*}$ Turner and the Pre-Raphaelites, and French Impressionist painters. He reacted against classical forms, declaring the symphony to be dead. He described critics who called him an 'impressionist' as 'imbeciles' because his writing was exceptionally precise not hazy, preferring to identify himself with the Symbolists. The String Quartet (1893) and Prélude à l'après midi d'un faune (1894), a ballet score, based on a poem by *Mallarmé, were the first works of his maturity. He was primarily occupied with the opera Pélleas and Mélisande (libretto by *Maeterlinck) from 1894 to 1902; its success earned him wider recognition. Printemps (1896), Nocturnes (1899), La Mer, his masterpiece (1905), Images (1906-12) and the ballet Jeux (1913) demonstrate his genius as an orchestrator. He composed two books of Préludes (1909-10; 1911-13) for piano, many piano solos and songs and incidental music to *D'Annunzio's Le Martyre de St Sébastien (1911). A fine pianist, he made some acoustic recordings as an accompanist, and toured Europe giving many concerts. Politically, he was a conservative patriot, mildly anti-Dreyfusard. His last works were three sonatas for piano and cello (1915), flute, viola and harp (1915), piano and violin (1917), written in neo-classical style. His music had a profound influence on *Janáček, *Bartók, *Messiaen, ${ }^{*}$ Boulez and — up to a point- ${ }^{*}$ Ravel and ${ }^{*}$ Stravinsky, even *Puccini. In his last years he suffered from rectal cancer and was burdened by debt.

Walsh, S., Debussy. A Painter in Sound. 2018.

Decatur, Stephen (1779-1820). American naval commander. During the war against Tripoli pirates in the Mediterranean (1801-05), and under fire from 141 guns, he entered the harbour and boarded and burned the captured ship Philadelphia, a feat that Nelson described as the 'most daring of the age'. He captured the Macedonian in the 'war of 1812' against Britain but was forced to surrender in 1814. In 1815 he resumed the contest with the pirate regimes of Algeria, Tunis and Tripoli, defeated them and obtained indemnities. Violence pursued him to the last: he was killed in a duel. To Decatur, Americans owe the toast 'May she be always in the right: but my country, right or wrong.'

Decius (Gaius Messius Quintus Decius, later Traianus Augustus) (201-51). Roman emperor 249-51. Born in Serbia, he was a soldier, senator and consul in Rome, and a governor in Spain, raised to the purple by his troops. In 250 he imposed an oath of loyalty to himself and compulsory sacrifices to the Roman gods. This was not specifically aimed at Christians, and Jews were exempted, nevertheless, it became the first serious persecution suffered by Christians since 177: there were some executions and many exiles and apostates. Decius was killed in battle at Abritus (modern Razgrad, in Bulgaria).

Dee, John (1527-1608). English astrologer, mathematician and reputed magician. $\mathrm{He}$ was educated at Cambridge and Louvain and travelled extensively. Although he was imprisoned by *Mary Tudor under suspicion of arranging her death by magic, he impressed *Elizabeth I with his scientific and occult skills. Many of his interests, previously dismissed by historians and others as 'on the lunatic fringe' of learning and enquiry, are now seriously investigated. Dee has been recognised as one of the most enterprising and intelligent, if still somewhat ambivalent, figures of the Elizabethan period.

Ackroyd, P., The House of Doctor Dee. 1993.

Deffand, Marie de Vichy Chamrond, Marquise du (1697-1780). French literary hostess. Her salons were famous in 18 th-century Paris. The witty and lively conversations there are recalled in her letters to *Voltaire and Horace *Walpole, with whom she developed a passionate friendship in her old age.

Defoe, Daniel (1660-1731). English writer, born in London. Son of a prosperous tallow chandler, James Foe, of Flemish descent, Daniel adopted the name Defoe. Excluded as a nonconformist from Oxford and Cambridge, he became a hosier and general merchant. By 1700 he was known as a vigorous political pamphleteer. The issue of an ironic pamphlet which purported to be an attack on the Dissenters but in reality was directed against the Anglican High Church resulted (1703) in imprisonment, the pillory and bankruptcy. This crisis necessitated a volte-face. Though a Whig, he started the Review with the aid and patronage of *Harley, leader of the moderate Tories. When ${ }^{*}$ George I came to the throne he reversed the 
process by getting control of Tory periodicals and, gradually, without attracting attention, reconciling their policies.

At the age of 60 he started the new career as a prolific writer of fiction that brought him so much renown. In 1719 appeared Robinson Crusoe, based on the experiences of Alexander ${ }^{*}$ Selkirk; Moll Flanders (1721) leads the story of a lady of easy virtue through many episodes to an ending of penitence and prosperity. Other works include $A$ Journal of the Plague Year (1721), Jack Sheppard (1724) and Roxana (1724). The History of Apparitions (1727) is among the books showing his continuing interest in the supernatural revealed by The Apparition of Mrs Veal (1706). His Tour Thro' the Whole Island of Great Britain (3 vols, 1724-26) displays the author as a shrewd and observant traveller. He wrote a vast amount of hackwork, sometimes under pseudonyms, on economic, social, political and historical matters, all of it very competent and readable.

Sutherland, J. R., Defoe. 1954.

De Forest, Lee (1873-1961). American physicist and engineer. He introduced the 'grid' into the thermionic valve and so made possible the large-scale amplification of radio signals. In 1916 De Forest was responsible for the transmission of the first radio program, and in 1923 he invented a technique for recording sound on film. He later also devised a process for transmitting photographs by radio (E. H. *Armstrong).

De Forest, L., Father of Radio. 1950.

Degas, (Hilaire-Germain) Edgar (1834-1917). French painter and sculptor, born in Paris. From a prosperous mercantile family, he studied with Louis Lamothe, a follower of *Ingres and although at first he seemed likely to become an academic painter, he developed into one of the great innovators of his time after coming to know ${ }^{*}$ Manet and his circle. In 1874 he took part in the first Impressionist Exhibition (he exhibited in seven of their eight exhibitions). He had private means and unlike many of the Impressionist painters did not depend on selling his pictures. After the Franco-Prussian War he turned in his painting to such unposed subjects as ballet girls and models in their off-duty moments, working girls and cabaret artists, showing a detached objectiveness of great power. He used a wide variety of media-oil, gouache, tempera, pastel-the last increasingly as his eyesight failed. ${ }^{*}$ Renoir thought him superior to ${ }^{*}$ Rodin as a sculptor. He was a misanthrope and anti-Semite.

Rich, D., Degas. 1954.

De Gasperi, Alcide Amadeo Francesco (18811954). Italian politician, born in Pieve Tesino, in the Austrian Tyrol (now the Italian Trentino). He studied philology, became an editor and was elected to the Austrian Reichsrat 1911-17. When his native province was joined to Italy at the end of World War I, he became active in the PPI (Partito Popolare Italiano) and a member of the Chamber of Deputies 1921-24. After a brief enthusiasm for ${ }^{*}$ Mussolini, he became a strong anti-Fascist and was imprisoned 1927-28. After his release (1928) he withdrew from politics and worked in the Vatican library. He founded (1944) the Christian Democratic party which, like the pre-war Popular party that it replaced, had Vatican support. When Italy became a republic he was its first Prime Minister 1946-53. Under his leadership Italy joined NATO.

de Gaulle, Charles André Joseph Marie (18901970). French general and statesman, born in Lille. His father (a reluctant Dreyfusard) taught philosophy at a Jesuit college. Trained at the Military Academy at St Cyr, he was commissioned in 1909, fought at Verdun and became a prisoner of war in Germany 1916-18: captivity not only saved his life but forced him to study. He served under *Weygand in Poland against the Red Army 1919-21. In 1924-25, as a lecturer at St Cyr he first formulated his ideas about tactics and especially the use of mechanised forces, which were published in France in 1932-34 and in English as The Army of the Future (1940). Little notice was taken in France but his basic ideas were adopted by the German general staff and later used in the 'Blitzkrieg' attacks of 1940. In June 1940 , promoted brigadier, de Gaulle was appointed under-secretary of war, but France was already defeated and a few days before the French armistice he went to London, where he declared himself the leader of the Free French. The numbers of the troops at his disposal were few, and neither ${ }^{*}$ Roosevelt nor ${ }^{*}$ Churchill found him an easy colleague, but gradually he succeeded, by his personality and self-dedication, in creating, not only in his own mind but in the minds of millions of his fellow countrymen, an identification between himself and a new and glorious France, untarnished by defeat. In the later stages of the war, as leader of the Resistance movement he was associated with France's most active patriots and when the moment of victory came he was clearly the only man who could lead his country. In attempting to do this through a coalition of all parties, including the Communists, he failed; moreover the constitution' of the Fourth Republic seemed to him no better than the old. His sense of frustration caused him to resign (1946) and found a new party, the 'Rally of French People' (RPF), but despite its electoral success (40 per cent of the votes in 1947) he felt the curb of party ties and retired from its leadership in 1953 . He was thus free of all party commitments when in May 1958, after the failure of successive governments to defeat or conciliate the Algerian rebels, and the prospect of a military coup, the Fourth Republic virtually collapsed, and he accepted President René *Coty's invitation to form a government. Almost his first act was to bring in a new constitution, that of the Fifth Republic, passed by referendum, which gave the President almost unlimited power. As President of France 1959-69, de Gaulle ruled decisively and while the legislature was still a forum for discussion and advice he deprived it of any decisive role. He faced the 
facts of the Algerian situation and gave the country full independence (1962), thus making himself a target for frequent attempts at assassination by aggrieved French colonists. He repeated this pattern throughout the French territories, all of which became free, held to France only by language, economic ties and the vague description of French communities. Domestically de Gaulle was helped by the general prosperity of western Europe. He brought France into the European Economic Community, but maintained his support for it only so long as France's autonomy was unassailed and the needs of her agriculture served, and lest French hegemony be challenged he banned Britain's entry. In foreign affairs he saw western Europe as a third great power under Franco-German leadership. He welcomed the security of the American alliance but resented the curbs of NATO and asserted France's independence by manufacturing nuclear weapons and recognising the People's Republic of China. In the presidential election of 1965, he defeated *Mitterrand by a smaller margin ( 55 per cent to 45 per cent) than expected. France was rocked by strikes and mass demonstrations, led by workers and students, in May 1968, and de Gaulle seemed to lose his nerve. In 1969, when a further referendum on reform of the Senate was defeated, he resigned unexpectedly and retired to the country. De Gaulle had significant personal advantages - his height, his magnificent rhetoric, the clarity of his writing and thinking all marked him out as a great national leader. Moreover he had succeeded in the task to which he dedicated himself in 1940. His singleness of purpose, his obduracy and his prestige, within a framework of his own devising, dispelled the disillusion and frustration of a defeated and tortured France.

Crozier, B., De Gaulle: The Warrior. 1973, De Gaulle: The Statesman. 1974; Jackson, J., A Certain Idea of France. The Life of Charles de Gaulle. 2018.

De Gennes, Pierre-Gilles (1932-2007). French physicist. Educated in Paris, he served in the navy, with the French Atomic Energy Commission, and was a professor at the Orsay University 1961-71 and the Collège de France 1971-76. He worked on magnetism, liquid crystals (as used for displays in calculators, watches and computers) and polymers, and won the 1991 Nobel Prize for Physics for his contribution to understanding how complex forms of matter behave during the transition from order to disorder. He worked at increasing public understanding of science, gave superb lectures in French and English and wrote satirical poetry.

Degrelle, Léon Marie Joseph Ignace (19061994). Belgian Fascist politician. He led the Rexist party (from 1935) and collaborated with the Nazis during World War II. He served as a colonel in the Waffen-SS, escaped to Norway in 1945 and then to Spain, remaining there until he died. de Havilland, Sir Geoffrey (1882-1965). English aviation pioneer. He built his first plane in 1908 but it never flew. He then joined the Army Aircraft Factory at Farnborough, where he produced the BE1, DH2, DH4, and DH9, which played an important part in World War I. He formed his own firm in 1920. Perhaps the best known of his many commercial aircraft was the tiny Moth, which was priced within the reach of many hundreds of private flyers. In World War II the most successful of his achievements were the multi-purpose Mosquito and the Vampire jet; after the war came the Comet. Two of his three sons were lost in test flying. He received the OM in 1962.

Dekker, Thomas (c.1572-1632). English dramatist, poet and pamphleteer. His plays are lively and realistic and are notable for their witty dialogue. His plays include The Shoemaker's Holiday (1600), Old Fortunatus (1600), and The Honest Whore (1604, Part II 1630). Among the most interesting of his many pamphlets is The Gull's Hornbook (1609), a racy account of London's places of public resort. His collaborators included Ben *Jonson, *Middleton, *Massinger, John *Ford, and *Webster.

de Klerk, Frederik Willem (1936-2021). South African Nationalist politician, born in Johannesburg. He was a nephew of J. G. *Strijdom and his father served as a minister in *Verwoerd's Government. Educated at Potchefstroom University, he practised law 1961-72 and after a brief period as a professor became a Member of the House of Assembly 1972-89. He was Minister for Posts and Telecommunications 1978-79, of Mines and Energy 1979-82, of Internal Affairs 1982-85 and National Education and Planning 1985-89. He succeeded P. W. *Botha as State President 1989-94 and introduced a series of reforms, including the release of Nelson * Mandela, lifted the ban on the African National Congress, securing majority support at a 'whites only' referendum for the abolition of apartheid and working towards a common electoral roll for future elections. He was attacked by the ANC for not proceeding fast enough but there was broad international support for his initiatives and sporting boycotts, and trade sanctions were lifted. He shared the 1993 Nobel Peace Prize with Mandela with whom he collaborated in working towards a Government of National Unity based on universal suffrage. In the election of 1994 the National Party won 20.4 per cent of the vote and de Klerk became Second Deputy President. In May 1996 the Nationals withdrew from the Government of National Unity and he retired as party leader in August 1997.

de Kooning, Willem (1904-1997). American painter, born in Rotterdam. He settled in New York in 1926 and became a leading abstract expressionist, best known for his powerful images of women, 
varying from sensual to aggressive. He received the Presidential Medal of Freedom in 1964. His painting Interchange (1955) sold for \$US300 million in 2015.

Rosenberg, H., De Kooning Drawings. 1967; Stevens, M., and Swan, A., de Kooning: An American Master. 2004.

De La Beche, Sir Henry Thomas (1796-1855). English geologist and palaeontologist, born in London. His father, an army officer whose family name was Beach, owned a slave plantation in Jamaica. Henry grew up in Lyme Regis, Devon, and was influenced by Mary *Anning's discoveries of fossils there and he became an avid collector and illustrator. In the 1820 s he explored Devon, Cornwall, France and Switzerland, and published widely in descriptive stratigraphy. He was a scrupulous fieldworker, stressing the primacy of facts and distrusting theories, as can be seen from his Sections and Views Illustrative of Geological Phenomena (1830) and How to Observe (1835). His important watercolour Duria Antiquior-A More Ancient Dorset (1830) became a widely circulated lithograph; the sales assisted Anning. He clashed with Roderick *Murchison, Charles *Lyell and Adam *Sedgwick in dating the fossil record. In 1835 he persuaded the government to establish the world's first national geographical survey and became the first director of the Geological Survey of Great Britain. The Survey began work in Cornwall and on the South Wales coalfield, flourished and expanded. De La Beche's career reached its peak with the establishment of a Mines Record Office and then the opening in 1851, under the aegis of the Geological Survey, of the Museum of Practical Geology and the School of Mines in London.

McCartney, P., H. T. De La Beche. 1978.

Delacroix, (Ferdinand Victor) Eugène (1798-1863). French painter, born in Charenton-Saint-Maurice. The illegitimate son of *Talleyrand, he was the great leader of Romanticism in painting and the defender of colour (at the expense of draughtsmanship, though he drew admirably) and movement. He opposed *Ingres' more static line and balance. He had been in Baron Gros' studio, knew the dying ${ }^{*}$ Géricault, studied *Rubens and the Venetians, was a friend of *Bonington and admired *Constable's Hay Wain so much that he repainted the sky in The Massacre at Chios (1824) just before it was exhibited. He admired English colour and freshness of handling. The exuberance both of his colours and of his subjects (mainly contemporary or exotic) was much attacked. His visit to North Africa (1832) provided many new subjects, e.g. scenes from Arab life and animals fighting. From the mid 1830s he undertook large-scale official decorations, e.g. the ceiling of the Salon d'Apollon in the Louvre (1849), works in the libraries of the Palais Bourbon and the Senate (1838-47) and murals in St Sulpice Church. His Journals give a remarkable picture of Parisian life and of the many celebrities who were his friends. His careful studies of colour and the prominence he gave to it had a great effect on later painters, notably *Renoir, *Degas and *Cézanne.

Jullian, P., Delacroix. 1963.

de la Mare, Walter John (1873-1956). English poet, born in Kent. Of Huguenot descent, he retired from his employment with the Anglo-Iranian Oil Company in 1908 to give his full time to writing, which included book reviewing as well as poetry. In his volumes of short poems Songs of Childhood (1902), The Listeners (1912), and Peacock Pie (1913) he evoked a delicate and enchanting fantasy world. He also wrote short stories, children's books, and novels, e.g. The Return (1910) and Memoirs of a Midget (1921). The latter won the Hawthornden and James Tait Black prizes. He received a $\mathrm{CH}$ in 1948 and the OM in 1953.

Cecil, D., Walter de la Mare. 1973; Whistler, T., Imagination of the Heart. 1993.

Delane, John Thaddeus (1817-1879). English journalist. After working as a parliamentary reporter he was editor of The Times (1841-77), and his knowledge of world affairs, his innumerable sources of information, extraordinary flair for news and complete independence of judgment gave his paper a prestige and influence that extended far beyond his own country. His attacks during the Crimean War on the mismanagement responsible for shortages of food, warm clothing and ordinary necessities, revealed by the famous Times correspondent W. H. *Russell, are an example of the way in which he could unseat a government.

De la Roche, Mazo (1885-1961). Canadian novelist. Her novel Jalna (1927) was the first of a series which told the story of the Whiteoaks family and achieved an enormous popular success.

De la Roche, M., Ringing the Changes. 1957.

Delaunay, Robert (1885-1941). French painter. Influenced by ${ }^{*}$ Cézanne and the Post-Impressionists, he made vibrant use of colour which he applied to Cubism. He developed his own theory of 'colour orchestration', called 'Orphism' by the poet *Apollinaire, which in turn influenced the German Blaue Reiter Expressionists and painters in the US and Australia. His wife Sonia Delaunay-Terk (née Stern) (1885-1979), born in Russia, painted in Orphic style and was an important textile designer.

De la Warr, Thomas West, 12th Baron (1577-1618). English administrator. He was the first Governor of Virginia 1610-11 and rescued the colony from ruin. The American state and river Delaware are named after him.

Delbrück, Max (1906-1981). German American molecular biologist. He trained in physics under Niels *Bohr and biology with T. H. *Morgan and 
was a professor of biology at the California Institute of Technology 1947-81. His work on phage (a virus that attacks bacteria) and genetic recombination in bacteria laid the basis for molecular biology and he won the 1969 Nobel Prize for Medicine.

Deledda, Grazia (1875-1936). Italian novelist, born in Sardinia. She wrote novels in the verismo style, many reflecting harsh conflicts in Sardinian life, including Elias Portolu (1903), Ashes (1910) and The Mother (1920). She won the Nobel Prize for Literature in 1926.

Delibes, (Clément Philibert) Léo (1836-1891). French composer. He studied at the Paris Conservatoire, and spent most of his life in Paris where among his musical occupations were those of organist and chorus master with opera companies. His compositions include the very successful ballets Coppélia (1870) and Sylvia (1876) and the comic opera Lakmé (1883).

De L'lsle, William Philip Sidney, 1st Viscount (1909-1991). English politician, soldier and administrator, born in London. A descendant of Sir Philip *Sidney, he was educated at Eton and Cambridge, served with the Grenadier Guards, rising to major, and won the Victoria Cross at Anzio (1944). A Conservative MP 1944-45, he was Parliamentary Secretary to the Ministry of Pensions 1945 and Secretary of State for Air 1951-55. He held directorships in banking and insurance and became the last UK resident to be appointed (1961) as Governor-General of Australia, serving until 1965.

DeLillo, Don (1936- ). American novelist, playwright, essayist and short story writer. Educated at Fordham University, he became an advertising copywriter. His novels include Americana (1971), White Noise (1985), Libra, a plausible fictional treatment of John *Kennedy's assassination (1988), Mao II, a powerful story of a reclusive intellectual challenged by mass political action (1991), Underworld (1997), Falling Man (2007) and Point Omega (2010). He has been much praised by fellow writers but failed to win major awards.

Delius, Frederick (Theodore Albert) (1862-1934). English composer, born in Bradford. Of German descent, as a young man he went to Florida to grow oranges, became a music teacher in Virginia, and, on returning to Europe, moved to Leipzig where he first made his mark as a composer. From 1890 he lived in France. His music, rhythmic, rhapsodic, and harmonically luxuriant, was at first poorly received except in Germany. Its acceptance in England, where alone it has obtained a lasting hold, came largely through the efforts of Sir Thomas *Beecham, whose performances were a model for other interpreters. His works include Paris: The Song of a Great City (1899), Brigg Fair (1907), Eventyr (1917), concertos for violin (1918) and cello (1921), the opera $A$ Village
Romeo and Juliet (1901), Appalachia (traditional songs, 1903), Sea Drift (*Whitman, 1903), A Mass of Life ( ${ }^{*}$ Nietzsche, 1905) and $A$ Song of the High Hills (textless: 1911) for orchestra and chorus, chamber music and songs. In later years, blind and paralysed from syphilis, he dictated his work to the musician Eric Fenby (1906-1997), who wrote a memoir of him. He received the $\mathrm{CH}$ in 1929.

Fenby, E., Delius. 1971.

Deller, Alfred (George) (1912-1979). English counter-tenor. He worked in the furniture trade for 13 years, sang in the choirs in Canterbury (1940-47) and St Paul's (1947-62) Cathedrals and, with the encouragement of Michael *Tippett, revived the art of the counter-tenor (male alto) after 300 years of neglect, except in Anglican choirs. A natural baritone, Deller sang falsetto with exceptional breath control and masterly ornamentation. He devoted himself to the alto repertoire of ${ }^{*}$ Dowland, ${ }^{*}$ Purcell (himself an accomplished counter-tenor), *Buxtehude, *Händel, ${ }^{*}$ Bach and ${ }^{*}$ Britten, and made many recordings. Alan Blyth remarked on 'Deller's otherworldly sound, at once ethereal yet strangely sensual'.

Delors, Jacques Lucien Léon (1925- ). French politician, economist and administrator, born in Paris. Educated at the University of Paris, he worked for the Banque de France 1945-62, 1973-79, and became a public servant specialising in labour programs and social research. He was Minister for the Economy and Finance 1981-84 and President of the Commission of the European Communities 1985-94.

De Mille, Cecil B(lount) (1881-1959). American film director. He entered the film industry in 1913, founded the Paramount Company and pioneered the production of such lavish and spectacular films as The Ten Commandments (1923, 1957), The Sign of the Cross (1932), and The Greatest Show on Earth (1952). His daughter Agnes de Mille (1908-1993), a dancer from 1928, won fame as choreographer for musical comedies such as Oklahoma (1943) and Brigadoon (1947). She also devised her own ballets, e.g. Fall River Legend (1948) and The Rib of Eve (1956).

Demirel, Süleyman Göndoğdu (1924-2015). Turkish politician. He became an electrical engineer, worked in the US for five years, then taught English at a technical university. He led the Justice Party 1964-81 and the True Path Party 1987-93 and was Prime Minister 1965-71, 1975-77, 1977, 1979-80, 1991-93 and President 1993-2000.

Democritus (c.460-370 BCE). Greek philosopher, born in Abdera, Thrace. Known as 'the laughing philosopher', he was amused at the weaknesses of mankind. His atomic theory stimulated the thought of many future thinkers. The essence of it was that the only ultimate realities are (a) atoms, minute, solid, invisible and indestructible, (b) void. The atoms, whirring in the void, combine and coalesce in an 
infinite number of patterns and shapes which present 'images' to the senses. He is known to have left a vast quantity of writing on every aspect of human knowledge. Unfortunately only 200 or 300 fragments survive and almost all that is known of his work is at second hand.

De Morgan, William Frend (1839-1917). English potter, designer and novelist. Influenced by the PreRaphaelites, William *Morris, and Islamic decoration, he designed stained glass and decorative tiles, and invented lustre glazes. He wrote seven popular novels.

Demosthenes (c.384-322 BCE). Athenian orator and politician. Having studied law and oratory to regain his inheritance from fraudulent guardians, he became a speech writer for litigants in the courts. When 30 years old he entered politics. By two series of brilliant speeches known as the Olynthiacs and the Philippics he tried to convince the Athenians and their allies of the danger from *Philip of Macedon. The Athenians did indeed go to war but failed to save Olynthus. From 346 to 340 Demosthenes was actively building up a coalition but it was decisively defeated by Philip at Chaeronea (338). Demosthenes vindicated himself in one of his greatest speeches, On The Crown, a reply to an attack by his great rival *Aeschines on a proposal to award him a crown of honour. In 325, however, he went into exile after being charged (probably falsely) with embezzling money from the state treasury. He returned after *Alexander the Great's death but an attempt to throw off the Macedonian yoke again met with disaster. Fleeing from the battlefield, Demosthenes was caught by the enemy and took poison.

Dempsey, Jack (né William Harrison) (1895-1983). American boxer, born in Colorado. A cultural icon of the 1920s, he was world heavyweight boxing champion 1919-26, defeating Jess Willard, then losing to Gene *Tunney.

Dench, Dame Judi(th Olivia) (1934-). English actor, born in Yorkshire. She demonstrated exceptional versatility in stage, screen and television, and was best known internationally for playing ' $M$ ' in James Bond films from 1995 to 2015. She also gained awards for performances in plays by ${ }^{*}$ Shakespeare, ${ }^{*}$ Chekhov, ${ }^{*}$ Wilde and ${ }^{*}$ Coward, and in film adaptations of Jane *Austen and Charlotte *Brontë and portrayals of Queens *Elizabeth I and *Victoria. A Quaker, she was a passionate campaigner for causes and received a $\mathrm{CH}$ in 2005.

Deneuve, Catherine (née Dorleac) (1943-). French film actor. Sister of the actor Françoise Dorleac (1942-1967), from 1956 she made more than 60 films including Les parapluies de Cherbourg (1964), *Polanski's Repulsion (1964), *Bunuel's Belle de jour (1967), Tristana (1970), Benjamin (1967), Mayerling (1969), *Truffaut's Le Sauvage (1975), Le dernier metro (1980), The Hunger (1983) and Indochine
(1992), Place Vendôme (1999), Palais Royal (2006) and Potiche (2011). Her extraordinary beauty and cool, intelligent acting left an unforgettable impression, although many of her films were of poor quality. She married the English photographer David Bailey and had sons by the director Roger Vadim and the actor Marcello *Mastroianni. In 1985 she became the model for Marianne, symbol of the French Republic in statues and stamps.

Deng Xiaoping (Teng Hsiao-p'ing in Wade-Giles) (1904-1997). Chinese Communist politician, born in Sichuan province. Son of a landlord, he studied in Paris, working at a Renault plant, joined the CCP in 1925 and spent 1926 at university in Moscow. He served as an officer and political commissar in the Red Army in Jiangxi and Shaanxi and later in the People's Liberation Army. In 1933 he was demoted and imprisoned for being too close to *Mao but took part in the Long March (1934-36) and became General Secretary of the Central Committee in 1936. He was political commissar of the PLA 8th Route Army 1937-51 and a Central Committee member 1943-66. Vice Premier 1952-66, he became a Politburo member in 1955 and Secretary-General of the CCP in 1956-66. During the 'cultural revolution' he was denounced with *Lui Shaoqi as a 'capitalist roader', forced from office, publicly humiliated, and he attempted suicide (1967). Forced to work as a manual labourer until 1969, in April 1973 he was reinstated as Deputy Premier and took charge of government operations during *Zhou Enlai's last illness. He rejoined the Politburo and in 1975 became PLA Chief of Staff. In April 1976 he was dismissed from all posts, denounced again as a 'capitalist roader' and subjected to a campaign of attack for months. In July 1977 he was restored as 1st Deputy Premier, Vice Chairman of the CCP, and PLA Chief of Staff, working with Chairman *Hua Guofeng until forcing him to resign in 1981. Deng's supporters, heirs of ${ }^{*}$ Zhou Enlai, then took charge of government, party and armed forces. In 1978 he visited Tokyo to conclude the China-Japan Friendship Treaty and toured the US in 1979. He closed down the communes, proposed an 'open door' economic policy, encouraged the entry of foreign capital and negotiated the return of Hong Kong to Chinese sovereignty. However, the CCP maintained a political monopoly and Deng was largely responsible for crushing prodemocracy demonstrations in Tiananmen Square (June 1989). He gave up all official posts in 1989 but, despite age and failing health, continued to be recognised as 'paramount leader', promoting 'market force socialism'.

Salisbury, H., The New Emperors: Mao and Deng. 1992; Deng, M. M., Deng Xiaoping: My Father. 1995.

Denikin, Anton Ivanovich (1872-1947). Russian general. He rose from the ranks and after the first Russian Revolution was imprisoned for supporting *Kornilov's attempted revolt against *Kerensky's 
Socialist Government but escaped to raise an army in the south. Meanwhile (November 1917) the Bolsheviks under *Lenin had seized power and Denikin's 'White' army, with Allied support, occupied the Ukraine and northern Caucasus. As Bolshevik power grew, the 'Red' army gradually forced the 'Whites' back to the Crimea and in 1920 Denikin abandoned the struggle. He died in exile in France.

de Niro, Robert (1943-). American film actor, born in New York. He starred in Martin *Scorsese's Mean Streets (1973), Taxi Driver (1976) and Goodfellas (1990) and won Academy Awards for his roles in The Godfather Part II (1974) and Raging Bull (1980). Other films include The Mission (1986) and Awakenings (1990).

Denis (Dionysius), St (d.c.258). Italian martyr: patron saint of France. Sent from Rome (c.250) to convert the Gauls, he won many converts in and around Paris, and became the first bishop. During one of the periodical persecutions of Christians, Denis, with two others, was beheaded at Montmartre by order of the Roman Governor. According to the pious legend, he walked (head tucked under his arm) to the site of the Abbey of St Denis, a distance of $5.5 \mathrm{~km}$. Founded (c.630) by King *Dagobert, the Abbey acquired great wealth and for centuries was the burial place of French kings.

Denning, Alfred Thompson Denning, Baron (1899-1999). English judge. Educated in Oxford, he became a judge in 1944, a Lord of Appeal 1957-62 and Master of the Rolls 1962-82. His judgments attracted professional controversy because of his interest in filling in gaps in the law, reflecting deeply held social convictions (e.g. that unions should be held accountable for strike losses). He received the OM in 1997.

Dennis, C(larence) J(ames) (1876-1938). Australian poet and journalist. He worked as a journalist in Adelaide and Melbourne and achieved success with his volumes of vernacular verse tales, The Songs of a Sentimental Bloke (1915), The Moods of Ginger Mick (1916) and The Glugs of Gosh (1917).

Depardieu, Gérard (1948- ). French actor, director and producer. He starred in Cyrano de Bergerac (1990), The Green Card (1990), Germinal (1994), Les Miserables (2001), Mammuth (2010), Life of Pi (2012) and many other films. In 2013, irritated at proposed increases in income tax, he became a Russian citizen.

\section{de Paul, St Vincent see Vincent de Paul, St}

Depretis, Agostino (1813-1887). Italian politician. A supporter of ${ }^{*}$ Mazzini, he was a journalist and founded the journal Il Progresso in Turin (1850). As Premier of Italy 1876-78, 1878-79, 1881-87 he developed the policy of trasformismo, an attempt to accommodate a variety of policies without ever making clear or painful choices.
De Quincey, Thomas (1785-1859). English writer, born in Manchester. Son of a merchant, he was famous as the author of Confessions of an English Opium Eater. The experiences which gave rise to this book began at Worcester College, Oxford, where he went in 1803 after running away from Manchester Grammar School and a year's adventurous and hard wandering which had undermined his health. The Confessions first appeared in the London Magazine in 1821 and from then onwards he became one of the leading essayists of his day. In 1809 he went to live at *Wordsworth's old home, Dove Cottage, Grasmere, and thus came to know well the Lakeland poets, Wordsworth himself, ${ }^{*}$ Coleridge and *Southey, though his later brilliant accounts of them in his Literary Reminiscences (1834-40), published after his removal to Edinburgh in 1828, were waspish enough to cause offence. In 1816 he married Mary Simpson, daughter of a Lakeland farmer, who bore him a large family and did much to curb his addiction to opium. In all his writing de Quincey uses a beautiful and rhythmical, if sometimes intricate, prose. He had a genuine interest in German philosophy, to which he tried to direct English attention.

Hayter, A., Opium and the Romantic Imagination. 1968.

Derain, André (1880-1954). French painter. He was one of the original 'Fauves' (a word meaning 'wild beasts' and referring to the sense of violence and heightened intensity imparted by strong colour and distortion) and much influenced by *Cézanne, *Vlaminck and *Matisse. Before 1914 he used very bright colour and (often) a pointillist technique. His later works are more academic and mostly painted in browns and greens.

Sutton, D., André Derain. 1959.

Derby, Edward Geoffrey Smith Stanley, 14th Earl of (1799-1869). English politician. He first entered the House of Commons (where his dash and brilliance won him the nickname the 'Rupert of debate') in 1820 as a Whig, and supported the Reform Bill (1832). As Colonial Secretary he carried the act for the emancipation of West Indian slaves (1833), however, from 1834 he was a Conservative. On his father's death (1844) he led the wing of his party in the Lords opposed to *Peel's free-trade policy. He was leader of the Conservative Party 1846-68, the longest period for any British politician. Prime Minister for three short terms (1852, 1858-59 and 1866-68), he was, with ${ }^{*}$ Disraeli, responsible for the passing of the second Reform Bill (1867). He was a classical scholar who translated The Iliad (1864), a keen sportsman, and cared little for office. (He declined to form a ministry in 1855.) His great-grandson, Edward George Villiers Stanley, 17th Earl of Derby (1865-1948), racehorse owner and friend of *George V, proposed the 'Derby scheme' for recruitment before the introduction of conscription (1916) and was Secretary of State for War 1916-18, 1922-24. 
Derrida, Jacques (1930-2004). French philosopher, born to a Jewish family in Algiers. Educated in Algiers and at the École Normale Superieure, Paris, he taught at the Sorbonne and the ENS. He emphasised the primacy of written language over speech and was a pioneer of 'deconstruction', a rigorous analysis of the language used in literary texts which concluded that authors often convey meaning through unconscious (or conditioned) selection of vocabulary, for example by using masculine terminology. Deconstruction was an important element of 'postmodernism' with its radical attack on assumptions about intrinsic literary merit in particular texts e.g. the classics. His books included Of Grammatology (1967), Writing and Difference (1967), Margins of Philosophy (1972), What is Poetry? (1991) and The Other Heading (1992).

Peeters, B., Derrida. 2013.

Desai, Morarji Ranchhodji (1896-1995). Indian politician. A Gujerati, he became a public servant, a follower of Mahatma *Gandhi from 1930 and was imprisoned five times. He became Chief Minister of Bombay 1952-56, and served in the Union Government as Minister for Commerce 1956-58, Minister for Finance 1958-63 and 1967-69, and Deputy Prime Minister 1967-69. He contested the Congress leadership against Indira *Gandhi in 1966, supported by the traditionalists, founded the Janata Party, and became Prime Minister 1977-79 in a coalition united only by opposition to Mrs Gandhi.

Descamps, Chevalier Edouard Eugène François, Baron (1847-1933). Belgian jurist and politician. A professor at Louvain, he was an ardent proponent of an International Court of Justice, and was nominated for the Nobel Peace Prize 27 times (without success). He was the world's first Minister for Sciences and Arts 1907-10.

Descartes, René (1596-1650). French philosopher, mathematician and scientist, born at La Haye, Touraine. Educated by the Jesuits, he was impressed by the certainty of mathematical conclusions, which he tried to make the basis of his philosophical system. From 1628 he lived and worked in Holland for 20 years. In 1649 Queen ${ }^{*}$ Christina of Sweden invited him to live in Stockholm, but he died there after a few months. In his philosophy, he attempted to set out an account of the universe based on undoubted premises from which all else could be rigorously deduced. Following the method which came to be known as 'Cartesian', he found that there was only one thing that he could not possibly doubt: since he did have certain thoughts, whether or not true, he must exist as 'a thinking substance' (cogito ergo sum: 'I think, therefore I am'). He went on to establish the existence of his own body, of other 'extended substances' and hence of the material universe, and of God. A dualism of spirit and matter, so complete that the one cannot exercise influence on the other without the intervention of God, was a fundamental part of his system, which provoked criticism by later psychologists. His approach was highly mechanistic and he regarded animals as animated machines (machinae animatae) and infinitely exploitable. His work, set out in Discourse de la Méthode (1637), Méditations de prima philosophia (1641) and Principia philosophiae (1644), was the first great philosophy written in French. It also established literary style which has been of immense influence. In mathematics, he instituted a system of co-ordinate geometry, the application of algebra to geometrical problems, and although he mistakenly believed, at least initially, that scientific investigation should proceed by a priori deduction, he did important experimental work in optics. He is thought to have been a sincere Catholic and after *Galileo had been condemned by the Inquisition he withdrew from publication an early work that advanced the Copernican system of the universe.

Vrooman, J. R., René Descartes: A Biography. 1970.

Deschanel, Paul Eugène Louis (1856-1922). French politician, born in Brussels. Elected as Deputy in 1885, he was President of the Chamber of Deputies 1898-1902 and 1912-20, but was never a minister. A member of the Académie française (1899), and a prolific author, he was a strong advocate of the separation of church and state, and an opponent of the death penalty. Elected President of the Republic in February 1920 (heavily defeating Georges *Clemenceau), he soon showed some mental health problems, fell off a presidential train in his nightshirt, an event that caused embarrassment, ridicule and, in September, resignation. This did not prevent his election to the Senate 1921-22.

de Sitter, Willem (1872-1934). Dutch mathematician and cosmologist. Professor of astronomy at Leiden University 1908-34, influenced by *Einstein's work on relativity, he hypothesised (1917) a theoretical model of an expanding universe. Later work by ${ }^{*}$ Lemaitre and ${ }^{*}$ Hubble demonstrated that de Sitter's estimates were far too modest. Asteroid 1686 De Sitter and a Moon crater are named for him.

Desmoulins, Camille (1760-1794). French revolutionary politician. A lawyer and journalist in Paris, despite his stammer, he helped to rouse the mobs at the storming of the Bastille (14 July 1789). He was a member of the National Assembly 178991 and of the National Convention 1792-94. In his newspaper, Le Vieux Cordelier, he attacked the terrorism of *Robespierre and his party, and was guillotined with his friend ${ }^{*}$ Danton.

De Soto, Hernando (c.1500-1542). Spanish explorer. He was with *Pizarro in the conquest of Peru, landed in Florida (1539), explored northwards as far as what are now the Carolinas, and then westward to the Mississippi, which he discovered and crossed in 1541. 
DesRochers, Alfred (1901-1978). French Canadian poet. His collections L'Ofrande aux vierges (1929) and Ál'Ombre de l'Orford (1930) revealed his remarkable gift for evoking the way of life of the country people in the province of Québec.

Dessalines, Jean Jacques (c.1758-1806). Haitian adventurer. After taking part in the slave revolt (1791) he became a provincial governor under ${ }^{*}$ Toussaint L'Ouverture. After the latter was captured he renewed the struggle, forced the French to surrender and in 1804 proclaimed Haitian independence. With British support he drove the French out of Haiti (1803), proclaimed himself as the emperor Jacques I (1804-06), but his cruelty and extortions led to his assassination.

Dessay, Natalie (1965- ). French coloratura soprano, born in Lyon. After studying ballet and acting, she began her operatic career in 1992, achieving international recognition for her versatility, virtuosity and dramatic gifts, excelling in *Händel, *Mozart, ${ }^{*}$ Donizetti, ${ }^{*}$ Bellini and ${ }^{*}$ Strauss.

Deterding, Henri Wilhelm August (1865-1939). Dutch oil magnate, born in Amsterdam. He was a bank clerk until he went to the East Indies to seek his fortune. In 1896 he joined the Royal Dutch Oil Company, of which he had become Director General by 1902 . The merger with the British 'Shell' company in 1907 made the Royal Dutch-Shell group one of the strongest oil combines in the world. Awarded an honorary KBE in 1920, he was Chairman of Royal Dutch Shell until 1936 when his sympathy for the Nazi regime led to a board revolt.

Deutscher, Isaac (1907-1967). English writer, born in Poland. He was a prominent Communist journalist in Poland until expelled from the party for his antiStalinist position. He fled to England (1939) and wrote for leading British periodicals. His biography Stalin (1949) was authoritative.

De Valera, Eamon (1882-1975). Irish republican politician, born in New York. After his father, a Spanish artist, died, he returned to his mother's family in Ireland, graduated at the Royal University, Dublin and became a mathematics teacher. He joined the nationalist Irish volunteers (1913) and was sentenced to death for his part in the Easter rebellion (1916), but was reprieved and, in 1917, released. He was elected Sinn Féin member of East Clare in 1917 but never took his seat. Another term of imprisonment (1918-19) was ended by a daring escape from Lincoln Jail. In 1919 he became head of the insurgent Irish government but did not accompany the negotiating team to London in 1921. He was bitterly opposed to concessions made by Arthur ${ }^{*}$ Griffith and Michael ${ }^{*}$ Collins and led the militant republicans in the ensuing civil war. In 1927 he finally abandoned his extremist attitude, formed a new political party the the Dáil Éireann (House of Representatives). After defeating ${ }^{*}$ Cosgrave in the 1932 election he became Prime Minister and held office 1932-48, 1951-54, 1957-59. (In 1937 when the Irish Free State became the Republic of Ireland-Poblacht Na hÉireann - the title of President of the Executive Council was replaced by Taoiseach.) Eire remained neutral during World War II but did not leave the British Commonwealth until 1948, when John ${ }^{*}$ Costello defeated de Valera. $\mathrm{He}$ became President of the Republic 1959-73. Devious and autocratic, de Valera remains an intensely controversial and enigmatic figure.

Fitzgibbon, C. and Morrison, G., The Life and Times of Eamon De Valera. 1974; Coogan, T.P., De Valera: Long fellow, long shadow. 1993.

De Valois, Dame Ninette (Edris Stannus) (18982001). British ballet director, choreographer and dancer, born in Ireland. She danced under *Diaghilev and from 1926 to 1930 was choreographer at the Old Vic Theatre, London. In 1931 she founded and became artistic director of the Sadler's Wells Ballet, now known as the Royal Ballet, retiring in 1963. She received the CH in 1981 and the OM in 1992. Her 100th birthday was celebrated in June 1998.

Walker, K. S., Ninette de Valois. 1987.

\section{Devereux, Robert see Essex, Robert Devereux, 2nd Earl of}

Devonshire, 4th Duke of, William Cavendish (1720-1764). English Whig politician and courtier. He was First Lord of the Treasury (i.e. Prime Minister) 1756-57, in a seven months ministry dominated by *Pitt the Elder, and Lord Chamberlain 1757-62. A collateral successor, Spencer Compton Cavendish, 8th Duke of Devonshire (1833-1908), educated at Trinity College, Cambridge, was, as Marquess of Hartington, MP 1857-91, a minister under *Gladstone, and Leader of the Liberal Party 187580 . He declined invitations to lead a government in 1880, 1886 and 1887. He broke with Gladstone over Home Rule (1886) and led the Liberal Unionists, serving under ${ }^{*}$ Salisbury as Lord President of the Council 1895-1903. In 1892 he married his mistress, Louisa, Duchess of Manchester, known as 'the double Duchess', and was Chancellor of Cambridge University 1892-1908.

De Vries, Peter (1910-1993). American novelist, born in Chicago. The son of Dutch immigrants, he studied at Calvin College, became a freelance writer (1931), editor of Poetry (1942) and a staff writer on the New Yorker. His dead-pan, multi-punned humour exposes many aspects of life without individual responsibility in a commercialised mass society. His novels include: No, But I saw the Movie (1952), Comfort Me with Apples (1956), The Mackerel Plaza (1958), The Blood of the Lamb (1962), The Cat's Pajamas and Witch's Milk 
(1968), Without a Stitch in Time (1972), The Glory of the Hummingbird (1974), I Hear America Swinging (1976) and Madder Music (1977).

Dewar, Sir James (1842-1923). Scottish physical chemist, born in Kincardine. Educated at Edinburgh University, he was Jacksonian Professor of Natural Philosophy, Cambridge, 1875-1923, and Fullerian Professor of Chemistry at the Royal Institution, London, 1877-1923. He is best known for his extensive researches into the properties of matter at very hot temperatures. He invented the vacuumjacketed flask, often referred to as a Dewar flask, the parent of the present-day vacuum flask. He showed that liquid oxygen and ozone are magnetic, and he was the first to prepare liquid and solid hydrogen. With Sir Frederick Abel he developed (1889) an early form of cordite. Nominated eight times for a Nobel Prize, he was awarded the Copley Medal in 1916.

De Wet, Christiaan Rudolph (1854-1922). Boer soldier and politician. A successful guerrilla leader in the Boer War (1899-1902), he never accepted the political implications of defeat. He wrote Three Years' War (1902). Believing that the outbreak of World War I (1914) provided an opportunity to re-establish a Boer republic, he led a rising against the *Botha government. He was captured and briefly imprisoned.

Dewey, George (1837-1917). American admiral. He led the US fleet in the Spanish American War (1898-99), destroyed the whole Spanish squadron and captured Manila (1898), and became a popular hero in the US.

Dewey, John (1859-1952). American philosopher. Important for his advancement of progressive education and professor of philosophy at Michigan, Chicago and Columbia universities, he was influenced by the pragmatism of *Peirce and William *James. He thought of philosophy as something relevant to practical problems, his views being sometimes crudely summarised as 'truth is what works'. In fact his thoughts covered a much wider field, as such books as Reconstruction in Philosophy (1920) show; he also wrote on psychology, logic and ethics. His views on education, through the many translations of his School and Society (1900) and Democracy and Education (1916), achieved international influence. On the grounds that 'education is life, not a preparation for life' and that a 'school is a community in miniature' he held that children should be faced with practical concerns and real problems rather than given traditional instruction, he emphasised 'learning by doing'.

Berstein, R. J., John Dewey. 1966; Ryan, A., John Dewey and the High Tide of American Liberalism. 1995.

Dewey, Melvil Louis Kossuth (1851-1931). American librarian. In 1876 he devised the 'Decimal Classification and Relative Index' for library books, widely adopted in public libraries not only in the US but in many other countries.
Dewey, Thomas Edmund (1902-1971). American Republican politician and lawyer, born in Michigan. Educated at Michigan and Columbia universities, he became a special prosecutor to root out organised crime in New York State 1935-38, winning a national reputation. District Attorney of New York County (Manhattan) 1938-41, he was narrowly defeated for Governor of New York in 1938. A leader of the moderate Republicans, at the 1940 National Convention, aged 38, he won the first three ballots for the presidential nomination, but lost to Wendell *Willkie. As Governor of New York State 1943-55, he enforced the death penalty and there were 90 executions. He became Republican candidate for president in 1944 (losing to Franklin *Roosevelt) and in 1948 (losing unexpectedly to ${ }^{*}$ Truman). He helped *Eisenhower win the 1952 Republican nomination. Offered the Chief Justiceship of the US by Eisenhower and *Nixon, he declined. Dewey was very able but oddly unlikeable. Theodore *Roosevelt's daughter, Alice Longworth, lethally despatched him as 'the little man on a wedding cake'.

Hughes, R., Thomas E. Dewey. 1944.

De Wint, Peter (1784-1849). English landscape painter, born in Staffordshire. His father, a doctor of Dutch descent, had worked in New York. He became a very successful water-colourist and teacher, working in London but painting extensively in Lincolnshire.

De Witt, Johan (or Jan) (1625-1672). Dutch statesman. Son of the burgomaster of Dordrecht, his family was traditionally opposed to the House of Orange. He took part in the administration of his native city until he became (1653) Grand Pensionary of Holland (an office which, as developed by him, made him the head of the largest of the Dutch provinces and predominant in the country as a whole). He connived with ${ }^{*}$ Cromwell that the peace treaty with England (1654) should stipulate that the House of Orange (which favoured the royalist cause in England) was to be excluded from all its offices. His foreign policy aimed at an alliance with France, so as to leave himself free to assert Dutch maritime power. Intervention in the Baltic proved profitable and some striking successes were achieved in an indecisive war with England (1666-67) but an unforeseen alliance between England and France created a crisis, in which the Dutch turned to their traditional saviours, the House of Orange. De Witt resigned in 1672 but a fortnight later, when visiting his brother Cornelius who had been imprisoned on a charge of conspiracy, he was killed by an angry mob of Orange partisans.

Diaghilev, Sergei Pavlovich (1872-1929). Russian ballet impresario, born in Novgorod. He was, with Leon ${ }^{*}$ Bakst and Alexandre *Benois, the driving force of the artistic movement and periodical Mir Iskusstva (World of Art, 1899-1904). In pursuit of an idea of introducing Russian art to western Europe, he presented $(1908){ }^{*}$ Chaliapin in a season 
of Russian opera in Paris. He followed this up with his famous Ballets Russes presented in Paris (1909) and London (1911) in the conviction that in ballet he could form a union of all the arts. To this end he secured the services of dancers of outstanding skill*Pavlova, ${ }^{*}$ Nijinsky, ${ }^{*}$ Karsavina and Lopokova-and choreographers such as ${ }^{*}$ Fokine and ${ }^{*}$ Massine: he commissioned Benois, Bakst, *Matisse, *Picasso, *Braque and others to design the decor and *Debussy, *Ravel, *Stravinsky and *Prokofiev to compose ballet scores. The Revolution broke his links with Russia, but with Paris as its headquarters his company continued to enjoy the highest reputation. He retired to Venice and died there.

\section{R. Buckle, Diaghilev. 1979.}

Diana (née Diana Frances Spencer, later MountbattenWindsor) (1961-1997). Princess of Wales. Daughter of the 8th Earl Spencer, she became a kindergarten assistant and married ${ }^{*}$ Charles, Prince of Wales in 1981. They had two sons, *William (b.1982) and *Harry (b.1984). The princess was the subject of enormous media coverage, at first adulatory, then critical. After a period of damaging media speculation about the marriage, Charles and Diana separated in December 1992. After encouraging damaging attacks on the Royal family in books, newspapers and television, she agreed to a divorce in 1996, then devoted herself to major causes (AIDS, leprosy, land mines). Killed in a car crash in Paris with her lover Dodi al-Fayed (31 August 1997), her death and funeral created unexpectedly intense international public reaction.

Dias, Bartolomeu (c.1450-1500). Portuguese navigator. Of noble birth, he became interested in geographical discoveries at the court of * Joáo II who sent him to explore the west African coast. In January 1488, driven by storms, he rounded the Cape of Good Hope (originally called the Cape of Storms), without seeing it. Owing to the discontent of his crew, he turned back without exploring the coast of east Africa. His discovery showed the route to India, but when he sailed with da *Gama in 1497 he was sent back after a short distance. He was drowned in 1500 on a voyage to Brazil.

Diaz, Armando (1861-1928). Italian general of World War I. He succeeded ${ }^{*}$ Cadorna as Commander-in-Chief after the disaster at Caporetto (1917), retrieved the situation and by his decisive victory at Vittorio Veneto (October 1918) forced the Austrians to accept an armistice a few days later.

Diaz (del Castillo), Bernal (1492-1581). Spanish soldier and historian. He was with *Cortés in Mexico 1519-21 and wrote the important True History of the Conquest of New Spain (1532).

Diaz, Porfirio (1830-1915). Mexican soldier and president. Originally a supporter of the liberal president *Juarez, he shared his triumph after the withdrawal of the French and the execution of their protégé, the emperor ${ }^{*}$ Maximilian. Feeling himself inadequately rewarded, he twice vainly opposed Juarez for the presidency (1867 and 1872). In the latter year Juarez died and in 1876 Diaz took up arms to prevent his successor, Manuel Gonzales, from embarking upon a second term. Having achieved his object, Diaz ruled as a dictator for the next 34 years. By enforcing law and order and by proving himself the friend of big business in the development and modernisation of the country, he greatly increased the state's revenues, but the discontents of nationalists, resentful of foreign control of their resources, of liberals, eager for democracy, and of the impoverished Indians and exploited peasants, accumulated. In 1911 Diaz was forced into exile by ${ }^{*}$ Madero.

Godoy, J. F., Porfirio Diaz. 1976.

Dickens, Charles (John Huffam) (1812-1870). English novelist, born near Portsmouth. Both his parents provided models for future characters: his father (an improvident clerk in the naval dockyard) for $\mathrm{Mr}$ Micawber, his mother for Mrs Nickleby. When his father was imprisoned (1824) for debt in the Marshalsea in London (see Little Dorritt, 1855-57) Charles, then 12, worked for some months pasting on labels in a blacking factory, an experience that left much bitterness behind. After two more years at school he worked as a lawyer's clerk (1827-30) and then, having learned shorthand, became a parliamentary reporter, an apprenticeship in journalism which stood him in good stead. In 1833 he began to write, for the Monthly Magazine and other periodicals, a number of short sketches of places seen and personal encounters that were collected under the name of Sketches by Boz (1836), Boz being his pen name for some years. Its success led to a suggestion by the publishers Chapman and Hall that he should write the text to fit a series of plates by the artist Robert Seymour. Dickens' counter proposal that the pictures should illustrate the text was accepted and his first great success. The Posthumous Papers of the Pickwick Club began to appear, serialised in parts like many of the later novels. In 1836, Seymour, who died before the second part had appeared, was replaced by 'Phiz' (Hablot K. *Browne), Dickens' illustrator for over 20 years. The gallery of humorous eccentrics portrayed in this work, Pickwick himself, Sam Weller, Mr Winkle and the rest was to be constantly enlarged as the years went by. It is sometimes urged that the balance of the plot of the novels is upset by the intrusions of such characters as Pecksniff (Martin Chuzzlewit, 1843), Mr and Madame Mantalini (Nicholas Nickleby, 1839), Mr Boffin (Our Mutual Friend, 1865). A vein of autobiography occurs in many of the novels, especially in David Copperfield (1849-50).

London itself, the sprawling, vulgar, fog bound, Cockney metropolis, is the setting of most of his novels, but sometimes he goes back into history for dramatic plots, the Gordon riots in Barnaby Rudge 
(1841) and the French Revolution (influenced by *Carlyle's famous book) in A Tale of Two Cities (1859). Mystery and crime always attracted him, partly no doubt because of his great friendship with Wilkie *Collins, and are a feature especially of the more elaborately planned novels of his later period, e.g. Bleak House (1859), Great Expectations (1861), and the last, unfinished, Edwin Drood (1870), to which many distinguished writers such as G. K. * Chesterton have tried to conjecture the solution. Especially when depicting children ill or doomed to die-Tiny Tim in A Christmas Carol (1843), Little Nell in The Old Curiosity Shop (1841) or Paul in Dombey and Son (1846)_Dickens can be over-sentimental. He is most effective as a satirist when he flays the nouveaux riches, the pompous and the hypocrites, or finds targets in the delays of the civil service ('Circumlocution Office') and the law. Any form of exploitation of the young or helpless by a schoolmaster, such as Wackford Squeers in Nicholas Nickleby, by a crook, such as Fagin in Oliver Twist (1838), or by a ruthless employer such as Bounderby in Hard Times (1854) earns his abhorrence.

Dickens was unhappy in his private life. An early love for Maria Beadnell (David Copperfield's Dora) was rejected. His marriage in 1836 to Katharine Hogarth was clouded a year later by the death of her dearly loved younger sister Mary (Little Nell); it finally was ended by separation 20 years later. Dickens maintained an intimate but complicated relationship with Nellie (Ellen) Ternan (1839-1914) from 1857 until his death. His son, Sir Henry Fielding Dickens (1849-1933), was a barrister, KC and judge.

Both *Dostoevsky and *Tolstoy admired Dickens. George *Orwell argued that Dickens describes, wonderfully, eloquently, evocatively, but he does not analyse, nor does he prescribe. His novels are never contemporary; he always writes of some decades earlier. There is a manic, driven, dark side to Dickens, shown in four areas: his constant exploitation of women, exceptional even for his time, his racism and celebration of cruelty, applauding atrocities following the Indian Mutiny, his growing sympathy for the Confederate cause in the US Civil War and his support for E. J. *Eyre after the bloody suppression of the Jamaica rebellion (1865).

Dickens wrote many short stories and sketches, A Child's History of England (1851-53), and American Notes for General Circulation (1842) and Pictures from Italy (1846), which illustrated his travels. He was first editor (1846) of the Daily News, he edited Household Words (1850-59) and All The Year Round (185970). He toured the US in 1842, 1867 and 1868, Canada in 1842 and Britain constantly, giving public readings from his novels, a total of 471 performances. This enabled him to display his extraordinary ability as an actor, which had a mesmerising effect on audiences, but exhausted him and hastened his death.
Dickens is one of the few authors who, after the publication of his first success, has been a continuous bestseller for 175 years. Modern criticism has rediscovered the richness of his imagination, the depth of his insight, and the consummate skill with which he combines the many disparate strands of his works. Dickens was one of the greatest 19th-century novelists in any language, demonstrating 'demonic and disturbed' elements, the odd combination of evil and comedy. Dickens was a darker, more conflicted, more powerful writer than generally recognised, even by his ardent supporters; a giant of world literature.

Collins, P., A Dickens Bibliography. 1970; Collins, P., Dickens, the Critical Heritage. 1971; Ackroyd, P., Dickens. 1990; Tomalin, C., Charles Dickens. A Life. 2011; Douglas-Fairhurst, R., Becoming Dickens. The Invention of a Novelist. 2011; Callow, S., Charles Dickens and the Great Theatre of the World. 2012.

Dickinson, Emily Elizabeth (1830-1886). American poet, born in Amherst, Massachusetts. Her father, a lawyer, served briefly in the Massachusetts Legislature and the US Congress and had been treasurer of Amherst College. She rarely left her birthplace and at the age of 23, possibly after an unhappy love affair, became a recluse, seeing only her family and a very few intimates and began writing poetry, intensely personal and daringly original in language and form, often written on small pieces of paper, including bills and envelopes. No one, not even her friends, recognised the merit of her poems, now numbered 1,775. Her most productive years were 1860-64, during the Civil War, although she never mentions it specifically. Epilepsy was probably a major factor in her seclusion and poetic intensity. Her brother's mistress, Mabel Loomis Todd (1856-1932) edited three volumes of her poems $(1890,1891,1896)$, the first two with T. W. Higginson, winning immediate recognition, but her sharp originality was timidly modified and lost until a new edition by Thomas Johnson in 1955. Her themes are those within her narrow experience, love, nature, the changing seasons, the birds, frogs and insects that inhabited her garden and her edgy relationship with God.

Reading her is like making a telephone call to an inner life.

I cannot live with You -

It would be Life -

And Life is over there -

Behind the Shelf ...

Because I could not stop for Death -

He kindly stopped for me -

The Carriage held but just Ourselves -

And Immortality ...

Faith is a fine invention

When Gentlemen can see -

But Microscopes are prudent

In an Emergency 
Hope is the thing with feathers

That perches in the soul,

And sings the tune without the words,

And never stops at all ...

Sewall, R. B., The Life of Emily Dickinson. 1974; Habegger, A., My Wars are Laid Away in Books: The Life of Emily Dickinson. 2002; Gordon, L., Lives Like Loaded Guns: Emily Dickinson and Her Family Feuds. 2010.

Diderot, Denis (1713-1784). French encyclopaedist, born in Langres, Champagne. He was an important member of the group of scholars and sceptical thinkers known as philosophes, who created the climate of opinion, known as the 'enlightenment', critical of the Ancien Régime. In this, his own great Encyclopédie played a most important part. Before embarking upon this enterprise Diderot had led a bohemian life and earned a precarious livelihood by writing plays, novels and art criticism, but the exuberance of his personality, his enthusiasm and wide knowledge gave him a secure place in intellectual society. The basis of the Encyclopédie (1751-72), for which he shared editorial responsibility with the mathematician d'*Alembert, was the English Cyclopaedia of Ephraim ${ }^{*}$ Chambers, which he was asked to translate, but the conception was constantly enlarged until it became a vast work of 17 volumes of text and 11 of plates. The intention of the work, which became the focus of the rationalism and anti-clericalism of the age, was to show the interconnexion of all branches of knowledge. Diderot wrote many articles himself on philosophical and mechanical subjects and gathered as contributors some of the greatest men of his time, including ${ }^{*}$ Voltaire, ${ }^{*}$ Rousseau (a great friend of Diderot, with whom he quarrelled in 1757), *Montesquieu, *Turgot and *Buffon. Diderot, who had suffered imprisonment for his Letter on the Blind (1749), one of the many works in which he set out his materialistic philosophy, had some trouble with the censorship, but comparatively few articles were banned. Diderot's last years were made easier by a kindly gesture of ${ }^{*}$ Catherine the Great, who bought his library and appointed him its custodian. He went to St Petersburg (1774) and before returning had written for the benefit of his patroness a plan for a Russian university, a proof of the amazing industry and versatility that made him one of the most universal influences of his era.

Furbank, P. N., Diderot: A Critical Biography. 1992; Curran, A. S., Diderot and the Art of Thinking Freely. 2019; Zaretsky, R. Catherine \& Diderot. 2019.

Didion, Joan (1934-2021). American writer, born in California. A reporter, editor, essayist, novelist and screenplay writer with an exceptional gift for analysis and a sharp critic of sentimentality, her books include Slouching Towards Bethlehem (1968) and The Year of Magical Thinking (2005).
Diefenbaker, John George (1895-1979). Canadian politician. Educated at the University of Saskatchewan, after service in World War I he became a successful barrister. He was a Progressive Conservative MP 1940-79 and party leader 195663. Prime Minister of Canada 1957-63, he won the greatest majority in Canadian history (until 1993) in 1958. In 1963 his opposition to a US contention that nuclear warheads for Canadian missiles were a necessary part of North American defence led to a rift in his Cabinet, his resignation and electoral defeat.

Diemen, Anthony van (1593-1645). Dutch administrator. As Governor-General of the Dutch East Indies 1636-45 he commissioned Abel *Tasman's voyages of exploration. The island off Australia named Van Diemen's Land was renamed Tasmania in 1853.

Diesel, Rudolf (1858-1913). German inventor, born in Paris. He moved to England and studied engineering and thermodynamics in Germany. The engine which bears his name, an internalcombustion engine in which the fuel is ignited by heat following compression, was patented in 1892 . After having been nearly killed in an explosion of an earlier model, he produced his first successful engine in 1897 . He disappeared at sea.

Nitske, W. R. and Wilson, C. M., Rudolf Diesel: Pioneer of the Age of Power. 1965.

Dietrich, Marlene (née Maria Magdalene) (19011992). German-American film actor and cabaret performer. After starring in her best known film, The Blue Angel (1930), in Germany, she went to Hollywood. She became an American citizen in 1937. She often played the part of an adventuress in films which included The Flame of New Orleans (directed by René *Clair), Destry Rides Again, Foreign Affair, Witness for the Prosecution, Touch of Evil and Judgment at Nuremberg. She died in Paris.

Dilke, Charles Wentworth (1789-1864). English writer and critic. A public servant, and friend of *Keats, he was the anonymous author of The Source and Remedy of the National Difficulties (1821), which had a significant influence on *Marx. His grandson, Sir Charles Wentworth Dilke, 2nd Baronet (1843-1911) was a politician, born in London. After graduating at Cambridge, he travelled extensively in the Australian colonies (1867-68) and wrote the influential Greater Britain: A Record of Travel in English-Speaking Countries During 1866 and 1867 (2 vols, 1868). He was MP for Chelsea 1868-86, an imperialist radical with republican leanings. Undersecretary for Foreign Affairs 1880-82 he joined *Gladstone's Cabinet as President of the Local Government Board 1882-85. Chairmanship of a royal commission on housing and work on parliamentary redistribution showed his interest in social conditions at home, while he closely associated himself with the imperial and colonial views of his (then) fellow radical Joseph ${ }^{*}$ Chamberlain. In 
1885-86, although cleared of adultery in a complicated divorce case, he imprudently sought a review to resolve any ambiguities (as later happened with Oscar *Wilde). Dilke, possibly a victim of a conspiracy, proved to be a disastrous witness in his own case, and this destroyed his political prospects. (Adultery had never harmed *Palmerston.) Though he re-entered parliament (1892) and his brilliant books on foreign and colonial affairs were highly praised, he never returned to high office. In his later years he worked closely with trade unions and Labour MPs.

Jenkins, R., Sir Charles Dilke. 1958; Nicholls, D., The Lost Prime Minister: Life of Sir Charles Dilke. 1995; Jenkins, R., Dilke: A Victorian Tragedy. 1996.

Dill, Sir John Greer (1881-1944). British field marshal, born in Ulster. He served in France, India and Palestine and was ${ }^{*}$ Churchill's Chief of the Imperial General Staff, May 1940-November 1941. Churchill thought him defeatist because in discussions on strategy he failed to fight back (as also happened with *Wavell). Sent to Washington as head of the Joint Staff Mission 1942-44, he achieved unexpected and brilliant success by winning the confidence of ${ }^{*}$ Marshall, *Hopkins, *Leahy and, through them, ${ }^{*}$ Roosevelt. He died in Washington and was buried at Arlington.

Dillinger, John (1903-1934). American gangster. After serving nine years of a sentence for robbery with violence he headed a gang of escaped convicts who terrorised the states of Indiana, Illinois, Ohio and Pennsylvania. He was eventually shot resisting arrest.

Dillon, (Clarence) Douglas (1909-2003). American administrator, born in Geneva. In 1931 he joined the family firm of investment bankers, and after navy service in World War II, became Chairman in 1953. Appointed by President *Eisenhower as Ambassador to France 1953-57, although a Republican, he became Secretary of the Treasury 1961-65 under Presidents *Kennedy and *Johnson.

DiMaggio, Joe (Joseph) (1914-1999). American baseball player, born in California. Played for the New York Yankees 1936-51 and had an outstanding record as a batter. He was briefly married to Marilyn *Monroe (1954) and loyally supported her until she died.

Dimitri (Dimitri Ivánovich) (1581-1591). Russian prince. Son of *Iván IV, when his elder brother *Fyodor became tsar, he was removed from the court and died mysteriously. The regent, Boris *Godunov, who reported that he had fallen on a knife during an attack of epilepsy, was accused by his enemies of murder. Subsequently several 'false' Dimitris appeared, of whom one, after defeating Boris' troops, was crowned tsar in 1605 , but was murdered by the nobles in the following year. *Mussorgsky's opera Boris Godunov gives a version of the story. See Dimitri, False.
Dimitri, False. Name given to three pretenders to the Muscovite throne during the Time of Troubles (1605-13). On the death of Fyodor I (1598), Boris *Godunov succeeded and the First False Dimitri challenged his right to the throne and claimed to be Dimitri, the son of *Ivan IV, who had died mysteriously in 1591 while still a boy. He is thought to have been, in fact, Yuri Otrepyev, a noble.

Threatened with exile he fled to Lithuania and in 1604 invaded Russia at the head of an army. In 1605 Boris died and Dimitri was proclaimed Tsar, but soon alienated his supporters and was murdered in 1606. Rumours that the First Dimitri had survived led to the appearance of a second pretender who quickly gained support and established his court at Tushino (1608). Initially very successful, he was ousted by Vasily Shuysky, the boyar who had murdered the first Dimitri and become tsar (1606), and was assassinated by one of his own followers (1610). In 1611 the Third False Dimitri, possibly a deacon named Sidorka, gained the allegiance of Cossacks who were ravaging Moscow's environs, but he was betrayed in 1612 and executed in Moscow.

Dimitrov, Georgi Mikhailovich (1882-1949). Bulgarian Communist politician. A printer, he came into international prominence when in 1933 he was tried in Berlin and acquitted on a charge of setting fire to the Reichstag, a crime almost certainly committed by his Nazi accusers. He was Secretary of the Communist International (Comintern) in Moscow 1934-43 and Premier of Bulgaria 1946-49.

Dimitry (Ivanovich) Donskoy (c.1350-1389). Grand Prince of Moscow 1359-89. Son of Ivan II ('the Fair'), and Grand Prince of Vladimir from 1363, he asserted his dominance over rival princes but his real importance lies in the fact that, by his two victories over the Golden Horde at the River Vozha and more decisively at Kulikovo (1380), near a crossing of the River Don (hence his additional name), he destroyed the legend of Tartar invincibility. Moreover, even though subsequently defeated, his prestige was so great that the princes of Moscow were thenceforth regarded as national rulers. One of the heroes of Russian history, he is a saint in the Orthodox Church.

\section{d'Indy, Vincent see Indy, Vincent d'}

Dine, Jim (1935- ). American painter, sculptor, print maker, photographer and poet, born in Ohio. Widely exhibited, his subjects were mostly ordinary objects, e.g. shoes, dressing gowns, tools, but invested with a life of their own.

Dinesen, Isak (pen name of Baroness Karen Christenze von Blixen-Finecke, née Dinesen) (18851962). Danish novelist, born in Rungsted. Writing in both Danish and English, she married unhappily and lived in Kenya 1914-31, managing a coffee plantation. Her lover Denys Finch Hatton, aviator and big game 
hunter, died in a plane crash in 1931. She updated the Gothic novel with Seven Gothic Tales (1934). Her nonfiction included Out of Africa (1937) and Shadows on the Grass (1960). In Denmark, during the German occupation, she wrote her only full-length novel, The Angelic Avengers (1946), under the pseudonym Pierre Andrezel. Babette's Feast (1958) became an Oscar winning film in 1987. Nominated 12 times for the Nobel Prize, she died, not of syphilis, as she claimed, but from self-prescribed over-medication.

Thurman, J., Isak Dinesen. 1982.

Dingaan (or Dingane) ka Senzangakhona Zulu (c.1795-1840). Zulu chief. He was half-brother of *Shaka, whom he murdered (1828). After permitting the Boers to settle in Natal, killed a party of 470 Voortrekkers under Piet Retief (1837), an act revenged by Andries *Pretorius (1838). 'Dingaan's Day' (16 December), celebrated by Boers for more than 150 years, became the Day of the Vow in 1980 but was chosen by Nelson *Mandela in 1995 as 'Day of Reconciliation'.

Dio, Cassius (Dio Cocceianus) (c.155-235). Greek historian, born in Nicaea, now Iznik. After a long period of distinguished public service under the emperor ${ }^{*}$ Commodus and his successors, he retired to write a comprehensive history of Rome in 80 books, of which Books 36-50 survive. His careful use of the best available sources give value to his record.

Millar, F., A Study in Cassius Dio. 1964.

Diocletian (Gaius Valerius Aurelius Diocletianus, originally Diocles) (245-313). Roman Emperor 284305. Born in Dalmatia, from a modest background, he became a cavalry commander and was proclaimed emperor at a council in Nicomedia after he had overcome a rival claimant, Carinus. In order to rule and defend the vast empire, in 293 he created a tetrarchy ('rule of four') in which administration was decentralised, shared with *Maximian (as coemperor, or 'Augustus', in the west) and two 'Caesars', virtually junior emperors, ${ }^{*}$ Constantius Chlorus and ${ }^{*}$ Galerius. Diocletian remained in a dominant position but ruled from the east as 'Augustus'. His main concern was to maintain the great armies necessary to defend the empire and he introduced a tax system to enable him to do so. Sons of soldiers had to serve and landowners to provide recruits, a regular land tax was introduced, based on acreage, productivity and labour employed, but this had the effect of making taxation a hereditary responsibility and of tying the peasantry to the land. His attempt to curb inflation by price control under the edict of 301 failed. Diocletian had been cautiously conservative about religion, but in 303 , probably at the urging of Galerius, he instituted public ceremonies of sacrifice to the Roman gods, intended as a unifying factor throughout the empire. This was anathema to Christians and led directly to the fourth and most serious campaign of persecution, which lasted until 311, involving executions, banishment and the destruction of churches. After 21 years as emperor, Diocletian abdicated and induced Maximian to resign as well. This was the first voluntary abdication by an emperor, demonstrating Diocletian's achievement in ending decades of fratricidal anarchy. Constantius Chlorus and Galerius became co-emperors, and Severus and Maximin were made Caesars. Apparently the scheme of succession had worked but confusion soon followed. The vast palace at Split (Croatia) was built for his retirement.

Williams, S., Diocletian and the Roman Recovery. 1997.

Diogenes (c.412-323 BCE). Greek 'cynic' philosopher, born at Sinope (on the Black Sea). His father was a magistrate convicted of 'defacing the currency'. Forced into poverty Diogenes found that it enabled him to lead a life in accordance with his belief in entire self-sufficiency and freedom from ordinary desires and conventions. He spent a wandering life begging his way and sleeping in the open or in such shelter as he could find, perhaps even in the proverbial tub. In Athens, where he was often to be found, he was called 'Cynic', a word much changed in meaning which then meant simply that he lived like a dog. He died, so legend goes, by eating raw cuttlefish in order to prove that cooking is unnecessary. Apparently he wrote plays and described an ideal republic where there were no armies or family life, but none of his work survives.

Dionysius (c.430-367 BCE). Tyrant of Syracuse 405-377 BCE. He was able to seize and maintain power in Syracuse, a Greek colony in Sicily, by playing on the fears of his subjects of the Carthaginians who held a substantial part of the island. Much of his reign was occupied by this task, and varied by his own expeditions against the Greek colonies in southern Italy. Dionysius was a poet and a patron of letters.

His son Dionysius II (c.390-344 BCE) succeeded him and ruled despotically until ejected in 356 by a fleet sent from Greece under Dion, who temporarily restored the republic. Dionysius regained power in 347.

Dionysius Exiguus (d.c.545). Roman monk and scholar, born in Scythia. Among the most learned men of his time, he worked in Rome from about 500, collecting and translating canons and documents of the early Christian era, and became abbot of a monastery in Rome, where he died. In 525, he proposed the Christian chronology, beginning with the birth of *Jesus Christ in Anno Domini I (i.e. 'Year of our Lord' = year 754 in the Roman calendar). His starting date was arbitrary: probably four to eight years too late. *Bede later proposed BC ('Before Christ') numbering.

Dior, Christian Ernest (1905-1957). French fashion designer. After World War II he launched the 'New Look', which brought the period of wartime austerity 
in women's clothes to an end. He also revolutionised the world of haute couture by having simplified versions of his models reproduced for the mass market.

Dioscorides, Pedanius (Pedánios Dioskourídes) (c.40-90 CE) Greek physician, pharmacologist and botanist, probably born in Anazarbus, Cilicia, Asia Minor. Employed as a physician in the Roman army, he identified herbs for their pharmaceutical properties. His De Materia Medica, in five volumes, circulated in Greek, Latin and Arabic, was the most influential of all herbals, used throughout the Middle Ages down to the 18th century. Other works, of doubtful authenticity, are attributed to him.

Dirac, $\mathbf{P}($ aul) $\mathbf{A}$ (drien) $\mathbf{M}$ (aurice) (1902-1984). British physicist, born in Bristol. Of Swiss parentage, he studied electrical engineering at Bristol and mathematics at Cambridge, becoming a pioneer of wave (quantum) mechanics. In 1928 he predicted the existence of the positron, a positively charged particle of the same mass as the negatively charged electron. This was observed by *Anderson in 1932 . He was Lucasian professor of mathematics at Cambridge 1932-69, and a research professor in Florida 197184. Dirac shared the 1933 Nobel Prize for Physics with *Schrödinger. He received the Royal (1939) and Copley (1952) Medals of the Royal Society and the OM (1973).

Farmelo, G., The Strangest Man: the Hidden Life of Paul Dirac. 2009.

Disney, Walt(er Elias) (1901-1966). American producer of cartoon films, born in Chicago. He devised the first successful film cartoon (Oswald the Rabbit) in 1923 and won immense popularity for the medium with his Mickey Mouse pictures and such favourite characters as Pluto and Donald Duck. Later he produced many full-length cartoon films in colour, e.g. Snow White and the Seven Dwarfs (1938), Fantasia (1940) and Bambi (1942). His nature films, e.g. The Living Desert (1953), won many Academy awards. In films such as Treasure Island (1950) he used living actors and combined live actors with cartoons in Mary Poppins (1965). He set up (1955) a vast amusement park in California called Disneyland.

Finch, C., The Art of Walt Disney. 1973.

Disraeli, Benjamin, 1st Earl of Beaconsfield (18041881). English Conservative politician and novelist, born in London. He was the son of Isaac D'Israeli (1766-1848), an Anglicised Sephardic Jew whose literary talents (e.g. his Curiosities of Literature) won him the friendship of *Byron, *Scott and *Southey. Benjamin was brought up as a Christian and studied law. His brilliant first novel, Vivian Grey (1826), won him immediate acclaim. After making the 'grand tour' of Europe and the Near East, he began (1831) the life of a man-about-town, remarkable for his novels and brilliant attire. After four unsuccessful attempts, he became a Tory MP 1837-76. In 1839 he married
Mary Anne Evans (1792-1872), widow of his friend Wyndham Lewis. Her wealth gave him financial independence and enabled him to buy Hughenden, Berkshire, later their home. The marriage, though childless, was happy. She was created Viscountess Beaconsfield in 1868.

In parliament, Disraeli addressed himself to advocating the ideas he later embodied in his political novels Coningsby (1844) and Sybil (1846). The Tory party as he envisaged it should no longer be representative merely of a small class of country gentlemen but should meet the needs of the growing electorate enfranchised by the Reform Act. Loyalty to the Church, the crown and a vision of national greatness combined with material and social progress had, he thought, a greater appeal than the Liberal slogan 'of peace, retrenchment and reform'. He found an opportunity to make his mark when Sir Robert *Peel's decision to repeal the Corn Laws split the Tory Party. Disraeli became leader of the 'Young England' group of Tories who believed that protection for British agriculture was essential, and his biting attacks on the new policy led to Peel's political eclipse.

He bought for Britain a controlling interest in the Suez Canal, had Queen *Victoria made Empress of India (1876), annexed the Transvaal (1877) and at the Congress of Berlin (1878) from which he brought back 'peace with honour', did much to ensure that the Russo-Turkish conflict did not develop into a European war and greatly impressed *Bismarck who commented, 'Der alte Jude, das ist der Mann' ('The old Jew, that is the man'). Meanwhile his ambition to extend his party's interest in social welfare brought into being an act giving legal protection to trade unions, a great Factory Act, and a Public Health Act. He was created Earl of Beaconsfield in 1876 and KG in 1878. In the 1880 election, in response to higher taxes and a trade recession, the electorate returned an overwhelming Liberal majority. Disraeli died the following year.

Blake, R., Disraeli. 1966; Weintraub, S., Disraeli. 1993.

Dix, Otto (1891-1969). German painter. He joined the Neue Sachlichkeit (New Objectivity) movement, which extended Expressionism but rejected abstraction. He painted working class life, some portraits and later turned to mysticism.

Dixon, Sir Owen (1886-1972). Australian jurist, born in Melbourne. Educated at Melbourne University, he became a Justice of the High Court of Australia 192952, serving during World War II as Minister to the US 1942-44, and Chief Justice 1952-64. He served as UN mediator in Jammu and Kashmir (1950) over the border dispute between India and Pakistan. Regarded as one of the greatest judges in the common law world, he was awarded the OM in 1963. In 1965 he declined appointment as Governor General.

Ayres, P., Owen Dixon. 2003. 
Djilas, Milovan (1911-1995). Yugoslav politician and author. One of the most active of the partisans during World War II he was, when *Tito came to power, at first the most trusted and certainly the most intellectually gifted of his lieutenants. He backed Tito in breaking with the Cominform but in 1954 he fell into disfavour for advocating greater democracy and in 1956 was imprisoned for supporting the Hungarian uprising. In 1957 he published The New Class, highly critical of communism in practice. He was subsequently imprisoned again for 'revealing official secrets' in his book Conversations with Stalin (published outside Yugoslavia in 1962).

Dobell, Sir William (1899-1970). Australian painter. Trained in London, influenced by *Renoir and *Soutine, he was Australia's leading portrait and landscape artist in the 1940s and 1950s.

Dodd, Charles Harold (1884-1973). English Congregational clergyman and biblical scholar. Professor of divinity at Cambridge University 1935-49, he had the general direction of the work of translation required for The New English Bible (New Testament published 1961, Old Testament and Apocrypha 1970).

Dodge, John Francis (1864-1920) and Horace Elgin Dodge (1868-1920). American manufacturers, both born in Michigan. John was a manager, Horace an engineer. Originally components manufacturers for Henry *Ford, they became heavy investors in Ford's company. In 1914 they began manufacturing under their own names. Both died of influenza and in 1928 their firm was bought by the *Chrysler Corporation, which used the Dodge brand name for trucks and, later, compacts.

\section{Dodgson, Charles Lutwidge see Carroll, Lewis}

Dodsley, Robert (1703-1764). English publisher. While in service as a footman he was encouraged to write by Daniel *Defoe. He published poems and plays, on the profits of the first of which, The Toyshop (1735), produced at Covent Garden, he established himself as a bookseller and publisher of (among others) *Pope, Lord ${ }^{*}$ Chesterfield, ${ }^{*}$ Goldsmith, ${ }^{*}$ Gray, ${ }^{*}$ Sterne and Dr * Johnson, in whose Dictionary he had a share. In 1758, with Edmund *Burke, he founded the Annual Register.

Doherty, Peter Charles (1940- ). Australian immunologist, born in Brisbane. Trained as a veterinarian at the University of Queensland, he took his $\mathrm{PhD}$ in Edinburgh, worked at The Australian National University and in Memphis, Tennessee and shared the 1996 Nobel Prize for Medicine with Rolf Zinkernagel (1944- ) for their research on how T cells recognise target antigens in combination with MHC (major histocompatibility complex) proteins. $\mathrm{He}$ was a Laureate Professor in Microbiology and Immunology at Melbourne University 2002- and the author of several books, including The Beginners Guide to Winning the Nobel Prize (2005), A Light History of Hot Air (2007) and Seasonal Chickens (2012). He was a vigorous contributor to public debate.

Dohnányi, Ernö (1877-1960). Hungarian composer, pianist and conductor, born in Pozsony. A friend and promoter of *Bartók, he was director of the Budapest Academy 1919 and 1934-41, and became musical director of Hungarian broadcasting 1931-34. His earlier music, notably the Rhapsodies for Piano and the Cello Sonata, was strongly influenced by *Brahms. His most popular works are Variations on a Nursery Song (1919) and Ruralia Hungarica (1926). He lived in the US from 1948.

During World War II, he stayed in Hungary then in Austria, leading to unsubstantiated accusations of Fascist collaboration. Long investigation confirmed that he acted very courageously to protect Jews, and was not in the Richard *Strauss class. He became a US citizen after the war, lived and taught in Florida and (like Bartók) died in New York.

His son, Hans von Dohnányi (1902-1945), grew up in Germany after his parents divorced and became a lawyer. He worked in the German administration, but became active in the resistance, and was involved in the plot to assassinate Hitler (20 July 1944). He was condemned by the SS and hanged on a piano wire, as was his brother-in-law Dietrich *Bonhoeffer. Hans' son Christoph von Dohnányi (1929- ) became conductor of the Cleveland Orchestra 1984-2002.

Dolci, Danilo (1924-1997). Italian social worker. He studied architecture in Rome but from 1952 devoted himself to a campaign for better living conditions in Sicily. He not only denounced economic extortion by landlords and Mafia terrorists but showed by his own example, and that of his fellow workers, how the poor could improve their own lot by shaking off their fatalistic lethargy, by improving methods of work and by mutual help. He survived many attempts upon his life.

Mangione, J., World Around Danilo Dolci: A Passion for Sicilians. 1973.

Dole, Bob (Robert Joseph) (1923-2021). American Republican politician, born in Russell, Kansas. Severely wounded in World War II, he became an attorney and was a US Congressman 1961-69, Senator from Kansas 1969-96, *Ford's vice presidential candidate (1976), and Republican Senate Leader 1985-96. He sought the Republican nomination for president in 1980 and 1988, winning it in 1996, but losing to Bill *Clinton. His wife Elizabeth Dole, née Hanford (1936- ), also an attorney, was US Secretary of Transportation 1983-87 and for Labor 1989-90. She was President of the American Red Cross 1991-98, and a US senator 2003-09. 
Dolin, Sir Anton (real name Patrick Healey Kay) (1904-1981). British ballet dancer, choreographer and writer. He studied ballet under ${ }^{*}$ Nijinsky and was premier danseur with the Old Vic Sadler's Wells Company 1931-35. Later, with Alicia *Markova, he formed the Markova-Dolin Ballet (1935-51).

Doll, Sir (William) Richard Shaboe (1912-2005). English physician and epidemiologist. Educated in London, he was an architect of the National Health Service. His research, with Bradford Hill and Richard Peto, demonstrated the link between smoking and lung cancer. He also worked on radiation and asbestos as carcinogenic agents. Regius Professor of Medicine at Oxford 1969-79, he received a CH in 1996.

Dollfuss, Engelbert (1892-1934). Austrian politician. Of peasant origin, a devout Catholic, only $150 \mathrm{~cm}$ tall, he was decorated for bravery and became a prisoner in World War I, graduated LLD from Vienna University and worked for the Chamber of Agriculture. He became a leader of the Christian Social (CS) Party, and was Minister for Agriculture 1931-34, Foreign Minister 1932-34 and Chancellor 1932-34. Nationalist and anti-Semitic, he developed Austro-fascism, which was corporatist and Catholic, with affinities to the Italian and Portuguese models. Faced with the fierce hostility of Socialists and Nazis, both, by their resort to violence, providing him with justification for raising a private army and for dictatorial rule. His ruthless shelling (1934) of the flats of Viennese workers and his flouting of democratic sentiment deprived him of the help and sympathy of those who might have been his staunchest allies against the Nazis, by whom he was murdered, during an attempted coup d'état. He was known as the 'pocket chancellor'.

Brook-Shepherd, G., Dollfuss. 1961.

Dolmetsch, (Eugene) Arnold (1858-1940). British musician and instrument maker, born in France. He was a great authority on early music and musical instruments, who settled (1917) with his family at Haslemere, in Surrey, where he demonstrated that composers' works could be best appreciated if played upon the instruments for which they were composed. His sons continued his work; Carl Dolmetsch (1911-1997) was a noted recorder player.

Domagk, Gerhard (1895-1964). German biochemist. One of the pioneers of chemotherapy, in 1934 he discovered the antibacterial action of the red dye prontone, demonstrated that the effective agent was the sulphanilamide that prontone produced in the body, and thus showed the way for the application of a wide range of sulphanilamide drugs. He was awarded the Nobel Prize for Medicine (1939), but declined it on instructions from the Nazi government.

Domènech i Montaner, Lluis (1850-1923). Spanish (Catalan) architect, born in Barcelona. His World Heritage listed buildings in Barcelona include the Palau de la Música Catalana and the Hospital of St Pau.
Domenichino (Domenico Zampieri) (1581-1641). Italian painter, born in Bologna. He went to Rome (1602), assisted Annibale *Carracci in the decoration of the Farnese Gallery but was soon accepting commissions on his own. He carried on the traditions of the Carraccis but developed a more severely classical style for the many ceilings and murals that he worked on in Rome and Naples. His most ambitious achievement was for the choir (1624-28) of S. Andrea della Valle, Rome.

Domingo, Placido (1941- ). Spanish opera singer, born in Madrid. Brought up in Mexico, where he made his debut (1961), he sang at the New York Met from 1968 and Covent Garden from 1969. $\mathrm{He}$ achieved great success in the major dramatic roles in *Verdi's operas. He was also an able operatic conductor and appeared in films.

Dominic, St (Domingo de Guzman) (c.11701221). Spanish (Castilian) priest and founder of the Dominican Order, born in Caleruega. He became a canon of Osma Cathedral. In 1205 he adopted voluntary poverty, in his missionary journeys, to convert the Albigensians (Cathars) of Languedoc, and he gathered a group of followers round him. $\mathrm{He}$ played an ambiguous role in Pope *Innocent III's savage Crusade against the Albigensians 1209-15. $\mathrm{He}$ attended the Fourth Lateran Council (1215) and petitioned Innocent for permission to establish an Order of Preachers (OP: known as the 'Black Friars') for the conversion of heretics. He established his headquarters in Toulouse. Told that the order must follow an existing rule he chose that of St Augustine, but he soon adopted absolute poverty, so that in fact a new order of mendicant friars came into being. To equip the friars for their task of preaching, an elaborate educational system was evolved. Each 'house' contained a doctor of theology, each province contained one or more houses for advanced studies and selected students were sent to the universities. In 1220 a new constitution was drawn up. The priors, who ruled the 'houses', were grouped under provincial priors subject to a master general. The legislative and disciplinary bodies were 'chapters', mainly elected, the supreme body being the annual general chapter, for which a complicated system was created to ensure that it was efficient and representative. This departure from the authoritarian rule of former religious orders was unique. Dominic died at Bologna, and was canonised in 1234. He saw the Order as a body of learned and ascetic defenders of the faith, and he was the first to put intellectual work as the first requirement of a friar. Dominic remains intensely controversial: was he attractive and open or closed and repellant? He is sometimes-but wrongly — credited with inventing the rosary.

Vicaire, M. H., Saint Dominic and His Times. 1964. 
Domitian (Titus Flavius Domitianus) (51-96). Roman Emperor 81-96. He was a son of the emperor *Vespasian, a younger brother of ${ }^{*}$ Titus, and the last of the Flavian dynasty. He fought defensively and, on the whole successfully on the German and Danubian frontiers, and his administration of Italy and the provinces was efficient. As his reign progressed, however, he not only persecuted Jews and Christians but developed suspicions of any who seemed capable of aspiring to power. The employment of informers followed by murders and confiscations provoked a palace conspiracy in which he was assassinated.

Donatello (Donato di Niccolo di Betto Bardi) (1386/7-1466). Florentine sculptor. The greatest sculptor before *Michelangelo, he also exerted great influence on the painters of the Paduan School and even on the Venetians. He introduced the 'heroic' style of sculpture, figures slightly larger than life infused with that feeling of determination and force so closely associated with the early Renaissance, and first exemplified in his St Mark (1412). His relief of St George killing the Dragon (c.1417) is the earliest datable example of the application of the new theory of perspective to sculpture. A further example is his very low relief in bronze of Salome (in Siena). His bronze, David, is one of the earliest free-standing nudes.

He was apprenticed to ${ }^{*}$ Ghiberti, whom he helped (1403) to carve the doors of the Baptistery, and shortly after was working on the Cathedral in Florence on which he continued to work intermittently for the next 30 years. He also worked at times in Rome and Padua. In his later years Donatello experimented with expressionistic and dramatic distortion, e.g. the Magdalen in carved wood (c.1445) which inspired the tense and dramatic quality of Florentine painting of the period.

Dongen, Kees (originally Cornelis Theodoris Maria) van (1877-1968). Dutch-French painter, born in Rotterdam. He lived in Paris from 1897, was briefly in the Fauves, then moved to Monaco and painted many figure studies and portraits.

Dönitz, Karl (1891-1980). German sailor. A submarine commander in World War I, as a firm adherent of *Hitler he played an important part in the secret building of a submarine fleet in the years preceding World War II, in which he directed the submarine campaign with ruthlessness, administrative efficiency and tactical skill. In 1943 he became Grand Admiral and succeeded *Raeder as naval Commanderin-Chief. Hitler named him his successor. He held the title of President of Germany for 20 days (April-May 1945), and authorised the surrender. At the Nuremberg War Crimes Tribunal (1946) he was convicted on two counts and was sentenced to 10 years imprisonment. Released in 1956, he wrote the self-serving Memoirs: Ten Years and Twenty Days (1958).
Donizetti, Gaetano (1797-1848). Italian opera composer, born at Bergamo. His early work reflected ${ }^{*}$ Rossini's influence but he developed a more personal style. He composed about 70 operas (the total is uncertain, because many were reworked and renamed), including three set in Tudor England: Anna Bolena (1830, his first great success), Maria Stuarda (1834) and Roberto Devereux (1837). The most performed, Lucia di Lammermoor (1835), was based on a novel by Walter *Scott. Among the best known are L'elisir d'amore (1832), Lucrezia Borgia (1833), La Favorita (1840), Don Pasquale and Maria di Rohan (both 1843). He suffered from syphilis, becoming paralysed and insane.

Ashbrook, W., Donizetti. 1965.

Donleavy, J(ames) P(atrick) (1926-2017). IrishAmerican novelist, born in New York City. Trained in Dublin as a microbiologist, his novels include The Ginger Man (1955, also a play 1959), A Singular Man (1963), The Beastly Beatitudes of Balthazar B (1968), The Onion Eaters (1971) and Leila (1983) and Wrong Information Is Being Given Out at Princeton (1998).

Donne, John (1571-1631). English poet and cleric, born in London. The son of a merchant, and, through his mother, grandson of the dramatist John *Heywood, he was brought up among adherents of Roman Catholicism, which he rejected in his twenties. He studied at both Oxford and Cambridge, and later at Lincoln's Inn, soon gaining a reputation as a manabout-town of profligacy, wit and much learning. He sailed with *Essex against Cadiz in 1596 and again in 1597, in 1598 he became secretary to Lord Egerton, whose niece, the 16-year-old Ann More, he secretly married. He served briefly as MP 1602-03, 1614-15. With no dowry and a constant succession of children the couple lived in great poverty until, having become a fervent believer in Anglicanism, at last in 1615 he took holy orders. He now attained a new reputation as a great preacher, becoming Dean of St Paul's in 1621.

His poetry is inspired by the phases of his life and is sensual, passionate, witty, subtle and deeply religious. The metrical form of the stanza is rough, the imagery vivid:

Go and catch a falling star,

Get with child a mandrake root ...

'I runne to Death, and Death meets me as fast, and all my Pleasures are like Yesterday' is in his 'Holy Sonnet VII', and the famous passage beginning, 'No man is an island entire of itself', concluding with 'Never send to ask for whom the bell tolls, it tolls for thee' is in his 'Meditation XVII'. 'A Hymn to God the Father' turns on the punning in the name/ word 'Donne/ done'. He is regarded as the greatest of the English metaphysical poets.

Keynes, G. L., A Bibliography of Dr John Donne. 1964; Lim, K., John Donne. An Eternity of Song. 2005; Stubbs, J., Donne. The Reformed Soul. 2006. 
Donskoy, Mark Semyonovich (1901-1981). Russian film director. After studying medicine and law, he worked in film under *Eisenstein and became a director, achieving his greatest critical success with the trilogy based on Maksim *Gorki's autobiography: My Childhood (1938), My Apprenticeship (1939) and My Universities (1940).

Doolittle, Hilda (1886-1961). American poet (pen name $H$. D.). One of the first, and most consistent, Imagist poets writing in English, she was a notable Greek scholar and the classical influence is apparent in her work. She married Richard *Aldington in 1913. They lived in France and divorced in 1937.

Guest, B., Herself Defined. The Poet H.D. and Her World. 1985.

Doolittle, James Harold (1896-1993). American airman. After service as a flying officer in World War $\mathrm{I}$, he won renown by his victory in the Schneider Trophy of 1925. As a civilian (from 1930) he became known as a test pilot and for aerobatic feats. Recalled to the service in World War II, he led the first raid on Tokyo (April 1942), a spectacular achievement which brought a series of promotions, culminating with the appointment to command of the 8th US Air Force (1944). After the war he was a businessman involved in insurance, oil and aeronautics.

Doppler, Christian Johann (1803-1853). Austrian mathematical physicist. He became professor of mathematics at Prague (1841) and professor of experimental physics at Vienna (1850). Although he wrote a number of mathematical works, his name is associated mainly with his contributions to physics. In 1842 he described in principle the phenomenon (later verified experimentally) now known as the 'Doppler effect' - that the pitch of sound (a siren, for example) rises as the source approaches the hearer and falls with increasing distance. He also hypothesised that stars would have a violet shift as they approached, a red shift as they receded, work confirmed by Armand Fizeau and William *Huggins.

Doré, Gustave (1832-1883). French artist. Famous for his book illustrations, early success came with his illustrations for *Balzac's Contes drolatiques. Other works he illustrated include *Dante's Inferno and Paradiso, *Cervantes' Don Quixote and *Tennyson's Idylls of the King. In his Paris studios he employed at times as many as 40 assistants working on his woodcuts. His style was often sensational and macabre. The drawings done for London (1871), which influenced Van ${ }^{*}$ Gogh, are held to be his best work.

Rose, M., Gustave Dore. 1945.

Doria, Andrea (1468-1560). Genoese soldier and statesman. Born of a noble family, he became a mercenary in the service of the papacy, Naples, and other Italian states. He also restored Genoese rule in Corsica. After the expulsion of the French King *Louis
XII from Italy he restored the Genoese republic (1512), but entered French service (1522) when *François I again imposed his suzerainty. A quarrel over François' treatment of Genoa caused Doria to change sides and put his services and the Genoese fleet at the disposal of François' rival for power in Italy, the emperor *Charles V. Now the virtual autocrat in a restored Genoese republic, Doria was engaged for several years in fighting the Muslim pirates of the Barbary Coast, in the course of which he captured Tunis (1535).

Doriot, Jacques (1885-1945). French collaborator. Elected as a Communist Deputy in 1924, and Mayor of St Denis in 1931, he broke with the Left in 1934 and became a strong supporter of ${ }^{*}$ Hitler. He was killed in an air raid.

Dornier, Claude (1884-1969). German aircraft pioneer and builder, born in Kempten. Leaving Munich technical college he began work for Ferdinand von *Zeppelin, in his airship factory at Friedrichshafen (1910) and in 1911 designed the first all-metal aeroplane. Zeppelin allowed him to establish a separate factory, the Dornier Aircraft Works. After World War I during which wooden and metal fighter planes built to his design were used, Dornier was given complete control of his factory. During the 1920s he built very successful seaplanes. In 1929 he produced DOX, then the world's largest aircraft, although not a financial success, with 12 engines and a passenger capacity of 169. Dornier twin-engined bombers became standard Luftwaffe type in World War II. After the war Dornier moved to Spain because aircraft building was prohibited in Germany by the Allies. When the ban was lifted in 1955 he opened a factory near Munich which produced US designed 'Starfighters'.

Dorsey, Jack Patrick (1976- ). American computer programmer, born in Missouri. He developed web programs for the despatch of taxis and coordinating emergency services. With 'Biz' *Stone, he was the co-founder of Twitter in 2006.

Dos Passos, John Rodrigo (1896-1970). American novelist, born in Chicago. Educated at Harvard College, he was an ambulance driver in World War I. Three Soldiers (1921) was a powerful novel about war. His best known work is the trilogy U.S.A., consisting of The 42nd Parallel (1930), Nineteen Nineteen (1932) and The Big Money (1936). With a quickly moving, constantly switching technique of the cinema in these and later books he expresses his concern with the cultural, social and political developments of the 'American way of life'. Originally on the far left, he moved steadily to the right and campaigned for ${ }^{*}$ Goldwater and ${ }^{*}$ Nixon.

Wrenn, J. H., John Dos Passos. 1961.

Dost Mohammed Khan (1793-1863). Amir of Afghanistan 1826-63, known as the 'Great Amir'. In 1839 he was overthrown by the British. Having 
regained power in 1842 , he eventually (1855) made a treaty of friendship with the British, after they had defeated the Afghans' hereditary enemies, the Sikhs.

Dostoevsky, Fyodor Mikhailovich (1821-1881). Russian novelist, born in Moscow. His mother died of tuberculosis in 1837 and his father, a widely read but profoundly Orthodox physician, died in 1839 of a stroke, not murdered by serfs as was widely believed. He studied at the Military Engineering College at St Petersburg, translated some texts but felt unsuited to army life or engineering. He embarked on a literary career and his first novel, Poor Folk (1846), was promoted by ${ }^{*}$ Belinsky. Originally attracted to socialism, he joined the Petrashevky Circle, a group that read forbidden books and theorised about changing how Russia was governed. In April 1849, at the instigation of Tsar *Nikolai, he was arrested with other members of the Circle, tried for sedition and condemned to death. In December 1849, Dostoevsky and 14 colleagues were facing a firing squad in what was essentially a mock execution when a pre-arranged commutation arrived. Four years in a prison camp in Omsk, Siberia, shackled for long periods, was followed by two years compulsory military service. His health was undermined, which he described in Memoirs from the House of the Dead (1861). Freed in 1855 , he engaged in unsuccessful journalism which left him deeply in debt, compounded by his obsession with gambling. In 1857 he married, unhappily, and began to experience gross epileptic seizures. His wife died in 1864 and in 1865 he travelled to Germany with a young woman, Polina Suslova, to retrieve his fortune by an 'infallible' method of winning at roulette, which, of course, failed. On his return he set about writing a potboiler to satisfy his creditors (The Gambler). He engaged Anna Snitken as stenographer and soon married her. They had again to go abroad to avoid creditors, a humiliating time for Dostoevsky. His wife gradually restored order to his finances and they returned to Russia. In his later years he evolved a peculiar Slavophilism compounded of hatred for aristocrats and socialists alike, and of religious obsessions. However, even in his lifetime he won recognition both inside and outside Russia as a great novelist.

His greatest novels are Crime and Punishment (1866) and the unfinished Brothers Karamazov (1881). *Freud called Karamazov 'the most magnificent novel ever written'. Dostoevsky probed more deeply into the mind than any previous novelist, especially into the abnormal and criminal mind. His other novels include Memoirs from the Underworld (1864), The Idiot (1869) and The Devils (The Possessed) (1871-72).

Dostoevsky and *Tolstoy, close contemporaries, had a distinctly uneasy non-relationship, with different perspectives, mutually suspicious, eyeing each other off from the distance like two old bears. Curiously, they never met. Dostoevsky declared his admiration for Tolstoy, but Tolstoy professed indifference until just before he died. Dostoevsky would have been less than human not to have resented Tolstoy for his energy, health, Olympian bearing, confidence, wealth and fame, while he was epileptic, deeply depressive, a compulsive gambler and often in penury.

During the Soviet era, Dostoevsky was dismissed as neurotic, morbid, mystical and reactionary, potentially anti-Soviet. As George ${ }^{*}$ Steiner wrote: 'Dostoevsky came to be recognised as a dangerous foe, as an engenderer of subversion and heresy ... Tolstoy, on the contrary, was securely enshrined in the revolutionary pantheon ...'

Steiner, G., Tolstoy or Dostoevsky. 1958; Grossman, L., Dostoevsky. 1974; Frank, J., Dostoevsky 4 vols, 1976ff, incomplete; Frank, J., Dostoevsky 5 vols, 1976-2002, 1 vol. condensation 2009; Coetzee, J. M., The Master of Petersburg. 1994; Frank, J., Lectures on Dostoevsky. 2021; Marullo, T. G., Fyodor Dostoevsky: A Life in Letters, Memoirs and Criticism, 2 vols. 2021.

Doubleday, Abner (1819-1893). American general. For many years he was credited with inventing (1839) the game of baseball at Cooperstown, NY, but revisionists now assert that the game is a variant of the English 'rounders' and that the modern rules were set in 1845 by Alexander Jay Cartwright. In the Civil War, Doubleday's troops fired the first shots at Fort Sumter, SC (1861) and he commanded a corps at Gettysburg.

Doudna, Jennifer Anne (1964- ). American biochemist. She shared the 2020 Nobel Prize for Chemistry with Emmanuelle Charpentier (1968-) for their pioneering work in genetic editing, using CRISPR (clustered regularly interspaced short palindromic repeats).

Isaacson, W., The Code Breaker: Jennifer Doudna, Gene Editing and the Future of the Human Race. 2021.

Doughty, Charles Montagu (1843-1926). English author and traveller. To write Travels in Arabia Deserta (1888), he mastered Arabic and lived (1876-78) among the tribesmen, disguised as an Arab. The book is written in a consciously archaic style. He also wrote verse dramas and epic poems, e.g. Adam Cast Forth (1908) and The Dawn in Britain (1906).

Douglas, Lord Alfred Bruce (1870-1945). British poet and journalist. Son of the 9th Marquess of *Queensberry, educated at Oxford, he became the lover ('Bosie') of Oscar *Wilde. His father's hatred led directly to Wilde's trial and imprisonment. On Wilde's release they lived together briefly in Rouen and Naples. Only one line of Douglas' poetry is now remembered: 'The love that dare not speak its name'. He became a Catholic convert, repudiated homosexuality, was an active anti-Semite in the journal Plain English, and was jailed in 1924 for criminal libel of Winston *Churchill.

Hyde, H. M., Lord Alfred Douglas. 1984. 
Douglas, Clifford Hugh (1879-1952). British economist. An engineer, known by his military rank of major, he published in 1919 his economic theory (Social Credit), intended to overcome the chronic shortage of purchasing power which he held to be the cause of economic depression. The method to be adopted was a carefully regulated distribution of money which he called a 'national dividend'. Douglas attracted many followers, especially in Canada. Social Credit governments held office in Alberta 1935-71 and British Colombia 1952-72, 1975-86 but adopted few of Douglas' policies.

Douglas, Donald Wills (1892-1981). American aircraft manufacturer. In 1920 he founded the Douglas Aircraft Company, and produced his first aeroplane, the Cloudster, in 1922. The Douglas Commercial (DC) series began with DC-1 (1933). The DC-3 (1935) was phenomenally successful, some aircraft remaining in service for more than 40 years. The 'Dakota', one of the safest and most widely used aircraft for military and civilian transport during and after World War II, was a development of the DC3. Douglas lost market share to *Boeing which adopted jet engines earlier and was merged with the McDonnell Company in 1967. The DC-9 rivals the Boeing 737 in medium haul aviation, but Boeing's 747 ('Jumbo') was far more successful than the DC10 for intercontinental flights.

Douglas, Gavin (c.1475-1522). Scottish poet and prelate. Third son of the 5th Earl of Angus, after the disaster at Flodden he joined the English faction and was appointed Bishop of Dunkeld (1515), but after the French party had regained power (1520) he had to retire to England where he died of the plague. He wrote moral allegories (The Palice of Honour and King Hart), but his fame rests on his verse translation into Scots of *Virgil's Aeneid, said to be the first rendering of a classical work into any form of English.

Douglas, (George) Norman (1868-1952). Scottish writer, born in Austria. Educated in England and Germany, he became a self-trained zoologist and voracious pederast, had three years in the diplomatic service (1894-97), then bought a villa in Capri (1898). He divided his life between London and Capri, wrote the travel book Old Calabria (1915) and the novel South Wind (1917), described as 'a love letter to Capri'. Fortunate to escape jail for his sexual exploits, Douglas appears as a character in novels by *Lawrence, *Huxley and *Highsmith. His writing was admired by ${ }^{*}$ Joyce, ${ }^{*}$ Forster, ${ }^{*}$ Woolf, ${ }^{*}$ Nabokov and ${ }^{*}$ Greene.

Greenlees, I., Norman Douglas. 1957; Holloway, M., Norman Douglas: A Biography. 1976.

Douglas, Sir Roger Owen (1937- ). New Zealand accountant and politician. A Labour MP 1969-90, he was Minister of Broadcasting 1973-75 (under ${ }^{*}$ Kirk), and an intensely controversial Minister of Finance 1984-88 (under ${ }^{*}$ Lange). He introduced free-market Thatcherite economic changes (known as 'Rogernomics'), cutting tariffs, deregulating the labour market, introducing a Goods and Services Tax (GST), and reducing government expenditure. $\mathrm{He}$ clashed with Lange, virtually forcing his resignation (1989). In 1993 he founded the ACT (Association of Consumers and Taxpayers) and was again MP 2008-11.

Douglas, Stephen A(rnold) (1813-1861). American Democratic politician, born in Vermont. He moved to Illinois, becoming a judge at the age of 27 . $\mathrm{He}$ served in the US House of Representatives 184347 and Senate 1847-61. His interest in westward expansion made him demand that the NebraskaKansas region should be opened to settlement and that it should be left to the settlers to decide whether slaves should be introduced. This attitude cost him the Democratic nomination for the presidency in 1852 and 1856 though he retained his seat as senator for Illinois in a contest with Abraham *Lincoln, who won the popular vote but lost in the State legislature. In 1860 the Democratic Party split three ways over slavery, and Douglas, whose position on slavery was ambiguous, was nominated as candidate for president by Democrats in the northern states. Lincoln became the candidate of the new Republican Party. Douglas ran second in the national vote $(29.5 \%)$ but carried only one state (Missouri). He opposed secession and supported Lincoln in the Civil War.

Johannsen, R. W., Stephen A. Douglas. 1973.

Douglas, T(homas) C(lement) (1904-1986). Canadian politician, born in Scotland. He became a Baptist minister in Saskatchewan and was a Member of the Canadian House of Commons 1935-44, 1961-79. He founded the Cooperative Commonwealth Federation (CCF) and as Premier of Saskatchewan 1944-61 led North America’s first socialist government. He was Federal Leader of the New Democratic Party 1961-71.

Douglas, William O(rville) (1898-1980). American jurist. Professor of law at Yale University 1931-39, he was a prominent supporter of civil rights and the New Deal. His appointment as a justice of the US Supreme Court (1939) by President Roosevelt aroused considerable controversy. He served a record term, retiring in 1975 after a stroke.

\section{Douglas-Home, Sir Alec see Home, Alec Douglas-, Baron Home of the Hirsel}

Douglass, Frederick (né Frederick Augustus Washington Bailey) (1817?-1895). American abolitionist, born in Maryland. Son of a slave mother and a white father, he escaped from slavery (1838) and devoted himself to the anti-slavery movement. His autobiography, Narrative of the Life of Frederick Douglass, first published in 1845, was constantly updated. In the Civil War he organised black units to help the northern army and campaigned for 
the rest of his life for civil rights for black people. He was an early advocate of female suffrage. He filled government posts in Washington DC, and was Minister to Haiti 1889-91.

Douglass, F., The Life and Times of Frederick Douglass. 1947; Bontemps, A., Free at Last. 1971; Blight, D.W., Frederick Douglass: Prophet of Freedom. 2019.

Doumer, Paul (1857-1932). French radical politician. A deputy 1889-96 and 1902-12, and senator 1912-31, he served as Minister of Finance 1895-96, 1921-22 and 1925-26. As GovernorGeneral of Indo-China 1897-1902, he set up a centralised administration which survived until 1945. President of the Senate 1927-31, he became 13th President of the Republic 1931-32, defeating *Briand. He was assassinated by a Russian anarchist, Paul Gorgulov.

Doumergue, Gaston (1863-1937). French politician. Elected as a radical socialist deputy in 1893, he moved steadily to the right, serving as Premier 1913-14, 1934, President of the Senate 1923-24, and President of the Republic 1924-31.

Dowding, Hugh Caswell Tremenheere Dowding, 1st Baron (1882-1970). British air chief marshal, born in Scotland. His life as a pilot began in 1914 when as a young artillery officer he was attached to the Royal Flying Corps. In 1919 he became a group captain in the RAF. Thereafter he held important administrative posts until in 1936 he was appointed Commander-in-Chief of Fighter Command. He held this post until 1940, when his brilliantly successful direction of the Battle of Britain proved the efficiency of the plans he had already prepared. He fell out with ${ }^{*}$ Churchill, was eased out of the RAF, and received a barony in 1943 as a consolation prize. Bitter about his supersession, he became a spiritualist, theosophist, and lecturer on reincarnation.

Wright, R., Dowding and the Battle of Britain. 1969.

Dowland, John (1563-1626). Anglo-Irish composer, singer and lutenist, possibly born in Dublin. His First Booke of Songs or Ayres of Foure Partes with Tableture for the Lute appeared in 1597, running to five editions by 1613 . His second and third books of airs appeared while he was abroad $(1600,1603)$. He was a highly paid musician at the court of Christian IV of Denmark 1598-1606, then from 1612 played for *James I. His second Lachrymae, accounted some of the finest instrumental consort music of the time. $\mathrm{He}$ is now remembered chiefly for his songs, among the most beautiful ever written, including 'Flow my tears...', 'Come heavy sleep...' and 'Come again'.

Dowling, Dame Ann Patricia (1952- ). English mechanical engineer. A Cambridge professor 19932014, she made important contributions to the reduction of emission combustion and road vehicle and aircraft noise, and was elected FRS in 2003, created DBE in 2007, and awarded the OM in 2016.

Downer, Alexander John Gosse (1951- ). Australian Liberal politician, born in Adelaide. From a patrician political family, he worked as an economist in a bank, then as a diplomat, until election as a Member of the House of Representatives 1984-2008. Briefly Leader of the Opposition 1994-95, under John *Howard he was Australia's longest serving minister for foreign affairs 1996-2007. He was High Commissioner to the United Kingdom 2014-18.

Downing, Sir George (1623?-1684). English soldier and diplomat. He served in *Cromwell's army in Scotland and was prominent among those who offered Cromwell the crown. He was British resident at the Hague under Cromwell and ${ }^{*}$ Charles II. From the sale of estates left by his grandson, Sir George Downing (1684?-1749), Downing College, Cambridge, was founded, after whom Downing Street, Whitehall is named. No. 10 Downing Street became the official residence of the First Lord of the Treasury/Prime Minister in 1735.

Doxiadis, Constantinos Apostolos (1913-1975). Greek architect and city planner, born in Bulgaria. He became an architect in the 1930s, served in the Greek underground during World War II and was administrator of Marshall Plan aid in Greece (194751). A change of government and a breakdown in health led Doxiadis to migrate to Australia where his architectural qualifications were not recognised. While working as a farmer in Western Australia (1951-52) he devised the principles of ekistics (the science of human settlements). After returning to Europe he won an international reputation for his prophetic work on the coming world city 'Ecumenopolis', needed to accommodate the population explosion. He was commissioned to design or restore many cities, e.g. Islamabad, Khartoum, Louisville (Ky.), and parts of Philadelphia and Washington DC. He founded his own university in Athens.

Doyle, Sir Arthur Conan (1859-1930). British novelist, born in Edinburgh. He graduated in medicine at Edinburgh and there encountered Dr Joseph Bell whose methods of deductive reasoning reappeared in Doyle's fictional detective Sherlock Holmes. After practising medicine in Southsea (1882-90) he turned to authorship, and in A Study in Scarlet (1887) he introduced Holmes and his friend Dr Watson. The short stories of which the detective was the hero first appeared in the Strand Magazine and were collected as The Adventures of Sherlock Holmes (1891) and The Memoirs of Sherlock Holmes (1894). In the last tale Holmes (of whom his author was wearying) fell off a cliff but popular demand led Conan Doyle to retrieve him for The Return of Sherlock Holmes (1904), His Last Bow (1918) and The 
Case Book of Sherlock Holmes (1928). Doyle himself regarded more highly his historical novels, e.g. The White Company (1891) and Brigadier Gerard (1896). In later life he became a convinced spiritualist and wrote a History of Spiritualism (1926).

Pearson, H., Conan Doyle: His Life and Art. 1961.

Doyle, Richard (1824-1883). British caricaturist, painter and illustrator, born in London. The son of John Doyle (1797-1868), a famous caricaturist, he was taught by his father, and at 15 , published the Eglington Tournament or The Days of Chivalry Revived. From 1843 he was a regular contributor to Punch. He illustrated many books, e.g. *Thackeray's The Newcomes and *Dickens' Christmas books, and painted landscapes, in particular, fantastic fairyland scenes, in watercolour and oils, e.g. In Fairyland, Pictures of the Elf-World.

Hambourg, D., Richard Doyle. 1948.

\section{D’Oyly Carte, Richard see Carte, Richard D'Oyly}

Drabble, Dame Margaret (1939-). English novelist, biographer and editor, born in Sheffield. Educated at Cambridge, she was a sister of the novelist A. S. *Byatt, and married (Sir) Michael Holroyd, biographer of G. B. *Shaw. Her novels include The Millstone (1965), The Middle Ground (1980), The Radiant Way (1987) and The Gates of Ivory (1991). She edited The Oxford Companion to English Literature (1985).

Draco (7th century BCE). Athenian lawmaker. The word 'draconian' preserves his memory. His code of laws (621 BCE) was of such severity that even laziness was punishable by death.

Draghi, Mario (1947). Italian economist, banker and administrator, born in Rome. An academic and civil servant he was President of the European Central Bank 2011-19 and became Prime Minister of Italy as a non-party technocrat 2021- .

Drake, Sir Francis (c.1540-1596). English sailor, explorer, privateer and slave trader, born in Tavistock, Devon. From 1565 he took part in expeditions organised and led by his kinsman, Sir John *Hawkins, to carry slaves from West Africa to the West Indies. Later he was active in the unofficial sea war with Spain secretly encouraged by Queen *Elizabeth, who shared in the plunder but denounced it as piracy if occasion demanded. On one such voyage he raided Spanish settlements on the Panama Isthmus (1572) and was the first Englishman to sight the Pacific. He aimed to reach this ocean when he set out with four small ships in December 1577. Two were still with him when (August 1578) he entered the Straits of Magellan, but when at last after being driven south he was able to sail northward up the South American coast he was, through the loss of one vessel and the return of the other, reduced to a single ship. After provisioning himself from coastal settlements and capturing a rich prize, he crossed the Pacific, eventually reached Java and headed for the Cape of Good Hope and home, which he reached in September 1580, having been the first Englishman to circumnavigate the globe. Despite Spanish protests, Elizabeth knighted him on board his ship. After another voyage to the Indies in search of plunder (1585-86), in the course of which he picked up and brought back 180 disillusioned colonists from Virginia, he turned to the task of forestalling the Armada by destroying as many Spanish ships as he could before they sailed. In 1587 he singed the King of Spain's beard' by entering Cadiz harbour and destroying, without loss, 33 enemy ships. When the Armada finally appeared (1588) Drake, who according to the familiar story was playing bowls at Plymouth, declared that there was time 'to win this game and to thrash the Spaniards too'. As Vice Admiral he commanded a division of the English fleet, out-fought the enemy in the Channel (he captured the Rosario off Portland) and later pursued them northwards up the east coast. The next few years were peaceful but in 1595 he left with Hawkins for the West Indies on a last unsuccessful voyage, but both died of dysentery. Drake was buried at sea in the Caribbean, off Portobelo, Panama. Drake Passage (Spanish: Pasaje de Drake), connecting the Pacific and Atlantic oceans, is named for him.

Williams, N., Francis Drake. 1973; Sugden, J., Sir Francis Drake. 1990; Cummins, J., Francis Drake. 1995.

Drayton, Michael (1563-1631). English poet, born in Warwickshire. He owed support and education to the patronage of Sir Henry Goodere, whose daughter Anne was named 'Idea' in his sonnets. Already as a child he was writing verse and in time attempted almost every kind of verse, eclogues in the manner of *Spenser, pastorals, odes, sonnets (including the famous 'Since there's no help, come let us kiss and part'), historical poems (e.g. Piers Gaveston, c.1593), imaginary exchanges of letters in verse between such famous lovers as *Henry II and Fair Rosamund and finally the unique Poly-olbion (i.e. having many blessings, 1612-22), a poetic topographical survey of England.

Berthelot, J. A., Drayton. 1961.

Dreiser, Theodore (1871-1945). American novelist, born in Indiana. Brought up in a poor and strict religious family, his own sexual repression and experience as a reporter of sordid life in St Louis, Chicago, New York and other cities gave him an insight into the problems of sex and ambition which are the themes for his frank and realistic novels, which offended his contemporaries. His first novel, Sister Carrie, appeared in 1900 and was followed by e.g. Jennie Gerhardt (1911), The Genius (1915) and his best known work, An American Tragedy (1925), which tells how obsession with sex and money leads a weak-willed boy to plan murder. He also wrote several 
autobiographical works, e.g. A Book about Myself (1922). Dreiser's later socialism inspired his Tragic America (1931).

Swanberg, W. A., Dreiser. 1965.

Dresser, Christopher (1834-1904). British product designer, born in Glasgow. Trained as a botanist, with a PhD from Jena, he pioneered design as an essential aspect of mass production in furniture, metalwork, ceramics, glassware, carpets and wallpaper, and was attacked by *Ruskin.

Dreyfus, Alfred (1859-1935). French soldier, born in Mulhouse. Victim of a famous miscarriage of justice, son of a Jewish industrialist, at the time of the affaire (1894) he was an army captain in the War Office, suspected of being the author of a letter (known as the bordereau and extracted from the German Embassy by a French agent) announcing the dispatch to the German military attaché of certain secret documents. On flimsy evidence based on similarity of handwriting Dreyfus was arrested, found guilty of 'collusion with a foreign power', sentenced to life imprisonment, stripped of his rank, degraded and transported to Devil's Island, remaining there 189599. In 1896 evidence was found by Colonel Georges Picquart indicating that the real culprit was Major Ferdinand Walsin *Esterhazy. Anti-Semitic prejudice in the army, combined with the effect on discipline of admitting the facts, prevented the case being reopened. A massive counter-campaign, in the course of which Émile *Zola wrote his famous open letter J'accuse, at last secured a retrial (1899). By the use of forged documents Dreyfus was again found guilty, but President *Loubet at once ordered a pardon and his release, subject to an implicit admission of guilt. In 1906 after a full review held in Rennes, his conviction was finally quashed and Dreyfus was restored to his army rank. He took part in World War I. In 1930 the published papers of Colonel Schwarzkoppen, the German military attaché of the time, confirmed Esterhazy's guilt.

Chapman, G., The Dreyfus Trials. 1972; Read, P. P., The Dreyfus Affair. 2012.

Drinkwater, John (1882-1937). English dramatist, poet, actor and critic, born in Birmingham. One of the leading Georgian poets, now unread, he was a cofounder of the Birmingham Repertory Theatre and wrote some successful historical plays, notably Abraham Lincoln (1918), which was filmed (1930) by D. W. *Griffith. He wrote two volumes of autobiography, Inheritance (1931) and Discovery (1932).

Drucker, Peter F(erdinand) (1909-2005). American social scientist, born in Vienna. In the US from 1937, he taught in New York and California and wrote important texts on management, shrewdly predicting major social changes: they included The Age of Discontinuity (1969) and Management for the
Drummond, (James) Eric, 16th Earl of Perth (1876-1951). British diplomat. After serving as private secretary to H. H. *Asquith, Sir Edward *Grey and A. J. *Balfour, he was the first SecretaryGeneral of the League of Nations 1919-33, became Ambassador to Italy 1933-39 and succeeded to his peerage in 1937.

Drummond, William (1585-1649). Scottish poet. Known as 'Drummond of Hawthornden', he studied at Edinburgh and abroad and succeeded his father as laird of Hawthornden in 1610. He was a Royalist and Episcopalian, though he played no active political part, and became the friend of Michael *Drayton and Ben *Jonson, whose visit to Hawthornden in the winter of 1618-19 is recalled in Drummond's lively Conversations. He wrote learned and ornate verses, religious, amatory and pastoral, in a style that belongs rather to the age of Spenser than to his own and which derives from his study of Petrarch and the Pléiade ( ${ }^{*}$ Ronsard). His best known prose work is The Cypress Grove (1623), a meditation on death. $\mathrm{He}$ also wrote a history of Scotland.

Fogle, F. R., A Critical Study of William Drummond. 1952.

Dryden, John (1631-1700). English poet and dramatist, born in Aldwinkle, Northamptonshire. From a well established family, he was educated at Westminster, under the famous Dr Richard Busby and at Trinity College, Cambridge. He seems to have had some secretarial post in ${ }^{*}$ Cromwell's Government but was quite ready to welcome ${ }^{*}$ Charles II (Astraea Redux, 1660) and was a consistent Tory for the rest of his life. His marriage (1663) to Lady Elizabeth Howard, daughter of the Earl of Berkshire and sister of his friend Sir Robert Howard, the dramatist, assured his place in the literary world. He retired to his father-in-law's house in the country in the plague year of 1665 and remained there to write Annus Mirabilis (1667), which relates the events of the Dutch War of 1665-66 and the Great Fire. In 1668 he became Poet Laureate. He had already written plays, but the success of The Indian Emperor (1667), a tragedy about the love of *Montezuma's daughter for ${ }^{*}$ Cortez, the conqueror of Mexico, encouraged him to continue, and over 20 plays, tragedies, comedies and satires followed. The one best remembered is All for Love (1678), a version of the Antony and Cleopatra story. His earlier plays were written in rhyming couplets. This was his first in blank verse.

In 1679 he was attacked and beaten in the street as a result of another of his activities, political satire. His best known poem in this field is the allegorical mockepic Absolam and Achitophel (1681), in which the title parts represent ${ }^{*}$ Monmouth and *Shaftesbury. Charles II is David, *Buckingham is Zimri and so on. Many of Dryden's best lyrical poems appear as songs in his plays, but he also wrote odes, including Alexander's Feast (1679), which he thought the best of 
his poetry. His Hind and the Panther (1678) indicated his conversion to Roman Catholicism which, after the expulsion of *James II, cost him his laureateship. His much admired translation of *Virgil's The Aeneid (1697) remains in print. Much of his voluminous prose writing was on historical subjects or literary criticism, his Essay on Dramatic Poesie was published as early as 1668 . His last major work was a collection of Fables (1699), of which the preface is a fine example of late 17 th-century prose. Dryden's greatness was fully acknowledged by the time of his death and he was buried in Westminster Abbey.

Myers, W., Dryden. 1973.

Drysdale, Sir (George) Russell (1912-1981). Australian painter, born in Sussex to an AngloAustralian pastoral family. His spare, harsh landscapes captured the outback and the people who lived there.

Du Barry, Marie Jeanne Bécu, Countess (17431793). French mistress. She was a dressmaker's daughter who rose to fortune by her good looks and vivacity. Her association with *Louis XV lasted from 1769 until his death (1774) but she took no part in politics. On the outbreak of the Revolution (1789) she fled to England but rashly returned in 1793, when she was arrested and guillotined.

Laski, P. M., Trial and Execution of Madame du Barry. 1969.

Dubcek, Alexander (1921-1992). Czechoslovak politician, born in Uhrovec, Slovakia. Partly educated in Russia, he became a factory worker, joined the resistance movement in World War II and fought in the 1944-45 Slovak uprising against the Germans. After World War II he graduated in law and worked his way up in the CP hierarchy. In 1960 he was appointed industrial secretary of the Central Committee of the Communist Party of Czechoslovakia and in 1962 made a full member of the Presidium. He replaced Karol Bacilek as Slovak Communist Party leader in 1963 and was Czechoslovak party leader 1967-69. After student riots in Prague in 1968, President Antonin Novotny resigned, and in the so-called 'Prague spring' Dubcek offered 'socialism with a human face', granted press freedom and rehabilitated political victims of the Stalinist years. On 9 April 1968 a reform program entitled 'Czechoslovakia's Road to Socialism' was announced and these moves aroused Soviet concern about a possible domino effect in Eastern Europe. The *'Brezhnev Doctrine', asserting that the USSR had the right to intervene in the affairs of its satellites, led to immediate invasion. Dubcek was replaced as Secretary-General of the CP by Gustav Husak, made Ambassador to Turkey 1969-70, expelled from the CP (1970) and worked in the forestry industry (1971-88). After the 'velvet revolution' of 1989 (*Havel), Dubcek became President of the Federal Parliament 1990-91.

Shawcross, W., Dubcek. 1970.
Du Bellay, Joachim (1522-1560). French poet. Born to a noble family, he became a leader of the group of poets who called themselves La Pléiade, after the constellation, first used by Alexandrian writers (c.280 $\mathrm{BCE}$ ). The group included his friend and fellow student*Ronsard. Du Bellay wrote many ardent and melancholic Petrarchan love sonnets and an important literary treatise, La Deffence et illustration de la langue françoyse (1549), the manifesto of the Pléiade. He was the friend and fellow student of Ronsard.

Du Bois, W(illiam) E(dward) B(urghardt) (18681963). American scholar and black civil rights leader, born in Great Barrington, Massachusetts. He taught economics and history at Atlanta University (18971910) and devoted himself to sociological research into black people in America. He published Souls of Black Folk (1903) in which he opposed Booker T. *Washington's accommodation strategy and in 1905 founded the Niagara Movement, whose members, black intellectuals, agitated for African-American rights. This merged with the National Association for the Advancement of Colored People (NAACP), which he helped form. He was editor of its journal, Crisis, but resigned from the movement in 1934, to return to writing and teaching. However, he rejoined the NAACP in 1944 as research director. His membership of the Communist Party dated from 1961 and in 1962 he emigrated to Accra, Ghana, and renounced US citizenship. Earlier he had advocated independence for African colonies.

Weinberg, M. (ed.), W. E. B. Du Bois: A Reader. 1970; Lewis, D. L., W.E.B. DuBois: A Biography, 2009; Horne, G., W.E.B. DuBois: A Biography. 2010.

Du Bois-Reymond, Emil Heinrich (1818-1896). German scientist. His early researches were into the well-known phenomenon of discharges from electric fish. He then moved on to investigate the presence of electrical charges in nervous impulses in general, particularly in muscle contractions. By devising ever more sensitive apparatus he was able to detect discharges in very localised muscle tissues, and he laid the foundations for almost all subsequent work in electro-physiology. He had strongly held views about scientific metaphysics. He condemned the vitalist beliefs that were prevalent in Germany in his day, denied that Nature contained life-forces independent of matter, insisting that all force resided at some place in the material world.

Dubos, René (Jules) (1901-1982). French-American microbiologist. Working at Rockefeller University from 1927, he conducted early research into the isolation of antibacterial substances from various soil micro-organisms, which led to the discovery of major antibiotics. His publications included Bacterial and Mycotic Infections in Man (1948), Pasteur and A Modern Medicine (1960) and Man, Medicine, and Environment (1968). He was editor of the Journal of 
Experimental Medicine. He won the Pulitzer Prize for So Human an Animal (1968) and coined the maxim: 'Think globally, act locally.'

Dubuffet, Jean (1901-1985) French painter, born in Le Havre. He worked in the wine trade until 1942, then developed his own art brut, influenced by *Klee and the Surrealists, rough, dreamy and often childlike collages.

Duccio di Buoninsegna (c.1255-c.1319). Italian (Sienese) painter. His influence on the Sienese school was comparable with that of ${ }^{*}$ Giotto in Florence. He has been called 'the last and greatest representative of the Byzantine tradition', but he imparted to his figures a liveliness and individuality quite unlike Byzantine portraiture. Duccio was a master of narrative, his finest work, the Maestà, painted for Siena Cathedral, consisting of 26 scenes from the Passion of Christ. He used much gold and surface pattern. An earlier work of his, the Rucellai Madonna, in Florence, was once ascribed to ${ }^{*}$ Cimabue.

Duchamp, Marcel (1887-1968). French-American painter. Associated with several modern movements including Futurism and Cubism, he became one of the leading Dadaists, the anti-aesthetics, anti-'art' protesters and precursors of Surrealism. His Nude Descending a Staircase (two versions, 1913) caused a sensation in New York in 1913. He lived in the US from 1915 and spent eight years working on The Bride Stripped Bare by her Bachelors Even (1915-23, Philadelphia), a famous and controversial 3-metrehigh glass and metal composition. He became an American citizen in 1955.

Lebel, R., Marcel Duchamp. 1959.

Duda, Andrzej Sebastian (1972- ). Polish politician, born in Kraków. Head of the Law and Justice Party, he was a conservative nationalist and President of Poland 2015- . He worked closely with *Xi and *Trump but outraged *Netanyahu by denying that Poland had any complicity in the Holocaust. He opposed gender equality and gay rights.

Dudamel (Ramirez), Gustavo Adolfo (1981- ). Venezuelan conductor and violinist. He was an outstanding product of El Sistema, the music education program, begun in 1975 by José Antonio Abreu (1939-2018), which has trained many thousands of young instrumentalists to professional standards. Dudamel conducted the Simón Bolívar Orchestra 1999- and was appointed as music director of the Los Angeles Philharmonic 2009- .

Dudley, Edmund (c.1462-1510). English lawyer. One of the main instruments through whom *Henry VII made his financial exactions, he was executed by *Henry VIII. His son, John Dudley, became Duke of *Northumberland. John's elder son, Lord Guildford
Dudley, married and shared the fate of Lady Jane *Grey, and his younger son became Elizabeth's favourite, the Earl of *Leicester.

Dufay, Guillaume (c.1400-1474). Flemish composer, probably born in Hainaut. Founder of the Burgundian School, a chorister at Cambrai Cathedral (1409), c.1420 he entered the service of Carlo Malatesta of Rimini, and in 1428 became a member of the Papal Choir at Rome. As a canon of Cambrai (from 1426), he supervised the cathedral music. The greatest composer of his time of Church and secular music, he created the style which is characteristic of the Burgundian composers and links late medieval music with that of the Renaissance, and the later Franco-Flemish composers. His works include 87 motets, 59 French chansons and seven Masses.

Dufferin and Ava, Frederick Temple HamiltonTemple-Blackwood, 1st Marquess of (1826-1902). British politician and diplomat, born in Florence. A great-grandson of ${ }^{*}$ Sheridan, he was educated at Eton and Oxford, held junior office under ${ }^{*}$ Russell, *Palmerston and *Gladstone, and was GovernorGeneral of Canada 1872-78 and Ambassador to Russia 1879-81. As Ambassador to the Ottoman Empire 1881-84, he went to Egypt and was involved in the reconstruction $\left({ }^{*}\right.$ Cromer) after the defeat of Arabi Pasha's rebellion (1882). As Viceroy of India 1884-88, he dealt diplomatically with the Russian threat through Afghanistan and was confronted with the quarrel with King Thibaw of Upper Burma, which led to that country's annexation. His career ended with two more ambassadorial posts, in Rome 1888-91 and Paris 1891-96. He died under a cloud after the collapse of the London and Globe Finance Corporation (1901), which he chaired.

Du Fu (Tu Fu in Wade-Giles) (712-770). Chinese poet, born in Honan Province. He came from a family of scholars and public servants under the Tang dynasty but failed examinations and suffered professional frustration, isolation and poverty. $\mathrm{He}$ met and admired * Li Bo and may have been a Daoist. Generally considered the greatest of all Chinese poets, his densely packed 'regulated verse' is full of haunting images, such as his self-description as a 'shabby parrot'.

Hung, W. Tu Fu, China's Greatest Poet. 1952.

Dufy, Raoul (1877-1953). French painter. One of the original 'Fauves' (*Derain, *Matisse), Dufy was noted for his varied use of colour, lively subjects (e.g. race meetings, regattas, flag-bedecked streets) and simplified form. He also designed wall decorations, textiles and ceramics. His drawing is swift and calligraphic. His La Fée electricité (193637 ), the world's biggest mural $(60 \mathrm{~m} \times 10 \mathrm{~m})$, is now in the Musée d'Art Moderne, Paris. 
Du Gard, Roger Martin (1881-1958). French novelist and dramatist. He won the 1937 Nobel Prize for Literature for his long series of novels about middle-class life in France, Les Thibault (1922-40).

\section{Du Guesclin, Bertrand see Guesclin, Bertrand du}

Duhamel, Georges (1884-1966). French novelist. He studied medicine, and his La Vie des Martyrs (1917) describes his experiences as an army surgeon in World War I. Among his best known novels are those in the Chronique des Pasquier (10 vols, 1933-43), in which every character in the circle of the Pasquier family is portrayed with observation, humour and understanding. Duhamel was elected to the Académie française in 1935.

Dukakis, Michael Stanley (1933- ). American Democratic politician. Of Greek descent, he was educated at Harvard, became a lawyer and lectured at Harvard 1979-82. He was Governor of Massachusetts 1975-79, 1983-91, and defeated Jesse *Jackson to win the Democratic nomination for president in 1988. He was beaten by George H. W. *Bush.

Dukas, Paul Abraham (1865-1935). French composer. He studied and afterwards taught (1910-13, 1928-35) at the Paris Conservatoire. The orchestral piece The Sorcerer's Apprentice (1897) is his best known work. The opera Ariadne and Bluebeard (1907), based on *Maeterlinck's play, and the dance-poem La Peri (1912) are still performed.

Dulles, John Foster (1888-1959). American lawyer and diplomat, born in Washington. Son of a Presbyterian minister, he was educated at Princeton University and the Sorbonne. Two relatives were Secretary of State: his grandfather John W. Foster and uncle Robert ${ }^{*}$ Lansing. He practised law in New York from 1911 but developed a keen interest in foreign affairs, in which, through a number of official and unofficial posts, he gradually became an acknowledged expert. Thomas ${ }^{*}$ Dewey appointed him to a vacancy as US Senator 1949, but he lost the ensuing election. Although a Republican he was employed (1950-51) by President ${ }^{*}$ Truman to negotiate the treaty with Japan, and when *Eisenhower won the presidency he became Secretary of State 1953-59. His resistance to any concession to the communist countries, carried sometimes to the brink of war (hence the word 'brinkmanship' applied to his tactics) sometimes alarmed his allies. Britain and France were angered by his strong opposition to their Suez intervention in 1956. Colon cancer forced him to resign. His son, Avery Robert Dulles (1918-2008), became a Catholic, a Jesuit theologian and a Cardinal. His brother, Allan Welsh Dulles (1893-1969), was director of the Central Intelligence Agency, 1953-61.

Hooper, T., The Devil and John Foster Dulles. 1973.
Dumas, Alexandre (1803-1870). French novelist, known as Dumas perre. His father, the illegitimate son of the Marquis de la Pailleterie, dropped this name for that of Dumas, the name of Alexandre's mother, a woman of African descent. His father was a general in the Revolutionary armies who left his family in poverty. Alexandre came to Paris to seek his fortune, which he achieved with a number of long-forgotten historical melodramas. From 1836 he turned to historical romances and built up what amounted to a factory for their production. In a single year (1844) it is said that more than 40 complete works were issued. 1500 novels were published under his name, most by hackwriters (his nègres). Dumas used his astonishing fertility of invention to supply plots, outline the sequence of events and write any purple passages that were required: a motley and changing collection of assistants did the rest. Nevertheless the best of his books have that remarkable gusto and vitality, which are Dumas' own special contribution. Foremost are The Three Musketeers (1844) with its sequels Twenty Years After (1845) and The Viscount of Bragelonne (1850). Of almost equal popularity are The Count of Monte Cristo (1845), The Man in the Iron Mask (1845), The Queen's Necklace and Black Tulip (both of 1848). His vitality spread to other fields, he travelled widely, made love prodigiously, and took part in the wars of Italian reunification (1859-60).

Craig Bell, A., Alexandre Dumas. 1950.

Dumas, Alexandre (1825-1894). French playwright, known as Dumas fils. Illegitimate son of the elder *Dumas, of the many successful plays he wrote between 1852 and 1887, only one, the first (which began as a novel), La Dame aux Camelias (1852), is still remembered. It is the affecting love story of a dying courtesan, and later provided a magnificent part for Sarah *Bernhardt, and Greta *Garbo on film. *Verdi's opera La Traviata (1853) was based on the play. Although, like his father, the younger Dumas led an irregular life, all his plays point a moral, made abundantly clear (from 1867) in provocative prefaces. Dumas fils was elected to the Académie française in 1875 .

Du Maurier, Dame Daphne (1907-1989). English novelist and playwright, born in London. Daughter of Sir Gerald *Du Maurier, in 1932 she married (Sir) Frederick Browning, later a general. Her sexuality is mysterious but she and her father had a mutual obsession. Her novels, usually stories with a Gothic or menacing theme are mostly set in Cornwall, where she lived. They include The Loving Spirit (1931), her first, and Rebecca (1938), her most successful. Alfred *Hitchcock filmed Jamaica Inn (1939), Rebecca (1940) and The Birds (1963) and Nicolas Roeg Don't Look Now (1973). Other works (some also filmed) include Frenchman's Creek (1942), My Cousin Rachel (1951), The Scapegoat (1957) and her father's biography Gerald (1934). 
Du Maurier, George Louis Palmella Busson (18341896). English novelist and cartoonist, born in Paris. In London from 1860, he illustrated several books and became a cartoonist on Punch. He also wrote the novels Peter Ibbetson (1892) and Trilby (1894), the story of the hypnotist Svengali, later dramatised and filmed several times. His son, Sir Gerald Du Maurier (1873-1934), was a famous London theatrical manager and actor, knighted in 1923, noted for his delicate understatement in comedies.

Ormond, L., George du Maurier. 1969.

Dumont d'Urville, Jules-Sebastian-César (17901842). French navigator and naturalist. He brought the Venus de Milo to France (1820) and ${ }^{*}$ Charles X to England (1830). He explored the Pacific (182629) and Antarctic waters (1838-39, 1840), sighting Terre Adélie, named for his wife. He was killed, with his family, at Meudon in France's first major railway accident.

Dumouriez, Charles François (1739-1823). French soldier. He served with distinction in the Seven Years War, but it is as the general who saved Revolutionary France from the Prussians and Austrians that he is remembered. By skilful manoeuvres he stemmed the enemy onrush in Champagne and after he had successfully withstood the Prussian cannonade at Valmy (September 1792) he forced a retreat. He followed this up with a victory (November 1792) at Jemappes near Mons, which put the Austrian Netherlands (Belgium) in French power, but in the next year he was defeated near the Belgian village of Neerwinden and, in fear of the consequences, defected to the enemy, settling in England in 1804.

Dunant, (Jean) Henry (or Henri) (1828-1910). Swiss philanthropist, born in Geneva. Founder of the Red Cross, he organised emergency aid services for those wounded in the Battle of Solferino (1859), and proposed in Un Souvenir de Solferino (1862) the formation of voluntary relief societies in all countries. $\mathrm{He}$ also advocated an international agreement relating to war wounded. In February 1863 the International Committee of the Red Cross was established and the first conference, with representation from 16 nations, was held in October. The first Geneva Convention was adopted in August 1864.

Dunant was regarded as too ambitious and idealistic by pragmatists on the committee and he became isolated. His business ventures in Algeria collapsed, he was forced into bankruptcy in 1867 and left Geneva, never to return, living in Paris 1870-74. He founded the Common Relief Society and the Common Alliance for Order and Civilization. He argued for the abolition of slavery, disarmament, creating an international court arbitration, fair treatment of prisoners of war, the creation of an independent Palestine and a 'world library', which anticipated both UNESCO and the internet. Originally a Calvinist,
Between 1875 and 1895, he was isolated, forgotten, and assumed dead. From 1892 he lived alone in a nursing home at Heiden, where he died, and which is now a museum. He was 'rediscovered' by a newspaper interview in 1895, which was reprinted throughout Europe. He received many honours and shared the first Nobel Peace Prize in 1901, with Frédéric *Passy, a pacifist. He spent none of his prize money. He was, understandably, paranoid and depressive in his last decades, pursued by creditors. He insisted that there should be no funeral ceremony: 'I wish to be carried to my grave like a $\operatorname{dog} . . . \mathrm{I}$ am a disciple of Christ as in the first century, and nothing more.' He was buried in Zürich.

The Henry Dunant Medal, created in 1963, funded by Australia, is the highest international award by Red Cross.

Pandit, H. N., The Red Cross and Henry Dunant. 1969.

Dunbar, William (c.1460-c.1530). Scottish poet. Little is known of his early life except what can be deduced from his poems. He was most probably a Franciscan friar whose wanderings as a mendicant friar took him to England and France. Later (c.1500) as a secular priest he entered the service of ${ }^{*} J a m e s I V$ : in 1501 he accompanied the diplomatic mission to London that negotiated the king's marriage to ${ }^{*} \mathrm{Henry}$ VII's daughter Margaret, whom in 1503 he welcomed to Scotland with the allegorical poem The Thrissil and the Rois (The Thistle and the Rose). An increase in his pension is mentioned in 1510 but after that nothing certain is known. The Dance of the Seven Deadly Sins is the best known of his other allegories. An elegy, The Lament for the Makers (i.e. poets), mourns the death of ${ }^{*}$ Chaucer and his successors. Dunbar was a metrical artist, who wrote with vigour, enjoyment and with humour, sometimes of a Rabelaisian kind.

Scott, T., Dunbar. 1966.

Duncan I (c.1001-c.1040). King of Scots 1034-40. He succeeded his grandfather, Malcolm II, but little is known of him except for his murder by *Macbeth, which provided the theme for *Shakespeare's tragedy.

Duncan, Isadora (1878-1927). American dancer. She lived in Europe from 1906 and her interpretative dancing, with bare feet and in flowing draperies, caused a sensation, as did her eccentric behaviour. She married the Russian poet Sergei *Yesenin (1922) but they separated in 1923. She died in an accident when her scarf caught in the wheel of a moving car.

Duncan, I., Isadora. 1968.

Dundas, Henry, 1st Viscount Melville (1742-1811). Scottish politician, born in Edinburgh. Lawyer, active in the Scottish Enlightenment, he won a judgment in 1776 declaring slavery illegal in Scotland. MP 1774 1802 , he was a close ally of *Pitt and held Cabinet office 1782-1801; 1804-05, with responsibilities for 
Admiralty, India, War and Home Affairs. He became the most powerful politician in Scotland. In 1792 he succeeded in amending *Wilberforce's bill to abolish the slave trade by inserting the word 'gradual'. His partisans argue that he acted pragmatically to secure the bill's passage, while detractors insist that he extended the slave trade for another fifteen years, to 1807. His statue, on a huge plinth, dominates central Edinburgh and is the subject of ongoing, bitter controversy about his ambiguous role.

Dundee, John Graham of Claverhouse, 1st Viscount (known as 'Bonnie Dundee') (1649-1689). Scottish soldier. He won the name 'Bonnie Dundee' when, after the revolution that brought *William III and *Mary to the throne, he raised the Highlanders in the cause of ${ }^{*}$ James II. At the battle fought in the pass of Killiecrankie, Perthshire, he out-manoeuvred and out-fought the enemy but was killed in the moment of victory. Earlier in his career the Scottish Presbyterians, whom he harried by order of the royal government, had bestowed on him the sobriquet of 'Bloody Claverhouse', but he does not seem to have shown exceptional cruelty by the standards of the time.

Scott, A.M., Bonnie Dundee. 1989.

\section{Dundonald 10th Earl see Cochrane, Thomas}

Dunlop, Sir (Ernest) Edward ('Weary') (19071993). Australian surgeon. He acquired heroic status for his leadership of Australian prisoners of war held by the Japanese in Java and on the Thailand-Burma railway, recorded in The War Diaries of Weary Dunlop (1986). He urged reconciliation with the Japanese and closer links between Australia and Asia.

Ebury, S., Weary; the Life of Sir Edward Dunlop. 1995.

Dunlop, John Boyd (1840-1921). Scottish inventor. Originally a veterinary surgeon, he invented (1887) the first successful pneumatic tyre, made of rubber tubing bound with linen tape, as a result of trying to improve one of his son's toys. The invention was patented in 1888 and in 1889 he was associated with Harvey du Gros (to whom he later assigned the patent) in setting up a factory in Dublin. Dunlop himself never made a large sum from his invention, nor was he closely associated with its development.

Dunois, Jean d'Orléans, Comte de (1402-1468). French soldier. Natural son of Louis, brother of *Charles VI, he was known as the 'Bastard of Orléans'. Comrade-in-arms of *Joan of Arc, he was the most successful of the French leaders who fought the English in France. He defended Orléans until the French, inspired by Joan, forced the English to raise the siege, and, in 1429, won with her the Battle of Patay. After Joan's death he took Chartres, freed Paris, and had soon reduced the English hold on France to Normandy and Guienne; the former he regained in 1448-50, the latter in 1455 .
Duns Scotus, Johannes (c.1265-1308). Scottish theologian, born near Roxburgh. He joined (c.1280) the Franciscans at Dumfries and was ordained priest at Northampton in 1291. By this time he seems to have been studying at Oxford and spent almost all the rest of his life studying or teaching there and in Paris and, briefly, just before he died, at Cologne. His work consisted mainly of commentaries on the Bible, ${ }^{*}$ Aristotle and the Sentences of Peter *Lombard. He gained an immense reputation for learning and owed his appellation doctor subtilis to the manner in which he criticised Thomas *Aquinas' views concerning the harmony of faith and reason. He argued that assent to such concepts as the immortality of the soul cannot be attained by reason but must spring from a wish to believe. In theology he was orthodox and gave the strongest support to the doctrine of the Virgin Mary's Immaculate Conception. Realism was the basis of his philosophy and he accepted the theory that a universal matter forms a common basis of everything that exists. His followers assailed the new learning of Renaissance humanists and in turn were attacked for pedantry and casuistry. The word 'dunce', derived from his name, thus unfairly came to mean a blockhead.

Dunstable (or Dunstaple), John (d.c.1453). English composer. He worked for the English courts in England and France, under the patronage of the Duke of ${ }^{*}$ Bedford. Rhythmically and harmonically radical, interested in mathematics and astrology, he challenged *Pythagoras' harmony by writing chords using 3rds and 6ths.

Dunstan, St (c.924-988). English prelate and statesman, born at Glastonbury. Abbot of Glastonbury for many years, after *Athelstan's death (939), Dunstan's advice was constantly sought by his successors, but it was only when *Edgar became king (959) that, as Archbishop of Canterbury, he attained full power. A great scholar himself, he encouraged education, but his greatest achievements were the revival of monasticism and association of the monasteries with the life of the lay community. The peace and prosperity associated with Edgar's reign was largely due to Dunstan's influence.

Duckett, E. S., Saint Dunstan of Canterbury. 1955.

Dunstan, Don(ald Allan) (1926-1999). Australian Labor politician, born in Fiji. Premier of South Australia 1967-68, 1970-79 he had a national reputation as a reformer, campaigning against White Australia, sexual discrimination and the death penalty, and promoting Indigenous causes, multiculturalism and the arts.

Duparc, (Marie Eugène) Henri (1848-1933). French composer. He studied law, then composition under ${ }^{*}$ Franck, and destroyed all his works except for 13 magnificent songs (1868-84). From the age of 
36 he was crippled by hyperaesthesia and withdrew to the country, maintaining an interest in literature, painting and his family.

Dupleix, Joseph François (1697-1763). French administrator. When he was 23 years old his father, a shareholder in the French East India Company, arranged for him to be given a post on the Council at Pondicherry, the company's headquarters near Madras. He was so successful there, and later in Bengal, that in 1741 he was made Governor-General of all the French Indies. He now set about the fulfilment of his great ambition of creating a French empire in India. To this end he impressed the Indians by adopting oriental luxury, intervened in the local intrigues and supported, with diplomacy and troops, rulers in Hyderabad and the Carnatic upon whom he could rely. War between France and England, and Clive's military victories, transformed the situation and as Dupleix's difficulties increased his enemies in Paris became increasingly active until in 1754 he was recalled. He died in 1763 with his reputation tarnished and fortune gone.

Du Pont, Eleuthère Irénée (1771-1834). American industrialist, founder of the chemical firm. His father, a French economist, Pierre Samuel du Pont (17391817), took him and the rest of his family to America in 1799. In 1801 Eleuthère started a gunpowder mill at Wilmington, Delaware, which grew into the vast industrial combine of E. I. Du Pont de Nemours, which now manufactures a great array of chemical and allied products ranging from explosives to paints, plastics, synthetic fibres, etc.

Durant, William C(rapo) (1861-1947). American industrialist. A speculator and promoter, he worked with David *Buick and founded General Motors in 1908 as a cooperative, decentralised competitor to *Ford, including such brand names as Chevrolet, Buick, Pontiac and Oldsmobile. He lost control of GM (1920) and the corporation had to be rescued by the ${ }^{*} \mathrm{du}$ Ponts.

Durant, Will(iam James) (1885-1981). American historian. Educated at Columbia University, his The Story of Philosophy (1926) became a bestseller. His 11-volume series The Story of Civilization (1935-75), completed with his wife Ariel Durant (née Chaya Kaufman) (1898-1981), was detailed, comprehensive, analytical, tolerant and readable, reflecting their socialist utopianism.

Dürer, Albrecht (1471-1528). German painter and engraver, born in Nuremberg. Son of an immigrant Hungarian goldsmith, he was apprenticed to Martin Wolgemut, a painter and engraver. He travelled widely in Germany from 1490 to 1494 , returning to Nuremberg to marry Agnes Frey. He first became famous for his engavings, woodcuts and book illustrations, then for his paintings. His Self-portrait (1498), now in the Prado, is an assured, even arrogant, masterpiece showing confidence in his capacity and social standing. Most of his life was spent in Nuremberg, except for visits to Venice (1494-95 and 1505-07), after which his paintings (e.g. the Rosenkranz altar-piece, and The Ascension of the Virgin and the later 'Four Apostles', now in Munich), show the marked influence of Venetian painters such as Giovanni *Bellini. The best of his portraits suggest the simplicity of sculpture, and his characterisation can, at least, be compared with that of *Holbein.

In general, Dürer stands between the Gothic and Renaissance periods, more interested in new techniques than new subjects. This is especially evident in his woodcuts and engravings, where the medieval preoccupation with the macabre is often combined with mathematical exactitude in reproducing the proportions of the human figure and a mastery of perspective. By a number of technical improvements he was able, too, to give a much greater flexibility to these branches of his art. His most important engravings include The Knight, Death and the Devil (1513), Melancholia (Melencolia I) and St Jerome in His Study (both 1514). In woodcuts he abandons the colour of tradition and achieves contrast by making the figures stand out from a hatched background. He used the woodcut process even for pictures of great size. The Triumphal Arch of the Emperor contained 92 blocks and was over $3 \mathrm{~m}$. high. His output was enormous, with book illustrating and designing for the fine arts to be added to his other works. In addition, over 1,000 drawings exist in the great public collections of the world. His animal and plant studies in watercolour are the first known. He wrote treatises on artistic theory, and a diary.

Wölfflin, H., The Art of Albrecht Dürer. 1971; Campbell-Hutchinson, J., Albrecht Dürer: A Biography. 1990; Bartrum, J., Albrecht Dürer and his Legacy. 2002; Wolf, N., Albrecht Dürer. 2010.

Durham, John George Lambton, 1st Earl of (17921840). English administrator. He came of an old Durham family and was MP for the county 1813-28, when he was created a baron (the earldom came in 1833). 'Radical Jack', as he came to be called, was one of the most progressive members in the Cabinet of his father-in-law, the Whig leader Lord ${ }^{*}$ Grey, and he took a prominent part in the drafting of the Reform Bill (1832). After a short spell as Ambassador to Russia 1835-37, he was appointed Governor-General of the provinces of Canada (1838) with a mission to report and advise on the situation arising from the FrenchCanadian rebellion. E. G. *Wakefield was one of his advisors. The famous Durham Report (1839) recommended the union of Upper and Lower Canada, as a means of integrating the English and French, and local self-government for all the provinces. He also envisaged the federation of the provinces, which took place in 1867 .

Cooper, L., Radical Jack. 1959. 
Durrell, Lawrence George (1912-1990). British novelist and poet. He spent part of his youth in Corfu, and during World War II was a press officer in several parts of the Middle East. This background helped him to write a highly successful series of novels The Alexandria Quartet (1956-59) beginning with Justine, which gave a vivid and atmospheric portrayal of Alexandria, and some of the odder personalities among its inhabitants. His brother Gerald Durrell (1925-1995), author and naturalist, wrote My Family and Other Animals (1956) and similar books describing their life in Corfu. He founded the Jersey Wildlife Preservation Trust in 1963.

Dürrenmatt, Friedrich (1921-1990). Swiss playwright and novelist. His tragi-comic plays include Romulus the Great (1949), The Marriage of Mr. Mississippi (1952), The Visit (1956) and The Physicists (1962).

Duryea, Charles Edgar (1861-1938) and J(ames) Frank (1869-1967). American automobile pioneers and inventors, born in Illinois. In September 1893, in Springfield, Mass., the brothers produced the first US motor vehicle, with a one-cylinder internal combustion engine, just ahead of Henry *Ford. The brothers quarrelled bitterly with each other over claims to priority.

Duse, Eleonora (1859-1924). Italian actor. She came of a family of Venetian actors, appeared on the stage at the age of four, played Juliet when she was 14 , and at the age of 20 was acclaimed as great. Thereafter, whether in Italy or in the capitals and great cities of the world, where she frequently toured, her fame was rivalled only by that of Sarah *Bernhardt. She thought *Ibsen the greatest dramatist of her time and played many of his parts, ${ }^{*}$ Maeterlinck's plays too, attracted her, while her love for the poet Gabriele *D'Annunzio, the subject of his novel Il Fuoco (1900), made her the ideal interpreter of his dramatic poems.

Signorelli, O., Eleonora Duse. 1959.

Duterte, Rodrigo Rao (also known as Digong) (1945- ). Filipino lawyer and politician. He boasted of his role in extra-judicial killings of suspected drug offenders, became Mayor of Davao City 2013-16 and a popular hero. He was President of the Philippines 2016-22, the oldest person to have been elected, and the first from Mindinao. His claims to have killed drug dealers seem to have been exaggerated.

Dutilleux, Henri (1916-2013). French composer. His music, reflecting the influences of ${ }^{*}$ Debussy, *Ravel, *Stravinsky and *Bartók, brilliantly orchestrated and imaginative, includes a violin concerto written for Isaac * ${ }^{*}$ tern, a cello concerto for *Rostropovich, two symphonies, chamber music, piano works, song cycles and Mystère de l'instant (1989) for strings, percussion and cembalon.
Dutton, Peter Craig (1970- ). Australian Liberal politician, born in Brisbane. After service in the Queensland police, he was a Federal MP 2001- and a minister under *Abbott, ${ }^{*}$ Turnbull and ${ }^{*}$ Morrison. He took a hard line on asylum seekers, became an icon of the Right, challenged Turnbull's prime ministership but lost narrowly to Scott Morrison. He became Liberal Leader 2022- , after Morrison's heavy defeat, promising to reveal his gentler characteristics.

Duval, Claude (1643-1670). French highwayman. He went to England at the restoration of ${ }^{*}$ Charles II, and by the gallant manner and daring with which he carried out his robberies became a hero of ballad and legend. He was hanged at Tyburn.

Duvalier, François (1907-1971). Haitian politician. Known as 'Papa Doc', and a physician by profession, he did much good work in combating malaria before entering politics. Before becoming President (the sixth in 10 months) in 1957 he had held the ministries of Labour and Public Health. Once in power his personality seemed to change. He violated the constitution by extending his term of office, became increasingly dictatorial in his methods and, unable to trust the army, he raised a force of brutal police known as the Tonton Macoute ('bogeymen'), to bolster his reign of terror. His son Jean-Claude Duvalier (1951-2014), known as 'Baby Doc', succeeded as President for Life 1971-86, moderated his father's excesses but was exiled (February 1986).

Diederich, B. and Burt, A., Papa Doc! Haiti and its Dictator François Duvalier. 1972.

Duveen, Joseph, 1st Baron Duveen (1869-1939). English art dealer, born in Hull. His father Sir Joseph Joel Duveen (1843-1906), born in the Netherlands, was a successful importer, who financed the Turner wing at the Tate Gallery (opened 1910) and presented many paintings to the nation. The son achieved an almost legendary success in inducing European owners to sell, and wealthy Americans to buy, many of the most important pictures in the world still in private possession. He continued the family tradition of making munificent gifts to British public collections and received a knighthood in 1919, baronetcy in 1927 and peerage in 1933. His role in the remorseless cleaning of the Parthenon (aka Elgin) marbles in the British Museum became notorious.

Behrman, S. N., Duveen. 1952; Secrest, M., Duveen: A Life in Art. 2005.

Dvořák, Antonin Leopold (1841-1904). Czech (Bohemian) composer, born near Prague. Son of a butcher and innkeeper, familiar from boyhood with the folk music of the countryside, he learnt to play the organ, piano and viola, studied at the Prague Organ School (later the Conservatoire), and at 21 became a viola player (under ${ }^{*}$ Smetana) in the orchestra of the National Theatre. His overture to an opera, King and Charcoal Burner, secured his first public recognition. 
From 1880 he was a friend of *Brahms, who admired his early works, helped to secure their publication and tried to persuade him to live in Vienna. In his vigorous and warmly emotional music, Dvorák extensively used Czech and Moravian folk dances; his Slavonic Rhapsodies were performed throughout Europe and America. He wrote 14 operas, few still in the repertoire. However, ${ }^{*}$ Wagner's works encouraged a late revival of interest with Dimitrij (1882), Jacobin (1897), Kate and the Devil (1899), Rusalka (1900) and Armida (1903). Other works include 12 string quartets, the exhilarating Piano Quintet No. 2 (1887), many songs, e.g. Songs my mother taught me and religious music, e.g. Stabat Mater (1883). From 1884 he visited England seven times and wrote The Spectre's Bride, the Requiem, an oratorio, St Ludmilla, and Symphony No. 7 in D minor especially for English audiences. He conducted in Russia in 1890 and received an honorary doctorate from Cambridge in 1891. Director of the New York National Conservatorium 1892-95, works from this period include the most performed of his nine symphonies, No. 9 in E Minor, From the New World (1893), String Quartet in F major, The American (1893) and Cello Concerto in B Minor, Op. 104 (1895), the greatest in the repertoire. Dvoř́k was exposed to, and influenced by, African-American and First Nations music. He directed the Prague Conservatoire 1901-04.

Hughes, G., Dvoŕák. His Life and Music. 1967; Butterworth, N., Dvoŕák, his life and times. 1980; Horowitz, J., Dvorák in America. 2003; Taruskin, R., Music in the Nineteenth Century. 2010.

\section{Dyck, Sir Anthony Van see Van Dyck, Sir Anthony}

Dyer, Reginald Edward Harry (1864-1927). British soldier, born in Murree, Pakistan. He rose to the rank of brigadier in the Indian army. In April 1919, in the Sikh holy city of Amritsar, following a general strike, Dyer ordered his troops, without provocation or warning, to machine gun crowds at a festival in the Jallianwala Bagh gardens. There was a high death toll: 379 in the British account, more than 1,000 in the Indian. The Amritsar massacre transformed *Gandhi's role and he began his campaign to end British rule in India. Dyer had strong imperialist supporters in Britain, but was censured and forced to retire in 1920. Even ${ }^{*}$ Churchill condemned him, but *Kipling remained a supporter.

Wagner, W. A., Amritsar 1919: An Empire of Fear and the Making of a Massacre. 2019.

Dylan, Bob (né Robert Zimmerman) (1941- ). American singer and composer, born in Duluth. Minnesota. After a turbulent childhood, he travelled round the country, imitating the folk singer Woody Guthrie in his life and singing style. He adopted his professional name from the poet Dylan *Thomas. He first performed professionally in coffeehouses, but was not recognised as a musician of real talent until the release of his first record albums
(1962-64). Two of his songs, Blowin' in the Wind and The Times They are A Changin' were adopted by the civil rights movement. His melodies and angry and sometimes cynical lyrics were tremendously popular and he became a cult figure. Some of his songs were considered by critics to be serious poetry (e.g. in Highway 61 Revisited, 1965). In 1965 he adopted electronic instruments and a new musical form: folk rock. After a motorcycle accident, he released an album John Wesley Harding (1968) which furthered his growing tendency to introspection and used country and western arrangements, as did his Nashville Skyline (1969). The 1970s saw what some consider to be some of his finest mature work, e.g. in the albums Blood on The Tracks (1974) and Desire (1975). In 1979 Dylan, now divorced, professed himself to be a Christian. Awarded the Nobel Prize in Literature 2016 'for having created new poetic expressions within the great American song tradition', he was slow to acknowledge it.

Grey, M., Song and Dance Man. 1973.

Dyson, Sir Frank Watson (1868-1939). English astronomer. Educated at Trinity College, Cambridge, he worked on the distribution and movement of the stars and with the structure of the universe. As Astronomer Royal 1910-33, he persuaded the BBC (1924) to broadcast the six pip signals that were the first accurate time checks available to the general public. In observing an eclipse of the sun in Brazil in 1919 he tested and confirmed *Einstein's theory of the effect of gravity on the path of light.

Dyson, Freeman John (1923-2020). AngloAmerican theoretical physicist and mathematician. Son of the composer George Dyson, he was educated at Cambridge, and worked at the Institute of Advanced Study, Princeton, from 1952, and had an exceptional range of disciplines, notably quantum field theory, prime numbers and space exploration. $\mathrm{He}$ was a contrarian on many issues (including climate change and ESP) and was a powerful writer.

Schewe, P. F., Maverick Genius. 2013.

Dyson, Sir James (1947- ). English inventor and industrial designer. His inventions include the 'dual cyclone' bagless vacuum cleaner, the air-blade hand dryer and a hairdryer. Elected FRS in 2015 and given the OM in 2016, he supported Brexit.

Dzerzhinsky, Felix Edmundovich (1877-1926). Russian Communist politician. Of Polish noble descent, he was imprisoned for revolutionary activities several times, and was the first head of the post-revolutionary secret police (Cheka) 1917-24, and of its successors the OGPU and GPU. 


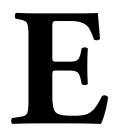

Eakins, Thomas (1844-1916). American painter, photographer and sculptor, born Philadelphia, Pennsylvania. He studied art and anatomy, then studied in Paris under Jean-Leon Gérome at the École des Beaux-Arts (1866-69). He then visited Spain and was deeply influenced by the works of *Velázquez and *Ribera. Returning to the US, he was professor of, and lecturer on, anatomy and painting at Pennsylvania Academy. A realist, called 'the American Courbet', his most famous picture The Gross Clinic (1875) provoked great revulsion, though his paintings are for the most part portraits of friends and depictions of outdoor sports. He was criticised for his teaching innovations which included working from live nude models. His unwillingness to abandon the use of models resulted in his resignation in 1896 . He was deeply interested in multiple image photography.

Eames, Charles (1907-1978). American industrial designer. Trained as an architect, he designed the 'Eames chair' (1946), moulded plywood supported by a tubular metal frame. His industrial and domestic creations were universally adopted.

Eames, Robin Henry Alexander, Baron Eames (1936- ). Irish prelate. Anglican Primate of All Ireland and Archbishop of Armagh 1986-2006, he received the OM (2007), presumably in recognition as his role as a reconciler both in doctrinal and community issues.

Earhart, Amelia Mary (1898-1937?). American aviator. A nurse, then a social worker, she married the publisher George P. Putnam in 1931. She was the first woman to fly solo across the Atlantic (1932) and from Hawaii to California (1935). She disappeared between New Guinea and Howland Island on an attempted round the world flight with Fred Noonan in a Lockheed Electra 10E. Her fate was the subject of extensive speculation, including capture and execution by the Japanese, or defection to the Japanese, becoming a US spy, assuming a new identity. There is an extensive literature. Claims that bones found on Nikumaroro Island are hers are controversial. She has been much memorialised.

Davis, B., Amelia Earhart. 1977.

Early, Jubal Anderson (1816-1894). American soldier, born in Virginia. A lawyer, he rose to the rank of Lieutenant General in the Confederate army in the Civil War. He made a rapid advance down the Shenandoah Valley in July 1864, which threatened Washington. He continued to be valuable in several campaigns and proved a formidable opponent even when his forces were outnumbered. After 1865 he fled to Mexico, then Canada, returning to practise law. He refused to swear an oath of allegiance to the US Government.

Eastman, George (1854-1932). American inventor. His invention of the first practicable roll film (1884) and his development of cheap, mass-produced 'Kodak' cameras made photography a popular hobby. Experiments conducted jointly with ${ }^{*}$ Edison did much to overcome the early difficulties of making motion pictures. He gave away $\$ 125$ million: major beneficiaries were the Massachusetts Institute of Technology, the University of Rochester and the Eastman School of Music. He never married, and shot himself in the heart after two years suffering from an agonising spinal deterioration.

Brayer, E., George Eastman. 1995.

Eastwood, Clint (1930- ). American film actor and director. The films he directed include Play Misty for Me (1971), Firefox (1982), Bird (1988), Unforgiven (1992), Midnight in the Garden of Good and Evil (1997), Mystic River (2003) and Million Dollar Baby (2004). As an actor, he starred as 'Dirty Harry' in a series of five films, and In the Line of Fire (1993).

Ebert, Friedrich (1871-1925). German Socialist politician, born in Heidelberg. A saddler by trade, and a lapsed Catholic, he became a journalist, secretarygeneral of the SDP 1905-19, and a Reichstag member 1912-19. When August *Bebel died, he became joint leader of the SDP in 1913, and voted (reluctantly) for war credits. The SDP split three ways in 1917, with Ebert leading the anti-Communists. When the Imperial Government collapsed, he became Chancellor (November 1918-February 1919) and Prime Minister of Prussia for two days (November 1918). The armed forces, encouraged by *Gröner, supported a Black-Red-Gold (Catholic Centre, Democrat and SDP) coalition in 1919, and Ebert was elected first President of the German Republic 1919-25. His rule was compromised from the outset, using the army and a Freikorps, units of unemployed ex-soldiers, in 1919 to crush the Spartacists (Rosa *Luxemburg) and suppress a Socialist Republic in Bavaria. He died of appendicitis.

Peters, M., Friedrich Ebert. 1954.

Eça de Queirós, José Maria de (1845-1900). Portuguese novelist, born in Pavoa do Varzim. $\mathrm{He}$ graduated in law from Coimbra University (1866) and settled in Lisbon. He began a career in law but his real interest lay in literature. He wrote for the Gazeta de Portugal (1866-67) and contributed a satirical review to As Farpas (1871). By 1871 he was closely associated with the 'generation of ' 70 ', rebellious Portuguese intellectuals who advocated social and artistic reform. Joining the foreign service he was Consul in Cuba 1872-76 and England 187479 , when he wrote the novels for which he is best remembered, $O$ Crime do Padre Amaro (1875), then 
O Primo Basilio (1878), stories of sexual misdeeds. In 1888 he wrote Os Maias, by which time he was designated the 'Portuguese *Zola'. This novel was, like its predecessors, an attempt to bring about social reform by exposing the evils of contemporary society. His other novels show a change of style: $O$ Mandarim (1880) is a fantasy, A Reliquia (1887) a satire and $A$ Cidade e as Serras (1901) a picture of rural life, praising the beauty of the countryside. He was Consul in Paris 1888-1900. Of aristocratic temperament, he was contemptuous of the backwardness of Portugal, but his last novel expresses a sentimental feeling for the country. He introduced naturalism and realism in literature to Portugal and was a master of character analysis and is generally regarded as Portugal's greatest novelist.

Eccles, Sir John Carew (1903-1997). Australian physiologist, born in Melbourne. Educated at Melbourne High School and Melbourne University, he undertook research on the spinal cord at Oxford (1925-37). He was professor of physiology at Otago University 1944-51 and at The Australian National University 1951-66. In Canberra he discovered the chemical means by which signals are communicated or repressed by nerve cells, for which he was awarded the Nobel Prize in physiology and medicine in 1963 (with A. L. *Hodgkin and A. F. *Huxley). His work has had considerable influence on the medical treatment of nervous diseases, and research on the function of kidney, heart and brain. His publications include Reflex Activity of the Spinal Cord (1932) and The Physiology of Nerve Cells (1957). He was President of the Australian Academy of Science 1957-61 and received the AC in 1990.

Eckert, John Presper Jr (1919-1995). American inventor, born in Philadelphia. With John W. Mauchly, professor of electrical engineering at the University of Pennsylvania, he improved computing equipment needed by the US War Department to recompute artillery firing tables (1943). They also won a government contract to build a digital computer (completed 1946), and ENIAC (Electronic Numerical Integrator and Computer) was the prototype for most modern computers. In 1948 Eckert and Mauchly established a computer manufacturing firm and in 1949 produced Binac (Binary Automatic Computer) which stored information on magnetic tape rather than punch cards. Their third model, Univac I (Universal Automatic Computer) was widely used in the commercial world, and really began the computer boom.

Eckhart, Johannes (c.1260-1327). German theologian, usually known as Meister Eckhart. One of the most profound medieval thinkers, the mystical and abstract nature of his speculations make them difficult to understand. They have been loosely described as Christian neoplatonism. He conceives an ultimate incomprehensible Godhead, of which the Father, Son and Holy Spirit are different manifestations. The soul of man also partakes of the essence of the
Godhead and on reaching a stage of self awareness is re-absorbed into the Godhead from which it came. Eckhart's mysticism did not, however, take the form of trances, visions etc. He was a powerful preacher and must have been a competent man of affairs. Two years after his death many of his teachings were condemned by the papacy. Opus tripartitum was his most important work.

Hustache, J. A., Master Eckhart and the Rhineland Mystics. 1958.

Eco, Umberto (1932-2016). Italian writer. A historian and philosopher, he taught at Bologna University, became an expert on James *Joyce and semiotics (*Barthes) and wrote the bestselling novels, The Name of the Rose (1980), Foucault's Pendulum (1988) and The Island of the Day Before (1995).

Eddington, Sir Arthur Stanley (1882-1944). English astronomer and astrophysicist, born in Kendal. An unmarried Quaker, deeply interested in religion, he studied at Trinity College, Cambridge, became assistant at Greenwich Observatory 1906-13, and was professor of astronomy and director of the observatory at Cambridge University 1913-44. He was a conscientious objector in World War I. In 1916 he began his work on the constitution of the stars, establishing their internal structure and bringing about a complete revision of ideas then current. In May 1919, he confirmed *Einstein's theory of general relativity by observing a solar eclipse from Principe, West Africa, and made important contributions to relativity theory, particularly in relation to cosmology. He hypothesised, correctly, in 1920, that the source of energy in the Sun and other stars was fusion of hydrogen into helium. He wrote a number of popular works expounding advances in physics. One of the best known is The Nature of the Physical World (1928). In 1935 he ridiculed his student Subramanyan ${ }^{*}$ Chandrasekhar for proposing the existence of 'black holes' but later nominated him as FRS. He was knighted in 1930 and awarded the OM in 1938. Nominated six times for the Nobel Physics Prize, without success, a lunar crater and Asteroid 2761 Eddington were named for him.

Douglas, A. V., Arthur Stanley Eddington. 1956.

Eddy, Mary Baker (née Mary Morse Baker)(18211910). American founder of the Christian Science movement, born in Bow, New Hampshire. From childhood a devout Bible student, she married George Washington Glover in 1843, was soon widowed but had a son to bring up. She married Daniel Patterson, a dentist in 1853 but they separated and divorced. In 1862 she studied with Phineas Parkhurst Quimby (1802-1866), a mental healer. After a serious injury caused by a fall on ice (1866), she attributed her recovery to applying the teaching of the healing of the palsied man in St Matthew's Gospel to her own condition. In 1875 she published Science and Health with Key to the Scriptures which 
asserted that matter was an illusion and that 'Spirit' (i.e. God) was everything. Thus all physical ailments could be overcome by prayer. In 1877 she married Asa G(ilbert) Eddy (1826-1882), a former patient and fervent supporter. In 1879 she founded the First Church of Christ, Scientist, in Boston and was pastor emeritus until her death. She founded a daily newspaper, The Christian Science Monitor, in 1908.

Peel, R., Mary Baker Eddy. 3 vols, 1966, 1971, 1977.

Edelman, Gerald Maurice (1929-2014). American molecular biologist, born in New York. He was trained at the Rockefeller University, taught there from 1960 and shared the 1972 Nobel Prize for Medicine for his determining the structure of the gamma-globulin blood molecule. Later, he developed a biological theory of mind, the Theory of Neuronal Group Selection (TNGS), and wrote Bright Air, Brilliant Fire: On the Matter of the Mind (1992).

Eden, (Robert) Anthony, 1st Earl of Avon (18971977). British Conservative politician, born in Co. Durham. Second son of Sir William Eden, a Durham baronet, he was educated at Eton, won an MC in World War I and studied oriental languages at Oxford (191922). MP for Leamington 1922-57, from the first he specialised in foreign affairs and was parliamentary private secretary to Sir Austen *Chamberlain 192629. His work at Geneva with the League of Nations gave him an international reputation for diplomatic skill. Undersecretary for Foreign Affairs 1931-33 and Minister for the League of Nations 1933-35, he became Foreign Secretary 1935-38 after the resignation of Sir Samuel Hoare (1st Viscount ${ }^{*}$ Templewood). Attempts by the Prime Minister, Neville ${ }^{*}$ Chamberlain, to bring about a rapprochement with Mussolini caused Eden to resign in 1938 . When ${ }^{*}$ Churchill formed his coalition ministry, Eden was briefly Secretary for War 1940, then Foreign Secretary 1940-45. Deputy Leader of the Conservative Opposition 1945-51, he was Foreign Secretary for a third time 1951-55. His first marriage failed and in 1952 he married Clarissa Churchill, the Prime Minister's niece. He was created a KG in 1954 . When Churchill reluctantly departed, Eden succeeded as Prime Minister 1955-57, despite serious health problems (ulcers, biliary and abdominal infections). His domestic policies were mildly progressive. In October 1956, his sponsorship of the Anglo-French military intervention in Egypt, after *Nasser had refused redress for seizing the Suez Canal, provoked a violent controversy within and outside his own party, and alienated President ${ }^{*}$ Eisenhower. There was a ceasefire in November. Under pressure from his colleagues, and with illness as a pretext, he resigned in January 1957. The Eden Memoirs (1960, 1962, 1965), ghost-written, in three volumes, sold well, although unreadable. He was awarded an earldom in 1961.

James, R. R., Anthony Eden. 1986.
Edgar (Eadgar) the Ftheling (c.1051-c.1126). English prince, born in Hungary. Son of Edward the Exile and grandson of ${ }^{*}$ Edmund Ironside, he was next in the royal line of descent when ${ }^{*}$ Edward the Confessor died and *Harold became King. After the Norman invasion and Harold's death, he was elected king (1066) by the Witanagemot but never crowned. After *William's conquest he submitted, but soon took refuge with his sister Margaret, who became the wife of ${ }^{*}$ Malcolm III of Scotland. After the northern rising of 1069-70, in which he took part, and wanderings in Europe, he made his peace with William. He was a crusader in 1099 and fought against ${ }^{*}$ Henry I at Tinchebrai, Normandy (1106). The last survivor of the royal house of Wessex, founded by ${ }^{*}$ Cerdic, his date of death and place of burial are unknown.

Edgar (Eadgar) the Peaceful (943-975). King of England 959-75. The first king for many years to be able to exercise undisputed rule over an undivided country, he was able to reform the administration, wisely allowing the Danes of eastern England to live under their own laws. His supremacy was symbolised by the legend that he was rowed on the Dee by eight subject kings. His chief advisor was ${ }^{*}$ Dunstan, who enthusiastically supported his monastic reforms.

Edgeworth, Maria (1767-1849). Anglo-Irish writer. Her father, Richard Lovell Edgeworth (1774-1817), a landlord of Co. Longford, was a scientist, politician and educationist, with a score of children upon whom he could try out his theories. Maria, the eldest, cooperated with him as joint author of the *Rousseauesque Practical Education (1798), and herself wrote The Parent's Assistant (1796-1801) and Moral Tales (1801). Better known are her realistic novels of Irish life: Castle Rackrent (1800), The Absentee (1812) and Ormond (1817). Excessive moralising marred these and her other novels, e.g. Belinda (1801). She was a friend of Sir Walter ${ }^{*}$ Scott.

Inglis-Jones, E., The Great Maria: A Portrait of Maria Edgeworth. 1959.

Edinburgh, Duke of, Philip Mountbatten (né Prince Philippos Andreou of Greece and Denmark) (1921-2021). British prince, consort of Queen *Elizabeth II. Born in Corfu, he was the son of Prince Andrew of Greece, but part of the Danish dynasty with the cumbersome name of ${ }^{*}$ Schleswig-HolsteinSonderburg-Glücksburg. His mother, Princess Alice of Battenberg, who became a nun, was a sister of Earl *Mountbatten of Burma, whose surname he adopted in 1947. After some precarious years as an exile, he was educated in France, England, Germany and at Gordonstoun in Scotland. He joined the Royal Navy in 1939 and served in the Pacific during World War II. He was created Duke of Edinburgh on the morning of his marriage to Princess Elizabeth (20 November 1947). He travelled extensively, taking a keen and often controversial interest in industry, education, science, sport and conservation. He became a prince 
of the United Kingdom in 1957, received the OM in 1968 but was never Prince Consort. He was Chancellor of Cambridge University 1976-2011, created Lord High Admiral in 2011 and celebrated 70 years of marriage in 2017.

Hoey, B., Philip, Duke of Edinburgh. 1991; Eade, P., Prince Philip. 2011.

Edison, Thomas Alva (1847-1931). American inventor, born in Milan, Ohio. Growing up in Michigan, he spent only three months at school, was taught at home by his schoolteacher mother, becoming a voracious reader and essentially selfeducated. He set up his own laboratory at home, and at the age of 12 began selling newspapers and candy on the Grand Trunk Railroad, soon employing assistants. Trained as a telegraphist, (1862) as a reward for saving a child's life, he became an expert operator (despite his growing deafness) and repairer of machines. After six years as an itinerant telegraphist, he settled in Boston (1868), working for Western Union, and after devouring *Faraday's work, devoted his free time to experiments in electricity. In 1869 he invented an improved stock market tickertape printer, his first great success, sold it for $\$ 40,000$, and began manufacturing high-speed telegraphic printers in Newark, New Jersey. His quadruplex telegraph (1874) doubled transmission capacity of lines. In 1876 he established the world's first industrial research laboratory, at Menlo Park, NJ, his 'invention factory'. The concept of commercial inventiveness was probably his greatest achievement. (This laboratory moved to West Orange, NJ, in 1887.) His favourite invention, the phonograph (1877), on which sound vibrations were recorded on tinfoil wrapped around a cylinder, made him internationally famous. Edison later used wax cylinders, from which copies could be made, but the phonograph was displaced by the gramophone developed by *Berliner and others, playing discs. His dictating machine and stencil duplication (1877) revolutionised-if not createdmodern office work, until the digital age. His carbon microphone (1878) was needed to make *Bell's telephone a commercial reality. (In 1877 Edison revived the relatively rare word 'Hello' by proposing it as a telephone greeting.)

General Electric, funded by J. P. *Morgan, was established in 1878; Edison sold his stock in 1894 to invest in mining. In 1879 he patented the first successful incandescent lightbulb, using a carbon filament in a vacuum ( ${ }^{*}$ Swan's lights burned out in a few minutes), devised a complete electrical distribution system including generators, switches, plugs and fuses, and by 1882 was supplying direct current (DC) to New York consumers on a grid. However, impatient of theory, he failed to grasp the significance of his employee Nikola *Tesla's work on alternating current (AC) which was far cheaper to distribute. His exact contemporary, George *Westinghouse adopted distribution battle: after 1892 his electrical patents were taken over by General Electric. In 1883 he made his only major scientific discovery, the 'Edison effect', one of the foundations of electronics, the flow of current between a hot and cold electrode due to the emission of electrons. The first execution by electric chair took place in New York (1890). In 1891 he developed the Kinetoscope camera which could film moving images on strips of celluloid - a technique later developed by the ${ }^{*}$ Lumière brothers. Edison thought the future of land transport lay with electric cars and development of the internal combustion engine was taken up by his onetime employee, Henry *Ford. During World War I he worked for the US Government, devised an improved alkaline storage battery and tried to produce synthetic rubber from weeds. Edison was the central figure of the Second (electric) Industrial Revolution with more than 1300 patents to his credit. Einstein called him 'the greatest inventor of all time'. He was deeply disappointed, as was Tesla, not to have been awarded a Nobel Prize. A classic 'rags to riches' story, Edison (like *Franklin) is part of the American dream. He always described genius as 'one per cent inspiration, ninety-nine per cent perspiration', preferring hands on experience and repeated trial and error to theoretical speculation. On the negative side, as Isaac *Asimov noted, he 'fostered a confusion between science and invention' which inhibited public support and understanding of basic science for decades. In a feature in Life magazine (Fall 1997) a panel of scholars ranked Edison as No. 1 of 'the 100 most important people of the millennium 1001-2000'.

Josephson, M., Edison: A Biography. 1959; Clark, R. W., Edison, 1977; Morris, E., Edison. 2019.

Edmund of Abingdon, St (Edmund Rich) (c.11751240). English ecclesiastic, born in Abingdon. He studied at Oxford and Paris, lecturing in both places. In 1222 he became Canon of Salisbury Cathedral, and in 1227 preached for the 6th Crusade, at the request of Pope Gregory IX by whom he was appointed Archbishop of Canterbury 1233. Outspoken, he clashed with *Henry III, criticising his reliance on favourites, and his foreign policies. Edmund averted civil war by bringing moral pressure to bear upon Henry but the threat of excommunication forced him to make concessions. Later, however, the papal legate, Otho, requested by Henry, undermined Edmund's authority, forcing him to leave England for Rome, to appeal to the Pope (1238). He died at Soissy en route to Pontigny to enter a monastery. Edmund's high ideals and virtue made him widely respected and he was canonised in 1247. Feast day: 16 Nov. His Speculum Ecclesiae is considered a major contribution to medieval theology.

Lawrence, C. H., St Edmund of Abingdon: A Study in Hagiography and History. 1960. 
Edmund (Eadmund) Ironside (980-1016). King of England 1016. Son of * Æthelred the Unready, he led the resistance to the Danish invaders under ${ }^{*}$ Cnut but after a long, and at first successful, struggle he was defeated at Ashington (1016) and had to divide his kingdom with Cnut, retaining the south for himself. After his death Cnut ruled over the whole kingdom.

Edmund (Eadmund) the Martyr, St (c.841-870). King of East Anglia 855/6-70). He was either slain in battle or martyred by the Danes, reputedly bound to a tree, scourged, shot with arrows and finally beheaded for refusing to renounce his Christian faith. His tomb at Bury St Edmunds, Suffolk, eventually became a shrine.

Edward (Eadweard) the Confessor, St (c.10031066). King of England 1042-66. He was the seventh son of *Æthelred the Unready by Emma, sister of the Duke of Normandy, at whose court he had been brought up for safety's sake, since England was in a state of turbulence. When he succeeded his half brother *Harthacnut, he had lived for less than two years in England. It was natural therefore that he should surround himself with Norman friends but he also took to a life of pious practice and religious observance. Westminster Abbey, which he founded and where he is buried, is his finest memorial. Meanwhile power rested with his ambitious fatherin-law *Godwine, Earl of Essex, and his son *Harold. Edward had no liking for either but was unable to assert himself and he eventually agreed that Harold should succeed to the throne. He posthumously acquired a reputation as a lawgiver. He was canonised in 1161 .

Edward (Eadweard) the Elder (870-924). King of England 899-924. Before he succeeded his father, *Alfred the Great, he defeated the Danes repeatedly but on coming to the throne he immediately had to face a revolt by his cousin Aethelwald supported by the Danes of the east and north. Edward continued his victorious career and after the death of his sister and staunch ally Aethelflaed, the 'Lady of the Mercians' (918), he was lord of all England south of the Humber, and by 921 was overlord also of the north, Wales and parts of Scotland. He maintained his power by strategically placed fortresses, some of which survive. He was succeeded by his son *Athelstan.

Edward (Eadweard) the Martyr (c.963-978). King of England 975-78. Son of Edgar the Peaceful, his reign was disorderly and he was murdered at Corfe Castle, Dorset, probably at the instigation of his stepmother Aelfthryth, whose son *Æthelred the Unready succeeded him. He was styled as martyr from c.1001.

Edward I (1239-1307). King of England 12721307. Born in Westminster, son of *Henry III, he was nicknamed 'Longshanks' for his unusual height, about $1.88 \mathrm{~m}$. In 1254, he married *Eleanor of Castile, to whom he remained devotedly attached. During the Barons' War (1264-65) he led his father's army and defeated and killed Simon de *Montfort at Evesham (1265). He played a minor role in the Ninth Crusade (1270-73), was wounded, and did not return to England until August 1274, two years after his father's death. He soon showed himself to be a great lawmaker. The first Statute of Westminster (1275) dealt with administrative abuses, that of Quo Warranto, by forcing the magnates to show warrant for the powers they claimed to exercise, was a protection against the usurpation of feudal power. The Statute of Mortmain prevented the handing over of land to the Church except under licence. Edward believed in government by consent and that those who had to find the money for wars and other emergencies should be consulted as to amounts and the methods by which it should be raised. Therefore he extended de Montfort's experiments of adding new elements to the Great Council until there actually came into existence a body which began to be known as parliament from about 1295 and had some resemblance to modern legislatures. Outside England, Edward had to contend with the French king's provocations, designed to secure control of Edward's French inheritance, and was forced into a long, expensive and indecisive contest. In Wales a rising by the prince *Llewelyn ap Gruffydd (1282) provided him with excuse and opportunity for a complete conquest secured by strategically placed castles, several of which still stand. From 1275, he took increasingly punitive measures against the Jews, leading to the Edict of Expulsion (1290), which excluded Jews from England until *Cromwell repealed the edict in 1656. His son, the future ${ }^{*}$ Edward II, was declared Prince of Wales (1301). In Scotland, where the death (1290) of the three-year-old queen, ${ }^{*}$ Margaret, the Maid of Norway, had left a gap in the succession, he was less successful. Edward made three expeditions in support of his candidate John de *Balliol, but though he could usually win pitched battles and hold the fortified towns, though he could even bring the Coronation stone from Scone to Westminster (1296) and defeat and execute the patriot leader William *Wallace (1305), he could achieve no permanent conquest and was marching northwards to suppress yet another rising (under Robert ${ }^{*}$ Bruce) when he died. $\mathrm{He}$ became known as 'the Hammer of the Scots' (Malleus Scotorum). He was buried in Westminster Abbey. He had a very intimidating manner, most of his wars were failures or indecisive, and his expulsion of the Jews set an appalling precedent; nevertheless, he promoted the idea of a representative parliament, governing by consent, ventilating grievances and making it easier to collect revenue. Edward I is generally regarded as one of the greatest of medieval kings.

Morris, M., A Great and Terrible King. Edward I and the Forging of Britain. 2009; King, A., Edward I: A New King Arthur? 2017. 
Edward II (1284-1327). King of England 130727. He was born in Caernarvon, the fourth son of *Edward I. Though he had the magnificent Plantagenet physique and was addicted to country sports and occupations (but not the jousting and tournaments of the nobility), he was always a weak and unstable king. He was also gay and strongly influenced by favourites; the first of these, the Gascon Piers *Gaveston, made Earl of Cornwall in 1307, so incited the hatred of the barons by his pride and extravagance that they had him executed (1312). Edward's authority was still further lowered when in an attempt to carry out his father's policy and bring Scotland to submission he marched northwards only to be decisively beaten by Robert ${ }^{*}$ Bruce at Bannockburn (1314). For the next few years power was in the hands of a group of barons known as Lords Ordainers, under the leadership of the Earl of Lancaster. At last, in 1322, Edward regained control and secured Lancaster's execution, but, disastrously for himself, he fell once more under the domination of a favourite, Hugh Despenser, a Lord of the Welsh March. Once more rebellion was provoked, this time organised by Edward's wife *Isabella of France and her lover Roger de *Mortimer. In January 1327, Edward was deposed and later murdered at Berkeley Castle, presumably by Mortimer's agents, but the exact circumstances are not clear. Christopher ${ }^{*}$ Marlowe wrote the play Edward II (1592).

Bingham, C., The Life and Times of Edward II. 1973; Warner, K., Edward II: The Unconventional King. 2014.

Edward III (1312-1377). King of England 132777. Born in Windsor, son of *Edward II and Isabella of France, he succeeded on his father's deposition. In 1328 he married *Philippa, daughter of the Count of Hainaut in Flanders. She gave birth to five sons who reached maturity and five daughters. In 1330 he obtained effective control by having his mother's lover Roger de *Mortimer seized and hanged, then resumed the Scottish War and by a major victory at Halidon Hill (1333) placed the son of John *de Balliol on the throne. He then turned his attention to France which provided all the justification he needed to gratify his love of chivalry and war. (The Order of the Garter, founded by him in 1348, imitated the knighthood gathered at Arthur's Round Table). Not only were there the provocations of the last two reigns but there was his own claim through his mother to the French throne, from which he was only excluded by the Salic Law debarring succession through the female line. Thus in 1337 began what became the Hundred Years' War, by no means a continuous conflict but a series of campaigns often separated by years and interrupted by treaties. In the first stages, marked by the victorious sea fight at Sluys (1340), which opened the way to the invaders, and the great battles of Crécy (1346) and Poitiers (1356), the English seemed invincible. Edward and his son, *Edward the Black Prince, achieved glory, but it was the dominance of the long bow over armoured knights that proved decisive. Calais was captured in 1347 , its burghers spared, so the story goes, by the intercession of Queen Philippa. By the treaty of 1360 the English regained the duchy of Aquitaine while renouncing the claim to the French throne. But when the French renewed the war in 1369 the English were forced to give up all possessions except the district round Calais. At home Edward was not a great ruler, he maintained law and order, but in his reign parliament was considerably strengthened by its claim to grant or withhold the funds necessary for the conduct of the war. In the king's last years he became senile and the government fell into the hands of his greedy mistress, Alice Perrers, and his son, *John of Gaunt, with the result that many difficulties awaited his successor and grandson, ${ }^{*}$ Richard II. Ardent and chivalrous, with a strong taste for good living, Edward III was a more venturesome warrior but a much less able administrator than *Edward I.

Johnson, P., The Life and Times of Edward III. 1973; Ormrod, W. M., Edward III. 2011; Mortimer, I., The Perfect King. The Life of Edward III. 2008; Davis, J. P., The Gothic King: A Biography of Edward III. 2013.

Edward IV (1441-1483). King of England 1461-70, 1471-83, first sovereign of the House of York. Born in Rouen, he was son of Richard, Duke of *York and great-grandson of Edmund, fourth son of *Edward III. During the Wars of the Roses he was, after the death of his father at Wakefield, the Yorkist candidate for the throne. After *Henry VI's forces had been defeated in 1461 at the battles of Mortimer Cross and Towton, Edward was proclaimed king. The powerful Earl of *Warwick, later known as 'the kingmaker', sustained his rule but was antagonised in 1464 when Edward married Elizabeth Woodville (or Wydeville) (c.1437-1492), a widow and the first commoner to be queen since the Norman Conquest. The advancement of her family led Warwick to change allegiances and in 1470 Edward was deposed, fled to Holland, and Henry VI was restored. Having rallied support Edward returned the next year, defeated the Lancastrians at Barnet (where Warwick was killed) and Tewkesbury, and regained his throne, ensured by the murder of Henry VI. Though notorious for his indolence and love of pleasure, he proved a resourceful and capable ruler, encouraged trade and supported William ${ }^{*}$ Caxton, who set up the first printing press in England. He was $193 \mathrm{~cm}$ tall and handsome in his prime, but became dissipated and gross in later years and died at the age of 40, probably of a stroke. His daughter Elizabeth of York (1466-1503) married *Henry VII.

Myers, A. R., The Household of Edward IV. 1959; Penn, T., The Brothers York: An English Tragedy. 2020.

Edward V (1470-c.1483). King of England AprilJune 1483. Born in Westminster, one of the 'princes in the Tower', on the death of his father, *Edward 
IV, he was proclaimed king under the guardianship of his uncle, Richard, Duke of Gloucester. In June 1483 an assembly of peers and commoners deposed him on the grounds that Edward IV's marriage to Elizabeth Woodville was bigamous and the offspring illegitimate and proclaimed Gloucester king, as *Richard III. Edward and his brother Richard, Duke of York (1473-c.1483) lived at the Tower of London, which was both a royal residence and prison. They were never seen again and while rumours abounded, there was no contemporary accusation of murder. The likeliest explanation is that they were murdered by their uncle or his agents. An alternative hypothesis is that they were later eliminated by ${ }^{*}$ Henry VII, whose claims to the throne were tenuous. Thomas *More was a powerful advocate for Richard's guilt. In 1674 the bones of two boys were found in a wooden chest in the tower. Assumed to be the remains of the 'princes in the Tower', they were interred in Westminster Abbey.

Edward VI (1537-1553). King of England 154753. Born in London, son of *Henry VIII, whom he succeeded, by his third wife *Jane (Seymour), he was precocious in his studies, interested in the reformed religion, but seems to have had a cold shrewdness, particularly unattractive in so young a boy. This was made apparent by the way in which he accepted and acquiesced in the execution of his uncle and first 'protector', Edward Seymour, Duke of *Somerset. John Dudley, Duke of *Northumberland, the new protector, persuaded Edward, on his deathbed, to nominate Lady Jane ${ }^{*}$ Grey, Northumberland's daughter-in-law, as his successor, to the exclusion of his sisters *Mary and *Elizabeth. During his reign the Church became steadily more national and Protestant and a second, more stringent Act of Uniformity was passed. He died of tuberculosis.

Jordan, W. K., Edward VI. 2 vols, 1968, 1971.

Edward VII (Albert Edward von Wettin) (18411910). King of the United Kingdom of Great Britain, Ireland and the British Dominions beyond the Seas, Emperor of India 1901-10. Born in London, he was the second child and eldest son of Queen *Victoria and Prince *Albert. Probably dyslexic, he was subject to extreme discipline and restraints on his natural inclinations in youth but had a brief encounter with education at Edinburgh University, Christ Church, Oxford, and Trinity College, Cambridge. As Prince of Wales he was entirely excluded by his mother from any share in, or indeed acquaintance with, affairs of state. He visited the US (1860) and India (1861) and married the beautiful Princess *Alexandra of Denmark in 1863. Reacting against his parents' rigid morality, he was renowned as a lover of wine, women and gambling. However, he was vaguely sympathetic to ${ }^{*}$ Gladstone, philosemitic, but also interested in *Wagner's operas. As king, he came to terms with democracy and gained surprising popularity. He pushed the entente-cordiale with France (1905) and his nickname 'the Peacemaker' had some validity. His nephew, Kaiser *Wilhelm II, called him 'an old peacock'; Henry *James dubbed him 'Edward the Caresser'. His eldest son *Albert Victor, Duke of Clarence, died in 1892 . He died of emphysema and heart failure at the age of 69 and was succeeded by his second son *George V.

Magnus, P., Edward VII. 1967; Weintraub, S., The Importance of Being Edward. 2000; Ridley, J., Bertie. A Life of Edward VII. (2013).

Edward VIII (Edward Albert Christian George Andrew Patrick David) (1894-1972). King of Great Britain, Ireland and the British Dominions beyond the Seas, Emperor of India January-December 1936, later Duke of Windsor. Born in Richmond, eldest son of ${ }^{*}$ George V and Queen *Mary, he was created Prince of Wales in 1910, given a naval education at Dartmouth College and proceeded to Magdalen College, Oxford. During World War I he served on the staff in France. From 1919 he toured the world constantly, winning adulation from vast crowds. He succeeded his father in January 1936. His long association with an American divorcee, Mrs Wallis Simpson (née Warfield) (18961986), was suppressed by the British press and the BBC. He advised ${ }^{*}$ Baldwin of his intention to marry Mrs Simpson after her second divorce. The British and Dominion governments opposed her becoming queen and would not agree to legislation providing for a morganatic marriage. After 325 days, he abdicated in favour of his brother Albert, Duke of York, who became *George VI. Created Duke of Windsor, in June 1937 he married Mrs Simpson in France. He served unhappily as Governor of the Bahamas 1940-45, where his major challenge was the murder of Sir Harry Oakes (July 1943). He lived in Paris from 1945 and died there. His autobiography, A King's Story, appeared in 1951. The Duke and Duchess were both buried at the royal mausoleum at Frogmore, Windsor.

Ziegler, P., King Edward VIII. 1990.

Edward the Black Prince, Duke of Cornwall, Prince of Aquitaine (1330-1376). English prince and soldier, born in Woodstock. Eldest son of ${ }^{*}$ Edward III, he became the first duke created in England (1337) and was an original KG (1348). He won his spurs at Crécy (1346) and proved his ability as a commander at Poitiers (1356), where he captured the French king, *Jean II. Less successful as ruler (from 1362) of his father's French possessions, Aquitaine and Gascony, he again proved his military prowess when he made a chivalrous incursion into Spain in aid of *Pedro ('the Cruel') of Castile and won another great victory at Najara (1367). This was the end of his glory. He returned ill and despondent to England in 1371, having had to yield during the previous two years to rebellions among his subjects and encroachments from France, by which the English possessions were gradually whittled away. He died before his father, and his son, by his wife Joan, 
the 'Fair Maid of Kent', succeeded Edward III to the throne as *Richard II. He was buried at Canterbury Cathedral where his armour can still be seen.

Edwards, Jonathan (1703-1758). American theologian and philosopher, born in Connecticut. He became a pastor of Northampton, Mass., where his powerful preaching and writing kindled the religious revival known as 'the Great Awakening'. His doctrinal inspiration came from ${ }^{*}$ Calvin and he was the last of the great New England Calvinists, advocating acceptance of the doctrine of predestination. For the last years of his life he worked as a missionary among the Native Americans, becoming President of the College of New Jersey (Princeton University) just before his death.

Miller, P., Jonathan Edwards. 1949; Jenson, R., America's Theologian. 1988; Hatch, N. and Stout, H. O. (eds), Jonathan Edwards and the American Experience. 1988.

Edwards, Sir Robert Geoffrey (1925-2013). English physiologist, born in Yorkshire. A pioneer in in vitro fertilisation (IVF), working with Patrick Steptoe (1911-1988), the birth of Louise Brown, in Oldham, in 1978 was the first resulting from the procedure. Further births soon followed in Melbourne, following the work of Carl Wood (1929-2011). Edwards won the 2010 Nobel Prize for Medicine and was knighted in 2011 .

Edwin (Eadwine or Æduinus) (c.585-633). King of Northumbria 616-33. Son of Ælle, King of Deira, he spent his youth in exile, probably in Wales, but was installed as king of Deira and Bernicia in 616 under the protection of Raedwald, King of East Anglia. He gradually expanded his kingdom to the borders of Scotland, and became overlord of the Anglo-Saxon kingdoms except Kent. His second wife was Æthelburh, sister of Eadbald, King of Kent. Through her and her confessor Paulinus, later the first Archbishop of York, he became a Christian. Edwin was killed in battle against an alliance of the Mercian king *Penda and Cadwallon, King of North Wales.

\section{Egalité, Philippe see Orléans, Philippe, Duc d'}

Egbert (Ecgberth) (771/5-839). King of Wessex 802-39. A descendant of ${ }^{*}$ Cerdic, the founder of the house of Wessex, as a young man he was an exile at the court of ${ }^{*}$ Charlemagne. Though he returned to become king in 802 , almost nothing is known of him until he defeated the kingdom of Mercia at the battle of Ellendun (825), a victory so decisive that it brought Mercian supremacy to an end and all southeast England under the control of Wessex. Egbert conquered Mercia in 829 and received Northumbria's submission in the same year. He could not hold his gains, however, and Mercia again had its own king the following year. But Egbert's reign pointed the way to the future destiny of the Wessex kings as rulers of all England.
Egk, Werner (1901-1983). German composer and conductor. He wrote the operas Peer Gynt (1938), Columbus (1948) and Der Revisor (1957), based on *Gogol's The Government Inspector. His role during the Nazi regime has been described as 'enigmatic opportunism' and he received significant commissions. Later compositions include the concertos Moira (1973) and Temptation (1977). He was President of the International Confederation of Authors and Composers 1976-78.

Egmont, Lamoral, Count d' (1522-1568). Netherlandish soldier and statesman. One of the great lords of the century, he served the emperor ${ }^{*}$ Charles $\mathrm{V}$ (who had acquired the Burgundian inheritance in the Netherlands) with great distinction, and in 1546 was made a knight of the Golden Fleece. When *Felipe II of Spain succeeded Charles (1556), the persecution of Protestants and imposition of the Inquisition by his minister in the Netherlands, Cardinal Antoine de Granvelle, intensified. *William the Silent became an exile but Egmont went to Madrid trying to secure redress for their grievances from Felipe himself. The extravagance of the language with which Egmont, on his return, expressed his anger at the failure of his mission gave Granvelle's successor, the Duke of *Alba, an excuse to crush opposition. Egmont and his ally Philip de Montmorency, Count of Hoorn, were arrested for heresy and publicly beheaded in Brussels. Their execution was a chief factor in sparking off open rebellion against Spanish rule. Egmont's life was celebrated in a play by ${ }^{*}$ Goethe, with music by *Beethoven.

Ehrenburg, Ilya Grigorevich (1891-1967). Russian writer. A war correspondent in World War I, he supported the Russian Revolution but spent most of his time between the wars in Paris (from 1934) as a correspondent for Izvestia. He was a most prolific writer of novels, of which The Adventures of Jullio Jurenito, satirising decadent western civilisation, is among the best known. He won the ${ }^{*}$ Stalin Prize in 1947 with The Storm, a major novel about World War II. The Thaw (1954) commented on the oppressions of Stalin's regime.

Ehrlich, Paul (1854-1915). German-Jewish bacteriologist, born in Silesia (now Poland). He graduated in medicine at Leipzig in 1878. After returning (1890) from treatment in Egypt for tuberculosis, he worked at the new Institute for Infectious Diseases in Berlin. He developed staining techniques (using *Perkin's synthetic mauve dyes) for the tuberculosis bacillus, assisting *Koch's work. With Emil von *Behring, he perfected a diphtheria serum. In 1896 he became director of the State Institute for Serum Research and in 1906 of the Royal Institute for Experimental Therapy at Frankfurt-onMain. He investigated blood cells and immunity to infection, including the 'chemical affinity' theory in which the 'side-chains' or receptors of cells can be stimulated chemically to promote immunity from 
toxins. He shared the 1908 Nobel Prize for Medicine with Elie Metchnikoff (1845-1916) for their 'work on the theory of immunity'. In 1910, with Hata Sahachiro, he developed an arsenical compound, originally numbered '606' and named 'salvarsan', which proved effective in treating syphilis - an early form of chemotherapy. 'Neosalvarsan' ('914'), much less toxic, was produced in 1912. He was renominated for the Nobel Prize in 1912 and 1913. The film Dr Ehrlich's Magic Bullet (1940), starring Edward G. Robinson, was a sympathetic account of his life and work.

Loewe, H., Paul Ehrlich. 1950.

Ehrlich, Paul (Ralph) (1932- ) American population biologist. He taught at Stanford University from 1959 and wrote The Population Bomb (1968), warning of a global population explosion and calling for ZPG ('zero population growth'). With his wife Anne Howland, he wrote The Population Explosion (1990) and Healing the Planet (1991).

Eichmann, (Karl) Adolf (1906-1962). Austrian Nazi bureaucrat. As head of the Gestapo's Jewish extermination department in World War II he suggested a 'final solution of the Jewish problem'. In 1960 he was found living in Argentina under an assumed name, kidnapped by Israeli agents, tried in Israel, condemned and executed (1962) for crimes against the Jewish people and against humanity.

Arendt H., Eichmann in Jerusalem. 1964.

Eiffel, (Alexandre) Gustave (originally Bonickhausen) (1832-1923). French engineer, born in Dijon. He designed a long bridge across the Duoro, near Oporto (1876-77), an elegant iron bridge-span of 162 metres, 120 metres high-across the Truyère river at Garabit (1880-84) and the structure for New York's Statue of Liberty (1885). He designed and built (1887-89) the famous 300.5 metre Eiffel Tower for the 1889 Paris Exposition. It was the world's tallest structure until 1930. The collapse of locks he designed for the first Panama Canal scheme involved him in a scandal (1893) which brought a fine and imprisonment. Later he conducted pioneer researches in aerodynamics and the use of wind tunnels.

Eijkman, Christiaan (1858-1930). Dutch physician. Professor of hygiene at Utrecht University 18981928, he was the co-discoverer, with Sir Frederick *Hopkins, of the 'accessory food factors' (later called vitamins) which combat beri-beri. He shared the Nobel Prize for Medicine (1929) with Hopkins.

Einstein, Albert (1879-1955). German-JewishSwiss-American theoretical physicist, born in Ulm. An only son (a sister was born in 1881), he attended school in Munich, spent some time in Milan and Pavia with his parents and from 1896 studied at the Federal Technical High School (Eidgenössische Technische Hochschule_ETH), Zürich. He became a Swiss citizen in 1901 and was a specialist examiner at the patent office in Berne 1902-09. In January 1903 he married Mileva Maric (1875-1948), a Serb, who played an important (but largely unrecognised) role in his early work. His obsession with research meant that he neglected his children seriously. Hendrik *Lorentz was a major intellectual influence. In 1905 , aged 26, he received his $\mathrm{PhD}$ from Zürich University and published three great papers that changed theoretical physics profoundly: on the photo-electric effect, asserting that light is composed of discrete quanta or photons, and accounting for anomalies in *Planck's work, explaining Brownian motion, the random movement of particles in suspension (Robert *Brown) as due to molecular bombardment, and the Special Theory of Relativity. The last paper argued that energy and matter are inter-convertible, proposing the famous equation $\mathrm{E}=\mathrm{mc}^{2}$ (where $\mathrm{E}$ is energy, $\mathrm{m}$ is mass and $c$ the speed of light), that the motion of a body can only be measured relative to another body, since nothing is absolutely at rest, that nothing can exceed the speed of light, and that measuring space and time are also relative, since the observer's motion is also involved (a thesis later developed by ${ }^{*}$ Heisenberg). Six major papers expanding his 1905 work appeared in 1906. An associate professor at Zürich University 1909-11, he became professor of physics in Prague 1911-12, at the Zürich Institute 1912-13, at Berlin University 1913-33 and Director of the Kaiser Wilhelm Institute for Physics 1917-33. In 1916 he published his General Theory of Relativity and became world famous in 1919 after observations of a solar eclipse (Arthur *Eddington) confirmed his contention that light was bent by gravity.

In 1916 Einstein debated with Willem *de Sitter about whether the universe was expanding but thought the evidence was inconclusive until Edwin *Hubble demonstrated (in 1929) what was later described as 'the big bang', which displaced the 'steady state' theory. He concluded that 'dark energy' was a central factor in gravitation, then retreated from the idea, which was later confirmed by Brian *Schmidt, Saul Perlmutter and Adam Riess. In 1919 he divorced his first wife and married his cousin Elsa Lowenthal (1876-1936).

From 1910, he received 62 nominations for the Nobel Prize for Physics, until in 1922 he was awarded the Prize for 1921 'for his discovery of the law of the photoelectric effect', a relatedly minor part of his unique achievement. He received the Royal Society's Copley Medal in 1925. From 1927 he engaged in long unresolved debate with Niels *Bohr about the foundations of quantum mechanics. He speculated about the hypothesis of an expanding universe but only accepted it in 1929 (*Lemaître, *Hubble). In December 1932 he left Germany for the US, resigning his Berlin post in 1933 and became an American citizen in 1940. A life member of the Institute for Advanced Studies, Princeton, NJ, he was a professor there 1933-45. He doubted that a 
mechanism for generating energy on a large scale by atomic fission was possible until he learned in 1939 that Otto ${ }^{*}$ Hahn and Lise ${ }^{*}$ Meitner had split a uranium isotope in Germany and that chain reaction had been confirmed by Leo *Szilard, and others, in New York. In October 1939 he sent President *Roosevelt a letter, drafted by Szilard, warning of the military implications of splitting the uranium atom. This led directly to the 'Manhattan Project' and the atomic bomb. Einstein was uninformed and uninvolved in further developments. Horrified by the dropping of atomic bombs on Hiroshima and Nagasaki, he campaigned actively for the international control of atomic power. For 30 years he attempted, without success, to reconcile gravitation, electromagnetism, general relativity and quantum theory in a 'unified field theory'. He was the last scientist to be a household name and his image is found as an icon in laboratories throughout the world. Generally regarded as the greatest mathematical physicist of all time, he declined the presidency of Israel (1952) on *Weizmann's death (to the relief of David *Ben-Gurion). Element 99 einsteinium (Es) and the main belt Asteroid 2001 Einstein were named for him. His hypothesis about gravitational waves was confirmed by observations in 2015 and 2017.

Clark, R. W., Einstein. The Life and Times. 1971; Fölsing, A., Albert Einstein. 1997; Pais, A., Subtle is the Lord ... 1982; Isaacson, W., Einstein. His Life and Universe. 2007; Stone, A. D., Einstein and the Quantum. 2013.

Eisenhower, Dwight D(avid) ('Ike') (1890-1969). American general and 34th President of the US 1953-61. Born in Denison, Texas, of Swiss-German descent, he grew up in Abilene, Kansas, and graduated from the West Point Military Academy, ranking 61st of 164 , became a training instructor and remained in the US during World War I. He was ADC to General Douglas *MacArthur in Washington 1933-35 and in the Philippines 1935-37, then had a series of very rapid promotions. As Chief of the War Plans Division in the War Department 1941-42 he showed a remarkable grasp of global strategy. In June 1942 General George *Marshall promoted him to be General Commanding US Forces in Europe, and, a month later, Supreme Commander, Allied Forces in North Africa. This led to the successful invasion of French North Africa, and, as Supreme Commander, Mediterranean, the invasion of Sicily (July 1943), working with *Alexander. In December 1943, President ${ }^{*}$ Roosevelt appointed him as Supreme Commander, Allied Expeditionary Force in Europe, a job Marshall had hoped for. $\left({ }^{*}\right.$ Churchill would have preferred *Alanbrooke.) The Normandy landing took place on D-Day, 6 June 1944. Eisenhower's strategy has been criticised as over-cautious (especially by his prickly rival *Montgomery), but he showed superior political, diplomatic and strategic skills, maintaining working relations with prima donna generals who suspected 'Ike' less than each other and remained popular with troops. He was promoted as a fivestar General of the Army (1944) and awarded the British GCB and OM in 1945. After a short period as Military Governor of the US Zone of Germany, President *Truman appointed him as Chief of Staff, US Army 1945-48, and suggested he should run for the Democratic presidential nomination in 1948. His memoir Crusade in Europe (1948) was a bestseller. President of Columbia University, New York 194851 , following the establishment of NATO he was appointed Supreme Commander, Allied Powers in Europe 1951-52. He won the Republican nomination for president in 1952 with liberal support, defeating Robert ${ }^{*}$ Taft, then won the election with 55 per cent of the vote over the Democrat Adlai ${ }^{*}$ Stevenson. He defeated Stevenson again in 1956 with 57 per cent. (Richard *Nixon was elected Vice President for both terms.) He took a more passive role as President than Roosevelt or Truman, but resisted 'old guard' pressures to dismantle the New Deal-Fair Deal welfare structures. For most of his term he worked with a Congress dominated by moderate Democrats. He helped to end the Korean War and *Stalin's death eased Cold War tensions. He took a moderate stand against Joe ${ }^{*} \mathrm{McC}$ Carthy and avoided military involvement in Indo-China. In 1953 he appointed Earl *Warren as Chief Justice (a choice he later regretted) and gave cautious support to enforcement of civil rights for black people, sending troops into Arkansas in 1957. In the 1960 presidential campaign his tepid endorsement of Nixon assisted *Kennedy's election. In his farewell address (January 1961), he gave a surprising warning 'against the acquisition of unwarranted influence ... by the military-industrial complex'. His reputation has risen since his death and in 19 Presidential ranking lists by historians and political scientists, he scored No. 9 in the aggregate.

Ambrose S. E., Eisenhower. 2 vols, 1985; Newton, J., Eisenhower: The White House Years. 2011; Smith, J. E., Eisenhower in War and Peace. 2012.

Eisenstein, Sergei Mikhailovich (1898-1948). Russian film director. He served as an engineer in the civil wars and later trained in Moscow as a stage designer and producer. He made his first film in 1924 . He developed consummate skill in the direction of crowds and the dramatic use of cutting, notably in such films as The Battleship Potemkin (1925), Alexander Nevsky (1938), his first talking picture, and Ivan the Terrible (1944-45).

Barna, K., Eisenstein. 1973.

Eleanor of Aquitaine (c.1122-1204). Duchess of Aquitaine 1137-1204, Queen consort of France 1137-52 and of England 1154-89. Born in Bordeaux, a member of the Ramnulfid dynasty, rulers of Poitiers, she was Duchess of Aquitaine in her own right. After her marriage (1137-52) to *Louis VII was annulled, she soon married the future ${ }^{*}$ Henry II of England. She brought much of southwestern 
France as her dowry. This became the cause of a struggle between the two countries which lasted, with intervals, for 300 years. A masterful woman, she supported her sons (the future *Richard I and *John) against her unfaithful husband, was imprisoned 1174-89, and after his death (1189) prevented them quarrelling. Her eldest son, Henry, died as a child, her third son was Geoffrey, who died before his father and whose son *Arthur of Brittany, was murdered in the Tower of London, probably on the instructions of John. She was buried at Fontevraud-l'Abbaye, Anjou.

Pernoud, R., Eleanor of Aquitaine.1967.

Eleanor of Castile (1246-1290). English queen consort 1272-90. She married the future *Edward I in 1254 . Before his accession (1272) she went with him on a crusade, but the story that she sucked poison from his wound is probably legendary. Edward showed his devotion to her memory by erecting crosses at each place where the funeral procession rested when her body was conveyed from Lincoln to Westminster. A replica of the final one stands at Charing Cross, London.

Elegabalus (originally Sextus Varius Avitus Bassianus, as Emperor Marcus Aurelius Antoninus Augustus) (c.204-222). Roman Emperor 218-22. Known, but only after his death, by the name of the Syrian Sun God, of whom he was hereditary high priest, he owed his elevation to the throne to the troops in Syria whom the intrigues of his grandmother (a sister of Julia, wife of the emperor ${ }^{*}$ Septimius Severus) had suborned. The fame of the young emperor rests on his reputation as a bisexual and his gaudy extravagance. The rites of the Sun God, whom he claimed to personify, were introduced by him to Rome and were so obscene that they scandalised the citizens. After an attempt to assassinate his cousin, *Alexander Severus, whom he feared as a potential usurper, Elegabalus was murdered by the praetorian guard.

Elgar, Sir Edward (William), 1st Baronet (18571934). English composer, born in Broadheath, Worcestershire. He succeeded his father as organist of St George's Roman Catholic Church, Worcester. Apart from violin lessons, he was self-taught: he read widely and became an amateur scientist. Although he made no use of the folksong tradition he was one of the pioneers of the English musical revival at the beginning of the 20th century, the first outstanding English composer since *Purcell. His earliest work, including pieces composed for the Worcester festivals, attracted only local attention, but he won an international reputation almost overnight when Richard *Strauss acclaimed his Variations on an original theme (Enigma) for orchestra (1899). The Dream of Gerontius (1900), an oratorio based on Cardinal Newman's poem, was even more highly praised. The Apostles (1903) and The Kingdom (1906) belong to an uncompleted trilogy on the early Christian Church. Other works include Symphony No 1 (1908) and No 2 (1911), and the Introduction and Allegro for strings (1905). The violin concerto in B Minor was first performed by ${ }^{*}$ Kreisler (1910). His more popular works, such as the five Pomp and Circumstance marches (190107) and the concert overture Cockaigne (1901), are warmly extrovert and reflect something of the vitality of Edwardian England. His last major work was the cello concerto in E minor (1919) and after his wife died (1920) he practically abandoned composition. Professor of music at Birmingham University 190508 and Master of the King's Musick 1924-34, he was awarded a knighthood (1904), the OM (1911), a baronetcy (1931) and a GCVO (1933), although he yearned for a peerage. His sketches for Symphony No. 3, completed and elaborated by Andrew Payne, were published in 1997 and soon performed and recorded, to critical approval.

Maire, B., Elgar, His Life and Work. 1973; Grimley, D. and Rushton, J. (eds), The Cambridge Companion to Elgar. 2004.

Elgin, 7th Earl of, and 11th Earl of Kincardine (both Scottish peerages), Thomas Bruce (17661841). Scottish soldier and diplomat, born in Fife. Claiming descent from the Scottish royal house of Bruce, educated in Harrow, Westminster and Paris, he was Minister to Brussels 1792-95 and to Berlin 1795-99. As Ambassador to Constantinople 17991803, when Greece was under Ottoman rule, in 1801 he acquired, under dubious circumstances, about half of the frieze metopes, and pedimental sculptures on the Parthenon at Athens, at a cost of about $£ 75,000$ (bribes + costs of removal), an act denounced at the time by Lord *Byron. In 1816 he sold the statues, known as 'the Elgin marbles' to the British Museum where they, controversially, remain. Promoted to general in 1837 , he appears to have been singularly uninvolved in military activity. He died in Paris. His son James Bruce, 8th Earl of Elgin, 12th Earl of Kincardine (1811-1863), educated at Oxford, was Governor of Jamaica 1842-43, Governor-General of Canada 1846-54, and was given a UK barony in 1849 . As High Commissioner and Plenipotentiary in China 1857-59; 1860-61, he ordered the destruction of the Old Summer Palace in Beijing by Charles *Gordon in 1860. *Palmerston appointed him as Viceroy of India 1862-63, the first directly chosen by government and subordinate to the Secretary of State for India. He died in India, after a heart attack. His son, Victor Alexander Bruce, 9th Earl of Elgin, 13th Earl of Kincardine (1849-1917), born in Montréal, and educated at Eton and Oxford, held minor offices under *Gladstone and was chosen by *Rosebery to become Viceroy of India 1894-99. Colonial Secretary 1905-08, he was dropped by *Asquith.

Robertson, G., Who Owns History? 2019.

\section{El Greco see Greco, El}


Elijah (Eliyahu) (fl. c.870-840 BCE). Israelite prophet. He denounced *Ahab and his Phoenician wife *Jezebel for trying to establish Baal worship, and for ordering the death of Naboth in order to secure his coveted vineyard. He appears in the Bible story as a worker of miracles and he is said to have been carried to heaven in a chariot of fire. The belief that he would return to earth, combined with the Messianic doctrine, led to his identification in the New Testament with *John the Baptist, Christ's forerunner.

Elion, Gertrude ('Trudy') Belle (1918-1999). American pharmacologist, born in New York. Of Lithuanian-Polish-Jewish descent, she studied at Hunter College and New York University, worked as a secretary, in schools and a supermarket, and became a researcher with Burroughs Wellcome 1944-83, collaborating with George ${ }^{*}$ Hitchings. A pioneer of rational drug design, analysing purines, she developed allopurinol (Zyloprim) to reduce the impact of gout, which was widely adopted from 1966. Other drugs included AZT, used to treat HIV/AIDS, and the immunosuppressant azathioprine. She shared the Nobel Prize for Medicine in 1988 with Hitchings and James *Black.

Eliot, George (pen name of Mary Ann Evans, from 1851 Marian) (1819-1880). English novelist, born in Warwickshire. Daughter of an estate agent she left school at the age of 16, when her mother died, and while looking after her father's household studied Latin, Greek, German and Italian under visiting teachers. She was brought up as a strict evangelical but at the age of 22 reacted violently against religion. After her father's death she went to London and became assistant editor (1851-53) of the Westminster Review under John Chapman, at whose home she lodged. While there she met Herbert *Spencer who introduced her to George Henry *Lewes, a versatile literary journalist who had written a well known history of philosophy and was preparing a biography of ${ }^{*}$ Goethe. When she met him he was living apart from his wife but was unable to obtain a divorce. Mary Ann and he lived happily together from 1854 until his death (1878). Hitherto, her published literary work had been confined to translations from the German but the encouragement of Lewes, who had seen and liked her story 'Amos Barton', which appeared later with two others as Scenes from Clerical Life under her pseudonym George Eliot, decided her career. The novels which followed are considered among the greatest of their epoch. Social criticism and moral values are seldom lost sight of and her wide knowledge is a constant spur to the intellect, but it is the humour, compassion and understanding with which she builds up and probes her characters that give her novels their unique and lasting value. Adam Bede appeared in 1859, followed by The Mill on the Floss (1860), Silas Marner (1861), Romola (1863), set in Renaissance Florence, Felix Holt (1866), Middlemarch (1872) and, last and least successful, anticipated Zionism and the creation of Israel. Minor works include a dramatic poem, The Spanish Gipsy (1868). In the year of her death she married John Walter Cross (1840-1924), an old friend of Lewes and herself.

Laski, M., George Eliot and Her World. 1973; Karl, F., George Eliot. 1995.

Eliot, Sir John (1592-1632). English parliamentarian. He entered Parliament in 1614. Originally a protégé of the King's favourite, *Buckingham, he later turned against him and took part in his impeachment. He opposed ${ }^{*}$ Charles I's forced loans and was instrumental in obtaining assent to the Petition of Right (1628). In 1629, with eight other members, he was sent to the Tower of London where he died. He left several manuscript works, including The Monarchie of Man, paradoxically, a defence of kingship.

Hulme, H., The Life of Sir John Eliot. 1957.

Eliot, T(homas) S(tearns) (1888-1965). AngloAmerican poet, critic and playwright, born in $\mathrm{St}$ Louis, Missouri. He studied philosophy at Harvard, the Sorbonne (with *Bergson) and Oxford. He taught at schools and at Birkbeck College in London, worked at Lloyd's Bank 1917-25, then became an editor with the publishers Faber and Gwynne, later Faber and Faber, where he became a director. From 1915 he was unhappily married to Vivien Haigh-Wood (18881947), a gifted woman who suffered from a variety of mental and physical problems.

His early poetry, e.g., The Love Song of J. Alfred Prufrock (1917), is sometimes satirical and often appears flippant:

I grow old ... I grow old ...

I shall wear the bottoms of

my trousers rolled.

Influenced by Charles *Maurras and the writings of Henry *Adams, he became conservative, authoritarian and anti-Semitic, rejecting the values of modern secular society. This was reinforced by the waste, disruption and upset of values caused by World War I. This is most apparent in Gerontion (1920) and in his longest poem The Waste Land (1922). Broadly based on the theme of the Holy Grail it is characterised by deep disillusion with contemporary spiritual blindness. The poem, edited and cut by his friend Ezra *Pound, uses quotations from or allusions to 31 authors in six languages.

April is the cruellest month, breeding

Lilacs out of the dead land, mixing

Memory and desire, stirring

Dull roots with spring rain. The Waste Land

He edited the literary journal Criterion for its entire life 1922-39. In 1927 he converted from Unitarianism to the Church of England, describing himself as 
an Anglo-Catholic, and became a British subject. After the 1930s Eliot's poetry became increasingly metaphysical and the religious influences, especially in the case of Christian symbolism, are more apparent. Pessimism has been replaced by 'penitential hope' e.g. in Ash Wednesday (1930) and Four Quartets (1943), philosophical poems which echo ${ }^{*}$ Beethoven's late compositions.

We shall not cease from exploration

And the end of all our exploring

Will be to arrive where we started

And know the place for the first time.'

'Little Gidding', from Four Quartets

His witty Old Possum's Book of Practical Cats (1939) was later dramatised in Andrew *Lloyd W *Lloyd Webber's musical Cats (1981). As essayist and critic he had gained a great and increasing influence especially in reviving interest in ${ }^{*}$ Dryden and metaphysical poets such as ${ }^{*}$ Donne. Lectures, as Charles Eliot Norton professor of poetry at Harvard, were reprinted as The Use of Poetry and the Use of Criticism (1933). Yet a third reputation awaited him as a dramatist. The Rock (1934), written as the words of a Church pageant, was followed by the verse drama Murder in the Cathedral (1935). After World War II he adapted verse drama to contemporary themes (with allegorical significance) in the very successful The Cocktail Party (1950), The Confidential Clerk (1954) and The Elder Statesman (1958). In 1948 Eliot was awarded the OM and the Nobel Prize for Literature.

Ackroyd, P., T. S. Eliot. 1984.

Elisabeth (Elisabeth Amalie Eugenie von HabsburgLothringen, née von Wittelsbach) (1837-1898). Empress consort of Austria, Queen consort of Hungary 1854-98. Born in Munich, to a branch of the Bavarian royal family, known as 'Sisi' or 'Sissi', and a great beauty, she married the emperor *Franz Joseph in 1854 , but her lively and wayward nature found the formality of court life in Vienna increasingly irksome. An expert equestrienne, accomplished linguist and aspiring poet, she spent much time in France, Italy, England and Switzerland and built herself a palace on Corfu. In 1889 her only son, *Rudolf, was found dead with his mistress, Marie Vetsera, in a shootingbox at Mayerling. She was stabbed to death by an anarchist, Luigi Lucheni, in Geneva. She appears as a character in many books and films.

Haslip. J., The Lonely Empress. 1965, repr. 1987.

Elisabeth (Elisabeth Gabriel Valérie Marie de Belgique, née von Wittelsbach) (1876-1965). Queen consort of the Belgians 1909-34. A Bavarian duchess, named for her aunt, the Empress of Austria, she married *Albert, later King of the Belgians, in 1900. She worked as a nurse, became a patron of the arts, especially music, was a friend of *Einstein, helped Jews to escape during the German occupation, andknown as 'the Red Queen'-supported some radical causes and visited Russia and China.
Elizabeth (Erzebét), St (1207-1231). Hungarian princess in Germany. Daughter of András II, King of Hungary, she was brought up at the court of the Landgrave of Thuringia, to whose son she was betrothed at the age of 4 . Though the court at the Wartburg was famed for its gatherings of poets and minstrels, she gave herself up, from childhood, to religious austerity and charity. When 14 she married and, under her influence, her young husband went on a crusade but died on the way. Elizabeth, expelled from court for wasting the revenues on charity, went to Marburg where, encouraged in an overstrict asceticism by a harsh confessor, she soon died. She was canonised in 1235 .

Elizabeth I (1533-1603). Queen of England and Ireland 1558-1603. Born in Greenwich, daughter of *Henry VIII and *Anne Boleyn, on her mother's execution Henry declared her illegitimate, but his will reinstated her in the line of succession. Before she came to the throne, either from compulsion or from prudence, she remained in studious retirement but she was for a time imprisoned in the Tower of London and later confined by her half-sister *Mary I, at Woodstock, on suspicion of being involved in *Wyatt's rebellion (1554). Highly intelligent, she had good teachers (mostly exponents of Erasmian 'new learning' e.g. Roger *Ascham) and was proficient in Latin, Greek and the Romance languages. Basically indifferent in matters of religion, when she came to the throne on Mary's death she favoured a conciliatory religious policy: her aim was to be governor of a Church whose doctrines would be acceptable to all but the most extreme. But she realised that to strengthen her position she must range herself with the Protestant rulers in Europe although her aim was to secure peace and prosperity and avoid foreign entanglement. Her Church Settlement was based on parliamentary statute (1559). Within three days of her accession she made William Cecil, later Lord *Burghley, her chief secretary, and she relied on his sage judgment until he died (1598). One crucial decision was expected of her-to choose a husband and to provide the country with an heir. Despite many suitors this she never did. Her sister's widower *Felipe II of Spain was an early suitor and well into her middle age others appeared, including two of ${ }^{*}$ Catherine de'Medici's sons, Henri, Duc d'Anjou (later ${ }^{*}$ Henri III) and François, Duc d'Alençon. Her attitudes to her suitors were highly ambiguous. Her inclinations turned to Robert Dudley, Earl of *Leicester, who remained at her side and served her at court and in the field, but she did not marry him. Known as the Virgin Queen (Walter *Raleigh named the colony of Virginia to honour this attribute), she was preoccupied with matrimonial schemes or affairs of apparent passion from her teens to her fifties. The heir to her throne was *Mary, Queen of Scots, who, expelled from her own country, had taken refuge in England. Too dangerous to be left at large she was confined to a succession of country houses from 1568 , the centre of 
many plots to kill Elizabeth which the indefatigable Francis *Walsingham unravelled. In 1580 Pope ${ }^{*}$ Gregory XIII proclaimed that eliminating Elizabeth would not be a sin and she felt exposed after the murder of her ally *William the Silent in 1584. Under pressure from Parliament and her Council, Mary was tried and convicted of treason, and Elizabeth signed a death warrant (1587). She later protested that she had not intended the sentence to be executed; but it was. Meanwhile captains ${ }^{*}$ Drake, ${ }^{*}$ Frobisher and ${ }^{*}$ Hawkins carried out piracy and undeclared war against the merchant fleets and overseas possessions of Spain with the queen's tacit approval. In 1588 Felipe of Spain organised a vast Armada to overwhelm England (while the parsimonious Elizabeth delayed her own preparations) which her sea captains, with their superior gunnery and tactics, put to rout. The defeat of the Armada did not mean the end of the war with Spain, which became one of attrition, lasting until her successor *James I made peace (1604). Late in the 1590s there was an Irish uprising, and in 1601 the Earl of *Essex, a former favourite, attempted an unsuccessful rebellion. But the period was also one distinguished by an unrivalled flowering of literature, especially drama ( ${ }^{*}$ Shakespeare, ${ }^{*}$ Marlowe). Elizabeth said of herself that she had 'the heart and stomach of a king' but she was also vain and capricious, could be fickle and even callous. Yet she had a gift for holding the affection and esteem of her subjects and for choosing wise advisors.

Neale, J. E., Queen Elizabeth I. 1971; MacCaffrey, W., Elizabeth I. 1993.

Elizabeth II (Elizabeth Alexandra Mary Windsor) (1926-2022). Queen of the United Kingdom and Head of the Commonwealth 1952-2022. Born in London, elder daughter of the Duke and Duchess of York (later King *George VI and Queen *Elizabeth), she was educated privately, and during World War II was commissioned in the Auxiliary Territorial Service. In November 1947 she married Lt Philip Mountbatten, Duke of *Edinburgh. Their children were ${ }^{*}$ Charles, Prince of Wales (b.1948), *Anne (b.1950), *Andrew (b.1960) and Edward (b.1964). On a visit to Kenya she heard of the sudden death of her father and her own accession (February 1952). She was crowned at Westminster Abbey in June 1953. In the course of her duties she toured every part of the Commonwealth and entertained many heads of state. Horse racing was prominent among her leisure interests and she was a successful owner. Her Silver Jubilee was celebrated in 1977 and she remained personally popular. The 'annus horribilis' of 1992 was marked by intense media scrutiny of the failed marriage of Charles, Prince of Wales and *Diana, a fire at Windsor Castle and the ending of tax exemption. In September 2015 she became the longest-reigning British monarch, passing Queen *Victoria. The Duke of Edinburgh died in April 2021, during the Covid pandemic. The queen's Platinum Jubilee in 2022 marked a reign of 70 years (close to ${ }^{*}$ Louis XIV).
Lacey, R., Majesty. 1977; Pimlott, B., The Queen: A Biography of Elizabeth II. 1996; Bradford, S., Queen Elizabeth II: Her Life in Our Times. 2012.

Elizabeth (Elizabeth Stuart, later Wittelsbach) (1596-1662). Queen of Bohemia 1619-20. Daughter of James VI of Scotland (*James I of England), she provided the future link between the Stuart and Hanoverian dynasties. In 1613 she married *Frederick $\mathrm{V}$ of the Palatinate and after his brief period as King of Bohemia (1619) she was known as the 'Winter Queen'. After their expulsion the family lived in Holland. Among her 13 children were the dashing Prince ${ }^{*}$ Rupert, and ${ }^{*}$ Sophia who married Ernst August, later elector of Hanover, and became the mother of Great Britain's *George I. Elizabeth, who returned to England after ${ }^{*}$ Charles II's restoration, was a vivacious fascinating creature who became known as the Queen of Hearts, the subject of a famous poem by Sir Henry *Wotton.

Elizabeth (Elizabeth Angela Marguerite, née Bowes-Lyon) (1900-2002). British queen consort 1936-52, known as the Queen Mother. Born in London, daughter of the 14th Earl of Strathmore and Kinghorne, she was educated by governesses. In 1923 she married Albert, Duke of York, later King *George VI and had two daughters, *Elizabeth (b.1926) and *Margaret Rose (b.1930). She retained her popularity well into her 10th decade and was the longest lived of British queens. Lord Warden of the Cinque Ports 1978-2002, she became the royal family's first centenarian on 4 August 2000.

Elizabeth (author of Elizabeth and her German Garden) see Arnim, Elizabeth von

Elizabeth of York (1465-1503). English queen consort 1486-1503. Daughter of *Edward IV, by her marriage to ${ }^{*}$ Henry VII she linked the dynasties of York and Lancaster. She is said to have died of grief at the death of her elder son, Arthur.

Elizabeth (Yelizaveta) Petrovna (1709-1762). Tsarina (Empress) of Russia 1741-62. Daughter of *Peter the Great and his second wife, Empress ${ }^{*}$ Catherine I, she became empress after a group of guards officers had deposed the infant Ivan VI. She built the Winter Palace in St Petersburg and introduced French culture and language into court circles. When the Seven Years War broke out (1756) she joined the Franco-Austrian alliance against ${ }^{*}$ Friedrich II (the Great) of Prussia, a policy reversed by her nephew and successor, *Peter III. She never married.

Ellenborough, Edward Law, 1st Baron (17501818). English lawyer. He made a great name for himself by his defence of Warren *Hastings during his long impeachment (1788-95), became AttorneyGeneral 1801-02 and Lord Chief Justice 1802-18. His judgments were an odd mixture: harsh and progressive. His son Edward Law, 1st Earl of 
Ellenborough (1790-1871) was President of the Board of Control for India 1828-30, 1834-35, 1841, 1858; and Governor-General of India 1842-44. His term in India was brief, controversial and violent. Despite instructions to withdraw from Afghanistan, he directed his forces to occupy Kabul (1842), annexed Sind (1842) and conquered Gwalior (1844). Dismissed by the East India Company, he was created earl on his return to England and campaigned for India to be controlled directly by the Crown.

Ellet, Charles (1810-1862). American engineer, born Penn's Manor, Penn. He worked for three years as a surveyor and assistant engineer, then studied at the École Polytechnique, Paris, and travelled widely in Europe, returning to the US in 1832. In 1842 he completed the first wire suspension bridge in the US, at Fairmount, Pennsylvania and between 1846-49 redesigned and built the world's first longspan wire cable suspension bridge, over the Ohio River at Wheeling, with a central span of 308 metres $(1,010$ feet). It failed in 1854 due to aerodynamic instability. He invented naval rams and in the US Civil War he equipped nine Mississippi river steamboats as rams, which defeated a fleet of Confederate rams. He died in the battle.

Ellington, 'Duke' (Edward Kennedy) (1899-1974). American composer, pianist and bandleader, born in Washington DC. Grandson of a slave, he worked in 'swing', but primarily in jazz, achieving national recognition from 1927 at the Cotton Club in Harlem. He composed about 900 works, including Mood Indigo; Don't Get Around Much Any More; Black, Brown and Beige; and the ballet The River. He made many recordings, toured constantly with his big band, appeared in a few films and on television, and wrote some film scores. He was recognised on a coin and a stamp, and received the Presidential Medal of Freedom (1969), 15 Emmys and a posthumous Pulitzer Prize.

Lambert, G. E., Duke Ellington. 1959; Hasse, J. E., Beyond Category: The Life and Genius of Duke Ellington. 1995; Teachout, T., Duke. 2015.

Ellis, (Henry) Havelock (1859-1939). English writer. He taught in rural New South Wales 187579 , then studied medicine in London and devoted himself to a scientific analysis of sex, leading to his pioneering work, Studies in the Psychology of Sex, published from 1898 onwards. Among his other works were a series of books on science (1889-1914) and essays on Elizabethan and Jacobean drama.

Calder-Marshall, A., Havelock Ellis: A Biography. 1959.

Ellroy, James (1948- ). American novelist. His dark crime novels include L.A. Confidential (1990), American Tabloid (1995), and My Dark Places (1996).
Ellsworth, Lincoln (1880-1951). American explorer. In 1926 he flew over the North Pole with Amundsen and Nobile in the airship Norge. He made a pioneering flight over Antarctica in 1935.

Elssler, Franjziske (or Fanny) (1810-1884). Austrian dancer. One of the most celebrated of 19th-century dancers, she was regarded as the chief rival of *Taglioni and, whether she was performing in London, Paris or America, she was equally acclaimed. She was seen at her best in Spanish dances, which demanded the particular exuberance for which she was famed.

Guest, I., Fanny Elssler, The Pagan Ballerina. 1970.

Elyot, Sir Thomas (c.1490-1546). English humanist, translator, essayist and lexicographer. He worked with *Wolsey as Clerk of the Privy Council 1523-30 and envoy to the Emperor ${ }^{*}$ Charles V 1531 but was ambiguous about major changes in the relationship of church and state. His great enthusiasm was for the use of the vernacular in public documents. The Boke Named the Governour (1531) set out a system of popular education for the gentry stressing their social and political role. A translator and coiner of new words (e.g. 'encyclopaedia'), he compiled a Latin into English dictionary (1536).

Elzevir, Louis (c.1540-1617). Dutch printer. His family became famous printers for many generations in Leyden. His son Bonaventura Elzevir (1583-1682), who took his nephew Abraham into partnership, produced (1634-36) beautiful editions of the classics, ${ }^{*}$ Caesar, ${ }^{*}$ Livy, ${ }^{*}$ Tacitus, etc. Other members of the family established themselves in Amsterdam where they produced a famous French Bible (1669).

Emerson, Ralph Waldo (1803-1882). American essayist and poet, born in Boston. One of six children of a Unitarian minister, on his father's death (1811) he was brought up by his mother and an intellectual aunt. Educated at Harvard, like his father he joined the ministry, but after his first wife died he abandoned it in 1832. He travelled in Europe and in England (1833), met *Wordsworth, ${ }^{*}$ Coleridge and other writers, finding a kindred spirit and lasting friend in ${ }^{*}$ Carlyle. After returning to America, he settled in Concord and in 1835 married Lydia Jackson. In Nature (1836) he set out his philosophy of transcendentalism, developed after years of study, including elements of German idealism, Greek and Hindu culture, centred on the concept of the immanence of the divine in the real world, linked with pantheism, celebrating individualism, rejecting materialism and empiricism. His essays were deeply influenced by ${ }^{*}$ Montaigne. His later works, for example Representative Men (1850), were often based on his notes for the long series of popular lectures for which he became famous. He regarded himself primarily as a poet but is chiefly remembered for his essays on politics, religion and literature. He was also 
an active abolitionist. He influenced *Whitman and *Thoreau, was noticed by ${ }^{*}$ Nietzsche, but irritated ${ }^{*}$ Melville, Henry *James and T. S. *Eliot. The Conduct of Life (1860) summarises and clarifies, in a series of essays, his philosophic views on such subjects as worship, fate, power, etc. Later essays are contained in, for example, Society and Solitude (1870). His Journals were published in 1909-14.

Richardson, R. R., Emerson. The Living Fire. 1995.

\section{Eminence Grise see Joseph, Père}

Emin Pasha, Mehmed (Eduard Schnitzer) (18401892). German doctor and explorer. He remained in the Equatorial province of Sudan after the death of *Gordon, whom he had served. He was eventually killed by Arab slave traders about $160 \mathrm{~km}$ east of Stanley Falls.

Emmet, Robert (1778-1803). Irish patriot. A Protestant radical, he joined the United Irishmen while still at Trinity College, Dublin. Compelled to leave, he went to France but returned (1802) convinced that he would have French support for an Irish rising. This, when it took place (1803), was premature and ineffective. Fifty men were killed and Emmet himself was betrayed, condemned and executed.

Landreth, H., The Pursuit of Robert Emmet. 1948.

Empedocles (c.493-433 BCE). Greek philosopher, born in Sicily. In his theory of matter he postulates four indestructible elements, fire, air, water, and earth, of which, variously blended and compounded, all material substances are composed. He also worked out an important system of sense perception. His long poems, On Nature and Purification, in which his philosophic and religious theories were set out only survive in part. The legend ascribing his death to a fall or plunge into the crater of Mount Etna has attracted several writers: ${ }^{*}$ Milton, ${ }^{*}$ Meredith, and Matthew *Arnold (Empedocles on Etna, 1852) refer variously to the theme.

Empson, Sir William (1906-1984). English literary critic and poet, born in Yorkshire. Educated at Winchester and Magdalen College, Cambridge, he studied mathematics and English with I. A. *Richards. His first book Seven Types of Ambiguity (1930), argued that the multiplicities of meaning in literature arose from ambiguities in the language used, drawing on *Freud and *Marx, and became an influential text of New Criticism. He taught English literature at the universities of Tokyo 1931-34, Beijing 1937-39, 1947-52 and Sheffield 1953-71 and worked for the BBC during World War II. His terse, witty, complex and emotional poetry was published in Poems (1930) and The Gathering Storm (1940) and he wrote studies of *Shakespeare and *Milton.

Haffenden, J., William Empson, 2 vols, 2005, 2006.
Enders, John Franklin (1897-1985). American bacteriologist. He studied English literature at Harvard, then turned to bacteriology, joined the faculty of the Harvard Medical School in 1932, worked at the Boston Children's Hospital and became a full professor only in 1956. In 1954 he shared the Nobel Prize for Medicine with T. H. Weller and F. C. Robbins for their discovery of the ability of the poliomyelitis virus to grow in cultures of different tissues. This led to the discovery of *Salk's polio vaccine. He also helped to develop a vaccine against measles (1962).

Enescu, George (Georges Enesco in France) (18811955). Romanian composer, conductor, violinist, pianist and teacher. He studied in Vienna (graduating at 13) and Paris, with ${ }^{*}$ Massenet and ${ }^{*}$ Fauré. He wrote a powerful Octet for strings (1900). His two Romanian Rhapsodies (1901), strongly influenced by folk music, were an instant success, which he came to regret. He conducted frequently in the US and became the teacher of Yehudi *Menuhin. He wrote two symphonies, piano sonatas and the opera Edipe (1931). Pablo *Casals described Enescu as 'the greatest musical phenomenon since Mozart'.

Engels, Friedrich (1820-1895). German socialist, born in Barmen. Son of a cotton manufacturer, he became (1842) the Manchester agent of his father's business and collected information for his The Condition of the Working Classes in England (1844). Meanwhile his lifelong friendship with *Marx had begun. In 1845 he gave up his business to be with him and they jointly produced the famous Communist Manifesto (1848) in London. Thereafter he sustained Marx with constant financial support, even reentering the business to do so and, when after his father's death he finally sold his partnership (1870), he joined Marx in London and stayed with him until he died (1883). The remaining years of his life were spent in editing and translating Marx's works. His The Origin of the Family, Private Property and the State (1884, English translation 1902) touches on what he called 'the woman problem'. Simone de *Beauvoir thought it superficial.

Mayer, G., Friedrich Engels. 1969; Green, J., Engels. A Revolutionary Life. 2008; Hunt, T., The FrockCoated Communist. The Revolutionary Life of Friedrich Engels. 2009.

Enghien, Louis Antoine Henri de Bourbon, Duc d' (1772-1804). French soldier. Eldest son of the Prince de Condé and related to the French royal family, he left France in 1792 during the Revolution to join the emigré army. In 1804 *Napoléon, on the assumption or pretence that he was implicated in a conspiracy, sent agents to abduct him from neutral territory and had him tried and executed. The effect upon Napoléon's reputation proved it to be a blunder as well as a crime. 
English, Sir Bill (né Simon William) (1961- ). New Zealand National politician. A farmer and public servant, he was twice Leader of the National Party 2001-03; 2016- , served as John *Key's Deputy and Finance Minister 2008-16 and succeeded him as Prime Minister 2016-17, losing office after Winston *Peters formed a coalition with Labour.

Ennius, Quintus (239-169 BCE). Latin poet. $\mathrm{He}$ wrote 22 tragedies, borrowing his themes mainly from *Euripides, and his Annals, written in hexameters, which relate the history of Rome from earliest times. Only fragments of his works survive.

Ensor, James, Baron (1860-1949). Belgian painter. His father was English but he spent almost all his life at Ostend. His grotesque and satirical pictures, reminiscent of ${ }^{*}$ Bruegel and ${ }^{*}$ Bosch but painted in the technique of ${ }^{*}$ Manet or ${ }^{*}$ Courbet, gained recognition very slowly, but in 1929 he was created a baron. Among his best known pictures were Christ's Entry into Brussels in 1889 (1888) and Dangerous Cooks (1896). He often painted masquerades and skeletons, and was a forerunner of Expressionism.

Tannenbaum, L., James Ensor. 1951.

Enver Pasha (1881-1922). Turkish soldier and politician, born in Istanbul. As a leader of the 'Young Turks' he was prominent in the revolution of 1908 which restored the 1876 constitution. In 1913 he led a coup d'etat, resulting in power passing to a proGerman triumvirate of *Taalat Pasha, Jamal Pasha and himself. As War Minister 1914-18 he brought the Ottoman Empire into World War I on Germany's side and with Talaat, bears main responsibility for the genocide of between 0.8 and 1.5 million Armenians from 1915. He was a political opponent of Mustafa Kemal (*Atatürk). He fled to Russia in 1918. Sent to Turkestan to establish Bolshevik power, he raised a revolt in his own interest and was murdered by Soviet agents in Bukhara.

Eötvös, Péter (1944- ). Hungarian composer and conductor. He studied with *Stockhausen, and his works include Psychokosmos (1993), for chamber orchestra, and the opera The Three Sisters (1998), based on *Chekhov.

Epaminondas (d.362 BCE). Theban soldier and statesman. He destroyed Spartan supremacy by his victory at Leuctra (371) in Boeotia and subsequent march south. He built a fleet to keep that of the Athenians in check and one more success against them would probably have enabled him to achieve his aims. Such victory was achieved (362) at Mantinea in the Peloponnese but at the cost of his life. But for his death at the moment of final victory he might have achieved his statesmanlike vision of a federation of all Greece.
Epictetus of Hierapolis (c.55-135 CE). Greek Stoic philosopher, born in Phrygia. A freed slave, he went to Rome to teach but was banished, with other philosophers, by ${ }^{*}$ Domitian and settled in Eporus. His moral view was that one ought to escape the slavery of desire and so become free to act in accord with divine providence. His maxims were collected by his pupil Arrian in the Enchiridion and in eight books of commentaries.

Epicurus (c.342-270 BCE). Greek philosopher, born in Samos. He founded the Epicurean system, the great rival of Stoicism in the Graeco-Roman world. He first opened a school at Mytilene in 310 but moved it to Athens in 306. Epicureanism, in which the senses, the only arbiters of reality, are judged infallible, has been widely misunderstood since it equates 'pleasure' with moral good. Pleasure, however, Epicurus regards as absence of pain in matters concerned with ethics and morals, an untroubled mind, a state only to be reached through the practice of virtue. He both practised and preached moderation in physical pleasures. Epicurus adapted the atomic theory of ${ }^{*}$ Democritus to the needs of his own system, e.g. by postulating that some soul atoms may depart from strict mathematical precision and swerve in their paths, thus allowing for free will. Little remains of his writings, but his doctrines were presented by the Roman poet ${ }^{*}$ Lucretius in the philosophical poem De rerum natura.

Epimenides of Knossos (fl. c.600 BCE). Cretan philosopher. Epimenides' paradox, 'All Cretans are liars', demonstrates a self-referential problem in logic that contributed to developments in mathematics and computing in the 20th century. Kurt ${ }^{*}$ Gödel discussed it in his 'incompleteness theorem' (1931).

Hofstadter, D. R., Gödel, Escher, Bach: An Eternal Golden Braid. 1980.

Epstein, Sir Jacob (1880-1959). American-British sculptor, born in New York. Of Jewish-RussianPolish parentage, he lived in England from 1905. His massive monumental pieces, in which distortion is used as a conscious technique for purposes of composition or emphasis, aroused at first much public protest. They include Oscar *Wilde's tomb in Paris (1912), Rima, a memorial to W. H. *Hudson in Hyde Park (1925), Genesis, a stone carving of a pregnant woman (1931), Ecce Homo a controversial figure of Christ (1933), and Adam (1938-39). Christ in Majesty, for Llandaff Cathedral (1957) and Victory over the Devil, at Coventry Cathedral (1958) are very powerful. He made vigorous and realistic bronze busts, in the manner of ${ }^{*}$ Rodin, of such celebrities as *Shaw, *Einstein and ${ }^{*}$ Churchill.

Buckle, R., Jacob Epstein, Sculptor. 1963; Gardiner, S., Epstein. 1993. 
Erasmus, Desiderius ('the desired beloved', originally Geert Geerts) (1466?-1536). Dutch humanist scholar and theologian, born probably in Rotterdam. He was the illegitimate son of a clerk Rogier Geert (or Gerard) in whose home at Gouda he was brought up. After the death of his father (1484) his guardians induced him to enter an Augustinian monastery, an experience which left him with a deep dislike of monastic life. Later he became a secular priest and was secretary to the Bishop of Cambrai, who sent him (1495) to the University of Paris where he acquired an unrivalled command of Latin. He remained in Paris to teach until invited by one of his pupils to visit England (1499-1500), where he first gained the friendship of Thomas ${ }^{*}$ More and John ${ }^{*}$ Colet. A second brief visit (1505-06) followed and after some years in Italy he was invited to return once more and became a Reader in Greek and Fellow of Queen's College, Cambridge 1511-14. He spent the years 1514-21 mainly in Basle, and from 1517 was in Louvain where the introduction of the new humanist studies gained his approving encouragement. Already he had written his most notable work, Adages, a collection of classical proverbs (1500), Praise of Folly (1509), a witty and satirical attack on the corruption, ignorance and superstition of both society and the Church, and Colloquies (1519) a collection of dialogues, which incidentally throw much light on his own life and convey a vivid and detailed picture of the times he lived in. In 1516 appeared his edition of the Greek text of the New Testament together with a Latin translation. After leaving Louvain he returned to Basle where he spent most of the rest of his life engaged in violent religious controversies, letter writing and preparing critical editions of the works of early Fathers of the Church such as St *Jerome and St *Augustine. He often attacked the shortcomings of the clergy and abuses within the Church but he refused to join *Luther's schismatic movement and constantly appealed for moderation. Erasmus, witty and provocative, but not an original thinker or writer, stood for reasoned debate and examination, opposing confrontation. His influence among contemporary scholars and theologians of his day was immense and no one of his time was held in greater esteem.

Bainton, R. H., Erasmus. 1970; Jardine, L., Erasmus, Man of Letters. 1993.

Erastus (originally Lüber or Liebler), Thomas (15241583). German-Swiss theologian and philosopher. A qualified physician, he went to Heidelberg University as professor of medicine (1557), then to Basle (1580). A follower of the Protestant reformer *Zwingli, he denied that excommunication, whether the sentence was imposed by the Pope or, for example, Presbyterian elders, was valid, claiming that the state has supreme authority over a Church in matters (except those concerned with doctrines) arising within its boundaries. This tenet (known as Erastianism) was later used to justify complete subordination of ecclesiastical to secular authority.
Eratosthenes (c.276-194 BCE). Greek astronomer, born in Cyrene (Shahat, Libya). He was employed by *Ptolemy III as librarian at Alexandria. He reasoned that the earth was a sphere and made one of the first estimates of its circumference by measuring the angle of the shadow cast by the sun at different points. His other contributions to science include a work on chronology and a treatise on geography which was used by *Strabo. Blind and tired of life, he is said to have starved himself to death.

Erckmann-Chatrian. French literary partnership of Emile Erckmann (1822-1899) and Alexandre Chatrian (1826-1890). They both came from Lorraine, and some of their stories and novels reveal their local associations; others recall the macabre fantasies of Edgar Allan *Poe. The best known, e.g. Histoire d'un conscrit (1864) and Waterloo (1865), present a common soldier's attitude to the Revolutionary and Napoléonic wars.

Erdoğan, Recep Tayyip (1954-). Turkish politician, born in Istanbul. Mayor of Istanbul 1994-98, he was imprisoned briefly for breaking rigid anticlerical laws and in 2001 he founded the Justice and Development Party (AK Parti), a moderate Islamist group, critical of the *Atatürk secularist tradition. He was Prime Minister of Turkey 2003-14. He maintained diplomatic relations with Israel, denounced the *Assad regime in Syria and sought close ties with the US. Massive protests in Istanbul against the AKP by radicals and secularists in June 2013 were violently suppressed by police. Erdoğan was elected as President of Turkey 2014- after the office was changed to provide for direct popular voting.

Following a referendum in 2017, an executive Presidency was created and after Erdoğan's re-election in June 2018 the regime became increasingly authoritarian and Islamist. Aya Sofia became a mosque again in 2020. In 2021 he protested at *Biden's characterisation of the Armenian massacres in 1915 as 'genocide'.

Erdös, Pál (1913-1996). Hungarian mathematician, born in Budapest. A child prodigy, in 1934 he left Hungary for Britain, then to the US in 1938, and later Israel, becoming notorious as an eccentric itinerant, publishing 1525 papers with 511 collaborators. He wrote important papers on phase transitions, complexity theory, probability, and prime numbers, won the Wolf Prize for Mathematics in 1985, was elected FRS in 1996 and died attending a conference in Warsaw. Hoffman, P., The Man Who Loved Only Numbers.
1998.

Erhard, Ludwig (1897-1977). German economist and Christian Democratic politician. $\mathrm{He}$ was a teacher and later director of the Nuremberg Trade High School 1928-42. Entering politics in 1945, he was Bavarian Minister for Economic Affairs (1946), 
Economic Director in the American and British zone of occupation 1947-49 and, under Chancellor *Adenauer, became Federal Minister for Economic Affairs 1949-63. He was an ardent advocate of competitive 'free market' economy and gained wide praise for his major contribution to the remarkable postwar recovery (the 'economic miracle') of West Germany. He succeeded Adenauer as Chancellor of the German Federal Republic 1963-66.

Eric the Red (c.950-c.1003). Norse explorer. According to the Icelandic saga that bears his name, he was banished from Iceland (982) on a charge of homicide, then, again outlawed, he discovered and named Greenland, and spent three years (982-985) exploring the southwest coast. He established two colonies there that survived until the 14 th century. His son was * Leif Ericcson.

Ericsson, John (né Johan) (1803-1889). SwedishAmerican engineer and inventor. He invented a hot-air engine and moved to England in 1826 to exploit it, remaining there 13 years. His locomotive Novelty competed (unsuccessfully) with *Stephenson's The Rocket. His outstanding contribution was his screw propeller for ships (patented 1836). In 1839 he went to the US where he applied his propeller to merchant and war ships. $\mathrm{He}$ is particularly remembered for designing the Monitor, a new type of turreted ironclad warship with very low free-board which proved its worth in the Civil War. In his later years he constructed a sun-motor.

Erigena, Johannes Scotus (c.810-870). Scots-Irish theologian and philosopher. He became head of a school at the court of the Frankish king *Charles the Bald. He was deeply versed in Platonism and derived from it the doctrine that all that exists emanates from a divine source. His attempt to reconcile Greek sources with the Bible and works by the Christian Fathers was later misunderstood and he was denounced by the Council of Paris (1210) and by Pope Honorius III (1225). Erigena's work prepared the way for medieval scholasticism.

Erlander, Tage Fritiof (1901-1985). Swedish Socialist politician. Originally a journalist, he worked on an encyclopaedia for nine years, and entered the Riksdag in 1933. He initiated major educational reforms, and was Prime Minister of Sweden 1946-60, a period of great prosperity.

\section{Ernst August, King of Hanover see Cumberland, Ernest Augustus, Duke of}

Ernst, Max (1891-1976). German artist, born in the Rhineland. With *Arp, he brought Dadaism (191622) from Paris to Cologne. With Arp, too, he made the transition to Surrealism. In his earlier work he had made much use of frottages. i.e. rubbings taken from, e.g., floorboards or any surface that would create interesting patterns, and collages, pictures composed of pieces of paper, cloth etc. stuck to a background, not so much for their plastic value as to combine disparate, anecdotal elements. For his later Surrealistic work he developed the techniques of painting. His paintings, more perhaps than those of any of his Surrealist contemporaries, evoke the emotional atmosphere of dreams.

Waldberg, P., Max Ernst. 1958.

Erskine, Thomas Erskine, 1st Baron (1750-1823). Scottish advocate and politician, born in Edinburgh. Son of the Earl of Buchan, he served in the navy and army, studied at Trinity College, Cambridge, was called to the bar in 1778, and rapidly won a great reputation. In 1779 he successfully defended Admiral Augustus Keppel, who was charged with incompetence, and in 1781 secured the acquittal of Lord George *Gordon, who was charged with treason following the riots that bear his name. He was a Whig MP 1783-84, 1790-1800, 1801-06. Some of his later defences of unpopular characters, such as Tom *Paine, cost him temporary loss of favour. In 1806-07 he was Lord Chancellor. He advocated the emancipation of black slaves, and in the 1820s he supported the independence of Greece, Queen *Caroline's cause and campaigned against animal cruelty.

Erté (né Romain de Tirtoff) (1892-1990). RussianFrench designer and artist, born in St Petersburg. In Paris from 1912, he was a prolific designer of sets and costumes for opera and ballet, then turned to furniture, posters, lithography and fashion.

Esarhaddon (d.669 BCE). King of Assyria 681669 BCE. After succeeding his murdered father *Sennacherib, he appeased the Babylonians by rebuilding their city and making it into a second capital. In 675 he attacked Egypt and annexed the Nile Delta. It was while advancing to put down a rebellion there that he died. His son *Ashur-bani-pal was the last of the great Assyrian kings.

Esau. Old Testament character, son of *Isaac and Rebecca, elder twin of ${ }^{*} \mathrm{Jacob}$, and ancestor of the Edomites according to Hebrew tradition. His name means 'hairy'. He became a nomadic hunter, and Jacob a shepherd. Jacob, though the younger, was the dominant character, and he persuaded Esau into selling him his birthright for some red pottage; he also took the father's blessing intended for the first born. He fled to escape the furious Esau, but on his return, 20 years later, Esau forgave him.

Escher, Maurits Cornelis (1898-1972). Dutch graphic artist. His lithographs, engravings and drawings explored visual paradoxes such as threedimensional representation, the ambiguity of relations between substance and shadow or upper and lower planes on cubes, and the phenomenon of 'strange loops' (e.g. quasi-fugal forms such as the representation of two hands, each drawing the other, or a waterfall in which the source is lower than the 
base but where each isolated element of the design is logically consistent: only the totality is impossible). He achieved considerable posthumous fame.

Hofstadter, D. R., Gödel, Escher, Bach: An Eternal Golden Braid. 1980.

Escoffier, (Georges) Auguste (1846-1935). French master chef. After being chef on the staff of *Napoléon III in the Franco-Prussian War, he went to London, where he gained an international reputation as chef at the Carlton and Savoy hotels. At the Savoy he invented the famous Pêche Melba in honour of the soprano Nellie *Melba.

Henboden, E., and Thalamas. P., G. A.Escoffier. 1955.

Escrivá de Balaguer, St Josemaría (1902-1975). Spanish cleric. He founded Opus Dei ('The work of God') as a lay movement in 1928, and it received papal approval in 1950. A charismatic but controversial figure, he was beatified in 1992 and canonised in 2002.

\section{Esenin, Sergei Aleksandrovich see Yesinin, Sergei Alexandrovich}

Esher, 2nd Viscount, Reginald Baliol Brett (18521930). English official and courtier. Son of a judge, educated at Eton and Trinity College, Cambridge, he was a Liberal MP 1880-85, then played a mysterious, influential but sometimes enlightened role as an advisor to Queen *Victoria, ${ }^{*}$ Edward VII and ${ }^{*}$ George $\mathrm{V}$, especially on army and civil service reform and arranging funerals. He persuaded Edward VII to establish the Order of Merit (OM) in 1902. With A. C. Benson, he edited the highly sanitised The Letters of Queen Victoria (3 volumes, 1907), covering the period 1837-61, declined the viceroyalty of India (1908) and played a significant but ill-defined role with British Intelligence in France during World War I.

Lees-Milne, J. The Enigmatic Edwardian. 1986.

Espartero, Baldomero Joaquin Fernandez (17931879). Spanish soldier and politician. He fought against and was captured (1826) by *Bolívar in the War of South American Liberation. He returned to Spain, fought with distinction (1833-39) against the Carlists $\left({ }^{*}\right.$ Carlos, Don) and was created Duque de la Victoria (1839). He became regent (virtually dictator) 1841-43 for the young queen *Isabella. Exiled in London 1843-48, he was again Prime Minister 1854-56. In 1870, he refused an offer of the crown following Isabella's deposition (1868).

Espronceda y Delgado, José de (1808-1842). Spanish poet and revolutionary. Often compared with *Byron, as a student he became involved in revolutionary societies and from 1827 to 1831 was an exile in London and Paris, where he came under the romantic influence of ${ }^{*}$ Scott, Byron and *Hugo. He returned to Madrid (1833), where he growing success as a poet modified his revolutionary sentiments. His two best known works, El Estudiante de Salamanca (1839) and El Diablo Mundo (1841), are based on the legends of Don Juan and Faust.

Essex, Robert Devereux, 2nd Earl of (1566-1601). English soldier and courtier. After distinguished service in the Netherlands under his stepfather, *Leicester, he returned to England (1587) and soon became a favourite of Queen *Elizabeth I. He offended the queen by marrying Sir Philip *Sidney's widow (1590) but regained her favour by his courage in the attack on Cadiz (1596). In 1598, during one of many quarrels with the queen, he burst out with the insolent remark that the conditions she imposed were as 'crooked as her carcass' and was never really forgiven. Sent to Ireland (1599) to fight the French insurgents, he not only failed but returned to England without permission to find himself in disgrace. After some months of house arrest, early in 1601 he tried to organise a rising of the citizens of London to regain his position by force. The attempt was a hopeless failure and Essex was arrested, tried for high treason, convicted and beheaded. He was a patron of literature and himself a minor poet.

Lacey, R., Robert, Earl of Essex, an Elizabethan Icarus. 1971.

Essex, Robert Devereux, 3rd Earl of (1591-1646). English nobleman and soldier. Educated at Eton and Oxford, the earldom was restored to him by *James I in 1604. In 1606 he married Frances Howard (1590-1632); both were children, the union apparently unconsummated and annulled in 1613. Frances was involved in the murder of Sir Thomas *Overbury, go-between with her lover James I's favourite Robert Carr, Earl of Somerset, whom she later married. Essex gained some military experience fighting for the Protestant cause in Europe. During the Civil War, Essex was the first Captain-General and Chief Commander of the Parliamentary Army 1642-43, with varied success. He was compelled to resign in the moves which led to the formation of the New Model Army and died shortly afterwards.

Snow, V., Essex the Rebel. 1971.

Esterhazy, (Marie Charles) Ferdinand Walsin (1847-1923). French soldier, of Hungarian ancestry. He stole secret military papers and sold them to the Germans in order to pay his gambling debts. The need for a scapegoat and anti-Jewish feeling in the French army led to the wrongful arrest and conviction of *Dreyfus (1894). In 1899 Esterhazy confessed and went to live in England. He changed his name to Fitzgerald and became a grocer in Hertfordshire.

Esther (also Edissah or Hadassah) (5th century $\mathrm{BCE}$ ?). Israelite heroine, probably legendary. In the Old Testament Book of Esther, she was queen to *Ahasuerus, King of Persia, saving her people from destruction. Her story was the subject of many paintings and an oratorio by ${ }^{*}$ Händel. 
Estrada, Joseph Marcelo Ejercito ['Erap'] (1937- ). Filipino actor and politician. A popular movie and television star, close to the *Marcos family, he became a mayor, senator and vice president $1992-98$. He succeeded *Ramos (who opposed his election) as President of the Philippines 1998-2001. Although impeachment proceedings on corruption charges collapsed, he lost support of the armed forces and resigned (January 2001) after massive demonstrations. He was arrested and jailed.

\section{Ethelbert see Æthelberht}

\section{Ethelred I and II see Æthelred I and II}

Etherege, Sir George (1635-1691). English Restoration dramatist. While working at the embassy at Constantinople he married a rich widow and was sent to the imperial court at Ratisbon. On return to England he spent much time in a court circle of witty, amoral friends. Influenced by ${ }^{*}$ Molière, his comedies, e.g. She Would lf She Could (1667-68) and The Man of Mode or Sir Fopling Flutter (1676), anticipated *Congreve and *Sheridan. His early work, The Comical Revenge or Love in a Tub (1664) was a prototype for Restoration comedy and influenced Congreve and ${ }^{*}$ Goldsmith.

Underwood, D., Etherege and the Seventeenth Century Comedy of Manners. 1959.

Etty, William (1779-1849). English painter. He studied under ${ }^{*}$ Lawrence, but owed much to the Venetian colourists seen during visits to Italy. He became an ARA in 1824 and an RA in 1828. He was admired by ${ }^{*}$ Delacroix, and is best known for luscious and voluptuous nudes and for large compositions, notable especially for their sense of design, on historical subjects or fanciful themes, e.g. Youth at the Prow and Pleasure at the Helm (National Gallery, London), Cleopatra and Joan of Arc.

Eucken, Rudolph Christian (1846-1926). German philosopher. His system, influenced by the 'Idealist' school, expounds and examines oppositions, e.g. between the spiritual life and modern materialism, which Eucken strongly attacked. Professor of philosophy 1874-1920 at Jena, he won the Nobel Prize for Literature (1908).

Euclid (c.330-260 BCE). Greek mathematician. Little is known about him except that after studying in Athens he lived in Alexandria. The 13 books of his The Elements of Geometry systematised existing knowledge of mathematics. The sections on geometry have remained the basis of standard textbooks for more than 2,000 years. He also wrote treatises on astronomy, optics and musical harmony, but most of his works are lost.

Berlinski, D., The King of Infinite Space; Euclid and His Elements.2013.
Eugène of Savoy, Prince (François Eugène de SavoieCarignan) (1663-1736). Franco-Italian-Austrian marshal, born in Paris. Son of the Comte de Soissons and a nephew of *Mazarin, brought up in the French court, he quarrelled with *Louis XIV and joined the imperial forces in 1683 . He fought with great distinction against Turkey and, having risen to the rank of field marshal, won the brilliant and decisive Battle of Zenta (1697), as a result of which the Turks were driven from Hungary and forced to sign the Treaty of Karlowitz (1699). In the War of the Spanish Succession he fought the French first in Italy and then on the Danube, where he invited *Marlborough to join him in resisting a French threat to Vienna. The result was the great victory of Blenheim (1704) by the combined armies. Another campaign in Italy followed, after which he joined Marlborough in Flanders in the Battles of Oudenarde (1708) and Malplaquet (1709). After Marlborough's recall he was Supreme Allied Commander until the end of the war. In 1716 he was again fighting the Turks and after a victory at Petwordein he captured Belgrade. Much of the rest of his life was spent in the collection of books and pictures and the building of the Belvedere Palace in Vienna. Much admired by *Friedrich II and *Napoléon as one of 'the seven great captains', he never married.

Eugénie (Marie Eugénie de Montijo de Guzman) (1826-1920). Empress consort of the French 185371. Born in Spain, she married *Napoléon III in 1853. A celebrated beauty, she became a leader of fashion and maintained a gay and brilliant court. She was an ardent (ultramontanist) supporter of the papacy and it was through her influence that a French garrison preserved the pope's rule in Rome after the unification of the rest of Italy. When the emperor abdicated after defeat in the Franco-Prussian War she lived with him in England and remained there after his death. Their son *Napoléon Eugène Louis was killed fighting in Africa. She commuted between Chislehurst and Menton, dying on a visit to Madrid.

Euler, Leonhard (1707-1783). Swiss mathematician, born at Basle. Pupil of Jean *Bernouilli, he joined him (1727) at the newly opened Academy at St Petersburg. He held professorships there from 1730 to 1741 , then spent 25 years at the new Academy of Sciences at Berlin, returning (1766) to St Petersburg where, though blind, he continued to work for the rest of his life. To a great extent he laid the foundations of modern mathematics. His works include a survey of analytical mathematics, with important contributions to the theory of equations and the first complete textbook on the calculus. He also carried out notable work in astronomy and physics.

Euripides (480-406 BCE). Athenian dramatist. Younger than *Aeschyhus and *Sophocles, he reveals a more 'modern' attitude to psychology, especially that of women, but his techniques are often inferior to those of Sophocles. He makes much use of the 
clumsy device known as deus ex machina by which a god is made to appear by a mechanical device to complete the denouement. His use of a prologue to explain the legend and outline the play is in itself a confession that the action is not self-explanatory. Traditional elements of Greek tragedy, e.g. the chorus, whose singing, dancing, explaining and bewailing often hold up action, seem to irk him but he found nothing to take their place. *Aristophanes ridiculed him unmercifully and found his language often pretentious and obscure. Of more than 80 plays which he has said to have written, only 18 survive. Among the most popular is Medea, the story of Jason's wife who, afraid of being supplanted, poisoned her children to leave her husband childless. Phaedra's unrequited passion which brings violent death to her stepson Hippolytus is told in the play that bears his name. The legends of Agamemnon's kin are told again in Iphigenia among the Taurians, Iphigenia at Aulis, Electra and Orestes. The remainder include Alcestis and Ion (founder of the Ionian race), The Trojan Women and Hecuba (both revealing the poet's detestation of war), The Bacchae, a horrifying portrayal of the orgiastic celebrations of Dionysian rites, and The Cyclops, a semi-burlesque. His first plays appeared in 455 and the last probably c. 408.

Murray, G., Euripides and His Age. 1965.

Eusebius of Caesarea (c.260/5-340). Roman-Greek theologian and historian, probably born in Caesarea Maritima. Bishop of Caesarea (c.313), he played a conciliatory part at the Council of Nicaea (325) but is best known for his History of the Christian Church, as a result of which he became known as the 'Father of Church History'. From * Gibbon onwards, historians have accused him of exaggerating the extent of Christian persecution and martyrdom. His Life of Constantine, a panegyric, asserts that the emperor was actually baptised but provides little detail. His Chronicle is the basis of many dates accepted in Greek and Roman history.

Wallace Wadrill, D. S., Eusebius of Caesarea. 1960.

Eustachio, Bartolomeo (1520-1574). Italian anatomist. After being personal physician to the Duke of Urbino and others, he taught anatomy at the Collegia della Sapienza in Rome. He rediscovered the Eustachian canal (auditory tube) of the ear, and the Eustachian valve in the foetus. He also studied and described the thoracic duct, larynx, adrenal glands and kidneys.

Evans, Sir Arthur John (1851-1941). English archaeologist. Educated at Harrow and Oxford, he went to Ragusa (Dubrovnik) in 1871 as Manchester Guardian correspondent, but was expelled by the Austrians (1882) for implication in a South Slav rising. Meanwhile he had developed an interest in antiquities inherited from his father, Sir John Evans. He met ${ }^{*}$ Schliemann in Athens in 1883. Keeper of the Ashmolean Museum in Oxford 1884-1908, he excavated an Iron Age site in Aylesford, Kent, in 1886. His study of Cretan inscriptions stimulated a lifelong passion and in 1894 he visited Crete (under Turkish rule until 1898), bought the site of Knossos in 1897, began excavating in 1900 and continued for most years until 1930. He applied the name 'Minoan' (after the legendary King Minos) to the advanced civilization on Crete which lasted from c.2000-c.1100 BCE, and was at its peak c.15501450 BCE. He linked archaeology, anthropology, linguistics and mythology on Crete and much of his pioneering work still seems persuasive. However, his restorations of buildings and frescoes at Knossos were overly robust and his conclusions about linkages between Crete and Mycenae have been challenged by later excavations. He discovered and named the Minoan scripts Linear A and Linear B (1901). His books include Scripta Minoa (1901) and The Palace of Minos (5 vols., 1921-35). Elected FRS (1901) and among the founders of the British Academy (1902), he was knighted (1911) and received the Copley Medal (1936).

Evans, J., Time and Chance. 1943; Brown, A., Arthur Evans and the Palace of Minos. 1983; Marinatos, N., Sir Arthur Evans and Minoan Crete. 2014.

Evans, Dame Edith Mary (1888-1976). English actor. Her first parts were the title roles in Troilus and Cressida (1924) and later Romeo and Juliet and Cleopatra. She was perhaps seen at her best in comedy, e.g. as Millamant in *Congreve's The Way of the World (1924) and as Mrs Malaprop in *Sheridan's The Rivals (1945-46). Modern plays in which she achieved striking successes were The Dark is Light Enough (1954) and The Chalk Garden (1956). She also made films, e.g. The Queen of Spades (1948) and as a formidable Lady Bracknell in The Importance of Being Earnest. She was awarded the DBE in 1946.

Evans, Gareth John (1944- ). Australian lawyer and Labor politician, born in Melbourne. Educated in Melbourne and Oxford, a barrister (QC) and academic lawyer, he was a senator 1978-96, AttorneyGeneral 1983-84, Minister for Resources and Energy 1984-87, for Transport and Communications 198788 and Foreign Minister 1988-96. An architect of the peace plan for Cambodia (1979), he negotiated the passage of native title legislation in the Senate (1993). Federal MHR 1996-99, he served as Chief Executive Officer of the International Crisis Group, Brussels, 2000-09, was a prolific author and Chancellor of The Australian National University 2010-20.

\section{Evans, Mary Ann see Eliot, George}

Evatt, Herbert Vere (1894-1965). Australian lawyer, writer and Labor politician, born in East Maitland. A gold medallist from Sydney University, he became a State MP 1925-30 and a KC. A justice of the High Court 1930-40, he resigned to re-enter politics and served under ${ }^{*}$ Curtin and ${ }^{*}$ Chifley as 
Minister for External Affairs and Attorney-General 1941-49. He represented Australia in the British War Cabinet 1942-43, became one of the architects of the United Nations and was President of the UN General Assembly 1948-49. He played a central role in the adoption in 1948 of the Convention on Genocide (influenced by Raphael *Lemkin) and the Universal Declaration of Human Rights. Leader of the Opposition 1951-60, he defeated *Menzies' referendum (1951) to ban the Communist Party. However, the ALP split in 1955, partly over attitudes to Communism, with the majority reluctantly supporting Evatt's approach and an overwhelmingly Catholic minority hiving off to form the Democratic Labor Party (DLP). Evatt's erratic leadership style, and concerns raised by his response to the defection of a Russian spy, Vladimir Petrov, also contributed. Evatt was Chief Justice of New South Wales 1960-62, but his memory and intellectual powers soon failed.

Crockett, P., Evatt: A Life. 1993; Murphy, J. W., Evatt. A Life. 2016; Haigh, G., The Brilliant Boy: Doc Evatt and the Great Australian Dissent. 2021.

Evelyn, John (1620-1706). English diarist and gardener, born at Wotton, Surrey. He grew up on the family estate and studied at the Middle Temple, London, and Balliol College, Oxford. At heart a Royalist, during the Civil War he lived in Europe 1643-52. On returning to England he lived for nearly 50 years at Sayes Court, Deptford, spending the last years of his life at Wotton, which he inherited in 1696. He was a foundation Fellow of the Royal Society (1660) and its secretary 1671-80. A prolific writer, on architecture, painting, engraving, sculpture, diet, horticulture, gardening, and a passionate advocate of reafforestation in Sylva, or a Discourse of Forest-Trees (1664), he wrote an early treatise on air pollution. His diary, discovered at Wotton in 1817 , covers the period from 1641 to 1706 , but not continuously, is an important record of contemporary life, discreet and cautious, in striking contrast to *Pepys' diary.

Keynes, G. L., Evelyn, A Study in Bibliophily and a Bibliography of His Writings. 1968; Darley, G., John Evelyn: Living for Ingenuity. 2006.

Everest, Sir George (1790-1866). English surveyor. Surveyor-General of India 1830-43, the world's highest mountain (Chomolungma in Tibetan, Sagamatha in Nepali) was mapped and named for him (1852).

Everett, Edward (1794-1865). American orator, scholar and administrator. He was the first American to be awarded a PhD, at Göttingen in 1817 . He became the first professor of Greek at Harvard 1819-25, a Congressman 1825-35, Governor of Massachusetts 1836-40, Minister to Great Britain 1841-45, President of Harvard University 1846-49, US Secretary of State under Fillmore 1852-53 and US Senator 1853-54. When *Lincoln delivered his famous address at the opening of the military cemetery at Gettysburg (19 Nov. 1863), Everett was principal speaker.

Eyck, Hubert van (c.1366-1426) and Jan van Eyck (c.1390-1441). Flemish painters, born in Maaseik. There is some documentation about Jan's life, and 18 works can be confidently attributed to him. He was probably influenced, or even taught, by the so-called 'Master of Flémalle', Robert ${ }^{*}$ Campin of Tournai. Jan was painter to the Count of Holland in The Hague 1422-25, worked for *Philippe le Bon (Philip the Good), Duke of Burgundy in Lille 142530 and went on two diplomatic missions to Spain and Portugal, living in Bruges from 1431 where he married and was buried. Hubert's reputation depends on the inscription on the frame of the great altarpiece in Sint Baafskathedral (St Bavo), Ghent, stating that he began the work, and his brother Jan completed it by 1432 . Hubert's very existence has been questioned, let alone his relationship to Jan. The Ghent altarpiece is a polyptych: opened up, there are 12 paintings, dominated by The Adoration of the Mystic Lamb and God the Father, and powerful studies of Adam, Eve, the Virgin and John the Baptist. When the wings are closed, 12 smaller paintings are seen. ${ }^{*}$ Durer called it 'stupendous' and the mastery of oil painting was unsurpassed to that time. His works are characterised by uncompromising realism, rich and brilliant colouring (his development of a paint that had great lasting qualities was an ancillary accomplishment), acute sensitivity to surfaces and textures, and a miniaturist's passion for detail. The Man in the Red Turban (1433), in London, is thought to be a self portrait, and a portrait of his wife Margaret van Eyck is in Bruges. Other masterpieces include The Marriage of Giovanni Arnolfini and Giovanna Cenami (1434, London), Cardinal Albergati (1435, Vienna), The Virgin of Canon van der Paele (1436, Bruges, only identified as van Eyck's work in 1847) and The Virgin and Chancellor Rollin (1436, Louvre). Entirely unemotional, Jan's painting moves us by its absolute truth and attention to detail and its marvellous rendering of textural effects. Returning six panels of the Ghent altarpiece which had been sold to Germany was a specific condition (Art. 247) in the Treaty of Versailles. One panel was stolen in 1934.

Baldass, L., Van Eyck. 1952; Dhanens, E., Van Eyck. 1973; Harbison, C., Jan van Eyck. The Play of Realism. 1991; Graham, J., Inventing Van Eyck. The Remaking of an Artist for the Modern Age. 2007.

Eyre, Edward John (1815-1901). English explorer and administrator, born in Bedfordshire. He emigrated to Australia in 1833, became a grazier and made the first direct crossing from Sydney to Adelaide (1838). In 1840 his most famous expedition advanced northwards from Adelaide into the interior. When unable to proceed further he turned westward and reached the head of the Great Australian Bight. Having sent the expedition back, he set out for 
Albany, in the extreme southwest, with his overseer and three Aboriginal men. He arrived there with a single Aboriginal man in July 1841 after great hardships. Publication of his experiences brought him a Royal Geographical Society medal and considerable fame. He became a magistrate and 'protector of the aborigines', studying their language and customs. $\mathrm{He}$ was Lieutenant Governor of New Zealand 1846-53 and worked to improve relations between whites and Maoris. As Governor of Jamaica 1864-66, he suppressed a black revolt led by George Gordon at Morant Bay (October 1865), imposed martial law and more than 400 were executed. He was recalled and never given official employment again. Attempts were made to have him tried for murder $(1867,1869)$ and British intellectuals were bitterly divided between his opponents ( ${ }^{*}$ Mill, ${ }^{*}$ Spencer, ${ }^{*}$ Darwin ${ }^{*}$ Huxley) and supporters $\left({ }^{*}\right.$ Carlyle, ${ }^{*}$ Dickens, ${ }^{*}$ Ruskin, ${ }^{*}$ Tennyson).

Dutton, G., The Hero as Murderer. 1967.

Eyre, Sir Richard Charles Hastings (1943- ). English theatre, film and opera director, born in Devon. Educated in Cambridge, he was director of the National Theatre, London, 1987-97, and showed exceptional versatility, from *Shakespeare, *Ibsen, *Williams and *Stoppard to Guys and Dolls. He directed his first opera in 1994, and his triumphs include Carmen and The Marriage of Figaro at the New York Met.

Ezekiel (fl. c.590-610 BCE). Hebrew prophet. Little is known of his life except that he was among those deported by *Nebuchadnezzar to Babylon (597). The book of the Bible ascribed to him presents problems of authorship. The first 25 chapters, though apparently written in Babylon, predict the fall of Jerusalem, which actually took place in 586 . This portion denounces neighbouring nations, while Chapters xxxiii-xxxix predict the reunification of Israel and Judah under a king of the House of *David. The last chapters paint an idealised picture of the restored state with its temple worship renewed and reformed. Much of this last section may well have been added later, though the earlier portions were probably written by Ezekiel himself, confusion being caused by an editor's attempt to weld together parts written at different times.

Ezra (5th century BCE). Hebrew priest and scribe. He led a group of returning exiles from the court of the Persian king *Artaxerxes I or II. He revived the Jews' conception of themselves as an exclusive and chosen people bound together by their unique religious observances. The Biblical book of Ezra is believed to be part of a larger whole containing also Chronicles and Nehemiah. 
$\mathbf{F}$

Fabergé, Peter Carl (1846-1920). Russian jeweller, of French descent. He achieved fame by the ingenuity and extravagance of the jewelled objects (especially Easter eggs) he devised for the Russian nobility and the tsar in an age of ostentatious extravagance which ended on the outbreak of World War I. He died in Switzerland.

Fabius, Laurent (1946- ). French socialist politician. He was Deputy 1978-81, 1986- , Minister for Industry and Research 1983-84, Premier of France 1984-86, Minister of Economics 2000-02 and Foreign Minister 2012-16, and President of the Constitutional Council 2016- .

Fabius Maximus Verrocosus Cunctator, Quintus (c. 280-203 BCE). Roman general and politician, born in Rome. Three of his ancestors had been Consuls, and two cognomens were added to his birth name: Verrocosus ('warty') and Cunctator ('delayer'). During the Second Punic War, *Hannibal's Carthaginian army inflicted a heavy defeat on Roman forces at Lake Trasimeno (217) and seemed likely to invade Rome. The Senate appointed Fabius as 'dictator' (essentially a short-term appointment to meet an emergency). He pursued a policy of 'masterly inactivity' (hence his sobriquet 'Delayer'), avoiding direct engagement and concentrating on harassing the enemy, guerrilla tactics, 'scorched earth' and cutting off supplies. After his term ended, Fabius' successors determined to defeat Hannibal in open battle, but despite superior numbers suffered humiliating defeat at Cannae (216). The Senate then resumed Fabius' approach. Hannibal's army remained in Italy until 203, winning two major battles, but it never threatened Rome again. Fabius was elected Consul five times. The word 'Fabian' has passed into the English language, e.g. the Fabian Society, dedicated to achieve socialism by gradual reforms. His grandfather, Quintus Fabius Maximus Rullianus (d.315 BCE), won several notable battles in the Samnite Wars.

Fabre, Jean Henri (1823-1915). French entomologist. He was a teacher for many years in Ajaccio, Corsica and (from 1852) at Avignon. In 1870 he retired to Serignan, near Orange, and devoted almost all his time to studying insects, which he observed with the utmost patience and precision. His writings about them were published in many volumes as Souvenirs entomologiques, parts of which had been issued separately as, e.g., The Life and Love of the Insect (1911) and Social Life in the Insect World (1913).

Gordon, S., Jean Henri Fabre. 1971.
Fabricius ab Aquapendente, Hieronymus (Geronimo Fabrizi) (1533-1619). Italian physician, born at Aquapendente, near Orvieto. He studied medicine under *Fallopio at Padua and succeeded him as professor of surgery and anatomy 15621613. He became actively involved in building the university's magnificent anatomical theatre, which is preserved today. $\mathrm{He}$ acquired fame as a practising physician and surgeon, and made extensive contributions to many fields of physiology and medicine, through his energetic skills in dissection and experimentation. He wrote works on surgery, discussing treatments for different sorts of wounds, and a major series of embryological studies, illustrated by detailed engravings. His work on the formation of the foetus was especially important for its discussion of the provisions made by nature for the necessities of the foetus during its intra-uterine life. The medical theory he offered to explain the development of eggs and foetuses, however, was in the tradition of *Galen. Fabricius is best remembered for his detailed studies of the valves of the veins. He thought the function of these valves was to slow the flow of blood from the heart, thus ensuring a more even distribution through the body. His pupil, William *Harvey, drew on these studies in his work on the circulation of the blood.

Fabritius, Carel Pieterszon (1622-1654). Dutch painter. A pupil of ${ }^{*}$ Rembrandt, and teacher of *Vermeer, he was killed when the Delft gunpowder magazine exploded. The Goldfinch (1654) is a small study of a chained bird.

Fadden, Sir Arthur ('Artie') William (1894-1973). Australian politician, born in Ingham, Queensland. He left school at 14 to join a sugar-cutting gang, later becoming an accountant, municipal councillor in Townsville 1930-33 and member of the Queensland Parliament 1932-35. Member of the House of Representatives 1936-58, Federal Treasurer 1940 41, Leader of the Country Party 1941-58 and acting Prime Minister January-May 1941, during Robert * Menzies' long absence abroad. After Menzies resigned, due to hostility within his own party, Fadden was Prime Minister August-October 1941, until he lost his narrow majority and John *Curtin's Labour government succeeded. Fadden was Leader of the Opposition 1941-43. He kept the Country Party in coalition with Menzies' re-formed Liberal Party and was Federal Treasurer again 1949-58.

Fadden, A. W., They Called Me Artie. 1969.

Fadeyeh (originally Bulyga), Aleksandr Aleksandrovich (1901-1956). Russian novelist, born near Kalinin. Educated in Vladivostock, after 1918 he fought against the White Russian army in Siberia, an experience which inspired his first important novel The Nineteen (1927). He was quickly recognised as a leader of a new, Soviet Communist, proletarian literature. He became a member of the board of the Union of Soviet Writers and was connected with the 
imposition of a stern party line, although in 1947 he suffered from official censure himself. His novel The Young Guard (1946) was criticised as failing to show the party as dominant, and he rewrote it. His later life was clouded by alcoholism and, after the official denunciation of Stalinism, he killed himself.

Fahrenheit, Gabriel Daniel (1686-1736). German physicist, born in Danzig. Educated in Holland, he eventually settled in Amsterdam as a maker of meteorological instruments. He introduced (1715) mercury as the fluid in thermometers and devised the temperature scale that bears his name, with boiling point of water at $212^{\circ}$ and freezing point at $32^{\circ}$.

Faidherbe, Louis Léon César (1818-1889). French soldier and colonial administrator. He began his military career with the corps of military engineers in 1840, and was given his first command, in Algeria, in 1849. In 1852 he went to Senegal as deputy director of engineers, he was made Governor 1854-61 and again 1863-65. He established a strong military presence in Senegal based on the capital Dakar, which he founded. His achievements laid the foundations of the French West African colonies. Recalled to fight in the Franco-Prussian war in 1870, he was defeated near St Quentin (1871).

Fairbanks, Douglas (originally Douglas Elton Ullman) (1883-1939). American film actor. He was famous as the swashbuckling and romantic hero of such films as The Three Musketeers (1921), The Thief of Baghdad (1924) and The Man in the Iron Mask (1929). He formed the film making company United Artists with Charles ${ }^{*}$ Chaplin and Mary *Pickford, and became her second husband. His son, Douglas Elton Fairbanks Jr (1909-2000), also an actor, settled in England in 1946 and was made honorary $\mathrm{KBE}$ in 1949.

Fairfax of Cameron, Ferdinando Fairfax, 2nd Baron (1584-1648). English general and politician. Holding a Scottish peerage, he was eligible to serve in the English House of Commons as MP 1614-29; 1640-48. A moderate in the Civil War, he commanded the Parliamentary army in Yorkshire with only moderate success. He died of gangrene. His son Thomas Fairfax, 3rd Baron Fairfax of Cameron (1612-1671), also a general and politician, served as a volunteer in Holland (1629-37) and when the civil war broke out (1642) gained such distinction as a commander, especially at Marston Moor (1644), that when *Essex had to give up his post as Commanderin-Chief under the Self-denying Ordinance, Fairfax took his place. The Battle of Naseby (1645) was his greatest triumph. Thereafter, he played a conciliatory role: he tried, but failed, to save the king's life and after refusing to march against the Scots (1650) was superseded by ${ }^{*}$ Cromwell. In 1660 he went to The Hague to arrange for the return of ${ }^{*}$ Charles II.
Faisal (Faisal bin Abdulaziz al Sa'ud) (1906-1975). King of Saudi Arabia 1964-75. Son of King *Ibn Sa'ud, he was Prime Minister and Foreign Minister of Saudi Arabia 1953-60, and virtually ruled the kingdom (1958-60) until forced to resign by his halfbrother King Sa'ud. Reconciliation took place early in 1964 and in November as a result of Sa'ud's continued ill health Faisal took his place as King. Murdered by a nephew, also called Faisal, he was succeeded by his brother Khalid.

Faisal I (Faisal bin Hussein bin Ali al-Hashimi) (1885-1933). First King of Iraq 1921-33. Son of ${ }^{*}$ Hussein, grand sharif of Mecca, who made himself king of the Hejaz, he became, during World War I, a leader of the Arab revolt, in which T. E. *Lawrence was prominent. On the breakup of the Ottoman Empire, he became King of Syria in March-July 1920, until expelled by the French. The British then imposed him as king of the mandated territory of Iraq, where he was virtually unknown. He negotiated with Chaim *Weizmann about the possibility of JewishArab cooperation in the Middle East, but by 1930 was protesting about increased Jewish immigration to Palestine. Iraq became fully independent in 1932. Britain rewarded him with a GCB, GCMG and GCVO. He died suddenly in Switzerland; poisoning was suspected. His only son Ghazi (Gāzi) I (1912-1939), who succeeded, was killed in a driving accident, which may have been planned.

Faisal II (Faisal bin Ghazi bin Faisal bin Hussein bin Ali al-Hashimi) (1935-1958). King of Iraq 1939-58. Son of King Ghazi and grandson of *Faisal I, he was educated at Harrow School in England. The effective ruler until 1953 was the regent, his uncle Abdul Illah. The proclamation (1958) by Faisal and his cousin, King ${ }^{*}$ Hussein of Jordan, of a federation of their two kingdoms was followed almost immediately by a revolutionary coup d'état led by Brigadier Kassem, in the course of which Faisal and his Prime Minister, *Nuri es-Said, were murdered.

Falkenhayn, Erich von (1861-1922). German soldier. After a successful career in the Chinese Boxer rebellion and elsewhere, he came to prominence in World War I when he succeeded von Moltke as Chief of the General Staff after the defeat on the Marne. His attempt to redeem this by an outflanking movement failed, but he achieved great success against the Russians (1915) and destroyed the Serbian army (1915-16). Deprived of his staff post after failure at Verdun and on the Somme, he conducted a victorious offensive against Romania.

Falkland, Lucius Cary, 2nd Viscount (1610-1643). English courtier, soldier and scholar. Educated at Trinity College, Dublin (his father had served in Ireland as Lord Deputy), he succeeded to his Scottish peerage in 1633. To his Oxfordshire home flocked scholars from nearby Oxford, poets, wits and eager spirits with young ideals from London. As a member 
of the Long Parliament 1640-42 he opposed the authoritarian rule of ${ }^{*}$ Laud and ${ }^{*}$ Strafford, but remained a keen Anglican. In a last effort to avert civil war he became Secretary of State 1642-43. After fighting began, he supported ${ }^{*}$ Charles I at Edgehill and Gloucester, but his death at the Battle of Newbury was virtual suicide. He wrote poems and theological treatises, e.g. Discourses of Infallibility.

Falla (y Matheu), Manuel de (1876-1946). Spanish composer, born in Cadiz. He studied composition in Madrid. After his opera La vida breve (1905; Life is Short) had won him a national prize he continued his studies in Paris (1907-14), *Debussy and *Dukas being major influences. He developed, however, a strikingly original style which embodies much of the dramatic intensity, intricate rhythms and floridity of traditional Andalusian music. He was unusually fastidious and his total output is small. Among his best known works are the ballets Love the Magician (1915) and The Three-Cornered Hat (1919), for which, last, Massine was the choreographer and *Picasso the designer. Others include Nights in the Gardens of Spain (first performed 1921) for piano and orchestra, a Harpsichord Concerto (1926) and the song cycle Seven Popular Spanish Songs. He lived in Argentina from 1939, died there but is buried in Cadiz.

Fallada, Hans (Rudolf Ditzen) (1893-1947). German novelist. His most famous work, Little Man, What Now? (1932), expresses the dilemma and disillusionment that faced the middle classes in Germany in the years following World War I.

Schueler, H. J., Hans Fallada. 1970.

Fallières, (Clément) Armand (1841-1931). French politician. A lawyer, he served as Deputy 1876-90, Premier for a month in 1883, Minister for Education 1883-85; 1889-90, Senator 1890-1906, President of the Senate 1899-1906 and President of the Third Republic 1906-13. He was strongly opposed to the death penalty.

Fallopio (Fallopius), Gabriele (1523-1562). Italian anatomist. Pupil and successor of *Vesalius at Padua, he made a notable study of the organs of generation. The Fallopian tubes (ovarian ducts) and the Fallopian aqueduct for the facial nerve (which he first described) are named after him.

Fan Kuan (pseudonym of Fan Xongzheng, courtesy name Zhongli) (c.990-c.1030). Chinese painter. A Taoist recluse, his greatest work was Travellers amid Streams and Mountains.

Fanfani, Amintore (1908-1999). Italian politician. An economist by profession, he succeeded de *Gasperi as Secretary-General of the Christian Democratic Party (1954). Prime Minister in 1954, 1958-59, 1960-63 and 1987, he acquired a great reputation as a maker and breaker of governments.
Fangio, Juan Manuel (1911-1995). Argentinian racing driver, born in Buenos Aires. In 1934 he began racing in South America and met with considerable success. In 1949 he went to Europe and subsequently dominated motor racing competitions in the $1950 \mathrm{~s}$, becoming World Champion in 1951, 1954, 1955, 1956 and 1957 . On his retirement in 1958 at the age of 47, he had won 24 Grands Prix, 16 of them World Championships.

Fanon, Frantz (1925-1961). French-African revolutionary theorist, born in Martinique. After army service, he studied in Paris, became a psychiatrist in Algiers and wrote The Wretched of the Earth (1961) which was used as a handbook by revolutionary and student movements in Africa and the US and originated the concept of 'negritude'. He died of leukemia in Washington DC.

Fantin-Latour, Ignace Henri Jean Théodore (1836-1904). French painter. He studied under *Courbet and first exhibited at the Salon in 1861 . $\mathrm{He}$ was a friend of the Impressionists and painted their portraits, e.g. *Manet's Studio at Batignolles. Fantasies suggested by the music of *Wagner and *Berlioz, and, above all, his exquisitely delicate flower pieces, are also well known.

Faraday, Michael (1791-1867). English chemist and physicist, born in Newington Butts, Surrey. Son of a blacksmith, he taught himself the rudiments of science while working as a bookbinder's apprentice. He attracted the attention of Sir Humphry ${ }^{*}$ Davy with a bound set of notes he had taken at Davy's Royal Institution lectures in 1813, and was given a post as his laboratory assistant (and occasional valet). From about 1821 Davy became very resentful of Faraday's success. He never mastered mathematics but had an astonishing capacity to visualize phenomena. He worked on the liquefaction of gases, was the first to liquefy chlorine and carbon dioxide (1823), discovered benzene (1825) and experimented on extreme cold, which led to cryogenics. In 1827 he became director of the laboratory at the Royal Institution and the first Fullerian professor of chemistry 1833-67, where his lectures were extremely popular. He was a member of the Sandemanians, a small sect that tried to revive primitive Christianity. His most important work was in electricity and electrochemistry. He discovered (1831) electromagnetic induction and deduced the laws governing the relative movement of magnets and current-carrying conductors. These discoveries, made independently by Joseph *Henry (1832), led directly to the development of electric generators and motors, and were explained theoretically in *Maxwell's quantum electromagnetic theory (1862). His discoveries (1832-33) of the laws of electrolysis (now known as Faraday's Laws) put this process on a sound quantitative basis. The records of Faraday's researches are collected in his Experimental Researches on Electricity. His work on 'lines of force' in magnetism anticipated the concept of the field 
universe, developed by Maxwell. He shared the Copley Medal with *Poisson in 1832 and ${ }^{*}$ Gauss in 1838 and was given a civil list pension in 1835 . He suffered a mental collapse in 1839 , probably due to exposure to chemicals in experiments. In 1845 , having recovered, he began work on magnetism again. Finding that the plane of polarised light was rotated by a magnetic field led him to suggest a connexion between light and electricity. He later studied the properties of weak magnetic materials and his work on colloidal gold (1847) anticipated nanotechnology. He declined the Presidency of the Royal Society in 1848 and 1858 and refused a knighthood in 1857 . In 1848 , Queen *Victoria gave him a grace-and-favour house at Hampton Court where he lived from 1858 (and died), his memory and mental capacity having declined. He was buried at Highgate Cemetery, having refused an offer from Westminster Abbey. The farad (symbol F), the SI unit of electrical capacitance, a lunar crater and Asteroid 37582 Faraday were named for him.

Pearce Williams, L., Michael Faraday: A Biography. 1965; Russell, C. A., Michael Faraday: Physics and Faith. 2000; Hamilton, J., Faraday: The Life. 2002; Hirshfeld, A. W., The Electric Life of Michael Faraday. 2006.

Farage, Nigel Paul (1964-). English politician. A commodity trader and former Conservative, he was a founder of the United Kingdom Independence Party (UKIP: 1993), a member of the European Parliament 1999-2020, and a leader of the successful campaign for Britain to leave the EU (2016).

Farel, Guillaume (1489-1565). French Protestant reformer, born in the Dauphiné. From a noble family, he became a Protestant missionary, mainly in Switzerland. After being twice expelled from Geneva he was largely responsible for the town council's decision to proclaim the Reformation there (1535). He became the friend of ${ }^{*}$ Calvin, who was, however, more closely concerned with administration, and shared with him a brief exile from Geneva (1538). Farel was pastor at Neuchâtel (1544-65). At the age of 69 he married a young wife, an action highly distasteful to the sterner Calvin.

Farinelli (professional name of Carlo Broschi) (17051782). Italian castrato or male soprano. Emasculated before puberty, he had a three octave range (tenor to soprano). He achieved remarkable success in London, Rome, Vienna, Paris, and finally Madrid where he became court singer to King *Felipe V of Spain, over whom (from 1737) he exercised an extraordinary influence in affairs of state. He is said to have sung the same four arias each night to ease the king's melancholy. He returned to Italy in 1759. The French film Farinelli, il castrato was released in 1994.
Farington, Joseph (1747-1821). English landscape painter and diarist. Though he became an RA, his fame rests much more firmly on his diary (first published 1922-28), a vivid presentation of the people and events of his life from 1793 to the day of his death.

Farman, Henri (1874-1958). Anglo-French aviator and designer, born in Paris. He worked with Gabriel and Charles Voison and in November 1909 established a long distance flying record of 232 kilometres in a Voisin-Farman I biplane. With his brother Maurice he began manufacturing aircraft and during World War I many were sold to the French army.

Farnese. Italian ducal family, rulers of Parma from 1545 when Pope *Paul III (Alessandro Farnese) invested his illegitimate son Pier Luigi (15031547) — the duchy-until 1731. Alessandro's sister Giulia was mistress of Pope *Alexander VI (Rodrigo Borgia). A grandson of Luigi, Alessandro Farnese (1546-1592), Duke of Parma, was the general of *Felipe II who (1578) became his governor in the Netherlands. Elisabeth (1692-1766), niece of the last Farnese duke, married and dominated *Felipe V, her ambition to obtain the Parma duchy for her son being a constantly disruptive factor in European politics.

Farnsworth, Philo Taylor (1906-1971). American inventor. In 1934 the US Patent Office recognised his priority over ${ }^{*}$ Zworykin in inventing an electronic television system [1927].

Farouk (1920-1965). King of Egypt 1936-1952. Son and successor of ${ }^{*}$ Fuad I, he was educated in England. He followed a vacillating policy during World War II and, in the years that followed, proved himself unable to compete with political turmoil and administrative corruption. At the same time he incurred censure by the extravagance of the court and by much publicised episodes in his 'private' life. His exile followed an army revolt under General *Neguib and Colonel ${ }^{*}$ Nasser and he was finally deposed in 1953 when a republic was proclaimed.

Farquhar, George (1678-1707). Anglo-Irish dramatist. He was an actor for a time in Dublin, but after wounding another actor in a stage duel went to London and achieved success with Love and a Bottle (1698), the first of his licentious but witty and amusing comedies. This followed by The Constant Couple (1699), said to have run for 53 nights at Drury Lane, and other plays, brought him esteem with little reward. He managed to obtain an army commission and performed the duties of the title part in his play The Recruiting Officer (1706). Poverty forced him to sell his commission, but a gift from the actor Robert Wilks enabled him to write his last and best play The Beaux Stratagem (1707). Farquhar's good nature and gift for satire are revealed in his plays, and by taking comedy out of the drawing room into a more 
realistic outside world he set a trend soon followed by *Goldsmith and others. The Recruiting Officer was the first play performed in Sydney (June 1789).

Farragut, David Glasgow (1801-1870). American admiral, born in Tennessee. The most successful naval commander of the Union in the Civil War, in spite of his long service on the outbreak of the civil war, he was at first suspected of Confederate sympathies. Given a command in 1862, he distinguished himself in a number of daring actions, first at New Orleans where he ran the gauntlet of forts to destroy the Confederate fleet on the Mississippi, after which he was made Senior Rear Admiral. In 1863 he won control of more of the Mississippi, which greatly helped *Grant's Vicksburg campaign. In 1864 he achieved his most outstanding victory off Mobile to end blockade-running by the Confederates. On his famous signal 'Damn the torpedoes', his fleet steamed through a screen of mines (then called torpedoes) to overwhelm the Confederate flotilla. The rank of Admiral was created for him in 1866.

Farrakhan, Louis (Louis Eugene Wolcott) (1933-). African-American political activist, born in New York City. A charismatic orator, he founded 'the Nation of Islam' in 1977 and organised the Million Man March in Washington in 1995.

Farrell, James Thomas (1904-1979). American novelist. After a variety of occupations, Farrell achieved fame with his realistic trilogy (completed in 1935) of slum life in Chicago, Studs Lonigan. His later novels include $A$ World I Never Made (1936) and Bernard Clare (1946).

Branch, E. M., James T. Farrell. 1963.

Farrer, William James (1845-1906). Australian wheat breeder. Educated at Cambridge he came to Australia for his health in 1870. Using Darwinian principles and paralleling the work of ${ }^{*}$ Mendel he developed rust and parasite-free wheat strains by cross-breeding. His 'Federation' wheat (1901) dominated Australian production for 30 years.

Fasch, Johann Friedrich (1688-1758). German composer. A friend of *Telemann, contemporary of ${ }^{*}$ Bach, he worked in Zerbst. Most of his Church music has been lost but his instrumental compositions illustrate the transition from Baroque to Classical style. He wrote 19 symphonies and 68 concertos.

Fastolf, Sir John (1378-1459). English soldier. Knighted for distinguished conduct at Agincourt and in other engagements, as landlord of huge estates in Norfolk, he is said to have been mean, rapacious and ill-tempered, but he was an educational benefactor and Magdalen College, Oxford, was eventually built from funds left by him. *Shakespeare may have borrowed his name (but nothing else) for his character of Falstaff.
Fatimah ('Shining One') (c.610-632). Arab religious. Daughter of *Muhammad by Khadijah, she married her cousin *Ali. Long after her death, Said Ibn Hussein, basing his claim on descent from Fatimah, founded a powerful Shi'ite dynasty (the Fatimite).

Fauci, Anthony Stephen (1940- ). American immunologist, born in Brooklyn. As a research scientist he worked on AIDS and was awarded the Presidential Medal of Freedom in 2008. Under President ${ }^{*}$ Trump, he was an increasingly beleaguered advisor on Covid-19, becoming *Biden's Chief Medical Advisor 2021-.

Faulkner, William (1897-1962). American author, born in Mississippi. He trained with the Canadian air force in World War I and worked at a succession of odd jobs while trying to sell his poetry and early novels, Soldier's Pay (1926), Mosquitoes (1927), and Sartoris (1929). He gradually secured literary recognition with The Sound and the Fury (1929), As I Lay Dying (1930) and Light in August (1932), with their vigorous and powerful portrayal of upper-class whites, poor whites and African-Americans in the South during a period of social conflict and disintegration, but he did not obtain wide popular responses until the publication of Sanctuary, a 'horror' story, employing the stream of consciousness technique, of a girl who becomes a nymphomaniac after rape.

Faulkner was deeply conflicted over race and Civil War history. Several of his novels are set in the imaginary Yoknapatawpha County, Mississippi, the scene of slavery, battle and cemeteries, and he reports the war as a Gothic horror. But in his private, heavydrinking life, he was nostalgic about the Confederacy, accepting slavery and racism as givens.

Later works include a comic trilogy (The Hamlet, 1940), The Town (1956), The Mansion (1959), Intruder in the Dust (1948), and Requiem for a Nun (1951), later dramatised. His many short stories include A Rose for Emily and the collection Go Down, Moses (1942). The film Long Hot Summer was based on one of Faulkner's stories. He won the Nobel Prize for Literature in 1949 and in 1955 the Pulitzer Prize for A Fable (1954), an allegory of fighting in the trenches in France.

Blotner, J., Faulkner: A Biography. 2 vols, 1974; Rollyson, C., The Life of William Faulkner, 2 vols, 2020; Gorra, M., The Saddest Words: William Faulkner's Civil War. 2020.

Faure, (François) Félix (1841-1899). French politician. Originally a leather merchant and ship owner, he was Deputy 1881-95, Minister of Marine 1894-95 and President of the Republic 1895-99. He cemented the Franco-Russian alliance by a visit to St Petersburg (1897). An opponent of *Dreyfus, he resisted demands for a new trial and contributed to bitter political division. He died in the arms of his mistress at the Elysée palace. 
Fauré, Gabriel Urbain (1845-1921). French composer, organist and teacher, born in Pamiers. A pupil of ${ }^{*}$ Saint-Saëns, he became chief organist at La Madeleine, Paris, 1896-1905, succeeded *Massenet as professor of composition at the Paris Conservatoire 1896-1905 and was Director 1905-20. He encouraged and influenced a whole generation of younger composers including *Ravel. His gentle, lyrical style, though unemphatic, is often harmonically audacious. He wrote a Requiem (188788), incidental music to *Maeterlinck's Pelleas et Melisande (1898) and a Ballade (1881) for piano and orchestra, but is at his best in chamber music (notably the two cello sonatas and two piano quartets), piano music and songs. His La Bonne Chanson (1891-92), settings of ${ }^{*}$ Verlaine, much recorded, is one of his finest works.

Orledge, R., Gabriel Fauré. 1979; Jones, J. B., Gabriel Fauré. 1989; Nectoux, J.-M., Gabriel Fauré: A Musical Life. 1991; Duchan, J., Gabriel Fauré. 2000.

Faust, Johann (or Georg) (c.1480-c.1540). German magician. The real man behind the Faust legends seems to have been a university student, an astrologer, magician, and debaucher, who travelled (or more probably was moved on) about the country, and who, after boasting that he had sold his soul to the devil, died mysteriously. Probably because his journeys made him so widely known, legends soon gathered round him. In 1587 appeared a printed account of his life, and subsequently many differing versions were issued. The Faust legend inspired dramatic works by *Marlowe and *Goethe. *Gounod's opera Faust (1859) is the most performed, *Busoni's Doktor Faust (1916-24) the most profound. *Berlioz, *Schumann, *Liszt, *Wagner and ${ }^{*}$ Mahler wrote music inspired by the story.

Fawcett, Dame Millicent (née Garrett) (18471929). English political reformer and campaigner for women's rights, born in Aldeburgh, Suffolk. Sister of Elizabeth Garrett *Anderson, in 1867 she married Henry Fawcett, a political economist who supported her work and was a leading social reformer. She made her first public speech advocating votes for women in 1868, founded the National Union of Women Suffrage Societies (NUWSS) in 1897, wrote Women's Suffrage (1912) and led the 'suffragist' movement until 1918. (Emmeline *Pankhurst's more militant followers were known as 'suffragettes'.) In April 2018 a statue of Fawcett was unveiled in Parliament Square, London, to commemorate the centenary of women's suffrage in the UK. She also advocated higher education for women, and was co-founder with Henry *Sidgwick of Newnham College, Cambridge.

Fawkes, Guy (or Guido) (1570-1606). English conspirator. He was a Roman Catholic convert of fanatical zeal and took part in the gunpowder plot to blow up the Houses of Parliament to kill King *James I. Arrested in the cellars on 5 November 1605 he revealed, under torture, full details of the plot and was executed soon afterwards. His own role was actually to fire the barrels. November 5 has been commemorated ever since with bonfires burning his effigy and with fireworks.

Edwards, F., Guy Fawkes. 1962.

Federer, Roger (1981- ). Swiss tennis player, born in Basle. A professional since 1998, he won Wimbledon eight times, between 2003 and 2017, and the Australian Open six times, but his record as No. 1 was interrupted by injuries and surgery.

Feingold, Russ(ell Dana) (1953- ). American Democratic politician. He studied at the University of Wisconsin, in Oxford as a Rhodes Scholar and at the Harvard Law School. A Wisconsin State Senator 1983-93, he was a US senator 1993-2011, and took a courageous line on civil liberties, campaign finances, the death penalty and the Iraq war.

Feininger, Lyonel Charles Adrian (1871-1956). American painter, born in New York. He lived in Germany 1887-1936, was a political cartoonist, then a painter, influenced by Cubism, and taught at the Bauhaus 1919-33. He painted many architectural and marine subjects.

\section{Feisal (name of Arab rulers) see Faisal}

Felipe I (called 'the Handsome': originally Philipp of Burgundy) (1478-1506). King of Castile and Leon 1504-06, Regent of Spain 1506. An Austrian archduke, son of the emperor ${ }^{*}$ Maximilian and Maria of Burgundy, he inherited Burgundy from his mother. He married Juana of Castille (1479-1555), daughter of ${ }^{*}$ Ferdinand of Aragon and *Isabella of Castile and lived in Flanders as an absentee sovereign. He died very suddenly after exercise and was probably poisoned. His wife (later called 'Juana el Loco') suffered an immediate mental collapse and travelled about with his corpse until she was restrained in the castle of Tordesillas. The first king of the ${ }^{*}$ Habsburg dynasty in Spain, he was father of the emperors *Charles $\mathrm{V}$ and *Ferdinand I.

Felipe (Philip) II (Felipe Habsburgo y Aviz) (15271598). King of Spain 1556-98, of Naples and Sicily 1554-98, jure uxoris, of England and Ireland 155458 and of Portugal 1581-98. Son of Carlos I (the emperor ${ }^{*}$ Charles V) and Isabella of Portugal, when his father abdicated as king of Naples and Sicily in 1554 and as king of Spain in 1556, Felipe acquired the whole of the western part of the Habsburg heritage, Spain and Spanish America, the Low Countries, Naples and Milan. The Philippines (Las Islas Filipinas) had been named for him in 1543. All four of his wives predeceased him. In July 1554 he married the English queen ${ }^{*}$ Mary I at Winchester Cathedral and Parliament agreed that Felipe would share the throne so long as she lived. She died in 1558 without providing an heir and his hope of adding England peacefully to his domains ended. 
With immense industry but little wisdom the proud and lonely king ruled his vast inheritance. He was *Titian's greatest patron. He considered himself the military arm of the Counter Reformation, destined to bring all Europe back into the Roman Catholic fold, though he was frequently in conflict with the papacy on political issues. He conquered Portugal in 1580 . He provoked a long struggle in the Netherlands and so deprived himself of much of the trade and wealth of Europe's richest land and he paid for the murder (1584) of *William the Silent.

Even before the defeat of the Armada (1588) the English privateers had sapped his overseas trade and naval strength. In addition he carried on a long dynastic war with France and felt it his duty to hold the Turks at bay. Meanwhile at home the over-centralised governmental machine creaked ominously, agriculture and industry were ruined by the inflationary flow of gold from Mexico and Peru, the Inquisition produced, indeed, an enforced unity, but the country lost much of its vigour through the imprisonment or expulsion of many of the most industrious citizens (especially those of Moorish descent). Felipe lived aloof in the monastic palace of the Escurial. He was suspected (unfairly) of murdering his eldest son, the unstable Don *Carlos. Only one son survived to succeed him: Felipe III (1578-1621). Pious and benevolent in his private life, he was indifferent to public affairs which he left to his favourite, the Duke of Lerma. Under Felipe III Spanish culture was at its height.

Parker, G., Philip II. 1979.

Felipe (Philipp) IV (1605-1665). King of Spain 1621-65 and Portugal 1621-40. Conscientious but ineffectual, he was dominated (1621-43) by his minister *Olivares, whose unsuccessful wars impoverished Spain, losing Portugal and the Netherlands. Felipe is best remembered as the subject of 10 surviving portraits by *Velázquez.

Felipe V (né Philippe, Duc d'Anjou) (1683-1746). First Bourbon King of Spain 1700-24, 1724-46. A grandson of *Louis XIV of France, he was named by the childless ${ }^{*}$ Carlos II of Spain as his successor. By permitting Philippe to become King Felipe, Louis provoked the War of the Spanish Succession. By the Treaty of Utrecht (1713) Spain ceded the Spanish Netherlands to Austria and some possessions, including Gibraltar, to Britain, but Felipe was able to retain his Spanish throne. He was much under the influence of two women: the Princesse des Ursins, his first wife's maid of honour, and his second wife, Elisabeth (Isabel in Spanish) Farnese, whose ambitions for her children moulded the foreign policy of the reign. A manic depressive, he abdicated in January 1724 but resumed the throne in September after his son, Luis (Louis) I, died, aged 17. His acute melancholia was soothed each night by the singing of *Farinelli.
Felipe (Philip) VI (Felipe Juan Pablo Alfonso de Todos los Santos de Borbón y de Grecia) (1968- ). King of Spain 2014- . He succeeded on the abdication of his father *Juan Carlos I.

Fellini, Federico (1920-1993). Italian film director. His films, for which he also wrote the scripts, included La Strada (The Road, 1957), Cabiria (the name of the Rome prostitute round whose life the film revolves, 1958), La Dolce Vita (The Sweet Life, 1960) and 81/2 (1963). Other important works are Clowns (1970), Roma (1972), Amarcord (1974) and Casanova (1975). He received many national and international awards.

Baxter, J., Fellini. 1993.

Fénelon, François de Salignac de la Mothe (1651-1715). French writer and cleric. He came of a distinguished Perigord family, was trained for the priesthood and ordained in 1675. In 1689 he was chosen as tutor to *Louis XIV's grandson, the Duke of Burgundy, for whose benefit he wrote Fables (published 1716), a series of imaginary dialogues between famous men in the manner of *Lucian, and his best known work, Les Aventures de Telemaque (imaginary adventures of Odysseus' son). Published without his consent, with keys to the characters, this was a main cause of his withdrawal from court (1699) to his bishopric of Cambrai, to which he had been appointed in 1695. His Explication des l'qaximes des saints sur la vie intérieure (1697), a defence of quietism (i.e. 'interior inspiration,' opposed to the extreme dogmatism of *Bossuet), was condemned by the Pope, a verdict immediately accepted by Fenelon.

Feng Yuxiang (1882-1948). Chinese soldier and warlord. Known as 'the Christian general', his forces twice occupied Peking (Beijing), in 1924 and 1928. From 1929 he was increasingly hostile to ${ }^{*}$ Chiang Kaishek, and he fought Japanese militarism in China from 1933.

Fenner, Frank John (1914-2010). Australian biologist, born in Ballarat. A graduate of Adelaide University, he was active in promoting the use of myxomytosis to combat a rabbit plague, worked with Macfarlane ${ }^{*}$ Burnet on 'acquired immunological tolerance' and became foundation professor of microbiology at The Australian National University, Canberra 1949-73. He was awarded the 1995 Copley Medal of the Royal Society for leading WHO's international campaign for the elimination of smallpox and won the Australian Prime Minister's Science Prize in 2002.

Ferber, Edna (1887-1968). American author. Her popular novel Showboat (1926), was transformed into a successful Broadway musical by ${ }^{*}$ Hammerstein and *Kern, and later filmed. Saratoga Trunk (1941) and Giant (1953), were also filmed. She collaborated with G. S. Kaufman in writing the successful play Dinner at Eight. A Kind of Magic (1964) was autobiographical. 
Ferdinand (Fernando) I (Ferdinand von Habsburg y Trastámara) (1503-1564). Holy Roman Emperor 1556-64, Archduke of Austria 1521-64. Born in Alcalá de Henares, Castile, son of Philipp 'the Handsome' (*Felipe I) and Juana of Castile, in 1521 his brother, the emperor ${ }^{*}$ Charles $\mathrm{V}$, gave him the ${ }^{*}$ Habsburg estates in Germany and made him President of the Imperial Executive. Having married Anna, sister of the king of Hungary and Bohemia, he was able to claim both thrones on his brotherin-law's death (1526). Bohemia he secured without difficulty but in Hungary a rival claimant, János Zápolya, with Turkish support was able to prevent him obtaining anything but the royal title, a strip of land in the northwest, and Croatia. Ferdinand played a conciliatory part in the struggle between Roman Catholics and Protestants and negotiated the compromise known as the Peace of Augsburg (1555). After Charles abdicated (1556), Ferdinand became Emperor. He died in Vienna and was buried in Prague.

Ferdinand I (Ferdinand Karl Leopold Joseph Francis Marcelin von Habsburg-Lothringen) (1793-1875). Emperor (Kaiser) of Austria, King of Hungary, Bohemia and Dalmatia 1835-48. Son of *Franz II and Marie Theresa of Naples and Sicily (double first cousins), he was genetically handicapped, hydrocephalic, suffered severe epilepsy, frequent seizures, a speech impediment and sexual dysfunction. However, his diaries suggest that he was not feeble-minded. He ruled through his counsellors, notably *Metternich and his rival Anton, Graf von Kolowrat. He abdicated in December 1848 in favour of his nephew *Franz Joseph, retiring to Prague, where he died.

Ferdinand I (Ferdinand Maximilian Karl Leopold Maria of Saxe-Coburg and Gotha-Koháry) (18611948). Tsar of Bulgaria 1908-18 (knyaz [prince] from 1887). Son of Prince Augustus of Saxe-CoburgGotha, he was chosen as Prince of Bulgaria, then still under Turkish suzerainty, after the abdication of Alexander of Battenberg. By adroit political manoeuvring, which earned him the epithet 'Foxy', he was able (1908) to declare Bulgaria's complete independence. He was a leading spirit in the creation of the alliance that deprived Turkey of almost all of its European territory in the First Balkan War (1912), but Bulgaria's excessive demands provoked the Second Balkan War (1913), in which most of Bulgaria's gains were transferred to its former allies. Ferdinand aligned his country with Germany in World War I. After defeat, forced to abdicate in favour of his son *Boris III, he lived in Germany and was active as author, botanist, entomologist and philatelist.

Ferdinand (Ferdinando/Ferdinannu) I (1751-1825). King of the Two Sicilies 1816-25. King of Naples (as Ferdinand IV) 1759-99, 1799-1805, 1815-16 and of Sicily (as Ferdinand III) 1759-1816. He became king as a minor when his father, of whom he was the third son, became * Carlos III of Spain (1759). In 1768 he married *Maria Carolina, daughter of *Maria Theresa of Austria, and fell completely under her dominance and that of her favourite minister, the British Sir John Acton. Ferdinand was driven from Naples by the French revolutionary armies in 1798 and again in 1806 by Napoléon who made his brother Joseph *Bonaparte, and later Joachim *Murat, kings of Naples while Ferdinand ruled in Sicily under British protection. His restoration (1815) and, in 1816, the uniting of Naples and Sicily as the Kingdom of the Two Sicilies were followed by ruthless repression of all liberal opinion, and Ferdinand only retained his throne with Austrian support.

Ferdinand I (Ferdinand Viktor Albert Meinrad von Hohenzollern) (1865-1927). King of Romania 1914-27. Born in Sigmaringen, Germany, brought up as a Catholic (unusual in that dynasty), he married Princess Marie of Edinburgh (1875-1938), a granddaughter of Queen *Victoria. Adopted as heir to the throne of his uncle ${ }^{*}$ Carol I, he succeeded in 1914. In 1916 Romania joined the Allied alliance and declared war on the Central Powers. Although Romania was occupied by German troops (1917-18), the final Allied victory added Transylvania, the Banat, Bukovina and Bessarabia to its territories. Ferdinand was much distressed by the scandals involving his eldest son, who eventually became * Carol II.

Ferdinand (Fernando or Ferrando) II (known as 'the Catholic') (1452-1516). King of Aragon 1479-1516 and, as Ferdinand V, King of Castile and Leon 1469-1504. Son of Juan II of Aragon, and a member of the Trastámara dynasty, he succeeded his father in 1479. His kingship of Castile he owed to his marriage (1469) to his kinswoman *Isabella, sister of King Enrique IV (d.1474). It was only after a civil war that Isabella's position, with Ferdinand as consort, was secure (1479), Ferdinand's third throne, that of Naples, was gained by conquest (1504). His main purpose was to achieve religious and national unity throughout Spain. He resumed the war against the Moors and by 1492 had forced Granada, the last Moorish kingdom to surrender. He obtained the cession from France of Roussillon and Cerdagne (1493) and of Navarre (1512). To secure religious unity he expelled from his kingdoms all Jews and Moors unconverted to Christianity, thus depriving Spain of many of its ablest citizens, and to ensure Catholic orthodoxy he secured a Papal Bull setting up the Inquisition. Though Aragon and Castile retained their separate administrations he took every possible measure to centralise the government, the nobles were deprived of feudal privileges, and their castles were destroyed, royal magistrates supplanted elected officials in the towns, royal councils were set up to advise the ruler in both kingdoms and royal courts of justice were established. The power of the Cortes (parliament) steadily declined. Ferdinand and Isabella sponsored *Columbus' voyage to America (1492) and from 1494, taking advantage of the Pope's arbitrary 
division of the territories of the New World, they steadily enlarged Spain's colonial empire in Central and South America. The occupation of the Canary Islands in the Atlantic was completed by 1496 . When Isabella died (1504), the throne of Castile passed to their daughter Juana, known as 'the Mad' for whom her husband *Felipe I (formerly Philipp of Burgundy) was co-ruler. On Felipe's death (1506), Ferdinand assumed the regency and so was able to hand over to his grandson the emperor ${ }^{*}$ Charles V (Carlos I of Spain), son of Felipe and Juana, a dynastically united country, great in wealth and power.

Ferdinand II (1578-1637). Holy Roman Emperor 1619-37. A grandson of*Ferdinand I, he was educated by Jesuits and was chosen by the older archdukes as the most suitable person to head the dynasty and restore Roman Catholicism throughout the Habsburg lands. In 1617 he became King of Bohemia, in 1618 of Hungary and in 1619 he was chosen to succeed the emperor Matthias, who had died in that year. It was in Bohemia, where Protestantism was strong, that the accession of so rigid a Catholic caused most alarm, the nobles rebelled and invited *Frederick $\mathrm{V}$ of the Palatinate (husband of the British princess *Elizabeth, daughter of *James I and VI) to be king. He ruled for a single winter before he was defeated at the White Mountain (1620) and expelled, but Ferdinand's measures were so repressive that other princes took alarm and war continued, to become the Thirty Years' War (1618-48). Ferdinand did not live to see its end. In his own territories, however, Protestantism was effectively suppressed.

Ferdinand (Ferdinando) II (1810-1859). King of the Two Sicilies 1830-59. Son of *Francesco I of Sicily and grandson of ${ }^{*}$ Ferdinand I, his attempts to maintain autocratic rule in face of the political ferment that eventually produced the unification of Italy led him to ever harsher measures of repression. His inhuman bombardment of rebellious cities while subduing the revolution of 1848-49 earned him the nickname 'Bomba'. His son *Francesco II was driven out by ${ }^{*}$ Garibaldi (1861).

Ferdinand (Fernando) VII (Fernando Francisco de Paula Domingo Vincente Ferrer Antonio José Joaquín Pascual Diego Juan Nepomuceno Januario Francisco Javier Rafael Miguel Gabriel Calisto Cayetano Fausto Luis Raimundo Gregorio Lorenzo Jerónimo de Borbón y Borbón-Parma) (1784-1833). King of Spain 1808 and 1814-1833. After being *Napoléon's tool in the manoeuvres by which his father ${ }^{*}$ Carlos IV was induced to renounce his rights, he was enticed over the frontier and held in captivity while Napoléon's brother Joseph *Bonaparte occupied the Spanish throne. After his restoration by the Allies (1814), he abrogated all constitutional reforms and enforced a policy of extreme reaction. * Goya painted a spectacularly ugly portrait (1815) of him. The loss of the Spanish American colonies occurred during his disastrous reign. A rebellion forced him to accept constitutional government for three years (1820-23), but then, having regained liberty of action with the aid of French troops sent in response to his appeal to the powers, he pursued a policy of reaction and vengeance until his death. In the 'Pragmatic Sanction' of 1830, he revoked the Salic Law which excluded females from the throne, and the succession of his daughter *Isabel II provoked the Carlist wars.

Ferdowsi (Firdausi or Firdosi) (Hakim Anu i-Qasim Ferdowsi Tusi) (c.940-1020). Persian poet, born in Tus. For about 35 years he devoted himself to the Shahnameh (The Books of Kings), the longest epic ever written by a single poet, with 62 stories, 990 chapters, and about 55,000 rhyming couplets, some added by later editors. It is three times longer than *Homer's Iliad, and 12 times longer than the German Nibelungenlied. An epic history of the Persian kings, both real and legendary, up to the Muslim conquest of 641, Shahmenah remains enormously popular and is venerated by Zoroastrians. Matthew *Arnold took the theme of his poem Sohrab and Rustum from it.

Ferguson (of Raith), Adam (1723-1816). Scottish philosopher and historian. Educated at St Andrews and Edinburgh universities, he was a chaplain in the Black Watch and held chairs in philosophy in Edinburgh 1759-85. He was an important thinker in the Scottish Enlightenment and one of the peace negotiators with the American colonists 1778-79. His Essay on the History of Civil Society (1767) was a pioneering work in sociology and emphasised the role of conflict in historical development. It was read closely by ${ }^{*}$ Hegel and Karl *Marx.

Fermat, Pierre de (1601-1665). French mathematician. A lawyer by profession in Toulouse, he was one of the founders of the modern theory of numbers. He developed a form of calculus that influenced *Newton's investigations and anticipated *Descartes' work on analytical geometry, and deduced much of the mathematical theory of probability and the principles of permutations and combinations. He published no written works and his achievements can only be gathered from his correspondence with Descartes, *Pascal and others and rough notes. 'Fermat's last theorem' (1637), hypothesised that the equation $\mathrm{a} n+\mathrm{b} n=\mathrm{c} n$, when the exponent is greater than 2 , has no solutions in positive integers. A general proof, appropriate to all numbers, challenged mathematicians for centuries and thousands of attempts were made. In 1993 Andrew *Wiles provided a solution, which contained a flaw, but after radical revision, in 1995 his proof of Fermat (after 358 years) was accepted.

Mahoney, M. S., The Mathematical Career of Pierre de Fermat. 1973; Aczel, A. D., Fermat's Last Theorem. 1996; Singh, S., Fermat's Last Theorem. 1997. 
Fermi, Enrico (1901-1954). Italian-American physicist, born in Rome. Specialising in nuclear and particle physics, he studied at Pisa, Göttingen and Leyden. He was awarded the Nobel Prize in 1938 for his work on radioactivity and in that year emigrated to the US to escape Fascist anti-Semitism (which discriminated against his wife). Professor of physics at Columbia University 1939-45, he built in Chicago (1942) the first 'atomic pile' for sustained and controlled nuclear fission, and cooperated in the research which resulted in the first atom bomb. Element 100 was named fermium in his honour.

Fermi, L., Atoms in the Family. 1954; Segrè, E., Enrico Fermi, Physicist. 1970; Cooper, D., Enrico Fermi. 1999.

Fernandel (Fernand Joseph Désiré Contandin) (1903-1971). French comedy actor. He is best known for his performances in such films as Carnet de bal (1937), Coiffeur pour dames (1953) and five films (1951-66) based on Giovanni Guareschi's novels about Don Camillo, an ingenious and ingenuous Italian priest and his rivalry with the Communist mayor.

Rim, C., Fernandel. 1952.

\section{Fernando (Ferdinand) VII see Ferdinand (Fernando) VII}

Fernel, Jean François (1497-1558). French physician and anatomist. An innkeeper's son from Montdidier, he studied astronomy and astrology, philosophy and mathematics in Paris. One of his early works, the Cosmotheoria, contains a good estimate of the degree of meridian. For a career he took up medical studies, and received a licence to practise in 1530 . He soon became one of the most sought-after physicians in France, especially after saving the life of the dauphin's mistress, Diane of Poitiers. His attempts to treat ${ }^{*}$ François I's syphilis without having recourse to mercury, however, met no success. Fernel published a number of works on the theory of medicine, which became influential texts for future teachers. His basic point of view was traditional and Galenic. His physiology depended upon a view that bodily conditions were the product of the interaction of humours, temperaments and innate spirits. He emphasised the importance of empiricism and personal observation, and denied the role of astrological forces in disease. His magnum opus, the posthumously published Universal Medicina, contained some new observations, especially on the systole and diastole of the heart. He also gave a good description of appendicitis.

Sherrington, C. S., Endeavour of Jean Fernel. 1946.

Ferranti, Sebastian Ziani de (1864-1930). English electrical engineer, born in Liverpool. At 18 he patented a dynamo, which was followed by a period of prolific designing of electrical plant and machinery.
He was a strong supporter of AC in electricity generation (in opposition to *Edison's advocacy of DC). From a small generating station in Bond Street he supplied central London with electricity, and in 1890-91 he built and designed the equipment for the Deptford power station, which introduced the use of voltages far higher than previously possible. He was elected FRS (1927). He died in Zürich. Ferranti International produced television, electric clocks and an early computer and survived until 1993.

Ferrari, Enzo (1898-1988). Italian designer of racing cars. He was President of Ferrari Automobili SpA Sefac 1940-77.

Ferraro, Geraldine Anne (1935-2011). American politician. Trained as a lawyer, she became a Democratic Member of the House of Representatives 1979-85, and became the first woman vice presidential candidate of a major party in 1984 .

Ferraro, G., Ferraro: My Story. 1986.

Ferrier, Kathleen Mary (1912-1953). English singer. First a telephonist, she did not take up singing professionally until she was 30, but from 1946, when she made her operatic debut in *Britten's Rape of Lucretia, she was recognised as one of the greatest of modern contraltos. Bruno *Walter used Ferrier in the *Mahler revival, especially Das Lied von der Erde (1952) and he recorded extensively with her. She died (1952) of cancer.

Rigby, C., Kathleen Ferrier: A Biography. 1956.

Ferry, Jules François Camille (1832-1893). French politician. In 1870, during the Franco-Prussian War, he joined the 'Government of National Defence', later became a leader of the republican left and, after several ministerial appointments, was Prime Minister 1880-81 and 1883-85. As Minister of Public Instruction he organised the modern educational system of France, based on free, compulsory, nonreligious primary education. As Prime Minister he was also the principal builder of the French colonial empire in North Africa and Indo-China. In 1887 he was shot at by a madman.

Fessenden, Reginald Aubrey (1866-1932). American engineer and inventor, born in Québec. $\mathrm{He}$ worked for *Edison, *Westinghouse, the US Weather Bureau and General Electric, taking out over 500 patents (second only to Edison). He developed amplitude modulation (AM) and on 24 Dec. 1906 made the first broadcast of music and speech. In 1906 he also established the first two way radio link across the Atlantic (*Marconi).

Feuchtwanger, Leon (1884-1958). German author, born in Munich. He sprang into European fame with his historical novels The Ugly Duchess (1923) and Jew Süss (1925), in which he employed a realistic technique unusual in books of his genre. He left 
Germany in 1933, was arrested in France by the Nazis in 1940 , but made a daring escape to the US, where he made his home.

Feuerbach, Ludwig Andreas (1804-1872). German philosopher. After studying theology at Heidelberg he was attracted by philosophy, but having gone to Berlin to work under ${ }^{*}$ Hegel he reacted against philosophical idealism. He argued that all religious feelings were projections of human needs or wish fulfilments, and that God was a deification of self. Later he tried to work out a philosophy (naturalistic materialism) that would be consonant with a program of human betterment, and so in some measure he prepared the way for ${ }^{*}$ Marx. He coined the phrase 'Man is [ist] what he eats [isst]'. His Essence of Christianity (1841) was translated into English by George *Eliot.

Kamenka, E., The Philosophy of Ludwig Feuerbach. 1970.

Feydeau, Georges (1862-1921). French dramatist. His father, Ernest Aimé Feydeau (1821-1873), was the author of the novel Fanny (1858). He first won acclaim with his play La Tailleur pour dames (1887), which was followed, at approximately yearly intervals, by a series of light comedies, mostly in the tradition of bedroom farce, culminating with $L a$ Dame de chez Maxim (1899). Later with such plays as La Main passe (1904) he went deeper, to reveal the pathos and absurdity of marital relationships in disintegration. The fortune he made from his plays he lost by speculation, and in later years his need for money spurred him to write many one-act farces. Comparative oblivion followed his death, but recent reassessment, noting that he, like his characters, veered 'between extremes of happiness and depression', sees his plays as 'acted out fantasies'. Renewed interest in him was followed in 1966 by the revival in London of two of his plays A Flea In Her Ear and The Birdwatcher.

Feyeraband, Paul (1924-1994). Austrian philosopher. He taught in the US, UK and Europe, and became a controversial writer on the history and philosophy of science, arguing vigorously for cultural pluralism and against rigid systematic positions.

Feynman, Richard Phillips (1918-1988). American physicist, born in New York. Educated at MIT and Princeton, his early work on quantum mechanics, with John Archibald Wheeler, displaced the work of James Clerk *Maxwell. He worked on the 'Manhattan project' which produced the first atomic bomb, and correctly estimated the resultant energy yield. He then taught at Cornell 1945-50 and the California Institute of Technology 1950-88. In 1948 he devised the 'Feynman diagram', graphic analogues which illustrated mathematically how subatomic particles behave and interact and it became an essential reference tool in theoretical physics. He shared the 1965 Nobel Prize for Physics for his development of 'quantum electrodynamics' (QED), the interaction between light and matter, with Julian ${ }^{*}$ Schwinger and Sin-Itiro Tomonaga. He developed the theory of 'partons', hard particles inside neutrons and protons, on superfluidity and quantum computing. He was a brilliant public lecturer, best known for The Feynman Lectures on Physics (1963), wrote QED: The Strange Theory of Light and Matter (1985) and a discursive autobiography Surely You're Joking Mr Feynman! (1985), became a gifted artist (selling under the name Ofey) and bongo-drum player. He also had a rare gift for irritating his colleagues. In the presidential commission on the space shuttle 'Challenger' disaster (1986) Feynman was central in identifying the causes of the accident. Asteroid 7495 Feynman was named for him and his life became the subject of an opera, a novel and a play. A 1999 poll of eminent physicists ranked Feynman No. 7 of the 10 greatest physicists in history.

Gleick, J., Genius: Richard Feynman and Modern Physics 1992; Mehra, J., The Beat of a Different Drum. 1994.

Fibiger, Johannes Andreas Grib (1867-1928). Danish pathologist. He studied with ${ }^{*}$ Koch and von *Behring and was awarded the Nobel Prize for Medicine in 1926 for identifying an organism, Spiroptera carcinoma, which he believed to be the primary agent for cancer. His work was discounted after Yamagiwa Katsusaburō (1863-1930) came up with more plausible (but unrewarded) explanations.

Fibonacci, Leonardo Pisano Bigolio, also known as Leonardo of Pisa (c.1170-1240). Italian mathematician. who traded in Algeria, he was one of the greatest early writers on arithmetic and algebra. In his Liber abaci (Book of the Abacus, c.1202) he introduced the Arabic system of numerals into Europe. In later works he made highly original applications of algebra to geometry. He enjoyed the patronage of *Friedrich II. 'Fibonacci numbers', named for him but probably of Indian origin, are used in search techniques and in describing biological systems such as tree branching or the arrangement of pine cones: the sequence is $0,1,1,2,3,5,8,13,21$, $34,55,89$ and so on, where each subsequent number is the sum of the previous two.

Gies, J., and Gies, F., Leonardo of Pisa and the New Mathematics of the Middle Ages. 1969; Hemenway, P., The Secret Code. 2008.

Fichte, Johann Gottlieb (1762-1814). German philosopher. He was an admirer of ${ }^{*}$ Kant and after meeting him he wrote the Kritik aller Offenbarung (1792), which established his reputation in learned circles. He was appointed (1793) to a chair of philosophy at Jena, which he had to give up on being accused of atheism (1799). He continued to lecture in Berlin and in 1805 he was given a professorship at Erhangen. His Addresses to the German Nation, delivered in Berlin (1807-1808) after the humiliating 
defeat suffered by Prussia at the hands of Napoléon, did much to rekindle national spirit. However, it was an empire of reason based on a system of public education rather than military success that he saw as paving the way to revival. His philosophical system has been called 'transcendental realism': it propounds that all reality depends on our personal, conscious egos and ultimately on an entity he calls the pure or infinite ego. In his ethics he stresses the importance of the individual conscience. His son Immanuel Hermann von Fichte (1797-1879) was also a moral philosopher and theist.

Field, John (1782-1837). Irish pianist and composer, born in Dublin. A child prodigy, he was a pupil of ${ }^{*}$ Clementi, for whom he worked (in his piano warehouse) for some years. After a tour with Clementi he made his name and settled in St Petersburg (1804) as a fashionable teacher. He is best known as the creator of 'Nocturnes' (of which he left 16), a form later developed by ${ }^{*}$ Chopin.

Piggott, P., The Life and Music of John Field. 1973.

Field, Marshall (1834-1906). American businessman and philanthropist. In Chicago he gradually built up the department store of Marshall Field \& Co. (founded in 1881) and through his skill and innovations amassed a great fortune, much of which he devoted to educational purposes. He founded the Field Museum of Natural History and was the principal donor to the University of Chicago, built on land he gave in 1890. His grandson Marshall Field III (1893-1956) abandoned commercial activities for newspaper publishing in 1936. He acquired the liberal New York paper P.M. and started the Chicago Sun, which supported Franklin D. *Roosevelt.

Field, Winston Joseph (1904-1969). Rhodesian politician, born in England. He became a tobacco farmer, served in World War II, entered parliament in 1957 and defeated the moderate Sir Edgar Whitehead to become Prime Minister 1962-64. He was displaced by Ian *Smith, even more intransigently opposed to whites sharing power with the black majority.

Fielding, Henry (1707-1754). English novelist and dramatist, born in Somerset. Educated at Eton and Leyden University, having already produced a play in 1728 , he wrote 20 more in as many years, many of them dramatic burlesques of which the best known is Tom Thumb (1730). Pasquin (1736) and The Historical Register for the Year 1736 (1737) were political and social satires. Official reaction to them led to the passing of the Licensing Act. Thwarted in his dramatic aspirations, Fielding became a barrister (1740) and was a notable Westminster magistrate 1748-54. Meanwhile he had tried his hand at novels and political journalism. His novel Joseph Andrews (1742) was intended as a satire on Samuel *Richardson's sentimental romance Pamela, while The History of the
Life of the Late Mr Jonathan Wild the Great, an ironic attack on the idea of popular heroes, describes the role of a gang leader in a manner curiously modern. This was the third volume of his Miscellanies, published in 1743, the first two containing essays, poems and plays. His greatest novel was Tom Jones or the History of a Foundling (1749). In it he carries out, in its most perfect form, his conception of the 'comic-epic' novel, so closely followed by ${ }^{*}$ Dickens. His last novel was Amelia (1751), concerned with the fortunes of one whom Samuel *Johnson described as 'the most pleasing heroine of all the romances'. Meanwhile Fielding had used his magistrate's position to wage war on the evils of society and his pamphlets show a wise and liberal mind. But his health was giving way: in 1754 he started on a voyage but died and was buried in Lisbon. His short trip is described in The Journal of Voyage to Lisbon (published in 1755). His sister Sarah Fielding (1710-1768) also wrote novels (e.g. The Adventures of David Simple, 1744) and translated from the Greek.

Rogers, P., Henry Fielding: A Biography. 1979.

Fields, Dame Gracie (née Grace Stansfield) (18981979). English singer and actor, born in Rochdale, Lancashire. A cotton mill worker, after achieving her first important stage success in $M r$ Tower of London (1918-25) she became, through her wit, warmth of personality and fine singing voice, one of the most popular stars of music hall and musical comedy. She was created a DBE in 1979.

Fields, W(illiam) C(laude) (originally Dukenfield) (1880-1946). American actor, born in Philadelphia. At the age of 11 he ran away from home and embarked upon a successful vaudeville juggling career. From 1915 to 1921 he had a comic juggling act on Broadway in the Ziegfeld Follies. In 1923 his first comic role on stage was in Poppy in which he created the grandiose fraud character type and his first important film was Sally of the Sawdust in 1925. By 1931 he was writing, directing and improvising action in Hollywood. Noted for his Mr Micawber in David Copperfield (1935) as well as for comic roles in such films as The Bank Dick (1940), My Little Chickadee (1940) and Never Give a Sucker an Even Break (1941). He was one of America's greatest comedians. His style was pretension-pricking humour, characterised by wooden expression and nasal drawl. He played the cynic's role on and off the stage.

Fillmore, Millard (1800-1874). 13th President of the US 1850-53. Largely self-educated, he became a lawyer in up-state New York, an active Whig, US Congressman 1833-35, 1837-43 and Comptroller of New York State 1848-49. Elected Vice President of the US in 1848, he assumed the presidency on the death of Zachary *Taylor (1850). The last Whig President, he lost much support in the North for compromising on slavery and enforcing the Fugitive Slave Act, but was more successful in foreign affairs, 
with Daniel *Webster as Secretary of State. In 1852 he lost the Whig presidential nomination to Winfield ${ }^{*}$ Scott, who was then defeated by Franklin *Pierce. He travelled in Europe 1855-56 and, although not a 'nativist', accepted nomination as the candidate of the American (or 'Know Nothing') Party in 1856, running behind ${ }^{*}$ Buchanan and ${ }^{*}$ Fremont but carried only one state (Maryland). He supported *Lincoln in the Civil War and *Johnson after it.

Raybeck, R. J., Millard Fillmore: Biography of a President. 1959.

Filmer, Sir Robert (c.1590-1653). English political writer. Educated at Trinity College, Cambridge, he was an ardent advocate of divine right, imprisoned in Leeds Castle from 1644. His posthumous Patriarcha, or the Natural Power of Kings (1680) was attacked by *Locke.

Finlay (y de Barrés), Carlos Juan (1833-1915). Cuban epidemiologist. Of Scottish descent, he worked on the etiology and prophylaxis of yellow fever, identifying the mosquito Aedes aegypti as the vector (1881-82), later confirmed by Walter *Reed. He was nominated 10 times for the Nobel Prize for Medicine.

Finsen, Niels Ryberg (1860-1904). Danish physician, of Icelandic parentage. He discovered that ultraviolet light has therapeutic properties, especially in the cure of lupus vulgaris (tuberculous infection of the skin) and smallpox, and in 1903 was awarded the Nobel Prize for Medicine.

Finzi, Gerald (1901-1956). English composer. His works included concertos for clarinet, cello and piano, and Dies natalis (settings of poems by *Traherne).

\section{Firdausi see Ferdowsi}

Firestone, Harvey Samuel (1868-1938). American inventor and manufacturer. He invented pneumatic rubber tyres, used in the Model ' $T$ ' *Ford, replacing solid rubber tyres. He invented tractor treads and other specialist tyres.

Firuz Shah Tughlaq (1309-1388). Turkic ruler in India; Sultan of Delhi 1351-88. A member of the Tughlaq dynasty, he assumed power reluctantly and, although a fervent Muslim, promoted tolerance of other religions. He faced several rebellions, lost much territory, but built much infrastructure around Delhi-canals, madrasas (educational institutions), hospitals, public baths and gardens. His regime was both benevolent and corrupt. He wrote a memoir and created a library.

Fischer, Bobby (Robert James) (1943-2008). US chess champion, born in Chicago. He learned to play chess at the age of six, and won the US Junior Championship at 13 . At 16 he left school and in 1958 became the youngest player ever to attain rank of Grand Master. In 1958 he also won the US championship and in 1972 defeated Boris Spassky to become World Chess Champion, the first American to hold the title officially. In 1975 he refused to meet Russian challenger Anatoly Karpov and lost the crown by default. Often regarded as the finest player of all time, he died in Reykjavik.

Fischer, R. J., My 60 Memorable Games. 1969.

Fischer, (Hermann) Emil Louis (1852-1919). German chemist. One of the foremost organic chemists of the 19th century, he elucidated the structure of many naturally occurring substances, e.g. sugars, purines, amino-acids and polypeptides. This work opened the way for later investigations into the structure of proteins, Professor of Chemistry in Berlin 1892-1919, he was awarded the Nobel Prize for Chemistry (1902) for his work on sugar and purine syntheses. With Adolf von *Baeyer he developed barbiturates. Depressed by war, and suffering from cancer, he committed suicide.

Fischer-Dieskau, Dietrich (1925-2012). German baritone. He had the largest repertoire of any singer of modern times, recording 600 of *Schubert's songs, appeared in operas by ${ }^{*}$ Mozart, ${ }^{*}$ Verdi and *Wagner, and performed sacred music by ${ }^{*}$ Bach and ${ }^{*}$ Brahms. He took up a second career as a conductor in the 1970 s, edited Schubert's works and was a gifted painter.

Fischer von Erlach, Johann Bernhard (c.16561723). Austrian architect, town planner and architectural historian, born near Graz. Trained in Italy, he was one of the great masters of Baroque. Oval cupolas and high transepts are characteristic of his heavily ornamented churches, of which the Collegiate Church at Salzburg (1694-1707) and the Karlskirche (dedicated to St Carlo *Borromeo) at Vienna (begun 1715) are among the finest. Among his secular buildings in Vienna are the Court Library, the Trautson Garden Palace and the town house of Prince ${ }^{*}$ Eugène (the last two having remarkable staircase halls). He took a scholarly interest in the architecture of antiquity and in buildings from Asia.

Fischer, Tim(othy Andrew) (1946-2019). Australian politician. An army officer in Vietnam, he was affected by 'agent orange', became a farmer, served in the New South Wales (1971-84) and Commonwealth (1984-2001) Parliaments and led the National Party 1990-99. Deputy Prime Minister 1996-99, he took a courageous line in supporting gun control. Ambassador to the Holy See 2009-12, he radicalised as he aged.

Fish, Hamilton (1808-1893). American politician and lawyer, born in New York City. Educated at Columbia, he became an attorney, and a Member of the US House of Representatives 1843-45. Governor of New York 1849-50 and a US senator 1851-57, he worked closely with ${ }^{*}$ Lincoln during the Civil 
War. He served in President *Grant's Republican administration as a notably honest Secretary of State 1869-77, and negotiated settlement (1871) of the Alabama dispute, resulting from Britain's sale of warships to the Confederacy.

Fisher, Andrew (1862-1928). Australian Labor politician, born in Scotland. He worked as a coal miner from the age of 12 until 1885, then emigrated to Queensland. There he worked as a collier and engine-driver before becoming a Member of the Queensland Legislature (1893) and of the Federal House of Representatives 1901-15. He led the Labor Party 1907-15, and was Prime Minister 1908-09, 1910-13 and 1914-15. In 1910 he became the first Australian Prime Minister with a majority in both Houses of Parliament. He established the Commonwealth Bank, maternity allowances, pensions for old age (1909) and invalidity (1910), supported Douglas *Mawson's Antarctic Expedition, strengthened the arbitration system, promoted the railway link with Western Australia, chose Canberra as the national capital, issued the first banknotes, currency and stamps, created the Royal Australian Navy and the Australian Flying Corps (1911). In his last term, at the onset of World War I he promised aid to Great Britain 'to the last man and the last shilling'. He was Australia's High Commissioner in London 1915-21, his intellectual powers failed and he remained in London.

Day, D., Andrew Fisher: Prime Minister of Australia. 2008.

Fisher, Geoffrey Francis, Baron Fisher of Lambeth (1887-1972). English Anglican prelate. He succeeded William *Temple as headmaster at Repton 1914-32, and was promoted Bishop of Chester 1932-39 and Bishop of London 1939-45. On Temple's death he became Archbishop of Canterbury 1945-61. He crowned Queen *Elizabeth II in June 1953. His Church leadership was marked by a program of reform of Church law, and by increasing commitment to the ecumenical movement. His visit to Pope *John XXIII in Rome in 1960 was the first by an Archbishop of Canterbury since the Reformation. Awarded a life peerage on his retirement in 1961, he became an assistant parish priest in Dorset.

Fisher, Herbert Albert Laurens (1865-1940). English historian and Liberal politician. Educated at Winchester, Oxford, Paris and Göttingen, he was Vice Chancellor of Sheffield University 1912-16, a Liberal MP 1916-26 and President of the Board of Education 1916-22. The 'Fisher Act' (1918) extended compulsory education to the age of 14 and proposed part-time continuation schools until 18. Warden of New College, Oxford 1925-40, he wrote History of Europe (3 vols, 1935) and received the OM (1937).

Ogg, D., Herbert Fisher, 1865-1940. 1947.
Fisher, Irving (1867-1947). American economist. Trained as a mathematician, he was Professor of Political Economy at Yale 1898-1935 and his influence on contemporary economic thinking was second only to J. M. * Keynes. He wrote Mathematical Investigations in the theory of Value and Prices (1892), Nature of Capital and Income (1906) and Theory of Interest (1930), and developed the theory of index numbers as a measure of economic change and the modern theory of investment appraisal.

Fisher, St John (1469-1535). English cardinal, theologian and martyr, born in Beverley, Yorkshire. A humanist, he wanted to reform the church from within but was strongly opposed to ${ }^{*}$ Luther. He became Bishop of Rochester 1504-35 and Chancellor of Cambridge University 1504-35. He brought *Erasmus, who much admired him, to teach in Cambridge. Alone of the bishops, he opposed *Henry VIII in getting his marriage with ${ }^{*}$ Katherine of Aragon annulled and in his subsequent quarrel with the Pope. For refusing to take the oath required under the Act of Succession (1534), he was imprisoned with Sir Thomas * More and in recognition Pope *Paul III created him a cardinal. Incensed, Henry ordered him to be tried for denying the King's ecclesiastical supremacy, and he was hastily condemned and executed on Tower Hill. He was canonised in 1935.

Fisher, John Arbuthnot, 1st Baron Fisher of Kilverston (1841-1920). English Admiral of the Fleet, born in Ceylon. He joined the Royal Navy in 1854 and served in the Crimean War. As First Sea Lord 1904-10, he was responsible for major changes in dockyards, gunnery, new ship design and the development of submarines and torpedoes. He became the main proponent of the 'Dreadnought' class of battleships, designed to counter an anticipated German naval threat. In fact, the 'Dreadnought' campaign helped to encourage Germany to respond with a similar program. He received the OM in 1904. In October 1914, *Churchill restored him as First Sea Lord after Prince Louis of *Battenberg had been sacked because of hysteria about his German origin. Fisher and Churchill had a classic love-hate relationship: he had misgivings about Gallipoli but failed to communicate them and resigned in May 1915. In any case, his age and eccentricities had become an embarrassment.

Morris, J., Fisher's Face. 1995.

Fisher, Sir Ronald Aylmer (1890-1962). English mathematical statistician. Educated at Gonville \& Caius College, Cambridge, his The Genetical Theory of Natural Selection (1930) provided statistical reconciliation for the researches of ${ }^{*}$ Darwin and ${ }^{*}$ Mendel, also arguing for ${ }^{*}$ Galton's eugenics. He taught at Cambridge 1943-59, received the Copley Medal in 1956, then worked for CSIRO in Adelaide, where he died. He became a consultant to the tobacco industry, attempting to refute links between smoking and lung cancer. 
Fitzgerald, Lord Edward (1763-1798). Irish nationalist. A younger son of the 1st Duke of Leinster and Lady Emily Lennox, he fought against the American Revolution 1781-83, was elected to the Irish Parliament (1783), and, while in Paris (1792), declared himself a supporter of the French Revolution, renouncing his title. Back in his own country he joined the revolutionary United Irishmen, again visited the Continent to secure help and returned to prepare a rising. He was wounded in Dublin in May 1798, while resisting arrest, and died in the following month before he could be tried and (presumably) executed.

Pakenham, T., The Year of Liberty. 1969.

Fitzgerald, Edward (1809-1883). English poet and translator. Famous for his version of The Rubaiiyat of Omar Khayyam, he was educated at Cambridge, lived quietly in Suffolk, and became the friend of *Thackeray, ${ }^{*}$ Tennyson and ${ }^{*}$ Carlyle. He used his knowledge of Greek, Spanish and Persian to translate plays of *Aeschyhus, *Sophocles and, with special success, those of the Spanish dramatist *Calderon. His method, which was to convey the spirit of the original rather than write an exact translation, was triumphantly displayed in his Rubáiyát. Here the metre, almost as much as the words, suggests the languid, sensuous atmosphere of the Persian background. It appeared, anonymously, in 1859. After ${ }^{*}$ Swinburne and ${ }^{*}$ Rossetti praised it The Rubáiyát became phenomenally popular and much of that popularity remains.

Martin, R. B., With Friends Possessed: A Life of Edward Fitzgerald. 1985.

Fitzgerald, Ella (Jane) (1917-1996). American jazz and ballad singer, born in Virginia. She worked with orchestras and in cabaret from the 1930s but achieved her first wide acclaim in the 1950s as the star singer of Norman Granz' Jazz at the Philharmonic concerts. She recorded many albums, either solo or with jazz musicians such as Louis *Armstrong. Her voice was noted for its sweetness of tone and its range. Her style has been widely copied.

Fitzgerald, F(rancis) Scott (Key) (1896-1940). American novelist, born in Minnesota. His novels vividly express the desperation and futility of a section of American life during the 'Jazz Age', his own term for the 1920s. His books include The Beautiful and Damned (1922), The Great Gatsby (1925), All the Sad Young Men (1926), Tender Is The Night (1934), his unfinished novel about Hollywood, The Last Tycoon (1941), and a posthumous collection, The Crackup (1945). Despite popular success he fell into an inner despair and became an alcoholic. He died of a heart attack in Hollywood, the day before his friend Nathanael *West. Several novels and films have been based on his life. His wife Zelda (née Sayre) (19001947), also a writer, had a series of mental breakdowns and was kept in hospitals; she died in a fire.
Miller, J., F. Scott Fitzgerald. 1966; Donaldson, S., Fool for Love: F. Scott Fitzgerald. 1983; Prigozy, R. (ed.), The Cambridge Companion to F. Scott Fitzgerald. 2002; Cline, S., Zelda Fitzgerald: Her Voice in Paradise. 2003.

Fitzgerald, George Francis (1851-1901). Irish physicist. Professor of natural philosophy at Dublin 1881-1901, he is best known for the hypothesis he put forward (1893) to explain the failure of the ${ }^{*}$ Michelson-Morley experiment to show the earth to be moving through the 'ether'. He suggested that because of its electrical structure, all matter in motion contracts in the direction of motion. This 'Fitzgerald contraction' now forms an essential part of relativity theory. Fitzgerald was the first to suggest that the tail of a comet is formed by the pressure of solar radiation.

FitzGerald, Robert David (1902-1987). Australian poet. Trained as a surveyor, he wrote lyrical verse in the 1920s but in the late 1930s and after World War II he developed as a narrative poet with a strong leaning towards philosophy. His best known works are probably Moonlight Acre (1938), Between Two Tides (1952) and Southmost Twelve (1962).

FitzGerald, R. D., Forty Years' Poems. 1965.

Fitzherbert, Maria Anne (née Smythe) (17561837). English morganatic wife. Twice widowed, she married George, Prince of Wales (later *George IV), in 1785 . This marriage, although canonically valid, contravened the Royal Marriages Act since the consent of the king had not been obtained; she was, moreover, a Roman Catholic. She continued to live with George until 1803 except for a short interval (1795) after he married *Caroline of Brunswick.

Leslie, A., Mrs Fitzherbert. 1960.

FitzRoy, Robert (1805-1865). English naval officer and meteorologist. A descendent of ${ }^{*}$ Charles II (via the Dukes of *Grafton), he joined the navy at the age of 12, was captain of HMS Beagle in two journeys of exploration: first (1828-30) a hydrographic study of the South Atlantic, then (1831-36) with Charles ${ }^{*}$ Darwin to explore South America, New Zealand, Australia and South Africa. As Governor of New Zealand 1843-45, he was sympathetic to the Māori but made enemies with white settlers and was withdrawn. In 1854 he became the first director of what became the Meteorological Office, designed an efficient barometer and published weather 'forecasts' (his coinage). Promoted Vice-Admiral and elected FRS, he experienced a religious conversion, denounced Darwin's On the Origin of Species, for which he felt some moral responsibility, and cut his throat. He has been the subject of books, plays and films. His half-brother Sir Charles Augustus FitzRoy (1796-1858), soldier and administrator, served at Waterloo, was MP 1831-32 and after some minor postings was appointed Governor of New South Wales 1846-55, succeeding the unpopular Sir 
George Gipps. His term included the beginning of the Gold Rush, the end of transportation of convicts, the separation of Victoria from New South Wales, the first university, railways and long arguments about the nature of constitutional government in the colonies. He held the title of Governor-General of all Australian possessions 1851-55. FitzRoy made some powerful enemies, including J. D. *Lang and Robert *Lowe.

Nichols, P., Evolution's Captain: The Dark Fate of the Captain Who Sailed Charles Darwin Around the World. 2003; Thompson, H., This Thing of Darkness. 2005.

Fitzsimmons, Bob (Robert Prometheus) (18621917). English boxer, born in Cornwall. Brought up in New Zealand, he migrated to the US (1890) and became world heavyweight boxing champion (1897) when he defeated Jim *Corbett. In 1899 he lost the title to James J. Jeffries.

Odd, G., The Fighting Blacksmith. 1976.

Flagstad, Kirsten Marie (1895-1962). Norwegian dramatic soprano. Both her parents, two brothers and a sister were all musicians. She made her operatic debut in 1913, and achieved her greatest success from 1935 in Wagnerian roles, as Isolde, Brünnhilde, Elsa, Kundry and Sieglinde, also excelling as Leonora in Fidelio and as Dido in Dido and Aeneas. She made notable recordings with the tenor Lauritz *Melchior and the conductor Wilhelm ${ }^{*}$ Furtwangler.

Flaherty, Robert Joseph (1884-1951). American film producer, of Irish descent. Explorations in the Canadian Arctic (1910-16) inspired Nanook of the North (1922) and so set the pattern of his career as the pioneer producer of documentary films. To their making he brought knowledge, sympathy and poetic imagination. Other successes include Man of Aran (1934), Elephant Boy (1935) and The Louisiana Story (1949).

Flambard, Rannulf (d.1128). Norman administrator in England. He entered royal service under *William I and rose to greatness as justiciar and Bishop of Durham (1089) under *William II. *Henry I deprived him of the wealth he had amassed by extortion and he was imprisoned in the Tower of London, but escaped to Normandy. He seems then to have become reconciled to Henry and returned to rule his see of Durham with his usual efficiency and rapacity.

Flammarion, Camille (1842-1925). French astronomer. His many books and lectures did much to popularise the science. He erected a private observatory at Juvisy, near Paris, and made it available to amateur observers. His own work included the study of double and multiple stars and of the surface of the moon.
Flamsteed, John (1646-1719). English astronomer. He was appointed by ${ }^{*}$ Charles II the first Astronomer Royal at Greenwich Observatory (1674) and for over 40 years made stellar observations of an accuracy hitherto unknown; they were published with a catalogue of 300 stars (completed by Abraham Sharp) in Historia Coelestis Britannica (1712). In spite of meagre financial support, Flamsteed made many improvements in observational technique but his conscientious methods led to long delays in responding to requests for observations and to consequent quarrels with *Newton and *Halley.

Flanagan, Richard (1961- ). Australian novelist, born in Longford, Tasmania. He won a Rhodes Scholarship to Oxford, wrote non-fiction and novels, including Gould's Book of Fish (2002), The Unknown Terrorist (2006) and The Narrow Road to the Deep North (2013), which won the Man Booker Prize in 2014.

Flandin, Pierre Etienne (1889-1958). French politician. He was Prime Minister 1934-35 during the critical period after ${ }^{*}$ Hitler came to power, but as Foreign Minister (1936) he was unable to secure British cooperation in resisting his military reoccupation of the Rhineland. During World War II he served in *Pétain's Government 1940-41.

Flaubert, Gustave (1821-1880). French novelist, born at Rouen. Son of a prosperous physician, he went to Paris to study law, which he soon abandoned for writing (1844). Throughout adult life he was subject to hysterico-epileptic fits, the fear of which induced in him a profound pessimism. He was forced, in consequence, to leave Paris (1846) and thereafter lived quietly in the family home at Croisset, near Rouen. In 1846 he met the poet Louise Colet (1810-1876), and though their love affair lasted till 1855 , it seldom ran smoothly. It may have been syphilis, too, which induced the tendency, against which he struggled, to an excessive and almost frenzied romanticism of style. In 1849 he made a long visit to Egypt with his friend Maxime Du Camp (1822-1894). This marked the beginning of travel photography.

His masterpiece Madame Bovary (1857) was in part a conscious effort, made on the advice of friends, to retreat from high romanticism and concentrate on realism. It was a carefully documented account of provincial middle-class dullness as background to a story of a woman's infidelity. Its (unsuccessful) prosecution for obscenity ensured the novel's success. For his next novel, Salammbô (1862), set in the highly coloured background of Carthage and with a violent and romantic theme, he also applied the rigid discipline of exact documentation and even visited Tunis for the purpose, one of the very few occasions he left his country home. The partly autobiographical L'Education sentimentale (1869), though praised by critics, was not popular. It is lightened by the portrait of the heroine, Madame Arnoux, inspired by 
Madame Schlesinger, the object of Flaubert's early but unrequited love. La Tentation de Saint Antoine (1876) had begun in 1845 as a series of highly dramatised pen pictures of the temptations that might have beset the saint; the final version was a controlled and objective work. The unfinished novel Bouvard et Pécuchet was published posthumously in 1881 . Flaubert also wrote some passionate and pessimistic short stories.

Steegmuller, F., Flaubert and Madame Bovary. 1977; Barnes, J., Flaubert's Parrot. 1985; Winock, M., Flaubert. 2013/16.

Flaxman, John (1755-1826). English sculptor, born in York. Brought up in London, the influence of the classical revival is shown in the designs for pottery decoration that he did for Josiah *Wedgwood 1775-85. He then spent seven years in Rome, to which period belong such ambitious works as Cephalus and Aurora (now at Port Sunlight). In 1793 his illustrations to Homer gave him an international reputation. Examples of statues by him are to be seen in Westminster Abbey and St Paul's Cathedral (e.g. ${ }^{*}$ Nelson). His work is remarkable for its purity of line and its cool style.

Flecker, James Elroy (1884-1915). English poet and dramatist. He joined the consular service, served in Constantinople, Smyrna and Beirut, and died in Switzerland of tuberculosis. His poetic works include The Bridge of Fire (1907), Forty Two Poems (1911) and, best known of all, The Golden Journey to Samarkand (1913). His play Hassan was successfully produced in London after his death.

Fleming, Sir Alexander (1881-1955). Scottish bacteriologist, born in Ayrshire. He studied at St Mary's Hospital, London, and while Hunterian professor at the Royal College of Surgeons 191928 devoted himself to the problem of discovering an effective antibiotic substance that would kill bacteria without harming cell tissue. In 1919 he identified Lysozyme, a mucus secretion, but took it no further. In 1928 he discovered, accidentally, the germ-killing qualities of the mould penicillium notatum, now known as penicillin. A decade later *Florey and ${ }^{*}$ Chain began work on it and, under the pressure of war needs, a technique was worked out for large-scale manufacture. Professor of bacteriology at London University 1928-48, elected FRS in 1943, knighted in 1944, he was President of the Society for Microbiology 1945-55. He shared the 1945 Nobel Prize for Medicine with Florey and Chain, both of whom detested Fleming who played no role in the development of penicillin but reaped much of the credit.

MacFarlane, R. G., Alexander Fleming: the Man and the Myth. 1984.

Fleming, Sir (John) Ambrose (1849-1945). English physicist. His investigations into the 'Edison effect' led to his most important work, the development of the thermionic valve and its application to radio technology. He also did important work on the electrical resistance of materials at low temperatures, and on various forms of electric lamp. Professor of electrical engineering at London University 18851926, he received the Hughes Medal of the Royal Society in 1910 and was knighted in 1929.

Fleming, Ian Lancaster (1908-1963). British writer. Educated at Eton, Munich and Geneva, he became a journalist and worked in the City of London before being engaged in naval intelligence in World War II. In 1953 he published Casino Royale, the first of his spy stories, featuring James Bond as hero, with a secret service background and a mixture of heroic adventure, sex, mystery, and sadism. The James Bond series has sold by the millions: among the best known books are Moonraker, Dr No, From Russia With Love and Diamonds Are Forever. Several achieved even greater popularity as films, including the sensational Goldfinger, released just after his death. His brother, Peter Fleming (1907-1971), achieved early success with his travel books Brazilian Adventure (1933) and News From Tartary (1936). Peter's works include a novel, The Sixth Column (1951), Invasion, 1940 (1957) and The Siege of Peking (1959). He married the actor Dame Celia Johnson (1908-1982).

Amis, K., The James Bond Dossier. 1965; Lycett, A., Ian Fleming. 1995.

Fleming, Renée (1959- ). American soprano, born in Pennsylvania. She made her operatic debut in Houston in 1988, followed by Covent Garden in 1989 and the New York Metropolitan in 1991. Her rich voice and strong dramatic sense made her outstanding in operas by *Händel, ${ }^{*}$ Mozart, *Rossini, ${ }^{*}$ Verdi, ${ }^{*}$ Massenet, and Richard ${ }^{*}$ Strauss. She recorded extensively and made sound tracks for films.

Fletcher, John (1579-1625). English poet and dramatist, born in Rye. Son of a vicar who eventually became Bishop of London, after studying at Cambridge University, he may have been an actor when (from about 1606) he began writing plays. His association with Francis *Beaumont produced one of the most interesting collaborations in literary history. Over 50 have survived of which Fletcher was at least part-author: the best known are those he wrote with Beaumont, e.g. The Knight of the Burning Pestle (1609), Philaster (1611) and The Maid's Tragedy (1611). He probably wrote about 10 plays with Philip *Massinger (e.g. The False One and The Spanish Curate) and is supposed to have collaborated briefly with *Shakespeare, notably on Henry VIII. Works by Fletcher alone include The Faithful Shepherdess, Valentinian, The Wild Goose Chase and The Island Princess. He died of the plague.

Fleury, André Hercule de (1653-1743). French statesman. Having been almoner to *Louis XIV and created Bishop of Frejus, he became (1726) a cardinal 
and the chief advisor of ${ }^{*}$ Louis XV, whose tutor he had been. Until his death he virtually ruled France. His great service was to restore order to the French economy, which had been practically ruined under Louis XIV. He consistently strove to maintain peace in Europe and ensured that France played a minimal part in the War of Polish Succession. He was, however, pushed by court intrigue into the War of the Austrian Succession (1741).

Flexner, Simon (1863-1946). American pathologist. While in the Philippines (1900) he established the bacillus that bears his name and causes one form of dysentery. He developed (1907) a serum to cure spinal meningitis, and showed (1909) that poliomyelitis is caused by a virus. He was Director of the Rockefeller Institute for Medical Research, New York 1920-35.

Flinders, Matthew (1774-1814). English navigator and cartographer, born in Lincolnshire. Inspired by Robinson Crusoe, he joined the Royal Navy in 1789, learning his seamanship under Captain William *Bligh. He went to Australia in 1795 and on one of several voyages discovered the strait between Tasmania and the mainland named after George *Bass, a surgeon who accompanied him. Almost immediately after his return to England (1800) he was appointed to command HMS Investigator in a scientific expedition (1801-03) that carefully mapped the southern coast up to Sydney, then circumnavigated the mainland. On his voyage back to England, his ship was breached on the Great Barrier Reef but he returned to Sydney after a voyage of $1100 \mathrm{~km}$ in a six-oared cutter. When his ship HMS Cumberland needed repairs in Mauritius, he was detained there for six years by a suspicious governor and only released in 1810 (despite *Napoléon's order to free him). On Mauritius he prepared a map (1804) with the name 'Australia or Terra Australis' (first used by *Mercator in 1538). In England, although broken in health, he completed A Voyage to Terra Australis (1814) and an atlas. Lachlan *Macquarie took up the name Australia instead of New Holland and it was officially adopted in 1824. Flinders died in London; his grave was lost but relocated in 2019. About 100 places in Australia are named for him.

Estensen, M., The Life of Matthew Flinders. 2003.

Flood, Henry (1732-1791). Anglo-Irish politician and orator. He entered the Irish parliament in 1759, and his powers as an outstanding orator brought him to prominence. He became leader of a reform group seeking ultimate independence. In 1775 he became Vice Treasurer of Ireland under the British Viceroy. In 1779 he relinquished this post and returned to his efforts for legislative autonomy; in this (achieved 1782) he worked with Henry ${ }^{*}$ Grattan. He challenged Grattan's leadership of the patriotic reform movement in 1783, but his attempt to reform the Irish parliament failed in 1784 , and he lost much of his support.
Florensky, Pavel Aleksandrovich (1882-1937). Russian Orthodox theologian, philosopher, mathematician and polymath, born in Azerbaijan. Ordained as a priest, he published on a great variety of topics including aesthetics, art history, geometry, mathematics and physics. He was exiled from 1928, then shot by the NKVD.

Flores y Aramburu, Juan José (1800-1864). Venezuelan/Ecuadorian general and politician. He fought under ${ }^{*}$ Bolívar in the war of independence against the Spanish. When Gran Colombia began to disintegrate, Flores led the secession of Ecuador and became its first President 1830-34. A conservative and clericalist, Flores negotiated with the liberals that their leader Vicente Rocafuerte should succeed him as president, while he remained as head of the army. Flores was again President from 1839, but his constitutional amendment (1843) extending the presidential term to eight years was regarded as treacherous and he agreed to go into pensioned exile (1848). He attempted to regain power in 1860.

Florey, Howard Walter, Baron Florey of Adelaide and Marston (1898-1968). Australian pathologist, born in Adelaide. Son of a shoe manufacturer, he was educated at St Peter's College and the University of Adelaide and in 1921 qualified in medicine and won a Rhodes Scholarship. In Oxford he worked under Sir Charles * Sherrington on blood flow in the capillaries of the brain and carried out research in the US (1925-26), Spain (1929) and France (1931). He became a lecturer in pathology at Cambridge 1931-37, professor of pathology at Sheffield 193235 and Sir William Dunn professor of pathology at Oxford 1935-62. At Oxford he worked on two discoveries by Alexander *Fleming of material that seemed to have promising anti-bacterial propertiesLysozyme, a mucus secretion (identified in 1919) and penicillium notatum, a blue-green mould found on foodstuffs, especially bread, cheese, fabric and leather (noted in 1928). Neither had been pursued by Fleming. Lysozyme proved to be ineffective and Florey decided (1939) to concentrate on penicillin. Florey's leading collaborator was Ernst ${ }^{*}$ Chain who developed a technique for extracting, synthesising and concentrating the active ingredient from the mould. Successful experiments were carried out on mice (May 1940) and humans (Jan.-Feb. 1941) and its importance as a non-toxic systemic chemotherapeutic agent was recognised. Techniques were developed for its large scale manufacture in the US and Australia. Florey was knighted in 1944 and shared the 1945 Nobel Prize for Medicine with *Fleming and *Chain. (Fleming received much of the public acclaim for penicillin, but Florey won the highest professional rewards: their relationship was very uneasy.) Awarded the Copley Medal of the Royal Society (1957), he became President of the Royal Society 1960-65 and in 1965 received both a peerage and the Order of Merit. He was Provost of Queen's College, Oxford from 1962 until his sudden death from 
angina. He advised on the establishment of the John Curtin Medical School at The Australian National University, Canberra and was Chancellor of ANU 1965-68. Reserved and laconic until his last years, he was distant from his great Australian contemporary F. M. *Burnet. Penicillin is estimated to have saved 50 million lives since 1944. Florey's portrait appeared on the Australian \$50 banknote 1973-95.

Bickel, L., Rise Up to Life. 1972.

Florio, John (Giovanni) (1553-1626). EnglishItalian linguist and translator, born in London. His father, a Reformed pastor, had been exiled from Italy, his mother was English. He tutored at Oxford. Like *Shakespeare, he enjoyed the patronage of the Earl of Southampton and may have known him-even wilder conjectures suggest that he was Shakespeare. He translated *Montaigne's Essays into English (1603) and coined many new words.

Fludd, Robert (1574-1637). English physician and philosopher. Son of a well-to-do family with court connexions, he studied at St John's College, Oxford. He then toured Europe, mainly pursuing medical studies. He was elected a Fellow of the Royal College of Physicians in 1609, and built up a lucrative London practice. In middle age, he began to set down on paper a full system of natural philosophy, in which he was dismissive of the authority of *Aristotle, ${ }^{*}$ Galen and the universities. Fludd sought to build up a new synthesis based on a mixture of personal observation, the truths of Scripture, and Neo Platonic and Hermetic writings. He thought the universe was suffused with powers of sympathy and antipathy. Man was the microcosm. He was filled with spirit from the Divine Principle, the Sun. Just as the earth circled around the sun, so in man, blood circulated round the body. Fludd denied the validity of Aristotle's four elements; he believed the Bible revealed the three original elements to be light, darkness and water. Heat and cold were derivatives of light and dark. Fludd stands at the crossroads between magic and science. He believed in an occult universe, yet supported most of the new scientific discoveries of his day, seeing in them proof of his own magical explanations. Thus, for instance, ${ }^{*}$ Gilberd's magnetic researches proved the truth of universal attraction and repulsion.

Debus, A., The Chemical Dream of the Renaissance. 1968.

Flynn, Errol (originally Leslie Thompson) (19091959). Australian film actor, born in Tasmania. He attracted international attention for his striking good looks and his legendary dissipation. He appeared in 63 films, usually in swashbuckling roles.

Fo, Dario (1926-2016). Italian dramatist, actor and director. He founded the theatre groups ' $\mathrm{La}$ Nuova Scena' (1968) and 'La Comune' (1970), and performed with his wife Franca Rama. The Nobel Prize for Literature 1997 was awarded to
Fo 'who emulates the jesters of the Middle Ages in scourging authority and upholding the dignity of the downtrodden'.

Farrell, J., Dario Fo and Franca Rama. Theatre, Politics, Life. 2019.

Foch, Ferdinand (1851-1929). French marshal, born in Tarbes. Trained by the Jesuits, he joined the army (1869) but saw no service in the FrancoPrussian War. The turning point in his career came when he was an instructor 1894-99 at the École de Guerre. In this post, through his book Principles and Conduct of War (1899), and later as the school's director 1907-11, he influenced a generation of officers and military thinkers with his strategic doctrines and with his views on the importance of the offensive. At the outbreak of World War I, as Commander of the 9th Army he played a notable part in the victory of the Marne. In the next two years his main task lay in coordinating the French, British and Belgian roles on the Allied left flank. He retired with *Joffre (1916) but after the failure of *Nivelle's offensive he became Chief of Staff (1917). When the Germans broke through (March 1918) the necessity for a unified Allied command was at last recognised and Foch was appointed Generalissimo. His policy of husbanding his reserves until the enemy had fought to a standstill and then using them for a series of devastating attacks swept the Allied armies forward to their final victory. He accepted the German surrender in a railway carriage at Compiègne (November 1918). He later supervised the carrying out of the military clauses of the peace treaty. He was made a Marshal of France, a Member of the Académie française, and a British field marshal, GCB and OM.

Marshall-Cornwall, J., Foch. 1972.

Fogel, Robert William (1926-2013). American economic historian, born in New York City. In Time on the Cross (1974), with Stanley N. Engerman, he argued that slavery had been economically efficient in the southern states. He pioneered 'cliometrics', the application of economic theory and quantitative methods to explain historic change and shared the 1993 Nobel Prize for Economics with Douglass North.

Fokine, Michel (né Mikhail Mikhailovich Fokin) (1880-1942). Russian-American dancer and choreographer, born in St Petersburg. He danced in the Imperial Ballet and taught in the ballet school, had early success as a choreographer, and in 1904 was influenced by the individuality and expressionism of Isadora *Duncan. He created ballets that integrated dancing, music and scenery. The Swan (the Dying Swan, 1905) and Les Sylphides (originally Chopiniana, 1907) established his reputation. His great period was with *Diaghilev's Ballets Russes in Paris, working with ${ }^{*}$ Nijinsky, creating Scheherazade, The Firebird, Petrushka, Le Spectre de la Rose and Daphnis and Chloe. 
He left Russia after the Revolution and, in New York from 1920, danced, taught and choreographed about 80 ballets.

Fokker, Anthony Herman Gerard (1890-1939). Dutch aircraft designer, born in Java. He set up a factory in Germany (1912) and it was Fokker fighters, with their forward-firing machine gun, that gave the Germans their air superiority in the early part of World War I. He also designed effective biplane and triplane bombers. After the war Fokker concentrated mainly on civil aircraft built in Holland. In 1924 he set up a factory in the US and became an American citizen. He pioneered the use of lightweight metal fuselages in aircraft. He wrote an autobiography, The Flying Dutchman (1931).

Folger, Henry Clay, Jr (1857-1930). American industrialist and collector. A lawyer, he worked for John D. *Rockefeller at Standard Oil. He became obsessed with the works of *Shakespeare and, with his wife, Emily Clara Folger (née Jordan) (18581936), established the Folger Shakespeare Library in Washington, which opened in 1932. It has the world's largest collection of Shakespearean material, including 82 First Folios.

Mays, A. E., The Millionaire and the Bard. 2015.

Fonda, Henry (Jaynes) (1905-1982). American actor, born in Nebraska. After early stage success, he appeared in more than 80 films, including The Grapes of Wrath (1940), The Ox-Bow Incident (1943), Mister Roberts (1955: also on stage), War and Peace (1956: as Pierre), Twelve Angry Men (1957) and On Golden Pond (1981) which won him an Academy Award. His daughter Jane Fonda (1937- ), an actor, won Academy Awards with Klute (1971) and Coming Home (1978). She was also an effective political activist and promoter of aerobics. She married Ted *Turner in 1991. His son, Peter Fonda (1939-2019), an actor and director, was best known for his film Easy Rider (1969).

Fontanne, Lynn (née Lillie Louise) (1887-1983). Anglo-American actor, born in London. She married Alfred *Lunt in 1922 and achieved early success in plays by ${ }^{*}$ Shakespeare, ${ }^{*}$ Shaw, ${ }^{*}$ Chekhov and ${ }^{*}$ Coward. They often appeared together and dominated the New York stage for decades. However, she made only four films, and some television and radio productions.

Fontenelle, Bernard Le Bovier, Sieur de (16571757). French philosopher and scientist, born in Rouen. Educated by the Jesuits, he wrote elegant popular dialogues, arguing the relative merits of ancient v. modern books, and proposing new scientific theories e.g. ${ }^{*}$ Copernicus. He produced some original mathematical writings, trying to develop a general theory of the calculus. He became a great celebrity, and was accorded extensive public honours. Elected to the Académie française in 1691 , he became its perpetual secretary in 1699 . For 40 years he edited the publications of the Académie. He delivered lengthy funeral eulogies on scientists, emphasising the importance of science in an enlightened society, subtly reinforcing the ideas of ${ }^{*}$ Descartes v. ${ }^{*}$ Newton. He was even prepared to accept that there might be life on other systems in the Universe-evidence of his own mild religious heterodoxy. He claimed to have 'never run, never lost his temper and never made ha ha'.

Fonteyn, Dame Margot (née Margaret Hookham). (1919-1992). English ballerina. She made her debut (1934) with the Sadler's Wells Ballet, then joined the Royal Ballet where she became prima ballerina, establishing a reputation as one of the most sensitive and accomplished interpreters of classical ballet. She became President of the Royal Academy of Dancing in 1954 and received a DBE in 1956. In 1955 she married Roberto Arias (1918-1989), then Panama's Ambassador to Britain. He became a paraplegic after an assassination attempt and she moved to Panama to nurse him. However, she made occasional appearances in London and some international tours with her new partner Rudolf *Nureyev.

Foot, Michael Mackintosh (1913-2010). British Labour politician. Member of a notable Cornish political family, educated at Oxford, he became a prolific polemical journalist, MP 1945-55; 1960-92, editor of Tribune 1948-52; 1955-60 and biographer of Aneurin *Bevan (1962; 1973). Secretary of State for Employment 1974-76 and Lord President of the Council 1976-79, he became Leader of the Labour Party 1980-83, defeating Denis *Healey. Moderates (Roy *Jenkins) defected from the party, Foot was satirised (as 'Worzel Gummidge') and, after a shambolic campaign, Labour's vote fell by 9.3 per cent and Margaret ${ }^{*}$ Thatcher gained 58 more MPs.

Jones, M., Michael Foot. 1994.

Foote, Eunice Newton (née Newton) (1819-1888). American scientist, inventor, painter, and women's rights activist, born in Connecticut. She lived and worked in Seneca Falls, NY. She published an important paper, 'Circumstances affecting the heat of the sun's rays' (1856) on the role of carbon dioxide and water vapour in absorbing solar radiation, anticipating John *Tyndall's more detailed work (published in 1861).

Forbes, George William (1869-1947). New Zealand politician. A farmer from Canterbury, MP 1908-43, he became Liberal Party leader 1925-28 and when the United Party (a Liberal-Reform coalition) was created in 1928, he became deputy leader under Joseph *Ward. When Ward resigned, Forbes succeeded as Prime Minister 1930-35, during the Depression. Although personally likeable, he proved passive and fatalistic and his government was defeated by Michael *Savage’s Labour Party in 1935. 
Forbes-Robertson, Sir Johnston (1853-1937). English actor-manager. Trained as an artist, and a reluctant thespian, he was acclaimed for his acting in *Shakespeare (notably Hamlet) and *Shaw.

Ford, Ford Madox (formerly Ford Hermann Hueffer) (1870-1939). English novelist, critic and poet, born in Merton. A grandson of the Pre-Raphaelite painter Ford Madox *Brown, he helped Joseph *Conrad to master English and collaborated with him in The Inheritors and Romance. The best known of Ford's 60 books are the quartet of novels dealing with the moral crisis of World War I. Some Do Not, No More Parades, A Man Could Stand Up and The Last Post (1924-28). He wrote studies of Henry *James and Joseph Conrad and many critical essays and poems.

Saunders, M., Ford Madox Ford: A Dual Life. 2 vols, 1996.

Ford, Gerald R(udolph) (1913-2006). 38th President of the US 1974-77. Born in Omaha, Nebraska, he was originally Leslie Lynch King, taking his stepfather's name when his mother remarried. Educated at the University of Michigan and Yale Law School, he was a notable university footballer, graduated in law and served in the US Navy 1942-46, practising law in Grand Rapids, Michigan 1946-49. As a Member of the US House of Representatives 1949-73, he was a conservative moderate and internationalist. He sat on the *Warren Commission of enquiry into the assassination of President *Kennedy 1963-64 and became Minority Leader in the House of Representatives 1965-73. On the resignation of Spiro *Agnew in 1973, President *Nixon used the provisions of the 25th Amendment of the US Constitution for the first time to nominate Ford as 40th Vice President. When Nixon resigned in August 1974, Ford automatically succeeded him as 38th President of the US, nominating Nelson *Rockefeller as his Vice President. The pardon he granted to Nixon was intended to bring a rapid end to the Watergate trauma, but aroused much controversy. He retained Henry *Kissinger as Secretary of State and continued Nixon's foreign policies. He survived two assassination attempts in 1975. In 1976 he sought election in his own right, narrowly survived a challenge for the Republican nomination by Ronald ${ }^{*}$ Reagan and in November Jimmy ${ }^{*}$ Carter won the election.

Ford, Henry (1863-1947). American motor manufacturer, born at Greenfield, near Dearborn, Wayne County, Michigan. Son of William and Mary Ford, farmers who emigrated from Ireland in 1847, he was educated at rural schools, learnt how to repair watches and clocks, and by the age of 15 had set up a machine shop and sawmill on his father's farm. He had constructed a gas engine and other appliances when he joined the ${ }^{*}$ Edison company in Detroit (1890). In 1893 he built his first petrol driven car, capable of $25 \mathrm{mph}$ (40 kph). He helped to form the
Detroit Automobile Company (1899) which made custom cars, then left to develop his own racing car ('999'), which broke records and attracted business partners. In 1903 he founded the Ford Motor Company and in his first year sold 1700 Model 'A' cars-2-cylinder, petrol driven vehicles-at a time when most automobiles were electric or steam driven. In later years he worked his way through much of the alphabet. He was President of the Ford Motor Co. 1903-19, 1943-45.

In 1908 (also the year when William C. *Durant founded General Motors), Ford produced the famous Model ' $T$ ', the first mass-produced vehicle: 4-cylinder, petrol driven, with a soft canvass hood and available only in black. This inaugurated the era of 'motoring for the millions'. He developed the production techniques of Ransom *Olds, introducing a continuous, moving assembly line (conveyor belt) in 1913. He sold 300,000 Model 'Ts' in 1914, the first to have a left-hand steering wheel. The price fell steadily, from $\$ 825$ in 1908 to $\$ 260$ in 1925 . In 1911 he won a court action to break George Selden's patent for a petrol engine. He adopted Harvey * Firestone's pneumatic rubber tyres for smoother riding.

Ford was originally a benevolent, paternalistic employer. Advised by the liberal James Joseph Couzens (1872-1936), his general manager, in 1914 he introduced the $\$ 5$ day for workers (far more than his competitors), cut daily hours from 12 to 8 , pushing for the goals of high wages, high productivity and low prices, a community of interest for employer, employee and customer, and-he hoped-an alternative to socialism. He also introduced profitsharing for employees and employed black people, not just in menial roles. However, he refused to allow trade unions in his factories.

He also abominated banks and the stock market, bought out other investors and the family established sole ownership after 1917.

Ford had an instinctive grasp of marketing strategies, pushing the idea that the motor car was a freedom machine, which took people away from the tyranny of the familiar. Ford was the first company to conduct mass advertising campaigns and create a dealer network. More than 15,000,000 'flivvers' or 'Tin Lizzies', as they were known, were produced (1923 was the peak year).

As a fervent isolationist, he opposed World War I and in 1915 chartered a 'Peace Ship' and sailed to Europe in the hope of negotiating peace. Nevertheless, after the US entered the war (1917), Ford became a leading manufacturer of armaments and engines for trucks, aircraft and tanks.

In 1918 Ford stood unsuccessfully in Michigan for the US Senate as a Democrat and was promoted as a potential candidate for the presidency. In the 1920s, with Ford at the height of his fame, he was revealed in 
a libel action as cranky, anti-foreign (and particularly anti-Jewish), deeply prejudiced and ill-informed, which was reflected in his appalling newspaper the Dearborn Independent and his book The International Jew (1920). His famous phrase 'History is bunk' was a defensive reaction to ridicule about his shaky and romanticised grasp of America's past. But he had his admirers, *Hitler among them.

In 1921 Ford began manufacturing in Britain and Europe. Ford's Model 'T' lost its market dominance, despite the low cost, because General Motors (now run by Alfred P. *Sloan) offered a variety of models, more comfortable and stylish. Ford produced a new Model 'A' in 1928; the V-8 engine followed in 1932. In the 1930s, Ford opposed *Roosevelt's 'New Deal', imposed a rigorous conformity on his workers and employed company police to suppress strikes and keep unions out. This led to bloodshed, much to the dismay of Ford's son Edsel. In 1941 it was agreed that employees could join the Automobile Workers' Union (UAW).

Ford was a curious mixture of philanthropy, philistinism, credulity and hatred. He set up (1936) the Ford Foundation to stimulate education and social research. In World War II his company was a major supplier to the armed forces. He also set up a museum of Americana ('Greenfield Village') at Dearborn and founded a major hospital.

Ford became the greatest pioneer of the car based society, mass production and the 'Fordist' model of industrial production, with profound implications for the development of cities, leisure and work, the creation of road building, vehicle service and petrol supplying industries. All these changes had a major political and cultural impact. In Aldous *Huxley's ironic and prophetic novel Brave New World (1932), the calendar dates from 1908, 'the year of our Ford'. His son, Edsel Bryant Ford (1893-1943) was President of the Ford Motor Co. 1919-43. The unsuccessful 'Edsel' model (1957) became a synonym for failure. Edsel's son Henry Ford II (1917-1987) was company President 1945-79, introduced new models such as the Mustang and Thunderbird and promoted employment opportunities for African-Americans.

Lacey, R., Ford. 1986.

Ford, John (1586-c.1640). English dramatist. Little is known of his life and many of his plays have been lost. In some of his best known works, e.g. 'Tis Pity She's a Whore (c.1626), a tragedy of incestuous passion, he explores some of the more devious paths of sexual psychology, in others he was evidently influenced by the publication (1621) of *Burton's Anatomie of Melancholie to analyse the effects of despair. Perkin Warbeck (1634) is an example of his skill with a chronicle play. He also collaborated with *Dekker, Rowley and *Webster.
Ford, John (Sean O'Fearn) (1895-1974). American film director, born in Maine. He made 65 short silent films 1917-29 and 70 sound films 1928-66. Up the River (1930) was the film debut for Spencer *Tracy and Humphrey *Bogart. Ford won four Academy Awards for best director, a record, for The Informer (1935), The Grapes of Wrath (1940), How Green Was My Valley (also best picture, defeating Citizen Kane, 1941) and The Quiet Man (1952), and two more Oscars for documentaries. The Searchers (1956), a Western starring John Wayne and Jeffrey Hunter, is generally regarded as his masterpiece, being ranked among the greatest films ever made, although it won no Academy Awards. Other films include Stage Coach (1939), Long Voyage Home (1940), Wagonmaster (1950) and The Man Who Shot Liberty Valance (1962). His work influenced Orson *Welles, Ingmar *Bergman, *Kurosawa Akira, Satyajit *Ray, Alfred ${ }^{*}$ Hitchcock and François *Truffaut.

McBride, J. and Wilmington, M., John Ford. 1975.

Forde, Frank (Francis Michael) (1890-1983). Australian Labor politician, born in Queensland. A Federal MP 1922-46, he was Deputy Leader of the ALP 1935-46, Minister for the Army 1941-46 and Prime Minister for one week (July 1945) between *Curtin's death and *Chifley's election as party leader.

Forester, $\mathbf{C}$ (ecil) $\mathbf{S}$ (cott) (né Cecil Louis Troughton Smith) (1899-1966). English novelist, born in Cairo. Best known for his 10 novels on the adventures of Captain Horatio Hornblower, RN, in the Napoléonic Wars, his first success was the novel Payment Deferred (1926), later dramatised. His novel The African Queen (1935) became a prize-winning film (1951), directed by John *Huston, for which he wrote the screenplay. His other writings included biographies of *Josephine, *Louis XIV and *Nelson.

Forrest, Edwin (1806-1872). American actor. A notable Shakespearian, at his best in tragic parts such as Lear or Othello, he performed with great success in New York and in London (1836-37). His rivalry with W. C. * Macready led to a riot at the Astor Place Opera House, New York (1849), in which 20 people were killed.

Forrest, Sir John (1847-1918). Australian surveyor, explorer and politician, born in Bunbury, Western Australia. As a member of the WA survey department, he explored vast areas of its interior and published Exploration in Western Australia (1876). SurveyorGeneral of Western Australia and MLC 1883-90, when responsible government was introduced, he became the first premier of WA 1890-1901, and was made KCMG (1891), PC (1897) and GCMG (1901). On Federation, elected a Commonwealth MP 1901-18, he was first a Protectionist, then a WA Independent, Liberal and National. He served as Minister for Defence 1901-03 and Commonwealth Treasurer 1905-07, 1909-10, 1913-14 and 
1917-18. Eager to become Prime Minister, he failed narrowly with his colleagues. In February 1918 it was announced that he would be created Baron Forrest of Bunbury, the first Australian peer, but letters patent were never issued. He died of skin cancer, at sea, while sailing to London for medical treatment and to take up his peerage.

Crowley, F., Big John Forrest 1847-1918. 2000.

Forrest, Nathan Bedford (1821-1877). American soldier, born in Tennessee. Brought up in poverty, he made a fortune as a cotton planter and slave trader and on the outbreak of the Civil War joined the Confederate army (1861). He raised a cavalry regiment and won fame for his daring, especially in raiding enemy communications in Tennessee, Mississippi and Alabama. In April 1867 he became the first Grand Wizard of the Ku Klux Klan.

Forrestal, James Vincent (1892-1949). American administrator. An investment banker, he was Undersecretary 1943-44, then Secretary 1944-47, of the Navy, and became the first US Secretary of Defense 1947-49. He committed suicide, after a mental breakdown due to Cold War stress.

Forster, E(dward) M(organ) (1879-1970). English novelist, born in London. Educated at Tonbridge School (the 'Sawston' of two of his novels) and at King's College, Cambridge, he spent much of the years 1904-07 in Italy and Greece and he came to contrast the truth and passion of the Mediterranean world with conventional English life. During this time he wrote his first two novels, Where Angels Fear to Tread (1905) and The Longest Journey (1907), both of them remarkable for their sensitive analysis of the delicate balance in human relationships. The novel $A$ Room With a View appeared in 1908 and Howards End in 1910, the latter's theme being the two-fold struggle in which the middle class characters were engaged, the outer one within the class structure and the inner one between the passionate and conventional sides of their natures. These and the collection of short stories, The Celestial Omnibus (1911), received critical rather than popular acclaim. He lived in India before and after World War I and as secretary to the Maharajah of Dewas (1921) collected material for his final novel, A Passage to India (1924). This sympathetic study of the problems of overcoming barriers of race, class and nationality won the Femina Vie Heureuse and James Tait Black Prizes, and made him a major figure in English literature. His reputation increased with every novel he did not write. He produced three volumes of essays, Aspects of the Novel (1927), Abinger Harvest (1936) and Two Cheers for Democracy (1951), and the libretto for Benjamin *Britten's opera Billy Budd (1953). He lived with his mother 1925-45 and became a resident Fellow of King's College, Cambridge from 1946. He was made a CH in 1953 and OM in 1968. After his death his homosexuality was freely discussed and entered as a factor into critical revaluation; an early novel, Maurice (1913-14), on the theme, was published in 1971. All six novels were filmed, including three (Room with a View, Maurice, Howard's End) by the Merchant-Ivory group, and David *Lean's A Passage to India (1984), with Peggy *Ashcroft as Mrs Moore.

Kirkpatrick, B. J., A Bibliography of Forster. 1965; Furbank, P. N., E.M. Forster: A Life. 1979.

Forster, John (1812-1876). English writer. Best known as the friend and biographer of Charles *Dickens (3 volumes, 1872-74), he worked in political journalism, succeeded Dickens as editor of the Daily News, and edited the Examiner (1847-56). He wrote several historical studies of the struggle between *Charles I and parliament, and biographies of ${ }^{*}$ Goldsmith, *Landor and (unfinished) of ${ }^{*}$ Swift.

Foster, Jodie (Alicia Christian) (1962- ). American film actor and director, born in Los Angeles. She achieved instant recognition for her role as a child prostitute in *Scorsese's Taxi Driver (1976), won Academy Awards for The Accused (1988) and The Silence of the Lambs (1991), then became a director, winning Emmys and Golden Globes.

Foster, Norman Robert, Baron Foster of Thames Bank (1935- ). English architect, born in Manchester. He studied at Manchester and Yale, collaborated with Buckminster *Fuller, attracted international interest with the Sainsbury Centre for the Visual Arts, Norwich 1974 and won many awards. He was the architect for the new Hong Kong airport, the new Reichstag, Berlin, the redevelopment of the British Museum, and major works in Tokyo, Barcelona, Frankfurt and Nîmes. He received the OM (1997) and a peerage (1999). In London, the Millennium Bridge (2000), City Hall (2002) and 30 St Mary Axe (a.k.a. 'the gherkin', 2003) are already iconic. His Millau viaduct bridge, in Provence, the world's tallest, opened in 2004, on time, on budget and without a life lost in construction.

Foster, Stephen Collins (1826-1864). American songwriter. Largely self-taught, he wrote about 200 songs (Old Folks at Home, My Old Kentucky Home, De Camptown Races etc.), performed and made famous by touring minstrel troupes. He had no financial acumen, and poverty and alcoholism led to his death in hospital.

Howard, J. T., Stephen Foster, America's Troubadour. 1953.

Foucault, (Jean Bernard) Léon (1819-1868). French physicist. He demonstrated (1851), by means of a pendulum, the rotation of the Earth, and named (but did not invent) the gyroscope. Between 1849 and 1862 he perfected a laboratory method of measuring the velocity of light, to 99.4 per cent accuracy, using a rotating mirror. He also devised highly accurate methods of testing lenses and mirrors for reflecting 
telescopes for spherical and chromatic aberration. Awarded the Copley Medal in 1855, and elected FRS in 1864 , asteroid 5568 Foucault is named for him.

Foucault, (Pierre-) Michel (Doria) (1926-1984). French philosopher. Professor of the history of systems of thought at the Collège de France 1970-84, he wrote extensively about the use of 'the conventional wisdom' as an instrument of power against cultural deviation e.g. in the treatment of insanity, criminality, and sexuality (Madness and Civilisation 1961, Discipline and Punishment 1975, History of Sexuality 1976-84). He died of AIDS.

Macey, D., The Lives of Michel Foucault. 1993.

Fouché, Joseph, duc d'Otrante (1759-1820). French politician. He played a devious part in the politics of the Revolution, in the course of which he checked a rising in the Vendée and suppressed a revolt in Lyons with extreme ferocity. He became (1799) Minister of Police under the Directory and then under *Napoléon Bonaparte, whom he had helped to power. While Napoléon was absent with his armies, Fouché maintained order at home with ruthless efficiency and in the course of his work amassed so many private secrets that he became a source of universal terror. Wealth and honours were showered upon him but by 1810 he was already intriguing with the royalist exiles as a precaution against Napoléon's downfall. He succeeded briefly in retaining office under the restored Bourbons (1815) but was exiled as a regicide and lived in exile at Trieste until his death.

Fouquet, Nicolas (1615-1680). French official. A protégé of *Mazarin, he became Superintendent of Finances and built the great chateau and gardens at Vaux-le-Vicomte, enraging (1661) *Louis XVI with its lavishness but inspiring construction of Versailles. Fouquet was jailed for life on charges of corruption.

Fouquier-Tinville, Antoine Quentin (1746-1795). French politician. Notorious for the ferocity with which he carried out his duties as public prosecutor during the Revolution, he was executed after the ending of the Terror.

Fourcroy, Antoine François, comte de (1755-1809). French chemist. His father was a poor apothecary, who started his son in life as a copying clerk. Through the patronage of Félix Vicq-d'Azyr, young Fourcroy was enabled to study medicine. He became a doctor in 1780 and took to lecturing privately and at the Jardin du Roi, becoming professor there in 1784. As a chemist, Fourcroy supported *Lavoisier's explanation of the role of oxygen in combustion. Most of his own research was on the chemical composition of various constituents of animal bodies. He analysed the composition of gall and kidney stones, trying to find effective solvents for them. He published extensive analyses of mineral waters and their medicinal properties. He carried out experiments on the constituents of muscle fibre, finding a high nitrogen content. He also pursued researches into herbal medicines, conducting analyses of cinchona bark. He had a distinguished career in public life, becoming a member of the National Convention 1793-95. He was asked to advise on the practicality of mass gassings of counter-revolutionaries - a real 20thcentury touch. A professor at the École Polytechnique in 1795, a consul in 1801 and Minister for Public Instruction 1802-08, he played a large part in the introduction of the metric system of weights and measures.

Smeaton, W. A. Fourcroy. 1962.

Fourier, (François-Marie) Charles (1772-1837). French socialist, born in Besançon. Son of a prosperous draper, he spent much of his early life as a commercial traveller in Holland and Germany. Gradually he became convinced of the evils of a competitive society and the harm done to the individual by the suppression of natural passions by 'civilisation'. His ideas and theories, set out in three major books (1808-29), attracted little attention during his lifetime, except among his disciples, and he died poor and ignored. His interests ranged over a wide religious and psychological field, but on the practical side he proposed that society should be based on life in communities (phalanges) of 1620 people, enough to include most varieties of talent and temperament in communal buildings, and entirely self-sufficient. Each man would be allowed to change his occupation when he wished, and would be paid a minimum wage, and the conventional idea of marriage was to be abandoned. Colonies set up on these lines in France rapidly failed, those established (notably by * Greeley) in the US flourished for a time and then died out. The Israeli kibbutz bears some resemblance to Fourier's phalanx.

Fourier, (Jean Baptiste) Joseph, Baron Fourier (1768-1830). French mathematician, born in Auxerre. Son of a tailor, he studied and later taught at the military school in his birthplace. During the Revolution, he became prominent in local politics. In 1795 he was appointed teacher at the École Polytechnique. He carried out research in Egypt 1798-1801. On *Napoléon's fall he conformed to the new regime of ${ }^{*}$ Louis XVIII, and was rewarded in 1822 with the position of Perpetual Secretary to the Académie des Sciences. Fourier was a fertile thinker in the fields of mathematics and physics. He produced novel techniques in his theory of the functions of the real variable, which served as the starting point for more rigorous formulations from *Riemann and ${ }^{*}$ Cantor. But his most important work lay in developing a mathematical approach to heat. Through much of the 18th century, heat had been studied as part of chemistry. French science at the beginning of the 19th century became far more concerned with the physics of heat. Fourier's contribution was to produce a series of equations to quantifying and theorising about heat diffusion and heat flow. He was interested 
in problems of probability and the use of statistics. He anticipated the 'Greenhouse effect' (1824) by proposing that surface heat on Earth was retained by the atmosphere: without it, mean temperature would be 33 degrees Celsius lower and the Earth would be too remote from the Sun to support life.

Grattan-Guinness, I., and Ravetz, J., Joseph Fourier 1768-1830. 1972.

Fowler, Henry Watson (1858-1933) and Francis George (1871-1918). English lexicographers. They wrote The King's English (1906) and compiled the Concise Oxford Dictionary (1911-14). After his brother's death, H. W. Fowler wrote the Dictionary of Modern English Usage (published 1926).

Fowler, Sir John, 1st Baronet (1817-1898). English civil engineer. At first, he worked for small railway companies designing track systems and in the 1860 s experimented with a fireless and smokeless engine, which failed. With his partner Benjamin *Baker, he designed an underground system for the London Metropolitan Railway which opened in 1863 and earned them huge fees. He became President of the Institute of Civilian Engineers 1865-67. With Baker he designed the Forth Bridge (across the Firth of Forth, near Edinburgh). Constructed 1882-89, using steel, it remains the world's second longest single cantilever bridge, spanning 521 metres, and is a UNESCO World Heritage site. He became a significant landowner in Scotland.

Fox, Charles James (1749-1806). English Whig politician, born in London. Son of Henry Fox, 1st Baron Holland, and Lady Caroline Lennox, he was a descendant of ${ }^{*}$ Charles II through his mother. Educated at Eton and Oxford, his father bought him a seat in the House of Commons in 1768, at the age of 19; he sat almost continuously until his death. He was Junior Lord of the Treasury under Lord *North 1770-74 until *George III dismissed him because he opposed coercive measures against the American colonies. In opposition he campaigned violently for triennial parliaments and relief from legal disabilities for Roman Catholics and dissenters; he also attacked the royal influence in parliament. When North fell (1782), Fox became Secretary of State under *Rockingham, whose death a few months later caused him to resign. He now came to terms with North but the coalition ended when George III by personal intervention killed Fox's India Bill (1783). During the first years of William *Pitt's ministry, which immediately followed, Fox led the opposition. He moved the impeachment of Warren *Hastings (1788), strongly supported the French Revolution (breaking off his cherished friendship with Edmund *Burke over this issue) and consistently opposed Pitt's foreign policy which he considered unduly sympathetic to European despotism. He especially denounced, too, Pitt's wartime suspension of habeas corpus (1794). In 1795 Fox married his mistress,
Mrs Elizabeth Armistead, and after 1797 was seldom seen in parliament, but he returned in 1803 to try to prevent the rupture of the Peace of Amiens (1802) with France. On Pitt's death he became Foreign Secretary in the 'All the Talents' administration of ${ }^{*}$ Grenville (1806), but died of dropsy a few months later when he was about to introduce a bill for the abolition of the slave trade (eventually secured in 1807). Fox was a close friend of the Prince of Wales (later ${ }^{*}$ George IV), but as it became clear that the prince's opposition to his father was personal rather than political, the intimacy lessened. Fox's fondness for drink and gambling (in 1793 his friends paid $£ 70,000$ to provide for him and clear his debts) won him a dubious reputation that weakened his authority as a national leader. But he was a generous-minded and much loved friend and the principles he stood for were those of liberty-political and individualtolerance and justice. *Burke characterised him as 'the greatest debater the world ever saw'.

Hobhouse, C., Fox. 1948; Derry, J. W., Charles James Fox. 1972; Mitchell, L., Charles James Fox. 1992.

Fox, George (1624-1691). English religious leader, born in Fenny Drayton, Leicestershire. Founder of the Society of Friends ('Quakers'), he was the son of a weaver. At the age of 19 he heard an 'inner voice' and became an itinerant preacher. He disliked the outward ceremony of religion (for him the 'Church' was the worshippers, not the building) and he often interrupted services to preach his own belief that everyone has direct access to God. He rejected the Calvinist doctrine that only the elect could escape predestined damnation: salvation, he held, was open to all who heard the inner voice of God. He believed in pacifism and opposed capital punishment. In about 1650 he founded the Society of Friends. He and his followers were constantly persecuted and Fox was imprisoned, at various times, for a total of six years. He and his supporters travelled widely in North America, the West Indies and the Continent, and by 1660 their numbers had grown to 60,000 . He married (1669) Margaret Fell, a widow of the judge at whose house the Friends had met as early as 1652. A prolific writer, he kept a valuable Journal.

Wildes, H. E., The Voice of the Lord. 1965.

Fox, William (né Wilhelm Fuchs) (1879-1952). American film producer, born in Hungary. His parents migrated to New York in 1879. After working in the fur and garment industry, he bought theatres, distributed films and in 1915 founded the Fox Film Corporation, running it until a hostile takeover in 1930, which he regarded as a Wall Street conspiracy. Jailed for bribing judges in 1936 and 1942, he died forgotten. His name is preserved in 21st Century Fox and Fox News.

Krefft, V., The Man Who Made the Movies. 2017. 
Fox Quesada, Vicente (1942- ). Mexican politician. He studied at Harvard, became President of CocaCola Mexico, a leader of PAN (National Action Party) and Governor of Guanajuato 1995-99. In 2000, Mexico's PRI (Party of Revolutionary Institutions) was defeated in a presidential election for the first time since 1929. Fox served as President of Mexico 2000-06 and with his cowboy style had a strong affinity with George W. ${ }^{*}$ Bush.

Foxe, John (1516-1587). English Protestant clergyman. Author of the book celebrated as Foxe's Book of Martyrs, this work, completed (in Latin) in 1559 and translated in 1563, contains (with much else) a prejudiced but valuable account of the persecution of Protestants under *Mary I. He subscribed to, and enhanced the belief that, the English were 'an elect nation'. During Mary's reign Foxe had lived in Strasbourg and Basle but returned to England after *Elizabeth's accession.

Mozley, T. F., John Foxe and His Book. 1948.

Fracastoro, Girolamo (1477-1553). Italian scientist and poet, born in Verona. Member of a patrician family, he studied philosophy and medicine at Padua University. From 1502 he taught medicine at Padua and perhaps served as a physician in the Venetian army. He spent the bulk of his life cultivating his medical and general cultural interests with the literati of the day in Verona or on his estates near Monte Baldo. His interests ranged widely, from science to poetry, taking in mathematics, geography and astronomy. He is mainly famous for two books, one a poem on syphilis, which he named, and in the other he proposed the concept of 'contagion', hypothesising that tuberculosis was infectious.

Fragonard, Jean Honoré (1732-1806). French painter and engraver. A master of the Rococo, a pupil of ${ }^{*}$ Chardin and especially of *Boucher, he went to Italy having won the Prix de Rome. On his return he was commissioned to design a tapestry by ${ }^{*}$ Louis $\mathrm{XV}$ and subsequently became famous for his delicate pictures of the gay and graceful world in which he moved. The 11 paintings of The Progress of Love (1771-72, in the *Frick Collection, New York) are elegant and erotic. He is ranked as one of the major painters of the 18th century.

Wildenstein, G., The Paintings of Fragonard. 1960.

Frame, Janet (Nene Janet Paterson Clutha) (19242004). New Zealand author, born in Dunedin. Educated at Dunedin Teachers College and Otago University, her painful shyness led to misdiagnosis and treatment as a schizophrenic, events unforgettably described in her autobiography An Angel at My Table (1984) and depicted in Jane Campion's film of the same name (1990). She wrote novels, poetry and books for children.
France, Anatole (Anatole François Thibault) (18441924). French writer, born in Paris. His father was a bookseller and he early devoted himself to writing. His philosophy, as expounded in, e.g. Le Jardin d'Epicure (1895), was tolerant and undogmatic - a person is born a believer or not, as he is born blond or brunette, beliefs are only personal opinions. Similar views appear in La Rôtisserie de la Reine Pédanque (1893), Le Lys rouge (1894). Histoire comique (1903) and La Révolte des anges (1914). Few writers display a more orderly arrangement of thought or have a clearer or simpler style. His earlier novels, e.g. Le Crime de Sylvestre Bonnard (1881), Le Livre de mon ami (1885) and Thais (1890), already show his tendency to criticise and ridicule what would be called today the 'establishment', and after his liaison with Madame de Caillavet his criticism became more biting. He was a strong partisan of ${ }^{*}$ Dreyfus and his sympathies are clearly expressed in L'Affaire Crainquebille (1902) and L'Ille des Pingouins (1908), possibly the greatest of his works. He won the Nobel Prize for Literature in 1921.

\section{Francesca, Piero della see Piero della Francesca}

Francesca da Rimini (Francesca da Polenta) (c.12551285?). Italian beauty. Heroine of one of the world's famous love stories, she was the daughter of the Lord of Ravenna, on Italy's Adriatic coast, and was given in marriage, in return for military services, to Gianciotto Malatesta, the Lord of Rimini, a hunchback. She fell in love with her brother-in-law, Paolo, and on discovery both were put to death by her husband. *Dante relates a conversation with her in Inferno and the story of Francesca and Paolo was the subject of 28 operas (including one by *Rachmaninoff), a symphonic poem by ${ }^{*}$ Tchaikovsky, art works by *Ingres, ${ }^{*}$ Delacroix, ${ }^{*}$ Rodin, ${ }^{*}$ Doré and ${ }^{*}$ Watts, and a play by ${ }^{*}$ D'Annunzio.

Francesco (Francis) II (Francesco d'Assisi Maria Leopoldo Borbone della Due Sicilie) (1836-1894). King of the Two Sicilies (Naples and Sicily) 185961. Born in Naples and successor of *Ferdinand II, the conquest of his kingdom by ${ }^{*}$ Garibaldi and his enforced abdication ensured the unification of Italy. Francesco then lived in exile, first in Rome, then in Austria-Hungary. He has been proposed as a candidate for sainthood.

Francis (Franciscus in Latin) (Jorge Mario Bergoglio) (1936- ). Pope 2013- : No. 266 from St *Peter. Born in Buenos Aires of Italian descent and ordained in 1969, he was Provincial of the Jesuits in Argentina 1973-79, then taught theology and studied in Germany. A prudent opponent of the Argentinian dictatorship which collapsed in 1983, he became Auxiliary Bishop of Buenos Aires 1992-98 and Archbishop 1998-2013. He ran second in the 2005 conclave that elected *Benedict XVI. Elected by cardinals on the fifth ballot in March 2013, he was the first non-European pope since St 
Gregory III in 741, the first Jesuit, the first from the Southern Hemisphere and the first to take the name Francis, invoking the memory of $\mathrm{St}^{*}$ Francis of Assisi. Regarded as cautious but open, he lived simply in Rome, was regarded as a crusader for the poor and for social justice, strongly resistant to curial influence and open to dialogue. He took a strong position against paedophilia, abortion and euthanasia, but thought that the church's approach to sexual issues generally was unduly rigid and unforgiving.

\section{Francis I and II of France see François I and II}

\section{Francis I and II of the Holy Roman Empire see Franz I and II}

\section{Francis Ferdinand see Franz Ferdinand}

\section{Francis Joseph see Franz Joseph}

Francis, Sir Philip (1740-1818). Anglo-Irish politician and pamphleteer, born in Dublin. Through Whig patronage, he was appointed to clerkships in the civil service. The 'Letters of Junius', published anonymously 1769-72, were strongly critical of the governments of ${ }^{*}$ Grafton and ${ }^{*}$ North; Francis was almost certainly the author. Appointed as a member of the Supreme Council of Bengal 1774-80, with a very large salary, he formed a profound dislike of Warren *Hastings, the Governor-General. In 1780 he fought a duel with Hastings and was wounded. Having made a fortune, he returned to England and was a Whig MP 1784-90; 1802-07. He was the driving force behind the prosecution in the impeachment and long trial of Hastings, providing much of the grossly exaggerated evidence. An enthusiast for the French Revolution, he campaigned against the slave trade and for parliamentary reform. He hoped to be offered the governor-generalship of Bengal in 1795 and 1806 but had to be consoled with a knighthood (1802).

Francis of Assisi, St (Giovanni di Bernardone) (1181/2-1226). Italian friar, founder of the Franciscan Order, born in Assisi. The son of a prosperous merchant, he was nicknamed Francesco because of his father's travels in France. After a selfindulgent youth, he went on military service, fought against Perugia and spent a year in prison. After serious illness, he became an ascetic, taking vows of poverty, prayer and care for the helpless. Working joyfully with lepers and social outcasts, he went on a pilgrimage to Rome (1206) and was disowned by his father. In February 1209 he felt that he had been commissioned by Jesus to 'repair my house' (i.e. the Church). He left Assisi, and went to Rome with 11 followers to persuade Pope *Innocent III to sanction a new order, the Friars Minor (OFM) called 'grey friars' from their habit. Formal authorisation was given in 1215, but Francis was never ordained a priest. In 1212 , a second order, nuns soon known as 'poor Ladies', was established by his follower St Clare (c.1193-1253): they are now called 'poor Clares'. The Friars Minor expanded rapidly, sending missionaries through Italy, France, Spain and North Africa. Francis himself visited Dalmatia, Egypt (where he persuaded the Ayyubid Sultan to grant his order guardianship of the Church of the Holy Sepulchre in Jerusalem, and secured better treatment for Christian prisoners) and Palestine (1219-20). Francis' teaching was joyful, with a celebration of nature as the mirror of God's creation, including sun, moon and stars, flowers and reverence for animals. Nevertheless he practised stern self-denial. In 1221, when his first order already had 5,000 members, he established a third, for the laity. From 1223 he withdrew from active direction of the Franciscans, retiring to a monastery at Monte La Verna (Alvernia). Here in 1224 he received the stigmata, carefully concealed while he lived, and was sick and almost blind until his death. Pope Gregory IX named him a saint in 1228 , but the title had been popularly conferred long before. His aim was to 'walk in the footsteps' of Jesus and in 1926 *Pius XI called him 'the second Christ'. In 1979 *John Paul II named Francis patron saint of ecologists.

Moorman, J. R. H., Sources for the Life of Saint Francis of Assisi. 1967.

Franck, César (Auguste Jean-Guillaume Hubert) (1822-1890). Belgian-French composer, born in Liège. When barely 11 he toured as a concert pianist. After his family had moved to Paris he entered the Conservatoire (1837) but was withdrawn by his father to resume concert playing. Franck received little attention as a composer during his lifetime but attracted a circle of admiring disciples, including the composer Vincent $d^{\prime *}$ Indy. His compositions are clearly influenced by the music of ${ }^{*}$ Beethoven, *Liszt and *Wagner (especially Tristan und Isolde) and his orchestration reveals his preoccupation with the sonorities and registration of the organ. Organist at St Clotilde from 1859, he worked closely with the organ builder Aristide ${ }^{*}$ Cavaillé-Coll and became professor of organ at the Paris Conservatoire (1872). A late developer, his greatest works were the Piano Quintet (1878-79), symphonic poem Le Chasseur maudit (1882), Variations symphoniques for piano and orchestra (1885), Violin Sonata in A (1886), Symphony in D Minor (1886-88), symphonic poem Psyche (1887-88) and String Quartet in D (1889). He also wrote many pieces for organ and piano, several songs and much Church music, including the oratorio The Beatitudes (1869). He was injured by a horse-drawn bus in Paris and died of pleurisy.

Stove, R. J., César Franck: His Life and Times. 2011.

Franco (Bahamonde), Francisco Paulino Hermenegildo Teodulo (1892-1975). Spanish Generalissimo and Chief of State (Caudillo), born in El Ferrol. He joined the army in 1907, served in Morocco and became Spain's youngest general in 1926, commanding the Foreign Legion. He crushed a rising of miners in Asturias (1934), and became 
Chief of the General Staff 1935-36 until the Popular Front government demoted him to command in the Canary Islands. The Civil War began in July 1936 with an army mutiny in Morocco. Franco joined the Insurgents, flew to Morocco and organised the Foreign Legion and Moorish troops. After General José Sanjurjo was killed in a plane crash in October 1936, Franco became Caudillo and his only potential rival, General Emilio Mola, soon died the same way. In 1937 he became leader of Falange Española, after José Antonio *Primo de Rivera had been executed by the Loyalists. With strong Italian and German aid, Franco defeated the Loyalist government of *Azaña and occupied Madrid on 1 April 1939. Franco set up a corporate state, killed about 100,000 opponents in the next five years and offered to join *Hitler and ${ }^{*}$ Mussolini if the Axis powers would pay for it. Spain technically remained neutral in World War II although Franco sent the 'Blue Division' (47,000 strong) to fight on the Russian front. The Axis defeat put Franco in a precarious position. The Cold War saved him and *Eisenhower set up US military bases in Spain (1953). Tourism became a major factor in the Spanish economy and the Falange lost its ideological fervour. Franco arranged that the Bourbon monarchy would be restored on his death (*Juan Carlos) and some political liberalisation took place.

Gallo, M. S., Spain under Franco. 1973; Preston, P., Franco. 1993.

François I (1494-1547). King of France 1515-47. Born in Cognac, son of Charles, Count of Angoulême, descended from a younger branch of the *Valois dynasty, he was a cousin of *Louis XII. In 1514 he married Claude (1499-1524), daughter of Louis and *Anne of Brittany, and succeeded as king in 1515.

In 1519 despite heavy bribes, he failed to secure election as Holy Roman Emperor. This began the long rivalry with, and mutual detestation of, the successful candidate, ${ }^{*}$ Charles $\mathrm{V}$, which was the central feature of his reign. At the Field of the Cloth of Gold (1520) he tried unsuccessfully to win the support of *Henry VIII of England. Captured by imperial troops at Pavia (1525), he was kept as a prisoner in Madrid until 1526, signed a humiliating treaty and two of his sons were kept as hostages for four years. In 1530 he established French as the national language, replacing Latin in official documents in 1539. The FrancoOttoman Alliance, the first between Christian and Muslim states, was settled with Sultan *Süleyman ('the Magnificent') in 1536 and survived until 1798. France and the Ottoman Empire combined against Charles V and his Empire, but when peace was secured (1546) neither side had made significant gains. François' reign overlapped with *Luther's challenge to Papal authority and the beginning of the Protestant Reformation. At first, influenced by his sister *Marguerite of Navarre, he was sympathetic to reform but then saw it as challenging all authority, including his own. French Protestants, known as
'Huguenots', mostly followers of *Calvin, were persecuted, exiled, and sometimes massacred. This continued until 1598 when ${ }^{*}$ Henri IV became king.

François established the nucleus of an efficient centralised administration. It was with his encouragement that ${ }^{*}$ Cartier crossed the Atlantic and claimed the Gulf of the St Lawrence for France. He was also a notable patron of the arts. He began reconstructing the Louvre in its modern form, built the huge chateau on the Loire at Chambord and palaces at Fontainebleau and Saint-Germain-en-Laye. He admired ${ }^{*}$ Erasmus, patronised ${ }^{*}$ Rabelais, bought the Mona Lisa in 1517 and summoned *Leonardo da Vinci to live (and die) at Amboise. He died at Rambouillet and was buried in St Denis. His symbol was the salamander.

Seward, D., Prince of the Renaissance: Life of François I. 1973.

François II (1544-1560). King of France 1559-60. The son of *Henri II and *Catherine de'Medici, he married (1558) * Mary Queen of Scots. During his brief reign his uncles (François and Charles de Guise) persecuted the Protestants.

François de Sales, St (François Bonaventure de Nouvelles) (1567-1622). French Catholic bishop and religious writer, born in Sales (Savoy). Brought up at the family chateau, he was a law student in Padua before becoming a priest. His success in converting Swiss Calvinists led to his becoming Bishop of Geneva 1602-22, living at nearby Annecy in his native Savoy. His spiritual friendship with Jeanne Françoise de Chantal (later canonised) led to their founding, jointly, the Order of the Sisters of the Visitation. His Introduction to the Devout Life and the mystical Treatise on the Love of God are the best known of his religious works.

Frank, Anne (1929-1945). German-Jewish diarist, born in Frankfurt-am-Main. The family fled to Amsterdam in 1933 to escape Nazi rule. When Germany occupied Holland in 1940 they went into hiding, living in attic rooms of a factory/warehouse, supplied with food by Dutch employees. They were betrayed by Dutch informers in 1944 and were taken to Bergen-Belsen where she died of typhus with her mother and sister; only her father, Otto Frank (1889-1980), survived. On returning to Holland, he was given the diary kept by his daughter 1941-44. The Diary of a Young Girl was published in 1947 and established her as a symbol of Jewish suffering under *Hitler. The book sold more than 30,000,000 copies. The book's quality of writing, especially its vitality and candour, aroused some initial scepticism, now completely dispelled. An unexpurgated version was published in 1997. Anne Frank House is preserved as a museum. 
Frank, Hans (1900-1946). German Nazi politician. A lawyer, he was a Reichstag member 1930-34 and Minister without Portfolio in *Hitler's Government 1934-40. As Governor-General of Poland 1939-45 he supervised deportations and exterminations of millions of Jews. He provided his extensive diaries to the prosecutors at the Nuremberg war crimes trials and converted to Catholicism, was convicted and hanged, apparently dying repentant. However, his son Niklas Frank was unforgiving, describing him as 'a slime-hole of a Hitler fanatic'.

Frankfurter, Felix (1882-1965). American jurist, born in Vienna. Professor of Administrative Law at Harvard 1914-39, he was a close friend of Franklin D. * Roosevelt and a valued advisor in the early days of the New Deal. As a justice of the US Supreme Court 1939-62, he combined strong liberal sympathies and conservative respect for judicial procedure.

Franklin, Aretha Louise (1942-2018). AfricanAmerican singer, songwriter and pianist, born in Tennessee. Known as the 'Queen of Soul', she toured and recorded extensively, had a strong emotional appeal and won many awards.

Ritz, D., Respect. 2014.

Franklin, Benjamin (1706-1790). American statesman and scientist, born in Boston. His father, a tallow chandler, married twice and had 17 children: Benjamin was the 15th, the 10th by the second wife. His schooling was brief and he was largely self-educated, helped in this by being apprenticed, at the age of 12 , to his half-brother James, a printer. Printing led to journalism and his career really started (though from 1724 he had already spent 18 months in London) when by 1728 he was settled in Philadelphia as owner of the Pennsylvania Gazette. He also published (1732-57) Poor Richard's Almanack, which achieved enormous success. Many of 'Poor Richard's' pithy aphorisms, some borrowed, some original, became proverbial. Franklin continued to be a powerful coiner of aphorisms, e.g. 'Remember that time is money'; 'Lost time is never found again'; 'They who give up essential liberty to obtain a little temporary safety deserve neither liberty nor safety'; 'There never was a good war or a bad peace'; 'In this world nothing can be said to be certain, except death and taxes.'

After starting a fire service (1736) and being postmaster (1737), he extended his interest in education by helping to found the American Philosophic Society (1743) and the Philadelphia Academy (1751), which developed into the University of Pennsylvania. He invented (c.1740) the 'Franklin stove' and 'Pennsylvania fireplace' for efficient heating and cooking, bifocal spectacles, a flexible catheter and the glass harmonica. Meanwhile he had become interested in electrical phenomena. With his famous kite experiment (1752) he proved that lightning is a form of electricity, produced a satisfactory explanation of the difference between positive and negative charges, and invented the lightning conductor, which brought him fame, the Copley Medal in 1753 and election to the Royal Society in London in 1756 . He also explained the operation of the Gulf Stream. His early writings on population anticipated *Malthus, and he argued for the wave theory of light and that temperature affects electrical conductivity.

After 1750, political interests now became increasingly important. He was a Radical member of the Pennsylvania Assembly 1751-64 and deputy postmaster for the American colonies 1753-74. As agent for the Assembly he visited England 175762 and was lionised in social and scientific circles. Again in England 1764-75, he played a conciliatory part in the quarrels between England and the American colonies and helped to secure the repeal of the Stamp Act (1766). When, however, a breach became inevitable, he returned to America to play a leading but always conciliatory part in the fight for independence. He helped to draw up the Declaration of Independence (1776), became the most successful of the three commissioners sent to enlist French aid (1776-78), and was Minister to France 1778-85. He helped to negotiate, and was a signatory to, the Treaty of Versailles (1783) by which American independence was finally recognised. In 1784 he collaborated with *Lavoisier in an important investigation, established by *Louis XVI, of animal magnetism (then currently in vogue: ${ }^{*}$ Mesmer) and which set out the principles of experimental method.

President of Pennsylvania 1785-88, he sat in the convention which drew up the US Constitution 1787-88. His wisdom and moderation in politics and the breadth of his scientific and political achievements make Franklin one of the greatest figures of American history.

His illegitimate son William Franklin (1731-1813), his scientific co-worker who became Governor of New Jersey 1763-76, remained loyal to *George III and later withdrew to live in England.

van Doren, C., Benjamin Franklin. 1948; Isaacson, W., Benjamin Franklin: An American Life. 2003; Lemay, J. A. L., The Life of Benjamin Franklin. 3 vols, 2005-08.

Franklin, Sir John (1786-1847). English Arctic explorer, born in Lincolnshire. He joined the navy (1801), fought under ${ }^{*}$ Nelson at Trafalgar and, when peace came, made several voyages of Arctic exploration after 1818. As Lieutenant Governor of Van Diemen's Land (Tasmania) 1837-43, working with Alexander Maconochie (1787-1860), he promoted humane treatment of transported convicts. In 1845 with his two ships, the Erebus and Terror he began his last voyage, in search of a northwest passage, from which no survivor returned. After several expeditions had sought in vain, a full record was found in a cairn at Point Victoria by John *Rae: 
the party had been caught in the ice on the west side of King William Island and Franklin had died in June 1847. The others left the ships but succumbed to scurvy and starvation. His second wife, Lady Jane Franklin (née Griffin) (1791-1875), was an indefatigable traveller, supporter of education and science, who campaigned for expeditions to establish what had happened to her husband's expedition but was enraged by John *Rae's report (1854) which suggested that Franklin's mission, while gallant, had been incompetently planned. Some human remains, providing evidence of cannibalism, were found in 1997 followed by the wrecks of HMS Erebus (2014) and HMS Terror (2016).

Lamb, G. F., Franklin, Happy Voyager. 1956; Alexander, A., The Ambitions of Jane Franklin: Victorian Lady Adventurer. 2013; Brandt, A., The Man Who Ate His Boots. 2013.

Franklin, Rosalind Elsie (1920-1958). English biophysicist. Educated at Cambridge, after early research on gas-phase chromatography, she pursued physical chemical work on the structure of coals and carbonised coals. She worked in Paris 194750 , using the techniques of $\mathrm{X}$-ray diffusion to illuminate the study of carbons, and from 1951 at King's College, London on the problems of virus structure. Her priority had been developing models of carbon structure and investigating changes under high temperatures. She now concentrated on X-ray diffraction pictures of DNA and her experiments demonstrated that the patterns of DNA crystallinity were compatible with a helical structure. She hoped to build up a picture of the structure using empirical means, while at the same time investigating various theoretical models (e.g. anti-parallel rods in pairs back-to-back). Her own attempts to find a satisfactory helical structure were pre-empted by ${ }^{*}$ Crick and *Watson's 'double helix' solution, which appeared in Nature for 25 April, 1953. They had access (and this is a matter of ongoing controversy) to vital X-ray photographs taken by her which they interpreted correctly and she did not. She devoted the next few years to further research on coal, and to improving her earlier X-ray pictures. She died of ovarian cancer before the Nobel Prize was awarded to Crick, Watson and her collaborator Maurice *Wilkins in 1962. She worked very closely on viruses with Aaron *Klug, also a Nobel Laureate, who admired her greatly.

There is an extensive literature on Franklin, now regarded as a classic victim of misogyny. Asteroid 9241 Rosfranklin, two universities, many buildings, laboratories and awards have been named for her.

Klug, A., 'Rosalind Franklin and the Discovery of the Structure of DNA', Nature, 219 (1968), pp. 808, 844; Maddox, B., Rosalind Franklin: The Dark Lady of DNA. 2002.
Franks, Oliver Shewell Franks, Baron (19051992). English scholar and administrator. Educated at Oxford, he was professor of moral philosophy at Glasgow from 1937, but worked in the Ministry of Supply during World War II, becoming its permanent secretary 1945-46. He was Provost of Queen's College, Oxford 1946-48 until *Attlee made him Ambassador to the US 1948-52, then Chairman of Lloyd's Bank 1954-62. He delivered the BBC's Reith Lectures in 1954 on Britain and the Tide of World Affairs. In 1960 he was memorably defeated by Harold *Macmillan for the chancellorship of Oxford University in a campaign in which Macmillan said that he was the candidate of the bookies and Franks of the parsons. Provost of Worcester College 1962-76, he chaired the Royal Commission on Oxford University 1964-66. $\mathrm{He}$ received the $\mathrm{OM}$ in 1977 . He refused invitations to run the Treasury, the BBC, The Times, the Bank of England, British Rail British Petroleum, the Atomic Energy Authority, the Coal Board and NATO. In 1982 he conducted an enquiry into the origins of the Falklands War. The Times obituary wrote of him that beneath an icy cold exterior was an icy cold interior.

Danchev, A. Oliver Franks: Founding Father. 1993.

Franz (Francis) I (né François Étienne de Lorraine, later Franz Stefan von Lothringen) (1708-1765). Holy Roman Emperor 1745-66. Born in Nancy, he succeeded his father Leopold, Duke of Lorraine in 1729. However, after the War of the Polish Succession he gave up Lorraine to *Louis XV's fatherin-law, Stanisław *Leszczynski, ex-king of Poland, and accepted instead (1737) the grand duchy of Tuscany. In 1736 he married *Maria Theresa of Austria and in 1745 was elected Emperor. His children included ${ }^{*}$ Joseph II, *Leopold II, and ${ }^{*}$ Marie Antoinette. He became a freemason.

Franz II (Franz Joseph Karl von HabsburgLothringen) (1768-1835). Last Holy Roman Emperor 1792-1806, first Emperor of Austria 180435. Son of the emperor *Leopold II, he declared war on the French Revolutionary Government in 1792, and his territory was whittled away in constant wars with France. In imitation of ${ }^{*}$ Napoléon, and to consolidate his rule over his remaining possessions, he declared himself (1804) Emperor of Austria, and when Napoléon, having conquered most of Germany, set up (1806) the Confederation of the Rhine, Franz abandoned the empty title of Holy Roman Emperor, which was never revived. From 1809-13 he was, on the advice of *Metternich, Napoléon's unwilling ally; to cement the alliance his daughter ${ }^{*}$ Marie Louise was married to the French emperor. After Napoléon's disastrous retreat from Russia, Franz rejoined his former allies (1813) and took part in the campaign of liberation. After Napoléon's downfall he was, under Metternich's continuing guidance, a constant supporter of the reactionary regimes which followed. 
Franz Ferdinand (Carl Ludwig Joseph Maria von Habsburg-Este), Duke of Hohenberg (1863-1914). Austrian Archduke, born in Graz. A nephew of the emperor *Franz Joseph and a ferocious hunter, he claimed to have killed 300,000 animals, travelled the world, and shot kangaroos, koalas and platypuses in Australia (1893). From 1896 he was heir presumptive to the throne and married, morganatically, his mistress Countess Sophie von Chotek in 1899. The assassination of Franz Ferdinand and his wife in Sarajevo (28 June 1914) by the Bosnian Serb Gavrilo *Princip precipitated World War I. Ironically, Franz Ferdinand favoured internal autonomy for the subject nationalities of Austria-Hungary.

Franz Joseph I (Franz Joseph Karl von HabsburgLothringen) (1830-1916). Emperor (Kaiser) of Austria 1848-1916 and King of Hungary 18671916. Born (and died) at the Schönbrunn Palace, Vienna. Son of Archduke Franz Karl (1802-1878), he ascended the throne, after a year of revolutionary turmoil, due to the incapacity of his uncle, Kaiser *Ferdinand, who abdicated in his favour. He agreed to modest constitutional reforms but his army suppressed rebellion in Hungary. In 1851 he abolished the constitution and exercised personal rule until 1867. In that year, following the loss of Austrian territories in North Italy (1859-60) and defeat by Prussia (1866), he agreed to the establishment of a 'dual monarchy', Austria-Hungary, two semiautonomous countries, one Imperial (Kaiserlich), the other kingly (Königlich), with two prime ministers and only three common ministries: War, Foreign Affairs and Finance. Croatia and Slovenia were attached to Hungary, the other Slav provinces to Austria. His life was marked by a series of personal tragedies: the execution of his brother, the Emperor *Maximilian, in Mexico (1867), the suicide of his only son *Rudolf at Mayerling (1889), the assassination of the Empress *Elisabeth (1898) and of his nephew and heir *Franz Ferdinand (1914). For the rest of his reign Franz Joseph struggled for peace abroad and a preservation of the status quo at home. In the process of time he became a revered institution, his subjects willing to await his death before change. His last days were darkened by the calamity of World War I. With his industry, grasp of detail and great sense of duty, Franz Joseph had the qualities of a conscientious civil servant but lacked the vision and inspiring leadership of a great ruler. $\mathrm{He}$ was impulsive in youth, listless in middle life, stoic in old age but long remained a venerated memory, rich with nostalgia, in Vienna. His grandnephew * Karl (Charles) I, the last emperor of Austria, was forced to abdicate in November 1918.

Corti, E., Vom Kind zum Kaiser. 1950; Bled, J.-P., Franz Joseph. 1992; Palmer, A., Twilight of the Habsburgs. The Life and Times of Emperor Franz Joseph. 1994; Beller, S., Francis Joseph. 1996; Van der Kiste, J., Emperor Francis Joseph. 2005; Owens, K., Franz Josef and Elisabeth. 2013.
Franzen, Jonathan Earl (1959- ) American novelist. His social realist novels The Corrections (2001), Freedom (2010) and Crossroads (2021) were critical successes and best-sellers.

Fraser, Lady Antonia (Margaret Caroline, née Pakenham) (1932- ). English biographer, historian and novelist, born in London. A member of the *Pakenham family, educated at Oxford, she married (Sir) Hugh Fraser in 1956, wrote biographies of *Mary, Queen of Scots, ${ }^{*}$ Cromwell and *Charles II, won the Wolfson History Prize with The Weaker Vessel (1984), and created the detective Jemima Shore (the basis of a television series). In 1980, she married Harold *Pinter, and received a DBE in 2011 and a $\mathrm{CH}$ in 2018.

Fraser, Bruce Austin, 1st Baron Fraser of North Cape (1888-1981). British admiral of the fleet. As Third Sea Lord and Controller of the Navy 1939-42, he directed a vast expansion, including construction of special ships for combined operations. $\mathrm{He}$ commanded the Home Fleet 1942-44, and organised the operation by which the battlecruiser Scharnhorst was sunk. He commanded the British Pacific Fleet 1944-46 from his headquarters in Sydney and was the British signatory to the Japanese surrender (Tokyo, 1945). He was First Sea Lord of the Admiralty 1948-51.

Fraser, (John) Malcolm (1930-2015). Australian Liberal politician, born in Melbourne. A grazier's son, educated at Oxford, he became a Member of the Australian Parliament 1955-83, serving as a minister 1966-71 and 1971-72, resigning in March 1971 after a clash with J. G. * Gorton. In March 1975 he became Leader of the Liberal Party and pushed a hard-line policy which led to the Senate deferring Supply to E. G. *Whitlam's Labor Government. When the Governor-General, Sir John *Kerr dismissed Whitlam for failing to secure Supply, Fraser was appointed Prime Minister 1975-83. He won the 1975 and 1977 elections with massive majorities and 1980 more narrowly. In the election of March 1983, he was defeated heavily by Bob *Hawke and resigned the Liberal leadership. He was awarded the $\mathrm{CH}$ (1977) and AC (1988). He became co-chairman of the Commonwealth 'eminent persons' group working to end apartheid in South Africa 1985-86. He left the Liberal Party in 2009 as a protest against its harsh policies against refugees.

Ayres, P., Malcolm Fraser. 1987; Simons, M., with Fraser, M., Malcolm Fraser: The Political Memoirs. 2010.

Fraser, Peter (1884-1950). New Zealand politician, born in Scotland. He emigrated in 1910, became a trade union leader in Auckland and on the formation of the New Zealand Labour Party (1916) became a committee member. He was elected to parliament (1918), became Minister for Education and Health 
1935-40 and Prime Minister 1940-49, coping with New Zealand's role in World War II and post-war reconstruction. He received a $\mathrm{CH}$ in 1945.

\section{Fraser, Simon, 11th Lord Lovat see Lovat, Simon Fraser, 11th Lord}

Fraser, Simon (Thomas) (1776-1862). Canadian explorer, born in New York State. At 18 he joined the North West Company which sent him (1805) to extend the company's activities beyond the Rocky Mountains. The expedition proved to be difficult and dangerous. In British Columbia in 1808, he explored the Fraser River (Sto:lo in the local language), later named for him by David Thompson. Unsuccessful in business, he left valuable journals of his explorations. Simon Fraser University was founded in 1965.

Fraunhofer, Joseph von (1787-1826). German optical physicist, born in Bavaria. Trained as a maker of optical instruments, while working to perfect an achromatic lens he invented a spectroscope that observed and recorded more than 300 dark absorption lines in the solar spectrum, and are now called 'Fraunhofer lines'. (*Wollaston had noted a few lines in 1802. Their significance was explained in 1858 by ${ }^{*}$ Kirchhoff.) Professor of physics at Munich 1823-26, he was ennobled in 1824.

Frazer, Ian Hector (1953- ). Australian medical scientist, born in Glasgow. Educated at Edinburgh University, he began work in Australia in 1981, and, with Jian Zhou, developed a vaccine for human papilloma virus (HPV) — the first designed to prevent cancer-which is being administered widely to girls to reduce the risk of cervical cancer. Elected FRS and FAA, he was Australian of the Year in 2006, won the Balzan Prize in 2008 and received an AC in 2012.

Frazer, Sir James George (1854-1941). British anthropologist, born in Glasgow. He was a fellow of Trinity College, Cambridge 1879-1941 and taught briefly (1907) at Liverpool. His greatest work, The Golden Bough (2 volumes, 1890, expanded into 12 volumes by 1915), is still greatly admired as a monumental source book for ritual beliefs throughout the world, although the interpretations he offered are no longer entirely accepted. His other major works are Totemism and Exogamy (1910) and Folklore in the Old Testament (1918). He received the OM in 1925.

Downie, A., Frazer and the 'Golden Bough'. 1970.

Frederick or Frederick William. German or Prussian Kings and Emperors see Friedrich or Friedrich Wilhelm

Frederick V (of Wittelsbach, known as 'the Winter King') (1596-1632). King of Bohemia 1619-20. Elector Palatine 1610-20, he was elected King of Bohemia when the Diet deposed the emperor *Ferdinand II, an event that marked the beginning of the Thirty Years' War. He ruled only for a winter until his defeat at the battle of White Mountain (1620). He married Elizabeth, daughter of *James I, and his children included Prince ${ }^{*}$ Rupert and the Electress ${ }^{*}$ Sophia, mother of ${ }^{*}$ George I.

Frederick Henry, Prince of Orange (1584-1647). Dutch soldier and statesman. Son of ${ }^{*}$ William the Silent, he became regent for the princes of Orange on the death of his half-brother ${ }^{*}$ Maurice of Nassau. He was the first member of the House of Orange to assume quasi-monarchical powers in his fight to free the country of Spanish domination. His military successes, domestic policies and international diplomacy all paved the way for an honourable peace with Spain in 1648.

Frederick Louis (or Lewis), Prince of Wales (1707-1751). British prince, born in Hanover. Son of ${ }^{*}$ George II, with whom he quarrelled bitterly, he was Prince of Wales 1727-51 and father of *George III. Incorrigibly addicted to intrigue, he plotted against Robert *Walpole, was a major promoter (and occasional player) of cricket and lawn tennis, suffering injuries in both. He died from a burst abscess in the lung: his parents did not attend the funeral. The dismissive lines: 'Here lies Fred/ who was alive and is dead/ but there's no more to be said' were unduly harsh.

Frederik IX (1899-1972). King of Denmark 194772. Son of ${ }^{*}$ Christian $X$, he married Princess Ingrid of Sweden (1935). Lacking male heirs, he sponsored a constitutional amendment to enable his eldest daughter, now Queen *Margrethe II, to succeed.

\section{Frederick the Great $s e{ }^{*}$ Friedrich II der Grosse}

Frege, (Friedrich Ludwig) Gottlob (1848-1925). German mathematician and philosopher. One of the pioneers of modern logic, he was particularly interested in the close connexion between logic and mathematics. His thinking exerted a strong influence on Bertrand ${ }^{*}$ Russell, who nevertheless criticised some of his propositions.

Frei (Montalva), Eduardo (1911-1982). Chilean Christian Democratic politician. A lawyer and academic, he led the conservative, anti-fascist Christian Democrats and was President 1964-70. His son Eduardo Frei (Ruiz-Tagle) (1941- ), was elected President in 1993 at the head of a centre-left coalition which received 58 per cent of the vote. He served 1994-2000.

Freire, Nelson (José Pinto) (1944-2021). Brazilian pianist, born in Boa Esperança. He played *Mozart in public at the age of 4 , later studying in Brazil and Vienna. His international career began in 1959 and he won awards for his CDs of *Mozart, *Beethoven, ${ }^{*}$ Chopin, ${ }^{*}$ Liszt, ${ }^{*}$ Brahms and ${ }^{*}$ Debussy. 
Frémont, John Charles (1813-1890). American soldier and explorer. Known as 'the Pathfinder', his surveys established various feasible overland routes from east to west in America. One of the first US senators elected from California 1850-51, he became the first Republican candidate for president in 1856, losing to *Buchanan. He was Major General in charge of the Department of the West 1861-62 until forced to resign. During the California gold rush he made a fortune which he then lost in railway speculations, resulting in a charge of fraud. He was Governor of Arizona territory 1878-83.

Nevins, A., Fremont: Pathfinder of the West. 1955.

French, John (Denton Pinkstone), 1st Earl of Ypres (1852-1925). English field marshal, born in Kent. He commanded the cavalry in the Boer War (1899-1901) with Douglas *Haig as his chief of staff. Chief of the Imperial General Staff 1912-14, promoted to field marshal in 1913, although closer to the Liberals than the Conservatives, he was obliged to resign for giving unauthorised undertakings that the army would not act against the Ulster Volunteer Force (UVF), despite its threat to use force against Home Rule for Ireland ('The Curragh Mutiny'). Despite this professional setback, he was chosen as Commander-in-Chief of the British Expeditionary Force (BEF) to France on the outbreak of World War I. He commanded during the retreat from Mons, the subsequent counter-attack at the Marne, the first two battles of Ypres, and the Battle of Loos (autumn) which he mishandled, leading to his recall and replacement by Haig. He became Commanderin-Chief of the Home Forces 1915-18 and LordLieutenant of Ireland 1918-21, at a time of civil war. His memoir 1914 (1919) was regarded as grossly selfserving. He was rewarded after every failure: the $\mathrm{OM}$ when he resigned over Ulster (1914); made Viscount French after his defeats in Flanders (1916); $£ 50,000$ when the war ended, and he was commanding the home forces, culminating in the earldom of Ypres (1922) after his disastrous term in Ireland. He was indiscreet in his private life, and often in debt. His sister Charlotte Despard (née French) (1844-1925) was a writer and social activist, a friend of Eleanor *Marx, a Catholic convert, and passionate suffragette.

Clark, A., The Donkeys. A History of the BEF in 1915. 1961; Holmes, R., The Little Field Marshal. 2004.

French, Robert Shenton (1947- ). Australian jurist, born in Western Australia. He graduated in science and law and was mildly involved in the Liberal Party. A Justice of the Federal Court 1986-2008 and President of the National Native Title Tribunal, he was appointed Chief Justice of the High Court 2008-17 by the *Rudd Government.
Frescobaldi, Girolamo (1583-1643). Italian composer. Organist of St Peter's, Rome, from 1608, he was regarded as one of the first great masters of composition for the organ and, through his pupils, a strong influence on European baroque music.

Fresnel, Augustin Jean (1788-1827). French physicist. An engineer by profession, he became interested in physical optics and was the first to produce the optical effects now known as interference fringes. His discovery that these effects resulted from interference between two beams of light gave great support to the wave theory of light. He also gave a clear explanation of polarisation and diffraction and invented the compound lighthouse lens. His many honours included the Rumford Medal of the British Royal Society.

Freud, Lucian Michael (1922-2011). British painter, born in Berlin. Son of an architect and grandson of Sigmund *Freud, he migrated to England with his family in 1933 . He became a powerful and disturbing figurative painter, with a deep impasto and convincing representation of flesh. He made several self-portraits, some nude, and studies of *Elizabeth II, Francis *Bacon, David *Hockney, Frank *Auerbach, the Australian-born performance artist Leigh Bowery, and of his mother. He received a $\mathrm{CH}$ in 1983 and the OM in 1993.

Feaver, W., The Lives of Lucian Freud. 2019.

Freud, Sigmund (1856-1939). Austrian-Jewish founder of psychoanalysis, born in Freiburg, Moravia (now Príbor, Czech Republic). He lived in Vienna from 1860, was educated first by his parents, then at the Leopoldstädt Obergymnasium, entered the Vienna University medical school in 1873 but did not graduate until 1881, because of a distracting preoccupation with zoology. The writings of ${ }^{*}$ Goethe and ${ }^{*}$ Darwin influenced him and he was well read in the classics. Freud passed through sharply contrasting periods of influence by successive mentors. He worked at the Physiological Institute 1876-82 with Ernst von Brucke (1819-1892), who insisted that all nervous disorders had purely physical causes, and at the General Hospital (1882-85) was an enthusiastic advocate for cocaine as a 'magical' and harmless drug for depression and indigestion. Appointed a lecturer in neuropathology at Vienna University (1885), he studied in Paris for four months at the Salpêtrière Hospital under Jean Martin ${ }^{*}$ Charcot, and on his return in 1886 began in private practice and married Martha Bernays (1861-1951). With Josef*Breuer he worked on hypnosis as a cure for hysteria and they published Studies in Hysteria (1895). Freud modified Breuer's cathartic treatment, which forced patients to confront suppressed (unconscious) memory of trauma, developing 'free association' instead of hypnosis in the technique of psychoanalysis. A Berlin otolaryngologist, Wilhelm Fliess (or Fließ) (1858-1928), proposed some bizarre theories of his own (e.g. linking sexual 
organs and the nose) but encouraged Freud's selfanalysis, leading to his identification of the Oedipus complex (*Sophocles) and theories of infantile sexuality, partly drawn from his own experience. His controversial 'seduction' theory was proposed, then withdrawn, accusations of sexual molestation being then mostly attributed to fantasy. Freud regarded The Interpretation of Dreams (1900) as his greatest achievement, arguing that repressed desires and frustrations were revealed in dreams: once exposed to the conscious (waking) mind, neuroses should disappear. By 1900 he had discounted possible physical causes for neurological problems, transferring interest from the body to the psyche (soul in Greek). In 1902 he was given the title of Extraordinary (i.e. Associate) Professor, being promoted to Ordinary Professor in 1920, but with no department. In 1908 he founded the International Psycho-Analytical Association, visiting the US in 1909. His early disciples, notably Carl *Jung, Alfred *Adler and Otto Rank, later departed from Freudian orthodoxy, rejecting infantile sexuality, and founded their own schools. Freud's work was highly subjective, philosophical, intuitive and speculative rather than clinical and statistical. Opponents have described it as a closed system, analogous to religion or politics, failing the scientific criteria of testability and replicability (proposed by *Popper). Other major works include Totem and Taboo (1913), Civilisation and its Discontents (1930) and Moses and Monotheism (1939). In The Ego and the Id (Das Ich und Das Es, 1923), he proposed three levels of mental activity: the 'I' (conscious and rational), the 'Id' (instinctive unconscious desires) and the 'Over-I', ('Überich' or 'Superego': ethical control mechanism, often unconscious). From 1923 he suffered, stoically, from cancer of the jaw and in 1938, after *Hitler's Anschluss in Austria, he left for Britain where he was welcomed and admitted as FRS, working in London until his death aged 83.

Extraordinarily prolific and a master of German prose, between 1915 and 1938 Freud was nominated for the Nobel Prize for Medicine 32 times and once for Literature (by Romain *Rolland). All nominations failed and his claims were probably superior in literature than in medicine. His followers compared him to ${ }^{*}$ Copernicus and ${ }^{*}$ Darwin but whatever his scientific credentials, Freud raised fundamental questions about human existence and his theories have had immense influence not only in psychology but in art (e.g. ${ }^{*} \mathrm{Klee},{ }^{*}$ Picasso, ${ }^{*}$ Dali, ${ }^{*}$ Miró),

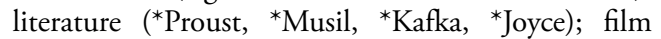
(*Fellini, ${ }^{*}$ Bergman), education and child rearing, anthropology and mythology. W. H. *Auden wrote of Freud 'he is no more a person now but a whole climate of opinion'. He remained intensely controversial. His scientific methodology was criticised by Popper and ${ }^{*}$ Medawar, his theories attacked by feminists as 'phallocentric', while Jeffrey Masson, having worked in the Freud archives, attacked his modification of the seduction theory as evasive.
His daughter Anna Freud (1895-1982) became a pioneer child psychiatrist in London. Grandsons included the painter Lucian *Freud, and Sir Clement Raphael Freud (1924-2009), broadcaster, chef, writer on food, and Liberal MP 1973-87: the brothers never spoke to each other.

Clark, R. W., Freud: The Man and the Cause. 1980; Gay, P., Freud. A Life for Our Time. 1985; Jones, E., Sigmund Freud: Life and Work. 3 vols, 1953-57, 1996; Ferris, P., Dr Freud. 1997; Kerr, J., A Most Dangerous Method: The Story of Jung, Freud and Sabina Spielrein. 1993.

Freyberg, Bernard Cyril Freyberg, 1st Baron (18891963). New Zealand soldier. Trained as a dentist, in World War I he won the VC and DSO with two bars and became the friend of Winston ${ }^{*}$ Churchill and Rupert ${ }^{*}$ Brooke. In World War II he commanded the New Zealand forces in Greece, Crete, North Africa and Italy. He was Governor-General of New Zealand 1946-52.

Freyre, Gilberto de Mello (1900-1987). Brazilian scholar, born in Recife. He made a detailed study of Brazilian social conditions. He visited many countries and his lectures and sociological writings won him an international reputation. His greatest work is Casa Grande e Senzule (Masters and Slaves, revised edition 1956), a penetrating study of Brazilian plantation life before the abolition of slavery. His other works include Sobrados e Mucambos (Mansions and Shanties) and (in English) Brazil: An Interpretation (1945).

Frick, Henry Clay (1849-1919). American industrialist. He supplied coke for Pittsburgh's steel mills, then worked with Andrew ${ }^{*}$ Carnegie, becoming a founder of the US Steel Corporation (1901), with a very bad record in labour relations. $\mathrm{He}$ is now remembered for the Frick Collection, paintings largely bought through Joseph *Duveen, on show in his mansion at 1 East 70th Street on 5th Avenue, New York. A second Frick Art Museum is in Pittsburgh.

Frick, Wilhelm (1877-1946). German Nazi administrator. A colourless civil servant and police administrator, he was the first Nazi to hold office, as Minister for the Interior in Thuringia 1929-33. *Hitler's Minister for the Interior 1933-43 and Protector of Bohemia and Moravia 1943-45, he was hanged at Nuremberg.

Friedan, Betty (née Betty Naomi Goldstein) (1921-2006). American feminist writer, born in Peoria, Illinois. Educated at Smith College, she wrote The Feminine Mystique (1963), a primary text for the women's liberation movement, founded the National Organisation for Women in 1966, taught at several universities, but was outflanked by more radical feminists. She wrote The Fountain of Age (1992) as a vigorous protest against the concepts of statutory senility and 'ageism'. 
Friedman, Milton (1912-2006). American economist. The most influential of conservative American economists, he was a trenchant critic of Keynesian theories, advocating a monetarist position, i.e. that changes in money supply precede changes in economic activity rather than following on. A professor of economics at Chicago University 1948-76, he received the Nobel Prize for Economic Science in 1976.

Friedrich (Frederick) I (known as Barbarossa) (c.1122-1190). Holy Roman Emperor 1155-90 and German King 1152-90. Son of the Hohenstaufen Duke of Swabia, he was linked through his mother with the Guelph dynasty. After his election as German King (1152) he was in a position to end the long dynastic feud that had rent Germany. He established his power in Northern Italy (1154) and was crowned Emperor by Pope *Adrian IV in Rome (1155). In 1158 his capture of Milan and enforcement of imperial claims in Lombardy produced a strained relationship between the papacy and empire, exacerbated when *Alexander III succeeded Pope Adrian. The imperialists elected an anti-pope and Friedrich was excommunicated. Time after time he returned to Italy to repair the damaging effects of his absence. He even captured Rome (1167) but was forced by the ravages of the plague to retire. In 1174 he found the Lombard cities again in revolt but, after a severe defeat at Legnano (1176), he made peace with the pope (1177) and eventually with the Lombards. Free now to deal with his Guelph cousin *Heinrich ('the Lion') who had been causing trouble in Germany, he deprived him of his estates and drove him into exile (1180). On his way to Palestine for the 3rd Crusade, of which he was chosen leader, Friedrich was drowned in a river in Asia Minor. He had an attractive personality and the qualities of a great ruler. There is a tradition that he is not dead, but sleeping, and one day will awake to defend Germany at a time of crisis.

Munz, P., Frederick Barbarossa. 1969.

Friedrich I (1657-1713). First King of Prussia 170113. He succeeded his father, ${ }^{*}$ Friedrich Wilhelm, the 'Great Elector', of Brandenburg in 1688 and assumed the title of king in 1701. He ranged himself against France in the War of the Spanish Succession and his policy throughout his reign was to sustain the Habsburg cause. He founded the Berlin Academy of Arts (1696) and Sciences (1707) and the University of Halle (1694) and was the patron of *Leibniz. An attempt to give peasants hereditary leases of his domains was foiled by the nobles.

Friedrich II (Italian: Federico Ruggero di Hohenstaufen) (1194-1250). King of Sicily 1198-1250, German King 1215-50, Holy Roman Emperor 1220-50, King of Italy 1220-50, King of Jerusalem 1225-28. Born in Jesi, Ancona, Italy, grandson of Emperor ${ }^{*}$ Friedrich I (Barbarossa), son of Emperor *Heinrich VI and Costanza (Constance), Queen of Sicily. Orphaned at four (1198) he inherited the throne of Sicily and was taken under the guardianship of Pope *Innocent III. He received papal support during his struggle against Otto of Bavaria for recognition as German king, which ended with Friedrich's coronation (1215) after Otto's defeat at Bouvines. He was crowned Emperor (1220) in Rome, having promised, in return for the Pope's aid, to give up the throne of Sicily to his son and lead a crusade. He delayed his start until 1227 and was excommunicated when, on the plea of illness, he almost immediately returned. He resumed his crusading activities, however, when having taken as his second wife the daughter of the King of Jerusalem he went to Palestine (1229), induced the Saracens to give up Jerusalem (where he was crowned King) and secured peace in the Holy Land for 10 years. He reformed and centralised the government of Sicily but allowed the German princes yet more autonomy (1231), while his protracted struggle in Italy during the last 20 years of his reign failed to break the resistance of the papacy and the Lombard League. Pope *Innocent IV, a fierce antagonist, declared him a heretic in 1245 , and purported to remove him as emperor. Friedrich suffered a severe defeat at Parma (1248) but was preparing a new campaign when he died. The conception of unified imperial rule over Italy and Germany had again proved impractical. Friedrich was a brilliant but unstable figure, capable of both great cruelty and scientific detachment. His court at Palermo became a great artistic and cultural centre, he was fluent in six languages, a legal reformer (his code for Sicily proved an enduring achievement), a natural historian (he wrote a textbook on ornithology) and a religious sceptic. Described by the English chronicler Matthew *Paris as 'the wonder of the world' (Stupor Mundi), he fostered Greek, Jewish and Islamic cultural heritages and insisted on the use of Arabic numerals instead of Roman. He died in Apulia and was buried in Palermo.

Masson, G., Frederick II of Hohenstaufen. 1973; Kantorowicz, E., Frederick the Second Wonder of the World. 1931. English translation 2019.

Friedrich II der Grosse ('Frederick the Great': Friedrich von Hohenzollern) (1712-1786). King of Prussia 1740-86. Born in Berlin, he was the son of *Friedrich Wilhelm I and Sophia, daughter of ${ }^{*}$ George I of Britain. His taste for music, poetry and philosophy and his predilection for French culture infuriated his boorish and tyrannical father, and the two lived in a state of mutual hatred. After an attempt by Friedrich to escape to England had been foiled, he was imprisoned and forced to watch the beheading of Hans von Katte, his friend and accomplice (1730). After 15 months he submitted to his father. Rewarded with the gift of a country estate at Rheinsberg, in 1733 he married Elisabeth Christina of Brunswick-Wolfenbüttel (1715-1797) but they soon separated and there were no children. 
Until 1740 he led the agreeable life of a dilettante, reading much, corresponding with ${ }^{*}$ Voltaire and other writers and conversing with the witty and the wise. His historical reading imbued him with a lust for fame, while his lifelong practice in concealing his thoughts and deeds from his father had left him with few scruples. A gifted librettist, flautist and composer, he employed C.P.E. *Bach, and J. S. *Bach dedicated The Musical Offering (1747) to him.

His accession coincided with the crisis caused by the death of the emperor ${ }^{*}$ Charles VI, who, lacking male heirs, had spent his last years in getting promises (the Pragmatic Sanction) from European rulers to support the transfer of his hereditary dominions to his daughter ${ }^{*}$ Maria Theresa. Friedrich Wilhelm had promised with the rest, but Friedrich, whose most valued inheritance was a fully trained and finely equipped army, revived an old claim to the duchy of Silesia which he invaded when it was denied. Friedrich's victories at Mollwitz (1741) and Chotusitz (1742) decided Maria Theresa to yield Silesia by the Treaty of Breslau (1742), but Austrian successes against Bavaria and its French ally alarmed Friedrich and in 1744 he again intervened. Another series of victories enabled him to emerge from the War of Austrian Succession with his possession of Silesia confirmed. Maria Theresa, however, retained the Habsburg territories and her husband, *Franz of Lorraine, was elected Emperor.

The years of peace witnessed a diplomatic revolution. Maria Theresa, eager for revenge, came to terms with France (with the result that Britain was allied with Friedrich in the ensuing Seven Years' War) and gained the alliance of Empress *Elizabeth of Russia. Friedrich, after receiving no reply to a demand for a declaration of their intentions, invaded Saxony (1756). In 1757 the Austrians, who had invaded Silesia, had to withdraw after his great victories of Rossbach and Leuthen. But numbers began to tell. Friedrich held his own in 1758, but in 1759 suffered a crushing defeat by Austrians and Russians at Kunersdorf and spoke of suicide. He rallied in 1760 but ultimate defeat seemed certain when the Tsarina died (January 1762) and was succeeded by Friedrich's admirer *Peter II, who left the alliance. Friedrich, thus saved, was glad to retain his position of 1756 by the Treaty of Hubertsburg (1763). The acquisition of West Prussia in the first partition of Poland with Austria and Russia (1772) enabled him to link East Prussia and Brandenburg. But from 1756 his time was mainly taken up with peaceful restoration of his country. The addition of Silesia had doubled the population of Prussia and his own efforts did much to increase its wealth. He played the role of benevolent despot, travelling constantly, remedying troubles as he went. A state bank, a state porcelain factory, and a silk industry were started, he bribed settlers to come in and cultivate reclaimed land. His personal extravagances were few. The small palace of
Georg von Knobelsdorff to Friedrich's design. And yet he continued to dislike and despise the people for whom he did so much. When Voltaire lived in Berlin and Potsdam (1750-53), the two found that it was distance that had lent the enchantment, but Friedrich remained true to his allegiance to French culture. He was a prolific writer in French, and is regarded as one of the 'enlightened despots'. His skill and acumen, both military and political, laid the foundations for Prussia's domination of the future Germany, but equally his aggressive policies and defiance of international obligations set a pattern that Germany was to follow. He died at Sans Souci but was only buried there, with his dogs, and according to his wishes, in 1991.

*Hitler admired Friedrich and this tarnished his reputation, but he was exceptionally capable and sometimes admirable.

Horn, D. B., Frederick the Great and the Rise of Prussia. 1964; Blanning, T., Frederick the Great: King of Prussia. 2015.

Friedrich III (1415-1493). Holy Roman Emperor $1452-93$ and King of the Romans (i.e. German king) 1440-93. Born in Innsbruck, he was son of Ernest, Duke of Styria, Carinthia and Carniola, and cousin to Albrecht II (1397-1439), king of Hungary, Bohemia and king-elect of Germany. Emperor Sigismund of Luxemburg died in 1537 and an interregnum followed. Friedrich, elected King of the Romans in 1440, only became Emperor in 1452, being the last crowned by the Pope in Rome. He was the first ${ }^{*}$ Habsburg Emperor. Only *Franz Joseph had a longer reign. From 1457 Friedrich also used the title Archduke of Austria. Emotionally remote, regarded by contemporaries as weak and indolent, he proved successful in avoiding conflict, was known as the Peaceful' and arranged dynastic marriages to expand Habsburg influence. He coined the motto AEIOU (Austriae est imperare orbi universo). He died after an amputation of his leg. His son ${ }^{*}$ Maximilian I succeeded.

Friedrich III (Friedrich Wilhelm Nikolaus Karl von Hohenzollern) (1831-1888). German Emperor and King of Prussia 1888. In 1858 he married Princess *Victoria of Great Britain and adopted her political views, based on British political practice; he therefore found himself in opposition to his father, *Wilhelm I, and ${ }^{*}$ Bismarck (there was deep mutual dislike). After a reign of only 99 days he died of cancer of the throat and was succeeded by his son *Wilhelm II.

Friedrich Wilhelm (known as the 'Great Elector') (1620-1688). Elector of Brandenburg 1640-88. He built up his state, which had been enlarged though much weakened by the Thirty Years' War (1618-48). To hold its scattered possessions together he managed by extreme frugality to build up a small standing army (about 30,000 men) which enabled him to pursue a foreign policy that varied 
in accordance with the amount of subsidy he could exact for the use of his troops. By changing sides in the war between Sweden and Poland he was able to secure the independence (1657) of the Prussian duchy which he had formerly held as a Polish fief. Internally his rule was based on a compromise with the nobility. He established a centralised bureaucracy but allowed the nobles increased powers on their own estates and over their serfs. After the revocation of the Edict of Nantes by * Louis XIV, Friedrich Wilhelm encouraged a large influx of Huguenot refugees, who helped the growth of industry. He founded libraries, introduced educational reforms and extended Berlin as the capital.

Schevill, F., The Great Elector. 1948.

Friedrich Wilhelm I (1688-1740). King of Prussia and Elector of Brandenburg 1713-40. His father, whom he succeeded, was *Friedrich I, his wife, Sophia Dorothea, daughter of ${ }^{*}$ George I of Great Britain. It was the centralised administration and the army that he perfected that enabled his son ${ }^{*}$ Friedrich II to turn Prussia into a great power. Friedrich Wilhelm ruled as a complete autocrat and martinet, his court was like an officers' mess. Anyone, such as his son, who opposed him he treated with savage intolerance, but despite his scorn for culture he introduced compulsory elementary education. His army was at once his pride and delight. To fill its ranks he compelled the peasants to enlist and the young nobles to become officer cadets, and he trained and equipped it to be the finest instrument of policy in all Europe. The collection of tall men for his personal guard was a favourite hobby, and kidnapping one of the methods used to indulge it. It was asserted that the forcible mating of its members with tall women was a way by which he hoped to secure future recruits. But he was reluctant to subject such a magnificent body of men to war and his foreign policy was to avoid conflict.

Friedrich Wilhelm II (1744-1797). King of Prussia 1786-97. He succeeded his uncle, ${ }^{*}$ Friedrich II ('the Great'), but proved a feeble administrator, dependent on favourites. He joined Austria in an ineffective attempt to overthrow by force the French Revolutionary government (1792-95). During his reign Prussia gained territory by the partitions of Poland (1792 and 1795).

Friedrich Wilhelm III (1770-1840). King of Prussia 1797-1840. The son of *Friedrich Wilhelm II, who came to the throne shortly before ${ }^{*}$ Napoléon Bonaparte seized power, his vacillating character made him incapable of coping with events which precipitated him into war against France (1806), and he was heavily defeated at Jena. The humiliation of the Treaty of Tilsit impelled him to turn to *Stein, ${ }^{*}$ Hardenburg and ${ }^{*}$ Scharnhorst, whose reforms and administration braced Prussia for its part in the final overthrow of Napoléon, after which, as a member of the Holy Alliance, he grew increasingly reactionary.
Friedrich Wilhelm IV (1795-1861). King of Prussia 1841-61. Succeeding his father, ${ }^{*}$ Friedrich Wilhelm III, after a long reactionary rule, he was essentially a romantic medievalist. The liberal revolutionaries of 1848 mistakenly thought he was sympathetic to reform. He agreed to some minor changes and opened up dialogue with the Catholic Church but refused to become ruler of a united democratic Germany, and would have preferred reviving the Holy Roman Empire under Austrian leadership. He yielded to the reactionaries around him headed by his brother, the future Kaiser *Wilhelm I, crushed the revolutionary forces and imposed a constitution (1850) that left the balance of political power virtually unchanged. In 1858 he became insane and his brother acted as regent.

Friedrich, Caspar David (1774-1840). German painter. A leading Romantic, with some parallels to his contemporary *Turner, his luminous landscapes are marked by melancholy and spirituality.

Friese-Greene (originally Greene) William (1855-1921). English pioneer of cinematography. Originally a portrait photographer in Bristol, he took out (1889) the first patent for camera and projector using celluloid film with perforated edges. He also worked on colour and stereoscopic films but lacked the finance necessary to exploit his discovery and died in poverty.

Frink, Dame Elizabeth (1930-1993). British sculptor and graphic artist. She studied at the Chelsea School of Art, and taught sculpture there 1953-60 and at St Martin's School of Art 1955-64. Her powerful bronzes are in many public collections and she illustrated The Odyssey (1974) and The Iliad (1975).

Frisch, Karl von (1886-1982). Austrian zoologist, born in Vienna. He studied in Munich, and later held chairs at Breslau, Munich and Graz. He conducted research on recognition and communication first in fish and later in bees. He demonstrated that fish had sharp hearing and could distinguish between colours and degrees of brightness. His most famous work established that honeybees orient themselves through the sun and can recall patterns of polarisation even when it is not visible, and that they communicate with other bees by dancing movements: wagging dances for distant food, round dances when food is close. He shared the 1973 Nobel Prize for Medicine with his fellow ethologists Konrad *Lorenz and Nikolaas *Tinbergen.

Frisch, Max Rudolf (1911-1991). Swiss novelist and playwright, born in Zürich. Trained as an architect, his novel I'm Not Stiller (1954) became a critical success, but he was better known for his plays, influenced, as he acknowledged, by Bertolt *Brecht and Thornton *Wilder. His main concern was with man's destiny and the difficulties of realising it through the normal 
behaviour patterns of a modern society. His first play was Nur Singen sie Wieder (Now They Are Singing Again, 1945), the best known, Andorra (1962).

Weisstein, U., Max Frisch. 1967.

Frisch, Otto Robert (1904-1979). Austrian-JewishBritish physicist, born in Austria. A nephew of Lise *Meitner, he graduated from the University of Vienna and worked with P.M.S. *Blackett in London and Niels ${ }^{*}$ Bohr in Copenhagen. At Birmingham University he conducted research on nuclear fission. With Rudolf *Peierls, he wrote the Frisch-Peierls memorandum (March 1940) which outlined how an atomic bomb could be built using a modest amount of uranium-235. He worked on the 'Manhattan Project' to construct the bomb 1943-45. In 1947 he became Jacksonian professor of natural philosophy at Cambridge, head of the nuclear physics section of the Cavendish Laboratory and a Fellow of Trinity College, being elected FRS in 1948.

Frisch, Ragnar (1895-1973). Norwegian economist. Professor of Economics at Oslo 1931-65, he was editor of the journal Econometrica 1933-55 and pioneered the use of advanced statistical techniques in economic theory. He shared the first Nobel Prize in Economic Science in 1969 with Jan *Tinbergen.

Frith, William Powell (1819-1909). English painter. His huge paintings, notable for their almost photographic realism, are packed with incidents and reveal many details of historical interest about Victorian England. They include The Great Exhibition (1851), Derby Day (1858) and The Railway Station (1862). He became an RA in 1852.

Frobenius, Johannes (c.1460-1527). German printer, born in Bavaria. By establishing himself (1491) at Basle he made the city the centre of the German book trade. He published a Latin Bible, a Greek New Testament and editions of several of the early Fathers of the Church. Among those who prepared his publications for the press were ${ }^{*}$ Erasmus and ${ }^{*}$ Holbein. He also printed the works of ${ }^{*}$ Hippocrates and ${ }^{*}$ Galen.

Frobisher, Sir Martin (1535-1594). English sailor and explorer, born in Yorkshire. Originally, with John *Hawkins and others, a privateer in the Indies, he sailed (1576) with a small expedition in search of the Northwest Passage. From Labrador he brought back some black earth believed to contain gold. Two other expeditions (1577 and 1578) brought further supplies but attempts to extract gold failed. He was knighted for his part in the Armada battles, after which he married and attempted to settle down. Soon he was at sea again on the lookout for Spanish treasure ships but was mortally wounded in an attack on Brest.

Froebel, Friedrich Wilhelm August (1782-1852). German educationist. Founder of the Froebel method for teaching small children, he worked with
*Pestalozzi in Switzerland (1807-09) and in several books developed his theories, based on the belief that children up to the age of seven should grow naturally and spontaneously like a plant or an animal, and that the development and coordination of mind and body should be helped by activities most calculated to achieve this purpose. Froebel opened (1807) his first Kindergarten (children's garden) in Blankenburg, Thuringia where traditional schooling was replaced by methods involving the more spontaneous and creative activities he had advocated in his books. The rest of his life was spent in founding schools and training teachers.

Lilley, I. M., Friedrich Froebel. 1967.

Froissart, Jean (c.1333-1405). French chronicler. $\mathrm{He}$ observed, and wrote in vivid detail about 14 thcentury life and events. He travelled widely in search of information for his Chroniques and in England was received by *Edward III and Queen *Philippa (who also came from Hainaut). Although a chief source for the period in which he lived, his record is of the life of courts and chivalry and does not provide an authentic broad picture of the century of the Hundred Years War and its attendant misery. He also wrote verses in a wide range of forms, including a metrical romance about the Round Table.

Fromm, Erich (1900-1980). German-American social psychologist, born in Frankfurt. Educated at Heidelberg, he lived in the US from 1922. His work attempted to link the teachings of ${ }^{*}$ Freud and ${ }^{*}$ Marx, applying psychoanalytical method to sociology. In The Fear of Freedom (1941) he postulated that humans have eight basic needs: relatedness, transcendence, rootedness, sense of identity, frame of orientation, excitation and stimulation, unity, effectiveness. Later books included The Art of Loving (1956) and The Anatomy of Human Destructiveness (1973).

Friedman, L. J., The Lives of Erich Fromm. Love's Prophet. 2013.

Frondizi, Arturo (1908-1995). Argentinian politician. Son of Italian immigrants, he made his reputation as a lawyer by defending left-wing political prisoners, and as a politician (he became a deputy in 1946) by leading the opposition to *Perón. In the first constitutional elections held after Perón's overthrow, Frondizi, leader of the left wing of the Radical party, was elected President (1957). However, he failed to rally the country behind him and to cure the inherent economic ills and was deposed (March 1962).

Frontenac, Louis de Buade, Comte de (16201698). French colonist. As Governor of New France in North America 1672-82 and 1689-98 he constructed a chain of forts and trading stations from Québec to the Gulf of Mexico with the aims of linking the colonies, encouraging commerce and confining the English settlers to the coastal territories. 
His remarkable success in winning the confidence of the Indians enabled him to make them his allies against the English.

\section{Le Sueur, W. D., Count Frontenac. 1964.}

Frost, Robert (Lee) (1874-1963). American poet, born in San Francisco. He studied briefly at Dartmouth College and Harvard, later working as carpenter, teacher 1905-12 and farmer. He lived in England 1912-15 and there published his first books of poetry, A Boy's Will (1913) and North of Boston (1914). Frost was professor of English at Amherst College for long spells between 1916 and 1938 and later gave lectures at Harvard. His later publications included Mountain Interval (1916), New Hampshire (1923), From Snow to Snow (1936), Witness Tree (1942) and Steeple Bush (1947). His Complete Poems was issued in 1951. In the Clearing appeared in 1962. He won the Pulitzer Prize for Poetry in 1924, 1931, 1937 and 1943. His poetry belongs in scene and character to rural New England, and extols self-reliance, self-knowledge and the simple life, conveying moreover, by the subtlest means, a hint of the mysterious or even the macabre to the most commonplace scene. He ranks among the greatest poets of the century.

Thompson, L., Robert Frost. 3 vols, 1966, 1970, 1974; Meyers, J., Robert Frost. 1996.

Froude, James Anthony (1818-1894). English historian and novelist, born in Devon. Son of a clergyman, educated at Westminster School and Oxford, he took deacon's orders, but, because of increasing scepticism, never became a priest. His greatest work was The History of England from the Fall of Wolsey to the Defeat of the Spanish Armada (12 volumes, 1856-70). This was followed by The English in Ireland in the Eighteenth Century (3 volumes, 1871-74). His novels, and his Tudor history, came under savage attack, but his industry and close reading of the archives in Britain and Europe was exceptional. Professor of modern history at Oxford 1892-94, he was the close friend and literary executor of Thomas *Carlyle and wrote Life of Carlyle (1884), a work of unparalleled frankness for the era. He also wrote biographies of ${ }^{*}$ Bunyan, ${ }^{*}$ Disraeli, *Luther and Julius *Caesar. Despite his gifts, Froude is no longer read. His writing had an obsessive quality which repels, but he had extraordinary flashes of insight.

Brady, C., James Anthony Froude: An Intellectual Biography of a Victorian Prophet. 2013.

Fry, C(harles) B(urgess) (1872-1956). English gentleman athlete. Educated at Wadham College, Oxford, he was a scholar who won blues for athletics, cricket and football, and held the world's long jump record 1893-95. He captained the English XI (at the age of 40) against Australia and South Africa (1912), made 30,886 runs in first class cricket and was regarded as the greatest batsman of his time. A journalist, he ran as a Liberal for the House of
Commons 1921, 1923, 1924, claimed to have been offered the Albanian throne and represented India at the League of Nations. Paranoid after 1929, he became a fawning admirer of ${ }^{*}$ Hitler in the 1930 s.

Fry, Christopher (originally Arthur Raymond Harris) (1907-2005). English dramatist, born in Bristol. Although he had written The Boy with a Cart for a pageant in 1938, he spent many years first as a teacher and then in directing repertory before he achieved his first major success with The Lady's Not for Burning (1948). Other plays included Thor, with Angels (1949), Venus Observed (1950) and The Dark Is Light Enough (1954). Ring Round the Moon (1950) was adapted from a play by *Anouilh and Tiger at the Gates (1955) from Jean *Giraudoux. Fantasy, lyricism and verbal facility almost give the effect of improvisation making him one of the rare successful verse dramatists of the 20th century.

Fry, Elizabeth (née Gurney) (1780-1845). English Quaker and pioneer of prison reform. She interested herself early in social reform, and in 1813 she was appalled by the condition of women prisoners in Newgate. She gave them decent clothing, and read and explained the Bible to them. In 1817 she formed an association which extended its activity to prisons outside London and to convict ships.

Fry, Joseph (1728-1787). English chocolate manufacturer. A Quaker, and at first a doctor, he manufactured pottery in Bristol before founding (1764) the famous chocolate factory, the basis of the family's fortunes. He also became famous as a typefounder. His great-grandson, Sir Edward Fry (18271918) was an eminent jurist in international disputes and father of Roger *Fry.

Fry, Roger Elliot (1866-1934). English art critic and painter. Curator of painting at the New York Metropolitan Museum of Art 1905-10 and art advisor to J. P. *Morgan, he coined the term 'postimpressionism', did much to secure recognition for *Cézanne, and later *Matisse and *Picasso, and was a leading member of the 'Bloomsbury' group (Clive ${ }^{*}$ Bell). His writings on art reflect an exact and formal approach to the exposition of aesthetic principles. His criticism appeared chiefly in essays, collected in Vision and Design (1921) and Transformations (1926). He maintained that the merits of a painting depended only on its form and that its content was unimportant.

Fuad I (1868-1936). King of Egypt 1922-36. Born in Cairo, he was the youngest son of ${ }^{*}$ Ismail Pasha. He succeeded his brother Hussein as Sultan of Egypt (1917) and became King (1922) when the British protectorate ended. His reign consisted mainly of a struggle between the king and the popularly elected Wafd party under its leaders *Zaghlul Pasha and *Nahas Pasha. 
Fuchs, Klaus Emil Julius (1911-1988). German physicist. Son of a theologian, he joined the German Communist Party (KPD) in 1932, and fled to England from Nazi Germany (1933). He gained a PhD from Bristol and a DSc from Edinburgh, and was interned on the Isle of Man and in Canada (1940). In 1941 he became assistant to Rudolf *Peierls, working with him in New York and Los Alamos in the 'Manhattan Project' which developed the atomic bomb (194345). Head of the theoretical physics department at the Harwell Atomic Energy Establishment from 1946, in 1950 he pleaded guilty to having supplied secret information to the Russians, and was sentenced to 14 years' imprisonment. Released in 1959, he took up a scientific position in East Germany.

Fuchs, Sir Vivian Ernest (1908-1999). British geologist and explorer. From undergraduate days at Cambridge he took part in many scientific expeditions. From 1947 he worked in the Falkland Islands Dependencies as leader of the survey and later Director of the Scientific Bureau. He is best known as the leader of the Commonwealth Transantarctic Expedition (1957-58) in connexion with the International Geophysical Year. The crossing was successfully achieved when his party met Sir Edmund *Hillary coming from New Zealand by the South Pole. With Hillary he wrote The Crossing of Antarctica (1958).

Fuentes, Carlos (1928-2012). Mexican novelist and diplomat. Educated in Mexico City and Geneva, he worked for the Foreign Ministry, was Ambassador to France 1974-77 and held chairs at Columbia, Harvard and Pennsylvania. His novels included A Change of Skin (1967), Terra Nostra (1975), The Old Gringo (1985) and The Campaign (1991). The Buried Mirror (1992), reflections on Spain and the New World, was also a television series.

Fugard, Athol (1932- ). South African playwright, novelist, actor and director. Born to an EnglishAfrikaner family, he wrote a number of plays that condemned apartheid in a broader context of intolerance, alienation and loss of identity and directed the Serpent Players in Port Elizabeth. His plays include Blood Knot (1960), Boesman and Lena (1970), A Lesson from Aloes (1979) and A Place with the Pigs (1988).

Fugger. South German (Swabian) merchant family. They ultimately achieved immense wealth and influence as one of the earliest bankers of Europe. Three brothers, of whom Jakob Fugger (1459-1525) was the most important, developed a successful business centred on Augsburg, involved with trade, silver and copper mining and banking. Through loans to the Emperor ${ }^{*}$ Maximilian and ${ }^{*}$ Charles V, Jakob, in addition to acquiring great riches, became a count and received grants of land. He built the first model town in Europe (the Fuggerei in Augsburg), which still exists. The family was staunchly Catholic and did much to oppose Lutheranism during the Reformation.

Fujimori Inomoto, Alberto Kenya (1939- ). Peruvian politician, probably born in Lima. Son of Japanese immigrants, educated in Peru, France and the US, he became a university administrator, and was elected as President of Peru 1990-2000, defeating Mario *Vargas Llosa. After serious accusations of corruption, he exiled himself to Japan and resigned there. He was extradited to Peru in 2007 and after four trials was convicted of murder, kidnapping, bribery and embezzlement and sentenced to four prison terms, 25 years in total. He suffered from cancer and heart disease. He was pardoned, controversially, in December 2017, then re-arrested on murder charges. His daughter, Keiko Sofia Fujimori Higuchi (1975- ) contested the presidential elections in 2011 and 2016.

Fulbright, J(ames) William (1905-1995). American Democratic politician. A Rhodes Scholar at Oxford, he taught law at the University of Arkansas and became its president 1939-41, Member of the House of Representatives 1943-45 and Senator 1945-75. $\mathrm{He}$ instituted the Fulbright Scholarships for the interchange of teachers and students between the US and foreign countries.

Fulk (Foulque), Count of Anjou, King of Jerusalem (1092-1143). French nobleman, born in Angers. A member of the Angevin dynasty, he was Count of Anjou 1109-29. His son *Geoffrey, progenitor of the *Plantagenet dynasty in England, was the father of *Henry II. A wealthy Crusader, as a widower Fulk married Melisende, daughter of *Baldwin II, and succeeded him as King of Jerusalem 1131-43.

Fuller, J(ohn) F(rederick) C(harles) (1878-1966). English soldier and military historian. He served in South Africa, India and France, retiring as a major general in 1933. His many books and lectures influenced German and Russian strategic thinking, but were largely ignored in Britain. $\mathrm{He}$ joined *Mosley's fascist movement, was an enthusiast for *Hitler and for the occult. He wrote The Decisive Battles of the Western World, and their Influence upon History (3 vols, 1954-56).

Fuller, Melville Weston (1833-1910). American judge. A Chicago lawyer, after a relatively minor career in Democratic politics in Illinois, he was nominated by Grover ${ }^{*}$ Cleveland to be Chief Justice of the US Supreme Court 1888-1910. A strict constructionist, he defended states' rights and struck down social legislation.

Fuller, (Richard) Buckminster (1895-1983). American engineer, architect and inventor. Twice expelled from Harvard, he worked in industry for many years and gradually evolved construction 
techniques designed to maximise efficiency and minimise costs in producing houses and vehicles by devising interchangeable modular units. His 'Dymaxion' automobile, an omnidirectional vehicle with high safety and low operating cost, was ignored by the motor industry. In 1917 he invented the geodesic dome which combined maximum strength with minimum structure and within 30 years 50,000 had been built. He lectured at several universities and his many books include Operating Manual for Spaceship Earth (1969).

Fuller, (Sarah) Margaret (1810-1850). American literary critic and feminist. She edited The Dial (1840-42), the magazine of the New England Transcendentalists, and became the friend of *Emerson and *Thoreau. She wrote Woman in the Nineteenth Century (1845). In order to take part in the revolutionary movements of 1848 she went to Italy where she married Marquis Ossoli. On the way back to America both were drowned in a shipwreck.

Fuller, Thomas (1608-1661). English writer and divine. He was author of the Worthies of England (1662), short biographical sketches of English notables; a history of the Church; and numerous other works, e.g. Good Thoughts in Bad Times (1645), which remain readable not only for their quaint facts of which he was an ardent collector but because of his wit and homely commonsense. In the Civil War he had been chaplain of the Royalist armies but was unmolested during the Commonwealth.

Fulton, Robert (1765-1815). American inventor and engineer, born near Lancaster, Pa. From a poor Irish family, almost uneducated, he became a successful painter and lived in England 1786-97, where he invented machines for sawing marble and twisting rope and many devices for improving canal navigation. While living in France (1798-1806) he built a primitive type of submarine. In 1803 he experimented with a steamship on the Seine. Later, back in the US he launched the Clermont which in tests on the Hudson River, New York State (1807), proved much more efficient than William *Symington's earlier Charlotte Dundas. He built (1815) the first steam warship, the Fulton, of 38 tons.

Funk, Casimir (1864-1967). Polish-American biochemist, born in Warsaw. He studied in Switzerland, worked in Berlin, Paris and London, then migrated to the US in 1915 . He studied the diseases caused by specific deficiencies in diet and his paper (1917) on the subject aroused immediate interest. He coined the word 'vitamin' for the critical food substances already identified by Frederick *Hopkins (1906) which he had called 'accessory food factors'.
Furet, François (1927-1997). French historian, born in Paris. He was a professor at the School of Higher Studies in social sciences 1961-77 and its president 1977-85. He emerged as the leading modern historian of the French Revolution with his Critical Dictionary of the French Revolution (1988), which emphasised political rather than economic factors. He directed the Raymond *Aron Institute 1985-92 and was elected to the Académie française in 1997. Professor at Chicago University 1985-97, he died there after a tennis accident.

Furtwängler, Wilhelm (1886-1954). German conductor and composer, born in Berlin. Noted for his romantic interpretations of the German masters, he was chief conductor of the Berlin Philharmonic 1922-27, 1938-50, the New York Philharmonic 1927-30 and the Vienna Philharmonic 1930-33. He remained in Germany during World War II (receiving *Goering's patronage) and both before and afterwards conducted in London and many leading cities as well as at Bayreuth and Salzburg. In 1952 he was awarded the Grand Cross of Merit by the West German Government.

Fuseli, Henry (1741-1825). Swiss painter. He modified his surname of Fussl to be more Italiansounding. After a brief career as a minister of religion he went to Berlin to study art (1763), and later went to London where ${ }^{*}$ Reynolds encouraged him. His style with its range of imagination, movement and distortion is often in the same mood, but at a less elevated level, as the work of ${ }^{*}$ Blake.

Tomoroy, P. T., The Life and Art of Henry Fuseli. 1972.

Fust, Johann (c.1400-1466). German printer. He lent money to finance the printing of * Gutenberg's first books, but having sued him successfully for repayment he took over his equipment (1455) and, in partnership with his son-in-law Peter Schöffer, printed a number of fine editions.

Fyodor I (Fyodor Ivánovich) (1557-1598). Tsar of Russia 1584-98. Last of the House of ${ }^{*}$ Rurik, son of *Iván IV, pious and withdrawn, known as 'the Bellringer' or 'The Blessed', effective power was in the hands of the Regent, his brother-in-law, Boris *Godunov. Although happily married, no child survived him. 


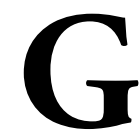

Gable, Clark (1901-1960). American film star. His casual and debonair charm, edged sometimes with a cynical aplomb, made him a box-office star. Fletcher Christian in Mutiny on the Bounty (1935) and Rhett Butler in Gone with the Wind (1939) were two of his most memorable roles. For his lighthearted and amusing part in It Happened One Night (1934) he won an Academy Award.

Gabo, Naum Neemia (originally Pevsner) (18901977). Russian-American sculptor, born in Bryansk. With his brother Antoine Pevsner (1886-1962), he was a pioneer of constructivist sculpture, rejecting traditional materials in favour of stainless steel, glass, plastic and wire. He left Russia in 1922 and lived in the US from 1946.

Gabor, Dennis (1900-1979). Hungarian-British electronic engineer, born in Budapest. The inventor of holography, he worked as a research engineer for an electrical company in Berlin from 1927, left Germany in 1933 and moved to England. He first developed holography (three-dimensional imagery) in 1947, but it did not become a commercial proposition until the invention of the laser (1960) provided the necessary light coherence. He was elected FRS (1956), made a CBE (1970) and awarded the Nobel Prize for Physics (1971) for his invention of holography. He wrote many books on scientific and social subjects including Inventing the Future (1963).

Gaboriau, Émile (1835-1873). French writer. Celebrated as a pioneer of the detective novel, L'Affaire Lerouge (1866) was his first great success and created the detective Lecoq.

Gabrieli, Andrea (c.1520-1586) and Giovanni (c.1556-1612). Venetian organists and composers. Uncle and nephew, Andrea was first singer and then organist at St Mark's. He studied composition with the cathedral's musical director Adriaan Willaert. $\mathrm{He}$ wrote madrigals, and ceremonial music for choir and instruments. Giovanni succeeded his uncle as second organist at St Mark's (Andrea having become first organist) in 1585. His two main publications were the Sacrae Symphoniae of 1597 and 1615. He is credited with introducing a new approach to orchestration, in that he directed, in detail, the specific instruments and types of voice to be used. Both composers were of great significance in Renaissance music.

Reese, G., Music in the Renaissance. 1954.

Gadda, Carlo Emilio (1893-1973). Italian novelist, essayist and poet, born in Milan. Praised by George *Steiner, little of his work is available in English other than That awful mess on via Merulana $(1946 ; 1957)$.
Gaddafi, Muammar Mohammed Abu Minyar (1942-2011). Libyan soldier and politician, born in Sirte. A Bedouin, he led the coup that deposed King *Idris I in 1969 and as Chairman of the Revolutionary Command Council he became Prime Minister of Libya 1970-72 and President 1972-77, after which he established the jamabiriya ('state of the masses') system and held a variety of titles, including Brotherly Leader and Guide of the Revolution of Libya 1977-2011. He became increasingly authoritarian, but rejected Islamic fundamentalism and became a Pan-African spokesman. When civil war broke out in 2011, NATO forces intervened and Gaddafi was brutally killed.

First, R., Libya: The Elusive Revolution. 1974.

Gaddis, William (1922-1998). American novelist. His works included $J R$ (1975), Carpenter's Gothic (1985) and A Frolic of His Own (1994).

Gadsden, James (1788-1858). American soldier. As US Minister to Mexico he negotiated (1853) a treaty, known as the Gadsden Purchase, by which 118,000 square kilometres of territory, now part of Arizona and New Mexico, were acquired by the US.

Gagarin, Yuri Alekseivich (1934-1968). Russian cosmonaut and aviator, born in Klushino. His childhood home was occupied by the Germans and he became an infant saboteur. Originally a foundry worker, he joined the Soviet Air Force in 1955 and was chosen as a cosmonaut because he was short and light. On 12 April 1961, in the space capsule Vostok 1, he became the first human to travel into space, orbiting the Earth for 108 minutes, then ejected from the capsule and parachuting safely in Kazakhstan. He became an international celebrity, a Hero of the Soviet Union, a Deputy in the USSR Supreme Soviet, and toured internationally, but was excluded from the US. He began drinking heavily and was demoted after Soyuz 1 crashed (April 1967), killing Gagarin's colleague Vladimir Komarov. Gagarin died when his plane crashed, probably due to unexpected turbulence, but the subject of much controversy and conspiracy theories. A moon crater was named for him.

Gagarin, V., My Brother Yuri. 1974.

Gage, Thomas (1721-1787). English soldier. He was Commander-in-Chief of the British forces in America from 1763, and in 1774 was appointed Governor of Massachusetts. His inflexibility precipitated the War of Independence. The first clash, at Lexington (1775) resulted from an expedition sent by him to seize arms stored at Concord. He was recalled three months later owing to the heavy losses incurred in forcing the colonists from their position on Bunker Hill.

Gainsborough, Thomas (1726-1788). English painter, born in Suffolk. He became famous both for portraits and landscapes and as founder of the 'English School' of painting. While living in London 
(from 1740), he married (1746) an illegitimate daughter of the Prince of Wales and in 1752 returned to Suffolk. It was not, however, until he moved to Bath (1759) that he gained a fashionable clientele. He became (1768) a foundation member of the RA, and settled in London (1774) where he soon rivalled *Reynolds as a painter of celebrities. His most important works were portraits (about 100 full-size and many smaller ones), where the influence of Van Dyck is clear. Of simple and warm character, unlike Reynolds, he needed to feel sympathy with his subject to be at his best, when he achieves a freshness and vitality that is entrancing. He takes a special delight in materials and clothes the sheen and creases of silk, the ripple of lace, the gleam of metal, e.g. in two of his best known works, the Blue Boy and the portrait of the actor Mrs *Siddons. Despite the fashion set by *Poussin for idealised landscapes, Gainsborough who loved the countryside, imparted much of the freshness of an observer's eye and can at least claim to anticipate ${ }^{*}$ Constable.

Corri, A., The Search for Gainsborough. 1984.

Gaitskell, Hugh Todd Naylor (1906-1963). British politician. Educated at Winchester College and Oxford and later a lecturer in political economy at University College, London he became a Labour MP in 1945. In *Attlee's post-war government he became Minister of Fuel and Power in 1947 and was Chancellor of the Exchequer 1950-51. In 1955 he succeeded Attlee as Leader of the Labour Party by then in opposition. He refused to recognise as binding a resolution passed (1960) by the Labour Party conference in favour of unilateral nuclear disarmament, and secured its reversal the following year. His unexpected death from lupus erythematosus deprived the Labour Party of a widely respected leader of great promise.

McDermott, G., Leader Lost. A Biography of Hugh Gaitskell. 1972.

Gaius (Gaius Julius Caesar Augustus Germanicus) see Caligula

Gajdusek, (Daniel) Carleton (1923-2008). American medical research scientist. Working at the National Institute of Health, Bethesda, Maryland (1958-97), he shared the Nobel Prize for Medicine in 1976 for discovering new mechanisms in the origination and dissemination of infectious diseases. He investigated kuru (degenerative disease of the nervous system, found only in New Guinea), and demonstrated its relationship with cannibalism (eating human brains). He also identified chromosomic deficiencies common to Down Syndrome and Alzheimer's disease. $\mathrm{He}$ pleaded guilty to charges of sexual offences against young men, was imprisoned 1997-98, then retired to Europe and died in Norway.

Galba, Servius Sulpicius (3 BCE-69 CE). Roman Emperor 68-69. Born to an ancient and rich family, he served as senator and consul and was Governor of Nearer Spain 60-68. He formed an army which overthrew ${ }^{*}$ Nero who then committed suicide. Upright himself, Galba's advisors were venal and after seven months he was murdered in the Forum by the Praetorian guard. *Vitelius succeeded.

Galbraith, John Kenneth (1908-2006). American economist, born in Canada. Educated at Toronto, California and Cambridge, he taught at Harvard from 1934 and was professor of economics 1949-75. He worked for the Office of Price Administration 1941-43, was Economics Adviser to President *Kennedy and US Ambassador in India 1961-63. One of his books, The Affluent Society (1958) whose title became a popular phrase, directed attention to new phenomena caused by the post-war prosperity of the US and Europe. Many of his astute observations became proverbial. 'Galbraith's Law' described the conviction by conservative governments that having more money is an incentive for the rich, while having less money is an incentive for the poor.

Galen (c.130-201). Greek physician, born at Pergamom, Asia Minor. He studied at the Asklepieion, an ancient hospital in Pergamon, and in Corinth and Alexandria. He directed the Asklepieion and developed many innovative treatments, according to Aelius Aristeides, including the use of massage, mineral springs, mud baths, diet, music therapy, incubation, autosuggestion and analysis of dreams. He lived in Rome from c.161 and became physician to ${ }^{*}$ Marcus Aurelius and later emperors. A prolific writer, he incorporated in his books the whole of Greek medical theory and practice, translated later into Arabic and Latin; they were accepted as authoritative for nearly 1400 years.

Sarten, G., Galen of Pergamon. 1954.

Galerius (Gaius Galerius Valerius Maximianus) (c.260-311). Roman Emperor 305-11. Born in Serdica (modern Sofia), son of a Thracian herdsman, he became an able soldier and destroyed the (Persian) Sassanid empire. *Diocletian appointed him as Caesar in 293. He ruled as 'Augustus' in the east and is often blamed for instigating the 'Diocletian persecution' of Christians from 303 until the edict of toleration in 311.

Galileo Galilei (1564-1642). Italian physicist and astronomer, born in Pisa. Son of Vincenzo Galilei, a mathematician from an old family which moved to Florence in 1574, he studied medicine at Pisa University (from 1581) before turning to mathematics and physics. When only 18 he made one of his most important discoveries while watching a swinging candelabrum in Pisa Cathedral: identical time was taken by each oscillation whatever the distance covered by the swing. This discovery he used years later for the making of improved pendulum clocks. This led to his being appointed professor of mathematics at Pisa. A more startling discovery, traditionally demonstrated by dropping stones from 
the Leaning Tower of Pisa, was that objects fall with equal velocity irrespective of their size and weight. This theory contradicted *Aristotle's teaching and provoked so much hostility that Galileo retired to Florence (1591), but in the next year he was appointed professor of mathematics at Padua, where he remained for 18 years, attracting students from all over Europe. He devised the first thermometer (c.1600) and constructed (1609) improved versions of the refracting telescope first produced by the Dutch Hans *Lippershey about a year earlier. Galileo attained a magnifying power of $x 32$ and carried out (from 1610) numerous astronomical observations which convinced him that ${ }^{*}$ Copernicus had been right in asserting that the earth rotates round the sun. He observed that the moon's light was reflected from that of the sun, that its surface was covered by mountains and valleys, and that the Milky Way was composed of separate stars. He also discovered the existence of the four satellites of Jupiter, sunspots (from which he deduced the rotation of the sun), the 'rings' of Saturn, and the phases of Venus and Mars.

In 1610, Cosimo II de'Medici, Grand Duke of Tuscany, had invited him back to Florence and appointed him his philosopher and mathematician extraordinary, a post with a satisfactory salary but no specific duties, which enabled him to continue his observations. In 1611 he was received with honour on a visit to Rome, but after the publication of a treatise on the sunspots (1613), in which he openly adhered to the Copernican theory, he became the object of ecclesiastical displeasure and was persuaded to promise (1616) not to 'hold, teach or defend' the new doctrines. After a long peaceful period his greatest work, Dialogue on the Two Chief Systems of the World, appeared (1632), and it was immediately evident that Galileo had not changed his views. His atomic theory-which threatened the basis of the Eucharist-may have provoked his heresy trial (1633). Brought before the Inquisition, on the threat of torture he recanted and because of age and ill health he was allowed to return to Florence, remaining under close house arrest until he died. In 1637 he became blind. (John *Milton was one of his visitors.) Among his later discoveries were the parabolic trajectory of projectiles and the monthly and annual librations of the moon. His misfortunes from the Church's hostility to his theories may have been compounded by his ironic and irascible nature. In 1992, Pope *John Paul II lifted the Inquisition's sentence on Galileo. His two daughters became nuns.

Redondi, P., Galileo: Heretic. 1983, trans. 1987; Drake, S., Galileo. 1980; Fölsing, A., Galileo. 1983; Heilbron, J. L., Galileo. 2010.

Gall, Franz Joseph (1758-1828). German physiologist. Regarded as the founder of phrenology, he practised medicine in Vienna (until 1802) and later in Paris. He concluded that human character and abilities depend upon the development of particular areas of the brain and that these can be inferred from the shape of the skull. This inference, no longer accepted as scientific, has been exploited by many quacks.

Gallatin, (Abraham Alfonse) Albert (1761-1849). American politician and diplomat, born in Geneva. Of aristocratic descent, he emigrated to America when 19, under the influence of*Rousseau's idealism. He settled in Pennsylvania and gradually rose in state and national politics. He sat in the US Congress 1795-1801, then as Secretary to the Treasury under *Jefferson and *Madison 1801-14 he reduced the public debt by over $\$ 14$ million. He was one of the negotiators of the Treaty of Ghent which brought the 'war of 1812' with England to an end. He was Minister to France 1816-23 and to Britain 1826-27.

Galle, Johann Gottfried (1812-1910). German astronomer. He first identified Neptune (1846), the existence of which had been predicted by ${ }^{*}$ Leverrier and *Adams.

Galli-Curci, Amelita (1889-1963). Italian coloratura soprano, born in Milan. Largely self-taught, she achieved dazzling success in the operas of *Verdi and *Puccini and was a star of the Metropolitan Opera, New York 1920-30.

Gallieni, Joseph-Simon (1849-1916). French soldier. Of Italian descent, he joined the army in 1868, served in Senegal, Martinique, Sudan and Indochina and was Governor General of Madagascar 1896-1905. A secular republican, he became Military Governor of Paris 1914-15. By mobilising taxis from Paris in support of a quick troop movement against the German right flank, he played a vital part in the Battle of the Marne. Minister of War 1915-16, he clashed with his former protege Joseph *Joffre over strategy. He died after a failed operation for cancer and was posthumously promoted to Marshal in 1921 .

Gallienus (Publius Licinius Egnatius Gallienus) (218-268). Roman Emperor 253-68: co-Emperor with his father *Valerian 253-60. Gallienus ruled in Italy, Valerian in the east. He ended the persecution of Christians by his father but was assassinated by officers of the Dalmatian army.

Bray, J. J., Gallienus. 1997.

Gallo, Robert Charles (1937- ). American medical researcher. Educated at the universities of Pennsylvania and Chicago, he worked at the National Cancer Institute, Bethesda, MD, 1965-96 and became head of the tumour cell biology laboratory 1972-96. Regarded as the leading AIDS researcher in the US, he concluded that AIDS was caused by a retrovirus, in which genetic material is made from RNA (not DNA). He wrote Virus Hunting, AIDS, Cancer and the Human Retrovirus 1991 but was badly damaged by a National Institute of Health report (1992) which rejected his claim to have isolated 
the AIDS virus independent of the work of Luc *Montagnier, with whom he had long feuded. He did not share the 2008 Nobel Prize with Montagnier but received a grant of $\$ 15$ million from the Bill and Melinda Gates Foundation in 2007.

Gallup, George Horace (1901-1984). American statistician. He devised a method of predicting election results and measuring other public reactions by sampling cross-sections of the population. 'Gallup poll' became synonymous with public opinion polls.

Galois, Evariste (1811-1832). French mathematician. He conceived the idea of group substitutions in the algebraic theory of equations. He was a political activist, once imprisoned, who suffered official rejection and died in a mysterious duel. Many of his papers were lost. Much of his work was confirmed by *Riemann, 30 years later.

Petsinis, T., The French Mathematician. 1997.

Galsworthy, John (1867-1933). English writer. Educated at Harrow and Oxford, he entered, but soon abandoned, the legal profession and after some years of travel determined to become a writer. His first novel, Jocelyn (1898) attracted little attention but he continued with his chosen theme, the virtues, prejudices and way of life of the upper-middle-class society to which he belonged. His masterpieces were The Forsyte Saga (published 1906-21), a series of novels describing the family of Soames Forsyte (The Man of Property, In Chancery, To Let), and the novels collectively titled A Modern Comedy (1929). His many plays, usually regarded as humane rather than profound, were influenced by the social dramas of ${ }^{*}$ Ibsen and reflect a preoccupation with ethical considerations. They include The Silver Box (1906), Joy (1907), Strife (1909), Justice (1910), The Skin Game (1920), Loyalties (1922) and Escape (1926). He was the first President of International PEN and was awarded the Order of Merit (1929) and the Nobel Prize for Literature (1932).

Dupre, C., John Galsworthy. A Biography. 1976.

Galton, Sir Francis (1822-1911). English statistician, anthropologist, meteorologist and polymath, born in Birmingham. An infant prodigy and half-cousin of Charles *Darwin, he studied medicine at Kings' College, London, and mathematics at Trinity College, Cambridge, graduating MA. He travelled in the Middle East and explored southwest Africa. One of the pioneers of meteorology, he devised the current system of weather-mapping and named anti-cyclones. His system of comparing fingerprints is still used by police. His Hereditary Genius (1869) speculated on the factors in human society (especially intermarriage) that encouraged achievement. He developed the study of 'eugenics', urging selective breeding to improve the human species. Although paved with good intentions, the path of eugenics has been taken by racists and elitists and in the early 20th century was harshly applied in education, welfare and immigration. He received the Copley Medal in 1910. His ideas were further developed by his disciple and biographer Karl Pearson (1857-1936) who held the Galton Chair of Eugenics at London University 1911-33.

Galvani, Luigi (1737-1798). Italian physiologist. His great contemporary reputation rested on his lectures on comparative anatomy at Bologna University. It is, however, through an electrical discovery that his name (e.g. in 'galvanise') has become incorporated in scientific language. He demonstrated (1791) that a frog's legs will twitch when placed in simultaneous contact with two different types of metal, but incorrectly interpreted the effect as being caused by 'animal' electricity, and not, as *Volta afterwards showed, by an electric current flowing between the metals, as in a cell.

Gama, Vasco da (c.1469-1525). Portuguese navigator. He had already made a name for himself as a mariner when he was chosen by King *Manoel the Fortunate to follow up the explorations of Bartolomeo *Diaz, who had reached the Cape of Good Hope (1488). Da Gama left Lisbon with four ships and 160 men in July 1497. Having rounded the Cape, the fleet turned northward up the African coast and then sailed eastward across the Indian Ocean to land at Calicut (May 1498). The Indians, at first friendly, turned hostile, and the Portuguese had to fight their way out, the fleet eventually reaching home in September 1499. A second expedition under Cabral founded a factory at Calicut but the 40 men left behind to man it were all murdered. To avenge their death da Gama, supplied this time with 20 ships, sailed in 1502, and after founding the African colony Mozambique again reached Calicut, destroyed 29 of the Indian ships, secured an indemnity and returned with rich booty. After 20 years of comparative inactivity he was sent (1524), now as Viceroy, to make Portugal's position secure again.

Gambetta, Léon Michel (1838-1882). French Radical politician. He became a lawyer and gained fame by his defence of opponents of *Napoléon III's regime. After the capitulation at Sedan in the FrancoPrussian War (1870), he joined the provisional government as Minister of National Defence. Leaving besieged Paris by balloon, he went to Tours to organise further resistance. After the war he succeeded in frustrating political attempts to restore the monarchy and was Premier 1881-82. He died after a pistol accident.

Bury, J. B., Gambetta and the Making of the Third Republic. 1973.

Gamelin, Maurice (Gustave) (1872-1958). French soldier. In World War I he was on *Joffre's staff in 1914 and drew up the orders for the Battle of the Marne and subsequently proved an outstanding 
divisional commander. A moderate republican and ally of ${ }^{*}$ Daladier, he was appointed Generalissimo of the allied forces in France (September 1939May 1940). After the German breakthrough he was superseded by *Weygand. He was tried for treason by *Petain's Vichy regime with Daladier and *Blum in an aborted trial at Riom, then imprisoned by the Germans. He wrote Servir. Les Armées françaises de 1940 (1946).

Gamow, George (originally Georgiy Antonovich) (1904-1968). Ukrainian-American physicist, born in Odessa. Educated in Leningrad, he lived in the US from 1934, teaching in Washington and Colorado. He worked on the evolution of stars and argued that nuclear fusion was increasing the sun's temperature. He supported *Lemaître's theory of the expanding universe (1948); however, Fred *Hoyle's dismissive term 'big bang' (1949) caught on, and is often attributed to Gamow. He also hypothesised a coding scheme for elements in genetic structures. He wrote more than 30 books popularising science, including some for children featuring $\mathrm{Mr}$ Tompkins.

Gance, Abel (1889-1981). French film director, born in Paris. After working in a lawyer's office he became an actor, script writer, theatrical producer and in 1911 directed the first of his 50 feature films, La Digue. He directed La Folie du Doeteur Tube (1915: expressionist in style, using optical distortion which anticipated Robert Wiene's The Cabinet of Dr. Caligari), J'Accuse! (1918: remade in 1937), La Roue (1922), Napoléon (1927: an epic projected on a triple screen, converted to sound in 1934), La Fin du Monde (1931: his first talking film), Un Grand Amour de Beethoven (1936), La Vénus A veugle (1940), La Tour de Nesle (1953: his first colour film), Austerlitz (1960) and Bonaparte et la Révolution (1971). He faced major problems in financing and distributing his films. They were notable for vigour, broad sweep and technical innovation, e.g. the use of wide-angle lens, widescreen projection, stereophonic sound, split screen images, hand-held cameras, low angled close ups, and rapid, impressionistic editing, which anticipated many techniques in cinéma-vérité.

Gandhi, Indira Priyadarshini (née Nehru) (1917-1984). Indian politician, born in Allahabad. Daughter of Jawaharlal *Nehru, she was educated in Switzerland, Oxford and with Rabindranath *Tagore. In 1929 she founded a children's organisation to help the movement for non-cooperation with British rule. In 1942 she married Feroze Gandhi (d.1960), and became a member of the Indian National Congress; she was its president 1959-60. From 1946 she was her father's personal assistant and played an active part in politics, especially in matters relating to child welfare and social reform. She served on UNESCO's Executive Board 1960-64. After her father's death (1964) she became Minister of Information in *Shastri's Government. When he died she became Prime Minister 1966-77, and won a landslide election victory in 1971. In 1975 she declared a state of emergency and ruled by decree, eventually losing the elections of 1977 to a coalition led by Morarji *Desai. In 1980 her Congress (I) Party was returned to office and she again became Prime Minister. Sikh members of her bodyguard shot her in New Delhi (31 October 1984). Her son Rajiv Gandhi (1944-1991) succeeded as leader of Congress (I) and Prime Minister in 1984. Educated at Cambridge, he became a pilot for Indian Airlines and entered the Lok Sabha after his brother, Sanjay Gandhi (1946-1980), regarded as heir apparent to the Nehru dynasty, died in a plane crash. He won a record majority in the December 1984 election. He was killed by Tamil separatists in a bomb explosion near Madras. His Italian widow Sonia Gandhi (née Maino) refused an offer of the Congress (I) leadership, which passed to P.V.N. *Rao, then accepted it in 1998.

Masani, Z., Indira Gandhi. A Political Biography. 1975.

Gandhi, Mohandas Karamchand (1869-1948). Indian religious and political leader, born in Porbander, Kathiawar. He was known as Mahatma (in Sanskrit, maha: great, atman: soul) a title first conferred by Rabindranath *Tagore. Son of a chief minister of Kathiawar, he was brought up as a member of a Hindu sect strictly opposed to taking life and therefore vegetarian. A quiet, studious boy, he was married at 13 to Kasturbai Nakanji (1869-1944) but continued his education. In 1888 he sailed to London where he was called to the bar (1891) and in 1893 went to Natal to represent an Indian firm, remaining in South Africa for 20 years (1893-1901, 1902-14). Jailed for refusing to register as an Indian alien, he urged his followers to burn their certificates - also organising passive resistance campaigns. This ultimately compelled the Transvaal Government to recognise the validity of monogamous marriages celebrated according to Indian rites. In 1913 he negotiated an agreement with J. C. *Smuts raising the status of Indian labourers. In South Africa he had become convinced that 'soul force' was the strongest power in the world and to maximise it in himself he must renounce sex, meat, tobacco, alcohol, and also threats, violence, coercion and other political weapons. Major influences on Gandhi included the Sermon on the Mount, the doctrine of 'non-possession' in the Bhagavad Gita, and writings by *Thoreau, ${ }^{*}$ Ruskin and ${ }^{*}$ Tolstoy. He corresponded with Tolstoy and set up a Tolstoyan commune and school in Phoenix, Natal (1910). He returned to India in January 1915 and with his followers withdrew to an ashram ('retreat') at Sabarmati, near Ahmadabad in Gujurat, where he campaigned on behalf of the 'untouchables' in the caste system. Britain's refusal to grant substantial self-government after the war persuaded Gandhi to lead a campaign for Swaraj ('self-rule'), employing the principles of Satyagraha ('soul force', literally 'firmness in the truth') which had proved successful in South Africa. He called for 'nonviolent non-cooperation' with government agencies 
and hartal (strikes with prayer and fasting) against economic regulation, and founded the influential journal Young India. However, the Amritsar massacre of April 1919 (R. E. H. *Dyer) was an unprovoked response to the hartal campaign. Gandhi urged non-cooperation with the British in all forms: all government posts were to be given up, government schools were to be abandoned. In the place of foreign-made cloth, homespun only was to be used (hence Gandhi's familiar appearance in a loincloth and homespun blanket and cape). He was opposed to violence in any form but was not always able to control his supporters. Such incidents as the burning of a police station with its inmates at Chauri Chaura (1922) in the United Provinces, forced the authorities to arrest Gandhi, who assumed responsibility. Sentenced to six years' jail, he was released in 1922 on the grounds of ill-health. He became President of the Indian National Congress Party (1924-35), the only office he ever held, and in 1929 launched a new 'civil disobedience' campaign. In March 1930 Gandhi, with hundreds of followers, marched to the sea at Dandi to protest against the imposition of a tax on salt. After the 'Salt March' his followers formally broke the law by scooping up taxfree salt. Gandhi was jailed again (1930-31) but released (with 60,000 supporters) after the Salt Law was relaxed by the Viceroy, Lord Irwin (later Earl of ${ }^{*}$ Halifax). A truce made during the abortive Round Table Conference in London (1931) was soon broken and he returned to jail, being released when he began a 'fast until death'. Winston ${ }^{*}$ Churchill was-and remainedimplacably hostile to Gandhi. Jailed for most of 1932 and again briefly in 1933, during the period 1935-41 Gandhi was in virtual retirement although publishing the weekly Harijan and campaigning on behalf of the untouchables. During World War II he gave moral support to Britain, but refused active cooperation on the grounds that Indian consent had not been obtained. Following another civil disobedience campaign (1942) he was interned until May 1944. Despite his alleged retirement from politics he played an active part behind the scenes in the negotiations that gave independence to India (1947) and the appointment of a congress government under *Nehru. He opposed partition, mourning the massacres and forced displacement of Muslim and Hindu minorities. He toured Bengal, preaching unity between Hindus and Muslims. The impact of his renewed fasts alarmed Hindu extremists: at a prayer meeting (30 January 1948) he was assassinated by a Hindu fanatic, Naturam Godse. Combining a natural shrewdness with the character of a saint, Gandhi was one of the most influential and impressive figures of the 20th century. He was nominated for the Nobel Peace Prize in 1937, 1947 and 1948 without success. Gandhi's model of non-violence was adopted by Martin Luther ${ }^{*}$ King, Nelson *Mandela and *Aung San Suu Kyi.

Woodcock, G., Gandhi. 1972.
Gandhi, Rahul (1970- ). Indian National Congress Party politician, born in Delhi. Son of Rajiv and Sonia ${ }^{*}$ Gandhi, he was educated at Cambridge. Leader of the INC 2013-19, he led the party to its worst defeat in 2014, with 19.5 per cent of the aggregate vote. In 2019 Narendra *Modi won again: the INC gained a few seats but the total vote was unchanged.

Gantz, Benny (né Binyamin) (1959- ). Israeli soldier and politician. Chief of the Israel Defence Force 2011-15, he led the Israel Resilience Party, and after a close election in 2020 entered into a power-sharing arrangement with Benjamin *Netanyahu, which soon collapsed, but he continued as Minister for Defence 2020- .

Gao Xingjian (1940- ). Chinese novelist, dramatist, director, critic and painter, born in Gangzhou. A political dissident, he left China in 1987 and became a French citizen in 1998. He was awarded the Nobel Prize for Literature in 2000 'for an oeuvre of universal validity, bitter insights and linguistic ingenuity.' His best known novel was Soul Mountain (1998). He translated works by *Beckett.

Garbo, Greta (Greta Louisa Gustafsson) (19051990). Swedish film star. While working in a Stockholm department store, she studied dancing and acting and achieved great success in the film The Atonement of Gösta Berling (1924). She then went to Hollywood and, with her beauty, sincerity and elusive charm, achieved immediate stardom in silent films. Her first talking part was in Anna Christie (1930), and she later added distinction to the title roles of e.g. Queen Christina (1933), Anna Karenina (1935), Camille (1936) and Ninotchka (1939). She disliked and avoided publicity and any intrusion into her private life, and retired from the screen in 1941 at the height of her fame.

Conway, M., Films of Greta Garbo. 1970.

Garcia. Spanish family of singers. Manuel del Populo Vicente Garcia (1775-1832) born in Seville, became a tenor, actor, impresario, composer and conductor, creating the role of Almaviva in *Rossini's Barber of Seville (Rome, 1816). He produced operas in New York and Mexico, composed many (mostly unperformed) himself, and became a teacher in Paris where he died. Two of his daughters were outstanding singers, Maria *Malibran and Pauline *Viardot. His son, Manuel Patricio Rodriguez Garcia (18051906), was a concert baritone who became a teacher from 1829, first in Paris and (from 1848) in London. He invented the laryngoscope (1854), wrote the first scientific text on the art of voice production, became the teacher of Jenny ${ }^{*}$ Lind and Mathilde Marchesi, received the CVO on his 100th birthday and was painted by John Singer *Sargent. 
García Márquez, Gabriel (José de la Concordia) (1928-2014). Colombian novelist and short story writer, born in Aracataca. His novels One Hundred Years of Solitude (1967), The Autumn of the Patriarch (1975) and Love in the Time of Cholera (1985) are passionate epics of life in South America, full of powerful and hypnotic imagery, generally described as 'magic realism'. He won the 1982 Nobel Prize for Literature 'for his novels and short stories, in which the fantastic and the realistic are combined in a richly composed world of imagination, reflecting a continent's life and conflicts'. Many of his stories are set in Macondo, a fictional town based on his birthplace.

Gardiner, Gerald Austin, Baron Gardiner of Kittisford (1900-1990). English lawyer, Labour politician and law reformer. Educated at Harrow and Oxford, he became an outstanding barrister. As Lord Chancellor 1964-70 in the *Wilson Government he drove many legal reforms, including abolition of the death penalty, decriminalising homosexuality, setting up an Ombudsman, the Law Reform Commission and securing property rights for women. Appointed $\mathrm{CH}$ in 1975, he was the target of an IRA bomb in 1981.

Gardiner, Sir John Eliot (1943-). English conductor. Educated in Cambridge and London, he studied with Nadia *Boulanger, founded the Monteverdi Choir in 1964, the London Baroque Soloists in 1978 and l'Orchestre Romantique et Revolutionaire in 1990. He was Director of the Lyon Opera 1983-88 and recorded extensively, notably ${ }^{*}$ Händel, ${ }^{*}$ Bach, *Mozart, and *Beethoven. He wrote Bach: Music in the Castle of Heaven (2013).

Gardiner, Samuel Rawson (1829-1902). English historian. Educated at Winchester and Oxford, he became professor of modern history at Kings College, London 1871-85. The scale, scope and accuracy of his research made him the great authority on the early Stuarts, and the Civil War and its aftermath. His books include History of England 1603-1640 (10 volumes, 1883-84), The Creat Civil War (3 volumes, 1886-91) and The Commonwealth and the Protectorate (3 volumes, 1895-1901).

Gardiner, Stephen (1483-1555). English ecclesiastic. As Thomas *Wolsey's secretary, he vainly negotiated on *Henry VIII's behalf for the annulment of his marriage with *Katherine of Aragon. Bishop of Winchester 1531-51; 1553-55, in 1535 he accepted Henry's royal supremacy and wrote a treatise in its support. He succeeded Thomas ${ }^{*}$ Cromwell as Chancellor of Cambridge University 1540-47; 1548-55. A reluctant Anglican, he opposed reformers around *Edward VI, was imprisoned 1547-48; 1548-55 and in 1551 stripped of his bishopric. On *Mary I's accession, he was restored, made Lord Chancellor 1553-55 and became chief agent of the Protestant persecution (although he delayed Thomas *Cranmer's execution).
Gardner, Erle Stanley (1899-1970). American detective story writer. He practised as a lawyer in California for 10 years but from 1930 devoted himself to writing. Most of his immensely popular stories end with a dramatic court scene of which the hero is the famous lawyer-detective, Perry Mason.

Garfield, James Abram (1831-1881). 20th President of the US 1881. Born on an Ohio farm, where he worked from the age of 10 (subject of the biography From Log Cabin to White House), he managed to enter and to graduate from Williams College. He then became a teacher, a lawyer, and a general in the American Civil War. A Member of the US House of Representatives 1863-80, during the corrupt era of 'Reconstruction' after the Civil War, he became Republican Leader in the House 1877-80. In 1880 he emerged as the compromise Republican candidate for president, an anti-spoilsman, on a balanced ticket with the spoilsman Chester A. *Arthur for Vice President. Garfield defeated Winfield Scott *Hancock, with an Electoral College vote of 214 to 155 but only fractionally ahead in the aggregate vote. In July 1881, four months after his inauguration, he was shot by a disappointed office-seeker, Charles J. Guiteau, in Washington DC and died in September.

Garibaldi, Giuseppe (Maria) (1807-1882). Italian patriot, born in Nice. Son of a fisherman, he became a sailor. Later he joined *Mazzini's 'Young Italy' movement, but after taking part in an abortive attempt to seize Genoa (1834) he fled to South America. He lived in Uruguay 1841-48, where he led a force of irregulars. His role in the insurrection of Brazil's Rio Grande province and his other interventions in the troubled politics of the continent gave him further experience of leading irregulars and a heroic reputation that followed him home. In 1842 he married Anita de Jesus Ribiero da Silva (1821-1849) who had accompanied his various expeditions and had borne him three children. Back in Italy in 1848 he led an irregular band against the Austrians after the defeat of the Sardinian regular army. Next he played a leading part (1849) in establishing a republican government in Rome after Pope *Pius IX had been forced to flee, but papal authority was restored by French and Neapolitan intervention. His fortunes were now at their lowest, Anita, pregnant with their fifth child, died from exhaustion. He escaped to New York in 1850, then moved to Lima. In 1852-53 he commanded the ship Carmen which traded in China and the Philippines and sailed past the south coast of Australia, and later to Boston and New York. In 1854 he returned to Italy and had settled as a farmer on the island of Caprera near Sardinia when, in 1859, the renewed war between the Austrians and the Sardinians (now under King *Vittorio Emanuele, this time with French support) again called him to battle. Northern Italy was liberated and Garibaldi and his Alpine troops had played a gallant part. In 1860 began his greatest triumph. With his 1,000 'redshirts' he landed in Sicily but met little serious resistance 
from the troops of King *Francesco II and within three months conquered the entire island. He then crossed to the Neapolitan mainland. Francesco found himself abandoned and now the only danger lay in a clash between the two liberators, Garibaldi advancing on Naples from the south, Vittorio Emanuele from the north. Good sense prevailed: Vittorio Emanuele was proclaimed king of a united Italy (except Rome and Venice) and Garibaldi, seeking no reward, returned to his island farm. He and his redshirts next appeared in 1866 in the brief campaign in which Italy, as Prussia's ally against Austria, gained Venice. But Rome remained his dream, and in 1867 he sailed from Caprera, gathered his volunteers and marched on the city. After a preliminary success he was overwhelmed by the French garrison left to protect the pope. It was the withdrawal of that garrison during the Franco-Prussian War (1870-71) that eventually enabled Rome to become the capital of the Italian state. In that war too, Garibaldi had his last taste of battle. After the fall of his enemy, *Napoléon III, he rallied to the side of the republican government and even achieved some success amid the general defeat. The rest of his life he spent (except for an occasional appearance in the Italian chamber, where he sat as a deputy) at Caprera, crippled by illness. He wrote novels, he signed manifestos, but his strength was in action not the pen. He was a man who never wavered from a single fixed purpose, the unification of divided Italy under Italian rule, and though others planned more wisely for the same ideal it was Garibaldi, with his enthusiasm, his leadership and colourful exploits, that fired the hearts of men and, more perhaps than any other, brought it about.

Riall, L., Garibaldi: Invention of a Hero. 2007; Ridley, J., Garibaldi. 1975.

Garland, Judy (née Frances Gumm) (1922-1969). American film actor and singer. She began her stage career as part of a music-hall act, and began to make films in 1936. Throughout the following 14 years she played leading parts in musicals and comedy films and achieved tremendous following. Her best known films from this period are The Wizard of $\mathrm{Oz}$ (1939), a series in partnership with Mickey *Rooney (1937-41), and musicals like For Me and My Gal (1942) and Meet Me in St Louis (1944). She later turned to dramatic roles as in A Star is Born (1954), and to concert and cabaret tours. She died in London of a drug overdose. Her daughter Liza Minnelli (1946- ) was acclaimed as an actor and singer, winning an Academy Award for her role in Cabaret (1972).

Garland, Merrick Brian (1952- ). American lawyer, born in Chicago. Educated at Harvard, he was a judge of the US Court of Appeals 1997-2021. Nominated by Barack *Obama to become a justice of the US Supreme Court in 2016, his nomination was blocked by Mitch ${ }^{*}$ McConnell and Senate Republicans. Joe *Biden appointed him as US Attorney-General 2021-
Garner, Helen (née Ford) (1942- ). Australian writer, born in Geelong. Once a teacher, her novels include Monkey Grip (1977), The Children's Bach (1984) and Cosmo Cosmolino (1992) and The Spare Room (2008). The non-fiction The First Stone (1995) was deeply controversial. Other works include Joe Cinque's Consolation (2004), This House of Grief: The Story of a Murder Trial (2014, winner of the 2016 WindhamCampbell Literary Prize in the US) and a collection of essays, in the Janet *Malcolm tradition, Everywhere I Look (2016).

Garner, John Nance (1868-1967). American Democratic politician, born in Texas. A Congressman 1903-33, and strong segregationist, he became Speaker of the House of Representatives 1931-33 and an increasingly unhappy vice president of the United States 1933-41 under Franklin D. *Roosevelt.

Garnett, Edward (1868-1937). English writer and critic. Son of Richard Garnett (1835-1906), ${ }^{*}$ Carlyle's biographer, his work as literary advisor to the publishers Fisher Unwin, Heinemann, and Jonathan Cape brought him into touch with many authors, and his home became a sort of literary club where advice, kindness and help were always available. He gave much encouragement to ${ }^{*}$ Conrad, ${ }^{*}$ Galsworthy and D. H. ${ }^{*}$ Lawrence. His wife, Constance Garnett (née Black) (1862-1943), introduced a new world of Russian literature to English readers by her translations of ${ }^{*}$ Tolstoy, ${ }^{*}$ Dostoevsky, ${ }^{*}$ Chekhov etc. Their only child, David Garnett (1892-1981), known as 'Bunny', novelist and publisher, was in the Bloomsbury Group and a vigorous bisexual. His short fantasy Lady into Fox (1922) won the Hawthornden and James Tait Black Memorial Prizes. He founded the Nonesuch Press, published the letters of T. E. *Lawrence, wrote an autobiography and the novel Aspects of Love (1955).

Garnier, Tony (1869-1948). French architect and planner. Over many years (from 1904) he elaborated his design (Une Cité industrielle, published 1917) for an integrated city for 35,000 people on original and revolutionary lines, some of which he was able to put into practice in Lyon, where he was city architect.

Garrick, David (1717-1779). English actor. As a youth in Lichfield he was briefly a pupil of Samuel *Johnson, whose close friend he became. The two went to London together (1737), Garrick intending to study for the bar. He joined his brother as a wine merchant before making his debut as an actor in 1741. His first part in London was Richard III, he was an immediate success and remained throughout his career the most popular actor of his age in both tragedy and comedy, Lear and Macbeth being among the most memorable of his Shakespearian parts. He was joint licence holder and Director of Drury Lane Theatre from 1747 to 1776 when he was succeeded by ${ }^{*}$ Sheridan. He also wrote several plays (of little merit), and some excellent prologues 
and epilogues. He remained a member of Johnson's social group and he was portrayed by ${ }^{*}$ Hogarth, ${ }^{*}$ Gainsborough and ${ }^{*}$ Reynolds.

Oman, C., David Garrick. 1958.

Garrison, William Lloyd (1805-1879). American journalist and reformer, born in Massachusetts. He became editor of two New England newspapers, in which he vigorously attacked slavery; for one article he was briefly imprisoned for libel. The Liberator, in which for 35 years he campaigned for emancipation, first appeared in 1831. In 1833 he was a founder of the American Anti-slavery Society. With a violence and self-righteousness that often injured the causes for which he pleaded, he also supported female suffrage, the abolition of capital punishment, and prohibition.

Gary, Romain (né Kacew) (1914-1980). FrenchJewish-Lithuanian novelist, diplomat and hoaxer, born in Lithuania. He won the Prix Goncourt in 1956 with The Roots of Heaven and a second (against the rules) with Life Before Us (1975), published under the name of Emile Ajar.

Bellos, D., Romain Gary. A Tall Story. 2010.

Gaskell, Elizabeth Cleghorn (née Stevenson) (1810-1865). English novelist, born in Chelsea. Brought up by an aunt in Knutsford, Cheshire, the scene of her best known novel Cranford (1853), in 1832 she married a Unitarian minister and moved to Manchester, which provided the background for Mary Barton (1848) and North and South (1855). She also wrote a notable life (1857) of Charlotte *Brontë, which provoked contemporary criticism for its frankness.

Uglow, J., Elizabeth Gaskell. 1993.

\section{Gasperi, Alcide de see De Gasperi, Alcide}

Gassendi, Pierre (1592-1655). French philosopher and scientist. He studied at Aix, and obtained a doctorate at Avignon, where he took holy orders. From an early age, studies in natural philosophy occupied his mind, and he became a partisan for the Moderns. His criticisms of Aristotelian philosophy were set out in his Exercitationes Paradoxicae adversus Aristotelos. He entered into deep study of *Epicurus, whose biography he wrote. In regard to philosophies of Nature, Gassendi was an eclectic. A pious Christian, he was aware that no man can penetrate to the heart of Nature's secrets. But he was a convinced supporter of the atomistic hypothesis of the composition of matter. Atoms were the first things created. Subsequently combinations of molecules formed by collision and complex bodies were built up. He believed that science could best proceed by the measurement of basic particles (weight, speed, acceleration, mass, density) rather than by inventing mythical 'virtues' such as 'powers', 'tendencies' and the other categories of Scholastic thought. Gassendi was of importance as a defender of the autonomy of science in the age of ${ }^{*}$ Galileo's persecution. He insisted that science was compatible with Christianity, so long as both sides knew their own place. Gassendi made few positive contributions to science in the technical sense. He offered a good approximation of the speed of sound (316.3 metres per second), disproving *Aristotle's view that this depended on pitch. He defined, accurately, the principle of inertia, seeing it not as a tendency to rest, but the tendency to resist change of state.

Gates, Bill (William Henry) (1955- ). American computer software executive, born in Seattle. A dropout from Harvard College, he worked for Honeywell, then founded the Microsoft Corporation (1976), becoming the first software billionaire. Among his successful software packages were 'MS-DOS' and 'Windows'. He bought a *Leonardo manuscript (the Hammer Codex) in 1994 for \$US32.5 million. His wealth was estimated at \$US101 billion in 1999 and he was gratified that it had fallen to $\$ 51$ billion by 2011. In 1994 he created the Bill and Melinda Gates Foundation which works to eliminate infectious disease, giving priority to HIV/AIDS, polio, malaria and measles, and to promote education. He was awarded an Hon. KBE in 2005.

Gates, Horatio (c.1728-1806). American soldier, born in England. He served with British forces in North America against the French (1754-63), returned to England but emigrated to West Virginia in 1772. Taking up the colonial cause, he was made Adjutant General of the Continental Army in 1775 and became a general in 1777 . He defeated British forces at Saratoga in that year and was considered by a group of officers as a replacement for General Washington, a scheme that came to nothing. He was defeated at the battle of Camden, South Carolina, in 1780 , was dismissed but returned to the army in 1782. He served as a Whig in the New York State Legislature 1800-06.

Gaudí (i Cornet), Antonio (1852-1926). Spanish (Catalan) architect, born in Reus. He studied in Barcelona from 1869 and developed a Mudejar style, influenced by Moorish building. His works were highly idiosyncratic, fantastic in design and construction, similar in spirit to Art Nouveau. He introduced colour, unusual materials and audacious technical innovations. His main works are around Barcelona, where the huge, unfinished, Basilica of the Holy Family (Basilica de la Sagrada Familia) is the greatest monument to his ingenuity and decorative virtuosity. 'The works of Antonio Gaudí' became a World Heritage site in 1984, expanded in 2005, including the basilica, Park Güell, Palau Güell, and Casa Milà. He died after being knocked down by a trolley bus. The basilica was consecrated by Pope *Benedict XVI in 2010.

Sweeney, J. J. and Sert, J. L., Antonio Gaudi. 1970; Zerbst, R., Antoni Gaudi. 1991. 
Gaudier-Brzeska (né Gaudier), Henri (1891-1915). French Vorticist sculptor and painter, born near Orléans. Originally Gaudier, he worked in London from 1910 with Ezra *Pound and Wyndham *Lewis and other members of the Vorticist group. He formed an intense relationship with the Polish writer Sophie Brzeska (1873-1925) and added her name to his own. They moved to London in 1910, working with Ezra *Pound and joining Wyndham *Lewis' Vorticist group. In his four active years as a sculptor he produced powerful work that influenced Jacob *Epstein. Killed as a soldier in World War I, his life was the subject of the book Savage Messiah (1931- revised 2011) by H. S. Ede, filmed by Ken Russell in 1972.

Gauguin, (Eugène-Henri) Paul (1848-1903). French painter, born in Paris. He grew up in Orléans, with his father, and in Lima, Peru, with his mother's family, became a sailor and joined a stockbroking firm in 1871 . He began painting with his friends *Pissarro and ${ }^{*}$ Cézanne, abandoned the stock market in 1883 , sent his wife with their five children to her parents in Denmark and devoted the rest of his life to art. Paris proving too expensive he settled in Brittany (1886). After a visit to Martinique and an acrimonious association with Van ${ }^{*} \mathrm{Gogh}$ he went (1891) to the South Seas, first to Tahiti and (1901) to the Marquesas, where he died. Originally influenced by the Impressionists, especially Pissarro, he parted from them in 1887, dissociating himself from their techniques of breaking up colour. He evolved a decorative style using simplified drawing, and flat, strong, pure and not necessarily naturalistic colouring; outlines, as in cloisonné enamels, were often intensified by black lines. The brilliant colours of Tahiti provided ideal inspiration and he was also influenced by primitive sculpture, as is seen in some of his pictures of serene impassive islanders represented in attitudes of repose. Gauguin's paintings were a major influence on later non-representational art. His Nafea Faa Ipoipo (When Will You Marry?, 1892) was sold privately for \$US210 million in 2015.

Goldwater, R., Paul Gauguin. 1957; Gauguin, P., The Intimate Journals of Paul Gauguin. 1985; Sweetman, D., Paul Gauguin. 1995.

Gaulle, Charles André Joseph Marie de see de Gaulle, Charles André Joseph Marie

\section{Gaunt, John of see John of Gaunt}

Gauss, (Johann) Carl Friedrich (1777-1855). German mathematician, born in Braunschweig. An infant prodigy, educated at Göttingen University, he gave early proof of his great powers in both pure and applied mathematics, becoming a professor there and director of the observatory (1807). From celestial mechanics and geodesy he turned his attention in the 1830 s to electromagnetic theory and research on terrestrial magnetism, establishing most of the important theory for the measurement of magnetic field strengths. Gauss was also, with *Riemann and ${ }^{*}$ Lobachevsky, one of the pioneers of non-Euclidean geometry. The unit of magnetic flux density is named after him. He developed (but did not originate) the concept of 'normal distribution', often described as 'the bell curve'. He received the Copley Medal in 1838.

Dunnington, G. W., Carl Friedrich Gauss, Titan of Science. 1955.

\section{Gautama Buddha see Buddha, The}

Gautier, (Pierre Jules) Théophile (1811-1872). French poet, novelist, essayist and critic, born in Tarbes. Prevented by short sight from being a painter, he began to write as a strong supporter of the Romantic movement, but was already mocking its excesses in his novel Mademoiselle de Maupin (1835). His friend *Berlioz set his poems Les nuits d'été (1840). His volume of poems Emaux et camées (1852) was among the principal influences on the 'art for art's sake' movement, which stressed beauty of form and sound rather than significance. Gautier was the first serious writer and critic of dance and also close to the painters ${ }^{*}$ Delacroix and ${ }^{*}$ Manet. His daughter, Judith Gautier (1850-1917), also a novelist, married the poet Catulle *Mendes, and later Pierre *Loti.

Tennant, P., Theophile Gautier. 1973; Grant, R., Théophile Gautier. 1975.

Gaveston, Piers, 1st Earl of Cornwall (c.1284-1314). English courtier. Of Gascon descent, he became the favourite, and perhaps lover, of *Edward II, arousing the hatred of the barons by his swaggering display of power and mocking tongue. Twice they forced his banishment, and his second return led to civil war. Gaveston was forced to surrender, but three of his most powerful opponents kidnapped him and had him beheaded.

Gay, John (1685-1732). English poet and dramatist, born in Devon. After attending a local grammar school, he went to London as a mercer's apprentice. His political satires and his amiable temperament won him much aristocratic patronage and the friendship of *Pope. His early publications included The Shepherd's Week (1714) and Trivia (1716), the latter, with its humorous accounts of London life, became extremely popular. Having just dedicated his satiric Fables (1727) to the Duke of Cumberland, he had hoped, when the Duke's father succeeded to the throne as ${ }^{*}$ George II, for more than the sinecure offered. Thus gibes at ${ }^{*}$ Walpole were included in his triumphant success The Beggar's Opera (1728), of which he wrote the libretto for an accompaniment of old tunes. Its sequel Polly (1729), though banned from the stage, also brought its author a large sum on publication. His Acis and Galatea appeared as an opera with music by ${ }^{*}$ Händel in 1732 . He was buried in Westminster Abbey.

Armes, S. M., John Gay: Social Critic. 1972. 
Gay-Lussac, Joseph Louis (1778-1850). French chemist. He was educated at, and was later professor at, the École Polytechnique, Paris. For a time he worked at the government chemical works at Arcueil, at first mainly on physical properties of gases and liquids. In balloon ascents of up to $7500 \mathrm{~m}(23,000 \mathrm{ft})$, he investigated the earth's magnetic field and atmospheric conditions. In 1808 he put forward his law of gas volumes which states that the volumes of gas (taking part and produced) in a chemical reaction are always in a simple proportion to one another $\left({ }^{*}\right.$ Charles, Jacques). With Thénard he made discoveries in inorganic chemistry and also worked out the first satisfactory scheme of organic analysis. He investigated iodine and cyanogen compounds, and in 1815 was the first to isolate cyanogen itself. He also made important improvements in a number of industrial processes, e.g. for the manufacture of sulphuric acid by the Chamber process in which he introduced the so-called GayLussac tower, first used in 1842.

Geddes, Sir Patrick (1854-1932). Scottish biologist, sociologist and town planner, born in Aberdeenshire. Educated in Edinburgh, London and the Sorbonne, his original disciplines were biology and physiology, but his interests were exceptionally broad. He held chairs in Edinburgh and Bombay (Mumbai) and founded his own institution in Montpellier. He wrote The Evolution of Sex (1889), City Development (1904) and Cities in Evolution (1914). He designed the new Hebrew University in Jerusalem (1919), planned the city of Tel Aviv, coined the terms 'conurbation' and 'the second industrial revolution' (electricity and chemicals), promoted the concept of 'ecology' and became an icon of the Green movement.

Boardman, P., Patrick Geddes: Maker of the Future. 1957; Kitchen, P., A Most Unsettling Person. 1975; Welter, V. M., Biopolis: Patrick Geddes and the City of Life. 2002.

Gehrig, (Henry) Lou(is) (1903-1941). American baseballer. He played 2130 consecutive games for the New York Yankees (1925-39), a record that stood until 1995. He died from motor neurone disease (named for him in the US).

Gehry, Frank Owen (originally Goldberg) (1929- ). Canadian-American architect, born in Toronto. He won the Pritzker Architecture Prize in 1989. His buildings include 8 Spruce Street, Manhattan; the Guggenheim Museum, Bilbao, 1995-98; the Louis Vuitton Foundation, Paris; Dancing House, Prague; and the Walt Disney Concert Hall, Los Angeles. He was made a Companion of the Order of Canada (CC).

Goldenberger, P., Building Art: The Life and Work of Frank Gehry. 2015.

Geiger, Hans (né Johannes) Wilhelm (1882-1945). German physicist. He was best known for research on the alpha particles given off from radioactive substances. For their detection he invented (1908), with *Rutherford, the device known as the Geiger counter. With Ernest Marsden he showed that alpha-particles passing through metal foil were occasionally deflected through large angles, and it was this observation that led Rutherford to formulate (1911) his nuclear model of the atom. Professor of Physics at Kiel, Tübingen and Berlin, during World War II he investigated uranium for use in a bomb.

Geikie, Sir Archibald (1835-1924). Scottish geologist, born and educated in Edinburgh. Heworked with the Geological Survey from 1855, became its director in Scotland in 1867 and was director general 1882-1901 for the UK. He was professor of geology at Edinburgh University 1871-82, President of the Royal Society 1908-13 and awarded the OM (1913). His notable Textbook of Geology (1882) was one of his many books that included an autobiography, A Long Life's Work (1924).

Geim, Sir André Konstantin (1958- ). RussianDutch-British physicist, born in Sochi. He held a chair at Manchester and shared the 2010 Nobel Prize for Physics 'for groundbreaking experiments regarding the two-dimensional material graphene', layers of carbon, one atom thick, also working on superconductivity and the impact of magnetism on water. He is the only scientist (so far) to win a Nobel Prize and an Ig Nobel Prize, in 2000, for his experiments on the levitation of frogs.

Gell-Mann, Murray (1929-2019). American theoretical physicist, born in New York. Educated at Yale, MIT and Chicago (where he studied with *Fermi), he was a professor at the California Institute of Technology 1956-93, working on subatomic particles. He proposed a systematic classification of particles which he called 'the Eightfold Way', now generally accepted, that led to his Nobel Prize for Physics in 1969. He also postulated the existence of 'quarks' (a name taken from James ${ }^{*}$ Joyce) as the basic building blocks for all matter. With Richard *Feynman, he explained the mechanisms of the 'weak nuclear force'. His interests included linguistics, archaeology, natural history and the psychology of creativity. He was a co-founder of the Santa Fe Institute, New Mexico, which works on complexity theory.

Gell-Mann, M., The Quark and the Jaguar. 1994; Johnson, G., Strange Beauty. Murray Gell-Mann and the Revolution in Twentieth-Century Physics. 1999.

\section{Gellée, Claude see Claude Lorrain(e)}

Geminiani, Francesco (1687-1762). Italian composer and violinist. A pupil of ${ }^{*}$ Corelli, he lived in London for many years and composed works for violin and string orchestra. His book The Art of Playing the Violin (c.1740), the earliest work of its kind, contains valuable information about the technique of his day. 
Genet, Jean (1910-1986). French novelist, dramatist and poet, born in Paris. Son of a prostitute, he lived in an orphanage as a child, then with a peasant family, followed by years in a reformatory and jail terms for theft and male prostitution. He began writing in jail with his Our Lady of the Flowers (1943) and was pardoned in 1948. His powerful plays included The Balcony (1956), The Blacks (1959) and The Screens (1961).

White, E., Genet. 1993; Barber, S., Jean Genet. 2004; Laroche, H., The Last Genet. 2010.

Geneviève, St (c.422-c.512). French religious, born in Naterre. She is said to have taken the veil at the age of 15 . When her parents died she went to Paris, where she lived a life of great austerity and when *Attila and the Huns invaded France (451) calmed the panic-stricken inhabitants by her absolute assurance, derived from her prayers and, soon justified, that the enemy would pass the city by. Venerated as the patron saint of Paris, her remains are in the church of SaintEtienne du Mont.

Genghis known as Genghis Khan (Chinggis Khaan, birth name Temüjin, i.e. blacksmith) (c.1162-1227). Great Khan of the Mongol Empire 1206-27. Born in Delüün Boldog, near Lake Baikal, a member of the Borjigin clan, he succeeded his father, Yesügei, who ruled the tribes in the steppes of central Asia from the Amur River to the Great Wall of China. He gradually extended his authority until in 1206 he took the title Genghis Khan ('universe ruler'). In c.1212 he followed up China's refusal to pay tribute by overrunning the country. Next he turned westwards and southwards, and even after he returned to Mongolia (1221) his captains continued the great conquering drives. Thus when he died, the Mongol empire stretched from the Yellow Sea to the Black Sea, and included Korea, Persia, Armenia, Southeast Russia, Turkestan and parts of Siberia and China. His religion was Tengriism, Central Asian shamanism, followed by Mongols, Huns and Turks. He had a reputation for religious tolerance and curiosity, but his conquests aroused terror among Christian and Muslim nations alike and his massacres became legendary. Despite his brilliance as a soldier and ability as a ruler, he left no permanent institutions behind him, though important indirect results of the forces he set in motion were the entry of the Turks into Europe and the Mughal Empire in India. His life has been the subject of 12 films, three television series, five novels and five video games. An international genetic team in 2003 concluded that Genghis had more direct descendants than anyone else in history and that 16 million males had the same Y-chromosome as the Great Khan. He was succeeded by his son Ögedai (c.11861241); *Kublai Khan was a grandson. *Timur claimed to be a successor of Genghis but this is doubtful.

De Hartog, L., Genghis Khan: Conqueror of the World. 1988; Turnbull, S., Genghis Khan \& the Mongol Conquests 1190-1400. 2003; Weatherford, J., Genghis
Khan and the Making of the Modern World. 2004; Man, J., Genghis Khan. Life, Death and Resurrection. 2004.

Gens, Véronique (1966- ). French soprano, born in Orléans. She became a baroque specialist, working with William *Christie, then made memorable CDs of *Mozart's operas with René *Jacobs. She also excelled in music by ${ }^{*}$ Purcell, *Berlioz, *Debussy, ${ }^{*}$ Ravel and ${ }^{*}$ Poulenc.

Genscher, Hans-Dietrich (1927-2016). German politician. He worked for the Free Democratic Party, became a deputy in the Bundestag 1965-92, and party leader 1974-85. He served as Minister for the Interior 1969-74 and Foreign Minister 1974-82, 1982-92 in both Socialist and Christian Democratic governments.

Gentile da Fabriano (c.1370-1427). Italian painter. He worked on historical frescoes, in the late Gothic style, for the Doge's Palace at Venice (1409-19) and later in Florence, Siena and Rome. His Adoration of the Magi (in the Uffizi, Florence), with its richly caparisoned procession of kings and the clever foreshortening of the horses greatly influenced Florentine technique.

Gentileschi, Artemisia (1597-1651?). Italian painter, born in Rome. Daughter of the painter Orazio Gentileschi (1563-1638), she painted in the style of ${ }^{*}$ Caravaggio, with brilliant colour and violent action. Agnes Merlet directed the film Artemisia (1998).

Geoffrey V (Plantagenet), Count of Anjou, Duke of Normandy (1113-1151). French nobleman, born (and died) at Château-du-Loir. Part of the Angevin dynasty, he succeeded his father *Fulk (Foulque) $\mathrm{V}$ as Count of Anjou in 1129 and was Duke of Normandy $1144-50$. He became the second husband of *Matilda, daughter of *Henry I of England, and as father of *Henry II founded the *Plantagenet dynasty.

Geoffrey of Monmouth (c.1100-1154). British chronicler. He became Bishop of St Asaph (Wales) in 1152 and wrote the Historia Regum Britanniae, in which he assembled much of the legendary history of King Arthur, giving it a 12th-century setting. His work influenced Wace and other medieval chroniclers.

Geoffroy Saint-Hilaire, Etienne (1772-1844). French anatomist and palaeontologist. He specialised in comparative anatomy, working out the principles that enable the scientist to deduce absent organic structures from surviving ones (in the case of defective extinct fossil creatures) and the principle of organic balance. Largely through contemplation of the palaeontological record, which seemed to show a historical succession from primitive to complex forms of life, from the invertebrates up to the mammals, he came to believe, like *Lamarck, in the reality of organic evolution. This he saw as 
proceeding by a series of big jumps, on the analogy of the embryological production of occasional monsters, when climatic and environmental conditions made survival of existing species precarious. He was bitterly attacked for his evolutionary views by his one-time collaborator, ${ }^{*}$ Cuvier. In his later years, he developed a broad ranging, if somewhat mystical, view of the organic unity of all Nature.

Bourdier, F. 'Geoffroy Saint-Hilaire and his Struggle against Cuvier' in Schneer, C. J. (ed.), Toward a History of Geology. 1969.

George (Geōrgios/ Georgius), St (d.c.303). Christian martyr, perhaps born in Cappadocia or Syria. It is difficult to distinguish legend from fact. A possible version of his life is that he was a military tribune in the Roman army in Palestine, who, having proclaimed his Christian faith during the persecutions inspired by ${ }^{*}$ Diocletian, was tortured and beheaded at Nicomedia, supposedly on 23 April. The story of St George and the dragon first appears in its present form in The Golden Legend (c.1275). When a dragon appeared before Silence in Libya, its hunger was daily satisfied by a sheep. When sheep failed, men and women were chosen by lot as substitutes. At last the lot fell upon the princess, but when, dressed as a bride, she faced her doom, St George, under the protection of the Cross, appeared and so wounded the dragon that it could be brought into the city and beheaded. A striking resemblance to the Greek story of Perseus and Andromeda is apparent. St George became popular in England during the Crusades, but supplanted *Edward the Confessor as patron saint only in the reign of ${ }^{*}$ Edward III.

George I (Georg Ludwig von Welf-Este) (16601727). King of Great Britain and Ireland 1714-27, Elector of Hanover 1698-1727. Born at Osnabrück, he was the son of the Elector Ernst August (d.1698) and ${ }^{*}$ Sophia of the Palatinate. In 1682 he married his cousin Sophia Dorothea of Celle in 1682 but having discovered (1694) her liaison with Count *Königsmark (who was speedily murdered), he divorced her and kept her confined at Ahlden until she died (1726), despite his own many mistresses. Through his mother, a granddaughter of *James I in the Protestant line of descent, he was able to succeed to the British throne by virtue of the Act of Settlement (1701), which excluded the Roman Catholic Stuarts. His reign marked the beginning of a long Whig supremacy, since the Tories were held to be tainted with complicity in the Jacobite rebellion of 1715. His long absences in Hanover and his lack of interest in British politics favoured the development of constitutional government with the rise of Robert *Walpole as de facto Prime Minister. Taciturn, and having little English, he conversed with Walpole in Latin. He was the patron of ${ }^{*}$ Händel. He died of a stroke in the room of his birth and was buried at Osnabrück.
George I (Geórgios in Greek: Christian Vilhelm Frederik Adolf Georg Schleswig-HolsteinSonderberg-Glücksburg) (1845-1913). King of the Hellenes (Greece) 1864-1913. Son of ${ }^{*}$ Christian IX of Denmark and brother of Britain's Queen *Alexandra, he was chosen king after the forced abdication of ${ }^{*}$ Otto, accepted a constitution with some democratic elements and was both accessible and relatively popular. His invitation (1909) to *Venizelos, the Cretan political leader, to head the government led to the formation of the Balkan alliance against Turkey, the successful Balkan Wars (1912-13) and the creation of a greater Greece. On the eve of his 50th anniversary, he was assassinated at Thessaloniki.

George II (Georg August von Welf-Este) (16831760). King of Great Britain and Ireland, Elector of Hanover 1727-60. Born in Hanover, son of *George I, he frequently deputised during his father's long absences in Germany and they rarely met. As King, he maintained *Walpole in office, encouraged to do so by his astute and able wife, Caroline of Anspach, whom he had married in 1705. Though George openly expressed his preference for Hanover and had limited interest in English politics, he was reasonably fluent and no puppet, but also philistine and subject to sudden rages. He successfully played, without liking, his constitutional role and gave his ministers the full benefit of his knowledge of foreign affairs. After the death (1740) of the emperor ${ }^{*}$ Charles VI, George, despite Walpole's reluctance, fulfilled his obligations under the Pragmatic Sanction to secure the succession to the Austrian inheritance of Charles' daughter, *Maria Theresa. At Dettingen (1743) he commanded his army in person, the last British sovereign to do so. In $1745^{*}$ Charles Edward Stuart (Bonnie Prince Charlie) landed in Scotland and the Jacobite army came as far south as Derby before the danger passed and George could again feel secure. Walpole had fallen in 1742 and, in the years that followed, the Duke of ${ }^{*}$ Newcastle, that industrious purveyor of patronage, was the constant political factor, with *Pitt, Carteret (*Granville), and others giving intermittent support. The opposition centred upon the childish and disagreeable *Frederick Louis, Prince of Wales, who predeceased his father. The reign ended in a blaze of glory: the success of the Seven Years' War, which began in 1756, included the British conquest of French Canada and the destruction of French influence in India. George II was brave, honest, quick tempered but sometimes mean and vindictive; he was also promiscuous before and after Queen Caroline's death (1737). The Hanoverian Amelia von Walmoden (Countess of Yarmouth) was the most conspicuous of the royal favourites. Succeeded by his grandson, *George III, he was the last British king to maintain the ancient claim to the throne of France. 
George (Geórgios) II (1890-1947). King of the Hellenes (Greece) 1922-24, 1935-47. Eldest son of *Constantine I, he served in the Prussian army, then the Greek, succeeding after his father's second abdication. Deposed in 1924 when the republic was proclaimed, he lived in Romania 1924-32 and England 1932-35. After 12 years of instability in Greece, the authoritarian Prime Minister Geórgios Kondylis organised a fake plebiscite in which 98 per cent voted to restore the monarchy (1935). After the sudden death of Kondylis, the recalled king appointed Ioannis *Metaxas as dictator. In World War II, Greece successfully resisted the Italian attack of 1940 but was overwhelmed in April 1941 when the Germans invaded. Briefly Prime Minister (April 1941), he evacuated to Crete, then Egypt, worked with the government-in-exile in England and, after a highly suspect plebiscite (1946), returned to Greece, dying suddenly six months later.

George III (George William Frederick von Welf-Este) (1738-1820). King of Great Britain and Ireland, from 1801 the United Kingdom of Great Britain and Ireland 1760-1820, Elector and, from 1814, King of Hanover 1760-1820. Born in London, son of *Frederick Louis, Prince of Wales, he succeeded his grandfather George *II. As he told his first parliament, 'Born and educated in this country, I glory in the name of Briton' and he never visited Hanover where his two predecessors had been born. Tutored by the Earl of *Bute, to whom he was devoted, in 1759 he fell in love with Lady Sarah Lennox, daughter of the Duke of Richmond. Bute persuaded him that he must marry a Protestant princess from Germany. George's aim, derived from *Bolingbroke's Idea of a Patriot King, was to choose the best men, irrespective of party, and to govern without 'influence' an impossible ambition in the political conditions of the time. His first step to this end was to get rid of his grandfather's ministers *Pitt and ${ }^{*}$ Newcastle and to install Bute as Chief Minister. This was a mistake, for Bute, already mistrusted as a Scot, a royal favourite and a totally inexperienced politician, earned more unpopularity by bringing the Seven Years' War to an end on terms held to be disadvantageous to Britain, the victor. Bute was forced to resign in 1763 but continued to advise until 1766 . There followed a period of frequent ministerial changes, complicated by the attacks of *Wilkes and his supporters, until George found Lord ${ }^{*}$ North, who by adroit use of patronage, considerable tactical skill and charm of manners managed to stay in office from 1770 to 1782 . He could not survive the loss of the American colonies, but after another short period of frequent change (1782-83), George appointed the younger *Pitt, who gradually removed control of government from royal hands. A devout and rigid Anglican, he bought Buckingham Palace (formerly House), restored Windsor Castle, and also lived in Kew. He barely travelled and never left England. George's refusal to violate his coronation oath by agreeing to any measure of Roman Catholic emancipation created the only real impasse. The last part of the reign was almost totally dominated by the impact of the French Revolutionary and Napoléonic wars. In 1761 George had married Princess ${ }^{*}$ Charlotte of Mecklenburg-Strelitz, by whom he had nine sons and six daughters. Faithful and devoted as he was, reaction against the atmosphere of happy and rather stuffy domesticity may have contributed to the extravagances of his eldest son $\left({ }^{*}\right.$ George IV) who became regent in 1811, when his father after earlier short periods of 'madness' (now thought to have been compounded by excessive medication, or possibly porphyria), became blind and incompetent. George's particular hobby, which earned him the nickname of 'Farmer George', was agriculture, and he set up a model farm at Windsor, which he made his permanent home. His well-used library of 65,000 volumes is displayed, enclosed in a six-storey glass tower, in the British Library. In his later years his high, if confused, idealism and his love and concern for England were recognised and his death, after the longest reign in British history to that time, was marked by widespread regret.

Brooke, J., King George III. Rev. ed. 1985; Hadlow, J., The Strangest Family. George III, Queen Charlotte and the Hanoverians. 2014; Roberts, A., George III. 2021.

George IV (George Augustus Frederick) (17621830). King of the United Kingdom of Great Britain, Ireland and Hanover 1820-30. Born in London, the eldest son of ${ }^{*}$ George III, he reacted against the restraints of a strict and pious father, and on acquiring his own establishment became notorious for extravagance and dissipation. He was, however, intelligent, and the political friends he gathered round him chosen from the Whig opposition as if further to spite and distress his father were men like Charles James *Fox and *Sheridan, who, whatever their tastes in pleasure, were among the most brilliant and cultured men of the age. He secretly married (1785) a Roman Catholic widow, Maria *Fitzherbert, but the marriage, entered into without his father's consent, was illegal under the Royal Marriage Act (1722). In 1795 he agreed to marry Princess *Caroline of Brunswick but they parted after the birth of Princess ${ }^{*}$ Charlotte. His attempt to divorce her (1820) failed. When, after his father had become insane (1811), he became regent, he failed to satisfy the hopes of his Whig friends and kept the Tories in office. The so-called Regency period in architecture, dress and decoration owed little to his direct encouragement, his own taste being more truly exemplified by the exuberant fantasy of the Brighton Pavilion. As King, George IV was prevented from effective action by languor and illness, but in the last years of his life, while opposing all reform at home, he strongly supported *Canning's liberal policy abroad.

Hibbert, C., George IV. 2 vols, 1972-73. 
George V (George Frederick Ernest Albert Windsor, né von Wettin) (1865-1936). King of Great Britain, Ireland and the British Dominions beyond the Seas, Emperor of India 1910-36. Son of Albert Edward, Prince of Wales (later *Edward VII) he was born at Marlborough House and trained in the navy. When his elder brother, *Albert Victor, Duke of Clarence died in 1892, George became heir presumptive and was created Duke of York. In 1893 he married Princess *Mary of Teck, a great-granddaughter of *George III, formerly his brother's fiancée. There were six children: Edward (later ${ }^{*}$ Edward VIII), Albert (later *George VI), Mary (Princess Royal, Countess of Harewood), Henry (Duke of * Gloucester), George (Duke of *Kent) and John (1905-1919). The marriage was successful, but George was an intimidating father and Mary a remote mother. He was an avid (and expert) stamp collector and regarded as England's leading shot, once shooting a thousand pheasants in six hours. As Duke of Cornwall and York he opened the first Commonwealth Parliament in Australia (May 1901) and became Prince of Wales later that year. After his coronation in June 1911 he went to India for the Delhi Durbar (December 1911). In August 1911 he had assented, reluctantly, to the Parliament Act which reduced the power of the House of Lords, was concerned about the prospect of Home Rule in Ireland, and appalled by the outbreak of World War I and the Russian Revolution (although he did not offer asylum to his cousin *Nikolai II). In July 1917 he changed the name of his dynasty from SaxeCoburg-Gotha (*Wettin) to Windsor. The political and social upheavals of the postwar period must have shocked the prejudices of the old-fashioned country gentleman that he was, but he accepted the election of a Labour Government led by Ramsay *MacDonald in 1924 and supported a National Government in 1931. He never flew but from 1932 he broadcast Christmas messages on the BBC, and, at his Silver Jubilee (1935), expressed surprise at the level of public affection. Alone of his family, he was early in recognising the threat of *Hitler and the Nazis. Always a very heavy smoker, the timing of his death was an 'assisted passage' by his physician, Bertrand Edward Dawson, 1st Viscount Dawson of Penn (1864-1945), who had saved him from pneumonia in 1928.

Rose, K., King George V. 1983; Cannadine, D., George V. 2014; Ridley, J., George V: Never a Dull Moment. 2022 .

George VI (Albert Frederick Arthur George) (1895-1952). King of Great Britain, Ireland and the British Dominions beyond the Seas 1936-52, Emperor of India 1936-47. Son of * George V, born at Sandringham, known as Prince Albert ('Bertie') from boyhood, and trained for the navy he was present at the Battle of Jutland (1916). He briefly attended Trinity College, Cambridge 1919-20. In 1920 he married Lady Elizabeth Bowes-Lyon (*Elizabeth). There were two children, the future Queen *Elizabeth II and Princess *Margaret. He visited Australia in 1927 to throne on the abdication of his elder brother *Edward VIII (December 1936), was crowned in May 1937 and toured Canada and the US in 1939. His reign was overshadowed by World War II. He and the Queen remained in London during the 'blitz' and helped to create the feeling of solidarity among the people. $\mathrm{He}$ suffered all his life from diffidence, a stammer, and, in his later years from Burger's disease and lung cancer.

Wheeler Bennett, J. W., King George VI. 1958; Bradford, S., George VI. 1989.

\section{George, David Lloyd see Lloyd George, David}

George, Henry (1839-1897). American economist, born in Philadelphia. Promoter of the 'single tax' theory, he went to California at the age of 19 and became, as journalist and editor, interested in current problems. Our Land and Land Policy (1870) was his first work on his chosen subject but it was in Progress and Poverty (1879) that his theory was clearly worked out. Faced with the anomaly that increase in productive power did not appear to lead to a rise in wages and general prosperity, he concluded that the reason lay in the constant increase (as the demand and with it speculation grew) in land values and so in rent, which absorbed the surplus accruing from higher production. His remedy was to bring the increment in land values into public use by a single tax and abolish all others that fall upon industry or discourage thrift.

George, Stefan Anton (1868-1933). German poet. He was the leader of an esoteric group of German poets over whom he exercised influence mainly through his literary journal Blätter für die Kunst (founded 1892). He in turn was clearly influenced by *Baudelaire, *Mallarmé and the French symbolists. His belief was that it was the form rather than the content of verse that was important: metre and word harmonies should create a mental picture irrespective of literal meaning. He left Germany when the Nazis seized power. His most famous disciple was *Rilke. George was also a gifted translator.

Goldsmith, U. K., Stefan George: A Study of His Early Work. 1960.

Gephardt, Dick (Richard Andrew) (1941- ). American Democratic politician. A lawyer, he served in the US House of Representatives 1977-2005, becoming Democratic Leader 1989-2003, and sought the presidential nomination in 1988 and 2004.

Gergiev, Valery Aisalovich (1953- ). Russian conductor, born in Moscow. He was director of the Mariinsky Opera, St Petersburg 1988- , chief conductor of the London Symphony Orchestra 2006-15 and appeared often at the Metropolitan Opera, New York. His specialities included *Mussorgsky, *Tchaikovsky, *Mahler, *Stravinsky, *Prokoviev and *Shostakovich. He enjoyed the patronage of Vladimir *Putin. 
Gericault (Jean-Louis-André) Theodore (17911824). French painter, born in Rouen. A pupil of Vernet and Guerin, he developed a passion for ${ }^{*}$ Michelangelo, ${ }^{*}$ Caravaggio and ${ }^{*}$ Rubens and evolved from being a copyist to a strikingly original and powerful Romantic who, with his friend *Delacroix, broke the prevailing neo-classical fashion. His works included Charging Chasseur (1812), Wounded Cuirassier (1814), Raft of the Medusa (1819), Derby at Epsom (1821), swirling studies of battles and horses, and five extraordinary portraits of the insane. He had three riding accidents which led to Pott's disease (tuberculosis of the bone) and an early death.

German, Sir Edward (E. G. Jones) (1862-1936). English composer. A violinist and conductor, he wrote popular comic operas, notably Merrie England (1902) and Tom Jones (1907), many songs and incidental music to plays, e.g. Henry VIII and Nell Gwyn.

Geronimo (né Goyaałé) (1829-1908). American Apache leader, born in Arizona. A shaman of the Bedonkohe clan, his name meant 'one who yawns' and the Mexicans called him Geronimo. He fought against Mexican and US occupation and led guerrilla operations in 1874 and 1886. He was captured and confined in Florida (1886-94), then lived in Oklahoma.

Gerry, Elbridge (1744-1814). American politician. He became prominent in Massachusetts politics and was a signatory of the Declaration of Independence. As Governor of Massachusetts 1810-12, he rearranged the electoral areas in a way designed to benefit his own Republican party, a practice later known as 'gerrymandering'. He was Vice President of the US 1813-14.

Gershwin, George (originally Jacob Bruskin Gershowitz) (1898-1937). American composer and pianist, born in Brooklyn. Of Russian-Jewish parentage, he wrote many outstanding songs including 'Swanee', 'Somebody Loves Me', 'S Wonderful', 'Love Walked In', 'I Got Rhythm', 'Do It Again' and experimented with 'symphonic jazz' in his Rhapsody in Blue (1924) for piano and orchestra, and in the opera Porgy and Bess (1935). Other important works by Gershwin include the Piano Concerto in F (1925) and An American in Paris, for orchestra (1928). He developed a malignant brain tumour and died after an operation (as did *Ravel, whom he greatly admired, five months later). It has been calculated that his estate had the largest earnings of any major composer. His brother Ira Gershwin (1896-1983) was a lyricist.

Crawford, R., Summertime: George Gershwin's Life in Music. 2020.

Gesell, Arnold Lucius (1880-1961). American psychologist. As director of the Clinic of Child Development 1911-48 and professor of child hygiene at Yale, he acquired great authority on his subject. His best known books are The Child from Five to Ten (1946), Youth: The Years from Ten to Sixteen (1956).

Gesner, Konrad (1516-1565). Swiss naturalist. $\mathrm{He}$ produced encyclopaedic surveys of several subjects, from botany to comparative philology. The best known is his Historia animalium ( 5 volumes, 1551-58), which surveyed all known forms of animals, and provided the foundation for much later work. He also produced bibliographies of all known Greek, Latin and Hebrew writers.

Getty, J(ean) Paul (1892-1976). American oil magnate. He took control of Pacific Western Oil in 1932, changed its name to Getty Oil and amassed a great fortune which he left to the J. Paul Getty Museum in Malibu, California. He lived in England from 1951 (he never saw his museum) and died there.

Ghazāli, Abū Hāmid Muḥammad ibn Muḥammad al- (1058-1111). Persian theologian and mystic, born in Tus. A Sunni, he taught in Baghdad, wrote in Arabic, and was known in the West as Algazel. In his immensely influential The Incoherence of Philosophers, he denounced the adoption of Aristotelean thinking and scientific method by Muslim philosophers and scientists such as *Avicenna. Despite later rebuttal by *Averroës, his work led to a Muslim withdrawal from science, mathematics and discourse with Europe. He became a Sufi mystic and retired to a monastery in Tus.

Ghibellines. Name of an Italian faction of princes that supported Imperial power against the Papacy from the 12th century, derived from a ${ }^{*}$ Hohenstaufen war-cry. Their pro-Papal rivals were the Guelphs, the name derived from the German *Welf dynasty.

Ghiberti, Lorenzo (1378-1455). Italian sculptor and goldsmith, born in Florence. In 1402 he won a competition for designing two bronze doors for the Baptistery of St John in Florence on the theme of Abraham and Isaac. Completed in 1424 these were followed by a second pair (1425-52), called the Porta dei Paradiso, *Michelangelo is said to have remarked that they are 'worthy to be the gates of Paradise'. In these, Ghiberti abandons the Gothic framework and the scenes are placed in rectangular compartments, the crowded figures in relief against backgrounds displaying his mastery and perspective. His output was small and nothing else he made equalled these famous doors, unsurpassed in their excellence.

Ghirlandaio, Domenico (Domenico di Tommaso Bigordi) (1449-1494). Italian painter, born in Florence. After an apprenticeship as goldsmith, he started painting c. 1470 . His many frescoes in Florence reveal not only the earnestness and dignity of his style but collectively provide a wonderful panorama of Florentine dress and ways of life. From 1481 to 1482 he worked in the Sistine Chapel in the Vatican for 
Pope *Sixtus IV: he painted the fresco The Calling of St Peter and St Andrew as well as the figures of several popes. In addition to frescoes his work included mosaics in the cathedral at Florence and many fine altarpieces. He employed many assistants, amongst whom was *Michelangelo. His realistic and tender An Old Man and his Grandson (c.1490) is in the Louvre.

Giacometti, Alberto (1901-1966). Swiss sculptor. After 1922 he worked mostly in Paris. At first working from nature, under the influence of Cubism he became (1930-34) the most distinguished sculptor of the Surrealist group. From 1935 he returned to working from nature, developing his very personal style of figures, mostly standing or walking men and women, of exaggeratedly slender proportions. His Man Pointing (bronze; 1947) sold for \$US141.3 million in 2015, the highest price ever paid for a sculpture.

Lord, J., Giacometti. 1985.

Giap, Vo Nguyen (1911-2013). Vietnamese general, born in Annam. The son of a mandarin, he became a lawyer, teacher and journalist, and by 1939 was a leader of the Indochinese Communist Party. Imprisoned for some years, his sister was executed by the French and his wife died in jail. During World War II he led Vietminh guerrillas against the Japanese and worked with the Chinese. As Minister of Defence and Commander-in-Chief of the People's Army of Vietnam 1946-81 he defeated the French at Dien Bien Phu (1954) and led the long successful campaign against the South and the US.

Gibbon, Edward (1737-1794). English historian, born in Putney. Educated at Westminster School, he was removed from Magdalen College, Oxford, after 14 months on his temporary conversion to Roman Catholicism. A 'cure' was effected by sending him to live with a Calvinist pastor in Lausanne and this persuaded him to become a lifelong agnostic. While there he transformed reading for pleasure into unremitting study, and became engaged to Suzanne Curchod, the future Madame *Necker. His father ordered him to break his engagement and, as he wrote: 'I sighed as a lover, I obeyed as a son.' He had 'a wandering life of military servitude' as a noncombative major in the Hampshire militia 1760-62, odd training for an historian with brilliant insights about warfare. His first publication was Essai sur l'Étude de la Littérature (1761).

He wrote that on 15 October 1764, on the Capitoline Hill in Rome, 'the idea of writing the decline and fall of the city first started to my mind', a project which matured into The History of the Decline and Fall of the Roman Empire (6 volumes, 1776-88), covering the period from *Trajan and the Antonines to the fall of Constantinople (1453). For its style, lucidity and completeness, it is one of the greatest masterpieces of historical writing. Even now its accuracy (except perhaps on the Byzantine material) can seldom be impugned. He made no secret of his conviction that Christianity weakened the empire, while his obsessive conviction that history is 'little more than the register of the crimes, follies, and misfortunes of mankind' may have led him to neglect other factors. Nevertheless, the book is a superb and lasting monument to the 'Age of Enlightenment'. Gibbon replied to his theological critics in $A$ Vindication ... (1779).

He sat, mute, as an MP 1774-80, 1781-83, first as a Whig then as a follower of the Tory, Lord *North. $\mathrm{He}$ lived in Lausanne again 1783-87, 1789-93, then returned to London suffering from a huge and disfiguring hydrocele of the scrotum. He died of peritonitis after a failed operation.

Gibbon cut a peculiar, if not ludicrous, figure in society, but the quality of his research and writing is extraordinary.

Swain, J. R., Edward Gibbon the Historian. 1966; Burrow, J. W., Gibbon. 1985; Porter, R., Gibbon: Making History. 1989.

Gibbons, Grinling (1648-1721). Dutch-English woodcarver and sculptor, born in Rotterdam. His work attracted the attention of John *Evelyn who introduced him to ${ }^{*}$ Wren. Gibbons entered the Board of Works and was 'master carver' under five British sovereigns. Much of his work, in which flower and fruit motifs predominate, was done for $\mathrm{St}$ Paul's Cathedral, the royal palaces, Windsor Castle, Hampton Court, Blenheim Palace and St James's, Piccadilly, etc.

Green, D., Grinling Gibbons. 1964.

Gibbons, Orlando (1583-1625). English composer, born in Oxford. In 1596 he became a chorister at King's College, Cambridge, may have studied with William *Byrd and was appointed organist of the Chapel Royal (1604) and later of Westminster Abbey (1623). He wrote works for keyboard and viols and was a noted composer of Church music (services and anthems such as Lift Up Your Heads) and of madrigals, e.g. The Silver Swan.

Fellowes, E. H., Orlando Gibbons. 1951; Harley, J., Orlando Gibbons and the Gibbons Family of Musicians. 1999.

Gibbs, J(osiah) Willard (1839-1903). American mathematical physicist, born in New Haven, Connecticut. Son of a Yale professor, Gibbs studied mathematics and natural philosophy at Yale, and received a $\mathrm{PhD}$ in 1863 . He travelled widely in Europe in the 1860s and became professor of mathematical physics at Yale 1871-1903. He pioneered chemical thermodynamics and statistical mechanics, applying *Clausius' Second Law of Thermodynamics (as the amount of usable energy in the world diminishes, entropy tends to increase, material systems tend towards equilibrium) to 
chemical reactions. His 'phase rule' explained how equilibria varied when a compound had different phases (e.g. ice, water, steam). He also worked on the electromagnetic theory of light. Gibbs influenced the work of Clerk *Maxwell in England, but had less impact on *Helmholtz and *Planck in Germany, who pursued their researches independently. He received the Copley Medal in 1901.

Wheeler, L. P., Josiah Willard Gibbs. 1970.

Giblin, Lyndhurst Falkiner (1872-1951). Australian economist. Son of a Tasmanian Premier, educated in Cambridge, he worked as a farmer, gold prospector, fur trapper, lumberjack, state MP, soldier (DSO and $\mathrm{MC}$ in World War I), statistician, professor of economics (Melbourne) and government advisor. He anticipated the 'multiplier' theory, later taken up by J. M. *Keynes, and became the first Keynesian economist in Australia. He had a profound influence on J. B. *Chifley and H. C. *Coombs.

Coleman, W., Cornish, S., and Haggar, A., Giblin's Platoon. 2006.

Gibran, Khalil (1883-1931). Syrian-Lebanese poet and artist, in the US from 1895. His metaphysical prose poems, The Prophet (1923) and Jesus, the Son of Man (1928), have been bestsellers for decades, their beauty of language being matched by extreme vagueness of thought.

Gibson, Althea (1927-2003). American tennis player and golfer, born in South Carolina. The first AfricanAmerican to win international tennis competitions, she played in the US (Forest Hills) championship in 1950, and at Wimbledon in 1951. She won the women's singles championships in the US and Great Britain in 1957 and 1958.

Gide, André (Paul Guillaume) (1869-1951). French writer, born in Paris. His parents were Protestants, but his mother's family were such recent converts that Gide felt himself born 'of two faiths'. His father, a distinguished professor of law, died when Gide was 11 and he was brought up by his strict and narrowminded mother and her friend, Anne Shackleton. His education was interrupted by recurrent psychological troubles. Despite maternal disapproval Gide early determined to become a writer and through Pierre *Louÿs he joined in the literary life of Paris. *Mallarmé's poetry was a major influence. His mother died in 1895 leaving him a large fortune. Shortly after, he married his cousin Madeleine, whom he had long admired, but the marriage, though never broken up entirely, was unhappy, largely because of Gide's homosexuality. A founder and literary editor of $L a$ Nouvelle Revue Française (from 1908), he rejected the works of his rival-but later, friend-Marcel *Proust. His social conscience led him to help refugees in World War I and in the Spanish Civil War, and later to protest at the treatment of Africans in the Congo. For a time inclined to support communism, he was disillusioned by a visit to Russia (1936). He spent the last years of his life (his wife having died in 1938) in North Africa and Paris. He was awarded the Nobel Prize for Literature (1947). His early works, though highly esteemed by fellow writers, made no impact on the public. It was not till Gide was 50, when general literary taste had evolved after World War I, that he received wide recognition; even then his works remained controversial and, in particular, repugnant to most Catholics. (He described his 'two obsessions' as being Christianity and pederasty.) But his reputation grew until he was generally regarded as the greatest modern French writer after Proust. His books reflected, with unsparing candour, his innermost feelings and struggles, his search for 'authentic' experience, his rejection of the moral conventions of society. They are also, in a sense, a continuing autobiography. His early works, Les Nour ritures terrestres (1897), Saul (1896), L'Immoraliste (1902), La Porte étroite (1909) and Corydon (1911), deal each in a different way with the struggle between the spiritual and sensual sides of his nature. Si le Grain ne meurt (1926) was his actual autobiography, supplemented by his extensive Journal (1889-1947). His later novels, Les Caves du Vatican (1914) and Les Faux-Monnayeurs (1925), were less intimately personal.

Cordle, T., André Gide. 1976; Sheridan, A., Andre Gidé: a Life in the Present. 2000.

Gielgud, Sir (Arthur) John (1904-2000). English actor. A grandnephew of Dame Ellen *Terry, he made his debut at the Old Vic in 1921. He established himself as one of the greatest Shakespearian actors, notably for his subtle interpretation and beautiful speaking voice. He specialised in plays by ${ }^{*}$ Molière, ${ }^{*}$ Congreve, ${ }^{*}$ Sheridan, *Wilde, ${ }^{*}$ Shaw and ${ }^{*}$ Chekhov. He appeared in many films, mostly in character parts, and won an Academy Award in 1981 for Arthur. He directed plays and operas, toured in a Shakesperean recital 'The Ages of Man' and wrote an autobiography An Actor and his Time (1979). He was knighted in 1953, receiving a CH in 1977 and the OM in 1996.

Gierek, Edward (1913-2001). Polish politician. His father, a miner, was killed in a mining accident in Silesia, Gierek and his mother emigrated to France, where he joined the Communist Party in 1931. During World War II he was in Belgium. In 1948 he returned to Poland and became organiser of the party in Upper Silesia. He was made head of the government's heavy industry program in 1954, and a member of the Politburo in 1956 . He became First Secretary of the Central Committee after the foodprice riots of 1970 , promising a less austere economic policy and a modification of Russian communism to national needs. He was forced out of office in 1980 .

Gieseking, Walter (1895-1956). German pianist, born in Lyon. An interpreter of great subtlety and refinement, especially in ${ }^{*}$ Debussy and ${ }^{*}$ Ravel, he 
recorded extensively. He remained in Germany under the Nazi regime and, like ${ }^{*}$ Furtwängler, was accused (but cleared) of cultural collaboration.

Gigli, Beniamino (1890-1957). Italian singer. Considered one of the greatest operatic tenors of his age, he made his debut in 1914 at Rovigo, and later toured widely, making his New York debut in 1920 and his first London appearance in 1930. His voice combined lyricism with power and an apparently effortless production.

Gilberd (or Gilbert), William (1540-1603). English physician, born in Colchester. Known for his work on magnetism and electricity, he became President of the College of Physicians (1599) and physician to both *Elizabeth I (1601) and after her death to *James I. His De Magnete (1600) described the properties of magnets and explained his hypothesis that the earth itself acts as a large magnet. He coined the terms 'electric' and 'pole'. He also investigated frictional electricity, e.g. of amber and glass and tried to find a connexion between magnetism and electricity. The unit of magnetomotive force is named after him.

Gilbert, Sir Humphrey (1537-1583). English navigator, born in Devon. Half-brother of Sir Walter *Raleigh, his conviction that there was a northwest sea route to China was set out in his Discourse of a Discoveriefor a New Passage to Cataia (China), published in 1576, which inspired a series of English seamen to seek the 'Northwest Passage'. His own explorations were unsuccessful. He was drowned when returning from an expedition in a very small vessel which capsized.

Gilbert, Walter (1932- ). American molecular biologist. Educated at Harvard and Cambridge, he held a chair in molecular biology at Harvard 1968, shared a Nobel Prize for Chemistry in 1980 with Fred *Sanger and became a leading figure in the commercialisation of biotechnological research.

Gilbert, Sir William Schwenck (1836-1911). English humorist. Famous for operas written in collaboration with Arthur *Sullivan, after some years in the civil service Gilbert was called to the bar (1864). As a writer he first attracted notice with his $B a b$ Ballads (collected 1869-73). Between 1871 and 1890 he wrote the libretti for the highly successful comic operas, which (from Iolanthe onwards) were played at the Savoy Theatre built by Richard D'Oyly *Carte in 1881. These included Trial by Jury (1875), H.M.S. Pinafore (1878), The Pirates of Penzance (1880), Patience (1881), Iolanthe (1882), The Mikado (1885), The Yeomen of the Guard (1888) and The Gondoliers (1889). He quarrelled bitterly with Sullivan (1890) and the long partnership was dissolved. Two or three years later they resumed collaboration but never achieved the same success. He died after saving a youth from drowning.
Gilbert \& George. English collaborative artists: Gilbert Prousch (1943- ), born in Italy, and George Passmore (1942-), born in England. They studied in London and worked as a team from 1967. They described themselves as 'singing sculptures', antielitist, but politically conservative and monarchists. As painters and sculptors, they depicted London's East End and their subjects included religion, patriotism, violence and sex.

Gildas (c.500-570). Roman-British writer. His De Excidio et Conquestu Britanniae, a highly coloured and obscene medley of events and castigations of contemporary vice, remains the only contemporary authority for the early period of the Anglo-Saxon invasions of Britain after the departure of the Romans. King Arthur is not mentioned.

Gilels, Emil Grigorevich (1916-1985). Russian pianist, born in Odessa. He achieved a national reputation for his wide repertoire which included bravura works (e.g. *Tchaikovsky), *Mozart, ${ }^{*}$ Beethoven and ${ }^{*}$ Brahms, and did not appear outside the USSR until 1953.

Gill, (Arthur) Eric (Rowton) (1882-1940). British sculptor and engraver. In 1904 he became a stone cutter and attracted notice by his beautifully carved inscriptions. An ultimate result of his interest in lettering were his now widely used typefaces, e.g. Perpetua and Gill Sans (i.e. san serif). From 1910 Gill began also to undertake the carving of stone figures, mainly of religious subjects, symbolic in style but not abstract. Examples in London are the Stations of the Cross in Westminster Cathedral and the Prospero and Ariel sculpture on Broadcasting House. Controversy was aroused by the revelation in 1989 of Gill's sexual experimentation and violence.

MacCarthy, F., Eric Gill. 1989.

Gillard, Julia Eileen (1961- ). Australian Labor politician, born in Barry, Wales. She grew up in Adelaide and became an industrial lawyer and political staffer in Melbourne. She was a Member of the House of Representatives 1998-2013, and became Australia's first female Deputy Prime Minister 2007-10, also holding the portfolios of Education, Employment and Workplace Relations, and Social Inclusion. Following a Caucus coup against Kevin ${ }^{*}$ Rudd in June 2010, she became Australia's first female Prime Minister 2010-13. The election of August 2010 produced a hung Parliament and, although the ALP had a minority of seats she negotiated skilfully with independents to secure passage of an extensive list of legislative reforms in education, disability, health and carbon pricing. Tony *Abbott and radio shock jocks attacked her viciously and she made a memorable speech on misogyny. Public opinion polls indicated a fall in the ALP's primary vote and in June 2013 Rudd challenged for the leadership, became Prime Minister 
again, but lost to Abbott's Coalition in September. Awarded an AC in 2017, she became chair of the UK's Wellcome Trust 2021- .

Gillard, J., My Story. 2014.

Gillespie, Dizzy (John Birks) (1917-1993). American jazz trumpeter and composer. He became a professional musician in 1935, modelling himself on Roy Eldridge. In 1944 he joined Billy Eckstine's band and was recognised as a modern jazz innovator. He formed his own orchestra in 1945.

Gillray, James (1757-1815). English caricaturist. Though he continued the tradition of social satire in the manner of ${ }^{*}$ Hogarth, his most important targets were the courts of ${ }^{*}$ Napoléon and ${ }^{*}$ George III and the political world. He often used colour and achieved a huge output, of some 1500 subjects, partly by dispensing with drawings and etching direct on copper. During his last four years he was insane.

Hill, D., Mr Gillray, The Caricaturist. 1965.

Gilmore, Dame Mary Jean (née Cameron) (18651962). Australian poet, feminist and social crusader, born near Goulburn. She was a journalist for many years, deeply committed to radical causes, pacifism and justice for Aboriginal people, but also a gifted lyrical poet. She is commemorated on the Australian $\$ 10$ note.

Gilot, (Marie) Françoise (1921- ). French painter and designer. Educated at Cambridge and the Sorbonne, she was *Picasso's mistress 1943-53 and the mother of Claude and Paloma. She married the actor Luc Simon (1955) and virologist Jonas *Salk (1970), taught, and designed stage sets and costumes. Gilot, F, and Lake, C. Life with Picasso. 1964.

Gil-Robles y Quiñones de León, José Maria (18981980). Spanish politician. A lawyer and academic, a member of the Cortes 1931-36, he led National Action and CEDA, a conservative Catholic party, and was Minister of War 1935. CEDA lost support to the Falange, *Franco pushed him aside and Gil-Robles went into exile.

Gingrich, Newt(on Leroy) (1943- ). American Republican politician. He was a US Congressman from Georgia 1979-99, and Speaker of the House of Representatives 1995-99, resigning after Republican losses in the 1998 Congressional elections. He campaigned vigorously for the Republican nomination for president in 2012 .

Ginsberg, Allen (1926-1997). American poet and guru. Educated at Columbia, his long poem Howl! (1956), an incantatory lament for a lost generation, written in the style of ${ }^{*}$ Whitman, became a gospel for the 'Beats' of the 1950s and the 'hippies' of the 1960 s. He experimented with the poetic effects of psychedelic drugs, was active in the flower power movement and mysticism and closely associated with Jack *Kerouac. He wrote Reality Sandwiches (1963) and The Yage Letters (with William *Burroughs: 1963), appeared in films, public performances, made recordings and published books of photographs.

Ginsburg, Ruth Bader (née Bader) (1933-2020). American jurist, born in New York City. As an advocate, she persuaded the US Supreme Court to change the law on major issues of gender equity and women's rights, and served as a Justice of the Federal Court 1980-93 and the Supreme Court 1993-2020.

Knizhnik, S. and Carmon, I., Notorious RBG. 2015; De Hart, J. S., Ruth Bader Ginsburg. 2018.

Giolitti, Giovanni (1842-1928). Italian politician. He first held office as Finance Minister in 1889. Thereafter he was an almost indispensable figure in all political combinations until *Mussolini's accession to power (1922). A superb parliamentary manipulator, he was Prime Minister five times 1892-93, 1903-05, 1906-09, 1911-14, 1920-21. He led Italy to victory in the war with Turkey (1911), by which Libya was gained. He did not support Italian entry in World War I, and opposed Mussolini after 1924.

Giorgione (Giorgio da Barbarelli da Castelfranco) (1475/8-1510). Italian painter, born in Castelfranco Veneto. One of the greatest Venetian painters of the High Renaissance, a pupil of Giovanni *Bellini, very little is known about his career and life. A major difficulty lies in the fact that none of his works was signed or dated and that his high contemporary reputation caused him to be much imitated. The difficulties of attribution and dating are therefore particularly great. Those held most likely to be his include Judith (St Petersburg), The Tempest (Venice) and The Three Philosophers (Vienna), which X-ray photography has shown to have originally represented The Three Magi, Laura and Boy with an Arrow (both in Vienna) and an unnamed portrait (San Diego). The background of the famous Dresden Venus was almost certainly painted by ${ }^{*}$ Titian. A spiritual harmony between figures and background, well shown in the Concert Champetre (Louvre)-if indeed it is his - distinguishes his landscapes. He was the first great romantic artist. In portraiture he shows the beginning of a psychological approach, and his claim to be an innovator is enhanced by a new type of small intimate easel picture for private collectors. He died in Venice of the plague, and several of his paintings were completed by others.

Pignatti, T., Giorgione. 1971.

Giotto di Bondone (1266/7-1337). Italian painter, born near Florence. Famous for having freed his painting from the formalised traditions of Byzantine art, his figures acquire solidity, and their faces, no longer restricted to the stereotyped expressions of the Byzantine style, show variety and individual character. Giotto owed much to ${ }^{*}$ Cimabue, but for showing the way to Renaissance freedom he is rightly held 
to be a key figure in western art. His main surviving works are three famous sets of frescoes. The earliest, those in the church of St ${ }^{*}$ Francis at Assisi, present difficulties of attribution but the inspiration, if not in every case the execution, is certainly his. Thirty-eight vivid frescoes (1303-05) in the Scrovegni Chapel at Padua, illustrating the Life and Passion of Christ, show Giotto's work in its full maturity. The third set of frescoes (c.1317), which have lost much of their quality through repainting, are in chapels of the Santa Croce church in Florence. They relate the stories of St Francis and the two St Johns (the Baptist and the Evangelist). Of Giotto's other work one of the finest examples is the great altarpiece now in the Uffizi at Florence showing the Madonna in glory with the Child and angels. In 1334 Giotto became official architect in Florence where he is believed to have designed the Campanile of the cathedral and almost certainly executed relief decorations on its ground floor.

Battisti, E., Giotto. 1966.

Giraldus Cambrensis (Gerald of Wales) (c.11461223). Norman Welsh prelate and chronicler. He went with Prince *John to Ireland (1185) and wrote extensively on the history and topography of that country; his descriptions of Wales are equally valuable. He also wrote lives of St David, St Hugh of Lincoln and others. His books contain much useful information about conditions in the reign of *Henry II.

Jones, T., Gerald of Wales. 1947.

Giraud, Henri Honoré (1879-1949). French general. In World War I, captured by the Germans, he escaped, served in Morocco in the 1920s and commanded the 9th French Army 1939-40. Captured again in 1940, he escaped to Vichy, then to Algeria. After *Darlan's assassination the Americans made him Commander-in-Chief of French forces 1942-43 and he became co-President of the French Committee for National Liberation with Charles *de Gaulle. Despite *Roosevelt's support, Giraud proved to be politically inept, tainted by some sympathy for *Pétain's Vichy regime. So, de Gaulle, reluctantly supported by ${ }^{*}$ Churchill, soon displaced him, and Giraud's role as Commander-in-Chief became titular only. He was elected as a conservative to the French Constituent Assembly 1945-46.

Giraudoux, Jean (1882-1944). French writer. He wrote a number of novels, e.g. Simon le pathétique (1918) and Bella (1926), but is best known as the author of plays mainly based on classical themes treated satirically in modern terms. They include Amphitryon 38 (1929), Intermezzo (1933), La Guerre de Troie n'aura pas lieu (1935) and Électre (1937, translated by Christopher *Fry as Tiger at the Gates, 1955). During Wor1d War II he was head of the French Ministry of Information until the collapse of France.

Cohen, R., Giraudoux: Three Faces of Destiny. 1968.
Girtin, Thomas (1775-1802). English painter and engraver. He was a pioneer and one of the finest exponents of watercolour painting, and revealed its full possibilities. He abandoned the concept of a watercolour as an outline drawing filled in with colour wash, and established a technique that turned it into a fully developed work of art. Much of his work was commissioned by publishers of books of engravings, e.g. of old monasteries and castles.

Giscard d'Estaing, Valéry Marie René George (1926-2020). French politician, born in Koblenz. $\mathrm{He}$ was active in the Resistance but his father supported *Pétain's Vichy regime. Trained at the École national d'administration (ENA), he worked for the Inspection des Finances. He was a member of the National Assembly 1956-58, 1967-69, 1984-89 and 1993-2002 and the European Parliament 198993. Giscard served as Minister for the Economy and Finance 1962-66 (under *De Gaulle) and 1969-74 (under *Pompidou). After Pompidou's death he defeated François *Mitterrand to become President of France 1974-81. He introduced some liberal reforms (divorce, abortion, lower voting age, increased pensions) but, despite his personal opposition, failed to abolish the death penalty. He was a strong supporter of the European Union. His reputation suffered because of diamonds given to him by JeanBédel Bokassa of the Central African Republic. In 1981 Giscard lost the support of Jacques *Chirac and Mitterrand won the election. He wrote two novels, was elected to the Académie française in 2003 and became the longest lived French head of state.

Gissing, George Robert (1857-1903). English novelist, born in Yorkshire. His experience, as a young man in London and the US, of the depressing effects of poverty produced such powerful and pessimistic novels as Demos (1886) and New Grub Street (1891). His later works include the literary study Charles Dickens (1898), and The Private Papers of Henry Ryecroft (1903), a fictional fulfilment of his own hopes for a serene old age. A historical novel, Veranilda, appeared after his death.

Tindall, G., The Born Exile. 1974.

Giuliani, Rudy (Rudolph William Louis) (1944- ). American Republican politician and lawyer. Mayor of New York City 1993-2002, he gained international recognition after the 9/11 2001 attacks on the World Trade Centre. He earned $\$ 8$ million on the lecture circuit in 2006 and wrote two books. He failed in his bid for the Republican nomination for president in 2008 and 2012. He became President *Trump's personal attorney, and pursued derisory attempts to invalidate the 2020 US election results.

Giulio Romano (Giulio Pippi de'Giannuzi) (c.1499-1546). Italian painter and architect. A pupil and assistant of *Raphael in Rome, he helped to finish the stucco ornamentation for the Loggia of 
the Vatican after the master's death. In his own work he exaggerated the tendencies of *Raphael's later period and so came to be regarded as a founder of the Mannerist school. This exaggeration is especially apparent in The Fall of the Giants in the Palazzo del Te at Mantua, where he went to work under the patronage of the ducal Gonzaga family (1524). His finest architectural work there was the reconstruction of the cathedral and the ducal palace, while his drainage of the marshes showed his engineering skill. His method of combining stucco work with fresco panels was imitated all over Europe. ${ }^{*}$ Shakespeare refers to him in $A$ Winter's Tale.

Gladstone, William Ewart (1809-1898). British politician, born in Liverpool. Son of Sir John Gladstone, a slave owning merchant and MP of Scottish descent, he was educated at Eton and Oxford and at first intended to become an Anglican priest. Indeed, when he accepted an opportunity to enter the first reformed parliament (1832) as Tory member for Newark, it was at least partly in order to benefit the Church. He served as MP 1832-45, 1847-95. Described by *Macaulay as 'the rising hope of those stern unbending Tories', the future Liberal Prime Minister was given several junior offices by Robert *Peel before becoming Colonial Secretary 1845-46. When the party split over Peel's decision to repeal the Corn Laws (1846) Gladstone followed his leader. Until 1853, out of office, Gladstone passed through a period of furious inner turmoil, sexual obsession and self-flagellation. In Naples in 1851 he was appalled by the cruel treatment of political dissidents which profoundly shook his faith in conservatism. However, he was still a Peelite when he joined Lord *Aberdeen's ministry as Chancellor of the Exchequer 1852-55, but when he again held this office under *Palmerston and Lord John *Russell 1859-66 the transition to Liberalism was made. As Chancellor, Gladstone carried forward Peel's free-trade policy and accomplished the feat of reducing income tax to $4 \mathrm{~d}$. in the pound. The Post Office Savings Bank was introduced in 1861. When Russell became Prime Minister after Palmerston's death (1865), Gladstone was leader in the Commons, but a brief Conservative administration intervened before he defeated ${ }^{*}$ Disraeli (1868) in a landslide election victory fought with the widened franchise of 1867 . Gladstone, now almost 60 years old, became Prime Minister 186874, leading the first Liberal Government. Showing how far he had moved from his early Anglican intolerance, he disestablished the Church of Ireland (1869), abolished religious tests for universities, and passed an Education Act that inter alia enabled rates to be used for building non-denominational schools. The Irish Land Act (1870) was an attempt, that ultimately failed, to appease Irish grievances without constitutional change. The secret ballot for elections was introduced in 1872 . To these measures must be added the army reforms of Gladstone's war minister, Edward ${ }^{*}$ Cardwell. Discontent was, however, aroused by weakness in foreign affairs and the Liberal attitude to trade unions. The ministry fell in 1874 and Disraeli returned. Gladstone went into semi-retirement at Hawarden Castle, in Wales (near Chester), a home that came through his wife's family, and he renewed his studies in theology and ${ }^{*} \mathrm{Homer}$. He re-entered public activity in 1876, denouncing Conservative indifference to the massacre of 12,000 Christians in Bulgaria by the Turks - the first foreign 'human rights' case (other than African slavery) raised in domestic politics. In 1880, although technically not leader of the Liberals, he began a famous whirlwind election campaign in his new seat of Midlothian, and after Disraeli's defeat became Prime Minister again 1880-85. New reforms included an Act (1884) extending the franchise to farm labourers. But in this and his last two administrations, 1886 and 1892-94, his main preoccupation was with Home Rule for Ireland and his relationship with the Irish Party in parliament under *Parnell. The Home Rule policy was adopted hastily (1886) and without consultation. The issue split the Liberal Party and both Gladstone's Home Rule Bills (1886 and 1893) were defeated. He finally retired in 1894 . Queen *Victoria thought him pompous and he was not offered a peerage because, she wrote, he would have declined it. To many he was held up as a bogeyman, but few politicians have achieved so many lasting reforms or maintained the highest principles with such lofty eloquence. Educational reform bored him and he opposed votes for women. He had a profound influence on Woodrow *Wilson and his concept of 'liberalism' shaped political life in Britain until the rise of Margaret *Thatcher. In later years he was known as 'the Grand Old Man' (GOM). By his wife Catherine Glynne (1813-1900), Gladstone had eight children. Herbert John Gladstone 1st Viscount Gladstone (1854-1930), was Home Secretary 1905-10 and the first Governor-General of South Africa 1910-14, working closely with Louis *Botha.

Morley, J., Life of Gladstone. 3 vols, 1903; Magnus, P., Gladstone. 1954; Jenkins, R., Gladstone. 1995.

Glass, Philip (1937- ). American composer. He studied at Chicago University, the Juilliard School of Music and with Nadia *Boulanger and founded the Philip Glass Ensemble in 1968. His operas included Einstein on the Beach (1976), Satyagraha (1980), The Civil Wars (1982-84) and Akhnaten (1984). Other works include concertos for violin and cello, six symphonies and four string quartets.

Glass, P., Words Without Music. 2015.

Glazunov, Aleksandr Konstantinovich (18651936). Russian composer. His early works are romantic and reveal the influence of his teacher ${ }^{*}$ Rimsky-Korsakov, and of ${ }^{*}$ Tchaikovsky. Later he leaned more toward classical forms. He taught in $\mathrm{St}$ Petersburg and *Shostakovich was a student. He wrote eight symphonies, a series of popular concert waltzes, 
and violin concertos and ballet music (but no operas). Although honoured by the Soviet Government, he emigrated (1928) to Paris, where he died.

Gleeson, (Anthony) Murray (1938- ). Australian jurist. Educated at Sydney University, he was an outstanding advocate, serving as Chief Justice of New South Wales 1988-98 and Chief Justice of the High Court of Australia 1998-2008.

\section{Glendower, Owen see Glyndŵr, Owain}

Glenn, John Herschel (1921-2016). American politician and astronaut. During World War II he was awarded the Distinguished Flying Cross (DFC) five times for his exploits as pilot in the Marine Corps. He was the first to fly across the US faster than sound (1957) and the first American to orbit the earth in space (1962). He served as a Democratic US senator from Ohio 1975-99. He returned to space with NASA in 1998.

Glière, Reinhold Moritzevich (1875-1956). Russian composer, born in Kiev. A pupil of *Taneyev and Ippolitov-Ivanov, he became professor of composition (1913) and director (1914) at the Kiev Conservatoire, and professor of composition at the Moscow Conservatoire (1920). He taught *Prokofiev, *Khachaturian and ${ }^{*}$ Miaskovsky. A prolific composer, Glière was highly honoured by the Soviet Government. His works include several symphonies, of which the best known is No. 3, Ilya Mourometz (1909-11), the ballet The Red Poppy (1926-27) and a Cello Concerto.

Glinka, Mikhail Ivanovich (1804-1857). Russian composer. Rejecting the influence of German and Italian composers, he turned to folk music for his inspiration. His A Life for the Tsar (1836) is the first important Russian opera and one of the first examples of nationalism in music. He also composed the opera Russlan and Ludmilla (1841), after a poem of *Pushkin.

Brown, D., Mikhail Glinka. 1974.

Gloucester, Henry William Frederick Albert, Duke of (1900-1974). British prince. The third son of ${ }^{*}$ George V, he made his career in the army and was Governor-General of Australia 1945-47. His widow, Princess Alice (née Montagu-Douglas-Scott) (19012004) became the royal family's second centenarian.

\section{Gloucester, Humphrey, Duke of see Humphrey, 1st Duke of Gloucester}

Gluck, Christoph Willibald von (1714-1787). German composer, born in the Upper Palatinate. He studied in Prague, supporting himself as an organist and music teacher. He lived for a time in Italy and London (where he came to know *Händel and *Arne), but spent most of his life in Paris and Vienna where he was court musician to *Maria Theresa 1754-70. In his later operas he avoided excessive vocal display in the interests of dignity and simplicity. They include Orpheus and Eurydice (1762), Alceste (1768), Iphigenia in Aulis (1774) and Iphigenia in Tauris (1779). The last of these won him the final victory in the battle between 'the Gluckists' and the supporters of Niccolò Piccinni (1728-1800) ('the Piccinnists'), representing respectively the French and Italian operatic styles.

Einstein, A., Gluck. 1964.

Glück, Louise Elizabeth (1943- ). American poet and essayist, born in New York. Extremely prolific, often drawing on mythology, and autobiographical, and influenced by ${ }^{*}$ Blake, ${ }^{*}$ Dickinson and ${ }^{*}$ Lowell, she was the US Poet Laureate 2003-04. She received the Nobel Prize for Literature in 2020 for her unmistakable poetic voice that with austere beauty makes individual existence universal'.

Glyndŵwr, Owain (c.1350-c.1415). Welsh ruler. Descended from the Princes of Powys, he may have studied in London, and served in the English army under *John of Gaunt. Personal disputes over land ownership and increasing resentment of English rule in Wales led to a general rising in Wales about 1400. He took control of the north, winning the support of Henry *Percy ('Hotspur'). However, *Henry IV defeated (and killed) Hotspur at Shrewsbury (1403). Glyndŵr called a Parliament, negotiated a treaty with France and was the last Welshman to claim the title of Prince of Wales (Tywysog Cymru) 1404-15. Henry IV imposed a blockade on Wales, Glyndŵr's support gradually fell away and in 1412 he disappeared. He is a character in *Shakespeare's Henry IV, Part 1.

Gneisenau, August Wilhelm Anton, Count Neithardt von (1760-1831). Prussian soldier. The principal reorganiser of the Prussian army after its crushing defeat by ${ }^{*}$ Napoléon at Jena, he was *Blücher's Chief of Staff at Waterloo.

Gobineau, Joseph Arthur, Comte de (1816-1882). French diplomat, novelist and racial theorist. $\mathrm{He}$ served as a diplomat in Newfoundland, Persia, Greece, Brazil and Sweden, and was a widely read novelist, essayist and poet. In his Essay on the Inequality of Human Races (1853-55) he maintained that the white races and especially those of the north are innately superior to all others and that they degenerate when they interbreed with others. This work had great influence in Germany, e.g. on *Wagner, and eventually was used to justify Nazi racial doctrines. He was obsessed with the Vikings and promoted the idea of an Aryan super-race; however, the Nazis failed to observe that he admired the Jews for their survival and achievements.

Godard, Jean-Luc (1930-2022). French-Swiss film director and critic, born in Paris. In the 1960s, he was a leader in the 'nouvelle vague' with $A$ bout de souffle (1960), Alphaville (1965) and La Chinoise (1967). 
Goddard, Robert (1882-1945). American scientist. $\mathrm{He}$ was a pioneer in the design of high-altitude rockets (1919) and in the theory of rocket propulsion. His ideas and experiments in the US attracted no government interest but were developed successfully in Germany.

Gödel, Kurt Friedrich (1906-1978). AustrianAmerican logician and mathematician, born in Brno (now in the Czech Republic). Trained as an engineer at the University of Vienna, he published a paper, 'On Formal Theoretical Advances' (1931), which argued that not all mathematical problems are soluble and that any program for producing consistency in theory will ultimately break down, i.e. that mathematics contains unresolvable paradoxes. Gödel's 'incompleteness (or undecidability) theorem' had an impact comparable to *Heisenberg's 'uncertainty principle' in physics. Gödel lived in the US from 1938 and became a professor at the Institute of Advanced Study, Princeton 1953-76. He died of malnutrition.

Hofstadter, D. R., Gödel, Escher, Bach: An Eternal Golden Braid. 1980; Dawson, J., Logical Dilemmas: The Life and Work of Kurt Gödel. 2005.

\section{Goderich, 1st Viscount see Ripon, 1st Earl of}

Godfrey (Godefroy) de Bouillon (c.1060-1100). Duke of Lower Lorraine and a leader of the 1st Crusade. With a force of c.15,000 Germans he was prominent in the capture (1099) of Jerusalem, of which he became the first Christian ruler with the title of 'defender of the Holy Sepulchre'. After his death his brother *Baldwin became first king.

Godiva, Lady (c.1040-1085). English countess. Wife of Leofric, Earl of Mercia, according to legend, her husband promised to remit a tax he had imposed on the citizens of Coventry if she rode naked through the streets of the city. This she did. The only citizen to look through the shuttered windows was nicknamed 'Peeping Tom'.

Godolphin, Sidney, 1st Earl of Godolphin (16451712). English Tory politician, born in Cornwall. An Oxford MA and favourite of *Charles II, who neatly said of him, 'he was never in the way and never out of the way', he became MP 1668-84, holding office as a Lord of the Treasury 1679-84, 1687-88. Created baron in 1684, in 1688 'he remained faithful to *James II until the last respectable moment'. *William III restored him to office as First Lord 1690-96 but dropped him after discovering his correspondence with the Jacobites. As Lord High Treasurer 1702-10 under Queen *Anne, he was made a KG and promoted to an earldom in 1706 , maintained a favourable political background for *Marlborough's exploits on the Continent and made available the necessary supplies. Their friendship was cemented by the marriage of Godolphin's son to Marlborough's daughter, Henrietta, 2nd Duchess of Marlborough (1681-1733), and both fell from favour together. An able financier, he was a major architect of the Act of Union (1707) with Scotland.

Sundstrom, R. A., Godolphin-Servant of the State 1993.

Godowsky, Leopold (1870-1938). LithuanianJewish-American pianist and composer, born near Kaunas. Trained in Berlin, in the US from 1890, his technical mastery was disguised by an impassive platform manner. He added contrapuntal complexities to arrangements of ${ }^{*}$ Chopin and Johann ${ }^{*}$ Strauss, including the amazing Symphonic Metamorphosis on Artist's Life (Kunsterleben; 1905). His friends included *Einstein, ${ }^{*}$ Ravel, *Stravinsky and ${ }^{*}$ Gide.

Godoy (y Álvarez de Fana), Manuel, Duke of Alcudia, Prince of the Peace (1767-1851). Spanish royal favourite and minister. While serving in the royal bodyguard, he became the lover of Queen Maria Luisa and through her exercised a dominant influence on her husband ${ }^{*}$ Carlos (Charles) IV, becoming Prime Minister 1792-97 and 1801-08. Although moderately enlightened and always anticlerical, he was corrupt and had a disastrous record in foreign affairs, declaring war on France (1793) and England (1797, 1804), with Spain becoming essentially a French client state. *Napoléon forced Carlos' abdication in 1808 and Godoy accompanied his patrons into exile in Rome. From 1819 he lived in Paris and died there. ${ }^{*}$ Goya painted a memorable portrait of Godoy.

Godunov, Boris Fyodorovich (c.1551-1605). Tsar of Russia 1598-1605. He rose to importance under *Ivan the Terrible, and married a sister of Ivan's heir, the detached and devout *Fyodor. During Fyodor's reign (1584-98) Boris acted as regent, and after his death became tsar. He was an able but tyrannical ruler. He was suspected of the murder of Fyodor's younger brother *Dimitri, who had died mysteriously (1591). Boris was killed in suppressing a revolt stirred up by a pretender claiming to be Dimitri. His life was the subject of *Pushkin's drama Boris Godunov, best known as an opera by ${ }^{*}$ Mussorgsky.

Grey, I., Boris Godunov: The Tragic Tsar. 1973.

Godwin, William (1756-1836). English author and political thinker. Son of a non-conformist minister, he became an atheist and advocated an ideal society of universal benevolence in which the compulsory restraints of religion, marriage and centralised government should be abolished. His Political Justice (1793) greatly influenced English radicalism and was much admired by ${ }^{*}$ Coleridge, *Wordsworth and *Shelley, but, though it preached anarchy, it also deplored violence, and so its author escaped prosecution. The purpose of his novel The Adventures of Caleb Williams (1794) was to expose the domestic and unrecorded despotisms by which human beings destroy each other. In 1796 
he married Mary *Wollstonecraft. Their child Mary (Mary Wollstonecraft *Shelley) eloped with (1814), and later married, *Shelley, who was for a time a disciple of Godwin and helped him in his incessant financial difficulties. Godwin's second wife was, by her first husband, the mother of *Byron's mistress Claire Clairmont.

Locke, D., The Life and Thought of William Godwin, 1756-1836. 1980.

Godwin of Wessex (1001-1053). Anglo-Saxon nobleman. Earl of Wessex, he advised King ${ }^{*}$ Cnut and supported his sons. ${ }^{*}$ Edward the Confessor, though married to Godwin's daughter, Edith, resented his domination and banished him (1051), but was forced to submit when he returned with an invading force. On Godwin's death his power passed to his son *Harold, afterwards king.

Goebbels, (Paul) Joseph (1897-1945). German Nazi propagandist, born in Rhine-Westphalia. From an impoverished Catholic family, he suffered from osteomyelitis and was crippled by an operation on his left foot. He won a PhD in aesthetics from Heidelberg, worked as a tutor, bank clerk and journalist and joined the Nazi Party in 1925, originally as a supporter of ${ }^{*}$ Strasser's more radical economics. He then backed ${ }^{*}$ Hitler who made him party chief in Berlin. As Minister for Propaganda and Public Enlightenment 1933-45 he mastered all techniques of mass persuasion: films, newspapers, magazines and mass rallies, and was second only to Hitler as an orator (some put him first). In 1944 he became Minister for Total War and was named as Chancellor in Hitler's will. On 1 May 1945 he killed his wife, six children, dogs and himself. He left very important diaries, later published.

Lochner, L. (ed.), The Goebbels Diaries. 1965.

Goering, Hermann Wilhelm (1893-1946). German Nazi politician and Marshal, born in Bavaria. The son of a colonial governor, his family lost its money and Goering developed his anti-Semitism after his mother married an ennobled Jew. In World War I he was a highly decorated fighter pilot, then a transport pilot for a Swedish company, marrying a wealthy Swedish baroness. He joined *Hitler's Nazi party in 1921, soon founded the paramilitary SA ('Brownshirts' or 'Storm Troops') with *Rohm and left Germany after the 1923 Munich putsch, returning in 1926. A Reichstag member 1928-33, and its president 1932-33, Hitler appointed him to a number of posts including Minister-President of Prussia, where he founded (1933) the Gestapo, Air Minister and head of the Luftwaffe (air force), and Minister in charge of the economic preparations for war. He was made a general in 1933 and a field marshal in 1938, the rank of Reich Marshal was invented for him in 1940. In the early stages of World War II he was named Hitler's deputy and successor, but with the defeat of the Luftwaffe in the Battle of Britain and the subsequent revelation of Germany's inadequate air defence he steadily lost influence. In the last days of the régime he plotted to oust Hitler and was already disgraced when he was captured by the Americans. However, during the Nuremberg trials he was far more impressive (and appalling) than any of his colleagues under cross-examination. Condemned to death, he committed suicide by poison the night before he was to hang. His apparent geniality, to which his corpulence and pomposity gave a touch of the ridiculous, masked a greed and brutality equal to that of any of his colleagues.

Butler, E. and Young, G., Marshal without Glory: Hermann Wilhelm Goering. 1973.

Goes, Hugo van der (d.1482). Flemish painter. He worked in Ghent (probably his birthplace) and in c. 1475 executed the Portinari Altarpiece which went to Florence where it aroused great admiration. He entered a monastery as a lay brother shortly afterwards, but continued to paint and to travel. He became insane and died young. He ranks as one of the best of the early Netherlands painters, distinguished by a highly perfected technique.

Goethe, Johann Wolfgang von (1749-1832). German poet and dramatist, born in Frankfurtam-Main. Son of a prosperous businessman and official, he owed his love of learning to his father and his gaiety and imaginative gifts to his vivacious mother. Before going to Leipzig University to study law-which he never seriously practised-he already knew much Latin, Greek, French, Italian, English and had studied music. After two years at home, during which he became interested in mysticism and the supernatural, he resumed his legal studies at Strasbourg, where he came under the influence of Herder, who stimulated his interest in folk music, Gothic architecture, ${ }^{*}$ Rousseau and-above allthe works of ${ }^{*}$ Shakespeare. Goethe was prominent in the Sturm und Drang literary movement. In this Strasbourg period, he first became obsessed with the *Faust legend, inspired by a sense of guilt over a love affair. He wrote a version down two to three years later, discovered and published (as Urfaust) only in 1887. His play Götz von Berlichingen (1771-73), based on the life of a medieval knight, was a response to ${ }^{*}$ Herder's demand for a national drama to match what Shakespeare had done for the English stage. Back in Frankfurt more love affairs provided an autobiographical basis for the novel, The Sorrows of Young Werther (1774), written in letter form, which ends with the hero's suicide. Among his many admirers at this time was the young duke Karl August of Saxe Weimar who invited him to settle at Weimar. Goethe accepted the move readily as it provided him with an opportunity to break his engagement with Lili Schonemann, his accomplished and patrician fiancée. In Weimar he was Minister of State 177679, of War 1779-82 and President of the Council of State 1782-86, showing his practical abilities 
and growing sense of responsibility. Another aspect of his many-sided genius now began to be revealed. To science he made the approach of the ancient or medieval polymath, the importance of the part resting, in his view, on its relationship to the whole. Thus he preferred a synthesis based on intuition and imagination to a reductionist mathematical analysis such as *Newton's. His most important discoveries, revealed in several books, were in biology and some seemed to anticipate *Darwin's theories. He found in the human jaw traces of an intermaxillary bone such as apes possess; the leaf, he discovered, was the primary form of the plant. His observation that the skull of vertebrates is a modification of the bones of the spine led him to believe in the basic principle of metamorphosis. In optics, his distrust of the mathematical approach played him false and his conclusions were wrong. His literary work was inevitably retarded by his other activities, but under the influence of a new lover (Charlotte von Stein) he continued to write tender lyrics and acquired a new social grace. His poems are best known as songs: ${ }^{*}$ Beethoven set 10 of them, ${ }^{*}$ Schubert 64 (including some of the greatest: The Erl-King; Gretchen at the Spinning Wheel, Ganymede, Hedgeroses, To the Moon, The Son of the Muses); *Schumann 13 and *Wolf 57 (including several settings of Mignon's song: Knowest thou the land?). He felt constrained by the demands of public service in Weimar and went off to explore Italy and Sicily 1786-88. In Italy he finished the verse plays Egmont, and Iphigenie begun years before, and additions were made to Faust, which had been taking shape in his head and intermittently on paper since the Strasbourg days. He mused over the specimens in the botanic gardens at Palermo, studied classical art, made hundreds of drawings, and, inevitably, on his return to Weimar was found to have a new love, Christiane Vulpius (1764-1816), who came to live with him, bore him several children and whom he later married (1806). The Italian visit, too, marked the definite end of the Sturm und Drang period. Almost immediately after his return the French Revolution broke out. As an advisor to the Duke of Weimar, Goethe observed the French victory at the battle of Valmy (Sept. 1792), commenting that 'a new epoch in the history of the world has begun'. He wrote The French Campaign 1792 (1822). Later repelled by Revolutionary excesses, he came to admire *Napoléon, meeting him on his visit to Weimar as conqueror (1808).

The first part of Faust was at last published in 1808, the second in 1832. The story tells of Faust's pact to sell his soul to the devil (Mephistopheles), in return for 24 more years of pleasure, knowledge and power, of the seduction and death of Marguerite and of his final redemption. The second part is more classical in form and largely metaphysical in content. Faust is most accessible in operas by *Gounod (1859) and ${ }^{*}$ Busoni (1924), *Berlioz's The Damnation of Faust (1846) and works by Schumann, ${ }^{*}$ Liszt and ${ }^{*}$ Mahler. Goethe directed the state theatre at Weimar 1791-1813, aided by ${ }^{*}$ Schiller, with whom he wrote ballads in rivalry and maintained a fascinating correspondence on aesthetic subjects. In 1796 appeared the first part of his novel Wilhelm Meister, begun 10 years before, describing the wanderings of a stagestruck youth with a theatrical troupe that included Mignon (of operatic fame). In the second part, published in 1830, Goethe is much more concerned with the educational and sociological impact of the travels than with the travels themselves. He continued to write on many subjects, and his lyrics, inspired as before by his transient loves, lost none of their intensity and beauty. Some of the best lyrics in the collection The Divan (West-ostliche Divan, 1819), attributed to Suleika, were written by Marianne Willemer (née Jung) (1784-1860). He believed in life, in accepting it and in living it to the full, that was the essence of his philosophy. He practised it to the end.

Friedenthal, R., Goethe: His Life and Times. 1965; Boyle, N., Goethe: The Poet and the Age. Vol. 1. 1991, Vol. 2, 2000, incomplete; Safranski, R., Goethe. Life as a Work of Art. 2013/17.

Gogarty, Oliver St John (1878-1957). Irish author and wit. By profession a surgeon in Dublin, he is chiefly remembered for the literary reminiscences of As I was Going Down Sackville Street (1937) and as 'Buck Mulligan' in *Joyce's Ulysses. He also wrote several volumes of poetry and was an Irish senator 1922-36.

\section{O’Connor, U., Oliver St John Gogarty. 1964.}

Gogh, Vincent van (1853-1890). Dutch painter, born in Zundert. Son of a Calvinist preacher in Holland, after he left school he tried several occupations without success, including working for an art dealer's firm in Amsterdam and London, teaching, and as an evangelist on the Belgian coalfields, before turning finally to art (1880). His early pictures, e.g. The Potato Eaters, are sombre in tone and subject, a change coming in 1886 , when in Paris he came to know the work of *Millet and the Impressionists. But, though he painted some 200 pictures at this time, the Impressionist techniques did not satisfy him and he did not reach his full maturity until he went (1888) to Arles in Provence. Here in the blaze of southern sunshine, he expressed the hidden turbulence of his nature in pictures vibrant with power and cascading with colour. Primary colours, reds, yellows, blues, were squeezed straight from tube to canvas and spread with broad curving brushstrokes. Landscapes, interiors, sunflowers, cafe scenes, selfportraits - the subjects were repeated over and over again during this last period of astonishing productivity. But, though this is seldom discernible in his pictures, his mind was already giving way. In December 1888, as an act of desperation (aggravated by tinnitus), he cut off part of his left ear with the razor he used to threaten *Gauguin. (The celebrated Self-portrait with bandaged ear is a mirror image.) In 1889 he went to a local asylum and in May 1890 put himself under the care of Dr Paul 
Gachet at Ouvers-sur-Oise, near Paris, and in 70 days he painted 70 pictures. However, at Dr Gachet's house, he shot himself, dying two days later. Only four or five of Van Gogh's paintings were sold in his lifetime, and only the understanding help of his brother Theo, to whom he wrote most movingly of his sufferings, saved him from complete destitution and enabled him to struggle on in poverty, and unceasing despair overtook him. His sister-in-law, Johanna van Gogh-Bonger, organised exhibitions and promoted his work, and fakes were circulating by 1900 . Of 879 paintings in the 1970 catalogue, perhaps 100 are in doubt. His Irises (1890) was knocked down at auction in New York to the Australian Alan Bond for \$US53.9 million in November 1987 and later sold at a lower price to the Getty Museum. The centenary of van Gogh's death created international interest and in May 1990 his Portrait of Dr Gachet was sold for \$US82.5 million to a Japanese collector, Ryoei Saito, who announced that he wanted the painting to be cremated with him on his death. A pen drawing, Garden of Flowers, was sold for \$US8.36 million in 1990.

Schapiro, M., Vincent van Gogh. 1950; Pollock, G. and Orton, F., Vincent van Gogh: Artist of His Time. 1978; McQuillan, M., Van Gogh. 1989.

Gogol, Nikolai Vasilyevich (1809-1852). Russian author, born in Sorochintsy. From a Ukrainian family of landed gentry, he went to St Petersburg where, after an unsuccessful attempt to be an actor, he (from 1831) gained literary success with several volumes of short stories and a romantic novel, Taras Bulba (1835), about a Cossack chief. He is best known for the play The Government Inspector, produced in 1836, satirising the bureaucracy. Much of the rest of his life was spent in Rome where he wrote the first part of Dead Souls (1837), a satirical novel in which Chichikov, an adventurer, buys up serfs who have died since the last census but are ostensibly alive since their owners still pay tax on them and use them as security for loans. He destroyed a draft of the second volume in the mood of religious melancholy into which he fell in his later years. Among his best known stories are The Nose, a fantasy about a severed nose which gained a government job on its own merits and the nightmarish The Overcoat. In portraying character, Gogol lacks psychological subtlety, but for sheer imaginative power and caricature he has few equals.

Troyat, H., Gogol: The Biography of a Divided Soul. 1971.

Golding, Sir William Gerald (1911-1993). English novelist. Educated at Marlborough and Oxford, he was a schoolmaster for many years. His novels, which have strong allegorical or symbolic undertones, include Lord of the Flies (1954), Pincher Martin (1956), Free Fall (1959), The Spire (1964), Rites of Passage (1980) and The Paper Men (1983). He received the 1983 Nobel Prize for Literature.
Goldmark, Karl (1830-1915). Hungarian-Jewish composer. He lived mostly in Vienna working as a violinist, music teacher and critic. His works included the popular symphony A Rustic Wedding (1870), and operas, e.g. The Queen of Sheba (1875) and one based on *Dickens' The Cricket on the Hearth.

Goldmark, Peter Carl (1906-1977). US engineer, born in Budapest. From 1936 he worked for the Columbia Broadcasting System (CBS) laboratories, devising an early form of colour television and perfecting the microgroove record, electronic video recording (EVR), and electronic scanners used in space probes. He proposed decentralised wired cities to provide for greater access to more services at substantially lower cost.

Goldoni, Carlo (1707-1793). Italian dramatist, born in Venice. He began his career as a lawyer but from 1734 turned to writing plays. In 1761 he accepted an invitation to go to France where he received a pension from the king. This ended with the Revolution and he died in poverty. He is said to have written altogether some 250 plays in French, Italian and in dialect. He was much influenced by ${ }^{*}$ Molière. His plays are well constructed, his characters are real, they behave naturally in comic situations and his satire is seldom unkind. Il servitore di due padroni (The Servant of Two Masters: 1745) was successfully adapted by Richard Bean as One Man, Two Guvnors (2011). Il mondo della luna (The World on the Moon) became an opera by *Haydn (1777).

Goldschmidt, Hans (1861-1923). German chemist. $\mathrm{He}$ invented the thermite process, whereby certain metals, e.g. iron, chromium and manganese, can be extracted from their oxides by reduction with powdered aluminium. Great heat is given off during the reaction and a temperature of about $2500^{\circ} \mathrm{C}$. is attained. This reaction is used in some types of incendiary bomb, and also in welding.

Goldsmith, Oliver (1728-1774). Anglo-Irish writer. Son of an Anglican Irish clergyman, he was educated at Trinity College, Dublin. After wandering about Europe he went to London where he failed as a doctor and barely supported himself as a hack writer on almost every conceivable subject. In 1761 he was introduced to Samuel *Johnson and thenceforth was a regular member of his 'club'. His poem The Deserted Village (1770), showing the Industrial Revolution's effect on the idyllic village of Auburn, earned immediate acclaim. Equally famous are his novel The Vicar of Wakefield (1776) and the amusing play She Stoops to Conquer (1773), still frequently revived. *Boswell represents Goldsmith as absurd, blundering and vain, but Johnson regarded him highly.

Rousseau, G. S., Oliver Goldsmith. 1974.

Goldwater, Barry Morris (1909-1998). American businessman and politician, born in Phoenix, Arizona. He was a pilot in World War II and Senator 
for Arizona 1953-65 and 1969-87. From this background he emerged as an extreme conservative and strongly anti-Communist and a staunch supporter of Joseph ${ }^{*} \mathrm{McC}$ arthy. His selection as the Republican candidate for the presidency (1964) antagonised many middle of the road voters and led to the decisive Democratic victory of Lyndon *Johnson. He took a major role in securing *Nixon's resignation (1974). Despite his heavy defeat in 1964 , Goldwater's political agenda became the basis of the presidential victories of Ronald *Reagan (1980, 1984) and George *Bush, père et fils (1988, 2000, 2004).

Goldwyn, Samuel (1882-1974). American film producer, born in Warsaw. He entered the film industry in 1910 and was a co-founder of MetroGoldwyn-Mayer. Notable productions include Wuthering Heights (1938), The Secret Life of Walter Mitty (1946) and Guys and Dolls (1955).

Gollancz, Sir Victor (1893-1967). English publisher. After army service he became a master at Repton, then set up his own publishing company in 1928. He founded the Left Book Club (1936), campaigned for humanitarian and radical causes, but retained a lifelong enthusiasm for ${ }^{*}$ Stalin.

Gombert, Nicolas (c.1495-c.1560). Netherlandish composer. Probably a pupil of ${ }^{*}$ Josquin, he worked for ${ }^{*}$ Charles V, and his polyphonic choral works include 160 motets, eight settings of the Magnificat and 10 Masses.

Gömbös, Gyula (1886-1936). Hungarian soldier and politician. As Defence Minister 1931-36, he was the effective ruler during the ${ }^{*}$ Horthy regency and promoted his own Fascist ideology.

Gombrich, Sir Ernst Hans (1909-2001). British art historian, born in Vienna. He worked at the Warburg Institute, London 1936-76, held chairs in art history at London and Oxford, and received many international awards as well as the OM in 1988. His books include The Story of Art (1950), which sold six million copies by 1998, Art and Illusion (1960), The Sense of Order (1978), The Image and the Eye (1982) and New Light on Old Masters (1986).

Gômez, Juan Vicente (1864-1935). Venezuelan dictator. A man of little education, brought up in a remote mountainous province (hence his nickname, 'tyrant of the Andes'), he joined Cipriano Castro's revolutionary movement and became the chief military support of his regime. He supplanted Castro (1908), became Acting President 1908-10 and President 1910-15, 1922-29, 1931-35, maintaining an almost unchallenged dictatorship until his death. The beginning of oil drilling (1918) enabled him to run the country like a vast and successful business enterprise, and with the aid of the money accruing from the oil exploitation, Venezuela presented the appearance of an orderly, stable and well-run state.
Behind the façade Gômez maintained his power by one of the most bloodthirsty and unscrupulous tyrannies in South American history, the full extent of which only became known after his death.

Gompers, Samuel Taylor Barnes (1850-1924). American labour leader, born in London. Of DutchJewish origins, he went to America with his family (1863). In his father's cigar factory he came to pity the poverty and insecurity of unprotected workers, and devoted his life to trade union organisation. He founded the American Federation of Labor and was its first president (1885-1924). He concentrated on economic issues, wages, hours, conditions, etc. and avoided all political affiliations. His Federation secured great advances for American workers. His autobiography Seventy Years of Life and Labor was published in 1925. He favoured the closed model of 'craft unionism' in sharp contrast to the 'new unionism' involving unskilled and semi-skilled workers and opposed forming a political labor party.

Gomulka, Wladyslaw (1905-1982). Polish politician. He joined the Communist Party in 1926 and was imprisoned 1933-35, 1936-39. During the German occupation of Warsaw he joined the resistance movement. He was Secretary-General of the Polish United Workers' (i.e. Communist) Party 1943-48, 1956-70. In 1948 he was accused of deviationism for advocating a 'Polish way to Socialism' and imprisoned 1951-56. In the turmoil created by antiStalinism (1956) Gomulka was released and obtained Soviet consent to a more relaxed regime. Some of the concessions then granted were later repeated, but Gomulka asserted a measure of Polish independence within the Communist bloc.

Goncharov, Ivan Aleksandrovich (1812-1891). Russian novelist. A public servant for most of his working life, his greatest work was the novel Oblomov (1848-58), an acute psychological study of an indolent and indecisive Russian gentleman of the 19 th century.

Goncourt, Edmond Louis Antoine Huot de (18221896) and Jules Alfred Huot de (1830-1870). French writers and critics. The brothers Goncourt were inseparable, and collaborated throughout their lives. The taste and sensuality of the 18th century especially appealed to them and they pictured its way of life in a fascinating series of 'histories' and 'lives'. They applied the same technique in their realistic novels of contemporary life. They shocked public and critics alike by choosing to describe characters such as a prostitute and nymphomaniac and writing novels such as Soeur Philomene (1861), Renee Mauperin (1864) and Madame Cervaisais (1869) in a style of vivid impressionism which tended to disdain grammar. They were notable critics of 18th-century art and letters and Edmond encouraged European interest in Japanese art, especially by his study of *Hokusai. The brothers kept (from 1851) a notable 
Journal des Goncourt. Edmond published nine volumes (1887-95). Edmond left his estate to fund the annual Prix Goncourt, first awarded in 1903.

Grant, R. B., The Goncourt Brothers. 1972.

Gonzaga. Italian noble family. In 1328 Luigi Gonzaga was elected Captain General of Mantua, and from that date until 1707, when the Emperor deposed Ferdinando Carlo, members of the family ruled in the tiny state as marquis (from 1403) and as duke (from 1530).

Gonzalez Marquez, Felipe (1942- ). Spanish politician. Educated at the Louvain University, Belgium, he was active in the Spanish Socialist Party from 1964, became its General-Secretary 1974-97 and was Prime Minister of Spain 1982-96, a record term.

Gonzalo de Córdoba (Gonzalo Fernández) (14531515). Spanish soldier, known as 'El Gran Capitan'. Having fought with distinction against the Moors, he achieved brilliant successes for King *Ferdinand II by expelling the French from Naples and eventually from the whole of Italy (1498). In the renewed war which followed the partition of Granada (1500), he once more occupied Naples and southern Italy and in December 1503 won the most spectacular victory of his career by crossing the Garigliano near Minturno with all the conditions including the weather, in favour of the enemy. (In May 1944 Free French forces achieved a similar victory.) He ended his career as Viceroy of Naples 1504-07 and died in Granada.

Gooch, George Peabody (1873-1968). English historian. Educated at Eton, London and Trinity College, Cambridge, and with independent means, he was a Liberal MP 1906-10 and, with J. S. *Lidgett, editor of the Contemporary Review 1911-60. The volume of his work and his skill in marshalling material made him one of the most impressive recent historians. Among his greatest achievements were History and Historians of the Nineteenth Century (1913) and Germany and the French Revolution (1920). With Harold Temperley he showed immense skill and industry in documenting the origins of World War I. After World War II he reached a wider public with the biographies Frederick the Great, Louis $X V$, Maria Theresa and Catherine the Great. He was awarded the $\mathrm{CH}$ in 1939 and the OM in 1963.

Goodall, Dame (Valerie) Jane (Morris) (1934- ). English primatologist and anthropologist, born in London. Trained as a secretary, and inspired (at first) by L. S. B. * Leakey, she worked for years studying primates in Gombe Stream, Tanzania, gaining a Cambridge PhD, publishing, lecturing and filmmaking on the behaviour of chimpanzees.

Goodman, Benny (1909-1986). American clarinettist and bandleader. He formed several bands and from 1935 was called the 'King of Swing', appearing in films and on radio. He recorded much of the classical clarinet repertoire and commissioned works from *Bartók and ${ }^{*}$ Copland.

Goodyear, Charles (1800-1860). American inventor. After many years of experimentation he discovered (1839) the process for vulcanising (i.e. elasticising and strengthening) crude rubber by mixing it with sulphur and heating it.

Goons, The (1949-60). British comedy group on BBC radio. Its members were Spike (Terence Alan) Milligan (1918-2002), Sir Harry (Donald) Secombe (1921-2001) and Peter (Richard Henry) Sellers (1925-1980). Milligan, the principal writer, performed several roles, acted in many films and was also a prolific novelist, poet and playwright (e.g. The Bed Sitting Room 1973). An Irish national, he became an honorary KBE in 2001. Secombe ('Neddy Seagoon') was a powerful tenor who became a popular concert and nightclub artist. Sellers, a gifted character actor, became an international superstar with his performances in many films (e.g. Lolita, Dr Strangelove, Being There and the Inspector Clouseau series). The Goons worked in the tradition of surrealist verbal humour which began with Lewis ${ }^{*}$ Carroll.

Goossens, Sir (Aynsley) Eugene (1893-1962). British conductor and composer, born in London. The family was Belgian and his grandfather and father, Eugene I and II, were both conductors. Educated in Bruges and London, he became a violinist, formed his own orchestra, worked closely with *Beecham and gave the first London performance of * Stravinsky's Rite of Spring (1921). He was Director of the Rochester Philharmonic 1923-31, the Cincinnati Symphony 1931-46 and the Sydney Symphony 1947-56, also directing the NSW Conservatorium. Principal promoter of the project to build a Sydney Opera House (Joern *Utzon), his career abruptly ended after his arrest for importing pornographic material, at a time of high Puritanism, and he retreated to London. His compositions included two symphonies, two operas and much chamber music. His brother Léon Goossens (1897-1988) was an oboist, regarded as the world's best, who recorded extensively and had works written for him by *Elgar, *Vaughan Williams and *Britten. His sisters Marie Goossens (1894-1991) and Sidonie Goossens (1899-2004) were harpists.

Rosen, C., The Goossens. 1994; Hubble, A., The Strange Case of Eugene Goossens. 1998.

Gorbachev, Mikhail Sergeyevich (1931-2022). Russian politician, born in Privolnoye. He worked as a machine operator in Stavropol in 1946, studied law at the Moscow State University and agriculture at the Stavropol Agricultural Institute. Active in the Komsomol, he joined the Communist Party in 1952, rose through the Stavropol Party apparatus and was First Secretary there 1970-78. He served as a member 
of the Central Committee of the CPSU 1971-91, Secretary for Agriculture (a post that helped him build an important rural support network) 197885 and a Politburo member 1980-91. A protégé of Yuri *Andropov, he shared his opposition to the corruption of the ${ }^{*}$ Brezhnev era. Andropov was crippled by illness in his short period as party leader (November 1982-January 1984) and when he died the succession went to K.U. *Chernenko, who died 13 months later. In March 1985 Gorbachev was elected as First (or General) Secretary of the CPSU, retaining office until the position was abolished in December 1991. He initiated major administrative reforms (Perestroika) to modernise the Soviet Union, released *Sakharov from exile and encouraged a policy of 'openness' (Glasnost) to new ideas and closer contacts with the West, despite resistance from party conservatives. The last President of the USSR 1988-91, he was Commander-in-Chief of the armed forces and withdrew Soviet troops from Afghanistan in February 1989. With the fall of the Berlin Wall in November 1989, acceptance of a unified Germany and the rolling back of Communism in eastern Europe, Gorbachev sought closer economic and political ties with the US and Western Europe but he failed to win significant economic aid. He received the 1990 Nobel Peace Prize for helping to end the Cold War and gave President *Bush cautious support in the 1991 'Gulf War'. Extremely popular abroad (unique for a Soviet leader), at home he made an uneasy and ultimately self-defeating alliance with his opponents in the armed forces and the party bureaucracy. His sole power base and proposed instrument for reform, the Communist Party, was a decaying and rigid organisation, deeply opposed to Gorbachev's proposals. On 19 August 1991, party officials, led by Gennadi Yanayev, Gorbachev's personal choice as Vice President, organised a coup against him while he was on holidays in the Crimea. He was released within two days because of the resistance of Boris *Yeltsin and reform elements in the KGB and armed forces. The CPSU's credibility was destroyed and Gorbachev failed to create a popular democratic constituency, a role that went to Yeltsin by default. In December 1991 the USSR and the CPSU were dissolved. Ukraine, Belorussia, Kazakhstan, Georgia and 10 other republics refused to accept domination by the Russian Federation and a loose Commonwealth of Independent States (CIS) replaced the USSR, with no role for Gorbachev. A Gorbachev Foundation was set up in Moscow, he became President of the International Green Cross 1992- , an environmental organisation set up after the Rio Earth Summit, and undertook lecture tours abroad. Among his advisors were Georgi *Arbatov, Edvard ${ }^{*}$ Shevardnadze and Aleksandr *Yakovlev. In June 1996 he received only 0.5 per cent of the votes in the presidential election.

Sakwa, R., Gorbachev and His Reforms. 1991; Gorbachev, M. S., Memoirs. 1995; Taubman, W., Gorbachev. His Life and Times. 2017.
Gorchakov, Mikhail Dimitrievich, Prince (17931861). Russian soldier. He fought in the Napoléonic wars, in Turkey and Poland and was Commanderin-Chief in the Crimean War 1854-56, burning and retreating from Sevastopol. He became GovernorGeneral of Poland 1856-61.

Gordian I (Marcus Antonius Gordianus Sempronianus Romanus Africanus) (c.159-238). Roman Emperor March-April 238. His father may have been of Anatolian descent. Gordian was a general, then a Senator, widely read, and in 'the year of six Emperors', at the age of 79, he displaced Maximinus Thrax, ruling jointly with his son for only 36 days. He hanged himself on learning of the death of his son, Gordian II (Marcus Antonius Gordianus Sempronianus Romanus Africanus Augustus) (c.192-238), in battle at Carthage. Edward *Gibbon memorably wrote of Gordian II: 'Twentytwo acknowledged concubines, and a library of sixtytwo thousand volumes, attested the variety of his inclinations, and from the productions which he left behind him, it appears that the former as well as the latter were designed for use rather than ostentation.'

Gordian III (Marcus Antonius Gordianus Pius Augustus) (225-244), Roman Emperor 238-44, grandson of Gordian I, was the youngest of all Caesars. Popular, he was presumably murdered by agents of his successor, Philip, known as 'the Arab'.

Gordimer, Nadine (1923-2014). South African novelist. Unhappy at school, she began writing at the age of nine. Her novels include The Lying Days (1953), A World of Strangers (1958), The Late Bourgeois World (1966), Burger's Daughter (1979), A Sport of Nature (1987) and My Son's Story (1990) and she also wrote short stories and criticism. She joined the African National Congress, was a strong critic of apartheid and her books were banned in South Africa until 1991 when she won the Nobel Prize for Literature.

Gordon, Adam Lindsay (1833-1870). Australian poet, born in Portugal. After an erratic adolescence, he migrated to Adelaide in 1853, becoming a horse breaker, jockey and MP in the South Australian Parliament 1865-66. His poems include 'The Swimmer' and 'The Sick Stockrider.' He shot himself on the beach at Brighton, Victoria. He is the only Australian writer commemorated in 'Poet's Corner' in Westminster Abbey.

Gordon, Charles George (1833-1885). British major general, born at Woolwich. Of Highland Scottish origins, he joined the Royal Engineers in 1852, served in the Crimean War 1854-56 and in China 1859-65. In the 'Arrow War', he took personal responsibility for burning down the Imperial Summer Villa at Jehol (Chengde), China's Versailles (1860). He commanded the mercenary 'Ever Victorious Army' (1863-64) which defended the Qing (Manchu) dynasty against the Taiping Rebellion led by *Hong Xiuquan, returning to Britain as a popular hero, 
known as 'Chinese Gordon'. In 1874 he succeeded Samuel *Baker as Governor of the Equatorial Province, in the service of the khedive of Egypt. He fought against the slave trade, contended with disease and corruption and was promoted Governor-General of the Sudan 1877-80, 1884-85. He opened up the Sudan by bringing steamers past the cataracts and swamps of the Nile, launching them on Lake Albert. He was directed to withdraw European and Egyptian citizens from the Sudan, which had been overrun by followers of El *Mahdi who had declared a fatwah. With his small force, he was shut up in Khartoum and after a 317-day siege of incredible hardship the city fell and Gordon and his men were killed. Two days later G. J. *Wolseley's relief expedition arrived. Public outrage about Gordon's death contributed to the downfall of *Gladstone's Government. Gordon's religious fanaticism and willingness to accept martyrdom meant that he rejected the opportunity for an honourable withdrawal from the Sudan.

Nutting, A., Gordon: Martyr and Misfit. 1966.

Gordon, Lord George (1751-1793). British agitator. Son of the 3rd Duke of Gordon, he entered parliament in 1774. The passing of the Catholic Relief Act (1778) caused him to become President of the Protestant Association and instigate protests which culminated in the Gordon, or 'No Popery', riots (1780). Gordon marched to parliament to present a petition at the head of a mob of hooligans which later raged through the city, pillaging, burning and, if opposition was met, killing. Newgate Prison was among many buildings destroyed. After the riots (vividly described in *Dickens' Barnaby Rudge) had been suppressed by troops, it was estimated that over 400 had been killed. Gordon, acquitted of high treason because of insanity, later became a Jew.

Hibbert, C., King Mob. 1958.

Gordon, Patrick (1635-1699). Scottish soldier. As a boy of 16 he sailed to the Baltic and took part, on both sides in turn, in the Swedish-Polish Wars. He joined the Russian army (1661), attained high rank and became friend and advisor of *Peter the Great.

Gore, Al(bert Arnold, Jr) (1948- ). American Democratic politician, born in Washington. Son and grandson of US senators, and a cousin of Gore *Vidal, he was educated at Harvard, served in Vietnam 1969-71, became an investigative reporter and studied philosophy and law at Vanderbilt. A developer and tobacco farmer, he was a US Congressman 1977-79 and a senator from Tennessee 1985-93. He sought the Democratic nomination for president in 1988 and ran third in the primaries. The High Performance Computing Act (1991), known as the Gore Bill', promoted the Internet as 'an information super-highway'. He gained recognition as an ardent conservationist with his book Earth in the Balance (1992). Vice President of the US 1993-2001, serving under Bill ${ }^{*}$ Clinton, he secured the Democratic nomination for president in 2000 . He won the popular vote nationally by 540,000 (a total second only to *Reagan's in 1984) but lost to George W. *Bush in the Electoral College, after a bitter dispute about voting in Florida which was determined by the US Supreme Court on a 5-4 vote. (Ralph *Nader secured 3 per cent of the vote as a Green candidate, thereby helping to elect Bush.) Gore won the 2007 Academy Award for his film An Inconvenient Truth (based on his book, 2006) and shared the 2007 Nobel Prize for Peace with the Intergovernmental Panel on Climate Change (IPCC) for his advocacy about human induced climate change.

Górecki, Henryk Mikolaj (1933-2010). Polish composer, born in Czernica. A student of ${ }^{*}$ Messiaen, he taught composition at Katowice and won several international awards. His Symphony No. 3 ('Symphony of Sorrowful Songs', 1976) became a critical and popular success in Britain and Europe in 1992.

Gorgas, William Crawford (1854-1920). American army physician. His work in controlling mosquitoes in Florida and Cuba to reduce yellow fever and malaria was critically important in completing the Panama Canal (1904-14). He became US Surgeon General 1914-18.

Gorki, Maksim (né Aleksei Maksimovich Peshkov) (1868-1936). Russian novelist, born in Nizhny Novgorod. His pen name Gorki means 'bitter' and his birthplace was renamed in his honour 1932-90. Orphaned at the age of five, he was brought up by his grandmother, whose immense fund of Russian folktales gave him a bent for literature. At 12 he ran away to lead a roving and penurious existence in contact with the poorest strata of society. He began to write, and achieved success with Sketches and Stories (1898). His social novels that followed are concerned with the lives of the poor and outcast, and are remarkable for their stark realism. He was involved in revolutionary activities and after the failure of the 1905 revolution left Russia, not to return until 1914, when he engaged in revolutionary propaganda and got to know most of the Bolshevik leaders. He left Russia in 1922 for health reasons and lived in Capri until 1928. When he went back he was received with enthusiasm and hailed as the outstanding Communist novelist, the promoter of 'social realism' in Soviet literature.

Among his many works the autobiographical trilogy My Childhood (1913), My Apprenticeship (1916) and My Universities (1923) is considered his best. They were filmed by Mark *Donskoy.

Gormley, Sir Antony Mark David (1950- ). English sculptor, born in London. Educated at Trinity College, Cambridge, he was influenced by Buddhism and attempted 'to materialise the place at the other side of appearance where we all live'. His works include Another Place (1997), 100 figures at Crosby 
Beach, near Liverpool and Angel of the North (1998), a huge public sculpture near Gateshead. His Inside Australia (2002-03) is a suite of 51 metal figures, set in $10 \mathrm{~km}^{2}$ in the (mostly) dry Lake Ballard, 130 $\mathrm{km}$ northwest of Kalgoorlie. He was elected RA and FRIBA. His Transport (2010), made of medieval nails, is suspended above the site of *Becket's tomb in Canterbury Cathedral. He took out German citizenship in 2022 as a protest against Brexit.

Gort, 1st Viscount (UK peerage) and 6th Baron (Irish), John Standish Surtees Prendergast Vereker (1886-1946). British field marshal, born in London. Succeeding to his peerage in 1902, he joined the Grenadier Guards (1905), and in World War I won a VC, DSO and two bars, and an MC. After service in India 1936-37, he was promoted over 90 senior officers to become Chief of the Imperial General Staff 1937-39. He led the British Expeditionary Force in France 1939-40 and had major responsibility for the Dunkirk evacuation May-June 1940. ${ }^{*}$ Churchill praised his skill, then exiled him to three difficult and increasingly remote postings, Governor of Gibraltar 1941-42, Governor of Malta 1942-44 and High Commissioner in Palestine and Transjordan 1944-45. He was promoted to a viscountcy one month before his death from liver cancer.

Gorton, Sir John Grey (1911-2002). Australian Liberal politician, probably born in Wellington, New Zealand. Educated at Oxford, he became an orchardist, a pilot in World War II, and a Liberal Senator from Victoria 1950-68. A minister from 1958, he was responsible for science 1962-68 and education 196368. On Harold *Holt's sudden disappearance, Gorton was unexpectedly elected Liberal Leader and became Prime Minister in a Liberal-Country party coalition 1968-71, the first from the Senate. He transferred to the House of Representatives 1968-75. His innovations, attempts to increase Commonwealth power at the expense of the states, caused resentment in the Liberal Party and he resigned when a vote of confidence was lost on a split vote. He left the Liberal Party in 1975, rejoining in 1999.

Hancock, I., John Gorton. 2002.

Gosse, Sir Edmund William (1849-1928). English poet and critic. Son of the zoologist Philip Gosse (1810-1888), a Plymouth Brother, he wrote a critical but compassionate account in Father and Son (1907). He wrote poems, numerous critical works and biographical studies e.g. of *Donne, ${ }^{*}$ Ibsen and * Swinburne. His collected poems appeared in 1911 and his essays in 1912-27. He did much to encourage younger writers and was a great friend of Henry *James. Librarian to the House of Lords 1904-14, he was knighted in 1925.

Gottfried (Gotfrid) von Strassburg (fl. 1200-10). German poet. A leading exponent of the Middle High German epic, his major work Tristan, 20,000 lines long, based on Celtic legend and a poem by Thomas of Brittany, was the principal source of *Wagner's Tristan and Isolde.

Gottschalk, Louis Moreau (1829-1869). American pianist and composer, born in New Orleans. He studied in Paris, impressed ${ }^{*}$ Chopin and ${ }^{*}$ Berlioz with his playing and wrote picturesque pieces for piano and orchestra.

Gottwald, Klement (1896-1953). Czechoslovak Communist politician, born in Moravia. He was conscripted during World War I with the Austrian army, from which he deserted after Russia's collapse. He was an early member of the Communist Party in the independent Czechoslovakia and in 1929, having meanwhile become its Secretary-General, entered parliament. In 1938, after violently opposing the Munich agreement, he went to Moscow, becoming Secretary of the Comintern 1939-45. Returning to Prague in 1945, he was Premier of Czechoslovakia 1946-48. Following a coup in 1948, the constitution changed, *Beneš resigned as President and Gottwald succeeded him 1948-53.

Gould, Glenn (Herbert) (1932-1982). Canadian pianist, born in Toronto. A prodigy, he gained an international reputation as a recording artist, especially for his interpretations of J. S. *Bach, but also as an isolate and eccentric who withdrew from concert giving in 1964. However, he continued to record and made radio and television documentaries. He suffered a fatal stroke just after his 50th birthday.

Gould, Jay (1836-1892). American speculator. A surveyor by profession, he began his speculation in tanning but soon turned to railways. A spectacular attempt, with the collaboration of Jim Fisk, to corner gold caused the 'Black Friday' panic (24 September 1869). Having overcome *Vanderbilt to gain control of the Erie Railway he was forced to resign (1872) for issuing fraudulent stock. Railway finance continued to be his main activity and he controlled at one time more than half the track in the southwest. $\mathrm{He}$ died worth about $\$ 70$ million. His son, George Jay, continued in the same railroad tradition, but eventually was completely ruined.

Klein, M., The Life and Legend of Jay Gould. 1986.

Gould, Stephen Jay (1941-2002). American palaeobiologist. He taught geology, biology and the history of science at Harvard and became internationally known with his books Ever Since Darwin (1977), The Panda's Thumb (1980), The Mismeasure of Man (1981), Bully for Brontosaurus (1991), Wonderful Life (1991), Eight Little Piggies (1994), Dinosaurs in the Haystack (1995) and Questioning the Millennium (1997). He proposed the 'punctuated equilibrium' theory to explain evolutionary transitions in species. 
Gounod, Charles François (1818-1893). French composer, born in Paris. Son of a painter, he won the Prix de Rome in 1839, studied *Palestrina, and contemplated the priesthood. In Paris he attracted the interest of *Berlioz, met *Mendelssohn in Leipzig in 1843 and was introduced to the music of J. S. *Bach. Ave Maria (1853), based on Bach's BWV 846, is his most performed work, by far. Encouraged by Pauline *Viardot, he developed in interest in opera and wrote twelve, ten disappearing without trace. Faust (1859), based on *Goethe, much performed for a century, is now out of fashion. Roméo et Juliette (1867), based on *Shakespeare, is worth performing. Disturbed by the Franco-Prussian War, he lived in London 1870-74. He taught ${ }^{*}$ Bizet, influenced ${ }^{*}$ Massenet and was respected by ${ }^{*}$ Debussy.

Gower, John (c.1330-1408). English poet. He wrote three long poems, the didactic Speculum Meditantis, a satire in old French, telling of the struggle of seven virtues and seven vices for the possession of man, the Latin Vox Clamantis about the Peasants' Revolt of 1381, and, most important, Confessio Amantis, in Old English, in which stories in the Chaucerian manner take the form of the confessions of a lover weary of life. Gower was a friend of ${ }^{*}$ Chaucer and like him did much to develop English as a language.

Gowers, Sir Ernest Arthur (1880-1966). English civil servant. He campaigned for the writing of good English and wrote several books designed to reduce 'officialese' in official documents including Plain Words (1948) and ABC of Plain Words (1951). As Chairman of the Royal Commission on Capital Punishment (1949-53) he became a convinced opponent of hanging and wrote $A$ Life for a Life? (1956).

Gowrie, 1st Earl of, Alexander Gore Arkwright Hore-Ruthven (1872-1955). British soldier, born in Windsor. He won the VC in the Sudan in 1899, served in France and Gallipoli 1914-18 and became Governor of South Australia 1928-34, New South Wales 1935-36 and Governor-General of Australia 1936-45-a record term. His grandson, Alexander Patrick Greysteil Hore-Ruthven, 2nd Earl of Gowrie known as Grey Gowrie (1939-2021), was Minister for the Arts 1983-85, Chairman of Sotheby's 1985-94, and a writer, critic and poet.

Goya y Lucientes, Francisco José de (1746-1828). Spanish painter, engraver and etcher, born at Fuendetodos, near Zaragoza. Son of a gilder, and a mother from a family of artists, he studied in Zaragoza and Madrid, and travelled throughout Italy 1769-71. He was commissioned to paint frescoes at Zaragoza basilica, which he executed in the fashionable *Tiepolo style (1771-81). In 1775 he began working on a series of cartoons for the royal tapestry factory and continued until 1792. His first, neoclassical, period ended in 1778 when he was commissioned to make a series of engravings of *Velázquez' paintings previously confined profound impression on Goya and the engravings soon spread the fame of both Goya and Velázquez. In 1775 Goya married into a painter's family and moved up the patronage ladder, becoming a court painter in 1786, Director of the Royal Academy from 1795 and chief painter to the royal family in 1799: he received the patronage of Manuel *Godoy, the Duchess of Osuna and the Duchess of Alba (immortalised in the 'Naked Maja', one of the rare nudes in Spanish painting). In 1792 a mysterious illness, probably caused by lead poisoning, left him deaf, suffering from vertigo and hallucinations. This marked the beginning of his third period. His later works flayed the corruption of Church and State and aspects of cruelty and servility in Spanish life. It is astonishing that his paintings of Carlos IV and his Family and Queen Maria Luisa (both 1800) and Ferdinand VII (1814), revealing his royal sitters as imbeciles or degenerates, did not lead to his dismissal or arrest. After the French invasion he supported Joseph *Bonaparte's regime and remained court painter, continuing under the restored Bourbons.

The Prado in Madrid exhibits 122 Goya paintings and 485 etchings and sketches. His most famous series of etchings were Los caprichos (The Caprices: 1799), 80 scathing illustrations of proverbs, popular sayings and grotesqueries, The Disasters of War (1810), Bullfights and Proverbs (both 1814-19). His sketches are piercing, nightmarish visions of horrors and death made sometimes by working thick, gummy ink-blots with the fingers on small pieces of buff paper. The most famous of his wartime paintings was Execution of the Defenders of Madrid (3rd May 1808: painted 1814), with its penetrating tableaux of the horror and futility of violence. Other late paintings include Colossus (1809), Senora Sabasa Garica (1808), The Balloon (1818), The Witches' Sabbath (1820), and Saturn Devouring one of his Children (1823). He left Spain in 1824 and died in Bordeaux at the age of 82 . His fantastic later works look towards the expressionism of 20th-century painters.

Gassier, P. and Wilson, J., The Life and Complete Work of Francisco Goya. 1971; Hughes, R., Goya. 2004; Tomlinson, J. A., Goya: A Portrait of the Artist. 2020.

Gracchi. Tiberius Sempronius Gracchus (161-133 BCE) and Gaius Sempronius Gracchus (c.159121 BCE). Roman statesmen and reformers. Their mother Cornelia, the daughter of *Scipio Africanus, was a woman of great character and a devoted citizen of Rome. Tiberius won recognition as a soldier and returned to Rome to press for reforms to alleviate the misery of the peasantry, who were being crushed by the concentration of land and power in the hands of a few. He was elected tribune (133) and proposed a land reform (Lex Sempronia Agraria). To obtain its passage he resorted to methods technically unconstitutional in the face of the opposition of the senate who promoted a riot on the next election day, in which he was beaten to death by a mob, organised by his cousin, Scipio Nasica. In 123 Gaius attempted 
to carry out similar reforms and introduced laws that benefited small landowners; he also won the support of the Roman wealthy class of equites by a legal reform. The senate was again firmly opposed, Gaius failed to secure re-election (121) and he was killed in disturbances which then broke out. The reform effort of the Gracchi was thus ended and the reactionary policy of the senate led to social and political war, which ruined the Republic (*Marius, ${ }^{*}$ Sulla).

\section{Grace, Princess see Kelly, Grace}

Grace, W(illiam) G(ilbert) (1848-1915). English cricketer. A Bristol surgeon, he played for Gloucestershire from 1864 and continued playing first-class cricket until 1908 by which time he was known as the 'grand old man' (GOM) of the game. He toured frequently and captained the English team in Australia (1873-74 and 1891-92). He is said to have scored 54,896 runs and to have made 126 centuries in first-class cricket (on pitches that were frequently illprepared) and also to have taken 2876 wickets.

Weston, G. N., W. G. Grace: The Great Cricketer. 1973.

Grafton, Augustus Henry FitzRoy, 3rd Duke of (1735-1811). English Whig politician. Grandson of Henry FitzRoy, 1st Duke, son of *Charles II and Barbara Villiers, Duchess of Cleveland, he was First Lord of the Treasury 1766-70 in a government dominated by ${ }^{*}$ Pitt the Elder and succeeded him (aged only 33) as virtual Prime Minister 1768-70. A friend of *Wilkes, sympathetic to Unitarianism, he opposed coercing the American colonies but was outvoted by his own Cabinet. Chancellor of Cambridge University 1768-1811, he served as Lord Privy Seal under *North and *Rockingham. In 1769 he divorced his wife by an Act of Parliament and remarried. He was a racing enthusiast and horse owner.

Graham, Billy (William Franklin) (1918-2018). American evangelist. He was ordained (1939) in the Baptist ministry and from 1946 conducted a series of 'Crusades' throughout the US, Europe, India, Australia and Africa. He was mildly supportive on civil rights in the US and opposed nuclear proliferation, but backed the Vietnam War and Richard *Nixon.

Graham, Martha (1894-1991). American dancer and choreographer, born in Pittsburgh. Trained by Ruth St Denis and Ted Shawn, she soon reacted against the 'Denishawn' style and, after teaching at the Eastman School of Music in Rochester, founded the Martha Graham Dance Company in New York in 1926 and made her debut as a soloist. She developed a unique repertoire of body movements based on 'contraction and release': their performance depended on vigorous physical discipline, tremendous virtuosity and emotional intensity. She refused to attend the 1936 Olympic Games in Berlin. One of the predominant influences on modern dance, she created 181 ballets of which the best known were Appalachian Spring (1944) and Clytemnestra (1958). She was awarded the Presidential Medal of Freedom in 1976.

McDonagh, D., Martha Graham. 1973; de Mille, A., The Life and Work of Martha Graham. 1991; Franko, M., Martha Graham in Love and War. 2012.

Graham, Thomas (1805-1869). Scottish chemist, born in Glasgow. Professor of Chemistry at Anderson's College, Glasgow 1830-37, University College, London 1837-55 and Master of the Mint 1855-69, he worked mainly on the absorption and diffusion of gases and on osmosis. His discovery that the rates of diffusion of two gases are inversely proportional to the square roots of their densities is now known as Graham's Law. He also investigated the properties of substances in the state between suspension and solution, and named these substances 'colloids'.

Grahame, Kenneth (1859-1932). Scottish writer, born in Edinburgh. His mother died when he was six and his father abandoned him. Unhappily educated at a school (but not university) in Oxford, he joined the Bank of England in 1879 and rose steadily until he retired as Secretary in 1908 . He had a second life as a bohemian, wrote for the Yellow Book, and flirted with 'paganism'. He wrote the children's classic The Wind in the Willows (1908), a celebration of a child's world, and of an idyllic countryside, with no female characters involved. The book had a slow start, but became a classic; however, it marked the end of his creativity. Disastrously married, his only son, Alastair, for whom The Wind in the Willows was written, committed suicide in 1920. Grahame lived in domestic squalor in his last years and left his estate to the Bodleian Library, Oxford. A. A. * Milne dramatised The Wind in the Willows in 1929, as Toad of Toad Hall. The book has been filmed 13 times, Alan ${ }^{*}$ Bennett adapted it for the stage in 1991 and two musicals are based on it.

Green, P., Kenneth Grahame 1859-1932. 1959; Prince, A., Kenneth Grahame. An Innocent in the Wild Wood. 1994; Dennison, M., Eternal Boy. The Life of Kenneth Grahame. 2018.

Grahame-White, Claude (1879-1959). English aviator and entrepreneur. Trained as an engineer, he attended Louis *Blériot's flying school in France, qualified as an aviator in 1910, and won prizes in England and the US. He established Hendon Aerodrome (1911), later acquired by the RAF, ran a flying school and designed 18 aircraft. He then became a property developer and died in Nice.

Grainger, Percy Aldridge (1882-1961). Australian composer and pianist, born in Melbourne. He studied in Germany with ${ }^{*}$ Busoni, played for ${ }^{*}$ Grieg and befriended ${ }^{*}$ Delius. Like ${ }^{*}$ Bartók, he was a pioneer collector of folk song, using the gramophone to record harmonic variations. He wrote many popular piano pieces, including Country Gardens, Handel in the 
Strand, Mock Morris, a touching arrangement of The Londonderry Air, and some major works for orchestra and chorus. He settled in the US in 1914, teaching in Chicago and New York. Eccentric as a performer and in private life, he experimented with indeterminate or aleatory musical forms $\left({ }^{*} \mathrm{Cage} /{ }^{*}\right.$ Berio $)$ and founded the Grainger Museum of Australian Music in Melbourne (1935).

Bird, J., Percy Grainger. 1982 (revised); Dreyfus, K. (ed.), The Farthest North of Humanness: Letters of Percy Grainger 1901-14. 1985.

Gramm, (William) Phil(ip) (1942- ). American Republican politician. An economist, he taught at the Texas A \& M University, became a US Congressman 1979-85 and US senator 1985-2002. A passionate advocate of balanced budgets, he sought the presidential nomination for 1996.

Gramme, Zénobe Théophile (1826-1901). Belgian electrical engineer. The Gramme dynamo (1869) provided a reliable direct current (DC) power source for electric motors and was the precondition for the electric revolution of the 1880s. Gramme also invented an AC motor, but *Tesla's model (distributed by *Westinghouse) proved far more efficient.

Gramsci, Antonio Francesco (1891-1937). Italian Communist writer, born in Sardinia. Of Albanian descent, he was a hunchback, crippled by illness, probably Pott disease. Educated at Turin University, he became a journalist and a foundation member of the Italian Communist Party (1921) which he led 1923-26. A Deputy 1924-26, he was imprisoned 1926-37, but wrote prodigiously in jail. He proposed polycentrism - the idea that Communist parties should adapt to local circumstances and ideas instead of following a rigid line imposed by Moscow. $\mathrm{He}$ rejected the cruder forms of historical materialism and originated the concept of 'cultural hegemony'.

Joll, J., Antonio Gramsci. 1977; McNally, M., Antonio Gramsci. 2015.

Granados (y Campina), Enrique (1867-1916). Spanish composer and pianist. He studied in Barcelona and Paris and wrote many works for piano, of which the best known were Goyescas (1911-13), poetic evocations of *Goya's art, including the beautiful 'Lover and the Nightingale'. His opera Goyescas was premiered in New York in 1916. On their return to Europe the composer and his wife drowned when the Sussex was sunk by a German submarine.

Grandi, Dino, Conte di Mordano (1895-1988). Italian Fascist politician, born in Mordano. Son of a landowner, educated in Bologna, he was wounded in World War I, became a journalist, joined the Fascist Party in 1921 and was a potential rival to ${ }^{*}$ Mussolini. Undersecretary for Internal Affairs 1923-29, he was Foreign Minister 1929-32 and, as Ambassador to Britain 1932-39, he cultivated powerful men and beautiful women. During the Italian conquest of Ethiopia, the Spanish War, and the successive crises immediately preceding World War II, he so persuasively presented the case for Mussolini's ultimate good intentions and his possible detachment from ${ }^{*}$ Hitler that he disarmed effective opposition. Created a count in 1937, he became Minister for Justice 1939-43 but was sacked under pressure from ${ }^{*}$ Hitler. In July 1943 he organised the numbers in the Fascist Grand Council that resulted in Mussolini's dismissal by the Italian king.

Grant, Cary (né Archibald Alexander Leach) (19041986). Anglo-American film actor, born in Bristol. In the US from 1920, he made 77 films between 1932 and 1966, including The Philadelphia Story (1941), Arsenic and Old Lace (1944), Notorious (1946), To Catch a Thief (1955) and North by Northwest (1959). As homosexuality was considered a liability in the Hollywood star system, he was encouraged to marry (and did so five times). He combined good looks, elegance and a gift for comedy. In 1999 the American Film Institute ranked him second to Humphrey *Bogart as the 'greatest male star of all time'.

Glancy, M., Cary Grant: The Making of a Hollywood Legend. 2020; Eyman, S., Cary Grant: A Brilliant Disguise. 2020.

Grant, Ulysses S(impson) (originally Hiram Ulysses Grant) (1822-1885). 18th President of the US 186977. Born near Cincinnati, Ohio, son of an abolitionist leather merchant, he was trained as an army officer at West Point. He served in the Mexican War and in 1848 he married Julia Dent (1826-1902), whose family were slave owners. Disliking the tedium of army life he retired (1854) but in civil life he was incompetent, and had a low tolerance for alcohol. Recommissioned as a Colonel when the Civil War came, his first major success was in February 1862 when he captured Fort Henry and Fort Donelson in Tennessee, after insisting on 'unconditional surrender' (his coinage). However, surprised by Confederate forces at Shiloh (April 1862), he only won narrowly, after suffering 24,000 casualties. He followed this by the capture of Vicksburg (1863) on the Mississippi, which resulted in cutting the Confederate states in two. Further successes in eastern Tennessee persuaded President ${ }^{*}$ Lincoln to make him (1864) commander of the Union armies. As such he devised the strategy- ${ }^{*}$ Sherman's army to march through Georgia and approach the Confederate capital (Richmond, Virginia) from one side, while Grant himself made a direct attack which brought the war to an end with the Confederate surrender (1865) at Appomattox. Grant's reputation as the hero of the war secured his nomination as the Republican Party's presidential candidate (1868). He was elected and served two terms, marred by poor administration, financial scandals and official corruption. Honest himself, though naive enough to accept gifts from wealthy place-seekers, he was exploited and deluded 
by men whom he had appointed. The Alabama dispute with Great Britain was settled in 1871 by his able Secretary of State, Hamilton *Fish. He tried to settle the issues over which the Civil War had been fought, secured passage of the 15th Amendment to the US Constitution giving political rights to African-Americans, fought and largely suppressed the $\mathrm{Ku}$ Klux Klan, and appointed African-Americans, Native Americans and Jews to the public service. His Indian Peace Plan, although well intentioned, failed in execution and more than 200 battles were fought. He contemplated a third term in 1876, had two years of overseas travel (1877-79) and actively sought renomination in 1880 .

Naively, he invested heavily (including borrowed money) in the brokerage firm Grant \& Ward, run by Ferdinand Ward, with his son 'Buck' Grant as a figurehead. The firm operated a Ponzi scheme, went bankrupt in 1884, and Ward was jailed. U. S. Grant became a pauper and to secure his family wrote his Personal Memoirs, published by Mark *Twain. Grant was dying of cancer in the tongue, throat and neck (caused by his cigar addiction) as he completed his book, which earned $\$ 450,000$ for his family and is regarded as a masterpiece.

McFeely, W. S., Grant: A Biography. 1982; Chernow, R., Grant. 2017.

Granville, John Carteret, 2nd Earl (1690-1763). English diplomat and politician, born in Westminster. Inheriting his father's title of Baron Carteret at the age of five, he entered the House of Lords in 1711. Educated at Oxford, he was a skilled linguist and student of the classics. As Ambassador to Sweden 1719-20, he negotiated a series of agreements that paved the way to lasting peace in the Baltic area. On his return he was appointed Secretary of State for the Northern Department 1721-24, but *Walpole, jealous of his success, soon transferred him to Ireland as Lord Lieutenant 1724-30. Intended as political exile, his period in Ireland proved happy and fruitful and enabled him not only to pacify the country but to enjoy the friendship of Dean *Swift. Convinced of Walpole's hostility, he led the opposition to him from 1733 until his fall in 1742. As Secretary of State for the Northern Department 1742-44, Carteret was the dominant figure in *Wilmington's ministry and had charge of Great Britain's part in the War of the Austrian Succession then taking place on the Continent. The use of British troops on Hanover's behalf was so unpopular that Henry *Pelham and his brother the Duke of *Newcastle found themselves able to manoeuvre the too brilliant Carteret out of office. In the same year he had inherited the earldom of Granville from his mother, countess in her own right. In 1751 the Pelhams brought Granville back into the Cabinet as Lord President of the Council and, as a much esteemed elder statesman, he stayed in office until he died.

Pemberton, N. W. B., Carteret. 1936; Williams, B., Carteret and Newcastle. 2014.
Granville-Barker, Harley (1877-1946). English playwright, actor and producer. As actor and producer for the London Stage Society, he introduced many of the plays of *Shaw. His own plays include The Voysey Inheritance (1905) and Waste (1907). He also wrote the interesting Prefaces to Shakespeare (published in four series 1927-45) which examine *Shakespeare's plays from an actor's and producer's viewpoint.

Grass, Günter (Wilhelm) (1927-2015). German novelist, poet and playwright, born in Danzig (now Gdansk). He served in the Waffen-SS 1944-45, but did not disclose it until 2006. His allegorical writing, on the condition of Germany during and after the Third Reich, began with the novel Die Blechtrommel (The Tin Drum, 1959). This was followed by Katz und Maus (Cat and Mouse, 1963), Hundejahre (Dog Years, 1965) and Die Rättin (The Rat, 1987). He received the 1999 Nobel Prize for Literature. The citation read (rather oddly): 'whose frolicsome black fables portray the forgotten face of history.'

Gratian (Flavius Gratianus Augustus) (359-383). Roman co-Emperor 375-83 with his half-brother, Valentinian II. Though a civilised man and a moderate ruler, he alienated many by his attempts to suppress paganism in Rome by force. When the rebel Maximus crossed from Britain to Gaul Gratian, faced with a mutiny of his troops, fled, and was killed at Lugdunum (Lyon).

Grattan, Henry (1746-1820). Irish politician. A Protestant, educated at Trinity College Dublin, he was a Member of the Irish Parliament 177598; 1800-01, which under *Poyning's Law was virtually subservient to the Privy Council. Grattan, a brilliant orator, fought for and secured the right of the Irish Parliament to initiate laws. He advocated the emancipation of Catholics and won for them the right to vote (1793). The measure was thwarted because of ${ }^{*}$ George III's strong opposition to the election of Catholic MPs, and long delays in securing reform provoked Grattan to resign (1798). He bitterly opposed (but was unable to prevent) the linking of Ireland with Great Britain by the Act of Union, by which *Pitt hoped (vainly as it turned out) to secure Catholic emancipation without political domination. Grattan was elected to the House of Commons 1803-20, and spent most of his remaining years in promoting the cause of emancipation (achieved in 1829).

Graves, Robert von Ranke (1895-1985). English poet, novelist and critic, born in London. Son of Alfred Perceval Graves (1846-1931), Irish poet and folksong collector, he was educated at Charterhouse and Oxford, served in the army during World War I and became known as a poet. (His poetical works were collected in 1959.) From 1929 he lived mainly in Majorca. His autobiography Goodbye to All That appeared in 1929. Later he wrote a series of vivid, scholarly historical novels, notably I, Claudius (1934) 
and its sequel Claudius the God(1934), Count Belisarius (1938) and Wife to Mr Milton (1943). He also wrote several works attempting to place Christianity in a mythological context, e.g. King Jesus (1946). He translated The Golden Ass of Apuleius (1949) and other classics, and published Greek Myths (1955). His biography of his friend *Lawrence of Arabia appeared in 1938. He succeeded W. H. *Auden as professor of poetry at Oxford University 1961-66.

Seymour-Smith, M., Robert Graves. 1982; Wilson, J. M., Robert Graves. 2018.

Gray, Elisha (1835-1901). American engineer, born in Ohio. He was the first to transmit musical tones across a telegraph wire and made significant improvements to telegraphy generally. His patent application for a telephone was lodged on 14 February 1876, just hours after Alexander Graham ${ }^{*}$ Bell and his claim for priority is still controversial. His consulting firm became part of Western General Manufacturing.

Gray, Thomas (1716-1771). English poet, born in London. Educated at Eton and Cambridge, he was the lifelong friend of Horace *Walpole, with whom he toured the Continent (1739-41). His poetical output was small, but his best poems, e.g. Ode on a Distant Prospect of Eton College, Elegy written in a Country Churchyard, The Progress of Poesy and Ode on the Death of a Favourite Cat (i.e. Walpole's), are among the finest products of the 18th-century reflective tradition, combining sensibility with an Augustan discipline and conciseness of expression. He declined the laureateship in 1757. Apart from visits to Scotland and the Lake District the whole of his adult life was spent in scholarly quiet in Cambridge, where he was professor of modern history 1768-71. Though esteemed as the most learned man in England in this and other fields, he never delivered a lecture, had a pupil or published anything except his poetry. His letters reveal his character to a remarkable degree. His grave in the country churchyard at Stoke Poges, Bucks, believed to be that of the poem, is still a point of pilgrimage.

Golden, M., Thomas Gray. 1964.

Graziani, Rodolfo, 1st Marchese of Neghelli (1882-1955). Italian marshal, born in Filettino. An ardent Fascist, he commanded Italian forces in Libya 1930-34, suppressed a popular rising, used poison gas and established concentration camps. Governor of Italian Somaliland 1935, he led the successful invasion of Ethiopia from the south 1935-36, was Viceroy of Italian East Africa 1936-38, and was responsible for 30,000 deaths in Addis Ababa. Chief of the staff of the army 1939-41, and GovernorGeneral of Libya 1940-41, he attempted to invade Egypt but was decisively defeated by *Wavell. He remained loyal to ${ }^{*}$ Mussolini, serving as Minister of Defence 1943-45 in his puppet government in Salo, northern Italy. Imprisoned from 1945, he received a 19-year sentence in 1950, but was soon released and became patron of the neofascist movement.

Greco, El (Doménikos Theotokópoulos) (15411614). Born in Candia (Iráklion), Crete. In Italy he was called El Grequa and later in Spain El Greco. Few details of his life are known. He was in Venice by 1570 (he probably studied under the then aged *Titian), when he went to Spain is uncertain. His earliest known painting there was done in 1577 in Toledo, where he spent the rest of his life. His early work, reflecting his origin, shows the influence of Byzantine icons, but also the influence of *Michelangelo and Mannerism, and the Venetians (including ${ }^{*}$ Tintoretto and *Bassano). From this he progressed to his extraordinary, very personal religious style expressive both of Spanish fanaticism and his own spiritual ecstasy. His works are finished with passion and power. An otherworldly quality is suggested by the elongated bodies, the bold, almost phosphorescent, colours with sharp contrasts of blue, yellow and green. The emotional rather than the actual content of the subject became increasingly stressed as the Mannerism of his earlier style is modified by a baroque conception of space and movement. Among his masterpieces are The Burial of Count Orgaz (Toledo), View of Toledo (New York), The Scourging of Christ (Madrid) and The Disrobing of Christ (Munich). Despite the religious preoccupation of his painting, he was a humanist, very widely read.

Wethey, H., El Greco and His School. 1973; Bray, X., El Greco. 2004; Marías, F., El Greco of Toledo. 2014, El Greco: Life and Works. 2019; Scholz-Hänsel, M., El Greco. 2016.

Greeley, Horace (1811-1872). American journalist. His interest in political questions led him to found the New Yorker (1834), a newspaper-not to be confused with the magazine. He changed its name to The New York Tribune (1841) and worked closely with *Seward. For 30 years the Tribune exerted tremendous influence, campaigning for social reform. His advice 'Go West, young man' became proverbial. Strongly anti-slavery, he finally became a supporter of *Lincoln-somewhat lukewarm, as he was at heart a pacifist. Nominated for president by the Liberal Republican Party in 1872, he was reluctantly adopted by the Democratic Party as well, anxious to avoid a split vote. His campaign proved to be a disaster: his wife died before polling day, Greeley slipped into depression, and ${ }^{*}$ Grant won comfortably. He was housed in an asylum and died before the electoral votes were counted. (His hopes for returning to the Tribune were dashed by Whitelaw *Reid.)

Green, Henry (pen name of Henry Vincent Yorke) (1905-1973). English novelist. Educated at Eton and Oxford, he became Managing Director of H. Pontifex \& Co., a family engineering works in Birmingham. He wrote a series of highly praised short novels, remarkable for their laconic style and keen social 
insights, including Blindness (1926), Living (1929), Party Going (1939), Loving (1945) and Doting (1962). His admirers included W. H. *Auden, Rebecca *West, Angus *Wilson and John *Updike.

Green, John Richard (1837-1883). English historian, born at Oxford. Educated at Oxford University, he became a clergyman in London's East End. Forced by tuberculosis to retire (1865), he wrote his famous Short History of the English People (1874). Essentially a social history, it achieved immense success. His widow, Alice (Sophia Amelia) Stopford Green (1847-1929), was a social historian and Home Rule advocate who served in the Irish Senate 1922-29.

Addison, W. G., J. R. Green. 1946.

Green, Julien (Hartridge) (1900-1998). FrancoAmerican novelist, born in Paris. Of American parentage, he lived mostly in France and wrote almost entirely in French. His novels, while notable for psychological insight, paint a sombre and puritanical picture of French provincial life. They include Adrienne Mesurat (1927), Christine (1928), Le Visionnaire (1934). He was elected to the Académie française in 1971.

Burre, G. S., Julien Green. 1972.

Green, William (1873-1952). American trade union leader. After working as a miner in Ohio he took up trade union organisation and was Secretary and Treasurer of the United Mine Workers of America 1913-24. He succeeded Samuel *Gompers as President of the American Federation of Labor 1924-52.

Greenaway, Kate (née Catherine) (1846-1901). English illustrator, born in London. Daughter of an engraver, she studied at the Slade School, became a successful card and bookplate designer, illustrated children's books, using chromoxylography (coloured woodblocks) and gained international recognition.

Greene, (Henry) Graham (1904-1991). English novelist and playwright, born at Berkhamsted. Educated at Berkhamsted School (where his father was headmaster) and Balliol College, Oxford, he was a sub-editor on The Times 1926-30, film critic of the Spectator 1935-39, worked in the Foreign Office 1941-44 and later as a publisher. His reputation was first made by Brighton Rock (1938), a thriller of contemporary violence but with some social impact. His conversion to Roman Catholicism introduced a religious element, but serious purpose was always subordinate to swiftly moving narrative. His novels include The Power and the Glory (1940, Hawthornden prizewinner), The Heart of the Matter (1948), The End of the Affair (1951), The Quiet American (1955), the satirical Our Man in Havana (1958), The Burnt Out Case (1961), The Comedians (1966), The Honorary Consul (1973), The Human Factor (1978) and Dr
Fischer of Geneva (1980). Two of Greene's screenplays were filmed by Carol *Reed, The Fallen Idol (1948) and The Third Man (1949). His plays include The Living Room (1953), The Potting Shed (1957), The Complaisant Lover (1959), The Return of A. J. Raffles (1975) and Yes $\& \mathrm{No}(1980)$. He received the $\mathrm{CH}$ in 1966 , the $\mathrm{OM}$ in 1986 and many international awards. The Nobel Prize for Literature eluded him, despite 20 nominations. His brother, Sir Hugh Carleton Greene (1910-1987), was Director General of the BBC 1960-69.

Shelden, M., Graham Greene. The Man Within. 1994; Sherry, N., The Life of Graham Greene. Vol. 1 1989, Vol. 2 1994, Vol. 3 2004; Greene, R., Russian Roulette: The Life and Times of Graham Greene. 2020.

Greene, Robert (1558-1592). English poet, playwright, pamphleteer and wit. Autobiographical pamphlets tell of his acquaintance with London's rogues and swindlers, an aspect of his life also reflected in Greenes groats-worth of witte, bought with a million of repentance (1592). His poems and romances, in which *Shakespeare dipped more than once for a plot, contain passages of lyric beauty, but they and his plays are now mainly of academic interest, Greene probably shared in the composition of Shakespeare's Henry VI. He is said to have died from a 'surfeit of pickled herrings and Rhenish wine'.

Greenspan, Alan (1926- ). American financier. Chairman of the Federal Reserve Bank 1987-2006, his economic pronouncements had profound international impact.

Greenwood, Arthur (1880-1954). English Labour politician. An economics teacher, he was elected MP 1922-31; 1932-54, serving under Ramsay *MacDonald as Minister of Health 1929-31, and was Deputy Leader of the Labour Party 1935-45, under Clement *Attlee. As acting Leader, he played an important role in forcing ${ }^{*}$ Chamberlain's resignation and supported *Churchill's 'no surrender' policy in the War Cabinet as Minister without Portfolio 1940-42. He became Leader of the Opposition $1942-45$ in the House of Commons, to ensure that the National Government was subject to scrutiny. In Attlee's postwar Labour Government, as Lord Privy Seal 1945-47 he was an architect of the National Health Scheme but alcoholism made him an ineffective administrator. He received a $\mathrm{CH}$ in 1945.

Greer, Germaine (1939- ). Australian writer, born in Melbourne. Educated at Melbourne, Sydney and Cambridge universities, she taught English at Warwick University 1968-73. Her The Female Eunuch (1970) was a trenchant attack on the subjugation of women in a male-dominated society. Originally a strong advocate of the sexual revolution, she modified her view in Sex and Destiny (1984). She also wrote The Change (1991), about menopause.

Wallace, C., Greer: untamed shrew. 1997; Kleinhenz, E., Germaine. The Life of Germaine Greer. 2019. 
Gregory (Gregorius) I, St (known as 'the Great') (540-604). Pope 590-604. A Roman patrician, he was prefect of Rome (c.573) but soon resigned to become a Benedictine monk, and was later summoned to represent the pope at Constantinople 579-86. He was Abbot of St Andreas monastery, Rome, 586-90, until elected by acclamation as Pope, despite his strong objections. As Pope, he extended the area of papal primacy through missions, e.g. that of St *Augustine of Canterbury, and by skilled diplomacy. He did much, too, to spread the rule of $\mathrm{St}$ *Benedict among the devotees of monastic life. Many of his letters survive to indicate his constant activities as well as his austere piety. The Gregorian chant is named for him, but it is doubtful whether all or any of the liturgical changes attributed to him were really his. Canonised in 604, in 1298 he was proclaimed as one of the four great Doctors of the Western Church (with Sts *Ambrose, *Jerome and *Augustine).

Gregory VII, St (Hildebrand of Savona) (c.1020 1085). Pope 1073-85. Born in Tuscany, Hildebrand became a Benedictine monk, and a learned and enlightened canon lawyer. As papal envoy (from 1048) and as archdeacon of the Roman church, and cardinal (from 1058), he exercised a strong influence on the ineffectual Popes Stephen IX, Nicholas II and Alexander II. Elected Pope by acclamation, he was successful in winning the 'investiture controversy', the claim by monarchs that by investing bishops and clergy with lands and legal protection, they could exercise both spiritual and temporal authority, including the right of appointment. Under Gregory, the papacy claimed universal jurisdiction and he was described as 'Vicar of Christ'. He enforced the existing discipline of clerical celibacy. In 1074 his attempt to organise a Crusade failed because secular rulers refused to join in. Gregory forced the Holy Roman Emperor ${ }^{*}$ Heinrich IV to do penance at Canossa (January 1077) in the snow. The tables were turned when (1084) imperial troops compelled Gregory to leave Rome and end his life in exile at Salerno. He was canonised in 1606.

Gregory XIII (Ugo Buoncompagni) (1505-1585). Pope 1572-85. Born in Bologna, he became a lawyer, had a late vocation to the priesthood, soon becoming prominent in the Vatican administration, legate to Spain 1564-66 and Cardinal Priest of Sisto 1566-72. On the death of Pius V, he was speedily elected as Pope, despite his age (70). A zealous proponent of the Counter-Reformation, he adopted the reforms of the Council of Trent, promoted the Jesuits and established a university in Rome. He encouraged rebellion against Queen *Elizabeth in Ireland, and struck a medal to celebrate the massacre of Protestants in France on St Bartholomew's Day (1572). He introduced the Gregorian Calendar (1582), to replace the Julian Calendar, with the year beginning on 1 January. Outside the Catholic world, adoption of the new calendar was slow: Germany in 1700, Great Britain and the American colonies in 1752, Russia in 1918, Greece in 1923.

Gregory XVI (Bartolomeo Alberto Cappellari) (1765-1846). Pope 1831-46. A monk, trained in science and philosophy, he worked in the Papal Curia and was elected Pope with support from *Metternich. He opposed modernism, secularism and nationalism, encouraged missionaries and denounced slavery. $\mathrm{He}$ set up Egyptian and Etruscan museums in the Vatican.

Gregory, Isabella Augusta, Lady (née Persse) (18521932). Irish playwright, folklorist and political campaigner. Widowed in 1892, she became absorbed with Irish folklore and language from 1893. In 1896 she met W. B. *Yeats: he proposed to her five times but they may not have had a physical relationship. They shared an interest in the occult. In 1904 they founded the Irish National Theatre Society and she became director of the Abbey Theatre, Dublin, until 1928 , believing that a literary revival would further the cause of Irish independence. She wrote the comedy Rising of the Moon (1907) and 18 more plays.

Kohfeldt, M. L., Lady Gregory: The Woman Behind the Irish Renaissance. 1985.

Grenfell, Sir Wilfred Thomason (1865-1940). English medical missionary. He equipped the first hospital ship for the North Sea fisheries. From 1892 he worked in Labrador and Newfoundland and established hospitals, orphanages, schools and agricultural centres for the Eskimos and the fishing communities.

Kerr, J. L., Wilfred Grenfell, His Life and Work. 1959.

Grenville, George (1712-1770). English Whig politician. Educated at Eton and Oxford, he was one of five brothers, all of them MPs. His sister Hester married William *Pitt (the Elder). One of the 'Boy Patriots', led by Pitt, as Prime Minister and Chancellor of the Exchequer 1763-65 he enacted the imprudent Stamp Act (1765) which inflamed the anger of the American colonists and he also became unpopular by prosecuting John *Wilkes. He was a notorious bore. His son William Wyndham Grenville, 1st Baron Grenville (1759-1834), educated at Eton and Oxford, was a Member of Parliament 1782-90, Speaker of the House of Commons 1789 and served under his cousin *Pitt the Younger as Home Secretary 1789-91 and Foreign Secretary 1791-1801. Prime Minister of the 'All-the-Talents' Ministry 1806-07, his government abolished the slave trade. He was Chancellor of Oxford University 1809-34.

Grenville, Sir Richard (1541-1591). English sailor. Of Cornish descent, he carried *Raleigh's first colonists to Virginia (1585) and took an active part in the undeclared sea war against the Spaniards. The incident that won him fame occurred when (1591) Lord Thomas Howard's squadron of 14 vessels 
encountered 53 Spanish ships off Flores, an island in the Azores. The rest of the squadron escaped, but Grenville disobeyed orders and stayed to fight it out. From 3 p.m. and all through the following night his ship Revenge, as *Tennyson's poem dramatically relates, beat off 15 Spanish ships in turn, of which four were sunk or foundered. In the morning Grenville, with his ship a wreck and ammunition gone, was forced to surrender, and died of his wounds on a Spanish ship. A less charitable view portrays Grenville as ambitious, cruel and obstinate, and the episode as a useless expenditure of lives.

Gresham, Sir Thomas (1519-1579). English financier, born in London. Founder of the Royal Exchange (1568), much of his life was spent as advisor to Queen *Elizabeth and financial agent of the crown. Gresham's Law, a 19th-century coinage, summarised as 'bad money drives out good', says that when two coins are of equal legal exchange value but one has greater intrinsic value, it will be hoarded while one with lower intrinsic value remains in circulation. Revenue from shops in the Royal Exchange building was used to found Gresham's College (rebuilt 1841).

Jordan, J. D., The Queen's Merchant-The Life and Times of Sir Thomas Gresham. 2017 ; Guy, J., Gresham's Law. 2019.

Greville, Charles Cavendish Fulke (1794-1865). English writer of memoirs. As Clerk of Council in Ordinary 1821-59 he had a unique opportunity for observing and recording with great psychological insight, the public and private lives of the celebrities whom he met. His famous Memoirs appeared (with tactful suppressions) in 1874-87.

Greville, Fulke, 1st Baron Brooke (1554-1628). English writer and courtier. He held office under *Elizabeth of whom he was a favourite and *James I, but is mainly remembered for his life of his friend Sir Philip *Sidney (published posthumously in 1652), which contains vivid contemporary portraits.

Grévy, (François Paul) Jules (1807-1891). French politician, born in the Jura. An opponent of *Napoléon III, a lawyer, republican and freemason, he was President of the Constituent Assembly 1871-73, of the Chamber of Deputies 1876-79 and succeeded Marshal *McMahon, a covert monarchist, as President of the Republic 1879-87. Re-elected in 1885 , he was forced to resign because his son-inlaw, Daniel Wilson, had been trafficking in honours. A zebra is named for him.

Grey, Dame Beryl (née Groom) (1927- ). English ballerina. She made her first solo appearance at Sadler's Wells as Sabrina, in Comus, in 1941. She danced with the Sadler's Wells company 1942-57 and appeared for seasons with the Bolshoi Ballet (1957-58) and Chinese Ballet (1964).
Grey, Charles Grey, 2nd Earl (1764-1845). English Whig politician. Educated at Eton and Trinity College, Cambridge, he entered parliament in 1786, joined the opposition and attacked *Pitt for his foreign policy, his repressive legislation at home and the Union with Ireland. By 1792 he was already thinking of parliamentary reform and formed the Friends of the People Club with that aim. He joined the Whig ministry (1806) and on *Fox's death became Foreign Secretary and Leader of the Commons. After he inherited his father's earldom (1807) he withdrew from politics during the long period of Tory ascendency but returned to lead the Whig party after the August 1830 election and, on *Wellington's resignation, became Prime Minister 1830-34, the first Whig in office since 1807 . He won a clear majority in an election held in July 1831 . To secure the passage of the Reform Bill (1832) he persuaded a reluctant *William IV to threaten to create a sufficient number of peers to outvote opposition in the Lords, and the Great Reform Act became law in June 1832. In July 1832 an election was held on the new boundaries, eliminating 'rotten boroughs', and enfranchising Birmingham and Manchester. His ministry also secured (1833) the historic measure, proposed by *Wilberforce, abolishing slavery throughout the empire. After a split in the Cabinet (1834) over Irish Church reform, Grey resigned, living in retirement at Howick.

Grey, Sir George (1812-1898). English colonial administrator, born in Lisbon. He explored in Western Australia 1837-39 and became Governor of South Australia 1841-45 and then of New Zealand 1845-53. $\mathrm{He}$ ended the war with the Maoris, to whom he was sympathetic. After a spell as Governor of Cape Colony 1854-61, during which he vainly urged South African federation, he had a second term as Governor of New Zealand 1861-67, but became involved in a quarrel concerning the conduct of the renewed Maori War, and was recalled. He returned to enter New Zealand politics and was Liberal Prime Minister 1877-79. He represented New Zealand at the Australasian Convention of 1891, but was cool about the prospect of federation with Australia. An able linguist, his major collection of medieval manuscripts was given to libraries in Cape Town and Auckland. He was buried in St Paul's Cathedral, London.

Grey, Lady Jane (1537-1554). English claimant to the crown. She was the daughter of Henry Grey, Marquess of Dorset (afterwards Duke of Suffolk), and was linked with the royal family through a grandmother, a sister of ${ }^{*}$ Henry VIII. Jane married (1553) Lord Guildford Dudley, son of the Duke of *Northumberland who, as protector of the realm, persuaded the dying boy-king *Edward VI to name Jane as his successor (1553), overruling the Third Succession Act (1543), which provided that the order of succession should be the daughters of Henry VIII, (i) *Mary, a Catholic, and (ii) *Elizabeth, whose legitimacy was in dispute. Four days after Edward's death, Jane was proclaimed Queen (10 July 1553), 
with the support of the Privy Council. However, Mary quickly rallied support, the Privy Council switched allegiance, and nine days later Jane was deposed and imprisoned in the Tower of London. Her father joined Sir Thomas *Wyatt's rebellion and this led to the execution of Jane, together with her husband and her father. She had beauty, intelligence - she read five languages, including Greek and Hebrew—and piety.

Chapman, H., Lady Jane Grey. 1962; Bartlett, D. W., The Life of Lady Jane Grey. 2010; Ives, E., Lady Jane Grey-a Tudor Mystery. 2011; Tallis, N., Crown of Blood. 2017.

\section{Grey Eminence see Joseph, Père}

Grey of Fallodon, Edward Grey, 1st Viscount (1862-1933). English Liberal politician. Educated at Winchester and Balliol College, Oxford, where he majored in tennis and scraped a degree, he was a Liberal MP 1885-1916 and Undersecretary for Foreign Affairs in *Gladstone's last administration 1892-95, when the 'Grey declaration' warned the French off the Sudan. In the Liberal Governments of ${ }^{*}$ Campbell Bannerman and *Asquith, he was Foreign Secretary 1905-16, the first to sit in the House of Commons since 1868, and the longest serving. (In that time he made only one short visit to Europe.) During that time he cemented the Triple Entente with France and Russia to counter the threat from Germany and its allies. In the Morocco crisis (1911) his support of France averted war; it was also, largely, through his influence that the Balkan Wars 1912-13 were localised. His role in the events leading to the outbreak of World War I was ambiguous: he told Cabinet little, left commitment to the generals and depended on French initiatives. He retired from office in 1916 due to failing sight. He was created KG (1912), a viscount, declining an earldom (1916), was Ambassador to the US 1919-20 and became Chancellor of Oxford University 1928-33. He wrote The Charm of Birds (1927) and books on fly fishing. Historians now judge Grey harshly: he had little interest in the Balkans, failed to grasp the momentum towards war in 1914, was secretive and did not communicate its seriousness to his colleagues.

Trevelyan, G. M., Grey of Fallodon. 1937; Waterhouse, M., Edwardian Requiem: a Life of Sir Edward Grey. 2013; Otte, T. G., Statesman of Europe: A Life of Sir Edward Grey. 2020.

Grieg, Edvard Hagerup (1843-1907). Norwegian composer, born in Bergen. Leader of a new national school, influenced by the music of *Mendelssohn and *Schumann, he studied in Leipzig from 1858. In 1863, in Copenhagen, he met the Norwegian composer Rikard Nordraak (1842-1866) and through him discovered his own folk tradition. His own music was based on this tradition, refined by his own natural lyricism. His works included the Piano Concerto in A Minor, Op. 16 (1868), incidental music to *Ibsen's Peer Gynt (1874-75), the Holberg Suite for strings (1884), three violin sonatas, many songs and piano solos.

Horton, J., Grieg. 1972; Grimley, D., Grieg: Music, Landscape and Norwegian Cultural Identity. 2007.

Griffin, Walter Burley (1876-1937). American architect and town planner. A disciple of Frank Lloyd *Wright, he won the international competition (1912) for the design of Canberra, endured years of frustration at the hands of politicians and bureaucrats but was ultimately vindicated (posthumously). His wife Marion Lucy Mahoney (1871-1961) was a designer and draftsperson with Wright. He died in Lucknow.

Griffith, Arthur (1872-1922). Irish politician. A Protestant, he became a journalist, encouraged the Gaelic revival and influenced Irish nationalist opinion. He founded 'Sinn Féin' ('We Ourselves') in 1905 and edited a newspaper of that name 1906-14. The movement gradually became increasingly militant and republican. Imprisoned several times (1916-20), he was *de Valera's deputy when the Irish Republic was declared (1919). With Michael ${ }^{*}$ Collins he led the Irish delegation which signed the treaty (1921) setting up the Irish Free State, and, after de Valera had refused cooperation, he was President of the Republic for the last seven months of his life. He dropped dead in the street.

Griffith, David (Lewelyn) Wark (1875-1948). American film producer and director, born in Kentucky. Son of a Confederate colonel, he left school early, became a salesman and touring actor. He entered the film industry in 1908 and made 460 short films in seven years. His Enoch Arden (1911), based on *Tennyson's poem, ran for 33 minutes and was considered lengthy at the time. He made his great contribution to the history of cinema with two long spectacular silent movies, with musical accompaniment: The Birth of a Nation (1915, originally The Clansman: two versions, 133 and 193 minutes) and Intolerance (1916: 197 minutes). The Birth of a Nation was a box office success, but was intensely controversial—a romanticised account of the Civil War that probably contributed to the revival of the Ku Klux Klan. Griffith was incensed by attacks on his work. Intolerance, oddly, was, in part, a response. Comprising four stories: a modern account of victimisation (but not racial), the massacre of the Huguenots, ancient Babylon and the crucifixion of Jesus, it was a financial failure but influenced Russian filmmakers. In 1919 he was a co-founder of United Artists, but soon broke away. Griffith used music (including *Wagner) effectively to emphasise drama, and employed 'close ups', 'flashbacks', 'fade outs', crosscutting, changing camera angles and other now familiar techniques. His two full-length 'talkies', Abraham Lincoln (1930) and The Struggle (1931), both failed. Ephraim Katz described Griffith 
as 'the single most important figure in the history of American film'. He received an honorary Academy Award in 1935 but died alone and neglected.

Schickel, R., D. W. Griffth. 1984.

Griffith, Sir Samuel Walker (1845-1920). Australian politician and judge, born in Wales. Educated in Sydney, he served as Premier of Queensland 1883-88 and 1890-93, becoming principal draftsman (1891) of the Commonwealth Constitution (adopted in 1901), and Chief Justice of Queensland 18931903. With the establishment of the High Court of Australia in 1903, Griffith was made Chief Justice, retiring in 1919.

Grillparzer, Franz (1791-1872). Austrian dramatist. He became a lawyer and an increasingly unhappy public servant in the Treasury whose works and mental processes influenced ${ }^{*}$ Kafka, ${ }^{*}$ Musil and ${ }^{*}$ Kraus. His works contrast the exercise of modern totalitarian power (as with *Napoléon) with the bureaucratic style (as with *Joseph II). His plays include King Ottocar, His Rise and Fall (1823), The Waves of Sea and Love (1831) and $A$ Dream of Life (1834).

Grimm, Jakob Ludwig Karl (1785-1863) and Wilhelm Karl (1786-1859). German brothers, philologists and collectors of fairy tales and myths. The development of Germanic languages, law, folklore, sagas and songs was to them a single composite study which one or both pursued down many avenues and recorded in numerous learned books. Jakob was particularly interested in language: 'Grimm's Law' concerns the sound shifts that produced the German language from its Indo-European origins.

Michaelis-Jena, R., The Brothers Grimm. 1970.

Grimond, Jo(seph), Baron Grimond (1913-1993). English Liberal politician. Educated at Eton and Oxford, he was called to the bar (1937) and served in World War II. He was MP for the Orkney and Shetland constituency 1950-83. He succeeded Clement Davies as Liberal Leader 1956-67. In the 1964 election the party vote was almost double that of the previous election at over 3,000,000.

Grímsson, Ólafur Ragnar (1943- ). Icelandic politician. He was Professor of Political Science at the University of Iceland 1973-88, and President of Iceland 1996-2016, a record period, and was a passionate advocate for renewable energy.

Gris, Juan (né José Victoriano Carmelo Carlos González-Pérez) (1887-1927). Spanish Cubist painter. In Paris from 1906, deeply influenced by ${ }^{*}$ Cézanne, he was, with *Braque and *Picasso, one of the leading Cubist artists, enlarging the still-life tradition. He also designed ballet sets for *Diaghilev.

Grivas, Georgios (1898?-1974). Greek soldier, born in Cyprus. During World War II, under the nomme de guerre 'Dighenis Akritas', he led guerrilla bands against the Germans and the rival Communist underground. In 1954 he returned to Cyprus to direct the EOKA terrorist forces in support of the Enosis movement for union of Cyprus with Greece. After the settlement (1959) he withdrew, but returned (1964) to command the Greek Cypriot troops. He led a terrorist campaign against the Turks in Cyprus 1971-74.

Grock (né Charles Adrien Wettach) (1880-1959). Swiss musical clown. A master of miming, he captivated audiences of all nationalities without uttering a word. The most famous of his acts displayed him in his clown's makeup in a state of complete bewilderment when confronted with an array of musical instruments whose eccentricities he appeared unable to master, until with a sudden change of mood he revealed himself as a virtuoso performer.

Grocyn, William (c.1446-1519). English humanist scholar. He was educated at Winchester and New College, Oxford, and held a number of scholastic and ecclesiastical preferments before becoming (1506) Master of the collegiate Church of All Hallows, Maidstone, where he was buried. He was held in great respect by ${ }^{*}$ Erasmus, Sir Thomas ${ }^{*}$ More and ${ }^{*}$ Colet, and is important as one of the first to teach Greek publicly in England.

Gromyko, Andrei Andreyevich (1909-1989). Russian Communist politician and diplomat, born in Belarus. He became Ambassador to the US 1943-46, Permanent Representative on the UN Security Council 1946-48, Ambassador to Great Britain 1952-53 and Deputy Minister for Foreign Affairs 1953-57. As Foreign Minister 1957-85, a record period, he signed (1963) the partial nuclear test ban agreement, played a key role in the detente conferences of the 1970s, and became a Politburo member 1973-88. He was President of the USSR 1985-88.

Gröner, Wilhelm (1867-1939). German general. In World War I he was officer in charge of railways, personnel and supplies, succeeding ${ }^{*}$ Ludendorff as Quartermaster General (October 1918). With ${ }^{*}$ Hindenburg he engineered the Kaiser's abdication, then worked with *Ebert against the Communists. He became a conservative deputy in the Reichstag 1920 33, was a minister and a strong opponent of the Nazis.

Groom, William Henry (1833-1901). EnglishAustralian transportee and politician, born in Plymouth. Convicted of embezzlement in 1846, he was transported to New South Wales in 1849. Soon released, he was convicted of theft in 1855 . He relocated to Queensland, was a publican, journalist, auctioneer and the first Mayor of Toowoomba. Elected to the Queensland Parliament 1862-1901, and Speaker 1883-88, he was the only transportee elected to the first Commonwealth House of Representatives 1901, and was the first member of the House to die. His son Sir Littleton Ernest Groom (1867-1936) succeeded his father in the ensuing by-election and 
was MP 1901-29; 1931-36, and Attorney-General 1906-08; 1921-25; a striking transition from convict to first law officer in two lives.

Gropius, Walter (Adolph George) (1883-1969). German architect, born in Berlin. A pioneer of 'functional' architecture, of which his early industrial buildings are fine examples; glass and concrete are the chief materials used. In 1915 he married Alma *Mahler (his lover from 1910) and they divorced in 1920. He founded the Bauhaus School (1919) and was its director until 1928, first in Weimar and (from 1926) in Dessau, where his design for the new premises was hailed as a landmark. He left Germany in 1934 and settled in the US after three years in England. He was professor of architecture at Harvard 1937-52.

Fitch, J. M., Gropius. 1960; Wolfe, T., From Bauhaus to Our House. 1981; Isaacs, R., Walter Gropius. 1991; MacCarthy, F., Walter Gropius. Visionary Founder of the Bauhaus. 2019.

Grosseteste (i.e. Bighead), Robert (c.1175-1253). English prelate and scholar, born in Suffolk. Coming from a poor family, he studied theology at Oxford and Paris, became Chancellor of Oxford University 1214-21 and Bishop of Lincoln 1235-53. He anticipated *Aquinas in reviving interest in *Aristotle, brought scholars from the Byzantine Empire to work on Latin translations and wrote a commentary on Posterior Analytics. He also encouraged the study of the Arab contribution to science, especially in light and optics and was the teacher of Roger ${ }^{*}$ Bacon. He emphasised the primacy of the Church over the State and defended the Jews against *Henry III.

Grossman, Vasily Semyonovich (1905-1964). Russian-Jewish author, born in Berdichev. His long novel Life and Fate (1959), was published abroad in 1980, in English translation in 1986 and in the USSR in 1989 .

Grossmith, George (1847-1912). English actor and author. Though he achieved great success on the stage, notably in *Gilbert and *Sullivan operas at the Savoy, and wrote hundreds of songs and sketches, it is as the author, with his brother Weedon Grossmith (1854-1919), of The Diary of a Nobody (1892) that he is remembered.

Grosz, George (1893-1959). German satirical artist. He began his career as a savage caricaturist, and after World War I, e.g. in his series Faces of the Ruling Class, he venomously assailed militarists, bureaucrats and capitalists. From 1933 he worked in the US and in World War II he painted anti-war pictures, whose power lay in their macabre and horrifying symbolism.

Bittner, H., George Grosz. 1965.
Grote, George (1794-1871). English historian and politician. A 'philosophical radical' MP 1832-41, he was an early advocate of the secret ballot, worked as a banker but is best known for his History of Greece (begun in 1822 and published in 10 vols, 1846-56), a work of great scholarship infused with a deep and understanding love of Greek civilisation. He actively participated in the founding of University College, London, and was Vice Chancellor of London University 1862-71. He refused a peerage (1869).

Clarke, M. L., George Grote, a Biography. 1962.

Grotewohl, Otto (1894-1964). East German politician. After some years as a printer he turned to politics and became prominent as a Social Democratic member of the Reichstag 1925-33. He was twice imprisoned by the Nazis. After World War II, as leader of his party in East Germany when it merged with the Communists, he became the first MinisterPresident (i.e. Premier) of the German Democratic Republic 1949-64. He became a virtual figurehead, as real power passed to his deputy Walther *Ulbricht.

Grothendieck, Alexander (1928-2014). GermanFrench mathematician, born in Berlin. A pioneer of algebraic geometry, he became a philosopher and political activist.

Grotius, Hugo (Huig de Groot) (1583-1645). Dutch international jurist, born at Delft. He went to Leyden University at the age of 11 , and at 15 accompanied a diplomatic mission to ${ }^{*}$ Henri IV of France. On his return he began to practise law at The Hague and soon gained public appointments. He became involved, however, in the violent religious disputes of the time and was sentenced to life imprisonment, escaping in 1621 when his wife managed to get him carried out of prison in a book chest. He went to Paris, was pensioned by *Louis XIII and produced his De Jure Belli et Pacis (1625), the first great work on international law. Beyond its legal aspects it was a plea for more human conduct in the pursuit of war. He also devoted himself unsuccessfully to reconciling the Roman Church and sects of a divided Christendom. Axel *Oxenstierna appointed Grotius as Sweden's Ambassador to Paris 1634-45. Shipwrecked near Rostok, on a voyage from Sweden to the Netherlands, he soon died and was buried in Delft.

Grouchy, Emmanuel, Marquis de (1766-1847). French marshal. He joined the Revolutionary armies and is said to have been wounded 14 times before he was captured at the Battle of Novi (1799). He fought with *Napoléon's Grand Army from 1805, was prominent during the retreat from Moscow, rejoined the emperor after his escape from Elba and was made a marshal (1815). He was much criticised, perhaps unjustly, for failing to prevent ${ }^{*}$ Blücher's junction with *Wellington at Waterloo. 
Grove, Sir George (1820-1900). English engineer, musicologist and editor. He built the first cast-iron lighthouse (in the West Indies) and was Secretary of the Crystal Palace Company 1852-73. In his other spheres of activity he edited Macmillan's Magazine and was a major contributor to Smith's Dictionary of the Bible. He is best known as editor 1878-90 of the standard work: A Dictionary of Music and Musicians. He was knighted in 1883. The New Grove Dictionary of Music and Musicians is currently available online or in print. Knighted in 1883, he was founder and first director of the Royal College of Music 1883-94.

Young, P. M., George Grove, 1820-1900. 1980.

Groves, Leslie Richard (1896-1970). American engineer and army officer. After supervising the construction of the Pentagon in Washington DC, he led the 'Manhattan Project' at Los Alomos, New Mexico (1942-45), which produced and tested the first atomic bombs, working with J. R. *Oppenheimer.

Gruen, Victor David (originally Viktor David Grünbaum) (1903-1980). Austrian-Jewish-American architect, born in Vienna. He designed shopping malls/supermarkets. The 'Gruen effect' (or 'Gruen transfer') describes the impact of a welcoming, open, well-lit, air-conditioned environment, with abundant products and food in reach, which becomes a home away from home, and weakens sales resistance and encourages compulsive spending.

Grundtvig, N(ikolai) F(rederik) S(everin) (17831872). Danish bishop, poet, theologian and educator. $\mathrm{He}$ was an outstanding hymn-writer and as a philosopher of religion he anticipated and influenced *Kierkegaard. He studied the Icelandic sagas and published a translation of *Beowulf. He also inspired the creation of residential folk high schools and campaigned for liberal causes, including parliamentary government.

Grünewald, Matthias (Mathis Gothardt or Neithardt) (c.1470/1480-1528). German painter, possibly born at Wurzburg. Very little is known of him and the familiar name Grünewald was a misattribution, made nearly 150 years after his death. He was both artist and engineer and worked for the see of Mainz and eventually was court painter (1515-25) to its cardinal archbishop Albrecht of Brandenburg. His mysticism and extreme piety are discernible in all his work, and in his portrayals of the crucifixion he reveals the depth of his compassion. His masterpiece the Issenheim (or Eisenheim) Altarpiece was painted between 1512-16 for a now demolished convent hospital for plague victims at Issenheim in Alsace, dedicated to St Anthony. It is now in a former Dominican chapel at the Unterlinden Museum, Colmar. The altarpiece consists of two fixed panels and two sets of mobile wings, painted on both sides, 10 distinct paintings including the powerful and appalling Crucifixion, The Angelic Concert,
The Annunciation, The Resurrection, and a *Bosch-like Temptation of St Anthony. In emotional power it ranks next to ${ }^{*}$ Michelangelo's works in the Sistine Chapel but was virtually unknown until publicly displayed in 1852. Grünewald achieved none of the fame of his exact contemporary ${ }^{*}$ Durer: he had no pupils and made no woodcuts or engravings. A few other works survive, in Basle, Karlsruhe and Washington. His last years were miserable-suspected of Protestant sympathies, he became a seller of paints and medicine, and died of the plague in Halle. Paul *Hindemith's opera Mathis der Maler (1938) was based on his life.

Guardi, Francesco de (1712-1793). Venetian painter. His teacher was ${ }^{*}$ Canaletto, who for long was esteemed above Guardi, whose paintings, most of Venice, though superficially similar to those of Canaletto, are in fact far different in their more sensitive treatment of light and colour. Whilst Canaletto is concerned with architectural precision, Guardi takes delight in the fleeting moment, catching the interplay of light and shadow on water, the atmospheric effects on the lagoon and using a technique approaching that of the Impressionists.

Shaw, J. B., The Drawings of Francesco Guardi. 1951.

Guarneri (or Guanieri). Italian family of violin makers in Cremona. The chief were: Andrea (c.1626-1698), taught by Nicolo *Amati, his sons Pietro (1655-1720), who lived in Mantua, and Giuseppe (1666-c.1739), another Pietro, known as Peter of Venice (c.1698-1732), a nephew of Pietro of Mantua; lastly, perhaps the most famous of all, Giuseppe's son, known as Giuseppe Guarneri del Gesù (1698-1744), because his violins were signed IHS, a Latin approximation of the first three letters of the name Jesus (in Greek), familiar in religious ornamentation.

Gubaidulina, Sofia Asgatovna (1931- ). Russian composer, born in Chistopol. Educated in Kazan, encouraged by *Shostakovich, she lived in Germany from 1992. Very prolific, her works include two violin concertos (Offertorium 1980, 2007), Hommage à T S Eliot (1987), Seven Last Words - partita for cello, bayan and strings (1987) and Johannes Passion (2007).

Gucci, Guccio (1881-1953). Italian designer and manufacturer. He worked as a waiter in London, then established a business in Florence (1920) making leather and travel goods, establishing a dynasty and a high reputation for style and quality.

Guderian, Heinz (1888-1954). German general. An expert in mechanised warfare, he planned several of the great German armoured thrusts. $\mathrm{He}$ commanded a Panzer corps in the Polish campaign (1939) and the Panzer army in Russia (1941). In 1944, having become Chief of Army staff, he was virtually Commander-in-Chief against Russia. He retired because of ill health in 1945. 
Guelphs (or Guelfs). Name of the pro-Papal faction in Italy from the 12th century, which resisted expansion of Imperial power, derived from the German (Swabian) *Welf-Este dynasty.

Guericke, Otto von (1602-1686). German physicist, born at Magdeburg. He was noted for his investigations into pneumatics. He invented the air pump when carrying out experiments to produce a vacuum. His most famous experiment was that of the 'Magdeburg hemispheres', in which two hollow copper hemispheres were placed together to form a globe and emptied of air. Teams of eight horses pulling in opposite directions failed to separate them. He also studied electrical attraction and repulsion, obtaining his electricity by friction on a globe of sulphur.

Guesclin, Bertrand du (c.1320-1380). French general. The greatest warrior of the Hundred Years' War, he won his first battle at Rennes, Brittany (1356-57), then defeated the English in a series of encounters that cleared them from the Seine valley; he was, however, captured at Auray (1364) and subsequently ransomed. He was made Constable of France by ${ }^{*}$ Charles V (1370) and gradually deprived the English of all their possessions there except for a few fortified towns.

Guevara (de la Serna), 'Che' (Ernesto) (1928-1967). Argentinian revolutionist. The son of an architect, he studied medicine, became a determined opponent of the Perón regime and left Argentina in 1952. He served in the Popular Front Government of Guatemala until it was overthrown in June 1954. In 1956 he met Fidel ${ }^{*}$ Castro in Mexico, accompanied his guerrillas to the Sierra Maestra as physician, and soon emerged as Castro's closest aide. In the Cuban Revolutionary Government he was President of the National Bank (1959) and Minister for Industry 1959 65. He left the Cuban Government in 1965 and disappeared. He visited the Congo and North Vietnam, reappearing in 1967 at the head of a guerrilla organisation in Bolivia. In October he was captured and killed by the Bolivian army. His fascinating Diaries were published in 1968.

Guggenheim, Meyer (1829-1905). American industrialist, born in Switzerland. He migrated to Philadelphia (1847) and eventually, with his sons, succeeded in establishing international enterprises for the mining and processing of copper, tin, gold and diamonds. His sons created the well-known Guggenheim Foundations: that of Daniel (18561930) was 'to promote the well-being of mankind', that of Simon (1867-1941) to help scholars, artists and writers, and Solomon Robert (18611949) for the advancement of art. The Solomon R. Guggenheim Museum in New York, opened in 1959, was designed by Frank Lloyd *Wright. Peggy (Marguerite) Guggenheim (1898-1979), a granddaughter of Meyer, ran galleries in London and New York, promoted new artists such as Jackson *Pollock, built up one of the greatest collections of modern art and created a Guggenheim Foundation in Venice where she died. Her second husband was the painter Max *Ernst.

Guicciardini, Francesco (1483-1540). Italian historian of the Renaissance. For much of his life he held distinguished diplomatic and administrative posts in the service of the Medicis, whether in the government of Florence, where he was born, or under the Medici popes ${ }^{*}$ Leo X and ${ }^{*}$ Clement VII. His greatest work The History of Italy, covering the period $1492-1534$, is detailed, accurate and shrewd in its judgment of affairs and men.

Guido d'Arezzo (Guido Monaco, or d'Aretino) (c.991/2-c.1050). Italian music theorist and Benedictine monk, born near Arezzo. At monasteries in Pomposa (near Ferrara) and Arezzo, he wrote a textbook Micrologus (c.1026), to teach singers how to read musical notation for new and old works, instead of relying on memory. He devised what was later named 'tonic solfa' where the six pitches were called ut (later doh), re, $m i$, fa, sol, and la. Guido is credited with inventing the modern form of musical notation, where 'neumes', a variety of signs on staves, to indicate phrases, pauses and melodic lines, were replaced by notes, indicating pitch and length, and syllables within a word ('solmization'), in a hexachord (a six-note tone row). His system enabled changes in key by the use of 'accidentals', where pitches move from 'natural' (घ) up to 'sharp' (\#), or down to 'flat' (b). This enabled development from plainchant towards polyphony, writing complex compositions for instruments, exploiting transitions from consonance to dissonance. He probably introduced the mnemonic device of giving the tips and joints of the fingers names of the various notes.

\section{Guido Reni see Reni, Guido}

Guillotin, Joseph Ignace (1738-1814). French physician. A member of the Estates General/ Constituent Assembly 1789-91, he recommended the use of, but did not invent, the instrument of execution introduced in 1792 and named after him.

Lom, H., Dr Guillotine. 1992.

Guimard, Hector (1867-1942). French architect, designer and decorator. The leading French exponent of Art Nouveau, his most familiar works are the castiron plant decorations for the Paris Metro (18981901), a style which has been retained. He also designed apartment buildings and the staircase at the Grand Palais, Paris.

Guinness, Sir Alec (1914-2000). English actor. He appeared on the London and New York stage from 1933, in leading roles in, e.g. The Rivals (1938), An Inspector Calls (1948), The Cocktail Party (1949), Ross (1960), and in many films, e.g. Great Expectations, Oliver Twist, Kind Hearts and Coronets, The Lavender Hill Mob, Tunes of Glory and Lawrence 
of Arabia. In 1958 he won the Academy Award for his role as Major Nicolson in The Bridge on the River Kwai. His main theatrical characteristics were intelligence, wit and versatility. He was knighted in 1959 and awarded a CH in 1994.

Guinness, Sir Benjamin Lee, 1st Baronet (17981868). Irish brewer. He enlarged the Dublin brewery of his father, Arthur Guinness, until it became a vast enterprise, and its product, Dublin stout, a household word. His eldest son, Arthur Edward Guinness (1840-1915), was created 1st Baron Ardilaun. His third son, Edward Cecil Guinness, 1st Earl of Iveagh (1847-1927), having amassed a fortune through the business, endowed a trust for slum clearance and rebuilding in Dublin and London and gave to the nation Kenwood, the family mansion on Hampstead Heath, with a fine collection of pictures.

Guiscard, Robert (c.1015-1085). Norman adventurer in Italy. With his brothers he carved out a territory for himself in Calabria and Apulia, with which he was invested by Pope Nicholas II in 1059. With the aid of his brother, *Roger I, Sicily was conquered and added to the family possessions. Robert conceived the idea of seizing Constantinople on behalf of his daughter's father-in-law, the deposed emperor, Michael VII but, after capturing Durazzo (1082), he returned to support Pope ${ }^{*}$ Gregory VII against the emperor ${ }^{*}$ Heinrich IV. On his way to resume his Byzantine enterprise he died.

Guise. French noble family of Lorraine. The first duke was Claude (1496-1550), whose daughter Mary (1515-1560) married *James V of Scotland and became regent for their infant daughter, *Mary Queen of Scots. Claude's son, François (1519-1563), Second Duke, helped by his brother, Charles (15251574), Archbishop of Rheims and cardinal, led the extreme Catholic party which fought the Huguenots in the religious wars; he was assassinated. The third duke, Henri (1550-1588), was mainly responsible for the massacre of St Bartholomew (1572), for which the connivance of the queen mother, ${ }^{*}$ Catherine de'Medici, had been with difficulty obtained. She subsequently was forced to come to terms favourable to the Huguenots. Guise, in protest, formed the Catholic League, and a triangular contest developed between the League, the Huguenots, and the crown, worn since 1574 by the vacillating *Henri III who at last cut the Gordian knot by arranging for the treacherous murder of Guise at Blois (1588). After Henri's own assassination (1589) and the succession and conversion to Catholicism of the Protestant leader ${ }^{*}$ Henri of Navarre, the power of the Guises steadily declined.

Guitry, Sacha (Alexandre) (1885-1957). French actor and playwright. With his father Lucien Guitry (1860-1925) and Yvonne Printemps (1895-1977), third of Sacha's five wives and the heroine of many of his plays, he formed a trio 'the Guitrys', who played a dominant role in French theatrical life for a generation. In addition to being a leading actor, producer and manager, he wrote over 100 plays, mainly light comedies, and in later life achieved new success as a film director (e.g. Les Perles de la couronne, 1938). Lucien played opposite Sarah *Bernhardt in many of his favourite parts, e.g. as Armand to her Marguerite Gautier in La Dame aux camélias. Arrested as a collaborator in 1944, he was soon released.

Guizot, François Pierre Guillaume (1787-1874). French politician and historian, born in Nîmes. A Protestant, he was professor of modern history at the Sorbonne 1812-22, 1828-30. Turning to politics, he supported the revolution (1830) against ${ }^{*}$ Charles $\mathrm{X}$, but under ${ }^{*}$ Louis Philippe he headed the rightcentre in the chamber, his chief rival being *Thiers. When Minister for Public Instruction 1832-40, he organised primary education; he also restricted the freedom of the press. He was elected to the Académie française in 1836. After briefly being Ambassador in London (1840), he became Foreign Minister 184047 and virtually controlled the government. Premier $1847-48$, his refusal to concede any reform caused the downfall of the regime. His extensive historical works, several on English history, e.g. Histoire de la révolution en Angleterre 1826-1856, earned him high respect as a historian.

Gulbenkian, Calouste Sarkis (1869-1955). Armenian oil magnate, born in Istanbul. His wealth and his nickname, 'Mr Five Percent', were originally based on a holding of one twentieth of the shares of the Anglo-Iranian Petroleum Company. He accumulated a fine collection of paintings and ceramics now in the Gulbenkian Museum in Lisbon (where he died), leaving most of a huge fortune (estimated at $£ 300$ million) to an international trust for educational, artistic and charitable purposes. His son, Nubar Gulbenkian (1896-1972), became a colourful figure on the British social scene.

Gunn, Thom(son William) (1929-2004). English poet. His first volume of poems was Fighting Terms (1954), followed by The Sense of Movement (1957), Positive (with Ander Gunn, about Londoners, 1966), Jack Straw's Castle (1976) and The Passages of Joy (1982). He taught in California at Stanford 1954-58 and Berkeley 1958-66, 1977 and depicted modern urban society with great skill.

Gur, Mordechai ('Motta') (1930-1995). Israeli soldier, born in Jerusalem. A courageous soldier, he led the forces that occupied Jerusalem in 1966. Chief of the Defence Forces 1972-78, he was a Labor MP in the Knesset and Minister for Health 1984-86. Diagnosed with inoperable cancer, he shot himself.

Gurdjieff, George Ivanovich (1874-1949). Russian occult teacher. Of Greek-Armenian parentage, and raised in the Caucasus, he travelled extensively in Central Asia seeking occult knowledge and founded 
the Institute for the Harmonious Development of Man in Moscow in 1912. It was re-established at Fontainebleau 1922-36 and among his disciples were Katherine ${ }^{*}$ Mansfield, Hart ${ }^{*}$ Crane and Peter Demianovich Ouspensky (1874-1947). His Meetings with Remarkable Men was published in 1963 and secured a cult following among seekers of the 'higher consciousness'.

Gurdon, Sir John Bertrand (1933- ). English developmental biologist. Educated at Eton and Christ Church, Oxford, he held chairs in molecular biology and zoology at Cambridge and was Master of Magdalene College, Cambridge, 1995-2002. He shared the 2012 Nobel Prize for Medicine with Sinya Yamanaka for their demonstration that mature cells can be converted to stem cells.

Gürsel, Cemal (1895-1966). Turkish soldier and politician. After serving with distinction in World War I and under Kemal *Atatürk, he became Commander-in-Chief in 1958. When replaced (1960), he led a military revolt against the unpopular Prime Minister ${ }^{*}$ Menderes, and became President of Turkey 1960-66, and Prime Minister 1960-61, retiring due to illness.

Gusmáo, Xanana (José Alexandre) (1946- ). Timorese politician. President of Timor Leste 200207, he was Prime Minister 2007-15, and Minister for Planning 2015- .

Gustaf I (Gustavus Vasa) (1496-1560). King of Sweden 1523-60. From a leading noble family, he led a successful revolt against the rule in Sweden of Christian II of Denmark. By confiscating Church lands he later established a national Protestant Church. He brought under his own direct control some of the lands held by the nobles, and encouraged trade and industry (partly by using a keen business sense to direct many concerns himself), thus bringing about financial stability and economic progress. Risings provoked by his policies were quickly suppressed. In alliance with Denmark he destroyed the domination of the Hanseatic towns and finally obtained from parliament a declaration that his dynasty should be hereditary.

Gustaf II Adolf (Gustavus Adolphus) (1594-1632). King of Sweden 1611-32. Son of *Karl IX by his second wife, he was preferred as king to a cousin with a better hereditary claim. Aided by his chancellor *Oxenstierna, his advisor throughout the reign, he re-organised the administration by defining the spheres of local and central governments with a proper apportionment of finance. Finding himself at war with three countries, he came to terms with Denmark, led a successful campaign against Russia (1617), and then turned against Poland with whom he concluded an armistice on favourable terms (1629). His object throughout was Swedish domination of the Baltic with command of the river mouths and therefore control of trade. In the hopes of achieving this through a Swedish controlled league of Protestant German states, in 1631 he took part, in agreement with the French, in the Thirty Years' War. He marched victoriously through Germany and at Breitenfeld in Saxony met and defeated the imperial general *Tilly, who was again defeated and mortally wounded at the passage of the Lech (1632). After overrunning much of Germany, Gustaf abandoned an attack on Austria to meet a threat to his rear by *Wallenstein, the result being the Swedish victory of Lutzen near Leipzig, in which Gustaf was killed. Gustaf's military innovations swept away the last medieval aspects of warfare from his campaigns. He introduced regimental uniforms, better discipline and also insisted on attention to the welfare of his troops. He provided them with lighter and more effective firearms and the consequent increase in mobility and fire power were main contributions to his military success.

Roberts, M., Gustavus Adolphus: A History of Sweden 1611-1632. 2 vols, 1953-58.

Gustaf III (1746-1792). King of Sweden 1771-92. Son of King Adolf Fredrik, of the House of HolsteinGottorp, he was born in Stockholm. One of the most remarkable 18th-century 'enlightened despots', he seized power from the parliamentary factions, the 'Hats' (pro-French and anti-Russian) and the 'Caps' (pro-Russian and anti-French), dissolved the Riksdag in 1772, granted freedom of the press, abolished torture, guaranteed religious toleration, provided poor relief, reorganised administration and taxation, simplified trade laws and was a great patron of the arts. He founded the Swedish Academy (1786) and the Royal Opera, wrote and acted in plays, and was a great orator and conversationalist. In February 1789, just before the French Revolution, he used the support of the commons to crush the remaining powers of the nobility. However, this did not endear him to constitutional liberals. Recognising that the French Revolution had made enlightened despotism obsolete, he tried to organise an army of intervention and his agent Count Fersen stage-managed the tragicomic flight of ${ }^{*}$ Louis XVI and *Marie Antoinette to Varennes. Many plots against Gustaf were laid by competing groups and on 16 March 1792, at a masked ball at his own opera house, he was shot in the back by Captain J. J. Anckarstroem and died 13 days later. This incident was the basis of *Verdi's opera The Masked Ball (1859), although censorship (anxious about the theme of regicide) required its setting to be changed to Boston.

Gustaf V (Oscar Gustaf Adolf Bernadotte) (18581950). King of Sweden 1907-50. Son of * Oscar II, during his long life he dined with *Disraeli and *Hitler. He attempted to maintain his monarchical prerogatives, and appointed a ministry (Hjalmar ${ }^{*}$ Hammarskjöld) that kept Sweden out of World War I but was heavily defeated in 1917 , after which the 
king lost his political authority. Fearful of the USSR, Gustaf was sympathetic to Hitler's invasion in 1941, but Sweden remained neutral in World War II. He was an active tennis player until his $80 \mathrm{~s}$. The court made payments to silence a presumed lover, at a time when homosexuality was a criminal offence.

Gustaf VI Adolf (Oscar Fredrik Wilhelm Olaf Gustaf Adolf Bernadotte) (1882-1973). King of Sweden 1950-73. In 1905 he married Princess Margaret of Connaught (1882-1920) and, in 1923, Lady Louise Mountbatten (1889-1965). An able archaeologist, he excavated in Greece, China and Italy, published studies on Chinese porcelain and was elected FBA (1958). His British honours were KG, GCB, GCVO and Royal Victorian Chain. He was the last Swedish monarch to have constitutional responsibilities. His son, also Gustaf Adolf (19061947), died in a plane crash, and his grandson *Carl XVI Gustaf (1946-) succeeded.

\section{Gustavus Adolphus see Gustaf II Adolf}

Guston, Philip (1913-1980). American painter, born in Montréal. He worked for the Federal Art Project 1935-40, and became one of the pioneers of Abstract Expressionism. His huge, crudely painted canvasses are profoundly disturbing social commentaries about urban life in contemporary US.

Gutenberg, Johannes (Johannes Gensfleisch zur Laden zum Gutenberg) (c.1400-1468). German printer, born in Mainz. The first European to print from movable type, he worked in Strasbourg 1430 44 and his first great achievement was the mass production of metal type from clay matrices, a distinct advance on Chinese or Korean woodblock printing. Around c. 1448 he returned to Mainz where a rich goldsmith, Johann ${ }^{*}$ Fust, financed his printing shop. After a quarrel (1455) and an action to recover his money, Fust acquired the press and conducted it with the aid of his son-in-law, Peter Schöffer. Meanwhile Gutenberg received support that enabled him to set up another press. These events and the absence of dates, names or colophons on works printed at Mainz make ascription difficult. The great 'Gutenberg Bible' (sometimes called the 'Mazarin Bible'), generally credited to him, was probably printed in 1455 . It is a magnificent edition (in Latin) of 1282 folio pages in double columns, each of 42 lines of Gothic type, decorated by coloured woodcuts in the margin. About 300 copies were printed, of which 45 survive. His next masterpiece was an extraordinarily elaborate Psalter, using multiple inking, which appeared in 1457 over the names of Fust and Schöffer after Gutenberg had lost control of his property. He may have experimented in copper engraving. Many other works are attributed to Gutenberg but without certainty.

Guterres, António Manuel de Oliveira (1949- ). Portuguese diplomat and politician, born in Lisbon. $\mathrm{He}$ was an academic, then a Socialist politician,
Prime Minister of Portugal 1995-2002, UN High Commissioner for Refugees 2005-15 and SecretaryGeneral of the United Nations 2017- .

Guthrie, Sir (William) Tyrone (1900-1971). British theatre director. He began as an actor and assistant stage manager with the Oxford Repertory Company in 1923. He then worked for the BBC, where he did much to realise the full potential of radio drama. He was Director of the Festival Theatre, Cambridge, 1929-30. His production of James *Bridie's The Anatomist in London, 1931, was successful and was followed by *Pirandello's Six Characters in Search of an Author (1932). He achieved wide recognition for his fresh approach to traditional plays with his work for the Old Vic Company and at Sadler's Wells Theatre.

Guthrie, T., A Life in the Theatre. 1960.

Guy, Thomas (c.1644-1724). English philanthropist. He was a bookseller in London from 1668, printer to Oxford University 1679-92 and MP 1695-1707. Successful speculation in South Sea shares enabled him to multiply the fortune made by trade and economical living. He endowed and built Guy's Hospital, Southwark with $£ 500,000$ in 1722 .

Guy-Baché, Alice (née Guy) (1873-1968). French film maker, born near Paris. From 1896 to 1922 she made over 400 films, 22 of them of feature length, founding the Solax Company in 1910. The first woman film director, she was forgotten after 1922 and died in the US.

Guzmán Blanco, Antonio (1829-1899). Venezuelan dictator. Leader of the 'Yellow' (liberal) faction in the civil wars of the $1860 \mathrm{~s}$, he was Acting President 1870-73 and President of Venezuela 1873-77, 1879-84, 1886-87 but, in effect, ruled as dictator for 20 years. He improved the Venezuelan economy, built up infrastructure but failed to help the peasants. Strongly anti-clerical, he became immensely rich and made long trips to Europe, leaving men of straw to rule in his absence. He was in Paris when, in 1889, one of these was overthrown by a revolution. He stayed there until his death.

Gwyn (or Gwynne), Nell (or Eleanor) (1650?1687). English courtesan. She is said to have started her career as an orange seller at Drury Lane, where she later acted. 'Pretty, Witty Nell' was the liveliest and most popular of ${ }^{*}$ Charles II's mistresses. He is alleged to have said on his deathbed 'Let not poor Nelly starve'. She bore him two sons, Charles and James Beauclerk, the former of whom became Duke of St Albans. It is said that she persuaded the king to found Chelsea Hospital for veteran soldiers.

Bevan, B., Nell Gwyn. 1969. 


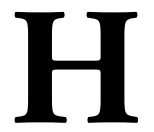

Haakon VII (Christian Frederik Carl Georg Valdemar Axel) (1872-1957). King of Norway 1905-57. Born near Copenhagen, known as Prince Carl of Denmark, a member of the ${ }^{*}$ Schleswig-Holstein-SonderburgGlücksburg dynasty, he served in the Danish navy and in 1896 married his cousin Princess Maud of Wales (1869-1938), daughter of the future ${ }^{*}$ Edward VII. When Norway's union with Sweden was dissolved, he was chosen (1905) to be king of the newly independent Norway, and revived the name Haakon, last used in 1380. His father became King of Denmark as Frederik VIII in 1906. In 1940 he led the resistance of his country to German aggression, at home and later from England. His son *Olaf V succeeded to the Norwegian throne.

Haber, Fritz (1868-1934). German chemist, born in Breslau (Wroclaw). A non-practising Jew (and Lutheran convert), he was educated at Karlsruhe and became professor of physical chemistry there 190811, and Director of the Kaiser Wilhelm Institute for Physical Chemistry, Berlin 1911-33. With Carl *Bosch, he developed (1908-09) a process for nitrogen fixation from the air, which led to production of ammonia and nitrates on an industrial scale, a discovery that made him very rich and transformed the manufacture of fertilisers, herbicides and explosives. His contributions to German agriculture and munitions were vital in World War I, and he also promoted the use of chlorine and mustard gases as weapons. His first wife, Clara Helene Immerwahr (1870-1915), the first German woman with a PhD in chemistry, and a pacifist, committed suicide. His award of the Nobel Prize for Chemistry in 1918 was controversial as Haber faced investigation as a war criminal. He also invented the herbicide Zyklon B, later used in Nazi extermination camps. Despite his fanatical patriotism, he had to leave Germany in 1933, was unhappy in Cambridge and soon died in Basle.

\section{Haber, L. F., The Poisonous Cloud. 1986.}

Habermas, Jürgen (1929- ). German social theorist. He taught philosophy at Heidelberg, Frankfurt and Starnberg. In his major texts, notably Theory and Practice (1963, translated 1973), he proposed a major anti-positivist critique of human knowledge, arguing that science is not value-free, and that reason is often applied as an instrument of authority and oppression.

Habibie, B(ucharuddin) J(usuf) (1936-2019). Indonesian engineer and politician. Educated at Aachen, he was an aeronautical engineer with Messerchmitt, became Minister for Research and Technology 1978-98 and *Soeharto's Vice President 1998 . His family controlled 80 companies in the power, transport and engineering sectors. On Soeharto's sudden resignation in May he became President of Indonesia 1998-99 and promised some moderate reforms. He supported a plebiscite in East Timor which resulted in a vote for independence, provoking extraordinary violence, directed by the Indonesian army and militia supporters, leading to intervention by a UN peace-keeping force. Habibie lost credibility and withdrew as a presidential candidate in 1999.

Habsburg (or Hapsburg). German-Austrian dynasty. Radbot, Count of Klettgau (985-1045), originally from Swabia, built the fortress of Habsburg in 1020 at Aargau, Switzerland, and its name was adopted by his dynasty. From Rudolf I (1218-1291) in 1273, several Habsburgs were elected as kings of the Germans. They became Archdukes of Austria in 1282 and kings of Hungary and Bohemia 1437-57; 1526-1918. Habsburgs were elected as Holy Roman Emperors almost continuously from *Friedrich III in 1440. The male line, extinct in Austria in 1740, survived through ${ }^{*}$ Maria Theresa's descendants. *Franz II assumed the title of Emperor of Austria in 1804 and in 1806 the Holy Roman Empire, by then moribund, was dissolved. The last Habsburg emperor, *Karl (Charles), was deposed after World War I. His son Otto von ${ }^{*}$ Habsburg-Lothringen became the pretender.

The Habsburgs were immensely successful in acquiring territories through dynastic marriages, including the Low Countries from 1482 and Spain (and the New World) which they ruled from 1516 to 1700 .

*Felipe (Philipp), son of the emperor ${ }^{*}$ Maximilian, married Juana, heiress of ${ }^{*}$ Ferdinand of Aragon and *Isabella of Castile. Their son *Charles $\mathrm{V}$ became King of Spain, as Carlos I, before his election as Holy Roman Emperor. The partition after his abdication left the imperial title and the central European lands to his brother ${ }^{*}$ Ferdinand, Spain with its overseas possessions, and the Low Countries to his son ${ }^{*}$ Felipe II. When ${ }^{*}$ Carlos II died in 1700 , and the male line became extinct, the Bourbons succeeded the Habsburgs in Spain. Inbreeding over centuries had led to serious genetic defects.

Taylor, A. J. P., The Habsburg Monarchy, 1809-1918. 1948; Evans, R. J. W., The Making of the Habsburg Monarchy, 1550-1700. 1979; Judson, P. M., The Habsburg Empire: A New History. 2016; Mitchell, A. W., The Grand Strategy of the Habsburg Empire. 2018; Rady, M., The Habsburgs: The Rise and Fall of a World Power. 2020.

Habsburg-Lothringen. Austrian dynasty. With the death of Emperor ${ }^{*}$ Karl VI in 1740, the male Habsburg line became extinct. His daughter *Maria Theresa married *Franz (François) of Lorraine (Lothringen in German) and a new dynastic name was adopted. 
Habsburg-Lothringen, Otto von (baptised as Franz Joseph Otto Robert Maria Anton Karl Max Heinrich Sixtus Xavier Felix Renatus Ludwig Gaetan Pius Ignatius) (1912-2011). Austrian-German political activist, writer and former Archduke. Son of *Karl I, last Kaiser of Austria and King of Hungary, and Zita of Bourbon-Parma, he was the final Crown Prince of Austria-Hungary 1916-18. Exiled from Austria 1919-66, he grew up in Spain, lived in France, Switzerland, the US and Bavaria and was fluent in seven languages. From 1922 monarchists recognised him as Emperor-King (Kaiser-König) since his father never formally abdicated. Francisco *Franco offered him the Spanish throne in 1961 but he declined. After years as a stateless person, he became a German citizen in 1978. A conservative, deeply opposed to Nationalism, Nazism and Communism, he was President of the International Pan-European Union 1973-2004 and a Member of the European Parliament 1979-99.

Hadid, Dame Zaha Mohammad (1950-2016). Iraqi-British architect, born in Baghdad. Trained in Beirut and London, her works included museums, art galleries, bridges and offices in England, Scotland, China, Japan, Germany, Italy, France and Australia. The first woman awarded the Pritzker Architecture Prize (2004), she won the Stirling Prize in 2010 and 2011 and the RIBA Gold Medal in 2015. Her works were described as 'sweeping fluid forms of multiple perspective points and fragmented geometry'.

Hadrian (Publius Aelius Hadrianus) (76-138). Roman Emperor 117-38 CE. He was probably born in Italica, Hispania Baetica, near modern Seville, where his Italian colonising family had settled about 250 years earlier. Educated in Rome and wellconnected there, he gained advancement through his father's cousin, the future emperor ${ }^{*}$ Trajan. He became Tribune of the plebs in 105 and Praetor in 106. He was made a provincial governor, on the Danube, in 107 and a consul in 108. This rapid rise was largely due to the favour of the politician Lucius Licinius Sura. Sura died shortly afterwards and Hadrian's advancement seemed at an end, but in 117 Trajan adopted him, assuring his succession when he died in August. He made lengthy tours of the Empire, 121-125 and 128-c.133. A philhellene, he preferred the eastern provinces and did much for the arts and for religious and public life in Greece. His tours in the rest of the Empire, however, had lasting results in the form of defence systems (such as Hadrian's Wall-Vallum Hadriani-in Britain, which marked the north-west boundary of empire) and both military and civil administrative reform. His periods of rule in Rome also produced judicial reforms of great importance. He rebuilt *Agrippa's Pantheon (118-25) to his own design: it is the oldest building in the world still in daily use. Hadrian's Villa in Tivoli demonstrates his passionate interest in architecture and travel. (He was also a poet.) When his lover Antinous (d.130) drowned in the Nile,
Hadrian proclaimed him divine and named a city for him. In 134 he made a last journey to Judaea to crush the Second Jewish Revolt (partly caused by his own ban on circumcision which he considered inhumane) and renamed Jerusalem as Aelia Capitolina. He nominated ${ }^{*}$ Antoninus Pius as his successor and died near Naples. Hadrian's Mausoleum in Rome (now Castel Sant'Angelo) was begun in 139.

Yourcenar, M., Memoirs of Hadrian. 1954.

Haeckel, Ernst (1834-1919). German zoologist. In 1861 he became lecturer in Medicine at Jena, in 1862 Professor of Zoology and in 1865 Director of the Zoological Institute. Although medically qualified, he had no desire to practise medicine clinically. Zoology was his first love, and much of his scientific career was occupied in work in comparative anatomy and morphology. The publication of Charles *Darwin's Origin of Species (1859) made an enormous impact on him. He accepted evolution readily. Thereafter his detailed zoological work was increasingly concerned with evaluating structure in terms of evolutionary adaptation. He was above all interested in the way in which the embryonic development of each individual creature showed (as he claimed) its own evolutionary history, or, as he put it 'ontogeny recapitulates phylogeny'.

Unable to accept either traditional Christianity or dogmatic materialism, Haeckel developed his own philosophy of Nature, 'monism', a form of pantheism which celebrated the progressive emergence of ever higher forms in Nature. Partly as a result of this, Haeckel gradually swung over to more Lamarckian forms of evolutionary theory, emphasising the participation of Will in the evolutionary process.

Hemleben, J., Ernst Haeckel. 1964.

Håfiz (or Hafez) (pen name of Khwāja Shams-udDīn Muhammad Hāfiz-e Shīrāzī) (1325/6-1389/90). Persian lyric poet and mystic, born in Shiraz, where he lived and died. The name 'Hafiz' is given to scholars who have memorised the entire Qu'ran. His poetry was held to be so sweet that he was called 'Chagarlab' ('sugarlip'). He was a Sufu, one of the mystic philosophical sects of Islam, and while his poetry superficially deals with sensuous delight and beauty and may be seen simply as love songs, it yet possesses a deeper esoteric significance. His tomb is a shrine and is visited by pilgrims from all parts of Iran. He was much admired by *Goethe.

Arberry, A. J., The Ghazals of Håfiz. 1947.

Hagen, Walter Charles (1892-1969). American golfer. Hagen, who played a notable part in the history of American golf, won the American Open championship twice, the British four times and took part six times in the competition for the Ryder Cup (once as a non-playing captain). 
Haggard, Sir H(enry) Rider (1856-1925). English author, born in Norfolk. He worked as an official in South Africa 1875-82, married, then returned to England. His African experiences provided the background of very successful adventure novels, which pioneered the 'lost world' literary genre: King Solomon's Mines (1885), She (1887), Allan Quatermain (1887) and Ayesha or The Return of She (1905).

Higgins, D. S. (ed.), The Private Diaries of Sir Henry Rider Haggard. 1980.

Hague, William Jefferson, Baron Hague of Richmond (1961-). English Conservative politician. MP 1989-2015, Welsh Secretary 1995-97, in June 1997 he became the Conservative Party's youngest leader since ${ }^{*}$ Pitt the Younger, resigning after his defeat in 2001. He served as Foreign Secretary 201014. First Secretary of State 2010-15 and Leader of the House of Commons 2014-15. He wrote William Pitt the Younger (2005).

Hahn, Otto (1879-1968). German physical chemist. In 1918, with Lise *Meitner, he discovered the radioactive element No. $91($ protactinium $=\mathrm{Pa})$ and in 1935 found evidence of four other elements corresponding to the atomic numbers 93, 94, 95, 96. In 1938 he succeeded in splitting the uranium atom and this basic discovery, as developed by Meitner and O. R. *Frisch, led to the production of the atomic bomb. Paradoxically, scientists expelled from Germany realised the implications of Hahn's discovery before Hahn himself. He remained in Germany through World War II as Director of the Kaiser Wilhelm Institute for Chemistry in BerlinDahlem 1928-46, won the 1944 Nobel Prize for Chemistry, and was President of the Max *Planck Institute at Göttingen 1946-60.

Hahn, Reynaldo (1874-1947). French composer, conductor and critic, born in Venezuela. Of GermanJewish-French-Basque descent, in Paris from 1877, he was a prodigy, achieving success at 13 with a setting of a poem by Victor *Hugo. He wrote many songs to poetry by ${ }^{*}$ Verlaine, ${ }^{*}$ Gautier, ${ }^{*}$ Heine and *Stevenson. A Chloris (1913) is the most performed. An intimate of Marcel ${ }^{*}$ Proust, he became a successful conductor and ${ }^{*}$ Mozart specialist, but his own operas are neglected.

Hahnemann, Christian Friedrich Samuel (1755-1843). German physician and founder of homoeopathic medicine. He studied medicine at Leipzig, Vienna and Erlangen where he graduated in 1779. He practised in Saxony, and settled in Dresden. $\mathrm{He}$ cultivated interests in medical chemistry, and published on related subjects, including the treatment of venereal diseases with mercurous oxide. From 1796 onwards he developed his own medical views, to be known as homoeopathy, spelt out in Organon der rationellen Heilkunde (Organon of Rational Healing, 1810). He had been persistently worried about harm caused by drugs ordinarily used. Hence he recommended testing out drugs on healthy persons, and ensuring the absolute purity of drugs, which were to be administered to patients in very small quantities. He believed that a drug that produced in a healthy body identical primary symptoms to those produced by a disease, was likely to be efficacious in curing the disease, since it would set up reactions in the body.

Hahnemann's fame grew (although he caught the anger of apothecaries since he prepared all drugs himself, and refused to administer more than one drug to patients at a time). In 1835 he remarried and set up in Paris, where he managed a large practice until the age of 88. Doctors were soon practising the homoeopathic system in almost every European country. In the US Konstantin Hering (1800-1880) was commissioned to attack it, was converted and devoted his life to further research.

Hobhouse, R. W., Christian Samuel Hahnemann. 1961.

Haidar Ali (1728-1782). Indian ruler. He served as a soldier under the Maharaja of Mysore, whom he virtually displaced as ruler. He fought successfully against the Mahrattas and also the British, with whom, however, he formed an alliance. When help under this alliance was refused in a renewed war against the Mahrattas he allied himself with the French, and ravaged the Carnatic to within 40 miles of Madras. He was ultimately defeated by Sir Eyre Coote. His son was ${ }^{*}$ Tippoo Sahib.

Haig, Alexander Meigs, Jr (1924-2010). American soldier and administrator. Educated at West Point and Georgetown University, he was deputy to Henry *Kissinger in the National Security Administration 1970-73, Vice Chief of Staff in the US Army 1973, and, as White House Chief of Staff and Assistant to the President 1973-74, took a critical role in the resignation of Richard ${ }^{*}$ Nixon and the transition to Gerald *Ford. He was Commander-in-Chief of US and NATO forces in Europe 1974-79 and became Secretary of State under Ronald *Reagan 1981-82.

Haig, Douglas, 1st Earl Haig of Bemersyde (18611928). Scottish field marshal, born in Edinburgh. Son of a whisky distiller, he was educated at Brasenose College, Oxford. Inspector General of cavalry in India (1903-06), he was again there (1909-11) as Chief of the General Staff. Meanwhile he had been Director of Military Training at the War Office in London. During World War I he took the 1st Corps to France (1914), commanded the 1st Army (1915) and after Sir John *French's recall was Commander-in-Chief on the Western Front from 1915 until the end of the war. He was thus responsible for the Battle of the Somme (1916), the Passchendaele campaign (1917) and the final victorious offensive (1918), undertaken in cooperation with Marshal *Foch. He was granted an earldom, the $\mathrm{OM}$ and a KT and voted $£ 100,000$ in 1919. He retained the confidence of the British 
public throughout the war despite his bitter quarrels with the Prime Minister, ${ }^{*}$ Lloyd George, but in recent years his handling of the British armies has been severely criticised, especially since the publication (1952) of his private papers. He was devoted to the welfare of ex-servicemen and the creation of the British Legion was largely his work. He asserted that in future wars, horses would still be more significant than aircraft or tanks.

Sixsmith, E. K. G., Douglas Haig. 1976.

Haile Selassie (1891-1975). Emperor of Ethiopia 1930-74. His father Ras Makonnen, had been cousin of the emperor * Menelik, and before succeeding to the throne he was known as Ras Tafari. The Rastafarian movement, very strong in the Caribbean, was named for him. He led the revolt against Menelik's grandson Lij *Iyasu and acted as regent for Menelik's daughter Zauditu from 1917 until her death (1930), when he succeeded her on the throne. The Italian conquest of his country forced him to take refuge in England (1936) but in World War I the British drove the Italians from Ethiopia and restored him to his throne (1941). Despite his attempts at social and economic reform, such as abolishing the slave trade and setting up a parliament, his country remained one of the most backward in Africa. He was deposed in 1974 and smothered to death.

Kapuscinski, R., The Emperor. 1983.

Hailsham of St Marylebone, Quintin McGarel Hogg, Baron (1907-2001). English Conservative lawyer and politician. His father was Douglas Hogg, 1st Viscount Hailsham (1872-1950), Attorney General 1922-24, 1924-28 and Lord Chancellor 1928-29, 1935-38. He became a barrister, served as MP 1938-50 (leaving the Commons reluctantly on his father's death) and again 1963-70, having renounced his viscountcy to contest the Tory leadership on *Macmillan's resignation (1963). Lord President of the Council 1957-59, 1960-64, Minister for Science and Technology 1959-64, he accepted a life peerage in 1970 and was Lord Chancellor 197074, 1979-87. He was awarded a CH (1975) and KG (1988). His grandfather, also Quintin Hogg (18451903), founded the Polytechnic in Regent Street, London (1880).

Haitink, Bernard (1929-2021). Dutch conductor. $\mathrm{He}$ was principal conductor or music director of the Netherlands Radio Philharmonic Orchestra 1955-61, the Concertgebouw Orchestra, Amsterdam 1964-88, London Philharmonic Orchestra 196779, Glyndebourne Opera 1978-88, Royal Opera House, Covent Garden 1987-2002 and the Chicago Symphony Orchestra 2006-10. He received an honorary $\mathrm{KBE}$ and $\mathrm{CH}$.

Hakluyt, Richard (1552-1616). English geographer. He may have acquired his passionate interest in geography from a cousin, a lawyer to the Muscovy
Company. A student and lecturer at Oxford (c.1570 1588), he was ordained but became increasingly absorbed in reading about and discussing the great exploratory voyages of his time. By 1582 he had gained the friendship of ${ }^{*}$ Drake, ${ }^{*}$ Gilbert, ${ }^{*}$ Raleigh and other great seamen, and had written a book on the American discoveries. In 1583 an appointment as chaplain to the British Embassy in Paris gave him the opportunity to gather information about explorers of other countries. His greatest work, Principal Navigations, Voyages and Discoveries of the English Nation, appeared in 1589 (enlarged edition 15981600). After being appointed rector of Wetheringsett, Suffolk (1590), he worked hard as a propagandist for further American colonisation. In 1602 he became a canon of Westminster Abbey where he is buried. The Hakluyt Society was formed in 1846.

Haldane, J(ohn) B(urdon) S(anderson) (18921964). English scientist, born in Oxford. He was the son of John Scott Haldane (1860-1936), an experimental physiologist who worked on the problem of gas exchanges in the blood, e.g. why divers suffer from 'the bends' and how poor ventilation in mines causes death, receiving the $\mathrm{CH}$ in 1928 and the Copley Medal in 1934. They experimented together, sometimes as 'human guinea pigs'. J. B. S. was educated at Eton (which he hated, but became school captain) and Oxford, graduating in mathematics and classics; he never had a science degree. He served in the Black Watch in World War I, then pursued research in genetics and went to Cambridge as Reader in Biochemistry 1922-25; 1926-30. Fullerian Professor at the Royal Institution 1930-32, he held chairs in genetics 1933-37 and biometry 1937-57 at University College, London. He predicted a postcarbon economy based on wind power and hydrogen (1923). In 1929 he proposed (independently from A. I. *Oparin in Russia) the 'primordial soup theory', a pioneering contribution to pre-biotic organic chemistry, an attempt to explain the creation of cellular life. His major scientific work lay in relating evolutionary biology to the development of studies of heredity. He succeeded in synthesising *Darwin's evolutionary theory and *Mendel's genetics. He was a pioneer of population genetics. During World War II he worked for the admiralty investigating the physiological aspects of life in, and escape from, midget submarines and similar underwater work. He used himself (and his friends!) as an experimental subject. In 1963 he coined the words 'clone' and 'cloning'.

Haldane was a dedicated populariser of science in such books as Daedalus, or Science and the Future (1924). A committed Marxist, he saw a future in which socialism and science together provided better living conditions and a more rational society for everyone. He helped the Republican Government in Spain during the Civil War. He wrote for the Daily Worker from 1937, joined the Communist Party in 1942 , left it in 1950 , becoming disillusioned over the 
*Lysenko issue in the USSR. However, he retained his admiration for Stalin.

He emigrated to India in 1957, became an Indian national in 1961 and died of cancer at Bhubaneswar.

Clark, R. W., J. B. S.: The Life and Work of J. B. S. Haldane. 1968; Subramanian, S., A Dominant Character: The Radical Science and Restless Politics of J. B. S. Haldane. 2020.

Haldane, Richard Burdon, 1st Viscount Haldane of Cloan (1856-1928). Scottish lawyer and politician, born in Edinburgh. Educated in Germany. he became a barrister, QC (1890), and Liberal MP 1885-1911. As Secretary of War 1905-12, he carried through major reforms in the armed forces, then became Lord Chancellor 1912-15 until forced from office by anti-German hysteria: he was given the OM as a consolation prize. He joined the Labour Party after the war, became its leader in the Lords and was Lord Chancellor again 1924. A distinguished amateur scientist and neo-Hegelian philosopher, he became FRS in 1906. He was the brother of John Scott *Haldane.

Campbell, J., Haldane. 2020.

Hale of Richmond, Baroness, Brenda Marjorie Hale (1945- ). English jurist, born in Leeds. Educated at Cambridge, she was a law professor at Manchester, justice of the High Court 1994-99, then the first woman appointed to the Court of Appeal 1999-2003 and as a Lord of Appeal in Ordinary 2004-09. A justice of the newly constituted Supreme Court of the United Kingdom 2009-20, she became Deputy President 2013-17 and President 2017-20.

Hale, Sir Matthew (1609-1676). English judge. Neutral in the Civil War, although he defended some Royalists ( ${ }^{*}$ Laud), he became a judge in the Court of Common Pleas (1654) under ${ }^{*}$ Cromwell, sat in parliament 1660, and was Chief Baron of the Exchequer Court 1660-71 and Lord Chief Justice 1671-76. He wrote History of the Pleas of the Crown.

Hales, Stephen (1677-1761). English scientist. He became an undergraduate at Corpus Christi College, Cambridge in 1696, decided upon a career in the Church, and became curate of Teddington in 1709 , remaining there for the rest of his life, much of which he gave over to scientific research. He was a convinced adherent of Newtonian natural philosophy, accepting the particulate nature of matter and a largely mechanistic set of explanations (he always preferred physics to chemistry). Like Robert *Boyle, he excelled in detailed experiments in which accurate weighing, measuring and recording were all important. Much of his work concerned experiments on plants, written up in his Vegetable Staticks (1727). He studied the rise of sap, measuring its pressure, and the variations of that pressure according to time of year and climatic conditions. He carried out impressive experiments upon transpiration.

The pressure of blood in animal arteries also drew his attention. He performed experiments to gauge its force in horses, oxen, dogs etc. He conducted important experiments on air. Although he did not recognise that air is made up of a mixture of gases, he did collect the vapours severally given off by different substances, in some cases as a result of burning. To collect these he invented the pneumatic trough. The ill effect of bad air in spreading disease concerned him, and led him to invent systems of ventilators that could be used on ships, in prisons and hospitals.

Halévy, Jacques François Fromental (1799-1862). French composer, writer and administrator. A pupil of ${ }^{*}$ Cherubini, he wrote 30 operas, including La juive (1835), La reine de Chypre (1841) and La dame de pique (1850), taught *Gounod and *Bizet and was admired by *Berlioz and *Wagner.

Halifax, Charles Montague, 1st Earl of (16611715). English Whig politician. As *William III's Chancellor of the Exchequer 1694-97, he was responsible for the establishment of the National Debt by issuing the first government loan to which the general public could subscribe. He moved the bill that established the Bank of England (1694) and gave it power to issue paper currency. He came into literary prominence as an author with Matthew ${ }^{*}$ Prior of a parody of *Dryden's Hind and the Panther and later was a patron of ${ }^{*}$ Addison and ${ }^{*}$ Congreve.

Halifax, 1st Earl of (new creation), Edward Frederick Lindley Wood (1881-1959). English Conservative politician. Son of Charles Wood, 2nd Viscount Halifax (1839-1934), a leading Anglo-Catholic, he was educated at Eton and Oxford, became a Tory MP 1910-25 and Minister for Education 1922-24 and Agriculture 1924-25. Created Baron Irwin on his appointment as Viceroy of India 1926-31, he tried to guide India towards dominion status, which displeased the British government, ${ }^{*}$ Gandhi began a civil disobedience campaign, and was imprisoned. Irwin then negotiated with Gandhi to establish some rapport with Congress. Back in England, he was Minister for Education again 1932-35, Chancellor of Oxford University 1933-59 and Leader in the House of Lords 1935-38, 1940. He succeeded *Eden as Foreign Secretary 1938-40, and was the primary instrument for Neville *Chamberlain's appeasement policy until a sudden conversion (September 1938) convinced him that Nazism had to be resisted, but he later equivocated. When Chamberlain resigned (May 1940), Halifax was a possible successor as Prime Minister and the first preference of ${ }^{*}$ George VI, but, recognising that he lacked *Churchill's aggression and advocacy skills and was unacceptable to the Labour Opposition, he withdrew from consideration. Ambassador to the US 1941-46, created earl in 1944, 
he received the OM in 1946, but was harshly criticised in The Second World War by Churchill, who privately dubbed him 'the holy fox'.

Birkenhead, Lord, Lord Halifax. 1965; Roberts, A. The Holy Fox. 1997; Lukacz, J., Five Days in London, May 1940. 1999.

Halifax, George Savile, 1st Marquess of (16331695). English politician and author. A Member of Parliament 1660-85, he was instrumental in securing the rejection of the bill for the exclusion of ${ }^{*}$ Charles II's brother James, Duke of York, from the succession (1681). For this he was made Marquess of Halifax (1682), and when the Duke became King as *James II, Halifax was made Lord President of the Council, but was soon dismissed for opposing the repeal of the Test Acts and the Habeas Corpus Act. Later he was one of the committee of peers that negotiated with *William of Orange about his accession as King. Known as 'the Trimmer', he attempted to vindicate his policies in The Character of a Trimmer (1688). He was actually a shrewd statesman whose advice, if taken, could have saved James' throne.

Foxcroft, H. C., A Character of the Trimmer. 1946.

Hall, Asaph (1829-1907). American astronomer. From 1862-91 he worked at the naval observatory at Washington. In 1877 he discovered the two satellites of Mars: Phobos and Deimos.

Hall, Charles Martin (1863-1914). American chemist. In 1886, simultaneously with Paul Heroult (1863-1914), his exact contemporary in France, he discovered the technique of electrolytically smelting aluminium from bauxite. He helped to found the American Aluminium Company in 1890, became its Vice President and left a fortune to Oberlin College.

Hall, Sir Peter (Geoffrey) (1932-2014). English geographer and planner. Educated at St Catherine's College, Cambridge, he held chairs at Reading, Berkeley and London and wrote Cities in Civilization (1998).

Hall, Sir Peter (Reginald Frederick) (1930-2017). English director. Educated at St Catherine's College, Cambridge, he produced and acted in repertory and became Director of the Royal Shakespeare Co., Stratford, 1960-68 and the National Theatre, London 1973-88. He was outstanding in *Shakespeare, ${ }^{*}$ Chekhov, ${ }^{*}$ Beckett and ${ }^{*}$ Pinter, directed operas by *Monteverdi, *Mozart, *Verdi, *Wagner and *Britten, and some films and television. He delivered the Clark Lectures in Cambridge (2000).

Hall, (Marguerite) Radclyffe (1886-1943). English author. She wrote several interesting novels including Adam's Breed (1924) before achieving a succès de scandale with Well of Loneliness (1926), a sympathetic study of lesbian characters.
Hall, Rodney (1935- ). Australian novelist, poet, musician and actor, born in Warwickshire. He grew up in Queensland from 1948. He twice won the Miles Franklin Award, for Just Relations (1982) and The Grisly Wife (1993), and was short-listed three times for the Man Booker Prize. Other novels include Kisses of the Enemy (1987), The Day We Had Hitler Home (2000), The Last Love Story (2004) and Love Without Hope (2007). He published 13 volumes of poetry, chaired the Australia Council 1991-94 and wrote the autobiographical popeye never told you (2010).

Hall, G(ranville) Stanley (1844-1924). American psychologist. President of Clark University, Mass. 1889-1920, and an important educator, he was Sigmund *Freud's first disciple in the US.

Hallam, Arthur Henry (1811-1833). English poet. A friend of *Tennyson, In Memoriam was inspired by his early death. His father, Henry Hallam (1777-1859), presented careful, accurate and welldocumented accounts of medieval and English constitutional history from a Whig viewpoint. He also wrote a history of European literature (4 volumes 1837-39).

Hallé, Sir Charles (1819-1895). Anglo-German conductor, pianist and teacher. $\mathrm{He}$ settled in Manchester in 1848 and founded (1857) the Hallé Orchestra. The first Principal of the Royal Manchester College of Music, he was knighted in 1888.

Haller, Albrecht von (1708-1777). Swiss-German physiologist, born in Bern. He studied medicine under *Boerhaave at Leyden, received his MD in 1727, and in 1736 became professor of anatomy, botany and medicine at the newly founded University of Göttingen. In 1744 he returned to his native Bern, where he spent the rest of his life in research and writing. His major work lay in physiology. He studied the operation of muscle fibres, and defined as irritability their action of contracting when under external stimulus (mechanical, thermal, chemical, or electrical). He recognised that the nerves as such played no part in this process. By contrast, sensibility was a property of tissues imbued with nerves. His studies of irritability and sensibility helped bring a major reorientation of human physiology in the latter part of the 18th century, away from the notion that the body was essentially mechanical in its operation, emphasising instead that the key to bodily function lay in the nervous system.

Haller also pursued researches on the circulation of the blood and the automatic actions of the heart. Having become addicted to opium (taken to relieve pain from gout and constant stomach disorders), Haller recorded his own observations upon its actions. He was an all-round man. Pious in religion, he wrote large quantities of verse, and was a pioneer bibliographer.

Lindskog, G. F., Albrecht von Haller. 1978; Frixione, E., Albrecht von Haller. 2006. 
Halley, Edmond (1656-1742). English astronomer. He went at the age of 20 to St Helena to make the first map of the stars of the southern hemisphere, and from there he observed (1677) the transit of Mercury across the sun. By collecting observations of 24 bright comets between 1337 and 1658 he predicted the appearance of the great comet of 1758 ('Halley's Comet') on the grounds that it was the same comet as those of 1531, 1606 and 1682 . He similarly predicted its later appearances. His observations on comets were collected in his Astronomiae Cometicae Synopsis (1705) which put forward theories of their motion based on the work of *Newton.

Halley discovered the 'proper motions' of the socalled fixed stars. He also compiled charts of magnetic deviation, published the earliest wind map (1688) and was the first to use a barometer to reckon heights. He was professor of geometry at Oxford 1700-03 and succeeded *Flamsteed to become the second Astronomer Royal 1721-42.

Ronan, C. A., Edmund Halley: Genius in Eclipse. 1970.

Halonen, Tarja Kaarina (1943- ). Finnish politician. A Social Democrat, she was a Member of Parliament 1979-2000, Foreign Minister 1995-2000 and President of Finland 2000-12.

Hals, Frans (1581/5-1666). Dutch painter. Of Flemish extraction, he lived in Haarlem. His first important painting was the life-size group portrait The Banquet of the Officers of the St George Civic Guard (1627), which is outstanding and unprecedented in its strong characterisation. His group portraits culminated in Regents of the St Elizabeth Hospital of Haarlem (1641) and Regentesses of the Old Men's Alms House (1664). In Dutch portrait painting, they assure him a position next to ${ }^{*}$ Rembrandt. Hals also painted genre scenes with dramatic chiaroscuro, and vigorous single portraits of which The Laughing Cavalier (1624) is the best known.

Trivas, N. S., The Paintings of Frans Hals. 1941.

Halsbury, Hardinge Stanley Giffard, 1st Earl of (1823-1921). English lawyer and Conservative politician, born in London. He became SolicitorGeneral under ${ }^{*}$ Disraeli $1875-80$, and served three times as Lord Chancellor 1885-86, 1886-92, 18951905. He led the 'diehards' against the Parliament Bill (1911) which stripped the House of Lords of its power to veto Budgets. The Laws of England, which he edited (1903-16) and which is continuously updated, bears his name.

Halsey, William Frederick, Jr('Bull') (1882-1959). American Fleet Admiral. He served with destroyers in World War I and by 1938, as Rear Admiral, commanded a carrier division. During World War II he proved himself one of the great fighting admirals then as Commander-in-Chief of the South Pacific area 1942-45 when he conducted the great sweep northwards in support of the army's island-hopping offensive by which the Japanese conquests were regained. He commanded the 3rd Fleet 1944-45 and destroyed the Japanese navy in the Battle of Leyte Gulf (October 1944).

Hamelin, Marc-André (1961- ). Canadian pianist and composer, born in Montréal. A virtuoso, with exceptional dramatic gifts, he performed works by *Alkan and ${ }^{*}$ Godowsky in addition to the standard repertoire, toured widely and recorded extensively.

Hamer, Sir Rupert James ('Dick') (1916-2004). Australian Liberal politician, born in Kew. An officer throughout World War II, he became a solicitor, Victorian MLC 1958-71, MLA 1971-81, and Minister 1962-72. He succeeded Henry *Bolte as Premier of Victoria 1972-81, initiating many reforms including abolishing capital punishment, establishing an Ombudsman, law reform generally, strongly supporting the environment, heritage and the arts.

Hamilcar (Hamílkas) Barca (d.228 BCE) Carthaginian (Punic) general, possibly born in Libya. The Carthaginians were Semites, descended from the Phoenicians (called 'Punic' by the Romans). His sons were *Hannibal, Hasdrubal and Mago, all generals. In the First Punic War against the Romans (264-241 $\mathrm{BCE})$, he commanded the Carthaginian army in Sicily and, after destruction of his navy, was forced to accept a humiliating peace (241), and also came under political attack from ${ }^{*}$ Hanno. He drowned after an ambush in Spain.

Hamilton, Alexander (1757?-1804). American statesman, born in Nevis, British West Indies. Illegitimate son of a Scottish merchant, he showed such precocity that he was sent to New York for further study. During the War of American Independence he was aide and confidential secretary to *Washington 1779-81 and later commanded in the field. His marriage (1780) to Elizabeth Schuyler assured him of a favourable social background. After the war he established a successful law practice in New York and attended (1787) the constitutional convention at Philadelphia. Though he would have preferred a more centralised and oligarchic form of government, he defended what emerged (as the best obtainable) in a brilliant series of articles in which he cooperated with James *Madison in The Federalist. Appointment by Washington as the first US secretary of the treasury 1789-93 made him one of the most influential leaders shaping the new state. He consolidated the state debts into a funded national debt, he advocated excise and tariffs as the principal source of revenue and created the first National Bank; opposition to these measures resting on the fact that they placed financial power in federal rather than state hands. Hamilton returned to his law practice in 1793 but remained an important figure behind the scenes in the councils of the 
Federalist Party. He quarrelled bitterly with Aaron *Burr, blocked his election as President (1800) and Governor of New York State (1804) and was killed by Burr in a duel (July 1804). The musical Hamilton (2014) by Lin-Manuel Miranda was premiered in New York in 2015 and won many awards.

Chernov, R., Alexander Hamilton. 2004; Randall, W. S., Alexander Hamilton. A Life. 2014.

\section{Hamilton, Charles see Richards, Frank}

Hamilton, George, 1st Earl of Orkney (16661737). Scottish peer and field marshal. Son of the Earl of Selkirk, he fought in Ireland for *William III, was wounded at Namur, and led his troops at Blenheim and Malplaquet. A courtier after 1714, he became the first British field marshal in 1735.

Hamilton, Sir Ian Standish Monteith (1853-1947). British general, born in Corfu. Scholarly, and a fine writer, he passed as an intellectual in the British Army. He served in India and South Africa and was GOC in the Mediterranean 1910-14. He commanded the Anglo-French-ANZAC Dardenelles expedition in 1915, was unrealistically optimistic about its outcome and bore responsibility for its failure.

Hamilton, Richard William (1922-2011). British artist and teacher. An influential teacher at the Institute of Contemporary Art in London, he was a founder of pop art and created many iconic images of artists, performers and consumer society and received a $\mathrm{CH}$ in 2000.

Hamilton, Sir William (1730-1803). Scottish diplomat, antiquarian, archaeologistand vulcanologist. Grandson of the 3rd Duke of Hamilton, he was Envoy Extraordinary to the Kingdom of Naples and Sicily 1764-1800. He became an expert on volcanoes (ascending Vesuvius 22 times), earthquakes and was awarded the Copley Medal in 1770. He published his Collection of Etruscan, Greek, and Roman Antiquities (1766-76) in four magnificent volumes; the objects were acquired by the British Museum. His wife, Emma, Lady Hamilton (née Lyon, also known as Hart) (1761?-1815), extravagant, beautiful and fascinating, had been his mistress from 1786. They married in 1791 . She became the lover of ${ }^{*}$ Nelson, bore his daughter Horatia Nelson (1801-1881) and died in obscure poverty in Calais.

Sontag, S., The Volcano Lover. 1992.

Hamilton, Sir William, 9th Baronet (1788-1856). Scottish philosopher. Educated at Glasgow and Balliol College, Oxford, he gained a reputation for vast erudition. He was professor of history at Edinburgh 1821-36 then of logic and metaphysics 1836-56. His main interest was to show that human knowledge is relative and is attained only in relation to known properties. J. S. *Mill wrote an extensive examination of his philosophy.
Hamilton, Sir William Rowan (1805-1865). Irish mathematician and astronomer, born in Dublin. A child prodigy, son of a solicitor, he was selfeducated. He could speak 13 languages at the age of 12 , made notable mathematical discoveries by 17 , became professor of mathematics at Trinity College, Dublin, at 22 and received a knighthood at 30 . In 1824 he discovered various peculiarities of conical refraction. He made a major contribution to establishing the wave theory of light, linking optics, mathematics and mechanics, in 1827. He followed and expanded ${ }^{*}$ Lagrange in reformulating classical mechanics (1834-35).

On 16 October 1843, in a sudden flash of inspiration, as he was crossing Brougham Bridge, Dublin, he grasped the concept of 'quaternions', a three-dimensional algebra or geometry in each object has four scalar variables, which can be processed as a single unit. (*Gauss had a similar insight in 1819 but his work was unpublished until 1900.)

Unlike normal mathematics, the order in which quaternions are multiplied is significant (they are 'noncommutative'): they led ultimately to the basis of quantum mechanics. However, by 1900 quaternions had largely been displaced by *Gibbs' 'vector analysis' but are still relevant in representing three dimensional transformations (for example, on computers.) The algebra of quaternions is denoted by ' $\mathbf{H}$ ' and was satirised by Lewis *Carroll. Hamilton received awards from Ireland, Russia, Prussia and the United States but was never elected FRS (despite receiving its Royal Medal in 1835). He died at 60, his life shortened by excessive eating and drinking. He suffered agonies from gout. His work is an important element in Thomas *Pynchon's Against the Day (2006).

Hamlin, Hannibal (1809-1891). American Republican politician, born in Maine. A lawyer and strong opponent of slavery, he served in the US Congress 1843-47, was US Senator 1848-57, 185761, and briefly Governor of Maine 1857. Elected with Abraham *Lincoln on the Republican ticket in 1860, he served as Vice President of the US 1861-65. Replaced by Andrew *Johnson at the National Union Convention in 1864 , Hamlin returned to the Senate 1869-81 and was Minister to Spain 1881-82.

Hammarskjöld, Dag Hjalmar Agne Carl (19031961). Swedish administrator, born at Jonkoping. Son of Hjalmar Hammarskjöld (1862-1953), Conservative Prime Minister 1914-17, jurist and Chairman of the Nobel Prize Foundation 192947, he studied law and economics at Uppsala and Stockholm and became a civil servant. Deputy Foreign Minister 1951-53, he succeeded Trygve *Lie as Secretary-General of the United Nations 1953-61. He extended the executive powers of the secretariat, especially by his organisation and utilisation of UN forces in the Congo (1961). While flying to Ndola in 
Northern Rhodesia on a truce making mission he was killed in an air crash. He was posthumously awarded the Nobel Peace Prize.

Lash, J. P., Dag Hammarskjöld. 1962.

Hammer, Armand (1898-1990). American businessman, born in New York. The son of a Russian émigré physician, he claimed to have been named for the emblems of the Socialist Labor Party. He became a doctor himself and in 1920 established personal links with *Lenin, leading to trade (wheat for furs, caviar and asbestos). He became a major producer of coal, sulphur and-after 1956-oil and gas (Occidental Petroleum). A tireless self promoter, many of his claims were exaggerated and his great art collection partly acquired by fraud.

Hammerstein, Oscar II (Greeley Clendenning) (1895-1960). American librettist, producer and publisher. He wrote the lyrics for many successful Broadway musicals including Rose-Marie (composed by Friml, 1924), The Desert Song (Romberg, 1926), Showboat (Kern, 1927) and a series with Richard *Rodgers: Oklahoma! (1943), South Pacific (1949), The King and I (1951) and The Sound of Music (1959).

Hammett, (Samuel) Dashiell (1894-1961). American author. As a young man he worked for the Pinkerton Detective Agency in New York, and gained the experience that helped him become the finest US writer of 'private eye' crime fiction. His best known works are The Maltese Falcon (1930) and The Thin Man (1934).

Johnson, D., The Life of Dashiell Hammett. 1983.

Hammond, Philip Anthony, Baron Hammond of Runnymede (1955- ). English Conservative politician. Educated at Oxford, he became a company director, MP 1997-2019, Secretary of State for Transport 2010-11; for Defence 2011-14; for Foreign and Commonwealth Affairs 2014-16 and Chancellor of the Exchequer 2016-19.

Hammurabi (d.c.1750 BCE). King of Babylonia c.1792-1750 BCE. He conquered all Mesopotamia and renamed Akkad as Babylonia, but is remembered for the code of laws named for him, a copy of which is in the Louvre, essentially derived from earlier codes.

Hampden, John (1594-1643). English parliamentary leader, born in Buckinghamshire. A large landowner, educated at Oxford, he was a Member of Parliament 1621-22, 1624-29, 1640-43. He rarely spoke in Parliament but was a very effective networker and organiser, and was imprisoned in 1627 for refusing to pay a 'forced loan'. He strongly supported the Petition of Right (1628), aimed at curbing ${ }^{*}$ Charles I's illegal practices, and in 1636 refused to pay 'ship money', a levy previously confined to ports. In 1637 his prosecution before the Court of Exchequer, made him a champion of liberties and the most popular man in England. When Parliament again met (1640) he was active in the impeachment of $*$ Strafford and one of the 'Five Members' whom Charles tried to arrest in the House of Commons in 1643. When war broke out he joined the parliamentary army, fought bravely at Edgehill, but died of a wound received in the skirmish of Chalgrove Field.

Adair, J., A Life of John Hampden the Patriot. 1976.

Hamsun, Knut (Pederson) (1859-1952). Norwegian novelist and dramatist, born at Lom, northern Norway. Of poor farming stock, in the 1880 s he spent two periods in the United States, where he worked as a dairy farmer, coal miner, shop assistant, fisherman and Chicago tram conductor. Back in Norway he was a school teacher. Deeply influenced by ${ }^{*}$ Nietzsche and *Strindberg, he became passionately concerned with the individual's role against his environment (in distinction to *Ibsen who, in Hamsun's view, wrote merely of men struggling within a partly alien society). His novel Hunger (1890), largely autobiographical, later became an outstanding film. Other works were Pan (1894), Victoria (1898), Look Back on Happiness (1912), The Growth of the Soil (1917) and The Women at the Pump (1920). He won the Nobel Prize for Literature in 1920. His profound hatred of modern capitalism made him a sympathiser with the Nazis: he collaborated with German occupation forces (1940) and met *Hitler. After the war, treason charges were dropped on account of his age but he was fined Kr.500,000 and his reputation suffered for a generation.

Han. Chinese dynasties, of native Chinese stock. The Western Han overthrew the *Qin dynasty, ruled 206 BCE-24 CE and expanded China's boundaries to Korea and Central Asia. Its capital was Xi'an. The Eastern Han ruled 25-220 CE from Luoyang when Buddhism was introduced.

Hancock, John (1736/7-1793). American merchant and politician, born in Braintree, Massachusetts. A rich Boston merchant, he was Governor of the Commonwealth of Massachusetts 1780-85, 178793, and President of the Continental Congress 177577, 1785-86. His large signature was the first on the US Declaration of Independence 1776.

Hancock, Sir (William) Keith (1898-1988). Australian historian, born in Melbourne. He held chairs in Adelaide, Birmingham, Oxford, London and Canberra, became first president of the Australian Academy of the Humanities 1969-71 and founded the multi-volume Australian Dictionary of Biography. His influential books include Australia (1930), a biography of *Smuts $(1962,1968)$ and Professing History (1976).

Davidson, J., A Three-Cornered Life. 2010.

Hancock, Winfield Scott (1824-1886). American soldier. He fought in the Mexican War (1846-48) but his fame rests on his success in the Civil War and 
especially at Gettysburg (1863) where, in command of the 2 nd Corps, he chose the position that stood firm against all General *Lee's attacks. Chosen as the Democratic candidate for President in 1880, he secured 48.3 per cent of the popular vote, a virtual dead heat with James *Garfield, but lost heavily in the Electoral College. He became president of the National Rifle Association (NRA) in 1881.

Hand, (Billings) Learned (1872-1961). American jurist. Educated at Harvard, he was a Federal District Court Judge 1909-24 and a Federal Circuit Court Appeals Judge 1924-51, establishing a lasting reputation for the learning, breadth and humanity of his judgments. He had been a supporter of Theodore *Roosevelt, then ${ }^{*}$ Hoover and Franklin *Roosevelt, opposed isolationism and was passed over for the Supreme Court in 1930 and 1932. He turned against judicial activism, and was especially critical of the *Warren Court's decision in the school desegregation case (Brown v. Topeka, 1954.)

Gunther, G. Learned Hand: The Man and the Judge. 1994.

Händel, George Frideric (1685-1759). GermanEnglish composer, born in Hallé, Saxony. Son of a barber-surgeon, he was a child prodigy and from the age of eight played the organ, violin and klavier and composed. His teacher, F. W. Zachau, was the organist of Hallé Cathedral. After studying law at Hallé University (1702), Händel worked as a violinist and conductor at the Hamburg opera (1703-06) where his first two operas Almira and Nero (both 1705) were performed. In 1707 Händel went to Italy where he wrote much music and earned international fame but failed to gain a permanent appointment. In 1710 he was appointed Kapellmeister to the Elector of Hanover, who succeeded to the English throne as *George I (1714). Händel went to London for the production of his opera Rinaldo (1711), and after a brief return to Hanover to resign his appointment, took up permanent residence in England (1712). He was pensioned by Queen *Anne for his Birthday Ode (1713) and received the patronage of the Earl of *Burlington and the Duke of Chandos (171215, 1718-20). He composed 40 operas in England of which the best known are Giulio Cesare (1724), Rodelinda (1725), Alcina (1735), Berenice (1737), Serse (Xerxes, 1738).

In 1719 Händel's patrons founded the Royal Academy of Music as a joint stock company for the promotion of Italian opera. He was made director of the project and also managed the King's Theatre 1728-34.

After 1735 Händel devoted himself to the composition of oratorio and produced a series of spacious, vigorous dramatic works including Alexander's Feast (1736), Saul (1738), Israel in Egypt (1738), Messiah (1742), Samson (1744), Belshazzar (1745), Judas Maccabaeus (1745), the lavish and operatic Solomon (1749) and Jephtha (1751). His instrumental works include the suites Water Music (1717) and Music for the Royal Fireworks (1749), 16 concertos for organ and orchestra (1738-40), 18 Concerti grossi for orchestra (1734-39), 16 harpsichord suites, and solo works for a variety of instruments.

Händel's health began to fail in 1743 and in 1751 he became partially blind. He was operated on by John Taylor, who had been even less successful with J. S. *Bach, and lost his sight completely by 1753 . On his death he left $£ 20,000$ to charity, and was buried in Westminster Abbey. He was an internationally famous cosmopolitan whose religious works were essentially designed for the theatre and concert hall. *Beethoven considered him the greatest of all composers, and he is still regarded as one of the outstanding musical figures of the 18th century. He never married.

Lang, P. H., George Frederick Handel. 1966; Robbins Landon, H. C., Händel and his World. 1984; Burrows, D. (ed.), The Cambridge Companion to Händel. 1997; Deutsch. O. E., Händel. 2004.

Haneke, Michael (1942-). Austrian film director, born in Munich. His parents were actors, he read philosophy at Vienna University, becoming a critic and television director. His powerful films include The Piano Teacher (2001), Caché (Hidden, 2005), The White Ribbon (2009), and Amour (2012), which won the Academy Award for Best Foreign Film.

Hanna, Mark Alonzo (1837-1904). American Republican politician. 'Boss' Hanna controlled the Republican Party in Ohio, was an innovator in centralised control of campaigns, secured the 1896 Presidential nomination for William ${ }^{*}$ McKinley and served as US Senator 1897-1904.

Hannibal (Hanniba'al) Barca (c.247-c.183 BCE). Carthaginian (Punic) soldier, born in Carthage (now in Tunis). Son of ${ }^{*}$ Hamilcar Barca and brother of Hasdrubal (Azrubaal) (245-207 BCE) and Mago (243-203 BCE), both generals, from 221 he commanded in Spain (Hispania) and by 219 had won all of the south as far as the Ebro River, except for the Roman enclave of Saguntum. Its fall (218), by removing the threat to his rear, enabled him to launch the Second Punic War (218-201 BCE). From Cartagena (Spain) he led an army of about 40,000 , supported by 37 elephants, to the east of the Pyrenees, into Gaul, down the Rhône Valley, defeating the Gallic tribes that barred his way, and after almost insuperable difficulties crossed the Alps. At the first great battle on the River Trebbia, he scattered the Roman army and, marching on towards Rome, crossed the Apennines (where he lost an eye) and defeated (and killed) Gaius Flaminius at Lake Trasimene (217). Skilful delaying tactics by ${ }^{*}$ Fabius Maximus gave the Romans time to recover but in 216 Hannibal crushed another Roman army under less cautious generals at Cannae, probably Rome's greatest military defeat. Although not strong enough to take Rome, Hannibal maintained himself in southern 
Italy and although through the years his army dwindled and he could not get reinforcements, he still managed, by his masterly skill, to win several pitched battles. At last in 207 his brother Hasdrubal marched from Spain in a daring effort to relieve him but before junction could be made was defeated and killed at the Battle of Metaurus river. In 203 Hannibal was finally recalled to Carthage to meet a Roman invasion and in 202 his first defeat was inflicted on him by *Scipio Africanus at Zama, and the war ended, with Carthage losing control of Spain and paying a heavy indemnity. Hannibal became the head of the Carthaginian government but political opposition to his reforms, and Roman pressure, made him a voluntary exile. Hannibal departed for Tyre, then Antioch where, from 196 to 190 , he was a general for *Antiochus III, ruler of the Seleucid Empire. After time in Crete, he served Prusias I Cholus, king of Bithynia. There are contradictory accounts of his death, which occurred in Libyssa, on the Sea of Marmara: he may have poisoned himself on learning that Prusias proposed to surrender him to the Romans, or died (blood poisoning?) after a wound to his hand.

One of the greatest generals of antiquity, Hannibal was much admired by ${ }^{*}$ Napoléon and ${ }^{*}$ Freud.

Toynbee, A. J., Hannibal's Legacy. 1963; Cottrell, L., Hannibal: Enemy of Rome. 1992; Mahaney, W., Hannibal's Odyssey. 2008; Hoyos, D., Hannibal: Rome's greatest enemy. 2008; MacDonald, E., Hannibal: A Hellenistic Life. 2015.

Hanno (Hannon; also known as Hanno the Great) (3rd century BCE). Carthaginian (Punic) general and oligarch. He was a powerful opponent of *Hamilcar and ${ }^{*}$ Hannibal, who pursued the First and Second Punic Wars against Rome. He favoured the exploration and settlement of North Africa, cultivating relations with Rome and not competing in the Mediterranean.

Hansard, Luke (1752-1828). English printer, born in Norwich. He printed the verbatim reports of debates in the House of Commons and bought the business in 1798. His family owned the concession until 1889 . Parliamentary reports are known as Hansard in Britain, Canada, Australia and New Zealand.

Hanson, Pauline (née Seccombe) (1954- ). Australian politician. She was a Federal MP 199698, founding her own party, Pauline Hanson's One Nation, which opposed multiculturalism and concessions to Indigenous people. Jailed for fraud in 2003, her conviction was overturned on appeal. After repeated defeats, she was elected as a Senator, with three supporters, in July 2016.

Hansson, Per Albin (1885-1946). Swedish Social Democratic politician. He worked as a clerk, journalist and trade union organiser before election to the Riksdag in 1918. He served as Defence Minister 1921-23 and 1924-26. He succeeded Hjalmar *Branting as party leader 1923-46 and was Prime Minister 1932-36 and again, after a short break, 1936-46, dying in office. He promoted the welfare state and maintained strict neutrality during World War II. On his death Tage *Erlander became Prime Minister.

Han Suyin (pen name of Elizabeth Comber, née Rosalie Matilda Kuanghu Chow) (1916-2012). British writer, born in Beijing. Her father was Chinese and her mother Belgian. She studied medicine in Beijing, Brussels and London, then practised in Hong Kong, Malaysia and Singapore. She wrote the novels A Many Splendoured Thing (1952), My House has Two Doors (1980) and Tigers and Butterflies (1990), a study of Mao and the Chinese Revolution, and an autobiography.

\section{Hapsburg see Habsburg}

Harald Bluetooth (Old Norse: Blatonn) Gormsson (Danish: Harald Blåtand Gormsen) (d.c.986). King of Denmark 958-86 and Norway 970-75. Son of Gorm the Old, he introduced Christianity to Denmark, built fortresses and bridges and is commemorated by the Jelling runic stones. Bluetooth wireless technology was named for him in 1997, and its icon $\mathscr{B}$ combines the runes for $\mathrm{H}$ and $\mathrm{B}$.

Harcourt, Sir William George Granville Venables Vernon (1827-1904). English Liberal politician, born in York. Of remote Plantagenet descent, he was educated at Cambridge, became a barrister (QC), Liberal MP 1868-1904 and Whewell professor of international law at Cambridge 1869-87. He served under *Gladstone as Home Secretary 1880-85, Chancellor of the Exchequer 1886 and 1892-95, and introduced death duties. He succeeded Lord *Rosebery as Leader of the Liberal Party 1896-98, resigning because of opposition to his anti-imperialist policies.

Hardenberg, Karl August von, Prince (Fürst) (1750-1822). Prussian administrator. Originally in the service of ${ }^{*}$ George III (as King of Hanover), he was Prussian Foreign Minister 1804-06; 1807; 1814-18 and Chancellor 1810-22. *Napoléon demanded his dismissal when he conquered Prussia in 1806. As Chancellor, he secured some remarkable reforms, including the emancipation of the Jews and the abolition of serfdom. He was created a prince in 1814 and in the negotiations that followed Napoléon's downfall he achieved the aggrandisement of his country, especially in the Rhineland. He represented Prussia at the Congress of Vienna $1814-15$ but was outwitted by ${ }^{*}$ Metternich. He stayed in office until his death but became increasingly bureaucratic in old age.

Hardie, (James) Keir (1856-1915). British Labour politician, born in Lanarkshire. He worked as an errand boy and in a mine before taking to journalism (1882-87). He became secretary of the newly formed Scottish Mines Federation (1886). He was elected 
(1892) to parliament for West Ham as the first and then only Labour member. He lost the 1893 election but was elected consistently for Merthyr Tydfil 190015. Meanwhile the Independent Labour Party had been formed with Keir Hardie as Chairman 18931900. He was the first and most revered leader of the parliamentary party 1900-11, devoting himself to the cause of the unemployed. A lifelong pacifist, he was deeply opposed to the Boer War and disillusioned by the failure of international socialism to stop World War I, but tinged with anti-Semitism.

Morgan, K. O., Keir Hardie. 1975.

Harding, John (né Allan Francis), 1st Baron Harding of Petherton (1896-1989). English field marshal. He began his army career as a subaltern in World War I, and rose to Chief of Staff, Allied Army in Italy, 1944. As C-in-C of Far East Land Forces 1949-51, his troops suppressed the Malayan insurgency. Promoted Chief of the Imperial General Staff 1952-55, he used extreme force against the Mau Mau rising in Kenya, setting up concentration camps, with 1090 executions, unprecedented in the British Empire. As Governor of Cyprus 1955-57, he imposed martial law against Greek-Cypriot nationalists, with suspension of the rule of law, concentration camps, nine executions and the banishing of Archbishop *Makarios. He was rewarded with a barony in 1958.

Harding, Warren Gamaliel (1863-1923). 29th President of the US 1921-23. Born in Corsica (Blooming Grove), Ohio, son of a homoeopath, and educated at Ohio Central College, he was editor and owner of the Marion Star 1884-1914, entering Ohio politics as a state senator 1900-04, Lieutenant Governor 1904-06 and a US senator 1913-21. As a senator, he avoided voting on contentious issues when he could, and his voting record ranked 78 th out of 96 . He rarely spoke and originated no legislation. He opposed ratification of the Versailles Treaty. Theodore * Roosevelt indicated that he would seek the Republican presidential nomination in 1920 and his sudden death (1919) left an open field. Republican powerbrokers who favoured a weakened presidency secured Harding's nomination at the Chicago Convention on the 10th ballot. Harding was elected in November 1920 with 60.3 per cent of the vote, defeating James M.*Cox, also from Ohio, promising a return to 'normalcy', after *Wilson's years of strenuous idealism. His Cabinet included some able men (Charles Evans *Hughes, Herbert *Hoover, Andrew ${ }^{*}$ Mellon and Henry *Wallace, Sr) but also small-time fixers (Harry Daugherty and Albert Fall). The 'Teapot Dome' scandal involving conflict of interest in the sale of oil leases, and revelations of embezzlement and frauds by people he trusted, destroyed Harding's reputation after his death. He was surprisingly liberal on racial issues, advocated ending the 12-hour day and child labour, set up the US Budget Bureau, released Eugene ${ }^{*}$ Debs and took the US into the World Court. After visiting
Alaska and British Columbia, Washington State and Oregon, he died suddenly in San Francisco, probably of coronary thrombosis, after food poisoning and pneumonia. Tall, handsome, the image of the elder statesman as portrayed in the movies of the time, likeable, with an easygoing temperament, he became a symbol of small-town self-interest, the world of Sinclair *Lewis' novels. In 20 Presidential ranking lists by US historians and political scientists, Harding scored No. 38 in the aggregate.

Sinclair, A., The Available Man. 1965; Russell, F., President Harding. 1969; Dean, J. W., Warren G Harding. 2004.

Hardinge, Henry, 1st Viscount Hardinge (17851856). English field marshal. He served under *Wellington, was a Tory MP 1820-44, Secretary at War 1828-30; 1841-44, Chief Secretary for Ireland 1830; 1834-35, and Governor General of India 1844-48. He succeeded Wellington as Commander-in-Chief of the Forces 1852-56 and made a disastrous start to the Crimean War. His grandson, Charles Hardinge, 1st Baron Hardinge of Penshurst (1858-1944), was a distinguished ambassador to Russia 1904-06 and Under Secretary for Foreign Affairs 1906-10; 1916-20. As Viceroy of India 1910-16, he moved the Indian capital from Calcutta to Delhi (1911), cultivated relations with *Gandhi and secured Indian recruits for World War I. Ambassador to France 1920-23, he received six knighthoods.

Hardwicke, Sir Cedric Webster (1893-1964). English actor. He first came to prominence with the Birmingham Repertory Company, where he shone in *Shakespeare and *Shaw, was knighted in 1934 and worked in the US from 1937 . He took character roles in 75 films, working with ${ }^{*}$ De Mille, ${ }^{*}$ Hitchcock, *Olivier and many other directors.

Hardwicke, C. and Brough, J., A Victorian in Orbit. 1962.

Hardy, G(odfrey) H(arold) (1877-1947). English mathematician. Educated at Winchester and Cambridge, he was a Fellow of Trinity 1900-19; 1931-47, and held chairs in Oxford, Princeton and Cambridge. Close to Bertrand ${ }^{*}$ Russell and J. M. ${ }^{*}$ Keynes, he mentored Srinivasa *Ramanujan, wrote A Mathematician's Apology (1940), was a passionate advocate for 'pure mathematics' and received the Copley Medal (1947).

Hardy, Thomas (1840-1928). English novelist and poet, born in Dorset. The West Country as 'Wessex' was the background of his novels and of his whole life. Articled to an architect, he did some work as a restorer of churches before turning to literature. He married (1874) Emma Louisa Gifford and they lived at Max Gate, near Dorchester, built to his own design. His first novel, Desperate Remedies (1871), could be described as a 'thriller' and though he became more and more 
interested in character he never disdained a strong plot or a melodramatic situation. Of the novels that immediately followed, the best known are Under the Greenwood Tree (1872), Far from the Madding Crowd (1874), The Return of the Native (1878), The Mayor of Casterbridge (1886), and The Woodlanders (1886-87). Hardy was by then widely read and esteemed, but Tess of the D'Urbervilles (1891), one of the greatest novels in English, was bitterly assailed by conventional moralists for condoning the immoralities of its tragic heroine. This attitude and similar attacks on Jude the Obscure (1895) so disturbed Hardy that after the publication of The Well Beloved (1897) he wrote no more novels, but found a new reputation as a poet with the publication of Wessex Poems (1898) and Poems Past and Present (1901). He considered the highest pinnacle of his literary achievement was The Dynasts (1904-08), a colossal epic-drama, written in blank verse, of the Napoléonic wars. It embodies, with a classical fatalism, his view of man as a weak creature struggling against the inexorable forces of nature and the gods, but its inflated style alienated many readers.

He received 25 nominations for the Nobel Prize for Literature: all failed. In 1910 he was awarded the OM. In 1913 his wife died, and he married Florence Dugdale in 1914. Hardy continued to write, mainly poetry, into old age.

Gittings, R., The Young Thomas Hardy. 1975; The Older Thomas Hardy. 1978; Tomalin, C., Thomas Hardy. The Time Torn Man. 2006.

Hardy, Sir Thomas Masterman, 1st Baronet (1769-1839). English sailor. He served under *Nelson as flag-captain of the HMS Victory 1803-05. At Trafalgar, it was to him that Nelson, as he died, addressed the (disputed) words 'Kiss me, Hardy'. He became First Naval Lord 1830-34 and was promoted to Vice Admiral (1837).

Harewood, George Henry Hubert Lascelles, 7th Earl of (1923-2011). English arts administrator. Son of the 6th Earl of Harewood and Princess * Mary, the Princess Royal, he was educated in Cambridge, served in the guards in World War II and was a prisoner in Germany. He was an effective arts administrator in the UK and Australia and an active campaigner against the death penalty.

Hargrave, Lawrence (1850-1915). Australian inventor, born in England. Son of a judge, he migrated to New South Wales in 1865, worked as an engineer, became involved in exploring New Guinea and in astronomical observation. He invented a compressed air engine (1889) and a box kite (1894) in which he flew briefly. The importance of his work was unrecognised by contemporaries.

Hargreaves, James (1720-1778). English inventor, born in Oswaldtwistle, Lancashire. He was working as a carpenter in the calico mills of Robert Peel (the statesman's grandfather) when, between 1764 and
1767, he invented a 'spinning jenny' capable of spinning eight threads at once. He had to move to Nottingham (1768) when fellow workers broke into his house and destroyed the frame. Later he became a partner in a small cotton mill. Delay in patenting (1770) prevented him gaining a great fortune, but he died in comfort.

Harington, Sir John (1561-1612). English poet and inventor. A godson of Queen *Elizabeth, his wit gave him privileges at court although he was sent to the country for a time for fear that his verses might corrupt the ladies-in-waiting. This gave him time to write a complete translation of *Ariosto's Orlando Furioso (1591) but he had returned by 1596 , when he published anonymously Metamorphosis of Ajax, in which he playfully advocated the earliest design for a type of flush water-closet, apparently of his own invention. He was knighted by his friend, the 2 nd Earl of ${ }^{*}$ Essex, during his ill-fated Irish campaign.

Harley, Robert, 1st Earl of Oxford and Earl Mortimer (1661-1724). English politician, born in London. Of no strong political convictions he was elected as a Whig (1689) and was Speaker of the House of Commons 1701-05 and (with some overlap) Secretary of State for the North 1704-08. He intrigued with the Tories, shifted his allegiance to that party and became head of a Tory Government as Chancellor of the Exchequer 1710-11 and Lord High Treasurer 1711-14 (the last person to hold that office). An attempt by a French spy to assassinate him made him suddenly popular, he received an earldom from Queen *Anne and was made a KG. His government ended the War of Spanish Succession by the Treaty of Utrecht (1713).

It was said of him that 'he grew by persecutions, turnings out and stabbings'. However, he fell from office when his former friend Henry St John, Viscount *Bolingbroke, became a bitter enemy, was impeached, imprisoned for a time, then acquitted. He was a great book collector and a patron of ${ }^{*}$ Swift, ${ }^{*}$ Pope and ${ }^{*}$ Gay. He founded the Harleian Collection of books and MSS in the British Museum.

Harman, Harriet Ruth (1950- ). English Labour politician. MP 1982-, she was Secretary of State for Social Security 1997-98, Solicitor-General 2001-05, Minister of State for Justice 2005-10 and Deputy Leader of the Labour Party 2007-15. She was twice acting Leader of the Labour Party, in 2010 (after the resignation of Gordon *Brown) and 2015 (after Ed *Miliband).

Harman, H. R., A Woman's Work. 2017

Harmsworth. English journalistic and publishing dynasty. Alfred Harmsworth, who became Lord *Northcliffe, and his brother Harold (Lord *Rothermere), together started (1888) the weekly Answers. Harmsworth also published a number of Sunday magazine papers and in 1896 revolutionised 
English newspapers with the American-style Daily Mail. In 1903 the brothers pioneered the first newspaper for women, the Daily Mirror. Among their dynastic successors was Northcliffe's nephew, Cecil Harmsworth King (1901-1987), who held an increasingly powerful position in the newspaper and periodical fields from the 1950s but then fell (1968).

Harnoncourt, Nikolaus (1929-2016). Austrian conductor, born in Berlin. A cellist with the Vienna Symphony Orchestra 1952-69, he founded the Vienna Concentus Musicus in 1953, directing performances of early music with original instruments. He recorded all *Bach's cantatas and revived works by ${ }^{*}$ Monteverdi and ${ }^{*}$ Rameau, later turning to the Romantic repertoire. His complete set of ${ }^{*}$ Beethoven symphonies was acclaimed in 1992.

Harold Godwinson (or Harold II) (c.1022-1066). King of England 1066. The last of the Saxon rulers, he succeeded (1053) his father ${ }^{*}$ Godwin as Earl of Essex and was virtual ruler under ${ }^{*}$ Edward the Confessor, on whose death (1066) he took the crown. Some three years previously, forced to land in Normandy, Harold had given his oath of loyalty (which he retracted once back in England) to *William of Normandy, who on Edward's death at once set sail to invade England. Harold found himself faced with enemies in both north and south and met the twofold threat with almost incredible energy. He crushed his rebel brother Tostig, who was aided by Hardrada of Norway, at Stamford Bridge, Yorkshire, on 23 September, and hurried south to fight William of Normandy at Senlac, near Hastings on 14 October. Here, despite gallant resistance, he was defeated and killed. The Bayeux Tapestry shows him being shot in the eye by an arrow but he was probably hacked to death by knights.

Compton, P., Harold the King. 1961.

Harold Harefoot (or Harold I) (1016-1040). King of England 1035-40. Son of *Cnut, born in England, he seized the English throne when his halfbrother *Harthacnut was preoccupied with problems in Denmark. He died suddenly in Oxford. When Harthacnut took up his English kingdom, Harold's body was exhumed, beheaded and dumped in the Thames.

Harper, Stephen Joseph (1959- ). Canadian politician, born in Toronto. He studied economics in Alberta, became MP 1993-97, 2002-16, Leader of the Conservative Party 2004-15, Prime Minister 2006-15, increasing his majority in 2011 but being heavily defeated by Justin *Trudeau and the Liberals in 2015. He had opposed strong action on climate change and, out of office, indicated broad support for Donald *Trump.

Harriman, W(illiam) Averell (1891-1986). American diplomat and Democratic politician. Son of the railway magnate Edward Henry Harriman, he worked with Franklin *Roosevelt on his New Deal and in World War II came to Britain as Lend-Lease administrator (1942-43). As Ambassador to the USSR 1943-46 and to Britain 1946, and in several other official and unofficial roles, he played an important part in the diplomatic history of the war and postwar years. Governor of New York State 1955-59, he failed to win nomination as Democratic presidential candidate in 1952 and 1956. His published works include Peace with Russia? (1960) and Special Envoy (1975). His third wife, Pamela Beryl Harriman (née Digby) (1920-1997), formerly married to Randolph *Churchill, became US Ambassador to France 1993-97.

Harrington, James (1611-1677). English political theorist. He attended ${ }^{*}$ Charles I personally, by order of parliament, both before and at his execution. After the King's death he retired to write Oceana, a political romance in which, recognising that political power is dependent on economic circumstances, he propounded a more equal distribution of land, leading to government by a senate debating and proposing, the people deciding the legislation, and a magistracy (chosen on a principle of rotation by popular suffrage by the ballot) executing the laws. His theories influenced the doctrines of both the American and French revolutions.

Russell-Smith, H. F., Harrington and the 'Oceana'. 1971.

Harriot (Hariot or Heriot), Thomas (c.1560-1621). English polymath, born in Oxford. He studied at St Mary Hall, Oxford, became interested in navigation, worked for Walter *Raleigh, visited North Carolina and wrote A Briefe and True Report of the New Found Land of Virginia (1588). He is credited with introducing the potato and tobacco to England and transcribed the Algonquian language. He corresponded about optics with *Kepler, set out the principles of refraction, drew a map of the Moon (1609) and observed sunspots (1610). Imprisoned after Raleigh's fall, he died of cancer, an early victim of smoking. An exoplanet and a Moon crater are named for him.

Arianrhod, R., Thomas Harriot. A Life in Science. 2019.

Harris, Sir Arthur Travers, 1st Baronet (18921984). English airman, born in Gloucestershire. In Rhodesia as a young man, he served in World War I, then remained in the RAF. Marshal of the RAF, known as 'Bomber Harris', he was Commanderin-Chief of Bomber Command 1942-45 in charge of the bombing raids on Germany during World War II. His campaign involved area bombing, such as the firestorm of Dresden (February 1945), instead of precision targeting, which remains deeply controversial.

Probert, H., Bomber Harris. His Life and Times. 2006. 
Harris, Frank (né John Thomas Harris) (1855-1931). Irish-American journalist, novelist, short-story writer and diarist, born in Galway. He emigrated to the US in 1869 , becoming a citizen in 1921 but his most productive years were spent in England and France. A friend and biographer of Oscar *Wilde (1916) and Bernard *Shaw (1931), he became notorious with his My Life and Loves (4 vols, 1922-27), long banned as obscene, now regarded as a triumph of the imagination.

Harris, Joel Chandler (1848-1908). American author. A journalist on the Atlanta Constitution 18761900, he collected African-American folk myths and dialect, reproducing many stories of plantation life in his book Uncle Remus (1880-83), and introduced the characters Brer Fox and Brer Rabbit.

Cousins, P. M., Joel Chandler Harris: A Biography. 1968.

Harris, Kamala Devi (1964-). American Democratic politician, born in Oakland, California. Her mother was an Indian oncologist, her father a Jamaican economist. Educated in Montréal and at Howard and California universities, she was District Attorney for San Francisco 2004-11, Attorney-General of California 2011-17 and US Senator 2017-21. She sought the Democratic nomination for President in 2020 , became Joe *Biden's running mate and the first female Vice President of the US 2021- .

Harris, Roy Ellsworth (1898-1979). American composer. A pupil of Nadia *Boulanger, he wrote seven symphonies of which the powerful No. 3 (1937), in one movement, is most performed, and an important piano quintet.

Harrison, Benjamin (1833-1901). 23rd President of the US 1889-93. Grandson of W. H. *Harrison, born and educated in Ohio, he became an attorney, settled in Indiana and rose to Brigadier in the Civil War. A US senator from Indiana 1881-87, he was a compromise Republican choice for the presidency in 1888 and defeated Grover ${ }^{*}$ Cleveland in the Electoral College (although trailing slightly in the popular vote). Although a capable administrator, his high tariff legislation caused distress and he had none of the gifts that command popularity. His attempt to secure a second term in 1892 met overwhelming defeat by Cleveland. The Sherman Anti-trust Law and the Silver Purchase Acts were passed during his term of office.

Sievers, H. J., Benjamin Harrison, 3 vols, 1952-68.

Harrison, James (1816-1893). Scottish-Australian engineer, printer, publisher and politician, born in Dumbartonshire. In Victoria from 1839, he owned and edited The Geelong Advertiser 1842-62, and devised a refrigeration system for ships which enabled Australia to become a meat exporter.
Harrison, John (1693-1776). English horologist. A carpenter's son, in 1736 he won the Board of Longitude's prize of $£ 20,000$ for constructing an accurate marine chronometer that enabled navigators to calculate longitude accurately and was awarded the Copley Medal in 1749. He did not receive all the prize money until 1773, and only then with the intervention of * George III, after producing his fifth version.

Sobel, D., Longitude. 1995.

Harrison, Sir Rex Carey (1908-1990). British actor. He first appeared on the stage at the Liverpool Repertory Theatre (1924). He performed in both the plays and films of Blithe Spirit, My Fair Lady and Doctor Dolittle.

Harrison, Wallace K(irkham) (1895-1981). American architect. Encouraged by Nelson *Rockefeller, he designed the trylon and perisphere for the New York World's Fair 1939-40, the United Nations buildings 1947-50, the Metropolitan Opera House and the Lincoln Centre for the Performing Arts 1961-66 and the Exxon Building 1971, all in New York.

Harrison, William Henry (1773-1841). 9th President of the US March-April 1841. Born in Virginia, son of a planter who had been a signatory of the Declaration of Independence, he became a soldier and governor of the newly formed territory of Indiana 1800-12. He won a renowned victory over the Indian chieftain *Tecumseh at Tippecanoe River (1811), was a general in the war of 1812 against the British, a US senator from Ohio 1825-28 and a unsuccessful candidate for president against *Van Buren in 1836. He won the Whig nomination for president in December 1839, defeating Henry ${ }^{*}$ Clay and Winfield ${ }^{*}$ Scott, and after Daniel *Webster declined the vice presidential nomination, it went to John ${ }^{*}$ Tyler. It was his reputation as a war hero (using the slogan 'Tippecanoe and Tyler too') rather than his skill as a politician that won his election in November 1840. Harrison, the last president born a British subject, and the oldest to be elected until *Reagan, delivered a speech of record length (100 minutes) at his inauguration, caught a cold and died of pneumonia one month later. Harrison was the shortest-serving president, the first to die in office and to be succeeded by a vice president.

Harry (Henry Charles Albert David MountbattenWindsor), Duke of Sussex (1984- ). British prince, born in London. Second son of Prince ${ }^{*}$ Charles and Princess ${ }^{*}$ Diana, after a rebellious youth he served in the army $2005-15$ and became a helicopter pilot. He married (Rachel) Meghan Markle (1981- ), an American, formerly an actor, in 2018 and was identified with a variety of causes, injured and depressed service personnel and conservation. In 2020 he withdrew from royal duties and announced plans to relocate to Canada, soon changed to California. 
Harsanyi, John Charles (1920-2000). American economist, born in Budapest. A pioneer of games theory, he taught in Brisbane 1954-56, Canberra 1959-61, Detroit 1961-63 and Berkeley 1964-90 and shared the 1994 Nobel Prize for Economics with John *Nash.

Hart, Gary Warren (né Hartpence) (1936- ). American Democratic politician, born in Kansas. Educated at Yale, he became a lawyer in Denver (1967), US senator from Colorado 1975-87 and was regarded as a leading Democratic presidential contender for 1988. Accused of infidelity, his forced withdrawal was dramatised in the film The Front Runner (2018). US Special Envoy to Northern Ireland 2014-17, Hart wrote history and novels and gained an Oxford DPhil.

Hart, Sir Robert, 1st Baronet (1835-1911). British official in China, born in Ulster. A graduate of Queen's University, Belfast, he worked as a consular official in China 1854-63 then became Inspector General of the Maritime Customs Service 1863-1911. He was a significant influence in reforming infrastructure and administration.

Harte, Francis Bret (1836-1902). American author, born in Albany, New York. He went to California as a youth and won fame by his stories, e.g. The Luck of Roaring Camp (1868) and The Outcasts of Poker Flat (1870). From 1883 he lived in London.

Harthacnut (or Hardicanute) (1018-1042). King of Denmark 1035-42 and of England 1040-42. Born in England, son of *Cnut, he succeeded his father in Norway and his half-brother ${ }^{*}$ Harold Harefoot in England. The last Scandinavian ruler in England, he died suddenly at a wedding feast, probably of a stroke, but he could have been poisoned. The Anglo-Saxon House of Wessex was then restored with *Edward the Confessor.

Hartley, David (1705-1757). English physician and pioneer psychologist, born in Armley, Yorkshire. Son of a poor clergyman, he attended Jesus College, Cambridge, receiving his BA in 1726 and his MA in 1729. Hartley had scruples about signing the 39 Articles, and so took up a career in medicine. $\mathrm{He}$ practised in London and later in Bath. His major book was the two-volume Observations on Man, his Frame, His Duty, and his Expectations (1749). In this he attempted to prove that there is no knowledge innate in the mind, nor any innate moral disposition. All our knowledge and ideas are built up by patterns of associations formed in the mind from the data that comes in from our senses. Such patterns of associations are themselves determined by our disposition to pursue pleasure and shun pain. Such a sensationalist psychology and associationist epistemology was not in itself totally original: much is to be found in *Locke. Hartley's originality lay in giving these a physiological basis. He saw the associations literally as vibrations and pathways of particles in the brain. Hartley was thus the first materialist psychologist in England. He believed his cause-and-effect psychology was compatible with Newtonianism, and also with his Christianity (man's psychology became part of predestination). It was enormously influential in the development during the next century of a more scientific psychological theory.

Halevy, E., The Growth of Philosophic Radicalism. 1952.

Hartmann, Karl Amadeus (1906-1963). German composer. A pupil of *Webern, he was influenced by ${ }^{*}$ Mahler, ${ }^{*}$ Reger, ${ }^{*}$ Stravinsky and ${ }^{*}$ Berg and wrote eight symphonies. He founded Musica Viva in Munich in 1947.

Hartmann, Karl Robert Eduard von (1842-1906). German philosopher. Known for his synthesis of ${ }^{*}$ Hegel and ${ }^{*}$ Schopenhauer, his reputation for pessimism arises from a mistaken interpretation of his belief that the amount of pleasure in the world is exceeded by the amount of pain. His chief work Philosophy of the Unconscious (1869) was translated into English (1884).

Hartnell, Sir Norman (1901-1979). English couturier. He founded his own business in 1923 and was dressmaker to the Queen by 1940 . He designed the wedding and coronation dresses of Queen *Elizabeth II. He was created a KCVO in 1977.

Harty, Sir (Herbert) Hamilton (1879-1941). British conductor and composer, born at Hillsborough, County Down. He was conductor of the Hallé Orchestra 1920-33. He arranged *Händel's Water Music (1922) and Royal Fireworks Music (1924) for modern orchestra, and composed An Irish Symphony (1924) and concertos for piano and violin.

Hārūn al-Rashid (ibn Muhammud al-Mahdi) (763809). Fifth Abbasid Caliph of Baghdad 786-809. He was born in modern Iran, son of the third caliph, AlMahdi, and a former Yemeni slave-girl, Al-Khayzuran, who remained an important influence. He moved his court from Baghdad to Raqqa (modern Syria) in 796 but established the 'House of Wisdom' ('Bayt alHikma') in Baghdad. His fame as a ruler induced even the distant ${ }^{*}$ Charlemagne to send gifts, and word of his generous patronage attracted to his magnificent court artists and scholars from many lands. An underlying cruelty was shown when, from jealously or fear of conspiracy, he ordered (803) the extermination of the Barmecides, a family which for 50 years and more had dominated the administration. Legend, as recorded in The Thousand and One Nights and elsewhere, relates how he walked in disguise through the city to seek adventure and learn the grievances of his subjects. Buried in Mashhad, he appears as a character in many stories, poems and films. 
Harvard, John (1607-1638). English clergyman. In 1637 he went as a preacher to Charlestown, Mass., where he died of tuberculosis. He bequeathed his library and half his estate $(£ 779)$ as the basis of the college, founded in 1636, which took his name in 1638 and became the first university in North America.

Harvey, William (1578-1657). English physician, born in Folkestone. Famous for his discovery of the circulation of the blood, after graduating at Cambridge (1597) he studied under the great anatomist *Fabricius in Padua. Elected FRCP (1607) he became physician to St Bartholomew's Hospital (1609) to King *James I (1618) and to ${ }^{*}$ Charles I (1640). His strong royalist sympathies led him to attend Charles I through the Civil War. He retired from professional life after the triumph of the parliamentary forces and occupied himself entirely with research. As early as 1628 he had published An Anatomical Exercise on the Motion of the Heart and the Blood in Animals in which he wrote that 'the blood performs a kind of circular motion' through the bodies of men and animals. Until then physicians knew of the existence of arteries and veins but did not understand that the function of the latter was to enable the blood to return to the heart; they regarded the inexplicable arterial movement as being in the nature of an irrigation of the body. Harvey demonstrated (after actually viewing it in animals) that the heart is a muscle, that it functions as a pump and that it effects the movement of the blood through the body via the lungs by means of the arteries, the blood then returning to the heart through the veins. He pointed out the difference between venous and arterial blood. Harvey's notable Essays on Generation of Animals (1651) comprise his researches in embryology. The doctrine that every living thing has its origin in an egg was affirmed by him.

Keynes, G., The Life of William Harvey. 1966.

Hasek, Jaroslav (1883-1923). Czech novelist, born in Prague. A journalist and satirist, he became a prisoner of war of the Russians in World War I. He wrote The Good Soldier Svejk (4 volumes, incomplete, 1920-23).

Hashimoto Ryutaro (1938-2006). Japanese politician. He became Leader of the Liberal Democratic Party (LDP), and Prime Minister 199698. He changed the electoral system, introducing single member electorates and won an election in October 1996, resigning after Japan entered a recession.

Hasluck, Sir Paul Meernaa Caedwalla (1905-1993). Australian Liberal politician. An academic, diplomat, war historian and poet, he was a Federal MP 194969, a minister from 1951, Foreign Minister 1964-69 and Governor-General of Australia 1969-74. Created KG in 1979, he published five volumes of poetry and an autobiography Mucking About (1977). His notes, making sharp comments on colleagues, including ${ }^{*}$ Casey, ${ }^{*}$ Gorton and ${ }^{*}$ McMahon, were posthumously published as The Chance of Politics (1997).

Hassan II (1929-1999). King of Morocco 1961-99. Son of *Mohammed V, he was educated in France, directed relief operations after the Agadir earthquake (1960), was Prime Minister 1961-63, 1965-67 and wrote memoirs (1979).

Hassanal Bolkiah (Sultan Haji Hassanal Bolkiah Mu'izzaddin Waddaulah ibni Al-Marhum Haji Omar Ali Saifuddien Sa'adul Khairi Waddien) (1946- ). 29th Sultan of Brunei 1967- . Educated at Sandhurst, he succeeded as Yang di-Pertuan (Head of State) on his father's abdication and was also Prime Minister 1984-. One of the last absolute monarchs, he imposed sharia law. His fortune was estimated at \$US20 billion. Britain made him an honorary GCB, GCMG and Admiral of the Royal Navy.

Hasselblad, Victor (1906-1978). Swedish inventor, born in Göteborg. In 1941 he developed a camera for the Swedish Air Force which was launched commercially in 1948, used by NASA on the first moon landing (1969) and in many other space flights. Hastings, 1st Marquess of, Francis Edward
Rawdon-Hastings, 2nd Earl of Moira (17541826). Anglo-Irish soldier and politician, born in Dublin. He dropped out of Oxford, bought an army commission and served in a variety of roles in the American War of Independence 1774-81. Created a peer in his own right in 1783 , elected FRS, he led a military expedition to France in 1794, but broke with *Pitt for not providing adequate support. In 1797 there was an ill-considered attempt to make Hastings Prime Minister. Promoted general, he was Commander-in-Chief in Scotland 1803. A Whig and supporter of Catholic Emancipation, he became close to the Prince of Wales but failed in another bid to become Prime Minister (1812). Appointed Governor-General of Bengal 1813-23, he proved to be relatively successful and secured the cession of Singapore (1819). Governor of Malta 1824-26, he died at sea.

Hastings, Warren (1732-1818). English administrator, born in Churchill, Oxfordshire. Son of a clergyman, he joined the East India Company (EIC) as a 'writer' in 1750, served in Madras 176972 and as Governor of Bengal 1772-74. He became the first Governor-General of Bengal (i.e. of nearly all British India) 1774-85, the title of GovernorGeneral of India not being created until 1833, by statute (*Bentinck). He reformed the whole system of administration, set up a board of revenue and established regular law courts for which he had old Hindu law books specially translated. He spoke Bengali, Urdu and Persian and encouraged William *Jones to found the Asiatic Society of Bengal to study oriental culture (1784) and publish a translation of 
the Bhagavad Gita (1785). Hastings abolished private trading by the servants of the EIC, and successfully held the Marathas at bay. Unfortunately three of the four members of his Governor-General's Council consistently opposed and hampered him; one of them, Sir Philip *Francis, with personal malignancy. When Hastings retired (1785), Francis persuaded ${ }^{*}$ Burke, ${ }^{*}$ Fox, ${ }^{*}$ Sheridan and ${ }^{*}$ Pitt to move to impeach him for oppression, maladministration and corruption. From 1788 the trial dragged on for seven years. Hastings was targetted as if he personified the EIC. He had made some misjudgments, including the judicial murder of a whistleblower and some harsh tax measures, but most charges, such as the torture of women, were raised for purely theatrical effect. Richard Shawe (1755-1816) was counsel for Hastings.

Compared to ${ }^{*}$ Clive, who was never impeached, Hastings' concerns for India and its culture were genuine and he lived modestly.

In April 1795, Hastings was acquitted on all charges. (Many peers who had been sitting when the trial began had died). The impeachment cost him $£ 70,000$ but the EIC provided a loan of $£ 50,000$ and a pension of $£ 4,000$ and he bought back his old family home in Daylesford. He was elected FRS in 1801. Probably the ablest of the great administrators of British India he was the least rewarded, becoming Privy Counsellor in 1814. He was the model for Colonel Christopher Brandon in Jane Austen's Sense and Sensibility. Towns in Victoria and New Zealand were named for him.

Turnbull, P., Warren Hastings. 1975; Lawson, C., The Private Life of Warren Hastings. 2012.

Hathaway, Anne (1555/6-1623). English wife of Shakespeare, probably born in Shottery. In 1582 she married William *Shakespeare, seven or eight years her junior, and bore him a daughter, Susanna (1583) and the twins Judith and Hamnet (or Hamlet, 1585). In his will, Shakespeare left her the furniture and his 'second-best bed'.

Hatoyama Yukio (1947- ). Japanese politician, born in Tokyo. A Diet Member 1986-2012, he led the Democratic Party of Japan and was Prime Minister 2009-10, introducing major reforms in social welfare and education, but was forced to resign over a financial scandal. His grandfather Hatoyama Ichiro (1883-1959) was Prime Minister 1954-56.

Hatshepsut (d.c.1482 BCE). Egyptian Queen (15041482 BCE). Daughter of Thutmose I, she married her half-brother Thutmose II, and on his death proclaimed herself pharaoh. She built the great temple at Deir elBahri (West Thebes) and four obelisks at Karnak. After her death, possibly murdered, her stepson and co-ruler *Thutmose III obliterated her name.

Tyldesley, J., Hatchepsut. 1996.
Hatta, Mohammed (1902-1980). Indonesian politician. Trained as an economist in Europe and imprisoned by the Dutch (1933-42), he worked for the Japanese during World War II and during the *Soekarno era was Prime Minister 1948-50 and Vice President 1950-56.

Hatton, Sir Christopher (1540-1591). English lawyer and courtier. He was a great favourite of Queen *Elizabeth, who knighted him and gave him large estates in Dorset including the historic Corfe Castle. He was often her spokesman in parliament and actively prosecuted Anthony *Babington and *Mary Queen of Scots. He became Lord Chancellor 1587-91 and Chancellor of Oxford University 1588-91.

Brooks, E. St J., Sir Christopher Hatton. 1946.

Haughey, Charles James (1925-2006). Irish politician. A lawyer, he was elected to the Dail in 1957, led Fianna Fáil 1979-92, and served as Taoiseach (Prime Minister) 1979-81, 1982 and 1987-92. Known as 'the Great Houdini', he was an audacious embezzler, tax evader and hypocrite who acquired great wealth and had the Chief Justice's wife as his mistress.

Dwyer, T. R., Short Fellow: A Biography of Charles Haughey. 1987; O'Brien, J., The Modern Prince: Charles J. Haughey and the Quest for Power. 2002.

Hauptmann, Gerhardt (1862-1946). German dramatist and novelist, born in Silesia. He became an art student before going to Berlin (1885) and turning to literature. His early plays, social dramas influenced by ${ }^{*}$ Ibsen, roused opposition by their 'naturalism', a technique he applies, as in Die Weber (1892), to comparatively recent events (e.g. the revolt of the Silesian weavers in 1844) and even to remoter history, e.g. in Florian Geyer (1896) on the Peasant's War. A transition to fantasy is marked by Hanneles Himmelfahrt (Hannele's Journey to Heaven, 1893), in which a child's vision and sordid realism are successfully blended, and the popular Die Versunkene Glocke (The Sunken Bell, 1896). His later plays range through many styles from the realistic to the mystical and classical. Of his novels the best known are the psychological The Fool in Christ: Emanuel Quint (1910) and the classical Atlantis (1912). The verse epic Till Eulenspiegl (1928) symbolically portrayed Germany after World War I. Hauptmann won the Nobel Prize for Literature (1912).

Knight, K. G., and Norman, F. (eds), Hauptmann Centenary Lectures. 1964.

Haushofer, Karl Ernst (1869-1946). German soldier, geographer and political theorist. After serving in the Bavarian army (1887-1918) and becoming a general, he became the mentor of Rudolf *Hess. He lectured in political geography at Munich University from 1919, becoming a professor in 1933, published widely and broadcast effectively. Developing Halford *Mackinder's theory of the Eurasian 'heartland', he developed a 
geopolitical theory, including 'Lebensraum', which promoted the idea of German expansion. He also encouraged political linkages between Germany and Japan. He and his wife committed suicide. His son Albrecht Georg Haushofer (1903-1945), worked with Hess, then became disillusioned with the Nazis, collaborated in an attempt to assassinate ${ }^{*}$ Hitler and was executed by the SS.

Haussmann, Georges-Eugène (1809-1891). French administrator and lawyer. He joined the public service in 1831. *Napoléon III appointed him as Prefect of the Department of the Seine 1853-70, with responsibility for modernising Paris, to accommodate for the large increase in population. He became a Senator in 1857. He created new water supply and sewerage systems, introduced the railways, created boulevards, including the Champs-Élysées, parks (including the Bois de Boulogne and Buttes Chaumont), and built bridges, but tore down hundreds of medieval dwellings. His work had significant influence in Rome, Berlin, Vienna, Madrid, Barcelona, Stockholm, New York and Chicago. He became deeply controversial, spending huge sums of money, masked by some creative accountancy, and was the subject of attack by Napoléon's enemies. Forced to resign, he was elected as a Deputy, representing Corsica, 1877-81. He is often described, inaccurately, as Baron Haussmann.

Haüy, René-Just (1743-1822). French scientist, born at St Just-en-Chaussée, Oise. He became a priest, taught in Paris and investigated mineralogy and crystallography. In 1802 he became professor of mineralogy at the Museum of Natural History, moving to a chair at the Sorbonne in 1809. His two major works are the Treatise of Mineralogy (1801), and the Treatise of Crystallography (1822). Haüy's importance lay in effectively redefining the questions to be posed in the study of crystals. The regular forms of crystals had drawn throughout the 17th and 18th centuries a plethora of causal explanations, in terms of shaping forces - some chemical, some physical, some atomistic but none satisfactory. Haüy's approach was not to explain the causes of the regularly varied forms of crystals, but to try to classify those forms in terms of geometry and above all, he hoped, through the geometry of simple relationships between integers. He envisaged crystals as structured assemblages of secondary bodies (integrant molecules: a concept deriving from Buffon) which grouped themselves according to regular geometric laws. He proposed six types of primary forms: parallelpiped, rhombic dodecahedron, hexagonal dipyramid, right hexagonal prism, octahedron and tetrahedron, and spent much of his career elaborating on this typology of forms.

His approach won strong supporters, but also met many detractors, who believed that physical questions were being neglected in this purely structural, geometrical approach.

Burke, J. G., Origins of the science of Crystals. 1966.
Havel, Vaclav (1936-2011). Czech dramatist and politician, born in Prague. He began publishing essays and plays in 1956, although his works were not performed in Czechoslovakia until 1968. His plays include The Memorandum (1965), The Conspirators (1971), Audience (1975) and Largo Desolato (1985). In 1977 he helped to found Charter 77, a human rights organisation, and was jailed many times. In prison 1979-83, he wrote Letters to Olga (his wife), later dramatised. In 1989, on the collapse of Communism, Havel became the last President of Czechoslovakia 1989-92 in 'the velvet revolution', leaving office when he proved unable to maintain political union between Czechs and Slovaks. He was elected President of the Czech Republic 1993-2003.

Havelock, Sir Henry (1795-1857). English general. Originally intended for the law, a collapse in the family's fortunes made him a soldier, widely read, a good linguist, and full of Baptist missionary fervour. He served in India from 1822, fighting with distinction in Burma, Afghanistan, Gwalior and the Punjab. In the Indian mutiny (1857) he was sent to the relief of Cawnpore and Lucknow. Having reached Cawnpore only to find that on news of his coming all the European women and children had been killed, he fought his way through to Lucknow and so enabled the city to hold out until it was finally relieved by Sir Colin ${ }^{*}$ Campbell. Havelock died of dysentery within a month.

Hawke, Bob (Robert James Lee) (1929-2019). Australian Labor politician, born in South Australia. Educated in Perth, he became a Rhodes Scholar at Oxford, returning to join the Australian Council of Trade Unions (ACTU) as research officer (1957) and industrial advocate (from 1959). As President of the ACTU 1970-80, he was highly visible on television and gained immense popularity in resolving industrial disputes, and was also National President of the Australian Labor Party 1973-78. He entered the Australian Parliament in 1980, took the Labor leadership from Bill *Hayden in a bloodless coup in February 1983 and a month later defeated Malcolm *Fraser decisively to become Prime Minister, being re-elected in 1984, 1987 and 1990. Hawke converted the ALP to uneasy support of economic rationalism and the domination of the market, and promoted economic links with Asia. Phasing out of tariffs, responding to globalisation, floating the $\$ \mathrm{~A}$, financial deregulation, achieving universal secondary education, universal health care, Commonwealth power over the environment, compulsory superannuation, the Australia Act (1986) were all achieved by Hawke, working closely with his treasurer, Paul *Keating. $\mathrm{He}$ also led the successful international fight, with Jacques Yves *Cousteau and Michel *Rocard, to exclude mining from Antarctica for 50 years (1991) and played a significant role in weakening the apartheid regime in South Africa. After 1987 he worried that the pace 
of change was causing social hardship. In December 1991 Keating defeated Hawke in a Caucus ballot and became Prime Minister.

d'Alpuget, B., Robert J. Hawke. 1982; Hawke, B. The Hawke Memoirs. 1994; Bramston, T., Bob Hawke: Demons and Destiny. 2022.

Hawke, Edward Hawke, 1st Baron (1705-1781). English sailor. After much distinguished service he became a full admiral in 1755 when he superseded *Byng in the Mediterranean. After two years he was back in the English Channel. His victory at Quiberon Bay (1759) was one of the greatest in British naval history. Hawke had been lying outside Brest watching the French fleet intended to cover an invasion of England, but in November a gale forced the British to withdraw and so allowed the French, under Admiral de Couflans, to escape. Anticipating rightly that the aim was to join a sister fleet at Rochefort, Hawke intercepted the enemy fleet at Quiberon Bay and, despite the gale and a menacing lee shore, forced action and destroyed it. Member of Parliament 1747-76, he was First Lord of the Admiralty 1766-71 and promoted to Admiral of the Fleet in 1768.

MacKay, R. F., Admiral Hawke. 1965.

Hawker, Harry George (1889-1921). Australian aviator, born in Melbourne. In England he began working with T.O.M. *Sopwith (1911), and in 1912 set records for time aloft ( 8 hours 23 minutes), distance $(1,609 \mathrm{~km})$ and height (3,490 metres). In May 1919 he attempted to cross the Atlantic but was forced to ditch. He designed aircraft and a two-stroke motor cycle and was killed while testing a French Goshawk. His name survived with the Hawker Hurricane fighter and the Hawker-*de Havilland aerospace company.

Hawking, Stephen William (1942-2018). English cosmologist, applied mathematician and theoretical physicist, born in Oxford. Educated at Oxford and Cambridge, he collaborated with Roger *Penrose, was professor of gravitational physics 1977-79 at Cambridge and Lucasian professor of mathematics (a chair that ${ }^{*}$ Newton had held) 1979-2009. His work helped to confirm the 'big bang' theory of creation but his best known research is on the nature of 'black holes' and their relationship with the laws of thermodynamics. From 1963, Hawking was severely handicapped with a rare form of motor neurone disease (ALS, known as Lou *Gehrig's disease in the US), which prevented him from moving or writing without assistance and he communicated through a speech synthesiser. His book A Brief History of Time (1988) became a phenomenal bestseller (more than $10,000,000$ copies) and was filmed. He also wrote an autobiography, My Brief History (2013). He was awarded the $\mathrm{CH}$ in 1989, the Copley Medal in 2007 and the US Presidential Medal of Freedom in 2009. He lost in a major dispute about the existence of the
*Higgs boson, and the Nobel Prize for Physics eluded him because his conceptual work, although profound, was hard to confirm experimentally.

Seife, C., Hawking Hawking; The Selling of a Scientific Celebrity. 2021.

Hawkins (or Hawkyns), Sir John (1532-1595). English sailor, administrator and slave trader. He was the first Englishman to traffic in African slaves, a venture that ended (1573) when his fleet was destroyed by storms on his third voyage across the Atlantic. $\mathrm{He}$ is credited/blamed for introducing tobacco to England. As Treasurer of the Navy 1577-95, he did much to equip the fleet and turn it into an efficient fighting force. Knighted for his services against the Spanish Armada (1588), he harassed the Spanish West India trade for many years and died off Puerto Rico while commanding an expedition to the Spanish Main with his second cousin, Sir Francis *Drake.

Williamson, J. A., Hawkins of Plymouth. 2nd ed. 1969.

Hawthorne, Nathaniel (1804-1864). American novelist, born in Salem, Massachusetts. From a Puritan family, he developed a taste for solitude and as a young man lived for 12 years the life of a recluse in a single room at Salem, where he wrote the stories collected in two series as Twice-Told Tales (1827-1842). Marriage (1842) to Sara Peabody, as a preliminary to which he had taken a position in the Boston Customs House, restored him to normal life. The couple lived in Concord with ${ }^{*}$ Emerson and *Thoreau among their neighbours. He returned to Salem as surveyor of customs but was dismissed and took up writing again. The result was his masterpiece, the novel The Scarlet Letter (1850), which, against a Puritan New England background, paints a tragic picture of the cumulative effects of prejudice, guilt and sin. Among other works of this productive period were The House of the Seven Gables (1851), the satirical The Blitheswood Romance (1852), and the famous children's book Tanglewood Tales (1852). He was US Consul in Liverpool 1853-58. His last work of importance, inspired by an Italian visit, was The Marble Fawn (1860).

Crowley, J. D. (ed.), Hawthorne: The Critical Heritage. 1970 .

Hay, John Milton (1838-1905). American diplomat and author. At the request of John G. Nicolay, Private Secretary 1861-65 to President ${ }^{*}$ Lincoln, Hay was appointed his assistant, and the two friends wrote the enormous Abraham Lincoln (10 volumes, 1886-90). Hay was US Ambassador to Great Britain 1897-98 and Secretary of State 1898-1905. He enunciated the 'Open Door' policy in China and negotiated the Hay-Pauncefote Treaty (1901) with Britain which enabled the US to build the Panama Canal. He was an intimate friend of Henry *Adams. 
Hayden, Bill (William George) (1933- ). Australian Labor politician. After 10 years as a Queensland policeman, he was a Member of the Australian Parliament 1961-88, Minister for Social Security 1972-75, and Treasurer 1975 under Gough *Whitlam. Leader of the Labor Party 1977-83, he was displaced by Bob *Hawke but served as Hawke's Foreign Minister 1983-88 then became GovernorGeneral 1989-96.

Murphy, D. J., Hayden. 1980; Hayden, B., Hayden: an autobiography. 1996.

Haydn, (Franz) Joseph (1732-1809). Austrian composer, born at Rohrau. Second of 12 children, he studied at the St Stephen's Cathedral choir school, Vienna (1740-49) until his voice broke. In the next eight years he taught himself the fundamentals of composition (studying the works of C.P.E. *Bach), working as a valet to the Italian composer Niccolo *Porpora (who instructed him in writing for the voice), and coaching pupils in the klavier and singing. In 1760 he became assistant Kapellmeister to Prince Esterházy at Eisenstadt and Kapellmeister at the castle at Esterháza (1766), remaining there until 1790. By 1790 he had written more than 70 symphonies, 50 piano sonatas, 125 works for baryton, 60 string quartets and much Church music. Gradually, he acquired a European reputation and his status rose with the Esterházys. From 1781 he was the friend and mentor of *Mozart.

Haydn ran some risk of being written off as a musical bookend, both preceding and following Mozart. He made a unique contribution to the history of music as creator of the string quartet (composing 68, although some doubtful attributions increase the number to 83) and the piano sonata (62). He also composed 20 piano trios. While Giovanni Battista Sammartini (1700?-1775) composed the earliest dated symphony (in 1732), Haydn is the first great master of the form, writing 104, strongly influencing Mozart and *Beethoven. He also composed 32 concertos, 14 operas and 14 Masses. Symphony No. 104 in D major ('The London') was the last, and perhaps his greatest, anticipating *Beethoven's Romanticism. In 1792 he had taught Beethoven briefly, without mutual benefit.

Haydn spent two periods in England (1791-92; 1794-95) at the invitation of the London impresario J. P. *Salomon. He wrote 12 symphonies for Salomon (Nos 93-104) and six string quartets. Haydn was immensely popular in England and received an honorary Mus D from Oxford (1791).

His Seven Last Words of our Saviour on the Cross (1786), originally for orchestra, was commissioned for Cádiz Cathedral, later adapted for string quartet (1787) and for chorus and orchestra (1796).

His finest string quartets are the six in op. 76 (179697; H. 75-80). His piano sonatas, long neglected, are now available on at least four sets of CDs which make a compelling case for them being in the same league as Mozart's. The Mass No. 11 in D Minor (Missa in angustiis-Mass in times of fear), first performed in 1798, is better known as 'The Nelson Mass', having been played in *Nelson's presence in 1800 . The Mass, joyous, despite its ominous title, has a driving urgency, operatic intensity, with soaring vocal writing, powerful tympani, a piercing trumpet, pulsating strings, obsessive ornamentation and pungent dissonance. The most familiar of his choral works is The Creation (1798), written to an English text, based on Genesis and *Milton's Paradise Lost, but often performed in German as Die Schöpfung. Die Jahreszeiten (The Seasons, 1801), much performed, is set to a text by Baron Gottfried van Swieten.

His works were catalogued by Antony van Hoboken, with the letter ' $\mathrm{H}$ '.

Robbins Landon, H. C., Haydn: Chronicle and Works. 1980; Rosen, C., The Classical Style. 2nd edition, 1997.

Haydon, Benjamin Robert (1786-1846). English painter. An untalented, frustrated high Romantic, he fought against the Royal Academy and left valuable autobiographical writings. He was a friend of *Wordsworth and *Keats and committed suicide.

Hayek, Friedrich August von (1899-1992). Austrian-British economist, born in Vienna. A second cousin of Ludwig *Wittgenstein, he taught in Austria, Britain (where he was naturalised in 1938) and the US, became a strong opponent of *Keynes and the welfare state, and wrote The Road to Serfdom (1944). He attacked all centralised systems as potentially totalitarian, arguing that liberty grew out of a variety of 'spontaneous orders', arising locally. A passionate advocate of the free market, he shared the 1974 Nobel Prize for Economics with Gunnar ${ }^{*}$ Myrdal (a bizarre pairing), became a major influence on Margaret *Thatcher and was made a CH in 1983.

Gamble, A., Hayek. The iron cage of liberty. 1996; Wapshott, N., Keynes Hayek. 2011.

Hayes, Rutherford Birchard (1822-1893). 19th President of the US 1877-81. Born at Delaware, Ohio, he practised law at Cincinnati and rose to be a major-general in the Civil War. Member of the US House of Representatives 1864-67, he became Governor of Ohio 1867-71 and 1875-77. In 1876 he was chosen as a compromise candidate for the Republican presidential nomination and the ensuing campaign against Samuel Jones *Tilden was unusually dirty. Tilden led on the popular vote $(4.3 \mathrm{~m}$ to $4.04 \mathrm{~m})$, but there were disputed returns from Louisiana, South Carolina and Florida, all under 'carpetbag' rule. The returns were referred by Congress to an Electoral Commission which in each case ruled in favour of Hayes by 8 votes to 7 . He was then declared elected with an Electoral College vote of 185 to 184 . In the 'Compromise of 1877', Tilden and the Democrats agreed to accept the result 
provided that 'Reconstruction' ended and Federal troops were withdrawn from the South. This ended Federal action to assist black rights for more than 50 years. In 20 Presidential ranking lists by US historians and political scientists, Hayes scored No. 25 in the aggregate.

Davison, K. E., The Presidency of Rutherford B. Hayes. 1971.

Hazlitt, William (1778-1830). English essayist and critic, born in Maidstone. The son of a Unitarian minister, he was employed on the Morning Chronicle and Examiner in London in 1812, and contributed to the Edinburgh Review 1814-30. Collections of his essays were published in Round Table, Table Talk and Plain Speaker. He wrote a series of contemporary portraits in Spirit of the Age (1825) and a life of Napoleon (1828-30).

Healey, Denis Winston, Baron Healey (19172015). British Labour politician. Educated at Oxford, he was a major in the Commandos during World War II, became MP 1952-92, serving as Minister of Defence 1964-70, and Chancellor of the Exchequer 1974-79. He contested the leadership of the Labour Party in 1976 and 1980, but was Deputy Leader under Michael *Foot $1980-83$. He was an able writer and photographer.

Healey, D., The Time of My Life. 1989.

Heaney, Seamus (Justin) (1939-2013). Irish poet, playwright and translator, born in Northern Ireland. He taught in Belfast, and was professor of rhetoric at Harvard 1985-97, and of poetry at Oxford 1989-94. He published 13 collections of poetry, adaptations of *Sophocles' plays Philoctetes and Antigone, a highly praised translation of Beowulf (1999, which he did not much like himself) and Aeneid: Book VI (posthumous, 2016). He received the 1995 Nobel Prize for Literature for 'works of lyrical beauty and ethical depth, which exalt everyday miracles and the living past'. He declined nomination for the Presidency of Ireland in 2011. Bill *Clinton commented, on Heaney's death: 'His mind, heart, and his uniquely Irish gift for language made him our finest poet of the rhythms of ordinary lives and a powerful voice for peace.'

Vendler, H., Seamus Heaney. 2000; Foster, R. F., On Seamus Heaney. 2020.

Hearn, Lafcadio (1850-1904). American writer. Of Greek-British parentage, he became a journalist in the US, lived in Japan from 1890, taught there and was naturalised. He wrote several penetrating books explaining Japanese life and culture.

Hearst, William Randolph (1863-1951). American newspaper proprietor, born in San Francisco. The son of a millionaire mine owner, he took charge of his father's paper, the San Francisco Examiner, in 1887, bought the New York Journal in 1895, and by 1925 owned 25 newspapers in 17 cities. His introduction of the 'the yellow press', characterised by banner headlines, sensationalism and lavish illustration, revolutionised journalism. A congressman 1903-07, he ran for the Democratic nomination for president in 1904 (losing to Alton B. *Parker) and was candidate for Governor of New York State in 1906 (losing to Charles Evans *Hughes). After supporting Franklin D. ${ }^{*}$ Roosevelt in 1932 he became an extreme isolationist and Anglophobe. Orson *Welles' film Citizen Kane (1940) was largely based on his life (with some elements from the Chicago Tribune's R. R. McCormick).

Heath, Sir Edward Richard George (1916-2005). British Conservative politician, born in Broadstairs, Kent. Son of a carpenter, educated at Chatham House School and Balliol College, Oxford, he served in the army, was a civil servant, and a Tory MP 1950-2001. He was Minister of Labour 1959-60, Lord Privy Seal, in charge of European Community negotiations 1960-63, Secretary of State for Industry and President of the Board of Trade 1963-64. After the 1964 election defeat, Sir Alec Douglas-Home (*Home) retired as Leader of the Conservative Party, and Heath was elected to succeed him (1965), the first to be chosen in a ballot. He was Leader of the Opposition 1965-70, 1974-75. In June 1970 the Conservatives defeated Harold *Wilson's Labour Government with a small majority. As Prime Minister 1970-74, Heath vigorously pursued entry to the European Community. In an effort to restore the economy and contain industrial strife he called an election in February 1974, was defeated narrowly, and when Wilson called a second election in October 1974, Heath failed to make significant gains. In February 1975, Margaret *Thatcher defeated him in a leadership contest. During her prime ministership, and beyond, he remained truculently on the backbench. A bachelor, he devoted himself to his hobbies. A gifted organist, conductor and yachtsman, he won the Sydney-Hobart yacht race in 1970 . He was created KG in 1992 . His sexuality is a matter of ongoing speculation-perhaps, like *Ravel, he had none.

Laing, M., Edward Heath: Prime Minister. 1972; Campbell, J., Edward Heath. 1993.

Heaviside, Oliver (1850-1925). English physicist. Despite having little formal education he made important contributions to the knowledge of how radio waves are propagated. In 1902 he put forward the theory that an ionised layer in the atmosphere, now known to be $90-150 \mathrm{~km}$ above the earth's surface, is responsible for the reflection of mediumwave radio signals. The same hypothesis was advanced, almost simultaneously, in the United States by Arthur Edwin Kennelly (1861-1939) and the layer is now known either as the Kennelly-Heaviside or the Heaviside layer. Its existence was confirmed experimentally by Edward *Appleton. Heaviside found difficulty in communicating his findings to 
others, was often engaged in academic controversies and for the latter part of his life lived as a recluse in Devonshire. Elected FRS in 1891, in 1896 he was awarded a Civil List pension.

Hébert, Jacques René (1757-1794). French revolutionary. A journalist, he was one of the most extreme members of the political faction, the Cordeliers. He was one of the prominent founders of the atheistic cult of Reason. His popularity with the Paris Commune earned him * Robespierre's animosity and after planning an abortive insurrection he was arrested and executed (1794).

Hedayat, Sadeq (1903-1951). Iranian novelist and playwright. Considered the most important Iranian writer of the 20th century, in his youth he was greatly influenced by *Maupassant, Edgar Allan *Poe, ${ }^{*}$ Chekhov, ${ }^{*}$ Dostoevsky and Franz ${ }^{*}$ Kafka. All these he had discovered during a period in France and Belgium, but in 1930 he returned to Iran and became interested in the Iranian folk tradition. Most of his work is melancholy and deeply pessimistic, most human effort seemed to him absurd. He committed suicide in Paris. His best known works are probably Buried Alive (1930), Neyrangestan (1932) and The Blind Owl (1937).

Kamshad, H., Modern Persian Prose Literature. 1966.

Hedin, Sven Anders von (1865-1952). Swedish explorer and geographer. In 1885 he began a series of expeditions to Central Asia and mapped areas formerly unrecorded. In 1908 he made the first detailed map of Tibet. He wrote My Life as an Explorer (1925). He was sympathetic to ${ }^{*}$ Hitler and the Nazis but deplored the anti-Jewish atrocities.

Hefner, Hugh Marston (1926-2017). American publisher and entrepreneur. In 1953, he founded the magazine Playboy, which played a significant role in the ensuing sexual revolution.

Hegel, (Georg Wilhelm) Friedrich (1770-1831). German philosopher, born in Stuttgart. He studied theology at Tubingen and in his early life was a critic of accepted Christian thought. He then turned to philosophy and, after working at Jena and elsewhere and achieving a growing reputation by his writings, he was appointed (1818) to succeed to the chair formerly occupied by J. G. *Fichte as professor of philosophy at the University of Berlin. His views and those of his followers (known as Hegelianism) greatly influenced subsequent philosophy, sometimes indirectly, sometimes by reaction. Marxism, according to *Marx, is Hegelianism turned right side up, and existentialism owes something to Hegel's thought. There were also outgrowths of Hegelian idealism in British and American philosophy. Essentially, Hegelianism makes the claim that spirit, sometimes conceived as the human spirit, more often as something transcendental and all-encompassing, is the true reality, and all else stages of development consisting of the attainment of a synthesis, when an antithesis is brought into antagonism with a thesis; this triadic process Hegel described as dialectical. Human history displays this development, as does philosophy itself. Hegel regarded his own philosophy as the furthest point to which philosophy had yet advanced. The chief works published during his lifetime were The Phenomenology of Mind (1807), The Science of Logic (1812-16), Encyclopedia of Philosophical Sciences (1817) and The Philosophy of Right (1821); much more of his writing was published posthumously. It has been criticised or disdained by many philosophers for its extravagant claims to be setting out a train of necessary truths.

Taylor, C., Hegel. 1975; Plant, R., Hegel. 1983; Singer, P., Hegel. 2001; Beiser, F. C., Hegel. 2005.

Heidegger, Martin (1889-1976). German philosopher, born in Messkirch. Born into a Catholic family, educated at Freiburg University, he studied with ${ }^{*}$ Husserl, and became a professor at Marburg 1923-28. Major influences on his thinking include *Aristotle, St*Augustine, *Kierkegaard, *Nietzsche, *Hölderlin, Buddhism and Taoism.

His best known book Sein und Zeit (1926, translated as Being and Time, 1962) examines the concept of Being, emphasising the word Dasein, a compound of $\mathrm{Da}$ (there) and Sein (being), the central element of being human, including 'being in the world', 'being with others' and 'states of mind' (including anxiety, fear and love). He used Husserl's phenomenological methods. His emphasis on 'being' was parallel to the existentialist principle that 'existence' precedes 'essence' but he objected to being described as an existentialist, although his teaching clearly influenced *Sartre.

'Being-towards-death' is the challenge of grasping that life can only be fully understood and realised by coming to terms with extinction, and that 'being' is 'time', the context in which we live, and it is finite. The deaths of others are irrelevant to the primary subject, a harsh view that throws light on Heidegger's support of Nazism, which cut him off from Husserl.

He was a professor at Freiburg 1928-45, and rector 1933-34. A member of the Nazi Party 1933-45, Heidegger was deprived of his chair after the war, but resumed lecturing in 1951. He later gave evasive and contradictory explanations about his relations with the Third Reich.

With his emphasis on engagement rather than detachment, physical not metaphysical, the particular and immediate rather than the infinite, abstract and universal, he saw Nazi ideology as a validation of his concepts.

His language was very dense, unusually complex and hard to translate, so his influence on English speaking philosophers has been limited. He wrote about 'the hermeneutics of facticity' which meant 
the interpretation of meaning in the context of the quality or condition of being fact, reality or truth. He argued that intelligibility is suicide for philosophy', and he proved his point. There is an extensive literature on Heidegger and his work. His students included Hannah *Arendt (also his lover) and Herbert *Marcuse.

Blackham, H. J., Six Existentialist Thinkers. 1952; Ott, H., Martin Heidegger: A Political Life. 1993; Collins, J. and Selina, H., Introducing Heidegger. A Graphic Guide. 1998; Skinner, Y., Hitler's Philosophers. 2013.

Heifetz, Jascha (1901-1987). Lithuanian-JewishAmerican violinist, born in Vilnius (then in the Russian Empire). A child prodigy, he performed the *Mendelssohn Violin Concerto at the age of 5, studied with Leopold Auer, made his St Petersburg debut in 1911 and left Russia in 1917. He toured Australia in 1921 and 1927. Regarded as the most brilliant virtuoso performer since *Paganini, Heifetz was in great demand as a concert and recording artist, where his deadly accuracy in bowing and fingering and the extraordinary breathing quality of his tone produced a style of playing that was immediately recognisable. He made memorable recordings of trios with Arthur ${ }^{*}$ Rubinstein, Emanuel Feuerman and-later-Grigor Piatigorsky. Heifetz directed a chamber music group in Los Angeles from the 1960s, and after injuring his right shoulder in 1972 retired from public performance and devoted himself to teaching. His favourite violin was a ${ }^{*}$ Guarneri Del Gesu c.1742. The film Jascha Heifetz: God's Fiddler (2011) is a comprehensive biographical account.

Heine, Heinrich (originally Harry) (1797-1856). German poet, born in Düsseldorf. One of the poor branch of a rich Jewish family, he grew up under the French occupation and became an admirer of *Napoléon. An uncle set him up in his own business (Harry Heine \& Co.) in Hamburg, which soon failed. He then studied law in Bonn, literature in Göttingen (under ${ }^{*}$ Schlegel) and philosophy in Berlin (under ${ }^{*}$ Hegel and Friedrich August Wolf). Several love affairs disturbed him. *Goethe snubbed him, and to avoid the civil disabilities aimed at Jews he unhappily accepted Christian baptism in 1825, the year he took out his doctorate in law. He published Reisebilder ('Pictures of Travel', 1826) in which he proclaimed his revolutionary sympathies, and Buch der Lieder ('Book of Songs', 1827) which established him as Germany's greatest lyric poet after (or perhaps even ahead of) Goethe. From 1831 his political opinions obliged him to live in Paris where he became an ardent disciple of *Saint-Simon. He worked as a journalist, secretly accepted a pension from the French Government (secured by his admirer *Thiers), had several more unhappy love affairs and became friendly with the brilliant French Romantics including *Hugo, George ${ }^{*}$ Sand, ${ }^{*}$ Chopin, de ${ }^{*}$ Musset and ${ }^{*}$ Berlioz. In 1841 he married Mathilde Eugénie Mirat, a shallowminded Parisian grisette with whom he had lived since 1835 . Heine was torn by many conflicts and he was the Doppelganger of his own poem: the baptised Jew, the expatriate German, the unhappy lover, the unconvinced radical, the bittersweet poet. The pure classical form of his poetry combines exquisite sensitivity and pessimism, marred at times by bitter cynicism, malicious satire and sentimentality. He has been called the 'poetic psychologist of love' and his later works, including Romancero (1851) and Last Songs and Thoughts (1853, 1854), were dubbed 'the swan song of romanticism'. From 1848 he was bedridden with spinal paralysis and suffered acute pain until his death. As a young man he called himself a 'soldier in the war of the liberation of mankind', but became cynical about political processes, observing: 'When the heroes go off the stage, the clowns come on.' Heine wrote in both French and German and strove to make both nations aware of their mutual artistic and intellectual achievements. He also read English literature extensively. In his penetrating political essays he seemed to anticipate the rise of Nazism, his works were suppressed in Germany (1933-45) and the Nazis insisted that his most famous poem, The Lorelei, was anonymous. Heine's lyrics were set to music by ${ }^{*}$ Schubert (6), *Schumann (23), *Brahms (6) and Hugo *Wolf (19).

Kaufmann, H. (ed.), Heinrich Heine: Werke und Briele. 10 vols, 1961-64; Kossoff, P., Valiant Heart: A Biography of Heinrich Heine. 1983.

Heinemann, Gustav (1899-1976). German politician. A lawyer, he was a founder of the Christian Democratic Party, then joined the Social Democrats and became Minister of Justice 1966-69. He was President of the Federal Republic of Germany 1969-74.

Heinkel, Ernst Heinrich (1888-1958). German aircraft engineer. He was chief designer for the Albatros Aircraft Company in Berlin before World War I. In 1922 he founded Ernst Heinkel Flugzeugwerke where he built a number of aircraft that were successful in World War II, the He III and $\mathrm{He} 162$, and the first rocket-powered aircraft.

Heinrich (Henry) IV (1050-1106). Holy Roman Emperor 1084-1106, King of Germany, Italy and Burgundy 1056-1106. Son of Heinrich III of the Salanian dynasty, he was brought up by his mother after his father's death. After coming of age (1065) he spent some years in recovering the royal domains in Saxony. He then tried to assert his position in Italy, which led to a quarrel with Pope *Gregory VII whom he declared deposed. The Pope excommunicated Heinrich in reply and forced him to make humble submission at Canossa (1077). Meanwhile in Germany, Rudolf of Swabia had been set up as a rival king and in 1080 he won papal support. Once more the Emperor declared the Pope deposed, once more he in turn was excommunicated. Rudolf, Duke of Swabia, having died in battle, Heinrich invaded 
Italy (1081), entered Rome (1084) and was belatedly crowned Emperor by the anti-pope Clement III. In his absence Germany was again in arms with rival kings in the field and as soon as Heinrich had restored some sort of order more rebellions occurred, this time aided by the treachery of his sons. In the last years of his life Heinrich lost his power in both Germany and Italy and died a broken man. He had the vision to see what was needed and to pursue it, but lacked the power to persuade or conciliate, and the diplomatic skill to divide his enemies.

Heinrich V (1082-1125). German King and Holy Roman Emperor 1106-25. He continued *Heinrich IV's struggle with the papacy on the question of investiture until a compromise was reached at the Concordat of Worms (1122). He married *Matilda, the daughter of *Henry I of England.

Heinrich VI (1165-1197). Holy Roman Emperor 1190-97. He was elected German King (1169) while his father, the Hohenstaufen emperor ${ }^{*}$ Friedrich I (Barbarossa), was still alive. Immediately after his accession as Emperor he went to Italy to secure the kingdom of Sicily, the heritage of his wife Constance. The Sicilians, however, chose Tancred of Lecce, and Heinrich had to return to Germany to face a rebellion by ${ }^{*}$ Heinrich der Löwe. By making skilful use of the bargaining power which the chance capture of England's *Richard I, returning from the crusade, put in his hands, he obtained peace. Thus freed, he had little difficulty in mastering Sicily and was crowned at Palermo (1194). Able but ruthless, Heinrich left a sinister reputation behind him.

Heinrich VII (c.1274-1313). Holy Roman Emperor 1308-13. Born in Hainault, and Count of Luxembourg, after election as Emperor and German King he led an army into Italy, with limited success and died near Siena, of malaria. *Dante's De Monarchia (1313) was written to advocate a universal monarchy with authority over the Pope.

Heinrich der Löwe (Henry the Lion) (1129-1195). Duke of Saxony and Bavaria. Head of the powerful *Guelph family, he played a dominant role in German history for many years, extending his power in the Baltic area and crusading against the Slavs beyond the Elbe. In later years he was in rebellion against the emperors *Friedrich I and *Heinrich VI and suffered temporary banishment and loss of estates. His second wife, Matilda, was a daughter of England's *Henry II. $\mathrm{He}$ was the founder of Munich (München). 'The Gospels of Henry the Lion', a manuscript volume illustrated with Romanesque paintings, was sold in London in 1983 for $£ 8.1$ million, then the highest priced book in history.

Heinz, Henry John (1844-1919). American food manufacturer, born in Pittsburgh. Of German descent, he sold produce from the family garden as
J. Heinz, which became H. J. Heinz Co. in 1888. He applied himself particularly to high standards of hygiene and quality.

Potter, S., The Magic Number 57. 1959.

Heinze, Sir Bernard Thomas (1894-1982). Australian conductor and teacher, born in Shepparton. Of German descent, he became a violinist, studied in Europe and served as an officer in World War I. Ormond Professor of Music at Melbourne University 1925-56, he promoted free concerts for schools, from 1929 was a driving force in the ABC (originally Australian Broadcasting Company, then Commission, now Corporation), which created orchestras, establishing subscription concerts which were broadcast, and initiated 'Youth Concerts'. Chief conductor of the Melbourne Symphony Orchestra 1933-53, he succeeded Eugene * Goossens as Director of the NSW Conservatorium 1956-67.

Radic, T., Bernard Heinze. 1986.

Heisenberg, Werner Karl (1901-1976). German theoretical physicist, born in Würzburg. He studied at Munich and Göttingen, was influenced by Arnold ${ }^{*}$ Sommerfeld, Wilhelm ${ }^{*}$ Wien and David ${ }^{*}$ Hilbert. From 1922 he began collaborating with Niels *Bohr ('the Copenhagen interpretation') on the meaning of quantum mechanics, on which they often disagreed. Professor of physics at Leipzig University 1927-42, he gained rapid recognition for his work on the general quantum theory in atomic physics, investigation of atomic structure and of the * Zeeman effect. He won the 1932 Nobel Prize for physics for his development of quantum mechanics based on the principle of 'indeterminacy', sometimes called the 'uncertainty principle', i.e. that the position and momentum of any body (or particle) cannot be simultaneously determined: the more precise the determination of one, the less precise is the other. Thus it is safer to refer to statistical probabilities than to formulate general laws. His 'uncertainty principle' is increasingly applied, by analogy, to philosophy and biology. He had been vaguely involved in right-wing politics in his youth, but lacked zeal for the Nazi cause. He directed the Kaiser *Wilhelm Institute for Physics at Berlin $1942-45$.

In 1942 he wrote papers describing, with a high degree of accuracy, how the fission of uranium 235 could produce enormous energy outputs but concluded that it would require three years of intensive work to build a reactor and Germany lacked access to raw materials. His role in developing a possible atomic bomb remains highly controversial: he claimed to have been opposed to developing a weapon, but may have been a Nazi pawn, or even a bungler in some technical areas.

He directed the Max * Planck Institutes of Physics at Göttingen 1946-58 and Munich 1958-70. He was an important influence on the creation of CERN in Geneva (1957), planned Germany's first nuclear 
reactor in 1957 but campaigned against stockpiling nuclear weapons. He worked on superconductivity, cosmic radiation and turbulence. He was a Christian, but also interested in eastern religions and wrote Physics and Philosophy (1958, translated 2007).

Frayne, M., Copenhagen. 1958; Cassidy, D. C., Uncertainty. The Life and Science of Werner Heisenberg. 1991; Powers, T., Heisenberg's War. 1993 ; Carson, C., Heisenberg in the Atomic Age. 2014.

Helena, St (Flavia Julia Helena) (c.248-328). Roman empress dowager, born in Drepanum (modern Bulgaria). Wife of Constantius Chlorus and mother of *Constantine I, she was divorced by her husband, who wanted to marry upwards, and went to live in Trier. Constantine became Emperor in 306. Helena was converted to Christianity about 312, and she was proclaimed as 'Augusta' in 325, later 'Augusta Imperatrix'. According to tradition, in 326 she went on pilgrimage to Jerusalem and there discovered the site of the Holy Sepulchre and the True Cross. Some relics that Helena discovered are displayed in Rome at Santa Croce in Gerusalemme.

Heller, Joseph (1923-1999). American novelist. Educated at Columbia and Oxford, he became an advertising copywriter and taught creative writing. His best known novel Catch-22 (1961), also a successful film, added a new phrase to the language. He also wrote Good as Gold (1979), God Knows (1984) and Picture This (1988).

Daugherty, T., Just One Catch. A Biography of Joseph Heller, 2011.

Helmholtz, Hermann Ludwig Ferdinand von (1821-1894). German physiologist. Professor of physiology at Königsberg 1849-55, Bonn 1855-58, Heidelberg 1858-71 and Berlin 1871-87, in 1887 he became director of the new Physico-Technical Institute at Berlin Charlottenberg. His early researches on animal heat and on the body system as a balance of inputs and outputs, led him to his fundamental memoir of 1847 'On the Conservation of Force', where he set out the mathematical principles of the conservation of energy. In the 1850 s he pursued physiological researches on the eye, making early use of the ophthalmoscope. He moved on to studies of the relationships between the ear, the nervous system and the psychology of hearing. He received the Copley Medal in 1873. His students included Max *Planck, Albert *Michelson and Wilhelm *Wien.

Helmholtz wished to free science from religious and metaphysical constraints. He saw scientific investigation and mechanical and mathematical explanations as the essential source of truth about all phenomena, physical and psychological. He believed in the unity of nature, and devoted himself to searching out those great forces which operated throughout it, above all, energy.

Cahan, D., Helmholtz. A Life in Science. 2018.
Helmont, Jan Baptist van (1580-1644). Flemish physician and chemist, born in Brussels. He travelled widely, studied medicine in Antwerp, and was influenced (but not uncritically) by *Paracelsus. Although a practising Catholic, he was challenged by ecclesiastical authorities for questioning miracles. Central to his methodology was the careful weighing of processes; for example, burning wood, weighing the residue and concluding that the lost mass formed gas, with air. He coined the word 'gas', from the Greek khaos. He demonstrated that a willow tree, over five years, increased its mass by taking in water, while the amount of soil around the roots was unchanged. He discovered how stomach acid is involved in digestion, and used gravimetry (analysis by weight) to study urine. He came close to identifying enzymes and a genetic code.

Helms, Jesse (1921-2008). American Republican politician. A senator from North Carolina 19732003, he took a hard Right position on social and foreign policy issues.

Héloïse (c.1098-1164). French religious. Abbess of Paraclete, Nogent-sur-Seine, she was mistress and wife of the scholar Peter *Abelard. Her uncle Fulbert appointed Abelard her tutor. They fell in love and fled to Brittany where Héloïse bore a son; she was later married to Abelard. Fulbert, in revenge, arranged that Abelard should be attacked and castrated. Héloïse entered the convent of Argenteuil and was later given Abelard's own foundation of the Community of the Paraclete.

Helpmann, Sir Robert (Murray) (1909-1986). Australian dancer, choreographer and actor, born in Mount Gambier. He made his debut in Australia in 1923, toured with Anna *Pavlova's company and went to England to join the then Vic-Wells Ballet in 1933. He became their leading male dancer in 1934 and danced with Sadler's Wells until 1950. His dancing and choreography were always strongly dramatic, and he was also involved in theatrical production. His partners included *Fonteyn, ${ }^{*}$ Ashton and *Nureyev. He choreographed many ballets including La Valse (1939), Miracle in the Gorbals (1946) and The Display (1964). He appeared in 12 films including *Olivier's Henry V (1944), The Red Shoes (1948), The Tales of Hoffmann (1951) and Don Quixote (1973). He became artistic co-director of the Australian Ballet 1965-76 and received a knighthood in 1968.

Salter, E., Helpmann. 1978; Sexton, C., Sir Robert Helpmann: A Life. 1992.

Helvétius, Claude Adrien (1715-1771). French philosopher, born in Paris. Trained in finance, he became chamberlain to the queen's household (1749) but was forced to resign public office when his book De l'Esprit (1758) was published. His materialism involved the claim that all thought is derived from sensations, and he argued that 
self-interest is the motive of all human action. Men, he thought, are originally equal in mental endowment and are made unequal by the influence of environment. His work influenced *Bentham's utilitarianism.

Hemingway, Ernest (Miller) (1899-1961). American novelist and short-story writer, born in Oak Park, Illinois. Son of a physician, he left school to become a reporter on the Kansas City Star, then during World War I was a volunteer ambulance driver in France and Italy, being severely wounded and hospitalised (1918). He returned to Europe in 1921 as Paris correspondent for the Toronto Star and later the Hearst papers. The expatriates Scott ${ }^{*}$ Fitzgerald, Gertrude ${ }^{*}$ Stein and Ezra *Pound encouraged and influenced his writing and he was friendly with James * Joyce. He evolved a terse and precise prose style, devoid of emotional colouring, meticulous in observing externals. Blood, death and impotence were recurrent themes. Hemingway was preoccupied with war, bullfighting, boxing, big game fishing and hunting, and most admired courage: 'grace under pressure', as he put it. He wrote seven novels, including The Sun Also Rises (1926), A Farewell to Arms (1929), To Have and Have Not (1937), For Whom the Bell Tolls (1940) and Across the River and into the Trees (1950), several volumes of short stories including In Our Time (1924) and Men without Women (1927) and accounts of his travels, adventures, hunting and fishing.

His primary residence was Key West, Florida 192839 and Cuba 1939-60 but he lived and worked for extended periods in Spain and France, and vacationed in Idaho. He married four times and his third wife, Martha Gellhorn (1908-1998) became a muchadmired war correspondent.

Collier's magazine sent Hemingway to report on the Spanish Civil War and World War II and he took part in the Normandy landings and the liberation of Paris (1944). He was awarded a Pulitzer Prize for The Old Man of the Sea (1952) and the Nobel Prize for Literature (1954) 'for his powerful, style-forming mastery of the art of modern narration'.

He survived two plane crashes in Africa in 1954, many other accidents, became diabetic, suffered constant pain, and was alcoholic and deeply depressed. After retiring to Idaho, ECT treatments failed and he shot himself. His grandmother, father, sister and two brothers had all committed suicide.

Twenty eight films or television series were based on Hemingway's works. 88 Poems was published in 1979. Minor planet 3656 Hemingway and a crater on Mercury were named for him.

Meyers, J., Hemingway. 1986; Reynolds, M., Hemingway. three vols, 1989, 1998, 1999; Oliver, C., Hemingway A to Z. 1999.
Henderson, Alexander (1583-1646). Scottish ecclesiastic. Early in his career he began to oppose English control of the Church in Scotland and in 1638 he was elected moderator of the General Assembly of the Covenanters, which established Scottish Presbyterianism despite the declared opposition of ${ }^{*}$ Charles I. He is reckoned as second only to John ${ }^{*}$ Knox in the history of the Church of Scotland.

Henderson, Arthur (1863-1935). British Labour politician, born in Glasgow. As an iron moulder in Newcastle he was active from his early youth in the trade union movement. He served broken terms as MP 1903-18, 1919-22, 1923, 1924-31, 1933-35. General Secretary of the Labour Party 1912-34, he was three times parliamentary Leader of the Labour Party 1908-10 (after Keir *Hardie), 1914-17 and 1931-32 (succeeding Ramsay ${ }^{*}$ MacDonald both times). In the coalition War Cabinet, he served as President of the Board of Education 1915-16 and Minister without Portfolio (de facto Minister for Labour) 1916-17. In MacDonald's two Labour governments, Henderson was Home Secretary 1924 and Foreign Secretary 1929-31. President of the World Disarmament Conference 1932-33, he received the 1934 Nobel Peace Prize.

Hengest (d.c.488) and Horsa (d.c.455). Jutish chieftains. Forerunners of the Anglo-Saxon invasion of Britain, according to the chroniclers they were invited by a British king, Vortigern, to help against the Picts, landed at Ebbsfleet (c.449) and were given the Isle of Thanet as a home. They are said to have turned against their hosts, though Horsa was soon killed. Hengest, who according to another legend married Vortigern's daughter Rowena, is said to have conquered Kent.

Henlein, Konrad (1898-1945). German politician. He led the Sudeten German Youth Movement from 1923 and, when *Hitler seized the Sudetenland from Czechoslovakia in 1938, he became Gauleiter 1938-39 and Commissioner for Bohemia 1939-45. He committed suicide after capture by the Americans.

Henley, William Ernest (1849-1903). English poet, dramatist and critic. He lost a foot through tuberculosis and spent much of his life in hospital, where he wrote his only remembered poem Invictus (1875). Long John Silver, the creation of his friend R. L. * Stevenson in Treasure Island, was based on Henley. As editor of the National Observer he published work by ${ }^{*}$ Hardy, ${ }^{*}$ Shaw, ${ }^{*}$ Wells and ${ }^{*}$ Kipling.

Henri (Henry) I (c.1008-1060). King of France 1031-60. His reign was a period of fratricidal strife, marked by the loss of Burgundy and defeat by *William, Duke of Normandy. 
Henri II (1519-1559). King of France 1547-59. Son and successor of *François I, he continued his policy of strengthening the power of the monarchy. He persecuted his Protestant subjects, the Huguenots, on both religious and political grounds since he feared their disruptive influence. In alliance with Scotland he carried on a war against England notable mainly for the capture of Calais (1558), which had been in English hands for 210 years. He also continued the struggle against the emperor ${ }^{*}$ Charles $\mathrm{V}$ and won the frontier bishoprics of Metz, Toul and Verdun. He married (1533) *Catherine de'Medici and their three sons became kings of France.

Henri III (1551-1589). King of France 157489 , the last of the ${ }^{*}$ Valois. Third son of ${ }^{*}$ Henri II and ${ }^{*}$ Catherine de'Medici, he succeeded his brother, *Charles IX. As Duke of Anjou he had been a candidate for the hand of England's Queen *Elizabeth, was credited with the victory of Jarnac and other successes in the religious wars and helped to organise the Massacre of St Bartholomew (1572). Elected King of Poland in 1573, he resigned on his accession to the French throne. As King he tried to hold a balance between the extreme Roman Catholic faction under Henri, Duc de ${ }^{*}$ Guise, and the Protestants under *Henri of Navarre, his natural heir. Fearful above all of an attempt by Guise to usurp the crown, he organised his murder (1588) and that of his brother, the cardinal of Lorraine, in the chateau of Blois. Surrounded by his pampered favourites ('les mignons'), Henri was a despised and sometime ludicrous figure but he had a certain astuteness that enabled him to retain some semblance of royal authority in faction-ridden France. He was assassinated a year later.

Henri IV (Henry of Navarre, né Henri de Bourbon) (1553-1610). King of France 1589-1610, the first of the *Bourbon dynasty; King of Navarre 1572-1610. Born in Pau, son of Antoine de Bourbon, Duke of Vendôme and Jeanne d'Albret, Queen of Navarre, he adopted the Protestant faith of his mother and succeeded her in June 1572. In August 1572 some 4,000 Huguenots who had gathered in Paris to celebrate his marriage with Marguerite de Valois, sister of King ${ }^{*}$ Charles IX, were killed in the Massacre of St Bartholomew. Henri escaped by renouncing his faith but was virtually a prisoner until 1576 , when he assumed the Protestant leadership. In 1588 he was in alliance with his distant cousin *Henri III of France against the Catholic League, Henri III was assassinated, but a four-year struggle, which included his great victory at Ivry (1590), followed before Henri IV could make his throne secure. Even then it was only by accepting the Catholic faith ('Paris is worth a Mass', he is supposed to have remarked), that he could gain entry (1594) to his capital. Having made peace with Spain (1596), and by the Edict of Nantes (1598), which guaranteed religious freedom for the Protestants, he set himself to restore the country after 30 years of civil war. With the help of his great minister *Sully he reorganised finances, repaired and extended roads and canals, developed agriculture and manufactures (e.g. the silk industry), while at the same time centralising the machinery of government and strengthening the monarchy. He declared as his aim for universal prosperity that every peasant would 'have a chicken in his pot every Sunday'. His first marriage having been dissolved, he married (1600) Marie de Médicis, who became the mother of his successor *Louis XIII. Of his mistresses (the number of whom won him the nickname Le Vert Galant), the best remembered is Gabrielle d'Estrées (d.1599). Henri was assassinated by a fanatic, François Ravaillac, probably of the extreme Catholic faction.

Henrietta Maria (Henriette-Marie) (1609-1669). Queen consort of England 1625-49. Daughter of ${ }^{*}$ Henri IV of France and *Marie de Médicis, and sister of *Louis XIII, she married * Charles I in 1625 and became very unpopular by maintaining a French and Roman Catholic entourage at court. A devoted wife and mother, she encouraged Charles' absolutist tendencies and incurred further odium by going to France (1642) to raise money for armed resistance to parliament. She finally left England (1644), returning only for short visits after the Restoration.

Bone, Q., Henrietta Maria. 1972.

Henry. French and German kings or emperors see Henri or Heinrich

Henry I ('Beauclerc') (1068-1135). King of England $1100-35$. Fourth and youngest son of *William the Conqueror, born at Selby, Yorkshire, he secured election to the English crown while his elder brother Robert was returning from a crusade. He defeated Robert, who retained possession of Normandy, at Tinchebrai (1106) and held him captive for the rest of his life. He gained the support of the Saxons by a charter restoring the laws of *Edward the Confessor, and by a politic marriage to Matilda, daughter of ${ }^{*}$ Malcolm III of Scotland. The archbishop of Canterbury, ${ }^{*}$ Anselm, was recalled, and a compromise agreed on the investiture dispute (1106). Henry created an efficient administrative machine, controlled the barons and ruled with severity but in accordance with the laws: his appellation 'the lion of justice' was well earned. His only legitimate son, William Adelin, was drowned in the White Ship (1120). His daughter ${ }^{*}$ Matilda thus became his natural heir. Henry was posthumously called 'Beauclerc' or the Scholar, as a tribute to his learning, which was unusual for a king at his time.

Henry II (Henry Plantagenet, also known as FitzEmpress or Curtmantle/ Courtmanteau) (11331189). King of England 1154-89, first of the house of *Plantagenet, Duke of Normandy and Aquitaine, Count of Anjou. Son of ${ }^{*}$ Matilda (daughter of *Henry I) and Geoffrey Plantagenet, born at Le Mans. He inherited Normandy through his mother 
and Anjou through his father, his marriage (1152) to *Eleanor of Aquitaine added Poitou and Guienne to his dominions. He curbed the baronial power, worked to integrate the Norman, Old English and Roman laws, organised juries, itinerant judges, assizes, and a central court of justice, and raised a militia. His attempts to limit the Church's independence and especially the power of the Church courts by the Constitutions of Clarendon (1164) led to his quarrel with his old friend and chancellor *Becket, whom he had appointed Archbishop of Canterbury. Four of Henry's knights travelled from Bayeux, in Normandy, to Canterbury to kill Becket, assuming that this was his wish. In July 1174 Henry did public penance at Becket's tomb, was ritually flogged by senior clergy, but managed to avoid major concessions. He warred with *Louis VII of France, invaded Wales and crushed the power of the Norman nobles in Ireland (1171-72). He obtained the overlordship of Scotland by the Treaty of Falaise (1174). Henry was a man of extraordinary ability and energy, the last king who ruled as a chief executive (mostly in absentia). He understood English but spoke in French or Latin. He failed with his own family. His many liaisons-the partly legendary story of Fair Rosamond (Rosamond Clifford) is well known — antagonised his high spirited wife and she in turn influenced his sons against him. He died at Chinon while endeavouring to suppress a rebellion led by ${ }^{*}$ Richard and ${ }^{*}$ John, aided by King *Philip II of France, and was buried at Fontevraudl'Abbaye, Anjou.

Warren, W. L., Henry II. 2000; Barber, R., Henry II: A Prince Among Princes. 2015; Gold, C., King of the North Wind. 2018; Barratt, N., The Restless Kings. Henry II, His Sons and the Wars for the Plantagenet Crown. 2018.

Henry III (1207-1272). King of England 1216-72. Born in Winchester, he succeeded his father King ${ }^{*}$ John, and declared himself of age in 1227 . Five years later he deprived the regent, Hubert de Burgh, of all offices and took over the administration himself. His favouritism towards the relatives of his wife, Eleanor of Provence (married 1236), financial chaos caused by his acceptance from the papacy of the crown of Sicily for his son, and his inefficiency, antagonised the barons and the people alike. He exacted money from the Jews, then subjected them to persecution and murder after the 'blood libels' of 1244 , culminating in a pogrom after hysteria provoked by the murder of Hugh of Lincoln (1255), one of the worst episodes in English history. He appointed foreigners to bishoprics and at court. Led by Simon de *Montfort, the nobles compelled him to assent to the 'Provisions of Oxford' (1258) which transferred power to a commission of barons. His subsequent repudiation of this (with support from *Louis IX of France) resulted in the Barons' War, the defeat and capture of Henry at Lewes (1264) and his enforced acceptance of humiliating terms of surrender. De Montfort then summoned the first 'parliament' (January 1265). The military skill of his son Edward I and a split among the barons turned the scale: de Montfort was defeated and killed at Evesham (1265) and Henry spent the rest of his reign in peace. Westminster Abbey, a large part of which was built in his reign, is a monument to his artistic taste.

Church, S., Henry III. 2017; Carpenter, D., Henry III 1207-1258. 2019.

Henry IV (Henry Plantagenet, known as Henry Bolingbroke) (1367-1413). King of England 1399-1413, first of the House of Lancaster. Born in Bolingbroke, Lincolnshire, he was the son of *John of Gaunt and Blanche of Lancaster. He distinguished himself abroad as a soldier and returned to play an important part in the reign of his cousin *Richard II. At first he sided with the king's baronial enemies but became reconciled with Richard and was created Duke of Hereford (1397). In the following year Richard, whose rule was now unchallenged, found an excuse to banish his former rival and, when John of Gaunt died, he seized the Lancaster estates. Henry's reaction was to land in Yorkshire and head the forces of discontent. Richard on his return from Ireland found himself confronted with overwhelming strength: he surrendered and was imprisoned in Pontefract Castle from which he never emerged. The vacant throne was seized by Henry but his usurpation was contested. He had to overcome the Welsh under Owain *Glyndwr (1399), the Scottish under the 4th Earl of Douglas (1402), and Sir Henry *Percy ('Hotspur'), with the adherents of his family, at Shrewsbury (1403) before he could feel secure. To win support Henry had to make concessions to his parliaments and council and to the Church, introducing a law for the burning of heretics and the persecution of the Lollards. Illness in later life made him secretive and suspicious, but he was also devout, and the patron of ${ }^{*}$ Chaucer, ${ }^{*}$ Gower and other poets. He died from a disfiguring disease, probably leprosy.

Kirby, J. L., Henry IV of England. 1970; GivenWilson, C., Henry IV. 2016.

Henry V (1387-1422). King of England 1413-22. Born at Monmouth, the eldest son of ${ }^{*}$ Henry IV, he distinguished himself as a soldier at the Battle of Shrewsbury (1403) and during his father's last years of illness proved his ability as an administrator. It is probable that the stories of his wild youth were much exaggerated. As King he aimed to restore the Percys and others to favour, but rallied his countrymen behind him by renewing *Edward III's claim to the French throne. He invaded France (1415), won the Battle of Agincourt against seemingly insuperable odds and in a few years so asserted his supremacy that in 1420 he was able to conclude the 'perpetual peace' of Troyes. By this he married *Catherine of Valois, *Charles VI's daughter, and was recognised as regent and 'heir of France'. His death, probably from dysentery, at Vincennes two years later cut short the 
career of an outstandingly able, devout and successful soldier and administrator. He decreed that laws and proclamations had to be published in English.

Earle, P., The Life and Times of Henry V. 1972; Vale, M., Henry V. 2016.

Henry VI (1421-1471). King of England 1422-61 and 1470-71. Born at Windsor, he succeeded his father *Henry $\mathrm{V}$ in infancy, the administration being carried on by his uncles Humphrey, Duke of *Gloucester, and John, Duke of *Bedford, in England and France respectively. In France, where by the Treaty of Troyes he had nominally been king since the death of *Charles VI, national resistance, fired by *Joan of Arc, had steadily increased, nonetheless, the peace policy of his advisors was regarded as a betrayal of his father and the nation. Henry grew up to be devout, timid, scholarly and quite unsuitable to rule. He was a Benedictine confrator and his followers considered him a saint. Henry's most lasting achievements were his three foundations of All Souls College, Oxford (1438), Eton College (1440) and King's College. Cambridge (1441), in which he took great interest and pride. His obvious incapacity, made further evident by his subservience to his wife *Margaret of Anjou (married 1445), encouraged Richard, Duke of *York to assert that he had a stronger claim to the throne than the Lancastrian line. So began the War of the Roses. Throughout the conflict, Henry, intermittently comatose 1453-55, suffered from melancholia and paralysis (presumably catatonic schizophrenia, inherited from Charles VI) and was only a puppet. His armies were defeated and he lost the throne to ${ }^{*}$ Edward IV (son of the dead Richard of York). In 1470, a mere shell, he was restored briefly by *Warwick the Kingmaker until the Lancastrian army was defeated at Barnet (1471). Henry was captured, imprisoned in the Tower of London and died there. A proclamation stated that he died of 'pure displeasure and melancholy' but his exhumed body revealed trauma to the head, and Edward IV must have given the order. Henry's only son, Edward of Westminster (1453-1471), was killed at the Battle of Tewkesbury.

Johnson, L., Shadow King. The Life and Death of Henry VI. 2019.

Henry VII (Henry Tudor, in Welsh Harri Tudur) (1457-1509). King of England 1485-1509, first of the Tudor dynasty. Born in Pembroke Castle, he was the posthumous child of Edmund Tudor, 1st Earl of Richmond (1430-1456), son of *Henry V's widow, ${ }^{*}$ Catherine of Valois. His mother, Lady Margaret Beaufort (c.1443-1509) was the great-granddaughter of *John of Gaunt. He lived in exile in Brittany from 1471 , and after the death of ${ }^{*}$ Henry VI and his son, was recognised as Lancastrian leader. In 1485 he landed at Milford Haven and won the Battle of Bosworth Field, Leicestershire, where ${ }^{*}$ Richard III was killed; Henry was recognised as King. To unite the rival houses of Lancaster and York he married Elizabeth, daughter of
*Edward IV, but still had to overcome two pretenders, Lambert ${ }^{*}$ Simnel and Perkin *Warbeck. The main purpose of his reign, to restore law and order and build up a strong and efficient administrative system after the chaos of the Wars of the Roses, he successfully achieved. He weakened the nobles by enforcing laws against liveried retainers and inaugurating the Star Chamber, a special court intended to curb the overmighty subject. Through his notorious agents, Richard Empson and Edmund *Dudley, and many dubious expedients he collected fines and forfeits. In his way and by the strictest economy he gave the monarchy the added strength of a full treasury, an achievement helped by a cautious and peaceful policy abroad.

Chrimes, S. B., Henry VII. 1972; Towle, C. and Hunt, J., Henry VII. 1998; Cunningham, S., Henry VII. 2007; Penn, T., Winter King: Henry VII and the Dawn of Tudor England. 2011.

Henry VIII (Henry Tudor) (1491-1547). King of England 1509-47 and of Ireland 1541-47. Born in Greenwich, he was the son of ${ }^{*}$ Henry VII and heir to the throne after the death of his elder brother, Arthur. He fulfilled his father's dynastic purposes by marrying, within two months of his accession, Arthur's widow, *Katherine of Aragon. Henry, with ${ }^{*}$ François I of France, and the emperor ${ }^{*}$ Charles V (also King of Spain), was one of the three talented, ambitious rulers who came to power almost at the same time and between them controlled the destinies of Europe. Enabled by his father's parsimony to pursue an active policy, Henry aimed, with the help of his great minister *Wolsey, to maintain a balance between France and Spain. At the outset of his reign he invaded France and won the Battle of the Spurs, while his army of the north won the Battle of Flodden Field (1513) at which France's ally, *James IV of Scotland, was defeated and killed. François now tried to win Henry to his side but, though he staged a spectacular meeting at the Field of the Cloth of Gold (1520), he failed in his purpose. Henry, an orthodox Catholic, who had received from the Pope the title of Defender of the Faith for a book on the Sacraments (1521), began to profess doubts about the legitimacy of his marriage to his brother's widow. Moreover, Katherine was older than Henry and plain, while of all the children she had borne him only one, *Mary, had survived. He was determined to marry *Anne Boleyn but Wolsey failed to get a papal annulment of the marriage and was disgraced (1530). In 1533, after *Cranmer, Archbishop of Canterbury, had declared his former marriage invalid, Henry secretly married Anne. In 1534 his obedient parliament confirmed the invalidity of the marriage with Katherine, severed all links with the papacy and declared Henry Supreme Head of the Church. This was the most important single event of his reign. A very few, e.g. Henry's old friend and chancellor, Sir Thomas *More, refused to accept this and were executed, but resistance was surprisingly small. Henry now set about making the change profitable by suppressing first the lesser 
then the greater monasteries and confiscating their property, some of which was used for educational purposes. This action, of which Thomas *Cromwell was the instrument, provoked a rising in the north, the Pilgrimage of Grace (1537), which was crushed with great harshness.

In 1536 Anne Boleyn (mother of *Elizabeth I) was beheaded for adultery and Henry immediately married one of her ladies-in-waiting, *Jane Seymour, who died giving birth to the future *Edward VI (1537). Cromwell's intention in furthering the fourth marriage, with *Anne of Cleves, was to gain alliance with the German Protestants, but when the lady failed to exhibit the charms of her portraits she was divorced and pensioned. Henry's next wife, ${ }^{*}$ Catherine Howard, shared Anne Boleyn's fate, and his last, ${ }^{*}$ Catherine Parr (married 1543), survived him. Despite the fact that he had at different times denied the legitimacy of his daughters, he prescribed in his will the order of succession, which was in fact carried out: Edward, Mary, Elizabeth.

In 1546, six weeks before his death, he founded Trinity College, Cambridge, incorporating two earlier foundations, Michaelhouse (1324) and King's Hall (1337).

Henry was a gifted scholar, poet and musician, a strong ruler with political skills. In his last years he became more and more tyrannical, his suspicions increased and the number of judicial murders, for example, that of the young Earl of *Surrey (1546) mounted, but the memories of handsome, talented, pleasure-loving 'Bluff King Hal' remained in the minds of the people and he retained his popularity to the end.

Ridley, J., Henry VIII. 1984; Starkey, D., and Doran, S., Henry VIII: Man and Monarch. 2009.

Henry, Joseph (1797-1878). American physicist, born in Albany, New York State. Son of a labourer, he was largely self-educated, like his contemporary *Faraday. He became a watchmaker's apprentice, then taught mathematics in country schools. He discovered how to make more powerful electromagnets with improved insulation and by 1832 could lift a ton of iron. He anticipated *Morse's development of the telegraph by using relays, and discovered the principle of induction (transferring a current or signal from one coil to another) independently of Faraday. The unit of induction is named for him. He designed but did not build the first practical electric motor (1831), but its widespread adoption depended on the development of a reliable power supply (Thomas ${ }^{*}$ Davenport). Henry was professor of physics at Princeton 1832-46, first secretary of the Smithsonian Institution 1846-78 and virtual founder of the US Weather Bureau.

Henry, O. (William Sydney Porter) (1862-1910). American short-story writer, born in North Carolina. His stories written in an ironic, pungent, epigrammatic style, and usually ending with a sardonic unexpected twist, mainly relate some small but fateful incident in the lives of those, even the humblest, who together form New York. Among his books are Cabbages and Kings (1904), The Four Million (1906), The Heart of the West (1907), and The Voice of the City (1908).

Henry, Patrick (1736-1799). American politician, born in Virginia. Essentially self-taught, he quickly established himself as a successful lawyer. He was elected to the Virginia House of Burgesses (1765), and it was the eloquence and vigour of his speeches that inspired the agitation against the Stamp Act. He quickly became the leader in Virginian politics and summoned the Continental Congress. In the course of a speech in Richmond in 1775 urging military readiness he shouted the famous words 'give me liberty or give me death'. He took part in the events that led to the Declaration of Independence and he was Governor of Virginia 1776-79 and 1784-86, but a quarrel with *Jefferson stultified his later activities. He fought bitterly against the constitution on the grounds that liberty had been betrayed, and delayed its ratification by Virginia for 23 days. He refused all invitations by ${ }^{*}$ Washington to serve in his administration.

Mayer, H., A Son of Thunder. 1986.

Henry (Henrique) the Navigator (1394-1460). Portuguese prince. Son of King *João I of Portugal and a grandson of ${ }^{*}$ John of Gaunt, an expedition to North Africa, which resulted in the fall of Ceuta (1415) and in which he played a distinguished part, fired his interest in exploration. Though he made no voyages himself he planned, charted and sent out more than 30 expeditions to sail south along the Atlantic coast of Africa. His sailors went farther and farther south and at last reached Sierra Leone. Henry also sent explorers overland and they reached Senegal and the Sudan. He financed these expeditions in part by granting licences to merchants, who soon discovered the profits to be won from trade in slaves. He sent out settlers to the uninhabited islands of Madeira and the Azores and established trading posts on the African coast.

Major, R. H., Life of Prince Henry of Portugal. 1967.

Henryson, Robert (c.1425-c.1505). Scottish poet. Possibly a schoolmaster of Dunfermline, his works include The Tale of Orpheus and Erudices, his Quene (630 lines), Testament of Cresseid (616 lines) and Morall Fabillis of Esope the Phrygian (13 poems, based on *Aesop, 2975 lines).

Harvey Wood, H. (ed.), Collected Poems and Fables of Robert Henryson. 1958.

Hensen, Matthew Alexander (1866-1955). AfricanAmerican explorer. Robert E. *Peary and Hensen were the first explorers to reach the North Pole (1909), but Hensen's role was played down by Peary. 
Henslowe, Philip (1550-1609). English theatre builder and impresario. He made money from timber, animal skins, dyeing, property, pawnbroking and brothels. In 1587 he built The Rose Theatre, the first in Bankside, and the Fortune Theatre in 1598, and The Admiral's Men played in both. He was the father-in-law of the actor Edward *Alleyn. He kept a valuable diary 1592-1609 with many references to *Shakespeare's work with a rival company. He also had a financial interest in bearbaiting and animal shows.

Henson, William Samuel (1805-1888). English engineer, born in Nottingham. He improved lacemaking machines and, in collaboration with John *Stringfellow, patented a light-weight steam engine (1841), then designed the Henson Aerial Steam Carriage (1843), an ambitious monoplane that failed to fly. He migrated to the US in 1849 and also invented the ' $\mathrm{T}$ ' safety razor.

Henze, Hans Werner (1926-2012). German composer and conductor. He taught in Germany, the UK and Italy, composed eight symphonies, ballets, film scores, chamber music and 10 operas including Elegy for Young Lovers (1961) and The Bassarids (1966), both to libretti by W. H. *Auden and Chester Kallman.

Hepburn, Katharine (Houghton) (1907-2003). American stage and film actor, born in Connecticut. Distinguished by a combination of elegance and eccentricity, she was educated at Bryn Mawr, and made her stage debut in 1928. Her first film was A Bill of Divorcement (1932). Eight of her best and most successful were made with her lover Spencer ${ }^{*}$ Tracy. The Philadelphia Story (1941) and The African Queen (1951) were much admired. She received Academy Awards for four films: Morning Glory (1933), Guess Who's Coming to Dinner (1967), The Lion in Winter (1968) and On Golden Pond (1981).

Hepplewhite, George (d.1786). English cabinetmaker and furniture designer. After his death his widow published a book of some 300 designs called The Cabinet-Maker and Upholsterer's Guide. It is unknown whether the designs were Hepplewhite's own but they epitomised the taste of his time and have since been identified by his name.

Edwards, R., Hepplewhite Furniture Designs. 1948.

Hepworth, Dame (Jocelyn) Barbara (1903-1975). English sculptor, born in Wakefield, Yorkshire. Trained in Leeds, London, Florence and Rome, she came from a similar background to Henry * Moore. She married the painter Ben ${ }^{*}$ Nicholson in 1933 and gave birth to triplets; they divorced in 1951. She began with abstract or semi-abstract forms, in stone or wood, characterised by pierced shapes and stringed figures, notable for smooth form and texture, later moving on to monumental bronzes. She exhibited at the Venice Biennale (1950), won the Grand Prix at the São Paulo Biennale in 1959 and was represented in the world's major galleries. She lived at St Ives, Cornwall from 1939 and died there in a fire.

Heraclitus of Ephesus (fl. c.500 BCE). Greek natural philosopher. He wrote a book, On Nature, fragments of which survive as quotations and opinions in the writings of others, from which his views can be gauged. Heraclitus seems to have seen the world in terms of the tensions between pairs of opposites (an instance being a bow string, pulled in different directions). Plenty and hunger, sickness and health, life and death, hot and cold, are some of Heraclitus' pairs. Yet he also asserts that the two figures in each pair are essentially one, that they contain each other in a dialectical way. From this, Heraclitus draws the conclusion that the universe is a Oneness, but continually in a state of flux. It is probable that Heraclitus was not so much arguing that, because everything changed, nothing could be known, but rather that, although everything changes, these changes are governed by some sort of order and natural law. It is possible that Heraclitus believed that the universe originated out of fire, and that it would at times be restored by cosmic conflagrations.

Kirk, G S. and Raven, J. E., The Pre-Socratic Philosophers. 1957.

Herbart, Johann Friedrich (1776-1841). German philosopher and educationist. A pupil of J. G. *Fichte, with whom he disagreed, he became professor of philosophy at Göttingen and Königsberg. He developed the philosophy of*Kant by stressing the existence of a world of real things behind the world of appearances, and he made an attempt to make psychology a mathematical science. In education, he stressed what are known as the 'Herbartian steps': preparation, presentation, comparison or association, generalisation, application.

Dunkel, H. B., Herbart and Herbartianism. 1970.

Herbert, George (1593-1633). English metaphysical and religious poet, born in Wales. Younger brother of Lord *Herbert of Cherbury, and educated at Trinity College, Cambridge, he was already making his mark at court, and briefly MP (1624), when he turned against a worldly career and entered the priesthood (1625). In 1629 he became vicar of the parish of Fugglestone St Peter with Bemerton, near Salisbury, Wiltshire, where he remained until he died of tuberculosis. His poems, almost all contained in The Temple (1633), constitute an emblematic survey, for the most part serene, of the interaction of the soul with God. The finest include 'Love bade me welcome' and 'Vertue'. Strikingly homely imagery sometimes contrasts with extravagant conceits and even puns. About 100 of his poems have been set to music, many as hymns. He was a skilled lutenist and wrote poems in English, Latin and French. His chief 
prose work A Priest to the Temple or the Country Parson (posthumous, 1752) was described by Izaak *Walton as 'plain prudent useful rules'.

Gardner, H. (ed.), George Herbert Selected Works. 1961; Drury, D., Music at Midnight. The Life and Poetry of George Herbert. 2013.

Herbert of Cherbury, Edward Herbert, 1st Baron (1583-1648). English soldier, diplomat and poet. After fighting in the Low Countries and spending some years in travel, he was Ambassador to France 1619-24. A royalist at the outbreak of the Civil War, he came to terms with parliament and was left undisturbed. In Of Truth (1624) he propounded an anti-empirical theory of knowledge. His Of the Religion of the Gentiles (1663), in which he found satisfactory common factors in all religions, provided a basis for English 'Deism'. His Autobiography (to 1624), a notable picture of the man and his period, departs from accuracy when it conflicts with his conceit. His poetry, in Latin and English, belongs to the metaphysical school of *Donne.

Herbert, Sidney, 1st Baron Herbert of Lea (1810-1861). English politician. Son of the Earl of Pembroke and a Russian countess, he was an MP 1832-61, at first Tory, then Liberal. Secretary at War 1845-46, 1852-54 and 1859-61, he sent Florence *Nightingale to the Crimea, became her fervent supporter and exhausted himself in the cause of reform.

Herbert, Xavier (original name Alfred Jackson) (1901-1984). Australian novelist, born in Geraldton. He worked as a pharmacist, journalist, miner, fettler, woodcutter and union organiser and his massive novels included Capricornia (1938) and Poor Fellow My Country (1975).

Herbert, Zbigniew (1924-1998) Polish poet, essayist, playwright and philosopher, born in Lviv. His family was related to ${ }^{*}$ George Herbert. His poems, much admired by Seamus *Heaney and John ${ }^{*}$ Coetzee, were translated into 38 languages.

Herder, Johann Gottfried (1744-1803). German philosopher and poet. He studied with Johann Georg Hamann (1730-1788), was influenced by *Vico, rejected universalism and Utopianism, arguing that cultures are shaped by national or regional factors. ${ }^{*}$ Goethe and the German Romantics read Herder closely.

Berlin, I., Vico and Herder. 1976.

Hereward the Wake (c.1035-1072). Anglo-Saxon patriot. After plundering Peterborough with Danish help, he held out for many months against *William the Conqueror in the marshes of the Isle of Ely and was defeated only with difficulty in 1071. Many legends grew up around his name.
Hernández, José (1834-1886). Argentinian poet. His chief works, two poems on Martin Fierro (1872 and 1879), glorify the life of the gauchos (mounted herdsmen) of the pampas. The gaucho poetry of Argentina corresponds to the folksongs of other lands.

Hero of Alexandria (c.10-70 CE). Greek mathematician. Remembered mainly for his mechanical inventions, some of the best known are described in his Pneumatics. They include a simple form of steam turbine, a fire engine pump, a fountain in which the jet is sustained by air compressed by a column of water, and a water-organ. He wrote also on the principles of mechanics and their practical applications.

Herod. Judean dynastic name borne by rulers before and after the beginning of the Christian era. Herod the Great (c.72-4 BCE) was the second son of Antipater the Idumaean (d.43 BCE), appointed as Procurator of Judaea by Julius ${ }^{*}$ Caesar. Mark *Antony made Herod tetrarch of Judaea in 40, and in $31^{*}$ Augustus granted him the title of King. The friendship of Rome enabled him to rule in peace and his taste for the magnificent in architecture caused him to rebuild Caesarea and restore Samaria. In 20 he began the reconstruction of the Great Temple at Jerusalem, but his fears and jealousies led to gross cruelties and wholesale butcheries. He made lavish extensions to the great hill fortress of Masada, planning to use it as a last refuge if needed. He was sophisticated and cosmopolitan, travelled widely, owned an estate in Provence and was President of the Olympic games (12 BCE). But with age came mental instability. Every member of the rival Hasmonean dynasty was killed and even several of his own family, the 'Massacre of the Innocents' at Bethlehem, although not recorded by *Josephus, would be in keeping with his character. Herod, who is said to have had 10 wives, left his kingdom to be divided among three of his sons-Philip, Archelaus and ${ }^{*}$ Herod Antipas.

His son, Herod Antipas (c.20 CE-c.40 CE) was tetrarch of Galilee and Peraea 4 BCE-39 CE. *John the Baptist was executed for protesting against his marriage with Herodias, the wife of his half-brother Philip. It was to this Herod that *Pontius Pilate, in an effort to evade responsibility, sent ${ }^{*}$ Jesus for examination after discovering that he was a Galilean, but Herod refused to exercise jurisdiction. Herod travelled to Rome (38) to seek recognition as king, but failed through the intrigues of his nephew *Herod Agrippa and was banished to Lugdunum (Lyon) where he died.

His nephew, Herod Agrippa I (10 BCE-44 CE), who succeeded, had been brought up luxuriously in Rome. He suffered an eclipse under the emperor *Tiberius but became a favourite of ${ }^{*}$ Caligula and later of ${ }^{*}$ Claudius. As a result he gradually acquired (37-41) a larger territory than that of his grandfather 
${ }^{*}$ Herod the Great and the coveted title of king. In the Acts of the Apostles it is related that he had the apostle St *James put to death, that he imprisoned St *Peter and that he died at Caesarea, being 'eaten by worms'. His devotion to Jewish observances and national interests won the affection of his subjects.

His son Herod Agrippa II (27-100 CE) was only 17 and was living in Rome when his father died. *Claudius, therefore, took the opportunity of reconverting the kingdom into a Roman province. Herod held family prestige and possessions but no political authority, thus the Roman procurator Festus was present, according to the Acts, when St *Paul made his defence at Caesarea.

Herodotus (c.485-425 BCE). Greek historian, born in Halicarnassus (now Bodrum), Asia Minor. Known as 'the father of history', his narrative of the Graeco-Persian wars in the time of *Xerxes was the first to attempt critical assessment of historical data. His style was witty, discursive and sharply observant. A political exile, he lived in Samos and Athens, travelled to Egypt then settled (442) in the Athenian colony of Thurii, in southern Italy, where he died. His rational and scientific approach to writing history (as opposed to chronicles which attempt no explanation of events) was unique in the Greek world, and reflects the influences of Asian philosophy and Athenian experience on the growth of his mind.

Myres, J. L., Herodotus: Father of History. rev. 1971; Gould, J., Herodotus. 1989; Dewald, C., and Marincola, J., (eds.). The Cambridge Companion to Herodotus. 2006.

Heron, Patrick (1920-1999). English painter, born in Leeds. Influenced by ${ }^{*}$ Cézanne and ${ }^{*}$ Matisse, he produced both figurative and non-figurative works, notable for powerful design and strong colour. He also worked with stained glass and wrote criticism.

Herophilus (c.4th century BCE). Greek anatomist, born in Chalcedon, in Asia Minor. He taught and practised medicine at Alexandria. An expert in dissection, Herophilus laid the foundations of modern anatomy and physiology. He carried out important anatomical investigations of the brain, eye, genital organs and vascular system. He argued that it was the brain that was the centre of intelligence and control in the body. He recognised that it was through the nerves that the brain exercised its powers over the extremities of the body. In the brain he distinguished the cerebellum from the cerebrum, and understood the difference in function between sensory and motor nerves. He stressed the distinction between arteries and veins, and (contrary to common opinion) held that the arteries contain blood, not pneuma (spirit). His work on the heart stressed that the pulse was purely involuntary, and caused by the contraction and dilation of the arteries. As a clinician, Herophilus seems to have been particularly interested in gynaecology. He wrote a treatise on midwifery in which he offered accurate descriptions of the ovaries, the cervix and the uterus. He was probably also interested in menstruation, and its relation to general health.

Herreweghe, Philippe (1947-). Belgian (Flemish) conductor. Trained as a psychiatrist, he worked in Ghent and Paris and won awards for his recordings of J. S. *Bach, *Beethoven and ${ }^{*}$ Berlioz.

Herrick, Robert (1591-1674). English poet. Apprenticed to his father, a London goldsmith, he studied at Cambridge, and on returning to London became friends with Ben *Jonson and his literary set. Before 1627 he had taken holy orders and became rector of Dean Priory, Devonshire 1629-17 and 1662-74, being dismissed during the Puritan supremacy. He was a prolific writer of exquisite love lyrics, Hesperides (1647) containing some 1,200 poems, many in the manner of ${ }^{*}$ Horace, on the general theme of the transience of beauty:

Gather ye rosebuds while ye may

Old Time is still a-flying.

Noble Numbers (1647) contains his religious poems.

Scott, G. W., Robert Herrick. 1974.

Herriot, Edouard (1872-1957). French politician. As Senator 1912-19, Deputy 1919-42, and a leader of the Radical Socialist Party, he was a prominent member of many left-centre coalition ministries between the wars: on three occasions 1924-25, 1926 and 1932 he briefly combined the offices of Prime Minister and Foreign Minister. Meanwhile he was the almost perpetual mayor of Lyon 1905-42, 1945-57. Interned in Germany 1942-45, he became a member of the Académie française in 1946 and the first president of the National Assembly under the Fourth Republic 1947-54. He wrote a biography of *Beethoven (1929).

Herschel, Sir John Frederick William, 1st Baronet (1792-1871). British astronomer, born in Buckinghamshire. Son of William *Herschel, he attended St John's College, Cambridge. He began to study law, but was persuaded to follow his father into science. In the 1810 s he helped his father with his astronomical observations, developed skill in the manufacture of telescopes, made some useful discoveries in optics and attempted the first chemical analysis of the solar spectrum. He produced a catalogue of nebulae and star clusters in the Northern Hemisphere 1825-33. Knighted in 1831, he assisted W.H.F. *Talbot in his pioneering work in photography and later developed the use of sensitised paper and of hypo as a fixing agent. He moved to the Cape of Good Hope in 1834, set up an observatory and produced the massive and definitive Results of Astronomical Observations Made During the Years 1834-1838 at the Cape of Good Hope, the first full stellar map of the Southern Hemisphere. He made the first detailed description of the Magellanic Clouds. He pioneered 
stellar photography from 1850, interested himself in geophysics and (like *Newton) was Master of the Mint. He twice received the Copley Medal of the Royal Society $(1821,1847)$. He served on the Royal Commission investigating Oxford and Cambridge universities and was also on the Committee of the Great Exhibition of 1851. He wrote on the philosophy of science, translated The Iliad and published a very popular Outlines of Astronomy (1849). After 1855 he suffered from illness and depression.

Buttmann, G., The Shadow of the Telescope. 1970.

Herschel, Sir (Frederick) William (né Friedrich Wilhelm) (1738-1822). Anglo-German astronomer and composer, born in Hanover. Of Jewish ancestry, son of an oboeist in a military band, he took early to mathematical and scientific studies, but followed his father into becoming a military musician. He went to England in 1757, settling in Bath in 1766 as an organist, concertmaster, composer and music teacher, and building up an income sufficient to enable him to pursue his love of astronomy. He was a prolific composer of symphonies, oboe concertos and keyboard works. From the 1770s he devoted himself to grinding mirrors for Newtonian reflecting telescopes. He began making systematic sweeps of the heavens, and in 1781 discovered a hitherto undescribed object that he first took for a comet, but quickly recognised to be a planet (Uranus). For this discovery he was rewarded by ${ }^{*}$ George III with a pension of $£ 200$ per annum and received the Copley Medal. Between 1785-89 he built (assisted by $£ 4,000$ from George III) his 'Forty Foot Telescope', for 50 years the world's biggest, with a focal length of $12 \mathrm{~m}$ and a reflector with a diameter of $1.25 \mathrm{~m}$ ( $491 / 2$ inches). With his sister Caroline Lucretia Herschel (1750-1848), also born in Hanover, he undertook massive surveys of the skies, producing numerous catalogues. The first notable woman astronomer, she discovered eight comets and received many awards. (Election as FRS was denied her.) He sought out nebulae, raising the known total from a few hundred to over 2500 . He speculated whether nebulae were very distant clusters of stars, or swirling clouds of gaseous material (which might one day coalesce into stars), and also upon the possibility that the whole heavens might have developed out of such nebulae. Amongst his other speculative ideas was a belief that life existed on the moon. He was also one of the discoverers of infrared radiation in the light of the sun. Asteroid 2000 Herschel, craters on the Moon and Mars, and a gap in Saturn's rings are named for him.

Hoskin, M. A., William Herschel and the Construction of the Heavens. 1964; Holmes, R., The Age of Wonder. 2008.

Hertz, Heinrich Rudolf (1857-1894). German physicist, born in Hamburg. An assistant of ${ }^{*}$ Helmholtz at the University of Berlin 1880-85, he later became professor of physics at Karlsruhe 1885-89 and Bonn 1889-94. In 1887 he confirmed *Maxwell's electromagnetic theory of light, by generating and detecting radio waves, which exhibited the same characteristics as light, being subject to polarisation, refraction, diffraction and interference. Hertz failed to recognise the practical importance of his discovery but 'Hertzian waves', as they were known until 1910, were used by *Marconi (1896) for transmitting his first wireless signals. In 1892 Hertz demonstrated that cathode rays could penetrate thin foil, contributing to the development of X-rays by *Röntgen. He also described the photoelectric effect (the impact of ultraviolet radiation on a charged object), later explained by *Einstein. Under *Hitler's regime, Hertz' work was discounted because, although a Lutheran, his family had been Jewish. The Hertz $(\mathrm{Hz})$ is the SI unit of frequency (formerly cps, cycles per second).

Hertzog, J(ames) B(arry) M(unnik) (1866-1942). South African soldier and politician. A lawyer by training, and a commando leader in the Boer War 1899-1902, he was engaged in Orange Free State politics before becoming (1910) Minister of Justice in *Botha's national administration. Excluded (1913) for his anti-British views, he formed the Nationalist Party aiming at absolute equality, linguistically and otherwise, between Afrikaaners and English. After bitterly opposing South Africa's entry into World War I he became Prime Minister 1924-39 and in 1933 entered into a coalition with ${ }^{*}$ Smuts, which ended with his resignation when he demanded neutrality during World War II.

Herzen (Yakovlev), Aleksandr Ivanovich (18121870). Russian writer and political philosopher. Morganatic son of a rich nobleman Ivan Yakovlev, who made him his heir, he became a civil servant and was exiled from Moscow (1834-42) for his espousal of radical causes. He evolved a 'left Hegelian' philosophy and supported the Westernisers against the Slavophils. He left Russia in 1847 and never returned, living mostly in Paris (where he died) and London. His weekly journal Kolokol ('The Bell') was widely circulated in Russia 1857-67. Herzen became disillusioned with the West and developed sympathy with the Slavophils, arguing that peasant communes could be the base for a revolutionary state. Drawn by elements in ${ }^{*}$ Mazzini, ${ }^{*}$ Proudhon, ${ }^{*}$ Bakunin and *Marx, he failed to develop a coherent position of his own or a political machine, but is remembered for his advocacy of glasnost ('openness'). His memoirs, $M y$ Past and Thoughts (1852-55), were a major literary achievement.

Herzl, Theodor (1860-1904). Hungarian Zionist leader, born in Budapest. Trained as a lawyer and journalist, his experience of French antiSemitism, particularly the ${ }^{*}$ Dreyfus case, led him to propose (in Judenstaat, 1896) a separate Jewish state. He convened the first Zionist Congress in 1897 and became first president of the World 
Zionist Organisation. He spent the rest of his life in unsuccessful negotiations with various powers in order to acquire land for the new state.

Bein, A., Theodor Herzl. 1957.

Herzog, Chaim (Vivian) (1918-1997). Israeli lawyer, soldier and diplomat, born in Belfast. Educated in Ireland and England, he directed Israeli military intelligence 1959-62, was Ambassador to the UN 1975-78, a Labour member of the Knesset 1981-83 and President of Israel 1983-93. His books included Battles of the Bible (1978) and The Arab-Israeli Wars (1982).

Herzog, Werner (1942- ). German film director. He grew up in poverty in Munich, worked as a welder and became an enthusiastic amateur film maker. His films include Aguirre, Wrath of God (1973), The Enigma of Kaspar Hauser (1974), Woyzeck (1979), Nosferatu (1979), Fitzcarraldo (1982) and Where the Green Ants Dream (1984) (Klaus *Kinski).

Heseltine, Michael Ray Dibdin, Baron Heseltine (1933- ). British Conservative politician, born in Wales. Educated at Oxford, he became a successful publisher and an MP 1966-2001. Secretary of State for the Environment 1979-83 and for Defence 198386 under Margaret *Thatcher, he resigned and by challenging her leadership in 1990 virtually forced her out. Under John *Major he became Secretary of State for the Environment again 1990-92 and for Trade and Industry 1992-95. He became Deputy Prime Minister and First Secretary of State 1995-97.

\section{Heseltine, Philip see Warlock, Peter}

Hesiod (Hēsiodos) (fl. 700 BCE). Greek poet, born probably in Boeotia. A near contemporary of *Homer, he wrote Theogony, an account of the origin of the Greek gods.

Hess, Germain Henri (1802-1850). Swiss-Russian physical chemist. Professor of chemistry at St Petersburg 1830-50, he made an important advance in thermochemistry when (1840) he showed that the heat change in a chemical reaction is always the same, irrespective of whether the reaction is performed directly or in stages. This is now known as Hess' Law. It put thermochemistry on a quantitative basis and made it possible to calculate the heat change in reactions where it could not be measured.

Hess, Dame Myra (1890-1965). English pianist. Outstandingly successful from her first appearance (1907) and a noted interpreter of ${ }^{*}$ Bach, she organised a memorable series of lunchtime concerts (in the National Gallery, London) during World War II. She was made DBE in 1941.

Hess, Rudolf Walter Richard (1894-1987). German Nazi politician born in Alexandria. He was with *Hitler from the movement's beginnings, took part in the Munich Putsch (1923), and by 1933 had become Deputy Leader of the Nazi Party. During World War II, in May 1941 (on the eve of Germany's attack on Russia) he flew solo to Scotland, a mysterious and never satisfactorily explained exploit, undertaken apparently with the unauthorised aim of offering a compromise peace. While a prisoner he showed signs of mental instability but was tried by the international court at Nuremberg after the war and sentenced to life imprisonment. He appeared to have hanged himself in Spandau prison, but there are troubling discrepancies about how he died and even his identity.

Hess, W. R., My Father Rudolf Hess. 1986.

Hess, Victor Franz (1883-1964). Austrian-American physicist, born in Styria. Graduate of the University of Graz, observations from balloon ascents (1911-12) convinced him that radiation, later named 'cosmic rays', was of extraterrestrial origin, and for this he shared the Nobel Prize for Physics (1936) with Carl D. *Anderson. He held chairs at Graz, Innsbruck and Vienna, but migrated to the US in 1938 and was professor of physics at Fordham University 1938-56.

Hesse, Hermann (1877-1962). German novelist and poet, born in Württemberg. He dealt in vivid, sensuous language, with the problems of divided personality and the individual's need for harmonious self-fulfilment and integration. His novels include Peter Camenzind (1904, translated 1961), Demian (1919, translated 1958), Steppenwolf (1927, translated 1965) and Das Glasperlenspiel (1943, translated as Magister Ludi, 1949 and again as The Glass Bead Game, 1970). In 1946 he won the Nobel Prize for Literature.

Decker, G., Hesse. The Wanderer and His Shadow. 2018.

Heuss, Theodor (1884-1963). German politician, born in Württemberg. Educated in Munich and Berlin, he was a political journalist and publisher in Berlin and a member of the Reichstag 1924-28; 1930-33, but was forced out of public life under the Nazi regime. He taught history in Stuttgart 194647, became the leader of the Free Democratic Party (FDP) 1948-49 and was elected by the Bundestag as the first president of the Federal Republic of Germany 1949-59.

Hevelius, Johannes (1611-1687). German astronomer, born and educated in Danzig. He built up what was probably the world's finest observatory (destroyed by fire in 1679 but subsequently rebuilt), made extensive observations and published them regularly. His maps of the moon were of the highest quality, and traced a whole range of hitherto undescribed mountains and craters. He also made masterly observations of comets, publishing them in his Cometographia of 1668 . He thought that comets were exhalations from planets, and believed that they might be the material cause of sunspots. Hevelius' 
theoretical notions in science were of much less importance than his skill as an instrument maker, and as an astronomical observer. His magnum opus was the Prodromus astronomiae (1690) which listed 1564 stars arranged alphabetically under constellation and stellar magnitude. This star catalogue was greatly used during the 18 th century.

Hewish, Antony (1924- ). British radio-astronomer. Professor of radioastronomy at Cambridge 1971-89, where he established a large Scintillation Array, he supervised the work of Jocelyn *Bell when she first identified pulsars in 1967. Despite his initial scepticism about pulsars, he shared the 1974 Nobel Prize for Physics with Sir Martin *Ryle and Bell was excluded.

Hewitt, Angela (1958- ). Canadian pianist, born in Ottawa. A *Bach and *Mozart specialist, she toured extensively and directed the Lake Trasimeno Festival 2006-

Hewson, John Robert (1946- ). Australian economist and Liberal politician. Educated at Sydney, Saskatchewan and Johns Hopkins universities, he became an economist and consultant, professor of economics at the University of New South Wales 1978-87, and a merchant banker. A Member of the House of Representatives 1987-95, he was Federal Leader of the Liberal Party 1990-94, and proposed radical changes to Australia's taxation and welfare systems. He became a powerful critic of Liberal policies on accountability, secrecy and climate change.

Heydrich, Reinhard Tristan Eugen (1904-1942). German Nazi official. As the Nazi Deputy Protector of Bohemia and Moravia (Czechoslovakia) during World War II he became notorious for his brutal suppression of the Resistance movement. As a reprisal for his assassination in Prague (1942) the village of Lidice was destroyed and its male inhabitants massacred.

Heyerdahl, Thor (1914-2002). Norwegian ethnologist, writer and film maker. Noted for his transoceanic scientific expeditions in primitive craft, the voyage of the raft Kon-Tiki in 1947 was intended to demonstrate that Polynesia could have been settled from South America (a view generally rejected). He made two journeys, in the reed boats $R a$ (1969) and $R a I I$ (1970), from Morocco to Central America. In 1977 in the Tigris, he sailed from Iraq (Mesopotamia) along the ancient trade routes of the Indian Ocean. He led expeditions to Easter Island and the Maldives.

Heyerdahl, T., Kon-Tiki Expedition. 1948; The Ra Expeditions. 1971.

Heyse, Paul Johann Ludwig von (1830-1914). German poet. Leader of the Munich traditionalist school, opposed to radicalism and materialism, his translations were set by Hugo ${ }^{*}$ Wolf in the
Spanisches Liederbuch (1889-90) and the Italianisches Liederbuch, (1890-91; 1896). He received the 1910 Nobel Prize for Literature.

Heywood, John (1497?-1580). English musician, playwright and epigrammatist. As a singer and player on the virginals he won favour at court. His 'interludes' (i.e. plays or dialogues given not in theatres but in the halls of the nobility, colleges, etc.) included The Play of the Wether (1533) and A Play of Love (1534). Later he published a collection of proverbs and epigrams, in which many familiar phrases, e.g. 'The fat is in the fire' first appeared in print. A devout Catholic, in 1564 he fled to Brabant after passage of the Act of Uniformity. He was the grandfather of John *Donne.

Heywood, Thomas (c.1574-1641). English dramatist. Very little is known of his life though he appears to have joined Philip ${ }^{*}$ Henslowe as actor and dramatist soon after leaving Cambridge. He claimed to have written over 200 plays. The first to be published under his own name was $A$ Woman Killed with Kindness (1603, published 1607), and others include The Rape of Lucrece (1608), The English Traveller (printed 1633), and A Maidenhead Well Lost (1634). Apart from plays his works include An Apology for Actors (1612), much verse, and a miscellany (1624) which might have been called an apology for women.

Clark, A. M., Thomas Heywood: Playwright and Miscellanist. 1967.

Hickok, 'Wild Bill' (James Butler) (1837-1876). American crack marksman, scout and marshal, born in Illinois. He worked for a stagecoach company and, in 1861, defeated single-handed an attack on Rock Creek stagecoach station by the McCanles gang. He was a Federal Scout (1861-65) and US Marshal for the district around Fort Riley, Kansas, after 1865. He was shot in the back during a poker game in 1876.

Hicks, Sir John Richard (1904-1989). English economist. Educated at Oxford, he taught at Manchester and Oxford and shared the 1972 Nobel Prize for Economics with Kenneth Joseph Arrow (1921-2017) for work on general economic equilibrium theory and risk.

Hideyoshi Toyotomi (1537-1598). Japanese soldier and ruler, born in Nakamura. Son of a peasant, he became a foot soldier, rising in the service of his patron Oda Nobunaga, on whose death (1582) he continued the task of unifying Japan after centuries of civil war. A brilliant strategist, in 1583 he built his famous castle at Osaka, and was made Chief Minister, virtually dictator, in 1585. In 1586 his forces subdued the islands of Kyushu and Shikoku and by 1590 unification was complete. However, his invasions of Korea (1592, 1597) failed. Hideyoshi imposed a rigid class structure and on his death, power was seized by his former rival *Ieyasu Tokugawa, founder of the shogunate. 
Higgins, Henry Bournes (1851-1929). Australian politician and judge, born in Northern Ireland. In Melbourne from 1870, he was a barrister, Victorian MP 1894-1900 and an active progressive in the Federation debates. He secured adoption of s.116 of the Constitution, separating church and state, but opposed the final draft as potentially too rigid. He was a Federal MP 1901-06, Attorney-General 1904, Justice of the High Court 1906-29 and first President of the Court of Conciliation and Arbitration 1907-29. In the Harvester case (1907), he established the principle of a 'fair and reasonable' basic wage for a family.

Higgs, Peter Ware (1929-). British theoretical physicist, born in Newcastle-upon-Tyne. Educated at Kings College, London, he taught in London and was a professor at Edinburgh University 1980-96. The word 'boson', a theoretical sub-atomic particle, was coined by Paul *Dirac as a tribute to S. N. *Bose but its existence was not proved until a team from CERN identified 'the Higgs boson' in 2012. Higgs received a $\mathrm{CH}$ and shared the Nobel Prize for Physics in 2013, and was awarded the Copley Medal (2015).

Highsmith, (Mary) Patricia (née Plangman) (19211995). American novelist and short story writer, born in Texas. Her psychological thrillers, far darker than *Simenon's, include Strangers on a Train (1950: filmed by ${ }^{*}$ Hitchcock), A Dog's Ransom (1972), a series based on the character Tom Ripley, and Carol (1990). Edith's Diary (1977) was a psychological study. She lived in Europe from 1963, first in France, then Switzerland. She was a self-loathing alcoholic who destroyed many relationships and also collected snails.

Schenkar, J., The Talented Miss Highsmith - The Secret Life and Serious Art of Patricia Highsmith. 2009.

Hilarius (or Hilary) (d. 468). Pope 461-68. Born in Sardinia, he was a firm advocate of papal supremacy and opposed schismatic sects.

Hilbert, David (1862-1943). German mathematician, born in Königsberg. Professor of mathematics at Göttingen 1895-1930, strongly influenced by Georg *Cantor's work, he was a major contributor to mathematical logic, on the theory of numbers, the theory of invariants and integral equations. In Foundations of Geometry (1899) he tried to establish formal proof of axioms, moving from intuition (assumptions made without verification) to logic. Developing the theories of *Leibniz, in 1929 he published a paper on the Entscheidungsproblem ('decision problem' or 'halting problem'), which concluded that all mathematical problems are solvable, a thesis challenged by Kurt ${ }^{*}$ Gödel and refuted, independently, in 1936, by Alonzo *Church and Alan *Turing.

Hildebrand of Savona see Gregory VII
Hildegard of Bingen, St (1098-1179). German abbess. Of noble birth, she became a novice at 15 , founded a monastery at Rupertsburg, on the Rhine, near Bingen, before 1150 , and a daughter house opposite, near Rudesheim. Sometimes called 'the Sybil of the Rhine', her range of accomplishment was prodigious: visionary, naturalist, playwright, theologian, poet and composer. She recorded 26 revelations in Scrivas (1141-51) and treatises on natural history and medicine. She made the first clinical description of migraine, complete with a diagram illustrating the characteristic fortificationshaped 'scintillations'. She wrote lyric poetry and religious music of great beauty. Much is now recorded, including the 1986 anthology called A Feather on the Breath of God, drawn from The Symphony of the Harmony of Celestial Revelations. She also wrote The Play of the Virtues, a morality play with music. She corresponded with popes and emperors, went on four missions throughout Germany and was proposed (unsuccessfully) for canonisation soon after her death. Pope *Benedict XVI proclaimed her a saint and a Doctor of the Church in 2012. Minor planet 898 Hildegard is named for her.

Hill, Octavia (1838-1912). English reformer. She pioneered the movement for public open space and improved housing, both inspired originally by her concern for the living conditions of the poor. She was a founder of the National Trust (1895) and established her first housing project in St Marylebone, London, in 1864 where she was assisted by John *Ruskin.

Hill, O., Homes of the London Poor. 1875; Hill, O., Our Common Land. 1878.

Hill, Sir Rowland (1795-1879). English educationist and administrator, born in Kidderminster. Son of a teacher and influenced by Joseph *Priestley, he taught for 30 years and was a significant educational reformer. He was also actively involved in the planned colonisation of South Australia and the development of railways. He campaigned for uniform penny post (1840), over bureaucratic objections, and is regarded as the founder of modern postal systems. Between 1835 and 1837 he argued that a low postage rate would lead to an increased volume of mail: a flat rate, irrespective of distance, would reduce administrative costs, and stamps should be prepaid, the cost borne by the sender. To achieve this he proposed prepaid adhesive postage stamps or envelopes incorporating a stamp imprint. The penny black stamp was issued in May 1840 . Hill became secretary to the Postmaster-General in 184654, and to the Post Office 1854-64, was awarded a KCB and elected FRS.

Hillary, Sir Edmund Percival (1919-2008). New Zealand mountaineer, explorer, diplomat, philanthropist, born in Auckland. An air force navigator in World War II, he became an apiarist. He was one of the party that made a reconnaissance of Mt Everest (1951), and as a member of *Hunt's 
expedition (1953) he and the sherpa *Tenzing Norgay were the first to reach the summit: for this feat he was knighted. In January 1958 his New Zealand party in the Commonwealth Trans-Antarctic Expedition became the first explorers to reach the South Pole overland since *Amundsen in 1911 and ${ }^{*}$ Scott in 1912, arriving before the expedition leader Sir Vivian *Fuchs, who had been held up by vehicle failure. In 1985 he landed at the North Pole with Neil *Armstrong in a ski-plane. He became High Commissioner in India and Nepal 1984-89, devoted decades to improving life for the sherpas in Nepal and was awarded a KG in 1995. Politically, he was a progressive.

Hillel (c.65 BCE-9 CE). Jewish rabbi, born in Babylonia. He became a leader of the Pharisees, president of the Sanhedrin in Jerusalem, an important innovator in scriptural analysis, and a liberal interpreter of the law. His grandson Gamaliel (d.c.50 CE) was the teacher of St *Paul.

Hilliard, Nicholas (c.1547-1619). English miniature painter. Trained as a jeweller, he was the leading English miniaturist 1580-1600 and enjoyed a high reputation also in France, which he visited c. 1577. His work was noted for its grace and delicacy, and for his technique of modelling features with flesh tones.

Auerbach, E., Nicholas Hilliard. 1961.

Hilton, Conrad (1887-1979). American hotelier, born in San Antonio, New Mexico. He was originally involved in local businesses including his father's hotel which he helped to establish. He began buying hotels after his father's death (1918) and expanded worldwide.

Hilton, James (1900-1954). English-American novelist, born in Lancashire. Educated in Cambridge, eight of his novels were filmed and he moved to California in 1938. He wrote Lost Horizon (which created 'Shangri-La', 1933), Goodbye, Mr Chips (1934) and Random Harvest (1941).

Himmler, Heinrich (1900-1945). German Nazi politician. A poultry farmer, he studied agriculture in Munich, joined the Nazi Party in 1926 and became leader 1929-45 of the Schutz-Staffen (SS: Security Force or 'Blackshirts') and, after *Hitler's accession to power, head of the secret police, the Gestapo and of all police forces in Germany (from 1936). This quiet sinister man, son of a schoolmaster, was thus ultimately responsible for the annihilation of the Jews, the deportations and forced labour, and for tortures and murders on a scale unparalleled in history. He was Minister of the Interior 1944-45 and briefly Commander-in-Chief of the Army 1945. On the eve of Germany's final defeat in the following year he attempted vainly to come to terms with the Allies. When captured by British soldiers he killed himself by taking poison.

Manvell, R. and Fraenkel, H., Himmler. 1969.
Hindemith, Paul (1895-1963). German composer, violist, pianist and conductor, born near Frankfurt. Leader of the Frankfurt Opera Orchestra 1915-25, he later played viola with the Amar-Hindemith quartet. He worked in a variety of styles, Romantic, expressionist and neo-classical, and advocated the production of gebrauchsmusik ('utility music'), written on commission to meet a particular demand. $\mathrm{He}$ left Germany in 1936 and taught at Yale 1940-53. He composed seven operas, of which Mathis der Maler (1938), based on the life of the painter Matthias *Grünewald, has remained in the repertoire. He wrote more than 50 major works and a number of sonatas for chamber groups and solo instruments. Other major works include Concert Music for Strings and Brass, Op. 50 (1930), Nobilissima visione (ballet, 1938), Symphonic metamorphosis on themes by Carl Maria von Weber (1943), seven string quartets and concertos for cello, viola, violin, piano, clarinet, horn and organ.

Kemp, I., Hindemith. 1971.

Hindenburg, Paul Ludwig Hans Anton von Beneckendorff und von (1847-1934). German soldier and president, born in Posen (now Poznan, Poland). Son of a Prussian Junker, he became an army cadet at 11 , served in the war against Austria (1866) and France (1870-71), retiring as a general in 1911. In 1914 he was recalled and given command of the army in East Prussia with *Ludendorff as his Chief of Staff. The great victory over the Russians at Tannenberg (August 1914) made him a national hero and he remained an immensely popular father figure throughout the war. The combination of Hindenburg (made a field marshal) and Ludendorff-the former providing the dignity and prestige, the latter the strategic skill, lasted throughout the war. Victories on the eastern front (1915-16) were followed, when Hindenburg had been made Chief of General Staff (1916) with Ludendorff, as his assistant, by the stalemate in the west from which the Germans sought to emerge by their great breakthrough in March 1918. When the allied counterattack brought disaster Hindenburg secured an armistice that enabled him to lead the armies back intact to the frontiers, and so create a myth of an undefeated Germany.

He returned to public life when, despite his monarchist sympathies, he was elected (1925) as President of Germany, succeeding *Ebert, and re-elected in 1932, with 53 per cent of the vote, defeating ${ }^{*}$ Hitler. Although his faculties were weakened by old age he tried to delay Hitler's accession to power but at last gave way and in January 1933 appointed him Chancellor. He died in office.

Wheeler-Bennett, J. W., Hindenburg: The Wooden Titan. 1967.

Hinshelwood, Sir Cyril Norman (1897-1967). English chemist. He became professor of chemistry at Oxford in 1937, and was President of the Chemical Society 1946-48 and of the Royal Society 1955-60. 
He was an authority on the kinetics of chemical reactions, especially of those involved in the growth of bacterial cells. He shared with ${ }^{*}$ Semenov the Nobel Prize for Chemistry (1956), and was awarded the Copley Medal and the OM (1960). His works include Kinetics of Chemical Change in Gaseous Systems (1926). He was a gifted linguist, classical scholar, painter and music lover. He lived with his mother and never married.

Hipparchus (c.180-125 BCE). Greek astronomer, born in Nicaea (Bithynia). He catalogued the positions of some 1080 fixed stars. He erected an observatory at Rhodes where he discovered inter alia some of the irregularities in the moon's motion and showed the existence of the precession of the equinoxes, a circular swing of the earth's axis so slow that it takes 25,000 years to complete each circle. The method of fixing the position of a place on the earth's surface by giving its latitude and longitude was devised by Hipparchus, and he improved the methods of predicting eclipses and calculated the length of the year to within six minutes. He was also the inventor of trigonometry.

Hippocrates (c.460-c.375 BCE). Greek physician, born on the island of Cos, in the Aegean. Regarded as the 'Father of Medicine', he was the first to insist that the art of healing depended on scientific method and clinical observation. His family was in a hereditary guild of magicians, reputed to be descended from Aesculapius, the god of medicine. He visited Egypt and may have studied with ${ }^{*}$ Democritus. In Cos he established a medical school and is said to have taught under the traditional plane tree. The so called Hippocratic collection, which almost certainly comprises not only his own work but that of pupils and followers, consists of more than 70 books on medicine, of which the Aphorisms and the Airs, Waters and Places are among the most important, the section on epidemics is of great interest as are the clinical descriptions, e.g. of pneumonia, malaria and mumps. Knowledge of anatomy was very limited and disease was defined as disharmony of the 'four humours' (a doctrine that survived into the 18th century). In the consideration of epidemics, however, the importance of diet, environment and climate is recognised. Descriptions of the ancient instruments are an interesting part of the surgical writings. Hippocrates prescribed a code of medical ethics for his disciples, summarised in the traditional Hippocratic Oath (though the exact wording may not be his), still administered to physicians on qualification.

Hippolytus (c.160-c.236). Greek theologian and anti-pope. He lived in Rome and his defence of the doctrine of the Logos, which implied that the Son, * Jesus Christ, incarnate on earth had a pre-existence as the word (Logos) or creative power of God (cf. St John's Gospel), brought him into conflict with Callistus, who became Pope in 217, and he seems to have received consecration as an anti-pope. He submitted, however, to Callistus' successor Pontianus when (235) both leaders were sent as convicts to the Sardinian mines and later martyred. A work entitled Philosophumena, a refutation of heresy, found (1842) at Mt Athos, can almost certainly be attributed to Hippolytus. His Commentary on Daniel (202) is the earliest extant Christian work of its kind.

Hirohito (regnal name Showa, i.e. 'enlightened peace') (1901-1989). Emperor of Japan 1926-89. Son of *Yoshihito, he was educated in the Peer's School in the imperial palace and became the first crown prince to visit Europe (1921-22), acting as regent after his father's mental collapse. After a comparatively brief liberal period, Japanese politics deteriorated in the 1930 s. Military cliques and secret societies imposed their wills on ministers and Hirohito appeared unable or unwilling to intervene, although his actual role remained a matter of controversy. Japan invaded Manchuria (1931) and China (1937) and attacked US bases (1941). After the dropping of the atomic bombs on Hiroshima and Nagasaki, Hirohito intervened, making an unprecedented broadcast in support of unconditional surrender, ceding power to General Douglas *MacArthur (1945), who took on a role similar to the Shogun of earlier centuries. The allies agreed not to put the emperor on trial and he proved to be a valuable symbol of adaption and cooperation. In 1971 he returned to Europe and in Britain was restored as an honorary KG. He visited the US in 1975 . He was a gifted poet and marine biologist.

Hiroshige Andō (birth name Andō Tokutarō, also known as Hiroshige Utagawa) (1797-1858). Japanese graphic artist, born in Edo (Tokyo). Son of a fireman who worked for the Shogun, he trained in the Ukiyo-e ('floating world') tradition of contemporary urban life, publishing his first prints in 1818 . His greatest works are landscapes and seascapes, more lyrical than those of his contemporary ${ }^{*}$ Hokusai, produced before 1844. They include the series Fifty Three Stages of the Tokaido Highway. His work influenced *Manet, ${ }^{*}$ Monet and van ${ }^{*}$ Gogh.

Robinson, B. W., Hiroshige. 1964; Oka, I., Hiroshige: Japan's Great Landscape Artist. 1992; Calza, G. C., Hiroshige: The Master of Nature. 2009; Uspensky, M., Hiroshige. 2012.

Hirst, Damien (Steven) (1965- ). English artist, born in Bristol. Preoccupied with the theme of death and many works feature preserved animals, and the shark returned in The Physical Impossibility of Death in the Mind of Someone Living (1991) and A Dead Shark (2003). His complete show, Beautiful Inside My Head Forever, was auctioned in London in 2008 and realised $£ 111$ million. Robert ${ }^{*}$ Hughes was a trenchant critic of Hirst's oeuvre.

Hiss, Alger (1904-1996). American administrator, born in Baltimore. A Harvard graduate, he was law clerk for Justice Oliver Wendell *Holmes, Jr, 1931-32, 
joined the US Justice Department in 1933, under the 'New Deal', and transferred to the State Department in 1936. Among other important assignments he was secretary to the Dumbarton Oaks Conference (1944), accompanied President ${ }^{*}$ Roosevelt to Yalta 1945 and was Secretary-General of UNCIO (United Nations Conference on International Organisation) at San Francisco 1945-46. In 1947 he became President of the Carnegie Endowment for International Peace. He was accused before the House Un-American Activities Committee in 1948 by Whittaker * Chambers, a former Communist, of being part of a spy ring and, later, of betraying secret information. Hiss strenuously denied the accusation, denied the charges on oath and began a libel action against Chambers. The strong pursuit of Hiss by Richard *Nixon helped gain him national recognition. Hiss was tried for perjury in 1949, and was convicted after a second trial in 1950 when the jury disagreed, and was sentenced to five years jail. Released in 1954, Hiss continued to assert his innocence and had many supporters. In October 1992 former KGB officials announced that their files provided no evidence that Hiss had been recruited as an agent: supporters hailed this as vindication, opponents were sceptical. In 1996, release of the 'Venona tapes', intercepts of wartime telegrams to Moscow, appeared to incriminate Hiss, but the material is ambiguous.

Hitchcock, Sir Alfred (Joseph) (1899-1980). English-American film director, born in Essex. $\mathrm{He}$ worked in films from 1919, spent time in Germany, lived in California from 1939 and became a US citizen in 1955. His 59 films (including some remakes) include Blackmail (1929), The Man Who Knew Too Much (1934 and 1956), The Lady Vanishes (1938), Rebecca (1940), Suspicion (1941), Notorious (1946), Rope (1948), Strangers on a Train (1951), Dial $M$ for Murder (1954), Rear Window (1954), To Catch a Thief (1955), Vertigo (1958), North by Northwest (1959), Psycho (1960) and The Birds (1963). His films produced some of the best performances of Cary ${ }^{*}$ Grant and Grace *Kelly.

Durgnat, R., The Strange Case of Alfred Hitchcock. 1974; Ackroyd, P., Alfred Hitchcock. 2015; Wood, M., Alfred Hitchcock: The Man Who Knew Too Much. 2015.

Hitchens, Ivon (1893-1979). English painter. In his landscapes and flower pieces, he carried on the English lyrical tradition into a semi-abstract discipline, relying on an interplay of rich colours.

Hitchings, George Herbert (1905-1998). American physiologist. A Harvard graduate, he worked at the Wellcome Research Laboratories in New York from 1942, became an expert in chemotherapy and collaborated with Gertrude *Elion in pioneering rational drug design, developing treatments for malaria, leukemia and herpes. He shared the 1988 Nobel Prize for Medicine with Elion and James *Black.
Hitler, Adolf (1889-1945). Austrian-German Nazi politician, born in Braunau am Inn, Austria. Son of Alois Hitler (originally Schickelgruber) (1837-1903), a middle ranking customs official who married three times, he was third of five children; three died in childhood, only his sister Paula (1896-1960) survived him. Unsuccessful and unhappy at the Linz Realschule, he gave up his studies at 16 because of lung trouble. $\mathrm{He}$ was twice rejected as a student at the Vienna Academy of Art, sold drawings and watercolours and lived at the Home for Men until he moved to Munich in 1913. (It is barely possible that he visited relatives in Liverpool in 1912-13.) In World War I he served in a Bavarian regiment, rose to the rank of lancecorporal, was temporarily blinded and won the Iron Cross. In September 1919, employed as an investigator by army authorities, he joined Anton Drexler's German Workers' Party. Within a few months his oratory enabled him to displace Drexler and become leader of the National Socialist German Workers' Party (Nationalsozialistische Deutsch Arbeiterpartei, or NSDAP), better known by the abbreviated form Nazi Party. After the failure of a Putsch organised by him with the aid of General *Ludendorff (1923) he spent nine months in prison where he dictated to his companion Rudolf *Hess his book Mein Kampf (My Struggle). From 1925 he reorganised his shattered party, helped financially by industrialists who saw in him, with his anti-Semitism, anti-Marxism and extreme nationalism, a barrier against liberals and communists. Thus aided, Hitler asserted an unchallenged despotism within the party and created an effective propaganda machine, using radio and the newspaper Völkischer Beobachter, run by his friend Max Amann (1891-1957), to further his cause.

He organised strong-arm gangs of supporters (SA or 'Brownshirts' - ${ }^{*}$ Röhm) and also an elite guard (SS or 'Blackshirts'-*Himmler). The prevailing worldwide depression made his economic theories plausible and acceptable and led numbers of unemployed to join him. In the 1930 election the number of Nazis in the Reichstag rose from 12 to 104 and in July 1932 to 230, though there was a fall to 196 in November 1932. In April 1932 he contested the presidency against ${ }^{*}$ Hindenburg and won 37 per cent of the vote. He cautiously refused to sanction a coup and party rivals called him 'Adolf Legalité'. In January 1933 a reluctant ${ }^{*}$ Hindenburg appointed Hitler, as leader of the largest single party, as Chancellor. The burning of the Reichstag (February 1933), attributed by the Nazis to the Communists, and by the Communists to the Nazis, but almost certainly the act of a single person (Marinus van der ${ }^{*}$ Lubbe), gave him the excuse to assume dictatorial powers. He proceeded to turn Germany into a one-party state, and to secure his own pre-eminence in the party, purged it of critics and possible rivals in the 'Night of the Long Knives' (30 June 1934), in which about 1,000 people, including von *Schleicher, ${ }^{*}$ Röhm and ${ }^{*}$ Strasser, were slaughtered by the SS. Röhm's SA was downgraded and the SS became the main uniformed party organisation. 
On Hindenburg's death (1934) Hitler became President though he preferred the title Der Führer and while indulging his own phobias by a reign of terror against Jews and communists he carried away the majority of his countrymen by frenzied eloquence, elaborate propaganda and by his spectacular successes in foreign policy, apart from an unsuccessful coup in Austria (June 1934). In startling succession came rearmament, military reoccupation of the Rhineland (1936), and political union (Anschluss) with Austria (March 1938), overwhelmingly endorsed by referendum.

In September 1938, the Munich Pact, made by Hitler, *Mussolini, *Chamberlain and *Daladier, agreed that Hitler could take the German-speaking Sudetenland from Czechoslovakia, making it indefensible. ( ${ }^{*}$ Beneš and ${ }^{*}$ Stalin were not invited to Munich.) Suggestions that the army would have deposed Hitler if he had then failed seem implausible.

Britain and France failed to cooperate with Russia against German expansion: appeasement was popular at home, they hoped to buy time and many saw Hitler as the only barrier to Communism. In March 1939 Hitler occupied the remainder of Czechoslovakia and secured a diplomatic volte face in August with the signing of a Non-Aggression Pact in Moscow by *Ribbentrop and *Molotov. Stalin's promise to support Hitler when he invaded Poland made World War II inevitable. The Wehrmacht began fighting Poland on 1 September, followed on 3 September by Britain and France declaring war. In June 1940 German armies quickly crushed the Allied forces and after the collapse of France only Britain still held out. Although Hitler's decision to attack Russia in June 1941 ('Operation Barbarossa') was to prove a fatal error, his run of success lasted into 1942. Then the joint strength of Britain and Russia, joined by the US, inexorably broke Hitler's boasted 'Thousand Years Reich' in its 'Fortress Europa'. He ordered a 'final solution' ('Die Endlösung' i.e. extermination) in January 1942 for Europe's Jews and about 6 million died, 75 per cent of them in concentration camps. Millions of Slavs were also killed in the camps. The total death toll in Hitler's war was about 38 million, of which 7 million were German and 22 million Russian. Only a small minority of Germans raised the slightest opposition to Hitler and there was only one serious conspiracy when he narrowly escaped death at Rastenberg, East Prussia (July 1944), from a bomb planted by a staff officer Col. Klaus von *Stauffenberg. When defeat finally came Hitler and Goebbels were in the bomb-proof Führerbunker in besieged Berlin. There he married his mistress Eva *Braun, and there, on 30 April 1945, she bit into a cyanide capsule and he shot himself in the head. Both bodies were incinerated and the remains were soon found by Russian troops, Hitler being identified conclusively by complicated dental work. However, Soviet propaganda asserted that there was no definitive evidence of Hitler's death and that he might have survived and been working with the West.
Hitler was a vegetarian, fanatical anti-smoker and liked children and animals. Like ${ }^{*}$ Goethe's Mephistopheles, Hitler was 'the spirit that denies', the supreme sceptic, 'a rationalist and realist' (in Alan Bullock's words) who rejected Christianity, despised attempts to revive the old Teutonic religion and in his political testament turned even against patriotism, declaring that Germany and its army were 'not worthy of him'. Only Stalin, 'a beast, but a great beast', won his admiration in the end.

Bullock, A. L. C., Hitler: A Study in Tyranny. 1969; Trevor-Roper, H., The Last Days of Hitler. 4th ed. 1971; Fest, J. C., Hitler. 1974; Bullock, A. L. C., Hitler and Stalin: Parallel Lives. 1991; Kershaw, I., Hitler, 1899-1936: Hubris. 1998; Rosenbaum, R., Explaining Hitler. 1998; Kershaw, I., Hitler, 1936-1945: Nemesis. 2000; Simms, B., Hitler: Only the World Was Enough. 2019; Longerich, P., Hitler: A Life. 2019.

Hnatyshyn, Ray (Ramon John) (1934-2002). Canadian lawyer and Progressive Conservative politician. Of Ukrainian descent, he was a lawyer in Saskatchewan, Member of the House of Commons 1974-88, Minister for Energy 1979-80, Minister for Justice 1986-88, and Governor-General of Canada 1990-1995.

Hoare, Samuel John Gurney, 1st Viscount Templewood (1880-1959). English Conservative politician, born in London. Son of a baronet, educated at Harrow and Oxford, he was an MP 1910-44, served in World War I, and became Secretary of State for Air 1922-24; 1924-29; 1940. He initiated, as Secretary of State for India 1931-35, the act of 1935 which granted provincial self-government. As Foreign Secretary 1935 he was forced to resign by a storm of protest against the Hoare-*Laval Pact which proposed a partition of Ethiopia and recognition of the Italian conquests. He returned as Home Secretary 1937-39 and served during World War II in the sensitive post of Ambassador to Spain 1940-44, retiring with a peerage. He became an active opponent of capital punishment.

Hobbes, Thomas (1588-1679). English philosopher, born at Malmesbury. Son of a clergyman, educated at Oxford, he was employed for most of his life by the Cavendish family as tutor and secretary. This career left him with much leisure for study of both classical authors and contemporary thinkers. Some of the latter, such as ${ }^{*}$ Galileo and ${ }^{*}$ Descartes, he met while visiting the Continent; in England he knew *Bacon and others distinguished in the arts and letters. His own philosophical writing seems to have stemmed from a chance discovery of *Euclid's geometry. This was a natural step to the 'mechanical philosophies, then current (which regarded the universe in motion, rather than the universe at rest, as the natural state of things). From these matured his own distinctive contribution to human thought. 
Meanwhile the Civil War had broken out in England and when the royalist cause faced defeat, Hobbes, who in 1640 had written in defence of the royal prerogative, took refuge on the Continent and for a time (1647) was mathematics tutor to Prince Charles ( ${ }^{*}$ Charles II). He was allowed to return in 1651, the year of the publication of Leviathan, the greatest of the works in which his political philosophy is expounded. He was in disfavour after the Restoration and his sketch of the Civil Wars, Behemoth (1680), was suppressed. In his extreme old age he wrote verse translations of the Iliad and Odyssey. In his ethics, rejecting as he did the supernatural and also any religious basis for morality, he regarded human action as directed solely by egoistic motives which, if given free play as in the natural state, would make man's life 'nasty, brutish and short'. Self-interest therefore leads men to what he calls a 'social contract' whereby they give up their natural rights of aggression in return for the security of a society controlled by a 'sovereign', who may be an individual or a republic. Should he fail in his side of the contract the sovereign may be deposed. Although Hobbes held the rationalist view that philosophy ought to be a matter of rigid deduction from premises, his own work is empirical in nature and its acute semantic analysis sometimes foreshadows the philosophy of the present age.

Warrender, H., The Political Philosophy of Thomas Hobbes. 1957.

Hobbs, Sir Jack (John Berry) (1882-1963). English cricketer. He was one of the greatest batsmen of his time and the first professional cricketer to be knighted (1953). During his first-class career with Surrey (1905-34) and England (1907-30) he scored a record total of 61,237 runs with 197 centuries. It was not only his play but his personality that endeared Hobbs to the crowd.

Hobsbawm, E(ric) J(ohn Ernest) (1917-2012). British historian, born in Alexandria. Of PolishJewish ancestry, he grew up in Austria and Germany, studied at King's College, Cambridge, and taught social history at Birkbeck College, London, 1947-82. He joined the Communist Party in 1936 and, despite his hostility to some aspects of Soviet rule, remained in the decaying British party until 1991. Polyglot and polymath, he was a compelling writer whose works included the bestselling The Age of Revolutions: Europe 1789-1848 (1962) and The Age of Extremes (1994). His books were probably the most widely read and translated of any modern historian and he received a $\mathrm{CH}$ in 1998. As 'Francis Newton', he was also a jazz critic.

Evans, R. J., Eric Hobsbawm: A Life in History. 2019.

Hochhuth, Rolf (1933-2020). German playwright. He achieved immediate recognition with Der Stellvertreter (1963, translated as The Deputy or The Representative), a scathing and controversial accusation of Pope *Pius XII's passivity over *Hitler's extermination campaigns. Soldiers (1967), an attack on *Churchill's alleged wartime complicity in atrocities, was initially banned in Britain.

Ho Chi Minh (1890-1969). Vietnamese Communist leader, born in Annam. (His real name was Nguyen That Thanh, later changed to Nguyen Ai Quoc. Ho Chi Minh means 'he who enlightens'.) Son of a mandarin, he left Annam in 1911, worked as a merchant seaman (in the US 1915-16), assistant pastry cook to *Escoffier in London and a photographic retoucher in Paris. A foundation member of the French Communist Party (1920), he lived in Moscow, Bangkok, Canton, Hong Kong and Shanghai 1923-30. He founded the IndoChinese Communist Party in Hong Kong (1930) and, on his return after 30 years (1941), the Vietnamese Independence League (Vietminh). In March 1945 the Japanese proclaimed Vietnamese independence with Ho as President of the Democratic Republic (DRV), and they withdrew leaving him in control in September. Ho formed the Lao Dong ('Workers Party') in 1951 and retained office until he died. The French soon tried to reimpose their rule and established a puppet state in the South under *Bao Dai. War with France continued until 1954, then a temporary partition at the 17th parallel was followed by war between North and South in which the Americans played an increasingly dominant role from 1963 (rising to a peak in 1969). Like ${ }^{*}$ Mao, Ho was an able strategist, poet and patriotic hero.

Lacouture, J., Ho Chi Minh. 1968.

Hockney, David (1937- ). English painter, designer and photographer, born in Bradford. Influenced as a painter by pop art, he soon evolved his own distinctive, witty, spare, narrative style. He designed sets and costumes for productions of The Magic Flute (1977), Triple Bill (*Satie, *Poulenc, *Ravel, 1980) and Tristan and Isolde (1987). His experimental photographic collages ('joiners'), presenting a collage of images that convey a sense of time and motion, were recorded in his book, Cameraworks (with Lawrence Wechsler 1984). He moved to California in 1963 but returned, increasingly, to Yorkshire after 1997. His A Bigger Grand Canyon (1998) is in the Australian National Gallery, Canberra. In Secret Knowledge: Rediscovering the Lost Techniques of the Old Masters (2001), both a book and television documentary, he argued plausibly that use of camera obscura and lens by artists after 1400 had a major effect on painting technique and the rapid development of realism. (The book was revised in 2006.) He was elected RA in 1991, received a $\mathrm{CH}$ in 1997 and the OM in 2012. He donated his largest painting Bigger Trees Near Warter $(2007,4.5 \mathrm{~m}$ $\mathrm{x} 12.2 \mathrm{~m}$ ) to the Tate Gallery.

Hockney, D., David Hockney. 1976; Hockney, D., That's the way I see it. 1993; Evans, G., Hockney's Pictures: the Definitive Retrospective. 2004; Hockney, D., A Yorkshire Sketchbook. 2012; Hockney, D., A Bigger Picture. 2012. 
Hodgkin, Sir Alan Lloyd (1914-1998). British physiologist. In 1963 he shared (with Sir Andrew ${ }^{*}$ Huxley and Sir John *Eccles) the Nobel Prize for Physiology or Medicine, for his discovery of the chemical processes by which impulses travel along individual nerve fibres. He received the Copley Medal (1965) and the OM (1973). President of the Royal Society 1970-75, he became Master of Trinity College, Cambridge 1978-84.

Hodgkin, Dorothy Crowfoot (née Crowfoot) (1910-1994). English biochemist, born in Cairo. She became Wolfson research professor of the Royal Society 1960-77 and professorial Fellow of Somerville College, Oxford. She was specially distinguished for her use of X-ray techniques in the determination of the structures of biochemical compounds, notably penicillin and vitamin B12, the latter essential to combat pernicious anaemia. She was awarded the Nobel Prize for Chemistry (1964), and in 1965 received the $\mathrm{OM}$, the first woman so honoured since Florence *Nightingale. She became the first (and so far the only) woman to become a Copley Medallist of the Royal Society (1976).

Hodgkin, Sir (Gordon) Howard (Eliot) (19322017). English painter, born in London. His sensual paintings, reminiscent of *Vuillard and *Matisse, were marked by brilliant colour and luscious texture. $\mathrm{He}$ received a $\mathrm{CH}$ in 2003.

Auping, M., Edelfield, J., Sontag, S., Howard Hodgkin Paintings. 1995; Graham-Dixon, A., Howard Hodgkin. 2001.

Hodgson, Ralph (1871-1962). English poet. One of the 'Georgian' group of English poets, simplicity, metrical facility and delicate irony distinguish his work. Some of his poems, e.g. Time, You Old Gypsy Man, attained wide popularity. He lived in Japan (1924-38), then in Ohio, publishing nothing between 1917 and 1958 .

Hofer, Andreas (1767-1810). Austrian inn-keeper and patriot. He had fought against *Napoléon 17961805 and when his native Tyrol was transferred by the emperor from Austria to Bavaria, he organised and led a local rising (1809). Twice in that year he drove out the Franco-Bavarian troops; twice Austrian submission to the French terms brought them back. In October 1809 he roused the country once again but this time the enemy were in overwhelming force. He was forced into hiding, betrayed and shot.

Hoff, Jacobus Henricus Van't see Van't Hoff, Jacobus Henricus

Hoffman, Dustin (1937- ). American actor, born in Los Angeles. His films include The Graduate (1967), Marathon Man (1976), Tootsie (1982), Rain Man (Academy Award, 1988), Hook (1991) and
I Huckabees (2004). As a stage actor he performed on Broadway and in London and made his debut as a film director with Quartet (2012).

Hoffman, Philip Seymour (1967-2014). American actor, born in New York State. He first appeared on television in Law \& Order (1991) and in film in 1992. His films include Capote (2005), where he won an Academy Award and a Golden Globe for his portrayal of Truman *Capote, Doubt (2008), The Master (2012) and A Late Quartet (a.k.a. Performance, 2012). He was a memorable Willy Loman on Broadway in 2012. He died of a drug overdose.

Hoffmann, Felix (1868-1946). German-Swiss chemist. In August 1897, working for Bayer \& Co., he synthesised aspirin (acetylsalicylic acid), probably under the direction of Arthur Eichengrün (1867-1949). It was sold internationally (originally as a powder) from 1899. Hoffman also synthesized heroin. An isolate, he lived and died unknown.

Hofmann, August Wilhelm von (1818-1892). German chemist. After working with *Liebig, he went to London, encouraged by Prince *Albert, to be superintendent of the newly founded Royal College of Chemistry 1845-65. W. H. *Perkin was a student. He returned to Germany as professor of chemistry at Berlin 1865-92. Organic chemistry was the main field of his research and his production of aniline from coal products led to the development of the great synthetic dye industry in Germany. Awarded the Copley Medal in 1875, he devised three dimensional models of molecules.

Hofmann, Josef Casimir (Józef Kazimierz) (18761957). Polish-American pianist, born in Krakow. He made his debut in Warsaw at the age of six, became Anton *Rubinstein's only pupil and settled in the US in 1898 . He made only a few, poor recordings, but contemporaries regarded his playing as a unique combination of poetry, precision and passion. He was a prolific (but now unperformed) composer, director of the Curtis Institute, Philadelphia 1927-38 and a successful inventor (including a pneumatic shock absorber). Alcoholism crippled his final years.

Hofmannsthal, Hugo von (1874-1929). Austrian poet and dramatist, born in Vienna. His poems, written for the most part in early life, mainly display a nostalgic melancholy over a civilisation in decay, a mood evident, but less so, in his plays, which he first began writing in his teens. The best, however, date from his later life when he took themes mainly from the Middle Ages or classical antiquity, as in Elektra (1903) and the morality play Jedermann (Everyman) of 1912. He also wrote the libretti for Richard *Strauss' operas Der Rosenkavalier (1911), Ariadne auf Naxos (1912), etc. With Strauss and Max *Reinhardt he founded the Salzburg Festival.

Kobel, E., Hugo von Hofmannsthal. 1970. 
Hofmeyr, Jan Hendrik (1845-1909). South African politician, born in Cape Town. Originally a journalist and editor, he was a member of the Cape House of Assembly 1879-95, only briefly a minister 1881 , but a powerful figure in determining the fate of governments, operating behind the scenes (and known as 'the mole'). He worked to promote the political interests of the Dutch through the Afrikaaner Bond. He distrusted *Kruger's extreme nationalistic policy in the Transvaal, but broke with Cecil *Rhodes (with whom he had hitherto worked closely) over his part in organising the Jameson Raid (1895). Failing to avert the South African War ${ }^{*} 1899-1902$, he retreated to Europe, then worked for reconciliation and was prominent in the negotiations that led to the Union of South Africa. He died in London.

His nephew, Jan Hendrik Hofmeyr (1894-1948), a Rhodes Scholar, became professor of classics at Witwatersrand University 1917-24, then Vice Chancellor. A Unionist MP 1929-48 and a racial liberal, he was a minister 1933-38, 1939-48 and *Smuts' Deputy Prime Minister until his sudden death.

Hogarth, William (1697-1764). English artist. At 15 he was apprenticed to a silver engraver, and was an independent engraver by 1720 , painting being then a spare-time study. From 1730 he painted his moral series of narrative pictures: A Harlot's Progress (c.1731), A Rake's Progress (c.1735) and Marriage à la Mode (c.1742-44). These were painted to be later engraved, and the engravings sold widely. They are today regarded as unique, but of lesser quality as paintings than his more spontaneous work, portraits such as The Shrimp Girl and Hogarth's Servants. He published his theories in An Analysis of Beauty in 1753 .

Antal, F., Hogarth and His Place in European Art. 1962.

Hogben, Lancelot Thomas (1895-1975). English population geneticist. Educated at Trinity College, Cambridge, he wrote the bestsellers Mathematics for the Million (1933) and Science for the Citizen (1938), and devised the synthetic universal language Interglossa (1943).

Hohenstaufen. German dynasty, deriving its name from an ancestral castle in Swabia. Members of it were German kings and Holy Roman emperors from 1238 to 1254 . The most important were *Friedrich I, *Heinrich VI, and *Friedrich II.

Hohenzollern. German dynastic family, deriving its name from a castle in Swabia. The family's prominence began when Graf (Count) Friedrich von Hohenzollern was made elector and margrave of Brandenburg (1415). A later Hohenzollern, Albrecht of Brandenburg, grandmaster of the Teutonic Knights, dissolved that order and became first Duke of Prussia (1525). Brandenburg and Prussia rule, and its ruler (then *Wilhelm I) became the first emperor of the united Germany formed in 1871 after the Franco-Prussian War. The dynasty thus ruled as electors of Brandenburg 1415-1701, kings of Prussia 1701-1918 and German emperors 1871-1918.

Hokusai Katsushika (1760-1849). Japanese graphic artist, born at Edo (Tokyo). Brought up by the affluent Nakajima family, he worked in a bookshop and was apprenticed first to a woodblock engraver, then to the artist Katsukawa Shunsho. His first published works (1780) are in the Ukiyo-e ('floating world') tradition, depicting contemporary urban life: street scenes, actors, lovemaking, processions. $\mathrm{He}$ moved frequently (about 90 times) and changed his name (about 20 times) so the complete range of his activity is not known. He concentrated on drawing, painting and print-making of innumerable studies of landscapes and seascapes, animals, birds, many of them published in book form or as illustrations of novels and poems. His Thirty Six Views of Mt Fuji (1826-33) are regarded as his greatest achievement and the summit of Japanese graphic art: this series includes the famous The Breaking Wave off Kanagawa. He wrote an autobiography Once Hokusai, Today the Old Man Mad about Drawing (1835). His Manga (or Ten Thousand Sketches) appeared in 15 volumes (1812-75). From about 1890 his work was known and admired in Europe.

Holbein, Hans (1497/8-1543). German painter, born in Augsburg. His father Hans Holbein the Elder was a painter in the city. He settled in Basle c.1514, at first working as a printer's designer. His paintings changed after 1526, becoming softer and richer in colouring; it is possible (although there is no evidence) that he had visited Italy and seen work of the Italian Renaissance. His Madonna of Burgomaster Meyer (1526) combines this Italian richness with northern realism. In 1526 he came to England with an introduction (from *Erasmus) to Sir Thomas *More. His outstanding group portrait of More's family was the main work of this visit. He came back to England in 1532 and stayed for some years at the court of *Henry VIII. In 1537 he painted a mural at Whitehall (only the cartoon survives) showing the king with his third queen, *Jane Seymour, and his parents. His famous study of Henry VIII was for this mural, and was copied after the destruction of Whitehall Palace in 1698. Later royal portraits, although beautiful in technique, were impersonal compared with this strongly characterised piece.

Wilson, D., Hans Holbein. 1996.

Hölderlin, (Johann Christian) Friedrich (17701843). German poet. Trained for the Lutheran ministry, he fell in love with Greek mythology and his employer's wife and became a schizophrenic (from 1806). His lyric poetry was largely unrecognised until the 20th century. 
Holdsworth, Sir William Searle (1871-1944). English legal historian, born in London. Vinerian Professor of Law at Oxford University 1922-44, he wrote a History of English Law, in 17 volumes, the first published in 1903, the last in 1966, long after his death. Awarded an OM in 1943, his work is now regarded as deficient in understanding the social and economic context of law.

Holiday, Billie (Eleanora Fagan) (1915-1959). American jazz singer. Singing professionally from 1930, she worked with Benny * Goodman and Count *Basie, developing a powerful emotional style singing the blues. Portrayed in the film Lady Sings the Blues (1972), her early death was the result of heroin addiction.

Holinshed, Raphael (d.c.1580). English chronicler. He was commissioned by a London printer, Reginald Wolfe, to compile the Chronicles of England, Scotland and Ireland (2 volumes, 1577). Holinshed himself wrote the history of England; others contributed the Scottish and Irish sections. The Chronicles were much used by *Shakespeare, especially for Macbeth, King Lear and Cymbeline.

Holland, Henry Richard Fox, 3rd Baron (17731840). English politician. His ideas were formed by his uncle Charles James *Fox. He served as Lord Privy Seal 1806-07 and as Chancellor of the Duchy of Lancaster twice 1830-34, 1835-40. He supported enlightened initiatives to abolish the slave trade and the Test Act, and was influential through his hospitality at Holland House in London on the leading personalities, political and literary, of his day.

Holland, Sir Sidney George (1893-1961). New Zealand politician. Wounded in World War I, he ran an engineering business, succeeded his father as MP $1935-57$ and by 1940 was Leader of the National party in opposition to Labour. He was Prime Minister 1949-57, fought against the trade unions, reduced regulations, and restored the death penalty. He was awarded a GCMG and $\mathrm{CH}$.

Hollande, François Gérard Georges Nicolas (1954- ). French Socialist politician, born in Rouen. Educated at ENA, he worked for *Mitterrand, was a deputy in the National Assembly 1988-93, 19972012, and First Secretary of the French Socialist Party 1997-2008. His first wife was Ségolène *Royal. As candidate of the Socialist and Left Radical Party, he defeated Nicolas * Sarkozy and was President of France 2012-17. His popularity fell in 2014 and hovered between 12 per cent and 30 per cent in the polls, but rose after he reacted strongly to terrorist attacks in Paris (2015). He did not seek re-election in 2017.

Hollerith, Herman (1860-1929). American engineer. $\mathrm{He}$ taught at MIT and combined *Jacquard's punch cards with electromagnetic sensors which could 'read' them automatically (1885). His machines were used to tabulate the results of the 1890 US census. He founded the Tabulating Machine Company (1896) which later became part of IBM (International Business Machines).

Hollingworth, Peter John (1935-). Australian cleric. He was Anglican Archbishop of Brisbane 1990-2001 and Governor-General of Australia 2001-03.

Hollis, Sir Roger Henry (1905-1973). English civil servant. Educated briefly at Oxford, he worked in business in China, then entered the civil service. $\mathrm{He}$ was Director-General of the British counterespionage agency MI5 (Military Intelligence, section five) 1956-65. MI5's conspicuous lack of success in that period led to continuing but unproved accusations that Hollis was a Soviet 'mole' (concealed agent).

Hollows, Fred(erick Cossom) (1929-1993). Australian-New Zealand ophthalmologist, born in Dunedin. Trained in New Zealand and England, he worked in Australia from 1965, and initiated a campaign on Indigenous eye health, particularly trachoma. He set up eye clinics to treat cataract and other conditions in Nepal, Eritrea and Vietnam, became Australian of the Year in 1990, received an AC in 1991 and established the Fred Hollows Foundation in 1992.

Holm, Sir Ian (1931-2020). English actor. He played character roles in many films and was an outstanding Lear.

Holmes, Oliver Wendell (1809-1894). American author and physician, born at Cambridge, Massachusetts. He spent most of his life in or near Boston and was among the last and best known of that traditional and exclusive group that gave Boston its cultural ascendancy. He studied in Paris (183335) and gained a Harvard MD (1836), as a professor at Dartmouth College 1839-41 and at Harvard 1847-82 he gave popular and important lectures on anatomy. $\mathrm{He}$ is best known, however, for his humorous and genial essays and verses, contributed to the Atlantic Monthly. Some of these were collected in The Autocrat of the Breakfast Table (1858), The Professor at the Breakfast Table (1860), and The Poet at the Breakfast Table (1872). He also wrote novels, and memoirs of his friend Ralph Waldo *Emerson.

His son, Oliver Wendell Holmes, Jr (1841-1935), after fighting in the American Civil War took a degree in law at Harvard (1866). He achieved international legal fame as a result of his Lowell lectures (published 1881). Theodore ${ }^{*}$ Roosevelt appointed him to the US Supreme Court (1902). He ranks as one of the greatest of all Supreme Court justices and as a liberal (except for Buck v. Bell [1927] which approved of forced sterilisation without the subject's consent). At a time when a majority of his colleagues declared social legislation controlling wages and other labour matters unconstitutional he disagreed with their conservative 
attitude and earned himself the title of 'The Great Dissenter'. In 1927 he wrote: 'Taxes are the price we pay for civilisation'. He retired in 1932, aged 91. His lengthy correspondence with Sir Frederick Pollock and Harold *Laski was published.

Tilton, E. M., Amiable Autocrat. 1947.

Holst, Gustav (Theodore von) (1874-1934). English composer, born in Cheltenham. Grandson of a Swedish teacher of harp and piano, he began his career as an organist and choirmaster, and studied at the Royal College of Music under Sir Charles ${ }^{*}$ Stanford. He worked as a trombonist and as a teacher. He was director of music at St Paul's Girls' School, Hammersmith 1906-34, where he conducted the orchestra and at Morley College 1907-34. Highly original, he was imbued in the English tradition, including folksong, but was far broader, with a knowledge of Indian music and German romanticism. The orchestral suite The Planets (1914-16) is the most performed British work in the international repertoire. Other works include the St Paul's Suite for strings (1913), The Hymn of Jesus (1917), an opera The Perfect Fool (1922), Egdon Heath (a homage to *Hardy, 1927) and Hammersmith (for military band, 1931). His daughter Imogen Holst (1907-1984) was a conductor, composer and writer who worked closely with *Britten.

Holst, I., Gustav Holst. 1938.

Holt, Harold Edward (1908-1967). Australian Liberal politician, born in Sydney. A Melbourne lawyer and Member of the House of Representatives 1935-67, he was a minister under Sir Robert *Menzies 1940 and 1949-66, succeeding him as Prime Minister 1966-67. Often underrated, in his 23 months in office he took the opportunity to initiate reforms that Menzies refused to tackle: the 1967 referendum on Indigenous rights, phasing out the White Australia Policy, engaging with Asia, relaxing censorship, early stages of promoting the arts, and a conciliatory approach to trade unions. However, he was uncritical in his support of US action ('All the way with LBJ!') in Vietnam. He drowned while swimming at Portsea, and was commemorated, oddly, in his former electorate, by the Harold Holt Memorial Swimming Centre.

Frame, T., The Life and Death of Harold Holt. 2004.

Holub, Miroslav (1923-1998). Czech immunologist, poet and essayist. He was a prolific researcher in pathology and immunology, wrote extensively on the philosophy of science (e.g. The Dimension of the Present Moment, 1990) and published 14 volumes of poetry, including Vanishing Lung Syndrome (1990).

Holyoake, Sir Keith Jacka (1904-1983). New Zealand Nationalist politician. He first entered parliament in 1932 and was Deputy Prime Minister 1949-57. He succeeded Sir Sidney *Holland 1957
1960-72. He was Governor-General 1977-80 and became the first New Zealand Knight of the Garter (KG) in 1980 .

Home, Alec (Alexander Frederick) Douglas-, Baron Home of the Hirsel formerly 14th Earl of Home (1903-1995). British Conservative politician, born in London. Son of the 13th Earl of Home, educated at Eton and Oxford, (as Lord Douglass) he was MP for Lanark 1931-45, 1950-51. Parliamentary private secretary to Neville ${ }^{*}$ Chamberlain $1938-39$, he was hospitalised with spinal tuberculosis during World War II and devoted himself to study. Undersecretary for Foreign Affairs in *Churchill's caretaker ministry 1945, he succeeded to the peerage in 1951 and received the KT in 1962. Secretary of State for Commonwealth Relations 1955-60 and Foreign Secretary 1960-63, when Harold *Macmillan resigned (October 1963) he emerged as a compromise choice as Prime Minister, in preference to R. A. ${ }^{*}$ Butler, Lord ${ }^{*}$ Hailsham and Reginald ${ }^{*}$ Maudling. The Earl of Home renounced his six peerages four days after becoming Prime Minister and as Sir Alec Douglas-Home won a Scottish byelection: for 15 days he was a member of neither House. He lost the October 1964 election to Harold *Wilson (wits said that electors faced the choice of 'Dull Alec' or 'Smart Alec') but the result was unexpectedly close. He resigned as Conservative Leader in July 1965 after organising the party's first formal election procedure and Edward ${ }^{*}$ Heath succeeded. Home was Foreign and Commonwealth Secretary 1970-74 and accepted a life in peerage in 1974 .

Douglas-Home, A.F., The Way the Wind Blows. 1976.

Homer (Hómēros = 'hostage') (fl. 750-700 BCE). Greek epic poet. Tradition has attributed to Homer the authorship of The Iliad, the story of the siege of Troy (or Ilium) and other events during the Trojan War, and The Odyssey, which, except for the Epic of Gilgamesh and the Pentateuch, constitute the oldest surviving literature of antiquity, with an incomparable influence on Western culture. Nothing certain is known about the date of Homer's birth, and seven places (Argos, Athens, Chios, Colophon, Rhodes, Salamis and Smyrna) claimed him. One tradition asserts that he was born near Smyrna (now Izmir), the illegitimate son of Maion, travelled extensively collecting material for his epics, becoming blind and spending the rest of his life as a wandering minstrel. Some legends say that he spent his last years as a blind beggar at the gates of Thebes, declaiming the ballads and stories that were later incorporated in The Iliad and The Odyssey. He is thought to have died (if he lived at all) on the island of Ios.

In the 18th and 19th centuries, some historians concluded that Homer never existed and that works attributed to him were merely anthologies of older ballads and legends. George *Steiner argues that The Iliad was 'the product of an editorial act of genius', converting a voluminous oral tradition at 
the beginning of written language (at the same time that Hebrew scriptures were organised and put on papyrus) while The Odyssey was a literary creation, the first novel. Steiner suggests that the early ascription of blindness to Homer was made by the Homeridae, professional singers of the two epics, to mask their own illiteracy.

On balance, critical opinion now supports Homer's authorship of The Iliad largely because such a large personality comes through the words, rather than mere syntheses of legends. The Anglo-American classicist Bernard Knox commented: 'The architecture of the poem is magnificent, and it strongly suggests the hand of one composer ...'

Homeric scholars, including Martin *West and Peter Green, now argue convincingly that The Odyssey was written a generation or two after The Iliad (perhaps as late as $650 \mathrm{BCE}$ ) by another editor of genius, strikingly different in voice, warmth, point of view and vocabulary, and West has ' $\mathrm{P}$ ' as author of The Iliad and 'Q' The Odyssey.

Both works are characterised by vivid and precise descriptions and sharp observation of human behaviour. The Iliad is notable for Homer's constant use of fixed, or recurring, epithets, e.g. 'the wine-dark sea', 'Hector, breaker of horses', 'the prudent Penelope', 'Tiryns of the mighty walls', varying the choice ['the stalwart Odysseus' or 'Odysseus, sacker of cities', 'brilliant Achilles' or 'god-like Achilles', 'magnificent, brave Paris' or 'appalling Paris'] according to the length of line available. Ships can be 'black' or 'hollow' or 'fast moving', depending on whether one, two or three syllables are needed. Often the fixed epithet is used ironically, when a brilliant or god-like character is doing something stupid or appalling.

The Iliad describes the siege of Troy (or Ilion in Greek, Ilium in Latin), a powerful city-state in Anatolia, the northwest of modern Turkey, south of the Dardanelles, 35 kilometres from Gallipoli. In the Trojan War, between 1194 and 1184 BCE, during the Bronze Age, Achaeans (Greeks) from the mainland attacked and destroyed Troy. The Iliad begins abruptly with the rage of Achilles, a deadly Greek warrior, commander of the Myrmidons, against his overlord King Agamemnon, and his withdrawal from action. The Iliad covers a period of only 45 days, at the end of the war and has been described as 'an Iron Age reminiscence of Bronze Age culture'.

In The Iliad, Homer's approach is God-like in its detachment, cold-eyed and free of sentiment, with the reader/listener left to form his/her own judgment. In its clinical detail, the text anticipates a film script, using techniques such as the flashback, setting the scene and the leading actors powerfully, explaining the context later. There are unforgettable scenes of war, sex, desolation and despair.
Achilles kills Hector, the Trojan hero, and desecrates his body for 12 days. The Iliad ends with the aged Priam, King of Troy, visiting Achilles to beg for the return of his son's body. The last chapter is deeply poignant.

The Odyssey is the model for the 'quest' novel, a popular genre. 'Odyssey' has become a generic description of a long and wandering journey or quest, including journeys of self-discovery.

Odysseus (translated as Ulysses in Latin), king of Ithaca, was versatile, proverbially cunning (architect of the Trojan horse), a spellbinding orator but a plundering pirate, master of deceit, malicious and a philanderer. He also appears as a character in dramas by *Aeschylus, *Sophocles and *Euripides.

The Odyssey avoids duplication but assumes that readers/listeners will have some knowledge of the events in The Iliad.

In The Iliad, Odysseus is one of many heroes - in The Odyssey he is the only hero, full of contradictions, eager, after 10 years absence at war, to return to his wife, family, home and kingdom, carrying riches looted from Troy. He is also avid for new experiences, challenges and knowledge. As Bernard Knox observed, he begins as an admiral of a small fleet, and ends as a ship-wrecked sailor. Odysseus' account of his weird adventures, an early form of magic realism, are completely different from the flinty, metallic context of The Iliad.

After 10 more years, Odysseus returns to Ithaca, disguised by the goddess Athena, patron of human ingenuity, as a wandering beggar. He finds Penelope being pursued by hordes of voracious suitors who, assuming his death, consume his estate. He kills the suitors, re-establishes relations with the dog Argos, son Telemachus, and wife Penelope, meets the ghosts of the great Greek heroes, and goes to see his father Laertes. All ends happily, except for the suitors and some disloyal maids.

There have been more English translations of Homer than of the Bible, including by George *Chapman, Alexander ${ }^{*}$ Pope, William *Cowper, Samuel *Butler, T. E. *Lawrence, E. V. Rieu, Richmond Lattimore and Robert Fagles. Homer's works had a profound impact on *Aeschylus, *Sophocles, *Euripides, ${ }^{*}$ Virgil and ${ }^{*}$ Dante, ${ }^{*}$ Goethe, Victor ${ }^{*}$ Hugo, ${ }^{*}$ Tolstoy and ${ }^{*}$ Kazantzakis and, in the English language, *Chaucer, *Shakespeare, *Tennyson, *Joyce, *Pound, *Hemingway and Robert *Lowell.

A wine cup found in Rhodes, dated about 750 BCE, quotes three lines of The Iliad. This is within 50 or so years of the formulation of the Greek alphabet around 800 BCE, adapted from Phoenician, after earlier syllabic scripts, called Linear A and Linear B, disappeared. There is only one passing reference to writing in The Iliad. 
Standardised written Homeric texts seem to date from the Panathenaic Games of 566 BCE, on orders from the tyrant ${ }^{*}$ Peisistratus. Homeric language was already archaic, comparable to our reading of the Authorised Version of the Bible. Dividing both Homeric works into 24 'books' was adopted in the 3rd century BCE. Homer's epics were venerated in antiquity. *Alexander the Great directed *Aristotle to prepare manuscript copies of the texts and preserve them in a golden box.

Steiner, G., Homer. 1962; Kirk, G. S., Homer and the Epic. 1965; Lane Fox, R., The Classical World. 2005; Powell, B. B., Homer. 2007. West, M. L., The Making of The Iliad. 2011.

Homer, Winslow (1836-1910). American painter, born in Boston. First a lithographer, he became a magazine illustrator, attracting international recognition during the Civil War. From 1876 he devoted himself to painting landscapes, marine and genre scenes in oils and watercolours. He is extensively represented in major US galleries.

Honda Soichiro (1906-1991). Japanese industrialist. A garage apprentice from 1922, he set up his own garage in 1928, manufactured piston rings from 1934, motorcycles from 1948, then (against the advice of MITI, the Ministry for International Trade and Industry) motor cars-originally racing carsfrom 1962, winning a high reputation for quality.

Honecker, Erich (1912-1994). German politician. A lifelong Communist, imprisoned (1935-45) under the Third Reich, after the partition of Germany he became an assistant to Walter ${ }^{*}$ Ulbricht, First Secretary of the Socialist Unity party (SED) in the German Democratic Republic, and succeeded him as First Secretary 1971-89 and as President of the German Democratic Republic (DDR) 1976-89. With the collapse of the Berlin Wall in 1989 and the absorption of the Democratic Republic in a united Germany, he fled to Moscow, returning in 1992 to face charges of manslaughter and embezzlement. When the charges were dropped in 1993 on account of age and cancer he went to exile in Chile.

Honegger, Arthur (1892-1955). Swiss-French composer, born at Le Havre. One of the group of French composers known as 'Les Six', Honegger was a prolific composer and an exponent of polytonality. Although many of his works remained classical in form, they include the dramatic psalm Le roi David (1921), ballet Skating Rink (1922), orchestral works Pacific 231 (evoking the sounds of a locomotive, 1924) and Rugby (1928), opera Antigone (Cocteau, after Sophocles, 1927), stage oratorio Jeanne d'Arc au bucher (Claudel, 1938) and Une cantate de Nöel (1953). He wrote the film score for Abel *Gance's film Napoléon (1927). His five symphonies (No. 1,
1930; No. 2, for strings with trumpet solo, 1941; No. 3, 1946; No. 4, 1946 and No. 5, 1951) are among the finest in the French repertoire.

Hong Xiuquan (Hung Hsiu-ch'uan in Wade-Giles) (1812-1864). Chinese leader of the Taiping rebellion, born near Guangzhou (Canton). With messianic claims and a social and political program not unlike Communism, he claimed to be ruler of 'the great peaceful heavenly empire'. Taipings, as his followers came to be called, soon numbered tens of thousands. They marched from Guizhou in the south to the Yangtze, and by 1853 had seized Nanjing, where a massacre took place that showed the underlying savagery of the leader. For 11 years in Nanjing, Hong exercised an increasingly unpredictable despotism over some 20,000,000 people. At last in their helplessness the Chinese Government enlisted the help of a British officer, Charles *Gordon, who trained 'the ever victorious army', the main factor in bringing about the defeat of the Taipings and the suicide of their leader.

Spence, J. D., God's Chinese Son: The Taiping Heavenly Kingdom of Hong Xiuquan. 1995.

Hongwu ('vastly martial': personal name Zhu Yuanzhang) (1328-1398). Chinese emperor 136898 , founder of the ${ }^{*}$ Ming dynasty. Born a peasant, he became a monk, then a soldier, establishing himself as Prince of Wu (1368). He destroyed the *Yuan (Mongol) dynasty and established his capital at Nanjing. The *Yongle emperor was his fourth son.

Hongxi ('vastly bright': personal name Zhu Gaozhi) (1378-1425). Chinese emperor 1424-25, fourth of the Ming dynasty. Son and successor of the *Yongle emperor, he started to reverse many of his father's policies, cancelling *ZZheng He's explorations, reducing the power of the army, restoring Confucian values and returning to Nanjing as the capital.

Hooch, Pieter de (1629-1683). Dutch genre painter, born in Rotterdam. He began work in Delft and his studies of courtyards and domestic interiors show the effects of light and weather, anticipating *Vermeer. He had a mastery of perspective and conveys a strong sense of reality. He lived in Amsterdam from 1660 and his later paintings, recording an overpadded, richer style of living, were far less successful. He went mad and died in an asylum.

Hood, Samuel Hood, 1st Viscount (1724-1816). British sailor. Having reached the rank of Rear Admiral he was appointed (1786) to command a squadron in the West Indies, and under *Rodney's command played a decisive part in the Battle of the Saints. He became Lord of the Admiralty in 1788. When the French Revolutionary wars opened (1793) he was given the Mediterranean command and conducted the operations that led to the occupation of Toulon, and those islands off the Corsican coast. Nelson, who served under him, praised his skill as a tactician. 
His younger brother, Alexander Hood, 1st Viscount Bridport (1737-1814), was also a distinguished naval officer and commanded a squadron at *Howe's famous 'First of June' victory at Ushant (1794). He became a baron in 1796, promoted to viscount in 1800 .

Hooke, Robert (1635-1703). English scientist and polymath, born in the Isle of Wight. Son of a clergyman, and a frail child, he developed curvature of the spine. Educated at Westminster School; at Wadham College, Oxford, he was a chorister and organist, but gave up a clerical vocation, and, encouraged by John *Wilkins, become involved in science, assisting Thomas *Willis and, from 1655, Robert *Boyle. His family was royalist, and many scientists were anxious that a free spirit of enquiry would be limited under the Commonwealth, with Puritans asserting that the Bible was the ultimate authority on nature. He did not take out his MA until 1662, and became a 'doctor of physic' in 1691.

Hooke's genius for increasing the capacity of scientific instruments was central to his observations and discoveries. He invented an efficient anchor escapement and a spring-controlled balance wheel, which enabled small timepieces (although *Huygens contested his priority). His improved vacuum pump was a precondition for 'Boyle's law' (1660) and his conclusion that sounds could not be heard without a medium.

Elected FRS in 1663, he was Curator of Experiments at the Royal Society 1663-1703, Secretary 1677-82, and Professor of Geometry at Gresham College, London, 1665-1703.

He developed the first practical compound microscope, with objects for observation illuminated by an oil lamp and convex mirror. His Micrographia: or, Some Physiological Descriptions of Minute Bodies Made by Magnifying Glasses (1665), published by the Royal Society, included magnificent illustrations of the microscopic world of animal and plant structure. In it he named 'cells' (from the Latin 'cella' = small room), which he first identified in cork. (*Leeuwenhoek observed living cells in 1678.) He also speculated, correctly, about the organic origin of fossils and the wave theory of light. The book was very successful and excited Samuel ${ }^{*}$ Pepys.

After the Great Fire of 1666, Hooke became Surveyor of the City of London 1667-76, worked closely with Christopher *Wren, and seems to have conducted more than half of the surveys of the areas destroyed (a very lucrative practice), producing an important plan-form map of the city, also working as an architect, designing 'The Monument' and at least three churches.
He worked on the diffraction of light (1672), atmospheric pressure and magnetism, speculated about evolutionary processes and the concept of heat as energy. He built an improved Gregorian telescope, identified a double star in 1665, observed Mars and the red spot on Jupiter, and calculated the rotation of both planets (1673).

He stated, first as an anagram (1676), then as a precisely expressed scientific principle (1678), Hooke's Law, that 'extension in an elastic body is proportional to the force applied'. He almost certainly anticipated *Newton's statement of the 'law of inverse squares and universal gravity' (1684); this became a matter of bitter controversy between them. He was close to Wren, but Newton detested him.

Hooke was a contradictory character, solitary and convivial, irascible and agreeable. He never married, and left a fortune. Asteroid 3514 Hooke is named for him. No portrait of him has survived.

Chapman, A., England's Leonardo: Robert Hooke. 1967; Drake, E. T., Restless Genius and His Earthly Thoughts. 1998; Inwood, S., The Man Who Knew Too Much. 2002; Jardine, L., The Curious Life of Robert Hooke. 2003, Bennett, J., London's Leonardo. The Life and Work of Robert Hooke. 2003.

Hooker, Joseph (1814-1879). American soldier. Having fought with distinction in the Mexican War (1846-48), he retired (1853) but offered his services to the Union Government on the outbreak of the Civil War. As a divisional and corps commander he earned the title 'Fighting Joe' for the energy with which he sought out and attacked the enemy. At the beginning of 1863 he took over the command of the army of the Potomac but was superseded in June for having allowed himself to be surprised and outflanked near Chancellorsville and forced to retreat. In another exploit, known as the 'battle above the clouds', he stormed a summit at the Battle of Chattanooga (November 1863); he also took part with *Sherman in the spectacular march through Georgia (1864).

Hooker, Sir Joseph Dalton (1817-1911). English botanist, born in Suffolk. He took a medical degree at Glasgow University, but botany and plant geography became his lifelong studies. He was botanist on HMS Erebus on an exploration (1839-43) of the flora of the Antarctic, Tasmania, New Zealand and the Falkland Islands, and published his discoveries in Flora Antarctica (1844-47), Himalayan Journals (1854) and Flora of Tasmania (1859). He became a lifelong friend and supporter of Charles *Darwin. His most important work (written in collaboration with George *Bentham) was Genera Plantarum (1862-83). His 'Flora' included The Student's Flora of the British Isles (1870) and Flora of British India (7 volumes, 1897). He succeeded his father Sir William Jackson Hooker (1785-1865) as director of Kew 
Gardens 1865-85, was President of the Royal Society 1873-78, and received the Copley Medal (1887) and the OM (1907).

Hoover, Herbert Clark (1874-1964). 31st President of the US 1929-33. Born in West Branch, Iowa, to a Quaker family, he graduated as an engineer from Stanford and worked for 12 years with the British mining firm Bewick, Moreing and Co. in Western Australia 1896-98, China 1899-1902 and Burma, forming his own company in 1908. With his wife Lou Henry he made a notable translation of *Agricola's De re metallica (1913). During World War I he became famous for his organisation of famine relief in Belgium and elsewhere, eventually becoming US Food Administrator 1917-19. He entered political life as Secretary for Commerce 1921-28 under *Harding and ${ }^{*}$ Coolidge. When Coolidge announced his retirement (1928), Hoover won the Republican nomination for president on the first ballot and defeated $\mathrm{Al}{ }^{*}$ Smith in November, winning 58.2 per cent of the vote and 40 states. His term of office coincided with the financial collapse of 1929 and the ensuing depression and unemployment on an unparalleled scale. He believed in ultimate recovery through private enterprise, and the measures he initiated were ineffective. Despondency grew and the situation deteriorated; in 1932 he was defeated by Franklin D. * Roosevelt when his vote fell to 39.7 per cent. He toyed with seeking the Republican nomination in 1936 and, more seriously, in 1940. Harry *Truman appointed him as coordinator of the European food program 1946-47 and he chaired two commissions on organising the Executive Branch of Government 1947-49, 1953-55. He wrote Memoirs (3 vols, 1951-52) and a biography of Woodrow *Wilson (1958). In 20 Presidential rankings by US historians and political scientists, Hoover scored No. 29 in the aggregate.

Smith, G., The Shattered Dream. 1970; Jeansonne, G., Herbert Hoover: A Life. 2016.

Hoover, J(ohn) Edgar (1895-1972). American public official. A law graduate of George Washington University, he became a clerk in the Justice Department and was Director of the Federal Bureau of Investigation (FBI) from 1924 until his death. His skilful manipulation of publicity, and emotional appeals to patriotism, made him an increasingly powerful political figure and successive presidents were wary of offending him. Hoover was both a beneficiary and victim of blackmail, apparently subject to Mafia pressure over his concealed homosexuality.

Gentry, C., J. Edgar Hoover: The Man and his Secrets. 1992.

Hope, Anthony (pen name of Sir Anthony Hope Hawkins) (1863-1933). Educated at Oxford, and a barrister, he wrote the very successful romances The Prisoner of Zenda (1894) and the sequel Rupert of Hentzau (1898), both set in the imaginary state of Ruritania.
Hope, Bob (Lester Townes Hope) (1903-2003). American actor and comedian, born in London. His family lived in the US from 1907. After success in vaudeville, he made 59 films between 1938 and 1977, many with his friend Bing *Crosby, and became the first show business billionaire. He was also successful on radio and television, received four special Academy Awards and many decorations including an Hon. KBE (1998).

\section{Hopetoun, 7th Earl of, John Adrian Louis Hope, later 1st Marquess of Linlithgow (1860-1908).} Scottish aristocrat, born in West Lothian. Educated at Eton and Sandhurst, he succeeded to his earldom at the age of 12, was a youthful Governor of Victoria 1889-95 and, on returning, Paymaster-General 1895-99 and Lord Chamberlain 1898-1900 under *Salisbury. Appointed first Governor-General of the Commonwealth of Australia 1901-03, 'the Hopetoun blunder' was his abortive nomination of Sir William Lyne, Premier of New South Wales to be the first Prime Minister (1901), instead of Edmund *Barton, leader of the federation campaign. He clashed with Barton's government over expenditure and left Australia in July 1902, before his term ended. The youngest Governor-General ever appointed, created marquess in 1902, he became the youngest to die. He served briefly as Secretary of State for Scotland 1905. His son, the 2 nd Marquess of *Linlithgow, was Viceroy of India 1936-43.

Hopkins, Sir Anthony (1937- ). Welsh actor. Successful on stage, after a struggle with alcoholism he became an outstanding film actor, winning Academy Awards for best actor with The Silence of the Lambs (1991) and The Father (2021). Other films include The Elephant Man (1980), Spotswood (1991), Howards End (1992), The Remains of the Day (1993), Nixon (1995), Surviving Picasso (1995) and Amistad (1997), Beowulf (2007) and Hitchcock (2012).

Hopkins, Sir Frederick Gowland (1861-1947). English biochemist. A cousin of G. M. *Hopkins, he became a Fellow of Trinity College, Cambridge, discovered (1906-07) how essential amino acids must be supplied in the diet for animals to survive, proved by experiment (1912) the existence of 'accessory food factors' (now known as vitamins) and established their necessary place in a normal diet. He also helped discover the relationship between lactic acid and muscular contraction, and devised a method for the quantitative estimation of uric acid. Professor of biochemistry at Cambridge 1914-43, he received the Copley Medal in 1926. He shared the Nobel Prize for Medicine (1929) with *Eijkman, for pioneer research in 'accessory food factors'. President of the Royal Society 1930-35, he was awarded the OM (1935).

Hopkins, Gerard Manley (1844-1889). English poet, born in Essex. A cousin of F. G. *Hopkins, he was educated at Oxford, influenced by ${ }^{*}$ Newman and became a Catholic in 1866 . He joined the Jesuits in 
1868, was ordained in 1877, taught in Lancashire and became professor of Greek literature, University College, Dublin 1884-89. In publishing his poetry he accepted the guidance of his friend, Robert *Bridges, and only a few poems appeared in anthologies during his lifetime. Bridges published a complete edition in 1918, which gave rise to much controversy and it was only after the second edition (1930) in a different climate of literary appreciation that their quality was widely recognised. Hopkins' intense awareness of good and evil is, in itself, remarkable but even more so are the sensuous language and the rhythmic innovations with which his wide ranging moods-exultant, contemplative, desolate-are expressed. His best known poems include The Wreck of the Deutschland, The Windhover, Pied Beauty, The Leaden Echo and the Golden Echo and Carrion Comfort. Hopkins used the technique of 'sprung rhythm', using sequences of stressed syllables ('Brúte béauty and válour and act, óh, air, pride, plume, hére/Búckle!') rather than the conventional alternation of stressed and unstressed. He had a major influence on *Eliot, *Auden and Dylan *Thomas.

Schneider, E. W., The Dragon in the Gate. 1968; Martin, R. B., Gerard Manley Hopkins: A Very Private Life. 1991.

Hopkins, Harry Lloyd (1890-1946). American administrator, born in Iowa. A social worker, he worked with Franklin D. *Roosevelt when he was Governor of New York, and followed him to Washington as head of the Federal Emergency Relief Administration (FERA) 1933-35 and Director of the Works Progress Administration (WPA) 1935-38. He was US Secretary of Commerce 1938-40 and Director-General of Lend Lease 1940-41. As Special Assistant to the President 1941-45, he was constantly sent on confidential missions, winning the trust of ${ }^{*}$ Churchill and ${ }^{*}$ Stalin. Roosevelt wanted Hopkins to succeed him as president, but his health was appalling.

Sherwood, R. E., Roosevelt and Hopkins. 1948; O'Sullivan, C., Harry Hopkins: FDR's Envoy to Churchill and Stalin. 2014.

Hopkins, Johns (1795-1873). American financier, born in Maryland. Originally a grocer, he became a banker and made a fortune from railroads. He left money to establish the Johns Hopkins University in Baltimore (1876), the first US institution devoted primarily to research and with the oldest university press, and the Johns Hopkins Hospital (1878).

Hopper, Edward (1882-1967). American painter, born in Nyack, New York. He became the leading figure in the 'Ashcan' social realist school, depicting scenes from urban life, while insisting that he had no social message. His bleak paintings were much admired in the 1990s.
Hopper, Grace Brewster Murray (1906-1992). American computer scientist. Educated at Yale, she was a pioneer in writing computer programs, including COBOL. She became a rear-admiral in the US Navy and in 2016 *Obama posthumously awarded her the Presidential Medal of Freedom.

Horace (Quintus Horatius Flaccus) (65-8 BCE). Roman poet. Son of a freed-man, he studied at Athens University, served under ${ }^{*}$ Brutus in the Civil War and according to his own story ran away at Philippi. When Octavian (*Augustus) came to power Horace came under the eye of that great patron of literature *Maecenas and under his auspices became the friend of ${ }^{*}$ Virgil who introduced him to the emperor. Horace was given a small estate near Rome and lived in modest comfort until his death. In his Epodes and Odes (Carmina), he adapted to the demands of the Latin language the Greek metres of Archiloechus, *Sappho, and Alcaeus. Witty and urbane, he possessed an almost uncanny genius for the right word and phrase. His subjects include love poems (graceful rather than passionate), appeals to patriotism, drinking songs and occasional and not very virulent attacks on his enemies. In the Satires, written in hexameters, are included episodes of everyday life (e.g. encounters and conversations in an inn) and humorously satirical poems on the vices and follies of mankind. In later life he produced a new literary form, letters (Epistolae) in verse. Those in the first volume are written to a variety of friends, acquaintances and servants, those in the second are more in the nature of essays; one of them, his famous Ars Poetica, containing much sensible advice (mainly on drama) to aspiring writers. More than most authors Horace had the gift of producing the quotable phrase, of which 'Dulce et decorum est pro patria mori' is among the most famous.

Noyes, A., Portrait of Horace. 1947.

Horne, Donald Richmond (1921-2005). Australian journalist, editor and academic. His book The Lucky Country (1964) argued that Australia's mineral abundance and 'lucky' elements in its history had retarded some elements in its social, economic and technological development. He edited the Observer and The Bulletin, wrote 20 books, taught at the University of New South Wales and was Chairman of the Australia Council 1985-90.

Horne, Marilyn (1934- ). American mezzo-soprano, born in Pennsylvania. She first achieved success in European opera houses, making her US debut in 1960. She had a wide range (low $\mathrm{E}$ to high $\mathrm{C}$ ), a vivacious personality, and excellent acting, especially admired in ${ }^{*}$ Rossini, *Bellini, *Verdi, *Bizet and ${ }^{*}$ Berg.

Horowitz, Vladimir Samuilovich (1903-1989). Russian-American pianist, born in Kiev. Resident in the United States from 1928, son-in-law of the conductor Arturo *Toscanini, he first gained an 
international reputation in the 1920s. Nervous breakdowns forced his withdrawal from concert giving 1953-65, 1969-74. Horowitz established his reputation as the pre-eminent virtuoso pianist, a high romantic, especially in his interpretation of ${ }^{*}$ Chopin, ${ }^{*}$ Liszt, ${ }^{*}$ Tchaikovsky and ${ }^{*}$ Rachmaninoff. In his last years he began recording works by ${ }^{*}$ Mozart and ${ }^{*}$ Schubert. He made a triumphant return to Russia in 1986.

Horrocks, Jeremiah (1619-1641). English astronomer, born near Liverpool. An Anglican curate, he corrected the Rudolphine Tables of *Kepler, made the first prediction and observation of a Transit of Venus (1639), anticipated *Newton's theory of universal gravity and postulated the elliptical orbit of the moon.

Horszowski, Mieczylaw (1892-1993). PolishAmerican pianist, born in Lvov. A pupil of Theodor *Leschetizky, he made his debut in 1901 and lived in New York from 1940. He was a distinguished chamber music player, still performing and recording after his 100th birthday.

Horthy (de Nagybánya), Miklós (1868-1957). Hungarian admiral and regent. Commander-inChief of the Austro-Hungarian navy 1917-19, he led the 'Whites' in a campaign which led to the defeat and expulsion of the Communist Government of Bela *Kun. He was regent of Hungary 1920-44, acting, according to the constitutional fiction of the time, as head of state on behalf of the absent king *Karl (Charles), formerly Austrian emperor. Effective power was exercised by Count Istvan Bethlen (1874-1946) as Prime Minister 1929-31 and by General Gyula *Gömbös as Defence Minister 1931-36. During World War II Hungary joined the German alliance (1941) but in October 1944 Horthy proclaimed Hungary's withdrawal from the war and was imprisoned by the Germans. Released by the Allies, he retired to Portugal.

Horthy, M., Memoirs. 1956.

Hosokawa Morihiro (1938- ). Japanese politician. Grandson of Prince Konoye (Prime Minister 193739, 1940-41), he was a journalist, a minister briefly and Governor of Kumamoto 1983-91. He broke with the LDP and formed the Japan New Party in 1991. After defeat of the LDP in the July 1993 elections after 38 years, he became Prime Minister in a seven party coalition, but resigned in April 1994 when his Budget was rejected.

\section{Hotspur, Harry see Percy, Sir Henry}

Houdini, Harry (né Erik Weisz) (1874-1926). American-Jewish-Hungarian showman, born in Budapest. Son of a rabbi, his family migrated to Wisconsin in 1878. Famous for his sensational escapes from bondage, his ability to free himself from shackles, locked boxes, strait jackets, handcuffs and all kinds of sealed containers, brought him worldwide fame. He was an implacable foe of spiritualism. In March 1910 he made one of Australia's earliest powered flights, in a Voisin biplane. He appeared in six silent films and published 11 books. He died of peritonitis in Detroit, following an incident in Montréal when a student repeatedly punched his abdomen to test his claim that his stomach muscles were strong enough to resist force.

Randi, J. and Sugar, B. R., Houdini: His Life and Art. 1977.

Houdon, Jean-Antoine (1741-1828). French sculptor. Probably the greatest sculptor since *Bernini, he made powerful sculptures of contemporaries, including ${ }^{*}$ Voltaire, * Rousseau, ${ }^{*}$ Diderot, ${ }^{*}$ Franklin, *Washington and *Jefferson.

Hounsfield, Sir Godfrey Newbold (1919-2004). English electronics engineer. He gained a diploma at an engineering school, served in the RAAF and worked for EMI (later Thorn EMI) 1951-86. He invented the CAT (computerised axial tomography) scanner, which enabled X-rays to be taken on a cross-section in a flat plane. Elected an FRS (1975), he shared the 1979 Nobel Prize for Medicine with the SouthAfrican born American radiologist Allan McLeod Cormack (1924-1998).

Houphouët-Boigny, Félix (1905-1993). African politician, born in Yamoussoukro. Son of a chief, he worked as a doctor, became prominent in the Rallye Démocratique Africaine which later became the major political party in several French colonies, was elected to the French National Assembly in 1946 and became the first African appointed as Minister (1957). When the Cote d'Ivoire became independent (1959), he was first Prime Minister and then President 1960-93. He built the world's largest cathedral (to the embarrassment of ${ }^{*}$ John Paul II) at his birthplace.

Housman, A(lfred) E(dward) (1859-1936). English poet and scholar, born in Fockbury. A first-class in Classical Mods and a failure at 'Greats' at Oxford was one of the many paradoxes that puzzled his contemporaries. A gay high-church atheist, he edited works by ${ }^{*}$ Ovid, Manilius, *Juvenal and *Lucan and after a spell at the Patent Office became professor of Latin at London 1892-1911 and Cambridge 191136. He was also a fellow of Trinity College 1911-36. The supreme paradox was that this aloof, lonely scholar, held in awed reverence, was the author of $A$ Shropshire Lad (1896), a collection of poems which for all their pessimism and nostalgia are among the most enchanting and exquisitely contrived of any in the language. *Vaughan Williams' song cycle $O n$ Wenlock Edge (1909) was based on poems from $A$ Shropshire Lad. George *Butterworth also wrote two cycles (1911) and an orchestral rhapsody of the same 
name. Housman's Last Poems (1922) showed an even deeper pessimism. He declined all public honours, including the OM (1929).

His brother, Laurence Housman (1865-1959), was a writer and critic before he achieved fame when his series of plays Victoria Regina (1935) were later welded into a single play and professionally performed. His earlier series Little Plays of St Francis (1922) originated the method of treatment.

Housman, L., My Brother: A. E. Housman. Repr. 1969; Vincent, E., A. E. Housman-Hero of the Hidden Life. 2018.

Houston, Sam(uel) (1793-1863). American soldier, frontiersman and politician, born in Virginia. He lived as a youth among the Cherokee Indians. A supporter of Andrew *Jackson, he was a member of the US House of Representatives 1823-27 and Governor of Tennessee 1827-29, resigning after divorcing his first wife, and relocating first to Arkansas and (from 1832) to Texas. On declaring its independence from Mexico, he became Commander-in-Chief of the Texan forces. After the surrender of the Alamo (1836) to the Mexicans, Houston defeated them decisively at San Jacinto, and was elected first president of the new republic of Texas 1836-38 and again 1841-44. On the admission of Texas to the Union (1845) Houston represented it in the US Senate 1846-59 and became Governor 1859-61. On the outbreak of the Civil War, Houston, contrary to popular opinion, opposed Texas joining the Confederacy and was deposed by a Convention in March 1861. The city of Houston, the largest in the South, a university, national forest, battleship and army base are named for him.

Michener, J. A., The Eagle and the Raven. 1990.

\section{Howard, Catherine see Catherine Howard}

Howard of Effingham, 2nd Baron, Charles Howard, later 1st Earl of Nottingham (1536-1624). English courtier and sailor. As Lord High Admiral of England 1585-1618 he commanded the English fleet which defeated the Spanish Armada (1588). With *Essex, whose rebellion (1601) he later put down, he led an expedition (1596) to destroy shipping at Cadiz. For this he received his earldom.

Howard, John Winston (1939- ). Australian Liberal politician, born in Sydney. He was a Federal MP 1974-2007, Commonwealth Treasurer 1977-83 and Liberal Leader 1985-89 and again in 19952007. Prime Minister 1996-2007, he defeated Paul *Keating decisively, but without a majority in the Senate. A strong opponent of 'political correctness', he resisted native title claims on pastoral leases and was hostile to republicanism. His major policy aims were reduction of trade union power, selling Telstra, introducing a goods and services tax (GST) and resisting greenhouse gas limitations. He won a second election in October 1998 with a sharply reduced majority and a third in November 2001 with an increased majority in a campaign dominated by the issue of refugees ('boat people') and security, after the September 11, 2001 attacks in New York. Australia joined George W. *Bush's 'coalition of the willing' which invaded Iraq in March 2003 and Bush called Howard 'a man of steel'. Howard won a fourth election in October 2004 and in December 2004 became Australia's second longest serving Prime Minister. Heavily defeated by Kevin * Rudd in November 2007, he lost his own seat. He received the US Presidential Medal of Freedom in 2009 and the $\mathrm{OM}$ in 2012.

Barnett, D. and Goward, P., John Howard. Prime Minister. 1997; Van Onselen, P. and Errington, W., John Winston Howard: The Biography. 2007; Howard, J. W., Lazarus Rising: A Personal and Political Autobiography. 2010.

Howard, Leslie (né L. H. Steiner) (1893-1943). British actor, film director and writer, born in London. Of Hungarian-Jewish descent, he was a bank clerk and World War I officer before achieving success as a stage actor in London and, especially, Broadway. He appeared in 39 films, notably as Alan Squier in The Petrified Forest (1936), Professor Higgins in Pygmalion (1938) and Ashley Wilkes in Gone with the Wind (1939). He was killed when a Luftwaffe plane shot down a civilian aircraft over the Bay of Biscay.

Efogan, E., Leslie Howard: The Lost Actor. 2010.

Howard, Michael, Baron Howard of Lympne (1941- ). English Conservative politician, born in Wales. The son of Romanian Jewish refugees, he was educated at Peterhouse, Cambridge, became a barrister and MP 1983-2010, Home Secretary 1993-97 and Leader of the Opposition 2003-05.

Howard, Sir Michael Eliot (1922-2019). English military historian, born in London. Chichele Professor of the History of War 1977-80 and Regius Professor of Modern History 1980-89 at Oxford, his books include Grand Strategy (1972), Clausewitz (1983) and The First World War (2001). He received a $\mathrm{CH}$ in 2002 and the OM in 2005.

Howe, (Richard Edward) Geoffrey, Baron Howe (1926-2015). British politician, born in Wales. A barrister, he was a Conservative MP 1964-66 and 1970-92, a junior minister under Edward *Heath 1970-74 and Margaret *Thatcher's Chancellor of the Exchequer 1979-83, given the task of implementing her Friedmanite 'free market' policies. He was Foreign Secretary 1983-89 and Lord President of the Council and Deputy Prime Minister 1989-90, resigning in protest at Thatcher's attitude to Europe. His powerful speech in the Commons helped to bring her down. $\mathrm{He}$ received a $\mathrm{CH}$ in 1996. 
Howe, Julia Ward (née Ward) (1819-1910). American author and social reformer. She campaigned for the abolition of slavery, and wrote (1862) The Battle Hymn of the Republic. Later she was one of the leaders of the women's suffrage movement and first woman member of the American Academy of Arts and Sciences.

Howe, Richard Howe, 1st Earl (1726-1799). English admiral. Known as 'Black Dick', when only 20 he drove off two French ships coming to reinforce Prince ${ }^{*}$ Charles Edward in the Jacobite rebellion (1745). He gained successes in the Seven Years' War, and in the American War of Independence he repelled the French fleet off Rhode Island. Meanwhile he had been a Lord of the Admiralty 1763 and Treasurer to the Navy (1765). He was First Lord of the Admiralty 1783-88, commanded the Channel fleet when the French Revolutionary war broke out (1793), and in 1794, off Ushant, gained the greatest victory of his career (known as the Glorious First of June), in which seven enemy ships were destroyed and 10 more unmasted. In 1797 he brought back to duty the mutineers at Spithead. Howe had inherited an Irish peerage (1758), received a UK viscountcy (1782) and an earldom (1788). Lord Howe Island was named for him in 1788.

His younger brother, William Howe, 5th Viscount Howe (Irish peerage) (1729-1814), who succeeded him in the Irish viscounty, was one of the most successful British generals in the War of American Independence. Under Thomas ${ }^{*}$ Gage, whom he succeeded, he captured Bunker's Hill, and in the following year took New York and Washington, but failed to follow up his successes to decisive victory.

Howel (known as 'the Good') (d.950). Welsh king. Through inheritance and marriage his rule gradually extended over south Wales and from 943, when his cousin Idwal died, over north Wales as well. He is remembered as a lawmaker. His code, probably quite a simple and uncomplicated affair, was expanded later until it developed into the full legal system of medieval Wales known as the Law of Howel the Good.

Howells, Herbert Norman (1892-1983). English composer. A pupil of ${ }^{*}$ Stanford, he succeeded ${ }^{*}$ Holst as Director of Music at St Paul's Girls School, London 1936-62 and was a professor of composition at the Royal College of Music, London 1920-83. His greatest work, Hymnus Paradis (1938), written after his son died suddenly from polio, was not performed until 1950 . He wrote many songs and a concerto for strings (1938) and received a CH in 1972.

Hoxha, Enver (1908-1985). Albanian politician. A founder member of the Albanian Communist Party, and Secretary-General 1943-85, he led the resistance movement against the Italians in World War II. He became Prime Minister when Albania was proclaimed a republic (1946) and also filled the posts of Minister of Foreign Affairs and Commander-in-Chief until 1954. On the death of * Stalin, his close ties with the USSR were replaced by adherence to the Beijing line until 1978.

Halliday, J. (ed.), The Artful Albanian: The Memoirs of Enver Hoxha. 1985.

Hoyle, Sir Fred (1915-2001). English mathematician, astronomer and science-fiction writer, born in Yorkshire. Educated at Cambridge, he worked on radar during World War I and lectured in mathematics from 1945. In 1948, with the mathematician Hermann *Bondi and astronomer Thomas Gold, he proposed the 'steady state' theory of the universe, arguing that matter is being created at a rate fast enough to keep an expanding universe at a constant mean density, a theory first suggested in the 1920s by Sir James *Jeans. The 'steady state' theory was dominant in cosmology until the discovery of cosmic microwave background radiation resulted in general acceptance of the rival 'big bang' theory, a term that Hoyle coined dismissively in 1949. After working at the Mount Wilson and Palomar Observatories near Pasadena, California, Hoyle became Plumian professor of astronomy and experimental philosophy 1958-72 and Director of the Institute of Theoretical Physics 1966-72 at Cambridge University. His novels included The Black Cloud (1957) and Ossian's Ride (1958).

Hoyle, F., Of Men and Galaxies. 1966.

Hrdlicka, Ales (1869-1943). American anthropologist, born in Bohemia. On appointment to the US National Museum he organised (1903) a department of physical anthropology, which he curated 1910-42. He pursued his anthropological studies throughout the world and is especially known for his study of the route of migration of the American Indian.

Htin Kyaw (1946- ). Burmese politician. Son of a poet and a computer expert, he worked closely with *Aung San Suu Kyi and was elected as President of Myanmar 2016-18, essentially as a proxy for her.

Hu Jintao (1942- ). Chinese Communist politician. Born in Jiangsu province, he served on the CCP Presidium 1983- and was Vice President of the Republic 1998-2003, General Secretary of the Chinese Communist Party 2002-12 and President of the Republic 2003-13.

Hu Yaobang (1915-1989). Chinese Communist politician. A veteran of the Long March, close associate of *Deng Xiaoping, he was twice purged in the Cultural Revolution. He became GeneralSecretary of the CCP $1980-81$ and succeeded ${ }^{*}$ Hua Guofeng as party chairman 1981-82. GeneralSecretary again from 1982, he resigned in 1987 to placate military and conservative party elements opposed to economic change and social liberalisation. His funeral was marked by student demonstrations. 
Hua Guofeng (Hua Kuo-Feng) (1921-2008). Chinese Communist politician, born in Shanxi province. He joined the Communist Party of China in 1935 and served as an army officer for 10 years. $\mathrm{He}$ acted as party secretary in Xiang-Dan county 1953-58, promoting projects in Shaoshan, *Mao Zedong's birthplace. He became Vice Governor of Hunan province 1958-67, a member of the Central Committee of the Communist Party 1969, secretary of the party in Hunan province 1970-71, Administrator of the State Council Secretariat 1971-73, and a Politburo member (1973). Mao chose him as Deputy Premier and Minister of Public Security 1975-76, and Deputy Chairman of the Party (April October 1976) and wrote 'with you in charge I am at ease'. When *Zhou Enlai died, Hua became acting Premier (February-April 1976) and Premier from April 1976. After Mao's death, Hua was elected Chairman of the Communist Party (October 1976). With the trial of the 'Gang of Four' the party distanced itself from Mao's legacy and Hua lost power to the pragmatic followers of Zhou, notably ${ }^{*}$ Deng Xiaoping. Hua resigned as Chairman on 30 June 1981 and was succeeded by ${ }^{*} \mathrm{Hu}$ Yaobang.

Hubbard, L(afayette) Ron(ald) (1911-1986). American author, entrepreneur and cult founder, born in Tilden, Nebraska. He was a successful writer of science fiction before publishing Dianetics (1950), proposing a new system of encouraging self-help to overcome psychological problems. He founded the Church of Scientology in 1952 and this became an intensely controversial organisation, attracting, long after Hubbard's death, passionate advocacy from actors and other public figures, and bitter hostility from people who claimed to have been victimised and brain-washed, e.g. Lawrence Wright's Going Clear: Scientology, Hollywood, and the Prison of Belief (2013).

Hubble, Edwin Powell (1889-1953). American astronomer born in Missouri. Educated at the universities of Chicago and Oxford (Rhodes Scholar), after service in World War I, and research in Cambridge, from 1919 he worked at the Mount Wilson Observatory, near Pasadena, California. Using its Hooker reflector telescope $(2.5 \mathrm{~m})$, he observed (1923) that the Andromeda Galaxy (M31) contained cepheid stars, with variable luminosity and pulsation (a phenomenon discovered in 1912 by Henrietta Swan ${ }^{*}$ Leavitt). He was able to prove that M31 was about 800,000 light-years from the earth, well outside our own galaxy, the Milky Way, and itself a galaxy of comparable size. He identified 24 galaxies, but now there are estimated to be millions, distributed throughout space. He helped to propound the theory of the expanding universe, which Georges *Lemaittre first proposed in a Belgian science journal in 1927, and published (1929) his hypothesis that the velocities of receding galaxies are directly proportional to their distance from the solar system.
He helped to design the $5.1 \mathrm{~m}$ Hale Telescope at $\mathrm{Mt}$ Palomar and was the first to use it (1949). Asteroid 2069 Hubble, a moon crater and the Hubble Space Telescope (launched in 1990) were named for him, but in his lifetime astronomers were not considered eligible for a Nobel Prize.

Christianson, G., Edwin Hubble: Mariner of the Nebulae. 1995; Bartusiak, M., The Day We Found the Universe. 2009.

Huberman, Bronislaw (1892-1948). Polish-Jewish violinist, born in Częstochowa. A major virtuoso in the Viennese tradition, he left Europe in the 1930s and founded the Palestine Symphony Orchestra (now the Israel Philharmonic) in 1936. His Stradivarius violin, stolen in 1936, is now played by Joshua Bell.

Huc, Evariste Régis (1813-1860). French missionary and explorer. In 1844 he set out on a mission which took him through nearly every province in China before, after many hardships, he reached Tibet. There he spent some time in a monastery where the lamas taught him the Tibetan language; he reached Lhasa but was quickly expelled.

Huddleston, (Ernest Urban) Trevor (1913-1998). British missionary and Anglican bishop. Ordained in 1937, he joined the Community of the Resurrection (CR), worked in South Africa 1943-56 and became Bishop of Masai (Tanzania) 1960-68, Bishop of Stepney 1968-78 and Archbishop of the Indian Ocean 1978-83. He wrote Naught for your Comfort (1956), on faith and apartheid.

Hudson, Henry (d.1611). English navigator. He tried to discover a route through the Arctic from Europe to Asia the 'North West Passage'. After sailing round the north coast of Norway and exploring the Svalbard archipelago, he embarked on his voyage to North America in 1609. He discovered the bay, river and strait named after him, but failed to find a passage to the Pacific. He was deserted by his crew on a subsequent expedition and set adrift in Hudson Bay.

Hudson, William Henry (1841-1922). British writer, born in Argentina. Of American parentage, he went to England in 1869. His books reflect his devotion to birds and animals. Rima, the bird-girl of his novel Green Mansions (1904), was the subject of Epstein's controversial sculpture in the bird sanctuary in Hyde Park, London.

Tomalin, R., W. H. Hudson. 1954.

\section{Hueffer, Ford Madox see Ford, Ford Madox}

Huerta, Victoriano de la (1856-1916). Mexican soldier and politician. He served under ${ }^{*}$ Diaz, and was Commander-in-Chief under *Madero, whom in 1913 he induced to resign to facilitate his murder. Huerta's reactionary reign as President 1913-14 was ended by 
US intervention. He fled to Europe and subsequently settled in the US, where he was arrested for plotting against Mexico, and died in prison in Texas.

\begin{abstract}
Huggins, Godfrey Martin, 1st Viscount Malvern (1883-1971). Rhodesian politician, born in Bexley, Kent. He practised as a surgeon in Rhodesia from 1911, both before and after his service in the RAMC during World War I, and became a Member of the Legislative Assembly of Southern Rhodesia in 1924. He was Prime Minister of Southern Rhodesia 1933-53 and then of the newly formed Federation of Rhodesia and Nyasaland 1953-56, all representing the small white minority. The longest serving head of government in British Commonwealth history, he was rewarded with a KCMG (1941), CH (1944) and a viscountcy (1956).
\end{abstract}

Huggins, Sir William (1824-1910). English astronomer, born in London. Son of a rich draper, he did not attend university. A pioneer of stellar spectroscopy, from a private observatory in Tulse Hill, London, he applied *Kirchhoffs work on spectroscopy to researches into the spectra of the stars and nebulae, marking the beginnings of astrophysics. With the stellar spectroscope which he and William Miller invented (1856), he proved that some nebulae are composed of glowing gas out of which new star systems are being born. He also explained how novae are formed. Huggins demonstrated that the sun and the stars are similar in composition, and he used the Doppler effect to determine the velocity of some of the stars relative to earth. From 1880 he produced large photographic plates. He worked with his wife Margaret Lindsay Huggins (née Murray) (18491915). Copley Medallist in 1898, he was President of the Royal Society 1900-05 and a foundation member of the OM (1902). Asteroid 2635 Huggins was named for him.

Hughes, Charles Evans (1862-1948). American politician and jurist. Educated at Colgate, Brown and Columbia universities, he gained public attention as a vigorous investigator of corruption of public utilities in New York, defeated William Randolph *Hearst to become Governor of New York State 1907-10 until *Taft appointed him a justice of the US Supreme Court 1910-16. He resigned from the court (1916) to run as Republican candidate for president, losing narrowly to Woodrow *Wilson. He served under ${ }^{*}$ Harding and ${ }^{*}$ Coolidge as Secretary of State 192125 . He supported US entry to the League of Nations and the World Court, and isolationist opponents called him 'Wilson with whiskers'. He was Chief Justice of the United States 1930-41.

Hughes, David Edward (1831-1900). English physicist. He went to America as a child, taught music and physics and in 1855 patented a printing telegraph, forerunner of the Telex machine. He returned to London in 1867, and, simultaneously with ${ }^{*}$ Berliner, invented the carbon microphone
(1878). He was elected FRS in 1880. The Hughes Medal for physical discoveries (especially in electricity and magnetism) commemorates his name.

Hughes, Howard (Robard) (1905-1976). American businessman, aviator and film producer. In 1923 he took over his father's company, Hughes Tool Company, in Houston, Texas. He went to Hollywood in 1926 and produced Hell's Angels (1930) and Scarface (1932). The profits from his Hughes Aircraft Company helped him to establish the Howard Hughes Medical Institute, he flew his own aircraft and broke three speed records. He held a controlling interest in TWA until 1966, when he sold his shares for \$US500 million. In 1950 he retreated into increasingly pathological seclusion which provoked international curiosity.

Higham, C., Howard Hughes: The Secret Life. 1993; Irving, C., The Hoax. 1999; Real, J., The Asylum of Howard Hughes. 2003.

Hughes, Robert Studley Forrest (1938-2012). Australian writer and art critic, born in Sydney. His books The Art of Australia (1970), The Fatal Shore (1987) and Nothing If Not Critical (1990) were strongly polemical. He became art critic for Time Magazine 1970-2003. His art documentary series for television, The Shock of the New (1980), Barcelona (1992) and American Visions (1997), also appeared in book form. Later books include Goya (2004), Things I Didn't Know (memoir, 2006) and Rome. A Cultural, Visual and Personal History (2011). He died in New York.

Hughes, Ted (Edward James) (1930-1998). English poet. Educated at Cambridge, he married the poet Sylvia *Plath in 1956 and was a prolific author of plays, novels and children's stories, translator (e.g. of ${ }^{*}$ Ovid), anthologist and he edited poetry collections by Emily *Dickinson and Plath. Poet Laureate 198498, he won many awards for his poetry. Publication of Love Letters (1998), 88 poems about his marriage and his wife's suicide, was intensely controversial. $\mathrm{He}$ received the OM in 1998, just before he died.

Bate, J., Ted Hughes: The Unauthorised Life. 2015.

Hughes, Thomas (1822-1896). English author and lawyer. His famous novel Tom Brown's Schooldays (1857) was prompted by memories of his education at Rugby under Thomas *Arnold. A Christian socialist, Hughes was a Liberal MP 1865, 1868-74, county court judge 1882-96 and the biographer of David *Livingstone.

Hughes, William Morris ('Billy') (1862-1952). Australian politician, born in Pimlico. Educated in Wales and London, he emigrated to Queensland (1884), and after a variety of jobs, including cook, drover, shopkeeper and umbrella mender, he became Secretary of the Sydney Wharf Labourer's Union 1893-1915. (He founded the Waterside Workers 
Federation in 1902 and became its first president.) He served 58 continuous years as an MP, first in the New South Wales Legislative Assembly 1894-1901, then in the Commonwealth House of Representatives 1901-52. He qualified as a barrister in 1903 and became a KC in 1919. He served in the *Watson Labor Government as Minister for External Affairs 1904 and under ${ }^{*}$ Fisher as Attorney-General 1908-09, 1910-13, 1914-15. A remarkable and quick-witted orator, despite being deaf, and notable for energy and often unscrupulous opportunism, his character strongly resembled David *Lloyd George. He was Prime Minister of Australia 1915-23, Labor until Nov. 1916, when the ALP split on the bitterly divisive issue of conscription for overseas military service. Two referenda $(1916,1917)$ to authorise compulsory service were defeated. Hughes toured World War I battlefields, insisting on independent control of Australian forces and was dubbed 'The Little Digger'. He led a minority National Labour Ministry, then formed (February 1917) a Nationalist coalition with ${ }^{*}$ Cook, ${ }^{*}$ Forrest and other conservatives. It was said of Hughes that he was 'too deaf to listen to reason, too loud to ignore and too small to hit.' At the Paris Peace Conference (1919) he played a leading role, in J. M. *Keynes' judgment, entirely damaging in the long term, defeating Japan's campaign to adopt the principle of racial equality (because it challenged 'White Australia') and encouraging *Clemenceau and *Lloyd George in imposing punitive sanctions on Germany. In Paris he secured an Australian mandate for part of New Guinea and other German colonies in the Pacific. He was forced out of office in February 1923 after the Nationalists lost their majority, and Stanley *Bruce formed a coalition with the Country Party (Earle *Page). Hughes continued in politics and helped to defeat Bruce in 1929. Under Joseph *Lyons, he was Minister for Health 1934-35, 1936-37 and Minister for External Affairs 1937-39. The first Australian minister to grasp the significance of *Hitler and resist 'appeasement', during World War II he was Attorney-General 1939-41 and Minister for the Navy 1939-40. He received a CH in January 1941. After Robert ${ }^{*}$ Menzies resigned in October 1941, Hughes was narrowly elected as Leader of the United Australia Party, and, when Menzies returned, became Deputy Leader 1943-44. Expelled from the UAP in 1944, he joined the Liberal Party in 1945, and won his last election in 1951.

Fitzhardinge, L. F., William Morris Hughes. 2 vols, 1964, 1979; Horne, D., The Little Digger. 1983.

Hugo, Victor Marie (1802-1885). French poet, novelist and dramatist, born in Besançon. Son of an officer in *Napoléon's army, his childhood was a series of moves from one military station to another in Italy, Spain and France. He won prizes for poetry from the age of 17, married Adèle Foucher at 20, published his first novel Han d'slande (1823) and heralded the rise of Romantic drama with his play Cromwell (1827). The long run of the tragedy Hernani (1830), which withstood the boos, hisses and even rioting of the classicists among its audiences, assured the victory of the Romantic movement and Hugo's own position. Among later plays were Le Roi s'amuse (1832), the basis of Verdi's Rigoletto, Lucrèce Borgia (1833) in which a part was played by Juliette Drouet, his mistress for nearly 50 years, although he remained a devoted husband, and Ruy Blas (1838). More than 100 operas were based on his works including *Donizetti's Lucrezia Borgia (1833), Verdi's Ernani (1844), and *Ponchielli's La Giaconda (1876). Meanwhile his Les Orientales (1829), mainly on Grecian and Moorish themes, and Les Feuilles d'Automne (1831) confirmed his reputation as a great lyric poet. His great novel Nôtre Dame de Paris (1831), set in medieval times, told the story of the hopeless passion of the hunchbacked bellringer Quasimodo for Esmeralda.

Hugo was elected to the Académie française in 1841. Politics, in which he was a somewhat unpredictable liberal, began to play an increasing part in his life. King *Louis-Philippe made him a peer, but during the dictatorship and empire of *Napoléon III, whom Hugo attacked in verse and prose, he lived in exile in Brussels, Jersey, and from 1855 at Hauteville House, Guernsey, still preserved much as he left it. Much of his writing during exile was philosophic and historical (the first part of La Légende des Siècles was published in 1859), but it includes his greatest novel Les Misérables (1862), the story of the criminal Jean Valjean, and Les Travailleurs de la mer (1866), a wonderful evocation of a Guernsey fisherman's life. Hugo returned to France after the fall of Napoléon and was present at the siege of Paris. He sat in the Constituent Assembly (1870-71) and became a senator in 1874. Now a national institution, he continued to write novels, e.g. Quatre-vingt-treize (1874), concerned with the Revolutionary year of 1793-and a verse drama, Torquemada (1882). Vast crowds attended his funeral at the Panthéon. Hugo wrote too much for too long and his work is, therefore, uneven. Moreover Romanticism lost its vogue and he shared loss of favour with, for example, *Scott. But few writers have produced so much that is first-rate, in so many different fields, and he does not deserve André *Gide's taunt that 'France's greatest poet was Victor Hugo, alas'. Also a gifted artist, his powerful ink drawings ranged from architectural subjects to nightmares.

Robb, G., Victor Hugo. 1997.

Hugues (Hugh) Capet (938-996). King of France 987-96. Grandson of Robert I (c.865-923), King of France 922-23, and son of Hugues le Grand (d.956), Duke of the Franks and Count of Paris, he was elected king by the nobles when the last Carolingian, *Louis V, died without heirs. His son Robert II (970-1026) soon became co-ruler. One of his first acts was to make his son joint king and so secure the succession of his dynasty, which ruled by direct descent until 
1328. Even before his accession, some members of his family had been elected rulers. The surname was not used during his lifetime.

Hulagu Khan (1217-1265). Mongol ruler. Grandson of Genghis Khan, he led a successful campaign against the Persians who were in revolt, captured Baghdad and advanced beyond Damascus until he was checked by the Mamelukes. He then retreated, and, having adopted Islam, founded the Il-Khan dynasty which lasted until 1335 .

Hull, Cordell (1871-1955). American politician, born in Tennessee. A congressman 1907-21, 1923-31, and senator 1931-33, he campaigned for an income tax and tariff reform. He was President Franklin *Roosevelt's Secretary of State 1933-44, a record term. Roosevelt usually bypassed Hull, acting in foreign policy matters through Sumner *Welles. He was associated with creating a new friendly relationship between the US and the South American states, and the promotion of more liberal trade and tariff policies. He was awarded the Nobel Peace Prize (1945).

Hull, C., The Memoirs of Cordell Hull. 1948.

\section{Humbert I and II. Kings of Italy see Umberto I and II}

Humboldt, (Friedrich Wilhelm Heinrich) Alexander von (1769-1859). Prussian explorer, naturalist, geographer, born in Berlin. Son of the chamberlain to the king of Prussia, while still a student at the universities of Göttingen, Frankfurt-on-Oder and Freiburg, and in the years following, he did field work locally on geology, mineralogy and botany, and made laboratory studies of the nervous systems of animals. In 1799 he sailed with his friend, Aimé Bonpland (1773-1858), on a five-year scientific expedition to Mexico, Cuba, Venezuela, Colombia and Peru, with particular emphasis on areas adjacent to the Amazon and Orinoco valleys. The sorting, collating and describing of the vast amount of data and materials gathered on the journeys occupied most of the ensuing 20 years and resulted in the vast Le voyage aux régions equinoxiales du Nouveau Continent, fait en 1799-1804 (23 volumes, 1805-34), containing not only scientific sections on physical geography, geology, astronomical observations etc., but also a historical survey and abundant maps.

He conceived of the earth as 'one great living organism where everything was connected ... All forces of nature are interlaced and intertwined ... Everything is interaction and reciprocal.' He speculated that species were not immutable, anticipated some aspects of evolutionary theory, that the continents must have moved-anticipating tectonic plate research-and as early as 1829 campaigned for the international collection of data about deforestation and its potential impact on climate. He introduced 'isotherms', lines linking areas with similar average temperatures and atmospheric pressures.
The most famous scientist of his time, more than 100 animal species and 300 plants are named for Humboldt, in addition to Asteroid 54 Alexandra (observed in 1858, and 'Alexander' given a female ending), a moon sea and crater, the Humboldt Current, mountain ranges, rivers, towns, forests, parks and universities.

At the request of Tsar ${ }^{*}$ Nikolai I, he made, with two friends, an expedition (1829) to the Urals and a large part of Asiatic Russia (where he located gold, platinum and diamonds). This was described in Asia Central (3 volumes, 1843). His famous work Kosmos (5 volumes, 1845-62) is a masterly attempt to give a comprehensive description of the physical universe as it was then known. Some of his own most valuable scientific work was in the fields of meteorology, climatology and earth magnetism. Elected FRS in 1815, he received the Copley Medal in 1852.

He was a friend of ${ }^{*}$ Goethe and had a profound influence on *Wordsworth, *Coleridge, *Lyell, *Darwin, ${ }^{*}$ Thoreau, ${ }^{*}$ Marsh, ${ }^{*}$ Emerson, ${ }^{*}$ Haeckel and ${ }^{*}$ Muir.

His elder brother, (Karl) Wilhelm, Baron von Humboldt (1767-1835), reformed the secondary and higher education of Prussia (1806) and later carried out many diplomatic missions before he retired (1818) in disgust at his country's reactionary policy and turned to philology. He made a complete study of the Basque language and identified the MalayPolynesian group. He was particularly interested in the philosophy of language on the grounds that it expresses the mind and culture of those that use it.

Kellner, K., Alexander von Humboldt. 1963; Botting, D., Humboldt and the Cosmos. 1973; Helferich, G., Humboldt's Cosmos. 2004; Walls, L. D., The Passage to Cosmos. 2011; Sachs, A., The Humboldt Current. 2006; Wulf, A., The Invention of Nature: The Adventures of Alexander von Humboldt, the Lost Hero of Science. 2015.

Hume, (George) Basil (1923-1999). English cardinal. Educated at Oxford and Fribourg, he became a Benedictine monk, Abbot of Ampleforth, York 1963-76 and Archbishop of Westminster 197699. He received the OM in 1999.

Hume, David (1711-1776). Scottish philosopher and historian, born in Edinburgh. Often regarded as the greatest of British empiricists, he attended Edinburgh University and began preparing his greatest work, A Treatise of Human Nature, before he was 20. Because of his notorious atheism his applications for the professorships of philosophy at Edinburgh and Glasgow were unsuccessful, and instead he served the insane Marquess of Annandale as tutor and went on military and diplomatic missions as secretary to General James St Clair. In 1752 he became keeper of the Advocates' Library in Edinburgh, and was secretary to the British embassy in Paris 1763-65, where he moved in a literary circle and made a friendship with 
*Rousseau which ended with the almost inevitable quarrel. In his own time he was much better known as a historian than as a philosopher and his History of Great Britain (1754-61) long remained a standard work, but it is by his earlier philosophical works that his name is now chiefly remembered. His Treatise (173940) sets out to establish empirically a science of the human faculties. He describes the mind as consisting of impressions and ideas; by 'impressions' he means first of all sense-impressions. There are simple ideas, which are reflections of impressions, and complex ideas, which are got by combining simple ideas. All thought is thus based on experience and we have no innate ideas. Reasoning is either the setting-out of necessary relations between ideas, as in the assertion of mathematical truths, or else based on empirical fact. There is no possibility of logically necessary reasoning about claims of fact, e.g. one cannot 'demonstrate' the existence of God. Reasoning about facts involves assertions of cause and effect. With respect to causation, Hume argued that we regard something as being the cause or effect of something else because the two always go together, not because there is such a thing as a necessary connexion between them in the world. In ethics he is important for his enunciation of the principle that one cannot deduce a moral judgement from any statement of fact, since the deduction of any deductive inference must be implicit in its premise. Moral judgments, in fact, are expressions of their maker's approval or disapproval. Hume's influence was considerable, notably on utilitarians, phenomenalists, and on ${ }^{*}$ Kant, who said he had been awakened by Hume from his dogmatic slumbers. Hume's other philosophical works include the Enquiry Concerning Human Understanding (a simplified version of the Treatise, published 1748), The Enquiry Concerning the Principles of Morals (1751), and Dialogues Concerning Natural Religion (1779). His concept of the invisible hand' in economics (1758) anticipated Adam *Smith.

Basson, A. H., David Hume. 1958; Harris, J. A., Hume. An Intellectual Biography. 2015.

Hume, John (1937-2020). Northern Ireland politician. A teacher and Catholic moderate, he was Leader of the Social Democratic Labor Party, a member of the European Parliament 1979-2004 and of the House of Commons 1983-2005. He shared the 1998 Nobel Peace Prize with David *Trimble for their attempts to achieve a political settlement in Northern Ireland, also winning the Gandhi Peace Prize and Martin Luther King Award.

Hummel, Johann Nepomuk (1778-1837). Austrian composer, pianist and teacher, born in Bratislava. A pupil of *Mozart (with whom he boarded), *Haydn and $*$ Salieri, he toured Europe as a pianist from 1788 and in Vienna was promoted as a rival to ${ }^{*}$ Beethoven. $\mathrm{He}$ was a court musician for the Esterhazys at Eisenstadt 1804-11, and at Weimar 1820-37 where he became a friend of *Goethe. A prolific but uneven composer, his works included brilliant concertos for piano, trumpet, bassoon and mandolin, a superb Septet (op. 74), a Mass in B Minor (op. 77), violin sonatas and long-forgotten operas and cantatas.

Humperdinck, Engelbert (1854-1921). German composer and teacher. After studying in Cologne and Munich, he worked as *Wagner's assistant at Bayreuth 1880-83 and taught briefly in Barcelona. His opera Hansel und Gretel was premiered in Weimar by Richard *Strauss (1893). He was a prolific composer of songs and choral works, but only his opera is now performed. The English pop singer who used the same name was not related.

Humphrey (or Humfrey) (Plantagenet), 1st Duke of Gloucester (1391-1447). English prince. Youngest son of *Henry IV, of the House of Lancaster, he was Protector of the Realm during *Henry VI's minority, while his brother John, Duke of Bedford, whom he kept ill-supplied, acted as regent in France. Greedy and factious, he was constantly embroiled with his uncle, Cardinal Henry *Beaufort, by whose adherents he was arrested (1447); he died in captivity. A patron of learning, he collected more than 200 illuminated manuscripts. Most were destroyed in the reign of ${ }^{*}$ Henry VIII, but many of his books survive in 'Duke Humphrey's Library' at the Bodleian, in Oxford. The affability of 'good Duke Humphrey' long (but wrongly) lingered in popular memory.

Humphrey, Hubert Horatio (1911-1978). American politician, born in South Dakota. An academic and administrator, he was elected as mayor of Minneapolis 1945-48. As senator for Minnesota 1944-64 and 1971-78 he was one of the most outspoken liberals in the Democratic Party. After losing the 1960 presidential nomination to *Kennedy he was *Johnson's Vice President 1965-69. After Eugene *McCarthy and Robert *Kennedy contested primaries, in March 1968 Johnson announced that he would not run for President. In June, Kennedy was murdered and at the Chicago convention and in August Humphrey won the nomination, with the support of party bosses, essentially as Johnson's proxy, despite not having won delegates in primaries. He lost narrowly to Richard *Nixon, with George *Wallace winning five states in the South.

Solberg, C., Hubert Humphrey, A Biography. 1985.

Humphries, (John) Barry (1934- ). Australian writer and actor, born in Melbourne. In his stage appearances in Australia and Britain he created a series of powerful, savagely satirical stereotypes, reflecting aspects of Australian society: Sandy Stone, (Dame) Edna Everage, (Sir) Les Patterson, Lance Boyle, and performed on television and in films, especially as narrator/voice over. He wrote My Life As Me: A Memoir (2002).

Lahr, J., Dame Edna Everage and the Rise of Western Civilisation: Backstage with Barry Humphries. 1991. 
Hundertwasser, Friedensreich (Friedrich Stowasser) (1928-2000). Austrian painter and graphic artist. Influenced by the works of *Klimt, he became a popular, exaggeratedly romantic artist, much reproduced, a critic of rationalism in architecture and built apartment blocks in Vienna He adopted the name 'Friedensreich' ('kingdom of peace') to demonstrate his conviction that art can be an instrument for promoting international harmony. He proposed new flags for New Zealand (where he sometimes lived) and Australia.

\section{Hung Hsiu-ch'uan see Hong Xiuquan}

Hun Sen (originally Hun Bunal) (1952- ). Cambodian politician. He served with *Pol Pot's Khmer Rouge, then with Vietnamese support became Foreign Minister 1979-86; 1987-90, and Prime Minister 1985- . Following a period of civil war and UN intervention, the Cambodian Monarchy was restored and Hun Sen shared the prime ministership with Prince Norodom Ranariddh 1993-98, then forced him out. His Cambodian Peoples' Party (CPP) polled well in the July 1998 election, winning again in 2003, 2008, 2013 and 2018. He endorsed Donald *Trump in 2016. The Cambodian election of 2018 in which the CPP won every seat was almost universally condemned as a fraud.

Hunt, Jeremy Richard Streynham (1966- ). English Conservative politician. Educated at Oxford, he became a controversial entrepreneur, MP 2005- , Secretary of State for Culture, Media and Sport 2010-12, for Health 2012-18 and for Foreign and Commonwealth Affairs 2018-19. He contested the Tory leadership in 2019, losing to Boris *Johnson. He became Chancellor of the Exchequer 2022- , first under Liz *Truss, continuing with Rishi ${ }^{*}$ Sunak.

Hunt, (James Henry) Leigh (1784-1859). English poet, critic and essayist. He edited the Examiner, a liberal journal (1808-21): here and in several other journals he came to edit he 'discovered', by publication or praise, ${ }^{*}$ Shelley, ${ }^{*}$ Keats, ${ }^{*}$ Tennyson, ${ }^{*}$ Browning, ${ }^{*}$ Dickens (who caricatured him in Bleak House as Harold Skimpole) and others. In 1812 he was sentenced to two years' jail and a fine for libelling the Prince Regent. He joined the Shelleys and *Byron in Italy (1822) to edit a magazine The Liberal but the death of both poets wrecked the enterprise and he returned. Although some of his poems, e.g. The Story of Rimini (about Paolo and Francesca) and Abou Ben Adhem, are still read, his importance was as a focus of literary life. His essays and his Autobiography (1850) provide valuable sketches of his friends, his opinions, and of events in his life.

Blainey, A., Immortal Boy: A Portrait of Leigh Hunt. 1985.

Hunt, (Henry Cecil) John, Baron Hunt (1910-1998). British soldier and mountaineer. Much of his service was in India and he had considerable Himalayan experience before he led the Everest expedition (1953), two members of which, Edmund *Hillary and the sherpa *Tenzing Norgay, were the first to reach the summit. He wrote The Ascent of Everest (1954). For his part in the achievement Hunt was knighted, created a life peer in 1966 and given a KG in 1979.

Hunt, W(illiam) Holman (1827-1910). English painter. One of the founders of the pre-Raphaelite movement, he described its aims as: expressing serious ideas, direct study from nature, reconstruction of events according to realistic probability and not according to principles of design. His best known pictures are religious-The Scapegoat and The Light of the World. The harshness and the sometimes crude colouring of his work are equalled by his extreme sentimentality. He declined election as RA but received the OM (1905).

Hunt, W. H., Pre-Raphaelitism and the Pre-Raphaelite Brotherhood. 1905; Maas, J., Holman Hunt and the Light of the World. 1984; Amor, A. C., William Holman Hunt. The True Pre-Raphaelite. 1989.

Hunter, John (1728-1793). Scottish anatomist, physiologist and surgeon. After working as a cabinetmaker in Glasgow he came to London to assist dissecting at the school of anatomy directed by his elder brother William *Hunter. He also studied surgery and became surgeon-pupil (1754) and surgeon (1768) at St George's Hospital. Later (1776) he became surgeon-extraordinary to ${ }^{*}$ George III. He made numerous discoveries about human anatomy and has been recognised as the founder of scientific surgery. He was the first to apply methods of pressure (e.g. the ligature) to the main trunk blood arteries, and to succeed in grafting animal tissues. Meanwhile he was busy in biological and physiological research, for which he made extensive collections of specimens illustrating the living processes of plant and animal life. His museum, his finest memorial, was bought by the government (1799) and subsequently administered by the Royal College of Surgeons; it contained 13,600 preparations at the time of his death. His biological studies included work in hibernation, the habits of bees, silkworms etc., on the electric organs of fish, and egg incubation. His treatise on human teeth (1771-78) gave dentistry a scientific foundation.

Hunter, John (1737-1821). Scottish admiral and administrator, born in Leith. Well educated in classics, music and science, he joined the Royal Navy and, under Arthur ${ }^{*}$ Phillip, commanded H.M.S. Sirius in the First Fleet (1787-88) to New South Wales. The ship's loss at Norfolk Island (February 1790) was a disaster for the colony; Hunter was honourably acquitted after a court martial. (One of the unluckiest figures in colonial history, four of his ships were lost by accident, none in combat.) Appointed as Phillip's successor, there was a long hiatus before he took office. During that time the New South Wales Corps 
and John ${ }^{*}$ Macarthur were in control. His term as Governor 1795-1800 was marked by corruption and deception, which he seemed unable to suppress, and inadequate support from London. He published a vigorous defence of his years in New Holland and was promoted vice-admiral in 1810 .

Hunter, William (1718-1783). Scottish physician, elder brother of John *Hunter. Educated at Glasgow University, he studied medicine under William Cullen and the first Alexander Monro before moving to London where he soon acquired a high reputation as surgeon and lecturer on anatomy, later specialising in obstetrics.

Hunyadi János (c.1387-1456). Hungarian soldier. Famed as a champion of Christendom against the Turks, in a series of brilliant campaigns he succeeded in clearing the Turks from most of the Balkans, but suffered a severe defeat at Varna (1444) when the Hungarian King was killed. As regent for the king's successor, Ladislas, Hunyadi continued to keep the Turks at bay, and was with the army when he died of the plague. His younger son was Matthias *Corvinus.

Hurd, Douglas Richard, Baron Hurd of Westwell (1930- ). British Conservative politician. Educated at Eton and Oxford, he became a diplomat, was Edward *Heath's political secretary 1968-74, MP 1974-97, Secretary of State for Northern Ireland 1985-89 and Foreign Secretary 1989-95. He also wrote detective stories and received a $\mathrm{CH}$ in 1996.

Hurley, David John (1953- ). Australian soldier and administrator, born in Wollongong. He joined the army in 1972, advancing to Chief of the Defence Force 2011-14, then became Governor of New South Wales 2014-19 and Governor-General 2019- .

Hus, Jan (c.1369-1415). Bohemian religious reformer, born in Husinec. He became a lecturer in philosophy at Prague University 1398-1401, dean of philosophy 1401-02 and rector 1402-03 and 140912. He entered the Catholic priesthood in 1400 . Deeply influenced by the writings of John *Wycliffe, he denounced the corruption of the papacy. His preaching was banned but he continued to preach, even after his excommunication in 1410. Despite his popularity in Prague, Hus had to leave the city and in virtual retirement he wrote On the Church (1413). In 1415 Hus was summoned to the Council of Constance under a promise of safe conduct from the Emperor Sigismund. He was arrested at the Council and charged with heresy because the emperor insisted that heretics could not be given the benefit of an 'agreement of honour'. He refused to recant all his views and was burnt at the stake.

Huskisson, William (1770-1830). English Tory politician. He observed the French Revolution as secretary to the British ambassador in Paris, became a Tory MP 1796-1830, held office under *Pitt,
*Portland, *Perceval, *Liverpool, *Canning and *Goderich and was President of the Board of Trade 1823-27 and Colonial Secretary 1827-28. His friend Canning thought him the ablest businessman of his time. A convinced free trader, he had a major influence on *Peel who later abolished the Corn Laws (1846). At the opening of ${ }^{*}$ Stephenson's Liverpool and Manchester Railway, he became the world's first railway fatality.

Hussein (Hussein ibn Ali al-Hashimi) (1854-1931). King of the Hejaz 1916-24. Born in Istanbul, a member of the Hashemite family, 37th in direct descent from *Muhammad, he was sharif and emir of Mecca 1908-24. He supported the Arab rising against the Turks during World War I, undertaken with British support (T. E. *Lawrence) and was rewarded by being made first king of the Hejaz. He proclaimed himself as Caliph in 1924, but was expelled by the rival Arabian leader *Ibn Sa'ud and took refuge in Cyprus, then in Annam, where he died. Three of his sons became kings, Ali in Hejaz, *Abdullah in Transjordan (later renamed Jordan) and *Faisal, first in Syria, then Iraq.

Hussein (1935-1999). King of Jordan 1952-99. Great-grandson of *Hussein, King of the Hejaz, he succeeded his father Talil (1911-1972), removed from the throne due to insanity. Educated in England, married four times, he showed great dexterity in attempting to resolve Middle East tensions. He was friendly to the US (although opposed to the 1991 Gulf War), conciliatory to Israel, and subject to intense pressure from dispossessed Palestinians. He died of cancer and was succeeded by his son *Abdullah.

Snow, P., Hussein: A Biography. 1972.

\section{Hussein, Saddam see Saddam Hussein}

Husserl, Edmund Gustav Albrecht (1859-1938). German philosopher, and mathematician, born in Moravia. He converted from Judaism in 1887 , studied at Leipzig and Berlin, and at Vienna came under the influence of Franz ${ }^{*}$ Brentano and made philosophy his career. He lectured at Halle 1887-1901 and became professor at Göttingen 1901-16 and Freiburg 1916-28, being succeeded by his student Martin *Heidegger. He pioneered 'phenomenology', which he named. Rejecting the philosophical a priori assumptions of logicians and natural scientists, he maintained that the approach should be made by analysing the experience of phenomena by self. This process, which Husserl called a 'phenomenological reduction', leads to the revelation of a 'transcendental self', the experiences of which it is the task of the researcher in this field to explore. In his last years he adopted a more all-embracing concept of consciousness, which satisfied nobody. Husserl broke with Heidegger over his support for *Hitler. 
Huston, John (1906-1987). American film director. Son of the character actor Walter Huston (18841950) he worked as a scriptwriter and actor, winning an Academy Award for direction and screenplay in The Treasure of the Sierra Madre (1943) in which his father also won an Oscar. His films include The Maltese Falcon (1941), Key Largo (1949), The Red Badge of Courage (1951), The African Queen (1951), Moulin Rouge (1952), Beat the Devil (1956), Moby Dick (1957), Under the Volcano (1984) and Prizzi's Honor (1985). He also played character roles in many films. His daughter Anjelica Huston (1952- ) won an Oscar with Prizzi’s Honor.

Hutcheson, Francis (1694-1746). Scottish-Ulster philosopher, born in Northern Ireland. After studying at the University of Glasgow, he taught in Dublin, published important essays, and returned as professor of moral philosophy at Glasgow 1729-46. In An Inquiry into the Original or Ideas of Beauty and Virtue (1726), he argued for promoting 'the greatest happiness for the greatest number' as the basis of ethical principles, drawn from a 'moral sense'. This was taken up by *Beccaria, and in *Bentham's 'utilitarianism'. Profoundly original on aesthetics, he examined ideas of beauty, virtue and the nature of the passions. He suggested six 'internal senses': consciousness, beauty, public responsibility, morality and awareness of the ridiculous. His longest work, A System of Moral Philosophy (1755) was published posthumously. His writings also influenced David *Hume, Adam *Smith, *Joseph II, John *Adams and Thomas * Jefferson.

Hutten, Ulrich von (1488-1523). German poet and reformer. A man of puny stature but impetuous pride, he gave up monastic life, studied in Germany and Italy and then found employment at the court of the Archbishop of Mainz. The anonymous and satirical Letters of Obscure Men, of which he was part-author, poured ridicule in dog-Latin on the doctrines, morals, follies, speech etc. of the monks and ecclesiastics of the time, and provided much of the intellectual tinder that * Luther and others were to set aflame. Meanwhile he had been made (1517) Poet Laureate by the emperor ${ }^{*}$ Maximilian. He supported Luther at first from national sentiment against papal claims, but later became one of the most formidable religious propagandists. Forced to leave the archbishop's service he led a dangerous existence until with the help of *Zwingli he found an island refuge in Lake Zürich.

Hutton, James (1726-1797). Scottish geologist. After studying medicine at Edinburgh, Paris and Leyden he returned to Scotland to devote himself to agriculture, chemistry, and (from 1768 when he moved to Edinburgh) to geology. In his Theory of the Earth (1795) Hutton expounded his view that the continuing geological processes of erosion by rivers and seas result in the sedimentary deposit accumulating under great pressure on the sea bed and subsequently splitting into cracks and fissures, into which the flowing of molten mineral matter would produce granite and other igneous rocks in the earth's crust. Rain, he explained, was caused by condensation due the mingling of two air strata of different temperatures.

Huxley, Aldous (Leonard) (1894-1963). English novelist and essayist, born in Godalming. Grandson of T. H. *Huxley, he suffered from karatitis punctata from childhood and near blindness prevented him from studying biology. Educated at Eton and Balliol College, Oxford, he contributed essays and criticisms to several London journals before attracting attention with a series of satirical novels, Crome Yellow (1921), Antic Hay (1923), Those Barren Leaves (1925) and Point Counter Point (1928). Huxley became the mouthpiece of the disillusioned generation that followed World War I. In Brave New World (1932) he mockingly described a 'Utopia' in which human beings allowed themselves to be directed by an elite of planners who are able to satisfy emotional cravings by drugs. He returned to the theme in Brave New World Revisited (1958), and less pessimistically in Island (1962). His own favourite was Time Must Have a Stop (1944), set in London and Florence in the 1920s. Apart from Grey Eminence (1941), a brilliant biography of Richelieu's alter ego, François Leclerc du Tremplay, and Ape and Essence (1949), a satirical appraisal of the results of atomic war, most of his later work was philosophic or mystical. He lived in Italy (1923-30), France (1930-38) and California (from 1938).

Bedford, S., Aldous Huxley. 1973.

Huxley, Sir Andrew Fielding (1917-2012). British physiologist. A half-brother of Aldous and Julian Huxley, he studied at Cambridge and was professor of physiology at London 1960-83. He shared the 1963 Nobel Prize for Medicine with J. C. *Eccles and A. L. *Hodgkin for their work on the transmission mechanism of nerve impulses. Awarded the Copley Medal in 1973, he was President of the Royal Society $1980-85$, and received the OM in 1983. He became Master of Trinity College, Cambridge 1984-90.

Huxley, Sir Julian Sorell (1887-1975). English biologist. Grandson of T. H. *Huxley, he was professor of zoology at King's College, London 192527 , professor of physiology at the Royal Institution 1927-30, secretary of the Royal Zoological Society 1935-42, and first Director-General of UNESCO 1946-48. His very numerous and important books on biological and sociological topics include Scientific Research and Social Needs (1934), Essays of a Humanist (1963) and Evolution, the Modern Synthesis (1942). He was an effective advocate for the conservation of wildlife and the creation of nature reserves.

Huxley, Thomas Henry (1825-1895). English biologist, born in Ealing. Having studied medicine, he sailed (1846) as assistant surgeon with HMS 
Rattlesnake which had been commissioned to chart areas off the Australian Great Barrier Reef. He took the opportunity to collect, examine and compare some of the myriad marine organisms in those seas, from which he derived and published evidence that later lent support to ${ }^{*}$ Darwin's evolutionary theory. Huxley's work was immediately appreciated and he was elected FRS in 1850, the year of his return. In 1854 he became lecturer in natural history at the Royal School of Mines. Meanwhile he continued his studies of the invertebrates and when Darwin published On the Origin of Species (1859) Huxley was one of his warmest supporters. Faced with the criticism that the human brain had no counterpart in the animal kingdom he used the recent discovery of Neanderthal Man and his own anthropological studies to make a reply which forms the substance of his book of essays Man's Place in Nature (1863). Huxley is said to have introduced the word 'agnostic' to define his own philosophical viewpoint, which is set out in his Science and Morals (1886). He retained his position at the School of Mines until his health gave way (1885). Meanwhile he had held other academic or honorary appointments, e.g. Fullerian professor at the Royal Institution 1863-67, Secretary 1871-80, and President 1880-85 of the Royal Society. He was awarded the Copley Medal in 1888 and was made a privy counsellor (PC) in 1892. His great interest in education was recognised by his seat on the first London School Board 1870-72. The first biological laboratory in Britain was opened through his inspiration and his Science and Education (1899) contains many of his papers on this theme. Many of his public lectures, among the most popular of the period, appeared in Lay Sermons, Addresses and Reviews (1870). In moulding opinion in the great controversies of his own and succeeding generations on the relationship of religion and science and the place of science in a general education, Huxley's role was of outstanding importance.

Bibby, C., Scientist Extraordinary: T. H. Huxley. 1972; Desmond, A., Huxley — the Devil's Disciple. 1994.

Huygens (or Huyghens), Christiaan (1629-1695). Dutch mathematician, astronomer and physicist, born in The Hague. Son of a diplomat, he was educated at Leiden and Breda and attracted the interest of *Descartes. He developed the art of grinding lenses, and designed an eyepiece that greatly reduced spherical aberration. With a powerful telescope of his own making he investigated and explained the 'rings' of Saturn. He built (1656) the first clock to be regulated by a compound pendulum, and also applied the balance wheel to the same purpose. He lived in Paris 1661-83 and visited London in 1689, proposing an alternative to *Newton's theory of gravity. He published Horologium Oscillatorium (1673), his great work on pendulum clocks, and in 1690 his Traité de la Lumière (1690), a partially satisfactory wave theory of light. He also translated John *Donne's poems.
Huysmans, Joris Karl (1848-1907). French writer, of Dutch descent. His first novels, e.g. Marthe (1876), were in the naturalistic and often sordid pattern set by Émile*Zola. His best known novel A Rebours (1884), however, in revolt from this style, tells of a sensualist's search for new experience through perverse and deliberate derangement of the senses. The writing of Là-bas (1891), a life of the Satanist Gilles de *Rais, had the paradoxical effect of converting him to Catholicism; En Route (1895) describing the journey that took him to this goal.

Hyde, Douglas Ross (Dubhghlas de Híde) (18601949). Irish writer and philologist. Mainly concerned with the survival of the Gaelic language and its use in literature, he founded (1893) the Gaelic League and was professor of modern Irish at the National University of Ireland 1909-32. Nonpolitical and a Protestant, he became the first president of the Republic of Ireland (Eire) 1938-45 under the 1937 constitution.

Daly, D., The Young Douglas Hyde. 1974.

Hyde, Edward and Anne see Clarendon, 1st Earl of

Hyder Ali see Haidar Ali 


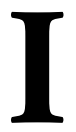

Iacocca, Lee (Lido Anthony) (1924-2019). American automobile executive, born in Pennsylvania. The son of Italian migrants, he was educated at Lehigh and Princeton universities. He joined the Ford Motor Company in 1946 and rose to its presidency 1970-78 until sacked by Henry *Ford II. As Chairman of the Chrysler Corporation 1979-92, he secured \$2 billion in federal government support, shed labour and returned Chrysler to profit. Iacocca: An Autobiography (1984) sold 2.6 million copies, becoming the biggest selling life in US publishing history.

\section{Ibáńez, Vicente Blasco see Blasco Ibáńez, Vicente}

Ibn Battutah (1304-1369?). Arab explorer, born in Tangier. Trained as a judge, from 1325 he travelled extensively in North Africa, Syria, Arabia, Mesopotamia and Persia, going to India (after 1332) by crossing the Black Sea and journeying through Central Asia. In Delhi he was employed by the Sultan Muhammad Ibn Tuqhluq, who sent him as an envoy to China in 1342 . He reached the Chinese imperial court only after many adventures in Southeast Asia. After his return to Morocco in 1349 he visited Granada and western Sudan. In 1353-54 he dictated an account of his travels and his experience of different rulers and societies.

Ibn Battuta, Travels in Asia and Africa 1325-1354. Repr. 1983.

Ibn Khaldun (Abdurahman bin Muhammad bin Muhammad bin Muhammad bin Al-Hasan bin Jabir bin Muhammad bin Ibrahim bin Abdurahman bin Ibn Khaldun) (1332-1406). Arab historian, philosopher, economist and demographer, born in Tunis. His family had been expelled from Andalusia and he served as an administrator, teacher, judge and occasional diplomat in Morocco, Algeria, Tunisia, Egypt and Spain. His Muqaddima (or Prolegmena, i.e. Introduction: 1377) is an ambitious attempt at a universal history, written in a strictly Islamic context, but which anticipates parallel developments in Western thought, including sociology, economics, leadership theory and 'clannism'. Controversial in his time, with many enemies, several times a prisoner, elitist and sometimes politically treacherous, he was hostile to *Averroës, committed to the supernatural and fascinated by the occult. He may have been a Sufi. He negotiated with ${ }^{*}$ Timur in Damascus in 1400 and died in Cairo.

Irwin, R., Ibn Khaldun. An Intellectual Biography. 2018.

Ibn Sa'ud, Abdulaziz (Abdulaziz ibn Abdul Rahman ibn Faisal ibn Turki ibn Abdullah ibn Muhammad Al Saud) (1875-1953). King of Nejd and Hejaz
1926-32, and Saudi Arabia 1932-53. Born in Riyadh, son of the Emir of Nejd, his family was overthrown and exiled in 1890. In 1902, he organised a force that seized Riyadh and made it the base for a revival of the Wahabis, a puritanical Muslim sect dating from the 18th century. By 1906, he had forced the Ottomans out of the Nejd and expanded his emirate to the east coast of Arabia by 1912. During World War I, he declined to join the Arab revolt organised by T. E. * Lawrence but used the opportunity to throw off Turkish suzerainty and greatly expanded his territories. Recognised from 1921 as the sultan of Nejd, he came into conflict with ${ }^{*}$ Hussein, King of Hejaz, whom he dethroned and whose kingdom he annexed (1926), thus acquiring Mecca, with the prestige and wealth attached to its possession; in 1932 he assumed the title King of Saudi Arabia. The discovery of oil (1933) and the lucrative concession to the Americans provided him with great wealth, which he used personally or by distributing to the tribal sheiks, mainly his relatives. Ibn Saud was a great Arab warrior of the traditional type, who proved his potency by the number of his wives and children as much as by his physical prowess in war, but, shrewd and often harsh as he was, and although he avoided any close international alignment, he was loyal to principles and obligations.

Howarth, D. A., The Desert King. 1964.

\section{Ibn Sina see Avicenna}

Ibrahim Pasha (1789-1848). Egyptian soldier, born in Cairo. Son of*Muhammad Ali, the Turkish Viceroy of Egypt, as a general Ibrahim achieved military success against the Wahabis (*Ibn Sa'ud) in Arabia (1818) and the Greek insurgents (1824) during the Greek War of Independence. After his father broke away from the Ottoman sultan he was made Governor of Syria, where he became involved in hostilities against the Turks. He succeeded in conquering much of Asia Minor but British and Austrian intervention forced him to withdraw (1841). In the last year of his life, when his father became insane, he was regent in Egypt.

Ibsen, Henrik (Johan) (1828-1906). Norwegian dramatist, born in Skien. His father, ruined by speculation, apprenticed him to an apothecary. His first play was rejected but he became a stage manager at Bergen and later was artistic director of the Norwegian Theatre in Christiania (Oslo). During this time he was writing plays, at first in the conventional Romantic mould and later inspired by the old sagas. The historical drama The Pretenders (1864) already showed much psychological insight. Angered that Sweden and his own Norway should leave the Danes to fight alone against Prussia (1864), he lived mainly in Italy and Germany for many years. The first fruits of his disillusion, the lyrical dramas Brand (1867) and Peer Gynt (1867), were both intended to display the timidity and irresolution of which he accused 
his countrymen. He returned to a historical subject with The Emperor and the Galilean (1873) about the struggle of Christianity with paganism under Julian the Apostate, and then at last, when he was already middle-aged, came the series of prose dramas that revolutionised the European theatre. By relating the character of individuals to their social environment, by relying for drama on psychological development rather than external events, by substituting realism for romanticism, and by revealing the passions, the deprivations and the rebellions of women, he made the theatre a reflection of the contemporary world outside. Without Ibsen, *Shaw, ${ }^{*}$ Hauptmann, ${ }^{*}$ Brieux and many others could hardly have written as they did. The plays that brought about this remarkable change were Pillars of the Community (The Pillars of Society, 1874), A Doll's House (1879), Ghosts (1881), which dealt frankly with hereditary disease, A Public Enemy (An Enemy of the People, 1882), The Wild Duck (1884), Rosmersholm (1886), The Lady from the Sea (1888), Hedda Gabler (1890), The Master Builder (1892), perhaps marking the highest point of his technique, Little Eyolf (1894), John Gabriel Borkman (1896) and When We Dead Awaken (1900). He was nominated for the Nobel Prize for Literature in 1902, 1903 and 1904, without success.

McFarlane, J. (ed.), Henrik Ibsen: Penguin Critical Anthology. 1970; Meyer, M., Ibsen. 1971; de Figueiredo, I., Henrik Ibsen. The Man \& the Mask. 2019.

Ichikawa Kon (1915-2008). Japanese film maker. Trained as an animator, his films include The Burmese Harp (1956), The Key (1959), a story of sexual obsession which opened a door in Japanese film, Fires on the Plain (1959), Tokyo Olympiad 1964 (1965) and Genji Monogatari (for television, 1967).

Ickes, Harold LeClaire (1874-1952). American administrator. A Chicago reporter, one of Theodore *Roosevelt's 'Bullmoosers', then a lawyer, he served as Franklin D. *Roosevelt's Secretary of the Interior, and briefly under Harry *Truman, for a record term 1933-46, began implementing conservationist measures and attracted the enmity of big business. Known as 'the Old Curmudgeon' for his blunt speaking and stormy temperament, he disliked most of the New Dealers.

Idris (Muhammad Idris bin Muhammad al-Mahdi as-Senussi) (1889-1983). King of Libya 1951-69. As chief of the Senussi tribesmen he led resistance to the Italians, who after defeating Turkey (1911-12) occupied Tripolitania and Cyrenaica. Italy's defeat in World War II provided an opportunity for Idris, exiled in Egypt, to return. Emir of Cyrenaica from 1945, in 1951, when the United Nations established the new kingdom of Libya, Idris was chosen as first king. He was deposed by a military coup d'état in September 1969.

\section{Ieyasu, Tokugawa see Tokugawa Ieyasu}

Ignatieff, Michael Grant (1947-). Canadian political scientist and politician, born in Toronto. Educated in Toronto, Oxford and Harvard, he wrote prolifically, including a biography of Isaiah *Berlin, histories and novels, made television programs and held a chair in Harvard. Despite his long absence from Canada, he became MP 2006-11 and Leader of the Liberal Party 2009-11. Despite his brilliant record as a public intellectual, he made serious errors of judgment and the Liberals suffered devastating losses in 2011. He then returned to Harvard and wrote Fire and Ashes: Success and Failure in Politics (2013).

\section{Ignatius Loyola, St see Loyola, St Ignatius}

Ignatius of Antioch, St (also known as Theophorus or Norono) (c.35-107). Syrian Father of the Christian Church. Probably the third bishop of Antioch, according to ${ }^{*}$ Eusebius he was executed in Rome under ${ }^{*}$ Trajan, being thrown to lions in the Colosseum. His seven 'epistles', which seem to have been written on the journey from Antioch to Rome for his execution, contain valuable information about the early Church. There is a legend that he was the child taken up in his arms by Christ (Mark ix. 36).

Chadwick, H., The Early Church. 1967.

Ii Naosuke (1815-1860). Japanese nobleman and statesman, born in Edo. The 14 th son of a daimyo, he lived in a temple until 1850. He favoured developing relations with the West, ending Japan's long isolation, an issue raised when the US sent a fleet in in 1853 under Commodore *Perry. The government of the *Tokugawa shogunate, which Ii supported, was not in a position to repel the fleet, and began on his advice to negotiate new relations and trade. This exacerbated disagreements between factions in Japan, already divided over the succession to the Shogunate (military dictatorship). Ii Naosuke took direct control as Chief Councillor in 1858, settled the question of succession and forced acceptance of a Japanese-American treaty. He was murdered by political enemies.

Ikeda Hayato (1899-1965). Japanese politician. After serving many years in the Ministry of Finance, he was elected to the Diet (1949) as a Liberal Democrat and held several offices in connexion with finance and trade before becoming Prime Minister 1960-64, retiring through ill health, having earned much credit for Japan's spectacular economic advance.

Illich, Ivan Denisovich (1926-2002). AustrianAmerican social theorist. Educated in Rome and Salzburg, he became a priest, moved to the US in 1951 and later worked in Puerto Rico and Mexico. His 'subversive' books applied lateral thinking to question fundamental assumptions about social structures and demystify professionalism, e.g. Deschooling Society (1971), Energy and Equity (1973), Medical Nemesis (1974) and The Right to Useful Unemployment (1979). 
Ilyin, Ivan Aleksandrovich (1883-1954). Russian nationalist ideologue and philosopher, born in Moscow. Of aristocrat lineage, he studied law and philosophy, becoming an authority on ${ }^{*}$ Hegel. Originally a liberal, he was expelled from Russia, living in Berlin 1922-38 and Geneva 1938-54. The principal ideologist of the White Russians, his quasiFascist ideology profoundly influenced Vladimir *Putin.

Ilyushin, Sergei Vladimirovich (1894-1977). Russian aircraft designer. A lieutenant general in the Red Army, he designed the Soviet military and civilian aircraft that bore his name.

Imhotep (fl. 2650 BCE). Egyptian sage. Traditionally versed in alchemy and astrology as well as medicine, some accounts say that he designed the step pyramid of Sakkara for King ${ }^{*}$ Zoser, whose chief minister he was. In Ptolemaic times he was identified with Asclepios (Aesculapius), the Greek god of healing.

\section{Imran Khan see Khan, Imran}

Indy, (Paul Marie Theodore) Vincent d' (18511931). French composer. A pupil of César *Franck, and an ardent Wagnerian, he was a prolific composer of operas and religious, instrumental and orchestral music, a notable teacher and a vigorous opponent of the modern movement, now remembered only for his Symphony on a French Mountain Air (1886) and Istar (1896). He was a reactionary and anti-Semite.

Ingenhousz, Jan (1730-1799). Dutch physician. $\mathrm{He}$ practised medicine in Holland, Austria and England, at the same time carrying out scientific studies of considerable interest. In 1779 he published his Experiments Upon Vegetables in which he described the respiration of plants and drew attention to the importance of the process in relation to animal life.

Ingres, Jean Auguste Dominique (1780-1867). French classical painter, born at Montauban. Son of a sculptor, he went to Paris (1797) to study under *David, whose influence is marked in the brilliant portraits (1805, now in the Louvre) of the Riviere family. He won the first Prix de Rome (1802) with the Ambassadors of Agamemnon and lived in Rome 1806-20, 1835-41 (and in Florence 1820-24). Greatly impressed by 15 th-century Italian painting, he became increasingly convinced that the highest effects in painting were to be achieved by line and form, emphasised by the cold jewel-like brilliance of his colour. He now came under the spell of *Raphael who remained a major influence on his style and it was perhaps some consequent softening of his line that won his Vow of Louis XIII such instant acclaim at the Salon (1824). ${ }^{*}$ Delacroix and ${ }^{*}$ Picasso were among his admirers.

Rosenblum, R., Jean-Auguste-Dominique Ingres. 1967.
Innocent III (Lotario de'Conti de Segni) (11611216). Pope 1198-1216. Son of a noble family in the Papal States, he was a nephew of Pope ${ }^{*}$ Celestine III, wrote the widely read tract $O n$ the Misery of the Human Condition, and was elected Pope in a very brief conclave, at the age of 37 and in full vigour. Though his interventions were sometimes illadvised, he was one of the most successful medieval popes in exercising the papal right of intervening in temporal affairs. He deposed the emperor ${ }^{*}$ Otto IV, excommunicated King ${ }^{*}$ John of England but attacked the Magna Carta, promoted the 4th Crusade (diverted to the conquest of Constantinople), and the bloody crusade that crushed the Albigensians in France. He presided at the Fourth Lateran Council (1215).

Innocent IV (Sinobaldi de'Fieschi) (1195-1254). Pope 1243-54. Born in Genoa, created cardinal in 1227 , he was originally on good terms with the emperor *Friedrich II, but the ongoing conflict between church and state flared up, Innocent went into exile in France and in 1245 declared the imperial throne vacant.

Innocent X (Giovanni Battista Pamphilj) (15741655). Pope 1644-55. Born in Rome, to a rich and powerful family, he became a curial lawyer, apostolic nuncio to Spain 1626-29 and a cardinal in 1626. Elected to the papacy as a compromise candidate, he was anti-French and pro-Habsburg, opposed concessions to Protestantism in the Treaty of Westphalia (1648) and was influenced by a rapacious sister-in-law Olimpia Maidalchini. 'Velázquez' portrait of Innocent (1650) is a masterpiece: the subject commented 'troppo vero'.

Innocent XI (Benedetto Odescalchi) (1611-1689). Pope 1676-89. Born in Como, deeply pious, he was Bishop of Novara 1650-56, then an official in the Roman Curia. He became involved in a bitter struggle with *Louis XIV of France over the rights of the Gallican Church, and especially Louis' claim to administer and collect the revenue of vacant bishoprics. Louis vetoed his election to the papacy in 1669 but relented in 1676 . He brought about and sustained the alliance between the emperor *Leopold I and Jan *Sobieski, King of Poland, which relieved Vienna from the Turkish threat (1683).

Inönü, Ismet (originally Mustafa Ismet Bey) (18841973). Turkish soldier and politician, born in Smyrna (Izmir). He was the comrade-in-arms of Mustafa Kemal (*Atatürk) and fought in the Balkan Wars and World War I. He was Atatürk's Chief of Staff in the campaigns (1919-23) that expelled the Greeks from Anatolia (Asia Minor). He signed the Treaty of Lausanne (1923) on behalf of Turkey, and was the first Prime Minister of the new republic, serving 1923-24; 1925-37. On Atatürk's death, he succeeded him as President $1938-50$. Defeated in 1950 by Celal Bayer and Adnan *Menderes, he led the Republican People's 
Party in opposition. Following a military coup (1960) he was again Prime Minister 1961-65, resigning after the defeat of his government in the Assembly.

Frey, F. W., The Turkish Political Elite. 1965.

Ionesco, Eugène (1912-1994). French playwright, born in Romania. He spent his childhood in Paris and adolescence in Bucharest, settling permanently in France in 1942. His first play The Bald Prima Donna (1950) established him as the most important writer in the 'theatre of the absurd'. He went on to write numerous plays, mostly translated into English and successfully performed in England and the US. They include The Lesson (1951), Rhinoceros (1960), Exit the King (1962) and Hunger and Thirst (1965). His ballet, The Triumph of Death, was first performed in Copenhagen (1972). He was made a member of the Académie française (1970) and Légion d'Honneur (1970).

Iqbal, Sir Muhammad (1876-1938). Indian poet and philosopher. He taught philosophy in Lahore, before visiting Europe at the age of 30 . His poetry, written in Persian and Urdu under the name of 'Iqbal', at first dealt mainly with general themes of grief and love and their philosophic implications but became increasingly a means of awakening the social consciousness of the Muslims of India, whose poverty and passivity he considered unworthy of their ancestors. He was originally a believer in Hindu-Muslim unity, but, although never a narrow nationalist, he gradually came to advocate a separate Muslim state and was President of the Muslim League (1930).

Schimmel, M., Gabriel's Wing. 1963.

Ireland, John (Nicholson) (1879-1962). English composer, born in Cheshire. His music was often inspired by ancient traditions and sites, e.g. his orchestral prelude The Forgotten Rite (composed 1913) by the Channel Islands and the rhapsody Mai-Dun (1920-21) by Maiden Castle, Dorset. Influenced by the French impressionists, he wrote much church music, piano works and many songs, setting poems by e.g. ${ }^{*}$ Hardy, ${ }^{*}$ Housman and ${ }^{*}$ Masefield (Sea Fever). His music has been neglected.

Longmire, J., John Ireland. 1969.

Ireland, William Henry (1777-1835). English forger. Son of an engraver, he became a forger of 'Shakespearian' manuscripts, including the plays Vortigern and Rowena and Henry II, which he was able to impose even on acknowledged experts. *Sheridan produced Vortigern at Drury Lane. Ireland eventually confessed he was a fraud.

Irene of Athens (née Eirénē Sarantapechaina) (c.752803). Byzantine Empress regnant 797-802. Born in Athens to a powerful noble family, she married the future Emperor Leo IV and gave birth to Constantine VI. She made powerful enemies by her opposition to the iconoclast movement. In 797 she had her son blinded, he soon died and she then seized power. Pope *Leo III denounced her, declared the Eastern Roman (Byzantine) Empire at an end and in 800 crowned ${ }^{*}$ Charlemagne as Imperator Romanorum. Irene was deposed by patricians and exiled to Lesbos where she supported herself by spinning wool.

Ireton, Henry (1611-1651). English soldier and politician, born in Nottinghamshire. Educated at Trinity College Cambridge, he joined the Parliamentary army, was taken prisoner at Naseby (1645) but was soon rescued by Oliver *Cromwell's cavalry charge. MP 1645-49, he married Cromwell's daughter Bridget in 1646. Prominent in army politics between 1647 and 1649, and generally moderate in his views, at the robust discussions with members of the New Model Army (including many Levellers) ('The Putney Debates', October 1647), he opposed the radical proposals of Thomas *Rainborough for universal suffrage, insisting that only those with 'a permanent fixed interest' (i.e. property owners) could make the laws. But he became more radical, was an instigator of Pride's Purge (December 1648), took part in the trial of ${ }^{*}$ Charles I, and signed his death warrant. He was second-in-command to Cromwell in Ireland, became Lord-Deputy (1650) and died of the plague after the fall of Limerick. He had a clear mind, a ready tongue and had considerable influence with Cromwell.

Ramsey, R. W., Henry Ireton. 1949.

\section{Irigoyen, Hipóleto see Yrigoyen, Hipóleto}

Ironside, (William) Edmund, 1st Baron Ironside of Archangel (1880-1959). British soldier, born in Edinburgh. He joined the army in 1897, served in South Africa and was the model for John *Buchan's soldier-hero Richard Hannay. He commanded the unsuccessful British army of intervention against the USSR at Archangel 1918-19 and also served in Persia and India and as Governor of Gibraltar 1938-39. He had a working knowledge of 14 languages but was a poor negotiator, and his world view was ambiguous: close to J.F.C. *Fuller, who admired the Nazis, and to Winston *Churchill, who loathed them. Chief of the Imperial General Staff (CIGS) September 1939May 1940, he clashed with the French and his own generals, and was C-in-C Home Forces in May 1940, when Churchill kicked him upstairs as field marshal and baron.

Ironside, W. E., Archangel, 1918-19. 1953.

Irving, Sir Henry (né John Henry Brodribb) (18381905). English actor and manager, born in Somerset. He made his debut in Sunderland (1856) and first appeared in London in 1859. His first appearance as Matthias in The Bells (1871), a play that was to prove such a standby in the years to come, marked a stage on his road to popularity, and his Hamlet which ran for 200 nights (1874-75) established him as a tragic actor of the highest rank. In 1878 began his tenure, 
as lessee manager, of the Lyceum Theatre, London, where in memorable association with Ellen *Terry he directed and acted in a series of Shakespearian and other plays that made theatrical history. The first actor to be knighted (1895), he was buried in Westminster Abbey.

Irving, L., Henry Irving, the Actor and his World. 1951.

Irving, Washington (1783-1859). American author and diplomat, born in New York. Son of an English immigrant merchant, he spent many years in Europe, where he made many literary friendships, e.g. with ${ }^{*}$ Scott at Abbotsford. He held occasional diplomatic appointments, and is remembered for his success, while a member of the American embassy in Madrid, in rescuing the Alhambra from falling into ruins. He made his reputation as a writer with his goodhumoured satire History of New York ... by Diedrich Knickerbocker (1809), but his lasting popularity depends upon the short pieces in his Sketch Book (1819-20), containing Rip Van Winkle, Bracebridge Hall (1822) and Tales of a Traveller (1825).

Hedges, W. L., Washington Irving. 1974.

Irwin, 1st Baron see Halifax, Edward Frederick Lindley Wood, 1st Earl of

Isaac (or Yiṣhāq). (fl. c.2000 BCE). Hebrew prophet, born in Canaan. Born to *Abraham (aged 100) and Sarah, according to Genesis xxi-xxviii, Abraham was preparing to obey a divine command to sacrifice his son Isaac when, at the last moment, God substituted a ram for the boy. By his wife Rebecca, Isaac was the father of *Jacob and Esau, and died aged 180 years.

Isaacs, Sir Isaac Alfred (1855-1948). Australian lawyer, judge and Governor-General, born in Melbourne. He grew up in Beechworth, graduated at Melbourne University, was a Victorian MP 1892-1901 and Attorney-General 1894-99; 1900-01. Elected to the first Commonwealth Parliament 1901-06, he was *Deakin's AttorneyGeneral 1905-06, then became a long-serving Justice of the High Court 1906-30, much disliked by his brother judges. ${ }^{*}$ Scullin appointed him as Chief Justice of the High Court 1930-31, then, despite the hostility of King *George V, insisted on Isaacs as Governor-General of Australia 1931-36. He became the first Australian-born to hold the office. He received a GCMG in 1932 and GCB in 1937. A practising Jew, he was strongly anti-Zionist, widely read and a formidable linguist.

Cowen, Z. Isaac Isaacs. rev. 1993.

\section{Isaacs, Rufus Daniel see Reading, 1st Marquess of}

Isabel II (María Isabel Luisa de Borbón y BorbónDos Sicilias) (1830-1904). Queen of Spain 1833-68. Born in Madrid, daughter of *Ferdinand (Fernando) VII and his fourth wife (and niece) Maria Christina of the Two Sicilies, her father decreed (1830) the repeal of the Salic Law, which excluded female succession to the throne. Isabel's uncle Don ${ }^{*}$ Carlos, the former heir, instigated what became known as the First Carlist War (1833-39) against Isabel and her mother, the Regent. The Carlists were defeated by a combination of the army, moderates and progressives, and in 1843 Isabel was declared to be of age. In 1846 she married her double cousin Francisco de Asis de Borbón, Duke of Cádiz (1822-1902), who was King-consort 184668. Isabel had 12 children, of whom five survived infancy; their paternity is doubtful because Francisco had other interests and the couple separated amiably in 1874. An unreliable and wilful intriguer, her rule was inefficient and corrupt. Following another period of civil war, her forces were defeated and she was deposed in 1868, abdicating formally in 1870 . After the so-called 'Glorious Revolution', the Cortes elected *Amadeo, an Italian prince, as King of Spain in 1870 but he abdicated in 1873 and a republic was established. After another army rising, the republic was overthrown and Isabel's son, the well-intentioned *Alfonso XII, became king. Isabel went into exile in France and died in Paris. She was enormously fat.

Isabella I of Castile (known as 'the Catholic') (1451-1504). Queen regnant of Castile and León 1474-1504, Queen consort of Aragon 1479-1504. Daughter of Juan II of Castile, from the House of Trastamára, she married (1469) the prince who, already King of Sicily, became *Ferdinand II of Aragon in 1479. She had succeeded her half-brother Enrique IV on the throne of Castile in 1474, so she and her husband were joint rulers of the whole of Spain, which became a united country under their successors. For the main events of the reign see Ferdinand II.

Mariéjol, H., trans. Keen, B., The Spain of Ferdinand and Isabella. 1961; Tremlett, G., Isabella of Castile. 2017.

Isabella of France (c.1292-1358). Queen consort of England 1308-27. Daughter of *Philippe IV of France, she married *Edward II of England in 1308, became the lover of Roger de ${ }^{*}$ Mortimer and was central to the deposition (1327) of her husband, and his murder. She became Regent for her son *Edward III 1327-30, who then took power in his own hands, had Mortimer executed, and his mother imprisoned. Known as the She-Wolf of France', she was characterised as a femme fatale in plays by ${ }^{*}$ Marlowe and ${ }^{*}$ Brecht. In her last years she acquired great wealth, had a wide range of interests and became a nun.

Isaiah (c.770-700 BCE). Hebrew prophet. $\mathrm{He}$ received his call in the temple in the year of King Uzziah's death (c.727) and seems to have acted as advisor, both in spiritual and temporal affairs, to Kings Jotham, Ahaz and Hezekiah. The interpretation of the biblical Book of lsaiah has always been difficult as so many of his prophecies may equally well refer to contemporary as to future events. He foresees 
the survival of a national remnant (referring either to those who returned from Babylonian exile or to those who maintained their religious identity after the great dispersal) and looked forward to the coming of a Messiah. Almost all scholars are now agreed that chapters $x i-x v i$ are by a later hand, since the background events belong to the 6th rather than the 8 th century BCE.

Kissane, E. J., The Book of Isaiah. Rev. ed. 1960.

Isherwood, Christopher William Bradshaw (19041986). British author, American by naturalisation. The period he spent in Berlin (1928-33) before the Nazis came to power provided the material for his best known novels, $M r$ Norris Changes Trains (1935), Goodbye to Berlin (1939), and for his play (and film) I am a Camera, on which was based the musical Cabaret. He later wrote plays, e.g. The Ascent of F. 6 (1936), in collaboration with his friend W. H. *Auden. He settled in America in 1939, and wrote for films. His interest in Indian religion led him to translate, inter alia, The Bhagavad Gita (1944).

Isherwood, C., Christopher and his Kind. 1977.

Ishiguro, Sir Kazuo (1954- ). Japanese-British novelist, born in Nagasaki. Living in England from 1960, educated at the universities of Kent and East Anglia, he won the Booker Prize with The Remains of the Day (1989, filmed in 1993). Other novels include A Pale View of Hills (1982) and An Artist of the Floating World (1986). He was awarded the 2017 Nobel Prize for Literature for writing 'novels of great emotional force, [which] uncovered the abyss beneath our illusory sense of connection with the world'.

Ishmael (Yishma'el) (fl. c.2000 BCE). Hebrew outcast. First son of*Abraham, by Hagar (the Egyptian handmaid of Abraham's wife Sarah), according to Genesis xvi, xvii and xxi, he and his mother were driven into the desert as a result of Sarah's jealousy. Muslims consider Ishmael to be the ancestor of Arab tribes and of ${ }^{*}$ Muhammad. He died (it was said) at the age of 137 and was buried in Mecca.

Isidore of Seville, St (c.560-636). Spanish prelate, scholar and Doctor of the Church, born in Cartagena. Bishop of Toledo 601-36 (succeeding his brother), he was prominent at the councils of Seville (619) and Toledo (633), but is best known as a writer on religion, science (astronomy etc.) and history (e.g. of the Goths, Vandals and Sueves). His most important work is his Etymologies, a kind of encyclopaedia which, as an early medieval reference book, transmitted much classical knowledge. It was one of the earliest books printed and was much consulted until the 17th century. Canonised in 1598, two brothers (Leander and Fulgentius) and a sister (Florentina) were also recognised as saints. Isidore is the patron saint of the Internet and computer users.
Isma'il ibn-Jafar (c.720-755/60). Arab religious leader, born in Medina. He was the son of Jafar alSadiq, sixth Imam of the line stemming from *Ali, ${ }^{*}$ Muhammad's son-in-law. This line, according to the Shi' ite sect, is the true succession to the Prophet. When Jafar died, the majority of the Shi'ites passed over Isma'il and chose his younger brother Musa as imam. A minority recognised Isma'il and formed a separate sect. The Ismailites eventually spread to India where the *Aga Khan became its spiritual leader.

Ismail Pasha (1830-1895). Khedive of Egypt 186779. Grandson of ${ }^{*}$ Mehemet Ali, he was appointed as the Ottoman viceroy in 1863 and created khedive in 1867 . He obtained large credits owing to the rise in the value of the cotton crop when American shipments dwindled in the Civil War. He embarked on an extravagant development program: much of Alexandria and Cairo was rebuilt and the construction of the Suez Canal put in hand. But his plans were too grandiose for his means and some of the money was squandered. Egypt's national debt rose from $£ 7$ million in 1863 to $£ 100$ million in 1879 . Crippled by interest payment, he sold his Suez Canal shares to Britain, but despite temporary relief he was forced to accept Anglo-French financial control (1876) and to abdicate (1879) in favour of his son Tewfik.

Ismay, Hastings Lionel Ismay, 1st Baron (18871965). British general. As Military Secretary to the War Cabinet (1940-45) he was one of Winston *Churchill's closest companions and advisors during World War II. He became *Mountbatten's Chief of Staff in India 1947-48, Secretary of State for Commonwealth Relations 1951-52 and the first Secretary-General of NATO 1952-57. Knighted in 1940, he received a $\mathrm{CH}$ in 1945, a peerage in 1947 and a KG in 1957.

\section{Israel see Jacob}

Isocrates (436-338 BCE). Greek philosopher, born in Athens. His family was rich, he studied under *Socrates, founded a school of oratory and wrote speeches for clients. He went into political exile after Athens came under Macedonian rule and died at the age of 98 after starving himself. He is identified as a promoter of 'rhetoric' (or 'pedagogy'), arguing that knowledge should emphasise practical outcomes, in sharp contrast to ${ }^{*}$ Plato who argued that philosophy should seek the truth, wherever it led.

Issigonis, Sir Alec (1906-1988). British automobile engineer and designer, born in Izmir. He worked for the British Motor Corporation, designed the Morris Minor (1948) and the fuel-efficient Mini (1959) and had a profound influence on Japan's car industry.

Itamu Juzo (1933-1997). Japanese film director and actor. His black comedies include The Funeral (1985), Tampopo (1986), A Taxing Woman (1987) and A Taxing Woman's Return (1988). 
Itō Hirobumi, Prince (né Hayashi Risuke) (18411909). Japanese statesman, born in Tsukari. Son of a poor farmer, he was adopted by a samurai family, became a student activist in the movement to end the shogunate (*Ieyasu) and restore the emperor to active rule, and studied in London 1863-64. After the Meiji Restoration (*Mutsuhito) in 1868, Itō joined a group of able advisors determined to bring Japan out of isolation and create a powerful modern state. He visited the US in 1870-71 to examine its Constitution, and was principal architect of the taxation system, railways, cabinet government and foreign policy. He travelled to Germany in 1882 and secured adoption of its model in Japan. Appointed as the first Prime Minister of Japan in 1885, he held the office four times 1885-88, 1892-96, 1898, 1900-01, but was probably more powerful as a genro, a behind the scenes advisor to the emperor. He negotiated the Anglo-Japanese Alliance in London (1902), receiving a GCB: this enabled Japan to wage victorious war against Russia (1904-05) without risk of outside intervention. Created a Duke in 1907, he was Resident-General in Korea 1905-09, a virtual protectorate of Japan; after his assassination in Harbin, it was annexed.

Akita, G., Foundations of Constitutional Government in Modern Japan, 1868-1900. 1967.

Itúrbide, Augustin de (1783-1824). Emperor of Mexico 1822-23. Having fought in the Spanish royalist army (1810), he led the revolution (1821) promising to establish representative government under a monarchy. Most of the country supported him and the new Spanish Viceroy handed over Mexico City to him. When the constituent assembly proved far from submissive, Itúrbide's followers proclaimed him Emperor and for a few months he ruled as an imitation ${ }^{*}$ Napoléon, bestowing titles lavishly upon his family and friends. Early in 1823 the army revolted, Itúrbide abdicated and fled, but was arrested and later shot on his return.

Ivan III Vasilievich ('the Great') (1440-1505). Grand Duke of Muscovy (Moscow) 1462-1505. Born in Moscow, son of Vasili II (1415-1462), of the Rurikids dynasty, he drove out the Tartar rulers, conquered and annexed a great part of Novgorod and brought the scattered provinces and principalities of his realm under central rule. His marriage, in 1472, to Sophia (Zoë) Palaiologina, niece of the the last Byzantine emperor, gave him imperial ideas, he styled himself 'Prince of Rus' and described Moscow as 'the third Rome'. His defeat of the Golden Horde in 1480 extended his rule into Ukraine. He brought in Italian architects and craftsmen to beautify Moscow with palaces and churches, and greatly expanded the Kremlin.

Fennell, J. L. I., Ivan the Great of Moscow. 1961.
Ivan IV (known as 'the Terrible') (1530-1584). Tsar of Russia (Muscovy) 1547-84. Son of Vasily III and grandson of *Ivan III, he was crowned at the age of 17 . His minority spent at the mercy of boyars (nobles) competing for power had implanted in him a bitter hatred of the whole class. In the early part of his reign he carried out many legal and social reforms, but from about 1564 his behaviour, always harsh, rapidly deteriorated and his fear and suspicion developed. He instituted a secret police (oprichnina), and torture, execution and imprisonment became the everyday instruments of a neurotic sadism. In a fit of rage he killed his son Ivan (1580); he spent the rest of his life in penance. Despite, or because of these methods, his personal power was greater than that of any previous Russian ruler and he established firmly the autocratic tsarist tradition. He conquered the Tartars' Khanates of Kazan and Astrakhan and extended his territory to the Caspian. He formed links also with the west and offered to Queen *Elizabeth of England a trade treaty and even his hand in marriage. He was the subject of a remarkable film by Sergei *Eisenstein.

Payne, R. and Romanoff, N., Ivan the Terrible. 1975.

Iveagh, Edward Cecil Guinness, 1st Earl of see Guinness, Sir Benjamin Lee

Ives, Charles Edward (1874-1954). American composer, born in Danbury, Connecticut. The son of a bandmaster with an enthusiasm for *Bach and musical experimentation, he was educated at Yale, had some composition lessons from the conservative Horatio Parker, but was essentially self-taught. He became an actuary and ran a New York agency for Mutual Insurance, Ives \& Myrick. Until he retired in 1930 Ives composed only at weekends, when he also played the organ in church. A bold experimenter with 12-tone music, dissonance, and complex rhythms, little of his music was performed in his lifetime. ${ }^{*}$ Schonberg recognised him as a genius and his cause was taken up by *Copland, *Stokowski and ${ }^{*}$ Bernstein. His works included The Unanswered Question (1906) and Three places in New England (1908-14), for orchestra, four symphonies, much chamber and piano music and over 100 songs. $\mathrm{He}$ is now generally regarded as the greatest American composer.

Iwakura Tomomi, Prince (né Horikawa Kanemaru) (1825-1883). Japanese nobleman and bureaucrat, born in Kyoto. Son of a low-ranking courtier, but a cousin of the emperor Kōmei (through his mother), he was adopted by the Iwakura family. Anti-foreign at the time of American penetration of Japan (1853-54), he changed his opinion, was exiled from the imperial court 1862-67, became a priest, but returned as a central figure in the *Meiji Restoration (*Mutsuhito) 1867-68, opening up Japan to foreign contact while retaining its culture and imperial rule. Appointed Minister of the Right in 1871, from December 1871 
to September 1873 he led a mission of 50 officials to investigate modern institutions, education and technology in the US and Europe. In effect, he was Chief Minister 1873-82, promoting railways, electrification, the telegraph and modern armaments. He died of cancer.

Iyasu, Lij (Iyasu V, originally Kifle Yacob) (1895?1935). Emperor of Ethiopia 1913-16. Grandson of *Menelik II, he was markedly eccentric, showed some sympathy for the Central Powers in World War I and for his Muslim neighbours, and was deposed by the nobles, led by his cousin *Haile Selassie, on the grounds of his alleged apostasy. He was imprisoned; the circumstances of his death are unknown. 


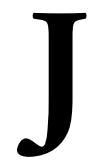

Jabotinsky, Ze'ev (Vladimir Evgenyevich) (18801940). Russian Zionist, born in Odessa. A journalist, translator and orator, he advocated an organised Jewish defence against pogroms in Russia. During World War I, he served in the British army as an officer in a Jewish battalion, formed the Haganah in 1920 as a Jewish self-defence force against the Arabs and was briefly imprisoned. He advocated the establishment of a Jewish state on both banks of the River Jordan, founded the Zionist Revisionist organisation in 1925 and was working for the establishment of a Jewish army when he died in New York State. His followers organised the Irgun Zvai Leumi, and, after the establishment of Israel, the Herut Party, which merged in 1973 with Likud. He was reburied in Israel in 1964.

Schechtman, J. B., Vladimir Jabotinsky. 1956-61; Katz, S., Lone Wolf: A Biography of Vladimir (Zéev) Jabotinsky. 1986.

Jack the Ripper. Pseudonym of murderer in London who stabbed and mutilated five, possibly seven, prostitutes in the Aldgate and Whitechapel areas of East London in 1888. He was never caught. Public alarm at his escape brought pressure to bear on the police and produced reforms in detection methods. There have been numerous ingenious attempts to identify him, most recently Patricia Cornwell's expensive but unconvincing identification of the painter W. R. *Sickert.

Jackson, Andrew (1767-1845). 7th President of the US 1829-37. Born in South Carolina, he fought as a boy in the American War of Independence. Later, as a lawyer in Tennessee, he entered local politics and became a general in the militia. His defence of New Orleans in the war of 1812 against the British, and subsequent exploits against the Indians in Florida (of which he became military governor in 1821) made him a national hero. He had already served briefly in the US House of Representatives 1796-97 and US Senate 1797-98, 1823-25 and his political allies decided to exploit his popularity by putting him up for the presidency. In 1824, four candidates, Jackson, John Quincy *Adams, Henry ${ }^{*}$ Clay, and William Crawford from Georgia (all from the DemocraticRepublican Party), ran for president. Jackson led on the primary vote but without a majority in the Electoral College. The election was then referred back to the House of Representatives, which elected Adams. However, in 1828 Jackson beat Adams decisively, campaigning as a 'Democrat', the friend of the people, standing for what later came to be known as 'the common man'. In encouraging the 'spoils system', by which political service was rewarded by official positions, he saddled the Democratic party and indirectly the whole of American public life with this lasting incubus. His attitude to the issues that confronted him was distinctively personal. He supported a strong federal government against states' rights, and struck a blow at the power of money by vetoing the rechartering bill for the Bank of the United States, which he later crippled by removing federal deposits. He overcame what might have developed into a disruptive refusal to accept a new tariff bill by accepting compromise under which the tariff was imposed on condition that it was steadily reduced. In his second term he tried to purchase Texas from Mexico and would have annexed it when it revolted had he not been prevented by the opponents of slavery (it finally joined the Union in 1845). He was succeeded by his nominee Martin *Van Buren and continued to dominate Democratic politics. Though there was much of the simple frontiersman indicated by the nickname 'Old Hickory' in Andrew Jackson, he had an imaginative perception of the popular will and an astute and logical mind to interpret it, together with a deep sense of loyalty to the people. Jackson remains an intensely controversial figure, and in 20 Presidential ranking lists by US historians and political scientists there is great divergence of opinion; in the aggregate he scores No. 11.

Schlesinger, A. M., Jr, The Age of Jackson. 1946.

Jackson, Glenda (1936- ). English actor and politician. She trained at the Royal Academy of Dramatic Art (RADA), made her New York and Paris debuts in 1965, performed in *Shakespeare, ${ }^{*} \mathrm{O}$ 'Neill and ${ }^{*}$ Brecht and won Academy Awards for Women in Love (1971) and A Touch of Class (1974). She was a Labour MP 1992-2015, and Undersecretary for the Environment and Transport 1997-99. After a long absence she returned to the London stage as a magnificent King Lear (2016).

Jackson, Jesse Louis (1941- ). American clergyman and Democratic politician, born in North Carolina. He became a Baptist minister in Chicago, an active leader in the black community, and came second to Mike ${ }^{*}$ Dukakis in the Democratic presidential primaries for 1988 .

Jackson, John Hughlings (1835-1911). British neurophysiologist. After 1863 he practised at the London Hospital and at the National Hospital for the Paralysed and Epileptic and was preoccupied with the neurological explanation of physical and mental disorders. Best remembered for his work on the localisation of brain function, there was still great debate in mid-century as to whether bodily movements were controlled by the brain as a whole, or by different sectors of the brain for each function. Partly on the basis of studies of patients with injured, diseased, or deficient brains, he proposed a localisation model. His insights were confirmed by the electrical experiments of Fritsch and Hitzig, and David Ferrier. 
Jackson, Michael Joseph (1958-2009). American singer born in Gary, Indiana. His album Thriller (1982) held the world record for sales, 38 million in a single year. He appeared in films and television, toured extensively, became a universally recognised and sexually ambiguous symbol. In 1988 he earned \$US20 million for a television commercial for PepsiCola. In 1993 he was accused of sexual molestation of juveniles. In 1994 he married Lisa Marie, the daughter of Elvis *Presley. His death, following a drug overdose, led to a manslaughter conviction for his physician.

Jackson, Sir Peter Robert (1961- ). New Zealand film director and producer, born in Wellington. He left school at 16 and was essentially self-trained, making his first film, Bad Taste, in 1987. He scripted, directed and produced The Lord of the Rings trilogy (2001-03) and The Hobbit trilogy (2012-14). He won three Academy Awards. Other films include King Kong (2005).

Jackson, Robert H(oughwout) (1892-1954). American jurist, born in Pennsylvania. After a brief period at law school (he lacked a degree), he worked closely with Franklin D. ${ }^{*}$ Roosevelt and became US Solicitor General 1938-40, US Attorney-General 1940-41 and a Justice of the US Supreme Court 1941-54. He took leave of absence from the court to act as chief US prosecutor at the International Military Tribunal in Nuremberg 1945-46.

Jackson, Thomas Jonathan (known as 'Stonewall Jackson') (1812-1863). American soldier. He served in the Mexican War (1846-48) and taught at the Virginia Military Institute (1851-61). His stand at the Battle of Bull Run (1861) in command of the Confederate forces in the Civil War earned him his nickname. In 1862, as commander in the Shenandoah Valley, by successively defeating his opponents and constantly threatening Washington he relieved the Confederate capital, Richmond, of much of the pressure upon it. Later in the year he joined Lee at Richmond and played an important part in the invasion of Maryland. At Chancellorsville (May 1863), when returning from a reconnaissance, he was mistaken for the enemy and shot by one of his own men. His firmness of character, sustained by rigid Calvinism, made him a strict disciplinarian but his masterly tactics, based on those of *Napoléon, and his personal idiosyncrasies gave him popularity with his troops.

Freeman, D. S., Lee's Lieutenants: A Study in Command. 1942-46.

Jacob (Yàaqob: later called Israel) (fl. c.1900 BCE). Hebrew patriarch. Second son of *Isaac and Rebecca, according to Genesis xxvii, he tricked his elder brother Esau out of his birthright. By his two wives Leah and Rachel (for each of whom he had to serve their father Laban seven years) he had 12 sons, from whom were descended the 12 tribes of Israel: Reuben, Simeon, Levi, Judah, Zebulon, Issachar, Dan, Gad, Asher, Naphtali, Joseph and Benjamin.

Jacobs, Jane (née Butzner) (1916-2006). Canadian social scientist, born in Pennsylvania. Originally a reporter, she married an architect and began writing original critiques of urban life. Her books included The Death and Life of Great American Cities (1961) and Cities and the Wealth of Nations (1984).

Jacobs, René (1946-). Belgian conductor and singer, born in Ghent. Originally a counter-tenor and *Bach specialist, he became an outstanding conductor, winning awards for recordings of Bach's cantatas, *Haydn's The Creation and *Mozart's operas.

Jacobsen, Arne Emil (1902-1971). Danish architect. He was among the most prominent of those who in the 1930s introduced 'functionalism' into Danish architecture. He designed (sometimes in collaboration) many civic and industrial buildings in Denmark, e.g. Aalborg Town Hall (1938-42), the Glostrup Town Hall (1953), office and residential buildings and his influence soon spread. He was chosen to design the new building for St Catherine's College, Oxford (completed 1965). He also turned his attention to applied art and designed furniture, lighting appliances, textiles etc.

Jacquard, Joseph-Marie (1752-1834). French inventor. After many years of experimenting with textile machinery he devised a successful loom for the mechanical weaving of complicated patterns (1801). This was bought by the French Government (1806), but Jacquard received a royalty on all machines sold. The Jacquard loom has played a major role in the development of patterned textiles for 150 years. His use of punched cards on which details of patterns were recorded was adopted by ${ }^{*}$ Babbage in his calculating machine. Jacquard's cards remained indispensable until the electronic era.

Jadwiga, St (c.1373-1399). Polish Queen. Daughter of Lajos (Louis) the Great of Hungary and Poland, she married Władysław II *Jagiełło and was canonised in 1997.

Jagger, Mick (Sir Michael Philip) (1943- ). English singer, actor and songwriter, born in Kent. He was a co-founder of The Rolling Stones in 1962 and its lead singer for decades.

Jagiellon. Lithuanian dynasty which ruled medieval Poland, Hungary, Bohemia and Croatia, named for Jagietto (or Jogaila) (c.1362-1434), Grand Duke of Lithuania (the last pagan state in Europe) 13811434. In 1386 he married *Jadwiga, heiress to the Polish throne, and, having converted to Christianity, was King of Poland as Władysław (Ladislas) II 1386-1434. He renamed the expanded University of Kraków as Jagiellonian. Six kings of his dynasty reigned in Poland until 1572. Another Władysław, 
son of ${ }^{*}$ Casimir IV, was elected King of Bohemia (1471) and became (1490) King of Hungary also, but the defeat and death of his son Lajos (Louis) II at the Battle of Mohacz (1526) ended the Jagiellon dynasty in both those countries.

Reddaway, W. F., et al. (eds), The Cambridge History of Poland. 1941-50.

Jahangir (Mirza Nur-ud-din Beig Mohammad Khan Salim) (1569-1627). Emperor of India 1605-27. Fourth of the Mughals, he succeeded his father *Akbar the Great. He was cruel, idle, and self-indulgent, but artistic. He left the administration to his wife, the strong-minded Nur-Jahan ('light of the world'), who is said to have varied her governmental duties 'by polo playing and shooting tigers'. Jahangir's reign saw the arrival of the first Englishmen ever to visit the Mughal court. One of them, William Hawkins, who brought a letter from James 1, was favourably received and given leave to start a trading port at Surat. Jahangir laid out the Shalimar gardens in Kashmir and erected several magnificent buildings in Lahore and elsewhere.

Jahn, Friedrich Ludwig (1788-1852). German philologist. Known as 'Father' Jahn (but not a priest), he was a gifted publicist who promoted the idea of Germany as an 'organic state', based on the Volk (folk) principle: this was timeless, involving all Germans, living, dead or unborn, in contrast to the English or French ideal of individualist, liberal society. His ideas were largely adopted by the Nazi movement.

James (the Great), St (Ya'aqob in Aramaic) (d.c.44 $\mathrm{CE}$ ). Christian apostle. Son of Zebedee and brother of *St John (the Divine), he was prominent among the apostles and after the Resurrection became a leader of the Church in Jerusalem. Beheaded on the order of ${ }^{*}$ Herod Agrippa, he was the first apostle to be martyred. According to legend his body was taken to Spain, where in 835 the bones were found at Santiago (St James) da Compostella, which became and remains a great centre of pilgrimage. James became Spain's patron saint. Another apostle, identified as James the son of Alphaeus or 'James the Less' plays no distinctive part in the New Testament story.

James (the Just), St (d.c.62 CE). Christian apostle. Leader of the Church in Jerusalem after the Resurrection, Paul called him (Galatians i:19) 'James the Lord's brother' but Catholics translate the Greek adelphos as 'kinsman'. He presided at the first apostolic council, held in Jerusalem c.49-50 CE, to decide whether Gentile converts had to undergo circumcision, and proposed a compromise position (Acts xv:13-21). The Epistle of James, one of the earliest books in the New Testament, was probably written about $58 \mathrm{CE}$. He was ascetic, a vegetarian and never married. Generally conservative, he appears to have interpreted Jesus' teachings in an essentially Jewish context, in contrast to the appeal to the Gentiles by *Peter and *Paul. *Josephus reports that James was hurled from the pinnacle of the Temple and stoned to death: *Eusebius adds that he was beaten to death by a fuller's club. His followers retreated to Pella. Supporters of the Roman Petrine tradition played down James' leadership of the Jerusalem Church.

Eisenman, R., James the Brother of Jesus. 1997.

James (the Less), St (fl. 1st century CE). Christian apostle. Not to be confused with James 'son of Zebedee' or *James 'the Lord's brother', he was son of Alphaeus and may have been the brother (or father?) of St *Jude. His fate is unknown.

James of St George, Master (né Jacques de SaintGeorges d'Espéranche) (c.1230-1309). Savoyard architect. One of the greatest medieval architects, he was commissioned by ${ }^{*}$ Edward I to build castles in North Wales at Conwy, Harlech, Caernarfon and Beaumaris, earning 3 shillings per day.

James (Jaíme) I (1208-1276). King of Aragon and Catalonia 1213-76. Although known as 'the Conqueror' for his victories over the Moors, Majorca was conquered by Catalans (1229-32) and the Moorish Kingdom of Valencia by the Aragonese in 1245. By relinquishing fiefdoms on the French side of the Pyrenees by the Treaty of Corbell (1258) he made Catalonia a purely Spanish kingdom. He initiated many legal reforms and the first maritime code.

\section{James Edward Stuart see Stuart, James Edward}

James I (1394-1437). King of Scotland 1406-37. Son of *Robert III, while at sea on the way to be educated in France, he was captured and detained in England for 21 years, honourably treated at court and made a Knight of the Garter. Ransomed in 1424, he returned to Scotland where his energetic attempt to introduce a parliament on the English model failed, his personal foibles lost him general support and the antagonism of the nobles led to his assassination. James is credited with having written The King is Quair, a fanciful poem about his love for Joan Beaufort, whom he married in 1424 . His son James II (1430-1460) and his grandson James III (1452-1480), succeeded in turn. The reigns of both began with long minorities, both had to contend with a discontented and factious nobility, and both met violent deaths, the former killed at the siege of Roxburgh, the latter found murdered near the battlefield of Sauchieburn.

James I (1566-1625). King of England and Ireland 1603-25, from 1604 of Great Britain, and (as James VI) King of Scotland 1567-1625. Born at Edinburgh Castle, he was the only child of *Mary Queen of Scots and Henry, Lord *Darnley. As a baby he succeeded his mother after her enforced abdication, in a Scotland torn by rival political and religious factions, for whom possession of his person and the powers of regency that went with it were valuable prizes to be won. There 
were two sides to James: (i) boring and often cranky moralist; and (ii) extravagant bisexual hedonist. He grew up nervous, awkward and pedantic, with a great fund of knowledge and little common sense and was dubbed 'the wisest fool in Christendom'. However, when he came to rule he managed with some astuteness to keep Roman Catholic and Presbyterian factions at bay by favouring each in turn and seeking a middle-way. He was helped to do this by the Treaty of Berwick (1586) under which, in return for subsidies, he pledged himself to be England's ally. Meanwhile his mother, whom he could not remember and whose folly had brought such misfortune, was a prisoner in *Elizabeth's hands. He interceded on her behalf but was careful not to jeopardise his own hopes of accession, based on descent from Margaret, daughter of *Henry VII and wife of Scotland's *James IV. These hopes, with the collaboration of Elizabeth's chief minister, Robert ${ }^{*}$ Cecil, were attained in 1603 . One of his earliest acts was the summoning of the Hampton Court Conference to discuss the grievances of the Puritans in the Church of England. This broke down but at least one of its projects was implemented, the 'Authorised Version' of the Bible which was completed in 1611 and sponsored by James. Despite their shared escape when Roman Catholic malcontents planned the Gunpowder Plot (*Fawkes) to blow up the king in parliament, the relations between James, a firm believer in the 'divine right' of kings, and his legislature were sometimes strained. From 1611 to 1621 he ruled without summoning parliament (apart from the 'Addled Parliament' in 1614 which lasted six weeks), raising troops for Ireland by creating baronetcies a title introduced by him and carrying this obligation and money by selling monopolies, benevolences etc.

The Roman Catholic conspiracy did not prevent James from reversing Elizabethan policy towards Spain, but by assenting to ${ }^{*}$ Raleigh's execution and by his attempt that ended in fiasco to arrange a Spanish marriage for Prince Charles, he only added to his own unpopularity. In 1589 James had married Anne of Denmark. Henry, the elder son, predeceased his father, the younger succeeded as ${ }^{*}$ Charles 1 , and from his daughter *Elizabeth, the 'Winter Queen' of Bohemia, was descended the house of Hanover. For much of his reign James was under the sway of two unworthy favourites, Robert Carr, whom he created Earl of Somerset, and George Villiers, Duke of ${ }^{*}$ Buckingham. In addition to several books on politics he wrote $A$ Counterblast to Tobacco (1604), and issued The Book of Sports (1617) defining the amusements (e.g. archery, dancing, but not bowls) permissible on Sundays. Historians have tended to stress James' deficiencies, but they can be exaggerated. The Elizabethan literary flowering (*Shakespeare, *Donne, *Jonson) continued in the Jacobean era.

Wilson, D. H., King James VI and I. 1956; Russell, C., Parliaments and English Politics: 1621-1629. 1979.
James II (1633-1701). King of England and Ireland and (as James VII) King of Scotland 1685-88. Second son of ${ }^{*}$ Charles I, born in London, before returning to England after the restoration of his brother, ${ }^{*}$ Charles II, he had fought with courage in the armies of France and Spain. As Lord High Admiral 1669-73 he did much to restore the efficiency of the navy and was a successful general against the Dutch (1664-67). His conversion to Roman Catholicism (1670) meant that after the passing of the Test Act (1673) he had to resign his command. The 'Popish Plot' (Titus *Oates), it was alleged, was designed to place him prematurely on the throne, but after the failure of two Exclusion Bills, he succeeded Charles II with parliamentary and general consent. A rising in the West Country under Charles' illegitimate son *Monmouth was quickly and cruelly suppressed, but James' precipitate attempts to advance the Roman Catholic cause quickly aroused antagonism. He used dispensing power' (i.e. from the provisions of the Test Act) to promote Catholics to office, raising a standing army, stationed on Hounslow Heath with obvious intent to overawe the capital. In 1687 he issued a Declaration of Indulgence giving toleration to dissenters, Catholic and Protestant alike. A second Declaration in 1688 was ordered to be read in all churches. The acquittal of 'the Seven Bishops' for seditious libel in petitioning not to have to do so was greeted with popular enthusiasm. Leading Anglican politicians invited James' cousin and son-in-law, *William of Orange, to intervene in England. William's landing in England (1688) found James with an army uncertain in its loyalty and with no strong body of support. James fled, leaving the way clear for William to take the throne jointly with his wife *Mary. These events are commonly labelled the Glorious Revolution. James attempted to regain his kingdom from Ireland, but his cause was finally lost when he was defeated in the Battle of the Boyne (July 1690). He went into exile in France, lived at St Germain-en-Laye, died there in his chapel during Mass and is buried there. By his first wife Anne Hyde (1638-1671), daughter of the Earl of ${ }^{*}$ Clarendon, he had two daughters: Mary II, wife of William III, and *Anne, afterwards queen. By his second wife * Mary of Modena, he was the father of James Edward *Stuart, the 'Old Pretender'.

Turner, F. C., James II. 1948; Miller, J., James II. 1978.

James IV (1473-1513). King of Scotland 14881513. Son of James III, he took part in the nobles' rebellion which led to his father's death but soon asserted his mastery over them. By strengthening the administration of justice he restored confidence in law and order. His court became renowned for pageantry, tournaments and sport. He renewed the traditional alliance with France but at the same time came to terms with England, and in 1503 made the marriage with *Henry VII's daughter *Margaret which eventually united the Scottish and English crowns. When *Henry VIII, in response to the pope's appeal, attacked France, James, torn by conflicting loyalties, took (1513) the 
fateful decision of invading England, but when the armies met at Flodden Field, James was killed and the Scots routed with great slaughter.

James V (1512-1542). King of Scotland 1513-42. He was only 17 months old when he succeeded his father, *James IV. During his minority, the English faction, headed by his mother and her second husband Archibald Douglas, Earl of Angus, competed for power with the French faction led by the Duke of Albany. Albany ruled until 1524 when, by declaring the 12-year-old king capable of rule, his mother and Angus began to exercise authority in his name. In 1528 James asserted his independence, quelled his turbulent subjects and with political and matrimonial alliances to offer was immediately courted by the rulers of Europe. France gained the day and he married (1538) *Mary of Guise. The consequences were persecution of the Protestants and a war with England. The humiliation of the defeat at Solway Moss (1542) coupled with the strain of maintaining an efficient administration in a country so difficult to rule was too much for a highly strung temperament. He died three weeks later, only a few days after his daughter *Mary, the future Queen of Scots was born.

James VI and James VII (Kings of Scotland) see James I and James II (Kings of England, Ireland and Scotland)

\section{James ('the Old Pretender') see Stuart, James}

James, Henry (1843-1916). American novelist, born in New York. Named for his father, a Swedenborgian theologian and amateur philosopher, he was a brother of William *James. His sporadic education, much of it in Europe but finishing at Harvard, made him cosmopolitan, and he was already a mature intellectual when (1865) he began writing essays and reviews for the Atlantic Monthly. But it was only in the more sophisticated circles in Europe that he was happy. He left America (1869) and lived in England from 1876. He never married. His work is usually divided into three periods, sometimes categorised as 'James the First, James the Second and the Old Pretender'. The predominant theme of the first is the impact of European culture on American life, e.g. in Roderick Hudson (1875), Daisy Miller (1879), one of his rare popular successes, The Portrait of a Lady (1881) and in the same year Washington Square (dramatised and filmed in 1949 as The Heiress), and The Aspern Papers (1888), also later dramatised. The second period, distinguished as the English one, shows the shrewdness with which this cosmopolitan American could assess national character, e.g. in The Tragic Muse (1890), and The Awkward Age (1899). He was a master of the long short story or novella. The Turn of the Screw (1898), a ghost story, equally successful as a play, became an opera by Benjamin *Britten. The last period, in which he returns to the contrast between Americans and Europeans, contains three of his greatest novels: The Wings of the Dove
(1902), The Ambassadors (1903) and The Golden Bowl (1904). Among his many miscellaneous writings is a biography of Nathaniel *Hawthorne. His Notebooks remained unpublished until 1948. He was mildly anti-Stratfordian in the ${ }^{*}$ Shakespeare authorship controversy, and somewhat dismissive of Jane *Austen and *Tolstoy. James' style has been interminably discussed, some find it tortuous and over-elaborate, addicted to the double negative, but his many admirers delight in the precision of his observation, meticulous care (like *Flaubert) in selecting a phrase, always using appropriate vocabulary for each character, the patience with which he follows the labyrinths of the human mind. He was nominated for the Nobel Prize for Literature in 1911, 1912 and 1916. As a gesture of sympathy for the Allied cause in World War I, James assumed British citizenship in 1915 and was awarded the OM in January 1916, just before he died.

Edel, L., Henry James. 1985 (revised edition); Novick, S. M., Henry James: The Young Master. 1996; Novick, S. M., The Mature Master. 2007.

James, M(ontague) R(hodes) (1862-1936). English scholar and author. During an academic career culminating in his appointment as provost of King's College, Cambridge 1905-18, and of Eton College 1918-36, he found relaxation in writing ghost stories with an antiquarian flavour. These were collected as Ghost Stories of an Antiquary (1905), More Ghost Stories (1911) etc. His scholarly books include The Apocryphal New Testament (1924). He received the OM in 1930.

James, $\mathbf{P}$ (hyllis) D(orothy), Baroness James (1920 2014). English author. A civil servant until 1979, her crime novels featuring Inspector Adam Dalgliesh were critically acclaimed and include Death of an Expert Witness (1977), Innocent Blood (1980) and A Taste for Death (1986).

James, William (1842-1910). American philosopher and psychologist. A brother of Henry *James the novelist, he studied art, chemistry and medicine at Harvard before turning to his real interests, psychology and philosophy. Meanwhile he had been incapacitated by melancholia for several years. After teaching physiology at Harvard he held professorships there in philosophy and psychology 1885-97. His Varieties of Religious Experience (1902) reveals the direction of much of his psychological work. He is also known for the disputed James-Lange theory which equates emotion with the perception of bodily change. In Pragmatism (1907) the word was originally used in this sense by Charles *Peirce. He expounds the doctrine that the validity of human ideas and principles can only be tested by an examination of their practical results. James' influence was extensive (John *Dewey).

Dooley, P. K., William James. 1974; Richardson, R. D., William James. In the Maelstrom of American Modernism. 2006. 
Jameson, Sir Leander Starr, 1st Baronet (18531917). South African politician, born in Edinburgh. A physician, he established a medical practice in the diamond town of Kimberley and became the friend and agent of Cecil *Rhodes. He administered Mashonaland (1891) after *Lobengula had granted concessions to Rhodes' company and became the virtual founder of Rhodesia. With Rhodes' support (and the collusion of Joseph ${ }^{*}$ Chamberlain, the Colonial Secretary), he led the notorious Jameson Raid (Dec.1895-Jan.1896), a three-day incursion into the Boer South African Republic (Transvaal), intended to coincide with a rising of the Uitlanders (British and other settlers) who had been denied civil rights. The raid was a fiasco. No uprising occurred and the incident strengthened *Kruger's international standing. Handed over to the British who sentenced him to 15 months' jail, he was released after 3 months because of illness. He became Prime Minister of Cape Colony 1904-08 and first Leader of the Opposition in the Union Parliament 1910. He died in London but was buried next to Rhodes in the Matopos National Park, now in Zimbabwe.

\section{Jan III Sobieski see Sobieski, Jan III}

Janáček, Leoš (né Leon Eugen) (1854-1928). Czech composer, folklorist and organist, born in Hukvaldy, Moravia. Son of a village teacher, he became a choir master in Brno, studied organ and piano in Prague and Leipzig, and compositionin Vienna. He wrote music for church performances, carried out research into folk music, and some early works were influenced by ${ }^{*}$ Dvořák. He composed nine operas, including five masterpieces from his maturity: Jenuifa (1896-1903), Káta Kabanová (1919-21), The Cunning Little Vixen (1921-23), The Makropulos Case (1923-25: based on a play by ${ }^{*}$ Čapek) and From the House of the Dead (1927-28, novel by ${ }^{*}$ Dostoevsky).

In 1917 he fell in love with a young married woman, Kamila Stösslová (1892-1935) and wrote her 722 letters of extraordinary poignancy and intensity until his death. This relationship stimulated a fresh burst of creativity that included the orchestral works Taras Bulba (1918) and Sinfonietta (1926), the song cycle The Diary of One Who Disappeared (1919) and two string Quartets (No.1, the Kreutzer Sonata, 1923, inspired by *Tolstoy's novella). The Glagolithic Mass was premiered in 1926. His powerful and original works were rarely heard outside his native country until after 1945, but he came to be recognised as one of the few outstanding 20th-century operatic composers. The Australian conductor (Sir) Charles Mackerras (1925-2010) played a central role in their revival, recording and promotion. Asteroid 2073 Janáček, an airport and an orchestra are named for him.

Vogel, J., Leoš Janáček. 1981, revised 1997; Tyrrell, J., Janácek: Years of a Life. 2 vols. 2006-07.
Jane, Frederick Thomas (1870-1916). English naval writer and artist. He founded and edited Jane's Fighting Ships in 1898 and All the World's Aircraft in 1909 . The series is still regarded internationally as the most authoritative independent catalogues.

\section{Jane (Lady Jane Grey) see Grey, Lady Jane}

Jane (Seymour) (1509-1537). English queen consort 1536-37. Sister of the Duke of *Somerset, she married *Henry VIII as his third wife. She gave birth to his only son, afterwards *Edward VI, and died 12 days later.

Jansen, Cornelius (1585-1638). Dutch Roman Catholic theologian. After teaching in school and college he became a professor at Louvain (1630) and Bishop of Ypres (1636). In his book Augustinus (published 1642) he claimed that the Jesuit teaching on the freedom of the will (i.e. that man's power to choose between good and evil is a matter for his own free choice and not necessarily dependent on divine grace) was identical with the heretical doctrine of the Pelagians condemned by St Augustine. The book attracted many Roman Catholics, especially in France, but aroused much controversy. Jansenism, whose best known proponent was *Pascal, found a stronghold among scholars and theologians of Port-Royal-lesChamps in Paris, but it was condemned as heretical by the papacy and harshly repressed by *Louis XIV.

Escholier, M., Port-Royal. 1968.

Jansky, Karl Guthe (1905-1950). American radio engineer. He worked for the Bell Telephone Laboratories and concluded (1932) that one source of communications static was waves from beyond the solar system. This was the beginning of radioastronomy, but Jansky took no further part in its development, which was taken up by Grote Reber (1911-2002) who invented the parabolic receiving dish, later working in Tasmania (*Penzias).

Jaques-Dalcroze, Émile (1865-1950). Swiss music teacher. He originated the system, now known as eurhythmics, by which musical appreciation is taught through physical movement. Graded exercises, musically accompanied, enable different rhythms to be expressed by movements of head, arms and legs.

Jarry, Alfred (1873-1907). French dramatist. His farce Ubu roi (1896), a parody of Macbeth, was a subversive work that anticipated surrealist theatre and set design in the late 20th century. The play was revived in Europe and the US in the 1950s.

Jaruzelski, Wojciech (1923-2014). Polish soldier and politician. Minister for National Defence 196883, he became First Secretary of the Polish United Workers' (Communist) party 1981-89 and Prime Minister 1981-85, after Soviet forces entered Poland 
and martial law was imposed to suppress *Walesa's Solidarity movement. He was President of Poland 1985-89.

Jaspers, Karl Theodore (1883-1969). German philosopher. Trained in medicine, he held chairs of psychology 1916-21 and philosophy 1921-37 at Heidelberg. His The Psychology of World Views (1919) was an early statement of existentialism, later adapted and popularised by ${ }^{*}$ Sartre. He took the pessimistic view that ultimately all reasoned analysis fails, and a leap of faith is required to reach transcendence. He was deeply critical of *Descartes, ${ }^{*}$ Darwin, ${ }^{*}$ Marx and ${ }^{*}$ Freud. He became a Swiss citizen in 1948.

Schilpp, P. A., The Philosophy of Karl Jaspers. 1957.

Jaurès, (Auguste Marie Joseph) Jean (Léon) (18591914). French Socialist politician and historian, born in Castres. He lectured in philosophy at Toulouse University 1883-85, 1887-93 and was a member of the Chamber of Deputies 1885-87, 1893-98, 1902-14. The *Dreyfus case converted him from liberalism to socialism. His Socialist History of the French Revolution (1901-07) was written 'under the triple inspiration of *Marx, *Plutarch and *Michelet' but he was not a Marxist in an organisational sense. He was a co-founder of the journal L'Humanité (1904) and after the creation of a united socialist party (Section Francaise de l'International OuvrierSFIO) in 1905, his pacifist, individualist, gradualist ideas were generally adopted. Fat, short and untidy, Jaurès was a great orator, held back to a degree by his personal unhappiness. He called for a general strike of French and German workers as a means of averting World War II but was shot by a young monarchist, Raoul Villain, later acquitted of murder who died in the Spanish Civil War (1936).

Javid, Sajid (1969- ). Anglo-Pakistani Conservative politician, born in Rochdale. Originally a banker, MP 2010- , he was Home Secretary 2018-19, Chancellor of the Exchequer 2019-20 and Secretary of State for Health 2021-22.

Jay, John (1745-1829). American judge and Federalist politician, born in New York City. He belonged to the revolutionary party in New York and later helped to draw up the state's constitution and became its first Chief Justice 1777-79. Meanwhile he had been a delegate to the first and second Continental Congresses, and later took part with *Hamilton and *Madison in the defence of the new US constitution in the The Federalist. In 1782-83 he was one of the commissioners who went to Paris and negotiated with Britain the Treaty of Versailles, by which American independence was recognised; he returned to be the acting US Secretary of Foreign Affairs 1784-89, renamed as Secretary of State 178990. *Washington appointed Jay as the first Chief Justice of the Supreme Court 1789-95. In 1794 he went to England to negotiate outstanding questions with William *Grenville. Concessions in what became known as Jay's Treaty (Nov.1789) provoked severe controversy. He resigned from the supreme court and was elected as the second Governor of New York State 1795-1801 In 1801 John *Adams reappointed Jay as the nation's Chief Justice but he declined. He owned slaves until 1800 but became increasingly opposed to admission of slave states to the Union. He farmed at Westchester until his death.

Morris, R. B. (ed.), John Jay: The Making of a Revolutionary. 3 vols, $1975 \mathrm{ff}$.

Jayawardene, Junius Richard (1906-1996). Sri Lankan politician. A lawyer, he became an MP in 1947, Minister for Finance 1947-53, 1960, Minister for External Affairs 1965-70 and Leader of the United National Party 1973-89. He was Prime Minister 1977-78 and President 1978-89.

Jean (Jehan) II, known as Jean le Bon (John the Good) (1319-1364). King of France 1350-64. Son of Philippe VI of the Valois dynasty, he was created Duke of Normandy at the age of 13, when most Norman nobles had divided loyalties. His reign was marked by the Black Death, war with England and his defeat and capture at Poitiers (1356) by *Edward the Black Prince. Taken as a prisoner, Jean was then ransomed, leaving his son Louis as a hostage. Back in France he created the franc (1360) to stabilise the French currency. After Louis escaped in 1363, Jean regarded himself as honour bound to return to England, and died there. His son ${ }^{*}$ Charles V ('the Wise') succeeded.

Jean Paul (pen name of Johann Paul Friedrich Richter) (1763-1826). German novelist, born in Wunsiedel, Bavaria. He grew up in a remote mountainous region of Bavaria, the Fichtelgebirge, where he found the simple characters about whom he wrote with most success. His early books were little noticed but with the publication of Hesperus (1795) and Siebenkäs (1796) recognition came. He married in 1801 and lived for the rest of his life at Bayreuth. Among the best known of his later works were Titmu (1803) and Dr Katzenberger's Badereise (i.e. visit to the spa) (1809). His books have no regular plots and he combines humour with sentiment somewhat in the manner of *Sterne, one of his favourite authors.

Jeans, Sir James Hopwood (1877-1946). English mathematical physicist and astronomer, born at Ormskirk in Lancashire. Educated at Trinity College, Cambridge, he lectured there and became professor of applied mathematics at Princeton 1905-09. He had a rich wife and was able to devote himself to writing and research, without any teaching duties. He became Secretary of the Royal Society 1919-29 and Vice President 1938-40. He was a proponent of the 'steady-state' theory, arguing that matter is continuously created throughout the universe. From consideration of the physics of rotating masses, he 
suggested how the stars and spiral nebulae are formed, and attributed the origin of the planets of the solar system to the forces between two stars passing close to each other. Jeans was a prolific author of popular works, e.g. The Mysterious Universe (1930) and Science and Music (1937), which gave simple explanations of complex scientific discoveries. He was a competent organist and authority on *Bach. In 1939 he received the OM.

Jebb, Sir Richard Claverhouse (1831-1905). Scottish classical scholar, born in Dundee. His distinguished academic career culminated in his appointment (1889) as Regius professor of Greek at Cambridge University. He wrote many books on classical subjects but his great edition of the plays of ${ }^{*}$ Sophocles (1883-86), with textual and critical commentary and prose translation, was his chief work. He helped to found the British School of Archaeology at Athens, was MP for Cambridge University 1891-1905 and received the OM (1905).

Jefferies, (John) Richard (1848-1887). English naturalist and author, born in Wiltshire. He grew up on a farm and began his career as a journalist specialising in rural subjects. In addition to, e.g. The Amateur Poacher (1879), and The Story of a Boy (1882), he wrote the strange introspective autobiography Story of My Heart (1883) and the imaginative After London, or Wild England (1885).

Looker, S. and Porteus, C., Richard Jefferies. 1965.

Jefferson, Thomas (1743-1826). 3rd President of the US 1801-09. Born at Shadwell. Virginia, his father was a well known surveyor. He began to practise law in 1767 and was learned in many subjects, European as well as classical languages, literature, history and above all mathematics and the natural sciences. Turning to politics, he was a member or the Virginia House of Burgesses 1769-74 and immediately became a prominent supporter of colonial claims. He attended both continental congresses $(1775,1776)$ and played a principal part in drafting the Declaration of Independence. Once more a member of the Virginian Legislature 1776-79, he was successful in obtaining the repeal of the Law of Entail, the passage of bills for religious freedom and prohibiting the import of more slaves (he would have enacted emancipation, had he been able) and a revision of the whole legal code. He was Governor of Virginia 1779-81. As a member of Congress 1783-84 he was responsible for the granting of free institutions to the new territories beyond the Ohio and for a report favouring decimal coinage. As Minister to France 1784-89, he saw the beginnings of the Revolution there and gave its first leaders the benefit of American experience. (His letters indicate a strong attraction to absolutist aspects of the Revolution.) He returned from France to be US Secretary of State 1790-94, under *Washington, and pursued a policy of no 'entangling alliances'. With his political followers he formed, in opposition to
Hamilton's centralising policy, a new grouping called the Republican party (despite its name, ancestor of the modern Democratic Party). Jefferson ran second to *Adams in the presidential election of 1796 and, according to the constitutional provision of the time, became Vice President (but virtually Leader of the Opposition). In 1800 he defeated Adams, but tied with Aaron *Burr in the Electoral College and was elected as President by the House of Representatives, Burr becoming a grossly disloyal Vice President. In 1804 he won re-election easily, defeating C.C. *Pinckney. Jefferson was the first president to be inaugurated in Washington (which he had helped to plan).

The most important event of his presidency was the 'Louisiana Purchase' (1803) of the French territories in the Mississippi basin, made possible by *Napoléon's difficulties in maintaining adequate communication and control. In internal affairs he followed a conciliatory policy and did not press his earlier campaign for states' rights. The slave trade was abolished (1808). In 1809 he retired to Monticello, the home of his own design, here he returned to the studies of his earlier years and in particular became absorbed in the work for the establishment of the University of Virginia, inaugurated (1825) at Charlottesville. Jefferson envisaged the United States as a mainly agricultural community, since industrialisation, in his opinion, would put power in the hands of financial interests. His political doctrines were based on those of *Locke and *Rousseau; his practice proved him to be one of the great liberal statesmen of history. He married (1772) a widow, Martha Skelton (née Wayles) who died in 1782; only two daughters survived infancy. Jefferson's relationship with the mixed-race slave Sally Hemings (c.1773-1835), who travelled to France with his family, is controversial but it is probable that he fathered six children, four of whom survived. All were freed on his death.

He died on the 50th anniversary of the signing of the Declaration of Independence, on the same day as John *Adams. In 20 Presidential ranking lists by historians and political scientists, Jefferson scored No. 5 in the aggregate.

Ellis, J. J., American Sphinx. 1997; Meacham, J., Thomas Jefferson: The Art of Power. 2012; Boles, J. B., Jefferson. Architect of American Liberty. 2017.

Jeffery, (Philip) Michael (1937-2020). Australian soldier. He served in Vietnam, was involved in counter-terrorism, rose to the rank of major-general, and became Assistant Chief of Staff for Materiel 1991-93. He was Governor of Western Australia 1993-2000 and Governor-General of Australia 2003-08.

Jeffrey, Francis, Lord Jeffrey (1773-1850). Scottish critic and judge. An advocate, in 1802 with Sydney ${ }^{*}$ Smith and Henry *Brougham, he founded the 
Edinburgh Review and was editor 1803-29. Critical of ${ }^{*}$ Scott, *Wordsworth and the Lakeland poets, he befriended *Macaulay and ${ }^{*}$ Dickens. He became a Whig MP 1831-34 and a judge of the Court of Session $1834-50$.

Jeffreys, George Jeffreys, 1st Baron (1648-1689). English lawyer. He rose rapidly in his profession, partly through royal favour, showing subservience and a talent for intrigue. He was knighted (1677), made a baronet (1681) and Chief Justice of the King's Bench (1683). His first trial resulted in the condemnation and execution of Algernon *Sidney, and he presided over the trial of Titus *Oates. Soon after the accession of James II, he was given a peerage and earned the reputation for infamy that still clings to his name by his conduct of the 'Bloody Assize' which followed the defeat at Sedgemoor (1685) of the rebellious supporters of the Duke of ${ }^{*}$ Monmouth. During his progress through Dorset and Somerset he condemned some 320 men to be hanged, more than 800 to be transported and even larger numbers to be imprisoned and flogged. Jeffreys was appointed Lord Chancellor in October 1685 and served *James II well. When in the autumn of 1688 , faced with the invasion of ${ }^{*}$ William of Orange and the desertion of many of his friends, James contemplated flight, Jeffreys delivered up to him the Great Seal, which James dropped into the Thames. Jeffreys tried to escape, disguised as a sailor, but was taken at Wapping and lodged in the Tower of London, where he died. Jeffreys had many of the qualities of a good lawyer, but his reputation was marred by his brutality, irascibility (he suffered from the stone) and his patent support for royal claims.

Jekyll, Gertrude (1843-1932). English artist, gardener and craftswoman. Trained in music and painting, she travelled in the Mediterranean, and from 1891 devoted herself to garden design. She wrote extensively and later collaborated with the architect (Sir) Edwin *Lutyens.

Festing, S., Gertrude Jekyll. 1991.

Jellicoe, John Rushworth Jellicoe, 1st Earl (18591935). English admiral, born in Southampton. He commanded the Allied expedition to relieve Peking during the Boxer Rising (1900). A strong supporter of Admiral ${ }^{*}$ Fisher, he was on the committee that produced designs for the revolutionary first Dreadnought and, having been Second Sea Lord 1912-14, became Commander-in-Chief of the Grand Fleet 1914-16. His tactics at the Battle of Jutland (31 May 1916) were criticised at the time and it seemed, at best, a draw. Only later it became clear from German documents that Jellicoe had won. The German fleet never put to sea again. He received the OM in 1916 and was First Sea Lord 1916-17, until *Lloyd George replaced him with the more dashing *Beatty. He became a viscount in 1918, an admiral of the fleet in 1919, Governor-General of New Zealand 1920-24 and an earl in 1925.
Jencks, Charles Alexander (1939- ). American architect and critic. He studied at Harvard and London, and became a prolific, penetrating and witty commentator on architecture. His books include Modern Movements in Architecture (1973), The Language of Post-Modern Architecture (1977), Post Modernism (1987) and The Architecture of the Jumping Universe (1995).

\section{Jenghiz Khan see Genghis Khan}

\section{Jeng Ho see Zheng He}

Jenkins, Florence Foster (née Narcissa Florence Foster) (1868-1944). American amateur singer. Celebrated for her eccentric concert performances in New York, her singing is still available on CD. Meryl * Streep played and sang the title role in the film Florence Foster Jenkins (2016).

Jenkins, Roy Harris, Baron Jenkins of Hillhead (1920-2003). British politician, born in Wales. Son of a miner who later became a union official and Labour MP, he was educated at Oxford, became an army captain in World War II, Member of Parliament 1948-77, and a member of the executive committee of the Fabian Society 1949-61. Regarded as a liberal (or right-wing) socialist, he was Minister of Aviation in Harold *Wilson's Cabinet 1964-65, Home Secretary 1965-67 and 1974-76 and Chancellor of the Exchequer 1967-70. His connection with European politics began in 1955 when he served as a delegate to the Council of Europe. He resigned from parliament in 1977 to accept appointment as President of the European Commission 1977-81. In 1979 he had advocated the formation of a 'Middle Party' in British politics and in 1981 he established the Social Democratic Party (SDP) with the support of Shirley *Williams, David *Owen and Bill Rodgers ('The Gang of Four'). He won re-election to the House of Commons in a by-election (1982) and was first leader of the SDP until 1983. He wrote biographies of *Attlee, *Dilke, *Asquith, *Truman, ${ }^{*}$ Gladstone and ${ }^{*}$ Churchill, and was Chancellor of Oxford University 1987-2003. He received the OM in 1993.

Campbell, J., Roy Jenkins. 2014.

Jenner, Edward (1749-1823). English physician, born at Berkeley, Gloucestershire. Renowned as the originator of vaccination, he became a resident pupil of John *Hunter in London and while there arranged the specimens brought back by Captain ${ }^{*}$ Cook from his first voyage. In 1773 he returned to his birth place to practise medicine and was elected FRS in 1789, partly for his study of the migration of birds. For 20 years his observation of smallpox cases confirmed the local belief that dairymaids who contracted cowpox (the milder bovine form of the disease) were immune. This led him to inoculate a boy of eight with lymph taken from cowpox sores (1796). Jenner's account of this and subsequent successful vaccinations (from the 
Latin for cow: 'vacca') was published in his Inquiry into the Causes and Effects of the Variolae Vaccinae (1798). A number of leading physicians soon declared their acceptance of his findings, vaccination began to displace variolation (which used smallpox) and the opposition of the majority of other doctors was overcome when the number of deaths from smallpox fell by about two thirds in less than a decade. Parliament awarded him $£ 10,000$ in 1802 and a further $£ 20,000$ in 1807 for his discovery which was rapidly taken up throughout the world. *Napoléon admired Jenner and had his troops vaccinated. In 1980 WHO declared smallpox to be eradicated. Minor planet 5168 Jenner was named for him.

Fisk, D. M., Jenner of Berkeley. 1959; Rains, A. J. H., Edward Jenner and Vaccination. 1974.

Jensen, Johannes Vilhelm (1873-1950). Danish novelist and lyric poet. His native Jutland provides a background for his Himmerland Tales (1898-1910). His six-volume epic The LongJourney (1908-22) traces the evolution of humanity from pre-glacial times to the age of ${ }^{*}$ Columbus. A convinced Darwinian, he was a prolific mythmaker. He was awarded the Nobel Prize for Literature (1944).

Nedergaard, L., Johannes V. Jensen. 1968.

Jeremiah (?650-c.570 BCE). Hebrew prophet. Active from c.626 BCE during the reign of the Judaean kings Josiah (d.609 BCE) and Jehoiakim (d.598 BCE), he spoke against the contemporary worship of gods other than Jehovah. This view, he foretold, would bring divine retribution in the form of attack from the north. When these prophecies were fulfilled in the assault by the Babylonians, he urged submission to what he saw as a just punishment of the Jews by Jehovah. This view aroused great hostility and he was kidnapped and exiled to Egypt c.586.

Blank, S. H., Jeremiah, Man and Prophet. 1961.

Jerome, Jerome K(lapka) (1859-1927). English humorous writer and playwright. His best known works are Three Men in a Boat (1889), Three Men on the Bummel (1900), and the morality play The Passing of the Third Floor Back (1908).

Jerome, St (Sophronius Eusebius Hieronymus) (c.340-420). Latin Doctor of the Church, born in Dalmatia. Educated in Rome, after a period of travel and study he fell ill at Antioch and for a time lived as an ascetic in the desert. He was ordained priest in 379. In 382 he went to Rome, became the secretary of Pope ${ }^{*}$ Damasus and was commissioned to revise Latin translations of the Gospels and Psalms. On the death of the pope he again went to Antioch where he was joined by Paula, a wealthy Roman matron. and a party of female devotees with whom he visited sacred sites in Egypt and the Holy Land before settling at Bethlehem, where he founded a convent with Paula in charge of the women, he of the men.
Here (from c.385) he spent the rest of his life and made his famous Latin translation of the Hebrew Old Testament, which, together with his New Testament revisions, forms the 'Vulgate' translation still used by Roman Catholics. In addition, he wrote biographies of well-known Christians, theological works, commentaries and letters. He is commemorated on 30 September.

Jespersen, Jens Otto Harry (1860-1943). Danish philologist. Professor of English at Copenhagen University 1893-1920, and an outstanding phonetician, he wrote several studies of English grammar, and originated (1928) the international language 'Novial'.

Jesus Christ (Greek name: Iesous Christos. Aramaic: Yeshu'a Mashiah. Also known as Jesus of Nazareth, to his contemporaries Yeshu'a ben Yosef) (c.8/4 BCE$30 \mathrm{CE}$ ). Jewish teacher and prophet; to his followers, Son of God and the central figure of Christianity. The main sources for the life of Jesus are the Letters of St *Paul, the Acts of the Apostles, the four Gospels, which barely cover 40 days, two brief references to the crucifixion in ${ }^{*}$ Suetonius and ${ }^{*}$ Tacitus and a disputed passage in *Josephus. The synoptic Gospels (attributed to ${ }^{*}$ Mark, ${ }^{*}$ Matthew and ${ }^{*}$ Luke) were written after the Pauline epistles, partly aimed at a Gentile audience and playing down Jesus' Judaism. *John's Gospel, written about 100, is more theological and mystical, deeply Hellenistic and anti-Jewish, and less biographical. Archaeological research in Palestine and the discovery of the Dead Sea Scrolls suggest interesting parallels between the Essenes and Jesus' teachings, but no specific evidence has been found.

The Gospel story, set in Judaea (Palestine) under Roman occupation with client Jewish rulers, is told with significant variations by the evangelists. Matthew and Luke state that Jesus was born, after the miraculous conception ('The Annunciation') by his mother, Mary, at Bethlehem in Judaea, where *Joseph, a Nazarene carpenter (or builder?) descended from *David, had brought his wife (or betrothed) for a census or to pay a Roman tax. (There are some historical and logical difficulties with these accounts: Jesus' background and his probable birthplace was Galilean, the Bethlehem claim by Matthew and Luke is presumably to reinforce Davidic links and Old Testament prophecies. Matthew asserts that Jesus was born in the reign of *Herod (d.4 BCE) while Luke specifies the year of a Roman census (6-7 CE). According to Matthew, soon after the birth of Jesus, his parents took him to Egypt to escape Herod's Massacre of the Innocents. The family returned to Nazareth (a village near Sepphoris) where Jesus was brought up. Matthew xiii: 55-56 refers to the brothers *James, Joses, Simon and Judas and sisters Mary and Salome, but Catholic teaching insists that Jesus had no siblings. A visit to Jerusalem at the age of 12 is the only recorded incident of his youth and early manhood but presumably he worked as a carpenter in Nazareth. Nothing is known of his education except 
that his literacy surprised his contemporaries. Baptised in the River Jordan by his kinsman *John the Baptist, after 40 days of 'temptation in the wilderness' he began his public ministry, a timing possibly determined by John's arrest by Herod Antipas. He also chose 12 disciples, beginning with Simon ( ${ }^{*}$ Peter) and ${ }^{*}$ Andrew. His career as preacher, which lasted two (perhaps three) years, was largely confined to Galilee with its mixed population of Arabs, Greeks, Syrians and Phoenicians, although he travelled in Samaria and as far north as Sidon, visited Jerusalem several times, and lived in Capernaum. The chronology of his life is uncertain. The Gospels are silent on Jesus' marital status and celibacy was rare among Jewish males. References to his age are ambiguous: Luke iii: 39 says he was 'about 30' when he began his mission while John viii:57 refers to him as 'not yet 50'. The crucifixion could have been as late as $36 \mathrm{CE}$. The Gospels record 34 miracles by Jesus: three raised from the dead, seven cured of blindness, five of paralysis, and the feeding of two great crowds, one of 4,000 and another of 5,000. In his preaching he used many parables of which the Gospels recount 40, illustrating the Fatherhood of God, the closeness of the Kingdom of Heaven, the brotherhood of man and the need for repentance. The disciples frequently failed to grasp the significance of his mission and it was many months before Peter recognised him as the Christ, 'the Son of the living God' at Caesarea Philippi (Matthew xvi:16). Included in the Sermon on the Mount (Matthew v, vi, vii) are the Beatitudes, the Lord's Prayer, and his limitation of the Mosaic Law. Later, Jesus sent out 70 (or 72) followers to preach throughout Palestine (Luke x:16). His popularity clearly dismayed the Jewish leaders, whose hypocrisy and rigidity he attacked. As Passover drew near Jesus and his disciples set out for Jerusalem. His approach caused great excitement in the city crowded with Jews gathered to celebrate the feast of Jewish independence. Jesus added to this by driving the money-lenders from the Temple. *Judas Iscariot, one of the 12 apostles, betrayed Jesus to the authorities, according to the Gospels, but his motivation is obscure: he may have been a disappointed zealot concerned that Jesus' kingdom was 'not of this world'. Then came the Last Supper, from which Judas Iscariot stole out to complete his betrayal, the night of prayer in the garden of Gethsemane, the arrest, a rushed hearing on a charge of blasphemy before a Jewish tribunal (which had no power to inflict a death penalty), and an appearance before the Roman procurator, Pontius *Pilate, at the Citadel (formerly Herod's palace). Pilate first attempted to refer the case to ${ }^{*}$ Herod Antipas, tetrach of Galilee who returned the case. Pilate eventually condemned Jesus to death on a charge of sedition, based on a misunderstood claim to Jewish kingship. The crucifixion took place immediately, on a Friday, at Golgotha (Calvary), outside Jerusalem. Permission was given for the body to be interred to the sepulchre of ${ }^{*}$ Joseph of Arimathea which was found to be empty on the morning of the third day (Easter Sunday). He appeared first to *Mary Magdalen, then to the disciples and others on several occasions in different places until the time, 40 days later when (in the words of the Apostles' Creed), 'he ascended into Heaven'. The Gospels and Paul's Letters seem to have been written in the expectation of an imminent Second Coming.

In the Christian calendar devised in the 6th century by ${ }^{*}$ Dionysius Exiguus, the starting point was the Annunciation of Jesus. Year I Anno Domini ('Year of Our Lord') was year 754 of the Roman calendar. This estimate was probably four to eight years too late.

Schillebeeckx, E., Jesus. 1979; Wilson, I., Jesus: The Evidence. 1984; Pelikan, J., Jesus through the Centuries. 1985; Wilson, A. N., Jesus. 1992; Vermes, G., The Changing Faces of Jesus. 2000; The Authentic Gospel of Jesus. 2003.

Jezebel (c.875-852 BCE). Phoenician princess. The wife of *Ahab, king of Israel, she introduced the worship of Baal and her name became a byword for wickedness or a painted wayward woman. She was eventually trampled to death by the horses of the successful rebel, Jehu, and reputedly eaten by dogs (II Kings ix:32).

Jhabvala, Ruth Prawer (1927-2013). Jewish-BritishAmerican writer, born in Cologne. She lived in India 1951-75 and the US 1975-2013 and became famous for her 24 film scripts, including Shakespeare Wallah (1965), Quartet (1981), Room with a View (1986) The Remains of the Day (1993) and won Academy Awards for Room with a View (1986) and Howard's End (1992). She won the Booker Prize with her novel Heat and Dust (1975).

\section{Jiang Jieshi see Chiang Kaishek}

\section{Jiang Qing see Mao Zedong}

\section{Jiang Tsolin and Jiang Xuehliang see Zhang Zuolin and Zhang Xueliang}

Jiang Zemin (1926- ). Chinese Communist official. Educated in Shanghai, he was a bureaucrat until appointment as Minister for the Electronics Industry 1983-85, Mayor of Shanghai 1985-87, and First Secretary of the Communist Party in Shanghai 1987-89. A son-in-law of * Li Xiannian and protégé of *Deng Xiaoping, he became General-Secretary of the Chinese Communist Party 1989-2002 and Commander-in-Chief of the armed forces 19892004. He was President of the People's Republic of China 1993-2003. His position was strengthened at the 1997 Party Congress and he made a successful visit to the US.

\section{Jimenes see Ximenes de Cisneros, Francisco}

Jiménez, Juan Ramón (1881-1958). Spanish poet. Although many of his poems are written in an evocative and melancholy mood he is a modernist in the sense that he constantly introduces new words, new sound-pictures and rhythms, e.g. those of jazz, from the modern world. He had much influence in 
Spain during the republican era but on the outbreak of the Spanish Civil War (1936) went to America and later lived in Florida and Puerto Rico. He won the Nobel Prize for Literature (1956), the citation praising the 'high spiritual quality and artistic purity' of his lyrics.

Young, H. T., Juan Ramón Jiménez. 1968.

Jinnah, Muhammad Ali (originally Mahomedali Jinnahbhai) (1876-1948). Pakistani politician, born in Karachi. He studied law in London, was called to the bar and became deeply impressed by W. E. *Gladstone. He practised in Bombay, entered politics in 1906 and became President of the All-India Muslim League 1913-47, although continuing to practice as a barrister in London for some years. He tried at first to work in concert with the Indian National Congress, was present at the Round Table Conference 1930-31 and promised to try to make the 1935 constitution effective. Gradually, however, he became convinced that Hindus and Muslims could not work in harmony and from 1940 he strenuously advocated the partition of India by the creation of a Muslim state to be known as Pakistan. All subsequent British attempts at compromise broke down, when the two dominions of India and Pakistan were established by a British Act of Parliament (August 1947). Jinnah became the first Governor-General 1947-48 of Pakistan. Known as 'Quaid-i-Azam' (Great Leader), he died of tuberculosis.

Hodson, H. V., The Great Divide. 1969; McDonagh, S., Mohammed Ali Jinnah, Maker of Modern Pakistan. 1971; Wolpert, S., Jinnah of Pakistan. 1984.

Joachim, Joseph (1831-1907). Hungarian-Jewish violinist, composer and teacher. A child prodigy, at the age of 12 he became the protégé of *Mendelssohn who conducted his London début (1844) in *Beethoven's violin concerto. He made many return visits to England. He became (1868) director of the Berlin Conservatoire (Hochschule) and founded (1869) the celebrated Joachim Quartet. He wrote much performed cadenzas for violin concertos by ${ }^{*}$ Mozart, ${ }^{*}$ Beethoven and ${ }^{*}$ Brahms, revived J. S. *Bach's sonatas and partitas for solo violin, and the late Beethoven quartets, and collaborated with *Schumann, Brahms and *Dvořák. His gramophone recordings (1903) are the earliest by a major violinist. His compositions are now neglected.

Joan of Arc, St (Jeanne d'Arc) (c.1412-1431). French heroine, known as the 'Maid of Orléans', born in Domrémy. The daughter of prosperous and devout peasants living on the borders of Lorraine, at 13 she began to hear mysterious voices, which she claimed to be those of St Michael, St Margaret and St Catherine, and became convinced that she had been chosen by God to deliver France from the English. Receiving a specific call to rescue beleaguered Orléans she went, early in 1429, to Robert de Baudricourt, in command of the neighbouring castle of Vaucouleurs, and persuaded him to supply an escort to take her to the Dauphin (the future * Charles VII) at Chinon. Having convinced him and the ecclesiastics who examined her of the genuineness of her call, she was allowed to join the army gathered for the relief of Orléans. Wearing armour, and with the shining confidence stemming from complete faith in her divine summons, she so inspired the troops that on 8 May 1429, within 10 days of her coming, the siege of Orléans was raised. Joan's next move was to persuade Charles to be crowned. Accompanied by Joan and with an army of 12,000 men, he marched deep into enemy-held territory to Rheims, where in the cathedral, the traditional place for the crowning of French kings, the coronation was held. The event raised French morale to its highest point and Joan pressed for an immediate advance on Paris, but Charles dallied and before anything was achieved Joan had been captured (May 1430) while she was leading a sortie from Compiègne, threatened by Burgundian attack. The Burgundians sold Joan to their English allies. She was tried by an ecclesiastical court, presided over by Pierre Cauchon, Bishop of Beauvais, which found her guilty of witchcraft and heresy. She had defended herself with great skill and superb courage, but now for the first time she weakened and made a recantation, almost immediately withdrawn: she was burned at the stake (30 May 1431) in the market place at Rouen. The judgment was reversed in 1456 and Joan was canonised in 1920 by Pope Benedict XV. She was the subject of Voltaire's La Pucelle and dramas by *Schiller, *Shaw and *Anouilh.

Sackville-West, V., Joan of Arc. 1936; Rankin, D. S. and Quintal, C., The First Biography of Joan of Arc with the Chronicle Record of a Contemporary Account. 1964; Warner, M., Joan of Arc. 1999; Castor, H., Joan of Arc. 2015.

Joáo (John) I (1357-1433). King of Portugal and the Algarves 1385-1433. The ex-nuptial son of King Pedro the Just/the Cruel, he was pushed into the throne since the legitimate heir, Beatriz, was married to the King of Castile. His wife was Philippa of Lancaster, daughter of *John of Gaunt. Joáo II (1455-1495, succeeded 1481) gave encouragement and help to *Bartolomeo Diaz who rounded the Cape of Good Hope (1488). Joáo III (1502-1557, succeeded 1521) was responsible for the introduction (1533) of the Inquisition into Portugal. Joáo IV (1603-1656, succeeded 1640) was the first king of the house of Bragança (Braganza), his reign marking the end of 60 years' union with Spain. His daughter Catherine married ${ }^{*}$ Charles II of England. Joáo V (1689-1750), succeeded 1707) was a great patron of learning. Fifty thousand men were employed for 13 years on the palace and monastery of Mafra which he started. Joáo VI (1769-1826, succeeded 1816) took refuge in Brazil during the Napoléonic Wars and remained there until 1821. In 1822 Brazil became independent with his son *Pedro as first emperor.

Livermore, H. V., A New History of Portugal. 1969. 
Job. Old Testament hero. The character of Job, according to the narrative in the Book of Job, was tested and his spiritual pride cured by the loss of his property and family and by much illness and suffering, all of which he endured with exemplary patience; wealth and a long life were his eventual reward. The authority of both story and text is a matter of controversy.

Jobs, Steve (Steven Paul) (1955-2011). American designer and entrepreneur, born in San Francisco. After a modest education in Oregon, he worked for Hewlett-Packard and Atari, and in 1976 was the designer, with Steve *Wozniak, of the Apple I computer, followed by the more successful Apple II and the Macintosh. He was chairman of Apple Computer Inc. 1975-85, resigning after personality clashes with his board. He founded NeXT Inc., in 1984 and $\operatorname{Tim}^{*}$ Berners-Lee used a NeXT computer to develop the World Wide Web (WWW). Jobs returned to Apple as Chief Executive in 1996. Essentially a designer and a marketer of genius, he developed the iPhone, iPad, iTunes, iPod, Pixar and the laser printer. He lived at Palo Alto and died of pancreatic cancer, after a long illness. His death was marked by an extraordinary outpouring of grief, internationally. However, colleagues found him erratic, domineering and difficult to work with.

Isaacson, W., Steve Jobs. 2011.

Jodl, Alfred Josef Ferdinand (1890-1946). German general. Chief of Operations Staff of the Supreme Command of the Armed Forces (OKW) 1939-45, he served directly under *Keitel. Sometimes described as the 'arch planner of the war', the great victories by which Europe and much of Russia were overrun were made possible by his strategic concepts and brilliant grasp of intricate detail. He signed the instrument of unconditional surrender at Rheims (May 1945). He was tried and hanged at Nuremberg for having authorised the execution of commandos and prisoners of war. In 1953, a German court posthumously cleared him.

Joffre, Joseph Jacques Césaire (1852-1931). French marshal, born in the Pyrénées-Orientales. Son of a vigneron, his early career as an engineer officer was spent mainly in the colonies, Tongking, French Sudan, Madagascar, and during a successful rescue operation (1894) he captured Timbuktu. An agnostic and freemason (unusual in the French Army's higher ranks), he became a divisional commander (1905) and Chief of the General Staff (1911), a post that made him automatically Commander-in-Chief of the French armies when World War I broke out. The original defence plans broke down, but the great victory of the Marne (September 1914), which halted and repelled the German advance on Paris, was largely due to his courage and decision. The prolonged stalemate which followed the stabilisation of the line, coupled with the heavy losses incurred on the Somme and at Verdun, caused his replacement (December 1916) by General *Nivelle. He was made a marshal in 1916 (the first created since 1870), elected to the Académie française in 1918 and received the British OM in 1919.

Johanson, Don(ald Charles). (1943- ). American palaeoanthropologist. Educated at the Illinois and Chicago universities, he held a chair at the Case Western Reserve University and, from 1997, in Arizona. In November 1974, with Mauruce Taieb and Yves Coppens, in Hadar, Ethiopia, he discovered the first skeleton of a new anthropoid species Australopithecus afarensis, named 'Lucy' after a *Beatles' song. His successful books included Lucy: The Beginnings of Humankind (1981), Lucy's Child: The Discovery of a Human Ancestor (1989) and From Lucy to Language (1996).

John the Baptist, St (Yohan'an) (c.9/5 BCE-28/29 $\mathrm{CE})$. Jewish prophet. According to the account in St Luke's Gospel, an angel appeared to a priest called Zacharias to tell him that his prayers had been answered and that his wife Elizabeth, hitherto believed barren, would bear him a son. This son, John, appeared (c.27 CE) in the desert beyond the River Jordan giving warning of the judgement to come and 'preaching the baptism of repentance and the remission of sins'. Some asked him if he was the promised Messiah but this he denied saying that he was only the forerunner of a mightier one, 'the latchet of whose shoes I am not worthy to unloose'. John showed his fearlessness in denouncing sin when he rebuked Herod Antipas for marrying his brother Philip's wife, Herodias. Cast into prison, he was executed at the request (prompted by her mother Herodias) of Salome-unnamed in the Bible-who had pleased Herod by her dancing. He may have been a member of the ascetic Essene community.

John (the Divine), St (Aramaic: Yohan'an) (also known as 'the Apostle' and 'the Evangelist) (c.3 CE100 CE?). Christian apostle, one of the four evangelists. He was a son of Zebedee and brother of *James and like him a Galilee fisherman. Jesus called them the 'Boanerges', sons of thunder, because they asked permission to call down fire from Heaven upon a Samaritan village. The identification of John with 'the disciple whom Jesus loved' of the fourth Gospel is traditional but disputed, but he was certainly in the inner ring of the apostles. He was present at the Transfiguration and the raising of Jairus' daughter and took part in preparing the Last Supper. He appears in the Acts as one of the leaders of the early Church. According to tradition, he was exiled to Patmos, and then lived in Ephesus where he took charge of *Mary and died in extreme old age. Around 540, *Justinian built a great basilica on the supposed site of his grave. (It is now being restored.)

St John is the reputed author of the fourth Gospel, three Epistles and the Book of Revelation (the Apocalypse). The last has been the subject of endless 
debate, and the author was probably Greek. Of the Epistles, only the first can, with any degree of certainty, be ascribed on grounds of style to the author of the Gospel. From the 19th century, scriptural scholars assumed that John was the last written of the four canonical Gospels, composed in Greek and showing Hellenistic influence. John denies that Christianity provides just another field for abstract speculation: 'The Word [Logos] became flesh.' Throughout there is a much more developed theology than in the three synoptic Gospels.

John (known as John Lackland) (1167-1216). King of England 1199-1216. Born at Oxford, youngest son of *Henry II and *Eleanor of Aquitaine, he succeeded his brother ${ }^{*}$ Richard I, having already attempted to usurp the throne during Richard's absence on crusade. This and the murder (1204) of his nephew Arthur, a possible dynastic rival, show unscrupulous ambition, but he was not quite the ogre that early historians portrayed; his misfortunes at least matched his crimes. The barons reproached him for losing Normandy, Anjou, Maine and Touraine, but they had done little to help him resist *Philip II, one of the ablest of all French kings. Moreover, in resisting the pope's claim to enforce his choice of Stephen *Langton as Archbishop of Canterbury, John was only making the same stand as the Emperor and his fellow monarchs were making all over Europe. Again, John's failure to command the barons' loyalty left him powerless against a pope as strong and determined as *Innocent III. After England had been placed under an interdict, and John himself excommunicated, he made abject surrender, even accepting (1213) the pope as overlord. This won him papal support, but Langton, the new archbishop, now headed the barons' resistance to the king, who was compelled (June 1215) to accept Magna Carta at Runnymede beside the Thames. This famous document, though it aimed at preserving baronial privilege, proved ultimately to be a symbol of the achievement of popular liberties. John's very virtues as an administrator, with his extension of the power of the royal courts and his reform of the machinery of government, had roused the fears of the barons. By curbing the powers of the king they confirmed their own. John, still struggling against the barons, died at Newark in the following year.

Holt, J. C., Magna Carta. 1965; Warren, W. L., King John. 1991; Church, S., King John: England, Magna Carta and the Making of a Tyrant. 2015; Morris, M., King John: Treachery and Tyranny in Medieval England. 2015.

\section{John (of Austria), Don see Juan de Austria, Don}

John ('the Fearless': Jean sans Peur/Jan zonder Vrees) (1371-1419). Duke of Burgundy 1404-19. He earned the name 'Fearless' by his courage at the siege of Nicopolis (1396) while on crusade. A struggle with Louis, Duke of Orléans, for control of the insane king of France, *Charles VI, ended when John had his rival murdered (1407). The heightened quarrel between the two factions, the Burgundians and the Orléanists (henceforward called Armagnacs, after Count Bernard of Armagnac, by whom they were reorganised), enabled ${ }^{*}$ Henry $\mathrm{V}$ of England to enter France and win the battle of Agincourt (1415), from which Burgundy was pointedly absent. After the fall of Rouen (1419) Burgundy and the Dauphin (as head of the royalist or Armagnac faction) became ostensibly reconciled, but at a meeting on Montereau Bridge, Burgundy was murdered by the Dauphin's followers in revenge for his assassination of the Duke of Orléans 12 years before.

John XXIII, St (Angelo Giuseppe Roncalli) (18811963). Pope 1958-63. Born near Bergamo, in northern Italy, the son of a peasant, he was ordained in 1904. As apostolic visitor to Bulgaria 1925-35, apostolic delegate to Greece and Turkey 1935-44, papal nuncio to France 1944-53, and the Holy See's observer at UNESCO in Paris 1946-53, he was remote from the Roman Curia, acquiring knowledge of other faiths and a breadth of vision that proved essential later. He wrote an important biography of St Carlo *Borromeo (5 volumes, 1936-52). In 1953 he became a cardinal and Patriarch (Archbishop) of Venice. After the death of *Pius XII, Roncalli was elected as Pope on the twelfth ballot and-at 77-apparently as a stop-gap. As Pope, his greatest achievement was the calling of the Second Vatican Council which first met in October 1962. (This was the first ecumenical council since Vatican I under *Pius IX in 1870.) The main aim of Vatican II was the promotion of Christian unity and the relationship of the Church with the modern world, including reforming the liturgy. Though by the simplicity and generosity of his character, Pope John became one of the best loved figures of his generation, he was a firm and shrewd administrator, deeply critical of the bureaucracy that surrounded him.

In 2000, he was beatified by *John Paul II. In 2001, his remains were brought from the Vatican grotto and displayed near the papal altar at St Peter's. Pope *Francis declared him a saint in July 2013.

John XXIII, Journal of a Soul. 1965; Hebblethwaite, P., John XXIII. 1984.

John XXIII. Title used by the anti-Pope Baldassarre *Cossa.

John, Augustus Edwin (1878-1961). British painter, born at Tenby, Wales. Gypsy life appealed to him and inspired such large and colourful pictures as The Mumpers, but he was best known as a portrait painter. His vigour, vitality and personality are reflected in, e.g. his Bernard Shaw (1914), the cellist Madame Suggia (1927), and Dylan Thomas (1937). John's paintings display few contemporary trends and owe almost everything to his own intuitive talent. He was elected ARA in 1921, RA in 1928, and awarded the OM in 1942. His sister, Gwen John 
(1876-1939), the model for and mistress of *Rodin, was distinguished for delicate, sensitive paintings, many of cats. His sailor son, Sir Caspar John (19031984), was First Sea Lord at the Admiralty 1960-63.

Holroyd, M., Augustus John. 1975.

John Chrysostom, St (347-407). Syrian prelate, born at Antioch. Ordained priest (386), he soon gained a great reputation as a preacher (Chrysostom = 'golden mouthed'). In 398 the emperor Arcadius secured his appointment as Patriarch of Constantinople. His outspoken preaching, however, which included attacks on the empress Eudoxia, earned the hostility of the court. He was temporarily exiled (403) and in 404 banished to Armenia. He died of exhaustion while walking to another place of exile in Pontus. Among his many works are $O n$ the Priesthood, an early treatise, and his Homilies, which give some idea of the eloquence for which he was famous. The liturgy of St Chrysostom has no authentic claim to the ascription. One of the four 'great Doctors of the Greek Church', he was a ferocious anti-Semite but had his admirers, including Cardinal *Newman.

John, Sir Elton Hercules (né Reginald Kenneth Dwight) (1947- ). English singer and composer. He attempted to mix pop and rock styles, toured widely and made films and records. A version of his greatest hit, Candle in the Wind, was performed at the funeral of *Diana, Princess of Wales. Knighted in 1998, he received a $\mathrm{CH}$ in 2017. More than 300 million recordings of his music were sold.

John of Gaunt (John Plantagenet), Duke of Lancaster (1340-1399). English prince, born in Ghent. Named for his birthplace, he was the fourth son of *Edward III and, having acquired the vast Lancastrian estates through his first wife, Blanche, was created Duke of Lancaster in 1362. After his second marriage, to Constance of Castile, he assumed the title King of Castile (1372), but having failed to establish himself he abandoned his claim when his daughter married (1388) the Castilian heir. When Edward III's powers began to fail, John of Gaunt virtually ruled the kingdom and continued in power during part of *Richard II's minority. In 1390 he was created Duke of Aquitaine and again was unsuccessful in establishing control of an overseas territory. In 1396 he married his mistress Catherine * ${ }^{*}$ wynford, and obtained from Richard legitimisation for her three sons, who took the name of ${ }^{*}$ Beaufort. (His great granddaughter, Margaret Beaufort, was the mother of ${ }^{*}$ Henry VII). He gave, for a time, powerful support to John *Wyclif to reduce Church privilege and was a patron of his brother-in-law Geoffrey *Chaucer. In *Shakespeare's Richard II John of Gaunt delivers a famous speech. He died in February 1399: by September his son Henry Bolingbroke had deposed Richard and, as *Henry IV, became the first Lancastrian king.

Armitage-Smith, S., John of Gaunt. 1964; Goodman,
John of Leyden (Jan Beuckelzoon) (1509-1536). Dutch anabaptist. An innkeeper of Leyden, he became a wandering preacher and established (1533) in Munster a 'Kingdom of Zion' in which he instituted polygamy and community of goods. Within a year the city was captured by the Bishop of Munster, and John and his chief supporters were tortured and killed.

John of Salisbury (c.1115-1180). English ecclesiastic, born in Salisbury. Educated in France and a pupil of *Abelard, he was secretary to Archbishop Theobald of Canterbury and went on missions to the Roman Curia. He wrote on Aristotle and was exiled to France by ${ }^{*}$ Henry II in 1163 . He wrote a life of *Becket, whose murder he witnessed, and pressed for his canonisation. John became Bishop of Chartres in 1176 and died there.

John of the Cross, St (San Juan de la Cruz) (1542-1591). Spanish mystic and monk. He joined St ${ }^{*}$ Teresa in trying to restore a stricter discipline for the Carmelite monks and nuns. This involved him in much persecution and eventually led to a split between the reformed houses of 'discalced' (i.e. shoeless or barefoot) and 'calced' Carmelites. Throughout the many vagaries of fortune resulting from the quarrel John was writing, in language combining great beauty of expression with spiritual ecstasy, the three great poems, with commentaries on them, upon which his fame rests: Dark Night of the Soul, The Spiritual Canticle and The Living Flame of Love. Together they describe the full range and depth of the mystical experiences of a contemplative life. He was canonised in 1726.

John Paul I (Albino Luciani) (1912-1978). Pope 1978. The son of poor parents, he was ordained a priest in 1935, became Bishop of Vittorio Veneto 1958-69, Patriarch of Venice 1969-78 and a cardinal in 1973 . On the death of $*$ Paul VI, he was elected Pope on the fourth ballot. Regarded as a theological conservative, but with wide pastoral experience and great personal simplicity, he ended some of the Vatican's traditional pomp. He died unexpectedly after a reign of 33 days.

John Paul II, St (Karol Wojtyla) (1920-2005). Pope 1978-2005. Born near Krakow, the son of an army lieutenant, he received a secular high school education, worked in a quarry and chemical factory, was active in Poland's anti-Nazi resistance and studied theology in an underground seminary. Ordained in 1946, he became a student chaplain and university teacher, writing many books and articles. Archbishop of Krakow 1963-78, created cardinal in 1967, he was elected Pope on the eighth ballot (24 Oct. 1978) after the sudden death of ${ }^{*}$ John Paul I, becoming the first non-Italian pope since *Adrian VI (elected 1523) and the youngest since *Pius IX. He made 104 papal journeys to 129 countries, and was the first pope to visit a mosque or synagogue. He reaffirmed traditional 
Catholic principles to large and enthusiastic congregations. His strong support for Lech *Walesa and Solidarity was a major factor in the collapse of Communism in Poland and, ultimately, the USSR. In 1993 he visited Russia and issued the encyclical Veritatis Splendor, a condemnation of liberalism, contraception and the exercise of private moral judgment. In March 2000 he asked for forgiveness for past 'errors and sins' committed by the Church against women, indigenous peoples, non-Christians and Jews, and visited Jordan and Israel, where he referred to the Holocaust. His pontificate was the second longest in Church history, after Pius IX, and he proclaimed a record 483 saints. In July 2013 his canonisation was announced by Pope *Francis.

Bernstein, C. and Politi, M., His Holiness. 1996.

John. Portuguese kings see João

Johns, Jasper (1930- ). American painter, sculptor and printmaker, born in Georgia. He grew up in South Carolina, and after army service moved to New York where he was influenced by Robert *Rauschenberg, his partner 1954-61, and held his first one-man exhibition in 1958. Johns used familiar, even banal, objects as the subjects of his paintings: numbers, alphabets, flags, maps, dart boards, hatched patterns with subtle tonal and textural variations between each work in the series. He often painted in encaustic, wax paints which were then baked, and made sculptures of familiar objects such as bottles and brushes in a coffee can. His painting Flag (1958), one of a series, was sold in 2010 for \$US 110 million. False Start (1959) had sold for \$US80 million in 2006. Map (1961) is at the Museum of Modern Art (MoMA), New York. He was awarded the Presidential Medal of Freedom in 2011.

Johnston, J., Jasper Johns: Privileged Information. 1996.

Johnson, Amy (1903-1941). English pioneer aviator, born in Hull. She became (1930) the first woman to fly alone from London to Australia (in 19 days). She made record flights e.g. from London to Cape Town and back (1932 and 1936) and, with her husband, James Allan Mollison (1905-1959), from London to the US (1933). During World War II she flew aircraft from factories to airfields and is believed to have drowned after parachuting into the Thames.

Johnson, Andrew (1808-1875). 17th President of the US 1865-69. Born in North Carolina, his parents were illiterate and he never went to school. Trained as a tailor, he set up his own business in Greenville, Tennessee. He soon became active in local politics as the champion of the 'little man', in local government, the state legislature and as a Member of the US Congress 1843-53. Governor of Tennessee 1853-57 and US Senator 1857-62, when the South seceded on the outbreak of the Civil War he declared for the Union and as Military Governor of Tennessee 1862-65 brought his state back to its federal allegiance. In 1864 he was chosen to run with Abraham * Lincoln as Vice President on a 'National Unity' ticket but served for only six weeks in that office (March-April 1865). On Lincoln's assassination, he assumed the Presidency. When the Civil War ended, faced with the difficult task of 'Reconstruction', he was convinced that the former slave states should themselves work out their relationship with the victorious North. He asserted that only those who had taken an active part against the Union should be penalised, a policy that incensed Republican radicals; both houses passed a Civil Rights Bill (1866) giving the vote to African-American males, which Johnson vetoed. He unsuccessfully opposed adoption of the 14th Amendment to the Constitution which granted citizenship to former slaves. Johnson's exaggerated selfimportance and attacks on the Republican leadership in Congress unleashed unprecedented antagonism. His dismissal (1867) of *Stanton, Secretary for War, gave his enemies the final excuse they needed for the president's impeachment. He was acquitted in the Senate, a single vote short of the two thirds needed to convict (35-19). In 1868 he sought the Democratic nomination for president but was heavily defeated. Very narrowly re-elected as a US Senator in 1875 , he died six months later. In 20 Presidential ranking lists by US historians and political scientists, Johnson scored No. 37 in the aggregate.

McKitrick, E., Andrew Johnson, a Profile. 1969; Trefousse, H. L., Andrew Johnson. A Biography. 1989; Stewart, D. O., Impeached. 2002.

Johnson, (Alexander) Boris (de Pfeffel) (1964- ). English journalist, historian and Conservative politician, born in New York City. Describing himself as 'a human melting pot', his ancestry was diverse, including English, Russian-Jewish, CircassianTurkish and King *George II. Baptised as Catholic, he became an Anglican at school but was nonpractising. Educated in Brussels and Eton, he read classics at Oxford, taught in Australia 1982-83, and became a controversial journalist and editor of The Spectator 1999-2005. He wrote the autobiographical novel Seventy-Two Virgins (2004), The Churchill Factor (2014), an adulatory work that emphasises his hero's eccentricities, and books on cars, Rome and London. MP 2001-08, 2015-, he was Mayor of London 2008-16. He led the successful 'Brexit' campaign in the June 2016 referendum, hoped to secure the prime ministership after David *Cameron resigned, but was scuttled by his former associates. Theresa *May appointed him as Foreign Secretary 2016-18, but bitter differences over her 'Brexit' strategy forced his resignation. When May was unable to carry her legislation for Britain to leave the EU, she resigned as party leader. Johnson won a ballot of party members in July and became Prime Minister 2019- . He won a general election (December 2019) with a comfortable majority and 43.6 per cent of the primary vote. Britain left the EU on 31 January 2020. The UK was sluggish in responding to Covid-19, and 
Johnson himself was infected, with days in intensive care; the death rate was among the highest in Europe. However, the vaccine roll-out was effective. In May 2021 he married, for the third time, at Westminster Cathedral. Johnson became the first Catholic Prime Minister of Great Britain, but could hardly be described as fervent. Johnson was both engaging and exasperating, an epitome of the 'post truth era' in politics, capable of the grand theatrical gesture but lazy, and weak on detail. He had a near fatal encounter with Covid himself. Damaged by revelations about 'Partygate' (in breach of Covid lockdown rules), he was fined, but survived a no confidence vote by Tory MPs (June 2022) 211 to 148 . In July he was forced to resign as Conservative leader when a significant number of ministers deserted him on the truth issue but he hung on to the prime ministership until September, when the party completed the labyrinthine process of choosing a successor. When Liz *Truss imploded, Johnson hoped to be restored. He won 100 nominations from MPs, which was a precondition for a contest, but withdrew in face of bitter hostility within the parliamentary party.

Purnell, S., Just Boris: The Irresistible Rise of the Political Celebrity. 2011.

Johnson, Hewlett (1874-1966). English clergyman. Called 'The Red Dean', he was ordained in 1905 after work in engineering and social welfare, and became Dean of Manchester 1924-31 and Dean of Canterbury 1931-66. He first visited Russia in 1938 and became famous for his uncritical praise of the Soviet system and of Marxist philosophy in The Socialist Sixth of the World (1939). After World War II he was active in the Peace movement.

Johnson, H., Searching for Light. 1968.

Johnson, Hiram Warren (1866-1945). American Republican politician. A reforming Governor of California 1911-17, he ran as Progressive candidate for Vice President in 1912 with Theodore *Roosevelt and was a US senator 1917-45. Johnson was a radical and an isolationist who opposed US entry to the League of Nations (1919) and United Nations (1945) but supported Franklin *Roosevelt's New Deal.

Johnson, Jack (John Arthur) (1878-1946). American boxer. By beating Tommy Burns (1908) in Sydney he became the first black world professional heavyweight champion. He lost the title to Jess Willard (1915).

Johnson, Lyndon Baines ('LBJ') (1908-1973). 36th President of the US 1963-69. Born in Stonewall, Texas, son of a state legislator, he was educated at the South West State Teachers College, taught briefly, then became a congressman's secretary. In 1934 he married Claudia Alta ('Lady Bird') Taylor (19122007), later a successful investor in communications. As a strong supporter of the 'New Deal', and protégé of Sam *Rayburn, he directed the National Youth
Congressman 1937-49 and served briefly in the navy (1941-42), visiting Australia, New Zealand and New Guinea. US Senator 1949-61, and Democratic Leader 1953-60, during *Eisenhower's presidency, he was a master tactician who built coalitions of support across party lines to defeat or promote legislation. After being defeated for the Democratic presidential nomination in 1960 by John F. *Kennedy, he agreed to take the vice presidential nomination, and served (unhappily) 1961-63. On Kennedy's assassination in Dallas, in Johnson's presence, he was immediately sworn in as President and pledged commitment to the 'Great Society'.

The Civil Rights Act (July 1964) outlawed major forms of discrimination on the basis of race, enthnicity and gender. He also promoted the Economic Opportunity Act ('war on poverty', 1964). Despite the deep unpopularity of desegregation measures in the South, Johnson won the 1964 election overwhelmingly, with 61.5 per cent of the popular vote and was the last Democrat candidate for president to win a plurality of white voters. (Barry ${ }^{*}$ Goldwater won his own state of Arizona and five old Confederate states.) The Voting Rights Act (August 1965) implemented, at last, the provisions of the 15th Amendment to the US Constitution (1870), guanteeing equal voting rights for all citizens, but was ignored in practice for nearly a century. Johnson also secured a measure of gun control (1968). Johnson's courage on civil rights, which ran counter to his record as a Texas legislator, destroyed the Democratic Party's iron grip on the South.

In his most difficult and continuing foreign problem, the war in Vietnam, he greatly increased the scale of American military participation. His credibility eroded over the Vietnam War and he became a symbol of national frustration and division. In March 1968 he withdrew from the presidential contest and secured the Democratic nomination for his Vice President, Hubert ${ }^{*}$ Humphrey. Humphrey was defeated by Richard *Nixon, with George *Wallace winning five southern states. Johnson retired to his ranch at Stonewall, wrote memoirs, The Vantage Point (1971) and died of heart disease. In 18 Presidential rankings by US historians and political scientists, LBJ scored No. 13 in the aggregate.

Caro, R. A., The Years of Lyndon Johnson. 1982, 1990, 2002, 2012, incomplete; Dallek, R., Flawed Giant. 1998.

Johnson, Philip Cortelyou (1906-2005). American architect, born in Ohio. Educated at Harvard, he directed the architecture department of New York's Museum of Modern Art 1930-36 and 1946-54, and became an influential critic, patron and propagandist of the 'International Style' of *Gropius and *Mies. In the 1930s he expressed a homoerotic enthusiasm for ${ }^{*}$ Hitler and the Nazis, a position he later resiled from. As an architect he won recognition with a 'glass house' built for himself at New Canaan, Conn. (1949). Further buildings were added in his grounds (to 1965). 
Johnson's designs, vehemently attacked as 'frivolous' or 'neo-Fascist', emphasised elegance and style. $\mathrm{He}$ saw architecture as primarily an art form and rejected functionalism, with its strong social concern. Among his major public buildings were the IDS Center at Minneapolis (1973), extensions to the Boston Public Library (1973), the twin towers at Pennzoil Place, Houston (1976) and the Avery Fisher Hall interior, New York (1976), all with John Burgee. He was awarded the first Pritzker Prize for Architecture in 1979.

Schulze, F., Philip Johnson. 1994; Lamster, M., The Man in the Glass House: Philip Johnson, Architect of the New Century. 2019.

Johnson, Samuel (1709-1784). English man of letters, born at Lichfield. Son of a bookseller, as a boy he suffered from scrofula, the 'King's evil', for which he was taken to London to be 'touched' by Queen *Anne. He left Pembroke College, Oxford in 1729, without a degree, after a breakdown, compounded by poverty and his sense of isolation, but Oxford awarded him an Honorary MA in 1755 and a DCL in 1775. (He received an Honorary LL.D from Trinity College, Dublin in 1765.) He taught and wrote until his marriage in 1735 to Elizabeth ('Tetty') Porter, née Jervis (1689-1752), a widow, provided him with over $£ 600$, with which he set up a small school near Lichfield. When this failed he set out (1737) with one of his pupils, David *Garrick, to seek his fortune in London. His first important poem London (1738) appeared anonymously and it was only after several years as a hack writer for the Gentleman's Magazine, to which he contributed poems, essays and parliamentary reports, that he achieved some degree of fame with his life of his friend, Richard *Savage (1744). The plan of $A$ Dictionary of the English Language appeared in 1749 , addressed to Lord ${ }^{*}$ Chesterfield, who received it coolly and was later suitably snubbed. This great work was eventually published in 1755 and an abridgement in 1756. Meanwhile an old play of Johnson's, Irene, was staged in 1749 at Drury Lane, through Garrick's kindness, but only ran for nine nights. In the same year came The Vanity of Human Wishes, a satire modelled on one by *Juvenal. Shortly afterwards he began to edit The Rambler 1750-52, which was followed by The Idler 1758-60. The contents of both periodicals were written almost entirely by himself and consisted mainly of essays on literary and social themes. To pay for his mother's funeral he also wrote, 'in the evenings of a single week' a most successful potboiler, Rasselas, Prince of Abyssinia, a novel of which the prince's vain journey in quest of happiness provides the theme. In 1763 Johnson escaped for the first time 'from the tyranny of writing for bread' by the grant of a crown pension of $£ 300$ a year, and was at last able to enjoy what to him was the greatest pleasure in life, the company and conversation of congenial friends. At this time that most brilliant and sympathetic of recorders, James *Boswell, entered his circle of friends - one of the happiest coincidences of literary history. Other members of the 'Club' included
${ }^{*}$ Reynolds, *Burke, *Goldsmith, *Garrick, *Gibbon, Adam *Smith and Boswell's rival biographer, Sir John Hawkins. Johnson's wife had died in 1752. In the last 20 years of his life he found great pleasure in the friendship of the lively Mrs Thrale, in whose home he was welcomed as an almost perpetual guest.

During these later years Johnson's literary works included a comprehensive edition of *Shakespeare's plays (1765), a notable critical achievement, $A$ Journey to the Western Islands of Scotland (1775), a parallel account to one made by Boswell, his companion on the tour, and finally the work which showed his full maturity as a critic, Lives of the Poets (1779-81). A chronic melancholic, markedly eccentric in his mannerisms and probably suffering from Tourette's Syndrome, he was always fearful of madness. Few writers have so dominated the literary scene as did Johnson in later life and his burial at Westminster Abbey was tribute not only to his work but to a character which, however rugged, was generous-hearted, virtuous, just and (mostly) marked by commonsense.

Boswell, J., The Life of Samuel Johnson, LL.D. 1791; Wain, J., Samuel Johnson. 1974; Meyers, J., Samuel Johnson. The Struggle. 2008; Nokes, D., Samuel Johnson. A Life. 2009.

Johnson, William Eugene (known as 'Pussyfoot') (1862-1945). American temperance reformer. His nickname referred to his methods of suppressing illicit traffic in liquor in Indian territory where he served as a special officer (1908-11). He was the dominating figure of the Anti-Saloon League (1912-20). The passage of the 18th constitutional amendment (1920) made prohibition mandatory throughout the US until it was repealed (1933).

Johnston, Sir Harry Hamilton (1858-1927). British colonial administrator. A self-trained botanist, zoologist, linguist and journalist, he led the Royal Society's expedition (1884) to Mount Kilimanjaro and became a protégé of Lord *Salisbury, pushing hard for imperial expansion in Africa. As ConsulGeneral in Mozambique 1889-91, he worked with Cecil *Rhodes and played a central role in the British acquisition of Malawi (formerly Nyasaland) and large parts of Zambia. He also served in Tunisia, Uganda and the Cameroons and wrote 30 books.

\section{Jokowi (contraction of Joko Widodo) see Widodo, Joko}

Joliot-Curie, (Jean) Frédéric (1900-1957). French physicist. He worked at the Radium Institute in Paris and in 1926 married his co-worker Irène *Curie (daughter of Pierre and Marie ${ }^{*}$ Curie), adding her name to his. In 1933 he and his wife, by bombarding boron with accelerated alpha particles, discovered that radioactivity could be artificially induced in nonradioactive substances. They later also discovered that there is a net emission of neutrons during nuclear fission. They were awarded the Nobel Prize for 
Chemistry (1935). Irène died (1956) of burns caused by radiation from radium. He built the first French atomic reactor (1948) and received the Stalin Peace Prize (1951).

Biquard, P. (trans. Strachan. G.), Frédéric Joliot-Curie: The Man and his Theories. 1965.

Jolley, (Monica) Elizabeth (née Knight) (19232007). Australian novelist, born in Birmingham. She migrated to Perth in 1959, working as a nurse, cleaner and teacher. Her novels include $M r$ Scobie's Riddle (1983), The Well (1986), The Sugar Mother (1989) and The Orchard Thieves (1995).

Jolson, Al (originally Asa Yoelson) (1886-1950). American singer and entertainer, born in Russia. He emigrated to the US c.1895, began his career in the New York variety theatre in 1899 and became successful by bringing a powerful voice and melodramatic style to sentimental songs, including Mammy. His film The Jazz Singer (1927) was the first to use sound so that the plot could progress through dialogue.

Freedland, M., Jolson. 1972.

Jonah (fl. c.760 BCE). Jewish prophet and missionary. The Book of Jonah relates, metaphorically, how he was summoned by God to go to Nineveh, the capital of Assyria, to preach repentance. To evade this mission he sailed for Tarshish, but a storm convinced the crew that a bearer of ill luck was among them. They established, by casting lots, that this was Jonah and threw him overboard. He was swallowed by a great fish which spewed him up three days later, alive, and he went to Nineveh, whose citizens he induced to repent.

Jones, David (1895-1974). English poet and artist. His major work In Parenthesis (1937) records, in a melange of blank verse and prose, his experiences and feelings during World War I.

Jones, Ernest (1879-1958). British neurologist and psychiatrist, born in Wales. He was *Freud's pupil, supporter and biographer.

Jones, Inigo (1573-1652). English architect, born in London. He was a carpenter and painter in London, then travelled extensively in Italy and became deeply impressed by the buildings of *Palladio, whose style, with its classical features, he introduced to England. Of his works his finest is held to be the Banqueting House at Whitehall (1619-22), the only part of the palace to survive. The elaborate plans he made (c.1638) for rebuilding the rest of the palace were never executed. Another masterpiece is the Queen's House, Greenwich, which reveals his liking for centrally planned cubic buildings, a characteristic of his work elsewhere; the famous double cube room at Wilton is his design. In addition to his architectural work he planned the layout of Lincoln's Inn Fields and Covent Garden. He was Surveyor-General of works
1615-43, but both *James I and *Charles I employed him to design elaborate sets for court masques as much as for building. As a theatrical designer he is said to have introduced the proscenium arch and movable scenery. Inigo Jones was the first in England to make a full-time profession of architecture.

Orgel, S. and Strong, R., Inigo Jones. 1973.

Jones, James (1921-1977). American novelist, born in Illinois. His From Here to Eternity (1951), about army life in Hawaii just before Pearl Harbor, became a successful film (1953) with Burt Lancaster, Montgomery Clift, Deborah Kerr and Frank * Sinatra and won eight Oscars.

Jones, Mary Harris ('Mother Jones') (1830-1930). American labour organiser, born in Ireland. After the deaths of her family, she began her 50-year career as a trade union organiser in 1867 and was a founder of the Industrial Workers of the World (IWW) in 1905.

Jones, Owen (1809-1874). English architect, writer and designer, born in London. Superintendent of works for the Great (London) Exhibition of 1851, he wrote The Grammar of Ornament (1856) which promoted design quality in mass produced articles, and created interest in Moorish architecture and decoration.

Jones, (John) Paul (1747-1792). American sailor, born in Scotland. His name was John Paul until he changed it, probably in 1773. Paul Jones, who had served in a slaver for five years, had already visited America several times before offering his services to the American colonists who, to aid their bid for independence, were in 1775 fitting out a small fleet. In 1778 in a brig of 18 guns he made several raids on the Scottish coast. He fired a ship and spiked 36 guns at Whitehaven in Cumberland and captured a sloop in Belfast Lough. In the following year, in command of a small French squadron in American service, he captured two British men-of-war in a fierce encounter off Flamborough Head, Yorkshire. For this he was awarded a congressional medal. In 1788 he served for a year in the Black Sea as a Rear Admiral in *Catherine the Great's navy, then at war with the Turks. He died in Paris, but in 1905 his remains were taken to the US, where he is regarded as a national hero.

Morrison, S. E., John Paul Jones. 1960.

Jones, Robert (Bobby) Tyre (1902-1971). American amateur golfer. He competed in the US amateur championship at the age of 14 and later won the US open championship four times and the British open championship three times. He was the outstanding golfer of the 1920-30 decade.

Jones, Sir William (1746-1794). English judge and comparative philologist, born in London. Son of a mathematician who promoted use of the symbol pi $(\pi)$, educated at Harrow and Oxford, he mastered Latin, Greek, Persian, Arabic, Sanskrit and Bengali 
and became a judge in the Bengal Supreme Court 1783-94. With the encouragement of Warren ${ }^{*}$ Hastings, he founded the Asiatic Society (later the Asiatic Society of Bengal) in 1784 to encourage oriental research, including Sanskrit. He proposed the hypothesis, now generally accepted, of a common origin for a group of languages, which Thomas *Young later called Indo-European (1813). He died in Calcutta (Kolkota).

Franklin, M., Orientalist Jones: Sir William Jones, Poet, Lawyer and Linguist, 1746-94. 2013.

Jonson, Ben (1573-1637). English dramatist and poet. He had a good education at Westminster School, but was a bricklayer, soldier and actor before taking to writing. Eighteen of about 30 of his plays survive. Every Man in his Humour (1598) was his first success (the word 'humour', as always in that period having a physical as well as a psychological connotation). In the same year he was imprisoned and his goods confiscated for killing an actor in a duel. The Poetaster (1601), though set in ancient Rome, was an attack on ${ }^{*}$ Dekker and ${ }^{*}$ Marston which caused offence. His first tragedy Sejanus was acted by *Shakespeare's company in 1603 , but neither this nor a later tragedy from Roman history, Catiline (1611), achieved much success. In collaboration with ${ }^{*}$ Chapman and Marston he wrote Eastward Ho! (1605), for which he was briefly imprisoned for disparaging the Scots. His masterpieces are Volpone or The Fox (1606), a savage attack on human greed, The Alchemist (1610), a lively study of gullibility, and one of his greatest successes, Bartholomew Fair (1614), notable for its vivid picture of low life in London. From 1603 he was also busily employed in writing masques for the court of *James I, some staged by Inigo *Jones. They include The Masque of Beauty (1608), and The Masque of Queens (1609). In 1616 he was given a pension and his literary pre-eminence was fully acclaimed. His many beautiful lyrics include Drink to me only with thine eyes. Jonson was forthright and quick-tempered, but his generosity and sincerity endeared him to a wide circle of friends, including *Donne, ${ }^{*}$ Bacon and Shakespeare and to his patrons, the ${ }^{*}$ Sidneys.

Chute, M., Ben Jonson of Westminster. 1953; Herford, C. H., and Simpson. P. and E. (eds). Works. 2 vols, 1925, 1951; Donaldson, I., Ben Jonson. 2013.

Joplin, Scott (1868-1917). American composer, born in Texarkana. He worked in St Louis, Chicago and New York, wrote The Maple Leaf Rag (1899) and a ragtime opera $A$ Guest of Honour (1900). His second opera Treemonisha (1909) was never performed in his lifetime and his music was forgotten until the film The Sting (1973) revived interest in ragtime. His music was awarded a Pulitzer Prize in 1975.

Jordaens, Jakob (1593-1678). Flemish painter. He lived and worked in Antwerp at the same time as *Rubens, whom he admired and assisted, and *Van Dyck. He did not equal these masters due to a certain harshness or crudity in his colour and technique. He peopled even religious and mythological paintings with the earthy, vigorous bourgeois or peasant types he encountered in everyday life.

Joseph (Yosef) (fl. c.1850 BCE). Hebrew patriarch. The elder son of *Jacob and Rachel, he was his father's favourite and his jealous brothers sold him into slavery in Egypt. There he gained a position of trust in the household of his master Potiphar. Resisting the blandishments of Potiphar's wife he won the pharaoh's favour and rose to be chief administrator, established a great granary and when his brothers came to Egypt to buy grain in the years of famine forgave them and secured a home for the family in the land of Goshen. His sons Ephraim and Manasseh became the ancestors of two of the tribes of Israel.

Joseph (Yosef), St (d. before 30 CE). Jewish carpenter. Born of the *Davidic line, he was a carpenter (or builder?) in Nazareth and a widower when he married *Mary, the mother of *Jesus. He is referred to in the gospels of Matthew, Luke and John, but not in Mark or the Pauline epistles. He presumably died before the crucifixion and is the patron saint of working men.

Joseph I (Josef Jakob Ignaz Johann Anton Eustachius von Habsburg) (1678-1711). Holy Roman Emperor 1705-11. Son of *Leopold I, he was King of Hungary from 1687, and Archduke of Austria, King of Bohemia and Croatia 1705-11. Despite the victories of his general Prince *Eugène of Savoy, he lost the War of the Spanish Succession to France.

Joseph II (Josef Benedikt Anton Michel Adam von Habsburg-Lothringen) (1741-1790). Holy Roman Emperor 1765-90, Archduke of Austria, King of Hungary and Bohemia 1780-90. Born in Vienna, he was the fourth child but first son of ${ }^{*}$ Maria Theresa, Archduchess of Austria and the Emperor *Franz I. In 1765 he succeeded as Emperor and ruled the Habsburg domains with his mother, but until she died his authority was limited to military and foreign affairs. After her death (1780) he showed himself as an 'enlightened despot' by attacking the power of the Church, reducing the clergy from 63,000 to 27,000 and issuing an edict (1781) granting complete religious toleration. He also abolished serfdom, greatly extended the facilities for general and scientific education, hospital treatment, care of orphans and the insane, and reformed taxation and the criminal law (abolishing the death penalty). He tried to establish German as a common language throughout his dominions. He was essentially a secular, utilitarian social engineer, anticipating *Bentham. His abolition of coffin burial (for entirely practical reasons) provoked a sense of outrage. To achieve these measures he centralised government in Vienna and extended in every direction the powers of the state, for which, however, he made it clear that he alone was entitled to speak. By this mixture of radicalism and despotism he antagonised many of his subjects, not 
only clergy, nobles and local administrators but all the inhabitants of the non-German lands. In 178788 there was an outright rebellion against Joseph's laws in the Austrian Netherlands (Belgium) and the beginning of the French Revolution weakened his position generally after 1789 . Joseph saw little of his chancellor, Prince *Kaunitz, and the Empire fared badly in war and foreign relations during his 10-year reign. He died deeply disillusioned.

Jones, B. O., Joseph II: Enlightenment in Politics. 1966; Beales, D., Joseph II. 2 vols, 1987, 2009.

Joseph, Keith Sinjohn, Baron Joseph (1918-1994). English politician. A Fellow of All Souls, Oxford, he was a Conservative MP 1956-87, Minister for Health and Social Services 1970-74, Secretary of State for Industry 1979-81, and for Education and Science 1981-86. A strong 'free marketeer' he drew inspiration from Adam * Smith and Milton *Friedman and promoted Margaret *Thatcher.

\section{Joseph (José), King of Spain see Joseph *Bonaparte.}

Joseph, Père (François Leclerc du Tremblay, known as 'Eminence Grise', 'Grey Eminence') (1577-1638). French Capuchin friar. Advisor and confidant of Cardinal *Richelieu, this position led to his nickname (from the colour of his habit), now applied to any unofficial power behind the throne. Richelieu used him from 1612 in all the most difficult negotiations of a critical period that included the Thirty Years' War. Aldous *Huxley's Grey Eminence gives a fascinating account of this somewhat mysterious personage.

Joseph of Arimathea (fl. 1st century CE). Samaritan merchant. He owned the tomb in which *Jesus was buried. According to legend he was the founder of Glastonbury as a Christian shrine (where he is reputedly buried). The Glastonbury thorn which flowered at Christmas was believed to be his staff plunged into the ground.

Joséphine (Marie Josèphe Rose Tascher de la Pagerie, later Bonaparte) (1763-1814). Empress-consort of the French 1804-09. Daughter of a planter in Martinique, she married (1779) Alexandre, Vicomte de *Beauharnais, who was guillotined in 1794 . After his death Josephine became one of the liveliest members of the gay society that came to the surface after the ending of the Terror. A member of the Directory, *Barras, whose mistress she had been, introduced her to *Napoléon Bonaparte. She married him in 1796 and during the Consulate and Empire she was the centre of his court. As she bore him no children, frustrating his dynastic ambitions, he divorced her (1809) to marry the Austrian archduchess ${ }^{*}$ Marie Louise. Josephine retired to Malmaison. Children of her first marriage included Eugène *Beauharnais and Hortense (17831837) who married Louis *Bonaparte and was mother of *Napoléon III.

Knapton, E. J., Empress Josephine. 1963; Aronson, T.,
Napoleon and Josephine: A Love Story. 1990; Bruce, E., Napoleon and Josephine: An Improbable Marriage. 1995; Delorme, E. P., Josephine: Napoleon's Incomparable Empress. 2002; Castlelot, A., Josephine. 2009.

Josephson, Brian David (1940- ). British physicist. He shared the 1973 Nobel Prize for Physics for his work on superconductivity in metals leading to the 'Josephson effect' - a flow of current between two pieces of super-conducting material separated by a thin layer of insulation. He was a professor of physics at Cambridge 1974-2007.

Josephus, Flavius (Yosef ben Mittatyahu) (c.37-c.100). Jewish priest, soldier and historian, born in Jerusalem. Descended from a royal and priestly line of the Maccabees, and a Pharisee, at first he took an active part in the Jewish revolt against the Romans (66) and was made Governor of Galilee. He fought valiantly but, after being captured, he sought and won the favour of *Vespasian (whose family name he adopted), and was with *Titus at the siege of Jerusalem. When the revolt was crushed he was rewarded by a grant of confiscated land, but spent the rest of his life in Rome. There he wrote in halting Greek his History of the Jewish War, the main authority for the events of Jewish history in the first century CE and of the Jewish war (66-70), and The Antiquities of the Jews (written in 93), a history of the Jews from the Creation up to the period covered by his earlier work. His Autobiography is mainly concerned to refute criticism of his own activities before and during the revolt. His knowledge of the country, its religion, politics and people, give the books a particular value except where self defence demands a biased account.

Williamson, G. A., The World of Josephus. 1964.

Joshua (fl. c.1300 BCE). Hebrew leader. Son of Nun of the tribe of Ephraim, he was an assistant to ${ }^{*}$ Moses, one of 12 sent out by him to spy the promised land of Canaan. He succeeded Moses as leader of the tribes of Israel. The Book of Joshua, first in the Old Testament after the Pentateuch, describes the various episodes of the conquest of Canaan.

Jospin, Lionel Robert (1937- ). French Socialist politician. A bureaucrat and academic, he was a deputy 1981-88, Minister for Education 1988-91 and candidate for president in 1995 . He became Premier 1997-2002, following a Socialist victory in the National Assembly elections. He was eliminated in the first round of the 2002 presidential election.

Josquin des Prez (c.1450-1521). French (or Burgundian) composer, born probably in Hainaut. A pupil of Johannes * Ockeghem, a master of contrapuntal technique, he was a chorister in Milan, worked for the Sforzas, and sang in the Sistine Chapel in Rome 1486-95. Choirmaster at Cambrai Cathedral 1495-99, he served *Louis XII of France 1499-1516, and became canon of the collegiate church of $\mathrm{St}$ Quentin, Condé. He published 17 Masses, at least 
100 motets (including Ave Maria, plena gratia ...) and many secular songs. The first composer to benefit from the invention of printing, he was a celebrity in his lifetime, regarded as a genius in counterpoint and expressive melody. He was forgotten during the 17 th century and partly rediscovered through Charles Burney's History of Music (1776-89).

Joubert, Petrus Jacobus (1834-1900). South African soldier. As Commandant General of the forces of the Transvaal, he defeated the British in the war of 188081 and *Jameson in the Raid of 1896. After directing the siege of Ladysmith in the Boer War he fell ill and died.

Jouhaux, Léon (1879-1954). French trade union leader. As General Secretary 1909-47 of the French General Confederation of Labour (CGT), he played the leading role in promoting the trade union movement in France. He was imprisoned by the Germans in World War II and won the Nobel Peace Prize (1951).

Joule, James Prescott (1818-1889). English physicist. Son of a Salford brewer, he had little formal training but was tutored by ${ }^{*}$ Dalton and showed exceptional aptitude for experimental work. He investigated the transformation of heat into other forms of energy and was one of the first to establish the principle of the conservation of energy. He established (1840) the law concerning the relationship between the heat developed in an electrical circuit and the strength of the current and resistance. He discovered (1843) a method for measuring the mechanical equivalent of heat, and published (1851) the first calculation of the average velocity of a gas molecule. His theories were initially rejected by the Royal Society but in 1850 he was elected a Fellow and awarded its Royal (1852) and Copley (1856) Medals. He is commemorated by the unit of energy, the joule.

Jowett, Benjamin (1817-1893). English classical scholar. A Fellow of Balliol College, Oxford from 1838, and Master 1870-93, he managed to attract and influence a succession of brilliant undergraduates who, for a generation and more, came to exercise an intellectual domination in the academic and political worlds. His own reputation as a possessor of universal knowledge depended as much upon his personality as upon his excellent, but at times inexact, translations of *Plato, *Thucydides and *Aristotle.

Faber, G., Jowett: A Portrait with a Background. 2nd ed. 1958.

Jowitt, William Allen Jowitt, 1st Earl (1885-1957). English lawyer and Labour politician. Educated at Oxford, he became a brilliant advocate and crossexaminer. He had broken terms as MP, 1922-24; 1929; 1929-31; 1939-45, first as a Liberal, then National Labour and Labour after 1939. He served as Attorney-General 1929-32, Solicitor-General
1940-42, first minister of National Insurance 1943-45 and finally Lord Chancellor under *Attlee 1945-51 and Labour's leader in the House of Lords $1951-55$.

Joyce, James (Augustine Aloysius) (1882-1941). Irish novelist and poet, born in Dublin. He was one of 10 surviving children, from 15 births, in the family of a gregarious, hard drinking and profligate civil servant. His mother died in 1903. Educated in Jesuit schools and at University College, Dublin, Joyce became an expert linguist, mastering French, Italian, Latin, modern Greek, German, Norwegian, and some Hebrew, Sanskrit and Arabic. After graduating from UCD in 1903 he attempted to study medicine in Paris for a few months before returning to Dublin. On 16 June 1904 he met Nora Barnacle (1884-1951) and lived with her for the rest of his life. They married in London in 1931.

Joyce both loved and hated the life of Dublin which featured prominently in all his prose works. $\mathrm{He}$ lived abroad in self-imposed exile (apart from two brief return visits 1909-10; 1912-13) and distanced himself from the 'Celtic Twilight' of modern Irish letters. He lived in Trieste 1905-15, Zürich 1915$20 ; 1940-41$ and Paris $1920-40$. For much of his life he had to struggle with poverty, acute eye disease (cataracts and episcleritis) and the schizophrenia of his daughter Lucia.

A short collection of poems Chamber Music (1907), was followed by the short stories, Dubliners (1914: banned in Australia 1929-33), the semiautobiographical novel $A$ Portrait of the Artist as a Young Man (1916), in which the central character is Stephen Dedalus (named for the Greek craftsman Daedalus), and a play Exiles (1918). He had an early enthusiasm for *Ibsen.

An English patron of literature and political activist, Harriet Shaw Weaver (1876-1961), generously financed Joyce from 1917 until his death. He was strongly encouraged by Ezra *Pound. His other supporters included H. G. *Wells, W. B. *Yeats, Sean ${ }^{*}$ O'Casey and T. S. *Eliot; Bernard *Shaw, E. M.* Forster and D. H. *Lawrence were sceptics. He had one inconsequential meeting with *Proust.

Ulysses (1922) was his first masterpiece. Its 18 'episodes', all named for chapters in *Homer's Odyssey, describe in minute detail and unprecedented realism a day in the life of Dubliners from 8.00 am to past midnight on Thursday, 16 June 1904 (now celebrated as 'Bloomsday'). The central characters are Leopold Bloom (parallel to Ulysses/Odysseus), a Hungarian Jew and unsuccessful advertisement canvasser in Dublin, his wife Molly Tweedy Bloom (Penelope), and, in a second coming, their scholarly friend Stephen Dedalus (Telemachus), representing Joyce himself. Joyce makes masterly use of the technique of 'stream of consciousness', words and sentences following one another by an automatic process of 
mental association. Some of the associations, such as similarity of sound (e.g. rhymes and puns) are fairly obvious; some derive from telescoping one or more words or ideas; others, springing from the width and depth of the author's knowledge, are beyond the grasp of most readers. Ulysses abounds in symbolism. Much of Joyce's writing has several simultaneous levels of meaning (e.g. 'Sheashell ebb music wayriver she flows'). He expanded the scope of the modern novel by projecting his characters against the history of western civilisation, revealing his encyclopaedic knowledge of history, mythology, theology, literature, psychology and music.

Ulysses, serialised in parts in The Little Review 1918-20, was published as a single volume in Paris in 1922 by Sylvia Beach's firm Shakespeare \& Co. It was banned as obscene in the United States and the United Kingdom until 1934. Australia lifted its ban in 1937, reimposing it in 1941 and (in theory) it became freely available only in 1953. Joseph Strick's film Ulysses (1967), with Milo O'Shea as Leopold Bloom, gives a faithful account of the novel but had very limited release and was restricted in Ireland until 2000. (It is available online.)

Pomes Penyeach (1922) was Joyce's only completed work between 1922 and 1939. Samuel *Beckett was Joyce's literary assistant and translator 1928-30.

Finnegans Wake, his second masterpiece, took 17 years to complete. This work records the dreams experienced during a single night by Humphrey Chimpden Earwicker (HCE), a Dublin hotel-keeper. His wife is Anna Livia Plurabelle (ALP) and their children are Shem the Penman, Shaun and Issy (Iseult/ Isolde). Fragments appeared in 1924 and 1926, and in 1929 whole chapters were published in the literary review transition under the title Work in Progress. 'Anna Livia Plurabelle' (1930) and 'Haveth Childers Everywhere' (1931) were published in book form by Faber and Faber. Joyce's 1929 recording of an excerpt from 'Anna Livia Plurabelle' can be downloaded on YouTube. The complete novel was published by Faber and Faber in May 1939. Even some of Joyce's supporters thought he had gone too far.

Joyce created a multi-dimensional, pun-strewn, language of his own in an attempt to express the complexity and timelessness of the dream-world e.g. 'Rats! bullowed the Mookse most telesphorously, the concionator, and the sissymusses and the zozzymusses in their robenhauses quailed to hear his tardeynois at all for you cannot wake a silken nouse out of a hoarse oar' ( $F W$, p. 154). He quotes from 65 languages. A single question in a radio quiz show ( $F W$, pp.126139) runs to 4646 words, the answer 'Finn MacCool' two. Nevertheless, the text can make readers laugh, cry or recoil even when it is not fully understood.

Finnegans Wake was influenced by the novels of * Swift and ${ }^{*}$ Sterne and *Vico's cyclical theory of history in man. The novel ends with an incomplete sentence ('A way a lone a last a loved a long the ...') which then runs into its first words ('riverrun, past Eve and Adam's, from swerve of shore to bend of bay, brings us by a commodius vicus of recirculation back to Howth Castle and Environs.'), suggesting that life is part of an endless cycle.

Finnegans Wake has been translated into French, Italian, German, Dutch, Spanish, Hungarian, Polish, Chinese, Japanese and Korean.

Joyce had created his own language, almost a pre-language, more in common with music than conventional linear narrative. T. S. Eliot called Joyce 'the greatest master of the English language since *Milton'.

Joyce died in Zürich after surgery for a perforated ulcer and is buried there. Unlike Yeats, his remains were not repatriated; however, Dublin commemorates many places associated with Joyce and his characters. He remained a British subject.

Joyce was one of a long list of great writers who failed to win the Nobel Prize for Literature: Ibsen, ${ }^{*}$ Tolstoy, Mark *Twain, *Zola, *Hardy, *James, *Strindberg, ${ }^{*}$ Chekhov, *Conrad, *Wells, *Orwell, *Levi, *Gorki, ${ }^{*}$ Proust, ${ }^{*}$ Musil, ${ }^{*}$ Woolf, ${ }^{*}$ Kafka, Pound, ${ }^{*}$ Borges, *Nabokov, *Malraux, *Greene, *Auden, Arthur ${ }^{*}$ Miller and Tennessee ${ }^{*}$ Williams.

Joyce, S., My Brother's Keeper. 1958; Ellmann, R., James Joyce. 1959, revised 1982; Bowker, G., James Joyce: A Biography. 2011.

Joyce, William (known as 'Lord Haw-Haw') (1906-1946). Irish-American propagandist, born in Brooklyn. After being a speaker and 'storm trooper' in Fascist organisations in the East End of London, he went to Germany (August 1939) and became the principal Nazi broadcaster in English during World War II, owing his nickname to his unpleasant sneering voice. After the war he was captured, being held subject to British jurisdiction on the tenuous grounds that he had secured a British passport, was tried, and hanged for treason.

Juan de Austria, Don (né Jeromin, known in English as Don John of Austria) (1547-1578). Spanish soldier and prince, born in Regensburg. The illegitimate son of the emperor ${ }^{*}$ Charles $\mathrm{V}$ and Barbara Blomberg, he was brought up in Spain and given princely rank by his half-brother ${ }^{*}$ Felipe II. His most notable exploit, when in command of the combined fleet, was to defeat the Turks at Lepanto (1571). In 1573 he captured Tunis. Governor of the Habsburg Netherlands 1576-78, he died suddenly of fever near Namur and is buried in the Escorial. The first opera written in Australia was Don John of Austria (1847) by Isaac Nathan. 
Juan Carlos I (Juan Carlos Alfonso Víctor María de Borbón y Borbón) (1938- ). King of Spain 19752014. Grandson of *Alfonso XIII, and son of the Infante Juan (1913-1993), he was born in Rome. General *Franco nominated him, in preference to his father, as his successor in 1969, and he helped in the transition to democracy (*Suárez). In February 1981, he opposed a military coup, which proposed to restore authoritarian rule and called for preservation of democracy. He abdicated in favour of his son *Felipe (Philip) VI. After financial corruption was exposed, in August 2020 he exiled himself to Abu Dhabi. He was an avid yachtsman and killer of wild life.

Juarez, Benito Pablo (1806-1872). Mexican president. A Zapotec Indian, he came as a servant to Oaxaca where, having married his employer's daughter and graduated in law, he eventually rose to be State Governor 1847-52. As minister of justice in a radical government he attempted to curb the power of the Church and the army. In 1857 the liberals declared him president but the conservatives rose against him and forced him to retire to Vera Cruz. He reentered Mexico City in 1860 and was confirmed as President by the election of 1861 . Suspension of interest payments led to a French invasion and the establishment of *Maximilian of Austria as Emperor. After Maximilian's execution (1867) Juarez was again elected President and resumed his program of reform, but when he was reelected (1871) he failed to quell a revolt by an unsuccessful candidate, Porfirio ${ }^{*}$ Diaz, and shortly afterwards died.

Roeder, R., Juarez and his Mexico. 1947.

Judah (fl. c.1850 BCE). Hebrew patriarch. Fourth son of *Jacob and Leah, he became the ancestor of the tribe that bears his name, to which the Royal House of * David belonged. The area in the south of Palestine occupied by the tribe and that of *Benjamin became, after the death of *Solomon, the separate Kingdom of Judah.

Judas Iscariot (d.c.30 CE). Christian apostle, betrayer of ${ }^{*}$ Jesus Christ. The name Iscariot is of uncertain origin. Perhaps he came from Kerioth or was a member of the Sicarii, a radical Jewish group. He was the treasurer of the apostles, and though no motive for his treachery is given in the Gospels it has been surmised that it was due to disappointment that Jesus had no plans to establish an earthly kingdom. After betraying Jesus for 30 pieces of silver he committed suicide.

\section{Judas Maccabeus see Maccabaeus}

Jude, St (also known as Thaddaeus, Lebbaeus or 'Judas not Iscariot) (fl. 1st century CE). Christian apostle. He may have been a Zealot and, according to tradition, was martyred in Persia. Since the 18th century, Jude has been the patron saint of desperate causes.
Judge, Igor, Baron Judge (1941- ). British jurist, born in Malta. Educated at Cambridge, he was a judge from 1988 and, after the reorganisation of the courts, served as Lord Chief Justice 2008-13.

Jugurtha (c.160-104 BCE). King of Numidia 118105 BCE. Having won control of Numidia (roughly modern Algeria) by murdering two co-rulers, he provoked the intervention of Rome by a massacre of Roman merchants. By going himself to Rome, he gained a respite, but war was soon resumed. Despite early success Jugurtha was forced to adopt guerrilla tactics by the systematic occupation of his bases by Metellus and *Marius. Finally he was betrayed by his ally, Bocchus of Mauritania, and died in prison at Rome.

Hawthorn, J. R., Rome and Jugurtha. 1969.

Juin, Alphonse Pierre (1888-1967). French soldier. Having fought in World War I and in Morocco, he was taken prisoner during the battle for France (1940) of World War II. Released by the Germans, he was appointed by *Pétain's Vichy Government to command the French forces in North Africa. He continued in command under ${ }^{*}$ Giraud and ${ }^{*}$ de Gaulle, and subsequently commanded French troops in Italy. $\mathrm{He}$ was then successively Chief of the French General Staff 1944-47 and Resident General in Morocco 1947-51. From 1951 he filled important posts in NATO and commanded Allied forces in central Europe 1952-56. In 1952 he became the only (living) French marshal. $\mathrm{He}$ remained loyal to de Gaulle but opposed his granting independence to Algeria.

Julia (39 BCE-14 CE). Roman matron. Only child of the Roman emperor *Augustus, she married Marcellus (25 BCE), *Agrippa (21 BCE), and the future emperor ${ }^{*}$ Tiberius (12 BCE). Her daughter by Agrippa was *Agrippina, mother of the emperor ${ }^{*}$ Caligula. Julia's last marriage gave her no happiness, she gave way to profligacy and in $2 \mathrm{BCE}$ was banished for adultery and scandalous behaviour. Eventually she starved herself to death.

Julian (Flavius Claudius Julianus, known as 'the Apostate') (c.331-363). Roman Emperor 361-63. Born in Constantinople, the nephew of ${ }^{*}$ Constantine I, he and his half-brother Gallus were the only males of the Flavian line spared in the general massacre that took place (337) on Constantine's death. His education in philosophy in Nicomedia, Constantinople and Athens turned him away from Christianity and he secretly adopted paganism (351). In 335 he was given command on the Rhine by his cousin the emperor ${ }^{*}$ Constantius and in the next five years succeeded in restoring the frontiers and purging the provincial government of dishonesty and corruption. He became highly popular with the army, and when the Emperor sought to transfer his troops to the East to restore the situation there, they mutinied and proclaimed him Emperor (360). 
In the same year he openly announced his paganism. He then moved eastwards, but Constantius' death (361) forestalled a conflict. Julian spent a year in Constantinople, introducing a number of reforms. Though he worshipped the pagan gods and deprived the Christian Church of its privileges, he exercised a wide tolerance. In 363 he began a war against Persia and was mortally wounded in a skirmish. Julian was one of the most accomplished of the emperors, and his writings-some philosophical and self-justificatory, some satires on the lives of his predecessors-are distinguished by the purity of their Greek.

Vidal, G., Julian. 1972.

Juliana (Juliana Louise Emma Marie Wilhelmina) (1909-2004). Queen of the Netherlands 1948-80. The only child of Queen *Wilhelmina, she studied law at Leiden University and in 1937 she married Prince *Bernhard of Lippe-Biesterfeld by whom she had four daughters: *Beatrix, Irene, Margriet and Christina. During the German occupation, she lived in Canada 1940-45, succeeded on her mother's abdication and proved to be a conscientious and popular constitutional monarch. Between 1948 and 1956 she was deeply influenced by a faith healer, Greet Hofmans, creating problems with her government and her husband. In the 1970s, Juliana's husband was accused of involvement in illicit financial dealings with American companies. She abdicated in 1980 in favour of Beatrix on the onset of dementia.

\section{Julius Caesar see Caesar, Julius}

Julius II (Giuliano della Rovere) (1443-1513). Pope 1503-13. Born near Genoa, his family was influential but not rich. However, the election of his uncle Francesco della Rovere as Pope *Sixtus IV, guaranteed his rapid promotion and in 1471 he was created cardinal and at one stage held eight bishoprics, including Archbishop of Avignon 14741503 and Bishop of Bologna 1583-1502. Papal legate to France $1480-82$, in 1484 he organised the election of the weak Pope Innocent VIII. When his arch-enemy *Alexander VI (Rodrigo Borgia) became pope in 1492, della Rovere went to France, induced ${ }^{*}$ Charles VIII to invade Naples in 1494-95 and, when this failed, went into hiding. After Alexander died (1503), Pius III was elected to succeed him but died 26 days later. Della Rovere became Pope on the first ballot in October 1503, in the shortest conclave in history, having won support of the Spanish and French cardinals, partly through bribes and promises given to Cesare *Borgia. He took the name of Julius II. His main aims were to end foreign rule in Italy and unite all papal territories under his control. In 1503 he granted *Henry VIII a dispensation to divorce *Katherine of Aragon. He turned on Cesare Borgia, forced him to give up his conquests and exiled him to Spain in 1504. In 1506 he created the Swiss Guards and the Vatican Museum (originally his collection of sculptures). Both institutions still flourish.
Julius was the last pope to lead his troops in battle and in 1506 he restored Perugia and Bologna to papal rule. Through the League of Cambrai, allied with France and the Empire, the papacy regained much of Romagna from Venice (1509). In 1510-11 his army regained Modena and Mirandola. By 1512 he had succeeded in expelling the French (now under *Louis XII) from Italy by the 'Holy League' alliance, of which Henry VIII of England was a not very active member.

He commissioned *Bramante to demolish the old St Peter's Basilica and design a new one, laying the foundation stone himself in 1506. To help meet the cost of building St Peter's he authorised the practice of granting 'Indulgences', absolving from guilt in return for a cash payment, which became a central factor in *Luther's revolt in Germany and the Protestant Reformation generally. He employed *Michelangelo to paint the ceiling of the Sistine Chapel and * Raphael to undertake major murals in the *Vatican. His empty tomb in the church of San Pietro in Vincoli, designed by Michelangelo, dominated by the great sculpture Moses (1515), was not completed until 1545. (Julius had been buried at St Peter's.) Raphael painted (1511) an outstanding portrait of Julius, now in the National Gallery, London, showing him with a beard, rare for a pope of his time, and his beard was a sign of mourning for the temporary loss of Bologna. Often called 'Il papa terribile ...', Julius had a commanding, aggressive manner but, once in the papacy, he was not venal and is regarded as perhaps the greatest Renaissance pontiff. He fathered three daughters but only one, Felice della Rovere, survived, and married well. His enemies traduced him as bisexual.

Shaw, C., Julius II: The Warrior Pope. 1993.

Jung, Carl Gustav (1875-1961). Swiss psychiatrist, born in Kesswil. He graduated in medicine at Basle and worked at the Burghölzli psychiatric clinic at Zürich until 1909. He became influenced by the Volkisch (*Jahn) tradition, ${ }^{*}$ Nietzsche, social Darwinism and the occult. He coined the word 'complex' to describe memories or emotions which, though repressed by the conscious mind, still influence behaviour and may cause neuroses. He met *Freud in 1907 and worked closely with him in Vienna for several years. They quarrelled (1912-13) largely because of disagreement over the extent of the contribution of sexuality to the life force. Freud and Jung were fundamentally opposed in their approach. Jung rejected Freud's critical and sceptical analysis of religious experience and he may have seen himself as the founder of a redemptive transforming cult. He was probably anti-Semitic and had mixed feelings about *Hitler. Jung's system, called 'analytical psychology', was an attempt to effect classification by psychological analysis: he divided people into two main types, 'introverts' and 'extroverts'. Another concept of his work is the 'collective unconscious' which is assumed to spring from collective atavistic experiences rather 
than of individuals, and he promoted the concept of 'archetypes'. Other coinages were 'anima', 'animus' and 'persona'. Jung held chairs at Zürich 1933-41 and Basle 1941-48. His books include The Psychology of the Unconscious (1921), Modern Man in Search of a Soul (1933) and Answer to Job (1954).

Kerr, J., A Most Dangerous Method: The Story of Jung, Freud and Sabina Spielrein. 1993; McLynn, F., Carl Gustav Jung. 1996; Noll, R., The Aryan Christ. 1997; Bair, D., Jung. A Biography. 2003.

Jünger, Ernst (1895-1998). German novelist. Wounded in World War I, his book Storms of Steel (1920) glorified battle and he became an ardent nationalist on the far right. Repelled by *Hitler, he retreated to study entymology, but served in World War II, wrote more vivid memoirs and became a cult figure in extreme old age.

Juppé, Alain Marie (1945- ). French politician. He worked with Jacques ${ }^{*}$ Chirac in the administration of Paris 1978-95 and became Premier 1995-97.

Justin, St (known as 'the Martyr') (c.100-c.165). Greek theologian, born in Samaria. He studied philosophy and was converted (c.134) to Christianity. He spent a wandering life preaching the Gospel, founded a school of Christian philosophy at Rome, where with some of his proselytes he was martyred. In his Apologies (c.155) he tried to reconcile Greek philosophy, especially that of*Plato, with the teaching of Christ. The Dialogue with the Jew Trypho is the only other work indisputably his.

Justinian I (Flavius Anicius Justinianus) (c.482-565). Byzantine (or east Roman) Emperor 527-65. Born in Illyria, the son of a Macedonian peasant, his uncle, an imperial guardsman made himself the Emperor Justin I, had him educated in Constantinople, and eventually made him co-Emperor and heir. Justinian's wife, *Theodora, a former actor and courtesan, a talented and courageous woman, was a constant source of strength. As Emperor, Justinian's military aim was to restore the Roman Empire to its ancient limits. With the help of his generals *Belisarius and *Narses he nearly succeeded in the west by the re-conquest of North Africa, most of Italy and part of Spain, but at a crippling financial and material cost. He held off the Persians in two wars. On other frontiers, especially in the north where raids from Slavs and Huns were a constant menace, he strengthened and renewed the old lines of fortifications. In Constantinople the perpetual feud between the supporters of the 'Blues' and 'Greens', rival teams in the chariot races in the Hippodrome, had spread into the streets. Gang warfare became political faction and after the extraordinarily destructive Nika Revolt (January 532), Belisarius massacred a crowd of 30,000. Justinian's political reforms were directed at removing corruption and at centralising the regime by breaking up the large selfgoverning departments and making more ministers directly responsible to himself. He was a strictly orthodox Christian and worked hard to bring unity both of doctrine and discipline into Church affairs. $\mathrm{He}$ employed Anthemios of Tralles and Isidore of Miletus to build Hagia Sophia (Aya Sofya, 532-37). He ordered construction of many important churches and the great cisterns in Constantinople. Justinian is best remembered for the codification of Roman law. This work, in which his minister Tribonius was his principal assistant, resulted in a revision, known as the Codex Justinianus (529, revised 535) of the Theodosian code of 438; the Pandeotae or Digesta (533) gave a selection from the writings of earlier jurists. The Institutiones provided elementary instruction mainly for use in schools. New laws made from time to time were known as Novella, and these, with the Institutiones, Digesta and Codex, make up the Corpus Juris Civilis, the Roman civil law that provided the pattern for many later codes. There are outstanding mosaics of Justinian and Theodora, and their courtiers in the Basilica St Vitale, Ravenna, a city he conquered but never visited.

Browning, R., Justinian and Theodora. 1971; Moorhead, J., Justinian. 1994.

Juvenal (Decimus Junius Juvenalis) (c.60-c.130). Roman satirical poet. Little is known of his life except that he lived most of it in poverty, the client of mean though wealthy men. He wrote 16 surviving satires in which he denounced the vicious Roman society of the time of*Trajan and ${ }^{*}$ Hadrian and aired his venomous view of Jews and women. He is regarded as one of the greatest masters of the 'satire of indignation', *Dryden and *Johnson (in London and The Vanity of Human Wishes) wrote versions of some of his works.

Highet, G., Juvenal the Satirist. 1962. 


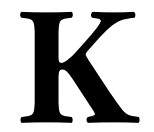

Kabila, Laurent-Desiré (1939-2001). Congolese politician. A guerilla and bandit for 30 years, his forces overthrew *Mobutu in July 1997 and he became President of the Democratic Republic of the Congo (formerly Zaire). Assassinated in January 2001 by his bodyguard, 135 people were tried, mostly convicted but apparently not executed. His son Joseph Kabila Kabange (1971- ) was President of the DRC 2001-19. In 2018, a corrupt and violent election was won by an opposition candidate Félix Tshisekedi; a bizarre result that appeared to be a democratic transition but was engineered to guarantee Kabila's continuing influence and preservation of his family's wealth.

Kaczyński, Jarosław (1949- ) and Lech Aleksander Kaczyński (1949-2010). Polish conservative politicians, identical twins, born in Warsaw. Jaroslaw broke away from Solidarity in 1990 and became Leader of the Law and Justice Party. He organised the election of Lech as President 2005-10, becoming Prime Minister himself 2006-07. Jarosław's sexuality became a controversial issue, using homophobic language while believed to be gay himself. Lech Kaczyński was killed in an air crash at Smolensk while visiting Russia for a commemoration of the Katyn massacre (1940). In the presidential election (July 2010), Jaroslaw Kaczyński failed to win.

Kadar, Janos (1912-1989). Hungarian politician. He joined the Communist Party, then illegal, in 1932. In 1948 when the party took control he became Minister for Home Affairs. After three years' imprisonment, accused of Titoism, he became Prime Minister and First Secretary of the Hungarian CP 1956-88. In the October 1956 rising, at first he joined the anti-Stalinist revolutionaries, then in November he set up an opposing, pro-Soviet government and with Soviet military help crushed the revolt. He later followed pro-Moscow policies while allowing some liberal measures until his deposition in 1988.

Zinner, P. F., Revolution in Hungary. 1962.

Kael, Pauline (1919-2001). American film critic. As film reviewer for the New Yorker 1967-78, 197991, she influenced directors deeply. Her volumes of collected criticism included I Lost it at the Movies (1965), Deeper Into Movies (1973), State of the Art (1985) and For Keeps (1996).

Kafka, Franz (1883-1924). Czech-Jewish novelist, writing in German, born in Prague. Son of an overbearing retailer and a withdrawn mother, he gained a doctorate in law and worked as a senior (and well-paid) public servant in the Workers' Accident Insurance Institute in Prague 1908-22. Between
1912 and 1917, he had a relationship with Felice Bauer (1887-1960). They were twice engaged but never married. (He wrote her 500 letters but they only met 17 times.) Kafka had the smallest output of any major writer, three short novels (all unfinished), one novella, 23 short stories, diaries and five collections of letters, almost all published posthumously. He lived briefly with two unhappily married women.

The novella Metamorphosis (Die Verwandlung), published in 1915, is famous for the image of the central character Gregor Samsa waking to find himself transformed into 'a monstrous vermin', which is usually rendered in English as an insect or beetle. Kafka does not explain why the transformation occurred.

He suffered from tuberculosis of the larynx, died - essentially of starvation-in a sanatorium at Klosterneuburg, near Vienna, and was buried in Prague. He left instructions that his literary works be burnt, unread, but his friend and executor Max Brod (1882-1968) ignored the direction and published his novels Der Prozess (The Trial, 1925), Der Schloss (The Castle, 1926) and Amerika (The Man Who Disappeared, 1927), as well as collections of short stories and letters. The first English translation, of The Castle, by Willa and Edwin *Muir, appeared in 1930.

Another fiancée, Julie Wohryzek, and his three sisters died in the Holocaust, Only after 1945 did Kafka gain full recognition for his extraordinary prophecy of totalitarianism and alienation. (The word Kafkaesque describes an individual oppressed by institutions or forces he is not able to understand). His introspective and symbolic novels are marked by a discomforting sense of spiritual oppression and frustration, their strange events seeming the more uncanny because of the clarity of the author's style. Some interpreters suggest that a hidden theme is humanity's vain struggle to establish a relationship with God. There is an enormous critical literature about Kafka. The Castle and The Trial were both filmed twice, the best known version being Orson *Welles' The Trial (1962).

Hayman, R., K: A Biography of Kafka. 1981; Calasso, R., K. 2005; Major, M., Kafka ... for our time. 2011; Stach, R., Kafka: The Years of Insight. 2013; Stach, R., Kafka: The Decisive Years. 2005; Kafka: The Years of Insight. 2008.

Kaganovich, Lazar Moiseivich (1893-1991). Russian Communist politician. Of Jewish origin, he became a shoemaker and joined the Bolsheviks in 1911. He worked for *Stalin in the CP apparatus, was a Politburo member 1930-57, ran the Moscow party machine 1930-35 and created the Moscow Metro (underground). His sister Rosa became Stalin's third wife. He became Commissar for Transport 1935-37, Heavy Industry 1937-42 and Oil 194042, ran all Soviet transport during World War II and was Deputy Premier 1938-46, 1947-53. He joined the 'anti-party group' against his former protégé 
*Khrushchev and was sacked. The last of the Old Bolsheviks, he remained an undeviating Stalinist to the end.

Kahlo, Frida (1907-1954). Mexican painter. Permanently damaged by a road accident in 1925 , she twice married Diego *Rivera (1929, 1940), and was a lover of ${ }^{*}$ Trotsky. She developed her own surrealistic treatment of Mexican folk and colonial art, marked by intense colour and strong figures and painted many powerful self-portraits. Her house in Coyoacan became an important museum of pre-Columbian art.

Kahn, Louis I(sadore) (1901-1974). American architect, born in Estonia. Educated at the University of Pennsylvania, but particularly influenced by buildings in Rome, Greece and Karnak, he was a relatively late developer whose first major project, the Yale Art Gallery, dates from 1947. Professor of architecture at Yale 1947-57 and Pennsylvania 195774 , he broke away from the sleek, bland 'International Style' with his monumental buildings, including the Kimbell Art Museum, Fort Worth, the Salk Institute at La Jolla, the capitol in Dacca, Bangladesh and government offices in Ahmadabad, India.

Kahn, Richard Ferdinand, Baron Kahn (19051989). English economist, born in London. A disciple of J. M. *Keynes, he worked with him at King's College, Cambridge. He is famous for developing the principle of the multiplier: the relation between increases and outputs in aggregate expenditure.

Kahneman, Daniel (1934- ). Israeli-American psychologist, born in Tel Aviv. His parents came from Lithuania; they moved to Palestine, then France. He survived the war with his mother. Educated in Israel and at Berkeley, he taught in Jerusalem, Vancouver, Berkeley and was professor of psychology at Princeton 1993-2007. With Amos Tversky (1937-1996) he developed 'prospect theory', which analyses rational and irrational factors in decision making. For this Kahneman received the Nobel Prize in Economic Science in 2002. In prospect theory, individuals use 'heuristics' (familiar short cuts) to make intuitive judgments, and are not always rational actors. He became the outstanding authority on behavioural economics and social psychology. His Thinking Fast and Slow (2011), a bestseller, described 'cognitive ease' in which people accepted ideas they were comfortable with and rejected facts that made their brains work harder. *Obama awarded him the Presidential Medal of Freedom in 2013.

Lewis, M., The Undoing Project. 2016.

Kaiser, Georg (1878-1945). German dramatist, born at Magdeburg. He was known as the playwright of Expressionism, because his style in some of his best known plays, e.g. The Burghers of Calais (1914), From Morning to Midnight (1916), and Gas (1918) was analogous to that of the Expressionists in art, but his range of subjects was wide enough to include social comedies, problem plays, and to take up many other themes, to each of which he adapted his style.

Kenworthy, B., George Kaiser. 1957.

Kalecki, Michał (1889-1970). Polish economist, born in Łódź. Trained as an engineer, he worked as a journalist and economic analyst, and in 1933 published (in Polish) Essays in Business Cycle Theory which largely anticipated J. M. *Keynes' theories on demand management and employment. (His priority was not recognised until after Keynes' death.) He worked in England 1936-45, then with the UN 1946-55, returning to Poland in 1955 in an attempt to provide a theoretical framework for growth in a socialist economy.

Kalinin, Mikhail Ivanovich (1875-1946). Russian Communist politician. A sheet metal worker, he joined the RSDLP in 1898, adhered to the Bolsheviks after 1905 and was a candidate member 1919-25, then a full member of the Politburo of the CPSU 1926-46. He succeeded Yacob *Sverdlov as head of state, retaining office until just before his death, with two different titles: President of the Central Executive Committee of the All-Russian Congress of Soviets 1919-38, Chairman of the Presidium of the Supreme Soviet $1938-46$. His wife was imprisoned by ${ }^{*}$ Stalin as a Trotskyist 1938-46.

Kamehameha. Five kings of Hawaii. Kamehameha I (1758-1819) was King of Hawaii 1795-1819. As a young chief he negotiated with James *Cook in 1779 and united the warring islands under his sole rule 1782-1810. He was friendly towards traders and encouraged western influences. Kamehameha II (1797-1824), King 1819-24, continued his father's policies. His brother Kamehameha III (1814-1854), King 1824-54, developed the islands into a modern monarchy of a constitutional kind, and obtained recognition of their independence by France, Britain and the US. Kamehameha V (1831-1872) succeeded his brother in 1863, abrogated the constitution and tried to restore tribalism and monarchical rule. However, he died without heir and the Kamehameha dynasty ended.

Daws, A. G., Shoal of Time: A History of the Hawaiian Islands. 1968.

Kamenev (né Rosenfeld), Lev Borisovich (18831936). Russian politician. Active in the Bolshevik wing of the Social Democratic Party, he married Leon *Trotsky's sister Olga Bronstein (1883-1941). Imprisoned in Siberia (1915-17), he was released after the 1917 Revolution and served briefly as the Russian head of state. A Communist Party Politburo member 1919-26, he was Deputy Premier 192326. When ${ }^{*}$ Lenin died in 1924 , with ${ }^{*}$ Stalin and *Zinoviev he formed the 'troika' opposed to Trotsky. Outmanoeuvred by Stalin (1925) he rallied to Trotsky and was expelled from the Communist Party (1927). 
In 1936 he was tried in the first big 'purge trial' and executed for treason. His two sons and first wife were executed later. In 1988, during 'perestroika', he was posthumously 'rehabilitated'.

Kamerlingh Onnes, Heike (1853-1926). Dutch physicist. Professor of physics at the University of Leyden 1882-1926, and a pioneer of low-temperature research, he was the first to achieve temperatures within $1^{\circ}$ of absolute zero and to liquefy hydrogen (1906) and helium (1908). During his studies of the properties of materials at low temperatures, he discovered the phenomenon of super conductivity, the disappearance of electrical resistance of some metals (e.g. lead) at temperatures near absolute zero. He won the Nobel Prize for Physics (1913).

Kames, Lord, Henry Home (1696-1782). Scottish judge and historian. Judge of the Court of Session 1752-82, he was an important figure in the Scottish Enlightenment, a rival of Lord *Monboddo, with a wide range of interests. He pioneered the study of civilisation and literary criticism, and befriended Adam ${ }^{*}$ Smith, David ${ }^{*}$ Hume and James *Boswell.

Kamprad, Ingvar Feodor (1926-2018). Swedish industrialist. He was a trader in matches, fish, pens and Christmas decorations as a teenager and in 1943 founded the furniture and fittings retailer IKEA. The name is an acronym of his initials and two places associated with his childhood (Einmaryd and Agunnaryd). He had a youthful enthusiasm for Fascism and later was a reformed alcoholic. The philosophy of IKEA is based on frugality, high quality, relatively low cost, and encouraging its customers. IKEA stores spread throughout the world. Kamprad created the INGKA Foundation which owns IKEA and, with capital of about $\$$ US40 billion, is one of the world's largest charities.

Kandel, Eric Richard (1929- ). American biologist, born in Vienna. In the US from 1939, he held a chair at Colombia University. He worked on the neural system of Aplysia, a sea slug with very large nerve cells, and shared the Nobel Prize for Medicine in 2000 for his work on the physiology of memory.

Kandinsky, Wassily Wassilyevich (1866-1944). Russian artist, born in Moscow. He was already 30 years old and had been a lawyer and economist before taking up art. He studied in Munich where he and Franz Marc formed (1911) a group that came to be called (after one of Kandinsky's pictures) the Blaue Reiter (Blue Rider), pioneers of abstract painting and theory. Kandinsky had painted his first abstract picture in 1910 and had begun to write Concerning the Spiritual in Art (1912). From 1914 to 1921 he was in Russia, where he played a part in re-establishing the arts after the revolution. He left to join the Bauhaus, a school of design and architecture at Weimar in Germany and from 1933 he lived in Paris. Features of his painting which have attracted particular attention have been the calligraphic brush strokes of his earlier period and afterwards his use of geometric symbols. His later pictures reveal a softening of mood and with it a less severe use of geometric forms.

Overy, P., Kandinsky: The Language of the Eye. 1969.

Kāngxī ('health and glory': personal name Xuányè) (1654-1722). Chinese Emperor 1662-1722, fourth of the ${ }^{*}$ Qing dynasty. He took control from the eunuchs of the Thirteen Offices at the age of 15 , defeated three feudal kingdoms (1681), annexed Outer Mongolia and Tibet, settled the border with Russia, opened four ports to foreign trade, encouraged introduction of Western arts and science and (until 1717) allowed the Jesuits to preach Christianity. He dredged the Grand Canal, travelled extensively, read voraciously and commissioned a great dictionary and an atlas. He was a good poet and wrote a fascinating autobiography. Kāngxī had the longest reign of any Chinese Emperor and his grandson *Qianlong abdicated to avoid exceeding it.

Spence, J. D., Emperor of China: Self Portrait of K'angHsi. 1974.

Kāng Yǒuwéi (1858-1927). Chinese scholar and political philosopher. He was a leader of the 'Hundred Days' Reform movement of 1898, aimed at creating a constitutional monarchy. This was crushed by the dowager empress ${ }^{*}$ Cixi and he fled to Japan with his disciple *Liang Qichao. He returned in 1914 and opposed *Sun Yat-sen. Kang, a voluminous writer and a great calligrapher, remained a Confucian and constitutional monarchist.

Kanishka I (d.151 CE). Kushan ruler in India 127-51. He ruled originally from Turpan in Xinjiang but his tribes were probably Indo-European and he used an Iran dialect (Bactrian) and absorbed cultural contact as appropriate. (His coins sometimes used Greek lettering.) His empire extended to Afghanistan, parts of Iran and northern India-Pakistan, and his capital Purushpura is the modern Peshawar, where he built an enormous stupa. He sent Buddhist missionaries to China.

Kant, Immanuel (1724-1804). German philosopher, born in Königsberg. Son of a saddler, he was educated and eventually became professor of philosophy in his birthplace. He travelled hardly at all and did not marry. Barely 1.5 metres high, his health was good and his brilliant conversation enlivened prolonged luncheons with friends and the social gatherings of his younger days. Interested in politics, approving both the French and American revolutions, he lived a quiet life devoted to philosophy, the course of which he greatly influenced. He also was a student of physics and mathematics, and is known for the Kant- ${ }^{*}$ Laplace theory of the origin of the solar system. In his philosophy, Kant argues that human knowledge is the result of our own ordering of sense experience, which by itself would be unintelligible. 
In the Critique of Pure Reason (1781), he sets out the a priori categories that we impose upon experience, e.g. the categories of space, time and relation. They are, it is sometimes said, the spectacles through which we are always looking. Without them, he claims, there could be no understanding of our experience. Since knowledge derives from and depends upon both experience and categories, there can be no knowledge of that which is beyond our experience. Kant thus denies the possibility of metaphysics, when conceived as the study of any reality beyond our actual experience. He thus also denies the possibility of proof of the existence of God, which remains a matter of faith. Supplementary to this great work were his Critique of Practical Reason (1788) and Critique of Judgement (1790), the latter containing his widely influential views on taste. In his writings on ethics, he enunciates the supreme moral principle that he called the Categorical Imperative. It has several formulations, of which the final one is that the will is completely autonomous in laying down laws that are to be applied universally and in accordance with which it is its duty to act.

Korner, S., Kant. 1955; Broad, C. D., Kant. 1978; Cassirer, E., Kant's Life and Thought. 1981; Guyer, P. (ed.), The Cambridge Guide to Kant. 1992; Scruton, R., Kant. A Very Short Introduction. 2001.

Kapell, William (1922-1953). American pianist, born in New York City. His father was of RussianSpanish-Jewish ancestry, his mother Polish. He developed a phenomenal technique and died in a plane crash on returning from a concert tour in Australia, giving his last concert in Geelong.

Kapitza, Pyotr Leonidovich (1894-1984). Russian physicist. Educated at Leningrad and at Cambridge (under *Rutherford), he was assistant director of research in magnetism at the Cavendish Laboratory 1924-32 and Messel research professor at the Royal Society's Mond Laboratory 1932-35. He did important work on the magnetic and electrical properties of substances at low temperatures, and also designed an improved plant for the liquefaction of hydrogen and helium. Kapitza was detained in the USSR in 1935, and later became Director of the Institute for Physical Problems at the Academy of Sciences, Moscow. He was awarded the Stalin Prize for Physics (1941, 1943), held the Order of Lenin, many foreign honours and shared the 1978 Nobel Prize for Physics.

Collected Papers, 3 vols, 1964-67.

Kapoor, Sir Anish (1954- ). British-Indian sculptor, born in Mumbai. With a Hindu father and Jewish mother, he lived in Israel, then in Britain from 1973. He worked in a diversity of forms, stone, wax, stainless steel, with effective use of mirrors, both smooth and multi-faceted, creating disturbing distortions, and with vibrant colour. Large installations of his work are found in Britain, France, Spain, Israel, Italy, Japan and the United States.
Kapteyn, Jacobus Cornelius (1851-1922). Dutch astronomer. While professor of astronomy at the University of Groningen 1878-1921, he established that there are two streams of stars moving in opposite directions in the plane of the Milky Way, and made considerable contributions to the knowledge of star distribution and the structure of the universe. $\mathrm{He}$ also pioneered the use of photographic methods for determining stellar parallax. His last student was J. H. *Oort.

Karađorđević (or Karageorgević). Serbian dynasty, founded by Đorđe (George) Petrović (1768-1817), probably of Albanian descent, nicknamed Karađorđe ('Black Dorde') by the Ottoman Turks Kara ('black') George. A cattle-keeper in his youth, he worked at a monastery in Smyrna, then fought with ${ }^{*}$ Habsburg forces against the Ottoman rulers of Serbia. He led the 1804 revolt against the Turks. For 10 years he waged guerilla warfare, striking terror in the Turks and gaining adherents amongst the Serbs by his gigantic size, ruthless discipline and immense courage. In 1808 the Serbs swore allegiance to him as their hereditary leader. Defeated at last, he took refuge in Austria but returned (1817) only to be assassinated by a member of the rival *Obrenović clan. He was highly praised by ${ }^{*}$ Napoléon as a guerrilla leader. Karađorđe's son Alexander (1806-1885), educated in Russia, became Prince of Serbia 1842-58, on the deposition of Mihailo Obrenović, but refused to take part in the Crimean War and was removed by the victorious allies. After the murder (1903) of *Alexander (Obrenović), the dynasty returned to power under Alexander's son, *Peter I, who was succeeded by his son, *Alexander I (of Yugoslavia), and his grandson, ${ }^{*}$ Peter II.

Karadžíc, Radovan (1945- ). Bosnian-Serb politician. A psychiatrist, educated at Columbia University after the break-up of Yugoslavia, he led a government in Bosnia-Herzegovina 1990-96 that imposed 'ethnic cleansing' on Muslims, including the murder of 7,000 at Srebrenica in July 1995. In 1995 the UN indicted him and his military commander Ratko Mladic for the killing of civilians but he remained at large until his capture in July 2008. An international criminal trial began in the Netherlands in October 2009; Karadžíc's defence began in October 2012. In March 2016 he was convicted and sentenced to 40 years jail.

Karajan, Herbert von (1908-1989). Austrian conductor, born in Salzburg. Of Greek-Slovak descent, he studied piano and conducting in Vienna and became an opera conductor at Ulm 1927-33, Aachen 1933-40 and Berlin 1938-42. He joined the Nazi Party in 1933, received *Goebbels' patronage and was promoted as a rival to ${ }^{*}$ Furtwängler (supported by ${ }^{*}$ Goering). After World War II he was plucked from obscurity by the English recording producer Walter Legge ( ${ }^{*}$ Schwarzkopf) and made his international reputation through the gramophone. 
He conducted in London with the Philharmonia Orchestra 1947-55, at the La Scala Opera, Milan 1948-52 and directed the Vienna State Opera 195664 and 1976-89, the Berlin Philharmonic Orchestra 1958-89, and the Salzburg Festival 1964-89. He made almost 900 records, and several films, leaving an estate of 500 million DM.

Karamanlis, Konstantinos (1907-1998). Greek politician. He entered the legislature in 1936, served as a minister 1946-55, succeeding *Papagos as Premier 1955-63, and went into exile in Paris (1963) when the military took power. He returned after Greece's military failure in Cyprus and was Premier again 1974-80, becoming President 1980-85, 1990-95.

Karl (Charles) I (Karl Franz Joseph Ludwig Hubert Georg Otto Marie von Habsburg-Lothringen) (1887-1922). Last Emperor (Kaiser) of Austria and (as Károly IV) King of Hungary 1916-18. In 1911 he married Princess Zita of Bourbon Parma (18921989). He succeeded on the death of his great-uncle *Franz Joseph I, and supported Pope *Benedict XV's attempts to negotiate an end to World War I (1917). Deposed in November 1918, he went into exile in Switzerland in 1919. After two unsuccessful bids in 1921 to regain the Hungarian throne, he retired to Madeira and died there of tuberculosis. He was beatified in 2004 by *John Paul II. Miracles have been attributed to support his cause for canonisation. His son was Otto von Habsburg-Lothringen.

Karl (Charles) VI (Karl Franz Joseph Wenzel Balthasar Johann Anton Ignaz von Habsburg) (1685-1740). Holy Roman Emperor 1711-40. Before succeeding his brother *Joseph he was Austrian candidate for the Spanish throne, left vacant on the death of ${ }^{*}$ Carlos II. During the War of the Spanish Succession (1700-13) he fought bravely in Spain. Ultimately the Bourbon Philippe was recognised as *Felipe V. As Emperor, Karl became obsessed with securing (by means of the Pragmatic Sanction) the recognition of the rights of his daughter * Maria Theresa to succeed him as ruler of Austria and Hungary. Despite these efforts the War of the Austrian Succession followed his death.

Karl (Charles) IX (Karl Vasa) (1550-1611). King (and Regent 1599-1604) of Sweden 1604-11. Son of ${ }^{*}$ Gustaf I Vasa, he was a brother of Johan III and succeeded his nephew Sigismund, who had been elected King of Poland. Karl's accession, following a successful revolt against Sigismund, ended the union of the two crowns and so achieved Karl's aim of preventing Sweden from remaining under Roman Catholic rule, and prepared the way for the decisive part Sweden played under Karl's son *Gustaf II in the Thirty Years' War. Internally, having eliminated his enemies among the nobles at the 'Linkoping blood bath', he efficiently developed the administration and economy of Sweden. In 1603 he founded Gothenburg (Göteborg) as a trading centre; in 1611 it was burnt down and re-established nearby in 1621 by Gustaf II.
Karl (Charles) X Gustaf (Karl von PfalzZweibrücken) (1622-1660). King of Sweden 165460 . Nephew of ${ }^{*}$ Gustaf II and cousin of ${ }^{*}$ Christina, he ascended the throne on her abdication. A daring soldier, he revived the plan of trying to form a great Swedish empire on both sides of the Baltic to include east Prussia and the northern part of Poland. By 1656 he was nearly successful, but the defeated Poles rose against him, supported by both the Russians and the Dutch. Denmark, which also joined his opponents, became Karl's immediate target. After he had led his troops across the ice to attack Copenhagen, the Danes were forced to accept a harsh separate peace (1658). Later, as the Danes showed signs of wavering in the fulfilment of its terms, Karl attacked again but his sudden death brought a general peace.

Karl (Charles) XI (Karl von Pfalz-ZweibrückenVasa) (1655-1697). King of Sweden 1660-97. Son of ${ }^{*}$ Karl X, in 1672 when after a long minority he assumed power, Sweden was closely associated with *Louis XIV of France and in 1675, as part of the general European conflict, found itself at war with Brandenburg and Denmark. Karl quickly reversed Denmark's early successes and by his victory of Lund (1676) reasserted Swedish power. His administrative reforms reduced the power of the aristocracy by depriving them of their official and feudal rights and powers exercised through the Riksdag (or council), and by raising lesser nobility into an official class dependent on royal favour, he created something closer to absolute monarchy.

Karl (Charles) XII (Karl von Pfalz-Zweibrücken) (1682-1718). King of Sweden 1697-1718. Son of *Karl XI, he was precocious, and at once assumed full control. Immediately after his accession the old struggle for Baltic supremacy reopened and Karl found himself confronted with a coalition of Russia, Poland and Denmark. The Great Northern War broke out in 1699, and lasted intermittently until 1721. Karl invaded Denmark and forced its withdrawal from the coalition in 1700 , then led his armies into Russia and defeated the forces of *Peter the Great at Narva (1700). Poland was then conquered, Karl forced the abdication of the king, *August II of Saxony, and secured the election of Stanisław *Leszczynski. In 1708 he again invaded Russia, gained initial successes but, forced to abandon his plan to seize Moscow, turned south to the Ukraine to link up with the rebel Cossack leader, *Mazeppa. The winter of 1708-09 was, however, the most severe for a century and the Swedes, weakened and ill-supplied, were decisively defeated by Peter at Poltava (1709) and Karl fled to Turkey. He persuaded the sultan to make war on Russia, which was soon concluded. The sultan then expelled Karl, and when he returned to Sweden he found the impoverished country on the verge of civil war. By drastic taxation and harsh measures he raised new armies and, after fruitless intrigues to divide his enemies, attacked Norway in the hope of compensating himself for losses 
elsewhere, but in November 1718, during the siege of Fredrikshald, he died after being shot in the head. A variety of explanations are offered: a Norwegian sniper, accident or murder. Karl abstained from alcohol and sex, never married, and was succeeded by his sister, Ulrika Eleonora (1688-1741). He had great military skill and amazing fortitude in adversity but his overwhelming ambition led to disaster and the decline of Sweden as a major power. August *Strindberg wrote the play Karl XII (1901). He was highly regarded by Swedish Nazis.

Hatton, R. M., Charles XII of Sweden. 1968.

\section{Karl XIV Johan, King of Sweden see Bernadotte, Jean Baptiste Jules}

Karlfeldt, Erik Axel (1864-1931). Swedish lyric poet. He worked as a schoolteacher and librarian. His themes are drawn from the countryside, its moods and seasons, and the loves, lives and deaths of country people. Secretary of the Swedish Academy, he declined a Nobel Prize for Literature, but it was awarded to him posthumously (1931).

Karloff, Boris (né William Pratt) (1887-1969). English film actor, born in Dulwich. He began as a character actor and, working in Hollywood, became famous playing grotesque roles in early horror films, notably Frankenstein (1931).

Karsavina, Tamara Platonovna (1885-1978). Anglo-Russian ballet dancer. After being prima ballerina of the Mariinsky Theatre, St Petersburg, from 1902, she starred (1909-22) in *Diaghilev's Ballets Russes. She scored a particular triumph with *Nijinsky in the Spectre de la Rose. She married a British diplomat, lived in England from 1918 and influenced Frederick *Ashton and Margot *Fonteyn.

Karsh, Yousuf (1908-2002). Canadian photographer, born in Armenian Turkey. He lived in Canada from 1925, studied in Boston and achieved international recognition with a famous portrait (1941) of Winston *Churchill. He published several volumes of portraits, held many international exhibitions and was awarded the CC (1968).

Karzai, Hamid (1957- ). Afghani politician, born near Kandahar. An ethnic Pashtun, and a Sunni, he was educated in India and worked with the CIA in supporting the mujahideen against the Taliban. $\mathrm{He}$ was President of Afghanistan 2001-14, originally as a provisional, then interim, leader, but then winning national elections in 2004 and 2009, despite strong accusations of corruption and electoral fraud. Discreetly subsidised by the US, CIA and the Iranians, in June 2003 the UK awarded him a Hon. GCMG.

Kasa-Vubu, Joseph (c.1915-1969). Congolese politician, born in the then Belgian Congo. A member of the Bakongo tribe, he was a teacher and a civil servant under the Belgian administration. In the struggle for power that followed independence (1960) Kasavubu obtained UN recognition and, in the civil war that followed, his supporters gained ascendancy over his main rival, Patrice *Lumumba. First President of the Republic of Congo 1960-65, he was supported at first by General *Mobutu who forced Lumumba from office and had him killed. After years of instability, Mobutu then deposed KasaVubu and exiled him.

Kassem, Abdul Karim (Abd al-Karim al-Qasim) (1914-1963). Iraqi soldier and politician. Having led the revolt during which King *Faisal was murdered (1958), he made himself President and Commanderin-Chief of the new republic. The failure of his attempt to establish an Iraqi claim (1961) to Kuwait lowered his prestige and he was assassinated during a coup d'etat.

Kästner, Erich (1899-1974). German novelist and journalist. He wrote many humorous and satirical books, including the children's book, Emil and the Detectives (1929), translated into many languages.

Katherine (Catalina) of Aragon (1485-1536). English queen consort 1509-33. Daughter of *Ferdinand and *Isabella of Spain, she was the first wife of *Henry VIII. For this marriage (1509) a papal dispensation had to be obtained as she was the widow of Henry's elder brother, Arthur. Despite this dispensation and the fact that she had borne him six children (of whom only the future *Mary I survived), Henry used this alleged irregularity as an excuse for getting the marriage annulled (though he had to break with Rome to do so) in order to marry *Anne Boleyn. Katherine lived in seclusion until her death, devoting herself to religion and literature. Although referred to in many historical works as 'Catherine', she generally signed with a ' $\mathrm{K}$ ' and her tomb in Peterborough Cathedral bears the bold inscription 'Katharine queen of England'.

Mattingly, G., Catherine of Aragon. 1950.

\section{Katherine Howard see Catherine Howard}

Katkov, Mikhail Nikiforovich (1818-1887). Russian journalist and editor, born near Moscow. As editor of The Russian Messenger 1856-87, he published novels by *Turgenev, ${ }^{*}$ Dostoevsky and *Tolstoy in serial form.

Katz, Sir Bernard (1911-2003). Russian-JewishAustralian-English biophysicist, born in Leipzig. He worked with J. C. *Eccles in Sydney, served in the RAAF, then returned to England, investigating the physico-chemical mechanism of neuromuscular transmission. He won the Copley Medal in 1967 and shared the Nobel Prize for Medicine in 1970.

Kauffmann, (Maria Anna) Angelika (1741-1807). Swiss painter. Having gained a reputation as a child artist in Rome she spent the years 1766-81 in 
England, where she was befriended by ${ }^{*}$ Reynolds and achieved success with portraits and mythological scenes; she was an original member of the Royal Academy (1768). She undertook decorative paintings for several houses designed by the *Adam brothers, e.g. Syon House, Harewood House.

Mayer, D. M., Angelica Kauffmann. 1972; Rosenthal, A., Angelica Kauffman: Art and Sensibility. 2006.

Kaufmann, Janos (1969- ) German tenor, born in Munich. He combined exceptional technique, excellent diction, a ringing tone and a memorable dramatic gift with a large repertoire, including ${ }^{*}$ Schubert, *Wagner, *Verdi, *Puccini and *Strauss.

Kaunda, (David) Kenneth (1924-2021). Zambian politician. A schoolteacher, he entered politics in Northern Rhodesia (now Zambia) in 1948. He founded (1958) the Zambia African National Congress, which was re-formed (1961) after being banned, Kaunda meanwhile having spent a short time in prison. When his party came to power (1964) after the first election to be held under a system of universal adult suffrage-he became Prime Minister, and, when independence was achieved, first president of the new republic of Zambia 1964-91. He lost power in a free election. He was Chairman of the Organisation of African Unity 1970-71, 1987-88. In December 1997 he was arrested and charged with organising a coup but by 1999 his political standing had been restored.

Mulford, D. C., Zambia: the Politics of Independence, 1957-64. 1967; Hall, R. S., The High Price of Principles: Kaunda and the White South. 1969.

Kaunitz, Wenzel Anton, Reichfürst (Prince) von Kaunitz-Rietberg (1711-1794). Austrian diplomat, born in Vienna. He gained a reputation for statesmanship as a negotiator of the Treaty of Aix-la-Chapelle (1748), which brought the War of the Austrian Succession to an end. Afterwards he convinced his sovereign, *Maria Theresa, that as Prussia had become the real enemy the traditional hostility to France had become an anachronism. He was thus able, as Ambassador to Paris 1751-53 and then as State Chancellor 1753-92, to bring about the famous 'diplomatic revolution', as a result of which France entered (1756) the Seven Years' War as Austria's ally against *Friedrich II ('the Great'). Kaunitz controlled Austria's foreign policy for 40 years and survived *Joseph II.

Kautsky, Karl (1854-1938). German socialist. A supporter of *Marx, he worked closely with *Engels in London (1881-83). He was best known for his violent controversies with ${ }^{*}$ Lenin over the interpretation of Marxist doctrines. Eventually the opinions of Lenin held the field and after the Russian revolution Kautsky refused to join the German Communist Party. Shortly after the end of World War
I he settled in Vienna, where he rejoined the Social Democrats. After *Hitler's annexation of Austria he fled to Amsterdam.

Kawabata Yasunari (1899-1972). Japanese novelist, born in Osaka. Influenced by traditional Japanese and modern French styles, he wrote lyrical, impressionistic novels dominated by the beauty of nature and the struggle to accept death. His works include Snow Country (1956) and Thousand Cranes (1959). He received the Nobel Prize for Literature in 1968 and committed suicide four years later.

Nakamura, M., Contemporary Japanese Fiction. 1969.

Kay, John (1704-1778?). English inventor, born near Bury, Lancashire. His trade as a clockmaker brought him into contact with the cotton-weaving industry. The most important of his inventions, the flying shuttle (patented 1733), greatly increased speed of manufacture and possible widths of finished fabrics. His invention was hated as a threat to unemployment, he was attacked and his model destroyed. For 10 years from 1747 he lived in France, where he introduced his invention. On his return to England, lawsuits to protect his patents seem to have brought about his ruin, and it is thought that he went back to France (1774) and there in 1778 received a pension. The date of his death is uncertain.

Kaye, Danny (Daniel Kaminsky) (1913-1987). American film comedian, born in New York. He began work on the variety stage but achieved his main popularity in films, of which the most successful was The Secret Life of Walter Mitty (1946). His early success arose from a talent for clowning, a direct contrast to the sophisticated situation comedy prevalent in Hollywood at the time. Later films include Five Pennies (1959) and The Madwoman of Chaillot (1968). He was Ambassador-at-Large for UNICEF.

Kay-Shuttleworth, Sir James Phillips, 1st Baronet (1804-1877). English educationist. As a medical practitioner in Manchester and as an assistant poor-law commissioner in East Anglia, he became acutely aware of the educational needs of the poor. He introduced teachers into workhouses, where he developed what was to become the pupil-teacher system of teacher training. He became (1839) secretary of the government committee for education and introduced the system of school inspection with the aim, not of control, but of seeing that knowledge of improved methods was spread as widely as possible. Having failed to obtain a state grant for a teachers' training college, he founded one on his own initiative (later called St John's College, Battersea). On his retirement (1850) he received a baronetcy. He was a member of various social and scientific commissions and wrote extensively on educational issues. 
Kazantzakis, Nikos (1885-1957). Greek novelist and poet, born in Crete. He studied philosophy with *Bergson in Paris, and served briefly as a minister of state in 1945. Among his best known works are The Odyssey (a poetic continuation, 33,333 lines long, of *Homer's epic, published in 1951), Freedom and Death (1947), Zorba the Greek (1952, also a film) and The Greek Passion (1953, filmed as He Who Must Die). Christ Recrucified, his last novel, was published posthumously in 1960.

Kean, Edmund (1789-1833). English actor. He learnt his craft as a strolling player before making his debut (1814) as Shylock at Drury Lane. His success was immediate and his fame steadily increased. He was one of the greatest tragic and emotional actors in the history of the English stage. ${ }^{*}$ Coleridge remarked that to see Kean 'was like reading *Shakespeare by flashes of lightning'. Macbeth and Richard III were among his greatest parts. He collapsed while playing Othello and died a few weeks later. He was a heavy drinker, extravagant and overgenerous. His son, Charles Kean (1811-1868), also a leading actor, was playing Iago on this occasion. Edmund Kean's private life was as tempestuous as his stage appearances. Jealous, passionate and violently intemperate, he shocked London by his excesses and was almost forced to retire when his involvement with an alderman's wife led to a cause celebre. Edmund's wife, Ellen Kean (18051830), also excelled in Shakespearian roles, notably Viola and Gertrude.

Playfair, G. W., Kean. 1950.

Keating, Paul John (1944- ). Australian Labor politician, born in Sydney. He left school early, worked in a union office and won preselection for the House of Representatives at the age of 24 . He was a Federal MP 1969-96, served briefly in the Whitlam Government (1975) and, as Treasurer 1983-91 under Bob *Hawke, sought to make the Australian economy less protected, by breaking down tariffs and encouraging deregulation. After defeating Hawke in a Caucus ballot he became Prime Minister, December 1991 and promoted new national objectives, including the republican cause, and native title. Keating won the March 1993 election comfortably but was defeated heavily by John *Howard in March 1996.

Edwards, J., Keating: The Inside Story. 1996; Watson, D., Recollections of a Bleeding Heart. 2002; O'Brien, K., Keating. 2015; Bramston, T., Paul Keating: The big-picture leader. 2017.

Keaton, Buster (Joseph Francis Keaton). (18951966). American film actor and director, born in Piqua, Kansas. He worked mainly in silent comedy playing the small, frail protagonist against overwhelming odds, which he defeated singlehanded without the smallest change of expression. Considered one of the greatest comedians of American silent film, they include The Navigator (1924), The General (1926) and Steamboat Bill Jnr (1927).

Beesh, R., Keaton. 1966.

Keats, John (1795-1821). English poet, born in London. Son of a well-to-do livery-stable keeper, he went to Clarke's School, Enfield, then well known, where, though athletic and pugnacious, he was already remarked upon for his sensitivity and tenderness. When his father died, John, then aged 16 , became the ward of a merchant named Richard Abbey, by whom he was apprenticed to an apothecary at Edmonton. Being near Enfield he was able to keep in touch with his former headmaster who lent him books (*Spenser's Faerie Queene particularly inspired him) and eventually introduced him to the circle of Leigh *Hunt. Thus he came to know *Haydon, *Shelley, and others as well as Charles Brown, a retired merchant, who enjoyed helping young men of promise; with him he shared a double house in Hampstead, now a Keats museum. Meanwhile he had passed his examination at the Apothecaries Hall and had 'walked' the hospitals, but by 1817 he had recoiled from (pre anaesthesia) surgery and abandoned the profession.

His first book of poems (1817), which included the famous sonnet On First Looking into Chapman's Homer, created little stir, but already he was working on Endymion (1819), with its familiar opening line 'A thing of beauty is a joy for ever'. A great but uneven poem in four books, it provoked savage criticism and some discerning praise. In 1818 he had lost both his dearly loved brothers: George emigrated to America, Tom died of tuberculosis. To the period that immediately followed belong some of his finest poems, which appeared in Lamia and Other Pooms (1820). This included Lamia, the odes To a Nightingale, To Psyche, To Autumn, On Melancholy and On a Grecian Urn, The Eve of St Agnes, La Belle Dame Sans Merci, and the unfinished Hyperion. To the same period belongs his love for Fanny Brawne, lively, kind and loyal, who tended him when ill but with little understanding of the poet's emotional needs. Early in 1820 with the coughing up of blood came signs of serious illness; he steadily got worse and became dependent on the charity of friends. In September he went to Italy with the artist Joseph Severn, who left a faithful record of the last days. In the following February he died in Rome. 'Here lies one whose name was writ in water' was inscribed (at his own request) on the nameless gravestone under the words 'Young English Poet'. Shelley's Adonais was written in lament for his friend.

Motion, A., Keats. 1997.

Keble, John (1792-1866). English clergyman and poet. Elected to a fellowship at Oriel College, Oxford (1811), he became tutor (1817), but from 1823 spent some years in parish work. His very popular 
book of poems The Christian Year appeared in 1827, and he was professor of poetry at Oxford (183141). His sermon on National Apostasy (1833) was afterwards held to have initiated the Tractarian (or Oxford) Movement in the Church of England which advocated the restoration of some of the forms of worship and practices, e.g. use of incense, vestments, intoning, which had fallen into disuse since the Reformation. He wrote seven of the Tracts for the Times but, unlike John Henry *Newman, remained loyal to the Anglican Church. He left Oxford (1836) after his marriage and later translated parts of the early Christian Fathers and wrote or edited several religious works. Keble College, Oxford, was built in his memory (1870).

Battiscombe, G., John Keble. 1964.

Keeling, (Charles) David (1928-2005). American chemist, oceanographer and meteorologist, born in Pennsylvania. Working at the Scripps Institution of Oceanography 1956-99, he developed an instrument for accurate measurement of carbon dioxide samples. At Mauna Loa, Hawaii, from 1958 he measured seasonal variations in $\mathrm{CO}_{2}$, with a sharp increase overall, known as the 'Keeling curve', a compelling demonstration of the impact of anthropogenic climate change. He received many international awards.

Kefauver, (Carey) Estes (1903-1963). American Democratic politician. A member of the House of Representatives from Tennessee 1939-49 and US Senator 1949-63, he became a television celebrity as chairman of a committee on crime. He sought the presidential nomination in 1952 and 1956 and was Adlai *Stevenson's running mate in 1956.

Keitel, Wilhelm Bodewin Johann (1882-1946). German soldier. An artillery officer during World War I, he became a devoted Nazi. In February 1938, *Hitler dismissed the high command of the Reichswehr, made himself supreme and appointed Keitel as Chief of Staff. During World War II, promoted to Field Marshal in 1941, he was virtually Hitler's second in command and executive officer. A courtier as much as a soldier, he showed skill in converting Hitler's occasionally brilliant strategic conceptions into practicable operations, but lacked the strength to combat his master's military follies. He was condemned for war crimes at Nuremberg and executed.

Keith, Sir Arthur (1866-1955). Scottish anthropologist, born near Aberdeen. He qualified in medicine and, known for his anatomical research, was also a recognised authority on morphology and evolution. He became Hunterian professor at the Royal College of Surgeons (1908), and President of the British Association (1927). He argued that homo sapiens had originated in Europe and advocated racial segregation. He was among the last to defend the authenticity of 'Piltdown man'.
Keith, James Francis Edward (1696-1758). Scottish soldier of fortune. Known, because of an office hereditary in his family, as Marshal Keith, after taking part in the Jacobite rising (1715) he became a colonel in the Spanish army. In 1728 he was made a general when serving for Russia and made a name for himself in the Turkish and Swedish wars. In 1747 he left the Russian service and was immediately employed as field marshal by *Friedrich II ('the Great') of Prussia. He fought for him in the Seven Years' War during which he was killed.

Kekkonen, Urho Kaleva (1900-1986). Finnish politician. A lawyer and popular athlete, he fought with the Whites during the civil war (1919) and joined the Agrarian Party. He was legal counsellor of the Agrarian Party and an administrative secretary of the Agriculture Department 1932-36 when he entered parliament in 1936. He served as Minister of Justice 1936-37, 1944-46, Minister of the Interior 1937-39, 1950-51, Chairman of the Finnish Olympic Games Committee 1938-46, Chief of the Bureau of Displaced Persons 1940-43 and Speaker of the Parliament 1948-50. In 1944 he assisted J. K. *Paasikivi in negotiating peace with the USSR and devoted his career to maintaining the 'Paasikivi line' (neutrality, no anti-Soviet policies, but no Russian domestic intervention). Prime Minister 1950-53, 1954-56, he was defeated for the presidency by Paasikivi in 1950 but elected in 1956, holding office for a record term, retiring in 1981 .

Jakobsen, M., Finnish Neutrality. 1968; Kekkonen, U., Neutrality the Finnish Position. 1970.

Kekulé von Stradonitz, Friedrich August (18291896). German chemist. Professor of chemistry at Ghent 1858-67 and Bonn 1867-96, he laid the foundations of structural organic chemistry with his discovery (1858) that each carbon atom can bond with four others (tetravalence) and form chains, and systematised the chemistry of alipathic (openchain) compounds. He repeated this with aromatic compounds when he devised (1865) the now familiar ring formula for benzene: the resolution of this problem came in a dream as he was dozing on a bus and he saw the elements dancing. He convened the First International Chemical Congress at Karlsruhe in 1860, and received the Copley Medal in 1885.

Keller, Gottfried (1819-1890). Swiss author. He went to Munich to study art but soon turned to literature, remaining in Germany, latterly in Berlin, until 1855, when he returned to Switzerland. His long, vivid and partly autobiographical novel, Der Grüne Heinrich (1854), achieved little popularity until it was revised and given a happy ending. $\mathrm{He}$ achieved most success with his humorous short stories of Swiss life: ${ }^{*}$ Delius' opera $A$ Village Romeo and Juliet was based on one of them.

Lindsay, J. M., Gottfried Keller: Life and Works. 1969. 
Keller, Helen Adams (1880-1968). American author and lecturer. She became blind and deaf at 19 months of age, after scarlet fever, but later learned to read Braille, to write and speak. Her teacher and constant companion from 1887 was Anne Sullivan (18661936). She became a symbol of human determination to overcome physical handicaps and an inspiration for all similarly disabled. In 1904 she graduated from Radcliffe College, Cambridge, Mass. She toured the world lecturing and wrote several books, e.g. The Story of My Life (1902), The World I Live In (1908) and Let Us Have Faith (1940).

Tribble, J. W. and A., Helen Keller. 1973.

Kellogg, Frank Billings (1856-1937). American Republican politician. A successful corporation lawyer, he served as US Senator from Minnesota 1917-23, and was US Ambassador in Great Britain 1924-25 and Secretary of State 1925-29. He worked for the Pact of Paris (Briand-Kellogg Pact, 1928) by which 15 nations renounced war as an instrument of policy. He was awarded the Nobel Peace Prize (1929) and became an associate judge of the Permanent Court of International Justice 1930-36.

Ellis, L. E., Frank B. Kellogg and American Foreign Relations, 1925-1929. 1961.

Kellogg, Will Keith (1860-1951). American manufacturer. In 1894 he developed the first breakfast cereal (wheat flakes) as a health food for an Adventist sanatorium at Battle Creek, Michigan, run by his brother John Harvey Kellogg (1852-1943). Corn flakes soon followed. Kellogg's principal rival, General Foods, was founded by C(harles) W(illiam) Post (1854-1914) who also produced Postum (a coffee substitute), Grape-Nuts and Post Toasties at Battle Creek.

Kelly, Ellsworth (1923-2015). American painter and sculptor. Trained in Boston and Paris, his powerful hard-edged abstract paintings made striking use of primary colours and he was represented in major galleries.

Kelly, Grace (Princess Grace of Monaco) (19291982). American actor. The daughter of a Philadelphia industrialist, she made 11 films in her brief career (1951-56) and her good looks, sexual elegance and cool style brought her international acclaim. She won an Oscar for The Country Girl (1954) and starred in three *Hitchcock films, Dial M for Murder (1954), Rear Window (1954) and To Catch a Thief (1955). She married *Rainier III, Prince of Monaco, in 1956 and had three children. She became involved in a religious cult and died after a car accident.

Lacey, R., Grace. 1994.

Kelly, Ned (Edward) (1854?-1880). Australian bushranger. Son of a transported Irish convict, he took to the hills with his brother Dan and two other mates after several clashes with the law. He killed three policemen in a shootout (October 1878) and was captured at Glenrowan after 18 months of flamboyant outlawry. He was tried and hanged in Melbourne. A film, The Story of the Kelly Gang, was made in 1906. Kelly has become a central figure in Australian mythology, the subject of many books, at least nine films, and 27 paintings by Sidney ${ }^{*}$ Nolan.

Jones, I., Ned Kelly: A Short Life. 1995; FitzSimons, P., Ned Kelly. 2015.

Kelly, Petra Karin (1947-1992). German politician and writer. Educated in the US, she worked for the SPD and the EEC, then became co-founder (1979) of the Green Party (Die Grünen), serving in the Bundestag 1983-90, campaigning on environmental issues, world peace, universal disarmament and women's rights. She and her lover Gerd Bastian, a former general, died by shooting, apparently murder and suicide.

Kelvin of Largs, 1st Baron, William Thomson (1824-1907). Scottish mathematician and physicist, born in Belfast. Son of a professor of mathematics, after showing brilliance in mathematics at Cambridge he became, when only 22, professor of natural philosophy at the University of Glasgow, a position he held 1846-99. In 1848 he proposed the adoption of an absolute temperature scale (later named for him) in which absolute zero $\left(-273^{\circ} \mathrm{C}\right)$ is $0^{\circ} \mathrm{K}$ (or Kelvin), and the boiling point of water $\left(100^{\circ} \mathrm{C}\right)$ is $373^{\circ} \mathrm{K}$. One of the founders of thermodynamics, he expanded *Joule's findings and enunciated the Second Law of Thermodynamics in 1851 , just after ${ }^{*}$ Clausius. Kelvin invented many instruments, mainly electrical, e.g. the mirror galvanometer, a magnetically shielded ship's compass, the dynamometer, tide gauges, and the quadrant electrometer. He was consultant to the company that laid the first transatlantic cable (1858). Knighted in 1866, he received the Copley Medal in 1883, served as President of the Royal Society 1890-94, became Lord Kelvin in 1892 and one of the original members of the OM in 1902. After 1880 he became increasingly rigid in his attitudes and rejected new discoveries in physics, e.g. radioactivity, atomic structure and X-rays.

MacDonald, D. K. C., Faraday, Maxwell and Kelvin. 1965.

\section{Kemal Atatürk see Atatürk, (Mustafa) Kemal}

Kemble, John Philip (1757-1823). English actor. Leading member of a famous English stage family, after some years in the provinces he was given the chance to come to London through the success of his sister Sarah *Siddons. Hamlet (1783) was the first of many tragic roles that he played with great distinction at Drury Lane. In keeping with his character, his approach was intellectual. In contrast with his successor Edmund *Kean, he was at his best in parts requiring dignity and nobility, Brutus and Coriolanus providing outstanding examples. $\mathrm{He}$ 
was appointed manager of Drury Lane by *Sheridan (1788), but in 1802 he bought a share in Covent Garden Theatre, which he managed and where he performed. The theatre was burnt down (1808), and the price of seats in the rebuilt theatre (1809) caused riots. He retired (1817) to live in Lausanne.

His brother Charles Kemble (1775-1854), whose grace and charm fitted him more especially for comedy, was the father of Fanny Kemble (18091893) who unwillingly followed the family tradition and in 1829 made a triumphant debut as Juliet at Covent Garden.

Kemp, Jack French (1935-2009). American Republican politician. A professional footballer, he became a public relations officer in a bank, and a US Congressman 1971-89. He sought the Republican nomination for president in 1988 and served under ${ }^{*}$ Bush as Secretary of Housing and Urban Development 1989-93. He ran as a candidate for Vice President with Bob *Dole (1996).

Kemp, Roger (1908-1987). Australian painter. A symbolic expressionist, his large canvasses express deep philosophical convictions about man's role in time, space and the universe. It took decades of persistence before his work was recognised.

Kempe, Margery (née Brunham) (c.1373-c.1440). English mystic and traveller, born in Lynn (now King's Lynn), Norfolk. She married John Kempe c.1393 and bore 14 children. She experienced religious ecstasies, marked by prolonged shrieking and sobbing, and narrowly escaped charges of Lollardry. From 1413 she went on three pilgrimages, to Jerusalem (via Constance, Venice, Assisi and Rome), to Santiago de Compostela (Spain), and to Wilsnack (now in Poland), via Norway and Danzig, returning through Aachen. Illiterate, she dictated The Booke of Margery Kempe, the first English autobiography, to two clerks (c.1432-36). Extracts were printed by Wynkyn de *Worde (1501) but the complete work was not published until 1940 .

Kempff, Wilhelm Walther Friedrich (1895-1991). German pianist. Also a teacher, editor, writer and composer, he recorded all the piano music of *Beethoven, ${ }^{*}$ Schubert and ${ }^{*}$ Schumann, gaining a late (but profound) international reputation. He made his London debut in 1951, New York in 1964.

\section{Kempis, Thomas a see Thomas à Kempis}

Ken, Thomas (1637-1711). English prelate and hymn writer. He was appointed Bishop of Bath and Wells (1684 despite his refusal to accommodate Nell *Gwyn during *Charles II's visit to Winchester 1683). Under *James II, he was one of seven bishops who refused to sign the Declaration of Indulgence. He lost his bishopric (1691) for refusing to take an oath of allegiance to *William and ${ }^{*}$ Mary. Later he was given a pension by
Queen *Anne and lived at Longleat until his death. His hymns include Praise God from whom all blessings flow and Awake, my soul.

Kendrew, Sir John Cowdery (1917-1997). English biochemist, born in Oxford. A Fellow of Peterhouse, Cambridge 1947-75, he shared the 1962 Nobel Prize for Chemistry with Max *Perutz for their studies of the structure of globular proteins, including myoglobin. He had diverse cultural interests and worked on public policy and philanthropy.

Keneally, Thomas Michael (1935- ). Australian novelist and historian, born in Sydney. His books include Three Cheers for the Paraclete (1968), The Chant of Jimmy Blacksmith (1972, also filmed), Season in Purgatory (1976) and Schindler's Ark (1982, winner of the Man Booker Prize, filmed as Schindler's List, 1993). He wrote impressive histories: The Great Shame (1982), Australians. Origins to Eureka (2009) and Australians. Eureka to the Diggers (2011). He was a leading figure in the Australian Republican Movement.

Kennan, George Frost (1904-2005). American historian, diplomat and foreign policy theorist. $\mathrm{He}$ served as a diplomat in Moscow (1933-38, 1945-46, 1952-53) and devised the policy of 'containment' of the USSR adopted by ${ }^{*}$ Truman after World War II. He was the BBC's Reith Lecturer (1957), a professor at the Institute for Advanced Study at Princeton 1956-74, Ambassador to Yugoslavia 1961-63, and won the Pulitzer Prize (1968) for his Memoirs.

Kennedy family. Irish-American political family in Massachusetts. Joseph Patrick Kennedy (18881969), son of a politician, educated at Harvard, married Rose Fitzgerald Kennedy (1890-1995), daughter of the Mayor of Boston, in 1914. He became a bank president, businessman, stockmarket speculator, investor in films, shopping centres and imported liquor. He contributed heavily to Democratic party funds and supported Franklin D. *Roosevelt until 1940. Ambassador to Great Britain 1937-40, he believed that Nazi domination in Europe was inevitable and urged an isolationist policy. His nine children included Joseph Patrick (1915-1944), intended for a political career but shot down in the USAF, *John Fitzgerald, *Robert Francis and ${ }^{*}$ Edward Moore.

Kennedy, Edward Moore ('Ted') (1932-2009). American Democratic politician, born in Boston. Educated at Harvard (where he was suspended) and the Virginia Law School, he succeeded to John F. *Kennedy's seat as US Senator from Massachusetts 1962-2009, winning a special election at the minimum age, after a temporary appointee obligingly stepped down. His presidential prospects were damaged by an incident at Chappaquiddick Island, Mass. (July 1969) when he failed to report the death of a woman passenger after he drove off 
a bridge. In 1980 he challenged Jimmy *Carter for the Democratic nomination. His supporters pointed to his courageous advocacy of unpopular, liberal causes, his detractors to his playboy lifestyle and heavy drinking. He was a vehement opponent of the Iraq war and campaigner for universal health care. In 2008 he strongly endorsed Barack *Obama for the Democratic nomination for president. Awarded an honorary KBE (2009), he died a year after being diagnosed with a brain tumour.

Hersh, B., The Shadow President. 1997.

Kennedy, John Fitzgerald ('JFK') (1917-1963). 35th President of the US 1961-63. Born in Brookline, Mass., son of Joseph *Kennedy, he was educated at the Choate School, (briefly) the London School of Economics, Harvard and the Stanford Business School. He interrupted his Harvard course to accompany his father on his London Embassy position and graduated in 1940 with a thesis later published as Why England Slept. In World War II he served in the US Navy and was decorated for heroic rescues of crew members after PT-109 was rammed off the Solomon Islands. This aggravated an acute spinal injury which caused him great pain and led to near-fatal operations (1954-55) and to Addison's disease. He served in the US Congress 1947-53 and as a senator from Massachusetts 1953-60. In 1953 he married Jacqueline Lee Bouvier (1929-1994) a beautiful journalist and photographer who later married Aristotle ${ }^{*}$ Onassis and became a successful book editor. In 1957 he won the Pulitzer Prize for history with his (ghost-written) Profiles in Courage, accounts of courageous senators. Oddly, his own senate record was equivocal and he failed to speak out against Joseph * McCarthy. After failing to secure the Democratic vice-presidential nomination in 1956, he began his campaign for the presidency in 1957. In 1960 he defeated Richard M. *Nixon in the closest race since 1916; Lyndon B. *Johnson became Vice President. He was the youngest president ever elected and the first Roman Catholic (although far from devout). As President, he pursued the liberal policies to which he had pledged himself, civil rights for black people, aid for underdeveloped countries, and setting up the Peace Corps. However, much of his domestic 'New Frontier' legislation was blocked by Congress. The abortive 'Bay of Pigs' invasion of Cuba (April 1961) showed a major error of judgment, redeemed by his coolness in the October 1962 confrontation with *Khrushchev over proposed establishment of Soviet missile bases in Cuba. The Nuclear Test Ban Treaty (1963) indicated a thaw in the Cold War. Kennedy's role in Vietnam was ambiguous at best: he increased US troops to 17,000 but expressed doubts privately about South Vietnam's defensibility. On 22 November 1963, on a political tour of Texas, he was shot in Dallas by Lee Harvey *Oswald and died in hospital barely 30 minutes later. The assassination caused widespread grief and shock internationally and in the US. The *Warren Commission concluded that Oswald was a lone assassin but the incident has generated continuing controversy with books and films proposing a variety of conspiracy theories. Kennedy's reputation has been subject to some revisionism, mostly relating to his private life, e.g. his alleged relationship with Marilyn ${ }^{*}$ Monroe. In 18 Presidential ranking lists by historians and political scientists, Kennedy scored No. 10 in the aggregate.

Manchester, W., One Brief Shining Moment. 1983; Hamilton, N., JFK: Reckless Youth. 1992; Logevall, F., JFK: Coming of Age in the American Century, 19171956. 2020.

Kennedy, Robert Francis (1925-1968). American politician. Younger brother of President John Fitzgerald *Kennedy, educated at Harvard and the University of Virginia Law School, he became counsel to a senate subcommittee in 1953, working briefly for Joseph *McCarthy, and gaining national recognition by exposing Jimmy Hoffa's corruption in the Teamsters' Union 1957-59. He became US Attorney-General in his brother's Cabinet 1961-64, with a special interest in promoting civil rights for black people. He resigned in 1964 and was elected Senator for New York, becoming a popular critic of President *Johnson's Vietnam policy. In 1968 he announced his candidacy for the presidency, but died on 6 June after being shot in Los Angeles by Sirhan Sirhan.

Kenneth I (MacAlpin) (d.858). King of the Picts and Scots 843-58. Regarded as the first Scots King, he united the kingdoms of Dalriada and the Picts.

Kenny, Elizabeth (1886-1952). Australian nurse. She developed the 'Kenny method' of treating poliomyelitis by stimulating the muscles. Although it was denounced by many physicians, some clinics using the treatment were established in Australia and the US.

Kent and Strathearn, Edward Augustus, Duke of (1767-1820). British prince. Born in London, fourth son of ${ }^{*}$ George III, he pursued a military career, serving in Canada (1791-93, 1796 and 17991802). He was the first prince to visit the United States after independence (1794) and the first to use the generic term 'Canadian'. Governor of Gibraltar 1802-05, he became a field marshal in 1805 and was the first army commander to dispense with flogging. To help secure the royal succession, he left his mistress of 20 years and in 1818 married Victoria of Saxe-Coburg (1786-1861). Their only child became Queen ${ }^{*}$ Victoria. His great-great-grandson, George Edward Alexander Edmund, Duke of Kent (1902-1942), was the fourth son of ${ }^{*}$ George V. He married (1934) Princess Marina of Greece, was appointed Governor-General of Australia in 1938, to take office in November 1939, but due to the outbreak of war remained in Britain. He was killed in an RAF air crash in Scotland. 
Kent, William (1685-1748). English architect, interior decorator and landscapist, born in Yorkshire. Apprenticed to a coach-builder, he was helped by rich well-wishers to go to Rome to study painting, at which, however, he never excelled. In Rome he met (1719) Lord *Burlington, whose enthusiasm for Palladian architecture he shared. Back in England he decorated a suite for Kensington Palace (1723), turned to architecture after 1730 and designed the Horse Guards (1750-58), the Treasury (1734) and several London houses. In the country, where Holkham Hall and Stowe were among his creations, he was a pioneer in the art of treating buildings and their surroundings as a single artistic conception; temples and pavilions in the grounds for example taking their appropriate place in a composition that included the house and gardens. This art of landscaping was carried further by his pupil, 'Capability' *Brown.

Kentridge, William (1955- ). South African-Jewish painter, sculptor, animator, film and opera director, born in Johannesburg. He worked in an extraordinary diversity of forms including animated drawings, paintings, prints, sculpture, also directing operas by ${ }^{*}$ Monteverdi, *Mozart, *Berg and ${ }^{*}$ Shostakovich. His films examine time, colonialism, revolutions and scientific advance. Triumphs and Laments (2016) is a huge mural in Rome.

Kenyatta, Jomo (originally Kamau) (c.1893-1978). Kenyan politician. A Kikuyu, he became a government clerk and journalist, and was away from Kenya 1929-46, living mostly in England where he studied anthropology at the London School of Economics, and twice visited the USSR. Returning home, he became President of the Kenya African Union in 1947. He was imprisoned 1953-61 for his part in the Mau Mau rebellion. Within two months of his release (1961) he was re-elected President of the Kenya African National Union (KANU). He became the first Prime Minister 1963-64 and, after proclaiming a republic, first president of Kenya 1964-78. He wrote several books, notably Facing Mount Kenya (1938). His son, Uhuru Kenyatta (1961- ), was Deputy Prime Minister 2009-12 and President of Kenya 2013- , despite being accused of crimes against humanity in the International Court of Justice.

Murray-Brown, J., Kenyatta. 1972; Delf, G., Jomo Kenyatta. 1961.

Kenyon, Dame Kathleen Mary (1906-1978). British archaeologist. She lectured at the Institute of Archaeology, London University 1948-62, specialising in Palestinian archaeology. She directed the British School of Archaeology in Jerusalem 195163, working herself at Jericho and Jerusalem. She was principal of St Hugh's College, Oxford 1962-73. Her numerous works include Archaeology in the Holy Land, 3rd ed. (1970), and Digging up Jerusalem (1974).
Kepler, Johannes (1571-1630). German astronomer, born in Weil der Stadt (now part of Stuttgart). At the University of Tübingen he first studied for the Lutheran ministry but became absorbed in scientific studies and in 1594 was appointed professor of mathematics at Graz. In 1600 he went to Prague and became assistant to Tycho *Brahe. After Brahe's death Kepler succeeded him as astronomer and mathematician (1601-30) to the emperor *Rudolf II, and inherited his valuable papers and records. As he received no salary he suffered great poverty. In 1612 he obtained a mathematical appointment at Linz and in 1627 became astrologer to *Wallenstein, the imperial general in the Thirty Years' War. Kepler was an adherent of the Copernican system and is regarded as one of the founders of modern astronomy. $\mathrm{He}$ enunciated the three fundamental laws of planetary motion now known as Kepler's Laws (1609): (1) each planet moves along an elliptical orbit of which the sun is the focus, (2) an imaginary line joining a planet to the sun will sweep out equal areas in equal times, (3) the square of the planet's orbit around the sun is proportional to the cube of its mean distance. Sixty years later these laws helped *Newton to formulate his universal law of gravitation. Kepler also suggested that tides are caused by the moon's gravitational pull on large bodies of water. His Rudolphine Tables (1627) giving the positions of sun, moon and planets, remained standard for about a century. He corresponded with ${ }^{*}$ Galileo but they never met. In 1611 he proposed an improved refracting telescope using two convex lenses and suggested the principle of the reflecting telescope later developed by Newton.

A supernova, three stars, remote planet Kepler 36b, asteroid 1134 Kepler, craters on the Moon and Mars, and NASA's Kepler space telescope were named for him. Operas about Kepler were written by Paul ${ }^{*}$ Hindemith and Philip *Glass.

Koestler, A., The Sleepwalkers. 1959; Banville, J., Kepler. 1981; Casper, M., Kepler. 1993.

Kerensky, Aleksandr Feodorovich (1881-1970). Russian lawyer and politician. He made his name as a brave and eloquent opponent of the tsarist government in the Duma of 1912, and during World War I, after the revolution (March 1917), Kerensky, as a leader of the Social Revolutionary party, became Minister of Justice, then Minister of War, and in July head of the provisional government. His decision to pursue the war against Germany undermined his popularity and in November he was overthrown by the Bolsheviks. He spent a life of exile and propaganda in Paris, then in the US 1920-45, 1946-70; and Australia 194546. He died in New York and was buried in London. His son, Oleg Aleksandrovich Kerensky (19051984), civil engineer and bridge designer in England, worked on the Sydney Harbour Bridge.

Browder, R. and Kerensky, F. (eds), The Russian Provisional Government, 1917. 1961; Kerensky, A., Russia and History's Turning Point. 1965. 
Kermode, Sir (John) Frank (1919-2010). British literary critic, born in Douglas, Isle of Man. Co-editor of Encounter 1966-67, he held chairs in English literature at Manchester, Bristol, London, Cambridge and Harvard, wrote the highly praised memoir Not Entitled (1996) and was a discriminating anthologist. He wrote Shakespeare's Language (2000).

Kern, Jerome David (1885-1945). American composer. He studied piano, harmony and music theory in New York and Heidelberg, and wrote about 1,000 songs, including Smoke Gets in Your Eyes and The last time I saw Paris, many interpolated into other productions. He composed 41 musicals. The most successful was Showboat (1927), based on Edna *Ferber's novel, to lyrics by Oscar *Hammerstein, including the song $\mathrm{Ol}$ ' man river. Other collaborators included P. G. * Wodehouse and Guy Bolton. He was a discriminating collector of antique manuscripts and documents.

Kerouac, Jack (1922-1969). American author. Exemplar of the lifestyle and discontents of the 'beat' generation, his best known novel, On the Road (1957), is written in a spontaneous, discursive idiom and embodies the attitudes and alienation of the '50's 'beatnik' youth. Later novels include The Subterraneans (1958) and Big Sur (1962).

Charters, A., Kerouac. 1974

\section{Kéroualle, Louise de see Portsmouth, Duchess of}

Kerr, Sir John Robert (1914-1991). Australian lawyer, born in Sydney. He became an industrial court judge, Chief Justice of New South Wales 197274 and Governor-General of Australia 1974-77 on the nomination of Gough *Whitlam. In November 1975 he dismissed the Whitlam Labor Government in an unprecedented use of the Governor-General's reserve powers, after the Opposition-dominated Senate deferred passage of Supply, and appointed Malcolm *Fraser as Prime Minister. Kerr became the centre of bitter controversy and resigned from his post in 1977 before the expiry of his five-year term. He left Australia and later wrote his memoirs Matters for Judgment (1978).

Kerry, John Forbes (1943- ). American Democratic politician, born in Denver. He served in the US Navy during the Vietnam War, became a lawyer and US Senator from Massachusetts 1985-2013. Democratic candidate for president in 2004, he lost narrowly to George W. *Bush. He became US Secretary of State 2013-17 in *Obama's second term. Joe *Biden appointed him as US Special Presidential Envoy for Climate 2021- .

Kesselring, Albert (1885-1960). German soldier and airman. Having transferred (1935) from the artillery to the Luftwaffe (air force) he commanded air fleets in the early offensives of World War II, including the Battle of Britain. He became Supreme Commander of the Axis forces in Italy (1943) and conducted a series of delaying actions with remarkable skill. In April 1945, when all was already lost, he superseded von *Rundstedt as Commander-in-Chief on the western front. He received a death sentence (commuted to life imprisonment) for war crimes in 1947 but was released in 1952.

Kessler, Harry Clemens Ulrich, Count [Graf] (1868-1937). German diplomat, art patron and diarist. With an Anglo-Irish mother, and partly educated in England, his diaries are a valuable resource for the politics and culture of la Belle Époque and World War I and he was radicalised by his experiences. His complete diaries were published in nine volumes in 2004.

Easton, L. M., The Red Count: The Life and Times of Harry Kessler. 2002; (ed.), Journey into the Abyss: The Diaries of Count Harry Kessler 1880-1918. 2011.

Kettering, Charles Franklin (1876-1968). American engineer and inventor. His inventions included the electric cash register (1908), the electric self-starter for cars (1912), quick drying lacquer and anti-knock petrol. He was Vice President and Director of Research at General Motors 1920-47. The Sloan-Kettering Institute for cancer research in New York was named for him and Alfred P. *Sloan, chairman of GM.

Key, Francis Scott (1779-1843). American lawyer and poet. He wrote the words of The Star-Spangled Banner, which became the American national anthem by an act of Congress (1931).

Key, Sir John Phillip (1961- ). New Zealand National politician, born in Auckland. His father was English, his mother an Austrian Jew. Educated in Christchurch, he became a merchant banker and worked as a foreign exchange dealer in Singapore and London. MP 2002-17, he became National Party leader 2006-16 and Prime Minister 2008-16.

Keynes (John) Maynard, 1st Baron Keynes of Tilton (1883-1946). English economist, born in Cambridge. Son of an economist who lectured in moral sciences, then became a college administrator, he was educated at Eton, studied under A.C. Pigou and Alfred ${ }^{*}$ Marshall at Cambridge and was influenced by the philosopher G. E. *Moore. He joined the civil service in 1906 and was active in the 'Bloomsbury set'. Fellow and lecturer at King's College, Cambridge, from 1909, he worked during World War I at the Treasury, of which he was the principal representative at the negotiations preparatory to the Treaty of Versailles. Having shown, by his resignation, disapproval of the financial proposals, especially those relating to reparations, he predicted trenchantly, in The Economic Consequences of the Peace (1919), the results of imposing obligations that a defeated Germany would be unable to meet. The book made Keynes the centre of immediate controversy and 
ensured his fame when his worst fears were realised. He was equally critical of Britain's return to the gold standard (1925) and predicted the rapid increase in unemployment that would arise from its deflationary effects. The direction in which his mind was working was shown by the proposals he made for dealing with unemployment in the 1929 election manifesto of the Liberal Party (to which he belonged), a large program of public works being among the chief recommendations. Keynes' broad approach was adopted in *Roosevelt's 'New Deal' after 1934. His matured ideas for regulating the economy as well as his new conclusions on monetary theory were elaborated with great skill and persuasive power in The General Theory of Employment, Interest, and Money (1936). The general acceptance of its main tenets in many countries after World War II constituted what is known as the Keynesian revolution. It marked the end of the classical economists' belief in the self-regulating economy: aggregate demand was to be adjusted to available supply, consciously using such financial techniques as enlarging or reducing the credit base or varying the rates of interest. Government expenditure, too, should be adjusted as necessary so as either to stimulate or to discourage public demand. Keynes himself modified some of his prescriptions in later years. It is clear from the 'stopgo' tactics enforced upon governments in Britain and elsewhere that the full answers have not been found, but the great overall postwar rise in prosperity in the developed countries and the absence of catastrophic unemployment is largely due to Keynes.

He was one of the few theoretical economists who had the opportunity or skill to bring his ideas into practice. In World War II he was advisor to the Chancellor of the Exchequer, having become a member of the Bank of England Board (1941) and a peer (1942). The years from 1943 on were mainly spent on financial missions to America. He was the chief British delegate at the Bretton Woods Conference (1944), and it was his plan, welded with similar American proposals, that became the basis of discussion and agreement there on the foundation of the International Monetary Fund and the World Bank. Keynes was a lover and patron of several arts, built and endowed the Cambridge Arts Theatre, chaired the Council for Encouragement of Music and the Arts (CEMA) 1942-45 and was the first Chairman of the Arts Council of Great Britain 194546. Despite his homosexuality, he married (1925) the Russian ballerina, Lydia Lopokova (1892-1981). He died just before the announcement that he had been awarded the OM.

Dillard, D. D., The Economics of John Maynard Keynes. 1948; Skidelsky, R., John Maynard Keynes. Vol 1, 1983, Vol 2, 1992, Vol 3, 2000; Davenport-Hines, R., Universal Man: The Seven Lives of John Maynard Keynes. 2015; Carter, Z. D., The Price of Peace: Money, Democracy and the Life of John Maynard Keynes. 2020.
Khachachurian, Aram Ilyich (1903-1978). Armenian composer, born near Tbilisi, Georgia. Growing up in a rich multicultural environment, he moved to Moscow in 1921 and studied at the Conservatorium 1929-34. His compositions were influenced by the Armenian, Georgian and other folk tunes that he collected. He wrote three virtuoso concertos (for piano, cello and violin) in addition to three symphonies, the popular ballet suites Gayaneh and Masquerade, a number of songs (some of them for the Red Army), and incidental music for films and plays. He was awarded the Order of Lenin (1939) and composed the national anthem for Soviet Armenia (1945).

Khama, Sir Seretse Goitsebeng Maphirim (19211980). African chief and politician. Grandson of Khama III, king of the Bamangwato people in the Bechuanaland protectorate, he was educated at Balliol College, Oxford. His marriage (1950) to an Englishwoman, Ruth Williams, led to a period of exile but he returned to Bechuanaland in 1956, but renounced his tribal kingship. He founded his own political party and became the first Prime Minister of Bechuanaland 1965-66 and first President of Botswana 1966-80.

Khamenei, Ali Hosseini (1939- ). Iranian ayatollah, born in Mashhad. A Shia cleric, he was President of the Islamic Republic 1981-89 and on the death of Ayotollah Ruhollah *Khomenei succeeded him as Supreme Leader 1989- and head of the Council of Guardians. An effective political networker, he gave broad support to Mahmoud*Ahmadinejad.

Khan (Niazi), Imran Ahmad (1952- ). Pakistani politician and cricketer, born in Lahore. A Pashtun, educated at Oxford, he played test cricket for Pakistan 1971-92 and was captain (intermittently) 1982-92. He founded Pakistan Tehreek-e-Insaf (PTI) in 1996. He broadly supported military rule as a means of ending corruption, became Prime Minister 201822, attempted modest reforms in the economy and environment, but cultivated links to Islamists. Defeated in the parliament, he was forced to resign in April 2022. He survived an assassination attempt in November 2022.

Khashoggi, Jamal Ahmed (1958-2018). Saudi Arabian journalist, born in Medina. Educated in the United States, he was an editor in Saudi Arabia and a foreign correspondent for $\mathrm{CNN}$, the BBC and other western outlets. Increasingly critical of Muslim fundamentalism and the Saudi royal family, he was murdered and dismembered at the Saudi consulate in Istanbul in October 2018. The CIA identified Crown Prince * Muhammad bin Salman as having ordered the murder. After originally totally denying the killing, the Saudi regime prosecuted and convicted eight unnamed men in a secret trial, characterising them as 'rogue' operatives. 
Khatami, Muhammad (1943- ). Iranian cleric, theologian and politician. Formerly Minister for Culture 1982-92, regarded as a moderate, he was elected as President in 1997 and 2001 (serving 19972005) after a high turnout of women voters.

Khomeini, Ruhollah Musavi (1902-1989). Iranian ayatollah and political leader. A Shi'ite, he taught theology at Qom, opposed attempts to westernise and secularise Iran by Shah *Mohammed Reza Pahlevi and was exiled in Turkey, Iraq and France 1964-79. In February 1979 he returned to Iran, the Shah's government collapsed and Khomeini nominated a new ministry. He became virtual head of state with the support of his Islamic Revolution Party. Under the new constitution, accepted by plebiscite, Iran returned to the shariat, strict observance of Islamic principles, traditions and punishments including stoning and amputation. Iran instigated international terrorist acts, held US embassy staff hostage for 444 days (1979-80), effectively destroying *Carter's presidency, and declared war on Iraq. Khomeini sentenced the novelist Salman *Rushdie to death (fatwah) for his novel Satanic Verses which satirised the ayatollah. His funeral was marked by extraordinary outbursts of grief and violence.

Khorana, Har Gobind (1922-2011). IndianAmerican organic chemist. Educated at the Punjab and Liverpool Universities, he worked in Britain, Switzerland, Canada and the US and held chairs at Wisconsin, Cornell and MIT. He shared the 1968 Nobel Prize for Medicine for the interpretation of the genetic code and its function in protein synthesis.

Khrushchev, Nikita Sergeyevich (1894-1971). Russian politician, born in Kalinkova, Kursk Province. The son of a miner and shepherd, he first worked on a farm, then became a plumber and a locksmith. He joined the Communist Party in 1918 and after training began his career as party organiser at the age of 35 . He was a member of the Central Committee of the party (1934), Secretary of the Moscow District Party Committee 1934-38, General Secretary of the Ukraine 1938-46, 1947-53, and held the rank of Lieutenant General when the Ukraine was occupied by Germany. As Premier of the Ukraine 1944-47 he purged the anti-Stalinists there after the war. Elected to the Politburo in 1939, he was also secretary of the Moscow Province Communist Party 1949-53. On *Stalin's death he acted as a liaison between the 'collective leadership' (*Malenkov, ${ }^{*}$ Molotov, ${ }^{*}$ Beria) and the party machine. As First Secretary of the Communist Party (March 1953-October 1964) he steadily eliminated the top echelon of leadership. At the 20th Congress of the CPSU (February 1956), he denounced Stalin for his 'capricious and despotic' rule and for promoting the 'cult of personality'. With the support of *Zhukov in June 1957 he defeated an attempted coup by the 'anti-party group' (*Malenkov, ${ }^{*}$ Kaganovich, ${ }^{*}$ Molotov). He replaced his nominee N. A. *Bulganin as Premier of the USSR 1958-64, visiting the US in 1959, India and China in 1960. Forced out of office in October 1964, he passed into obscure retirement. A volume of his autobiography, Khrushchev Remembers, was published in the West in 1970 . He denied its authorship, but the materials used were authentic.

Khufu (or Cheops, the Greek form) (d.c.2700 BCE). Egyptian king. The second ruler of the IVth dynasty, he succeeded his father Snefru and built the Great Pyramid of Cheops (or Khufu), at Giza, near Cairo. He was succeeded by his sons Djedefre and Khafre.

Kidd, William (1645-1701). Scottish privateer. After successful operations against the French, he was provided (1696) by London merchants with a ship of 30 guns to destroy pirates in the Indian Ocean. In 1698 rumours began to trickle through that Kidd had turned pirate himself. Two years later he returned to American waters but when he landed at Boston, which had been his home for some years, he was arrested, despite a half-promise of a safe conduct. He was sent to London, tried, condemned and hanged. Hoards of treasure said to have been his were found in Long Island and elsewhere, but the exploits that have made him notorious as a pirate chief are mostly legendary and he may even have been innocent, as he claimed to the end.

Kido Takayoshi (né Wada Kogorō; also known as Kido Kōin and Katsura Kogorō) (1834-1877). Japanese samurai from Chōshū. He was a prime mover in the Meiji Restoration (*Mutsuhito) and drew up the Charter Oath of April 1868. He travelled abroad 1871-73 observing foreign systems and became one of the three dominant figures in the civil government 1873-74; 1874-75. He died from a combination of illnesses. Kido became a Shinto deity of scholarship and the martial arts, and the subject of films, video games and manga.

Kiefel, Susan Mary (1954- ). Australian jurist, born in Cairns. She left school at 15, became a secretary, receptionist, then a legal clerk, studying at night and was admitted to the bar in 1975 . She was a justice of the Supreme Court of Queensland 1993-94, of the Federal Court 1994-2007, of the High Court 2007-17 and became the first woman Chief Justice of Australia 2017-.

Kiefer, Anselm (1945- ). German painter and sculptor. Originally a photographer, influenced by Joseph *Beuys, and the historic impact of the Holocaust, living in Paris, he produced dark, powerful works, often using shattered glass, lead sheets, broken concrete and metal frames. He was widely exhibited and critically praised. He also painted works inspired by *Wagner's Ring of the Nibelungs.

Kierkegaard, Søren Aabye (1813-1855). Danish philosopher and theologian. Though influenced strongly by the philosophy of *Hegel, he then reacted 
against the Hegelian notion that through the ultimate reality, the Absolute, nature exists rationally and systematically. In his revolt against reason he stressed that the great problems of men, which he identified chiefly as dread (Angst) and anxiety, could only be resolved by an individual search for God, whom he saw as infinitely different in quality from man. He rejected, therefore, all conventional, communal and ethical religion and indeed the Christian dogma of a historical incarnation. His major works include Either/Or (1843), Concluding Unscientific Postscript (1846) and his Journals. His theme that 'truth is subjectivity' and his anti-Hegelian 'existential dialectic', at first scarcely known outside Denmark, profoundly influenced 20th-century thought and led directly to existentialism.

Rohde, P., Soren Kierkegaard: An Introduction to his Life and Philosophy. 1963; Carlisle, C., Philosopher of the Heart. The Restless Life of Søren Kierkegaard. 2019.

Kiesinger, Kurt Georg (1904-1988). German politician. A lawyer, he dropped out of the Nazi Party after brief membership, was interned in 1945 but never charged. A follower of *Adenauer, he became a Bundestag member 1949-58, 1966-80, Premier of Baden-Wurttemberg 1958-66 and Chancellor in the CDU-SPD 'grand coalition' 1966-69.

Kilby, Jack St Clair (1923-2005). American electrical engineer. In 1958 he built the first microchip (integrated circuit: IC) for Texas Instruments, soon followed by Robert N(orton) Noyce (1927-1990) at Intel and also invented the hand-held calculator. In 2000 he shared the Nobel Prize for Physics with Zhores I. Alferov and Herbert Kroemer.

Kildare, Earls of. Irish earldom, held (from 1316) by the head of the FitzGerald family. Gerald FitzGerald (Gearóid Óg in Irish), 8th Earl (known as 'The Great') (d.1513), took advantage of English preoccupation with the Wars of the Roses to build, by marriage alliances and conquest, an all but independent domain. Though he supported the pretender Lambert *Simnel he managed to effect a reconciliation with *Henry VII. His son Gerald FitzGerald, 9th Earl (1487-1534), for some time maintained much of his power in face of *Henry VIII's centralising policy, until forced to obey a summons to London where he was imprisoned.

Kilvert, Francis (1840-1879). English cleric and diarist. His Diary was discovered in 1937 and edited by William Plomer in three volumes, 1938-40. It describes his life and environment in graphic and sometimes humorous detail and is an important document of social history.

Kim Dae-jung (1925-2009). Korean politician. A presidential candidate in 1971, 1987, 1992 and 1997, he was imprisoned 1976-78, 1980-82, sentenced to death in 1980 and survived several assassination attempts. President of the Republic of
Korea 1998-2003, he opened up dialogue with *Kim Jong Il in North Korea and won the 2000 Nobel Peace Prize.

Kim Il Sung (1912-1994). Korean Communist politician and soldier. Son of a school teacher, he probably studied in China. He founded the Fatherland Restoration Association (1936), led guerrilla forces against Japan in Manchuria and may have served as a colonel at Stalingrad. After Korea's partitioning in 1945. Russian troops occupied the North, and Kim, Secretary-General of the Korean Workers' Party, became chairman of the provisional government. On the Russian withdrawal, the Democratic Peoples' Republic of Korea was founded and Kim was Premier 1948-72 and President 1972-94. During the Korean war (1950-53) he commanded the armed forces of the North and became a marshal. The DPRK attempted an ambitious industrialisation program after the war and Kim's philosophy of 'Juche' had the force of law. His son Kim Jong il (1942-2011) was Supreme Commander of the Korean Peoples' Army 1991-2011 but did not take his father's title as President, although confirmed as Secretary-General of the Korean Workers' Party in 1998. He was succeeded by Kim Jong-un (1983- ), probably educated in Switzerland 1996-2001, the third generation in the family to take supreme power, hailed as a master tactician, military leader and golfer. He held the titles of Supreme Leader 2011- , Supreme Commander of the Armed Forces 2011- and First Secretary of the Korean Workers' Party 2012- .

Fifield, A., The Great Successor. The Secret Rise and Rule by Kim Jong Un. 2019.

Kim Young-sam (1927-2015). Korean politician. Leader of the New Democratic Party 1974-97, he was kept under house arrest for years, polled strongly in the 1987 presidential election and became President of the Republic of Korea 1993-98, the first civilian for 30 years, after a free election in 1992. The Korean economy contracted as his term ended.

King, Albert Freeman Africanus (1841-1914). American physician, born in England. He served as a surgeon for both the Confederate and Union armies during the Civil War, and attended Abraham ${ }^{*}$ Lincoln after he was fatally shot. In 1882 he argued that mosquitoes were the vector for malaria, a proposition ridiculed at the time but confirmed by Alphonse *Laveran (1880) and Ronald *Ross (1898).

\section{King, Cecil see Harmsworth}

King, Ernest Joseph (1878-1956). American fleet admiral. After serving in the Spanish American War and World War I, he became Vice Admiral commanding the aircraft battle force 1938-39. This experience was of great value for the air sea battles of World War II, when he was Commander-in-Chief of the Atlantic Fleet 1941, Commander-in-Chief of the US Navy and Chief of Naval Operations 1942-45. 
His mastery of strategy and supply was a major factor in Japan's defeat. His daughter wrote of him that he 'was very even-tempered: he was always in a rage'.

King, Martin Luther, Jr (1929-1968). American clergyman and reformer, born in Atlanta, Georgia. A Baptist clergyman, he became the most successful and powerful of American black leaders in campaigning for civil rights. He adopted *Gandhi's tactics of 'passive resistance', organised a boycott of segregated buses in Montgomery, Alabama in 1956 and won national recognition. Imprisoned briefly 12 times and constantly harassed by the FBI, he led black moderates and opposed violence and the 'Black Muslim' movement. He organised vast civil rights rallies and his famous 'I have a dream' speech in Washington (August 1963) is of enduring significance. He won the 1964 Nobel Peace Prize and was assassinated in Memphis, Tennessee on 4 April 1968 by James Earl Ray. His work was continued by his widow, Coretta Scott King (née Scott) (19272006), a singer, lecturer and writer.

King, Philip Gidley (1758-1808). English officer and administrator, born in Launceston, Cornwall. He joined the Royal Navy as a servant in 1771. Responsible for settling Norfolk Island as a convict settlement, he was lieutenant-governor there 178890; 1791-96. Supported by *Phillip and *Banks, he was appointed Governor of New South Wales 1800-06. Hot tempered but an able administrator, he clashed with the New South Wales Corps, worked diligently to create an economic base for the colony, promoting flax, wool, whaling, sealing and coal mining and encouraged the exploration of Port Phillip. He retreated into self-pity (not without reason), became ill and died, barely 50 .

King, Sir (Frederick) Truby (1858-1938). New Zealand physician. He founded many 'mothercraft' and infant welfare clinics and helped to make New Zealand's infant mortality rate the lowest in the world.

King, W(illiam) L(yon) Mackenzie (1874-1950). Canadian Liberal politician. Grandson of William Lyon *Mackenzie, he gained a $\mathrm{PhD}$ in industrial sociology at Harvard, was Deputy Minister of Labour 1900-08 and a member of the Canadian House of Commons 1908-11 and 1919-48. On Sir Wilfrid *Laurier's death in 1919, King (then out of parliament) was elected Liberal Party leader. He was Prime Minister of Canada over three terms 1921-26, 1926-30 and 1935-48, a record period of 21 years and 154 days. In June 1926 the Governor-General, Lord *Byng, refused his advice to call an election and appointed the Conservative Arthur ${ }^{*}$ Meighen as Prime Minister. King returned after Meighen's early defeat. His view that the relationship between each dominion and Britain should be completely equal was embodied in the Statute of Westminster (1931), based on the 1926 Westminster Conference where he had played a leading role. Foreign Minister 1926-30; 1935-46, externally he insisted on Canada's complete freedom of action and shunned all alliances, nevertheless he brought Canada into World War II on the side of Britain. On his retirement (1948), Louis *St Laurent became Prime Minister and Liberal Leader, and King received the OM. He was unmarried and an introverted mystic. He left 50,000 pages of diaries. King was a technocrat, with few friends, uncharismatic, but with exceptional skills as a political manager and strategist.

Pickersgill, J. W. and Forster, D. F., The Mackenzie King Record. 1960-70; Esberey, J. E., Knight of the Holy Spirit. 1980; Henderson, G. F., W. L. Mackenzie King. 2015.

Kinglake, Alexander William (1808-1891). English historian. He wrote an account of his travels in the east in Eothen (1844). In 1854 he followed the British army to the Crimea and wrote History of the War in the Crimea (8 volumes, 1863-87), a brilliant and detailed narrative based upon the papers of the Commander-in-Chief, Lord ${ }^{*}$ Raglan. He was a Liberal MP 1857-68.

Kingsford-Smith, Sir Charles Edward (18971935). Australian aviator, born in Brisbane. Originally an engineering apprentice, he was a pilot in World War I, winning an MC in 1917. In the three-engined Fokker monoplane Southern Cross he flew (with Charles *Ulm) from Los Angeles to Brisbane in June (1928), from Sydney to London (1929) and from Ireland to New York (1930). By 1931 he was the first airman to have flown around the world. He was lost off the coast of Burma, trying to break the EnglandAustralia record.

FitzSimons, P., Charles Kingsford-Smith and Those Magnificent Men. 2009; Blainey, A., King of the Air. The Turbulent Life of Charles Kingsford Smith. 2019.

Kingsley, Charles (1819-1875). English clergyman and author. One of the founders of the Christian Socialist movement, he became rector (1844) of Eversley, Hampshire, a living he held for the rest of his life. His social doctrines are most clearly expressed in his novels Yeast (1850), Alton Locke (1851) and Two Years Ago (1857). His historical romances include Westward Ho! (1855), Hypatia (1853) and Hereward the Wake (1866) and he also wrote the children's books The Heroes (1856, stories from Greek mythology) and The Water Babies (1863). He was professor of modern history at Cambridge 1860-69. His brother, Henry Kingsley (1830-1876), also a novelist, is best remembered for Ravenshoe (1861). His niece Mary Kingsley (1862-1900), wrote with unusual insight about the peoples and cultures of West Africa, where she travelled extensively.

Kinnock, Neil Gordon, Baron Kinnock (1942- ). British Labour politician. The son of a labourer and a nurse, he was educated in Wales, lectured in Cardiff, worked for the Workers' Educational Association and became MP 1970-94. He served as Shadow Minister 
for Education 1979-83 and succeeded Michael *Foot as Leader of the Opposition 1983-92. He was appointed as a commissioner of the European Union 1994-2004 and Vice President 1999-2004.

Kinsey, Alfred C(harles) (1894-1956). American zoologist and social scientist. The publication of his Sexual Behaviour of the Human Male (1948) and Sexual Behaviour of the Human Female (1953) roused considerable controversy, caused partly by the nature of the theme but more particularly because his conclusions were reached mainly from answers (not necessarily truthful) to standard questionnaires.

Jones, J. H., Alfred C. Kinsey: A publiclprivate life. 1997.

Kinski, Klaus (Nikolaus Gunther Naksznski) (19261991). Polish-German film actor, born in Gdansk. He began to act as a prisoner of war, appeared in 200 German films, then attracted international attention with his intense, often fanatical, performances in Aguirre, Wrath of God (1973), Woyzeck (1979), Nosferatu (1979), Fitzcarraldo (1982) and The Little Drummer Girl (1984). His daughter was the actor Nastassja Kinski (Werner *Herzog).

Kipling, (Joseph) Rudyard (1865-1936). English novelist, short-story writer and poet, born in Bombay (now Mumbai). Son of (John) Lockwood Kipling (1837-1911), an author-artist who wrote Beast and Man in India (1892), and Alice Caroline MacDonald (1837-1910), at the age of five he was sent back to England to board with relatives and was seriously abused, then attended Westwood Ho!, a United Services College in Devon, an experience he drew on in Stalky \& Co (1899). He returned to India to become (1882) assistant editor of the Civil and Military Gazette, Lahore. He first achieved fame with Departmental Ditties (1886) and two books of short stories (1888), Soldiers Three and Plain Tales from the Hills. He returned to England (1889) and published a novel, The Light that Failed (1890). He visited South Africa, New Zealand and Australia in 1891. Collaboration with the American Wolcot Balestier on The Naulahka (1892) led to his marriage to Balestier's sister, Caroline; they lived in the US 1892-96, and also made regular visits to South Africa. After living in America for a time the Kiplings returned to England in 1899. He published more than 500 poems: the best known include the chilling 'Danny Deever', 'The Road to Mandalay' and 'Gunga Din' (all in BarrackRoom Ballads, 1892), 'Recessional' (non-triumphalist, although written in Queen Victoria's Jubilee year, 1897), 'The White Man's Burden' (1899) and 'If-' (1910, once voted the most popular poem in English). In the two Jungle Books (1894-95) his skill as a writer for children was revealed, to be shown again in Just So Stories (1902), Puck of Pook's Hill (1906) and Rewards and Fairies (1910). Captains Courageous (1897) and Kim (1901) were both enormously successful a vagabond boy who settles to adventurous manhood in India, and is a powerful account of magnificence and squalor. Kipling lived in Sussex after the Boer War and concentrated on poems and short stories, some of the best of which appeared in e.g. Actions and Reactions (1909). He was the first English winner of the Nobel Prize for Literature (1907).

Kipling's writing is exceptionally vivid, with a striking economy and sharp immediacy. Henry *James admired him. George *Orwell loathed his 'jingoism ... and strain of sadism'. T. S. *Eliot called his poems 'great verse ... although not great poetry' and Somerset *Maugham described him as 'the greatest short-story writer in English'.

Eliot wrote that Kipling had 'a queer gift of second sight, of transmitting messages from elsewhere, a gift so disconcerting [that it makes him] a writer impossible wholly to understand and quite impossible to belittle'.

Hostile to Home Rule for Ireland and votes for women, he was vaguely anti-Semitic (but perhaps no more than English generally at that time) and fervently Imperialist. He had no religious convictions, calling himself 'a God-fearing atheist'. He was deeply pro-French, anti-German, anti-Communist and an active Freemason. From 1911 until 1933, his books bore a left-facing swastika as a good luck symbol, a practice he abandoned when ${ }^{*}$ Hitler took power in Germany.

He son John was killed in action in 1915, reinforcing a deep vein of pessimism. He became involved in selecting commemorative words in memorials such as London's Cenotaph ('Lest we forget') and war graves ('Known unto God'). He wrote *George V's first Royal Christmas Message in 1932.

A first cousin of Stanley *Baldwin, Kipling refused all the official honours offered to him, including a knighthood, the Poet Laureateship and the OM (1921 and 1924). His ashes are interred in Poets' Corner, Westminster Abbey.

Dobree, B., Rudyard Kipling: Realist and Fabullist. 1967; Wilson, A., The Strange Ride of Rudyard Kipling. 1977; Seymour-Smith, M., Rudyard Kipling 1989; Ricketts, H., The Unforgiving Minute. A Life of Rudyard Kipling. 1999.

Kirby, Michael Donald (1939- ). Australian jurist, born in Sydney. A judge from 1975, promoted to the High Court of Australia 1996-2009, he was a consultant to UN bodies and wrote extensively on criminology, information theory, AIDS, human rights and transborder data flows. He won the Gruber Prize for Justice in 2010. The UN Security Council commissioned him to report on human rights abuses in North Korea (2013-14).

Brown, A. J., Michael Kirby. Paradoxes \& Principles. 2011. 
Kirchhoff, Gustav Robert (1824-1887). German physicist, born and educated at Königsberg. He became professor of physics at Breslau (1850), Heidelberg (1854) and Berlin (1857). Working with *Bunsen, he developed the spectroscope and the technique of spectrum analysis by which they discovered caesium (1860) and rubidium (1861). Kirchhoff enunciated two basic laws (Kirchhoffs Laws of Electricity) that are used to calculate current and voltage in complex electrical circuits, and a law of radiation (Kirchhoffs Law) that relates emissive and absorptive power. He was the first to explain the Fraunhofer lines in the solar spectrum (1859). Elected FRS, he won the Rumford Medal (1862).

Kirchner, Ernst Ludwig (1880-1938). German Expressionist painter. He was a leading member of Die Brücke (The Bridge) group, based in Dresden, then in Berlin. His works were intense, violent and reflect a deep interest in primitive art.

Kirchner Ostoić, Néstor Carlos (1950-2010). Argentinian politician, born in Rio Gallegos, Patagonia. A lawyer, he became active in the Justicialist (formerly Peronista) Party, and was Governor of Santa Cruz 1991-2003 and President of Argentina 2003-07. His wife, Cristina Elisabet Fernández de Kirchner (1953-), born in La Plata, was a senator 2005-07 and President of Argentina 2007-15.

Kirk, Norman Eric (1923-1974). New Zealand Labour politician. An engine driver, he entered parliament in 1957. He led the Labour Party from 1964 and was Prime Minister and Foreign Minister 1972-74, dying in office.

Kirov, Sergey Mironovich (1888-1934). Russian Communist politician. He was a close associate of *Stalin and, from 1926, Secretary of the Communist Party in the Leningrad area and a Politburo member 1930-34. His assassination was followed by a witch hunt and the judicial execution of over 100 suspected opponents of Stalin's regime.

Kishi Nobusuke (1896-1987). Japanese politician. An elder brother of *Sato Eisaku and nephew of Matsuoko Yosuka, he was adopted by an uncle's family, became a civil servant and directed Japanese economic investment in Manchuria (Manchukuo) 1936-39. He served under General *Tojo as a Vice Minister and Minister of State 1943-44, was held as a war criminal 1945-48 but never tried. A Member of the Diet 1942-45, 1953-79, he was Foreign Minister 1956-57 and Prime Minister 1957-60, seeking close economic ties with the US and the right to rearm. He remained a powerful conservative force in the Liberal Democratic Party. *Abe Shinzō was his grandson.

Kissinger, Henry Alfred (1923- ). American academic and official, born in Fuerth, Germany. He emigrated to the US in 1938, studied at Harvard and served in the US Army. He established a reputation as an expert on international relations and defence. President *Nixon's National Security Advisor 196975, and US Secretary of State 1973-77, he negotiated the ceasefire between the US and North Vietnam in 1973 and was also instrumental in achieving a ceasefire between Egypt and Israel. Under the Constitution, he received Nixon's resignation as President (August 1974), continuing in office under Gerald *Ford. He was awarded the Nobel Prize for Peace in 1973 with *Le Duc Tho from Vietnam (who declined it). He negotiated a settlement between hostile factions in Rhodesia which was accepted by the Rhodesian Government but not by the Patriotic Front guerrilla movement. In 1977 he returned to academic life as professor of diplomacy at Georgetown University. A prolific writer, he published his memoirs in 1979.

Isaacson, W., Kissinger: A Biography. 1992; Gewen, B., The Inevitability of Tragedy: Henry Kissinger and His World. 2020; Schwartz, T., Henry Kissinger and American Power: A Political Biography. 2020.

Kitaj, R(onald) B(rooks) (1932-2007). American painter and graphic artist. He was a merchant seaman and soldier who studied in London and lived in England, evolving a striking figurative art, working in parallel to the pop artists of the US. Elected to the Royal Academy in 1991, he returned to the US in 1997 and committed suicide.

Kitasato Shibasaburo (1852-1931). Japanese bacteriologist. A pupil of *Koch, he was noted for his independent discoveries of the bacilli of anthrax (1889), diphtheria (1890) and bubonic plague (1894).

Kitchener of Khartoum, 1st Earl, (Horatio) Herbert Kitchener (1850-1916). Anglo-Irish field marshal, born in County Kerry. He endured a traumatic childhood and while still a cadet at the Royal Military Academy, he served with the French army in the Franco-Prussian War. As an engineer officer, fluent in Arabic and French, less so in Hebrew, he conducted an outstanding Survey of Western Palestine (3 vols, 1881-85), also working in Cyprus and (from 1882) in Egypt. He served in the failed expedition to relieve Charles *Gordon in Khartoum (1885). As Sirdar (i.e. Commander-in-Chief) of the Egyptian Army 189299, he invaded Sudan, ostensibly to avenge Gordon, but actually to prevent French colonial and military expansion. He won the decisive Battle of Omdurman (1898), was created a baron and, as GovernorGeneral of the Sudan 1899, planned the modern city of Khartoum. In the Boer War he was appointed (1899) Chief of Staff to Lord *Roberts, succeeding him as Commander-in-Chief 1900-02. Following the Spanish model in Cuba, he established concentration camps for civilians in which 20,000 people died, burned farms and applied collective punishments. However, he brought the war to an end, received a viscouncy, $£ 50,000$ and became a foundation member of the Order of Merit (1902). His tenure of the post 
of Commander-in-Chief in India 1902-09 was famous for his quarrel with the viceroy, Lord *Curzon, concerning spheres of authority, but he achieved significant improvements in hygiene and sanitation. Promoted to field marshal in 1909, he visited Australia and New Zealand to advise on defence, aspired to the Viceroyalty of India but was appointed instead as Commander-in-Chief in 1910-11, then returned to Egypt as British Consul-General and Minister Plenipotentiary 1911-14. Created earl in June 1914, on the outbreak of World War I *Asquith appointed him as Secretary of State for War 1914-16.

Alone of the generals, he predicted a long war of attrition and played a leading role in creating an army that could combat the Germans. A famous recruiting poster, 'BRITONS [image of Kitchener] wants YOU', helped to attract 1,700,000 volunteers by May 1915 and, ultimately, 70 infantry divisions were formed in 'Kitchener's Army'. He dismissed Gallipoli as a 'tragic irrelevance' but failed to stop it. His critics asserted that his reputation was based on colonial warfare, not conflict between highly mechanised combatants. He had a tense relationship with his generals who resented his tactical interventions and the politicians loathed him: *Lloyd George describing him as both 'secretive and indecisive'. Despite his vivid insights about World War I, he failed to ensure adequate provision of ammunition and equipment.

In June 1916 Kitchener embarked on an urgent mission to Russia, but HMS Hampshire was sunk by a mine off Orkney and he drowned. His colleagues were relieved. Conspiracy theories were advanced.

Large (188 cm in height), moustachioed and imposing, Kitchener's sexuality is controversial. He never married, loved porcelain, orchids and poodles, knitted, but had a brutal, ruthless side as well.

Magnus, P., Kitchener. 1958; Royle, T., The Kitchener Enigma, 1985; Warner, P., Kitchener: The Man Behind the Legend. 2006.

Kléber, Jean Baptiste (1753-1800). French marshal, born in Alsace. Having fought with distinction in the French Revolutionary campaigns, he went (1798) to Egypt as a divisional commander under *Napoléon. He was left in command in 1799 when Napoléon returned to Paris. On the refusal by the higher British authorities to ratify an agreement with the local commander, Sidney Smith, for the evacuation of his troops, he reopened hostilities, defeated the Turks at Heliopolis but was assassinated by a fanatic in Cairo shortly afterwards.

Klee, Paul (1879-1940). German-Swiss painter, born in Berne. Undecided at first whether to pursue art or music, he eventually went to Munich to study and joined the Blaue Reiter group (*Kandinsky). His eyes were opened to the use of colour during a visit to Tunis (1914), and henceforth his colour harmonies and contrasts were as much a feature of his work as his brilliant draughtsmanship. In 1920 he joined the Bauhaus in Weimar, but soon after ${ }^{*}$ Hitler came to power he was dismissed (1933) from an appointment at the Düsseldorf Academy, on the grounds that his art was decadent, and settled in Switzerland. As Klee has been one of the most important influences on modern art, his methods of composition are significant. Instead of consciously deciding upon a subject for a picture, his starting point would be splashes of colour intuitively conceived, which by the processes of association and suggestion, modified by his acquired knowledge of composition, set up a train of 'pictorial thinking' which he would follow until a picture was achieved. The naming of the picture was the final act, and his works often had evocative titles: The Twittering Machine, Dance, Monster to my Soft Song, Death and Fire. He wrote extensively on aesthetics, e.g. Pedagogical Sketchbook (1925, translated 1953) and The Nature of Nature (1973). His diaries were published in 1957. There were 9100 works in his catalogue-an output second only to *Picasso.

Grohmann, W., Paul Klee. 1956; Boulez, P., Le Pays Fertile: Paul Klee. 1989.

Kleiber, Erich (1890-1956). Austrian-Argentinian conductor, born in Vienna. He directed the Berlin State Opera 1923-34; 1954-55, performing the work of *Janácek, ${ }^{*}$ Bartók, ${ }^{*}$ Berg, ${ }^{*}$ Mahler and ${ }^{*}$ Schoenberg, left Germany in 1935, and directed the Teatro Colón opera in Buenos Aires 1939-43. He made superb recordings of ${ }^{*}$ Mozart and ${ }^{*}$ Beethoven. His son Carlos Luis Bonifacio Kleiber (1930-2004) born in Berlin, despite his father's discouragement became an outstanding operatic and symphonic conductor. He directed only 96 concerts and about 400 operatic performances, made few recordings, and had a very small repertoire: nine operas, nine symphonies, ${ }^{*}$ Strauss waltzes and a few concertos.

Brown, J., Great Wagner Conductors. 2012.

Kleist, (Bernd) Heinrich (Wilhelm) von (17771811). German writer. He followed family tradition by serving in the Prussian army (1792-99), then became absorbed in mathematics, philosophy, travel and writing. Much of his writing was inspired by a misinterpretation of *Kant, whom he believed to say that human beings are marionettes helplessly and hopelessly in the toils of inscrutable powers. He wrote the verse tragedy Penthesilea (1808). His masterpiece, the drama Prinz Friedrich von Homburg (1811) is, however, in lighter vein. As well as novels and plays he also wrote poems and short stories, e.g. Michael Kohlhaas (1808), of originality and and power. He shot an incurably ill woman, Henriette Vogel, and himself on the banks of the Wannsee. *Goethe disliked Kleist but he was a major influence on *Rilke.

Maass, J., Kleist: A Biography. 1983. 
Klemperer, Otto (1885-1973). German conductor. A protégé of Gustav *Mahler, he was an early champion of modern composers. He held various posts, mainly as operatic conductor, in Germany and then directed the Los Angeles Philharmonic Orchestra 1933-39. After years of illness, he conducted the Budapest Opera 1947-50 and from 1954 conducted regularly in England, where he was known chiefly as an interpreter of the German classics. In 1955 he was appointed Principal Conductor of the Philharmonia Orchestra, and after its disbanding in 1964 became President of the New Philharmonia Orchestra and Chorus.

Heyworth, P., Otto Klemperer, 2 vols, 1996.

Klimt, Gustav (1862-1918). Austrian painter. A co-founder of the Vienna Sezessionist school (1897), he was a leader in the Art Nouveau (Jugendstil) movement. His sumptuous and erotic style concealed a deep pessimism. He died in the influenza epidemic. His Portrait of Adele Bloch-Bauer (1907) sold for \$US135 million in 2006, setting the world's highest auction price for any art work.

Kline, Franz (1910-1962). American painter. A leading abstract expressionist in New York, associated with Jackson *Pollock and Willem *de Kooning, his works are characterised by huge dynamic calligraphy in black paint on a white background, although he later experimented with colour.

Klopstock, Friedrich Gottlieb (1724-1803). German poet. While still at school he read a translation of Milton's Paradise Lost and determined to create a German epic on an even more magnificent theme. The Messiah, resulting from this decision, took over 20 years to write (1746-73). It is an epic on the grand scale, written in hexameters, in 20 books, and its admirers and detractors have waged literary war over the years. For most, Klopstock is more accessible through his shorter poems. By using the lyric as a means of self-revelation and by his adaptation of the classical metres based on 'quantity' to a language like German based on stress, he influenced many later writers, even *Goethe himself.

Stahl, E. L. and Yuill, W. E., German Literature of the Eighteenth and Nineteenth Centuries. 1970.

Kluck, Alexander Heinrich Rudolph von (18461934). German soldier. As Commander of the German 1st Army at the outbreak of World War I he directed the drive through Belgium and France. In September 1914, *Joffre counter-attacked at the Marne and gained a crucial victory.

Klug, Sir Aaron (1926-2018). British mathematical physicist and crystallographer, born in Lithuania. Brought up in South Africa, a Cambridge PhD, he worked in London on viruses with Rosalind *Franklin, then at the Medical Research Council Laboratory of Molecular Biology, Cambridge, from 1962 and became its director 1986-96. He won the 1982 Nobel Prize for Chemistry for modelling the polio virus. Awarded the Copley Medal 1985 and the OM 1995, he became President of the Royal Society 1995-2000.

Kluge, (Hans) Günther von (1882-1944). German field marshal. Son of a general, he served in both World Wars and led the 4th Army in the invasion of Poland (1939), France (1940) and Russia (1941). In July 1944, he succeeded von *Rundstedt as commander-in-chief in the west but was dismissed in August. Although uneasy about ${ }^{*}$ Hitler, he accepted two generous bribes, knew about the July 1944 bomb plot against Hitler, but was a vacillator, and committed suicide in Metz.

Knausgård, Karl Ove (1968- ). Norwegian novelist, born in Oslo. An editor, publisher and art critic, his $M y$ Struggle (Min Kamp: 2009-11), six autobiographical novels, 3500 pages long, was intensely controversial but won many awards. He also wrote studies on Edvard ${ }^{*}$ Munch and Anselm *Kiefer.

Kneller, Sir Godfrey, 1st Baronet (1646-1723). English painter, born in Germany. Already well known as a portraitist on the Continent before he settled in England, he was appointed (1678) principal painter by ${ }^{*}$ Charles II, and reached the height of his fame as a court painter under ${ }^{*}$ William and ${ }^{*}$ Mary and Queen *Anne. He received a knighthood in 1692 and in 1715 a baronetcy from *George I. His portraits, which provide a magnificent series of illustrations for the book or fame, are of greater social than artistic interest, but his best pictures achieve their effect not only by assured technique and dignity of treatment but also by colour subtlety and psychological insight. His most famous pictures include the great equestrian portrait of William III and striking likenesses of ${ }^{*}$ Louis XIV and ${ }^{*}$ Peter the Great. Other well known portraits are the Beauties at Hampton Court, the Kit Cat club series in the National Portrait Gallery and the Admirals at Greenwich. His brother, John Zacharias Kneller (1644-1702), was also a painter. $\mathrm{He}$, too, settled in England and painted portraits and architectural scenes.

Killanin, Lord, Sir Godfrey Kneller and His Times, 1646-1723. 1948.

Kngwarreye, Emily Kame (1910?-1996). Australian painter, born in Alhalkere, Northern Territory. An Anmatyerre elder, she began to work with batik in 1978 , but was nearly 80 before she began to paint, producing almost 3,000 works over eight years, acrylics on canvas. Supported by Janet and Robert Holmes à Court, her works soon gained national recognition. Her Big Yam Dreaming (1995), 8m $\mathrm{x} 3 \mathrm{~m}$, is in the National Gallery of Victoria. She was still painting weeks before she died.

Knox, John (1513?-1572). Scottish religious reformer, born in East Lothian. Though from 1530 he had been a Roman Catholic priest, he became a close friend of the reformer George Wishart who 
was burned at the stake for heresy (1546). Knox then joined the reforming party, but was captured (1548) by French troops (serving the cause of Mary of Guise, Scotland's queen dowager) in St Andrew's Castle, the refuge of many reformers fearing reprisals of the murder of Cardinal *Beaton. Knox was taken to France and toiled as a galley-slave, until released at the request of England's *Edward VI, who made him a royal chaplain. On *Mary I's accession he fled to Geneva where he worked for three years with ${ }^{*}$ Calvin. He briefly returned to Scotland (1555-56), a visit during which the oppression suffered by his co-religionists at the hands of Mary of Guise, acting as regent for her daughter ${ }^{*}$ Mary Queen of Scots, inspired his famous First Blast of the Trumpet Against the Monstruous Regiment (i.e. 'regimen' or rule) of Women (1558), which offended Queen *Elizabeth, at whom it was not aimed. Knox returned to Scotland again (1559) after the lords of the congregation (the leading lay reformers) had established an organised 'kirk' with churches in Dundee and elsewhere and ministers assisted by elders. Despite the regent's retaliatory ban, Knox rallied the reformers by his preaching, and secured acceptance of the doctrine that 'the regent's commands must be disobeyed if contrary to God's'. With civil war imminent, the English government intervened by sending troops to occupy Edinburgh. This marked the triumph of the Protestant cause. The Scottish Parliament abolished papal authority, voted for reform, and later approved the Confessions of Faith prepared by Knox and five others. The General Assembly of the Church first met in 1560 and adopted the Book of Common Order (sometimes called Knox' Liturgy), thus ensuring that the Church of Scotland, based on *Calvin's teaching, should develop as a Presbyterian community. When Mary Queen of Scots returned (1561) from France with the idea of restoring Catholicism, she tried in vain to dazzle and charm Knox, and the murder of *Darnley, her flight with *Bothwell, and finally her imprisonment in England (from 1567) soon removed her from the scene. Knox, who had become minister of St Giles, Edinburgh's largest church, remained in the forefront of events except in the year 1566-67 when he withdrew into seclusion to complete his History of the Reformation in Scotland. That the Church of Scotland took the form it did was due almost entirely to the work of Knox. From his two marriages Knox had two sons and three daughters, but his many public activities left little time for family life.

Ridley, J. G., John Knox. 1968.

Knox, Ronald Arbuthnot (1888-1957). English scholar and priest. Son of an Anglican bishop, he became a chaplain at Oxford University, where he worked all his life. In 1917 he became a Roman Catholic and entered the priesthood. From 1939 he devoted himself to the great task of retranslating the Vulgate (which finally appeared complete in 1954).
He also engaged in theological controversy and wrote essays and novels. He was one of the wittiest men of his generation

His brother, Edmund Valpy Knox (1881-1971), known by his nom de plume 'Evoe', was a regular contributor to Punch, and editor 1933-49.

Waugh, E., The Life of Ronald Knox. 1959.

\section{Knud (or Canute) see Cnut}

Knussen, Oliver (1952-2018). English composer and conductor. His works included three symphonies, an opera, songs, settings of ${ }^{*}$ Whitman and *Rilke, and piano pieces.

Koch, Robert (1843-1910). German bacteriologist, born near Hanover. Having qualified at Göttingen and served as a surgeon in the Franco-Prussian War, he became a medical officer at Wollstein, where he devoted himself to the microscopic study of bacteria. He isolated (1876) the anthrax bacillus and perfected the method of inoculation against it; two years later his studies of wound infection appeared. In 1880 he moved to Berlin where he was successively a member of the Imperial Health Office, a professor of hygiene at the university and Director of the Institute for Infectious Diseases. He discovered (1882) the bacillus causing tuberculosis; the discovery of the one causing cholera followed his appointment (1883) to preside over a commission to study this disease in Egypt and India. During the decade 1897-1906 visits to New Guinea, South Africa, India and Uganda enabled him to do valuable work on malaria, rinderpest, bubonic plague and trypanosomiasis (sleeping sickness). He received the Nobel Prize for Medicine (1905).

Moellers, B., Robert Koch: Persönlichkeit und Lebenswerk, 1843-1910. 1950.

Köchel, Ludwig (Alois Ferdinand) (1800-1877). Austrian bibliographer. An amateur botanist and mineralogist, in 1862 he published a chronologicalthematic catalogue of *Mozart's compositions. His name is immortalised by the K. (Köchel) number.

Kodály, Zoltán (1882-1967). Hungarian composer and teacher, born in Kecskemét. He studied under Hans Koessler at the Budapest Conservatoire, where he later became professor. With *Bartók he started to collect and study Hungarian folk music. His best known works are the Cello Sonata (1915), the choral works Psalmus Hungaricus (1923) and Te Deum (1936), the comic opera Háry János (1926), Dances of Marosszek (1930), Dances of Galanta (1933) and Concerto for Orchestra (1940). He was an outstanding teacher and textbook writer: 'Kodály method' encouraged basic musical literacy in Hungary and was adopted abroad. He was also an ethnomusicologist, linguist and philosopher.

Eosze, L., Kodály, his Life and Work. 1962. 
Koenig, Pierre Joseph (1898-1970). French soldier. He worked closely with *de Gaulle, held off ${ }^{*}$ Rommel's Afrika Korps at Bir Hakeim (1942), led French forces at the Normandy invasion (1944), was military Governor in Germany 1945-49 and Minister for Defence 1954-55. He was posthumously created marshal in 1984.

Koestler, Arthur (1905-1983). British Hungarian author, born in Budapest. After dropping out of science, he went to Palestine in 1926 as a Zionist activist, working on a collective farm in Palestine, then became a reporter for a German newspaper and travelled in the Soviet Union. Later while reporting the Spanish Civil War for an English newspaper he was sentenced to death as a spy by *Franco's forces, but was released and went to France, here he was arrested and imprisoned after the fall of France but escaped to England. In 1938 he left the Communist Party-his disillusionment is described in The God that Failed (1950). Koestler first wrote in Hungarian but for his later writing mastered German, French and English. His first novel in England was Arrival and Departure (1943). Darkness at Noon (1941), regarded as his masterpiece, is a great political novel. He wrote works, e.g. The Yogi and the Commissar (1945) and the autobiographical Arrow in the Blue (1952). The Sleepwalkers (1959), The Act of Creation (1964) and The Roots of Coincidence (1972), on scientific themes, were controversial. A passionate opponent of capital punishment, he wrote Reflections on Hanging (1956) and Hanged by the Neck (with C. H. Rolph, 1961). Koestler, an advocate of euthanasia, committed suicide with his wife Cynthia Jefferies after long suffering from Parkinson's disease.

Frazier, T. and Merrill, R., Arthur Koestler An International Bibliography. 1979; Cesarini, D., Arthur Koestler: The Homeless Mind. 1999; Scammell, M., Koestler: The Literary and Political Odyssey of a Twentieth-Century Sceptic. 2009.

Kohl, Helmut Michael (1930-2017). German politician. Educated at Frankfurt and Heidelberg universities, he was a member of the Rhineland Palatinate legislature 1959-76 and Minister-President 1969-76. He became Chairman of the National Christian Democratic Union in 1976 and defeated Helmut *Schmidt to become Chancellor 1982-98. He played a central role in the reunification of Germany when the Federal and Democratic Republics combined in 1990. In November 1996 he became the longest serving German Chancellor since *Bismarck. Defeated in September 1998, in December 1999 his party was investigated for taking illegal donations. Kohl suffered from a long period of ill health after 2008.

Kohlrausch, Friedrich Wilhelm Georg (18401910). German physicist. Educated at Göttingen, he taught in Göttingen, Zürich, Darmstadt and Berlin, and directed the Imperial Technical Research Institute 1895-1905. Research conducted 1875-79 led to
'Kohlrausch's Law' on the independent migration of ions, demonstrating that electrical resistance in electrolytes could be precisely measured. This had a profound influence in developing electrochemistry, and he devised many measuring techniques. Elected FRS, he was nominated 9 times for the Nobel Prize for Physics.

Koivisto, Mauno Henrik (1923-2017). Finnish politician. A carpenter at a dockyard who gained a doctorate in economics, he led the Social Democrats and was Prime Minister 1968-70 and 1979-82, succeeding U. K. *Kekkonen as President of Finland 1982-94.

Kokoschka, Oskar (1886-1980). Austrian painter. He developed a very personal and imaginative Expressionist style: vivid colouring is combined with a sense of movement in the town scenes, landscapes and portraits for which, apart from his stage settings, he was best known. He was the lover of Alma *Mahler 1912-15. Unlike many of his contemporaries, he maintained traditional links with the old masters and preserved with penetrating insight the individual characteristics of the scenery and personalities he portrayed. In 1919 he became a professor at Dresden, then lived in Vienna (1931-34), Prague (1934-38), London (1938-53) and Switzerland. He became a British subject in 1947. He also wrote several plays.

Goldscheider, L., Kokoschka. 3rd ed. 1967.

Kołakowski, Leszek (1927-2009). Polish political philosopher. Professor of Philosophy at Warsaw University 1959-68, he was expelled for his incisive criticisms of Marxism. He became a senior Fellow at All Souls, Oxford, 1970-2009 and also taught in the US and Canada. His books include Main Currents of Marxism (1976-78), Metaphysical Horror (1988), My Correct Views on Everything (2005) and Why is Something Better than Nothing? (2007). He argued that 'We learn history not in order to know how to behave or how to succeed, but to know who we are.'

Kolchak, Aleksandr Vasilyevich (1874?-1920). Russian sailor. He reorganised the navy after the Russo-Japanese War (1904-05), in which he had taken part. In World War I he commanded the Black Sea fleet from 1916, and after the Bolsheviks seized power (1917) headed a counter-revolutionary government in Siberia. Despite early successes on his westward march he was checked by the Bolsheviks and forced to retreat. Eventually, he was captured and shot.

Kollontay (née Domontovich), Aleksandra Mikhailovna (1872-1952). Russian revolutionary, feminist and politician. Daughter of a tsarist general with progressive views, and a Finnish mother, she joined the Russian Social Democratic Labour Party (RSDLP) in 1899 and after the party split became a Menshevik 1906-15. Expelled from Russia in 1908, she lectured on feminism and pacifism in 
Europe and the US. *Lenin's Commissar for Public Welfare 1917-18, she was hostile to the increasing concentration of Bolshevik power and resigned. She became Ambassador to Norway 1923-25 and 192730, Mexico 1925-27 and Sweden 1930-45.

\section{Porter, C., Alexandra Kollontai. 1981.}

Kollwitz (née Schmidt), Käthe (1867-1945). German graphic artist and sculptor, born in East Prussia. She lived from 1891 in Berlin where both her life and art were a constant protest against poverty and oppression. Her artistic protest was made through representations of historic scenes, e.g. The Peasants' Revolt, realistic studies of working-class life, and illustrations to books, e.g. *Zola's Germinal, that expressed compassion for and indignation at the miseries of the poor. The first woman elected to the Prussian Academy of Arts in 1920, with the rank of professor, she was forced to resign in 1933 when the Nazis took power. She produced 275 prints, etchings, woodcuts and lithographs, including 50 self-portraits. As a sculptor she managed by a roughhewn technique to convey the same message as in her other works.

Kollwitz, K. S., Prints and Drawings (ed. Zigrosser, C.). 2nd ed. 1969 .

\section{Komensky, Jan Amos see Comenius, Johannes Amos}

Kondratiev, Nikolai Dimitrievich (1892-1938). Russian economist. After examining statistics of prices, wages, interest and consumption in Europe and North America since the 1780 s, Kondratiev identified 'long waves of cyclical character' which Joseph *Schumpeter named for him. If his cycles are extended to the future (which he did not attempt) 1970-95 would be an era of downswing. He was imprisoned under ${ }^{*}$ Stalin, shot and never rehabilitated.

Konev, Ivan Stepanovich (1897-1973). Russian soldier. After serving as a private in World War I he rose rapidly under the Soviet regime. He distinguished himself in World War II as an army commander in the 1941 counter-offensive to the northwest of Moscow, and later in command of an army group during the Ukrainian campaigns, and the subsequent great offensive that ended with his advance to Berlin in March 1945. In May he liberated Prague. He was made a marshal and commanded the Warsaw Pact armies 1955-60.

Königsmarck, Philipp Christoph, Greve (count) von (1665-1694). Swedish adventurer. While in the service of Ernst August of Hanover he became aware of the unhappy plight of Sophia Dorothea, wife of Elector Georg Ludwig (later *George I of Great Britain). Whether he was her lover or whether his motives were those of pure chivalry, he tried and failed to aid her to escape. He was arrested, disappeared and was almost certainly put to death, the unfortunate Sophia Dorothea being secluded at Ahlden Castle for the rest of her life.

\section{Kooning, Willem de see de Kooning, Willem}

Koons, Jeff (1955- ). American artist, born in Pennsylvania. His sculptures emphasised and reproduced the banal, and were completely out of scale, such as the huge Puppy, executed in flowers, which is now at the Guggenheim Museum in Bilbao. His Balloon Dog (Orange) sold for \$US58.4 million in 2013.

Kopatchinskaja, Patricia (1977- ). MoldavianAustrian-Swiss violinist. Her technique was brilliant and she excelled in complex works including concertos by ${ }^{*}$ Schoenberg, ${ }^{*}$ Stravinsky, ${ }^{*}$ Berg, ${ }^{*}$ Ligeti and ${ }^{*}$ Eötvös.

Korda, Sir Alexander (Sandor) (1893-1956). British film producer and director, born in Hungary. Originally a journalist, he worked with his brothers Zoltan and Vincent, producing films in Budapest, Vienna, Berlin, Hollywood and Paris. He founded London Films in 1932. Many of his films were international successes, including The Private Life of Henry VIII (1933), The Scarlet Pimpernel (1934), Rembrandt (1936), Things to Come (1936) and The Thief of Baghdad (1940). He married the Bombayborn actor Merle Oberon (1911-1979).

Korda, M., Charmed Lives. 1979.

Korngold, Erich Wolfgang (1897-1957). AustrianJewish-American composer, born in Brno. A prodigy, his opera Die Tote Stadt (The Dead City) (1920), set in Bruges, was an instant success. In the US from 1934 (naturalised 1943) he wrote scores for 21 films, winning two Oscars and he composed a violin concerto (1945) for Jascha *Heifetz.

Kornilov, Lavr Georgyevich (1870-1918). Russian soldier. He served in the Russo-Japanese War (190405), and in World War I as a divisional commander in Galicia, when, captured by the Austrians, he made a sensational escape. After the revolution (March 1917) he was appointed Commander-in-Chief but *Kerensky's refusal to satisfy his demands for the restoration of army discipline provoked him to a vain attempt to establish a military dictatorship. Kerensky had him arrested, but when he fell Kornilov escaped to join *Denikin's anti-Bolshevik army on the Don, where he was killed in action.

Kościuszko, (Andrzej) Tadeusz (Bonawentura) (1746-1817). Polish patriot. He received military training in France. Being devoted to the cause of national freedom, he offered his services to the revolutionary forces in America (1777), and served with distinction in the War of Independence. In 1786 he returned to Poland, which had made a remarkable recovery from the effects of the first partition between Russia, Prussia and Austria, but his attempts to introduce democratic government as a means of reviving the national spirit frightened the nobles. After a second partition (1793) Kościuszko 
inspired a national uprising against the tsar. At first he achieved striking success and freed Warsaw, but with the Prussians threatening in the rear he was defeated and captured. Released two years later by the tsar he went to Paris. Though he continued to work for the national cause, he refused overtures made (1806) by *Napoléon, whom he distrusted, to cooperate with him in the achievement of Polish freedom. He attended the Congress of Vienna (1814) and vainly pleaded his country's cause with the tsar *Aleksandr. He died after a riding accident in Switzerland. He was buried in Kraków and is revered as one of the greatest Polish patriots.

Kosky, Barrie (1967- ). Australian theatre and opera director, born in Melbourne. Describing himself as a 'gay Jewish kangaroo', after achieving early success directing opera and plays in Melbourne, Sydney and Adelaide, he gained international recognition in Vienna, Berlin, Bayreuth, Munich, London and Glyndebourne, producing works by *Euripides, *Ovid, *Monteverdi, *Händel, *Mozart and *Wagner.

Kossuth, (Ferencz) Lajos (Akos) (1802-1894). Hungarian revolutionary leader. An advocate, he was a member of the Hungarian Diet 1825-27 and won fame and popularity with his newspaper campaigns to free Hungary from Austrian control. For these attacks upon the Habsburg regime he suffered two terms of imprisonment, but he weakened his cause by insisting on Magyar supremacy and so alienating the Slav peoples, Slovenes and Croats, who had come under Hungarian rule. He sat again in the Diet 1832-36, 1847-49. In 1848, the 'year of revolutions' throughout Europe, he was mainly instrumental in passing the 'March laws' which abolished the privileges of the nobles, freed the peasants, and created a ministry responsible to the legislature. He became Minister of Finance. In 1849 the final step was taken: the Hungarian parliament declared Hungary independent, and Kossuth became President of the Hungarian Republic. The Russians intervened to support the Austrian Government, the combined Austrian and Russian forces were too strong for the Hungarian army and the short-lived republic was overcome. Kossuth fled to Turkey and lived as an exile in London (1852-59) and Turin (1859-94). He wrote Memories of My Exile (1880).

Koster (or Coster), Laurens Janszoon (c.13701440). Dutch craftsman. Some authorities credit him with the invention of printing with movable type (using first wooden and then tin letters). He is said to have gone to Mainz, the presumption being that *Gutenberg learned from him, thus not deserving the credit that posterity has bestowed.

Koštunica, Vojislav (1944-). Serbian politician, born in Belgrade. A lawyer and academic, deeply critical of *Tito, he founded the conservative Democratic Party of Serbia and led it 1992-2014. He defeated Slobodan *Miloševic to become the last president of the Federal Republic of Yugoslavia 2000-03. Prime Minister of Serbia 2004-08, he was deeply hostile to the West's recognition of Kosovo.

Kosygin, Aleksei Nikolaievich (1904-1980). Russian Communist politician, born in St Petersburg. He joined the CPSU in 1923, became a textile engineer, and was Mayor of Leningrad 1938-39, Minister for the Textile Industry 1939-40, Premier of the RSFSR 1943-46 and Minister for Light Industry 1948-58. A protégé of A. A. *Zhdanov and a Politburo member 1948-52, 1960-80, he succeeded ${ }^{*}$ Khrushchev as Premier of the USSR 1964-80. He tried to improve Soviet economic efficiency but lost power to *Brezhnev's supporters, and died shortly after resigning.

Kotelawala, Sir John Lionel (1895-1980). Sri Lankan politician. Educated at Cambridge, he rose to colonel in the Ceylon Defence Force, served in the first *Senanayake government after independence (1948) and became Prime Minister 1953-56. He was a conservative participant in the Asian Prime Ministers' conference at Colombo (1954) and the African-Asian conference (1955) at Bandung, Indonesia.

Kotzebue, August Friedrich Ferdinand von (17611819). German dramatist, born in Weimar. As a young man he held various offices in the Russian civil service. In Estonia where he was posted (1785-95) he established an amateur theatre for which he wrote Menschenhass und Reue (Misanthropy and Repentance, 1789). Its fame rapidly spread, *Sheridan produced it (1789) at Covent Garden as The Stranger. In the same year Sheridan produced Kind der Liebe as Lovers' Vows and in 1799 Der Spanier in Peru as Pisarro. Kotzebue wrote some 200 plays as well as tales, historical works and satires. His admirers included *Beethoven and Jane *Austen and he wrote many satires against ${ }^{*}$ Napoléon. In the last years of his life he was the tsar's representative at Weimar, where a new German constitution was being developed. He was stabbed to death in Mannheim by a member of the Burschenschaften, a nationalist student society.

Bonford, W. H., Theatre, Drama and Audience in Goethe's Germany. 1950.

Koussevitzky, Sergei Aleksandrovich (1874-1951). Russian-Jewish-American conductor. From 1894 he played double-bass in the Bolshoi Orchestra, was soon hailed as a virtuoso and in 1905 married a tea heiress, Natalie Ushkova. He studied conducting under Arthur ${ }^{*}$ Nikisch and in 1909 founded his own orchestra which toured Russia, also conducting in Berlin, London and Paris. After the 1917 Revolution, he settled in Paris in 1920 and created 'Concerts Koussevitzky'. As conductor of the Boston Symphony Orchestra 1924-49, he made many recordings and raised it to the highest rank. He commissioned *Ravel's orchestration of *Mussorgsky's Pictures at an Exhibition, *Bartók's Concerto for Orchestra, 
*Britten's opera Peter Grimes and works by *Stravinsky, ${ }^{*}$ Hindemith, ${ }^{*}$ Harris, ${ }^{*}$ Copland and ${ }^{*}$ Barber. Leonard ${ }^{*}$ Bernstein was his disciple. He created the Tanglewood Festival and the Koussevitzky Foundation and was also an important publisher.

Kovalevskya, Sofya Vasilyevna (née Krukovskaya) (1850-1891). Russian mathematician and novelist. She studied in Germany, taught in Sweden, wrote an important novel Vera Vorontzoff (1893) and contributed to the theory of differential equations.

Kozintsev, Grigori Mikhailovich (1905-1973). Russian-Jewish film director, born in Kiev. Some of his films have been lost and his reputation depends on powerful versions of Don Quixote (1957), Hamlet (1964) and King Lear (1971).

Kraepelin, Emil (1856-1926). German psychiatrist. Having studied medicine, he filled a number of clinical and academic posts before holding professorships of psychiatry at Heidelberg 1890-1903, and Munich 1904-22. He claimed that the basic cause of mental disorders was physiological and that many problems of insanity would be solved by clinical observations made throughout the patient's lifetime. A research institute was founded (1917) in accordance with his plans. His Textbook of Psychiatry (first published 1883) was enlarged and modified in successive editions. He visited India, the East Indies and Mexico to pursue comparative psychology.

Krafft-Ebing, Richard, Baron von (1840-1902). German neurologist. He held several chairs of psychiatry in Strasbourg, Graz and Vienna. His case studies Psychopathia Sexualis (1886) were a notable contribution to the study of sexual perversion.

Kraft (or Krafft), Adam (c.1455-1508/9). German sculptor. One of the most prolific and popular of the Nuremberg sculptors, his development makes him a link between the Gothic and Renaissance styles. His most famous work is the 1.6 metre high tabernacle in St Lorenz, Nuremberg, especially remarkable for its tracery and reliefs and for the self-portrait statue on one knee before it.

Kraft, James L(ewis) (1874-1953). CanadianAmerican manufacturer, born in Ontario. Of German descent, he began manufacturing low cost cheese in Chicago and his brand became the world's biggest seller.

Kraus, Karl (1874-1936). Austrian-Jewish satirist, journalist and poet. In his journal Die Fackel ('The Torch'), founded in 1899 and running for 922 issues until his death, he was an insistent, but not totally consistent, critic of corruption, sexual hypocrisy, militarism and the misuse of language, e.g. in propaganda. His public readings were enormously successful and his admirers included *Schoenberg, *Wittgenstein and ${ }^{*}$ Canetti.
Kravchuk, Leonid Makarovich (1934-). Ukrainian politician. He worked as an apparatchik for the Communist Party of the Soviet Union from 1958, rising to the Politburo. However, he recognised the growing power of Ukrainian nationalism and on the dissolution of the USSR won election as the first president of Ukraine 1991-94, with separate currency, defence forces and treaty arrangements.

Krebs, Sir Hans Adolf (1900-1981). German British biochemist. He worked with O. H. *Warburg (whose biography he wrote) and F. G. *Hopkins, sharing the 1953 Nobel Prize for Medicine for elucidating the 'Krebs cycle', the major energy producer in living organisms, a series of chemical changes in which acids exchange carbon atoms.

Kreisky, Bruno (1911-1990). Austrian politician. Of Jewish origin, he held a doctorate in law from Vienna University, and after ${ }^{*}$ Hitler annexed Austria in 1938, Kreisky lived in Sweden until 1951. He was a socialist Member of Parliament 1956-90, Foreign Minister 1959-66 and Chancellor 1970-83.

Kreisler, Fritz (1875-1962). Austrian violinist and composer, born in Vienna. He became a Catholic convert in 1887 , studied in Vienna, attending classes by *Bruckner, and in Paris under Massart. His playing, though often flawless, could be variable in quality, and it was chiefly for his warm and sensuous tone that he became one of the most popular virtuoso soloists in Europe and in the US, where he lived 1914-24, 1939-62. He wrote effective cadenzas for concertos by ${ }^{*}$ Mozart, ${ }^{*}$ Beethoven and ${ }^{*}$ Brahms. In 1935 he revealed that he had composed works which he performed as by ${ }^{*}$ Vivaldi, ${ }^{*}$ Couperin, ${ }^{*}$ Tartini, Martini and other pre-Romantic composers.

Lochner, L. P., Fritz Kreisler. 1950.

Křenek, Ernst (1900-1991). Austrian composer. A disciple of ${ }^{*}$ Schoenberg, he married *Mahler's daughter Anna briefly, wrote the popular opera Jonny spielt auf (Johnny Strikes Up!, 1927), and worked in the US from 1938. He wrote prolifically in the 12tone mode and experimented with electronic music.

Kreuger, Ivar (1880-1932). Swedish financier. Using his family firm of Kreuger and Toll as a base for his operations, he became head of the Swedish Match Company, which he developed into a vast international trust and financial agency by lending money to a dozen or more countries impoverished by World War I, in return for match monopolies and contracts. When he committed suicide in Paris, it was discovered to the surprise and consternation of the financial world that he had tried to avert the collapse of his enterprises by a huge and complex conspiracy of forgery and falsification.

Shaplen, R., Kreuger, Genius and Swindler. 1960. 
Krishna Menon, Vengalil Krishnan (18971974). Indian politician and diplomat. He lived in England from 1924, studied at the London School of Economics, became a lawyer, was a St Pancras borough councillor 1934-47 and the first editor of Pelican Books (1936). A left-wing member of the Indian National Congress, he was strongly antiBritish. After India gained independence (1947), he became the first high commissioner in Great Britain. From 1952 to 1956 he was Indiass representative at the United Nations and a strong advocate of nonalignment. Back in Indian politics, he represented the left wing in *Nehru's Congress Government. In 1957 he was appointed Defence Minister. He was forced to resign when the Chinese aggression (1962) revealed the inadequacy of India's military preparedness. In the elections of 1966 he was defeated.

Krishnamurti, Jiddu (1895-1986). Indian mystic, born near Madras. Sponsored by the theosophist Annie *Besant, who believed him a messiah, he was proclaimed by devotees as leader of the Order of the Star of the East (1911). He disbanded the order in 1929.

Lutyens, M., Krishnamurti: The Years of Awakening. 1975.

Kropotkin, Pyotr Alekseivich, [Prince] (18421921). Russian geographer, explorer and anarchist. After investigating glaciation in Finland, Siberia and Manchuria 1871-73, he became attracted to anarchism and renounced his title. After two years' imprisonment in Russia (1874-76) for his iconoclastic opinions, he escaped to England, Switzerland (until expelled in 1881) and France (being imprisoned on a trumped up sedition charge 1883-86). He lived in England 1886-1917, twice visiting the US, and publication of his ideas (e.g. in The Nineteenth Century and The Atlantic Monthly) caused no problems. He wrote Memoirs of a Revolutionist (1899) and Mutual Aid (1902), the latter a critique of *Darwin's concept of the survival of the fittest, arguing that mutual cooperation works in sparsely occupied environments, such as Siberia. He returned to Russia after the 1917 Revolution and, although opposed to *Lenin's dictatorship, was allowed to write and publish. The moral basis of his anarchism was set out in Ethics (1924).

Arakumovic, I. and Woodcock, G., Anarchist Prince. 1971.

Kroto, Sir Harry (Harold Walter Krotoschiner) (1939-2016). British chemist. Of Silesian descent, he studied at Sheffield University and held research chairs at Sussex and at the Royal Society. He worked on carbon atoms found in the form of a ball, known as buckminsterfullerenes, or 'buckyballs', sharing the 1996 Nobel Prize for Chemistry for his work on carbon chains and their bonding, then worked in nanotechnology. He was awarded the Copley Medal in 2004 for his work on the fundamental dynamics of carbon chain molecules, leading to the detection of these species (polyynes) in the interstellar medium by radioastronomy. An effective science advocate, he was co-author of the education report chaired by Sir Ken *Robinson.

Kruger, (Stephanus Johannes) Paulus (1825-1904). South African (Boer) politician, born in Cape Colony. His parents were Voortrekkers who took him northwards to the Transvaal, territory outside British control (1839). Prominent as farmer, soldier and politician, after the British annexation of the Transvaal (1877), Kruger was one of the leaders of the revolt (1880) by which independence was regained. Kruger was President of the South African Republic-Transvaal 1883-1902 and had to face the political and social problems raised by the influx of Uitlanders (non-Boer settlers) after the discovery of gold in the Rand. He refused to grant civil rights to the Uitlanders, fearing that they would support *Rhodes' expansionist policies and dominate the Transvaal. This, coupled with the provocation of the *Jameson Raid were basic causes of the Boer War. Kruger took some part in the early phase of the war but in 1900 sailed to Europe on a Dutch warship in the vain hope of obtaining support for the Boers. He did not return to Africa and died in Switzerland. Kruger, who belonged to a puritanical sect known as Doppers, had honesty, shrewdness and common sense, but lacked any adaptability for conciliation. Known to the Boers as 'Oom [Uncle] Paul', he was revered as the exemplar of resistance to the British. In 1898 he created the Sabie Game Reserve, the world's first, renamed as the Kruger National Park in 1926 and later expanded to 19,500 square kilometres.

Kruger, D. W., Paul Kruger. 1961-63.

Krugman, Paul Robin (1953- ). American economist. Educated at Yale and MIT, he was Professor of Economics at Princeton 2000- and an influential columnist for the New York Times. He won the 2008 Nobel Prize for Economics for his work 'explaining the patterns of international trade and the geographic concentration of wealth, by examining the effects of economies of scale and of consumer preferences for diverse goods and services'.

Krupp, Alfried (1812-1887). German steel and armament manufacturer. After taking over his father's metal foundry at Essen (1848) he developed a process for making cast steel, and introduced (1862) the Bessemer steel process. The manufacture of guns started in 1861 and Bismarck's frequent wars hastened a vast expansion. Coal and iron mines were added in 1876 . His paternalistic relationship to his large labour force became traditional in the firm and he offered the best wages and welfare conditions of any in Germany. Under his son Friedrich Alfried Krupp (1854-1902), who added armour plating (1890) and shipbuilding (1902), expansion continued and the number of employees had risen to 
43,000 when the firm was taken over by his daughter Bertha (1886-1957). On her marriage (1906) she transferred administrative power to her husband, Gustav von Bohlen und Halbach (1870-1950) known as Krupp von Bohlen. Under his regime, gun manufacture reached a culmination in World War I with the huge howitzers, known as 'Big Berthas', with a $42 \mathrm{~cm}$ calibre, that smashed Belgian forts, and the 'Paris Gun', with only a $21 \mathrm{~cm}$ calibre, which shelled Paris in 1918 at a range of $120 \mathrm{~km}$. German defeat meant a temporary decline in Krupp's fortunes and a switch to the manufacture of locomotives and agricultural machinery. However, an even greater degree of prosperity was attained when ${ }^{*}$ Hitler, whom Krupp partly financed, began rearmament. He was senile at the end of World War II and never tried. His son Alfried Krupp (1907-1967), tried at Nuremberg and sentenced to 12 years' prison, released in 1951 , soon resumed control of his vast industrial empire. In 1968 the company became a public corporation and the family relinquished control.

Klass, G. von, Krupps: The Story of an Industrial Empire. 1954; Manchester. W., The Arms of Krupp. 1968.

Krupskaya, Nadezhda Konstantinovna (18691939). Russian revolutionary. She married V. I. *Lenin in 1898, shared his exile and became a powerful influence in education after the Revolution.

\section{Krushchev, N. S. see Khrushchev, N. S.}

Krylov, Ivan Andreyevich (1768-1844). Russian writer. Though he also edited satirical journals and wrote plays, his fame rests on his racy and humorous fables. He had translated *La Fontaine, but drew his material largely from peasants met during his years (1793-1806) of wandering through Russia. He has been called 'the Russian La Fontaine'.

Kubelik, Jan (1880-1940). Czech violinist and composer. He began his platform career in Vienna in 1898 and gained international success through his virtuosity and dramatic style. His son Rafael Kubelik (1914-1996), a conductor and composer, was chief conductor of the Czech Philharmonic 1942-48, leaving after the Communist takeover, and of the Chicago Symphony 1950-53, Covent Garden Opera 1955-58, Bavarian Radio Symphony Orchestra 1961-85 and Metropolitan Opera, New York 197374. He married the Australian soprano Elsie Morison.

Kubitschek de Oliviera, Juscelino (1902-1976). Brazilian politician. Of Czech descent, he became a physician, was Governor of Minas Gerais 1950-54 and secured election as President of Brazil 1956-61. The political heir of *Vargas, he inaugurated Brasilia as the new capital (1960). He was blamed for high rates of inflation and increased foreign debt.

Kublai Khan (1216-1294). First Mongol (Yuan) Emperor of China 1271-94. Grandson of *Genghis nominal suzerainty over a territory stretching from the Black Sea to the Pacific. But it was China that stirred his imagination and absorbed his energies. He proclaimed himself Emperor of China to become the first of a new Yuan dynasty and ruled from his capital of Dadu (or Khanbaliq, called Cambaluc by Marco *Polo: the modern Beijing) which he made splendid. Hangzhou, then China's biggest city, capital of the Sung dynasty, was taken in 1276 but another 15 years elapsed before all China was conquered. During his reign he also sent expeditions to Tibet. Further south he subdued Burma but failed to achieve success against Japan. Unlike his ferocious ancestors, Kublai Khan was a liberal-minded ruler: he welcomed foreigners and fostered the arts and commerce, he established lamaistic Buddhism as the state religion but was tolerant of other faiths. He improved the civil service, and many great public works were carried out during his reign.

Saunders, J. J., The History of the Mongol Conquests. 1971.

Kubrick, Stanley (1928-1999). American film director, born in New York. Originally a magazine photographer, he made low-budget documentaries then a series of powerful films including Paths of Glory (1957), Lolita (1962), Dr Strangelove or How I learned to Stop Worrying and Love the Bomb (1964), 2001: A Space Odyssey (1968), A Clockwork Orange (1971), Barry Lyndon (1975), The Shining (1980), Full Metal Jacket (1987) and Eyes Wide Shut (1999).

Kuhn, Thomas S(amuel) (1922-1996). American historian and philosopher of science. Educated at Harvard, he became a physicist and taught at Harvard, Princeton and MIT. In The Structure of Scientific Revolutions (1962 revised 1970) he argued that revolutionary changes occurred when it was recognised (often on inadequate evidence) that the conventional patterns ('paradigms') of explanation were no longer adequate: transitions from Ptolemaic to Galilean cosmology, or Newtonian to Einsteinian physics were rapid and demolitionist, not evolutionary and incrementalist.

Kun, Béla (1886-1938). Hungarian Communist revolutionary, born in Transylvania. His father was a secular Jew, his mother a Protestant. He became a journalist, fought in World War I and was captured by the Russians. A co-founder of the Hungarian Communist Party (1918), he led the Hungarian Soviet Republic (March-August 1919), until suppressed by the 'Whites' under Miklós *Horthy. He escaped to Vienna, then to the USSR where he directed the brutal purge of 'Whites' in Crimea (1920-21). Active in the Comintern, he worked in Germany, Austria and Czechoslovakia, then was imprisoned in 1937 as a supporter of ${ }^{*}$ Trotsky and was executed. He was 'rehabilitated' in 1956.

Tokes, R. L., Bela Kun and the Hungarian Soviet Republic. 1967. 
Kundera, Milan (1929- ). Czech novelist, born in Brno. He worked at the Prague film school, left Czechoslovakia in 1969 and became a professor at Rennes 1975-80. His novels include The Joke (1967), Life is Elsewhere (1973), The Book of Laughter and Forgetting (1979) and The Unbearable Lightness of Being (1982). He became a French citizen in 1981 and wrote in French after 1993.

Küng, Hans (1928-2021). Swiss Catholic theologian. Ordained a priest in 1954, he taught at Tübingen from 1960 until his liberal questioning of Catholic orthodoxy led to sanctions (1980) by the Church. His books include Justification (1957), The Church (1967), On Being a Christian (1974) and Does God Exist? (1980).

Kurosawa Akira (1910-1998). Japanese film director, born in Tokyo. Trained in Western art, he became a scriptwriter, working for the director Yamamoto Kajiro. A neo-realist, he combined humanist, radical and traditional elements in his powerful films, emphasising moral and ethical choices, but was also admired for discriminating use of colour, and was generally regarded as the greatest Japanese film maker (certainly the one most admired in the West. His first film was Sugata Sanshino (1943) followed by Rashomon (1951), The Idiot (after *Dostoevsky, 1951), The Seven Samurai (1954), The Throne of Blood (an adaption of Macbeth, 1957), The Lower Depths (after *Gorki, 1957), Red Beard (1965), Derzu Uzala (1976) and Ran (a Samurai version of King Lear, 1985). He won three Oscars.

Richie, D., The Films of Akira Kurosawa. 1965.

Kurtág, György (1926- ). Hungarian composer, born in Romania. He studied with ${ }^{*}$ Messiaen, became a pianist and teacher, then was influenced by the minimalism of Anton *Webern and Samuel *Beckett. Exceptionally prolific, in many forms, piano, chamber, orchestral, vocal and choral, his works include Kafka Fragments (1986), Stele (1994) and the opera Beckett: Fin de Partie (Endgame, 2018). He received many international awards.

Kutuzov, Mikhail Ilarionovich, Prince (17451813). Russian marshal, born in St Petersburg. He joined the army at 14, lost an eye fighting the Turks (1774) and learnt about strategy from ${ }^{*}$ Suvarov. $\mathrm{He}$ fought against the Turks again 1788-91, became an administrator and diplomat and retired in disfavour in 1802. When Russia joined the coalition against ${ }^{*}$ Napoléon, *Aleksandr I recalled Kutuzov and forced him to engage at Austerlitz (December 1805), against his advice. He lost heavily and was retired again. When Napoléon invaded Russia (1812) Kutuzov replaced *Barklay de Tolly as Commanderin-Chief. He at first continued Barklay's strategy in avoiding a pitched battle until just before Moscow, at Borodino where, after fearful carnage on both sides, the Russians withdrew. Napoléon occupied Moscow but the advent of winter and the threat of Kutuzov's undestroyed army decided him to begin his disastrous retreat. Kutuzov won a great victory over *Davout and ${ }^{*}$ Ney at Smolensk and harassed the Grand Army continuously as it straggled homewards. He is revered by the Russians as one of their greatest generals. He plays a significant role in *Tolstoy's War and Peace.

Kuyper, Abraham (1837-1920). Dutch theologian and politician. Founder of the Anti-Revolutionary Party (1878), he was Prime Minister 1901-05 and helped to negotiate an end to the Boer War (1902). His Calvinist theology had a profound influence on Afrikaner thinking (D. F. *Malan).

Kwaśniewski, Aleksander (1954- ). Polish socialist politician. A former apparatchik and security informer under the United Workers' Party (i.e. Communist) regime, he was Minister for Sport and Youth Affairs. He founded the Democratic Left Alliance in 1993 and after a very professional electoral campaign defeated Lech *Walesa to become President of Poland 19952005. He was a great collector of foreign honours, and went to teach in the United States.

Kyd (or Kydd), Thomas (1558-1594). English playwright, born in London. Little is known of his life except that he was educated at Merchant Taylors' School, was an associate of *Marlowe, was imprisoned and tortured in 1593 for publishing blasphemies, and died intestate. His fame rests on a single play The Spanish Tragedie, or Hieronimo is mad again (presented 1585-89 and printed in 1592). It tells of a father driven almost mad by the murder of his son, a situation exactly opposite to that in *Shakespeare's Hamlet, Kyd possibly having written an earlier version, usually called $U r$-Hamlet, of which no copy survives. Of other attributions to Kyd, none is certain except Cornelia (1595), a play by Robert Garnier, translated from French.

Freeman, A., Thomas Kyd. 1967. 


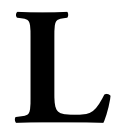

Labiche, Eugène Marin (1815-1888). French playwright, born in Paris. A lawyer, then a journalist, he wrote more than 100 comedies for the Palais-Royal Theatre, many still performed, including Le Chapeau de paille d'Italie (1851: The Italian Straw Hat, later filmed by René Clair) and Le Voyage de M. Perrichon (1861). He was elected to the Académie française in 1883 .

La Bruyère, Jean de (1645-1696). French essayist and moralist. He studied law but disliked it and eventually (1684) became tutor to Louis de Bourbon, grandson of the Prince de *Condé. In 1688 appeared the work for which he is renowned: Les Caracteres ou les Mours de ce Siècle, containing disguised and satirical pen-portraits of contemporaries, accompanied by moral maxims. Originally a pendant to a translation of the Characters of Theophrastus, it gradually developed as a separate work and the number of 'Characters' steadily increased with each edition. The fitting of the right cap to the right anonymous head became a social relaxation and several keys were published, the authenticity of all being denied by the author. The 'maxims' are scathing about not only human wickedness and folly but also the inequalities and harshness of the social system. Yet he was no revolutionary and seems to have accepted in a disillusioned spirit the inevitability of human ills.

Richard, P., Bruyère. 1946.

Lacan, Jacques (1901-1981). French psychoanalyst, psychologist and literary critic. In an important collection Ecrits (1966, translated into English 1977), using the techniques of structural linguistics, he proposed a radical revision of *Freud's theories and methodology, arguing that the whole structure of language was to be found in the unconscious, as revealed by psychoanalysis.

La Condamine, Charles Marie de (1701-1774). French geographer. Sent to Peru on an expedition (1735-43) to measure the meridional arc there, he also explored the Amazon. He obtained positive evidence concerning india-rubber and brought back the poisonous plant curare. His journal of the expedition was published in 1751 .

Lacoste, René (1904-1996). French lawn-tennis player. With Jean *Borotra and Henri Cochet he was one of the famous 'Three Musketeers' who monopolised the Wimbledon singles championship from 1924 to 1929 . Lacoste won in 1925 and 1928 . He manufactured sportswear with the familiar alligator logo.
Laden, Osama bin Mohammed bin Awad bin (1957-2011). Saudi jihadist leader, born in Riyadh. His family, originally from Yemen, made a fortune in the construction business. He accepted US support in organising guerrilla warfare against Soviet control of Afghanistan, then created the al-Qaida network, which made terrorist attacks on New York and Washington on 11 September 2001. He was killed by US operatives (2 May 2011) in Abbottabad, Pakistan, and buried at sea. His son, Hazma bin Osama bin Mohammed bin Awad bin Laden (1989?-2019?), groomed as a potential leader of al-Qaida, was also killed by US operatives.

\section{Ladislaus see Wladislaw}

\section{Ladurie, Emmanuel Bernard Le Roy see Le Roy} Ladurie, Emmanuel Bernard

Laënnec, René Théophile Hyacinthe (17811826). French physician, born in Brittany. As a hospital physician he made important contributions to research on tuberculosis, peritonitis, parasitic complaints etc. His greatest contribution was to devise the stethoscope and the method of ausculation for diagnosis of diseases of the chest. He developed the disease from which he died (probably tuberculosis) four years after becoming professor of medicine at the Collège de France.

Lafayette, (Marie Joseph Paul Yves Roch) Gilbert du Motier, Marquis de (1757-1834). French soldier and politician. A liberal-minded member of a rich aristocratic family, he went to America (1777) to fight for its independence, became a friend of *Washington and returned to France to urge his country to go to war with Great Britain on America’s behalf. Successful in this he was back in America in time to take part in the events that led to the capitulation of Yorktown (1781). With a hero's reputation and his liberal principles he was elected to the Estates-General of 1789 and became Commander of the National Guard. A constitutionalist rather than a violent revolutionary he tried to restrain mob rule in Paris and, after the failure of Louis *XVI's flight to Varennes, to protect the king. Courageous but mediocre, avid for praise and easily manipulated, *Mirabeau called him 'Gilles [i.e. simpleton] César'. Forced to give up his post in Paris he became commander of the army of the east, but a final effort (1792) to avert the danger to the king's life by a march on Paris failed. Lafayette sought refuge across the Rhine and was held in prison until the peace of 1797 . Under Napoléon he lived quietly, but after the emperor's fall he served in the Chamber of Deputies 1815, 1818-24. He made a triumphant return to the US (1824-25) where he was made an honorary citizen and is still regarded as a symbol of Franco-American friendship. In the 1830 Revolution he commanded the National Guard which overthrew ${ }^{*}$ Charles X and replaced him with ${ }^{*}$ Louis Philippe. He was offered the Belgian throne in 1830 . 
La Fayette, Marie Madeleine Pioche de la Vergne, Comtesse de (1634-1693). French novelist. She was the first French writer to publish a novel of psychological insight and sincere observation. La Princesse de Clèves (1678) deals with a married woman's renunciation of a love affair-a theme probably inspired by her own unsatisfactory marriage. In 1667 she became an intimate of the Duc de la *Rochefoucauld - an attachment that lasted until his death in 1680-who may have helped her with her novels.

La Follette, Robert Marion (1855-1925). American politician. He played a notable part in the politics of his native state, Wisconsin, and as Governor 1901-06, carried out a program of reform (the Wisconsin idea) which gained him a national reputation. As US Senator 1906-25 he continued to fight for progressive causes and in 1924 stood as an independent Progressive candidate for the presidency and polled 4,800,000 votes.

La Fontaine, Jean de (1621-1695). French poet. His marriage was early dissolved and he later frequented numerous patrons, including Madame de La Sablière and Nicolas *Fouquet. He wrote a variety of forms of poetry but his enduring masterpiece was his 12 books of Fables (1668-94) (240 in all), many of them adaptations of *Aesop's fables, often concealing under their childish appeal a biting satire of the foibles and weaknesses of French society in particular and human nature in general. He was elected to the Académie française in 1683, despite the king's objections.

Clarac, P., La Fontaine. Rev. ed. 1959.

Lagerkvist, Pär (Fabian) (1891-1974). Swedish novelist, dramatist and poet. He was concerned with destructive forces in society. Two poems in expressionist style, Angest and Kaos, were written during World War I to emphasise its horrors. He later widened his scope to attack all political and social extremism and its destructive power. He won the Nobel Prize for Literature for the novel Barabbas (1951).

Spector, R. D., Pär Lagerkvist. 1973.

Lagerlöf, Selma Ottiniana Lovisa (1858-1940). Swedish novelist and poet. Crippled from girlhood, she was a schoolteacher for many years and wrote a series of popular children's stories, e.g. The Wonderful Adventures of Nils (1907), and religious stories, e.g. Legends of Christ (1904). Her greatest work was the romantic story of peasant life in Sweden, Gosta Berlings Saga (1891). Nominated 28 times, she became the first woman to win the Nobel Prize for Literature (1909) and to be elected to the Swedish Academy.
Lagrange, Joseph-Louis, Comte de (né Giuseppe Lodovico Lagrangia) (1736-1813). Italian-French mathematician, born in Turin. Of partly French ancestry, he studied in Turin, became interested in calculus and mechanics and taught at the Turin Artillery School from 1755. Before the age of 20 he had won a place in the front ranks of mathematicians as the result of a memoir he sent to ${ }^{*}$ Euler, in the course of which he developed the calculus of variations, one of his most important contributions to mathematics. He helped to develop the theory of sound and, with *Laplace, carried out investigations that led to the formulation of the law governing the eccentricity and stability of the solar system. He was director of the Berlin Academy of Sciences 1766-87 and then settled in France, where he headed the commission appointed during the Revolution to draw up the new system of weights and measures. He also introduced the system of decimal coinage. His greatest work was his Mecanique Analytique (1788).

La Guardia, Fiorello H(enrico) (1882-1947). American Republican politician. He served in the US House of Representatives 1917-21, 1923-33, then became an immensely popular mayor of New York City 1933-45. Here he initiated housing and labour schemes, was Civil Defence Director and an early opponent of ${ }^{*}$ Hitler's anti-Semitic policies. He was the first Director General of the UN Relief and Rehabilitation Administration (UNRRA) (1946).

Mann, A., La Guardia, 1882-1933. 1959.

Laing, R(onald) D(avid) (1927-1989). British psychiatrist. Influenced by existentialism, he argued in Sanity, Madness and the Family (1964) that madness is a reflexive reaction to the stresses of family life, rather than having biological causes. His controversial views, rejected by mainstream psychiatrists, were the subject of continuous media interest.

Laing, R. D., Wisdom, Madness and Folly. 1985.

Lakatos, Imre (1922-1974). Hungarian mathematician and philosopher of science. He lived in Britain from 1956, teaching at the London School of Economics, and editing the British Journal for the Philosophy of Science (1971-74). He urged far more rigorous analysis of decision-making in science policy, for example the comparative evaluation of research programs.

Lalande, Joseph Jérôme Lefrançois de (1732-1807). French astronomer, he was professor of astronomy in the Collége de France (1762-1807) and (from 1768) Director of the Paris Observatory. His Histoire céleste (1801) gave the positions of nearly 50,000 stars. His Traité d'Astronomie (1764) was his principal work. The Lalande Prize was instituted by him (1802) for the most important observation or book of the year. 
Lalor, Peter (1827-1889). Irish-Australian activist and politician, born in Raheen, Co. Laois. Born to a well-connected family, he migrated to Victoria in 1852 and, perhaps surprisingly, because he was neither Chartist nor republican, became a leader of protests by 12,000 diggers at Ballarat against the imposition of a 'poll tax' (licence fee), arbitrary interference by police and officials, and denial of the right to vote. Appointed Commander-in-Chief, Lalor led 1500 miners (plus a few spies and informers) to Eureka where a stockade was improvised as protection against what appeared to be inevitable attack and raised the 'Southern Cross' flag. On Sunday, 3 December 1854, at 3.00 a.m. at Eureka, troops and police attacked the stockade, killing about 30 people and taking one hundred prisoners. Lalor, shot in the left arm, escaped, but his arm had to be amputated at the shoulder. He was never tried but 12 miners charged with treason were all acquitted. Lalor became a State MP, took conservative positions on many issues and vehemently denied being 'a democrat.' Five films have been made about Lalor and the Eureka Stockade incident.

Lamarck, Jean-Baptiste Pierre Antoine de Monet, Chevalier de (1744-1829). French naturalist. After three years in the army, he took up banking but soon turned to natural history. He published a Flore françoise (1778) and in 1779 was put in charge of the royal garden which became the nucleus of the later Jardin des Plantes in Paris where he gave lectures over many years on the invertebrates until 1818 when failing eyesight forced him to retire. He put forward the theory, often called Lamarckism, that explains variations in species as being primarily due to environment and which concludes that such adaptive variants are hereditary. He introduced the term 'biology', which he made into a science with his system of classification, and is regarded as the founder of invertebrate palaeontology. In his own time he was regarded as something of an eccentric, but later his evolutionary theories aroused considerable scientific interest. His ideas concerning the inheritance of acquired characteristics are now discredited though the Soviet biologist * Lysenko attempted to establish their validity.

Cannon, H. G., Lamarck and Modern Genetics. 1960.

Lamarr, Hedy (originally Hedwig Eva Maria Kiesler) (1914-2000). Austrian-American film actor and inventor, born in Vienna. An extraordinary beauty, she attracted attention with her first film Ecstasy (1933), and worked in the US from 1938, making 26 films over 20 years. In 1940, with the composer George Antheil, she developed a system, adapted from a player-piano mechanism, to produce a frequencyhopping radio signal that could not be tracked or jammed. They received very late recognition in 1997 for their achievement and an electronic version became central to Wi-Fi.
Lamartine, Alphonse Marie Louis de (1790-1869). French poet and politician. He achieved his first great poetic success with the Romantic Médiations poétiques (1820) in which the influence of *Bron is evident. He had minor diplomatic appointments in Italy until 1828 where, in 1820, he married an English woman Maria-Ann Birch. His religious orthodoxy was given lyrical expression in his Harmonies poétiques et religieuses. Later works include the epic in 15 visions La Chute d'un Ange (1838), and La Vigne et la Maison (1856), which has been described as 'his finest individual poem'. As a politician, Lamartine was a moderate and he won a great reputation as an orator in the parliaments of *Louis Philippe. After the latter's fall he was briefly Foreign Minister but the election of his rival Louis Napoléon (later *Napoléon III) as President closed his political career. Later he wrote historical and autobiographical works in a vain effort to pay off a vast accumulation of debt.

Whitehouse, H. R., Life of Lamartine. 2 vols. Repr. 1969.

Lamb, Lady Caroline (née Ponsonby) (17851828). English writer. Daughter of the 3rd Earl of Bessborough, she married William Lamb, later 2nd Viscount ${ }^{*}$ Melbourne in 1805 and he tolerated her hysteria and alcoholism. Her passionate pursuit (1812-13) of Lord *Byron (whom she described as 'mad, bad and dangerous to know'), made her ridiculous and embarrassed him. After their rupture she caricatured him in Glenarvon, published anonymously in 1816 . This, the first of three not very distinguished novels, was republished (1865) as The Fatal Passion. She died of dropsy.

Lamb, Charles (1775-1834). English essayist, known as 'Elia'. Educated at Christ's Hospital London, where he formed a lifelong friendship with S. T. *Coleridge, at the age of 17 he went to work as a clerk at the London office of the East India Company, where he remained for 33 years. In 1796 his sister Mary killed their mother in one of the fits of recurring insanity to which she was subject, Lamb declared himself her guardian and devoted his life to her care, which was repaid with deep affection. Together they wrote Tales from Shakespeare (1807) and Poetry for Children (1809). During the next decade Charles wrote little of importance except the criticism that appeared (from 1812) in Leigh *Hunt's paper the Reflector, but in 1820 he began the famous series of essays in the London Magazine under the pen name 'Elia'. A considerable depth of thought, concealed by a style of infinitely varied harmonies and a persuasively whimsical charm have made these essays (collected 1823 and 1833) one of the most abidingly popular books in the field of belles-lettres. All the qualities that give delight in his essays are present though less formally presented, in his letters, published in several collections after his death. He also wrote poetry throughout his life. Despite his circumstances Lamb was a man of many 
friends, deeply loved for his genial companionship, generosity and courage. His sister Mary survived him for 13 years.

Wilson, E. G., Dream-Child. A Life of Charles Lamb. 2022.

Lambert, Constant (1905-1951). English composer and conductor. Son of the artist George Washington Lambert (1873-1930), he studied at the Royal College of Music with *Vaughan Williams, became friends with the ${ }^{*}$ Sitwells and *Walton and at 20 was commissioned by ${ }^{*}$ Diaghilev to write the ballet Romeo and Juliet (1926). The Rio Grande (1929), for piano, orchestra and chorus, to words by Sacheverell *Sitwell, used jazz idioms successfully. He was music director for the innovative Carmago Society 1930-33 and the Vic-Wells, later Sadler's Wells, Ballet 193147. His polemic Music Ho! (1934) still reads well, although many of his judgments (e.g. his dismissal of ${ }^{*}$ Mahler) have been overtaken by events. Later works include the choral Summer's Last Will and Testament (1936), and the ballets Horoscope (1937) and Tiresias (1951). His son Christopher ('Kit') Lambert (19351981) made a fortune as a rock-music promoter and drank himself to death.

Motion, A., The Lamberts: George, Constant and Kit. 1986.

Lambert, John (1619-1684). English soldier. During the Civil War he fought with distinction under ${ }^{*}$ Fairfax at Marston Moor, and under ${ }^{*}$ Cromwell at Preston, Dunbar and Worcester. He commanded the Parliamentary army in Scotland at the time of King *Charles' trial and execution, supported Cromwell as Lord Protector and on his death, with strong backing from the army, could probably have displaced the feeble Richard Cromwell. But any ambitions he may have had were frustrated by the Restoration secretly organised and carried out by ${ }^{*}$ Monck who brought him to trial for treason. Convicted (1662), Lambert was confined for life, first on Guernsey, then on Plymouth Sound.

Lamennais, Hugues Félicité Robert de (17821854). French political theorist. A Catholic priest, in his chief work Essay on Religious Indifference (1818-24), he presented an untraditional view of Christianity. Although he also argued that the evils of the time could only be overcome by a universal Christian society in which kings and peoples were subject to the pope, his unorthodox views were condemned by the papacy. In 1840, one of his books earned him a year's imprisonment. He was, for a short time after the revolution of 1848 , a member of the Constituent Assembly.

Lamerie, Paul de (c.1688-1751). Dutch silversmith. Apprenticed to a London goldsmith in 1703, he was his own master from 1712. He became one of the most famous craftsmen of the century and his work is correspondingly valued. His earlier work shows a simplicity and delicacy lacking in the rococo elegance of his later productions.

La Mettrie, Julien Offray de (1709-1751). French physician and philosopher. He published his first important work, Histoire naturelle de l'âme in 1745. Its belief in a materialistic theory of mind offended the Church and the medical establishment, and from then until his death, La Mettrie was involved in a running war with both. His major work was L'Homme machine of 1748 which expounded both materialism and atheism quite openly. He saw the body as nothing other than a machine. Mental states, such as love, hunger, illness, ideas, all had physiological roots. Man was superior to the animals simply because he possessed a bigger brain. He was fascinated by the close interaction of brain and body to produce delicate feelings and purposive bodily behaviour, and he explored the possible interface between medicine and morals, the relationship between sin and sickness. He also wrote four medical treatises, on venereal disease, vertigo, dysentery and asthma. His Observations de médecine pratique (1743) indicates his clinical practice, in which he gives specially important place to autopsies.

Lamont, Norman Stewart Hughson, Baron Lamont of Lerwick (1942- ). British Conservative politician, born in Shetland. After leaving Cambridge, he became a merchant banker and a Tory MP 1972-97, serving in Treasury posts from 1986 and as Chancellor of the Exchequer 1990-93.

Lampedusa, Giuseppe Tomasi, Prince of (18971957). Italian novelist. His novel, Il Gattopardo (The Leopard), appeared posthumously (1958) and was widely praised for its description of social and political change in Sicily in the mid-19th century.

Buzzi, G., Tomasi di Lampedusa. 1973.

Lancaster, House of. English dynasty, a branch of the *Plantagenets. *John of Gaunt, fourth son of Edward III, was created Duke of Lancaster after the death of the 1st Duke whose daughter and heiress he had married. The Lancastrian kings were John of Gaunt's son *Henry IV, followed by his son *Henry V and grandson *Henry VI.

Storey R. L. The End of the House of Lancaster. 1966.

Lancaster, Joseph (1778-1838). English educationist. He is remembered for the monitorial system, which is described in his Improvement in Education (1803). It was similar to one introduced in Madras by Andrew Bell (1753-1832). Lancaster first opened a school for the poor in Southwark in 1798 , where by the system of teaching by monitors, 100 pupils could be taught under the supervision of a single master. Lancaster's supporters included ${ }^{*}$ Brougham, ${ }^{*}$ Wilberforce and ${ }^{*}$ Mill, but in time he 
quarrelled with his backers, quit their organisation (the Royal Lancasterian Institution) and emigrated to New York in 1818. He worked with *Bolivar in Venezuela (1825-27) but quarrelled with him too.

Lancaster, Sir Osbert (1908-1986). British cartoonist, author and theatrical designer. He was a cartoonist at the Daily Express from 1939, wrote shrewd and witty books on architecture, e.g. Pillar to Post (1938), Drayneflete Revealed (1949), Sailing to Byzantium (1969), two volumes of autobiography and designed many opera and ballet sets.

Lanchester, Frederick William (1868-1946). British engineer and physicist. A pioneer of the motor industry, he designed the Lanchester car (1899) and during the next 30 years was consultant to the Daimler and other companies. He carried out research in aeronautics, and published several books. In 1922 he was elected FRS.

Lancret, Nicolas (1690-1745). French painter. Under *Watteau's influence he painted fetes galantes and other gay court occasions. Despite the artificial nature of his subjects and the fastidious elegance of his style his keen observation gave life and realism both to characters and to the background details in his scenes.

Land, Edwin Herbert (1909-1991). American inventor. He dropped out of Harvard to work on inventions including the Polaroid-a plastic sheet incorporating many tiny crystals that polarised light. This was used in Polaroid sunglasses and the Polaroid Land camera, which provided immediate prints.

Landon, Alf(red Mossman) (1887-1987). American politician and businessman, born in Pennsylvania. An oil producer in Kansas he later acquired radio and TV interests. Governor of Kansas 1933-37, he won the Republican nomination for president in 1936 on the first ballot, but was defeated in a landslide by Franklin D. *Roosevelt, winning only two states (Maine and Vermont). A rural progressive, he was a strong supporter of the United Nations, the Marshall Plan, and urged recognition of *Mao's China. His daughter, Nancy Landon Kassebaum (1932- ), was a US senator from Kansas 1978-97.

Landon, Letitia Elizabeth (known as L.E.L.) (1802-1838). English poet and novelist, born in London. She was a prolific poet and novelist, publishing under her initials, and became subject to sexual exploitation, leading to curiosity, admiration and attack. She married late and died of an overdose, possibly accidental, in what is now Ghana.

Miller, L., L.E.L.: The Lost Life and Scandalous Death of Letitia Elizabeth Landon, the Celebrated Female Byron' 2019.
Landor, Walter Savage (1775-1864). English writer, born in Warwick. The consequences of an irascible nature which caused him to be removed from Rugby and rusticated from Oxford, pursued Landor throughout his life. Although both physically and intellectually impressive, his life was a series of quarrels and lonely wanderings. From 1815 to 1835 , the year in which they had their decisive quarrel, he lived in Italy with his wife. Despite his pugnacity his impulses were nearly always generous. Much of his inherited wealth was used to equip volunteers for the Peninsular War, more went into a scheme of agricultural and social reform at Llanthony. He turned over his property to his children only to be rewarded by ingratitude and he would have died in extreme poverty had not Robert and Elizabeth *Browning rallied his brothers to his support and enabled him to spend his last years in Florence in a comparative tranquillity. Except by a few his literary work was never highly esteemed: his best known book is Imaginary Conversations (1824-29).

Landowska, Wanda Louise (1879-1959). Polish pianist, harpsichordist and musicologist, born in Warsaw. She lived in France 1900-40 and in the US from 1940 onwards, becoming famous for her energetic interpretations of ${ }^{*} \mathrm{Händel},{ }^{*} \mathrm{Bach},{ }^{*}$ Scarlatti and other 17th- and 18th-century composers. She was responsible for the modern revival of the harpsichord, and concertos were written for her by *Falla and *Poulenc.

Landseer, Sir Edwin Henry (1802-1873). English painter. He gained immense popularity with his animal pictures, especially of deer and dogs which, in the excellent engravings made by his brother, Thomas Landseer, appeared in countless Victorian homes. Despite a certain sentimentality of subject, his animals are natural and realistic and his drawings reveal a much wider and less conventional talent. The lions of Trafalgar Square, London, were modelled by him. He was Queen *Victoria's drawing teacher, declined election as President of the Royal Academy, and became a melancholy alcoholic in his last years.

Landsteiner, Karl (1868-1943). AustrianAmerican pathologist, born in Vienna. Working at the University of Vienna, he became famous for his discovery (1901) of the four main human blood groups, $\mathrm{A}, \mathrm{B}, \mathrm{AB}$ and $\mathrm{O}$. He won the Nobel Prize for Medicine in 1930 for this. He worked for the Rockefeller Institute in New York from 1922 until his death. He also discovered, in collaboration with A. S. Wiener, the $\mathrm{Rh}$ factor, so called because it was first found in the Rhesus monkey.

Lane (originally Williams), Sir Allen (1902-1970). English publisher. With his brothers Richard Grenville Lane (1905-1982) and John Lane (19081942) he founded Penguin Books which grew from modest beginnings (1935) into one of Britain's major 
publishing houses within a few years, pioneering the paperback book. His uncle John Lane (1854-1925), of the Bodley Head, published the famous Yellow Book, the art quarterly which with Aubrey*Beardsley's illustrations was a succès de scandale in the 1890s.

Murpurgo, J., Allen Lane: King Penguin. 1979; Kells, S. Penguin and the Lane Brothers. 2015.

Lanfranc (Lanfranco) (1005?-1089). Italian prelate in England. Born in Pavia, he became a Benedictine monk, left Lombardy c.1039 and directed an important school at Avranches. As prior of the Abbey of Bec in Normandy 1045-66, he attracted the notice of Duke *William, whose gratitude he earned by obtaining papal dispensation for his marriage. Abbot of Saint-Etienne, Caen, 1066-70, when William conquered England, Lanfranc was rewarded (1070) with the archbishopric of Canterbury. He reorganised the English Church to meet the changes caused by the conquest and showed his legal talent and diplomatic skill in reconciling the demands of a reforming pope ( ${ }^{*}$ Gregory VII) and an autocratic king.

Lang of Lambeth, Cosmo Gordon Lang, 1st Baron (1864-1945). Scottish Anglican prelate, born in Fyvie. Educated at Glasgow and Oxford universities, and originally a Presbyterian, he became an Anglican priest in 1890 . He made his mark by his demeanour, eloquence and social work, and became suffragan Bishop of Stepney 1901-08, then, in a meteoric rise, Archbishop of York 1908-28 and Archbishop of Canterbury 1928-42. His vehement opposition to *Edward VIII's proposed marriage to Mrs Simpson was a decisive factor in the King's abdication (December 1936). Unmarried, he developed an embarrassing passion for the actress Anne Todd.

Lockhart, J. G., Cosmo Gordon Lang. 1949; Beaken, R., Cosmo Lang: Archbishop in War and Crisis. 2012.

Lang, Fritz (1890-1976). German film director, born in Vienna. Originally an architect, his early films were important examples of Expressionism, including Dr Mabuse, the gambler (1922), Nibelungen (1925), Metropolis (1926), and $M$ (1932). He worked in the US 1933-58, directing a variety of films including Westerns, thrillers and psychological dramas.

Lang, John Thomas (generally known as J. T., or Jack Lang) (1876-1975). Australian Labor politician, born in Sydney. A member of the New South Wales Parliament 1913-46, he was ALP State leader 192339. As Premier of NSW 1925-27 and 1930-32, he introduced welfare state measures and promoted construction of the Sydney Harbour Bridge. During the Depression he adopted reflationary policies later advocated by J. M. *Keynes, repudiating payments on foreign debts and to the Commonwealth Government. He controlled the party machine in NSW and his supporters in the Australian Parliament contributed to the defeat of the *Scullin government in 1931. The semi-fascist 'New Guard' had been formed (1930) to work for his overthrow and in May 1932 the New South Wales Governor, Sir Philip Game dismissed him. Replaced as Labor leader in 1939 by William *McKell, he was expelled from the ALP in 1943, formed the Lang Labor Party and sat in the House of Representatives 1946-49 as a bitter opponent of the Labor Governmemt led by J. B. ${ }^{*}$ Chifley, an old enemy. Lang was much admired by Paul *Keating who secured his readmission to the ALP in 1971.

Lang, J. T., I remember. 1956; Nairn, B., The Big Fella. 1986.

Lang, John Dunmore (1799-1878). Australian clergyman, politician and educator, born in Greenock. Educated at Glasgow, he became a Presbyterian cleric, arriving in Sydney in 1823. He founded schools, campaigned against transportation, for free immigration and disestablishment of the Church of England, advocated self-government for Victoria and Queensland and (from 1850) proposed that Australia should become a republic.

Lange, David Russell (1942-2005). New Zealand Labour politician, born in Otahuhu. A barrister, and a brilliant debater, he was an MP 1977-96 and Leader of the Labour Party 1983-89. He defeated Sir Robert *Muldoon in July 1984, and was Prime Minister 1984-89, Foreign Minister 1984-89, Minister for Education 1987-89 and Attorney General 1989-90. His government introduced a GST, deregulated the economy and banned nuclear ships from New Zealand ports. Increasing uneasy about Thatcherite changes to the economy proposed by his Minister for Finance, Roger *Douglas, he resigned as Prime Minister in August 1989 and received a $\mathrm{CH}$. He suffered from diabetes and kidney failure and published My Life (2005) just before his death.

Langevin, Paul (1872-1946). French physicist. He studied with Pierre ${ }^{*}$ Curie, worked on X-rays and magnetic theory, became the lover of Marie ${ }^{*}$ Curie, and was a courageous campaigner against Fascism.

Langland, William (c.1330-c.1400). English poet, probably born in or near Worcestershire. All that is known of his life is deduced from his work. He was educated at a monastery at Great Malvern, later went to London and seems to have acquired some knowledge of law. He is now remembered only as the author of the Vision of Piers Plowman an allegorical and didactic poem in alliterative verse. The survival of 50 manuscripts shows its popularity in medieval times but its later influence was small. The fact that the poem survives in three versions (c.1362, 1377 and 1393-98), the two later ones being nearly three times as long as the first, has suggested multiple authorship, but critical opinion has veered to the acceptance of the first two at least, as the work of a single hand. The subject of the poem is the salvation of souls, 
but its chief interest for modern readers lies in its descriptions of the scenes (roads, inns, law courts etc.) and characters of medieval life.

Vasta, E. (ed.) Interpretations of Piers Ploughman. 1969; Goodridge, J. F. (ed. and trans.), Langland: Piers the Ploughman. 1970.

Langley, Samuel Pierpont (1834-1906). American astronomer and physicist. He was professor of the observatory at the Western University of Pennsylvania (now Pittsburgh University) 1867-87, and secretary of the Smithsonian Institution, Washington 18871906. He made important studies of solar radiation and with the aid of a sensitive instrument called a bolometer mapped the infra-red region of the solar spectrum. His observations of infra-red radiation from the moon were the basis of *Arrhenius' quantification of the greenhouse effect. He was a pioneer in aerodynamics ( ${ }^{*}$ Cayley) and carried out two experiments in aviation. In 1896 he built two model airplanes, both powered with small steam engines: the second, weighing $9.7 \mathrm{~kg}$, flew $1280 \mathrm{~m}$. In December 1903 (nine days before the *Wright Brothers succeeded), a piloted aircraft weighing 386 $\mathrm{kg}$, with a $14.6 \mathrm{~m}$ wingspan, crashed on take-off.

Langmuir, Irving (1881-1957). American physical chemist. He joined the General Electric Company (1909) and was its Director of Research 1932-50. He was much concerned with the handling of high vacua and developed a number of inventions, e.g. the gasfilled tungsten lamp, the mercury vapour lamp and the atomic hydrogen welding torch. In the course of his work on surface chemistry he derived the equation (now known as the Langmuir absorption isotherm) relating the pressure to the extent of absorption of a gas on a solid surface at constant temperature, for this he won the Nobel Prize for Chemistry (1932).

Langton, Stephen (c.1150-1228). English prelate. A fellow student in Paris of the future Pope *Innocent III, he was later given a place in the papal household and (1206) made a cardinal. King *John's refusal (1207) to accept him as Archbishop of Canterbury led to a prolonged struggle between the king and the papacy and Langton was not able to enter his see until after John's submission to the pope (1213). Langton sided with the barons in their struggle with the king, and played an important part in drafting the Magna Carta.

Cheney, C. R., From Becket to Langton. 1956.

Langtry, Lillie (née Emilie Charlotte Le Breton) (1852-1929). British actor, born in Jersey. Famed for her beauty, she was for some years the mistress of *Edward VII. After Edward Langtry's death she married (1899) Sir Hugo de Bathe. She appeared in *Shakespeare and *Goldsmith, becoming a successful theatre manager and racehorse owner.
Lanier, Sidney (1842-1881). American poet, born in Georgia. He fought with the Confederate army in the American Civil War which was the subject of his novel Tiger Lilies (1867). Later he became a flautist in a symphony orchestra in Baltimore. In a series of lectures at Johns *Hopkins University, he proposed a scientific approach to poetry, which he regarded as a kind of verbal music. Such a definition permitted the discarding of metrical restrictions replaced by more flexible musical rhythms. The best of his own poems include Corn, The Symphony and The Song of The Chattahoochee.

Lansbury, George (1859-1940). English Labour politician. A Christian pacifist and supporter of women's rights, he was a Poplar Borough councillor 1903-40, MP for Bromley and Bow 1910-12 and 1922-40 and editor 1912-22 of the Daily Herald, the organ of the Labour Party. Leader of the Opposition 1931-35, he resigned during the Abyssinian crisis (1935), feeling unable as a pacifist to support a policy of sanctions against Italy that might lead to war. His granddaughter, Dame Angela (Brigid) Lansbury (1925-2022) was a popular film, television and stage actor in the US.

\section{Lansdowne, 1st Marquess of see Shelburne,} 2nd Earl of

Lansdowne, Henry Charles Keith Petty Fitzmaurice, 5th Marquess of (1845-1927). English politician and administrator, born in London. He studied at Eton and Oxford, and as a Liberal was a Lord of the Treasury 1868-72 and Undersecretary for War 1880, and Governor General of Canada 1883-88. He broke with *Gladstone in 1886 over Ireland, became a Liberal Unionist, then after 1912 a Conservative. He was Viceroy of India 1888-93, War Secretary 1895-1900 and Foreign Secretary 190005 , being responsible for the negotiations leading to the Anglo-Japanese Alliance (1904) and the AngloFrench Entente (1910). A minister briefly in World War I, he was out of office when he wrote the famous 'Lansdowne letter' (1917) to the Daily Telegraph advocating a negotiated peace with Germany.

Lansing, Robert (1864-1928). American administrator. A specialist in international law, Woodrow *Wilson appointed him as US Secretary of State 1915-20 and principal executant of US foreign policy during World War I. A leading delegate at the Paris Peace Conference (1919), he called Cabinet meetings after Wilson's incapacitating illness and was dismissed.

Lǎožr (= 'old master', Lao Tzu in Wade-Giles; birthname traditionally $\mathrm{Li}$ Er) (fl. 500 BCE). Chinese philosopher, probably legendary. Regarded as the founder of Taoism, his followers asserted that he was born in Henan, held office at court but became a travelling scholar and met several times with *Confucius. Tao te ching sets out the ideas and 
practices that came to be known as Daoism (Taoism). A unity (dao) underlying the apparently conflicting phenomena of the universe is perceived, the attitude to the fundamental laws of the universe should be unconditional acceptance, the achievement of such acceptance being helped by quietist techniques, complete relaxation 'sitting with a blank mind' (tso wang) etc. The other book of early Daoism, Chuang $T z u$, may have been written by a pupil of that name.

Waley A., Lao-Tzu: The Way and the Power. 1956.

La Pérouse, Jean François de Galaup, Comte de (1741-1788). French sailor and explorer. He was put in command (1785) of an expedition of exploration, and from the northwest coast of America crossed the Pacific with two ships. He explored the northeast coasts of Asia and in particular, while sailing to investigate the possibility of a northeast passage, found the strait (named after him) between Sakhalin and Hokkaido (Yezo), thus proving both to be islands. By 1788 he was in Australia and in February his two ships sailed from Botany Bay never to be seen again. They foundered on a coral reef to the north of the New Hebrides.

Laplace, Pierre Simon, Marquis de (1749-1827). French astronomer and mathematician, born in Normandy. His origins are uncertain but he became a raging snob and political opportunist. He attracted the attention of $d^{\prime *}$ Alembert and worked with ${ }^{*}$ Lavoisier and ${ }^{*}$ Lagrange. He made an important contribution to the theory of capillarity and corrected *Newton's equation for the velocity of sound in a gas. He developed a calculus of probabilities which he applied to the theory of gravitation. His major work was in astronomy. In his Exposition du systeme $d u$ monde (1796) he put forward his well known 'nebular hypothesis' suggesting that the solar system originated from the gradual contraction of a rotating sphere of nebulous material. Although this theory has now been superseded, it acted as a powerful stimulant to 19 th-century astronomical thought. In his greatest work, the five-volume Mécanique celeste (17991825), Laplace worked out a generalised statement of the laws governing movement throughout the whole solar system. Sometimes called 'the French Newton', he also foreshadowed thermochemistry and developed the 'Laplace transform' for solving partial differential equations. In addition to his academic work he took part in public life. After the coup d'état by Bonaparte (*Napoléon), he was made a count and eventually, under *Louis XVIII a marquess. In 1817 he became President of the Académie française.

Lara, Brian Charles (1969- ) Trinidadian cricketer. A batsman, he scored 501 runs not out, playing for Warwickshire at Edgbaston (6 June 1994), beating Hanif Mohammed's record of 499 (1959), and *Bradman's 452 (1930). In November 2005, he became the greatest run-maker in Test cricket history, until overtaken by Sachin *Tandulkhar in 2008.
Lardner, Ring(gold Wilmer) (1885-1933). American author. A sports writer for many years, he became famous for his short stories which displayed remarkable powers in the use of colloquial dialogue and a bitter contempt for average Americans, especially those connected with sport and the theatre, with which he was well acquainted. His How to Write Short Stories (1924) is typical of several volumes in this vein.

Largo Caballero, Francisco (1869-1964). Spanish politician. A construction worker, he led the Workers' General Union (UGT) 1925-31 and was Minister for Labour Relations 1931-33. He became Prime Minister 1936-37 for the first part of the Civil War, as Madrid was threatened by the nationalist insurgents his government operated first from Valencia, then from Barcelona. Juan ${ }^{*}$ Negrin succeeded him. Arrested by the Germans in 1940, he was held in a concentration camp until 1945 .

Larkin, Jim (James) (Séamas Ó Lorcáin) (18761947). Irish labour leader, born in Liverpool. He formed (1909) the Irish Transport and General Workers' Union in Dublin and became famous when a lockout (1913) of his members by employers was followed by an eight-month strike ending in a partial victory for Larkin. He lived in the US 1914-23 but was imprisoned for 'criminal anarchy' 1920-23, then deported. He founded the Irish Workers League (IWL) in 1923. Associated with the Comintern, he then lost enthusiasm for ${ }^{*}$ Stalin, served three brief terms in the Dáil, and rejoined the Labour Party and Catholic Church. Larkin appears as a character in plays, books and films.

Larkin, Philip (Arthur) (1922-1985). English poet. Educated at Oxford, he worked as a provincial librarian and at the University of Hull 1955-85. Shy and unmarried, he deliberately kept out of the limelight but won critical acclaim for five short books of poetry including The Less Deceived (1955) and High Windows (1974), a novel, essays and writings on jazz and he received a CH in 1985. Kingsley *Amis' Lucky Jim was partly based on Larkin. Publication of his Collected Letters (1992) revealed Larkin's isolation, bitterness, resentment, obsessions and prejudices, elements that appeared as detachment and irony in his poems.

Motion, A., Philip Larkin: A Writer's Life. 1993.

La Rochefoucauld, François, Duc de (1613-1680). French writer. A political opponent of ${ }^{*}$ Richelieu, he later quarrelled with *Mazarin and partly because of his passion for ${ }^{*}$ Condé's sister, the Duchesse de Longueville, joined the Fronde, but after being wounded he retired (1652) to write his memoirs. Even though he was forgiven by the court he devoted himself thenceforth to a literary life. He attended the salons of, amongst others, Mademoiselle de Scudéry and the Marquise de Sablé and was a friend of ${ }^{*}$ Corneille, ${ }^{*}$ Molière and ${ }^{*}$ La Fontaine. He later set 
up house with Madame de *La Fayette. In his Maxims (Réflexions on Sentences et Maximes morales, 1665 etc.) he made no attempt to preach but set out objectively his own cynical view of human nature, to which he ascribed self-love as the mainspring.

Moore, W. G., La Rochefoucauld: his Mind and Art. 1969.

Larousse, Pierre Athanase (1817-1875). French lexicographer and encyclopaedist. Largely selfeducated, he was a radical, obsessed with the use of knowledge to transform society and produced a series of grammars, dictionaries and textbooks. He founded his own publishing house in 1852 . His Grand Dictionnaire universel du XIXe siècle (15 volumes, 1866-76) is of lasting value, republished on DVD in 2001.

Larsson, Stieg (Karl Stig-Erland) (1954-2004). Swedish journalist and novelist. He worked for newspapers as a writer and photographer, became a social activist and was briefly in the Communist Party. The three novels in his 'Millenium' series, published posthumously, The Girl with the Dragon Tattoo (2005), The Girl Who Played with Fire (2006), and The Girl Who Kicked the Hornets' Nest (2007) became international bestsellers and successful films.

La Salle, Sieur de, René-Robert Cavelier (16431687). French explorer and fur trader, born in Rouen. Originally trained to be a Jesuit, Cavelier settled in New France, near the site of Montréal, in 1666 and bought the title (and estate) by which he is known in 1667. The chronology and extent of his early explorations is disputed but in 1669 he began to traverse the Great Lakes, with Seneca guides, seeking a great river that he hoped would be a western passage to the Pacific and China. He was granted a valuable concession for fur trading.

The mouth of the Mississippi River had been observed by Hernando de *Soto in 1541, and its upper reaches by French explorers in 1673 and 1680 . (English expeditioners found the Ohio River in 1671 and 1674.) In 1682-83 La Salle led a party of French and Indians, sailing down the Mississippi to the sea and back. He named the Mississippi Basin Louisiana (1682), in honour of *Louis XIV.

In 1684 he led an expedition of 300 colonists and four ships from France to establish permanent settlements in Louisiana. Due to a $2^{\circ}$ navigation error, the ships entered Matagorda Bay (Texas), assuming it to be the Mississippi Delta, $680 \mathrm{~km}$ ENE. La Salle and his men established a settlement and spent two years in a vain search for the Mississippi. Hardships and disease provoked a mutiny and La Salle was murdered. La Belle, one of his ships, was found in 1995.

Las Casas, Bartolomé de (1476-1566). Spanish colonial reformer. He went (1502) to the West Indies where he became a priest (c.1510) and started to work to improve the position of all Indians under Spanish rule, in particular to abolish the system by which grants of Indian serfs were made to settlers. Visits to Spain won him the support of King ${ }^{*}$ Ferdinand and his successor Carlos I (the emperor ${ }^{*}$ Charles V) but having failed to make the reforms effective he assented to a proposal to introduce African labour, a decision he bitterly regretted as it encouraged the growth of the slave trade. Another disappointment came when a settlement, which he had started (1520) in Venezuela to prove the advantages of free colonisation over slave-run estates was destroyed by the Indians, who distrusted all Spaniards. Before the conquest of Peru (1531) he again visited Spain and returned with royal instructions for the protection of the Indians. He became Bishop of Chiapas in Mexico (1542) and continued to struggle for the enforcement of the laws against Indian serfdom. In 1547 he finally returned to Spain. His books bear witness to his compassion and zeal.

Hanke, L., Bartholomé de Las Casas: An Interpretation of his Life and Writings. 1951.

Lasker, Emanuel (1868-1941). German chessmaster and mathematician. He was world chess champion from 1894 until 1921 when ${ }^{*}$ Capablanca defeated him in a great contest at Havana.

Laski, Harold Joseph (1893-1950). English political scientist, born in Manchester. He was a lecturer at Yale University in the US and McGill University in Canada before joining (1920) the London School of Economics, where he was professor of political science 1926-50. His students included Jawaharlal *Nehru and Pierre ${ }^{*}$ Trudeau. Chair of the British Labour Party 1945-46, Clement *Attlee detested him.

Martin, K., Harold Laski. 1953.

Laslett, (Thomas) Peter (Ruffell) (1915-2001). English social historian. He worked at the BBC, edited Locke's Two Treatises of Government (1960), directed the Cambridge Group for the History of Population and Social Structure and demonstrated the emergence of a new demographic group_-'the Third Age', who lived to an advanced age after retirement. He was a cofounder of the Open University and the Universities of the Third Age (U3A) and wrote The World We Have Lost (1965) and A Fresh Map of Life (1989).

Lassalle (né Lassal), Ferdinand Johann Gottlieb (1825-1864). German socialist, born in Breslau (now Wroclaw). Son of a rich Jewish silk merchant, he abandoned his religion as a young man and devoted several years at the universities to the study of ${ }^{*}$ Hegel. He attracted the friendship of Alexander von ${ }^{*}$ Humboldt and Heinrich ${ }^{*}$ Heine and gained notoriety by conducting a protracted law suit (1846-54) on behalf of the Countess Sophie von Hatzfeldt whose estate had been seized by her estranged husband, rewarded by gratitude and a substantial annuity for his success. By 1848 he was a convinced socialist, imprisoned for six months in Berlin after the revolutionary uprisings. 
He knew Karl *Marx and Friedrich *Engels but fundamentally disagreed with both. Marx argued that the state preserved existing class relations and would wither away under socialism, but Lassalle was an advocate of 'state socialism', using government as an instrument of reform. He founded the General German Workers' Association (ADAV) in 1863; renamed the Social Democratic Party (SPD) in 1875. Lassalle believed that universal suffrage would place the power of the state at the service of the working population. He became a reluctant admirer of *Bismarck and played a significant role in persuading him to adopt universal male suffrage.

Outside Geneva, he fought a duel for the hand of Helene von Dönniges with a Wallachian prince favoured by her parents. He was shot and died of wounds three days later.

Lassus, Orlando de (also known as Orlando di Lasso, originally, perhaps, or Roland de Lattre) (1532?-1594). Netherlandish, or Flemish-French, composer, born in Mons (now in Belgium). He became choirmaster at St John Lateran in Rome but for most of his life was court composer of the Duke of Bavaria in Munich 1556-94. His works (reputed to number more than 2,000) include four Passions, 60 Masses, 530 motets, psalms and the Lamentations of Jeremiah (1585). His madrigals and songs, set to German, Italian and French words are still highly regarded for their melodic beauty. His work is more varied and adventurous, if less profound, than *Palestrina, with whom he is often compared. Ennobled (1570) by Emperor Maximilian II, he received a papal knighthood but was treated for depression in his last years

Latham, Sir John Grieg (1877-1964). Australian judge and politician, born in Melbourne. A conservative rationalist, he was the son of a tinsmith. He graduated in law from Melbourne University, became a barrister, a naval officer in World War I and worked with the Australian delegation at the Paris Peace Conference (1919). Federal MP 1922-34, he served as Attorney-General 1925-29; 1932-34, Leader of the Opposition 1929-31 (resigning in favour of J. A. *Lyons), and Minister for External Affairs and Industry 1932-34. Chief Justice of the High Court 1935-52, he became chancellor of Melbourne University 1939-41 and, having been a strong supporter of appeasement, Minister to Japan $1940-41$.

Cowen, Z., Sir John Latham and Other Papers. 1965.

Latham, Mark William (1961- ). Australian commentator, controversialist and former Labor politician. Educated at Sydney University and a staffer for Gough *Whitlam, he was Mayor of Liverpool 1991-94 and a Federal MP 1994-2005. He wrote Civilising Global Capital (1998), and became an advocate for 'third way' policies. He served as a shadow minister 1996-98, 2003 and after Simon *Crean's resignation, beat $\mathrm{Kim}{ }^{*}$ Beazley to become Leader of the Labor Party 2003-05. After the *Howard Government won the 2004 election he retired, due to illness and internal party criticism. The Mark Latham Diaries (2005) were bitterly controversial. He became an increasingly erratic media commentator, strongly misogynist and homophobic, and left the ALP. He became the leader of Pauline *Hanson's One Nation Party in New South Wales in 2018 and was elected MLC 2019- .

Latimer, Hugh (1485-1555). English Protestant martyr, born near Leicester. A yeoman's son, he was educated at Cambridge University and there became a university preacher. For his support of the annulment of *Henry VIII's marriage to *Katherine of Aragon he was taken into royal favour and became (1535) Bishop of Worcester but resigned (1539) when it was clear that his reforming zeal had outpaced that of the king, and he was in prison for most of the remainder of Henry's reign. After *Edward VI's accession (1547) Latimer's influence as a preacher denouncing the evils of the day reached its zenith, but under Queen *Mary, persecution of Protestants was resumed. Latimer was taken to Oxford and there, after confrontation with Roman Catholic divines had failed to induce him to recant, he was burned at the stake. His last words, to his fellow martyr Bishop *Ridley were 'We shall this day light such a candle by God's grace in England as I trust shall never be put out'.

Lattre de Tassigny, Jean Joseph Marie Gabriel de (1889-1952). French soldier. The youngest French general in World War II, he defied the orders of the Vichy Government and continued to fight the German invaders. Arrested in November 1942, he escaped to London in September 1943, joined *de Gaulle and led the French First Army from the invasion of southern France in 1944 to the crossing of the Rhine in 1945 and signed the instrument of surrender at Berlin (1945) on behalf of France. He commanded the French armies in Indochina 1950-51, died of cancer and was posthumously created a marshal.

Salisbury-Jones, G., So Full a Glory. 1954.

La Tour, Georges de (1593-1652). French painter. Little is known of him except that he lived in Lorraine. Popular in his lifetime (and often copied), he was forgotten after his death and his paintings attributed to other artists until Herman Voss (1884-1969), German art historian, published an important study (1915) re-establishing his importance. The influence of ${ }^{*}$ Caravaggio is especially noticeable in his groups of figures by candlelight. In his use of colour, especially of crimson and lilac, he shows marked individuality. About 40 of his works survive including, St Joseph the Carpenter, Nativity with Shepherds, Mary Magdalen with oil lamp and Cardsharps.

Bloch, V., Georges de la Tour. 1950; Thullier, J., Georges de la Tour. 1993; Conisbee, P., Georges de La Tour and His World. 1996. 
Laud, William (1573-1645). English prelate, born at Reading. Son of a wealthy clothier, he was educated at Oxford and ordained in 1601. Despite, or because of, his opposition to the prevalent Puritanism, his industry, administrative ability and religious sincerity won him powerful patrons. He became Bishop of Bath and Wells (1626), of London (1628) and Archbishop of Canterbury (1633). In the period that followed the murder of Buckingham (1628) he tried, with *Strafford and King *Charles I himself, to impose authoritarian rule on Church and State alike. Laud was determined to free England of Calvinism and Scotland of Presbyterianism. Many English Puritans were deprived of their livings, ritual was reintroduced, the doctrine of the Real Presence reasserted and among other contentious measures, the Communion table was removed from the centre of the church to the east end. His attempt to Anglicise the Church of Scotland however, led to riots, to the signing of the Covenant to the Bishops War between the two countries, and eventually (to meet the costs of the war) to the summoning of the Long Parliament, which impeached Laud of high treason, He was found guilty by the House of Lords on several counts, none of which however, amounted to treason and it was on a bill of attainder that he was beheaded on Tower Hill.

Trevor Roper, H., Archbishop Laud 1573-1645. 2nd ed. 1962.

Lauder, Sir Harry (Harold MacLennan) (18701950). Scottish singer. With such famous songs as Roamin in the Gloamin, I Love a Lassie and A Wee Deoch-an-doris, he was for two generations one of the most famous and popular of music-hall stars. He was knighted (1919) for services in World War I.

Lauderdale, John Maitland, 1st Duke of (16161682). Scottish politician. During the Civil War he acted as agent for Scottish Presbyterians at the court of ${ }^{*}$ Charles I and later established a similar connexion with the exiled Prince Charles (later ${ }^{*}$ Charles II) and became a close friend. When Charles crossed to Scotland to make a bid for the crown, Lauderdale went with him but was captured at Worcester (1651) and held prisoner for nine years. Under the Restoration he was Secretary for Scotland 1660-80 and tried to make the Crown absolute there. After the fall of *Clarendon, from 1667 to 1673 he was the 'L' of the famous 'Cabal' ministry (*Buckingham). In Scotland he tried to work in harmony with the Presbyterians but this became increasingly difficult. Disillusion, combined with the corruption of power, made him harsh and intractable. Once a supporter of the Convenanters, he suppressed them with great brutality (1666-79). He inherited the earldom of Lauderdale (1645), was created duke in 1672 and dismissed from all offices in 1680 .
Laue, Max von (1879-1960). German physicist. Director of the Institute for Theoretical Physics, Berlin 1919-50, he was a pioneer in X-ray analysis using the pattern of diffracted X-rays to determine crystal structure. He won the Nobel Prize for Physics (1914).

Laughton, Charles (1899-1962). Anglo-American actor. He portrayed, at first on the London stage and after 1932 in films, many characters of ruthless and overbearing personality. Film parts such as the king in The Private Life of Henry VIII and Captain Bligh in Mutiny on the Bounty revealed him at his powerful best. Although actively gay, he married (1929) the actor Elsa Lanchester (1902-1986), lived in Hollywood from 1934 and became a naturalised American (1950).

Callow, S., Charles Laughton: A Difficult Actor. 1987.

Laurel, Stan (né Arthur Stanley Jefferson) (18901965) and Hardy, Oliver (1892-1957). American film comedians. Stan Laurel, born in Lancashire, began work in circuses and music halls as a slapstick comedian. In 1916 he joined Hardy, an American, who began his career in vaudeville but appeared in silent film comedy since 1913. Together they made over 100 films in which they combined slapstick with clashes of personality: Laurel the bumbling innocent, Hardy the self-assured blunderer.

Laurier, Sir Wilfrid (1841-1919). Canadian Liberal politician, born in Québec. He made his name as a lawyer and entered the provincial legislature 1871 and the Canadian parliament in 1873. In 1887 he became leader of the Liberals and Prime Minister 1896-1911, being the first French-Canadian to lead a national government. His period of office was one of prosperity and expansion, especially in the wheat-growing provinces in the west. The issue on which he finally fell, in the election of 1911, was his support for commercial reciprocity with the US. He led the anti-conscriptionist wing of his party in World War I. His political (and legal) heir was W. L. Mackenzie *King.

Schull, J., Laurier. 1966.

Lauterpacht, Sir Hersch (1897-1960). PolishJewish-British lawyer, born in Zolkiew (now in Ukraine). He grew up in Lviv (now in Ukraine, then in Poland), moving to England in 1923. He became a law professor at Cambridge, a prosecution advisor at the Nuremberg trials, and a Judge of the International Court of Justice 1955-60. He was critical of*Lemkin's concept of genocide as a war crime, emphasising the importance of emphasising individual victims and individual perpetrators rather than groups.

Sands, P., East West Street. 2016.

Lautrec, Henri Toulouse see Toulouse-Lautrec, Henri 
La Vallière, Louise Françoise de la Beaume le Blanc, Duchesse de (1644-1710). French mistress. She was only 17 when *Louis XIV first saw her and fell in love. By her sweetness and sincerity, coupled with a lack of ambition or greed, she won-to everyone's surprise-the admiration of the court. When supplanted by Madame de *Montespan (1674), she departed without rancour to the Carmelite convent where she spent the rest of her life. Only one of her three children by Louis survived her.

Laval, Pierre Jean-Marie (1883-1945). French politician, born in the Auvergne. Possibly of Moorish descent, he was largely self-educated but won academic degrees, and became a lawyer, small businessman and publisher. He was a member of the Chamber of Deputies 1914-19, originally a radical, pacifist and socialist then an independent deputy 1924-27 and Senator 1927-44. He became a premier 1931-32, 1935-36 and as Foreign Minister 1934-36 negotiated the ${ }^{*}$ Hoare-Laval Pact (1935), accepting Italy's occupation of Ethiopia. He advocated friendship with Italy and Germany. After the collapse of France he took a leading part in the establishment of Marshal *Pétain's Vichy regime, was Premier briefly (1940) until forced out by Pétain who detested him. In April 1942 he became Prime Minister again in active collaboration with the Germans: he set up the notorious French milicia with its Gestapo-like activities and supplied conscript labour for German factories. After the liberation of France he fled to Germany and then to Spain. He was repatriated, tried, condemned and executed for treason. Laval was ambitious, persuasive and subtle. He may have deluded himself that by his appeasement he preserved some degree of independence for Vichy France; in fact, he went further than the Germans expected. There is an extensive literature on the Laval case.

Cole, H., Laval. 1963; de Chambrun, R., Mission and Betrayal 1939-45. 1993; Curtis, M., Verdict on Vichy. 2002.

Laveran, (Charles Louis) Alphonse (1845-1922). French parasitologist. He served as a military surgeon in Algeria and in 1880 discovered the parasite that causes malaria. He established the laboratory of tropical diseases at the Pasteur Institute, Paris, in 1907, won the Nobel Prize for Medicine (1907) and published 600 research papers.

Lavigerie, Charles Martial Allemand (1825-1892). French cardinal. After teaching at the Sorbonne, he became Bishop of Nancy 1863-67, Archbishop of Algiers 1867-84, and also of Carthage (now Tunis) and Primate of Africa 1884-92. He founded the order of the White Fathers in 1868 and was created cardinal in 1882. He took a leading role in organising international opposition to slavery in central Africa.
Lavoisier, Antoine(-Laurent) (1743-1794). French chemist, born in Paris. In 1768 he invested heavily in the 'Ferme générale', a private syndicate that collected taxes on behalf of the crown, retaining a percentage, and this provided him with funds to pursue scientific research. Elected to the Académie de Sciences (1768), he directed the Gunpowder Office 1776-91. He also made practical use of his scientific knowledge in agriculture and acquired an estate for experimental purposes. Lavoisier has been called the father of modern chemistry. By his experimental work he not only made many new discoveries but refuted the long-held belief that water could be converted into earth and the current theory that the existence of an invisible, inflammable gas, phlogiston, explained many of the problems of combustion. His own experiments showed that air was composed of two gases, which he called oxygen and 'azote' (later known as nitrogen), and that oxygen played an essential role in the respiration of animals and plants. In 1783, almost simultaneously with ${ }^{*}$ Cavendish and ${ }^{*}$ Priestley, he announced that water is a combination of hydrogen and oxygen. He wrote the important Opuscules physiques et chymiques (1774) and constructed the first table of elements. Methods of Chemical Nomenclature (1787), written with the assistance of ${ }^{*}$ Berthollet and *Fourcroy, coined about 30 names still in use for elements. In 1789, he proposed the law of the conservation of massessentially that matter is neither created nor destroyed, but is transformed in the course of chemical changes. By burning, for example, coal is converted into carbon dioxide, other gases and particulates, but the total mass is conserved. Although mass cannot be created or destroyed, it may be rearranged in space and changed into different types of particles. (This is a central premise in the argument for anthropogenic global warming.) By burning objects in a sealed chamber he established that combustion was accompanied by the chemical combination of oxygen with the substance burned (creating what became known as oxides). From 1791 he worked with *Laplace and *Legendre to establish a uniform metric system of weights and measures, adopted in 1799 . He was a liberal constitutionalist, believed in social reform, and played his part in the various Revolutionary assemblies, but he had made powerful scientific enemies, including ${ }^{*}$ Marat. His previous role as tax farmer led to his arrest and condemnation during the Terror. Appeals to delay his guillotining met with the chilling response: 'The Revolution has no need of savants or chemists.' $\mathrm{He}$ was executed with his father-in-law and 25 others. His widow later married (briefly) Count *Rumford.

McKie, D., Antoine Lavoisier: Scientist, Economist, Social Reformer. 1952; Donovan, A., Antoine Lavoisier: Science, Administration and Revolution. 1993; Poiner, J-P., Lavoisier. 1996; Smart Bell, M., Lavoisier in the Year One. 2005. 
Law, Andrew Bonar (1858-1923). British Conservative politician, born in New Brunswick, Canada. A successful iron merchant in Glasgow, he served as Member of Parliament 1900-06, 1906-10, 1911-23, being twice defeated, and was Parliamentary Secretary to the Board of Trade 1902-06 until the Liberals swept into office. When *Balfour retired as Conservative leader, Law was unexpectedly elected (as a compromise candidate) to succeed him, marking an end to the tradition of aristocratic leadership. His principal target was *Asquith's Home Rule Bill. When World War I broke out (1914) he supported the government and in 1915 served as Colonial Secretary in the coalition formed by *Asquith. Law's close friend (and fellow Canadian) Max Aitken (*Beaverbrook) played a central role in dislodging Asquith as Prime Minister and replacing him with David *Lloyd George. Law then became Chancellor of the Exchequer 1916-18 and Lord Privy Seal 1919-21, until his resignation due to illness. In October 1922 a Conservative revolt ended the coalition, Lloyd George had to resign and Law succeeded as Prime Minister for six months until inoperable cancer forced his resignation (May 1923); he died in October. He had a mastery of detail and could deliver long, intricate speeches without notes.

Blake, R., The Unknown Prime Minister. 1955.

Law (of Lauriston), John (1671-1729). Scottish financier, born in Edinburgh. He narrowly escaped execution in London (1694), for killing a man in a duel, escaped to the Netherlands, then Venice, and finally, France. He wrote Money and Trade Considered (1705), founded a private bank in Paris, attracted interest through his adventurous ideas on how governments could trade out of bankruptcy and served, improbably, as Controller General of Finances 1720. He was responsible for 'the Mississippi Bubble', selling stocks for a company to exploit France's colonies in North America which then collapsed. He died in Venice.

Law, Phillip Garth (1912-2010). Australian explorer and administrator. $\mathrm{He}$ directed the Australian National Antarctic Research Expedition (ANARE) 1949-66, explored 4,500 km of coast and set up bases at Mawson, Davis and Casey. He wrote Antarctic Odyssey (1983).

Law, William (1686-1761). English clergyman. Forced to give up his Cambridge fellowship for refusing to swear an oath of allegiance to ${ }^{*}$ George I, he spent most of his life in controversial and devotional writings, which, however, sparkle with epigrammatic wit. His books, especially $A$ Serious Call to a Devout Way of Life (1729), in which he asserted that Christianity is not mere obedience to a moral code but a complete pattern of life, had great influence on Dr *Johnson and, amongst others, the *Wesleys, and thus on the whole Evangelical movement.
Lawes, Sir John Bennet, 1st Baronet (1814-1900). English agricultural chemist. Educated at Eton and Oxford, he inherited his birthplace Rothamsted Manor, Harpenden, Hertfordshire and in 1843 established the Rothamsted Experimental Station, England's first agricultural laboratory. He followed *Liebig's experiments and developed the first superphospate, which revolutionised Australian farming. He worked with Sir Joseph Henry Gilbert (1817-1901) and also conducted experiments in animal nutrition.

Lawrence (or Laurence. Latin: Laurentius, Italian: Lorenzo), St (225-258). Roman martyr, born in Spain. He was one of seven deacons of Pope Sixtus II, who were beheaded in Rome during the persecution in the reign of the emperor *Valerian. His symbol is a gridiron, because of the tradition, the subject of many paintings but rejected by scholars, that he was burned to death. Patron saint of librarians, archivists, miners, comedians, cooks and tanners, St Lawrence River in Canada was named for him.

Lawrence, Carmen Mary (1948- ). Australian politician and psychologist. She was an academic psychologist in Perth and Melbourne, a State MP 1986-94 and Premier of Western Australia 1990-93, the first female Premier in Australian history. In the Commonwealth Parliament 1994-2007, she served as *Keating's Minister for Human Services and Health 1994-96. The first National President of the ALP directly elected (2003) by branch members, she served 2004-05. She was outspoken about asylum seekers and the environment.

Lawrence, D(avid) H(erbert) (1885-1930). English novelist, poet and essayist, born in Eastwood, Nottinghamshire. His father was a drunken and almost illiterate coal-miner, his mother a former school teacher with Puritan values. His early years were squalid. Frail but studious, he left high school at 16 , working first as a clerk, then as a teacher in Nottingham and London. His youth was troubled by an obsessive relationship with his mother and by tuberculosis symptoms which made him increasingly irritable. The publication of The White Peacock (1911) pointed to his future career; it was followed by the semi-autobiographical Sons and Lovers (1913). Meanwhile he had fallen in love and eloped with Frieda von ${ }^{*}$ Richthofen, the German wife of an English scholar, Ernest Weekley, whom he married in 1914. Such a marriage in wartime, added to his bitter class-consciousness, heightened the persecution mania from which he had always suffered. Expelled from Cornwall in 1917 as a suspected German spy, he became a restless traveller after the war, living in Italy, Germany, Ceylon, Australia, the US (New Mexico) and Mexico. Books from this period include Sea and Sardinia (1921) Kangaroo (1923) and Mornings in Mexico (1927). He finally settled on the French Riviera and died near Nice. The novels reflect the often contradictory emotional and intellectual 
impulses stirred by the circumstances of his life and the theories he formed in an attempt to build up a personal philosophy that would enable him to cope with them. Thus the mother-son relationship becomes the basis of a theory that the instincts of the blood are superior to the reasonings of the mind; he wrote: 'My religion is in the blood, the flesh, as being wiser than the intellect.' In rebellion against his Puritan background he stands for sexual freedom and frankness, but though in the longbanned Lady Chatterley's Lover (1928) the language of the gamekeeper-lover is wilfully coarse, the main impression left by the lovemaking scenes is one of deep tenderness. To be set against this attitude to sex is his vision of woman as an inert consumer of man's vitality, keeping him earthbound and preventing his spirit and intellect from taking wing. Lawrence was torn and almost destroyed by these inner conflicts.

Among his other novels were Women in Love (1921), Aaron's Rod (1922) and The Plumed Serpent (1927). His short stories, in such collections as The Woman Who Rode Away (1928), range over many countries and many themes, including the macabre, his poetry (collected 1932) is vivid and sensitive. He remains one of the most important and controversial influences in 20th-century literature. He disliked and dismissed Joyce, and the feeling was mutual. The Plumed Serpent (1926) suggests some affinity to Fascism.

Nehls, E. (ed.), D. H. Lawrence, A Composite Biography. 3 vols, 1957-59; Maddox, B., The Married Man: A Life of D.H. Lawrence. 1994; Wilson, F., Burning Man: The Ascent of D. H. Lawrence. 2021.

Lawrence, Ernest Orlando (1901-1958). American physicist. Professor of physics at the University of California 1928-58, in 1930 he proposed a machine that could accelerate atomic particles to enormous speeds and then use them to bombard atoms. He constructed (1931) the first model of such a machine, which he called the cyclotron and used it to carry out transmutation of elements and to produce artificial radioactivity. He was awarded the Nobel Prize for Physics (1939).

Lawrence, John Laird Mair Lawrence, 1st Baron (1811-1879). British administrator, born in Yorkshire of Ulster parentage. Educated at Haileybury College, he joined the East India Co. in 1829, serving for almost 30 years as an administrator, judge and tax collector in Calcutta, Delhi and the Punjab. As a moderate reformer, as Chief Commissioner in the Punjab 1853-57 he worked to curb princely powers. In the Indian Mutiny (1857-58) he raised an army of 40,000 in the Punjab which preserved British rule in Delhi and he opposed savage reprisals on mutinous communities. Direct Crown rule replaced the East India Co. from 1858 and Lawrence returned to London, as a member of the Supreme Council on India $1858-63$, to organise the new administrative system. After the sudden death of Lord *Elgin,
*Palmerston appointed Lawrence as Viceroy of India 1863-68, and he built railways, irrigation and sanitation systems. Created a baron in 1869, he opposed the Afghan War 1878-79.

Lawrence, Sir Thomas (1769-1830). English painter, born in Bristol. Son of an innkeeper, he entered the Royal Academy Schools in 1787 and in 1789 achieved instant fame with a picture of Queen ${ }^{*}$ Charlotte (now in the National Gallery, London). He became ARA (1791), court painter (1792), RA (1794), and President of the Royal Academy 1820 30. Described as 'always in love and always in debt', he was the most prolific and fashionable portrait painter of his time. The future ${ }^{*}$ George IV commissioned him to paint portraits of delegates to the Congress of Vienna (1814-15), now at Windsor Castle. His subjects included Walter ${ }^{*}$ Scott, Warren ${ }^{*}$ Hastings, *Wellington, *Wilberforce, Pope *Pius VII, ${ }^{*}$ Metternich and Lady Peel (Frick Gallery, New York). He became unfashionable in the Victorian era but is now considered to be a virtuoso. He helped acquire the Elgin Marbles and works by ${ }^{*}$ Michelangelo and *Raphael for the new National Gallery.

Garlick, K., Sir Thomas Lawrence. 1951; Levey, M., Sir Thomas Lawrence. 2005.

Lawrence, $\mathbf{T}$ (homas) $\mathbf{E}$ (dward) (known as 'Lawrence of Arabia') (1888-1935). British archaeologist, soldier and writer, born in Tremadoc, North Wales. Son of Sir Thomas Chapman, 7th Baronet (who had abandoned his family in Ireland) and Sarah Lawrence (née Junner), after a punitive childhood, he was educated at Oxford Boys High School and Jesus College. On his own, he explored France in 1908 and Syria in 1909, returning to Syria and Palestine in 1910 to study Crusader castles which he later vividly described. He undertook archaeology and surveying at Carchemish between 1911 and 1914 with David Hogarth (1862-1927) and Leonard *Woolley, learned Arabic and developed deep sympathy for Arabs living under Turkish rule.

When the Ottoman Empire entered World War I, Military Intelligence sent Lawrence to Egypt to encourage and organise an Arab revolt behind Turkish lines. He joined General Sir Edmund *Allenby's staff, and worked with and became a close advisor of the emir *Faisal, from the Hashemite dynasty in the Hejaz. A significant innovator of guerrilla warfare, between January 1917 and October 1918 he led many attacks on bridges and railways, with heavy casualties and brutal reprisals. Although wounded and captured several times, his accounts of war experiences are sometimes embellished.

When the Ottoman Empire entered World War I, Military Intelligence sent Lawrence to Egypt to encourage and organise an Arab revolt behind Turkish lines. He joined General Sir Edmund *Allenby's staff, worked with and became a close advisor of the emir *Faisal, from the Hashemite dynasty in the Hejaz. 
A significant innovator of guerrilla warfare, between January 1917 and October 1918 he led many attacks on bridges and railways, with heavy casualties and brutal reprisals. Although wounded and captured several times, his accounts of war experiences are sometimes embellished.

Awarded a CB (1917) and DSO (1918) and promoted to colonel, he was deeply disillusioned by what he regarded as betrayal of self-rule for the Arabs by the secret Picot-Sykes agreement (1916), which divided control of former Ottoman territories between Britain and France. He declined a knighthood (KCB) and suggestions that ${ }^{*}$ George $\mathrm{V}$ offered him the $\mathrm{OM}$ are implausible. At the Paris Peace Conference (1919) he was part of the British delegation, but assisted the Arab delegation in arguing for self-rule.

The American journalist Lowell Thomas (18921981), recognising the dramatic appeal of Lawrence's exploits, produced the immensely successful documentary film With Allenby in Palestine and Lawrence in Arabia (1919) which made him a celebrity.

After brief service under ${ }^{*}$ Churchill in the Colonial Office 1921-22, he sought anonymity in the RAF as Aircraftsman J. H. Ross. He corresponded regularly with Churchill, Thomas *Hardy, Bernard *Shaw, Edward *Elgar, E.M. *Forster and Robert *Graves. He described his wartime activities in The Seven Pillars of Wisdom (1926, published in a limited, expensive edition) and in shortened form Revolt in The Desert (1927), which was a best seller. Publicity caused him to disappear once more, and he returned to the RAF under the name of Aircraftsman T. E. Shaw and served in (modern) Pakistan 1926-28 in a clerical post. While there he translated *Homer's The Odyssey, published in 1932 in a magnificent edition under the name of T. E. Shaw. His brutal account of life in the RAF, The Mint (1929), was published posthumously in 1955 . However, he remained in the RAF until just before his death, working on marine aircraft.

Lawrence had a high pain threshold, and his sexuality was solitary and masochistic: he may have invented, in detail, his gang rape by Turkish captors in 1917 .

He died after a motorbike accident in Dorset. The complex character of this scholar-hero has been a constant subject of speculation and controversy in books, plays (including Ross by Terence *Rattigan and Lawrence After Arabia by Howard Brenton) and films, notably David *Lean's Lawrence of Arabia (1962).

Wilson, J., Lawrence of Arabia. 1990; Korda, M., Hero: The Life and Legend of Lawrence of Arabia. 2010.

Lawson, Henry (Archibald Hertzberg) (18671922). Australian poet and short-story writer, born in Grenfell. His father, Niels Larsen, a miner, was Norwegian, his mother Louisa Lawson (née Albury) (1848-1920) a poet, publisher and suffragist. He left
South Wales, Western Australia and Queensland. His first verses appeared (1887) in the Sydney Bulletin, and thereafter, though his travels continued, he gave his life to authorship and became one of the most important figures in the Australian literary tradition. His short stories 'The Bush Undertaker', 'The Drover's Wife' (both 1892), 'The Union Buries Its Dead' (1893) are very powerful and unlike 'Banjo' *Paterson, he was a realist about the harshness of the bush. His short story collections include While the Billy Boils (1896), On the Track, and, Over the Sliprails (1900).

His sexuality was ambiguous. He visited New Zealand in 1897. His powers declined from 1902 when he had an unhappy period in London. Jailed seven times between 1905 and 1907 for drunkenness and failure to provide support for his estranged wife, and committed to periods in an asylum, he was, nevertheless, granted a state funeral and later commemorated by stamps and banknotes.

Philips, A.A., Henry Lawson, 1970; Murray-Smith, S., Henry Lawson. 1975; Clark, M., In Search of Henry Lawson, 1978.

Laxness, Halldor Kiljan (original name Gudjonsson) (1902-1998). Icelandic novelist. Influenced successively by German expressionism, Roman Catholicism and Communism, he returned to introspective passivity. Some of his novels, all written in Icelandic, were translated into 30 languages, and include Independent People (1935), The Fish Can Sing (1957) and Paradise Reclaimed (1962). He was awarded the Nobel Prize for Literature (1955).

Layard, Sir Austen Henry (1817-1894). British archaeologist and diplomat, born in Paris. He worked in a solicitor's office 1833-39, then travelled through Turkey, Syria and Persia. Stratford ${ }^{*}$ Canning (later Stratford de Redcliffe) used him as an unofficial diplomat agent (i.e. spy) from 1842 and also sent him to make archaeological investigations of Assyrian sites. At Nineveh (Mosul) and Babylon (1845-47 and 1849-51) he unearthed a great mass of sculptured material and cuneiform tablets (now in the British Museum), from which the history of Assyria has been largely deduced. In 1849 he found 12 tablets in Nineveh containing the Epic of Gilgamesh. Liberal MP 1852-57; 1860-89, he served as Under Secretary for Foreign Affairs 1852; 1861-66 and First Commissioner (i.e. Minister) for Works 1868-69. Ambassador to Spain 1869-77 and to the Ottoman Empire 1877-80, he assisted *Disraeli at the 1878 Congress of Berlin. He was an early enthusiast for *Piero della Francesca and Venetian glass, and published very successful volumes of autobiography.

Leach, Bernard Howell (1887-1979). English potter, born in Hong Kong. The main influence on 20th-century ceramics in Britain, from 1909 he studied as a potter in Japan, and also visited artist potters in Korea and China. In 1920 he returned 
to England and with Shoji Hamada founded the Leach Pottery at St Ives. He subsequently practised and taught the Japanese tradition, bringing back into English ceramics a close relationship between artist and raw material, which had almost been lost. He received the $\mathrm{CH}$ in 1973.

Leach, B. H., A Potter's Work. 1973.

Leacock, Stephen (Butler) (1869-1944). Canadian humorist and political scientist, born in Hampshire. His family migrated to Canada in 1875 . He studied in Toronto and Chicago, was professor of economics and political science at McGill University, Montréal 1908-36 but is best remembered for his humorous essays and stories, e.g. Literary Lapses (1910), Nonsense Novels (1911), and Sunshine Sketches of a Little Town (1912). It was a fresh vein of humour that he discovered and one that brought him sudden and immense popularity. Later he turned to more general literature, e.g. My Discovery of England (1922).

Davies, R., Stephen Leacock. 1960.

Leahy, William Daniel (1875-1959). American Fleet Admiral. Close to Franklin D. *Roosevelt from 1913, he transported troops to France in World War I, and became Chief of Naval Operations 1937-39. As Ambassador to France 1941-42 he was sympathetic to *Pétain and hostile to *de Gaulle, returning to serve as Chief of Staff to the Commander-in-Chief (i.e. Presidents Roosevelt and *Truman) 1942-49, essentially de facto Chairman of the Joint Chiefs of Staff. In December 1944 he was promoted to Fleet Admiral, the first in US history. He opposed using the atomic bomb against Japan but pushed a hard line in the Cold War.

Leakey, Louis Seymour Bazett (1903-1972). English palaeoanthropologist and archaeologist, born in Kenya. Son of a missionary, Leakey studied in Cambridge taking a $\mathrm{PhD}$ in African prehistory. $\mathrm{He}$ was much influenced by the anthropologist, A. C. Haddon. In 1924 he took part in an archaeological research expedition to Tanganyika (Tanzania) and from 1926 led his own expeditions to East Africa. Palaeontological work with his wife Mary Douglas Leakey (née Nicol) (1913-1996) on the Miocene deposits of western Kenya led him to discover the skull of Proconsul Africanus, the earliest ape skull then found. His archaeological investigations led him to the Acheulian site of Olduvai, in the Rift Valley where the skull of Australopithecus boisei, and the first remains of Homo habilis, a hominid dated at some 1.7 million years, were found. Leakey's archaeological work on the early hominids was set out in many books of which the most important are The Stone Age Cultures of Kenya (1931) and The Miocene Hominidae of East Africa (1951). Other skulls have since been discovered of the founders of Acheulian culture at Olduvai, dubbed Homo erectus. His son Richard Erskine Frere Leaky (1944-2022) discovered hominid remains in tufas dating back perhaps 2.5 million years. He directed the National Museum of Kenya 1974-89, broke with President *Moi and formed his own political party, the Safina, in 1995. He lost both legs in an aircraft crash in 1993 and was elected FRS in 2007.

Leakey, M., Disclosing the Past. 1984.

Lean, Sir David (1908-1991). English film director. A skilled writer and editor, his 16 films won 28 Academy Awards and include Brief Encounter (1945), Great Expectations (1946), The Bridge on the River Kwai (1957), Lawrence of Arabia (1962), Dr. Zhivago (1965) and A Passage to India (1984).

Lear, Edward (1812-1888). English artist, illustrator, poet and musician, born in London. He claimed to be one of 21 siblings (but the number is gynaecologically improbable), was raised by a sister, suffered from epilepsy from the age of six, then from depression ('the Morbids'). He worked for the Zoological Society of London, making superb ornithological drawings, and was then engaged by the 13th Earl of Derby to provide plates for The Knowsley Menagerie (1846). He wrote many famous limericks, quirky and original, but often with a hint of unease. His famous Book of Nonsense includes 'The Owl and the PussyCat went to sea/In a beautiful peagreen boat'. His travels in Greece, Italy and elsewhere are described in books illustrated by his own delightful line and tone drawings. Suffering from depression and epilepsy, he settled in San Remo in 1871 with Foss, his cat, and died there.

Noakes, V., Edward Lear. 1968; Attenborough, D., The Natural History of Edward Lear. 2016; Uglow, J., Mr Lear. A Life of Art and Nonsense. 2016.

Leavis, F(rank) R(aymond) (1895-1978). English literary critic, born in Cambridge. Editor of the literary quarterly Scrutiny 1932-53 and a Fellow of Downing College, Cambridge 1936-64, he was a formidable critic and controversialist, promoting George *Eliot, Henry *James, Joseph ${ }^{*}$ Conrad, D. H. *Lawrence and what he called 'the great tradition' and denouncing *Flaubert, *Joyce and C. P. * Snow. $\mathrm{He}$ received the $\mathrm{CH}$ in 1978 . His wife Q(ueenie) D (orothy) Leavis (1906-1981) was also a powerful critic. After decades of denigrating ${ }^{*}$ Sterne, ${ }^{*}$ Dickens and ${ }^{*}$ Hardy, they softened their position on Dickens in 1970 .

Leavitt, Henrietta Swan (1868-1921). American astronomer, born in Massachusetts. She worked as a stellar photographer at the Harvard Observatory, and developed new techniques for determining the magnitude of stars. She discovered four novas and 2,400 stars. In 1912, she observed that in the Cepheid variable stars there is a highly regular cycle of fluctuation in brightness determined by the stars' luminosity. This had a profound influence on Edwin *Hubble. 
Lebed, Aleksandr Ivanovich (1950-2002). Russian general and politician. In 1991 he defended *Yeltsin during the attempted coup and won 15 per cent of the vote in the first round of the presidential election of June 1996. Yeltsin then appointed him as Chief of National Security, sacking him in October. He died in a plane crash.

LeBlanc, Roméo (-Adrien) (1927-2009). Canadian politician. A journalist, he became a Liberal MP 1972-84, Minister 1974-84, President of UNESCO 1979-80 and Governor-General of Canada 1995-99.

Lebrun, Albert François (1871-1950). French politician. A Left Republican Deputy 1900-20, Minister for the Colonies 1911-13, 1913-14, Minister for Liberated Regions 1917-19, Senator 1920-32 and President of the Senate 1931-32, he was elected President of the Republic in 1932 and re-elected in 1939. On France's collapse (1940) in World War II, unable to assert any authority, he was dismissed by Marshal *Pétain.

Lebrun, Charles (1619-1690). French artist. He first studied in Rome and was much influenced by ${ }^{*}$ Poussin. With the support of ${ }^{*}$ Colbert he became something akin to an artistic dictator in the reign of *Louis XIV. He was a leading light in the newly founded Académie Royale and was appointed director of the tapestry factory of Les Gobelins. With these positions he was able to direct and combine the works of artists in different fields into a single decorative scheme. He can be regarded as the virtual creator of the Louis XIV style and it is against this setting that his vast and rather overpowering pictures must be judged. Much of his work is in the Palace of Versailles, where he decorated the state apartments (1679-84).

Le Brun, (Marie) Elisabeth Louise (née Vigée) see Vigée Le Brun, (Marie) Elisabeth Louise

Le Carré, John (pen name of David John Moore Cornwell) (1931-2020). English novelist, born in Devon. His father was jailed for fraud and his mother deserted the family. Educated at the universities of Berne and Oxford, after army service he taught at Eton, then joined MI5, serving abroad under diplomatic cover. He achieved popular and critical success with a series of novels about spying, 11 of which were filmed. His books include The Spy Who Came in From the Cold (1963),Tinker, Tailor, Soldier, Spy (1974), Smiley's People (1979), The Little Drummer Girl (1983), A Perfect Spy (semi-autobiographical and his masterpiece, 1986), The Russia House (1989), The Night Manager (1993), The Tailor of Panama (1996), The Constant Gardener (2001), Absolute Friends (2003), Our Kind of Traitor (2010), A Delicate Truth (2013) and A Legacy of Spies (2017).

Sisman, A., John le Carré: The Biography. 2015.
Lecky, William Edward Hartpole (1838-1903). Anglo-Irish historian, born near Dublin. Educated at Trinity College, Dublin he had independent means and devoted himself to research. He wrote Rationalism in Europe (1865) and A History of European Morals (1869), but his great work was $A$ History of England in the Eighteenth Century (8 volumes, 1878-90) in which ideas and institutions are given as much prominence as political events. Secular, sceptical and conservative, progressive but pessimistic, and an opponent of Home Rule for Ireland, he was Unionist MP for Trinity College Dublin 1895-1902 and received the OM (1902).

McCartney, D., W.E.H. Lecky. 1994.

Leclerc de Hautecloque, Philippe François Marie (1902-1947). French general. A member of an ancient aristocratic family, he joined the army in 1920 and, despite having flirted with Action Française, resisted the German invasion. On the collapse of France (1940), he escaped to England, adopted the nomme de guerre of Leclerc and joined the Free French forces under *de Gaulle. He showed his brilliance when (1942) he led an expeditionary force from the Chad for 2,400 km across the Sahara to join the British in the Western desert. Later he was a divisional commander in Tunisia (1943) and in the campaign (1944) for the liberation of France. The Germans surrendered Paris to him in August 1944. Commander-in-Chief in Indochina 1945-46, he was killed in an air crash in Algeria and posthumously created a marshal.

Le Clézio, Jean-Marie Gustave (1940- ). FrenchMauritian novelist, born in Nice. Educated in Britain and France, he worked in the US, Thailand, Panama and Mexico. He wrote in a variety of forms and his themes turn on exile, migration, childhood and ecology. Les Géants (The Giants, 1973), published by Vintage Classics is an attractive introduction. Like *Sterne and *Perec, he experiments with form, inserting diagrams and even advertisements in his text. He won the 2008 Nobel Prize for Literature as an 'author of new departures, poetic adventure and sensual ecstasy, explorer of a humanity beyond and below the reigning civilization' but little of his work has been translated into English.

Leconte de Lisle, Charles Marie René (1818-1894). French poet, born in Reunion (Indian Ocean). Son of a planter, he went to Brittany (1837) to study law which he abandoned for literature. His family recalled him but by 1845 he was again in France struggling to make a living by journalism. He took part in the revolution of 1848 but, disillusioned by its result, abandoned politics. His first work Poèmes antiques appeared in 1852; his Poésies barbares (1862) attracted more attention. He became the recognised leader of the Parnassian group of poets who in a reaction from Romanticism and subjective emotionalism sought objectivity and perfect form. 
He also produced adaptations of the Greek dramatists and translations of classical authors from ${ }^{*}$ Homer to *Horace; his Poèmes tragiques was published in 1884. But he was moved as much by hatred of the present as by love of the past. In his disillusion he saw history as a series of stands, in which one by one the upholders of strength and beauty perished. Apart from his poetry he published historical works anonymously or as 'Pierre Gosset'. In 1886 he was elected to the Académie française.

Le Corbusier (Charles-Édouard Jeanneret) (18871965). Swiss-French architect, town planner and writer, born in La Chaux-de-Fonds, Switzerland. Son of a craftsman in enamel, he was trained at a local art school and tried his hand at Art Nouveau in Italy and Vienna, before he went in 1908 to Paris where he achieved some success among the modern artists who followed *Cézanne. From 1916, however, he turned almost exclusively to architecture. His aim, expressed in print in Towards a New Architecture (1922), being to make use of engineering techniques (steel frameworks, concrete etc.) not merely functionally but to give artistic freedom to the architect in his endeavour to provide brighter living in terms of air, sunlight and space. Rooms leading into one another with movable partitions were among his methods for achieving this. He designed many interesting buildings in France and elsewhere, but perhaps the most impressive illustration of his ideas is the Unité d'Habitation (1952) at Marseille, a great block of twostorey maisonettes with shops, recreation facilities etc., making a complete community-vertical living as it was called. Though much of the work of his imitators is merely monumental, in Le Corbusier himself the artist is always uppermost. His Swiss House (1932) in the Cité Universitaire, Paris, has been described as 'a precise and monumental interplay of form within light' and the chapel Notre-Dame-du-Haut at Ronchamp, France (1950-55) as a 'tense dynamic rhythm of plastic forms'. Le Corbusier was chosen to design (1951-56) Chandigarh, the new capital of the Punjab. Through his writings and his drawings, despite his comparatively few finished works, he was one of the most important influences on modern architecture.

Le Corbusier, My Work. 1960.

Lederberg, Joshua (1925-2008). American geneticist. Educated at Columbia and Yale, he shared the Nobel Prize for Medicine with G. W. *Beadle and E. L. Tatum for their work on the sexual recombination of bacteria.

Ledoux, Claude Nicolas (1736-1806). French neoclassical architect, born in Champagne. He studied in Paris and reacted against the prevailing Baroque style. A Utopian, he planned an ideal city at Chaux, reflecting visionary Enlightenment concepts. His masterpiece, the Royal Saltworks at Arc-et-Senans, near Besançon, built $1775-80$, is a large semi-circular complex, magnificently restored, inscribed on the World Heritage List in 2009. He designed many elegant tollgates which were demolished during the Revolution.

Le Duan (1908-1986). Vietnamese politician. Born to an Annamese peasant family, he worked on the railways, became an effective guerrilla and was jailed (1930-36 and 1940-45). General-Secretary of *Ho's Lao Dong party (1960-86), he was regarded as a pragmatist.

Lê Dúc Thợ (Phan Dinh Khai) (1911-1990). Vietnamese soldier and politician. Imprisoned 1930-36, 1939-44, he served on the Vietnamese Communist Party's Politburo from 1955 and negotiated the Paris Peace Accords (January 1973), which ended years of war. Awarded the 1973 Nobel Peace Prize with Henry ${ }^{*}$ Kissinger, he declined his share of the prize money.

Lee, (Nelle) Harper (1926-2016). American novelist, born in Alabama. To Kill a Mockingbird (1960) won the Pulitzer Prize and was a successful film. She received the Presidential Medal of Freedom in 2007. Go Set a Watchman, written before Mockingbird, but describing events 20 years later, was published in 2015 when the author was disabled by illness.

Lee Kuan Yew (1923-2015). Singaporean politician. Educated at Raffles College, Singapore, and Fitzwilliam College, Cambridge, he was called to the bar in London (1950), and returned to Singapore as a trade union advisor. He founded the People's Action Party (PAP) in 1954, originally accepting Communist support. He was elected to the Legislative Council in 1954 and took a leading role in the negotiations that led to the granting of full self-government for Singapore (1959). The PAP defeated David Marshall's Labour Front in 1959. As Prime Minister 1959-90 he followed pro-Western and moderately authoritarian rule, encouraged economic growth and technological development. His left-wing associates broke away shortly after his appointment, but their efforts against him were defeated by a referendum in 1962 . His only major mistake was taking Singapore into the new Federation of Malaysia in 1963. He underestimated the strength of Malay-Chinese hostility and was forced to withdraw in 1964. Politically, he moved steadily from Left to Right. His approach combined Confucian philosophy, the puritan work ethic and Hobbesian pessimism about human nature, and was an enthusiast for capital and corporal punishment. He was an enthusiast for intimidating opponents, controlling the media, short hair, clean streets and high execution rates. Made an honorary $\mathrm{CH}$ (1970) and GCMG (1972) in 1990 he was succeeded by Goh Chok Tong, but remained in the government as Senior Minister 1990-2004 and Minister Mentor 2004-11. His son Lee Hsein Loong (1952- ), educated at Cambridge and Harvard, became a soldier, Deputy Prime Minister 1990-2004 and Prime Minister 2004- .

Josey, A., Lee Kuan Yew, 3 vols, 1969, 1974, 1980. 
Lee, Robert E(dward) (1807-1870). American Confederate general, born in Stratford, Virginia. He was the son of Henry Lee (1756-1818), a brilliant cavalry commander in the War of Independence, known as 'Light Horse Harry', friend of *Washington and Governor of Virginia 1792-95. Robert E. Lee served in the Mexican War (1846-48) and gained rapid promotion. He was superintendent (1852-55) of the military school at West Point, and in 1859 led the force that suppressed John *Brown's anti-slavery rising at Harper's Ferry. When the Civil War broke out (1861), although personally opposed both to slavery and secession, as a Virginian he supported the Confederacy, and in 1862 was given supreme command in Virginia. Though in the Richmond campaign of that year he was outnumbered, he manoeuvred to gain local superiority at decisive points and thus discomfited *McClellan, the Union commander. Having disposed of John Pope by a threat to his rear, he boldly invaded Maryland. Though he had a narrow escape at Sharpsburg he was able to retire almost without loss. In 1862 and 1863 the tactical and strategical skill which enabled him to see the enemy's move was nearly always apparent. Gettysburg, Pa. (July 1863) was the turning point of the war, the most northerly battle and the one with the greatest loss of life, both sides fighting to the point of exhaustion. But *Meade won the day. By 1864 the disparity in numbers was having its effect, but Lee still held his opponent, ${ }^{*}$ Grant, at bay by a clever use of field fortifications. The long postponement of the inevitable ended with the surrender at Appomattax Courthouse (April 1865). Lee, with his modesty, generosity and strategic skills became a legendary hero to Southerners (although he opposed erecting monuments to Confederate generals, concerned that the wounds of the Civil War would never heal). Respected by the Northerners, he cooperated with 'Reconstruction' but always opposed giving the vote to African-Americans. Lee became almost a legendary hero to southerners and northerners alike. Lee became President of Washington College (now Washington and Lee University), Lexington, Va. 1865-70. A huge equestrian statue of Lee, erected in Richmond in 1890, was removed in September 2021.

Dowdey, C., Lee. 1965; Thomas, E. M., Robert E. Lee. A Biography. 1997; Field, R., Robert E Lee. 2010; Trudeau, N. A., Robert E. Lee. 2011.

Lee, Sir Sidney (né Solomon Lazarus) (1859-1926). English editor. He succeeded Sir Leslie *Stephen as editor-in-chief (1891-1917) of the Dictionary of National Biography (DNB) 1891-1917. His own numerous books included biographies of *Shakespeare, Queen *Victoria and *Edward VII.

\section{Leeds, 1st Duke of see Danby, Thomas Osborne,} Earl of

Leeuwenhoek, Antoni Philips van (1632-1723). Dutch microscopist and biologist, born in Delft. his own drapery and received patronage from the Delft council. Having used an optical lens to examine the quality of cloth, he developed a method of grinding lenses for greater magnification. He made 419 single lens microscopes, which could magnify up to 275 times. He became a self-taught student of anatomy and biology and from 1673 wrote about 190 letters to the Royal Society in London with details of his observations and was elected FRS in 1680 . $\mathrm{He}$ observed protozoa ('animalcules'; 'diertjes' in Dutch), bacteria in 1683 and described spermatozoa. He demonstrated the blood circulation through the capillaries, was the first to describe red blood cells accurately and made important observations of the structure of muscle, hair, teeth, skin and eye. His equally valuable zoological work revealed the Infusoria and Rotifera and disproved the idea of spontaneous generation. Visited by *Leibniz, *Peter the Great, ${ }^{*}$ William III and Queen ${ }^{*}$ Mary, he was secretive about his methods. He became *Vermeer's executor (1675).

Dobell, C., Antony van Leeuwenhoek and His Little Animals. rev. 1958; Payne, A. P., The Cleere Observer. 1970; Ford, B. J., The Leeuwenhoek Legacy. 1991; Snyder, L. J., Eye of the Beholder: Johannes Vermeer, Antoni van Leeuwenhoek, and the Reinvention of Seeing. 2015.

Legendre, Adrien Marie (1752-1833). French mathematician. Through the influence of*d'Alembert he became (1777) professor of mathematics at the École Militaire, Paris, transferring (1795) to the École Normale. He carried out important researches on the theory of elliptical function, and wrote a treatise on the theory of numbers.

Léger, (Joseph) Fernand (Henri) (1881-1955). French painter, sculptor and filmmaker, born in Argentan, Normandy. Son of a farmer, he went to Paris (1905) to follow art. Influenced at first by Impressionism and *Cézanne, he began to develop his individual style from the time (1910) he met ${ }^{*}$ Picasso and ${ }^{*}$ Braque and joined in the first Cubist exhibition. Service in World War I drew his attention to the possibilities inherent in mechanical contrivances of all kinds, wheels, cogs, shining surfaces etc. which he introduced into his paintings with their broad planes and bright colours. As his art developed, his pictures became warmer and more human, acrobats began to appear, boys with bicycles, and suggestions of landscape. His versatility was shown in murals, tapestries, stained-glass windows (at Audincourt) and mosaics.

Delevoy, R., Léger. 1962; Buck, R. T., Fernard Léger. 1982; Néret, G., Fernard Léger. 1993.

Léger, Paul Emile (1904-1991). Canadian cardinal. After service in France and Japan he became Archbishop of Montréal 1950-67 resigning to work as a missionary to lepers in Africa. His brother Jules Léger (1913-1980) was an academic, diplomat and 
administrator: Ambassador to Italy 1962-64, to France 1964-68, Undersecretary for Foreign Affairs 1968-73 and Governor-General of Canada 1974-79.

Lehár, Franz (Ferenc) (1870-1948). Hungarian composer. After studying music he went to Vienna as a conductor of military bands. He then turned to composing operettas which won great popularity, e.g. The Merry Widow (1905).

Lehman Brothers. American bankers. Henry (Hayum) (1822-1855), Emanuel (Mendel) (1827-1907) and Mayer (1830-1897) Lehman, all born in Franconia, founded Lehman Brothers bank in Montgomery, Alabama, then the centre of world cotton trading, in 1850 , relocating to New York in 1858. Its bankruptcy in 2008, the biggest in US history, triggered off the global financial crisis (GFC). Mayer's son Herbert Henry Lehman (1878-1963), became a Democratic politician, working closely with Franklin D. ${ }^{*}$ Roosevelt as Lieutenant-Governor of New York State 1929-32, then Governor 1933-42 and Director General of the UN Relief and Rehabilitation Administration (UNRRA) 1944-46. US Senator 1949-57, he was for most of his term the only Jewish member. The play The Lehman Trilogy (2013) by Stefano Massini was translated into 24 languages.

Lehmann, Lotte (1888-1976). German soprano. In Vienna 1916-38, then in the US, she achieved early success in Strauss operas, and between 1924 and 1946 was the outstanding Marschallin in *Strauss' Rosenkavalier. She also excelled in *Mozart, *Wagner and as Leonora in Fidelio and was an accomplished lieder singer and teacher.

Leibniz, Gottfried Wilhelm, Baron von (16461716). German philosopher and mathematician, born in Leipzig. Son of a professor at Leipzig University, he studied law and philosophy there, and then entered the service of the Archbishop-Elector of Mainz. A diplomatic mission to Paris gave him the opportunity of four years' (1672-76) intensive study and contact with other leading scientists. He then became librarian to the Duke of Brunswick, on his return journey visiting England, where he was made a Fellow of the Royal Society (1673) for his invention of the calculating machine.

One of Leibniz' fundamental beliefs was that the search for truth should be the common task of men of all nations. To this end he tried to invent a universal language and at the same time worked on a system of symbols, like those of algebra, to be used in logic so as to give it a mathematical basis. It was this work that led to his discoveries relating to the differential and integral calculus, for which he invented the notation still used. The accusation that his system was stolen from *Newton was completely unfounded.

As a philosopher, Leibniz was influenced by *Descartes and also by ${ }^{*}$ Spinoza, whom he met. His metaphysical system, which has interested later philosophers (notably
Bertrand *Russell), grew out of a dissatisfaction with existing doctrines, including the atomic view of the universe. He argued that everything consists of certain substances (monads) which are immaterial, have no extension whatever in space and do not interact in any way. To explain the fact that these independent monads do not seem to act in unison-go together to make up things-he supposed that God had instituted what he called 'a pre-established harmony', i.e. monads move in accordance with a built-in plan that gives rise to the world as we know it. Leibniz, whose versatility extended to religion (an attempt to reunite the Churches) history (publication of documents relating to the house of Brunswick), and codification of law, was satirised by *Voltaire in Candide as Dr Pangloss, who believed that 'everything happens for the best in the best of all possible worlds'. Optimism is central to Leibniz' beliefs and is the subject matter of theodicy (Essais de Theodicée sur la bonté de Dieu, la liberté de l'homme et l'origine du mal, 1710). Nevertheless, he died alone and neglected: like Newton, he never married.

\section{Leicester of Holkham, 1st Earl of see Coke, Thomas William, 1st Earl of Leicester of Holkham}

Leicester, Robert Dudley, 1st Earl of (15321588). English courtier. Son of the Duke of *Northumberland, he was sentenced to death with his father for their attempt to secure the crown for Lady Jane * Grey. Northumberland was executed but his son was pardoned and freed in 1554, coming into court favour with the accession of Queen *Elizabeth, his childhood friend at *Henry VIII's court. Offices and emoluments were lavished upon him, and when (1560) his wife, Amy *Robsart (married 1550), was found dead at the foot of the stairs at Cumnor Place near Abingdon, where she lived in seclusion, it was rumoured that Leicester (with or without Elizabeth's complicity) had contrived her death in order to be free to marry the Queen. But though Elizabeth stood by him and in 1564 created him Earl of Leicester, the prospect of their marriage became increasingly remote. He was Chancellor of Oxford University 1564-88, founder of the Oxford University Press, expert dancer and tennis player, patron of the arts, financial backer of Francis ${ }^{*}$ Drake, and investor in training, exploration, mining and manufacturing companies. He endowed a hospital, which still survives. His famous 19-day reception for the Queen at Kenilworth in 1575 is described in ${ }^{*}$ Scott's novel of that name. He had a son, also Robert Dudley, by Douglas (née Howard), the dowager Baroness Sheffield, but it is unlikely that they married, as she later claimed. In 1578, he secretly married Lettice Knollys, the widowed Countess of Essex, greatly distressing the Queen, when she found out. Their son, yet again Robert Dudley, died at the age of three. Apart from his role at court, he worked (often uneasily) with William Cecil, Lord *Burghley in running Elizabeth's government. In 1585, he was given command of an English army to support the Dutch in their struggle for independence with the 
Spaniards, and, in spite of the military incapacity he then displayed, he was chosen in the Armada year (1588) to command the forces gathered at Tilbury to prevent a Spanish landing. The celebrations of her fleet's victory in October were clouded for Elizabeth by news of her favourite's death. Her pet name for him was 'Eyes' (ôô) and she kept his letters with her until she died.

Jenkins, E., Elizabeth and Leicester. 1972.

Leichhardt, Friedrich Wilhelm Ludwig (18131848). Prussian explorer. He arrived in Sydney in 1841, and led an expedition 1843-45 from Moreton Bay near Brisbane to the Gulf of Carpentaria. In November 1847 he again started from Moreton Bay in an attempt to cross the Continent from east to west, but, last heard of in the following April, he disappeared without trace.

Leif Ericsson (Eriksson) (c.970-1020). Norse explorer. Reputedly the first European to discover the American continent, and son of *Eric the Red, first coloniser of Greenland, he sailed along the North American coast about the year 1000, and after passing 'Helluland' (Baffin Island?), 'Markland' (almost certainly Labrador), he landed in 'Vinland' (Newfoundland), basing himself at L'Anse-auxMeadows. A later attempt to settle Vinland failed.

Leigh, Vivien (née Vivian Mary Hartley) (19131967). English actor, born in India. Remarkable for her delicate beauty, she made her film debut in 1934. She won Academy Awards as Scarlett O'Hara in Gone With the Wind (1939) and Blanche du Bois in Streetcar Named Desire (1951). Married (1940-60) to Laurence *Olivier, she appeared on stage with him in *Shakespeare, *Sheridan and *Shaw.

Edwards, A., Vivien Leigh. 1977.

Leighton, Frederic, 1st Baron Leighton of Stretton (1830-1896). English painter and sculptor, born in Scarborough. Son of a doctor, he lived in Europe with his family and studied in Frankfurt, Florence, Rome and Paris. He returned to London in 1859 and became the leading neoclassical painter of the Victorian era. His nudes, refined almost to the point of sexlessness and elegantly posed in Grecian architectural settings, became immensely popular. President of the Royal Academy 1878-96, he was knighted in 1878, created a baronet in 1886, and in 1896 became the first and only British artist raised to the peerage. He died the day after the date of his patent, making his the shortest peerage in history. He never married and was secretive about his private life.

\section{L.E.L. see Landon, Letitia Elizabeth}

Lely, Sir Peter (Pieter van der Faes) (1618-1680). Dutch painter. He lived in England (from 1641 and became painter at court in succession to *Van Dyck. Although after the parliamentary victory in the Civil
War he managed to adapt his style to the demands of his new patrons, he was happier at the Restoration to revert to court paintings. His most famous pictures are the Beauties of King ${ }^{*}$ Charles II's entourage (now at Hampton Court), and the more remarkable series, because more expressive of character (now at Greenwich), of the 12 British admirals in the Second Dutch War. Despite his large output, Lely, who amassed fame, property and a knighthood (1680), seldom became perfunctory.

Beckett, R. B., Lely. 1951.

Lemaître, Georges-Henri Joseph Édouard (18941966). Belgian astronomer and mathematician, born in Charleroi. He began to study engineering, served in World War I and was then ordained as a priest in 1923. He studied physics at Cambridge and MIT and became professor of astrophysics at Louvain in 1927. In that year in a Belgian scientific journal he proposed that the universe began with a small 'cosmic egg' which has been expanding ever since, and in 1929 this was confirmed by Edwin *Hubble's observations. In 1948 George ${ }^{*}$ Gamow helped to popularise this concept, dismissed by Fred *Hoyle as 'the big bang', a term which was soon widely adopted. Lemaître became President of the Pontifical Academy of Science 1960 66. An asteroid (1565 Lemaître) was named for him.

Lemkin, Raphael (1900-1959). Polish-JewishAmerican lawyer, born in Bezwodne (now in Belarus). He grew up in Lviv (now in Ukraine, then in Poland) and was a multi-lingual prodigy. He escaped from Poland in September 1939 and taught in the US. In Axis Rule in Occupied Europe (1944), he coined the word 'genocide' to describe acts intended 'to destroy in whole or in part, a national, ethnical, racial or religious group' (e.g. Jews, Armenians, gypsies, Tutsi). 'Genocide' was a factor in the prosecution case at the Nuremberg trials of Nazi leaders (1945-46) and was adopted by the UN Convention on the Prevention and Punishment of the Crime of Genocide (1948, in force from 1951). H. V. *Evatt was a significant ally in the UN. Lemkin received 10 nominations for the Nobel Peace Prize; all failed, and he died impoverished and exhausted. (*Lauterpacht.)

Sands, P., East West Street. 2016.

Lemon, Mark (1809-1870). English author and journalist. He wrote many plays, novels and children's stories, but is best remembered as the founder, with Henry Mayhew, of Punch, of which he was sole editor from 1843 until his death.

Lenard, Philipp Eduard Anton (1862-1947). German physicist, born in Bratislava (then in Hungary). He studied at Budapest and Heidelberg universities and held chairs in theoretical physics in Kiel 1898-1907 and Heidelberg 1907-31. He pioneered research into cathode rays. In 1894 he first obtained cathode rays outside a tube, by allowing them to pass from the tube through a window of 
aluminium foil; such rays became known as Lenard rays. His observations helped to prepare the way for *Rutherford's first atomic model in 1911-he had suggested a model of the structure of the atom as early as 1903. He also studied the ejection of electrons from metals by the action of ultraviolet light, and found that the energy of the emitted electrons is independent of the intensity of the incident radiation, and depends only upon its wavelength. He won the Nobel Prize for Physics in 1905 . Under *Hitler he was an ardent proponent of 'Aryan science'.

Lenclos, Anne (called Ninon de Lenclos) (16201705). French courtesan. She was a woman of intelligence and great beauty and amongst her many lovers (and friends) were distinguished men such as ${ }^{*}$ La Rochefoucauld. Her salon in Paris was a meeting place for literary figures. In her last years she took a special interest in her lawyer Arouet's son, who afterwards took the name *Voltaire.

Magne, E., Ninon de Lenclos. 1948.

LEnfant, Pierre Charles (1754-1825). French architect. An engineer in the French army, he served on the American side in the War of Independence. He was commissioned (1791) by George *Washington to prepare the original plans for Washington, the new capital city. The central feature of his grandiose plan was the dome-surmounted Capitol, built upon a small hill and approached by four great converging avenues, thus dominating the city. The plans, clearly influenced by Versailles, were discarded as far too extravagant and he was dismissed (1792). His designs were later restudied and the existing city, built up over the years, follows his original plan fairly closely.

Lenglen, Suzanne (1899-1938). French lawn tennis player. She dominated women's lawn tennis in the years following World War I and raised the standard of women's play to a height far beyond any previously reached. She was women's singles champion at Wimbledon 1919-23, 1925. In 1926 she turned professional.

Lenin, Vladimir Ilyich (V. I. Ulyanov) (1870-1924). Russian revolutionary and creator of the Soviet state, born in Simbirsk. Son of a school inspector, his mother was the daughter of a doctor and from this middle-class family sprang two revolutionary sons. The elder, Aleksandr, took part in a revolutionary conspiracy to assassinate Tsar *Aleksandr III and was hanged in 1887 . The younger, who was to take the name Lenin, studied law and was expelled from Kazan University for subversive activity. He abandoned the legal profession and after having studied Marx intensively went to St Petersburg where he organised the illegal League for the Liberation of the Working Class. Arrested in 1897 he was exiled for three years in Siberia, where he married a fellow revolutionary, Nadezhda *Krupskaya. He then left Russia to pursue his revolutionary activities abroad.
At a conference (1903) in London the Russian Social Democratic Labour party split into two factions the Mensheviks ('minority') and the more extreme Bolshevik ('majority') dominated by Lenin. He was clandestinely in Russia for the abortive risings of 1905 but fled to Switzerland in 1907. From there and other places in Europe he continued, through his political writings and underground organisation, to control the revolutionary movement in Russia. In 1912 the Bolsheviks became in fact (though not formally until 1917) a separate party upon the expulsion of the Mensheviks from the RSDLP. During World War I Lenin stayed in Switzerland to await a chance to lead a revolution in Russia. On the outbreak of the first Russian Revolution (March 1917) the Germans, with the object of weakening Russian war efforts, brought Lenin and a group of supporters through Germany from Switzerland in a sealed train and sent them to Petrograd (as St Petersburg had been renamed) via Stockholm and Helsinki. He then set about overthrowing the provisional government of ${ }^{*}$ Kerensky. Under the slogan 'All power to the Soviets' he seized power in a second revolution in November. He was Chairman of the Council of People's Commissars (i.e. Premier) 1917-24 (technically of the Russian Soviet Socialist Republic 1917-22; of the Union of Soviet Socialist Republics 1922-24). He agreed to the severe terms of the Treaty of Brest-Litovsk to secure peace with Germany but the Red Army had to struggle until 1921 to overcome the various counter revolutionary movements of the 'white' Russian leaders *Denikin and *Kolchak, who had some support from the Western Allies. Meanwhile as Chairman of the Communist Party and a Politburo (Political Bureau) member 1917-24, Lenin was effectively dictator. In 1919 he established the Comintern (Communist International) to foster world revolution. In the chaotic economic conditions then prevailing it was impossible to carry through his projected communist revolution (War Communism). There was a temporary retreat into the New Economic Policy, which was a partial return to private enterprise. His health deteriorated rapidly after a gunshot wound (1918) and he was incapacitated by a stroke in 1922 .

After 1922 he lived at his dacha in Gorki, an outer suburb of Moscow, now Leninskie Gorki, and died there. Shortly before his death Lenin wrote a warning that ${ }^{*}$ Stalin should be removed from his post as Secretary-General of the Communist Party. This was suppressed, and in the struggle for power after Lenin's death between his chief lieutenants, *Trotsky and Stalin, the latter triumphed. Although in his writings Lenin was the chief theoretician of Marxism he was most important as a skilful revolutionary and a master of political and party organisation. Aleksandr *Yakovlev estimated that 8 million died in the Civil War and terror 1918-22 and 5 million more in the 1921 famine. 
Petrograd was renamed Leningrad five days after his death; the name St Petersburg was restored in 1991. Lenin's embalmed body was displayed in a mausoleum in Red Square, Moscow, which became a national shrine visited by thousands daily. Though for a time Stalin enjoyed an equal place with him before the Soviet public (and shown at his side in the Lenin Mausoleum 1953-61), Lenin was restored to primacy after ${ }^{*}$ Khrushchev denounced the 'personality cult' of Stalin and, even after the collapse of the USSR, he still evokes a wary respect.

Shub, D., Lenin. Rev. ed. 1966; Volkogonov, D., Lenin: Life and Legacy. 1994; Sebestyen, V., Lenin the Dictator. 2017.

Lennon, John Winston (1940-1980). English singer, songwriter, artist and political activist, born in Liverpool. After creating The Quarrymen, a skiffle group, he joined Paul *McCartney, Ringo Starr and George Harrison in the ${ }^{*}$ Beatles (1962-70). They changed popular culture. He wrote many songs, including Imagine and Give Peace a Chance. He came to detest McCartney, the Beatles broke up acrimoniously and he devoted himself to peace protests, coming under FBI surveillance. In 1969, he married the singer, artist and political activist Yoko Ono (1933- ), withdrew from performances in 1975, returning in 1980. In December 1980, he was shot dead in Manhattan by a paranoid fan who wanted to be remembered for his association with Lennon.

Lenoir, Jean Joseph Étienne (1822-1900). Belgian French inventor. He built the first internal combustion engine in 1859 (fuelled by lighting gas) and the first 'horseless carriage' followed in 1860 . However, Lenoir's machine was much less efficient than *Otto's and he died poor.

Le Nôtre, André (1613-1700). French landscape architect. He succeeded his father as Chief of the Royal Gardens. Later (1657) he became 'controller' of the royal buildings as a result of the impression he created by the park and grounds (1656-61) laid out at Vaux-le-Vicomte for Nicolas *Fouquet. Among his other parks were those of St Germain-en-Laye, St Cloud and Chantilly. His greatest achievement was the gardens of Versailles (1662-90).

Fox, H. M., André le Nôtre, Garden Architect to Kings. 1962.

Lenthall, William (1591-1662). English politician. He was Speaker of the House of Commons 1640-53, 1654 and 1659-60, famous for refusing *Charles I access to the Commons (1642) when he sought to arrest five members, and for being dragged from the chair when ${ }^{*}$ Cromwell forcibly dissolved the Long Parliament (1653).
Lenya, Lotte (1898-1981). Austrian-American singer and actor. She married the composer Kurt *Weill in 1926, created the role of the prostitute Jenny in Die Dreigroschenoper (1927), appeared on the Broadway stage and in films, e.g. From Russia with Love.

Leo I, St ('the Great') (c.390-461). Pope 440-61. Born in Rome of Tuscan parents, a noble character and distinguished theologian, he did much to establish the primacy of Rome. His exposition of the divine and human natures of Christ was accepted by the Council of Chalcedon (451). His resolute bearing persuaded *Attila the Hun to spare Rome but he could not save the city from sacking by the Vandals (455).

Leo III (known as 'the Isaurian') (c.680-740). Byzantine Emperor 717-40. He was a successful general who rebelled against the feeble Theodosius and usurped the throne. After saving Constantinople from the Saracens he stabilised Asia Minor, strengthening the administration by subdividing the Asiatic provinces. He is chiefly remembered for the pronouncement (726) by which he tried to suppress the use of religious pictures and images (icons) and so started the great iconoclast controversy.

Leo X (Giovanni de’Medici) (1475-1521). Pope 1513-21. Second son of Lorenzo the Magnificent (*Medici) of Florence, he was made a cardinal at the age of 13 . He led a graceful, cultured life and used the opportunities provided by his position as Pope to become, in the tradition of the Medicis, a munificent patron of the arts. The tapestries of the Sistine Chapel of the Vatican were executed by *Raphael on his orders and he invited *Leonardo da Vinci to Rome. He proved his skill in diplomacy by maintaining a balance in Italy between *François I of France and the emperor ${ }^{*}$ Charles V. However, he underrated the influence of ${ }^{*}$ Luther and took no active steps to forestall him by initiating the necessary reforms.

Leo XII (Annibale Francesco Clemente Melchiorre Girolamo Nicola Sermattei della Genga) (17601829). Pope 1823-29. A papal diplomat and administrator, he had no pastoral experience in a see. As Pope, he gave the Jesuits control of Catholic education, attacked the idea of religious toleration, revived the Index of Prohibited Books, was hostile to the Jews and loved shooting birds.

Leo XIII (Vincenzo Gioacchino Raffaele Luigi Pecci) (1810-1903). Pope 1878-1903. Son of a nobleman, he studied law but became a priest in 1837, Apostolic Nuncio to Belgium 1843-48 and Bishop of Perugia 1848-78. Elected on the third ballot to succeed *Pius IX, much of the credit for the modernisation of the papacy can be ascribed to him. In many encyclical letters he expounded his Church's attitude to the social and political ideas of his day. He denounced both materialism and socialism but in his famous Rerum Novarum (1891) he analysed the conditions 
and problems of the working classes with generosity, understanding and realism, and in this and other letters, restated the Christian ideas in relation to the changing patterns of social life. In theology he asserted the pre-eminence of St Thomas *Aquinas and directed that Thomism should be the basis of all priestly training. His attitude to colonised peoples was liberal and constructive and he encouraged a great increase of missionary activity. He achieved an important diplomatic success by bringing to an end the German Kulturkampf, *Bismarck's campaign to remove Catholic influence from education. In 1883 he opened the Vatican archives to scholars of all faiths and encouraged the study of astronomy and natural science. He published 86 encyclicals and is regarded as the most brilliant pope of recent times and also the oldest (dying at 93). His was the third longest pontificate (after Pius IX and *John Paul II) and he became the first pope to be filmed, to record his voice, use a telephone or be driven in a motorcar.

Gargan, E. T. (ed.), Leo XIII and the Modern World. 1961; Chadwick, O., A History of the Popes 1830 1914. 2003.

\section{Leonardo da Pisa see Fibonacci, Leonardo}

Leonardo da Vinci (in full, Leonardo di ser Piero da Vinci) (1452-1519). Italian polymath, painter, sculptor, architect, military engineer and scientist, born at Vinci, between Pisa and Florence. The illegitimate son of Piero da Vinci, a Florentine notary, and Caterina di Meo Lippi, a 15-year-old orphan, from the age of 12 he lived with his widowed father, who, having no children in wedlock, treated him as legitimate. (Later, in Milan, Leonardo's mother came to live with him.) At 15, he was apprenticed to the Florentine painter and sculptor ${ }^{*}$ Verrocchio, in whose workshops he worked until 1481, having been accepted into the painters' guild of Florence in 1472. Unique in the history of art because of the exceptional scope of his intellect, his powers of observation and the versatility and strength of his technique, his interest in natural science was sustained by a conviction that knowing how to see is the basis of understanding nature. His diverse talents led him to attempt an enormous variety of work, much of it never completed. Left-handed, vegetarian, probably heretical and certainly gay, he escaped from charges of sodomy in 1476 .

In 1482 , he went to the court of Ludovico *Sforza, Duke of Milan, as painter, sculptor, designer of court entertainments and technical advisor on military buildings and engineering. In 1482, he was commissioned to produce a huge statue of a horse, 7.3 metres high, honouring Francesco Sforza, to be cast in bronze. Drawings and plans for mounting it survive, but the project was never completed and a full-size clay model was destroyed by French troops in 1499. In 1506-08, he planned a great equestrian statue (Gran Cavallo), but only sketches survive. Three small sculptures have been attributed to him. His drawing Vitruvian Man (1490; *Vitruvius), regarded as a European icon, has been much reproduced, including on EU coins. In Milan, he painted the great (but severely damaged) mural The Last Supper (c.1495-98), in fresco, and a version of The Virgin of the Rocks in oils. He also began to write down his own theories of art, and to record his scientific observations in books of drawings and explanatory text. In 1499-1500, he returned to Florence, leaving again in 1502 to work for a year as military advisor to Cesare *Borgia. In 1503, he began work on the mural painting The Battle of Anghiari, which he never finished. Before returning to Milan in 1506 he had also begun three paintings which he worked on in subsequent years-Leda and the Swan (now lost, c. 1500), The Virgin and Child with St Anne (1500) and Mona Lisa (La Gioconda, 1503-06).

Leonardo and his young rival *Michelangelo shared a mutual detestation. Sforza had been overthrown by the king of France in 1499, but Leonardo nevertheless returned to Milan as the king's advisor on architecture and engineering. In 1513, he went to Rome, possibly expecting papal commissions which he did not receive, and in 1516 left Italy for France, appointed painter, architect and engineer to *François I. Most of the rest of his life was devoted to finishing St John the Baptist and to editing his scientific studies. He died at the Château Cloux, in Amboise, where he is buried.

His surviving work consists of 18 paintings definitely attributable, thousands of drawings and extensive writings. Notes and diagrams are all that survive of his varied and sometimes enormous civic engineering schemes. His notebooks covered painting, architecture, mechanics and natural science, including plans for a flying machine and parachute, detailed studies on anatomy, embryology, bird flight, hydrodynamics, vortices, cloud formation and astronomy. More than 7,500 pages of his notes (written in mirror script) survive-perhaps one third of his output, but were not published until 1883. Leonardo was a man of great sensitivity and compassion.

In November 2017, a heavily restored small painting, Salvator Mundi (c.1500), bought as a copy in 2005 for \$US1175, was sold as an original at auction in New York for \$US450 million, setting a world record for an art work.

Clark, K. M., Leonardo da Vinci: an Account of his development as an Artist. 2nd ed. 1952; Richter, J. P., The Literary Works of Leonardo da Vinci. 2 vols. 3rd ed. 1970; Bramly, S., Leonardo: The Artist and the Man. 1992; Isaacson, W., Leonardo da Vinci. 2017.

Leoncavallo, Ruggiero (1858-1919). Italian operatic composer. He achieved fame and wealth with Pagliacci (1892), one of the most widely performed of all operas. His other works include La Bohème (1897), overshadowed by *Puccini's more successful work, and Zaza (1900). He wrote his own librettos. 
Leonidas I (c.540-480 BCE). King of Sparta 489-480 BCE. A national hero of Greece, he was a member of the Agiad dynasty which ruled the citystate of Sparta. With only 300 Spartans he held the pass of Thermopylae, north of Athens, against the invading army of the Persian king, *Xerxes, but after two days of heroic resistance, a path leading to his rear was betrayed to the enemy. Fighting to the end, Leonidas and all his men were killed.

Leontieff, Wassily Wassilief (1906-1999). American economist, born in Russia. Educated in Leningrad and Berlin, he taught at Harvard from 1931. He won the 1973 Nobel Prize for Economics for his development of input-output analysis, a study of the relationship within an economy between total inputs (raw materials, labour, manufacturing and related services) and total demands for final goods and services.

Leopardi, Giacomo, Conte (1798-1837). Italian poet. Described by critics as the greatest Italian lyricist since the 14th century, he suffered greatly from constant ill health. His parents distrusted his liberal ideas and he fled as soon as he could from the reactionary atmosphere of his home. He prepared an edition of *Cicero's works for a Milan publisher, settled later in Florence and spent his last years in Naples. Apart from his works of scholarship and philosophy, he found in lyric poetry an instrument that proved sensitive to all his moods, mainly of disillusion with life as he found it. The main collection of his poems, I Canti (1836) has been translated into English many times.

Leopold I (Leopold Ignaz Joseph Balthasar Felicien von Habsburg) (1640-1705). Holy Roman Emperor 1658-1705. Ruler of Austria, Hungary and Bohemia, most of his reign was spent in a prolonged struggle with the Turks. In 1683 Vienna was saved only by the intervention of the Poles under Jan *Sobieski. In 1701 he joined the coalition against France to secure the Spanish throne for his son Charles in whose favour he had renounced his own rights (*Felipe V of Spain).

Léopold I (Léopold-Georges-Chrétien-Frédéric von Wettin) (1790-1865). King of the Belgians 1831-65. Born in Coburg, son of Franz, Duke of Saxe-CoburgSaalfeld, he fought with the Russian armies in the later stages of the Napoléonic Wars. A Protestant, he married (1816) *Charlotte, daughter of the British prince-regent $\left({ }^{*}\right.$ George IV), but she died in childbirth a year later. Created a field marshal, KG and GCB, his connections with Great Britain gave him some insight into its political system which he used to good effect. In 1830 he refused the Greek throne, but in the following year was chosen as the first King of the Belgians. He ruled with such constitutional prudence that his country escaped the revolutionary turmoils of 1848. Léopold was a trusted advisor of his niece Queen *Victoria, who married one of his nephews, *Albert.
Leopold II (Peter Leopold Josef Anton Joachim Pius Gotthard von Habsburg-Lothringen) (1747-1792). Holy Roman Emperor 1790-92. Third son of the empress *Maria Theresa and brother and successor of *Joseph II, as grand-duke of Tuscany (1765-1790) he had, among other reforms, abolished the death penalty and torture. As Emperor, he had no time to display his qualities and died before he could give effective aid to his sister ${ }^{*}$ Marie Antoinette in revolutionary France.

Léopold II (Léopold Louis Philippe Maria Victor von Wettin) (1835-1909). King of the Belgians 1865-1909. Son of *Léopold I, during his reign Belgium's industrial and colonial activities expanded greatly. In 1876, in collaboration with $\mathrm{H}$. M. *Stanley, he founded (in his private capacity, not as king) an association to explore and exploit the Congo. In 1884 a European International Congress on African affairs sanctioned the establishment, under Léopold's personal control, of a 'Congo Free State', from which he gained an immense fortune, first from ivory, then rubber. Forced labour and other inhumane practices used by the administrators caused a scandal, following which Léopold transferred the Congo to the Belgian Government. At home, industrialisation proceeded rapidly and the attendant deterioration in social conditions led to labour troubles and political unrest. Energetic, rapacious and hypocritical, he was unhappily married with no male heirs. Separated in 1895, he had many mistresses and married the last, secretly, days before he died.

Hochschild, A., King Leopold's Ghost. 1998.

Léopold III (Léopold-Philippe-Charles-AlbertMeinrad-Hubertus-Marie-Miguel de Saxe-Cobourg) (1901-1983). King of the Belgians 1934-51. Son of *Albert I, in 1926 he married Astrid, Princess of Sweden (1905-1935) who was killed near Lucerne when a car driven by Léopold crashed. During World War II, he took command of the army, surrendered to Germany (1940), and remained in Belgium during the Nazi occupation, all against the advice of his Cabinet. In 1941 he married morganatically the exceptionally beautiful Mary Lilian Baels (19162002), who was created Princesse de Réthy, but not queen. Both actions aroused intense hostility. After liberation a regency was created under his brother Charles and Léopold lived in Switzerland. In 1950 a plebiscite voted 57 per cent in favour of his return but following strikes and demonstrations he abdicated in favour of his son *Baudouin I. Léopold's second son *Albert II succeeded in 1993.

Le Pen, Jean-Marie (1928- ). French politician. He graduated in law, served as a parachutist in Indochina and Algeria, became a follower of Pierre *Poujade and a deputy 1956-62. He was leader of the National Front (FN) 1972-2011, using his oratory and organisational skills to build up strong national support by advocating forced repatriation of non-European immigrants. His party won no seats in the French elections of March 
1993 despite winning 12 per cent of the vote. In June 2002 he was runner-up in the first round of the election for President, losing heavily to *Chirac in the second, and in 2007 became the oldest presidential candidate in French history. His youngest daughter Marine (Marion Anne) Le Pen (1968- ), a lawyer, municipal councillor and MEP 2004-, succeeded him as leader of the FN 2011-17. In 2015, she excluded her father from any role in the FN for his persistent denial of the Holocaust and justification of French collaboration in World War II. In the 2017 presidential election, she ran second in the first round, then lost to Emmanuel ${ }^{*}$ Macron in the second, with 34 per cent of the vote. However, she won a seat in the National Assembly 2017- . In the presidential election of 2022 she was defeated again by Macron but secured 41.5 per cent on the second ballot, winning some votes from the hard Left.

Lepidus, Marcus Aemilius (d.13 BCE). Roman leader. A strong supporter of Julius *Caesar, after his murder he joined with Mark *Antony and Octavian (*Augustus) in forming (43) the Second Triumvirate. In 36 Lepidus, who had been assigned Africa as his sphere of command, left there to seize Sicily. Augustus then deprived him of office.

Lermontov, Mikhail Yuryevich (1814-1841). Russian poet. Of Scottish descent, he became a cavalry officer (1832) but was exiled to the Caucasus for a year for publishing a revolutionary poem on the death of *Pushkin (1837). He was again banished in 1840 for fighting a duel, and in another duel in the following year he was killed. His poems reveal him as a true romantic: they consist mainly of lyrics, many inspired by the wild beauties of the Caucasus. The Demon (1839), a supernatural narrative poem, shows Byronic influence (indeed Lermontov has been compared with *Byron both for his passionate praise of freedom and for his impulsive character). In another vein is The Song of the Merchant Kalashnikov, which is imbued with the spirit of Russian folklore. Masquerade is the best known of his verse plays. His finest work was the short novel $A$ Hero of Our Times (1840) an isolated masterpiece, but the first of the long line of Russian psychological novels.

L'Ami, C. E. and Welikotny, A., Michael Lermontov: Biography and Translation. 1967.

Le Roy Ladurie, Emmanuel Bernard (1929- ). French historian. A pupil of Fernand *Braudel, he taught at the Collège de France 1973-99. He worked within the Annales tradition but made effective use of econometrics and anthropology, e.g. in Montaillou (1978) the story of a French village 1294-1324, which became an international bestseller. Director of the Bibliothèque Nationale Paris 1987-94, he was particularly interested in environmental factors (e.g. the impact of climate change) and micro-history. He classified historians as 'parachutists or truffle hunters'.
Lerroux, Alejandro (1864-1949). Spanish politician. Originally an ardent republican, he was exiled several times before 1931 but served as Foreign Minister 1931-33 and 1934-36 and Prime Minister 1933-34, 1935. His opponents denounced him as an opportunist.

Lesage (Le Sage), Alain René (1668-1747). French dramatist and novelist, born in Brittany. He started his literary career with translations from Latin, Greek and Spanish. His early plays too, were adapted from the Spanish and it was not until 1707 that his first original work appeared. Turcaret a satirical comedy about financiers and considered the best work of its kind since ${ }^{*}$ Molière, was produced at the Comédie Française in 1708 . Lesage gained a greater reputation as a novelist with Le Diable boiteux (The Devil on Two Sticks) published in 1707 . This was followed by a picaresque novel, Gil Blas de Santillane (1715-35), in which the hero climbs the ladder of success from robber's servant to a ministerial post and encounters on the way a wonderful array of characters in almost every class of Spanish society. This great work, which influenced ${ }^{*}$ Smollett (who translated it) and *Fielding, marked the peak of Lesage's achievement. He married in 1694 and lived quietly and happily with his wife and three sons.

Leschetizky (Leszetycki), Theodor (1830-1915). Polish pianist and teacher. A pupil of ${ }^{*}$ Czerny, he toured widely but became famous as a teacher in Vienna: his students included *Paderewski, ${ }^{*}$ Schnabel and ${ }^{*}$ Horszowski. He was also a conductor and composer.

Leskov, Nikolai Semyonovich (1831-1895). Russian writer. Having visited many parts of Russia and met people of all classes, he was able to cover a wider range of Russian society than his contemporaries *Turgenev and ${ }^{*}$ Dostoevsky. He was clever at catching individual oddities of appearance and speech, but though he often writes with irony, optimism is the keynote of his mood. The best known of his novels is The Cathedral Folk (1872) about the provincial clergy.

Lesseps, Ferdinand Marie, Vicomte de (18051894). French diplomat, born in Versailles. After resigning from the diplomatic service (1851), he revived his interest in the project he had conceived, during a visit to Egypt (1832), of constructing a canal across the isthmus of Suez. His opportunity came in 1854, when an old friend, *Muhammad Sa'id Pasha, became khedive. Funds were raised by loan and in 1860 work began. On the canal's completion (1869), honours were showered upon de Lesseps, the hero of the hour: created a viscount, elected to the Académie française, awarded a GCSI by Britain.

A grandiose plan to repeat his success, this time at Panama, was launched in 1879. Work on a sea-level canal without locks began in 1881, but fever and the difficulties of the task exhausted the funds, and so caused the financial jugglery that brought disaster to 
the scheme and disgrace to de Lesseps. Though his sentence of five years' imprisonment for fraud was quashed on technical grounds, he was a ruined man.

Bonnet, G. E., Ferdinand de Lesseps. 2 vols, 1951, 1959.

Lessing, Doris May (née Taylor) (1929-2013). British novelist, born in Iran. Educated in Rhodesia (now Zimbabwe), where some of her books were set, she became a Communist and early feminist, living in England from 1949. She wrote novels and short stories, mainly in a forthright, colloquial style, which express her socialism and her interest in feminine psychology. Her novels included The Grass is Singing (1950), Martha Quest (1952), The Golden Notebook (1962), The Good Terrorist (1985) and The Fifth Child (1988). She was a prolific writer of science fiction, short stories, plays, and essays. She received a $\mathrm{CH}$ in 2000 and the Nobel Prize for Literature in 2007.

Thorpe, M., Doris Lessing. 1973.

Lessing, Gotthold Ephraim (1729-1781). German dramatist and critic, born in Saxony. He studied theology at Leipzig University, went to Berlin (1748) and with a friend started a theatrical journal to which he contributed several articles including one on *Plautus. A second journal of the same type followed (175458 ), and he resumed university studies in Wittenberg. Back in Berlin he formed a close friendship with the philosopher Moses Mendelssohn. In discussion and correspondence at this time he formulated his ideas that the natural drama of *Shakespeare and his English successors was to be greatly preferred to the classical tragedies of *Corneille, against which he waged incessant critical warfare. His own Miss Sara Sampson (1755) a tragedy of common life-a new type in Germany-exemplified his viewpoint, as does his second tragedy Emilia Galotti (1772). In between came one of the best German comedies, Minna von Barnhelm (1767), in which the influence of English writers is clear. In Laokoon (1776), an influential work on aesthetics, he assigns limitations to the various arts (unacceptable nowadays), e.g. that only static treatment of subjects should be attempted by the plastic arts. Lessing was secretary to the Governor of Breslau (1760-65) and was then (until 1769) occupied at Hamburg with another journal of theatrical criticism and comment. Eventually (1770) he settled permanently in Wolfenbüttel. Lessing was a great fighter for intellectual liberty and religious toleration to which subject his poem Nathan der Weise (1779) was devoted.

Garland, H. B., Lessing, the founder of Modern German Literature. 2nd ed. 1962.

Leszczyński, Stanisław (1677-1766). King of Poland 1704-09 and 1733-35. Son of a Count of the Holy Roman Empire, he became a protégé of ${ }^{*}$ Charles XII of Sweden, who forced (and bribed) his election as king by the Polish Diet. When the at Poltava (1709), Stanisław was deposed and went into exile in Pomerania, then to Alsace. In 1725, his daughter Marie was married to *Louis XV of France but his son-in-law gave him little effective support in the War of the Polish Succession, which followed the second election (1733) of Stanislas as King of Poland, and he once more lost his throne. In compensation, he was made Duke of Lorraine and Bar 1738-66. An enlightened ruler and patron of the arts, his treatises on government reveal the influence of *Montesquieu. His capital at Nancy became a model of city planning, with the superb Place Stanislas, Place de la Carrière and Place d'Alliance. He died at Lunéville, his second capital.

\section{Le Tellier, François Michel see Louvois, François Michel le Tellier, Marquis de}

Lettow-Vorbeck, Paul Emil von (1870-1964). German soldier. During World War I he defended German East Africa (now Tanzania) against General *Smuts in one of the most brilliant campaigns of colonial military history. He became active in rightwing politics, was a Reichstag member 1929-30, and an opponent of *Hitler.

Levene, Phoebus Aaron Theodore (1869-1940). American chemist, born in Lithuania. His family migrated to the US in 1893 . He worked at the Rockefeller Institute, New York, on nucleic acids and in 1909 isolated and named RNA (ribonucleic acid). He was nominated seven times for a Nobel Prize.

Lever, William Hesketh, 1st Viscount Leverhulme of the Western Isles (1851-1925). English industrialist, born in Lancashire. He left school early, worked in his father's wholesale grocery in Bolton, moved to Wigan and, from 1884, began the manufacture of soap on a large scale, using vegetable oils (especially palm oil) instead of tallow. Sunlight Soap included the brands Lux and Lifebuoy. Port Sunlight, on the Mersey, in Cheshire, begun in 1888, a factory centre that provided model housing for its workers, was inevitability paternalistic in operation. Lever, an active Freemason, Congregationalist and Liberal Imperialist, was MP 1906-09. He looked to the United States for inspiration about advertising and marketing. Much of his raw material was extracted by slave labour in Africa. By mergers and purchase the business continued to expand and, linked with its Dutch counterparts, came to form the great international combination, Unilever. Lever, who became a baronet (1911), a baron (1917) and a viscount (1922), devoted much of his wealth to public and private benefactions.

Le Verrier, Urbain Jean Joseph (1811-1877). French astronomer. He taught astronomy at the École Polytechnique from 1839 and in 1846 was admitted to the Académie. In the turmoil that followed the revolution of 1848 he played a political role, was made a senator by Louis Napoléon (*Napoléon III) 
in 1852 and director of the Paris Observatory. From his study of the irregularities of the motions of the planet Uranus he was able to predict the position (independently predicted by J. C. *Adams) of the previously unidentified planet Neptune. Later he found the theoretical solutions that permitted him to construct more accurate tables of the movements of the sun and the more important planets.

Grosser, M., The Discovery of Neptune. 1962.

Lévesque, René (1922-1987). Canadian politician. $\mathrm{He}$ was a journalist, foreign correspondent and broadcaster, and a member of the Québec legislature 1960-85, Liberal until 1970, when he founded the Parti Québécois. He defeated the Liberals to become Premier of Québec 1976-85.

Levi, Primo (1919-1987). Italian novelist, born in Turin. Trained as a chemist, he was a Partisan during World War II and survived Auschwitz. The experience haunted him and he committed suicide. His books include If this is a Man (1947), The Periodic Table (1975) and If Not Now, When? (1982).

Levi ben Gershom (Levi Gersonides of Avignon, also known as Ralbag) (c.1228-1344). Jewish philosopher, astronomer and Biblical commentator. His chief work, Wars of the Lord deals with the immortality of the soul, the nature of prophecy, God's omniscience, divine providence, the nature of the celestial sphere and the eternity of matter. He wrote a notable commentary on *Euclid.

Levi-Montalcini, Rita (1909-2012). Italian neurologist, born in Turin. She worked with refugees, conducted research at St Louis 1947-77 and Rome (from 1969) and shared the 1986 Nobel Prize for Medicine for her work in isolating the nerve growth factor (NGF) in cells. She became a Senator for Life in 2001 and, in 2009, the first Nobel centenarian.

Lévi-Strauss, Claude (1908-2009). French social anthropologist, born in Brussels. He taught at the University of Sao Paulo, Brazil 1935-39, worked in New York as an academic and diplomat 1942-47, returning to France in 1949 as director of studies at the École Pratique des Hautes Études 1950-74, and then as a professor of the Collège de France 1959-82. In Structural Anthropology (1958) he attacked the prevailing functionalist (*Malinowski) school of sociology, proposing, along Hegelian lines, that a universal primitive logic imposed patterns of meaning on natural phenomena, i.e. that totemism is not a reflex reaction to mysterious natural forces but a conscious imposition of symbolism to preserve complex divisions in tribal society. He was elected to the Académie française in 1973.

Lévi-Strauss, C., A World on the Wane. 1961.
Levine, James Lawrence (1943-2021). American conductor and pianist, born in Cincinatti. He studied at the Juilliard School and worked under Georg *Szell. He was music director of the Metropolitan Opera New York 1976-2016, the Munich Philharmonic 1999-2004, and the Boston Symphony Orchestra 2004-11.

Lewes, George Henry (1817-1878). English writer. Editor of the Fortnightly Review (1865-66), he wrote many popular philosophical works and a biography of *Goethe, and lived with Mary Ann Evans (George *Eliot) from 1854 until his death. He wrote Problems of Life and Mind (5 vols, 1873-79).

Lewis, Carl (1961- ). American athlete. In the Olympic Games of 1984, 1988, 1992 and 1996 he won nine gold medals for long jump and sprinting.

\section{Lewis, Cecil Day see Day Lewis, Cecil}

Lewis, C(live) S(taples) (1898-1963). English scholar and writer. He was a fellow and tutor at Magdalen College, Oxford 1925-54 and professor of medieval and Renaissance English at Cambridge 1954-63. He wrote on medieval courtly love in The Allegory of Love (1936) and on Christian belief in a number of popular works, especially the well known Screwtape Letters (1942). He also wrote science-fiction allegories, e.g. Out of the Silent Planet (1938) and children's books, The Chronicles of Narnia. One of the 'Narnia' series, The Lion, the Witch and the Wardrobe (1950), was translated into 47 languages and sales are estimated at 65 million copies. His late finding of love was the basis of the film Shadowlands (1993).

Wilson, A. N., C. S. Lewis. 1991.

Lewis, Essington (1881-1961). Australian industrialist. He became a mining engineer, joined Broken Hill Proprietary (BHP) in 1904, rising to become General Manager 1921-38, then Chief General Manager 1938-50 and a central figure in Australia's mineral and industrial development. $\mathrm{He}$ was Director-General of Munitions and Aircraft Production 1941-45, receiving the CH in 1943.

Lewis, Gilbert Newton (1875-1946). American physical chemist, born in Massachusetts. As Dean of the College of Chemistry at Berkeley, California 1912-40, he turned the department into one of the leading centres for chemistry in the United States. Lewis' career was a series of endeavours to unite chemistry and physics, theoretical and experimental approaches. He first worked in the field of thermodynamics, attempting to apply *Gibbs' and Duhem's ideas of free energy to chemistry via the concept of the 'escaping tendency' (or 'fugacity') of gases, the tendency of a substance to pass from one chemical stage to another. He was, however, more successful with his work on valence theory. In 1916 he proposed his theory that the chemical bond was a pair of electrons shared jointly by two atoms. This 
idea was successfully taken by Irving *Langmuir, who took most of the credit. In his later years, Lewis did important work in photochemistry. In the late 1930 s and early 1940s he produced important experimental papers on fluorescence and phosphorescence spectra.

Lewis, John L(lewellyn) (1880-1969). American trade union leader. Having worked as a miner from the age of 12, he became (1920) President of the United Mineworkers of America, an office he held until 1960. In 1935 he broke away from the American Federation of Labor (AFL) and formed the Congress of Industrial Organisations (CIO), a more political and aggressive body of which he became president. In 1942 he led his union out of the CIO. It rejoined the CIO in 1946, but withdrew once more in 1947. Lewis was successful in obtaining better conditions and wages for coalminers. He accepted mechanisation with the inevitable consequence of massive reductions in the numbers of coalminers employed.

Alinksy, S., John L. Lewis. 1949.

Lewis, Matthew Gregory (1775-1818). English novelist. His sobriquet 'Monk' Lewis derived from his famous 'Gothic' romance, Ambrosia, or the Monk (1795), a tale of horror that won him the friendship of Sir Walter ${ }^{*}$ Scott, *B Byron and the Prince Regent. Other novels and poems followed in the same vein. He died from yellow fever, caught during a visit to the West Indies to improve the lot of the slaves on estates he had inherited.

Peck, L. F., Life of Matthew G. Lewis. 1961.

Lewis, Meriwether (1774-1809). American explorer. A soldier with strong scientific knowledge, he became private secretary to Thomas *Jefferson who chose him to lead an expedition to find a northwest passage to the Pacific. His co-leader was William *Clark. With a party of 40 ('the Corps of Discovery'), Lewis and Clark left Wood River, near Missouri (May 1804), sailed up the Missouri River, crossed the Rocky Mountains, reached the Pacific via the Columbia River, returning to St Louis (September 1806), having travelled 12,800 kilometres. He became Governor of Louisiana Territory and died of an unexplained gunshot wound in Washington (*Sacagawea).

Dillon, R. H., Meriwether Lewis. A Biography. 1965; Ambrose, S. E., Undaunted Courage. 1996; Danisi, T. C., Meriwether Lewis. 2009.

Lewis, (Henry) Sinclair (1885-1951). American novelist, born in Sauk Center, Minnesota. Son of a doctor, he became a journalist and wrote several minor works before beginning, at 35, the series of penetrating social satires on American life for which he is now remembered. In Main Street (1920) he pilloried the narrow-mindedness of small-town life in the Midwest; Babbitt (1922) described the spiritual vulgarity of the business classes; Arrowsmith (1925) inroads of commercialism; Elmer Gantry (1927) was an attack on a hypocritical evangelist. In 1930 Lewis became the first American to win the Nobel Prize for Literature. His later novels include It Can't Happen Here (1935), an attack on Nazism, Cass Timberlane (1945), and Kingsblood Royal (1947), a study of racial bigotry.

Lewis, Sir W(illiam) Arthur (1915-1991). West Indian economist, born in St Lucia. He held chairs at Manchester and Princeton, investigated thirdworld economies and wrote The Evolution of the International Economic Order (1978). Knighted in 1963, he shared the 1979 Nobel Prize for Economics with Theodore Schultz.

Lewis, (Percy) Wyndham (1884-1957). English painter and novelist, born in New York. Trained at the Slade School, London, he was a pioneer of modernism in English art. The Vorticist group, which he led and of whose periodical Blast he was co-editor with Ezra *Pound, derived some of its ideas from Futurism and Cubism, but in his own paintings Wyndham Lewis never restricted himself to a single style. He was a founder member of the London Group. Outside his art he had a separate reputation as a satirical novelist, his works including Time and the Western Man (1918) and The Apes of God (1930). Rude Assignment (1950) is his autobiography.

Handley-Read, C. (ed.), The Art of Wyndham Lewis. 1951.

Ley, Robert (1890-1945). German politician. A chemist, he joined the Nazi Party in 1924 and was notorious for his anti-Semitism in the Rhineland district. Ley was the head of the German labour front 1933-45, suppressed trade unions and recruited slave labourers. He committed suicide during the Nuremberg trials.

Leys, Simon (pen name of Pierre Ryckmans) (1935-2014). Belgian social scientist, Sinologist, essayist and critic, born in Brussels, lived in Australia. He studied in Louvain, Taiwan, Singapore, and Hong Kong, migrated to Australia in 1970 and held chairs in Chinese at The Australian National University and Sydney University. He was briefly a Belgian cultural attaché in Beijing (1972). His books included a devastating critique of *Mao's regime, Chinese Shadows (1974, translated 1977), a novella about historical contingency, The Death of Napoleon (1986, translated 1992, also filmed), The Analects of Confucius (commentary and translation, 1997), With Stendhal (2010), and The Hall of Uselessness (essays, 2011). His writings won many international awards.

Pacquet, P., Simon Leys. 2017.

Li Bo (or Li Bai, courtesy name Taibai, Li Po in Wade-Giles) (c.700-762). Chinese poet of the Tang dynasty. Whenever he was not wandering in disgrace because of his dissipated life, Li Bo appears to have 
lived at the emperor's court. His 2,000-odd surviving poems - seldom more than 12 lines long-treat of the pleasures of life, and are famous for their delicate imagery and lyrical quality. $\mathrm{Li} \mathrm{Bo}$ is said to have been drowned while trying (drunkenly) to embrace the reflection of the moon. Arthur *Waley translated many of his verses into English.

Li Hongzhang (Li Hung-Chang in Wade-Giles) (1823-1901). Chinese minister and mandarin, born in Anhui. He supported General ${ }^{*}$ Gordon and the 'Ever Victorious Army' in suppressing the Taiping Revolt (1864) and became Viceroy of Zhili 1870-94, 1900-01 under the Manchus. He tried to introduce reforms along more modest lines than those of the Meiji restoration in Japan but found the Manchu dynasty and the Confucian system were resistant to change. Chinese influence in Vietnam was replaced by France (1883$85)$ and China was beaten in the Japanese war (189495) and humiliated in the Boxer Rebellion (1900-01). He tried to urge reform on the Dowager Empress ${ }^{*}$ Cixi Hsi. The first railway was built and the services were reformed during his term as Prime Minister 1895-98. He was often called 'the Asian *Bismarck'.

Li Lisan (originally Li Rongzhi) (1899-1967). Chinese Communist politician, born in Hunan Province. Son of a teacher, he studied for a year in Paris and after his return joined the Chinese Communist Party in 1921. An effective organiser, he became General Secretary of the CCP 1928-30. His strategy of attacking the Guomintang in the cities (instead of *Mao's concentration on the peasantry) failed spectacularly. Li was blamed, sent to Moscow to repent, stayed there 1931-46 and married a Russian. Brought back to China by Mao in 1946, he became Commissar for Labour 1949-54. After the ChinaRussia split he was accused of being a Soviet agent, beaten up by Red Guards and denounced in the Cultural Revolution. His death was attributed to suicide, but murder is a distinct possibility. He was rehabilitated in 1980 .

Li Peng (1928-2019). Chinese Communist politician, born in Chengdu, Sichuan. His father Li Shuoxon, a radical writer, was executed by the Guomintang in 1930. As a young man he received the patronage of ${ }^{*}$ Zhou Enlai, studied electrical engineering and worked in Russia and (briefly) England. He became Vice Minister for Electric Power 1980-81, Minister for Water and Electric Power 1981-85 and Minister for Education 1985-88. A member of the CCP Politburo 1985-2003 and its Steering Committee 1987-2003, he became Acting Prime Minister 1987-88 and Prime Minister 1988-98. He ordered the army to suppress the demonstration in Tiananmen Square, Beijing, in July 1989 , but primary responsibility lay with *Deng Xiaoping. He chaired the National People's Congress 1998-2003.

\section{Li Po see Li Bo}

Li Si (Li Ssu in Wade-Giles) (280?-208 BCE). Chinese statesman. He worked with the emperor ${ }^{*}$ Qin Shihuang in unifying China, promoting the concept of 'the mandate of heaven', creating the structure of centralised government, punishing dissent and executing 'burning of the books'.

Li Xiannian (1905-1992). Chinese Communist politician. He joined the CP in 1927, was a veteran of the Long March and served as Vice Premier and Finance Minister 1954-76. He was appointed President of the Peoples' Republic 1983-88 after the office had been left vacant for 15 years.

Li Yuanghong (1864-1928). Chinese general and politician. Originally a naval engineer, he became a general, a reluctant revolutionary and an uneasy ally of *Sun Yat-sen. He was Vice President of the Chinese Republic 1912-16, and President 1916-17, 1922-23.

Liang Qichao (Liang Ch'i-ch'ao in Wade Giles) (1873-1929). Chinese teacher and publicist. He founded the first Chinese newspaper in Peking (1898) and was associated with *Kang Yuwei in the 'Hundred Days of Reform' and fled to Japan when the movement was crushed. He supported attempts to set up a constitutional monarchy but then collaborated with *Sun Yat-sen and held several government administrative and diplomatic posts. He translated and popularised ${ }^{*}$ Darwin and ${ }^{*}$ Spencer, and became *Mao Zedong's favourite author.

Liaquat Ali Khan (1895-1951). Pakistani politician, born in Punjab. His parents were high-caste Muslims and he studied at Aligarh and Oxford universities. Deputy leader of the Muslim League under *Jinnah 1940-47, he served under *Nehru as India’s Finance Minister 1946-47, then, after partition, became the first Prime Minister of Pakistan 1947-51, also Minister for Defence 1947-51 and Foreign Affairs 1947-49. He was assassinated by a Pashtun gunman: the reasons are unclear. He remains the longest serving Pakistani Prime Minister.

Libby, Willard Frank (1908-1980). American chemist. He worked on the atomic bomb during World War II and was a member of the US Atomic Energy Commission 1954-59. He taught at Chicago and UCLA, winning the 1960 Nobel Prize in Chemistry for developing a technique using the radioactive isotope carbon-14 $\left({ }^{14} \mathrm{C}\right)$ to date materials such as trees, parchments and fabrics, an indispensable tool in archaeology and earth science. He was a member of the US Atomic Energy Commission 1954-59.

Libeskind, Daniel (1946- ). American architect, artist and set designer, born in Łódź. His buildings include the Imperial War Museum, Manchester; the Jewish Museum, Berlin; and the One World Trade Centre, New York (2003-14). 
Lichtenstein, Roy (1923-1997). American painter and sculptor, born in New York. He worked as a product designer, taught at New York State and Rutgers universities and held his first one-man exhibition in New York in 1962. He was a pioneer in pop art and his most famous works involved blowing up the kitsch images found in comic strips and advertising; later he transformed familiar art images into comic strip form. He was also an accomplished sculptor in metal. Ohhh ... Alright (sic) was sold for \$US42.6 million in 2010 and 'Woman with Flowered Hat' for \$US56 million in 2013.

Liddell Hart, Sir Basil Henry (1895-1970). British military expert. He served in World War I and retired from the army (1927) to become military correspondent for The Times and the Telegraph. He advocated mechanised forces and a strategy of movement. His theories were closely studied in Germany and greatly influenced the organisation of the rejuvenated German army under ${ }^{*}$ Hitler. He wrote many books on the history of strategy and tactics and on military leaders, e.g. The Future of Infantry (1933), The German Generals Talk (1948), and The Tanks (1959).

Liddell Hart, B. H., Memoirs. 2 vols, 1965-66.

Lidgett, John Scott (1854-1953). English clergyman. A theologian and Progressive on the LCC 1908-28, he led the successful campaign for the uniting of the separated branches of the Methodist Church in Britain and was first president of the United Church 1932-33. Lidgett became Vice Chancellor of London University 1930-32 and received a CH (1933). He was joint editor (with G. P. *Gooch) of the Contemporary Review 1911-53.

Lie, Trygve Halvdan (1896-1968). Norwegian lawyer, politician and UN administrator, born in Oslo. He was legal advisor to the Norwegian trade union movement 1922-35, a Socialist member of the Storting 1935-46, Minister for Justice 1935-39, Minister for Trade 1939-40 and Foreign Minister $1940-46$, in the wartime government in exile. He chaired the commission that drafted the United Nations Charter and was elected as the first SecretaryGeneral of the United Nations 1946-52. He took initiatives in resolving deadlocks, at first with Soviet support, and sought China's admission to the UN, but after backing UN intervention in Korea (1950) was denounced as being under State Department influence. He compromised UN independence by collaborating with the FBI to purge American leftwingers from its secretariat during the ${ }^{*}$ McCarthy period. He wrote In the Cause of Peace (1954) and returned to Norway as Governor of Oslo 1955-63, and was a minister again 1963-65.

Lieberman, Joe (Joseph Isadore) (1942- ). American Democratic politician. Educated at Yale, he became Attorney-General of Connecticut 1983-89. He was US Senator from Connecticut 1989-2013, and
Al *Gore's candidate for Vice President in 2000. He lost Democratic endorsement for the Senate in 2006 because of his support for the Iraq war but was re-elected as an Independent Democrat. He endorsed John *McCain in 2008 and Hillary *Clinton in 2016.

Liebermann, Max (1847-1935). German painter. He studied in Weimar and (1872-79) in Paris, where he came under the influence of ${ }^{*}$ Millet and ${ }^{*}$ Courbet. His early pictures were realistic, many of them genre scenes (e.g. Women Plucking Geese), but after moving to Berlin (1884) he painted from a much brighter palette, and from 1890 , under the influence of the French Impressionists, his subjects, e.g. bathing scenes on the Wannsee, became full of light. He became leader (1899) of the newly founded Berlin movement known as the Sezession.

Scheffler, K., Max Liebermann. 1953.

Liebig, Justus, Baron von (1803-1873). German chemist. He first studied under *Gay-Lussac in Paris, and became professor of chemistry at Giessen 1834 52 and Munich 1852-73. He was an important contributor to organic chemistry and its application to agriculture. He especially studied plant and nutrition processes. He also isolated chloroform (1832).

Liebknecht, Wilhelm (1826-1900). German journalist and politician. With his friend Karl *Marx, he was founder of the Social Democratic Party (1869), served in the Reichstag and edited Forwards. His son, Karl Liebknecht (1871-1919), as a member of the extremist left wing of the Social Democratic party in the Reichstag (1912-16), assailed his party's acquiescent attitudes to World War I and was imprisoned (1916-18) for incitement to treason. He formed with Rosa * Luxemburg, the Communist body known as Sparticists and in 1919 led their rising in Berlin. Arrested after its defeat, he was killed while being taken to prison.

Meyer, K. W., Karl Liebknecht: Man without a Country. 1957.

Ligeti, György Sándor (1923-2006). JewishHungarian composer, born in Romania. His father and brother died in concentration camps. He studied in Budapest, left Hungary in 1956, working in Vienna, Cologne and Hamburg. Enormously prolific, he experimented with many different styles: in the 1960s he moved towards the removal of melody, harmony and rhythm. His works include Poème Symphonique for 100 metronomes (1962), Requiem (1963-65), a chamber concerto for 13 instrumentalists (1969-70), Le Grand Macabre (opera, 1974-77), concertos for piano (1985-88) and violin (1990-93).

\section{Lij Iyasu see Iyasu, Lij}

Lilburne, John (c.1614-1657). English political agitator. Having already been imprisoned as an antiChurch pamphleteer, he rose during the civil war to 
be Lieutenant Colonel in the parliamentary army, and there became leader of a Puritan and Republican sect whose adherents were known as Levellers, since their demands included extreme egalitarian social reforms. ${ }^{*}$ Cromwell, whose arbitrary methods they had denounced, easily defeated a mutiny in 1649 and the movement and its leader suffered temporary exile and soon lost importance.

Gregg, P., Free-Born John. 1961; Hill, C., The World Turned Upside Down. 1991; Gregg, P., Free Born John. rev. 2001.

Lilienthal, David Eli (1899-1981). American administrator. He was a director 1933-41 and chairman 1941-46 of the Tennessee Valley Authority (TVA) and later first Chairman of the Atomic Energy Commission (1946-50).

Lilienthal, Otto (1848-1896). German engineer. A pioneer in aeronautics and keen student of the flight of birds, he designed successful gliders and he made more than 2,000 flights before he was killed in a glider accident.

Lillie, Beatrice (Lady Peel) (1894-1989). British revue artist and comedian, born in Canada. She began as a straight ballad singer, with little success, and turned to comic singing in 1914. During the 1920 s she achieved international fame as a singer and comedian in revue.

Lili'uokalani (née Lydia Lili'u Loloku Walania Kamaka'eha) (1838-1917). Queen of Hawaii 189193. The last sovereign and only reigning queen, she succeeded her brother (David) Kalakkaua (18361891) king 1874-91, a moderate liberal, and tried to impose an older style of autocratic monarchy. In 1893 she stepped down at the request of the Missionary Party, but appealed to the US to reinstate her. When this failed she finally abdicated in 1895 . When the US proposed annexation in 1898 she opposed it bitterly and supported a nationalistic independence movement. She wrote the popular song Aloha Oe in 1898 .

Linacre (or Lynaker), Thomas (1460?-1524). English humanist and physician. After becoming a Fellow of All Souls, Oxford (1484), he travelled in Italy and felt the invigorating impact of the new learning upon continental scholarship. He graduated in medicine at Padua, then returned to Oxford, became Greek tutor to ${ }^{*}$ Erasmus and ${ }^{*}$ More, and from 1509 was one of the royal physicians. He founded the Royal College of Physicians (1518) but abandoned the practice of medicine on becoming a priest (1520). He wrote a Latin grammar for Princess *Mary (1523), followed by a much larger work on the same subject. He also made Latin translations from the Greek medical works of ${ }^{*}$ Galen and parts of *Aristotle.
Lin Biao (also Lin Piao) (1907-1971). Chinese soldier and politician, born in Hubei. He joined the Socialist Youth League in 1925, the year he began his military career at the Huangpu Academy. He took part in ${ }^{*}$ Chiang Kaishek's Nationalist uprising but, when the Communist and Socialist groups abandoned Chiang in 1927, he went with the Communists and joined *Mao Zedong in Jiangxi Province. He became a commander with Mao's Red Army in 1928 and a corps commander in 1934. As such he helped to head the 'Long March' north when Jiangxi was overrun by Nationalist Forces.

In 1937-38 (when the civil war in China was halted in order to fight the Japanese) he served as a divisional commander. He was in Russia for medical treatment 1939-42. The civil war began again in 1946, when Lin Biao's victories in Manchuria were largely responsible for the fall of Chiang. In the People's Republic (established in 1949) he became Vice Premier of the State Council in 1954 and Minister of Defence in 1959. His reorganisation of the army, combining military skill with political consciousness, was the main spur to the Great Cultural Revolution of 1966-69. He became Vice Chairman of the party in 1969 and Mao's designated successor. However, in September 1971, he appears to have led an abortive coup against Mao and tried to reach Moscow but his plane crashed in Mongolia.

Lincoln, Abraham (1809-1865). 16th President of the US 1861-65. He was born in a log cabin near Hodgenville, Kentucky (on the same day as Charles *Darwin), son of Thomas Lincoln (1778-1851), a farmer of restless temperament from Virginia who moved on first to Indiana and, when Abraham was 21 , to Illinois. In 1819 , a year after his first wife's death, Thomas married Sarah Bush Johnston, a widow with three children who brought order into the household and introduced her stepson to the delights of reading with such books as The Pilgrim's Progress and Robinson Crusoe, so providing the spur to a remarkable feat of self-education. Meanwhile Abraham helped the family income with odd jobs such as operating a ferry on the Ohio River. It was a river journey to New Orleans (1828) that gave the awkward, lanky youth, $1.93 \mathrm{~m}$ in height, his first view of the greater world and the shock of seeing slavery in action. Soon afterwards he left home, he worked in New Salem, Illinois, as clerk, store-keeper and (in 1833) postmaster, and was captain of the local volunteers, becoming well known for his racy anecdotes and homespun humour. He was elected to the Illinois State Legislature in 1834, serving until 1841. His romance with Anne Rutledge who died of fever in August 1835 has passed into American folklore but rests on very slender foundations. In 1837 the year he moved to Springfield, he was admitted to the bar after having virtually taught himself law. His marriage (1842) to Mary Todd (1818-1882) to whom he was temperamentally unsuited probably led him to pursue his political 
interests more single-mindedly. The Lincolns had four sons, two died before 1865. Lincoln was a very successful advocate who acted in many railroad and criminal cases. He was a Whig member of the US House of Representatives 1847-49 where he took an unpopular stand against the Mexican War and began to campaign against the extension of slavery to the northwestern territories. His reputation was still largely local. He failed to secure appointment as US Commissioner for Lands in Illinois (1849), declining an offer of the secretaryship of Oregon Territory in the same year. In 1854 the Kansas-Nebraska Act, promoted by Stephen A. *Douglas, had abolished the 'Missouri Compromise' of 1820 which had prohibited slavery north of $36^{\circ} 30^{\prime}$, and left the issue of slavery to the vote of settlers in each new state. When 'bleeding Kansas' became a battle ground over slavery, this led to the formation of the Republican Party (1854). Lincoln did not join until 1856 but soon became a leading member, although he failed to win nomination for the Senate or as Vice President. He was not an abolitionist-he saw slavery as an economic question that threatened the status of white labourers in the new states and territories of the west, and his moral objections to the 'peculiar institution' only developed later. In 1858 he campaigned against Douglas for US Senator and in seven great debates (published in broadsheets and in book form soon after) the rivals argued the implications of the slavery issue. Lincoln declared, "A house divided against itself cannot stand". I believe this government cannot endure permanently, half slave and half free.' He won the debates and the popular vote but lost the election which was decided by the Illinois legislature. In February 1860, a powerful speech at the Cooper Union, New York, attracted national interest and won him support outside the mid-West. At the Republican Convention held at Chicago in May 1860 he gained the presidential nomination on the third ballot, defeating his better known rivals W. H. *Seward, Simon Cameron from Pennsylvania, S. P. ${ }^{*}$ Chase. Douglas, his 1858 rival for the Senate, won the Democratic nomination for president. Lincoln made no campaign speeches but his policies were well known from his debates with Douglas and the Cooper Union address. In November he won the election with 40 per cent of the votes because the Democrats were split between three candidates (Douglas, Breckinridge of Kentucky, Bell of Tennessee). Six weeks later South Carolina led a secession from the Union of the southern slave-owning states; in February 1861 the Southern Confederacy was formed and in April an attack on the federal Fort Sumter at Charleston, SC, sparked off the Civil War on the issues, not only of slavery but of the right to secede. (Many Southerners referred to the War of Southern Independence.) It was not until 1863 that a proclamation emancipating slaves (but only in the states in arms against the Union) was issued. Lincoln had to contend with a divided Cabinet and blundering and miscalculation in the conduct of the war. But his firmness and wisdom enabled the weight of numbers, equipment and wealth, which lay with the North, to have decisive effect. The Gettysburg Address, at the dedication of a war cemetery (November 1863), only 272 words long, defined democracy as 'government of the people, by the people, for the people', emphasising the concept of 'nation' rather than 'union'. Re-elected President by defeating General George *McClellan (1864), in his second inaugural address he proposed a policy of conciliation: 'With malice toward none; with charity for all ... let us strive on to finish the work we are in; to bind up the nation's wounds ... to do all which may achieve a just and lasting peace ...'. Only Lincoln, perhaps, was brave, generous and strong enough to give reality to his own vision and to him the opportunity was denied. Five days after Lee's surrender (April 1865) at Appomattox had brought the Civil War to an end, Lincoln was shot in Ford's Theatre, Washington by the fanatical actor John Wilkes *Booth. Lincoln was reflective, self-doubting and he talked in testable, evidencebased propositions, appealing to the better angels of our nature'. He never used his own name in a speech and wrote wonderful letters. Superficially he seemed a simple and straightforward characterbut closer examination reveals his great depth and complexity. Underlying his ironic whimsy was a vein of deep mysticism and melancholy, intensified by his unhappy marriage. His law partner and biographer W. H. Herndon wrote, 'That man who thinks that Lincoln calmly gathered his robes about him, waiting for the people to call him, has a very erroneous knowledge of Lincoln. He was always calculating and planning ahead. His ambition was a little engine that he knew no rest.' Not a great administrator but an outstanding moulder of public opinion, he was devout in the manner of an 18th-century deist and had little sympathy for the religion of the Churches. Lincoln had a high-pitched, penetrating voice, awkward hands and movements, and his feet hurt. He was the first bearded president and may have suffered from Marfan's syndrome (a hereditary heart and bone disease). He left an estate of \$90,000. The Lincoln Memorial in Washington, with its huge statue by Daniel Chester French, was dedicated in 1922. In 20 major studies by historians and political scientists ranking US presidents, Lincoln was chosen as No. 1 by 11 , and ahead of Franklin *Roosevelt and George *Washington in the aggregate.

His son Robert Todd Lincoln (1843-1926) was Secretary of War under *Garfield and *Arthur 188185, Ambassador to Britain 1889-93 and President of the Pullman Railway Company 1897-1911.

Thomas, B. P., Abraham Lincoln. 1952; Vidal, G., Lincoln. 1984; Wills, G., Lincoln at Gettysburg. 1992; Donald, D. H., Lincoln. 1995; Holzer, H., Lincoln at Cooper Union: The Speech That Made Abraham Lincoln President. 2004; Goodwin, D. K., Team of Rivals: The Political Genius of Abraham Lincoln. 2005; White, R. C., A. Lincoln. A Biography. 2009; Gopnik, A., 
Angels and Ages. 2009; Reynolds, D. S., Abe: Abraham Lincoln in His Times. 2021.

Lind, James (1716-1794). Scottish physician. Originally a naval surgeon, he was a pioneer of clinical trials (1747) and recommended adding citrus fruits and salad to sailors' diets to reduce the incidence of scurvy. His ideas were applied by James ${ }^{*}$ Cook. He also proposed using solar energy to distil salt water and applied hygienic measures to reduce the incidence of typhus.

Lind, Jenny (Johanna Maria Lind-Goldschmidt) (1820-1887). Swedish soprano. Long resident in Britain, famed for her brilliant coloratura singing, she was known as the 'Swedish nightingale'. She performed until 1849 mainly in opera, and later in concerts and oratorios. She married the German conductor and composer Otto Goldschmidt. Her kindness and generosity added to her popularity.

Lindbergh, Charles A(ugustus) (1902-1974). American aviator, born in Detroit. His Swedishborn father was a US Congressman 1907-17. He achieved unprecedented international fame when he flew The Spirit of St Louis, a $220 \mathrm{hp}$ monoplane, built by the Ryan Co. of San Diego to his own design, on the first solo non-stop flight across the Atlantic, from Roosevelt Field, New York to Le Bourget, Paris (5,809 km-3,610 miles, 331/2 hours), 20-21 May 1927. The 'Lone Eagle' received the Congressional Medal of Honor and decorations from Britain (AFC), France, Belgium and Germany. In 1929 he married Anne (Spencer) Morrow (1906-2001), daughter of US Senator Dwight Morrow. Their infant son Charles Augustus Lindbergh, Jr (1930-1932) was kidnapped and murdered, a crime for which (Bruno) Richard Hauptmann was convicted and executed (1936). From 1931 he worked with Alexis * Carrell on devising a perfusion pump for a future artificial heart. In 1936 he inspected European air forces, met *Hitler and ${ }^{*}$ Goering in 1938 , expressed strong views about German military superiority and joined the America First' movement which campaigned for US neutrality in the event of a European war. He advised the Ford Motor Company and United Airlines during World War II but flew (unofficially) on 50 combat missions in the Pacific. A consultant to Pan American Airways after the war, he received the Pulitzer Prize for The Spirit of St Louis (1953) and was made a brigadier in the USAF reserve by President ${ }^{*}$ Eisenhower (1954). Anne Lindbergh, an aviator herself, wrote books about flying, including Listen! The Wind (1938), essays, novels and The Wave of the Future (1940), an apologia for fascism. After 1957, Lindbergh adroitly managed to maintain and conceal three families in Germany simultaneously, and to sire seven children. He became actively involved in conservation issues, especially whales and eagles, retired to Hawaii and died there.

Berg, A. S., Lindbergh. 1998; Lindbergh, R., Under a Wing. 1998; Forward From Here. 2008.
Lindemann, Frederick Alexander see Cherwell, 1st Viscount

Lindsay, Norman (Alfred William) (1879-1969). Australian artist and author, born in Creswick, Victoria. He joined the Sydney Bulletin in 1901 and became its chief cartoonist, sharing its racist and ultra-nationalist views. His voluptuous nudes, in watercolour, oil, pencil and etching, were deeply controversial. His novels, including A Curate in Bohemia (1913), Redheap (1930), Saturdee (1932) and Age of Consent (1935) challenged middle-class morality. The children's book The Magic Pudding (1918) was his most admired work. His brothers: (Sir) Lionel Lindsay (1874-1961), (Sir) Daryl Lindsay (1889-1976) and sister Ruby Lindsay (1885-1919) were all artists. His son, Jack (John) Lindsay (19001990) was a publisher, novelist and translator. Born in Melbourne, educated in Queensland, he left Australia in 1926, established Fanfrolico Press, wrote 169 books, including 38 novels, 25 translations, studies of *Petronius, ${ }^{*}$ Blake, ${ }^{*}$ Turner, ${ }^{*}$ Cézanne and William *Morris, and was active in the Communist Party.

Linklater, Eric (1889-1974). Scottish author. The best known of his humorous novels include Poet's Pub (1929), Juan in America (1931), Juan in China (1937) and Private Angelo (1946).

\section{Linlithgow, 1st Marquess of see Hopetoun, 7th Earl of}

Linlithgow, 2nd Marquess of, Victor Alexander John Hope (1887-1952). Scottish Conservative politician and administrator. Son of the 7th Earl of *Hopetoun, later created a marquess, he was educated at Eton, served in World War I, became a colonel, held minor offices in Conservative governments and chaired two commissions on India: one on nutrition, the other on constitutional reform. Having declined appointment (1935) as Governor-General of Australia, an office held by his father, he became an unexpected choice as Viceroy of India 1936-43, the longest term ever served. He faced growing civil disobedience, World War II and *Gandhi's 'Quit India' campaign (1942).

Linna, Väinö (1920-1992). Finnish novelist. He left school early, became a lumberjack and served in the war against Russia 1939-40. He won fame with his novel The Unknown Soldier (1954) and the trilogy Under the North Star (1959-63).

Linnaeus, Carolus (Carl von Linné) (1707-1778). Swedish botanist and taxonomist, born in Småland. He studied medicine at the universities of Lund, Uppsala (Sweden) and Harderwijk (Netherlands), but became preoccupied with natural history, botany and classification. In 1732, in a 2,000 km exploration of Lapland, he discovered and classified many new plants. Linnaeus was the founder of modern 
taxonomy, the systematic classification of plants and animals, demonstrating the interconnectedness in a virtual tree of life.

He developed a binomial system (generic name + specific name) for plants and animals and published the first edition of Systema Naturae in the Netherlands in 1735. His methodology enabled accurate definitions of species, and was applied to zoology and mineralogy. Although later modified, it brought order to scientific nomenclature. Later editions of Systema Naturae expanded, and in the 10th edition (1758) he classified humans as homo sapiens ('wise man', using himself as the type specimen) and whales as mammals (blue whale = Balaenoptera musculus). He was the first to use symbols for male $\sigma^{\prime \prime}$ and female $ᄋ$.

He visited England in 1736 and made influential converts. He was professor of medicine and botany at Uppsala University 1742-62 and rector 1762-72.

Linnaeus, ennobled in 1761, was much admired by ${ }^{*}$ Rousseau, ${ }^{*}$ Goethe and ${ }^{*}$ Darwin. Despite his opposition to the concept of evolution (he thought that, once created, species were unchanging), his work laid the basis for it. His favoured students, or 'apostles', included Daniel Solander who sailed to Australia with ${ }^{*}$ Cook. Other 'apostles' sent Linnaeus specimens from North America and Japan.

After Joseph *Banks declined an offer, James Edward Smith bought Linnaeus' collection of books, papers, letters and specimens in 1784, brought them to London and founded the Linnean Society in 1788.

Anderson, M., Carl Linnaeus: Father of Classification. 1997; Blunt, W., Linnaeus: The compleat naturalist. 2004; Broberg, G., Carl Linnaeus. 2008.

\section{Lin Piao see Lin Biao}

Linus (c.10-c.76 CE). Second Bishop of Rome c.6776, born in Volterra, Tuscany. Son of Herculanus and Claudia, he is referred to in II Timothy 4:21 as being in Rome with St *Paul. *Irenaeus names him as St ${ }^{*}$ Peter's successor as Bishop of Rome (i.e. Pope). He was almost certainly not martyred.

Lin Yutang (1895-1976). Chinese author and teacher. Educated in the US and Europe, he became a professor at the Peking National University and wrote many works on history and philosophy, including My Country and My People (1935), The Wisdom of Confucius (1938), The Wisdom of China and India (1942) and The Importance of Understanding (1960). He left China in 1936.

Lipatti, Dinu (Constantin) (1917-1950). Romanian pianist and composer, born in Bucharest. He studied in Bucharest, then in Paris with ${ }^{*}$ Cortot, ${ }^{*}$ Boulanger and ${ }^{*}$ Dukas. In his brief career he acquired a unique reputation as virtuoso and poetic interpreter. He died of Hodgkin's lymphoma, leaving a legacy of magnificent recordings.
Lipchitz, Jacques (1891-1973). French sculptor, born in Latvia. Of Polish-Jewish parentage, he worked in Paris from 1909 and was the first to produce Cubist sculpture. Later works were based on Biblical or mythological themes.

Lipperschey, Hans (c.1570-1619). Dutch inventor. A spectacle maker in Middelburg, he is usually credited with inventing the first telescope (c.1608), traditionally after inadvertently watching a child playing with a lens. ${ }^{*}$ Galileo soon improved Lipperschey's crude instrument.

Lippi, Filippino (1457-1504). Italian painter. Son of Filippo *Lippi, he was a pupil of ${ }^{*}$ Botticelli whose influence (as well as that of his father) is reflected in his works. He skilfully finished (1484-85) *Masaccio's frescoes in the Brancacci Chapel, Florence, and most of his subsequent work was done in Florence or Rome. At his best he can be compared with the greatest, but some of his work is pretentious, fussy and even vulgar. Among his best known pictures are the Madonna kneeling before the Child (Uffizi, Florence) and the Madonna and Child with St Jerome and St Francis (National Gallery, London).

Lippi, Fra Filippo (c.1406-1469). Italian painter. He was sent to a Carmelite monastery (1421) but in 1431 was allowed to leave the cloister. Some of the romantic incidents of his career are probably exaggerated or even invented. Whether he was captured by pirates is uncertain, but he seems to have been accused of forgery (1450) and to have abducted a nun who became the mother of Filippino ${ }^{*}$ Lippi. His earlier work was strongly influenced by *Masaccio, but later he freed himself and developed a more lively and dramatic style. Like Fra *Angelico, he painted mostly Madonnas and angels, but despite the radiance of their innocence he portrayed them with a closer approach to realism. His frescoes at Prato and Spoleto are considered his finest work.

Pittalugu, M., Filippo Lippi. 1949.

Lippmann, (Jonas Ferdinand) Gabriel (1845-1921). French-Jewish-Luxembourgish physicist. He held a chair of physics at the Sorbonne 1883-1921 and in 1891 demonstrated a method for photographing in colour, producing a faithful picture of the spectrum. He was awarded the 1908 Nobel Prize for Physics. Lippmann also predicted the nature of the 'piezoelectric' effect later discovered by Pierre ${ }^{*}$ Curie. During World War I he worked out a primitive type of radar that was used for detecting the presence of submarines.

Lippmann, Walter (1899-1974). American editor and author. His articles on political affairs, which appeared in the New York Herald Tribune (1931-66), were syndicated throughout the world. They were influential in the formation of public opinion in the US. He coined the phrase 'cold war' and acquired an 
enormous reputation as a pundit with a sound grasp of US and European affairs, but showed little interest in the 'third world'.

\section{Lipton, Sir Thomas Johnstone, 1st Baronet} (1850-1931). British merchant and sportsman, born in Glasgow. Of Irish parentage, after spending five years in various jobs in America he returned to Glasgow and in 1871 opened his first small grocery. Gradually, he built up a chain of shops throughout Great Britain, supplied by the tea, coffee and cocoa plantations he had acquired overseas. As his wealth grew, Lipton became a friend of ${ }^{*}$ Edward VII and a noted yachtsman. His five attempts (1899-1930) to win the America's Cup in Shamrock and its similarly named successors made him one of the best known sportsmen of his time.

Lisle, 1st Viscount, Arthur Plantagenet (1461/751542). English courtier, born in Calais. Son of the future king ${ }^{*}$ Henry IV and (probably) Elizabeth Wayte, he lived in the household of his half-sister Elizabeth of York, wife of *Henry VII and mother of *Henry VIII. Constable of Calais 1533-40, he wrote about 3,000 surviving letters, which are a valuable resource. He was arrested in 1540, released in 1542 and apparently died of excitement.

Lister, Joseph Lister, 1st Baron (1827-1912). English surgeon, born in Essex. He was the son of Joseph Jackson Lister (1786-1869) a Quaker wine merchant and amateur microscopist whose researches on the structure of red corpuscles gained him an FRS. The young Joseph studied medicine at London University and, having become MD and FRCS (1852), joined the famous Edinburgh surgeon, James Syme (whose daughter he married), as assistant. From 1855, when he was appointed assistant surgeon at the Edinburgh Royal Infirmary, and especially after his appointment as professor of surgery at Glasgow University (1860) and as surgeon to the Glasgow Royal Infirmary (1861), his reputation steadily mounted. It was not only for his surgical skill but for his investigations, which shed important new light on the involuntary muscles of eye and skin, on the causes of inflammation, on pigmentation and on coagulation of the blood. The major problem in surgery at the time was the high rate (25-60 per cent) of deaths from post-operative sepsis (partly a result of the introduction of anaesthesia, which had greatly increased the number of major operations performed, and had also lessened the need for speed). In the light of ${ }^{*}$ Pasteur's discoveries, Lister rejected the theory that the introduction of air was harmful. He concluded that the blood poisoning and suppuration that occur in a wound surgically or otherwise inflicted are due to micro-organisms (loosely called germs). To destroy these he used a spray of carbolic acid with such success that in his wards the post-operative mortality rate fell almost at once from 43 to 15 per cent. He found means to overcome the difficulty that carbolic acid is itself a tissue-irritant. He also introduced catgut, which is absorbed by the body, for ligatures instead of silk or hemp, the removal of which often caused renewed haemorrhage.

He was greater as a teacher and innovator than surgeon, designed special operating tables and surgical tools, introduced the use of white operating costumes instead of street dress, emphasised aseptic (excluding germs) rather than antiseptic (killing germs) measures, and used drainage tubes for wounds and incisions. Lister's successes were followed by further distinctions: he became a professor of surgery at Edinburgh (1869) and at King's College, London (1879), and was President (1895-1900) of the Royal Society. A baronetcy was awarded in 1883, in 1897 a peerage and in 1902 the OM and the Copley Medal. The Lister Institute of Preventive Medicine (founded 1903) preserves his name.

Goldman, M., Lister Ward. 1987.

Liszt, Franz (Ferencz) (1811-1886). Hungarian composer and pianist, born in Raiding. Son of a steward on Prince Esterhazy's estate, he studied music under his father, a keen amateur, and gave his first public performance as a pianist at the age of nine. With money provided by a group of Hungarian noblemen, he went to Vienna, where he studied under ${ }^{*}$ Czerny and ${ }^{*}$ Salieri, and won praise from ${ }^{*}$ Beethoven. From 1823 his tours, which included three visits to England, won him widespread admiration but after the death (1827) of his father, who had accompanied him, Liszt taught in Paris and came under the musical influence of ${ }^{*}$ Berlioz, *Paganini (whose works he transcribed for the piano) and *Chopin. His thought and way of life were affected by a friendship with the romantic novelist George *Sand, coincident (from 1833) with a love affair with the Comtesse d'Agoult, who bore him a son and two daughters, the younger of whom, Cosima, became the second wife of Richard *Wagner. Liszt parted from his mistress in 1839 and spent the next eight years making concert tours throughout Europe, in the course of which he reached the pinnacle of his fame as a virtuoso pianist. In 1847 he met the Princess Caroline zu Sayn-Wittgenstein, with whom he lived until 1865, when he entered the Franciscan Order and was known as 'Abbé Liszt'. Liszt became conductor of the ducal opera at Weimar in 1848 and thereafter ceased to play the piano professionally. In his new post he was a generous patron of many artists, producing several operas by Wagner, whom he supported financially, and helping Berlioz and ${ }^{*}$ Schumann. After his resignation (1858) he spent his remaining years mainly in teaching at Weimar, Budapest and Rome. He composed about 1300 works. Almost half are transcriptions. The finest of the 400 original compositions include the symphonic poems Tasso, Orpheus, Mazeppa and Prometheus, two piano concertos (1857 and 1863), the Dante Symphony (1856), the Faust Symphony (1853-56) and the Piano Sonata (1854). He wrote many 'Transcendental Studies' for piano, transcribed many songs and violin 
works as display pieces, and composed organ pieces and several major religious works including the oratorio Christus (1866). Liszt was one of the most important pioneers of the Romantic school in music. His invention of the one-movement symphonic poem influenced composers such as *Tchaikovsky and Richard *Strauss, while Wagner learned from his principle of thematic transformation. His bold harmonic innovations affected composers even in the 20th century. Contemporary critics considered Liszt the greatest virtuoso pianist of all time. By giving a complete solo recital for the first time and playing a whole program from memory he gave the concert pianist an unpredecented status. Moreover through his pupils, many of whom he taught without payment, his new pianoforte techniques shaped those of future generations.

Walker, A., Liszt. 3 vols, 1971, 1987, 1998; Watson, D., Liszt. 1990.

Littleton, Sir Thomas (1402-1481). English jurist. He was recorder of Coventry (1450), King's Sergeant (from 1455) and a judge of Common Pleas (from 1466). He wrote a notable textbook on land tenure (originally in legal French), on which Sir Edward *Coke later published a famous commentary, Coke upon Littleton (1628).

Littlewood, Joan (Maud) (1914-2002). British theatrical producer. With her repertory company, founded in 1945 and established (1953) at the Theatre Royal, Stratford, in East London, she became known for advanced ideas and techniques which included much improvisation and, in the manner of *Brecht, audience participation. Among the young playwrights who achieved success under her auspices were Brendan *Behan (The Quare Fellow) and Sheelagh Delaney (A Taste of Honey). Oh What a Lovely War! produced in 1963 after a short retirement, was an original and controversial treatment of World War I, later filmed.

Litvinov, Maksim Maksimovich (real name M. M. Vallakh) (1876-1951). Russian diplomat. An early Bolshevik and friend of *Lenin, he worked in London from 1907, married an English woman, and was appointed diplomatic agent to Britain after the 1917 Revolution. As Deputy Foreign Commissar 1921-30, 1939-46 and Foreign Commissar 1930-39 he had little authority in directing foreign policy, but attempted to make it more palatable. By leading Russia into the League of Nations (1934) and championing the cause of collective security, especially against Nazi Germany, he made Soviet policies more generally acceptable.

Liu Shaoqi (Liu Shao-ch'i in Wade-Giles) (18981969). Chinese Communist politician, born in Hunan. From a moderately rich peasant family, he studied in Moscow (1920), joined the CCP in 1921, worked with ${ }^{*} \mathrm{Li}$ Lisan, organised major strikes and was an official in the Communist Government of Jiangxi 1932-35. He suffered from tuberculosis and did not take part in the Long March, a significant omission. Regarded as one of the leading theoreticians of the Chinese Communist Party, he wrote the pamphlets How to be a good Communist and On the Party Struggle. He was Deputy Premier 1949-59 and succeeded *Mao as President of China 1959-68 until his expulsion from the party and denunciation as 'China's *Khrushchev ... a lackey of imperialism, modern revisionism and Kuomintang reactionaries ... a Renegade, Traitor and Scab'. Liu stood for a scientifically controlled urban industrial China against Mao's vision of 'revolutionary romanticism' and the spontaneity of the masses. He was imprisoned in 1967 , and was tortured to death. He was rehabilitated in 1980.

Liu Xiaobo (1955-2017). Chinese writer, critic and human rights activist, born in Changchun, Jilin. $\mathrm{He}$ taught at Beijing University, was imprisoned four times and sentenced to 11 years jail in December 2009. Awarded the Nobel Peace Prize for 2010 'for his long and non-violent struggle for fundamental human rights in China', his diagnosis of liver cancer led to an international campaign for his release for treatment in the US or Europe. He became the second Nobel Peace Prize winner to die in custody (Carl von *Ossietzky).

Liverpool, Robert Banks Jenkinson, 2nd Earl of (1770-1828). English Tory politician. Son of Charles Jenkinson, 1st Earl of Liverpool (1729-1808), leader of the 'King's friends' and his Anglo-Indian wife, he was educated at Charterhouse School and Oxford. Elected MP 1790-1803, he only took his seat in 1792 when he came of age. *Pitt appointed him to the Indian Board of Control 1793-96 and under his successor *Addington, he had a sudden promotion as Foreign Secretary 1801-04 and was responsible for the Treaty of Amiens (1802). Created Baron Hawkesbury in 1803, and Home Secretary 1804-06, 1807-08, on Pitt's death he declined to become Prime Minister. In 1808, he succeeded his father as Earl of Liverpool. In the most critical stage of the Peninsular War he was Secretary of State for War and the Colonies 1809-12. On Spencer *Perceval's assassination, he became Prime Minister 1812-27, holding office for 15 years until he had a stroke. He had some able ministers, including ${ }^{*}$ Canning, ${ }^{*}$ Castlereagh, ${ }^{*}$ Wellington and ${ }^{*}$ Peel, keeping together the liberal and reactionary wings of his party, by tact, experience and common sense. $\mathrm{He}$ opposed the slave trade and the Combination Acts, modified the criminal law but was ambivalent about Catholic emancipation. He guided his country through the last stages of the Napoléonic wars, the period of repression that followed and its more liberal aftermath. He was the first Prime Minister to wear trousers.

Gash, N., Lord Liverpool. 1984; Hay, W. A., Lord Liverpool. A Political Life. 2018. 
Livia (Livia Drusilla, also known as Livia Augusta) (58 BCE-29 CE). Roman patrician. Daughter of a senator, she married first a cousin, Tiberius Claudius Nero, and had two sons, *Tiberius, the future emperor, and Drusus. Her father and husband were opponents of Julius ${ }^{*}$ Caesar, and after his assassination the family was exiled in Greece. Octavian, later known as *Augustus, met her, fell in love, divorced his own wife and persuaded Livia to divorce her husband and marry him (38 BCE). Their marriage lasted for 51 years but was childless. Livia cultivated an image of domestic simplicity, spinning her own wool, but was suspected of involvement in intrigue and even murder. She was an important influence on Augustus, who adopted his stepson as heir. When Augustus died, the Senate gave Livia the title 'Augusta'. Tiberius soon resented his mother's interventions but she was posthumously deified in $42 \mathrm{CE}$ by her grandson ${ }^{*}$ Claudius, son of Drusus.

Livingstone, David (1813-1873). Scottish explorer and missionary, born at Blantyre, Lanarkshire. From the age of 10 he worked for 16 years in a local cotton mill. He read the missionary journals that his devout father received and also learnt Latin at evening classes. In 1832 he left the Church of Scotland to become a Congregationalist and was attracted by American revivalism. He studied science at Anderson's College, theology and Greek at Glasgow University and had some medical training at the Charing Cross Hospital, London (1838-40).

Having joined the London Missionary Society he was sent (1840) to the settlement in Bechuanaland created by Robert Moffat, and married his daughter Mary (1821-1862) in 1845. He began to explore and to carry the Christian message northwards and discovered Lake Ngami, now in Botswana in 1849. Having sent his wife and children to England in 1852, he started from Cape Town on a journey across Central Africa that ended (1856) at Quilimane at the mouth of the Zambezi River. In November 1855 he was the first European to see the great waterfall Mosi-oa-Tunya ('the smoke that thunders') which he named Victoria Falls.

On his treturn to England and the publication of Missionary Travels (1857), he was acclaimed by the public, but the London Missionary Society felt that he spent too much of his time in exploration. His next expedition (1858-64) was sponsored by the government. During this period his wife, and many helpers, died. He explored Lake Shirwa and much of the Lake Nyasa area, which he thought suitable for a mission and commercial centre, but the steamers sent out to him proved defective, and he found, to his indignant horror, that slave traders were using his discoveries to extend their activities. He published The Zambezi and its Tributaries (1865) on his return, and in March 1866 set out again, hoping to combine missionary work with settling the dispute concerning the sources of the Nile. He discovered Lakes Moero and Bangweulu (1867-68) and, after returning for rest to Ujiji, again struck westward and reached the River Lualaba, uncertain whether it was the Nile or, as it afterwards proved, the Congo. Meanwhile nothing had been heard of him at home until, in October 1871, he was discovered ('Dr Livingstone, I presume?'), once more in Ujiji, by H. M. *Stanley at the head of a relief expedition. Together they proved that Lake Tanganyika had no northern outlet, but, though ill, Livingstone refused to return with Stanley until he had made one more attempt to solve the Nile problem. He went back to Lake Bangweulu, but having reached the village of Chief Chetambo, was found dead one morning by his followers, aged 60. Despite all dangers, his embalmed body was carried to the coast and then taken to London for burial in Westminster Abbey.

Seaver, G., David Livingstone: his Life and Letters. 1957; Jeal, T., Livingstone. 1973.

Livy (Titus Livius) (59 BCE-17 CE). Roman historian, born in Padua. He became a member of the literary circle of the emperor ${ }^{*}$ Augustus. His greatest work, which took 40 years, was a history of the Roman people in 142 books, 35 of which survive. Books 1-10 (to 293 BCE) and Books 21-45 (218-167 BCE), which include the struggle with ${ }^{*}$ Hannibal in the Second Punic War, Livy wrote with the patriotic purpose of glorifying Rome. $\mathrm{He}$ consulted the earlier annalists and the Greek historian *Polybius but though he does not wilfully distort, he does not bring to bear any critical faculty. His narrative, however, seldom flags and his reputation as a writer has been maintained.

Walsh, P. G., Livy: His Historical Aims and Methods. 1961.

Llewellyn, Richard (né Richard Dafydd Vivian Llewellyn Lloyd) (1907-1983). Welsh novelist, born in Pembrokeshire, writing in English. His novel How Green Was My Valley (1939), a romantic chronicle of a 19th-century mining community, was an immediate success. Later books, moderately successful, did not have the background of the mining valleys with their strong character.

\section{Llewelyn ap Iorwerth see Llywelyn ap Iorweth}

\section{Llewelyn ap Gruffydd see Llywelyn ap Gruffudd}

\section{Llosa, Mario Vargas see Vargas Llosa, Mario}

Lloyd, Harold (Clayton) (1893-1971). American film actor and comedian, born in Nebraska. From 1912 he appeared in about 200 short, and 18 feature length, comic films and by the 1920s rivalled ${ }^{*}$ Chaplin and ${ }^{*}$ Keaton. He failed to make the transition to talkies but his films were successfully revived on television and he left a fortune.

Lloyd, John Selwyn Brooke, Baron Selwyn Lloyd (1904-1978). British Conservative politician. A barrister, he rose to be a brigadier in World 
War II and in 1945 entered parliament. He served in a succession of Conservative governments from 1951: as *Eden's Foreign Secretary 1955-60, he was the principal defender of the Suez campaign, then Chancellor of the Exchequer 1960-62, and Speaker of the House of Commons 1971-76.

Lloyd George, David, 1st Earl Lloyd George of Dwyfor (1863-1945). British (Welsh) Liberal politician, born in Manchester. After his father, William George, a teacher, died he was brought up in Wales by his mother and her brother, Richard Lloyd, a bootmaker. Educated at a village school, he became a solicitor, local councillor, and organiser of a rural union. Liberal MP for Carnarvon Boroughs 18901945, he was a Welsh nationalist, ardent Gladstonian, fierce opponent of the Boer War and the object of Conservative hatred. Under ${ }^{*}$ Campbell-Bannerman he became President of the Board of Trade 1905-08. As *Asquith's Chancellor of the Exchequer 1908-15 he was architect of the 'welfare state', introducing the Old Age Pensions Act (1908) and the National Insurance Act (1911). His Budget of 1909, providing for a graduated income tax, was rejected by the House of Lords, leading to a constitutional crisis resolved by the Parliament Act of 1911, which ended the veto power of the Lords over legislation. Originally opposed to World War I, he became the most vehement activist in the coalition Cabinet as Minister for Munitions 1915-16 and, after *Kitchener was drowned, Secretary of State for War 1916. He intrigued with Conservatives to overthrow Asquith, whose talents were ill-suited for war, and became Prime Minister, December 1916, holding office until October 1922. He had an uneasy relationship with his generals but worked closely with *Clemenceau and backed *Foch as Generalissimo. After the 'khaki' election of November 1918, called to capitalise on patriotic fervour, he won decisively but was inceasingly dependent on Conservative support in the House of Commons. He led the British delegation to the Versailles Peace Conference in 1919, and was at the peak of his influence. Personally mistrusted, he became increasingly notorious for his sexual exploits and amassed a fortune by selling knighthoods, baronetcies and peerages. In October 1922 he was forced from power when Tory MPs voted by majority to withdraw from the coalition. In the November 1922 election, won by Bonar *Law, the Liberals fell to third place, behind Labour, and the party never recovered. He attempted a reconciliation with Asquith, led the Liberal Party 1926-29, and (advised by *Keynes) proposed a vigorous economic program in the 1929 election.

A passionate orator, he was known as 'the Welsh wizard'. He published War Memories (1933-36) and The Truth about the Peace Treaty (1938). He received the OM in 1919 and an earldom in 1945. J. M. Keynes called him 'the most intellectually subtle' of the World War I leaders. In 1936 he visited *Hitler and was impressed, but he became an opponent of appeasement, helped to eject *Chamberlain in 1940 , declined *Churchill's offer of a seat in the War Cabinet and may have hoped for a return to leadership himself. His second son Gwilym (1894-1967) was first elected as a Liberal MP, then became a Conservative, rising to be Home Secretary and Minister for Welsh Affairs 1954-57, and was created Viscount Tenby in 1957. His daughter Megan (1902-1966) was a Liberal MP 1929-51, then transferred her allegiance and was elected as a Labour MP 1955-66.

Grigg, J. Lloyd George. 4 vols, 1973, 1978, 1984, 1985; Hattersley, R., David Lloyd George. The Great Outsider. 2010.

Lloyd Webber, Andrew, Baron Lloyd Webber (1948- ). British composer. Educated at Westminster, Magdalen College, Oxford and the Royal College of Music, he wrote a series of phenomenally successful musicals. They include Jesus Christ Superstar (lyrics by Tim Rice, 1970), Evita (1976), Cats (poems by T. S. *Eliot, 1981), The Phantom of the Opera (Richard Stilgoe and Charles Hart, 1986), Aspects of Love (Stilgoe and Hart, 1989) and Sunset Boulevard (1993). He also wrote a much performed Requiem Mass (1985). His second wife Sarah Brightman created most of his soprano leads. His brother Julian Lloyd Webber (1951- ) was a cellist, made many television programs and recordings and wrote Travels with my Cello (1984).

Llull, Ramon (1232/5-1315). Spanish theologian and mystic, born in Majorca. After a life of ease in his youth, he was converted by a vision and fired with the desire to convert all Muslims to Christianity. He became an Arabic scholar and also wrote Ars Generalis sive Magna which was to be the intellectual instrument of his mission. Having spent some 30 years in travelling Europe in the hope of getting support for his plan, he made a direct attempt to convert the Muslims of Tunis (1292) and Bougie (1306). Imprisonment and banishment were the only results. In a third mission he was stoned, and died on shipboard in sight of his native Majorca. In Llibre de Contemplació, which reveals the mystical side of his complex personality, he was a pioneer in the use of the Catalan language for serious works of this kind.

Llywelyn ap Gruffudd (c.1223-1282). Last sovereign Prince of Wales 1258-82. Trying to emulate the achievements of his grandfather, ${ }^{*}$ Llywelyn the Great, he overcame his brothers and exacted homage from other princes. He even obtained from *Henry III, fully occupied with his problems in England, recognition (1267) as Prince of Wales, but he overreached himself by refusing homage on *Edward I's accession (1272). War followed (1277) in which Llywelyn lost his title and all lands except Anglesey and Snowdonia. In 1281 he was goaded again into rebellion. His death in a skirmish in the following year facilitated Edward's conquest of Wales. 
Llywelyn ap Iorwerth (known as 'the Great') (d.1240). Prince of Gwynned 1195-1240. By first consolidating his ancestral lordships in North Wales and then gradually extending his power over rival princes to the south, he did more than any other single man to create the possibility of a Welsh national state. Moreover, by taking advantage of the difficulties of the English king *John, whose daughter he married, he was able to stem further AngloNorman aggression.

Lobachevsky, Nikolai Ivanovich (1793-1856). Russian mathematician. Professor of mathematics at the University of Kazan 1822-46, he proposed, in Principles of Geometry (1829-30), the first complete system of non-Euclidean geometry. He was dismissed from the university in 1846 and died in poverty.

Bonola, R., Non-Euclidean Geometry. Repr. 1955.

Lobengula (c.1833-1894). Matabele chief (from 1870). A section of the Zulu people, escaping (c.1820) from the tyranny of King *Shaka, had subdued the Mashonas and settled in what became known as Matabeleland. Here Lobengula was chief when he was persuaded (1888) to grant Cecil ${ }^{*}$ Rhodes mining rights in his territory (which later became part of Rhodesia, now Zimbabwe). He died a fugitive after being defeated by white settlers with whom he came into conflict.

Locke, John (1632-1704). English philosopher, born in Wrington, Somerset. Son of a lawyer, he was educated at Westminster School and Christ Church, Oxford, where he was later a tutor. He also became interested in science and began to practise medicine. Through his practice he met Lord Ashley, later 1st Earl of *Shaftesbury (with whose political ideas he was closely in tune), and became his secretary. After Shaftesbury's final disgrace (1682) Locke lived for five years in Holland. He returned to England after the accession of *William III and Mary and eventually became eminent as the provider of a philosophical basis for Whig doctrine. His greatest work, the starting point for empirical theories of philosophy, was his Essay Concerning Human Understanding (1690). All knowledge, he claims, derives from sense-experience. Every mind is initially a tabula rasa or blank slate upon which the lessons of sense-experience are subsequently written. This experience, in Locke's language, is of ideas, both those that result from sense impressions or sense-data, and those introspective ones that refer to the operation of the mind. The world, indeed, which gives rise to these ideas does not, in fact, reflect them in every way, some ideas (those of primary qualities, e.g. solidity and extension) having counterparts in the actual world, but others (those of secondary qualities, e.g. colour and taste) being dependent on our own perceptual equipment and not existing in the actual world. Locke's theory of knowledge and metaphysics, as has been pointed out, is in essence the 17th-century scientific view. His political ideas, as set out particularly in his treatise Civil Government (1690) are similarly tied to his age. He argues that the ruler of a state is to be regarded as one party to a contract, the other party being those over whom he rules. If the ruler breaks his contract by not serving the good end of society he may be deposed. Locke's contemporary influence was enormous and he became known throughout Europe as the philosopher of freedom. From 1691 Locke, already in ill health, found a home and tranquillity (except for four years from 1696 as Commissioner of the Board of Trade) with Sir Francis and Lady Masham at Otes, their house at High Laver, near Epping. His literary activity was mainly concerned with successive editions of his Essay and replies to criticism. In the anonymous Reasonableness of Christianity (1695) he brought to religion the same spirit of tolerance that he had already brought to politics, and sought to recall the Churches to scriptural simplicity from their obsession with dogma.

Cranston, M. W., John Locke: A Biography. 1957; Laslett, P., Locke's Two Treatises of Government. 3rd edn. 1988.

Lockhart, John Gibson (1794-1854). Scottish writer and editor, born in Lanarkshire. He studied at Oxford, met *Goethe in 1817 and married Walter *Scott's daughter, Sophie in 1820 . He edited the Quarterly Review 1825-53, disparaged the poetry of *Burns, *Shelley, *Keats and ${ }^{*}$ Tennyson and wrote several novels and biographies, notably the Life of Sir Walter Scott (7 volumes, 1837-38), understandably partisan, but once ranked as one of the greatest since *Boswell's Life of *Johnson.

Lockyer, Sir (Joseph) Norman (1836-1920). English astronomer and pioneer astrophysicist. A civil servant, not university educated, he worked at the War Office until 1875 but became an enthusiastic amateur astronomer. He later became director of the Solar Physics Laboratory at the Royal College of Science. He pioneered the use of the spectroscope for analysing the chemical composition of the sun, and he gave the name 'helium' to the new element that was discovered (1868) in the solar spectrum as a result of observations made independently by Lockyer and Pierre Janssen. $\mathrm{He}$ founded the scientific periodical Nature (1869) and was its editor 1869-1919. A pioneer of archeoastronomy, he was professor of astronomical physics at the Royal College of Science (now Imperial College), London 1885-1913. A prolific author on science and golf, knighted in 1897, he became President of the British Association 1903-04.

Lodge, Henry Cabot (1850-1924). American Republican politician, born in Boston. Educated at Harvard, he lectured in history there, edited the North American Review 1873-76 and the works of Alexander ${ }^{*}$ Hamilton, and was a US Congressman 1887-93. As a US senator 1893-1924, he was both imperialist and isolationist, successfully leading the fight against ratifying the Treaty of Versailles and US membership of the League of Nations (1920). 
His grandson, Henry Cabot Lodge, Jr (1902-1985) was US Senator from Massachusetts 1937-44, 194753. Ambassador to the United Nations 1953-60, Republican vice presidential candidate 1960, and Ambassador to South Vietnam 1963-64, 1965-67. In 1969 he became US delegate to the Paris peace talks.

Garraty, J. A., Henry Cabot Lodge, a Biography. 1953.

Lodge, Sir Oliver Joseph (1851-1940). English physicist. After helping in his father's business as a boy, he gained an exhibition at the Royal College of Science and was later a demonstrator at University College, London. In 1881 he became professor of physics at Liverpool University and was principal of Birmingham University 1900-19. He did pioneer work on wireless telegraphy, and invented the coherer, a tube loosely filled with iron filings, that could be used as a simple detector for electromagnetic signals. Later he devised the system of radio 'tuning' that became generally used. In later life Lodge became a convinced spiritualist and wrote widely on the subject. Among many academic and professional honours he was awarded (1887) the Rumford Medal of the Royal Society and a knighthood (1902).

Lodge, Thomas (1558?-1625). English writer. Son of a lord mayor of London, he is best known as the author of a romance Rosalynde (1590), the source of Shakespeare's As You Like It. He combined with a versatile literary career the study of law and medicine and freebooting expeditions to the Canaries (1588) and South America (1591). In addition to Rosalynde he wrote amorous sonnets, imitations of *Horace, translations from * Josephus, and historical romances. With Robert * Greene he wrote the play A Looking Glasse for London and England (1594) which exposed contemporary vice and demanded reform.

Tenrey, E. A., Thomas Lodge. 1969.

Loeb, Jacques (1859-1924). American biologist, born in Germany. His early work was concerned with the localisation of the brain's visual functions, but in 1891 he went to America, where his principal studies were connected with instinct and free will, leading to the investigation of behaviour and regeneration in the lower animals. Among the best known of his experiments was one in which he achieved a kind of artificial parthenogenesis, initiating, by chemical means, the development of a sea urchin's unfertilised egg. From 1910 he worked with the Rockefeller Institute for Medical Research.

Loewi, Otto (1873-1961). German-Jewish pharmacologist. Professor of pharmacology at Graz University 1909-38 and New York University 1940-45, he shared the Nobel Prize for Medicine in 1936 with Sir Henry *Dale for his discoveries on the chemical transmission of nerve impulses.
Loewy, Raymond Fernand (1893-1986). American industrial designer, born in Paris. Trained as an electrical engineer, he lived in the US from 1919, working first as a fashion illustrator, then as an industrial designer. He designed the Coca Cola bottle, Studebaker cars, biscuits for Nabisco, domestic consumer goods, and created logos for Lucky Strike cigarettes and the US Post Office.

Lohmann, (Hans) Karl Heinrich Adolf (18981978). German chemist. In 1929 he identified and named ATP (Adenosine triphosphate), 'a molecular unit of currency', which transfers energy between cells and is a precursor of DNA and RNA. It was synthesized by A. R. *Todd in 1948.

Lombard, Peter (c.1100-1160). Italian theologian. $\mathrm{He}$ studied at Bologna and in Paris, where he eventually became bishop (1159). He was known as the 'master of sentences' from his four books, in which sentences culled from *Augustine and other early Christian Fathers were accompanied by comments from other religious writers, the whole providing a systematic discussion of various aspects of Christian faith.

Lombroso, Cesare (1836-1909). Italian criminologist. After studying mental diseases he became professor of forensic medicine at Turin. $\mathrm{He}$ evolved the theories, set out in his books The Delinquent Man (1876) and The Man of Genius (1888), that criminals belong to a distinct anthropological type and that genius springs from some form of physical or mental illness. His theories have been largely rejected, but his vast collection of anthropometric data on criminals was of the greatest value to ${ }^{*}$ Bertillon and other criminologists. His observation, that when in the course of interrogation a person tells a lie his blood pressure changes, significantly anticipated the modern lie-detector.

Lomonosov, Mikhail Vasileivich (1711-1765). Russian scientist, born in Archangel. Son of a shipowner, he studied in many places, including Kiev, St Petersburg, Moscow, and Marburg (with Christian Wolff). He first showed talent as a linguist and philosopher, but increasingly inclined towards chemistry and mathematics. Mining and mineralogy then caught his interest, and he studied at Freiberg under Johann Henckel. He returned to St Petersburg in 1741 , and spent the rest of his life there. He was imprisoned (1743-44) for the vehemence of his protests against corruption in society. Much of his work in physics consisted of attempts to find, within the framework of corpuscularian matter theory, adequate theoretical explanations of heat, gravity and weight. He anticipated ${ }^{*}$ Lavoisier in proposing (1748) the law of the conservation of mass and rejecting the phlogiston theory. He also performed mineralogical experiments, attempted to provide a theory of electricity, and kept tables of the weather. He was 
the first to lecture about science in Russian. He took keen interest in the mineral resources of Russia, wrote about Russian geography, and speculated on the Arctic regions. A man of great culture, he wrote a large body of poetry, much of it religious, and made compilations of Russian history and antiquities. He also wrote a grammar and a rhetoric textbook, made the first accurate maps of Russia and became the virtual founder (1755) of the University of Moscow, renamed Lomosonov in 1940. He was buried as a public hero, but ${ }^{*}$ Catherine the Great destroyed his political writings. Craters on the Moon and Mars, asteroid 1379 Lomonosowa, and a Moscow airport are named for him.

London, Jack (John Griffith) (1876-1916). American novelist, born in San Francisco. Largely self-educated, he gathered material for his highly successful adventure stories from his early experiences as (among other occupations) a sailor, a gold prospector and a tramp. His novels, several of which are set in Alaska include The Call of the Wild (1903), The Sea Wolf (1904) and The Iron Heel (1907). Martin Eden (1909) and John Barleycorn (1913) are autobiographical. He also wrote socialist tracts and never lost his revolutionary fervour. He committed suicide during a bout of depression. His works were widely read in Russia.

Long, Crawford Williamson (1815-1878). American surgeon. In 1842 he used ether while removing a tumour from a boy's neck, but as this and subsequent cases were unpublicised for many years, he had no effect on the development of anaesthesia.

Long, Huey Pierce (1893-1935). American politician. A farmer's son, he became a lawyer, gained control of the Democratic party machine in his native Louisiana and built it up to sustain his personal power. He was elected Governor of the state 1928-31 and US Senator 1931-35. His 'Share the Wealth' campaign, which he pursued with all the arts of a demagogue, gained him considerable popularity and the nickname 'the Kingfish', derived from his slogan 'Every man a king'. He also became famous for the prolonged 'filibusters' by which he held up the business of the Senate. In Louisiana his dictatorial rule, secured by intimidation and falsification of election results, ended only with his assassination. His son Russell Billiu Long (1918-2003) was US Senator 1948-87 (elected at the minimum constitutional age of 30). Huey's brother Earl Kemp Long (1895-1960) was Governor of Louisiana 1939-40, 1948-52, 1956-60. Towards the end of his third term he was abducted, taken to Texas and certified insane. However, he soon escaped and resumed the governorship, claiming that he had been victimised by extreme segregationists.

Liebling, A. J., The Earl of Louisiana. 1961; Williams, T. H., Huey Long. 1970.
Longfellow, Henry Wadsworth (1807-1882). American poet, born at Portland, Maine. Educated at Bowdoin College, he became professor of modern languages there 1829-36 and at Harvard University 1836-54. Craigie House in Cambridge, Mass. is preserved as a literary shrine. Longfellow was at his best in long narrative poems, e.g. Evangeline (1847), Hiawatha (1855) an Indian epic later set to music by Samuel Coleridge-Taylor, and The Courtship of Miles Standish (1863). Tales of a Wayside Inn (1863 with a further series in 1872) contained such poems as Paul Revere's Ride. In an earlier collection (1842) had appeared The Wreck of the Hesperus, The Village Blacksmith and Excelsior. Longfellow himself took special pride in the Christmas trilogy, an attempt to reconcile religion with modern thought. The first part, The Golden Legend (1851), is a particularly successful reconstruction of a medieval story. Longfellow's enormous reputation has declined, much of his poetry is now seen to be superficial, and the predictable rhythms and cadences of his verse have often been parodied. His translation of *Dante's The Divine Comedy (1867, further revised), a major achievement, is still available as a book, on CDs and as a download. Longfellow was twice widowed. His prose-romance Hyperion (1836) expressed his grief at the death of his first wife. His second wife Frances Elizabeth Appleton, by whom he had six children, was burned to death.

Wagenknecht, E. C., Henry Wadsworth Longfellow: Portrait of an American Humanist. 1966.

\section{Longford, Earl and Countess of see Pakenham}

Longman, Thomas (1699-1755). English bookseller and publisher. The son of a merchant from Bristol, he bought a bookseller's shop in Paternoster Row, London, in 1724. One of his best-known projects was a share in the publication of Samuel *Johnson's Dictionary. He was followed by a nephew, also Thomas (1730-1797), and then by Thomas Norton Longman (1771-1842) and his son Thomas (1804-1879). The company published works by *Wordsworth, *Southey, ${ }^{*}$ Coleridge, ${ }^{*}$ Scott and ${ }^{*}$ Macaulay.

Longstreet, James (1821-1904). American soldier, born in South Carolina. One of the leading Confederate generals, but with a tense relationship with Robert E. *Lee, he fought in the battles of Bull Run (1862), Antietam (1862), Fredericksburg (1862) and Gettysburg (1863). After the Confederate defeat, he supported U.S. *Grant's administration and 'Reconstruction', was Minister to the Ottoman Empire 1880-81 and became a Catholic convert.

Lonsdale, Frederick (Leonard) (1881-1954). English playwright. Son of a tobacconist, he wrote witty and fast-moving comedies of upper class life, with a swift repartee in the tradition perfected later by Noël *Coward. His best known plays are The Last of Mrs Cheyney (1925) and On Approval (1927).

Donaldson, F., Freddy Lonsdale. 1957. 
Lonsdale, Dame Kathleen (née Yardley) (19031971). Anglo-Irish crystallographer, born in Kildare. Educated at University College, London, she worked with W. H. *Bragg in developing X-ray analysis of crystals. A pacifist and Quaker, she was imprisoned briefly during World War II. She and the biochemist Marjory Stephenson were the first women to be elected FRS (1945) and she became professor of chemistry at University College, London, 194968. 'Lonsdaleite', a hexagonal diamond, found in meteorites, the hardest substance known, was named for her.

Loos, Adolf (1870-1933). Austrian architect, born at Brno. He studied in Germany and the US and became an admirer of the American architect Louis *Sullivan, returning to Europe to head the attack on 'Art Nouveau' and excessive decoration, designing buildings of uncompromising severity. His ideas were published in his Ornament and Crime (1908). He pioneered the use of reinforced concrete in building municipal housing in Vienna. In 1923 he settled in Paris.

Loos, Anita (1888-1981). American writer. Her two books, Gentlemen Prefer Blondes (1925) and its sequel But Gentlemen Marry Brunettes (1928) with their new style of sophisticated humour, achieved tremendous success.

\section{Lope de Vega see Vega Carpio, Lope Félix de}

López Obrador, Andrés Manuel (known as AMLO) (1953- ). Mexican politician, born in Tabasco. Trained as a political scientist, he was a member of several parties and became Head of Government (i.e. Mayor) of Mexico City 2000-05. He lost narrowly in the Presidential elections of 2006 and 2012, winning decisively in 2018.

Lorca, Federico Garcia (1899-1936). Spanish poet, born near Granada. Much of his poetry was inspired by the cave-dwelling gypsies of the Granada area. This became apparent in his Poema de Cante Jondo (1931), his first important work, and in Romancero Gitano which fully established his fame. Here he sees the endless fight of the gypsy against the world around him as a kind of symbolic struggle. The poem Oda del Rey de Harlem with its suggestion of jazz rhythms is one of several recalling a visit to America (192931). On his return he made a new reputation as a playwright with Blood Wedding Yerma and The House of Bernarda Alba. Though he belonged to no political party Lorca was shot by the Falangists at the outbreak of the Civil War.

Brown, G. G., A Literary History of Spain. Vol. 6. 1972.

Lord, Thomas (1755-1832). English sportsman, born in Yorkshire. He was noted as the founder of Lord's cricket ground in St John's Wood, the home of the Marylebone Cricket Club since 1787.
Lorentz, Hendrik Antoon (1853-1928). Dutch physicist. Professor of mathematical physics at Leyden 1878-1912, he was an authority on *Planck's quantum theory, to which he made important contributions. His studies on the application to moving bodies of *Maxwell's theory of electromagnetism helped to prepare the way for *Einstein's formulation of the theory of relativity. Lorentz attempted to unify the mathematical treatment of light, electricity and magnetism. One of the results of his work was his explanation of the Zeeman effect. He shared, with *Zeeman, the Nobel Prize for Physics (1902).

Lorenz, Konrad (Zacharias) (1903-1989). Austrian ethologist, born in Vienna. Son of a surgeon, he was educated at the University of Vienna and later lectured there in comparative anatomy and animal psychology. Working from the family home at Ahtenberg in the 1930s, he made comprehensive studies of how animals behave in natural environments and became known as the 'father of ethology'. He wrote both scholarly and popular books, e.g. King Solomon's Ring (1949, English translation 1952), Man Meets Dog (1950, 1954) and On Aggression (1963, 1966). In 1973 he shared the Nobel Prize for Physiology or Medicine with Karl von *Frisch and Nikolaas *Tinbergen. Lorenz was sometimes criticised for undue emphasis on genetically fixed (innate) action patterns and for extrapolating animal behaviour to humans.

Nisbet, A., Konrad Lorenz. 1976.

\section{Lorenzo the Magnificent see Medici}

\section{Lorrain(e), Claude see Claude Lorrain(e)}

Los Angeles, Victoria de (1923-2005). Spanish soprano, born in Barcelona. She toured extensively as a recitalist, and won great success in opera in London, New York and Milan.

Lothair I (799?-855). King of the Franks 843-55, Roman Emperor 817-855. Son of the emperor *Louis $\mathrm{I}$, and grandson of ${ }^{*}$ Charlemagne, he was made coEmperor in 817 but his father's arrangements in the following year for the partition of the Frankish empire between his sons after his death, was followed by feuds and fighting between the members of his family which continued almost without intermission for the rest of the reign. Lothair's claim to be sole emperor on his father's death (840) was followed by renewed fighting with his brothers Louis and Charles which ended with the partition set out in the Treaty of Verdun (843), by which Lothair retained the imperial title but only that portion of imperial territory bounded by the rivers Rhine, Meuse, Saône and Rhône. This area, named Lotharingia after him and steadily reduced by the encroachment of its neighbours, was the Lorraine of future history. This partition marked the end of the Carolingian Empire. 
Loti, Pierre (pseudonym of Louis Marie Julien Viaud) (1850-1923). French writer. He served as a naval officer for most of his adult life and spent some years in the South Seas, Indochina, Japan and China during the Boxer Rising. He retired as captain in 1910 but returned to fight in World War I. He wrote memoirs, descriptions of his voyages, and a number of very popular novels that are notable for their sensuous descriptions, their vein of romantic melancholy and their power of evoking the exotic places and peoples among whom he had lived so long. His novels include Pêcheur d'Islande (1886) Madame Chrysanthème (1887), Ramuntcho (1897) and Désenchantées (1906). He was a member of the Académie française from 1891.

Lotka, Alfred J(ames) (1880-1949). American biomathematician, statistician and demographer, born in Lviv (now in Ukraine) to US parents. Educated at Leipzig, Birmingham and Cornell universities, after years of teaching and government work, he became an actuary with the Metropolitan Life Insurance Co. and published major studies on the mathematical implications of biological and societal change, e.g. ageing, population growth and distribution, demographic movement. In Elements of Physical Biology (1925), he anticipated anthropogenic climate change.

Lotto, Lorenzo (c.1480-c.1556). Italian painter, born in Venice. Influenced by ${ }^{*}$ Bellini, he was an acute observer, a prolific painter of altarpieces and portraits, and retired to a monastery in 1554 .

Loubet, Emile François (1838-1929). French Radical politician. He served as a senator 1885-99, Premier 1892, and President of the Senate 1896-99. His term as President of France 1899-1906 was marked by the 'Entente-Cordiale' with England (1904), the separation of Church and State (1905), and the conclusion of the *Dreyfus case.

\section{Louis I and II. Kings of Bavaria see Ludwig I and II}

Louis (Ludwig) I (known as 'the Pious') (778-840). King of the West Franks (Francia, later France) and Emperor of the West 814-40. Born in Aquitaine, the third son of *Charlemagne, his father made him coEmperor in 813 and he succeeded to the throne the following year. In 816 the Pope went to Rheims and placed the crown upon his head, an assertion of papal supremacy which pointed to the controversies of the future. Louis' first acts were aimed at cleansing the court of profligacy, even his own sisters were sent to convents. As a ruler, however, he was quite inadequate and his attempts (818) to arrange for the partition of the empire after his death between his three sons, *Lothair, Pepin and Louis (the German) opened a period of strife that outlasted his reign. Matters became worse when his second wife, Judith of Bavaria, gave birth to the future ${ }^{*}$ Charles the Bald: that he should have a kingdom of his own, and her character, which enabled her to dominate her husband, introduced new and even more disruptive elements into the family struggle, which was still raging when Louis died, worn out and broken hearted.

Louis II ('la Bègue': 'the Stammerer') (846-879). King of the West Franks 877-79. Nephew of the Emperor ${ }^{*}$ Charles II (the Bald), his succession was shared by his son Louis III (c 862-882), who reigned 879-882 and defeated the Vikings. Louis IV (d'Outremer, i.e. the foreigner) (921-954), was exiled in England until installed as King by nobles at a time of civil war, and reigned 936-54. His grandson Louis V ('le Fainéant', i.e. Do-nothing) (967-987), the last of the Carolingians, reigned 986-87, died childless and was succeeded by Hugues *Capet.

Louis VI ('le Gros': 'the Fat') (1081-1137). King of the Franks 1108-37. Of the Capetian dynasty, he faced constant attack from *Henry I of England and the Holy Roman Emperor *Heinrich V, but strengthened royal control of his kingdom. He married *Eleanor of Aquitaine but this was annulled and she married the future *Henry II of England. He fought (1147-49) in the unsuccessful Second Crusade. His son Louis VII (the Young) (1120-1180), reigned 1137-80.

Louis VIII (1187-1226). King of France 1223-26. Son and successor of *Philippe II, Auguste before he came to the throne, he was offered the English crown by a group of barons who wished to depose King *John. He arrived in England (1216) and was proclaimed King, but was forced to withdraw when John's death deprived him of baronial support. As King, Louis took over the campaign against the Albigensian heretics and made important gains in Languedoc.

Louis IX, St (Louis de Capet) (1214-1270). King of France 1226-70, canonised 1297. Born in Poissy, son of *Louis VIII and Blanche of Castille, during his minority his remarkably capable mother was regent and brought the Albigensian war to an end, ensuring a tranquil opening to his period of personal rule. The first disturbance resulted from his investiture (1241) of his brother with the government of Poitou. The feudatories rose in rebellion and invoked the aid of *Henry III of England, who crossed to France in their support. Louis' victory enabled him to acquire the north of Aquitaine at English expense. In 1244 he fell ill, and was inspired by gratitude for his apparently miraculous recovery to lead the Seventh Crusade (1248-54) against Egypt, where he was captured by the Saracens (1250). When ransomed, he spent two years in the Holy Land, to return (1254) on the death of his mother, whom he had left as regent. Back in France, Louis ruled with wisdom and firmness, improving the administration of law and taxes. He expanded the power of the Inquisition in charges of heresy, but instituted the principle of presumption of innocence in civilian trials. Architecture flourished in his reign during which the cathedrals of Chartres, Amiens and 
Beauvais took shape and the beautiful Sainte Chapelle, Paris was built (1246-48) by *Pierre de Montreuil, at his direction, to house relics acquired in the Crusades. He was regarded as the ideal medieval king, religious but not bigoted nor unduly subservient to the Church, simple in habits, friendly and popular. In 1270 he embarked upon the Eighth Crusade, invading North Africa but he was soon captured, then ransomed. His army was weakened by disease and Louis died of dysentery at Carthage, near Tunis.

Pernond, R. (ed.), Le Siècle de Saint Louis. 1970.

Louis X (le Hutin) (1289-1316). King of France 1314-16. Son of *Philippe IV, he was dominated by his uncle Charles of Valois and gave important concessions to the barons.

Louis XI (1423-1483). King of France 1461-83. Born in Bourges, son of ${ }^{*}$ Charles VII, even as a young man he showed his gift for dissimulation and was twice exiled. Known as 'the universal spider' ('universelle aragne), as king he saw as his main task the strengthening of the monarchy, a course that brought conflict with the great feudal lords. The chief of these was *Charles the Bold, from 1467 Duke of Burgundy, and the struggle between these two and the combinations of power allied with each lasted throughout his reign. Louis' principal weapons, dissimulation, corruption, treachery and intrigue account for his sinister reputation, but his cause was no more selfish and far less harmful to the country than that of his opponents. On one occasion, Louis, relying on his wits to outmatch those of Charles, overreached himself: almost unguarded he visited (1468) the Duke at Peronne. His arrival coincided with the news of an uprising at Liège (then part of the Burgundian heritage), thought to be fomented by Louis. Confronted with Charles' rage, he barely escaped with his life after making the most humiliating concessions. The English Wars of the Roses provided another occasion for the rivals to take different sides, Louis favouring Lancaster, Burgundy York, but when the triumphant Yorkist, *Edward IV, invaded France, Louis found a wedge to split the alliance and bribed him to depart. The final account was settled only when (1477) Charles, embroiled with the Swiss and with René of Lorraine, both heavily subsidised by Louis, was defeated and killed. Louis seized the opportunity to annex the provinces of Burgundy and Artois, and Charles' heiress, Mary, managed to save her inheritance in the Netherlands only by marrying Maximilian of Austria. By the time of his death Louis, by contrivance or accident, had gained in addition Maine and Provence, Roussillon and Cerdagne, Anjou and Guienne, and had rid himself of nearly all the nobles who had taken sides against him. It was thus an immeasurably strengthened monarchy he left to his son, *Charles VIII. His advisors (rather than ministers) were masters of corruption and intrigue, such as the barber Olivier le Dain, his notorious
Cardinal La Balue, who was caged on the walls of Loches for betraying his master's secrets. Louis appears in *Shakespeare, *Scott and Victor *Hugo.

Kendall, P. M., Louis XI: The Universal Spider. 1970.

Louis XII (1462-1515). King of France 1498-1515. He succeeded his brother-in-law, ${ }^{*}$ Charles VIII, and his first aim was to retain Brittany by marrying Charles' widow *Anne, who would otherwise inherit. The obstacle, his own wife Jeanne, daughter of *Louis XI, was removed by dissolution of the marriage with the Pope's connivance, gained by the bestowal of a dukedom and a pension upon the latter's son Cesare * Borgia. Married to Anne, Louis pursued his dynastic claims in Italy, he succeeded in ousting Lodovico *Sforza from Milan, and, by coming to a bargain with his rival, *Ferdinand of Spain, was able to expel the king of Naples and share the spoils. The unnatural partners soon fell out and a catastrophic French defeat on the Garigliano led to the expulsion of the French. Louis' subsequent attempts to maintain and enlarge his hold on northern Italy led to a bewildering series of shifting alliances and even more confusing campaigns, but by the end of his reign French power in Italy was broken. Despite his disastrous foreign policy, Louis was popular in France and the country was prosperous. On the death (1514) of Anne, he married the English princess Mary, sister of ${ }^{*}$ Henry VIII, but almost immediately the accompanying festivities brought about the death of the ailing king.

Louis XIII (1601-1643). King of France 1610-43. Son and successor of ${ }^{*}$ Henri IV, his personal part in the events of his reign was small. Under the regency of his mother *Marie de Médicis the early years saw the Huguenots in rebellion and the nobles competing for power. When he was 16, Louis tried to assert himself by entrusting power to his favourite, Charles Albert de Luynes, whose incompetence and unpopularity provoked renewed civil war. Fortunately his death (1621) paved the way for the rise to power of ${ }^{*}$ Richelieu who entered the council in 1622 and from 1624 exercised almost supreme power. The years of his rule were marked by France's skilful intervention in the Thirty Years' War, the prelude to a long period of greatness. Not the least of Richelieu's triumphs was the reconciliation, after a long estrangement, of Louis and his wife Anne of Austria, with the result that in 1638 a dauphin, the future *Louis XIV, was born.

Louis XIV (Louis Dieudonné; known as le Grand Monarque or le Roi Soleil) (1638-1715). King of France 1643-1715. Born at St Germain-en-Laye, under the will of his father, *Louis XIII, his mother Anne of Austria became regent for the boy king, but the substance of power she confided to ${ }^{*}$ Richelieu's successor Cardinal *Mazarin. The Thirty Years' War, ended triumphantly for France by the Treaty of Westphalia (1648), was followed by the civil war known as the Fronde (after the frondeurs or stone-slingers in Paris street brawls). This began as a constitutional 
struggle by the Paris parlement and developed into an attempt to gain power by sections of the nobility, mortified at Mazarin's exclusion of them from the tasks and perquisites of office. The insurrection failed, helped though it was by Spain, which in 1659 came to terms cemented by Louis' marriage (1660) with *Maria Theresa, daughter of ${ }^{*}$ Felipe IV. It was thus a peaceful and united country over which, on the cardinal's death (1661), Louis began his personal rule. From the first he was determined that neither an over-powerful minister nor factions of the nobility should share in the function of government, he became his own Prime Minister and with unremitting industry and unfailing regularity presided over the daily meetings of his council. He chose his ministers carefully and they were seldom changed. The best known were *Colbert, who restored financial stability, encouraged industry and created a strong navy, and *Louvois, who was responsible for creating the strongest army in Europe. The main weakness of a system by which every aspect of government centred on the king and his small ministerial entourage was that as the king grew older the machinery of government also showed down. Ministers were replaced by lesser men and the brilliant successes of the early years were later dimmed by setbacks.

Since the monarchy was the centre of power, Louis proceeded to glamorise it. He built the palace of Versailles, Europe's largest, between 1661 and 1710, using the architect *Mansart and the landscape designer ${ }^{*}$ Le Nôtre and lived there from 1682. Versailles not only reflected the King's love of grandeur but was deliberately intended to impress the world with the greatness of the monarchy and the glory of France. There gathered round him at Versailles not only ministers, functionaries and courtiers but men of every kind of genius, e.g. ${ }^{*}$ Molière, ${ }^{*}$ Racine, ${ }^{*}$ Poussin, ${ }^{*}$ Lully. Louis' foreign policy matched his grandiose taste in architecture. His first efforts to seize the Netherlands and the Franche Comté (on behalf of his wife after Felipe IV died) were partially foiled, but as his diplomatic skill and the strength of the army grew so did his ambitions. He failed to subdue Holland in the long war which opened in 1672, but gained considerable successes over his Habsburg opponents, the Emperor and the King of Spain. The peace of Nijmegen (1678) left France with the Franche Comté and the frontier towns of Flanders, turned by *Vauban into almost impregnable fortresses. Louis at once used these gains as bases for further encroachments but Europe was now fully alarmed. William of Orange, infinitely strengthened when (1689) he became *William III of Great Britain, patiently built up coalitions against Louis, resulting in the War of the League of Augsburg (1689-97), which marked a decline in French power, for though Louis lost only minor territories (chiefly Luxembourg) he had to disown *James II and recognise William.

France might have suffered only temporary exhaustion had not Louis been unable to resist the temptation to accept, on behalf of his grandson Philippe, the legacy of Spain bequeathed by the childless ${ }^{*}$ Charles II.
In the War of Spanish Succession (1702-13), of which *Marlborough was the hero, he met with a series of defeats. He lost, thanks to diplomacy, little territory, and that mainly colonial, and *Felipe $\mathrm{V}$ continued to rule in Spain, but Louis' glory was irretrievably tarnished and the country's finances were in ruins. During this long period of fighting, the Edict of Nantes, which gave security and privileges to the Huguenots, was repealed (1685). Louis' motives were partly religious but mainly sprang from his desire for administrative unity. The consequent emigration of many of the most skilled workers and merchants was a great loss. The king's private life seldom interfered with his task of kingship. His three important mistresses were Louise de la Vallière, Madame de *Montespan, and Madame de *Maintenon, and he secretly married the last after the death (1683) of Maria Theresa. In the latter part of his reign, public misfortunes were matched by private grief. One after another members of the royal family died and it was his great-grandson who succeeded as *Louis XV.

Mitford, N., The Sun King. 1966; Wolf, J. B., Louis XIV. 1968; Dunlop, I., Louis XIV. 2000; Treasure, G., Louis XIV. 2001; Mansel, P., King of the World. The Life of Louis XIV. 2019.

Louis XV (known as le bien-aimé) (1710-1774). King of France 1715-74. Born at Versailles, son of Louis, Duke of Burgundy (d 1712), he succeeded his great-grandfather *Louis XIV at the age of five. France was then ruled by a regency for the third successive period, but neither the regent, the indolent, dissolute Duke of Orléans, nor his creature, the infamous Guillaume Dubois, showed talent for government. The main events were a useless war against Spain and the financial scandal caused by William *Law. Louis came of age in 1723 and in 1725 married Marie, daughter of Stanisław * Leszczyński, the deposed King of Poland. In 1726 the government came into the capable hands of Cardinal *Fleury and there followed a long period of tranquillity (broken only by the War of Polish Succession), in which France was at last able to rebuild its shattered economy and regain prosperity. Fleury died soon after the opening of the War of Austrian Succession (1741-48), to which he had reluctantly assented. In this war France supported *Friedrich II ('the Great') of Prussia against Austria and England, but a change of alliances was organised by the Marquise de *Pompadour, the mistress now in control of the king's will, and her chosen minister, the Duc de *Choiseul, and in the Seven Years' War (1756-63) France was allied against England and Prussia. The expense of these two wars, in which Canada and many other colonial possessions were lost by France, accelerated the coming of the Revolution. At Versailles, the king, intelligent and good-natured, with his mistresses (La Pompadour, *du Barry and many more) lived amidst an extravagant court.

Gooch, G. P., Louis XV. The Monarchy in Decline. 1956. 
Louis XVI (Louis-Augustus) (1754-1793). King of France 1774-92. Born at Versailles, son of the Dauphin Louis (1729-1765) and grandson of *Louis $\mathrm{XV}$, he was 20 when crowned and had already been married for four years to *Marie Antoinette, youngest daughter of *Maria Theresa. Until his phimosis was relieved by an operation he was unable to consummate his marriage for seven years. To his wife he remained devoted, but her frivolity and extravagance and her ingrained opposition to political changes were constantly harmful to her husband's popularity.

The early part of the reign witnessed valiant efforts by ministers such as *Turgot and ${ }^{*}$ Necker to sort out the financial tangles, but as soon as a serious attempt was made to tax the nobles and the privileged classes the court party, encouraged by the queen, forced their dismissal. Matters had become worse owing to France's intervention on the American side in the War of Independence for, though the result assuaged French pride after the losses of the Seven Years' War, it increased the burden of debt and popularised the ideas of constitutional liberty favoured by the colonists. Financial controllers, ${ }^{*}$ Calonne and Brienne, failed in turn and at last in 1788 Necker, recalled, demanded the summoning of the EstatesGeneral. In May 1789, at Versailles, this body met for the first time since 1614. The tiers-état (third estate or commons), representing the merchant classes and more liberal elements, decided to sit as a 'national assembly', in which members of the other estates, the nobility and the clergy could (though in fact few did) take part. This was the first revolutionary act. In July the Bastille was taken by the Paris mob and in October the royal family was brought by a triumphant crowd to Paris. Louis, well-meaning but slow witted, became progressively less able to control events. In April 1791, *Mirabeau, who might have guided him to constitutional safety, died. In June the royal family, under the queen's influence, made a ludicrous attempt to flee the country but were caught at Varennes and ignominiously brought back. The king was soon at loggerheads with his legislative assembly, at the queen's instigation, he and she wrote secretly to their fellow monarchs for aid. By 1792 France was at war with Prussia and Austria. The king's part was suspected and in August the Tuileries palace was stormed by the mob. The royal family, which had taken refuge in the Assembly, was imprisoned. In September 1792 the newly elected National Convention deposed Louis and proclaimed the republic. He was brought to trial, sentenced on 20 January and guillotined the following day a brave, bewildered, unfortunate man. His son Louis (17851795?), proclaimed by the monarchists as Louis XVII, was said to have died in prison (June 1795), but there were persistent claims that he was smuggled out of France. Many pretenders later came forward. Pierre Poiret (d 1856) who lived in the Seychelles had some advocates, so did J. J. *Audubon. Louis XVI's other child, Marie Therese (1778-1851), married her cousin, son of ${ }^{*}$ Charles $\mathrm{X}$, to become Duchess
d'Angoulême and a figure of some importance in the days of the revived monarchy after *Napoléon's fall.

Padover, S. K., Life and Death of Louis XVI. Rev. ed. 1963; Hardman, J., Louis XVI. 1993.

Louis XVIII (Louis-Stanislas-Xavier) (1755-1824). King of France 1814-15, 1815-24. Younger brother of *Louis XVI, he was Comte de Provence, known as 'Monsieur', thus avoiding confusion over the use of Christian names. During the Revolution, he became an emigré (1791) and after his brother's execution and his nephew's death (1795) took the title of Louis XVIII and was recognised as king by monarchists. $\mathrm{He}$ moved his court to Brussels, Coblenz, Verona, Mittau (now in Latvia) and Stockholm, maintaining links between the various groups of monarchist exiles, but not until *Napoléon fell (1814) was he able to return to France and take up his kingship. Napoléon's escape from Elba forced him to withdraw to Ghent but after Waterloo he resumed his throne. He hoped to achieve national conciliation by mild constitutional rule, but he had neither the strength of will nor the ability to prevent the government passing into the hands of the ultra-royalists, led by his brother, the future ${ }^{*}$ Charles X.

\section{Louis (Bonaparte). King of Holland see Bonaparte, Louis}

Louis, Joe (Joseph Louis Barrow) (1914-1981). African-American boxer, born in Alabama. He grew up in desperate poverty, and his family moved to Detroit. He won the world heavyweight boxing championship in 1937 and retained it until 1949, when he retired undefeated, having defended the title 25 times. He returned to the ring in 1950 and lost his title to Ezzard Charles. He then won eight more fights before being knocked out by Rocky Marciano in 1951.

\section{Louis Napoléon see Napoléon III}

Louis Philippe I (1773-1850). King of the French 1830-48. Like his father, the Duc d*Orléans, who became known as Philippe Egalité, he supported the Revolution of 1789 during its early stages but later withdrew to live abroad, mainly in England. After Waterloo, he was looked upon with suspicion by the restored *Louis XVIII but was allowed to return (1817) to France, where he wisely remained in the background until, after the revolution of 1830, he was chosen king to replace the deposed ${ }^{*}$ Charles X. Known as the 'citizen king' because of the informal bourgeois manners he adopted, he was at first very popular but he came to rely more and more on the conservative *Guizot and the nouveaux riches of the upper bourgeoisie, a change in the national mood being shown by several attempts on the king's life. The most important external event of the reign was the French conquest of Algeria. As hopes for reform by constitutional means dwindled, the republican strength increased, but the revolution of 1848 was 
unexpected, and resulted from an almost accidental chain of circumstances. Louis Philippe took refuge in England and the eventual heir to the revolution was *Napoléon III. He died at Claremont, near Esher, Surrey, and was reburied in France, at Dreux, in 1876.

Haworth, T. E. B., Citizen King. 1961.

Louvois, François-Michel le Tellier, Marquis de (1641-1691). French minister. His father Michel de Tellier (1603-1685), Secretary of War 1643-66 and Chancellor of France 1677-85, encouraged *Louis XIV's absolutist inclinations. Louvois succeeded his father as Secretary of War 1666-91, and proved to be a gifted organiser, increasing the army to 400,000 , improved weaponry, imposed harsh discipline but improved health and nutrition.

Louÿs, Pierre (né Pierre-Félix Louis) (1870-1925). French poet and novelist, born in Ghent. A friend of Oscar *Wilde and dedicatee of Salomé, he was close to André *Gide. Chansons de Bilitis (1894) claimed to be translations of ${ }^{*}$ Sappho and ${ }^{*}$ Debussy set songs from the cycle. His speciality was the erotic prose poem, many of them subjects of paintings.

Lovat, Simon Fraser, 11th Lord (Scottish peerage) (c.1667-1747). Scottish Jacobite, known as 'the Fox'. He studied at King's College, Aberdeen, and concerned by the weak leadership of Clan Fraser by his kinsman Hugh Fraser, 9th Lord Lovat, and the growing power of the Mackenzie and Murray clans, recruited his own private army and secured the succession to the Lovat lordship to his father, Thomas Fraser. In 1667 he sought to marry Amelia Fraser, the daughter and heiress of the 9th Lord, and, when this failed, forcibly married her mother, the dowager Lady Lovat (also named Amelia). Charged with rape and rebellion, he went into exile in France and was sentenced to death, in absentia. He returned to Scotland as a double agent, helping to prepare for a Jacobite invasion but communicating the plans to the British Government. After a period of imprisonment in France he was in Scotland again to offer his services to the government in the 1715 rising. In the later rising (1745) he sent his son to head his clansmen in support of the Jacobites, while he stayed at home expressing loyalty to *George II. After Prince *Charles Edward's defeat at Culloden, Lovat was taken to London, tried by the House of Lords, and, aged more than 80 , became the last peer executed for treason and the last person in Britain to be decapitated.

Lovelace, (Augusta) Ada King (née Byron), Countess of (1815-1852). English mathematician. Only legitimate child of Lord *Byron, the poet, she was tutored in mathematics by Mary Somerville (née Fairfax) (1780-1872), a Scottish science writer. She became a friend and supporter of Charles *Babbage. If not quite the world's first programmer, she published the first algorithm for a computer (1843) and, influenced by the complex textiles produced by *Jacquard's automated looms, went further than Babbage in speculating about what could be achieved with symbols, not just numbers, in a general-purpose computer.

Moore, D. L., Ada, Countess of Lovelace. 1977; Toole, B. A., Ada, the Enchantress of Numbers: Prophet of the Computer Age. 1998.

Lovelace, Richard (1618-1658). English Cavalier poet. Heir to large estates in Kent, in 1649 he published the collection Lucasya, which includes his most famous poems: To Althea, From Prison ('Stone walls do not a prison make/Nor iron bars a cage') and To Lucasta, going to the Wars ('I could not love thee (Dear) so much,/Lov'd I not honour more'). Both reflect episodes in his career, the first a term of imprisonment (1642) after he had presented a 'Kentish Petition' to parliament, the second (probably) his departure to join the French army at Dunkirk, where he was wounded (1646). Back in England he was again in prison (1648-49) and died in poverty.

Weidhorn, M., Richard Lovelace. 1970.

Lovell, Sir (Alfred Charles) Bernard (1913-2012). English astronomer. He was Director of the Jodrell Bank (Cheshire) Radio Telescope 1945-80, a pioneering facility in radio-astronomy, and professor of radio astronomy at Manchester University 1951-81.

Lovell, B., Story of Jodrell Bank. 1968.

Lovelock, James Ephraim (1919-2022). English environmentalist. Originally a medical scientist, he became an effective campaigner to reduce the impact of climate change and proposed the 'Gaia hypothesis': that the earth is essentially self-regulating in the long term. He became FRS and CH.

Lovett, William (1800-1877). English Chartist. He went penniless (1821) to London, where he worked as a cabinet-maker and educated himself. In 1836 he became one of the founders and secretary of the London Working Men's Association, which put forward the People's Charter (with six points including manhood suffrage and voting by ballot), the starting point of the Chartist movement. It was incongruous that a man so averse to violence should spend a year in prison because of riots during the convention at Birmingham (1839), but it gave him time to write (with John Collins) Chartism: a New Organisation of the People (1840). The stress on moral rather than political action alienated his more extreme colleagues and he gradually lost influence. In later life his main interest was in education for the working classes.

Low, Sir David Alexander Cecil (1891-1963). British cartoonist, born in New Zealand. He made his reputation on The Bulletin in Sydney, and worked in England from 1919 as cartoonist for the London Star (1919-27), Evening Standard (1927-50), Daily Herald (1950-53) and finally for the Manchester 
Guardian. Though his viewpoint was in general antiConservative (especially during the appeasement era), pretentious stupidity, rather than party affiliation, was his real target. Some of the most effective of his cartoons featured 'Colonel Blimp'.

Lowe, Sir Hudson (1769-1844). Anglo-Irish soldier, born in Galway. He became a lieutenant general in the French wars and after Waterloo was made Governor of St Helena. He was accused of undue severity towards *Napoléon, especially by Barry *O'Meara, the latter's surgeon, yet it seems though his manner was stiff and he refused to address his prisoner by his imperial rank, his conduct was formally correct. He was Commander-in-Chief in Ceylon 1824-31.

Lowe, Robert, 1st Viscount Sherbrooke (18121892). English lawyer and politician. An albino, he studied at Winchester and Oxford, became a lawyer in Sydney and served in the New South Wales Legislative Council 1843-49. A British MP 185280, he consolidated company law, was *Gladstone's Chancellor of the Exchequer 1868-73, but opposed trade unions and extending the franchise.

Lowell, James Russell (1819-1891). American writer, editor and diplomat. He came from a distinguished Massachusetts family and was grandson of John Lowell (1743-1802), a noted judge. J. R. Lowell abandoned law for a literary career, he was first editor (1857-61) of the Atlantic Monthly and joint editor (1864-72) of the North American Review and had succeeded (1855) Longfellow as professor of modern languages at Harvard. Gradually his poetry, essays and critical studies won him an unchallenged leadership in literature. His best known verse was contained in the satirical Biglow Papers (1848), written to oppose the Mexican War and the annexation of Texas. Of his later prose works Among My Books (1870-76) and My Study Windows (1871) are well known. Lowell served as Minister to Spain 1877-80 and to Great Britain 1880-85.

Among other members of the great Lowell clan were: Percival Lowell (1855-1916), an orientalist and astronomer who founded the Lowell Observatory, Flagstaff, Arizona (1894). He was an ardent proponent of canals on Mars, and hypothesised (from 1905) a trans-Neptunic 'planet X'. Pluto was identified in 1930 by Clyde *Tombaugh and its name begins with Lowell's initials; Amy Lawrence Lowell (1874-1925), his sister, was a poet who succeeded Ezra *Pound as leader of the Imagist group. Her collections of poems include Pictures of the Floating World (1919), and she also wrote critical essays and an incomplete biography of *Keats (1925). She was awarded a posthumous Pulitzer Prize for Poetry.

Duberman, M., James Russell Lowell. 1967.

Lowell, Robert Traill Spence (1917-1977). American poet. Educated at Harvard, he became a Catholic in 1940 and served a short jail sentence during World War II as a conscientious objector. His first book of poetry was The Land of Unlikeness (1944) and he won the Pulitzer Prize for poetry with his second Lord Weary's Castle (1957). Other volumes include The Mills of the Kavanaughs (1952), The Old Glory (1964), For the Union Dead (1965) and Near the Ocean (1967). He became a leader in the antiVietnam movement in the US. In addition to his powerful and pessimistic verse, he published muchpraised translations, e.g. of *Aeschylus' Prometheus Bound (1967) and of *Baudelaire.

Hamilton, I., Robert Lowell. 1982.

Lowry, L(aurence) S(tephen) (1887-1976). English painter, born in Manchester. He worked as a rent collector, and slowly gained recognition for his spare, deceptively simple, industrial landscapes (peopled by matchstick figures) and seaside scenes and was elected RA in 1962. He declined honours five timesprobably a record.

Rolde, S., Private View of L. S. Lowry. 1979.

Lowry, (Clarence) Malcolm (1909-1957). British novelist. Educated at Cambridge, he became an alcoholic whose life was marked by a long series of personal disasters and constant movement (Mexico, Canada, Haiti, the US). His masterpiece is Under the Volcano (1947), a richly textured account of cultural and personal tensions in Mexico in the 1930s. All his other works were published posthumously.

Bowker, G., Pursued by Furies. 1993.

Loyola, St Ignatius of (né Iñigo López de Oñaz y Loyola: in Basque Ignazio Loilakoa) (c.1491-1556). Spanish-Basque founder of the Jesuit order, born in Loyola, Castile. When fighting against the French he was wounded (1521) at the siege of Pamplona in Navarre. During his long convalescence he underwent a conversion and at Manresa spent a year (1522-23) in prayer, in religious austerity and in service to the sick and poor. There, too, he probably wrote most of Spiritual Exercises, a book of rules and meditations designed to overcome passions, make sin abhorrent and bring the soul closer to God. After making pilgrimages to Rome and to Jerusalem he studied for several years in Spanish universities and in Paris. In 1534 with a handful of companions, including St Francis *Xavier, he took the vows at Montmartre that established the Society of Jesus. Loyola was ordained priest (1537) and when a Bull of Pope *Paul III officially established the order (1540) became its first general. With its founders insistence on strict discipline and devotion, and complete obedience to the Pope, the order although not designed as such, became almost at once the spearhead of the Counter-Reformation, at all times it has concentrated on education and missionary work. Ignatius was canonised in 1622.

Dudon, P., St Ignace de Loyola. 1949. 
Lubbe, Marinus van der (1909-1934). Dutch communist. In February 1933, he was charged with arson in burning the Reichstag in Berlin, was sentenced to death and guillotined in Leipzig. Posthumously pardoned in 2007, his guilt is still deeply controversial but he probably acted alone, as he insisted during his trial.

\section{Lubbock, Sir John see Avebury, 1st Baron}

Lübke, Heinrich (1894-1972). German politician. Not active in public life during the Third Reich, he was considered a suitable worker for the reorganised Christian Democrats of Westphalia after 1945. He served as a member of the North Rhine Westphalia Landtag 1946-52 and was Land Minister for Food, Agriculture and Forestry from 1947. He sat in the Federal Bundestag 1949-50 and 1953-59. In 1953 Chancellor *Adenauer appointed him Federal Minister for Food, Agriculture and Forestry. $\mathrm{He}$ worked constructively with Adenauer and served two terms as President of the Federal Republic 1959-69.

Lucan (Marcus Annaeus Lucanus) (39-65 CE). Roman poet, born in Córdoba. A nephew of *Seneca, he was educated in Rome and Athens. A favourite of ${ }^{*}$ Nero for some years, he later joined in a conspiracy against him, was betrayed and committed suicide. His greatest work is the epic Pharsalia (10 books of which survive), describing the civil war between ${ }^{*}$ Caesar and *Pompey. It is factually unreliable, being especially unfair to Caesar, and revels in gruesome details of the battle scenes, but it is eminently readable and was long popular.

Housman, A. E., Lucan. Repr. 1950.

Lucan, George Charles Bingham, 3rd Earl of (1800-1888). British soldier. He commanded the cavalry in the Crimean War when the jealous hostility between him and his subordinate, the Earl of ${ }^{*}$ Cardigan, Commander of the Light Brigade, caused the misunderstanding that resulted in the famous and heroic charge up the 'valley of death' at Balaclava (October 1854) from which less than 300 out of nearly 700 men returned. He became a field marshal in 1887. His great-great-grandson, (Richard) John Bingham, 7th Earl of Lucan (1934-1974?), a charismatic figure once considered for the film role of James Bond, became an unsuccessful professional gambler. With the murder of his children's nanny and an attack on his estranged wife in 1974, Lord Lucan was the immediate suspect. His role and disappearance became the subject of intense interest for decades. He was officially declared dead in 2016, presumably as a suicide, although it was speculated that he may have been fed to a tiger.

Lucas, George (Walton) (1944- ). American film producer and writer. A significant technological innovator, his films included six in the enormously successful Star Wars series (1977, 1980, 1983, 1999, $2002,2005)$ and the Indiana Jones series (1981, 1984, 1989, 2008).

Lucas, Robert (1937- ). American economist. Professor of economics at Chicago, he won the 1995 Nobel Prize for Economics for his work on 'rational expectations' as a factor in economic choice.

Luce, Henry Robinson (1898-1967). American journalist and publisher. In 1923 he founded and edited the weekly news magazine Time followed by Fortune (1930) a business magazine, and Life (1936). His wife, Clare Boothe Luce (1903-1987) wrote successful plays, e.g. The Women (1937) and was a Republican Member of the House of Representatives 1943-47 and US Ambassador to Italy 1953-56.

Lucian (c.120-c.190). Greek satirical writer, born in Syria. After being a rhetorician in Antioch, he travelled in Italy, Greece and Gaul. He was already about 40 when he studied in Athens and learned enough about philosophy to be able to satirise the dogmas of almost every school, including Christianity. Later he held a government post in Egypt. All his writing shows his talent for satire and parody. In verse there are mock tragedies such as Tragoedopodagra (Tragic Gout), in prose such amusing works as True History, a parody of travellers' tales, which is said to have influenced ${ }^{*}$ Rabelais, ${ }^{*}$ Swift and ${ }^{*}$ Voltaire. He uses the savagery of his wit in Dialogues of the Dead and his powers of burlesque in Dialogues of the Gods. Zeus Crossexamined is a title that suggests its contents.

Lucretius (Titus Lucretius Carus) (99-55 BCE). Roman philosophical poet. Almost nothing is known of his life. His fame rests on his great work De rerum natura (The nature of things), one of the greatest of all didactic poems. It is an epic in six books, written in hexameters, and contains the clearest exposition that we have of the philosophic system of *Epicurus. Books I and 2 describe the atomic system of *Democritus as adapted by *Epicurus; Book 3 deals with the nature of the soul; Book 4 with the doctrine of perception and with sexual emotions; Book 5 is devoted to the theories of Epicurus concerning the evolutionary development of mankind, the earth and the universe; Book 6 covers a variety of topics and includes a description of the great plague of Athens. He denounced all forms of religion and superstition and considered that since death means annihilation it should present no terrors.

Greenblatt, S., The Swerve: How the Renaissance Began. 2011.

Lucullus, Lucius Licinius (c.110-c.57 BCE). Roman soldier and administrator. Of noble birth, he first became prominent under *Sulla in the war (88-85) against * Mithridates, King of Pontus in Asia Minor. His later campaigns (from 74) were also waged against Mithridates and his ally Tigranes of Armenia, but though Lucullus gained many successes and did 
much, by his financial measures, to restore prosperity to the Asian province, he was unable to bring the wars to a decisive conclusion before he was superseded by *Pompey. After his return to Italy his great wealth enabled him to lead a life of luxury in Rome, where his gardens were renowned, or in his villas at Naples and Tusculum. The banquets for which he was famous were distinguished for the conversation as well as for their splendour.

Ludendorff, Erich Friedrich Wilhelm (1865-1937). German soldier. Son of a railway official, he had a staff officer's training. The deployment of the armies at the outbreak of World War I was largely due to his planning. When the Russians achieved their early successes in East Prussia, Ludendorff and ${ }^{*}$ Hindenburg, to whom he was Chief of Staff 1914-18, turned the tide by the Battle of Tannenberg and other victories. This partnership_-Ludendorff, the brains, and Hindenburg, the character, personality and prestige-remained in being until the end of the war. He was Quartermaster General 1916-18 and virtually ruled Germany through Hindenburg and puppet chancellors. He allowed *Lenin's return to Russia via Germany (1917). Transferred to the Western Front in 1916, they restored the German line's stability, shaken by the Battle of the Somme, and planned the great offensive of spring 1918 which so nearly achieved a complete breakthrough. Ludendorff's defects of character showed, however, when the situation was once more reversed and the Allies again pressed forward. He lost his nerve and left it to Hindenburg, whom he despised, to bring the army back to Germany. After Germany's defeat, which he attributed to 'a stab in the back', he fled to Sweden and did not return to Germany until 1920. Associated with the Kapp putsch (1920), he marched with *Hitler in the attempted Munich putsch of 1923 , was tried for treason but acquitted. He contested the German presidency in 1925, polled badly and founded the Tannenberg League, a mystical-religious sect, antiChristian and anti-Jewish, which tried to revive the old Teutonic religion. In his last years he became a pacifist.

Goodspeed, D. J., Ludendorff. 1966.

Ludwig I (1786-1868). King of Bavaria 1825-45. His artistic taste led him to enrich Munich, his capital, with many buildings and paintings. The cost of these extravagances, and the money Ludwig lavished upon the object of his infatuation, the dancer Lola *Montez, exacerbated the indignation caused by his increasingly arbitrary rule and he was forced to abdicate (1848). His tastes were shared in an exaggerated form and to the point of eventual madness, by Ludwig II (1845-1886) who succeeded to the throne in 1864 . He was the patron of*Wagner, for whom he built the theatre at Bayreuth. His mania for fantastic castles endowed Bavaria with buildings, Neuschwanstein the most famous, which have become tourist attractions. In 1886 he was declared insane, and shortly after drowned his physician and himself in Lake Stainberg.
Ludwig, Karl Friedrich Wilhelm (1816-1895). German physiologist. He held chairs at Marburg 1846-49, Zürich 1849-55, Vienna 1855-65 and Leipzig 1865-95. He was able to keep animal organs alive in vitro (1856) and invented important instruments, such as the mercurial blood pump (1859) and the flowmeter (1867) for measuring the rate of blood flow. His own research concentrated mainly on the kidneys and their secretions. The problem of how secretion takes place through membranes was a lifelong preoccupation and the secretion of the saliva via the glandular nerves was another field in which he worked. The circulation of the blood also attracted his attention. He investigated how blood pressure related to heart activity, and the role of muscles in the fluidity of the blood.

Lueger, Karl (1844-1910). Austrian lawyer and politician. A co-founder of the Christian Socialist Party (1889), he became-despite Emperor ${ }^{*}$ Franz Josef's strong objection-an immensely popular lord mayor of Vienna 1897-1910, promoting municipal socialism, universal suffrage and cynical antiSemitism. As he said, 'I decide who is a Jew'. Lueger significantly influenced the young *Hitler.

Lugard, Frederick John Dealtry Lugard, 1st Baron (1858-1945). British colonial administrator. He had a varied career as soldier and administrator in India, Burma, the Sudan, Central and West Africa before he was appointed the first high commissioner of Northern Nigeria 1900-06. Here he put into practice his principles of 'indirect rule' through indigenous rulers and institutions, for which he became famous. He left Africa (1906) to become Governor of Hong Kong 1907-12 but returned to govern North and South Nigeria (amalgamated 1914) and was Governor-General of Nigeria 1914-19. He wrote The Dual Mandate in British Tropical Africa (1922) and received a peerage in 1928 .

Perham, M., Lugard, the Years of Authority. 1960.

Luhrmann, Baz (né Mark Antony) (1962- ). Australian director, producer and writer, born in Sydney. The most successful Australian director/ producer, his films include Strictly Ballroom (1992), Romeo + Juliet (1996), Moulin Rouge! (2001), Australia (2008), The Great Gatsby (2013) and Elvis (2022). He won many awards, was a music producer and fashion designer.

Lukacs, Georg (Gyorgy Szegedy von Lukacs) (18851971). Hungarian philosopher and literary critic. The most influential of 20th-century Marxist scholars, he revived interest in the Hegelian background of Marx's work and emphasised the concepts of 'alienation' and 'reification'. He took an active, but not always consistent, role in politics and served as minister of culture in two revolutionary governments (1919 
and 1956). He was an advocate of 'cultural realism', opposing both Modernism and *Brecht, and appears as Naphta in Thomas *Mann's The Magic Mountain.

Lukashenko, Alyaksandr Ryhoravich (1954-). Belorusian politician. Son of an unknown father, he gained a degree in agriculture, served in the Russian army and joined the CPSU. In 1991, Belarus became independent after the breakup of the USSR, and a new Constitution provided for direct popular election of a President. President of Belarus 1994-, Lukashenko was first elected as an Independent, campaigning against corruption. In office, and after four reelections, he became increasingly authoritarian, described as the last dictator in Europe. His election of 2020, for a sixth term, was not recognised by the EU, US and UK.

Luke, St (Loukas in Greek) (d.c.90 CE). Christian apostle, one of the four evangelists. Regarded as the author of the third Gospel and of the Acts of the Apostles, the only known facts of his life are contained in three passages in the epistles of St Paul, which describe him as a Gentile, a physician and a close associate of St Paul, and his companion in imprisonment in Rome.

The strong tradition that he was the author of the Gospel attributed to him and of the Acts dates from the late 2 nd century and there seems little reason to dispute it. Critical examination of the texts suggests that the two books were almost certainly by one hand and it is clear that much of the Acts must have been written by someone in the closest touch with St Paul. The Gospel was probably written for Greekspeaking Christians at Antioch in the years before Paul's death (c.67 CE). It is clear that the author consulted St Mark's Gospel and had access, as did the author of St Matthew's Gospel, to the source known as 'Q'. Other sources must have also been available as there are discrepancies in detail and some incidents not found elsewhere. For example the incidents concerning the Virgin Mary are elaborated, and several women are mentioned who are not referred to elsewhere. He may have died at Ephesus (or Antioch).

Lula da Silva, Luiz Inácio (1945- ). Brazilian politician, born in Pernambuco. He had very little formal schooling, learning to read at the age of 10 , growing up in Sáo Paolo where his father had two households, becoming a street vendor, then an assembly line worker in a motor parts factory. A cofounder of the Workers' Party (PT-Partido dos Trabalhadores) in 1980, he ran unsuccessfully for the presidency in 1989, 1994 and 1998. He won in 2002 and 2006, serving as President 2003-11. He introduced a series of domestic reforms, reducing poverty and promoting education, pursued an activist foreign policy, seeking international cooperation on disarmament and climate change issues. He received many international awards including a British GCB. Convicted of money laundering and accepting bribes, after a highly politicised trial, he was sentenced to 12 years in prison. The courts disqualified him from contesting the presidency in 2018 . He served 580 days as a prisoner (2018-19) and on his release another court increased his sentence to 17 years. In March 2021 his convictions were annulled by a judge and his political rights restored. In 2022 he announced his candidature for President against *Bolsonaro, and after a bitterly personalised campaign, won narrowly (with 51 per cent of the vote) to be President 2023-.

Lully, Jean Baptiste (né Giovanni Battiste Lulli) (1632-1687). French composer, born in Florence. Taken to France as a child, when his musical talents were discovered, he was a scullion in the service of a cousin of the king. An appointment in the royal orchestra quickly followed and soon he was presiding over his own players and composing ballets (some of them as divertissements in *Molière's plays) in which *Louis XIV himself liked to dance. Both in ballet and in opera (from 1652) he so transformed the musical techniques as almost to create a new art, and he defined the form of the French overture. He also introduced female dancers to the stage. Among his 15 operas are Alceste (1674), Atys (1676) and Aeis et Galathée (1686). He died from blood poisoning resulting from striking his foot with a heavy baton while keeping time during a performance of his Te Deum.

Lumière, Louis Jean (1864-1948). French industrial chemist and pioneer photographer. With his brother Auguste Lumière (1862-1954) he constructed (1895) a practical motion-picture camera and a projector that incorporated what have since become the standard devices for photographing and projecting motion pictures.

Lumumba, Patrice Émery (né Elias Okit'Asombo) (1925-1961). Congolese politician, born in the province of Kasai. He was a post-office clerk before setting up in business in Leopoldville. In 1958 he founded the Mouvement National Congolais (MNC), and on independence (June 1960) became first Prime Minister of the Republic of the Congo. Katangan separatists, led by Moïse ${ }^{*}$ Tshombe, and supported by Belgium, broke away from the central government, and the army mutinied. The UN sent a peacekeeping force in July 1960 but refused to intervene in suppressing Katangan secession. By September, Lumumba had lost control of the central government, though he still governed in Stanleyville, with the support of the USSR. In December, he was arrested by troops sent by the central government and flown to Katanga, where he was executed in January 1961. *Mobutu Sese Seko then ruled the Congo. Part of the University of Moscow reserved for African students was named for Lumumba.

Lunacharski, Anatoli Vasilievich (1875-1933). Russian educationist and Communist politician. A brilliant orator and propagandist, he supported 
the Bolsheviks from 1903 and lived in Italy and France until the October Revolution of 1917 brought ${ }^{*}$ Lenin to power in Russia. He became Commissar for Education 1917-29 and introduced many important reforms in public education, including drama, music and dance. He was dismissed by ${ }^{*}$ Stalin. He wrote 14 plays and much literary and artistic criticism. Asteroid 2446 was named for him.

Fitzpatrick, S., The Commissariat for Enlightenment. 1970.

Lunt, Alfred (1893-1977). American actor and producer. With his wife, Lynn *Fontanne, he appeared in many plays, e.g. Design for Living, The Seagull, Amphitryon 38, Love in Idleness etc., in the US and Britain, and was also a successful producer.

Lupescu, Magda (née Elena Grünberg, or Wolff) (1895?-1977). Romanian adventurer. Mistress and (from 1947) wife of *Carol II of Rumania, whose exile she shared, she was created Princess Elena.

Lurçat, Jean (1892-1966). French artist. His great contribution as a tapestry designer of striking designs and flamboyant colour gave a new lease of life to the tapestry industry of France.

Lustiger, Aaron Jean-Marie (originally Aaron) (1926-2007). French cardinal, born in Paris. Son of Polish-Jewish immigrants, his mother died in Auschwitz. He became a Catholic convert, studied at the Sorbonne, and was a university chaplain, Bishop of Orléans 1979-81 and Archbishop of Paris 19812005. He was elected to the Académie française in 1995 .

Luther, Martin (1483-1546). German Protestant leader, born in Eisleben, Saxony. From a modest family, after schooling in Magdeburg and Eisenach he went to Erfurt University, where he studied law. The death of a friend turned him towards religion, he became an Augustinian friar and was ordained priest (1507). In 1508 he moved to Wittenberg in Saxony to teach philosophy and theology at the university. On a mission to Rome (1511) he was shocked by the luxury and corruption of the papal court, but for several years he remained faithful to the Church, attracting thousands by his lectures and sermons and working out a personal theology based on the Augustinian doctrines of faith and grace and the study of St *Paul, rather than on the writings of *Erasmus and the humanists.

The arrival (1517) of Johann Tetzel, a Dominican friar sent by the Archbishop of Mainz to raise money for the rebuilding of St Peter's, Rome, by the sale of indulgences (i.e. remission of the penalties of $\sin$ ), a practice against which Luther had already preached, caused him to write to his bishop proposing 95 theses against the sale of indulgences. (The story that he nailed his theses to the church door is regarded as been printed, translated and widely circulated. Luther refused to withdraw his theses before a papal legate at Augsburg (1518) and in disputations, especially in one with the theologian Johann Eck (1519), he was goaded to take a more extreme position and even challenged the condemnation of Jan ${ }^{*}$ Hus as a heretic. Luther next published his address To the Christian Nobility of Germany (a call to resistance and reform), The Liberty of a Christian Man (on the doctrine of justification by faith alone, not by good works), and The Babylonish Captivity of the Church (on the Sacraments, especially rejecting transubstantiation). To these attacks on the Church the pope replied by a Bull of excommunication, which Luther burned publicly.

The printing press was a central factor in the Reformation, both as cause and effect, because it had enabled the production of indulgences on an almost industrial scale, the rapid dissemination of Luther's writings, accessibility to his German translation of the Bible, and the familiarisation of his image by his supporter Lucas *Cranach.

An attempt at conciliation was made by the emperor ${ }^{*}$ Charles $\mathrm{V}$ who summoned Luther, under safe conduct, to the Diet of Worms (1521), but Luther withdrew nothing. ('Here I stand, I can do no other, so help me, God'.) He was allowed to depart but, with the issue of an imperial ban, the Elector of Saxony placed him under protection in the Castle of Wartburg. He risked leaving his security (1522), however, as his deputies were unable to control the fast growing movement. Luther still hoped that separation from Rome would be only temporary but the issue of the Augsburg Confession (1530), mainly the work of ${ }^{*}$ Melanchthon, and still the basic statement of Lutheran belief, was tantamount to creating a new Church. Meanwhile, in 1525, Luther had married (a decisive step for a former priest), Katharina von Bora, herself a former Cistercian nun, and she bore him three sons and two daughters. Their happy home became a meeting place for his friends and admirers.

The Peasants' Revolt (1523-25) partly the result of the example set by his own rebellion and the ensuing violence, so shocked Luther that he urged its repression with extreme ferocity but the political result was that the Reformation ceased to be a largely popular movement and came to rely on the support of the princes. The compromise finally established by the religious peace of Augsburg (1555) cujus regio ejus religio (i.e. that the religion of the state should follow that of the ruler) set a limit on the extent of the Lutheran reformation. Luther was extremely intolerant of other Protestant groups: he despised the English reformers and Catholic moderates such as Erasmus, joined with the Catholic Bishop of Munster in suppressing the Anabaptists, and quarrelled bitterly with ${ }^{*}$ Zwingli and ${ }^{*}$ Carlstadt over the doctrine of the Lord's Supper. He was deeply pessimistic and superstitious, convinced of the reality of demon possession. He insisted that Scripture is the sole 
rule of faith alone', believing mankind to be totally depraved and vehemently rejecting reason.

He was anti-Roman, but also virulently anti-Semitic, described by Lyndal Roper as 'proto-Hitlerite', driven by conviction that his followers had become God's chosen people, and that Jew-baiting was integral to Protestant identity. (Ironically, Judaism was far closer in form to Lutheranism than the Catholic church: based on the Scriptures, non-hierarchical, austere in practice.) He was not ascetic, had a robust sexuality and liked to eat and drink well.

Luther's translation of the Bible into German was not the first, but incomparably the most important, with a unique influence on the development of the literary language. Confined in the Wartburg, he translated the New Testament in 11 weeks, working directly from the Greek edition of *Erasmus: it was published in 1522. The Old Testament, translated from Hebrew, was completed in 1534. Throughout his life he was engaged in writing and expanding his theoriescontroversies with such contrasting opponents as ${ }^{*}$ Henry VIII and Erasmus were innumerable-and his sermons, letters and theses all show the vigour and clarity of his mind.

Todd, J. M., Martin Luther. 1964; Oberman, H. A., Luther. 1989; Pettegree, A., Brand Luther. 2015; Roper, L., Martin Luther: Renegade and Prophet. 2016; Schilling, H., Martin Luther. Rebel in an Age of Upheaval. 2012/17; Stanford, P., Martin Luther. Catholic Dissident. 2017.

Lutosławski, Witold Roman (1913-1994). Polish composer, conductor and pianist, born and educated in Warsaw. His father and brother were executed by the Bolsheviks in 1918. His works include three symphonies (1947, 1967, 1983), Concerto for Orchestra (1954), Chain 1 for chamber orchestra (1983), Chain 2 for violin and orchestra (1985), Chain 3 for orchestra (1986), concertos for cello (1970) and piano (1988). He also wrote compositions for films, theatre, radio and children's groups. His international awards included the Grawemeyer and Sonning Prizes and the Gold Medal of the Royal Philharmonic Society, London.

Stucky, S., Lutostawski and His Music. 1981; Bodman Rae, C., The Music of Lutostawski. 1999.

Lutuli (Luthuli), Albert John (1898-1967). South African (Zulu) chieftain and politician, born in Natal. The son of an African Christian missionary, he was educated by American missionaries at the Adams College and later taught there for 15 years. He was elected by tribal elders to succeed his uncle as Chief of the Abasemakholweni Zulu tribe at the Umvoti Mission Reserve 1935-52, until dismissed by the South African Government for refusing to resign as PresidentGeneral of the African National Congress, an office he held 1952-67. He was arrested on a charge of treason in 1959 but released in 1960, although banned from leaving his village at Groutville without permission. He burned his pass in public after the police shot black people at Sharpeville. Lutuli repeatedly urged that South Africa become a multi-racial society but adopted *Gandhi's policy of passive resistance. He was awarded the 1960 Nobel Prize for Peace.

Lutyens, Sir Edwin Landseer (1869-1944). English architect, born in London. His earlier country houses, of which he built, enlarged or restored over 40 between 1899 and 1909, showed the 'picturesque' influence of William *Morris and he worked closely with the garden designer Gertrude *Jekyll. He later turned with equal success to the Renaissance style. In 1908 he was architect to the Garden Suburb scheme in Hampstead, where he built the church and other buildings. His public buildings and especially the architectural scheme for New Delhi (the Viceroy's house and other official buildings) designed in collaboration (from 1912) with Sir Herbert *Baker, revealed his talent for the grandiose. Other works included the Cenotaph in Whitehall, London (1918), and the British Embassy at Washington (1926). His plans for a massive Catholic cathedral in Liverpool (1910) were abandoned because of cost after World War II. Lutyens was President of the Royal Academy 1938-44 and received the OM (1942). His daughter (Agnes) Elisabeth Lutyens (1906-1983) was a composer, working in the 12-tone technique, independently of ${ }^{*}$ Schoenberg. She set Japanese poetry and texts by ${ }^{*}$ Canetti and ${ }^{*}$ Wittgenstein.

Hussey, C., Sir Edwin Landseer Lutyens. 1950.

Luxembourg, François Henri de MontmorencyBouteville, Duc de (1628-1695). French soldier. His aunt was the mother of the great *Condé whom he supported against the crown in the wars of the Fronde. Subsequently pardoned by *Louis XIV, he became one of his most brilliant generals and was in charge of the French armies in the Netherlands in 1672. Created a marshal in 1675, he was out of favour for 12 years, having quarrelled with the minister of war, *Louvois. He then returned to achieve his most famous victories: over *William III in Flanders, in the battles of Fleurus (1690), Steinkerk (1692) and Neerwinden (1693), none of which, however, was fully exploited.

Luxemburg, Rosa (Róża Luksemberg) (1870-1919). Polish-Jewish-German philosopher, economist and revolutionary leader, born in Russian Poland. She gained a PhD in Zürich and was imprisoned (1915-18) for opposing World War I, but after the German defeat she founded, with Karl *Liebknecht, the Communist group known as Spartacists, whose revolt in January 1919 she organised. She was a brilliant orator and political writer and is regarded by Communists as one of their great heroes. Both she and Liebknecht were murdered by officers who arrested them.

Nettl, J. P., Rosa Luxemburg. 1966; Evans, K., Red Rosa: A Graphic Life of Rosa Luxemburg. 2015. 
Lu Xun (real name Zhou Xujen) (1881-1936). Chinese author. Trained as a physician, his sardonic and incisive short stories and essays, e.g. The True Story of Ah Q (1921) and Call to Arms (1923), were derisive of Chinese traditionalism and fatalism. He refused to join the Communist Party but was an active fellow traveller, hailed as a revolutionary hero by ${ }^{*}$ Mao Zedong. He is the most widely read author in modern China.

Lvov, Georgy Yevgenyevich, Prince (1861-1925). Russian statesman. A leading liberal member of the Duma 1905-17, he was prominent in developing a system of local government (zemstvo). As Chairman of the all-Russian Union of Zemstvos it devolved upon him to head the provisional government in the first months of the Russian Revolution (1917). His moderation and dislike of violence made him unsuited for a revolutionary situation and he resigned later in the year in favour of *Kerensky. When the Bolsheviks came to power he escaped to France.

Lyadov, Anatoly Konstantinovich (1855-1914). Russian composer. One of the most brilliant of *Rimsky-Korsakov's pupils, he wrote a number of symphonic poems, national in spirit, including The Enchanted Lake Kikimora and Baba-Yaga.

Lyautey, Louis Hubert Gonzalve (1854-1934). French soldier and administrator, born in Nancy. He joined the army in 1872 and, although a conservative royalist, developed an enthusiasm for social reform and education. He served in IndoChina, Madagascar and Algeria and was ResidentGeneral in Morocco 1912-16, 1917-25 where he created a relatively modern infrastructure. He was Minister for War 1916-17. Elected to the Académie française in 1912, he became a marshal of France in 1921. In Morocco he faced a revolt by *Abd el-Krim, who was finally defeated by *Pétain in 1926.

Lycurgus (9th century BCE?). Spartan lawgiver. Traditionally he was the author of the rigid social code by which the Spartiate aristocracy was kept apart from the other inhabitants, and of the system of military education by which, from the ages of six to 20 , the strictest obedience, self-discipline and rigorous training were imposed on all Spartan boys. (These institutions almost certainly belong to a later date and the very existence of Lycurgus may be mythical.)

Lydgate, John (c.1370-c.1450). English poet. Almost certainly born at and called after Lydgate in Suffolk, he was a monk of Bury St Edmunds. He produced long narrative poems, mostly adapted or translated, e.g. Troy-Book (from a Latin work), The Falls of Princes (from *Boccaccio), The Siege of Thebes (intended to be a supplement to The Canterbury Tales by *Chaucer, his acknowledged master), and a drearily prolix allegory, The Pilgrimage of Man (translated from the French). The satirical London Lickpenny, a shorter poem, gives a lively picture of the contemporary scene.

Pearsall, D. A., John Lydgate. 1970.

Lydia of Thyatira (fl. c.50 CE). Greek merchant and convert. A trader in purple, she met ${ }^{*}$ Paul and *Silas in Philippi, offered them hospitality and was the first named Christian convert in Europe (Acts xvi:14-15).

Lyell, Sir Charles, 1st Baronet (1797-1875). Scottish geologist. A barrister, from 1827 he devoted himself to geology. After investigatory tours in Europe (1824 and 1828-30), he published Principles of Geology (3 volumes, 1830-33), which had immense influence on the development of the science. Equally important was The Geological Evidences of the Antiquity of Man (1863) which gave powerful support, from the evidence of a different science, to ${ }^{*}$ Darwin's evolutionary theories. Further publications (1845 and 1849) resulted from travels in North America. Lyell was professor of geology at King's College, London 1832-33, President of the Geological Society 1836, 1850 and President of the British Association 1864.

Lyly, John (1553-1606). English dramatist and novelist. His best known work is Euphues a romantic 'novel' in two parts (1578 and 1580). It is written in an amusing but rather affected ('euphuistic') style, which *Shakespeare both adopted and parodied in several of his plays. His comedies were mostly written for troupes of boy players and probably for this reason have more delicacy and a gentler wit than others of the time.

Lynn, Dame Vera Margaret (née Welch) (19172020). English singer. She first performed at the age of seven. During World War II she won extraordinary recognition for performances (and recordings) of emotionally charged songs (We'll Meet Again, The White Cliffs of Dover, A Nightingale Sang in Berkeley Square, There'll Always Be an England) and was dubbed 'the Forces' Sweetheart'. She appeared in films and on television, was awarded a DBE in 1975 and a $\mathrm{CH}$ in 2016.

Lyons, Joseph Aloysius (1879-1939). Australian politician, born in Tasmania. Son of Irish immigrants, he became a teacher, then a Tasmanian MP 190929 and Premier of Tasmania 1923-28. Elected to the Commonwealth Parliament in 1929, he was Postmaster-General and Minister for Works 192931 in the Labor Government of J. H. *Scullin. He broke with Labor in 1931 following personal clashes and policy differences with E. G. *Theodore about combatting the Depression and, with the Nationalist Party, formed the United Australia Party (UAP), won the 1931 election in a landslide and served as Prime Minister of Australia 1932-39. Fearful of the prospect of a World War, he was a despairing appeaser of *Hitler's aggression, faced a serious challenge from his deputy, Robert ${ }^{*}$ Menzies, and at Easter 1939, under 
enormous stress, became the first Australian Prime Minister to die in office. His wife, Dame Enid Muriel Lyons (née Burnell) (1897-1981), was the first woman member of the Commonwealth Parliament 1943-51 and the first woman minister 1949-51.

Henderson, A., Joseph Lyons: the People's Prime Minister. 2011.

Lysander (d.395 BCE). Spartan leader. He won a crushing victory over the Athenian fleet at Aegospotami (405), and in 404 took Athens, thus ending the Peloponnesian War. By imposing oligarchic regimes in the Greek city states, he secured Spartan domination throughout Greece. He died fighting in Boeotia, which had become restive under the assertion of Spartan power.

Lysenko, Trofim Denisovich (1898-1976). Russian biologist. He claimed that his experiments showed that acquired characteristics could be inherited and bolstered his presentation with 'Marxist' argument, hoodwinking both ${ }^{*}$ Stalin and ${ }^{*}$ Khrushchev. He persecuted the geneticist N.I. ${ }^{*}$ Vavilov and was attacked by J.B.S. *Haldane. His theory is at variance with the genetics of ${ }^{*}$ Mendel, and never found support outside the Soviet Union. Even there it was discredited after 1953, with some revival 1957-64.

Joravsky, D., The Lysenko Affair. 1971.

Lysimachus (c.662 BCE-281 BCE). Macedonian general. One of the Diadoche ('Successors'), generals who fought for control of *Alexander the Great's empire on his death, he became King of Thrace, Asia Minor and Macedonia. He was killed in the battle of Corupedium by the forces of *Seleucus.

Lytton, Edward George Earle Bulwer-, 1st Baron Lytton of Knebworth (1803-1873). English author and politician. Son of General William Bulwer, educated at Trinity College, Cambridge, he inherited the Lytton estate, Knebworth, from his mother (1843) and added her name to his father's. He wrote furiously, lived extravagantly, had a marriage from hell, made many enemies, including *Tennyson and *Thackeray, but was admired by ${ }^{*}$ Dickens and *Disraeli. He wrote 30 novels, mostly on historical themes, including Eugene Aram (1832), The Last Days of Pompeii (1834) and The Last of the Barons (1843). MP 1831-41, 1852-66, he was Colonial Secretary 1858-59. In 1862, he was offered the throne of Greece. He coined some famous remarks, including 'the pen is mightier than the sword' and 'the great unwashed'. In his science fiction novel The Coming Race (1871), he described a mysterious people energised by a substance called Vril, an idea that captivated Theosophists and (later) Nazis. The name was incorporated in Bovril.

His only son, Edward Robert Bulwer Lytton, 1st Earl of Lytton (1831-1891), educated at Harrow and Bonn, had an unremarkable career as a diplomat, becoming Minister to Portugal 1872-76 until unexpectedly chosen by ${ }^{*}$ Disraeli to be Viceroy of India 1876-80. The unpopular Afghan War, which he helped to provoke, led to Disraeli's defeat (1880) and his own removal. He became Ambassador to France 1887-91. He wrote copious poetry, now forgotten, under the name of 'Owen Meredith'. He called himself 'a sensitive second rate poet' (but he was even less). 


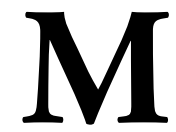

Ma, Yo-Yo (1955- ). Chinese-American cellist, born in Paris. Son of a singer (mother), violinist and academic (father), he gave concerts from the age of five. The family migrated to the US in 1962. He travelled extensively, specialising in ${ }^{*}$ Bach, and promoted humanitarian causes.

Maazel, Lorin (1930-2014). American musician, born in Paris. An infant prodigy, he was a conductor, violinist and composer. He directed the Deutsche Oper, Berlin 1965-71, the Cleveland Orchestra 1972-82, the Vienna State Opera 1982-84, the Pittsburgh Symphony 1988-96, the Bavarian Radio Symphony 1993-2002 and the New York Philharmonic 2002-09 and made many recordings.

Mabuse (Gossaert), Jan (c.1478-1533/5). Flemish painter. His early work was done in Antwerp where he became a master in 1503. Although often described as a 'Flemish Romanist', a visit to Rome in 1508 had little effect on his style except perhaps in his use of light. The influence of ${ }^{*}$ Dürer (not only on his woodcuts and engravings) was much stronger. The nudes Hercules and Deianira (Birmingham) and Neptune and Amphitrite (Berlin) may have been painted (1516-17) as part of a project by Philip, prince bishop of Utrecht, to decorate his castle of Souberg. The earlier Adoration of the Kings (National Gallery, London) is more typically Flemish.

McAdam, John Loudon (1756-1836). Scottish engineer and road-maker, born at Ayr. He went to New York at the age of 14 and returned to Britain in 1783 with a fortune made in commerce. From 1810 his interest in road-making became dominant and the building of experimental stretches of road absorbed most of his fortune. His road-making technique built on a cambered base for better drainage, paved by two layers of broken stone: the lower level, $200 \mathrm{~mm}$ thick, used stones of less than $75 \mathrm{~mm}$ in diameter, the upper was limited to $20 \mathrm{~mm}$. The stones were held together by natural interlock. Although later bitumen/mastic was applied for a smoother surface McAdam's pavements had twice *Telford's carrying capacity. In 1827 he received a government grant of $£ 10,000$ and was appointed surveyor-general of metropolitan roads. 'Macadamised' roads had been introduced to France, Russia, North America and Australia by 1830 .

Lay, M. G., Ways of the World. 1993.

McAdoo, William Gibbs (1863-1941). American politician, born in Georgia. He became a lawyer in Tennessee, then entered business in railway and tunnel construction in New York. Regarded as a progressive on social issues, he was campaign director for Woodrow *Wilson's campaign for President in 1912. US Secretary of the Treasury 1913-18, in 1914 he married Wilson's daughter, Eleanor. He introduced the Federal Reserve system as a central bank. A 'Dry' on prohibition, McAdoo twice sought the Democratic nomination for president. In 1920 he led on 21 ballots at the Convention but failed to win the required two-thirds majority. In 1924, endorsed both by the $\mathrm{Ku}$ Klux Klan and organised labour, he led on 77 ballots, but failed again. He lived in California from 1922 and was a US Senator 1933-39.

McAleese, Mary Patricia (née Leneghan) (1951- ). Irish lawyer, academic and politician, born in Belfast. A barrister and professor of criminal law at the Queen's University, Belfast, she was elected as President of Ireland 1997-2011, as a political independent. In 2011 she hosted a state visit to the Republic by Queen *Elizabeth II.

MacArthur, Douglas (1880-1964). American General of the Army, born in Little Rock, Arkansas. His father, Lieutenant-General Arthur MacArthur (1845-1912), won the Medal of Honor (1863) in the Civil War, served as Military Governor of the Philippines 1901-05 and as an observer of the Russo-Japanese war. Douglas MacArthur graduated from West Point in 1903 at the head of the class and won a brilliant reputation in France as Commander of the 42nd ('Rainbow') division 1918-19. He became Superintendent of the West Point Military Academy 1919-22 and saw further service in the Philippines. As Chief of Staff of the US Army 193035, he led troops in Washington (1932) to break up demonstrations by the unemployed. The Filipino Government appointed him as Director of National Defence 1935-37 and he lived in Manila after retirement. The US recalled him to active service in July 1941 and after Pearl Harbor he became General Commanding US Forces in the Far East 1941-42. Ironically, his scheme for defending the Philippines led to a major US defeat, despite skilful delaying actions at Bataan and Corregidor. He was awarded the Medal of Honor in 1942. This was the first time a father and son had been so recognised. President *Roosevelt ordered him to leave the Philippines for Australia. As Supreme Commander, Allied Forces in the South West Pacific 1942-45, he directed US and Australian troops, working closely with ${ }^{*}$ Curtin and *Blamey. The Japanese advance was stopped in New Guinea by Australian soldiers. With Admiral Chester *Nimitz, MacArthur devised an 'island hopping' strategy for the recovery of the Pacific. In October 1944, US troops landed on the island of Leyte, fulfilling MacArthur's pledge: 'I will return.' He was promoted five-star General of the Army in 1944 and received a GCB (UK) in 1945. (Lord *Alanbrooke considered him the greatest general of World War II.) MacArthur formally accepted the Japanese surrender (August-September 1945), and as Supreme Commander of Allied Forces in Japan 1945-51, virtually revived the Shogunate, ruling 
with Emperor *Hirohito's cooperation. A democratic constitution was adopted, trade unions legalised, the armed forces abolished and war crimes trials held. MacArthur became Commander-in-Chief of UN Forces in Korea 1950-51, checked the invasion from North Korea, backed by China, and proposed to bomb Chinese bases north of the Yalu. President *Truman sacked him (April 1951) for challenging a direction to limit the fighting. MacArthur was given a hero's welcome when he returned to the US for the first time since 1937, but an attempt to launch him politically received little support and he withdrew into retirement. In 1952 he supported Robert A *Taft for the Republican presidential nomination. An impressive and dominating personality combined with longsighted strategic perception and a mastery of the military art place him among history's greatest commanders.

Clayton James, D., The Years of MacArthur. 3 vols, 1970; Herman, A., Douglas MacArthur. American Warrior. 2016.

Macarthur, John (1767-1834). Australian pioneer, born near Plymouth. He joined the army and in 1789 was posted to the New South Wales Corps, arriving in Sydney with his wife Elizabeth MacArthur (née Veale) (1766-1850) in June 1790. Ambitious, with a flair for publicity and making enemies, he remained in the army but became a landowner at Elizabeth Farm, Parramatta and Camden Park. By breeding merino sheep for wool rather than meat he pioneered the industry that became an Australian mainstay. He clashed with successive governors of New South Wales, and was active in the Rum Rebellion (January 1808), which overthrew William *Bligh. He was in England 1809-17 and his wife managed his sheep flocks with great success. Macarthur became an ultra-conservative in the Legislative Council 1825-32.

Ellis, M. H., John Macarthur. 1955.

Macartney, 1st Earl, George Macartney (17371806). Anglo-Irish diplomat and administrator. Educated at Trinity College, Dublin, he became envoy to St Petersburg 1765-67, Governor of the Caribee Islands 1775-79, of Madras 1780-86 and the Cape of Good Hope 1796-98. He led an important but unsuccessful mission to China 1792-94, during the reign of ${ }^{*}$ Qianlong.

Peyrefitte, A., The Collision of Two Civilisations. 1992.

Macaulay, Dame (Emily) Rose (1881-1958). English novelist. Educated at Oxford, she first won success with Potterism (1920). Among the best known of her many novels are Orphan Island (1924) and, almost at the end of her life, The Towers of Trebizond (1956) for which she was awarded the James Tait Black Memorial Prize. Her astringent and ironic style was much admired. In 1958 she was made a DBE.
Macaulay, Thomas Babington Macaulay, 1st Baron (1800-1859). English historian, poet and politician. A precocious child with a prodigious memory, he abandoned law for literature and politics soon after leaving Cambridge. His essays began to appear in the Edinburgh Review in 1825. Their pretext was always a recently published book but in reality they were Macaulay's own assessments of the subject. First collected in 1843 they give a magnificent impression of brilliance sustained over nearly 20 years, those on ${ }^{*}$ Chatham and ${ }^{*}$ Clive are among the best, that on Warren *Hastings among the most unfair. As a Whig MP 1830-34, 1839-47 and 1852-56, Macaulay displayed his talent in parliament in oratory rather than debate. He went to India (1834) as legal advisor to the supreme council and there he wrote a famous 'minute' on education and played the leading part in drawing up a new criminal code. On his return he was Secretary for War 1839-41 and Paymaster General 1846-47. His History of England from the Accession of James II (5 vols, 1848-61, incomplete) was passionate advocacy written from the Whig perspective, with great narrative skill but flawed by an incapacity to understand other points of view.

Millgate, J., Macaulay. 1973.

Macbeth (né MacBheatha mac Fhionnlaigh) (c.1005-1057). King of Alba (Scotland) 1040-57. Probably son of Fhionnlaigh (Finlay), Thane of Angus and Mormaer (sub-king) of Moray, he married Gruoch, granddaughter of Kenneth III. He killed *Duncan I, seized his throne and ruled until defeated and killed in battle by Duncan's son *Malcolm III. His reign seems to have been relatively prosperous. He is said to have made a pilgrimage to Rome (1050). *Shakespeare's tragedy is based on the account in *Holinshed's Chronicle but the characters are largely fictional.

MacBride, Sean (1904-1988). Irish politician and lawyer, born in Paris. His father, John MacBride (1868-1916), was executed by the British after the Easter rising and his mother Maud Gonne (18661953), an actor and patriot, was the lover of *Yeats. A journalist, active in the Irish Republican Army (IRA), he became its Commander-in-Chief 1936, and from 1937 was a senior barrister. He served in the Irish Dail 1947-57 and was Minister for External Affairs 1948-51. He helped to found Amnesty International (1961), became its chairman 1961-75, worked for UN and UNESCO and won the Nobel Peace Prize in 1974.

Maccabaeus, Mattathias (d.c.166 BCE). Jewish Hasmonean ruler. The first members of his dynasty were known as the Maccabees. Mattathias was a Jewish priest who led the revolt against King *Antiochus IV of Syria. It is said that after rejecting all promises made to him to induce him to abandon his faith he killed the first Jew to approach the heathen altar. This was the signal for rebellion. Mattathias 
gathered an increasing number of followers in the wilderness whence they raided the towns and villages, attacked Syrians and reconverted Jews. After his death his son Judas (Judah) Maccabaeus (d.160 BCE) took command, reconquered Jerusalem and purified the temple (165-164). He made an alliance with the Romans but was killed in battle (160). His brother Jonathan (d.142 BCE), who became high priest, was treacherously executed by the Syrians. Another brother, Simon (d.135 BCE), who also gained Roman recognition and support, completely re-established the independence of the nation (141) and ruled with wisdom and justice until he was murdered by his son-in-law. The Hasmonean dynasty was continued by Simon's son Johanan Hyrcanus (164-104 BCE), whose son Judas Aristobulus (d.103 BCE) took the title of King. Eventually it was superseded by the Idumaean dynasty to which ${ }^{*}$ Herod the Great belonged.

McCahon, Colin (1919-1987). New Zealand painter. Largely self-taught, he worked through landscapes and religious subjects to word paintings, powerful and disturbing works in which messages, often Biblical or Maori texts, conveyed a desperate need to communicate an inner anguish, e.g. Will he save him? (1959).

McCain, John Sidney III (1936-2018). American Republican politician, born in Panama. Son of an admiral, he served as a naval pilot, became a prisoner of war in Vietnam 1967-73, then entered politics as Congressman 1983-87 and US Senator from Arizona 1987-2018. He was a candidate for Republican nomination for president 2000, losing to George W. *Bush. In 2008 he had a spectacular series of wins in the Republican primaries, was unopposed for the presidential nomination at the convention, but lost to Barack ${ }^{*}$ Obama in November.

McCall Smith, Alexander (1948- ). Scottish novelist and lawyer, born in Zimbabwe. Educated in Botswana and Scotland, McCall Smith became Professor of Medical Law at Edinburgh University, and was an authority on bioethics and an amateur bassoonist. An astonishingly prolific writer of academic texts, he wrote more than 100 novels and children's books, including The No. 1 Ladies' Detective Agency series (1999ff) and the 44 Scotland Street series (2005ff.)

McCarthy, Eugene Joseph (1916-2005). American politician, born in Minnesota. He studied for the priesthood, but became a social science teacher, first at high schools, then at colleges in Minnesota. He was a US Congressman 1949-59 and a senator from Minnesota 1959-71. He became closely identified with the political cause of Adlai ${ }^{*}$ Stevenson and was recognised as a witty and fastidious man with a distaste for the vulgarities of the political routine. In 1968 he campaigned against President *Johnson's renomination and fought for the Democratic nomination against Hubert ${ }^{*}$ Humphrey and Robert
*Kennedy. He sought the nomination again in 1972, ran for president as an Independent in 1976, endorsing Ronald *Reagan in 1980 and Ralph *Nader in 2000 . He wrote essays and columns, published volumes of poetry and worked as an editor.

McCarthy, Joe (Joseph Raymond) (1909-1957). American Republican politician. Senator for Wisconsin 1947-57, as chairman of a senatorial committee on subversion, from February 1950 his hectoring inquisitorial methods, hysteriaraising, and a technique of charging people with 'guilt by association' constituted a smear campaign ('McCarthyism') that provoked mounting national and international criticism. In 1954 the Senate passed a vote of censure on him for breach of constitutional privilege and thereafter his influence rapidly declined. *Truman described him as a 'pathological character assassin'.

Rorty, J. and Decker, M., McCarthy and the Communists. 1972.

McCarthy, Mary (Therese) (1912-1989). American novelist and critic, born in Seattle. A satirist of the intellectual's attempts to come to terms with modern urban life and human relationships, she is best known for Memories of a Catholic Girlhood (1957), The Groves of Academe (1952) and The Group (1963), the last drawn from her own education at Vassar College. She married four times, once to Edmund *Wilson.

McCartney, Sir (James) Paul (1942- ). English composer, singer and instrumentalist, born in Liverpool. In 1961, he joined the *Beatles, which had been formed by John *Lennon, as singer and bass guitarist. Many of their works were collaborations, but McCartney's Yesterday became one of the most performed songs in musical history. The Beatles broke up in 1970, but McCartney continued to compose and perform. He became a billionaire, received a knighthood (1997) and a $\mathrm{CH}$ (2017) and was an active campaigner for animal rights and music education.

McClellan, George Brinton (1826-1885). American soldier, born in Philadelphia. He served as an engineer in the Mexican War (1846-48) and in 1855 was sent as an observer to the Crimean War, returning to his profession in 1857. On the outbreak of the Civil War he was recalled to military service as Commander of the Department of the Ohio 1861 and briefly (aged only 35) General-in-Chief of the Union Army 186162. He disliked and despised President ${ }^{*}$ Lincoln who demoted him (slightly) to command the Army of the Potomac 1862. He blamed Lincoln for the early success of Robert E. *Lee's advance on Washington, then planned a major amphibious campaign to capture Richmond, the Confederate capital. It was brilliantly conceived but poorly executed. The Battle of Antietem (a.k.a. Sharpsburg), in Maryland (17 September 1862) was the first major action on 
Union territory and the bloodiest day in US military history. Tactically, it was a draw but proved to be a turning point in the war. McClellan's failure to pursue Lee resulted in his removal from command; his bitterness never ended. (U. S. *Grant regarded McClellan as 'a mystery'.) In the 1864 election he was the Democrat candidate for the presidency against Lincoln, essentially repudiating his party's platform, winning 45 per cent of the popular vote but only three states. He then became a railroad executive and Governor of New Jersey 1877-81.

McClintock, Barbara (1902-1992). American geneticist. Educated at Cornell University, she devoted herself to plant breeding, working at the Cold Spring Harbor Laboratory of the Carnegie Institute from 1942. Her decades of work on maize led to the identification of 'jumping genes', mobile elements in chromosomes which helped to explain mutability in hereditary traits in some plants. The importance of her research was not recognised until after the revolution in molecular biology promoted by F. H. C. * ${ }^{*}$ rick and J. D. *Watson. She won the 1983 Nobel Prize for Medicine.

McConnell, (Addison) Mitch(ell) (1942- ). American Republican politician, born in Alabama. A lawyer, he was a US Senator from Kentucky 1985, and Republican leader in the Senate 2007- . He opposed Donald *Trump's candidacy in 2016, then became a strong collaborator. He conceded that *Biden had won the 2020 election and in Trump's second impeachment trial (February 2021) voted to acquit on the grounds that he had already left office, but denounced his behaviour as 'disgraceful'.

McCormack, John (1884-1945). Irish lyric tenor, born in Athlone. He began recording in 1904, was encouraged by Nellie *Melba and sang in opera in Italy, Britain and the US 1906-23. He had exceptional breath control and diction and toured for many years, giving concerts. He became an American citizen in 1919, but returned to Ireland in 1927 and was made a papal count in 1928.

Strong, L. A. G., John McCormack. 1949.

McCormick, Cyrus Hall (1809-1884). American inventor. He was the son of Robert McCormick (1780-1846), a Virginian farmer, who invented (1809) a successful but crude reaping machine. Young McCormick patented a greatly improved model in 1839 and in 1848 arranged for the manufacture of a more advanced version in Chicago. It was exhibited at the Hyde Park Exhibition in London (1851). On his election (1879) to the French Académie des Sciences, McCormick was acclaimed as having done 'more for science than any living man'. Under the presidency of his son and namesake, also Cyrus Hall McCormick (1859-1936), the firm became the International Harvester Company, one of the greatest firms in the US.
McCormick, C. H., The Century of the Reaper. 1931; Aldrich, L. A., Cyrus McCormick and the Mechanical Reaper. 2002; Welch, C. A., Farmland Innovator. 2007.

McCullers, Carson (née Lula Carson Smith) (19171967). American novelist, born in Georgia. She studied music and writing in New York, and wrote in the Southern Gothic tradition. Although crippled by strokes and alcoholism, she achieved consistent success with her novels, several of which were filmed, including The Heart is a Lonely Hunter (1940), The Member of the Wedding (1946) and Clock without Hands (1961).

MacCulloch, (Sir) Diarmaid Ninian John (1951-). English historian, born in Kent. Professor of Church history at Oxford 1997-, his magisterial A History of Christianity: The First Three Thousand Years (2009) became a BBC television documentary series. $\mathrm{He}$ wrote Thomas Cranmer: A Life (1996), Reformation: Europe's House Divided 1490-1700 (2003), Silence: A Christian History (2013), and Thomas Cromwell: A Life (2018).

MacDiarmid, Hugh (pen name of Christopher Murray Grieve) (1892-1978). Scottish nationalist leader and poet. Written mostly in Scots, the best of his poems give lyrical expression to his feelings for his native land. He became both a Communist and a Scots Nationalist, and his later works, reflecting his social and philosophical concerns which could not be adequately written in Scots, were published in English.

Buthley, K., Hugh MacDiarmid. 1964.

Macdonald, Dwight (1906-1982). American critic, born in New York City. Educated at Yale, originally a supporter of *Trotsky, sympathetic to anarchism, he wrote for Fortune magazine (1930-36), then Partisan Review (1938-43), Politics (1944-49), New Yorker (1951-71), Esquire (1960-66) and New York Review of Books (1963-80). His range of interests included film, politics and literature. He was a penetrating opponent of dictatorship and some aspects of mass culture. He edited Parodies: An Anthology from Chaucer to Beerbohm - and After (1960), and some of his most trenchant writing is in Against the American Grain: Essays on the Effects of Mass Culture (1962).

MacDonald, Flora (1722-1790). Scottish heroine. After the defeat at Culloden had ended the Jacobite rising (1745-46), she aided the escape of Charles Edward *Stuart (Bonnie Prince Charlie) by bringing him, disguised as her maid, safely to the island of Skye. Captured 10 days later, she was released in 1747. She married in 1750 and, after living in North Carolina 1774-79 with her husband (also a MacDonald), she died in Skye leaving many descendants to hand down the story.

Linklater, E., The Prince in the Heather. 1965; MacLeod, R. H., Flora MacDonald. 1995. 
MacDonald, J(ames) Ramsay (1866-1937). British Labour politician, born at Lossiemouth. Educated at the village school where he later became a pupil teacher, he went to London (1884) but, after a breakdown of health, abandoned his studies in science for political journalism. A determined propagandist for socialism, he joined the Independent Labour Party (1893) and became Secretary (1900) of the newly formed Labour Party. He was a Member of Parliament 1906-18; 1922-35; 1936-37, originally elected for Leicester, but later holding three other seats. He became Chairman (in effect, Leader) of the Parliamentary Labour Party 1911-14, resigning because of his pacifist opposition to World War I. (Arthur *Henderson succeeded.)

Defeated in Leicester in the 'khaki election' of 1918, he was re-elected in 1922 as one of 140 Labour members, relegating the Liberals to third place. MacDonald again became Leader of the British Labour Party 1922-31, and Leader of the Opposition 1922-24. In a snap election (December 1923) called by *Baldwin on the protection issue, Labour and the Liberals won a majority for free trade. MacDonald became the first Labour Prime Minister (and foreign minister) January-November 1924, with Liberal support. The * Zinoviev letter incident led to press allegations of Communist influence on Labour. The Liberals withdrew their support and the elections of November 1924 resulted in a Conservative victory. (The Liberals suffered even heavier losses.) MacDonald was Prime Minister again 1929-35 (Labour 1929-31, then, after his expulsion, as 'National Labour', a small rump, 1931-35). MacDonald's second government lacked any clear idea of how to deal with the Great Depression and his chancellor, *Snowden, was ultra-cautious, rejecting *Mosley's alternative program. When a majority of Labour ministers refused to accept Budget cuts, MacDonald resigned, then continued as Prime Minister of a National Government 1931-35 with the Conservatives and some Liberals, and was expelled from the Labour Party. He came under increasing Conservative domination and in declining health, suffered memory loss and occasional incoherence. He resigned as Prime Minister, served as Lord President of the Council under Baldwin 1935-37, then retired, dying a week later on a sea voyage to South America.

Marquand, D., Ramsay MacDonald. 1976.

MacDonald, Sir John A(lexander) (1815-1891). Canadian Conservative politician, born in Glasgow. He emigrated with his parents to Canada when he was five and became a lawyer in Kingston, Ontario. In 1844 he became a Conservative member of the Legislature of Upper Canada and from 1847 held Cabinet offices. From 1856, as leader of the government, he played the principal part in the discussions and negotiations leading to the formation of the dominion of Canada, of which he became first Prime Minister 1867-73 and 1878-91. One of the great benefits he conferred upon Canada was encouraging the building of railways, as a means of linking the widely separated areas of the vast country and providing a secure basis for unity. He also introduced tariff protection of industry. Following the 'Pacific scandal', charges that he accepted campaign funds from a railroad contractor, Sir Hugh Allan, he resigned (1873) and was beaten in the ensuing elections. Alexander *Mackenzie then became Prime Minister, but MacDonald returned to office at the 1878 election, remaining in office until his death from a stroke.

Creighton, D., Sir John A. MacDonald, 2 vols, 1952-55.

MacDonald, Malcolm John (1901-1981). British administrator. Son of J. Ramsay *MacDonald, he was an MP 1929-35 and 1936-45 (Labour until 1931, then National Labour), Dominions Secretary 193539 and Colonial Secretary 1935 and 1938-40. High Commissioner to Canada 1941-46 and GovernorGeneral of the Malayan Union 1946-48, he became Commissioner-General for Southeast Asia 1948-55 and High Commissioner in India 1955-60. He served in Kenya at the time of transition to self-government (*Kenyatta) as Governor-General 1963-64 and High Commissioner 1964-65. He was awarded the OM in 1969.

McDormand, Frances Louise (née Cynthia Ann Smith) (1957-). American actor and producer. She won the Academy Award for best actress for Fargo (1996), Three Billboards Outside Ebbing, Missouri (2017) and Nomadland (2021).

McDougall, William (1871-1938). Anglo-American psychologist. Educated in England and Germany, he became professor of psychology at Harvard 1920-27 and Duke University, North Carolina 1927-38, collaborating with J. B. *Rhine. He followed ${ }^{*}$ Lamarck and ${ }^{*}$ Jung rather than ${ }^{*}$ Darwin and ${ }^{*}$ Freud, opposed behaviourism, advocated eugenics, devoted much effort to psychic research and the paranormal and sold many books.

McEwan, Ian (Russell) (1948- ). English novelist, short story and screen writer. He graduated from the University of East Anglia, and his novels include Enduring Love (1997), Amsterdam (1998: Man Booker Prize), Atonement (2001), Saturday (2005), On Chesil Beach (2007), and Solar (2010).

McEwen, Sir John (1900-1980). Australian politician and farmer. A soldier settler after World War I, he entered parliament in 1934, was a minister 1937-41 and 1949-71, becoming became Leader of the Country Party 1958-71 and Deputy Prime Minister. Long recognised as the strong man of the Commonwealth Government, on the disappearance of Harold ${ }^{*}$ Holt he was Prime Minister briefly (December 1967-January 1968). He received a CH 
in 1969 and was knighted (GCMG) in 1971. In retirement he suffered agonies from dermatitis, and died of self-imposed starvation.

McGovern, George Stanley (1922-2012). US politician. The son of a clergyman, he was trained for the Methodist ministry, served as a bomber pilot in World War II, then took a PhD in history. $\mathrm{He}$ served as a congressman from South Dakota 1957-61, foundation Director of the Peace Corps 1961-62 and US Senator 1963-81. In 1972, he won the Democratic nomination for president as an anti-war candidate, but Richard ${ }^{*}$ Nixon defeated him by a 61 per cent to 37 per cent margin. He was US Ambassador to the UN Food and Agriculture Organization (FAO) 1998-2001.

MacGregor, (Robert) Neil (1946- ). British art historian and museum director, born in Glasgow. Educated in Paris, Oxford, Edinburgh, and London, he worked with Anthony *Blunt and was editor of The Burlington Magazine 1981-87. He was Director of the National Gallery, London, 1987-2002 and the British Museum 2002-15. He presented illuminating television and radio series and wrote History of the World in 100 Objects (2010), Shakespeare's Restless World (2013), Germany: Memories of a Nation (2014) and Living with the Gods (2018). He was awarded the $\mathrm{OM}$ in 2010.

McGuffey, William Holmes (1800-1873). American educator, born in Pennsylvania. He taught in Ohio, after picking up a sporadic education, and was appointed to the chair of mental and moral philosophy at the University of Virginia in 1845 . His name was immortalised by his five volumes known as McGuffey's Eclectic Readers (1836-44) of which 122,000,000 copies were sold between 1836 and 1920. These became the model for school readers throughout the world and had an extraordinary influence in the US, especially where reading material was scarce. They contained extracts from the Bible, *Shakespeare, Samuel ${ }^{*}$ Johnson and ${ }^{*}$ Dickens and proclaimed a philosophy based on Alexander *Hamilton's concept of democracy, *Calvin's theology, and *Blackstone's view of property.

McGuinness, (James) Martin (Pacelli). (Séamus Máirtín Pacelli Mag Aonghusa) (1950-2017). Irish politician. After being active with the Provisional IRA, he worked with Sinn Féin, was elected to the UK House of Commons 1997-2013, but never sat. Following a peace agreement in Ulster, he served as Deputy First Minister 2007-17, working with Ian *Paisley.

Mach, Ernst (1838-1916). Austrian physicist and philosopher. He was professor of mathematics at Graz 1864-67, of physics at Prague 1867-95 and at Vienna 1895-1901. He investigated the behaviour of projectiles at high speeds and thus provided valuable data on the phenomena of supersonic flight, the ratio of the airspeed on an aircraft to the speed of sound was named, after him, the 'Mach number'. His theoretical studies of mechanics and thermodynamics led him to a reassessment of Newtonian concepts and influenced Einstein in his development of the relativity theory. As a philosopher, Mach held that the laws of physics should be divorced from metaphysical speculation and should be pure descriptions of observed data. In that sense he can be described as a phenomenalist.

Machado de Assis, Joaquim Maria (1839-1908). Brazilian novelist and poet, born in Rio de Janeiro. Of mixed African and Portuguese descent, he suffered from epilepsy and poverty as a youth. He became a typesetter, then a journalist. Regarded as the most important Brazilian writer, his novels include The Posthumous Memoirs of Brás Cubas (1881 translated as Epitaph of a Small Winner 1952) and Dom Casmurro (1900, 1953). His work combined cynicism, urbanity, irony, wit and pessimism. Machado was the first president of the Brazilian Academy of Letters 1896-1908.

Machaut, Guillaume de (1300-1377). French composer and poet. A priest in the service of ${ }^{*}$ Charles $\mathrm{V}$, he is credited with the first complete Mass by one composer and his Messe de Nostre Dame was one of the greatest works of the 14th century.

Machiavelli, Niccolò (1469-1527). Italian diplomat and writer, born in Florence. Son of a lawyer, he held office as Secretary of the Council of Ten in charge of Florentine foreign affairs from 1498 until 1512 when the republic fell and the ${ }^{*}$ Medici regained power. During those years he was sent on diplomatic missions to ${ }^{*}$ Louis XII of France and the emperor ${ }^{*}$ Maximilian, and while in attendance upon Cesare *Borgia was able to study the practices and motives of the ambitious prince. Back in Florence he organised the citizen army that captured Pisa (1509). When the Medici returned, Machiavelli was imprisoned for a time and had to retire from public life. $\mathrm{He}$ occupied himself by writing not only to instruct but to amuse, as in the lively, satirical and bawdy play $L a$ Mandragola. His serious works include Discourses on Livy, The Art of War, a History of Florence and the book upon which his fame and his sinister reputation rest, Il Principe (The Prince, 1513), largely based on his observations of Cesare *Borgia. Originally dedicated to the younger Lorenzo de' Medici (1492-1519), grandson of 'the Magnificent', by whom Machiavelli may have hoped that Italy might be saved from foreign intervention and united under a single rule, the book was not actually published until 1532 . Il Principe sets out to give precise and practical information concerning the qualities and practices necessary for a prince to achieve these worthy ends in a corrupt age. It is thus a work not of moral precept but of practical instruction, and in so far as it is held to reflect Machiavelli's personal character, it defames him. The view of *Spinoza and *Rousseau is now generally accepted: that The Prince is a savage satire 
against tyranny by a man of profoundly pessimistic insight who recognised that the methods he detested (and scrupulously refrained from in his own life) were likelier to be successful than policies of restraint and conciliation. He bases the argument of The Prince on the contention that in an age where everyone is self-seeking the only hope lies in a single ruler whose sole interest would be his people's welfare, but that in order to obtain that position and achieve that aim it is necessary to rule despotically, to cast all moral principles aside and concentrate entirely on the end in view. The cynical dictum 'the end justifies the means' had long been approved in practice. The odium that was attached to Machiavelli's name was due to the fact that he seemed to give it theoretical justification. In Elizabethan and Jacobean England, Machiavelli and their perception of machiavellian politics were so execrated that his works and possibly his name (Old Nick) became synonymous with the devil. Machiavelli returned to public life in his later years and performed some services for Pope *Clement VII.

Hale, J. R., Machiavelli and Renaissance History. Rev. ed. 1972; de Grazia, S., Machiavelli in Hell. 1989; Skinner, Q., Machiavelli. A Very Short Introduction. 2000; Oppenheimer, M., Machiavelli: a life byond ideology. 2011; Vivanti, C., Niccolò Machiavelli: An Intellectual Biography. 2013.

McKell, Sir William John (1891-1985). Australian Labor politician. Originally a boiler-maker, he entered the New South Wales State Parliament in 1917, studied law and became a KC and was Premier 1941-47, retiring on his controversial appointment as the second native-born Governor-General of Australia 1947-53.

McKellen, Sir Ian Murray (1939- ). English actor. He excelled in *Shakespeare and *Chekhov and was a memorable *Salieri in Amadeus. He starred in Richard Locraine's film Richard III (1996) and as Gandalf in The Lord of the Rings (2001). He was an outstanding Edgar in *Strindberg's The Dance of Death, Lear in King Lear and Estragon in *Beckett's Waiting for Godot, and received a CH in 2008.

O’Connor, G., Ian McKellen. 2019.

Mackensen, Anton Ludwig Friedrich August von (1849-1945). German field marshal. One of the most successful commanders of World War I, he drove the Russians from Galicia, overran Serbia 1915, and conquered Romania 1916-17.

Mackenzie, Sir Alexander (1764-1820). Scottish explorer of Canada. His interest in a fur-trading company provided opportunities for journeys of exploration. He reached (1789) the mouth of what is now called the Mackenzie River and (1792-93) made the first expedition across the Rockies to the Pacific. He was knighted in 1802.
Mackenzie, Alexander (1822-1892). Canadian politician, born in Scotland. He emigrated (1842) to Canada and led the Liberal opposition to Sir John *MacDonald in the dominion parliament 1867-73. He became the first Liberal Prime Minister 1873-78, serving as Opposition Leader again 1878-80.

Mackenzie, Sir (Edward Montague) Compton (1883-1972). English novelist and editor, born in Durham. Educated at Oxford, his earlier novels, include The Passionate Elopement (1911), Carnival (1912), Sinister Street (1913-14), perhaps his greatest achievement, and Sylvia Scarlett (1918). During World War I he served in the Gallipoli campaign and in military intelligence in the Near East. In 1923 he founded The Gramophone the first magazine of its type, and remained its editor until 1961. An ardent Scottish nationalist, he was elected as Lord Rector of Glasgow University (1931-34) and in 1938 published The Windsor Tapestry a study of ${ }^{*}$ Edward VIII's abdication. Four Kinds of Love (1937-45), a somewhat pretentious novel about the inter-war years, followed. He lived on the island of Barra 1939-45 and his Scottish experiences led to the very funny novels Monarch of the Glen (1941) and Whisky Galore (1947: also a successful film). Mackenzie was also a poet, essayist, journalist, and television lecturer. His autobiography $M y$ Life and Times appeared, in 10 'octaves' between 1963 and 1971.

Mackenzie, William Lyon (1795-1861). Canadian politician. An emigrant from Scotland (1820) he founded in York (now Toronto) a newspaper, the Colonial Advocate in which he demanded selfgovernment for Upper Canada. Several times he was elected to the assembly and as often expelled. In 1837 he led an armed rebellion that proved a complete fiasco. Mackenzie took refuge in the US but returned (1849) under an amnesty and served (1850-58) in the legislature. His main achievement was to bring home to the British Government the urgency of constitutional reform. His grandson was W. L. Mackenzie *King.

MacKillop, Mary Helen (St Mary of the Cross MacKillop) (1842-1909). Australian Catholic religious, born in Melbourne. Of Scottish descent, in 1866 in Penola, South Australia, she founded the Order of the Josephites (Congregation of the Sisters of St Joseph of the Sacred Heart), devoted to Indigenous people and the poor. She had a turbulent relationship with superiors and was briefly excommunicated (1871). Her beatification was proclaimed in Sydney in 1995 by *John Paul II and canonisation occurred in Rome in October 2010.

Gardiner, P., Mary MacKillop. 1993.

Mackinder, Sir Halford John (1861-1947). English geographer. His appointment as reader in geography at Oxford (1887) marked a belated English recognition of the subject as an academic discipline. In 1899 
he made the first recorded ascent of Mt Kenya. He directed the London School of Economics 1903-08, became professor of geography at London University 1908-15 and a Conservative MP 1910-22. His application of geography to political questions was borrowed by Karl *Haushofer, associated with the Eurasian 'Heartland' theory. Mackinder's books include Britain and the British Seas (1902).

Gilbert, E. W., Sir Halford Mackinder 1861-1947. 1963.

McKinley, William (1843-1901). Born in Niles, Ohio, he worked as a clerk and teacher, served in the Union forces during the Civil War, fought at Antietam and the Shenandoah Valley and was promoted to major. After briefly studying law, he became an attorney, married in 1871 and was a devoted husband to his invalid wife. A Republican Congressman from Ohio 1877-83; 1885-91, he was committed to a high tariff policy and, with support from industrialists, was elected as Governor of Ohio 1892-96. In 1896, after a masterly campaign organized by his patron Mark *Hanna, he won the Republican nomination for President on the first ballot, and was elected in 1896 and re-elected in 1900 , both times defeating William Jennings *Bryan. His policy agenda included supporting high tariffs for manufacturing, the gold standard and American interventionism. After victory in the Spanish-American War (1898), the US took control of Cuba, the Philippines, Puerto Rico and Guam. It also annexed Hawaii. The economy boomed and McKinley was considered to have ended the post-Civil War political stalemate. Shot at Buffalo station by an anarchist, Leon Czolgosz, he died eight days later and was succeeded by his Vice President, Theodore ${ }^{*}$ Roosevelt. In 18 Presidential ranking lists by US historians and political scientists, McKinley scored No. 14 in the aggregate.

Leech, M. K., In the Days of McKinley. 1959; Vidal, G., Empire. 1987.

Mackintosh, Charles Rennie (1868-1928). Scottish architect and designer, born in Glasgow. A pioneer of the 'Modern Movement', Mackintosh discarded historicism in his buildings and became the centre of a group in Glasgow which, having aroused Continental interest, was asked to exhibit in Vienna (1901) and Turin (1902). His Glasgow School of Art (1896-99), designed when he was 28 , is, with its great area of window glass, remarkably advanced for its time.

Howarth, T., Charles Rennie Mackintosh and the Modern Movement. 1952; McKean, J., Charles Rennie Mackintosh, Architect, Artist, Icon. 2001; Stark, D., Charles Rennie Mackintosh and Co. 2004; Pickeral, T., Mackintosh. 2004.

MacLeish, Archibald (1892-1982). American poet and dramatist. In his earlier lyrics, e.g. Frescoes for $\mathrm{Mr}$ Rockefeller's City (1933), he showed himself to be a social critic but was better known for his long poem,
Conquistador which won the Pulitzer Prize (1932). He lived in France for many years and his poetry was deeply influenced by *Eliot and *Pound. As Librarian of Congress 1939-44 and Assistant Secretary of State 1944-45, he took an active role in preparing war propaganda and was a founder of UNESCO (1945). He won a second Pulitzer Prize (1953) for his Collected Poems. His play, J. B., a religious parable based on the story of Job, was produced in 1958 and won a third Pulitzer. Edmund *Wilson despised him as an opportunistic mediocrity.

MacLeod, George Fielden, Baron MacLeod of Fuinary (1895-1991). Scottish clergyman. Educated at Winchester and Oxford, he won an MC in World War I and in 1938 founded the Iona Community which attracted international interest. He was Moderator of the Church of Scotland 1957-58. A notable broadcaster and preacher, he called himself 'an uncomfortable socialist and a reluctant pacifist'. He inherited a baronetcy but refused to use the title, but accepted a life peerage in 1967 and later joined the Greens.

Macleod, Iain Norman (1913-1970). English Conservative politician. After war service, he became a journalist and writer on bridge, was an MP 1950 70 , and a reforming minister 1952-63, declining to serve under *Home. He wrote a biography of Neville ${ }^{*}$ Chamberlain (1961), edited The Spectator 196365 and died suddenly after four weeks as *Heath's Chancellor of the Exchequer 1970.

McLuhan, (Herbert) Marshall (1911-1980). Canadian media analyst, born in Alberta. Educated at Manitoba and Cambridge, he taught in the US and Canada, directing the centre for culture and technology at Toronto University 1964-76. His work examined the impact of mass media and advertising. His controversial books include The Mechanical Bride (1951), The Gutenberg Galaxy (1962), Understanding Media (1964), The Medium is the Massage (1967), War and Peace in the Global Village (1968), Take Today: Executive as Drop-Out (1972) and City as Classroom (1977). He defined 'media' as extensions of human capacity and included electric light, vehicles and tools as well as newspapers, telephones, radio and television. He described television as a 'cool' (low definition) medium aimed at group (or family) viewing, favouring low intensity subjects or events (e.g. J. F. ${ }^{*}$ Kennedy not R. M. ${ }^{*}$ Nixon, sports programs not war reportage, variety not intensity), while 'hot' (high definition) media such as film or radio were better suited for propaganda aimed at an isolated individual. He argued that the medium is the message (or massage)', i.e. communication environments influence total response rather than specific program content: literacy or television availability alters lifestyle more than individual books or programs. 
MacMahon, (Marie Edmé) Patrice Maurice de (1808-1893). French marshal. Of Irish descent, he served in the Crimea, was made a marshal and given the title Duke of Magenta for his part in the North Italian campaign (1859), and was Governor-General of Algeria 1864-70. In the Franco-Prussian War he commanded the 1st Army Corps and was captured at Sedan. In 1871 he suppressed the revolt of the Paris commune. Though a monarchist, he was elected as President of the Third French Republic in 1873, succeeding Adolphe *Thiers, but resigned in 1879.

McMahon, Sir William (1908-1988). Australian Liberal politician. A Sydney solicitor, he was a member of the Commonwealth Parliament 1949-82, a minister from 1951, Treasurer 1966-69 and Foreign Minister 1969-71. He displaced John ${ }^{*}$ Gorton as Liberal Leader and was Prime Minister 1971-72. He lacked gravitas and by 1972 he, and the Coalition, had run out of ideas. His surprisingly narrow defeat by Gough *Whitlam ended 23 years of Coalition rule. His reputation for deviousness meant that he had no defenders, in or out of his Party. He was created CH in 1972 and GCMG in 1977.

Mullins, P., Tiberius with a Telephone. 2018.

Macmillan, Daniel (1813-1896), and Alexander (1818-1896). British publishers. Sons of a Scottish crofter, they made their way to England, had a small bookshop in Aldersgate St, London, and borrowed money to buy a larger one in Cambridge (1844). Among their most successful early publications were Westward Ho! by Charles *Kingsley and Tom Brown's Schooldays by Thomas *Hughes. They set up a London branch in 1858 and soon based the firm there.

McMillan, Edwin Mattison (1907-1991). American physicist. He worked at the University of California, Berkeley, with E. O. *Lawrence, and in 1940 produced the transuranic element Neptunium $(\mathrm{Np})$. During World War II he worked on radar, sonar and the 'Manhattan Project'. He shared the 1951 Nobel Prize for Physics with Glenn *Seaborg.

Macmillan, (Maurice) Harold, 1st Earl of Stockton (1894-1986). British Conservative politician, born in London. A member of the famous publishing family, he was educated at Eton and Balliol College, Oxford, and was five times wounded as a Guards officer in World War I. He returned to publishing in 1920 and was a Conservative MP 1924-29, 1931-45, 1945-64. He gained some reputation (even notoriety, with his colleagues) as an independent minded politician with sympathy for the unemployed and a supporter of the interventionist economics of his friend J. M. *Keynes. He was 46 when ${ }^{*}$ Churchill first appointed him as an Undersecretary (1940), and his service as Minister Resident in North Africa 1942-45, based in Algiers, helped to develop a working relationship with General Charles *de Gaulle and General Dwight *Eisenhower. He lost his seat in the 1945 election but soon returned through a by-election and was active in the Oppositon front bench. After Churchill's return to office in 1951 he was an energetic and successful Minister for Housing 1951-54, exceeding a party promise to increase the total number of houses built to 300,000 per annum. Minister of Defence 1954-55, he succeeded Anthony *Eden as Foreign Secretary April-December 1955 and became Chancellor of the Exchequer 1955-57. His role in the political crisis over the British-French invasion of Suez was ambiguous: his rival *Butler said he was 'first in and first out'. When Eden resigned after the Suez adventure failed, complicated by his ill-health (January 1957), Macmillan was appointed Prime Minister, serving until October 1963, the longest single term since ${ }^{*}$ Asquith. He rapidly restored the party image blurred by the Egyptian adventure and for a time (marked by his election triumph in 1959) seemed to have the magic touch that brought prosperity and success. But as the years went by the administration seemed to lose momentum and the government's popularity began to decline. His important 'wind of change' speech (February 1960) to the South African Parliament gave strong support for decolonisation and democratic rule in Africa. Elected as Chancellor of Oxford University in March 1960, defeating Oliver *Franks, he served until his death. Macmillan drastically reconstructed his government in 1962 . In January 1963 de Gaulle's refusal to admit Britain to the Common Market, and later the *Profumo affair were major failures. Macmillan's future resolved itself when in October a diagnosis of prostate cancer, wrongly thought to be inoperable, led to his resignation. He ensured that ${ }^{*}$ Butler did not succeed and the prime ministership went unexpectedly to the 13th Earl of Home (Sir Alec Douglas *Home). Macmillan married (1920) Lady Dorothy Cavendish (1900-1966), daughter of the 9th Duke of Devonshire, and the marriage was deeply unhappy: she loved another MP, Robert Boothby, and he continued to mourn. His six volumes of autobiography (1966-73) were surprisingly dull: Enoch ${ }^{*}$ Powell wrote that reading them was like 'chewing on cardboard'. His languid Edwardian demeanour was deceptive, concealing a conflicted interior. Like ${ }^{*}$ Churchill, he had an American mother (from Indiana); with *Attlee he was the only British Prime Minister in three centuries wounded in action; he had the unhappiest prime ministerial marriage since Lord * Melbourne; and was the best-read Prime Minister since ${ }^{*}$ Gladstone. Awarded an OM in 1976, he received an earldom on his 90th birthday. He outlived his son, Maurice Victor Macmillan (1921-1984), who followed him into publishing and politics as a Conservative MP and was Chief Secretary of the Treasury 1970-72, Secretary of State for Employment 1972-73 and Paymaster-General 1973-74.

Hutchinson, G., The Last Edwardian at No 10. 1980; Horne, A. Macmillan: An Official Biography. 2 vols, 1988, 1989; Thorpe, D. R., Supermac: The Life of Harold Macmillan. 2010. 
MacMillan, Sir James (Loy) (1959- ). Scottish composer, born in Ayrshire. A practising Catholic, very prolific, his passionate and inventive choral works attracted international attention and include Magnificat (1999), the cantata Seven Last Words from the Cross (1993), the St John Passion (2007), Tu es Petrus (2010), Since It Was the Day of Preparation... (2012), the St Luke Passion (2013), and Stabat Mater (2016). He composed four symphonies, concertos for piano, violin, viola, cello, oboe, trumpet and percussion, three operas and three string quartets.

McMillan, Margaret (1860-1931). Scottish educationist, born in New York. Her special interest and that of her sister Rachel McMillan (1859-1917) was the physical education and health of small children. A Christian Socialist and active Fabian, she founded several clinics on her own initiative, that at Deptford (1910) being the largest. She wrote The Child and the State (1911) and was created CH in 1927.

MacMillan, Margaret Olwen (1943- ). Canadian historian, born in Toronto. A great granddaughter of David *Lloyd George, educated in Toronto and Oxford, where she later held chairs, her books include Peacemakers: The Paris Peace Conference 1919 (2001), History's People: Personalities and the Past (2015) and War: How Conflict Shapes Us (2020). She received a $\mathrm{CH}$ in 2018.

MacNamara, Robert Strange (1916-2009). American administrator, born in San Francisco. A graduate of Berkeley and Harvard, after serving in World War II with the air force he joined the Ford Motor Company (1945) and became its managing director (1955) and president (1960). He was the longest serving US secretary of defense 1961-68, under *Kennedy and ${ }^{*}$ Johnson, during the Vietnam War. Originally a 'hawk' on Vietnam, he became profoundly disillusioned. President of the World Bank 1969-80, he wrote a poignant memoir In Retrospect (1995). The Fog of War: Eleven Lessons from the Life of Robert S. McNamara (2003) was an Academy Award winning documentary.

McNaughton, Andrew George Latta (1887-1966). Canadian soldier, born in Saskatchewan. Educated as an engineer at McGill, after serving as an artillery officer in World War I he was Canada's Chief of the General Staff 1929-35, President of the National Research Council 1935-39 and commanded Canadian forces in Britain in World War II 1939-43. He had good relations with ${ }^{*}$ Churchill, bad with *Alanbrooke. Mackenzie *King wanted McNaughton as the first Canadian national to be Governor-General but he made the mistake of entering politics as Minister for National Defence 1944-45, then failed to win a seat in Parliament. Appointed CH in 1946, he became Chairman of the United Nations Atomic Energy Commission 1946-48 and Ambassador to the UN 1948-49.

MacNeice, Louis (1907-1963). Anglo-Irish poet, born in Belfast. Educated at Oxford, he was associated with *Auden, *Day Lewis and *Spender in the 'Oxford Group' in the 1930s. He lectured in classics at Birmingham and London, joining the BBC in 1941. His Collected Poems appeared in 1949. Apart from translations from the Greek and critical works, e.g. on *Yeats (1941), he wrote Christopher Columbus (1944) one of several radio plays, and The Dark Tower (1947) a collection of scripts.

Press, J., Louis MacNeice. 1966.

McNeile, (Herman) Cyril (pen name 'Sapper') (1888-1937). English thriller writer. A retired army officer, he became a best-selling author with his novels featuring the character 'Bulldog' Drummond (largely based on himself); 23 films were also made.

Macpherson, James (1738-1796). Scottish author. From 1760 he published a series of poems he claimed were translations from the Gaelic of a 3rd-century CE bard named Ossian. These poems were widely admired, by *Jefferson, ${ }^{*}$ Goethe, *Napoléon, ${ }^{*}$ Ingres and others, and were an important influence behind the Romantic revival. But their genuineness was soon suspect, with Samuel *Johnson conspicuous among the doubters. Challenged to produce his sources, Macpherson fabricated Gaelic originals. After his death a commission considered that the works (Fingal, an epic in six books, is the best known) were free adaptations, with passages of Macpherson's own inserted, of traditional Gaelic poems. This is still the general view. He was London agent to the Nabob of Arcot and an MP 1780-96.

McPherson, Aimée Semple (née Aimée Elizabeth Kennedy) (1890-1944). American Christian revivalist, born in Canada. She toured in the US, China and Europe, and was the founder of the Angelus Temple in Los Angeles (1921) and the International Church of the Foursquare Gospel (1930), which soon had several hundred churches in America and many missions abroad. Three marriages and a claim to have been kidnapped (1926) were among the episodes of her colourful career. She died of an overdose of barbiturates, probably accidental.

McPherson, A. S., The Story of My Life. 1951.

Macquarie, Lachlan (1761-1824). Scottish soldier. Army service took him to Canada, India, the East Indies and Egypt before he came to Australia as Governor of New South Wales 1810-21. By encouraging the construction of roads, bridges and public buildings, by founding the first bank (1817) he changed a penal settlement into a flourishing embryo colony, and founded civilian society in Australia. He believed that 
ex-prisoners ('emancipists') should have equal rights with free settlers. He met opposition on this and resigned (1821).

Ellis, M. H., Lachlan Macquarie. His Life Adventures and Time. 1947.

Macready, William Charles (1793-1873). British actor. He came from a theatrical family and made his debut in Birmingham in 1816. After the death (1833) of *Kean, Macready became the leading actor of his time and his management (1837-43) at Covent Garden and Drury Lane, during which he was both producer and actor, was famous. During a visit to New York (1849), 20 lives were lost when a mob, incited by an envious American actor, Edwin *Forrest, supported by Nativists, tried to break into the theatre where Macready was performing. His most famous parts included Macbeth, Lear, Iago and King John and it is said that he tried 'to combine the dignity of the Kembles with the naturalness of Kean'.

Trewin, J. C., Mr. Macready, a 19th Century Tragedian and his Theatre. 1955.

Macron, Emmanuel Jean-Michel Frédéric (1977- ). French politician, born in Amiens. Son of a physician and a neurologist, he won degrees at the University of Paris X, Sciences Po and ENA (École nationale d'administration), became an inspector of finances, briefly joined the Socialist Party, then worked for the Rothschild Bank. He was a staffer for President ${ }^{*}$ Hollande 2012-14, then Minister for Economics, Industry and Digital Affairs 2014-16. He resigned in 2016 and founded a new political party, La République en Marche! (LREM). He won election as President of France 2017- , after the Socialist vote collapsed, the conservatives faded and in the second round he faced Marine *Le Pen. At 39, Macron became the youngest French Head of State since *Napoléon. LREM won a comfortable majority in the National Assembly elections in June 2017, but voter turnout was very low. Despite protests from the gilets jaunes (yellow vests) and Covid-19 frustrations, he was re-elected in April 2022, defeating Le Pen again on the second ballot with 58 per cent of the vote.

MacSwiney, Terence (1880-1920). Irish nationalist. He took part in the Easter Rising (1916) and after revolutionary activity in the Irish Republican Army became Lord Mayor of Cork in 1920. In August he was arrested on a sedition charge and his death in October after a 74-day hunger strike provoked worldwide sympathy and protest.

McVeigh, Timothy J(ames) (1968-2001). American terrorist. A Gulf War veteran, he was convicted of murder for the Oklahoma City bombing of April 1995, in which 168 people died, and was executed by lethal injection.
Madariaga y Rojo, Salvador (1886-1978). Spanish author. He served as Director of Disarmament for the League of Nations 1922-27. He was professor of Spanish studies at Oxford University 1928-31 and, after the establishment of the Republic, Ambassador to the US 1931-32 and to France 1932-36. He stood aloof from the Spanish Civil War but in England after 1950 he was a frequent and outspoken critic of the ${ }^{*}$ Franco regime. Amongst his extensive literary works are books on ${ }^{*}$ Bolívar, ${ }^{*}$ Columbus, Don Quixote, Hamlet and ${ }^{*}$ Shelley, and he also wrote on historical and political topics.

Madero, Francisco (1873-1913). Mexican politician. Educated abroad, he returned with liberal and humanitarian ideas to become (1909) the principal opponent of the re-election of the dictatorial president ${ }^{*}$ Diaz. When Diaz declared himself reelected, a local rising in response to Madero's agitation caused the administration suddenly to collapse and Diaz fled (May 1911). Madero was elected President with popular acclaim but, when his incompetence provoked rebellions, he was induced to resign and then murdered by his own Commander-in-Chief, General *Huerta.

Madison, James (1751-1836). 4th President of the US 1809-17. Born at Port Conway, Virginia, son of a landowner from a prominent family, he studied at New Jersey College (later Princeton University) and at a precocious age helped to draft the Virginia State Constitution (1776), serving in the Continental Congress 1780-83 and the Virginia Legislature 1784-86. At the Federal Constitutional Convention (1787) held at Philadelphia he was, despite his youth, the major intellectual force in shaping the US Constitution (although Gouverneur *Morris was the principal draftsman). He contributed to The Federalist (1787-88) with *Hamilton and *Jay, showing remarkable prescience about the problems of large government, the development of factions, information flow and oligopoly. As a Member of the US House of Representatives 1789-97, he campaigned for the adoption of the Bill of Rights and against Hamilton's financial policies. He was *Jefferson's Secretary of State 1801-09, arranged the 'Louisiana purchase' from France, and succeeded as Leader of the Democratic-Republicans. Elected as President in 1808 (defeating C.C. *Pinckney) and 1812 (De Witt ${ }^{*}$ Clinton), his second term was marked by the unpopular war with Britain (181214), known as 'Madison's war', in which Washington was captured and the White House burned. His wife Dolley Madison (née Payne) (1768-1849) was White House hostess for Jefferson (a widower) and himself. He was rector of the University of Virginia 1826-36 and died at his home in Montpelier. In 20 Presidential ranking lists by historians and political scientists, Madison scored No. 14 in the 
aggregate. His presidency was disappointing, after the brilliance he showed as a young man in framing the Constitution and the Bill of Rights.

Brant, I., The Fourth President. 1970; Ketcham, R., James Madison: A Biography. 1990; Rutland, R. A., James Madison and the American Nation. 1995; Wills, G., James Madison. 2002; Feldman, N., The Three Lives of James Madison: Genius, Partisan, President. 2017.

Madonna (Louise Veronica Ciccone) (1958- ). American singer and actor, born in Bay City, Michigan. She became a super-celebrity, appearing in several films including In Bed with Madonna (1991) and sold about 60,000,000 records. Her fame depended on shock appeal rather than talent. Her book Madonna: Sex (1992) was an immediate succès de scandale, despite contemptuous reviews.

Maecenas, Gaius Cilnius (c.70-8 BCE). Roman magnate, political and patron. Of Etruscan descent, and friend and counsellor of Octavian, later the emperor *Augustus, he refused to join the Senate, remaining as an equestrian, but acted as vice-regent and exercised enormous influence, especially in the arts. He was renowned for his wealth and luxury and for his patronage of writers, e.g. *Virgil and ${ }^{*}$ Horace. He left his fortune to Augustus.

Maeterlinck, Maurice (Mooris) Polidor Marie Bernhard, Comte (1862-1949). Belgian poet and dramatist, born in Ghent. He studied law at Ghent but went to Paris (1887) and soon came under the influence of the French' symbolists' as seen, notably, in his metaphysical dramas, e.g. Pelleas and Melisande (1892) later the basis of an opera by *Debussy, and The Bluebird (1909) a children's favourite despite its mysticism. Maeterlinck also wrote a series of popular works on natural history, e.g. The Life of the Bee (1901) and The Intelligence of Flowers (1907). After being nominated eight times, in 1911 he won the Nobel Prize for Literature and in 1932 was created a count.

Halls, W. D., Maurice Maeterlinck. 1960.

Magellan, Ferdinand (Fernão de Magalhães) (c.1480-1521). Portuguese explorer. While on service in Morocco he was accused of theft and made an unauthorised return to Portugal to appeal against the charge. Unable to gain satisfaction, he offered his services to Spain and obtained acceptance of a scheme to sail to the Moluccas (East Indies) from the west. He sailed (1519) with five ships and rounded South America through the straits that now bear his name into the Pacific (the name of which was suggested to him by the fine weather he encountered there). He reached the Philippines, where he was killed in a skirmish with the indigenous inhabitants. His ship was sailed back to Spain by his second in command, Sebastian del Cano, who then completed (1522) the first circumnavigation of the world, which also established that the Americas were a separate continent.
Guillemard, F. H. H., The Life of Ferdinand Magellan and the first Circumnavigation of the Globe 1480 1521. Repr. 1971.

Magendie, François (1783-1855). French physician. Considered a founder of experimental physiology, he investigated the relationship of the nervous system with the spinal chord and the effects and uses of strychnine, iodine, morphine and various other drugs. He demonstrated the stomach's passive role in vomiting and studied emetics. He did much work on the nerves of the skull and a canal leading from the fourth ventricle is named after him the 'foramen of Magendie'. He was elected a member of the Académie des Sciences (1821) and was its president (1837). In 1831 he became professor of medicine at the Collège de France.

Maginot, André (1877-1932). French politician. As Minister of War 1922-24 and 1929-32, he ordered the construction of the 'Maginot line', a series of immense fortifications, concealed weapons, underground storehouses and living quarters on the Franco-German frontier. In World War II it was outflanked by the German advance through Belgium and its defensive strength was never put to the test.

Magritte, René François Ghislain (1898-1967). Belgian artist. An important member of the Surrealist movement, he trained at the Brussels Academy from 1916 and began his career as a wallpaper designer. He became a full-time painter in 1926 and held his first one-man exhibition 10 years later. His pictures are realistic, even mundane, but they are put together in composite images that are bizarre, sinister, comic or nightmarish.

Nadeau, M., The History of Surrealism. 1965.

Magsaysay, Ramon (1907-1957). Filipino politician. A mechanic by trade, he became famous for his exploits in the anti-Japanese underground movement. Afterwards he was equally successful against the revolutionary Communists. Secretary of National Defence 1950-53 and President 1953-57, he was killed in an air crash.

Mahan, Alfred Thayer (1840-1914). American naval historian, born in West Point. He joined the Union navy in 1856, served during the Civil War (1861-65), retiring as Captain in 1896, but was recalled to the reserve as Rear Admiral in 1906. He wrote four important works The Influence of Sea Power upon History 1660-1783 (1890), The Influence of Sea Power upon the French Revolution and Empire, 17931812 (1892), The Influence of Sea Power in relation to the War of 1812 (1905) and The Life of Nelson: the Embodiment of the Sea Power of Great Britain (1897). His theories were extremely influential in the US, particularly naval expansion in the Pacific and 'New imperialism', Germany, France, Britain and Japan. He coined, and popularized, the term 'Middle East' (1902). 
Mahathir bin Mohammed (1925-). Malaysian politician. Educated in Singapore, he practised medicine, was active in the United Malay National Organisation (UMNO) from 1964 and became Minister for Education 1974-77, Trade and Industry 1977-81 and Prime Minister 1981-2003. He also held other portfolios including Defence, Home Affairs and Justice. In 1998 he sacked his deputy *Anwar Ibrahim, whose jailing for sedition and sodomy was seen as a political act.

At the age of 92 he returned to active politics in an unexpected alliance with Anwar, defeated his former protégé *Najib Razak on the issue of corruption and was Prime Minister again 2018-20, ending the 61year rule of his former party.

Mahdi, El ( = 'the expected one'). Title used by Shi'ite Muslims for a hidden imam who will reveal himself as a deliverer, especially claimed by Mohammed Ahmed ibn Abdullah (c.1841-1885), a Sudanese tribesman who proclaimed himself in 1881 and led a revolt against Egyptian rule. He controlled the Sudan by 1883. General *Gordon, sent to evacuate foreigners (1884), was killed at Khartoum after a long siege. *Wolseley arrived too late to save Gordon. Within weeks, El Mahdi had died of typhus. The Mahdists controlled the Sudan until their final defeat at Omdurman (1898) by *Kitchener, who desecrated El Mahdi's tomb.

Holt, P. M., The Mahdist State in the Sudan. 2nd ed. 1970.

Mahfouz, Naguib (1911-2006). Egyptian novelist, playwright and screenwriter, born in Cairo. Educated at Cairo University, he worked in the cultural section of the civil service 1934-71. He wrote 40 novels and 30 screenplays, some of which were banned because of his political and social views. His novels include The Cairo Trilogy (1956-57), Chatting on the Nile (1966) and Miramar (1967). He was the first writer in Arabic to receive the Nobel Prize for Literature (1988).

Mahler, Gustav (1860-1911). Austrian composer and conductor, born in Kaliste, Bohemia. Son of a distiller and tavern owner, he was the second of 14 children, only six of whom survived infancy. $\mathrm{He}$ studied at the Vienna Conservatoire and the University, and attended *Bruckner's lectures (which he sometimes denied). In 1897 he converted from Judaism to Catholicism. Regarded as the greatest conductor of his era, he directed the Budapest Opera 1888-91, the Hamburg Opera 1891-97, the Vienna Court Opera 1897-1907, the Metropolitan Opera, New York 1908-10 and the New York Philharmonic Orchestra 1909-11. (In 1892 he had premiered *Wagner's Ring cycle in London.)
As a composer, he was greatly influenced by *Beethoven, *Schubert, *Wagner, Bruckner and, later, ${ }^{*}$ Bach. He wrote 10 symphonies. Symphonies No. 1 ('The Titan', 1888), 5 (1902), 6 (1904), 7 (1905) and 9 (1910) are for orchestra. Nos 2 ('Resurrection', 1894), 3 (1896), 4 (1900), 8 ('Symphony of a Thousand', 1907) include movements for solo voice, soli and chorus, with orchestra. The unfinished Symphony No. 10 was performed in 1964 in a version partly reconstructed from Mahler's notes by Deryck Cooke. He wrote four important song cycles for voice and orchestra: Lieder eines fahrenden (Songs of a Wayfarer, 1883-85), Des Knaben Wunderhorn (Youth's Magic Horn, 1892-98), Kindertotenlieder (Songs on the Death of Children, 1901-04) and Das Lied von der Erde (The Song of the Earth, 1908-09).

Mahler's music, in its prolixity (most of the works, including all the symphonies, are unusually long), its emotionalism, its sudden and extreme changes of mood, its programmatic content and its use of large orchestral and vocal forces, represents in many ways the culmination of the Romantic movement in music. Mahler commented to *Sibelius that 'the symphony should be like the world: it must embrace everything'. Resemblances between Mahler and Bruckner are only superficial (length, complex texture, much repetition, heavy orchestral palette). Bruckner's world is religious - nature as a revelation of God's glory. Mahler's world is secular, fuelled by angst, mitigated by understanding and release. Bruckner seems to be contemplating a mountain range or a cathedral nave, Mahler seems to be gazing into an abyss, or anticipating the Holocaust, which occurred barely 30 years after his death.

While Mahler had outstanding early advocates including *Mengelberg, *Walter, *Klemperer and ${ }^{*}$ Stokowski, there were notable sceptics, ${ }^{*}$ Toscanini being the most important. Since the 1950s Mahler has been regarded as a master, and 20 complete sets of his symphonies were available on CD or for download in 2017.

The fluctuating quality of the musical material and the uncertainty of taste which are the obverse of its positive qualities have led to critical division as to its worth, but Mahler's originality and inventiveness have been widely recognised, and influenced $*$ Shostakovich and (notably in his use of the orchestral song cycle) ${ }^{*}$ Britten. He died in Vienna of infective endocarditis which destroyed his heart valves.

His widow Alma (Maria) Mahler, née Schindler (1879-1964) composed impressive songs, of which 17 survive. When she married Mahler (1902) he forbade her to compose. They had two daughters: one died in 1907. In 1910 she began an affair with the architect Walter ${ }^{*}$ Gropius, but stayed with Mahler until his death. She was married to Gropius 1915-20, and to Franz *Werfel 1929-45. Her lovers included Oskar 
*Kokoschka and Gustav *Klimt. She lived in the United States from 1940, published an autobiography And the bridge is love (1958) and died in New York City. Although two of her husbands (and some lovers) were Jewish, she was virulently anti-Semitic.

de La Grange, H.-L., Mahler. 4 vols, 1979, 1995, 2000, 2008; Kennedy, M., Mahler. 1974; Lebrecht, N., Why Mahler? How One Man and Ten Symphonies Changed the World. 2010; Fischer, J. M., Gustav Mahler. 2011; Haste, C., Passionate Spirit. The Life of Alma Mabler. 2019.

\section{Mahomet see Muhammad}

Mailer, Norman (1923-2007). American novelist, essayist, journalist, commentator, film maker and political activist, born in Brooklyn. Educated at Harvard, his army service in the Pacific during World War II provided the background for that 'nightmarish piece of realism' The Naked and the Dead (1948). Later writings include The White Negro (1958), Advertisements for Myself (1959), An American Dream (1966), The Armies of the Night (1968, Pulitzer Prize), A Fire on the Moon (1971), Marilyn (1973), The Executioner's Song (1979, Pulitzer Prize), Ancient Evenings (1983), Harlot's Ghost (1991), The Gospel According to the Son (1997) and The Time of our Time (1998).

Maillol, Aristide Joseph Bonaventure (1861-1944). French sculptor, painter and print-maker. He turned from painting to tapestry designing and then, owing to failing sight, to monumental sculpture (c.1900). Nearly all his works are nudes, realistic in conception but idealised to some extent in execution. He made a special study of the proper use of his materials, clay, bronze and marble.

George, W., Aristide Maillol. 1965; Lorquin, B., Maillol. 1995.

Maimonides (also known as RaMBaM, acronym for Rabbi Moishe ben Maymun) (1135-1204). Jewish philosopher, jurist and physician, born in Córdoba, Spain. The fundamentalist Almohads seized power in Córdoba in 1148 and in 1159 Maimonides and his family moved to Fez, Morocco, then in 1165 to Palestine. He received orthodox Jewish training, and in addition studied philosophy and law. In 1166 he settled in Egypt, where he became head of the Jewish community and physician to *Saladin. A polymath, he wrote works of popular Jewish religious devotion, a major codification of the Jewish law, a philosophicalreligious work, called The Guide for the Perplexed and a number of medical works. He is the leading exponent of the school of Jewish Aristotelianism. Like *Aristotle, Maimonides asserts the rationality of God, and man's duty through the use of his reason to comprehend the Divine Mind. But Maimonides also emphasised the limits of human reason, which was unable to know the Divine attributes directly and positively. This secured a place for faith, and for positive revelation, both of which were central to his beliefs. This religious vision informed his scientific studies. He did not believe that science had achieved certain knowledge of nature. As a physician, Maimonides closely followed ${ }^{*}$ Galen, although he regarded him as ignorant of theology. His writings became canonical for Jewish philosophy for the next few centuries, and also exercised considerable influence over Thomas *Aquinas and other Scholastics.

Minkin, J. S., The World of Moses Maimonides. 1958.

Maine, Sir Henry James Sumner (1822-1888). English legal historian. After showing academic brilliance he became Regius professor of civil law at Cambridge University 1847-54, being called to the bar in 1850 . The remainder of his career was divided between academic legal appointments and positions in India and the Indian Office at home, which enabled him to reform and shape the legal system of that country. He is most famous, however, for his classic studies of the evolution of legal and social institutions, e.g. Ancient Law (1861), Early History of Institutions (1875) and Early Law and Custom (1883).

Maintenon, Françoise d'Aubigné, Marquise de (1635-1719). French morganatic wife of *Louis XIV. She lived in Martinique with her exiled and impoverished Huguenot father until his death, when she returned to France, was converted to Roman Catholicism, and married the poet Paul ${ }^{*}$ Scarron (1652). In 1669, by then a widow, she was chosen as governess to the king's sons by Madame de*Montespan whom she succeeded in the king's affections (1680). In 1684 the king married her secretly. She was an intelligent and attractive woman, who behaved with complete discretion and exercised little influence on politics. The king bestowed upon her the chateau of Maintenon and the title of Marquise.

Maistre, Joseph de (1753-1821). French (Savoyard) writer and diplomat. He studied with the Jesuits, became a passionate opponent of the French Revolution, was a senator from Savoy 1788-92, then lived in Switzerland. The King of Piedmont-Sardinia sent him as Ambassador to Russia 1803-17 and in his St Petersburg Dialogues (left incomplete on his death) he argued for a divinely ordained authoritarian state, insisting that the executioner protected society from disorder. He produced a catalogue of enemies, including scientists, humanists, intellectuals, liberals, Protestants, Jews and Freemasons.

Berlin, I., The Crooked Timber of Humanity. 1990.

Maitland, Frederick William (1850-1906). English legal historian, born in London. Educated at Eton and Trinity College, Cambridge, after 15 years at the bar he devoted the rest of his life to historical work. In 1884, he became Reader, then Professor of the Laws of England at Cambridge 1888-1906. He founded the Selden Society in 1887 . The breadth and profundity of his research, his imaginative power of 
recalling the past and his brilliance of style combine to make his History of English Law Before the Time of Edward I (1895), with contributions by Sir Frederick Pollock (1845-1937), a classic work in this field. His other works include a constitutional history (from Edward I) published posthumously.

Major, Sir John Roy (1943- ). British Conservative politician, born in Merton. Son of a trapeze artist who later manufactured garden ornaments, he was educated at Rutlish Grammar School but did not attend university. He worked for the Standard Chartered Bank in England and Nigeria and was a Lambeth Borough councillor 1968-71. A Conservative MP 1979-2001, he held several minor offices until his period of rapid promotion began in 1986 . He served as Minister for Social Security 1986-87, Chief Secretary to the Treasury 1987-89, Foreign Secretary July-Oct. 1989 and Chancellor of the Exchequer 1989-90. When Margaret *Thatcher was challenged for the Conservative leadership in November 1990 by Michael ${ }^{*}$ Heseltine, after an inconclusive first ballot she withdrew and ensured Major's succession, although his social and political views were more liberal than hers. Prime Minister 1990-97, he supported President *Bush strongly in the Gulf War 1991. The Conservatives won the April 1992 general election but Major faced growing internal dissension from opponents of his moderately pro-European policies. In May 1997 the Conservatives suffered their heaviest defeat since 1832 , losing to Tony *Blair's New Labour. He received a CH in 1998 and a KG in 2005, but declined a peerage in 2001 .

Makarios III (Mikhail Khristodolou Mouskos) (1913-1977). Cypriot Archbishop and President. As Archbishop of the Orthodox Church of Cyprus (1950-77), he was political leader of the Enosis movement which demanded the end of British rule and union with Greece. He was exiled to the Seychelles (1956) but returned to Cyprus (1957) and became its first President (1960-74, 1974-77) after the conclusion of an agreement between Britain, Greece and Turkey for an independent Cyprus. There were several assassination attempts and in 1974 he was deposed as President for a few days and escaped after an attempt on his life. He returned to Cyprus as President in December 1974. His presidency was marred by a failure to weld Cyprus into a single sovereign state.

Malaki, Nouri Mohammed Kamit Hasan al(1950- ). Iraqi politician. Educated in Baghdad, and a Shi'ite, in exile in Damascus 1979-2003, he was Prime Minister 2006-14.

Malala (Malala Yousafzai) (1997- ). Pakistani feminist, peace and education activist, born in Mingora. She grew up in the Swat Valley in northwestern Pakistan, an area which came under Taliban influence, and from the age of 12 published a blog advocating education for women and girls, which shot in the head by a Taliban gunman, and after several operations in Pakistan was flown to England for treatment. On recovery, she resumed her studies in Birmingham. She spoke eloquently to the United Nations, received the Sakharov Prize (2013) and the World Children's Prize (2014).

At the age of 17 , she was awarded the 2014 Nobel Prize for Peace, making her the youngest Laureate by far. She shared the prize with Kailash ${ }^{*}$ Satyarthi, an Indian campaigner for children's rights.

Malamud, Bernard (1914-1986). American novelist, born in Brooklyn. His masterpiece was The Fixer (1966), based on an accusation of ritual murder in tsarist Russia. Other novels included The Assistant (1957), A New Life (1961) and God's Grace (1982).

Malan, Daniel François (1874-1959). South African Nationalist politician, born in Cape Colony (now Cape Province). He was a preacher and journalist before entering political life as a member of the Union House of Assembly 1919-54. Under ${ }^{*}$ Hertzog, as Minister of the Interior, Public Health and Education 1924-33, he legislated for a national flag and recognition of Afrikaans as an official language. He led the Nationalists 1936-54 and urged neutrality in World War I. In 1948 his party defeated *Smuts' Unionists and instituted the policy of apartheid, complete social and political segregation of the races, although he seemed mild compared with his successors *Strijdom and *Verwoerd.

Malaparte, Curzio (né Kurt Erich Suckert) (18981957). Italian journalist, playwright and novelist. After war service, he was an enthusiastic propagandist not only for Fascism but also for avante garde literature and wrote on revolutionary violence in his Coup d'etat (1932). He was expelled from the party in 1941 and imprisoned. He wrote two powerful war novels, Kaputt (1944) and The Skin (1949).

Malatesta, Sigismondo Pandolfo (1417-1468). Italian soldier. He succeeded his uncle as lord of Rimini in 1432. Though he was a condottiere or mercenary captain, cruel, profligate and described by Pope *Pius II as 'the enemy of God and man' he was a scholar and friend of scholars: on his orders the cathedral of Rimini was converted into a temple of the arts.

Malcolm III (Canmore) (c.1031-1093). King of Scots 1058-93. Son of *Duncan I, after his father was killed and the throne usurped by ${ }^{*}$ Macbeth he took refuge in England. In 1054, with the help of his uncle Siward, Earl of Northumbria, he recovered southern Scotland and in 1057 he defeated and killed Macbeth in battle. After the Norman conquest of England he supported the claims of ${ }^{*}$ Edgar the Aetheling (brother of his wife, ${ }^{*}$ St Margaret) but was forced by ${ }^{*}$ William I to pay tribute. When *William Rufus succeeded, Malcolm was trapped and killed during a raid on Northumbria. 
Malcolm X (Malcolm Little) (1925-1965). AfricanAmerican political and religious leader, born in Omaha. Imprisoned for robbery (1946-52), he joined Elijah Muhammed's Black Muslims, became its leading spokesman and advocated black violence to redress the history of white violence against African Americans. Expelled from the Black Muslims, he formed the Organisation of Afro-American Unity (1964), began urging closer racial harmony and was murdered in Harlem.

Malcolm X, Autobiography. 1965.

Malcolm, Janet (née Jana Wienovera) (1934-2021). American journalist and essayist, born in Prague. Her family escaped from Czechoslovakia in 1939, she grew up in New York and studied at the University of Michigan. An outstanding practitioner of 'the New Journalism', she wrote for the New Yorker and the New York Review of Books. Her essays and reviews had a disconcerting penetration. Her books include: Psychoanalysis: The Impossible Profession (1981), In the Freud Archives (1984), The Journalist and the Murderer (1990), The Silent Woman: Sylvia Plath and Ted Hughes (1994), Reading Chekhov (2001) and Two Lives: Gertrude and Alice (2007). Helen *Garner commented 'Her writing turns you into a better reader ... She is brilliant in revealing things in stages ... [and] yokes the familiar with the strange in the way dreams do'.

Malebranche, Nicolas (1638-1715). French philosopher. His philosophical ideas brought him a contemporary esteem second only to that of ${ }^{*}$ Descartes, many of whose views he shared. Dismissing the information provided by the senses as confused, Malebranche taught that truth could only be apprehended through what he termed 'clear ideas' and that the seat of such 'clear ideas' (though not in a vocational sense) was God. He denied that there was a direct causal relation between mind and matter. Sensation on the one hand, and the physical activity that follows an act of willing on the other, he explained as occasional acts of God in creating new mental images to correspond with items in the physical order or in creating new physical conditions to correspond with a mental picture. His De la Recherche de la vérité (1674) contains the best exposition of his philosophy. Apart from philosophy Malebranche was well known as a physicist, especially for his work in optics.

Malenkov, Georgi Maksimilianovich (1901-1988). Russian Communist politician. He rose quickly in the Communist Party organisation and as head of the party secret service was closely associated with the purges of 1936-39. During World War II he reorganised industrial production and railway transport. As Deputy Premier 1946-53 and a Politburo member 1946-57, he was Stalin's closest associate and on his death (March 1953) succeeded him as Premier and (for eight days, until he lost that position to *Khrushchev), General Secretary of the CPSU. Forced out as Premier in 1955, in favour of Khrushchev's nominee *Bulganin, he became Minister for Electric Power Stations 1955-57. He attempted a coup against Khrushchev in 1957, was exiled to Kazakhstan, expelled from the CPSU in 1961, and, after a long period of depression, became an Orthodox convert.

Malherbe, François de (1555-1628). French poet and grammarian. His early life was spent mostly in Provence but in 1605 he obtained a post at court and the patronage of ${ }^{*}$ Henri IV, ${ }^{*}$ Louis XIII and Cardinal *Richelieu. His importance lay not so much in his own verse, which consisted mainly of conventional accounts of noble deeds or adaptations of poems by ancient or contemporary writers, as in his achievements as a grammarian. He was largely responsible for creating a clear and easily understandable literary language, free of the archaisms, pedantries and foreign influences that had made the work of his predecessors obscure. Moreover he laid down firm rules for the various verse forms and showed how to combine euphony with sense.

Fromilhagne, R., Malherbe. 1954.

Malibran, Maria (Felicitas) (née Garcia) (18081836). French mezzo-soprano, born in Paris. Daughter of Manuel *Garcia and sister of Pauline *Viardot, she studied with her father, but performed under her husband's name. In 1825 she sang in London and New York, specialising in *Rossini's operas, but appeared as Leonora in Fidelio. Malibran could sing as soprano and contralto and her extraordinary range made her a sensation in London, New York, Paris and Milan. She created the role of Maria Stuarda in *Donizetti's opera (Milan, 1835) and died after a riding accident.

Malik, Jacob Aleksandrovich (1906-1980). Russian diplomat, born in Ukraine. He rose to high office under *Stalin. After serving as Ambassador to Japan 1942-45 he became Deputy Foreign Minister in 1946 and Soviet Ambassador to the UN 1948-53, 1968-76, Ambassador to Britain 1953-60 and Deputy Foreign Minister 1960-68.

Malinovsky, Rodion Yakovlevich (1898-1967). Russian marshal. He served with the French army in World War I, and in World War II he was one of the most successful Russian commanders. After a fighting retreat in the Ukraine (1941) he commanded one of the armies which in 1942-43 surrounded Stalingrad and forced the surrender of Field Marshal Paulus. Taking the offensive, he retook Odessa (April 1944) and by the end of that year was advancing through Romania and Hungary. In the next year he liberated Czechoslovakia. He succeeded *Zhukov as Minister of Defence 1957-67.

Malinowski, Bronislaw Kaspar (1884-1942). Polish anthropologist. In 1914 he accompanied an anthropological expedition to New Guinea and continued to Australia, where he worked with Baldwin 
*Spencer. On his return he joined the teaching staff at London University and became (1927) professor in social anthropology. He introduced the method of investigation by functional comparison of the activities of different peoples. Among his books were Crime and Custom in Savage Society (1926) and Sex and Repression in Savage Society (1927).

Malipiero, Gian Francesco (1882-1973). Italian composer. Musicologist, teacher (from 1934) and director of the Liceo Musicale in Venice 1939-52, he edited the works of *Monteverdi and *Vivaldi. He composed symphonic poems, chamber music, piano solos and some operas, e.g. Julius Caesar (1936) and Antony and Cleopatra (1938).

Mallarmé, Stéphane (1842-1898). French symbolist poet, born in Paris. Having decided to learn English in order to read and translate Edgar Allan *Poe, he was in London for that purpose (1862-63) and spent the rest of his active life teaching English in various French towns and eventually in Paris. There he came to admire the Impressionists and especially *Manet, whose close friend he became. He tried to bring light and movement into his creations with words as the Impressionists had done with paint, thus the sound and rhythm of the words, as in music conveyed their meaning directly to the senses of the reader. Moreover, as a follower of *Baudelaire, he gave to certain key words the quality of symbols which evoke picture patterns in the mind that go far beyond a purely linguistic interpretation. Mallarmé was not prolific and was at his best in short pieces such as L'Après midi d'un faune (1875), which inspired *Debussy's prelude. Mallarmé also had a talent for gay, witty but, alas, unrecorded talk, and the gatherings on his 'Tuesday evenings' became famous.

Malle, Louis (1932-1995). French film director. His films included Le feu follet (1963), Le Souffle au coeur (1971), Lacombe,Lucien (1973), Atlantic City (1980), Au revoir les enfants (1987) and the long documentary L'Inde fantôme (1972). He married the actor Candice Bergen in 1980.

\section{Malmesbury, William of see William of Malmesbury}

Malone, Edmund (1741-1812). Irish editor and critic. He abandoned the law for literature and moved to London, where he became a friend of Samuel *Johnson. His great edition of *Shakespeare appeared in 1790, and the revised edition published after his death in 1821 was by far the best up to that time. He also exposed the literary forgeries of William Henry *Ireland and Thomas *Chatterton. $\mathrm{He}$ is commemorated by the Malone Society (founded 1907) which prints texts and documents relating to the study of Elizabethan drama.

Malory, Sir Thomas (c.1415-c.1471). English writer of Arthurian romances. Little is known with certainty about his life, the most probable identification is with a Warwickshire knight in the service of the Earl (later Duke) of Warwick. If so, most of his writing must have been done in prison, where he spent a large part of his life charged with a number of violent crimes. His eight Arthurian romances were published by ${ }^{*}$ Caxton in 1485 (though the text found at Winchester College in 1934 is held to be more authentic). The work consists almost entirely of adaptations from the French 13thcentury versions, written to idealise the medieval code of chivalry. Malory, writing two centuries later in English prose, is no nearer than his originals to creating a realistic historical picture. Arthur is no Romano-British chieftain, and both he and his companions dress as 12th-century knights and their exploits are those about which the troubadours sang, but Malory's approach to character is more realistic and he writes with directness and vigour. Two main themes compose the story that runs through the eight romances: (a) the tragic end of Arthur's reign and the breakup of the knightly brotherhood that gathered at the Round Table; (b) Launcelot's failure, through sin, to find the Holy Grail (the cup used at the Last Supper) and Galahad's success. Almost all later versions of the legends, e.g. Tennyson's Idylls of the King, are based on Malory (*Geoffrey of Monmouth).

Reiss, E., Sir Thomas Malory. 1966; Field, P. J. C., The Life and Times of Sir Thomas Malory. 1993; Hardyment, C., Malory: The Life and Times of King Arthur's Chronicler. 2005.

Malouf, David George Joseph (1934- ). Australian novelist and poet, born in Brisbane. His novels include An Imaginary Life (1979), Fly Away Peter (1982), Harland's Half Acre (1984), The Great World (1990) and Remembering Babylon (1993). Ransom (2009) is a powerful adaptation, from The Iliad, of Priam's mission to reclaim the body of his son Hector from Achilles. He wrote the libretto for Richard Meale's opera Voss (1986), based on Patrick *White's novel.

Malpighi, Marcello (1628-1694). Italian anatomist and microscopist. He studied and (from 1666) was a professor at Bologna University. Malpighi virtually founded histology (including that of plants) and is noted for his studies of the structure of the brain, lungs, glands and liver and especially for extending *Harvey's work on the circulation of the blood, by discovering the capillaries. He also investigated muscular cells and wrote a treatise on the silkworm.

Adelmann, H., Marcello Malpighi and the Evolution of Embryology. 5 vols, 1966.

Malraux, André (1901-1976). French writer and politician. Having studied oriental languages he accompanied an archaeological expedition to IndoChina 1923-25, where, as a Communist, he claimed to have played an important part in Chinese politics 1925-27. He used his varied experiences in his novels, e.g. Les Conquéants (1928) and La Condition humaine (1933, winner of the Prix Goncourt) and L'Espoir 
(1937). He commanded the foreign air corps fighting against *Franco in the Spanish Civil War, and during World War II became a leader of the French resistance movement. As a friend and admirer of *de Gaulle, he was Minister for Information 1945-46, 1958 and an energetic and imaginative minister for cultural affairs 1958-69. His works on the psychology and history of art include The Voices of Silence (1951, translated 1953 ) and Museum without Walls (1952-54, 1967).

Suares, G., Malraux: Past Present and Future. 1974.

Malthus, Thomas Robert (1766-1834). English population theorist, born near Dorking. He distinguished himself in mathematics at Cambridge, where he became (1797) a Fellow of Jesus College. Meanwhile he had taken holy orders and led a county clergyman's life in Surrey until (1805) he became a teacher at Haileybury College, where he worked for the rest of his life. In his famous Essay on the Principle of Population (published anonymously in 1798 and revised in 1803) he argued that population tends to increase at a geometric ratio (each generation can double up) while the means of subsistence only increases incrementally (at an arithmetic ratio), and that the only constraints to population growth were famine, war, disease, celibacy, infanticide and the 'vicious practice' of contraception. When Malthus wrote, world population was 800 million. (By August 2021 it was 7.9 billion, most living far longer and consuming more than people of Malthus' time.) Marxists and Catholics both attacked Malthus for his complacent acceptance of high death rates for the poor. He ignored the impact of technology in agriculture, although the problems of water supply and inadequate soil for farming are increasingly serious. *Darwin's concept of 'the survival of the fittest' was influenced by his reading of Malthus.

Bonar, J., Malthus and His Work. 1966.

\section{Malvern, Godfrey Martin Huggins, 1st Viscount see Huggins, Godfrey Martin, 1st Viscount Malvern}

Mamum (Abul Abbas Abdallah al Mamum) (786833). Abbasid caliph of Baghdad 809-33. Son of *Harun al-Raschid, politically his reign was troubled, but it was a time of great intellectual distinction as Mamum encouraged learning, especially the study of Greek science. Many Greek works were preserved through their translation into Arabic in his 'House of Wisdom' (founded 830), where he gathered together the leading scholars of his day.

Mandela, Nelson Rolihlahia (1918-2013). South African political leader, born in Mvezo, Cape Province. A Xhosa, and a chief of the Tembu clan, he rejected tribal life, but was often called Mandiba, his Xhosa name. Educated at the University College of Fort Hare and the University of Witwatersrand, he became a lawyer in Johannesburg (1952) and national organiser of the African National Congress (ANC). In 1958 he married Winnie (Nomzano Zaniewe)
Madikizela (1936-2018). After a long trial for treason (1956-61) he was acquitted in 1961. He was sentenced to five years' jail in 1962 for 'incitement' and leaving South Africa without permission. In 1964 he was sentenced to life imprisonment, after a long trial at Rivonia, on a charge of sabotage and conspiracy. He survived 27 years in prison, (14 at Robben Island) without deterioration, renounced thoughts of retribution and assumed the moral leadership of the ANC while Oliver Tambo (1917-1993) ran the organisation from London. Following the election of F. W. * de Klerk as President, Mandela was released in February 1990 and was National President of the ANC 1991-97. He toured extensively and received many international awards. He wrote the autobiography Long Walk to Freedom (1994). Winnie Mandela was convicted of kidnapping in June 1992, sentenced to six years' jail but after an appeal this was reduced to a fine. The Mandelas separated in 1992 and divorced in 1996. He shared the 1993 Nobel Peace Prize with de Klerk. In May 1994 he was elected President of the Republic of South Africa in a Government of National Unity, after the ANC won 62.6 per cent of the vote in the first election based on universal suffrage. Winnie became Deputy Minister for Arts, Culture, Science and Technology 1994-95. $\mathrm{He}$ received the British OM (1995), a Canadian CC (1998), an Australian AC (1999), a British QC (2000), the US Presidential Medal of Freedom (2002), and many foreign citizenships and honorary degrees. He married Graça Macel, widow of the President of Mozambique, on his 80th birthday, and retired in June 1999, but was active in campaigning about HIV/AIDS and for world peace. He died of a lung infection in 2013. His memorial service in Johannesburg was attended by four US Presidents and he was acclaimed as a hero of our times.

Sampson, A., Mandela. The Authorised Biography. 1999; Meredith, M., Mandela. 1997, rev. 2010.

Mandelbrot, Benoît (1924-2010). FrenchAmerican mathematician, born in Warsaw. Educated in Paris and at CalTech, he taught at Geneva, Lille, Paris, and Harvard universities, worked for IBM in New York 1958-93, then, at 80, became Sterling professor of mathematical sciences at Yale (2004). From 1967 he worked on 'chaos' theory, an attempt to describe the operation of persistently unstable systems e.g. weather, traffic, erosion, turbulence. In 1975 he introduced 'fractal geometry' as a new branch of mathematics, describing the extreme complexity of three-dimensional natural shapes, in contrast to Euclidian geometry in which objects are represented as flat and straight lines are typical. He coined the word 'fractal' (i.e. broken) to describe the edging of clouds, trees, mountains or seacoasts characterised by 'scale invariant' repetition of shape, demonstrating order in systems that appear to be chaotic. 'Mandelbrot sets', with their spectacular imagery generated by algorithms, have become an increasingly familiar form of computer graphics. 
Fractal theory is being applied in many areas, including pollution control, coastal management, meteorology, astronomy, physiology and designer drugs. His books include Fractals: Form, Chance and Dimension (1977) and The Fractal Geometry of Nature (1982). Asteroid 27500 was named for him. He was awarded the Wolf Prize for Physics in 1993 and the Japan Prize in 2003.

Gleick, J., Chaos-Making a New Science. 1987; Mandelbrot, B. B., The Fractalist: Memoir of a Scientific Maverick. 2013.

Mandelstam, Osip Emilyevich (1891-1938). Russian poet, born in Warsaw. Educated in the West, he became a leader of the Acmeist (*Akhmatova) movement. He saw poetry as an instinctive recognition of cultural order and continuity in contrast to the chaos and fragmentation of man in nature, and published the collections Kamen (1913) and Tristiya (1922). In 1934 he was exiled and later died in a labour camp. Forgotten until the 1960s, he is now regarded as a poet of the first rank. His widow, Nadezhda Yakovlevna Mandelstam (née Khazina) (1899-1980) memorised his poetry to preserve it and wrote two remarkable memoirs, Hope against Hope (1971) and Hope Abandoned (1973).

Mandeville, Sir John (c.1300-c.1371). English travel writer. Ostensible author of a popular medieval travel book, in the preface he claims to have been born at St Albans and in the epilogue states that the memoirs were written in 1357 and that his journeys had begun 35 years previously. The earliest MS, which probably contains the original text, is the French (translations into English and many other languages exist) and dates from 1371. The first part, which takes the reader to the Holy Land and neighbouring countries, is possibly the genuine record of some traveller, but the second part describing journeys in Asia extending to China is merely a compilation from other writers.

Letts, M., Sir John Mandeville: The Man and His Book. 1949.

Manet, Edouard (1832-1883). French painter, born in Paris. From an affluent family, he was able to pursue his vocation and enjoy travel without hardship. Among early influences were *Goya and *Velázquez, and even in later life his paintings reflect what he had learnt from their work. The period which later made him recognised as a forerunner of the Impressionists began when (1863) his Déjeuner sur l'herbe was rejected by the Salon. The subject, in which two women-one naked and one halfnaked-are at a picnic with two fully dressed men, was an assertion in paint that the only point of view that should count is the pictorial one. But though to some such an explanation only added to the offence, the young men (*Monet, ${ }^{*}$ Renoir, *Pissarro etc.) who were later to be dubbed 'Impressionists' found inspiration in the picture. His Olympia (1865) was attacked as indecent with even more venom. Like the
Impressionists, Manet began (1870) to paint in the open air, but he was less concerned with landscape and the effects of sunlight than with the portrayal of the gay and lively scenes around him, e.g. racecourse scenes (1872) and at the end of his life famous Bar aux Folies Bergère (1882, National Gallery, London). Some of his portraits, e.g. of Zola, are important. His Execution of Emperor Maximilian (two versions, 1867, 1869) was influenced by *Goya. He died after surgery to remove his left, gangrenous, foot.

Mani (c.216-c.276). Persian mystic. Founder of the Manichean sect, he spent the last 30 years of his life on missionary journeys throughout the Persian empire and even reached the borderlands of India and China. He was put to death at the instigation of the Zoroastrian priesthood. In his teaching Mani speaks of the two 'roots', God and matter, equated with good and evil, light and darkness. Mani's teaching was intended to produce a synthesis of Christianity, Zoroastrianism and Buddhism; at first the sect grew rapidly but wilted under persecution, and by the 10 th century was virtually extinct. Traces of its teaching, however, survived among the Albigenses of medieval France and the Bogomili of the Balkans.

Manin, Daniele (1804-1857). Italian lawyer and politician, born in Venice. An ardent liberal and nationalist, he was imprisoned for his outspoken denunciation of Austrian rule in northern Italy but was released by the populace during the 1848 revolts and was subsequently elected President of the new Venetian republic. When the Austrians besieged the city he inspired a heroic defence (April-August 1849) ending in capitulation enforced by starvation and disease. Manin, excluded from an amnesty, died in Paris.

Mann, (Luis) Heinrich (1871-1950). German novelist. After an early period as a romantic monarchist, he was attracted by French liberal philosophy and adopted a utopian progressivism, breaking with his younger brother Thomas *Mann because of his passionate opposition to World War I. His books include Professor Unrat (1905) filmed by Fritz *Lang as The Blue Angel (1928), Der Untertan ('The Man of Straw', 1918) and the Henri Quatre novels (1935, 1938). He left Germany in 1933 lived in France until 1940, then in the US. He was recognised as leader of the German literary left.

Mann, (Paul) Thomas (1875-1955). German novelist and critic, born in Lübeck. His father, a merchant and official, came from an old Hansa family: his mother was Brazilian. Educated in Munich, he was working in an insurance office at Munich when he wrote his first novel Buddenbrooks (1901). In this and other works he illustrates the opposition between the extrovert life of the ordinary bourgeois and that of the intellectual and artist. It is the emergence of the traits of the latter that he regards as a sign of decay, remarking, too, on the affinity of genius with disease and the 'fascination 
of death'. Mann described himself as 'primarily a humorist' but it is with such psychological problems that he is most deeply concerned and in probing them he reveals the particular influence of ${ }^{*}$ Goethe, ${ }^{*}$ Schopenhauer, *Wagner and ${ }^{*}$ Nietzsche.

In 1905 he married Katherina Pringsheim, from a rich Jewish family.

The novellas Death in Venice (1912), Tristan (1913) and Tonio Kroger (1914) were all successful. A conservative monarchist and patriot during World War I, he shifted ground in the essay Reflections of an Unpolitical Man (1918) and from 1922 supported the Weimar Republic. His next major novel, The Magic Mountain (Der Zauberberg, 1924), set in a tuberculosis sanatorium in Davos, symbolises the disintegrating civilisation of Europe. Then followed Children and Fools (1928), Mario and the Magician (1930) and the biblical tetralogy Joseph and his Brethren (1933-43).

He won the Nobel Prize for Literature in 1929. He left Germany in February 1933 after ${ }^{*}$ Hitler took power, living in Switzerland, eventually migrating to the US in 1938, becoming a citizen in 1944 . He returned to Europe in 1952 and died in Zürich.

Among the novels of his last period were Doctor Faustus (1947), The Black Swan (1955) and the posthumously published comic novel The Confessions of Felix Krull. He also wrote many essays on literary subjects and contemporary themes. His diaries, largely homoerotic, were published between 1979 and 1995.

His daughter, Erika Mann (1905-1969), an actor and author, married the actor-director Gustaf Gründgens (1899-1963) and later (1935) the poet W. H. *Auden to obtain a British passport. Of his sons Klaus Mann (1906-1949), a novelist, essayist and playwright, wrote the novel Mephisto (1936), based on Gründgens' political accommodation with the Nazis (later an acclaimed film by Istvan Szabo, 1981), became a US citizen and committed suicide, while Golo Mann (1909-1994), a historian, taught in the US, Germany and Switzerland, and wrote many books.

Heibut, A., Thomas Mann: Eros and Literature. 1995; Hayman, R., Thomas Mann: A Biography. 1995; Harpprecht, K., Thomas Mann: Eine Biographie. 1995; Tóibín, C., The Magician. 2021; Ross, A., Wagnerism. Art and Politics in the Shadow of Music. 2022.

Mannerheim, (Carl) Gustaf (Emil), Baron (18671951). Finnish marshal and politician, born in Askainen. Of Swedish descent, he joined the Russian Army in 1889, explored Central Asia on horseback (1906-08) and became a lieutenant general in World War I. When Finland declared its independence from Russia after the November 1917 Revolution, he commanded the Finnish 'White' forces which (with German help) defeated the Bolshevik 'Reds' in a bitter four-month war. Regent of Finland 1918-19, he was defeated for the presidency in 1919 by Kaarlo *Stählberg and retired until recalled as Chairman of the National Defence Council 1931-39, when he built the Mannerheim Line as a defence against the USSR. Commander-in-Chief, Finnish Defence Forces 1939-46, he fought the invading Russians in 'the Winter War' 1939-40, leading to the cession of some territory. Hostilities with Russia resumed in 'the Continuation War' 1941-44, resulting in more territorial losses. In 1942, Mannerheim turned 75, was created Marshal of Finland and had an unexpected and unwelcome visit from ${ }^{*}$ Hitler. $\mathrm{He}$ refused to collaborate in persecuting Jews or gypsies, opposed a formal alliance with Germany and Finland and took no part in the siege of Leningrad. *Stalin seems to have had some wary respect for the Marshal, as did ${ }^{*}$ Churchill. Elected President of Finland (1944), he negotiated peace with Stalin, but retired through illness, suffering from stomach ulcers. $\mathrm{He}$ was treated in Switzerland from 1947 and died in Lausanne. In 2004, in a national poll, he was voted as the greatest of all Finns.

Warner, O., Marshal Mannerheim and the Finns. 1967.

Manning, Henry Edward (1808-1892). English cardinal. After a distinguished academic career at Oxford he was ordained (1832) an Anglican clergyman and became Archdeacon of Chichester (1841). A widower, in 1851 he became a Roman Catholic priest and soon rose to prominence. He established (1857) the Congregation of St Charles (Borromeo) in London and in 1865, after being provost of the metropolitan chapter of Westminster, succeeded Cardinal *Wiseman as Archbishop. Created cardinal in 1875, he was a strong supporter of the dogma of papal infallibility as defined at the Vatican Council (1870) and in social affairs was identified with prison reform, education and help for the poor. He had an uncomfortable relationship with Cardinal *Newman.

Mannix, Daniel (1864-1963). Australian Catholic prelate, born in County Cork, Ireland. $\mathrm{He}$ was President of Maynooth Theological College 190312, then went to Australia as coadjutor Archbishop of Melbourne (1913) succeeding as Archbishop 1917-63. He had been a strong supporter of Home Rule for Ireland and attacked World War I as a trade war. $\mathrm{He}$ assumed virtual leadership of Australian Catholics for more than 40 years. He fought for state aid for Catholic schools, against W. M. *Hughes over conscription in 1916 and 1917, and supported first the Australian Labor Party, then (from 1955) the anti-Communist Democratic Labor Party.

Griffin, J., Daniel Mannix. Beyond the Myths, 2012; Niall, B., Mannix. 2015.

Manoel I (known as 'the Fortunate') (1469-1521). King of Portugal 1495-1521. He succeeded his elder brother, *João II, who was assassinated. His nickname 
was due more to events and circumstances than to his own abilities. He did, however, encourage the great revival of arts and letters that marked his reign and the term 'Manoeline style' applied to the architecture of the period was not merely an empty compliment. Moreover the 'Manoeline Ordinances' were an important revision of the first systematic collection of laws made by Alfonso V. Manoel's reign. Marred by the expulsion of Moors and Jews, his reign saw the rounding of the Cape of Good Hope by *Dias, the voyage of Vasco da *Gama to India, the discovery of Brazil and finally the start of *Magellan on his last and greatest voyage.

Sanceau, E., The Reign of the Fortunate King 14951521. 1969.

Manoel II (Manuel Maria Filipe Carlos Amélio Luís Miguel Rafael Gabriel Gonzaga Francisco de Assis Eugénio de Orleães Sabóia e Saxe-Coburgo-Gotha Bragança) (1889-1932). Last King of Portugal and the Argives 1908-10. He succeeded when his father, King Carlos, and his elder brother Luis Felipe were assassinated, but abdicated on the outbreak of the 1910 revolution. He lived in Twickenham from 1910 and became known as bibliophile, author of Antique Portuguese Books 1489-1600 (1929), and an antiquarian.

Mansart, Jules Hardouin (1646-1708). French architect. His original surname was Hardouin, but he added the name of his great uncle François Mansart (1598-1666), the architect who developed the mansard (attic) roof, named for him. A lifelong favourite of ${ }^{*}$ Louis XIV, he rose in a short time to the position of Architect to the King (1675) and became Surveyor of the Royal Works in 1699. He was responsible for the Grand Trianon and other buildings at Versailles and for the Dôme des Invalides (1716), Paris. As a town planner, he created in Paris the Place des Victoires (1684-86) and the Place Vendôme (1699).

Mansfeld, Pieter Ernst, Graf von (c.1580-1626). German military commander. In the early stages of the Thirty Years' War (from 1618) he played a leading part in securing *Frederick V's (temporary) position as King of Bohemia. After Frederick's expulsion he waged an independent campaign against the emperor ${ }^{*}$ Ferdinand II. In 1624 with the aid of French and English subsidies he again took the field, but in 1626 he was defeated by the imperialists under *Wallenstein at Dessau and died in the same year.

Mansfield, Katherine (Kathleen Mansfield Beauchamp) (1888-1923). New Zealand short story writer, born in Wellington. She arrived in London at the age of 20 and wrote a series of sensitive and sometimes ironic short stories that soon proved her meticulous craftsmanship and mastery of that difficult form. Her volumes include In a German Pension (1911), written while recovering in Bavaria from a miscarriage, Bliss and Other Stories (1920), which established her fame, and The Garden Party (1922) containing 'The Daughters of the Late Colonel' and 'The Voyage'. She married (1918) John Middleton * Murry and died of tuberculosis in France.

Tomalin, C., Katherine Mansfield: A Secret Life. 1987.

Mansfield, William Murray, 1st Earl of (17051793). British lawyer, born in Scotland. Fourth son of David, Viscount Stormont, he was called to the bar (1731) and after 10 years of successful practice became a Member of Parliament 1742-56, Solicitor-General 1742-54 and Attorney-General 1754-56. *Newcastle appointed him as Lord Chief Justice of the King's Bench 1756-88, being created Baron Mansfield (1756), advanced to an earldom in 1776. Contrary to precedent, he remained as a Cabinet member 1757-63. He was a very efficient judge, speeded up trials, reformed the common law and consolidated commercial law. Attacks on the government between $1768-71$ by the anonymous pamphleteer 'Junius' led to the publishers being tried for seditious libel, but juries refused to convict. Mansfield's judgment in Scarlett's case (1772) declared slavery illegal in England and Wales (but did not affect the slave trade). He had powerful enemies, including *Pitt the Elder, but was admired for his eloquence and learning, and is regarded as one of the greatest common law judges.

Poser, N. S., Lord Mansfield. Justice in the Age of Reason. 2013.

Manson, Sir Patrick (1844-1922). Scottish physician and parasitologist, born in Aberdeen. From a wealthy family, he graduated in medicine from Aberdeen University and worked in China for 24 years. He specialised in elephantiasis, blackwater fever, leprosy and a heart disease he identified as beriberi. He determined that the transmission of elephantiasis was via the mosquito. His researches suggested that the worm that caught the disease developed in the common brown mosquito. Manson's understanding of the role of the mosquito as a parasite became fundamental for the diagnosis and treatment of a host of tropical illnesses. Manson, however, was mistaken in some of his ideas. He thought that mosquitoes bit only once, and that man became infected by ingesting the larvae in water. Manson later pioneered the understanding of the transmission of malaria by mosquitoes. By 1898 he had developed a sophisticated understanding of the life cycle of the parasite, and had grasped the importance of protecting humans against mosquitoes at night. He was largely instrumental in setting up the London School of Tropical Medicine in 1899 , and was a tireless teacher. He was nominated for the Nobel Prize 15 times.

Manson-Bahr, P., Patrick Manson, The Father of Tropical Medicine. 1962. 
Manstein, Fritz Erich von (1887-1973). German soldier. After serving as Chief of Staff in Poland and France in the early stages of World War II he held commands on the Russian front. In the great southern campaigns he showed, both in advance and retreat, superb skill in coordinating the movements of military formations of the largest scale, and was generally considered the ablest of German generals during the war. $\mathrm{He}$ was ordered to retire in 1944 by *Hitler, whose policy of clinging to untenable positions until they were overwhelmed he resolutely opposed. Sentenced in 1949 to 18 years' imprisonment for war crimes, he was freed in 1953.

Manstein, F. E. von, Lost Victories. 1959.

Mantegna, Andrea (c.1431-1506). Italian painter, born in Isola di Carturo. The founder of the Paduan school, Francesco Squarcione, adopted him when he was orphaned, but by 1458, when he painted a series of frescoes on the life of St James (destroyed in World War II), he was working independently. The most important influence on his work was derived from his study of archaeology, stimulated by the drawings of his father-in-law Jacopo *Bellini. He went to Rome to study classical buildings and was a collector of coins and fragments. Even in biblical subjects, e.g. the Agony in the Garden (National Gallery, London), he betrays his zeal to introduce classical details into his composition. His knowledge of perspective was profound and he used it, e.g. in the Lamentation of the Dead Christ (at Milan), in an astonishingly bold manner. In the early 1460s Mantegna was called to Mantua to decorate the Camera d'egli Sposi in the palace with scenes from the lives of the Gonzagas, the ruling House, with which he remained, with intervals, for the rest of his life. While there he painted the pictures representing the Triumph of Julius Caesar (c.1486-94), bought by ${ }^{*}$ Charles I of England and now, much damaged and restored, at Hampton Court.

Tietze-Courat, E. (ed.), Mantegna: Paintings, Drawings, Engravings. 1955.

Mantel, Dame Hilary Mary (née Thompson) (1952-2022). English novelist, born in Derbyshire. Educated at Sheffield University, she was a social worker and retailer, lived in Botswana and Saudi Arabia and suffered debilitating illness. Her first novel was Every Day is Mother's Day (1985). A Place of Greater Safety (1992) describes the Reign of Terror in France in 1794. She achieved great critical success and enormous sales with novels written around Thomas *Cromwell, *Henry VIII's advisor, Wolf Hall (2009) and Bring Up the Bodies (2012), winning the Man Booker Prize with each, and The Mirror and the Light (2020). She also wrote a memoir, critical essays and delivered the BBC's Reith Lectures in 2017.

Mantoux, Charles (1877-1947). French physician. $\mathrm{He}$ devised the Mantoux test for tuberculosis and investigated the formation of tubercular cavities in the lungs.
Manutius, Aldus (Teobaldo Pio Manuzio or Mannucci) (1450-1515). Italian scholar and printer. He founded (1490) the press in Venice now known as the Aldine, and he was the first to print and publish the works of such classical authors as *Aristotle, *Sophocles, *Plato and ${ }^{*}$ Xenophon. He devised italic printing and designed the first font of Greek type. Manutius was a friend of *Erasmus and other enthusiasts for the 'new learning'. His work was continued by his son Paolo Manutius (15121574) and grandson Aldus Manutius the Younger (1547-1597).

Manzoni, Alessandro (1785-1873). Italian writer, born in Milan. Grandson of Cesare *Beccaria, he spent his early manhood in Paris where he was influenced by the prevailing scepticism until he reconverted to Catholicism (c.1810) soon after his first marriage. All his work shows a liberal outlook and deep moral purpose. He worked very slowly: the two well known odes on the death of ${ }^{*}$ Napoléon and the Piedmontese rising (1812) against the Austrians, together with a few hymns, comprise almost his entire poetic output. Two tragedies with stories derived from the early Middle Ages reflect a mood of pessimism caused by the failure of liberal movements in the early 1820s; finally in 1827 came his great and only novel I Promessi Sposi (The Betrothed). This historical romance set in 17 th-century Lombardi under Spanish rule (the Spanish representing the Austrians of his own day), was at once hailed as a masterpiece and is still held to be among the greatest of Italian novels. It took six years to write and was constantly revised, but marks the end of his creative period, except for a number of critical essays. Both of his wives and most of his children predeceased him. He supported the struggle for Italian unification, promoted use of the Tuscan dialect as the national language and was a senator $1860-73 .{ }^{*}$ Verdi dedicated his Requiem to Manzoni's memory.

Colquhuon, A., Manzoni and His Times. 1954.

Mao Zedong (Mao Tse-tung in Wade-Giles) (18931976). Chinese Communist leader, born in Shaoshan, Hunan province. Son of a small landowner, he returned to school after a brief child marriage, and became a voracious reader $\left({ }^{*}\right.$ Rousseau, ${ }^{*}$ Darwin, ${ }^{*}$ Spencer and ${ }^{*}$ Mill), later turning to ${ }^{*}$ Marx. He served in ${ }^{*}$ Sun Yatsen's revolutionary army (1911) and studied at Changsha teachers' training school. Unlike * Li Lisan, ${ }^{*}$ Zhu De and *Zhou Enlai, he did not study abroad. Mao worked as a laundry man in Shanghai (1919), then as a teacher, trade union secretary and library assistant at Peking National University. $\mathrm{He}$ was one of the 12 foundation members of the Chinese Communist Party in Shanghai (July 1921, ${ }^{*}$ Chen Du-xiu). As CCP secretary in Hunan 1921-25, he organised trades unions and worked closely with the Guomindang. He set up more than 50 peasant unions 1925-27. After the risings of 1927 were defeated in the cities, he founded a workers' and peasants' army in 
Hunan with Zhu De and was a political commissar of the Red Army 1930-31. In 1930 his second wife Yang Kaihui and his sister were executed by a Guomindang warlord. Ultimately he won major support from the Central Committee for his view that revolution must be based on the peasantry rather than the proletariat which barely existed in China. Mao was Chairman of the Soviet Republic in Jiangxi Province 1931-34. Chairman of the CCP from January 1935 until his death in September 1976, he was only recognised as the dominant leader after the 'Long March' (October 1934-October 1935, with the rear guard arriving in January 1936). After repeated Guomindang attacks, 80,000 people walked 9,650 kilometres, fighting 15 major battles on the way, from Jiangxi to the caves in Yan'an, Shaanxi Province: only 20,000 survived and Mao's three children were lost on the way. From 1937 to 1945 Mao collaborated with ${ }^{*}$ Chiang Kaishek against the Japanese. By 1945 the Red Army had 1,000,000 soldiers and controlled the northwest. Civil war resumed in 1946. On the Guomindang's defeat and withdrawal to Taiwan, Mao proclaimed the foundation of the Chinese Peoples' Republic (1 October 1949) and served as Chairman (i.e. President) 1949-59, retiring as head of state to devote himself to party organisation and ideological formation. He visited the USSR Dec. 1949-Feb. 1950, for his first and only meeting with *Stalin, who resented Mao's success and had failed to support the resumption of civil war in China in 1945. The outbreak of the Korean War in June 1950 surprised Mao, who saw it as a Soviet operation. The US, however, was convinced that China had instigated the war. When ${ }^{*}$ MacArthur proposed to bomb Chinese bases north of the Yalu River in October 1950, China sent volunteers to Korea. Stalin then reduced his commitment to *Kim Il Sung, putting China in jeopardy. Mao returned to Moscow in 1953 (for Stalin's funeral) and in 1957 to meet ${ }^{*}$ Khrushchev. After a brief period of liberalism ('Let a Hundred Flowers Bloom') in 1956-57, came the Great Leap Forward (1958-61), a period of forced collectivisation in agriculture, mass mobilisation of labour and the introduction of small scale industrialisation. Food supply collapsed and deaths due to starvation have been estimated at 30 million. China occupied Tibet in 1959 and exploded its first atom bomb in 1964. The Great Proletarian Cultural Revolution was launched in 1965, as an attack on bureaucracy and privilege, but also on China's history, culture and tradition. Western cultural influence was also denounced. ${ }^{*}$ Zhou Enlai was abused but survived as Premier. *Deng was publicly humiliated, ${ }^{*}$ Liu Shaoqi disgraced and imprisoned. Mao's Communism was highly moralistic, decentralised and ostensibly anti-bureaucratic. Unlike the Soviet CP, Mao used rival forces (e.g. the army, Red Guards) to discipline the party organisation. He wrote many works on ideology and strategy and was a gifted lyric poet and 'grass' (i.e. vernacular) calligrapher. in the 'little red book', had the force of moral law. The Red Guards were especially destructive. In the Cultural Revolution some of the worst outrages were attributable to Kang Sheng (c.1900-1975), chief of the secret police and Chen Boda, one of Mao's secretaries. Perhaps four million people were killed in the terror. In 1968 the army stepped in and imposed some degree of military rule, which weakened Mao's position. After the defection of his chosen successor ${ }^{*}$ Lin Biao in 1971, Mao's direct power declined even further. From 1973 he was virtually blind and helpless until his death in Beijing. His fourth wife Jiang Qing (née Li He, later Lan Ping) (1914-1991) was a film actor before her marriage in 1938. In 1966 she emerged as a public figure, took a leading role in the Cultural Revolution, rose to fourth place in the Politburo and was a fierce opponent of Zhou. Demoted at the 1973 Congress, she was denounced as one of the 'Gang of Four', sentenced to death in 1981 after a show trial, but reprieved in 1983 and released in 1991. She hanged herself in hospital.

Wilson. D., Mao: The People's Emperor. 1979; Terrill, R., Mao. 1980; Salisbury, H., The New Emperors: Mao and Deng. 1992.

Marat, Jean Paul (1743-1793). French revolutionary journalist. A physician, especially interested in optics, he had travelled much and spent many years in England before returning to France and becoming physician to the Duke of Artois' household troops. After the outbreak of the Revolution he founded (1789) an extremist newspaper L'Ami du peuple which in 1793 played a considerable part in rousing public opinion against the Girondists. Charlotte *Corday, a member of that party, came from Normandy to assassinate him, found him in his bath where, as a sufferer from a skin disease (probably dermatitis herpetiformis), he transacted much business, and stabbed him to death.

Marceau, Marcel (1923-2007). French mime, born in Strasbourg. From 1949 he directed his own mime company, and a school of mime-drama in Paris from 1978. He toured incessantly, appearing in film, ballet and on television.

Marchand, Jean Baptiste (1863-1934). French soldier and explorer. Having successfully led an expedition from Senegal to the sources of the Niger he was ordered to extend the area of French interest by an advance across Central Africa. When he reached Fashoda in the southern Sudan (1898) he refused the demands of ${ }^{*}$ Kitchener to evacuate that area and thus caused such tension between France and Britain that a threat of war was averted only by the French Government's order to Captain Marchand to withdraw.

\section{Marco Polo see Polo, Marco}


Marconi, Guglielmo, Marchese (1874-1937). Italian physicist and inventor, born in Bologna. From an affluent family, with an Irish mother, he was privately tutored, studied at Livorno (Leghorn) under Prof. Vincenzo Rosa but did not attend a university. He experimented with primitive wireless equipment based on the work of ${ }^{*}$ Hertz and ${ }^{*}$ Maxwell and is credited with the first practical system using radio for signalling in Morse code, although several others, particularly the Russian scientist Aleksandr Stepanovich Popov (1859-1905), had paralleled his work to some degree. By 1895 he could transmit signals between points a mile $(1.6 \mathrm{~km})$ apart. By 1896, attracting no interest in Italy, he went to England and enlisted support from the British Post Office: he transmitted Morse over 9 miles $(14.5 \mathrm{~km}$ ) and took out the world's first radio patent. By 1898 he could send messages from England to France, and on 12 December 1901 successfully transmitted across the Atlantic from Poldhu, Cornwall, to St Johns, Newfoundland. He had assumed (correctly) that radio signals would follow the curvature of the earth, and not travel in a straight line. (The explanation was later proved by ${ }^{*}$ Heaviside.) The Marconi Telegraph Company which he founded in 1897 played a major part in the development of radio, television and electronics. In 1905 he married the Hon. Beatrice O'Brien and had three children. They divorced and he remarried in 1927. Marconi shared the 1909 Nobel Prize for Physics with Karl Ferdinand Braun (1850-1918), the developer of crystals as radio detectors. He became a senator 1915-37, delegate to the Paris Peace Conference (1919), a strong supporter of ${ }^{*}$ Mussolini, an anti-Semite and President of the Royal Italian Academy 1930-37. Britain gave him a GCVO in 1914 and he was created Marchese (Marquis) in 1929.

Baker, W. J., A History of the Marconi Company. 1970; Raboy, M., Marconi. The man who networked the world. 2016.

Marcos, Ferdinand Edralin (1917-1989). Filipino politician. He claimed to be the most highly decorated Filipino war hero, became a lawyer and a congressman 1949-65, serving as President of the Philippines 1966-86. The constitution was changed to allow him to rule for a record term and martial law imposed 1973-81. After a fraudulent election in 1986, pressure from the US, the Church and the military forced him into affluent exile and Mrs Corazon *Aquino took office. He died in Hawaii and was buried in the Philippines in 1993. His wife, Imelda Romualdez Marcos (1931- ), was appointed Governor of Metro Manila 1975-86, and Secretary of the Department of Ecology and Human Settlements 1978-86. In 1993 she was sentenced to 18 years' jail for corruption, but was released pending appeals.

Their son, Ferdinand Romualdez Marcos, Jr., (1957-), known as Bongbong Marcos (BBM), was a Representative 1992-95; 2007-10 and Senator
2010-16. President of the Philippines 2022-, he won the election overwhelmingly, running with Sara Duterte for Vice President, his family history either forgotten or lit in a golden haze.

Marcus Aurelius Antoninus (121-180). Roman Emperor 161-80. Born in Rome to a noble family, he took the additional name Antoninus when he was adopted (138) by *Antoninus Pius, whom *Hadrian chose as his successor and whose daughter, Faustina, Marcus married (145). When Marcus succeeded Antoninus as Emperor, he shared the government with Lucius Aurelius Verus, adopted by Antoninus at the same time as himself. From 162 to 165 the armies of Verus (d 169) fought the Parthians successfully in Armenia, where a puppet ruler was installed, and in Mesopotamia where Ctesiphon was taken by Avidius Cassius, whose subsequent rebellion (175) Marcus easily overcame. Meanwhile the Germanic tribes, the Marcomanni and Quadi, had broken through the northern frontiers and were threatening Italy and the Balkans. Marcus had fought two successful campaigns against them when he died at Vindabona (modern Vienna). A successful general, a wise and patient ruler, Marcus Aurelius is perhaps best known as a Stoic philosopher and his introspective Meditations, written in Greek, has been one of the most influential books ever composed by a ruler. He reveals himself, without arrogance, as an instrument used for a time by providence to guide the Roman Empire towards its destiny of becoming part of a dimly perceived world order. The virtues he espoused were those usually regarded as Christian, but he saw Christianity as an emotional, intolerant and disruptive sect that sought the empire's protection while refusing or avoiding military service and other duties. Such persecution as he practised was on public not religious grounds. His reign was looked back on by later Romans as a Golden Age. His son *Commodus succeeded.

Birley, A., Marcus Aurelius. 1966.

Marcuse, Herbert (1898-1979). German American philosopher, born in Berlin. Educated at Freiburg, he became Martin *Heidegger's assistant, left Germany in 1933 and worked in the US for the State Department and the Office of Strategic Services, later holding professorships at Brandeis University 1954-65 and the University of California at San Diego 1965-76. His books became enormously influential with the 'New Left' and the students in revolt during the late 1960s. Although deeply influenced by ${ }^{*}$ Marx and ${ }^{*}$ Freud, Marcuse was primarily a disciple of ${ }^{*} \mathrm{Hegel}$ and advanced a complete body of philosophical doctrine, being sharply critical of logical positivism, scientific attitudes or analysis. He denounced the 'hell of the affluent society', argued that sexual freedom was an anti-revolutionary device and (in his Critique of Pure Tolerance, 1966) contended that tolerance was outmoded when it served subtle enslavement through fraudulent democracy in the industrial state. He called for 'selective intolerance' 
and 'counter-indoctrination' where necessary. His books include Eros and Civilisation (1955) and One-Dimensional Man (1964).

Margaret, 'Maid of Norway' (Norse = Margrete; Gaelic = Maighread) (1283-1290). Queen-designate of Scotland 1286-90. Daughter of Erik II Magnússen, king of Norway and Margaret of Scotland, she was granddaughter to the Scottish king *Alexander III whose death (1286) left her as sole heir to the throne. *Edward I of England intended that she should marry his son (afterwards ${ }^{*}$ Edward II) and so effect the union of the two crowns. She sailed to Scotland but died on Orkney, probably of food poisoning, at the age of seven, leaving thirteen claimants to the throne.

Margaret (Marguerite) of Anjou (1430-1482). English queen consort 1445-61, 1470-71. Daughter of René, Duc d'Anjou, titular king of Naples, Sicily and Jerusalem, she married ${ }^{*}$ Henry VI in 1445 , but her French birth made her very unpopular in England. When the Wars of the Roses broke out and her saintly husband began to show mental incapacity, she was, with her courage and strength of character, the life and soul of the Lancastrian cause. Finally captured after the Battle of Tewkesbury (1471), where her son Edward, Prince of Wales, was killed, she became a prisoner, until ransomed by her cousin *Louis XI of France.

Bagley, J. J., Margaret of Anjou, Queen of England. 1948.

Margaret (Rose), Countess of Snowdon (19302002). British princess. Younger daughter of King ${ }^{*}$ George VI and sister of Queen *Elizabeth II, she was born at Glamis Castle in Scotland, the seat of her mother's family. She married (1960) Antony Armstrong-Jones, a London photographer, afterwards created Earl of *Snowdon; they divorced in 1978.

Brown, C., Ma'am Darling. 2017.

Margaret (Tudor) (1489-1541). Scottish queen consort 1503-13. Daughter of *Henry VII of England, her marriage (1503) to *James IV of Scotland provided the link between the Tudor and Stewart (Stuart) dynasties, upon which depended the union of the crowns of the two countries under *James VI and I, the first king of Great Britain. After her husband's death at Flodden, she married Archibald Douglas, 6th Earl of Angus, who headed the English faction at the Scottish court.

Margrete (or Margaret: Margrete Valdemarsdatter) (1353-1412). Queen of Denmark and Norway 13871412 and Sweden 1389-1412. Daughter of Valdemar IV of Denmark and wife of Haakon VI of Norway she became, on her father's death (1376), regent for her son Olaf, infant King of Denmark and (1380) of Norway. A tribute to her qualities was paid when on Olaf's sudden death (1387) she was permitted to continue her rule of both countries. In 1389 at the
King Albrecht and added that country (nominally on behalf of her grandnephew, Eric of Pomerania) to the area under her control. By the Union of Kalmar (1397) Eric became King of all three countries but Margaret maintained her strong personal rule until her death.

Margrethe II (1940- ). Queen of Denmark 1972- . Daughter of King *Frederick IX, she travelled extensively, illustrated *Tolkien's Lord of the Rings and became a British LG.

Marguerite (Margaret) of Navarre (1492-1549). French author, Queen of Navarre. Sister of ${ }^{*}$ François I of France, through her marriage to ${ }^{*}$ Henri II of Navarre she became the grandmother of ${ }^{*}$ Henri IV of France and the ancestress of the Bourbon kings. She was learned and pious but also gay and tolerant; her courts became centres of humanist culture and places of refuge for persecuted scholars. In the Heptameron, following the pattern set by *Boccaccio's Decameron, five gentlemen and ladies held up by the floods beguile the time with stories, but though ribaldry is present in her stories, Margaret, unlike Boccaccio, treats love as a serious, and often tragic passion.

Maria II (Maria da Glória Joana Carlota Leopoldina da Cruz Francisca Xavier de Paula Isidora Micaela Gabriela Rafaela Gonzaga Habsburgo-Bragança) (1819-1853). Queen of Portugal 1826-28; 1834-53. Born in Rio de Janeiro, she was daughter of *Pedro I, Emperor of Brazil and King of Portugal. Pedro renounced the Portuguese throne in favour of his young daughter in 1826 , but she was deposed by her absolutist uncle Miguel I (1802-1866). Her father abdicated from the throne of Brazil, led a liberal revolt against Miguel and restored Maria as queen in 1834. She was known as 'the Educator'.

Maria Carolina of Austria (Maria Carolina Louise Josepha Johanna Antonia) (1752-1814). Queen consort of Naples and Sicily. Daughter of *Maria Theresa of the Holy Roman Empire, she married *Ferdinand I and through her favourite Sir John Acton (1736-1811) became de facto ruler of her husband's kingdoms. Like her brothers *Joseph II and ${ }^{*}$ Leopold II she was an enlightened despot, but turned reactionary after the French Revolution and the execution of her sister * Marie Antoinette.

Maria Theresa (Maria Theresia Walburga Amalia von Habsburg, later von Habsburg-Lothringen) (17171780). Archduchess of Austria, Queen of Hungary and Bohemia 1740-80, Empress consort 1745-65. Daughter and heiress of the emperor ${ }^{*}$ Karl VI she became Empress when her husband *Franz of Lorraine (married 1736) was elected Emperor (1745). By the Pragmatic Sanction, Karl VI had sought to guarantee his daughter's succession to all Habsburg lands but on his death (1740) * Friedrich II (the Great) of Prussia invaded Silesia and provoked the War of the Austrian Succession, as a result of 
which he retained the province but recognised the Pragmatic Sanction in other respects. By making an alliance with France, Maria Theresa hoped to regain Silesia but failed to achieve her purpose in the Seven Years' War (1756-63). She was an unwilling partner in the partition of Poland (1772), from which she acquired Galicia. In the administration of her many territories, Maria Theresa proved herself a wise and prudent practitioner of the system of paternal government then in vogue. She freed the peasants from many feudal burdens, abolished torture and did much to foster education, trade and industry and to reform the legal and taxation systems. She associated her son *Joseph II with herself as ruler when he was elected Emperor on his father's death (1765). Her 15 other children included the emperor *Leopold II and *Marie Antoinette, Queen of France.

Pick, R., Empress Maria Theresa. 1966.

Marie Antoinette (1755-1793). Queen consort of France 1774-92. Daughter of *Maria Theresa of Austria, she married the future *Louis XVI of France in 1770 , four years before he became King. She retained his complete devotion throughout his life. Her frivolity and extravagance made her unpopular but she was not unkind. She was further discredited by an obscure confidence trick by which Cardinal de Rohan was induced to promise payment for a diamond necklace of great value allegedly for the queen. Marie Antoinette was almost certainly ignorant of the entire affair. In the Revolution, Marie Antoinette inspired the court partly by her firmness and courage but her course of action, e.g. the mismanaged flight of the royal family to Varennes (1791) and her secret correspondence (especially with her brother the emperor ${ }^{*}$ Leopold II) asking for intervention, did much to bring about the deposition of her husband (1792), his death on the guillotine (January 1793) and her own in the following October. Her son ( ${ }^{*}$ Louis XVII) died in prison. Her daughter Marie Thérèse Charlotte (1778-1851) became Duchess of Angoulême.

Cronin, V., Louis XVI and Marie Antoinette. 1974.

Marie de Médicis (1573-1642). Queen consort of France and Navarre 1600-10. Daughter of the Grand Duke Francesco of Tuscany, she became (1600) the second wife of ${ }^{*}$ Henri IV of France. As regent after his assassination (1610), she dismissed the experienced minister *Sully and squandered wealth on her favourite, Concino Concini. Her son Louis *XIII had Concini murdered but was content to let power pass to ${ }^{*}$ Richelieu. Having failed to displace him, she retired to live in exile, mainly in the Low Countries.

Marie Louise (1791-1847). Empress of the French. Daughter of *Franz II, last Holy Roman emperor and first emperor of Austria, she was forced to marry (1810) *Napoléon I, and became the mother of his son (1811), known later as the Duke of Reichstadt (*Napoléon II), who, after his father's abdication, was brought up by his Austrian grandfather. Marie Louise, who refused to accompany her husband into exile, was given the duchies of Parma, Piacenza and Guastalla. She became the mistress of the Austrian general, Adam Adalbert Neipperg, whom she secretly married (1821) after Napoléon's death. In 1834 she married Charles-René, Comte de Bombelles.

Turnbull, P., Napoleon's Second Empress: Marie Louise. 1971.

Marin, John (1870-1953). American painter, born in New Jersey. Most of his paintings depict scenes on the coasts of Maine. His composition shows the influence of *Cézanne, and he used expressionist and abstract painting techniques to achieve representational results. He is best known for his watercolours but used oils more freely in later life.

Williams, W. C., John Marin. 1956; Young, J. S., John Marin: The Edge of Abstraction. 2006; Balken, D. B., John Marin: Modernist at Mid-Century. 2011.

Marinetti, Filippo Tommaso (1876-1944). Italian writer, born in Alexandria. After studying in France he developed his theory of 'Futurism', which rejected the past and exalted present and future, glorifying machinery and war (seen as a cleansing mechanism). He joined the Fascists, hailed ${ }^{*}$ Mussolini as an embodiment of Futurist aims and was a prolific writer of poetry, plays and novels.

Maritain, Jacques (1882-1973). French philosopher. After being a pupil of ${ }^{*}$ Bergson, he was converted to Catholicism (1906) and became an exponent of the philosophy of St Thomas *Aquinas, seeing in it a solution of modern problems of the mind, of society and of culture. He became a professor of the Institut Catholique in Paris and from 1933 taught at Toronto. After World War II he was French Ambassador to the Vatican 1945-48 and then a professor at Princeton, NJ 1948-52.

Marius, Gaius (157-86 BCE). Roman soldier and politician. Seven times elected consul, his first campaign was in Spain (134-133) where he later served as propraetor. He took part (109-108) in the war in Numidia against *Jugurtha under Metellus to whose command he succeeded (107). As Consul in that year he abolished the property qualification for military service and thus founded a virtually professional and more efficient army. He brought the war in Africa to an end (107-105), though it was actually * Sulla, soon to be his deadly rival, who captured Jugurtha. He was again elected Consul for the five successive years 104 to 100 , during which he trained his army and eventually crushed the Teutoni (at Aquae Sextiae in 102) and the Cimbri (at Vercellae in 101), who were invading Italy from the north. These successes were followed by a period of eclipse after he had let himself become the tool of the demagogue Saturnius during his consulship of 100. He took part in the Social War (91-88) which 
was followed by enfranchisement of the Italians as Roman citizens, but in 88 the new electors were organised to vote for the super-session of the consul Sulla by Marius in the war against Mithridates. Sulla responded by marching his legions back to Rome, getting the legislation repealed and Marius exiled. But as soon as Sulla was in the East the new consul Cinna brought Marius back and for Sulla's supporters a reign of terror followed (87), for which vengeance came only after Marius' death. Meanwhile it had been shown how easily a successful general could usurp civil power, an example that inspired many similar events.

Carney, T. F., A Biography of Gaius Marius. 1970.

\section{Mark Antony see Antony, Mark}

Mark, St (also called John Mark, Yohan'an to the Jews, Marcus to the Romans) (c.10-70 CE). Christian apostle, one of the four evangelists. The earliest Christians met at the house of his mother, Mary, and he met *Paul through his cousin *Barnabas. Mark accompanied them on their first missionary journey, but at Perga left them to return to Jerusalem, which led Paul to refuse to take him on his second journey. The result was a split, with Barnabas taking Mark to his native Cyprus. The friendly references in Paul's Epistles indicate a reconciliation, and Mark is mentioned as sharing Paul's imprisonment, probably in Rome. He then worked closely with *Peter ('my son Mark', I Peter v:13) and, according to Papias and Irenaeus, his Gospel was written after the martyrdom of Peter and Paul but probably before the destruction of Jerusalem. St Mark's Gospel is the shortest of the synoptics, with a dramatic, abrupt narrative and is thought to be the earliest. Written in Greek, it is addressed to a Roman audience, somewhat antiJewish in tone and with a shaky grasp of Palestinian geography (curious in a work thought to embody Peter's recollections). According to tradition, Mark became the first bishop of Alexandria and died there, but in 828 his remains were stolen and transferred to Venice.

\section{Mark Twain see Twain, Mark}

Markievicz, Constance Georgine, Countess (née Gore Booth) (1868-1927). Irish suffragist and nationalist, born in London. She studied painting in Paris and married (1900) a Polish artist who claimed noble status. Active in the Irish nationalist cause, she was sentenced to death for her part in the Easter Rising in Dublin (1916) but, after commutation, was released in 1917. A Catholic convert, she was imprisoned again when, in December 1918, as a Sinn Féin candidate, she became the first woman elected to the House of Commons, refusing to take her seat. She was Minister of Labour under *De Valera 1919-22 and a Member of the Dáil Éireann 1921-22; 1923-27.
Markova, Dame Alicia (Alice Marks) (1910-2004). English ballerina. She joined the *Diaghilev company in 1924, her work with them being the strongest influence on her future career. She danced with the Sadler's Wells Ballet (1933-35), toured with her own Markova-Dolin Ballet (1935-38), joined the Ballets Russes de Monte Carlo (1938) and danced with the New York Metropolitan Opera Ballet during World War II. She was a founder and prima ballerina (195052) of the London Festival Ballet. Her dancing, particularly in partnership with Anton *Dolin, was probably the nearest approximation to the Russian tradition and she did much to raise technical and artistic standards. In 1963 she was made a DBE, retired from dancing and began a new career as producer and teacher. She was Director of the New York Metropolitan Opera Ballet (1963-69), professor of ballet at Cincinnati University Conservatory of Music (1970), and Governor of the Royal Ballet (1973).

Marlborough, Duchess of, Sarah Churchill (née Jennings) see under Marlborough, 1st Duke of

Marlborough, John Churchill, 1st Duke of (1650 1722). English general, born in Ashe, Devon. His father, Sir Winston Churchill, a royalist, forced to sell his property to pay a fine for his part in the Civil War, was recalled to court in 1663. John was sent to St Paul's School; his sister Arabella became the mistress of the Duke of York (later *James II), who obtained for her brother a commission in the guards. Churchill served in Tangiers (1668-70) and in the third Dutch War, at first with the fleet (1672) and then (from 1673) with a British contingent under the French commander ${ }^{*}$ Turenne, from whom he learnt much of the art of war. In the winter of 1677-78 he married one of the Duchess of York's ladies-in-waiting, the dominating and ambitious Sarah Jennings (16601744), who commanded his lifelong devotion and did much to steer his fortunes.

Under James II, Churchill played a leading part against ${ }^{*}$ Monmouth at Sedgemoor, but joined *William of Orange when he landed (1688) and was created Earl of Marlborough. Commander-inChief in England during William's absence in Ireland (1690), in 1692 he was suddenly dismissed from all his posts and for a time imprisoned in the Tower of London on forged evidence that he was plotting to restore James. Restored to favour in 1698, when the War of the Spanish Succession broke out (1701) he was appointed to command the British forces in Holland. On the accession of ${ }^{*}$ Anne (1702), over whom the influence of Marlborough's wife Sarah was complete, he was made Captain General of all British forces at home and abroad, and with Dutch consent, Supreme Commander of all allied forces against France. Further to safeguard his power, his friend Sidney ${ }^{*}$ Godolphin, whose son was married to Marlborough's daughter, was Lord Treasurer. Marlborough's first great victory at Blenheim (1704) 
resulted from a march to the Danube and the effective support of the imperial commander Prince ${ }^{*}$ Eugène. The chain of victories was continued by Ramillies (1706), Oudenarde (1708), which led to the fall of Lille, and Malplaquet (1709) which opened the way (1710-11) to the capture, one by one, of the great fortresses protecting the French frontier. But at home, from Marlborough's point of view, catastrophe had occurred. His wife was replaced in the royal affections by Mrs Abigail Masham, and as head of the government, the sympathetic Godolphin was replaced by the hostile Robert ${ }^{*}$ Harley. In autumn 1711 Marlborough was dismissed from all his offices and the war was hurried to a close (1713). After Anne's death (1714) Marlborough was reinstated by *George I, and he had to console him with the ducal title (1702) and the parliamentary vote, earned by his first great victory, which resulted in the construction of *Vanbrugh's magnificent Blenheim Palace. Sarah, his duchess, fruitfully spent the 22 years by which she survived him in embellishing the mighty domain and haggling over the necessary funds; she left $£ 3$ million. Marlborough was among the greatest captains of his own or any time. He was avaricious and his political loyalties sometimes wavered, but his care for the welfare of his troops won their love and he had a generosity of mind and a greatness of spirit that matched his deeds. Later dukes of Marlborough (and Sir Winston Spencer *Churchill) were descended from the 1st Duke's daughter, Anne Spencer, Countess of Sunderland.

Churchill, W. S., Marlborough. 4 vols, 1933-38; Rowse, A. L., The Early Churchills. 1956; Jones, J. R., Marlborough. 1993; Holmes, R., Marlborough. England's Fragile Genius. 2006.

Marlowe, Christopher (1564-1593). English dramatist and poet, born in Canterbury. Two months older than *Shakespeare, he was the son of a shoemaker, went to King's School, Canterbury, and graduated BA (1584) at Corpus Christi College, Cambridge. (Following intervention by the Privy Council he was promoted MA in 1587.) After moving to London (1587?), he seems to have lived, despite his almost immediate fame as a playwright, a dangerous underworld existence linked in some sort of way with secret service work. Actively gay and a religious sceptic, a warrant for his arrest on charges of atheism and sedition was issued three weeks before he died. He was stabbed to death, probably murdered, by Ingram Frizer in a tavern brawl in Deptford. Frizer was quickly pardoned.

The subject of his first play Tamburlaine the Great (1587) is the life of the great Mongol conqueror *Timur the Lame. It was followed by The Tragical History of Dr Faustus (1588), relating the story of the German necromancer who sold his soul to the devil, The Jew of Malta (1589), an almost fantastic tale of revenge and murder, and Edward II (1592).
Lesser works are The Massacre of Paris (1593) and Dido Queen of Carthage (c.1593, written in collaboration with Thomas *Nash). Marlowe was the first to realise the full potentialities (both rhetorical and dramatic) of blank verse for tragedy and thus paved the way for ${ }^{*}$ Shakespeare, with whom he may have collaborated in the writing of Titus Andronicus and Henry VI. He also introduced the tragedy of character (e.g. the effects of power) as opposed to the tragedy of events, though he does this with less subtlety than Shakespeare and his minor characters are often sketchily drawn. In addition to his dramatic work Marlowe translated from ${ }^{*}$ Ovid and ${ }^{*}$ Lucan and wrote much poetry; Hero and Leander (1598), completed by George *Chapman, is his best known poem. The song Come live with me and be my love was published in The Passionate Pilgrim (1599).

Burgess, A., A Dead Man in Deptford. 1995; Nicholl, C., The Reckoning: The Murder of Christopher Marlowe. 1995.

Marmot, Sir Michael Gideon (1945- ). AngloAustralian epidemiologist and health equity analyst, born in London. Educated in Sydney, he then worked in California and London, becoming director of the Institute of Health Equity at University College, London. He was recognised as the international authority on the impact of class, location, education and diet on life expectancy and chronic illness. He wrote The Status Syndrome (2004) and The Health Gap (2015), chaired the World Medical Association 2015-16 and delivered the 2016 ABC Boyer Lectures.

Marot, Clément (1496-1544). French poet, born in Cahors. At the court of ${ }^{*}$ François I and his sister *Margaret of Navarre, Marot gained favour by graceful and witty satires, elegies, rondeaux and ballads. His translation of the Psalms led to furious attacks from the Sorbonne, despite the king's protection. He moved to Geneva but felt uncomfortable under ${ }^{*}$ Calvin's regime and died as an exile in Turin. In literary history, he stands at the junction point of medieval and Renaissance styles.

Mayer, C. A., Clément Marot. 1972.

Marquand, J(ohn) $\quad \mathbf{P}$ (hillips) (1893-1960). American novelist. He became popular with a series of stories about the Japanese detective, Mr Moto, but later wrote a series of sharp edged satires on society in New England, e.g. The Late George Apley (1937), which won the Pulitzer Prize, and H.M. Pullam Esq. (1941).

Marquet, Albert (1875-1947). French painter. One of the Fauves, closely associated with ${ }^{*}$ Matisse, his later landscapes were naturalistic.

Marquez, Gabriel Garcia see García Márquez, Gabriel 
Marquis, Don(ald Robert Perry) (1878-1937). American journalist and humorist. As a journalist he worked in Atlanta with Joel Chandler *Harris, creator of Uncle Remus. In archy and mehitabel (1927), and later collections, he published the stories of archy the cockroach and mehitabel ('toujours gai') the cat.

Anthony, E., O Rare Don Marquis. 1962.

Marriner, Sir Neville (1924-2016). English conductor, born in Lincoln. A violinist, he studied with Pierre *Monteux and founded the Academy of St Martin in the Fields in 1958. He received a CH in 2015 .

Marryat, Frederick (1792-1848). English sailor and novelist. After many years in the navy, during which he fought in the Napoléonic Wars and in Burma, he retired to write popular adventure stories, e.g. Peter Simple (1834), Mr Midshipman Easy (1836), Masterman Ready (1841) and The Children of the New Forest (1847).

Warner, O., Captain Marryat. 1953.

Marsh, Dame (Edith) Ngaio (1899-1982). New Zealand novelist and theatre director. She was second only to Agatha ${ }^{*}$ Christie as a prolific writer of detective stories and superior as a stylist.

Marsh, George Perkins (1801-1882). American writer, born in Woodstock, Vermont. He was a lawyer, philologist (said to have mastered 20 languages), US Congressman 1843-49, art collector and diplomat, who served as Minister Resident to the Ottoman Empire $1850-53$ and Minister to Italy 1861-82. $\mathrm{He}$ was buried in Rome. Profoundly influenced by *Humboldt, his book, Man and Nature (1864, revised and retitled in 1874 as The Earth as Modified by Human Action) developed the concepts of resource management and anticipated ecology as a major study. He warned that 'climatic excess', compounded by deforestation, might lead to 'extinction of the [human] species'.

Marshal, William, 1st Earl of Pembroke (second creation) (1147?-1219). Anglo-Norman knight and administrator, born in Caversham. Son of a minor landowner, he became famous for his success in tournaments and as a warrior. His marriage to Isobel, daughter of 'Strongbow', Earl of *Pembroke, brought him wealth and a recreation of the earldom. Jointmarshal and justiciar to *Richard I, he was consistently faithful to King *John but played a major role in the adoption of Magna Carta (1215). As Regent for the young *Henry III (1216-19), he expelled a French invasion and resisted papal influence. He became a Templar and was buried in the Temple Church in London. Regarded as a paragon of chivalry, he was the subject of a very early biography (in French) and appears as a character in books and films about medieval England.
Crouch, D., William Marshal: Knighthood, War and Chivalry 1147-1219. 2002; Asbridge, T., The Greatest Knight: The Remarkable Life of William Marshal, Power Behind Five English Thrones. 2015.

Marshall, Alfred (1842-1924). English economist. From the time he became an undergraduate at Cambridge his whole life was spent in academic circles. After resigning (1881) for health reasons as principal of the new University College at Bristol he returned to Cambridge as professor of political economy 1885-1908. He was the last of the line of the great classical economists and his Principles of Economics (1890) became a standard work used by generations of students. Though some of its conclusions are now disputed or outmoded it remains a basic work. He also wrote Industry and Trade (1919) and Money, Credit and Commerce (1923).

Marshall, Barry James (1951- ). Australian medical scientist, born in Kalgoorlie. His pioneering work, with Robin *Warren, overturned conventional wisdom and identified Helicobacter pylori as a major cause of peptic ulcer and gastric cancer. They shared the Nobel Prize for Medicine in 2005.

Marshall, George C(atlett) (1880-1959). American general, born in Uniontown, Pa. Heentered the Virginia Military Institute in 1897 and was commissioned in 1902. He served in the Philippines (1902-03) and France (1917-19), became ADC to General J. J. *Pershing 1919-24, was a military observer in China (1924-27) and Assistant Commandant of the Ft. Benning, Ga. Infantry School 1927-33. President *Roosevelt appointed him as Chief of Staff of the US Army 1939-45, promoting him over 200 senior officers (many of them younger). The US Army increased from 200,000 soldiers to $8,300,000$ under his direction. He attended the important wartime conferences at Casablanca, Québec, Cairo, Teheran and Yalta and played a vital role in determining the 'beat *Hitler first' strategy. He was the original choice as Supreme Commander for the allied invasion of Europe, but when Roosevelt preferred to keep Marshall in the US the job went to *Eisenhower. He became a five-star general of the army in 1944 and the British gave him a GCB. *Truman appointed him as Special Ambassador to China 1945-47, hoping that he could mediate in the civil war between ${ }^{*}$ Chiang and ${ }^{*}$ Mao. As US Secretary of State 1947-49, he proposed the European Recovery Plan (the Marshall Plan), providing \$US12 billion in economic aid in the period 1948-51 for the reconstruction of Europe. (The USSR was invited to participate in Marshall aid but refused.) After the outbreak of the Korean War, Marshall became US Secretary of Defence 1950-51 and supported Truman's dismissal (1951) of Douglas *MacArthur. He received the Nobel Prize for Peace in 1953 and refused to write memoirs. Truman 
considered him the greatest contemporary American. (British observers were less generous and thought that his slowness just indicated slowness.)

Pogue, F. C., George C. Marshall. 4 vols, 1963, 1966, 1973, 1987; Mosley, L., Marshall: Organiser of Victory. 1982.

Marshall, John (1755-1835). American lawyer and judge, born in Midland, Virginia. He served in the War of Independence, was called to the bar and from 1783 practised in Richmond where he soon rose to be head of the Virginian bar. He served in the state legislature 1782-88 and 1795-97 and led the Federalist Party in Virginia. Wider fame came when he was sent to Paris to negotiate with the Directory. The exposure in the famous XYZ letters of*Talleyrand's unsuccessful attempt to bribe the delegates made Marshall a popular hero. He was elected to the US Congress in 1799 and President *Adams made him Secretary of State 1800-01 and Chief Justice of the Supreme Court 1801-35. Marshall used his powers of interpreting the Constitution to strengthen the Federal Government and issued several judgments invalidating acts of state legislatures that aimed at or tended to nullify acts of Congress. However, he tried to protect the individual from state oppression.

Marshall, Sir John Ross (1912-1988). New Zealand politician. A lawyer, he was MP 1945-75, a minister 1951-57, 1960-72, Leader of the National Party 1971-72 and Prime Minister 1971-72.

Marshall, Thomas Riley (1854-1925). American Democratic politician, born in Indiana. A lawyer and mild progressive, he was Governor of Indiana 190913 , and served two terms as Woodrow *Wilson's Vice President 1913-21. They disagreed about policy and the Vice President's role in the administration. When Wilson suffered strokes in 1919, senior officials urged Marshall to assume the role of Acting President but he refused to set a precedent, despite the executive appearing to be paralysed.

Marshall, Thurgood (1908-1993). American lawyer and judge, born in Maryland. The great-grandson of a slave, educated at Lincoln and Howard universities, he was admitted to practice in 1933 and as legal counsel for the National Association for the Advancement of Colored Peoples (NAACP) 1940-61, argued many important cases establishing black rights. He was a Circuit Court Judge of Appeal 1961-65, Solicitor General of the US 1965-67 and became the first African-American appointed a justice of the US Supreme Court 1967-91.

Marsiglio of Padua (c.1280-c.1342). Italian scholar. He was the author (or co-author) of Defensor Paeis, an exposition of political ideas, based on the constitutions of some of the city states of northern Italy, that (a) the source of political power should be the people (i.e. all adult citizens); but (b) executive action should be delegated either to a council or to a single despot; and (c) the Church should be a solely spiritual body and papal supremacy was unjustified. These views were immediately condemned as heretical (1327) and Marsiglio fled to Paris. Later he was to see his persecutor, Pope John XXII, deposed, and an emperor elected by an assembly in Rome. Though this development proved ephemeral, Defensor Pacis guided much subsequent political thinking.

Marston, John (1576-1634). English dramatist. He wrote coarse, vigorous satire and a number of tragedies, some of them in collaboration with other dramatists. He started the campaign of mutual satire (1599-1601), the 'war of the theatres', with Ben *Jonson, but later became his friend and collaborator. His most interesting plays include The Malcontent (1604, with additions by Webster), Eastward Ho! (1605, with Ben Jonson and George Chapman) and The Dutch Courtesan (1605).

\section{Martel, Charles see Charles Martel}

Marti, José (1853-1895). Cuban writer and patriot. $\mathrm{He}$ was equally distinguished as a writer of prose and poetry and as leader of the Cuban struggle for independence from Spain. When only 16 he was exiled for political activity and for many years he was obliged to live abroad in Mexico, Guatemala, Spain and the US. While in the US he organised the Cuban revolutionary party of which he was an outstanding leader. The Cuban rising against the Spaniards began in 1895 and Marti was killed in the opening stages at the Battle of Dos Rios.

Martial (Marcus Valerius Martialis) (c.40-c.104). Latin poet and epigrammatist, born in Spain. He went to Rome where the wit and topicality of his verses won the approval of the emperors Titus and Domitian and widespread support. He wrote 15 books, containing several hundred epigrams, polished, cunningly twisted and frequently indecent, which became the models for the epigram in post-Renaissance Europe. He spent his last years at his native Bilbilis.

Carrington, A. G., Aspects of Martial's Epigrams. 1960.

Martin, Frank (1890-1974). Swiss composer, born in Geneva. He was a prolific producer with an eclectic style, including the passionate Mass for double choir (1922-26), ballets and operas, a concerto for seven wind instruments (1949), Polyptych for violin and two string orchestras (1973), concertos for cello, violin, piano and saxophone, much chamber music and the familiar Petite symphonie concertante (1945). The conductor Ernest *Ansermet premiered much of his work.

Martin, George R(aymond) R(ichard) (1948- ). American novelist, born in New Jersey. Originally a science fiction writer, he turned to vampire and horror stories. His incomplete historical series $A$ Song of Ice and Fire (1996ff) sold 60 million copies and was the basis of the Game of Thrones series on television. 
Martin, John (1789-1854). English painter of the Romantic school. For a time hailed as a rival to Turner, his vast canvases, e.g. Belshazzar's Feast (1821) and The Deluge (1826), teem with people and incident and brought him a great, but transient, popularity.

Balston, T., John Martin 1789-1854-His Life and Works. 1947.

Martin, (Basil) Kingsley (1897-1969). English journalist. During his editorship of the New Statesman (1931-60), he secured a commanding influence over the left-wing intellectuals of the Labour Party but had a blind spot about Stalin.

Rolph, C. L., Kingsley: Life, Letters and Diaries of Kingsley Martin. 1973.

Martin, Micheál (1960- ). Irish politician. He was a teacher, Dáil Member 1989- , Lord Mayor of Cork 1992-93, Foreign Minister 2008-11, Leader of Fianna Fáil 2011- and Opposition Leader 2011-20. He became Taoiseach (Prime Minister) 2020- in a coalition with Fine Gael and the Greens.

Martin, Paul (1938- ). Canadian Liberal politician. Minister for Finance 1993-2002, he succeeded Jean ${ }^{*}$ Chrétien as Prime Minister of Canada 2003-06.

Martin du Gard, Roger (1881-1958). French novelist. His work went unrecognised until his novel Jean Barois (1913) a powerful description of the France of the *Dreyfus era. His eight-part novel The World of the Thibaults won him the Nobel Prize for Literature (1937).

Schalk, D. C., Roger Martin du Gard, the Novelist and History. 1967.

Martin of Tours, St (c.316-397). Roman prelate in Gaul, born in Pannonia (now Hungary). Son of a military tribune, he served in the Roman army. Converted to Christianity, he studied under Hilary of Poitiers, founded a convent nearby, sharing with the monks a life of seclusion and great austerity. As Bishop of Tours (c.371-397), to avoid the distraction of the crowds attracted by his reputation for saintliness and miracles, he founded and lived in the monastery of Marmoutier. His feast day (11 November) became associated with a period of warm weather which often occurs about that time known as a St Martin's Summer.

Martineau, Harriet (1802-1876). English writer, born in Norwich. Daughter of a manufacturer, in her time her books were very popular. They included Illustrations of Political Economy (1832-34), Poor Law and Paupers Illustrated (1833), Society in America (1837), written after a visit to America, and Letters on Mesmerism (1845), a result of her belief that she owed recovery from serious illness to hypnotic treatment. Her aim in each case was to present a simplification (sometimes in fictional disguise) of serious themes.
Her other work, historical, philosophic and autobiographical, much of it quite ephemeral, includes a novel, Deerbrook (1839), and books for children. She was a model for *Dickens' Mrs Jellyby in Bleak House.

Webb, R. K., Harriet Martineau, a Radical Victorian. 1960.

Martinet, Jean (d.1672). French military engineer. His severe system of drill made his name a synonym for a harsh disciplinarian.

Martini, Carlo Maria (1927-2012). Italian cardinal, born in Turin. Ordained in 1952, and a Jesuit, he was Archbishop of Milan 1980-2002. He criticised the organisation of the Church as being '200 years out of date'.

Martini, Simone (c.1284-1344). Italian painter, born in Siena. Regarded as second only to ${ }^{*}$ Giotto of the late Gothic painters, he returned to Siena (1321) after working at Naples for the Angevin court, at Orvieto and at Pisa. Except for intervals at Assisi to work on the scenes from the life of St Martin in the lower church of St Francis, he stayed at Siena until 1339, when on the summons of Pope Benedict XII he went to Avignon, where his work included the small panel (now at Liverpool) of the Holy Family, and where he died. Of his work at Siena, the fresco (1328) of Guidoriccio da Fogliano, destined for the council chamber, and the altarpiece of the Annunciation for the cathedral (now in the Uffizi, Florence) are among the best known. The two saints at the outside of the latter are probably the work of Lippo Memmi, but the work as a whole, with its graceful figures harmoniously posed against a gold background shows his treatment of his subjects at its best.

Paccagninni, G., Simone Martini. 1957.

Martinu, Bohuslav (1890-1959). Czech composer. A pupil of ${ }^{*}$ Suk and ${ }^{*}$ Roussel, he became a teacher and orchestral violinist, living in Paris 1923-40, the US 1941-53 and dying in Switzerland. His works include six symphonies, 11 concertos, 16 operas, including Julietta (1937), the oratorio The Epic of Gilgamesh (1954), and vast quantities of chamber music.

Martov, Yulie Osipovich (originally Zederbaum) (1873-1923). Russian-Jewish politician. Once ${ }^{*}$ Lenin's closest friend, he led the Mensheviks from 1903, opposed the Bolshevik dictatorship in 1917 and was consigned to 'the garbage can of history' by *Trotsky. He died in exile in Germany.

Marvell, Andrew (1621-1678). English poet. Son of a Yorkshire clergyman, he held a number of posts as tutor, notably to Lord *Fairfax's daughter at Nun Appleton where some of his best work, poems of wit and grace in praise of gardens and country life, was 
written. Politically a follower of *Cromwell, he could not withhold admiration for ${ }^{*}$ Charles I's bearing on the scaffold:

He nothing common did or mean

Upon that memorable scene.

Later he worked with *Milton in government service, was Latin secretary 1657-60 and went with an embassy to Russia 1663-65. He was MP for Hull 1659-78. Marvell did not marry and his love poems seldom carry conviction, though occasional lines such as

But at my back I always hear

Time's wingèd Chariot hurrying near

have earned immortality. In later life he became a satirist of an arbitrary government which he deplored. He died of malaria.

Legouis, P., Andrew Marvell: Poet, Puritan, Patriot. 2nd ed. 1968.

Marx, Karl Heinrich (1818-1883). German-Jewish political philosopher, born at Trier. His father, a lawyer, converted to Christianity from Judaism. Educated at the universities of Bonn and Berlin, he abandoned law for history and philosophy. His comic novel Scorpion and Felix (1837), influenced by ${ }^{*}$ Sterne, was unpublished. (Sterne and ${ }^{*}$ Swift were major stylistic influences.) He edited the Rheinische Zeitung from 1842 to 1843 , when the Prussian government suppressed it for its radicalism. In 1843 he married Jenny von Westphalen (1814-1881) and moved to Paris, where he came to know Friedrich *Engels. Expelled from France (1845), he moved to Brussels where, with Engels, he reorganised the Communist League, for which they wrote the famous Communist Manifesto (1848). This, though it contained a preformulation of the views later worked out in detail, was essentially a call to revolutionary action, ending with the exhortation 'The proletarians have nothing to lose but their chains. They have a world to gain. Workers of the world unite.' Marx took part in the revolutionary risings in the Rhineland in 1848 and after their failure, settled (1849) in London for the rest of his life. After 15 years of research he wrote Grundrisse ('Foundations') at great speed in 1857-58. This was the framework of a vast incomplete work of which Das Kapital was only a part. Grundrisse included material on alienation, the impact of technology, the economies of time and his utopian vision. His writing was passionate and often ironic. Karl *Kautsky published excerpts in 1903, but the complete Grundrisse did not appear until 193941 in Moscow, and in English translation until 1973.

Despite his background, Marx's writings suggest elements of anti-Semitism and anti-feminism.

He resumed active political work as founder and secretary of the International Working Men's Association (later known as the First International) 1864-72. Here he had to contend with the views of rival leaders, especially the anarchist ${ }^{*}$ Bakunin, whose withdrawal he forced in 1869. After the death of *Lassalle, Marx's influence became predominant in the German Social Democratic Party, and Marxist parties were founded in France and Russia during his lifetime. For more than 12 hours each day he worked in the reading room of the British Museum on Das Kapital. Volume I was published in Hamburg in 1867 (in Russian translation in 1872, French 1872-75 and English 1887). Volume II, edited by Engels, appeared in 1885 and Volume III, completed by Engels from Marx's notes and private papers, in 1894. Marx was often in extreme poverty and from 1868 depended on an annual allowance of $£ 350$ from Engels. His application for British citizenship (1874) was refused. He died in Kentish Town in March 1883 and was buried in Highgate Cemetery.

Marx's philosophical basis is an adaptation of *Hegel's dialectical system. With Marx it becomes dialectical materialism: historical stages succeed one another by way of conflict; the economic basis of one phase provokes its antithesis and the two then merge into a third. Thus the bourgeoisie displaced feudal society and the stage was then set for the final struggle between the bourgeoisie and the working classes. On the theoretical economic side Marx followed the classical economists in their concept of the labour theory of value. A capitalist society depended, in his view, on 'surplus value', i.e. that part of the amount received for the product of labour in excess of the amount paid for labour. Moreover, as the larger capitalist devoured the smaller, so its members would become fewer and richer, while the proletariat, its bargaining power reduced as the means by which labour can be employed (hand, factories, machines etc.) became concentrated in fewer and fewer hands, would become relatively poorer. That being so, a clash was inevitable and the Communist's part therefore must be to educate the proletariat in the role it must play both to hasten events and to bring about the desired future, in which production would be carried out for the good of all in a classless society. Since a capitalist state is the instrument by which the exploitation of the proletariat is carried out political action must be revolutionary. If successful, the next stage (from which no Communist state has yet emerged) must, as Marx foresaw, be a dictatorship of the proletariat, necessary to prevent counterrevolution. This would be eventually followed by the third stage, the withering away of the state and the emergence of a classless society living and working in the perfectionist conditions referred to above. Marx developed his theories against the background of capitalist development as it existed in England in the middle of the 19th century. He claimed to have done for economics and history what Charles * Darwin had achieved in biology.

While authoritarian states claiming to be Marxist (or Marxist-Leninist) mostly failed spectacularly, Marx raised many issues with 21 st-century significance: a 
technological revolution, the rise of a managerial and professional class, the distinction between labour/ time-saving and labour/time-absorbing work, that liberty depends on having 'disposable time', rejecting the idea that production and wealth creation are ends in themselves.

The influence of Marx's writings, though often misunderstood, has been immense. Socialist parties, claiming to be 'Marxist', were created in his lifetime, but Marx kept his distance. In 1882 he wrote: 'What is certain is that, as for me, I am not a Marxist.'

His youngest child (Jenny Julia) Eleanor Marx, often known as 'Tussy' (1855-1898), was her father's closest companion and secretary. She made the first English translation (1892) of *Flaubert's Madame Bovary, translated four plays by *Ibsen and works by ${ }^{*}$ Bernstein and ${ }^{*}$ Plekhanov. From 1884 she lived with Edward Aveling (1849-1898), who had been a translator of Das Kapital. Together they wrote The Woman Question (1886), toured the US in 1886 (with Wilhelm *Liebknecht) raising money for the SDP. She had unfulfilled ambitions as an actor, and committed suicide after Aveling deserted her and married secretly. He died of kidney disease four months after Eleanor.

McLellan, D., Karl Marx. 1973; Singer, P., Marx. 1980; Wheen, F., Karl Marx: A Life. 1999; Sperber, J., Karl Marx: A Nineteenth-Century Life. 2013; Stedman Jones, G., Karl Marx. Greatness and Illusion. 2016; Claeys, G., Marx and Marxism. 2018; Barker, J., Marx Returns. 2018; Kapp, Y., Eleanor Marx. 1976; Holmes, R., Eleanor Marx. A Life. 2014; Dawkins, P., Miss Marx. 2015; Liedman, S.-E., $A$ World to Win: The Life and Works of Karl Marx. 2015/2018.

Marx Brothers. Jewish-American family of comedians, born in New York City. Four of them, 'Groucho' (Julius, 1890-1977), 'Chico' (Leonard, 1891-1961), 'Harpo' (Arthur, 1893-1964) and, until his withdrawal (1935), 'Zeppo' (Herbert, 1901-1979), became famous in vaudeville and developed a surrealistic humour of their own in 13 successful films (after 1929) including Duck Soup, A Night at The Opera, A Day at the Races, At the Circus, Go West and The Big Store. Another brother 'Gummo' (Milton, 1898-1977), left vaudeville early and became successful in business.

Mary (Hebrew: Miriam) (fl 1st century CE). Mother of *Jesus Christ, known also as the Blessed Virgin. According to apocryphal gospels, she was the daughter of St Anne and Joachim. The narratives of the Annunciation, the miraculous conception and the birth of Jesus Christ at Bethlehem are told with varying details in the Gospels of St *Matthew and St *Luke, where also it is recorded that her husband Joseph was a carpenter of Nazareth in Galilee. The most important of the very few other biblical references is in St John's Gospel which relates that she stood by the cross at the Crucifixion and that Jesus entrusted her to the care of that unnamed 'beloved disciple', who took her to his own home. According to tradition, she lived at Ephesus in the care of St ${ }^{*}$ John the Divine; in Catholic teaching she was 'bodily assumed'.

The doctrine of her Perpetual Virginity (i.e. that she had no natural children) was adopted by the Council of Chalcedon in 451. Her Immaculate Conception (i.e. that she was the subject of a virgin birth) was proclaimed in 1854 by Pope *Pius IX, followed by the doctrine of the Bodily Assumption (1950) and the title Queen of Heaven (1954).

Mary I (Mary Tudor, later Habsburgo y Aviz) (1516-1558). Queen of England 1553-58. Daughter of *Henry VIII by his first wife *Katherine of Aragon, Mary's prospects were at first brilliant and negotiations for marriage were pressed forward with royal suitors (including the emperor ${ }^{*}$ Charles $V$ ) from her childhood days. But all was changed when Henry and her mother became estranged and the marriage was annulled (1533). Mary had to live in retirement and even acknowledged herself to be illegitimate. She was restored to the line of succession by her father's will but her way of life was hardly changed while her Protestant brother ${ }^{*}$ Edward VI was on the throne. On his death, however, she foiled, with general public support, the Duke of *Northumberland's bold attempt to transfer the crown to his own family by establishing the claim of his daughter-in-law Lady Jane *Grey. Unfortunately Mary, who began her reign with the avowed aim of restoring the supremacy of the Roman Catholic Church, was already a frustrated and embittered woman and, though she at first acted with caution, her proposed marriage to Philipp (later *Felipe II) of Spain deprived her of much of her popularity and provoked a rebellion by Sir Thomas *Wyatt. This was suppressed, but the marriage (1554) brought her no joy, as Felipe, who left the country in 1555, could not conceal his indifference and the false pregnancies which deluded her into making all preparations for an expected child deprived him of his political hopes. She may have suffered from a pituitary gland disorder, accounting for her infertility, deep voice and dry skin.

Meanwhile Roman supremacy was restored (1554) and Cardinal Reginald *Pole, the papal legate and later Archbishop of Canterbury, became Mary's chief advisor. The persecutions which were to make the queen remembered as 'Bloody Mary' began in 1555. The first to die were *Ridley and *Latimer, and ${ }^{*}$ Cranmer (1556) and almost 300 followed, 60 of them women, for which she bears the main responsibility. She became hated and even Felipe was appalled by her severity. In 1557 the English were dragged into the Spanish war against France, the only result being the loss (1558) of their last Continental possession, Calais, the name said to be written on Mary's heart when, tormented in mind and body and almost unlamented, she died. She was succeeded by her half-sister *Elizabeth. 
Mary II (née Stuart, by marriage van Oranje-Nassau) (1662-1694). Queen regnant of England, Scotland and Ireland 1689-94. The elder daughter of James, Duke of York (*James II), by his first wife Anne Hyde, she married (1677) her first cousin William, Prince of Orange (later *William III). After her father's deposition, she and her husband were invited to become joint sovereigns. She was estranged from her sister *Anne and they last met in 1692. Mary was much loved and after her early death, from smallpox, deeply mourned.

Van Der See, B. and H. A., William and Mary. 1973; Van der Kiste, J., William and Mary. 2003.

Mary, Queen of Scots (1542-1587). Queen of Scotland 1542-67. Born in Linlithgow Palace, daughter of *James $\mathrm{V}$ of Scotland and Mary of Guise, she was half French, one quarter Scots, one quarter English. She became Queen of Scotland, the eighth of the *Stewart dynasty, when her father died six days after her birth. To keep her out of the hands of the Protestant or 'English' party who wished her to marry the future ${ }^{*}$ Edward VI, she was sent to France, her mother remaining in Scotland as regent. On her return in August 1561, while remaining a Catholic, she was able to negotiate a political-religious settlement with the nobility and supporters of John *Knox. She married three times: (1) in 1558 to the French dauphin who became *François II and died in 1560, (2) in 1565 to her cousin, Henry Stuart, Lord *Darnley, who fathered her only child *James VI of Scotland (and I of England), murdered her confidante David *Rizzio and was blown up in February 1567, and (3) in May 1567 to James Hepburn, Earl of *Bothwell, who had murdered Darnley. Her last marriage was politically disastrous and she lost all support: the army deserted, Bothwell fled to Denmark and in June 1567 she was deposed in favour of her son. After an attempt to regain power failed in June 1568, she sought asylum in England. Her grandmother ${ }^{*}$ Margaret (Tudor) had been *Henry VIII's sister and if *Elizabeth I died without issue Mary was next in line for the English throne: Catholics considered Elizabeth to be illegitimate which would make Mary the rightful queen already. Elizabeth kept her as a prisoner until her death because she was a rallying point for English Catholics. Elizabeth believed that she was part of a series of conspiracies (the evidence is not completely convincing) and after the ${ }^{*}$ Babington plot, Mary was tried for treason at Fotheringay Castle (October 1586), convicted and beheaded (February 1587) and buried at Peterborough Cathedral. On Elizabeth's death in 1603, Mary's son James succeeded as King of England. In 1612 Mary was exhumed and reinterred in Westminster Abbey, parallel to Elizabeth. Mary was a romantic figure, the subject of books, plays, films and *Donizetti's opera Maria Stuarda.

Fraser, A., Mary Queen of Scots. 1969.
Mary (Victoria Mary Augusta Louise Pauline Claudine Agnes Windsor, formerly von Wettin, née von Hohenstein) (1867-1953). Queen consort of the United Kingdom 1910-36. Born in London, daughter of Francis, Duke of Teck, and a greatgranddaughter of ${ }^{*}$ George III, originally known as 'May of Teck', in 1891 she became engaged to Albert Victor, Duke of Clarence (d.1892), eldest son of the future ${ }^{*}$ Edward VII. In July 1893 she married his brother, the Duke of York, later Duke of Cornwall and Prince of Wales, who ascended... the throne (1910) as *George V. There were six children but George was intimidating and Mary remote. Three of them predeceased her. She was more intelligent, and far more widely read, than her spouse, gave him strong support but had very rigid views, and her great dignity remained firmly anachronistic. She was an aggressive collector of antiques.

Edwards, A., Matriarch: Queen Mary and the House of Windsor. 1984; Pope-Hennessy, J. and Vickers, H., The Quest for Queen Mary. 2018.

Mary Magdalen, St (or Mary of Magdala) (fl. 1st century CE). Christian disciple. The Gospels relate that *Jesus cast out seven devils from her, that she became a devoted disciple and that she was the first to whom Jesus appeared after the Resurrection. Tradition also links her with a penitent, unnamed sinner mentioned by St *Luke. Her name has come to symbolise the harlot restored to purity by faith and penitence. In Eastern tradition she died in Ephesus, in French tradition in Provence. Some legends describe her as the wife of *John the Divine, others as the wife of Jesus (assuming that he survived the crucifixion). Sometimes identified with Mary of Bethany, sister of Martha and Lazarus, her name is commemorated by churches or colleges bearing the name Madeleine or Magdalen. In religious art she is often depicted as weeping, hence the word 'maudlin'.

Haskins, S., Mary Magdalen. 1993.

Mary of Modena (Maria Beatrice Anna Margherita Isabella d'Este) (1658-1718). Queen consort of England, Scotland and Ireland 1685-88. Born in Modena, daughter of Duke Alfonso IV, she married James, Duke of York (later *James II) in 1673. Birth (1688) of a son, James Edward ${ }^{*}$ Stuart, an event that seemed likely to perpetuate a Roman Catholic dynasty, was one of the causes of the revolution that deposed James. The story that the baby was not hers but had been smuggled into the palace in a warming pan may be discarded.

Masaccio ('clumsy', nickname of Tommaso di Ser Giovanni di Simone) (1401-1428). Italian painter, born in San Giovanni Valdarno. He lived and worked mostly in Florence until he went (1427) to Rome where he died. He probably derived from his contemporary *Brunelleschi much of the knowledge of perspective and space revealed in his pictures. In particular he mastered tonal perspective, by which 
an appearance of depth is achieved by gradations of colour. He is also said to have been the first to light his pictures at a constant angle from a single point of origin. The figures are solidly and realistically conceived and belong naturally to their surroundings. His finest work is generally held to be the frescoes in the Brancacci Chapel of the Carmelite Church, Florence, but the fact that he worked in collaboration with ${ }^{*}$ Masolino has caused an acute artistic controversy as to the part played by each. The finest of Masaccio's undisputed works include the Expulsion from Paradise and Tribute to Caesar. Masaccio is ranked as one of the greatest figures in Renaissance art between *Giotto and *Leonardo da Vinci.

Salmi, M., Masaccio. 1948; Spike, J. T., Masaccio. 1996; Ahl, D. C., The Cambridge Companion to Masaccio. 2002.

\section{Masaryk, Tomáš Garrigue (1850-1937).} Czechoslovakian politician, writer and academic. Son of a Slovak coachman, he studied sociology and philosophy at Vienna University and in 1882 took up a professorship at the re-established Czech University at Prague, and wrote several books on philosophy, sociology and Slav nationalism. Meanwhile, in Brooklyn (1878) he married an American, Charlotte Garrigue, whose name he adopted. In 1891 he was first elected to the Reichsrat and though he resigned in 1893 he gradually became recognised as the spokesman of all the Slav minorities in the AustroHungarian Empire. He was re-elected to parliament in 1907 but when World War I broke out (1914) he at once saw it as an opportunity to obtain independence for the subject peoples. In December 1914 he escaped to Italy and in one country after another, Switzerland, France, Britain, Russia and the US, pressed his cause. He organised a Czech national council in Paris (1916) and in May 1917 went to Russia to build up a Czech Legion (mainly from prisoners of war). After the Bolshevik Revolution the Legion reached the Pacific via Siberia and reached America where Masaryk awaited it.

At last (June 1918) the governments of Great Britain, France and the US recognised Czechoslovakia as an independent ally, with Masaryk as the government's provisional head. In December with the AustroHungarian regime collapsed around him, Masaryk returned triumphantly as President Liberator of the new state of Czechoslovakia. As President 191835, his wisdom and liberality of mind inspired the growth of Czechoslovakia as the most prosperous and progressive country of the new Europe. He retired at the age of 85 and was succeeded by Eduard *Beneš.

The shadow of ${ }^{*}$ Hitler was already looming when he died but it was upon his son Jan Garrigue Masaryk (1886-1948) that the darkness fell. He was Ambassador of Czechoslovakia in London 1925-28, resigning after the Munich agreement. He served as Foreign Minister of Czechslovakia 1940-48, first in the government-in-exile established in London in
World War II, then under the restored government of *Beneš, remaining under *Gottwald's National Front, hoping to retain a democratic presence. One month after Gottwald took complete control (February 1948), he died, mysteriously and controversially; almost certainly being defenestrated from the Foreign Office by NKVD agents. (The alternative version is that he shot himself.)

Birley, R., Thomas Masaryk. 1951.

Mascagni, Pietro (1863-1945). Italian composer. After abandoning law he became famous with the one-act opera Cavalleria Rusticana (1890). This, a brutal and melodramatic treatment of a subject drawn from working-class life, established the style of Italian opera known as verismo. None of his later operas, e.g. L'Amico Fritz (1891) and La Maschera (1901), won the same celebrity.

Masefield, John (Edward) (1878-1967). English poet and novelist, born in Herefordshire. After an unhappy childhood, he was a merchant seaman 1889-97, discovered poetry and after intense reading (and marriage to a teacher) began composing poetry himself. Some of his finest poems and stories are concerned with the sea. Salt Water Ballads (1902), including 'Sea Fever', was followed by the long narrative poem The Everlasting Mercy (1911), Reynard the Fox (1919) and Right Royal (1920). His prose works include Gallipoli (1916) and The Battle of the Somme (1919), 24 novels, including books for children and Sard Harker (1924), eight plays and literary studies. He succeeded Robert *Bridges as Poet Laureate 1930-67 and received the OM (1935).

Babington-Smith, C., John Masefield. 1978.

Masinissa (Massinissa) (c.238-149 BCE). King of Numidia. His state (roughly modern Algeria) was a vassal of Carthage. He transferred his allegiance to Rome during the Second Punic War (206) and his cavalry carried out the decisive charge at the Battle of Zama when ${ }^{*}$ Hannibal was defeated. His kingdom grew strong and prosperous. In 150 a Carthaginian attack on Numidia, then the ally of Rome, led to the Third Punic War.

Maslow, Abraham Harold (1908-1970). American psychologist and educator. His text book Motivation and Personality (1954) identified a 'hierarchy of needs' in human development and has been influential in sociology.

Masolino da Panicale (c.1383-1447). Italian painter. He assisted ${ }^{*}$ Ghiberti and may have taught *Masaccio, with whom he collaborated and by whose techniques he was much influenced. His most important works are the frescoes rediscovered (1843) under whitewash at Castiglione d'Olona. The frescoes in San Clemente at Rome have also been attributed to him. 
Mason, Charles (1730-1787). American surveyor. Employed with Jeremiah Dixon to mark out (176367) the boundary between the American colonies Pennsylvania and Maryland, this Mason-Dixon line came to be regarded as the frontier between North and South in the US.

Maspero, Gaston Camille Charles (1846-1916). French Egyptologist. While in Egypt (1880-86) as director of excavations and curator of the museum at Cairo, he discovered 40 royal mummies (including ${ }^{*}$ Seti I and *Rameses II) at Deir el Bahri. He returned (1886) to Paris to take up a professorship, but was appointed Director of the Department of Antiquities in Cairo 1889-1914 and reorganised with an efficiency that earned him a KCMG.

\section{Masséna, André, Duke of Rivoli, Prince of Essling} (1758-1817). French marshal, born in Nice (then in the kingdom of Sardinia). He became a soldier, but during the Revolution he volunteered for the French army and by the end of 1793 was a divisional general. He made a name for himself in the Italian campaigns against the Austrians where the Rivoli (1797), from which he took his title, was his most striking success and against the Russian general *Suvarov in Switzerland (1799). Thereafter he fought in nearly all *Napoléon's campaigns in central Europe and won his princely title by his heroic covering of the Danube crossing (1809) at Aspen or Essling. Sent to Spain in 1810 he drove *Wellington right back to the lines of Torres Vedras but, on finding the position impregnable, extricated himself by a masterly retreat. Napoléon chose to make him a scapegoat, refused to employ him on his Russian campaign and himself received no reply when he called for Massena's aid after the escape from Elba.

Massenet, Jules Emile Frédéric (1842-1912). French composer. He won the Prix de Rome (1866) and taught at the Paris Conservatoire 1878-96. *Ravel was a pupil. He wrote 26 staged operas, unfailingly melodious, strikingly orchestrated, deeply romantic and psychologically astute. (*Debussy called him 'the musical historian of the female soul'.) His most performed operas are Manon (1881), Esclarmonde (1889), Werther (1892) and Thaïs (1894). He also wrote 281 songs and orchestral, choral and piano works.

Massey, (Charles) Vincent (1887-1967). Canadian diplomat and administrator. The grandson of Hart Massey (1823-1896), founder of an agricultural machinery company (later named Massey-Harris, then Massey-Ferguson), he served as Minister to the US 1926-30 (Canada's first diplomatic posting), High Commissioner in London 1935-46 and the first native-born Governor-General of Canada 1952-59. He received a CH in 1946. His brother, Raymond Massey (1896-1983), was a character actor on stage and screen in Britain and the US.
Raymond's son Daniel (1933-1998) and daughter Anna (1937-2011) were distinguished stage, screen and television actors in England.

Massey, William Ferguson (1856-1925). New Zealand politician, born in Derry. He emigrated in 1870 , worked on his father's farm, and became active in farmers' organisations. Elected to the House of Representatives 1894-1925, he became Leader of the Reform Party 1903-25 and Prime Minister 191225. He led New Zealand through World War I and attended the Paris Peace Conference.

Massine, Léonide (Feodorovich) (1895-1979). Russian ballet dancer and choreographer. $\mathrm{He}$ was principal dancer (1914-20) of *Diaghilev's Ballets Russes in Paris and was chief choreographer (from 1915). He created several new ballets including $L a$ Boutique Fantasque (music by *Rossini) and Le Sacre du printemps (music by ${ }^{*}$ Stravinsky). He worked with the Ballets Russes de Monte Carlo 1932-41 and with Martha *Graham in New York 1942-47.

Massine, L., My Life in Ballet. 1968.

Massinger, Philip (1583-1639/40). English dramatist, born at Salisbury. He collaborated with other dramatists, notably John *Fletcher and Thomas *Dekker, plays which are probably independent include dramas, often on religious and political themes, which to his audience suggested contemporary parallels. Among them are The Duke of Milan (1623), The Maid of Honour (c.1625) and The Roman Actor (1626). He is better known for his satirical comedies, The City Madam (acted 1632) and A New Way to Pay Old Debts (published 1633). Psychological interest and constructive power are Massinger's main assets.

Masson, André (1896-1987). French painter, sculptor, stage designer and writer. Severely wounded in World War I, he worked in a variety of styles, Cubist, then Surrealist, Abstract and Neo-Realist.

\section{Massys, Quentin see Matsys, Quentin}

Masters, Edgar Lee (1869-1950). American author and poet. His collection of poems, Spoon River Anthology (1915), contains what purport to be confessions of and revelations about those lying in a mid-western cemetery. He also wrote biographies of *Lincoln, Walt *Whitman and Mark *Twain, and the autobiographical Across Spoon River (1936).

Mastroianni, Marcello (1923-1997). Italian film actor. A versatile performer, he appeared in 70 films including White Nights (*Visconti, 1957), La Dolce Vita (*Fellini, 1960), La Notte (*Antonioni, 1961), 81/2 (*Fellini, 1963), Casanova '70 (1965) and Pret-aPorter (*Altman, 1994). 
Mata Hari (Margarethe Gertrude Zelle, later MacLeod) (1871-1917). Dutch dancer and courtesan. She lived in Java and Sumatra (hence her Malay stage name, 'eye of the day'), and danced in Paris from 1905. In World War I, by consorting with officers, she was able to obtain information and allegedly pass it to the Germans. Tried and shot as a spy by the French, MI 5 documents released in 1999 indicate that Mata Hari was guilty only of being a fantasist, who blew kisses at the firing squad.

Wagenaar, S., The Murder of Mata Hari. 1964.

Matanzima, Kaiser Daliwonga (1915-2003). South African politician. Chief of the Xhosa people and a qualified lawyer, he was elected (1963) by his fellow chiefs to head the government of the Transkei, the first of the ostensibly self-governing 'Bantustan' areas, reserved for Africans, set up under the apartheid policy, and President 1979-85.

Mather, Increase (1639-1723). American Congregationalist minister. After taking his degree at Harvard, he spent some time preaching in England and Guernsey before returning to America as minister of the Second Church, Boston 1664-1723. He was Acting President of Harvard from 1685, and a largely absentee President 1692-1701. During the Salem witch trials, he urged the judges to be careful, but failed to condemn them. He wrote Causes of Conscience concerning Witchcraft (1693). His son, Cotton Mather (1662-1727), a theologian, was responsible above others for fanning the flames of the Salem witchcraft mania by his many books on the subject of possession by evil spirits.

Murdock, K. B., Increase Mather: The foremost American Puritan. Repr. 1966.

Mathew, Theobald (1790-1856). Irish friar. His work amongst the poor in Cork 1812-38 convinced him that drink aggravated their misery and he led a great temperance crusade that had astonishing success. In 1848 he went to America, where he achieved similar results. On his return to Ireland (1851) he declined a bishopric. Temperance advocates still hold Father Mathew festivals.

Matilda (or Maude) (1102-1167). Holy Roman Empress 1114-25, claimant 'Lady of the English' 1141-48. Daughter of *Henry I and Matilda of Scotland, born probably in Berkshire, she married, at the age of 10 , the Emperor ${ }^{*}$ Heinrich V, but had no children. In 1120 her younger brother William Adelin was drowned in the White Ship and Henry persuaded his barons to recognise Matilda as heir to the English throne. Heinrich died in 1125 and in 1127 Matilda married Geoffrey, Count of Anjou (*Plantagenet) and gave birth to the future *Henry II, but the union was unhappy. When her father died in 1135, many of the barons, despite their previous oaths, refused to recognise her as queen, and her cousin ${ }^{*}$ Stephen of Blois seized the throne and was supported by the Church. In 1139 civil war ensued when Matilda, backed by Norman nobles and the Scottish king, landed in England. Stephen was captured in Lincoln but hostile London crowds prevented Matilda's coronation: never proclaimed as queen, she used the title 'Lady of the English' (domina Anglorum). Later, Matilda was captured in Oxford, but escaped, and the conflict became a stalemate. She then returned to Normandy. Peace was restored when Stephen gave up the duchy of Normandy to Matilda's husband and accepted her son Henry as his heir. She then reverted to using the title 'Empress'. Regarded as pious, she endowed churches and died in Rouen.

Matilda of Tuscany (or Matilde di Canossa) (10461115). Italian ruler, born in Lucca. She inherited Tuscany, and acquired lands in Lorraine and Bavaria through her two marriages, ruling from her castle at Canossa. In his war against the Emperor ${ }^{*}$ Heinrich IV about Imperial power in church affairs she supported Pope ${ }^{*}$ Gregory VII. He took refuge in Canossa. Widely read, she is said to have donned armour and fought in battle. Her tomb was relocated to St Peter's, Rome, by *Urban VIII, with a statue by *Bernini.

Matisse, Henri (1869-1954). French painter, born in Picardy. He studied art in Paris, copied pictures in the Louvre and was influenced by the Impressionists, ${ }^{*}$ Cézanne and ${ }^{*}$ Gauguin. In 1905 he became the leader of a revolutionary group of artists, labelled 'Les Fauves' ('wild beasts'). To them colour was an end in itself and its use was unconnected with the colour of the subject portrayed. Matisse covered large unbroken areas with colour, disregarding perspective and the distortion its absence produced, but discovering new decorative effects by the vibrancy and luminosity of the colour itself, yet though the effect of his work was to hasten the arrival of abstract art, he was not an abstract painter. Similarly, though his colour patterns often took geometrical shapes he was never a Cubist. In fact as the years went by he reduced the element of violence, and 'balance, purity and moderation' became his aims. Just as fruit and flowers supplied him with decorative themes so did women-his Odalisques adorn and delight but convey no sensual message. After a period in which his pictures became smaller and less spontaneous, he was again, in the 1930s, seeking bolder effects. A commission for the *Barnes Foundation (Pennsylvania) allowed him to undertake murals. His last years were mainly devoted to designing and decorating with murals and stained glass a Dominican chapel at Vence near Nice, but even when he was over 80 he showed his versatility in a new way by using decorative collages (paper cutouts) as an art form.

Escholier, R., Matisse: From the Life. 1960; Spurling, H., The Unknown Matisse. 1998.

Matsushita Konosuke (1896-1989). Japanese industrialist, born near Osaka. From a peasant family, he started (1918) a manufacturing firm on a very 
small scale for the production of electrical appliances. World War II gave a tremendous impetus to his business and he emerged from the war period as a leader in the field of electronic equipment and quickly became the undisputed giant. His mass production of electrical household accessories eased and simplified the traditional domestic duties of Japanese women and his brand name, National, soon became a leader, followed by the brand names Panasonic and JVC.

Matsys (or Massys), Quentin (c.1465-1530). Flemish painter. His early altar pieces followed the tradition of the Van *Eycks, though with almost lifesized figures, but his later religious pictures, e.g. the Magdalen at Antwerp, reveal a softer modelling and a sweetness of expression reminiscent of the work of *Leonardo da Vinci, by which he may have been influenced. He is also known for gently satirical genre pictures and portraits.

Mattarella, Sergio (1941- ). Italian politician, born in Palermo. Originally a lawyer and academic, his brother's murder by the Mafia (1980) resulted in a commitment to politics. He served in several ministries, was a judge 2011-15 and President of Italy $2015-$.

Matteotti, Giacomo (1885-1924). Italian politician. A leader of the Socialist party, he was a courageous opponent of Fascism. He was kidnapped and murdered by a gang of Fascists who went virtually unpunished, after which there was no effective opposition to ${ }^{*}$ Mussolini and the last vestiges of political liberty disappeared.

Matthew, St (Mattay in Aramaic: 'gift of God'; or Levi) (c.5-85 CE). Christian apostle, one of the four evangelists. Son of Alphaeus, presumably a Galilean, nothing certain is known about him except that at the time he was called upon to be a disciple he was a publican (perhaps a customs official) and therefore despised and hated for his profitable association with Roman rule. He was probably identical with Levi, mentioned in the Gospels of *Mark and *Luke in which Matthew's name does not appear. There is continuing controversy about the priority of the Gospels of Mark and Matthew. The Jerusalem Bible's editors argue that the Gospel bearing Matthew's name may have appeared in two versions, first in primitive Aramaic, perhaps as early as $40-50$ and known to Mark (augmented by a collection of sayings attributed to Matthew), then a Greek version produced 70-80, which in turn was influenced by Mark. Matthew's Gospel, possibly written in Antioch, is longer and more systematic than Mark, with a strong emphasis on Jesus' Messiahship, on teaching and on his fulfilment of Old Testament prophecies. Presumably aimed at a Jewish audience, nevertheless it emphasises Jewish responsibility for Jesus' death and minimises the Roman role. The Sermon on the Mount only appears in Matthew (v-vii). There are three separate traditions about Matthew's martyrdom-Ethiopia,
Persia and Judaea. The Magdalen Papyrus of Matthew (Oxford) is thought to be the oldest surviving Gospel fragment-perhaps before $200 \mathrm{CE}$.

Matthias Corvinus (1440-1490). King of Hungary (from 1458). Second son of János *Hunyadi, having successfully continued his father's struggle against the Turks, he was able to add Moravia and Silesia to his dominions, conquer Carinthia and Styria and capture Vienna, which he made his capital. His vigour and justice as a ruler were matched by his fame as a scholar, a sign of which was the magnificent library he founded. He died without legitimate heirs at the height of his power.

Maudling, Reginald (1917-1979). British Conservative politician. He was called to the bar (1940), served in RAF intelligence, and was an MP 1950-79. A minister from 1955 to 1964 and Chancellor of the Exchequer 1962-64, he contested the Conservative leadership in 1965, losing to *Heath. He became Deputy Leader and was Home Secretary 1970-72.

Maudling, R., Maudling's Memoirs. 1978.

Maudsley, Henry (1835-1918). English psychiatrist, born in Yorkshire. He settled in London and exercised important influence on the treatment of mental illness, notably through his book The Pathology of Mind (1867). Believing that insanity was a disease of the brain, he stressed the need for treating it as such and not merely controlling the symptoms, he gave special attention to hereditary factors. In the hope of securing systematic research into mental disease and early treatment for sufferers he gave a large sum to the London County Council for a psychiatric hospital to be linked with London University. The Maudsley Hospital opened shortly after his death.

Maugham, W(illiam) Somerset (1874-1965). British author, born in Paris. Trained in medicine at St Thomas' Hospital, London, he drew on his experience as a physician in the London slums in his first novel, Lisa of Lambeth (1903). But it was as a playwright that he first attained fame and wealth in the years preceding World War I: a succession of plays with a sharp flavour and astringent wit, e.g. Lady Frederick, filled the theatres. After the war the plays became more sophisticated and satirical, e.g. The Circle (1921), Our Betters (1923) and The Letter (1927). During the war he did secret service work, reflected in the spy stories in Ashenden (1928). Meanwhile he had continued writing novels: Of Human Bondage (1915) is discursive and partly autobiographical; the character of Strickland in The Moon and Sixpence (1919) is based on that of *Gauguin; Cakes and Ale (1930) contains thinly veiled portraits (not always kind) of literary friends, e.g. Hugh Walpole. Maugham was, however, at his best as a writer of short stories, material for many of which he found during travels in Malaysia and the 
East. Though the plots were often melodramatic, his gift for economy of phrase, his scepticism and his narrative skill found their most effective use in this genre. In the story Rain, set in the South Seas, later made into a play and a film, he displays something of a quality often lacking in his work-warmth. Several other stories were filmed with an introduction by himself, e.g. Quartet (1948). Other books include the autobiographical Strictly Personal (1941), A Writer's Notebook (1949) and Ten Novels and Their Authors (1954). Actively bisexual, he lived in the French Riviera from 1928 (apart from World War II) and received a $\mathrm{CH}$ in 1954 . He was nominated six times for the Nobel Prize for Literature, and resented not being offered the OM.

Morgan, T., Somerset Maugham. 1981; Hastings, S., The Secret Lives of Somerset Maugham. 2009.

Maupassant, Guy de (1850-1893). French author, born in Normandy. His father was a profligate aristocrat, his mother artistic and sensitive. All these traits were visible in their son. He served briefly in the army during the Franco-Prussian War and then became a civil servant. In the following years he was a friend, protégé and pupil of*Flaubert, who introduced him to *Zola. The immediate success of the well known story Boule de Suif, Maupassant's contribution to an anthology edited by Zola (1880), decided him to devote his whole time to writing.In the remaining years of his short life he wrote six naturalistic novels, e.g. Une Vie (1883) and Bel Ami (1885), travel books inspired by frequent journeys for his health (which had begun to deteriorate in 1876), and some 300 short stories upon which his fame rests. He writes as an observer not an analyst, letting his characters be judged by their actions, not their thoughts and feelings, and the actions he observes are those of sensual, self-seeking but never spiritual human beings. He views the consequences of these actions with some pity but he neither condemns, condones nor even examines their cause. For this limited end he mastered, with the guidance of Flaubert, a superb technique: his style is taut and his economy of phrase exactly suits the brevity of his tales, his construction is skilful and he uses the trick of the surprise ending effectively. In his last years Maupassant's illness developed into insanity and he died after 18 months in an institution.

Lanoux, A., Maupassant le 'Bel-Ami'. 1967.

Maupertuis, Pierre Louis Moreau de (1698-1759). French mathematician and astronomer. He led an expedition to Lapland to measure the length of a degree of the meridian and as a result was able to confirm *Newton's assertion that the earth is slightly flattened at the poles. He published his conclusions in Sur la Figure de la Terre (1738). He entered (1740) the service of *Friedrich II ('the Great') of Prussia and became (1745) President of the Academy at Berlin.
Maupin, Armistead (1944- ). American writer, born in Washington DC. He grew up in North Carolina and after US Navy service became a journalist. In the San Francisco Chronicle from 1983 he wrote Tales of the City, accounts of gay life, which appeared in book form and as a television series.

Mauriac, François (1885-1970). French novelist and dramatist. An ardent Roman Catholic, he was preoccupied with the conflict of Christian morality with human passions and temptations. His novels include Le Baiser au lépreux, Le Désert de l'amour, Thérèse Desqueyroux, Le Naud de vipères written between 1922 and 1932, and La Pharisienne (1941). His most successful plays were Asmodée (1937) and Les Mal-Aimés (written 1939, first performed 1945). Mauriac was elected to the Académie française (1933) and won the Nobel Prize for Literature (1952).

Mauriac, F., Mémoires. 3 vols, 1959-67.

Maurice, Prince of Orange, Count of Nassau (1567-1625). Stadtholder of Holland. After the assassination (1584) of his father *William the Silent he continued (with the help for a time of the Earl of ${ }^{*}$ Leicester and an English contingent) the struggle against the Spaniards. As a result of his series of brilliant successes the United Provinces were recognised (1609) by Spain as a free republic. In the following years, Maurice and the Orange party were involved in a quarrel with domestic opponents, but he emerged victorious and renewed the war with Spain (1621).

Maurois, André (pen name of Emile Herzog) (18851967). French writer. His first book Les Silences $d u$ Colonel Bramble (1918), draws on his experience as a liaison officer with the British army in World War I. His preoccupation with the English is shown in the list of his biographies, which includes *Shelley (Ariel, 1923), *Disraeli, *Byron and ${ }^{*}$ Dickens as well as such French writers as *Voltaire, ${ }^{*}$ Proust and George *Sand (Lélia, 1952). He also wrote novels, essays, and histories of England (1937) and the US (1947). He was elected (1938) to the Académie française. His autobiography, I Remember, I Remember, was published in 1942 .

Lemaitre, G., André Maurois. 1968.

Maurras, Charles (1868-1952). French political writer, born in Provence. A classical scholar and poet, he became stone deaf in early life, lost his religious faith but, as a despairing conservative, became convinced that only a union of Church and monarchy could save Europe from anarchy. He became a passionate opponent of *Dreyfus, Jews and foreigners. In 1899 he founded Action française and wrote for the paper of that name 1908-40. Imprisoned several times, his election to the Académie française (1938) was controversial and he was expelled in 1945 . He disliked *Hitler and *Mussolini but supported *Pétain. Tried as a collaborator (the evidence being no stronger 
than the case against Dreyfus had been), he was imprisoned 1945-52, released because of illness and age, and became a Catholic convert on his deathbed.

Mauser, Paul von (1838-1914). German inventor and gunsmith. The Mauser pistol, was named for him and his brother Wilhelm. He also developed an improved needlegun, a breechloading cannon and (in 1897) the first magazine rifle.

Mausolus (d.353/352 BCE). Persian satrap of Caria (Asia Minor) 377-353/352 BCE. He was commemorated by the magnificent memorial (one of the Seven Wonders of the Ancient World) erected by his widow Artemesia at Halicarnassus, which gave rise to the word mausoleum.

Mawson, Sir Douglas (1882-1958). Australian geologist and Antarctic explorer, born in Shipley, Yorkshire. His family emigrated to Australia in 1884 and he graduated from Sydney University. After geological work in the New Hebrides (1903) he joined the staff of Adelaide University (1905). In 1907 he was among the members of *Shackleton's expedition which reached the South Magnetic Pole. He led the Australasian Antarctic Expedition (AAE) 1911-14 in which much of the coast of Queen Mary Land was explored. After a 600-mile sledge journey he returned ill and alone after losing his two companions, Belgrave Ninnis and Xavier Mertz. He was knighted in 1914, served in Russia during World War I and became professor of geology at Adelaide 1921-52. He led the British, Australian and New Zealand Antarctic Research Expedition (BANZARE) 1929-30, 1930-31 when 2,500 km of coast was mapped for the first time. Elected FRS in 1923, he was a foundation Fellow of the Australian Academy of Science (FAA) in 1954. He published The Home of the Blizzard (1930) and for several years appeared on the Australian $\$ 100$ note.

Mawson, P., Mawson of the Antarctic. 1964; FitzSimons, P., Mawson 2011; Day, D., Flaws in the Ice. In search of Douglas Mawson. 2013.

Maxentius (Marcus Aurelius Valerius) (d.312). Roman Emperor 306-312. Son of *Maximian, he was made Caesar by the Roman praetorian guard, quarrelled with his father and fought with ${ }^{*}$ Constantine. At the Milvian Bridge, near Rome, Constantine defeated Maxentius who was drowned trying to escape.

Maxim, Sir Hiram Stevens (1840-1916). AngloAmerican inventor, born in Maine. He settled in England in 1883, became naturalised in 1884 and was knighted in 1901 . The best known of his many inventions-he took out over 100 patents-is the Maxim (recoil-operated) machine gun (1884), later lightened and simplified as the 'Vickers', which continued to prove its outstanding merits in both world wars. 'Maximite', a smokeless powder, was among his other inventions.
Maximian (Marcus Aurelius Valerius Maximianus) (d.310). Roman Emperor 286-305, 306-308. He was chosen by ${ }^{*}$ Diocletian to be co-Emperor (i.e. Augustus) with himself, with two junior emperors (Caesars) under them. Maximian, in charge of the West, pacified Gaul and drove back the Germanic tribesmen on the Rhine frontiers until in 305 , by arrangement with Diocletian, both senior emperors retired in favour of ${ }^{*}$ Constantius (West) and *Galerius (East) with two new Caesars. On the death of Constantius (306), however, his son ${ }^{*}$ Constantine and Maximian's son *Maxentius, notorious for cruelty and greed, combined to dethrone Severus II, the new Western emperor. Maximian emerged from retirement to help his son, but they soon fell and he went to Gaul to the court of ${ }^{*}$ Constantine, his son-inlaw. However, unable to endure a subordinate role, he took advantage of Constantine's absence on campaign by seizing power. Constantine's vengeance was swift and Maximian found himself besieged in Marseille. He was handed over by the citizens and committed suicide.

Maximilian I (1459-1519). Holy Roman Emperor 1493-1519. Son of Emperor *Friedrich III, he added greatly to his inheritance by marrying Maria, the heiress of ${ }^{*}$ Charles the Bold of Burgundy, though in fact he found it necessary to relinquish the French provinces while retaining the Netherlands for his son ${ }^{*}$ Felipe. His policy of consolidating the Habsburg dominions by marriage and conquest was on the whole successful, though it involved a number of indecisive wars in France and Italy, but his dream, in accordance with medieval thought, of reviving a universal empire in the west (he even conceived the idea of also becoming pope) inevitably failed. The administrative reforms he achieved were minor, but the enforced acceptance of a committee of princes as a supreme executive would have rendered him impotent had he not succeeded in finding a means to frustrate its efforts. Maximilian had the courage and many of the virtues of a medieval knight, he was a patron and connoisseur of arts and letters, and won wide popularity with a gracious and conciliatory manner. He was succeeded by his grandson ${ }^{*}$ Charles V.

Maximilian (Fernando Maximiliano José María de Habsburgo-Lorena) (1832-1867). Emperor of Mexico 1864-67. Younger brother of the Emperor *Franz Joseph of Austria, he was married to *Carlota, daughter of *Leopold I of the Belgians. This liberalminded, well-meaning man, whose short experience of administration (1857-59) had been as Governor of the Austrian-controlled Lombardo Venetian territory in Italy, acceded to *Napoléon III's request to found a new kingdom in Mexico. After defeating the conservatives in the war of 1857-60, the Mexican 'liberals' under Benito *Juarez had found themselves unable to meet foreign debts. France being a principal creditor, Napoléon decided to send a French army primarily to collect debts. His forces soon held most of the country and the enthronement of Maximilian 
was the French Emperor's solution to the problem of what to do next. While Maximilian was planning freedom for Indians, education and social justice for all, the republican forces were gathering strength, and when the French (on US insistence) departed, Maximilian was helpless. Defeated and betrayed, he was given a pretence of trial and shot. The empress Carlota, who had returned to Europe on a vain quest for help, became insane.

Maxton, James (1885-1946). Scottish socialist politician, born in Glasgow. A teacher (and the son of teachers), a pacifist who opposed both World Wars, he was imprisoned 1916-17 for inciting shipyard workers to strike. He represented the Independent Labour Party (ILP) as MP 1922-46 and became the ILP chair 1926-31; 1934-39. He detested Ramsay *MacDonald and the ILP broke with mainstream Labour in 1932. An outstanding orator, he was a republican and an early advocate of Scottish independence.

McNair, J., James Maxton, the Beloved Rebel. 1955; Brown, G., Maxton. A Biography. 1986.

Maxwell, James Clerk (1831-1879). Scottish physicist, born in Edinburgh. Educated at the Edinburgh Academy and at Edinburgh University and Trinity College, Cambridge, while still a schoolboy of 15 he communicated his first paper to the Royal Society of Edinburgh. He was a professor at Aberdeen 1856-60 and King's College, London 1860-65, and the first Cavendish professor of experimental physics at Cambridge 1871-79. Maxwell showed (1859), on mechanical principles, that the rings of Saturn could consist only of separate small particles revolving like satellites. Later he worked on the kinetic theory of gases and deduced many of the laws governing their behaviour. His major work, however, was on electricity and magnetism. He evolved the electromagnetic theory of light and showed that there should be electromagnetic waves travelling at the speed of light; these were observed (1887) by *Hertz. Maxwell redetermined the speed of light with great precision and pointed out the fundamental nature of this natural constant. He also evolved many of the theoretical relationships which contributed to the development of electricity. His books include Treatise on Electricity and Magnetism (1873) and Matter in Motion (1876). *Einstein regarded Maxwell as the 'most profound' physicist since *Newton.

Campbell, L., and Garnett, W., The Life of James Clerk Maxwell. Repr. 1969.

Maxwell, (Ian) Robert (né Jan Ludvik Hyman Binyamin Hoch) (1923-1991). Czech-Jewish-British publisher born in Czechoslovakia (now in Ukraine). He escaped from Hungary to France in 1939, joined the British Army, became an officer and won a MC. Most of his family died in Auschwitz. He entered scientific publishing in 1951, bought Pergamon Press, served as a Labour MP 1964-70, bought the
British Printing Corporation in 1981 and the Daily Mirror in 1984. He launched The European in 1990 and bought the New York Daily News in 1991. He disappeared overboard from his yacht in the Canary Islands (November 1991) and suicide was suspected but never proved. His companies were heavily in debt and he had removed \$US1.3 billion from employee pension funds.

Davies, N., The Unknown Maxwell. 1992.

Maxwell Fyfe, David Patrick, 1st Earl of Kilmuir (1900-1967). Scottish lawyer and Conservative politician, born in Edinburgh. He was MP 1935-54, an effective prosecutor at the Nuremberg War Crimes Tribunal 1945-46, and took a harsh line on capital punishment and homosexual law reform as Home Secretary 1951-54. He became Lord Chancellor 1954-62.

May, Phil(ip William) (1864-1903). English humorous draughtsman. After early struggles he went to Australia (1884) and worked on the Sydney Bulletin. On his return (1892) he began to work for Punch and later, as a regular member of the staff, became one of the best known humorous artists with a great economy of line.

May, Robert McCredie, Baron May of Oxford (1936-2020). Australian theoretical ecologist, born in Sydney. He took a PhD in theoretical physics at Sydney University, taught at Harvard and held chairs at Sydney and Princeton. Professor of Theoretical Ecology at Oxford 1988-95, he was chief scientific advisor to the UK Government 1995-2000 and President of the Royal Society 2000-05. He received the OM in 2002 and the Copley Medal in 2007.

May, Theresa Mary (née Brasier) Lady May (1956-). English Conservative politician, born in Sussex. A vicar's daughter, she mostly attended government schools, read geography at Oxford, worked in the Bank of England and as a financial consultant, and was elected to a council. In 1980 she married (Sir) Philip May, banker. MP 1997- , she was a Shadow Minister 1998-2010 and Home Secretary 201016. May had been a low key supporter of the UK remaining in the EU, but after the referendum of June 2016 voted to leave, David *Cameron resigned, May was elected as Conservative Party leader and became Prime Minister 2016-19. Despite her assurances that the House of Commons would run its full term, she called a snap election (June 2017), expecting to be assisted by Jeremy *Corbyn's perceived weakness, and to strengthen her hand in negotiating terms of 'Brexit' from the EU, with a larger majority. She failed spectacularly, and in a hung parliament had to rely on support from the Democratic Unionist Party in Northern Ireland. Her attempts to negotiate a 'soft Brexit' failed both with the EU and Conservative hardliners. Boris *Johnson and other Brexiters 
resigned from her Cabinet and in December 2018 she stared down a leadership challenge (200 votes to 117$)$.

After failing to secure passage of a compromise formula for leaving the EU, she resigned as Conservative Party leader and was succeeded by Johnson who became Prime Minister in July. She was re-elected as MP in December 2019.

Mayakovsky, Vladimir Vladimirovich (18941930). Russian futurist poet. He came to prominence as the poet of the 1917 revolution with such works as 150,000,000 (1920), in which President ${ }^{*}$ Wilson personifies capitalism. He also wrote satirical plays, of which The Bed Bug (1921) is the best known. Mayakovsky later fell from official favour and committed suicide. Much of his work is crudely propagandist but it has pathos and sincerity and shows original ideas.

Brown, E. J., Mayakovsky: A Poet in the Revolution. 1973.

Mayer, Julius Robert von (1814-1878). German physicist and physician. After serving as a ship's doctor, he carried out research on the transfer of heat energy by working horses, which led to the first hypothesis (1842) of the law of the conservation of energy. Credit was given to *Joule and *Helmholtz who independently provided (1847) more detailed proofs. A forgotten figure who spent years in an asylum and was assumed dead, Mayer received belated recognition, including ennoblement and the Copley Medal of the Royal Society (1871).

Mayer, Louis Burt (1885-1957). American film producer, born in Minsk. He merged his production company with Sam *Goldwyn's in 1924 to form MGM (Metro-Goldwyn-Mayer).

Mayer, Sir Robert (1879-1985). British philanthropist, born in Germany. He made a fortune in metal trading and became a notable promoter of music, especially concerts for children. He received a $\mathrm{CH}$ on his 100 th birthday.

Mayo, Charles Horace (1865-1939). American surgeon. With his father and brother he founded (1889) the Mayo Clinic at Rochester, Minnesota. His researches into goitre cut the US death rate from this disease by 50 per cent.

Clapesattle, H. B., The Doctors Mayo. 2nd ed. 1954.

Mayo, Richard Southwell Bourke, 6th Earl of (1822-1872). Irish politician, born in Dublin. Educated at Trinity College, he was a Conservative MP 1847-67, Chief Secretary for Ireland 1852, 1858-59 and 1866-68, and *Gladstone's surprising choice as Viceroy of India 1869-72, proving to be an effective reformer, especially in education and irrigation. He was assassinated in the Andaman Islands.
Mayor Zaragoza, Federico (1934- ). Spanish (Catalan) biologist, politician and administrator, born in Barcelona. Rector of the University of Granada 1968-72, he served in the Cortes and the European Parliament, was Minister for Education and Science 1981-82 and Director-General of UNESCO 1987-99. He was a gifted poet and orator in three languages.

Mayr, Ernst (1904-2005). American biologist and taxonomist, born in Germany. Educated in Greifswald and Berlin, he lived in the US from 1932, working at the American Museum of Natural History 1932-53 and was Agassiz professor of zoology at Harvard 1953-75. Regarded as the world's greatest authority on the classification and naming of species, he wrote extensively on systematic zoology and evolutionary synthesis.

Mazarin, Jules (Giulio Mazarini) (1602-1661). French statesman and cardinal, born in Italy. Educated by the Jesuits in Rome and Spain, he entered the Church and was Papal Nuncio in France 1634-36 and in 1639 assumed French nationality. Meanwhile he had come to the notice of Cardinal *Richelieu, who took him as his assistant and, having secured his cardinalate (1641), recommended him as his successor to ${ }^{*}$ Louis XIII. Mazarin retained his power when the boy-king *Louis XIV came to the throne, largely through the affection of the widowed queen, now regent, ${ }^{*}$ Anne of Austria, to whom Mazarin may have been secretly married. Mazarin brought the Thirty Years' War to a successful end (1648) with the acquisition for France of Alsace and the bishoprics of Toul, Metz and Verdun, but was immediately involved in the civil wars of the Fronde, a last attempt by the nobles and legalists to avert a centralised autocracy. Again successful he made an advantageous peace with Spain (1659) and prepared France for its great role under Louis XIV. In other respects he was less admirable. He amassed a vast fortune with part of which he provided large dowries to enable his several pretty nieces to marry well. His valuable collection of books and manuscripts was left to the royal library.

Hassall, A., Mazarin. 1973.

Mazeppa, Ivan Stepanovich (c.1645-1709). Cossack leader. After an adventurous early life he was elected hetman (military leader) of the Cossacks (1688), served Peter the Great as soldier and diplomat but later, in the hope of acquiring a semi-independent kingdom in the Ukraine, joined the invading army of *Charles XII of Sweden. After Charles' defeat at Poltava (1709) Mazeppa took refuge in Turkey.*Byron's poem Mazeppa relates how, detected in a love affair with a magnate's wife, the Cossack hero was bound naked to a wild horse which was lashed to madness and galloped across country from Poland to the Ukraine before dropping dead. 
Mazzini, Giuseppe (1805-1872). Italian patriot, born in Genoa. Deeply angered by the absorption (1815) of the Genoese republic into the kingdom of Sardinia, he joined the revolutionary elements among the university students and in 1829 became a member of the Carbonari, a secret republican society. He soon abandoned it, however, disliking its elaborate ritual and formed at Marseilles (1832) his own society, 'Young Italy', for which he edited a periodical of the same name, his aims being a united, free, republican Italy. After a first ineffective invasion (1834) he lived as an exile in Switzerland and in England (1836-48). His writing and correspondence kept him in touch with revolutionary movements abroad and in England he formed a warm friendship with Thomas *Carlyle and his wife. The year of revolutions, 1848, created the conditions for his return to Italy, where he was greeted as a hero. But by 1849 Austrian power had asserted itself and only the republics of Venice and Rome, whence the Pope had fled, survived. Mazzini became a triumvir of the republic of Rome but after the intervention of French troops had to return to London. When the liberation and unity of Italy were finally achieved (1859-60) it was carried out by statesmen such as *Cavour and men of action such as ${ }^{*}$ Garibaldi. It might never have happened at all had not the ferment been started by Mazzini, the political idealist and persistent propagandist whose hopes in the end were but half fulfilled. He was much admired by Woodrow *Wilson, *Lloyd George and *Gandhi.

Mack Smith, D., Mazzini. 1995.

Mbeki, Thabo (1942- ). South African politician. Son of an African National Congress veteran, he studied in Britain and Russia, went into exile until 1990, becoming the ANC's international spokesman. $\mathrm{He}$ was first deputy president of the Republic 1994-99 and President of the ANC 1997-2007. He succeeded Nelson *Mandela as President of South Africa 1999-2008. His insistence that HIV/AIDS is essentially caused by poverty rather than the sexual transmission of a virus caused concern to health professionals internationally. He insisted that only African pressure against Robert *Mugabe's regime in Zimbabwe was legitimate and achieved a compromise power-sharing arrangement after the 2008 elections.

Mboya, Tom (1930-1969). Kenyan trade unionist and politician. From 1953 he was Secretary of the Kenya Local Government Workers' Union (later the Federation of Labour). He was among the first African members to be elected (1957) to the Kenya Legislative Council and became one of the most important members of the Kenya African National Union (KANU), the leading political party before and after independence. From 1962, when he entered the coalition government, his influence increased. Minister of Economic Planning and Development 1964-69, he was assassinated.
Mead, Margaret (1901-1978). American anthropologist and social psychologist. She worked in Samoa and New Guinea and made an intensive (but not always accurate) study of tribal customs and marriage laws. She noted the difficulty that exceptional characters find in what were then called 'primitive societies', closely regulated by custom, in coming to terms with the norm. Her books include Coming of Age in Samoa (1928), Growing up in New Guinea (1930) and Male and Female (1949).

Freeman, D., Margaret Mead and Samoa. 1983.

Meade, George Gordon (1815-1872). American soldier. As an engineer officer he fought in the Mexican War (1848) and was then employed on survey and construction duties until the outbreak of the Civil War. Having distinguished himself as a divisional commander he was given command of the army of the Potomac (1863-65), almost at once winning the great victory over *Lee at Gettysburg, Pa. (July 1863), the turning point of the war.

Meade, James Edward (1907-1995). British economist. Educated at Oxford and Cambridge, he worked in the civil service and taught at both universities and at the London School of Economics. He shared the 1977 Nobel Prize for Economics for his work on the theory of international economic policy.

Meany, (William) George (1894-1980). American trade union official, born in New York. A plumber by trade he made his career in the trade union movement and succeeded William Green as President of the American Federation of Labor (AFL) 1952-55. When the AFL amalgamated with the Congress of Industrial Organisations (CIO), Meany became first President of the combined AFL-CIO 1955-79, retiring the age of 84 . He fought against corruption, was strongly anti-Communist and supported the Vietnam War.

Mechnikov, Ilya Ilyich (1845-1916). Russian biologist. After studying in Germany he was professor of zoology at Odessa University 1870-82, worked with *Pasteur in Paris (from 1888) and became Deputy Director of the Pasteur Institute 1904-16. In a study of the digestion processes of invertebrates he discovered phagocytosis (the engulfing of solid particles by amoeboid cells). Later he showed that the white blood corpuscles of vertebrates play a part in defence against disease by engulfing bacteria in the blood stream. He won the Copley Medal in 1906 and shared the 1908 Nobel Prize for Medicine with Paul *Ehrlich (1908) for their work in explaining immunity and developing vaccines.

Medawar, Sir Peter Brian (1915-1987). British biologist, born in Rio de Janeiro, of Lebanese descent. Educated at Oxford where he worked with *Florey, he was professor of zoology at Birmingham 1947-51 and professor of zoology and comparative anatomy at University College, London 1951-62, then worked for the Medical Research Council. He gave the BBC 
Reith Lectures (1959) on The Future of Man. He shared the Nobel Prize for Physiology and Medicine (1960) with Sir Macfarlane *Burnet for their studies of 'acquired immunological tolerance'. He also wrote The Uniqueness of the Individual (1957), The Hope of Progress (1972) and Advice to a Young Scientist (1979). He was knighted in 1965, received the Copley Medal (1969), the CH in 1972 and the OM in 1981. He was seriously disabled by a stroke in 1969 . He published several volumes of literary and scientific essays, brilliantly and scathingly written, including Pluto's Republic (1982) and, with his wife Jean Medawar (née Shinglewood Taylor) (1913-2005), the reference work Aristotle to Zoos (1985).

Medawar, P., Memoir of a Thinking Radish. 1986; Medawar, J., A Very Decided Preference. 1990.

Medici. Florentine ruling family. The power of the family was founded upon the huge fortune amassed as a banker by Giovanni de'Medici (1360-1429). His son Cosimo (1389-1464) was exiled as a popular rival by the ruling oligarchy but returned (1434) and, though preserving republican forms succeeded in suppressing faction and was virtual ruler for the rest of his life, he was the generous patron of ${ }^{*}$ Brunelleschi, Gliberti, ${ }^{*}$ Donatello, Filippo *Lippi, Fra Angelico etc. Cosimo was succeeded in power by his son Piero (1416-1469) and his grandson Lorenzo (1449-1492), known as 'the Magnificent'. The failure of a conspiracy in which his brother Giuliano (1453-1478) was killed, enhanced Lorenzo's popularity and enabled him to increase his powers. Like his grandfather he patronised artists and beautified the city. After his death the invasion of Italy by ${ }^{*}$ Charles VIII of France in search of a Neapolitan crown led to the temporary exile of the Medici and though they came back (1512), power was mainly exercised from Rome where ${ }^{*}$ Leo X, a grandson of Lorenzo, was Pope. When the Medici were again deposed (1527) a second Medici pope *Clement VII, posthumous son of the murdered Giuliano, once more brought back the family (1530), but it was a collateral Cosimo (1519-1574) who restored it to greatness. Having been granted Siena by the Emperor, he was created (1569) the first grand-duke of Tuscany by the Pope, starting a line which became extinct on the death of the seventh grand-duke (1737), when the duchy passed to the House of Lorraine ( ${ }^{*}$ Catherine de'Medici, *Marie de Medicis).

Brion, M., The Medici: A Great Florentine Family. 1969.

Medina-Sidonia, Alonso Perez de Gúzman, Duque de (1550-1619). Spanish nobleman. Owing to the sudden death of Admiral Santa Cruz, a last-minute decision was taken to give the command of the Armada against England (1588) to Medina Sidonia, a tunafish magnate who protested that he had no fighting experience and was a victim of seasickness. He shares blame for the disaster with those who forced him to take a role for which he was completely unsuited.
Medtner, Nikolai Karlovich (1880-1951). Russian composer and pianist. He wrote three piano concertos, 13 sonatas and many songs, and lived in England from 1936. An anti-modernist, he received the unlikely patronage of the Maharajah of Mysore.

Medvedev, Dimitri Anatolievich (1965- ). Russian politician, born in Leningrad. A lawyer, he worked for Anatoli ${ }^{*}$ Sobchak, then transferred his allegiance to Vladimir ${ }^{*}$ Putin. He attempted to reform Gazprom. He was First Deputy Prime Minister 2005-08, President of Russia 2008-12 and Prime Minister 2012-20.

Meegeren, Hans van (1889-1947). Dutch artist. One of the most famous fakers in art history, having failed to find a regular market for pictures under his own name, he started painting in the style of *Vermeer and from 1937 sold six pictures as genuine works of the master, although on even a superficial examination it is hard to see why. His career reached a fantastic climax during World War II when he succeeded in selling them at inflated prices to the German occupation authorities and even to Marshal ${ }^{*}$ Goering. He was tried after the war and sentenced to a year's imprisonment but died soon afterwards.

Megawati Soekarnoputri (1947- ). Indonesian politician. Daughter of ${ }^{*}$ Soekarno, she led the opposition to *Soeharto. In the June 1999 elections, her Indonesian Democratic Party of Struggle outpolled the Government's Golkar Party, but in October 1999 Abdurrahman *Wahid was elected President, and Megawati became Vice President. In July 2001, following Wahid's impeachment by the People's Consultative Assembly, she became President of Indonesia. In September 2004 she was defeated in Indonesia's first popular presidential election by Susilo Bambang *Yudhoyono.

Mehta, Zubin (1936- ). Indian conductor, born in Mumbai. A Parsee, he studied music in Vienna, specialising in ${ }^{*}$ Bruckner and ${ }^{*}$ Mahler, and became conductor or music director for major orchestras: Montréal Symphony 1960-67, Los Angeles Philharmonic 1962-78, Israel Philharmonic 1977-, New York Philharmonic 1978-91, and opera houses in Florence and Munich. He devoted himself to improving Israeli-Palestinian relationships.

Mehemet Ali see Muhammad Ali (Pasha al-Mas'ud ibn Agha)

Mehmed V Reşâd (Meḥmed-i hâmis) (1844-1918). Sultan of the Ottoman Empire 1909-18 and Caliph of Islam 1909-18. Born in Constantinople/Istanbul, he was kept in seclusion in the Topkapi Palace for decades, and ceded his authority to leaders of the Young Turk movement, *Enver Pasha and ${ }^{*}$ Talaat Pasha. His brother Mehmed VI (Mehmed-i sâdis Vahideddin) (1861-1926) was the 37th and last Sultan of the Ottoman Empire 1918-22 and Caliph 
of Islam 1918-22. He collaborated with the Allies after World War I, tried to suppress the nationalists, and was deposed and exiled by Kemal *Atatürk and died in San Remo. His feeble-minded brother Abdul Mecid II (1868-1944) was the last caliph 1922-24.

Mehmed II Fatih (= 'the Conqueror': Mehmed bin Murad Han) (1430-1481). Seventh Sultan of the Ottoman Empire 1444-46; 1451-81. Born in Edirne, son of Sultan *Murad II and a slave, his father abdicated in 1444 but resumed the throne in 1446. On his second accession the Ottoman Empire already included most of Asia Minor and much of the Balkans, but he conquered (1453) Constantinople, ending the Eastern Roman (Byzantine) Empire, a feat that transformed world history and he assumed the title of Qayser-i Rûm ('Caesar of Rome'). His forces occupied much of the Balkan peninsula, including Greece, and a war with Venice (1463-79) added to his possessions in the Adriatic and Aegean. He was painted by ${ }^{*}$ Bellini (1480).

Freely, J., The Grand Turk: Sultan Mehmet II. 2009.

Mehmed Aga (d.1618). Turkish architect. A pupil of * Sinan, he designed the magnificent Blue Mosque (Sultan Ahmed Cami) in Istanbul (1609-16).

Meighen, Arthur (1874-1960). Canadian Conservative politician, born in Ontario. Originally a lawyer in Manitoba, he was a member of the House of Commons 1908-21 and 1922-26 and a senator 1932-42. He served as a minister under *Borden 1913-20 and led the Conservatives 1920-26 and 1941-42. He succeeded Borden as Prime Minister 1920-21, then lost to Mackenzie *King's Liberals. In June 1926, after the Governor-General, Lord *Byng, rejected King's advice to dissolve Parliament, Meighen was appointed Prime Minister and three months later lost government and his own seat. He advocated protective tariffs against US economic penetration of Canada. Meighen returned to law practice in Ontario and was a minister under R. B. *Bennett 1932-35. Appointed Conservative leader again in 1941, he was unable to win a seat in the House of Commons.

\section{Meiji see Mutsuhito}

Meir, Golda (née Golda Moshevna Mabovitch) (1898-1978). Israeli politician, born in Kiev. She grew up in Milwaukee and emigrated to Palestine in 1921 to work on a collective farm. She had already been involved in Zionism in America and she became active in local political life in 1928, through the Labour movement. She served on the Executive and Secretariat of the Federation of Labour 1929-46. She sat on the War Economic Advisory Council from 1939 and, after the war, became head of the Political Department of the Jewish Agency for Palestine. After independence, her first Cabinet appointment in the Knesset was as Minister of Labour and Social Insurance 1949-56, then Foreign Minister 1956-66 and Prime Minister 1969-74. She worked for support from the US and from the non-aligned countries, particularly in Africa. She was a co-founder of the Israeli Labour Party (1967).

Meir, G., My Life. 1975.

Meissonier, Jean Louis Ernest (1815-1891). French artist. His historical pictures, especially those relating to the Napoléonic campaigns, realised large prices in his lifetime but are now largely forgotten.

Meitner, Lise (1878-1968). Austrian-JewishSwedish physicist. Until she emigrated to Denmark (1938) she carried out research in radio-chemistry and nuclear physics at Berlin University and the Kaiser Wilhelm Institute for Chemistry. In 1938, with Otto ${ }^{*}$ Hahn and her nephew O. R. *Frisch, she played an important part in the discovery of the nuclear fission process for the liberation of atomic energy, but the Nobel Prize for Physics was awarded to Hahn alone. She received 48 nominations for the Nobel Prize. She settled in Sweden (1940), became a Swedish citizen (1949) and retired to England in 1960. Element 109 Meitnerium (Mt), craters on the Moon and Venus, and asteroid 6999 Meitner were named for her.

Melanchthon (né Schwartzerdt), Philipp (14971560). German Lutheran reformer and scholar, born in Bretten, in the Palatinate. Son of an armourer, he was influenced by his great-uncle Johann *Reuchlin who persuaded him to adopt the Greek translation of his name, 'black earth'. Educated at Heidelberg and Tübingen, from 1518 he was professor of Greek at Wittenberg University, where he became an early adherent of *Luther, helping him also with his translation of the New Testament from the Greek. He issued the first systematic formulation of the Protestant dogma (1521) and the Augsburg Confession (1530). He was much more tolerant and conciliatory than Luther, and when he succeeded to the leadership he lost the confidence of many Protestants by the concessions he made to the Catholics in his quest for peace.

Melba, Dame Nellie (Helen Porter Armstrong, née Mitchell) (1861-1931). Australian soprano, born in Melbourne. After a brilliant operatic debut in Brussels (1887) she became prima donna at Covent Garden (1888) and sang throughout Europe and America until her retirement (1926). Her greatest successes were in lyric and coloratura roles in the operas of ${ }^{*}$ Verdi and ${ }^{*}$ Puccini. (She sang no ${ }^{*}$ Mozart roles.) She was created DBE in 1918 and promoted GBE in 1927. Pêche Melba, the sweet dish invented in her honour, is evidence of her contemporary reputation.

Radic, T., Melba. 1986; Blainey, A., I am Melba. 2008; Wainwright, R., Nellie. 2021.

Melbourne, William Lamb, 2nd Viscount (17791848). English Whig politician, born in London. Probably the son of Lord Egremont, educated at Eton and Trinity College, Cambridge, he was called to the bar (1804) and in 1805 married the eccentric Lady 
Caroline Ponsonby (Caroline * Lamb), later notorious for her infatuation with *Byron. He was a Member of Parliament 1806-12, 1816-28, then succeeded to the peerage. Originally a supporter of Charles James ${ }^{*}$ Fox, he also admired ${ }^{*}$ Canning and became his Chief Secretary for Ireland 1827-28. Home Secretary 1830-34, his harsh treatment of the Tolpuddle Martyrs in 1834 marred his generally humane record. He reluctantly supported *Grey's Reform Act (1832) and succeeded him as Prime Minister 1834, until dismissed by ${ }^{*}$ William IV (the last time the Crown so acted). When *Peel lost the ensuing election, Melbourne returned as Prime Minister 1835-41. On Queen *Victoria's accession, he also acted as her private secretary and tutored her in the art of constitutional government. He resigned after a vote of censure (1841). Stricken with paralysis (1842), he played no further significant role.

Cecil, D., The Young Melbourne. 1939; Cecil, D., Lord M. 1954; Ziegler, P., Melbourne. 1976; Mitchell, L. G., Lord Melbourne. 1997.

\section{Melchett, 1st Baron see Mond, Ludwig}

Melchior, Lauritz (Lebrecht Hommel) (1890-1973). Danish-American heroic tenor, born in Copenhagen. He made his operatic debut in Copenhagen 1913 as a baritone, then became a tenor, appearing first in London in 1920, Bayreuth in 1924 and New York in 1926. The greatest of all Wagnerian heldentenors, he was a regular at Covent Garden 1924-39 and sang 519 times at the Metropolitan Opera, New York, 1926-50. He made many recordings, appeared in five films and some television programs. He was an expert bridge player.

Méliès, Georges (1861-1938). French film maker, born in Paris. A magician and illusionist, he made 531 films, mostly short, 1896-1913, including L'Affaire Dreyfus (1899, a sympathetic account), and Le voyage dans la lune (1902). He was the subject of The Invention of Hugo Cabret (2008) by Brian Selznick and Martin *Scorsese's film Hugo (2011).

Mellon, Andrew William (1855-1937). American financier, born in Pittsburgh. He accumulated a huge fortune through a complex of financial and industrial interests, notably the Mellon National Bank of Pittsburgh and the Aluminium Corporation. Turning to politics, he served under presidents ${ }^{*}$ Harding, *Coolidge and ${ }^{*}$ Hoover as Secretary to the Treasury 1921-31 and Ambassador to Great Britain 1931-33. Among the greatest of all American art collectors, a considerable part of his wealth was used to construct and endow the National Gallery of Art in Washington DC.

Cannadine, D., Mellon: An American Life. 2006.

Meloni, Giorgia (1977- ) Italian politician. An admirer of ${ }^{*}$ Mussolini, she became the leader of Brothers of Italy and Prime Minister 2022- .
Melville, Herman (1819-1891). American novelist and poet, born in New York. Of Scottish and Dutch descent, his father was a merchant who lived extravagantly, became bankrupt and died insane in Albany in 1832. Forced to leave school, he worked as a bank clerk, then resumed his education in Albany and taught briefly in Massachusetts and New York. He sailed to Liverpool in 1839 and in January 1841 joined the whaler Acushnet, bound for the Pacific. Because of harsh treatment he deserted the ship and lived for two months in the Marquesas Islands (1842). Picked up by an Australian whaler, Lucy Ann, he was delayed in Tahiti by a mutiny and was eventually shipped to Hawaii in a US frigate. He served in the US Navy 1842-43. On his return, Melville wrote novels based on his adventures, Typee (1846), Omoo (1847) and White-Jacket (1850), the first two especially popular for their exuberant descriptions of native life. After marriage (1847) to Elizabeth Shaw he bought a farm in Massachusetts where his mother, and his sister Augusta Melville (1821-1876), his copyist and amanuensis, lived with them and Nathaniel *Hawthorne was a neighbour. Moby-Dick; or, the Whale (1851), dedicated to Hawthorne, is the story of the fatal voyage of the Pequod under Captain Ahab whose obsession it is to track down and kill 'the great white whale' which had crippled him in a previous encounter. Although Melville denied that Moby-Dick was an allegory, critics have regarded the book as expressing man's struggle with nature, or even with God. Even more puzzling to critics was the quasi-autobiographical Pierre: or, The Ambiguities (1852), about the destruction of personal history, with an ambiguous sub-theme about incest (mother; sister). Its themes reflected the melancholia into which Melville sank. He visited Europe, the Mediterranean and Palestine 1856-57 and wrote the novellas The Confidence-Man (1857) and Bartleby, the Scrivener (1857). Billy Budd, Sailor, left unfinished, was not published until 1924, and became an opera by Benjamin *Britten (1951). The Civil War turned him to poetry, but his collection Battle Pieces and Aspects of the War (1866) and Clarel (1876) sold poorly. Melville was a customs inspector in New York 1866-86, appointed by the future President Chester A. *Arthur. His style is rhetorical, his vocabulary eccentric, rich and varied, which bewildered the critics and for 70 years repelled the public. Almost forgotten, his revival and reassessment from 1919 gave him a very exalted position among American writers.

Humphreys, A. R., Melville. 1962; Robertson-Lorant, L., Melville: A Biography. 1996; Parker, H., Herman Melville: A Biography. 1996, 2002; Duberstein, L., The Handsome Sailor. 1998; Delbanco, A., Melville: His World and Work. 2005.

Memling (or Memlinc), Hans (c.1440-1494). Flemish painter, born near Frankfurt. Almost certainly a pupil of Rogier van der *Weyden, he lived in Bruges from 1465, became rich and is commemorated there by a museum in the old hospital. His best works include the Donne Triptych 
(?1468, once at Chatsworth and now at the National Gallery, London), The Man of Sorrows in the Arms of the Virgin (1475, National Gallery, Melbourne), The Betrothal of St Catherine (1479, for an altar at Bruges), Compassion for the Dead Christ, with a Donor (1485?, Rome) and The Legend of St Ursula (1489, Bruges). His portraits show originality and he is said to have introduced the practice of setting a three-quarter bust against a scenic background.

Menander (c.343-291 BCE). Athenian poet. Principal dramatist of the 'New Comedy', his innovations included the disappearance of the chorus (except as a 'turn' between the acts) and the presentation of humorous situations of everyday life (in contrast to the fantasies of Aristophanes). Here are the slave or servant with a taste for intrigue, the jealous husband, lover, wife or mistress, the long-lost child suddenly restored, the shrew, the cheat all to reappear in the Latin plays of *Plautus and *Terence, and in *Shakespeare, ${ }^{*}$ Molière and many lesser writers. Until large portions of several of Menander's plays were discovered in the 20th century, it was thought that only fragments of his work had survived.

Sandbach, F. H., Menander: A Commentary. 1973.

Menchù (Tum), Rigoberta (1959- ). Guatemalan human rights worker. A Mayan, whose language was Quiché, she claimed that her parents and brother were tortured and murdered by the army. She went to Mexico, then Europe, and was assisted to write an autobiography I, Rigoberta Menchú (1983) which illustrated the plight of indigenous peoples generally. She was awarded the 1992 Nobel Peace Prize as a gesture of protest against persecution of Indians in Central America. In 1999 she admitted that some experiences in her book had not been personal, but justified publication as having directed international attention to appalling cruelties.

Mencius (Latinised form of Mèng Kē or Mengzi) (c.370-c.290 BCE). Chinese Confucian philosopher, born in Shantung province. Sometimes called 'second sage' ('Ya sheng'), he founded a school devoted to the study of the works of ${ }^{*}$ Confucius. After wandering through China for over 20 years attempting to persuade princes and administrators to rule in a moral rather than opportunist way, he retired to teach and write.

Legge, I. (ed.), The Chinese Classics. Vol. 2., Mencius. 3rd ed. 1960; Yearley, L.H., Mencius and Aquinas. 1990; Shun, K., Mencius and Early Chinese Thought. 1997.

Mencken, H(enry) L(ouis) (1880-1956). American author and critic, born in Baltimore. He was on the staff of the Baltimore Sun (1906-41) and his greatest work is the monumental The American Language (4 vols, 1919-48). As editor of the American Mercury (1925-33) he helped to gain public recognition for Theodore * Dreiser and Sinclair
*Lewis. He was an outspoken critic who denounced religion, intellectuals, politicians, sentimentalists and foreigners. His diaries confirm his racism and antiSemitism. Although violently prejudiced, his attacks on complacency and conformity did much to raise the standards of US writing. He also wrote books on *Shaw, *Nietzsche and ${ }^{*}$ Ibsen.

Stenerson, D. C., H. L. Mencken: Iconoclast from Baltimore. 1971; Rodgers, M. E., Mencken. The American Iconoclast. 2005; Hart, D. G., Damning Words. The Life and Religious Times of H.L. Mencken. 2016.

Mendel, Gregor Johann (né Johann Mendel) (1822-1884). Austrian geneticist and botanist, born in Hynčice (now in the Czech Republic). Discoverer of the Mendelian laws of inheritance, he became an Augustinian friar at Brno (Brunn), was ordained in 1847 and adopted the name of Rehor (Gregor). His scientific studies at Vienna University were encouraged and paid for by the monastery, of which he later became abbot (1869). Many of his experiments on the breeding and hybridisation of plants were carried out in the garden there. He kept (1857-68) systematic records of the pedigrees of many generations of plants, closely examining the effects of heredity on the characteristics of individual plants and discovering the statistical laws governing the transmission from parent to offspring of unit hereditary factors (now called genes). His results were only published (1865 and 1869) in a local journal. His work, dismissed by ${ }^{*}$ Nägeli, was not appreciated until its rediscovery c. 1900 by de ${ }^{*}$ Vries. Complicating factors have since been discovered but Mendel's fundamental principles remain undisturbed by later research.

Stern, C. and Sherwood, E. R. (eds), The Origin of Genetics: A Mendel Source Book. 1967; Orel, V., Gregor Mendel: The first geneticist. 1996; Henig, R. M., The Monk in the Garden. 2000; Bateson, W., Gregor Mendel. 2009.

Mendeleev, Dmitri Ivanovich (1834-1907). Russian chemist, born in Tobolsk. The youngest of a large family, son of a school principal, he was educated at Heidelberg and St Petersburg, becoming professor of chemistry at St Petersburg University 1867-90. In 1869 he published his first periodic table of the elements, a complete classification of the relation between the properties and the atomic weights of the chemical elements. His classification of the elements in the periodic table enabled him to predict correctly the existence and properties of several elements, later discovered, for which there were gaps in the table. Elected FRS in 1892, he received the Copley Medal in 1905 and, although chosen for the 1906 Nobel Prize in Chemistry, was over-ruled by the Swedish Academy. The moon crater Mendeleev and element 101, mendelevium, are named for him. He was an outspoken liberal in politics. 
Mendelsohn, Erich (1887-1953). German architect. An exponent of Expressionism, his early work is characterised by an exuberant plasticity which was first realised in his Einstein Tower (Potsdam Observatory). He became a leading architect in Germany, but was forced to leave (1933) on the advent of Nazism. After a short stay in England, he spent some years in practice in Palestine before finally settling in the US. He specialised in factories and department stores but his designs were less purely functional than those of *Gropius.

Whittick, A., Erich Mendelsohn. 2nd ed. 1956.

Mendelssohn(-Bartholdy), (Jakob Ludwig) Felix (1809-1847). German-Jewish composer, conductor and pianist, born in Hamburg. Son of a rich banker and grandson of Moses * Mendelssohn, his family adopted the double name Mendelssohn-Bartholdy on conversion to Christianity. He began to compose when only about 10 years old, and between the ages of 16 and 21 reached the height of his powers. His String Octet Op. 20 (1825), a vivacious work of Mozartian inventiveness, was followed by the overture to $A$ Midsummer Night's Dream (1826, the incidental music, including the famous Wedding March, dates from 1842). The overture The Hebrides (1829, also known as Fingal's (ave) was inspired by a visit to Fingal's Cave on the island of Staffa during a study tour, organised by his father, to Britain (1829) - the first of 10 visits. Travel also inspired Symphony No. 3 (Scottish, 1830-42) and No. 4 (Italian, 1833). Other important works include the two piano concertos $(1831,1837)$, two piano trios $(1839,1847)$, the deeply romantic Violin Concerto in E Minor (1838-44) and the oratorio Elijah (1846). Mendelssohn played a central role in the ${ }^{*}$ Bach revival and in Berlin (1829) directed the first performance of the St Matthew Passion since 1750. He conducted the Leipzig Gewandhaus Orchestra from 1835, raising it to new standards, and premiered *Schubert's Symphony No. 9 (in 1839). He also performed *Beethoven's piano concertos in London and (with Joseph *Joachim) revived the violin concerto (1844). He was also a gifted organist. He married (1837) Cecile Jeanrenaud and, with his family wealth, escaped the struggles and hardships with which so many artists have had to contend. However, he died early, of an aneurism in the brain, after the death of his much-loved sister Fanny.

Werner, E., Mendelssohn. 1963; Mercer-Taylor, P., The Life of Mendelssohn. 2000; Todd, R. L., Mendelssohn: A Life in Music. 2007.

Mendelssohn, Moses (1729-1786). German-Jewish philosopher. Grandfather of Felix *MendelssohnBartholdy, he was a noted propagandist for the social and legal emancipation of the Jewish people and at the same time tried to break down the prejudiced isolation of the Jews from those who did not share their faith. He was a close friend of the writer and critic *Lessing and collaborated with him on a book on the philosophy of ${ }^{*}$ Pope. He also wrote popular explanations of the sensations and metaphysics. In the dialogue Phaedon (1767) he discusses in Socratic manner the immortality of the soul, in Jerusalem (1783) he defends Judaism as a religion.

Attman, A., Moses Mendelssohn. 1973.

Menderes, Adnan (1899-1961). Turkish politician. He helped to found (1945) the Democratic party, led it in opposition and, when it came to power (1950), became Prime Minister. He brought Turkey into full membership of NATO (1951) and helped to bring about the Baghdad Pact (1955). He was reelected in 1957, but the extravagance of his social and economic policies and the allegedly corrupt practices of his administration provoked (1960) a successful military revolt. In May 1961 Menderes, found guilty of a number of personal and political offences, was hanged.

Mendès, Catulle (1831-1907). French poet, novelist and playwright, born in Bordeaux. Son of a Jewish banker, he lived in Paris from 1859. As co-founder of Le Parnasse contemporain (1866) he helped to give cohesion to the Parnassian group led by *Leconte de Lisle. He wrote a history of the movement (1884). His own poems owed more to facility of expression than to literary distinction.

Mendès France, Pierre (1907-1982). French Radical Socialist politician. A lawyer by profession, he gained a reputation through his books as a financial analyst before becoming a deputy (1932). He joined the air force in World War II, and eventually reached Algiers, later joining *de Gaulle and becoming Commissioner of Finance in the provisional government 1943-44. He was Minister of National Economy 1944-45 and, as Prime Minister 1954-55 played a leading part in bringing the war in Indo-China to an end. He became a powerful opponent of de Gaulle during the Fifth Republic. His autobiography, Pursuit of Freedom, was published in 1955.

Menelik II (originally Sahle Maryan) (1843-1913). Claiming descent from *Solomon and the Queen of Sheba, he was Negus of Shewa province 1866-89, and although nominally subject to the emperor Yohannes IV, greatly extended his dominions. Having subdued his rivals he was able to succeed when the emperor died. His relations with the Italians, who invaded Eritrea in 1885 and whose interests were extensive throughout the country, were at first friendly but difficulties of the interpretation of the Treaty of Ucciali (1889) led to war and Italy's calamitous defeat at Adowa (1896). Thus fortified, Menelik did much to modernise the administration and, by skilful bargaining with European powers, increased Ethiopia's economic strength. The British awarded him a GCB and GCMG. His grandson, Lij *Iyasu, converted to Islam and was deposed (*Haile Selassie).

Marcus, H., The Life and Times of Menelik II of Ethiopia, 1844-1913. 1975. 
Menem, Carlos Saúl (1930-2021). Argentinian politician, born in La Rioja. Of Syrian descent, and raised as a Muslim, he became active in the Peron Youth Group, graduated in law from Cordoba University and worked for trade unions in the La Rioja province. Governor of La Rioja 1973-76, 1983-89, he was imprisoned and then sent into internal exile by the military regime 1976-81. President of Argentina 1989-99, elected on the Peronista ticket, he amazed his supporters by repudiating his party's platform and instituted rigorous economic reform. In 1994 the constitution was changed to allow for a second presidential term (reduced to four years), and in 1995 Menem was re-elected, with 50 per cent of the vote, retiring in 1999. In 2001 he was charged with corruption over arms sales and escaped to Chile until 2004. Elected as Senator 2005-21, he was sentenced to seven years jail in 2013 for arms smuggling but avoided prison by claiming parliamentary immunity.

Mengelberg, (Josef) Willem (1871-1951). Dutch conductor. As conductor of the Amsterdam Concertgebouw Orchestra 1895-1945 he raised this ensemble to the first rank in Europe. His intensely romantic interpretations of *Bach, *Beethoven, ${ }^{*}$ Tchaikovsky, ${ }^{*}$ Mahler and Richard ${ }^{*}$ Strauss were successfully recorded. He was co-conductor of the New York Philharmonic 1921-29. He collaborated with the Germans during World War II and died in Switzerland as an exile.

\section{Menno Simons see Simons, Menno}

\section{Menon, V. K. Krishna see Krishna Menon, V. K.}

Menotti, Gian Carlo (1911-2007). Italian-American composer, born in Cadegliano. After studying at the Milan Conservatory, he emigrated to the US in 1927 and studied at the Curtis Institute, Philadelphia. He was the lover of Samuel *Barber 1930-70. He composed and wrote the libretti for a number of short incisive operas, e.g. The Consul (1950), an effective treatment of a modern theme that achieved great success, The Medium (1946), Amahl and the Night Visitors (1951, first performed on television) and The Saint of Bleecker Street (1955). He won the Pulitzer Prize in 1950 and 1955.

Trecoire, R., Gian Carlo Menotti. 1966.

Menshikov, Aleksandr Danilovich, Prince (c.16601729). Russian soldier and politician. The son of a groom, he was a guardsman in attendance on ${ }^{*}$ Peter the Great and became his close friend and advisor. He served with distinction against Sweden, and after the victory of Poltava (1709) was made a field marshal. On Peter's death (1725) Menshikov placed his widow ${ }^{*}$ Catherine I (his own former mistress whom he had introduced to the tsar) on the throne, and, during her brief reign of two years, virtually ruled the kingdom. His last days were spent in exile.
Menuhin, Yehudi, Baron Menuhin (1916-1999). American-British violinist, born in New York. Of Russian-Jewish parentage, he made his debut at seven. His precocious talent was shared by his pianist sister Hephzibah Menuhin (1922-1981). He developed into a brilliant virtuoso and a thoughtful interpreter of the concertos of ${ }^{*}$ Bach, *Beethoven, *Brahms, *Elgar and *Bartók. He toured the world with a triumphant success for many years but lived mainly in England, where he founded (1959) a music festival at Bath. Naturalised British in 1985, he received the OM in 1987, and a peerage in 1993.

Menzies, Sir Robert Gordon (1894-1978). Australian Liberal politician, born in Jeparit, Victoria. Educated at Melbourne University, he became a barrister and KC (1929), served in the Victorian Parliament 1928-34 and was Deputy Premier 1932-34. Member of the House of Representatives 1934-66, he was Attorney-General and Minister for Industry 1934-39 in the United Australia PartyCountry Party coalition led by J. A. *Lyons, and Deputy Leader of the UAP 1935-39. He resigned in March 1939 over the government's withdrawal of support for a national insurance scheme; 18 days later Lyons died suddenly and Earle *Page was sworn in as interim Prime Minister. Menzies defeated W. M. *Hughes to become Leader of the UAP and was Prime Minister 1939-41 and relied on the support of independent MPs after the 1940 election. Bitter personal differences inside the UAP were compounded by Menzies' long absence (January-May 1941) overseas to argue for greater Australian involvement in World War II strategy. Arthur *Fadden became acting Prime Minister. In Britain, Menzies had hoped for appointment to the War Cabinet, but ${ }^{*}$ Churchill was wary. Menzies resigned as Prime Minister in August and Fadden succeeded him August-October 1941 until John *Curtin's Labor Party took office. Menzies resigned as Leader of the UAP in October 1941 and Hughes was narrowly elected. After a devastating defeat in the 1943 election, the UAP fragmented and Menzies created a new anti-Labor coalition, the Liberal Party, which he led 1944-66. Prime Minister again 1949-66, for a record term, he maintained a strong political commitment to the British connexion and to closer economic and military alliance with the US. His political dominance was assisted by the split in the Labor Party over attitudes towards Communism. A persuasive orator, he was awarded the CH (1951), a KT (1963), AK (1976) and succeeded Winston ${ }^{*}$ Churchill as Lord Warden of the Cinque Ports 1965-78.

Hazelhurst, C., Menzies Observed. 1979; Martin, A. W., Robert Menzies: A Life. Vol 1. 1993; Brett, J., Robert Menzies' Forgotten People. 1992; Day, D., Menzies \& Churchill at War. 2001; Bramston, T., Robert Menzies: The Art of Politics. 2019. 
Mercator, Gerhardus (Gerhard Kremer) (15121594). Flemish geographer and cartographer, born in Rupelmonde (now in Belgium). He graduated from Louvain University where he worked as a map-maker and instrument designer until, as a Protestant, he emigrated to Germany (1552). In his double cordiform projection world map (1538), he first applied the name 'Americae' to both continents of the New World. On the edge is printed 'Climata Australia', but it is not linked to a specific location. Originally a follower of *Ptolemy, he devised the familiar 'Mercator projection' which represents the world, in effect, as a cylinder, not a globe, in which the meridians of longitude remain parallel without converging to a point at each pole. He used this projection for his world chart of 1569 (18 sheets). His maps facilitated sailing by dead reckoning and became useful and popular, since few sailors ventured beyond $50^{\circ} \mathrm{N}$ or $\mathrm{S}$. He also constructed globes. Two parts of his great atlas (107 maps in all) were published in 1585 and 1589; his son published the third part (1595) after his death.

Mercer, John (1791-1866). English calico printer. $\mathrm{He}$ discovered that cotton fibres could be made stronger and more receptive to dyes if treated with a solution of caustic alkali, a process known as 'mercerising'.

Merck, (Heinrich) Emanuel (1794-1855). German pharmacist. Working in the family business in Darmstadt, in 1827 he isolated alkaloids (common factors in morphine, cocaine, quinine, caffeine, nicotine) and produced them in large volume.

Meredith, George (1828-1909). English novelist and poet, born in Portsmouth. He contributed to periodicals, published much poetry and wrote an oriental fantasy The Shaving of Shagpat (1856) before the appearance of his first novel, The Ordeal of Richard Feverel (1859). He shared rooms with ${ }^{*}$ Swinburne and *Rossetti 1861-62. In 1862 he published his tragic poem Modern Love and became a reader to the publishers Chapman \& Hall (until 1894). In 1876 he settled at Flint Cottage, Box Hill, Surrey, his home for the rest of his life. Among his best known novels are Rhoda Fleming (1865), Beauchamp's Career (1876), The Egoist (1879), The Tragic Comedians (1880), based on the love story of Ferdinand *Lassalle, and Diana of the Crossways (1885), the only one to achieve real popularity. Meredith combined intellectual clarity, a hatred of the commonplace and an impressionistic technique. From this emerged a style so difficult and convoluted that Oscar *Wilde commented 'As a writer he mastered everything but language'. Meredith was twice married, in 1849 to a daughter of Thomas Love *Peacock, who left him in 1858 and died in 1861, and (1864) to Marie Vulliamy (d.1885), who lived with him at Box Hill. He received the OM in 1905.

Stevenson, L., The Ordeal of George Meredith. 1953.
Merian, Maria Sybilla (1647-1717). German entolomologist and illustrator, born in Frankfurt. She was an acute observer of caterpillars, silkworms, butterflies, moths, beetles and frogs. She understood the process of metamorphosis, producing strikingly accurate (and beautiful) illustrations, which were widely published. She worked in Surinam and lived in Amsterdam. Her admirers included *Peter the Great, Carolus *Linnaeus and David *Attenborough.

Mérimée, Prosper (1803-1870). French novelist and heritage pioneer, born in Paris. He studied law, language and literature, was inspired by his friend *Stendhal, and by the works of *Scott and *Pushkin and first gained attention with the publication of fake translations (actually original compositions). As the first Inspector-General of Historical Monuments 1833-60, he initiated the restoration and conservation of the abbey church at Vézelay, Notre Dame, Saint Denis, Carcassonne and many other decaying sites (*Viollet-le-Duc). In 1843 the Musée de Moyen Age (Cluny Museum) was established as a national institution. He had a great knowledge of archaeology and travelled widely. He was a friend of the future empress *Eugénie and became a member of the Académie française in 1844 and a senator in 1853 . He wrote many historical novels, but his best remembered works were Mateo Falcone (1833), a short story, Colomba (1840) and Carmen (1846), used as the basis of *Bizet's opera. His letters, published posthumously, were a critical appraisal of the Second Empire. He died in Cannes.

Raitt, A. W., Mérimée. 1970.

Merkel, Angela Dorothea (née Kasner) (1954- ). German Christian Democratic politician, born in Hamburg. Her father, a Lutheran pastor, took his family to East Germany when she was an infant; her mother was of Polish descent. She gained a doctorate in quantum chemistry at Leipzig University, married her first husband Ulrich Merkel in 1977, but only became politically active after the fall of the Berlin Wall (1989). She represented Leipzig in the Bundestag 1990-2021 and was Minister for Women and Young People 1991-94 and for the Environment 1994-98. A protégé of Helmut *Kohl, she later broke with him over the issue of corruption. Secretary General of the Christian Democratic Union (CDU) 1998-2000, she was Leader 2000-18. In November 2005, she became Chancellor of Germany, the first woman to hold the office and the first from the former East German Republic. The longest serving European political leader, she lost votes to the far right in the September 2017 election, but in February 2018 formed a coalition with the SPD (Social Democratic Party) She retired in September 2021. The CDU polled poorly in the 2021 election, in which she was not a candidate, and Merkel was criticised for failure in succession planning. Of post-World War II Chancellors, Merkel held office for a month less than Kohl. 
Merleau-Ponty, Maurice (1908-1961). French philosopher. He taught at Lyon, the Sorbonne and the Collège de France, and worked with *Sartre in editing Les Temps Modernes (1945-52) and defending Stalinist terror. He wrote The Phenomenology of Perception (1945, English translation 1962).

Merrick, Joseph Carey (1862-1890). English patient. He suffered from neurofibromatosis, a disease that caused grotesque malformation of the skull and he was exhibited in fairs and sideshows as 'The Elephant Man' until given sensitive treatment by the surgeon Sir Frederick Treves. In the film The Elephant Man (1980), Merrick's role was played by John Hurt. An alternative diagnosis was Proteus disease.

Howell, M. and Ford, P., The True History of the Elephant Man. 1980.

Mersenne, Marin (1588-1648). French scientist. Educated by the Jesuits, in 1611 he joined the Minim Order, and lived at the Minim Convent in Paris until his death. Mersenne's major contribution to European intellectual life lay in his vast correspondence. $\mathrm{He}$ acted as a kind of clearing house for all the great contemporary intellects in the fields of philosophy and science. He supported the modern, mechanistic philosophy against the science of the Ancients, and defended the right to pursue scientific knowledge against theological bigots. But he was also violently opposed to what he saw as 'atheistic' and 'materialistic' currents in the thinking of *Bruno, Campanella, and *Fludd. Mersenne's own scientific research was largely concerned with the physics of sound. He experimented with pitch and harmonies counting the vibrations of long strings against time: he succeeded in formulating quantified explanations of consonance, resonance and dissonance. He was interested in the effect of music on the human emotions, which he sought to attribute to entirely rational and mechanical forces. Mersenne emphasised that languages were merely combinations of signs invented by men for the sake of convenience in communication. Like many 17 th-century scholars he was eager to develop a perfect, universal language, based on scientific principles. Mersenne dedicated himself to scientific explanations. His dying wish was for an autopsy to discover the cause of his own death.

Mesmer, Franz Anton (1734-1815). Austrian physician. The word 'mesmerism' is derived from his name. His theories concerning the influence of planets on the human body and the existence of an all-pervasive 'magnetic fluid' that affected the nervous system naturally did not commend themselves to the medical profession. It was even less attracted by the healing sessions in Paris in which he appeared dressed in purple silk with an iron rod in his hand. A commission set up by the Académie des Sciences rejected (1784) his magnetic theories and thereafter his popularity waned. He owed his successes partly to the his patients, and partly to amelioration produced by hypnotism which he had the power to induce without being able to comprehend it.

Messager, André Charles Prosper (1853-1929). French composer and conductor. A pupil of *SaintSaëns, he first won wide acclaim with a comic opera, La Basoche (1890). He was artistic director Covent Garden, London, 1901-06 and the Paris Opera 1908-14. Monsieur Beaucaire (1919) was the best known for his 30 comic operas and operettas.

Ferner, H., André Messager. 1948.

Messalina, Valeria (24-48 CE). Roman Empress. Wife of ${ }^{*}$ Claudius, she was only 15 when she married, and as the beautiful young mother of his son Britannicus held Claudius completely enthralled, though notorious in Rome for her lasciviousness, amorality and the murders she instigated. Her downfall and execution was due to her 'marriage' in public to her favourite lover, Silius.

Messerschmitt, Willy (1898-1978). German aircraft designer and manufacturer. He produced his first aeroplane in 1916 and, a few years later, founded his own firm for their manufacture. His fighters and fighter bombers, Me. 109, 110, 210 and 410, were among the most successful German aircraft of World War II.

Messiaen, Olivier (Eugène Prosper Charles) (19081992). French composer, born in Avignon. Son of a professor of English and a poet, he taught himself the piano, then studied organ with Marcel Dupré and composition with Paul *Dukas. From 1931 he was organist at the Trinité Church, Paris, taught at the Schola Cantorum 1935-39, and was a professor of composition at the Sorbonne 1942-88: Pierre *Boulez, Yannis *Xenakis and Karlheinz ${ }^{*}$ Stockhausen were pupils. After army service, he was a prisoner of war at Görlitz (1940-41). Primarily a melodist, he used innovative tone-colouring influenced by his studies of Greek chants, Hindu ragas, bird songs, plainsong and microtonality. He wrote on musical theory and his philosophy was imbued with his Catholic faith. His major pieces include La Nativité du Seigneur (1935, organ solo), Quatuor pour la fin $d u$ temps (1941, piano, clarinet, violin, cello), Visions de l'Amen (1943, two pianos), Vingt Regards sur l'EnfantJesus (Twenty contemplations on the infant Jesus; 1944, piano, long, complex and mesmerising), TurangalilaSymphonie (1946-48, a luxuriantly romantic work, probably his most accessible), Chronochromie (1960, 'The Colour of Time' for large orchestra), Couleurs de la Cité Celeste (1963) and Et Exspecto Resurrectionem Mortuorum (1964). His second wife, Yvonne Loriod (1924-2010) was a magnificent pianist and teacher who premiered works by her husband and Boulez.

Griffiths, P., Olivier Messiaen. 1985; Hill, P. and Simeone, N., Messiaen. 2005. 
Mestrovic, Ivan (1883-1962). Yugoslav sculptor, born in Dalmatia. He studied in Vienna and Paris and between the two world wars became widely known for the vigorous monumental style and emotional intensity he applied to the many war memorials for which he was commissioned. In his own country his best known works include the great Yugoslav national temple at Kossovo and the immense statue of Bishop Gregory outside the walls of Split. He became a US citizen in 1954.

Metaxas, Ioannis (1870-1941). Greek soldier and dictator, born in Ithaca. He trained in Germany, and in the Balkan Wars 1912-13 secured Macedonia and Thrace for Greece. Chief of the General Staff 1913-17, he was close to King ${ }^{*}$ Constantine and opposed involvement in World War I. When *Venizelos seized power in 1917 and Greece joined the Allies, Metaxas was exiled to Corsica. He returned, and in 1922 founded the ultra-royalist Freethinkers Party. After the monarchy was restored, under ${ }^{*}$ George II he became Minister for War and for the Interior 1935-36. Prime Minister and Foreign Minister 1936-41, he ruled as a dictator until his death. He urged neutrality in World War II but his hand was forced when *Mussolini's forces invaded Greece, and Metaxas organised resistance, which succeeded until the Germans took over.

\section{Methodius, St see Cyril, St}

Metsu, Gabriel (1629-1667). Dutch genre painter, born at Leyden. He lived in Amsterdam from about 1650. His early work was religious, but, influenced by ${ }^{*}$ Rembrandt and ${ }^{*}$ Steen, he turned to subjects of domestic or urban life. His cheerful, robust paintings reveal a skilled handling of colour, and the effects of sunlight on dress and furniture.

Metternich(-Winneburg), Clemens Wenzel Lothar, Prince (1773-1859). Austrian statesman, born in Coblenz. Some experience of revolutionary methods gained as a student at Strasbourg University is said to have implanted his hatred of democracy but, as son of a diplomat and as a creator and expositor of Habsburg policy all his life, he could hardly have been otherwise. His diplomatic heritage was enlarged and his social and material standing greatly increased when he married the granddaughter and heiress of the Prince of ${ }^{*}$ Kaunitz-Rietberg. He became Austrian Minister to Saxony 1801-03, and Ambassador to Prussia 1803-05, Russia 1805-06 and France 1806-09. He was Austrian Chancellor and Foreign Minister 1809-48. His task was to provide a breathing space in which Austria could recover from successive defeats at the hands of the French. To achieve this he played a double game with great caution and skill. He negotiated the marriage of the Austrian archduchess Marie Louise with *Napoléon, and when the latter quarrelled with Russia provided him with a small Austrian contingent while secretly informing the tsar that he had nothing more to fear.
Thus, though he expected a French victory he was well placed to steer Austria to the winning side after the Moscow retreat of 1812 , and as the princely host (his title was conferred in 1814) at the Congress of Vienna, to play a dominating part in the reshaping of Europe after Napoléon's fall. The final settlement, for which Metternich found allies in ${ }^{*}$ Castlereagh for Britain and *Talleyrand, now acting for the restored monarchy of France, was a cleverly contrived balance of power, with Austria left at the head of a confederation of sovereign German states. Sustained by the 'Holy Alliance' of the rulers of Russia, Prussia and Austria, Metternich's Europe survived for some 30 years. He controlled Austria throughout, not so blind to the need for reforms as is often supposed, but so underrating the forces of nationalism that the revolutions of 1848 took him by surprise. He was forced to resign and, after spending 18 months of the intervening period in England, returned to Vienna in 1851 after the revolution had been suppressed.

Palmer, A. W., Metternich. 1972; Siemann, W., Metternich. Strategist and Visionary. 2016/19.

Meyer, Julius Lothar (1830-1895). German chemist. Professor of chemistry 1868-76 at Karlsruhe Polytechnic and then at Tübingen University, in Die modernen Theorien der Chemie (1864) he discussed the relation between the atomic weights and the properties, in particular the atomic volumes, of the chemical elements. In 1870 he put forward a periodic classification of the elements independently of, and a little later than, *Mendeleyev, but he did not see the important consequences of this relationship as clearly.

Meyerbeer, Giacomo (Jakob Liebmann Beer) (1791-1864). German-Jewish composer. Originally a boy pianist, he studied opera in Italy and there composed several works now forgotten. Once settled in Paris he developed a grandiloquent style, to which *Wagner, whom he befriended, owed much. This he successfully applied to such operas as Robert le Diable (1831), Les Huguenots (1836) and L'Africaine (produced 1865). Meyerbeer was immensely selfcritical and rewrote many passages time after time. He was known especially for his magnificent stage effects and choral climaxes.

Miaskovsky, Nikolai Yakovlevich (1881-1950). Russian composer. A pupil of *Glière and *RimskyKorsakov, he wrote 27 symphonies, other orchestral works, and chamber and piano music.

Michael I (Mihai von Hohenzollern-Sigmaringen) (1921-2017). King of Romania 1927-30 and 194047. He succeeded his grandfather, ${ }^{*}$ Ferdinand, as king, his father (later ${ }^{*}$ Carol II) having renounced his rights. In 1930, Carol seized power but in 1940 was again forced to abdicate. Michael, king once more, attempted to resist German encroachments in World War II and organised (1944) the coup d'état that took his country out of the war. In 1947, he was forced 
by Communist pressure to abdicate. A year later he married Princess Anne of Bourbon-Parma. He lived in England and Switzerland, became a test pilot, had his nationality restored in 1997 and was buried in Romania.

Michelangeli, Arturo Benedetti (1920-1995). Italian pianist, born in Brescia. Although he rarely gave concerts or recorded, Michelangeli acquired a legendary reputation for his performances of *Bach, ${ }^{*}$ Beethoven, ${ }^{*}$ Chopin, ${ }^{*}$ Debussy and ${ }^{*}$ Ravel.

Michelangelo Buonarroti (1475-1564). Italian painter, sculptor, artist and poet, born at Caprese, near Florence. Son of an official, Lodovico di Buonarroti Simoni (1444-1531) and Francesca Rucellai (1455-1481), as a boy of 13 he was apprenticed to *Ghirlandaio in Florence. In 1489 he came to the notice of *Lorenzo de'Medici who admitted him to his sculpture school in the Medici Gardens and took him into his house, where he met and was influenced by the poet *Politian and many humanist scholars. The Madonna of the Steps (in low relief) and the Battle of the Centaurs (in high relief and already showing the strength and energy of his maturity) belong to this period. In the confused years following Lorenzo's death (1492), Michelangelo left Florence for Bologna (1495-96) and in 1496 went to Rome, where he created the Bacchus (now in Florence) and the Pietà (1499) in St Peter's, showing the crucified Christ lying in the arms of the Virgin (perhaps a portrait of the artist's mother: she looks younger than her son). In Florence, 1501-04, he executed the colossal $(4.34 \mathrm{~m})$ marble statue David (now in the Accademia in Florence), in which the use of distortion and tension create the illusion of a perfect male form. Already contemporaries referred to his terribilita - the quality that inspired awe-although his famous outbursts of rage probably contributed. Michelangelo returned to Rome (1505) commissioned by Pope *Julius II to design and work on his tomb. The scheme was constantly reduced by the pope and his heirs, and Michelangelo completed only after years of intermittent work, the great statue of Moses (c.1513-15) and the figures of four slaves now in St Pietro in Vincoli. Many of his most powerful works were unfinished, including the Slaves in the Louvre and the Accademia. From 1508 to 1512 Michelangelo was again in Rome occupied with one of his greatest tasks, the decoration of the ceiling of the Sistine Chapel, a huge area of 340 sq. m. He painted 28 Old Testament subjects (Genesis, Prophets, Scenes of Salvation, Ancestors of Jesus) and five Sibyls, more than 300 figures. The outstanding central sections are Creation of Adam, Creation of Eve and The Fall of Man. Technically the work presented immense difficulties, partly of perspective, partly because the painting was awkward to execute. The figures depicted, e.g. those in the Creation of Adam and the nudes surrounding the main panels, illustrate the neo-Platonist theory that the beauty of the human body symbolises divine beauty. This idea, derived from his studies and colloquies with the scholars in Lorenzo's garden, permeates all
Michelangelo's work. From 1521 he devoted 14 years (with interruptions) to the Medici Chapel in the Church of St Lorenzo, Florence. The wall decorations and the tombs of Lorenzo and Giuliano de'* Medici were complete, or nearly so, as were the reclining figures of Day, Night, Dusk and Dawn. The chapel wall-an architectural experiment much imitated-is solely designed to provide a sculptured setting for the figures. But the project as a whole was left unfinished. Intermittently, until 1559, the library of St Lorenzo at Florence was also constructed to Michelangelo's designs. Here Manneristic techniques (e.g. pillars set in niches to conceal their function) begin to appear. In 1534 the Medici pope ${ }^{*}$ Clement VII summoned him to Rome to paint a fresco of the Last Judgment for the altar wall of the Sistine Chapel. The work, carried out (1536-41) under *Paul III, is one of the most awesome pictures ever painted, with Christ, the stern judge (but essentially an Apollonian figure, in the Greek style), the elect, observant and fearful, and the crowd of struggling nudes (about 300) representing the damned, it provoked controversy from the first, although the astounding quality of execution and the overwhelming power of the message was undeniable. (A major cleaning and restoration of the Sistine Chapel was completed in 1996.) The same mood of tragedy provoked by the sufferings of the world he lived in is visible in his last great paintings, the frescoes in the Pauline Chapel of the Vatican-the Conversion of St Paul and the Crucifixion of St Peter.

Michelangelo devoted his last 20 years mainly to architecture. In reconstructing the Capitol in Rome he designed the first planned square of modern times, he made additions to the Palazzo Farnese, but most important he was chosen (1546) to succeed Antonio da Sangallo (1483-1546) as chief architect of St Peter's. Here he modified *Bramante's original plans for transepts and choir and designed the new higher, lantern topped dome which towers over the building. Michelangelo never married and his longest sustained friendship was for the noblewoman and poet Vittoria Colonna (1490-1547), to whom he wrote some of the 100 or so sonnets which place him high among the poets of his time. Among his last sculptures were the Florence Pietà, including a self-portrait (c.154855) and the (disputed) Palestrina Pietà (c.1556). In his 80 s he devoted himself to solitary religious and mystical contemplation, between moods of ecstasy and despair and conscious of the dark abyss beneath the thin layer of civilisation. Michelangelo was the first great Mannerist artist, imposing his conceptions on nature. Primarily a sculptor, his pictures have been described as sculptures in paint, but just as his works are monumental, so he is a colossus dominating all the fine arts, painting, sculpture and architecture during the Renaissance.

Goldscheider, L., Michelangelo: Paintings, Sculpture, Architecture. 1953; Drawings. 1966; Summers, D., Michelangelo and the Language of Art. 1981; Stone, I., The Agony and the Ecstasy. 1987; Bull, G., 
Michelangelo. 1995; Neret, G., Michelangelo. 2000; Wallace, W. E., Michelangelo The Artist, the Man and his Times. 2011; Gayford, M., Michelangelo. His Epic Life. 2013; Hirst, M., Michelangelo: The Achievement of Fame. 2013; Wallace, W. E., Michelangelo: God's Architect. 2020.

Michelet, Jules (1798-1874). French historian. Professor of history at the Collège de France, Paris 1838-51, he conceived his longest work, the Histoire de France (24 volumes, 1833-46, 1854-67), as, in effect, a biography of the nation. However, his greatest achievement was Histoire de la Revolution (7 volumes, 1847-53) in which he defined the Revolution as a combination of 'Law, Right and Justice'. He saw the Revolution as both 'the heir and adversary of Christianity', based on a human community, not divine order. He rejected royalist reaction and Jacobin Terror. He was influenced by the work of *Vico.

Barthes, R., Michelet. 1978. trans. 1992; Johnson, D., Michelet and the French Revolution. 1990; Viallaneix, P., Michelet. 1998.

Michelson, Albert Abraham (1852-1931). American physicist, born Prussia (now in Poland). His family emigrated to the US in 1855. Early in his career he was an instructor in physics and chemistry at the US Naval Academy. Later he studied in Europe and on his return held two professorships before he was appointed (1893) chief professor at the Ryerson Physical Laboratory, Chicago. Much of his success was due to his extreme skill in designing optical instruments, e.g. the interferometer with which he carried out, with Edward *Morley, the famous Michelson-Morley experiment to determine the speed and direction of the earth through the ether. The basis of this experiment was to determine, with great accuracy, the velocity of light in two directions at right angles to each other. The two velocities were found to be exactly equal, this surprising result leading *Einstein to the formulation of his theory of relativity. Michelson made many determinations of the speed of light, the most accurate of which were made in 1924 and 1925. In 1907, he was awarded the Nobel Prize for Physics and the Copley Medal, and in the 1920s he used the interferometer to measure the diameter of stars.

Jaffe, B., Michelson and the Speed of Light. 1960.

Michener, James A(lbert) (1907-1997). American writer. His Tales of the South Pacific (1947) won the Pulitzer Prize, became the *Rodgers and *Hammerstein musical South Pacific, and a film (1958). A prolific novelist, he also wrote The Hokusai Sketch-Books (1958) and travel books on Iberia, Poland, Hawaii, Mexico, Alaska, the Caribbean and Texas. He received the Presidential Medal of Freedom in 1977.
Michurin, Ivan Vladimirovich (1855-1935). Russian horticulturist. He revived *Lamarck's thesis that even genetically inferior plants can be altered over generations if the environment is improved sufficiently. His views were enthusiastically promoted by his disciple T. D. *Lysenko.

Mickiewicz, Adam (1798-1855). Polish poet, born in Lithuania. The founder of the Romantic movement in Poland, he is regarded as among the greatest of its poets. During a period of exile he met *Pushkin; from 1829 he lived abroad, mostly in Paris. His poems are nearly all devoted to the exaltation of the Polish nation in one or other of its aspects. They include Ballads and Romances (1822), short epics, e.g. Konrad Wallenrod (1825-28), about the medieval struggles with the Teutonic knights, and above all his masterpiece, Pan Tadeusz (1834), an epic in 12 books describing the life of the Polish gentry and their decay, in the years 1811-12. Mickiewicz died at Constantinople, where he was trying to form a Polish legion to fight the Russians in the Crimean War.

Lednicki, W. (ed.), Adam Mickiewicz in World Literature. 1956.

Middleton, Thomas (1570?-1627). English dramatist, born in London. Educated at Oxford, he wrote for the Globe and Swan theatres in London and produced pageants. His comedies include $A$ Mad World, My Masters (1604) and his tragedies Women beware Women (1621) and The Changeling (1622). He probably collaborated with *Shakespeare on Timon of Athens (1605-06) and The Second Maiden's Tragedy (1611).

Mies van der Rohe, Ludwig (1886-1969). GermanAmerican architect, born in Aachen. Trained (like ${ }^{*}$ Gropius and ${ }^{*}$ Le Corbusier) by Peter ${ }^{*}$ Behrens, his architecture is notable for its use of glass walls, subtlety of proportion and refinement of detail. $\mathrm{He}$ is associated with the aphorism, 'Less is more'. He attracted international attention in 1921 with an all-glass skyscraper. In 1927 he was put in charge of a housing development in Stuttgart where steel construction was first applied to domestic building. His German Pavilion for the Barcelona International Exposition (1929) was a simple, elegant structure, a steel frame with glass and polished marble. Demolished in 1930, it was rebuilt in 1986 . He was the last director of the Bauhaus 1930-33, at Dessau. In the US from 1937, the best known of his later works include the Farnsworth house and the IBM Building in Chicago and the Seagram Building in New York. He directed the Illinois Institute of Technology's school of architecture 1946-58.

Blaser, W., Mies van der Rohe: The Art of Structure. 1965; Spaeth, D., Mies van der Rohe. 1985; Daza, R., Looking for Mies. 2000; Zimmerman, C., Mies van der Rohe. 2015. 
Mi Fei (Mi Fu) (1051-1107). Chinese painter, calligrapher, poet and scholar, born in Kiangsu province. A high ranking official, famous for eccentricity and a sharp tongue, he evolved his own distinctive 'pointillist' style, known as Mi dien ('Mi dots').

Mifune Toshiro (1920-1997). Japanese actor, born in China. The greatest Japanese screen actor, he achieved international recognition in *Kurosawa's films Rashomon (1950), Seven Samurai (1954) and The Lower Depths (1957). He later appeared in US and British films.

Mihailovich, Draga (1893-1946). Yugoslav soldier. In World War II, after the collapse of Yugoslav resistance of the German attack (1941), Mihailovich organised a resistance movement under the direction of the Yugoslav royal government in London. He was accused by ${ }^{*}$ Tito, the Communist leader, of acting with more vigour against his rival partisans than against the Germans. After the war Mihailovich was charged with collaboration and shot.

Mikhail (Romanov) (1596-1645). Tsar of Russia (1613-45). Grandnephew of *Ivan IV's wife, Anastasia, he was a member of a noble boyar family, elected as tsar during the 'time of troubles', an era of political instability, civil war and the claims of several pretenders ( ${ }^{*}$ Dimitri, False). Mikhail's father, the patriarch Philaret, dominated government until he died in 1633. During his reign the status of the peasantry deteriorated towards serfdom. The Romanov dynasty ruled until 1917.

Mikoyan, Anastas Ivanovich (1895-1978). Russian (Armenian) politician. After fighting in the revolutionary wars he rose quickly in the Communist ranks and from 1926, when he became Stalin's Commissar of Trade, showed an extraordinary ability to survive all political upheavals. Most of his appointments were connected with internal and external trade, he was a Politburo member 1935-66, first deputy premier 1955-64, and the first nonRussian president of the USSR 1964-65.

Milanković, Milutin (1879-1958). Yugoslavian (Serbian) mathematician and geophysicist. Trained in Vienna as a civil engineer, he was a professor at Budapest University 1919-41, 1945-58. He concluded that the very long-term variability in the Earth's climate was determined by changes in three cycles: (i) eccentricity in orbit-100,000 years; (ii) axial tilt relative to the sun- 41,000 years; and (iii) precession, or changes in orientation, of the Earth's axis-23,000 years. He published his major work Canon of Insolation and the Ice-Age Problem, in six volumes, in 1941, a bad time for scientific discourse. His work only gained general acceptance in the 1970s. Craters on the moon and Mars and Asteroid 1605 Milanković are named for him.
Miles, Bernard Miles, Baron (1907-1989). English actor and director. A successful character actor (e.g. as Joe Gargery in the film Great Expectations), he founded the Mermaid Theatre in 1950, producing operas, repertory and musicals. He was knighted in 1969 and created a life peer in 1979.

\section{Milford Haven, 1st Marquess of see Mountbatten}

Milhaud, Darius (1892-1974). French composer. One of 'Les Six', a group of French modernists who were active after World War I, and associated with important literary figures e.g. ${ }^{*}$ Claudel and ${ }^{*}$ Cocteau, he was both prolific and versatile. His works include the ballets Protéc (1913-19), Le Boeuf sur le toit (1919), and Le Création du monde (1923), in which he uses jazz techniques, the operas Bolivar (1943) and Christophe Colombe (1928), the suite Scaramouche (1939) for two pianos, much chamber music and many symphonies, some of them only a few minutes long. Milhaud was professor of music at Mills College, California 1940-47, and then returned to Paris to teach at the Conservatoire. He published Notes sans Musique (1952).

Roy, J., Darius Milhaud. 1969.

Miliband, David Wright (1965- ). English Labour politician, born in London. Of Polish-Jewish descent, he was educated at Oxford and MIT. MP 2001-13, he served as Secretary of State for the Environment 2006-07 and Foreign Secretary 2007-10. He became President and CEO of the International Rescue Committee in New York City 2013- . His brother Ed(ward Samuel) Miliband (1969- ), an economist, educated at Oxford, was MP 2005- , appointed by Gordon *Brown as Secretary of State for Energy and Climate Change 2008-10. After a close contest between the two brothers for Labour's leadership, after Gordon *Brown resigned, Ed Miliband was elected (September 2010) and became Leader of the Opposition. Heavily defeated in the May 2015 election, he resigned as Labour leader.

Mill, James (1773-1836). Scottish philosopher and political scientist. Son of a shoemaker, intended for the ministry he studied Greek and philosophy at Edinburgh University, but went to London (1802) and became a close friend of Jeremy *Bentham, who became a major influence. For some time he was editor of the Literary Journal and contributed articles to various other periodicals. In 1806 he began work on his History of British India, and its publication (181718) secured him a post at the London offices of the East India Company. He continued to write articles on political and economic subjects. His Elements of Political Economy (1821-22) was written primarily to educate his son John Stuart ${ }^{*}$ Mill. He also wrote Analysis of the Human Mind (1829).

Mill, John Stuart (1806-1873). British philosopher and economist, born in London. Rigorously educated by his father James *Mill, he began to 
learn Greek at the age of three, showed prodigious gifts, experiencing an abnormal (but not unhappy) childhood. He joined his father in the London office of the East India Company, working there 1823-58. *Bentham was a major influence, but Mill modified Utilitarianism's goal of 'the greatest happiness for the greatest number' by adding idealism, ethics and the need for long-term satisfaction. In philosophy he was an advocate of Induction (*Bacon's scientific method) and was influenced by *Locke's Empiricism. He wrote $A$ System of Logic (2 vols, 1843). His theory of Induction, arguing from the particular to the general, is now regarded as simplistic and overconfident. His Principles of Political Economy (1848) followed the general approach of ${ }^{*}$ Ricardo, but cautioned against harsh imposition of abstract reasoning. In On Liberty (1859), his greatest work, he warned against the danger of tyranny by majority, forcing conformity on minorities, emphasising the need to recognise and protect individual differences. He was also influenced and softened by his wife Harriet Taylor (née Hardy), the one romance in his life: he knew her from 1830, they married in 1851 and she died in 1858. As MP for Westminster 186568 , he advocated votes for women, proportional representation, and sympathised with trade unions and farm cooperatives. He died in Avignon and his Autobiography (1873) was published posthumously. His ideas and analytical method influenced the Fabian Society (founded in 1884).

Britton, K. W., John Stuart Mill: His Life and Philosophy. 2nd ed. 1969; Reeves, R., John Stuart Mill: Victorian Firebrand. 2008.

Millais, Sir John Everett, 1st Baronet (18291896). British painter, born in Southampton. From a Jersey family, he exhibited at the Royal Academy at the age of 17 . In 1848 he joined with his friends Holman *Hunt and *Rossetti in the foundation of the Pre-Raphaelite Brotherhood. His first picture in the Brotherhood's detailed manner, Christ in the House of his Parents (1850), caused controversy but such pictures as Ophelia, The Blind Girl and Autumn Leaves show the Pre-Raphaelites' preoccupation with colour, detail and design combined with the artist's own poetic vision. With the end (c.1859) of his PreRaphaelite period Millais lapsed into conventional sentimentality with such pictures as The Boyhood of Raleigh and the notorious Bubbles, a portrait of his grandson (Admiral Sir William James), which was bought as an advertisement for Pears' Soap, one of the earliest examples of a picture by a famous artist being used for such a purpose. He married (1854)*Ruskin's former wife, Euphemia (Effie) Gray. After *Leighton's sudden death in January 1896, Millais was elected President of the Royal Academy, then died himself in August.

Fleming, G. H., John Everett Millais: A Biography. 1998.
Millay, Edna St Vincent (1892-1950). American poet and playwright, born in Maine. Educated at Vassar, her verses, often in sonnet form, are intensely lyrical and derive in spirit and technique from the Elizabethans. In 1923, although actively bisexual, she married Eugen Jan Boissevain who supported her literary and social activism, and won the Pulitzer Prize for poetry. She also wrote short stories and plays, e.g. The Murder of Lidice (1942), and translated *Baudelaire's Flowers of Evil.

Miller, Arthur (1915-2005). American author. He wrote a number of powerful plays, some of which were filmed. They include All My Sons (1947), Death of a Salesman (which won the 1949 Pulitzer Prize), The Crucible (1953), based on the Salem witch trials, with uncomfortable parallels to McCarthyism ( ${ }^{*}$ McCarthy), filmed by a French company as Les Sorcieres de Salem, and A View from the Bridge (1955). He also wrote the novel Focus (1945). He married (1956) the film actor Marilyn *Monroe and following her death wrote After the Fall.

Miller, A., Timebends. 1987.

Miller, (Alton) Glenn (1904-1944). American dance-band leader, trombonist and composer. He formed his own band in 1938 and became world famous for a sweet orchestral sound, mainly saxophones, which was unique. He was made leader of the US Air Force Band in Europe during World War II and disappeared on a flight from England to France, becoming subject of a number of conspiracy theories. His posthumous popularity increased and his style and sound were widely imitated.

Miller, Henry (1891-1980). American writer, born in New York. He lived in Paris (1930-39) and later settled in California. His works are largely a passionate indictment of modern, especially American, civilisation, and an equally passionate affirmation of what is called the Bohemian life. His novels (largely works of heightened personal reminiscence) include Tropic of Cancer (1934) and Tropic of Capricorn (1938). Other works include The Colossus of Maroussi (1941), describing travels in Greece, and The AirConditioned Nightmare (1945). The early novels, first published in Paris, were banned as obscene in the US and Britain until 1961.

Gordon, W. A., The Mind and Art of Henry Miller. 1968.

Miller (né Meunier), Jacques Francis Albert Pierre (1931-). Australian medical scientist, born in Nice. In Australia from 1941, he worked at the Hall Institute in Melbourne. In 1961, he discovered the function of the thymus, the last human organ to be explained, and in 1967 he distinguished between T-lymphocytes (originating in the thymus) and B-lymphocytes (from bone marrow). He received the Copley Medal 
(2001), the (Australian) Prime Minister's Science Prize (2003), the Japan Prize (2018), and the Lasker Award (2019).

Miller, Joaquin (né Cincinnatus Heine Miller) (1837-1913). American poet, born in Indiana. His adventurous life among the Indians is reflected in his Songs of the Sierras (1871).

Marberry, M., Splendid Poseur. 1953.

Miller, Sir Jonathan Wolfe (1934-2019). English director and physician. Educated at Cambridge and London, he appeared with Alan *Bennett, Peter Cook and Dudley Moore in the review Beyond the Fringe 1961-64. He was an outstanding director of plays and operas, while also teaching and pursuing research in neurophysiology. He wrote books on psychology and physiology and presented many television programs.

Miller, J(oseph) Irwin (1909-2004). American industrialist, born in Columbus, Indiana. Educated at Yale and Balliol College, Oxford, he worked for the Cummins Diesel Engine Co. Inc in Columbus, Indiana, from 1934 and was Chief Executive 194477, making it an exemplary employer of women and African-Americans, commissioned outstanding architecture, and promoted the arts, environment and civic improvement. He undertook many commissions for the US Government-on housing, urban affairs, trade, health, money and credit. A strong supporter of *Johnson's civil rights legislation and a gifted linguist, he played a ${ }^{*}$ Stradivarius violin and promoted ecumenism in the World Council of Churches 196168. Several political scientists considered him the best qualified person to be President of the US, but he rejected all attempts to enter politics.

Miller, Stanley Lloyd (1930-2007). American chemist, born in California. A student of Harold *Urey, at the University of Chicago, he investigated pre-biotic organic chemistry (A. I. *Oparin, J. B. S. *Haldane). In 1953 he demonstrated that by creating a 'primordial' atmosphere of hydrogen, ammonia and methane, mixing this with distilled water, and exposing the combination to repeated electrical discharges, amino acids could be produced, suggesting a possible explanation for the development of cellular life on Earth. He taught at the University of California San Diego from 1960. In 1972 he repeated his earlier experiment, with more sensitive devices, detecting 23 different amino acids. However, his assumptions about the 'primordial' atmosphere were flawed, understating the predominance of nitrogen.

Millerand, (Étienne) Alexandre (1859-1943). French politician, born in Paris. Originally a lawyer and journalist, he began on the far left, then drifted steadily to the right. A Deputy 1885-1919, he was Minister for Commerce 1899-1902 and Minister for War 1912-13 and 1914-15. In 1919-20 he reorganised the administration of Alsace and Lorraine, regained from the Germans. Briefly Premier 1920, he was elected President of France 1920-24, resigning after a left victory in the Parliamentary elections, and became a Senator 1925-40.

Millet, Jean François (1814-1875). French painter. The son of a Normandy peasant, he idealised the life of the labourer in such pictures as The Angelus and The Man With a Hoe, painted with a deep religious sense but with a sentimentality which has alienated later generations. He lived for many years (from 1849) at Barbizon, a small town near Fontainebleau which gave its name to the 'school' of landscape painters gathered there. He was a profound influence on van *Gogh.

\section{Milligan, Spike (Terence Alan) see Goons, The}

Millikan, Robert Andrews (1868-1953). American experimental physicist, born in Illinois. Educated at Columbia University, he was professor of physics at Chicago University 1910-21, Director of the Norman Bridge Laboratory, Pasadena, and Chairman of the California Institute of Technology 1921-46. He carried out much research into atomic structure and cosmic rays, but is best known for his accurate determinations (1909) of the charge on the electron from measurements of the charge picked up by oil drops exposed to X-rays and for this was awarded the Nobel Prize for Physics (1923). He was over-cautious about ${ }^{*}$ Einstein's revolutionary theories and his name was removed from commemorative buildings due to his enthusiasm for eugenics.

Millin, Sarah Gertrude (née Leibson) (1889-1968). South African writer, born in Lithuania. She wrote 17 novels, including The Dark River (1919), God's Stepchildren (1924) and The Herr Witchdoctor (1941) and biographies of ${ }^{*}$ Rhodes (1933) and ${ }^{*}$ Smuts (1936). She became an increasingly anxious supporter of Apartheid.

Milne, A(lan) A(lexander) (1882-1956). British author, born in Scotland. He was assistant editor of Punch (1906-14) and later wrote successful comedies, e.g. Wurzel Flummery (1917), Mr Pim Passes By (1919), and The Dover Road (1922), but he is best known as the author of children's books written originally for his son Christopher Robin: When We Were Very Young (1924), Winnie the Pooh (1926), Now We Are Six (1927) and The House at Pooh Corner (1928). He dramatised Kenneth *Grahame's Wind in the Willows as Toad of Toad Hall.

Thwaite, A., A. A. Milne. 1990.

Milner, Alfred Milner, 1st Viscount (18541923). British administrator and politician, born in Germany. Educated at Tübingen, London and Oxford, he became a journalist, edited Arnold *Toynbee's work The Industrial Revolution and helped to found Toynbee Hall. Undersecretary of Finance in Egypt 1890-92, he returned as Chairman of 
the Board of Inland Revenue 1892-97. As High Commissioner for South Africa 1897-1905 and Governor of Cape Colony 1897-1901, he worked closely with ${ }^{*}$ Rhodes and pushed ${ }^{*}$ Kruger towards war (1899). With *Kitchener he negotiated the Treaty of Vereeniging which ended the Boer War (1902) and was created Viscount. He governed Transvaal and the Orange Free State until 1905, introduced Chinese indentured labour and with his 'Kindergarten' of young Oxford-trained advisors (including Lionel Curtis, Leo *Amery, John *Buchan, and Philip Kerr) attempted to set up representative institutions. He became the ideologist of a British Commonwealth which was to be an organic 'race-empire' with a prescribed constitution. In the House of Lords he led the 'die-hard' opposition to *Asquith and *Lloyd George (1909-11) and covertly supported a coup in Ulster against Home Rule proposals (1913). He served in *Lloyd George's Cabinet 1916-21, pushed for a unified command in France under ${ }^{*}$ Foch and campaigned for Imperial Preference.

\section{Milnes, Richard Monckton, 1st Baron Houghton} (1809-1885). English politician and literary patron, born in London. Educated at Trinity College, Cambridge, he travelled in Europe extensively, and was MP 1837-63 for Pontefract (where he lived the life of a cultural dilettante at Fryston Hall), first as a Tory, then a Whig, sponsoring such liberal causes as slave emancipation and women's rights. Although an unsuccessful suitor of Florence ${ }^{*}$ Nightingale, he actively promoted her causes. He was also a major collector of pornography. Through his support his friend *Tennyson became Poet Laureate, and he early perceived *Swinburne's genius. He wrote poetry and travel books which recorded such adventures as his penetration of an eastern harem. ${ }^{*}$ Disraeli depicted him in Tancred as $\mathrm{Mr}$ Vavasour. His son became Marquess of ${ }^{*}$ Crewe.

Pope-Hennessy, J., The Years of Promise; The Flight of Youth. 1949.

Milosevic, Slobodan (1941-2006). Serbian politician. After a career in student politics, he became a Communist Party administrator and bureaucrat in Belgrade, involved in the gas industry and banking, and rose to be head of the Serbian CP. After the breakup of the former Yugoslavia, he became President of Serbia 1989-97, then won the ceremonial post of President of Yugoslavia 1997-2000, expecting to exercise power through subordinates. He bore major responsibility for the continued bloodshed in fighting against Croatia and within Bosnia-Herzegovina. The expulsion and killing ('ethnic cleansing') of Albanians from Kosovo (April-June 1999) led to NATO bombing and missile attacks on Serbia and NATO occupation of Kosovo under UN direction. However, Milosevic retained power, exploiting intense Serbian national feeling until defeated in elections held in October 2000. He reluctantly conceded defeat after huge public demonstrations throughout Serbia, and was sent to the Netherlands for trial before an international tribunal, but he died suddenly before the trial concluded.

Milosz, Czeslaw (1911-2004). Polish poet, novelist and essayist, born in Lithuania. He fought in the Resistance but left Poland in 1951, becoming a US resident in 1960 and a professor of Slavic literature at Berkeley 1960-78. He won the 1980 Nobel Prize for Literature.

Milstein, César (1927-2002). Argentinian-JewishBritish molecular biologist, born in Argentina. He worked in Cambridge on monoclonal antibodies and received the Nobel Prize for Medicine (1984), the Copley Medal (1989) and a CH (1995).

Milstein, Nathan Mironovich (1903-1992). Russian-Jewish-American violinist, born in Odessa. He studied with Leopold Auer and Eugène *Ysaÿe, and is ranked with ${ }^{*}$ Heifetz and ${ }^{*}$ Oistrakh as one of the greatest modern violinists, and a superb interpreter of ${ }^{*}$ Bach.

Miltiades (d.c.488 BCE). Athenian general. Famous for his great victory over the Persians at Marathon (490), it was through his persuasion that the outnumbered Athenian army left the doubtful protection of the city walls and met the enemy near their landing place. By strengthening his flanks at the expense of his centre he achieved an encircling movement, from which few of the enemy escaped. According to legend, news of the victory was taken to Athens (about $240 \mathrm{~km}$ ) by the runner *Pheidippides, a feat commemorated by the Marathon race at the Olympic Games.

Milton, John (1608-1674). English poet, born in London. Son of a scrivener (i.e. a legal draftsman), he was a precocious scholar at St Paul's School, London, and spent seven years at Christ's College, Cambridge, graduating MA in 1632 . He then spent six years at his father's country house at Horton, Buckinghamshire, and in this Anglican and Puritan household studied in preparation for his poetic vocation. There and at Cambridge he wrote many of his earliest works, e.g. the Hymn on the Morning of Christ's Nativity (1629), Il Penseroso and L'Allegro (both 1632), the masque Comus (1634), and the great pastoral elegy Lycidias (1637), written in memory of his friend Edward King, drowned in the Irish Sea. Milton travelled (1638-39) in Italy, where he met ${ }^{*}$ Galileo in prison. After returning to England he virtually gave up writing poetry for 20 years (except sonnets, e.g. On the late Massacre in Piedmont), and devoted himself to parliamentary causes, writing pamphlets against episcopacy, e.g. The Reason of Church Government (1642). He married (1642) Mary Powell, who left him after a few months and did not return until 1645. During her absence Milton wrote The Doctrine and Discipline of Divorce, which advocated the dissolution of unhappy marriages. Two other famous 
pamphlets are Tractate on Education and Areopagitica (both published 1644), the latter championing the liberty of the Press. A pamphlet defending the execution of ${ }^{*}$ Charles I was published in 1649. As Secretary for Foreign Tongues to the State Council 1649-59, he became an official propagandist for ${ }^{*}$ Cromwell. He suffered from glaucoma (or retinitus pigmentosa) from 1644 and became totally blind in 1654 , continuing to work with the assistance of his daughter and several amanuenses, including Andrew *Marvell. After his first wife died (1652), he married Catherine Woodcock in 1656, her death two years later prompting the famous sonnet $O n$ His Deceased Wife. On the fall of the Commonwealth in 1659, the blind poet was briefly imprisoned. After ${ }^{*}$ Charles II's restoration he went into hiding but was soon pardoned and in 1662 he married Elizabeth Minshull, who survived him.

Paradise Lost (published 1667), his great epic in blank verse, tells the story of Satan's rebellion against God, of the subsequent scenes in Eden and of the fall of Man. In 1671 the 12 books of Paradise Lost were followed by the four of Paradise Regained, which recounts Christ's victory over Satan after the temptation in the wilderness. It is an allegory on a much less ambitious scale, less highly coloured in style and language but with a distinctive subtlety of its own. Samson Agonistes (1671), constructed like a Greek tragedy, gives the biblical theme a pathos and inspirational power transcending the original. Milton's later prose works, e.g. the tract Of True Religion (1673), are of less interest. Because of the majesty and sublimity of his language Milton has generally been placed next to * Shakespeare, but he has never moved the hearts of the masses. Some critics have even contended that he was a bad influence, especially on 18th-century poets, who imitated his solemn and sonorous verse without matching the grandeur and intensity of his thought.

Tillyard, E. M. W., Milton. Rev. ed. 1966; Wilson, A. N., The Life of John Milton. 1983; Lewalksi, B. K., The Life of John Milton. 2002; Campbell, G., and Corns, T., John Milton: Life, Work and Thought. 2008; Beer, A., Milton: Poet, Pamphleteer and Patriot. 2008; Hawkes, D., John Milton: A Hero of Our Time. 2009.

Mindszenty (né Behm), József (1892-1975). Hungarian prelate, born in Csehimindszent. Strongly opposed to the Hungarian Arrow Cross, imprisoned (1944) by the Nazis, he was Archbishop of Esztergom 1945-73, Primate of Hungary and a cardinal in 1946. An ardent upholder of the Church's rights and of the national cause, he was imprisoned by the Communists (1949). During the revolt of 1956 he was released but, when the Russians restored Communist power, he was forced to take refuge in the US embassy and lived there for 15 years. Pope *Paul VI retired him in 1973, against his will. His Memoirs were published in 1975.
Ming. Chinese dynasty which ruled 1368-1644, the last Han imperial family, and the only one from the south, founded by ${ }^{*}$ Chu Yuan-chang.

Minto, 1st Earl of, Gilbert Elliot (1751-1814). British soldier and administrator. He took part in the impeachment of Warren ${ }^{*}$ Hastings and was Governor-General of Bengal 1806-13. He captured Mauritius and Batavia during the Napoléonic Wars. His great-grandson, Gilbert John Murray Kynynmond Elliott, 4th Earl of Minto (18451914), had an adventurous early career as soldier and war correspondent in many parts of the world. ( $\mathrm{He}$ also rode in the Grand National five times.) In 1891 he inherited the earldom and was Governor-General of Canada 1898-1904 in the Klondike gold rush period. As Viceroy of India 1905-10, he initiated the Minto-* Morley reforms which increased the numbers and powers of the central and provincial executive and legislative councils and introduced more Indians at all government levels. He also banned the export of opium.

Mintoff, Dom(enico or Duminku) (1916-2012). Maltese politician. A Rhodes Scholar, he studied in Oxford, becoming an architect and civil engineer, practising in Britain 1941-43. Elected to the Government Council in 1945 and the Legislative Assembly in 1947, he was Deputy Prime Minister and Minister for Public Works and Reconstruction 1947-55 and Prime Minister 1955-58. After a party split, he refounded the Malta Labour Party and led it 1949-84. Bitterly opposed by the Catholic hierarchy, he left government to work for Maltese autonomy after his proposal for full integration with the UK failed.

Malta became fully independent in 1964 and a republic in 1974. Mintoff, again Prime Minister 1971-84, was criticised for corruption and an authoritarian streak.

Minton, Thomas (1765-1836). English potter. After working for Josiah *Spode he started his own factory (1796), produced earthenware and bone china, and became well known for his decorated vases and 'Parian' figures and groups. He was also a noted engraver.

Mirabeau, Honoré-Gabriel Victor Riqueti, Comte de (1749-1791). French politician and orator, born in Bignon. His father Victor Riqueti, Marquis de Mirabeau (1715-1789), soldier, agronomist and political economist, was associated with the Physiocrats. Wild and dissipated as a young man, he was imprisoned and exiled by his father for debt and sexual offences. He lived as a hired propagandist, by journalism and pamphleteering, including the famous On Despotism (1772). He interviewed *Friedrich II ('the Great') in Potsdam and wrote The Prussian Monarchy (largely plagiarised, 1787). When ${ }^{*}$ Louis XVI summoned the Estates-General in 1789, 
Mirabeau was elected by the third estate for Aix and, by his virtuosity as an orator, soon became dominant. He proposed converting the Estates-General to the National Assembly. The phase that followed the fall of the Bastille and the transference of the royal family (October 1789) from Versailles to Paris saw Mirabeau at the height of his power. On the one hand he led the Assembly in its debate on a new constitution, on the other he was acting as secret advisor to Louis XVI and accepting bribes for his help in preserving as much as he could of the royal prerogative. That he would have performed in the same way without bribes (for, despite the violence of his oratory, he was a cautious and moderate constitutionalist) is likely but irrelevant to the moral issue. Unfortunately neither Louis nor *Marie Antoinette (whom Mirabeau met only once) could overcome their aversion to his reputed character, and they withheld the trust that would have enabled Mirabeau to act with confidence on their behalf. After his sudden death at 42 there was no one to protect them from their own weakness and folly.

Miranda, Francisco de (1750-1816). Spanish American soldier, born in Venezuela. He served in the Spanish army against the British in Florida. Suspected of disloyalty to the Spanish crown he spent many years in the US and Europe (and fought for a time as a general in the French Revolutionary armies), trying to enlist support for freeing Venezuela from Spanish rule. He returned to London (1798) and finally gained British and American support for an expedition that sailed (1806) from New York. The result was a fiasco, but when a junta seized power in Venezuela (1810), he again left England to lend support. Eventually he became Commander-in-Chief of the Venezuelan forces but was forced to capitulate (1812). He died in prison.

Miró, Joan (1893-1983). Spanish (Catalan) artist, born in Barcelona. Son of a goldsmith, after some years as a clerk, he suffered a breakdown, then devoted himself to art, working as painter, sculptor, lithographer, engraver, ceramicist, costume designer and in stained glass. He worked with the French Dadaists for a time, later joined André *Breton's Surrealist group and designed settings and costumes for *Diaghilev's Ballets Russes. His familiar style, internationally recognised from the 1940s, had a variety of influences ranging from Paleolithic cave art, *Bosch, van ${ }^{*}$ Gogh, ${ }^{*}$ Klee, the Fauves and Cubists, and the experiences of dreams and hallucinations (some induced by hunger). It was an art of hieroglyphs and symbols painted with strokes and spots in primary colours, red, blue, yellow, usually against a green or black background. He preferred to work on a large scale as in his The Wall of the Moon and The Wall of the Sun, in ceramic tiles, for the UNESCO building, Paris (1957) and a mural at Barcelona airport (1969). After 1945 he divided his time between Majorca, Barcelona and Paris.

Penrose, R., Miró. 1970, rev. 1985; Dupin, J., Miró. 1993.
Mirren, Dame Helen Lydia (originally Mironoff) (1945- ). English actor, born in Chiswick. Of Russian-English parentage, she joined the Royal Shakespeare Company in 1966 and played many roles by ${ }^{*}$ Shakespeare, ${ }^{*}$ Chekhov, ${ }^{*}$ Strindberg and *O'Neill. From 1967 she acted in more than 75 films, including the title role in Elizabeth I (2005) and as *Elizabeth II in The Queen (2006, Academy Award) and in The Tempest (2010), as Prospera. At the National Theatre she was a memorable Phèdre (2009). Her performance as Elizabeth II in The Audience (2013) was also acclaimed.

Mirrlees, Sir James Alexander (1936-2018). Scottish economist. Educated at Edinburgh and Cambridge universities, he taught at MIT, Oxford, Cambridge, Yale, Berkeley, Melbourne and Hong Kong. He shared the 1996 Nobel Prize for Economics with William Vickrey for their independent work on 'the economic theory of incentives under asymmetric information', essentially how to ensure that the rich pay taxes when they can exploit ways to avoid it.

Mises, Ludwig von (1881-1973). Austro-American economist and social philosopher. A pioneer (with F. A. von ${ }^{*}$ Hayek) of the neo-classical revival in economics, he lived in the US from 1940 and was a powerful critic of government intervention in the economy.

Mishima Yukio (1925-1970). Japanese novelist, born in Tokyo. The son of a civil servant, he was rejected for war service, studied law and worked in the finance ministry. He devoted himself to writing after the success of his autobiographical Confessions of a Mask (1948). His novels include The Temple of the Golden Pavilion (1959) and The Sea of Fertility (1970). He also directed and starred in the film Yukoku (1966). Obsessed with the disappearance of the bushido tradition, he formed a small private army, attempted a coup and died by hara-kiri in the traditional manner.

Mistinguett (Jeanne-Marie Bourgeois) (1875-1956). French dancer, singer and comedian. One of the great stars of the Paris music-halls, she appeared in revue from about 1899 and in the 1920s her partnership with Maurice ${ }^{*}$ Chevalier at the Folies Bergère and elsewhere made her world famous.

Mistral, Frederi (Frédéric) (1830-1914). French poet, born near Avignon. He lived in Provence, and the Provençal language was both the object of his study and the instrument of his creative work. The rural epic Miréio (1859) was the most popular of his books but with Nerto (1883), a novel in verse about Avignon in the years of papal residence, he achieved almost equal success in another field. In his longer works he showed narrative skill and a great sense of character, while his lyrics are often exquisite. After 14 nominations, he received the Nobel Prize for Literature in 1904. 
Mitchell, Margaret (Munnerlyn) (1900-1949). American novelist, born in Atlanta, Georgia. In 1936 she published Gone with the Wind, which won her the Pulitzer Prize (1937) and sold 28 million copies. The film (1939), with Clark ${ }^{*}$ Gable, Vivien ${ }^{*}$ Leigh and Leslie *Howard, produced by David O. ${ }^{*}$ Selznick was even more successful.

Edwards, A., The Road to Tara. 1983.

Mitchell, Sir Thomas Livingstone (1792-1855). Scottish soldier, explorer and collector, born in Grangemouth. He served in the Peninsular War as a surveyor, arrived in Sydney in 1827 and became Surveyor-General of New South Wales 1828-55, leading four major expeditions to explore the interior, in $1831,1835,1836$ and $1845-46$.

Mitchell, William Lendrum (1879-1936). American soldier and airman. After World War I, in which he rose to be chief of air operations, he carried out a vigorous campaign against official failure to realise the importance of air power. When he attacked a superior for 'almost treasonable incompetence', he was court-martialled and had to resign. In one of his many books on air warfare he predicted the Japanese attack on Pearl Harbor. Nine years after his death he was vindicated by Congress, posthumously promoted to the rank of Major General and awarded the Medal of Honor.

Mitchell, R., My Brother Bill, the Life of General 'Billy' Mitchell. 1953.

Mitford, Nancy Freeman- (1904-1973). English novelist and biographer. Eldest of six daughters of

David Bertram Ogilvy Freeman-Mitford, 2nd Baron Redesdale (1878-1958), she was educated at home. Her romantic comedies of upper class manners were widely popular and her historical biographies well regarded. In 1956 she edited Noblesse Oblige, a catalogue of class mannerisms which defined behaviour as ' $U$ ' (Upper class) or 'Non-U'. Her best known novels are probably The Pursuit of Love (1945) and Love in a Cold Climate (1949). Her biographies include The Sun King (a study of *Louis XIV, 1966). Her sisters were celebrated in their own right: Diana (1910-2003) married Oswald *Mosley, Unity (19141948) had an unrequited passion for *Hitler, Jessica (1917-96), an investigative journalist in the US, was firmly identified with radical causes and Deborah Vivien (later Cavendish) (1920-2014) became Duchess of Devonshire and wrote extensively.

Hastings, S., Nancy Mitford. 1985.

Mithradates VI ('the Great') (c.132-63 BCE). King of Pontus (c.120-63). Sixth ruler of a Hellenised state in Anatolia, bordering on the Black Sea, he succeeded his father and in 115 deposed his mother who had ruled as regent. He added Crimea and Colchis to his kingdom, but when he occupied Bithynia and was forced by *Sulla to withdraw and pay a large indemnity. When Rome became involved in civil war, Mithradates felt it safe to refuse to pay and so provoked the First Mithradatic War (89-84). He began it by overrunning Asia Minor and sending troops to Greece to raise that country against Rome. Sulla, victorious in the political struggle at home, went to Greece where he defeated Mithradates at Chaeronea and Orchomenos. Having crossed to Asia Minor he found that the Roman army sent by his opponents was already victorious, and was thus able to impose a settlement by which Mithradates renounced his conquests. The Second Mithradatic War (83-81), a minor affair provoked by an irresponsible act of aggression by the Roman legate left in command, made Mithradates angry and suspicious and he began to make preparations for a renewal of the struggle by forming alliances with Egypt, Cyprus and Roman malcontents. To anticipate him, Rome declared war (74). Mithradates won an early naval victory, but the Roman commander *Lucullus forced him to the defensive, and he took refuge with his son-in-law Tigranes of Armenia. A mutiny among the Roman troops allowed him to return to Pontus (67), but *Pompey completely defeated him. According to legend, Mithradates, from his youth, took increasing quantities of poison to render himself immune from murder: at his end, in the Crimea, he ordered a soldier to kill him.

Mitropoulos, Dimitri (1896-1960). GreekAmerican conductor, born in Athens. Also a composer and pianist, he studied with *Busoni and *Kleiber, conducted the Minneapolis Symphony 1937-47 and the New York Philharmonic 1949-59. Leonard *Bernstein was a disciple. He died of a heart attack conducting *Mahler's Symphony No. 3.

Mitscherlich, Eilhardt (1794-1863). German chemist. A pioneer of crystallography, he recognised isomorphism, dimorphism, and stated (1819) the law of isomorphism which bears his name, i.e. that substances that crystallise in the same crystal form have similar chemical compositions. This law was of great value during the early 19th century in fixing the formulae of newly discovered compounds. Professor of chemistry at Berlin University 1822-63, elected FRS (1828), he synthesised and named benzene (1834) and recognised catalytic action.

Mitterrand, François Maurice Marie (19161996). French Socialist politician, born in Jarnac, Charente. Educated at the University of Paris, after a conservative youth and military service, he worked with the Vichy regime but also joined the Resistance. He was a deputy $1946-58,1962-81$ and a senator 1959-62, serving as a minister in 11 governments under the Fourth Republic. He contested the French presidency in 1965 and 1974, losing to Charles *de Gaulle and Valery * Giscard d'Estaing. He organised a coalition of all socialist parties (other than the Communists) and became first secretary of the 
unified French Socialist Party 1971-81. He served two terms as President of the French Republic 1981-95, defeating Giscard in 1981 and Jacques ${ }^{*}$ Chirac in 1988 . His foreign policies were essentially Gaullist and domestically his bold interventionist policies, especially in industry, were constrained by the impact of recession. He promoted the creation of great monuments in Paris, notably La Grande Arche (at La Defense), extensions to the Louvre (and I. M. *Pei's glass pyramid), the Opera Bastille, and the science centre at La Villette. The longest serving French head of state since *Napoléon III, he died 15 years after prostate cancer was diagnosed. The huge Bibliothèque National at Tolbiac was named for him (1996). He became an honorary British GCB and received the Royal Victorian Chain.

Péan, P., Une jeunesse française: François Mitterrand 1934-37. 1994; Lacouture, J., Mitterrand. 2 vols, 1998; Short, P., Mitterrand: A Study in Ambiguity. 2013.

Miyazawa Kiichi (1919-2007). Japanese politician. He worked in the Finance Ministry 1942-52, served in the House of Councillors 1953-65 and the House of Representatives 1967-2003, holding many ministries, including Foreign Affairs 1974-76 and Finance 1986-88. He was Prime Minister 1991-93, leading the Liberal Democratic Party (LDP) to heavy defeat and loss of office after 38 years.

Mizoguchi Kenji (1898-1956). Japanese film maker. From 1922 he directed 87 films, very few seen in the West, the greatest probably being Ugetsu Monogatari (The Story of Ugetsu, 1953), Sansho Dayu (1953) and The Street of Shame (1957), eloquent and often beautiful expositions of universal values.

Mobutu Sese Seko Nagpendu Wa Zu Banga (né Joseph-Desiré Mobutu) (1930-1997). Congolese soldier and dictator. Employed in the Belgian Congo Force Publique 1949-56, he became a member of Mouvement National Congolaise, and was a delegate to the Brussels conferences on independence, 195960. Following independence he became Secretary of State for National Defence in the Cabinet of Patrice *Lumumba in 1960, and he was also Commanderin-Chief of the army 1960-65. In 1965, he displaced President ${ }^{*}$ Kasa-Vubu and Prime Minister Kimba in a bloodless coup and was President of the Democratic Republic of the Congo (which he re-named Zaire in 1971) 1965-97. He established authoritarian rule, torturing and executing opponents and amassing great wealth, while shrewdly negotiating political alliances with foreign governments. He became a marshal in 1982 and was overthrown and exiled in May 1997, then died of cancer in Morocco.

Moctezuma II (or Xocoyotzin, the Spaniards called him Montezuma) (c.1468-1520). Mexican (Aztec) Emperor 1502-20. Son of the emperor Axayacatl (d.1481), he succeeded his uncle Ahuitzotl at the height of the Aztec empire, extending to Nicaragua, with a population of perhaps 8 million (estimates vary wildly, from 4 to 30 million). Originally trained for the priesthood, and deeply superstitious, he was not warlike by nature and when the Spanish conquistador ${ }^{*}$ Cortés arrived in 1519 may have believed he was a reincarnation of the god Quetzalcoatl. He offered Cortés propitiatory gifts of gold and silver. These only whetted the Spanish appetite for plunder and when repeated embassies and an ambush also failed to stop Cortés he decided to give him a ceremonial welcome at Tenochlitlan, his lake-encompassed capital. Cortés managed to seize him as a hostage but, on returning from a temporary absence, he found that his men in sudden panic had started a massacre (the Noche Triste) and were now besieged with Moctezuma. The Spanish explained that while Moctezuma was trying to appeal to his own people from the walls, he was struck by many stones and died four days later. The Aztecs believed he had been strangled (or put to the sword).

Thomas, H., The Conquest of Mexico. 1993.

Modi, Narendra Damodardas (1950- ). Indian politician. Chief Minister of Gujerat 2001-14, he led the Bharatiya Janata Party (BJP) to an overwhelming majority in the elections of May 2014, smashing the Congress Party and its allies, and became Prime Minister of India 2014- .

Modiano, (Jean) Patrick (1945- ). French novelist. He wrote the screenplay for Lacombe, Lucien (1974). Sometimes described as the 'Marcel Proust of our time', he won the 2014 Nobel Prize in Literature 'for the art of memory with which he has evoked the most ungraspable human destinies and uncovered the lifeworld of the occupation' [of France by the Germans 1940-45]. Since winning the prize, 22 of his novels have been published in English.

Modigliani, Amadeo (1884-1920). Italian artist, born in Livorno. After an artistic education based on study of the old masters, he went to Paris (1906) and met several of the 'Fauves' group. He lived in great poverty and died of tuberculosis, complicated by drink. His portraits and melancholy nudes, which now command high prices, show the influence of ${ }^{*}$ Cézanne and primitive African sculptors, but the melody of line produced by subtle linear distortion expresses his own individual genius. La Belle Romaine sold at auction for \$US68.9 million in 2010, and Reclining Nude (No. 2) for \$US140 million in 2015.

Werner, A., Modigliani. 1967.

Modigliani, Franco (1918-2003). Italian-American economist. In the US from 1940, he taught at the Massachusetts Institute of Technology and won the 1985 Nobel Prize for Economics. 
Mohammad Reza Pahlavi (1919-1980). Shah of Iran 1941-79, Shahanshah from 1967. Born in Tehran, he succeeded his father ${ }^{*}$ Reza Shah, who was forced to abdicate by the Allies in World War II. He made efforts to modernise his country, to reform economic inequalities, but he scorned western liberalism. From the 1970 s onwards he was under increasing pressure from an Islamic fundamentalist movement ( ${ }^{*}$ Khomeini). In January 1979 he left Iran with his family and stayed in Morocco, Mexico, the US and Panama. The religious leaders demanded his return to Iran to answer charges of corruption. In March 1980 he moved to Egypt and died of cancer in Cairo in July.

Kapuscinski, R., Shah of Shahs. 1982.

\section{Mohammed see Muhammad}

\section{Mohammed II ('the Conqueror') see Mehmet II Fatih}

Mohammed V (Sidi Mohammed ben Yussuf) (19101961). King of Morocco 1956-61. He succeeded as sultan under French protection (1927) but in 1953 he put himself at the head of the nationalist movement until deposed and exiled by the French. Restored in 1955, when Morocco gained independence (1956) he became its first king, abandoning (1957) the title sultan. He was succeeded by his son ${ }^{*}$ Hassan II.

Mohammed VI (1861-1926). Last sultan of Turkey 1918-22. The defeat of Turkey in World War I left him a helpless pawn in the hands of the Allies and he was unable to contend with the nationalist rising under Mustafa Kemal (*Atatürk). He was deposed and retired to the Italian Riviera, where he died.

\section{Mohammed Ali see Muhammed Ali}

Moi, Daniel Toroitich arap (1924-2020). Kenyan politician. He became a teacher, entered the Legislative Assembly in 1957 and the House of Representatives in 1961, serving as Minister for Education 1961-62, Local Government 1962-64 and Home Affairs 1964-67. Vice President of Kenya 1967-78, he succeeded Jomo *Kenyatta as President 1978-2002, winning re-election in a reasonably free election in 1992, despite accusations of corruption. A further re-election (1997) was bitterly contested.

Moiseiwitsch, Benno (1890-1963). BritishUkrainian-Jewish pianist, born in Odessa. He studied at the Odessa Academy of Music, won the Anton Rubinstein Prize at nine, and became a pupil of ${ }^{*}$ Leschetizky in Vienna. He first appeared in Britain in 1908, settled there, toured extensively and was admired by *Rachmaninoff.

Moissan, Ferdinand Frédéric Henry (1852-1907). French chemist. He was best known for his success in isolating the elusive element fluorine (1886), and for his development of the electric arc furnace, with which he studied high-temperature reactions, preparing new compounds, e.g. the metal carbides and nitrides. He became (1889) a professor of chemistry in Paris and won the Nobel Prize for Chemistry (1906).

Molière (stage name of Jean-Baptiste Poquelin) (1622-1673). French playwright and actor, born in Paris. Son of the king's upholsterer, he received his education at a Jesuit college in Paris but more serious studies were abandoned when he formed a theatrical company (1643), adopting the stage-name, Molière. After touring the provinces for many years his company returned to Paris (1658) and gained the patronage of the king's brother and eventually (1665) of *Louis XIV himself. He was thus able to provide court entertainments, though, in fact, most of his greatest plays were performed at his own theatre at the Palais Royal. These plays, in most of which he played the leading part, range from slapstick farce to philosophical satires and many of them reveal the extent of his debt to *Plautus, ${ }^{*}$ Terence and ${ }^{*}$ Lope de Vega. Molière's motto was 'No truth without comedy and no comedy without truth', and in his works he poked fun at hypocrites, quacks, extremists and all those 'enslaved by a ruling passion'. He achieved his first big success with Les Précieuses ridicules (1659), followed by a series of masterpieces, e.g. L'École des femmes (1662), Tartuffe (1665), an attack on religious hypocrisy which was banned for four years, Le Misanthrope (1666), Le Bourgeois gentilhommne (1671) and Les Femmes savantes (1672). His last play was Le Malade imaginaire (1673). While acting in it he suffered a haemorrhage and died later the same night. After his death his company joined with another to form the Comédie Française, where the traditions of the original performances are observed.

Bray, R., Molière, homme de theatre. Rev. ed. 1963; Scott, V., Molière. A Theatrical Life. 2000.

Mollet, Guy (1905-1975). French politician. A teacher and an active Socialist, he joined the army in World War II, was a prisoner of war 1940-42 and later joined the Resistance movement. He entered (1945) the Constituent Assembly and became (1946) Secretary-General of the Socialist Party. After a number of ministerial appointments he was Prime Minister 1956-57 and so directed French participation in the Suez attacks (November 1956). He supported *de Gaulle's return to power (1958) and served in his ministry until 1959.

Mollison, Amy and James see Johnson, Amy

Molnár, Ferenc (1878-1952). Hungarian playwright. He settled in the US in 1910, was a war correspondent in World War I, and both before and after wrote popular and successful comedies, e.g. The Guardsman (1910), Liliom (1924), The Glass Slipper (1924) and The Good Fairy (1937). 
Molotov (originally Skryabin), Vyacheslav Mikhailovich (1890-1986). Russian Communist politician, born in Vyatka province. From a middleclass family, he joined the Bolsheviks in 1906 and later adopted the name Molotov ('hammer'). He was a candidate member of the Politburo 1921-25, Deputy General-Secretary of the Communist Party 1921-22, and a full Politburo member 1926-57, working closely with *Stalin. Premier 1930-41, he displaced ${ }^{*}$ Litvinov as Foreign Minister when, in 1939, Stalin made the volte-face which led to the Nazi-Soviet pact and retained office until 1949. He took an extremely rigid line towards the US and UK during World War II and the Cold War. He was Deputy Premier 1941-57 and again Foreign Minister 1953-57. After Stalin's death (1953) he was, with *Beria and *Malenkov, one of the ruling triumvirate, but the struggle for power that brought ${ }^{*}$ Khrushchev to the front ended Molotov's long ascendancy. He was Ambassador to Mongolia 1957-60, then to the International Atomic Energy Agency, Vienna 1960-62. In 1964 the CPSU expelled him.

Moltke, Helmuth Karl Bernhard, Graf [Count] von (1800-1891). German field marshal, born in the Duchy of Mecklenburg-Schwerin. Originally in the Danish army, he entered the Prussian service (1822) and was appointed (1832) to the general staff. He remodelled the Turkish army (1835-39), and became Chief of the Prussian General Staff (1858), reorganised the army and planned the successful lightning campaigns against Denmark (1864), Austria (1866) and France (1870-71). He was one of the first generals to base his strategy on the use of railways for the rapid assembly and movement of troops. With the formation of the German empire (1871) he became Chief of the Imperial General Staff 1871-88. He made the only voice recordings known of anyone born in the 18th century. His nephew Helmuth Johann Ludwig von Moltke (1848-1916), a friend of *Wilhelm II, became a theosophist and was plagued by self-doubt. Nevertheless, he became Chief of the General Staff 1906-14, retiring after a stroke. His grandnephew, Helmuth James, Graf von Moltke (1907-1945), a jurist, worked for the Abwehr, founded the Kreisau Circle, a resistance group, and was hanged. He opposed attempts to assassinate ${ }^{*}$ Hitler believing that would make him a martyr, and planned thoughtfully about a post-Nazi democratic Germany.

Kessel, E., Moltke. 1957.

Momigliano, Arnaldo Dante (1908-1987). Italian historian, born in Piedmont. A refugee from *Mussolini, he lived in England from 1938 and was professor of ancient history at University College, London 1951-75. A polymath, he published historiography, classical studies and biographies.

Mommsen, (Christian Matthias) Theodor (18171903). German historian. He reached the climax of a successful academic career when he went to Berlin
University (1858) as professor of ancient history, a post he retained for the rest of his life. The History of Rome (3 volumes, 1854-56), for which he is famous, ends with the fall of the Republic and reveals the author's hero worship of Julius ${ }^{*}$ Caesar. A supplementary volume on the imperial provinces appeared in 1885 . In addition Mommsen wrote specialised works on Roman coinage, chronology, constitutional law and the provinces. His great Corpus of Latin inscriptions was a remarkable editorial feat. He was a liberal in the Reichstag 1881-84 and received the Nobel Prize for Literature in 1902, when other nominees included *Ibsen, *Tolstoy, ${ }^{*}$ Zola and ${ }^{*}$ Meredith.

Wickert, L., Theodor Mommsen. 1959.

Monash, Sir John (1865-1931). Australian general and engineer, born in Melbourne. Of GermanJewish parentage, he became an eminent civil engineer, lawyer and citizen soldier. In World War I he fought at Gallipoli and later, after commanding the 3rd Australian Division in France, became (1918) Commander-in-Chief of the Australian Corps. *Montgomery named Monash as 'the best general of the Western front' and suggested that he should have replaced ${ }^{*}$ Haig in command. However, he was the victim of prejudice by the official Australian war historian C. E. W. *Bean and only received promotion to full general in November 1929 (together with Harry ${ }^{*}$ Chauvel), long after he had retired. He became Chairman of the Victorian State Electricity Commission 1920-31 and Vice Chancellor of Melbourne University 1923-31. Monash University, established in Melbourne in 1959, was named for him. There was a serious (but unsuccessful) campaign for Monash to be posthumously promoted to Field Marshal.

Serle, A. G., John Monash. 1982; Fischer, T. A., Maestro John Monash. 2014; Kieza, G., Monash: The soldier who shaped a nation. 2015.

Monboddo, Lord, James Burnett (1714-1799). Scottishjudge, pioneer anthropologistand comparative linguist. Educated in Aberdeen, Edinburgh and Groningen, he was a judge of the Court of Session 1767-99, a leading but eccentric figure in the Scottish Enlightenment, an enemy of David *Hume, a rival of Lord *Kames, but sympathetic to Robert *Burns. In Of the Origin and Progress of Languages (6 volumes, 1773-92), he anticipated evolutionary theory in the development and complexity of language. His work was read closely by Erasmus and Charles *Darwin.

Monck (or Monk), George, 1st Duke of Albemarle (1608-1670). English soldier and politician, born in Devon. He gained military experience fighting in the Netherlands in the Thirty Years War. In the English Civil War he served first with the Royalists, was captured and held in the Tower of London 1644-46, then gained *Cromwell's confidence. As a commander he distinguished himself at Dunbar and (at sea) with *Blake. In 1654 Cromwell appointed him 
Governor of Scotland where he successfully restored order. Cromwell's death gave him the opportunity to exercise judgment in political matters. On $\mathrm{New}$ Year's Day 1660 he entered England with 6,000 men, reached London unopposed, reinstated the Long Parliament and secured a new election. He worked skilfully to reconcile the army to the growing public desire for a restoration of the monarchy. ${ }^{*}$ Charles II, from whom he had obtained pledges of constitutional rule before inviting him to return, created him KG (May 1660) and made him a duke when he landed on Dover Beach (July 1660). Monck became Lord Lieutenant of Ireland 1660-62 and First Lord of the Treasury 1667-70.

Mond, Ludwig (1839-1909). German-British chemist. A pupil of *Bunsen at Heidelberg, he invented processes for recovering sulphur from alkali waste, and ammonia from nitrogenous substances. He settled in England (1867) and formed (1873), with (Sir) John Brunner, the firm of Brunner, Mond \& Co. (later merged with Imperial Chemicals) to produce soda from common salt by the Solvay process. One of Mond's most valuable discoveries was the carbonyl process for extracting nickel from its ores. His son, Alfred Moritz Mond, 1st Baron Melchett (1868-1930), like his father a strong Zionist, was an MP 1906-22, 1924-28 (Liberal until 1926, then Conservative) and Minister for Health 1921-22.

Mondale, Walter Frederick (1928-2021). American politician and lawyer, born in Minnesota. A protégé of Hubert *Humphrey, he was State Attorney-General 1960-64, US Senator from Minnesota 1964-77 and Vice President under Jimmy ${ }^{*}$ Carter $1977-81$. In 1984 he became the Democratic nominee for president, losing heavily to Ronald *Reagan. He was Ambassador to Japan 1993-96.

Mondrian, Piet(er Cornelis) (1872-1944). Dutch painter. His earliest work was in landscape in the Dutch Romantic and Impressionist tradition. In Paris (1912-14) he was influenced by the 'Fauves'. He went back to Holland (1914) and began his search for a formal purity without 'content' or reference and by 1922 his paintings had become geometric, rectilinear, in primary colours against a grey or ochre background. With Theo van Doesburg (1883-1931), Mondrian founded (1917) the magazine De Stijl, a name also given to the 'school' of painting that followed his lead. He called his work 'Neo-plasticism' and in the US (to which he emigrated in 1944 after living in Paris and London), it was held to be the purest, least literary expression of the age of technology. Some modification of the earlier stark severity was admitted in his last works.

Elgar, F., Mondrian. 1968; Deicher, S., Piet Mondrian, 1872-1944. 1995; Blotkamp, C., Mondrian. The Art of Destruction. 1996.
Monet, (Oscar) Claude (1840-1926). French Impressionist painter, born in Paris. He grew up in Le Havre and acquired an early love for the Seine with its reflections of trees, buildings, boats and its scenic effects. He studied painting with *Boudin. When, in 1862, he settled in Paris, he met *Cézanne, *Renoir, *Sisley and others who were later to become the Impressionists, a name mockingly bestowed by a critic of Monet's picture Impression, Soleil levant, shown at an exhibition organised by Monet, Berthe *Morisot and Sisley in 1874. The group's greatest innovation was to take painting out of the studio into the open air. With Renoir, at first at Argenteuil on the Seine, Monet tried to achieve greater naturalism by exact analysis of tone and colour and to render the play of light on the surface of objects, using a flickering touch and paint applied in small bright dabs in a high key and with a lack of outline. His pictures were mostly landscapes, many with water or snow. Influences included ${ }^{*}$ Turner and ${ }^{*}$ Hokusai. He would paint the same objects, e.g. haystacks or cathedrals, at different times of the day to get different light effects, but in his later works the light patterns began to be used mainly for their aesthetic effect rather than as a means to describe form. He worked in England, the Netherlands and Norway. From 1883 he lived at Giverny where he created a great garden and painted irises, roses and the Japanese bridge there.

Seitz, W. C., Claude Monet. 1960; Hodge, S., Monet. 2009; Wildenstein, D., Monet. The Triumph of Impressionism. 2015; Christoph, H., Monet. 2015; Westheider, O., Claude Monet. The Truth of Nature. 2019.

Monge, Gaspard (1746-1818). French scientist. His early work was concerned with improving teaching methods in military engineering. He made systematic advances in descriptive geometry, and modern engineering drawing owes much to him. While continuing his military studies (he was much concerned with logistic problems of moving materials for use in fortifications), he developed interests in fields of applied and pure mathematics. He developed new techniques for applying the calculus to curves and faces in three dimensions. After his election to the Academy in 1780, Monge spent more time in Paris, and his interests moved towards physics and chemistry. He aided *Lavoisier in the analysis and synthesis of water, and carried out experiments on the composition of iron, steel, and carbon dioxide. In the Revolutionary period, Monge played increasingly prominent roles in public life. He became Minister for the Navy in 1792, and then, in 1795, director of the newly founded École Polytechnique. He was closely involved in establishing the metric system of weights and measures. Monge's substantial publications, including his Géometrie descriptive (1795) and Traité élémentaire de statique (1810) became key teaching texts.

Mongkut see Rama IV 
Moniz, Antonio Caetano de Abreu Freire Egas (1874-1955). Portuguese neurologist. He held chairs at Coimbra and Lisbon, served as a deputy 1903-17 and Foreign Minister 1918. He shared the 1949 Nobel Prize for Medicine with Walter Hess for their development of prefrontal leucotomy (a technique now completely discredited.)

Monmouth, James Scott, Duke of (1649-1685). English rebel, born in Holland. Son of ${ }^{*}$ Charles II of Great Britain and his mistress Lucy Walters, he went to England after the Restoration and was created (1663) Duke of Monmouth. On marrying Anne, Countess of Buccleuch, he adopted her surname, Scott, and was made Duke of Buccleuch. Spoilt by his father and the adulation of the people, he was a ready tool of *Shaftesbury and those who put him forward as a candidate for succession to the throne to the exclusion of the Duke of York (*James II). It was even said that proofs of his legitimacy were contained in a mysterious black box. The discovery of the extremist Rye House plot to hasten Monmouth's accession by assassinating King Charles forced him to flee to Holland (1683), but on James II's accession (1685) he landed at Lyme Regis and claimed the throne. His little army, mostly peasants, was quickly defeated at Sedgemoor, and Monmouth was captured and executed.

Chevenix-Trench, C., The Western Rising. 1969.

Monnet, Jean Omer Marie Gabriel (1888-1979). French financier and bureaucrat, born in Cognac. Pioneer of European unity and recognised as a founder of the European Community, he was the first deputy secretary-general of the League of Nations 1919-23. He worked as an international financier in the US, eastern Europe and China and was *de Gaulle's representative in Washington during World War II. He originated the French Modernisation Plan and, later, the ${ }^{*}$ Schuman Plan for organising European resources. This led to the formation of the European Coal and Steel Community of which he became President 1952-55. Chairman of an action committee for a United States of Europe, he was awarded the Charlemagne Prize in 1953, the US Presidential Medal of Freedom (1963), the Schuman Prize (1966), a British CH (1972), and the title 'Honorary Citizen of Europe' (1976). He was reinterred in the Panthéon in 1988.

Monnet, J., Mémoires. 1976.

Monod, Jacques Lucien (1910-1976). French biochemist. Educated at the University of Paris and the California Institute of Technology, he was a colonel in the Resistance during World War II and worked at the Pasteur Institute 1945-76. He shared the 1965 Nobel Prize for Medicine with André Lwoff and François Jacob for work on the regulatory action of genes. Monod was a brilliant controversialist and debater, an excellent writer on the philosophy of science (Chance and Necessity, 1970) and a gifted cellist.

Judson, H. F., The Eighth Day of Creation. 1979.

Monroe, James (1758-1831). 5th President of the US 1817-25. Born in Westmoreland County, Virginia to a prominent family, his education was cut short by the War of Independence in which he served with distinction. He entered Virginian politics (1782) and opposed the ratification of the US Constitution on the grounds that it would lead to excessive federal control of the individual states. Elected to the US Senate 1790-94 as a strong supporter of his friend *Jefferson, then Secretary of State, he was appointed Minister to France 1794-96. He served as Governor of Virginia 1799-1802 and 1811. When Jefferson became President he sent Monroe to Europe on a series of diplomatic missions (from 1803), on the first of which he helped to negotiate the purchase from *Napoléon of a vast area of the Mississippi basin (the Louisiana Purchase). He was Minister to the United Kingdom 1803-08. Secretary of State 1811-17, he was Madison's natural successor as president. In 1816, as the Democratic-Republican candidate, he defeated the New York Federalist Rufus King (1755-1827). In 1820, the Federalists having collapsed, he was reelected without opposition. He is best remembered for his promulgation of the Monroe Doctrine (1823), a declaration of US opposition to further European colonisation of the Americas and European interference with independent governments. He was the last of the 'Founding Fathers' to serve as President, one of three to die on Independence Day (like John *Adams and *Jefferson), and the last to wear a powdered wig.

Cresson, W. P., James Monroe. 1946; Cunningham, N. E., The Presidency of James Monroe. 1996.

Monroe, Marilyn (Norma Jeane Mortenson, later Baker) (1926-1962). American film actor, born in Los Angeles. After a tough childhood with an unstable mother, she became a model, and, in 1948, gained her first bit part in a film. Her blonde beauty and voluptuous body soon made her an international sex symbol and she achieved enormous popular success in a series of comedies, e.g. Seven Year Itch (1955), The Prince and the Showgirl (1957, with Laurence *Olivier), Some Like it Hot (1959) and The Misfits (1961, with Clark *Gable). She married the baseball star Joe *DiMaggio (1954) and the playwright Arthur *Miller (1956). She combined sensuality, humour and a certain mysterious quality. She had unfulfilled cultural and political ambitions, took up acting classes seriously and had close, if discreet, connections with John and Robert *Kennedy. She died of a drug overdose.

Mailer, N., Marilyn. 1974; Steinem, G., Marilyn. 1986. 
Monsarrat, Nicholas (John Turney) (1910-1979). British author. He began writing novels in 1934, but it was his wartime experience in the Royal Navy that inspired his instantly successful The Cruel Sea (1951). He later wrote other popular sea novels. His autobiography in two volumes, Life is a Four Letter Word, was published 1966 and 1970.

Montagnier, Luc Antoine (1932- ). French virologist. Director of Research at the Centre National de Recherche Scientifique (CNRS) 197498, and a professor at the Pasteur Institute 19852000, he was the leading French researcher on HIV/ AIDS. In 1983 he identified the AIDS virus but proved unable to grow it in cells. He became involved in a bitter controversy with the American researcher Robert ${ }^{*}$ Gallo who claimed to have isolated the virus independently. He shared the 2008 Nobel Prize for Medicine but became deeply controversial with his unverified claims that autism could be cured by antibiotics and by endorsing homeopathy.

Montagu, Lady Mary Wortley (née Pierrepont) (1689-1762). English letter writer. Daughter of Evelyn Pierrepont, 5th Earl and later 1st Duke of Kingston-upon-Hull, she accompanied her husband, Edward Wortley Montagu, on a diplomatic mission (1716-18) to Constantinople, where she observed the practice of variolation, rubbing material from smallpox scabs or pustules into scratches on the skin, producing a degree of immunity, long practiced in China, India and the Ottoman Empire, She acquired considerable education and this, combined with her own lively intelligence, enabled her, on her return, to become the centre of a fashionable group of artists, writers and wits. From 1739 she lived mainly in Italy. Her letters, covering the years 1709-62, are her real claim to fame. In them she gives vivid descriptions of places, people and events, revealing herself as a woman of much worldly wisdom, of warm and compassionate affection and an engaging wit, spiced with malice.

Halsband, R. (ed.), Complete Letters of Lady Mary Wortley Montagu. 1965-67.

Montaigne, Michel Eyquem, Seigneur de (15331592). French essayist, born at the Chateau de Montaigne, near St Emilion, in Périgord. His father had been Mayor of Bordeaux and his mother was a Huguenot of Jewish origin. After his father's death (1568), and that of his elder brothers, he inherited the family estate.He served as a 'counsellor' of the Bordeaux parlement and eventually became Mayor 1581-85. From 1571 he devoted most of his time to travel and to the writing of the famous Essais, a term he originated.

He worked for decades in his library in a tower on his estate at St Michel de Montaigne, in Périgord, essentially writing about himself, pursuing the question: 'Que sçay-je?' (Old French spelling, 'Que sais-je?' in modern: 'What do I know?') The words were inscribed on his heraldic emblem. Montaigne's starting point is his own experience and he writes on familiar subjects - his house, his tower, his library, his garden, his body, his mind, his travels, occasionally even his family - extracting from them a sense of the universal, but also the infinite and inexplicable, examining the unpredictable ways his mind worked, then projecting his thoughts into speculation about the universe, discussing in a detached, sceptical fashion philosophical, religious and moral questions with a tolerant awareness of the fallibility of reason. His Essays broke a long taboo against people writing at length about themselves, and it is the first great autobiographical work since St *Augustine's Confessions, but broader, more open and speculative.

Books I and II appeared in 1580, Book III was included in an enlarged edition (1588), and a further edition was published (1595) after his death. He suffered agonies from kidney stones after 1578, and this influenced his meditations on illness, death and life's brevity. His essays were first translated into English by John Florio (1603). Montaigne influenced many writers, including *Shakespeare, *Bacon, *Burton, ${ }^{*}$ Emerson, ${ }^{*}$ Stendhal, *Tolstoy and ${ }^{*}$ Proust.

Frame, D. M., Montaigne. 1965; Scholar, R., Montaigne and the Art of Free-Thinking. 2010; Bakewell, S., How to Live: Or A Life of Montaigne in One Question and Twenty Attempts at an Answer. 2011; Frampton, S., When I am playing with my cat, how do I know she is not playing with me? 2011; Green, F., Montaigne and the Life of Freedom. 2013; Desan, P., Montaigne. A Life. 2014/17.

Montefeltro, Federico Ubaldi da, Duke of Urbino (c.1420-1482). Italian nobleman, born in Gubbio. The last of the great condottieri, he ruled as Duke of Urbino 1444-82 and, because he often held the balance of power in northern Italy, was able to increase his duchy three-fold. The pupil of *Vittorino da Feltre, he owned the finest library in Italy after the Vatican, patronised humanist scholars, never lost a battle, was considered the greatest soldier of his era, became an honorary Knight of the Garter and the subject of a memorable double portrait (with his wife Battista Sforza) by *Piero della Francesca. His son Guidobaldo da Montefeltro (1472-1508) was the model for *Castiglione's The Courtier.

Montefiore, Sir Moses Haim, 1st Baronet (17841885). Anglo-Jewish philanthropist, born in Livorno (Leghorn). He settled in England (1805), made a fortune on the London Stock Exchange and retired (1824) to devote his energies to philanthropic work to help Jews. He also negotiated agreements with Russia, Turkey and Egypt by which persecution in Poland, Syria and elsewhere was mitigated. He was knighted in 1837 and created a baronet in 1846.

Montespan, Françoise Athenaise Rochechouart, Marquise de (1641-1707). French mistress of *Louis XIV. She was of high birth, gay, sophisticated and 
witty, in contrast to the shyly devoted Louise de la Vallière who finally left the court in 1674 having watched for some years her rival's gradual ascent. Madame de Montespan bore the king seven children, but her increasing haughtiness and bouts of jealousy (not unjustified) had already shaken her position when, in 1680, her name was mentioned with those of many others during secret investigations into charges of poisoning and witchcraft. Her share (if it existed) in the matter was hushed up, but though she remained at court the liaison was ended. Her successor was her children's governess, Madame de *Maintenon.

Montesquieu, Charles Louis de Secondat, Baron de la Brède et de (1689-1755). French political philosopher, born in La Brède, near Bordeaux. Of Huguenot descent, he studied law and in 1716 succeeded his uncle, the Baron de Montesquieu, as president of the parlement of Bordeaux, also inheriting his title and fortune. For a time he was interested in science but abandoned it for letters and, with the publication of his Letters persanes (1721), he became famous. The book purports to contain the letters of two Persians visiting Paris, to each other and to their friends at home. Witty and frivolous comment is mingled with serious observations on the social and political institutions and the various influences (climate, religion etc.) on the people. In 1726 he gave up his official position at Bordeaux and settled in Paris with interludes of travel. He visited England (1729-31) and studied its constitutional procedures. In his next major work, Considérations sur les causes de la Grandeur des Romains et de leur décadence (1734) he tried to explain the greatness and the decline of the Roman Empire by giving full weight to economic, cultural, climatic and racial factors; the first time that historic processes had been submitted to such a scientific examination. The monumental De l'Esprit des lois (2 volumes, 1748) occupied him for 20 years and summarised his life's work. By the 'spirit' of the laws he meant the social and natural (e.g. climatic) conditions which have brought laws and constitutions into being. The English system of constitutional government is analysed in detail and the functions of legislature and executive assessed and presented for admiration and imitation (although he exaggerated the separation of powers). France's rulers failed to heed the book's message in time to avert revolution but its influence was profound in shaping the intellectual background to political life there and elsewhere. He coined the terms 'separation of powers', 'checks and balances' and 'Byzantine Empire'.

Shackleton, R., Montesquieu: A Critical Biography. 1961.

Montessori, Maria (1870-1952). Italian educationist. She worked as a doctor in a Rome asylum teaching mentally handicapped children and applied this experience to the education of all pupils. From 1911 she lectured throughout the world on the
'Montessori method', which emphasised that young children learn best through spontaneous activity and under minimal constraint.

Standing, E. M., Maria Montessori, her Life and Work. 1957.

Monteux, Pierre (Benjamin) (1875-1964). French conductor, born in Paris. A gifted violist, he soon developed conducting skills and worked for *Diaghilev's Ballets Russes in Paris (1911-14), giving premieres of *Debussy's Jeux, *Stravinsky's Petrushka and The Rite of Spring, and *Ravel's *Daphnis and Chloe. He directed the French repertoire at the New York Met 1917-19, was conductor of the Boston Symphony Orchestra 1919-24, joint-conductor of the Concertgebouw Orchestra, Amsterdam, 192434, founder of the Orchestre de Paris 1929-38, conductor of the San Francisco Symphony 1936-52 and the London Symphony Orchestra 1961-64. He was an outstanding teacher.

Monteverdi, Claudio Giovanni Antonio (15671643). Italian composer, born at Cremona. Little is known of his early years but he won fame by his nine books of madrigals, the first of which appeared in 1587 and the second in 1590, the year he joined as a player of the viol the service of Vincenzo Gonzaga of Mantua, with whom he stayed until the duke's death (1612). In 1613 he became choirmaster of St Mark's, Venice, then the most important musical post in Italy. In 1632 he was ordained. His first opera, $L a$ Favola d'Orfeo (The Legend of Orpheus), was produced at Mantua for the carnival of 1607 . In this work, the first opera of importance, Monteverdi consolidated the experiments of the earliest opera composers, the far less accomplished Jacopo Peri and Giulio Caccini. He was the first composer to employ an orchestra and in his moving vocal music revealed the psychological possibilities of the operatic medium. Of the many other operas and ballets of this period the best is Arianna (1608). The operas of his Venetian period were destroyed during the sack of Mantua (1630), but two later works, The Return of Ulysses (1640) and The Coronation of Poppaea (1642) remain. As the pioneer of opera (he also introduced opera techniques into Church music) and composer alike, he is among the greatest figures in musical history, not only of the Baroque.

Arnold, D., Monteverdi. 1975; Whenham, J. and Wistreich, R. (eds), The Cambridge Companion to Monteverdi. 2007; Fabbri, P., Monteverdi. 2007.

Montez, Lola (née Eliza Rosanna Gilbert) (18211861). Irish-American dancer and adventuress, born in Limerick. Claiming Spanish ancestry on her mother's side, after a disastrous early marriage she became a dancer, making her London debut in 1843. She toured Europe and her lovers included *Dumas père and ${ }^{*}$ Liszt. In 1846 she reached Munich where the eccentric Bavarian king *Ludwig I became enthralled and created her Countess of Lansfeld. His 
obsession and her role in government contributed to his forced abdication in the revolution of 1848 . She moved to New York in 1851 and toured Australia 1855-56.

\section{Montezuma II see Moctezuma II}

Montfort, Simon de, 6th Earl of Leicester (c. 12081265). Anglo-French nobleman, born in Montfortl'Amaury, in Yvelines, west of Paris. His father, Simon de Montfort, 5th Earl of Leicester (c.1175-1218), French nobleman and soldier, fought in the Fourth Crusade, led the campaign to exterminate the Albigensians (Cathars), captured Carcassone and became ruler of Toulouse, where he was killed in a siege. He had succeeded to the earldom of Leicester in 1204 through his mother, sister of Robert de Beaumont, the 4 th Earl.

The younger Simon married Eleanor, the sister of *Henry III in 1238, was invested with the earldom of Leicester in 1239, went on Crusade in 1240, became the king's capable Vicegerent in Gascony in 1248 and engaged in missions in France, Rome, Scotland and Wales. However, aggrieved that he had not received sufficient recognition from Henry, he led a baronial revolt in which his fellow nobles insisted on sharing power in government. By the Provisions of Oxford (1258) and of Westminster (1259) it was held that the king should govern through a council of 15 magnates, but de Montfort's contention that the barons themselves should be subject to the council caused a split in their ranks which enabled the king and his son ${ }^{*}$ Edward to repudiate the Provisions. Civil war followed, decided by de Montfort's victory at Lewes (1264) which left him in command of the country with Henry and Edward prisoners in his hands. To regularise proceedings he summoned (1265) a 'parliament' (parlement or session of the magnates). The difference from earlier sessions was that to strengthen his position, since many hostile barons did not respond to the summons, he summoned also knights of the shire (i.e. the country gentry). By adding a more representative element (likely to give him support), the association of de Montfort's name with the first English parliament (in the modern sense) can somewhat dubiously be justified. In the same year Prince Edward escaped from surveillance, rallied the royalist supporters and gained the decisive victory of Evesham, where de Montfort was killed.

Labarge, M. W., Simon de Montfort. 1962; Ambler, S. T., The Song of Simon de Montfort. England's First Revolutionary and the Death of Chivalry. 2019.

Montgolfier, (Jacques) Etienne (1745-1799) and Joseph Michel (1740-1810). French inventors of a man-carrying balloon. The brothers, papermakers by profession, experimented first by filling paper bags with hot air, and later used a bag of silk with an open bottom under which paper was burnt to heat the air to lift the balloon. After an experiment with animals (September 1783) and captive flights, the first free manned ascent was made on 21 November when a balloon $15.7 \mathrm{~m}$ (48 ft) in diameter and $24.6 \mathrm{~m}(75 \mathrm{ft})$ high travelled for nine kilometres (nearly six miles) across Paris at a height of $100 \mathrm{~m}$ (328 ft.)

Gillispie, C. C., The Montgolfier Brothers and the Invention of Aviation. 1983.

Montgomery of Alamein (1887-1976). Anglo-Irish field marshal, born in Surrey. Son of a bishop, he grew up in Tasmania, joined the Royal Warwickshire Regiment (1908) and fought on the western front throughout World War I. At the beginning of World War II he led the 3rd Division in France, his corps commander being the future Lord *Alanbrooke. After Dunkirk he served in England and was G.O.C. Southeastern Command when (August 1942) he was sent to Egypt to take over the 8th Army, which had already checked *Rommel on the Alamein position guarding Alexandria. After defeating a strong German attack (31 August) he planned, and the 8th Army achieved, a decisive breakthrough (October). The chase continued westwards across Africa: the 8th Army joined the American and British forces in Tunisia where early in 1943 the last German forces surrendered. Montgomery remained with the 8th Army for the invasions of Sicily and Italy but at the end of 1943 left to prepare for the liberation of France. He commanded all US, British and Canadian troops in the Normandy landings of June 1944 and later the 21st Army Group forming the left wing. Once the break out had been achieved the advance to the Dutch frontier was amazingly fast. After the German surrender (April 1945), Montgomery commanded the British Military Zone. Created viscount and given a KG in 1946, he became Chief of the Imperial General Staff 1946-48 and Deputy Commander, Supreme Headquarters, Allied Powers in Europe 1951-58. His Memoirs (1958) made sharp criticisms of his former Commander-in-Chief *Eisenhower, for overruling his 1944 plan for a swift thrust on a narrow front direct to the Ruhr in favour of a slower and more systematic advance along the whole front. Montgomery's supreme self-confidence, which encouraged his troops, was loathed by his fellow generals.

Chalfont, A., Montgomery of Alamein. 1976.

Montgomery, L(ucy) $\mathbf{M}$ (aud) (1874-1942). Canadian author. She wrote an enormously successful series of eight novels beginning with Anne of Green Gables (1908), ending with Rilla of Ingleside (1921), short stories, poetry and an autobiography.

Montherlant, Henry Millon de (1896-1972). French novelist, poet and playwright. An aristocrat by birth, he was wounded in World War I, was a bullfighter in Spain for a time and lived in the Sahara (1925-32). His forceful and cynical novels, e.g. Les Bestiaires (1925), Les Célibataires (1934) and Les Jeunes Filles (1939), reveal his contempt for bourgeois values. After World War II he wrote successful plays, 
including Le Maître de Santiago (1947). Elected to the Académie française in 1960, he committed suicide, fearing the onset of blindness.

\section{Cruickshank, J., Montherlant. 1964}

Montpensier, Anne Marie Louise d'Orléans, Duchesse de (1627-1693). French princess. For her heroic conduct in support of *Condé during the French civil war called the Fronde, she became known as 'la Grande Mademoiselle'.

\section{Montreuil, Pierre de see Pierre de Montreuil}

Montrose, James Graham, 1st Marquess of (1612-1650). Scottish leader. After returning from continental travels he joined the anti-royalists and helped to draw up the National Covenant, but, disgusted by the extremism of the Covenanters, he abandoned their party and was appointed (1644) Lieutenant General in Scotland by *Charles I. With an army mainly of Highlanders, he achieved an astonishing series of victories that made him virtually master of the country. In 1645, however, he was surprised at Philiphaugh and forced (1646) to take refuge in Holland. In 1650, determined to avenge Charles' death, he invaded the north of Scotland from the Orkneys, but he found no support, was defeated at Invercarron, betrayed and hanged at Edinburgh. He was a chivalrous, romantic leader and gifted poet.

Wedgwood, C. V., Montrose. 1952.

Moody, Dwight Lyman (1837-1899). American evangelist. After being a Boston salesman, he went to Chicago (1856) and began the missionary work for which he became famous. With the singer and hymn writer Ira David Sankey (1840-1904), he made remarkably successful revivalist tours of the US and Great Britain.

Pollock, J. C., Moody without Sankey. 1964.

\section{Moody, Helen see Wills Moody, Helen}

Moon, Sun Myung (1920-2012). Korean religious leader, born in Sangsan. He founded the Unification Movement in Seoul in 1954 and migrated to the US in 1970 . He supported *Nixon, *Reagan and both ** Bushes, and 'The Moonies' became an influential pressure group within the religious right.

Moore, George (1852-1933). Irish writer. Life in Ireland, where his father was a landlord and racehorse owner, had little appeal to Moore as a youth. He went to London, joined a bohemian set and when aged 18, he inherited the family estate, went to Paris and studied art, with no great success. He returned to Ireland (1879) with an enthusiasm for the French Impressionists and the novelist ${ }^{*}$ Zola, who became his model for a series of realistic novels culminating in Esther Waters (1894), in which the humiliations and hardships that follow surrender to passion are, as in his other novels, the prevailing theme. Meanwhile
Moore's life was spent between Ireland and London, where he finally settled (1911). A new phase of his literary life, an autobiographical one, began in 1888 with the publication of Confessions of a Young Man followed at intervals by portrayals of himself in later years, all written in an easy conversational style quite unlike that of his other works. In his final group of books the aesthete in George Moore predominates, the style, smooth and flowing, is everything, and human warmth is almost lacking. He uses this style for the reconstruction of old stories and legends, e.g. The Brook Kerith (1916), Héloise and Abelard (1921) and Aphrodide in Aulis (1930).

Moore, George Edward (1873-1958). English philosopher, born in London. Educated at Trinity College, Cambridge, he was a contemporary of ${ }^{*}$ Russell on whom he had a significant (but unreciprocated) influence. Part of the 'Bloomsbury set' in London, he lectured at Cambridge from 1911, was professor of philosophy 1925-39 and editor of Mind 1921-47. Moore, who distinguished between knowing and analysing, asserted that what is commonly understood (appreciated by common sense) to be the meaning of a term was frequently at variance with the results achieved by those who analysed its meaning. He therefore used analysis not for demonstrating meaning but as a tool for discovering the component parts of a concept and its relationship to other concepts. Much of his work was in the field of ethics, and his principal books were Principia Ethica (1903) and Philosophical Studies (1922). He received the OM in 1951.

Moore, Henry Spencer (1898-1986). English sculptor and graphic artist, born in Castleford, Yorkshire. Son of a coal miner, he was educated at Castleford Grammar School, served in France 1917-19 and, after studying at Leeds School of Art and the Royal College of Art, won a travelling scholarship (1925). His style verged on the abstract but he was concerned with the aesthetic problems of the human figure, a major aim being the relation of sculpture to natural environment. Thus the anatomy of his 'reclining figures' was so disposed as to reflect natural landscape forms. Early influences were African, Mexican and Polynesian sculptures but any borrowings were adapted to suit his own aims. Moore showed a deep understanding of the nature of his material, the importance of the grain in his wood sculptures providing a striking example. His drawings of Londoners sheltering in the Underground during World War II were widely reproduced and he became a prolific and powerful lithographer and engraver. His sculptures won first prize at the Biennales at Venice 1948, São Paulo 1953-54 and Tokyo 1959. His Atom Piece (1964-65) was used as a model for Nuclear Energy (1964-66) at the University of Chicago. Generally regarded as the most important sculptor since ${ }^{*}$ Rodin (and possibly since ${ }^{*}$ Michelangelo), Moore's works were prominently displayed in public 
places in Britain, the US, Canada, Germany, Italy, Israel, Japan and Australia. He was awarded the $\mathrm{CH}$ in 1955 and the OM in 1963.

Moore, H. and Hedgecoe, J., Henry Moore. 1986.

Moore, Sir John (1761-1809). British general. After serving in many parts of the world, including Corsica, St Lucia in the West Indies, the Helder campaign in Holland, and in Egypt, he won new fame at Shorncliffe Camp, Kent, where he proved himself (1803) one of the most remarkable trainers of troops in British army history. The rapidly moving light infantry regiments were his creation and his new drill system was a major factor in later British successes. In 1808 he was given command in the Peninsula and despite Spanish defeats, concealed his whereabouts from *Napoléon and made a diversionary movement which delayed and disconcerted *Soult while allowing time for the Spaniards to raise new armies. So much achieved, he retreated rapidly to the coast at Corunna, and his troops had already begun to embark when Soult attacked, but was soon repulsed with heavy losses. However, Moore was killed and his burial on the ramparts of Corunna was the subject of a famous poem by Charles Wolfe, 'Not a drum was heard, not a funeral note ...'

Oman, C., Sir John Moore. 1953.

Moore, Marianne Craig (1887-1972). American poet. She contributed to the imagist poetry magazine Egoist and edited the Dial 1925-29. Her urbane and precise poetry first appeared in book form in Poems (1921), later followed by e.g. Observations (1924).

Hadas, P. W., Moore: Poet of Affection. 1977.

Moore, Mike (Michael Kenneth) (1949- ). New Zealand Labour politician. A former social worker and printer, he was MP 1972-75, 1978-99, Minister for Overseas Trade 1984-90, for Foreign Affairs 1990 and Prime Minister Sept-Oct 1990. He served as Director-General of the World Trade Organization (WTO) 1999-2002 and Ambassador to the United States 2010-15.

Moore, Thomas (1779-1825). Irish poet. He published several collections of graceful songs and verses, notably Irish Melodies (10 parts, 1808-34), for some of which he also wrote the tunes: among the most familiar of the lyrics are 'Tis the Last Rose of Summer, The Minstrel Boy and The Harp that Once through Tara's Halls. He gained a European reputation with Lalla Rookh (1817), a series of oriental verse tales linked by a prose narrative. From the time of his marriage (1811) to Bessy Dyke, an actor, he lived mostly at Sloperton Cottage, Wiltshire.

Moravia, Alberto (Alberto Pincherle) (1907-1990). Italian novelist. His books deal with the frustrations of love in the modern world, they include The Woman of Rome (1947) and The Empty Canvas (1960).
Moray, James Stewart, 1st Earl of (1531-1570). Scots nobleman. Illegitimate son of ${ }^{*}$ James $\mathrm{V}$ of Scotland and half-brother of ${ }^{*}$ Mary Queen of Scots, he was a Protestant and in the early part of her reign gave Mary prudent advice about her dealings with the Reformed Church and other matters. Alienated by her follies, he turned against her and after she abdicated he returned from France to act as regent for her infant son, James VI (later *James I of Great Britain). When she escaped he defeated her forces at Langside and subsequently maintained order, despite bitter factional rivalries. He was shot by a supporter of Mary, the first assassination of a head of government by firearm.

Mordaunt, Penny (née Penelope Mary) (1973- ). English Conservative politician. Educated at a Catholic school and Reading University, she served in the RN, became MP 2010-, supported Brexit but distrusted Boris *Johnson. She served as Secretary of State for Defence 2019, Minister for Trade 2021-22 and Lord President of the Council 2022- .

More, Henry (1614-1687). English philosopher and poet, born in Lincolnshire. Educated at Eton and Cambridge, he became an Anglican priest, DD (1660) and FRS (1664). Influenced by *Descartes, he attempted rational explanations for the mindbody problem, proposed the concept of a 'fourth dimension' and dismissed medieval scholasticism as arguing about the number of angels who could dance on the point of a needle. A prolific writer of poetry and prose, he turned against Descartian dualism, was a critic of ${ }^{*}$ Hobbes but accepted the reality of witchcraft and apparitions.

Lichtenstein, A., Henry More. 1962.

More, St [Sir] Thomas (1478-1535). English scholar, writer and lawyer, born in London. Son of Sir John More, a lawyer and judge, he was educated in London and at Oxford where he met ${ }^{*}$ Colet and *Erasmus. He practised law with great success and in 1504 entered parliament. In the same year he married Jane Colt, and made a home at the 'Old Barge' in London, where he lived for 20 years, becoming undersheriff (1510). In 1515 he accompanied a trading mission to Flanders. Antwerp provided him with a setting for the introductory scene of Utopia (1516), the meeting with Raphael Hythlodaye, who had discovered the island of Utopia, the ideally tolerant state, where possessions are shared and an education is available for men and women alike. The book, written in Latin, at once became popular and was widely translated (into English in 1551). Earlier More had written Praise of Folly (1510) and his History of Richard III (1513), the main authority for the story of the princes in the Tower. So brilliant a man could not escape the notice of ${ }^{*}$ Henry VIII. More was present at the Field of the Cloth of Gold (1520), he became a privy counsellor and was given a number of offices of growing importance until, after *Wolsey's downfall 
(1529), he unwillingly became Lord Chancellor. Meanwhile he was living in his new house built (1524) at Chelsea. His daughter Margaret and her husband, William *Roper, his future biographer, were living under the same roof; his other daughters married (1525). There are several accounts of a happy, devoted highly intellectual family group with many friends coming and going, of discussions both serious and gay and something of the atmosphere of a school.

Henry turned confidently to More to arrange for the dissolution of his marriage with *Katherine of Aragon, but More justly feared this would lead to a schism within the Church and offended the king by resigning his chancellorship (1532). In 1534 the Act of Supremacy was passed, by which Henry was declared Head of the Church in England. Though an intellectual and, to some extent a humanist, who recognised the need for some Church reforms, he was also a zealot, and could not tolerate apostasy and the denial of papal supremacy. He was arrested and after a year's imprisonment was convicted of treason and executed. Canonised by *Pius XI in 1935, he was named by ${ }^{*}$ John Paul II as patron saint of politicians in 2000 .

Reynolds, E. E., The Field is Won: The Life and Death of St Thomas More. 1968; Ackroyd, P., The Life of Thomas More. 1998.

Moreau, (Jean) Victor Marie (1761-1813). French marshal, born in Morlaix. After becoming a divisional general under Dumouriez in Belgium (1794), he succeeded Pichegru on the Rhine (1796) and drove the Austrians back to the Danube. In 1798 he was given the command in Italy and saved the French army from destruction. After Jourdan's defeat at Novi he brought the army safely home to France. He supported *Napoléon Bonaparte's coup of 18 Brumaire (9 November 1799) and in 1800 gained a succession of victories over the Austrians, culminating in the decisive triumph of Hohenlinden. With Bonaparte's jealousy rapidly mounting, Moreau was given no further opportunities. Instead he was accused of connivance with plotters against Napoléon's life (1804) and a two-year sentence of imprisonment was commuted to banishment. He lived near Trenton, New Jersey 1805-13 until after Napoléon's retreat from Russia he set out (1813) to join the Allied armies. He died of wounds while with the Russian army at Dresden. The most brilliant Revolutionary general, if he had political ambitions he might have forestalled Napoléon.

Morgagni, Giovanni Battista (1682-1771). Italian anatomist. In 1711 he obtained a chair of medicine at Padua, where he stayed for the rest of his life. Morgagni devoted himself to the study of the mechanisms of the body. His investigations of the glands of the trachea, of the male urethra and of the female genitals broke new ground. Above all, he pioneered the study of morbid anatomy. He undertook 640 postmortems, and was careful to relate the diseased organs he dissected to the patient's own life history and symptoms. Morgagni regarded each organ of the body as a complex of minute mechanisms, and the life of the whole was an index of its balanced functioning. His pioneering work in morbid anatomy was made specially valuable to later clinicians on account of his highly detailed case notes which he published in his De sedibus et causis morborurn per anatomen indagatis (1761).

Morgan, Charles Langbridge (1894-1958). English novelist and playwright. He was trained as a naval officer, served in World War I, became drama critic for The Times 1926-39 and worked for naval intelligence 1939-45. His polished and thoughtful novels include The Fountain (1932), Sparkenbrooke (1936) and The River Line (1937), later successfully dramatised. Among his other plays are The Flashing Stream (1938) and The Burning Glass (1953). His literary essays were collected as Reflections in a Mirror.

Morgan, Sir Henry (c.1635-1688). Welsh buccaneer. He was the most famous of the piratical adventurers who, like their Elizabethan prototypes, carried on a private and profitable war against the Spanish Empire in the West Indies and South America. Among his most daring exploits was his march (1681) across the isthmus of Panama to capture and plunder the city of that name. For the buccaneers this opened the way to the Pacific, which was to become one of their richest hunting grounds. In later life Morgan made peace with authority, he was knighted by ${ }^{*}$ Charles II and was Deputy Governor of Jamaica 1674-83.

Forbes, R. T., Henry Morgan, Pirate. 1946.

Morgan, John Pierpont (1837-1913). American financier. Son of Junius Spencer Morgan, who had built up a reputation and a fortune in international finance, J. P. Morgan expanded his financial interests into the industrial field, at first in partnerships with others and later through his own firm, J. P. Morgan \& Co. (founded 1895). He had meanwhile taken over the London interests of George Peabody, whose firm eventually became (1910) Morgan, Grenfell \& Co. Much of Morgan's money was made by great industrial mergers especially of railway and shipping companies, for which the financial crisis of 1873 provided many opportunities. Even the US Government, faced with a run on gold (1895), turned to Morgan for help. His most spectacular achievement took place when he formed (1900) the United States Corporation. Although in 1912 his affairs were carefully scrutinised as a result of antitrust legislation, no charge could be brought against him. Like so many American millionaires he was a great collector, most of his pictures and works of art were eventually presented to the Metropolitan Museum of Art, New York. His library, containing many rare books and MSS, was endowed and made available to the public by his son, John Pierpont Morgan, Jr (1867-1943), who played an important role in 
World War I, acting as purchasing agent in the US in the financing of the Allied war effort for the British and French governments.

Morgan, Lewis Henry (1818-1881). American anthropologist. He lived among the Iroquois Indians for many years and wrote some important studies on kinship and the development of tribal societies. The classificatory system he deduced is contained in his Systems of Consanguinity in the Human Family (1869).

Morgan, Thomas Hunt (1866-1945). American geneticist and embryologist, born in Kentucky. One of the founders of modern genetics, he was educated in Kentucky and Johns Hopkins, and taught at Bryn Mawr and Columbia. His academic career culminated in his becoming professor of biology at the California Institute of Technology from 1928. Morgan experimented on breeding mice and rats, and then fruit flies (drosophila), tracing patterns of variation over many generations of breeding, and demonstrating that particular characteristics (e.g. eye colour) were inherited through the transmission of genetic material. He termed the particles that conveyed the messages for these characteristics in the chromosome, 'genes'. Morgan's work proved that heredity could be treated rigorously. His laboratory became the training ground for a generation of Mendelian geneticists Bridges, *Muller, Dobzhansky and ${ }^{*}$ Monod. Morgan attempted to summarise his work in his 1934 volume, Embryology and Genetics, which argued that because inherited characteristics were genetically coded, they produced the quite sharp variations needed by Darwin's theory of evolution by natural selection. Thus modern genetics has come to lend support to Darwin. He received the 1933 Nobel Prize for Medicine.

Dunn, L. C., Short History of Genetics. 1965.

Morgenstern, Oskar (1902-1977). American economist, born in Germany. With John von *Neumann he wrote the enormously influential Theory of Games and Economic Behaviour (1944).

Morgenthau, Henry, Jr (1891-1967). American administrator. The son of a banker and diplomat, also Henry Morgenthau (1856-1946), he became a gentleman farmer and friend of Franklin D. *Roosevelt. He was Secretary of the US Treasury for a record term 1934-45. In 1943 he proposed that Germany be converted to an agricultural economy, and took a leading role at the Bretton Woods Conference (1944) which set up the International Monetary Fund (IMF) and the World Bank.

Morison, Stanley (1889-1967). British typographer. $\mathrm{He}$ was typographical advisor to Cambridge University Press 1923-44 and 1947-59 and to the Monotype Corporation. He designed Times New Roman typeface which was introduced in 1932.
He wrote extensively on typography and calligraphy, edited The Times Literary Supplement 1945-47 and the History of the Times 1935-52.

Barker, N., Stanley Morison. 1972.

Morisot, Berthe (1841-1895). French artist. Granddaughter of ${ }^{*}$ Fragonard, she was assisted by *Monet (whose brother she married), becoming one of the first and most important Impressionist painters. She was also a lithographer and etcher.

Stuckey, C. F. \& Scott W. P. Berthe Morisot. 1987.

Morland, George (1763-1804). English painter. His paintings, influenced by Dutch genre pictures, present homely subjects, e.g. Interior of a Stable and The Alehouse Door (both in the National Gallery, London). Popular, too, were his drawings for engravings on moral subjects, e.g. The Effects of Extravagance and Idleness. Drink and dissipation accelerated his death.

Morley, Edward Williams (1838-1923). American chemist and physicist. He became (1869) a professor at the Western Reserve College, Hudson, with which he remained when it moved to Cleveland and became a university; he retired in 1906 . He joined ${ }^{*}$ Michelson in carrying out the Michelson-Morley experiment (1881). He is also known for his accurate determination (1895) of the ratio of combination by weight of hydrogen and oxygen (1: 7.9395), which allowed the atomic weight of oxygen to be accurately fixed on the hydrogen scale.

Morley, John, 1st Viscount Morley of Blackburn (1839-1923). English Liberal politician and writer, born in Blackburn. Educated at Oxford, influenced by ${ }^{*}$ Mill and *Huxley, he became an agnostic and Positivist, working as a journalist. He wrote biographies of *Rousseau (1873), *Burke (1879), ${ }^{*}$ Cobden (1881), ${ }^{*}$ Walpole (1889) and ${ }^{*}$ Cromwell (1900). As editor of the Fortnightly Review (1867-82) he promoted rationalist and anti-imperialist policies that influenced the left of the Liberal Party. A Liberal MP 1883-95, 1896-1908, *Gladstone made him Chief Secretary for Ireland 1886, 1892-95, responsible for Home Rule, unachieved until 1921. An original member of the Order of Merit (1902), he was nominated for the Nobel Prize for Literature 11 times over a decade. He wrote The Life of Gladstone (3 vols, 1903) and served as Secretary of State for India 1905-10 and Lord President of the Council 1910-14. A pacifist, he resigned in protest at the outbreak of World War I.

Morley, Thomas (c.1557-1607/8). English composer. A pupil of William *Byrd, he was organist of St Paul's, London (from 1592), and a member of the Chapel Royal. One of the greatest of English madrigal composers, he set a number of *Shakespeare's songs (e.g. It was a lover and his lass) for voice and lute, 
composed Church music and works for viols and for virginals, and wrote the textbook $A$ Plaine and Easie Introduction to Practical Musick.

Morny, Charles Auguste Louis Joseph de Morny, Duc de (1811-1865). French politician and businessman, born in Switzerland. Grandson of *Talleyrand and son of Hortense Beauharnais (wife of Louis *Bonaparte), he was an illegitimate halfbrother of ${ }^{*}$ Napoléon III. A shrewd and unscrupulous manipulator, he organised the coup d'état of December 1851, became President of the Corps Legislatif 185465 and was a liberalising influence during the Second Empire.

Moro, Aldo (1916-1978). Italian politician. A Christian Democrat, he served as Prime Minister 1963-68, 1974-76 and Foreign Minister 1970-72. In 1978 he was kidnapped and murdered by the Red Brigade.

Moroni, Giovanni Battista (c.1525-1578). Italian painter. He may have had some link with *Titian, but worked in his home town of Bergamo, outside the artistic mainstream. However, his portraits are powerful, with acute psychological insight, and he is well represented in major European and American collections.

Morphy, Paul Charles (1837-1884). American chess player, born in New Orleans. He learnt chess by observing his family, and was a serious player from the age of 12. In the period 1858-60 he won competitions in the US and Europe, then retired, aged 22, and became an unsuccessful, alcoholic and paranoid lawyer.

Morricone, Ennio (1928-2020). Italian composer. He wrote scores for more than 400 films. His music, in a variety of genres, became more familiar to a larger audience than any other major contemporary composer. He won two Oscars and many other awards. His most admired film scores include The Mission, The Good, the Bad and the Ugly, Once Upon a Time in the West and Le Professionnel.

Morris, Gouverneur (1752-1816). American politician. Of partly Huguenot descent, he became prominent in New York politics and was a conservative at the Federal Constitutional Convention (1787), where he argued for a strong central government and became principal draftsman of the US Constitution (although *Madison and ${ }^{*}$ Franklin contributed more substance). He was Minister to France 1792-94 at the time of the revolutionary 'Terror', of which his Diary gives a graphic firsthand account. He spent some years in travel before returning to the US. A senator from New York 1800-03, he retired to view the increasing egalitarianism of the times with aristocratic disdain.
Morris, William (1834-1896). English artist, writer, craftsman and socialist, born in London. Son of a prosperous city bill-broker, as a boy he lived in a large house on the borders of Epping Forest. As a pupil at Marlborough he already showed his architectural interests and at Oxford became friends with *Burne-Jones and later *Rossetti and the other Pre-Raphaelites: *Ruskin's books guided his architectural taste at this time. After graduating he trained as an architect, first in Oxford and then in London, where he shared rooms with Burne-Jones. His marriage (1859) to the lovely Jane Burden (1839-1914) (immortalised by her lover Rossetti), and the building for them of the famous Red House by Philip Webb, provided the incentive to found (1861) the firm of Morris, Marshall \& Faulkner (later Morris \& Co.) for the manufacture of carpets, wallpaper, furniture etc. This enterprise, of which his friends Ford Madox *Brown, Rossetti, Burne-Jones and Webb were all original members, enabled Morris to express his hatred of industrial civilisation and love of the medieval past, reflected also in his poetic works The Defence of Guinevere (1858) and The Earthly Paradise (1868-70). The Morris designs are now being restored to favour but it has been argued that the vogue for 'handicrafts' that they heralded delayed the evolution of good industrial design.

Morris' wish to revive the dignity and joy of work led him to a romantic form of socialism. He joined (1883) *Hyndman's Social Democratic Federation and founded (1884) The Socialist League. In The Dream of John Bull (1888) and News from Nowhere (1891) he presented his vision of a more human and joyful society. The last years of his life were occupied in the writing of prose romances partly inspired by his study of Icelandic sagas, and in founding the Kelmscott Press which, by reviving and improving the old standards of book binding and type design, had an important influence on the history of printing.

Henderson, P. P., William Morris, His Life and Friends. 1967; MacCarthy, F., William Morris: A Life for our Time. 1994.

Morris, William Richard, 1st Viscount Nuffield (1877-1963). English motor manufacturer and philanthropist. Originally owner of a bicycle shop in Oxford, he started (1912), in an improvised works at Cowley just outside the city, to build motor cycles and then the first Morris Oxford and Morris Cowley cars. World War I intervened, but his 1925 output on 53,000 cars achieved a European record. In 1931 he gave $£ 50,000$ to Oswald *Mosley’s 'New Party'. In 1937 he endowed the foundation of Nuffield College, Oxford, supported Birmingham University, and in 1943 established the Nuffield Foundation. During World War II, his project to speed up the production of fighter planes failed. Alec ${ }^{*}$ Issigonis designed the Morris Minor in 1948. Morris Motors merged with the Austin Motor Company in 1952 to form the BMC (British Motor Corporation), which Morris 
chaired briefly, but the brand name survived until 1984. Morris was made a baronet (1929), a baron (1934), promoted to viscount (1938), also garnering a GBE (1941) and CH (1958).

Andrews, P. W. and Brunner, E., Life of Lord Nuffield. 1955; Leasor, J., Wheels to Fortune: The Life and Times of William Morris, Viscount Nuffield. 2008.

Morrison, Herbert Stanley, Baron Morrison of Lambeth (1888-1965). British Labour politician, born in South London. Son of a policeman, he worked as an errand boy, shop assistant and for a newspaper. Secretary of the London Labour Party 1914-47, he was an MP 1923-24, 1929-31 and 1935-59, and Minister for Transport 1929-31 in Ramsay *MacDonald's second government. He led the Labour group in the London County Council 1933-40, gaining a great reputation as an organiser. Loathed by Ernest *Bevin and mistrusted by Clement *Attlee, during World War II he was a successful Home Secretary 1940-45 in Churchill's coalition. In Attlee's Labour Government he was Deputy Prime Minister and Lord President of the Council 1945-51, and Foreign Secretary 1951. When Attlee retired as party leader in $1955,{ }^{*}$ Gaitskell beat Morrison for the succession.

Donoughue, B. and Jones, G. W., Herbert Morrison. 1973.

Morrison, Scott John (1968- ). Australian Liberal politician, born in Sydney. Educated at the University of NSW, he worked in the tourism industry in New Zealand and Australia as a manager and marketer, then became a Liberal Party official and Federal MP 2007- . As Minister for Immigration and Border Protection 2013-14, he imposed a harsh regime against refugees attempting to arrive by boat. Minister for Social Security 2014-15 and Treasurer 2015-18, he became Prime Minister 2018-22, beneficiary of a right-wing attempted coup to replace Malcolm *Turnbull with Peter *Dutton, creating an opportunity for Morrison to come through the middle. An active Pentecostal, his unexpected victory in the 2019 election was explained as 'a miracle'. The Coalition's commitment to action on climate change was ineffective, due to National Party opposition. Early action on Covid 19 in 2020 was successful due to limiting international travel, but vaccines were slow to arrive and tensions with states soon developed. Morrison was vulnerable on failures on climate change, pork-barrelling, accountability and integrity, and misogyny. In May 2022 the Coalition was heavily defeated, losing seats to the ALP, Independents and Greens. His secret appointment of himself as Treasurer, Minister for Health, and three other ministries in 2020 and 2021 was deeply controversial.

Smethurst, A., The Accidental Prime Minister. 2021; Kelly, S., The Game. 2021.
Morrison, Toni (Chloe Ardelia Wofford) (19312019). American novelist, born in Ohio. Educated at Howard and Cornell Universities, she lectured at Princeton 1987-2006. Her novels include The Bluest Eye (1970), Song of Solomon (1977), Tar Baby (1981) and Jazz (1992). She received the Pulitzer Prize in 1988 for Beloved, the Nobel Prize for Literature in 1993 and the Presidential Medal of Freedom in 2012.

Morse, (Samuel) Finley (Breese) (1791-1872). American inventor, born near Boston. Educated at Yale, he studied art in England and became a successful portrait painter and pioneer photographer in the US. From 1832 he experimented with means of transmitting messages using either electricity or a system of flashing lights, adopting (without acknowledgement) the work of Joseph *Henry. He devised the 'Morse Code' and patented (1840) an electric telegraph. In 1844 he sent a telegraphic message from Washington DC to Baltimore. He was politically active, deeply anti-Catholic and a strong supporter of slavery.

Morsi, Mohamed (1951-2019). Egyptian politician and engineer. He gained a $\mathrm{PhD}$ in materials science at the University of Southern California, then became active in the Muslim Brotherhood and was a founder of the Freedom and Justice Party (2011). Described as a moderate, he expressed scepticism about al-Qaida links to the World Trade Centre attacks in 2001. After *Mubarak's fall, he was elected as President of Egypt in June 2012. In July 2013, after days of huge public demonstrations, there was an army coup, Morsi was deposed and arrested and a process of 'national reconciliation' was begun, aimed at restoring Egypt to being secular and pluralist. He was held for trial on charges of incitement to murder and espionage, and a death sentence was passed in May 2015.

Mortimer, Roger de, 1st Earl of March (12871330). English nobleman. He played a conspicuous part in the struggle for power in the reign of ${ }^{*}$ Edward II. He allied himself with Queen *Isabella, whose lover he became, in the conspiracy by which her husband was deposed (1327) in favour of her son, the boyking ${ }^{*}$ Edward III, and soon murdered, presumably on Mortimer's orders. Three years later the hatred inspired by Mortimer's rule encouraged Edward to have him seized and hanged at Tyburn without trial. Another Roger Mortimer (1374-1398), his descendant, became heir presumptive to ${ }^{*}$ Richard II and (through the marriage of his daughter, Anne) the source of the Yorkist claim to the throne.

Morton, James Douglas, 4th Earl of (c.1516-1581). Scottish nobleman. A Protestant, he was (from 1557) at the centre of the plots and intrigues against *Mary Queen of Scots. He took part in *Rizzio's murder and was almost certainly privy to that of *Darnley. It was he who discovered the 'casket letter' which, if genuine, implicated Mary. After the death of *Moray he was twice Regent of Scotland, 1572-78 and 1578-80, for 
*James VI and attempted to restore tranquillity to a land torn by religious dissension and war. A party of the nobles plotted to secure his dismissal. He seized Stirling Castle and the young king, but a further plot resulted in his execution for the murder of Darnley.

Morton, James Douglas, 14th Earl of (1702-1768). Scottish nobleman, born in Edinburgh. Educated at Cambridge, he travelled widely and was an enthusiast for astronomy. President of the Royal Society 1764-68, he instigated James *Cook's expedition to Tahiti and New Holland, and encouraged respect for Indigenous people. Moreton Bay (wrongly spelled) in Queensland was named for him.

Morton, John (1423-1500). English ecclesiastic and lawyer. After various turns of fortune during the Wars of the Roses he became *Henry VII's most trusted advisor: he was Archbishop of Canterbury 1486-1500, Lord Chancellor 1487-1500, and became a cardinal (1493). It is said (though the story is probably apocryphal) that he assisted the king's extortions by impaling potential victims on the horns of a dilemma known as Morton's Fork, but he certainly used his visits to nobles to assess their wealth: if they had a costly retinue, he concluded they were rich and able to pay heavy taxes; if modest, that they were avaricious and equally able to pay.

Morton, William Thomas Green (1819-1868). American dentist. Famous for introducing ether as an anaesthetic, he used it (1846) at Massachusetts General Hospital, Boston, in the first successful major operation using general anaesthesia; however, Crawford *Long was earlier (1842), but unreported. Morton used anaesthesia extensively as a surgeon in the Union Army.

Keys, T. E., The History of Surgical Anaesthesia. 1945.

Mosaddegh (or Mussadiq), Mohammad (18761967). Iranian politician, born in Tehran. His father was a high official, his mother from a princely clan. He studied law in France and Switzerland, served briefly as Finance Minister 1921-22 and Foreign Minister 1923 and in 1944 founded the National Front, proposing democratic reform and nationalisation of the Anglo-Iranian Oil Company (AIOC). Appointed as Prime Minister 1951-53, he nationalised the oil industry, introduced land reforms and weakened the power of the Shah. Britain imposed a virtual boycott, paralysing the AIOC and there were strikes in protest against economic hardship. The CIA and MI6 organised a successful coup, led by General Fazlollah Zahedi, in August 1953. Mosaddegh was tried and imprisoned until 1956, then kept under house arrest until he died.

Moseley, Henry Gwynne Jeffreys (1887-1915). English physicist. Educated at Eton and Oxford, he worked with Ernest ${ }^{*}$ Rutherford in Manchester as a research assistant 1910-13, studied the X-ray spectra of many elements and discovered (1913) that the frequency of the characteristic line in each spectrum increases in regular sequence from one element to the next in the periodic table. He thus showed the fundamental importance of the atomic number of an element, which defines the element and is directly related to its atomic structure. He was killed at Gallipoli.

Moses (Moshe, probably from the Egyptian mos, 'child') (c.14th-13th centuries BCE). Hebrew leader and law-giver, born in Egypt. According to the Pentateuch, he was a Levite, hidden in bullrushes to avoid slaughter by the Egyptians, found and brought up by Pharaoh's daughter, an account paralleling birth legends in mythology. After killing an Egyptian overseer, he took refuge with the Midianites and married Zipporah. After many years he received in a vision an order from Jehovah to lead the Jewish people from their captivity in Egypt to Palestine. The 10 plagues that afflicted Egypt are reputed to have been among the reasons why Pharaoh allowed them to depart. Moses and his brother Aaron led them to Mount Sinai where the 'Ten Commandments' were received. Moses led his people for many years in the wilderness but died at the age of 120 on Mount Nebo (Sinai) in sight of the 'Promised Land' of Palestine, which he never reached. The Pentateuch took its present form about 600 years after his time and he was almost certainly a composite figure.

Freud, S., Moses and Monotheism. 1939.

Moses, Grandma (Anna Mary Robertson) (18601961). American painter. A farmer's wife, she took up painting at the age of 77 and won fame for her gay and spontaneous pictures of rural scenes.

Mosley, Sir Oswald Ernald, 6th Baronet (18961980). English Fascist politician. Educated at Winchester and Sandhurst, he was wounded in World War I, served in government offices and developed political ambitions. In 1920 he married Lady Cynthia Blanche Mosley (1898-1933), daughter of Lord *Curzon, who was a Labour MP 1929-31. Member of Parliament 1918-24 and 1926-31, Conservative until 1922, Independent 1922-24 he joined the Labour Party in 1924. Under Ramsay *MacDonald, he served as Chancellor of the Duchy of Lancaster (de facto Minister for Unemployment) 1929-30, resigning because of Labour's failure to cope with the Depression. He formed the New Party (1931) and founded the British Union of Fascists (1932). In 1936, in Berlin, he married his mistress Diana *Mitford; Adolf *Hitler was guest of honour. The violence of his 'Blackshirts' was a feature of prewar politics, with a pitched battle in East London in October 1936. He was interned during World War II 1940-43, then put under house arrest. Deeply anti-Semitic, and a Holocaust denier, he founded the Union Movement in 1948 and lived in France from 1951. Mosley was parodied in novels by Aldous ${ }^{*}$ Huxley, H.G. *Wells and P. G. *Wodehouse. 
Mosley, N., Rules of the Game: Sir Oswald and Lady Cynthia Mosley, 1896-1933. 1982; Beyond the Pale: Sir Oswald Mosley 1933-1980. 1983.

Mostel, Zero (Samuel Joel) (1915-1977). American actor, born in Brooklyn. A masterful mime, skilled in drama and comedy, he starred in Ulysses in Nighttown (1958), *Ionesco's Rhinoceros (1961, stage and film) and created the role of Tevye in Fiddler on the Roof (1964). He starred in the film The Producers (1968).

Motley, John Lothrop (1814-1877). American historian. He wrote the classic The Rise of the Dutch Republic (1856) and served as US Minister to Austria 1861-67 and Great Britain 1869-70.

Moulin, Jean (1899-1943). French administrator and Resistance leader. Prefect of Chartres 1936-40, he became the courageous leader of the Underground, supported *de Gaulle's leadership of the Free French and encouraged him to embrace more progressive policies. He died in German custody and is much commemorated in France.

Mountbatten, Louis Alexander (né Ludwig Alexander von Battenberg), 1st Marquess of Milford Haven (1854-1921). English admiral and (former) German prince, born in Graz, Austria. A member of the ducal family of Hesse, he moved to England as a child, joined the Royal Navy in 1868 and in 1884 married his cousin, Princess Victoria of Hesse, a granddaughter of Queen *Victoria. An extremely skilful sailor, despite his royal connections, he was a great promoter of technological improvements in the fleet. Promoted to First Sea Lord of the Admiralty 1912-14, he was forced out after World War I began, due to strong anti-German feeling. In 1917 he abandoned his princely title, adopted the anglicised surname of Mountbatten and was created a marquess. Placed on the retired list, he was promoted Admiral of the Fleet in August 1921 and died unexpectedly a month later. He was the father of Queen Louise of Sweden, Earl * Mountbatten of Burma and Princess Alice of Greece, mother of Prince Philip, Duke of *Edinburgh.

Mountbatten of Burma, 1st Earl Louis Francis Albert Victor Nicholas Mountbatten (1900-1979). British Admiral of the Fleet and administrator, born in Windsor. Son of Prince Louis von Battenberg, later ${ }^{*}$ Mountbatten, Marquess of Milford Haven, and great-grandson of Queen *Victoria, he joined the Royal Navy in 1913 and became the ADC (and close friend) of his cousin, Edward, Prince of Wales (*Edward VIII). In 1922 Lord Louis Mountbatten married Edwina (Cynthia Annette) Ashley, later Countess Mountbatten (1901-1960), an heiress, and they became glamorous figures in London society. His exploits as captain of the destroyer HMS Kelly (193941) were celebrated in Noel *Coward's film In Which We Serve (1942). As Chief of Combined Operations 1942-43, he organised several successful commando raids (and one disaster in Dieppe). Techniques and equipment devised under his direction (including 'Pluto' and the 'Mulberry' harbours) proved essential in the Normandy invasion (1944). As Supreme Commander, Allied Forces, South East Asia 1943-46, he had a genius for publicity, mostly remaining at his headquarters at Kandy, Ceylon, while the defence of India and expulsion of the Japanese from Burma were left to *Auchinleck and ${ }^{*}$ Slim respectively. Created a viscount and a KG in 1946, he was appointed as the last viceroy of India March-August 1947 by Clement *Attlee. The original date set for transfer of power and partition into India and Pakistan was June 1948, but Mountbatten insisted on speeding up the process which took place on 15 August 1947. Boundary lines were drawn to benefit India, and Mountbatten was skilful in evading responsibility for almost $1,000,000$ deaths in the ensuing conflict. He became first Governor-General of the new dominion of India 1947-48, working closely with ${ }^{*}$ Nehru, with whom his wife had an intimate relationship. Promoted earl in 1947, in the same year his nephew, Philip, Duke of *Edinburgh, married the future *Elizabeth II. He returned to naval duties in 1948 and became Commander in Charge of NATO Naval Forces in the Mediterranean 1953-54, First Sea Lord of the Admiralty 1955-59 and Chief of the UK Defence Staff 1959-65. Promoted Admiral of the Fleet in 1956, he received the OM in 1965 and was elected FRS in 1966. Countess Mountbatten devoted herself to the St John's Ambulance and overseas aid; she died suddenly in North Borneo. He was actively involved in 179 organisations, featured in an autobiographical television series and had a major influence on the future *Charles III. He was killed by an IRA bomb while on a boating holiday in Ireland. Handsome, imaginative, but superficial and distrusted by his contemporaries $\quad\left({ }^{*}\right.$ Alanbrooke, ${ }^{*}$ Montgomery, *Templer, ${ }^{*}$ Ismay, Slim), Mountbatten's reputation has declined since his death.

Ziegler, P., Mountbatten. 1985.

Mountbatten-Windsor. Family name of descendants of Queen *Elizabeth II and the Duke of *Edinburgh, but the dynasty remains 'House of Windsor'.

Mowat, Farley (McGill) (1921-2014). Canadian author. After war service and polar exploration, he devoted himself to travel and writing about threats to species and natural environments. His books include Never Cry Wolf (1963), A Whale for the Killing (1972), And No Birds Sang (1979) and Sea of Slaughter (1984).

Mo Yan ('Don't speak': personal name Guan Moye) (1955-) Chinese novelist, born in Shandong province. During the Cultural Revolution he left school at 12 to work in the fields. He served in the PLA, began to read widely and was influenced by ${ }^{*} \mathrm{Lu}$ Xun and translations of *Faulkner and *Garcia Marques. Red Sorghum (1987) was filmed by *Zhang Yimou. Other novels include Life and Death Are Wearing Me Out 
(2006), Sandalwood Death (2013), and Pow! (2013). $\mathrm{He}$ was awarded the Nobel Prize for Literature in 2012 for his work which 'with hallucinatory realism merges folk tales, history and the contemporary'. Mo Yan was criticised by Salman *Rushdie and others for failing to protest against the treatment of dissidents in China. ( ${ }^{*}$ Gao Xingjian).

Moynihan, Daniel Patrick ('Pat') (1927-2003). American politician, sociologist and diplomat, born in Oklahoma. Highly idiosyncratic, he worked with the *Kennedys, Ralph *Nader, Richard ${ }^{*}$ Nixon and the ${ }^{*}$ Clintons. He was Ambassador to India 1973-75, to the United Nations 1975-76 and a US Senator (Democrat) from New York 1977-2001. He observed: 'Everyone is entitled to his own opinion, but not to his own facts.'

Mozart, Wolfgang Amadeus (Johann Chrysostom) (1756-1791). Austrian composer, born in Salzburg. $\mathrm{He}$ was the son of the distinguished violinist and composer Leopold Mozart (1719-1787), director of the Archbishop of Salzburg's orchestra. The most precocious genius in the history of music, Mozart began to play the harpsichord at the age of three, composed an Andante and Allegro and gave his first public performance when he was five (by which time he had mastered the violin), and at the age of six played at the court of the empress * Maria Theresa. By 1763 he was an accomplished alto singer and organist and amazed the French Court with his skill. In 1764 he visited London, played for ${ }^{*}$ George III, met J. C. ${ }^{*}$ Bach and was the subject of a report to the Royal Society. He composed his first symphony (1764-65) and a motet, God is our Refuge, in 1765. In 1768 he composed a one-act opera Bastien und Bastienne and made his debut as a conductor with his Missa Solemnis. He toured Italy at 13, was made a Knight of the Golden Spur by Pope Clement XIV and gave a series of extraordinary concerts at which he demonstrated his astounding improvisatory skills. In 1782 he married Constanze Weber (1763-1842). The couple had six children of whom only two survived infancy Karl (d.1858) and Franz (d.1844). Soon after his marriage Mozart met *Haydn who helped him greatly, especially with the string quartets, and remained a loyal friend. He wrote to Leopold 'Your son is the greatest composer known to me either in person or by name.' After a series of successful concerts in Prague (1787), Mozart was appointed as Imperial and Royal Chamber Composer (Kammermusicus) by *Joseph II, a sinecure which paid 800 florins. His income in the 1780 s varied between 2,000 and 6,000 florins (about the same as Haydn, who was thought to be affluent) but he lived well, moved in expensive circles, did not budget properly and borrowed when he could. It has been estimated that income in his last years averaged the equivalent of $\$ U S 175,000$. He taught, gave as many concerts as the market would support and arranged dance music and salon pieces. He declined two lucrative offers from J. P. *Salomon to work in London (1790). He died in December 1791 at his lodgings in the Rauhensteingasse (now demolished), probably from acute rheumatic fever complicated by broncho-pneumonia, a more likely cause than chronic renal (kidney) failure. His death certificate gave the cause as 'heated miliary fever' (essentially a symptom rather than a disease). His last work, appropriately, was the Requiem, left incomplete. He was buried in an unmarked communal grave in the $\mathrm{St}$ Marx cemetery, Vienna, in conformity with the burial laws of Joseph II.

Mozart's works were catalogued in chronological order by Ludwig von *Köchel: the Requiem (1791) is K. 626. However, some lost works have since been found and the total number of compositions exceeds 670, about 400 surviving in Mozart's autograph. There are 41 numbered symphonies, the most performed being Nos 28, 31 ('Paris'), 35 ('Haffner'), 36 ('Linz'), 38 ('Prague'), 39, 40 and 41 ('Jupiter'); the last three were composed in six weeks (1788). Nine more juvenile symphonic works or fragments must be added. Mozart's 27 piano concertos (and concertos for two and three pianos) are of extraordinary quality especially Nos 9, 12, 15, 19, 20, 21, 23, 25 and 27. The six violin concertos, elegant salon pieces, are ressentially divertimentos. He wrote a superb clarinet concerto (K. 622: 1791), four concertos for horn, concertos for flute, flute and harp, oboe and bassoon, and a Sinfonia Concertante for violin and viola (K. 364: 1779). The Serenade in B flat (Gran' Partita) (K. 361: 1781-82) for 13 wind instruments, conceived on a huge scale, is a virtuoso work of unprecedented vitality. He wrote 17 Masses, of which 14 survive: the 'Great' Mass in C Minor (1782) and the Requiem have an astonishing power. The Requiem left incomplete, begins with a gut-wrenching introduction of 29 notes, barely 50 seconds long. Cellos and basses open, followed by the mournful sound of a bassoon, soon joined by the lowest register (chalumeau) of a clarinet, and ending with four notes, fortissimo, from three trombones. Those 29 notes, not one wasted, demonstrate exceptional economy and power.

His chamber works include 23 string quartets (the most important being six dedicated to Haydn, written 1782-85), 6 string quintets (K. 515 in C major and K. 516 in G Minor, both 1787, among his masterpieces), the serenade for strings Eine kleine Nachtsmusik (K. 525: 1787), the String Trio (K. 563: 1788), seven piano trios, and the Clarinet Quintet (K. 581: 1789), the greatest in the repertoire. His 14 piano sonatas, notably transparent, are deceptively simple: as Artur *Schnabel commented, 'Too easy for amateurs: too hard for professionals'. He wrote about 30 songs.

Mozart wrote 22 dramatic works, some incomplete. 13 more or less complete operas survive. Le nozze di Figaro (The Marriage of Figaro, 1786, based on a comedy by Caron de *Beaumarchais), Don Giovanni (1787) and Cosi fan tutte ('Thus do they all ...', 1790) 
have incomparable Italian librettos by Lorenzo da *Ponte which contributes to rich characterisation. Mozart wrote the greatest scenes in the whole operatic repertoire, including the familiar trio from Cosi fan tutte ('Soave sia il vento ...'), the last scene of Don Giovanni, and from The Marriage of Figaro the exhilarating sextet ('Riconosci in quest' amplesso') in the third act. In Figaro's sublime finale, the theme of reconciliation is compressed to a bare five lines. Psychologically and politically complex, the music and libretti reflect the social turbulence of his time.

Die Zauberflöte (The Magic Flute, 1791) is set to a German text by Emanuel *Schikenader, a Viennese promoter: the work has many beautiful arias, but the characters lack depth and the story is more pantomime (deliberately) than drama. Mozart's last opera was La clemenza di Tito (1791).

Bernard *Shaw argued that Mozart's 'voice' was unique. After listening to only a few bars, even in an unfamiliar work, it is clear that the music can only be his. Characters in his operas have an individual sound. In The Marriage of Figaro, the Countess, Susannah and Cherubino sing in exactly the same register, as do the Count, Figaro and Dr Bartolo, and yet even with closed eyes audiences are never in doubt about who the character is. The Mozart operas are far more than elegant and witty costume dramas-with elements of violence and exploitation included with Don Giovanni. At the deepest level they raise central and disturbing questions about identity: 'Who am I?' and, the orchestra (especially the violas) sometimes tells a different story to what is being enacted on stage.

Peter *Shaffer's play Amadeus (1979), later a successful film (1984), generated interest and controversy, emphasising the contrast between the sublimity of Mozart's music and some childish and scatalogical elements in his behaviour. By the bicentennial of his death (1991) all of Mozart's music was available on CD.

Hildesheimer, W., Mozart. 1982; Robbins Landon, H. C., Mozart: the Golden Years. 1989; Robbins Landon, H. C., The Mozart Compendium 1990; Morris, J. M., On Mozart. 1995; Solomon, M., Mozart: A Life. 1995; Gutman, R. W., Mozart. A Cultural Biography. 1999.

Mravinsky, Yeygenyi Aleksandrovich (1903-1988). Russian conductor. Chief conductor of the Kirov Ballet, Leningrad 1932-38 and of the Leningrad Philharmonic 1938-88, he kept out of politics, rarely toured but made memorable recordings of *Beethoven, *Tchaikovsky and *Shostakovich.

Mu'āwiyah ibn Abī Sufyān (602-680). Fifth caliph of Islam 661-80, founder of the *Umayyad dynasty. Born in Mecca, in the Quraysh tribe, he deposed *Ali's son Hasan and ruled from Damascus.
Mubarak, (Muhammad) Hosni (El-Sayad) (19282020). Egyptian officer and politician. He joined the air force in 1950, and as Commander-in-Chief 1972-75 took a central role in the 1973 war with Israel. Vice President of Egypt 1975-81, after *Sadat's assassination, he succeeded as President 1981-2011. He maintained good relations with Israel and was heavily subsidised by the US as a reliable opponent of Islamic fundamentalism. His government became increasingly authoritarian and in February 2011, during the 'Arab Spring', after 18 days of huge demonstrations, he was forced to resign. Convicted of murder and sentenced to life imprisonment (2012), a retrial was ordered in 2013. The murder conviction was overturned but he and his sons were convicted of corruption and embezzlement. He was released in 2017.

Mueller, Baron Sir Ferdinand Jakob Heinrich von (1825-1896). German-Australian botanist. In Australia from 1847, he was an indefatigable explorer and botanical taxonomist, Government Botanist in Victoria 1853-96 and director of the Melbourne Botanic Gardens 1857-73. He discovered many new species, published exhaustively and received many awards, including FRS, KCMG and a barony from Württemberg.

Mugabe, Robert Gabriel (1925-2019). Zimbabwean politician, born in Kutama. A Shona, educated by the Jesuits, after training at Fort Hare, he went to Northern Rhodesia (now Zambia) to teach and from there to Ghana in 1958. Later, he became Secretary-General of the Zimbabwe African National Union (ZANU) and was Secretary-General 1963-74, and President from 1974. After 10 years in prison (1964-74), when he gained four more degrees by correspondence, he left Rhodesia for Mozambique and ZANU became guerrilla-based. After four years of armed conflict with the regime led by Ian *Smith, pressure from the UK and (surprisingly) South Africa led to the Lancaster House negotiations in London (1979), aimed at securing a transition from armed conflict to democracy. ZANU won 57 of 80 seats reserved for Africans in the February 1980 elections. Christopher Soames, interim Governor of Southern Rhodesia, commissioned Mugabe to form a government. Rhodesia was immediately renamed Zimbabwe. Mugabe was the first Prime Minister of independent Zimbabwe 1980-87 and President 1987-2017. Mugabe and his ZANU-PF (i.e. Patriotic Front) regime became increasingly corrupt, dependent on army and police support, and agriculture collapsed. In 2006, WHO reported that Zimbabwe had the world's shortest life expectancy. The presidential election of 2008 in which Mugabe defeated Morgan *Tsvangirai was generally regarded as fraudulent. Mugabe had been awarded an honorary GCB in 1994, but the honour was 'annulled' in 2008. Tsvangirai became Prime Minister in 2009, in an attempt to negotiate a unity government, but had little power. Mugabe was re-elected for a 
seventh term in August 2013, claiming 61 per cent of the vote on a disputed roll. In November 2017, after Mugabe sacked Emmerson Mnangagwa as Vice President, intending to appoint his own wife Grace, the army intervened, placed him under house arrest and negotiated his resignation in a bloodless action.

Norman, A., Mugabe: Teacher, Revolutionary, Tyrant. 2008.

Muggeridge, (Thomas) Malcolm (1903-1990). English journalist. Educated at Selwyn College, Cambridge, he taught in India and Egypt, then became a journalist for the Manchester Guardian, working in Cairo and Moscow. He served in army intelligence during World War II and was editor of Punch 195357. Best known as a witty and controversial television performer, he made an influential film about Mother *Teresa, became increasingly preoccupied with religion and joined the Catholic Church in 1982. His books include The Thirties (1940), Tread Softly for you Tread on my Jokes (1966), Something Beautiful for God (1971), Paul (1972) and Chronicles of Wasted Time (an autobiography, Vol. 1 1972, Vol. 2 1973).

Muhammad (or Mohammad, Arabic = praised $)(\mathrm{Abu}$ al-Qasim Muhammad ibn Abdu'llah ibn 'Abdu'lMuttalib ibn Hashim) (c.570-632). Arab religious teacher, founder of Islam, born in Mecca. A member of the Quraysh clan which ruled Mecca, he was orphaned early and later adopted by an uncle, Abu Talib. When about 25, he was engaged by Khadijah (c.555-619), a wealthy woman, to accompany one of her caravans and he later married her. Despite the disparity in age the marriage was happy. Muhammad had two sons and four daughters by her, one of whom, ${ }^{*}$ Fatimah, married his cousin ${ }^{*} \mathrm{Ali}$ - a union from which all the direct descendants of the prophet sprang.

From 610, when he was 40, Muhammad had a series of visions in which the archangel Gabriel dictated the text of what became known as the Qu'ran (Koran). Muhammad could not read or write but dictated the text from memory, either to *Ali (as Shi'ites believe) or to ${ }^{*}$ Abu-Bakr (the favoured scribe of the Sunnis). Thefaith Muhammad preached was strict monotheism: while he accepted that Jews and Christians also worship the same god he felt that they had strayed from the strict monotheistic path. He denounced idols, proclaimed a single God, Allah, and promised true believers physical resurrection in Heaven. He preached complete submission to the will of God (this is the meaning of 'Islam') and the equality of all men (but perhaps not women) of every race. Christians and Jews he classed not as pagans but as Ahl al Kitab (people of the book), towards whom he extended toleration. At first only his wife believed in him and in the first 10 years he made fewer than a hundred converts, but this was enough to alarm the citizens of Mecca who had a vested interest in preserving the image of their city as a religious centre of all Arabs with the Kaaba and its many idols. To escape their animosity Muhammad and his followers moved unobtrusively (622) to Yathrib (renamed Medina, 'city of the prophet'), about 330 kilometres to the north which offered them security. This was the hegira (flight) from which the Muslim era dates $(\mathrm{AH})$. In Medina he had greater success in winning adherents than in Mecca and he became the revered law-giver and ruler of the city. His followers organised attacks on caravans from Mecca and his fame spread and attracted support. In 623 the Muslims won a signal victory over the Meccans at Badr and in 630 Muhammad marched on Mecca, which surrendered. The Kaaba was cleared of its idols and became the shrine of Islam. Muhammad was recognised as a prophet and the new faith spread rapidly throughout Arabia. He returned to Medina, where he died. After his first wife's death (probably in 619), Muhammad took several wives, of whom his favourite was A'ishah (Ayesha), her father, Abu-Bakr, became Muhammad's successor, as first caliph of Islam.

Muhammad was a unique combination of religious and secular leader, ruling central Arabia with a population of about two million. He has been described as the Islamic equivalent of a combination of *Jesus, St *Paul, the four evangelists and ${ }^{*}$ Constantine, but no claim of divinity was made by or for him.

There is little about Muhammad's life to explain those undoubted qualities that inspired such devotion among his followers, an inspiration which founded a great new world religion and carried the hitherto backward peoples of Arabia to the conquest of an empire which, at its peak, was greater in extent than that of the Romans. It also led to a flowering of arts and sciences that shone all the more brightly against the background of the Dark Ages in Europe.

Watt, W. M., Mohammed: Prophet and Statesman. 1961; Anderson, K., Muhammad: A Life of the Prophet. 1991; Muhammad: A Prophet for Our Time. 2006; Hazelton, I., The First Muslim. The Story of Muhammad. 2013.

Muhammad Ali (Pasha al-Mas'ud ibn Agha) (1769-1849). Albanian-Egyptian commander, born in Kavala, then in Macedonia, now in Greece. Of Albanian descent, orphaned early, he was brought up in the household of an officer of janissaries, with whom he gained some military experience. After fighting with Turkish troops in Egypt against the French army of occupation, he remained there in command of Albanian troops and emerged from a confused struggle for power as Wāli (or Viceroy) 1805-48, preferring to use the title of Khedive (a Persian word). At first, he was confronted by the Mamluk beys, descendants of the Mamluk sultans who, though conquered by the Turks in 1517, still retained semi-independence. By organising their treacherous massacre (1811), Muhammad 
Ali became supreme and, though nominally under Turkish suzerainty, built up Egypt into a virtually independent state. Immediately after the massacre he invaded Arabia where an extremist Islamic sect, the Wahabis (*Ibn Sa'ud), had seized the holy cities of Mecca and Medina. The war was ended (1818) by Mehemet's son *Ibrahim, and the Wahabi prince Abdullah was sent to Constantinople for execution.

Muhammad Ali now proceeded to create some aspects of a modern state, deriving revenues from monopolies for the sale of agricultural produce and from new industries that he established. He was thus able to raise new armies with which he conquered the Sudan (1820-30) and aided the Turks against the Greek independence movement (1824-27). The Turks were, however, made restive by the increasing power of their overgrown subject and when Ibrahim conquered Syria they enlisted British aid to make him withdraw—a major setback for Muhammad Ali who was, however, compensated by having his office made hereditary and was thus enabled to found the khedival dynasty. In 1848 Muhammad Ali became insane; Ibrahim, who succeeded, died in the same year.

His fourth son, Muhammad Sa'id Pasha (18221863), educated in Paris, was khedive of Egypt and Sudan 1854-63 and collaborated with Ferdinand de *Lesseps in promoting the Suez Canal. His family ruled Egypt, at least in name, until *Farouk's abdication in 1952.

Muhammad bin Salmān bin 'Abd al-'Azīz Āl Sa'ūd (1985- ). Saudi Arabian Crown Prince. Son of King Salman, known as MBS, he was Minister for Defence and Deputy Prime Minister 2015- and associated with opening up and diversifying the economy, and allowing women to drive. He supported *Trump's election in 2016 but the CIA concluded that he was responsible for the murder of Jamal *Khashoggi in 2018. In 2017 he had bought *Leonardo's Salvator Mundi for \$US450 million.

Muir, Edwin (1887-1959). Scottish poet, born in Orkney. After working as a clerk in Glasgow, he became involved in left wing politics. He married Willa Anderson (1919) and went to Prague, where, with his wife, he translated the works of *Kafka and began to publish his own poetry. He worked for the British Council 1942-50, then became warden of Newbattle Abbey College. His Collected Poems appeared in 1952. His prose works include a study of John *Knox and his Autobiography (1954).

Muir, John (1838-1914). American conservationist, born in Scotland. He lived in the Sierra Nevada from 1868, devoted himself to nature, travelled extensively in the west and Alaska and campaigned for forest conservation, national parks and the preservation of wilderness. The Sequoia and Yosemite National Parks were proclaimed in 1890 and he won the support of presidents ${ }^{*}$ Cleveland and Theodore ${ }^{*}$ Roosevelt. He was Founder-President of the Sierra Club and a prolific writer.

\section{Mujibur Rahman, Sheikh (1920-1975).} Bangladeshi politician. A lawyer, he was Secretary of the Awami League 1950-71 and campaigned for the succession of East Pakistan (Bengal). In 1970 the League won 151 of 153 Bengali seats. In March 1971 Mujibur proclaimed an independent Republic of Bangladesh with Indian support, while China backed Pakistan. Pakistan was defeated in open war (December 1971), Mujibur became Prime Minister 1972-75, and in 1975 'President for Life'. With the Bangladesh economy facing collapse, he established a one-party state, provoked violent opposition from the army and was soon assassinated.

Muldoon, Sir Robert David (1921-1992). New Zealand politician. Trained as a cost accountant, he entered parliament as member for Tamaki, for the National Party, in 1960. He was parliamentary Undersecretary to the Minister of Finance 1964-66, and Minister of Finance 1967-72. He became Leader of the Opposition in 1974 and Prime Minister 1975-84.

Muller, Hermann Joseph (1890-1967). American geneticist. Educated at Columbia University, and a student of T. H. *Morgan, he worked on the genetics of the fruit fly. In 1926 he produced an experimental induction of mutations by the use of $\mathrm{X}$-rays and received the Nobel Prize for Medicine in 1946 for this work. He taught at the University of Texas 1920-32, in the USSR 1933-37 (leaving over a dispute with *Lysenko), Edinburgh 1937-40, Boston 1941-45 and Indiana 1945-67. He was among the first scientists to warn of the dangers of X-rays and nuclear fallout.

Müller, Johannes Peter (1801-1858). German physiologist. In 1833 he took the chair of physiology at Berlin University. His early researches were chiefly in two fields, embryology and the nervous system as it relates to vision. $\mathrm{He}$ experimented to determine whether the foetus breathes in the womb. He tried to establish the relations between the kidneys and the genitals. In optics, he investigated the capacity of the eye to respond not just to external but also to internal stimuli (whether organic malfunction, or simply the play of imagination). Müller's physiological work was summarised in his Handbuch der Physiologie (1830$40)$. He argued that life was animated by some kind of life-force not reducible to the body, and that there was a soul separable from the body_-ideas rejected by the next generation of German physiologists.

Müller, Paul Hermann (1899-1965). Swiss chemist. He studied at the University of Basel and worked for the J. R. Geigy AG chemical company. DDT (dichloro diphenyl trichlorethane) had been identified 
as early as 1874 by Othmar Zeidler (1850-1911) but its effectiveness as an insecticide was not recognised. Müller synthesised DDT (1939) and discovered that it could be effective in killing mosquitoes, ticks and lice (1942). DDT was speedily adopted by the British and American forces, but not by the Germans and Japanese, and had a major role in combating malaria and typhus during World War II. Müller won the Nobel Prize for Medicine (1948) 'for his discovery of the high efficiency of DDT as a contact poison against several arthropods'. However, DDT had damaging side effects, became concentrated in the food chain and injured animals and people. Rachel *Carson campaigned against DDT and its use was generally phased out in the 1970s.

Müller, (Johann Ludwig) Wilhelm (1794-1827). German lyric poet and philologist, born in Dessau. He volunteered in the war against *Napoléon, became librarian for a duke, wrote prolifically, stimulated interest in ${ }^{*}$ Homer, influenced ${ }^{*}$ Heine and died at the age of 32. Schubert wrote two great song cycles based on Müller's poems: Die schöne Müllerin (Fair Maid of the Mill, 1823) and Wintereisse (Winter Journey, 1827). Müller heard neither.

Mullis, Kary B(anks) (1944-). American biochemist. $\mathrm{He}$ won his $\mathrm{PhD}$ at Berkeley, worked for the Cetus corporation 1979-86 and developed the technique of polymerase chain reaction (PCR), enabling the amplification and replication of fragments of DNA. He won the 1993 Japan Prize and shared the 1993 Nobel Prize for Chemistry with Michael Smith, but was subject to peer criticism for his scepticism about HIV/AIDS, which he doubted was spread by virus.

Mulroney, (Martin) Brian (1939-). Canadian lawyer and politician, born in Québec. Son of an electrician, he graduated in law from Université Laval, became a labour lawyer and gained a national reputation as President of the Iron Ore Co. 1976-83. Elected as Leader of the Progressive Conservative Party 1983, he was the first from Québec for 90 years and the first recruited directly from industry. He became Prime Minister in September 1984, negotiated a free trade agreement with the US and Mexico, lost popularity and retired in July 1993.

Multatuli (pen name of Eduard Douwes Dekker) (1820-1887). Dutch novelist. He worked in Java in the colonial service 1838-57 and his novel, Max Havelaar (1860), an exposure of imperialism, is regarded as a masterpiece. It was made into a powerful film by Fons Rademakers in 1976.

Mumford, Lewis (1895-1990). American town planner and social philosopher. His lectures and books are mainly concerned with the growth or creation of a social environment best suited to meet all the needs of a city's population: shelter, work, leisure, religion, culture the whole complicated organisation of modern urban living. His works include Technics and
Civilisation (1934), The Culture of the Cities (1938), The City in History (1961), The Myth of the Machine (1967) and The Pentagon of Power (1970). He had a major impact on the environment movement and was awarded the Presidential Medal of Freedom (1964) and an honorary KBE (1975).

Mumford, L., The Letters of Lewis Mumford and Frederick J. Osborne: A Transatlantic Dialogue, 193870. 1972.

Munch, Charles (1891-1968). French-German (Alsatian) conductor and violinist, born in Strasbourg. Related to ${ }^{*}$ Schweitzer and ${ }^{*}$ Sartre, he became a violinist, was conscripted into the German army and became concertmaster of the Gewandhaus Orchestra, Leipzig, 1926-33. He first conducted in Paris (1932), and directed the Boston Symphony Orchestra 194962 and the Orchestre de Paris 1967-68.

Munch, Edvard (1863-1944). Norwegian painter, born in Löten. The misfortunes and miseries that surrounded him as he grew up seem to have embittered his attitude to life and left him with a feeling of the malignancy of fate. Having been much influenced in Paris by the work of van ${ }^{*}$ Gogh and ${ }^{*}$ Gauguin, and by the ideas of ${ }^{*} \mathrm{Ibsen}$ and ${ }^{*}$ Strindberg he held an exhibition in Berlin (1892) which caused an immediate scandal but paved the way for the German Expressionist movement. His most famous work, The Scream (Skrik, in Norwegian), full of angst, dates from 1893. He painted sets for Ibsen and Strindberg. In later work he depicted emotional states by colour and form alone thus the 'Threat' in the picture of that name is conveyed by the black treetops. From 1899 to 1908 he worked mainly in Paris, thereafter mainly in Norway. A nervous breakdown (1908) was followed by a happier period during which he painted murals at Oslo University (1909-15) and found solace in the serene Norwegian landscape. He did much, too, to revitalise the woodcut and other graphic arts.

Benesch, O., Edvard Munch. 1960.

Münchausen, Hieronymus Karl Friedrich, Baron von (1720-1797). Hanoverian soldier. The real bearer of this name seems to have fought in the Russian army against the Turks and to have become notorious for his exaggerated accounts of his own exploits. His name was attached, therefore, to a collection of apocryphal and fantastic tales, published in English as Baron Münchausen's Narrative of his Marvellous Travels and Campaigns in Russia (1785), by Rudolf Erich Raspe (1737-1794), a German friend who had fled to England to escape prosecution for theft.

Munro, Alice Ann (née Laidlaw) (1931- ). Canadian short story writer, born in Ontario. Ironic, ambiguous, preoccupied with time and transitions, much of her work has a regional emphasis, set in Huron County, Ontario. In 2009 she won the Man Booker Prize and received the 2013 Nobel Prize for 
Literature as a 'master of the modern short story'. Her writing has been compared with *Chekhov's for its sharp, compressed observation.

\section{Munro, Hector Hugo see Saki}

Munro Ferguson, Ronald Craufurd, 1st Viscount Novar of Raith (1860-1934). Scottish politician and landowner. MP 1884-85, 1886-1914, he was a 'Liberal Imperialist' and protégé of Lord *Rosebery. Governor-General of Australia 1914-20, the ablest of his time, he wanted to be an activist and had a tense, but generally supportive, relationship with W. M. *Hughes. He became Secretary of State for Scotland 1922-24 and received a KT.

Munrow, David John (1942-1976). English musician and historian, born in Birmingham. Educated in Cambridge, he was a virtuoso on the recorder, a leader in reviving interest in medieval and Renaissance music, toured extensively and made radio and television programs. He hanged himself.

Munthe, Axel (Martin Fredrik) (1857-1949). Swedish physician and author. After a successful professional career, in 1887 he retired to the Villa San Michele on the Italian island of Capri, but also practised in Rome and became a physician to the Swedish royal family. In Capri he wrote The Story of San Michele (1929). Largely through his influence, a sanctuary for migrating birds was established on the island.

Munthe, G. and Vexkull, G., The Story of Axel Munthe. 1953.

Müntzer, Thomas (c.1490-1525). German Anabaptist leader. He toured Germany preaching his communistic doctrines and eventually settled at Mühlhausen (1525): there he set up a communist theocracy which, despite *Luther's denunciations, won the support of large numbers of the peasantry. The movement was crushed by *Philipp of Hesse and Müntzer was captured and executed.

Murad II Koca (= 'the Great': Murad bin Mehemmed Han) (1404-51). Sixth Sultan of the Ottoman Empire 1421-44; 1446-51. Son of Murad I and an unknown mother, he proclaimed himself as a 'ghazi' (just) ruler, encouraged translation of many works into Turkish, laid siege to Constantinople, and his forces conquered much of the Balkans and invaded Hungary. He abdicated in favour of his son *Mehmed II, but resumed the throne in 1446 .

Murasaki Shikibu (usually called Lady Murasaki = 'purple') (978?-1026?). Japanese novelist. A member of the Fujiwara clan, she was a court lady in Kyoto to the Empress Akiko during the Heian period. She wrote the long romance Genji Monogatari (Tale of Genji), generally regarded as the world's oldest surviving novel, a subtle and complex picture of aristocratic life built around the life of Prince
Genji Hiraku. First translated (1925-33) by Arthur *Waley, more recently (2001) by Royall Tyler, Genji Monogatari has often been compared with In Search of Lost Time by Marcel *Proust.

Murat, Joachim (1767-1815). French marshal, later King of Naples 1808-15. Son of an innkeeper, he rose to prominence during the Revolutionary Wars, being noted for his courage and brilliance as a cavalry leader. He served in Italy and Egypt with *Napoléon, whose sister Caroline he married (1800). His fighting career continued, Austerlitz being one of the many battlefields where he won renown. He was made a marshal of France (1804) and was appointed (1808) to succeed Joseph *Bonaparte as King of Naples, where he proved himself capable and popular. He accompanied Napoléon to Moscow (1812) and commanded the retreating armies after the emperor had returned to France. He then resumed his kingship and after Napoléon's escape from Elba made a vain attempt to raise Italy on his behalf. After taking refuge in Corsica he landed at Pizzo, in Calabria, where he was captured and shot.

Murayama Tomiichi (1924- ). Japanese politician. He served as a Socialist, later Social Democrat, MP in the Diet 1972-2000 and, never having held any office, was an unexpected choice as Prime Minister in a coalition government with the Liberal Democratic Party (June 1994), serving until 1996. He made a formal apology for Japanese atrocities committed in World War II, which earned him the scorn of the Right.

Murchison, Sir Roderick Impey, 1st Baronet (1792-1871). Scottish 'gentleman' geologist. After years as a soldier, encouraged by Humphry *Davy, he spent a generation surveying strata according to clear interpretative principles. He believed in a near universal order of deposition, indicated by fossils rather than purely lithological features. Fossils themselves would show a clear progression in complexity from 'azoic' items (i.e. pre-life) to invertebrates, and only up to vertebrate forms, man being created last. This progression was aligned to the earth's cooling. The great triumph of these principles, and his own field-working, was to unravel the 'Silurian System' (i.e. those strata beneath the Old Red Sandstone) which he named (1835). For Murchison the Silurian contained remains of the earliest life (though no fossils of vertebrates or land plants were to be expected). Controversy over the younger end of the Silurian led to him proposing, with Adam *Sedgwick, a new geological era, which they named Devonian (1840). He explored the Alps, Scandinavia, Finland and the Urals and named the Permian geological period (1841), from a site in Russia (1841). He anticipated (1845) the discovery of gold in Australia after examining rock samples. Awarded the Copley Medal (1849), he became a dogmatic opponent of Darwinian evolution, supporting successive creations instead of transmutation. A Moon crater, rivers and 
towns in Canada, Australia and New Zealand, and sites in Uganda, Greenland and Antarctica were named for him.

Murcutt, Glenn Marcus (1936- ). Australian architect, born in London. His parents were Australian, he practised in Sydney and won an international reputation for his sensitivity to the environment and emphasis on sustainability in domestic architecture. He won the Pritzker Prize in 2002, and gold medals from the UK and US.

Murdoch, Dame (Jean) Iris (1919-1999). AngloIrish writer and philosopher, born in Dublin. Educated at Oxford, she was a civil servant in the treasury (1942-44), an administrator with UNRRA in Europe (1944-46) and a fellow and tutor in philosophy at St Anne's College, Oxford (1948). She turned from writing philosophy and a study of J. P. *Sartre (1953) to a series of novels notable for wit and black humour, starting with Under the Net (1954), including The Bell (1958), An Unofficial Rose (1962), The Nice and the Good (1967) and The Sacred and Profane Love Machine (1974). She won the Booker Prize (1978) for The Sea, the Sea. Murdoch's characters are complex, often caught in a prism of irreconcilable conflicts, in which the search for truth and selfknowledge appears from time to time as inevitable, painful, selfish or irrelevant, and guilt punishes those it is intended to protect. She also wrote plays, The Servants and the Snow (1970) and The Three Arrows (1972), and a study of *Plato, The Fire and the Sun. In 1956 she married John Oliver Bayley (1925-2015), professor of English literature at Oxford and a critic. She suffered from Alzheimer's disease from 1995.

Bayley, J. O., Iris. 1998.

Murdoch, (Keith) Rupert (1931- ). AustralianAmerican media proprietor and executive, born in Melbourne. His father Sir Keith Arthur Murdoch (1885-1952), a journalist, exposed the incompetence of military leadership at the Gallipoli landings (1915), became in 1928 chief executive of the Herald and Weekly Times, Melbourne, proprietor of The News, Adelaide, and chair of News Ltd. Rupert was educated at Geelong Grammar and Oxford University. On his father's sudden death he inherited The News, then began a series of strategic investments, beginning with The Dominion, Wellington, New Zealand, in 1964, and making his first US purchase in 1973. Chairman and chief executive of News Corp 1980- , he bought the Herald and Weekly Times group in 1987. His papers included The Times, Sun and News of the World (London), the New York Post, the Wall Street Journal, The Australian, the Daily Telegraph (Sydney), the Herald-Sun (Melbourne), the Courier Mail (Brisbane) and the Advertiser (Adelaide). He briefly owned the Ansett airline in Australia, bought 20th (later 21st) Century Fox and became a US citizen in 1985. $\mathrm{He}$ also ran the publishing house HarperCollins, Fox News, Foxtel, SKY television and a satellite transmitting information and entertainment to Asia. By 2000, News Corp had acquired 800 companies. News of the World came under hostile scrutiny after a series of phone hacking scandals (2011-12) and was closed down. In 2019 he sold SKY and 21st Century Fox to the *Disney Corporation. News Corp's newspapers and television were politically active and highly partisan, supporting *'Thatcher, *Blair, *Johnson, *Trump, *Abbott, *Morrison, Brexit and climate change denialism.

His mother, Dame Elisabeth Joy Murdoch, née Greene (1909-2012) was a philanthropist, gardener and supporter of the arts.

Shawcross, W., Murdoch. 1992.

Murdoch, William (1754-1839). Scottish inventor. He joined the Birmingham engineering firm of *Boulton and *Watt (1777), helped Watt with the development of his steam engine and invented a practical slide-valve (1799). His experiments with the production of gas from coal enabled the factory to be lit up with gas to celebrate the Treaty of Amiens (1802), a development that led to the widespread adoption of gas for internal and external lighting.

Murger, Henri (1822-1861). French novelist. His life in Paris among poverty-stricken artists provided the background for his famous Scènes de la vie de Bohème, which appeared serially (1847-49), was dramatised (1849) and was published in book form (1851). It inspired *Puccini's opera La Bohème. His later novels are of small account.

Murillo, Bartolomé Estebán (1617-1662). Spanish painter, born in Seville. He lived in his birthplace and was a friend of *Velázquez (who soon left). He was primarily a painter of religious subjects but his style, which at first displayed a rather hard naturalism, gradually became warmer and more charming and eventually over-sweet, tender and glamourised. He is best known for his representations of the Virgin, among the most famous being the Immaculate Conception (now in the Louvre). Perhaps even more appealing to modern taste are his realistic genre pictures of young fruit-sellers and beggar-boys.

Murnane, Gerald (1939- ). Australian novelist and poet, born in Coburg. Trained for the priesthood, he became a lecturer, lived in the country, rarely left Victoria, saw only a few films, never flew or swam, typed with one finger, worked part-time as a bartender and was obsessed with horse-racing. However, his mesmeric writing attracted international attention and critical approval. His novels were essay-like, but strongly lit, meditations and observations, much admired by John *Coetzee, with echoes of *Borges, *Proust and *Beckett. They include The Plains (1982), Precious Bane (1985), and Border Districts (2018). The poetry collection Green Shadows appeared in 2019. 
Murphy, Lionel Keith (1922-1986). Australian Labor politician, lawyer and judge, born in Sydney. With degrees in law and science, he became a barrister and QC, then a Senator 1962-75. He revitalised the Senate, making it more powerful, and as *Whitlam's Attorney-General 1972-75 initiated sweeping law reforms, including no-fault divorce. His appointment as a High Court Justice 1975-86 was controversial. Accused of intervening in a prosecution to help a friend, he was convicted of conspiracy, then acquitted in a retrial, just before his death from cancer.

Murray, (George) Gilbert (Aimé) (1866-1957). British-Australian classical scholar, born in Sydney. Son of a prominent New South Wales politician, he was educated at Oxford, became Professor of Greek at Glasgow 1889-99, and as Regius Professor of Greek at Oxford 1908-36 he became well known for his translations of the Greek dramatists, especially *Euripides, *Socrates and *Aeschylus, used in many notable productions. He interpreted the spirit of ancient Greece to the modern world by a series of books, including his last great work Hellenism and the Ancient World (1953). He was a keen Liberal (but a failed parliamentary candidate) and chair of the Executive of the League of Nations Union 1923-28. He was a member of the International Committee on Intellectual Cooperation (CICI) from 1922 and its chair 1928-39. CICI was a precursor of UNESCO. Murray received the OM in 1941.

Murray, Sir James Augustus Henry (1837-1915). British lexicographer and editor, born in Denholm, Roxburgh. Educated at secondary schools, he became a teacher in Roxburgh 1854-64 and London 187085 , worked in a bank and graduated BA from London (1873). President of the London Philological Society 1878-80, 1882-84, he was appointed as editor of The Oxford English Dictionary (A New English Dictionary on Historical Principles) 1879-1915, planning and outlining the whole project. The first volume appeared in 1884. In 1885 he moved to Oxford and personally edited letters $\mathrm{A}-\mathrm{D}, \mathrm{H}-\mathrm{K}, \mathrm{O}, \mathrm{P}$ and T. He also wrote on Scots language and literature. A man of vast erudition, although elected FBA in 1902 and knighted in 1908, he was grieved not to have been offered the OM, and Oxford was slow to grant him a doctorate.

Murray, K. M. E., Caught in the Web of Words. 1977.

Murray, John (1745-1793). British publisher, born in Edinburgh. Changing his name from MacMurray to Murray, he bought a small publishing business in London which continued to expand under his dynastic successors in the 19th and 20th centuries. John Murray II (1778-1843) founded the Quarterly Review and established links with ${ }^{*}$ Scott and other famous authors, including *Byron, whose unpublished Memoirs he burned (1824) after the poet's death. *Darwin's Origin of Species (1859) was
Murray, Les(lie Allan) (1938-2019). Australian poet, critic and editor. He worked as a public servant, translator and book editor, was a powerful polemicist and won international awards for his poetry. His collections include The Boys Who Stole the Funeral (a verse novel, 1980) and Subhuman Redneck Poems (1996).

Murray, Philip (1886-1952). American trade union leader, born in Scotland. He was President 1940-52 of the Congress of Industrial Organisations (CIO), one of the two great trade union confederations that amalgamated with the American Federation of Labor (AFL) in 1955.

Murrow, Edward R(oscoe) (1908-1965). American journalist and broadcaster. He worked as a CBS war correspondent, then ran wide-ranging and compassionate interview programs on television, including Person to Person and Small World. George Clooney's film Good Night, and Good Luck (2005) celebrated his achievement.

Murry, John Middleton (1889-1957). English writer and critic. As editor of various journals, including The Athenaeum (1919-21), and The Adelphi (1923-30) he had considerable influence on English intellectual life in the 1920s. He was a friend of D. H. *Lawrence and married (1918) Katherine *Mansfield, whose biography he wrote (1932). His books include studies of *Blake, *Keats, *Shakespeare and ${ }^{*}$ Dostoevsky.

Murry, K. M., Beloved Quixote. 1986.

Musa I (c.1280-1337). Mansa ('King of Kings') of Mali 1312-37. The 10th Mansa, he succeeded a distant kinsman. He accumulated vast wealth, estimated at about $\$$ US400 billion (in current values), by exporting gold and salt and is claimed to have been the richest person in history.

Musharraf, Pervez (1943- ). Pakistani soldier and politician, born in New Delhi. He was Chairman of the Joint Chiefs of Staff 1998-2001, and in 1999 after public demonstrations against corruption he led a coup, took charge of the government and (after stage-managed elections) was President of Pakistan 2001-08. He worked closely with the US Government but became increasingly authoritarian and, following mass demonstrations, went into exile in London, then Dubai. Tried for high treason, in absentia, and sentenced to death in 2019 , the verdict was overturned by an appeal court in 2020 .

Musil, Robert, Edler von (1880-1942). Austrian novelist, born at Klagenfurt. He trained to be a soldier (his Young Törless, 1906, gives an unforgettable picture of the military academy), then qualified as an engineer and took a PhD in Berlin (1908) for a study of the philosophy of Ernst ${ }^{*}$ Mach. He worked as a librarian in Vienna so that he could devote himself to writing, served with the Austrian army during 
World War I, then spent some years in Berlin and acquired a modest reputation as a freelance writer. He returned to Vienna in 1933 and moved from there to Switzerland in 1938. He died in Geneva. His masterwork was The Man Without Qualities (Der Mann ohne Eigenschaften), a colossal work begun in 1920 and left incomplete at his death, worthy of ranking with *Joyce and *Proust. The central character Ulrich (a self-portrait), a man of scientific training unable to commit himself passionately to any aspect of life, is given the post of secretary (in 1913) of a committee charged with commemorating Franz Josef's 70th anniversary as emperor by making 1918 'the Austrian year'. The novel was first published in English in 1953-60 in three volumes translated by Eithne Wilkins and Ernst Kaiser. A new translation by Sophie Wilkins appeared in 1995, with 635 pages of Posthumous Papers translated by Burton Pike.

Musk, Elon Reeve (1971- ). Canadian-American engineer and entrepreneur, born in South Africa. He dropped out of Stanford, but created PayPal, which he sold to eBay, then set up Space X, a commercial space exploration company, and *Tesla Motors, which produced electric cars with radically improved battery capacity. Musk launched the first commercial manned spacecraft in May 2020 and by 2021 he was the world's richest person. Elected FRS in 2018, he bought Twitter in 2022.

Vance, A., Elon Musk. 2019.

Muskie, Ed(mund Sixtus) (1914-1996). American Democratic politician. Son of a Polish immigrant (the family name was Marciszewski) and educated at Cornell, he served in the navy during World War II, was Governor of Maine 1953-59 and a US senator 1959-80. He ran for Vice President in 1968 with Hubert ${ }^{*}$ Humphrey, sought the presidential nomination in 1972 and served as Jimmy *Carter's Secretary of State 1980-81.

\section{Mussadiq, Mohammed see Mosaddegh, Mohammad}

Musset, Alfred de (1810-1857). French poet and dramatist, born in Paris. He dabbled in law and medicine and published, at the age of 18, a translation of *De Quincey's Confessions of an English Opium Eater. As an aristocratic dandy he frequented the literary circle of Victor ${ }^{*}$ Hugo, who praised his poems, Contes d'Espagne et d'Italie (1830). The influence of Hugo's Romanticism is evident in $L a$ Nuit venitienne (1830), Musset's first play: its failure decided him to write plays for reading only. The hero who agreeably combined charm with debauchery, and the flirtatious but tender heroine were popular at this period and $A$ quoi révent les jeunes filles (1831) was a typical and revealing title. In 1833, the year in which appeared the witty and emotional prose plays André del Sarto and Les Caprices de Marianne, began his stormy love affair with George *Sand, described after its breakup in his series of poems, Les Nuits
(1835-37). The autobiographical Confession d'un Enfant du siècle (1836) also reflects the pessimism induced by his sufferings. The play $O n$ ne badine pas avec l'amour ends tragically but Le Chandelier (1836) shows something of the old sparkle. Un Caprice (1837), had such success that his later plays were frequently played at the Comédie Française. Musset was elected to the Académie française in 1852.

Mussolini, Benito (Amilcare Andrea) (1883-1945). Italian dictator, born at Predappio, near Forli. He early absorbed the socialist and revolutionary views of his blacksmith father. He started his career as a teacher (1901) but a year later went to Switzerland, where he lived as a revolutionary exile until 1904. In 1908 he served his first prison sentence for revolutionary activity and then took to journalism. Having joined a socialist paper at Trento (then in Austria) he became fired with nationalist zeal for recovering the lost provinces. Another term of imprisonment brought him increased prestige in his own party and secured him the editorship of the national socialist newspaper, Avanti (1912). World War I caused him to split with the socialists, who favoured neutrality. Mussolini saw that only by joining the Allies could Italy regain from Austria the unredeemed provinces, and in November 1914 he was editing his own paper Popolo d'Italia, a powerful voice in favour of intervention. When Italy entered the war (May 1915), he joined the army, but after being wounded (February 1917) he returned to his paper. After the war, with the Socialist Party closed to him and Communism threatening disruption, he founded (1919) the first Fascio di Combattimento, nominally to serve the cause of the neglected exservicemen. This proved the starting point of 'Fascism'. Mussolini took over the nationalist theme and the theatrical equipment (black shirts, banners etc.) from *D'Annunzio and was quick to realise that by turning his gangs against the communists he would win government toleration and much outside support. In 1921 Mussolini, already called il Duce ('the leader') by his followers, was elected to the Chamber of Deputies and in October 1922 he organised the celebrated 'march on Rome'. (Most Fascisti arrived by train.) There was no resistance because the Prime Minister, Luigi Facta, failed to secure King *Vittorio Emanuele III's approval to declare martial law. The armed forces, whose cause Mussolini had so consistently espoused, stood inactively by, and the ordinary citizen, weary of the anarchy of faction, favoured strong rule. The king decided to put a constitutional gloss on the accomplished fact by making Mussolini Prime Minister. He held that office 1922-43 and his dictatorship was virtually unchallenged until the end. The economics of Fascism were based on the syndicalism of Georges * Sorel, its political institutions were merely a background to il Duce's personal rule. With his overbearing personality and bombastic oratory Mussolini deceived the Italians, deceived Europe and even deceived himself. He was made an honorary GCB by the UK. In spite of the completion 
of grandiose public works and road building, in terms of real wages the Italians were worse off after 10 years of his rule than before. Even such military successes as he achieved, the conquest of Ethiopia, the overrunning of Albania and support for Franco in Spain, involved quarrelling with all his natural allies and becoming entirely dependent on Nazi Germany. World War II revealed his weakness: though he delayed entry into the war (June 1940) until it seemed that Germany's victory was certain, Italy's war record was calamitous. Italian forces were everywhere defeated until German backing was received: Ethiopia, Eritrea and Somalia were lost. Mussolini was a puppet in *Hitler's hands. When (July 1943), after the Allied landings in Sicily, the Fascist grand council turned against him, he was swept aside without a struggle. He was dramatically rescued from captivity by German paratroops and, already a pathetic figure without will or purpose, briefly headed a puppet government at Saló in northern Italy. When the Allied victory was achieved he tried, with his mistress Clara Petacci, to reach safety in Switzerland, but both were caught and summarily executed in Milan. In 1957 he was reburied in Predappio, his birthplace, and the mausoleum has become a place of pilgrimage.

Of his five children by his wife Rachele, Edda, the elder of the two girls, married Count ${ }^{*}$ Ciano, Mussolini's Foreign Secretary 1936-43. His son Romulo (1921-1998) was a jazz pianist and his granddaughter Alessandra (1962- ), formerly an actor and model, was a member of the European Parliament 2004-08 and the Italian Chamber of Deputies 2008- .

Mack Smith, D., Mussolini. 1982.

Mussorgsky, Modest Petrovich (1839-1881). Russian composer, born in Karevo. From an impoverished minor noble family in the Ukraine, he was a gifted pianist from childhood, served in the army as an alcoholic officer until 1858, then became a public servant in St Petersburg. He spent the rest of a chaotic and rambling life between the capital and the countryside, where his sympathetic study of the peasants introduced him to the folk idioms that appear in his music. Frenzied spells of composing alternated with drinking bouts, by which his health and character were gradually destroyed. Befriended by ${ }^{*}$ Cui and ${ }^{*}$ Balakirev, he was (with *Rimsky-Korsakov and *Borodin) one of 'The Five' who promoted a distinctive national style, in contrast to *Tchaikovsky's romantic cosmopolitanism. His outstanding operatic masterpiece Boris Godunov, based on *Pushkin's drama, was completed in 1869 and first performed in 1874. The opera broke sharply with musical convention and was soon withdrawn. RimskyKorsakov cut and reorchestrated Boris and this 1896 version was staged internationally. However, much of its stark realism and rich characterisation was lost. The complete original score was not published until 1975. Other operatic fragments include The Marriage,
Khovanshchina and Sorochintsky Fair. His piano suite Pictures at an Exhibition (1874), often performed in *Ravel's orchestration, has been frequently recorded. He wrote about 60 songs, including The Song of the Flea (*Goethe, 1879) and the song cycles The Nursery (his own poems, 1873) and Songs and Dances of Death (Arseni Golenischchev-Kutuzov, 1877). His music had a significant influence on *Debussy and Ravel.

Calvocoressi, M. D., Mussorgsky. rev. 1974.

\section{Mustafa Kemal see Atatürk, Kemal}

Mutesa II, Sir Edward (1924-1969). Kabaka of Buganda and first president of Uganda. He inherited (1939) the sovereignty of Buganda (which formed part of the protectorate of Uganda). In 1953 the British withdrew recognition because of his demand for Buganda's independence from Uganda, and he was deported. He returned (1955) under a new constitution, when Uganda achieved independence he became (1963) its first president. In 1966 he was ousted in a coup led by Milton * Obote, he escaped to Britain and died there.

Muti, Riccardo (1941- ). Italian conductor, born in Naples. He became chief conductor of the Philharmonia Orchestra 1973-82, the Philadelphia Orchestra 1980-92, and La Scala Opera, Milan, 1986-2005, resigning after increasing friction with the orchestra. He became an Hon. KBE in 2000. He was director of the Chicago Symphony Orchestra 2010- .

Mutsuhito (regnal name Meiji i.e. 'enlightened') (1852-1912). Emperor of Japan 1867-1912. Son of the emperor Otahito (1821-1867, regnal name Komei), born in Kyoto, he succeeded at the age of 15. The term 'Meiji Restoration' refers to the period that began with the abdication of the last hereditary shogun of the ${ }^{*}$ Tokugawa clan, Keiki (1837-1913) in January 1868, the transfer of his powers to the emperor and the imperial court's move from Kyoto to Tokyo. Mutsuhito's advisors, mostly young and able samurai (including *Iwakura, *Kido, Okubo, *Saigo, Arisugawa, ${ }^{*}$ Ito, *Yamagata), investigated reforms in Europe and the US and, within a few years, primary schools were developed on American lines and a variation of the Code Napoléon and some elements of the British parliamentary system were adopted. Feudal land tenure and the samurai class were abolished. Railways and the telegraph, the Gregorian calendar and western dress were quickly accepted. Mutsuhito's reign was marked by suppression of the Satsuma revolt (1877), successful wars against China (1894-95), Russia (1904-05) and the annexation of Korea. Intelligent and sympathetic to reform, he took little direct part in administration. He was an amateur painter and poet, and modelled his uniform, hair and bearing on Napoléon III. He was succeeded by ${ }^{*}$ Yoshihito, and *Hirohito was his grandson. 
Muybridge, Eadweard (originally Edward John Muggeridge) (1830-1904). English photographer, in the US 1865-1900. His studies of 'animal locomotion' led to recognition of the phenomenon of persistence of vision. His 'Zoöpraxiscope' which showed human and animal movement was a direct forerunner of the cinema. In 1874 he was acquitted of murdering his wife's lover.

Myer, Sidney (néSimcha Myer Baevski) (1878-1934). Jewish-Australian merchant and philanthropist, born in Belarus. He migrated to Victoria in 1899, became a draper in Bendigo, then established the Myer Emporium in Melbourne (1914) which became Australia's largest retailer. The Myer family were major philanthropists, supporting universities, medical research and the arts over three generations. His son Kenneth Baillieu Myer (1921-1992) was President of the Howard Florey Institute 1971-92, declined the Governor-Generalship in 1974, but became Chair of the National Library of Australia 1974-82 and the ABC (Australian Broadcasting Corporation) 198386. He died in a plane crash in Alaska.

Ebury, S., The Many Lives of Kenneth Myer. 2008.

Myers, F(rederick) W(illiam) H(enry) (1843-1901). English writer. Once known as a literary critic (e.g. *Wordsworth and *Virgil), he is remembered as a pioneer in applying the methods of science to the investigation of apparently supernatural phenomena. A founder member of the Society for Physical Research, he wrote Human Personality and its Survival of Bodily Death (1903).

Myrdal, (Karl) Gunnar (1898-1987). Swedish economist. One of the first economists to write on population pressure and world poverty, he was Minister for Commerce 1945-47, held chairs in Sweden and the US, wrote many books including The Asian Drama (3 vols, 1968) and The Challenge of World Poverty (1970), and shared the 1974 Nobel Prize for Economics with Friedrich von ${ }^{*}$ Hayek (whose views were markedly different). His wife Alva Myrdal, née Reimer (1902-1986), worked for UNESCO and the ILO, conducted research into 'futures' scenarios and disarmament, and became Minister for Disarmament 1967-73. She was awarded the 1982 Nobel Prize for Peace.

Mytens, Daniel (c.1590-c.1642). Dutch artist. He possibly studied under ${ }^{*}$ Rubens before going to England, where he was settled 1618. He worked for ${ }^{*}$ James I, and under ${ }^{*}$ Charles I he held a court appointment. His portraits are mostly of members of the nobility, e.g. Charles I and the 1st Duke of Hamilton (both in the National Gallery, London), in a natural, informal style. 


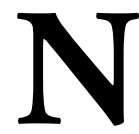

Nabokov, Vladimir Vladimirovich (1899-1977). Russian-American novelist, born in St Petersburg. Son of a rich liberal politician (murdered by Russian monarchists, probably by mistake, in Berlin in 1922), trilingual (Russian, English, French) from childhood, he left Russia in 1919, graduated from Trinity College, Cambridge, lived in France and Germany 1922-40, and migrated to the US in 1940 . He was a research fellow in lepidoptera at Harvard, then taught literature at Wellesley, becoming professor of Russian literature at Cornell 1948-59. He translated Alice in Wonderland into Russian (1923) and had already made a name for himself by a brilliant series of novels in Russian (Mashenka; King, Queen, Knave; Invitation to a Beheading, etc.), before publishing his first English novels: The Real Life of Sebastian Knight (1938) and Bend Sinister (1947). Lolita, a story of the infatuation of a middle-aged intellectual, Humbert Humbert, for a 12-year-old girl, and her sexual exploitation, was published in Paris in 1955, New York in 1958 and London in 1959. Lolita was filmed (1962) by Stanley *Kubrick. Nabokov lived in Montreux from 1959. Later novels included Pale Fire (1962), Ada (1969) and Transparent Things (1972). His memoir, Speak, Memory, was published in 1967. Nabokov never received a major literary award but his writing influenced later writers, including Thomas *Pynchon, Salman *Rushdie, Don *DeLillo and W. G. *Sebald.

Field, A., VN: The Life and Art of Vladimir Nabakov. 1986; Boyd, B., Vladimir Nabokov. 2 vols, 1990, 1991; Pitzer, A., The Secret History of Vladimir Nabokov. 2013.

Nadar (pseudonym of Gaspard-Félix Tournachon) (1820-1910). French photographer, born in Paris. Originally a journalist and caricaturist, he opened a photographic studio in Paris (1853), and, using collodion glass-plate negatives, made powerful portraits of ${ }^{*}$ Rossini, ${ }^{*}$ Liszt, ${ }^{*}$ Verdi, ${ }^{*}$ Bakunin, ${ }^{*}$ Balzac, *Hugo, *Flaubert, *Turgenev, George *Sand, Sarah *Bernhardt, *Mallarmé, *Baudelaire, *Corot, ${ }^{*}$ Manet, ${ }^{*}$ Monet, ${ }^{*}$ Pasteur and ${ }^{*}$ Debussy, took the first aerial photographs (1858) and conducted the first photo-interview (1886, with ${ }^{*}$ Chevreul). In 1863 he commissioned a 60-metre-high balloon, Le Géant, but after its comparative failure became an advocate of heavier air flying machines.

Begley, A., The Great Nadar. The Man Behind the Camera. 2018.

Nader, Ralph (1934- ). American lawyer, born in Connecticut. Of Lebanese parentage, educated at Princeton and Harvard, he wrote Unsafe at Any Speed (1965), an attack on General Motors' Corvair; GM had to pay him $\$ 300,000$ damages for personal to carry out research, raise levels of community awareness and put pressure on governments to strengthen laws on consumer protection, car and highway safety, pollution, pure food and access to information. In 2000 he contested the US presidency as a Green candidate, winning 3 per cent of the popular vote, a decisive factor in enabling *Bush to defeat ${ }^{*}$ Gore. He ran for president in 2004 , polling barely 1 per cent, and 0.6 per cent in 2008 .

Nadir Khan (or Nadir Shah) (c.1880-1933). King of Afghanistan 1929-33. He was descended from a brother of ${ }^{*}$ Dost Mohammed and as King Amanullah's Commander-in-Chief was prominent in the Third Afghan War with British India (1919). Having fallen into disfavour in 1924 he lived in exile in France, which he left in 1929 to make his successful bid for the Afghan throne. Assassination ended a brief reign in which he showed personal integrity as well as skill and moderation as an administrative reformer.

Nadir Shah (1688-1747). Shah of Persia 1736-47. By origin a Turcoman tribesman, he emerged as dominant figure from the period of confused fighting following the breakup of the Safavid dynasty, and proclaimed himself as shah. In 1738, he found a pretext to invade India, marched to the plains below, and met his first serious resistance only $160 \mathrm{~km}$ from Delhi. In March 1739, he routed the forces of the Mughal Emperor, Muhammad Shah, who accompanied his conqueror to Delhi. A false report of Nadir's death provoked a rising in the city, which he punished with one of the most terrible massacres in history. Loaded with plunder, including the famous peacock throne, he returned home having annexed large areas west of the Indus. Nadir continued to fight with success against internal revolt, external enemies (especially the Ottoman Turks), but assassination, caused by disgust at his atrocities, brought his career to an end.

Nägeli, Karl Wilhelm von (1817-1891). Swiss botanist. Son of a physician, he chose to specialise in botanical studies, and took up the study of cells. Between 1845 and 1858 he was involved in brilliant researches into the formation of tissues in the roots and stems of vascular plants, particularly from the point of view of cell-division, for which he hoped to find quasi-mathematical laws. He correctly observed the distinction between formative tissues (ones multiplying) and structural tissues (those no longer multiplying). Later in his career, he became increasingly interested in the building blocks of plant life, especially starches and cellulose. But though this work took a more chemical turn, Nägeli always held to the somewhat teleological approach that his early training in Naturphilosophie had given him. He accepted organic evolution, but saw it as the fulfilment of an internal organic drive. He rejected *Mendel's work out of hand.

Naguib, Mohamed (1901-1984). Egyptian general, born in Khartoum. A gifted linguist, with Gamal *Nasser as his deputy, he led the revolt (1952) that 
dethroned King *Farouk. Prime Minister 1952-53, and then President of Egypt 1953-54, he was forced to resign by Nasser and kept in comfortable isolation until 1972.

Nagy, Imre (1896-1958). Hungarian politician. A locksmith, he joined the Communists in 1918, lived in Moscow 1929-44, and was a minister 194548. Premier 1953-55, he was forced out because of his independent line and sympathy for peasant interests. In the October 1956 rising against Soviet rule, Nagy was Premier again, appealed unsuccessfully for Western intervention, and was executed after a show trial. His remains were reburied in a place of honour in 1989.

Nahas Pasha, Mustafa (1876-1965). Egyptian politician. He succeeded (1927) Saad *Zaghloul as leader of the Wafd, a nationalist party. In 1936 he led a delegation to London and negotiated a treaty of perpetual alliance with Britain, by which inter alia, British forces could be stationed in the Suez Canal zone for 20 years and the Egyptian position in the Sudan was restored. This was followed (May 1937) by a convention by which capitulations (special discriminatory arrangements favouring foreigners) were abolished. In December Nahas was dismissed by King *Farouk but during World War II the British forced his recall (1942) when the German threat to Egypt was at its greatest. Again dismissed in 1944, Nahas played no active part in the events leading to the revolution of 1952 .

Naipaul, Sir V(idiadhar) S(urajprasad) (1932-2018). British novelist and essayist, born in Trinidad. Of Indian descent, son of a journalist, he won a scholarship to Oxford, moved to London in 1954 and worked for the BBC. His first masterpiece, A House for $M r$ Biswas, was published in 1961. Other much acclaimed works include The Mimic Men (1967), In a Free State (Booker Prize, 1971), Guerrillas (1975), India: A Wounded Civilisation (1977), A Bend in the River (1979), The Return of Eva Peron (1980), Among the Believers: An Islamic Journey (1981) and The Masque of Africa (2010). He won the Nobel Prize for Literature in 2001 'for having united perceptive narrative and incorruptible scrutiny in works that compel us to see the presence of suppressed histories'. His brother Shiva Naipaul (1945-1985), also an author, wrote North of South (1978) and Black and White (1980).

White, L., Naipaul: A Critical Introduction. 1975. French, P., The World Is What It Is: The Authorized Biography of V. S. Naipaul. 2003.

Najib Razak (in full Haji Mohammad Najib bin Tun Haji Abdul Razak) (1953- ). Malaysian politician. Son and nephew of two Malaysian prime ministers, he studied in England, became a banker, a protégé of *Mahathir bin Mohamad and entered Parliament. He was Minister for Defence 1991-95; 2000-09, Minister for Education 1995-2000 and Prime
Minister 2009-18. Following widespread accusations of large-scale corruption against Najib, in 2018 Mahathir returned to politics and, in alliance with *Anwar Ibrahim, defeated Najib who was then arrested and charged with fraud and money laundering. He was convicted of seven offences in July 2020.

Nakasone Yasuhiro (1918-2019). Japanese politician. Trained as a lawyer, he served in the Japanese navy, was a Diet member 1947-2003 and held several portfolios, also rising rapidly through the Liberal Democratic Party machine. He was Prime Minister of Japan 1982-87.

Namier, Sir Lewis Bernstein (né Ludwik Bernstein vel Niemirowski) (1888-1960). British historian, born in Poland. Of Jewish parentage, he was educated at Lausanne, the London School of Economics and Oxford, worked in the Foreign Office in World War I and was political secretary of the Jewish Agency for Palestine 1929-31. Professor of modern history at Manchester University 1931-55, he threw entirely new light on 18th-century political affiliations in his The Structure of Politics on the Accession of George III (1929). By probing the life, background and opinions as well as the voting records of individual MPs he showed how often personal considerations outweighed those of party alignment. With John Brooke he wrote the definitive The House of Commons 1754-90 (3 vols, 1964).

Namier, J., Lewis Namier: A Biography. 1971; Hayton, D. W., Conservative Revolutionary: The Lives of Lewis Namier. 2019.

Nana Sahib (Dhondu Pant) (c.1820-c.1859). Indian sepoy leader. Adopted son of the last of the Mahratta 'peshwas', and swayed by a personal grievance about his pension he became a leader of the sepoys (Indian troops under British command) in the mutiny (1857). The isolated British garrison of Cawnpore capitulated on terms safeguarding the lives of the men and their dependants. Despite this pledge Nana Sahib ordered a general massacre of men, women and children alike. He fled after the defeat of the mutiny and presumably died in the hills of Nepal.

Nanak (1469-1538). Indian guru ('preacher'). Founder (c.1505) of the Sikhs, he preached a puritanic, monotheistic, tolerant form of Hinduism, rejecting the caste system and the quest for power. Later, under persecution, the Sikhs became a militant sect.

Nancarrow, (Samuel) Conlon (1912-1997). American composer, born in Arizona. He fought in the Spanish Civil War and lived in Mexico City from 1940. On the fringes for most of his life, he wrote 51 'Studies for Player Piano' (1948-93), employing techniques of unparalleled complexity that influenced *Ligeti and ${ }^{*}$ Adès but intimidated mainstream music audiences. He received a MacArthur Award in 1982 and won international recognition. He also wrote three string quartets and works for small orchestra. 
Nansen, Fridtjof (1861-1930). Norwegian explorer, scientist, diplomat and humanitarian, born in Oslo (Christiania). He studied zoology at Oslo University and was curator of zoology at the Bergen Museum 1881-87. In 1888 he crossed Greenland on skis and in 1893-97 carried out a daring project of forcing the Fram, a ship specially built to withstand ice pressure, into the pack-ice and letting it drift with the great northwest current. Entering the ice near the New Siberian Islands in the eastern Arctic, the Fram drifted with the current and reached Spitsbergen in just under three years. Meanwhile Nansen (with F. H. Johansen) had left the ship (March 1895) and on foot had reached a latitude of $86^{\circ} 14^{\prime}$. They wintered in Franz Josef Land, and were picked up in the spring. Professor of oceanography at Oslo University 1908-30, after Norway's independence (1905) he was its first Ambassador to Great Britain 1906-08. After World War I he worked for the repatriation of prisoners of war, for famine relief in Russia, and (on behalf of the League of Nations) for refugees, particularly Armenians, to whom the issue of a 'Nansen passport' often meant a new life. Nansen won the Nobel Prize for Peace (1922).

Shackleton, E., Nansen the Explorer. 1959; Huntford, R., Nansen-The explorer as hero. 1998.

Napier, John (1550-1617). Scottish mathematician and engineer. By introducing the comma (where we now use the decimal point), he simplified the notation of the decimal system. His most important contribution to mathematics was his invention (1594) of the number ratios which he called 'logarithms'. He spent almost 20 years calculating the necessary tables, which he published in his Mirifici Logarithmonwn Canonis Descriptio (1614). $\mathrm{He}$ also devised a simple calculating system made of rods (Napier's bones), which he described in his Rabdologiae (1617). As an engineer, he invented a hydraulic screw for pumping water, and other devices. He was also interested in millenarianism and wrote a commentary on the Revelation of St John the Divine.

Napier of Magdala, Robert Cornelis Napier, 1st Baron (1810-1890). British field marshal. He commanded (1868) the expedition against King Theodore of Abyssinia, his march from the coast to the final storming of Magdala showing a remarkable combination of organisational, engineering and military skills. For this he was awarded a peerage and an annuity. He served as Commander-in-Chief in India 1870-76 and Governor of Gibraltar 1876-82.

Napoléon I (Napoléon Bonaparte) (1769-1821). Emperor of the French 1804-14 and 1815. Born at Ajaccio in Corsica, the son of Carlo Buonaparte (*Bonaparte) and his wife Letizia, Napoléon left the island (1778) to learn French at Autun and to attend military schools at Brienne (1779-84) and at Paris (1784-86). He emerged as a lieutenant of artillery the Revolution he went to Corsica and took a leading part in overthrowing the royalist government, but when a quarrel developed between the followers of *Paoli who demanded Corsican independence and those, including the Bonapartes, who favoured union with revolutionary France, the whole family moved to the mainland. In 1793 Napoléon was in charge of the artillery in the French republican army besieging Toulon, which had been seized by the British, and he was largely responsible for the city's capture. For this he was made a brigadier general by ${ }^{*}$ Robespierre but on the latter's fall he was imprisoned briefly. His rise to power was resumed when Barras, shortly to become the leading figure in the Directory, appointed him as his second-in-command to suppress the Paris rising (1795). Napoléon's quick success, which showed his promise, brought him into the new rich society of the moment where he met, fell in love with and married (1796) * Josephine de Beauharnais, a fascinating widow six years his senior. Almost immediately he was given command of the army in Italy, where he conducted a whirlwind campaign against the Austrians, culminating in the brilliant victories of Arcola and Rivoli and the capture of Mantua. Back in France, Napoléon secured consent for an ambitious plan for the conquest of Egypt. In May 1798 a fleet carrying 36,000 troops shipped out of Toulon. Napoléon received the surrender of Malta on the way and (avoiding *Nelson's fleet) reached Egypt. After winning the Battle of the Pyramids outside Cairo he quickly conquered the country (while the accompanying scientists practically instituted Egyptology) but when Nelson destroyed the French fleet at the Battle of the Nile the army was cut off from France. Afraid of losing political opportunities and checked at Acre in Syria, Napoléon left the army, reached France after again avoiding the British in a fast frigate, and engineered the coup d'état of 18 Brumaire (9 November 1799) which overturned the unpopular Directory and made him the first of three consuls and virtual ruler of France. At once he proved himself a great administrator: local government was centralised through prefects; the civil code of law (Code Napoléon) was issued; the Bank of France was created, and, with military needs in mind, roads (e.g. Mont Cenis pass), bridges etc. were built and ports reequipped. Meanwhile victories over Austria (again at war) at Marengo and Hohenlinden (*Moreau) enabled peace to be made with them at Luneville (1801) and at Amiens with Britain (1802); the latter enabling the army of Egypt to return. A referendum in May 1802 voted overwhelmingly (99 per cent) to make him Consul for life. In 1803 he sold Louisiana, acquired from Spain, to the United States. In 1804 a docile Senate proclaimed the conqueror Emperor of the French, and in December, Pope *Pius VII was brought to Paris for the coronation in Notre Dame. A court formed from some returned émigrés and a new aristocracy of talent achieved a somewhat artificial splendour. Titles of nobility were restored. In 1805 continental war was resumed after ${ }^{*}$ Pitt organised a coalition of Britain, Austria, Russia, Sweden and Naples against France. 
Napoléon moved the army, assembled at Boulogne for the invasion of England, into central Europe: Austerlitz (1805), Jena (1806) and Friedland (1807) were the most important of the victories by which the coalition now including Prussia, was subdued. In 1806 he dissolved the Holy Roman Empire, simply by declaring that it no longer existed. After the Treaty of Tilsit (1807) Russia became his firm ally. A major purpose of his reorganisation of the Continent was to weaken Britain by shutting it off from European trade. During the next few years he made his brother ${ }^{*}$ Louis King of Holland and created the Confederation of the Rhine (later the kingdom of Westphalia), for his brother *Jerome. He became King of Italy himself while his brother *Joseph (succeeded later by his brother-in-law *Murat) was made King of Naples. His greatest mistake was to invade Spain (1808), where he transferred Joseph as King, and Portugal, thus opening up a battleground for the British (the Peninsular War) where *Wellington's army was a constant drain on his resources. Austria again took up arms (1809) but after the Battle of Wagram had to sue for peace. To satisfy his pride and prolong his dynasty, Napoléon divorced Josephine (1809) and married (1810) *Marie Louise, daughter of the Austrian emperor *Franz II. Their son, the future Duke of Reichstadt (*Napoléon II), was born in 1811. Restiveness at the restrictions on trade caused by Napoléon's Continental System, directed against Britain, was the prime cause of the tsar's estrangement, which led to Napoléon's invasion of Russia (1812). The catastrophic winter retreat from Moscow after the burning of the city virtually destroyed the Grand Army, and though Napoléon raced ahead of his exhausted troops and raised new armies they were never of the quality of the old. In 1813 all his old enemies resumed the struggle, Napoléon's hold on Germany was lost and after his decisive defeat at the 'Battle of the Nations' at Leipzig in October he had to withdraw across the Rhine. In 1814, with Wellington's army advancing from Spain and the Allies breaking into France from Germany, Napoléon's skill could only delay the end. He abdicated at Fountainebleau in April and was granted sovereignty of the Italian island of Elba. From there, in March 1815, to the victors haggling over terms at the Congress of Vienna came the electrifying news that Napoléon had escaped to France. As though by magic the country rallied to his side, his old marshals, troops, the country at large. King *Louis XVIII fled and for a hundred days Napoléon was emperor once again. But Europe had had enough. The Prussians and British were first in the field, and though for a time it looked as if by dividing and defeating his opponents in turn Napoléon might achieve yet another miracle, his final defeat at Waterloo, south of Brussels (18 June 1815), by coalition forces under the command of *Wellington and ${ }^{*}$ Blücher, ended the story. He abdicated once again and surrendered to the British. He was sent to the Atlantic island of St Helena where he spent his last years in creating, through his self-justificatory Memorial, the Napoleonic legend, with such effect that in 1840 his body was reburied with pomp and splendour in Paris at the behest of Louis Philippe, a member of the royal line that Napoléon had consistently opposed.

Napoléon was a great commander and administrator and few men have had a greater gift for inspiring devotion. His legal codes and his centralised administrative system have endured in France, and several other countries of Europe. By sweeping away the feudal remnants of the Holy Roman Empire he enabled a new Germany to be born, and he showed that a united Italy could be more than a dream. But he was ambitious beyond measure, cynical, unscrupulous and ruthless.

Geyl, P., Napoléon, For and Against. 1965; Lachouque, H., The Anatomy of Glory: Napoléon and His Guard. 1978; Schom, A., Napoléon Bonaparte. 1997; Dwyer, P., Napoleon 1769-1799: The Path to Power. 2008; McLynn, F., Napoleon: A Biography. 2011; Roberts, A., Napoleon: A Life. 2014; Gueniffey, P., Bonaparte. 2015; Broers, M., Napoléon, vol. 1 Soldier of Destiny, 1769-1805. 2014, vol. 2. The Spirit of the Age, 1805-10. 2018; Zamoyski, A., Napoleon. The Man Behind the Myth. 2018.

Napoléon II (Napoléon François Charles Joseph Bonaparte), Duke of Reichstadt (1811-1832). Titular King of Rome 1811-14. Son of *Napoléon I and the empress *Marie Louise, he received the title of 'King of Rome' at birth. After his father's second abdication (June 1815), he was, at the age of four, proclaimed as Emperor Napoléon II by loyal Bonapartists, but never recognised. Brought up at the court of his grandfather, ${ }^{*}$ Franz II, he became a serious student, served in the Imperial Habsburg army, but was kept under strict supervision until his early death from tuberculosis. Known as 'L'Aiglon' ('the Eaglet'), his remains were transferred from Vienna to Paris in 1940 at ${ }^{*}$ Hitler's orders.

Napoléon III (Charles Louis Napoléon Bonaparte) (1808-1873). Emperor of the French 1852-70. His father, Louis *Bonaparte, was the brother of *Napoléon I, who had made him King of Holland, his mother, Hortense de Beauharnais, was a daughter of the empress *Josephine. Brought up in Germany and Switzerland, he was fired as a young man by liberal causes, took part in a rising in the Romagna against the pope's temporal power and organised revolts against the French monarchy, including one at Strasbourg (1836) for which he was deported. In England (where he lived 1839-40) he published Idées Napoléoniennes, which interpreted his uncle's political thought and showed where his own ideas were heading. In 1840 he was sentenced to life imprisonment for trying to stir the troops in Boulogne to revolt, but after six years escaped from the castle of Ham and fled to London. After the deposition of King ${ }^{*}$ Louis Philippe (1848) he was elected to the National Assembly, at once returned to Paris and in December was elected president of 
the new republic, winning 74 per cent of the vote, defeating Louis-Eugène ${ }^{*}$ Cavaignac. In a coup d'état (December 1851) he proclaimed himself Emperor, though his action was approved by plebiscite and he imitated his uncle's institutions. He tried to forestall future opposition by creating prosperity at home and pursuing a liberal policy abroad. Thus he opened up the country with railways, encouraged the formation of banks, created and protected new industries and, through Georges-Eugène ${ }^{*}$ Haussmann, rebuilt the capital. Great exhibitions (1855 and 1867) displayed French achievements to the world. He avoided his uncle's mistake of quarrelling with Britain; both nations were allies in the Crimean War (1854-56). Without his help and the French victories over the Austrians (1859) at Magenta and Solferino the unification of Italy would have been impossible, but he lost much of the credit by exacting Savoy and Nice as the price of his support, and by using a French garrison to maintain papal rule in Rome, so keeping the Italians out of their natural capital. In doing this he was partly influenced by his beautiful Spanish wife, *Eugénie de Montijo (married 1853), an active supporter of the papal cause. A much worse loss of prestige resulted from sending an army into Mexico on a debt-collecting mission. Having gained control of the country and installed *Maximilian, an Austrian archduke, as Emperor, he withdrew his troops under American pressure, leaving Maximilian to his fate.

Meanwhile republican opposition had been growing and the Emperor had only halfhearted support when he allowed himself to be manoeuvred by ${ }^{*}$ Bismarck into the France-Prussian War. In the military debacle which followed, Napoléon was captured at Sedan (1870) and two days later a republic was declared. After the war Napoléon spent the last two years of his life at Chislehurst, Kent, and died after a failed operation for kidney stones. He was reburied at Farnborough in 1888. His only son, Napoléon Eugène Louis (1856-1879), known as the Prince Imperial, was killed fighting for Britain in the Zulu War.

Ridley, J., Napoléon and Eugenie. 1979.

Narayan, R(asipuram) K(richnaswamy) (19062001). Indian novelist, born in Madras. His novels and short stories, set in Malgudi, an invented area in south India, and written in English, were much admired by Graham ${ }^{*}$ Greene and V. S. *Naipaul for their penetrating analysis of the conflict of cultures, class and caste, Hinduism and secularism. His novels include Swami and Friends (1935), Waiting for the Mahatma (1958), The Guide (1958), A Tiger for Malgudi (1983), The World of Nagaraj (1990) and The Grandmother's Tale (1993).

Narayanan, Kocheril Raman (1921-2005). Indian politician. An 'Untouchable', educated in London, he became a journalist and diplomat. He was Minister for Science and Technology 1986-89, Vice President of India 1992-97 and President 1997-2002.
Narses (c.478-c.573). Armenian administrator and general. A eunuch, he rose to high office in the imperial household at Constantinople and proved his usefulness to the emperor *Justinian by suppressing (532) an insurrection in the city. He was sent to Italy (538) to assist (and perhaps spy upon) *Belisarius and to gain experience of command. He was soon brought back to Constantinople but after the Goths had taken advantage of the recall of Belisarius (548) to conquer most of the country, Narses was sent to Italy (552) with a large army to retrieve the situation. To the surprise of all he showed great military skill, defeated the Ostrogothic leader Totila in a decisive battle, recaptured Rome and by 554 had driven Totila's Frankish allies from northern Italy. He governed Italy until 567, when, in his ninth decade, he retired to Naples. His date of death is uncertain.

Naruhito (regnal name Reiwa, i.e. 'beautiful harmony') (1960- ). Emperor of Japan 2019- . Born in Tokyo, the son of *Akihito, he became the 126th emperor on his father's abdication in April 2019.

Nash, John (1752-1835). English architect. Having developed his professional skill while employed by Sir Robert Taylor, he used money inherited from an uncle for speculative building, a venture that led to bankruptcy. He then moved to Wales where he practised with success and formed a partnership with the landscape gardener Humphry ${ }^{*}$ Repton, who may have brought him to the notice of the Prince of Wales (*George IV). The connexion brought him many commissions for country houses and when the prince became regent (1811), it was to Nash that he turned for the realisation of his ambitious scheme for developing London's West End. Regent Street (now rebuilt) began the approach to the redesigned Marylebone Park (now Regent's Park), round part of which were built the famous 'Nash terraces' of stucco houses that still survive. The planning of Trafalgar Square and its relationship to a redeveloped St James's Park area were all part of the general scheme, and Buckingham House was reconstructed as Buckingham Palace. Nash also created the Brighton pavilion for his royal patron (1818-21). As a town planner he had few equals, as an architect he popularised the Regency style of stucco-covered houses in the classical idiom which, despite technical defects, had much dignity and charm and set the pattern (followed with little taste and understanding) for the monotonous Victorian developments of the next decades.

Davis, T., The Prince Regent's Architect. 1973.

Nash, John Forbes, Jr (1928-2015). American mathematician. He worked for the Rand Corporation but suffered from schizophrenia and was often institutionalised over a 30-year period. He shared the 1994 Nobel Prize for Economics for his work on games theory, based on research at Princeton in 1950. His life was the basis of an Academy Award winning film, A Beautiful Mind (2001).

Nasar, S., A Beautiful Mind. 1998. 
Nash, Ogden (1902-1971). American poet. His humorous verse, featured in the New Yorker, was notable for lines of irregular length and unconventional rhymes. Several collections have been published, e.g. The Private Dining Room (1953), You Can't Get There from Here (1957) and The Untold Adventures of Santa Claus (1965).

Nash, Paul (1889-1946). English painter. Trained at the Chelsea Polytechnic, he was a regular exhibitor at the New English Art Club and became known mainly for landscapes in a simplified geometric style influenced by Cubism. An official artist in both World Wars, he was adept at investing with symbolism the debris of a battlefield. Some of the most striking of his war pictures are in the Imperial War Museum. From 1927 he introduced a note of surrealism and exhibited at the London surrealist exhibition (1936). He also designed, especially in his earlier career, textiles, book illustrations and stage settings. His brother, John Nash (1893-1977), was also a landscape painter.

Eates, M., Paul Nash. 1973.

Nash, Richard (known as 'Beau' Nash) (1674-1762). English fashion leader and dandy, born in Swansea. Educated at Oxford, he was a soldier and lawyer, but lived by his wits and as a gambler. He went to Bath in 1704 and soon became 'master of ceremonies' at the spa, with autocratic powers over dress and behaviour in the assembly rooms and other places of resort. He introduced gambling, duelling, and a dance band from London. Road improvements and even street lighting came under his control, and Bath became the most fashionable of English spas.

Nash (or Nashe), Thomas (1567-1601). English pamphleteer and dramatist. Educated at Cambridge, he became one of the group of playwrights and pamphleteers known as 'university wits'. The Anatomy of Absurdities (1589) and Pierce Penilesse (1592) were satirical exposures of the evils of society in his day. He wrote the first picaresque novel in English, The Unfortunate Traveller (1594). His play The Isle of Dogs (1597), which attacked abuses of state power with such freedom that he was imprisoned, is lost.

Hibbard, G. R., Thomas Nash. 1962.

Nash, Sir Walter (1882-1968). New Zealand politician. He emigrated from England (1909) and became a Labour MP 1929-68 and Minister of Finance 1935-49. He wrote New Zealand: A Working Democracy (1943). After Labour's 1949 defeat he succeeded Peter ${ }^{*}$ Fraser as party leader 1950-63. Prime Minister for a single term 1957-60, he received a GCMG and CH.

Sinclair, K., Walter Nash. 1976.

Nasmyth, James (1808-1890). Scottish engineer. He invented the first successful steam hammer, which he patented in 1842 . That the first one to be built was constructed in France was probably due to the pirating of his design. The hammer permitted the production of metal forgings of better quality and much greater size. He also invented the stop-valve and a steam piledriver. The success of his foundry, established (1834) at Bridgewater, near Manchester, enabled him to retire with a fortune at the age of 48 . His autobiography was edited by Samuel *Smiles (1883).

Nasser, Gamal Abdel (1918-1970). Egyptian soldier and politician, born in Alexandria. He had a successful military career and emerged with credit from the war with Israel (1948-49). He was the chief organiser of the revolt (1952) which under General *Neguib deposed King Farouk. Having supplanted Neguib, he was Prime Minister 1954-56 and President of Egypt 1956-70. His nationalisation of the Suez Canal (1956) provoked Anglo-French-Israeli military intervention. Egypt and Syria made a political union in 1958, as the United Arab Republic, under Nasser's presidency; despite Syria's withdrawal in 1961 the name was retained. His later attempts to form an Arab federation under Egyptian leadership were constantly foiled. He obtained much economic and military aid from Russia but remained doctrinally 'neutralist'.

Lacouture, J., Nasser: A Biography. 1973.

Nathan, George Jean (1882-1958). American editor and dramatic critic. With H. L. ${ }^{*}$ Mencken he edited Smart Set (1914-23) and founded the American Mercury (1924). He was for many years the leading American dramatic critic. His collection of criticisms included The House of Satan and The Morning after The First Knight.

Nation, Carry (Amelia) (née Moore) (1846-1911). American temperance advocate. Famous for her hatchet-wielding exploits in Kansas against bars and saloons, she also campaigned against foreign foods, pornography, tobacco and corsets and for female suffrage. She was jailed many times.

Navratilova (originally Šubertova), Martina (1956-). American tennis player, born in Prague. She defected to the US in 1975 . The most consistent winner in women's tennis, she won the singles titles at Wimbledon 1978-79, 1982-87, 1990. She retired in 2006 and became an active campaigner for animal and gay rights.

Nebuchadnezzar (or Nebuchadrezzar) II (d.562 BCE). King of Babylonia 605-562. He recovered many of the lost provinces of the empire and added more. In 597 he took Jerusalem and in 586, after a revolt, destroyed the city and took most of the people into captivity in Babylonia. He rebuilt the city of Babylon, where at his palace he constructed the famous 'hanging gardens', regarded as one of the Wonders of the Ancient World.

Nechayev, Sergei Gennadyevich (1847-1882). Russian anarchist. A professional revolutionary, he was the archetypical terrorist and died in prison. 
Necker, Jacques (1732-1804). French-Swiss financier, born in Geneva. Having made a large fortune as a banker he represented Geneva in Paris, where his wife's salon attracted literary celebrities as well as businessmen. As French Director-General of Finance 1777-81, Necker made such an impression by his integrity and was so successful with his administrative economies that he was able to raise money without difficulty for the War of American Independence. Those who had suffered from his measures forced his retirement (1781) and he was not recalled until 1788, when France was on the brink of the Revolution. He advised *Louis XVI to summon the Estates-General but the consequence of this step lost him the King's confidence. He was dismissed (July 1789), only to be reinstated a few days later when the Bastille fell. Disillusioned by events, he finally retired to Switzerland in 1790 . His daughter became famous as Madame de *Stael.

Needham, (Noel) Joseph (Terence Montgomery) (1900-1995). English biochemist and historian of China, born in London. Educated at Cambridge, where he worked all his life, he produced the encyclopaedic Chemical Embryology (1931). A Christian Marxist, he visited China 1942-46 as head of a scientific mission, then devoted the rest of his career to a massive study of Science and Civilisation in China (1954 ff: seven volumes by 2004). Elected FRS and FBA, he was Master of Gonville \& Caius College 1966-72 and received a CH in 1992.

Werskey, G., The Visible College. 1978; Winchester, S., The Man Who Loved China. 2008.

Nefertiti (or Neferneferuaten) (c.1370-c.1330 BCE). Egyptian queen, and possibly pharaoh. Probably the daughter of *Ay II, a wife of *Akhenaten, she gave birth to six daughters and was stepmother to *Tutankhamun, and may have preceded him briefly as Pharaoh (like *Hatshepsut). A beautiful limestone polychrome bust of her, one of the world's greatest art works, was found in Tel-el-Amarna (Akhetaten) in 1912 and first displayed in Berlin in 1923.

Negrín López, Juan (1892-1956). Spanish politician. As a professor at the University of Madrid he played an active role in the socialist party. On the outbreak of the Spanish Civil War Negrin's resolution singled him out as a leader and he was Premier 1937-39. He took refuge in France and England on the Republican defeat.

Nehru, Jawaharlal (1889-1964). Indian politician, born in Allahabad. A Kashmiri Brahmin by descent, he was son of Motilal Nehru (1861-1931) a rich lawyer who had led the Swaraj (Home Rule) party. Educated at Harrow and Trinity College, Cambridge (where Bertrand ${ }^{*}$ Russell was his tutor), he was admitted to the English bar and returned to India in 1916. From the moment he met ${ }^{*}$ Gandhi his life was given to politics. He joined the Indian National Congress (1918) and was President in 1929 and four times subsequently. He was not a pacifist like Gandhi and did not share his economic views but his personal devotion was intense, and while agitation and propaganda were the main activities their differences lacked practical importance. Nehru's terms of imprisonment 1921, 1926-29, 1931-34, 1942-44 increased his influence. Complete independence was always his aim for India and after the failure of the ${ }^{*}$ Cripps mission he was interned for his rebellious attitude. After the war, when the subcontinent was partitioned between India and Pakistan, Nehru's prestige inevitably made him the first Prime Minister of India 1947-64 (and also Foreign Minister 194664). Owing to the immense difficulties of his task his success was only partial. He kept his country within the Commonwealth, achieved some success with industrialisation and maintained democratic forms of government, with stability and order. But the Kashmir problem remained unsolved and he shocked world opinion by invading Goa. His policy of nonalignment with the eastern or western power blocs did not prevent the Chinese invasion of 1962. Nevertheless when he died the consensus was that a great influence for good had gone from the world. His daughter Indira *Gandhi became Prime Minister in 1966. He wrote an autobiography (1936) and several historical works including Glimpses of World History (1939) written from an Asian perspective.

Gopal, S., Jawaharlal Nehru. 2 vols, 1975, 1979.

Nelson, Horatio, 1st Viscount Nelson (1758-1805). English sailor, born in Burnham Thorpe, Norfolk. Son of a clergyman, he joined the navy (1770) and served in the Arctic, North America, and the West Indies 1783-87, where he married a widow Frances Nisbet. He lived, unemployed, on half pay in Norfolk 1787-93 until recalled to service by war with France. $\mathrm{He}$ served in the Mediterranean (with spectacular actions in the North Atlantic) 1793-97, 1798-1800, 1803-05, gaining rapid promotion and a reputation as an outstanding leader. In the battle of Cape St Vincent, off Portugal (February 1797), as second-incommand to Sir John Jervis (later Earl of *St Vincent), he took a decisive role in defeating a larger Spanish squadron and received a knighthood. He lost the sight of his right eye in an assault on Calvi, Corsica (1794) and his right arm was shattered and amputated in a failed action at Tenerife in the Canary Islands to capture a treasure ship (1797). In the Battle of the Nile (August 1798), Nelson, having pursued the French Mediterranean Fleet to Aboukir (Abu Qir) Bay, off Alexandria, destroyed it and cut off Bonaparte's forces in Egypt. He was created a baron in 1798. In Naples in 1793 he had met Sir William and Lady (Emma) *Hamilton; five years later she became his mistress with her husband's apparent approval. They often travelled as a ménage à trois and Nelson was prominent in Neapolitan society. King *Ferdinand I appointed him commander of his fleet and created him Duke of Brontë (1799). The Admiralty disapproved of Nelson's Neapolitan involvements and made him deputy Commander-in-Chief of the North Sea and Baltic 
Fleet 1801-03. He won the Battle of Copenhagen (1801), inflicted heavy losses on the Danes, Napoléon's allies, and was promoted Viscount (1801) and Vice Admiral. Commander-in-Chief of the Mediterranean Fleet $1803-05$, he kept watch on Toulon for two years but the French admiral *Villeneuve used bad weather as an opportunity to escape, planning to link up with the French Atlantic fleet as part of a proposed invasion of Britain. At Trafalgar (just west of Gibraltar), 21 October 1805, Nelson had his last and greatest victory, when his 27 ships defeated a French-Spanish fleet of 33, establishing British naval supremacy for a century. Fatally shot by a French sniper on his flagship HMS Victory, he was buried in St Paul's Cathedral after a great upsurge of national grief and patriotism, in the sarcophagus designed for Cardinal *Wolsey. Nelson, subject of many legends, created a new leadership style, involving consultation with other officers and improving conditions at sea. He became extraordinarily popular with both sailors and public, although *Wellington (understandably envious) thought him absurdly vain. His elder brother William Nelson (1757-1835), an opportunist Anglican priest, was created 1st Earl Nelson (1805).

Pocock, T., Horatio Nelson. 1987; Sugden, J., Nelson. The Sword of Albion. 2012.

Nenni, Pietro (1891-1980). Italian Socialist politician. Exiled by ${ }^{*}$ Mussolini (1926), he fought for the Loyalists in the Spanish Civil War. After Mussolini's fall (1943) he was able to resume political life in Italy and became President of the Socialist Party. In the postwar coalitions he was a Deputy Prime Minister 1945-46 and Foreign Minister 1946-47. His close association with the Communists caused a party split (1947) and a breakaway, under *Saragat, of the Socialist right wing. He rejoined the government in 1963, and in successive coalitions under ${ }^{*}$ Moro he was Vice President of the council.

Nennius (or Nemnius) (fl. c.830). Welsh historian. His Latin work Historia Brittonum is now thought to be a compilation and translation of lost originals. It describes the Anglo-Saxon invasions and gives the earliest account of King *Arthur and his knights of the round table.

Nepos, Cornelius (c. 100-25 BCE). Roman historian. Of his lives of the famous (De Viris Illustribus) some 25 survive. His lost writings include a universal history and letters to his friend ${ }^{*}$ Cicero.

Neri, St Philip (1515-1595). Italian religious reformer, born in Florence. He went to Rome (1533) as a tutor but from 1538 led an ascetic life, sleeping in the catacombs, visiting the sick and instructing the poor. He was ordained (1551) and while continuing his work among the poor he found a new vocation in making religion attractive to the young by holding informal meetings that combined religious instruction and discussion with social and musical entertainment.
In 1575 with papal consent he founded the first Oratory in Rome, a brotherhood of secular priests, which to some extent formalised his earlier work. Remembered as one of the most vivacious, human and lovable of all saints, he was canonised in 1622 .

Nernst, Walther Hermann (1864-1941). German physical chemist. A professor at Göttingen 18911905 and Berlin 1905-33, his many important contributions to structural chemistry included his 'solution pressure' theory (1889) to explain the production of electromotive force in electrical cells, the concept of solubility product (1889), which governs the precipitation of solids from solution, and the 'Nernst heat theorem' (1906), which later became known as the Third Law of Thermodynamics (that entropy falls towards zero at $-273.15^{\circ} \mathrm{C}$ ). For this he won the Nobel Prize for Chemistry (1920). He also described the phenomenon of chain reaction (1918), later taken up by Leo *Szilard. He was a supporter of *Einstein, and opposed the Nazis.

Nero (Nero Claudius Drusus Germanicus) (37-68 CE). Roman Emperor 54-68. Proclaimed Emperor at the instigation of his mother *Agrippina (a sister of ${ }^{*}$ Caligula) on the death of her husband the emperor *Claudius, he began his reign with his tutor *Seneca, timid but wise, to guide his inexperience. Only too soon, however, his character showed itself. Claudius' son Britannicus, the rival claimant, was poisoned, Agrippina and Nero's own wife, Octavia, were also put to death. Nero instituted a fierce persecution of the Christians to provide scapegoats who could be blamed for the great fire (64) which destroyed much of Rome, for which he was the obvious suspect. His grandiose plans for rebuilding work, including his 'golden palace' on the Palatine Hill, demanded money that could only be obtained by exactions of every kind. Plots, real or imaginary, yielded victims such as ${ }^{*}$ Seneca, ${ }^{*}$ Lucan and a host of rich, distinguished men, whose property could be confiscated. Meanwhile the Emperor's vanity led him to appear in public as a musician or charioteer; passion and cruelty caused him, one crime of many, to kick his wife Poppaea to death. Finally the legions of Gaul and Spain proclaimed *Galba Emperor in his place. The praetorian guards and senate also turned against him, and Nero, in desperate flight and already hearing the sounds of pursuit, nerved himself to take his own life. External events of the reign included Boadicea's revolt in Britain and peace treaties with the Parthians.

Neruda, Pablo (Neftali Ricardo Reyes) (19041973). Chilean poet. Considered one of the most original modern Spanish poets, he began publishing his verse in Chile in 1923. He met the Spanish poet Federico Garcia *Lorca in 1933 and his work was introduced to Spain. Much of his strongest realist poetry was written in reaction to the Spanish Civil War and the outbreak of World War II. After the war he entered political life in Chile as a Communist but was forced out in 1948, went into hiding and wrote 
Canto general (1950), an epic poem, set as an oratorio by Mikis *Theodorakis (1972). He returned to Chile in 1952 and was Ambassador to France 1970-72. Awarded the 1971 Nobel Prize for Literature, he served on UNESCO's Executive Board 1972-73.

Aguirre, M. (ed.), Obras completas de Pablo Neruda. 2nd edn. 1968.

Nerva, Marcus Cocceius (c.30-98 CE). Roman Emperor 96-98. Born to a noble family, son and grandson of consuls, brother-in-law of *Otho, he worked for ${ }^{*}$ Nero, then for the Flavian dynasty, as an administrator, and was consul himself 71 and 90. After the assassination of ${ }^{*}$ Domitian, the Senate speedily elected him as Caesar; being old and childless were probably factors in the choice. He proved to be humane and tolerant, but was essentially a stop-gap. He assured a vigorous successor by selecting *Trajan as his heir.

Nerval, Gérard de (Gérard Labrunie) (1808-1855). French Romantic writer. His translation of *Goethe's Faust (1828) was praised by the poet and used by *Berlioz and ${ }^{*}$ Gounod; he knew Victor ${ }^{*}$ Hugo and collaborated with Alexandre ${ }^{*}$ Dumas in a successful comic opera, Piquillo (1837). Théophile ${ }^{*}$ Gautier was a lifelong friend. While living a self-consciously bohemian life in Paris (he is said to have led a lobster on a ribbon), he wrote essays, poems including the beautiful mysterious sonnets known as the Chimères (1854) and travel sketches, resulting from his searches in Europe and the East for exotic backgrounds. The ecstasies and agonies of his love affair with Jenny Colon are told in Sylvie, one of his many short stories, which became increasingly fantastic in later years. After a schizophrenic breakdown (1841), he was eight times committed to a hospital. His ability to distinguish reality from dream became more and more intermittent and eventually he hanged himself. He was much admired by ${ }^{*}$ Proust.

Nervi, Pier Luigi (1891-1979). Italian engineer. He was a pioneer in the application of 20th-century engineering techniques to the construction of large buildings, especially the use of steel mesh clad with concrete, and of prefabricated components. This enabled him to design and build vast and often intricate structures. Outstanding are the Exhibition Halls at Turin (1949-50) and his buildings for the Olympic Games in Rome (1956-59).

Nesbit, E(dith) (married name Edith Bland) (18581924). English writer. After a sketchy education, she married the economist and serial philanderer Hubert Bland (1856-1914), was a follower of William *Morris and a friend of Eleanor *Marx, and a foundation member of the Fabian Society (1884). She wrote extensively to raise money for the family: 60 books ( 40 for children), including detective fiction, ghost stories and poetry. She published with the initial E to disguise her gender. Her children's stories were noted for their cheerful realism. Five Children and It (1902), The Railway Children (1906), The Magic City (1910) and a series about the Bastable children are still in print, and some have been filmed. Her writing influenced J. K. * Rowling.

Moore, D. L., E. Nesbit. 1933, rev. 1966; Briggs, J., A Woman of Passion. 1987; Fitzsimons, E., The Life and Loves of E. Nesbit. 2019; Galvin, E., The Extraordinary Life of E. Nesbit. 2019.

Nesselrode, Karl Vasilyevich (1780-1862). Russian official, born in Lisbon. He was chief Russian representative at the Congress of Vienna 1814-15.

Nestlé, Henri (1814-1890). Swiss manufacturer, born in Germany. An artisan and inventor, he experimented with supplementary milk products for babies and established a plant in Vevey for making condensed milk. He sold out his interest in 1875 but the name was retained. The Nestlé company did not enter the chocolate market until 1904, now it is the world's largest manufacturer. It currently describes itself as a 'nutrition, health and wellness company'.

Nestorius (c.386-c.450). Persian theologian, born in Cilicia (now in Turkey). A member of a community of monks near Antioch he was chosen (428) to be patriarch of Constantinople by the emperor Theodosius II. His interpretation of the doctrines concerning the Godhead and Manhood of Jesus Christ were held to be heretical by the ecumenical synod of Ephesus (431) and Nestorius was deposed and (436) exiled to Egypt. The Nestorian Church came into being (c.500) under Persian protection, but it shrank under constant Mongol and Turkish persecution and only a remnant, now known as Assyrians, survives in the Middle East and the US.

Netanyahu, Benjamin (1949- ). Israeli politician, born in Tel Aviv. Son of the historian Benzion Netanhayhu (1910-2012), he was educated at MIT and Harvard, becoming a management consultant, then Ambassador to the United Nations 1984-88. He led the Likud party 1993- and narrowly defeated Shimon *Peres to become Prime Minister of Israel 1996-99, Foreign Minister 2002-03, 2003-05 under Ariel *Sharon, and again Prime Minister 2009-21. Netanyahu was close to Donald *Trump, Vladimir *Putin, Silvio *Berlusconi and Jair *Bolsanaro. The longest-serving Israeli Prime Minister, after two indecisive elections in 2019, he was charged with corruption in January 2020. A third election in 2020 resulted in a power-sharing government with Benny *Gantz, which soon collapsed. A fourth election, in March 2021, was indecisive and in May bombings and rocket attacks broke out between Israel and Hamas. In June 2021 the Knesset narrowly installed a coalition government led by $\mathrm{Naftali}{ }^{*}$ Bennett. After a fifth election, he returned as Prime Minister 2022- .

Netanyahu, B., Bibi: My Story. 2022 
Neuberger, David Edmond, Baron Neuberger of Abbotsbury (1948- ). British judge, born in London. After studying chemistry at Oxford, and working in a merchant bank, he became a barrister, a judge in 1996 and President of the Supreme Court of the United Kingdom 2012-17.

Neumann, (Johann) Balthasar (1687-1753). German architect, born in Bohemia. He studied in Paris, travelled in Italy and Austria, and built 100 churches. He brought German rococo to its highpoint in the Basilika Vierzehnheiligen (Fourteen Helpers), built 1750-72, at Bad Staffelstein, near Bamberg, in Bavaria and in the Residenz Palace at Würzburg.

Neumann, John von (né Neumann János Lajos) (1903-1957). Hungarian-Jewish-American mathematician, born in Budapest. He studied chemistry in Zürich, received a PhD in mathematics from Budapest, published a classic definition of ordinal numbers at the age of 20 , and taught at Göttingen. He migrated to the US in 1930, became a professor at Princeton University 1930-33 and at the Institute for Advanced Study (Princeton) 1933-57. He wrote more than 150 papers on quantum theory, pure mathematics, logic, meteorology, games theory and computer programming. During World War II he worked on designing the atomic bomb and later was a 'Cold War' hardliner. He turned *Turing's concept of a 'universal computing machine' into reality. His Electronic Discrete Variable Automatic Computer (EDVAC), operational from 1947, was the first fully electronic computer, using binary notation and stored internal programming. Conventional computers are sometimes called 'von Neumann machines'. He was a member of the US Atomic Energy Commission 1955-57. With Oskar *Morgenstern he wrote Theory of Games and Economic Behaviour (1944).

Bhattacharya, A., The Man from the Future. 2021.

Neurath, Konstantin Hermann Karl, von (18731956). German diplomat and administrator. An officer in World War I, he was Ambassador to Italy 1921-30 and Britain 1930-32. Foreign Minister 1932-38, originally appointed by von *Papen, he continued under ${ }^{*}$ Hitler. Protector of Bohemia and Moravia 1939-43, from 1941 effective power was exercised by his deputy, ${ }^{*}$ Heydrich. Sentenced in the Nuremberg trials to 15 years jail, he was released in 1954 .

Neveu, Ginette (1919-1949). French violinist. A pupil of Georges *Enescu and Carl Flesch, she played with passion and classical grace and was killed in an aircraft crash.

Neville, Sir Henry (1562?-1615). English diplomat. Claimed (implausibly) as a possible author of *Shakespeare's plays, he was an MP, widely travelled and Ambassador to France.
Newcastle-upon-Tyne, 1st Duke of, Thomas Pelham-Holles (1693-1768). English Whig politician, born in London. Son of the 1st Baron Pelham, he added the name Holles when, as adopted heir, he inherited the estates of his uncle, Duke of Newcastle-upon-Tyne of an earlier creation. The dukedom was recreated for him in 1715 . Thus richly endowed and having married a daughter of Lord ${ }^{*}$ Godolphin he began his political career with every advantage. He and his younger brother Henry *Pelham worked closely with Robert *Walpole as adroit and indefatigable wielders of patronage. As a result, no Whig administration, for more than 40 years from 1717, could exist without them. Secretary of State for the Southern Department 1724-48 and for the Northern 1748-54, he succeeded his brother as Prime Minister (i.e. First Lord of the Treasury) 1754-56, 1757-62. In the period 1757-61 the driving force was William *Pitt and many great victories were won in the Seven Years' War (1756-63). Chancellor of Cambridge University 1748-68, he was given a second Dukedom, Newcastle-under-Line, in 1756.

Newcomb, Simon (1835-1909). American astronomer and mathematician, born in Nova Scotia. Largely self-educated, he held an appointment at the Washington Naval Observatory, and a professorship at Johns Hopkins University 1884-93. He became the great authority on ephemerides (the trajectories of astronomical objects), and tabulated the motions of the Sun, Mercury, Mars and Venus. In 1896 an international conference in Paris adopted a worldwide unified system of astronomical constants based on Newcomb's work. He collaborated with A. A. *Michelson in determining the velocity of light (1879). His popular books included Astronomy for Everybody (1903), he also edited the US Nautical Almanac. He was elected FRS and awarded the Copley Medal (1890). He hated the philosopher C. S. *Peirce, blocking publication of his work, and categorically rejected the possibility of manned flight. Asteroid 855 Newcombia, and craters on the Moon and Mars are named for him.

Newcomen, Thomas (1663-1729). English inventor, born in Devon. He invented the first practical steam engine, which he erected in 1712 after 10 years of experiment. Its main purpose was to pump water from mine shafts (e.g. of the tin mines of his native county). Its principles were later modified to achieve greater efficiency for wider use (*Watt). Owing to patenting difficulties, Newcomen made little or no financial profit from his invention.

Ne Win ('Brilliant as the Sun', originally Shu Maung) (1910?-2002). Burmese general and dictator. During World War II, he collaborated with the Japanese, then began a guerrilla campaign against them. Premier 1958-60, 1962-74, he organised a military coup in 1962 and cut Burmese contacts with the outside world. President 1974-81, he remained the dominant influence under the State Law and Order Restoration 
Council (SLORC) military dictatorship. Although he retired from public life in 1988 he continued to exercise power behind the scenes.

Newman, Barnett (1905-1970). American painter. One of the New York school of Abstract Expressionists, he became a pioneer of colour field painting, characterised by large masses of unmodulated colour.

Newman, Ernest (né William Roberts) (1868-1959). English music critic. He studied in Liverpool, worked in a bank and was largely self-educated in music. Music critic for the Manchester Guardian, Birmingham Post and then for the Sunday Times 1920-59, he was learned, trenchant and witty. His many books include a definitive life of *Wagner (4 volumes, 1933-47), an authoritative monograph on Hugo *Wolf and studies of *Beethoven, *Liszt and Richard ${ }^{*}$ Strauss.

Newman, V., Ernest Newman: A Memoir. 1963.

Newman, St John Henry (1801-1890). English cardinal, theologian and poet, born in London. Educated in Ealing, he studied at Trinity College, Oxford and was elected a Fellow of Oriel in 1822. As rector of St Mary's, Oxford 1828-43, and in spiritual charge at Littlemore, he won an immense reputation as a preacher. In 1833 he heard a sermon on 'National Apostasy' by *Keble which he regarded as the starting point of the Tractarian (or Oxford) Movement, in which he played so pre-eminent a role. Its purpose was to reinvigorate the Anglican Church and, by turning back to the early Christian Fathers (of whose works Newman had made a profound study) as the custodians of doctrine, to reconcile the beliefs of the Roman and Anglican branches of the Catholic Church. Newman wrote many of the Tracts for the Times, but the same logic that made many of the movement's supporters turn to the Roman Church led Newman eventually (1845) to take the same step. Ordained priest in 1847 , shortly afterwards he founded an Oratory, a brotherhood of secular priests without vows (St Philip *Neri). Its branch in London came to be known as Brompton Oratory, the main body was at Edgbaston, Birmingham. Here Newman lived in seclusion, partly because of an estrangement between him and the more ultramontane Cardinal *Manning. Any suspicion of Vatican disapproval was, however, removed when Pope ${ }^{*}$ Leo XIII made Newman a cardinal (1879). As a writer Newman was a supreme stylist as can be seen in his Apologia Pro Vita Sua (1864), a vivid and moving spiritual autobiography written in reply to Charles *Kingsley, who had challenged his integrity. His other works include The Dream of Gerontius (1866), a dramatic poem on the flight of the soul from the body, which *Elgar set as an oratorio (1900). In 1852 he gave lectures on the nature of university education (emphasising the pursuit of truth rather than professional training or the dissemination of knowledge) which he expanded and published as The Idea of a University Defined proposed Catholic University of Dublin 1854-58 was deeply frustrating and he asked to be relieved. His major theological work was The Grammar of Assent (1870). Lead, Kindly Light, written before his conversion, is the best known of his many hymns. In the last years of his life Newman was revered by people of all denominations and his influence did much to encourage the progressive tolerance that has made possible the present-day search for a basis for Church reunion. He was beatified by Pope *Benedict XVI in September 2010, and canonised by Pope ${ }^{*}$ Francis in October 2019.

His brother Francis William Newman (1805-1897), a Latin scholar and missionary, also left the Anglicans but became a Unitarian.

Ker, I., John Henry Newman. 1988; Martin, B., John Henry Newman. 2000; Gilley, S., Newman and His Age. 2002; Ker, I. and Merrigan, T., (eds), The Cambridge Companion to John Henry Newman. 2009.

Newton, Sir Isaac (1642-1727). English mathematician and physicist, born in Woolsthorpe, Lincolnshire. Posthumous son of a small landowner, he was brought up in his birthplace after his mother's remarriage (1645), by his maternal grandmother. Already, as a school boy, he had a reputation for making sundials and water clocks. He went in 1661 to Trinity College, Cambridge, where he graduated in 1665 . When the college closed during the plague he was back at Woolsthorpe (1665-66) where at the age of 23 he worked out practically the whole of his universal law of gravitation. He built upon the work of *Galileo, but it was his genius to supply a generalised set of principles and provide a new and infinitely challenging conception of the universe. Moreover he devised the tools with which to give his concept mathematical expressions: by 1665 he had evolved the binomial theorem and devised the elements of the differential calculus, which he called fluxions. He also developed the integral calculus (inverse fluxions). Because of his inherent dislike of publications, these discoveries were not published until 1685 and this caused a bitter 'priority' controversy with *Leibniz. Yet another major discovery was made by this astonishing young man: he found (1666) that so-called white light is composed of many colours, which may be separated by a prism and then combined into white light again. Having returned to Cambridge in 1667 he was Lucasian professor of mathematics 1669-95. He constructed (1668) the first reflecting (Newtonian) telescope, in which he used a parabolic mirror to reflect and magnify the object observed. All of his discoveries were made by the age of 30 . In 1672 he became a fellow of the Royal Society but more than 12 years elapsed before he published his findings, and even then it was only through the eager encouragement and help of the astronomer *Halley that his great Philosophiae Naturalis Principia Mathematica (1687), known as The Principia, appeared. In this he sought to explain all physical phenomena by a few generalised laws. His three 'Laws of Motion' and 
a systematised study of mechanics provide a starting point and he goes on to explain the action of the tides and the orbits of the planets. He ends by showing the philosophical conclusions to be deduced from the earlier sections of the work. In 1704 he published his Optics in which he advanced the corpuscular theory of light, later disproved by Thomas *Young. Newton was also a student of alchemy and biological chronology, to which he appears to have attached as much significance as to his scientific work.

Newton was President of the Royal Society 1703-27, MP for Cambridge 1689-90, 1701-02 and received a knighthood in 1705 . His reports on the coinage (1717 and 1718) resulted from his appointment (1699) as Master of the Mint. He is buried in Westminister Abbey and is universally recognised as one of the greatest thinkers of all time. Newton was an isolate who never married and quarrelled bitterly with *Flamsteed, *Hooke and ${ }^{*}$ Boyle.

The newton is the international unit of force and 8000 Isaac Newton is a minor planet.

White, M., Isaac Newton: The Last Sorcerer. 1997; Christianson, G. E., Isaac Newton and the Scientific Revolution. 1996; Hawking, S. (ed.), On the Shoulders of Giants. 2002; Gleick, J., Isaac Newton. 2003.

Ney, Michel (1769-1815). French marshal. Called by *Napoléon 'the bravest of the brave' he was a noncommissioned officer when the Revolution broke out. He rose quickly and by 1796 was general of a brigade. He was given the title Duke of Elchingen by Napoléon for the heroism with which he stormed the entrenchments in that engagement (1805). He won further distinction at Jena, Eylau and especially Friedland, and for the part he played at Smolensk and Borodin during the advance into Russia (1812), he was created Prince of Moscow. As leader of the rear-guard during the disastrous retreat he saved the remnants of the Grand Army from annihilation. When Napoléon abdicated (1814) Ney was allowed by ${ }^{*}$ Louis XVIII to retain a command but when the emperor again landed (1815) his marshal joined him with his troops. Ney showed his courage once more in the Waterloo campaign but was caught when trying to reach Switzerland after the defeat and, despite efforts by ${ }^{*}$ Wellington and others to save him, he was shot as a traitor.

Morton, J. B., Marshal Ney. 1958; Horricks, R., Marshal Ney, The Romance and the Real. 1982; Atteridge, A. H., Marshal Ney: The Bravest of the Brave. 2005.

Ngo Dinh Diem (1901-1963). Vietnamese politician, born in Annam. Son of a mandarin, and a Roman Catholic, he became a civil servant and minister of the interior from 1933. He refused to cooperate with the Japanese, ${ }^{*} \mathrm{Ho}$ Chi Minh or *Bao Dai, and lived abroad as a virtual recluse 1950-54. He was Prime Minister of the 'State of Vietnam' (i.e. the South) 1954-55, engineered Bao's deposition, succeeding him as President (1955-63), during the period of open war with the North. A bachelor, his family aroused great hostility, especially his brother Ngo Dinh Nhu and his wife. Although utterly dependent on US support, he refused advice, launched a campaign against the militant Buddhists and was murdered by army officers, together with Nhu (November 1963).

\section{Nicholas I and II. Russian tsars see Nikolai I and II}

Nicholas, St This semi-legendary figure, also known as 'Santa Claus', seems to be based on two historical bishops of Lycia in Asia Minor: Nicholas of Myra (d.c.326) was venerated for miraculously saving three generals condemned to death by *Constantine; Nicholas of Sion (d.564) was revered throughout the Byzantine Empire and his cult spread to Russia, of which he became the patron saint. Whatever his origin, the cult of St Nicholas spread rapidly in the west. Nicholas of Myra was first buried on the island of Gemile, which became an important place of pilgrimage (rediscovered in 1993), then buried in Myra. Bari, where his alleged bones-rescued it is said from the Seljuk Turks-were brought from Myra, became one of the most important places of medieval pilgrimage. As well as being the patron saint of children and the bringer of gifts on the day of his festival (6 December) his identification with 'Father Christmas' came later. He was impartially the patron of judges and murderers, pawnbrokers, merchants and thieves and especially scholars and sailors.

Nicholas of Cusa (1401-1464). German theologian, mathematician and philosopher. Son of a Moselle boatman, he was nevertheless able to study at Heidelberg and Padua universities and presented to the Council of Basle (1413) his ideas (contained in On Catholic Concord but afterwards abandoned) on reforming the Church by giving a general council supremacy over the Pope. He also presented calendar reforms derived from his mathematical studies, which he pursued with the aim of arriving at exact truth. $\mathrm{He}$ did not, as scholars once claimed, anticipate *Copernicus' conclusion that the earth revolves round the sun. After acting as papal legate in Germany 1440-47 he was made a cardinal (1448).

Nichols, Mike (né Mikhail Igor Peschkowsky) (1931-2014). American film, television and stage director, producer and actor, born in Berlin. Distantly related to ${ }^{*}$ Einstein, he escaped with his family to New York in 1939. He achieved early recognition as a satirist, on stage, with Elaine May (1932- ), then became a stage director. His 18 films included Who's Afraid of Virginia Woolf? (1966), The Graduate (1967), Catch-22 (1970), Carnal Knowledge (1971), Silkwood (1983), The Birdcage (1996) and Primary Colours (1998). He won an Oscar, a Grammy, four Emmys, nine Tonys and three BAFTA awards. 
Nicholson, Ben(edict) (1894-1982). British abstract artist. Son of Sir William ${ }^{*}$ Nicholson and husband (1938-51) of the sculptor Barbara *Hepworth, in the 1930s he was a member of the Unit One Group of British artists seeking a truly contemporary approach, and he developed a style allied to the Russian 'constructivism' and to *Mondrian. His work was first exhibited at the Venice Biennale in 1934, after which he exhibited widely and gained an international reputation. He was awarded the OM in 1968.

Nicholson, Jack (1937- ). American actor and film director. His films included Easy Rider (1969, Academy Award), Carnal Knowledge (1971), Chinatown (1974), The Passenger (directed by *Antonioni, 1974), One Flew over the Cuckoo's Nest (1975, Academy Award), Terms of Endearment (1984, Academy Award), Prizzis Honour (1984), The Witches of Eastwick (1987), Batman (as the Joker, 1989), A Few Good Men (1992), Hoffa (1992) and As Good As It Gets (1997, Academy Award).

Nicholson, Sir William (Newzam Prior) (1872-1949). English painter, wood-engraver and lithographer, born in Nottinghamshire. With his brother-in-law James Pryde he became a popular artist with posters produced (1893-98) under the pseudonym 'The Beggarstaffs'. He designed the first settings for *Barrie's Peter Pan and painted many cool still lives e.g. The Hundred Jugs (1916), Onions and soup pot (1923). He taught Winston *Churchill to paint.

Nicias (d.414 BCE). Athenian politician and general. Cautious, conservative and virtuous, he was, after the death of *Pericles, the most important of the 'generals' (popularly elected commanders) left to carry on the Peloponnesian War against Sparta. His efforts for peace and pleas for prudence were constantly thwarted by the demagogue Cleon and by the headstrong *Alcibiades, who with Lamachus was appointed to share with Nicias the command of an attack upon Syracuse in Sicily, then a Spartan colony. When Alcibiades was recalled for impiety and Lamachus killed, Nicias was left in sole command of an expedition in which he did not believe. In the event he delayed evacuation too long, the Athenians were all killed or captured and Nicias taken and put to death.

Nicolle, Charles Jules Henri (1866-1936). French bacteriologist. Director of the Pasteur Institute at Tunis, he discovered (1909) that the body louse transmits typhus fever, and he also claimed success for immunisation against trachoma. He won the Nobel Prize for Medicine (1928).

Nicolson, Sir Harold George (1886-1968). English author, born in Teheran. Son of Lord Carnock, educated at Oxford, he became a diplomat and in 1913 married the poet Vita *Sackville-West, and lived at Sissinghurst. After a brief political fling with Oswald *Mosley (1931), he was a National Labour (virtually independent) MP 1935-45, a strong opponent of the Munich agreement (1938) and held minor office under ${ }^{*}$ Churchill. He joined the Labour Party in 1945 . He wrote lives of *Byron, *Curzon and the official biography of * George V (1952) for which he received a KCVO. Other books include Some People (1927), Public Faces (1932) and Good Behaviour (1955). His Diaries and Letters 1930-62 (3 vols, 1966-68), edited by his son Nigel Nicolson, are valuable source documents for the period.

Nicolson, N., Portrait of a Marriage. 1973.

Niebuhr, Barthold Georg (1776-1831). German historian. After many years spent in public service, culminating with a term as Prussian Ambassador in Rome 1816-23, he lectured at Bonn on ancient history. His great History of Rome (3 volumes, 1811, 1812,1832 ) set new standards of scholarship by his critical examination of original sources. Many of his conclusions remain unchallenged.

Niebuhr, Reinhold (1892-1971). American theologian. Educated at Yale, he taught at the Union Theological Seminary, New York 1928-60 and wrote many books, including The Nature and Destiny of Man (1941-43), which promoted the concept of a 'social gospel' with a heavy political emphasis.

Nielsen, Carl August (1865-1931). Danish composer. His Symphony No. 1 (1892-94) shows the influence of ${ }^{*}$ Brahms, but other works of the 1890 s illustrate a tendency towards combining contradictory keys which, first asserted prominently in the Symphony No. 2 (1902), led Nielsen towards polytonality. His works include four more symphonies, the comic opera Maskarade (1906) and a violin concerto (1911). He directed the Royal Danish Academy of Music 1930-31.

Grimley, D., Carl Nielsen and the Idea of Modernism. 2010.

Niemeyer, Oscar (né Oscar Ribeiro de Almeida Niemeyer Soares Filho) (1907-2012). Brazilian architect. Strongly influenced by *Le Corbusier's functional architecture, he designed many strikingly original buildings in Rio de Janeiro and São Paulo and was commissioned to design (1956) the principal buildings for the city of Brasilia, the new capital of Brazil. He was awarded the Lenin Peace Prize in 1963 (Lúcio *Costa).

Niemöller, Martin (1892-1984). German Lutheran pastor. After being a submarine commander in World War I he was ordained in 1924. He at first supported but later actively opposed the Nazi regime and was held in a concentration camp from 1937 until the end of World War II. He was President of the World Council of Churches 1961-68.

Schmidt, D., Pastor Niemöller. 1959. 
Niepce, Joseph Nicéphore (1765-1833). French inventor. He devised heliography, using sunlight to fix images on plates coated with Jericho pitch as early as 1822 , and this was the precursor of photography. He later collaborated with *Daguerre who developed a much faster process for fixing sharper images.

Nietzsche, Friedrich (Wilhelm) (1844-1900). Prussian philosopher, philologist and cultural critic, born in Röcken. Son of a pastor, he studied classical philology at Bonn and Leipzig and showed such ability that in 1869 even before graduation he was appointed to a professorship at Basel University. He served in the Franco-Prussian War (1870) and contracted dysentery and diphtheria which kept him in pain for much of his life. His earliest work, The Birth of Tragedy ... (1871), was dedicated to *Wagner whose operas he clearly regarded as being in the line of descent from Greek dramas. The influence of Wagner again and of ${ }^{*}$ Schopenhauer is apparent and acknowledged in a group of essays published 1873-76, in one of which he enunciates the principle, elaborated in his later work, that it is not the movements of masses that are historically significant but the deeds of the great. He admired the culture of the 'pagan' Greeks and the Renaissance and considered Christianity to be 'slave morality' and democracy ('a mania for counting noses'), the machinery by which quantity (i.e. of the weak and the mediocre) usually prevails over quality. In summarising the last 2,000 years of history as a conflict between Rome and Judaea, he was using these nations primarily as symbols for his two contrasting types, the hero and the weakling slave.

His sexuality is ambiguous. He twice proposed marriage to Lou Andreas-* Salomé in 1882 and was briefly in a ménage à trois with her and the writer Paul Reé. Some of his writing is misogynist, some deeply sympathetic to women being forced into sex within marriage.

In The Gay Science (1882) he wrote that 'God is dead. And we have killed him'. Thus Spake Zarathustra (1883-85), his major work, he argued there is no life other than the short physical one on earth, there is no transcendence, predicted that the collapse of religion would lead to 'nihilism' with no coherent set of beliefs, and that only great leaders could change this. He developed the concept of the Übermensch, a term first used by ${ }^{*}$ Goethe (usually translated as 'Superman', but more accurately as 'Above man'), 'beyond good and evil', demonstrating his (her?) own characteristics courage, self-reliance, pride in his strength and superiority, an enthusiastic or defiant acceptance of everything, good fortune or ill, that life has to offer. He developed these propositions in Beyond Good and Evil (1886) and Towards a Genealogy of Morals (1887).

Although some of his ideas were adapted and adopted by Fascists and Nazis, and his Superman seemed to be epitomised by ${ }^{*}$ Mussolini and ${ }^{*}$ Hitler, Nietzsche despised genetic racism and anti-Semitism. In 1888 he wrote an autobiography, Ecco Homo, and Nietzsche contra Wagner, a rather lightweight attack on his former hero, because he detested the Christianity implicit in Parsifal (much preferring *Bizet's Carmen).

In January 1889 in Turin he had a spectacular mental collapse, apparently triggered by observing a horse being flogged, was sent to a clinic, but after 1890 was in the care of his mother and sister. Nietzsche suffered from frontotemporal dementia, probably caused by a brain tumour, rather than syphilis or strokes. He lacked enthusiasm for Prussian or German nationality, oddly claiming Polish ancestry and was probably stateless when he died, in Weimar. He was admired by ${ }^{*}$ Strindberg, Richard ${ }^{*}$ Strauss, Bernard *Shaw, H. G. *Wells and W. B. *Yeats.

Deplorably, Nietzsche's ideas have been misused to justify authoritarian and/or nationalist rule by both the Left and Right in many countries. His sister, (Therese) Elisabeth (Alexandra) Förster-Nietzsche (1846-1935), married Bernhard Förster who organised a failed Aryan colony, Neuva Germania, in Paraguay in 1887 and committed suicide in 1889. She returned to Germany in 1893, became her brother's gatekeeper, created the Nietzsche Archive (1894) and promoted the falsity that Nietzsche's philosophy was an intellectual foundation for anti-Semitism and, later, Nazism. She published works under his name which seriously misinterpreted his ideas and, bizarrely, was nominated seven times for the Nobel Prize for Literature and joined the Nazi Party.

Hollingdale, R. J., Nietzsche: The Man and His Philosophy. 1965; Prideaux, S., I Am Dynamite!' A Life of Friedrich Nietzsche. 2018.

Nightingale (originally Shore), Florence (1820 1910). English pioneer of modern nursing, social reformer and statistician, born in Florence. Daughter of a wealthy Hampshire landowner, she was named for the city of her birth. Her parents were liberal Unitarians and she was privately educated in languages (she read six fluently) and mathematics. In 1837 she became convinced that she had been 'called by God' to undertake a mission but it was not until 1844 that she determined on nursing. She endured (and rejected) a nine-year courtship by Richard Monckton *Milnes. She travelled extensively (as far as Abu Simbel) and wrote her perceptive Letters from Egypt 1849-50, illustrated by herself, but not published until 1987 . She gradually wore down parental opposition to her taking up nursing, visited and compared hospitals in England and Europe. In 1850 she worked closely with Lutheran deaconesses at Kaiserwerth-am-Rhein, and wrote an anonymous report (1851), also training with nursing sisters in a convent in Paris. In 1853 she became superintendent of the London Institute for the Care of Sick Gentlewomen. On the outbreak of the Crimean War (1854), Sidney *Herbert, Secretary at War, asked her to take 38 nurses (and 15 Catholic nurses sent by Cardinal *Manning) to Istanbul (still called Constantinople in the West) and run the military hospital at Scutari (now Üsküdar). 
Its appalling death rate was primarily caused by contaminated water, lack of sanitation, poor ventilation, bad food and inadequate care rather than by battle injuries and was higher than in some other military hospitals. Doctors were hostile to nursing intervention but the troops idolised her and, as her work was extensively reported in England, she became an almost legendary hero as 'the Lady with the Lamp'. She emphasised the need for observation/monitoring and clean hands and at last the appalling death-rate began to shrink to comparatively low proportions. A similar task was attempted at hospitals at Balaklava in the Crimea.

She returned to England in 1856, gained the support of Queen *Victoria and urged the creation of a Sanitary Commission in 1857. She wrote the important textbook Notes on Nursing (1859). She had a powerful grasp of statistics and made effective use of her 'rose diagram' (essentially a pie-chart) to mount a continuous battle against officialdom, medical jealousy, incompetence and inertia, but at last she managed to overcome chaos and introduce cleanliness and sanitation, organise the provision of food as well as raising nursing standards. She used her own money and influence unsparingly. With $£ 50,000$ raised by public subscription she founded (1860) a nurses' training school at St Thomas' Hospital, London. A uniform for nurses and competitive examinations were among her other reforms that gave the nursing profession an entirely new status. She supported the 'miasma' theory for the spreading of disease, emphasising environmental factors rather than *Pasteur's 'germ theory', which was only generally accepted after 1867 .

She was an invalid 1858-80, suffering from chronic brucellosis and depression and was probably bi-polar. However, she had a new burst of energy from 1880 until 1896.

She supported votes for women from 1867, married women's property rights, and access to education for the professions but was oddly ambivalent on gender issues, regarding females as being generally less capable than males, relied heavily on her male supporters, sometimes describing herself as 'a man of action'.

She devoted herself to many other causes. She never visited India but maintained a 40-year interest, presenting statistical material on public health to the Royal Commission on India (1863) and writing at length on mysticism and eastern religions. From 1896 illness confined her to bed and gradually she sank into dementia. In 1907 she became the first woman to be awarded the Order of Merit. Asteroid 3122 Florence was named for her and India presents annual National Florence Nightingale Awards.

Woodham-Smith, C., Florence Nightingale. 1969; Smith, F. B., Florence Nightingale: Reputation and Power. 1982; Small, H., Florence Nightingale, Avenging Angel. 1998; Bostridge, M., Florence Nightingale, the
Nijinsky, Vaclav Fomich (1889?-1950). Russian ballet dancer and choreographer. Trained at the Imperial school at St Petersburg, he became *Diaghilev's lover and the leading dancer in his Ballets Russes in Paris (1909), where he enjoyed enormous popularity, especially in Le Spectre de la rose (1911). Later he created the leading roles in Petrushka, Scheherazade etc. His work as a choreographer, e.g. for *Debussy's L'Après-midi d'un faune (1912) and Jeux (1913), and *Stravinsky's Le Sacre du Printemps (1913), provoked both controversy and scandal. His health was undermined by a period of internment in Hungary during World War I and from 1919 he was schizophrenic. He is remembered as one of the greatest male dancers of all time and especially for the agility, lightness and grace of his prodigious leaps. Moreover his technical skill was matched by his interpretative powers and dramatic sense. His extraordinary diaries were published in a heavily expurgated form in 1922, in full in 1999. He died in London. His sister, Bronislava Nijinska (1891-1972), made a name for herself as a choreographer with such works as Les Noces (1923), Les Biches (1924) and Le Train bleu (1924).

Buckle, R., Nijinsky. 1971; Moore, L., Nijinsky. 2013.

Nikisch, Artur (Augustinus Adalbertus) (18551922). Hungarian conductor. Originally an orchestral violinist, he played under ${ }^{*}$ Wagner and ${ }^{*}$ Bruckner and became chief conductor of the Boston Symphony 1889-93, the Budapest Opera 1893-95, both the Leipzig Gewandhaus and the Berlin Philharmonic 1895-1922 and the London Symphony 1905-13. He had a profound influence on conductors as diverse as *Koussevitzky, *Monteux, Talich, ${ }^{*}$ Furtwängler, ${ }^{*}$ Reiner, ${ }^{*}$ Boult and ${ }^{*}$ Szell.

Nikolai I (Nikolai Pavlovich) (1796-1855). Tsar of Russia 1825-55. Son of *Paul I, he became tsar when his elder brother Konstantin (1779-1831) renounced the succession. Konstantin's name was invoked by the so-called 'Decembrist' plotters who were demanding reforms. The movement was easily suppressed, and though Nikolai appointed a committee to investigate the state of the country it was clear that he would permit no reform not emanating from himself. A codification of the law was, however, a definite achievement of the reign. Meanwhile Nikolai maintained his autocracy with the aid of censorship and secret police, cruelly suppressed a Polish rising (1830-31) and in 1849 sent an army to help the Emperor of Austria in quelling the Hungarian revolt. His readiness, however, to champion Turkey's Christian subjects against the sultan involved him in the humiliations of the Crimean War, during which he died.

Nikolai II (Nikolai Aleksandrovich Romanov) (1868-1918). Last tsar of Russia 1894-1917. Eldest son of *Aleksandr III, he was an amiable weak man, failed to support any liberal movement and accepted the advice of reactionary ministers. The aftermath of the humiliating Russian defeat in the war with Japan (1904-05) forced him to accept an elected 
duma (parliament) but he quickly acquiesced in rendering it ineffectual. Socialist and revolutionary movements were driven underground, and, though for a time war with Germany temporarily relieved internal difficulties, defeats and governmental incompetence fanned discontent into open rebellion. Distrust of the tsarina, moreover, lost him the support of many of the aristocracy, his natural allies. Nikolai had married (1894) Princess Alix of Hesse Darmstadt (*Aleksandra). Of the five children of this happy marriage, only the youngest was a boy, Aleksei, who suffered from haemophilia. A charlatan monk *Rasputin, who seemed to have the power of relieving the boy's illness, gained such complete power over the tsarina (and through her the tsar) that they were suspected of such treasonable acts as correspondence with the enemy. Thus when the Revolution broke out (March 1917) the tsar, lacking the determination or support to contest the issue, abdicated. In August with his wife and children he was taken to Siberia and in the following July the whole family was murdered by the Bolsheviks (*Anastasia), at Yekaterinberg. Nikolai was a kindly, well-meaning man but lacked the strength, ability and ruthlessness to be a successful autocrat. In 1993 the family's remains were positively identified by DNA testing and interred in St Petersburg in July 1998.

Radzinsky, E., The Last Tsar. 1992; Massie, R. K., Nicholas and Alexandra. 1969.

Nimitz, Chester William (1885-1966). American fleet admiral, born in Texas. He joined the US Navy in 1905 and served in submarines during World War I. He became Chief of the Bureau of Navigation 1939-41 and after Pearl Habor was appointed as Commander-in-Chief of the US Pacific Fleet 194145 and Supreme Commander of Allied Forces in the Pacific 1942-45. With Douglas *MacArthur, he devised an 'island-hopping' strategy to defeat the Japanese and commanded the largest forces in naval history. Promoted to the five-star rank of Fleet Admiral in 1944, he received a British GCB in 1945. He was Chief of Staff of the US Navy 1945-47 and UN Mediator in Kashmir 1949.

Ninian, St (c.360-432). Scottish evangelist. While on a pilgrimage to Rome he was consecrated bishop (c.395) and, having visited St Martin at Tours on the way back, named after him the church of Whithorn in Galloway, which he founded. He succeeded in making many converts among the southern Picts.

Nirenberg, Marshall Warren (1927-2010). American biochemist, born in New York City. He shared the 1968 Nobel Prize for Medicine with Har Gobind Khorana and Robert Holley for decoding the base sequences in DNA and RNA.

Nivelle, Robert Georges (1856-1924). French general. Bilingual (his mother was English) and a Protestant, Nivelle was an artillery officer who served with *Pétain at Verdun (1916), then succeeded him as GOC of the Second Army. He replaced *Joffre as Commander-in-Chief (December 1916), planned a massive offensive against the Germans (1917), which failed to win significant territory despite huge casualties, provoking an army mutiny and a collapse in morale. Pétain then became Commander-in-Chief and Nivelle was relegated to North Africa.

Nixon, Richard M(ilhous) (1913-1994). 37th President of the US 1969-74. Born in Yorba Linda, California, he was the son of a gas station owner who tried lemon growing, then became a grocer in Whittier; his mother was a Quaker. Educated at Duke University, he became an attorney, served in the US Navy in World War II and then entered politics. As a Republican Congressman 1947-51 he gained prominence for his zeal on the notorious House Committee on Un-American Activities, and especially in his pursuit of Alger *Hiss. Elected as a senator from California 1951-53, he served as *Eisenhower's Vice President 1953-61, playing an active role (unusual in the holders of that office), and travelled widely, e.g. to Russia in 1959. He won the Republican nomination to succeed Eisenhower in 1960 but lost narrowly to John F. *Kennedy, partly due to a series of television debates which appeared to put him at a disadvantage. He lost a contest against Pat *Brown for Governor of California in 1962, moved to New York as a lawyer, and did not seek presidential nomination in 1964. In 1968, with the Democrats in disarray over Vietnam, he was elected President, winning 43.4 per cent of the aggregate vote, defeating Hubert *Humphrey (42.7 per cent) and George *Wallace (13.5 per cent). Spiro *Agnew was his Vice President.

He promoted legislation on clean air, clean water, endangered species, created the Environment Protection Agency (EPA) and expanded Medicare. His unexpected visit to Mao Zedong in Beijing (February 1972) eased much Cold War hysteria about the People's Republic of China, but discomfited many of his traditional supporters. He began to ease the US out of Vietnam and attempted detente with the Soviet leadership. Nixon, encouraged by Pat ${ }^{*}$ Buchanan, was the architect of the Republican Party's successful 'Southern Strategy' in which states from the old Confederacy, which had voted Democrat since the Civil War, became strongly Republican, influenced by support for states' rights, a conservative social agenda, gun ownership, patriotism, religious fundamentalism and silence on race. He pitched his political appeal to what he called 'the silent majority', citizens who accepted the status quo and avoided controversy.

Nixon's obsessive but unfounded anxiety that the 1972 election would be another close result led to the sabotaging of Democrat candidates and illegal acts by his staff, notoriously an attempt to steal material from Democratic headquarters at the Watergate Hotel, Washington. Nixon won a landslide victory in 1972 over George *McGovern, winning 49 of 50 states.

Evidence of links between the Watergate burglary and the White House seeped out through hearings 
of the Senate Watergate Enquiry, chaired by Senator Sam Ervin, resulting in an indictment for conspiracy of seven close associates, including the AttorneyGeneral, John Mitchell, and strenuous attempts to cover up the Watergate scandal. The 'Watergate tapes', recordings of conversations in the presidential office, were compelling evidence, and attempts to persuade courts to suppress them failed. A grand jury found Nixon was an 'unindicted co-conspirator' and a House Committee recommended impeachment. In October 1973 Agnew had been forced to resign after conviction for receiving bribes from contractors as Governor of Maryland. In December Gerald *Ford was sworn in as Vice President after confirmation by the Senate and House of Representatives. Nixon became the first US president to resign (9 August 1974) and Ford succeeded him. He retired to San Clemente, California, published $R N$ : The Memoirs of Richard Nixon in 1978, relocated to New Jersey and died in New York after a stroke.

In 18 Presidential ranking lists by US historians and political scientists, Nixon scored No. 30 in the aggregate.

Ambrose, S. E., Nixon. 3 vols, 1987, 1989, 1991; Aitken, J., Nixon. 1993; Summers, A., The Arrogance of Power. The Secret World of Richard Nixon. 2000; Black, C., Richard M. Nixon. A Life in Full. 2007; Perlstein, R., Nixonland. 2008; Farrell, J. A., Richard Nixon: The Life. 2018.

Ni Zan (or Ni Tsan) (1301-1374). Chinese painter, calligrapher and poet. With Huang Gongwang, Wu Zhen, and Wang Meng, he is described as one of the 'Four Masters of the Yuan Dynasty'.

Nkrumah, Kwame (1909-1972). Ghanaian politician. Educated at Achimota College, from 1935 he studied theology and philosophy in the US and in 1945 he attended the London School of Economics. Two years after his return to the Gold Coast (1947) he founded the Convention People's Party and spent two years in prison 1949-51 for political agitation. In 1951 he was appointed first Prime Minister of the Gold Coast (Ghana from 1957) and became the first president of the Republic of Ghana 1960-66. He established authoritarian rule in a single-party state, and increasing vanity led him to self-glorification (e.g. he took the title of Redeemer) and to extravagant projects which had all but ruined the country's economy when, during his absence in Moscow, he was deposed by a military coup (1966). His ambitious plan to unite the emergent African states in a federation under his leadership met with constant rebuffs. He lived in exile in Guinea and died in Bucharest.

Bretton, H. L., The Rise and Fall of Kwame Nkrumah. 1967.

Nobel, Alfred Bernhard (1833-1896). Swedish chemist. His main interest, the development of explosives, was inspired by his father, a manufacturer of explosives at St Petersburg (Leningrad), where he was brought up. From 1859 he studied the subject in Stockholm, and while seeking an effective means of making nitroglycerine safe to handle he invented (1867) dynamite, in which the introglycerine was dispersed in an earthy material called Kieselguhr. He left most of the large fortune he had made from the manufacture of explosives (about $£ 2$ million) for the establishment of five prizes to be awarded annually for literature, medicine (or physiology), physics, chemistry and the promotion of peace. The first Nobel Prizes were awarded in 1901.

Bergengren, E., Alfred Nobel: The Man and His Work. 1962; Bergengren, E., Nobel the Man and His Prizes. 1972.

Nobile, Umberto (1885-1978). Italian airman and explorer. Having risen to the rank of general, he took the airship Norge (with *Amundsen) across the North Pole (1926). He was severely censured for the crash (1928) of his airship Italia from which he was rescued after 40 days on the ice, but cleared in 1945. Meanwhile he had served as an aeronautical consultant in the USSR and the US, returning to Italy after *Mussolini's fall.

Noel-Baker, Philip John, Baron Noel-Baker (18891982). English Labour politician and peace advocate. Educated at Cambridge, he was an athlete in the 1912 and 1920 Olympic Games. A professor of international relations at London University, 1924-29, he became a Labour MP 1929-31 and 1936-70, and served as a minister under *Attlee 1945-51. He won the 1959 Nobel Peace Prize for his book The Arms Race (1958).

Noether, (Amalie) Emmy (1882-1935). GermanJewish mathematician. She taught at Göttingen 1915-33, left Germany for the United States in 1935 but soon died after an operation. Considered as the greatest woman mathematician, she worked on abstract algebra and theoretical physics. 'Noether's theorem' (1915) states: 'If a system has a continuous symmetry property, then there are corresponding quantities whose values are conserved in time.'

Noguchi, Isamu (1904-1988). Japanese-American sculptor. Son of Japanese and American writers, he studied in Paris with *Bancusi and was a prolific abstract artist who also designed furniture and stage sets.

Nolan, Sir Sidney Robert (1917-1992). Australian painter and lithographer, born in Melbourne. He studied at the Prahran Technical College and the National Gallery of Victoria Art School, and his early work, e.g. Ocean Grove (1938), reveals an individual style remote from mainstream Australian art. He became a voracious reader and, having deserted from the Australian Army, came to see himself as an outsider. From 1942 he was associated with the 'Angry Penguins' group of Australian modernists and enjoyed the patronage of John and Sunday Reed, at Heide, in Bulleen, near Melbourne. In 1946-47, at Heide, he painted 27 oils on the life of Ned *Kelly, iconic works in 
which the outlaw stares at the world through a helmet. His art attracted the interest of Kenneth *Clark. Later paintings develop themes from Australian history, e.g. the explorers *Burke and Wills, Mrs Fraser, the Eureka Stockade, and Gallipoli (a sequence of 252, from 1955, partly influenced by his reading of ${ }^{*}$ Homer), as well as the Australian outback, flora, fauna, China, Africa, Antarctica, mythology, e.g. Leda and the Swan, and scenic designs for ballet (notably The Display, 1964, music by Malcolm Williamson, choreographed by Robert ${ }^{*}$ Helpmann) and opera. He lived in England from 1951. Snake (1970-72), mixed media on 1620 panels, $46 \mathrm{~m} \times 9 \mathrm{~m}$, is displayed in a purpose-built gallery at the Museum of Old and New Art (MONA), Hobart. He engaged in a memorable feud with his former friend Patrick *White, received the $\mathrm{OM}$ in 1983, an AC in 1988 and became Australia's first, and only, RA (1991). He was extraordinarily prolific, experimenting with a diversity of techniques.

Clark, K., MacInnes, C., and Robertson, B., Sidney Nolan. 1961; Adams, B., Sidney Nolan: Such Is Life. 1987; Underhill, N., Sidney Nolan: A Life. 2015.

Nolde, Emil (1867-1956). German painter and graphic artist. Originally a woodcarver, he joined the Brücke ('Bridge') group in Munich, became an Expressionist, travelled extensively and lived as a hermit. He is remembered for his landscape, flower and primitive paintings. Despite his brief enthusiasm for ${ }^{*}$ Hitler, the Nazis denounced him as a degenerate artist. His First-Class Marksman (1946) sold for \$AU5.4 million in 2010.

Nollekens, Joseph (1737-1823). English sculptor. Of Dutch descent, he worked (1760-70) in Rome, where he made busts of ${ }^{*}$ Garrick and ${ }^{*}$ Sterne. On his return to London he quickly achieved success and became ARA (1771) and RA (1772). Though commissioned to execute many public monuments, often adorned with mythological figures, his most memorable works were busts of ${ }^{*}$ George III, Samuel ${ }^{*}$ Johnson, ${ }^{*}$ Fox and ${ }^{*}$ Pitt.

Nollet, Jean Antoine (1700-1770). French abbé and physicist. Professor of physics in the University of Paris, he was the first clearly to describe (1748) osmosis (the passage of a solvent through a semipermeable membrane separating a weaker from a stronger solution).

Nono, Luigi (1924-1990). Italian composer, born in Venice. He married *Schoenberg's daughter, joined the Communist Party, was deeply committed to the music of 'struggle and ideas' and wrote extensively on music theory. He composed concert music with and without electronics and stage works, including Intolleranza (1960).

Nora, Simon (1921-2006). French public servant. L'informatisation de la société (with Alain Minc, 5 volumes, 1978) was a seminal text on the information age.
Norman, Jessye (1945-2019). American soprano, born in Georgia. Trained in the US, she developed a voice of extraordinary range and opulence, with excellent diction and command of languages. She made her operatic debut in Berlin, toured widely, appeared in many operas and recorded works by ${ }^{*}$ Mozart, ${ }^{*}$ Verdi, ${ }^{*}$ Mahler, Richard ${ }^{*}$ Strauss and *Berg.

Norman, Montagu Collet Norman, 1st Baron (1871-1950). British banker. His policies as Governor of the Bank of England 1920-44 were deeply controversial, especially during the interwar period and the most vital years of World War II have been the subject of continuous controversy, especially the deflationary return to the gold standard (1925) and the devaluation of the pound (1931). Norman had much influence with the governments of the period. His reputation as an éminence grise was enhanced by his habit of crossing the Atlantic under the easily penetrable disguise of an assumed name.

Clay, H., Lord Norman. 1957.

Norodom Sihanouk (1922-2012). Cambodian prince and politician. Educated in Saigon and Paris, he succeeded his grandfather as King of Cambodia 1941-55, abdicating in favour of his father Norodom Suramarit to found the Popular Socialist Community Party. He was Prime Minister and Foreign Minister 1955-60 and, after his father's death, Chief of State 1960-70 until deposed by a military coup led by Lon Nol. He lived in Beijing 1970-75, returned briefly and had 16 more years in exile. He returned to Cambodia in November 1991, was elected President again but proved unable to exercise authority over a country bitterly divided between Chinese, Vietnamese and Khmer Rouge forces. Elections were held in July 1993. He became King of Cambodia again 1993-2004, this time as (in theory) a constitutional monarch. He composed and directed many films. He went into self-imposed exile in 2004, suffering from cancer, and died in Beijing.

Osborne, M., Sihanouk. 1994.

Norstad, Lauris (1907-1988). American soldier and airman. He became a pilot in 1931 and in World War II was appointed (December 1943) Director of Operations of the Allied Air Forces in the Mediterranean. He also directed bombing offensives against Japan. In 1950 Norstad became Commanderin-Chief of US Air Forces in Europe, and succeeded General *Gruenther as Supreme Allied Commander in Europe 1956-62. He retired in 1963.

North, Baron, Frederick North, 2nd Earl of Guildford (1732-1792). English politician, born in London. Educated at Eton, Oxford and Leipzig, he was MP 1754-90, originally Whig then Tory, with the courtesy title of Lord North until he succeeded (1790) his father as Earl of Guildford. Able and well liked, his reputation for idleness has been exaggerated. He served 
as Chancellor of the Exchequer 1767-82 and as Prime Minister 1770-82. Because of his appearance, it was speculated that he may have been a half-brother of ${ }^{*}$ George III, who found him an excellent instrument through whom, while maintaining a parliamentary majority by royal patronage, he could exercise his influence over the government. Most of his term of office was occupied by the American colonies' struggle for independence. North's attempts at conciliation were constantly thwarted by royal obduracy. He remained in office only out of loyalty and gladly resigned in 1782; he returned briefly as Home Secretary (1783) in coalition with *Fox. Important legislation passed during his term of office included the Royal Marriage Act, an act submitting the East India Company's policies to parliamentary control, and the Quebec Act (1774), which guaranteed to French Canadians their traditional religion and laws. Chancellor of Oxford University 1772-92 and a patron of *Gibbon, he became blind in 1790 .

Butterfield, H., George III, Lord North and the People. 1949; Whiteley, P., Lord North. 1996.

North, Sir Thomas (1535?-1602). English translator. His fame rests on his English version (1579) of *Plutarch's Lives, translated not from the original Greek but from the French rendering (1559) by Jacques Amyot, Bishop of Auxerre, whom North may have met when accompanying a diplomatic mission to *Henri III of France. *Shakespeare borrowed freely from it for his classical dramas, sometimes using the actual words as well as reconstructing the scenes.

Northbrook, 1st Earl of, Thomas George Baring (1826-1904). English politician and administrator. Member of a banking family (*Baring), he was a Liberal MP 1857-66 and Undersecretary for India 1859-61, 1868-72. *Gladstone appointed him as Viceroy of India 1872-76 and First Lord of the Admiralty 1880-85 but they broke on the issue of Home Rule for Ireland.

Northcliffe, Alfred Charles William Harmsworth, 1st Viscount (1865-1922). British journalist and newspaper proprietor. He began his journalistic career (1880) on the Hampstead and Highgate Gazette. The step which led to his future greatness was the launching (1888), with his brother Harold *Harmsworth, of Answers, a weekly magazine in which snippets of information and competitions with lavish prizes procured a success that enabled them to buy (1894) the London Evening News. Two years later they launched the Daily Mail, which sold at $1 \mathrm{~d}$, and with its bold headlines and brightly written features provided a quickly copied pattern for popular newspapers. In 1908 he bought The Times, but though he greatly increased its circulation and at one time reduced the price to $1 \mathrm{~d}$., his touch was unsure when handling a national institution. In World War I his papers helped to expose the shell shortage and venom. He headed a war mission to the US (1917) and in 1918 was director of propaganda in enemy countries. Progressive illness produced signs of megalomania in his last years. He was made a baronet in 1903 (aged 38), became Baron Northcliffe in 1905, and a viscount in 1918.

Greenwall, H. J., Northcliffe: Napoléon of Fleet Street. 1957.

Northumberland, John Dudley, 1st Duke of (1502-1553). English Lord Protector 1552-53. Son of Edmund *Dudley, *Henry VII's minister, he grew to importance under ${ }^{*}$ Henry VIII and was an executor of his will. Made Earl of Warwick in recognition of his support of Edward Seymour, Duke of * Somerset, as Lord Protector during *Edward VI's minority, he at once intrigued against him, succeeded him (1552) and secured his execution. He tried to prolong his power by inducing the sickly Edward to exclude his sisters from the succession, and so leave the way clear for Lady Jane *Grey (whom he married to his son Guildford Dudley) to ascend the throne. The scheme failed when on Edward's death (1553) the country rallied to Queen Mary. Northumberland was taken and executed. For his son Robert, Elizabeth's favourite, see Earl of *Leicester.

\section{Norwich, 1st Viscount see Cooper, (Alfred) Duff}

Norwich, John Julius (John Julius Cooper, 2nd Viscount Norwich) (1929-2018). English historian and television producer. Son of Duff ${ }^{*}$ Cooper, 1 st Viscount Norwich, he wrote popular but scholarly works on Sicily, Venice, Byzantium and the Popes, produced 30 television documentaries and was a vigorous promoter of music.

Nossal, Sir Gus(tav Joseph Victor) (1931- ). Australian immunologist, born in Austria. Educated in Sydney, he succeeded *Burnet as Director of the Walter and Eliza Hall Institute for Medical Research (in Melbourne) 1965-96 and was President of the Australian Academy of Science 1994-98.

Nostradamus (Michel de Nôtre Dame) (1503-1566). French astrologer and physician, born in Provence. From a Jewish family, with university qualifications in medicine, he gained much esteem for his devotion to duty during times of plague. He published two collections of prophecies, 948 in all, entitled Centuries $(1555,1558)$, written in rhyming quatrains. Although obscure and ambiguous, he attracted such notice that ${ }^{*}$ Catherine de'Medici invited him to court and he became physician to ${ }^{*}$ Charles IX.

Randi, J., The Mask of Nostradamus. 1990.

Nouvel, Jean (1945- ). French architect. His buildings include the Institute du Monde Arabe, Musée du Quai Branly-Jacques Chirac, both in Paris, and Philharmonie de Paris. Other works are 
in New York, London, Sydney, Melbourne, Madrid, Barcelona, Vienna, Lucerne, Copenhagen and Abu Dhabi. He won the Pritzker Prize in 2008.

Novalis (Friedrich, Baron von Hardenberg) (17721801). German lyric poet and novelist. His poetic works include Hymns to the Night (1800), inspired by his grief at the death of Sophie von Kuhn, whom he loved. His novel Heinrich van Ofterdingen (1802), the story of the development of a young poet, ranks high among the achievements of the German Romantic movement.

Noverre, Jean Georges (1727-1809). French choreographer. In 1747 he became maître de ballet at the Opéra Comique in Paris and in 1754 gained fame as a choreographer with Fétes chinoises and La Fontaine de Jouvence for which *Boucher did the décor. The outbreak of the Seven Years' War (1756) interrupted a London season which he had undertaken for *Garrick, who called him 'the *Shakespeare of the dance'. His Lettres sur la danse et sur les ballets (1759-60) established an aesthetic tradition that still influences choreography.

Noyes, Alfred (1880-1958). English poet. His poetry, e.g. The Barrel Organ and The Highwayman is firmly traditional. His most ambitious work The Torchbearers (3 volumes 1922-30), now forgotten, described the transmission of scientific knowledge. As a Visiting Professor of English Literature at Princeton 1914-23, his students included F. Scott *Fitzgerald and Edmund *Wilson. He was involved in the controversy over the execution of Roger *Casement in 1916, and the use of his 'black diaries' to weaken any campaign for his reprieve. Noyes believed that the diaries were authentic, then had serious doubts, expressed in his last book The Accusing Ghost (1957). (Regrettably, forensic evidence confirms that they were Casement's, but should not have been used to ensure that he was hanged.)

Nu, U (also Thakin U) (1907-1995). Burmese politician. Educated at Rangoon University, he joined *Aung San as a student leader, was jailed by the British and briefly served as Foreign Minister during the Japanese occupation. Prime Minister 1948-56, 1957-62, he was overthrown by a military coup led by ${ }^{*} \mathrm{Ne}$ Win.

\section{Nuffield, 1st Viscount see Morris, William Richard, 1st Viscount Nuffield}

Nureyev, Rudolf Hametovich (1938-1993). Russian ballet dancer, born in Siberia. Having become a leading dancer of the Russian Kirov ballet he defected while the company was in Paris (May 1961) and later came to England. There he won new fame in the Royal Ballet, especially when partnered by Margot *Fonteyn in e.g. Le Corsair, Marguerite and Armand, Giselle and Swan Lake. Of some ballets (e.g. Raymonda) he revised the choreography to satisfy the demands of his technical skill and the agility and strength that won him great acclaim. He appeared in the films Don Quixote (with Sir Robert ${ }^{*}$ Helpmann and the Australian Ballet, 1973) and Valentino (1977). He directed the ballet at the Paris Opera 1983-89, died of AIDS and left a great fortune.

Nuri es-Said (1888-1958). Iraqi soldier, born in Baghdad. He served in the Ottoman army against the British, was captured in 1916, then joined the Sharifian army revolt against the Turks. On Iraq's creation in 1921, Nuri became a committed supporter of the Hashemite regime of *Faisal I and a permanent alliance with Britain. Between 1930 and 1958 he served as Prime Minister of Iraq 14 times and became first Prime Minister of the Arab Federation (Iraq and Jordan) May-July 1958. His pro-Western views were increasingly unpopular with Iraqis and he was murdered with *Faisal II.

Nurmi, Paavo (1897-1973). Finnish athlete. Known as 'the flying Finn', he won six individual Olympic gold medals, two each in 1920, 1924 and 1928, for the 1,500 metres, 10,000 metres and cross country events, and three more for team events. He also held the world record for the mile ( $4 \mathrm{~min}$. $10.4 \mathrm{secs}$ ) 1923-31. As a professional, he was excluded from the 1932 Olympics.

Nurse, Sir Paul Maxime (1949- ). English geneticist and cell biologist, born in Norwich. Educated at Birmingham and East Anglia universities, he shared the Nobel Prize for Medicine in 2001 for his discoveries in cell cycle regulation, working primarily in yeast, received the Copley Medal in 2005 and was President of the Royal Society 2010-15. He became foundation director of the Francis ${ }^{*}$ Crick Institute 2015- , the largest biomedical research institute in Europe. He wrote What Is Life? (2020) and received a $\mathrm{CH}$ in 2022.

Nyerere, Julius Kambarage (1921-1999). Tanzanian politician. Son of a chief, he studied at Makerere College in Uganda and at Edinburgh University. In 1954 he founded the Tanganyika African National Union with a policy aimed at independence. In his successful pursuit of this aim he was successively Chief Minister (1960) of Tanganyika, Prime Minister when independence was granted (1961), and President (1962) when a republic was proclaimed. When Zanzibar, after the revolution of 1964, became linked with Tanganyika, Nyerere became President of the combined country, known thereafter as Tanzania, retiring in 1985 . His publications include a Swahili translation of The Merchant of Venice (1969) and Julius Caesar (1969).

Nyman, Michael (1944- ). English composer. A critic and author, he wrote music for films by Peter Greenaway and Jane Campion, and concertos for trombone, saxophone and two pianos. 


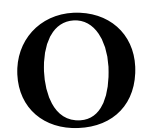

Oates, Lawrence Edward Grace (1880-1912). English soldier and explorer. He joined *Scott's Antarctic expedition in 1910, during the arduous return from the South Pole in 1912 he became convinced that with his frost bite injuries he would handicap his companions and lessen their chances of survival. He accordingly left camp and walked, 'a very gallant gentleman' as Scott recorded in his log, to his death in the blizzard.

Oates, Titus (c.1649-1705). English conspirator. After being dismissed as a naval chaplain, he claimed to have spent some time in the guise of a convert in Jesuit seminaries abroad in order to discover their secrets. In 1678 he reappeared in London and made a declaration on oath before Sir Edmund Berry Godfrey concerning an alleged 'Popish plot' for the murder of ${ }^{*}$ Charles II and the massacre of Protestants. When Sir Edmund was found dead in a ditch (possibly murdered by Oates or his followers) the story of the plot, hitherto ridiculed, seemed to acquire some plausibility. Mass hysteria, fanned by *Shaftesbury for political reasons, followed. Oates poured forth his denunciations and some 35 Roman Catholics were executed for treason. Meanwhile the king was manipulating opinion in favour of sanity. A reaction set in and in 1685 Oates was found guilty of perjury and imprisoned for life. The revolution that expelled *James II brought him release and a pension, but he died destitute.

Lane, J., Titus Oates. 1949.

Obama, Barack Hussein (1961- ). 44th President of the US 2009-17. Born in Honolulu, the son of a Kenyan father and an American mother from Kansas, after living in Indonesia and Hawaii as a child, he was educated in Los Angeles and New York, graduating from Columbia and Harvard Law School. He worked as a community organiser and civil rights lawyer in Chicago and taught at the University of Chicago Law School. His books include Dreams from my Father (1995) and The Audacity of Hope (2006). He served in the Illinois State Senate 1997-2004 and the US Senate 2005-08. After defeating Hillary *Clinton narrowly in the Democratic primaries, he was nominated for president in Denver (August 2008) and elected in November, over the Republican candidate Senator John ${ }^{*}$ McCain, winning a popular vote of 69.5 million. Joe *Biden served two terms as his Vice President. Faced with the Global Financial Crisis (GFC) early in his term, he acted effectively. The award of the Nobel Peace Prize for 2009, disconcertingly early in his first term, perhaps reflected approval for aspirations rather than achievement. He was elected to a second term in November 2012, defeating Mitt
*Romney, with a popular vote of 65.9 million and a decisive majority in the Electoral College (332206). He campaigned for Hillary *Clinton in 2016 but *Trump's unexpected presidency reversed many of Obama's policies, especially climate change and environmental protections, although the Affordable Care Act (aka 'Obamacare') remained. In 2020 he was cautious about endorsing a Democrat nominee but then worked closely to secure *Biden's victory.

Remnick, D., The Bridge: The Life and Rise of Barack Obama. 2010; Garrow, D., Rising Star: The Making of Barack Obama. 2017; Obama, B. H., A Promised Land. 2020; Levingston, S., Barack and Joe. 2021.

Obrador, Andrés Manuel López see López Obrador, Andrés Manuel

Obregón, Alvaro (1880-1928). Mexican soldier and politician. His original family name was O'Brien. He joined forces with ${ }^{*}$ Carranza and *Villa against *Huerta, but when the two fell out he supported Carranza and by his military skill overcame Villa. Obregón temporarily retired but, after the revolution in which Carranza was murdered while in flight, became President 1920-24. He achieved valuable reforms on behalf of organised labour and assisted education. By arrangement with his successor ${ }^{*}$ Calles he was re-elected President in 1928 but assassinated before inauguration.

Obrenović. Serbian dynasty that ruled as Princes (1817-42; 1858-82) and Kings (1882-1903). They were in a hereditary feud with the *Karađorđević dynasty, which escalated after Karađorde was murdered (1817) by supporters of Miloš Obrenović (c.1783-1860), who became Prince of Serbia 1817-39; 1858-60, winning a degree of sovereignty from the Ottoman Turks. The Obrenovićs favoured collaboration with the Habsburgs against the Turks, the Karađorđevićs were close to the Russians. Miloš son Mihailo (Michael) (1823-1868), also had two periods as Prince of Serbia 1839-42 (forced to abdicate) and 1860-68 (assassinated by a member of the Karađorđević clan). His great-nephew Milan (1854-1901) succeeded, was proclaimed as the first King of Serbia in 1882 but abdicated (1889) as a result of domestic scandals. His son Alexander succeeded, but, with his notorious wife, Draga, was murdered by a group of officers (1903). Peter Karađorđević then succeeded as *Peter I, King of Serbia.

O'Brian, Patrick (pen name of Richard Patrick Russ) (1914-2000). English novelist, translator and biographer. He wrote 20 novels with naval themes, featuring the characters Captain Jack Aubrey and Dr Stephen Maturin, which attracted a cult following, and lives of *Picasso (1976) and Joseph *Banks (1987).

O'Brien, Edna (1936-). Irish novelist and playwright. Convent educated and trained as a pharmacist, she achieved recognition with The Country Girls (1960, 
later filmed), Girls in their Married Bliss (1963), Johnny I Hardly Knew You (1977), The High Road (1988) and The House of Splendid Isolation (1994). She also wrote screenplays, short stories and poetry.

O'Brien, Flann (pen name of Brian O'Nolan) (1911-1966). Irish novelist. He was a civil servant and morose alcoholic who wrote a weekly satirical column in the Irish Times under the name Myles na Gopaleen. His masterpiece At Swim-Two-Birds failed on its first publication in September 1939, although praised by James *Joyce, and was recognised as a work of genius only in the 1960 s. Other works include The Third Policeman (1940), The Hard Life (1960) and The Dalkey Archive (1965).

Obuchi Keizo (1937-2000). Japanese politician. A conservative, he was Foreign Minister 1997-98 and Prime Minister 1998-2000. Removed in April 2000 after suffering a stroke, he died in May.

O'Casey, Sean (1884-1964). Irish playwright, born in Dublin. Educated, so he said, in Dublin's streets, after working as a labourer he became active in politics and literature. His first plays, produced at the Abbey Theatre, Dublin, were The Shadow of a Gunman (1923), Juno and the Paycock (1924) and The Plough and the Stars (1926). Their harsh realism contrasted strongly with the mythological drama of ${ }^{*}$ Yeats, their language was often poetic, but this stemmed mainly from effective use of the Dublin vernacular. His next play, The Silver Tassie, rejected by the Abbey, was produced in London (1929). Thereafter, O'Casey was a voluntary exile from Ireland and criticised the oppressiveness of Irish life in some of his later plays, e.g. Red Roses for Me (1943), Cocka-Doodle Dandy (1949), The Bishop's Bonfire (1955) and The Drums of Father Ned (1958). His six volumes of autobiography, beginning with I Knock at the Door (1939), contain many vivid and acid descriptions of his life and times.

Fallon, G., Sean O'Casey. 1965.

\section{Occam, William of see Ockham, William of}

Occleve (or Hoccleve). Thomas (c.1370-c.1450). English poet. He wrote in the Chaucerian tradition but his main work De Regimine Principum, an English version (addressed to the future *Henry V) of a Latin treatise on the duties of a ruler, is less interesting for the advice given than for irrelevant insertions about Occleve's own troubles. More autobiography, often unflattering, is contained in La Male Règle (1406).

Ockeghem, Jean de (c.1410-1497). Franco-Flemish composer, probably born near Mons. He worked in Antwerp and for the French court, was a master of polyphonic complexity and had a profound influence on *Josquin. His few surviving works include 12 Masses, five motets and some songs.
Ockham (or Occam), William of (Latin: Gulielmus Occamus) (c.1287-1349). English philosopher, probably born at Ockham in Surrey. He early joined the Franciscans and studied at Oxford. Summoned to Avignon by Pope John XXII on a charge of heresy (1326), he was confined to a friary until 1328 when, after siding against the Pope in a Franciscan dispute concerning poverty, he fled to live under the protection of the emperor *Louis IV at Pisa and Munich, where he wrote vigorously in support of the Emperor's political supremacy and in opposition to the Pope's claim to authority in temporal affairs. He sought reconciliation with the Church in 1349 . Ockham's political writings were only part of his general attack on the medieval scholastic system and the secular order it sustained. His system (known as nominalism), which included a denial that universals exist outside the mind, led to a philosophic scepticism which in some measure provided an intellectual preparation for the Reformation. 'Ockham's razor' is the 'principle of parsimony', that in explaining anything 'entities are not to be multiplied without necessity' (i.e. in the absence of contrary evidence, the simplest explanation is the likeliest to be correct). Known variously as 'Venerabilis Inceptor' and 'Doctor Invincibilis', he died in Munich of the Black Death.

Duncan, D., Occam's Razor. 1958; Spade, P., The Cambridge Companion to Ockham. 1999; Keele, R., Ockham Explained: From Razor to Rebellion. 2010.

O'Connell, Daniel (1775-1847). Irish patriot, born in County Kerry. Known as 'the Liberator', he was educated in France, read at Lincoln's Inn (1794) and joined the Irish bar (1798). He later started an agitation in favour of the repeal of the Act of Union with England, demanding complete Roman Catholic emancipation. By his energy, organising ability and his emotional oratory he roused the country and transformed the conservative Catholic Association into a mass movement (1823). Its success caused its suppression (1825) but O'Connell, elected MP for Clare (1828), continued his agitation and Roman Catholic emancipation was obtained (1829). After 1832 he headed a group of 45 Irish MPs in the English Parliament, and launched (1840) a new mass movement for the repeal of the Act of Union. This involved him in a trial for sedition (1844). His sentence was quashed by the House of Lords but his refusal to adopt revolutionary methods and his conservative attitude to social questions militated against his success. He died in Genoa.

O’Connor, Feargus Edward (1794-1855). Irish Chartist leader, born in County Cork. From a Protestant family, educated at Trinity College, Dublin, he was MP for Cork 1832-35, as a follower of *O'Connell, but he took a far more radical approach on social conditions and the Poor Law, and was disqualified in 1835 . He was the principal leader of the Chartist movement (whose six demands included universal suffrage and voting by secret ballot). MP 
for Nottingham 1847-52, he organised the Chartist 'monster petition', presented to Parliament in 1848 , followed by a huge rally. However, he became increasingly erratic, alcoholic and violent and was certified in 1852 .

O'Connor, Sandra Day (née Day) (1930- ). American jurist. A lawyer in Phoenix, Arizona, she was a state senator 1969-74, a state judge 1975-81, until her appointment by President *Reagan as the first woman to be a justice of the US Supreme Court 1981-2008.

\section{Octavian(us) see Augustus}

Odets, Clifford (1906-1963). American playwright. Originally an actor, he wrote several socio-political dramas, e.g. Waiting for Lefty (1935), Awake and Sing (1935), Till the Day I Die (1935), and probably his best known play, The Golden Boy (1937). Much of his work was produced by the Group Theatre, New York, of which he was a founder.

Odo (c.1036-1097). Norman prelate. Bishop of Bayeux 1048-97, he ruled England during the absence of his half-brother, ${ }^{*}$ William the Conqueror. He built Bayeux Cathedral, the Abbaye des Hommes in Caen, and commissioned the Bayeux tapestry. He lost all his English possessions for joining a revolt against *William II and died at Palermo on the way to the 1 st Crusade. He was a patron of scholarship.

Odovacar (or Odoacer) (d.493). King of Italy 476493. Probably a Germanic chieftain from the Sicrii tribe, after the abdication of *Romulus Augustulus, last of the Roman emperors of the west, he was proclaimed King of Italy by his troops (476). After four years he gained full control of Italy and later proved his ability to defend and extend the area he had won. Alarmed by his growing power, the Byzantine emperor Zeno encouraged *Theodoric, King of the Ostrogoths, to invade Italy (488). After three defeats (489-90) Odovacar retired to Ravenna, where he was besieged until he was forced by famine to yield (493). $\mathrm{He}$ is said to have been stabbed to death by Theodoric at a feast.

Oe Kenzaburo (1935- ). Japanese novelist. His novels included Screams (1962), A Personal Matter (1964) and The Silent Cry (1974). He received the Nobel Prize for Literature in 1994.

Oersted, Hans Christian (1777-1851). Danish physicist. Professor of physics at the University of Copenhagen 1806-29 and director of the Polytechnic Institute, Copenhagen 1829-51, he discovered (1820) the magnetic field created by an electric current, showing for the first time that electricity and magnetism are connected. This important discovery was taken up by *Ampère and *Faraday. The unit of magnetic field strength, the oersted, is named after him.
Offa (d.796). King of Mercia 757-96. One of the greatest Anglo-Saxon kings, by conquest or marriage ties he controlled all England south of the Humber and protected his subjects from Welsh raiders by the mighty earthwork known as Offa's Dyke, which stretched from the estuary of the Dee to that of the Wye. He was a patron of monasticism and a lawmaker.

Offenbach, Jacques (Jakob Levy Eberst) (18191880). German-Jewish composer, born in Cologne. $\mathrm{He}$ lived in Paris from 1833 and wrote many successful operettas and opéras bouffes, e.g. Orpheus in the Underworld (1858) and La Belle Hélène (1865). The opera on which he worked for many years, The Tales of Hoffmann, was produced posthumously (1881).

Ogden, Charles Kay (1889-1957). English educationist. With I. A. *Richards of Harvard University, in 1929 he devised 'Basic English', a simplified form of the language by which most ordinary concepts could be expressed with a vocabulary of some 850 key words and 18 verbs.

Oglethorpe, James Edward (1696-1785). English soldier, colonist and philanthropist. After service with Prince *Eugène of Savoy against the Turks (1717), he returned to England where as an MP 1722-54 he roused public opinion against the press gang, prison conditions and imprisonment for debt. He obtained a charter to found the colony of Georgia, which he peopled mainly with English debtors and refugee Austrian Protestants. The first Governor of Georgia 1732-43, he accompanied the original contingent of settlers (1733) and raised a regiment with which he successfully defended the colony against the Spaniards. He opposed slavery, which only began in Georgia in 1750. In 1743 he returned to England to answer charges of incompetence and was later courtmartialled for his conduct of operations in the Jacobite rebellion (1745). Both times he was acquitted, but his military career was ended and in 1754 he was not reelected to parliament. Among his many friends were *Johnson, *Boswell and *Burke.

O'Higgins (Riquelme), Bernardo (1778-1842). Chilean liberator. He never met his father Ambrosio O'Higgins (1720?-1801) who rose in the Spanish service in South America to be Viceroy of Peru. Bernardo studied in London 1795-98, then joined a group of men plotting to free South America from Spanish rule. He inherited his father's estates, returned to Chile (1802) and, after playing a prominent part in the revolution of 1810-11, became Commander-inChief of the Chilean forces. After military setbacks he fled to join *San Martin, who gave him a command in the army about to cross the Andes to liberate Chile. When he returned with the victorious army O'Higgins was appointed (1817) dictator of Chile, 
proclaiming its independence in 1818 , but his rule proved so unpopular that he was forced to resign and retire to Peru (1823).

\section{Kinsbruner, J., Bernardo O’Higgins. 1968.}

Ohm, Georg Simon (1787-1854). German physicist. He did fundamental work on the mathematical treatment of electric currents and published (1827) the law stating that the current flowing in a conductor is directly proportional to the potential differences between its ends (Ohm's Law). He also did important work on acoustics. The unit of electrical resistance, the 'ohm', is named after him. His most important work was done as a teacher at the Cologne Gymnasium. Later he was a professor of physics at Nuremberg 1833-49 and Munich 1849-54.

Ohsumi Yoshinori (1945- ). Japanese cell biologist. He was awarded the Nobel Prize for Medicine in 2016 for his work in explaining 'autophagy': how cells recycle their components.

Oistrakh, David Fyodorovich (1908-1974). Russian-Jewish violinist and conductor, born in Odessa. He graduated from Odessa Conservatory in 1926, made his debut in Moscow in 1933, but for many years was known in western Europe only from recordings. He began extensive tours after 1951. His son Igor Davidovich (1931- ) was also an outstanding player.

O'Keeffe, Georgia (1887-1986). American painter. She achieved recognition from the 1920s for her vivid semi-abstractions of animal bones, flowers and landscapes. In 1924 she married the photographer Alfred Stieglitz (1864-1946). His work includes two sets of 400 portraits of her.

O'Kelly, Sean Thomas (1882-1966). Irish politician. A journalist, he was active in Sinn Fein and took part in the Easter Rising (1916). He opposed the Irish Free State and became prominent in *de Valera's Fianna Fail party. When de Valera won power (1932), O'Kelly became Minister for Local Government 1932-39 and for Finance and Education 1939-45. He served two terms as President of the Irish Republic 1945-59.

Ōkubo Toshimichi (1830-1878). Japanese bureaucrat, born in Kagoshima. A samurai from Satsuma, he was part of the movement known as the Meiji Restoration, which ended rule by the *Tokugawa shogunate. Part of the *Iwakura Mission 1871-73, and Minister for Home Affairs 1873-78, he initiated large infrastructure projects, but his suppression of local autonomy led to his assassination.

Ōkyo Maruyama (Maruyama Masataka) (17331795). Japanese painter. Working in Kyoto, he was aware of Dutch painting and its use of perspective. Innovative and diverse, his paintings include the first Japanese nudes and striking minimalism, e.g. Cracked ice (c. 1780), a two-part screen in the British Museum.
Olaf II (St Olaf) (995-1030). King of Norway 101528. He propagated Christianity in his country but with such severity that he was forced to take refuge in Russia (1028). Returning (1030), he was defeated and killed in battle against King ${ }^{*}$ Cnut (Canute) of Denmark, thus becoming the symbol of Norwegian resistance to Danish domination. He became the hero of legend and saga and came to be considered the patron saint of Norway. He is commemorated in England by several churches (St Olave's) and Tooley Street, London (a corruption of his name s'Tolof).

Olav V (Alexander Edward Christian Frederik) (1903-1991). King of Norway 1957-91. Born in Sandringham, son and successor of the future *Haakon VII and Princess (later Queen) Maud, daughter of *Edward VII, he was educated at Oxford. He won an Olympic gold medal for yachting in 1928, commanded Norwegian forces in World War II and promoted the practice of democratic monarchy. His son, Harald V (1937- ) succeeded to the throne.

Oldcastle, Sir John (c.1377-1417). English Lollard. He took the title of Lord Cobham through his third wife. Condemned as a heretic (1413), he escaped from prison and led a Lollard rising (1414). After its failure he remained in hiding for three years until recaptured and executed. He is sometimes thought to have been the original of *Shakespeare's Sir John Falstaff: the character was, indeed, originally called 'Oldcastle' but the name was changed on the objection of the Lord Cobham of the day. Oldcastle (like Falstaff) was a friend of ${ }^{*}$ Henry $\mathrm{V}$ as Prince of Wales. Regarded as a martyr by Tudor protestant reformers, he was extolled by Bale, *Foxe and Weever.

Oldenbarnevelt, Johan van (1547-1619). Dutch statesman. Prominent in the estates (parliament) of Holland, he became a leading figure in the struggle for independence from Spain. After the death of *William the Silent he offered the throne to the English Queen Elizabeth, effected the appointment of Prince ${ }^{*}$ Maurice of Orange as stadtholder of Holland and Zeeland, and as the most important member of the Republican Government did everything possible to support and finance the war. Alliances were made with England and France (1596) and eventually a 12year truce with Spain (1609). The religious conflict, however, between Remonstrants and Counterremonstrants, brought about a breach between him and Maurice. Oldenbarnevelt was accused of corruption and treason and Maurice had him arrested, tried and executed.

Oldenburg. North German (Saxon) dynasty who, from 1101, were counts, then dukes, then kings of Denmark 1448-1863, Sweden 1457-1521; 1751-1818, and married into the Russian imperial family (*Peter III). With the death of the childless Frederik VII (1808-1863), the Danish throne 
passed to a junior branch of the Oldenburg family with the cumbersome name of *Schleswig-HolsteinSonderburg-Glücksburg. ( ${ }^{*}$ Christian IX).

Oldenburg, Henry (1618-1677). German scientist in England. One of the most important figures in 17th-century scientific communications, he went to England in 1653, joined the Royal Society in 1661 and soon became its secretary. He devoted the rest of his life to the Society's administration and was one of the chief reasons for its early success. Oldenburg helped launch the Philosophical Transactions (1665), the first modern scientific journal, which published scientific findings, news, book reviews and correspondence. He was an ideal secretary for the Society, since he had extensive foreign contacts. There was evidently some danger in keeping up correspondence with enemy nations: he was temporarily put in the Tower in 1667 during the Anglo-Dutch War. Oldenburg made no scientific contributions of his own, but passionately supported the Baconian, empirical, utilitarian approach to science.

Olds, Ransom Eli (1864-1950). American inventor and manufacturer. He made the Oldsmobile, the first successful US automobile brand name, from 1901 and was a forerunner of Henry ${ }^{*}$ Ford in mass-production.

Oliphant, Sir Mark (Marcus Laurence Elwin) (1901-2000). Australian physicist, born in Adelaide. He studied at Adelaide University and St John's College, Cambridge, became *Rutherford's assistant at the Cavendish, isolated tritium $\left({ }^{3} \mathrm{H}\right)$ a radioactive isotope of hydrogen, and helium ${ }^{3}\left({ }^{3} \mathrm{He}\right)$ in 1934 and was professor of physics at Birmingham University 1937-50 and a pioneer in radar. In the US (1943-45), he worked on the 'Manhattan Project', developing the atomic bomb, and his studies on hydrogenisotope interactions contributed (much to his horror) to the hydrogen bomb. In 1943, he designed the first 'proton synchrotron', but none was built until the 1950s. He directed the research school of physics at the new Australian National University at Canberra 1950-63, was foundation President of the Australian Academy of Science 1954-57 and Governor of South Australia 1971-76. He became FRS in 1937, KBE in 1959 and AC in 1977.

Cockburn, S. and Ellyard, D., Oliphant. 1981.

Olivares, Gaspar de Guzmán (y Pimental Ribera y Velasco de Tovar), Count-Duke of (1587-1645). Spanish statesman born in Rome. He entered the service of*Felipe IV of Spain (1615) and so completely dominated his master that he was Chief Minister and virtual ruler of the country from 1621 until 1643, when he was dismissed. During those years, wholly occupied by the Thirty Years' War, Spain's hold on Holland was irretrievably lost, Portugal resumed its independence and Catalonia was in revolt. He was memorably painted three times by *Velázquez.
Olivier, Laurence Kerr, Baron Olivier of Brighton (1907-1989). English actor and director, born in Dorking. Son of a clergyman, he began acting as a child and his skills matured in Sir Barry Jackson's Birmingham Repertory Co. (1926-30). In 1930 he made a London hit with Noël *Coward's Private Lives and was soon in constant demand for films and stage productions in the 1930s. He attracted international attention in the films Wuthering Heights (1939), Rebecca (1940, directed by ${ }^{*}$ Hitchcock) and Pride and Prejudice (1940). After brief war service in the Fleet Air Arm, he produced, directed and starred in the patriotic epic Henry $V$ (1944), the most successful Shakespearean film to that time. He was Director or co-Director of the Old Vic Theatre Company 1944-49, toured Europe in 1945, the US in 1946 and Australia-New Zealand in 1948, being acclaimed for his performances as Richard III, Hotspur and Oedipus. The film Hamlet (1948) won him an Academy Award and his films of Richard III (1955) and Othello (1965) were deeply impressive. He created the role of Archie Rice in *Osborne's The Entertainer (1957, filmed 1960) and showed his virtuosity in *Ionesco's Rhinoceros (1960), *Farquhar's The Recruiting Officer (1964), as Edgar in *Strindberg's Dance of Death (1967), and in plays by ${ }^{*}$ Sheridan, ${ }^{*}$ Ibsen and ${ }^{*}$ Chekhov. He was a rather frustrated Director of the National Theatre 1962-73, then played character roles in several popular films including Sleuth (1972), Marathon Man (1976) and The Boys from Brazil (1978). His last great performance was in a television production of King Lear (1983). He married the actors Jill Esmond (1930), Vivien *Leigh (1940) and Joan *Plowright (1961). Knighted in 1947, he was created a life peer in 1970, given the $\mathrm{OM}$ in 1981 and buried in Westminster Abbey.

Ollenhauer, Erich (1901-1963). German Socialist politician. He fled to Czechoslovakia when *Hitler came to power in Germany, and was in England during World War II. He succeeded Schumacher as Leader of the West German Social Democratic party (1952) and opposed *Adenauer's policy of joining the western alliance. He was replaced (1960) by Willy *Brandt.

Olmert, Ehud (1945- ). Israeli politician, born in Palestine. A lawyer, he was Mayor of Jerusalem 1993-2003 and Prime Minister 2006-09. In 2012 he was convicted on corruption charges, and following conviction for bribery (2014) was imprisoned 2016-17.

Olsen, John (Henry) (1928- ). Australian painter, born in Newcastle. He trained in Sydney and Paris, lived in Spain, and his paintings (and some pottery) expressed an exuberant lyricism, joyous, inventive, celebrating nature and human vitality. They include a series based on the theme of Journey to You Beaut Country (1961ff), McElhone Steps (lithograph, 1963) and Salute to Five Bells (mural in Sydney Opera House, 1973). He was an imaginative recorder of 
figurative landscape, with brilliant colour. He won the Archibald Prize in 2005 for Self Portrait Janus Faced. The King Sun (2013), $6 \mathrm{~m} \times 8 \mathrm{~m}$, in eight panels, was commissioned for Collins Square, Docklands, Melbourne.

Bungey, D., John Olsen: An Artist's Life. 2014.

\section{Omar I and II see Umar I and II}

Omar Khayyám (Ghiyāth ad-Dīn Abu'l-Fath 'Umar ibn Ibrāhīm al-Khayyām Nīshāpūrī) (c.1050-1132). Persian poet, astronomer and mathematician, born in Nishapur. Long famous in his own and adjacent countries, his Rubáiyát (i.e. 'quatrains') first became widely popular in the west in the English verse paraphrases of Edward *Fitzgerald, and were later translated more accurately into many languages. The Rubáiyát is a collection of epigrammatic verses recommending enjoyment of wine, poetry and love while professing a gentle scepticism about the future, whether expressed in human hopes or divine plans. (Omar's exact part in writing the poems has been the subject of prolonged controversy). His mathematical work produced improvements in algebra, the calendar and the compilation of astronomical tables.

Dashti, A., In Search of Omar Khayyam. 1971.

O’Meara, Barry Edward (1786-1836). Irish surgeon. He served on HMS Bellerophon, which conveyed *Napoléon to St Helena. At the fallen emperor's request he stayed to attend him on the island and became his ardent partisan in his quarrels with Sir Hudson *Lowe. Having been sent home (1818) for this, he suggested that Napoléon's life was in danger in the governor's hands. He was dismissed and wrote Napoléon in Exile (1822), a sensational but one-sided account of the events.

Onassis, Aristotle Socrates (1906-1975). Greek millionaire and ship-owner, born in Smyrna. He bought his first ships in 1932 and gradually built up one of the largest independent fleets. He was one of the first owners to develop the 'super-tanker' for bulk liquid cargo. For many years the lover of Maria *Callas, in 1968 he married, as his second wife, Jacqueline, the widow of President John *Kennedy.

Evans, P., Ari. 1986.

Ondaatje, (Philip) Michael (1943-). Canadian novelist and poet, born in Sri Lanka. He taught at Toronto University and was active as an editor and poet. The English Patient (1992) won the Booker Prize and was filmed; in 2018, by public vote, it was chosen for the Golden Man Booker Prize as the best winner in 50 years. Later novels included Anil's Ghost (2000), Divisadero (2007), The Cat's Table (2011) and Warlight (2018). He published 13 volumes of poems.

O’Neill, Eugene Gladstone (1888-1953). American playwright, born in New York. Son of James O'Neill, an actor, he worked, during an adventurous early life, as a gold prospector in Central America, an actor and a newspaper reporter. He joined (1915) the Provincetown Players and not only acted for them but wrote and produced a number of short plays. $\mathrm{He}$ won the Pulitzer Prize for his first full-length play, Beyond the Horizon (1920), and also for Anna Christie (1921), a realistic drama of the water front and the regenerating influence of the sea upon the heroine. The Emperor Jones (1920) shows how an African-American adventurer establishes himself as a dictator in the Caribbean; the title of The Hairy Ape (1922) refers to a powerful stoker on a liner, whose vain attempt to overcome his handicaps provides the theme. All God's Chillun got Wings (1924) deals with the problem of a black-white liaison in which the white woman is disabled, with which the black man tries to contend. The much discussed Desire under the Elms (1924), dealing with a father-son conflict, was followed by The Great God Brown (1926), in which masks were used to symbolise characters. In Strange Interlude (1928), which lasts five hours, O’Neill tried another experiment with the 'stream of consciousness' technique. Mourning Becomes Electra (1931) attempts to place the Oresteian trilogy in a modern context. From 1934 there was a gap until The Icemen Cometh (1946). The 'iceman' symbolises death and the play handles the touch of death on a group of waterfront characters. The posthumously published Long Day's Journey into Night (1957) is mainly autobiographical. These plays are the most important of a long series that caused O'Neill to be regarded as America's greatest dramatist. He won the Nobel Prize for Literature (1936).

Sheaffer, L., O'Neill, Son and Playwright. 1969.

O’Neill, Hugh, 2nd Earl of Tyrone (c.1550-1616). Irish nobleman. The last member of his family to exercise independent rule, he was grandson of the O'Neill who, having submitted to the English king ${ }^{*}$ Henry VIII was created (1543) the 1st Earl. Hugh O'Neill had an English education, remaining on good terms with England until he had had his earldom recognised and made his position secure in Ireland, where he aspired to rule all Ulster. This aim brought him into conflict with *Elizabeth I and after a long struggle (1593-1603) he was forced to submit, though allowed to retain his personal estates. Finding English supervision intolerable, he left Ireland (1607), and travelled throughout Europe, finally settling in Rome from 1608 to his death. The O'Neills had ruled turbulently in Ireland, with constant quarrels between branches of their own line and rival families, e.g. the O'Donnells, ever since the days of Niall of the Nine Hostages (d.405), from whom they claimed descent.

O’Neill, Peter Charles Paire (1965- ). Papua New Guinea politician. Of Papuan-Irish-Australian descent, he was a businessman, MP 2002- , and Sir Michael *Somare's Treasurer 2007-11. He displaced Somare as Prime Minister 2012-19, provoking controversy about its constitutionality; however, he 
won the election of June-July 2012 comfortably. In July 2013 he agreed with the *Rudd government's policy that asylum-seekers arriving by boat would be permanently resettled in Papua New Guinea.

\section{Onnes, Heike Kamerlingh see Kamerlingh Onnes, Heike}

Onsager, Lars (1903-1976). American chemist, born in Norway. He taught at Yale from 1935, developed the gas-diffraction method of separating U 235 from U 238 and won the 1968 Nobel Prize for Chemistry. His discovery of reciprocal relations in irreversible chemical processes has been called 'the Fourth Law of Thermodynamics' (*Nernst).

Oodgeroo Noonuccal (originally Kath(leen Jean Mary) Ruska, later Walker) (1920-1993). Australian poet, born in Brisbane. We Are Going (1964) was the first volume of poetry published by an Aboriginal person. An active campaigner for Indigenous rights, education and recognition in the Australian Constitution, from 1988 she was known as Oodgeroo ('paperbark tree') Noonuccal (name of her tribe).

Oort, Jan Hendrik (1900-1992). Dutch astronomer. A student of J. C. *Kapteyn at Groningen University, he worked at Leyden University from 1924 and was professor of astronomy and director of the observatory 1945-70. His model of the structure of the universe, as a rotating disc spread around a nucleus containing 90 per cent of all stars, published 1925-27, has been confirmed by observation and is generally accepted. He estimated that the Sun is 30,000 light years from the centre of the galaxy and takes 225 million years to orbit around it. The 'Oort cloud', cosmic fragments at the edge of the solar system, and Asteroid 1691 Oort, were named for him.

Oparin, Aleksandr Ivanovich (1894-1980). Russian biochemist. A graduate of the Moscow State University, and a professor of biochemistry there 1927-60, in 1922 he hypothesised that the interaction of light and heat on a methane/ammonia atmosphere could lead to the development of amino acids and-ultimately_cellular life. In 1929 J. B. S. *Haldane independently proposed the same theory, which was expanded in Oparin's The Origin of Life on Earth (1936), and confirmed experimentally by $S$. L. ${ }^{*}$ Miller in 1953. An ardent supporter of ${ }^{*}$ Lysenko and a party loyalist, winning the Lenin Prize five times, Oparin's star waned after *Stalin's death.

Ophüls, Max (originally Maximilian Oppenheimer) (1902-1957). German-Jewish film director. He worked in Germany, France and the United States and his stylish films include Letter from an Unknown Woman (1948), La Ronde (1950) and The Earrings of Madame de ... (1953). His son, Marcel Ophüls (1927- ), an actor and director, educated in the United States, was best known for Le Chagrin et la Pitie (The Sorrow and the Pity, 1969), a controversial documentary about France and the Vichy regime, not released in France until 1981. He won an Academy Award for Hotel Terminus (1988).

Oppenheim, E(dward) Phillips (1866-1946). British author. He was one of the most prolific and popular novelists in the thriller and spy tradition, producing some 150 books and memoirs The Pool of Memory (1941).

Oppenheimer, Sir Ernest (1880-1957). South African businessman, born in Germany. He lived in South Africa from 1902, formed the Anglo American Corporation of South Africa, Ltd, in 1917 (with the backing of J. P. *Morgan) and began to exploit the Witwatersrand goldfield. He formed Consolidated Diamond Mines of South West Africa, Ltd, in 1919. Through the success of this company he was able to gain control of De Beers, the predominant diamond company. He also mined Rhodesian copper through his Rhodesian Anglo American Corporation. He was Mayor of Kimberley 1912-15, received a knighthood in 1921 and became a Unionist MP 1924-38. His son, Harry Frederick Oppenheimer (1908-2000), was a Unionist MP 1947-58, chairman of over 60 companies, a notable art collector and a racial liberal.

Oppenheimer, J(ulius) Robert (1904-1967). American theoretical physicist, born in New York. His parents were rich, radical and cultivated, and he studied at Harvard, Cambridge (unhappily) and Göttingen. Associate professor of physics 1928-36, then full professor 1936-42 at the University of California at Berkeley and professor at Caltech 1936-42, 1945-47, he worked on astrophysics, nuclear disintegration, cosmic rays and relativity. Despite his political naiveté, because of his extraordinary command of detail and ability to determine priorities, he became the central figure in 'the Manhattan Project' and at the Los Alamos (New Mexico) Laboratory 1942-45 led the team that designed and built the first atomic bombs. As Chairman of the Advisory Council of the US Atomic Energy Commission 1946-53, he opposed developing the hydrogen bomb. From 1952 he was persistently attacked by his former colleague Edward *Teller and suspended as a 'security risk' on the grounds of past association with Communists. He became director of the Institute for Advanced Study at Princeton 194767. He delivered the BBC's Reith Lectures in 1953, was given the Legion of Honour by France in 1957, elected FRS in 1962 and received the Fermi Award in 1963. A chain smoker, he died of throat cancer.

Monk, R., Inside the Centre: The Life of J. Robert Oppenheimer. 2012.

Orbán, Viktor Mihály (1963- ) Hungarian politician. Leader of the conservative Fidesz party 1993-2000, 2003- , he was Prime Minister of Hungary 1998-2002; 2010- , and pursued a radical nationalist policy, very hostile to Muslim refugees. 
Orczy, Emmuska, Baroness (in full, Emma Magdolna Rozália Mária Jozefa Borbála Orczy de Orczi) (1865-1947). English writer, born in Hungary. In London from 1880, she won immediate success when she turned her rejected novel The Scarlet Pimpernel (1905) into a play about Sir Percy Blakeney, the heroic rescuer of French aristocrats doomed to the guillotine. It became a successful film (1935) with Leslie *Howard. She wrote other romances, some detective stories collected as The Old Man in the Corner, and an autobiography, Links in the Chain of Life (1947).

Oresme, Nicole (1320-1382). Norman French philosopher. He seems to have been particularly interested in the notion of the universe operating as if by clockwork, and yet he made no break with the Aristotelian idea of intelligences being directly responsible for motion in nature. He pondered over the problem of the possibility of the plurality of worlds. He believed that science was against such a view, but stressed that God undoubtedly possessed the free will to have created such a state of affairs. Oresme denied the validity of astrological forces on both physical and theological grounds. Some of his most prescient thinking in physics relates to his studies of falling bodies. His emphasis that acceleration depends upon time of fall, rather than distance fallen, contains an idea developed later by ${ }^{*}$ Galileo.

Clagett, M., The science of mechanics in the Middle Ages. 1959; Hansen, B., Nicole Oresme and the Marvels of Nature. 1985.

Orff, Carl (1895-1982). German composer and music educator, born in Munich. His Schulwerk (1930) was highly influential in promoting music performance in schools. Influenced by the early *Stravinsky and ${ }^{*}$ Monteverdi, he developed an individual style, with strongly marked rhythms and flowing melody. The scenic cantata Carmina Burana (1937), a series of medieval Latin and German verses set for soloists and chorus with accompaniments of dancing and mime, was designed for stage performance. The work is often performed and has been recorded at least 116 times. Its sequel Catulli Carmina (1943) has had less exposure. Among his other works are the operas Der Mond (1939), Die Kluge (1942), Antigone (1949) and incidental music to A Midsummer Night's Dream (1939), written to replace ${ }^{*}$ Mendelssohn's score. Orff collaborated with the Nazi regime, being anxious to conceal his partly Jewish ancestry.

\section{Orford, Robert Walpole, 1st Earl of see Walpole, Robert}

Origen (Origenes Adamantius) (c.185-c.253). Christian theologian and biblical scholar, born at Alexandria. He accepted the orthodox Christian doctrines as revealed in the Bible but held it to be the right and the duty of individual Christians to seek for themselves answers to unanswered questions (e.g. the nature of the soul) in philosophical writings, even those of pagans on the ground that there were 'Christians before Christ'. As his reputation grew, his Alexandrian friends and followers encouraged him to publish his views and he wrote De Princepiis (On First Principles), one of the most influential books of early Christian philosophy. He was ordained in Palestine (230) but Demetrius, his bishop, regarded such ordination as irregular and exiled him. He settled at Caesarea, and there produced his Hexapla, a revised version of the Septuagint (the Greek text of the Old Testament) and other versions and the Hebrew original set out in parallel columns. During the persecutions of the emperor Decius, Origen was imprisoned and tortured, which led to his death. The official ecclesiastical view continued to be hostile to Origen. *Justinian condemned the study of his voluminous works with the result that the greater part is lost.

Danielou, J., Origen. 1955.

Orlando, Vittorio Emanuele (1860-1952). Italian politician. First elected to the Chamber of Deputies in 1897, he held ministerial offices and in the last years of World War I was Prime Minister 1917-19. As Italy's chief representative at the Paris Peace Conference (1919) he was one of the 'Big Four' and had frequent clashes with President *Wilson in his attempt (largely successful) to obtain implementation of the secret Treaty of London, by which Italy had been induced to enter the war on the side of the Allies.

Orléans, Philippe, Duc d' (1674-1723). French regent. A nephew of *Louis XIV, he set aside (1715) the late King's will and made himself sole regent, an act which encouraged suspicions that the numerous recent deaths in the royal family were caused by poison on his orders. Such suspicions (based on his dissolute character, rather than on evidence) were almost certainly unfounded. Orléans, guided by his old tutor, Abbé Dubois, shrewd and energetic but as dissolute as his master and entirely corrupt, made a special effort to put the finances in order. However, an inquisition, extending back over more than 20 years to discover any moneys that might be owed to the state by tax-gatherers and others, was abandoned because of its unpopularity, nor was his involvement with the banker John *Law much more fortunate. He completely reversed Louis XIV's foreign policy by allying France with its former enemies, England, Holland and Austria, against his dynastic rival *Felipe $\mathrm{V}$ of Spain. He retired when *Louis XV came of age.

His grandson Louis Philippe Joseph, Duc d' Orléans (1747-1793) was an atheist and equally debauched. Perhaps hoping for the crown, he espoused the revolutionary cause, adopted the nickname 'Philippe Egalité and voted for *Louis XVI's death. This did not save him, however, and he was condemned and executed. His son became *Louis Philippe, King of the French. The present French 'pretender' belongs to the Orleanist line. 
Orlov, Grigory Grigoryevich (1734-1783). Russian noble. He was prominent in the revolution that replaced *Peter III by his wife, *Catherine II (Catherine the Great). He was already Catherine's lover and, even when he ceased to be so, remained her principal advisor.

Ormandy, Eugene (né Jenö Blau) (1899-1985). American conductor, born in Hungary. A juvenile prodigy as violinist, he migrated to the US in 1921, became conductor of the Minneapolis Orchestra 1931-36 and succeeded Leopold *Stokowski at the Philadelphia Orchestra 1936-80.

Orsay, Alfred Guillaume Gabriel de Grimaud, Comte d' (1801-1852). French dandy. Son of a general, he resigned from *Louis XVIII's bodyguard (1822) to attach himself to Lord and Lady *Blessington, whom he had met in England and who were touring Europe. His marriage (1827) with the Blessingtons' 15-year-old daughter soon ended in separation, and in 1831 Lady Blessington (whose husband had died two years before) returned to London with d'Orsay. For the next 20 years the pair dominated the fashionable world, d'Orsay proving his accomplishment as a gentleman not only by his style in clothes but by practising painting and sculpture. In 1849 they fled from their creditors to France, where Louis Napoléon (*Napoléon III) made the count Director of Fine Arts.

Orsini, Felice (1819-1858). Italian conspirator. Having already served in the galleys for plots against the papacy, he took part in many conspiracies designed to further the cause of Italian unification. Considering *Napoléon III, who maintained a garrison in Rome, as the greatest single obstacle, he threw three bombs at the imperial carriage outside the Paris Opera. The Emperor and Empress were unhurt, but 10 bystanders were killed and 156 injured. Orsini was captured. Before he was guillotined he wrote to Napoléon urging him to free Italy and, admiring his courage, the Emperor published his last letter.

Ortega y Gasset, José (1883-1955). Spanish writer and philosopher, born in Madrid. He became professor of metaphysics at Madrid University 191136, supported the 1931 revolution, became Civil Governor of Madrid, and lived abroad after *Franco seized power. His philosophy shows the influence of * Kant but he is best known for his essays on modern civilisation, which he regarded as being destroyed by totalitarianism. His works include Meditations of Quixote (1914), a symbolic framework for a comparison of the Spanish spirit with that of other nations, Invertebrate Spain (1923), an analysis of the historical development of the national character, The Revolt of the Masses (1930), which looks forward prophetically to the Civil War, and studies of Kant, ${ }^{*}$ Goethe and ${ }^{*}$ Mirabeau.

Mora, J. F., Ortega y Gasset: An Outline of His Philosophy. 1956.
Orton, Arthur (1834-1898). Anglo-Australian imposter, born in Wapping. He impersonated Roger Charles Doughty Tichborne (1829-1854?), heir to an old Catholic family in Hampshire, presumed to have been lost at sea. Tichborne's father, the 10th baronet, died in 1862 and was succeeded by a second son. On the latter's death in 1886, Orton (alias Tom Castro), a butcher from Wagga Wagga, appeared in England, claiming the baronetcy and estates, and gained support from the dowager Lady Tichborne. Two trials (for ejectment against Orton as 12th baronet, 1871-72, and for perjury, 1873-74) were among the longest, most sensational and most expensive in Victorian history. At the second trial he was sentenced to 14 years' imprisonment.

Woodruff, D., The Tichborne Claimant. 1957.

Orwell, George (né Eric Arthur Blair) (19031950). English essayist and novelist, born in Bengal. Educated at Eton, his early life with the police in Burma (1922-27) and subsequently in poverty in Europe is described in Burmese Days (1935) and Down and Out in Paris and London (1933). He fought for the Republicans in the Spanish Civil War, was wounded and wrote Homage to Catalonia (1938). The Road to Wigan Pier (1937) is an angry portrait of working class life and an attack on middle class socialists. During World War II he joined the Home Guard, worked for the BBC 1941-43, reviewed for Tribune and wrote powerful essays, including 'Politics and the English Language' (1946). Animal Farm (1946) is a powerful satire on Stalinism, in the form of a farmyard fable. Nineteen Eighty-four (1949), his last book, is a terrifying vision of a future technocratic totalitarian state. He long suffered from tuberculosis and recuperated for some years on the Isle of Jura, Scotland. He was an Anglican atheist, somewhat homophobic, but intransigently opposed to all forms of totalitarianism, and to their collaborators. His volumes of essays include Inside the Whale (1940), Shooting an Elephant and Other Essays (1950), and England, Your England (1953).

Williams, R., Orwell. 1970; Bowker, G., Inside George Orwell. 2003.

\section{Osama bin Laden see Laden, Osama bin}

Osborne, Dorothy, Lady Temple (1627-1695). English letter writer. Her love letters to Sir William *Temple, whom she married (1655) after a long courtship, reveal the writer's lively mind and paint a vivid picture of 17th-century English life. First published in 1888, the 79 surviving letters are in the British Library.

Cecil, D., Two Quiet Lives. 1947.

Osborne, John James (1929-1994). English playwright. He became an actor (1948) and began to work at the Royal Court Theatre, where his play Look Back in Anger was first produced (1956). Its hero 
(or antihero), Jimmy Porter, came to be regarded as a representative figure of a new classless generation. Sir Laurence *Olivier played the lead in his next play, The Entertainer (1957). Epitaph for George Dillon, an earlier play written in collaboration with Anthony Creighton, was produced in 1957. Later plays include The World of Paul Slickey (1959), a musical; an historical drama Luther (1961); West of Suez (1971) and Sense of Detachment (1972). His autobiography, A Better Class of Person (Vol. I, 1981) and Almost a Gentleman (Vol. II, 1991) caused a sensation, with his bitter account of failed marriages.

Trussier, S., The Plays of John Osborne. 1969.

Osbourne, Lloyd (1868-1947). American author. He wrote three novels in collaboration with his stepfather, Robert Louis *Stevenson: The Wrong Box, The Wrecker and The Ebb Tide.

Oscar I (Joseph-François-Oscar Bernadotte) (17991859). King of Sweden and Norway 1844-59. Born in Paris, his father, Marshal *Bernadotte, had become King of Sweden as Karl XIV Johan in 1818, after the Napoleonic wars. Far more liberal than his father, he supported penal reform and freedom of the press, and had a passion for music.

Oscar II (Oscar Fredrik Bernadotte) (1829-1907). King of Sweden 1872-1907, and of Norway 18721905. Second son of *Oscar I, he succeeded his brother Karl XV. He was an able historian, poet, translator, and enthusiast for science, theatre and Arctic exploration. A brand of tinned sardines was named for him. He accepted Norway's independence (1905) without rancour and establishment of a separate dynasty ( ${ }^{*}$ Haakon VII).

O’Shea, Katie (Katharine) see under Parnell, Charles Stewart

Oshima Nagisa (1932-2013). Japanese director, producer and screenwriter, born in Kyoto. A film theorist and documentary maker, his feature films include Death by Hanging (1968), The Ceremony (1971), Realm of the Senses (1976) and Merry Christmas, $\mathrm{Mr}$ Lawrence (1983).

Osler, Sir William, 1st Baronet (1849-1919). Canadian physician, born in Ontario. A McGill University graduate, he held chairs in clinical medicine at McGill 1874-84, Pennsylvania 1884-89 and the new Johns Hopkins University, Baltimore, 18891904, where the clinical unit became internationally famous under his direction. Elected FRCP and FRS, he became Regius professor of medicine at Oxford University 1904-19, receiving a baronetcy in 1911. The most important of his many works is The Principles and Practice of Medicine (1891). He was also a noted bibliographer and classical scholar and died during the great influenza epidemic. Oddly, despite many discoveries, he was never nominated for the Nobel Prize.
Bliss, M., William Osler. A Life in Medicine. 2000; Beht, W. R., Osler. 1952; Cushing, H. W., The Life of Sir William Osler. 1925.

\section{Osman I see Uthman I}

Osman Nuri Pasha (1832-1900). Turkish soldier. After distinguishing himself in the Crimean War, he gained an international reputation for the skill and courage with which he defended Plevna in Bulgaria for five months against the Russians (1877). He was promoted to field marshal, given the title of 'Gazi' and served four times as Minister for War.

\section{Ossian see Macpherson, James}

Ossietzky, Carl von (1889-1938). German pacifist and journalist, born in Hamburg. Horrified by the carnage of World War I, in which he had been a conscript, he exposed the extent of German rearmament and the crimes of paramilitary groups, even before ${ }^{*}$ Hitler came to power, and was imprisoned 1931-32. He denounced Nazism and anti-Semitism and was sent to a concentration camp in 1933. In 1935, he received the Nobel Peace Prize, much to Hitler's fury, and died of tuberculosis in a prison hospital.

Ostade, Adriaen van (1610-1684). Dutch painter. Although a pupil of Frans *Hals, little of his teacher's influence is seen in his genre scenes in which topers, fiddlers, dancers, often performing in country inns, play a conspicuous part. His brother, Isaack van Ostade (1621-1649), at first chose similar subjects but later turned to the streets and countryside (especially in winter) for inspiration.

Ostrom, Elinor Claire (née Awan) (1933-2012). American political economist. She taught in Indiana and Arizona and wrote extensively about the concept of managing 'the commons'. Her books included Understanding Knowledge as a Commons: from Theory to Practice (2005). She was the first woman to win the Nobel Prize for Economics, sharing the 2009 award with Oliver Williamson.

Ostrovsky, Aleksandr Nikolaievich (1823-1886). Russian dramatist. He had close associations with the Maly Theatre in Moscow, where he became noted for realistic plays mostly concerned with the middle classes, merchants, officials etc. There is much more poetic force, however, in The Storm (1860), usually considered his masterpiece.

Ostwald, Wilhelm Friedrich (1853-1932). German physical chemist. Professor of chemistry at Riga 1881-87, and at Leipzig 1887-1916, he adopted and advocated the electrolytic dissociation theory of *Arrhenius, and applied the laws of mass action to obtain what is now known as Ostwald's dilution law. He discovered the process for the catalytic oxidation of ammonia into nitric acid by which most nitric acid 
is now made and won the Nobel Prize for Chemistry (1909). He was a profound sceptic about atomic theory.

Oswald, St (c.604-642). King of Northumbria 634-42. Son of King Æthelfrith of Bernicia, he returned from exile to succeed King ${ }^{*}$ Edwin. At the time Cadwallon, king of Gwynedd, was ravaging Northumbria, but Oswald defeated him at Hexham (634) and was able to consolidate and extend his rule until he was overlord of nearly all England. He revived Christianity in Northumbria by inviting *Aidan and monks from Iona to found a monastery at Lindisfarne. Oswald was killed in battle against the pagan king *Penda of Mercia and received almost immediate recognition as a saint and was praised by *Bede.

Oswald, Lee (Harvey) (1939-1963). American assassin. After joining the US Marines in 1954, he defected to the USSR in 1959, married there and returned to the US, apparently disillusioned, in 1962, and worked in Texas for Communist-fringe organisations. On 22 November 1963 he assassinated President John F. * Kennedy by shooting him twice as he drove in an open car through the streets of Dallas. Oswald also wounded Governor John ${ }^{*}$ Connally of Texas and killed a policeman. Two days later Oswald was shot by Jack Ruby, a nightclub owner, as he was being transferred from one jail to another. Oswald's record indicated him to be a psychopathic isolate. Despite his political associations the president's murder was generally thought to have a psychological rather than a political significance, although speculation about conspiracies continued for two decades.

Posner, G., Case Closed. 1993.

\section{Othman (or Osman) I see Uthman I}

Otho, Marcus Salvius (32-69). Roman Emperor (69), one of four in that year. While Governor of Lusitania (Portugal) he joined *Galba (68) against *Nero, but, disappointed in his hopes of the succession, he was proclaimed Emperor by his troops in the Roman forum and had Galba put to death. Meanwhile, the troops in Germany had proclaimed Vitellius, and he defeated Otho in north Italy. Otho then committed suicide.

Otis, Elisha Graves (1811-1861). American inventor, born in Vermont. He worked on many inventions including train brakes, a snow plough and a rotary oven, but secured immediate success at the 1854 New York World's Fair with his elevator (lift) that made the vertical city possible. He died of diphtheria.

Otto I (1815-1867). First King of the Hellenes 1833-62. A Bavarian prince, he was imposed on the Greeks by the London Conference (1832). Although well-meaning, he was deeply resented and deposed after a military revolt. ${ }^{*}$ George I, imported from Denmark, replaced him.

Otto I (known as 'the Great') (912-973). German King 936-73 and Holy Roman Emperor 962-73. $\mathrm{He}$ was the son of Heinrich ('the Fowler'), Duke of Saxony and German King 919-36. Crowned Emperor at Rome (962), because of the extension of his power into Italy and close relations with the papacy he is held to be the founder of the Holy Roman Empire. In Germany he centralised the administration, controlled the Slavs and repelled the Magyars. In Italy he became King of the Lombards, mastered Rome and the country to the south as far as Capua. His first wife was a daughter of ${ }^{*}$ Edward the Elder of England. His son, Otto II (955-983), crowned German King in 961, while his father was still alive, and later Emperor, was defeated by the Saracens in southern Italy and in consequence lost control of the Slavs in Germany. An attempt by his son, Otto III (980-1002), to establish an empire on the Byzantine pattern centred on Rome failed and was resented by his German subjects. Otto IV (c.11751218), a son of ${ }^{*}$ Heinrich der Löwe, was crowned German King (1198) but his title of Emperor was constantly in dispute. In alliance with the English king *John he was completely defeated at Bouvines (1214) by *Philip II of France.

Otto, Nikolaus August (1832-1891). German inventor. He was co-inventor (1867) of a successful internal combustion engine and patented (1884) the four-stroke Otto engine. Gottlieb *Daimler was the chief engineer of the company formed to exploit the patent.

Ottoboni, Pietro (1667-1740). Italian cardinal, born in Venice. Created a cardinal in 1689, he was not ordained as priest until 1724 . He patronised the arts, especially music, and among his protégés were Arcangelo ${ }^{*}$ Corelli, Alessandro ${ }^{*}$ Scarlatti, George Frideric *Händel and Antonio *Vivaldi.

Otway, Thomas (1652-1685). English Restoration dramatist. He left Oxford without taking a degree and went to London, where, after failing as an actor, he produced his first successful play, Don Carlos (1676). Adaptations from *Racine's Bérenice and *Molière's Les Fourberies de Scapin followed (1677). He is chiefly remembered for the blank verse tragedy The Orphan (1680) and his masterpiece Venice Preserved (1682). After a breach with his patron, the Earl of Rochester, he died in poverty.

Ham, R. G., Otway and Lee. 1969.

Oudinot, Nicolas Charles, Duc de Reggio (17671847). French marshal, born in Lorraine. Son of a farmer, before the Revolution he was ineligible for promotion. Wounded 34 times in battle, his 'Grenadiers Oudinot' won fame at Austerlitz (1805), and after the Battle of Wagram (1809) he 
was promoted marshal and duke. With ${ }^{*}$ Ney he covered the crossing of the Beresina River in the heroic rearguard action that saved the remnants of the Grand Army retreating from Moscow, and held commands in Leipzig and Berlin. After *Napoléon abdicated in 1814, Oudinot prudently supported the Bourbon restoration.

Overbury, Sir Thomas (1581-1613). English poet

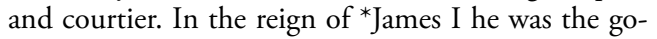
between of the beautiful Frances Howard, Countess of Essex, and her lover Robert Carr, the king's favourite, afterwards Earl of Somerset. Overbury's remark to Carr during a discussion about divorce, that the Countess was all right for a mistress but not for a wife, seems to have been repeated and so angered the lady that she contrived a pretext on which Overbury was confined to the Tower of London, where he was found dead from poison. Four minor participants in the crime were later hanged and afterwards the Countess of Somerset (as she had become) admitted her guilt but was pardoned by the King, as was her husband.

McElwee, W., The Murder of Sir Thomas Overbury. 1952; Lindley, D., The Trials of Frances Howard. 1993; Harris, B., Passion, Poison and Power. The Mysterious Death of Sir Thomas Overbury. 2010.

Ovid (Publius Ovidius Naso) (43 BCE-17 CE). Roman poet, born in Sulmona. Among his earliest poems were the Amores, written to an imaginary mistress, Corinna. Equally imaginary are the letters in the Heroides, allegedly written by legendary heroines, to their husbands or lovers (e.g. Penelope to Ulysses). In the Art of Love, often regarded as his masterpiece, the poet tells a lover how to gain a courtesan's favour and advises a girl on how to win and hold a lover. The Metamorphoses contains myths where change of shape provides the central theme. Having written this, Ovid was suddenly and mysteriously banished by *Augustus (perhaps because he had become involved in one of the intrigues of the Emperor's daughter Julia) to Tomi (now Constanta) on the Black Sea. Tristia, his laments for the misfortune, was already started while he was on the way. While in exile, from which he was never recalled, he also revised the Fasti, a month-bymonth description of the festivals of the Roman year. Only six of these survive and perhaps no more were written. Ovid had an astonishing facility for turning almost any subject into hexameters and pentameters without metrical blemish, and provided themes and examples for many writers, e.g. *Shakespeare and *Pope. He was often translated, notably by *Dryden, and his reputation remains high.

Syme, R., History in Ovid. 1978; Slavitt, D. R., Ovid. 1990.

Owen, David Anthony Llewellyn, Baron Owen (1938- ). English politician. Educated at Cambridge, he became a neurologist and MP (1966-92), Labour until 1981, and was ${ }^{*}$ Callaghan's Foreign Secretary
1977-79. He published Face the Future (1981), left Labour to be a co-founder of the Social Democratic Party, which he led 1983-87. He opposed the SDP merger with the Liberals and became an independent. $\mathrm{He}$ was the UN mediator in Bosnia 1992-95 (with Cyrus *Vance until March 1993) and received a $\mathrm{CH}$ in 1994.

Owen, Sir Richard (1804-1892).English zoologist and palaeontologist, born in Lancaster. Trained as a surgeon in Edinburgh and London, he attended lectures by ${ }^{*}$ Cuvier in Paris, became Hunterian professor of surgery at the Royal College of Surgeons 1836-56, superintendent of natural history at the British Museum 1856-84, and founded the Natural History Museum at South Kensington (1881). He was the leading expert on Australian fossils. He promoted public interest in palaeontology, but took credit for discoveries by Gideon Mantell and others. He coined the term 'dinosaur' ('terrible lizard') in 1841: a serious error because lizards, although reptiles, are a different species. He wrote important studies of the platypus, dodo, moa, kiwi and archaeopteryx, received the Copley Medal in 1851 and became an increasingly shrill and isolated antagonist of ${ }^{*}$ Darwin on the issue of natural selection.

Owen, Robert (1771-1858). Welsh social reformer, born in Montgomeryshire. After being a draper's assistant in Manchester, he became a master spinner and took over (1800), with partners, the New Lanark mills, originally started by*Arkwright and David Dale, whose daughter Owen married. Here he improved working conditions and housing, shortened hours and, for the children, introduced a new educational system (visual methods etc.) designed to bring out the special aptitudes of each particular child. Some of his improvements were incorporated in the Factory Act (1819). In the industrial depression that followed the Napoléonic Wars, Owen proposed as a substitute for the poor relief system 'villages of cooperation' in which each member was expected to work according to his ability for the good of the whole. The few experimental settlements all failed, for though New Harmony (1825) in Indiana, USA, survived, the cooperative principle was soon abandoned.

As early as 1813 Owen had, in A New View of Society, propounded the view that man's character was formed by his environment and he denounced the Churches for holding people responsible for sins resulting from capitalism and other social evils. He also held that such evils could be swept away if only the 'industrial classes' would combine to overthrow them. He took the lead in the foundation (1833) of the 'Grand National Consolidated Trades Union', but this collapsed within a year. Undeterred, he and his followers, now called 'Socialists', founded a new settlement, Queenwood in Hampshire, but this too only survived a few years.

Cole, G. D. H., Life of Robert Owen. 1965. 
Owen, Wilfred Edward Salter (1893-1918). English poet. A teacher by profession, he served in World War I and was killed a week before the Armistice. His war poems, written with irony, pity and ruthless honesty, were published after his death by his friend Siegfried *Sassoon. Some were set by Benjamin *Britten in his War Requiem (1962).

Stallworthy, J., Wilfred Owen: A Biography. 1974.

Owens, Jesse (né James Cleveland) (1913-1980). American athlete, born in Alabama. Son of a sharecropper, at the 1936 Olympic Games at Berlin, watched by *Hitler, he won four gold medals, for 100 metres, 200 metres, 4 x 100 metres relay and long jump, the last (8.135 metres) not surpassed until 1960. Such feats, performed in Berlin by an African-American, when the Nazis were proclaiming their theories of Nordic racial superiority, caused a sensation.

Oxenstierna af Södermöre, Axel Gustafsson, Count [Grevar], (1583-1654). Swedish statesman, born in Uppland. Of aristocratic birth, he was instrumental in securing a settlement between the nobles and ${ }^{*}$ Gustaf II Adolf and served as chancellor (Riksansler) 1612-54. The diplomatic preparations which left Gustaf free to sweep into Germany as the Protestant hero of the Thirty Years' War were in Oxenstierna's hands and, after his master's death at Lutzen (1632), it was he, as regent for Gustaf's daughter ${ }^{*}$ Christina, who kept the war going and made sure that Sweden was adequately rewarded by territorial gains. Meanwhile he had made notable administrative reforms, but after the war a faction of the nobility asserted itself, Queen Christina's support was lukewarm and finally, despite his persuasions, she abdicated. Soon after this final disappointment Oxenstierna died.

Oxford, 17th Earl of, Edward de Vere (1550-1604). English courtier and poet. Educated at Cambridge, he was violent and improvident, although a poet and patron of writers. T. J. Looney (sic) proposed in 1920 that Oxford was the 'real' author of the plays attributed to ${ }^{*}$ Shakespeare, and ${ }^{*}$ Freud joined the 'anti-Stratfordian' cause.

Oxford and Asquith, 1st Earl of see Asquith, Herbert Henry

Oxford and Mortimer, 1st Earl of see Harley, Robert

Oyama Iwao, Prince (1842-1916). Japanese field marshal. He became Minister of War 1880-95 and Chief of the General Staff 1899-1906, defeating the Russians at Mukden (1905). He received an honorary OM from Britain (1906).
Oz, Amos (1939-2018). Israeli novelist, born in Jerusalem. Educated at Hebrew University, he was a high school teacher at the Kibbutz Hulda until 1986, then taught at universities in Israel and the US and won many prizes. His novels include Elsewhere, Perhaps (1966), Touch the Water, Touch the Wind (1973), A Perfect Peace (1982) and Black Box (1987).

Ozal, Turgut (1927-1993). Turkish politician. He studied engineering and economics in Istanbul and the US, became a political conservative and an economic liberal. He held office under the military regime in Turkey 1980-82, founded the Motherland Party in 1982 and was elected as Prime Minister 1983-89. As President of Turkey 1989-93, he worked cautiously with his rival Suleyman *Demirel from 1991.

Ozawa, Seiji (1935- ). Japanese-American conductor, born in Manchuria. He was Musical Director of the Toronto Symphony 1965-68, the San Francisco Symphony 1970-75, the Boston Symphony 19732002 and the Vienna State Opera 2002-10, worked extensively in Europe and made many recordings. Ozu Yasujiro (1903-1963). Japanese film director. $\mathrm{He}$ directed 54 films, most filmed from a fixed position at a very low angle, suggesting the hierarchic nature of Japanese society. They include $A$ Story of Floating Weeds (1934), Tokyo Story (1953) and An Autumn Afternoon (1962). 


\section{$\mathbf{P}$}

Paasikivi, Juho Kusti (originally Johan Gustaf Hellsen) (1870-1956). Finnish politician. Brought up by an aunt, he won an LLD at Helsinki University, becoming an inspector of finances, then a banker. Finland declared its independence from Russia (1917) and Paasikivi served as Prime Minister 1918, resigning when his proposal for a constitutional monarchy failed. He returned to banking and flirted with the semi-Fascist Lapua movement. He was Ambassador to Sweden 1936-39 and to the USSR 1939-41. World War II forced him to move from conservatism to realism. ${ }^{*}$ Mannerheim appointed him Prime Minister 1944-46, and he won two terms as President 1946-56. With U. K. *Kekkonen, he negotiated peace with the USSR and Finland's neutralist policy is known as 'the Paasikivi line'.

Pabst, Georg Wilhelm (1885-1967). Austrian film and opera director, born in Raudnitz. Originally an actor and stage director, his first film was The Treasure (1923). He promoted the careers of Greta *Garbo, Leni *Riefenstahl, Asta Nielsen and Louise Brooks. His films included Pandora's Box (1929), The Threepenny Opera (1931), Don Quixote (1933), The Comedians (1941) and The Last Ten Days (1955). He also directed four operas.

Pachacuti (d.1471). Sapa Inca of Peru 1438-71. He brought the Inca Empire (Tawantinsuyu or 'Land of the Four Quarters') to its height, extending from northern Ecuador to central Chile, and built Machu Picchu.

Pachmann, Vladimir de (1848-1933). GermanRussian pianist, born in Odessa. He studied in Vienna and *Bruckner was a teacher. One of the most popular and accomplished (though often eccentric) concert performers of his generation, he was a notable interpreter of *Chopin. He died in Rome.

Packard, Elizabeth Parsons Ware (née Ware) (1816-1897). American social reformer, born in Ware, Massachusetts. Married to a domineering Calvinist cleric, Theophilus Packard, 14 years her senior, when she challenged his beliefs he had her certified as insane, confined to an asylum 1860-63, then locked up at home. A court declared her sane and she campaigned effectively for reforms of the law on insanity and married women's property rights.

Carlisle, L. V., Elizabeth Packard: A Noble Fight. 2010; Moore, K., The Woman They Could Not Silence. 2021.

Packer, Kerry Francis Bullmore (1937-2005). Australian media proprietor. Son of Sir (Douglas) Frank (Newson) Packer (1906-1974), founder of Australian Consolidated Press and The Women's Weekly, his private company owned magazines, a television network, casinos and gambling facilities, and cattle ranches with a value of \$AU7 billion. He created World Series Cricket in 1977.

Barry, P., The Rise and Rise of Kerry Packer. 1993.

Paderewski, Ignacy Jan (1860-1941). Polish pianist, composer and politician, born in Kuryłówka, then in Russia, now in the Ukraine. He studied under *Leschetizky (1884-87) before specialising as a virtuoso pianist, and touring Europe and America (and Australia 1904; 1927) with enormous success. He wrote two operas, a symphony, two concertos and much piano music, including the notorious Minuet in $G$ (1887). He settled in California in 1913. His international reputation and his efforts for his country in raising relief funds and in nationalist propaganda during World War I were major factors in influencing President Woodrow *Wilson to propose the creation of an independent Polish state as an Allied war aim. Marshal *Piłsudski appointed Paderewski as Prime Minister and Foreign Minister (1919) and he represented Poland at the Paris Peace Conference and signed the Treaty of Versailles (1919). In December he retired and returned to his music but in 1939, after Poland had been overrun in World War II, he reappeared briefly in political life as chairman of the Polish national council in exile.

Páez, Juan Antonio (1790-1873). Venezuelan liberator. He fought against the Spanish with varying success until he joined (1818) *Bolívar and shared with him in the victory of Carabobo (1821) by which Colombia and Venezuela were liberated. When Bolívar went to Ecuador, Páez stayed in Venezuela and when Venezuela seceded from Colombia he became first president (1831), dominating the country, either in office himself or through nominees, until he was defeated by a rival (1850) and forced into exile. In 1858 he returned to power but in 1863 was again expelled, dying in New York.

Paganini, Niccolo (1782-1840). Italian violinist and composer, born in Genoa. He toured Europe repeatedly and wrote many virtuoso pieces, notably his 24 Caprices and the Concerto in D. His technique was regarded as phenomenal and he enlarged the range of the violin by introducing left-hand pizzicatos and double harmonics. His tempestuous career and odd appearance made him a popular idol.

Page, Sir Earle Christmas Grafton (18801961). Australian politician, born in Grafton. An accomplished surgeon, he was a Member of the House of Representatives 1919-61, a co-founder of the Australian Country Party and its Leader 1921-39. Instrumental in forcing W. M. *Hughes from the prime ministership, he became Deputy Prime Minister and Treasurer 1923-29 under S. M. *Bruce. Deputy Prime Minister again (and Minister for Commerce) under J. A. *Lyons 1934-39, after Lyons died suddenly he was Prime Minister April 1939, for 19 days. When R. G. *Menzies was 
chosen as Lyons' replacement, a deeply resentful Page resigned from Cabinet. He became MinisterResident in London 1941-43. As Minister for Health 1949-56, he introduced a national health scheme. Suffering from lung cancer, he was comatose during the 1961 election and died without knowing that he had been defeated. Page was a PC (1929), GCMG (1938) and $\mathrm{CH}$ (1942).

Wilks, S., 'Now is the Psychological Moment'. Earle Page and the Imagining of Australia. 2020.

Page, Sir Frederick Handley (1885-1962). English aircraft designer. He founded Handley Page Limited in 1909 and during World War I designed and built his twin-engined $0 / 400$, one of the earliest heavy bombers. He established a civil air service between England and the Continent in 1919 and continued to build aircraft, notably the Heracles airliner. During World War II Handley Page Limited built transport planes and bombers, notably the Halifax. He was President of the Royal Aeronautical Society 194547 and received the society's Gold Medal in 1960. His company closed down in 1970.

Gibbs-Smith, C. H., Aviation: An Historical Survey from Its Origins to the End of World War II. 1970.

Page, Larry (Lawrence Edward) (1973-). American entrepreneur, born in Michigan. Educated at Stanford, he developed 'PageRank' technology which classifies material on websites and in 1998 founded the Google search engine with Sergey *Brin.

Pagnol, Marcel (1895-1974). French author, playwright and film director. His plays include Catulle (1922), Topaze (1928) and the trilogy Marius, Fanny, César (1929-36). He directed or produced several films, e.g. César (1936), Le Reyain (Harvest, 1937) and La Femme du boulanger (1938). Among his novels are Le Château de ma mère, Le Temps des Secrets. He was the first film-maker elected to the Académie française (1946).

Pahlavi. Iranian dynasty, which ruled 1925-79: see *Reza Shah Pahlavi and *Mohammad Reza Pahlavi.

Paine, Thomas (1737-1809). Anglo-American political theorist and activist, born in Norfolk. Having tried several occupations including that of excise officer, he went, on the advice of Benjamin *Franklin to America, where he published Common Sense (1776), a pamphlet demanding complete independence from Britain, and The Crisis (1776-83), a series of pamphlets advocating the same end. Meanwhile he had fought in the colonial armies and had been administratively concerned with the framing of the constitution. In 1791 he returned to England, but publication of his greatest work, The Rights of Man (1791-92), a reply to Edmund *Burke's Reflections on the Revolution in France, forced him to go to France to avoid prosecution. There he was elected to the Convention but, after opposing the execution of *Louis XVI, was for a time in prison, where he began The Age of Reason (1794-96), a work defending deism (i.e. a belief in God that is divorced from Christianity or any other 'enslaving' religion). He returned to America in 1802, where he came into conflict with the Federalists. He died in New York. Paine's writings continued to inspire radicals in the century after his death.

Keane, J., Tom Paine. 1994.

Paisley, Ian Richard Kyle, Baron Bannside (19262014). Northern Ireland clergyman and politician. He led the breakaway Free Presbyterian Church of Ulster (1951). A gifted mob orator, he whipped up hostility towards Catholics and Protestant moderates, serving in the British Parliament 1970-2010 and the European Parliament 1979-2004. He campaigned against the Northern Ireland peace agreement (1998) but ultimately served as first minister 2007-08. His wife Eileen Emily Paisley (née Cassells), Baroness Paisley of St George's (1934- ) made a life peer in 2006, later indicated irritation with the Democratic Unionist Party and some sympathy for Martin *McGuinness and Sinn Féin.

Pakenham. English writing and political family. Frank Aungier Pakenham, 7th Earl of Longford (1905-2001), a Labour minister under *Attlee and *Wilson, wrote biographies of ${ }^{*}$ Lincoln, ${ }^{*}$ Nixon, ${ }^{*}$ Kennedy, ${ }^{*}$ De Valera, ${ }^{*}$ Jesus and $\mathrm{St}{ }^{*}$ Francis, became a Catholic convert, a publisher and committed proponent of penal reform. His wife, Elizabeth Pakenham (née Harman), Countess of Longford (1906-2002) wrote biographies of *Wellington, *Byron and Queen *Victoria. Their daughter was Lady Antonia *Fraser and their son Thomas Francis Dermot Pakenham, 8th Earl of Longford (1933- ) wrote The Year of Liberty (1969), The Boer War (1979), The Scramble for Africa (1991) and Meetings with Remarkable Trees (1996).

Palaeologus. Byzantine dynasty. The family was famous in the history of Constantinople from the 11 th century, but its first Emperor was Michael VIII (c.1224-1282, reigned 1258-82). His successors ruled the empire until Constantine XI (1403-1453, reigned 1443-53) died while vainly trying to defend Constantinople against the Turks.

Nicol, D. M., The Last Centuries of Byzantium, 12611453. 1972; Norwich, J. J., Byzantium: The Decline and Fall. 1995.

Palafox (y Melci), José, Duke of Saragossa (17761847). Spanish patriot. In the early stages of the Peninsular War he was a leader of those Spaniards who, with British aid, resisted the invasion of Napoléon's armies. He became famous for his heroic defence of Saragossa but after its final capitulation (February 1809) he was imprisoned by the French until 1813. He was created Duke in 1834.

Palamas, Kostas (1859-1943). Greek writer. His epics, e.g. The King's Flute (1910), concerned with the Byzantine period, reawakened Greek pride and 
sorrow in the events of their great history: liberty and justice were his constant themes. In addition to poetry, lyric and philosophical as well as epic, he wrote stories, essays and a tragedy. His use of 'demotic', the language of contemporary Greece, did much to enhance its literary status.

Palestrina, Giovanni Pierluigi da (c.1525-1594). Italian composer, born at Palestrina (Praeneste). Known from his birthplace, he became organist and choirmaster there at St Agapito in 1544. In 1551 Pope Julian III (who as Bishop of Palestrina had been the composer's master) appointed him a member of the Julian choir at St Peter's. In 1555 Palestrina was briefly a member of the pontifical choir until he was forced to resign by the reformist pope *Paul IV. He remained in Rome as musical director of the Church of St John Lateran 1555-60 and of S. Maria Maggiore 1561-67, returning to St Peter's (1570) as master of the Julian choir, a post he held until his death. Palestrina's output was enormous and included motets, litanies, magnificats and 94 Masses. (The legend that his famous Missa Papae Marcelli had the effect of dissuading the Council of Trent from burning polyphonic Church music is unfounded.) His work represents the culminating point of development in polyphonic vocal music, but the new ideals inaugurated by his immediate successors led to its neglect until the late 19th century, since when it has remained, at least in technique, the chief model for liturgical composers.

Paley, William (1743-1805). English clergyman and theologian. He held a number of livings and diocesan appointments but is chiefly remembered for his View of the Evidences of Christianity (1794), drawing arguments from the observation of nature, which had a powerful influence, including on *Darwin. He campaigned against the slave trade.

Paley, William S(amuel) (1901-1990). American business executive, born in Chicago. He was Chairman of CBS (Columbia Broadcasting System) 1928-46, Chairman 1946-83 and Chief Executive 1946-77 and played a decisive role in shaping television programming. CBS was also an important book publisher and record producer.

Palin, Sir Michael Edward (1943- ). English actor, writer and documentary producer. Educated at Oxford, he was a leading figure in the BBC's television series Monty Python's Flying Circus (1969-74), with Eric Idle, Terry Jones, John Cleese and Graham Chapman, acted in 22 films, including Monty Python's Life of Brian (1979), made numerous travel documentaries and published books and diaries.

Palin, Sarah Louise (née Heath) (1964- ). American Republican politician, born in Idaho. Governor of Alaska 2006-09, she was Republican candidate for Vice President (with John *McCain) in 2008 and author of Going Rogue (2009). Popular with the 'Tea Party' and the far right, she did not seek a presidential nomination in 2012 .

Palladio, Andrea (1508-1580). Italian architect, born in Padua. His ability was first noticed, while he was working as a stone mason at Vicenza, by the humanist Gian Giorgio, who enabled him to study and make drawings of classical antiquities in Rome (1545-47). In and around Vicenza he built, in a distinctive classical style which became known as 'Palladian', the famous Basilica (1549), with two arcaded storeys round an older hall, town palaces and country villas, and his last important work, the Teatro Olimpico (begun 1580). The churches of S. Giorgio Maggiore (1566) and Il Redentore (1576), both in Venice, have remarkable facades. Through his Quattro libri dell'architettura (1570), which contained many of his designs, his influence spread widely, in England his style was introduced by Inigo *Jones and later popularised by Lord *Burlington. He was also copied in 18th-century America.

Ackerman, J. S., Palladio. 1966.

Palme, (Sven) Olof Joachim (1927-1986). Swedish Social Democratic politician. Partly educated in the US, he was a prominent youth leader and a Riksdag member (1956-86), succeeding Tag *Erlander (whose secretary he had been) as Prime Minister of Sweden 1969-76, 1982-86. He was assassinated in Stockholm.

Palmer, Sir Geoffrey Winston Russell (1942-). New Zealand lawyer and Labour politician. He taught law in Wellington, Iowa, Virginia and Oxford, worked on compensation issues in Australia and served as MP 1979-90. He was Attorney-General 1984-89, Minister for the Environment 1987-90 and Prime Minister 1989-90, and architect of the New Zealand Bill of Rights Act (NZBORA, 1990). He returned to academic life and was President of the Law Reform Commission 2005-10.

Palmer, Samuel (1805-1881). English painter and engraver. Son of a bookseller, he was largely self-educated as an artist but exhibited at the Royal Academy as early as 1819 . He first met William *Blake in 1824 and, deeply inspired, produced landscapes full of vision and fire. He painted his most original work living at Shoreham (1825-36) where, with George Richmond, he formed a group of Blake's admirers (known as 'The Ancients'). His later work, largely in watercolour, was uninspiring.

Peacock, C., Samuel Palmer: Shoreham and After. 1968.

Palmerston, Henry John Temple, 3rd Viscount (1784-1865). British politician, born in Broadlands, Hampshire. Educated at Harrow and the University of Edinburgh, as the holder of an Irish peerage he was eligible to be elected to the House of Commons, and sat as an MP 1807-65. Emily Lamb, Countess of Cowper (1787-1869), sister of Lord *Melbourne, 
was his mistress from 1810; they married in 1839 after her husband's death. Originally a Tory, he served as Secretary at War 1809-28, a record period, but broke with the party (1830). Henceforth, as a Whig or Liberal he favoured a policy of nonalignment with European powers and support for national movements. Thus, as Foreign Secretary 1830-34, 1835-41, he supported Belgian independence and the constitutionalists in Spain and Portugal, and saved the decaying Turkish Empire from domination by Russia. After a period in opposition (1841-46) he was again Foreign Minister 1846-51 and in 1848 supported nationalist risings in Europe, especially those against Austria. When ${ }^{*}$ Louis Philippe was deposed in France he recognised the republic and later, without consulting his colleagues, the coup d'état (1851) of Louis Napoléon (*Napoléon III). Lord John ${ }^{*}$ Russell forced his resignation over this but he returned as Home Secretary 1852-55 in Lord *Aberdeen's coalition. He was Prime Minister 185558 and 1859-65, and died in office. He brought the Crimean War to a satisfactory end and, after the brutal suppression of the Indian Mutiny (1857), he transferred the British East India Company's authority to the Crown. The Liberal Party was formed in 1859. Despite some liberal attributes (e.g. legalising divorce), his methods were often domineering and his judgment was often faulty, especially in his later years (e.g. over the American Civil War, where he sympathised with the Confederacy). He was extremely popular with the British public, but Queen *Victoria and his colleagues found his enthusiasm for forceful action very trying. Being cited as a corespondent in a divorce case at the age of 79 seems to have contributed to his popularity.

Ridley, J., Lord Palmerston. 1970; Brown, D., Palmerston. 2010.

Pamuk, (Ferit) Orhan (1952- ). Turkish novelist, screenwriter and academic, born in Istanbul. His novels include The Black Book (1990), My Name is Red (2000) and Snow (2002). He also wrote short stories and essays. He had several periods of teaching at Columbia University and in 2005-06 faced harsh criticism in Turkey and threats of prosecution for protesting about historic aggression against Armenians and Kurds. In 2006 he won the Nobel Prize for Literature. The citation read: 'In the quest for the melancholic soul of his native city, [he] has discovered new symbols for the clash and interlacing of cultures.'

Paneth, Friedrich Adolf (1887-1958). AustrianBritish chemist, born in Vienna. He left Germany in 1933 and became professor of chemistry at Durham 1939-53, then director of the Planck Institute for Chemistry, Mainz 1953-58. His most important work was on the use of radio-isotopes in chemical research. He devised techniques for measuring the minute quantities of helium produced in rocks by radioactive decay, and thus provided a method of finding the age of rocks. The lunar crater Paneth and the mineral Panethite are named for him.

Panhard, René (1841-1908). French engineer and motoring pioneer. Founder of the Panhard company, in 1886 he formed a partnership with Emile Lavassor (1844?-1897). They acquired the French and Belgian rights to use *Otto's internal combustion engine and pioneered the building of true cars with the engine mounted on a chassis.

Georgano, G. N. (ed.), The Complete Encyclopaedia of Motorcars 1885-1968. 1968.

Pankhurst, Emmeline (née Goulden) (1858-1928). English militant suffragette. She worked with her husband, Richard Marsden Pankhurst (1839-1898), on behalf of many radical causes, but after his death concentrated on votes for women. In 1903 she founded the Women's Social and Political Union (WSPU) which engaged in direct confrontation and militant protest to secure female suffrage and had a tense relationship with Millicent *Fawcett and her 'suffragists' in the National Union of Women Suffrage Societies (NUWSS). Dubbed as 'suffragettes' from 1906, Mrs Pankhurst's followers pursued their goals, including chaining themselves to lamp posts, slashing pictures, assaulting the police, and going on hunger strike in prison. (Mrs Pankhurst was confined eight times.) Many less extreme supporters were estranged, but World War I, in which women proved their ability in almost every occupation, broke down opposition. In 1918 women over 30 acquired the vote and in 1928 they were given equality of franchise with men. In 1926, fearful of Bolshevism, she joined the Conservative Party and was nominated as a candidate. Her three daughters were active suffragettes: Dame Christobel Harriette Pankhurst (1880-1958) was first imprisoned in 1905, took out a law degree, wrote The Great Scourge (1913), about sexually transmitted diseases, but during World War I became a strident campaigner for conscription. She stood for Parliament in 1918, lived in the US from 1921, became an Adventist evangelist and was created DBE in 1936; (Estelle) Sylvia Pankhurst (18821960), studied as an artist, was imprisoned and forcefed in prison for her suffragette protests, broke with her mother over her opposition to World War I, joined the Communist Party in 1920 but was soon expelled. She later devoted herself to the cause of Ethiopia (Abyssinia) when it was invaded by the Italians and lived in Addis Ababa from 1956. Adela (Constantia Mary) Pankhurst (1885-1961), imprisoned for her suffragette militancy, migrated to Australia in 1914, was imprisoned in Melbourne for anti-war protests married the trade unionist Tom Walsh in 1917, and they were co-founders of the Communist Party of Australia in 1920. Expelled by the CPA, they turned hard right by 1927, joined the Australia First movement in 1941 and she was interned in 1942. Adela became a Catholic convert.

Hoy, L., Emmeline Pankhurst. 1985. 
Paoli, Pasquale de (1725-1807). Corsican patriot. After many years in exile (1739-55) for opposing the Genoese, he was chosen as President of Corsica. When the Genoese sold Corsica to France he opposed the French authority but, after a valiant resistance, was defeated and fled to England, where *Boswell befriended him. In 1791 he was appointed Governor of Corsica by the French Revolutionary Government, and when accused (1793) of being a counter-revolutionary, he proclaimed Corsica independent. With the help of the British Navy he defeated the French and the island was declared a British protectorate. After he was recalled to England (1795) the pro-French islanders drove the British from Corsica.

\section{Paolo and Francesca see Francesca da Rimini}

Papadopoulos, Georgios (1919-1999). Greek soldier and politician. A brigadier, he led the military coup of April 1967 which overthrew the civilian government. He became Prime Minister of the junta 1967-73, and President of the Republic 1973. Sentenced to death for treason in 1975 after the restoration of democracy, his sentence was commuted to life imprisonment.

Papagos, Alexandros (1883-1955). Greek field marshal, born in Athens. He fought in both Balkan wars, World War I and the Turkish War and in 1935 was part of the military coup which led to the restoration of the Greek monarchy and the dictatorship of *Metaxas. As Commander-in-Chief of Hellenic Forces 1939-41, despite inferiority of numbers and equipment he gained a series of remarkable victories until German intervention made further resistance impossible. He organised resistance to Axis occupation, and was taken to Germany as a prisoner. Awarded a GBE (1945) by the British, he was Commander-in-Chief again 1949-51 and crushed the Communists in the civil war with the use of American fire-power. He founded the Greek Rally, won the 1952 elections decisively and was Prime Minister 1952-55. He tried to modernise Greece and restore the economy, and took a cautious line about Cyprus.

Papandreou, Georgios (1888-1968). Greek Socialist politician. He was Premier of Greece 1963 and 196465 until forced out of office by the army and jailed (1967). His son Andreas Papandreou (1919-1996), an American trained economist, taught in Minnesota and California, returning to Greek politics to lead the Pasok party. Premier of Greece 1981-90, and 199396, he was forced out by illness.

Papen, Franz Joseph Herman Michael Maria von (1879-1969). German politician and diplomat. When military attaché in the US during World War I he was expelled (1915) for promoting sabotage. He was elected to the Prussian Diet (1921) and subsequently used his friendship with President *Hindenburg's son, Oskar, to secure advancement.
Finally (June 1932) he was appointed Chancellor. His first attempt to bring *Hitler into his government failed, but after another election (November 1932) and Papen's resignation the two came to terms: Hitler became Chancellor and Papen Vice Chancellor, with a secret assignment from Hindenburg to curb Nazi excesses. Papen soon became critical of his new ally and narrowly escaped death in Hitler's 'Night of the Long Knives' (30 June 1934). The warning was enough. He accepted the post of Ambassador to Vienna 1934-38 and prepared the ground for the Nazi occupation of Austria. He was sent to Turkey 1939-44, where his embassy became the centre of a spy network. After the war he was acquitted at Nuremberg, and released after serving two years of a nine-year sentence imposed by a German denazification court.

Papen, F. von, Memoirs. 1952.

Papin, Denis (1647-1713). French physicist. He assisted *Huygens and (from 1675) Robert *Boyle in work on air pumps. Among his inventions were the double-stroke air pump, the condensing pump and the autoclave (then known as the 'digester'), a pressure vessel in which temperatures above the boiling-point of water may be obtained. A pioneer of the steam engine, and elected as Fellow of the Royal Society (1680), he died in London, destitute.

Papineau, Louis-Joseph (1786-1871). FrenchCanadian politician, born in Montréal. He was elected (1808) to the Québec legislative assembly, of which he was later Speaker 1815-37. His bitter oratory gave fervent support to the cause of FrenchCanadian self-government and after the defeat of the 1837 rebellion he took refuge in the US and then France. He returned to Canada in 1845, was elected to the lower house 1848-54, then retired from politics.

Pappus of Alexandria (fl. 300-350 CE). Greek geometer. His treatise, the Synagogue, is particularly valuable as a source of information about earlier Greek mathematicians and geometers. When giving proofs from earlier figures, Pappus frequently offers alternative solutions, or his own improvements. $\mathrm{He}$ offers full discussions of many of the classic problems of Greek mathematics, such as squaring the circle or the trisection of an angle. Pappus also evidently had interests in geography; he is known to have composed a geographical work, which has not survived. He wrote commentaries on *Euclid and *Ptolemy's Almagest.

Paracelsus (Theophrastus Bombastus von Hohenheim) (c.1493-1541). Swiss physician and alchemist. He travelled widely in Europe, lecturing and practising medicine, and won considerable renown. Although he practised alchemy and the occult sciences, he did not accept demonological explanations for insanity, and many of his medical views were advanced for his time: he attacked the traditional belief that diseases were caused by 
'humours' in the body and taught the use of specific remedies. He introduced opium, laudanum, mercury, sulphur iron and arsenic as medicines. Of his numerous works, the Paragranum gives the best exposition of his medical views. Robert *Browning's dramatic poem Paracelsus (1835) is based on his life.

Pachter, H. M., Paracelsus: Magic into Science. 1951.

Paré, Ambroise (1510-1591). French army surgeon. Known especially for introducing more humane methods in surgery, he abandoned the boiling-oil treatment of wounds in favour of dressings with egg yolk, attar of roses and turpentine, and used ligatures to seal blood vessels after amputations instead of cauterisation. He was surgeon to all French kings from ${ }^{*}$ François I to ${ }^{*}$ Charles IX. He has been called the 'father of modern surgery'. He stressed the importance of proper nursing, and was much concerned about the treatment of women in childbirth. His Apology is a vivid autobiography.

Hamby, W. B., The Case Reports and Autopsy Records of Ambroise Paré. 1960.

Pareto, Vilfredo (1848-1923). Italian economist and sociologist, born in Paris. Trained as a mathematician and engineer, he was a professor of economics at Lausanne from 1893. He applied mathematical analysis and logical rigour to the study of income distribution. In Mind and Society (1916-23) he argued that both revolutionary and evolutionary social change led merely to the 'circulation of élites', that real power could not be distributed equitably because human capacity is unequal. *Mussolini claimed him as a major influence on Fascism.

Parini, Giuseppe (1729-1799). Italian poet. His work was modelled on Latin poets, especially ${ }^{*}$ Horace, but he abandoned the artificialities of the preceding period and wrote creatively with elegance and feeling. His most famous poem, Il Giorno (The Day, begun 1763), gives an ironic and lively account of a day in the life of a young nobleman in a corrupt age.

Paris, Matthew (1200?-1259). English monk and chronicler. He entered (1217) the monastery of St Albans, where he acquired skill not only as a writer and illuminator but in gold and silverwork. He continued Roger of Wendover's Major Chronicles from 1235 to 1259 , enlarging their scope to include foreign events. His Minor History is a summary of events from 1200 to 1250 . He was favoured by *Henry III, and his chronicles, apart from their historic value, are vigorous and vivid and not without critical comment on contemporary trends and developments.

Park Chung Hee (1917-1979). Korean soldier and politician. In 1961 he led a military coup in the Republic of Korea, and was President 1963-79. His wife Yuk Young-soo (1925-1974) was assassinated by a North Korean agent. Park promoted rapid growth and technological change until his assassination by the head of Korea's Central Intelligence Agency. Their daughter, Park Geun-hye (1952- ), was a member of the Korean Parliament 1998-2012, survived a stabbing attack in 2006 and became leader of the conservative Saenun party. She was elected as the first woman president of the Republic of Korea 2013-17, but was impeached on corruption charges, removed from office, tried and sentenced to 24 years jail, extended to 32 years on appeal.

Park, Mungo (1771-1806). Scottish explorer in Africa. A surgeon, in 1795 he went to Africa to explore the course of the river Niger and find its exit to the sea. After much hardship he joined the Niger at Segou, followed it downstream and, before being forced by obstructions to return, proved that it had an eastward flow at this point. The problem of its point of exit remained unsolved. His Travels in the Interior of Africa (1799) proved a popular success, and in 1805 he made another journey but of his 45 companions only seven reached the Niger. They struggled on as far as Boussa (Bussa), where the canoe was wrecked and Park and four remaining Europeans were attacked by indigenous people and drowned while trying to escape.

Schiffers, H., The Quest for Africa. 1957.

Parker, Alton Brooks (1852-1926). American jurist. A judge from 1885, he was Chief Justice of the New York Court of Appeals 1898-1904. In 1904 he was a surprising choice as the Democratic candidate for president, defeating William Randolph ${ }^{*}$ Hearst, because, as a judge, he had been silent on political issues and offended nobody. Theodore *Roosevelt was considered unbeatable and Parker was a sacrificial lamb. He is the only major presidential candidate never to have been the subject of a biography.

Parker, Dorothy (née Rothschild) (1893-1967). American writer. She was well known for short stories, collected in, e.g. Laments for the Living (1930) and Her Lies (1939), and for her mordantly humorous poems, sayings and book reviews contributed to the New Yorker. (When told that the taciturn President *Coolidge had died, she asked 'How can they tell?'.)

Keats, J., You Might As Well Live: The Life and Times of Dorothy Parker. 1970.

Parker, Matthew (1504-1575). English prelate, born in Norwich. Educated at Corpus Christi College, Cambridge, he was a moderate reformer, became chaplain to *Anne Boleyn, Master of Corpus Christi 1544-53, Vice Chancellor of Cambridge 1545-46; 1548-49 and Dean of Lincoln 1552-54. He supported Lady Jane ${ }^{*}$ Grey and under *Mary was lucky to lose only the Deanery and not his life. *Elizabeth appointed him (1559) her first archbishop of Canterbury, and he was largely responsible for the Prayer Book of 1559 and the Thirty-nine Articles of 1562, both modelled on the corresponding publications of *Edward VI's reign. One of Parker's main problems was that the clergy who returned from 
exile demanded the much more drastic Protestantism that they had met on the Continent. It was they who reinforced the growing body of 'Puritans' and were opposed to Parker's course of compromise. As Archbishop he retrieved outstanding illuminated manuscripts from monasteries that had been dissolved by *Henry VIII, bequeathing 480 manuscripts and about 1,000 printed books to Corpus Christi to establish the Parker Library.

Parkes, Sir Henry (1815-1896). Australian Liberal politician, born in England. He reached New South Wales in 1839, founded a newspaper (1850) and became a prominent opponent of convict transportation. He entered the legislature (1854). In five broken terms he was premier of New South Wales 1872-75, 1877, 1878-83, 1887-89, 188991 , state education being among the many reforms he introduced. His restrictions on Chinese immigration were first steps towards the White Australia Policy. His most important contribution was in raising the Federation issue (1889-90) and afterwards devoting all his energy to its promotion. He received a KCMG (1877) and GCMG (1888) and was President of the National Australasian Convention (Sydney, 1891). He wrote on Australian politics and history and published some poetry.

Martin, A. W., Henry Parkes. 1980.

Parkinson, C(yril) Northcote (1909-1993). British writer, historian and political scientist. He was the propounder of Parkinson's Law, a serio-comic analysis of the growth of bureaucracy, e.g. work expands in order to fill the time available for its completion.

Parkinson, C. N., Parkinson's Law, the Pursuit of Progress. 1958.

Parkinson, James (1755-1824). English surgeon and palaeontologist, born in London. A political activist, enthusiastic for the French Revolution, he was accused of plotting against *George III but avoided prosecution. Developing an expert knowledge of geology, his pioneering textbook on fossils Organic Remains of a Former World (3 vols, 1804, 1808, 1811) was influential for decades and he became a co-founder of the London Geological Society. He wrote on gout (1805) and carried out the first English operation for appendicitis (1812). He made the first detailed description of 'shaking palsy' (paralysis agitans, 1817). *Charcot promoted adoption of the name 'Parkinson's disease'.

Morris, A. D., James Parkinson. 1989; Lewis, C., The Enlightened Mr Parkinson. 2017.

Parmenides (fl. c.475 BCE). Greek philosopher, born at Elea, southern Italy. Founder of the Eleatic school, his views, presented in a poem and containing ideas on 'being', had much influence on later philosophers, e.g. *Plato and *Aristotle (who held that 'atomism' was derived from Eleatic teaching). Unlike *Heraclitus, who held that everything was in a state of flux, Parmenides taught that the universe is a single, unchanging whole, indivisible, immobile and indestructible, and that any appearances to the contrary are delusions of the senses. Not only a philosopher, Parmenides played an active part in the political life of his native city.

Guthrie, W. K. C., A History of Greek Philosophy. 1965.

Parnell, Charles Stewart (1846-1891). Irish Nationalist politician, born in Avondale, Co. Wicklow. His father was from an influential Protestant Anglo-Irish landowning family, his mother was American: they separated when Charles was six. Unhappily educated in English schools, he studied briefly at Cambridge. He was elected MP for Country Meath 1875-80 and for Cork 1880-91. He toured the United States 1875, 1877 and 1879-80, with great success, raising funds for campaigns. In the House of Commons Parnell led the Home Rule League 1880-82, then the Irish Parliamentary Party 1882-90, the first disciplined and organised party in Europe, and had exceptional skills as a tactician. In 1880 he initiated the policy of the 'boycott' (C.C. ${ }^{*}$ Boycott) which led to a sharp increase in violent agricultural protests, including arson. Evictions and violent attacks were directly related and increased to thousands each year. Imprisoned in Dublin (188182 ), he negotiated a settlement with ${ }^{*}$ Gladstone's government to reject violence in return for protecting tenants from eviction for rent arrears. However, the murder of Lord Frederick Cavendish, Chief Secretary, and his deputy, Thomas Burke, in Phoenix Park, Dublin (May 1882) immediately jeopardised the settlement. By 1885 Parnell's MPs held the balance of power in Westminster, which led to Gladstone introducing a Home Rule Bill (1886). This split the Liberal Party and *Salisbury's Conservatives returned to office in July 1886. In 1887 The Times published allegations, based on documents forged by Richard *Pigott, that Parnell had condoned the Phoenix Park murders. Pigott was exposed and shot himself. Parnell had become the lover of Katie O'Shea (née Katharine Page Wood) (1845-1921), sister of a Field-Marshal and wife of his close colleague Captain William O'Shea. Parnell fathered three of her children and in 1889 was cited as co-respondent in O'Shea's divorce action. Adultery, in effect, shattered the relationship in Ireland between Catholicism and nationalism. Parnell refused to resign as leader of the IPP, which then split, the Irish Catholic hierarchy denounced him and the alliance with Gladstone collapsed. He married Katie O'Shea in June 1891, but his kidneys had failed and he died of pneumonia in Hove in October. Home Rule was delayed until 1921.

Lyons, F. S. L., Parnell. 1963; Kee, R., The Laurel and the Ivy. 1993.

\section{Parr, Catherine see Catherine Parr}


Parry, Sir (Charles) Hubert (Hastings), 1st Baronet (1848-1918). English composer. He became professor of the Royal College of Music on its foundation (1883) and was its director 1895-1918. A prolific composer, especially of choral and orchestral music, his best known works are the choral ode Blest Pair of Sirens (1887) and his setting of *Blake's Jerusalem (1916), inspired by World War I. He was made a baronet in 1902. Like his contemporary *Stanford, Parry is important less for the quality of his own works than as a pioneer of the revival of English music which began at the end of the 19th century. Among his pupils were ${ }^{*}$ Vaughan Williams and ${ }^{*}$ Holst. He died in the Spanish flu epidemic.

Parry, Milman (1902-1935). American scholar, born in California. An assistant professor at Harvard, he worked in Bosnia in 1933 and 1935, observed the recitation of long, ancient oral epics by often illiterate bards, and proposed that The Iliad and The Odyssey evolved, over centuries, in a bardic oral tradition, long before the development of a written language. He died of a gunshot wound, either an accident or suicide. His 'Oral Formulaic Hypothesis' was adopted and expanded by Albert B(ates) Lord (1912-1991) in The Singer of Tales (1960) and is now generally accepted. The Making of Homeric Verse: The Collected Papers of Milman Parry, edited by his son, was not published until 1971.

Kanigel, R., Hearing Homer's Song: The Brief Life and Big Idea of Milman Parry. 2021.

Parry, Sir William Edward (1795-1855). British Arctic explorer. In the second of two attempts to find the Northwest Passage to the Pacific (1819), he almost succeeded by reaching Melville Island, but he failed again in 1824-25. He discovered (1821-22) the Hecla and Fury Straits, which he named after his ships. His last (1827) expedition, an attempt to reach the pole by boat and sledge from Spitzbergen, was unsuccessful (though he reached latitude $82^{\circ} 43^{\prime} \mathrm{N}$ ).

Pary, A., Parry of the Arctic. 1963.

Parsons, Sir Charles Algernon (1854-1931). Anglo-Irish engineer. Son of the Earl of *Rosse, he developed the stream turbine named after him which revolutionised marine propulsion. The Turbinia (1897), the first turbine-powered ship, achieved the unprecedented speed of 36 knots. He was also concerned with optics and manufactured $86 \mathrm{~cm}(34$ inch) and $193 \mathrm{~cm}$ (76 inch) reflecting telescopes. He received the KCB (1911) and the OM (1927).

Parsons (or Persons), Robert (1546-1610). English priest. After leaving Oxford University he became a Roman Catholic convert, went to Rome and became (1575) a Jesuit. He returned to England (1580) to minister to Roman Catholics and eluded capture for a whole year. After the arrest of Edmund ${ }^{*}$ Campion he returned to the Continent, where he intrigued with
*Felipe II of Spain to invade England. He wrote many controversial pamphlets, became rector of the English College in Rome and died there.

Pärt, Arvo (1935- ). Estonian composer. He worked for Estonian Radio, taught at Tallinn Conservatory, and lived in Berlin 1980-. His St John Passion (1982), powerfully compressed, minimalist and repetitive, is frequently performed, despite its lack of movement or modulation. He also wrote Stabat Mater (1985) and Miserere (1989).

Parvus, Aleksandr Lvovich (originally Israel Lazarevich Gelfand) (1867-1924). Russian-JewishGerman revolutionary, born in Belarus. He studied in Switzerland, lived in Germany, joined the Mensheviks and influenced ${ }^{*}$ Trotsky and *Lenin. He made money as an arms trader in Istanbul, and in 1917 persuaded contacts in the German General Staff to send Lenin to Russia to foment revolution and its withdrawal from World War I.

Pascal, Blaise (1623-1662). French physicist, mathematician and philosopher, born at ClermontFerrand. Son of an exchequer official of great mathematical ability, he was precocious and at 16 wrote a treatise on conic sections, greeted with admiration by *Descartes (who doubted it was Blaise's own work). The experiments he conducted with his father, and in 1647 described, on the problems of a vacuum and the effects of air pressure on tubes of mercury, led to the construction of barometers. To facilitate his father's work he also invented a calculating machine (patented 1647). Later in life he did basic work on the mathematical theory of probability, and laid the foundation for the invention of differential calculus.

In complete contrast to ${ }^{*}$ Montaigne, Pascal begins with the vastness of space and eternity compared to man's isolation and impotence, and tries to relate the universal and infinite to the human and particular. If there is order, it is a mystery, comprehended through grace, too complex for a single formula. 'It is not in space that I must seek my human dignity, but in the ordering of my thought. It will do me no good to own land. Through space the universe grasps me and swallows me up like a speck; through thought I grasp it.'

Two years after his father's death (1651), his sister, Jacqueline, became a nun at Port-Royal, near Versailles, a headquarters of the Jansenists, whose doctrines, later declared heretical, stressed those parts of St *Augustine's teaching that appear to support predestination and redemption solely through grace. On 23 November 1654, the 'night of fire', he experienced a revelation of Christ, wrote a short Memorial and kept it on his body until his death. The foundation of all his religious thought is devotion to Christ, the Saviour: 'I lay all my actions before God who shall judge them and to whom I have consecrated them.' In December 1654 he went to live 
at Port Royal, although he took no vows, and wrote his Lettres provinciales (1656-57), a defence of the Jansenists combined with a brilliant, if unfair, attack on the casuistry of their main adversaries, the Jesuits. His more personal views on religion and philosophy as well as his most brilliant writing are, however, contained in his Pénsees, notes for a projected apology for the Christian religion, collected and published in 1669, after his death. Many of the Pensées have become proverbial e.g. 'Man is but a reed, the weakest in nature, but he is a thinking reed' and 'The state of man: inconstancy, boredom, anxiety'. 'Men despise religion. They hate it and fear it may be true ...'; 'The heart has its reasons which reason knows nothing of'.

'Pascal's wager' (Pensées, part III, \$233) proposes the argument: 'Let us weigh the gain and the loss in wagering that God is. Let us estimate these two chances. If you gain, you gain all; if you lose, you lose nothing.'

Mesnard, J., Pascal: His Life and Works. 1952; Adamson, D., Blaise Pascal: Mathematician, Physicist, and Thinker about God. 1995.

Pasmore, (Edwin John) Victor (1908-1998). British painter and graphic artist. Largely self-taught, he passed through naturalism and post-impressionism to evolve a personal style, of which his three dimensional abstractions and relief paintings are best known. He migrated to Malta in 1965 and received the $\mathrm{CH}$ in 1981 .

Pasolini, Pier Paolo (1922-1975). Italian film maker and writer. A poet, novelist and scriptwriter, his controversial films include Accatone (1961), Mamma Roma (1962), The Gospel According to St Matthew (1964), The Decameron (1971), and Salò (1975). He was murdered by a male lover.

\section{Passfield, 1st Baron see Webb, Sidney}

Passmore, John Arthur (1914-2004). Australian philosopher, born in Sydney. He studied at Sydney University under John Anderson (1893-1962), held chairs at Otago 1950-54 and the ANU, Canberra 1959-79, published and broadcast extensively and wrote an autobiography, Memoirs of a Semi-Detached Australian (1997).

Passy, Frédéric (1822-1912). French economist and politician. He was a deputy $1874-89$, a cofounder of the International League of Peace and the International Parliamentary Union. He shared the first Nobel Prize for Peace with Henry *Dunant, having received 39 nominations.

Pasternak, Boris Leonidovich (1890-1960). Russian novelist and poet, born in Moscow. His father was an artist and friend of *Tolstoy, and Boris studied law, art and music before turning to literature. He was well known within the Soviet Union as a poet, original story writer and a translator of ${ }^{*}$ Shakespeare. He was refused permission to publish his wide-ranging novel Doctor Zhivago (completed 1957) about Russia in the years 1903-29. It was smuggled out of the Soviet Union and published abroad (in Italy 1957). It immediately attracted international acclaim and won for Pasternak the Nobel Prize for Literature in 1958. It was attacked in the USSR for its lack of enthusiasm for revolutionary values, and Pasternak declined, under pressure, the Nobel award. He made a conventional apology for errors as the price for remaining in Russia. He also wrote the autobiographical Safe Conduct (1931) and Essay in Autobiography (1959) in addition to much poetry.

Pasteur, Louis (1822-1895). French bacteriologist, born at Dôle in the Jura. His father, a tanner, had been a Sergeant Major during the Napoléonic Wars. His education led him to the École Normale in Paris where he eventually became (1857-63) director of scientific studies, having earlier taught at Dijon, at Strasbourg (where he married Marie Laurent, daughter of the university rector) and as professor of chemistry at Lille. A devout Catholic, three of his children died of infectious diseases. His early researches were on crystallography and the polarisation of light. He pointed to odd asymmetries (which he called 'left and right handedness') in molecules, crystals and other chemical structures. In 1857 he began to study why fermentation in wine vats produced lactic acid which caused the wine to go sour. He proved conclusively that this fermentation was caused by bacteria in the air (and his success was said to have saved France more than was paid in reparations after the FrancoPrussian War). This verified the 'germ theory' of disease and demolished the old idea of spontaneous generation. These conclusions (published 1864) were of basic importance in *Lister's development of antiseptic surgery. In 1865 Pasteur discovered, and found how to cure, a disease that was attacking silk worms and threatened the whole French silk industry. He devised (1870) the process known as pasteurisation for killing bacteria in milk, and developed vaccines against the cattle disease anthrax (1877, later successfully extended to hydrophobia, or rabies) and chicken cholera (1880). He received the Copley Medal of the Royal Society (1874) and was elected to the Académie française in 1882. The first Pasteur Institute was founded in 1885 and a branch was established in Sydney in 1890. Pasteur's work ranks him as one of the greatest of all benefactors of the human race, and in effect the founder of bacteriology.

Nicolle, J., Louis Pasteur: a Master of Scientific Enquiry. 1961; Nicolle, J., Louis Pasteur: the Story of his Major Discoveries. 1961.

Patel, Vallabhbhai Jhaverai (1875-1950). Indian politician and lawyer, born in Gujarat. He became a barrister, was widowed in 1908, then studied at the Middle Temple London, returning to set up practice at Ahmadabad in 1913. He joined the Indian Congress Party in 1917 as a follower of 
${ }^{*}$ Gandhi, became the leader of its conservative wing and a rival of ${ }^{*}$ Nehru. Although an opponent of violence (on pragmatic grounds), during the civil disobedience campaigns he was imprisoned 1930, 1932-34, 1940-41, 1942-45, despite his advocacy of resistance to Japanese invasion. He was among the first to recognise the inevitability of Indian partition and the creation of Pakistan. Deputy Prime Minister 1947-50 under Nehru, he successfully integrated the princely states into the Indian Union.

Pater, Walter Horatio (1839-1894). English essayist and critic, born in London. A fellow of Brasenose College 1865-94, a journey to Italy (1865) and the works of ${ }^{*}$ Ruskin and *Winckelmann influenced his thought, but his polished and poetic style, first known to the public through the essays collected as Studies in the History of the Renaissance (1873), is highly individual. His belief that the cultivation of beauty should be an end in itself, irrespective of its relationship to life, provided academic justification for the aesthetic movement, then blossoming into fame. His best known book is the philosophical romance Marius the Epicurean (1885), set in the time of Marcus Aurelius and concerned with the intellectual and spiritual processes by which a young Roman moves towards Christianity.

Paterson, A(ndrew) B(arton) ('Banjo') (1864-1941). Australian poet and journalist, born in Orange. Articled to a solicitor, his poems were published in The Bulletin from 1885 and include 'Clancy of the Overflow', 'The Man from Snowy River' and the best known, 'Waltzing Matilda' (1895). He was a war correspondent in the Boer War and the Boxer Rebellion in China.

Paton, Alan Stewart (1903-1988). South African writer. His famous novel, Cry the Beloved Country (1948), presents with compassion rather than bitterness, the psychological problems besetting the coloured man in South Africa, where the environment is created for and by the white. He was President of the South African Liberal Party (made illegal in 1968).

Patrick (Latin: Patricius, Irish: Pádraig), St (d.457 or 493?). Romano-British missionary, born probably near Hadrian's Wall. Patron saint of Ireland, he was the son of Calpornius, a Christian deacon and decurion (official). Kidnapped by Irish marauders when about 16 years old, he worked as a slave (traditionally in County Antrim) for about six years before he escaped to Gaul (France) and thence back to Britain. He then seems to have had a vision summoning him to convert the Irish, for which he did not rapidly obtain sanction, but at last he was ordained Bishop and started his Irish mission (432 is the traditional date). Christianity had already penetrated parts of the country, but he was the first missionary in the more remote areas. His method was to convert the princes and through them the common people (hence the story of his preaching before the 'high king' at Tara).
He organised the Irish Church on a territorial basis and became the first bishop of Armagh (444?). He describes his life and work in his Confessio. St Patrick's Day is 17 March and his emblems are the snake and the shamrock.

Bieler, L., Works of St Patrick. 1953; Hanson, R. P. C., Saint Patrick: his Origins and Career. 1968.

Patten, Chris(topher), Baron Patten of Barnes (1944- ). English Conservative politician, born in Lancashire. Educated at Balliol College, Oxford, he worked as a party organiser. MP 1979-92, Secretary of State for the Environment 1989-90 and Chairman of the Conservative Party 1990-92, he was the last Governor of Hong Kong 1992-97. He advised the *Blair Government on Northern Ireland, became EU Commissioner for External Relations 1999-2004 and Chancellor of Oxford University 2003- (being the first Catholic to hold the office since 1558). $\mathrm{He}$ received a $\mathrm{CH}$ in 1998, a peerage in 2005 and served as Chairman of the BBC 2011-14.

Patti, Adelina (Adela Juana Maria) (1843-1919). Italian soprano, born in Madrid. She sang in New York at the age of seven, and made her operatic debut there in 1859 . Noted for her brilliant execution of coloratura roles, she was much admired by ${ }^{*}$ Verdi and made a few acoustic recordings. From 1878 she lived at Craig-y-Nos Castle in the Swansea Valley, with her last husband, Baron Rolf Cedestrom, and died there. She was buried at the Père Lachaise Cemetery, Paris.

Patton, George Smith (1885-1945). American soldier, born in California. One of the most successful and colourful generals of World War II, in 1940 he commanded an armoured division. He led the invasion of US forces in North Africa (November 1942) and in Sicily (July 1943) but was relieved of his command for 11 months for striking two soldiers whom he suspected of malingering. He returned to lead the 3rd Army in the European liberation campaign (1944), exploiting its breakout of the Cotentin Peninsula (south of Cherbourg) with a triumphant drive across France, outflanking the Germans in Normandy, taking Paris and reaching the Moselle. He died after a motor accident in Heidelberg.

Whiting, C., Patton. 1973; D’Este, C., A Genius for War. 1996.

Paul, St (Paulos in Greek: Sha'ul in Aramaic) (c.8 CE-c.67 CE). Christian apostle, born in Tarsus. A Jew and a Roman citizen, known as Saul before his conversion, his life can only be partially reconstructed from the Acts of the Apostles and some of his epistles. A tent-maker by trade, he was a zealous Pharisee and took part in the persecution of Christians, but on his way to Damascus (37?) to bring back some Christians for trial he was temporarily blinded by a sudden vision and miraculously converted. After some time meditating in the desert he went to preach at Jerusalem, but, though supported by *Barnabas, 
he was regarded with suspicion. He had an uneasy relationship with *James and ${ }^{*}$ Peter. Paul returned to Tarsus where he remained for 10 years before Barnabas sought him out and took him to Antioch. A year later, the two friends, with ${ }^{*}$ Mark as assistant, set out on their first missionary journey through Cyprus and many cities of Asia Minor. They made many converts but ultimately were stoned and expelled, mostly by hostile Jews.

When Paul and Barnabas (Mark having left them) returned to Antioch, they were faced with controversy about whether Gentile converts were required to be circumcised and follow other prescribed Jewish observances. Paul and Barnabas argued for exempting Gentiles from such requirements and the eventual compromise, reducing them to a minimum, enabled him then to continue their work. The term 'Christian' was first applied in Antioch. A second missionary journey was begun but in Cyprus a dispute as to whether Mark should again be taken led to a parting, Barnabas taking Mark as his companion, leaving Paul with Silas. For part of the way Paul retraced his steps in Asia Minor, but after a dream in which he was begged to come over to Macedonia and help, he crossed to Greece. The first Christian presence in Europe was in Philippi (c.51) and Paul's first convert was a cloth dealer, ${ }^{*}$ Lydia (Acts xvi). Paul and Silas were driven out of Thessalonica by hostile Jews, and in Athens, the home of philosophy, they had little success. In Corinth (from c.51) Paul found a home for 18 months before returning to Antioch.

In the New Testament, 14 books are attributed to Paul, advice and instruction to churches he had founded, or sought to influence. These were certainly written before the gospels. Modern scholarship is only confident about Paul's authorship of seven epistles: 1 Thessalonians (the earliest, perhaps 50-51, written in Corinth or Athens), Philippians, Philemon, 1 Corinthians, Galatians, 2 Corinthians and Romans (the longest, probably written in Corinth). The epistles were decisive in influencing early church theology.

After again visiting churches in Asia Minor (it was his practice to organise a congregation of believers in as many as possible of the places he passed through) he made Ephesus the focal point of his third journey. He stayed there nearly three years and from there wrote 1 Corinthians (c.57). He then returned to Jerusalem where his old enemies roused the mob against him. Only the intervention of the commandant saved him, but the Roman governor Felix and his successor Festus kept him imprisoned for two years until at last Paul, as a Roman citizen, exercised his right to appeal to Caesar (*Nero). Wrecked at Malta on the way, Paul eventually reached Rome in c.60 or 61 and was held in custody there (though with considerable liberty) for about two years, and probably visited Spain (Romans xv:24, 28). He appears to have been well-connected in Rome. There is a strong tradition that he was beheaded in the Neronian persecutions, probably on the site of the Basilica of St Paul outside the Walls. St Paul, the Apostle of the Gentiles, was above all instrumental in transforming Christianity from a Jewish sectarian creed to a universal religion.

Hengel, M. and Schwemer, A. M., Paul Between Damascus and Antioch. 1996; Murphy-O'Connor, J., Paul: a critical life. 1996; Wilson, A. N., Paul. 1997; Wright, T., Paul. A Biography. 2018.

Paul (Pavel) I (1754-1801). Tsar of Russia 17961801. He succeeded his mother ${ }^{*}$ Catherine the Great, having been kept from the throne by her for 34 years. He established a law of primogeniture. He broke his alliance with England to come to terms with *Napoléon and planned to invade India. His rule as a capricious tyrant provoked a military plot and he was strangled by officers.

Paul (Pávlos) I (1901-1964). King of the Hellenes (Greece) 1947-64. Son of *Constantine II, he was exiled in England 1923-35, served in the Greek army during World War II and in 1947 succeeded his brother ${ }^{*}$ George II as king. He attempted to popularise the monarchy, but his wife, Frederika of Brunswick, was disliked because of her alleged proNazi sympathies. He was the father of ${ }^{*}$ Constantine II (XIII).

Paul (Paulus) III (Alessandro Farnese) (1468-1549). Pope 1534-49. Born of a noble family, he combined the roles of zealous Church reformer and Renaissance potentate. He confirmed the first Jesuit constitution (1540), established the Inquisition in Rome (1542) and initiated the Council of Trent. A great patron of the arts, he commissioned *Michelangelo to design the dome of St Peter's and paint the fresco of the Last Judgment for the Sistine Chapel.

Paul (Paulus) IV (Gian Pietro Carafa) (1476-1559). Pope 1555-59. Born of an aristocratic Neapolitan family, he was made a cardinal by *Paul III and recognised as leader of the Counter-Reformation long before becoming Pope at the age of 70. A strict and ruthless moralist, he introduced the Index of prohibited books and increased the range of the Inquisition and the severity of its sentences. After his death a mob destroyed his statue and burned the prisons of the Inquisition.

Paul (Paulus) V (Camillo Borghese) (1550-1621). Pope 1605-21. Born in Rome to a patrician family, he was a canon lawyer and Bishop of Iesu 1597-1605. He protected *Galileo and avoided blame for the 'Gunpowder Plot' (1605) by encouraging Catholics to be loyal to *James I.

Paul (Paolo: Italian. Paulus: Latin) VI (Giovanni Battista Montini) (1897-1978). Pope 1963-78. Born near Brescia, son of an anti-Fascist editor and Unione Popolari deputy, he was educated by the Jesuits. Ordained in 1920, he joined the Vatican's Secretariat of State, served in Poland (1923) and became 
assistant to the future ${ }^{*}$ Pius XII. Undersecretary of State 1939-44 and Prosecretary for Extraordinary (i.e. non-diplomatic) Affairs 1944-54, he was not made a cardinal in 1953 (effectively excluding him from the succession to Pope Pius) but became Archbishop of Milan 1954-63. He was *John XXIII's first appointment as cardinal (1958) and on his death was elected Pope on the 6th ballot. He continued the work of adapting the teaching and practices of the Catholic Church to modern needs through the ecumenical council summoned by his predecessor. He took a number of unprecedented initiatives, e.g. his pilgrimage to Jerusalem (1964, but without mentioning the Jews or Israel) and his speech to a session of the United Nations in New York. He made the first papal visits to Asia (1964), North America (1965), South America (1968), Africa (1969) and Australia (1970). His encyclical Humanae Vitae (1968) reaffirmed the Church's traditional opposition to contraception. He was beatified in 2014 .

Gonzalez, J. L. and Perez, T., trans. Heston E. L., Paul VI. 1964; Hebblethwaite, P., Paul VI-the first modern Pope. 1993.

Pauli, Wolfgang (1900-1958). Austrian physicist. Professor of physics at the Zürich Institute of Technology 1928-40, 1946-58, he taught at Princeton 1940-46. A pioneer in the application of the quantum theory to atomic structure, his most notable contribution was the 'exclusion principle' stating that two electrons cannot occupy the same quantum mechanical state at the same time. He suggested (1931) the existence of the neutrino, an uncharged particle of almost zero mass. Pauli won the Nobel Prize for Physics (1945).

Kronig, R. and Weisskopf, V. F. (eds), Collected Scientific Papers. 1964.

Pauling, Linus Carl (1901-1994). American chemist. Professor of chemistry at the California Institute of Technology 1929-64, the University of California, San Diego 1964-69 and Stanford 196974, he was best known for his work on molecular structure and valency. He introduced (1931) the concept of resonance, the rapid alternation of a pair of structures to produce a median structure or resonance hybrid, and this idea made it easier to elucidate the structure of several compounds that had previously offered great difficulties. He won the Nobel Prize for Chemistry (1954) and the Nobel Prize for Peace (1962), the second award recognising his opposition to nuclear weapons and advocacy of a Nuclear Test Ban Treaty.

Pausanias (d.c.470 or 465 BCE). Greek soldier. A regent of Sparta, he was the general who led the Greek army to victory over the Persians at Plataea (479 BCE). Later he adopted Persian clothes and manners and according to *Thucydides, entered into treacherous relations with the enemy. (*Herodotus defended him.) When finally he tried to gain power in Sparta by raising the serfs in revolt he was starved to death in the temple to which he had fled.

Pausanias (fl. 143-176 CE). Greek geographer, born in Lydia. He travelled through Greece, Italy and parts of Asia Minor and Africa, and may be regarded as the first writer of guide books, since his Itinerary of Greece gives the history of and legends connected with all the places he visited as well as details of all the works of art he saw there. It has thus inestimable value for the historian, geographer, archaeologist and mythologist.

Pavarotti, Luciano (1935-2007). Italian operatic tenor, born in Modena. From 1963 he was an increasingly popular lyric tenor in Italy, Britain and the US, excelling in opera, recitals and as a teacher. He appeared in several films and was much recorded.

Pavelic, Ante (1889-1959). Croatian politician and lawyer. Deeply opposed to Serbian domination of Yugoslavia, in 1929, with *Mussolini's patronage, he founded Ustasha (Arise) and organised the assassination of *Alexander I and *Barthou in Marseille (1934). In 1941 the Germans established Croatia as a client state, with Pavelic as dictator. His regime is estimated to have murdered more than 500,000 Serbs, 60,000 Jews and many Muslims. He escaped in 1945 through Italy and lived in Buenos Aires and Madrid.

Pavlov, Ivan Petrovich (1849-1936). Russian physiologist. He took a medical degree (1883) and from 1891 was director of the physiology department of the Institute of Experimental Medicine at St Petersburg. He won the Nobel Prize for Medicine (1904) for his study of gastric secretions in the digestive glands. The experiments on dogs undertaken in the course of this work and the studies which developed from it won him worldwide notice. In his best known experiment Pavlov rang a bell before giving food to dogs, whose glands would begin to secrete saliva at the sight of food. After repetition the dogs salivated when they heard the bell even if no food was forthcoming. Such experiments revealed the 'conditioned reflexes' and led to a study of their effect on human behaviour and so to the behaviourist theories in modern psychology.

Babkin, B. P., Pavlov: A Biography. 1949.

Pavlova, Anna Pavlovna (1882-1931). Russian ballerina, born in St Petersburg. Educated at the Imperial Ballet School, she quickly won renown and after a single season (1909) in Paris with *Diaghilev, formed her own company, with which she toured the chief cities of the world for the rest of her life, visiting Australia in 1926 and 1929. She was most famous for her solo performances in divertissements, e.g. The Dying Swan (music by *Saint-Saëns), but she was also acclaimed for her roles in such ballets as Don Quixote, Chopiniana and Autumn Leaves (the last her own creation). She was also a gifted sculptor.

Franks, A. H. (ed.), Pavlova. 1956. 
Paxton, Sir Joseph (1806-1865). English gardener and architect. As superintendent of the Duke of Devonshire's gardens at Chatsworth he gained experience in the construction of large conservatories, which led to his commission to design the Crystal Palace for the Great Exhibition (1851), a landmark in the development of structural steel architecture. He was knighted for this work. The Crystal Palace, originally built in Hyde Park, was re-erected in Sydenham (1853-54) and survived until a fire in 1936. Paxton was a Liberal MP 1854-65.

Chadwick, C. F., The Works of Sir Joseph Paxton. 1966.

Payette, Juliet (1963- ). Canadian engineer, astronaut, linguist, administrator, born in Montréal. She flew on two space missions (1999, 2009), was chief astronaut for the Canadian Space Agency 200007, CEO of the Montréal Science Centre 2011-14, an active board member and Governor-General of Canada 2017-21, resigning after accusations of bullying.

Paz, Octavio (1914-1998). Mexican poet, essayist and diplomat. He held minor diplomatic posts in Paris and Tokyo, became Ambassador to India 1962-68 and held chairs at Cambridge 1970-71 and Harvard 1971-72. He won the Nobel Prize for Literature in 1990 'for impassioned writing with wide horizons, characterised by sensuous intelligence and humanistic integrity'. His books include One Earth, Four or Five Worlds (1985), Convergences (1987) and Eagle and Sun (1990).

Peabody, George (1795-1869). American banker and philanthropist, born in Danvers, Massachusetts. Having made a fortune as a wholesaler in the US, he settled in London (1837) as a merchant banker. His benefactions included over $£ 1$ million for educational purposes in the US and $£ 500,000$ for working class flats in London. Praised by ${ }^{*}$ Gladstone and Victor *Hugo, he declined (understandably) the offer of a British baronetcy. He refused honours, but on his death a British battleship conveyed his body to America where the name of his birth place, Danvers, Massachusetts, was changed to Peabody.

Peacock, Andrew Sharp (1939-2021). Australian Liberal politician. A lawyer, he was a Member of the House of Representatives 1966-94, a minister 196972, 1975-81 and 1982-83, Foreign Minister 197580, and Leader of the Liberal Opposition 1983-85, following Malcolm *Fraser's defeat by Labor, Deputy Leader 1987-89, and Leader again 1989-90. He was Ambassador to the US 1997-99.

Peacock, Thomas Love (1785-1866). English novelist and poet. He worked for the East India Company from 1809. His conversational novels, interspersed with lyrics, satirise contemporary writers, philosophers and literary fashions. They include Headlong Hall (1816), Melincourt (1817), Nightmare Abbey (1818), Crotchet Castle (1831) and Gryll Grange, which did not appear until 1860 . He also wrote two romances, Maid Marian (1822) and The Misfortunes of Elphin (1829). Peacock was a close friend of $*$ Shelley (from 1814) and his executor. His Memorials of Shelley, edited by H. Brett Smith, appeared in 1909. One of Peacock's four daughters was George *Meredith's first wife.

Mills, H., Peacock. 1969.

Peale, Charles Willson (1741-1827). American painter and gallery director. He opened his own museum in Philadelphia and painted over 1,000 portraits in neo-classical style, including *Franklin, *Washington, *Adams and *Jefferson. His sons Raphaelle, Rembrandt and Titian were also painters. The last was also a naturalist who explored the Upper Missouri, Florida and the South Seas.

Pears, Sir Peter Neville Luard (1910-1986). English concert and opera singer. A high tenor with superb diction, he was the lifelong partner and interpreter of Benjamin *Britten. He made his stage debut in 1942 and later sang at Covent Garden, at Sadler's Wells and with the English Opera Group. He was (with Britten) co-founder of the Aldeburgh Festival (1948) and created principal roles in 13 of Britten's operas, notably Peter Grimes (1945). He was knighted in 1978 .

Pearse, Pádraig Anraí (né Patrick Henry Pearse) (1879-1916). Irish teacher, barrister, poet and republican leader, born in Dublin. He combined enthusiasm for the revival of Gaelic with a political extremism which induced him to join the Irish Republican Brotherhood and the nationalist Irish Volunteers (1913-16). He was chosen as President of the provisional republican government proclaimed during the Easter Rising (1916), and after its suppression was court-martialled and shot. He was a man of the highest ability and integrity.

Pearse, Richard William (1877-1953). New Zealand pioneer aviator. A self-educated farmer, he built a monoplane at Waitohi, South Island, and it is possible that he succeeded in a short manned flight on 31 March 1903, some eight months before the *Wright Brothers. He was derided as a crank and became easily discouraged, concluding that the Wrights would have much easier access to finance and engineering support. He abandoned aviation and later became a recluse.

Ogilvie, G., The Riddle of Richard Pearse. 1973.

\section{Pearson, Karl see Galton, Sir Francis}

Pearson, Lester Bowles ('Mike') (1897-1972). Canadian politician. After lecturing in history at Toronto University he entered the Department of External Affairs, was Ambassador in Washington 1945-46 and Secretary of State for External Affairs 1948-57. He was President of the United Nations General Assembly 1952-53, Leader of the Liberal 
Opposition 1958-63 and Prime Minister 1963-68. His diplomacy, especially his attempts to settle the Suez crisis (1956), won him the Nobel Prize for Peace (1957). He received the OM in 1968.

Pearson, L. B., The Four Faces of Peace. 1964.

Peary, Robert Edwin (1856-1920). American Arctic explorer. He joined the US navy (1881) and an expedition to Greenland roused his interest in the problem of reaching the North Pole. In 1891-92 he crossed the Greenland ice pack from west to east and discovered what is now Peary Land. Subsequently (on leave from the navy) he made repeated expeditions with his aim always in view, and finally, on 6 April 1909, he and Matthew *Hensen, after a dangerous sledge journey, became the first explorers to reach the Pole. His book The North Pole (1910) describes the achievement but minimises Hensen's role. (His rival Frederick Albert ${ }^{*}$ Cook claimed to have beaten him to the Pole, in 1908.) Peary was promoted to Rear Admiral in 1911.

Peckinpah, Sam (1926-1984). American film director. His major films include The Wild Bunch (1969) and Straw Dogs (1971) which aroused considerable controversy over their explicit violence.

Pedro I (known as 'the Cruel', or 'the Just') (13341369). King of Castile and León 1350-69. The only legitimate son of Alfonso XI, and the last ruler of the house of Ivrea, he had to contend with the implacable enmity of his illegitimate half-brothers. Three were disposed of by assassination, but the most important, Enrique of Trastámara, who had taken refuge in France, returned with a mercenary army. Pedro fled to Gascony and enlisted the support of the English Black Prince, who won a great victory at Najera but retired in disgust at Pedro's vengeful atrocities. Once more Enrique invaded Castile, and after his victory at Montiel (1369), the two half-brothers met in single combat and Pedro was killed.

Pedro I (Pedro de Alcântara Francisco António João Carlos Xavier de Paula Miguel Rafael Joaquim José Gonzaga Pascoal Cipriano Serafim d'OrléansBragança) (1798-1834). Emperor of Brazil 1822-31, and (as Pedro IV) King of Portugal 1826. During the Peninsular War, when Portugal was invaded by *Napoléon's armies, his father, *João VI, and other members of the royal family took refuge in the Portuguese colony of Brazil. When Joáo returned to Europe (1821) Pedro was left as regent, but, when Brazil resisted Portuguese efforts to reimpose a colonial relationship, Pedro put himself at the head of the independence party, and a declaration, the 'Grito do Ipiranga' (1822), gave independence to Brazil with himself as first emperor. He granted a constitution (1826) and in the same year, on his father's death, he also became King of Portugal. Shortly after, however, he renounced the Portuguese crown in favour of his daughter * Maria. His involvement in the affairs of Portugal brought him unpopularity in
Brazil, and in 1831 he abdicated in favour of his son *Pedro II. He then returned to Europe and in 1832, with the help of the English naval forces, defeated the Miguelist faction in Portugal which had driven out Maria, and re-established her as Queen.

Haring, C. H., Empire in Brazil: a New World Experiment with Monarchy. 1958.

Pedro II (Pedro de Alcântara João Carlos Leopoldo Salvador Bibiano Francisco Xavier de Paula Leocádio Miguel Gabriel Rafael Gonzaga d'Orléans-Bragança) (1825-1891). Emperor of Brazil 1831-89. Though only 16 when he assumed power after a period of troubled regency, Pedro proved himself a liberalminded constitutional ruler and he showed skill in reconciling the political disputes of the various parties. He strongly opposed the death penalty. In 1870 a long war with Paraguay ended successfully but the heavy Brazilian losses caused recriminations. The army's support for the regime weakened and a republican party appeared. The landed gentry, the emperor's strongest supporters, were offended by extensions of the franchise, and his position became untenable in 1888 when, during his absence on a trip to Europe, his daughter freed the slaves without compensating the owners. After a bloodless revolution Pedro retired to Europe (1889). He died in Paris and was reburied in Petropolis (1939).

Barman, R. J., Citizen Emperor: Pedro II and the Making of Brazil 1825-1891. 1999.

Peel, Sir Robert, 2nd Baronet (1788-1850). English politician, born in Lancashire. Son of a rich cotton manufacturer, he was a friend of *Byron at Harrow and distinguished himself at Oxford. A Tory MP 1809-50, first elected at 21, at 24 he became Chief Secretary for Ireland 1812-18, where Daniel ${ }^{*}$ O'Connell was his powerful opponent. As Home Secretary 1822-27, 1828-30, his terms of office were made famous by the creation of the Metropolitan police force (whose members were nicknamed after him 'peelers' or 'bobbies'). Though he had worked in harmony with ${ }^{*}$ Canning, he resigned with the Duke of *Wellington (1827) as a protest against Roman Catholic emancipation, which, however, they both accepted and passed through parliament when they returned to office in the same year after Canning's death. By the election following *George IV's death, the Whigs returned to power and passed the famous parliamentary Reform Act (1832) against Peel's opposition. He succeeded Wellington as Tory leader, and served twice as Prime Minister 1834-35, 1841-46. When *Melbourne resigned (May 1839) Peel's return to office was delayed by Queen Victoria's refusal to part with her ladies of the bedchamber (all Whigs). After the election of 1841 Peel became Prime Minister with a useful majority, and in defiance of his Tory supporters, gradually became a convert to free trade. His first step was to introduce a sliding scale by which the duty on corn varied in accordance with the price at home, the lost revenue 
being replaced by an income tax of $7 \mathrm{~d}$. in the pound. But when the potato blight in Ireland, followed by famine, made the cheapest possible corn an urgent necessity in Peel's opinion, he introduced (1846) his measure for Corn Law repeal. A Party split was the inevitable result and, though Peel pushed the act through with Whig support, he was forced to resign. He was never again in office but his prestige in the House of Commons and his popularity in the country remained undiminished. He died as a result of being thrown from his horse on Constitution Hill. In public life Peel appeared cold and austere, and O'Connell remarked, 'His smile was like the silver plate on a coffin'. Although highly competent, he was never a good Party man. In private he led an ideally happy domestic life with his wife (née Julia Floyd) and seven children, and he was a genial and generous friend.

Gash, N., Sir Robert Peel. 1972; Evans, E. J., Sir Robert Peel. 2006; Gaunt, R. A., Sir Robert Peel. 2007; Hurd, D., Robert Peel: A Biography. 2007.

Péguy, Charles (Pierre) (1873-1914). French poet and publisher. He combined active socialism with Catholicism and sincere patriotism, revealed in the drama Jeanne d'Arc (1897), which he wrote in pseudonymous collaboration with his friend Marcel Baudouin. He founded (1900) the journal Cahiers de la Quinzaine, in which he published his own works and those of other writers, several of whom, e.g. Romain *Rolland, subsequently became important. Péguy's later works include Le Mystère de la charité de Jeanne d'Arc (1910) and La Tapisserie de Notre Dame (1913). He was killed in World War I.

Wilson, N., Charles Péguy. 1965.

Pei, I(eoh) M(ing) (1917-2019). American architect, born in Canton. In the US from 1935, he taught at Harvard and won international recognition with a series of important buildings in Boston-the Christian Science Church Centre, the west wing of the Museum of Fine Arts, the Kennedy Memorial Library (Harvard), and (with Henry Cobb) the John Hancock Tower. He designed the east wing of the National Gallery in Washington, the Place VilleMarie in Montréal and the Bank of China building, Hong Kong. His glass and steel Pyramide in the Cour Napoléon at the Louvre, opened in 1989, illuminates and coordinates the underground visitors' reception area and the Carrousel (shops and restaurants).

Wiseman, C., I.M. Pei. 1990.

Peierls, Sir Rudolf Ernest (1905-1995). GermanJewish-British physicist, born in Berlin. He studied in Zürich and Cambridge, remaining in England after *Hitler's regime took power. He worked on nuclear physics with James ${ }^{*}$ Chadwick, and with Otto *Frisch proposed a specific model for an atomic bomb, worked at Los Alamos 1943-45, and personally assembled the parts for the Hiroshima bomb. (Klaus *Fuchs was his assistant.) He held chairs at Birmingham and Oxford and was a founder of the Pugwash movement.

Peierls, R., Bird of Passage. 1985.

Peirce, Charles Sanders (1839-1914). American philosopher, born in Cambridge, Massachusetts. Son of Benjamin Peirce, professor of mathematics and astronomy at Harvard, he studied mathematics, physics and chemistry, spending much of his life in the US Government Coast and Geodetic Survey. Because of his unconventionality he obtained no proper academic recognition, and most of his writing became available only after his death. He is best known for his view of the meaning of concepts: our idea of something is made up of notions of that thing's effects. William *James and others turned this 'pragmatic maxim' into the dubious theory ('pragmatism') that the test of a statement's truth is whether or not it has (good) effects, but this extension was disdained by Peirce. His own theory of truth, which he named 'pragmaticism' to distinguish it from James' version, involved the verification of hypotheses by the scientific community.

\section{Brent, J., Charles Sanders Peirce: A Life. 1993.}

Peisistratus (c.600-528 BCE). Athenian tyrant. He fought successfully against Megara, then by claiming that his wife was threatened he obtained a bodyguard, with which (c.560) he seized the Acropolis. He was twice expelled but as the owner of gold and silver mines he was able to hire mercenaries to ensure his victory over his opponents. He ruled with wisdom and success and, by using his own fortune and money confiscated from his adversaries, helped the farmers, and did much to assist the poor, as well as fortifying and beautifying Athens. $\mathrm{He}$ is traditionally held to have been the first to collect *Homer's poems. He was succeeded by his sons Hippias and Hipparchus.

Andrewes, A., The Greek Tyrants. 1956.

Pelagius (c.360-c.418). British (or Irish?) theologian. The name may be a Greek form of the Celtic name Morgan ('Sea-born'). He settled in Rome about 380 and there met his impetuous disciple Caelestius, a lawyer. When the Visigoths sacked Rome in 410 they both left for Carthage but made powerful enemies of (St) *Augustine of Hippo and (St) *Jerome by attacking the doctrine of original sin in De libero arbitrio ('On Free Will') in 416. Central to the Pelagian controversy was the affirmation that Adam would have died whether or not he had sinned, and that each of his descendants is born as innocent as he. He further held that it is at least theoretically possible for a man to live without sin, solely by his own free will, a doctrine that seemed to diminish the need for God's grace. Pelagianism was first officially condemned in 416 and more formally at the Councils 
of Carthage and Ephesus (418 and 431). Pelagius was banished from Rome (418) and probably died in Palestine.

Evans, R. F., Pelagius. 1968.

Pelé (real name Edison Arantes de Nascimento) (1940- ). Brazilian soccer player. He played as an inside centre-left for the Santos Football Club 1956-74, the Brazilian national team 1956-77 and the New York Cosmos 1975-77. He appeared in the film Escape to Victory (1981). Generally regarded as the greatest player in the history of football, he won many awards including a KBE from the UK in 1997.

Pelham, Henry (1694-1754). English Whig politician, born in Sussex. Younger brother of the Duke of *Newcastle, educated at Oxford, he was an MP 1717-54, and worked very closely with Robert *Walpole as Secretary at War 1724-30 and Paymaster of the Forces 1730-43. After Walpole's fall in 1742, the Earl of *Wilmington was briefly head of the government until he died in 1743. Pelham then became, in effect, Prime Minister of Great Britain 1743-46 and, after a two day break, 1746-54, until his death. (The term 'Prime Minister' was not official; technically, he was First Lord of the Treasury, and also Chancellor of the Exchequer.) Shrewd use of patronage meant that no administration could exist without the Pelhams. They distrusted the continental policies of the brilliant John Carteret (Earl ${ }^{*}$ Granville), manoeuvred him out of government in 1746 and, over *George II's objections, insisted on appointing ${ }^{*}$ Pitt the Elder to office. More than eight years of efficient and unspectacular rule followed. Major events during Pelham's government were the Jacobite rising (1745) and adopting the Gregorian calendar for Great Britain and North America (1752). Pelham died relatively poor. The Duke of Newcastle, less intelligent, and with whom he sometimes clashed, succeeded Pelham as Prime Minister.

Owen, J. B., Rise of the Pelhams. 1971.

Pell, George (1941- ). Australian cardinal, born in Ballarat. Educated in Ballarat and Oxford, he was Archbishop of Melbourne 1996-2001, of Sydney 2001-14, and created cardinal in 2003. A firm advocate of Roman supremacy in the church, conservative in faith and morals, less so in economics, he supported a republic, was a 'climate change' sceptic and came under attack for lacking empathy with victims of clerical sexual abuse. He became Prefect of the Secretariat for the Economy at the Vatican 2014-18. In December 2018 he was convicted on five charges of child sexual abuse and sentenced to six years imprisonment. The verdict was upheld by Victoria's Court of Appeal, but quashed by the High Court (April 2020).

Pelosi, Nancy Patricia (née D’Alesandro) (1940- ). American Democratic politician, born in Baltimore. Member of the US House of Representatives (from
California) 1987-, she became the first woman to be Congressional leader of a major party 2002-22, the first elected as Speaker of the House 2007-11 and to be re-elected 2019-23.

Pembroke, Richard de Clare (or FitzGilbert), 2nd Earl of (known as 'Strongbow') (c.1130-1176). Anglo-Norman adventurer. He led an expedition into Ireland (1169) and married Eva, the daughter of the deposed Diarmid (Dermot) of Leinster, whose kingdom he recovered. On his father-in-law's death (1171), he ruled Leinster, for which he paid homage to *Henry II of England, thus inaugurating the long and unhappy period of English rule in Ireland. His sonin-law William *Marshal became Earl of Pembroke in a second creation.

Pence, Mike (Michael Richard) (1957- ). American Republican politician. A Christian conservative, he was a Congressman 2001-13, Governor of Indiana 2013-17 and Vice President of the US 2017-21, serving under Donald *Trump. On 6 January 2021 he presided in the Senate when the Electoral College votes were counted, was denounced by Trump, becoming a target of the mobs that attacked the Capitol, and declared *Biden elected. Pence was attacked by Trump's supporters but he was careful not to reciprocate, positioning himself for a potential Presidential candidature in 2024.

Penda of Mercia (c.606-655). King of Mercia 626-55. An Anglo-Saxon, successor of Cearl, he gradually built up the strength of his kingdom and finally (633) allied himself with the Christian Welsh king Cadwallon to defeat and kill *Edwin of Northumbria and so make Mercia independent. For a time Penda was the most powerful king in England, but Northumbria reasserted its power when Oswald's brother Oswy (Oswiu) defeated and killed Penda in a battle near Leeds.

Penderecki, Krzysztof Eugeniusz (1933-2020). Polish composer, born in Debiça. He won international recognition with his Threnody for the Victims of Hiroshima (1960), followed by St Luke Passion (1966), an eclectic work showing the influence of *Monteverdi and *Bach, but using an atonal style. He composed eight symphonies, two violin concertos, four operas and Polish Requiem (1984).

Penfield, Wilder Graves (1891-1976). Canadian neurosurgeon, born in the US. A Rhodes Scholar at Oxford, he studied under *Osler and *Sherrington, and worked in Montréal from 1926. His operations on epileptics led to his 'mapping' brain areas responsible for memory, sensory and motor functions. He was a prolific writer on the mechanism of the brain and received the OM in 1953. He also wrote two novels and an autobiography No Man Alone. A Surgeon's Life (published posthumously, 1977). 
Penn, William (1644-1718). English Quaker and founder of Pennsylvania, born in London. He was the son of Admiral Sir William Penn (1621-1670), originally a supporter of ${ }^{*}$ Cromwell, who lent the future *Charles II $£ 16,000$ and helped return him from exile. The younger Penn adopted the beliefs of the Society of Friends (Quakers), which he expounded in The Sandy Foundation Shaken (1668), for which he was confined in the Tower of London, and No Cross, No Crown (1669). His advocacy of toleration for all religions, Quakers, Lutherans, Calvinists, Amish, Catholics, Jews alike, attracted support from the future *James II, then Duke of York. Penn visited the New World and, after petitioning Charles II for a grant of land to repay the debt to his father, was given ownership of 120,000 square kilometres, which became 'the proprietary colony of Pennsylvania' (named for his father). He returned to America, founded Philadelphia ('the city of brotherly love') and was governor (mostly absentee) 1682-92. He spent only four years in the new colony (1682-84; 16991701); however, his guarantee of religious toleration resulted in the colony being settled by refugees from persecution in England, Holland and Germany. Penn drew up a remarkably liberal Constitution, in which the governor could rule only by consent, the legislature was chosen by ballot and, most important of all, toleration was enjoined for all forms of religion compatible with Christianity. Penn's later years were clouded by religious disputes and financial difficulties, but he remains one of the most practical idealists of his time. He wrote extensively on theological matters and from time to time was an itinerant preacher.

Dunn, M. D., William Penn: Politics and Conscience. 1967.

Penney, William George, Baron Penney (19091991). English mathematician and physicist, born in Gibraltar. After teaching mathematics at the Imperial College of Science and Technology, London 193544, he directed armament research in the Ministry of Supply 1946-52. In 1953 he superintended the testing at Woomera, Australia, of the second British atomic bomb, was awarded the $\mathrm{KBE}$, and became director of the nuclear weapons establishment at Aldermaston, Berks. He was Chairman of the United Kingdom Atomic Energy Authority 1964-67 and Rector of Imperial College 1967-73. He received the OM in 1969.

Penrose, Sir Roger (1931- ). English mathematical physicist, born in Colchester. Educated at London and Cambridge, as Rouse Ball Professor of Mathematics at Oxford 1973-98, he became deeply involved in cosmology and worked with Stephen *Hawking. Describing himself as 'a recreational mathematician', he wrote The Emperor's New Mind (1989) and Shadows of the Mind (1995). He was awarded the OM in 2000 and the Copley Medal in 2008 and shared the Nobel Prize for Physics in 2020 for his work on the formation of black holes.
Penzias, Arno Allan (1933- ). American radioastronomer, born in Germany. He worked for the Bell Telephone Laboratories 1961 and with Robert Woodrow Wilson (1936- ) continued research, begun by Karl *Jansky, into the origins of background interference to radio signals. After all specific sources had been eliminated, a weak, evenly spread signal was detected which they concluded came from the universe at large and was decisive evidence for the 'big bang' theory. Penzias and Wilson shared the 1978 Nobel Prize for Physics with Pyotr *Kapitza.

Bernstein, J., Three Degrees Above Zero. 1984.

Pepin (or Pippin). Frankish family of administrators. They served the Merovingian kings and were the ancestors of ${ }^{*}$ Charlemagne and the Carolingian dynasty. Pepin I (d.640) and his grandson Pepin II (d.714) were administrators with the title 'mayor of the palace'. The son of ${ }^{*}$ Charles Martel, Pepin III ('the Short') (714/5-768) took the decisive step of deposing the Merovingian king ${ }^{*}$ Childeric III and assuming the royal title. By helping the pope to regain the papal territories he obtained consecration, and his victories over the Arabs in France enabled him to hand over an enlarged and strengthened kingdom to his son Charlemagne.

Wallace-Hadrill, J. M., The Barbarian West 400 1000. 3rd ed. 1967.

Pepys, Samuel (1633-1703). English diarist and public servant, born in London. During the Dutch War 1664-67, when his duties in the Admiralty were mainly concerned with supply, he waged a continuous struggle with corrupt officials and dishonest contractors. In the Admiralty he rose to be Secretary to the Commission 1673-79 and 1684-89, where he worked with great industry and efficiency. He served as MP 1673-79, 1679, 1685-87. One of many falsely accused (1679) in the Popish plot (Titus ${ }^{*}$ Oates), he was briefly imprisoned in the Tower of London, and not restored to his post until 1684. A friend of *Wren, *Newton and ${ }^{*}$ Dryden, Pepys was President of the Royal Society 1684-86.

His famous diary covers the years 1660-69. The gossip and scandal of ${ }^{*}$ Charles II's court, theatrical life, and public events (e.g. the Plague, the sailing up the Thames by the enemy Dutch fleet and the Great Fire) are all vividly recorded. The diary also describes his own domestic life with his lively wife, Elizabeth St Michel, daughter of a Huguenot refugee, who was only 15 when he married her (1655). Throughout his constant philanderings, their mutual jealousies and ardent reconciliations, he and his wife, 'poor wretch', never ceased to be in love. The diary, written in Thomas Shelton's system of short-hand (tachygraphy), lay unread in the library of Magdalen College, Cambridge. Successful publication (1818) of John *Evelyn's diaries revived interest in Pepys. Transcribed by John Smith, bowdlerised sections of the diary were published in 1825. About 90 per cent appeared in the edition of $\mathrm{H}$. 
B. Wheatley, published 1893-99. The complete work, transcribed by William Matthews, edited by Robert Latham, was published in 11 volumes 1970-83.

Ollard, R., Pepys. 1974; Latham, R. (ed.), Shorter Pepys. 1985.

Perahia, Murray (1947- ). American pianist and conductor, born in New York. Of Spanish Sephardic ancestry, he became a friend of Vladimir *Horowitz (although their styles were radically different), recorded all *Mozart's piano works and toured extensively. He suffered a series of hand injuries and withdrew from playing for several years, but turned to conducting. Awarded an Hon. KBE (2004), he became a specialist in ${ }^{*}$ Bach, ${ }^{*}$ Beethoven, ${ }^{*}$ Schubert and ${ }^{*}$ Chopin.

Perceval, Spencer (1762-1812). British Tory politician and barrister. Educated at Trinity College, Cambridge, he entered parliament in 1796 and with the support of *Pitt had risen to be Attorney-General when Pitt died (1806). He served as Chancellor of the Exchequer under Portland 1807-09 and succeeded him as Prime Minister 1809-12. He was shot by a lunatic, John Bellingham, in the lobby of the House of Commons, the only British Prime Minister ever assassinated.

Percy, Sir Henry (known as 'Hotspur') (1364-1403). English nobleman. His Norman family held lordships in the north from 1067 and his father, Henry Percy, 1st Earl of Northumberland (1342-1408) was a supporter of *Wyclif. 'Hotspur' had already gained renown as hero of the Battle of Otterburn (1388) against the Scots when supporting his father in his quarrel with ${ }^{*}$ Henry IV, he joined a conspiracy to replace the king by a rival claimant, Edmund, Earl of March. Intercepted on his way to join the Welsh rebel leader Owen *Glendower, he was killed in the battle of Shrewsbury.

Perec, Georges (1936-1982). French novelist, born in Paris. Of Polish-Jewish descent, he became an archivist in a medical research laboratory and joined a group of literary experimenters, OuLiPo (Ouvroir de Littérature Potentialle). His first novel, Les Choses (1965, translated as Things, 1990) won the Prix Renaudot. W ou le Souvenir d'enfance (1975, W or The Memory of Childhood 1989) presents, in alternating chapters, an autobiographical account of a young man of uncertain identity whose parents are lost in war and the history of a totalitarian state devoted to the Olympic ideal. His masterpiece La Vie mode d'emploi (1978, superbly translated by David Bellos as Life A User's Manual, 1987 ) is a complex and encyclopaedic jigsaw of life in an apartment block in the XVIIth arrondisement of Paris. His last novel, 53 Days, partly written in Brisbane in 1981, was published incomplete in 1989 (English translation, 1992). Perec received great posthumous literary acclaim.

\footnotetext{
Bellos, D., Georges Perec: A Life in words. 1993.
}

Perelman, S(idney) J(oseph) (1904-1979). American humorist, born in New York. He wrote scripts for the *Marx Brothers' films Monkey Business and Horse Feathers, was a regular contributor to the New Yorker from 1931 until his death, produced several travel books and won a 1956 Academy Award for his Around the World in 80 Days. He had a genius for parody and a mastery of language comparable to ${ }^{*}$ Joyce and ${ }^{*}$ Nabokov.

Herrmann, D., S. J. Perelman. 1986.

Peres, Shimon (né Szymon Perski) (1923-2016). Israeli Labour politician, born in Poland. He migrated to Palestine in 1934 and studied in the US (NYU and Harvard). He served in the Knesset 1959-2006, 2006-07, and was Minister of Defence 1974-77, Labour Leader 1977-92, 1995-96, 2003-05, Prime Minister in a 'national unity' coalition 1984-86 and Foreign Minister 1986, 1992-95, 2001-03, $2004-$ 07 . Yasser *Arafat, Itzhak *Rabin and Peres shared the 1994 Nobel Peace Prize. After Rabin's assassination he became Prime Minister again 1995-96, until his narrow defeat by Binyamin *Netanyahu. He served as a minister under Ehud ${ }^{*}$ Barak and was unexpectedly defeated for the presidency in 2000. Defeated as Labour Leader in November 2005, he joined *Sharon's new Kadima Party. He became President of Israel 2007-14. He was a cousin of the actor Lauren Bacall and received a GCMG in 2008 from the UK and the US Presidential Medal of Freedom in 2012.

Perez de Cuellar, Javier (1920-2020). Peruvian diplomat. He was permanent delegate to the United Nations 1971-75, Undersecretary-General 1979-81 and succeeded Kurt *Waldheim as Secretary-General 1982-91. He contested the presidency of Peru against Alberto *Fujimori in 1995 but on his fall became Prime Minister 2000-01.

Pérez Galdós, Benito (1843-1920). Spanish writer, born in the Canary Islands. Considered the greatest Spanish novelist since *Cervantes, in his 46 Episodios nacionales (1873-1912) he followed a plan of relating important historical events to ordinary lives. In his extensive series of Novelas espanolas contemporneos he throws into dramatic relief the incompatibles of 19th-century life and thought, e.g. liberalism and absolutism, science and imagination, progress and tradition, in others (e.g. the Torquemada series) he dramatises the parallel conflicts in the individual conscience. Many of his plays are dramatised versions of his novels.

Varey, J. E. (ed.), Galdós Studies. 1970.

Peri, Jacopo (1561-1633). Italian composer, born in Rome. He worked for the *Medici in Florence and composed Dafne (1598), probably the first opera, now lost. Euridice (1600), based on the Orpheus legend, is occasionally performed, but Peri was unlucky to have been overtaken by *Monteverdi. 
Pergolesi, Giovanni Battista (1710-1736). Italian composer. He wrote religious music (e.g. the famous Stabat Mater for female voices and strings), instrumental pieces and operas (serious and comic) but is best known for the enormously successful La Serva Padrona (1733), which, though it came to be performed as a comic opera, was initially a series of intermezzi between the acts of his serious opera Il Prigionier superbo. Tuberculosis and personal disappointments clouded his short life.

Pericles (c.495-429 BCE). Athenian statesman. Son of Xanthippus and Agriste, both from powerful families, he was educated by leading thinkers, e.g. *Anaxagoras. Though aloof in manner and never courting popularity, politically he was a radical and opposed the ruling oligarchy headed by the Commander-in-Chief, Kimon (c.510-450 BCE) and backed by the Spartans. A rift between the latter and Kimon enabled Pericles to reorient the constitution by depriving the Areopagus (the conservative council of ex-magistrates) of its power (462) and securing the ostracism of Kimon (461). A change in foreign policy followed, Athens and Sparta parted company and thereafter were either at war or enjoying uneasy peace. Peace too was made with Persia, and most of the states that comprised the Delian League against Persia were gradually converted under the guidance of Pericles, who dominated the Athenian assembly until his death, into a maritime empire under Athenian control. He even secured the acceptance of a proposal that the League funds collected for the war should be used not only for policing the seas but for rebuilding and beautifying Athens, which had suffered much during the Persian invasion. Under his guidance, and through his patronage of such artists as the great ${ }^{*}$ Phidias, Athens grew in a few years into the most beautiful city in the world: the Parthenon, the Propyhaea and the Odeum being among the buildings constructed at this time. About 445, he divorced his first wife and then lived with Aspasia of Miletus (d.c. 400 BCE), a friend of *Socrates and brilliant conversationalist, but deeply unpopular in Athens.

There was mounting jealousy of Athens' growing strength. Some of the allies, including Samos (which was decisively crushed), revolted, and the Spartans invaded Attica (446) but were bribed by Pericles to withdraw and renew the truce. The crisis was thus delayed until 433 when Pericles, feeling that the time was ripe for a final trial of strength, induced the assembly to accept the plea of Corcyra (Corfu) for an alliance against Sparta's ally Corinth. This provoked the Peloponnesian War with Sparta (which lasted with intervals from 431 to 404 and eventually brought about the Athenian Empire's downfall). His celebrated Funeral Oration for the war dead, recorded (and presumably edited) by *Thucydides, was much admired, and influenced *Lincoln's Gettysburg Address. Pericles' death was caused by the great plague of 430 , during which a quarter of the population died.
His son by Aspasia, Pericles the Younger (c.445-406 $\mathrm{BCE}$ ) was a strategos (general), executed for failure to rescue survivors of the Battle of Arginusae.

The play Pericles, Prince of Tyre (c.1608), partly by *Shakespeare, is not about the Athenian Pericles.

Burn, A. R., Pericles and Athens. 1970; Kagan, D., Pericles of Athens and the Birth of Democracy. 1991; Aird, H., Pericles: The Rise and Fall of Athenian Democracy. 2004.

Perkin, Sir William Henry (1838-1907). English chemist. While attempting to synthesise quinine when he was only 18 , he discovered the first aniline dye, which he named 'mauve'. The commercial application of his discovery was pursued much more intensively in Germany than in Britain, which had no sizable synthetic dye industry until after World War I. Perkin made a number of discoveries in organic chemistry, the most important of which was probably the 'Perkin synthesis' (1867) for the preparation of unsaturated aromatic acids. He was knighted in 1906. His son, also William Henry Perkin (1860-1929), was an organic chemist who worked on the formation of rings of carbon atoms and berberine, and made important contributions to the organisation and extension of chemical studies and facilities at Oxford.

Garfield, S., Mauve, 2000.

Perkins, Frances (1882-1965). American social worker. A pioneer consumer lobbyist and industrial safety investigator in New York, she was a friend of Franklin D. *Roosevelt who appointed her Secretary of Labor 1933-45. She was the first US woman cabinet member.

Perlman, Ithzak (1945- ). Israeli-American violinist and conductor, born in Tel Aviv. Handicapped by polio from the age of four, he studied in New York, gained early recognition as an exceptional player, toured and recorded extensively, then became an active teacher and conductor. He received the Presidential Medal of Freedom in 2015.

Perón, Juan Domingo (1895-1974). Argentinian soldier and politician, born in Lobos. One of a group of discontented officers in the 1930s, he served as military attaché in Rome 1939-41, observing ${ }^{*}$ Mussolini, then led a revolt (1943) against President Ramón Castillo and became Vice President and War Minister under Edelmiro Farrell. He won favour with labour unions by decrees that granted social welfare benefits. Briefly imprisoned in 1946 he was released following labour demonstrations largely organised by his wife Eva, and in the general election of 1946 was elected President by an overwhelming majority. For the next nine years (he was re-elected in 1951) he ruled as a dictator backed by the militant support of the industrial workers who were delighted with his policy ('peronismo'), which was in essence to favour the workers at the expense of other classes and fiscal 
stability. From 1952 Perón had increasing difficulty in managing the country and was foolish enough to provoke the antagonism of the Roman Catholic Church. This, together with the chaos caused by inflation, provoked the revolt of the army and navy (1955) which led to his exile. He remained in exile for 18 years but in 1973 he returned to Argentina and assumed the presidency. At his death the country was in political chaos.

His second wife Eva Perón (née María Eva Duarte), generally known as 'Evita' (1919-1952), was a stage and radio actor. She threw her vast energy and ambition on the side of Perón whom she married in 1945. She skilfully wooed the support of Argentinian women, especially through the Eva Perón Social Aid Foundation for dispensing help to the poor. Her death from cancer led to extraordinary public demonstrations of grief (a mood captured in Andrew *Lloyd Webber's 1976 musical Evita). After periods refrigerated in Buenos Aires, Milan and Madrid her body was finally interred in Buenos Aires in 1976. Perón's third wife, Isabel Martínez de Perón (née María Estela Martínez Cartas) (1931- ), was a folk and cabaret dancer when he married her in 1961. Elected as Vice President in 1973, she succeeded as President on his death (1974) until deposed by the army (1976).

Ferns, H. S. Argentina. 1969; Rock, D. (ed.), Argentina in the Twentieth Century. 1975.

Perot, H(enry) Ross (1930-2019). American industrialist, born in Texarkana. Educated at the US Naval Academy, he served with the navy and with IBM before forming Electronic Data Systems in 1962, and was its Chief Executive until 1986. A billionaire, he attracted international interest by securing the release of EDS personnel held prisoner in Iran and for attempting to find missing US military personnel in Vietnam. In 1992 he ran as an independent candidate for president, withdrew, then re-entered, securing 19 per cent of the vote and contributing to the defeat of President George H. W. *Bush. He ran for president again in 1996 when his vote fell to 8 per cent.

Pérotin [Perotinus Magnus] (c.1160-1205). French composer. His three- and four-part music [organum] for voices, written in Paris, perhaps for Notre Dame, was of tremendous importance in the development of polyphony. He is considered to be the earliest great European composer.

Perrault, Charles (1628-1703). French civil servant and writer. The son of a lawyer, he became advisor on art to ${ }^{*}$ Colbert and was elected (1671) to the Académie française. In his own time he was known in France for his part in the 'quarrel of the ancients and the moderns' in which he championed the moderns in a lengthy controversy with *Boileau. His greater fame comes from his Histoires $d u$ Contes $d u$ temps passe (1697), a collection of eight traditional fairy stories, among them Sleeping Beauty, Red Riding which he gave a definitive shape of lasting popularity. They are sometimes called Mother Goose's Tales after the secondary title Contes de ma mère l'Oye on the frontispiece of the original edition.

Perret, Auguste (1874-1954). French architect, born in Brussels. He worked in the Art Deco style, using reinforced concrete. His major works in Paris included apartments in Rue Franklin (1902-04), ferro-concrete structures with large windows, and the Théâtre des Champs-Élysées (1913). His reconstruction of Le Havre after World War II became a World Heritage site. *Le Corbusier was a protégé.

Perry, Matthew Calbraith (1794-1858). American sailor. As commodore of a US squadron he was sent to Japan (1853) by President *Fillmore to conclude a trade agreement and succeeded in his second attempt in January 1854. In March he signed the Treaty of Kanagawa with the shogun's advisor *Ii Naosuke, opening up two ports, Shimoda and Hakodate, to the US, ending Japan's isolation from the West since 1642 . He received a grant of $\$ 20,000$ from Congress, wrote Narrative of the Expedition of an American Squadron to the China Seas and Japan (1856) and died in New York.

Perse, Saint-John (pen name of Marie René Auguste Alexis Saint-Léger Léger) (1887-1975). French poet and diplomat, born near Guadeloupe. He became Permanent Secretary for Foreign Affairs and was consistently opposed to appeasement. He escaped from Vichy France to the US (1940) where he became an advisor on French affairs to the US administration. His best known poem, Anabase (1924), was translated into English by T. S. *Eliot (1930). Later volumes of poetry include Exil (1942), Vents (1946), Amers (1957) and Chroniques (1960). He won the Nobel Prize for Literature (1960) for 'the soaring flight and evocative imagery of his poetry, which in visionary fashion reflects the condition of our times'.

Little, J. R., Saint-John Perse. 1973.

Pershing, John Joseph (1860-1948). American general, born in Missouri. He served in Cuba (1898), the Philippines (1899-1903) and invaded Mexico (1916) to capture Pancho *Villa. Known as 'Black Jack', he was Commander-in-Chief of the US Expeditionary Force in France 1917-19. He accomplished a remarkable feat in building up a huge army of 38 divisions, which played a critical role in stopping the last German offensive (1918). He was created General of the Armies in 1919. He became Chief of Staff of the US Army 1921-24, and won the Pulitzer Prize in 1932 for his My Experiences in the World War (1931).

Persson, Göran (1949- ). Swedish Socialist politician. Active in cooperatives and education, he succeeded Ingvar ${ }^{*}$ Carlsson as Prime Minister of Sweden 1996-2006. 
Pertinax (Publius Helvius Pertinax Augustus) (126$193 \mathrm{CE})$. Roman Emperor 193. Son of a freed slave, he became a teacher, then a soldier, provincial governor and senator. After the murder of *Commodus, he was raised to the purple in the 'Year of the Five Emperors'. He attempted modest reforms but after three months was murdered.

Pertini, Alessandro (1896-1990). Italian Socialist politician. A lawyer who was active in the anti-Fascist underground and imprisoned many times between 1930 and 1943, he served in parliament 1946-76, becoming chairman of the Chamber of Deputies 1968-76. As President of Italy 1978-85, he brought dignity, unpretentiousness, warmth and humour to the office and remained a consistent advocate of human rights.

Perugino, II (Pietro Vannucci) (c.1445-1523). Italian painter. After working in Florence and Rome he settled at Perugia, where some of his best work remains. His art is characterised by clearly articulated composition, and he is traditionally regarded as the teacher of *Raphael, and certainly Raphael's early works bear striking Peruginesque qualities. Perugino executed (1481) part of the decorative program in the Sistine Chapel at the Vatican (e.g. the fresco of Christ giving the keys to Peter). He is represented in the National Gallery, London, by a characteristic triptych, originally at Pavia.

Castellanata, C., Pietro Vannucci Perugino. 1969.

Perutz, Max Ferdinand (1914-2002). British biochemist, born in Vienna. He left Austria in 1936, worked at Cambridge but was interned during World War II as an enemy alien. He directed the Medical Research Council Laboratory (originally Unit) of Molecular Biology at Cambridge 1947-79 and won the 1962 Nobel Prize for Chemistry (with J. C. ${ }^{*}$ Kendrew) for their use of X-ray diffraction in working out the structure of protein molecules. Awarded the CH (1975), the Copley Medal (1979) and the OM (1988), he was also a perceptive writer on scientific issues e.g. Is Science Necessary? (1989).

Pessoa, Fernando Antonio Nogueira (1888-1935). Portuguese poet. He grew up in South Africa, returning to Portugal in 1908 and worked as a commercial correspondent. Virtually nothing was published in his lifetime (his experience paralleled ${ }^{*}$ Cavafy's in Egypt) but he is regarded as the greatest Portuguese poet since ${ }^{*}$ Camóens.

Pestalozzi, Johann Heinrich (1746-1827). Swiss educational reformer. Under the influence of *Rousseau he believed that primary education for the masses (and especially for destitute children) would best achieve its aim of creating useful and virtuous people in the natural surroundings and occupations of agricultural life; he therefore started his first educational experiment in a farm at Neulof, but lack of practical ability led to its failure (1780). He then gave up for a time his educational experiments to think out a system derived from his experience. His books, especially the social novel How Gertrude Teaches her Children (1801), propound his basic theory that education should develop and train all the faculties, not merely the intellect. In 1798 he again opened an orphan school at Stanz but within eight months it was ruined by peasant bigotry. Finally (1805) he established himself at Yverdon, but, though he had many admirers and followers, the attempt to extend his methods to secondary education was one of several mistakes that caused him to die a disappointed man.

Pétain, (Henri) Philippe (Omer Benomi Joseph) (1856-1951). French marshal and politician, born in Cauchy-a-la-Tour. He joined the army in 1875 , studied at St Cyr and taught at the War College. His promotion was slow because his preference for defensive tactics was unfashionable. During World War I, as Commander in Charge of the Centre Group 1916-17, he became famous for his defence of Verdun (1916). He succeeded (1917) General ${ }^{*}$ Nivelle as Commander-in-Chief of the French armies in the field. He restored discipline and morale and, under Foch's supreme command, conducted the final victorious offensives. On Armistice Day 1918 he was made a marshal. He suppressed *Abd el-Krim's nationalist revolt in Morocco 1926-28 and was elected to the Académie française in 1929 . He became Ambassador to *Franco's Government in Spain 1939-40, until his recall in May to become Vice Premier in *Reynaud's Government. As Premier, June 1940, he negotiated surrender with the Germans, and with the overwhelming support of the Senate and the Chamber of Deputies became 'Chief of the French State' 1940-45. France was divided, and Pétain's authority was confined to the southern unoccupied portion, with its capital at Vichy. Pétain, with his deeply conservative and mystical concept of patriotism, influenced by *Maurras, detested democracy and the French Revolutionary tradition, and in a senile Bonapartism replaced 'Liberty, Fraternity, Equality' with 'Work, Family, Fatherland'. He collaborated with the Nazis in the persecution of the Jews and the provision of forced labour, but tried to hedge his bets by secret contact with the Allies. He dismissed his premier Pierre * Laval in December 1940 but was forced to take him back in April 1942 after which Pétain's influence declined, although as late as April 1944 his official visit to Paris was cheered by more than 1,000,000 people. After the allied invasion of France and the recapture of Paris (August 1944), the Germans put Pétain into protective custody at Sigmaringen. On his return to France (1945) he was tried and condemned to death but *de Gaulle commuted the sentence to life imprisonment.

Griffith, R. M., Pétain. 1970; Lottman, H. R., Philippe Pétain. 1984; Atkin, N., Pétain. 1997; Williams, C., Pétain. 2005. 
Peter, St (Petros in Greek: Shimon in Aramaic) (d.c.64 CE). Christian apostle, born in Bethsaida. The name Peter (from the Greek petra, the equivalent of the Aramaic Kephas, 'stone') is the Anglicised form of the name given by Jesus to the most prominent of his disciples, Simon, son of Jonah. The interpretation of the sentence 'Thou art Peter and upon this rock I will build my Church' (Matthew xvi:18) has long been the subject of controversy between Roman Catholics (who use the text to assert the supremacy of Peter's Church in Rome) and Protestants.

Peter, a fisherman on the Sea of Galilee, lived with his wife at Capernaum. He and his brother *Andrew, followers of *John the Baptist, were among the first disciples of ${ }^{*}$ Jesus, regarded with special affection. He was the first to hail Jesus as Messiah, but just before the Crucifixion, he denied three times that he had any connexion with Jesus. Peter (as Kephas) was, with *James and *John, one of the 'three pillars' of the Christian community. He had an uncomfortable relationship with James and, later, *Paul. Peter preached in Antioch and became its first bishop. In the controversy concerning the observance of Jewish practices by Gentile converts, Peter appears to have supported the compromise view eventually adopted. The first and second Epistles of St Peter seem to be by different hands: the first, early in date and simple in doctrine, is usually accepted as Peter's work. Both Peter and Paul were in Rome and presumably shared leadership of the Christian community. Acts xxviii locates Paul in Rome but 1 Peter v: 13 has only a single reference linking Peter with 'the Church that is at Babylon'. He is said to have lodged for seven years with the family of Pudens. According to Catholic tradition, Peter became first Bishop of Rome and was martyred there during *Nero's persecution, as was Paul, either in 64 or 67. Presumably crucified, the tradition that he was executed head down is very late. The assumption of Petrine primacy by Church in Rome had a decisive influence on the adoption of Christianity as a state religion by ${ }^{*}$ Constantine. However, some historians reject the Petrine primacy, arguing that the Church had a collegiate leadership until about 200. Peter is often represented in art holding keys, as the gatekeeper of Heaven. St Peter's is the metropolitan church of the bishopric of Rome. In 324 Constantine began to build a basilica on the presumed site of his burial. This was pulled down in the 15 th century and the new St Peter's, designed by ${ }^{*}$ Bramante, was begun by *Julius II in 1506 . Excavations 1939-49 uncovered a tomb believed to be Peter's.

Culmann, O., Peter. 1962; Grant, M., Saint Peter: A Biography. 1995.

Peter (Pyotr) I ('the Great') (1672-1725). Tsar (Emperor) of Russia 1682-1725. Only son of Tsar *Aleksei by his second wife, he succeeded Fyodor II, but, after a revolt engineered by his half-sister Sophia, he shared the throne (under her regency) the latter died (1696) Peter assumed full power. Much of his education, mainly in mechanics, navigation, and military science, he had acquired from young foreigners in Moscow whom he made his companions. Two expeditions (1695 and 1696) against the Turks, by which Russia acquired the fortress of Azov and so gained access to the Black Sea from the Don, gave him his first experience of leadership. While travelling abroad (1696-98) he spent much of his time in the shipyards of Holland and England (where he worked for a time at Deptford) working with his own hands and learning shipbuilding and navigation. He also engaged skilled men to go to Russia as instructors. With the aim of modernising Russia he started schools, arranged for textbooks to be translated, edited the first Russian newspaper, opened the first museum; he brought the Church entirely under state control by abolishing the patriarchate and substituting a Holy Synod; and, without abandoning any of his autocratic powers, he turned the administration into an efficient machine, but the poll-tax and other impositions to provide revenue were not popular. Peter's most spectacular undertaking, designed to make the country look westwards, was to build an entirely new capital on swampy ground won from Sweden at the point where the Neva joins the Baltic Sea. Thousands of peasants, many of whom died in the unhealthy conditions, were forcibly enrolled for the task, government offices and palaces sprang up, and nobles and wealthy men were compelled to build houses in the new capital. So, through the Emperor's initiative and genius for planning, the city of St Petersburg became one of the most beautiful cities of the world.

Peter's foreign policy was in line with his westernising policy. In the course of a prolonged war with Sweden (1700-21), defeat after defeat was finally reversed by a great victory over ${ }^{*}$ Karl XII of Sweden at Poltava (1709) which enabled him to annex parts of Finland, Estonia and Livonia and secure for Russia a commanding influence in the Baltic.

Peter's domestic life was unhappy. Under the influence of his first wife, his son Aleksei joined the faction opposed to his policies and died mysteriously during the investigation into their intrigues. After his divorce, Peter married Catherine, his peasant mistress and ultimate successor, whom he had taken over from his friend and collaborator *Menshikov. She bore him 12 children, but Peter died without naming an heir.

Kliuchevskii, V., Peter the Great. 1965; Anderson, M. S., Peter the Great. 1978; De Jorge, A., Fire and Water. 1979; Massie, R. K., Peter the Great. 1981.

Peter I (Petar Karađorđević) (1844-1921) King of Serbia 1903-18 and of the Serbs, Croats and Slovenes 1918-21. As a member of the Karađorđević dynasty, he lived in exile in France and Switzerland and served in the French Foreign Legion. He translated J. S. *Mill's On Liberty in 1868. The assassination (1903) of King *Alexander of the rival *Obrenović dynasty 
resulted in his election by the Serbian parliament. He experimented with democratic forms, promoted education and created a small but effective army. He secured great territorial advantages for his country at the expense of Turkey and Bulgaria in the two Balkan Wars (1912-13). Meanwhile he had reversed his predecessor's policy by aligning Serbia with Russia instead of Austria, and it was a Serb patriot who murdered the Austrian Archduke *Franz Ferdinand, sparking off World War I. Peter remained steadfast while his country was overrun and after the final victory, which united the Austro-Hungarian South Slav territories with his own, he was declared King of the Serbs, Croats and Slovenes (Yugoslavia). He was succeeded by his son *Alexander I. His grandson, Peter II (1923-1970), became King in 1934 and was declared of age (1941) when his uncle Paul was deposed from the regency during World War II for acquiescing to ${ }^{*}$ Hitler's demands. Peter went into exile in London (1941) but in 1945, after the allied victory, Marshal *Tito abolished the monarchy. Peter worked in New York, became an alcoholic and died in Los Angeles.

Peter (Potyr) II (1715-1730). Tsar of Russia 172730. As the son of Aleksei, *Peter the Great's dead son, he would have been his grandfather's natural successor had not ${ }^{*}$ Menshikov secured the proclamation of the emperor's widow as *Catherine I. On her death Peter II inherited peacefully, but died from smallpox within three years.

Peter (Pyotr) III (né Karl Pieter Ulrich von HolsteinGottorp, later Pyotr Fydorovich Holstein-GottorpRomanov) (1728-1762). Tsar of Russia 1761-62. Born in Kiel, his father was Duke of Holstein-Gottorp, his mother Anna Petrovna, daughter of *Peter the Great. His aunt, the Tsarina *Elizabeth (Yelizaveta), nominated him as her successor. He made his single contribution to European history when he immediately withdrew Russia from the coalition which at that stage of the Seven Years' War was threatening *Friedrich II ('the Great') with disaster. $\mathrm{He}$ was one of Friedrich's most uncritical admirers, and one of his more harmless hobbies was drilling soldiers dressed in Prussian style. Vain, obstinate and feeble minded, Peter was soon seen to be unfit to rule. A plot was formed by the guards regiment and successfully carried out by which his wife was to be proclaimed Empress as *Catherine II. Peter abdicated and was killed a week later, allegedly in a drunken brawl.

Peter the Hermit (Pierre l'Ermite) (c.1050-c.1115). French monk. One of the many preachers in Germany and France who aroused enthusiasm for the 1st Crusade, in 1096 he led a group of fanatical peasants across Hungary into Asia Minor. By then they had become so unruly that he left them to almost inevitable slaughter at the hands of the Turks. He returned to Constantinople and joined the main body of crusaders who in 1099 captured Jerusalem. On his return he founded a monastery at Huy (now in Belgium), where he died.

Peterborough, Charles Mordaunt, 3rd Earl of (1658?-1735). English adventurer. After naval service in the Mediterranean he was able to render such help to *William III in his bid for the throne that he received high office and rewards. Under Queen *Anne he was given joint command (1705), with Sir Clowdisley *Shovell, of an expedition sent to Spain during the War of the Spanish Succession. He captured Barcelona and made a spectacular victorious march through Catalonia, quarrelling constantly, however, with his associates or allies. Ambassadorial appointments followed, each ended by some irregular or impetuous action. His appointment (1714) as Governor of Minorca was terminated when Queen Anne died in the same year. This closed his official career though he continued to tour Europe as a selfappointed and self-accredited envoy. He was a friend of * Pope and *Swift.

Peters, Winston Raymond (1946- ). New Zealand politician. Of Scottish-Maori parentage, he worked in Australia, then became a rugby player, MP and National Minister. He founded the New Zealand First Party in 1993 and was Deputy Prime Minister and Treasurer 1997-98 in coalitions under Jim *Bolger and Jenny *Shipley. He was Foreign Minister in Helen *Clark's Labour Government 2005-08, lost his seat but was re-elected 2011-20. New Zealand First supported Labour after the 2017 election and Peters became, again, Deputy Prime Minister and Foreign Minister until his defeat in 2020.

Petipa, Marius (1822-1910). French dancer and choreographer. He performed at the Comédie Française and soon became well known throughout France and in Spain. He went to Russia (1847) where he was immediately acclaimed, and he is regarded as one of the founders of the Russian ballet. His best remembered works were produced in association with *Tchaikovsky, e.g. The Sleeping Beauty (1890) and Swan Lake (1895).

Petit, Roland (1924-2011). French dancer and choreographer. He worked as a boy with the Paris Opera ballet, and in 1948 formed his own company which appeared at the Théâtre Marigny. He created many new ballets, e.g. Le Loup, Ballabille (for the London Royal Ballet) and Cyrano de Bergerac (1959), his first full length ballet. In 1965 he created and danced in Notre Dame de Paris, suggesting the hunchback's deformity without padding.

Petrarch (Francesco Petrarca) (1304-1374). Italian poet and scholar, born at Arezzo. His father moved (1311) to Avignon, then the seat of the papacy, and Francesco later returned there after three years uncongenial study of civil law at Bologna; he then took minor orders. He first saw Laura (plausibly identified as the wife of Hugues de Sade) in church 
at Avignon at Eastertide in 1327. Worshipped from a distance, she remained the love of his life until and even after her death (1348) and was the inspiration of his famous love poems (Rime or Canzoniere). Petrarch did not invent the 14-line sonnet form, in which nearly 300 of them were written, but his fame inspired the many imitators (e.g. Sir Thomas *Wyatt) and so justifies the name Petrarchan sonnet. By his contemporaries, however, Petrarch was acclaimed for scholarship. He was among the first to revive interest in the language and literature of classical Rome. He took advantage of his travels to search for and discover old MSS., including an interesting batch of *Cicero's letters. Through the patronage of the Colonna family, in Avignon and Rome he came to know the learned and great and even to correspond with rulers on political affairs. Evidence of his fame came after he had settled (1337) in retirement at Vaucluse in Provence and had started his epic Africa on the life of ${ }^{*}$ Scipio Africanus. Invitations came to him simultaneously from the university of Paris and the Roman Senate to accept the tribute of a laurel crown. Back in Vaucluse he must have begun to question his own motives, for in the imaginary dialogues of De Contemptu Mundi (1343) he finds himself confronted with *St Augustine's censure for his attachment to Laura and to fame. Laura's death and the failure of the attempt (1347) by his friend *Cola di Rienzi to establish a republic in Rome seem to have stirred in him a deep pessimism about the state of Italy. From Rome, where he met and won the admiration of ${ }^{*}$ Boccaccio, he went to Padua and then to Venice, where he advocated peace with Genoa. He returned to France (1351), but after further travels in Italy he settled at Arqua in the hills near Padua and there he was found dead with his head resting on a book. Petrarch is commonly regarded as the father of Italian humanism.

Petrie, Sir (William Matthew) Flinders (18531942). English archaeologist, born near Greenwich. A grandson of Matthew *Flinders, he was educated at home. He first went to Egypt in 1881, surveyed the pyramids at Giza, establishing new standards of excavation procedure. He explored the Greek city of Naukratis in the Nile delta 1884-85. In 1888 he discovered hundreds of vivid, naturalistic portraits in encaustic at Fayum and exhibited them in London. From 1890 he worked on stratification and established the principle of sequence dating from potsherds and other artefacts. He was professor of Egyptology at University College, London 1892-1933. He also excavated Abydos, Tell el Armana, the Ramesseum at Thebes and in Palestine from 1926. He shared the racism of many scientific contemporaries and was an enthusiast for eugenics. He retired to Jerusalem in 1933 and died there.

Marek, W. K., Gods, Graves and Scholars. 2nd ed. 1967.
Petronius (Arbiter), Gaius (d.66). Roman courtier and author, born in Massalia. As 'Arbiter elegantiae' at the court of *Nero, he directed the Emperor's lavish entertainments. His only surviving works are fragments of the Saturae (wrongly known as Satyricon), a prose extravaganza interspersed with verse, parodying the sentimental Greek romances of the day, among episodes relating the obscene adventures of three rascals in Dinner with Trimalchio, a banquet in the house of a typical nouveau riche. To avoid execution by Nero, Petronius staged an elaborate suicide to the accompaniment of a witty discourse, delaying his death by continually rebandaging the opened veins.

Sullivan, J. P., The Satyricon of Petronius. 1968.

Peugeot, Armand (1849-1915). French automobile maker. His family ran weaving, dying and steelmaking firms. After a career as a bicycle-maker, Peugeot produced a steam car in 1889, a petrol car in 1891 and the popular 'Bébé Peugeot' in 1911.

Pfeiffer, Michelle (1958- ). American film actor. Her films include The Witches of Eastwick (1987), Dangerous Liaisons (1988), The Russia House (1990) and The Age of Innocence (1993), White Oleander (2002), Hairspray (2007), Personal Effects (2009) and Dark Shadows (2012).

Pheidippides (5th century BCE). Greek runner. He carried the news of the Persian invasion and a request for help from Athens to Sparta (490 BCE), covering the distance of $240 \mathrm{~km}$ in two days. Some versions of the story name him also as the runner who fell dead after conveying news of victory from the battlefield of Marathon to Athens. This exploit is commemorated in the modern Olympic Games by the Marathon race $(42.2 \mathrm{~km})$.

Phelps, Michael Fred (1985- ). American swimmer, born in Baltimore. He won a total of 23 Gold Olympic medals, setting a record, six in Athens (2004), eight in Beijing (2008), four in London (2012) and nine in Rio (2016).

Phidias (c.490-c.430 BCE). Athenian sculptor. He was the principal artist employed by ${ }^{*}$ Pericles to carry out the beautification of Athens, which he had planned. The frieze of the Parthenon was probably carved from his designs, but none of his actual work survives. Representations of the two works for which he was most famous in the Ancient World, the ivory and gold statues of Athena Parthenos in Athens and of Zeus at Olympia can be seen on coins etc. Accusations of theft and sacrilege, made by the enemies of Pericles, caused Phidias to leave Athens (432).

Richter, G., A Handbook of Greek Art. 1969.

Philby, Kim (Harold Adrian Russell) (1912-1988). British journalist and KGB agent, born in India. Son of (Harry) St John (Bridger) Philby (1885-1960), an explorer and writer on Arab affairs, educated at 
Trinity College, Cambridge, he was a journalist in Germany, Austria and Spain and joined MI6 in 1940, using membership of the foreign service as a cover, becoming First Secretary at the British Embassy in Washington 1949-51. After the defection to Moscow of *Burgess and Maclean, his friendship with Guy Burgess led to an investigation and, although nothing was proved against him, he was forced to resign, largely because of his Communist associations in the 1930s. He went to the Middle East as an Observer correspondent until he disappeared from Beirut in January 1963. He soon surfaced in Moscow as a KGB Major General and confirmed that he had been 'the third man' in the Burgess and Maclean case.

Seale, P. and McConville, M., Philby, the Long Road to Moscow. 1972; Macintyre, B., A Spy Among Friends. 2014.

Philidor, François André Danican (1726-1795). French musician and chess-player. He composed many operas, and through his Analyse du jeu des échecs (1749) he became one of the most famous names in the early history of chess. His 'Philidor's Defence' is an example of his tactical mastery of the game.

\section{Philip the Good see Philippe le Bon}

Philip, St (Philippos in Greek: 'lover of horses') (d.c.80 CE). Christian apostle, born in Bethsaida. He may have been a follower of *John the Baptist. He traditionally preached in Phrygia, Scythia and (possibly) Ethiopia, and is said to have died in Hierapolis, now in Turkey.

Philip I, II, III, IV, V and VI. Spanish Kings see Felipe I, II, III, IV, V and VI

Philip II and IV. French kings see Philippe II and IV

Philip II (Philippos) (382-336 BCE). King of Macedon 359-336 BCE. Father of *Alexander the Great, born in Pella, youngest son of Amyntas III and Eurydice, he was chosen to succeed his infant nephew Amyntas IV, for whom he was briefly regent. When he began to rule, his kingdom was poor and backward, but when he died he had made it by war and diplomacy the dominant power in Greece and had created an army with which his son achieved his great victories. An early success (356) which made the others possible was his occupation of Grenides (Philippi) to gain control of the vital gold and silver deposits. Another stage was his occupation of Thessaly. To Thebes he readily gave help against Phocis, thus bringing both states into his power-orbit. Roused by the warnings of ${ }^{*}$ Demosthenes (in the famous Philippics), Athens at last saw her danger, but it was too late and after Philip's great victory at Chaeronea (338) all Greece except Sparta lay at his mercy. He now showed his statesmanship by creating the League of Corinth, a confederacy in which every state but Sparta had votes to accord with its military strength,
Philip himself being its supreme head. Now all was ready for the trial of strength with Persia, which Philip had long planned, but as the first Macedonian troops moved into Asia Minor he was assassinated by Pausanias. His tomb and remains were found in 1977 at Vergína.

Momigliano, A., Philip of Macedon (ed. M. Hatzopoulos and L. Loukopoulos). 1981; Parker, G., Imprudent King: A New Life of Philip II. 2014.

\section{Philip, Prince see Edinburgh, Duke of}

\section{Philip Neri, St see Neri, St Philip}

Philipp (Philip) I ('the Magnanimous') (15041567). German ruler, Landgrave of Hesse 1509-67. He succeeded his father Wilhelm II as a child and exercised full power from 1518. He became one of the most prominent supporters of the Protestant cause: he initiated the Reformation in Hesse (1526) and founded (1527) the first Protestant university at Marburg, where in 1529 he tried to reconcile *Luther and *Zwingli. However, he had shown no mercy to Thomas ${ }^{*}$ Müntzer and the Anabaptists. A farsighted plan to reform the constitution of the Holy Roman Empire and at the same time overcome the dominance of the Habsburg emperors was frustrated when the League of Schmalkalden, formed for that purpose, was defeated (1547). Philipp's bigamy, agreed to by his first wife and (reluctantly) by Luther, was a lively scandal of the time.

\section{Philipp of Burgundy see Felipe I, King of Castile and Leon}

Philippa of Hainaut (1314?-1369). English queen consort 1327-69. Daughter of William, Count of Hainaut and Holland, she married her second cousin *Edward III (1328) and bore seven sons and five daughters. It was her pleas that resulted in the sparing of six prominent burghers of Calais, whose lives Edward, incensed by his year-long siege, had demanded as his price for not sacking the city. She appointed the chronicler ${ }^{*}$ Froissart as her secretary and is buried at Windsor.

Philippe II Auguste (1165-1223). King of France 1180-1223. Son of *Louis VII. He was more successful than any other French medieval king in asserting his suzerainty over the feudal nobles, winning his greatest triumph over the most powerful of all his feudatories, the English King. He quickly returned from the 3rd Crusade and was able to take advantage of the captivity of *Richard I to despoil him of his possessions. Interrupted briefly by Richard's return, he was soon able to exploit *John's difficulties and eventually gained Normandy, Anjou and parts of Poitou. At Bouvines, between Lille and Tournai, Philippe Auguste gained his greatest victory (1214) over a coalition of the court of Flanders, the emperor *Otto IV and King *John. By his success he 
established the strength and prestige of the French monarchy for a century and more. He was the first ruler to be styled 'King of France'.

Painter, S. and Tierney, B., Western Europe in the Middle Ages: 1300-1475. 1970.

Philippe IV ('le Bel'; 'the Fair') (1268-1314). King of France 1285-1314. A strong ruler, he was determined to extend the royal power. This led him into quarrels with *Edward I of England, the Flemish burghers, his own nobles and above all with Pope *Boniface VIII, this last settled only by the pope's death, when Philippe secured the election of a Frenchman, Clement V, and the removal of the papacy from Rome to Avignon. He further asserted his strength by forcing the pope to disband the Order of the Templars. The monarchy's power was also increased by developing centralised institutions, e.g. the Parlement of Paris.

Philippe le Bon (Philip the Good; in Dutch, Filips de Goede) (1396-1467). Duke of Burgundy 141967. A member of the *Valois dynasty, he was the son of Jean sans Puer (John the Fearless/Jan vonder Vrees) (1371-1419). To avenge his father's murder by adherents of the Dauphin (later ${ }^{*}$ Charles VII), he negotiated the Treaty of Troyes (1420) with the English king *Henry V. This treaty disinherited the Dauphin in favour of any child that Henry might have by Princess Catherine of France. Philippe therefore supported the cause of ${ }^{*}$ Henry VI in the wars in which *Joan of Arc played a notable part, but he was reconciled with Charles in 1435 . He employed Jan van *Eyck from 1425. Most of his energies were devoted to the extension of his inheritance in the Netherlands, almost all of which he brought under his control, suppressing a rebellion (1454) with great bloodshed. He founded (1430) the Order of the Golden Fleece and made his court one of the most magnificent of medieval Europe. He died in Bruges.

Vaughan, R., Philip the Good. 1970.

Philips, Anton Frederik (1874-1951). Dutch industrialist. Son of a banker, with his elder brother Gerard he founded a factory at Eindhoven in 1892 for the manufacture of electric light bulbs. The company became the largest European manufacturer of radios and television, with subsidiaries throughout the world. The Philips brothers were young cousins of *Marx.

Phillip, Arthur (1738-1814). English sailor and administrator, born in London. Son of a German language teacher (possibly Jewish) from Frankfurt, he trained as a merchant seaman, joined the Royal Navy during the Seven Years War, but saw little active service. He was a skilled surveyor and modest property developer. Seconded to the Portuguese navy 1774-78, he served in Brazil. The reasons for his appointment as first governor of the penal settlement in New South
Wales are unclear, but he showed firmness and courage in his period in office 1788-92. In January 1788 he chose the site on Port Jackson where Sydney was to be built, clearly foresaw the colony's future greatness, and was committed to Enlightenment principles. In February 1788 he established a penal settlement on Norfolk Island. He faced tremendous difficulties, the risk of famine, insubordinate officers and corrupt contractors. Sympathetic to Aboriginal people, he lacked enthusiasm for the death penalty. After a long period of illness, he returned to active naval service in the French wars, retired to Bath in 1805 and was promoted to Admiral of the Blue. He was buried at $\mathrm{St}$ Nicholas' Church, Bathampton, but there is controversy about whether his gravestone has been moved. His reinterment in Australia has been proposed.

Frost, A., Arthur Phillip. His Voyaging. 1987; Parker, D., Arthur Phillip. Australia's First Governor. 2012.

Phillipps, Sir Thomas, 1st Baronet (1792-1872). English bibliomaniac, born in Manchester. He inherited a substantial fortune (textile manufacturing and land) but devoted himself to amassing what was probably the greatest single collection of 40,000 books and 60,000 manuscripts, driving his family to distraction in the process.

Philo of Alexandria (Philo Judaeus, originally Yedidia HaCohen) (c.20 BCE-c.45 CE). Jewish philosopher, born in Alexandria. He made a wide study of Greek philosophy and literature, but remained a Jew and accepted the Old Testament without reservations. $\mathrm{He}$ conceived his task as the integration of Greek philosophy, based on reason, with Jewish religion, based on revelation and faith. The lógos ( $\lambda$ ó $0 \varsigma)$, word, message, thought or narrative, especially originating from God, he regarded as supreme, but recognised that it can reach mankind through the lips of Greek philosophers such as *Plato. This thought was taken up by the neoplatonists, both Christian and pagan, and is at the root of nearly all medieval philosophy.

Sandmel, S., Philo's Place in Judaism. 1956.

\section{'Phiz' see Browne, Hablot K.}

Phryne (4th century BCE). Greek courtesan. Traditionally, she was the model for a picture by Apelles of Aphrodite (Venus) rising from the waves and for the Aphrodite of Cnidos, a famous statue by *Praxiteles. Accused of profaning the Eleusinian mysteries, she was acquitted after her robe was cast aside to reveal her naked beauty to the judges.

Phyfe, Duncan (originally Fife) (1768-1854). American furniture designer, born in Scotland. He became a cabinet maker in New York, employing more than $100 \mathrm{craft}$ workers, and designed in the Neoclassical and Empire style. 
Piaf, Edith (Edith Giovanna Gassion) (1915-1963). French singer. 'The Little Sparrow's' career began with street singing at 15 . She achieved success as a cabaret and concert performer, touring the US, and appearing in films.

Lauge, M., Piaf. 1982.

Piaget, Jean (1896-1980). Swiss psychologist. Educated in Neuchâtel, Zürich and Paris, he was professor of child psychology at Geneva 1929-71 and wrote over 50 books, many on the intellectual developmental stages in children, such as concept formation, classification and ordering. He argued that classroom teaching is inappropriate when it attempts to impose adult reasoning on children who are not yet genetically programmed to receive it. He was a member of UNESCO's Executive Board 1950-54.

Piano, Renzo (1937- ). Italian architect, born in Genoa. Educated in Milan, he was joint winner with Richard *Rogers of the competition to design the Pompidou Centre Paris (1971). Other works include the Menil Art Gallery, Houston; Bercy commercial centre, Paris; Zentrum Paul Klee, Berne; and Auditorium Parco della Musica, Rome.

Piazzolla, Ástor Pantaleon (1921-1992). Argentinian composer. Son of Italian migrants, his father became a hairdresser in New York. He mastered the bandaneon, studied in Paris with Nadia *Boulanger and created 'tango neuvre', a fusion of tango, jazz and the classics. He composed 46 film scores and a total of about 3,000 works, 500 of them recorded.

Picasso, Pablo Ruiz (in full Pablo Diego José Francisco de Paula Juan Nepomuceno María de los Remedios Cipriano de la Santísima Trinidad Ruiz y Picasso) (1881-1973). Spanish painter and sculptor, born in Málaga. Son of a Castilian artist and teacher, José Ruiz Blanco, and an Andalusian mother Maria Picasso y Lopez, his family moved to Corunna in northwest Spain in 1891. Pablo studied with his father and in 1895 painted his first important oils, in the style of the old masters. In Barcelona he attended the School of Fine Arts (1895-97), then the San Fernando Academy in Madrid (1897-99). He held his first one-man exhibition in Barcelona (Feb. 1900), showed paintings in Paris (June 1901) and the powerful large blue SelfPortrait dates from the end of that year. He moved to and from Spain, settling in Paris in 1904 and remained there for 44 years, apart from a short period in Holland (1905). The works of *Cézanne and *Toulouse-Lautrec were among the strongest influences on him. In his 'Blue Period' (1901-05), the colour provided symbolic background for anguished pictures of the poor and lonely. The poet *Apollinaire published the first book on Picasso in 1905. The Lady with a Fan (1905) was a transitional work. His 'Rose Period' (1905-07) was notable for many paintings of circus life, e.g. Family of Saltimbanques (1905) but included the striking Portrait of Gertrude Stein (1906) and young nudes, strangely vulnerable against their rose and terracotta backgrounds. An abrupt change of style (1907) derived from a study of African, Iberian and Pacific Island art in museums, demonstrates the forcefulness that a work of art can gain from simplification and distortion. 'Cubism', developed by Picasso and Georges *Braque, began in 1907 with Les Demoiselles d'Avignon, and Picasso continued his experiments until about 1925. The impact of photography and film meant that painters could abandon static representation, interpreting 'reality' in a new way, seeing objects from every geometric position, as with sculpture. His shapes, now in subdued greys and browns, were not entirely abstract, retaining some relationship to actual objects. Picasso's art usually reflected his private life and his extraordinary sexual energy. He lived with Fernande Olivier 1905-12 and with Marcelle ('Eva') Humbert (d.1915) from 1911. The impact of World War I revived his interest in colour and decoration. He designed Parade (1917), The Three Cornered Hat (1919) and Pulcinella (1920) for *Diaghilev's Ballets Russes. In 1918 he married the Russian dancer Olga Koklova (d.1955). A son Paulo was born in 1921 and his Classical period (1920-25), influenced by *Ingres, reflects a rare serenity e.g. Mother and Child and Woman Bathers. Then the women in his paintings become huge and shapeless until Marie-Thérèse Walter entered his life in 1927, followed by Dora Maar in 1936. Both inspired some of his most passionate paintings. He turned to sculpture and his Woman with a Vase (1933), a masterpiece, is on his grave. Political turmoil in the 1930s drew Picasso towards Surrealism. He was a strong (but absentee) supporter of the Republicans during the Spanish Civil War and was made Honorary Director of the Prado Museum, Madrid 1936-39. His enormous tormented work Guernica (1937), denouncing German bombing of a Basque town, has the power of *Goya. He lived in Paris undisturbed during the German occupation, joining the Communist Party after liberation in 1944, although the CP considered his work decadent, contrary to *Stalin's doctrine of 'socialist realism'. He lived 194353 with the painter Françoise *Gilot, and had two children by her. He moved to the south of France in 1947, first to Vallauris, then to Cannes, Vauvenargues and to Mougins (where he died). He spent much of his creative energy from the 1950s on lithographs, ceramics and sculptures, especially of animals (bulls and bullfights), birds (notably the 'Dove of Peace') and flowers. He wrote the Symbolist play Desire Caught by the Tail (1952) and some poetry. In AugustDecember 1957 he painted 44 studies of *Velázquez's Maids of Honour (Las Meninas) and completed a huge (unsuccessful) mural The Fall of Icarus for UNESCO. He lived with Jacqueline Roque (1927-1986) from 1954, marrying her in 1961: in 1962 he produced 70 Jacquelines-paintings; drawings; engravings and ceramic tiles. He was buried at his home at the Chateau de Vauvenargues, near Aix. Picasso claimed to be the most important artist since Michelangeloand for sheer originality, range and influence, few have exceeded him. *Titian, *Rembrandt, *Velázquez, 
${ }^{*}$ Goya and $\mathrm{El}{ }^{*}$ Greco climbed higher peaks, but they worked within an established tradition: Picasso created several new traditions. Picasso's catalogue raisonné, in 33 volumes, records more than 16,000 works. He was certainly the greatest artist of the 20th century. He asserted that painting 'isn't an aesthetic operation. It's a form of magic designed as a mediator between this strange, hostile world and us, a way of seizing power by giving form to our terrors as well as our desires'. In 1971 the Louvre held a retrospective Picasso exhibition-the first for a living artist. Picasso made the world look at reality in a new way but he remains intensely controversial. He was also a great collector. Picasso Museums were established in Antibes (1947), Barcelona (1963) and Paris (1985). The literature on him is enormous.

His daughter, Paloma Picasso (1949- ), a couturier, designed jewellery for Yves *Saint Laurent, ceramics and pottery for Villeroy and Boch, and produced perfume under her own name.

Penrose, R., Picasso. 1971; Palau i Fabre, J., Picasso, the Early Years 1881-1907. 1980; Richardson, J., A Life of Picasso. Vol. 1. The Prodigy: 1881-1906. 1991, Vol. 2. The Painter of Modern Life: 1907-1916. 1996, Vol. 3. The Triumphant Years: 1917-32. 2007.

Piccard, Auguste (1884-1962). Swiss physicist. Best known as a pioneer explorer of the stratosphere and the deep oceans, he was professor of physics at the Free University of Brussels (1922-54) and a close associate of ${ }^{*}$ Einstein. With his twin brother JeanFelix (1884-1963), a pioneer in studying cosmic radiation, he took up ballooning and finally (1932), in an airtight gondola designed by himself, reached a height of $17,766 \mathrm{~m}(54,150 \mathrm{ft})$. After World War II he turned to investigating the ocean depths and designed a special steel diving capsule or 'bathyscaphe'. With his son Jacques Piccard (1922-2008) he descended to a record depth of $3391 \mathrm{~m}(10,335 \mathrm{ft})$ off the island of Capri (1953) and Jacques, with a US naval officer, reached a depth of $14,401 \mathrm{~m}(37,800 \mathrm{ft})$ off the Pacific island of Guam (1960), Jean's son Bertrand Piccard (1958- ), a psychiatrist, completed, with Brian Jones, the first balloon circumnavigation in the Breitling Orbiter III (March 1999).

Pichegru, Charles (1761-1804). French soldier. He gained rapid promotion in the revolutionary armies. In 1793 as Commander-in-Chief of the Rhine army he thrust back the Austrians and overran the Palatinate. In the following year he was given the command in Flanders and in January 1795 entered Amsterdam. After this triumph he returned to the Rhine, but was soon in active correspondence with the Bourbons. Arrested in Paris (1797), he was sentenced to banishment in Cayenne but managed to escape. He returned to France (1804) with another conspirator against the life of ${ }^{*}$ Napoléon but was arrested and shortly after found strangled in prison.
Pickford, Mary (née Gladys Smith) (1893-1979). American film star, born in Canada. Having first appeared on the stage at the age of five, she started to act in films in 1909 and through her childlike sentimental parts soon became known as 'the world's sweetheart'. With her second husband, Douglas *Fairbanks, she was one of the founders (1919) of the cinema company United Artists. Among the most popular of her films were Poor Little Rich Girl (1916) and Daddy Long Legs (1919). She has been described as the founder of the Hollywood 'star system'.

Pico della Mirandola, Giovanni (1463-1494). Italian philosopher. Having settled in Florence (1484), he applied his immense industry and powers of memory to the search for Christian truths in the works of ${ }^{*}$ Pythagoras, ${ }^{*}$ Moses and ${ }^{*}$ Zoroaster. Subsequently he offered to defend 900 theses at public disputations, but 13 of the theses were condemned (1487) by Pope Innocent VIII, and Pico went into exile in France, where he was briefly imprisoned. His book De Hominis Dignitate, with its stress on the spiritual freedom of humanity, provided a philosophic justification for the proudly individualistic outlook of Renaissance man. His writings influenced Sir Thomas *More (who translated some) and John *Colet.

Kristeller, P. O., The Renaissance Concept of Man. 1973.

Pierce, Franklin (1804-1869). 14th President of the US 1853-57. Born in New Hampshire, where his father became governor, he became prominent in state politics and later served as a US Congressman 183337 and senator 1837-42. He fought with distinction in the Mexican War 1846-48, and in 1852 was chosen as Democratic candidate for president, being elected as a compromise on the 49th ballot, after Lewis *Cass and James *Buchanan withdrew in his favour. In November he defeated Winfield ${ }^{*}$ Scott. Pierce was the only president to take an affirmation of office. With the Gadsden Purchase he secured from Mexico some 76,800 square kilometres of valuable territory (now in Arizona or New Mexico), but the unpopularity of his Kansas-Nebraska Act, which left the question of slavery there to the decision of the inhabitants and so provoked a competing rush of partisan immigrants, led to his defeat for renomination by Buchanan at the 1856 Democratic Convention in Cincinnati. In 20 Presidential rankings by US historians and political scientists, Pierce scored No. 36 in the aggregate.

Piero della Francesca (Piero di Benedetto de'Franceschi) (c.1416-1492). Italian Renaissance painter of the Umbrian school, born at Sansepolcro, between Arezzo and Urbino. He studied in Florence under Domenico Veneziano, whose methods of revealing form by sight he learned and improved upon. During his career his patrons included Sigismondo ${ }^{*}$ Malatesta of Rimini, Federigo da *Montefeltro, Duke of Urbino and Pope *Pius II. He studied mathematics and wrote treatises on geometry and perspective which he hoped would influence later artists. His composition followed a geometric pattern. 
Most of his works are frescoes based on religious themes, e.g. his most ambitious work, The Story of the True Cross in Arezzo (1452-66). Like *Caravaggio and *Vermeer, Piero was a forgotten artist until Edouard ${ }^{*}$ Manet and Henry *Layard revived interest in his work, and only in the 20 th century was he recognised as one of the supreme artists of his time. Among his outstanding paintings are The Baptism of Christ (1450, National Gallery, London); The Flagellation of Christ (1460, Urbino); The Resurrection (c.1465, Sansepolcro), which Aldous *Huxley hailed as 'the best picture in the world', and magnificent portraits of Montefeltro and his wife Battista (Uffizi, Florence).

Clark, K. M., Piero della Francesca. 1951; PopeHennessy, J., The Piero della Francesca Trail. 1991.

Pierre de Montreuil (d.1267). French architect. He worked for ${ }^{*}$ Louis IX and built the chapel at the palace at St Germain-en-Laye (1235-38). His masterpiece was Sainte Chapelle in Paris, designed in the Rayonnant style and consecrated in 1248.

Pigott, Richard (1828?-1889). Irish journalist. He forged documents purporting to implicate *Parnell in the murders (1882) of Lord Frederick Cavendish and T. H. Burke (the Irish chief secretary and his Undersecretary) in Phoenix Park, Dublin. The publication of these documents in The Times (April 1887) caused a political sensation which was not abated until a commission of inquiry (1888-89) proved them to be forged. Pigott, having confessed, escaped to Madrid where he shot himself.

Piketty, Thomas (1971- ). French economist, born in Paris. He studied in Paris and London and directed the Paris School of Economics in 2006- . His research concentrated on wealth distribution. His book Capital in the Twenty-First Century (2013) became a bestseller and stimulated debate. Capital and Ideology (2020) was also controversial.

Pilate, Pontius (d.c.55 CE). Roman official. Procurator of Judaea and Samaria 26-36, he is remembered for his question 'What is truth?' put to *Jesus at his trial and for sentencing him to be crucified. He was ignorant of Jewish character and beliefs and was recalled to Rome to face charges of venality and brutality. Among many legends is one that he became a Christian; his wife Claudia Procula, said to have been converted, even became a saint in the Orthodox Church. His later career is unknown but ${ }^{*}$ Eusebius wrote that he committed suicide. Mt Pilatus, near Lucerne, has been traditionally identified as where he fell to his death.

Piłsudski, Józef Klemens (1867-1935). Polish soldier and politician, born in Zułów, then part of Russia, now in Lithuania. Educated in Vilnius, he began studying medicine in Kharkov. He spent the first part of his life in two overlapping causes, revolutionary socialism and freeing what was then Russian Poland from tsarist rule. Sent to Siberia (1887-92), on release he founded the Polish Socialist party. Arrested again (1900), after pretending to be insane he escaped abroad. He soon returned and from 1907 began to create units of Polish riflemen on Austrian territory. With these he fought for Austria against Russia in World War I but, finding himself exploited for German aims, disbanded his forces and was imprisoned (1917) at Magdeburg. On the Allied victory, he became Chief of State (November 1918) of the newly proclaimed Poland and played a prominent part in the battles, political as well as military, by which Poland's frontiers were determined. He was appointed 'First Marshal of Poland' in March 1920 but refused the presidency in 1922 and 1926 . He lived in retirement until, in May 1926, he organised a coup d'état after which he exercised almost dictatorial powers until his death, in a variety of roles: Prime Minister 1926-28, 1930, Inspector General of the Armed Forces 1926-35 and Minister of Military Affairs 1926-35. He became increasingly critical of democracy but opposed totalitarianism and rejected anti-Semitism.

Pinckney, Charles Cotesworth (1746-1825). American soldier and politician, born in Charleston, South Carolina. Educated at Westminster School and Christ Church, Oxford, he practised as a lawyer in his home town and was a slave owner. Active in the first Continental Congress, which precipitated the War of Independence, he became ADC to *Washington and rose to be a brigadier general. At the Constitutional Convention (1787), he introduced the clause forbidding religious tests. He served as US Minister to France 1796-97. He was an unsuccessful Federalist candidate for the presidency, losing to ${ }^{*}$ Jefferson in 1804 and *Madison in 1808.

Pincus, Gregory Goodwin (1903-1967). American biologist. He directed the Worcester (Mass.) Foundation for Experimental Biology 1944-67 and led research that produced the oral contraceptive pill.

Pindar (c.522-c.440 BCE). Greek lyric poet, born near Thebes. He wrote numerous ceremonial odes, hymns, convivial songs etc. for rulers and cities throughout Greece. From 476 to 474 he was at the court of Hieron, King of Syracuse and other rulers in Sicily. Of the 17 book rolls of his poetry only four survive almost entire, i.e. those celebrating victories in the Olympic, Nemean, Pythian and Isthmian games. Into these he introduced myths and other apparent irrelevancies which give colour and variety to what might seem a monotonous theme, though to the Greeks themselves the games were religious festivals and victory symbolised divine favour as well as conferring prestige on the athletes and their cities. The poems are choral odes to be accompanied by dancing, but owing to their early date and linguistic problems they are hard to translate and their merits difficult to assess. The Greeks, however, counted Pindar among their greatest poets. ${ }^{*}$ Dryden's Alexander's Feast is an imitation of a Pindaric ode.

Bowra, C. M., Pindar. 1964. 
Pinel, Philippe (1745-1826). French physician, born in Languedoc. He qualified at Toulouse and went to Paris (1778), in 1787 he began to write about insanity, of which he had made a firsthand study. Both at the Bicêtre, of which he became head in 1793, and later at the Salpêtrière he introduced more humane treatment of the insane (e.g. removal of chains by which they were restrained) and as far as possible substituted empirical and psychological treatment for the then customary drugs, bleeding etc. He paved the way for future improvements by establishing the custom of keeping case histories and records for research.

Pinkerton, Allan (1819-1884). American detective, born in Scotland. He emigrated to the US (1842) and founded in Chicago the private detective agency which became the best known in the world. During the American Civil War he did secret service work and in 1861 frustrated a plot against *Lincoln's life. The agency was continued and enlarged by his sons.

Pinochet Ugarte, Augusto (1915-2006). Chilean general. As army Commander-in-Chief, he led the coup that deposed President Salvador *Allende (September 1973), headed a provisional government 1973-74, and was President of Chile 1974-90. He remained Commander-in-Chief until 1998, then became a senator for life. In 1998 he was arrested in London, after surgery, when Spain demanded his extradition. He returned to Chile in March 2000 after the *Blair Government made a controversial decision to release him on the grounds of his age and incapacity. The Chilean courts then removed his immunity from prosecution. His supporters insisted that he had saved the Chilean economy; his opponents charged that he was brutal and corrupt.

Pinter, Harold (1930-2008). English playwright and producer, born in London. He left school at 16, and was an actor in repertory before turning to writing. He attracted attention with The Dumb Waiter (1957) and The Caretaker (1960), plays written in ostensibly colloquial, 'ordinary' speech, and concerned with problems of communication between individuals. His screen plays include The Servant (1962), The GoBetween (1969), The Last Tycoon (1974) and Betrayal (1983). He was Associate Director of the National Theatre 1973- 83. He married Lady Antonia Fraser (née *Pakenham) in 1980, received a CH in 2002 and the Nobel Prize for Literature in 2005.

Piper, John Egerton Christmas (1903-1992). English painter. His vivid and effective use of bold, vigorous draughtsmanship and dramatic colour contrasts was seen at its best in architectural themes (e.g. the pictures of bombed buildings for which he became known in World War II). He designed stage sets, engraved glass and tapestries, e.g. in Coventry cathedral. Piper also wrote poetry and architectural and topographical guides. He was awarded a $\mathrm{CH}$ in 1972.
Pirandello, Luigi (1867-1936). Italian writer, born in Sicily. His novels include Si Gira (1916) which introduces the reader to film stars and photographers. During World War I he began to write plays of a slightly surrealistic nature: among the best known of about 40 are Six Characters in Search of an Author (192l), in which a rehearsal stage is invaded by a group of characters seeking to take part in a play, and Henry IV (1922), where the theme of madness is treated in an original way. He won the Nobel Prize for Literature (1934).

Starkie, W., Luigi Pirandello, 1867-1936. 4th ed. 1967.

Piranesi, Giambattista (1720-1778). Italian draftsman and etcher. His powerful series Carceri d'invenzione ('Imaginary Prisons', 1745) were precursors of Romantic art and his Roman scenes were conceived on the grand scale.

Pires, Maria Joáo (Alexandre Barbosa) (1944- ). Portuguese pianist, born in Lisbon. Long esteemed in Portugal and Brazil, where she taught, she won late recognition internationally for her superb performances of *Mozart and *Beethoven.

Pisano, Andrea (c.1290-1348). Italian architect, sculptor and goldsmith, born near Pisa. Apparently unrelated to Nicola and Giovanni *Pisano, he produced two doors for the Baptistry at Florence ( ${ }^{*}$ Ghiberti) and worked on the cathedral's campanile with *Giotto.

Pisano, Nicola (or Niccolò Pisano) (c.1225-c.1284) . Italian sculptor, born in Apulia. Founder of the Pisan school, he had made a study of classical sculpture, and though he applied the knowledge that he had gained to essentially Gothic structures he has a claim to be regarded as the first Renaissance sculptor. For example, on the pulpit of the baptistery at Pisa, for the characteristically Gothic line of figures against a flat background he substitutes groups, each member of which is expressively natural in pose, dress and expression and so carved as to give an impression of depth. Among the best known of his other works are the pulpit at Siena Cathedral and the fountain in the market place, Perugia. In much of his work Nicola was helped by his son Giovanni Pisano (c.1250-1330) who won an independent reputation both as architect and as sculptor and was praised by *Michelangelo.

Pope-Hennessy, J., Italian Gothic Sculpture. 1955.

Pissarro, Camille (1830-1903). French painter, born in the West Indies. His early pictures show the influence of *Corot, but after meeting *Manet (1866) he worked closely with the Impressionist group, of which he was the oldest member. For a time (1884-88) he adopted *Seurat's pointillist techniques. In the last years of his life he painted figure studies of peasants etc. and pictures of warmly sunlit Paris streets.

Rewald, J., Camille Pissarro. 1963. 
Pitman, Sir Isaac (1813-1879). English inventor. His shorthand system based on phonetic principles gained worldwide popularity. He also devised a simplified spelling of English but he won little support for this.

Pitt, William ('the Elder'), 1st Earl of Chatham (1708-1778). English Whig politician, born in Westminster. Grandson of 'Diamond Pitt' who had made a fortune in India, he inherited little, was educated at Eton and, briefly, at Oxford and Utrecht. After service in the King's Own Horse Regiment 1731-36, he became a Whig MP 1735-66 (originally in the rotten borough of Old Sarum), earning the enmity of *George II by serving as Groom of the Bedchamber 1737-45 to *Frederick, Prince of Wales. As Paymaster General of the Forces 1746-55, he created a precedent by refusing bribes. He married (1754), Hester Grenville, sister of Earl Temple and George * Grenville, and had a strong network of family connections. He was Secretary of State for the South (in effect, Minister for War) December 1756April 1757 under the nominal leadership of the Duke of *Devonshire and July 1757-October 1761 under the Duke of ${ }^{*}$ Newcastle. He was an expansionist, or Big Englander, who thought that Britain should be actively involved in European affairs, in sharp contrast to *Walpole's isolationist policy. He proved an outstanding leader during the Seven Years' War and was the virtual founder of the British Empire, the colonial system and ensuring primacy in sea power. Under his direction, ${ }^{*}$ Clive established British supremacy in India, ${ }^{*}$ Amherst and ${ }^{*}$ Wolfe defeated the French in Canada and *Rodney dominated the West Indies. Claiming to have 'conquered America on the plains of Germany', Pitt retired in 1761 on the grounds of health (he suffered acutely from gout and manic depression, which he called 'attacks of gout in the head'), securing a peerage and a $£ 3,000$ pension for his wife. He opposed the Treaty of Paris (1763) as too favourable to France. In 1765 he attacked *Grenville's Government over the Stamp Act, a measure that imposed taxation without representation on the American colonies. He returned to office under the Duke of ${ }^{*}$ Grafton as Lord Privy Seal July 1766-October 1768 , but de facto Prime Minister, until acute depression forced his withdrawal early in 1767 . Known as 'the Great Commoner', he had made the grave mistake of going to the House of Lords (1766) as Earl of Chatham, at which, as ${ }^{*}$ Chesterfield observed, 'his enemies rejoiced and his friends were stupefied', since his power base was in the Commons and the City of London. In 1768 he resigned when Charles *Townshend imposed new taxes on the Americans. When the American War of Independence began, Chatham was in an untenable position: opposed both to British military intervention and to withdrawal. He collapsed after his last speech in the Lords, denouncing government weakness in America, died at Hayes five weeks later and was buried in Westminster Abbey. Aloof, aggressive, passionate, wayward and anti-social, Pitt had allies but no friends and was not an effective party leader or manager. His oratory was powerful and his mood-swings alarming.

Plumb, J. H., Chatham. 1965; Brown, P. D., William Pitt, Earl of Chatham: The Great Commoner. 1978; Black, J., Pitt the Elder. 1992.

Pitt, William ('the Younger') (1759-1806). English Tory politician, born in Hayes. Second son of *Pitt the Elder, ill health prevented him from attending school, and although a precocious classical scholar, isolation from contemporaries increased his reserve and aloofness. He went to Pembroke College, Cambridge in 1773, read at Lincoln's Inn, London 1778 and was a Member of Parliament 1781-1806. He attached himself to Lord *Shelburne, an oppositionist who had supported the elder Pitt. After Lord *North fell in March 1782, there were three ministries in the following 21 months: *Rockingham, who soon died, Shelburne, who appointed Pitt as Chancellor of the Exchequer (July 1782-Apr. 1783), and *Portland (essentially a ${ }^{*}$ Fox-North coalition). *George III appointed Pitt as First Lord of the Treasury, in effect Prime Minister, although the title was not then used, and he served in that office and also as Chancellor of the Exchequer December 1783-March 1801, May 1804-January 1806. He disregarded defeats in the Commons and held on until winning a majority in the general election of 1784 . Notably efficient in public finance, he was a reformer in his first years, bringing India into shared control between the East India Company and the government (1784), admitting Roman Catholics to the bar and the army and attempting to achieve parliamentary reform. After the French Revolution and especially after the reign of terror, Pitt became more conservative, reflecting fear of change in society. He was a strong administrator, an effective manager in the House of Commons and a persuasive orator. He emphasised national security and sometimes acted ruthlessly to crush political dissent. He abandoned the cause of parliamentary reform and failed to moderate harsh penal and game laws. In 1800 he secured the passage of the Act that incorporated Ireland in the United Kingdom and dissolved its parliament. Pitt was prepared to legislate for Catholic emancipation to enable Irish MPs to represent Catholic voters in Westminster, but the king objected so strongly that he felt obliged to resign. *Addington proved to be embarrassingly inept as a successor. In 1803 war was resumed and a year later Pitt returned, organising the Third Coalition against ${ }^{*}$ Napoléon. He died 20 months later at the age of 46, his health worsened by his heavy drinking. In his last speech, at the Guildhall, he said: 'England is not to be saved by a single man: England has saved herself by her exertions and will, I trust, save Europe by her example.' Pitt had an extraordinarily narrow range of experience. He never married, had few friends, never travelled far from London apart from a few weeks in France (and knew nothing of Scotland and Ireland), 
read little and was ignorant of art and science. He left debts of $£ 40,000$ ( $£ 3.4$ million in 2021 values), which were paid off by the Parliament.

Ehrmann, J., The Younger Pitt. 3 vols, 1969, 1983, 1996.

Pitt-Rivers, Augustus Henry Lane-Fox (18271900). British archaeologist and army officer. He began his career in the army in 1845 and rose to Lieutenant General. In 1880 he succeeded to the Dorset estate of his cousin, Lord Rivers, adopting his surname Pitt-Rivers, and pioneered there scientific, properly recorded archaeological digs. His work in Dorset is preserved in the Pitt-Rivers museum at Farnham. His personal ethnological and archaeological collection formed the Pitt-Rivers Museum at Oxford University. He was also the first Inspector of Ancient Monuments 1882-1900 and elected FRS. He wrote Excavations in Cranborne Chase (1887-98).

Pius II (Enea Silvio de Piccolomini) (1405-1464). Pope 1458-64. Born near Siena, of noble parentage, he was poet laureate at the court of *Friedrich III, worked as a diplomat, wrote histories, a play and a novel and generously patronised artists and writers. He became Bishop of Siena 1450-58. As Pope, he strove for European unity against the Turks and died at Ancona, trying to organise a crusade.

Pius VI (Giovanni Angelo Braschi) (1717-1799). Pope 1775-99. Born in Emilia, of aristocratic family, he had no pastoral experience, worked in the Papal Curia, became secretary to ${ }^{*}$ Benedict XIV and was created cardinal in 1773 . Elected after a four month conclave, his long pontificate was a disaster. Vain, extravagant and inclined to nepotism, he completed St Peter's Basilica and patronised the arts. In 1782 he visited Vienna in a futile attempt to persuade * Joseph II to moderate his anti-clerical policies. He condemned the French Revolution for legislating State control of the clergy and Church property. In 1798 Napoléon's troops occupied Rome, and Pius died in Valence (France) as a prisoner.

Pius VII (Luigi Barnaba Chiaramonti) (1742-1823). Pope 1800-23. A Benedictine, he became a professor of theology and Bishop of Imola 1785-1800. In 1797 he expressed some sympathy for political change. He had the extraordinarily difficult task of facing the consequences of the French Revolution and *Napoléon's rise to power without offending Austria, the papacy's firmest ally. His first great achievement, assisted by ${ }^{*}$ Consalvi, his Secretary of State, was the Concordat (1801) with France, whereby he recognised the Republic and Napoléon's rule in return for the withdrawal of all anti-Catholic laws. In 1804 he went to Paris to anoint Napoléon at his coronation. He refused, however, to take part in the French Emperor's measures against England and in consequence the papal states were invaded and the
Pope held in captivity (1809-14). His reign is also remembered for his restoration (1814) of the Society of Jesus (Jesuits).

Pius VIII (Francesco Saverino Castiglione) (17611830). Pope 1829-30. A disciple of *Pius VII, imprisoned by the French 1808-14, Bishop of Frascati 1821-29, he attacked Freemasonry and the rise of nationalism and laid down rules about mixed marriages.

Pius IX (Giovanni Maria Mastai-Ferretti) (17921878). Pope 1846-78. Son of a count, ordained in 1819, he served in Chile 1823-25 and was Bishop of Imola 1832-46. On his election as Pope, he began as a liberal reformer of the constitution and government of the papal territories, but his failure (1848) to head a national movement against Austria's influence in Italy caused an uprising in Rome, the murder of several members of the administration, the flight of the Pope to Neapolitan territory and the establishment of a republic under ${ }^{*}$ Garibaldi and ${ }^{*}$ Mazzini. Restored by a French army (1849) and his secular power maintained by a French garrison, the reformer became a conservative, his main preoccupation being to retain his political status. In the 'Syllabus of Errors' (1864) he denounced 80 elements relating to 'progress, liberalism and modern civilisation', including socialism, democracy, science and freedom of conscience. During the Franco-Prussian War (1870) the French withdrew and Rome became the capital of unified Italy. Pius responded by refusing to recognise these events and henceforth remained in self-imposed imprisonment in the Vatican, an example followed by his successors until *Pius XI concluded the Lateran Treaty with the Italian state (1929). During his papacy - the longest in history - the doctrine of the Immaculate Conception was promulgated (1856), and at the Vatican Council, which ran for seven months 1869-70, the dogma of Papal Infallibility in matters of faith and morals was defined. Pius IX was amiable, witty and of great charm, with no personal enemies. He was an epileptic. His beatification by *John Paul II in 2000 was controversial.

Hales, E. E. Y., Pio Nono. 1954.

Pius X, St (Giuseppe Melchiorre Sarto) (18351914). Pope 1903-14. Born in Riese, he came from a very poor family and had spent his whole previous career in diocesan work, so his talents were essentially practical. He was bishop of Mantua 1884-93 and cardinal-patriarch of Venice from 1893 until his election to the papacy. A strong conservative, deeply opposed to 'modernism', he codified the canon law, reorganised the papal administration and rearranged the missal and the breviary. His refusal to accept secular control over the French Church led to a 20year breach between the papacy and the French State. Much beloved for his simplicity and holiness, he was canonised in 1954. 
Pius XI (Achille Ambrogio Damiano Ratti) (18571939). Pope 1922-39. He won three doctorates at the Gregorian University, Rome and worked at the Ambrosian Library, Milan 1888-1911 and the Vatican Library 1911-18. He was an expert palaeographer and intrepid mountaineer. At the age of 61 he was appointed Nuncio to Poland (1918). After seven months as cardinal and Archbishop of Milan 1921-22, he was elected Pope on the 14th ballot as a compromise candidate. He showed great ability as a diplomat. He signed the Lateran Treaty (1929) with *Mussolini, by which, in return for recognition of his papal sovereignty within the Vatican City and of Roman Catholicism as the state religion of Italy, the papacy recognised the kingdom of Italy under the House of Savoy. He established Catholic Action, updated *Leo XIII's social teachings in Rerum Novarum (1891) in his Quadragesimo anno ('In the fortieth year...', 1931) and supported ${ }^{*}$ Franco in Spain. He made some concessions to modernism, promoted scholarship and established a Vatican radio station (1931). He attacked Nazism as anti-Christian in the encyclical Mit brennender Sorge (With burning anxiety, 1937) and his relations with Mussolini worsened.

Pius XII (Eugenio Maria Giuseppe Giovanni Pacelli) (1876-1958). Pope 1939-58. Born in Rome, to an aristocratic family, he studied at the Gregorian University, became a priest in 1899 and joined the papal secretariat in 1902. He was Papal Nuncio to Bavaria during World War I and to Germany 1925-31. Created a cardinal in 1929, he became *Pius XI's Secretary of State 1931-39, travelled widely, including South America and the US, and was multilingual (although awkward with English). Thus he had considerable diplomatic experience when, on the eve of World War II, he was elected Pope on the second ballot, in the shortest conclave of modern times. (He was the first Roman pope since 1730.) His main objective was to ensure that the Roman Catholic Church survived with its independence and strength unimpaired. His fear of Communism's threat to Christianity made him unduly accommodating to the regimes of Mussolini and *Franco. He conspicuously failed to denounce *Hitler's Third Reich, and its genocide against the Jews, although some individuals were saved in Rome. (This issue remains deeply controversial.) Power became concentrated during his pontificate and bishops who questioned his authority were pushed aside (e.g. the future *Pius VI). However, he appointed many non-Italian cardinals and reduced Italian dominance in the Curia. He made effective use of radio and television and published 41 deeply conservative encyclicals on social issues and sexuality. In 1950 he proclaimed the doctrine of the bodily Assumption of the Virgin Mary-the first exercise of papal infallibility since 1870 . Processes for the beatification, or even canonisation of Pius XII, which began in 1965, were described as 'stalled' in 2014 by Pope *Francis. The Vatican's war-time archives were opened up in 2019.
Falconi, C., The Popes in the Twentieth Century. 1967; Cornwell, J., Hitler's Pope: The Secret History of Pius XII. 1999; Dalin, D. G., The Myth of Hitler's Pope. 2005.

Pizarro, Francisco (c.1475-1541). Spanish (Castilian) conquistador, born in Trujillo, Extremadura. Illegitimate and illiterate, he became a soldier and went to Darien (Panama) and in 1524 and 1526-27 made his first attempts, with Diego de *Almagro, to conquer Peru. This failed but after returning to Spain and receiving authorisation and the title of Governor, he again set out (1531), from Panama, with his brothers Hernando, Juan and Gonzalo and a band of 62 horsemen and 106 infantry to conquer the Inca empire (Tawantinsuyu-'Land of the Four Quarters'), landing at Tumbes in May 1532. Luck was with him - the Incas were fighting a savage civil war and the use of armour, guns, steel swords, cannon and horses gave the Spaniards a great advantage. So did introduced smallpox. In Cajamarca (Nov. 1532), he seized *Atahualpa, the Inca ruler (whom he later had murdered), and, with the heart of the resistance broken, spent the next nine years in overrunning the country and amassing a vast treasure from the Inca hoards. He founded Lima in 1535. A dispute with Almagro, his fellow conquistador, mainly concerned with the ownership of Cuzco, proved disastrous. Almagro occupied the city (1537) but was defeated by Hernando Pizarro, tried and strangled. In revenge Francisco Pizarro was attacked and killed in his own house by some of Almagro's men. He and the conquistadors wiped out the whole Inca nobility and virtually destroyed every trace of Inca culture. He was buried in Lima.

Innes, H., The Conquistadors. 1969.

Place, Francis (1771-1854). English reformer, born in London. Son of a bailiff, he achieved a remarkable feat of self-education and became a successful master tailor, while sponsoring practical causes such as the monitorial schools associated with the name of Joseph *Lancaster, and birth control. He retired from business in 1817 but the library behind his old shop in Charing Cross remained a centre for his political activities, in which he was associated with Jeremy *Bentham and other reformers. Although not an MP he became a master of parliamentary lobbying, his greatest achievement being to secure the repeal (1824) of the Combination Acts which made trade unions illegal. He was a leading figure in the agitation that led to the Reform Act (1832) and he helped William Lovett to draw up the People's Charter in 1838.

Thale, M., Francis Place. 1972.

Planck, Max Karl Ernst Ludwig (1858-1947). German physicist, born in Kiel. Son of a professor at Kiel, he studied at the Friedrich Wilhelm University, Berlin and was influenced by *Kirchhof, succeeding him there as professor of physics 1889-1926. Planck originated (1900) the quantum theory stating that energy, like matter, is not continuous in nature but is 
radiated and absorbed in small portions called quanta. Planck won the Nobel Prize for Physics (1918) and the Copley Medal (1925). He was President of the Kaiser Wilhelm Society 1930-37; 1945-46, renamed for him in 1948. His son Erwin Planck (1893-1945) was hanged in January 1945 for his involvement in the plot to kill *Hitler.

Asteroid 1069 Planckia, a Moon crater and a space observatory were named for Max Planck.

Planck, M., Scientific Autobiography and Other Papers. 1949.

Plantagenet. English dynasty sprung from ${ }^{*}$ Geoffrey V, Count of Anjou, whose badge was a sprig of broom (planta genista). The first English Plantagenet king was *Henry II, Geoffrey's son by ${ }^{*}$ Matilda, daughter of ${ }^{*}$ Henry I: the last of the line was *Richard III.

Harvey, J., The Plantagenets, 1154-1485. 1970.

\section{Plantagenet, Geoffrey see Geoffrey V (Plantagenet)}

Plantin, Christophe (1514-1589). French printer. He settled in Antwerp and is one of the best known of the early printers, and versions of the type which he designed for his Biblia Polyglotta and editions of the classics are still in use. He established branches for his sons-in-law in Paris and Leyden and his Antwerp office is now maintained by the city as a museum.

Plath, Sylvia (1932-1963). American poet, born in Boston. She graduated from Smith College, won a Fulbright Scholarship to Cambridge and in 1956 married the poet Ted *Hughes. Her searingly painful poetry was published in The Colossus (1960), Ariel (1965) and Collected Poems (1981, which won a posthumous Pulitzer Prize). She wrote an autobiographical novel The Bell Jar (1963) and committed suicide by gassing herself shortly afterwards. Her death became a feminist cause célèbre, with blame directed at her husband.

Malcolm, J., The Silent Woman.1994; Wilson, A., Mad Girl's Love Song. Sylvia Plath and Life Before Ted. 2013.

Plato (Plátōn) (c.427-347 BCE). Greek philosopher, born in Athens. Of noble descent, he almost certainly studied under ${ }^{*}$ Socrates. After Socrates was put to death by the restored democracy (399), Plato lived and travelled abroad for a number of years, visiting probably Egypt and certainly Sicily, where he won Dion to his philosophy. On his return (388) he set up a school at his house in Athens which became known as the Academy because it was near the grove of the mythical hero Academus. The students, mainly young aristocrats, devoted themselves to philosophy and mathematics and to practical studies in politics and administration. After the death (368) of *Dionysius I of Sicily, Plato was invited by Dion, the tyrant's sonin-law, to return to Syracuse to train Dionysius II to become the philosopher-king of Plato's dreams. The young ruler soon tired of his studies; he quarrelled with Dion, and Plato had to depart. A later visit (c.361), undertaken to reconcile Dionysius with Dion, was again unsuccessful. Plato is said to have died at a wedding feast.

Almost all Plato's work seems to have survived: most is in the shape of dialogue, a method of discussion known as dialectic. Socrates, the venerated teacher of his youth, is nearly always a participant. It is not clear therefore how much of the thought is that of the historic Socrates and how much Plato's own. The Socratic method was not to propound a philosophic scheme but, by exposing a pupil's statements to a searching cross-examination, to achieve precise definitions and so enable him to reach towards the truth for himself. Thus an approach to a general answer to such questions as 'What is beauty?' 'What is justice?' or 'What is knowledge?' is made by a series of questions leading to the elucidation of specific points. In the Republic, a discussion about the ideal state, a conclusion is reached favouring rule by a philosopherking. Theories about the universe ascribed to *Pythagoras are expounded in the Timaeus, the dialogue which was regarded as essentially Platonic by those neoplatonists who helped to give Christian theology its Platonic character. The influence of Pythagoras is also apparent in the Symposium, from a literary point of view one of Plato's most attractive works. Here Socrates, *Aristoplanes, *Alcibiades and others discuss the nature of love, the real background and real people here, as so often in Plato adding to the charm and naturalness of the dialogue. Perhaps the most important of Plato's own contributions to philosophic thought is his theory of 'ideas' (or more literally 'forms'). According to this theory the 'idea' of a thing is the unchanging and fundamental reality behind the superficial and mutable concepts produced by imagination or the senses. Highest of such 'ideas' is 'the good', knowledge of which is supreme virtue. But, since such complete knowledge is all but unattainable, for practical purposes man must act in accordance with his true nature under such guidance or constraint as the education implicit in the laws of the ideal state would provide.

Through his own writing and those of his most famous pupil, *Aristotle, Plato's influence has probably been the greatest of any philosopher.

Taylor, A. E., Plato, the Man and his Work. 7th ed. 1960; Kraut, R. (ed.), The Cambridge Companion to Plato. 1993; Fine, G., Plato. 2000; Jackson, R., Plato: A Beginner's Guide. 2001; Moore, E., Plato. 2007.

Plautus, Titus Maccus (Maccius) (c.250-184 BCE). Roman writer of comedies. He began to write plays (c.224) after failing in business and continued to produce them with remarkable regularity for the rest of his life. Twenty-one comedies - those regarded by Varro as the only certainly genuine ones-survive complete. The plots of the plays were derived from Greek originals (e.g. Menander), as were the stock 
characters-the clever rascal of a servant, the long-lost daughter, the duped father, the interchangeable twins. Indeed they have served the turn of *Shakespeare, *Molière and many lesser men, but Plautus made the farce much broader than that of his Greek originals and introduced songs and sometimes a chorus. One of his best known plays is Miles Gloriosus (Boastful Soldier): its chief character, Captain Pyrgopolynices, may have been a model for Falstaff.

Duckworth, G. E., The Nature of Roman Comedy. 1952.

Playford, Sir Thomas (1896-1981). Australian Liberal politician. An orchardist who fought in World War I, he was a Member of the South Australian Parliament 1933-68, serving as Premier 1938-65 for a record term, assisted by an electoral redistribution that favoured rural voters. $\mathrm{He}$ was a vigorous interventionist in economic policy.

Plekhanov, Georgi Valentinovich (1857-1918). Russian socialist and propagandist. Born to a noble family, he was an army officer, then joined the Populists, became a Marxist and was exiled, living in Geneva 1883-1917. Regarded as the founder of the Russian Social Democratic Labour Party (RSDLP), he founded the journal Iskra (The Spark) in 1900 but gradually active leadership passed to his disciple ${ }^{*}$ Lenin. He became a Menshevik after 1904 and opposed Lenin's dictatorship after 1917. He was a prolific theoretical writer.

Pletnev, Mikhail (Vasilievich) (1957- ). Russian pianist and conductor. He won the 1978 Tchaikovsky International Piano Competition in Moscow, toured extensively, made many recordings and founded the Russian National Orchestra in 1990.

Plimsoll, Samuel (1824-1898). British politician. Known as 'the merchant seaman's friend', he was in the coal trade in London when he became interested in the condition of merchant ships and seamen. Overloading and undermanning and the deliberate sending out of unseaworthy ships in order to collect insurance after shipwreck were among the evils he fought against. To obtain reform he became a Liberal MP 1868-80, but the Merchant Shipping Act was not passed until 1876 . One provision was that ships should carry the 'Plimsoll line', a disc with a horizontal line drawn through it to indicate the loading limit.

Pliny the Elder (Gaius Plinius Secundus) (23-79 CE). Roman official and writer. Brought up as an accomplished, well-educated soldier, administrator and naval commander, he is known to have practised law. But he is chiefly remembered for his interest in natural history. His Natural History is the most comprehensive account of its kind written in antiquity. The first two books deal with astronomical and cosmological matters; Pliny then moves on to cover the geography of the globe and the nature of man. Books 8-11 treat of the animal world, and books 12-19 deal with plants, including long discussions of agriculture and the use of herbs for medical purposes. The last sections of the work discuss such topics as pharmaceuticals, metals, precious stones, the history of painting, magic and charms. Pliny's work is essentially a compilation; it is comprehensive, but Pliny was careless in his use of sources, and frequently credulous. He enjoyed the fabulous and the moralistic aspects of natural history, and retold old wives' tales. Pliny's Natural History remained the standard encyclopaedic compilation covering the three kingdoms of nature down to the 17th century. He commanded the fleet in the Bay of Naples, described the eruption of Mt Vesuvius with remarkable accuracy but after landing for closer examination was overcome by fumes and died.

A figure of lesser stature was his nephew and adopted son Pliny the Younger (Gaius Plinius Caecilius Secundus) (61/2-c.114), a notable orator and a diligent official under ${ }^{*}$ Trajan. His letters are factually interesting as they deal with the lives of ordinary respectable citizens in provincial towns, and his exchanges of letters with Trajan reveal how even the more enlightened men of his time regarded the early Christians, whom he found 'unboundedly superstitious' but not 'grossly immoral'.

Pliny, Natural History (ed. and trans. Rackham, H. et al.). 10 vols, 1938-63.

\section{Plisetskaya, Maya see Shchedrin, Rodion}

Plotinus (205-270). Roman philosopher, born in Egypt. Having studied philosophy in Alexandria, he joined a military expedition to the east in the hope of learning the philosophy of Persia and India and barely escaped with his life in Mesopotamia. In 244 he went to Rome, where he founded a school and lived for the rest of his life. As an old man he attempted to found in Campania a 'republic' on the pattern of Plato's ideal state. Relying on inward vision rather than reasoning, he effects in his writings an integration of all Greek philosophy in order to provide a philosophic basis for a renaissance of Greco-Roman civilisation. He regards all souls as one with a world-soul, all intelligences as one with a world-mind, the source of both being the Light of God within us (variously described as the 'One' or the 'Good'). This pagan version of the Trinity was adapted by Christian neoplatonists to accord with their own creed.

Plowright, Dame Joan (Ann) (1929- ). English actress. She made her London debut in 1954 and married Laurence ${ }^{*}$ Olivier in 1961. Successful on stage, her films included Enchanted April (1992) and Tea with Mussolini (1999).

Plücker, Julius (1801-1868). German physicist and mathematician. Professor of mathematics 1836-47 and of Physics 1847-68 at Bonn, his investigations into electrical discharge in gases at low pressure led to 
his discovery (1859) of cathode rays, which formed the basis of later work on atomic structure and of many technical developments, including television.

Plumer, Herbert Charles Onslow, 1st Viscount Plumer (1857-1932). English field marshal. He was a cautious field commander in France in World War II, with a low casualty rate, defeating the Germans heavily at Messines in June 1917. He declined appointment as Chief of the Imperial General Staff but later served as Governor of Malta 1919-24 and High Commissioner in Palestine 1925-28.

Plunket, St Oliver (1629-1681). Irish Roman Catholic bishop and martyr. Primate of all Ireland from 1669, he was one of many victims of the Popish Plot campaigns of Titus *Oates, who accused him of plotting a foreign invasion of Ireland. He was tried and acquitted in Ireland, tried again in London, convicted and executed. He was canonised in 1975.

Curtayne, A., The Trial of Oliver Plunket. 1953.

Plutarch (Ploútarkhos, later Lucius Metrius Plutarchus) (c.46-120CE). Graeco-Roman historian, born in Chaeronera. Educated in Athens, he often visited Rome but spent most of his life in his native Boeotia. Best known of his works on history and philosophy is his Lives of the Noble Greeks and Romans (often called Parallel Lives), containing biographies of 23 Greek and 23 Roman figures notable in history. Distinguished by their literary excellence and narrative interest, the lives vary much in historical value owing to Plutarch's uncritical use of his sources. They became available to Elizabethans through *North's translation (1579) of Amyot's great French translation (1559) and *Shakespeare used them for his Roman plays.

Barrow, R. H., Plutarch and his Times. 1967.

Pobedonostsev, Konstantin Petrovich (18271907). Russian administrator, jurist and philosopher. From 1880 he was the government administrator of the Russian Orthodox Church, a powerful influence on Tsars *Aleksandr III and *Nikolai II, and, in part, a model for *Tolstoy's Aleksei Karénin. (He excommunicated Tolstoy in 1901.)

Pocahontas (or Matoaka) (1595-1617). American Indian princess. When Captain John ${ }^{*}$ Smith, leader of the settlement of Jamestown, Virginia, was captured, Pocahontas, though only 11 years old, allegedly saved his life 'by taking his head in her arms'. Five years later, when she was held as a hostage in Jamestown, one of the settlers, John Rolfe, fell in love with her. They were married and in 1616 he took her (now baptised 'Rebecca') to England where she was received by the king and queen. She had one son.

Poděbrad, Jiř́i (George) z Kunštátu (1420-1471). King of Bohemia 1458-71. As leader of the moderate Hussites, he was elected King by the Diet although he had no blood ties with the former rulers. He quickly restored the country after the Hussite Wars and strengthened the power of the monarchy at the expense of the nobility, the Catholic members of which formed a league against him. This acted in concert with the invading army of ${ }^{*}$ Matthias Corvinus, King of Hungary, whose pretext was a mandate of deposition by the Pope, by whom Jiří had been excommunicated (1446). Jiří, however, held his opponents at bay and fighting was still in progress when he died.

Podgorny, Nikolai Viktorovich (1903-1983). Russian Communist politician, born in the Ukraine. Originally a mechanic, he became a food technologist and a protégé of *Khrushchev, serving as Secretary of the Ukraine CP 1957-63 and a Politburo member 1960-77. He was President of the USSR 1965-77.

Poe, Edgar Allan (1809-1849). American poet and short-story writer, born in Boston. Both his parents were on the stage, and on his mother's death (1811) he was adopted by John Allan, a merchant who sent him to school in England and to the University of Virginia, from which he ran away after a quarrel over debts. A projected career as an army officer became financially impossible when Allan married again, and Poe had to manoeuvre his dismissal from West Point (1831). Meanwhile his first book Tamberlane and Other Poems (1827) had appeared, but like its two successors (1829 and 1831) attracted little notice. A prizewinning short story, MS. Found in a Bottle (1833), obtained for him the editorship of a paper in Richmond, Virginia, which he turned into a success. In 1836 he married his 13-year-old cousin Virginia Clemm and to better himself moved to New York and then Philadelphia. In 1840 he published Tales of the Grotesque and Arabesque (which included The Fall of the House of Usher) and in 1841 he joined George Graham for whom he edited Graham's Magazine, the circulation of which he raised from 5,000 to 35,000 , his own contributions including the famous detective story The Murders in the Rue Morgue. Recognition as a major poet came with the publication of The Raven and Other Poems (1845). After the death of his wife (1847) he had a nervous breakdown and he died in Baltimore two years later on his way to fetch his aunt, Mrs Clemm, to attend his second marriage to a boyhood sweetheart, Sarah Elmira Royster. The commonly held view that Poe was a drug addict and an alcoholic is derived from a slanderous account in the preface to the collected edition written by his literary executor, Rufus W. Griswold, an old enemy with whom Poe believed himself reconciled. Every item has been refuted by his many loyal friends but the myth persists. He was in fact hard working and much loved. Few writers have equalled Poe in his presentation of the macabre and his tales of mystery and horror (e.g. The Pit and the Pendulum, The Gold $B u g$ a classical reference for the solution of ciphers and The Cask of Amontillado) have been reprinted over and over again. His poems, e.g. The Raven, Annabel Lee and The Bells, show metrical mastery, 
haunting rhythms and resonances and undertones of melancholy which deeply influenced *Baudelaire and the French Symbolists.

\section{Quinn. A. H., Edgar Allan Poe: A Critical Biography.} 1969.

Poincaré, (Jules) Henri (1854-1912). French physical scientist and mathematician. Originally trained as a mining engineer, he became a physics lecturer first at Caen University and then at the Paris Faculté des Sciences where he taught until his death. His major work was in the field of functions. He developed important techniques of probing their properties by partial differential equations (which he termed 'fuchsian' and 'kleinian' functions). In much of his mathematical work he was a follower of Charles Hermite, especially in regard to the application of non-Euclidian geometry to the theory of quadratic forms. Another interest was an investigation of the properties of integral curves of differential equations. His longstanding concern for probability theory was expressed in his book of 1895 Leçons sur le Caleul des Probabilités. By the turn of the century he was thinking more philosophically about the foundations of Newtonian physics, and becoming aware of some of the dimensions of relativity. He grasped how absolute motion was incapable of being observed (i.e. that for the observer, everything in nature must be relative to something else). Poincaré was a gifted writer with deep insight into the creative process of mathematical discovery and logic, capable of being understood by the layman.

Poincaré, Raymond Nicholas Landry (18601934). French politician, born in Lorraine. A cousin of Henri *Poincaré, he first became a deputy in 1887 and held a number of government offices including two terms as Finance Minister 1894-95 and 1906, and was elected to the Académie française in 1909. A firm but popular Premier 1912-13, as President of the Republic 1913-20, he expanded the powers of his office during World War I. Premier again 1922-24, he insisted upon a stern reparations policy towards Germany and ordered the occupation of the Ruhr when German payments were in arrears (1923). Recalled to 'save the franc' he was Premier for the last time 1926-29.

Poiret, Paul (1879-1944). French fashion designer. ${ }^{*}$ Matisse and ${ }^{*}$ Dufy created fabrics for him; he designed stage costumes and popularised Oriental motifs.

Poisson, Simon-Denis (1781-1840). French mathematical physicist. He adopted a two-fluid theory of electricity: like fluids repelled and unlike attracted. Their strengths were in proportion to the inverse square law. He presupposed that the normal condition of any body was to possess equal quantities of both fluids. Bodies became electrically charged when they acquired a superfluity of one. Using *Lagrange's methods, he attempted to render these ideas in mathematical terms. He developed the bell shaped normal distribution curve. He shared the Copley Medal with *Faraday (1832).

Poitiers, Diane de (1499-1566). French mistress. Although she was 48 when her lover ${ }^{*}$ Henri II came to the throne she long kept her beauty and used her power to counteract that of the Guises.

Pol Pot (originally Saloth Sar) (1925-1998). Cambodian (Kampuchean) Communist politician. A rubber worker and teacher, educated in Paris, he led the Khmer Rouge which took power on the US withdrawal from Indo-China and he became Premier 1976-79, with China's backing, until overthrown by Vietnamese forces. He imposed a totalitarian regime that sought to eliminate all religion, urbanisation and Western influence (Year Zero). Deaths in the 'killing fields' have been estimated at 3 million.

Chandler, D., Brother Number One. 1993.

Polanski, Roman (1933- ). Polish-French film director. Educated at the Polish Film School, Lodz, his first film was Two Men and a Wardrobe (1958), followed by Repulsion (1964), Rosemary's Baby (1968), Chinatown (1978) and Frantic (1988). He also directed the operas Lulu, Rigoletto and Tales of Hoffmann. In 1968 his wife Sharon Tate was murdered by Charles Manson.

Polanyi, Michael (né Mihály) (1891-1976). Hungarian-Jewish-British chemist, social scientist and philosopher, born in Budapest. He made fundamental contributions to adsorption, X-ray diffraction and reaction kinetics, lived in England from 1933 and created a new career as a social scientist. His son John Charles Polanyi (1929- ), a professor at Toronto, shared the 1986 Nobel Prize for Chemistry for his work in chemical kinetics, and was active in the Pugwash Group on Sciences and World Affairs. Michael's brother, Karl Paul Polanyi (1886-1964), economic anthropologist, was born in Vienna. A lawyer and journalist, he lived in England 1933-40 and the US 1940-64. His book The Great Transformation (1944) was a powerful critique of neo-liberalism.

Pole, Reginald (1500-1558). English cardinal, born in Staffordshire. His mother, Margaret Pole (née Plantagenet), Countess of Salisbury (14731541) was the niece of ${ }^{*}$ Edward IV and ${ }^{*}$ Richard III. Educated at Oxford and Padua, he became a distinguished humanist scholar and a friend of ${ }^{*}$ Henry VIII. Ecclesiastical preferment, including the archbishopric of York, was offered in the hope that he would approve the annulment of Henry's marriage to ${ }^{*}$ Katherine of Aragon. Unable to respond, Pole withdrew abroad and made public his disapproval of the divorce and of Henry's claim to supremacy of the English Church in De Unitate Eeclesiastica (1536). Henry was even more enraged when (1536-37) Pope *Paul III made Pole a cardinal, although not then ordained, and appointed him papal legate. He 
attainted him, arrested members of his family and later had his mother executed. Pole continued in papal employment and in 1545 was one of the three legates who presided over the opening of the Council of Trent. He remained abroad during *Edward VI's reign, but on the accession of Queen *Mary I, he returned as papal legate and was the principal instrument by which Roman Catholicism was reimposed. He succeeded ${ }^{*}$ Cranmer as Archbishop of Canterbury (1556) and was instrumental in the burnings of Cranmer, ${ }^{*}$ Latimer and ${ }^{*}$ Ridley as Protestant martyrs. However, in 1558 his legateship was revoked by *Paul IV and he died of influenza on the same day as Queen Mary.

Schenk, W., Reginald Pole. 1950.

Politian (or Poliziano: Angelo Ambrogini) (14541494). Italian scholar and poet. He was educated in the Florence of Lorenzo *de'Medici, whose patronage he attracted by a Latin translation of ${ }^{*}$ Homer's Iliad which he began at the age of 17 . His later works include translations of the great medical writers *Hippocrates and ${ }^{*}$ Galen. In 1584 he became professor of Latin and Greek at Florence University. Some of his poetry (e.g. his Latin elegy on Lorenzo) shows both depth of feeling and metrical skill. His Orfeo was the first secular drama written in Italian. He was a major influence on *Michelangelo.

Polk, James Knox (1795-1849). 11th President of the US 1845-49. Born in North Carolina, he became a lawyer in Tennessee. He entered the US House of Representatives in 1825, was speaker 1835-39, and Governor of Tennessee 1839-41, being defeated twice (1841, 1843.) In 1844 he was the original 'dark horse' candidate, winning the Democratic nomination on the eighth ballot, after Martin *Van Buren, having won a simple majority, failed to gain the two-thirds vote. Although comparatively unknown, and failing to win his own state, in November he defeated Henry *Clay and won the presidency. His term of office was notable for the settlement of the Oregon boundary dispute with Britain, the occupation of Texas and the ensuing war with Mexico by which California and New Mexico were acquired. He pledged to serve only a single term and did not contest the 1848 election, when Zachary ${ }^{*}$ Taylor succeeded, and died three months after his term ended. In 20 Presidential ranking lists by US historians and political scientists, Polk scores No. 12 in the aggregate, far ahead of any President between Andrew *Jackson and Abraham *Lincoln.

Pollini, Maurizio (1942- ). Italian pianist, born in Milan. His repertoire was exceptionally wide, from Renaissance music to the works of ${ }^{*}$ Boulez, * Stockhausen and *Nono, and he combined technical brilliance with deep interpretative gifts.

Pollock, Jackson (1912-1956). American painter. The pioneer and leading exponent of New York Abstract-Expressionism, by spraying or dribbling paint on to an unstretched canvas tacked to floor or wall and being thus enabled to approach his picture from all sides, he claimed that he could achieve an intimacy with his subject otherwise unattainable. Using this method, he created tense and intricate patterns of swirling lines and shapes into which representational elements were sometimes introduced. He had great influence among his contemporaries. His Blue Poles (1952) was bought by the Australian National Gallery for \$US1.9 million in 1973, at that time a record price for his work. (In 2016 Blue Poles was insured for $\$ 350$ million.) In 2006 his Number 5 (1948) sold for \$US140 million.

Polo, Marco (1254-1324). Venetian traveller, born possibly in Korčula, Dalmatia. The journeys which he vividly described resulted from an earlier expedition (1260-69) by his two uncles to Mongol territory during which they were persuaded to visit the great khan, *Kublai, who as the result of Mongol conquests was also Emperor of China. They set out (1271) on a second journey, taking Marco with them, and travelled overland from Acre through Persia, Turkestan and the Gobi Desert, reaching Cambuluc (Peking) in 1275. Marco became a favourite of Kublai Khan who employed him on missions that took him to the furthest parts of the country, and also appointed him Governor of Yangchow. So high were the Polos in the khan's favour that it was not until 1292 that they were allowed to leave as part of the escort of a Mongolian princess on her way to Persia to marry a prince. The voyage took two years and the bridegroom had died meanwhile, but she married his brother, and the Polos eventually reached Venice in 1295. In 1296 Marco commanded a galley against the Genoese and was captured. While in prison he was allowed to send for his notes and, with the help of a fellow prisoner, Rustichello (or Rusticiano), he composed from them a record of his adventures. The book was published in 1298 as Divisament dou Monde ('Description of the World') but was soon better known, because of the incredulity it provoked, as Il milione, and became the great bestseller of the pre-Gutenberg age. Although the book contains some legendary material, its descriptions of China are generally accurate.

Latham, R., ed. and trans., The Travels of Marco Polo. 1958.

Polybius (c.200-c.120 BCE). Greek historian. Sent to Rome (166) as a hostage, he became friendly with *Scipio Aemilianus whom he accompanied when Carthage was destroyed (146). It was thanks to the encouragement of the Scipio family that he wrote his Universal History, one of the greatest historical works ever written. The first five books survive intact, but of the other 35 only fragments remain. The extant books mainly cover the period 221-168 BCE and provide a careful and critical account of the Punic Wars.

Walbank, F. W., Polybius. 1973. 
Polycarp, St (c.70-155/6). Greek Bishop of Smyrna. His long life made him a link between the apostles and the Fathers of the Church: ${ }^{*}$ Irenaeus relates that as a boy he had heard Polycarp speaking of his 'intercourse with *John and others who had seen the Lord'. He wrote a notable epistle to the Church at Philippi. He was martyred in Smyrna. His feast day is 26 January.

Polyclitus (5th century BCE). Greek sculptor. $\mathrm{He}$ worked particularly in bronze and was contemporary with *Phidias. *Pliny thought his Doryphorus perfect sculpture.

Polycrates (d.522 BCE). 'Tyrant' of Samos c.535522 BCE. Having built a large fleet, he dominated the Aegean as a kind of pirate king. Enriched with spoils, he beautified Samos and made it temporarily the cultural centre of the Greek world, Anacreon being one of the many poets and artists attracted to his court. At last the Persian Governor of Lydia, whose ships and ports had suffered most heavily, lured him to Magnesia where he had him assassinated. The famous legend of the ring and the fish relates to Polycrates: told to throw away something precious, lest his prosperity provoke the envy of the gods, he hurled a valuable ring into the sea. When the ring came back to him the next day in the belly of a fish, it was taken as a portent of his doom.

Pombal, Sebastião José de Carvalho e Melo, Marquis of (1699-1782). Portuguese statesman. He showed his outstanding ability as Foreign Minister 1750-55 and Prime Minister 1755-77 under King *José (Joseph). The skill with which he met the problems created by the earthquake that destroyed Lisbon (1755) gave him a reputation that enabled him to carry out important reforms and curb powers of the Church he thought excessive. Thus sentences passed by the Inquisition now required government approval, censorship passed to state control; he also expelled the Jesuits, whom he suspected of political intrigue. Facilities for education, hitherto almost entirely in Church hands, were extended by building 800 schools and reforming the universities. He promoted the development of Brazil and decreed the liberation of the Indian slaves. Ruthlessness in carrying out his policies gradually built up opposition and when Maria I succeeded (1777), he was dismissed. Energy, honesty and vision made Pombal one of the greatest figures of Portuguese history.

Maxwell, K., Pombal: Paradox of the Enlightenment. 1995.

Pompadour, Jeanne Antoinette, Marquise de (1721-1764). French mistress of *Louis XV. Daughter of a speculator, François Poisson, she was beautiful and accomplished, and married Lenormant d'Etoiles, a man rich enough to enable her to entertain and be entertained. She became the king's mistress in 1745 and for the rest of her life maintained a hold over him even after her sexual attractions had ceased.
As her beauty faded her extravagance increased, but she had good taste and her patronage of literature and the arts was wisely bestowed, e.g. on *Voltaire and ${ }^{*}$ Boucher. She founded the porcelain factory at Sèvres and the École Militaire. Her meddling in politics resulted in the diplomatic upheaval by which the hereditary enemies France and Austria fought as allies in the disastrous Seven Years War (1756-63). Her protégé the Duc de ${ }^{*}$ Choiseul became Foreign Minister in 1758.

Mitford, N., Madame de Pompadour. 1964.

Pompeo, Mike (Michael Richard) (1963- ). American Republican politician and administrator. Educated at Harvard, he was a Congressman 201117, Director of the CIA 2017-18 and US Secretary of State 2018-21.

Pompey the Great (Gnaeus Pompeius Magnus) (106-48 BCE). Roman soldier and politician. He sided with ${ }^{*}$ Sulla against ${ }^{*}$ Marius in the Civil War and for his successes in Africa won the title Magnus ('the great'). After Sulla's death (78) he put down a revolt by ${ }^{*}$ Lepidus, and in Spain crushed the remaining faction of Marius. Back in Rome, his quest for office led him to break with the senatorial party, heal an old feud with ${ }^{*}$ Crassus and jointly with him hold the consulship of 70 , gaining popularity by restoring the power of the tribunes. He received a special commission to clear the Mediterranean of pirates, which he accomplished in a single brilliant campaign (67). His next achievements were to finish off the war with ${ }^{*}$ Mithridates (66), annex Syria and capture Jerusalem (63). On his return to Rome (61) he found the timid and jealous Senate reluctant to concede his two reasonable demands: provision for his veterans and confirmation of his eastern settlement which involved the creation of four new Roman provinces, Bithynia (with Pontus), Cilicia, Syria and Crete. He was thus almost forced into forming (60) the First Triumvirate with ${ }^{*}$ Caesar, whose daughter Julia he married, and Crassus. Caesar departed to pursue his conquests in Gaul, and Crassus went east. Pompey began to be suspicious of the activities of Caesar's friends in Rome, and following the deaths of Julia (54) and Crassus (53) the friendship deteriorated. The death of *Clodius, followed by anarchy in Rome, brought about the final breach. Pompey and the Senate, the only sources of law and order, were reconciled and in 52 Pompey was made sole consul. Caesar, seeing his prospects of renewed power and even his life endangered if he returned unarmed, took the symbolic step of crossing the Rubicon and entering Italy with his legions (49). Pompey with most of the senators withdrew to Greece to collect an army but when the rivals finally met at Pharsalus (48), Pompey was defeated, fled and was murdered in Egypt.

His son, Sextus Pompeius (Magnus Pius) (c.67-36 $\mathrm{BCE}$ ), a general, fought against the Second Triumvirate ( ${ }^{*}$ Octavian, Mark *Antony and ${ }^{*}$ Lepidus), controlled 
Sicily 42-36 and invaded southern Italy. He defeated Octavian in two battles $(37,36)$ but *Agrippa destroyed his navy (36). Escaping to Asia Minor, he was captured and summarily executed in Miletus.

Gelzer, M., Pompeius. 1959; Seager, R., Pompey the Great: A Political Biography. 2002; Southern, P., Pompey the Great: Caesar's Friend and Foe. 2002.

Pompidou, Georges Jean Raymond (1911-1974). French politician, born in Montboudif. Originally a teacher of literature, during World War II he became active in the Resistance, joined *de Gaulle's personal staff in 1944 and was a member of the Council of State from 1946 until he became director general of Rothschild's French banking house (1954). When de Gaulle returned to power (1958) he chose Pompidou to plan the transition to the Fifth French Republic and assist in drafting a Constitution. He then returned to banking until appointed to succeed Michel *Debré as Prime Minister 1962-68, holding office for a record term, although never serving in the National Assembly. He fell out with de Gaulle, but when the latter resigned suddenly, Pompidou won the nomination of the Gaullist Party (UDR) and was President of France 1969-74, dying in office, suddenly, from Waldenström's macroglobulinemia, a rare form of lymphoma. The great Centre Pompidou (Beaubourg), for modern art, was named for him and he encouraged *Boulez' avant-garde music.

Poncelet, Jean Victor (1788-1867). French mathematician and engineer. He served in the Napoléonic army at Walcheren and in Russia, where he was wounded, and imprisoned. During his years of captivity (until 1814) he applied himself to the mathematical works of Monge, and wrote some important papers. He returned to Metz in 1814 and worked in the field of projective geometry, producing his Traité des Propriétés Projectives des Figures in 1822. Poncelet's most fertile period in applied mechanics was between 1825 and 1840 . He spent much time on the improvement of water wheels and turbines. He made some important advances in the field of fortifications, and wrote extensively about the theory of machines. His main influence, however, was as a practical teacher. In 1848 he was made head of the Paris École Polytechnique.

Ponchielli, Amilcare (1834-1886). Italian composer. A prolific writer of opera, he is now remembered only for La Giaconda (1876), and his significant influence on *Puccini.

Poniatowski, Josef Antoni (1762-1813). Polish patriot and marshal of France. A nephew of ${ }^{*}$ Stanisław II August, the last king of Poland, in the struggle that preceded the final partition of the Polish kingdom (1793), he gained several victories over the Russians. In 1794 he commanded the division of *Kosciuszko's patriot army which vainly defended Warsaw. When *Napoléon formed the grand duchy of Warsaw, Poniatowski became War Minister and
Commander-in-Chief. In 1812 he headed the large Polish contingent which fought its way with Napoléon to Moscow and, still with the French army after the retreat, he performed so gallantly at Leipzig (1813) that Napoléon created him Marshal. He was drowned whilst covering the French retreat.

\section{Poniatowski, Stanisław II August see Stanisław II August Poniatowski}

Ponti, Gio(vanni) (1891-1979). Italian architect, designer and craftsman. From 1923, when he appeared at the Triennale Exhibition as a ceramics designer, he designed furniture, industrial products, the interiors of liners, and stage costume and settings, as well as buildings throughout Europe and America. Of his modern commercial buildings, the Pirelli tower (1957) in Milan is among the most striking. He founded (1928) the magazine Domus and became its editor.

Pontiac (c.1720-1769). American Ottawa Indian chief. He planned a large-scale concerted attack on the British colonists in which all the frontier forts from Canada to Virginia except Detroit and Pittsburgh were captured (1763). Pontiac agreed to a peace treaty in 1766 .

Peckham, H. H., Pontiac and the Indian Uprising. 1947.

Pope, Alexander (1688-1744). English poet, born in London. Son of a linen merchant, his family, to avoid persecution as Roman Catholics, left London (c.1700) to live in Windsor Forest. Deprived of a normal education by lifelong deformity caused by a tubercular spine, the boy Alexander educated himself, with his father's encouragement and help. By precocious reading and writing he began an epic at the age of 12 . His pastoral poems were the first to be published, followed by the Essay on Criticism (1711) and the mock-heroic Rape of the Lock (1712). With these works and other poems he was steadily building up a reputation when the publication of his Homeric translations, The Iliad (1715-20) and The Odyssey (1725-26), brought fame and enough fortune to enable him to rent a villa at Twickenham and lay out a five-acre garden in the romantic fashion of the time, with a temple, obelisk (in memory of his mother), 'sacred groves', an orangery and above all a grotto, where he could talk with his many and famous visiting friends.

His edition of $*$ Shakespeare (1725) produced much criticism, to which the Dunciad (1728), in which his opponents were satirised as pedants and dunces, was a reply. His Essay on Man (1733-34) is a popular exposition in verse of current philosophical beliefs, while his Moral Essays (1731-35) deal with the characters of men and women, the use of riches, and good taste. The fitting of names to the imaginary characters involved the author in several literary quarrels. The most famous of them was with Lady Mary Wortley *Montagu by whom Pope was at first 
dazzled but whose unkind cynicism soon disillusioned him. In his Imitations of Horace, perhaps the best of Pope's satirical works, she saw herself in the lines:

From furious Sappho scarce a milder fate.

Poxed by her love, or libelled by her hate.

But if Pope had a talent for making enemies, he had also a gift, much truer to his real character, of making friends—*Swift, *Gay, *Bolingbroke, *Arbuthnot, and Martha Blount. Pope's 'heroic couplets' in which so much of his work is written would be monotonous were it not for the flexibility he introduced by variation of stress, turn of phrase and exact choice of word. The wit and wisdom is accompanied, too, by a poet's imaginative vision. In spite of his deficiencies of character, Pope is one of the great figures of English literature.

Mack, M. Alexander Pope, 1985.

Popper, Sir Karl Raimund (1902-1994). AustrianBritish philosopher, born in Vienna. His father, a successful lawyer and bibliophile, converted from Judaism to Lutheranism. He studied at Vienna University, became a Marxist, briefly, and worked as a cabinet maker, then schoolteacher. He left Europe after ${ }^{*}$ Hitler came to power, lectured at Canterbury University College, Christchurch, New Zealand 1937-45, was denied Sydney University's senior lectureship in philosophy (1945), and became reader in logic 1945-49 and professor of logic and scientific method 1949-69 at the London School of Economics. His books e.g. The Logic of Scientific Discovery (1934), The Open Society and its Enemies (1945), The Poverty of Historicism (1957) and Conjectures and Refutations (1963), examine the conditions of scientific and social progress and elaborate his main theories that the confirmation of a theory can never be more than provisional, while its refutation will always be final; that ethical standards are 'autonomous' (i.e. are not derivative from facts), hence that individuals have the right to criticise authorities and institutions, and finally that progress is made possible not by Utopian approach but by readiness to make the best of existing material resources. He argued that the proponents of an idea must be able to propose methods for testing 'falsifiability', leading to confirmation or refutation of the hypothesis. In Popper's view, followers of *Marx, *Freud, religions and most economic theories are unable (or unwilling) to meet the test. He was elected FRS (1976), a rare honour for a non-scientist, and made a CH (1982).

Popper, K., Unended Quest: An Intellectual Autobiography. 1976.

Porpora, Nicola Antonio (1686-1768). Italian composer and teacher, born in Naples. He worked in Naples, Vienna, Venice, London and Dresden and was considered as a rival to ${ }^{*}$ Händel. He wrote about 50 operas (some in one act, beginning with
Agrippina,1706), ending with The triumph of Camilla (1760). He taught the outstanding castrato *Farinelli, for whom he wrote many virtuoso arias.

Porsche, Ferdinand (1875-1951). German engineer and motorcar designer. He began work with *Daimler and Auto Union, and set up his own workshops in 1931. In 1934 he designed the revolutionary Volkswagen, a cheap, reliable people's car with a rear engine, intended for a mass market in the 1930s but not produced until after 1945 . The Porsche company produced very sophisticated sports cars.

Georgano, G. N. (ed.), The Complete Encyclopaedia of Motorcars: 1885-1968. 1968.

Porson, Richard (1759-1808). English classical scholar. The founder of scientific textual criticism, his editions of ${ }^{*}$ Euripides and those of ${ }^{*}$ Aeschylus and *Aristophanes compiled from his notes, set new standards of criticism. He was also a connoisseur of wine, and his correspondence reveals a mischievous sense of humour.

Portal of Hungerford, Charles Frederick Algernon Portal, 1st Viscount (1893-1971). British airman. Educated at Winchester and Oxford, after a brilliant record (MC, DSO, and bar) in World War I, he held important administrative posts between the wars and became Chief of Bomber Command 1940. As Chief of Staff, RAF 1940-45 he largely directed operational strategy, was proponent of the firebombing of German cities, and became Chairman of the Joint Chiefs of Staff 1945. Created a marshal of the RAF (1944), he was made a baron in 1945 , a viscount, KG and OM in 1946. He was controller of production (atomic energy) 1946-51. *Eisenhower thought him the most impressive of Britain's war leaders.

Porter, Cole (1891-1964). American composer and lyricist, born in Indiana. Educated at Yale and Harvard, he spent years in France and studied music with Vincent d'*Indy in Paris. Rich, married and gay, he lost a leg after a riding accident. He developed an astringent, sophisticated style with both words and music. His musicals include Anything Goes (1934), Kiss Me Kate (1949), Can Can (1953) and Silk Stockings (1955) and he wrote the film score for High Society (1956). His best songs include You're the Top, Begin the Beguine, Night and Day, In the Still of the Night and My Heart Belongs to Daddy.

Porter, George, Baron Porter of Luddenham (19202002). British chemist. Educated at Cambridge, he taught there at Sheffield and (from 1963) at the Royal Institution, London. He shared the 1967 Nobel Prize for Chemistry for work on photo-chemistry. He was a successful populariser of science in writing and on television, became President of the Royal Society 1985-1990, and received the OM and a peerage. 
Porter, Michael Eugene (1947- ). American economist. He taught economics at Harvard from 1973, and was a professor 1982- . In The Competitive Advantage of Nations (1980) he modified *Ricardo's concept of 'comparative advantage', demonstrating how nations with no history or experience in particular areas developed niche markets against ferocious competition, e.g. Finland's Nokia mobile telephones or Kone medical assay equipment.

Portillo, Michael Denzil Xavier (1953- ). English politician and television presenter. His father was Spanish, his mother Scottish. Educated at Harrow and Peterhouse, Cambridge, he worked in the oil industry, was MP 1984-97, Minister for Employment 1994-95 and Secretary for Defence 1995-97. He was re-elected as MP 1999-2005 and became Shadow Chancellor 2000-01, failing in a bid for the Conservative leadership. He left the Conservative Party in 2006 and became a presenter in many television series.

Portland, 3rd Duke of, William Henry Cavendish Bentinck (1738-1809). English politician, originally Whig, later Tory. Educated at Oxford, MP 1761-62, he was Lord Lieutenant of Ireland 1782. He served twice as Prime Minister, in April-December 1783 as nominal head of the ${ }^{*}$ Fox $-{ }^{*}$ North coalition and 1807-09 in a government dominated by ${ }^{*}$ Canning and ${ }^{*}$ Castlereagh. He was Chancellor of Oxford University 1792-1809.

Portsmouth, Louise de Keroualle, Duchess of (1649-1734). French mistress of ${ }^{*}$ Charles II of Britain. She also acted as confidential agent of *Louis XIV of France. Charles Lennox, her son by the king, was created Duke of Richmond and Gordon.

Post, Emily (1873-1960). American writer, born in Baltimore. After writing some novels on social themes she turned to becoming mentor to Americans in all matters of social behaviour and etiquette, broadcasting and writing newspaper articles on these subjects. Her reputation was based on the book Etiquette (1922).

Potemkin, Grigori Aleksandrovich, Prince of Tauris (1739-1791). Russian soldier. He was one of the guards officers who conspired to put ${ }^{*}$ Catherine the Great on the throne (1762), he became her lover (1769) and perhaps her secret husband (1774). He was of impressive physique and personality and showed his talents as an administrator when he was sent to colonise territory conquered from Turkey. He also created the Russian Black Sea fleet and founded the naval base of Sevastopol. He acquired his princely title and vast wealth from Catherine, but he was not merely the self-seeking rascal portrayed by those who invented the tale that, to deceive foreigners, he had built cardboard villages to convey a false impression of the prosperity of the Crimea.

Potter, Dennis (Christopher George) (1935-1994). English playwright. A journalist and critic, he wrote many successful television dramas, reaching a vast international audience. They include Blade on the Feather (1980), Pennies from Heaven (1981) and The Singing Detective (6 parts, 1987).

Potter, (Helen) Beatrix (1866-1943). English author and illustrator. She produced notable children's books, e.g. The Tale of Peter Rabbit (1900) and The Tailor of Gloucester (1902). She lived in the Lake District for many years and left her extensive estate to the National Trust. Her books have been translated into many languages, modern and classical, and are still highly popular.

Lane, M., The Tale of Beatrix Potter. 1970.

Poujade, Pierre (1920-2003). French bookseller. In 1953-54 he organised a tax revolt by small businessmen, and in 1956, 52 Poujadist deputies were elected (with 12 per cent of the vote) on a policy proposing tax cuts, regionalism and vaguely Fascist social policies. His movement faded with *de Gaulle's return to power (1958).

Poulenc, Francis (1899-1963). French composer and pianist, born in Paris. One of 'Les Six' (*Honegger), his output included concertos for harpsichord (1928), two pianos (1932) and organ (1938), chamber music, piano pieces, e.g. Mouvements Perpetuels (1918), the ballet Les Biches (1923), the Mass in G Minor (1937), the cantata La Figure Humaine (1943) and the operas Les Mamelles de Tirésias (1944) and Dialogues des Carmélites (1956). An outstanding composer of songs, he wrote many for his sometime lover, the baritone Pierre Bernac (1899-1979), touring and recording with him.

Roy, J., Francis Poulenc. 1964.

Pound, Sir (Alfred) Dudley (Pickman Rogers) (1877-1943). British Admiral of the Fleet. A captain in World War I, after distinguishing himself at Jutland, he became director of operations at the Admiralty. He was Commander-in-Chief, Mediterranean 1936-39 and promoted Admiral of the Fleet and First Sea Lord 1939-43, gaining credit for successes against U-boats in the Atlantic, and in the Mediterranean, and blame for failures in the Far East. A stroke forced his retirement. He was consoled with the OM a month before his death.

Pound, Ezra (Weston Loomis) (1885-1972). American poet, born in Idaho. After spending the years 1906-07 in European travel he lived mainly in England. His early works, e.g. Provenca (1910), Canzone (1911) and Ripostes (1912), included adaptations of Latin, Provençal, Chinese and Japanese verses (the latter two based on literal translations). As a leader of the Imagist group (c.1914), which attempted to transfer to poetry the modern movements in art, he was distinctive with his 'velvet coat ... pointed beard ... and fiery hair'. In pursuit of the same aim he was co-editor with Wyndham Lewis of Blast, the organ of Vorticism. He was also foreign correspondent of Poetry (Chicago) (1912-19) and the Little Review (1917-19). Among 
his best works were Quia Paupera Amavi (1919) and Hugh Selwyn Mauberley (1920). During this time he formed literary friendships with W. B. *Yeats (whose secretary he became), Robert *Frost, James *Joyce, Ernest ${ }^{*}$ Hemingway and T. S. *Eliot (and edited his The Waste Land). He lived in Paris from 1920, moved to Rapallo in 1924, became an enthusiastic supporter of ${ }^{*}$ Mussolini and helped to revive interest in *Vivaldi. From about 1919 to 1960 , he worked intermittently on his Cantos, a vast, complex compilation, publishing the first part in 1925. He made much use of 'free association' and distorted spellings and contained a sprawling medley of quotations ranging from ancient Greek and Chinese to modern slang. Meanwhile he had taken up, in turn, Social Credit (C. H. *Douglas) and Fascism, for reasons deriving in part at least from his obsessive hatred of 'usury' as the basis of all the evils of modern life, and wrote Jefferson and/ or Mussolini (1935). During World War II he made regular broadcasts from Italy supporting Mussolini, and in 1945 he was arrested, charged with treason and returned to the US. Certified insane, he was held in St Elizabeth's Hospital, Washington, but produced the controversial The Pisan Cantos (1948). Released in 1958 , he returned to Italy and died in Venice, where he is buried. He had a major influence upon modern poetry but critics are sharply divided about the quality of his poetry.

Pound, E., Letters. 1951; Stock, N., The Life of Ezra Pound. 1970; Tytell, J., Ezra Pound. The Solitary Volcano. 1987; Moody, A. D., Ezra Pound: Poet. 3 vols, 2007, 2014, 2015; Swift, D., The Bughouse. The poetry, politics and madness of Ezra Pound. 2017.

Pound, Roscoe (1870-1964). American jurist. Trained as a botanist, and without a law degree, he held a number of academic appointments, especially in his native Nebraska and in the Harvard Law School, where he was Story professor 1910-13, Carter professor of jurisprudence 1913-16 and then Dean 1916-36. His influence in the development of modern jurisprudence was important in directing attention to social implications. He turned against the New Deal after 1937.

Poussin, Nicolas (1594-1665). French painter, born in Normandy. He was trained in Paris then went to Rome (1624), where he remained for the rest of his life. The carefully planned compositions for which he is famous show historical, mythological and biblical scenes in settings where usually some statue or building exactly copied from the antique gives the necessary verisimilitude. His work is remarkably homogeneous but the passage of years is marked by the change from the warm colours of the Venetians, *Titian and ${ }^{*}$ Tintoretto, to the cool, clear tones of the north. From about 1645 Poussin devoted more attention to landscapes, which he peopled with mythological figures. In these he achieves, even more significantly than in other works, the beauty that comes from perfect compositional balance. In 1640 Poussin accepted an invitation from ${ }^{*}$ Louis XIV to return to France and decorate the long gallery of the Louvre, but he found the work uncongenial and returned to Rome. Poussin's influence was strong during the classical revival of the following century.

Blunt, A., Nicolas Poussin. 1967.

Powell, Anthony Dymoke (1905-2000). English novelist, born in London. Educated (unhappily) at Eton and Oxford, he worked in publishing, married Lady Violet *Pakenham and became an assiduous book reviewer for Punch and The Daily Telegraph. His first novel was Afternoon Men (1931). In 1951, he published Question of Upbringing, the first of a 12-novel sequence called $A$ Dance to the Music of Time, completed in 1975 with Hearing Secret Harmonies. The books, running to $1,130,000$ words, have a single narrator, Nick Jenkins, who records (somewhat satirically) his own life and circle in a prosperous, fashionable society from 1914 to 1971 . V. S. *Pritchett thought the sequence was like *Proust translated by ${ }^{*}$ Wodehouse: it became a television series in 1997-98. Powell also wrote John Aubrey and His Friends (1948) and received a CH in 1988.

Spurling, H., Anthony Powell. Dancing to the Music of Time. 2017.

Powell, Colin Luther (1937-2021). American general, born in New York. Of Jamaican parentage, he was educated at the City University of New York and George Washington University. Commissioned in the US Army in 1958, he had an unusual degree of political experience for a serving soldier and became the first African-American to be National Security Advisor 1987-89 and Chairman of the Joint Chiefs of Staff 1989-93. His memoirs My American Journey (1995) encouraged support for Powell as a Republican presidential candidate in 1996 but he declined to run. As Secretary of State 2001-05, he was deeply uneasy about George W. *Bush's plan to invade Iraq (2003) but became compromised by his assertion at the United Nations that *Saddam Hussein had 'weapons of mass destruction'. He endorsed Barack *Obama in 2008 and 2012 and despised Donald *Trump. He died of Covid complications.

Powell, (John) Enoch (1912-1998). English politician and classicist. Educated at Trinity College, Cambridge, he was professor of Greek at the University of Sydney 1937-39. During World War II he served in the army (general staff) and rose to the rank of brigadier. He became Parliamentary Secretary to the Ministry of Housing and Local Government in the Conservative Government of 1955, Financial Secretary to the Treasury 1957-58 and Minister for Health 1960. He became famous for his views on the dangers he saw attending coloured immigration and for his opposition to Britain's membership of the Common Market. He refused to stand as a Conservative in the general election of February 1974 and was an Ulster Unionist MP 1974-87.

Powell, J. E., Wrestling with the Angel. 1977. 
Powys, John Cowper (1872-1963). British writer. His works include the historical novels A Glastonbury Romance (1933) and Owen Glendower (1941), the epic poem Lucifer (written 1905), and literary criticism, e.g. Dostoevsky (1947) and Rabelais (1948). His brother Llewelyn (1884-1939) was also a novelist and essayist of distinction e.g. The Pathetic Fallacy (1928) and Love and Death (1939) as was his brother Theodore Francis (1875-1953). He wrote chiefly on rural and allegorical themes, notably $\mathrm{Mr}$ Weston's Good Wine (1927).

Graves, R. P., The Powys Brothers. 1983.

Poynings, Sir Edward (1459-1521). English statesman. An opponent of *Richard III, he fled to France to join the Earl of Richmond, who became King of England as *Henry VII (1485). Poynings was later appointed (1494) the king's deputy in Ireland and his name is given to the law (1494) which laid down that the summoning of an Irish parliament and its legislative agenda were both dependent upon the consent of the English Privy Council and that all laws passed in Westminster were applicable in Ireland.

Pozzo, Andrea (1642-1709). Italian painter, architect, stage designer and art theorist, born in Trento. He worked for the Jesuits and his masterpiece is the astonishing trompe l'oeil ceiling, Apotheosis of St Ignatius (1685-94) at the Church of St Ignatius (S. Ignazio) in Rome. He designed the tomb of St Ignatius *Loyola in the Church of the Gesù, then worked in Vienna, where he died.

Praetorius, Michael (originally Schulz or Schultheiss) (1571-1621). German composer, born in Silesia. Influenced by Giovanni *Gabrieli and the Venetians, he was prolific in many forms, both religious and secular, including Terpsichore, arrangements of 300 dances. A distant kinsman, Hieronymous Praetorius (1560-1629) was organist at Hamburg and wrote a splendid Magnificat (1599).

Pramoedya Ananta Toer (1925-2006). Indonesian novelist and essayist, born in Java. His first major novel, The Fugitive, written 1947-49 as a prisoner of the Dutch, was published in 1950. Imprisoned without trial on the island of Buru 1965-79, he wrote The Buru Quartet (This Earth of Mankind, Child of All Nations, Footsteps, House of Glass). His books were translated into 33 languages in the 1980s but banned in Indonesia until 2005. Kept under house arrest until 1992, he was nominated several times for the Nobel Prize and won international awards in absentia.

Prasad, Rajendra (1884-1963). Indian politician. A lawyer, teacher and follower of ${ }^{*} \mathrm{Gandhi}$, he was President of the Indian National Congress Party 1932-43, 1939-41 and 1947-48, and imprisoned for nationalist activities 1942-45. He entered *Nehru's Government as Minister of Food 1946-47 and became first president of the Republic of India 1950-62.
Pratchett, Sir Terry (Terence David John) (19482015). English novelist. He wrote 40 fantasy novels in the Discworld series and campaigned vigorously for more research into *Alzheimer's disease.

\section{Pratt, Sir Charles see Camden, 1st Earl}

Praxiteles (c.390-330 BCE). Greek sculptor. He was the first to sculpt an entire female nude figure, using his mistress, Phryne. The only surviving statue believed to be original is of 'Hermes carrying off the infant Dionysus', in the Archaeological Museum in Olympia. His famous statue of 'Aphrodite of Cnidus (Venus)' no longer exists but some ancient copies survive, of which the finest are in the Vatican and at Munich.

Richter, G., A Handbook of Greek Art. 1969.

Prendergast, Maurice Brazil (1859-1924). American painter, born in Newfoundland. He trained in Boston, painted extensively in France and Italy, was influenced by *Cézanne, *Whistler, ${ }^{*}$ Signac, ${ }^{*}$ Degas and ${ }^{*}$ Sickert, and had seven paintings in the 1913 Armory Show in New York. His work, first in watercolour, then oil, reflects the colour and form of Impressionism, in sharp contrast to the prevailing academic style in American painting.

Prescott, John Leslie, Baron Prescott (1938- ). English Labour politician. He worked as a ship's steward and union official, became MP 1970-2010, a leader of the Left, and Deputy Leader 1994-2007. He was Deputy Prime Minister and Secretary of State for Environment, Transport and the Regions 19972007 under Tony *Blair.

Prescott, William Hickling (1796-1859). American historian, born in Salem, Mass. Educated at Harvard, he was blinded in the left eye, had limited sight in the right and suffered from acute rheumatism. He devoted himself to the history of Spain and the conquest of the Aztec and Inca empires, working from primary sources where possible although he never visited South America. His major works are History of the Reign of Ferdinand and Isabella the Catholic (3 vols, 1838), History of the Conquest of Mexico (3 vols, 1843), History of the Conquest of Peru (2 vols, 1847) and $A$ History of the Reign of Philip the Second, King of Spain (3 vols, 1858), impressive but biased in favour of the Spanish.

Gardner, C. H., William Hickling Prescott. 1970.

Presley, Elvis Aron (1935-1977). American rock and roll singer and film actor. He became an international cult-figure for teenagers and succeeded in widening his appeal even after his early death.

Goldman, A., Elvis. 1981.

Pressler, Manahem (1923- ). Israeli-American pianist, born in Germany. He escaped from Germany in 1939, taught in the US, was pianist with the Beaux Arts Trio 1955-2008, then began touring as a soloist, with his Berlin debut at the age of 90 . 
Prester John (Latin: Presbyter Johannes). Legendary Christian patriarch, elder and king, a subject of great medieval interest. His location moved through the centuries, identified first with India where St ${ }^{*}$ Thomas had established Christian communities, then with Nestorians in Mongolia, later with the Christian (Coptic) rulers of Ethiopia. Prester John was referred to by *Marco Polo and *Shakespeare.

Silverberg, R., The Realm of Prester John. 1996.

\section{Pretender, the Old and the Young see Stuart, James Edward and Stuart, Charles Edward}

Pretorius, Andries Wilhelmus Jacobus (17991853). South African Boer leader, born in Cape Colony. He became prominent during the Great Trek from the Cape to Natal, when by his victory over the Zulus (1838) he avenged the massacre of Piet Retief and his 60 followers by the Zulu chief, *Dingaan. After the British occupation of Natal, Pretorius moved on to the Transvaal, the independence of which was secured by the Sands River Convention (1842). First President of the Transvaal South African Republic 1852-53, its capital Pretoria was named for him. His son Marthinus Wessels Pretorius (18191901), President of both the Transvaal 1855-71 and the Orange Free State 1859-63, tried, vainly, to unite them.

Prévost (d'Exiles), Antoine François (1697-1763). French novelist, known as l'Abbé Prevost. Having left his Jesuit college to serve as a soldier, he joined the Benedictines and became a priest. His vocation was real enough but often in conflict with the demands of his nature for passion and adventure. His life in consequence contained clashes with his Church superiors (and even the police) as well as periods when he found it wise to live abroad, especially in England. The conflict was to some extent resolved by his writings in which he could enjoy by proxy some of the experiences otherwise denied. In the Abbey of St Germain des Prés in Paris, he wrote the novel Les Memoires d'un homme de qualité (1728-31). This included the famous love story Manon Lescaut (later an opera by ${ }^{*}$ Puccini) in which the titular heroine was the femme fatale in the life of the chevalier Des Grieux, a young man closely resembling Prevost himself. He translated several of *Richardson's novels into French.

Price, Richard (1723-1791). Welsh Unitarian minister. A thinker on moral and political problems and ideas, he advocated the reduction of the National Debt in 1771 and defended the policies and aspirations of the American Revolutionaries. A friend of Benjamin *Franklin, he was well regarded in America and was invited over by Congress in 1778, after his Observations on Civil Liberty and the War with America (1776).

Prichard, Katherine Susannah (1883-1969). Australian novelist, born in Fiji. She grew up in poverty in Tasmania and Victoria, became a governess, then a journalist, lived in London 1908-16 and in Western Australia from 1919. Her novels included The Pioneers (1915), Working Bullocks (1926), Coonardo (1929) and The Roaring Nineties (1946). She joined the Australian Communist Party in 1920 and became an inflexible Stalinist. Her husband, Jim (Hugo Vivian Hope) Throssell (1884-1933) won a VC at Gallipoli, supported her politics and pacifism but suffered from depression and shot himself.

Hobby, N., The Red Witch. A biography of Katherine Susannah Prichard. 2022.

Priestley, J(ohn) B(oynton) (1894-1984). English novelist, playwright and essayist, born in Bradford. Wounded in France in World War I, he studied at Cambridge University, then worked as publisher's reader in London. After making his name with critical studies of Meredith (1926) and Peacock (1927) he wrote the picaresque novel The Good Companions (1929), the most popular of all his works, followed by e.g. Angel Pavement (1930), Bright Day (1946) and Festival at Farbridge (1951). The plays Dangerous Corner (1932) and Laburnum Grove (1933) show his skill and originality in a new medium. Four others Time and the Conways (1937), I Have Been Here Before (1937), Music at Night (1938) and An Inspector Calls (1946) have plots based on J. W. *Dunne's space-time concepts. He wrote more than 100 books, including three volumes of autobiography, history and criticism, and was a particularly effective broadcaster (especially during World War II). He received the OM in 1977.

Priestley, Joseph (1733-1804). English Unitarian clergyman and chemist, born in Yorkshire. The orphaned son of a preacher, he was largely selfeducated, with a gift for languages. He met ${ }^{*}$ Franklin in 1766 and this encouraged him to concentrate on science and to write a History of Electricity (1767). He was the first to produce several gases e.g. ammonia, sulphur dioxide and the oxides of nitrogen. Experiments with carbon dioxide led to the invention of soda water (1772), which earned him the Copley Medal. He became librarian (1772-80) to Lord ${ }^{*}$ Shelburne, advisor to Josiah *Wedgwood and a member of the Birmingham Lunar Society. The first to realise that air is not an elementary substance, but a compound of gases, Priestley isolated-as did ${ }^{*}$ Scheele- the active component which he called 'dephlogisticated air' (1774), named 'oxygen' by *Lavoisier in 1779. His History of Early Opinion concerning Jesus Christ (1786) was deeply controversial. He strongly supported the French Revolution and this led to his Birmingham house being sacked by a mob (1791). Cold, remote and disagreeable, he felt increasingly isolated and migrated to America (1794). He first advocated the goal of 'the greatest happiness for the greatest number', later taken up by *Bentham.

Gibbs, F. W., Joseph Priestley: Adventurer in Science and Champion of Truth. 1965. 
Prieur de la Cöte-d'Or (originally PrieurDuvernois), Claude-Antoine (1763-1832). French military engineer and politician. He served in the Legislative Assembly 1791-92, Convention 179295, Committee of Public Safety 1793-94 and the Council of 500 1795-99. He worked with *Carnot as de facto Minister for Supply in providing the weapons in the revolutionary wars. He founded the École Polytechnique, pushed for adoption of the metric weights and measures, then ran a wallpaper factory.

Prigogine, Ilya Romanovich (1917-2003). Belgian physicist, born in Russia. He held chairs in physics at Brussels 1951-87, Chicago 1961-66, and the University of Texas (Austin) 1967-2003. He won the Nobel Prize for Chemistry in 1977 for his work on the thermodynamics of systems which are not in a state of equilibrium. His books include From Being to Becoming (1980).

Primakov, Evgenyi Maksimovich (1929-2015). Russian economist and politician. He was *Yeltsin's Foreign Minister 1996-97 and Prime Minister 1998-99.

Prim y Prats, Juan, Count of Reus, Marques de los Castillejos (1814-1870). Spanish soldier and politician. A capable general and military administrator in several fields and he also had a chequered but influential political career. He played a large part in the rivalries of Queen *Isabella II's reign and helped to overthrow ${ }^{*}$ Espartero. Exiled for a time for complicity in a military plot, he returned to Spain in 1850. Again exiled (1864-66) he was prominent in the revolution that deposed Isabella (1868) and in 1870, now Prime Minister, he took the unpopular step of offering the crown to Prince *Amadeo of Savoy, which provoked his murder by an unknown assassin.

Primo de Rivera (y Orbaneja), Miguel, Marques d'Estella (1870-1930). Spanish dictator. After a military career which took him to Morocco, Cuba and the Philippines, he held a number of administrative appointments. After a military coup (1923) he set up a dictatorship welcomed by King *Alfonso XIII. Prime Minister 1923-30, with French support, he crushed *Abd el-Krim revolt in Morocco (1926) and improved Spain's infrastructure. However, opposition to his authoritarian rule steadily grew and in January 1930 he was forced to resign, dying in Paris six weeks later. His son José Antonio Primo de Rivera (19031936), a charismatic lawyer, whose friends included the poet Garcia *Lorca, founded the Falange Party, was elected to the Cortes and executed by Republican extremists in Alicante. ${ }^{*}$ Franco, who saw him as a rival but found him a useful martyr, posthumously created him a duke in 1947. His name is memorialised on many church walls in Spain.

Payne, S. G., Falange. 1961; Carr, R., Spain 18081939. 1966.
Princip, Gavrilo (1895?-1918). Bosnian Serb nationalist. A student, he joined the Black Hand and assassinated ${ }^{*}$ Franz Ferdinand and his wife at Sarajevo (28 June 1914). Fifteen youths were arrested for treason and six executed. Reprieved on account of his age, Princip died of tuberculosis in prison.

Prior, Matthew (1664-1721). English poet and diplomat, born in Wimborne. Son of a joiner, he was educated under the patronage of Lord Dorset and sent to Holland as secretary to the British Ambassador. There he was noticed by William of Orange (*William III) and later played so important a part in the Treaty of Utrecht (1713) that it was known as 'Matt's Peace'. The success of his Poems on Several Occasions (1718) relieved him of financial anxiety and, though the Whigs had no use for his political services, he led an agreeable life much courted for his wit. Much of his work was in the form of burlesque and he was a successful writer of light verse.

Pritchett, Sir V(ictor) S(awdon) (1900-1997). English author and critic. He wrote biographies of *Balzac, *Turgenev and *Chekhov, an autobiography, many essays and much admired short stories. He was awarded the $\mathrm{CH}$ in 1993.

Proclus (410-485). Greek philosopher, born in Constantinople. Of wealthy parentage, he studied rhetoric, grammar and law, and was a mathematician and astronomer as well as a philosopher. He is ranked with neoplatonists, and indeed he carries to an extreme their practice of forming a synthesis of all beliefs and philosophical systems, using not only the inner vision of *Photinus but a Euclidian method of classification of gods, demons etc. derived from all the mythologies and theologies known to him. Using the method of dialectic, he also applied this system of subdivision to the Intellect (or Mind) and Soul, forming an elaborate chain of descent from the One. Having thus carried the neoplatonist process of integration to an extreme point, he could have no direct successors, though he influenced ${ }^{*}$ Descartes and ${ }^{*}$ Spinoza among others, and in a sense anticipated deism. He lived as an ascetic and, though like the other neoplatonists he interpreted *Plato as a theologian, he was an initiate of the pagan mysteries.

Procopius (d.c.565). Byzantine historian. He accompanied *Belisarius on his campaigns, and wrote De Bellis (Wars) in eight books and the scurrilous Anecdota (Historia arcana or Secret History), which provide valuable first-hand accounts of the wars against the Vandals and other events of *Justinian's reign. His De aedificiis, a book describing the public buildings of his time, has great archaeological interest.

Prodi, Romano (1939- ). Italian economist and politician. A professor at the University of Bologna, he was Premier of Italy 1996-98, as head of the 'Olive Tree' Centre-Left coalition. He became President of the European Union 1999-2001, and Prime Minister 
2006-08, after a tight contest with *Berlusconi, but his left coalition fell apart in 2008 and Berlusconi returned to office.

Profumo, John Denis (1915-2000). English soldier and Conservative politician. Of Italian descent, he was MP 1940-45, 1950-62, served in World War II and reached the rank of brigadier. In 1954 he married the beautiful film star Valerie Hobson (1917-1998). As Secretary of State for War 1960-63, under Harold *Macmillan, he was at the vortex of a scandal ('the Profumo Affair') involving his liaison with Christine Keeler, who had informal relations with a Russian agent, creating media frenzy about sex, snobbery, espionage and the consequences of lying to Parliament. The affair paralysed the last months of the Macmillan Government. The disgraced Profumo redeemed himself by active involvement in charities.

Davenport-Hines, R., An English Affair. 2013.

Prokhorov, Aleksandr Mikhailovich (1916-2002). Russian physicist, born in Peeramon, Queensland. His family, political exiles, returned to Russia in 1923. With Nikolai Basov he worked out the theoretical basis of the maser, which led to the laser, independent of C. H. *Townes' research. All three shared the 1964 Nobel Prize for Physics.

Prokofiev, Sergei Sergeyevich (1891-1953). Russian composer, born in the Ukraine. A brilliant pianist from his early childhood, he studied composition with *Glière, *Rimsky Korsakov and ${ }^{*}$ Lyadov. Among his early works written before he left Russia in 1918 or during his sojourn abroad were his Classical Symphony (1916-17) the first and still perhaps the best known of seven symphonies, the opera Love of Three Oranges (1921) and ballet scores for ${ }^{*}$ Diaghilev in Paris (1921-27). He returned to the USSR in 1933. A prolific composer, his later works included two violin concertos, five piano concertos, the operas The Flaming Angel (1922-25) and War and Peace (1941-42), scores for *Eisenstein's films Alexander Nevsky and Ivan the Terrible, the ballets Romeo and Juliet (1935) and Cinderella (1941-44), the popular 'symphonic fairy tale' for children Peter and the Wolf (1936) and nine piano sonatas. His music is noted for its satirical, often astringent, tone.

Shlifstein, S. (ed.), S. Prokofiev: Autobiography, Articles, Reminiscences. 1960

Propertius, Sextus (c.50-c.15 BCE). Roman poet. He spent most of his life in Rome. Almost all his poems are dedicated to his passion for 'Cynthia', the courtesan Hostia. His elegiacs lack the smooth perfection of *Ovid's but show much deeper feeling.

Luck, G., The Latin Love Elegy. 2nd ed. 1969.

Protagoras (c.485-c.411 BCE). Greek sophist from Abdera in Thrace. His religious scepticism was, he explained, due to ignorance of the existence of the gods, owing to 'the obscurity of the subject and the shortness of human life'. He is remembered for his maxim 'Man is the measure of all things, of the existence of the things that are and the non-existence of the things that are not'. Good (i.e. efficient) conduct, leading to success, was the target at which his teaching was aimed. He is portrayed in *Plato's dialogue bearing his name.

Guthrie, W. K. C., A History of Greek Philosophy. 1965.

Proudhon, Pierre-Joseph (1809-1865). French political theorist, born in Besançon. From a poor family, he was educated with the help of friends and later won a three-year bursary given by the Besançon Académie. He went to Paris where he published Qu'est-ce que la proprieté? (1840), the answer to the question being 'property is theft', arguing that owners of property whether in land or industry exact the produce of labour in the form of rent, interest, profit etc., without giving equivalent recompense. The clearest exposition of his views is found in his Systeme des Contradictions économiques (1846). In the revolution of 1848 he was elected to the assembly. His hostility to *Napoléon III resulted in imprisonment (1849-52) and exile. His writings fill 33 volumes with another 14 of correspondence. Another main thesis, that anarchy is the culmination of social progress, predicts that when man attains his full social development he will have acquired enough selfdiscipline to enable police and government restraints to be dispensed with. He was anti-Semitic andanomalously-supported the patriarchal family, even condoning violence towards women. Much of Proudhon's thought was adopted by others, but he died neglected.

Woodcock, G., Pierre-Joseph Proudhon: His Life and Work. 1972.

Proulx, E(dna) Annie (1935- ). American novelist, born in Connecticut. After years writing magazine articles, she gained critical recognition with her first novel Postcards (1992), and won the 1994 Pulitzer Prize with her second, The Shipping News (1993).

Proust, (Valentin Louis Georges Eugène) Marcel (1871-1922). French novelist, born in Auteuil (now a suburb of Paris). His father, a physician, was Catholic, his mother Jewish, and he grew up in a wealthy bourgeois environment. Asthmatic from the age of nine, his education was much interrupted by illness. He abandoned law studies at the Sorbonne but read avidly and was influenced by the aesthetics of John *Ruskin and the philosophy of his relative by marriage Henri *Bergson. He was an early and active supporter of Alfred ${ }^{*}$ Dreyfus. He lived as a dilettante until he was 35 , ambitious to rise in society and haunting the literary salons. During this time he published only a few volumes of verse and, although his grasp of English was imperfect, translations of Ruskin's The Bible of Amiens (1899-1900) and Sesame and Lilies (1904-05). 
He had become attracted to Bergson's views on time and the unconscious. He explored the limitations placed on the intellect's ability to grasp and hold by the continuous process of time, and finally on the superiority of intuition over intellect in assessing reality. His mother's death (1905) brought a complete change. Without her protective care and understanding the sensitive invalid withdrew into the seclusion of a cork-lined flat and devoted himself for the rest of his life to writing seven novels $(3,300$ printed pages in total; 1,240,000 words) which bear the collective title $\dot{A}$ la recherche $d u$ temps perdu.

$\grave{A}$ la recherche du temps perdu describes events (estimated as 182 days) between 1877 and 1925 (a projection, three years after Proust's death), but providing a panoramic view of French society, especially in the decade 1892-1902, la belle époque, during the Third French Republic, seen through the eyes of a social climber, a heterosexual and non-Jew, not Proust himself. The Narrator describes himself as 'I' ('je') throughout, but there are two casual references to 'Marcel'. The work provides a penetrating analysis of personalities, class, painting and music, the belle époque, the Dreyfus case and the demoralising impact of war. It is both a comic masterpiece and an examination of time and memory. Proust's psychological insights are profound. The dividing line between real and imaginary is often unclear. But this is no dream sequence; the characters are sharply, and often ironically, drawn. It defies definition and comparison. The contrast between Swann's Way (Du côté de chez Swann, 1913) and The Guermantes Way (Le côté de Guermantes, 1920) is both literal and metaphorical: two areas bisected by the Seine, the bourgeois Faubourg Saint-Honoré on the right bank, the aristocratic Faubourg Saint-Germain on the left.

Proust had a profound psychological understanding, matched by his analysis of time and aesthetics. In Time Regained the Narrator writes: 'Every reader is, as he reads, actually the reader of himself. The work of the writer is only a kind of optical instrument that he offers the reader so he is able to discern what he would perhaps never have seen in himself without this book. The reader's recognition in himself of what the book says is the proof of the book's truth.' The novel is marked by a preoccupation with opticswith the process of seeing, sorting and interpreting images. Even more important is memory, especially involuntary memory, the celebrated and often quoted moments bienheureux, incidents apparently trivial which keep being recalled: a madeleine dipped in tea, his mother's failure to kiss him good night, the unevenness of cobblestones, the clink of cutlery on a plate. Proust picked up from ${ }^{*}$ Montaigne the concept of 'soul error' ('une erreur d'âme'), the persistent undervaluing of our own observation or experience. Nevertheless, he recognised that memory is not fixed, but ever-changing as creativity interacts with the raw material of experience.
The first novel Du côte de chez Swann (Swann's Way) was completed in 1912 but only published at the author's expense; the first volume appeared in 1913. (André ${ }^{*}$ Gide had rejected it for serialisation in Nouvelle Revue Française.) World War I interrupted publication and meanwhile the author had changed and expanded his plan. A new publisher took over, and a second volume, $\grave{A}$ l'ombre des jeunes filles en fleur, was awarded the Prix Goncourt (1919). The remaining volumes, including the notorious Sodome et Gomorrhe (3 volumes, 1922), continued to appear until his death and afterwards (1920-25). $\dot{A}$ la recherche appeared in an English translation by C. K. Scott Moncrieff between 1922 and 1931, under the Biblical and Shakespearean title Remembrance of Things Past. Since the 1992 revision, based on a corrected French text, the title In Search of Lost Time (less poetic but closer to Proust's own title) has been used. Although he was never even nominated for the Nobel Prize, by the year 2000 Proust was often identified in surveys as the greatest novelist of the 20th century.

Painter, G. D., Marcel Proust: 2 vols, 1959, 1965; Shattuck, R., Proust. 1974; Hayman, R., Proust. 1990; de Botton, A., How Proust Can Change Your Life. 1997; Carter, W. C., Marcel Proust: A Life. 2000; Tadie, J.-Y., Marcel Proust: A Life. 2000.

Prout, William (1785-1850). English chemist and physician. Educated at Edinburgh University, he became a physician in London. 'Prout's hypothesis' (1815) proposed that all atomic weights are whole numbers, essentially integral multiples of hydrogen, the sole fundamental particle, so that elements such as oxygen, nitrogen and carbon are essentially conglomerates of hydrogen atoms. In the $1850 \mathrm{~s}$, with more accurate measurement of atomic weights, Prout's hypothesis was discredited, but was resurrected with the discovery of isotypes and influenced *Soddy, *Aston and *Rutherford.

In 1824 he identified hydrochloric acid as a central factor in stomach secretions in humans and animals, divided the components of foods into what are now called proteins, fats and carbohydrates and received the Copley Medal (1827) for his work on digestion. $\mathrm{He}$ improved the barometer and coined the word 'convection'. The Prout is a unit of binding energy.

Prynne, William (1600-1669). English Puritan politician and pamphleteer. Because his Histriomastix (1632), a huge work attacking the stage and its players, was alleged to defame ${ }^{*}$ Charles I and his queen Prynne, he was savagely sentenced by the Star Chamber to imprisonment in the Tower of London, a large fine and the loss of his ears. Three years later he was again fined, and branded 'S. L.' (seditious libeller) on his cheeks for attacking Archbishop ${ }^{*}$ Laud in pamphlets. He was released in 1640, became an MP in the Long Parliament and a strong supporter of the parliamentary cause. In December 1648 he was expelled, following Pride's Purge. 
He wrote many pamphlets attacking the army and the developments of the 1650 s. Under ${ }^{*}$ Cromwell he suffered imprisonment and became a vigorous propagandist for the Restoration, after which event he was rewarded by being appointed Keeper of the Records at the Tower of London. He published valuable historical work.

Lamont, W. H., Marginal Prynne. 1963.

Ptolemy (Claudius Ptolemaeus) (c.90-168). Greek astronomer and geographer. He lived in Alexandria and wrote an astronomical treatise (known under its Arabic name Almagest) which is the source of almost all our knowledge of Greek astronomy and was a fundamental textbook until the discoveries of ${ }^{*}$ Copernicus upset its basic theory that the earth is the centre of the universe. His Guide to Geography, with the accompanying maps, was equally influential. He conceived of the world as a sphere and he introduced the method of fixing locations by means of parallels of latitude and meridians of longitude. That he made mistakes of measurement is of small account when compared with the greatness of his achievement, to which the whole science of cartography owed its origin. It was due to Ptolemy's mismeasurement of the equator that ${ }^{*}$ Columbus believed that he had reached Asia by a westward route when he discovered the West Indies.

Thomson. J. O., History of Ancient Geography. 1948; Dreyer, J. H. E., A History of Astronomy. 1963; Bevan, E. R., The House of Ptolemy. 1968.

Ptolemy I Soter (c.367-282 BCE). Macedonian founder of an Egyptian dynasty. One of*Alexander the Great's Macedonian generals, he became Governor of Egypt when the Macedonian conquests were divided after the king's death. In 305 for his assistance to besieged Rhodes he was named Soter (Saviour), and in the same year assumed the title King of Egypt. He made Alexandria, his capital, a centre of commerce and Greek culture. He wrote a history-now lost, but frequently quoted by his contemporaries.

His son Ptolemy II Philadelphus (c.308?-246 BCE) founded the great Alexandrine library and raised Ptolemaic Egypt to its zenith. There followed a long line of which Ptolemy XIV (47-30 BCE) was the last. Ptolemy XII was the brother of *Cleopatra.

Bevan, E. R. The House of Ptolemy. 1968.

Puccini, Giacomo (Antonio Domenico Michele Secondo Maria) (1858-1924). Italian composer, born in Lucca. Last of a musical family, he became an organist and studied composition at Milan. He wrote some religious and instrumental music but, influenced by ${ }^{*}$ Verdi and *Wagner, turned to opera and had his first success at La Scala in 1884 with Le Villi, followed by Edgar (1889). The last great practitioner of verismo (realism) in Italian opera, his melodic gift, capacity to exploit vocal and orchestral resources, and theatrical sense were enormously successful. Far more than his contemporary Richard * Strauss, he was open to new ideas and recognised the importance of *Debussy, ${ }^{*}$ Schoenberg and *Stravinsky. His intensely romantic operas, e.g. Manon Lescaut (1893), La bohème (1896), Tosca (1900), Madama Butterfly (1904), La fanciulla del West (The Girl of the Golden West, 1910) and La rondine (1917) brought him international fame and great wealth. Il trittico (The Triptych, 1918) comprises three one-act operas, Il tabarro (The Cloak), Suor Angelica (Sister Angelica) and Gianni Schicchi. He died in Brussels after a failed operation for throat cancer. Turandot, unfinished at his death, was completed by Franco Alfano and premiered in 1926.

Marek, G. R., Puccini. 1951; Phillips-Matz, M. J., Puccini: A Biography. 2003.

Pugachev, Emelian Ivanovich (1744?-1775). Russian impostor. He was a Cossack who posed (1773) as *Catherine the Great's dead husband *Peter III. He managed to attract a large force, mainly of serfs whom he had enlisted with promises of freedom. Despite early successes he was defeated, betrayed into captivity, taken to Moscow in an iron cage and there executed.

Pugin, Augustus Welby Northmore (1812-1852). English architect and writer. Protagonist of the Gothic Revival, although he designed more than 60 churches (e.g. St Chad's Cathedral, Birmingham, and his masterpiece, St Giles, Cheadle, Staffordshire) and many country houses, he exercised more influence through his writings, notably The True Principles of Pointed or Christian Architecture (1841), which became the textbook of Victorian Gothic. He worked under *Barry on the Houses of Parliament and much of the elaborate detail of ornament and fittings was designed by him. Pugin was no mere copyist but indicated how Gothic forms and structural principles were adaptable to modern buildings.

Stanton, P., Pugin. 1971; Hill, R., God's Architect: Pugin and the Building of Romantic Britain. 2007.

Pulitzer, Joseph (1847-1911). American newspaper proprietor, born in Hungary. Having fought in the Civil War he became a reporter, and later acquired the St Louis Post Despatch (1877) and the New York World (1883), which he made the leading Democratic newspaper. In his will he established a fund for annual prizes for journalism, literature and music.

Pullman, George Mortimer (1831-1897). American industrialist. He invented and, in America, practically monopolised the manufacture of the railway sleepingcars and luxury day-coaches that bear his name. The town of Pullman in Illinois was built for his employees.

Pullman, Sir Philip (Nicholas Outram) (1946- ). English novelist, born in Norwich. Educated at Oxford, he became a teacher. His fantasy trilogy His Dark Materials (Northern Lights, 1995; The Subtle Knife, 1997; The Amber Spyglass, 2000), aimed at 
children, was a bestseller and critical success. The Good Man Jesus and the Scoundrel Christ (2010) was controversial, but had influential supporters. His trilogy The Book of Dust is incomplete.

Pulteney, William, 1st Earl of Bath (1684-1764). English politician and orator. He served as a Whig MP 1705-42, was Secretary of State for War 171417 and originally a strong supporter of *Walpole. However, he came to regard Walpole as corrupt and from 1725 led 'the Patriot Whigs' in opposition to him. He accepted a peerage from *George II in 1742. In 1742 and 1746 he almost became Prime Minister but on both occasions lacked enough support in the House of Commons.

Purcell, Henry (1659-1695). English composer, born in London. He came from a family of musicians and as a boy was a chorister of the Chapel Royal, London (1669?-73). He later sang as a counter-tenor 'with incredible graces'. After being a music copyist at Westminster Abbey he was appointed (1677) composer to the king's violin band. Two years later he became organist of Westminster Abbey, and from 1682 of the Chapel Royal. He composed much Church music, over 200 songs, duets and catches, keyboard works, chamber music (some early string fantasies on the Elizabethan model and later works in the new Italian concerted style), nearly 70 anthems, many with orchestral accompaniment, and incidental music for plays. His six operas and semi-operas include Dido and Aeneas (1689?), King Arthur (1691), The Fairy Queen (1692), an adaptation of *Shakespeare's Midsummer Night's Dream, and The Indian Queen (1695) to words by ${ }^{*}$ Dryden. His occasional works include the ode for St Cecilia's Day Hail, Bright Cecilia (1692) and odes of welcome and birthday odes for the sovereign, e.g. Come ye sons of art (1694). His name is pronounced like the soap powder.

Westrup, J. A., Purcell. 7th ed. 1973; Holman, P., Henry Purcell. 1995; Keates, J., Henry Purcell. 1995.

Purkyně (or Purkinje), Jan Evangelista (17871869). Czech physiologist, born in Libochovice. Educated at the Charles University, Prague, where he held a chair, in 1819 he described the 'Purkinje shift', different perceptions of colour in bright and low light. Much of his work centred on cell observations, cutting wafer thin slices of tissue, examined with a compound microscope. He discovered sweat glands in 1833 and 'Purkinje cells', large neurons with branching dendrites in the brain, in 1837. 'Purkinje fibres' (1839) conduct electrical impulses to the ventricals of the heart. He coined the terms 'plasma' for the extracellular matrix in blood and 'protoplasm' for the fluid in a cell in 1839. He pioneered research into the physiology of the senses and performed selfexperimentation on the visual effects of applying pressure to the eyeball. The physiological basis of subjective visual effects had been examined but hitherto largely ignored in the German-speaking world, partly because of the assumption, made by ${ }^{*}$ Goethe and other Romantics, that they were essentially products of the imagination. A moon crater and Asteroid 3701 Purkyně are named for him.

Pusey, Edward Bouverie (1800-1882). English religious leader. After being ordained (1828), he was Regius professor of Hebrew at Oxford 1829-82. With *Newman and *Keble he was a leader of the Tractarian or Oxford Movement which started in 1833 with the publication of the first issues of Tracts for the Times, to which Pusey made notable contributions on the eucharist and baptism. The movement was designed to combat rationalism and by stressing the common heritage of the Roman Catholic and English Catholic churches it was hoped to pave the way for eventual reunion. But Pusey did not himself follow Newman's example of joining the Roman Catholic Church and in his writings and sermons argued against such a course. He was responsible for many benefactions and worked in the East End of London during the cholera epidemic of 1866 . His book collection formed the nucleus of the library at Pusey House, Oxford, opened in his memory in 1884 .

Pushkin, Aleksandr Sergeivich (1799-1837). Russian poet, dramatist and short-story writer, born in Moscow. He came of a poor but noble family, with an exotic strain in his ancestry: his maternal greatgrandfather, Abram Petrovich Gannibal, claimed to be an Abyssinian prince and became a general under *Peter the Great. In St Petersburg as a young man, he combined work at the Foreign Office with life as a poet and man about town, but many of his poems, e.g. the fiery Ode to Liberty (1820), were infected with the ideas that the French armies had carried with them through Europe and he was exiled to south Russia. There, under *Byron's influence, he began to replace the rigid classicism that Russia had borrowed from France by freer, romantic and more dramatic forms. Twenty-four of his works became operas (some set several times). In Odessa he began (1824) his verse novel Evgeny Onegin suggested by *Byron's Don Juan and later converted into an opera by ${ }^{*}$ Tchaikovsky. A similar musical destiny awaited several of Pushkin's best known creations. Ruslan and Lyudmila (1820), his first major work, became an opera by *Glinka. The tragic drama Boris Godunov (1825) is even better known as *Mussorgsky's opera. The Queen of Spades, a remarkable short novel, had a future not only as an opera by Tchaikovsky but also as a film. Mozart and Salieri (1831) and Ruslan and Lyudmilla (1820), his first major work, was set by *Glinka. The Gypsies (1824), an epic poem, became *Rachmaninoff's opera Aleko (1892). Mozart and Salieri (1831) and The Golden Cockerel (1835) became operas by *Rimsky-Korsakov. Among Pushkin's other works was the narrative poem The Bronze Horsemen (1833) and the novel The Captain's Daughter (1836). He also wrote folk and fairy stories and many beautiful lyrics, several of which have been turned into songs. Pushkin returned to St Petersburg after the accession of Tsar *Nikolai I, and a visit to the 
Caucasus (1829) resulted in a finely descriptive prose work, The Journey to Aryrum. In 1831 he succeeded at last in making the beautiful but frivolous Natalya Nikolaeyevna Gonchorova (1813-1863) his wife, but the marriage was unhappy and he died of wounds received in a duel with a French officer Georges d'Anthès whom he suspected of being his wife's lover. Like *Shakespeare and *Goethe, Pushkin's work is all the more extraordinary because he created a national literary tradition rather than building on one. *Gogol, *Turgenev, *Dostoevsky and *Tolstoy were his heirs.

Troyat, H., Pushkin. 1974; Feinstein, E., Pushkin. 1998; Binyon, T. J., Pushkin. 2002.

Putin, Vladimir Vladimirovich (1952-). Russian administrator and politician, born in St Petersburg (then Leningrad). A law graduate from Leningrad University, he was a KGB operative 1975-91, and a spy in Dresden 1985-90. He became an advisor to Anatoli *Sobchak, Mayor of St Petersburg, 1991-96, then relocated to Moscow, working in Boris *Yeltsin's secretariat 1996-99. Prime Minister of the Russian Federation 1999-2000, he became Acting President after Yeltsin's sudden resignation (December 1999). President of Russia 2000-08; 2012- , he won the March 2000 election on the first ballot, with 53 per cent of the votes, gaining 72 per cent in 2004 . In 2008, constitutionally barred from seeking a third consecutive term, he secured the election of Dmitri *Medvedev, who then appointed him Prime Minister 2008-12. Putin and Medvedev exchanged roles in 2012, with Putin being re-elected with 64 per cent of the votes. In March 2018, after the Constitution was amended to provide for six year terms, Putin secured a vote of 76 per cent after a campaign in which he was the only serious candidate, with total media support. In 2020 the Constitution was amended enabling Putin to remain in office until 2036. Putin's regime was often described as a kleptocracy but his personal wealth remains controversial, with estimates ranging from \$US1 billion to \$US200 billion.

He won the support of the Orthodox hierarchy, invoked the spirit of * Peter the Great and Imperial expansion, proposing the restoration of the Soviet Union, without Communism. Putin directed the invasion of Ukraine in February 2022, the only major war in Europe since 1945. It became a war of attribution, after *Zelenskyy mounted unexpectedly strong resistance and Putin became a pariah.

Gessen, M., The Man Without a Face: The Unlikely Rise of Vladimir Putin. 2012; Myers, S. L., The New Tsar: The Rise and Reign of Vladimir Putin. 2014.

Puvis de Chavannes, Pierre (1824-1898). French painter. He attempted with partial success to restore to wall paintings their significant place in art. Examples of his work are the paintings of the life of St Genevieve on the walls of the Panthéon, which occupied him from 1874 until his death.

Jullian, P., Dreamers of Decadence. 1971.
Pǔyí, Aisin Gioro (regnal name Xuāntǒng: 'proclamation of unity') (1906-1967). Last Qing (Manchu) Chinese Emperor 1908-12; 1917. Son of Prince Chun Zaifeng (1883-1951) and nephew of the murdered Guangxu emperor, he was appointed to the throne, at the age of two, by the dowager empress *Cixi (Tz'u Hsi). The Qing dynasty collapsed in the Xinhai Revolution (from October 1911), when the army mutinied, and nationalists, democrats and intellectuals combined to force change. Puyi's reign ended in February 1912, although he was unaware of it, continuing to live in luxury in the Forbidden City, engaging in mindless sadism. In July 1917 General Zhang Xun restored him to the throne for 12 days. He had an English tutor from 1919, learned to bicycle and telephone, planned to study in Oxford and adopted the name Henry. In 1922 he married and cut off his queue. Expelled from Beijing in 1924, from 1925 he lived in Tianjin, effectively under Japanese control, then in Manchuria (1931). The Japanese made him Chief Executive of the puppet state of Manchukuo 1932-34, then Emperor 1934-45, as Kang-de. Held by the Russians 1945-50, he was a witness at the Tokyo war crimes trials (1946). Jailed in China as a political criminal 1950-59, he declared himself as a supporter of the Peoples' Republic, worked as a gardener in Shenyang, then as a research worker in Beijing. He wrote memoirs and was the subject of *Bertolucci's film The Last Emperor (1986).

Pym, Barbara (Mary Crampton) (1913-1980). English novelist. She published six novels between 1950 and 1961 with modest success, only gaining wider recognition after 1977 when critics in the Times Literary Supplement singled her out as one of the most underrated writers of the century. Her books include No Fond Return of Love (1961), Quartet in Autumn (1977) and The Sweet Dove Died (1978).

Byrne, P., The Adventures of Miss Barbara Pym. 2021.

Pym, John (1584-1643). English parliamentarian, born in Somerset. He studied law at Oxford, was a Member of Parliament 1614-22; 1624-29; $1640-43$, and after the accession of ${ }^{*}$ Charles I became the crown's sternest and most effective opponent. Prominent in the impeachment of *Buckingham, he took an active part in promoting the Petition of Right (1628). After the 11 years during which Charles called no parliament (1629-40) he was foremost in pressing the proceedings against *Strafford and *Laud. In 1642 he was one of the five MPs whom Charles tried to arrest. Until his death in December 1643, he led the Commons. After the outbreak of the Civil War he devised the alliance with the Scots which eventually gave the parliamentarians the victory. An outstanding parliamentary orator, he died of cancer, was buried in Westminster Abbey, then exhumed on the Restoration.

Hexter, J. H., The Reign of King Pym. 1941; Glow, L., Pym and Parliament: The Methods of Moderation. 1964. 
Pynchon, Thomas (Ruggles) (1937- ). American novelist, born in New York. He studied engineering at Cornell University, wrote several short stories and published the novels $V$ (1963), The Crying of Lot 49 (1966) and Gravity's Rainbow (1973), hailed by critics as major works. He published nothing further until some early short stories, Slow Learner (1984), and the novels Vineland (1990), Mason \& Dixon (1997), Against the Day (2006), Inherent Vice (2009) and Bleeding Edge (2013). Pynchon was a recluse, rarely photographed and never interviewed.

Pyrrho of Elis (c.310-270 BCE). Greek philosopher. He taught an extreme form of scepticism, which held that it was impossible to understand the nature of things and that the best state of mind was obtained by suspending judgment rather than attempting to make decisions. He would admit that man could have a sensation of sweetness or pain but in the latter case would lessen its effect by not believing it to be evil. The term 'Pyrrhonian scepticism' passed into common speech. None of his writings survive.

Zeller, E., Stoics, Epicureans and Skeptics. 1962.

Pyrrhus (319-272 BCE). King of Epirus c.297-272 BCE. After the death of *Alexander the Great, to whom he was related, he tried to carve an empire for himself out of the Macedonian heritage. With the help of *Ptolemy I he became joint king of Epirus (roughly the equivalent of modern Albania). Seeking new conquests, he accepted an invitation (281) from Tarentum (Taranto), a Greek city in Italy, for help against Rome, and his army of 25,000 men with elephants (seen by the Romans for the first time) gained a hard fought victory near Heraclea with the loss of 4,000 men. Another victory near Asculum (279) brought such losses that the phrase 'Pyrrhic victory' gained immortal currency. After further campaigns he returned to Epirus (275). After an unsuccessful attack on Sparta he retreated to Argos, where he was killed by a tile thrown by a woman.

Hammond, N. G. H., Epirus. 1967.

Pythagoras (6th century BCE). Greek philosopher and mathematician, born in Samos. He later established a school or brotherhood in Croton, a Greek colony of southern Italy. The brotherhood seems to have formed a mystical cult, to have led an ascetic life and to have practised purification rites. It seems also to have formed a ruling oligarchy, for, after 20 years, the people rose against it and forced it to leave Croton. Pythagoras withdrew to Megapontum, where he died. No writings of his have survived, and it is difficult therefore to separate his views from those of his followers.

Pythagoras adopted the belief in transmigration of souls, both from animal to man and from man to animal, the necessity for this being removed when purification, attained by ritual practices and spiritual contemplation, was complete. Pythagoras was primarily a mathematician. He had a mathematical conception of the universe: that its order is due to the mathematical relationships of one component to another, both location and movement conforming to strict mathematical laws. This concept has been followed by many others, e.g. *Copernicus, ${ }^{*}$ Galileo, ${ }^{*}$ Newton and ${ }^{*}$ Einstein. These laws he related to those of music, hence such terms as music (or harmony) of the spheres, and his analysis of harmony was unchallenged until the 15 th century (*Dunstable). He ascribed day and night to the rotation of the earth, which he is said to have discovered. To his mathematical conception he gave philosophic point by asserting that by the contemplation of such harmonies man achieves virtue and that virtue is in fact a harmony of the soul just as health indicates a harmony of the body. Many of these ideas were adopted by *Plato and *Aristotle or critically examined by them. Pythagoreanism, with its emphasis on discernible order in being, paved the way for rational metaphysical speculation as against a materialistic (or simply positive) classification and explanation of knowledge. It fathered most schools of philosophy that existed in the European tradition for the next two millennia.

Guthrie, W. K. C., A History of Greek Philosophy. 1962; Vogel, C. J. de, Pythagoras and Early Pythagoreanism. 1966.

Pytheas (4th century BCE). Greek navigator and geographer, born at Massilia (Marseilles). He sailed past the coasts of Brittany and reached Cornwall, where he traded in tin at an island believed to be St Michael's Mount. Eventually he reached 'Thule' (probably one of the Shetlands) and the Baltic Sea. His account, now lost, was received with incredulity in his own day, but was used by ${ }^{*}$ Strabo and seems to have been as accurate as possible with his limited resources. He attributed tidal movement to lunar attraction. 


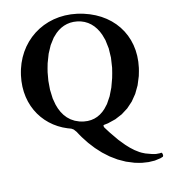

\section{Qaddafi see Gaddafi}

Qiánlóng ('lasting eminence': personal name Hóngli) (1711-1799). Chinese Emperor 1736-96, sixth of the *Qing dynasty. Grandson of*Kangxi, he abdicated so that his reign would be of identical length. He built the beautiful Chengde (Jehol) summer resort with its famous gardens, was a gifted calligrapher, painter and poet and a major collector of art works. Although he received Lord *Macartney's mission (1792-94), he sealed China, rejected Westernisation, and banned and burned books. China's population doubled during his reign.

Qin. Chinese dynasty, formerly called Ch'in (WadeGiles), founded by Qin Shi Hung, the first emperor, which unified the country and ruled 221-206 BCE.

Qin Shihuang (Shi Huang Di) ('First sovereign emperor', personal name Ying Zheng) (259-210 BCE). Chinese Emperor 221-210 BCE, founder of the Qin dynasty. From the age of 13 he was King of the state of Qin, based on Shaanxi in the northwest. Through war and diplomacy he defeated six rival states to unify China under his rule. Assisted by his minister ${ }^{*} \mathrm{Li} \mathrm{Ssu}$, he imposed an authoritarian regime from his capital Xianyang, near the present city of Xi'an. Writing, weights and measures (even axle widths) were standardised. He built the Great Wall with remarkable speed and efficiency, imposed a rigorous censorship, had 460 scholars burnt alive, and destroyed ancient manuscripts, only preserving those on farming and medicine. He made frequent journeys through his empire and died while travelling. His dynasty fell in 206 BCE to the Western Han. Traditionally regarded as one of the arch villains of Chinese history, his reputation was restored under the Peoples' Republic. Since the discovery in 1974 of the 'entombed warriors', 6,000 magnificent terracotta figures of soldiers, with horses and weapons, there has been intense interest in Qin Shihuang. Two more pits full of warriors have been discovered but are not yet open to the public. The huge tumulus built over his tomb has not been excavated.

Qing. Chinese dynasty, formerly called Ch'ing (Wade-Giles) or Manchu, which ruled 1644-1912. See ${ }^{*}$ Qianlong, ${ }^{*} \mathrm{Cixi},{ }^{*}$ Puyi.

Quadros, Janio da Silva (1917-1992). Brazilian politician. A teacher and lawyer and an able campaigner with an eccentric style, he was Governor of São Paulo 1955-59 and President of Brazil 1961, resigning unexpectedly after seven months and going into exile. He was Mayor of São Paulo 1985-89.
Quant, Dame (Barbara) Mary (1930- ). British designer, born in London. In 1955, she established her first shop, promoted (and named) the miniskirt (1966), used denim in fashion, created her own garments, textiles and cosmetics, won many awards and wrote an autobiography Quant by Quant (1966).

Quarles, Francis (1592-1644). English metaphysical poet. The most successful verse-moralist of his day, Divine Emblems (1635) was the main source of his fame. Some of his epigrams are remembered, e.g. 'No man is born unto himself alone', 'He that begins to live, begins to die'. A royalist in the Civil War, he was plundered by the Roundheads.

Hasan, M., Quarles: A Study of his Life and Poetry. 1966.

Quasimodo, Salvatore (1901-1968). Italian poet, critic and translator, born in Sicily. Trained as an engineer, he taught literature at the Milan Conservatory 1935-64 and translated works by *Aeschylus, ${ }^{*}$ Ovid, ${ }^{*}$ Shakespeare, ${ }^{*}$ Molière and ${ }^{*}$ Neruda. He is considered the leading writer of the Italian Hermeticist movement which was inspired by a symbolical use of language. His later poems are much concerned with 'la poesia sociale', expressing a social conscience and a sense of history. He received the Nobel Prize for Literature in 1959.

Tondo, M., Salvatore Quasimodo. 1970.

Quayle, (James) Dan(forth) (1947- ). American Republican politician. Educated at Indiana University, after service in the national guard and as a reporter he became an attorney. He was a US Congressman 1977-79, US Senator 1981-88 and Vice President of the US 1989-93.

Queen, Ellery. Pen name of Frederic Dannay (1905-1982) and Manfred B(ennington) Lee (1905-1971), American authors. They wrote 35 fulllength detective novels and hundreds of short stories. 'Ellery Queen' is the name not only of the author but of the detective hero.

Queensberry, 9th Marquess of, John Sholto Douglas (1844-1900). Scottish peer, born in Florence. A keen patron of boxing, he devised the rules that bear his name (1865). Oscar *Wilde's intimacy with his son Lord Alfred *Douglas provoked Queensberry's fury, and his card, left at Wilde's club, accusing him of sodomy provoked Wilde, foolishly, to initiate a prosecution for criminal libel, and, when this failed, his own arrest became inevitable. He also pursued Lord *Rosebery. Queensberry was a militant secularist who refused to swear an oath.

Queensberry, William Douglas, 4th Duke of (known as 'Old Q') (1725-1810). Scottish peer. $\mathrm{He}$ was notorious in his lifetime as an extreme example of worthless and dissolute aristocracy. 
Queneau, Raymond (1903-1976). French novelist and poet. Originally a surrealist, he became a master of parody and word play, along Joycean lines, and had a profound influence on young writers, notably Georges *Perec.

Quesnay, François (1694-1774). French physician and economist. Physician to *Louis XV, he was best known for his many books on economics and for his contributions, on agricultural and economic subjects, to the famous Encyclopédie. As the leader of the Physiocrats, he held that land was the ultimate source of all wealth and that to interfere with production or exchange must lead to disaster. His Tableau économique (1758) anticipates to a limited extent the tables of national income and expenditure of today.

Gooch, G. P., Louis XV: The Monarchy in Decline. 1956.

Quetelet, (Lambert) Adolphe Jacques (1796-1874). Belgian mathematician, statistician, sociologist and astronomer, born in Ghent. Educated at the Ghent Lycée, where he taught, he received a doctorate at the newly founded University of Ghent in 1819. In the 1820s he developed an interest in astronomy, and began to take a mathematical approach to meteorology. First director of the Royal Observatory, Brussels, 1828-74, he was elected FRS in 1839, and promoted international collaboration between statisticians. The work for which he was feted in his own day emerged in the 1830s. He began to develop the theory of mathematical statistics, devised careful tests for the validity of statistical information, and pioneered the use of social statistics for the understanding of the 'average man'. Quetelet's belief, that the regularities of human behaviour revealed by weight of data demonstrate that man, too, operates under natural law, was not original (political economists, for example, had always assumed it). But much use was made of Quetelet's mathematical prestige in attempts to generate an empirical sociology or a theory of man as part of Nature. He pioneered the concept of the normal distribution curve, which became an important tool in later studies of criminal and deviant behaviour. He also developed the body mass index (BMI). Asteroid 1239 Queteleta is named for him.

Quevedo y Villégas, Francisco Gómez de (15801545). Spanish writer. He became secretary to *Felipe IV (1632) but after opposing *Olivares was imprisoned, which so injured his health that he died soon after release. His works, both in poetry and prose, display a striking contrast between those that are moral or religious in tone and the burlesques noted for their broad humour, puns, slang and exaggerated style. A picaresque novel, La Vida del Buscón Pablos (1626) is perhaps his best known work. His Suenos, translated as Visions, were popular in Stuart England.

Jones, R. O., A Literary History of Spain. 1971.
Quezon y Molina, Manuel Luis (1878-1944). Filipino politician. He fought in the revolt led by Emilio *Aguinaldo against the Spanish occupation. The United States defeated the Spanish, displaced the first Filipino Republic in 1901 and assumed direct rule. Quezon led the nationalists in the Philippine Assembly 1907-16 and campaigned vigorously for independence both as Commissioner to the US 1909-16 and as President of the Philippine Senate 1916-35. On creation of the Commonwealth of the Philippines, Quezon was elected President 1935-44, defeating Aguinaldo. He secured votes for women and welcomed Jewish refugees. After the Japanese invasion (1941-42), he took refuge in the US, established a government in exile in Washington and died in New York State. Quezon City, the capital, was named for him. He was an accomplished pianist and bridge player.

Quiller-Couch, Sir Arthur Thomas (1863-1944). English scholar and anthologist. Of Cornish origin, educated at Oxford, he was a prolific essayist under the pen name 'Q'. He edited The Oxford Book of English Verse (1900), received a knighthood in 1910 and became the first King Edward VII professor of English literature at Cambridge 1912-44. His 30 novels, many set in Cornwall, have disappeared without trace.

Brittain, F., Quiller-Couch: A Biographical Study of Q'. 1947.

Quilter, Roger Cuthbert (1877-1953). English composer. Educated at Eton, he studied music in Frankfurt, wrote songs to poems by *Shakespeare, *Herrick, *Wordsworth, *Shelley and *Tennyson, incidental music to the fairy play Where the Rainbow Ends (1911) and A Children's Overture (1920) for orchestra.

Quincy, Josiah (1772-1864). American politician. Continuing the tradition of his father, Josiah Quincy (1744-1775) who had been a prominent New England revolutionary, he played an important political role. Elected to the House of Representatives in 1802, he became known as a staunch individualist, strongly opposed to slavery. A US senator 1813-20 and an energetic and reforming mayor of Boston 1823-28, he became head of Harvard University, where his long presidency $1829-45$ was marked by liberalism and progress. In 1854 he emerged from retirement to greet the new Republican Party and welcome its denunciation of all compromise with slavery.

Quine, W(illard) V(an Orman) (1908-2000). American philosopher, born in Ohio. Educated at Oberlin College and Harvard, he taught at Harvard from 1933, as a professor 1948-78, and received many academic awards. His publications on set theory and mathematical logic were highly influential. 
He criticised *Wittgenstein's linguistic philosophy and urged reconsideration of a relationship between science and metaphysics. Quiddities (1987) and Pursuit of Truth (1989) were aimed at a popular audience.

Quintilian (Marcus Fabius Quintilianus) (c.3096?). Latin rhetorician, born in Spain. He became famous for his Institutio Oratoria (The Training of an Orator). The theme is wider than the title since it discusses what to say as well as how to say it. It not only advises the would-be orator on everything from dress to figures of speech but provides the basis of an elementary education, and lists authors whose style merits imitation. None of his own speeches, however, has survived. Little is known of his life and the date of his death is uncertain.

Clarke, M. H., Rhetoric at Rome. 1953.

Quiríno y Rivera, Elpídio (1890-1956). Filipino politician. A close ally of ${ }^{*}$ Quezon, he was a Senator 1925-35; 1945-46. He led the Filipino resistance to the Japanese and was first vice president of the independent Philippines 1946-48 and succeeded Manuel Roxas as president 1948-53. Ramon *Magsaysay defeated him in 1953 on the issue of government corruption.

Quiroga, Juan Facundo (1790-1835). Argentinian soldier. He took part in the revolution of 1810 against Spain and soon established himself as caudillo (chieftain) of the Andean provinces. To ensure his local supremacy he was a strong advocate of a federal form of government, which was adopted in 1827 . He was notorious for his pitiless suppression of a faction that favoured a unitary state and raised a rebellion. He was assassinated, probably at the instigation of Juan de *Rosas, Governor of the province of Buenos Aires.

Quisling, Vidkun Abraham Lauritz Jonssøn (18871945). Norwegian politician. After serving in the army, as an assistant in *Nansen's relief work in Russia (1920-23), and as a consul, he became Minister for Defence 1931-33 and founded (1933) the National Union Party, a Norwegian version of *Hitler's Nazi organisation in Germany. After the German invasion (1940) he proclaimed himself head of the Norwegian Government and, though temporarily disowned by the Germans, was appointed as Minister President 1942-45 of a puppet administration by the Germans. After the Nazi defeat he was sentenced to death by a criminal court and shot. His name has become a synonym for a traitor and renegade.

Qutb (Ibrahim Husayn Shadhili), Sayyid (19061966). Egyptian Islamist and writer, born in Musha. He became a teacher, bureaucrat, writer and critic, studying in Colorado 1948-50. He became a leader of the Egyptian Muslim Brotherhood, contributing to a radical critique of Western values, based on his extreme distaste for culture and morality in the
United States, and reviving concepts of jihad. He wrote a long commentary, In the Shade of the Qu'ran. $\mathrm{He}$ opposed the Arab nationalism of Gamal Abdel *Nasser, and was imprisoned 1954-64. Re-arrested in August 1965, after a show trial he was convicted of plotting to overthrow the state and hanged. He is regarded as a spiritual founder of al-Qaida and a major influence on Osama bin *Laden.

Nolan, J. L., What They Saw in America. 2016. 


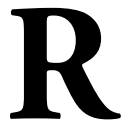

Raab, Dominic Rennie (1974- ). British Conservative politician. Of Czech-Jewish descent, he was a lawyer, MP 2010- , Foreign Minister 201921, Deputy Prime Minister and Lord Chancellor 2021-22. Lord Chancellor and Secretary of State for Justice 2021-22; 2022- , and Deputy Prime Minister 2021-22; 2022- .

Rabelais, François (c.1494-1553). French writer, born near Chinon in Touraine. His father was probably an advocate. He entered (c.1520) the Franciscan Order but transferred, with papal consent, to the Benedictines (c.1524). He seems to have visited several universities and acquired a great range of learning before finally leaving the Order to become a lay priest. In 1532 he graduated in medicine at Montpellier and afterwards practised at Lyons, where he wrote Pantagruel (1532) and Gargantua (1534) under the pseudonym Alcofri bas Nasier, an anagram of his own name. The giant Gargantua is Pantagruel's father and so in a sense the two books and those which followed are parts of a single work. A third book was published in 1546 and a fourth appeared complete in 1552. The authenticity of a fifth published after Rabelais' death is doubtful. The books were condemned at various times by the Sorbonne, though it was not the doctrines of the Church that were satirised but the ignorance and obscurantism of monks and priests and the many abuses that had become established. *François I refused to ban them and Rabelais himself was protected by Jean du Bellay, Bishop of Paris (cardinal from 1536), whom he twice accompanied to Rome, probably as his physician. The details of Rabelais' later life are obscure. Most of the time must have been spent in medical practice. He seems to have again visited Rome more than once. After the condemnation of the third book (1545) he took refuge in Metz and finally received an appointment (which he seems never to have taken up) as curé of Meudon, a small town near Paris. The books, which achieved an astonishing contemporary success (by 1600 more than a hundred editions had appeared), tell of the travels of two giants, Pantagruel and Gargantua, with their companion Panurge. They are a compound of great learning, bawdy wit and satire, expressing in an extreme form and by unusual means the humanism not only of the author but of Renaissance culture generally. Sir Thomas Urquhart (1611-1660) made a famous English translation (Books 1 and 2 published 1653, Book 3 1693) in language almost as exuberant as the author's own.

Screech, M. A., Rabelais. 1979.

Rabi, Isidor Isaac (1898-1988). American physicist, born in Austria. In 1937 he became professor of physics at Columbia University in New York where he worked on the magnetic properties of atomic nuclei and perfected the molecular-beam resonance method. For this he was awarded the Nobel Prize for Physics (1944).

Rabi, I., My Life and Times as a Physicist. 1960.

Rabin, Yitzhak (1922-1995). Israeli soldier and Labour politician, born in Jerusalem. He was Chief of Staff of the Israel Defence Forces 1964-68, Ambassador to the United States 1968-73, Leader of the Labour Party 1974-77, 1992-95, Prime Minister 1974-77 and 1992-95, and Minister for Defence 1984-90. In September 1993, in a historic agreement, signed in Washington, limited self-government was given to the Gaza strip and Jericho, in return for PLO recognition of Israel. He shared the 1994 Nobel Peace Prize with Yasser ${ }^{*}$ Arafat and Shimon *Peres. In November 1995 he was assassinated by Yigal Amir, a young Israeli extremist.

Rachel (Élisa Félix) (1821-1858). French actor, born in Switzerland. From her first stage appearance in Paris (1837) her greatness as a tragédian was recognised. As she played the great parts of*Corneille, * Racine (above all as Phèdre) and *Voltaire she won renewed acclaim. During the revolution of 1848 her public recital of La Marseillaise provoked a sensation. She had a reputation for avarice and amassed a huge fortune. Through her liaison with Count *Walewski, the emperor's natural son, she became the mother of a grandson of *Napoléon I.

Rachmaninoff (Rakhmaninov), Sergei Vasilievich (1873-1943). Russian-American composer, pianist and conductor, born in Semyonovo. He studied first at St Petersburg and then (1885-92) at the Moscow Conservatoire, where he was the pupil of *Arensky and ${ }^{*}$ Taneyev and knew ${ }^{*}$ Tchaikovsky, who was a major influence. By the age of 20 he had written the opera Aleko, the Piano Concerto No. 1, the ubiquitous Prelude in C Sharp Minor (its popularity irritated him) and many songs. In his 20s he was conducting, teaching and giving piano concerts. The failure of his Symphony No.1 (1897), due to *Glazunov's poor conducting, caused three years of acute depression until he responded to treatment by hypnosis. The piano concertos No. 2 (1900-01) and No. 3 (1909), Cello Sonata (1901) and Symphony No. 2 (1906-07) marked his recovery.

Rachmaninoff left Russia immediately after the 1917 Revolution. From 1918 he lived in New York, with an estate in Switzerland, then moved to Los Angeles. He only became a US citizen in the year of his death, remained steeped in the Russian tradition and was never comfortable with English.

Generally regarded as one of the greatest pianists in the history of the instrument, he undertook concert tours quite late in his career, from 1918, when he was 44 , essentially because he needed the money. His piano repertoire was very limited but 
he recorded extensively, from 1919 to 1942, mostly his own music but also *Chopin, some ${ }^{*}$ Schumann and ${ }^{*}$ Beethoven and many short familiar pieces. He rated his conducting more highly than his playing but three times declined appointment as conductor of the Boston Symphony Orchestra.

Later compositions included Concerto No. 4 (1927, revised 1938), Rhapsody on a Theme of Paganini (1934), Symphony No. 3 (1935-38), preludes and études-tableaux for piano, piano transcriptions and Symphonic Dances for orchestra (1940). He died of melanoma in Beverley Hills. His works remain popular because of their melodic strength, emotional intensity, and the dazzling virtuosity of the piano writing.

Norris, G., Rakhmaninov. 1976; Norris, G., Rachmaninoff. 2000; Harrison, M., Rachmaninoff: Life, Work Recordings. 2006; Scott, M., Rachmaninoff. 2011.

Racine, Jean (1639-1699). French dramatist, born in Picardy. Son of a lawyer, he was educated at PortRoyal and influenced there by Jansenist teachings. In Paris, where he sought literary fame, he became a friend of ${ }^{*}$ Molière, ${ }^{*}$ La Fontaine and later ${ }^{*}$ Boileau, meanwhile winning the favour of ${ }^{*}$ Louis XIV with complimentary poems. Molière's company staged his first play, La Thébaïde, in 1664, but the production of the second, Alexandre le Grand (1665), led to the famous quarrel between the two playwrights. After a fortnight's run Racine, dissatisfied with the performance of Molière's company, transferred the production to that of his main rival, at the same time, it is said, stealing his mistress and star actor Mademoiselle du Parc. There were, indeed, many defamatory stories about Racine's life in Paris at this time, including one said to have been extracted under torture from a well known sorcerer that he had poisoned his mistress, but Racine had the art of making enemies as well as friends and much can be attributed to malice. With the production of his third play, Andromaque (1667), Racine entered his great period. In this play and those that followed he displayed the great human emotions of love, jealousy and hatred at their highest point of intensity with their consequences of crime, madness or death. Though he was bound by the same classical formulas as his predecessors, he achieved freshness by a remarkable simplification of design combined with a psychological subtlety hitherto unknown. Moreover, he was a great poet and his lines are distinguished by their musical cadences.

The plot of Andromaque was taken from *Euripides, as were those of Iphigénie (1674) and Phèdre (1677) a grim tale of illicit passion and jealousy which provides one of the finest parts ever written for a tragic actor. Bajazet (1672), which with Britannicus (1669), Bérénice (1670) and Mithridate (1673) forms a historical group, has an uncharacteristically complicated plot and an atmosphere of oriental intrigue. His only comedy, Les Plaideurs, appeared in 1668. In 1677 the office of royal historiographer enabled him to leave the theatre in dignity and comfort. The event coincided with a 'conversion', inspired perhaps by the coming of middle age, the influence of Madame de *Maintenon and Boileau and his own underlying piety inculcated at PortRoyal. To this period belong his last two plays, Esther (1689) and Athalie (1691), both on biblical themes and written for the Maison de Saint-Cyr, the school founded by Madame de Maintenon. With the possible exception of Phèdre, Athalie is considered Racine's greatest work. Its mighty theme, concerned with God's anger and divine providence, is enriched by stage effects and choruses of outstanding beauty.

Brereton, G., Jean Racine: A Critical Biography. 1951.

Radcliffe, Ann (née Ward) (1764-1823). English novelist. She was the most important of the writers of the 'gothick romances', the fashion for which was set by Horace *Walpole's Castle of Otranto (1765). The principal ingredients are romantic settings in which occur deeds of darkness, strange and mysterious events, and 'supernatural' happenings, afterwards rationally explained. Her best known work is The Mysteries of Udolpho (1794), set in a sombre castle in the Appenines. She influenced ${ }^{*}$ Byron and ${ }^{*}$ Scott, but Jane *Austen, in Northanger Abbey, ridiculed her inferior imitators.

Grant, A., Ann Radcliffe. 1952.

Radek, Karl Berngardovich (né K. B. Sobelsohn) (1885-1939). Russian-Jewish author and politician, born in Lviv, now in Ukraine. He became a journalist and supported the German Social Democratic Party from 1904. He was imprisoned several times, fought in the Russian Revolution (1917) and tried to organise a communist revolution in Germany (1918-19). He was a member of the presidium of the Communist International 1919-1923 but his influence declined when the Comintern proved ineffective, and he became head of the Sun Yat-sen University for Chinese Students in Moscow 1923-27 until expelled from the Communist Party for having supported ${ }^{*}$ Trotsky. Restored to favour, he wrote for Izvestia and helped draft the 1936 constitution. In 1937 he was sentenced to 10 years' jail for treason (a surprisingly light penalty) and presumably died there.

Radetzky von Radetz, Johann Josef Wenzel Anton Franz Karl, Graf (1766-1858). Austrian field marshal. He fought against France throughout the Revolutionary and the Napoléonic Wars and was Commander-in-Chief in Austrian Italy from 1831. In the revolutionary year of 1848-49 he defeated the insurgents and their Sardinian allies at Custozza and Novara and forced the surrender of Venice. He held the country in firm control until his retirement (1857). Johann *Strauss the elder wrote the much performed Radetzky March (1848). 
Radhakrishnan, (Sir) Sarvepalli (1888-1975). Indian philosopher, born in Madras. Educated in Madras, he held chairs in philosophy at Madras, Mysore and Calcutta before his appointment as Spalding professor of eastern religions at Oxford 1936-52 and he was concurrently Vice Chancellor of Benares University 1938-39. His works on eastern philosophy and religion include History of Indian Philosophy (1923-27), The Hindu View of Life (1927) and An Idealist View of Life (1932). He served as Chairman of UNESCO 1948-49, Ambassador to the USSR 1949-52, Vice President of India 1952-62 and President 1962-69. Awarded a knighthood (later disclaimed) in 1931, he became an Honorary OM in 1963.

Gopal, S., Radhakrishnan. 1992.

Radischev, Aleksandr Nikolayevich (1749-1802). Russian philosopher, poet and radical thinker. In 1790 he wrote Journey from St Petersburg to Moscow, which portrayed the miseries of serfdom and called for a social revolution. He was later sentenced to death, the sentence being commuted to exile in Siberia. He was allowed to return home after the death of ${ }^{*}$ Catherine the Great in 1796. In 1801 he became a member of a law commission but, despairing of any progress towards abolishing serfdom, committed suicide. His writings influenced Russian reformers throughout the 19th century.

Lang, D. M., The First Russian Radical. 1959.

Rae, John (1813-1893). Scottish (Orcadian) explorer and doctor, born in Orkney. He worked for the Hudson's Bay Company, explored northern and northwestern Canada, explained (1854) the mystery of the loss of Sir John *Franklin and his expedition (enraging Lady Jane *Franklin in the process) and failed to receive appropriate recognition as the discoverer of the Northwest Passage, other than election as FRS and FRGS.

Raeburn, Sir Henry (1756-1823). Scottish portrait painter, born in Edinburgh. After two years in Rome 1785-87 he became a fashionable portrait painter in his birthplace. A keen sense of character, combined with strong colour and vivid effects of light, make his portraits lively as well as realistic. His best painting was The Skating Minister (1794). Sir Walter *Scott was among his sitters, often presented in national costume or on horseback in parkland settings. He became President of the Royal Scottish Academy in 1812, elected RA in 1815, and knighted in 1822 .

Raeder, Erich (1876-1960). German sailor. Chief of Staff 1912-18 to Admiral Franz von Hipper, who commanded the battle cruisers in World War I, having been appointed Grand Admiral in 1939, he became Commander-in-Chief during World War II until superseded by Admiral Karl *Dönitz (1943). Condemned by the Nuremberg tribunal to life imprisonment for his part in planning the war and especially the invasion of Norway, he was released in 1955 .

Raemaekers, Louis (1869-1956). Dutch cartoonist. The bitter irony of his cartoons attacking the Germans in the Amsterdam newspaper De Telegraaf had a remarkable effect on neutral opinion in World War I.

Raffles, Sir (Thomas) Stamford (Bingley) (17811826). English colonial administrator, born at sea. Son of a sea-captain, he joined the East India Company and went to Malaya (1805) as assistant secretary at Penang. In 1811 the British occupied Java (Holland then being under *Napoléon's rule). As Lieutenant Governor of the Dutch East Indies 1811-15, he founded the magnificent Bogor Botanical Gardens and began systematic recovery and restoration of two great temple sites in West Java, Prambanan (Hindu) and Borobodur (the world's largest Buddhist site). $\mathrm{He}$ was removed for alleged financial impropriety and returned to England, visiting Napoléon in St Helena on the way. He wrote the monumental The History of Java (1817) and returned to the East as Lieutenant Governor of British Bencoolen, on the west coast of Sumatra, 1818-24. On his personal initiative, and despite official misgivings, he founded (1819) Singapore, and so secured British control of Malaya. In 1824 a fire on board the ship on which he was returning to England destroyed his botanical and zoological specimens but with such replacements as he could collect he founded the London Zoological Society, of which he became first president 1824-26. He died of a brain tumour.

Wurtzburg, C. E., Raffles of the Eastern Isles. 1954.

Rafsanjani, Ali Akbar Hashemi (1934-2017). Iranian politician and cleric. Educated in Qom, he was Speaker of the Islamic Consultative Assembly 1980-89 and became President of Iran 1989-97. In 2005 he contested the Presidency again, losing narrowly to Mahmoud *Ahmadinejad and in 2013 was disqualified as a candidate by the Council of Guardians.

Raglan, 1st Baron, FitzRoy James Henry Somerset (1788-1855). British soldier. Eighth son of the 5th Duke of Beaufort, as ADC to the Duke of *Wellington he was present at all the great battles of the Peninsular War, and lost an arm at Waterloo. $\mathrm{He}$ served as Wellington's secretary 1819-52 and on his death received a barony and became Master General of the Ordnance. In 1854 he was appointed to command the British forces in the Crimea. For his victory at Inkerman, although made a field marshal, he was blamed for the misconstrued order that led to the fatal charge of the Light Brigade at Balaclava. Though an excellent tactician, he lacked the outstanding qualities demanded of a commanderin-chief. He died of dysentery and clinical depression in the Crimea. 
Raikes, Robert (1735-1811). English philanthropist, born at Gloucester. His father was a printer and owner of a local newspaper which he inherited. Concern for the children whom he saw wandering in the streets on Sundays fired him to start a Sunday school (1780), where children might learn to read and repeat the catechism. Newspaper reports led to the scheme spreading to all parts of the country.

Rainborough (or Rainboro), Thomas (d.1648). English soldier and republican. A naval commander in the Parliamentary fleet, he became a colonel in the army and MP for Droitwich 1646-48. In the Putney Debates of the General Council of the New Model Army (October-November 1647), he led the republican officers, in opposition to ${ }^{*}$ Cromwell and *Ireton, proposing manhood suffrage and religious toleration. He was killed by Cavaliers at Doncaster while resisting capture.

Rainier III (Rainier Louis Henri Maxence Bertrand Grimaldi) (1923-2005). Prince of Monaco 19492005. Head of the House of Grimaldi which has ruled in Monaco since 1297, he succeeded his grandfather Louis II and married (1956) the film star Grace *Kelly. Much of the tiny state's revenue is derived from the casino at Monte Carlo.

Rais (or Retz), Gilles de (1404-1440). French soldier and murderer. After fighting with ${ }^{*}$ Joan of Arc at Orléans and being made a marshal by ${ }^{*}$ Charles VII, this Breton nobleman took to necromancy and murder. Over 140 children are said to have been tortured and killed by him before he was taken and hanged. Breton tradition links him with the fairytale figure of Bluebeard.

Rajagopalachari, Chakravarti (1878-1972). Indian politician, lawyer and writer, born near Madras. He joined ${ }^{*}$ Gandhi's non-cooperation movement, but served as Prime Minister of Madras 1937-39. During World War II he supported the British and opposed the 'Quit India' movement. After partition and independence, he was Governor of West Bengal 1947-48 and *Mountbatten's successor as GovernorGeneral 1948-50, the last to hold that office. He was *Nehru's choice to become first President of India, withdrawing because of opposition within the Indian National Congress Party. He joined the Cabinet as Minister for Home Affairs 1950-51, resigning over Nehru's alliance with Russia. He returned to Madras and became a non-elected Chief Minister 1952-54. He left the INC in 1957 and was co-founder of the conservative Swatantra Party in 1959.

Rákosi, Mátyás (1892-1971). Hungarian Communist politician, of Jewish descent. As a young man he worked in a London bank, became a minister under Belá *Kun (1919), and was jailed (1927-40) under ${ }^{*}$ Horthy. As first secretary of the United Workers (i.e. Communist) Party 1945-56 and Prime Minister 1952-53, he took a tough Stalinist line. He coined the phrase 'salami tactics'-dividing opponents ideologically and cutting them off piece by piece.

Raleigh (or Ralegh), Sir Walter (1552?-1618). English courtier, adventurer and writer, born in Devon. After accompanying his half-brother Sir Humphrey ${ }^{*}$ Gilbert on an unsuccessful colonising expedition to the West Indies (1578), he served in Ireland (1580) and in 1582 went to court as a protégé of the Earl of *Leicester. He quickly won the favour of *Elizabeth I by his good looks, his wit and his fine clothes, and he received estates, trading monopolies in wine and wool, and a knighthood (1585). His haughty impatient manner brought him, however, many bitter enemies. He used his wealth to finance privateering expeditions and colonising schemes, but he was not lucky. He found money for Gilbert's last and fatal voyage. The attempts (1585 and 1587) to found a colony of Virginia, named after the queen, failed. $\mathrm{He}$ did not accompany the expeditions, but by planting on his Irish estates the potatoes his men brought back, and by setting a persuasive example of smoking the tobacco, he popularised the use of both (though they had already been discovered by the Spanish and Portuguese). The rivalry of a new favourite, ${ }^{*} \mathrm{Essex}$, and the discovery (1592) of Raleigh's liaison with Elizabeth Throckmorton, one of the queen's maids-of-honour (whom he later married), brought temporary disgrace. In 1595 he was again at sea bound for the Orinoco, but gold from the fabled 'El Dorado' eluded him, and his discoveries in Guiana stirred few. He shared with *Howard and Essex the credit for the successful Cadiz raid (1596) but by taking no part in the intrigues which brought *James I to the throne, he earned the new King's suspicious hostility. On trumped-up charges of conspiracy he was condemned to death (1603) and, though finally reprieved, he was confined in the Tower of London until 1616. Then at last he was allowed to lead another gold hunting expedition to Guiana, on condition that he did no injury to Spanish interests (an impossible condition as Spain claimed all these lands). He returned unsuccessful, and to appease the Spanish was executed on the old charge. James had indeed exalted his enemy and by his shameful treatment had turned an unpopular (and arrogant) court favourite into a national hero.

Like many of his contemporaries, Raleigh wrote verse. His political thought, e.g. in The Prerogative of Parliaments (written 1615, published 1628), was liberal and progressive and his religious thought (which brought accusations of atheism) showed wide tolerance. His most famous achievement was his great History of the World (1614), written while in prison. The completed portion carries the story from the creation to the fall of Macedonia (130 BCE). It has little historical value but is a fine example of Elizabethan prose style, much admired by Oliver ${ }^{*}$ Cromwell for its moral lessons.

Adamson, J. H., and Follard, H. F., The Shepherd of the Ocean. 1969; Coote, S., A Play of Passion. 1993. 
Rama IV (Mongkut) (1804-1868). King of Thailand (Siam) 1851-68. Originally a monk, he began modernising Thailand, entered into treaties with the US and Britain and introduced the first railway. $\mathrm{He}$ had 27 wives and 82 children. Memoirs $(1870,1872)$ by a Welsh governess Anna Leonowens became the basis of the book Anna and the King of Siam and the musical The King and I.

Rama V (Chulalongkorn) (1853-1910). King of Thailand 1868-1910. Son of Rama IV, he abolished feudalism and slavery, introduced telephones and extended the railways, created postal services, unified weights, measures and currency, built schools and a university and reorganised government along vaguely Western lines.

\section{Rama IX see Bhumibol Adulyadej}

Ramakrishna (Gadadhar Chatterji) (1834-1886). Indian mystic. Son of a poor Brahman of Bengal, he lived as a wandering ascetic and in his meditations became convinced that the fundamental unity of Hinduism, Islam and Christianity could be attained by the practice of piety. His teachings were widely spread in America and Europe by his disciple Svami Vivekananda (1862-1902) who on his return to India founded (1897) the Ramakrishna mission for the destitute.

Ramakrishnan, Sir Venki (Venkatraman) (1952- ). Indian-British structural biologist, born in Tamil Nadu. He studied at Baroda, Ohio and Yale, worked at Yale and Utah and moved to Cambridge in 1999. He shared the 2009 Nobel Prize for Chemistry 'for studies of the structure and function of the ribosome' (particles of RNA + protein found in cells), using crystallography to explain its three-dimensional structure and how protein production operates at the atomic level. He became President of the Royal Society 2015-20.

Raman, Sir Chandrasekhara Venkata (18881970). Indian physicist, born near Madras. From a landowning family, son of a physics teacher, he graduated from the Presidency College, Madras at 16 and was largely self-educated. Professor of physics at the University of Calcutta from 1917, he became director of the Indian Institute of Science, Bangalore (1933-47), and of the Raman Research Institute (from 1947). He discovered (1928) that when a transparent substance is irradiated with monochromatic sight of a given frequency the scattered light contains additional frequencies characteristic of the substance. This is known as the Raman effect, and study of the Raman spectra so produced gives valuable information about molecular structure. He was knighted in 1929 and awarded the Nobel Prize for Physics (1930).

Ramanujan, Srinivasa (1887-1920). Indian mathematician, born near Madras. A devout Hindu, from the Tamil Brahmin Iyengar caste, he dropped out of college, married an illiterate child bride, worked as a clerk but showed extraordinary gifts as a mathematician and carried out research at Madras University. G. H. *Hardy invited him to Trinity College, Cambridge, where he worked 1914-19, was elected FRS in 1918 and a Fellow of Trinity. Gravely ill (probably hepatic amoebiasis), he returned to India to rejoin his wife and died a year later. His mathematical grasp was partly intuitive, expressed as 'the thought of God', and sometimes dismissed as alien to Western reasoning and method. But his output was prodigious, ranging from partition and superstring theory to algebraic geometry, all worked out in his head, without computing and is still relevant nearly a century after his death. One of his lost notebooks is displayed in the Wren Library, Trinity College, next to *Newton's Principia. The film The Man Who Knew Infinity (2015), based on an earlier book, drew international attention to his work, followed by documentaries, plays and novels.

Kanigel, R., The Man Who Knew Infinity. 1991.

Ramaphosa, (Matamela) Cyril (1952- ). South African political organiser, born in Soweto. He was General Secretary of the African National Congress (ANC) 1991-97 and Chairman of the Constitutional Commission 1994-97. Defeated by Thabo *Mbeki in a bid for the presidency in 1997, despite his socialist principles he went into business and made a fortune. He became Vice President of the ANC 2012-17. He was narrowly elected as President of the ANC in December 2017, pledging to reform both the party and the South African government. When Jacob *Zuma was forced to resign, Ramaphosa was immediately elected as President of the Republic of South Africa in February 2018.

Rambert, Dame Marie (née Cyvia Rambam) (18881982). British ballet producer and teacher, born in Poland. Trained by ${ }^{*}$ Cecchetti, she worked with *Diaghilev's company (1912-13) but devoted most of her life to teaching. She launched (1931) the Ballet Rambert in London, and from it many important dancers and choreographers have emerged. Among her honours were the Legion d'honneur (1957) and the DBE (1962).

Clarke, M., Dancers of Mercury. 1962.

Rambouillet, Catherine de Vivonne, Marquise de (1588-1665). French literary hostess. During the reign of *Louis XIII she presided (in her 'blue room') over one of the most famous salons in French literary history, its guests from c.1615 to 1650 including *Richelieu, *Malherbe, Madeleine de Scudéry, *La Rochefoucauld, *Saint-Evremond, Marie de ${ }^{*}$ Sevigny and ${ }^{*}$ Corneille, whose new plays were read there. The good conversation and refined manners of her salons set a highly civilised model in French social circles. 
Rameau, Jean-Philippe (1683-1764). French composer, born at Dijon in the same decade as *Telemann, *Händel, J. S. *Bach and Domenico ${ }^{*}$ Scarlatti. After studying in Italy he became a church organist. In his important Treatise on Harmony (1722) he published the results of some years of study of the composition and progression of chords: in later theoretical works he improved the system he had advanced. He was a prolific composer of keyboard works, chamber music and Church music. His Suite in D (1724) for harpsichord includes Les Cyclopes and L'entretien des muses, dramatic works suggesting vivid images. Rameau was important as *Lully's successor in the history of French opera, and as a bold innovator in harmony and orchestration. However, his fame came late, after the age of 50 . The first of more than 20 operas and ballets to achieve success was Hippolyte et Aricie (1733), from *Racine's Phèdre but it was also attacked by Lully's partisans, and the term 'baroque', applied for the first time, as a term of abuse. Les Indes galantes (1735), Castor et Pollux (1737) and Dardanus (1739) were enormously successful. He collaborated with *Voltaire on several projects. His last opera, Les Boréades (1764), unperformed in his lifetime, makes dramatic use of a wind machine and special effects.

Girdlestone, C. M., Jean Philippe Rameau. His Life and Work. Rev. ed. 1969.

Ramesses (Rameses or Ramses). Name of 11 pharaohs of Egypt of the XIXth and XXth dynasties. Ramesses I (d.c.1306 BCE) succeeded at an advanced age, founded the XIXth dynasty and began the hypostyle hall at Karnak. Ramesses II ('the Great') (d.1224 BCE), grandson of Ramesses I and son of *Seti I, ruled from 1290 to 1224 BCE. He fought the Hittites for 15 years, defeating them in Syria, then made a treaty of friendship. He enlarged Egypt's power in wars against the Libyans and Nubians. The greatest temple-builder, he extended the temple of Amun at Karnak and erected the Luxor temple, the mortuary temple Ramesseum (*Shelley's Ozymandias) and the great and small temples at $\mathrm{Abu}$ Simbel (lifted 65 metres 1964-68 when the Aswan High Dam raised water levels). He reigned for 66 years and fathered 120 children. The Exodus of the Israelites might have occurred in his reign. In 1976 he was issued a passport when his mummy was sent to Paris for treatment. Ramesses III (d.1163 BCE) ruled from 1195, defeated the Libyans, Philistines and the Sea Peoples, exploited gold and copper mines, and built temples at Karnak and West Thebes (Medinet $\mathrm{Habu}$ ). He was murdered.

Gardiner, A. H., Egypt of the Pharaohs. 1961; Tyldesley, J., Ramesses: Egypt's Greatest Pharoah. 2000. Ramón y Cajal, Santiago see Cajal, Santiago
Ramón y
Ramos, Fidel Valdez (1928-2022). Filipino soldier and politician. He served in Korea and Vietnam, became Commander-in-Chief of the armed forces 1986-98, Minister for Defence 1988-92, and was elected as President 1992-98, succeeding Corazon ${ }^{*}$ Aquino.

Ramos-Horta, José (1949- ). Timorese journalist and advocate. After the Indonesian occupation of East Timor in 1975, he was the leading international spokesman for independence, working from Portugal and Australia. He shared the 1996 Nobel Prize for Peace with Carlos Felipe Ximines Belo (1948- ), Bishop of Timor. After independence, Ramos-Horta was Foreign Minister 2002-06, Prime Minister 2006-07, and President 2007-12. He survived an assassination attempt in 2008, was defeated for reelection in 2012 but became UN representative in Guinea-Bissau. He was elected, with a large majority, for another term as President 2022- .

Ramphal, Sir Sonny (Shridath Surandranath) (1928-). Guyanan lawyer and administrator. He was Secretary-General of the Commonwealth 1975-90 and a member of the ${ }^{*}$ Brandt Commission on Development Issues 1977-79.

Ramsay, Sir William (1852-1916). Scottish chemist, born in Glasgow. Educated in Scotland and Germany, he became Professor of Chemistry at University College, Bristol 1880-87 and University College, London 1887-1913. In 1892, *Rayleigh had found that atmospheric nitrogen is heavier than nitrogen produced from compounds. Ramsay investigated 'noble' (formerly 'inert') gases, leading to the discovery of argon (announced 1894) and of neon, krypton and xenon (1898). Helium, discovered in the sun in 1868, had been extracted by Ramsay from pitchblende (uraninite) in 1895 . He won the 1904 Nobel Prize for Chemistry for his work on noble gases.

Ramsey, Allan (1713-1784). Scottish painter. After studying in Italy he returned to Edinburgh but settled in London (c.1762). He became painter to ${ }^{*}$ George III (1767). His portraits of the king and of Queen ${ }^{*}$ Charlotte are in the National Portrait Gallery, London. His intellectual interests made him a friend of *Johnson and the correspondent of *Hume, ${ }^{*}$ Rousseau and ${ }^{*}$ Voltaire.

Ramsey, (Arthur) Michael, Baron Ramsey of Canterbury (1904-1988). English prelate, born in Cambridge. Educated at Magdalene College, Cambridge, and ordained in 1928, he was professor of divinity at Durham 1940-50 and Cambridge universities 1950-52, Bishop of Durham 1952-56 and Archbishop of York 1952-56. He succeeded Geoffrey *Fisher as the 100th Archbishop of Canterbury 1961-74 and was also President of the World Council of Churches 1961-68. A high churchman and distinguished theologian, he wrote several books. As Archbishop of Canterbury he 
worked hard to reconcile the differences between the various churches and in 1966 made the first official visit by an English archbishop to the pope since the Reformation. He was made a life peer on his retirement. His brother, Frank Plumpton Ramsey (1903-1930), philosopher, mathematician and economist, was a prodigy who became a Fellow of King's College, Cambridge. He worked with Bertrand ${ }^{*}$ Russell in mathematics, J. M. ${ }^{*}$ Keynes in economics, G. E. *Moore in philosophy, translated *Wittgenstein's Tractatus Logico-Philosophicus and developed penetrating critiques of all four. $\mathrm{He}$ published important papers on optimal taxation and optimal savings, probability (anticipating 'games theory'), and the 'Ramsey theory' on the relationship between order and disorder, later taken up by *Gödel, ${ }^{*}$ Church and *Turing. He died at 26 of a bacterial infection. His arguments for maximising aggregate wellbeing for the indefinite future are central to the case for taking preemptive action on climate change. The significance of Ramsey's research was not fully recognised until the 1960s; Harvard and Cambridge named chairs in economics for him.

Ramsey, A. M., Canterbury Pilgrim. 1974; Chadwick, O., Michael Ramsey, a Life. 1990; Misak, C. J., Frank Ramsey: A Sheer Excess of Powers. 2020.

Ramsey, Robert (c.1590-1644). Scottish composer. He became organist at Trinity College, Cambridge, and wrote arresting and original (but neglected) choral works, including 'How are the mighty fallen' and 'Sleep, fleshly birth'.

Ramus, Petrus (Pierre de la Rame) (1515-1572). French scholar. Son of a charcoal burner, he was able to educate himself by taking advantage of his position as the servant of a wealthy scholar. His statement that 'all *Aristotle said was false' was symptomatic of a lifelong rebellion against scholastic authority. After some years of travel and exile he returned to France (1571) only to meet his death in the Massacre of St Bartholomew. As well as his explorations in philosophy and a new system of logic for which he became famous, he brought his rational and original mind to bear upon the study of Greek and Latin, mathematics, astronomy and almost every known subject. His followers, known as Ramists, exercised a strong educational influence, notably at Cambridge.

Rand, Ayn (Alisa Rosenbaum) (1905-1982). American writer, born in St Petersburg. Her novels The Fountainhead (1943) and Atlas Shrugged (1957), both filmed, set out her philosophy of 'Objectivism', advocating selfishness, individualism and laissez faire capitalism, which prefigured the 'neo-conservative' movement of the 1980 s. She had a major influence on Steve *Jobs and Alan *Greenspan.

Ranjit Singh (1780-1839). Sikh ruler, known as 'the Lion of the Punjab'. At the age of 12 he succeeded his father as chief of the Sukerchakias clan, and by his shrewdness and advantageous marriages became leader of the Sikhs. In 1799 he seized Lahore from the Afghans and proclaimed himself Maharajah of the Punjab in 1801 . He negotiated with the British (1809) to establish his eastern boundary on the Sutlej River and by 1819 had expelled the Afghans from the Vale of Kashmir. He modernised his army from 1820 and recruited foreign officers (some former veterans of the Napoléonic wars). Although illiterate, he was well informed, tolerant, and a masterly politician and strategist.

Ranjitsinjhi Vibhaji, Maharajah Jam Saheb of Nawanagar (1872-1933). Indian prince and cricketer. Educated at Cambridge University, he played for the Sussex Country club 1895-1904 and for England 1896-97, 1899-1904, playing against Australia 15 times. In 1899 he became the first cricketer to score 3,000 runs in a year, achieving 3065 in 1900. Known as 'Ranji', he was graceful and popular with an unorthodox style. As ruler of Nawangar from 1907, he built up roads, railways and irrigation. He served as a colonel in France during World War I, represented India at the League of Nations (1920) and received a GCSI and GBE.

Rank, J(oseph) Arthur Rank, 1st Baron (18881972). English financier. With a fortune derived from his family's flour milling interests he gradually gained, by purchase and amalgamation, a predominant position in the production and distribution of British films.

Ranke, Leopold von (1795-1886). German historian. He was noted as a pioneer in the application of modern critical methods to historical sources and for the thoroughness and objectivity with which he documented his narratives. In the preface to the first of his many books, a history of medieval and later Europe, he announced his purpose merely to relate what actually occurred. His best known work is The History of the Popes (1840). Though it is confined to the Counter Reformation period and its author was denied access to the Vatican library, it is numbered among the world's historical masterpieces. Ranke was over 80 when he started on the world history of which nine volumes (to the 15 th century) were complete when he died.

Gooch, G. P., History and Historians in the Nineteenth Century. 1952.

Ransome, Arthur Mitchell (1884-1967). English writer. He reported on the Russian Revolution for the Manchester Guardian and married *Trotsky's former secretary. Realistic treatment and keen observation characterise his stories of children's adventures, several of which, e.g. Swallows and Amazons (1931), are concerned with the handling of small boats.

Hart Davis, R. (ed.), The Autobiography of Arthur Ransome. 1976. 
Rao, P(amulaparti) V(enkata) Narashima (19212004). Indian politician. Educated in science and law, said to be fluent in 16 languages, he was a member of the Andra Pradesh Legislative Assembly 1957-72 and Chief Minister 1971-72. Elected to the Lok Sahba 1972-98, he was Foreign Minister 1980-84, 1988-89, Minister for Home Affairs 1984-85, for Defence 1985, and for Human Resources (including Education) 1985-88. On Rajiv *Gandhi's assassination he succeeded as leader of the Congress (I) Party and became Prime Minister 1991-96. The first of India's nine prime ministers from the south, he encouraged Manmohan *Singh to begin dismantling the 'Licence Raj' system in Dia.

Raoult, François-Marie (1830-1901). French physical chemist. Professor of chemistry at Grenoble (1870-1901), his chief work was the investigation of the changes that occur in the boiling point, freezing point, and vapour pressure of liquids when solids are dissolved in them. From these investigations he was able to deduce the fundamental law (Raoult's law) relating the vapour pressure of a solution to the concentration of the dissolved substance, and he thus laid the foundations on which *Van't Hoff built the modern theory of solutions.

Raphael Santi (Raffaello Sanzio) (1483-1520). Italian Renaissance painter, born at Urbino. Son of a court painter, his mother died in 1491 and his father in 1494. Influenced by the works of *Uccello, *Mantegna, *Piero and ${ }^{*}$ Signorelli, he was apprenticed to *Perugino. The Crucifixion (1503) in the National Gallery, London, is an early masterpiece. He left Urbino and lived in Florence 1504-08, when *Leonardo da Vinci and *Michelangelo were working there. His Florentine paintings include The Lady with the Unicorn (1506) and The Deposition of Christ (1507), both in the Borghese Gallery, Rome. He moved to Rome in 1508. The rest of his short life was spent in Rome, where his agreeable nature as well as his astounding gifts ensured immediate success. His 26 surviving portraits include Pope *Julius II (1511), Pope *Leo X (1519), Baldassare *Castiglione (1515), several cardinals and himself. Julius II commissioned him to paint frescoes in four rooms (Le Stanze) in the papal apartments at the Vatican; they include The School of Athens and The Dispute over the Holy Sacrament. After *Bramante's death he was appointed architect in charge of building St Peter's but none of his proposals survive. He drew the cartoons for the tapestries in the Sistine Chapel (at the same time painting the mythological Galatea cycle for the Palazzo Farnese). He also produced many large and small altarpieces as well as portraits. Raphael's output was large for so brief a life though in his last years he left completion of his intentions more and more to his assistants (Giulio *Romano being the most gifted). He died of a sudden fever, according to *Vasari after sexual excess, and was buried in the Pantheon in Rome. Raphael's nature was receptive rather than dynamic and he absorbed ideas from
Leonardo, Michelangelo and ancient sculptures without destroying the unity of his own work. Few, if any, artists have excelled him in the facility with which he transferred his intuitive ideas into paintings.

Fischel, O., Raphael. 1964; Forcellino, A., Raphael. 2012.

Rapp, Jean, Comte (1772-1821). French soldier, born in Alsace. One of the bravest of the revolutionary soldiers, he gained distinction in Germany and Egypt before becoming ADC to *Napoléon. A brilliant charge at Austerlitz won him the rank of a divisional general and for further services he was made a count. He served throughout the Russian expedition, the plan of which he had opposed, and on his return held Danzig for nearly a year.

\section{Ras Tafari see Haile Selassie}

Rashi (formed from the initials of Rabbi Shelomo Yitzchaki, i.e. Solomon ben Isaac) (c.1040-1105). Jewish exegete and grammarian, born in Troyes, France. His commentary on the Pentateuch is believed to have been the first Hebrew book to be printed (1475). The Talmud is usually printed with his commentary. He also died at Troyes after wanderings probably confined to Lorraine but greatly expanded by legend.

Rasputin, Grigori Efimovich (1869-1916). Russian mystic and faith healer, born in Pokrovskoye, Siberia. Son of a peasant, he claimed to have experienced a religious vision at a monastery at the age of 18 , and became a wandering pilgrim (strannik), visiting Greece and Jerusalem. In 1903 he arrived in St Petersburg, where mystical religion was then fashionable. An introduction to the tsarina *Aleksandra followed and his apparent success in alleviating her son *Aleksei's haemophilia gave him her complete devotion and confidence. The absence of Tsar ${ }^{*}$ Nikolai II at the front during World War I enabled Rasputin to exploit his power for private gain and the political advancement of his friends. Changes in the ministries became so unpredictable that confusion, easily interpreted as treachery, grew. He seems to have argued that sin, followed by repentance, was a pre-condition for salvation, and chose alcohol and sex as his ways to grace. He had many enemies at court and in the Russian Orthodox hierarchy and his growing opposition to the war aroused foreign concern, especially from British intelligence. A group of conservative nobles, led by Prince Felix Yusopov, decided to kill him but the accounts of his murder (29 December 1916) are contradictory. He was shot four times, clubbed and then thrown into the Neva River. (A British intelligence officer was present and may have fired the fatal shot in the forehead.)

Minney, R. J., Rasputin. 1972.

Rathenau, Walther (1867-1922). German industrialist and politician. Of Jewish origin, his father was the virtual founder of the German electrical 
industry and Walther was president (1915-20) of the great electrical company abbreviated as AEG. In the republican government after World War I he was Minister of Reconstruction (1921) and in 1922, as Foreign Minister, signed the Russo-German Treaty at Rapallo. Soon afterwards he was assassinated by two young nationalist fanatics.

Rattigan, Sir Terence Mervyn (1911-1977). English playwright. He ranged from brilliant farce, e.g. French Without Tears (1936), to character studies in depth, e.g. that of Lawrence of Arabia in Ross (1960). The Winslow Boy (1946) was based on the Archer Shee case and here, as in The Browning Version (1948), Rattigan introduced poignant situations without sentimental over-emphasis. Other plays include The Deep Blue Sea (1952).

Rattle, Sir Simon (Denis) (1955- ). English conductor, born in Liverpool. Trained as a pianist and percussionist, he worked with the $\mathrm{BBC}$ and became principal conductor of the City of Birmingham Symphony Orchestra 1980-98. He won awards for his recordings of ${ }^{*}$ Brahms, ${ }^{*}$ Mahler, ${ }^{*}$ Messaien, ${ }^{*}$ Shostakovich and ${ }^{*}$ Gershwin. He succeeded Claudio *Abbado as conductor of the Berlin Philharmonic Orchestra 2002-18. His third wife was Magdelena Kožená (1973- ), Czech mezzo-soprano, and a specialist in ${ }^{*}$ Händel and ${ }^{*}$ Mozart. He received the $\mathrm{OM}$ in 2014. He became conductor of the London Symphony Orchestra 2017- , and conductordesignate of the Bavarian Radio Symphony Orchestra 2023- . Outraged by Brexit, he announced that he had applied for German citizenship.

\section{Ratzinger, Joseph Alois see Benedict XVI}

Rauschenberg, Robert (1925-2008). American artist, born in Texas. He studied in Kansas City, Paris and New York and with Josef*Albers, became a designer of stage sets and a choreographer. From 1953 he developed 'combine paintings' in which threedimensional manufactured objects were incorporated into the flat plane of the painting. He worked with lithography and silk screen printing in the 1960s and then to three-dimensional reliefs with fragile materials. With Jasper *Johns, his partner 1954-61, he was important in leading American pop art away from abstract expressionism towards minimalism, and also encouraged 'happenings', spontaneous performance art, a form that John ${ }^{*}$ Cage had pioneered in music and Josef ${ }^{*}$ Beuys in the plastic arts.

Rautavaara, Einojuhani (1928-2016). Finnish composer. Educated in Finland, the US and Germany, he was extremely prolific and much performed. His works include 8 symphonies, 12 concertos, 9 operas, 5 string quartets and many instrumental and choral pieces.

Ravel, Maurice (Joseph) (1875-1937). French composer, born in Ciboure. His father was SwissSavoyard, his mother a Basque. He studied in Paris under *Fauré and others and lived an uneventful life. He was a mother's boy, never married and lived in a doll's house outside Paris. A chain-smoking dandy, he looked like an erudite jockey but drove an ambulance at the front line in World War I, earned a fortune from his music and travelled to Britain, the United States and Canada. In October 1932 he suffered a brain injury in a taxi accident. Pick's disease, a rare neurodegenerative condition, led to five years of memory loss. He died after a brain operation in December 1937. (In July 1937, George *Gershwin also had a fatal brain operation.)

His total output is the smallest of any major composer: 88 works in the catalogue, some were mere fragments, but with an exceptional consistency. His longest ballet, Daphnis et Chloé (1912) and the two operas, L'heure espagnole (1909) and L'enfant et les sortilèges (1925), run for barely 50 minutes each. He never attempted a symphony but described Daphnis as 'symphonie choréographique'.

Ravel wrote evocative settings for the voice, notably his song cycle Shébérazade (1903) for soprano and orchestra, settings of poems by Tristan Klingsor. His genius as an instrumental writer and orchestrator is unsurpassed, challenging players to achieve exceptional performance standards. A competent pianist, but not a virtuoso, he showed a perfect understanding of keyboard technique in the Sonatine (1903-05) and in the suites Miroirs (1905, including Alborada del Gracioso, later orchestrated), Gaspard de la Nuit (1908 - including Scarbo, one of the most challenging works in the piano literature) and Ma Mère l'oye (Mother Goose, duet, 1908). His chamber worksthe String Quartet (1903), the Septet for two violins, viola, cello, flute, clarinet and harp (1905), and the powerful Piano Trio (1914) — have a pellucid clarity. His major orchestral scores reveal unparalleled mastery of technique, but also profound rhythmic sweep and voluptuous sensuality. He orchestrated *Mussorgsky's Pictures at an Exhibition (1922). *Stravinsky's dismissal of Ravel as 'the Swiss watchmaker' was clever but misplaced.

Ravel's 'choreographic poem for orchestra, La Valse (1920), echoes the impact of World War I and contains a distinctive historic perspective. The sumptuous world celebrated in waltzes by ${ }^{*}$ Strauss (Johann and Richard) is turned into savage parody. Boléro (1928), Ravel's most famous work, achieved international notoriety, to the composer's irritation. An 18 bar melody is played 18 times, accompanied by an unchanging ostinato rhythm on the snare drum: increasingly complex orchestration leads to a long sustained crescendo until a dramatic key change (from $\mathrm{C}$ major to $\mathrm{E}$ major), just before a shuddering end.

The two piano concertos, both completed in 1931, are outstanding. Concerto in $\mathrm{G}$ major has a beautiful slow movement, containing perhaps the longest single theme in serious music, 44 bars long, Mozartian in style. The witty last movement is inspired by jazz. 
Concerto in D major for Left Hand, written for Paul *Wittgenstein, is a powerful work with sinister (appropriately) elements and obvious parallels with La Valse, requiring a virtuoso to manage the rhythmic sweep of one hand across the entire keyboard.

Ravel's music reflects such disparate influences as *Couperin, *Mozart, *Liszt and ${ }^{*}$ Rimsky-Korsakov. His music is less impressionistic and more classical, than *Debussy's with which it is often compared.

Stuckenschmidt, H. H., Maurice Ravel. 1968; Nichols, R., Ravel. 2011.

Rawlinson, Sir Henry Creswicke, 1st Baronet (1810-1895). English archaeologist, administrator and diplomat. He held many official appointments in India and the Middle East, and was known mainly for his work on cuneiform inscriptions as the father of Assyriology'. His brother George Rawlinson (18121902) was Camden Professor of Ancient History at Oxford 1861-89 and author of a notable translation and commentary upon *Herodotus (1858-60). His son, Henry Seymour Rawlinson, 1st Baron Rawlinson (1864-1925), a general, commanded the 4th Army at the Somme (1916). His greatest success, a breakthrough in the Hindenburg Line near Amiens (August 1918), opened the way for the final advance. He commanded British forces in Russia 1919-20 and India 1920-25.

Rawls, John Bordley (1921-2002). American philosopher. Educated at Cornell, he was professor of philosophy at Harvard University 1962-91 and wrote the influential $A$ Theory of Justice (1971).

Rawsthorne, Alan (1905-1971). British composer. He taught 1932-34, but afterwards worked exclusively at composition, establishing a reputation with Symphonic Studies, performed at the Warsaw Festival in 1939. After World War II he wrote concertos for oboe, violin and piano. His music is atonal and his works small in scale.

Mellers, W., Studies in Contemporary Music. 1948.

Ray, John (1627-1705). English naturalist. Son of an Essex blacksmith, he studied botany and zoology at Cambridge University. He spent the years 165866 in extensive travels, during which, by observation and collection, he gained a unique knowledge of European flora and fauna. He systematised and classified this vast amount of material in a series of volumes, a foundation on which ${ }^{*}$ Linnaeus and others were to build. He was no mere compiler, however, as he proved and was the first to distinguish between monocotyledons and dicotyledons. Major works were Methodus Plantarum Nova (1682), Historia Plantarum (1686-1704) and Synopsis Methodica Anunalium (1693). Ray was also a philologist and published $A$ Collection of English Proverbs (1670).
Ray, Man (né Emmanuel Rudnitzky) (1890-1976). American painter, photographer and film maker, born in Philadelphia. Secretive about his real name, he worked in Paris 1921-40, 1946-76, was involved in the Surrealist and Dada movements, became active in fashion and portrait photography and used new techniques such as solarisation.

Ray, Satyajit (1921-1992). Indian film producer and film director. A Bengali, since 1953 his films have been highly regarded both for their visual beauty and realism. They include Pather Panchali (1956), Apu Sansar (1959), The Coward and the Holy Man (1965), Days and Nights in the Forest (1970) and The Chessplayers (1979). He composes the background music for his own films. In 1947, Ray founded the first Film Society in Calcutta.

Rayburn, Sam(uel Tallifiero) (1882-1961). American Democratic politician. A Texas lawyer, he was a US Congressman 1913-61, Speaker of the House of Representatives 1940-47, 1949-53 and 1955-61 (a record period), and a close confidant of *Roosevelt, *Truman and *Johnson.

Rayleigh, John William Strutt, 3rd Baron (18421919). English mathematical and experimental physicist. Educated at Trinity College, Cambridge, he succeeded ${ }^{*}$ Maxwell as Cavendish professor of experimental physics at Cambridge 1879-84, professor of natural philosophy at the Royal Institution 1887-1905, and finally Chancellor of the University of Cambridge 1908-19. His researches covered a wide range of subjects, e.g. sound and other aspects of vibratory motion, scattering of sight and the colour of the sky, the theory of radiation. He discovered (1892) that atmospheric nitrogen is heavier than nitrogen from compounds, which led to *Ramsay's work on the inert gases. Rayleigh, who succeeded to his father's title in 1873 , received the Copley Medal in 1899, the Order of Merit in 1902, won the Nobel Prize for Physics (1904), and was President of the Royal Society 1905-08. Craters on the Moon and Mars and Asteroid 22740 Rayleigh were named for him.

Strutt, R. J., Life of John William Strutt, Third Baron Rayleigh. 1968.

Raynouard, François Juste Marie (1761-1836). French poet and philologist. A prosperous Paris advocate, he entered the Legislative Assembly (1791), joined the Girondins, and was imprisoned. His poems and tragedies were successful, and in 1807 he was elected to the Académie française, later becoming secretary (1817). He wrote on Provençal language and literature, notably his Lexique Roman (1838-44).

Razi, Abu Bakr Muhammad Ibn Zsksriyya Al(known as Rhazes) (c.854-925). Persian physician. His main scientific interests lay in alchemy with a strong empirical concern with descriptions of exact processes, closely related to a descriptive and clinical 
approach to medicine. Sceptical about *Galen's theories, he wrote many manuals and distinguished between smallpox and measles. In cosmology and natural philosophy, he took issue with *Aristotle, believing that the world had been created in time and that there were five eternal principles: Creator, soul, matter, time and space. Time was not-as for Aristotle-a measure of movement or process, but rather a boundary principle, existing independently of objects. In the Islamic world, Razi had a high reputation as an alchemist and medical writer, but his scepticism and pugnacious character led to religious and philosophical attack.

Razumovsky, Andrey Kyrillovich, Count (17521836). Russian statesman, art collector, amateur violinist and patron of music. Ambassador in Vienna 1792-1807, he was Russia's main representative at the Congress of Vienna in 1814 and was later made a prince. From 1808-14 he maintained the celebrated Razumovsky Quartet. Razumovsky's name was immortalised through the dedication to him of *Beethoven's three string quartets, Op. 59, and (with Prince Lobkowitz) the Fifth and Sixth Symphonies. He was a munificent and prodigal patron of art: his enthusiasm for music had drawn him to *Haydn, he knew ${ }^{*}$ Mozart well and had close associations with Beethoven (1796-1816). However, after the destruction by fire of his Vienna palace, he was forced to discontinue his way of life, and lapsed into obscurity.

Read, Sir Herbert Edward (1893-1968). English critic and poet, born in Yorkshire. Educated at Leeds University, he fought in World War I (winning the DSO and MC). His early poetry (Naked Warriors, 1919) was influenced by the carnage. He became an anarchist, curator at the Victoria \& Albert Museum 1922-39, professor of fine arts at Edinburgh 193133, editor of The Burlington Magazine (1933-38), and promoted the work of T. S. *Eliot, Henry ${ }^{*}$ Moore, Ben *Nicholson and Carl *Jung. He taught at Harvard 1953-54. He was an influential thinker on creativity in education (Education though Art, 1943) and some aspects of philosophy, especially existentialism.

Woodcock, G., Sir Herbert Read. 1972.

Reading, 1st Marquess of, Rufus Daniel Isaacs (1860-1935). British lawyer and administrator, born in London. He worked in the family fruit business, at sea, and on the stock exchange, read at the Middle Temple and became a barrister in 1887 , without having a university degree. After establishing a reputation as a brilliant cross-examiner, appointed a QC in 1898, he entered parliament in 1904 as a Liberal and in *Asquith's Government was SolicitorGeneral 1910 and Attorney-General 1910-13. He was involved (1912) in the Marconi scandal (favour was alleged to have been shown to the company in return for an opportunity to make private profit), but after a parliamentary inquiry he and other ministers were absolved from blame. He was Lord Chief Justice 1913-21, with a peerage, but led a wartime financial mission to the United States 1915 and served as Ambassador 1918-19. As Viceroy of India 1921-26 he adopted a sympathetic attitude towards Congress moderates but *Gandhi's leadership was increasingly important. Created a marquess in 1926 (the first commoner to reach this rank since *Wellington, and the only Jew), he became Chairman of ICI 1928-31 and 1931-35. He briefly returned to political life (1931) as Foreign Secretary in Ramsay *MacDonald's coalition and was Lord Warden of the Cinque Ports 1934-35.

Reagan, Ronald Wilson (1911-2004). 40th President of the US 1981-89. Born in Tampico, Illinois, he graduated from Eureka College and became a radio sports announcer. Between 1937 and 1964 he acted in 54 films, mostly as a second lead. These include Kings Row (1942) and The Hasty Heart (1950). In 1940 he married the leading actor Jane Wyman (1917-2007). They divorced in 1948 and in 1952 he married another actor, Nancy Davis (née Anne Frances Robbins) (1921-2016). President of the Screen Actors Guild 1947-52 and 1959-60, he was originally a staunch liberal but became a hardline conservative in the 1950s. For some years he was an effective spokesman for the General Electric Co., both on television and in public appearances. $\mathrm{He}$ supported Barry*Goldwater for president in 1964 and in 1966 was elected Governor of California 1967-75, defeating Edmund G. (Pat) *Brown who had beaten Richard ${ }^{*}$ Nixon in 1962 . In 1976 he challenged Gerald *Ford in a close race for the Republican presidential nomination. He won the nomination in 1980 and defeated Jimmy ${ }^{*}$ Carter by 51 to 41 per cent of the popular vote, winning 44 states. He proclaimed commitment to small government and to market-force economics, but his administration continued to spend heavily, especially on defence. His robust anti-Communism, appeals to patriotism, support of traditional American values and gifts as a communicator swept him to a second-term victory over Walter ${ }^{*}$ Mondale (1984) in 49 states, with 59 per cent of the popular vote, the highest aggregate in US history.

In October 1986 his summit meeting with Mikhail ${ }^{*}$ Gorbachev in Reykjavik led to the IntermediateRange Nuclear Forces (INF) Treaty (1987). Revelations in November 1986 of his careless or ill-informed handling of arms sales to Iran 198587 to finance 'Contra' activity in Nicaragua ('The Iran-Contra Affair') led to vigorous attacks on his credibility, but his popularity remained high. In January 1987 he proposed the first trillion dollar Budget (\$US1,024,000,000) to Congress. The savings and loan scandals and the US's transition from being a creditor to a debtor nation were not held against him and he was often credited with the collapse of Soviet Communism and the ending of the Cold War. George H. W. *Bush's election as president 
in 1988 was a virtual third term for Reagan. He was awarded the British GCB and the US Medal of Freedom. In 1994 he announced that he was suffering from Alzheimer's disease. In 16 Presidential ranking lists by US historians and political scientists, there was a striking divergence in Reagan's scores, from 6th to 26th, No. 14 in the aggregate.

Reeves, R., President Reagan. 2005; Brands, H. W., Reagan: The Life. 2015; Spitz, B., Reagan. An American Journey. 2018.

Réaumur, René Antoine Ferchault de (1683-1757). French scientist. His work for the Académie des Sciences, of which he became a member in 1708 , led him into such diverse avenues of research as metallurgy, turquoise mines and the manufacture of opaque glass. The thermometer which bears his name has the boiling point of water at $80^{\circ}$ and the freezing point at zero.

\section{Reber, Grote see Jansky, Karl}

Récamier, Françoise Julie Adelaide (née Bernard) (1777-1849). French beauty and wit. Her salon attracted some of the most notable literary and political personalities of the day. Among them were Madame de ${ }^{*}$ Staël, Benjamin ${ }^{*}$ Constant and *Chateaubriand. Her husband, a middle-aged banker, died in 1830 . The painter ${ }^{*}$ David perpetuated the charm of Madame Récamier as she reclined at ease.

Trouncer, M., Madame Récamier. 1949.

Redford, (Charles) Robert (1936-). American actor, director and producer, born in California. He acted in many films including Butch Cassidy and the Sundance Kid (1969), The Sting (1973), The Great Gatsby (1974) and Spy Game (2001). Films he directed included Ordinary People (1980, Academy Award), Quiz Show (1994), The Horse Whisperer (1998), Conspirator (2010) and All Is Lost (2013). An active environmentalist, he received the US Presidential Medal of Freedom in 2016.

Redgrave, Sir Michael Scudamore (1908-1985). English actor. He went to the stage after a brief career as a teacher, and gained much of his early experience at London's Old Vic. He became outstanding as a Shakespearian actor and returned to the familiar parts, but he also adapted his technique to suit the continental classics (e.g. The Father, Uncle Vanya and A Month in the Country) and to modern plays such as The Aspern Papers, where stylish acting combined with acute characterisation was required. His film career, equally varied, included parts in The Importance of Being Earnest, The Browning Version and The Dam Busters. He was knighted in 1959. He married the actor Rachel Kempson (1910-2003) and their three children were all successful performers. Dame Vanessa (1937- ), a stage and film actor, won an Academy Award for her role in Julia (1977). She was a strong opponent of US foreign policy and a PLO supporter. Corin (1939-2010) was an able character actor and Lynn (1943-2010) won an international reputation with Georgy Girl (1966).

Redmond, John Edward (1856-1918). Irish nationalist politician, born in Wexford. A barrister, he was an MP in the House of Commons 1881-1918, led the Parnellite (*Parnell) minority in the Irish Parliamentary Party (from 1891) and the reunited party 1900-18. He accepted *Asquith's Home Rule Bill (1912-14), but, when Sir Edward *Carson raised a volunteer force in the north to resist it, Redmond countered him with volunteers raised in the south. Civil war was imminent when World War I broke out. Redmond's commitment to maintaining a united Ireland led to failure to embrace the strong revival of a distinctive Irish culture. He died suddenly after surgery (March 1918) and in November 1918 his party was swept out of Parliament by Sinn Féin.

Redon, Odilon (1840-1916). French Symbolist painter, lithographer and etcher. Influenced by *Goya, he developed a style of fantastic and haunted imagery, which evokes the world of *Poe and *Mallarmé. His later works anticipated the psychedelic art of the 1970 s.

Redouté, Pierre Joseph (1759-1840). French flower painter, born in Liège. He went to Paris and became famous in his specialised field, popularised through engravings. Both ${ }^{*}$ Marie Antoinette and the empress *Josephine were among his pupils.

Reed, Sir Carol (1906-1976). English film director. Son of Sir Herbert Beerbohm *Tree, he became an actor and directed 33 films including Odd Man Out (1947), Outcast of the Islands (1952), Oliver! (1968), and three based on Graham *Greene stories The Fallen Idol (1948), The Third Man (1949) and Our Man in Havana (1959).

Reed, John (1887-1920). American journalist. In 1917 he went to the USSR and became a friend of ${ }^{*}$ Lenin. His Ten Days that Shook the World (1919) is considered one of the best eye-witness accounts of the Bolshevik Revolution. He founded a US Communist Party in 1919, returned to the USSR, died of typhus and was buried in the Kremlin Wall.

Reed, Walter (1851-1902). American surgeon and bacteriologist. He joined the US army medical corps (1874) as an assistant surgeon and became (1893) professor of bacteriology at the Army Medical School. He headed a commission sent to Cuba to study yellow fever (1899) and his team proved the thesis of Carlos *Finlay that the disease is transmitted by the Aedes aegypti mosquito. He died of appendicitis.

Rees, Lloyd Frederick (1895-1988). Australian painter. Deeply influenced by ${ }^{*}$ Monet, he achieved a late but sustained reputation with his evocative, atmospheric landscapes. 
Rees, Martin John, Baron Rees of Ludlow (1942- ). English radio-astronomer, born in York. Educated at Trinity College, Cambridge, he became Plumian professor of astronomy at Cambridge 1973-91, a Royal Society research professor 1992-2004 and Astronomer Royal 1995- . His books include Before the Beginning (1997) and Just Six Numbers (1999). Master of Trinity College 2004-12 and President of the Royal Society 2005-10, he received the Order of Merit in 2007 and delivered the BBC's Reith Lectures in 2010, on Scientific Horizons. Asteroid 4587 Rees was named for him.

Reger, (Johann Baptiste Joseph) Max(imilian) (1873-1916). German composer, conductor, pianist and teacher, born in Bavaria. Influenced by ${ }^{*}$ Beethoven, ${ }^{*}$ Wagner, ${ }^{*}$ Brahms and ${ }^{*}$ Bach (an unusual combination), he was extraordinarily prolific, acquiring a largely unjustified reputation for writing turgid, ponderous academic music, rarely performed outside Germany. His Variations and Fugue on a Theme of J. A. Hiller (1907), piano concerto (1910), Variations and Fugue on a Theme of Mozart (1914), violin sonatas and some songs and organ pieces have been brilliantly recorded, leading to a re-evaluation of his achievement. He was professor of composition at Leipzig University 1907-16, conductor of the Meiningen Orchestra 1911-14 and toured extensively.

Regiomontanus (Johann Müller) (1436-1476). German astronomer and mathematician, born at Königsberg. Son of a miller, he studied philosophy at Leipzig and astronomy and geometry under Georg von Peurbach at Vienna, from 1452. It was at this time that he came to recognise the inadequacy of the current astronomical tables (the Alfonsine). On Peurbach's death, Regiomontanus completed his work on *Ptolemy's Almagest, which finally appeared in 1496. This digest was a work of current scholarship in its own right. ${ }^{*}$ Copernicus' careful study of it revealed to him some of Ptolemy's errors, and stimulated the development of his own system of astronomy. Regiomontanus learned Greek from Cardinal Bessarion, and spent much of the 1460s combing Italy for astronomical manuscripts. His concern was to purify the learning of antiquity. He discovered an important manuscript of the mathematician Diophantus, but did not live to edit it. Amongst his completed works, however, were lectures on astrology and important trigonometrical writings that gave tables of tangents and sines. He was more important as a publisher of astronomical data- he made early use of the printing press-than as a theorist in his own right.

Rehnquist, William Hubbs (1924-2005). American judge. Educated at Stanford, he was Nixon's Assistant Attorney-General 1968-71, a justice of the US Supreme Court 1971-86 and leader of the conservative ('strict constructionist') wing, and Chief Justice 1986-2005. He presided at President *Clinton's impeachment trial in the Senate (1999).

Reich, Robert B(ernard) (1946- ). American economist. Educated at Dartmouth and Yale, he became a Rhodes Scholar at Oxford, worked in government and taught at Harvard. $\mathrm{He}$ wrote influential books about the changing global economy including The Work of Nations (1991) and was US Secretary of Labor 1993-97.

Reich, Wilhelm (1897-1957). Austrian-American psychoanalyst, born in Vienna. One of the most controversial figures in the history of psychoanalysis, he lived in the US from 1939, and developed a theory of sexuality based on the 'orgone' (a compound word derived from organism and orgasm). He built 'orgone accumulators' to treat patients, but was charged with fraud and when he violated an injunction was sent to jail where he died of heart failure and his publications were burnt by court order.

\section{Reichstadt, Duke of see Napoléon II}

Reid, Sir George Houstoun (1845-1918). BritishAustralian politician, born in Renfrewshire, Scotland. $\mathrm{He}$ emigrated to Australia at the age of seven, was educated in Melbourne, called to the bar (1879) and entered the New South Wales Parliament 1880-84; 1885-1901. As Minister of Public Instruction he introduced 1883-84 a public system of secondary education, became Leader of the Opposition 189194 and was Premier 1894-99. In addition to tax simplification and a factories act, he freed the civil service from political control. A strong free-trader, after an initial hesitancy ('Yes-No Reid'), he supported federation. Elected to the House of Representatives 1901-09, he was the first Leader of the Opposition in the Federal Parliament 1901-04; 1905-08. He became Prime Minister for 11 months 1904-05 in a Free Trade-Protectionist coalition. Appointed by Alfred *Deakin, he went to London as Australia's first High Commissioner 1910-16, and became a British MP 1916-18. His obesity caused him to be underrated, but he was an outstanding debater, strongly liberal, and an able strategist. He was the first Australian Prime Minister to die.

Reid, Thomas (1710-1796). Scottish philosopher. After a number of academic appointments he succeeded Adam *Smith as professor of moral philosophy at Glasgow 1764-80. In his Inquiry into the Human Mind on the Principles of Common Sense (1764) he argued, against *Hume and others, that in perception we are directly aware of physical objects and not of sensations or 'ideas' which may be related to them. He believed that all knowledge is based on self-evident principles established in 'common sense', a term that came to be applied to his philosophy as a whole. His larger Essays on the Intellectual Active Powers of Man (1785) is in effect a theory of knowledge based on these principles, while in his Essays on the 
Active Powers of the Human Mind (1788) he discusses moral issues and arrives at the conclusion that 'moral approbation implies a real judgement'.

Grave, S. A., The Scottish Philosophy of Common Sense. 1960.

Reiner, Fritz (1888-1963). Hungarian-American conductor, born in Budapest. He conducted the Dresden Royal Opera 1914-21, went to the US in 1922, taught at the Curtis Institute, Philadelphia and directed the Pittsburgh Symphony 1938-48, the Metropolitan Opera 1948-53 and the Chicago Symphony 1953-63.

Reinfeldt, (John) Fredrik (1965- ). Swedish politician and economist. He led the Moderate Party 2003-15, and was Prime Minister 2006-14, handling the global financial crisis (GFC) skilfully.

Reinhardt, Max (1873-1943). Austrian American theatrical producer. $\mathrm{He}$ acted at the Deutsches Theater, Berlin 1894-1905 became its director and filled the next 25 years with a remarkable series of some 450 productions, which brought fame to the theatre and himself. As well as the ancient Greek and European classics he staged the works of *Ibsen, *Strindberg and *Shaw. He was closely identified, too, with the Salzburg Festival. He specialised in spectacular productions, e.g. The Miracle in London (1911), which entailed the handling of crowds of performers and remarkable lighting effects. He left *Hitler's Germany in 1933 and later became a naturalised US citizen.

Adler, G., Max Reinhardt. 1964.

Reis, Oruç ('Baba Reis', known as Barbarossa = 'Redbeard'), (c.1474-1518). Turkish-Albanian-Greek corsair, born in Lesbos. The elder brother of Kheir ed-Din *Barbarossa and three others, he founded the family business of privateering. In 1504 the brothers established a base in Tunis, and until 1510 Oruç transported Muslim and Jewish refugees from Spain to North Africa. A fluent linguist, he raided the Lebanon, Italy, Sicily and Sardinia and received support from France. In 1512 he lost his left arm in battle and used a silver prosthetic. He seized control of Algiers in 1516, displacing the Spanish, proclaiming himself as Sultan, but in 1517 became 'chief governor' for the Ottoman Empire. Oruç and his brother Ishak were killed in battle at Tlemcen (Algeria) by the forces of ${ }^{*}$ Charles V.

Reis, Piri (d.1534). Turkish admiral and cartographer. Nephew of the pirate Kemal Reis, he served at Lepanto and commanded the Ottoman fleet under *Suleyman the Magnificent. In 1513, at Gallipoli, he compiled a detailed map of the Atlantic, now held in the Topkapi Museum in Istanbul, thought to have been based on lost materials, possibly Chinese, including a world map dating from about 1428 and which may have been known to ${ }^{*}$ Columbus.
Reith of Stonehaven, John Charles Walsham Reith, 1st Baron (1889-1971). Scottish administrator, born in Stonehaven. Son of a clergyman, he trained as an engineer and was wounded as an officer in World War I. He became the first general manager of the British Broadcasting Company Ltd 1923-27, and when it became publicly owned, first director-general of the British Broadcasting Corporation (BBC) 1927-38. He implanted a tradition of complete integrity in the presentation of news and of educational and cultural zeal, setting out the mission statement 'inform, educate, entertain'. Autocratic and prudish, his diaries indicate some enthusiasm for ${ }^{*}$ Hitler and ${ }^{*}$ Mussolini. Knighted in 1927 , he received a peerage in 1940. Reith was the first chairman of BOAC 1939-40, then became Minister for Works 1940-42 under ${ }^{*}$ Churchill, who detested him. He chaired the Commonwealth Telecommunications Board 194650, the National Film Finance Corporation 1948-51 and the Colonial Development Board 1950-59. Created a KT in 1969, the BBC established (1947) an annual series of 'Reith Lectures' in honour of his services to broadcasting.

Reith, J. C. W., Into The Wind. 1949; McIntyre, I., The Expense of Glory. 1993; Boyle, A., Only the Wind Will Listen. 1972.

Réjane Gabrielle (née Gabrielle Charlotte Reju) (1856-1920). French comedy actor. She acquired a reputation comparable with Sarah ${ }^{*}$ Bernhardt: wit, brilliant technique and subtlety of mood, rather than beauty of face or voice, were central to her success.

Remarque, Erich Maria (1897-1970). GermanAmerican author. He served in World War I and his novel All Quiet on the Western Front (1929), one of the most realistic and effective war novels enjoyed great popularity and was filmed twice. He lived in Switzerland (1932-39) and then the US, where he became a citizen. In 1958 he married the actor Paulette Goddard (1911-1990), formerly *Chaplin's wife.

Rembrandt (Rembrandt Harmenszoon van Rijn) (1606-1669). Dutch painter, born at Leyden. Son of a miller, he left university early (1621) to study painting. After three years' apprenticeship to a local artist he spent six months in Amsterdam with Pieter Lastman who had been to Italy and had become familiar with the work of ${ }^{*}$ Carracci and others. Rembrandt seems to have been more influenced by the Dutch followers of *Caravaggio, who by directing the fall of light from a single direction could create emphasis by contrast and suggest sculptured form. From this technique was developed Rembrandt's famous chiaroscuro, with several illuminated points gradually fading into the golds and browns of deepening shadow. He returned to Leyden (1625) and soon acquired a considerable reputation and several pupils. Chiaroscuro effects are already to be seen in, for example, Simeon in the Temple. 
In 1631 Rembrandt moved to Amsterdam and quickly became a fashionable portrait painter, and since his subjects were mostly rich burghers whom he did not have to flatter unduly, provided he gave them the dignity and trappings of wealth, he was free to display his great gift for interpreting human personality. The romantic side of his own character was shown (as indeed earlier at Leyden) by his delight in dressing his sitters in all sorts of fantastic finery, not only silks and satins but furs, turbans and even armour. To indulge this taste to the full he painted large numbers of self-portraits, thus arrayed. Biblical and classical subjects continued to attract him and he excelled in dramatic narrative. Group portraits, of which The Anatomy Lesson of Dr Tulp (1632) was among the first to achieve fame, were also popular and by their greater size provided scope for the stronger colours he now liked to employ. The year 1642 marked a turning point in his life. His wife, Saskia van Uylenburgh (married 1634), whose dowry combined with his own earnings had enabled him to lead the life of a substantial citizen, died in 1642, a year after the birth of Titus, their only child to survive infancy. In the same year the group portrait The Night Watch failed to attract, mainly because the background figures were not sufficiently individualised to please the vanity of the persons portrayed. In the years that followed, Rembrandt's earning power steadily declined until (1656) his house and possessions were auctioned to pay his debts. But, ironically, the change in his circumstances marked no decline in the powers of the artist, but the reverse. His increasing impatience with the artistic conventions of the time may have frightened off his patrons but it completed his emancipation as an artist. The rich burghers may have been less often seen in his studios, but that only left him freer to concentrate upon the intense inner life of those who took their place and who had no social importance that it was necessary to convey. Some of his most perceptive portraits are of his son Titus, of Hendrickje Stoffels (who became his mistress in 1645, bore him a daughter, Cornelia, and was his constant attendant in old age), and the continuing series of self-portraits reflecting alike the passing years and his changes of mood and style. As regards the latter, Rembrandt was becoming increasingly interested in the texture of his works. He abandons the illusionist convention by which the activity of the paint is always concealed and discovers the emotive power of brush strokes left visible. He no longer pursues the search for the dramatic with its attendant contrasts of light and shade; the vivid colours of the middle years are subdued to the browns, russets and olive greens familiar in his later work. Biblical (and sometimes mythological) subjects recur more often but they are simpler and more serene. Among the most famous of the pictures of these later years are Saul and David and the group portrait of the Syndics of the Cloth-makers Guild. About 300 of his 500 paintings survive, together with 300 etchings and over 1,000 drawings.

Haak, B., Rembrandt: his Life, his Work, his Time. 1969; Schama, S., Rembrandt's Eyes. 1999.
Remington, Frederic (1861-1909). American painter, sculptor and illustrator. $\mathrm{He}$ travelled extensively in the West, became a war correspondent, and depicted the violent action of life on the frontier.

Renan, (Joseph) Ernest (1823-1892). French religious writer. Brought up for the priesthood, but after a long period of doubt he abandoned his faith and turned to academic work, and became famous with the first volume of an immense work on the history of the origins of Christianity. This volume, the Vie de Jésus (1863), tells the life story of an 'incomparable man'. Under *Napoléon III its antireligious content cost him his professorship, restored after the Franco-Prussian War. He continued his great history and other works, was elected to the Académie française (1878), and became (1883) Administrator of the Collège de France, playing a notable part in the form of French education. The substance of his personal belief was that though God does not exist he is in the process of becoming, through man's struggle for perfection.

Chadbourne, R. M., Ernest Renan. 1968.

Renault, Louis (1877-1944). French manufacturer and industrialist. With his brothers Marcel and Fernand, he founded Renault Frères in 1899, made significant improvements in transmission and suspension and in World War I manufactured vehicles, tanks and shells. A supporter of the far right, after German occupation in World War II his company was run by the Wehrmacht but he argued that collaboration was preferable to workers being transported to Germany. In 1944, Renault Frères was nationalised by *de Gaulle. Renault died in custody, probably having been tortured and beaten, a conclusion which is contested.

Rendell, Ruth Barbara (née Grasemann), Baroness Rendell (1930-2015). English writer. She wrote 24 detective stories featuring Chief Inspector Reginald Wexford, and also wrote thoughtful novels under the name of Barbara Vine. She was a Labour life peer.

Reni, Guido (1575-1642). Italian painter, born in Bologna. He became one of the most prominent of the Baroque painters, the main influences on his style being ${ }^{*}$ Carracci, under whom he studied, and ${ }^{*}$ Caravaggio, whose contrasting effects of light and shade he adopted, in later years his colours became paler and cooler. His subjects are mainly mythological and Biblical, e.g. Aurora, a famous ceiling painting, and Ecce Homo and Mater Dolorosa.

Rennie, John (1761-1821). Scottish civil engineer. Using technologies developed by *Watt and *Boulton, he built the great Kennet and Avon canal (17941810), $140 \mathrm{~km}$ long with 104 locks, which linked Bristol and London. Other works include the old Waterloo Bridge in London (1817), London Bridge (incomplete at his death), dockyards at Chatham, harbours and aqueducts in England and Ireland. 
Renoir, Jean (1894-1979). French film director. Son of the painter Pierre Auguste *Renoir, he began work as a director in 1924 and established a reputation by a unique blend of lyricism and realism. His films include Nana (1926), Une Partie de Campagne (1936), La Grande Illusion (1938), Le Regle du Jeu (1939) and French Can-Can (1956).

Renoir, J., My Life and My Films. 1974.

Renoir, Pierre Auguste (1841-1919). French painter, born in Limoges. One of the most important of the Impressionists, as a boy he was employed as a painter on porcelain. At Gleyre's studio in Paris (1861) he met and became friends with *Monet and *Sisley. With them he worked in the open air concentrating on the problems of sunlight and its reflection, for example, on water or human flesh. It was with the latter that Renoir showed his special skill and the exuberant delight that his painting gave him and which he always wished to impart. There is no exotic frailty about his nudes: their flesh is rosy and their limbs are muscular. For Renoir, love of painting and a love of life were inseparable. A more sophisticated gaiety is seen in La Loge, Les Parapluies and Au Théatre: la Premiere Sortie. He experimented briefly with pointillism but in general he was a more scholarly painter and more concerned with composition, e.g. his large paintings of Bathers in the 1880s, than many of his contemporary Impressionists. He spent most of his life between Paris and the French countryside and, though his hands were crippled with arthritis, continued to paint in his garden near Cagnes to the time of his death. He achieved a total of 6,000 paintings. He was happily married.

Drucker, M., Renoir. 1944; Gaunt, W. (ed.), Renoir: Paintings. 1971.

Repton, Humphry (1752-1818). English landscape gardener. He began to design gardens c.1790, sometimes working in partnership with the architect John ${ }^{*}$ Nash. He restored a formal setting to country houses by planting the immediate surroundings of the house in a decorative and obviously artificial style. This was a departure from the carefully 'natural' parkland, unrelieved by planted beds, that was formerly prevalent. He wrote Observations on the Theory and Practice of Landscape Gardening. (1794).

Respighi, Ottorino (1879-1936). Italian composer, violinist, conductor and musicologist, born in Bologna. An outstanding orchestrator, he scored piano works by *Rossini for the ballet La Boutique fantasque (1918). He composed several high-spirited 'pictorial' orchestral works, e.g. The Fountains of Rome (1917), The Pines of Rome (1924) and Roman Festivals (1929). His edition of Monteverdi's Orfeo (1935) exemplified his valuable work in reviving interest in early Italian music. He was important in the revival of interest in *Vivaldi. His three Suites of Ancient Airs and Dances $(1917,1923,1932)$ and The Birds (1928) were based on works by 17 th-century composers.
Reszke, Jean de (né Jan Mieczysław Reszke) (18501925). Polish tenor, born in Warsaw. He made his operatic debut at Venice (1874) as a baritone, but developed into one of the most famous tenors of his epoch, especially in Wagnerian roles.

\section{Retz, Gilles de see Rais, Gilles de}

Retz, Jean François de Gondi, Cardinal de (16131679). French cleric and politician. A colourful character, famed as a young man for his duels, love affairs and wit, he played an important part in the wars and disturbances of the Fronde (1648-53). He was arrested (1652) but escaped from prison (1654) and reached Spain and Italy. In 1662 he became reconciled with *Louis XIV by giving up his archbishopric (in return, however, for generous compensation elsewhere). His Mémoires (published 1717) show a lively talent for describing character and events.

Salmon, J. H. M., Cardinal de Retz. 1969.

Reuchlin, Johann (1455-1522). German humanist. Having mastered Greek and Hebrew (the latter from a Jewish physician) he became the principal promoter of these two languages in Renaissance Germany. $\mathrm{He}$ protested successfully against the destruction of Jewish books and did much, by his writing and teaching, to encourage intellectual tolerance.

Reuter, Paul Julius, Baron von (né Israel Beer Josaphat) (1816-1899). Anglo-German journalist and entrepreneur, born in Kassel. Founder of the famous news agency, as a bank clerk at Göttingen he realised the importance for business of speedy information and organised (1849) the transmission of stock exchange prices between Aachen and Brussels by pigeon post. He moved to Paris and then London where he set up (1851) an office for the collection of, not only share prices, but also news items from the Continent. From these small beginnings sprang the huge international news agency which still bears his name. Reuter became a naturalised British citizen and was created baron in 1871 by the Duke of Saxe-Coburg-Gotha.

Reuther, Walter Philip (1907-1970). American trade union leader. He began to organise workers in the motor industry in 1935 . He became (1952) President of the Congress of Industrial Organisation (CIO), and when it merged (1955) with its rival, the American Federation of Labor (AFL) he became Vice President of the new organisation.

Revere, Paul (1735-1818). American patriot, born in Boston. Of French Huguenot descent, he took part in the 'Boston Tea Party', the prelude to the War of Independence, but is remembered as the hero of a famous 'ride' from Charlestown, near Boston, to Lexington and Concord (April 1775). The story is told in a well known poem by *Longfellow but there were in fact two rides, the purpose of the first being to warn the insurgents to move their stores to 
Concord, and that of the second, two days later, to raise the alarm that British troops were on the move. Professionally, he was a silversmith, printer, engraver, bellfounder, and metals processor. His work was of exhibition quality and much of it survives.

Green, M., Paul Revere, Man Behind the Legend. 1964.

Reynaud, Paul (1878-1966). French politician. A successful advocate from 1908, he was a member of the Chamber of Deputies 1919-24, 1928-42 and the National Assembly 1946-58. Finance Minister 1938-40, he succeeded *Daladier as Premier MarchJune 1940 and worked with ${ }^{*}$ Churchill to organise more effective resistance to the German invasion. But most of his Cabinet were defeatist and he was replaced by *Pétain who negotiated a surrender. Detained by the Germans 1940-45, Reynaud was a deputy again 1946-58 and Vice Premier 1953-54.

Reynolds, Sir Joshua (1723-1792). English painter, born in Plympton, Devon. Son of a schoolmaster, he began his art studies under Thomas Hudson (174043), and widened his range by practice and study. The turning point came with a visit to Italy (1749-53) during which he made an intensive study of the work and methods of the great masters, *Raphael, ${ }^{*}$ Michelangelo, ${ }^{*}$ Correggio, ${ }^{*}$ Titian and the other Venetians. The rest of his life was spent in London where his record as a fashionable portrait-painter was one of continued and remarkable success. The versatility with which he could adapt his knowledge and technique to the changes of time and fashion amazed his contemporaries. He was equally successful with the formal or informal occasion, the latter often enhanced by a parkland or garden setting. He also shows something of *Van Dyck's pleasure in the texture and decorative value of fine clothes. He was one of the founders of the Royal Academy (1768) and was its first president, remaining in office for the rest of his life. His prize-giving Discourses retain their value for the student, and also give a valuable account of his own aims. He visited Flanders and Holland (1781) and a renewed study of * Rubens in particular brought fresh life into his later pictures. He painted almost every celebrity of his time (over 2,000 in all): Lady Cockburn and her Children and Mrs *Siddons as the Tragic Muse are perhaps the best known of his works. Reynolds, sociable and good-natured, was a member of Dr *Johnson's circle, almost all of whom he painted.

Waterhouse, E. K., Reynolds. New ed. 1973.

Reza Shah Pahlavi (1878-1944). Shah of Iran (Persia until 1934) 1925-41. A man of unusual energy and untutored intelligence, he rose from the ranks in the army to become a distinguished officer. He led a military coup (1921), became military dictator, and deposed Ahmed Shah, last of the Qajars (1925). As shah he adopted the dynastic name 'Pahlavi' to recall an early and famous Persian dynasty. He abolished (the Muslim clergy) and strove to modernise the country, whose name, he insisted, should be 'Iran'. His pro-German attitude during World War II led Britain and the USSR to occupy Iran and force him to abdicate (1941) in favour of his son *Mohammed Reza. He died in Johannesburg.

Avery, P., Modern Iran. 1965.

Rhee (Yi) Syng-man (1875-1965). Korean politician, born in Whanghae. Educated at a Methodist school, he became a Christian while imprisoned for nationalist activities by the Japanese, then ruling Korea. In 1904 he went to America. After the failure of the Korean rising of 1919 he was Chairman of the Korean government in exile. On the Japanese defeat, Korea was partitioned on the 38th parallel. Rhee was first president of the Republic of Korea (i.e. the south) 1945-60. When the Democratic Peoples' Republic of Korea invaded the south (June 1950), Rhee called on the US and UN for aid. An international force, largely American and led by General *MacArthur, helped the South Koreans in a long and costly war to restore the frontier. Rhee was re-elected in 1956 and 1960 but his dictatorial rule had become increasingly unpopular, and after hostile demonstrations (April 1960) he was removed and exiled to Hawaii.

Rhodes, Cecil John (1853-1902). South African politician and financier, born in Bishop's Stortford. Son of a clergyman, he went for health reasons to South Africa at the age of 17 and secured many valuable claims at the diamond diggings at Kimberley. Eventually he joined 'Barney' Barnato in forming (1888) the De Beers Consolidated Mines Company to unite their interests. Meanwhile he had been to Oxford University, gained a degree and became one of the youngest of self-made millionaires. Already his mind was busy with his dream of a British-controlled Africa from the Cape of Good Hope to Cairo. For this he needed the cooperation of the Cape Dutch and he secured it by promising their leader Jan *Hofmeyr support for the protection of Cape farmers in return for acquiescence in his northward advance. First he limited the expansion of the Dutch South African Republic (the Transvaal) by inducing the British to declare a protectorate over Bechuanaland. With the same motive he purchased from the Matabele chief ${ }^{*}$ Lobengula the mining rights in his territory. As a result the British South Africa Company was formed by royal charter (1889). The creation of Rhodesia soon followed. Rhodes was Prime Minister of the Cape 1890-96. Still in cooperation with ${ }^{*}$ Hofmeyr, he passed an act giving the coloured population votes for their local government. While in pursuit of his expansionist policy he completed the Cape-Cairo telegraph and, to overcome the most difficult obstacle, tried to negotiate a confederation with President *Kruger's South African Republic (Transvaal). He failed in this. The discovery of gold meant that the Transvaal could remain independent and Kruger refused all political rights to the British and other foreigners (the Uitlanders) who had come to exploit the goldfields and upon whom the country's prosperity 
depended. Angry and impatient, he organised the notorious *Jameson Raid (December 1895-January 1896), an armed incursion from the north that turned into a fiasco when its intended beneficiaries failed to rise. Rhodes was forced to resign when his part in it was discovered, and the divisions it created brought about the Boer War. Rhodes was a supporter of the Liberals in the UK and sympathetic to *Parnell's Irish nationalism. Rhodes spent much of his remaining life in developing Rhodesia (now Zimbabwe and Zambia). He is buried (with Jameson) at the Malindidzimu Hill ("View of the World') in the Rhodes Matopos National Park, Zimbabwe. He never married. Of his huge fortune, all bequeathed for public purposes, he left a large sum for the foundation of Rhodes scholarships at Oxford University for students from the British Empire, the United States and Germany.

Lockhart, J. G. and Woodhouse, C. M., Rhodes. 1963.

Rhys, Jean (née Ella Gwendoline Rees Williams) (1890-1979). Anglo-Welsh novelist, born in Dominica. She lived in England from 1907, often precariously, married three times, drank a great deal and wrote powerfully about vulnerable and exploited women and girls. Her novels include Quartet (1928), Voyage in the Dark (1934), Good Morning, Midnight (1939) and Wide Sargasso Sea (1966). There is an extensive literature on her work.

Angier, C., Jean Rhys. Life and Work. 1990; Seymour, M., I Used to Live Here Once. 2022

Ribbentrop, Joachim von (1893-1946). German diplomat. Originally a champagne salesman, after working in Canada he joined the Nazi party (1933) and became *Hitler's advisor on foreign affairs. He negotiated the Anglo-German naval treaty (1935) and served as Ambassador to Britain 1936-38 and Foreign Minister 1938-45. His greatest coup was negotiating the Russo-German Non-Aggression Pact of August 1939 with *Molotov, a condition precedent to the outbreak of World War II. Ribbentrop, despised by the other Nazi leaders, was tried by the Nuremberg Tribunal and hanged.

Bloch, M., Ribbentrop. 1992.

Ribera, Jusepe (or José, known as Spagnoletto, 'little Spaniard') (1591-1656). Spanish painter. He studied in Spain and Italy, and eventually settled in Naples (1616) where he became court painter to the viceroys. He adopted ${ }^{*}$ Caravaggio's style of chiaroscuro and painted subjects such as The Massacre of St Bartholomew with brutal realism.

Ricardo, David (1772-1823). English economist, born in London. Son of Dutch-Jewish immigrants, estranged by his marriage to a Quaker, he became a successful stockbroker, and added to his business experience the theoretical knowledge of economics acquired through his friendship with Jeremy *Bentham and James *Mill to produce the famous
Principles of Political Economy and Taxation (1817). In his own words he gives an account 'of the natural course of rent, profit and wages'. The method of assessing value by the amount of labour put into the production of commodities was later abandoned by him (at least in its unmodified form) but was used by Karl *Marx and so achieved a lasting influence. His theory of 'comparative advantage', a refinement of Adam *Smith's 'absolute advantage', argued that, in international trade, nations should concentrate on areas where natural endowments, history or experience, provided cost benefits (e.g. Australian wool). This pointed the way towards Free Trade. Ricardo was MP for an Irish pocket borough 181923 (Michael * Porter).

Ricci, Matteo (1552-1610). Italian Jesuit missionary. He learned Chinese and went to China (1583) but was expelled from place after place until allowed to settle in Peking (Beijing) in 1601. Here he attracted interest by showing and explaining European clocks and maps and soon made converts. His adaptation of Christian theology to accord with Chinese custom, however, aroused controversy and disapproval in Rome.

Spence, J., The Memory Palace of Matteo Ricci. 1985.

Rice, Condoleezza (1954- ). American administrator, born in Alabama. Educated at Denver and Notre Dame universities, she taught political science at Stanford, and served George W. ${ }^{*}$ Bush as National Security Adviser 2001-05 and Secretary of State 2005-09.

\section{Rich, St Edmund see Edmund of Abingdon, St}

Richard I (known as 'Cour de Lion') (1157-1199). King of England 1189-99. Born at Oxford, son and successor of *Henry II and of his queen *Eleanor of Aquitaine. At the time of his father's death, Richard and his brothers, incited by their mother (by then separated from Henry), were in rebellion against him. Almost immediately after his succession Richard joined the 3rd Crusade provoked by the capture (1187) of Jerusalem by Saladin. He conquered Cyprus (where he married Berengaria of Navarre), proved his military skill by the capture of Acre, but, having quarrelled with, and been deserted by, *Philippe II of France and Duke Leopold of Austria, he had to be content with only a sight of Jerusalem before making a truce (1192). On the way home he was wrecked in the Adriatic and while trying to return overland in disguise was caught by his enemy Duke Leopold and imprisoned for two years until a sufficient instalment of the vast ransom demanded had been paid. (The legend that the King's place of captivity was discovered by the troubadour ${ }^{*}$ Blondel de Nesle is unsubstantiated.) On his return he forgave his brother *John, who had been in arms against him, and spent the rest of his reign defending his French dominions against Philippe II. He was killed by a chance arrow shot at the siege of Chaluz. He had spent only a few months in England during his 
reign, but his justiciars, William de Longchamp and Hubert de Burgh ruled well and the ransom was ungrudgingly paid. Richard earned his nickname for his bravery and was generous and chivalrous. He is buried at Fontevraud-l'Abbaye, Anjou.

Harvey, J. H., The Plantagenets. 1970; Flori, J., Richard the Lionheart Knight and King. 1999.

Richard II (also known as Richard of Bordeaux) (1367-1400). King of England 1377-99. Born at Bordeaux, he was the son of *Edward, the Black Prince, and succeeded his grandfather, *Edward III. During the crisis of the Peasants' Revolt (1381), Richard, though still under the regency of *John of Gaunt, personally intervened and when their leader, Wat *Tyler, was struck down he courageously took charge and promised to redress their grievances. From c.1382 Richard tried to assert his kingship, but his aims were frustrated by the magnates in his council (Lords Appellant) who objected to the favours bestowed upon members of the court party. Richard tried to resist, but from 1386 to 1389 the Lords Appellant were in complete control. Their divisions destroyed them. Richard regained the initiative and for the next eight years ruled constitutionally and well. But he foresaw danger, and for an expedition to Ireland (1394) he raised an army dependent only upon himself. Thus fortified, he struck back (1397) at his opponents. Execution or exile was their fate, and with parliament packed and submissive he established a despotism that became increasingly severe. He made the mistake, however, of quarrelling with and exiling his cousin Henry Bolingbroke, and more foolish still, sequestrating the Lancastrian estates when his uncle, John of Gaunt, died (1399). While Richard was absent in Ireland, Henry landed in Yorkshire and marched across England gathering adherents. The King returned and, judging the position hopeless, surrendered. He was taken to Pontefract Castle in Yorkshire from which he never emerged. His cause of death is uncertain he may have been smothered, or starved himself. He was married twice but died childless. Bolingbroke succeeded him as *Henry IV. Richard encouraged the arts and his court became a centre for culture.

Saul, N., Richard II. 1997.

Richard III (Richard Plantagenet) (1452-1485). King of England 1483-85. Born at Fotheringhay Castle, Northamptonshire, son of Richard, Duke of *York, he was created Duke of Gloucester (1461) when his brother *Edward IV deposed *Henry VI for the first time. In 1472 Richard married Anne Neville (1453-1485), daughter of *Warwick the Kingmaker. When Edward IV died (1483), the boy king *Edward $\mathrm{V}$ succeeded and Richard ruled, as protector. The events that followed arose directly from the hostility to him of the widowed queen, Elizabeth (Woodville), and the swarm of her relations raised to wealth and power by Edward IV. Richard proceeded to isolate the king from his mother, to seize and kill the most prominent of the queen's relations and then to induce parliament to declare the queen's marriage invalid and the king a bastard, and consequently to dethrone him. Richard then accepted the crown as next in line of inheritance. Meanwhile, young Edward and his brother Richard were in the Tower of London, where they were killed in circumstances that have never been established: Sir Thomas *More's narrative (followed by ${ }^{*}$ Shakespeare), which made Richard Crouchback the exemplar of all wicked uncles, may be exaggerated and certainly contains Tudor bias, and, significantly, there is no contemporary accusation of murder against him. Richard, a successful and just administrator and hitherto very popular, now began to lose adherents, a process accelerated when the Lancastrian claimant Henry Tudor (*Henry VII) landed at Milford Haven, and Richard was defeated and killed in the battle which ensued at Bosworth in Leicestershire. Richard's reputation has had several champions in recent decades, and he is to some extent rehabilitated. In a 1984 television 'trial' in Britain, with a former lord chancellor as judge and leading criminal QCs as prosecutor and defence counsel, Richard was acquitted. In September 2012 a skeleton, later convincingly identified as Richard's, was excavated in a Leicester car park and he was interred in Leicester Cathedral in March 2015.

Cheetham, A., The Life and Times of Richard III. 1972; Horspool, D., Richard III. A ruler and his reputation. 2016; Hicks, M., Richard III: The SelfMade King. 2019.

Richard (Plantagenet), Earl of Cornwall (12091272). King of the Romans 1257-72. Born at Winchester, son of King *John and brother of *Henry III of England, he was Count of Poitou before 1225 and probably created Earl of Cornwall in 1227. He first went on crusade in 1236, was commanderin-chief of the crusaders 1240-41 and ambassador to France and the Papacy in 1250 . Extremely rich through extorting taxation from the Jews, he played an important part in continental politics in the confused period following the death (1250) of the Holy Roman Emperor ${ }^{*}$ Friedrich II. He refused the Sicilian crown offered (1253) by Pope Innocent IV but in 1257 was the successful candidate for the office of King of the Romans (i.e. emperor elect) and was crowned German King at Aachen, but only gained partial recognition. In the baronial civil war in England he tried to mediate but finally sided with his brother, was captured at Lewes and held prisoner until after the Royalist victory at Evesham.

\section{Richard, Duke of York see York, 3rd Duke of, Richard Plantagenet}

Richards, Frank (pen name of Charles Harold St John Hamilton) (1876-1961). English author. Probably the most prolific author of all time (more than 100 million published words), he wrote two weeklies for boys, Gem (as Martin Clifford, 1907-39) and the better known Magnet (as Frank Richards, 1908-40). Magnet, set at Greyfriars School, featured 
the fat boy Billy Bunter (who later appeared in books, on stage and television), Harry Wharton and Bob Cherry. As Hilda Richards he also wrote girls' school stories. George *Orwell's critical essay Boy's Weeklies (1940) provoked a strong defence by Richards.

Richards, F., Autobiography. 1952.

Richards, I(vor) A(rmstrong) (1893-1979). English literary critic. He taught at Cambridge 1922-29 and Harvard 1939-63 and was a pioneer of New Criticism, applying rigorous scientific and analytical method to the study of texts. With C. K. ${ }^{*}$ Ogden he devised 'Basic English'.

Richardson, Henry Handel (pen name of Ethel Florence Lyndesay Richardson) (1870-1946). Australian novelist, born in Melbourne. She left Australia in 1888 to study music in Leipzig, but after her marriage to the philologist and German literary scholar John George Robertson (1867-1933) devoted herself to writing and translation. She lived in Germany until 1903, then in England, only returning to Australia for one brief visit in 1912. Her massive first novel Maurice Guest (1908) was set in Leipzig. The Getting of Wisdom (1910), semi-autobiographical, with a lesbian sub-text, was her most successful book, filmed in 1978. In her trilogy The Fortunes of Richard Mahony $(1917$; 1925; 1929) the central character, loosely based on her father, is a doctor in Victoria in the turbulent period of the Gold Rush (1850s and 1860s), facing intellectual, religious, physical and financial challenges. She conveys the ruthless inevitability of great tragedy, yearned for the Nobel Prize but was never nominated.

Kramer, L., Henry Handel Richardson. 1967; Buckley, V., Henry Handel Richardson. 1970; Niall, B., Friends ¿r Rivals. 2020.

Richardson, Sir Ralph David (1902-1983). English actor. He first won fame by his Shakespearian performances with the Old Vic, and especially in the New Theatre season, immediately following World War II, during which he had done naval service. From the 1930s he was equally well known for his appearances in many films, including Things to Come (1936), Anna Karenina (1948), The Fallen Idol (1948) and The Heiress (1949). Among his stages successes were Arms and the Man, The Heiress, Flowering Cherry. He was knighted in 1947.

Richardson, Samuel (1689-1761). English novelist. Son of a cabinetmaker 'who understood architecture', he had a grammar school education, after which he was apprenticed to a London printer, whose daughter he married (1721). He established (1724) his own business in Salisbury Square and managed it successfully for the rest of his life. He was already 50 when at the suggestion of two friends he wrote a book of specimen letters for various occasions for the benefit of those unable to express their own thoughts. From one of these letters, 'A Father to a Daughter in Service on hearing of her Master's attempting her Virtue', sprang Pamela, or Virtue Rewarded (1740), the first of three epistolary novels intended, since Richardson was primarily a moralist, 'to promote religion and virtue'. Often described as the first modern novel, Pamela, a hugely popular book, was followed by Clarissa (1747-48), a prodigious work in seven volumes where death appropriately follows a lapse from virtue. In Sir Charles Grandison (1753-54) the hero and heroine, their virtue proof against all trials and misfortunes, ultimately and happily unite. Richardson's influence was various and widespread. Pamela was parodied by *Fielding in Shamela and Joseph Andrews, and *Voltaire made use of it for one of his own plays; Clarissa was translated by the Abbé *Prévost, and ${ }^{*}$ Diderot and ${ }^{*}$ Rousseau were among the author's fervent admirers.

Duncan Eaves, T. C. and Kimpel, B. D., Samuel Richardson. A Biography. 1971.

Richelieu, Armand Jean du Plessis, Duc de (1585-1642). French statesman and cardinal, born at Richelieu, Poitou. He was a younger son of François du Plessis, grand provost of France, and at the age of 21 was nominated Bishop of Luçon. Representing the clergy at the States-General of 1614, he made contact with the court and in 1616 was appointed Secretary of State as the protégé of Concino Concini, favourite of the Queen Mother and regent *Marie de Médicis. Concini's assassination (1617), consented to by *Louis XIII to assert his independence, seemed likely to end Richelieu's career but, by reconciling the king and his mother, he made himself acceptable to both. Richelieu became a cardinal in 1622, Chief Minister in 1624 and for 18 years was virtual ruler of France. He crushed the political power of the Huguenots (1625-29) by reducing the strongholds granted to them as places of refuge by ${ }^{*}$ Henri IV. La Rochelle, the most important, fell (1628) after heroically resisting a siege of 15 months, Richelieu himself ensuring the result by building a huge dyke across the harbour and so preventing relief by the English fleet. Richelieu next had to contend with attempts by the feudal nobility, aided by the king's vain and foolish brother Gaston, Duke of Orlans, to undermine his power. Plot after plot Richelieu unveiled and punished, and even overcame a desperate attempt by Marie de Médicis, now turned against him, to have her former adherent removed from office. Having created the centralised autocracy of which ${ }^{*}$ Louis XIV was to be the beneficiary, Richelieu turned to foreign affairs. The Thirty Years' War was raging and with the death of the Swedish king *Gustaf II (1632) the Protestant cause might have foundered and France been at the mercy of Habsburg Austria had not Richelieu, Catholic cardinal though he was, stepped in with subsidy and armed forces to fill the gap. During the last two years of Richelieu's life (1640-42), Artois, Alsace and Roussillon were occupied by France. Though primarily a politician, Richelieu proved himself a discerning patron of the 
arts and learning, and in 1635 founded the Académie française, his most abiding memorial. Richelieu was known as 'Eminence Rouge', his confidential agent as 'Eminence Grise' (*Joseph, Père).

Burckhardt, C. J., Richelieu and his Age. 1940-70; Church, W. F., Richelieu and Reason of State. 1973.

Richler, Mordecai (1931-2001). Canadian novelist and essayist, born in Montréal. His novels include The Apprenticeship of Duddy Kravitz (1959, also filmed), Cocksure (1968), St Urbain's Horsemen (1971) and Solomon Gursky was Here (1990). He published several collections of essays and edited anthologies of humour.

Richter, Charles Francis (1900-1985). American seismologist. He taught at the California Institute of Technology 1927-70 and in 1935, with Beno Gutenberg, devised the Richter scale for the measurement of earthquakes.

Richter, Gerhard (1932- ). German artist, born in Dresden. Trained in a socialist realist tradition, he escaped to the West in 1961, and worked as a painter, print maker, sculptor and glass worker, in a diversity of styles, influenced by politics, history, science and music, including photorealism, abstraction and pop art. He created a magnificent stained glass window for Köln (Cologne) Cathedral (2007). His Abstraktes Bild sold at auction for \$US44.5 million in 2015.

Richter, Hans (originally János) (1843-1916). Austro-Hungarian conductor, born in Hungary. A horn and trumpet player, he became *Wagner's assistant, conducted the first performance of The Ring cycle (1876) and remained at Bayreuth until 1912. He was chief conductor of the Vienna Court Opera 1880-99, the Hallé Orchestra, Manchester 18991911, the London Symphony Orchestra 1904-11, and premiered major works by ${ }^{*}$ Brahms, ${ }^{*}$ Bruckner and *Elgar.

\section{Richter, Johann Paul Friedrich see Jean Paul}

\section{Richter, Sviatoslav see Rikhter, Sviatoslav}

Richthofen, Manfred, Baron von (1892-1918). German aviator. His exploits as a fighter pilot made him an almost legendary figure in World War I; he is said to have shot down 80 planes before being killed in action. ${ }^{*}$ Goering served in his squadron. His sister, Frieda von Richthofen (1881-1956), married (1914) D. H. *Lawrence.

Rickover, Hyman George (1900-1986). American admiral and engineer, born in Russian Poland. He was responsible for the US Navy's nuclear submarine project, leading to the commissioning of the Nautilus (1954). He remained on the naval staff until the age of 82 .
Ridgway, Matthew Bunker (1895-1993). American soldier. Much of his early service was on the staff, but in World War II he commanded a division in Sicily and Italy 1942-44, and during the liberation campaign in northern Europe 1944-45 the 18th Airborne Corps. He was GOC of the US 8th Army in Korea 1950-51 and succeeded (1951) *MacArthur in the supreme command of UN forces. In 1952 he took over *Eisenhower's command of NATO forces in Europe and was Chief of Staff of the US Army 1953-55.

Ridgway, M. B., Soldier. 1956.

Riding, Laura (Jackson) (1901-1992). American poet and critic, born in New York. Educated at Cornell, she worked closely with Robert ${ }^{*}$ Graves from 1926 and was a pioneer of the New Criticism.

Ridley, Nicholas (c.1500-1555). English Protestant martyr. A strong but unbigoted supporter of the Reformed doctrines, he became Bishop of Worcester (1547) and of London (1550). As long as *Edward VI was alive he had a powerful influence in the Church and helped Archbishop ${ }^{*}$ Cranmer to prepare the Forty-two Articles. On the king's death he supported the cause of Lady Jane *Grey, but when Queen *Mary succeeded he was arrested, tried for heresy at Oxford with *Latimer and Cranmer, and burned at the stake.

Ridley, J. G., Life of Nicholas Ridley. 1957.

Riebeeck, Jan van (c.1619?-1677). Dutch administrator. A surgeon, he was sent by the Dutch East India Company (1652) with 70 Dutch burghers to found a settlement at the Cape of Good Hope which could act as revictualling station for ships bound for the East Indies. He remained for 10 years, the settlement he started forming the nucleus of the South African Republic of today. He died in Batavia (Jakarta).

Riefenstahl, Leni (Helene) (1902-2003). German actor, film maker and photographer, born in Berlin. She trained as a dancer, starred in several romantic 'ice' pictures in the 1920s and directed four important films: The Blue Light (1932); Victory of Faith (1933); Triumph of the Will, a powerful evocation of Germany's mood at the time of *Hitler's accession (1934); and Olympia 1936 (1938). Barred from film making after 1945 because of her Nazi links, she turned to photography and published three dramatic books, The Last of the Nuba (1973), The People of Kau (1976) and Coral Gardens (1978).

Riel, Louis (1844-1885). Canadian insurgent, born in Manitoba. In 1869 he led a rebellion of Métis (mixed European and Indian descent) against the introduction of settled government to Manitoba by the Dominion of Canada. The rising was easily suppressed. Riel fled to the US, then returned, was twice elected as a Dominion MP, but refused to take his seat. He lived in Montana 1879-84 and became 
a US citizen. Returning to lead an uprising of Métis in Saskatchewan (March 1885), on its defeat Riel was tried for treason, convicted and hanged in Regina.

Davidson, W. M., Louis Riel. 1955.

Riemann, Georg Friedrich Bernard (1826-1866). German mathematician. He studied under *Gauss at Göttingen, where he returned to teach (1851) and was professor of mathematics 1857-66. He put forward (1854) a system of non-Euclidean geometry that includes the idea of a finite but unbounded space capable of any number of dimensions and rejects many of the basic concepts of *Euclid, e.g. the notion that parallel lines meet only at infinity.

Rienzo, Cola di (1313-1354). Italian patriot, born in Rome. Son of an innkeeper, trained as a lawyer, he looked back to the glories of the ancient republic and convinced himself that it was his destiny to restore the squalid city of his own time to its former greatness. He headed a mission (1343) to Avignon, where the papacy was installed in voluntary exile, to secure constitutional reforms from Pope Clement VI. Returning empty-handed, he succeeded by his eloquence in obtaining popular support for the revival of the Roman republic and he was proclaimed Tribune (1347). As long as he used his despotic power to maintain law and order all was well, but by stirring the people against the nobles he provoked fights and bloodshed and his pretensions to exercise the old Roman supremacy over the rest of Italy were resented. Seven months after assuming office he was forced to flee. He went to Prague (1349-50) to enlist the support of the emperor Charles IV in his plans for a revived Roman Empire. Charles sent him captive to Avignon but in 1353 Pope Innocent IV, hoping to use him to restore papal power, sent him back to Rome, where he resumed despotic rule. But now the mob turned against him, stormed the Capitol and killed their former hero. His story is told in *Lytton's novel and *Wagner's opera, both called Rienzi.

Rifkind, Sir Malcolm Leslie (1946- ). British Conservative politician. Educated at Edinburgh University, he was MP 1974-97, Secretary of Defence 1992-95 and Foreign Secretary 1995-97.

Rikhter, Sviatoslav Teofilovich (1915-1997). Russian pianist, born in Zhitomir, Ukraine. He worked in the Odessa Opera House as a repetiteur, then studied with Heinrich Neuhaus from 1937. He did not visit the West until 1960. He made highly praised recordings of ${ }^{*}$ Mozart, ${ }^{*}$ Beethoven, *Chopin, *Schubert, *Schumann, *Liszt, *Mussorgsky, *Rachmaninoff, *Bartók, *Prokoviev, *Shostakovich and ${ }^{*}$ Britten.

Riley, Bridget Louise (1931- ). British painter, born in London. Educated at Goldsmiths' College and the Royal College of Art, she achieved international recognition from 1962. Her paintings were created within the op art tradition, depending on tension between contrasting colours in stripes and curves, leading to an instability of focus so that the canvas seems to be in motion. She received a CH in 1999 .

Rilke, Rainer Maria (originally René Karl Wilhelm Johan Josef Rilke) (1875-1926). Bohemian-Austrian poet, born in Prague. After his parents separated, he was unhappily educated at a military school and at Prague, Munich and Berlin universities. His earliest works were melancholy reveries. With *Nietzsche's friend, Lou Andreas-Salomé, who became his mistress, he visited Russia 1899-1900, met *Tolstoy and developed a mystical preoccupation with its history and religion. His poems became concerned with the interrelationship of God (identified with Life), Man and Death. He married (1901) a pupil of the French sculptor *Rodin, and became his secretary (1905-06) and fervent admirer. Though his spiritual search continued, he learnt from Rodin the importance of form; his poems thus lost much of their vague mysticism and as his vision became more objective he directed it to more concrete themes. His novel The Notebook of Malte Laurids Brigge (1910) is partly autobiographical. He lived in Duino, near Trieste 1910-12. After further travels he settled in Switzerland (1919), and with the publication (1923) of the 10 Duino Elegies (1912-15, 1922) and the Sonnets to Orpheus he seemed to have found tranquillity in the cult of beauty. He was preoccupied with the 'inseparability of uniqueness and transience' in human life, and the centrality of courage, awareness and aesthetics, and is regarded as the greatest modern German poet. He died of leukaemia.

Holthusen, H. E., Portrait of Rilke. 1971; Prater, D., A Ringing Glass. 1994; Freedman, R., Life of a Poet. 1996; Corbett, R., You Must Change Your Life. 2016.

Rimbaud, (Jean-Nicolas) Arthur (1854-1891). French poet, born in Charleville. He reacted against the dominating puritanism of his mother and an unhappy home life by running away from home several times before settling in Paris (1870). His amazing precocity was shown in all his early pieces and especially in his Le Bateau ivre (The drunken boat) in which the rhythms and images already have the magical quality that appears in the work of the later symbolists. He lived with *Verlaine in Paris from 1871 but the association ended abruptly when Verlaine was sent to prison for firing two shots at Rimbaud who was threatening to leave. But it was Verlaine who made Rimbaud famous with an analysis of his poems in Les Poètes maudits (1884). Rimbaud never knew of this. All his poems were written before he was 20, many under the deliberate stimulation of drink, drugs, or debauchery: all the fragments, Les Déserts de l'amour (1871), Les Illuminations (the basis of a song cycle by ${ }^{*}$ Britten, 1872-73), Une Saison en enfer (1873) are infinitely revealing of a genius in the making and the spoiling. After that he drifted round the world until, in 1883, he reached Abyssinia, where he established a harem and set himself up in trade. His account of his travels there was published in 
1928. He had a working knowledge of Latin, English, Italian, Greek, German, Dutch, Russian, Arabic and Amharic. He died in hospital at Marseilles after an amputation for a tumour on the knee.

Starkie, E., Arthur Rimbaud. 3rd ed. 1961; Robb, G., Rimbaud. 2000; White, E., Rimbaud. The Double Life of a Rebel. 2008.

Rimsky-Korsakov, Nikolai Andreyevich (18441908). Russian composer, born in Tikhvin. Born to an aristocratic family, he became a naval officer but joined *Balakirev's group of 'nationalist' composers known as 'the Five' (the other three being *Borodin, ${ }^{*}$ Mussorgsky and ${ }^{*}$ Cui), who made it their rule to introduce the themes and spirit of Russian folk music into all their compositions. His first symphony (1861-65), his second (1868, twice revised and eventually published as a symphonic suite, Antar, in 1903), and an opera The Maid of Pskov (1868-72) belong to this period. The group broke up c. 1870 , but, as all lacked academic training, RimskyKorsakov was astonished to find himself appointed (1871) professor at the St Petersburg Conservatoire. He succeeded, none the less, in making himself a master of orchestration and contrapuntal technique, and, though the effects upon his work were at first devitalising, he later achieved the brilliance of Capriccio Espagnol (1887) and Scheherazade (1888). From 1888 he turned to opera but only gave of his best when he had succeeded in shedding *Wagner's influence with such fairytale operas as Sadko (1894-96), The Snow Maiden (1880-81) and The Golden Cockerel (1906-07), his last work. RimskyKorsakov's fame rests on his outstanding gift for orchestration, which influenced ${ }^{*}$ Debussy, ${ }^{*}$ Ravel and ${ }^{*}$ Stravinsky. He revised and re-orchestrated works by other composers who lacked his technical versatility, especially Dargomyzhski's Stone Guest, *Mussorgsky's Boris Godunov (here the original has more individuality) and *Borodin's Prince Igor.

Abraham, G., Rimsky-Korsakov: A Short Biography. 1948.

Rinehart, Gina (née Georgina Hope Hancock) (1954- ). Australian mining heiress, born in Perth. Daughter of Lang Hancock (1909-1992), who made a fortune opening up the Pilbara, Western Australia, for iron ore mining, she became Australia's richest person, with \$AU22 billion net worth (2013), and the fourth richest woman in the world. She was a powerful advocate for conservative causes, and was strongly opposed to action on climate change.

Ripon, 1st Earl of, Frederick John Robinson (1782-1859). English Tory/Conservative politician. Educated at Harrow and Cambridge, he became a barrister and MP 1806-27, and held office in every Tory Government between 1809 and 1846 . He introduced the Corn Laws (1815) and as Chancellor of the Exchequer 1823-27 was known as 'Prosperity Robinson' or 'Prosperity Fred'. Created
Viscount Goderich in 1827, on *Canning's death he became Prime Minister briefly 1827-28 and had the unique distinction that his Ministry never met parliament. (*Disraeli called him 'a transient and embarrassed phantom'.) His son, George Frederick Samuel Robinson, 1st Marquess of Ripon (18271909) declared himself a Christian Socialist, first held office as *Palmerston's Undersecretary for War 1859-63 and retired as *Campbell-Bannerman's Lord Privy Seal 1905-08. He was Grand Master of the Freemasons 1870-74, then became a Catholic. He chaired the commission that settled the 'Alabama' dispute with the US (1871) and, as *Gladstone's Viceroy of India 1880-84, encouraged moves towards self-government.

Ritz, César (1850-1918). Swiss hotelier. He created Ritz Hotels in London, Paris and New York and his name became synonymous with luxury (as in the adjective 'ritzy').

Rivera, Diego (1886-1957). Mexican painter. He studied in Paris where he came to know the principal Cubists and was influenced by the works of *Gauguin. His best known works are large murals and frescoes for which he revived the encaustic methods of the ancient Maya sculptors. His themes were revolutionary episodes from history intended to promote the communist cause. His style was a composite of 'folk art', symbolism and Aztec undertones directed towards political ends. He was, for a time, obliged to leave Mexico. After his return (1935) he began to adopt surrealist techniques. His second wife was the painter Frida *Kahlo.

Wolfe, B. D., The Fabulous Life of Diego Rivera. 1963.

\section{Rivera, Primo de see Primo de Rivera y Orbaneja, Miguel}

Rizal (y Mercado Alonso Realonda), José Protasio (1861-1896). Filipino writer and patriot, born in Manila. Of mixed Tagalog, Spanish and Chinese descent, he was trained as an ophthalmologist, with a passion for zoology, and was an accomplished poet. As a writer he aimed at fostering a desire for Filipino independence. His novels Noli me Tangere (1886) and El Filibusterismo (1891) were eloquent attacks on Spanish misrule. He founded a nationalist society, and was exiled from Manila. When the Filipino revolt of 1896 broke out Rizal was arrested in Spain, brought to Manila and executed. He is regarded as a national hero.

Rizzio (or Riccio), David (c.1533-1566). Italian musician and secretary, born near Turin. He went to Scotland (1561) and became the favourite and secretary of *Mary Queen of Scots. His arrogant assumption of power and his personal relations with the Queen roused such anger and jealousy that *Darnley, her husband, joined a group of nobles in a conspiracy to murder. The Queen was having supper in her room with Darnley, Rizzio and Lady 
Argyll, when Lords *Morton and Ruthven burst in and denounced the favourite. Other conspirators appeared and during the ensuing fracas Rizzio was dragged out and immediately stabbed to death.

Robbia, Luca della (1400-1482). Florentine sculptor. A skilled worker in bronze and silver, he is best remembered for his terracotta sculptures to which, in the manner of the Moors in Spain, white and coloured enamels were applied. The Madonna and Child 'type', which he developed, perhaps influenced *Raphael's Florentine Madonna series. Luca's first dated and justly celebrated major work was the Cantoria or Singing Gallery for Florence Cathedral (1431-38), known for its panels of singing and dancing boys. Luca's nephew, Andrea della Robbia (1435-1525), his partner and less accomplished successor, is remembered for the medallions of babes in swaddling clothes on the Foundling Hospital in Florence. His sons, including Giovanni della Robbia (1469-1529) and Girolamo della Robbia (14881566) carried on the family workshop.

Pope-Hennessey, J., Italian Renaissance Sculpture. 1971.

\section{Robert I see Bruce, Robert}

Robert II (1316-1390). King of Scotland 137190. Son of Walter the Steward, his hereditary office passed to him and so made him the first king of the *Stewart (Stuart) dynasty. His claim to the throne came through his mother Marjorie Bruce, daughter of Robert I (Robert *Bruce) and sister of David II, for whom he acted as regent during his captivity in England.

Robert III (1340-1406). King of Scotland 13901406. Son and successor of *Robert II, injury from the kick of a horse made him incapable of rule, and power was exercised by his brother, the Duke of Albany. Robert was succeeded by his surviving son *James I.

Roberts, Frederick Sleigh, 1st Earl Roberts of Kandahar, Pretoria and Waterford (1832-1914). British field marshal, born in Cawnpore, India. Educated at Eton and Sandhurst, as a young officer in the Bengal artillery he won the VC during the Mutiny (1858). He became a national hero in the Afghan wars, when in 1880 he led an army of 10,000 men from Kabul through the mountains to the relief of Kandahar, covering a distance of 495 kilometres in 22 days and then defeating the Afghans. After brief service as commander in Natal and Transvaal (1881), he returned to India and was Commander-in-Chief 1885-93, receiving a peerage in 1892 . He became Commander-in-Chief in Ireland 1895-99, and was promoted to field marshal (1895). After the serious defeats with which the Boer War opened (December 1899) Roberts was sent out as Commander-in-Chief and quickly retrieved the situation. Pretoria was captured (June 1900) and, though guerrilla warfare continued, organised operations were at an end. On his return, he succeeded *Wolseley as Commanderin-Chief of British Forces 1901-04, until the post was abolished. Promoted to an earldom in February 1901, he became the first recipient of the Order of Merit in June 1902. After 1904, with the threat from Germany in mind, he campaigned in vain for conscription for military service. He condoned threats by the Ulster Volunteer Force (UVF) to use force against the establishment of Home Rule in Ireland, and broke with John *French. He died in France visiting troops in World War I. He had the longest set of post-nominal awards in British history: VC, KG, PC, KP, GCB, OM, GCSI, GCIE.

Hannah, W. H., Bobs: Kipling's General. 1972.

Roberts, John Glover, Jr (1955- ). American jurist, born in Buffalo. A Harvard graduate, he was a legal administrator under *Reagan and George H. W. *Bush, a judge of the US Court of Appeals 2003-05, and Chief Justice of the Supreme Court 2005- .

Roberts, Tom (Thomas William) (1856-1931). Australian painter, born in Devon. He migrated to Melbourne in 1869 and studied art there, and in London 1881-84. He was a central figure in the Heidelberg School of painters (1887-90), with his friend Arthur * Streeton. Apart from important portraits and landscapes, his iconic paintings include Coming South (1886), Shearing the Rams (1890), A Break Away! (1891), Bailed Up (1895) and The Big Picture (opening of first Commonwealth Parliament, 1903). Back in England 1903-19, 1921-23, he returned to live in Victoria, then Tasmania, where he died.

Robertson, Pat (Marion Gordon) (1930-). American evangelist, political activist and broadcasting executive, born in Virginia. Son of a conservative Democrat US Senator from Virginia, he became a Southern Baptist minister, founded the Christian Broadcasting Network, was a famous televangelist, sought the Republican nomination for president in 1988 and wrote 13 books.

Robertson, William (1721-1793). Scottish historian. A Presbyterian cleric, Principal of Edinburgh University 1762-93, he was a leading figure in the Scottish Enlightenment. His biography of ${ }^{*}$ Charles V was praised by *Voltaire and *Gibbon.

Robertson, Sir William Robert, 1st Baronet (18601933). English soldier, born in Lincolnshire. Son of a tailor, he was a footman in service and joined the army as a private in 1877 . After long service in India, he was an intelligence officer under Lord *Roberts in South Africa and subsequently held a succession of staff appointments until he became, on the outbreak of World War I, Quartermaster General (QMG) to the British armies in France and Chief of the Imperial 
General Staff 1915-18. He commanded the armies on the Rhine 1919-20. He was the only soldier to rise from private to field marshal (1920).

Robertson, W. R., From Private to Field-marshal. 1921.

Robeson, Paul Le Roy (1898-1976). American singer and actor, born in Princeton. Son of a runaway slave who became a Methodist minister, he became an All-American footballer and studied arts and law at Rutgers and Columbia Universities. He appeared as Brutus Jones in Eugene *O'Neill's The Emperor Jones in New York (1923), London (1925) and in the film (1933) and was a notable Othello (1930, 1943-45, 1959). He achieved his greatest success with the song 'Ol' man river' in Showboat and as Bosambo in Sanders of the River and his resonant bass voice was memorable in African-American spirituals and worksongs. He visited the USSR for concert tours and was blacklisted during the 'cold war' for his advocacy of black rights, the peace movement and other radical causes. He lived in England 1958-63, toured Australia in 1960 and was an outspoken advocate for Indigenous rights. He suffered from depression, attempting suicide several times, then returned to the US. He died in Philadelphia.

Duberman, M. B., Paul Robeson 1989; Sparrow, J., No Way But This. In Search of Paul Robeson. 2018.

Robespierre, Maximilien François Marie Isidore de (1758-1794). French Revolutionary leader, born at Arras. Orphaned at 7 and brought up (with his brother Augustin) by maiden aunts, he was a leading lawyer, judge and littérateur in Arras until elected (1789) to the Estates-General, soon renamed the National Assembly. At first little known, he spoke 500 times in the National Assembly-nearly every sitting day. In 1791, having moved to Paris, he was elected to the Paris Commune and consolidated his great support among the Jacobin clubs. His rigidity and honesty earned him *Marat's description as 'incorruptible' ('the seagreen Incorruptible' in *Carlyle's famous phrase), but it was by his speeches and his gift for putting into words what others were feeling that he gradually gained ascendancy in the Jacobin Club, the meeting place of the extreme republicans encouraged and supported by the Paris mob. As leader of the left Jacobins, he made 100 speeches in Paris between September 1791 and August 1792. He opposed declaration of war on Austria (April 1792) bitterly-and predicted its outcome. He was elected as the first of Paris' 24 delegates to the Convention in September 1792. He proposed and secured the passage of the 1793 Constitution, modelled along the ideas of his idol J. J. *Rousseau. In July 1793 the murder of Marat contributed to the proscription of the Gironde and the election of Robespierre to the Committee of Public Safety, where he served from 27 July 1793 to 26 July 1794 . This was his first exercise of power, more as a resident conscience than a minister. He called for a regime based on 'virtue without which terror is baneful, terror without which virtue is powerless' and purged the Convention of 'ultra-revolutionaries' such as *Hebert (March 1794) and moderate 'indulgents' led by *Danton (April 1794). He introduced the 'Maximum', rigorous government control of the economy, and planned what was virtually a welfare state. He proposed a state cult based on Rousseau's 'civil religion', seeing this as a compromise between atheism and Catholicism. His great day of triumph, presiding at the 'Festival of the Supreme Being' (8 June), marked the beginning of a conspiracy against him by *Tallien, ${ }^{*}$ Fouché and *Barras, corrupt men who feared for their own lives as the Reign of Terror increased in intensity. The battle of Fleurus (June 1794) confirmed that the Committee of Public Safety had placed France militarily in the ascendant, thus removing the main justification of Terror. A scene was staged in the Convention 27 July (9 Thermidor in the Revolutionary calendar) during which Robespierre was denounced and arrested. Next day, after rescue and recapture he was guillotined without trial with 21 other leaders of the Terror. The historians Mathiez and Lefebvre have gone far towards rehabilitating his reputation as a sanctimonious butcher and Crane Brinton has suggested that he was best explained as essentially a religious figure, pledged to destroy corruption and error. Nevertheless he was a flawed character, cold, remote and inflexible. He was a bachelor and owned poodles.

Rudé, G., Robespierre: Portrait of a Revolutionary Democrat. 1985; Jordan, D., The Revolutionary Career of Maximilien Robespierre. 1985; McPhee, P., Robespierre. A Revolutionary Life. 2011.

Robey, Sir George (né George George Edward Wade) (1869-1954). English music-hall comedian. Educated in Germany, he was a clerk who played in amateur theatre, made his professional debut in London (1891), and soon being known as 'the Prime Minister of Mirth'. In World War I he had a triumphant success in the revue The Bing Boys are Here. In 1935 he played Falstaff on stage in Henry IV Part I and repeated it in *Olivier's film Henry V(1944).

Robin Hood. Legendary English folk-hero, probably based on a bandit-rebel active during the reign of *Richard I (1189-99). Robin originally in all probability a hero of oral folktales, appears first 'formally' in the 14th-century poems Piers Plowman, but popularity was mainly stimulated by 15 th-century ballads. These depict him living in Sherwood Forest as the leader of a gang of outlaws, an expert archer and champion of the poor, particularly active against the injustices and extortions of the Sheriff of Nottingham.

Oman, C., Robin Hood. 1973.

Robinson, Edwin Arlington (1869-1935). American poet, born in Maine. Educated at Harvard, he lived in poverty until Theodore ${ }^{*}$ Roosevelt gave him a post in the New York Custom House (1905). He published 26 volumes of epigrammatical and conversational verse in strict classical forms. His best 
known poem is Miniver Cheevy, from The Town Down the River (1910). He sees man as a creature trapped between his animal and spiritual natures and in each he studies 'the small Satanic king': the poet is 'the modern man seeking light in a dark universe'. He wrote a pessimistic Arthurian trilogy in blank verse, Merlin (1917), Lancelot (1920) and Tristram (1927). He won the Pulitzer Prize three times and had four nominations for the Nobel Prize.

Robinson, (William) Heath (1872-1944). English illustrator and comic artist. He was best known for his drawings of weird elaborate machines for performing elementary operations.

Robinson, Jackie (John Roosevelt Robinson) (19191972). American baseballer, born in Georgia. In 1947 he became the first African-American in a major baseball team (Brooklyn Dodgers), stoically resisted racist attacks and was an important role model.

Robinson, Joan Violet (née Maurice) (1903-1983). English economist. Educated at St Paul's Girls' School, London and Girton College, Cambridge, she lectured in economics at Cambridge from 1931 and was a professor 1965-71. She worked with J. M. ${ }^{*}$ Keynes in the 1930 s and wrote several lucid textbooks including three volumes of Economic Papers (1951, 1960, 1965).

Robinson, Sir Ken(neth) (1950-2020). English educator, born in Liverpool. He studied at Leeds and London universities and was professor of arts education at Warwick 1989-2001. He chaired a UK commission on creativity, education, and the economy (1998) and the report, All Our Futures: Creativity, Culture, and Education proposed radical changes in education, with heavy emphasis on the arts and creativity. He became an influential speaker in TED conferences (Harold *Kroto).

Robinson, Mary (1758-1800). English actor. Known as 'Perdita' from her role in Shakespeare's The Winter's Tale, she played at Drury Lane (1776-80) and became (1779) the mistress of the Prince of Wales (*George IV). She wrote poetry, plays and novels, but despite a pension, she died in poverty.

Robinson, Mary Therese Winifred (née Bourke) (1944-). Irish politician, born in Dublin. Educated at Trinity College, Dublin, and at Harvard, she became a lawyer, married a Protestant, joined the Labour Party, taught at Trinity and was active in the International Commission of Jurists. As a senator 1969-89, she was an ardent advocate of women's rights. In November 1990 she was elected as President of Ireland with 53 per cent of the votes, defeating the government's candidate. She resigned to become United Nations Commissioner for Human Rights 1997- .

Robinson, Sir Robert (1886-1975). English organic chemist. Educated at Manchester, he held chairs at Sydney, Liverpool, St Andrews, Manchester and
London before becoming Waynflete professor of organic chemistry at Oxford (1930-55), where he headed a team investigating the chemistry of penicillin. His researches into organic chemistry were mainly in the fields of the alkaloids, plant pigments and phenanthrene derivatives. Knighted in 1939, he was President of the Royal Society 1945-50, won the Nobel Prize for Chemistry (1947) and received the Order of Merit in 1949.

Rob Roy ('Red Robert'; Robert Roy MacGregor, in Gaelic: Raibeart Ruadh MacGriogair) (1671-1734). Scottish outlaw. A grazier on the braes of Balquhidder (where he is buried) in southwest Scotland, he maintained an armed band for the protection of his flocks and those of his neighbours as well as for purposes of his own. His exploits, real and legendary, earned him the reputation of a Scottish Robin Hood, robbing the rich for the benefit of the poor, while at the same time pursuing a personal vendetta against the Duke of Montrose.

Robsart, Amy (1532-1560). English noble woman. First wife of Robert Dudley, later Earl of *Leicester, she became estranged, and died of a broken neck at the foot of the stairs at Cumnor Place, Berkshire. This aroused suspicions that she had been killed on her husband's order (with or without *Elizabeth's most improbable connivance), to enable him to pursue his ambition to marry the queen. Her story forms the basis for Sir Walter *Scott's Kenilworth.

Robson, Dame Flora McKenzie (1902-1984). English actor. She made her debut in 1921 and played her first season at the Old Vic Theatre, London, in 1934, after which she appeared frequently in London, on tour and in New York in an unusually wide variety of classical and contemporary plays. Her first film was *Korda's Catherine the Great (1934). She was made $\mathrm{DBE}$ in 1960.

Dunbar, J., Flora Robson. 1960.

Rocard, Michel Louis Lon (1930-2016). French Socialist politician. Son of a physicist, educated at the University of Paris and the École Nationale d'Administration (ENA), he became an inspector general of finances and stood in 1969 as a presidential candidate for the Parti Socialiste Unifie (PSU), which later merged with *Mitterrand's Socialists. He was Minister for Planning 1981-83, for Agriculture 1983-85 and Prime Minister 1988-91 and had a poisonous relationship with Mitterrand. With Bob ${ }^{*}$ Hawke and Jacques Yves ${ }^{*}$ Cousteau, he played a central role in organising a 50-year moratorium (1991) against mineral exploration in Antarctica. He was Leader of the Socialist Party 1993-94.

Rochefoucauld, Duc de la see La Rochefoucauld, Duc de 
Rochester, John Wilmot, 2nd Earl of (1647-1680). English poet and courtier. Son of a Royalist general ennobled by ${ }^{*}$ Charles I, he was one of the profligate wits who attended the court of ${ }^{*}$ Charles II, of whom he wrote 'He never said a foolish thing, Nor ever did a wise one'. An exaggerated reputation of being a debaucher overshadowed his achievements as a poet. Some of his lyrics are exquisite expressions of tender feeling, and his Satire Against Mankind (1675) sparkles with devastating, sometimes pornographic, wit. Bishop *Burnet described his deathbed repentance.

de Sola Pinto, V. (ed.), Poems by John Wilmot, Earl of Rochester. 1964.

Rockefeller, John Davison, Sr (1839-1937). American industrialist and financier, born in Richford, New York. The son of a farmer and patent medicine salesman (who later disappeared), his family moved to Cleveland, Ohio in 1853 and he left school at 16 . He progressed from bookkeeper to oil well owner in the young oil industry (1862) and in Ohio founded (1870) the Standard Oil Company. This, by 1878 , controlled 98 per cent of the American oil industry. In 1892 the monopoly was broken by court order, but he continued to dominate the industry through a holding company (Standard Oil of New Jersey) until he retired in 1911. He gave over \$550 million to charity, founded Chicago University and the Rockefeller Institute of Medical Research and was reputed to be the richest man in the world. He founded (1931) Rockefeller Center, New York, the largest non-governmental building so far built. His son John Davison Rockefeller, Jr (1874-1960) was an active philanthropist and gave the United Nations the site on which it stands (East River, New York) and his son, Nelson Aldrich Rockefeller (1908-1979), was Assistant Secretary of State for Latin American Affairs 1944-45 and Undersecretary of State for Health and Public Welfare 1953-54. He was Governor of New York State 1959-73, being the only Republican to score a major victory in 1958 . He campaigned as a liberal for the Republican presidential nomination in 1960, 1964 and 1968. Under Gerald *Ford he was appointed as Vice President of the US 1974-77. He was a notable patron and promoter of ethnographic and modern art.

Collier, P. and Horowitz. D., The Rockefellers. 1976.

Rockingham, Charles Watson Wentworth, 2nd Marquess of (1730-1782). English politician. A member of the same family as *Charles I's famous minister *Strafford, he led the main body of the Whigs after the retirement of ${ }^{*}$ Newcastle, but he had too many outside interests (including the turf) and too little force of character to be a great leader. $\mathrm{He}$ favoured the conciliation of the American colonists and was Prime Minister 1765-66 in the government that repealed the Stamp Act. Prime Minister again March-July 1782, he died in office. He owed many of his political ideas to ${ }^{*}$ Burke, his private secretary (1765).
Rodgers, Richard (1902-1979). American composer. $\mathrm{He}$ wrote musical comedies in collaboration with the librettists Lorenz Hart (1919-42) and Oscar Hammerstein (1942-60). Among the many successes for which he wrote the music are Pal Joey, Oklahoma, South Pacific, The King and I and The Sound of Music.

Rodin, (François) Auguste (René) (1840-1917). French sculptor, born in Paris. He began his art training at the age of 14 but was slow to mature. During a visit to Italy (1875) he was influenced by *Donatello and ${ }^{*}$ Michelangelo, while a tour of French cathedrals (1877), about which he wrote a book, led him to call himself a latter-day Gothic artist. This was true only in the sense that he eschewed the plastic smoothness of the antique and expressed spiritual and emotional stresses through the effect of light and shade on roughened surfaces. After his tour he settled at Meudon near Paris and lived there or in Paris itself for the rest of his life. His most famous works include Danaïde (1884-85), The Burghers of Calais (1884-95), The Kiss (1898) and The Thinker (1904), the last two intended as part of a vast work The Gate of Hell (186 figures), inspired by *Dante's Divine Comedy, which preoccupied him from 1880 . His love affairs with Camille *Claudel and Gwen *John caused lasting damage to both women. Politically, he was a conservative and a moderate anti-Dreyfusard. The poet *Rilke was his secretary 1905-06. Rodin did many sculptures, both busts and full length, of famous subjects e.g. *Balzac, *Hugo, *Baudelaire, *Mahler, *Clemençeau, Bernard *Shaw. In 1914 he presented 18 pieces from his London exhibition to Britain in gratitude for its support of France in World War I. He gave the remainder of his unsold works to France and they are now displayed in the Rodin Museum, Paris. In January 1917 he married Rose Beuret, his long term mistress. She died three weeks later.

Chabrun, J. F. and Descharnes, R., Auguste Rodin. 1967; Butler, R., Rodin: The Shape of Genius. 1993.

Rodney, George Brydges Rodney, 1st Baron (1719-1792). British admiral. He served as Governor and Commander-in-Chief in Newfoundland 1748-52, and in the Seven Years' War (1756-63) destroyed the flat-bottomed boats assembled in Le Havre for the invasion of England (1759) and captured Martinique, Grenada and St Lucia (1761). He defeated the Spanish 1779-82 and gained a great victory (the Battle of the Saints) over the French in 1782. A domineering character, Rodney made many enemies, in and out of the navy.

Spinney, D., Rodney. 1969.

Rodrigo, Joaquin (1902-1999). Spanish composer. Blind from the age of three, caused by diphtheria, he studied with *Dukas in Paris and was influenced by ${ }^{*}$ Satie, ${ }^{*}$ Debussy and Spanish folk music. His Concierto de Aranjuez for guitar and orchestra 
(1939) is the most popular ever written. He also wrote Concierto andaluz for four guitars (1967) and a large amount of piano and vocal music.

Roebuck, John (1718-1794). English inventor. He devised (1749) the first commercially practicable method of producing sulphuric acid, and set up (1762) a factory for converting pig iron to malleable iron by means of a blast furnace. He collaborated with *Watt in producing the steam engine.

Roemer, Olaus (1644-1710). Danish astronomer, born in Jutland. He went to Paris (1671) and, working with Picard at the Observatory there, achieved his best known discovery (1675), that the velocity of light is finite, which he deduced from the fact that the observed time of eclipses on one of the satellites of Jupiter varied with the planet's distance from earth. He returned to Denmark (1681) and was professor of astronomy at Copenhagen 1685-1710 and mayor of the city $1705-10$.

\section{Roentgen see Röntgen, Wilhelm Konrad}

Roger I (1031-1101). Norman ruler. Count of Sicily 1072-1101. Son of Tancred of Hauteville, he joined his brother the adventurer Robert ${ }^{*}$ Guiscard, in an enterprise by which much of southern Italy as well as Sicily was conquered. Left to rule Sicily, he showed great administrative gifts which enabled him to leave his successor a united state. His second son, Roger II (1097-1154), who succeeded (1105) his brother, united the Norman conquests into a single kingdom of Sicily, Calabria and Apulia (with Naples and Capua also included). Though the Pope and Emperor temporarily combined against him, he extended his absolute rule over Malta and the African coast from Tripoli to Tunis. His Sicilian capital, Palermo, embellished with buildings in a blend of Romanesque and Saracenic styles, became a great meeting place for scholars from the Greek and Arab worlds.

Norwich, J. J., The Normans in the South. 1967; Norwich, J. J., The Kingdom in the Sun 1130-94. 1970.

\section{Rogers, Richard George, Baron Rogers of Riverside} (1933-2021). English architect, born in Florence. Educated at London University and Yale, in 1971 he won the design competition for the Pompidou Centre (Beaubourg) in Paris with Renzo *Piano. He was also architect for the rebuilding of Lloyds of London, redevelopment of the London Docks, the European Court of Human Rights, Strasbourg, the Inmos factory, Gwent, the Music Research Centre, Paris, and other major projects in Tokyo, Berlin, Florence, Princeton and Quimper. He designed the controversial Millennium Dome at Greenwich. He received the $\mathrm{CH}$ in 2008.

Appleyard, B., Richard Rogers. 1986.

Rogers, Will(iam Penn Adair) (1879-1935). American actor and humorist, born in Oklahoma of Indian descent. His cowboy act in vaudeville, with its shrewd and homely monologues filled with sharp criticisms of manners and politics, achieved enormous success. Films, newspapers and books, e.g. Illiterate Digest (1924), provided him with further outlets. He was killed in a plane crash with the aviator Wiley Post.

Roget, Peter Mark (1779-1869). English physician, inventor and lexicographer. His work on the sliderule earned him his FRS, and his investigations into 'persistence of vision' suggested the possibilities of cinematography, but he is best remembered for his Thesaurus of English Words and Phrases (1852).

\section{Rogier van der Weyden see Weyden, Rogier van der}

Röhm, Ernst (1887-1934). German Nazi politician. A professional soldier, he joined the National Socialists before ${ }^{*}$ Hitler, and with ${ }^{*}$ Goering founded the Sturm Abteilungen (SA: Storm Troops or 'Brownshirts'), a semi-military organisation. He was a military instructor in Bolivia 1928-30. After 1933, in Germany, the SA became a huge auxiliary police force, a potential rival to state power. As leader of the SA, Röhm was a potential threat to Hitler, and on 30 June 1934, 'the Night of the Long Knives', he was murdered with about 180 others and denounced as a vicious sexual pervert.

Roh Tae-woo (1932- ). Korean soldier and politician. He served in the army of the Republic of Korea until 1981, becoming a four-star general, then entered politics. He was Foreign Minister 1981-82 and Minister for Home Affairs and Sport 1982-88, with responsibility for organising the successful Olympics in Seoul (1988). Elected as President in 1988 as a candidate of the Democratic Justice Party, he served until 1993 after the democratic election of his successor *Kim Young Sam. In 1996, with *Chun Doo Hwan, he was tried for mutiny and sedition, sentenced to 22 years' imprisonment but amnestied in 1997.

Rokitansky, Karl (1804-1878). Austrian pathologist, born in Bohemia. He studied medicine at Prague and later Vienna, where he graduated in 1828. From an early stage he specialised in pathology. His first post was in the pathological department of the Vienna Hospital and he became associate and full professor (1834 and 1844) at the university. Together with a small number of assistants, Rokitansky devoted his time entirely to autopsies, insisted upon making the fullest case histories and claimed to have performed 30,000 autopsies between 1827 and 1866. The results of his research were set down in his Handbook of Pathological Anatomy of 1846. This work revealed unrivalled knowledge of abnormalities. Rokitansky, in particular, worked out the various forms of pneumonia and enumerated their symptoms, studied the atrophy of the liver, was an expert on gastric diseases, and wrote a famous book on the diseases of the artery. 
Rokossovsky, Konstantin Konstantinovich (1896-1968). Russian marshal. A major in World War I, he joined the Red Army (1919). In World War II a brilliant turning movement carried out before Moscow (1941) brought him immediate fame. He fought outside Stalingrad (Volgograd), in White Russia and in Poland, where his orders did not include aid to the Warsaw insurrection (1944). In the spring of 1945 he invaded East Prussia and, marching to the north of *Zhukov's Berlin army, met the British near Lübeck. He was imposed on Poland as Minister of Defence 1949-56.

Roland (Old Frankish: Hrōpiland; Italian: Orlando or Rolando) (d. 778). Frankish soldier and hero. He defended * Charlemagne's domain (Francia) against the Bretons. Killed fighting Basques at Roncevaux Pass in the Pyrenees, he was celebrated in the 11thcentury Chanson de Roland, *Ariosto's Orlando Furioso, and the operas Roland by *Lully and Orlando by ${ }^{*}$ Händel.

Roland (de La Platière), Jean Marie (1734-1793). French Girondin politician. An administrator and industrialist in Amiens, he became a leader of the Girondin faction and Minister for the Interior 1792 and 1792-93. His wife Jeanne-Marie Manon Roland (née Phlipon) (1754-1793) ran a celebrated Parisian salon for the Girondins and dominated her husband. On the fall of the Girondins, Roland escaped but his wife was imprisoned, then executed. Roland committed suicide.

Rolfe, Frederick William (known as Baron Corvo, or Fr Rolfe) (1860-1913). English novelist and eccentric, born in London. A schoolteacher, with a deep knowledge of history and art, but bitter and isolated, he became a Catholic convert and a rejected applicant for the priesthood, probably because of his homosexuality. He dramatised his experience in his novel Hadrian the Seventh (1903), where George Arthur Rose, similarly rejected but then admitted as priest, is unexpectedly elected Pope and proceeds to transform the Church before dying as a martyr. Hadrian was later dramatised and also filmed. A morose and embittered drifter, Rolfe lived as a remittance man in Venice, where he died, using the title Baron Corvo. Other novels include Don Tarquinio (1905) and The Desire and Pursuit of the Whole (1909, published 1934).

Symons, A. J. A., The Quest for Corvo. 1934; Woolf, C. and Sewell, B. (eds), New Quests for Corvo. 1965.

Rolland, Romain Edmé Paul Emile (1866-1944). French novelist, biographer and essayist. After studying archaeology and history in Rome he gained his doctorate (1895) at the Sorbonne in Paris with a thesis on the early history of music, and returned there to teach musical history (1904-10). His early plays, e.g. Danton (1900), lacked distinction, and he first achieved success with lives of*Beethoven (1903), major work of this period was the huge novel Jean Christophe (10 volumes, 1904-12), which describes the life of a musical genius in a world of mediocrity. As a pacifist opponent of World War I, he lived in Switzerland from 1914 where he wrote $A u$ dessus de la mêlée (1915). He won the Nobel Prize for Literature (1915). Between the wars he wrote another long novel L'Ame enchantée (7 volumes, 1922-33) and showed a lively interest in the nonviolent campaign in India by lives of ${ }^{*}$ Gandhi (1924) and ${ }^{*}$ Ramakrishna (1930). Growing Communist sympathies took him to Russia, where he spent some months with his friend Maksim *Gorki, but he modified his pacifist attitude as the Fascist-Nazi threat developed. His later works include Parla Révolution la paix (1935). He returned to France in 1938 and offered his full support to the Allies. He died in Vézelay.

Barrere, J. B., Romain Rolland. L'âme et l'art. 1966.

Rollo (or Gaange Rolf) (c.846-c.930AD). Viking/ Norman warrior. Of Danish or Norwegian origin, he invaded northern France, seized Rouen in 876, and became Duke of Normandy in 911. *William the Conqueror was his great-great-great-grandson.

Rolls, Charles Stewart (1877-1910). English aviator and motor manufacturer. A son of Lord Llangattock, he was a pioneer of motoring and aviation. With F. H. *Royce he founded (1906) the Rolls-Royce Company. He made a two-way cross-channel flight (1910), and he died in a flying accident.

Georgano, G. N. (ed.), The Complete Encyclopaedia of Motorcars, 1885-1968. 1968.

Rolph, C H (né Cecil Rolph Hewitt) (1901-1994). English sociologist. After serving in the City of London Police 1921-46, rising to Chief Inspector, he joined the editorial staff of the New Statesman 194770 and became an exceptionally powerful advocate of police reform, abolition of the death penalty and censorship. His books included The Trial of Lady Chatterley (1961), Hanged by the Neck (with Arthur *Koestler) and Law and the Common Man (1967).

Romains, Jules (pen name of Louis-HenriJean Farigoule) (1885-1972). French novelist, dramatist and poet. He taught philosophy in French universities, and wrote plays, e.g. Knock (1923), poetry and novels. He evolved the literary theory of 'unanisme' an attempt to convey the collective spirit of a city or locality. His major work is the novel sequence known as Les Hommes de bonne volonté (27 volumes, 1932-46), a vivid panorama of French life between 1908 and 1933, collectively the longest novel ever published. He lived in the US 1940-45 and was elected to the Académie française in 1946.

\section{Romano, Giulio see Giulio Romano}

Romanov. Russian dynasty that ruled from 1613 when ${ }^{*}$ Mikhail Romanov was chosen as Tsar; it included *Peter (Pyotr) the Great. The direct male 
line of descent ended with the death of *Elizabeth (Yelizaveta) in 1762. *Peter III, from the *Oldenburg dynasty, succeeded but adopted the Romanov name, which was used by tsars until *Nikolai II abdicated after the 1917 Revolution.

Kluchevsky, V., The Rise of the Romanovs. 1970.

Romberg, Sigmund (1887-1951). American composer, born in Hungary. He composed over 70 operettas including such great successes as The Student Prince (1924) and The Desert Song (1926).

Romero y Galdámez, St Óscar Arnulfo (19171980). Salvadorian prelate. Originally a social conservative, close to Opus Dei, he was Archbishop of San Salvador 1977-80, then denounced the use of terror and assassination and failure to relieve poverty. Killed by a gunman after saying Mass, Pope ${ }^{*}$ Francis took up his cause, resulting in his beatification (2015) and canonisation (2018).

Romilly, Sir Samuel (1757-1818). English lawyer. He had already achieved success at the bar, mainly in chancery practice, when his able pamphlet Thoughts on the probable Influence of the French Revolution on Great Britain (1790) attracted controversy. Solicitor-General 1806-07, and MP 1806-07, 1808-18, he devoted himself to the reform of the criminal law and especially into reducing the number of offences, then some 200, punishable by death. Bill after bill he presented but the results of his perseverance were seen only after his death. He joined the anti-slavery movement and firmly opposed all arbitrary acts (e.g. suspension of Habeas Corpus) by the government. He committed suicide three days after his wife's death.

Rommel, Erwin (1891-1944). German field marshal. He gained the highest decoration for valour in World War I and in 1933 joined the Nazi party. In World War II he commanded an armoured division in France (1940) and in 1941 was given command of the Afrika Korps sent to rescue the Italians in Libya. This he built up with astonishing speed into a powerful instrument of attack and counter-attack and became known as 'the Desert Fox'. In July 1942 he drove the British back into Africa as far as El Alamein, but *Auchinleck prevented the Germans from racing on to Alexandria. In October, when Rommel was in Berlin, *Montgomery, with superior forces, won the second Battle of El Alamein, one of World War II's turning points. This offensive eventually drove Rommel's forces westward across the Continent into Tunisia, where the German armies finally surrendered. Before this Rommel had been recalled; later he fought in Italy and in 1944 was given command of an army group resisting the Allied invasion of northern France. In July he was seriously wounded when his car was attacked by a British fighter plane. Following the attempted bomb plot on *Hitler (July 1944), Rommel was suspected of complicity and forced to commit suicide (October).

Douglas-Home, C., Rommel. 1973.
Romney, George (1734-1802). English portraitpainter, born in Lancashire. Son of a carpenter, he learnt to draw mainly from copying, but when he went to London (1762) he soon achieved considerable success. He paid his first visit to Paris in 1764 and the delicacy and charm then fashionable there is evident in his work. After a time he ceased to exhibit his pictures and so never became an RA. However, he had no difficulty in attracting sitters especially women, to whose portraits his style with its clean brushwork and clear light colouring was particularly adapted, whereas his drawing and composition were noticeably weak. In 1782 he met and became infatuated with Emma Hart, afterwards Lady ${ }^{*}$ Hamilton, of whom he painted portrait after portrait, many in the theatrical poses in which she took delight. In later life he developed melancholia and lived as a recluse. He was one of the most esteemed English portrait painters of the 18th century, although artistically excelled by *Gainsborough and *Reynolds.

Romney, (Willard) Mitt (1947- ). American businessman and Republican politician, born in Detroit. His father, George W(ilcken) Romney (1907-1995), headed American Motors 1954-62, serving as Governor of Michigan 1963-69, was a presidential aspirant in 1968 and became *Nixon's Secretary for Housing and Urban Development 196973. Mitt Romney was a Mormon missionary in France 1966-68), gained a Harvard MBA, and was a principal of the venture capital firm Bain \& Co from 1984. A moderately progressive Governor of Massachusetts 2003-07, he sought the Republican nomination for president in 2008, gained it in 2012, but lost to Barack *Obama after having to appeal to support from conservative ideologists in his party. A critic of *Trump, he was elected US Senator from Utah 2019- In Donald *Trump's impeachment trial, Romney voted to convict on the first count (February 2020).

Romulus Augustulus (d. after 476). Roman usurper. Sometimes called the last Roman emperor of the West 475-76, this description is a historical convenience, with no constitutional justification and would have surprised his contemporaries. Romulus was a usurper set upon the throne by his father, a rebel general, the patrician Orestes. Almost immediately the German mercenaries rose against him and their leader *Odovacar (or Odoacer) killed Orestes, contemptuously spared Romulus' life and proclaimed himself King of Italy. The Roman Empire reverted to its original constitutional form with a single ruler, now resident in Constantinople. A century later *Justinian reasserted the imperial power.

Ronsard, Pierre de (1524-1585). French poet, born in Couture-sur-Loir. Son of a courtier of noble family, his boyhood was spent as a page in the royal service. He accompanied *James $\mathrm{V}$ and his bride, Marie de Lorraine, to Scotland where he stayed for three years. In 1540 illness and deafness forced him to give up his career at court and after his father's death (1544) he 
went to Paris. Here he became the centre of a small group of poets (later called the Pléiade) whose aim was to improve French poetry by a close study of Greek, Latin and Italian verse, and by the introduction of new words and forms, e.g. the Petrarchan sonnet. The final test should be as for music, that of the ear. Five books of Ronsard's Odes were published in 1550-52 and the Amours, sonnets addressed to his mistresses, first appeared in 1552. *Henri II made him court poet (1554), an office he retained under *François II and ${ }^{*}$ Charles IX. The first collected edition of his poems appeared in 1560 , and was constantly enlarged until his death, that of 1578 containing the Sonnets to Hélène de Surgres. In addition he wrote political poems, e.g. Remonstrance au peuple de France (1562), which reveal his patriotism, and the ambitious, disappointing and unfinished epic Le Françiade (1572). Ronsard has been described as the 'prince of poets and poet of princes'.

Armstrong, E., Ronsard and the Age of Gold. 1968.

Röntgen, Wilhelm Konrad (1845-1923). German physicist, born in Lennep. Educated in Utrecht and at the Zürich Technical School, he became professor of physics at Strasbourg 1876-79, Giessen 1879-88, Würzburg 1888-94 and Munich 1900-20, and rector of the university of Würzburg 1894-1900. The discoverer of $\mathrm{X}$-rays (X = unknown, also called Röntgen rays) in 1895 , he found that when a highvoltage direct current is applied to a discharge tube containing a rarefied gas the resulting stream of electrons from the cathode, if made to bombard a metal target anode, will produce invisible rays capable of passing through many opaque substances. $\mathrm{He}$ also made notable contributions to other branches of physics and won the first Nobel Prize for Physics (1901).

Rooke, Sir George (1650-1709). English sailor. He played a distinguished part at Cape La Hogue (1692), the anchorage where 12 French warships taking refuge after their defeat off Cape Harfleur (as well as many troopships and storeships assembled for an invasion of England to restore *James II to the throne) were destroyed. As a reward Rooke was promoted to be Vice Admiral and knighted. Among other important successes was his capture of Gibraltar (1704) with Sir Clowdisley *Shovell.

Roon, Albrecht Theodor Emil, Graf von (18031879). German field marshal. After long service on the staff he was Prussian Minister of War 1859-71 and effected the military reorganisation that enabled victory in the Austro-Prussian War (1866) and the Franco-Prussian War $1870-71$ to be achieved with such remarkable speed and success.

Rooney, Mickey (né Joe Yule, Jr) (1920-2014). American actor. On the stage from infancy, he made his film debut in 1926 and appeared in 140 movies. He was a memorable Puck in Midsummer Night's and as Huckleberry Finn (1939). He became a fine character actor and starred in the Broadway musical Sugar Babies.

Roosevelt, (Anna) Eleanor (née Roosevelt) (18841962). American social worker and journalist. A niece of Theodore ${ }^{*}$ Roosevelt, she married her cousin Franklin D. * Roosevelt in 1905 and, although personally estranged from 1918, campaigned hard for him and was a strong liberal influence in the White House. She wrote an influential newspaper column, My Day. She remained a popular figure after FDR's death, attended the first United Nations Assembly as a US delegate, and served on the United Nations Commission on Human Rights 1946-53.

Lash, J., Eleanor and Franklin Roosevelt. 1974; Rowley, H., Franklin \& Eleanor: An Extraordinary Marriage. 2011.

Roosevelt, Franklin D(elano) ('FDR') (1882-1945). 32nd President of the US 1933-45. Born at Hyde Park, New York, into a distinguished family of Dutch descent he was the only child of James Roosevelt (1828-1900) and Sara Delano (1854-1941). Educated at home, he briefly attended schools in Germany and Switzerland (1891), entered Groton in 1896, then Harvard and Columbia, where he was only a moderate student. Having already married Eleanor *Roosevelt (niece of Theodore) in 1905, he joined a New York firm of lawyers. His branch of the family were Democrats and as an opponent of Tammany Hall, the corrupt party machine, he won election as a N.Y. State Senator 1911-13, He supported Woodrow *Wilson in 1912, and was appointed Assistant Secretary of the Navy 1913-20. James M. ${ }^{*}$ Cox won the presidential nomination in 1920 and Roosevelt was the vice presidential candidate. They were heavily defeated by ${ }^{*}$ Harding and ${ }^{*}$ Coolidge. In August 1921 at Campobello Island, New Brunswick, he was afflicted with poliomyelitis (or possibly Guillain-Barré syndrome (GBS), only identified in 1916), which left him permanently paralysed: he needed assistance to walk with crutches and was later confined to a wheelchair. In 1922 he returned to work in law, banking and insurance. With the support of his wife, a devoted personal staff (notably his secretary Louis Howe) and a strong political network, he developed a new maturity and toughness. $\mathrm{He}$ supported $\mathrm{Al}{ }^{*}$ Smith's unsuccessful campaign for the presidential nomination in 1924 . He wrote Smith's campaign biography The Happy Warrior, when he became the Democratic candidate in 1928 but lost to ${ }^{*}$ Hoover. However, FDR was elected Governor of New York State, serving 1929-33. The onset of the Great Depression in 1929 limited his scope as a social reformer but he won re-election in 1930 with a large majority.

At the Democratic National Convention in Chicago in June 1932, he defeated Smith and John N. *Garner of Texas to win the presidential nomination on the fourth ballot, with the support of W. R. *Hearst, 
and named Garner as candidate for Vice President. He flew to Chicago (an unprecedented gesture) to accept nomination and pledged a 'New Deal' for the American people. (Smith was a deeply resentful loser.) Hoover, frustrated by the Depression and 25 per cent unemployment, suffered a humiliating defeat. Roosevelt won 57 per cent of the vote (a popular majority of over 7,000,000 votes), carrying 42 of 48 states. After a short hesitation, he created a team of economic and social advisors, known as the 'Brain Trust' and embarked on a policy of 'relief, recovery, reform ... for the forgotten man at the bottom of the economic pyramid.' FDR's own economic knowledge was shaky, but his team took a central role in transforming the US economy. There were three major approaches to tackling the Great Depression*Stalin's, *Hitler's or FDR's. The 'New Deal', although imperfect, offered the only remedy compatible with democracy. If it had failed, democracy might have been fatally damaged, leading to a World War II which was, like the Spanish Civil War, essentially a struggle between Communism and Fascism. Novel remedies were adopted, parallel to, but not directly influenced by, propositions by J. M. *Keynes—budgeting for deficit, encouraging consumption, central control of credit, massive spending on public works. Weekly working hours were cut to 48, child labour abolished, minimum wages set and a 'Labor Code' entrenched the principle of collective bargaining. A Social Security scheme was established. The 'New Deal' pioneered soil conservation, reafforestation, and flood control, with agencies such as the Civilian Construction Corps (CCC) and the Tennessee Valley Authority (TVA), also providing electricity and irrigation. The Public Works Administration (PWA) employed 4,000,000 at its peak. The National Recovery Administration (NRA) virtually abolished laissez faire until the Supreme Court declared it unconstitutional in 1935. The psychological effect was immense and FDR was a persuasive advocate in his radio 'fireside chats': 'The only thing we have to fear is fear itself, unreasoning terror that paralyses the will.' Nevertheless, unemployment remained above 12 per cent until 1939. In the 1936 election he defeated Alf*Landon by 46 states to two, winning 61 per cent of the vote (an 8,000,000 majority). Roosevelt, frustrated by the conservative Supreme Court, attempted to appoint six younger judges but Congress rejected this. Encouraged by his wife, he took some hesitant steps towards economic and political rights for black Americans (very difficult when the Deep South voted faithfully for the New Deal) and took no action against segregation or lynching.

From 1920 isolationism had been overwhelmingly popular in the US and FDR was slow to challenge the conventional wisdom. He signed the Neutrality Act (1935) without demur but soon found ways of circumventing it. From 1938 he voiced increasing opposition to Hitler and ${ }^{*}$ Mussolini. In October 1939 he received a warning from *Einstein about the possibility of building atomic weapons, and directed Vannevar *Bush to initiate developments, leading to the 'Manhattan Project' ( ${ }^{*}$ Fermi, ${ }^{*}$ Oppenheimer) and the beginning of the atomic age. Although he helped Britain with Lend Lease (from September 1940) and built up defence industries, the US avoided military commitment.

FDR won an unprecedented third term in November 1940 with 54.7 per cent of the vote, defeating Wendell *Willkie. (Henry A. *Wallace became Vice President.) He took the US out of the tradition of isolationism that *Washington established, *Monroe defined, ${ }^{*}$ Lincoln maintained and Wilson failed to break. He declared that the US 'must become the great arsenal of democracy', proclaimed the Four Freedoms (January 1941), probably influenced by H. G. *Wells, and met *Churchill in August 1941 to conclude the 'Atlantic Charter'. The Japanese attack on Pearl Harbor (December 1941) took the US into World War II, followed by the inexplicable German declaration of war by Hitler. After 1942 the US became the great allied powerhouse and FDR dominated the overall direction of strategy, providing resources and articulating allied war aims. He clashed privately with his military advisors, opposing a 'beat Japan first' strategy, insisting on an allied invasion of North Africa rather than premature landings in Europe. His judgment appears to have been vindicated. He had a clear, sometimes naïve, view about developments in the post-war world, including de-colonisation, the end of European empires and extending democracy. His closest confidant Harry *Hopkins coordinated relations with the Allies. FDR attended conferences at Casablanca (January 1943), Québec (August 1943) and Cairo (NovemberDecember 1943). At Teheran (November-December 1943), sandwiched between two parts of the Cairo talks, 'the Big Three' (Roosevelt, *Stalin, Churchill) met for the first time and final defeat of the Axis powers was planned.

FDR was nominated for a fourth term in 1944 Because of his failing health, Democratic Party leaders, concerned that Wallace was too radical and unpredictable as a potential successor, secured the nomination of Harry *Truman as Vice President. In November 1944 FDR won 53.4 per cent of the primary vote, and 36 states, to defeat Thomas *Dewey. He was the principal architect of the United Nations, initiated the World Bank, International Monetary Fund and long term moves towards lower tariffs and global trade. In February 1945 he attended his last international conference at Yalta in the Crimea. $\mathrm{He}$ was unduly optimistic that he could negotiate with Stalin, appearing to push Churchill aside (something the British voters did for themselves in July) and has been accused of giving the USSR a free hand in eastern Europe. However, the Red Army was already in occupation and in October 1944 at Moscow, Churchill had conceded 'spheres of influence' to Stalin, acknowledging Russia's dominant role. $\mathrm{He}$ contemplated resigning as President to become the first UN Secretary-General. 
FDR's powers were weakened by exhaustion, his long physical debility, a mild stroke and possible cancer. In April he died suddenly of a cerebral haemorrhage at Warm Springs, Georgia, while his portrait was being painted, and was buried at Hyde Park.

He remains the most controversial figure in modern US history, denounced variously as 'Fascist', 'revolutionary', 'traitor to his class' and 'madman', while his supporters saw him as courageous, optimistic, creative and deeply committed to democracy and human advancement. His political tradition was continued by Truman, *Johnson, *Clinton and *Obama while his style influenced *Reagan. In 20 major studies by historians and political scientists ranking US presidents, FDR came No. 2 in the aggregate, behind ${ }^{*}$ Lincoln and ahead of *Washington.

Leuchtenberg, W. E., Franklin D. Roosevelt and the New Deal, 1932-1940. 1963; Schlesinger, A. M., The Age of Roosevelt. 3 vols, 1957-60; Morgan, T., FDR. 1985; Friedel, F., Franklin D. Roosevelt. 1990; Goodwin, D. K., No Ordinary Time. 1994; Black, C., Franklin Delano Roosevelt. Champion of Freedom. 2003; Smith, J. E., FDR. 2008; Butler, S., Roosevelt and Stalin. 2015; Dallek, R. M., Franklin D. Roosevelt: A Political Life. 2017.

Roosevelt, Theodore ('TR') (1858-1919). 26th President of the US 1901-09. Born in New York to a rich family which emigrated in the 16th century from Holland, he was admitted to the New York bar in 1881 . As a Republican member of his state legislature 188184 he took his stand against corruption, but after the death (1884) of his wife (née Alice Hathaway Lee of Boston) and a breakdown of health he became a rancher in North Dakota. In 1886 in London he married Edith Kermit Carow of New York and abandoned the outdoor life of a typical Westerner to return to politics. An ardent hunter, he was also an expert naturalist and birdwatcher. Unsuccessful in his bid for election as Mayor of New York, he was appointed (1889) by President ${ }^{*}$ Harrison to the Civil Service Commission, from which he resigned (1895) to become President of the Board of the New York City police. His spectacular attempt to break the link of corruption between police and underworld made him well known. In 1897 he was appointed Assistant Secretary of the Navy. He resigned on the outbreak of war with Spain (1898) to raise a mounted force known as 'Rough Riders' for the Cuban campaign, and gained national attention for leading a charge up San Juan Hill (July 1898). On his return as a national hero he was elected Governor of New York State 1899-1901 and showed in his legislation (e.g. the laws for slum clearance etc.) a zeal for social reform. In 1900 he was elected Vice President of the US and on the assassination of *McKinley (September 1901) succeeded him.

As President he used the presidential power more vigorously than any holder of the office since ${ }^{*}$ Lincoln. He was sympathetic to African-Americans but became preoccupied with falling Anglo-Saxon birth rates, railed against 'racial suicide' (1903) and encouraged women to breed.

In 1904 he won 56 per cent of the vote defeating Alton B. *Parker. He helped to settle the great coal strike of 1902, inspired the fight against monopolies ('trust busting'), the passage of the pure food act (1906) and the enforcement of laws against child and female labour. He established national parks and put conservation and environment issues on the political agenda. His interventions in foreign affairs, e.g. when troops were sent to Venezuela (1902) and Dominica (1904) and the seizure of the Canal Zone to facilitate the building of the Panama Canal, were characteristic of his belief in forceful policies. This was further illustrated by his mediation that brought the RussoJapanese War to an end (Treaty of Portsmouth, 1905) and won him the Nobel Peace Prize (1906). He coined the maxim: 'Speak softly and carry a big stick!'

In 20 Presidential ranking lists by historians and political scientists, TR scored No. 4 in the aggregate, just behind *Washington.

In 1908 he secured the nomination of his friend William Howard *Taft, who succeeded him as president. The next year he spent hunting in Africa and touring Europe. On his return Taft's increasing conservatism could no longer command his support. At the Chicago Republican Convention in 1912, he challenged Taft for the nomination but the conservative wing prevailed and Taft won easily. Roosevelt then stood as the candidate of a new Progressive ('Bull Moose') party and in the November election the Republicans split. The Democrat Woodrow *Wilson won easily, while Roosevelt came second, with Taft holding only two states. TR explored the Brazilian jungle in a scientific expedition 1913-14. A vigorous advocate of US entry into World War I, he was the leading Republican contender for the Presidency in 1920 until his sudden onset of inflammatory rheumatism followed by a fatal heart attack. In 1927 his sculpture by Gutzon *Borglum joined *Washington, *Jefferson and ${ }^{*}$ Lincoln on Mount Rushmore, South Dakata. In 2001 Bill *Clinton awarded him the Medal of Honor for his gallantry at San Juan Hill. (His son Theodore Roosevelt, Jr (1887-1944), also won the Medal of Honor for his service in Normandy.)

Mowry, G. E., The Era of Theodore Roosevelt. 1900 1912. 1958; Morris, E., The Rise of Theodore Roosevelt. 1979; Mowry, G. E., Theodore Rex. 2001; O’Toole, P., When Trumpets Call. Theodore Roosevelt after the White House. 2005; Morris, E., Colonel Roosevelt 2010.

Root, Elihu (1845-1937). American politician. A lawyer and district attorney, he became Secretary of War under ${ }^{*}$ McKinley and Theodore ${ }^{*}$ Roosevelt 1899-1904 and was Secretary of State 1905-09. US Senator from New York 1909-15, he served on The Hague Tribunal from 1910 and won the Nobel Peace Prize (1912). 
Roper, William (1496-1578). English biographer. In 1525 he married Margaret More (1505-1544), collector of the papers and letters-and subsequently the head-of her father Sir Thomas * More. After More's execution he wrote Mirrour of Vertue in Worldly Greatness or the life of Syr Thomas More (1535, first published in Paris 1626), one of the earliest biographies in English.

Rorem, Ned (1923- ). American composer, born in Indiana. Working in New York and Paris, his works include songs, chamber music, five concertos and three symphonies. He won the Pulitzer Prize in 1976 for Air Music for orchestra but may be best remembered for his lively diaries.

Rorty, Richard McKay (1931-2007). American philosopher. His pragmatism, influenced by ${ }^{*}$ Hegel, ${ }^{*}$ Darwin and John ${ }^{*}$ Dewey, attempted to reconcile historicism and naturalism. He held chairs at Virginia and Stanford and gave the 1987 Clark Lectures in Cambridge. His most quoted work was Objectivity, Relativism and Truth (1991).

Rosa, Carl August Nikolaus (1842-1889). German violinist, impresario and conductor, born in Hamburg. He married the soprano Euphrosyne Parepa and formed his first opera company in New York (1867), moving to London (1871) and Cairo. The Carl Rosa Opera Company opened with Figaro in London 1875 and Rosa gave British premieres of The Flying Dutchman (1876), Lohengrin (1880) and Aida (1880).

Rosa, Salvator (1615-1673). Italian painter, born near Naples. He became a pupil of Aniello Falcone, whose taste for battle scenes he acquired. He went to Rome in 1635 and in 1640 to Florence, where he received the patronage of the * Medici. Back in Rome (1649) he became popular, not only for his energetic landscapes in which with his fine use of chiaroscuro he often produced eerie and fantastic effects, but also for his other accomplishments as musician, satirist and poet. Babylon, his satire on Rome, won particular acclaim.

Salerno, L., Salvator Rosa. 1963.

Rosas, Juan Manuel de (1793-1877). Argentinian dictator. After winning popularity as a leader of irregulars in frontier defence against the Indians, he served as Governor of Buenos Aires province 1829-32. More successes against the Indians resulted in his returning (1835) with full dictatorial powers. For the first time since 1810 the country had stable government, but the methods of terrorism by which it was achieved undermined the popularity of Rosas, and a Franco-British blockade when he intervened in Uruguay weakened the country's economic strength. He was defeated and deposed by General Urquisa (1852) and died in exile in England.
Roscius, Quintus (d.62 BCE). Roman actor. The greatest comedian of his age, he won the patronage of ${ }^{*}$ Sulla and taught oratory to ${ }^{*}$ Cicero, who defended him in a speech, which survives, when he was sued for debt.

Rosebery, 5th Earl of, Archibald Philip Primrose, later 1st Earl of Midlothian (1847-1929). AngloScottish politician and writer, born in London. Educated at Eton and Oxford (where his preference for racing over study led to his expulsion), he inherited his peerage in 1868, and declared three ambitions: to become Prime Minister, marry an heiress and win the Derby. In 1878 he married Hannah de Rothschild (1851-1890). He served under ${ }^{*}$ Gladstone as Undersecretary at the Home Office 1881-83, Commissioner of Works 1884-85, and Foreign Secretary 1886 and 1892-94, leading the Liberal Party's imperialist wing. He was the first chairman of the London County Council 1889-90, an excellent orator, and a race horse owner who won the Derby in 1894, 1895 and 1905 . On Gladstone's retirement (1894), Queen *Victoria chose him as Prime Minister, in preference to Sir William *Harcourt and Earl Spencer. Rosebery, suffering from insomnia and increasingly isolated from his colleagues, resigned after a snap defeat in the Commons (1895). The Conservatives held office for a decade. He never returned to office and pursued an increasingly independent line. He opposed the entente with France on the grounds that it would provoke a German war and produced a plan of his own for the reform of the House of Lords. He was the richest Prime Minister and, despite his short term in office, well rewarded with a KG, KT, Royal Victorian Chain and a second earldom. His historical studies, e.g. Pitt (1891) and Napoleon, the Last Phase (1901), were well written.

James, R. R., Rosebery. 1963.

Rosenberg, Alfred (1893-1946). German writer and politician, born in Estonia. Of mixed German, Russian and Estonian descent, he studied architecture in Moscow, joined the Nazi Party (1920) and edited its daily newspaper Völkischer Beobachter (from 1921). He tried to create a new ideology, compounded of anti-Semitism, Nordic mythology and mysticism, and his unreadable book The Myth of the 20th Century (1930) promoted the theory of Aryan racial superiority. Even his fellow Nazis regarded him as a crank. Minister for Occupied Territories in the East 1941-44, he was hanged at Nuremberg.

Rosenberg, Julius (1918-1953) and Ethel Rosenberg (née Greenglass) (1915-1953). American radicals and convicted spies, born in Manhattan. The Rosenbergs, members of the Young Communist League, married in 1939 and had two sons. Julius, an electrical engineer, was charged, with his wife, with 'conspiracy to commit espionage in wartime' for passing, early in 1945, technical details of radar, sonar and a detonation device for an atomic bomb to 
the USSR (then an ally). The trial, in March 1951, was conducted in an atmosphere of Cold War hysteria and they were both convicted, sentenced to death and electrocuted at Sing Sing prison in June 1953.

In 1995 the release by the US of intercepted decoded messages (the Venona Project) confirmed that Julius had passed a substantial volume of material to the USSR but its value is still a matter of controversy. While there was a reasonable case against Julius (although the penalty was grossly excessive), the case against Ethel was threadbare, relying entirely on allegations by her brother David Greenglass, a machinist at Los Alamos. It was expected that the threat of her execution would induce Julius to reveal details of a spy ring. There were worldwide demonstrations against their execution. Pope *Pius XII, *Einstein, ${ }^{*}$ Sartre and ${ }^{*}$ Picasso called for commutation.

Sebba, A., Ethel Rosenberg. A Cold War Tragedy. 2020.

Ross, Harold (Wallace) (1892-1951). American editor. Co-founder of the New Yorker (1925), which he edited until his death, the magazine had a major impact on writing and cartooning. Ross promoted the work of *Thurber, *Arno, *Addams, *Steinberg, *Perelman, ${ }^{*}$ White, ${ }^{*}$ De Vries, Edmund *Wilson, Dorothy *Parker and many others.

Ross, Sir James Clark (1800-1862). British polar explorer. He was the nephew of the Arctic explorer Sir John Ross (1777-1856), under whose command he discovered (1829) the north magnetic pole. While leading a scientific expedition (1839-43) to the Antarctic for the British Government he discovered Mounts Erebus and Terror (named after his two ships) and the Ross Ice Shelf. He was knighted on his return. His last polar expedition (1848-49) searched for Sir John *Franklin.

Dodge, E S., The Polar Rosses. 1973.

Ross, Sir Ronald (1857-1932). British bacteriologist, born in India. After qualifying as doctor (1881) he served in the Indian Medical Service until 1889. During this time he studied the causes of malaria and concluded that it was transmitted by the female Anopheles mosquito. This discovery won him the Nobel Prize for Medicine (1902) and a KCB in 1911. As professor of tropical medicine at Liverpool University 1902-12 he carried his studies further in many expeditions to the tropics. He went to King's College Hospital, London, as physician for tropical diseases (1912) and became (1926) Director of the Ross Institute, founded at London University in his honour. He wrote Memoirs (1923).

Rosse, 3th Earl of (Irish peerage), William Parsons (1800-1867). Irish astronomer, born in York. Educated in Dublin and Oxford, MP 1821-35, he became a passionate, and expert, astronomer, building two telescopes with ground speculum reflectors, and apertures of $0.91 \mathrm{~m}$ and $1.83 \mathrm{~m}$. The latter, known as
1845 to 1917 . He identified and named the Crab nebula and spiral galaxies and was President of the Royal Society 1848-54. Sir Charles *Parsons was his son.

Rossellini, Roberto (1906-1977). Italian film director. Son of an architect, he made propagandist films during World War II, then became a leader of the neo-realist school. His Open City (1945) was the first internationally recognised European film after the war, followed by Paisan (1946), Ways of Love (1948) and Stromboli (1949). His affair with Ingrid *Bergman led to an unofficial boycott of their films and his career never recovered, although he continued to be a prolific producer, screenplay writer and operatic director.

Rossetti, Christina Georgina (1830-1894). English poet. Of Italian extraction, sister of Dante Gabriel ${ }^{*}$ Rossetti, her first published verse appeared in 1847. She continued to write poems that showed an exceptional sense of beauty combined with strong religious instincts. The best known collections are Goblin Market (1862) and The Prince's Progress (1866).

Packer L. M., Christina Rossetti. 1963.

Rossetti, Dante Gabriel (1828-1882). English painter and poet, born in London. Son of Gabriel Rossetti (1783-1854), a political refugee from Naples, he studied art at the Royal Academy School with Ford Madox *Brown, an important influence, and Holman ${ }^{*}$ Hunt. $\mathrm{He}$ and ${ }^{*}$ Millais discussed their aim of returning to the principles of preRenaissance painting by imposing upon themselves the disciplines of a noble subject, truth to nature and meticulous detail. The result was the formation of the Pre-Raphaelite Brotherhood in 1848, the year after Rossetti had written his best known poem The Blessed Damozel. The paintings produced (among which was Rossetti's Ecce Ancilla Domini, now in the National Gallery, London) were received with such abuse that he was discouraged and after 1850 produced no important oil painting for 10 years. In 1860 he painted an altarpiece for Llandaff Cathedral, followed by portraits and pictures in a highly individual imaginative style, with jewelled colouring and of a dreamlike character. The first of the new style portraits was an ethereal, idealised representation of his dead wife, Elizabeth Siddal. Only two years after their marriage (1860) she had died from an overdose of laudanum. In despair he buried his poems with her and only in 1870 were they retrieved and published, but attacked for belonging to the 'fleshly school of poetry'. His Ballads and Sonnets appeared in 1881. Meanwhile he had continued to paint. His most frequent model was the beautiful wife of William *Morris, with whose ventures in the applied arts Rossetti was closely connected. Of his other pictures the large Dante's Dream (1870) and The Blessed Damozel (1875-76) are among the best known. Partial paralysis marked the onset of his final illness.

Grylls, R., Portrait of Rossetti. 1965. 
Rossini, Gioachino Antonio (1792-1868). Italian composer, born at Pesaro. He studied at Bologna, but claimed that he had been more influenced by the music of ${ }^{*}$ Haydn and ${ }^{*}$ Mozart than by his teachers. At 14 , he was already working in local theatres, and by the age of 21 he had composed a dozen operas including LItaliana in Algeri (1813). In all he wrote nearly 40 operas, serious and comic. Most of the latter enjoyed outstanding contemporary success for their vivacity, humour and boisterous spirits. The best known include The Barber of Seville (1816), based on *Beaumarchaisprobably his best and certainly his most popular work-La Cenerentola (1817), and Le Comte Ory, which were triumphantly acclaimed in Vienna, Paris and London. His last opera William Tell (1829), based on *Schiller, was premiered in Paris. Suddenly, at the age of 37, he abandoned opera composition and apart from a Mass (1864) his only subsequent major work was his Stabat Mater (1832-41). There were also a few songs and piano pieces, some orchestrated by *Respighi for the ballet La Boutique fantasque and by Benjamin *Britten for Soirées musicales.

Weinstock, H., Rossini. 1968.

Rostand, Edmond (1868-1918). French dramatist and poet, born in Marseille. An early volume of verse, Les Musardises (1890), was followed by a series of light poetic plays, Les Romanesques (1894), La Princesse Lointaine (1896) and La Samaritaine (1897). Fame came with the play Cyrano de Bergerac (1897), based on the life of a 17th-century soldier and poet disfigured by his grotesque nose. This was followed by L'Aiglon (1900) about the life of the son of Napoléon and Marie Louise at the Austrian court: Sarah *Bernhardt played the young prince. Chantecler, a farmyard fantasy in which Lucien ${ }^{*}$ Guitry appeared (1910), proved disappointing. Rostand was elected to the Académie française in 1901.

Rostovtzeff, Michael Ivanovich (1870-1952). Russian historian. He was a professor at St Petersburg (Leningrad) from 1898 but after the Revolution went to the US, where he was professor of ancient history at Wisconsin 1920-25 and Yale 1925-44. His best known work The Social and Economic History of the Roman World (3 volumes, 1941), is important in being the first application of archaeological research to expand and illuminate ancient history.

Rostropovich, Mstislav Leopoldovich (19272007). Russian cellist, pianist and conductor. He made his debut in 1942, became a professor of the Moscow Conservatoire in 1957 and gained an international reputation as a solo cellist. Many works were written for him by *Shostakovich, *Prokoviev, *Britten and other composers. In 1955 he married the soprano Galina (Pavlovna) Vishnevskaya (19262012). He left the USSR in 1974 , became Director of the National Symphony Orchestra, Washington 1977-94 and received a KBE and the US Presidential Medal of Freedom in 1987 . He was an outstanding campaigner for human rights.
Rotblat, Sir Joseph (1909-2005). British physicist, born in Poland. He worked on the 'Manhattan Project' which built the first atomic bombs. He was co-founder (1957) of the Pugwash Conferences on Science and World Affairs and shared the 1995 Nobel Peace Prize with the organisation.

Roth, (Moses) Joseph (1894-1939). Austrian-Jewish novelist and journalist, born in Galicia. His essays The Wandering Jew (1927) and the novel Radetzky March (1932) were eerily prophetic of the Holocaust.

Roth, Philip (Milton) (1933-2018). American novelist, born in Newark, New Jersey. His books include Goodbye Columbus (1959), Portnoy's Complaint (1969), Sabbath's Theatre (1995), American Pastoral (1997) and The Plot Against America (2004). Nine of his novels were centred on Nathan Zuckerman, essentially Roth's alter ego. After a long liaison, he was unhappily married to Claire *Bloom from 1990 to 1995 . He suffered constant pain from acute muscular problems. He won the Pulitzer Prize 1997, the Man Booker International Prize 2011 and four PEN Awards for lifetime achievement.

Bailey, B., Philip Roth: The Biography. 2021.

Rothenstein, Sir William (1872-1945). English artist. A friend of ${ }^{*}$ Whistler, he studied in London and Paris and joined the New English Art Club (1894). An official war artist in World War I, he made many fine portrait drawings. As principal of the Royal College of Art 1920-35 he exercised a conservative influence on a generation of artists. He wrote Men and Memoirs (1932). His son Sir John (Knewstub Maurice) Rothenstein (1901-1992), was a critic who wrote studies of *Manet and *Turner, and was Director of the Tate Gallery, London 1938-64. Conservative in his acquisitions, he rejected major European and US contemporary works. He wrote an aggressive three-volume autobiography (1965, 1966, 1970).

Rothermere, Harold Sidney Harmsworth, 1st Viscount (1868-1940). English newspaper proprietor. He worked closely with his brother, Lord *Northcliffe, in many enterprises, providing the business acumen to match the other's journalistic flair. He bought the Daily Mirror (1914) and founded (1915) the Sunday Pictorial. He took over Northcliffe's business interests on his death and in turn handed them on to his son. As Air Minister 1917-18 he helped to create the RAF from the Flying Corps and the Naval Air Service and was made a viscount (1919). His newspapers were consistently pro-German 1933-39.

Rothko, Mark (originally Markus Yakovlevich Rothkovitch) (1903-1970). American painter, born in Latvia. His Russian-Jewish family migrated to the US in 1913. He grew up in Oregon and later studied painting in New York. After 1948 he became a leading figure of the Abstract Expressionist 
movement and his huge, brooding canvasses rely on the use of colour alone for their emotional impact. $\mathrm{He}$ is strongly represented in major US galleries and at the Tate in London. He committed suicide and the 658 paintings left in his estate were the subject of bitter litigation between his heirs and his agents. His Orange, Red and Yellow (1961) sold at auction for \$US87 million in 2012.

Waldman, D., Mark Rothko. 1978; Breslin, J. E. B., Mark Rothko: A Biography. 1993.

Rothschild, Mayer Amschel (1743-1812). German banker. During the Revolutionary and Napoléonic Wars he ensured the family fortunes (whatever the outcome of the wars) by sending his sons to operate in different European capitals. The eldest stayed with his father at Frankfurt-on-Main and the others went to London, Paris, Vienna and Naples. Nathan Mayer Rothschild (1777-1836), the London representative, made more than $£ 1$ million by arranging to receive speedy news of the result of the Battle of Waterloo and being able to speculate on the basis of knowledge. His son Lionel Nathan de Rothschild (1808-1879) was, from 1847, repeatedly elected MP for the city of London, but took his seat only when the act removing Jewish disabilities was passed (1858). He arranged the $£ 4$ million that enabled ${ }^{*}$ Disraeli to secure for the British Government a controlling interest in the Suez Canal (1875), and was the model for Sidonia in ${ }^{*}$ Disraeli's Coningsby. His son, Nathan Mayer Rothschild, 1st Baron Rothschild (1840-1915), Liberal MP 1865-85 and raised to the peerage in 1885, was the first Jew to sit in the House of Lords. His grandson, (Nathaniel Mayer) Victor Rothschild, 3rd Baron Rothschild (1910-1990), educated at Harrow and Trinity College, Cambridge, became a zoologist, succeeded his uncle in the peerage in 1937, joined MI5 and worked in disinformation and espionage. Despite allegations that he was a KGB agent ('The Fifth Man'), essentially based on his friendship with Guy *Burgess and Anthony *Blunt, his denials were plausible, andalthough a Labour peer-he was trusted by Edward ${ }^{*}$ Heath and, to a degree, Margaret ${ }^{*}$ Thatcher. His sister, Dame Miriam Louisa Rothschild (19082005), educated at home, was a code-breaker in World War II and conducted research into fleas, butterflies and schizophrenia. His son, (Nathaniel Charles) Jacob Rothschild, 4th Baron Rothschild (1936- ), was a banker, philanthropist and arts administrator, deeply involved in archaeological conservation. He was awarded the OM in 2002. The 4th Baron's sister, Emma Georgina Rothschild (1948- ), was an economic historian, Professor of History at Harvard and wife of Amartya *Sen.

Morton, F., The Rothschilds. 1962.

Rouault, Georges Henri (1871-1958). French painter, born in Paris. He first trained as a glass painter, which influenced his use of broad black outlines, enhancing the luminous colours in his pictures. His earliest paintings were of religious subjects in the manner of his teacher Gustave *Moreau. Later, as his constitutional pessimism deepened, he painted in passionate and horrified protest scenes in brothels or other places where human misery abounds. In his later work, the horror changes to pity, he returns to religious themes, but they are painted with the same passion and reveal the same distortions as his pictures of everyday life. These distortions are a reminder of his link with the group known as the 'Fauves', but though he joined them he was never truly of them: the conventions they used for decoration he used for emphasis; he was in fact an isolated figure in the world of art. His pessimism is seen also in his etchings, e.g. Miserere and Guerre (reminiscent of *Goya).

Courthion, P., Georges Rouault. 1962.

Roubiliac, Louis François (c.1695-1762). French sculptor. Trained in France, he lived in England as a Huguenot refugee from 1727 . His works include impressive sculptures of ${ }^{*}$ Shakespeare and ${ }^{*}$ Newton. His reputation was established by a statue of ${ }^{*}$ Händel made (1737) for Vauxhall Gardens. Strong modelling and subtle characterisation, in the style of ${ }^{*}$ Bernini, distinguish his works. His powerful tomb of Lady Elizabeth Nightingale (1761) is in Westminster Abbey.

Whinney, M. D., Sculpture in Britain, 1530-1830. 1970 .

Rouget de Lisle, Claude Joseph (1760-1836). French author and composer. He wrote $\mathrm{La}$ Marseillaise (1792), the French national anthem, while an engineer officer in the Revolutionary army. It was adopted as a marching song by a Marseilles battalion bound for Paris and its stirring words and music soon gave it national fame.

Rouhani, Hassan (originally Fereydun) (1948- ). Iranian cleric and politician. He secured a $\mathrm{PhD}$ in Glasgow and had a diverse career as lawyer, cleric, diplomat and administrator, serving in the Majlis (parliament) 1980-2000 and on the Supreme National Security Council 1989-2005. Regarded as a moderate, he was President of Iran 2013-21.

Rous, Francis Peyton (1879-1970). American physician. Educated at Johns Hopkins University, he worked at the Rockefeller Institute for Medical Research from 1909 and in 1911 identified the first tumour virus, known as the 'Rous chicken sarcoma virus'. In 1966 he shared the Nobel Prize for Medicine for his work on the chicken virus. At 87 he was the oldest recipient of the award and the gap between research and recognition ( 55 years) is a record.

Rousseau, Henri (known as 'le Douanier') (18441910). French painter. His nickname derives from his position as a customs officer 1871-85. At the age of 41 he went to Paris to devote his time to painting. He was a naive and natural painter belonging to none of the contemporary groups, but he was able to transfer to canvas with a wonderful child-like assurance the 
pictures that his vision saw, his memory recalled or his rich imagination conceived. It was as natural to him to paint streets, landscapes, neighbours as the mysterious jungles where tigers prowl. Animals and birds, human beings, he paints them all as they pass before his inner or outer vision, the colour schemes seeming the more original because they are seldom schemed at all. *Gauguin, *Seurat, ${ }^{*}$ Signac and *Pissarro were among his friends and in 1908 *Picasso gave a memorable banquet in his honour.

Rousseau, Jean-Jacques (1712-1778). Swiss-French writer and political philosopher, born in Geneva. His father, a watchmaker, abandoned him to relatives. He was apprenticed to an engraver but ran away from his harsh treatment, crossed the frontier into Savoy and found a refuge, half-servant, half-lover, with Madame Françoise-Louise de Warens, a woman of generous affections. In the years of vagrancy that followed he would always be welcomed back to her home and in the domestic interludes found time to study music, literature, and philosophy. In 1744 he was settled in Paris making a living by copying music and writing comedies, and having as mistress a kitchenmaid named Thérèse Levasseur with whom he lived for 25 years. Each of the five children she bore him he deposited on the steps of a foundling hospital, an inconsistency between principle and practice of which he became increasingly ashamed. Meanwhile his opera Les Muses galantes (1747) had led to a correspondence with *Voltaire and an acquaintance with *Diderot, for whose great Encyclopédie he wrote articles on music and political economy. His winning (1749) of a prize for an essay in which he argued that the arts and sciences merely corrupted the natural goodness of man may have encouraged him to develop the theme of the 'noble savage' which pervades much of his work. His political thoughts spring from the same romantic origins. In their natural state men are free, equal and good; it is institutions that have made them otherwise. His Discours sur l'origine de l'inegalite parmi les hommes (1755) explains how this came about. Even more influential was his Du contrat social (1762). The famous opening words, 'Man is born free, but everywhere is in chains', show the same romantic starting-point, the problem of political association being to enable the noble impulses of free man to find collective expression. Much of the book relates to the way in which there can emerge in a community a 'general will' in which the individual wills of each participant will find identification. Sovereignty lies with the people as a whole and is the exercise of the general will. There is an implied contract that each individual hands over all his personal rights to the community on the understanding that the precepts of the general will are observed. Sophistries abound in the book. It provides an intellectual preparation for the French Revolution, but has equally provided texts in support of the state despotisms of our own times. In Émile (1762) Rousseau uses the form of a novel to give views on education that resemble those described as 'modern' today: education should release and not inhibit natural tendencies; a child's natural curiosity should provide the incentive to learn; experience rather than book-learning is the key to knowledge. However, by 'child' he meant 'boy' and could see little point in educating girls for a life outside domesticity. In a lighter vein La Nouvelle Héloïse (1761), a novel in the form of letters, again takes up the theme of 'return to nature' in the context of sex and the family. After his death were published his Confessions (1781), where vanity and candour often compete. There are to be found episodes of his childhood and early manhood, his inner reveries and descriptions of the beauties of nature, and though there are many lapses of judgement and taste in this book, it contains, with its supplementary volume, Réveries d'un promeneur solitaire (1762), some of the most exquisite passages of French literature. Since Emile had provoked a threat of arrest, Rousseau went to Switzerland and then, on David *Hume's invitation, to England. Signs of delusional insanity began to appear here. (He imagined Hume was plotting against him.) $\mathrm{He}$ returned to France (1770) still suffering at times from insanity and died eventually of a heart attack. In 1794 his remains were buried in the Panthéon near those of Voltaire.

Guehenno, J., Jean-Jacques Rousseau. 1966.

Rousseau, Théodore (1812-1867). French landscape painter. He painted in the Auvergne and Normandy before he became a leading figure of the Barbizon school, called after a village in the forest of Fontainebleau (*Millet). Groupings of trees, marshy patches, all the quiet details of an unspoilt countryside are the subjects in which he takes unwearying delight.

Rousseff, Dilma Vana (1947- ). Brazilian economist and politician, born in Belo Horizonte. Of Bulgarian parentage, she became an economist and worked closely with Luis *Lula de Silva, becoming his Minister for Mines and Energy 2003-05 and Chief of Staff 2005-10. She was the first woman (and the first economist) to be president of Brazil 2011-16. In 2015, charged with budgetary offences, she was impeached by the House of Representatives and removed from office in August 2016 in a highly partisan vote by the Senate.

Roussel, Albert (1869-1937). French composer. Originally a naval officer, he devoted himself to music from 1893, studying (1898-1907) under Vincent D'*Indy in Paris at the Schola Cantorum, where he was also professor of counterpoint 1902-14. From 1918 he was forced by ill health to live in the country. His orchestral works include four symphonies and the ballets Le Festin de l'Araignee (The Spider's Banquet, 1912) and Bacchus and Ariadne (1930). He also wrote piano and chamber music. His sturdily individual style blends French influence with that of * Stravinsky.

Rowe, Nicholas (1674-1718). English poet and dramatist. Among the best known of his plays were Tamerlane (1702), The Fair Penitent (1703) and 
Jane Shore (1714), the last two of which provided excellent parts for Mrs ${ }^{*}$ Siddons. He also published a translation (highly praised by $\mathrm{Dr}{ }^{*}$ Johnson) of Lucan's Pharsalia. His edition of *Shakespeare (1709) divided the plays into acts and scenes. He became poet laureate in 1715 .

Rowe, N., Dramatic Works. 1971.

Rowland, Henry Augustus (1848-1901). American physicist. Professor of physics at Johns Hopkins University 1867-1901, he developed methods of producing better and larger diffraction gratings, and made (1882) the first concave grating. The Rowland circle, a circle having the radius of curvature of a diffraction grating, is named after him. He improved on the determinations of the mechanical equivalent of heat made by *Joule. He also investigated electromagnetic effects and made an accurate determination of the value of the ohm.

Rowland, (Frank) Sherwood (1927-2012). American chemist. Professor of Chemistry at the University of California, Irvine 1964-92, he shared the 1995 Nobel Prize for Chemistry with Paul *Crutzen and Mario Molina for their work in investigating and explaining depletion of the ozone layer by the use of chlorofluorocarbons, leading to the adoption of the Montréal Protocol (1989).

Rowlandson, Thomas (1756-1827). English draughtsman and caricaturist. Extravagant tastes, love of travel and a zest for life, combined with a determination to pay his way to make him one of the most industrious and prolific of artists. Wherever he went, he drew. He is best known for his book illustrations (e.g. A Sentimental Journey, by *Sterne, and Baron Münchausen'sTravels) and political cartoons and caricatures, the quality of which he and his contemporary ${ }^{*}$ Gillray raised almost to the level of a new art.

\section{George, D. M., Hogarth to Cruikshank. 1967.}

Rowling, J(oanne) K(athleen) (1965- ). English novelist, born near Bristol. Educated at Exeter University, she worked for Amnesty International, then taught in Portugal. Her series of seven novels about Harry Potter began with Harry Potter and the Philosopher's Stone (1997). After rejection by 12 publishers, her Harry Potter books sold 500 million copies. She received a CH in 2017.

Rowling, Sir Wallace Edward [Bill] (1927-1995). New Zealand Labour politician. A teacher and army officer, he was a Labour MP 1962-84, Prime Minister 1974-75 and Ambassador to the US 1985-88.

Rowntree, Joseph (1801-1859). English Quaker philanthropist and chocolate manufacturer. He founded the firm at York that still bears his name and helped to found the Friends' Education Society (1837) as well as schools in York and elsewhere.
(1871-1954), also combined his duties as head of the family firm with social work. His Poverty (1901) and Poverty and Progress (1941) resulted from social surveys in York, which set a pattern for later surveys and led to the foundation of the Industrial Welfare Society and similar organisations, in which he was active.

Brigg, A., Seebohm Rowntree. 1961.

Rowse, A(lfred) L(eslie) (1903-1997). English historian, novelist, poet and critic, born in Cornwall. Proud of his working class origins, he was educated at Oxford, taught there but retired to Cornwall in 1952. He made many enemies, published 105 books, including works on *Shakespeare, *Marlowe, *Swift and the ${ }^{*}$ Churchills, and received a CH in 1996.

Cauveren, S., A. L. Rowse: A Bibliophile's Extensive Bibliography. 2000.

Royal, (Marie-) Ségolène (1953- ). French Socialist politician, born in Dakar. Educated at the ENA, she was a deputy in the National Assembly 1988-92, 1993-97, 2002-2012, Minister for the Environment 1992-93 and Vice Minister for Family and Childhood 2000-02. She adopted Blairite 'third way' policies, won the Socialist nomination for president of France, losing to Nicolas *Sarkōzy in 2007. She was the partner of François *Hollande from 1970 to 2007, had four children by him and served as his Minister for Ecology, Sustainable Development and Energy 2014-17.

Royce, Sir Frederick Henry, 1st Baronet (18631933). British engineer. He was founder (with C. S. ${ }^{*}$ Rolls), and for many years engineer-in-chief of the firm of Rolls Royce at Derby.

Bennet, M., Rolls Royce Story. 1974.

Rubbia, Carlo (1934- ). Italian physicist. Educated at Rome and Columbia universities, he was a research physicist at the Conseil Européen pour la Recherche Nucléaire (CERN), Geneva from 1960, professor of physics at Harvard 1972-88, and Director of CERN 1989-93. He shared the 1984 Nobel Prize for Physics with Simon van der Meer (1925-2011), also at CERN, for their work in demonstrating the existence of massive short-lived particles called bosons.

Rubbra, Edmund Duncan (1901-1986). English composer. Pupil of *Vaughan Williams and *Holst, his compositions include 11 symphonies, a Sinfonia Concertante for piano and orchestra, piano and viola concertos, choral works (including unaccompanied settings of the Mass) and chamber music. He became a lecturer at Oxford University 1947-68. Influenced by the polyphonic composers of the late 16th and early 17 th centuries, and in the main unaffected by modern trends, his music is reflective in manner.

Rubens, [Sir] Peter Paul (1577-1640). Flemish painter, born in Westphalia. His father, a burgomaster of Antwerp, was exiled during the religious wars. 
Rubens returned with his mother (1587) after his father's death, was trained as a court page and was taught art in local studios. Art never consumed Rubens' full talents. He studied antiquity, absorbed the classics, learnt six languages and became an accomplished diplomat. In 1600 he went to Italy as court painter to the Duke of Mantua and in frequent travels had the opportunity of studying the works of the great Renaissance masters, especially ${ }^{*}$ Titian and *Tintoretto. He absorbed with a natural eclecticism the features of each, necessary for the maturing of his own style, which, as he gradually shed the effects of his early Manneristic training, displayed the full exuberance of the Baroque. In 1608 he returned to Antwerp where he became court painter to the Spanish regents. From his studios came a continuous flow of religious pictures, battle pieces and mythological subjects, portraits both singly and in groups. In the first category the Descent of the Cross can be contrasted with the Raising of the Cross (1610, both in Antwerp Cathedral), the latter (and earlier) showing a much greater sense of strain; in the second category, the Rape of the Daughters of Leucippus is well known, and the first Bacchanales, the nudes revelling in their unrestrained sensuality, bear witness to the intoxicating joy of life. Among the portraits, one of the artist himself with his first wife Isabella Brant (d 1626) is of special interest. By 1621 , the year in which he depicted for ${ }^{*}$ Marie de Médicis, the French Queen, episodes of her life in a magnificent allegorical sequence, Rubens had reached full maturity. Movement is freer, composition and colour more dramatic, draughtsmanship (e.g. his daring foreshortenings), confident and secure. His masterpiece was probably Fall of the Rebel Angels (c.1621), now in the Alte Pinakothek, Munich.

The death of his first wife left him freer to undertake confidential missions for which he was well equipped by his artistic and diplomatic talents. Thus he negotiated and painted in France (1620-28), in Spain (1628) and in England (1629-30) with ${ }^{*}$ Charles I, to whom he presented Allegory of the Blessings of Peace, and for whom he designed the ceiling panels for the Banqueting Hall at Whitehall and received a knighthood. Whenever he was at home the outflow of his pictures continued. For this purpose he maintained an elaborate organisation of assistants, of whom ${ }^{*}$ Van Dyck was among the chief, others being employed for painting, e.g., fruit and flowers (Jan *Brueghel) or animals. Rubens abandoned court life in 1633 and retired to his estate at Steen with his young second wife Helena Fourment whom he had married in 1630 and who appears in the nude as Andromeda and in several fine portraits, e.g. The Fur Coat. His subjects are little changed but outlines are softer, shadows less opaque and the colours more delicate, often with a silvery tone. Some of his most famous pictures belong to this period, e.g. The Rape of the Sabines (1635), The Judgement of Paris (163840) and the 'martyrdoms' (1635-40) e.g. Crucifixion of St Peter. Rubens ranks among the greatest of the world's artists not only because of the brilliance of his painting techniques, his superb draughtsmanship, inventiveness and observation, but also because his buoyant satisfaction with his life, his success, and his art communicates itself through his work.

Wedgwood, C. V., The World of Rubens, 1577-1640. 1967.

Rubinstein, Anton Grigoryevich (1829-1894). Russian composer and pianist. First director of the St Petersburg Conservatorium 1862-67, 1887-91, he toured Europe and the US, as a pianist, but his many compositions, including operas, symphonies, cantatas, and chamber and piano music are now infrequently performed. His brother Nikolai Grigoryevich Rubinstein (1835-1881) was an outstanding pianist, conductor and — to a lesser degree-composer.

Rubinstein, Arthur (1887-1982). Polish-JewishAmerican pianist, born in Łódz, then part of Russia. He first played in public at four, studied in Warsaw, made his debut in Berlin under *Joachim (1900), followed by New York (1906) and London (1912). After early success as a virtuoso, he gained a more serious reputation after 1937 as an interpreter of ${ }^{*}$ Chopin, ${ }^{*}$ Mozart, ${ }^{*}$ Beethoven and ${ }^{*}$ Ravel. A prolific recording artist, he toured incessantly for more than 60 years, appeared frequently on film and television, wrote a lively autobiography and was a witty raconteur. He received an honorary $\mathrm{KBE}$ and the US Presidential Medal of Freedom.

Rubinstein, Ida Lvovna (1883-1960) RussianFrench dancer, actor and art patron, born in Kharkov. From a rich family, after dancing for *Diaghilev's Ballet Russes, she formed her own company, commissioned *Ravel's Boléro and also acted on stage, and in film. Bisexual, she was generous, courageous, the subject of many paintings and a Catholic convert.

Rublev, Andrei (c.1365-c.1429). Russian icon painter. Trained in the Byzantine tradition, he painted in Zagorsk and Moscow and became a monk. The biographical film Andrei Rublev (1966), directed by Andrei Tarkovsky, was released in 1971 in a censored form.

Rudd, Kevin Michael (1957- ). Australian Labor politician, born in Queensland. Educated at the Australian National University, he became a diplomat, serving in Sweden and China (and achieving mastery in Mandarin), was head of the Queensland Cabinet office 1991-95, and a Federal MP 1998-2013. Shadow Foreign Minister 2001-06, he was Leader of the Opposition 2006-07, and Prime Minister 2007-10, defeating John *Howard. He made powerful enemies in the ALP factions, compounded by concentrating power in his own office. Following polling which suggested a sharp fall in the party's primary vote, he was removed from the leadership in a coup (June 2010) and replaced by Julia *Gillard. He was Foreign Minister 2010-12, resigning after 
having been provoked into making a failed bid for the leadership. After polls put the ALP's primary vote at 29 per cent, Rudd contested the leadership, defeated Gillard in Caucus and was Prime Minister again June-September 2013, then suffered a heavy election loss to Tony *Abbott. He relocated to New York, became a consultant and sought election as Secretary-General of the United Nations in 2016. He returned to live in Queensland in 2019.

Weller, P., Kevin Rudd: Twice Prime Minister. 2014; Rudd, K. M., Not for the Faint-hearted. 2017; The PM Years. 2018.

Rudolf (Franz Karl Joseph) (1858-1889). Austrian Archduke, born near Vienna. The only son and heir of Kaiser *Franz Joseph, he married Princess Stéphanie of Belgium (1864-1945), daughter of King Léopold II, in 1881. Regarded as a moderate liberal, he was interested in science, was an expert ornithologist and received a KG in 1887. In January 1889 the bodies of Rudolf and his lover, Baroness Marie (but known as 'Mary') von Vetsera (1871-1889), were found at his hunting lodge at Mayerling. Both had been shot. Suicide due to an 'unbalanced mind' was announced and murder can be presumed, but since all state records were destroyed the details remain obscure. The Mayerling story has been the subject of films, plays, musicals and a ballet. His widow invented the hostess trolley.

Rudolf II (1552-1612). Holy Roman Emperor 1576-1612. One of the most ineffective rulers of the Habsburg dynasty, after a half-hearted attempt to stiffen the laws against Protestants he ceased to play an active part in government and withdrew into his palace at Prague where he practised astrology, alchemy and, so it was said, demonology. His interest in more normal science was shown when, on Tycho *Brahe's departure from Denmark (1597), he gave him a pension and established him, with *Kepler as his assistant, in an observatory near Prague. In 1608 the Habsburg archdukes transferred their allegiance from Rudolf to his brother Matthias to whom the emperor ceded Hungary, Austria and Moravia. Rudolf retained only Bohemia, but this too had to be yielded in 1611 .

Rumford, Sir Benjamin Thompson, Count [Graf] von (1753-1814). Anglo-American scientist and administrator, born at Woburn, Mass. From 1770 he was a schoolmaster in Rumford, New Hampshire. His Anglophile views in the events that led to American independence caused him to go to England where he worked for the Colonial Office. His experiments with gunpowder won him election as FRS. He returned to America (1782) as a British officer, but the coming of peace (1783) brought him back to England and he was knighted. The next phase of his career, resulting from a friendship with the Elector Karl Theodor, was in Bavaria where, as Minister of War and Police and also Grand Chamberlain, he introduced army education, drained marshes, established workshops, and provided relief for the unemployed. In 1791 he was made a count of the Holy Roman Empire, choosing his title from his former American home. He received the Copley Medal in 1792. He finally left Bavaria in 1799, eventually settled in France, married *Lavoisier's widow in 1804 (but separated three years later) and died in Paris. Meanwhile, he had endowed Rumford medals for English and American scientists, had conducted researches and had written a paper (1798) for the Royal Society concerning the causes of heat, his conclusion being that heat was not a substance but a form of motion. He invented more efficient fireplaces, furnaces, ovens, gates and chimneys, which were immediately adopted and made him rich.

Larsen, E., An American in Europe. 1953.

Rumi (Jalāl ad-Dīn Muhammad Balkhī) (12071273). Persian poet and mystic, born in Balkhi, Afghanistan. A Sufi, he lived at Rum (now Konya, in Turkey), wrote Mathnawi, a poetic account of Sufism, and was virtual founder of the 'whirling dervishes'.

Rumsfeld, Donald Henry (1932-2021). American administrator and Republican politician, born in Illinois. Educated at Princeton, he served in the US Congress 1963-69 and became Ambassador to NATO 1973-74 and White House Chief of Staff 1974-75. He worked as a CEO in the pharmaceutical and electronics industries and had two terms as Secretary of Defense, 1975-77 and 2001-06. His interests included wrestling and poetry.

Runcie, Robert Alexander Kennedy, Baron Runcie (1921-2000). English prelate. Educated at Oxford and Cambridge, he served in World War II, and was Bishop of St Albans 1973-80 and Archbishop of Canterbury 1980-91.

Runciman, Garry (Walter Garrison), 3rd Viscount Runciman of Doxford (1934-2020). English historical sociologist. He had an active life as ship owner and company director but as a fellow of Trinity College, Cambridge 1959-63, 1971-2020, was a productive and original sociologist and expert on Max *Weber. He chaired the Royal Commission on Criminal Justice 1991-93 and was President of the British Academy 2001-05. His books include Great Books, Bad Arguments: Republic, Leviathan, and The Communist Manifesto (2010). His son, David Walter Runciman, 4th Viscount Runciman (1967- ), a professor of political theory at Cambridge, wrote The Politics of Good Intentions (2006), Political Hypocrisy (2008), and The Confidence Trap (2013).

Runciman, Sir Steven (James Cochrane Stevenson) (1903-2000). English historian. Educated at Trinity College, Cambridge, his books include The First Crusade (1951), The Sicilian Vespers (1958) and The Fall of Constantinople 1453 (1965). He received a $\mathrm{CH}$ in 1984 . The sociologist Garry *Runciman was a nephew.

Dinshaw, M., Outlandish Knight. 2016. 
Rundstedt, (Karl Rudolf) Gerd von (1875-1953). German field marshal. Born into an old Junker family, he fought in France, Russia and Turkey in World War I but, despite his seniority, he was passed over in favour of *Brauchitsch for chief command in World War II. He proved himself one of the greatest German generals. He commanded an army group in Poland (1939), he directed the drive across the Meuse (1940), which reached the Channel ports, and was in charge of the great sweep through southern Russia (1941). The massacre of Jews at Babi Yar (September 1941) took place under his command, but he denied direct responsibility. In 1942, he was transferred to the West to prepare for, and resist (1944), the Allied attack. Briefly supplanted by von *Kluge owing to strategical disputes, on his return he staged the last spectacular counter-attack in the Ardennes. Held prisoner in England for a time after the war, ill and old, he was never sent for trial to Nuremberg.

Runeberg, Johan Ludvig (1804-1877). Finnish poet. His works, written (as was then customary) in Swedish, include the long narrative poems The Elkhunters (1832) and The Tales of Ensign Stal (1848), an old soldier's memories of the war with Russia of 1808, the opening poem of which has become Finland's national anthem. King Fjaler (1844) is a romance cycle of the Viking period. Many of Runeberg's ballads and lyrics were set to music by ${ }^{*}$ Sibelius.

Runyon, Damon (1884-1946). American writer. Originally a sports writer, he gains fame by his stories and sketches of New York characters written in the present tense in a racy, continuously flowing style which gives an exciting immediacy. Among his characters are Harry the Horse, Ambrose Hammer, Little Dutch, Ropes McGonagle and many more. His tales make successful films, e.g. Guys and Dolls (1931), and Little Miss Marker (1934) starring Shirley *Temple.

Rupert of the Rhine, Prince (Ruprecht von Wittelsbach), 1st Duke of Cumberland (16191682). Anglo-German general and admiral, courtier and inventor, born in Prague. Son of the elector Palatine *Frederick (Friedrich) V, and of Elizabeth, daughter of *James I of Great Britain, after fighting in the Thirty Years' War he went to England (1642) to support his uncle ${ }^{*}$ Charles I. His brilliance as a cavalry officer won many successes in the early part of the conflict, though his reckless impetuosity sometimes led him to continue the pursuit instead of returning to consolidate victory. Criticism of his surrender of Bristol (1645) caused him to demand a court martial, which acquitted him. Convinced that the Royalist cause was lost, he urged Charles to negotiate with Parliament. After Charles' defeat and imprisonment, he continued the Civil War as a privateer in the Caribbean, explored Gambia and invested in the slave trade. He lived in France for a decade. He returned to England after the Restoration and served as an admiral in the Dutch Wars. He was Lord High Admiral 1668-82. His military exploits were supplemented by his achievements as artist, scientist and inventor. He was active in the formation of the Royal Society in 1662 and introduced (but probably did not invent) the mezzotint process. In 1668 he spent the winter in the Arctic, and he helped to found the Hudson's Bay Company (1670).

Ashley, M., Rupert of the Rhine. 1976; Kitson, F., Prince Rupert. 1994.

Rurik (d.879). Russian ruler and dynastic founder. A Varangian (Scandinavian), he probably reached Novgorod in 962 and after his death his descendants formed principalities in Kiev, Moscow and elsewhere. Indeed, until the failure of the Muscovite line in 1598 with the death of Feodor I, usurpers all over Russia claimed to be of Rurik's blood. Even in later times Rurik's descendants were automatically styled 'prince'.

Rush, Benjamin (1746-1813). American chemist and medical practitioner, born near Philadelphia. $\mathrm{He}$ studied medicine at the College of New Jersey, and at Edinburgh under William Cullen and Joseph *Black. He received an Edinburgh MD in 1769, then became professor of chemistry at the College of Philadelphia. In 1789 he moved to the chair of the Theory and Practice of Physick. His chemical thinking closely followed that of Black, but he was more original in his medical outlook. Whereas Cullen had explained most diseases in terms of the nervous system, Rush thought the arterial system more important. Thinking that most diseases originated from excessive tension in the arterial system, he became an enthusiastic exponent of reducing that pressure by heroic quantities of bleeding. Later in his life, his interest turned chiefly towards mental illness, having been placed in charge of the insane at Pennsylvania Hospital in 1787. His Medical Inquiries and Observations upon the Diseases of the Mind (1812) is the first American work of psychiatry. Rush was an ardent supporter of American Independence, being a signatory of the Declaration. He was opposed to slavery and capital punishment, and a promoter of women's education, being a founder of Dickinson College. He was an important teacher and one of the inspirational figures of American medicine.

Rush, Geoffrey Roy (1951- ). Australian actor and producer, born in Toowoomba. He gained international recognition as a film actor, winning the Academy Award for best actor in Shine (1996), an Emmy Award for The Life and Death of Peter Sellers (2004) and a BAFTA Award for The King's Speech (2010). He was Australian of the Year (2012) and foundation President of the Australian Academy of Cinema and Television Arts.

Rushdie, Sir (Ahmed) Salman (1947- ). IndianBritish writer. Born in Mumbai (Bombay) to a Muslim family on the day of Indian independence, he was educated at Mumbai, Rugby School and Cambridge and worked as an advertising copywriter and actor. His novels include Midnight's Children, 
about the separation of India and Pakistan on the day of Rushdie's birth, which won the 1981 Booker Prize, Shame (1983), The Satanic Verses (1988) and The Moor's Last Sigh (1995). Publication of Satanic Verses led to international protests in the Islamic community and the pronouncing of a fatwah (excommunication and sentence of death) by Ayatollah *Khomeini, who had been satirised in the novel, alleging blasphemy as the justification. Bookshops carrying the book were also attacked and protest marches occurred as far away as China. Rushdie then went into hiding. He also wrote The Jaguar Smile: A Nicaraguan Journey (1987), Imaginary Homelands: Essays and Criticism 1981-91 (1991) and books for children. . In August 2022 he was savagely stabbed in New York State.

Rusk, (David) Dean (1909-1994). American administrator, born in Georgia. After a professorship at Mills College, California, and army service (194046), he was Deputy Undersecretary of State under *Truman 1946-52, President of the Rockefeller Foundation 1952-61 and Secretary of State under *Kennedy and *Johnson 1961-69. He took a leading role in negotiating for the nuclear test ban treaty (1963) but was a prominent 'hawk' during the Vietnam war.

Ruskin, John (1819-1900). English author, art critic and social reformer, born in London. Son of a wealthy wine merchant, he was brought up in a cultured and religious family, but his mother's over protectiveness undoubtedly contributed to his later psychological troubles. On his frequent trips in Europe, he took an artist's and a poet's delight both in landscape and in works of art, especially medieval and Renaissance. His first great work, Modern Painters (5 volumes, 1843-60), began as a passionate defence of *Turner's pictures, but became a study of the principles of art. In The Seven Lamps of Architecture (1849) and The Stones of Venice (1851) he similarly treated the fundamentals of architecture. These principles enabled him, incidentally, to appreciate and defend the Pre-Raphaelites, then the target of violent abuse. To Ruskin the relationship between art, morality and social justice was of paramount importance and he increasingly became preoccupied with social reform. His concern inspired, among others, William *Morris and Arnold *Toynbee. He founded the Working Men's College (1854) and backed with money the experiments of Octavia ${ }^{*}$ Hill in the management of house property.

In his essay 'Unto This Last' (1860), he coined the word 'illth', the underside of 'wealth', the collateral damage caused by change and accumulation of power. He advocated social social reforms which later were adopted by all political parties: old age pensions, universal free education, better housing. Nevertheless, he described himself as a 'violent Tory of the old school, of Walter *Scott-and *Homer', working with Thomas ${ }^{*}$ Carlyle to defend Edward John *Eyre against prosecution for murder after his violent suppression of a rebellion in Jamaica (1865).

Gothic was for Ruskin the expression of an integrated and spiritual civilisation; classicism represented paganism and corruption; the use of cast iron, and the increasing importance of function in architecture and engineering seemed to him a lamentable trend. $\mathrm{He}$ was Slade professor of art at Oxford 1870-79 and 1883-84. His later works, e.g. Sesame and Lilies (1865), The Crown of Wild Olives (1866) and Fors Clavigera (1871-84), contain the program of social reform in which he was so interested. Ruskin married (1848) Euphemia (Effie) Gray (the child for whom he had written The King of the Golden River) but in 1854 , after six years of non-consummation, the marriage was annulled and Effie later married the painter John *Millais. Ruskin did not remarry, although on other occasions he fell in love with girls much younger than himself. His last disappointment over Rose la Touche contributed to a mental breakdown and his last years were spent in seclusion at Brantwood on Lake Coniston, where he wrote Praeterita, an unfinished account of his early life. Much of his wealth he devoted to the 'Guild of St George', which he founded, and other schemes of social welfare. Ruskin had (despite his sometimes violent views) profound influence on *Gandhi and *Proust.

Rosenberg, J. D., The Darkening Glass. 1961; Hilton, T., John Ruskin. 2002; Cooper, S. F., To See Clearly. Why Ruskin Matters. 2019; Hill, A., Ruskinland. How John Ruskin Shapes Our World. 2019.

Russell. Family name of the dukes of Bedford. The family fortunes were founded by John Russell (c. 1486-1555), favourite of*Henry VIII, who created him Earl of Bedford and gave him Woburn Abbey and other Church lands. Drainage of the Bedford Level in the Fens was begun by Francis, the 4th Earl. William, the 5th Earl (1613-1700), who had helped to restore ${ }^{*}$ Charles II, was created 1st Duke of Bedford (1694) by *William III. The names of the Bloomsbury squares (Russell, Bedford, Woburn) recall an enterprising piece of property development by the Russell family (*Russell, Bertrand; *Russell, Lord John; *Russell, Lord William).

Russell, Bertrand Arthur William, 3rd Earl Russell (1872-1970). English philosopher and mathematician, born in Wales. Son of the radical John Russell, Viscount Amberley (1842-1876) and grandson of Lord John *Russell, he studied mathematics at Trinity College, Cambridge where he was a Fellow 1895-1921, 1944-70 and lecturer 1910 15, 1919-21, being elected FRS in 1908. Having also studied philosophy (his Philosophy of Leibniz appeared in 1900), he was particularly well equipped to write (in collaboration with Alfred North *Whitehead) Principia Mathematica (3 volumes, 1910-13), an attempt to show that the truths of mathematics are derivable from the basic truths of logic; this great work had immense influence. The appearance of Problems of Philosophy (1912) marked a gradual transference of 
interest to less purely abstract fields. He had already abandoned his early Hegelian idealism for a form of realism demanded by his faith in mathematical truth. He now offered a theory of knowledge which had at its centre not idealistic inferences from the unknown but logical constructions out of sense data and other ascertainable phenomena.

He was greatly influenced by Gottlob *Frege and his own student Ludwig *Wittgenstein. With the austerity of Russell's academic thought is his exuberant championing of the unorthodox view in public life. A characteristic essay explained why he was not a Christian. He defended sexual freedom, and from a study of his own children established a progressive 'school'. In World War I he was fined and imprisoned (1918-1919) for sedition. A visit to Russia disillusioned him about Communism and he wrote The Practice and Theory of Bolshevism (1920) and several popular books about philosophy, science and education. He succeeded his brother Frank as 3rd Earl in 1931, married four times and had many amours. After being sacked from a New York chair (1940) for his writings on sexuality, he gave lectures at the *Barnes Foundation, Merion, Pa. (1941-42) which became the basis of his popular A History of Western Philosophy (1945). He abandoned his pacifist views in World War II, but later became a notable supporter of the Campaign for Nuclear Disarmament and the Committee of 100 . He was imprisoned again in August 1961. Among his many honours were the OM (1949) and the Nobel Prize for Literature (1950).

Russell, B., Autobiography. Vol 1. 1967, Vol. 2. 1968; Clarke, R. W., The Life of Bertrand Russell. 1975; Moorehead, C., Bertrand Russell, 1992; Monk, R., Bertrand Russell: The Spirit of Solitude. 1996; The Ghost of Madness. 2000.

Russell, Charles Taze (1852-1916). American preacher. Founder (1872) of the International Bible Students, in 1884 the movement was renamed the Watch Tower Bible and Tract Society, the members of which became known (1931) as Jehovah's Witnesses. They hold firm pacifist views and believe in the imminence of a second armageddon and a period of 1,000 years when sinners will be given a second chance to reform and repent.

Russell, George William (1867-1935). Irish writer. Better known under his pseudonyms AE, A E and A.E., he was closely linked with other leaders of the Irish literary renaissance, notably W. B. *Yeats, with whom he was associated in the creation (1904) of the Abbey Theatre, Dublin. Russell's drama Deirdre had been produced only two years before. Earlier he had joined Horace Plunkett's Irish Agricultural Organisation Society (IAOS) designed to improve the conditions of poor farmers, and edited the Irish Statesman 1923-30. Among his prose works are Imaginations and Reveries (1915) and Song and its Fountains (1932); his poems are mostly mystical.
Russell, John, 1st Earl Russell (1792-1878). English Liberal politician, born in London. Third son of the 6th Duke of Bedford, educated at Westminster School and Edinburgh University (but leaving without a degree), as Lord John Russell he was MP 1813-17, 1818-61. The nickname 'Finality Jack' indicated his firm support for all measures of civil and religious liberty, in the tradition of Charles James ${ }^{*}$ Fox. He was a member of Earl *Grey's ministry which carried the Parliamentary Reform Act of 1832, which Russell had a principal part in framing. As Home Secretary 1835-39 in Lord *Melbourne's second ministry he passed the Municipal Reform Act (1835) and the Titles Commutation Act (1836), but a moderate attempt to secure freer trade caused the defeat and fall of the government. To prove that he had the support of the financial community Russell stood for and was elected by the City of London, which he represented until 1861. When *Peel became Prime Minister, Lord John was Leader of the Opposition. He pronounced (1846) in favour of the complete repeal of the Corn Laws. The government fell but Russell was unable to form a ministry. Peel returned and, having legislated repeal with Whig support, was immediately defeated and again resigned. Russell now became Prime Minister 1846-52 and proved his worth by coping with the Irish famine and the Chartist agitation, until friction with *Palmerston, his Foreign Secretary (whom he dismissed), broke up the ministry. Russell was Foreign Secretary 1852-53 in Lord *Aberdeen's coalition but criticisms of the conduct of the Crimean War caused him to resign from Cabinet (1855). As British delegate to the Vienna Conference the compromise he tried to agree with Russia was rejected by Cabinet, and Russell was without office until, in 1859, he came to terms with Palmerston. As Foreign Secretary 1859-65 and Prime Minister 1865-66 he supported the unification of Italy under King *Vittorio Emanuele and maintained British neutrality in the American Civil War. He resigned after failing to secure the passage of a new Reform Bill.

Russell, Mary Annette Russell (née Beauchamp), Countess see Arnim, Elizabeth von

Russell, William, Lord Russell (1639-1683). English Whig politician. Son of the 5th Earl (later 1st Duke) of Bedford, educated at Cambridge, he was a Whig MP 1660-79, passionately antiCatholic, deeply opposed to the prospect of ${ }^{*}$ Charles II being succeeded by his Catholic brother James (later *James II) and hostile to the influence of the 'Cabal' (*Clifford of Chudleigh). He was convicted of treason after a reasonably fair trial and was beheaded for his alleged participation in the Rye House plot to assassinate ${ }^{*}$ Charles II on his return from Newmarket. Of Russell's ignorance of this conspiracy there is no doubt, but it is equally certain that he, Algernon *Sidney and the more violent Whigs were planning rebellion. Popular indignation aroused 
by the unmasking of the Rye House plotters spread to the others and enabled a charge of treason to be maintained.

Russell, Sir William Howard (1820-1907). AngloIrish journalist, born near Dublin. The first, and one of the greatest, war correspondents (a description he disliked), he began his career reporting the stormy politics of Ireland. In 1854, The Times sent him to the Crimea where his vivid descriptions of the great battles of Balaclava and Inkerman shocked readers with revelations of appalling sufferings caused to the troops by the failures of the supply and medical services, the latter leading to the dispatch of Florence ${ }^{*}$ Nightingale. Later he reported the Indian Mutiny (and by his articles stayed indiscriminate punishments), the US Civil War (where he sympathised with the Union but made enemies with his critical reporting) and, finally, the Austro-Prussian, Franco-Prussian and Zulu wars. He founded (1860) the Army and Navy Gazette.

Russell, W. H., Despatches from the Crimea, 1854 1856 (ed. Bentley, N.). 1970.

Ruth, 'Babe' (né George Herman, Jr) (1895-1948). American baseball player, born in Baltimore. The greatest player of the period 1914-35 (often called 'the Sultan of Swat'), and a left-hander, he established many records, e.g. the most home runs secured in a season (60 in 1927). He played for the Baltimore Orioles (1914), the Boston Red Sox (1914-19) and the New York Yankees (1920-34). After retirement he coached the Brooklyn Dodgers. In 2018 he was posthumously awarded the Presidential Medal of Freedom by Donald *Trump.

Rutherford, Ernest, 1st Baron Rutherford of Nelson (1871-1937). New Zealand physicist, born in Nelson. Educated at Canterbury College, Christchurch, he won an exhibition that took him to Cambridge where he worked with J. J. *Thomson on the long series of fundamental researches into radioactivity and the structure of the atom for which he became famous. His progress was marked by professorships of physics at McGill University, Montréal 1898-1907, Manchester 1907-19 and the Cavendish chair at Cambridge 1919-37. With *Soddy, he put forward (1903) the radioactive transformation theory, which showed that radioactivity arises from spontaneous disintegration of atoms. He also deduced the laws governing the transformations producing radioactivity. He suggested (1911) that the atom consists of a minute nucleus around which electrons orbit, and his model of the nuclear atom became the basis of modern concepts of atomic structure. He realised that if the atom could be split artificially, very large amounts of energy would be released. He succeeded in transforming nitrogen into an isotope of oxygen (1919) and thus, for the first time, achieved transmutation of elements. Apart from his own important discoveries, Rutherford was a great teacher and had, as pupils, many eminent scientists,
${ }^{*}$ Kapitza, ${ }^{*}$ Chadwick and ${ }^{*}$ Oliphant. He won the 1908 Nobel Prize for Chemistry (a surprise as he had expected Physics), was knighted in 1914, received the Copley Medal in 1922, the OM in 1925, became President of the Royal Society 1920-25 and a baron in 1931. A great experimenter, the next step for him was often the right one, although sometimes his judgment was wrong e.g. his dismissal of nuclear power as 'moonshine'. One of the greatest figures in the history of science, he had a warm, open nature and a kindly common sense for which he was loved by pupils and contemporaries alike.

Chadwick, J. (ed.), The Collected Papers of Lord Rutherford of Nelson. 1962-1965; Ramsey, A., The Basis of Everything. Rutherford, Oliphant and the Coming of the Atomic Bomb. 2019.

Rutherford, Dame Margaret (née Margaret Taylor Rutherford-Benn) (1892-1972). English actor. Her father murdered his own father and was certified insane. Famous for portraying elderly eccentrics, she was originally a teacher of elocution, and made her stage debut in 1925. Her most famous roles were Madam Arcati in Blithe Spirit (1941) and Miss Whitechurch in The Happiest Days of Your Life (1948). Her film career included the character of Miss Marple in the filmed detective novels of Agatha ${ }^{*}$ Christie, and she made films with Charles *Chaplin and Orson *Welles. She won an Academy Award in 1963 and was made DBE in 1967.

Rutskoi, Aleksandr Vladimirovich (1947- ). Russian soldier and politician. A fighter-bomber pilot, he served in Afghanistan and formed the Peoples' Party of Free Russia, which included many former CP hardliners. Vice President of Russia 1991-93, he was sacked by *Yeltsin and claimed the presidency himself.

Ruysdael (or Ruisdael), Jacob van (1628-1682). Dutch landscape painter, born at Haarlem. Originally a physician, probably trained by his uncle Solomon van Ruysdael (c.1600-1670), his quiet pictures of dunes, marshes, rivers and woodlands, mostly in golden-brown tones, are inspired with strong feeling and had much influence on the German Romantics, the Mill at Wijk being among the best known. His Scandinavian landscapes are also notable.

Ruyter, Michiel Adrianzoon de (1607-1676). Dutch sailor. He first went to sea as a cabin boy in a merchantman, but having transferred to the navy was a captain by 1635 . In the first Dutch War (1652-53), fought during the Commonwealth, he and ${ }^{*}$ Tromp contended with varying fortunes against the English admiral *Blake. In the second Dutch War (1664-67) against England he captured forts on the African coast, preyed upon shipping in the West Indies and fought (1666) a four-day battle against Prince *Rupert and *Monk off Dunkirk. In 1667 he made sensational raids up the Medway to Rochester and the Thames to Gravesend, burning ships as he 
went. In 1676-Holland and England having come to terms - he took his fleet into the Mediterranean to aid Spain, but died from wounds after a defeat by the French off Sicily.

Ryan, Paul Davis (1970- ). American Republican politician, born in Wisconsin. Catholic, originally inspired by reading Ayn *Rand, he studied at the curiously named Miami University (at Oxford, Ohio) and was a Member of the House of Representatives 1999-2019. Candidate for Vice President 2012, he was Speaker of the House 2015-19.

Ryan, Thomas Joseph (1876-1921). Australian Labor politician and lawyer, born in Part Fairy, Victoria. Son of Irish immigrants, educated in Melbourne, he was a teacher and lawyer, then moved to Queensland. A State MP 1909-19, he became ALP leader 1912-19, and Premier and Attorney-General of Queensland 1915-19. His reforming government had an ambitious social and economic agenda, but his Bill to abolish capital punishment (1916) was blocked by the Legislative Council. He transferred to the Federal Parliament 1919-21 and was regarded as certain to become leader when he died suddenly, of influenza, at Barcaldine.

\section{Ryckmans, Pierre see Leys, Simon}

Rykov, Aleksei Ivanovich (1881-1938). Russian politician. Originally a Social Democrat, he joined the Bolsheviks in 1905. Arrested and imprisoned several times, after the Revolution he was head of the Supreme Council of National Economy 1918-21; 1921-24, Deputy Premier of the USSR 1921-24, a Politburo member 1922-30. He succeeded Lenin as Premier 1924-30. *Stalin dismissed him, but he re-entered the government as Commissar for Communications 1931-37 when he recanted his opposition to Stalin's policies. Charged with complicity in a plot to murder Stalin (1936) he was tried and executed with Nikolai *Bukharin.

Schapiro, L., The Communist Party of the Soviet Union. 1960.

Rylands, 'Dadie' (George Humphrey Wolferstan) (1902-1999). English literary scholar and director. A Fellow of King's College, Cambridge 1927-99, he was close to the Bloomsbury Group, directed many innovative productions of ${ }^{*}$ Shakespeare, ${ }^{*}$ Marlowe and *Eliot, and received a $\mathrm{CH}$ in 1987.

Ryle, Sir Martin (1918-1984). English astronomer. He worked on radar during World War II, and at Cambridge (from 1945) developed new techniques involving the use of radar devices and, later, computers, leading to the aperture synthesis interferometer. He directed the Mullard Radio Astronomy Laboratory 1957-84, was a professor of radio-astronomy at Cambridge 1959-84 and Astronomer Royal 197284. He shared the 1974 Nobel Prize for Physics with
Antony ${ }^{*}$ Hewish for their work on quasars, originally discovered by Jocelyn *Bell who was excluded from the award.

Rysbrack, John Michael (1693-1770). Dutch sculptor. He worked in England from 1720, first worked for James Gibbs and William *Kent on figures for tombs in Westminster Abbey (e.g. Matthew Pryor, *Newton). Later the family tomb (1733) erected for the Marlborough family at Blenheim and the bronze equestrian statue of ${ }^{*}$ William III at Bristol led to a steady flow of commissions. He executed the statue of ${ }^{*}$ George II at Greenwich Hospital and many fine portrait busts (e.g. *Pope, ${ }^{*}$ Milton and Sir Robert *Walpole).

Ryti, Risto Heikki (1889-1956). Finnish politician, economist and banker. A progressive Anglophile, Governor of the Bank of Finland 1923-39; 1944-45, he served as Prime Minister 1939-40 and President of Finland 1940-44. The 'Continuation War' with Russia 1941-44 forced him into an uneasy alliance with Nazi Germany, which broke down in 1944. In 1945, under pressure from the USSR, Ryti was convicted of 'war responsibility', a new offence. He was sentenced to 10 years jail, but was released and pardoned in 1949. 


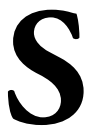

Saarinen, Eero (1910-1961). American architect, born in Finland. Son of the architect Eliel Saarinen (1873-1950), his family lived in the US from 1923. Eero's buildings include the General Motors technical centre at Detroit, the TWA terminal at Kennedy Airport, the US Embassy in London, and major buildings at MIT, Yale and Dulles Airport, Washington.

Temko, A., Eero Saarinen. 1962.

Sabatier, Paul (1854-1941). French chemist. Professor of chemistry at Nîmes, Bordeaux and Toulouse, he is best known for his discovery (1899), with Jean-Baptiste Senderens (1856-1937), of the method of converting oils into fats by hydrogenation over a catalyst of finely divided nickel. This is the basis of present-day manufacture of margarine from materials such as palm oil and whale oil. He won the 1912 Nobel Prize for Chemistry.

Sabatini, Rafael (1875-1950). English novelist, born in Italy. His popular historical novels and adventure stories include Scaramouche (1921), Captain Blood (1922) and The Black Swan (1932).

Sabin, Albert Bruce (1906-1993). American virologist, born in Russia. He graduated in medicine from New York University, worked for the Rockefeller Institute, Cincinnati University and the National Institute of Health. A rival of Jonas *Salk, he developed an oral vaccine against poliomyelitis which was adopted universally.

Sabine, Sir Edward (1788-1883). British soldier and scientist. After being commissioned in the Royal Artillery he accompanied several voyages of exploration as an astronomer. He carried out much research on terrestrial magnetism and discovered the connexion between sunspots and magnetic disturbances on the earth. He was President of the Royal Society 1861-71.

Sacagawea ('Bird Woman') (1787?-1812). American Indian (Shoshone) guide. Married to a Canadian trapper, she accompanied the expedition of *Lewis and ${ }^{*}$ Clark (1805).

Sacco, Nicola (1891-1927), and Bartolomeo Vanzetti (1888-1927). Italian anarchists, resident in the US. Following the murders of a paymaster and a guard at a shoe factory in South Braintree, Mass. (April 1920), they were tried and convicted at Dedham (1921) on circumstantial evidence. Because they were anarchists, it was widely believed that they were the victims of political prejudice. International protests followed but appeals were refused and they were electrocuted. In 1977, following a review, Governor Mike *Dukakis declared them to have been 'unfairly tried and executed'. Their case has been the basis for many books, a film, documentaries, songs and art works. Further research suggests that Sacco was probably guilty and Vanzetti innocent.

Russell, F., Tragedy in Dedham. 1971; Sacco and Vanzetti: The Case Resolved. 1986; Avich, P., Sacco and Vanzetti: The Anarchist Background. 1991; Watson, B., Sacco and Vanzetti: The Men, the Murders, and the Judgment of Mankind. 2007.

Sacheverell, Henry (1672-1724). English clergyman. He shared rooms with *Addison at Oxford and later became well known as a 'High-Church' preacher. He preached at Derby and St Paul's, in 1709, sermons so violent in their denunciation of the Act of Toleration and the Whig ministry that he was impeached and, despite his skilful defence and the encouragement of a yelling crowd of supporters outside, was suspended from preaching for three years. At the end of this time the government had changed, Sacheverell was invited to speak before the House of Commons and became rector of St Andrew's, Holborn, where he is buried. Quarrels with parishioners and Jacobite intrigues occupied his remaining years.

Holmes, G., The Trial of Doctor Sacheverell.1973.

Sachs, Hans (1494-1576). German poet and Meistersinger. A shoemaker by trade, he became a 'master singer' in the Nuremberg guild (1517), wrote more than 4,000 'master songs' and led the guild from 1554. An enthusiastic Lutheran, he is the central figure in *Wagner's opera, Die Meistersinger von Nürnberg (1868).

Sacks, Oliver Wolf (1933-2015). British writer and neurologist. Educated at Oxford, he worked in the US from 1962 and wrote a series of successful books about neurological conditions and treatment, including Migraine (1970), Awakenings (1973, also filmed), The Man who Mistook his Wife for a Hat (1985, also an opera) and Seeing Voices: a Journey into the World of the Deaf (1989). Uncle Tungsten (2001) is a memoir of boyhood.

Sackville-West, Victoria Mary ('Vita') (18921962). English poet, novelist and gardener, born in Knole, Kent. Daughter of 3rd Baron Sackville, she was largely educated at home. She married (1913) Sir Harold *Nicolson, and was the lover of Virginia *Woolf. In Knole and the Sackvilles (1922) she described her family's historic home, and set her novel The Elizabethans (1930) there. Her long poem The Land (1927) won the Hawthornden Prize. Best remembered as a gardener, especially at Sissinghurst Castle, Kent, she received a CH in 1948.

Sadat, Mohamed Anwar el (1918-1981). Egyptian soldier. He was commissioned in 1938, rising to the rank of colonel. He took part in the army officers' 
coup of 1952 which deposed King Farouk and was Minister of State 1955-56, Speaker of the United Arab Republic National Assembly 1961-69 and Member of the Presidential Council 1962-64. Vice President of Egypt 1964-66 and again in 1969, he was elected President in October 1970. Particularly noted for his initiative in going to Israel for peace talks in November 1977, his action put an end to a longstanding policy of Israeli-Egyptian confrontation. A peace treaty was finally signed in 1979. He shared the Nobel Prize for Peace with Prime Minister Begin in 1978. He was assassinated by dissident officers.

Sadat, M. A. el, In Search of Identity. 1978.

Saddam Hussein (1937-2006). Iraqi politician, born in Tikrit. Educated in Baghdad and Cairo, he was a militant in the Arab Ba'h Socialist Party and was twice exiled. In 1968, the Ba'athists seized power, Ahmed Hassan al-Bakr (1914-1982) became President of Iraq 1968-79, and Saddam, Deputy Chair of the Revolutionary Command Council, was Vice President 1968-79. Saddam pushed the ailing al-Bakr to resign and as President of Iraq and Commander-in-Chief of the Iraqi armed forces 1979-2003, he exercised absolute power. Secular Iraq was at war with Islamic fundamentalist Iran 1980-88 and both sides received material aid from the US. He suppressed minorities, especially the Kurds. In August 1990 Iraq occupied Kuwait and this led to the formation of an international coalition organised by President *Bush under UN auspices, which imposed economic sanctions and resulted in military invasion. The Iraqi forces were heavily defeated by 'Operation Desert Storm' in the Gulf War in February 1991. Saddam was forced to give up Kuwait but he remained in power, still a popular hero. UN forces resumed air attacks in January 1993. Saddam's failure to open up weapons storage sites to UN inspectors led to threats of US air attacks (February-March 1998), a situation averted by a settlement negotiated by the UN Secretary-General Kofi *Annan. In December 1998 after Saddam's refusal to cooperate with UN arms inspectors, the US and UK launched four days of attack on Baghdad: this merely consolidated his position. The US led a 'coalition of the willing' against Iraq, claiming that 'weapons of mass destruction' posed a serious threat to world peace. Iraq was occupied in April 2003 after 28 days of fighting, but continuous acts of violence continued. Saddam disappeared but was found near Tikrit in December 2003, and his trial for the murder of Shi'ites in 1982 began in November 2005. After an appeal court upheld his death sentence, Saddam was speedily hanged in Baghdad.

Sade, Donatien Alphonse François, Marquis de (1740-1814). French author. He fought in the Seven Years' War, and was imprisoned many times for crimes of wanton cruelty (hence the word 'sadism'). To avoid a death penalty he lived for a time in Italy but returned (1777) and was again imprisoned. Released in 1791, he began to publish a number of 'novels' (e.g. Justine) which are in part sexual fantasy, in part pseudo-philosophical attempts to justify his vices. He also wrote a melodrama, Otiern. He was confined on the orders of ${ }^{*}$ Napoléon in a criminal lunatic asylum where he died.

Gorer, G., The Life and Ideas of the Marquis de Sade. 1963.

Sa'di (or Saadi) (Abū-Muhammad Muslih al-Dīn bin Abdallāh Shīrāzī) (1210-1291). Persian poet, born and lived in Shiraz. His many books are concerned with morals and ethics and his long poem Bustan, and Gulistan, a miscellany in verse and prose, are still highly regarded and used as models of style in Iranian schools.

Safdie, Moshe (1938- ). Canadian architect, born in Israel. He worked with Louis *Kahn, created the controversial Habitat ' 67 for the Montréal Expo, and taught urban design at Harvard 1978-89. Other buildings included the National Gallery of Canada, Ottawa, the Toronto Ballet and the Museum of Civilisation, Québec.

Sagan (originally Quoirez), Françoise (1935-2004). French novelist. Her books, Bonjour Tristesse (1954) and Aimez-vous Brahms? (1959), probe with frankness and subtlety the sexual relationships of sophisticated youth in her social environment and achieved immense contemporary success. Later novels had less impact. She also wrote the plays Chateau en Suede (1960), Les Violons, parfois (1961) and Un piano dans l'herbe (1970).

Said, Edward Wadie (1935-2003). AmericanPalestinian academic and critic, born in Jerusalem. Educated at Princeton and Harvard, he became professor of English and comparative literature at Columbia University 1977-2003. His book Orientalism (1978) was enormously influential, and Said was identified (and attacked) as a pioneer of multiculturalism and the post-structural Left. A strong advocate for Palestinian statehood, he broke with Yasser *Arafat, and worked on cultural causes with Daniel *Barenboim.

Saigo Takamori (1827-1877). Japanese field marshal. A samurai from Satsuma, he was a notable warrior, famous for his bravery and height $(1.8 \mathrm{~m})$, who led imperial troops in the final overthrow of the shogunate. He urged invasion of Korea (1873) and resigned in a fury when his plans were rejected. He led the Satsuma revolt (January-September 1877) against foreign influence and the adoption of western technologies during the Meiji restoration, but was defeated by a conscript peasant army. Wounded in battle, he asked a friend to behead him. Japanese militarists in the 1930s regarded him as a hero.

Morris, I., The Nobility of Failure. 1980. 
Sainsbury. English retailing dynasty. John James Sainsbury (1844-1928), a London grocer, began a chain of stores that expanded throughout Britain. Family members became active in philanthropy, politics and support for the arts, science and mental health. There were three life peers (two Labour, one Tory); the Sainsbury Wing at the National Gallery, London; the Sainsbury Institute for Art in East Anglia; a Sainsbury Laboratory in Cambridge.

Saint Arnaud, Jacques Leroy de (1796-1854). French soldier. After achieving a high reputation in Algeria, he was created a marshal for helping to effect the coup d'état by which *Napoléon III became Emperor. He commanded French troops cooperating with the British in the Crimean War and took part in the Battle of the Alma. He died nine days later.

Saint-Beuve, Charles Augustin (1804-1869). French critic. After studying medicine he took to journalism and joined the group of Romantic writers of whom Victor *Hugo was the centre. Successful neither with his own poems nor a self-analytical novel, Volupté (1835), he turned to criticism, an art form much more suited to his natural scepticism. In a long series of critical studies beginning with Portraits littéraires (1832-39) and Portraits le femmes (1844), he arrived at his literary verdicts by identifying himself with the writers concerned, aided in this by his medical knowledge, psychological insight and analytical mind. His thoroughness is shown in his vast Histoire de Port Royal (1840-60) which, in order to explain the characters and background of the learned members of this headquarters of Jansenism, includes a series of vivid portraits of such great 17th-century figures as ${ }^{*}$ Corneille, ${ }^{*}$ Molière, ${ }^{*}$ Racine. After the revolution of 1848, Sainte-Beuve withdrew for a time to Belgium, but soon returned and became reconciled with the new regime. He was given teaching posts at the Collège de France and the École Normale Supérieure and, with a critical article produced regularly week after week, became one of the great literary figures of the Second Empire, and is considered one of the greatest critics.

Lehmann, A. G., Sainte-Beuve: a Portrait of the Critic 1804-1842. 1962.

Saint-Evremond, Charles de Saint-Denis de (16161703). French critic and essayist. Having offended *Mazarin by incautious criticism, he was imprisoned in the Bastille and later took refuge first in Holland and then in England where he spent the rest of his life except for a five-year interval following a flight from the plague of 1665 . From 1675 he was in devoted attendance upon Hortense, Duchesse de Mazarin, who had also fled from her uncle's displeasure. He kept in close touch with Paris, and the essays and correspondence of this wise and witty observer of the literary and political scene long remained popular. He was buried in Westminster Abbey.
Saint-Exupéry, Antoine Marie Roger de (19001944). French aviator and writer. He became a pilot in 1926, pioneered several commercial air routes, and despite his age flew for the French Air Force in World War II. He disappeared on a reconnaissance flight over the Mediterranean. Flying had always fascinated him, and he conveyed the rare sense of exaltation he derived from flying in books such as Vol de nuit (1931) and Pilote de guerre (1942). In this way he inspired a whole generation of flyers. Thought and fantasy make a successful blend in his children's story Le Petit Prince (1943).

Saint-Gaudens, Augustus (1848-1907). American sculptor, born in Dublin. Of French-Irish parentage, he settled in New York in 1875 and was highly praised for his memorials (*Lincoln, *Sherman, Mrs Henry *Adams, ${ }^{*}$ Farragut) and coin designs.

Saint-Just, Louis Antoine Lon de (1767-1794). French revolutionary. One of the most implacable of the extremist section, he voted for the death of *Louis XVI, and later turned against the Girondins. He was a member of the Committee of Public Safety, and a follower and friend of ${ }^{*}$ Robespierre, whose downfall he shared, being executed two days after his leader.

Curtis, E. N., Saint-Just, Colleague of Robespierre. 1955; Soboul, A., Proceedings de Saint-Just Symposium. 1968.

Saint Laurent, Yves (Henri Donat) (1936-2008). French couturier, born in Algeria. He worked for and succeeded Christian ${ }^{*}$ Dior as the dominant figure in French fashion, and also manufactured shirts, ties and stockings. He designed stage sets and costumes for films (e.g. Belle de Jour, 1967), ballets and plays.

St Laurent, Louis Stephen (1882-1973). Canadian lawyer and Liberal politician, born in Quebec. After a distinguished career as a lawyer and academic, he was recruited into government by his friend Mackenzie *King as Minister for Justice 1941-46, then succeeded King as Secretary of State for External Affairs 1946-48. As King's preferred successor, St Laurent became the Liberal Party Leader and Prime Minister 1948-57. His government was heavily defeated by ${ }^{*}$ Diefenbaker's Progressive Conservatives in 1957.

Saint-Pierre, Charles-Irénée Castel, Abbé de (1658-1743). French political theorist. Son of the Marquis de Saint-Pierre, he became a priest and was a significant influence on the Enlightenment, especially on ${ }^{*}$ Rousseau and ${ }^{*}$ Kant. He proposed an international court, free education for boys and girls, a progressive income tax, constitutional monarchy, and a European union. He wrote Project pour rendre la paix perpétuelle en Europe (1713).

Saint-Saëns, (Charles) Camille (1835-1921). French composer, pianist and organist, born in Paris. An infant prodigy, he first attracted recognition as a pianist, playing all *Mozart's concertos and *Beethoven's 
sonatas. *Liszt praised him, especially as an organist, and he played at the Madeleine Church 1857-77. He studied composition with Halévy at the Paris Conservatoire and was also an accomplished writer, linguist and amateur scientist. He promoted the music of ${ }^{*}$ Bach, ${ }^{*}$ Mozart and *Wagner, and toured extensively, visiting Russia, the US, Argentina, Brazil, Uruguay and Algeria. Of his 13 operas only Samson et Dalila (1877) remains in the repertoire, of five symphonies (only three of them numbered), the 'Organ' symphony No. 3 (1886) is often played and recorded. His best known work, Le carnaval des animaux (1886), a brilliant set of parodies, was not performed until 1922, at his direction, except for 'The Swan'. He also composed five piano, three violin and two cello concertos, Marche heroique (1871), Le rouet d'Omphale (1872) and Danse macabre (1875). He taught *Fauré and was a contemptuous antagonist of *Debussy and *Stravinsky.

Saint-Simon, Claude Henri, Comte de (17601825). French social philosopher. Belonging to the same family as the Duc de ${ }^{*}$ Saint-Simon, he fought in the American War of Independence, but during the French Revolution was suspected an aristocrat and briefly imprisoned though he resigned his title. His 'experiments in living', undertaken to prepare him for his task as a social philosopher reduced him to poverty, but his self-confidence was unbounded, as was shown by his unsuccessful proposal to Madame de * Staël on the grounds that the marriage of two such remarkable people would produce an even more remarkable child. His thought was revealed in such books as Du Systeme industriel (1821) and the more important Nouveau Christianisme (1825). The latter contained his fundamental precept, which was the Christian 'Love one another'. This was to be put into practice by reorganising society so that it should be controlled by industrial chiefs instead of military or feudal leaders and by scientists instead of priests. His ideas were, however, diffuse and vague and SaintSimon can be described as the 'founder of socialism' only through the activities of his followers and his influence on such thinkers as ${ }^{*}$ Comte.

Booth, A. J., Saint-Simon and Saint-Simonism. 1971.

Saint-Simon, Louis de Rouvroy, Duc de (16771755). French writer of memoirs. Having resigned a commission in the King's Musketeers because of his failure to gain promotion, he attended court and from 1710 to 1723 he lived at Versailles, an embittered observer of a way of life he shared but affected to despise. After the death of *Louis XIV (1715) he was a member of the regency council but never played an effective political role. His fame rests on his posthumously published Memoires which he began to write in their final form in 1740 . With malice and prejudice but with unique powers of memory and observation he recalls quarrels, love affairs, intrigues, dress, mannerisms and personal foibles with an authenticity and minuteness of detail seldom if ever equalled in descriptions of court life.
St Vincent, 1st Earl of, John Jervis (1735-1823). English admiral of the fleet. He served with *Wolfe in Québec and in the West Indies during the Seven Years' War (1756-63). MP 1783-94, he was Commander-in-Chief of the Mediterranean Fleet 1795-99, and, with *Nelson's support he defeated the Spanish fleet at Cape St Vincent (the southwest extremity of Portugal) in February 1797 and was created earl. A moderate reformer, he was First Lord of the Admiralty 1801-04.

Sakharov, Andrei Dimitrievich (1921-1989). Russian nuclear physicist. A pupil of Pyotr *Kapitza and Igor Tamm, he gained his PhD for work on cosmic rays and led research on hydrogen fusion, playing a decisive role in creating the hydrogen bomb (1953). After 1958 he campaigned against nuclear proliferation, calling for Soviet-American friendship and a convergence of capitalism and Communism in his Progress, Co-existence and Intellectual Freedom (1968). In 1970 he founded the Committee for Human Rights. He was awarded the Nobel Prize for Peace in 1975. In 1980 he was exiled to Gorky and kept under police surveillance. Reports of his failing health led to international concern about his welfare. In December $1986{ }^{*}$ Gorbachev allowed him to return to Moscow. He became the leader of the democratic movement in the USSR and was elected to the Congress of Peoples' Deputies in 1989, where he exerted an immense moral and intellectual influence. Within 11 months, at the height of his influence, he was dead.

Saki (pen name of Hector Hugo Munro) (18701916). Scottish author, born in Burma. Son of a colonial inspector-general of police, about 1900 he started in journalism in London as a political satirist on the Westminster Gazette and was the Morning Post correspondent in Russia and France (1902-08). The first of the volumes of fantastic, elegant and witty short stories for which he became famous was published in 1904 under his pseudonym and in 1912 appeared his novel The Unbearable Bassington. Interest in his work was later revived by television versions of many of his stories and a collected edition of his works (1963). He was killed in France during World War I.

Saladin (Salahal Din Yusuf ibn Ayyub) (11371193). Sultan of Egypt and Syria 1174-93. Born in Mesopotamia of Kurdish origin, he succeeded his uncle as Vizier of Egypt (1169). In 1171 the Caliph of the Fatimid dynasty in Egypt died. No successor was appointed and in 1174 Saladin was confirmed as Sultan of Egypt and Syria by the Caliph of Baghdad. He consolidated his hold over Syria, and conquered Mesopotamia (1180). He ruled his new empire from Damascus and in 1187 invaded the Christian kingdom of Jerusalem. The fall of the city provoked the 3rd Crusade, during which *Richard Coeur de Lion won back the coastal towns from Acre to Jaffa. Saladin retained Jerusalem but allowed 
pilgrims access. His chivalry was much admired by the Crusaders and he was a just and efficient ruler as well as a fine soldier. He built many roads and canals.

Salam, Abdus (1926-1996). Pakistani physicist. He was a pioneer in the study of superfields and directed the International Centre for Physics, Trieste, 1964-93. He shared the 1979 Nobel Prize for Physics for attempting to reconcile the weak and electromagnetic interactions in elementary particles. He won the Copley Medal in 1990.

Salazar, António de Oliveira (1889-1970). Portuguese economist and dictator. Originally trained for the Church, he became professor of economics at Coimbra University 1916-28, and became General *Carmona's Minister for Finance 1926; 1928-40. Prime Minister 1932-68, in 1933 he installed a corporatist regime, Estado Novo ('New State'), analogous to Austrian fascism, which held power until overthrown in 1974.

Conservative and nationalist, Salazar rejected political parties, parliament and popular democracy, suppressed opposition, relied on support from the church and the army but kept both at distance. He eschewed a cult of personality. He supported *Franco during the Spanish Civil War but regarded *Hitler and ${ }^{*}$ Mussolini as 'pagan Caesars', kept Portugal neutral during World War II, enabled refugees to escape from Europe and permitted Britain to use facilities in the Azores. He brought Portugal into NATO, the OECD and GATT. In 1968 he suffered a stroke in his bath and was apparently unaware that he was no longer premier at the time of his death in 1970 .

Salieri, Antonio (1750-1825). Italian composer, born near Verona. A protégé of ${ }^{*}$ Gluck, he served as court composer to the Habsburg emperors from 1774-88 (when *Mozart was a young rival) and music director 1788-1824. He composed 42 operas, instrumental, orchestral and sacred music. Suggestions that he poisoned Mozart, the basis of a dramatic poem (1830) by *Pushkin and an opera by ${ }^{*}$ Rimsky-Korsakov, were revived in Peter ${ }^{*}$ Shaffer's play Amadeus (1979): the poisoning was almost certainly metaphorical. Salieri was a friend of *Haydn and teacher of ${ }^{*}$ Beethoven, ${ }^{*}$ Schubert and ${ }^{*}$ Liszt.

Salinas de Gortari, Carlos (1948- ). Mexican politician. Educated at the National University of Mexico and Harvard, he became a statistician, entered the Department of Finance and became its DirectorGeneral 1978-79. He directed economic and social policy in the Budget Ministry 1979-81 and was Minister for Planning and Federal Budget 1982-87. Selected as the Party of Revolutionary Institutions (PRI) candidate in 1987, he was elected narrowly as President of Mexico and served 1988-94. He concluded the North American Free Trade Agreement (NAFTA) with the US and Canada in 1992. In 1995 he went into exile in the US after his brother Raul was charged with assassinating a party official.
Salinger, J(erome) D(avid) (1919-2010). American writer. He won acclaim with his novel The Catcher in the Rye (1951), the acutely observed story of a boy's teenage problems. Franny and Zooey (1961) and his short stories continued to deal with the subject of adolescents' ways of seeing and problems.

Hamilton, I., In Search of J.D. Salinger. 1986; Beller, T., J. D. Salinger. The Escape Artist. 2014.

Salisbury, 1st Earl of, Robert Cecil (1563-1632). English statesman, born in Westminster. Son of William Cecil, Baron *Burleigh, and a cousin of Francis *Bacon, he was briefly educated in Cambridge and the Sorbonne and became a silent MP. Appointed as Secretary of State 1596-1612 by Queen *Elizabeth, he succeeded his father as Lord Privy Seal 1598-1608. He dealt successfully with the rebellion of ${ }^{*}$ Essex but was increasingly occupied with the intrigues by which he secured the succession of the Scottish James VI as *James I of England. Not unnaturally, he was retained in office (as Lord Treasurer from 1608). He discovered the Gunpowder Plot and was largely responsible for the downfall of Sir Walter ${ }^{*}$ Raleigh, whose bellicose attitude towards Spain conflicted with his own pacific policy. Salisbury showed wisdom and moderation as a ruler but lacked his father's personality and was extremely conscious of the spinal deformity (scoliosis) that gave him a dwarflike appearance. He was created Baron Cecil (1603), Viscount Cranbourne (1604) and Earl of Salisbury (1605). He devoted much time to the building and adorning of Hatfield House, Hertfordshire, still the family's palatial seat.

Salisbury, 3rd Marquess of, Robert Arthur Talbot Gascoyne-Cecil (1830-1903). English Conservative politician, born in Hatfield, Hertfordshire. After an unhappy childhood, he attended Eton and Oxford, left early and visited South Africa, Australia and New Zealand 1851-52. A Member of Parliament 1853-68 (as Viscount Cranbourne), he served as Secretary of State for India 1866-67, 1874-78 and Chancellor of Oxford University 1869-1903. Foreign Secretary for 12 years $1878-80,1885-86,1886-92,1895-$ 1900 , he found this office very congenial. He went with *Disraeli to the Congress of Berlin where he revealed an independent mind unhampered by party shibboleths. He served three terms as Prime Minister June 1885-January 1886, July 1886-August 1892, June 1895-July 1902, a total of nearly 14 years. He declined Queen *Victoria's offers of a dukedom in 1886 and 1892. He was mainly concerned with agreements that secured peace in Egypt and the Mediterranean lands, and with the problems of African partition. He worked closely with *Bismarck but refused an alliance. He was a keen amateur botanist and astronomer, bored with the routine of politics, and was deeply anti-democratic. He allowed his ministers to retain involvement in business, despite conflict of interest, and the 'spoils system' was applied in judicial and imperial appointments and 
honours. He was succeeded as Conservative leader and Prime Minister by his nephew Arthur *Balfour. So many family members were accommodated in government that the term 'Hotel Cecil' was applied as a sneer. His successors in the marquessate and his younger sons, Robert (Viscount ${ }^{*}$ Cecil of Chelwood) and Hugh (Lord Quickswood), were all politically prominent.

Kennedy, A. L., Salisbury, 1830-1903. Portrait of a Statesman. 1953; Roberts, A., Salisbury: Victorian Titan. 1999.

Salk, Jonas Edward (1914-1995). American virologist and bacteriologist, born in New York. Graduate of CCNY and NYU, he was a consultant on epidemic diseases during World War II and held a series of professorships at the University of Pittsburgh 1947-63. He produced the first successful vaccine again poliomyelitis (1954) but refused to patent it. The Salk vaccine was speedily adopted throughout the world. In 1963 he founded the Salk Institute for Biological Studies at La Jolla, California, which he directed until 1975. In 1970 he married the painter Françoise *Gilot. Awarded the Lasker Medal (1956) and the Presidential Medal of Freedom (1977), oddly, he was never nominated for a Nobel Prize.

Sallust (Gaius Sallustius Crispus) (86-35/6 BCE). Roman historian. Having served under ${ }^{*}$ Caesar and enriched himself as a proconsul in north Africa, he bought ${ }^{*}$ Caesar's villa at Tivoli, there built the famous 'Sallustian gardens' and settled down to write histories of the Catiline conspiracy and the Jugurthine wars as well as the more general Histories, of which only fragments survive.

Syme, R., Sallust. 1964.

Salmond, Alex(ander Elliot Anderson) (1954- ). Scottish Nationalist politician, born in Linlithgow. MP (United Kingdom) 1987-2010; 2015-17, he led the Scottish National Party (SNP) 19902000, 2004-14. He was First Minister of Scotland 2007-14, resigning after a referendum on Scottish independence was defeated.

Salomé, Lou(ise) Andreas- (or Luíza Gustavovna Salomé) (1861-1937). Russian psychoanalyst, writer and fascinator, born in St Petersburg. Daughter of a general, her ancestry was French and German. She studied in Zürich, was twice proposed to by ${ }^{*}$ Nietzsche, became the lover and muse of ${ }^{*}$ Rilke, had a close relationship with ${ }^{*}$ Freud and, from 1887 , a celibate marriage to the linguist Carl Friedrich Andreas. She wrote studies on *Ibsen, Nietzsche and Rilke, many novels, pioneered the study of female sexuality and appeared as a character in plays, films and an opera.

Astor, D., Lou Andreas-Salomé, 2008; Vickers, J., Lou von Salomé. 2008.
Salomon, Johann Peter (1745-1815). German impresario, violinist and composer. A friend of C.P.E. ${ }^{*}$ Bach, he lived in London from 1781, gave solo concerts, conducted, brought ${ }^{*}$ Haydn to England for two successful seasons and was dedicatee of his Symphonies Nos 93-104.

Samaranch Torello, Juan Antonio (1920-2010). Spanish diplomat, born in Barcelona. He was Ambassador to the USSR 1977-80, President of the International Olympic Committee 1980-2001 and was created a marquess in 1991.

Samson (Shimshon) (fl. 11th century BCE?). Hebrew hero. From the tribe of Dan, he was one of the 'judges' of Israel and probably an authentic hero of the war against the Philistines. The Bible tells how he was charmed by the Philistine Delilah to reveal that the secret of his strength lay in the flowing locks on one who had taken the Nazarite vow. She cut off his hair, and thus weakened, he was captured, blinded and taken to Gaza, where, with a last effort of renewed strength, he pulled down the supporting pillars of the temple, killing both himself and his enemies. *Milton's Samson Agonistes is a poetic reconstruction of the tale.

Samuel (Shmu'el) (fl. 1040 BCE). Hebrew prophet. The last of the Hebrew 'judges' and the first of the prophets, when the people were attacked by the Philistines, inspired by God and yielding to the persuasions of the people, he anointed *Saul as the first king of Israel and Judah, but later broke with him and chose ${ }^{*}$ David as his successor.

Hertzberg, H. W., I and II Samuel: A Commentary. 1964.

Samuel, Herbert Louis Samuel, 1st Viscount (1870 1963). English-Jewish politician and administrator, born in Liverpool. Educated at Oxford, he became a Liberal MP 1902-18, 1929-35, served as a minister under ${ }^{*}$ Campbell-Bannerman and ${ }^{*}$ Asquith, was Home Secretary 1916 but resigned when *Lloyd George became Prime Minister. After World War I, he became the first British High Commissioner to Palestine 1920-25, Leader of the Liberal Party 1931-35 and again Home Secretary 1931-32 in the National Coalition. He wrote on philosophic and autobiographical themes, including In Search of Reality (1957), and received the OM in 1958.

Samuelson, Paul Anthony (1915-2009). American economist. Educated at Chicago and Harvard, he was a professor of economics at the Massachusetts Institute of Technology 1940, a proponent of *Keynes' ideas during wartime government work and wrote a standard text Economics (1948), which has remained in print. He advised the *Kennedy and *Johnson administrations and won the 1970 Nobel Prize for Economics. 
Sancroft, William (1617-1693). English prelate, born in Suffolk. After living abroad during the Commonwealth period he returned at the Restoration and rose quickly in the Church to become Dean of York and (1664) of St Paul's, and (1678) Archbishop of Canterbury. The same out-spokenness which he is said to have used at *Charles II's deathbed marked the dealings of this robust Tory High Churchman with later monarchs. He was the leader of the seven bishops tried by order of *James II for presenting a petition against having to read out publicly the Declaration of Indulgence, their acquittal being regarded as the starting point of the Glorious Revolution. However, having taken an oath of allegiance to James, Sancroft refused one to ${ }^{*}$ William and ${ }^{*}$ Mary. He was therefore deprived of his see and ejected from Lambeth Palace. He retired to the Suffolk village of his birth.

Sand, George (Aurore-Lucile Dupin) (1804-1876). French novelist, born in Paris. She was brought up by her grandmother, an illegitimate daughter of Marshal de Saxe, at the château de Nohant, in the province of Berry; it is now a museum maintained in her memory. She grew up with feminist views, an independent mind and a romantic disposition. After an incompatible marriage to Baron Dudevant, she went to Paris (1831) where she lived with Jules Sandeau, from whose name her pseudonym was derived. Her novels tended to be linked with the circumstances of her life: Indiana (1832) glorifies free love, Elle et lui (1859) and Lélia (1833) relate to her love affair with ${ }^{*}$ Musset; her socialism inspired other novels. Meanwhile her search for the perfect lover went on but she could offer only an excess of sentiment or maternal care for the passion demanded. Her love affair with the exiled and ill ${ }^{*}$ Chopin $(1838-47)$ was the nearest to her needs but even that progressed with bickering and ended with bitterness. The château at Nohant was her most constant and abiding love and there, after 1848, she retired to write rustic novels, e.g. La Mare au Diable (1846), and to show in her Histoire de ma vie (20 volumes, 1855) and her Correspondance (1882 and 1904) that her own life and character were more interesting than anything she could invent.

Cate, C., George Sand: A Biography. 1975.

Sandburg, Carl (1878-1967). American writer, born in Galesburg, Illinois. He led a wandering life collecting folksongs and ballads, and writing his own poems in the idiom of the country people he met. His collecting produced, e.g. The American Songbag (1927). His own verse is in such books as Smoke and Steel. His most ambitious enterprise was a four-volume biography of Abraham Lincoln (1926-42) which won the 1940 Pulitzer Prize for history. His Collected Poems won the 1951 Pulitzer Prize for poetry.

Sanders, Bernie (Bernard) (1941- ). American politician, born in Brooklyn. His father migrated from Poland in 1921 and his mother was of Russian-
Chicago, he moved to Vermont in 1968 , had a variety of jobs, including carpenter and film maker, and was Mayor of Burlington 1981-89. US Congressman 1991-2007 and Senator from Vermont 2007-, he contested the Democratic nomination for president against Hillary *Clinton in 2015-16. In 2020 he was a major contender for the Democratic nomination, identified himself as a 'socialist', but after polling strongly in early primaries fell behind Joe *Biden and withdrew in April.

Sandwich, John Montagu, 4th Earl of (17181792). English politician. Despite notorious profligacy he held several ministerial posts during an undistinguished career, including terms as First Lord of the Admiralty 1748-51, 1763 and 1771-82. The Sandwich Islands (now Hawaii) were named after him by Captain ${ }^{*}$ Cook. He is best known for inventing the sandwich to enable him to eat without interrupting his play at cards.

Sanger, Fred(erick) (1918-2013). English biochemist, born in Gloucestershire. A Quaker and pacifist, educated at St John's College, Cambridge, he worked at the Medical Research Council's Laboratory of Molecular Biology, Cambridge 1951-83. He won two Nobel Prizes in Chemistry: in 1958, for determining the first complete structure and the amino-acid sequencing of a protein (bovine insulin); in 1980, sharing the award for work on determining the chemical structures of elements in DNA. He was awarded the Copley Medal (1977), the CH (1981) and the OM (1986).

Brownlee, G. G., Fred Sanger: Double Nobel Laureate. 2020.

Sanger, Margaret (née Higgins) (1883-1966). American birth control advocate. Born to a large family, she worked as a teacher, nurse and set up the first US birth control clinic in Brooklyn (1916). She founded the American Birth Control League in 1921 and organised the first World Population Conference in Geneva in 1927. She also advocated more passionate and enjoyable sex and her lovers included H. G. *Wells and Havelock *Ellis.

San Martín, José de (1778-1850). Soldier, born in Yapeyù (Argentina). Having returned to Spain with his parents from South America as a child, he served with the Spanish army in the Peninsular War but in 1812 again crossed the Atlantic and volunteered his services to the revolutionary government of Buenos Aires. In 1816, independence was declared with his support. Regarding the whole of Spanish America as a single country he enlarged the area of independence by a daring march over the Andes, by passes across four cordilleras up to 4,000 metres high, into Chile; the Spaniards were defeated at Chacabuco, and Santiago occupied. Chileans and Argentineans, helped by a naval contingent under *Cochrane, now combined to liberate Peru. San Martin occupied 
Lima (1812) and declared himself 'protector', but the interior was still in Spanish hands while *Bolívar had reached Ecuador. The two 'liberators' met but, as they were unable to agree, San Martin with characteristic self-denial withdrew. He left South America (1824) and died in poverty and exile at Boulogne. He was buried in Buenos Aires.

Santa Anna, Antonio López de (in full, Antonio de Padua María Severino López de Santa Anna y Pérez de Lebrón) (1794-1876). Mexican soldier and politician. Having helped to overthrow * Iturbide he led a successful Liberal revolution in 1828 . He forced the surrender of a Spanish expedition sent to recover Mexico. He held the office of President of Mexico 11 times between 1833 and 1855, but his exercise of power was erratic and after a few months he would retire to the country. Originally a liberal, he became conservative and gained support from both the church and army. His victory over the Texans at the Alamo in March 1836 was soon followed by defeat by Sam *Houston. Victory over a French debt-collecting expedition (1838) made him again a popular hero. Another period of dictatorship (1841-46) was followed by exile, but he returned to lead the Mexicans to defeat against the US (1847-48). In 1853, he was again dictator, but was overthrown again in 1855. After many years in exile in Cuba and the United States, where he tried to promote cockfighting and chiclets (the basis of chewing gum), he was amnestied (1874), old, crippled and nearly blind.

Santamaria, B(artholomew) A(ugustine) ('Bob') (1915-1998). Australian political activist, born in Melbourne. He worked for the Catholic Rural Movement, founded the National Civic Council, campaigned passionately against Communist influence in trade unions and was a major figure in the Labor split (1954-55) which kept the ALP out of office nationally until 1972 (*Whitlam) and in Victoria until 1982. He encouraged Catholics to become active in the Liberal and National parties and was an effective publicist on television and in print.

Henderson, G., Santamaria: A Most Unusual Man. 2014.

Santayana, George (Jorge Agustín Nicolás Ruiz de Santayana y Borrás) (1863-1952). Spanish philosopher, novelist, essayist and poet, born in Madrid. He lived in the US 1872-1912, studied at Harvard, Berlin and Cambridge, and taught philosophy at Harvard 1889-1912, where his students included Robert *Frost, Gertrude *Stein, Felix *Frankfurter and T. S. *Eliot. He never became a US citizen, left in 1912 and never returned, living first in England, then, from 1924, in Rome. In his philosophy he was sceptical about proving the existence of matter or indeed anything, and suggested that ordinary beliefs derive from 'animal faith'. His view of the world was thus a species of naturalism. He also accepted, in a somewhat poetic way, the existence of a realm of universals or essences similar to the 'forms' of *Plato. His philosophical ideas are contained in The Life of Reason (5 volumes, 1905-06), Scepticism and Animal Faith (1923) and the 'realm' series, The Realm of Essence (1927), ... of Matter (1938) and ... of Spirit (1940). His more general books include Sense of Beauty (1896), a novel, The Last Puritan (1936), two volumes of poetry and autobiographical works. All reveal the author's wisdom and cultivated wit.

Cory, D., Santayana: The Later Years. 1963.

Santos-Dumont, Alberto (1873-1932). Brazilian aviation pioneer, born in Palmira, Minas Gerais. The son of a rich coffee producer, after building balloons and airships in France he experimented with aeroplanes and became the first man to fly one in France (1906). He campaigned for the creation of the Iguaçu National Park (1916). He committed suicide (or was murdered) in Sao Paolo. His birthplace was renamed for him.

Sappho (b.c.600 BCE). Greek poet. Born in Lesbos where she spent most of her life, her poems, with one or two exceptions, survive only in fragments. Passionate, graceful and intensely personal, they are mostly addressed to a group of young women, perhaps fellow devotees of the love goddess Aphrodite. She was married and had at least one daughter. Enough remains of her work to support the belief of the ancients that she was the greatest poetess of their time.

Saragat, Giuseppe (1898-1988). Italian Socialist politician. He led a minority group of Socialists that broke away from ${ }^{*}$ Nenni's leadership in protest against the alliance with the Communists. He founded (1947) the Social Democratic party, which entered into coalition with the Christian Democrats. Deputy Premier 1947-49 and 1954-57, he was President of Italy 1964-71.

Saramago, José (1922-2010). Portuguese novelist. He won the Nobel Prize for Literature in 1998, the first awarded to a writer in Portuguese.

Sarasate (y Navascues), Pablo Martin Meliton (18441908). Spanish violinist and composer. A brilliant player in the *Paganini tradition, he wrote many works that have remained in the repertoire, including Zigeunerweisen (1878) and The Carmen Fantasy (1883).

Sarasvati, Dayanand (1820-1883). Indian religious reformer. He founded (1875) an association called the Arya-Samaj which claimed for all Hindu castes the right to study the Vedas. The many adherents of the society form one of the most progressive elements of modern Hinduism.

Sardou, Victorien (1831-1908). French writer. The most successful playwright of his day, for 40 years from 1860, when he was first acclaimed, he produced success after success, the result not only of his superb 
technique but of his gift for creating parts specially adapted to the particular talents of the great players of his time. Thus the title roles of Fedora (1882), La Tosca (1887) and Cismonda (1894) were created for Sarah *Bernhardt and the comedy Madame Sans Gene (1893) was written for *Réjane. He also wrote for *Irving and others. His plays now seem artificial, and revivals are rare.

Sargent, John Singer (1856-1925). American artist, born in Florence. He studied painting there and in Paris, moved to England (1884) and soon won great success as a fashionable portrait painter. If his work sometimes seems too facile, he showed at his best a brilliant technique (e.g. in evoking the shimmer of satin) modelled on that of *Velázquez, and an eye for character, at times too penetrating for the comfort of his sitters (e.g. the Wertheimer portraits at the Tate Gallery, London). In America he worked on a series of decorative paintings for public buildings, including the Evolution of Religion for the Boston Library.

Olson, S., John Singer Sargent. 1986.

Sargent, Sir (Harold) Malcolm (Watts) (1895-1967). English orchestral conductor. Trained as an organist and composer, he was Chief Conductor of the Royal Choral Society from 1928, conducted concerts for children sponsored by Robert *Mayer, and became Musical Director of the Hallé Orchestra 1939-42, the Liverpool Philharmonic 1942-49 and the BBC Symphony 1950-57. He conducted the London Proms with great success, recorded many choral works and became an accomplished broadcaster.

Sargon I (or Šarru-ukīn) of Akkad (d.c.2284 BCE). King of the Akkadian Empire c.2334-2284 BCE. His origins were mysterious: found in bulrushes (like Moses) and raised by a gardener, he became a cupbearer to the king of Kish, whose successor Lugal-zage-si he deposed. With its capital at Akkad, his kingdom, by conquest, included all of Sumeria, extending to the edge of Arabia, Syria and Anatolia. Sargon is referred to in Isaiah 20:1.

Sargon II (d.705 BCE). King of Assyria 722-705 BCE. He inaugurated a period of great expansion by conquering Elam and Babylonia, subduing the Medes and extending his power from Anatolia to Egypt. He exiled whole nations of conquered peoples to the remoter reaches of his territories. The excavations of his palace at Khorsabad bear witness to his magnificence.

Sarközy (de Nagy-Bócsa), Nicolas Paul Stéphane (1955- ). French politician, born in Paris. Son of a Hungarian father and Greek-Jewish mother, he became a lawyer, municipal councillor, Minister for the Budget 1993-95, for the Interior 2002-04, 2005-07, and for the Economy 2004. Combative in style, he won political support from a coalition stretching from the centre to far right. Leader of the Union pour un he led in the first ballot for President of France (April 2007) and won 53 per cent of the vote in the second round (May 2007), defeating Ségolène *Royal, serving as President of France 2007-12. He was created an honorary GCB in March 2008. Defeated in 2012 by François *Hollande, he sought the presidency in 2017 but lost decisively in the primaries. In 2018, he was arrested and charged with bribery. His trial began in December 2020. Convicted in March 2021, he was sentenced to three years jail (two of them suspended). In September 2021 he was sentenced to one year in home detention.

Sarmiento, Domingo Faustino (1811-1888). Argentinian politician. A rural schoolteacher who was exiled to Chile, he became an influential journalist and his book Facundo: Civilization and Barbarism (1845) was an important examination of the gaucho tradition and culture and an attack on the *Rosas regime. Elected as Argentina's first civilian president 1868-74, he introduced public education in primary, secondary and technical schools.

Sarnoff, David (1891-1971). American entrepreneur, born in Russia. He worked for *Marconi, became a pioneer broadcaster and a founder of RCA (Radio Corporation of America, 1921) and NBC (National Broadcasting Company, 1926) which developed radio and television networks in the US. He was President 1930-47 and Chairman 1947-70 of RCA/NBC.

Saro-Wiwa, Ken(ule Beeson) (1941-1995). Nigerian writer and political activist. A leader of the Ogani people, he was arrested by Nigeria's military rulers, charged with murder and hanged with eight others after a rushed trial.

Saroyan, William (1908-1981). American author. Of Armenian descent, his first work was a volume of short stories, The Daring Young Man on the Flying Trapeze (1934). He wrote a number of novels and plays, including The Time of Your Life (1939) for which he was awarded (but did not accept) a Pulitzer Prize. The Human Comedy (1943) exemplifies the simplicity and optimism of much of his work.

Saroyan, W., The Bicycle Rider in Beverly Hills. 1952.

Sartre, Jean-Paul (1905-1980). French philosopher, playwright and novelist, born in Paris. A nephew of Albert *Schweitzer, he was educated at the École Normal Supérieure and the Sorbonne. In 1929 he met Simone de *Beauvoir, who shared his life from 1931 until his death, as mistress intermittently and confidante always and whom he exploited shamelessly, despite her strong feminist views. $\mathrm{He}$ taught (1931-39) at lycées in Le Havre, Laon and Paris, and published the novel La Nauseé (1938, Nausea) and the short stories Le Mur (1939, Intimacy). After brief army service he was a prisoner of war 1940-41. During German occupation of Paris, Sartre became a successful playwright with Les Mouches (1942, The Flies) and Huis-clos (1943, 
No Exit). His major philosophical works were L'Etre et le néant (1943, Being and Nothingness, translated 1956) and L'Existentialisme est un humanisme (1946, Existentialism and Humanism, 1948). Identified as the founder of existentialism (although *Kierkegaard was there first), his philosophy is often summarised as 'man's existence precedes his essence', by which is meant that a man's essence or essential being is determined by the facts of his nature. Standing alone in a godless world, man can, within the limits of these facts, determine and develop his own essence: thus men choose to make themselves what they become and they are therefore responsible for what they are.

He remained in France during the Occupation and, despite his known 'leftist' politics seems-like Pablo *Picasso- to have been left alone. Having avoided political engagement before and during the war, Sartre became hyperactive from 1945 . He edited the influential left-wing journal Les Temps modernes 194580 and became leader of left-bank literary society in Paris. He had an increasingly antagonistic rivalry with Albert ${ }^{*}$ Camus. He pursued radical causes after the war, was an avid Stalinist 1952-56, then switched allegiance to ${ }^{*} \mathrm{Mao}$, finally to ${ }^{*}$ Castro. Clive James wrote: 'Sartre ... never actually killed anybody. But he excused many who did, and most of those never actually killed anybody either: they just gave orders for their subordinates to do so.' He campaigned against *de Gaulle and US intervention in Vietnam. Other works include the novels L'Age de raison (1945, The Age of Reason) and Le Sursis (1945, The Reprieve), the play Les Mains sales (1948, Dirty Hands), a biography of his protégé Jean ${ }^{*}$ Genet (1952), some film scripts, the autobiography Les Mots (1963, Words) and a huge unfinished work on *Flaubert (1972). He was awarded, but declined, the Nobel Prize for Literature in 1964, on the grounds of his opposition to bourgeois society. Buried at Montparnesse cemetery, Simone de Beauvoir is next to him.

Cohen-Solal, A., Sartre: A Life. 1987.

Sassoon, Siegfried Loraine (1886-1967). English poet. Member of an ancient Jewish family from Baghdad, his father was disinherited for marrying a Christian. He dropped out of Cambridge, but became an officer in World War I, winning a MC and befriending Wilfred * Owen. The disgust produced by his experiences in World War I produced the fierce satire of Counter-attack (1918) and Satirical Poems (1926). He also wrote a series of semi-autobiographical works including Memoirs of a Foxhunting Man, which won the Hawthornden Prize (1929), Memoirs of an Infantry Officer (1930) and Sherston's Progress (1936). Other books more directly autobiographical followed, e.g. The Old Century (1938).

Sassoon, S. L., Siegfried's Journey 1916-1920. 1945; Egremont, M., Siegfried Sassoon. 2005.
Satie, Erik Alfred Leslie (1866-1925). French composer, born in Honfleur. An eccentric (a fanatical collector of umbrellas), he lived obscurely until, from 1910 , he was hailed as leader of the younger, more advanced composers, notably of the groups 'L'École d'Arcueil' and 'Les Six'. His work, harmonically advanced, also influenced *Ravel and other contemporaries. He wrote limpid, beautiful piano works, including the three Gymnopedies (i.e. 'naked feet', 1888, two later orchestrated by *Debussy); some with bizarre titles (e.g. Three Pear-shaped Pieces and Limp Preludes for a Dog); ballets, e.g. Parade (1917), commissioned by *Diaghilev's Ballets Russes with sets and costumes by *Picasso; the more serious symphonic drama Socrate (1919); and a Messe des pauvres (1895).

Myers, R., Erik Satie. 1948.

Sato Eisaku (1901-1975). Japanese politician. Younger brother of *Kishi Nobusuke, he gained a law degree at Tokyo Imperial University and became a railway administrator until elected a member of the Diet 1949-75. A follower of *Yoshida Shigeru, he was a major figure in forming the Liberal Democratic Party, served as Finance Minister 1957-60 under his brother, and minister of nuclear science, energy and technology 1960-64. As Prime Minister 1964-72, he was identified with Japan's rapid economic expansion and concluding the 1969 Sato-Nixon treaty with the US. The award to him of the Nobel Prize for Peace in 1974 was greeted with some international scepticism. Sato was a complex character-forceful and ruthless, but also a gifted calligrapher.

Satyarthi, Kailash (1954- ). Indian social activist. He founded the Bachpan Bachao Andolan ('Save the Children Movement') in 1980, campaigned against child labour, and for children's rights, and shared the Nobel Peace Prize for 2014 with *Malala Yousafzay.

Sauckel, Fritz (né Ernst Friedrich Christoph) (1894-1946). German Nazi administrator. From a poor working-class background, he rose through the party hierarchy and was Reich Governor of Thuringia 1933-45. As General Plenipotentiary for Labour Deployment 1942-45, in control of manpower in occupied territories, he deported millions of slave labourers. He was hanged after condemnation by the Nuremberg Tribunal.

\section{Sa'ud, Abdulaziz Ibn see Ibn Sa'ud, Abdulaziz}

Saul (Sa'ul) (d.c.1012 BCE). First King of Israel and Judah. Son of Kish, of the tribe of Benjamin, he was anointed by the prophet *Samuel in response to the need for a single warrior king to lead the Hebrew tribesmen in unity against the Philistines. A melancholic, Saul was at first successful, but his jealousy of *David and the bitter quarrel that followed so weakened national unity that he was defeated by the Philistines and killed at the Battle of Mount Gilboa. 
Saul, John Ralston (1947- ). Canadian novelist, essayist and lecturer, born in Ottawa. Educated at McGill University, he wrote collections of penetrating essays about the dilemmas of modern society, including Voltaire's Bastards: The Dictatorship of Reason in the West (1992), The Doubter's Companion: A Dictionary of Aggressive Common Sense (1994) and The Unconscious Civilization (1995). His wife, Adrienne Clarkson (née Poy) (1939- ), broadcaster and journalist, born in Hong Kong, was Governor-General of Canada 1999-2005.

Saunders, Dame Cicely Mary Strode (1918-2005). English physician and social worker. Author of Care of the Dying (1960) and Living with Dying (1983), she founded St Christopher's Hospice, Sydenham in 1967 and became recognised as a leader of the palliative care and hospice movement. She was awarded the $\mathrm{OM}$ in 1989.

Saussure, Ferdinand de (1857-1913). Swiss linguist. The father of modern linguistics and a pioneer of 'structuralism' who anticipated 'semiotics', he distinguished between 'synchronic' linguistics (language at any given moment) and 'diachronic' linguistics (language as it evolves over time). He was a professor at the University of Geneva from 1891 (Roland *Barthes).

Saussure, Horace Bénédict de (1740-1799). Swiss scientist. Professor of Philosophy at Geneva University 1762-86, he gained fame for his exhaustive studies of Alpine botany, geology and meteorology. He invented the anemometer. His experiments with glass hot boxes', capturing radiant heat from the Sun (1767), anticipated research on the 'Greenhouse effect' and he developed a solar oven. He offered a prize won (1786) by two guides, for the first ascent of Mont Blanc; he made the climb himself in the following year. His Voyage dans les Alpes (1779-96) is a personal record of seven expeditions. A lunar crater is named for him. His daughter Albertine Adrienne de Saussure (later Necker) (1766-1841) was a strong advocate for education for girls and having a life outside marriage. Ferdinand de *Saussure was his great-grandson.

Sauvé, Jeanne Mathilde (née Benoît) (1922-1993). Canadian Liberal politician. She was a teacher, journalist and broadcaster, MP 1972-84, minister for science and technology 1972-74 and the environment 1974-75, Speaker of the House of Commons 1980-84 and the first woman GovernorGeneral 1984-90.

Savage, Michael Joseph (1872-1940). New Zealand politician, born in Victoria. He arrived from Australia in 1907, entered parliament in 1919, and in 1935 became the first Labour Prime Minister of New Zealand. His pledge to Britain at the outbreak of World War II became historic, "Where she goes we go-where she stands we stand.' He died in office.
Savage, Richard (1697?-1743). English poet and dramatist. He claimed the 4th Earl Rivers and Anne, Countess of Macclesfield as his parents, a theme he pursued in his poems The Bastard (1728) and The Wanderer (1729). His best known play was The Tragedy of Sir Thomas Overbury (1724) in which he performed. His life was colourful and after a timely reprieve he escaped hanging for murder (1727). He died in debtors' prison. The Life of Savage (1744) by his friend Samuel *Johnson, more colourful than accurate, was the first literary biography written in English.

Holmes, R., Dr Johnson and Mr Savage. 1993.

Savall (i Bernadell), Jordi (1942- ). Catalan (Spanish) composer, conductor and viol player. Educated in Barcelona and Basle, he was a specialist in medieval and baroque music, founding Hesperion XX (known since 2000 as Hespèrion XXI) in 1974 and Le Concert de Nations in 1989, recording and touring extensively. His wife Montserrat Figueras (1941-2011) was an outstanding soprano.

Savery, Thomas (1650?-1715). English engineer. He patented (1698) a 'fire engine' which by direct steam pressure could raise water to a height of 1,330 metres (4,050 feet). The patent did not expire until 1733 and was held to cover the very different engine of Thomas *Newcomen. Savery was elected FRS in 1705 .

Savonarola, Girolamo (1452-1498). Florentine preacher. In 1475 he became a Dominican friar. He was sent to the convent of S. Marco in Florence in 1481 and again in 1490, after which he gained enormous influence by his sermons denouncing corruption, sensuality and luxury. When the 'Scourge' constantly predicted by him came (1494) in the form of the French army, which drove out the ${ }^{*}$ Medici, he emerged as the dominating figure of the new republic. Many great works of art (as well as rich dresses and other signs of luxury) perished in the 'bonfire of vanities' on the grounds that they commemorated pagan cultures. Savonarola was blamed for the inefficient administration of the republic as well as for his adherence to the French alliance. He was excommunicated (1497) by Pope *Alexander VI who was building an alliance against the French. His opponents in Florence gained the upper hand and after a trial by papal commissioners for heresy, Savonarola with two companions was strangled and burned.

Ridolfi, R., Life of Girolamo Savonarola. 1959.

Savoy (Savoia). Burgundian dynasty, founded by Umberto Biacamano (Humbert the Whitehanded), which ruled the county of Savoy (south of Lake Geneva) from 1003. Its members became kings of Sicily, then of Sardinia, Piedmont and of Italy 1861-1946. 
Saxe, Maurice, Comte de (1696-1750). French soldier. Usually known as Marshal de Saxe, he was an illegitimate son of *August II of Saxony and Countess Aurora von Königsmark. As a boy he ran away to join *Marlborough's army in Flanders; in 1711 he was fighting with Russo-Polish forces, and next with Prince *Eugène against the Turks. Made Duke of Courland, he had to withdraw in 1729 and thereafter fought only for France. In the War of the Austrian Succession he invaded Bohemia and took Prague (1741). He became a marshal in 1744, and defeated the Duke of *Cumberland at Fontenoy (1745), and again at Laffett (1747), whereas on other occasions he lost the full benefit of victory by failure to pursue. $\mathrm{He}$ wrote a book on the art of war, Mes Reveries (1757).

Saxe-Coburg-Gotha (or Sachsen-Coburg-Gotha). German dynasty that provided sovereigns of Belgium, Great Britain and Bulgaria. The family name-rarely used—was *Wettin.

\section{Saxe-Coburggotski, Simeon Borisov see Simeon II}

Saxo Grammaticus (also known as Saxo cognomine Longus) (c.1150-c.1220). Danish historian and cleric. Secretary to the Archbishop of Lund, he wrote, in Latin, Gesta Danorum (16 volumes), the first complete history of Denmark. Early books relate episodes from the Danish and Norse legendary past, including the story of Amleth (Hamlet), in Books 3 and 4 , written about 1216 . The last volume describes struggles with the Slavs in the Baltic. The surname 'Grammaticus' was added in the 15th century to commemorate Saxo's learning.

Say, Jean Baptiste (1767-1832). French economist. In preparation for a business career he spent some of his early years in England. On his return to Paris he became a journalist and wrote effectively about the new economic theories of Adam ${ }^{*}$ Smith. He was the most influential economist in France. His chief work was Traite d'économie politique (1803). He later lectured on political economy at the Conservatoire des Arts et Métiers and (from 1831) at the Collège de France.

Sayers, Dorothy L(eigh) (1893-1958). English novelist, poet, playwright and translator, born in Oxford. Educated at Somerville College, Oxford, she wrote 28 volumes of detective fiction, distinguished by fine writing, e.g. Busman's Holiday (1933) and The Nine Tailors (1934), in which the hero is an aristocratic detective, Lord Peter Wimsey. Her religious works include the series of radio plays The Man Born to be King (1942). She regarded the translation of *Dante's The Divine Comedy (Hell, 1949; Purgatory, 1955 and Paradise, 1962, completed by Barbara Reynolds) as her greatest achievement.

Scalfaro, Oscar Luigi (1918-2012). Italian politician and lawyer. A Christian Democrat deputy 1948-92, he served in many ministries and became a compromise choice as President of Italy 1992-99.
Scalia, Antonin Gregory (1936-2016). American jurist, born in New Jersey. Educated at Harvard, he was a Justice of the US Supreme Court 19862016, a 'strict constructionist', interpreting the US Constitution as it would have been understood by the Founding Fathers (no Mothers involved).

Scaliger, Joseph Justus (1540-1609). French scholar. Of Italian descent, he was son of the scholar Julius Caesar Scaliger (1484-1558), notorious for his scurrilous attacks on *Erasmus. At the University in Paris he acquired a complete mastery of Greek and Latin and some Hebrew; he also became a Protestant. After travels in Italy and England he was professor (1570-72) at *Calvin's academy at Geneva and then for 20 years lived in France with the Roche-Pozay family. During this time he produced the editions of ${ }^{*}$ Catullus, ${ }^{*}$ Tibullus and ${ }^{*}$ Propertius which made him famous, and above all his De Emendatione Temporum (1583) by which he is ranked as the founder of the modern science of chronology. He spent his last years at Leyden University preoccupied with controversies engendered by his arrogant disposition, which did not prevent his recognition as one of the greatest scholars of the age.

\section{Scanderbeg see Skanderbeg}

Scarlatti, Alessandro (c.1659-1725). Italian composer, born at Palermo, Sicily. He was maestro di cappella (i.e. court or household musician) to the eccentric Queen ${ }^{*}$ Christina of Sweden in Rome, to the viceroy of Naples, and to Cardinal *Ottoboni. He wrote over 100 operas of which 35 survive, as well as about 600 cantatas for solo voices, and choral works. He is believed to have invented or introduced the aria da capo which was of fundamental importance in 18th-century opera. For the opera Tigrane (1715) horns were introduced into the orchestra.

Dent, E. J., Alessandro Scarlatti. 1960.

Scarlatti, (Giuseppe) Domenico (1685-1757). Italian composer and harpsichordist, born in Naples. Son of Alessandro *Scarlatti, in Rome he wrote operas for the exiled Queen of Poland, and church music, including Stabat Mater (1715) for St Peter's 1715-19. He worked in Lisbon 1719-27, in Rome again 1727-29, then in Spain, first in Seville, then Madrid, where he died. In Spain, he was a patron of the castrato *Farinelli and composed his famous keyboard sonatas, some of them called Essercizi, of which 555 survive; short brilliant works, in binary form (two matching parts, often repeated), mostly in one movement, catalogued 'K' by Ralph Kirkpatrick, written for harpsichord (or, possibly, the early piano forte).

Kirkpatrick, R., Domenico Scarlatti. 1953.

Scarron, Paul (1610-1660). French writer. Known (from 1643) as a writer of burlesque verse, equally successful was Le Roman comique (1651-57), a satiric novel about strolling players which provided 
an agreeable contrast to the artificial romances then in vogue. From 1638 he was half paralysed. When a beautiful 15-year-old girl, Françoise d'Aubigné, was taken to visit him (1651) she wept in pity. The pity was mutual: it grieved him that so lovely a girl should be so poor, he offered to provide a dowry and when she refused he proposed marriage. They were married in 1652 and she showed her gratitude by watching over his health and his career for the rest of his life. She was later better known as Madame de *Maintenon.

Schacht, (Horace Greeley) Hjalmar (1877-1970). German financier, born in Tiglev (then in Prussia, now in Denmark). His mother was Danish, and his parents had lived in the US. He became President of the Reichsbank 1923-30 and 1933-39 and, as *Hitler's Minister for the Economy 1934-37, was much admired for the manoeuvres by which he enabled German rearmament to be financed. He lost to ${ }^{*}$ Goering in a power struggle over direction of the German economy. Minister without Portfolio 1937-43, he was arrested by the Gestapo in 1944 . He claimed at the Nuremberg trials that he had never been a Nazi and was acquitted. An eight year sentence of imprisonment by the German denazification court was quashed on appeal.

Schacht, H., My First 76 Years. 1955.

Schama, Sir Simon Michael (1945-). AngloAmerican historian, born in London. Educated at Cambridge, he was professor of history at Harvard 1980-94 and of the humanities at Columbia 1994- . His books include The Embarrassment of Riches (1987), Citizens (1989), Landscape and Memory (1995), Rembrandt's Eyes (1999) and The Power of Art (2006). His television documentaries include $A$ History of Britain (2000), John Donne (2009) and Shakespeare (2012)

Scharnhorst, Gerhard Johann David von (17561813). Prussian officer. After the Prussian defeats in the Napoléonic Wars he undertook (1807), with August ${ }^{*}$ Gneisenau, the complete reorganisation of the Prussian army, and forged the more efficient forces which won victories (e.g. Leipzig, 1813) against the French.

Schatz, Albert Israel (1920-2005). American microbiologist. He studied at Rutgers University, and as a graduate student identified (1943) that streptomycin, found in soil, was effective as an antibiotic in treating tuberculosis. His supervisor, Selman *Waksman, appropriated sole credit for the discovery. It was only in 1994 that Schatz's priority was recognised.

Scheel, Walter (1919-2016). German politician. He served in the Luftwaffe during World War II, became a merchant banker and was a Bundestag member 1953-74 and Leader of the Free Democratic Party 1968-74. He was Vice Chancellor and Foreign Minister 1969-74, and President of the Federal
Scheele, Carl Wilhelm (1742-1786). Swedish chemist. He made many important discoveries while working as an apothecary. Using very primitive equipment, he identified and isolated eight elements (chlorine, manganese, barium, molybdenum, tungsten, nitrogen, hydrogen and oxygen)—more than any other chemist-but was strikingly unlucky and his priority was not recognised for decades. He discovered oxygen in 1772 (two years before Joseph *Priestley did so independently) but did not publish his findings until 1777 . He was the first to prepare chlorine, phosphorus, hydrogen sulphide, glycerine, and many organic acids. He also discovered the action of light upon silver salts, a reaction basic to photographic reproduction. His work disproved the phlogiston theory three years ahead of *Priestley and ${ }^{*}$ Lavoisier. His death was hastened by his practice of tasting elements (such as mercury) on which he was working. The mineral from which tungsten is extracted was named scheelite for him.

Scheer, Reinhard (1863-1928). German sailor. During World War I he was appointed (January 1916) Commander-in-Chief of the High Seas Fleet and was in command at the Battle of Jutland (May 1916, *Jellicoe). After Jutland, he called for unrestricted submarine warfare and became Chief of Naval Staff August-November 1918.

Schiele, Egon (1890-1918). Austrian expressionist painter and designer. A follower of *Klimt, he developed a tight linear style and his figure drawings show great virtuosity. An important painter in the Sezessionist school, he died of influenza, aged 28.

Schiff, Sir András (1953- ). Hungarian-JewishBritish pianist and conductor, born in Budapest. An outstanding interpreter of ${ }^{*}$ Bach, ${ }^{*}$ Mozart, *Beethoven, ${ }^{*}$ Schubert and ${ }^{*}$ Schumann, he toured extensively and became a British subject in 2001 .

Schikaneder, Emanuel (1751-1812). Austrian dramatist, actor and theatre director. He wrote the libretto for *Mozart's opera Die Zauberflöte (The Magic Flute, 1791), a Masonic allegory, and created the role of Papageno.

Schillebeeckx, Edward (1914-2009). BelgianDutch theologian, born in Antwerp. He joined the Dominicans and became professor of theology at Nijmegen University 1958-83. As advisor to the radical Dutch bishops he was suspected of heresy by conservatives in the Vatican. His many books include the magisterial Jesus (1974, published in English 1979), Christ (1977: 1980) and Jesus in Our Western Culture (1987).

Schiller, Ferdinand Canning Scott (1864-1937). English philosopher. He taught at Corpus Christi College, Oxford 1897-1926 and was professor of philosophy at the University of Southern California 1926-36. His chief contribution to 
English philosophy was his part in the revival of the empirical tradition. Under the influence of William *James, with whom he formed an early friendship, he emphasised that the primary cause of human thinking is the need to act. He looked on pragmatism as a form of philosophical humanism, which rejected, as secondary or unreal, metaphysical idealism and the formal logic that so often fortified it. He had a deep knowledge of the physical sciences, wrote on eugenics, and was an active member of the Society for Psychical Research. His more general works include Studies in Humanism (1907) and Logic for Use (1929).

Schiller, (Johann Christoph) Friedrich von (17591805). German poet and dramatist, born at Marbach near Stuttgart. His father was a captain in the service of the Duke of Württemberg, at whose instigation the promising boy became (1773) a pupil at the new academy for officers and public servants. He became an army surgeon but absented himself without leave to watch a performance of his first play Die Räuber (1782, The Robbers) at Mannheim. For a similar offence he was briefly imprisoned, fled from the Duke's service and took refuge at Mannheim where, after an interval, he was appointed theatre poet. He continued to write plays but it was after a move (1785) to Leipzig and Dresden, on the invitation of admirers, that he completed his first dramatic masterpiece Don Carlos (1785), which, though involved with the fate of the unhappy son of ${ }^{*}$ Felipe II of Spain, finely expressed the 18th-century ideals of political and religious liberty. His next moves were to Weimar and Jena where he was professor of history 1789-99 and published his History of the Revolt of the Netherlands (1788) and History of the Thirty Years War (1789-93). After an illness from which he was slow to recover, he studied *Kant's philosophy, especially those parts relating to aesthetics, and wrote essays on such subjects as the nature of tragedy, the meaning of beauty, and aesthetic education. His philosophic poems of this time reflect the same themes. From 1794 he was a close friend of *Goethe and in 1799 he settled at Weimar to be near him. To the last period of his life belong some of his greatest plays, The Death of Wallenstein (1799), Mary Stuart (1800), The Maid of Orleans (1881) and William Tell (1804). He is also well known for his lyrics and ballads (e.g. Die Glocke, in which the processes of casting a bell symbolise the events and influences that make up the life of man).

Mainland, W. F., Schiller and the Changing Past. 1957.

Schindler, Oskar (1908-1974). German entrepreneur. Although a Nazi Party member, he saved more than 1,100 Jews in factories in Poland and Czechoslovakia during the Holocaust (194345), became honoured as a 'righteous gentile' in Israel, died in Argentina and was buried in Jerusalem. Thomas *Keneally's book Schindler's Ark (1982) was filmed as Schindler's List (1993) by Steven *Spielberg.
Schinkel, Karl Friedrich (1781-1841). German architect, town planner, painter and stage designer. He laid out Berlin, worked in classic, Gothic and romantic traditions and designed atmospheric productions of works by * Mozart and * Goethe.

Schirach, Baldur von (1907-1974). German Nazi politician. Youth leader of the Nazi Party 1936-40 and Gauleiter of Vienna 1940-45, he was sentenced to 20 years' imprisonment by the Nuremberg tribunal.

Schlegel, August Wilhelm von (1767-1845). German critic. In 1797 he became professor of literature at Jena, and his lectures there and at Berlin and Vienna provide a clear exposition of the romantic viewpoint. He is best known, however, for his translations of *Shakespeare's plays (1798-1810) and of ${ }^{*}$ Dante, ${ }^{*}$ Calderon and ${ }^{*}$ Camães. His brother, (Karl Wilhelm) Friedrich von Schlegel (17721829), is regarded as the finest critic produced by the Romantic movement and, with *Hegel, one of the most important influences on German thought of his period. He also wrote poetry and a novel, Lucinde (1799), based on his own love affair with a daughter of the philosopher Moses *Mendelssohn. He lectured at Jena 1800-01. First an atheist, then Catholic convert (1808), he worked for ${ }^{*}$ Metternich. Among the first in Germany to study Sanskrit, he wrote Über die Sprache und Weisheit der Indier (On the Language and Wisdom of India, 1808).

Schleicher, Kurt von (1882-1934). German general and politician. He served on the general staff in World War I and became politically important in 1932 as Defence Minister in June and Chancellor in December. His attempt to find a basis of power by alternately angling for the support of the Nazis and of the trade unions lost him the confidence of all. He resigned in January 1933 and was murdered during the Nazi's 'Night of the Long Knives' in June 1934.

Schleiden, Mathias Jakob (1804-1881). German botanist, born in Hamburg. He practised law unhappily, took up botany as a hobby and after studying in Göttingen and Berlin, became professor of botany at Jena 1839-64. His lifelong concern was to orientate botany away from the obsession with classification which had followed from the work of ${ }^{*}$ Linnaeus. His interest was in plant physiology, with cellular structure and growth. With ${ }^{*}$ Schwann he helped to formulate the notion of the cell structure of plants. He believed wrongly that cells formed out of a nucleus and then became encased in cell walls. Schleiden pursued a great variety of plant studies with the aid of the microscope. He was involved with the pathology of plants, and investigated fungoid infections that attacked plant roots. He was a strong supporter of ${ }^{*}$ Darwin.

Schlesinger, Arthur Meier, Jr (1917-2007). American historian, born in Ohio. Son of a historian of the same name, he taught at Harvard 1946-61, became special 
assistant to President *Kennedy 1961-63 and held the chair of humanities at the City University of New York 1966-. His books include The Age ofJackson (1945), and A Thousand Days: John F. Kennedy in the White House (1965), which both won a Pulitzer Prize, The Age of Roosevelt (3 volumes, 1957-60) and Cycles of American History (1986).

\section{Schleswig-Holstein-Sonderburg-Glücksburg.}

Danish-German dynasty. Descendants of *Christian IX of Denmark became rulers of Greece and Norway and included Philip, Duke of *Edinburgh.

Schlieffen, Alfred, Graf von (1833-1913). German soldier. He was a staff officer in the Prussian Wars of 1866 and 1870 and Chief of the Imperial General Staff 1891-1906. From 1894 he later developed a strategic plan for future wars by which France would be attacked through Belgium whilst only a holding operation would be fought on the Russian front. This plan was closely followed in both 1914 and 1940 .

Schliemann, Heinrich (1822-1890). German archaeologist. He amassed a fortune as a merchant and contractor in Russia and in the US, retiring in 1868 to devote himself to archaeology. He mastered 15 languages. He claimed to have been fascinated by ${ }^{*}$ Homer from childhood and dreamed of proving that The Iliad had a historical basis. He accepted in 1868 Frank Calvert's identification of Hisarlik as the site of Troy (Ilium) but the slow granting of permission to excavate delayed his major work until 1871-73. He worked at Troy 1876, 1882, 1889-90. He found nine layers of occupation and assumed that Homer's Troy was second from the bottom (Troy II). In 1890 his assistant Wilhelm Dörpfeld (1853-1940) persuaded him that Troy II was a millennium too early, the correct level being Troy VI or VIIa (c.1250 BCE). In 1876 his excavations at Mycenae proved the richness of its civilisation and made him world famous. He also worked at Orchomenos (1880-81, 1886) and Tiryns (1884) with Dörpfeld. He wrote several books about his discoveries, including Troia (1884), written in collaboration with Dörpfeld. He planned to excavate Knossos (Arthur *Evans) and Ithaca but died suddenly in Naples. His second wife Sophia Engastromenos (1852-1932) worked on the excavations with him. The artefacts in 'Priam's Treasure' were displayed in Berlin, taken to the USSR in 1945, and most are exhibited at the Pushkin Museum in Moscow. Negotiations for its return began in 1993. It is now generally agreed that the objects long predate Priam's Troy, as recorded in The Iliad.

Moorehead, C., The Lost Treasures of Troy. 1994; Traill, D. A., Schliemann of Troy: Treasure and Deceit. 1995.

Schmeling, Max(imilian Adolph Otto Siegfried) (1905-2005). German boxer, born in Pomerania. In 1930 he won the world heavyweight championship in New York when Jack Sharkey was disqualified; however, in 1932 Sharkey regained the title.
Schmidt, Brian Paul (1967- ). American-Australian astrophysicist, born in Montana. He grew up in Alaska and went to university in Arizona and at Harvard. In 1994 he moved to Australia, where he held a chair at The Australian National University and worked at the Mt Stromlo observatory. He shared the 2011 Nobel Prize for Physics with Saul Perlmutter and Adam Riess 'for the discovery of the accelerating expansion of the Universe through observations of distant supernovae', and worked on 'dark energy'. He was elected FAA and FRS, and awarded an AC in 2013. He became Vice-Chancellor of The Australian National University 2015- .

Schmidt, Helmut (Heinrich Waldemar) (19182015). German politician, born in Hamburg. He joined the Social Democratic Party in 1946 and was active in Land politics in Hamburg as Manager of Transport Administration 1949-53 and Senator for Domestic Affairs 1961-65. He became a member of the Bundestag 1953-61, 1965-87. Chairman of the Social Democratic Party in the Bundestag 1967-69, he was appointed Minister of Defence 1969-72, Minister of Finance 1972-74 and Federal Chancellor 1974-82. He was a gifted pianist.

Schmidt, H., Balance of Power. 1970; Schmidt, H., Als Christ in der Politischen Entscheidung. 1976.

Schnabel, Artur (1882-1951). Austrian pianist, teacher and composer, born in Lipnik, then in Moravia, now in Poland. A pupil of Theodor *Leschetizky, he lived in Berlin 1900-33 and became internationally famous for his interpretations of *Beethoven, *Mozart, ${ }^{*}$ Schubert and ${ }^{*}$ Brahms. In 1932 he recorded all 32 Beethoven sonatas. He toured Australia in 1938 and lived in the US from 1939. His advanced compositions were in the style of *Schoenberg.

Schneerson, Menachem Mendel (1902-1994). American rabbi, born in Nikolayev, Russia (now Ukraine). In 1950 he succeeded his father-in-law as chief rabbi of the Lubavitcher (Hasidic) sect, with its headquarters in New York, with 200,000 followers and synagogues worldwide. Some followers believed him to be the Messiah.

Schnittke, Alfred (1934-1998). Russian composer, born in Engels. Son of a German-Jewish journalist who migrated to the USSR, he studied in Vienna. Enormously prolific, his works included nine symphonies, eight concertos, six concerti grossi, chamber music, three operas, three ballets, many choral works and film scores. His piano quintet (1976) and three sonatas for violin and piano are powerful and original. He was professor of composition at the Hamburg Hochschule 1989-98.

Schnitzler, Arthur (1862-1931). Austrian physician dramatist and novelist. His medical profession made him interested in psychological problems, usually erotic but sometimes morbid. $\mathrm{He}$ is at his best in 
cycles of short plays, e g. Anatol (1893) and Reigen (1900) in which one or more characters of one play are carried on into the next. (The French film $L a$ Ronde was based on his work.) Schnitzler was a Jew and the theme of Professor Bernhardi (1912) is conflict between a Jewish doctor's sense of duty and Roman Catholic principles in an anti-Semitic country.

Schoenberg (Schönberg), Arnold (Franz Walter) (1874-1951). Hungarian-Czech-American composer, theorist, teacher and painter, born in Vienna. Raised in an Orthodox Jewish family, Schoenberg struggled with religion as he did with politics and aesthetics, became a Lutheran in 1898, and reconverted to Judaism in 1933. He worked as a bank clerk, was largely self-taught as an instrumentalist but had some lessons in composition from Alexander von Zemlinsky. His early work, notably Verklärte Nacht (Transfigured Night: string sextet, 1899) attempted to reconcile the influences of *Wagner and ${ }^{*}$ Brahms. His massive cantata Gurre-Lieder (Songs of Gurre: 1911), for four soloists, four choruses and large orchestra, in a romantic post-Wagnerian idiom, is based on Danish legend. He then began a process of discarding traditional tonality, based on a key in the diatonic (seven-note) scale, adopting the chromatic (twelve-note) scale. He first used this transformation in The Book of the Hanging Gardens (1908, settings of Stefan *George) and the monodrama Erwartung (1909). The word 'atonal' was applied to his works, but not by Schoenberg who insisted that he used pitches and chords that continued to relate to a tonic centre. In Pierrot lunaire (1912), a cycle based on poems by Albert Giraud, employing 'speech song' and instrumental accompaniment, he developed 'the twelve-tone row' in which notes in the chromatic scale are arranged in an arbitrary order. It is hypnotic and compelling. Schoenberg and his disciples Alban ${ }^{*}$ Berg and Anton *Webern are sometimes described as the Second Viennese School, although it is not clear who attended the first one.

Influenced by the Expressionists, Schoenberg became a prolific painter, notably self-portraits, exhibiting with *Kandinsky's Blaue Reiter group. He was an expert chess and tennis player. The period 1916-23 was his 'years of silence'. Almost all his work from the Serenade (1923) onwards was composed according to the twelve-tone row, one of the most important innovations in the history of music. The tone row for his Violin Concerto (1936), one of his most accessible works, is: $\mathrm{A}, \mathrm{B} b, \mathrm{E} b, \mathrm{~B}, \mathrm{E}, \mathrm{F} \#, \mathrm{C}, \mathrm{D} b, \mathrm{G}, \mathrm{A} b, \mathrm{D}, \mathrm{F}$. Later works include the String Quartets Nos 3 (1927) and 4 (1936), the Piano Concerto 1942), Ode to Napoleon (1943), A Survivor from Warsaw (1947), expressing passionate fury about the Holocaust, and the opera Moses und Aron, which was unfinished at his death. He lived in Vienna (apart from a few years in Berlin) until, at 51, he became a professor at the Prussian Academy of Arts in Berlin. Dismissed by the Nazis in 1933, after a brief stay in Paris he went to the US where he taught in New York and Boston, then became a professor at the University of California at Los Angeles. Schoenberg wrote, with good reason: '... if it is art, it is not for all, and if it is for all, it is not art.' (1946).

Reich, W., Schoenberg: A Critical Biography. 1971; Rosen, C., Schoenberg. 1975.

Scholl, Andreas (1967- ). German counter tenor. Born into a family of singers, he studied in Switzerland with René *Jacobs, and developed a style of exceptional agility, musicality and interpretive depth, especially in works by *Vivaldi, *Händel and *Bach.

Scholl, Sophia Magdelena (1921-1943). German resister. A student in Munich, she became active in the White Rose, a non-violent resistance group. She and her brother Hans Scholl were convicted of treason for handing out leaflets and both were guillotined.

Scholz, Olaf (1958- ). German Social Democratic politician. A lawyer, then a Bundestag member 200211; 2017- , he was Minister for Labour and Social Affairs 2007-09, Mayor of Hamburg 2011-18, and Vice-Chancellor and Minister of Finance 2018-21, in a Coalition with Angela *Merkel's CDU. Chancellor of Germany 2021-, he led a 'traffic-lights' coalition of the SDP, the Free Democratic Party (FDP) and the Greens.

Schöngauer, Martin (c.1430-1491). German artsist, born in Colmar, Alsace. Son of a goldsmith, he studied (and taught?) at Leipzig and was influenced by the Flemish masters, especially Rogier van der *Weyden. His masterpiece, The Madonna of the Rose Garden (1473), the only surviving painting certainly by him, is in St Martin's Dominican church in Colmar. He was the greatest German engraver before *Durer and 115 of his plates survive.

Schopenhauer, Arthur (1788-1860). German metaphysical philosopher, born in Danzig (now Gdansk). Best known for his view that will is the reality of the universe, he was a lecturer in philosophy at Berlin (1820-31) and suffered a dramatic reverse when he deliberately lectured at the same time as ${ }^{*}$ Hegel and did not win away students. Influenced by eastern philosophy, he stressed the existence of human suffering and is sometimes called the philosopher of pessimism. His major work is The World as Will and Idea, the will being the active principle, a blind irrational impulse, a term which includes all active processes, even those of gravity or motivation. The 'idea' on the other hand was merely something received, a brain picture, a nothing of itself and with no exploratory function such as would be implied in such phrases as 'intellectual intuition'. Schopenhauer's ethical system rests on sympathy which to him is much more than fellow feeling, the actual identification of self with another. But asceticism he places even above sympathy, since through it is attained the subjection of the will to live and the intellect is freed to pierce 
the veil of illusion. Schopenhauer spent the last 30 years of his life in isolation at Frankfurt-am-Main. He gained little acceptance until old age and received few academic distinctions. His subsequent influence has been partly due to his emphasis on the irrational.

\section{Gardiner, P., Schopenhauer. 1963.}

Schreiner, Olive (Emilie Albertina) (1855-1920). South African author, born in Lesotho. Daughter of German missionaries, she wrote The Story of an African Farm (1883), an outspoken story of life in a Boer homestead and of spiritual problems similar to her own. Its rebellious attitude to the subordination of women caused much controversy at the time. She supported Cecil *Rhodes, then broke with him on the issue of political rights for women and black people. She wrote Woman and Labour (1911), became a pacifist and corresponded with *Gandhi.

First, R. and Scott, A., Olive Schreiner. 1980.

Schröder, Gerhard Fritz Kurt (1944- ). German Social Democratic politician. He was a lawyer and administrator, Bundestag deputy 1980-86, MinisterPresident of Lower Saxony 1990-98, and SPD candidate for Chancellor 1998, defeating Helmut *Kohl and forming a coalition with the Greens. He was Chancellor 1998-2005 until defeated by a coalition led by Angela *Merkel. Married four times, known as 'Audi man' or 'Lord of the Rings', he left politics and entered business. He became close to Vladimir *Putin.

Schrödinger, Erwin (1887-1961). Austrian theoretical physicist. Educated at Vienna University, after a comparatively mediocre career, he had a sudden burst of creativity in a period of six months in 1926 when he wrote several brilliant papers which tackled major problems in quantum theory. He became professor of physics at Berlin University 1927-33. He was largely responsible for the development of wave mechanics, for which he deduced the fundamental equation (Schrödinger's wave equation). This makes it possible to treat atomic structure on a more mathematical basis than is permitted by *Rutherford's mechanical model. With *Dirac, Schrödinger won the Nobel Prize for Physics (1933). He taught in Rome and Oxford and was professor of physics at the Institute for Advanced Studies, Dublin 1939-56. His book What Is Life? (1944) influenced a generation of young scientists to turn from physics to the biological sciences. He also wrote Nature and the Greeks (1954).

Moore, W. J., Schrödinger: Life and Thought. 1989; Gribbin, J., Erwin Schrödinger and the Quantum Revolution. 2012.

Schubert, Franz Peter (1797-1828). Austrian composer, born in Vienna. Son of a schoolmaster, he was the 12 th of 14 children (only 5 surviving infancy). studied at the choir school in Vienna which provided singers for the Imperial Court chapel, and his teachers included *Salieri. In 1813, the year he left school, he composed his first symphony. In 1814, when he went to teach at his father's school, he composed his first opera The Devil's Pleasure Palace, the first six masses. Schubert was the first major Austrian composer to express the pleasure-loving, nostalgic and partly rustic atmosphere of Vienna, in the many songs and dances in which folk influence is discernible. He wrote in the Viennese classical tradition, with extraordinary melodic gifts and an increasing mastery of complex forms.

His lyricism, which has never been surpassed, found its finest expression in his songs (Lieder), which number 651 in the Deutsch (D) catalogue and he created the modern art of song. He set 63 of *Goethe's poems, some in several versions, beginning with Gretchen at the Spinning Wheel (1814), ending with Mignon's Song (Knowest thou the land?: 1826), and including some masterpieces: The Erl-King (Erlkönig), Hedgeroses, To the Moon, and The King of Thule. (Sadly, the poet was indifferent.) He also set texts by ${ }^{*}$ Schiller, ${ }^{*}$ Klopstock, ${ }^{*}$ Shakespeare, ${ }^{*}$ Heine, Wilhelm Müller and Friedrich von Matthisson. In 1815 he wrote 145 songs (nine on a single day) including many of his best. The song cycle Die schöne Müllerin (Fair Maid of the Mill, 1823), 20 poems by Müller, marks the highpoint of his lyricism. Wintereisse (Winter Journey, 1827), 24 poems, also by Müller, set for tenor (or baritone) and piano is, appropriately, chilling.

Schubert wrote four operas, none of which were performed in his lifetime and have only been rarely performed since, and was strikingly lacking in theatrical gifts, despite the drama, pathos and psychological insight of his songs. Choruses, both sacred and profane, poured from his pen. Twenty of his songs and many popular piano pieces were published in 1821. He derived his small income from music sales and teaching.

In 1816 he gave up school teaching, living a more or less hand-to-mouth existence, returned to his father's school in 1817, then was a music master in Count Johann Esterhazy's household in Hungary in 1818 and 1824. Schubert, a convivial character with many friends, frequently played and sang at concert parties (Schubertiaden) and receptions. He never married. The Piano Quintet ('The Trout', 1819) and Symphonies No. 4 (1816), 5 (1816) and 6 (1818) were rarely played until the 1930 s.

Much of his finest music dates from his last years e.g. the song cycles Die Schöne Müllerin (Müller, 1823) and Die Winterreise (Müller, 1827), the famous Symphony No. 8 (Unfinished, 1822: first performed 1865), and Symphony No. 9 (The Great, 1825-28: first performed 1839, but regarded as too long and ignored for decades). Later chamber works include the Octet in F (1824), the String Quartets in A Minor (1824), D Minor (Death and the Maiden, 1824) and G Major (1826). The String Quintet in C major, D 956 (two 
violins, one viola, two cellos), written in the year of his death but unperformed until 1850, is his masterpiece, full of a passionate intensity and symphonic in its range, lyrical, dramatic, tragic, even violent at times. The Adagio is one of the greatest movements in all music: it cuts to the heart. The Quintet is especially poignant because Schubert faced an early death, while his creative powers were still developing. He was a prolific writer for piano, including 21 Sonatas, the Wanderer Fantasy (1822), two sets of four Impromptus, the Fantasy in F Minor for piano duet, the Moments musicaux and many lively dances. The last three Piano Sonatas, ranking with *Beethoven's, were written only months before he died, and were dedicated to *Schumann (who failed to appreciate them). They were published first in 1838. Sonata No. 21 in B flat major, D. 960 , is a long masterpiece, poignant, threatening, self-revelatory, and confronting.

The misfortunes of his last years - ill health, financial difficulties, failure (1826) to obtain salaried posts were offset by belated recognition. He met the dying Beethoven, who appreciated his work. In March 1828 his only public concert took place in Vienna where, in November, he died of typhoid fever at the age of 31. He had long suffered from syphilis, complicated by alcoholism, which makes his productivity all the more astounding. Schubert, the shortest lived of the great composers, was much influenced by Beethoven, and suffered by appearing to be in his shadow (an accusation which later haunted ${ }^{*}$ Brahms). This was only an optical illusion. Schubert plumbed the depths of human emotion, of isolation, the separated soul, as few others have, before or since. He was buried next to Beethoven and had a profound influence on *Bruckner and *Mahler.

Deutsch, O. E., Schubert. A Documentary Biography. 1977; Rosen, C., The Romantic Generation. 1995; Mackay, E. N., Franz Schubert. A Biography. 1996; Newbould, B., Schubert: The Music and the Man. 1999; Gibbs, C. H., The Life of Schubert. 2000; Bostridge, I., Schubert's Winter Journey. 2015.

Schumacher, Ernst Friedrich (1911-1977). British economist, born in Germany. He lived in Britain from 1937, worked for the National Coal Board, then devoted himself to promoting 'intermediate' and alternative technology. His book, Small is Beautiful (1973) was a major bestseller.

Schuman, Robert (1886-1963). French politician, born in Luxembourg. He first became a deputy in 1919, played an active part in the Resistance during World War II and after the war was a prominent member of the MRP (Mouvement Républicain Populaire). Prime Minister 1947-48, as Foreign Minister 1948-53 in 10 administrations he proved himself a strong supporter of European integration. The 'Schuman plan' led to the European Coal and Steel Community (ratified 1952). In 1958 he became first president of the European Parliamentary Assembly.
Schumann, Clara Josephine (née Wieck) (18191896). German pianist and composer, born in Leipzig. Daughter of the important piano teacher Friedrich Wieck (1785-1873), she was a child prodigy, toured extensively and composed many piano pieces and songs. Despite her father's passionate opposition, she married Robert ${ }^{*}$ Schumann in 1840 , bore eight children between 1841 and 1854 and supported him during his mental breakdown. The intimate friend (but not lover) of Johannes *Brahms, she disapproved of *Liszt's florid style, introduced the practice of playing from memory, was recognised as the definitive interpreter of ${ }^{*}$ Beethoven ${ }^{*}$ Chopin, Schumann and Brahms, and taught in Frankfurt. She toured Britain 16 times.

Schumann, Elisabeth (1888-1952). German soprano. She sang opera and lieder, and was a member of the Vienna State Opera 1919-37. Much of her international success came from her recordings of songs by *Schubert. She settled in New York in 1938.

Schumann, Robert Alexander (1810-1856). German composer, born in Zwickau in Saxony. Son of a publisher and bookseller, he showed early musical ability but went as a law student to Leipzig, where he was unhappy, and to Heidelberg where law competed unsuccessfully with music and a gay and extravagant social life. From 1830 he was committed to music, studying piano with Friedrich Wieck, whose daughter (Clara *Schumann) he married. His hopes of a career as a virtuoso were ended by focal dystonia in his right hand. He founded and edited The New Journal of Music (Leipzig, 1834-44) in which his vividly written criticisms did much to promote the reputations of ${ }^{*}$ Chopin and ${ }^{*}$ Berlioz. Of his compositions in this first period the set of piano pieces known as Carnaval were inspired by an early love affair, while his love for Clara is immortalised in the C Major Fantasia, the Kreisleriana, the Etudes Symphoniques (1837) and other piano works. In 1840 he was absorbed by the romantic poems of ${ }^{*}$ Heine, many of which he turned into songs. In 1841 he turned to composition on a more extended scale: the Symphony No. 1 (Spring), the first version of the Symphony No. 4 and the first movement of the Piano Concerto (completed 1845) date from this year. In 1842 there followed three String Quartets and the great piano Quintet (op. 44). His first large choral work, Paradise and the Peri, was finished in 1843. A move to Dresden with its opera house suggested experiment in the theatrical field (e.g. incidental music for *Byron's Manfred). The directorship of the Dusseldorf Orchestra 1849-1853 proved too much for his health and mental stability, and despite the solace of the friendship of the young ${ }^{*}$ Brahms, he tried to drown himself (1854) and spent his last two years in an asylum at Endenich, near Bonn, at his own request. He presumably suffered from a manic-depressive disorder, complicated by heavy drinking, and died of malnutrition. 
Except for the Symphony No. 3 (Rhenish), two violin sonatas and the cello concerto (op. 129, 1850), his works in the last phase show a decline in creative power. With notable exceptions he was not at his best in the large instrumental works which demanded extended abstract musical thinking. He made his unique contribution in those miniature forms (the character piece for piano and the song) which he was able to fill at the prompting of a poet's idea. His Dichterliebe cycle and Liederkreis collection (both 1840) provide the perfect musical counterparts to the romantic poetry of ${ }^{*}$ Heine and ${ }^{*}$ Eichendorff respectively, and Schumann is ranked amongst the greatest of song composers.

Chissell, J., Schumann. 1967; Ostwald, P., Schumannthe inner voice of a musical genius. 1985; Worthen, J., Robert Schumann. Life of a Musician. 2007.

Schumer, Chuck (Charles Ellis). (1950- ). American Democratic politician. Harvard educated, he represented New York in the House of Representatives 1981-99 and the Senate 1999- and proved to be an exceptionally skilled campaigner, negotiator and party leader.

Schumpeter, Joseph Alois (1883-1950). Austrian economist. He served as Minister for Finance 191920 in the first Austrian republican government, became professor of economics at Bonn in 1925 and in 1932 moved to the US where he held a Harvard chair until his death. His Capitalism, Socialism and Democracy (1942) and History of Economic Analysis (1950) were enormously influential. His third wife, Elizabeth Boody (1898-1953), an economic historian, edited his work.

Schuschnigg, Kurt Alois Josef Johann von (18971977). Austrian politician, born in the Tyrol. A lawyer, he was a Christian Social deputy 1927-38, serving under *Dollfuss as Minister for Justice 1932-33 and Education 1933-34. An Austro-Fascist, with strong links to the Catholic Church and *Mussolini's regime, he opposed *Hitler's policy of annexation of Austria. After Dollfuss' murder, he became Chancellor of Austria 1934-38 until forced out after the Anschluss. Imprisoned 1938-45, he was a professor of political science at St Louis University, Missouri, 1948-67.

Schuschnigg, K. von, Austrian Requiem. Eng. ed. 1947.

Schütz, Heinrich (in Latin Henricus Sagittarius) (1585-1672). German composer, born in Saxony. He studied in Venice under Giovanni *Gabrieli, became an organist in Kassel and worked in Dresden from 1615 until his death, except for short periods in Venice (where he may have known *Monteverdi) and two years in Copenhagen. He wrote the first German opera, Dafne (1627, now lost), and much Church music, including three Passions (Luke, John, Matthew) and Christmas Oratorio. His Seven Words from the Cross (1645) and Resurrection (1623) represent a link between the 16th-century polyphonic composers and the accompanied choral works of *Bach and *Händel. He wrote more than 500 works.

Schuyler, Philip John (1733-1804). American politician. He was a member of the colonial assembly (from 1768) and delegate to the Continental Congress (1775). As well as being Commissioner for Indian affairs, he sat in Congress between 1778-81 and was a senator 1789-91 and 1797-98. He was a leader of the Federal Party in New York and helped to prepare the state's Constitution.

Schwab, Charles Michael (1862-1939). American industrialist. He worked his way up from being a stake-driver to become first President of the United Steel Corporation (1901-03) and President of the Bethlehem Steel Corporation (from 1903).

Schwann, Theodor (1810-1882). German physiologist, born in Cologne. Educated in Berlin, Bonn and Würzburg, he worked with J. P. *Müller and all his great achievements were in the 1830 s, investigating the chemistry of life processes. He devoted himself to the study of digestion, and discovered the enzyme 'pepsin'. He worked on the formation of sugar solutions and the role of yeast in ferments. His denials of spontaneous generation led to experiments on sterilisation which *Pasteur was later to build upon. Schwann is perhaps best known for his contributions to cell theory in plants and animals. He was concerned with showing the differentiation of cell structure in very different tissues (e.g. cartilage and bones). All aspects of animals and plants were either cells or their products. Cells had a physiological and chemical life of their own, which was, however, subordinate to the overall life of the organism. He coined the term 'metabolism'. Professor of Anatomy at Louvain 1838-47 and Liege 1847-80, he was awarded the Copley Medal in 1845.

Schwarzenegger, Arnold Alois (1947- ). American actor and politician, born in Austria. In the US from 1968, he worked as a body-builder and appeared in the films The Terminator (1984) and Kindergarten Cop (1990). After a referendum recalled the Governor of California, Grey Davis, in September 2003, Schwarzenegger, the Republican candidate, was elected to succeed him, serving until 2011.

Schwarzkopf, Dame (Olga Maria) Elizabeth (Friederike) (1915-2006). German soprano (naturalised British). Her career flourished after World War II with the encouragement of her husband Walter Legge (1906-1979), record producer and founder of the Philharmonia Orchestra. Her enormous ability as singer and actor, combined with striking good looks, made her the most admired operatic and concert soprano of her time, and she made several films. She was a notable Countess in Figaro and Feldmarschall in Rosenkavalier, and made many lieder recordings. 
Schwarzkopf, H(erbert) Norman (1934-2012). American general. Son of a brigadier, he grew up abroad, then graduated from West Point and the University of Southern California. He served in Vietnam, Grenada and Washington, and was appointed as Commander of the UN's 'Operation Desert Storm', in which 500,000 troops (mostly US) defeated Iraq in the Gulf War (1991). He wrote an autobiography It Doesn't Take a Hero (1992).

Schweitzer, Albert (1875-1965). French-German (Alsatian) medical missionary, theologian, philosopher, organist, biographer, born in Kayserberg, Alsace. Son of a Lutheran pastor, he studied organ in Mulhouse, theology in Strasbourg, and gained a PhD in Paris with a thesis on *Kant. His German and French Organ Building and Organ Art (1906) was influential in reviving interest in baroque organs, but he remained an enthusiast for ${ }^{*}$ Cavaillé-Coll's instruments. He first became known as an interpreter of J. S. *Bach and wrote an authoritative biography (1905/08, translated into English by Ernest *Newman). With C.-M. *Widor, he edited The Complete Organ Works of J.S. Bach (8 vols, 1912-14). (He also made some muchadmired recordings.) His controversial book The Quest of the Historical Jesus (1906, translated 1910) argued that *Jesus' mission was to warn of an impending end of the world. In 1905 Schweitzer decided to become a medical missionary in Africa and, after qualifying in medicine in Strasbourg, he established a mission hospital at Lambaréné in French Equatorial Africa (now Gabon), treating leprosy, sleeping sickness and other tropical diseases. He worked there 1913-17, 1923-65, apart from a period of internment in World War I (1917-18) and concert and lecture tours in Europe (1919-23, 1928, 1935, 1937, 1949-50, 195253) to raise funds. In 1949 he visited the US. He was criticised for neglecting modern methods of hygiene, e.g. by letting wives and children accompany the patients to hospital and cook meals etc. in the hospital precincts. His answer was that his methods won the affection and trust of those for whom he worked and that the fear of hospital was removed. Improvements were, however, gradually introduced. In his Civilisation and Ethics (1923) he urged adoption of the philosophy of 'reverence for life' (Ehrfurcht vor dem Leben). The Mysticism of Paul the Apostle (1931), a revisionist work, explains Paul in the context of Hellenism and is sharply critical of *Luther's interpretation. He wrote several autobiographical works, e.g. From my African Notebook (1936). In the early years of the Cold War, Schweitzer was often linked with Albert *Einstein and Bertrand ${ }^{*}$ Russell in campaigning against atomic weapons. $\mathrm{He}$ received the 1952 Nobel Prize for Peace, having been nominated 30 times since 1930. His Nobel Prize address is a careful examination of the causes of war and attempts to create organisations, which can eliminate the risk of annihilation. He refers to the horrors of World War II, including atomic bombs, fire bombings and displacement of refugees but, bizarrely, made no reference to ${ }^{*}$ Hitler, the Holocaust, the Middle East or Africa. He used his Nobel Prize money to build a leprosarium and died in Lambaréné.

His many honours included election to the Académie française (1953) and the British OM (1955). He was a second cousin of Jean-Paul *Sartre and related by marriage to the conductor Charles *Munch.

Seaver, G., Albert Schweitzer: The Man and His Mind. 6th ed. 1969; Brabazon, J., Albert Schweitzer. 1975; Brabazon, J., Albert Schweitzer: A Biography. 2000; Oermann, N. O., Albert Schweitzer: A Biography. 2016.

Schweppe, (Jean) Jacob (1740-1821). GermanSwiss inventor, born in Hesse. A jeweller in Geneva, he followed the experiments of Joseph *Priestley and invented a machine that produced the first aerated soft drinks. He was in commercial production by 1783 and set up a factory in London in 1792.

Schwinger, Julian Seymour (1918-1994). American theoretical physicist, born in New York. He was Robert *Oppenheimer's assistant on the 'Manhattan Project', shared the 1965 Nobel Prize for Physics with Richard *Feynman and Sin-Itiro Tomonaga for their work in formulating quantum electrodynamics.

Schwitters, Kurt (1887-1948). German artist and poet. A leader of the Dada movement, he developed three dimensional collages (collectively called Merzfrom the German word Kommerz), using everyday objects. He lived in England from 1940.

Sciascia, Leonardo (1921-1989). Italian novelist, born in Sicily. He wrote thrillers that attacked the Mafia, Red Terrorism and Church indifference, and served in the European Parliament.

Scipio Aemilianus, Publius Cornelius (185-129 BCE). Roman general. The adopted son of Publius Scipio, the son of *Scipio Africanus, he was elected consul (147), commanded the Roman forces in the Third Punic War and after a long siege took and utterly destroyed Carthage (146). Back in Rome, he became a leader of the conservative opposition to the reforms (especially the agrarian law) of his brother-inlaw Tiberius Gracchus (*Gracchi). Scipio's death was generally believed to be a political murder.

Astin, A. E., Scipio Aemilianus. 1967.

Scipio Africanus, Publius Cornelius (236-183 BCE). Roman general. Having gained self-confidence and public esteem in battle against *Hannibal in Italy, he was appointed, at the early age of 27 , proconsul in Spain. One by one he reduced the Carthaginian strongholds and by 207 had conquered the whole country, thus depriving Hannibal of his base. $\mathrm{He}$ was elected consul (205) but instead of directing his forces against Hannibal, still in Italy, he conceived the plan, which he carried out against strong opposition, of going direct to Africa and by a threat to Carthage itself ensuring Hannibal's recall. So it transpired. 
Scipio was victorious on the plains outside Carthage and Hannibal's army on its return was surrounded and destroyed at Zama (202). For the next 10 years Scipio's prestige gave him almost unlimited power, though his love of all things Greek and a policy to accord with it created a conservative opposition under Marcus Porcius ${ }^{*}$ Cato. Scipio's campaign (190-189) against *Antiochus of Syria provided an opportunity for his enemies. Lucius Scipio, Africanus' brother, was asked to account for using part of the indemnity received from Antiochus as a bonus to his troops. Africanus, who realised that he was the real target, was insulted by what he felt to be base ingratitude and retired from public life. By his victories and breadth of vision he had ensured the future of Rome as a great imperial power.

Scullard, H. H., Scipio Africanus: Soldier and Politician. 1970.

Scofield, (David) Paul (1922-2008). English actor. He created the stage role of Thomas * More in Robert *Bolt's A Man for All Seasons (1962) and *Salieri in Amadeus (1979) and toured as Hamlet and Lear. His films include John Schlesinger's The Train (1964), A Man for All Seasons (1966, for which he won an Oscar) and Peter *Brook's King Lear (1971). He received the $\mathrm{CH}$ in 2001.

Scopes, John Thomas (1901-1970). American teacher. After being dismissed for teaching the Darwinian theory of evolution (forbidden by Tennessee law), he was the protagonist of the famous 'monkey' trial at Dayton, Tenn. (1925). Defended by Clarence ${ }^{*}$ Darrow against a prosecution led by William Jennings *Bryan, he was fined $\$ 100$ but the sentence was reversed on appeal.

Scorsese, Martin (1942- ). American film director, screenwriter and actor, born in New York. He began making documentaries in the social realist tradition and his feature films include Mean Streets (1973), Taxi Driver (1976), Raging Bull (1980), King of Comedy (1982), The Last Temptation of Christ (1988) and The Age of Innocence (1993).

Scott, C(harles) P(restwich) (1846-1932). English newspaper editor, born in Bath. Educated at Oxford, he was editor of the Manchester Guardian 1872-1929 and made it a radical force, supporting Home Rule for Ireland and opposing the Boer War. Scott was a Liberal MP 1895-1906 but insisted 'Comment is free, but the facts are sacred'. When the proprietor J. E. Taylor died in 1905, Scott bought the paper.

Scott, Sir (George) Gilbert (1811-1878). English architect. After being articled to a London firm he gained a major success by winning (1844) an open competition for designing St Nikolai Church, Hamburg (now a ruin). From then on he was constantly in demand for building new churches, mainly in the Gothic style, and restoring old ones, including Westminster Abbey and the cathedrals of Hereford, Salisbury, Chester, Ripon, Exeter,
St Albans and Bath Abbey. Among his secular works were Reading Gaol (1844), the Foreign and Commonwealth Office (1868), St Pancras railway station and hotel (1868) and the Albert Memorial (1872) in London.

Clark, K., The Gothic Revival. Repr. 1950.

Scott, Sir Giles Gilbert (1880-1960). English architect. Grandson of Sir George Gilbert *Scott, he won a competition for designing the Anglican Cathedral for Liverpool (1902) and supervised its construction for many years. Among his other designs were those for the Cambridge University Library, the new Bodleian Library, Oxford, the new Waterloo Bridge, London, the new chamber of the House of Commons after World War II (designed 1944, completed 1950), and the Battersea Power Station (converted to the Tate Modern). He received the OM in 1944.

Scott, Michael (1175-1234). Scottish scholar. He translated parts of *Aristotle from Arabic and became official astrologer to the emperor ${ }^{*}$ Friedrich II. His magical powers are referred to by ${ }^{*}$ Dante. Some of his works survive. He was buried at Melrose Abbey, where his grave is still marked.

Scott, Sir Peter Markham (1909-1989). British ornithologist and artist. Son of Robert Falcon *Scott, he worked for the conservation of endangered species partly through the World Wildlife Fund but principally through his own Wildfowl Trust at Shimbridge which he founded in 1946 . He led ornithological expeditions to Iceland, the Galapagos Islands and the Antarctic.

Scott, P., The Eye of the Wind. 1961.

Scott, Robert Falcon (1868-1912). English sailor and Antarctic explorer. He joined the navy (1881) and was promoted captain in 1906 . He led two expeditions to the Antarctic: the first (1901-04) explored the Ross Sea area, in a second voyage (begun 1910) to the same area he commanded the Terra Nova and among his objectives, which included much scientific and exploratory work, was a sledge journey to the South Pole. When Scott and his four companions, E. A. Wilson, L. E. G. *Oates, H. R. Bowers and E. Evans reached their goal (18 January 1912) they found that the Norwegian explorer Roald *Amundsen had been there a month earlier. Disappointment became tragedy when, already delayed by a sudden drop in temperature, intense blizzards, and illness, the party remained in its tent until provisions were exhausted. Scott recorded the last days in his diary, later discovered and published in 1913.

Solomon, S., The Coldest March. 2001; Fiennes, R., Captain Scott. 2003.

Scott, Sir Walter, 1st Baronet (1771-1832). Scottish writer, born in Edinburgh. Partly crippled by polio (1773), he was increasingly lame throughout life. To 
please his father, an Edinburgh lawyer, he studied law and advanced in the profession, but medieval history and the Romantic literature becoming popular in Germany were his more fruitful regions of study. The collection Minstrelsy of the Scottish Border (1802-03) was followed by his own original The Lay of the Last Minstrel (1805), Marmion (1808) and several more ballads. Popular fame and wealth immediately ensued, the latter encouraging him to start building what was intended to be the ancestral home of Abbotsford on the Tweed near Melrose. He now turned from poetry to prose and Waverley (1814), published anonymously, introduced the great romantic and historical series known as the Waverley novels, from their author's thin disguise as 'the author of Waverley'. The best known include Guy Mannering (1815), Rob Roy (1818), The Heart of Midlothian (1818), The Bride of Lammermoor (1819) which inspired *Donizetti's opera, Ivanhoe (1819), The Monastery and its sequel The Abbott (both 1820), Kenilworth (1821), Quentin Durward (1823) and The Talisman (1825). Fiercely reactionary, he was created a baronet in 1820 .

Coincident with the publication of Woodstock (1826) came the disaster that shadowed Scott's last years. Partly to meet the cost of Abbotsford he had entered into partnership with his friend James *Ballantyne, the publisher. The firm crashed, Scott, with his delicate sense of honour, refused bankruptcy and with immense courage and industry assumed the task of repaying in full a sum of $£ 130,000$ due to creditors. This was eventually achieved by the sale of copyrights after his death, hastened by strain and exhaustion. The quality of his work inevitably declined but to this last period belong three more novels (e.g. Anne of Geierstein), the collection of stories from Scottish history titled Tales of a Grandfather (1828-30), and his Life of Napoleon (1827).

Scott's particular form of romanticism is out of fashion, his characterisation was often poor, but some of his historical portraits, e.g. of *Louis XI of France in Quentin Durward, are remarkable. He played an important part in the development of the historical novel. In his Journal (March 1826), he wrote, after commenting on Jane *Austen, 'The big bow-wow strain I can do myself like any now going; but the exquisite touch, which renders ordinary commonplace things and characters interesting, from the truth of the description and the sentiment, is denied to me.'

Abbotsford passed eventually to Scott's granddaughter Charlotte (child of his daughter Sophie and J. G. *Lockhart, his biographer), then to her descendants. Scott's fame was spread by the Caledonian diaspora. (In Melbourne alone, four suburbs are named for his home and novels.)

Johnson, E., Sir Walter Scott: The Great Unknown. 1970; Lincoln, A., Walter Scott and Modernity. 2007; Duncan, I., Scott's Shadow. 2007; Kelly, S., Scott-Land. 2010.
Scott, Winfield (1786-1866). American soldier and politician, born in Virginia. Originally a lawyer, he served in the War of 1812 in Canada and was wounded, led campaigns against the Black Hawks, Seminoles, Creeks and Cherokees, becoming a skilled negotiator in ending the Patriot War (1837-38). He sought the Whig nomination for president in 1840, 1844 and 1848 , losing, in turn, to *Harrison, *Clay and ${ }^{*}$ Taylor. As Commanding General of the US Army 1841-61, he introduced French tactics, and in the Mexican War (1846-48) defeated *Santa Anna and captured Mexico City. He won the soubriquet 'Old Fuss and Feathers'. In 1852 as an anti-slavery candidate he defeated Millard *Fillmore for the Whig presidential nomination, but lost to Franklin *Pierce (who had been a subordinate in Mexico). He remained loyal to the Union in the Civil War, retiring in November 1861.

Scott Moncrieff, C(harles) K(enneth) (1889-1930). Scottish writer and translator. Educated at Winchester and Edinburgh University, he translated Beowulf and *Stendhal, served as an officer in World War I and was injured. From 1921 until his death, he devoted himself to translating *Proust's $\dot{A}$ la recherche $d u$ temps perdu, as Remembrance of Things Past, a masterpiece in its own right, poetic but not always strictly literal. He lived in Italy from 1923, in Florence, Pisa and Rome, reporting to British Intelligence on ${ }^{*}$ Mussolini and the Fascist regime. He also translated ${ }^{*}$ Pirandello.

Findlay, J., Chasing Lost Time: The Life of C. K. Scott Moncrieff, Soldier, Spy and Translator. 2014.

Scriabin (or Skryabin), Aleksandr Nikolayevich (1872-1915). Russian composer and pianist. A contemporary of ${ }^{*}$ Rachmaninoff at the Moscow Conservatoire, he became professor of pianoforte there 1898-1904. His early piano works were strongly influenced by ${ }^{*}$ Chopin. After leaving Moscow he devoted himself to composition and lived in Switzerland, Belgium and France. Later under the influence of theosophy he developed doctrines that attached religious significance to all forms of art, and in his compositions subordinated everything to the achievement of ecstasy for which purpose he used such effects as clanging bells, incantations and blaring trumpets. The orchestral works Poem of Ecstasy (1908) and Prometheus (1911) and the last five piano sonatas (Nos 5-10) illustrate this development. In his later works he introduced a harmonic system based on a 'mystic' chord of ascending fourths.

Scribe, (Augustin) Eugène (1791-1861). French dramatist. He was a prolific writer of plays that entertain mainly by the skill of the plot and clever denouements, e.g. Adrienne Lecouvreur (1849, later an opera by *Puccini). He also wrote about 90 libretti, for operas by *Adam, *Auber, ${ }^{*}$ Bellini, Boieldieu, *Donizetti, *Halévy, *Meyerbeer, *Offenbach, ${ }^{*}$ Rossini and ${ }^{*}$ Verdi. He believed that the function of the theatre was to amuse, not to be a reflection of life or a means of instruction. 
Scullin, James Henry (1876-1953). Australian Labor politician, born near Ballarat. He was a grocer, journalist and union organiser, a member of the House of Representatives 1910-13, 1922-49 and Leader of the Australian Labor Party 1928-35. His term as Prime Minister 1929-32 coincided with the onset of the Great Depression in which Australia was severely hurt. His party split over means of combatting the crisis, with Jack *Lang defecting to the Left and J. A. *Lyons to the Right. In the December 1931 election, the ALP national vote fell to 26.7 per cent and Lyons led the United Australia Party to a landslide victory.

Sculthorpe, Peter Joshua (1929-2014). Australian composer, born in Launceston. After studying in Melbourne and Oxford, he taught composition at Sydney University 1963, becoming a Professor in 1992. Encouraged by the conductor Sir Bernard Heinze (1894-1982) and by the Australian Broadcasting Commission (now Corporation) his music was frequently performed. His works include 15 string quartets, Irkanda I and Irkanda IV for violin, Cello Dreaming, and Sun Music I, II and III, Earth Cry for didgeridoo and orchestra (1986), Kakadu (1988) for orchestra and Port Arthur In Memoriam (1996). Naxos and $\mathrm{ABC} /$ Eloquence produced two valuable collections of Sculthorpe's music.

Seaborg, Glenn Theodore (1912-1999). American physicist, born in Michigan. Educated at the University of California at Los Angeles and Berkeley, he worked on transuranic elements with Edwin ${ }^{*}$ McMillan and shared the 1951 Nobel Prize for Physics with him. He co-discovered (and named) the elements plutonium (No. 94), americum (95), curium (96), berkelium (97), californium (98), einsteinium (99), fermium (100), mendelevium (101) and nobelium (102). He chaired the US Atomic Energy Commission 1961-71 and campaigned for an end to nuclear testing. Seaborgium (106) was named for him in 1994, and Asteroid Seaborg in 1995.

Searle, Ronald William Fordham (1920-2011). English artist and cartoonist. He published his first work in 1935 and joined Punch in 1956. He was also attached to Life from 1955 and to the New Yorker from 1966. He published 60 books (21 with collaborators) of drawings and cartoons in a detailed, linear style and first gained wide popular success with his grotesque school children, whom he drew as inky-fingered caricatures of juvenile delinquency. The most famous of these, the girls of St Trinian's, appeared in the early 1950s.

Sebald, W. G. (né Winfried Georg Maximilian Sebald: he used the name Max) (1944-2001). German author, born in Wertach, Bavaria. He grew up in the small town of Sonthofen: his father, a Nazi party member and prisoner of war, returned home in 1947. World War II and the Holocaust was never spoken of. He studied at the universities of at Manchester 1966-67 and East Anglia 1970-2001, and was Professor of European Literature 1987-2001. Despite spending more than half his life in England and his complete mastery of English, he retained German nationality and published only in German. His four 'prose works with pictures' combine elements of novels, essays, biographies, natural histories, travel guides, and include photographs: Vertigo (1990), The Emigrants (1992), The Rings of Saturn (1995) and Austerlitz (2001). His works deal with the suppression of memory, the decay of civilization and the impact of the Holocaust. He had just begun to achieve international recognition when he died in a car crash in Norwich, after suffering an aneurysm. His work is powerful, disturbing and mysterious.

Angier, C., Speak, Silence. In Search of W.G. Sebald. 2021.

Sebastiáo (Sebastian) I (1554-1578). King of Portugal and the Algarves 1557-78. A posthumous child, he succeeded his grandfather * João III. He grew up with an antipathy to women and a fanatical sense of mission to lead a crusade against the Muslims of North Africa. He sailed to Morocco in 1578 but was defeated and never seen again. The mystery of his disappearance produced impostors and led to the growth of a legend that he would return to deliver Portugal in time of need.

Seddon, Richard John (1845-1906). New Zealand politician, born in Lancashire. He emigrated to Australia in 1863 and then went to the Westland goldfields of New Zealand (1866). First elected to the House of Representatives in 1879, he became (1891) a minister in the Liberal Government of John Ballance, whom he succeeded as Prime Minister 1893-1906. Known as 'King Dick', he straightened the affairs of the Bank of New Zealand, assisted Britain in the Boer War with New Zealand troops, introduced Imperial Preference (1903), and annexed the Cook Islands. He was no socialist but to control prices he introduced state coal-mining (1901), fire insurance (1903), and house-building (1905). He died at sea.

Sedgwick, Adam (1785-1873). English geologist. Son of the curate of Dent in Yorkshire, he studied at Trinity College, Cambridge, and became a Fellow in 1810. Despite having no knowledge of the subject, he was appointed Professor of Geology at Cambridge 1818-73, learned on the job and became one of the foremost British geologists. An empirical geologist, with strong Christian sentiments, he disapproved of *Lyell's Uniformitarianism, was suspicious of Glacial Theory, and rejected all theories of evolution, especially *Darwin's. He excelled in two fields, in palaeontology, especially palaeozoic fossils, and in understanding the stratigraphy of the British Isles, using fossils as an index of relative time. His greatest work lay in the geology of Wales, bringing to birth the concept of the Cambrian System on which he 
eventually quarrelled with *Murchison, another proponent of the Devonian system. He was awarded the Copley Medal in 1863.

Speakman, C., Adam Sedgwick. 1982.

Sedley, Sir Charles (1639-1701). English poet and dramatist. A member of the circle of wits and profligates who surrounded ${ }^{*}$ Buckingham and ${ }^{*}$ Rochester at the court of ${ }^{*}$ Charles II, he wrote charming lyrics, excellent translations of ${ }^{*}$ Virgil and ${ }^{*}$ Horace, and plays, e.g. the comedies The Mulberry Garden (1667), based on *Molière's L'École des maris, and Bellamira (1687).

Segovia, Andrés (1893-1987). Spanish classical guitarist. Regarded during his active period as the greatest in the world, he made his debut at 14 and established an international reputation mainly with Spanish music. He inspired many works for the guitar, notably by *Villa-Lobos, Ponce and CastelnuovoTedesco and adapted pieces by *Bach and *Mozart. He was ennobled as Marqués de Solobrefia in 1981.

Segrè, Emilio Gino (1905-1989). American nuclear physicist, born in Italy. Professor of physics at the University of Palermo 1935-38, he then worked in the US, where he became professor of physics at the University of California 1946-72. He helped to prepare artificially the elements technetium (No. 43) and astatine (No. 85), which are below uranium in atomic number but not found naturally on earth. Segrè was a pioneer in the investigation of anti-matter and discovered (1955) the anti-proton. He won the Nobel Prize for Physics (1959). His publications include Nuclei and Particles (1964).

Seidler, Harry (1923-2006). Australian architect, born in Vienna. Of Jewish-Romanian parentage, he escaped to London in 1938 and was briefly interned in Canada, studied architecture in Manitoba, then won a scholarship to Harvard where he worked with ${ }^{*}$ Gropius and *Breuer, and in Boston with *Aalto. In Sydney from 1948, he designed more than 180 buildings, including the Australian Embassy in Paris. He was associated with ${ }^{*}$ Niemeyer in Brasilia. The Grand Tour, Travelling the World with an Architect's Eye (2004) presents 1,000 photographs by Seidler.

O’Neill, H., A Singular Vision: Harry Seidler. 2013.

Sejanus, Lucius Aelius (d.31 CE). Roman politician and conspirator. A favourite of *Tiberius, he ran the praetorian guard, arranged murders inside the imperial family, but was detected in treachery and executed.

Selden, John (1584-1664). English jurist, parliamentarian and scholar. From 1621 he sat almost continuously in parliament. He helped to draw up the Petition of Right and (1629-31) was imprisoned in the Tower, but though he sat in the Long Parliament his refusal to vote for the attainder of ${ }^{*}$ Strafford made him suspect and he gradually withdrew from public life. His Titles of Honour (1614) and History of Tithes (1618) still have value, but most of his learned works are long forgotten and he is remembered mainly for his Table Talk (1689), a record collected by his secretary of his conversations and remarks during his last 20 years. He was also an orientalist whose collection of manuscripts came to the Bodleian Library, Oxford. The Selden Society (for legal publications) was founded in his honour.

Seleucus I Nicator (d.280 BCE). Macedonian general, founder of the Seleucid dynasty. After the death of *Alexander the Great (323) his conquests were divided among his generals. By 312 Seleucus, one of the ablest and most ambitious, had married a Persian princess and ruled Babylonia. He gradually enlarged his empire until it included much of Asia and extended from Syria to India. He was assassinated. Under his successors, known as the Seleucids, the eastern provinces were gradually lost and the power of the dynasty continued in Syria until 64 BCE, when the country was conquered by the Romans, though the Hellenistic culture introduced by the Seleucid dynasty survived.

Selīm I Yavuz (= 'the Grim', also 'the Resolute': Selīm şāh bin Bāyezīd Ḩān) (1470-1520). Ninth Sultan of the Ottoman Empire 1512-20, Caliph of Islam 1517-20. Youngest son of *Bāyezidd II, he defeated his father in battle and executed his brothers and some nephews. The Ottoman Empire expanded by 70 per cent during his reign. A fierce Sunni, he ordered the massacre of thousands of Shiites. He claimed the Caliphate in 1517. His forces occupied Egypt, Syria, Palestine and the Hejaz in 1516-17 and Algeria, Tunisia and Libya soon followed. He died as he was about to invade Hungary. He was also a gifted poet in both Turkish and Persian. His son *Süleyman succeeded.

Selkirk, Alexander (1676-1721). Scottish seaman. While serving under William *Dampier on a privateering expedition he was marooned (1704). According to one account he was left at his own request on one of the Juan Fernandez Islands in the Pacific. He was rescued (1709) and his story inspired *Defoe's Robinson Crusoe.

Sellars, Peter (1957- ). American theatre and opera director, born in Pittsburgh. The most innovative director of his time, he worked at many international festivals. His productions included works by *Aeschylus, *Shakespeare, *Bach, *Mozart, *Ligeti and John *Adams.

\section{Sellers, Peter see Goons, The}

Selznick, David O(liver) (1902-1965). American film producer, born in Pittsburgh. He worked in publishing and real estate, then moved to Hollywood and, after an unhappy period with Paramount, MGM and $\mathrm{RKO}$, became the most important independent 
producer. His films include Anna Karenina (1935), David Copperfield (1935), Gone with the Wind (1939), Rebecca (1940), Duel in the Sun (1946) and The Third Man (1949). He married the actor Jennifer Jones (1919-2009). She won the 1943 Academy Award for best actress in The Song of Bernadette, appeared in Madam Bovary (1949), Beat the Devil (1953) and Love is a Many Splendoured Thing (1957), and married the industrialist, philanthropist and art collector Norton Simon, whose gallery in Pasadena she chaired.

Semenov, Nikolai Nikolayevich (1896-1986). Russian physical chemist. Assistant professor of physics at Leningrad Polytechnic Institute 1928-31, he directed the Academy of Sciences Institute of Chemical Physics 1931-66 and was professor of physical chemistry at Moscow State University 194466. He carried out important researches in chemical kinetics and shared the Nobel Prize for Chemistry (1956) with *Hinshelwood for their important discoveries in this field.

\section{Semmelweis, Ignác Philipp (1818-1865).} Hungarian obstetrician. Working in a Vienna hospital he discovered in 1847 that the death rate from puerperal fever was far higher (10 per cent against 3 per cent) in the ward attended by doctors who had come straight from post mortem rooms than in that attended by midwives. He worked in Pest from 1849. By insisting on adequate use of antiseptics he reduced the death rate from infection to 1 per cent. The value of his work was recognised after his death but provoked much controversy at the time. Infected by a cut, he died of septicaemia in an asylum.

Gortvay, G. and Zoltán, I., Semmelweis, his Life and Work. 1968.

Sen, Amartya Kumar (1933- ). Indian economist and philosopher, born in Bengal. Educated at Calcutta and Cambridge, he held chairs in Calcutta, London, Oxford and was professor of Economics and Philosophy at Harvard 1987-97, 2004- and Master of Trinity College, Cambridge 1998-2003. He wrote Poverty and Famines (1981), Inequality Reexamined (1992), Development as Freedom (1999), Rationality and Freedom (2004) and The Idea of Justice (2009). He devised the Human Development Index (HDI) as an alternative to the gross domestic product (GDP) figures to measure quality of life. He won the 1998 Nobel Prize for Economics for his fundamental work on development and welfare economics, restoring an ethical dimension, combining tools from economics and philosophy. He received a $\mathrm{CH}$ in 2000 and was awarded more than 90 honorary degrees.

Senanayake, Don Stephen (1884-1952). Ceylonese (Sri Lankan) politician. He led Ceylon's independence movement, and as Minister of Agriculture 1941-46 he achieved much in irrigation and land reclamation. He became (1948) the first Prime Minister of the newly created dominion, dying in office after falling from a horse. His son, Dudley Senanayake (19111973), was Prime Minister 1952-53, 1960, 1965-70.

Seneca, Lucius Annaeus (c.4 BCE-65 CE). Roman tragedian and politician, born in Córdoba. His fame as an orator roused the jealousy of ${ }^{*}$ Caligula and almost cost him his life. Under ${ }^{*}$ Claudius the favour of the Emperor's sister brought the hostility of ${ }^{*}$ Messalina, the Emperor's wife, and Seneca was banished to Corsica. $\mathrm{He}$ was recalled (49 CE) to be tutor to the young *Nero and when his pupil became Emperor provided five years (the famous quinquennium Neronis) of model government. Later he became involved in a conspiracy and was forced to commit suicide. As a philosopher he inclined towards modified Stoicism and wrote essays on such subjects as Calm of Mind, Shortness of Life. He is better known for his nine surviving verse tragedies, which elaborate the familiar classical stories (Medea, Phaedra, Oedipus etc); with much melodrama, moralising and horror, they influenced Elizabethan drama and ${ }^{*}$ Corneille and ${ }^{*}$ Racine. Though Seneca's private life was blameless, he lacked strength of character, became a time-serving flatterer and condoned vices he could not prevent. He even wrote the oration defending Nero's matricide of *Agrippina. Nevertheless, as his 124 Moral Epistles show, he was, in his timid way, a seeker after virtue.

Senghor, Leopold Sédar (1906-2001). Senegalese politician and poet. A Member of the French National Assembly 1945-58, he became President of Senegal 1960-80 and was elected to the Académie française in 1983 .

Sennacherib (d.681 BCE). King of Assyria 705-681 BCE. He successfully maintained the empire of his grandfather, ${ }^{*}$ Tiglath-Pileser III and his father *Sargon II. He destroyed Babylon, constantly in revolt, and punished a revolt in Judea (see 2 Kings) by laying waste part of the country and besieging Jerusalem. His greatest achievement was the building of a large part of the capital city of Nineveh (on the Tigris opposite Mosul), where magnificently carved reliefs illustrated his campaigns. The remains of magnificent aqueducts near Mosul suggest that the famous 'Hanging Gardens', one of the world's seven wonders, were actually in Nineveh, not Babylon. He is the subject of *Byron's The Destruction of Sennacherib. He was murdered by his sons and succeeded by his youngest, ${ }^{*}$ Esarhaddon.

Sennett, Mack (Michell Sinott) (1880-1960). American film director and producer, born in Québec. He worked in film from 1908, as an actor, then director, and formed Keystone Films in 1912, directing a long series of comic shorts which featured Charles ${ }^{*}$ Chaplin and later the Keystone Kops. He was a victim of the transition to talking films but received a special Academy Award in 1937. 
Senussi (or Sanusi), Muhammad ibn Ali as(c.1787-1859). Arab religious and political leader, born in Algeria. Claiming descent from *Fatimah, he established an order or fraternity that aimed at a return to the pure and simple Islamic doctrines untainted by later 'reformers'. Forced to leave Arabia, he established himself and his followers in Cyrenaica, where the Senussi, whose numbers grew eventually to over 200,000 , formed a semi-independent state under him and his successors. The Senussi proved the most tenacious opponents of the Italian regime that succeeded that of Turkey after the war of 1911-12. Their leader Muhammad *Idris became the first (and only) king of Libya in 1951.

\section{Septimius Severus, Lucius see Severus, Lucius Septimius}

\section{Sequoia see Sequoyah}

Sequoyah (Ssiquoyah or Sequoya, also known as George Giss) (c.1770-1843). American Cherokee silversmith and soldier, born in Tuskegee, Tennessee. From 1809 he developed a written form of the Cherokee language, a syllabary, adopting Latin, Greek and Arabic letters. The genus sequoia is probably not named for him (1847).

Serra, Junipero (1713-1784). Spanish missionary, born in Mallorca. A Franciscan friar, he worked in Mexico (1750-69), then established nine missions in California along the Camino Real. He was sympathetic to the Indians and introduced them to European agriculture.

Serra, Richard (1939- ). American sculptor, born in San Francisco. Of Spanish and Russian-Jewish descent, he studied at the University of California, also working at a steel mill, then studied painting at Yale, where Josef *Albers and Philip ${ }^{*}$ Guston were influential, and won a *Fulbright Scholarship to work on sculpture in Rome. Serra produces huge metal works made from Cor-ten steel sheets. His works are not objects, but intended to transform space. His Torqued Ellipses (1996ff), stimulated by *Borromini's San Carlo alle Quattro Fontane, in Rome, challenged clock time and spacial perceptions. The Hedgehog and the Fox (1999), inspired by an essay of Isaiah *Berlin, is at Princeton University. The Museo Guggenheim in Bilbao features a collective permanent exhibition of eight works by Serra, with the collective name The Matter of Time (1994-2005), described by Robert *Hughes as 'the greatest sculpture of the past century', it incorporates Snake, a trio of sinuous steel sheets, 4.3 metres high, with a total length of 31.7 metres. The Te Tuhirangi Contour (1999/2001), at the Gibbs Farm, New Zealand, $257 \mathrm{~m} \mathrm{x} 6 \mathrm{~m}$, with an $11^{\circ}$ lean, is made of 56 Corten steel plates. East-West/West-East (2014) was erected in the Qatari desert. Serra also produced films, prints and drawings.
Sertorius, Quintus (123-72 BCE). Roman soldier. In the civil war between *Sulla and *Marius, Sertorius was among the most successful of the latter's generals and, after Sulla's victory, withdrew to Spain of which he had obtained complete mastery by 77 . Assassinated by a disloyal adherent, he was described by ${ }^{*}$ Mommsen as 'one of the greatest men, if not the very greatest man, that Rome had hitherto produced'.

Servetus, Michael (Miguel Serveto) (1511-1553). Spanish theologian and physician. While studying law at Saragossa and Toulouse he became interested in theology, an interest heightened by visits to Italy and Germany, where he encountered *Bucer and other reformers. An essay on the Trinity (1531), though not going so far as to express Unitarian views, was far from orthodox. In 1536 he went to Paris to study medicine and from 1541 practised at Vienna. He is famous for his demonstration of the pulmonary circulation of the blood. After secretly printing Christianismi Restitutio (1553) he was denounced to the Lyons inquisitor, but escaping from arrest he went to Geneva, where John ${ }^{*}$ Calvin ruled with rigid intolerance. Servetus, whose views were as antagonistic to the reformers at Geneva as to the Catholics, was again arrested and, after a prolonged trial, was burned alive in Geneva.

Wilson, E. M., A History of Unitarianism. 1945.

Service, Robert William (1874-1958). Canadian poet. Famous for his songs and ballads told in the rough idiom of the frontier country, the best known, often used as a recitation, is 'The shooting of Dan McGrew'. Titles of his verse collections include Songs of a Sourdough (1907) and Rhymes of a Rolling Stone (1912). He also wrote novels.

Seth, Vikram (1952-). Indian novelist and poet, born in Kolkota. His mother became Chief Justice of India, his father was an executive with a shoe manufacturer. Educated at Oxford and Princeton, his books include From Heaven Lake: Travels through Sinkiang and Tibet (1983), Golden Gate: A Novel in Verse (1986) and a successful novel of almost unprecedented length (1349 pages) in English, A Suitable Boy (1993). An Equal Music (1999) was also a bestseller.

Seti I (Menmaartre Set) (d.1279 BCE). Egyptian pharaoh of the XIXth dynasty 1290-1279 BCE. Son of *Ramesses I and father of *Ramesses II, his capital was Memphis.

Seurat, Georges (1859-1891). French painter. At the Salon des Indépendants (1884) he exhibited Une Baignade (now in the Tate Gallery, London), the first of the huge pictures in which he excelled. With *Signac and *Pissarro he developed, under the influence of optical theorists, the 'pointillist' technique by which the canvas is covered with dots of unmixed colour ('confetti' according to the scoffers) which merge at a distance into the required tones. This technique was the hallmark of the 
neo-Impressionists, more distinctive of Seurat was the nobility he gave to ordinary activities by strictly disciplined composition.

de Hauke, C., Seurat et son oeuvre. 1961; Russell, J., Seurat. 1985; Rewald, J., Seurat. 1990.

\section{Severus, Alexander see Alexander Severus}

Severus, (Lucius) Septimius (146-211). Roman Emperor 193-211. Born in Leptis Magna, now in modern Libya, he was governor of Upper Pannonia (parts of Austria and Hungary) when news of the murder of *Pertinax reached his troops, who immediately proclaimed him Emperor. He marched at once to Rome and, having overcome his rivals, turned against the Parthians, annexed northern Mesopotamia and built forts in Arabia and Mauretania. He introduced a complicated administrative system involving strict delimitation of function under imperial control. By encouraging troops to live and marry in the frontier regions, he increased the incentive to vigorous defence at the cost of mobility. In 208 he completed *Hadrian's Wall in stone, and with an army of 40,000 attempted to conquer Caledonia (Scotland) and after protracted asymmetrical warfare with the Scots, reached the Central Lowlands. He became fatally ill and died at Eboracum (York). The Romans then retreated to Hadrian's Wall. Septimius established a dynasty (Severan), was succeeded by his son *Caracalla and deified by the Senate. The claim by *Eusebius that he persecuted Christians appears to be wrong.

Elliott, M., Septimius Severus in Scotland. 2018.

Sévigné Marie de Rabutin-Chantel, Marquise de (1626-1696). French noblewoman. After the death of her husband in a duel (1651) she went to Paris where she wrote to her daughter in Provence her famous letters, which record with wit and apparent spontaneity her impressions of society in Paris and the provinces at the time of *Louis XIV.

Seward, William Henry (1801-1872). American Republican politician, born in New York. An attorney, he entered state politics as a Whig and was Governor of New York 1839-43. As a US senator 1849-61, he campaigned for emancipation of the slaves, sought Republican nomination for the presidency in 1860, lost to *Lincoln but became Secretary of State 1861-69. He drew up the Emancipation Proclamation (1863). After Lincoln's murder (he was stabbed on the same night) he continued to serve under Andrew *Johnson and was statesman enough to foresee the advantage to be obtained by the purchase (1867) of Alaska from Russia, although this was denounced as 'Seward's folly'. His incomplete Autobiography was published in 1877.

Sewell, Anna (1820-1878). English author, born and died in Norfolk. From a Quaker family, she was crippled in an accident and is remembered for a single book, Black Beauty (1877), written to draw attention to the cruel treatment of animals.

\section{Seymour, Edward see Somerset, 1st Duke of}

Seymour, Horatio (1810-1886). American Democratic politician. Governor of New York State 1853-54 and 1863-64, he was drafted as Democratic candidate for president (1868), being narrowly defeated by U. S. *Grant in the popular vote, losing heavily in the Electoral College.

\section{Seymour, Jane see Jane Seymour}

Seymour of Sudeley, Thomas Seymour, 1st Baron (1508?-1549). English nobleman. Brother of Edward Seymour, Duke of ${ }^{*}$ Somerset, and of Jane * Seymour, third wife of ${ }^{*}$ Henry VIII and mother of ${ }^{*}$ Edward VI, he married Henry's widow *Catherine Parr. In 1547 he was appointed Lord High Admiral but two years later was beheaded for intrigue against his brother, who had become protector of England during Edward's minority.

Seyss-Inquart (né Zajtich), Arthur von (1892-1946). Austrian Nazi politician. A lawyer, he was Chancellor and Governor of Austria for two days (March 1938) after *Hitler's annexation (Anschluss), administrator of southern Poland 1939-40, and Reichkommissar in the Netherlands 1940-44. He was Foreign Minister for a few days (1945) after Hitler's suicide. For the brutality of his rule in the Netherlands he was sentenced to death by the Nuremberg tribunal and hanged.

Sforza, Carlo, Conte (1872-1952). Italian diplomat. After a period of successful foreign service and a short spell (1920-21) as Foreign Minister, he resigned when *Mussolini came to power. He lived in Belgium and (from 1940) in the US, where he became prominent for his anti-Fascist views. After Mussolini fell he helped to form the provisional government of 1944 and was Foreign Minister under de *Gasperi 1947-51.

Sforza, Ludovico ('Il Moro') (1451-1508). Italian nobleman, Duke of Milan 1482-99, known as 'The Moor' for his dark skin. His father, Francesco Sforza (1404-1466), was a famous condottiere who fought on both sides in the struggle between Venice and Milan but whose allegiance was finally determined by his marriage to Bianca, an illegitimate daughter of the Visconti Duke of Milan. This enabled him to become duke in 1450 . The duchy passed to his son, then to his grandson the seven-year-old Gian Galeazzo Sforza (1476-1494) whose authority was usurped by his uncle Ludovico, strongly suspected of hastening his death. The court of Ludovico, and his brilliant wife Beatrice d'Este became a centre of Renaissance culture, *Leonardo da Vinci being the most famous of the artists he befriended and employed. Ludovico was expelled (1499) by *Louis XII of France and, after failing to regain his duchy, was imprisoned at Loches on the Loire, where he died. 
Shackleton, Sir Ernest Henry (1874-1922). AngloIrish Antarctic explorer, born in Kildare. He joined the RN and was with ${ }^{*}$ Scott on his first voyage of exploration, and sailing in the Nimrod he led his first expedition (1907-09) during which the magnetic pole and a record southern latitude of $88^{\circ} 23^{\prime}$ were reached. Knighted in 1909, he was a celebrity but constantly in debt and embarked on some dubious business enterprises. His second expedition (191416) was an attempt to cross Antarctica from the Weddell to the Ross Sea. After his ship, the Endurance, had been trapped in ice (January 1915), then crushed (November 1915), Shackleton and five companions made a hazardous journey from the Weddell Sea to Elephant Island, then to South Georgia Island, to bring relief. All 22 of his expedition, left behind, were saved. He helped to organise the northern expeditionary force intervening in the Russian Civil War (1918-19) and died in South Georgia while on a third voyage to Antarctica. He wrote about his expeditions in, e.g. Heart of the Antarctic (1909) and South (1919). His son, Edward Arthur Alexander Shackleton, Baron Shackleton (1911-1994) was an explorer, writer, BBC producer, Labour MP 1946-55 and Minister 1964-70, awarded a KG, AC and FRS.

Huntford, R., Shackleton. 1985.

Shadwell, Thomas (1642-1692). English poet and dramatist. His first play, The Sullen Lovers (1668), was followed by 16 more, the best of them comedies and the majority successful. As plays were used for political propaganda, he was, as a Whig, unable to produce plays from 1681, when the party fell into disfavour, until the revolution of 1688. In 1689 he replaced the Tory *Dryden as Poet Laureate. Shadwell's reputation for dullness is largely due to the brilliant but cruel lampoon of him in Dryden's MacFlecknoe, in fact he often presents a vivid and entertaining picture of contemporary life.

Shaffer, Peter Levin (1926-2016). British playwright. His plays include Five Finger Exercise (1958), The Royal Hunt of the Sun (1964), Equus (1973) and Amadeus (1979). All were successful in Britain and the US and also as films. His twin brother Anthony Shaffer (1926-2001) wrote Sleuth (1972) and many film scripts.

Shaftesbury, Anthony Ashley Cooper, 1st Earl of (1621-1683). English politician. In the Civil War he first fought as a Royalist, but in 1644 went over to the parliamentary side. A member of ${ }^{*}$ Cromwell's Council of State, by 1659 he was imprisoned as a suspected royalist. Thus at the Restoration he was favoured by ${ }^{*}$ Charles II, created Baron Ashley in 1661 and from then until 1672, when he was made Earl of Shaftesbury, he acted as Chancellor of the Exchequer (from 1667 as a member of the famous Cabal ministry). Lord Chancellor 1672-73, always disliked, he was then dismissed by Charles II and became the force behind the movement to exclude the
Roman Catholic Duke of York (*James II) from the succession, making use of the infamous Titus ${ }^{*}$ Oates to 'expose' a Catholic plot. In the ensuing reaction Shaftesbury was acquitted of treason but took refuge in Amsterdam where he died.

The most skilful politician of his day, he was the virtual founder of the Whig Party. His methods were devious, but, as is shown by his association with John *Locke and the part he played (1679) in amending the Habeas Corpus Act, he had liberal causes at heart. An envenomed satirical portrait of him is contained in *Dryden's Absalom and Achitopel.

Haley, K. H. D., The First Earl of Shaftesbury. 1968.

Shaftesbury, Anthony Ashley Cooper, 3rd Earl of (1671-1713). English philosopher. His chief work, Characteristics of Men, Manners, Opinions, Times (1711) discusses virtue, integrity, self-respect and the 'Affections' which he believed men had naturally for themselves, other men and even fellow living creatures. The good of society and the good of the individual in the nature of things run into one another. Men have a 'moral sense'- he introduced the term — which enables them to separate right from wrong.

Shaftesbury, Anthony Ashley Cooper, 7th Earl of (1801-1885). English philanthropist. As Lord Ashley he was an MP 1826-51 until he succeeded to the peerage. He took the lead in securing the passage of a succession of Factory Acts and the Coal Mines Act of 1842 . Among the many improvements he secured were the appointment of factory inspectors to ensure that children under nine were not employed in the mills, and that women and children should not work underground in the mines. Another of his measures prohibited the employment of children (such as Tom in *Kingsley's Water Babies) to climb and clean chimneys; he was closely associated with the 'Ragged Schools' movement, and legislation to provide lodging houses for the poor; he helped the work of Florence ${ }^{*}$ Nightingale and numerous other good causes. Politically he was a strong Tory and in religion strictly evangelical. $\mathrm{He}$ is commemorated by the statue of Eros (Love) in Piccadilly Circus, London.

Shah Jahan (1592-1666). Emperor of India 162758. The fifth of the Mughals, he fought successfully against the Deccan princes but several attempts to recover Kandahar from Persia eventually failed. He was an able ruler and by skilful financial management maintained a court of the greatest magnificence (he constructed the 'peacock throne'). He built the palace and great mosque at Delhi, and at Agra the beautiful 'pearl mosque' and the Taj Mahal, the most famous of all his buildings, erected as a mausoleum (1631-53) for his favourite wife Arjumand (the more familiar Mumtaz is a description - 'ornament' - not a name). In 1658 he fell ill and his son *Aurangzeb, successful in a struggle for the succession, deposed him and held him prisoner until his death. *Dryden's Aureng-Zebe (1676), is based loosely on these events. 
Shahn, Ben(jamin) (1898-1969). American artist, born in Lithuania. He was a painter, photographer, lithographer and graphic designer, who achieved early fame with his 23 paintings on the ${ }^{*}$ Sacco and Vanzetti executions (1930). He had a wide range, from political issues to abstractions.

Shaka (Chaka or Tshaka) kaSenzangakhona (c.17871828). Zulu chief 1816-28. A military genius, sometimes called 'the black Napoléon', he began the Difaqane (Mfecane) or 'Crushing' which destroyed rival tribes in the Natal and Transvaal area, leading to depopulation. (After his death this gave an opportunity for the Boer 'Voortrekkers' under *Pretorius to occupy the Transvaal.) He became psychotic after his mother died (1827) and was murdered by his half-brother *Dingaan.

Shakespeare, William (1564-1616). English dramatist and poet, born at Stratford-on-Avon, Warwickshire, on St George's Day, 23 April. Very few of the traditional stories of his early life can stand up to serious examination. His father, John Shakespeare (c.1529-1601) was a glover and wool-dealer who became an alderman, bailiff and money-lender in Stratford and, after a period of financial difficulty and obscurity, received a grant of arms in 1596. His mother, Mary Arden (c.1537-1608), came from a landed family whose genealogy could be traced to Anglo-Saxon times.

Educated at the King's New School (which had covert Jesuit connections), he would have been well grounded in Latin and rhetoric. Some scholars suggest that he was a servant or teacher in Catholic households in Lancashire 1581-82 (a variant of John *Aubrey's story that he was 'a schoolmaster in the country') and he seems to have known five men who were executed as recusants. The next positive evidence of Shakespeare's existence is the licence to marry Anne *Hathaway (1582). The christenings of their children are recorded, that of his elder daughter Susanna in May 1583, that of the twins Judith and Hamnet in February 1585. The boy Hamnet died aged 11 but Judith married and survived her father; his granddaughter Elizabeth (d.1670), the daughter of Susanna, who had married John Hall, a Stratford physician, was his last known descendant. A familiar, but less likely, legend relates that he left Stratford (c.1585) to avoid prosecution for poaching on the estate of Sir Thomas Lucy of Charlecote. He probably arrived in London between 1585 and 1587, drawn by the appeal of city life and growing realisation of his own talents, probably as an actor-writer with 'Lord *Strange's Men', an acting troupe, in theatres originally managed by James *Burbage. A disparaging reference to Shakespeare in 1592 by the dramatist Robert ${ }^{*}$ Greene confirms that he was well established in London. Circumstances favoured him: nine openair theatres were built in London in Shakespeare's lifetime, beginning in 1576, some accommodating
200,000 people. There was an ever increasing demand for plays and spectacles (including bearbaiting), a situation unprecedented until the explosive impact of cinema and television more than 300 years later.

London's theatres were closed in 1592-94 because of the plague. When they re-opened, Shakespeare was with 'The Lord Chamberlain's Men', which acted at court, as actor, writer and probably director. In 1603 the company was renamed 'The King's Men', under *James I's patronage.

Shakespeare's writing mirrors the circumstances of his times: drama in the theatre filled a psychological gap after the suppression of the Mass and abandonment of mystery plays, the upsurge of patriotic feelings after the defeat of the Spanish Armada in 1588, and publishing poetry when the theatres were closed.

There was an extraordinary burst of creativity in drama towards the end of the Elizabethan and in the early Jacobean periods, unparalleled until the literary explosion in Russia in the 19th century. Shakespeare's contemporary dramatists and poets included *Spenser, *Sidney, ${ }^{*}$ Greene, ${ }^{*}$ Middleton, ${ }^{*}$ Marlowe, ${ }^{*}$ Nash, *Jonson, *Kyd, *Webster, *Beaumont, *Fletcher, *Tourneur, ${ }^{*}$ Dekker, ${ }^{*}$ Ford, Thomas ${ }^{*}$ Heywood, George Wilkins, *Donne and the Metaphysical poets. Francis Meres, in Palladis Tania. Wit's Treasury (1598), rated Shakespeare highly both in comedy and tragedy.

Shakespeare's first published works were the narrative poems Venus and Adonis (1593), very successful and much reprinted, and The Rape of Lucrece (1594), both based on *Ovid and dedicated to Henry Wriothesley, the young Earl of Southampton. Most of the sonnets may date from this period.

Eleven plays (13 including disputed attributions) are based on mistaken /double identity. Answers to the questions 'Who are you?' or 'Are you who you say you are?' could be matters of life or death in Elizabethan England, after convulsive changes from Catholicism, to Anglicanism, back to Catholicism and returning to modified strains of Anglicanism.

Three of Shakespeare's plays (As You Like It, Twelfth Night, The Tempest) do not specify a location, 14 are set (in whole or in part) in England, 12 in Italy (Northern Italy 6, Ancient Rome 4, Sicily 3,), 5 (in whole or part) in France, 2 in Turkey (Ephesus and Ancient Troy), 2 in Athens and Ancient Britain, 1 each in Bohemia, Croatia (Illyria), Egypt, Denmark, Scotland, Lebanon (Tyre), and Vienna.

Some have several locations, for example Henry $V$ in England and France, Antony and Cleopatra in Rome, Alexandria, Messina and Athens, Othello in Venice and Cyprus.

He drew on material from *Homer, *Terence, *Plautus, ${ }^{*}$ Virgil, Ovid, ${ }^{*}$ Seneca, ${ }^{*}$ Plutarch, ${ }^{*}$ Boccaccio, ${ }^{*}$ Chaucer, ${ }^{*}$ Caxton, ${ }^{*}$ Bandello, ${ }^{*}$ Holinshed, ${ }^{*}$ Montaigne and the Geneva Bible (especially Job and St Matthew.) 
In Shakespeare's time, all the female characters, some of the greatest in all drama-Juliet, Lady Macbeth, Gertrude, Rosalind, Desdemona, Cleopatra, Portia, Beatrice-were played by men or boys. There are only two functional marriages in the 38 plays, Macbeth and Lady Macbeth, Claudius and Gertrude, suggesting that Shakespeare took a bleak view of the institution. Bill Bryson's conclusion that there is 'no evidence that Shakespeare had a warm relationship with any other human being' is probably correct.

The earliest plays included the political-historical tetralogy Henry VI Part 1, Part 2 and Part 3 and Richard III (1589-92). The Henry VI plays, popular in their time, are now sometimes cut and bracketed together and performed as a single work. However, Richard III is a dramatic masterpiece, despite the unremitting Tudor partisanship of Shakespeare's portrayal of *Richard.

The Comedy of Errors (a free adaptation of Plautus) and Titus Andronicus (from Seneca) are also early and despite skill in plot construction and versification, there are crudities which disappeared as the playwright matured. When the later tetralogy Richard II, Henry IV Part 1 and Part 2 and Henry V (159499) is compared with the first, it is clear how far Shakespeare's power and psychological insight have strengthened, notably in *Henry IV's torment about the murder of *Richard II.

Sir John Falstaff, fat, scheming and disreputable, Shakespeare's greatest comic creation, is a central character in Henry IV, parts 1 and 2, and The Merry Wives of Windsor, and his death is reported in Henry $V$.

In comedy, Shakespeare was gaining an increased sureness of touch in combining farcical incident with subtle understanding of human nature, demonstrated in The Taming of the Shrew, which, with The Two Gentlemen of Verona and Love's Labour's Lost, was almost certainly written before 1594. Some of his most popular plays were written in the period 1594-99: Romeo and Juliet and A Midsummer Night's Dream, followed by The Merchant of Venice and The Merry Wives of Windsor, and another history play, King John, now rarely performed.

Increasingly rich, in 1597 he bought New Place, a substantial house in Stratford. In 1599 Shakespeare's company acquired the Globe Theatre, which burned down in 1613.

On the eve of *Essex's rebellion in February 1601, his supporters commissioned a special performance of Richard II, where a weakening sovereign is overthrown. Shakespeare's company was never accused of complicity in the plot: the play was well known and it was clearly a commercial transaction.

Shakespeare's finest comedies were Much Ado About Nothing (1598), As You Like It (1599) and Twelfth Night (1600-02).
As a playwright he now reached his zenith, beginning with Julius Caesar (1599), the first of three Roman plays based on Plutarch, with powerful characterisation of Brutus-by far the longest part, Mark Antony and Caesar, and a chilling cameo of Octavian (the future Caesar *Augustus.)

The second and third of the Roman plays were Antony and Cleopatra (1606-07) and Coriolanus (1608).

Antony and Cleopatra, written in 42 scenes, is a complex epic, involving love, betrayal and conflicting loyalties, and critical opinion has long been divided on its ranking. Shakespeare borrowed from Plutarch and Virgil (whose account of Dido and Aeneas was in part a tactful account of Cleopatra and Antony, their contemporary prototypes). Frank *Kermode marvelled at the play's 'glamour ... and magnificence' and the contrasts between 'melting Alexandria and ... rigid, stony Rome.'

Coriolanus, a dark, rarely performed, late play, considered superior to Hamlet by T. S. Eliot, is the most overtly political work in the canon, with a disconcerting contemporary relevance: the central character's chilling sense of his own honour drives his ambition and self-justification.

Hamlet (1600-01) is the longest, greatest, most performed, most filmed, most quoted of all the plays and the one most resembling a novel, with its seven interior monologues (soliloquies), exploring the problem of self-knowledge and emotional paralysis. Then came Othello (1604), with its themes of sexuality, race and treachery, King Lear (1605-06), the darkest of all, with its paroxysms of grief, a metaphor for reversion from civilization to barbarism, and Macbeth, psychologically one of the most complex (1605-06).

Troilus and Cressida (1602), Measure for Measure (1603) and All's Well that Ends Well (1604-05) are sometimes described as Shakespeare's 'problem plays', where the boundary between comedy and tragedy is becoming blurred and mood changes are sudden and sometimes inexplicable.

Cymbeline (1610), set in Ancient Britain, is an extraordinary mixture of genres, full of anachronisms but with fine poetry. The Winter's Tale (1610-11) is a complex and uneven work about separation in families: a return to life after 16 years. Kermode points to ranting and pathology in the first part, then calm and acceptance in the last acts

His last completed play, The Tempest (1610-11), shows his creative powers at their highest and the character of Prospero, the deposed Duke of Milan, a magus-like figure on a remote island, seems to be strongly autobiographical and may have been played by Shakespeare himself. The Tempest, the most musical of the 38 plays, represents a farewell to his creative life in the theatre. 
Montaigne's influence, with its intense speculation about the inner life and its contradictions, is apparent in Hamlet and King Lear and he is quoted (without attribution) in The Tempest. Montaigne's Essays were translated by John *Florio who, like Shakespeare, enjoyed the patronage of the Earl of Southampton.

The plays are not dated and attempts to arrange them in chronological order have provoked endless controversy. At least 18 were published in Shakespeare's lifetime in quarto form, and they are of particular interest because of their relevance to specific productions, so that the name of an actor may appear in the text instead of the character played.

A collected edition of 36 plays, known as the First Folio, appeared posthumously in 1623, and the names of the editors, John Heminges and Henry Condell, friends and fellow-actors, vouched for its general authenticity, although the texts were drawn from actors' reconstructions and spellings and rhymes are inconsistent. The First Folio includes the rarely performed Timon of Athens (1605-06, probably written with Thomas *Middleton), the pageant play Henry VIII (1613, mostly written by John Fletcher) but excludes the collaborations Pericles, Prince of Tyre (1607, with George Wilkins?), and The Two Noble Kinsmen (1613, Fletcher). Cardenio, based on a story in *Cervantes' Don Quixote, and a collaboration between Shakespeare and Fletcher, performed in 1613 , is now lost.

About 750 copies were printed, selling for $£ 1$. Eighteen plays, including Macbeth, only survive because they appear in the First Folio. The Folger Shakespeare Library in Washington DC holds 82 of the surviving copies.

Shakespeare's plays are generally far longer than those written by his contemporaries.

The Sonnets were published in book form, possibly without authorisation, in 1609: Sonnets Nos 1-126 are homoerotic, addressed to a 'fair youth', Nos 127154 to an unidentified 'dark lady'. The dedication, by the publisher Thomas Thorpe (or T.T.) to 'Mr W. H.', as the 'onlie begetter' of the sonnets, has caused much unresolved speculation.

Very little is known about Shakespeare's life: what he read (other than the obvious sources), if he travelled, the inspirations for his powerful and original ideas, his political or religious beliefs, his sexual orientation. The richness, diversity and depth of his work led to the rise of 'bardolatry' in the 18th century but the meagre evidence of his personal life raised some questions, although it was not until 1856 that alternative authors were proposed. Francis ${ }^{*}$ Bacon came first, then Edward de Vere, Earl of ${ }^{*}$ Oxford. The 19th-century fiction that creative writing had to be autobiographical was picked up by ${ }^{*}$ Freud, who should have known better.
Seventy-nine alternate candidates have now been proposed. Three are royal, 16 are peers or peeresses, one a cardinal, one a saint, and 32 are published authors. None is remotely plausible. (J. S. *Bach also had an enigmatic interior life but his authorship is virtually unchallenged.)

Slips in writing about Europe or classical antiquity provide support for Shakespeare's authorship: no writer from a university would expose himself to such errors. Ulysses quotes Aristotle. There are clocks in Julius Caesar. There are striking examples of anatopism, having something out of place. The Winter's Tale refers to the coasts (and also a desert) of Bohemia. Characters in Two Gentlemen of Verona sail from Milan to Verona (although he might have been referring to travel by canal), and from Milan to the Adriatic in The Tempest. The only banks in Venice were mercantile and lovers would not be sitting on them. Shakespeare was a man of genius who trawled and reworked the secondary sources rather than having direct exposure to life outside England. His Venetians, Romans, Athenians, Sicilians, Ancient Britons are essentially Londoners.

Shakespeare's last five years were divided between London and New Place, Stratford, where his wife had remained. He died there on his birthday, 23 April 1616 (the same date as Cervantes, but 10 days later under the unreformed Julian calendar), and is buried in Holy Trinity Church. A GPR (ground penetrating radar) scan of Shakespeare's grave (2010) suggests that the skull is missing, possibly stolen in the 1790 s. New Place was substantially rebuilt in 1702, finally demolished in 1759. Archaeology continues on the site and the gardens have been imaginatively restored.

Shakespeare's plays remained popular in his lifetime and some 20 years after. The theatres closed from 1642-60 during the Civil War and the Commonwealth, and as fashions changed his work suffered some eclipse. (After the Restoration, *Pepys recorded seeing 15 performances of plays by and 26 adaptations of Shakespeare and 76 performances of plays by Beaumont and Fletcher). However, ${ }^{*}$ Dryden, and later ${ }^{*}$ Johnson, proclaimed his pre-eminence, which has never been challenged since.

Henry $I V$, Parts 1 and 2, were the first plays by Shakespeare performed in Australia (1800).

More than 270 operas are based on Shakespeare's plays, the finest being by ${ }^{*}$ Purcell, ${ }^{*}$ Berlioz, *Bellini, *Thomas, ${ }^{*}$ Verdi, ${ }^{*}$ Gounod, *Vaughan Williams, *Tippett, *Britten, *Bernstein and *Adès.

There have been more than 400 television productions or films of Shakespeare's plays, beginning with short excerpts from the silent era, e.g. King John (1899).

In Shakespeare's hands blank verse became an instrument of great delicacy whether for dialogue, narrative, description or argument; adaptable equally 
to any plot or situation, tragic or comic. His vocabulary was exceptionally large for his time: David Crystal cautiously estimates that Shakespeare used between 17,000 and 20,000 words, allowing for divergent spellings, definitions and ambiguities. Bill Bryson credits Shakespeare with the coinage, or first recorded use, of 2,035 words (including 'accommodation', 'addiction', 'assassination', 'barefaced', 'bloodstained', 'courtship', 'fashionable', 'frugal', 'generous', 'gossip', 'hobnob', 'lack-lustre', 'leapfrog', 'majestic', 'moonbeam', 'mountaineer', 'negotiate', 'obscene', 'premeditated', 'quarrelsome', 'rant', 'restoration', 'scuffle', 'torture' and 'vast'); 170 of them in Hamlet. His works have been translated more than any other author and many characters are household names. No writer has given more continuous delight or shown greater insight into the heart and mind, although we know so little of his own.

Chambers, E. K., William Shakespeare: A Study of Facts and Problems. 1930; Tillyard, E. M. W., The Elizabethan World Picture. 1966; Schoenbaum, S., Shakespeare's Lives. 1993; Kermode, F., Shakespeare's Language. 2000; The Age of Shakespeare. 2004; Wood, M., In Search of Shakespeare. 2003; Greenblatt, S., Will in the World: How Shakespeare Became Shakespeare. 2004; Ackroyd, P., Shakespeare: The Biography. 2005; Rosenbaum, R., The Shakespeare Wars. 2006; Bate, J., Soul of the Age: the Life, Mind and World of William Shakespeare. 2008; Bryson, B., Shakespeare. The World as a Stage. 2009.

Shalmaneser III (d.824 BCE). King of Assyria 859-824 BCE. Son and successor of Ashur-pasirpal, after regaining control of the Phoenician cities he achieved the great victory commemorated by the Black Obelisk in the British Museum, which shows the biblical King Jehu of the Israelites and other rulers bowing before him.

Shalom Aleichem ('Peace be upon you!', pseudonym of Shalom Rabinowitz) (1859-1916). Russian-Jewish writer, born in the Ukraine. Originally a rabbi, he wrote first in Russian and Hebrew, devoting himself to Yiddish after 1883 and producing more than 40 volumes. His plays and stories describe life in small Jewish towns during the tsarist era. The story cycle, Tevye and his Daughters, was adapted by Joseph Stein for the play Fiddler on the Roof, later a successful film (1971). He moved to the US, became known as the 'Jewish Mark Twain', and died in New York.

Samuel, M., The World of Shalom Aleichem. 1943.

Shamir, Yitzhak (1915-2012). Israeli politician, born in Poland. Migrating to Palestine in 1935, he was an activist in the Stern Gang and was imprisoned by the British during World War II. A Knesset member 1973-96, he became Speaker 1977-80, Foreign Minister 1980-83 and succeeded Menachem *Begin as Prime Minister 1983-84. In a 'national unity' coalition he became Foreign Minister again 1984-86 and Prime Minister 1986-92.
Shannon, Claude Elwood (1916-2001). American mathematician, electrical engineer and cryptographer, born in Michigan. A graduate of the University of Michigan, in 1937, at the Massachusetts Institute of Technology, he recognised Boolean logic (George *Boole) as being central to the operation of a universal computer (a discovery made independently by Victor Shestakov in Moscow in 1935, but not published until 1941). A cryptographer in World War II, he worked at the Bell Labs 1941-56, collaborated briefly with Alan *Turing, and taught at MIT 1956-78. His paper 'The Mathematical Theory of Communication' (with Warren Weaver, 1949) is regarded as the beginning of information theory: he developed *Boltzmann's insight (1894) that 'entropy is missing information' and pointed to entropy as the link between energy and information. The 'Shannon number' $\left(10^{120}\right)$ was his calculation of the number of possible moves in a game of chess.

Campbell, J., Grammatical Man. 1982; Gleick, J., The Information. 2011; Nahn, P. J., The Logician and the Engineer: How George Boole and Claude Shannon Created the Information Age. 2013; Soni, J. and Goodman, R., A Mind at Play: How Claude Shannon Invented the Information Age. 2017; Sen, P., Einstein's Fridge. 2021; Brooks, M., The Art of More. 2021.

Sharif, (Mian Muhammad) Nawaz (1949- ). Pakistani politician and businessman, born in Lahore. Appointed Premier of Punjab 1985-88 by President *Zia ul-Haq, he became leader of the Pakistan Muslim League and was Prime Minister of Pakistan 1990-93 (removed by the military, then lost the following election), 1997-99 (replaced by Pervez *Musharraf after an army coup) and 2013-17, being removed by the Supreme Court following charges of corruption. (His brother was named as his successor.)

Sharon (originally Scheinermann), Ariel (19282014). Israeli soldier and politician, born in Palestine. He served in the police and army, and, as Defence Minister 1981-83, took responsibility for the murders of Palestinian detainees by Lebanese Phalangists at Chatila and Sabra in 1982. Foreign Minister 199699 and Leader of the Likud 1999-2005, he defeated Ehud *Barak to become Prime Minister 2001-06. A secular Jew, he took tough military action against the Palestinian intefada, but after *Arafat's death he negotiated with the Palestinian Authority and formed a coalition with Labour. In 2005 he cleared Israeli settlers from the Gaza strip. This split Likud which he left in November 2005, forming a new centre party, Kadima, but in January 2006 he suffered an incapacitating stroke. His party won the March 2006 elections, but Sharon remained in a vegetative state.

Sharp, Cecil James (1859-1924). English collector of folk songs and dances. He began collecting folksongs in 1903 and thereafter made it his life's work. Like ${ }^{*}$ Grainger, he helped save the English folk tradition from extinction, although he bowdlerised a good many 
songs. He wrote English Folk Song-Some Conclusions (1907) and founded (1911) the English Folk Dance Society. The London headquarters of the English Folk Dance and Song Society is named after him.

Shastri, Lal Bahadur (1904-1966). Indian politician, born in Uttar Pradesh. Son of a schoolmaster, he became one of the most active workers for the Indian National Congress Party and for nine years was imprisoned for civil disobedience. He served in three of *Nehru's Cabinets, as Minister for Railways 1952-56, for Transport and Communications 1956-61 and for Home Affairs 1961-64. On Nehru's sudden death he succeeded as Prime Minister 1964-66. Much of his brief term of office was occupied with disputes with Pakistan and the frontier war that followed. He had just reached an agreement for a ceasefire at a conference held under Soviet auspices at Tashkent when he died. Of very small stature, he had a gentle, persuasive manner that commanded much affection.

Shaw, G(eorge) Bernard (1856-1950). Anglo-Irish dramatist, born in Dublin. He paid little attention to school subjects but acquired a cultural background at art galleries and concerts. After five years in a Dublin land agent's office, he went to London (1876), where his mother, a singing teacher, supported him while he wrote unsuccessful novels and haunted the British Museum to improve his education. He was already a vegetarian, teetotaller, and non-smoker, and now, having studied *Marx, became a socialist. As a St Pancras Borough councillor 1879-1903, he observed social distress at close range. He was among the first members of the Fabian Society (1884) and, having overcome his shyness, became a noted public speaker. His professional career began when as 'Corno di Bassetto' he was music critic on the Star (1888-90) and on The World (1890-94). He was a champion of *Wagner, wrote The Perfect Wagnerite (1898), and also warmly championed *Ibsen when he was appointed dramatic critic of The Saturday Review, then under the editorship of Frank *Harris. Since his defence of Ibsen was combined with attacks on *Shakespeare, Shaw doubly shocked many of his readers, but others revelled in the flippant irreverence of his style and were stimulated by his paradoxes. Thus when his first play Widowers' Houses was produced (1892) he had at least a nucleus of fervent support to set against the general disapproval. Nevertheless, his next play, The Philanderers (1893), was rejected by managements and the third, Mrs Warren's Profession (1893), by the censor (until 1924). These 'unpleasant plays' were followed by 'pleasant' ones: Arms and the Man (1894), Candida (1894), You Never Can Tell (1895-96), and The Devil's Disciple (1896). After a serious illness (1898) Shaw gave up regular journalism and married Charlotte Payne-Townsend (d.1943). He was always grateful for the money she then brought although his own earnings were soon to become prodigious. To what extent his emotions were involved with women is questionable. He was probably too self-centred for love and was at his happiest when in flirtatious correspondence with women he admired, e.g. Ellen *Terry or Mrs Patrick *Campbell. For the former he wrote Captain Brassbound's Conversion (1899). He had already written Caesar and Cleopatra (1898-99), a delightfully modern conception of a historic theme, for Johnston *Forbes-Robertson, his favourite actor. His views on creative evolution are expounded (1901-03) in Man and Superman (and he returned to the theme in the epic Back to Methuselah of 1917-20), a play which with John Bull's Other Island, Major Barbara and some of his earlier ones was produced under the management of Harley ${ }^{*}$ Granville-Barker at the famous repertory season at the Court Theatre. This finally brought the full recognition for which he had worked so long. Pygmalion (based on a Greek legend) was completed in 1912 and performed in Vienna and New York before its London première in 1914. Heartbreak House, begun just before World War I, during which Shaw's political views made him unpopular, analysed the breakdown of European society in a domestic setting evocative of ${ }^{*}$ Chekhov. The most financially successful of his plays was Saint Joan (1924) which was followed by the political satire The Apple Cart (1929). In 1925 he was awarded the Nobel Prize for Literature which he had previously declined. Among the non-dramatic works of his later period the best known are The Intelligent Woman's Guide to Socialism and Capitalism (1928) and The Black Girl in Search of God (1932). He declined the OM. He developed a perverse enthusiasm for ${ }^{*}$ Mussolini, ${ }^{*}$ Hitler and ${ }^{*}$ Stalin, visited the USSR and New Zealand, but not Australia. In old age, Shaw became obsessed with the idea of simplifying English spelling and left most of his money for that end. Shaw's wit made his audiences laugh and his flippancy often made them angry. These reactions would not have displeased him for his purpose was, by goading, provoking, ridiculing or cajoling them, to make them think. The subjects of Shaw's plays became anachronistic and they are now rarely performed. However, Pygmalion, a great success as a film (1938), directed by Gabriel Pascal, was transformed into the musical My Fair Lady (1956), by Alan Jay Lerner (script and lyrics) and Frederick Loewe (music), and performed throughout the world for six decades.

Holroyd, M., Bernard Shaw. 4 vols, 1988, 1989, 1991, 1992. 1 vol. abridgement 2011; O’Toole, F., Judging Shaw. 2017.

Shaw, Richard Norman (1831-1912). English architect. Under the influence of William *Morris he broke away from current Victorian Gothic and returned, in many London and country houses, to the classic principles of Georgian architecture and to traditional craftsmanship and use of materials. His London buildings included New Scotland Yard (1891), the Gaiety Theatre (1905), now demolished, and the Piccadilly Hotel (1905).

Shaw, Sir Run Run (Shao Renleng) (19072014). Hong Kong-Chinese film producer and philanthropist, born in Ningbo. He grew up in 
Singapore, established a film studio in Shanghai and moved to Hong Kong in 1937 . He became a dominant figure in television and endowed many schools and universities.

Shawn, William (1907-1992). American journalist. He worked on the New Yorker from 1933 and was its editor 1952-87.

Shchedrin, Rodion Konstantinovich (1932- ). Russian composer and pianist, born in Moscow. The son of a composer and teacher, he was deeply influenced by *Prokofiev, and composed some much performed works, notable for their wit and panache, including the Carmen Suite (1967, for strings and percussion), the ballet Anna Karénina (1972), five concertos for orchestra, six piano concertos and three symphonies. In 1958, he married Maya Plisetskaya (1925-2015), prima ballerina at the Bolshoi 1960-90.

Shelburne, 2nd Earl of, William Petty, later 1st Marquess of Lansdowne (1737-1805). English Whig politician, born in Dublin. Following distinguished army service in Germany in the Seven Years War he entered politics. After joining George *Grenville's ministry (1763) he became closely associated with Chatham (William *Pitt) both in office, as Secretary of State 1766-68, and later in opposition to Lord *North and his American policy. Again Secretary of State 1782 under *Rockingham, on his death he formed a government as First Lord of the Treasury (i.e. Prime Minister) 1782-83, notable because *Pitt the Younger served as Chancellor of the Exchequer. Shelburne was a man of great ability and a natural radical (favouring free trade, Roman Catholic emancipation and parliamentary reform) but the time was not ripe, his political shifts and turns to approach his objectives were misunderstood and secured him the nickname 'the Jesuit of Berkeley Square'. Given a consolatory marquessate on retirement (1784), he was a patron of the arts and a collector of manuscripts, purchased for the British Museum in 1807.

Shelley, Mary Wollstonecraft (née Godwin) (17971851). British novelist. Daughter of the rationalist philosopher William ${ }^{*}$ Godwin and the feminist writer and radical Mary ${ }^{*}$ Wollstonecraft, she became the second wife of the poet Percy Bysshe *Shelley. She wrote Frankenstein or the Modern Prometheus, about a man who created a monster (1818), and three other novels.

White, N. I., Shelley. 2nd ed. 1947; Shelley, P. B., Letters (ed. F. L. Jones), 1964; Leighton, M., Shelley's Mary: A Life of Mary Godwin Shelley. 1973; Mellor, A. K., Mary Shelley. 1990; Schor, E. (ed.), The Cambridge Companion to Mary Shelley. 2003; Seymour, M., Mary Shelley. 2000.

Shelley, Percy Bysshe (1792-1822). English poet, born near Horsham, Sussex. Grandson of a baronet, at Eton he read Enquiry into Political Justice by his future father-in-law William *Godwin, a book that did much to encourage his desire to reform contemporary social systems. He was expelled from Oxford (1811) for writing The Necessity for Atheism. This led to a breach with his father which left the poet constantly short of money. Soon afterwards he married his sister's school friend, the beautiful 16-year-old Harriet Westbrook, childish even for her years. Even on the prolonged honeymoon Shelley needed the mental stimulus of his great friend Thomas Jefferson Hogg who committed the quickly forgiven indiscretion of falling in love with Harriet. In London Shelley joined the radical Godwin circle: Shelley and Harriet were already estranged when he fell violently in love and (1814) eloped with Mary Godwin; they married two years later, when Harriet drowned herself. Shelley always refused to accept responsibility for her death, as he had never hidden his views about free love, but he was deeply wounded when the courts gave the care of his children by her into other hands. From 1818 the Shelleys lived in Italy where he, while composing some of the loveliest lyrics ever to be written in English, became involved in the tangled financial, emotional and political affairs of the Godwins, *Byron and Leigh *Hunt. In 1822 the Shelleys were living in a villa at Lerici on the Gulf of Spezia and on 8 July while Shelley, after a meeting with Byron, was sailing back from Leghorn (Livorno) his boat, the Ariel, was upset in a storm; he and his two companions were drowned. His ashes are buried in Rome, near ${ }^{*}$ Keats. Shelley had first revealed his greatness as a poet by long poems, e.g. Queen Mab (1813) and Alastor (1816), but with the exception of his verse plays, of which the greatest are The Cenci (1819), a grim tale of incestuous passion and Prometheus Unbound (1820), he is best remembered by his songs and odes. Ode to a Skylark, Ode to the West Wind and Adonais (1821), the great lament for the poet Keats, are among the many familiar titles. Mary Shelley's son by the poet inherited his grandfather's baronetcy.

White, N. I., Shelley. 2nd ed. 1947; Shelley, P. B. Letters (ed. F. L. Jones), 1964.

Shepard, Sam (Samuel Shepard Rogers) (19432017). American dramatist. After some years of wandering in the Midwest, he began writing a series of plays which John Lahr described as 'dreamscapes of the American landscape where past and present coexist'. They include: Chicago (1966), Red Cross (1966), Tooth of Crime (1974), Buried Child (1979, Pulitzer Prize), Curse of the Starving Class (1985) and A Lie of the Mind (1985).

Sheppard, Jack (1702-1724). English criminal. Whilst apprenticed to a London carpenter he took to crime (1720). In 1724 he was caught four times but always escaped, on one occasion forcing six of Newgate Prison's great doors. On the last occasion he was held and hanged at Tyburn before a vast and admiring crowd. He was the hero of many ballads and of a novel by Harrison *Ainsworth. 
Sher, Sir Antony (1949-2021). British actor, director and writer, born in Cape Town. Of JewishLithuanian background, in the UK from 1968, he was a powerful interpreter of Shakespearean roles e.g. Iago, Richard III, Shylock, Macbeth and Lear.

Sheraton, Thomas (1751-1806). English furniture designer, born at Stockton-on-Tees. Before moving to London (c.1790) he was a journeyman cabinetmaker and may later have supervised the manufacture of some furniture, but his style became influential through his illustrated design manuals, notably the Cabinet-maker and Upholsterer's Drawing Book (1791). Sheraton furniture is distinguished by lightness and simplicity, an emphasis on straight, vertical lines and a preference for inlay decoration.

Fastnedge, R., Sheraton Furniture. 1962.

Sheridan, Philip Henry (1831-1888). American soldier, born in New York State. A captain when the Civil War began (1861), *Grant soon gave him command of all the cavalry of the army of the Potomac and he became famous for his spectacular raids behind the enemy lines, in one of which he reached the outskirts of Richmond, the Confederate capital. Later as commander of the army in the Shenandoah Valley 1864-65, he at first showed unwonted caution, but while he was absent his army suffered a severe setback at Cedar Creek. A dramatic ride back to the battlefield enabled him to reverse the situation with a counter-attack in which 24 guns were taken. Sheridan displayed his dash and brilliance to the full as Grant's principal lieutenant in the operations leading to the surrender at Appomattox. He was Commander-inChief of the US army 1883-88.

Sheridan, Richard (Butler) Brinsley (1751-1816). Anglo-Irish dramatist and politician, born in Dublin. The son of an actor, his mother, Frances Sheridan (1724-1766), was a minor novelist and dramatist. Having fought two duels on behalf of Elizabeth Ann Linley with whom he eloped and (1773) married, he soon won fame with his three brilliant comedies, The Rivals (1775), The School for Scandal (1777) and The Critic (1779). The Duenna (1775) and others are much inferior. He bought ${ }^{*}$ Garrick's share of the Drury Lane Theatre (1776), assumed the managership and built (1794) a new theatre, burnt down in 1809 . He was a Whig MP 1780-1812, a friend of Charles James *Fox and an imprudent advisor to the Prince of Wales (later ${ }^{*}$ George IV), and was appointed Undersecretary for Foreign Affairs 1782, Junior Secretary to the Treasury 1783, Receiver-General of the Duchy of Cornwall 1804-07 and Treasurer of the Navy 1806-07. He became renowned as an orator, especially for his speech in the Commons (1787) calling for the impeachment of Warren ${ }^{*}$ Hastings, and was a manager of the prosecution in the long drawn out trial. When fire destroyed Drury Lane Theatre (1809), Sheridan was financially crippled and arrested for debt (1813). He
Sherman, William Tecumseh (1820-1891). American soldier, born in Ohio. When the Civil War broke out (1861) Sherman, who had abandoned his career as an officer to become a banker and a lawyer, was a professor at the Louisiana military academy. $\mathrm{He}$ at once rejoined the Union army, commanded a brigade at Bull Run and saved the day at Shiloh. Appointed by * Grant to command in the southwest he captured Atlanta (September 1864). Unable to bring his opponent, Hood, to battle, he began in November the great march through Georgia which created a wide band of destruction from Atlanta to the port of Savannah. The march incurred lasting odium, and its military usefulness has been a matter of controversy ever since. It seems certain that then, and on other occasions, Sherman showed himself more adept at destroying communications than in coming to grips with the enemy. He was Commander-in-Chief of the US army 1869-83. In 1884 he rebuffed attempts to draft him as Republican candidate for president with the words: 'I will not accept if nominated and will not serve if elected.' His brother, John Sherman (1823-1900), was a US senator from Ohio 1861-77 and 1881-97, Secretary of the Treasury 1877-81, sponsored the Anti-Trust Act (1890) that bears his name and became Secretary of State 1897-98.

Wilson, E., Patriotic Gore. 1962.

Sherriff, Robert Cedric (1896-1975). English dramatist. His play about World War I, Journey's End (1929), achieved an outstanding success not repeated by his later work.

Sherrington, Sir Charles Scott (1857-1952). English physiologist, born in London. He studied at Cambridge and St Thomas' Hospital, London, where, after research into cholera in Spain and Italy, he became a lecturer in physiology. Later appointments included professorships at Liverpool University 1895-1913 and Oxford 1913-35. He introduced the term 'synapse' (1897) to describe the point of transmission of neurons. His work on the nervous system and its control of muscles was of great importance, especially on the effects of reflex actions. He was elected FRS (1893) and PRS 1920-25, won the Royal (1905) and Copley (1927) medals and received the OM (1924). With E. D. *Adrian, he was awarded the Nobel Prize for Medicine (1932) for 'their discoveries regarding the function of neurons'. His books include Integrative Action of the Nervous System (1906) and Man on his Nature (1940). He was also a poet and an inspiring teacher whose students included Howard *Florey and John *Eccles.

Sherwood, Robert Emmet (1896-1957). American author. His successful plays include Idiot's Delight (1936), Abe Lincoln in Illinois (1939) and There shall be no Night (1941). He wrote some of President Franklin *Roosevelt's speeches and won the Pulitzer Prize (1949) for Roosevelt and Hopkins: An Intimate History. 
Shevardnadze, Eduard Amvrosis dze (1928-2014). Georgian politician. Active in the Komsomol and Communist Party in Georgia, he became Interior Minister 1965-72 and First Secretary 1972-85, gaining a reputation for toughness. A member of the CPSU Politburo from $1985,{ }^{*}$ Gorbachev unexpectedly appointed him as Soviet Foreign Minister 1985-90. Despite his lack of international experience, he played a central role in ending the Cold War. $\mathrm{He}$ resigned dramatically in December 1990, warning of dictatorship and protesting against Gorbachev's increased dependence on opponents of reform. A founder member of the Democratic Reform Movement 1991, After the break-up of the USSR, he became the effective head of an independent State of Georgia as Head of State 1992-95 and President 1995-2003.

\section{Shi Huang Di see Qin Shihuang}

Shinwell, Emanuel, Baron Shinwell (1884-1986). English politician. He entered parliament as Labour member for Linlithgow in 1922 and became Financial Secretary to the War Office in 1929. He was Parliamentary Secretary to the Department of Mines in 1924 and again 1930-31. In Attlee's Government he was Minister of Fuel and Power 1945-47, and Minister for War 1947-50 and of Defence 1950-51. In 1986 he became the oldest peer in British history.

Shinwell, E., I've Lived Through It All. 1973.

Shipley, Dame Jenny (Jennifer Mary, née Robson) (1952- ). New Zealand National politician. MP 1987-2002, she displaced Jim *Bolger as Prime Minister 1997-99, until defeated by Helen *Clark.

Shirley, James (1596-1666). English dramatist. After leaving Oxford he became a Roman Catholic and took up teaching but soon began writing for the stage. He wrote over 40 plays: the tragedies, e.g. The Maid's Revenge (c.1626), The Traitor (1631) and The Cardinal (1641), are undistinguished, but the comedies, e.g. The Gamester (1633), later adapted by *Garrick, and The Lady of Pleasure (1635), were revived after the return of *Charles II (1660) and strongly influenced Restoration comedy. He died from stress and exposure during the Great Fire of London.

\section{Shockley, William Bradford (1910-1989).} American physicist, born in London. He studied at the Massachusetts Institute of Technology, worked at the Bell Labs 1936-55 and conducted research on radar in World War II. He was co-inventor with ${ }^{*}$ Brattain and Bardeen of the germanium transistor and shared with them the Nobel Prize for Physics (1956). He had already determined that silicon was superior to germanium, but colleagues refused to work with him. He relocated to Silicon Valley, California, became a professor at Stanford University 1963-75 and held controversial views on eugenics, intelligence and race.
Shoenberg, Sir Isaac (1880-1963). Russian-British engineer. He worked in England for ${ }^{*}$ Marconi from 1914, pioneered stereo recording and, in parallel with *Zworykin in the US, developed electronic scanning techniques for television which were adopted by the BBC, displacing *Baird's mechanical scanning.

Sholokhov, Mikhail Aleksandrovich (1905-1984). Russian novelist. In his first major work, And Quiet Flows the Don and its sequel The Don Flows Home to the Sea (1928-40), he gave an account of the events leading up to and following the Revolution and Civil War (in which he fought in the Red army) and the effects on a Cossack village. His second epic, Virgin Soil Upturned (1932-33), dealt with the collectivisation of agriculture. They Fought for their Country (from 1959) is an epic of World War II. He also published many short stories and won the Nobel Prize for Literature in 1965.

Shore, Jane (d.1527?). English mistress of *Edward IV. Wife of a London goldsmith, famed for her beauty and wit, she was accused of sorcery and forced to do public penance by *Richard III. Sir Thomas *More writes of her and her story is the theme of ballads and of a tragedy by Nicholas * Rowe.

Shorten, Bill (William Richard) (1967- ). Australian Labor politician and union official, born in Melbourne. Educated at Xavier College, Monash and Melbourne Universities, and working briefly as a lawyer, he became a trade union official, and National Secretary of the Australian Workers' Union (AWU) 2001-07. Federal MP 2007-, he was the architect of a national disability policy, and served as Minister for Workplace Relations 2011-13 and for Education 2013. An effective and assiduous advocate, supported by the Right, he became the first Labor leader chosen by a combination of votes in the Caucus and ALP branch members, and was Leader of the Opposition 2013-19. Defeated by Scott *Morrison in 2019, he became Minister for Government Services 2022- .

Shostakovich, Dimitri Dimitrievich (1906-1975). Russian composer, born in St Petersburg. Son of an engineer of Polish descent, he was a child prodigy, entering the Petrograd Conservatorium at the age of 13 to study under *Glazunov. He won early recognition with his vivacious Symphony No. 1 (1925), No. 2 (1927) being dedicated to the October Revolution. His output included songs, choral works, many orchestral suites (mostly drawn from other compositions), the opera The Nose (after ${ }^{*}$ Gogol, 1928) and the ballet The Age of Gold (1930). His 36 film scores, nine for *Kozintsev, written, as he said, 'to pay the rent', include New Babylon (1928), The Gadfly (1955), Hamlet (1964) and King Lear (1970), and music was adapted for many stage productions.

Brooding seriousness and ironical gaiety are the dominant moods of Shostakovich's music. 
A magnificent pianist himself, his piano works include 24 preludes Op. 34 (1932-33), Concerto for Piano and Trumpet, Op. 35 (1933), Piano Quintet quintet Op. 57 (1940), 24 preludes and fugues, Op. 87 (195051), and Piano Concerto No. 2, Op. 102 (1957).

His opera Lady Macbeth of Mtsensk (1934) was an outstanding success until seen by ${ }^{*}$ Stalin, leading to a denunciation in Pravda and a 30-year ban. To conform with political reality he duly changed his style with the popular Symphony No. 5 (1937). Symphony No. 7 (the Leningrad, 1941) commemorates the German siege and was an immediate international success.

Fifteen powerful string quartets, a form in which he vied for mastery with Belá *Bartók, appeared between 1938 and 1974 . He originally planned to write 24 , one in each key, major and minor. No. 8 in C (1943) is the most played, followed by No. 2, No. 4 and No. 13, but all are outstanding, particularly the last six, which like *Beethoven's, explore an inner world and can be profoundly disturbing.

He admired *Mussorgsky, re-orchestrated Boris Godunov (1939-40) and orchestrated his Songs and Dances of Death (1962).

In $1948 *$ Zhdanov attacked Shostakovich for 'bourgeois formalism' and dismissed him from the Moscow Conservatorium. Despite decades of frustration (and fear) he learnt how to reconcile Soviet ideological demands and his own creativity in some of his finest works: Symphonies No. 8 (1943), No. 10 (1953), No. 13 (1962), No. 14 (1969) and No. 15 (1971).

He was probably the greatest composer of symphonies since *Mahler, who had been a profound influence, and certainly since ${ }^{*}$ Sibelius.

Symphony No. 13 (Babi Yar) in B flat minor, op. 113, a long work, turns on five poems by Yevgenyi *Yevtushenko, for bass, male chorus and orchestra. It begins with a meditation on the Nazi massacre of Jews at Babi Yar in 1943, and ends with 'A Career', a despairing cry against the cynical acceptance of playing safe to secure promotion.

Violin concertos (1948, 1967) were written for ${ }^{*}$ Oistrakh, cello concertos $(1959$; 1966) for ${ }^{*}$ Rostropovich and a violin sonata, Op. 134 (1968) for Oistrakh and ${ }^{*}$ Rikhter.

Diffident and obsessive, a heavy drinker and smoker, a sports enthusiast, constantly exhibiting physical tension, he joined the Communist Party in 1960, largely as a protective measure, and had trophy status at international peace congresses. He outwardly conformed to successive regimes (serving as a member of the Supreme Soviet 1962-75) but his music can be understood as a profound protest. The book Testimony: The Memoirs of Shostakovich (1979), edited by Solomon Volkov, remains deeply controversial, with some parts apparently authentic, others conjectural. His son Maksim Dimitrievich Shostakovich (1938-) was a conductor and pianist.
MacDonald, I., The New Shostakovich. 1990; Fay, L. E., Shostakovich: A Life. 2000; Wilson, E., Shostakovich: A Life Remembered. rev. 2006.

Shovell, Sir Clowdesley (1650-1707). English admiral of the fleet, born in Norfolk. He ran away to sea, and from being a cabin boy rose by sheer ability to become a rear admiral. When he was a lieutenant he burned four pirate ships in the Mediterranean (1674). He was knighted for his conduct at the Battle of Bantry Bay (1689). At Cap La Hogue (1692), now a rear-admiral, he burned 20 enemy ships. He served as MP 1695-1707. He took part in the capture of Barcelona (1705) but failed at Toulon (1707). On the way home his ship struck a rock and sank off the Scilly Isles, and he and 800 aboard were lost. How his body came to be found in Cornwall is a mystery (was it washed ashore? or was he murdered after landing?). He was buried in Westminster Abbey.

Shrapnel, Henry (1761-1842). English soldier. An artillery officer in the Duke of *York's army in Flanders (1793), he invented the spherical case shell, first used in 1804 and later named after him. It explodes in the air at a fuse-controlled height and propels bullets in a forward cone. He became a lieutenant general in 1837 .

Shrewsbury, 1st Earl of, John Talbot (1388?-1453). English commander. His exploits in the period when *Joan of Arc's death was followed by the decline of English power made his name one of odium and terror to the French. Among his successes were a victory over the Burgundians at Crotoy (1437) and the recapture of Harfleur (1440). A reckless and precipitate attack at Castillon (1453) brought defeat and death.

Shriver, Lionel (originally Margaret Ann) (1957- ). American-British novelist, born in North Carolina. Her novels include We Need to Talk About Kevin (2003), So Much for That (2010), and Big Brother: A Novel (2013). She became a British citizen in 2012.

Shultz, George Pratt (1920-2021). American administrator. Educated at Princeton and the Massachusetts Institute of Technology, he taught economics in Chicago, serving as Secretary of Labor 1969-70, Director of the Office of Management and Budget 1970-72, and Secretary of the Treasury 1972 74. He was President of the Bechtel Corporation, engineers, 1975-82, and Secretary of State 1982-89.

Sibelius, Jean (Johan Julius Christian) (1865-1957). Finnish composer, born in Hämeenlinna. Regarded as an embodiment of national culture, after abandoning law for music he studied in Helsinki, Berlin and Vienna (under ${ }^{*}$ Goldmark). His gifts were early recognised by the Finnish authorities with a grant for life which enabled him to devote himself to composition. Though not a conscious nationalist in music-he did not base his work on folklore-he was interested 
in Finnish mythology. He first won international recognition with the tone poem En Saga (1892, revised 1902). The first movement of the Symphony No. 2 (1902) introduces Sibelius' individual approach to formal structure: the movement is built up not from two clearly defined groups of subjects as in classical sonata form, but from a number of short phrases that gradually fuse and develop organically. This method, apparent also in the last movement of the Symphony No. 3 (1907), was to dominate the rest of the series. No. 4 (1911), remarkable for the compression of its material, economical orchestration and bitterness of mood, was followed by the glowing and expansive No. 5 (1915, revised 1916, 1919), the restrained No. 6 and the one movement No. 7 (1924). Comparable with the symphonies in mood and sometimes in manner, are the tone poems The Bard (1913), Luonnotar (1910) for soprano and orchestra, The Oceanides (1914) and Tapiola (1926), the last of his important works. He also wrote incidental music for plays (e.g. *Maeterlinck's Pelléas et Mélisande and *Shakespeare's The Tempest) and songs. His idiom was unmistakably personal in its melodic, harmonic and orchestral expression. The comparative lack of lyricism in his music and its preoccupation with nature (especially its sinister aspect) must partly account for lack of appreciation outside Scandinavia and the English-speaking world. His structural changes have not been significantly adopted. Long promoted by *Koussevitzky and *Beecham, his work was neglected after the revival of interest in *Mahler's symphonies (and, to a degree, his own contemporary Carl *Nielsen) until taken up by Leonard *Bernstein, Colin *Davis and Lorin *Maazel.

Layton, R., Sibelius. 1965; Blum, F., Jean Sibelius: An International Bibliography. 1965; Grimley, D., Jean Sibelius and His World. 2011.

Sica, Vittorio de (1901-1974). Italian film director and actor. After a stage career which began in 1923 he made films such as Bicycle Thieves (1948), Miracle in Milan (1950) and Umberto D. (1951) in which pathos, whimsical humour and a keen sense of character are combined. As a character actor in such films as Bread, Love and Dreams, he also won high esteem.

Sickert, Walter Richard (1860-1942). British painter of Danish descent, born in Munich. He studied in London at the Slade School and under *Whistler, and in Paris with *Degas. In 1886 he began to exhibit at the New English Art Club which he helped to found, and lived mainly in London, Dieppe and Venice. After returning to London (1905) he headed a group of artists who formed (1911) the 'Camden Town Group', which later (1913) became part of the 'London group'. Under Degas' influence he painted scenes of theatre life but many of his subjects were the dark rooms and dismal streets familiar to him from his early London days, painted in the subdued colour schemes he had learnt from Whistler, using French Impressionist and post-Impressionist techniques. In later years he introduced colour and sunshine into his pictures using a fuller and richer palette. He became an ARA in 1924 but, having been elected RA in 1934, resigned a year later. In Portrait of a Killer (2002), the writer Patricia Cornwell, after extensive research costing \$US6 million, concluded that Sickert was Jack the Ripper-but her verdict was unpersuasive.

Sickert, W. R., A Free House. 1947; Baron, W., Sickert. 1973; Sutton, D., Walter Sickert. 1976; Sturgis, M., Walter Sickert. A Life. 2005.

Sickingen, Franz von (1481-1523). German knight. After serving as a soldier of fortune under ${ }^{*}$ François I of France and the emperor *Charles V, he conducted, on behalf of the Protestant reformers, his own private war against the ecclesiastical princes. Placed under the ban of the empire, he died of wounds while besieged in his own castle. His death symbolised the end of the independent power of German knighthood.

Sickles, Daniel Edgar (1819?-1914). American soldier and politician. A New York attorney and state politician, he was a US Congressman 1857-61 and 1893-95. He married (1852) the daughter of Lorenzo *da Ponte's ward. In 1859 he was tried for murdering her lover, Philip Barton Key, son of Francis Scott *Key, and acquitted on the grounds of 'temporary insanity'. He served as a major-general in the Civil War, losing a leg at Gettysburg, then, as Minister to Spain 1869-73. He became the lover of *Isabella II.

Siddons, Sarah Kemble (1755-1831). English tragic actor. She came of a famous stage family, the Kembles, and was a sister of John *Kemble. At the age of 17 she married a member of her father's company, and two years later made her debut (1775), under *Garrick's management at Drury Lane as Portia. She was not notably successful and for the next six years she toured the provinces. She made a triumphant return to London (1782) and until her retirement (1812) dominated the London stage. In tragic roles, above all as Lady Macbeth, perfection was claimed for her, beauty of face, form and voice being allied with vibrant emotional power. She is immortalised in paintings by *Gainsborough and, as The Tragic Muse, by *Reynolds.

Sidgwick, Henry (1838-1900). English moral philosopher. Educated at Cambridge, he taught there from 1859 and became Knightsbridge professor of moral philosophy 1883-1900. A disciple of J. S. *Mill, in his The Methods of Ethics (1874) he compared three approaches to decision making: hedonism (self interest), utilitarianism (the greatest good for the greatest number) and intuitionism (instinct). In 1888 he founded the Society for Psychical Research. He campaigned against religious texts and founded Newnham College (1876) to promote education for women. His wife Eleanor Mildred Sidgwick (née Balfour) (1845-1936) was President of Newnham College 1892-1910.

Sidmouth, 1st Viscount see Addington, Henry 
Sidney, Algernon (1622-1683). English radical. Son of the 2nd Earl of Leicester and a grandnephew of Sir Philip *Sidney, in the Civil War he fought for the parliamentary forces. Though he opposed Cromwell's Protectorship he was forced after the Restoration to live as an exile on the Continent until 1677. After another visit to France (1679) during which it was alleged (without proof) that he was bribed by *Louis XIV, he returned to England and was arrested after the discovery of the Rye House plot to murder ${ }^{*}$ Charles II on his way back from Newmarket. Tried by Judge * Jeffreys, he was condemned on doubtful evidence for treason, and beheaded. His name was officially cleared in 1689. His Discourses Concerning Government, attacking the patriarchalism of *Filmer and advocating aristocratic republicanism, were printed in 1689.

Sidney, Sir Philip (1554-1586). English poet, scholar, courtier and soldier, born in Penshurst, Kent. Nephew of Robert Dudley, Earl of *Leicester, he was educated at Shrewsbury and Oxford. Travels as a young man enabled him to absorb continental and especially Italian culture, and on his return to *Elizabeth I's court he seemed, with his looks, his birth, talents and chivalrous attitude to life, the English personification of the Renaissance ideal. There were numerous portraits (including miniatures) painted of him. Ill-timed advice to the Queen against her proposed French marriage robbed him of her favour, but he returned to court in 1583 and was knighted. He married (1583) the daughter of Sir Francis *Walsingham. After his death at Zutphen (where he was said to have passed a cup of water to a wounded soldier in even greater need) during Leicester's campaign to aid the Dutch against the Spaniards, he became a national hero. Over 200 poems were produced in commemoration of his death.

None of his works was published in his lifetime. Arcadia, a pastoral prose romance with poems interspersed, was begun in 1580 and published in 1590. The Apologie for Poetrie (called in a later edition Defense of Poesie) was written about the same time; it was the first application of Italian critical methods to English poetry. Astrophel and Stella, consisting of 108 Petrarchan sonnets and 11 songs, is believed to have been inspired by his love for Penelope Devereux, daughter of the 1st Earl of Essex, after she had been forced to marry against her will (1580).

His sister Mary Sidney (1561-1621) married the 2nd Earl of Pembroke, was a lady in waiting to *Elizabeth I, a patron of Edmund ${ }^{*}$ Spenser, a gifted translator and a powerful (if neglected) poet.

Duncan-Jones, K., Sir Philip Sidney. Courtier Poet. 1991.

Siemens, (Ernst) Werner (1816-1892). German electrical engineer, born in Lenthe. He invented the pointer telegraph (1846), the self-excited dynamo, new techniques for electoplating, the first electric tramway (1879) and electric train (1881). With
Johann Georg Halske he founded Siemens \& Halske in 1847 and it became the largest international telegraph construction company. His brother Sir William (Karl Wilhelm) Siemens (1823-1883), Anglo-German engineer, was born in Hanover. $\mathrm{He}$ first visited England in 1843 and 1844 to launch two of his own and his brother's processes and settled there to take advantage of the more favourable patent laws. His principal researches were on applications of heat and electricity. Among his many inventions were a gas-fired regenerative furnace (1848) later used for open-hearth steel production, an early platinum resistance thermometer (1871), and the electric arc steel furnace (1879). He also designed the steamship Faraday, which laid the first transatlantic cable (1874). He was naturalised in 1859, elected FRS in 1862, became President of the British Association for the Advancement of Science 1882 and received a knighthood in 1883 .

Scott, J. D., The Siemens Brothers. 1958.

Sienkiewicz, Henryk (1846-1916). Polish novelist. His early novels belong to the idealistic school but in 1883 he published Fire and Sword which, with The Deluge (1884) and Pan Michael (1887), pictured the troubled scene of the 17th century in Poland. With Quo Vadis? (1896), a story of Nero's persecution of Christians, he won an international reputation, later enhanced by The Crusaders (1900), which told of the Polish struggle against the Teutonic knights. He won the Nobel Prize for Literature (1905).

Sieyès, Emmanuel Joseph, Comte (1748-1836). French politician. Often known by his preRevolutionary title, Abbé Sieyès, his pamphlet, Qu'estce que le tiers état?, written on the eve of the revolution and indicating the role the 'third estate' might take in bringing about constitutional change, had great influence. In the early days he was a prominent adherent of ${ }^{*}$ Mirabeau in the National Assembly and helped to draw up the Constitution of 1791. Later, though he voted for the king's execution, he was cautiously inactive. 'I survived' was his answer when asked what part he had played in 'the Terror'. At first he refused to join the Directory but became a member when it was reformed under *Barras' leadership (June 1799). But he saw the need for further change: 'We must have a head and a sword', he said. For 'the head' he did not have to look far, for the 'sword' he chose the popular General *Bonaparte and joined with him in staging the revolution of 18 Brumaire (9 November 1799). Unfortunately, Bonaparte was not content to be 'sword' alone. He emerged as First Consul and Sieyès' constitution was doctored to ensure Bonaparte's primacy. Disappointed, Sieyès refused to be Second Consul and was compensated by a seat in the Senate and a large estate. He was an exile in Brussels after Napoléon's defeat, returning after the 1830 Revolution. 
Signac, Paul (1863-1935). French painter. With *Seurat and *Pissarro he was a pioneer of 'pointillism', but with greater intensity, and a major theorist of Neo-Impressionism.

Signorelli, Luca (1441?-1523). Italian painter. A member of the Umbrian school, and a follower of *Piero della Francesco, his apocalyptic frescoes in Orvieto Cathedral, including a powerful Last Judgment, anticipated (and probably influenced) *Michelangelo.

McLellan, D., Luca Signorelli's Last Judgment Cycle at Orvieto. 1992.

\section{Sihanouk see Norodom Sihanouk}

Sikorski, Wladyslaw (1881-1943). Polish soldier and politician. In the Poland made independent by World War I he distinguished himself against the Russians (1920). He was Prime Minister (1922-23) and then Minister of War, but soon resigned after opposing the dictatorship of *Pilsudski. After Poland was overrun at the beginning of World War II he became Prime Minister of the government in exile, at first in France and then in England, raising troops among the Polish miners in northern France and elsewhere. He was killed in an air crash.

Sikorsky, Igor Ivanovich (1889-1972). RussoAmerican aeronautical engineer, born in Kiev. He studied engineering at the St Petersburg Naval Academy, in Paris and in Kiev, built experimental helicopters (following an idea of *Leonardo da Vinci) in 1909 and 1910 and on their failure turned to fixed wing aircraft. In 1913 he flew the first four-engine aircraft. The Bolshoi (Le Grand) and the 'Clippers' introduced by Pan American Airways in 1937 were a modification of his design. He lived in the US from 1919. Sikorsky's first successful single-rotor helicopter was flown in September 1939.

Sikorsky, I. I., Recollections and Thoughts of a Pioneer. 1964.

Silhouette, Étienne de (1709-1767). French administrator. As Minister of Finance (1759), he acquired such a reputation for parsimony that his name was given to likenesses obtained cheaply by tracing the shadow of a face in profile thrown by a lighted candle onto a sheet of paper and then blackening the enclosed space.

Sillanpäa, Frans Emil (1888-1964). Finnish novelist. The Finnish Civil War of 1918 provided the background of Mark Heritage (1919), by which he first became known. The Maid Silja (1931, Fallen Asleep While Young) brought international acclaim. He won the Nobel Prize for Literature (1939).

Silone, Ignazio (Secondo Tranquilli) (1900-1978). Italian novelist. Communist and socialist by turns, he was imprisoned several times by ${ }^{*}$ Mussolini before escaping to live in Switzerland (until 1944). His best known novel, Fontamara (1933), describes the effects of Fascism on an Italian village. Other works include The School for Dictators (1938), The Secret of Lucca (1958), and a play, The Story of a Humble Christian (1969).

Simenon, Georges (Joseph Christian) (1903-1989). Belgian novelist, born in Liège. He left school at 16, became a journalist and in 1922 went to Paris, where he wrote more than 400 short popular novels under 16 different pseudonyms. His best known character, Inspector Jules Maigret, featured in 75 novels and 28 short stories, written in 1930-35 and 1941-72 and there were more than 300 dramatisations for film or television. Maigret's popularity diverted attention away from Simenon's penetrating psychological novels (romans dur), including The Man Who Watched the Trains Go (1938) and Teddy Bear (1960). André *Gide wrote to Simenon: 'You are living on a false reputation-just like Baudelaire or Chopin ... You are much more important than is commonly supposed.' Suspected of collaboration, he left France for Canada, lived in the US 1945-55, then in Switzerland. Simenon published more than 200 novels in his own name and autobiographical studies, When I was Old (1972) and Intimate Memoirs (1981). He received seven nominations for the Nobel Prize (1958, 1961,1963). Simenon claimed to have had sex with 10,000 women but his second wife accused him of gross exaggeration: the correct figure was about 1,200.

Marnham, P., The man who wasn't Maigret. 1992; Bresler, F., The Mystery of Georges Simenon. 1989; Assouline, P., Simenon: A Biography. 1992.

Simeon II (Simeon Borisov Saxecoburggotski) (1937- ). Tsar of Bulgaria 1943-46. Son of *Boris III, he was subject to a regency until deposed by *Dimitrov's Communist Government. He went into exile in Spain, married an heiress and succeeded in business. He returned to Bulgaria, formed the National Movement which won the Parliamentary elections and became Prime Minister 2001-05.

Simeon Stylites, St (c.390-459). Christian ascetic, born in Cilicia. He is said to have spent about 30 years in preaching and contemplation on the top of a tall pillar (Greek stylos, hence his name), near Antioch. This feat, which attracted many imitators, is the subject of a poem by *Tennyson.

Simić, Charles (originally Duśan) (1938- ). SerbianAmerican poet and essayist, born in Belgrade. His family migrated to the US in 1954 . He was educated in New York, then taught in New Hampshire. He won the 1990 Pulitzer Prize for Poetry for the collection The World Doesn't End, was extremely prolific as poet and essayist, wrote the memoir $A$ Fly in the Soup (2000) and became Poet Laureate of the US 2007-08. His urgent, immediate, economic style is reminiscent of Emily *Dickinson. 
Simnel, Lambert (c.1475-c.1525). English pretender. Of humble birth, he was carefully coached by a priest, Roger Simon, to play the part of the Earl of Warwick, son of the Duke of Clarence and nephew of *Edward IV. He was 'recognised' by Warwick's aunt, the Duchess of Burgundy, was taken to Ireland (1486) and crowned in Dublin as Edward VI (1487). With a small Yorkist following and a few mercenaries sent from Burgundy, he then crossed to England, but was defeated and captured near Stoke-on-Trent. As a sign of contempt *Henry VII employed him in the royal kitchen.

Simon, St (Shimon in Aramaic, known as 'the Less', 'the Canaanite' or 'the Zealot') ( fl. 1st century CE). Christian apostle. One of the 12, his name is often linked with St ${ }^{*}$ Jude and he is said to have been martyred in Persia.

Simon, Herbert Alexander (1916-2001). American social scientist. He held chairs at the Carnegie-Mellon University, Pittsburgh, from 1949 and was professor of computer science and psychology 1965-81. He worked on the 'behavioural' theory of how firms work and on computer modelling. His books include The Sciences of the Artificial (1969) and Human Problem Solving (with Alan Newell, 1972). He won the 1978 Nobel Prize for Economics.

Simon, John Allsebrook Simon, 1st Viscount (1873-1954). English lawyer and politician, born in Manchester. Son of a Congregational minister, he was elected to a fellowship at All Souls College, Oxford, and was called to the bar in 1899 . He had a brilliant legal career (KC in 1908) and having entered parliament as a Liberal (1906) was Solicitor-General 1910-13, Attorney-General 1913-15, and then Home Secretary. He resigned (1916) in opposition to conscription in World War I and after brief military service returned to the bar, where for a time his income was $£ 50,000$ a year. His declaration that the May 1926 General Strike was illegal contributed to his collapse. He chaired a statutory commission on Indian constitutional reforms 1927-30. In 1931 he adhered to the coalition as Leader of the National Liberals, and was Foreign Secretary 1931-35, Chancellor of the Exchequer 1937-40 and Lord Chancellor 1940-45. He was a distinguished lawyer but, despite the force and clarity of his intellect, lacked the human qualities that would have made him a great politician.

Simon, J. A., Retrospect. 1952.

Simon, (Marvin) Neil (1927-2018). American playwright. Simon's plays were skilfully crafted and subtly written, numerous and phenomenally successful in their middlebrow appeal on television, stage and film. They include The Odd Couple (1965), Sweet Charity (musical, 1966), Plaza Suite (1968), California Suite (1976) and Biloxi Blue (1984).
Simon, Paul (1942- ) and Art(hur) Garfunkel (1941-). American songwriters and singers. Simon and Garfunkel achieved great success as a singing duo 1964-71, performing their own spare, elegant, evocative works including The Sounds of Silence; Parsley, Sage, Rosemary and Thyme; Bridge over Troubled Water; Scarborough Fair and Mrs Robinson. Simon, educated at Brooklyn Law School, won many awards as a composer and toured extensively after 1972. Garfunkel, educated at Columbia University, was a lyricist and actor who appeared in several films e.g. Catch 22 and Carnal Knowledge.

Simons, Menno (1492-1559). Dutch religious leader. After the suppression of the Anabaptists he organised the less fanatical remnants into a religious group known as Mennonites. More concerned with a Christian life than dogma, among their tenets are adult baptism and refusal to bear arms, to take oaths or to serve in public office. They were persecuted from the 1530s, many settled in West Prussia and from 1683 in Pennsylvania. *Catherine the Great invited them to set up colonies in the Ukraine in 1770 but a century later many Russian Mennonites migrated to Canada and the US.

Dyck, C. J., A Legacy of Faith: The Heritage of Menno Simons. 1962.

Simpson, Sir James Young, 1st Baronet (18111870). Scottish physician. Professor of medicine and midwifery at Edinburgh University 1839-70, he introduced the use of anaesthetics in childbirth (1847), using ether at first. He discovered (1847), the anaesthetic properties of chloroform previously used only as an antiseptic. The original antagonism to its use was overcome when it was given to Queen *Victoria for the birth of Prince Leopold. In 1866 he was made a baronet. He anticipated the discovery of Röntgen (or X-) rays.

Simpson, O(renthal) J(ames) (1947- ). American footballer, broadcaster and actor, born in San Francisco. He was an outstanding running back, first in college, then professional football, breaking records and winning many awards. He achieved legendary status, made many television advertisements, acted in films and became a sports broadcaster. He distanced himself from controversies about race and Vietnam. In June 1994 his former wife, Nicole Brown, and her friend Ron Goldman, were stabbed to death. Simpson was charged with murder. His televised trial (and acquittal, in October 1995) became a media sensation and also revealed sharp racial divisions about attitudes to crime and the law. After a civil trial, Simpson was ordered to pay $\$$ US33.5 million in damages to the family of the murder victims (Feb. 1997).

In 2008 he was convicted, in Nevada, of armed robbery and kidnapping and sentenced to 33 years in jail. He was released on parole in 2017. 
Sinan (Koca Mi'mâr Sinân Âğâ, known as 'Sinan the Architect') (c.1491-1588). Turkish architect, born in Cappadocia. Of Christian parentage, he became a military engineer in the Janissaries, then chief architect for the sultanate, constructing 130 mosques, 34 palaces and many other public buildings. The mosques of Sultan * ${ }^{*}$ üleyman I in Istanbul and Sultan Selim at Edirne and the Sokolovic bridge (1577) in Bosnia are considered to be his masterpieces. 196 of his works survive.

Sinatra, Frank (Francis Albert) (1915-1998). American singer and film actor, born in Hoboken, New Jersey. He began his career as a crooner with the Harry James and Tommy Dorsey bands in the 1930s, and made his first film in 1941. The most popular and successful of his early films were Anchors Aweigh (1945) and On The Town (1949). As an actor, the best of his 40 films were From Here to Eternity (1953, winning him an Oscar), The Man with the Golden Arm (1955) and The Manchurian Candidate (1962). He also gained an international audience as a cabaret singer. His style changed from the romantic to the abrasive c.1960, but he remained extremely popular, and a figure of legendary influence in politics and business.

Kaplan, J., Frank. The Voice. 2010.

Sinclair, Archibald Henry Macdonald, 1st Viscount Thurso (1890-1970). British Liberal politician. He served in World War I, becoming very close to *Churchill. An MP 1922-45, he was Secretary of State for Scotland 1931-32, Leader of the Liberals 1935-45 and Secretary of State for Air 1940-45 in the wartime coalition.

Sinclair, Ian McCahon (1929- ). Australian National politician. A lawyer and grazier, he was a Commonwealth MP 1963-98, Minister 196572, 1975-79, 1980-83, Leader of the National Party 1984-89, Chairman of the Constitutional Convention on the Republic 1998 and Speaker of the House of Representatives 1998.

Sinclair, Sir Keith (1922-1993). New Zealand historian. Professor of history at Auckland University 1963-87, his books include The Origins of the Maori Wars (1957), A History of New Zealand (1959) and A Destiny Apart (1986).

Sinclair, Upton (Beall) (1878-1968). American novelist and socialist. He wrote over 70 novels, most dealing with social evils. They include The Jungle (1906), an exposure of conditions in Chicago stockyards, The Moneychangers (1908), King Coal (1917) and Oil (1927). With World's End (1940) he began a series of 11 novels about his hero Lanny Budd. It provides, in the form of fiction, a socialist view of contemporary history. He founded End Poverty in California (EPIC), ran as Democratic candidate for governor (1934) and was narrowly defeated.

Sinclair, U. B., The Autobiography of Upton Sinclair. 1962.
Singer, Isaac Bashevis (1904-1991). American novelist and journalist, born in Poland. He emigrated to America in 1935 and joined the staff of the Jewish Daily Forward. Writing entirely in Yiddish, his novels and short stories include The Slave (1962), The Manor (1967) and The Estate (1969). He was awarded the Nobel Prize for Literature in 1978.

Singer, Isaac Merrit (1811-1875). American inventor. He patented (1851) a practical sewing machine. Although he lost a suit for infringement brought by Elias Howe, his company was already well established, soon took the lead in manufacturing sewing machines and became the first multinational corporation. He lived in France from 1861.

Singer, Peter Albert David (1946- ). Australian philosopher. Educated at Melbourne and Oxford universities, he was a professor of philosophy at Monash University 1977-79, and gained international recognition for his works on bioethics. His Animal Liberation (1975) raised novel ethical issues about exploitation and infliction of pain on animals. He held a chair in bioethics at Princeton 1999- but also taught at Melbourne University, and was a prolific writer and fearless controversialist.

Singh, Manmohan (1932- ). Indian economist and politician, born in the Punjab. A Sikh, he was educated at Oxford and Cambridge, and became a bureaucrat, academic and UN official. As Minister for Finance 1991-96 he changed economic direction, moving away from the interventionist model (sometimes called the 'Licence Raj' system) introduced by Jawaharlal *Nehru. Regarded as a technocrat, he unexpectedly became Prime Minister 2004-14, with the support of Sonia *Gandhi. India's growth rate reached 9 per cent in 2007 , but inflation was high and adopting further market-based reforms proved unpopular.

Sinopoli, Giuseppe (1946-2001), Italian conductor, composer, physician and anthropologist, born in Venice. With a medical degree from Padua, he turned to composition and wrote the opera Lou Salomé (1981). Chief conductor of the Philharmonia Orchestra, London 1984-94 and the Staatskapelle Dresden 1992-2001, he died in Berlin, after a heart attack, while conducting Aida.

Sisi, Abdel Saaed Hussein Khalil Fatteh el- (1954- ). Egyptian soldier and politician, born in Cairo. Commissioned in 1977, he undertook training in the UK and US, and was Minister of Defence and Commander-in-Chief 2012-14, reaching the rank of field marshal. He directed the coup that overthrew President Mohamed *Morsi in 2013, suppressed the Muslim Brotherhood and was elected President of Egypt 2014- . 
Sisley, Alfred (1839-1899). French painter, born in Paris. Of English parentage, he became a landscape painter, influenced by *Corot, a friend of *Monet, and a major figure among the Impressionists, although his colour range was rather subdued. The quality of his work was only recognised posthumously and he died poor.

Sitting Bull (Thathanka Iyotake = 'Jumping Badger') (1834-1890). American Sioux leader, born in Dakota territory. He led the Hunkpapa Lakota tribes of the Sioux people and, with the Cheyenne, defeated George *Custer's cavalry in the Battle of Little Bighorn (1876). He escaped to Canada, returning to appear in William F. *Cody's Wild West show (1885). With eight others he was murdered by Native American police.

Sitwell, Dame Edith Louisa (1887-1964). Sir Osbert, 5th Baronet (1892-1969) and Sir Sacheverell, 6th Baronet (1897-1988). English writers. Children of the eccentric Sir George Revesby Sitwell, 4th Baronet (1860-1943), it is probable that this formidable (though essentially kindly) personality was unconsciously instrumental in transforming his children into a closely knit literary clan. Their actual work was, however, highly individual. Edith Sitwell, by using startling or grotesque images, odd epithets (e.g. 'periwigged green leaves') and many other arresting techniques, e.g. the adaptation of poetry to dance rhythms, escaped from the conventional constraints of the poetry of her time. A miscellany called Wheels (1916-21), funded by her brothers, friends and herself, helped to make her work more widely known. Her best known collection was Façade (1923), declaimed with great success to chamber accompaniment by William *Walton. Her Collected Poems were issued in 1930. Among her prose works are a perceptive biography of *Pope (1930), The English Eccentrics (1933), and The Queens and the Hive (1962), in which are interwoven the stories of *Elizabeth I and *Mary Queen of Scots.

Osbert Sitwell's elegantly satirical verse and prose had a limited appeal before he reached a much wider public with his diverting and idiosyncratic autobiographical works, beginning with Left Hand, Right Hand (1945) and later including The Secret Tree (1946) and Laughter in the Next Room (1949).

Sacheverell Sitwell's books were confined to the arts, especially of southern Europe. They revealed a fastidious taste, an alert eye for landscape and a curiosity about the unknown. He wrote on Mozart (1932) and Liszt (1935), but more characteristic are Southern Baroque Art (1931), British Architects and Craftsmen (1945) and Gothic Europe (1969). He also published numerous small volumes of poetry.

Pearson, J., Façades. 1978.

Sixtus IV (Francesco della Rovere) (1414-1484). Pope 1471-84. Born in Liguria, he became a and theologian. Once elected as Pope, he abandoned Franciscan austerity, expanded the power of the Papal state and stacked the college of cardinals with members of powerful families, including six of his nephews, one of whom became Pope *Julius II. He approved the establishment of the Spanish Inquisition, condoned slavery in South America, annulled the decrees of the Council of Constance, called for a crusade against the Turks, became involved in a murderous plot against the Medici in Florence and encouraged the sale of indulgences. However, he was a notable patron of art and architecture, created the Sistine Chapel (named for him) and the Vatican archives, built bridges, widened roads and restored old churches.

Sixtus V (Felice Peretti) (1521-1590). Pope 158590. During his short term of office he proved himself one of the most effective of the counter-Reformation popes. He suppressed banditry in the papal states, disciplined the factious Roman nobility, and finished the dome of St Peter's. He reformed the ecclesiastical administration by raising the number of cardinals in council to 15 , each with a separate sphere of responsibility. He hastened the revision of the Vulgate. In foreign affairs, he prompted the Armada against England, but supported the compromise by which *Henri IV became King of France.

Sjón (pseudonym of Sigurjón Birgir Sigurðsson) (1962- ). Icelandic poet, novelist, playwright and lyricist, born in Reykjavik. His pen name (meaning 'sight') is an abbreviation of his given name (Sigurjón). Sjón frequently collaborated with the singer Björk and performed with The Sugarcubes as 'Johnny Triumph'. His works have been translated into more than 25 languages.

Skallagrímsson, Egill (c.910-990). Viking-Icelandic poet and warrior. Egil's Saga (c.1230) recounts his varied, often violent, exploits.

Skanderbeg (Skënderbej or Iskender Bey: Gjergj Kastrioti) (c.1403-1468). Albanian national hero. He rose high in Turkish service, but when an attempt was made to conquer Albania he renounced Islam and in 1443 led a national rising of the Albanian and Montenegrin chiefs. With some support from Venice, Naples and the Pope, he preserved Albanian independence for over 20 years. But as the years passed his followers dwindled and support from outside failed. His cause died with him.

Skelton, John (c.1460-1529). English poet, born probably in Norfolk. He became tutor to Prince Henry (*Henry VIII), was ordained (1498) and spent most of his time in London, where he became notorious for his wild life, buffoonery and practical jokes. Eventually, having offended *Wolsey by his satires on the clergy, e.g. Colyn Cloute (1522), he took sanctuary in Westminster Abbey where he remained till his death. One of his best known works, The Tunnying of Elynour Rummyng, describes a drunken 
woman's revels. His metrical lines (Skeltonics) have been described as 'voluble, breathless doggerel', but deserve a higher reputation. His one surviving morality play, Magnyfycence, was possibly written as a guide to good government for the young Henry.

Skinner, B(urrhus) $\mathbf{F}$ (rederic) (1904-1990). American experimental psychologist. He taught at Harvard from 1931 and was professor of psychology 1947-75. Skinner became the major proponent of 'behaviourism', an extension of the work of ${ }^{*}$ Pavlov and J. B. *Watson, which asserts that behaviour should only be examined empirically and objectively as a series of reactions to stimuli. Skinner's teachings aroused much controversy because they assumed a mechanistic view of human experience, with no recognition of 'inner states'. He wrote Science and Human Behaviour (1953), Walden Two (1948) and Beyond Freedom and Dignity (1971).

Skryabin, Aleksandr Nikolayevich see Scriabin, A. $\mathbf{N}$.

Slade, Felix (1790-1868). English antiquary and collector. He left $£ 350,000$ to found art professorships at Oxford, Cambridge and London universities. The Slade School of Art, London, is named after him.

Slim, William Joseph Slim, 1st Viscount (18911970). English soldier, born in Bristol. Commissioned in 1914, he served in Gallipoli (1915) and India (1917-20, 1926-34, 1939-40). In World War II he commanded an Indian division in the Middle East and the 15th Corps in Burma before being appointed to command the 14th Army 1943-45. In this capacity he was responsible for halting the Japanese offensive in Burma and for directing the great campaign by which Mandalay, Rangoon and the rest of the country were eventually liberated. He retired from the army in 1948 but *Attlee brought him back as Chief of the Imperial General Staff 1949-52, becoming a field marshal in 1949 and Governor-General of Australia 1953-60. He was created KG (1959) and a viscount (1960). His Defeat into Victory (1956) was one of the best books of World War II.

Slim, W. J., Unofficial History. 1959.

Sloan, Alfred P(ritchard), Jr (1875-1966). American industrialist. Educated at MIT, he ran a ball bearing company 1901-16, then joined General Motors (founded in 1908 by William C. *Durant), becoming its president $1923-37$ and chairman 1937-56, at a time when its sales overtook the *Ford Motor Co. He worked with the engineer C. F. * Kettering to improve car design and founded the Sloan-Kettering Institute for cancer research in New York (1945).

Sloane, Sir Hans, 1st Baronet (1660-1753). British physician. After studying medicine in France he made a journey to the West Indies from which he brought back (1689) some 800 species of plants. He then settled in practice in Bloomsbury, London.
His undiminished interest in natural history was, however, shown by his book $A$ Voyage to the Islands of Madeira (1707 and 1725). When the colony of Georgia was founded (1732-33) as a refuge for debtors, Sloane was one of the promoters. The great collection of books, manuscripts and curiosities that he handed over to the nation (1749) became the nucleus of the British Museum. He was made a baronet in 1716 .

Slovo, Joe (1926-1995). South African politician, born in Lithuania. Trained as a lawyer, he became leader of the South African Communist Party, was tried for treason and exiled for 27 years. His wife, Ruth First (1925-1982), biographer of Olive *Schreiner, was killed by a letter bomb. Originally a Stalinist, he became a supporter of ${ }^{*}$ Gorbachev and liberal economic reforms. In *Mandela’s Government of National Unity he was Minister for Housing 1994-95.

Smart, Christopher (1722-1771). English poet. Though a scholar of distinction, he was forced to leave Cambridge owing to debts, and his whole life was dogged by poverty. Most of his early work was trivial but, after a serious illness followed by attacks of insanity, he turned to religion and, besides a poetical version of the Psalms, wrote his tender, imaginative masterpiece A Song to David. In similar vein is his Rejoice in the Lamb. He died in a debtors' prison.

Smart, (Frank) Jeffrey (Edson) (1921-2013). Australian painter, born in Adelaide. He worked in Adelaide, and Sydney from 1951, moving to Italy in 1963. His hyper-realistic paintings make familiar scenes of modern life-streetscapes, road signs, building sites, scaffolding, container trains, decaying walls_-seem dreamlike or unnerving, e.g. Container Train in the Landscape (1983-84).

Smeaton, John (1724-1792). English engineer, born in Leeds. Son of a lawyer, he was intended to enter his father's firm, but from boyhood showed the keenest interest in mechanics and engineering. He was elected FRS in 1753 and won fame when he rebuilt the Eddystone Lighthouse (1756-59) to a new and successful design. He also rediscovered the lost Roman formula for making cement. For his work on the mechanical laws governing the construction of wind and watermills he received the Royal Society's Copley Medal (1759).

Smetena, Bedrich (1824-1884). Czech composer, born in Litomysl. Founder of the Bohemian Nationalist school, his father was the manager of a country brewery. He studied music in Prague and taught music in a nobleman's family and then in a school of his own. In 1856 he went to Sweden as a conductor to the Philharmonic Society of Göthenburg and in the next few years he wrote some symphonic poems (e.g. Wallenstein's Camp) on nonCzech subjects. Back in Prague in 1861, he eventually 
became the chief conductor of the Provisional Theatre, where the Austrians allowed plays and operas to be given in Czech. Of his eight patriotic operas, The Bartered Bride (produced 1870), a gay peasant comedy, is the most popular. Apart from the operas his best known works are Ma Vlast (My Country), a cycle of six symphonic poems (1874-79), and two string quartets (1876 and 1882). From 1874 he struggled against the handicaps of deafness and mental illness by which he was finally incapacitated. *Dvorák, *Suk and others maintained the nationalist tradition of Czech music he created.

Clapham, J., Smetana. 1972.

Smiles, Samuel (1812-1904). Scottish writer. After studying medicine at Edinburgh, and working as a surgeon in Leeds, an editor and a secretary to railway companies, he achieved enormous success with his Self-Help (1857), translated into 17 languages, a collection of lives of great or successful men held up as models to Victorian schoolchildren. This was followed by, e.g. Thrift (1875) and Duty (1880). He also wrote several biographies, e.g. George Stephenson (1857).

Smith, Adam (1723-1790). Scottish economist, born at Kirkcaldy, Fife. Posthumous child of a comptroller of customs, he studied at Oxford University for seven years before returning to Scotland where he was one of the brilliant intellectual circle of which David *Hume became the best known member. As professor of moral philosophy at Glasgow 1752-64 he gained fame as a lecturer and wrote Theory of Moral Sentiments (1759). He travelled in France (1764-66) as tutor to the young Earl of Buccleuch and in Paris met *Turgot and *Necker and discussed their economic ideas. In 1776 he settled in London where he joined Samuel *Johnson's literary circle. In the same year he published his Inquiry into the Nature and Causes of the Wealth of Nations, the original source of most future writing on political economy. He was opposed to the monopolistic mercantilism (e.g. Navigation Acts, trading monopolies such as the East India Company etc.) that had dominated previous economic thinking, but neither was he an uncritical advocate of laissez-faire. He believed, with Hume, that enlightened self interest ('the invisible hand') would promote public welfare, but insisted in all his works on the maintenance of the link between individual freedom and such moral obligations as kindness, sympathy and justice. Individual freedom releases the energy that produces wealth, but the wealth can only grow by the consumption of goods, not by being hoarded as gold. He also saw that unfettered individual enterprise must be combined with the division of labour (i.e. specialisation) to maximise efficiency. Specialisation entails the need for markets, which in turn need a common purchasing medium, a conclusion leading to considering methods of determining money values. Thus, one by one, he considered the many interlocking factors of political economy. There was a revival of interest in Smith's ideas with the rise of economic rationalism in the 1980s. Smith has been considered the founder of the study of political economy as a separate discipline.

Rae, J., Life of Adam Smith. Repr. 1965; Ross, I. S., Life of Adam Smith. 1995.

Smith, Al(fred Emanuel) (1873-1944). American Democratic politician, born in New York City. After acute poverty in childhood, he rose rapidly in the New York Democratic machine, serving four terms as State Governor 1918-20 and 1922-28. In 1928 he was the Democratic presidential candidate, the first Catholic nominee of a major party, but lost heavily to ${ }^{*}$ Hoover. He was a 'wringing wet' opponent of prohibition, and campaigned against child labour and for state parks. In 1932 he contested the presidential nomination against Franklin D. *Roosevelt, failed and was a bitter loser.

Smith, David (Roland) (1906-1965). American sculptor, born in Indiana. He worked as a rivetter for Studebaker, then built locomotives and tanks. He became a pioneer of welded and assembled metal sculptures, making use of industrial forms, later moving into Cubism. He was killed in a motor accident (Anthony ${ }^{*}$ Caro).

Smith, George (1824-1901). English publisher. A founder of Smith \& Elder (1846), he appointed *Thackeray as editor of his new Cornhill magazine (1860) and also started the Pall Mall Gazette (1880). Among the famous writers whose works he published were George ${ }^{*}$ Eliot, the ${ }^{*}$ Brownings, Mrs *Gaskell and Anthony *'Trollope. The original edition of the Dictionary of National Biography (1885-1900) was his biggest publishing achievement.

Smith, George (1840-1876). English Assyriologist. Trained as a bank note engraver, he worked for the British Museum and deciphered cuneiform tablets that *Layard found in Ninevah. In 1872-73 he discovered and translated The Epic of Gilgamesh, an Akkadian creation legend.

Smith, Ian Douglas (1919-2007). Zimbabwean (Rhodesian) politician, born in Rhodesia. A RAF pilot 1941-46, he was elected to the Southern Rhodesian Parliament in 1948, became a founder of the Rhodesian Front (1961), devoted to maintaining rule by the white minority. Prime Minister 1964-79, he broke off negotiations with Britain over moving to a multiracial system and adopted a unilateral Declaration of Independence (UDI, Nov. 1965), which remained in force until 1979 when a negotiated settlement was reached. He served in the Zimbabwean Parliament 1980-88 under Robert *Mugabe's regime.

Smith, John (1580-1631). English adventurer. He had already had an extraordinary career as a soldier of fortune mainly in service against the Turks during which he escaped from slavery and as a Mediterranean pirate when (1605) he joined the expedition to 
colonise Virginia. Captured by Indians, he was saved, it was said, by the young Princess *Pocahontas, whom he subsequently married. He wrote books about the colony as well as a highly coloured autobiography.

Smith, John (1938-1994). British Labour politician, born in Scotland. Educated at Glasgow University, he became a barrister in 1967 and a QC. He was an MP 1970-94, a junior minister from 1976 and Secretary of State for Trade 1978-79. In Opposition he served as Treasury Spokesman 1987-92, then succeeded Neil *Kinnock as Leader of the Labour Party 199294. He died of a heart attack and was buried in Iona.

Smith, Joseph (1805-1844). American religious teacher, born in Vermont. Founder of the Mormons, he was the son of a farmer and from boyhood claimed to have had visionary experiences. In 1830 he published the Book of Mormon, the original of which, inscribed on gold plates, was said to have come into his hands (with instructions for translation, using two magic stones called Urim and Thummim) as the result of an angelic visitation from the angel Moroni. The book purported to be supplementary to the Bible and to contain divine revelations to Mormon, a prophet of the era, concerning the history of a second 'chosen people' who came from Jerusalem and inhabited America before the Indians. The Church of Jesus Christ of Latter-Day Saints was founded in 1830 and attracted many converts as well as much ridicule and persecution, which forced the 'saints' to move several times before they found a permanent home. In 1843 Smith split the community, then settled in Illinois, by announcing a divine message favouring polygamy. More persecution followed. In 1844 he announced his intention to stand for the presidency. Smith and his brother Hyrum were arrested on charges of conspiracy and were murdered by a mob that broke into the jail at Carthage, Illinois.

Smith, Dame Maggie (Margaret Natalie) (1934- ). English actor, born in Essex. She made her stage debut in 1952, winning critical acclaim with *Shakespeare, *Ibsen, *Wilde, ${ }^{*}$ Chekhov, ${ }^{*}$ Coward and Alan ${ }^{*}$ Bennett. She appeared in more than 60 films and won Academy Awards for The Prime of Miss Jean Brodie (1969) and California Suite (1978). She starred in Gosford Park (2001), Quartet (2012) and some Harry Potter films and was the Dowager Countess of Grantham in the television series Downton Abbey. She received a $\mathrm{CH}$ in 2014.

Smith, Sir Matthew (1879-1959). English painter, born at Halifax, Yorkshire. He studied art in Manchester, London and eventually Paris, where he joined the school of *Matisse. His life thereafter was spent between France and England. His scale is large, his composition simplified and bold, and both are admirably suited to the luxuriance and translucence of his colours: for subjects he turned to flowers, fruits and nudes. He was knighted in 1954.
Smith, Sir Ross (1892-1922) and Sir Keith (18901955). Australian aviators, born in Adelaide. After service in World War I, the brothers won (1919) the Australian Government's $£ 10,000$ prize for the first Australian-manned aircraft to fly from England to Australia within 30 days. Ross Smith was killed in an air crash.

Smith, Stevie (Florence Margaret Smith) (19021971). British poet, born in Hull, Yorkshire. She published several collections of verse, three novels and two critical editions: one of T. S. *Eliot's verse, one of children's poetry. She won the Queen's Gold Medal for Poetry (1969). There is a great sense of humour, even comedy, in her work, at the same time as a sense of isolation and blankness, and a preoccupation with death. Her Collected Poems appeared in 1975.

Dick, K., Ivy Compton Burnett and Stevie Smith. 1971.

Smith, Sydney (1771-1845). English clergyman, journalist and wit, born in Essex. Educated at Winchester and Oxford, he became a tutor in Edinburgh and co-founder with Francis *Jeffrey and Henry *Brougham of the Edinburgh Review (1802). He returned to London in 1803 and wrote vigorously against slavery, transportation, prison conditions and the game laws, and for Catholic emancipation and the Reform Bill. He lectured in moral philosophy at the Royal Institution, held several rural livings and was canon of St Paul's 1831-45. His wit shone at Lady Holland's Whig soirées and anticipates *Gilbert and *Wilde; but he was wise too, viz: his advice against melancholy. Some of his expressions are still part of the language: 'out of the ark', 'a square peg in a round hole'. He called Daniel *Webster 'a steam engine in trousers' and *Macaulay 'a book in breeches'.

Smith, William (1769-1839). British cartographer. Known as 'Strata' Smith, his achievement was to determine the succession of English strata from the coal measures up to the chalk in greater detail than previously and to establish their fossil specimens. His greatest work lay in mapping. Smith rightly saw the map as the perfect medium for presenting stratigraphical knowledge. In developing a form of map that showed outcrops in block, he set the essential pattern for geological mapping throughout the 19 th century.

Cox, L. R., William Smith and the Birth of Stratigraphy. 1948; Winchester, S., The Map that Changed the World. 2001.

Smith, W(illiam) Eugene (1918-1978). American photojournalist. A war correspondent for Life magazine, who made outstanding photo-essays, marked by psychological insight, including Pittsburgh (1956ff), Japan (1963) and Minamata (1975).

Smith, W(illiam) H(enry) (1792-1865). English newsagent. He built up a small firm inherited from his parents by creating a speedy country delivery service, 
using fast carts, coaches and eventually railways. His son, also W(illiam) H(enry) Smith (1825-1891), secured contracts for most of the railway book stalls, became a Conservative MP 1868-91 and was First Lord of the Admiralty $1877-80$ and First Lord of the Treasury 1886-91. His widow was created Viscountess Hambledon.

Smithson, James Macie (1765-1829). English chemist, born in Paris. Natural son of the 1st Duke of Northumberland, he studied chemistry and mineralogy. In 1826 the Royal Society rejected a paper he had written and in revenge he left the reversion of $£ 105,000$ to found an institution in Washington 'for the increase and diffusion of knowledge among men'. This was the basis of the great Smithsonian Institution.

Smollett, Tobias George (1721-1771). British novelist, born in Dumbartonshire. He trained for medicine in Glasgow, went to London in 1739 and in 1740 sailed with the fleet to the West Indies as surgeon's mate. It was not until The Adventures of Roderick Random was published (1748) that he achieved literary success. The Adventures of Peregrine Pickle (1751) followed, and thus encouraged, Smollett started an intensive publishing career in Chelsea. Of the many works produced there by himself and his collaborators, the best was The Expedition of Humphry Clinker (1771). His last years were mainly occupied by travels in search of health, injured by hard work and the worries due to the ease with which he gave and took offence. He died near Leghorn (Livorno). In construction and characterisation his picaresque novels do not equal those of *Fielding, but he had a great gift for narrative and a very observant eye.

Knapp, L. M., Tobias Smollett: Doctor of Men and Manners. 1949.

Smuts, Jan Christiaan (1870-1950). South African soldier and politician, born in Cape Colony. After attending Victoria College, in Stellenbosch, he completed his education at Christ's College, Cambridge, where he won high honours in law. Admitted to the bar in Cape Colony (1895), he entered politics but turned against ${ }^{*}$ Rhodes after the Jameson Raid. Leaving the Cape for the Transvaal he became President *Kruger's Attorney-General. In the latter stages of the Boer War he proved himself one of the most successful guerrilla leaders, penetrating deep into Cape Colony with his raids. He played a leading part at the Peace Conference of Vereeniging (1902). In the following years he became a close political associate of *Botha and together they built up the South African Party. When the Union of South Africa was formed (1910), Botha became Prime Minister. Smuts served as Minister of Defence 1910-24 and Finance 1912-13 and 1915-19. Like Botha, he supported Britain strongly in World War I, and as GOC of British forces in East Africa 1916-17
George's war Cabinet in London as Minister without Portfolio (1917-18), responsible for organising the RAF and, at the Paris Peace Conference (1919), he was a major architect of the League of Nations. On Botha's death, Smuts succeeded as Prime Minister 1919-24. Defeated by *Hertzog, he became Deputy Prime Minister and Justice Minister in a coalition 1933-39. He became Prime Minister again 1939-48 on the outbreak of World War II, when parliament overturned Hertzog's neutrality policy. Trusted by ${ }^{*}$ Churchill, he served in his War Cabinet and was promoted to field marshal in 1941. His most enduring achievements were probably in international affairs, planning the United Nations and writing the preamble to its charter. He was the only person to sign the charters of both the League of Nations and the United Nations.

In South Africa, he attempted to weld together Europeans of British and Afrikaner (Dutch) descent, but saw no practical alternative to segregation, although he softened its impact by providing (limited) welfare and easing travel restrictions for Africans. An admirer of Mahatma *Gandhi and a strong sympathiser with Zionism, he was criticised as hypocritical for insisting that South Africa's racial policies were purely domestic matters. His minor concessions on race were anathema to many white voters and after 1945 he steadily lost ground to the Nationalists in rural areas and narrowly lost the 1948 election, despite his United Party winning 49 per cent of the vote. Dr Daniel *Malan became Prime Minister and introduced strict apartheid. Smuts' subtle and agile intelligence sometimes led outwitted opponents to charge him with duplicity. (He was known as 'Slim Jannie'.)

Awarded the CH (1917) and OM (1947), he was Chancellor of Cambridge University 1948-50, published several books on holistic philosophy and was an amateur botanist.

Hancock, W. K., Smuts. 2 vols, 1962, 1968.

Smyth, Dame Ethel Mary (1858-1944). British composer and feminist. She studied in Leipzig, and her early operas, the best known of which is The Wreckers (1906), were produced in Germany. A comic opera, The Boatswain's Mate (1916), was founded on a short story by W. W. Jacobs. She also wrote much chamber music and a Mass in D. She was imprisoned (1911) for her activities as a suffragette, and composed a marching song for the movement.

Snellius, Willebrord (or Willebrord Snel van Roijen) (1591-1626). Dutch mathematical physicist. He succeeded his father as professor of mathematics at Leyden 1613-26 and is best known for the general law (1621), named after him, governing the refraction of light when it passes into a medium of different density. This law which had eluded *Kepler, was published in a slightly improved form (1637) by ${ }^{*}$ Descartes, without acknowledgement. The lunar crater Snellius is named for him. 
Snorri Sturluson (1179-1241). Icelandic historian and mythologist. He was a chieftain, active in politics as a member of the Althing. One of the most versatile medieval historians, he wrote Heimskringla, a great history of the Norwegian kings, showing critical abilities and much insight into character. His Younger Edda surveyed Norse mythology and traditions, with the aim of giving help and guidance to poets in search of a theme. He was killed during a violent civil war, followed by Norwegian control of Iceland. His nephew, Sturla Thordson, was author of the Sturlunga Saga.

Snow, C(harles) P(ercy), Baron Snow (1905-1980). English novelist and physicist. Educated at Leicester, London and Christ's College, Cambridge, as a scientist and a civil servant he was much concerned with the cleavage between humane and scientific traditions of culture and wrote The Two Cultures and the Scientific Revolution (1959). His novels, e.g. The Masters (1951), The Affair (1959) and Corridors of Power (1964), explore the manipulations by which decisions are achieved in a university and in government. The critic F. R. ${ }^{*}$ Leavis detested him. He was a member of the Labour Government (October 1964) as Parliamentary Secretary to the new minister of technology, and resigned in March 1966 . He married the novelist Pamela Hansford Johnson (1912-1981), author of The Unspeakable Skipton (1959)

Snow, John (1813-1858). English physician and epidemiologist, born in York. Son of a colliery worker, he was apprenticed to a surgeon in Newcastle-uponTyne and later studied in London. He made several fundamental contributions to evidence-based medicine, pointing to deficiencies in bread as a factor in rickets, and calculated dosages for the use of ether and chloroform in anaesthesia. In September 1854 he identified a water pump in Broad Street, Soho as a transmission point for cholera, rejecting the prevailing 'miasma' theory. He never married and died of a stroke. In 2003, a poll of British doctors ranked Snow as the greatest physician of all time and his bicentenary was commemorated in 2013.

Snowden, Philip, 1st Viscount Snowden (18641937). English politician, born in Yorkshire. He became a public servant, studied economics and at 27 was crippled by a cycling accident. A Labour MP 1906-18, 1922-31, and an ardent free trader, he was Chancellor of the Exchequer 1924, 1929-31. When the Government split in 1931 he supported Ramsay ${ }^{*}$ MacDonald at first, but broke with the National Government in opposition to Imperial Preference and became increasingly isolated and bitter. $\mathrm{He}$ attacked MacDonald in his An Autobiography (1934) and embraced ${ }^{*}$ Keynes' ideas.

Snowdon, 1st Earl of, Antony (Charles Robert) Armstrong-Jones (1930-2017). English photographer, designer and film maker. In 1960 he married Princess *Margaret; they divorced in 1978. He was, despite his royal links, an exceptionally gifted photographer who published several books of portraits and made successful television documentaries.

Soane, Sir John (1753-1837). English architect. Son of a builder, after working under George *Dance the younger, he won a Royal Academy Gold Medal and a travelling studentship (1776-80). On his return he evolved an austere, highly individual modification of the classical style. From 1788 he was architect to the Bank of England, the rebuilding of which occupied 40 years. He built the Dulwich College picture gallery and the founder's mausoleum (1811-14), three London churches and many houses. His house in Lincoln's Inn Fields is a museum of prints, drawings, paintings and archaeological relics.

Stroud, D., The Architecture of Sir John Soane. 1961.

Soares, Mário Alberto Nobre Lopes (1924-2017). Portuguese Socialist politician. Educated in Lisbon and Paris, he was imprisoned 12 times under *Salazar's regime, then exiled in Paris. He served as Prime Minister 1976-85 and President of Portugal 1986-96. Soares was a very prolific writer.

Sobchak, Anatoli Aleksandrovich (1937-2000). Russian lawyer and politician, born in Siberia. Working as a lawyer in Stavropol 1960-64, he became an advisor to ${ }^{*}$ Gorbachev, won a doctorate in law at Leningrad University and was appointed a professor. $\mathrm{He}$ attracted attention in the USSR Congress of Peoples' Deputies 1989-91 and was elected Mayor of Leningrad/St Petersburg 1990-96. He played a decisive role in Leningrad in defeating the August 1991 coup against Gorbachev and reform.

Sobers, Sir Garfield (Garry St Auburn) (1936- ). Barbadian cricketer. A left-handed batsman and bowler, he made 8,000 test runs and took 200 wickets. He captained the West Indies test side 195374 and in 1958 made the record score of 365 not out in a test match.

Sobieski, Jan III (1624-1696). King of Poland and Grand-Duke of Lithuania 1674-96. Born in Galicia, educated at Jagiellonian University, he became a soldier and, after being engaged in constant warfare with Turks and Tartars, rose to be Polish Commanderin-Chief. A great victory over the Turks at Khotin (1673) made him a national hero and in the next year he was elected King. In 1683 he won European renown by putting the cause of Christendom before any considerations of national policy and marching to rescue Vienna from the Turks. Aristocratic faction and intrigue at home disturbed his reign.

Socinus, Faustus (Fausto Sozzini) (1539-1604). Italian theologian. He was known for his antiTrinitarian doctrines adopted from his uncle Laelius Socinus (Lelio Sozzini) (1525-1562). He left Italy (1575) to pursue his theological studies, thence he 
went to Transylvania and in 1579 to Poland where he remained for the rest of his life. Reason was the test he applied to doctrines and it was as an offence against reason that he condemned Trinitarianism, though he accepted the immortality of the spirit (but not of the body). He rejected the divinity of Christ, and the doctrine of Original Sin. Socinianism survived in Transylvania into the 20th century, and was influential elsewhere in the 16 th and 17 th centuries.

Socrates (c.469-399 BCE). Greek philosopher, born in Athens. Son of Sophroniscus, a friend of *Aristides and possibly a sculptor, he left no writings and the only first-hand evidence concerning his life and thought comes from *Plato and *Xenophon; the former makes him the chief spokesman of his dialogues, but the ideas expressed may well be those of Plato though the method of eliciting them is almost certainly Socratic. The known facts are simple: Socrates served and showed courage in the Peloponnesian War; the rest of his life was spent in Athens where he frequented public places such as markets and gymnasia and talked with anyone who would listen, but delighted especially in the company of young men of good mind and pleasing appearance. That these were most often to be found among the young aristocrats (*Alcibiades, Critias etc.) may have helped to estrange him from the general populace. He was ugly, with thick lips, bulging eyes and flat nose; he walked barefoot, wore the simplest of garments and was indifferent to comfort; but he was no ascetic and could outdrink any of the other guests at a banquet. As it is clear from the caricature of him in The Clouds by *Aristophanes, he was regarded as a sophist, but though he knew, and probably disputed with, sophists he had no use for their verbal pedantries. Nor was he a follower of any school of philosophy. His interests did not extend to the workings of the universe, that each of his followers and friends should learn to know himself was the aim to which his dialectical method was applied. He was no propounder of truths, he only guided the search for truth, or that part of it which lay within the mind of each of his companions. His method was to feign ignorance and then by question and answer to get nearer and nearer to the heart of the matter without achieving a final solution. The achievement of knowledge, he argued, would be the achievement of virtue, for virtue is the knowledge, in its fullest philosophical sense, of what ought to be done, and vice is correspondingly ignorance.

A minor mystery about his character was his claim to be guided in emergencies by a daimonion (divine sign) which, since it was peculiar to himself, had more affinity with intuition than conscience. Whatever its exact nature, his talk of it may help to explain the charge of blasphemy that was coupled with that of corrupting the morals of young men when he was brought to trial by the restored democracy in 399 . He was convicted by a jury of 501 by 280 votes to 221 , then condemned by a $360: 141$ vote, when 80 who supported acquittal then chose death. He refused an opportunity of escape and after an interval of 30 days took hemlock, the customary alternative to execution. A moving account of his last day is contained in Plato's dialogue Phaedo, in which Phaedo describes him as 'the wisest and justest and best of all men I have ever known'.

Guthrie, W. K. C., A History of Greek Philosophy. Vol 3. 1969; Stone, I. F., The Trial of Socrates. 1989.

Soddy, Frederick (1877-1956). English chemist. He was professor of chemistry at Glasgow 1904-14, Aberdeen 1914-19 and Oxford 1919-36. With *Rutherford he put forward (1903) the radioactive transformation theory showing that radioactivity arises from the spontaneous disintegration of atoms. Soddy's work led to the discovery that certain atomic species, which he called isotopes, could have the same atomic number but different atomic weight. He was elected FRS in 1910 and won the Nobel Prize for Chemistry (1921). Among his important books are Radioactive Elements (2 vols, 1912-14) and Matter and Energy (1912). He also wrote extensively (and eccentrically) on economics.

\section{Soeharto see Suharto}

Soekarno (or Sukarno, his personal name is given as Achmed or Koesnosoro) (1901-1970). Indonesian politician, born in Surabaja, East Java. His father was a Javanese Muslim school teacher, his mother a Balinese Hindu. He graduated as an engineer in 1925 and in 1927, with D. M. Kasuma, became co-founder of the Indonesian Nationalist Party (PNI). He fought against Dutch colonial rule, being imprisoned (1930-31) and exiled to remote islands (1933-42). After the Japanese invaded the Netherlands East Indies, Soekarno worked with them, visited Japan in 1943, and was made President of the Java central council and of Putera ('Centre of People's Power'), a nationalist Islamic body. On Japan's sudden collapse in August 1945, he proclaimed Indonesian independence and with Mohammed *Hatta set up a provisional government. He was Head of Provisional Government 1945-49, and President of the Republic 1949-67. The British occupied Indonesia and supported the restoration of Dutch rule, at least on a temporary basis, and four years of conflict followed, in which the islands were partitioned in a NetherlandsIndonesian Union. In 1949 the Netherlands recognised Indonesia as a federal state and withdrew; in December the United States of Indonesia was proclaimed. Named 'President for Life' in 1963, he was also Prime Minister 1963-67. He did much to stimulate a sense of national identity but his rule was marred by extravagance, corruption and caprice. For all his shortcomings as an administrator he was an extraordinary orator and master of communication. Following an abortive coup against the army by the Communist Party (PKI) in September 1965, probably with Soekarno's connivance, he lost power to General 
* Suharto and was removed from the presidency in March 1967. Muslim puritans disapproved of his private life (*Megawati Soekarnoputri).

Solomon (Shlomo, also Yedidyah) (c.990-c.931 BCE). King of Israel c.970-c.931. Son of *David and ${ }^{*}$ Bathsheba, under him the kingdom reached its widest limits and his wealth and luxury became proverbial. Known as a great builder, he is credited with the construction of the great temple at Jerusalem that bore his name. Surrounded by his concubines he ruled as an oriental despot, and his way of life offended the austere nationalists led by the prophets, while heavy taxation alienated popular support. These causes, combined with tribal jealousies, brought about the partition of the country in the next reign. Solomon left behind him a tradition of great wisdom and supernatural powers. He may have written parts of the biblical Book of Proverbs, but the Song of Songs, Ecclesiastes and the apocryphal works attributed to him are much later. The royal dynasty of Ethiopia claimed descent from Solomon and the Queen of Sheba.

Solomon (Cutner) (1902-1988). English pianist, born in London. Son of an East End tailor, he made his debut in 1911, toured extensively and made many recordings, retiring in 1956 after a stroke. He had a superb technique, but his interpretative skills were even greater, especially in ${ }^{*}$ Beethoven, ${ }^{*}$ Chopin, ${ }^{*}$ Schumann and ${ }^{*}$ Brahms. He never used his surname.

Solon (c.638?-559 BCE). Athenian legislator and poet. It seems that he first gained popularity by using poetry to express political aims (e.g. the relief of economic distress). As archon (594-563) he was given unlimited power to make economic and constitutional reforms. He started with his revolutionary Seisachtheia (shaking off of burdens) by which all debts were cancelled, land forfeited for debt restored, and those who had pledged their persons as security for debt were freed from slavery. The acceptance of such pledges was in future forbidden. Currency reforms and encouragement of homegrown food (e.g. corn for wine) were among his other measures. He divided the citizens into classes, by economic standards, rights and duties being prescribed accordingly. Though the people as a whole were more widely represented in the assembly and the courts, Athens was as yet far from being a democracy. After completing his reforms, he refused the offered role of 'tyrant' and spent several years in travels, about which many legends were told. $\mathrm{He}$ is numbered among the Seven Sages of Greece.

Solow, Robert Merton (1924- ). American economist. Educated at Harvard, he taught statistics and economics at MIT from 1949 and won the Nobel Prize for Economics in 1987 for his pioneering work on the impact of technology on economic growth and his advocacy of selective government intervention.
Solti, Sir Georg (né György Stern) (1912-1997). Hungarian-British conductor. A pupil of ${ }^{*}$ Bartók, *Kodály and *Dohnányi, he was an excellent pianist, turning to conducting after World War II. He was musical director of the Munich State Opera 194652, the Frankfurt Opera 1952-61, Covent Garden Opera 1961-71, the Chicago Symphony 1970-91, the Orchestre de Paris 1971-75 and the London Philharmonic Orchestra 1979-83. He won many awards with his recordings, e.g. the first complete *Wagner Ring cycle (1965).

Solzhenitsyn, Aleksandr Isayevich (1918-2008). Russian novelist and dissident thinker, born in Rostov-on-Don. Son of an office worker, he studied mathematics at Rostov and Moscow universities, served as an artillery officer and was decorated for bravery. He spent eight years (1945-53) in a forced labour camp in Kazakhstan for criticising * ${ }^{*}$ talin obliquely in a letter: this was the basis for One Day in the Life of Ivan Denisovich (1962). During a three-year exile in Central Asia he was cured of cancer; he used this experience in Cancer Ward (1967). Officially rehabilitated in 1957, he became a teacher at Ryazan and, in 1962 during a period of thaw, ${ }^{*}$ Khrushchev allowed his first book to be published. The First Circle (1968), set in 1948, described Marfino prison where skilled personnel worked on special KGB projects. Expelled from the Soviet Writers' Union in 1969, he was awarded the 1970 Nobel Prize for Literature but was prevented from receiving the prize in Stockholm. Later books include August 1914 (1972) and The Gulag Archipelago (1974), a study of a network of Soviet concentration camps, Lenin in Zurich (1975), and The Oak and the Calf (1980). In 1974 he was expelled from the USSR, settling first in Switzerland, then (1975) in Vermont, USA. He returned to live in Russia in 1994.

Scammell, M., Solzhenitsyn: A Biography. 1984.

Somare, Sir Michael Thomas (1936-2021). Papua New Guinean politician. A teacher and journalist, he became Chief Minister 1972-75 under Australian rule and the first Prime Minister of independent Papua New Guinea 1975-80, 1982-85, 2002-11. He was awarded a PC, GCMG and CH. In 2011 a constitutional crisis erupted when parliament ruled that Somare's prolonged absence due to illness disqualified him from being Prime Minister, but the Supreme Court attempted to overturn the decision.

Somers, John Somers, 1st Baron (1652-1716). English Whig politician. A barrister, he defended the Seven Bishops put on trial by *James II, and played an important part in drafting the Bill of Rights. As Keeper of the Seal he presided over *William III's informal Cabinet councils and was one of the king's most trusted advisors. Impeached by his opponents he lost office in 1700 but was briefly restored to power (1708-10) under Queen *Anne. 
Somerset, 1st Duke of, Edmund Beaufort (c.14061455). English nobleman. Grandson of *John of Gaunt, Duke of Lancaster, he became the leader of the Lancastrian faction and the rival of Richard, Duke of *York. His failures as military commander in France (1453) marked the end of the 'Hundred Years War'. Nevertheless, he was close to *Henry VI's wife *Margaret of Anjou and became Henry's chief minister. Conflicts with the Yorkists led to the 'Wars of the Roses' and Somerset was killed at a skirmish at St Albans. His son Henry Beaufort, 2nd Duke of Somerset (1436-1464) became leader of the Lancastrian forces but was defeated at Hexham and was summarily beheaded.

Somerset, Edward Seymour, 1st Duke of (1506?1552). English nobleman. He became prominent on the marriage of his sister *Jane Seymour to *Henry VIII. Soon after the accession of his nephew, the boyking *Edward VI, he was created Duke of Somerset and virtually ruled the country as Lord Protector. His rough wooing of *Mary Queen of Scots on behalf of his master led to the victory of Pinkie (1547), after which Mary was sent to France for safety. In England he hastened the growth of Protestantism, and his personal acquisitiveness, coupled with mildness, made him vulnerable to the intrigues of the Earl of Warwick (afterwards Duke of *Northumberland), who engineered his downfall and execution.

Sommerfeld, Arnold Johannes Wilhelm (18681951). German theoretical physicist. He worked in Munich on quantum mechanics and proposed a modification to *Bohr's model of the atom. His pupils included ${ }^{*}$ Rabi, ${ }^{*}$ Pauling, ${ }^{*}$ Pauli, ${ }^{*}$ Heisenberg and ${ }^{*}$ Bethe.

Sondheim, Stephen Joshua (1930-2021). American composer and lyricist, born in New York City. A dominant figure in American musical theatre, and a winner of eight Tony Awards, his compositions include A Funny Thing Happened on the Way to the Forum (1963), Company (1970), A Little Night Music (1973), Sweeney Todd (1979), Sunday in the Park with George (1984, Pulitzer Prize), Into the Woods (1988) and Passion (1994).

Song (or Sung). Chinese dynasty which ruled 9601279, sometimes called 'Northern Song'. Printing, ceramics and gunpowder were developed in this period.

Song Ziwen (or Soong Tse-Ven; called in the West, T.V. Soong) (1891-1971). Chinese politician. Son of a well known industrialist, he held many offices in Guomintang governments including that of Prime Minister 1944-47. One of his sisters married *Sun Yat-sen, the other ${ }^{*}$ Chiang Kaishek.

Sontag (née Rosenblatt), Susan (1933-2004). American critic, novelist and director, born in New York. After graduating from Chicago University at the age of 18, she worked at Harvard and Oxford, then published a series of highly original speculative works on philosophy and education, including Against Interpretation (1966), On Photography (1977), Illness as Metaphor (1978), AIDS and Its Metaphors (1989) and the novels The Volcano Lover (1992) and In America (2000).

Sophia of Hanover (formerly Sophia of the Palatinate, née Witttelsbach) (1630-1714). Electress-consort of Hanover 1692-1698. Born in The Hague, her parents were ${ }^{*}$ Frederick V of the Palatinate and *Elizabeth, daughter of *James I of Great Britain. Sophia married (1658) Ernst August von Welf-Este, Duke of Brunswick-Lüneburg (1629-1698) who became Elector of Hanover in 1692. The Act of Settlement (1701) excluded Roman Catholics from succeeding to the British throne. Sophia's descent from James made her, as a non-Catholic, the heiress: the Act provided that, if Queen *Anne was not survived by her children, the Crown would pass to the Electress Sophia and her descendants. Sophia died in June 1714; seven weeks later Anne, much younger, followed and Sophia's son succeeded as King *George I.

Sophocles (c.495-406 BCE). Greek dramatist, born at Kolonos, near Athens. A member of a prosperous family, he is said to have led a boys' choir which celebrated the naval victory of Salamis. Later, having failed as an actor owing to the weakness of his voice, he devoted himself to writing plays. A mark of his success was that he won first prize at the great festival of the god Dionysus 18 times. Of over 100 plays written by him only seven survive complete. Ajax, almost certainly the earliest, takes up the hero's story from the point when he is driven to suicide by anger and disappointment at not being awarded the arms of Achilles. Conflicts provoked by refusal to accord him honourable burial are the theme of the play, which ends with a change of decision by King Agamemnon. In Antigone the theme is similar, but the efforts of the Theban princess (the title role) to bury her brother Polynices result in a series of tragic events, including her own death. Oedipus the King (Oidipous Tyrannos better known by the Latin name Oedipus Rex), usually considered his masterpiece, and the sequel Oedipus at Colonus (the latest of the surviving plays) tell the terrible story of Oedipus, King of Thebes, who, having discovered that unknowingly he had killed his father and married his own mother, came in his last years, an old, blinded and impoverished exile, to seek his death. Electra is Sophocles' version of the events that followed the murder of the hero's mother Clytaemnestra, the unfaithful wife of Agamemnon. The Trachiniae (Maidens of Trachis) tells of the death of Heracles at the hands of his wife Deianira who gives him poison in the belief that it is a love charm. Philocteles is the story of a Greek hero who, stricken by a loathsome disease, is abandoned by his companions on the way to Troy, but is at last induced to come to their aid with his magic bow. Sophocles, who first introduced a third actor, was the most technically accomplished of all Greek dramatists, both in construction and 
dramatic language. He is essentially interested in human character and the interplay of one character upon another. Matthew *Arnold wrote that he 'saw life steadily and saw it whole'.

Kitto, H. D. F., Greek Tragedy. 3rd ed. 1961.

Sopwith, Sir T(homas) O(ctave) M(urdoch) (18881989). English aircraft designer. He founded Sopwith Aviation in 1912 and his aircraft 'Camel' and 'Pup' were used by the RAF in World War I. The company went into liquidation in 1920, Sopwith entered a partnership with Harry ${ }^{*}$ Hawker and chaired Hawker Aircraft. He became a very successful yacht designer.

Sordello da Goito (c.1180-c.1269). Italian-Provençal troubadour, born near Mantua. His love lyrics and other surviving poems, including the long 'Lesson of Honour', are written in Provençal. Mentioned several times in *Dante's Purgatorio, he was the subject of Robert *Browning's long narrative poem Sordello.

Sorel, Georges (1847-1922). French civil engineer and social philosopher. Deeply influenced by *Marx and ${ }^{*}$ Nietzsche, and profoundly pessimistic about the future of European civilisation, he was bitterly opposed to bourgeois morality, parliamentarianism and utilitarianism, which he saw as cowardly evasions of history. He became successively a liberal conservative (1889), Marxist revisionist (1893), Dreyfusard (1897), revolutionary syndicalist (1902), supporter of Action française (1910), and Bolshevik sympathiser (1919). In Reflections on Violence (1908) he urged a 'myth' of a heroic view of man and urged the use of (psychological) violence against the force of the State: out of such a confrontation would come a new order. Both *Mussolini and *Trotsky admired him.

Sorensen, Soren Peter Lauritz (1868-1939). Danish biochemist. As director of the chemical section of the Carlsberg Laboratory, his chief researches were on amino acids, proteins and enzymes. He is best known for his introduction of the $\mathrm{pH}$ scale for expressing acidity and alkalinity in terms of hydrogenion concentration. On this scale neutrality is represented by a $\mathrm{pH}$ value of 7 , different degrees of acidity and alkalinity are represented by $\mathrm{pH}$ values respectively below and above 7 .

Sorge, Richard (1895-1944). German-Russian spy, born in Baku of German parents. The most audacious modern spy, he studied in Berlin and became a journalist, penetrating the German diplomatic service and working in Japan (1933-41). His espionage coups were not given full credit in Moscow and he was arrested (1941), tortured, and hanged in Tokyo. Stalin declined to make representations to save him.

Soros, George (né György Schwartz) (1930- ). Hungarian-Jewish-American investor and activist, born in Budapest. A pupil of Karl *Popper, he achieved extraordinary success as a currency speculator, with a capital gain of \$US1.3 billion in
1993. The Soros Foundation encouraged democracy in Eastern Europe and Soros was critical of some aspects of economic liberalism.

Soult, Jean-de-Dieu, 1st Duke of Dalmatia (17691851). French marshal. After serving in the ranks he rose to become a general (1799) in the French Revolutionary armies and in 1802 was created a marshal. He played a decisive role at Austerlitz (1805) and commanded the right wing at Jena (1806). In 1807 he drove the British forces from Spain, and was made a duke in 1808. In the subsequent campaigns against ${ }^{*}$ Wellington in the Peninsula he fought with varying fortune but could never achieve a decisive success and, as *Napoléon became less able to reinforce him, was gradually driven back. In 1813 he was unable to prevent Wellington breaking through into France. Soult acted as Chief of Staff to Napoléon in the Waterloo campaign, after which he was banished. Recalled in 1820, he became a partisan of ${ }^{*}$ Louis Philippe, was created Marshal General in 1830 and served as Minister of War 1830-34, 1840 44 and Premier 1832-34, 1839-40, 1840-47.

Sousa, John Philip (1854-1932). American bandmaster and composer, born in Washington. Son of a Portuguese father and a Bavarian mother, he was leader of the band of the US marine corps (1880-92) and then formed his own band, with which he toured the world. Known as 'the March King', he composed 136 marches, marked by swaggering vitality and imaginative scoring, including The Stars and Stripes for Ever and The Washington Post.

Soustelle, Jacques (1912-1990). French anthropologist and politician. He studied and wrote about Aztec culture in Mexico, turning to politics during World War II when he joined *de Gaulle's Free French movement. He was a Deputy in the National Assembly 1945-46, 1951-58 and 1973-78, and Governor-General of Algeria 1955-56. He played a leading role in organising the coup that restored de Gaulle to power in 1958, was Minister for Information 1958-59 and for Overseas Development 1959-60. He broke dramatically with de Gaulle over the decision to grant Algerian independence and joined the OAS (Organisation armée secrète). He was exiled in 1961, amnestied in 1968, and elected to the Académie française in 1983.

Southampton, Henry Wriothesley, 3rd Earl of (1573-1624). English nobleman. Best known as the man to whom *Shakespeare dedicated Venus and Adonis and The Rape of Lucrece, he may have been the 'Mr W. H.' and the 'lovely boy' of Shakespeare's Sonnets. He lost the favour of *Elizabeth I after his secret marriage to Elizabeth Vernon, and was imprisoned for his part in *Essex's rebellion (1601). *James I pardoned him (1603) and he took part in a number of commercial and colonial enterprises, including the expedition to Virginia (1605). He died of fever on an expedition to the Netherlands to help the Dutch. 
Southcott, Joanna (1750-1814). English 'prophet', born in Devonshire. A domestic servant, in 1792 she began to claim divine inspiration for prophecies in prose and verse announcing the imminent 'second coming' of *Jesus Christ. At 64 she claimed that she was about to give miraculous birth to a Prince of Peace, but her own death intervened. An intensive propaganda continues for the opening of a box or boxes left by her. A box was opened in 1927 but no documents or articles of importance were found.

Southey, Robert (1774-1843). English writer. A close friendship with $S$. T. ${ }^{*}$ Coleridge marked his first years after leaving Oxford University. The two friends married sisters and in 1803 the two couples shared Greta Hall, Keswick. When Coleridge left Keswick that winter he entrusted his wife and family to Southey's care. Southey remained there for the rest of his life, one of the renowned Lakeland poets, with his friend *Wordsworth nearby. ${ }^{*}$ Landor, ${ }^{*}$ Lamb and Walter ${ }^{*}$ Scott were also among his friends, and the younger writers such as ${ }^{*}$ Carlyle and Charlotte *Brontë were helped by his kindness. A mainstay of the Tory Quarterly Review, he was made Poet Laureate in 1813. Overwork brought about his mental breakdown in 1839. Much of his vast output of poetry and prose, which included epics such as The Vision of Judgement (1820) and a valuable History of Brazil (1810-19), is now forgotten, even his lives of *Nelson and *Wesley, and the children's classic The Three Bears.

Simmons, J., Southey. 1945.

Southwell, St Robert (1561-1595). English Jesuit and poet. A distant cousin of *Shakespeare, he ministered to Catholics despite the threat of execution for priests who failed to leave England. His poems include 'The Burning Babe' and 'New Heaven, New War'. He was arrested in 1592, tortured and executed. He was beatified in 1929 and canonised in 1970 .

Soutine, Chaim (1893-1943). Russian-Jewish-French painter, born near Minsk. Living in Paris from 1913, he suffered great hardship. His convulsive and heavily painted expressionist works, often featuring human depravity and carcasses in the slaughterhouse, were a major influence on Francis *Bacon. He also painted many studies of cooks, hotel valets and page boys.

Soyer, Alexis Benoît (1809-1858). French chef de cuisine. He fled to London from the 1830 revolution in France. He was chef to the Reform Club and became the most famous cook of his time. $\mathrm{He}$ was sent to the Crimea to reform the army's food commissariat, and introduced the 'Soyer Stove'. Soyer wrote a variety of cookery books.

Morris, H., Portrait of a Chef. 1938; Arnold, A., Adventurous Chef. 2002; Brandon, R., The People's Chef. 2004; Cowen, R., Relish: The Extraordinary Life of Alexis Soyer. 2006.
Soyinka, Wole (Akinwande Oluwole Babatunde) (1934- ). Nigerian playwright, poet and novelist. Educated at Ibadan and Leeds universities, he wrote in English, worked at London's Royal Court Theatre and returned as professor of drama at Ife in 1972. His works include the plays The Invention (1955) and Death and the King's Horseman (1975), and the autobiography Ake (1982). In 1986 he became the first African to win the Nobel Prize for Literature.

Spaak, Paul-Henri Charles (1899-1972). Belgian socialist politician. A lawyer, elected as deputy in 1932, he was Foreign Minister five times 1936-38, 1939-46 (serving in the government in exile in London 1940-45), 1947-49, 1954-58 and 1961-66 and Prime Minister thrice 1938-39, 1946, 1947-49. A founding father of the United Nations, he was the first President of the UN General Assembly 1946-47. A strong advocate of European economic integration, he worked closely with Robert *Schumann and Jean ${ }^{*}$ Monnet, becoming President of the European Coal and Steel Community 1952-54 and SecretaryGeneral of NATO 1957-61. He was awarded the Charlemagne Prize in 1957 and received a British $\mathrm{CH}$, the US Medal of Freedom and many other honours.

Spaatz, Carl Andrews (1891-1974). American airman. He joined the American Army air force in 1916, and in 1941 was sent to Britain to organise the 8th Air Force which worked in close association with the British Bomber Command. He commanded (1943) all Allied forces taking part in the North African campaign. He was head of the US Army Air Force 1946-48.

Spacey, Kevin (Fowler) (1959- ). American actor, director and writer, born in New Jersey. He starred as Frank Underwood in the powerful television series House of Cards, was an outstanding Richard III on stage, and appeared in many films including The Usual Suspects (1995) and American Beauty (1999), receiving Academy Awards in both, and in Margin Call (2011). He was artistic director of the Old Vic, London, 2004-15, and became an Hon. KBE in 2015. His career was derailed in 2017 by accusations of sexual predation.

Spallanzani, Lazzaro (1729-1799). Italian zoologist. He studied law at Bologna and entered orders. In 1757 he became Professor of Mathematics and Physics at Reggio, moving on to Modena in 1763 and to the chair of Natural History at Pavia in 1769, where he divided his time between zoological research, teaching natural history and travelling. His reputation rests upon his skill as an experimenter in many fields of natural history. He carried out a notable series of experiments disproving spontaneous generation, by demonstrating that no life formed in sealed containers. He was a pioneer student of the chemical action of gastric juices in digesting foodstuffs. $\mathrm{He}$ hypothesised that this was due to the action of acids, 
but failed to locate these. In embryology, Spallanzani was a staunch preformationist, believing that the new creature already existed in microscopic form complete in the embryo.

Spark, Dame Muriel Sarah (née Camberg) (19182006). British novelist, born in Edinburgh. Her first published novel was The Comforters (1957). She wrote also some verse and criticism and a play, The Prime of Miss Jean Brodie (1961). Her novel The Mandelbaum Gate (1965) won the James Tait Black Memorial Prize. Like most of her work, it takes an ironic view of the results when personalities interact. Later books include The Abbess of Crewe (1974), The Only Problem (1984) and Symposium (1990).

Sparks, Jared (1789-1866). American journalist, Unitarian minister and biographer. He edited the North American Review (1824-31) and began in 1832 his Library of American Biography. He was later President of Harvard 1849-53. He edited the writings of George *Washington and Benjamin *Franklin.

Spartacus (d.71 BCE). Thracian gladiator. He led a slave revolt against the Romans (73-71 BCE). The insurrections began in Capua where 73 members of a school of gladiators broke out to become the nucleus of a slave army of nearly 100,000 men. Spartacus won several victories but was finally defeated and killed by the forces of Marcus Licinius *Crassus. Thousands died in the final battle or were later rounded up and executed.

Speer, Albert (1905-1981). German architect. His buildings attracted *Hitler's interest and on the death of Fritz *Todt he became Minister of Armaments and Munitions 1942-45, producing a record-breaking 3,031 fighter planes in the month of September 1944. He prevented Hitler's scorched earth policy being fully implemented in March-April 1945 and urged the Fuhrer to capitulate. He was sentenced to 20 years' jail at the Nuremberg trials for his use of slave labour. On his release he published the valuable memoirs Inside the Third Reich (1969).

Schmidt, M., Albert Speer: The End of a Myth. 1985; Sereny, G., Albert Speer. 1995.

Speidel, Hans (1897-1984). German soldier. *Rommel's Chief of Staff for a time in World War II, he was imprisoned (1944) for alleged participation in the attempt to assassinate *Hitler. Commander-inChief of the new West German army 1955-57, his appointment (1957) to command the NATO forces in Central Europe marked an important stage in the postwar history of the Federal Republic of Germany.

Speke, John Hanning (1827-1864). British explorer. After service in the Indian army he joined Richard *Burton to explore Somaliland (when he narrowly escaped with his life). Three years later (1857) the same two explorers were sent by the Royal Geographical Society to look for the great lakes of Central Africa. They reached Lake Tanganyika together but Speke was alone when he discovered Lake Nyanza and concluded (rightly) that it must be the source of the Nile. Burton disagreed and to settle the dispute Speke made another journey in 1860 (with Captain J. A. Grant) and followed the river emerging from the lake far enough to be sure that it was identical with the Nile. Burton still refused to be convinced. On the day before a public meeting to discuss the issue, Speke accidentally shot himself. $\mathrm{He}$ wrote Journal of the Discovery of the Source of the Nile (1863).

Spelman, Sir Henry (1562-1641). English antiquary. He made major contributions to the study of English medieval history, including writings on sacrilege and titles and his Glossarium Archaiologicum, produced over nearly 40 years. He is credited with the introduction of the term 'feudalism'. His son Sir John Spelman (1594-1643), also a historian, was an MP, a Royalist theorist and author of Life of Alfred the Great (published posthumously, 1678).

Spence, Sir Basil Urwin (1907-1976). British architect, born in Bombay. He worked in the office of Sir Edwin *Lutyens for a year before World War II. He produced (1951) the winning design for the rebuilding of Coventry Cathedral and became its architect. Among other appointments he was consultant architect to Edinburgh, Nottingham, Sussex and Southampton universities and for Basildon new town. He was president of the RIBA (1958-60), knighted in 1960 and received the OM in $1962 . \mathrm{He}$ designed the 'Beehive' extension to the New Zealand Parliament in Wellington.

Spencer, Sir (Walter) Baldwin (1860-1929). Australian anthropologist, born in Lancashire. Professor of biology at Melbourne University 1887-1919, with Francis James Gillen (1856-1912) he conducted pioneering anthropological surveys of Aboriginal people, wrote The Native Tribes of Central Australia (1899) and had profound but unacknowledged influence on Bronislaw *Malinowski.

Spencer, Herbert (1820-1903). English philosopher and sociologist, born in Derby. Son of a schoolmaster, he became first a teacher and then a railway engineer, and worked at this profession, with occasional incursions into journalism, until 1843 when he became subeditor of the Economist. In Social Statics (1851), he argued that laissez-faire liberalism, if allowed to work unchecked, would finally lead to social equilibrium. His System of Synthetic Philosophy (1862-92), in 10 huge unreadable volumes, asserted that there were universal laws, as in mathematics, physics or biology, which could be applied to human society. In Principles of Biology (1864), influenced by *Malthus, *Comte and *Lamarck, he proposed the concept of 'survival of the fittest', which he preferred to *Darwin's 'natural selection'. Darwin detested him. The term 'social Darwinism', coined in 1877 (not by Spencer), was 
widely used in the 20th century as a justification for imperialism, 'scientific racism' and European cultural superiority. Spencer also promoted 'positivism', arguing that the only authentic knowledge must have been tested by scientific method, rejecting every form of metaphysics and the creative arts (except for music, which he thought had a moral influence). Spencer had supported universal suffrage, then turned against it, was hostile to *Gladstone's reforms, opposed compulsory education, public health measures, safety regulations for workers and tax-funded libraries. His books were widely read and he had a major influence in the United States, which he visited in 1882 . He wrote almost 100 articles for Popular Science Monthly. The Man versus the State (1884) was a high-Tory manifesto. Spencer was an autodidact, a polymath whose interests included mathematics, biology, physics, astronomy, psychology, education and ethics. Agnostic and hypochondriac, he never married. Nominated for the Nobel Prize for Peace in 1901 and for Literature in 1902, he is buried opposite *Marx in Highgate Cemetery.

Peel, J. Y. D., Herbert Spencer: The Evolution of a Sociologist. 1971; Francis, M., Herbert Spencer and the Invention of Modern Life. 2007.

Spencer, Sir Stanley (1891-1959). English painter. Except during his service in Macedonia in World War I, he lived and worked in his native village of Cookham, Berkshire. The murals (1927-32) in the memorial chapel at Burghclerc, near Newbury, are his finest works. Equally impressive is the huge Resurrection in the Tate Gallery, London.

Rothenstein, W., Stanley Spencer. 1945; Mulvaney, J., Morphy, H. and Petch, A., My Dear Spencer. 1997.

Spender, Sir Stephen (Harold) (1909-1995). English poet and critic. At Oxford, he became, with his friends *Auden and *Day Lewis, one of the group of young poets who contributed to New Signatures (1932). In 1930 his own first volume of poetry, Twenty Poems appeared. He worked in Spain for the Loyalists, and his Poems from Spain (1939) reflect this period. His Collected Poems appeared in 1954. He also wrote fiction and literary criticism, eg. The Destructible Element (1935), and a poetic drama, Trial of a Judge (1938). From 1939 to 1941 he was coeditor, with Cyril *Connolly, of the monthly Horizon and in 1953 was co-editor of Encounter.

David, H., Stephen Spender. 1992; Spender, S., World Within World. 1951; Sutherland, J., Stephen Spender. 2004.

Spengler, Oswald (1880-1936). German philosopher. After some years as a teacher he came into sensational prominence with the publication (1918) of the first volume of Untergang des Abendlandes (Volume II, 1922, Eng. trans. The Decline of the West, 1926-29). His theme was that civilisations are subject
Spenser, Edmund (c.1552-1599). English poet, born in London. He left Cambridge University in 1576, and in 1580 became secretary to Lord Grey, Lord Deputy of Ireland. A year earlier he had published his first major work, The Shepheardes Calendar, dedicated to his friend Sir Philip *Sidney. After leaving Lord Grey's service he remained in Ireland in official appointments, living (from 1588) at Kilcolman Castle, Co. Cork, where he continued work on his great epic The Faerie Queene. In 1589 he went to London with Sir Walter *Raleigh to arrange for the publication of its first three books. Disappointed in his hopes of preferment, he returned to Ireland (1591), where he described his recent visit in Colin Clouts come home againe. The next three books of The Faerie Queene were published in 1596. This famous epic, which he left unfinished at his death, is an allegory (modelled to some extent on Ariosto's Orlando Furioso) of the England of his time, in which *Elizabeth appears as Gloriana, Queen of Fairyland. Much of the allegory is no longer easily comprehensible but the adventures of the knights can be enjoyed as separate episodes and there still remains the sensual delight of the poem's rich colouring and its metrical charm. It is written in what are now known as Spenserian stanzas. His other works include Astrophel (1586), an elegy on Sir Philip Sidney, and the sonnet sequence Amoretti, which immortalised his courtship of an Elizabeth (supposedly Elizabeth Boyle) whom he married in 1594. Epithalamion was probably written to celebrate the event, while the double wedding of the two daughters of the Earl of Worcester was commemorated by Prothalamion (1596). The prose work View of the Present State of Ireland (1596) was a defence of English policy. When Kilcolman was burnt by insurgents (1598), the last books of the Faerie Queene were probably destroyed. Spenser returned to London where he died in poverty but was buried in Westminster Abbey.

Judson, A. C., The Life of Edmund Spenser. 1945; Hadfield, A., Edmund Spenser. A Life 2012.

Speransky, Mikhail Mikhailovich, Count (17721839). Russian administrator. Son of a priest, he became *Aleksandr I's secretary and Minister of State 1809-12, proposing liberal constitutional reforms until forced into exile by fierce hostility from the nobles. Under ${ }^{*}$ Nikolai I he took a prominent part in the proceedings against the Decembrist conspirators, codified Russian law (in 45 volumes, 1830) and studied the peasantry.

Sperry, Elmer Ambrose (1860-1930). American inventor. He designed and manufactured numerous devices incorporating the principle of the gyroscope, among them the gyroscopic compass and stabilisers for ships. He also made improvements in the manufacture of electrical machinery and introduced (1915) the high-intensity searchlight. 
Sperry, Roger Wolcott (1913-1994). American neurobiologist and neurophysiologist, born in Connecticut. He studied literature and psychology at Oberlin, zoology at Chicago, primate biology at Harvard and was professor of psychobiology at Caltech 1954-84. Elected FRS, in 1979 he won both the Wolf Prize and the Lasker Prize. He shared the 1981 Nobel Prize for Medicine 'for his discoveries concerning the functional specialization of the cerebral hemispheres', one half being awarded to David Hubel and Torsten Wiesel for their research on visual field processing. The 'left' hemisphere of the brain is dominant in language, speech, logic, numbers, calculation and specific memory, while the 'right' brain processes pattern and spatial recognition, aesthetics, music, creativity and interpretation.

Spielberg, Steven (1947- ). American film director and producer, born in Cincinnati. He made a series of extraordinarily successful films, notable for strong story lines, spectacular special effects and action, including Jaws (1975), Close Encounters of the Third Kind (1977), Raiders of the Lost Ark (1981), E.T. (1982), Colour Purple (1985), Empire of the Sun (1988), Jurassic Park (1993), Amistad (1997) and Saving Private Ryan (1998). Schindler's List (based on Tom *Keneally's Schindler's Ark, 1993), won seven Academy Awards, including best picture and best director. Later films include Munich (2005), True Grit (2010), War Horse (2011) and Lincoln (2012).

Spielrein (or Shpilrein), Sabina Naftulovna (18851942). Russian-Jewish physician and psychoanalyst. She studied medicine in Zürich, and became closely associated with Carl *Jung, as patient, student, colleague and probably lover. Her research anticipated Jung's concept of transformation and *Freud's 'death wish'. She was killed with her family by a Nazi death squad.

Kerr, J., A Most Dangerous Method: The Story of Jung, Freud and Sabina Spielrein. 1993.

Spinoza, Benedict de (Baruch Despinoza) (16321677). Dutch philosopher of Jewish-Portuguese descent, born in Amsterdam. Given a traditional Jewish education, he became lax in his observances, was estranged from his people, and was excommunicated (1656). While earning his living as a lens grinder he learnt Latin and absorbed western culture. A version (1663) of *Descartes' Principles of Philosophy was the only book published under his own name during his lifetime, but Theological Political Treatise (1670) was generally recognised as his. While admitting that human passions necessitate strict obedience to the state, the book pleaded for liberty for the philosopher to express his ideas. Despite the uproar that it caused (difficult now to understand), he was offered (1673) a professorship by the Elector Palatine but preferred to devote himself to completing his greatest work, the posthumously published Ethics (1677). Beginning from the notion of substance, which may be roughly described as having properties or attributes but not being such itself, he proceeds by classically deductive argument to establish that nature is identical with God, the being who possesses infinite attributes but is not the personal God of Christianity. He sees man's mind as part of the divine one and for that reason incapable of exercising free will in an absolute sense. With the same integrating pantheistic vision he argues that man's highest good is his knowledge of his union with nature or intellectual love of God (amor Dei intellectualis). He died of a lung disease aggravated by the glass dust produced by lens grinding.

Hampshire, S., Spinoza. 1956; Nadler, S., Think Least of Death. Spinoza on How to Live and How to Die. 2020.

Spock, Benjamin McLane (1903-1998). American physician. About 50 million copies of his books on the care of children have been sold in America, Britain and many other countries. They include $A$ Baby's First Year (1950) and Feeding Your Baby and Child (1955). He was professor of child development at Western Reserve University, Ohio 1955-67.

Spode, Josiah (1733-1797). English manufacturing potter. He learned to make earthenware from Thomas Whieldon of Fenton, and set up his own factory at Stoke on Trent in 1770. His successor, Josiah Spode II (1754-1827) is credited with perfecting a formula for bone china c. 1800 which has been the basis of the English tableware industry ever since. He was potter to *George III. The firm of Spode was bought by William Copeland in 1833 and amalgamated with Wedgwood in 1964.

Spohr, Ludwig (1784-1859). German violinist and composer, born in Brunswick. He was aided in his studies by the Duke of Brunswick. After being musical director at theatres in Vienna and Frankfurt he was Kapellmeister at the Court of Hesse Kassell 1822-57. He composed many violin concertos, operas, oratorios, symphonies and chamber music. One oratorio, Die Letzten Dingen (1826), had a long vogue in England as The Last Judgement.

Spreckelson, (Johan) Otto von (1929-1987). Danish architect. A professor at the Academy of Fine Arts, Copenhagen, he won an international competition for the design of La Grande Arche at La Defense, Paris, an important monument opened in 1989 to commemorate the French Revolution.

Sprengel, Christian Konrad (1750-1816). German botanist. A pioneer of floral biology, he carried out research on the sexuality of plants and the role of insects in pollination. Ignored for decades, his work was confirmed by Charles *Darwin.

Springsteen, Bruce (Frederick Joseph) (1949- ). American composer, singer and instrumentalist, born in New Jersey. Guitarist, pianist and harmonica player, he worked in a diversity of genres, ranging from hard 
rock to heartland rock, gaining international fame with his albums Streets of Philadelphia (1994) and The Rising (2002), and his CD sales amounted to 200 million. He won 20 Grammy Awards and an Academy Award and toured constantly, appealing to devoted followers in very long concerts. He was a social activist and a strong *Obama supporter. He received the Presidential Medal of Freedom in 2016.

Spurgeon, Charles Haddon (1836-1892). English Baptist pastor. His preaching attracted vast congregations and the huge Metropolitan Tabernacle, in Elephant and Castle, London, with a 6,000-seat auditorium, was completed in 1861. (It was burned out in 1898.) He left the Baptist Union in 1887 , opposing its liberal tendencies. He was a prolific author, publishing weekly sermons.

Staël-Holstein, Anne Louise Germaine (née Necker, known as Madame de Staël) (1766-1817). French author, born in Paris. Daughter of the financier Jacques *Necker, she married (1785) Baron Erik Magnus Staël von Holstein (1749-1802), the Swedish Ambassador in Paris. She was regarded as the most intellectual and cultured woman of her time and her salons, both in Paris and later at her Swiss home at Coppet, were attended by many of her most brilliant contemporaries. Her efforts to attract ${ }^{*}$ Napoléon Bonaparte (who disliked clever women) failed, they became bitter enemies and in 1803 he ordered her to leave Paris. She went to Germany and there met ${ }^{*}$ Schiller, ${ }^{*}$ Goethe and August von ${ }^{*}$ Schlegel. A later visit resulted in De l'Allemagne (1810), which did much to introduce German Romanticism to France. It was suppressed by Napoléon. To escape his enmity she visited Vienna, Russia, Stockholm and England (where she was warmly welcomed). After the Emperor's downfall she again presided over salons in Paris and Coppet. Her literary career had opened (1788) with a panegyric of ${ }^{*}$ Rousseau. In $D e$ la littérature (1800) she compared French literature unfavourably with German and English. Her two novels, Delphine (1802) and Corinne (1807), contain self-portraits and relate to her long liaison (17941808) with Benjamin *Constant. Considérations sur la Révolution Française and the autobiographical Dix Années d'exil appeared posthumously.

Herold, C., Madame de Staël. 1964.

Stafford, Sir Edward William (1819-1901). New Zealand politician, born in Edinburgh. He became a large sheep owner in the Nelson settlement. As Prime Minister 1856-61, 1865-69 and 1872 he pursued an unpopular policy of centralisation, but was a capable administrator. He returned to England in 1874 and was knighted in 1879 .

Stahl, Georg Ernst (1660-1734). German scientist. Son of a Protestant minister, and inclined to Pietist views himself, Stahl studied medicine at Jena and taught there from 1683 until he was appointed professor at Halle in 1693. From 1716 he was personal physician to ${ }^{*}$ Friedrich I of Prussia. His medical writings stressed that living bodies possess some sort of soul, or life-source, which cannot be simply reduced to the total of the separate organs. This was at bottom a religious conception, but it harmonised with his chemical interest in gases and his concern with heat. In chemistry he developed the concept of phlogiston, a substance contained within combustible bodies and given up when burnt. In smelting metals, phlogiston was assumed to be transferred from the charcoal to the ore. The idea of phlogiston tied together the chemistry of combustion in the 18 th century until *Lavoisier's rethinking of the subject, and the development of the concept of oxygen (taken out of the air on combustion).

Partington, J. R., A History of Chemistry. 1961.

Stählberg, Kaarlo Juho (1865-1952). Finnish politician and judge. He was a lawyer, judge, professor and a member of the Finnish Diet who drafted the republican constitution of 1917 when Finland seized its independence during the Russian Revolution. He became the first President of Finland 1919-25. In 1930 he was kidnapped by the pro-Fascist Lapua movement and lost the presidential elections of 1931 and 1937 by very narrow margins.

Stair, John Dalrymple, 1st Earl of (1648-1707). Scottish politician. His father was the first codifier of Scots law, and on his death (1695) he became 2nd Viscount Stair. Eminent as a lawyer, he was AdvocateGeneral under *James II and *William III, whose cause he strongly supported. As Secretary of State at the time of the Massacre of Glencoe (1692) he was held chiefly responsible and was forced to resign. Later he played a part in preparing the Act of Union (1707) and securing its passage through the Scottish Parliament. On the morning after one of his most convincing speeches he was found dead.

Stakhanov, Aleksei Grigorevich (1905-1977). Russian miner. He worked in coal mines from 1927, and in 1935 achieved notoriety by cutting 12 tons of coal per shift (seven being the norm). He was praised by *Stalin who inaugurated the 'Stakhanovite movement', designed to raise production in Soviet industry.

Stalin Josef Vissarionovich (né J. V. Dzhugashvili) (1878-1953). Russian (Georgian) Communist politician, born in Gori, Georgia. Son of a shoemaker, educated at the Tiflis (Tbilisi) Theological Seminary, he was expelled for 'propagating Marxism' to his fellow students. He joined the Russian Social Democratic Labour Party in 1898 and when the party split into factions in 1903 he became a Bolshevik organiser in the Caucasus, using the name 'Koba' (and sometimes 'Soso'). He was imprisoned and escaped five times 1903-12. He met *Lenin in 1905, attended Congresses in Stockholm (1906) and London (1907) and founded Pravda ('Truth') in 1911. Known as Stalin 
('man of steel') from 1913, he led the Bolsheviks in the Duma (1913), wrote Marxism and the Nationalities and was exiled in Siberia 1913-17 until released by *Kerensky's Government. After Lenin's second 1917 Revolution, Stalin was a member of the Politburo of the Communist Party 1917-53, Commissar for Nationalities 1917-23 and for the Worker-Peasant Inspectorate 1919-23. His first wife Yekaterina Svanidze had died in 1907, leaving a son who died as a prisoner of war. He married Nadejda Sergeyena Alleluya in 1918 and she committed suicide in 1932. (His son Vassily, an airforce general, became an alcoholic. His daughter Svetlana, later Peters, left the USSR and became a US citizen.) His third wife, who he married in 1935, was Rosa Kaganovich. In the Civil War, Stalin was active in the defence of Tsaritsyn (later renamed Stalingrad, now Volgograd) in 1918 but his success deepened the enmity of ${ }^{*}$ Trotsky, Commissar for War. As General Secretary of the Communist Party of the Soviet Union (CPSU) 1922-53, he made this post the most powerful in the USSR. A dull speaker and even duller writer, he was persistently underrated by his rivals. When Lenin died (1924) Stalin soon eliminated his closest associates, the 'Old Bolsheviks'. He promoted the concept of 'socialism in one country', believing that the best way to ensure Communist supremacy was to build up the USSR's industrial base, in contrast to Trotsky's advocacy of the 'permanent revolution'. The 'Left Opposition' (Trotsky, *Zinoviev, *Kamenev) was removed in 1926-27 and the 'Right Opposition' (*Rykov, *Bukharin, Tomsky) by 1930. The first Five Year Plan was announced in 1928, involving the forced collectivisation of agriculture, elimination of the kulaks and industrialisation, followed by the second (1933) and third (1938) Plans. The 'Great Purges' of 1934-38 were provoked by the murder of S. M. *Kirov and a series of show trials were held 1936-38. Victims included Bukharin, Kamenev, Zinoviev and Rykov. Of Lenin's Politburo, only Stalin survived by 1938 . His closest advisors were V. M. *Molotov and A. N. Poskrebyshev. Stalin executed 446 of 621 senior officers in the Red Army, including Marshal *Tukhachevsky. The Nazi-Soviet pact (August 1939), purely opportunistic, led directly to *Hitler's invasion of Poland and the outbreak of World War II. Stalin rejected warnings of Hitler's plans to invade the USSR. When 'Operation Barbarossa' began in June 1941, after a short hesitation, Stalin showed decisive leadership in the 'Great Patriotic War' and succeeded in identifying the CPSU with the cause of national survival. He was Premier of the USSR 1941-53, Commissar for Defence and Commanderin-Chief 1941-46, taking the titles of Marshal (1943) and Generalissimo (1945). He took a dominant role at the Teheran, Yalta and Potsdam Conferences. His strategic grasp and mastery of detail was admired by *Alanbrooke and Henry *Stimson. Since wartime deaths numbered about 22,000,000 and the Red Army had occupied Eastern Europe, he was in a strong position to force Allied agreement to the extension of Soviet control. The USSR declared war on Japan in
August 1945. Stalin was dismissive of *Mao, regarding him primarily as a Chinese nationalist and urged him to work with *Chiang. By 1948 the Cold War was at its height, ${ }^{*}$ Tito had left the Soviet bloc and cultural and scientific conformity were imposed by A. A. ${ }^{*}$ Zhdanov and T. D. ${ }^{*}$ Lysenko. Stalin claimed expertise in linguistics and the arts and was credited with having written works on Marxist theory and history which were distributed and translated by the million, but were essentially unreadable. The USSR exploded its first atomic bomb in September 1949. Mao proclaimed the Chinese Peoples' Republic in October 1949 and two months later met Stalin in Moscow. Relations were uneasy at best, and the outbreak of the Korean War (June 1950), engineered by Stalin, was an unwelcome surprise for China which was blamed by the US. After a mild thaw in 1952, a new purge aimed at 'cosmopolitans' was imminent when Stalin died, having held absolute power for longer than any other ruler. His body was preserved next to Lenin's in Red Square. In 1956 at the 20th Party Congress, *Khrushchev attacked his character, operating methods, terrorism and cultivation of the 'cult of personality'. His body was removed from the Lenin Mausoleum in 1961.

With the opening up of Soviet archives and years of careful scholarship, it appears that Stalin was directly responsible for about 6 million civilian deaths from executions in purges, the liquidation of kulaks and 'The Great Terror', with 3 million more dying from starvation caused by his policies. These totals, while monstrous, are less than half of previous estimates. Nevertheless, Stalin preserved the USSR during World War II and played the central role in defeating Nazism.

Payne, R., Rise and Fall of Stalin. 1965; Ulam, A., Stalin. 1973; Bullock, A., Hitler and Stalin: Parallel Lives. 1991.

Stambolijski, Aleksandur (1879-1923). Bulgarian politician. He founded the Agrarian party and dreamed of a Balkan federation that would be part of a 'Green International' unifying the peasants of all Eastern Europe. Imprisoned for opposing King *Ferdinand's pro-German policy in World War I, he became Prime Minister on his abdication (1918). He lost popularity by favouring the country people at the expense of the towns and by compromising with Yugoslavia on the Macedonian question. His regime was overthrown, and he was assassinated.

Stamfordham, 1st Baron, Arthur John Bigge (1849-1931). English courtier. Son of a vicar, he became a soldier, then served as Private Secretary to Queen *Victoria 1895-1901 and to *George V, first as Prince of Wales 1901-10 and as king 1910-31. He thought strategically about preserving the monarchy from the impact of World War I, social and political changes, and the media. He engineered changing the dynastic name to ${ }^{*}$ Windsor, denying asylum to the Russian imperial family, appointing Ramsay 
*MacDonald as Prime Minister of a minority Labour government in 1924, acknowledging autonomy of the Dominions, making public appearances and broadcasting.

Standish, Myles (c.1584-1656). American colonist. He came of a Lancashire family and had made a career as a soldier of fortune when he was hired by the Pilgrim Fathers to accompany them on the Mayflower (1620). His skill in handling the American Indians was indispensable to the safety of the colony in its early years and he remained one of its most important members for the rest of his life. He is the subject of poems by *Longfellow and *Lowell.

Stanford, Sir Charles Villiers (1852-1924). English composer, conductor and teacher, born in Dublin. Organist at Trinity College, Cambridge 1873-92, he studied in Berlin and Leipzig and became professor of composition at the Royal College of Music 18831924 and at Cambridge 1887-1924. He wrote seven symphonies, concertos for clarinet and violin, much choral music and several operas. He was a sharp critic, a ${ }^{*}$ Bach enthusiast and an excellent teacher whose students included *Vaughan Williams, ${ }^{*}$ Holst, *Ireland, *Butterworth, *Bliss and ${ }^{*}$ Howells.

Stanhope, Lady Hester Lucy (1776-1839). English traveller. Daughter of the 3rd Earl Stanhope, she kept house for her bachelor uncle, the younger *Pitt, for the last three years of his life, which included his second premiership (1804-06). In 1810 she startled her aristocratic friends by going to the Levant, where on the slopes of Mount Lebanon she lived the life of an Oriental princess, entertaining friends, dispensing charity, and influencing the neighbouring tribes. Her prodigality exhausted her fortune and her last years were spent in poverty.

\section{Stanhope, Philip see Chesterfield, Philip Dormer Stanhope, 4th Earl of}

Stanislavsky, Konstantin (Konstantin Sergeyevich Alekseyev) (1863-1938). Russian actor and producer. As co-founder of the Moscow Art Theatre (1898), which he directed until his death, he devised the famous 'method' in which actors are trained to develop their own conception of their roles and to analyse and express emotion in an entirely natural manner. Stage settings have to be realistic. After the Russian Revolution it was discovered that his 'method' was in exact accord with the doctrine of 'socialist realism'. As actor and producer, he was accorded the highest distinctions, including the Order of Lenin (1937). His house is preserved as a museum and the street in which he lived named after him.

Stanislavsky K., An Actor Prepares. Eng. ed. 1980; Stanislavsky K., My Life in Art. Repr. 1980.

\section{Stanisław I see Leszczyński, Stanisław}

Stanisław II August Poniatowski (1732-1798). King of Poland and Grand Duke of Lithuania 176495. Born to an aristocratic family, he was a diplomat in St Petersburg, became the favourite of ${ }^{*}$ Catherine the Great, by whom he had a child, and she secured his election as Polish king. He never married. A significant art collector and patron, he attempted reforms in Poland, but after three partitions by Russia, Prussia and Austria $(1772,1793,1795)$ his kingdom disappeared.

Stanley. English noble family. In 1485 Thomas Stanley (1435-1504) was created 1st Earl of Derby for the decisive contribution that he and his brother Sir William Stanley made to the victory of *Henry VII at the battle of Bosworth Field (1485). The sovereignty of the Isle of Man was held by the Stanley family from 1406 until it passed to the Dukes of Atholl in the 18th century. Among Stanleys prominent in politics were the 14 th and 17 th earls of $*$ Derby.

Stanley, Fiona Juliet (1946- ). Australian paediatrician and epidemiologist, born in Sydney. Working in Perth, she became a specialist in maternal and child care, demonstrated the linkage between low levels of folic acid and spina bifida and became an effective advocate of public health measures, and the use of biostatistics in setting priorities.

Stanley, Sir Henry Morton (1841-1904). British explorer and journalist, born in Wales. An orphan (then known as John Rowlands), he ran away from the workhouse at the age of 15, sailed to America as a cabin boy and was adopted by a New Orleans merchant, whose name he assumed. After the Civil War (during which he served on both sides) he became a reporter and joined (1867) James Gordon *Bennett's New York Herald. After assignments with Robert * Napier in Abyssinia, in Egypt (for the opening of the Suez Canal) and elsewhere in the East, he was sent (1869) to find David *Livingstone, then missing in Africa. The meeting, made historic by Stanley's casual greeting 'Dr Livingstone, I presume?', took place at Ujiji on Lake Tanganyika (27 Oct. 1871), but after exploring the lake together they parted company, Stanley returning to Zanzibar and England while Livingstone, now re-equipped and re-provisioned, remained. Publication of Stanley's book How I Found Livingstone (1872) caused him to be feted as a hero, and after an interlude with *Wolseley on the Ashanti campaign, he was jointly commissioned (1874) by the New York Herald and the London Daily Telegraph to make another African expedition, which succeeded in solving several geographical problems, including the exact course of the Congo. A book followed each of his exploits, e.g. Through the Dark Continent (1878). From 1879 he established on behalf of King *Leopold II of the Belgians the trading stations on the Congo that led to the foundation of the Congo Free State. On his last journey (1887-89) he overcame immense hardships to rescue ${ }^{*}$ Emin Pasha, and discovered 
the Mountains of the Moon (Ruwenzori range). To complete an astonishing career he was a Unionist MP 1895-1900. He was awarded a GCB in 1899.

Farwell, B., The Man Who Presumed.1957; McLynn, F., Stanley. 1991.

Starling, Ernest Henry (1866-1927). English scientist. Son of a barrister, Starling studied medicine at Guy's Hospital from 1882, qualifying MB in 1889. From 1887 he was demonstrator at Guy's and from 1890 was researching part-time with Schafer at University College, London. Working with William Maddock Bayliss, Starling pioneered the study of hormones, the chemical messengers of the body produced by the endocrine glands. He then moved on to research on the heart, being interested in its response to stress in the body organism at large. Starling was a turbulent man of strong views. He campaigned for educational reform, demanding a larger place for science in the school curriculum and in national priorities. His contributions to physiology are amongst the most important of the early 20th century. Four times nominated for a Nobel Prize, he died in Jamaica on a cruise.

Starmer, Sir Keir (1962- ). English lawyer and Labour politician. A graduate of Leeds and Oxford, he became a barrister, specialising in human rights, a QC and Director of Public Prosecutions 2008-13. MP 2015- , he was a shadow minister under Jeremy ${ }^{*}$ Corbyn, with whom he clashed. He won the leadership of the Labour Party with $56.2 \%$ of the popular vote and became Leader of the Opposition 2020- .

Stas, Jean Servais (1813-1891). Belgian chemist. He studied organic chemistry under Jean Baptiste André Dumas of Paris and later worked with him, he was professor of chemistry 1840-45 at the École Royale Militaire, Brussels. He greatly improved methods for determining atomic weight and obtained much more accurate values for the common elements.

Stassen, Harold Edward (1907-2001). American Republican politician. A lawyer, and a progressive, he was Governor of Minnesota 1939-43, served in the US Navy 1943-45, and was President of the University of Pennsylvania 1948-53. He sought the Republican presidential nomination nine times, running third in 1948, then with diminishing credibility.

Stauffenberg, Claus Philipp Maria Justinian, Graf Schenk von (1907-1944). German soldier. From a Swabian aristocratic family, he served as an army officer and joined a conservative group which attempted to assassinate ${ }^{*}$ Hitler with a briefcase bomb at his Wolf's Lair headquarters on 20 July 1944. Hitler survived and Stauffenberg was executed in Berlin on the next day.

Walters, B., Treason. Claus von Stauffenberg and the plot to kill Hitler. ebook 2014, print 2021.
Stavisky, Serge Alexandre (1886?-1934). French speculator, born in Kiev. He promoted a series of fraudulent companies and as the scale of his operations grew he cultivated government and municipal officials, involving many of them in his transactions. His final and most ambitious plan was to obtain control of the issue of bonds, secured by goods pledged with the municipal pawnshops, and soon a flood of worthless bonds began to circulate. Though alerted, the police delayed action until Stavisky had disappeared. When traced to a villa near Chamonix he committed suicide to avoid arrest. The scandal mounted as more and more well known people were suspected of being involved, demonstrations in Paris led to the fall of the government and the scandal did much to shake national confidence in the years before World War II.

Stead, Christina (Ellen) (1902-1983). Australian novelist. She lived in Europe and the US 1928-74 and achieved international recognition with her scarifying novel The Man Who Loved Children (1940). Dark Places of the Heart (1966) is the story of a radical lesbian in the north of England.

Rowley, H., Christina Stead: A biography. 1993.

Steele, Sir Richard (1672-1729). English essayist and dramatist, born in London. He was educated at Charterhouse and Oxford, joined the army, but soon took to writing. His first works were the plays The Funeral (1702), The Lying Lovers (1703) and The Tender Husband (1705). The second of these introduced 'sentimental comedy', which, in contrast with Restoration drama, treated lapses from virtue sentimentally rather than with ribaldry. $\mathrm{He}$ started (1709) the Tatler, on which he was soon joined by an old school friend, Joseph *Addison. It contained a mixture of news, social comment, essays etc., and was intended to elevate morals and manners as well to amuse. Steele himself wrote as 'Isaac Bickerstaff. When the Tatler was succeeded by the Spectator (1711-12) the two friends again collaborated; the famous character Sir Roger de Coverley was invented by Steele and developed by Addison. Later, however, they became estranged by political quarrels. Steele's association with other papers never achieved the same success. He was a vigorous supporter of ${ }^{*}$ George I's succession, became a Whig MP (1714) and was knighted (1715). Soon after his last comedy The Conscious Lovers (1722) was produced, he left London and died in Wales.

Winton, C., Captain Steele. 1964; Sir Richard Steele. 1970; Loftis, J., Steele at Drury Lane. 1973.

Steen, Jan (c.1626-1679). Dutch painter, born at Leyden. One of the liveliest and most prolific of Dutch genre painters, nearly 900 works surviving, his works show a mastery of movement in group scenes, with humour and attention to detail, e.g. Skittle Players (1660, National Gallery London) and The Poultry Yard (1662. Amsterdam). His satire e.g. 
The Lovesick Maiden, is gentle, and the colour of such pictures as The Lute Player (Wallace Collection London) is of rare delicacy.

Steer, (Philip) Wilson (1860-1942). English painter. After studying in London and Paris he was, with *Sickert, a founder of the New English Art Club. In 1893 he became a teacher at the Slade School. In his early landscapes, e.g. The Beach of Walberswick (1890), now in the Tate Gallery, London, he was influenced by *Whistler. Later he adhered more closely to the traditions of ${ }^{*}$ Gainsborough and ${ }^{*}$ Constable, using Impressionist techniques (especially those of ${ }^{*}$ Monet) though he was not a true Impressionist since he did not paint directly from nature. From c. 1900 some of his paintings recall *Boucher in his rococo period, in others, e.g. The Muslin Dress (1910), the exactitude of detail recalls the pre-Raphaelites. The watercolour revival (from c.1918) owed much to Steer's example. He was awarded the OM in 1931.

Rothenstein, J., Modern English Painters Sickert to Smith. 1952.

Stefan, Joseph (1835-1893). Austrian physicist. His most important work was on radiation, the kinetic theory and hydrodynamics. While professor of physics at Vienna University he discovered the fundamental law of radiation, known as Stefan's Law: that the rate of radiation of energy from a black body is proportional to the fourth power of its absolute temperature. He was a precursor of *Planck.

Stefansson, Vilhjalmur (1879-1962). American anthropologist and explorer, born in Canada of Icelandic parentage. He studied Eskimo life and habits (1908-12) and wrote My Life with the Eskimo (1913). Later he did valuable exploratory work in the Arctic and discovered several new islands. He made two attempts to resist a Russian claim to Wrangel Island by planting the Union Jack (1914 and on behalf of Canada 1921-22) but the Soviet Government secured recognition of their sovereignty in 1924. His other books include Unsolved Mysteries of the Arctic (1939) and an autobiography, Discovery (1964).

Stein, Sir (Marc) Aurel (1862-1943). British archaeologist, born in Hungary. Naturalised in 1899, he explored much of central Asia and discovered evidence of cultural exchanges between the Chinese and the Greeks in the period of *Alexander the Great. Among the regions he visited were China, Turkestan, Persia and Mesopotamia. Knighted in 1912, he died exploring in Afghanistan.

Stein, St Edith (Teresa Benedictine of the Cross) (1891-1942). German-Jewish philosopher and martyr, born in Breslau. She rejected her Jewish faith in 1904, became an atheist, and studied philosophy at Göttingen with *Husserl, winning a PhD in 1916. She became a Catholic convert in 1921, joined the
Carmelites, wrote an important study on St John of the Cross and was murdered at the Auschwitz concentration camp. She was canonised in 1998.

Stein, Gertrude (1874-1946). American author, born in Pennsylvania. After studying psychology under William *James and medicine at Johns Hopkins, she lived in Paris from 1905, first with her brother Leo Stein, an art critic, and from 1912 with her lover Alice B. Toklas (1877-1967). The main elements in her poetic work include free association and repetition, as in her famous line 'A rose is a rose is a rose'. Her works include Three Lives (1909), Tender Buttons (1914, poetry), The Autobiography of Alice B. Toklas (1933), Portraits and Prayers (1939, art criticism), and Everybody's Autobiography (1937). She had much influence on modern art movements as well as on literature.

Sprigge, E. M. S., Gertrude Stein. 1957; Brinnin, J. M., The Third Rose. 1960; Toklas, A. B., What Is Remembered. 1963.

Stein, Karl, Baron von (1757-1831). German political reformer. His outspoken criticism of the backward political system caused his dismissal (1807) from the Prussian civil service, but he was soon recalled as Chief Minister by *Friedrich Wilhelm III in the hope of reinvigorating the country after *Napoléon's victories. He was unable to secure acceptance of representative government but he managed to introduce municipal self-government and abolish serfdom (1807-08). Eventually his opponents, now including the king, forced him to flee and in 1812 he entered Russian service. Tsar *Aleksandr I sent him to administer East Prussia and to organise resistance to Napoléon but, still unable to carry out reforms, he withdrew into private life (1813).

Steinbeck, John Ernest (1902-1968). American novelist, born in California. He first gained notice with the novel Tortilla Flat (1935), portraying the lives of Spanish Californian peasants. His masterpiece, The Grapes of Wrath (1939) is the story of a typical family of poor farmers in the dust bowl of Oklahoma. In its graphic depiction of human dignity in the face of adversity. it exposed exploitation, hardship and social inequity, and led to reforms, while winning for its author the 1940 Pulitzer Prize. Other works include Of Mice and Men (1937), The Moon is Down (1942), Cannery Row (1943) and The Wayward Bus (1947). He received the Nobel Prize for Literature (1962).

Davis, R. M., Steinbeck: A Collection of Critical Essays. 1972.

Steinberg, Saul (1914-1999). American graphic artist, born in Romania. Trained as an architect in Milan, he lived in the US from 1942 and won fame with his ingenious, penetrating, amusing and deeply disturbing illustrations for the New Yorker. He held many one-man exhibitions and his works were often reproduced, e.g. the world view from a New York 
perspective. His published collections included All in Line (1945), The Passport (1954), The Labyrinth (1960), The Inspector (1973), The Discovery of America (1992).

Bair, D., Saul Steinberg. 2012.

Steinem, Gloria (Marie) (1934-). American feminist writer, born in Ohio. She worked as a journalist in New York, founded Ms. magazine in 1972, and was a prolific author whose books include Outrageous Acts and Everyday Rebellions (1983).

Steiner, (Francis) George (1929-2020). AmericanJewish-Austrian philosopher, essayist and critic, born in Paris. His family moved from Vienna to Paris, then to New York in 1940. Educated at Chicago University and Harvard, he was a Rhodes Scholar at Oxford, wrote for The Economist, and taught at Princeton, Geneva and Cambridge. He succeeded Edmund *Wilson as chief book reviewer for the New Yorker in 1966. His books include Tolstoy or Dostoevsky (1959), Language and Silence (1967), After Babel (1975), Portage to San Cristobal of A.H. (1981) No Passion Spent (1996) and the autobiographical Errata (1997). He edited Homer in English (1996).

Steiner, Rudolf (1861-1925). German anthroposophist. First known as editor (1890-97) of *Goethe's works on natural science, he was a prominent theosophist until he evolved a system of his own known as 'anthroposophy', to develop which he opened (1912) a school (the Goetheanum) near Basle in Switzerland. The system aimed at a restoration of human contact with spiritual reality, lost since the days of myth-making. The fields in which his aims were particularly applicable were medicine, agriculture and education. The special schools his followers set up were often successful, where other educational methods had failed, in preserving the spiritual essence of the subjects taught.

Steinmetz, Charles Proteus (1865-1923). American electrical engineer, born in Breslau. He suffered from dwarfism, hip dysplasia and kyphosis and left his native Germany to avoid arrest for his activity as a socialist (1888). He became chief engineer for the General Electric (GE) Company 1893-1923 and was professor of electrical engineering 1902-13 and electrophysics 1913-23 at Union College, Schenectady, New York State. He was a major figure in the development of alternating current (AC) for generation and transmission, following ${ }^{*}$ Tesla and *Westinghouse in preference to direct current (DC), advocated by ${ }^{*}$ Edison. Of his many contributions to electrical engineering the most important are his law of magnetic hysteresis, his notation for alternatingcurrent circuits and his development of lightning arrestors for power transmission lines. He invented the metal halide lamp (1912), an electric car (1914) and flood lighting for sporting events.
Steinway, Heinrich Engelhard (originally H. E. Steinweg) (1797-1871). German piano manufacturer. He founded a factory in Brunswick but in 1851, leaving a son to run the German firm, he went to the US to establish a new factory, where pianos were manufactured under the name of Steinway.

Stendhal (pen name of Marie-Henri Beyle) (17831842). French novelist, born in Grenoble. He served as an administrator in the Napoléonic army in Italy, Germany and Russia, wrote travel sketches, books on the arts etc. and began his psychological analysis of love, De l'Amour (1822). He spent many years in Italy or in travel. After the revolution of 1830 he was appointed French consul in Trieste 1830-31 and Cività Vecchia 1831-36. In 1830 he published the first of two masterpieces, Le Rouge et le noir, a remarkable picture of his times (the 'red' being the army, the 'black' the church) and a penetrating analysis of the character, successes and downfall of its hero, Julien Sorel. His second great novel, $\mathrm{La}$ Chartreuse de Parme (1839), amid a magnificent medley of politics, diplomacy, plots and counterplots, contains a vivid impression of the Battle of Waterloo, and of life in a small Italian state. After years of illness, he collapsed and died in Paris. His posthumously published works include the unfinished novel Lucien Leuwen (1894). Stendhal was little recognised before 1880 , but from then his vogue steadily increased. $\mathrm{He}$ anticipated both the realism and the psychological approach of modern novelists. 'Stendhal's syndrome' is a term applied to an overpowering reaction, such as palpitations or fainting, caused by exposure to great art or natural beauty, experienced and described by Stendhal during a visit to Santa Croce, Florence, in 1817.

Fowlie, W., Stendhal. 1969; Wood, M., Stendhal. 1971; Leys, S., With Stendhal. 2010.

Stephen, St (Stéphanos: 'crown' in Greek, possibly Kelil in Aramaic). (c.5-c.34 CE). Jewish protomartyr. Probably a Hellenistic Jew, he was one of seven deacons in the early church in Jerusalem. Accused of blasphemy, he was tried before the Sanhedrin; his speech is recorded in Acts vii. Condemned, he became the first Christian martyr (after *Jesus) and was stoned to death. ${ }^{*}$ Paul (then Saul, not yet converted) was a witness.

Stephen, St (István) (c.977-1038). First King of Hungary 1000?-38. Originally known as Vajk, from the princely *Árpád family, he adopted the name of István (Stephen) on baptism. After overcoming rival leaders he was recognised as king by Pope Sylvester II. With this prestige he united and converted the whole country, which he divided into counties and bishoprics. Revered for his exemplary life, he was canonised in 1083. His feast day is 2 August. 
Stephen (of Blois) (c.1096-1154). King of England 1135-54. Born in Blois, son of the Count of Blois and of Adela, daughter of *William the Conqueror. When *Henry I's heir, William Adelin, drowned in the White Ship (1120), Stephen, who was with him, luckily escaped and became a potential claimant to the throne. He was elected king when Henry died (1135) despite having sworn fealty to Henry's daughter *Matilda. Most of his reign was marked by civil war. For a short time in 1141 he was Matilda's prisoner. After the death of his son (1152) a compromise was reached and he acknowledged Matilda's son, the future *Henry II, as heir to the throne and her husband, Geoffrey of Anjou (*Plantagenet) as Duke of Normandy. Stephen was a weak man, unable to control the barons upon whose support he relied.

Davies, R. H. C., King Stephen. 1967.

Stephen, Sir Leslie (1832-1904). English author and critic, born in London. Son of Sir James Stephen (1789-1859), an important figure in the abolition of slavery and Under Secretary for the Colonies 1836-47, he was educated at Eton and Trinity Hall, Cambridge. On becoming an agnostic he gave up his position as a Cambridge don and went to London (1864) to lead a literary life. He contributed to many journals, editor of the Cornhill Magazine 1871-82 and of the Dictionary of National Biography 188591, a field in which his lives of *Johnson (1878), *Pope (1880), *Swift (1882) etc. had shown his preeminence. Meanwhile he had also written his History of English Thought in the Eighteenth Century (1876). His main hobby was alpine climbing about which he wrote several books. His first wife was a daughter of *Thackeray, his daughters by his second wife were Vanessa Bell (Clive *Bell) and Virginia *Woolf.

Annan, N. G., Leslie Stephen. 1984.

Stephen, Sir Ninian Martin (1923-2017). Australian judge and administrator, born in Oxford. He was a barrister in Melbourne, a Victorian Supreme Court justice 1970-72 and a justice of the High Court 1972-82 before his appointment as GovernorGeneral of Australia 1982-89. He was Ambassador for the Environment 1989-92, chaired Anglo-Irish talks on the future of Northern Ireland 1992-93, and became a judge of the international tribunal to try war crimes in the former Yugoslavia. He received a KG in 1994.

Stephens, Alexander Hamilton (1812-1883). American politician, born in Georgia. Small and sickly (sometimes called the little pale star of Georgia'), he became a lawyer and a Whig Member of the House of Representatives 1843-59. Although he supported slavery, he strongly opposed Georgia's secession from the US and the creation of the Confederacy. Nevertheless he served as Vice President of the Confederate States 1861-65, offering critical support to Jefferson ${ }^{*}$ Davis' conduct of the war. $\mathrm{He}$ took an important role in the peace negotiations. He wrote Constitutional View of the Late War between the States (1868-70), returned to Congress 1873-82 and was Governor of Georgia when he died.

Wilson, E., Patriotic Gore. 1962.

Stephens, James (1882-1950). Irish writer, born in Dublin. He became known by The Crock of Gold (1912), The Demi-Gods (1914) and other prose fantasies in which fairies and mortals (e.g. policemen) meet on natural and familiar terms; the author's rhythmic style and happy use of Irish idiom adding a special charm. His collected poems appeared in 1921. Other books include Deirdre (1923) and Etched in Moonlight (1928).

Stephenson, George (1781-1848). English railway engineer, born in Northumberland. His parents were illiterate; his father, a fireman, worked on a ${ }^{*}$ Newcomen engine in a colliery. George had no formal education until the age of 17 , when he began work as an engineman in a pumping station. $\mathrm{He}$ devised several improvements to pumping machines and in his spare time taught himself engineering and mathematics. He won a prize of $£ 1,000$ for inventing a miner's safety lamp (1815) and became involved in a controversy with Humphry Davy who had independently invented a similar lamp. A year earlier he had built his first colliery locomotive. $\mathrm{He}$ constructed (1825) the first public railway between Stockton and Darlington, Durham (on which, however, horses were still used for passenger trains). He surveyed and constructed the 28 mile $(45 \mathrm{~km})$ railway line between Manchester and Liverpool, which was opened in 1830 . His engine The Rocket won (1829) a prize of $£ 500$ for maintaining an average speed of $29 \mathrm{mph}$ ( $46.6 \mathrm{kph})$. The Stephensons' 'standard gauge' for railways (4 feet 81/2 inches: 1,435 $\mathrm{mm}$ ) is still widely used. At his works at Newcastle, managed from 1827 by his son, Robert Stephenson (1803-1859), most of the notable locomotives for the next generation were made, and the two constructed many other railway lines in England and Scotland. George invested successfully in coal mining. Robert later became famous as a bridge builder, his works including the well known suspension bridges over the Menai Straits and at Conway in North Wales, as well as the Victoria Bridge over the St Lawrence at Montréal. George became the first President of the Institute of Mechanical Engineers 1847-48; Robert followed in 1849-53. A Tory MP 1847-59, Robert opposed extending education to the working class. He was elected FRS, buried in Westminster Abbey, but, like his father, declined all British honours.

Rolt, L. T. C., George Stephenson. 1960; George and Robert Stephenson: The Railway Revolution. 1984; Ross, D., George and Robert Stephenson: A Passion for Success. 2004. 
Stern, Isaac (1920-2001). American violinist, born in the Ukraine. His family moved to San Francisco in 1921. He toured internationally from 1947, and made many recordings and some films. He was identified with non-musical causes e.g. conservation and peace.

Sterne, Laurence (1713-1768). English novelist, born in Ireland. His great-grandfather was an archbishop of York, his father was a brave but erratic ensign in the army. Sterne's childhood was spent in camps and billets. At 17 when his father died, he was left penniless. However, with a cousin's help he went to Jesus College, Cambridge and in 1737 entered the Church. In 1737 he began his highly elaborate courtship of Elizabeth Lumley, even a handkerchief or a plate she had used called for a display of sensitivity, and through his letters he introduced the word 'sentimental' to her and to the world. They were married in 1741 , but the marriage soon faltered. Elizabeth became cantankerous and even, at times, insane. This gave Sterne freedom to pay frequent visits to 'Crazy Castle', the home of an eccentric Cambridge friend, John Hall-Stevenson, where he found Rabelaisian conversation, much wine and a library filled with rare (often obscene) books. Stimulated by such influences and by an eager flirtation with Mademoiselle Fourmantelle (the 'dear, dear Jenny' of his forthcoming masterpiece), he started writing The Life and Opinions of Tristram Shandy, an extraordinary medley of reminiscence and opinion, narrative and digression, in which Walter Shandy (Tristram's father and obviously modelled on Sterne's father), 'my uncle Toby', and Corporal Trim play the leading roles. The first two books, published in York at his own expense, appeared in 1759 and were immediately acclaimed. Sterne went to London and was lionised by Lord ${ }^{*}$ Chesterfield, ${ }^{*}$ Garrick and others. His portrait was painted by ${ }^{*}$ Reynolds and more volumes were commissioned (volumes 3-6, 1761-62, volumes 7 and 8, 1765, volume 9, 1767). Success and dissipation exacerbated Sterne's normal ill-health. He lived in Toulouse 1762-63 and in Paris was welcomed by ${ }^{*}$ Diderot and others and joined by his wife and daughter. A tour of France and Italy, begun in 1764, provided material for A Sentimental Journey (1768), the other work by which he is remembered. He died during a visit to London to supervise the publication of Volume 9 of Tristram Shandy. Its importance was recognised at once, being praised by ${ }^{*}$ Voltaire, ${ }^{*}$ Diderot, ${ }^{*}$ Burns, ${ }^{*}$ Goethe and ${ }^{*}$ Pushkin and later (surprisingly) by Karl *Marx. Samuel *Johnson was a notable dissenter and predicted, 'It will not last.' Among writers deeply influenced by Tristram Shandy have been ${ }^{*}$ Gogol, ${ }^{*}$ Tolstoy, *Thackeray, James * Joyce, Flann *O'Brien, Machado *de Assis, Spike *Milligan, Italo *Calvino, Thomas *Pynchon, and Salman *Rushdie. Tristram Shandy: A Cock and Bull Story (2005), a halffeature film/half-documentary, directed by Michael
Winterbottom, about the impossibility of filming the novel, is available online and is an excellent introduction to Sterne's masterpiece.

Howes, A. B., Sterne The Critical Heritage. 1974; Cash, A., Laurence Sterne. 2 vol. 1975; 1986.

Stettinius, Edward Reilley, Jr (1900-1949). American administrator. He resigned the presidency of the US Steel Corporation to become Lend-Lease administrator 1941-43. After being Undersecretary of State 1943-44 he succeeded Cordell *Hull as Secretary 1944-45. Under *Truman he served as US Ambassador to the United Nations 1945-46, resigning to become Rector of the University of Virginia 1946-49.

Stevens, Nettie Maria (1861-1912). American geneticist, born in Vermont. She gained a $\mathrm{PhD}$ from Bryn Mawr, was influenced by ${ }^{*}$ Mendel and worked with T. H. *Morgan. In 1905 she identified the distinction between male and female sex chromosomes. She died of breast cancer.

Stevens, Thaddeus (1792-1868). American Republican politician, born in Vermont. A lawyer, as a US Congressman from Pennsylvania 1849-53, 1859-68, he developed a detestation of slavery. After the Civil War he was the leader of the Radical Republicans who campaigned to ensure that free slaves could have access to land and the right to vote in the former Confederacy, ending white supremacy. The driving force behind the impeachment of President Andrew *Johnson, who tried, however ineffectively, to carry out *Lincoln's plans for reconciliation. Disappointment over Johnson's acquittal may have hastened Stevens' own death.

Stevens, Wallace (1879-1955). American poet, born in Pennsylvania. He worked for the Hartford Accident and Indemnity Company from 1916 and was its Vice President 1934-55. His first book, Harmonium (1923), was followed by a number of volumes, e.g. Ideas of Order (1935) and The Man with the Blue Guitar (1937). The Necessary Angel (1951) is a volume of essays. In his poems Stevens uses the techniques of Impressionism and Symbolism to explore the creative imagination and aesthetics at a time when belief was in decline. His Collected Poems (1954) won him the National Book Award (his second) and the Pulitzer Prize in 1955.

Kermode, F., Wallace Stevens. 1960.

Stevenson, Adlai E(wing) (1900-1965). American politician, born in Los Angeles. His grandfather Adlai E(wing) Stevenson (1835-1914) was ${ }^{*}$ Cleveland's Vice President 1893-97. Educated at Princeton, Harvard and Northwestern, he practised law in Chicago from 1926. After 1933 he served in Washington as legal assistant in several New Deal agencies and during World War II was Assistant Secretary of the Navy 1941-44 and Assistant Secretary 
of State 1944-45. As Governor of Illinois 1949-53 he carried out many reforms. After ${ }^{*}$ Truman decided to retire in 1952, he promoted Stevenson as Democratic presidential candidate. Although reluctant to run (he would have preferred 1956 or 1960), Stevenson won nomination over Estes *Kefauver and Richard Russell, losing to ${ }^{*}$ Eisenhower in the November election, with 44 per cent of the vote. Democratic nominee again in 1956 (although Truman switched his support to ${ }^{*}$ Harriman), he went on to a second defeat by Eisenhower, with only 42 per cent of the vote. His campaign speeches were published under the titles Call to Greatness (1954) and What I Think (1956). He was attacked as an 'egghead' at a deeply anti-intellectual period in US history. President *Kennedy appointed him Ambassador to the United Nations, an office he retained under President *Johnson (1961-65). Known for his liberal outlook and high intellectual integrity, he collapsed and died in the street in London. His son Adlai E(wing) Stevenson III (1930- ) was US Senator from Illinois 1970-81.

McKeever, P., Adlai Stevenson: His Life and Legacy. 1989.

Stevenson, Robert (1772-1850). Scottish engineer. He succeeded his stepfather (1796) as first engineer to the Northern Lighthouse Commission and during his 47 years of office constructed 23 lighthouses round the Scottish coasts, including the famous Bell Rock (1807). He also invented the system of intermittently flashing lights which enable a particular lighthouse to be identified. He was the grandfather of Robert Louis *Stevenson.

Stevenson, Robert Louis (Balfour) (1850-1894). Scottish novelist, essayist and poet, born in Edinburgh. He suffered from tuberculosis as a child, studied engineering and then law, but abandoned both for writing. On a canal tour in France and Belgium, which provided the subject of his first book, An Inland Voyage (1878), he met Mrs Fanny Osbourne (née Van de Grift) (1840-1914), they married in California (1880), and her son, Lloyd Osbourne (1868-1947), was later his companion and collaborator. Meanwhile Travels with a Donkey in the Cevennes (1879) had recalled another journey. Before embarking on the novels that made him famous he had written the essays collected as Virginibus Puerisque (1881) and Familiar Studies of Men and Books (1882), as well as the tales of fantasy in The New Arabian Nights (1882). In 1881 he started Treasure Island (1883), the first and most famous of his series of exciting and imaginative adventure stories, which combined Scott's historical method with the clarity and brevity of his own distinctive style. This was followed by Kidnapped (1886), The Black Arrow (1888), The Master of Ballantrae (1889) and Catriona (1893). Another immensely popular work was The Strange Case of Dr Jekyll and Mr Hyde (1886), in which the conflict of good and evil in a exciting tale. Stevenson undertook a tour of the South Seas (1889) for the sake of his health and settled in Samoa with his wife and stepson. Given the title of 'Tusitala' ('teller of tales'), he died there of a cerebral haemorrhage. Three of his last books, The Wrong Box (1889), The Wrecker (1892) and The Ebb Tide (1894), were written in collaboration with Lloyd Osbourne; St Ives (1897, completed by Arthur *Quiller-Couch) and Weir of Hermiston (1896), a masterpiece, were left unfinished. The best remembered of his poems are contained in A Child's Garden of Verses (1885).

Cooper, L., Robert Louis Stevenson. 1947; Furnas, J. C., Voyage to Windward: The Life of Robert Louis Stevenson. 1951.

Stevin (Stevinus), Simon (1548-1620). Flemish mathematician, born at Bruges. He studied law at Leyden University. $\mathrm{He}$ contributed to the development of algebraic notation and of decimals and put forward (1586) the law of equilibrium of a body on an inclined plane and a partial statement of the parallelogram of forces, disproving the concept of perpetual motion. He pioneered the science of hydrostatics. In 1586 he demonstrated that objects of different weights fall to the ground from the same distance at an identical speed-an experiment generally credited to ${ }^{*}$ Galileo. He measured magnetic declination, identifying 43 areas of variation. $\mathrm{He}$ wrote in Dutch, being one of the first great scientists to reject Latin. He was also well known as a military engineer and for his work on land drainage.

Stewart (or Stuart). Scottish dynasty which ruled in Scotland from 1371 and in England from 1603, when James VI of Scotland became *James I of England. It stemmed from the marriage of Walter, hereditary high steward (hence the family name) of Scotland, to Marjorie, daughter of Robert*Bruce. Their son *Robert II was the first Stewart king. From the time of *Mary Queen of Scots, whose second husband was Henry Stuart, Lord *Darnley, the French spelling became the commoner spelling. The dynasty ceased to reign when ${ }^{*}$ George, elector of Hanover, succeeded Queen *Anne (1714). The last Stewart/ Stuart in the direct line was Henry, Cardinal *York who died in 1807.

Ashley, M., The House of Stuart. 1980.

Stewart, Dugald (1753-1828). Scottish philosopher and mathematician, born in Edinburgh. A disciple of Adam *Ferguson, Adam *Smith and Thomas *Reid, he was a proponent of 'common sense' and an opponent of David *Hume. He taught ${ }^{*} \mathrm{~S} c o t t$, Sydney ${ }^{*}$ Smith, ${ }^{*}$ Brougham and ${ }^{*}$ Palmerston.

Stewart, James (Maitland) (1908-1997). American film and stage actor. Between 1935 and 1981 he appeared in 80 films, including $\mathrm{Mr}$ Smith Goes to Washington (1939), The Philadelphia Story (Academy Award,1940), Harvey (1950), Anatomy of a Murder (1959) and four directed by Alfred *Hitchcock, Rope (1948), Rear Window (1954), The Man Who Knew Too 
Much (1956) and Vertigo (1958). An active, hawkish Republican, he received the Presidential Medal of Freedom in 1985.

Stewart, Sir Patrick (1940- ). English actor, born in Yorkshire. He won international recognition in television series, as Captain Picard in Star Trek: The Next Generation and Prof. Charles Xavier in X Men. Active with the Royal Shakespeare Company, he was compelling as Prospero, Antony, Claudius and Macbeth, and excelled in *Beckett.

Stiglitz, Joseph Eugene (1943- ). American economist, born in Indiana. He studied at MIT and Chicago, taught at Cambridge, Oxford, Princeton and Columbia universities and was chief economist of the World Bank 1997-2000. He also produced economic modelling for the International Panel on Climate Change (IPCC). He shared the Nobel Prize for Economics in 2001 for his work on 'information asymmetry' and the operation of markets. The Price of Inequality: How Today's Divided Society Endangers Our Future (2012) was a bestseller.

Stikker, Dirk Uipko (1897-1979). Dutch politician and banker. He helped to finance the Resistance movement in World War II. He revived (1946) the liberal Freedom party, was Foreign Secretary in the coalition of 1948-52, Ambassador to Great Britain 1952-58 and Secretary-General of NATO 1961-64.

Stilicho, Flavius (c.365-408). Roman soldier. He was appointed by the emperor *Theodosius I (whose niece he had married) to be guardian of his son and successor Honorius. For several years, in the east, in Greece, Africa and Italy he held back the waves of barbarians who were engulfing the empire. Some of his most spectacular victories were gained (401-03) in northern Italy against *Alaric, leader of the Visigoths. Stilicho was suspected of aspiring to become Emperor himself. He was killed in a military revolt. Shortly afterwards, Alaric's army reached Rome.

Stilwell, Joseph Warren (1883-1946). American soldier. He became known as an authority on China, where he was military attaché in the years preceding World War II. As deputy to ${ }^{*}$ Chiang Kaishek, he commanded a Chinese-American force in Burma which acted in cooperation with the forces based on India against the Japanese. He became (1945) Deputy Supreme Commander of Allied Forces in Southeast Asia. No orthodox soldier, he was difficult to work with, hence his nickname 'Vinegar Joe' but of his courage and ability there is no doubt.

Stimson, Henry Lewis (1867-1950). American lawyer and administrator. A Republican, he twice served as US Secretary of War, first under *Taft 1911-13, and during World War II 1940-45 under Franklin D. *Roosevelt and *Truman. He was Governor-General of the Philippines 1927-29 and, as *Hoover's Secretary of State 1929-33, proposed the 'Stimson doctrine' in opposition to Japan's aggression in Manchuria. $\mathrm{He}$ took the ultimate responsibility in recommending that President Truman use the atomic bomb against Japan (1945). The term 'World War II' was his coinage.

Hodgson, G., The Colonel. The Life and Wars of Henry Stimson. 1990.

Stinnes, Hugo (1870-1924). German industrialist. $\mathrm{He}$ inherited a large concern he built up into a vast industrial empire, which made him an almost symbolic representative of acquisitive man. To river transport, coal mining and distribution he added shipping and shipbuilding, electricity, oil, motor cars and newspapers, his tentacles spread into almost every trade and industry. In 1920 he became a member of the Reichstag.

Stockhausen, Karlheinz (1928-2007). German composer. He studied under ${ }^{*}$ Messiaen and was part of the Musique Concrète group in Paris, experimenting with compositions based on electronic sounds. He wrote choral, orchestral and instrumental works, sometimes combining electronic with normal sonorities, and avant garde piano compositions.

Stokes, Sir George Gabriel, 1st Baronet (18191903). British mathematician and physicist, born in Sligo. After graduating with the highest honours at Cambridge University he became Lucasian professor of mathematics 1849-1903. Elected (1851) a fellow of the Royal Society, he was its president $1885-90$. He won the Rumford Medal (1853) and the Copley Medal (1893). He was a Tory MP for Cambridge 1887-92 and he played a major part in the development of hydrodynamics and aerodynamics. His contributions to optics were also important, e.g. his work on spectrum analysis (1852) and his explanation of fluorescence and phosphorescence (1878).

Wilson, D. B., Kelvin \& Stokes. 1987.

Stokowski, Leopold (Anthony) (1882-1977). American conductor, born in London. Of Polish-Irish parentage, he studied at the Royal College of Music and was organist at St James', Piccadilly 1902-05 and St Bartholomew's, New York 1905-09. He conducted the Cincinnati Symphony Orchestra 1909-12, the Philadelphia Orchestra 1912-36, the New York Philharmonic 1946-50 and the Houston Symphony Orchestra 1955-60. He made acoustic recordings from 1917, the world's first electric recording of an orchestra in April 1925 and continued until his death. He collaborated with Walt ${ }^{*}$ Disney in the film Fantasia (1940). In 1962 he founded the American Symphony Orchestra, based in New York. Stokowski premiered about 2,000 works in his long career.

Stolypin, Pyotr Arkadievich (1862-1911). Russian lawyer and politician. As a conservative Prime Minister 1906-11, he endeavoured to keep the Duma in being as an adjunct of government, under strict control, but not to suppress it. He combated revolutionary 
movements by severe repression accompanied by measures of social reform. He introduced changes in land tenure aimed at turning the peasants into satisfied and loyal small land holders, but these reforms, partly achieved, came too late to check the growing unrest. He opposed *Rasputin, whom he sent briefly into exile in 1911 and was murdered by a secret agent.

Stone, 'Biz' (Christopher Isaac) (1974- ). American entrepreneur, born in Massachusetts. With Jack *Dorsey, he was co-founder of Twitter in 2006, became active in environmental causes and a Visiting Fellow at Exeter College, Oxford.

Stone, Harlan Fiske (1872-1946). American jurist. Dean of Columbia University law school 1910-24, he served as US Attorney-General 1924-25, a justice of the US Supreme Court 1925-41 and Chief Justice 1941-46. A moderate liberal, he upheld much New Deal legislation and the right of dissent in civil liberties cases.

Stone, Oliver (1946- ). American writer and film director. He won Academy awards for Midnight Express (screenplay, 1978), Platoon (direction, 1986) and Born on the 4th of July (direction, 1989). He also directed JFK (1991) and Nixon (1995).

Stopes, Marie Charlotte Carmichael (1880-1958). English pioneer of women's rights. As the first female science lecturer, on palaeobotany, at Manchester University (1904), she developed a passionate interest in eugenics and birth control, on which she wrote several books, e.g. Married Love (1918) which broke new and unconventional ground. She founded the first birth control clinic in Britain (1921), a step that inspired similar clinics in other countries. She also wrote poetry and was deeply interested in drama.

Hall, R., Marie Stopes. 1977.

Stoppard, Sir Tom (né Tomáš Sträussler) (1937- ). English playwright and screenwriter, born in Zlin, Czechoslovakia. He escaped with his parents in 1939, first to Singapore, where his father died, then to Darjeeling, India. All four grandparents died in the Holocaust. His mother remarried and settled in England in 1946. He left school at 17, and became a journalist. His first stage play was Rosencrantz and Guildenstern are Dead (1967). Later successes include Jumpers (1972), Travesties (1974), Undiscovered Country (1980), Habgood (1988) and Arcadia (1993). $\mathrm{He}$ also wrote radio and television plays. His humour is based on juggling with philosophical concepts and on brilliant word play. He received the OM in 2000. The Coast of Utopia (2002), is a trilogy (Voyage, Shipwreck, Salvage) about ${ }^{*}$ Bakunin and ${ }^{*}$ Herzen. Later works include a screenplay for the film Anna Karenina (2012) and the stage play Leopoldstadt (2019).

Lee, H., Tom Stoppard. A Life. 2021.
Stout, Rex Todhunter (1886-1975). American author. After a varied career he made enough money to retire from business in 1929 and devoted himself to writing. He created the fictional detective Nero Wolfe (loosely based on Mycroft Holmes).

Stow, John (c.1525-1605). English chronicler and antiquarian. As well as doing original work he translated and summarised much of the work of earlier chroniclers. He is best known for A Survey of London (1598-1603), which gives valuable information about Elizabethan London and the customs and lives of its inhabitants.

Stow, (Julian) Randolph (1935-2010). Australian novelist and poet, born in Western Australia. His novels included To the Islands (1958), Tourmaline (1963), Visitants (1979) and The Suburbs of Hell (1984). His works won major awards but he retreated to England in the 1960s.

Falkiner, S., Mick: A Life of Randolph Stow. 2016.

Stowe, Harriet Elizabeth Beecher (1811-1896). American author. Sister of Henry Ward *Beecher, the preacher, she is remembered almost solely for her famous anti-slavery novel, Uncle Tom's Cabin (1851-52). In the years before the Civil War this book did much to solidify the movement in the north against slavery.

Wagenknecht, E., Harriet Beecher Stowe. 1965.

Strabo (= squint-eyed $)(64$ BCE-25 CE). Greek geographer, born in Amasia, Asia Minor. Of wealthy parents, he was Greek by language and culture but studied in Rome, specialising in geography, and became a convert to Stoicism. He travelled quite extensively, going up the Nile as far as Aswan and exploring the Ethiopian frontier. The only work of Strabo's that has survived is his Geographica. This was compiled more from reading than from personal observation, though he had travelled extensively as far east as Armenia and as far south as Ethiopia. Most of his sources were Greek and have been lost. He attempted a complete geography, which would tackle the questions of the globe from the mathematical, physical, topographical and political points of view. Strabo saw the known world as a single landmass comprising Africa, Asia and Europe, entirely north of the Equator, though he speculated on the existence of one or more southern continents. He thought the known world was about $11,000 \mathrm{~km}$ long, from East to West, and 5,000 km from North to South. He saw the Middle Territories of the Mediterranean as the cradle of civilisation. His detailed accounts of Spain, Asia Minor and Egypt are of high quality, other parts he knew less well. Strabo showed some interest in geophysics. He was aware of the role of earthquakes and volcanoes in changing the face of the globe, and he thought the Mediterranean had perhaps been a lake which had overflowed through the Straits of Gibraltar. He also studied the development of river 
deltas. Amongst ancient geographers, Strabo is the leading physical geographer, whereas * Ptolemy excelled him as a mathematical geographer.

Strachey, (Giles) Lytton (1880-1932). English biographer. Educated at Trinity College, Cambridge, and one of the 'Bloomsbury' group, his Eminent Victorians (1918), in which with brilliant satire he amusingly, but often unfairly, dissected the lives and characters of some of the great figures in 19th-century history, created a literary sensation and started a fashion for 'debunking'. His other works include Queen Victoria (1921), Elizabeth and Essex (1928) and Portraits in Miniature (1931). Although gay, from 1917 he shared a house with the painter Dora Carrington (1894-1932), who loved him. Their lives were dramatised in the film Carrington (1995).

Holroyd, M., Lytton Strachey. 1968.

Stradivari (Stradivarius), Antonio (1644-1737). Italian violin maker. The best known member of a family from Cremona, a pupil of Nicolo *Amati, he brought violin-making to its highest point of perfection. In later life he was helped by his sons, Francesco Stradivari (1671-1743) and Omobono Stradivari (1679-1742).

Strafford, Thomas Wentworth, 1st Earl of (15931641). English administrator. A member of a rich and distinguished Yorkshire family, he entered parliament in 1614 and became an opponent of ${ }^{*}$ Buckingham and the court party and supported the Petition of Right (1628). His opposition to the royal government was based on the grounds of inefficiency and petty illegality and he showed none of the political and religious ideals of his colleagues. He had an opportunity of putting into practice his plans for strong, honest, efficient government when he was appointed President of the Council of the North (1628) and still more so when, as Lord Deputy in Ireland 1633-40, he demonstrated the method of government he described as 'thorough'. If ${ }^{*}$ Charles I (who had made him Earl of Strafford in 1639) had followed his advice to bring troops from Ireland and overcome his Scottish and English opponents by force, history might have taken a different course, but Charles procrastinated. When at last the Scottish war forced him to call what became the Long Parliament, Strafford was impeached unsuccessfully. An Act of Attainder was passed by both Houses. Partly to divert hostility from the queen, Charles finally gave the royal assent. His betrayal of Strafford haunted him throughout the coming years until he suffered similar execution.

Wedgwood, C. V., Thomas Wentworth. 1961.

Strange, Lord, Ferdinando Stanley, later 5th Earl of Derby (1559-1594). English nobleman, patron and poet. Through his mother, he was in the line of succession to *Elizabeth I. A patron of
*Spenser, *Marlowe and *Shakespeare, he promoted a theatre troupe, 'Lord Strange's Men', later 'The Lord Chamberlain's Men', later still 'The King's Men', and was a singer and (probably) poet. He died mysteriously, probably by poison.

Strasser, Gregor (1892-1934). German Nazi politician. A prosperous pharmacist, he joined the Nazis in 1921, led the radical wing of the party in Berlin from 1926, and was regarded as a rival to ${ }^{*}$ Hitler until his murder in the 'Night of the Long Knives' (*Rohm).

Stratford de Redcliffe, 1st Viscount, Stratford Canning see Canning, Stratford, 1st Viscount Stratford de Redcliffe

Strathcona and Mount Royal, Donald Alexander Smith, 1st Baron (1820-1914). Canadian administrator, born in Scotland. He rose from clerk to Governor of the Hudson Bay Company 1838-99 but his name is chiefly associated with the construction of the Canadian Pacific Railway, the first to cross the country from coast to coast. He endowed McGill University and raised and equipped Strathcona's Horse for service in the Boer War. He was High Commissioner in London 1896-1914 and became the first Canadian peer (1897).

Strato of Lampsacus (d.c.271/268 BCE). Greek philosopher, born on the Asian coast of the Hellespont. He moved to Athens to study at *Aristotle's school under *Theophrastus. After spending some time in Alexandria as tutor to the future Ptolemy II, Strato returned to Athens to lead the Lyceum on the death of Theophrastus, a position he occupied between 287 and the time of his death about 268 . None of Strato's writings has survived, but much is known about them from accounts by other authors. He set himself the task of teaching Aristotelian doctrine, and he seems throughout his life to have been an orthodox follower of the philosopher. But he was also concerned to shape an interpretation of Aristotle in a particular direction, that is, to stress the purely naturalistic elements in Aristotle's thought. $\mathrm{He}$ stripped Aristotelianism of its religious and transcendental elements, and emphasised material causality. Strato thus underlined the difference between Aristotle's naturalism and *Plato's idealist views. He saw causality and force residing in natural objects themselves, rather than guiding them from above. He had no place for Aristotle's 'quintessence', preferring to see phenomena as the product of the mingling of the four elements, earth, air, fire and water. Strato was consistent in his discussion of man. He denied an immaterial soul. He thought intellect resided in the brain, and communicated itself to other parts of the body by some sort of 'air'. He was one of the most distinguished disciples of Aristotle, and of great influence in the ancient and medieval world. 
Straus, Oscar (1870-1954). Austrian composer. He won fame by his Viennese operettas, especially Waltz Dream (1907) and The Chocolate Soldier (1908), based on *Shaw's Arms and the Man.

Strauss, David Friedrich (1808-1874). German biblical critic. In his most celebrated work, The Life of Jesus (2 volumes, 1835-36, translated by George *Eliot, 1846), he applied the methods of literary criticism to the Gospels in an attempt to sift historical truth from what he held to be myth. This departure in biblical criticism was greeted with such hostility that his whole life was embittered and his academic career destroyed.

Strauss, Franz-Josef (1915-1988). German politician, born in Munich. Already prominent in Bavarian politics, he entered the Federal Bundestag in 1949. There, as leader of the Christian Social Union (the Bavarian counterpart of the Christian Democrats), he soon became prominent as *Adenauer's Minister of Defence 1956-62. His arbitrary arrests (for alleged revelation of military secrets) of the proprietor and editorial staff of Der Spiegel (1962) forced his resignation, but he kept his popularity in Bavaria and with his party. He returned as Finance Minister 1966-69, served as ministerpresident (i.e. premier) of Bavaria 1978-88, and was the unsuccessful candidate of the CDU-CSU Coalition for Chancellor (1980).

Strauss, Johann (1825-1899). Austrian composer, born in Vienna. His father, Johann Strauss the elder (1804-1849), also wrote waltzes but is best known for his famous Radetzky March (1848). The younger Johann Strauss wrote over 400 waltzes, including The Emperor, Voices of Spring, Tales from the Vienna Woods and, most popular of all, The Blue Danube (1867). In later life he wrote 16 operettas of which the best known is Die Fledermaus (The Bat, 1874). These works, like the waltzes, display the composer's melodic spontaneity and verve, his sense of style and skill in orchestration. His brother Josef Strauss (1827-1870), a composer, was also a poet, painter and inventor. His works include Music of the Spheres, Delirium, and Village Swallows.

Strauss, Richard (Georg) (1864-1949). German composer and conductor, born in Munich. Son of Franz-Josef Strauss (1822-1905), a virtuoso horn player who married into a brewing family, he was no relation to Johann ${ }^{*}$ Strauss. Largely self-taught as a composer, his first major work was the Horn Concerto No. 1 (1882, No. 2 dates from 1942). As a protégé of Hans von *Bulow, he gained conducting experience (1885-96) at opera houses in Meiningen, Munich and Weimar, becoming Chief Conductor at the Munich Opera (1896-98) and the Berlin Royal Court Opera (1898-1910) and joint Director of the Vienna State Opera (1919-24). Influenced by *Liszt and *Wagner, he wrote a series of dramatic symphonic poems, e.g. und Verklärung (1889), Till Eulenspiegel (1895), Also sprach Zarathustra (1896), Don Quixote (1897) and Ein Heldenleben (1898). While in his 30s he was recognised as the greatest German composer since Wagner and *Brahms. He wrote almost 200 songs (many of his best in the 1890s), and a monologue for speaker and piano, Enoch Arden (1897, after *Tennyson). Strauss wrote 15 operas, and they include his finest music. Salome (1905), based on *Wilde's play, was attacked as lurid, salacious and blasphemous, but this only aided its success. Elektra (1909), which Hugo von *Hofmannsthal adapted from his own play, was denounced for its polytonality and extreme modernity. His masterpiece Der Rosenkavalier (1909-10), a neoclassical comedy of manners, with libretto by Hofmannsthal, set in Vienna of 1740 , paid obvious homage to ${ }^{*}$ Mozart. It premiered in Dresden in January 1911. His other operas include Ariadne auf Naxos (1912), Die agyptische Helena (1928) and Arabella (1933), all with Hofmannsthal's dialogue, and Capriccio (1941). In the 1930s Strauss' creative powers waned and he unwisely accepted an appointment as President of the Reich Music Chamber under *Hitler (1933), however, he was able to protect Jewish relatives by marriage. During 1942-48 he experienced a remarkable 'Indian summer': works of his last period include Metamorphosen (for 23 strings, 1945), an oboe concerto (1945) and the Four Last Songs (1948). Strauss was in *Ravel's class as an orchestrator but his writing for voice was even finer, and only Mozart equalled him in setting the high soprano.

Krause, E., Richard Strauss, the Man and his Work. 1964; del Mar, N., Richard Strauss. 1972.

Stravinsky, Igor Feodorovich (1882-1971). Russian composer, born in Oranienbaum, near St Petersburg. Son of a famous operatic bass, he studied law but devoted himself to music from 1902, and was for three years a pupil of ${ }^{*}$ Rimsky-Korsakov in instrumentation. Reacting against *Wagner's music, he evolved a strikingly original but emotionally neutral style, influenced by ${ }^{*}$ Debussy and Russian folk music. For Sergei *Diaghilev's Ballets Russes he wrote three great scores that made him famous: The Firebird (L'Oiseau de feu, 1910), Petrushka (1911), and The Rite of Spring (Le Sacre du Printemps, 1913), the last a savage and mysterious evocation of primitive fertility dances employing a large orchestra, blazing colour and savage dissonance which caused a riot at its premiere under Pierre *Monteux in Pans, the audience having to be ejected by police. In the final 'Sacrificial dance', a young girl whirls herself to death to appease the gods. The Rite reached a wider audience through Walt ${ }^{*}$ Disney's film Fantasia (1940), in a 21 minute (Stravinsky thought 'mutilated') version, with images of nebulae, the creation of the earth, erupting volcanoes, amoebae, rampaging dinosaurs and solar eclipses.

Stravinsky lived in France 1910-14 and in Switzerland 1914-20, returning to France 1920-39. In the works of his second period (1914-20) he evolved a new style, abandoning the huge orchestra 
and blazing colour of The Rite of Spring for an austere preoccupation with line and structure. They include The Soldier's Tale (1918, for narrator, three actors and seven instruments), The Wedding (Svadebka/Les Noces, 1923, vocalists, four pianos and percussion), Symphonies of wind instruments (1920) and songs. In a third, neoclassical, period (1920-32) he wrote the ballets Pulcinella (1920, after Pergolesi), Apollo (1928, for strings), and The Fairy's Kiss (1928, after *Tchaikovsky), the opera-oratorio Oedipus rex (1927, set to *Cocteau's Latin text), the Symphony of Psalms (1930) and a violin concerto. His fourth period (1932-52) was both eclectic and prolific, marked by varied influences ranging from plainsong, *Bach, ${ }^{*}$ Beethoven, *Verdi, through jazz and swing. Music included the ballets The Card Party (1936), and Orpheus (1947), Symphony in C (1940), Symphony in three movements (1945), a Mass (1944), and the opera The Rake's Progress (1951, libretto by W. H. *Auden and Chester Kallman), based on *Hogarth's drawings. Stravinsky became a French citizen in 1934, lived in the US from 1939 and was naturalised in 1945 . His fifth period (from 1952) was influenced by the serial techniques of ${ }^{*}$ Schoenberg and, especially, ${ }^{*}$ Berg in such works as In memoriam Dylan Thomas (1954), the ballet Agon (1957), Threni (Lamentations of Jeremiah, 1958), two Masses, a cantata, Abraham and Isaac (1963, baritone and chamber orchestra) and Requiem Canticles (1966). There are obvious parallels between Stravinsky and *Picasso, exact contemporaries who created new traditions and worked in a diversity of styles, from a brutalist mode to neo-classical. Stravinsky made many recordings and toured the world as a conductor of his own works, visiting Australia and Africa in 1961 and making a triumphant return to Russia in 1962. He published an autobiography in 1935 and collaborated with Robert Craft in two volumes of Conversations (1959, 1962). He had enormous curiosity about literature, mathematics and aesthetics, and for two generations was the greatest figure in 20th-century music. He died in New York and was buried in the St Michele cemetery, Venice.

White, E. W., Stravinsky: The Composer and his Works. 1966; Young, P. M., Stravinsky. 1966; Craft, R., Stravinsky: The Chronicle of a Friendship. 1972.

Straw, Jack (John Whitaker) (1946- ). English Labour politician. He graduated in law from Leeds, became an MP 1979-2015, serving as Home Secretary 1997-2001, Foreign Secretary 2001-06 and Leader of the House of Commons 2006-07. Secretary of State for Justice and Lord Chancellor 2007-10, he was the first lord chancellor since 1578 to be a Member of the House of Commons.

Strawson, Sir Peter Frederick (1919-2006). British philosopher, born in London. Educated at Oxford, he taught there from 1947 and was Waynfleet professor of metaphysical philosophy 1968-87. He worked on 'descriptive metaphysics' and was a rigorous critic of Bertrand *Russell's philosophical logic.

Streep, Meryl (née Mary Louise) (1949-). American actor. Nominated for more Academy Awards (21) and Golden Globes (29) than any other film actor, she won both for Kramer vs. Kramer (1980), Sophie's Choice (1983) and The Iron Lady (2012). Her greatest portrayals included Lindy Chamberlain, Isak *Dinesin, Margaret *'Thatcher and Florence Foster *Jenkins. Barack *Obama awarded her the Presidential Medal of Freedom (2014).

Streeton, Sir Arthur Ernest (1867-1943). Australian painter. With his friend Tom *Roberts, he was one of the 'Heidelberg School' of painters (1887-90), applying plein air impressionist and Turneresque techniques to the Australian landscape. Away from Australia 1897-1923, apart from three short return visits, he was a war artist in France. He failed to attract much attention in England, and his later works, although beautifully painted, lack the excitement of his early decades. Golden Summer, Eaglemont (1889) sold for \$AU3.5 million in 1995.

Streicher, Julius (1885-1946). German Nazi politician. Originally a primary school teacher, he founded the German Socialist Party which merged with the Nazis in 1923. His journal Der Sturmer ("The Stormtrooper') was so pornographic in its attacks on Jews that many Nazis regarded it as distasteful. He had fallen from the front rank by 1939, was Governor of Franconia 1940-44 and hanged for war crimes after the Nuremberg trials.

Streisand, Barbra (Joan) (1942- ). American singer, actor and director, born in Brooklyn. Her first great success was in the Broadway musical Funny Girl (1964), later filmed (1968), winning her an Oscar. She showed her comic gifts in What's Up, Doc? (1972) and played a serious role in The Way We Were (1973). She retired from personal appearances in 1969 until offered \$US20 million for two performances (including film and television rights) at the MGM Grand Hotel, Las Vegas, 31 December 1993-1 January 1994.

Stresemann, Gustav (1878-1929). German politician. A successful businessman, he entered the Reichstag (1907) and after World War I founded the German People's Party. During a short period as Chancellor (1923) he succeeded in checking inflation. From November 1923 until his death he was Foreign Minister in a succession of governments. He was a main architect of the pacts by which it was hoped to build a permanently peaceful Europe: he signed the Locarno and Kellogg Briand Pacts and six years before the appointed date he secured the evacuation of the Rhineland by foreign troops. For 
much of the time he worked closely with *Briand and Austen ${ }^{*}$ Chamberlain. He shared the Nobel Peace Prize (1926) with Briand.

Hirsch, E. F., Gustav Stresemann: Patriot und Europrier. 1964; Gatzke, H. W., Stresemann and the Rearmament of Germany. 1969.

Strickland, Donna Theo (1959- ). Canadian optical physicist. She shared the Nobel Prize for Physics in 2018 with Gérard Mourou for their invention of chirped pulse amplification, using pulsed lasers in eye surgery.

Strijdom, Johannes Gerhardus (1893-1958). South African politician. Originally an ostrich farmer, he became a lawyer, entered the South African Parliament in 1929, led the extremist Transvaal wing of the Nationalist party and succeeded Dr D. F. * Malan as Prime Minister 1954-58. He entrenched 'apartheid' even more harshly than his predecessor.

Strindberg, (Johan) August (1849-1912). Swedish dramatist, born in Stockholm. From his childhood, spent in a depressing family home, his neurotic temperament was always at war with his surroundings. His three marriages were disastrous and among the causes of his persecution mania, leading to periodic insanity and alcoholism. In the 1870 s he began writing plays reflecting his radical views, and he gained a considerable reputation with his novel The Red Room (1879), a satirical and realistic account of artistic life in Stockholm. From 1883 to 1889 he lived in France, Switzerland, Germany and Denmark, returning in 1884 to defend himself successfully against a charge of blasphemy resulting from the publication of his collection of short stories Giftas (Marriage). Meanwhile he wrote poems on social and philosophical subjects, more plays, and the beginnings of his autobiography. To this middle period belong the three great plays by which he is best remembered, The Father (1887), Miss Julie (1888) and The Dance of Death (1901), all obsessed by family conflict in an atmosphere of foreboding. By this time Strindberg was falling under the influence of ${ }^{*}$ Nietzsche and adopting the attitudes, including contempt for democracy, of his mentor, and adding anti-Semitism. In his last years came a series of historical plays, novels, e.g. the trilogy To Damascus (1898-1904), and fairy plays, indicative of a growing interest in religious mysticism and the occult. He again went to live abroad in 1892 but returned finally in 1896. In 1907 he founded the Intimate Theatre for the production of what he called his 'chamber plays'. He was conspicuously ignored by the Swedish Academy and accepted an 'Anti Nobel' Prize, raised by public subscription, in the year of his death. In his last two years he had a radical period. Only in Germany and Austria were Strindberg's plays often performed. Despite the admiration of *Ibsen, *Shaw, ${ }^{*}$ Gorki, ${ }^{*}$ Mann and ${ }^{*} \mathrm{O}$ 'Neill, it took 40 years for his genius as a dramatist to be generally recognised. $\mathrm{He}$ was also a gifted painter, photographer, and linguist, with a passionate interest in music.

Meyer, M., Strindberg. 1985; Prideaux, S., Strindberg. A Life. 2012.

Stringfellow, John (1799-1883). English inventor. A lace manufacturer of Chard, Somerset, he worked with W. S. *Henson in designing a steampowered aircraft. However, Henson's steam engine was underpowered. In 1848, Stringfellow's model monoplane, with a 3-metre wingspan, flew for 27 metres, and in 1868 he demonstrated a tethered triplane at the Crystal Palace. He was also a pioneer photographer.

Stroheim, Erich von (1885-1957). AustrianAmerican film actor and director, born in Vienna. His first film role was in Intolerance (1916) and thereafter he tended to become typecast as a German officer. Among his most distinguished parts was that of a soldier in Renoir's La Grande Illusion (1938), as *Rommel in Five Gravesto Cairo and the butler in Sunset Boulevard (1950). The best known of the films he directed were Foolish Wives (1922), Wedding March (1928) and notably Greed (1923-24). He became a US citizen in 1926.

Quinn, T., Von Stroheim. 1973.

\section{Strongbow, Richard de Clare see Pembroke, 2nd Earl of}

Struve, Friedrich George Wilhelm von (17931864). German-Russian astronomer. A member of an astronomical dynasty, between 1816 and 1855 he was responsible for designing and constructing the Struve Geodetic Arc, a chain of 258 survey triangulations from Hammerfest in Norway to the Black Sea, a distance of $2,820 \mathrm{~km}$, passing through 10 countries. It was an important international collaboration which led to the accurate measurement of a meridian. Thirty-four of the surviving structures were added to the World Heritage List in 2005. In 1827 he published a catalogue of double-stars.

Strzelecki, Sir Paul (Pawel) Edmund de (17971873). Polish-British explorer and geologist, born in Poznan (then in Prussia, now in Poland). From a noble family, sometimes called Count Strzelecki, he left his homeland in 1830 , became a self-trained geologist and travelled extensively in North and South America, the Pacific islands and New Zealand. In Australia (1839-43) he explored New South Wales, Victoria and Tasmania, was an early discoverer of gold and named $\mathrm{Mt}{ }^{*}$ Kosciuszko in the Australian Alps. He lived in England from 1843, wrote extensively, worked on disaster relief in Ireland and the Crimea and became FRS and KCB.

Stuart family see Stewart 
Stuart, Charles Edward (known as 'Bonnie Prince Charlie' or 'the Young Pretender') (1720-1788). British prince, born in Rome. Eldest son of James Edward *Stuart, on whose behalf he led the Jacobite rebellion of 1745, he landed in Scotland with only seven followers but was joined by an increasing number of Highlanders as he moved south. He captured Edinburgh and secured his position by defeating the government army at Prestonpans. Six weeks later he marched south into England. After capturing Carlisle and reaching Derby he began to withdraw. At Falkirk (17 January 1746) he won a last success before his army was overtaken and virtually annihilated by the Duke of ${ }^{*}$ Cumberland, who here earned the name 'Butcher', at Culloden (16 April). Charles, with $£ 30,000$ offered for his capture, spent five months unscathed and unbetrayed among the hills and islands of western Scotland until, with the help of Flora *Macdonald, he was able to reach France. So far with his looks and charm he had been the true hero of romance, but the rest of the story is one of disappointment, disillusion and dissipation. Harried by English agents, he wandered about Europe seeking help for schemes by which he vainly hoped to regain his rights. He married (1772) Louisa of Stolberg, a childless and unhappy match. He finally settled in Italy and in his last years was looked after with devotion by a natural daughter. Debauched and discredited, he died in Rome and was buried in St Peter's.

Stuart, James (Francis) Edward (known as 'the Old Pretender') (1688-1766). British prince, born in London. Son of *James II of Great Britain and Mary of Modena, he was brought up in France. On his father's death he was acclaimed by the 'Jacobites' as King and number of risings were made on his behalf of which the best known were those of 1715 and 1745. For the former, ended by defeats at Sheriffmuir and Prestonpans, James Edward was in Scotland for a few weeks. He spent the remainder of his life mainly in Rome. The battle at Prestonpans was fought under the leadership of his son, Charles Edward *Stuart, born of his marriage to Clementina Sobieska of Poland. His second son was Henry, Cardinal *York. He was buried in St Peter's, Rome.

Stuart, John McDouall (1815-1866). Scottish explorer, born in Fife. Between 1858 and 1862 he led six expeditions to Central Australia and became the first explorer to cross the continent south to north (and return). He clashed with Aboriginal people but lost none of his party. He died in London.

Stubbs, George (1724-1806). English painter and engraver. In 1766 he published his Anatomy of a Horse based on the study of dead horses in his studio. The engravings created a revolution in animal painting and he was later able to use his anatomical knowledge to give his sporting pictures, e.g. The Grosvenor Staghunt a verisimilitude never obtained before. His masterpiece, Whistlejacket (1762), a huge horse painting, hangs in the National Gallery, London. He was elected RA in 1781 .
Stubbs, William (1825-1901). English historian and Churchman. He devoted himself to the study and publication of medieval documents. His fame rests on two great works, Select Charters and other Illustrations of English Constitutional History (1870), and The Constitutional History of England (3 volumes, 1874-78). He became Regius professor of history at Oxford 1866-84, Bishop of Chester 1884-89 and Bishop of Oxford 1889-1901.

Sturgeon, Nicola Ferguson (1970- ). Scottish politician, born in Ayrshire. A lawyer, she was Deputy First Minister of Scotland 2007-14 and First Minister 2014- , a strong advocate for Scottish independence and remaining in the EU.

Sturgeon, William (1783-1850). English electrical engineer. Son of a shoemaker, he was self-educated. He built the first practical electromagnet, capable of lifting 20 times its own weight. He devised the first moving coil galvanometer, and built, in accordance with the principles of Michael *Faraday, the first linear induction motor (1832), revived in the $1960 \mathrm{~s}$ for conveyor belts (Thomas *Davenport).

Sturt, Charles (1795-1869). English explorer, born in Bengal. An army officer, in Australia from 1827 to 1853 , he explored the rivers of New South Wales, mapped and named the Murray (1830), concluded that the continent had no inland sea (1844-46) and became an unhappy administrator in South Australia. He was a skilful observer, sympathetic to Aboriginal people.

Sturzo, Don Luigi (1871-1959). Italian priest and politician, born in Sicily. He founded the PPI (Partito Popolare Italiano) in 1919, clashed with *Mussolini and was exiled, living in London 1924-40 and the United States (mostly in Brooklyn) 1940-48. He wrote extensively on sociology, became a major influence on the Christian Democrats (Alcide *De Gasperi) and was appointed a Senator 1948-59.

Suárez Gonzales, Adolfo, Duque de Suárez (19322014). Spanish politician. The last Secretary-General of*Franco's Falange Party 1975-76, as Prime Minister of Spain 1976-81 he worked with king *Juan Carlos to effect a democratic transformation and was created a duke.

Sucre, Antonio José de (1795-1830). South American leader, born in Venezuela. He served under *Bolívar in the War of South American Independence and became a general in 1819 . His great victory near Guayaquil ensured the independence of the future Ecuador. With Bolívar he then won a long struggle for the independence of Peru and in 1826 was installed as first president of the newly created Bolivia, but his army mutinied and he was expelled. Two years later he was on his way through the mountains to rejoin Bolívar in Peru when he was killed by robbers. 
Sudermann, Hermann (1857-1928). German playwright and novelist. His plays include Die Ehre (1889), Sodoms Ende (1891) and Heimat (1893). The last named, translated into English as Magda, provided a star role for Mrs Patrick *Campbell and other well known actresses. His novels, of which Frau Sorge (1887) was the first and best known, are mostly set against a background of his native East Prussia.

Sue, Eugène (1804-1857). French novelist. He was among the most successful of writers at adapting his work to serial form. The best known example in an immense output of popular work was The Wandering Jew (1845). His socialist and republican views, shown in his novels by his idealisation of the downtrodden and criminal classes, earned him the disfavour of *Napoléon III and brought about his exile.

Suess, Eduard (1831-1914). Austrian geologist, born in London. Professor of geology at Vienna 1857-1901 and a liberal in the Reichsrat 1872-96, he first hypothesised the concept of a super-continent (1885) which he named Gondwanaland (*Wegener). He also originated the concept of 'the biosphere' and was awarded the Copley Medal in 1903.

Suetonius (Gaius Suetonius Tranquillus) (fl. 117138). Roman historian. He was *Hadrian's secretary. His best known work, De vita Caesarum, which has survived almost complete, contains the biographies of Julius *Caesar and the first 11 emperors, *Augustus to ${ }^{*}$ Domitian. His mixture of documented fact and gossip provides lively reading. Only part of another series on less exalted men (e.g. ${ }^{*}$ Virgil, ${ }^{*}$ Horace) survives.

Suger, Bernard (c.1081-1151). French prelate. Abbot of the Benedictine monastery of St Denis, north of Paris (from 1122), he was employed as Chief Minister by *Louis VI, and later virtually ruled the country while *Louis VII was absent on crusade. The beautiful Abbey Church of St Denis, reconstructed to his design, is one of the earliest examples of the Gothic style. His histories of the kings he served provide an important record of contemporary events.

Suharto (1921-2008). Indonesian general and politician, born in Java. Originally a bank clerk, he was a soldier from 1943, joining the guerrillas against the Japanese. He directed the army strategic reserve 1963-65 and was Army Chief of Staff 1965-66. Following the PKI coup in September 1965 he assumed emergency powers and took ${ }^{*}$ Soekarno into custody. He became President of Indonesia 1967-98, after Soekarno's deposition. He took a strong line against Muslim fundamentalism and against any separatist movements, notably in East Timor. He was re-elected for a seventh five-year term in March 1998 after a period of sharp economic decline, a collapse of the rupiah, intervention by the IMF, food riots, and attacks on the government support for companies run his resigned in favour of his protégé B. J. *Habibie. His daughter Siti ('Tutut') Hardiyanti Rukmana (1949-) was briefly Minister for Social Affairs 1998.

Jenkins, D., Suharto and His Generals. 1984.

Sui Wendi ('The cultured emperor', personal name Yang Jien) (541-604). Chinese Emperor 581-604, founder of the Sui dynasty. A general, he removed the Northern Zhou emperor, began the Grand Canal which connected the Yangtze and Huang He (Yellow River) and extended his rule to south China. He laid the foundations for the Tang dynasty.

Suk, Josef (1874-1935). Czech composer and violinist. Pupil (and son-in-law) of Antonin *Dvorák, he was second violinist in the Bohemian String Quartet 1892-1933 and taught composition at the Prague Conservatorium. He wrote Serenade for Strings (1892), the Asrael Symphony (1905-06), chamber music and songs.

\section{Sukarno see Soekarno}

\section{Sulaiman see Süleyman}

Süleyman I Muḥteşem ('the Magnificent': Süleyman Şah bin Selim Şah Han) (1494-1566). Tenth Sultan of the Ottoman Empire 1520-66. Son and successor of *Selim I, under him the Ottoman Empire reached its zenith. He captured Belgrade (1521) and Rhodes (1522). He crushed the Hungarians at Mohacz (1526) but failed to take Vienna in 1529 and eventually the emperor ${ }^{*}$ Ferdinand I, while retaining Austria, was left with only a small portion of Hungary. Meanwhile his fleet, under the celebrated corsair Khaireddin *Barbarossa, was terrorising the Mediterranean but it failed to capture Malta from the Knights of St John. Süleyman won Baghdad (from Persia) and it remained in Turkish hands until 1917. He died during renewed war in Hungary. His legal reforms, mainly relating to land tenure, earned him the name Kanuni (the lawgiver) and he proved himself a lavish patron of the arts, employing the famous architect *Sinan to build four mosques, the most magnificent being the Süleymaniye Camii 1550-57.

Merriman, R. B., Suleiman the Magnificent 1520 1566. Repr. 1966; Brotton, J., The Sultan and the Queen. 2016.

Sulla Felix, Lucius Cornelius (138-78 BCE). Roman soldier and dictator. He fought under *Marius against *Jugurtha in Africa and against the Cimbri and Teutones, but their mutual antipathy soon developed into political rivalry: Marius siding with the turbulent popular party ('Populares') and Sulla with the conservatives ('Optimates'). After his victories in the Social War (for the enfranchisement of the Italians as Roman citizens) Sulla gained his first consulship (88) but, angered by a proposal that the command in a war against ${ }^{*}$ Mithridates should be transferred to Marius, he led an army against Rome 
and captured the city. He obtained laws to legitimise his position and left for the east, but as soon as he had gone the Marians regained control. Meanwhile Sulla was expelling the armies of Mithridates from Greece and from the Roman province of Asia. He then returned with his army to Italy, and after another victory over the popular forces at the gates of Rome (82), the Senate appointed him as 'dictator', without a term limitation; the first use of the word in its modern sense, and a model for Julius ${ }^{*}$ Caesar. Massacres and proscriptions of his opponents followed. He then carried out a large constitutional and administrative program, the main feature being the restoration of full power to the Senate. He retired voluntarily in 79 and died the following year. Both ${ }^{*}$ Händel and *Mozart wrote operas based on his life.

Sullivan, Sir Arthur Seymour (1842-1900). English composer. After being a chorister at the Chapel Royal he studied music in London and Leipzig. He achieved successes with music for *Shakespeare's The Tempest and for the famous comedy Box and Cox before he began his long collaboration with W. S. *Gilbert and the impresario Richard D 'Oyly *Carte in the popular 'Savoy Operas' (so-called from their production at that theatre from 1881). The best known are Trial by Jury (1875) H.M.S. Pinafore (1878), The Pirates of Penzance (1880), Patience (1881) Iolanthe (1882), Princess Ida (1884), The Mikado (1885), Ruddigore (1887), The Yeomen of the Guard (1888) and The Gondoliers (1889). Sullivan's melodic gift and deft and lively scoring admirably partnered the witty libretti, but the two men later had a business quarrel and abandoned the partnership. Neither collaborator achieved comparable success alone, though Sullivan's serious opera Ivanhoe (1891) and ballads such as The Lost Chord were popular for a time. He was knighted in 1883.

Young, P., Sir Arthur Sullivan. 1971.

Sullivan, John L(awrence) (1858-1918). IrishAmerican boxer, born in Boston. Son of Irish immigrants, originally intended for the priesthood, he became a professional baseball player, then a boxer. He had 44 fights, all but two in the United States (the others were in Wales and France) and won 40, mostly by knockout. Until 1889 many of his bouts were bare-knuckle. Generally recognised as the first world heavyweight champion 1885-92, he held the title until defeated by J. J. *Corbett. He died in poverty.

Sullivan, Louis Henry (1856-1924). American architect. After studying in Paris he joined a Chicago partnership and became the most important pioneer of modern steel frame construction. His Transportation building for the World's Columbian Exposition (1893) provided a striking illustration of the new technique. He was a strong advocate of the unity of form and function but did not favour stark austerity and introduced original types of decoration in conformity with his ideas. The Schiller Theatre and the Stock Exchange were among his Chicago buildings. There are many other fine examples of his work in St Louis, Buffalo and New York.

Sully, Maximilien de Béthune, Duc de (15591641). French minister. Son of a Huguenot, Baron de Rosny, he fought for Henri of Navarre (*Henri IV of France) and became his chief friend and advisor. He approved Henri's adoption of Roman Catholicism in order to become king. His first task was to restore the finances and economy by removing abuses in the collection of taxes. He strictly controlled expenditure, reduced tax exemptions and re-established former taxes; he fostered agriculture and industry and the building of roads and canals. He was made a duke for negotiating Henri's marriage with *Marie de Medicis (1606). When he retired after Henri's assassination he had amassed a huge surplus in the treasury.

Sully-Prudhomme, René François Armand (1839-1907). French poet. He studied science and philosophy in Paris, and his earlier poems are permeated with melancholy. His later long poems are La Justice (1878) and Le Bonheur (1888), concerned with philosophic and scientific theories. In this he resembled the Roman poet *Lucretius, whom he translated (1866). He also wrote in prose. He was a leader of the Parnassians, a group which reacted against Romanticism and revived classical detachment. Elected to the Académie française in 1881, he was chosen for the first Nobel Prize for Literature (1901), against a weak field of nominees (mostly French), and is now completely forgotten.

Sumner, Charles (1811-1874). American Republican politician. A lawyer and US Senator from Massachusetts 1851-74, he was one of the most ardent and eloquent speakers against slavery and, in a famous speech, attacked the Kansas-Nebraska Act for creating opportunities for the expansion of slavery. In May 1856 Preston Brooks, Congressman from South Carolina, beat him savagely around the head, in the Senate chamber, with a heavy cane, which shattered, and Sumner took more than three years to recover. (Brooks received a modest fine, resigned from Congress, was triumphantly re-elected then died suddenly.) After the Civil War, Sumner was among the strongest advocates of punishment for the south and of harsh terms for aid in reconstruction.

Sunak, Rishi (1980- ) British-Indian Conservative politician, born in Southampton. His parents migrated to Britain from East Africa in the 1960s. Educated at Winchester College, Oxford and Stanford, he became a funds manager, worked for Goldman Sachs, married the daughter of an Indian billionaire and was MP 2015- . He supported Brexit, became Chancellor of the Exchequer 2020-22, but broke with Boris *Johnson and contested the Tory leadership, losing to $\mathrm{Liz}{ }^{*}$ Truss, who was preferred by Conservative Party branch members. When Truss' leadership collapsed in October 2022, Sunak was the 
only contender to receive enough nominations by MPs to qualify for election. Prime Minister 2022- , he was the youngest since 1783 , the richest and the first Hindu.

Sunderland, 2nd Earl of, Robert Spencer (16411702). English statesman, born in Paris. As Secretary of State 1679-88 under ${ }^{*}$ Charles II and *James II, he negotiated the secret treaty under which, in return for an annual pension from *Louis XIV, England was to become subservient to France. He was *James II's closest advisor and secretly adhered to the Roman Catholic faith, but at the same time conferred with William of Orange (*William III) and became his Lord Chamberlain 1695-99. His son, Charles Spencer, 3rd Earl of Sunderland (1674-1722), was a Whig politician. In 1700 he married Anne Churchill, *Marlborough's daughter. He once had republican sympathies, was part of the Whig 'Junto' under Queen *Anne (who disliked him) and established a working relationship with her prospective successor, the future ${ }^{*}$ George I. First Lord of the Treasury 1718-21, he promoted the South Sea Company and was accused, probably wrongly, of accepting a bribe of $£ 50,000$ in company stock. Although acquitted of bribery, he was forced to resign and Robert *Walpole succeeded him. Described as a 'singularly unattractive personage', with a violent manner, he was shrewd, a quick thinker, a great bibliophile (17,000 books) and patron of music. Recent historians conclude that he may even have been honest. Charles Spencer, 5th Earl of Sunderland (1706-1758), became 3rd Duke of Marlborough on the death of his aunt Henrietta in 1733 and was an ancestor of Winston *Churchill.

Kenyon, J. P., Robert Spencer, Earl of Sunderland. 1958.

Sun Tzu (Wade-Giles: Sunzi in pinyin, birth name Sun Wu) (c.544-496 BCE). Chinese warrior-philosopher, born in the State of Qi (now Shantung). Presumably a follower of Daoism (Taoism), he was the reputed author of The Art of War (Ping-fa), a short, shrewd and timeless analysis which emphasises the political aspects of war. *Mao Zedong read it closely, especially the maxim: 'To win without fighting is best'. He led the armies of the State of Wu.

Sun Yat-sen (Wade-Giles, Sun Yixian in pinyin: né Sun Te-ming, then Sun Wen, later Sun Zhongshan) (1866-1925). Chinese revolutionary politician, born Guangzhou (Canton). His parents were Christian peasants and he became influenced by western ideas at a missionary school in Honolulu (1878-83). Afterwards he took a medical degree (1892) at Hong Kong and practised at Macao and in Guangzhou. There he began his revolutionary activities, but the failure of the first of a series of plots forced him to live in exile in Japan, the US, Canada and England. In London (1896) he was kidnapped and confined to the Chinese embassy, facing the prospect of
12 days due to pressure from the Foreign Office and the press, he became famous. In 1905, in Tokyo, he became a founder of Tongmenghui (Revolutionary Alliance). Risings instigated from Tokyo, Hong Kong, Singapore and Penang failed, but in October 1911 ('The Xinhai Revolution') the army mutinied in Wuchang, Guangzhou and Wuhan, and popular demonstrations followed in other cities. The Qing dynasty collapsed, with the boy Xuantong emperor (*Puyi) abdicating in February 1912. Sun was elected as provisional President of the new Republic (January-March 1912) by a meeting of representatives from provinces in Nanjing, but was forced to retire in favour of ${ }^{*}$ Yuán Zhikai, the general who led the powerful Beiyang Army in the north. In August 1912 Sun founded the Kuomintang (Chinese Nationalist Party, or KMT: Guomintang in pinyin). It won a majority in elections for a National Assembly (December 1912-January 1913) but, after a failed coup against Yuán, was suppressed in November 1913. Yuán ruled as a dictator and proclaimed himself as emperor in December 1915. Sun lived in Tokyo 1913-17, returning from exile after Yuán's death. In Guangzhou, a military government was established that opposed the rule of Beijing, which was dominated by warlords. Sun had broken terms as generalissimo or president of the Guangzhou government in 1917-18; 1920-22; 1923-25, being twice forced out of office by southern warlords.

In 1919 he revived the KMT, actively collaborated with the USSR from 1923 and created a united front between the KMT and the CCP. (This caused the KMT to split after his death: ${ }^{*}$ Chiang Kaishek.) He tried to put into practice the Three People's Principles (lectures published in book form after his death). These were Nationalism (by which he meant the abolition of European exploitation and the unification of the many peoples of China), Democracy (a gradual approach under the guidance of a single party, the Kuomintang, to constitutional government), and Livelihood (the welfare of the masses as the priority of the state). He died in Beijing of gall bladder cancer and was ultimately buried in Nanjing. He did not live to see the reunification of China but the KMT and the CCP both acknowledge Sun as founder of the Chinese Republic.

His son Sun Fo (or Sun Ke) (1891-1973), Premier of China 1932 and 1948-49, followed Chiang to Taiwan. Sun Yat-sen's widow and third wife (Rosamond) Soong Ch'ing-ling (1893-1981), sister of *Chiang's wife, was Vice President of the People's Republic of China 1949-81, a supporter of ${ }^{*}$ Zhou and critic of *Mao. She never joined the CCP.

Schiffren, H. Z., Sun Yat-sen and the Origins of the Chinese Revolution. 1968; Sun Yat-sen: Reluctant Revolutionary. 1980; Wilbur, C. M., Sun Yat-sen, frustrated patriot. 1976; Bergère, M-C., Sun Yat-sen. 2000. 
Supervia, Conchita (née Maria de la Concepción Supervia Pascual, later Rubenstein) (1895-1936). Spanish mezzo-soprano, born in Barcelona. An outstanding Carmen, Rosina and Octavian, with a magnetic stage presence, unforgettable vibrato and excellent diction, she made many recordings. She died after childbirth in London.

Suppé, Franz von (1819-1895). Austrian composer, born in Dalmatia. Son of Belgian and Polish parents, and a distant relative of ${ }^{*}$ Donizetti, he lived in Vienna from 1835. He wrote music for ballet, chamber music and some sacred works, but his reputation was mainly based on his 26 successful operettas, including Poet and Peasant (1846), Light Cavalry (1866) and Boccaccio (1879).

Suraja Dowlah (d.1757). Nawab of Bengal. After his attack (1756) on the British settlement of Calcutta, his imprisonment of over 100 Europeans caused their death by suffocation in the notorious 'Black Hole'. Quick retribution came when his forces were routed by Robert *Clive at Plassey (1757).

Surrey, Henry Howard, Earl of (c.1517-1547). English poet. Son of the 3rd Duke of Norfolk, he attended ${ }^{*}$ Henry VIII at the Field of the Cloth of Gold and long remained in favour at court, even after the execution of his cousin, ${ }^{*}$ Catherine Howard. Eventually, however, he was tried and executed on a trumped-up charge of treason. Blank verse, introduced by him for a translation of *Virgil, was an adaptation of one of ${ }^{*}$ Chaucer's metres. He can also share with *Wyatt the credit for bringing to England the Petrarchan sonnet. His poems were first printed, with those of Wyatt and others, in Tottel's Miscellany (1557). Many of his love poems were written to 'the fair Geraldine', a daughter of the 9th Earl of Kildare.

Chapman, H. W., Two Tudor Portraits. 1960.

Suslov, Mikhail Andreivich (1902-1982). Russian politician and theorist. A peasant's son, he joined the Communist Party in 1921, was active in *Stalin's purges and became the leading Cominform propagandist. He served on the Politburo 1952-53 and 1955-82, and was regarded as the leading Soviet ideologist.

Sutherland, Graham Vivian (1903-1980). English painter. While an engineering apprentice he started art night classes in London. He first turned his talents to etching and engraving but from 1935 he devoted himself to painting. Influenced by ${ }^{*}$ Blake, Samuel *Palmer and the Surrealists, he produced Pembrokeshire landscapes in which fantastic and sinister-looking plant and insect forms dominate. After working as a war artist in World War II he painted vigorous and original portraits of Somerset *Maugham, Lord *Beaverbrook and Sir Winston *Churchill (the last, disliked by the subject, being destroyed by his family). He designed the altar tapestry, Christ in Majesty, for the new Coventry Cathedral. He received the OM in 1960.

Sutherland, Dame Joan (Alston) (1926-2010). Australian dramatic soprano, born in Sydney. She made her debut at Covent Garden, London in the Magic Flute (1952). In 1954 she married the conductor Richard (Alan) Bonynge (1930- ). She became internationally famous after her performance as Lucia in Lucia di Lammermoor at Covent Garden (1959), followed by immediate success in Paris, New York, and Milan. After she sang the title role in *Händel's opera Alcina in Venice in 1960 she was dubbed 'La Stupenda'. Her bel canto style was a major element in the revival of operas by *Händel, *Bellini and *Donizetti. She was awarded the OM in 1991.

Major, N., Joan Sutherland. 1987.

Sutter, Joe (Joseph Frederick) (1921-2016). American aircraft engineer and designer, born in Seattle. He was chief designer of the Boeing 747 ('Jumbo') which first flew in 1970. By 1992, one billion people had travelled on the 747 .

Suttner, Bertha Felicita Sophie, Baroness von (née Kinsky von Chinic und Tettau) (1843-1914). Czech-Austrian pacifist and novelist, born in Prague. Daughter of a field marshal, as a young woman she embraced her family's military tradition, then became a determined campaigner for various peace movements. She persuaded Alfred *Nobel to establish a Peace Prize and in 1901 received 14 nominations for the first award. Ultimately she was nominated 101 times and in 1905 became the first female Nobel Laureate.

\section{Suu Kyi, Aung San see Aung San Suu Kyi}

Suvorov, Aleksandr Vasilyevich (1730-1800). Russian marshal. Of Swedish descent, although sickly and small, he fulfilled his ambition by starting service as a soldier in the ranks at the age of 15. After gaining distinction in the Seven Years' War (1756-63) and the Polish War (1768-71), he fought against the Turks (1773), crushed a rising in the Caucasus (1780) and in a second Turkish War won a great victory at Focsani (1789). He crushed *Kosciuszko's nationalist rising in Poland (1794) and in the French Revolutionary Wars was sent to help the Austrians in Italy (1799). After several successes against the French in Italy he was ordered to join Korsakov in Switzerland, the march over the Alps involved his troops in terrible hardships and losses and he arrived to find that Korsakov had already been defeated by Massena. Suvorov extricated his troops with difficulty to Austria. He died soon after returning to St Petersburg. Never defeated in battle, he was known for his many eccentricities and beloved by his troops. * ${ }^{*}$ talin created the Order of Suvorov in 1943. 
Suzman, Helen (née Gavronsky) (1917-2009). South African politician. Daughter of a Lithuanian migrant, she became a statistician and academic and was a member of the South African House of Assembly 1953-89 (United Party until 1961, then a Progressive). She pursued a lonely criticism of apartheid and violation of human rights, received many awards including an Hon. DBE (1989), and wrote memoirs, In No Uncertain Terms (1993).

Suzuki Daisetz Teitaro (1870-1966). Japanese Zen Buddhist. He was the leading modern authority on Buddhism, with a particular interest in the Zen form. He wrote over 100 books or major studies on religious topics in both Japanese and English.

Sverdlov, Yakov Mikhailovich (real name Y. M. Nakhamkes) (1885-1919). Russian Communist politician. A professional revolutionary from the age of 17, he was exiled to the Arctic, escaped several times and became *Lenin's closest collaborator. After the Revolution he held three important posts 1917-19: Chairman of the All-Russian Executive Committee of Soviets and virtual head of state, General Secretary of the Bolshevik Party, and Commissar for Internal Security. He ordered the execution of the imperial family in Ekaterinburg (later renamed Sverdlovsk). He died of typhus.

Svevo, Italo (Ettore Schmitz) (1861-1928). Italian author, born in Trieste. Of Jewish origin, his early novels based on personal experience $A$ Life (1892) and As a Man Grows Older (1898) failed to attract, and for many years Svevo abandoned writing. He resumed with his masterpiece The Confessions of Zeno (1923) which brought some appreciation, maintained by at least one critical study. He was a friend of James *Joyce.

Svinhufvud af Qvalstad, Pehr Evind (18611937). Finnish politician. Of Swedish descent, he became a lawyer and judge in the Russian Grand Duchy of Finland, strongly resistant to Russian authoritarianism, becoming speaker of the Finnish Parliament 1907-12. When Finland declared its independence from Russia, Svinhufvud was the first State Regent 1918, and sought to establish a constitutional monarchy. He refused to Finnicise his Swedish name. In 1925 the conservative National Coalition nominated him for President but then pulled back. He returned to politics as Prime Minister 1930-31. President 1931-37, narrowly defeating K. J. *Ståhlberg, he maintained a careful balance between left and right but lost to Kyösto Kallio. Svinhufvud's historic reputation is rising and he was an expert shot.

Swammerdam, Jan (1637-1680). Dutch biologist. One of his major areas of interest was animal physiology, and he adhered to the mechanical philosophy, seeking to apply Cartesian (*Descartes) models of explanation to the action of the lungs, the heart, the respiratory system. Experiments on dogs demonstrated the contractility of muscles, even when separated from the body. In these and other instances his work was aiming to demonstrate the purely mechanical nature of bodily action, independent of transcendental principles like 'spirits' or 'virtues'. Swammerdam's other field of expertise was in the microscopic study of lower animals. He was one of the first naturalists to find insects worthy of scientific study. He made detailed studies of the development of insects within the chrysalis, and showed the life history of the butterfly and the dragonfly. He sought to refute the view that insects generate spontaneously (the making of something out of nothing seemed to him both unscientific and also contrary to his religious belief in the order of the world).

Swan, Sir Joseph Wilson (1828-1914). English inventor. A manufacturing chemist by profession, he invented, 20 years before *Edison (1860), an experimental carbon filament electric lamp which, however, was not commercially in production until he improved it (1881). He patented (1883) a process for carbon-filament production that revolutionised the manufacture of electric lamps. He also made a number of inventions of great practical value in the field of photography. A fast gelatin emulsion, for example, confirmed the supremacy of the dryplate technique. Many improvements in photographic printing were also due to him. He was elected FRS in 1894 and knighted 10 years later.

Swedenborg (originally Svedberg), Emanuel (1688-1772). Swedish scientist and theologian, born in Stockholm. At first employed by ${ }^{*}$ Charles XII as an assessor in the College of Mines, he gained a seat in the House of Nobles when his family was ennobled (1719). Meanwhile he wrote on all kinds of mathematical, mechanical and scientific subjects (sometimes anticipating later discoveries) on the calculus, on finding longitude at sea, on tides, decimal coinage and the planetary system, on the atom as a vortex of particles etc. His study of geology and palaeontology led him to a theory of creation, published in the Opera Philosophica et Mineralia (3 volumes, 1734). In other works, e.g. The Animal Kingdom (1745), he treats, among many other subjects, of anatomy, human and zoological, and eventually explores the relationship of body and soul. By this time his inquiries as a scientist were beginning to merge with his visionary speculations as a seer. He believed that in 1745 direct personal insight into the world of the spirit was conferred upon him to enable him to reveal the true sense of the Bible. In his Heavenly Arcana (8 volumes, 1749-56) he gives the first two books of the Bible an allegorical and symbolic meaning. In the following years he had further visions and published some 40 theological books, including The Christian Religion (1771) which systematically presents the theology that had appeared piecemeal in earlier writings. The essence of Swedenborg's theology is his view of *Jesus Christ whom he sees, not as a Person of the Trinity, but as a human possessed of a divine soul. He spent several of his last years in 
London where he died. He had organised no sect but the 'New Church' based on his doctrines was founded in London some 15 years after his death, and still has followers in Britain and elsewhere.

Jonsson, I., Emanuel Swedenborg. 1971.

Sweelinck, Jan Pieterszoon (1562-1621). Dutch composer, organist and teacher. Enormously prolific, especially with vocal works, he was a famous organist who rarely left Amsterdam.

Sweyn Forkbeard (or Swegen) (960-1014). King of Denmark 986-1014, and of England 1013-14. In revenge for the death of his sister, who perished in the massacre of St Brice's Day (1002) organised by ${ }^{*}$ Æthelred the Unready, he attacked and ravaged England repeatedly and just before his death was recognised as King but not crowned. He was succeeded by his son *Cnut.

Swift, Jonathan (1667-1745). Anglo-Irish satirist, novelist, essayist, poet and cleric, born in Dublin. His father, a lawyer, kinsman of *Dryden, died before his birth, and after his mother, kinsman of *Herrick, returned to England he was brought up by his father's family. Educated at Kilkenny College, and Trinity College, Dublin, after the Glorious Revolution of 1688 he joined his mother in England and became secretary to her relative Sir William *Temple at his Surrey home of Moor Park. He remained there with intervals (during one of which he took Anglican orders in Ireland) until Temple's death (1699). There he wrote The Battle of the Books (classics v. moderns), which was published (1704) with $A$ Tale of a Tub, a satire on religious humbug and corruption which effectively barred him from the highest offices in the Church. At Temple's house, too, he first met Esther Johnson, then a child of eight, to whom he later wrote the famous Journal to Stella (1710-13), which gives, mostly in childish language, an intimate account of his London life. The nature of the bond between them is one of those literary mysteries that many have probed: they may even have married though it seems clear that despite mutual dependence and devotion they had no sexual relations. Similar doubts concern Hester Vanhomrigh, the heroine of Cadenus (anagram of decanus, 'dean') and Vanessa. She loved him passionately, but, having encouraged her, he rejected her and broke her heart. Swift was the most formidable political satirist of his time, working closely with the Tories 1710-14, contributing to the fall of *Marlborough. He offended Queen *Anne, who thought $A$ Tale of a Tub blasphemous, by offering gratuitous advice on her household arrangements, and his appointment as Dean of St Patrick's Cathedral, Dublin, 1713-45 was virtual exile, although he made brief visits to his friends Alexander *Pope and John *Gay. The Whigs returned to power in 1714 .

Some of his best known tracts and treatises were written during this period, many, including Drapier's Letters (1724), protesting against the grievances under which Ireland suffered. Samuel *Johnson judged him harshly in his Lives of the Poets, but his poems are clear, direct, using vernacular speech. The most famous of all his works, Gulliver's Travels, part fairytale, part satire, appeared in 1726 . His $A$ Modest Proposal (1729) suggested selling children of the poor to be eaten (recipes being provided). Esther died in 1728. Swift long suffered acutely from Ménière's syndrome and years of agonising decline followed a stroke in 1738. He was buried beside Esther in St Patrick's. His epitaph on the nearby wall reads 'Ubi sæva Indignatio/ Ulterius/ Cor lacerare nequit' ('Where savage indignation can lacerate his heart no more'). He left his estate to found a hospital in Dublin for the mentally ill, which survives. But he remained a frustrated and unhappy man and something of an enigma to his contemporaries and to later generations. Everything he wrote was published anonymously and, except for Gulliver which earned $\operatorname{him} £ 200$, he received no payment.

Murry, J. M., Jonathan Swift: A Critical biography. 1955; Stathis, J. J., A Bibliography of Swift Studies. 1967; Steele, P., Jonathan Swift. Preacher and Jester. 1978; Glendinning, V., Jonathan Swift. 1998; Damrosch, L., Jonathan Swift. His Life and His World. 2013; Stubbs, J., Jonathan Swift. The Reluctant Rebel. 2016.

Swinburne, Algernon Charles (1837-1909). English poet and writer, born in London. Educated at Eton and Oxford he became a friend of *Landor, ${ }^{*}$ Meredith, ${ }^{*}$ Rossetti and ${ }^{*}$ Morris. The publication of his Poems and Ballads (1865), with their sensual rhythms, pagan spirit and contempt for conventional morality, had aroused both enthusiasm and violent criticism. Songs Before Sunrise (1871) was inspired by *Mazzini's republicanism; Tristram of Lyonesse (1882) and The Tale of Balen (1892) are his contribution to Arthurian legend. He wrote poetic dramas, including Atalanta in Calydon (1865) and an ambitious trilogy on *Mary Queen of Scots. His literary criticism, e.g. Essays and Studies (1875) and monographs on many individual writers, ${ }^{*}$ Shakespeare, Victor ${ }^{*}$ Hugo etc., display a characteristic over-emphasis, but are written with imagination and perception. An alcoholic and flagellant, in 1879 his health broke down under the strain of a dissipated life. His friend Theodore WattsDunton (1832-1914) took him into his home at No. 2, The Pines, Putney, where the bohemian rebel quietly spent the rest of his life. He was nominated 10 times for the Nobel Prize for Literature. Few poets have surpassed Swinburne in the composition of verbal music, but though he can still disturb he no longer shocks.

Fuller, J. O., Swinburne: A Critical Biography. 1968.

Swineshead, (or Suisset), Richard (known as 'The Calculator') (fl. c.1340-1355). English medieval philosopher and mathematician, possibly born in Glastonbury. He was at Merton College, Oxford, from about 1340, and wrote the important Liber 
calculatorium, an exhaustive treatise that provides techniques for calculating physical variables and their changes. Swineshead devotes attention to variables such as density and rarity, action and reaction, constant speed and acceleration, forces and resistances in a medium. His English 'calculatory' tradition exercised notable influence on the development of physical studies, especially on *Oresme. He became a Cistercian monk.

It is probable that Roger Swineshead (or Swyneshead) (d.1365), a Benedictine monk, logician and physicist, was at Oxford at the same time as Richard but they are assumed to be different persons. He wrote logical treatises and a work in physics De Motibus Naturalibus.

Weisheipl, J. A., 'Roger Swyneshead', in Oxford Studies Presented to Daniel Callus. 1964.

Swithin (or Swithun), St (d.862). English prelate. A man of great piety, he built many churches and for the last 10 years of his life was Bishop of Winchester. When his body was transferred from the churchyard to the cathedral itself (971), tradition says that heavy rain delayed the exhumation, which was to have taken place on 15 July. The belief that rain on St Swithin's Day portends a long rainy spell can be traced to this event.

Swynford, Catherine (née Roelt) (1350?-1403). English noblewoman. After the death of her first husband, Sir Hugh Swynford, she became the mistress of *John of Gaunt. They married in 1394, their children being legitimised under the name of *Beaufort. Her son, Sir Thomas Beaufort, was one of the murderers of ${ }^{*}$ Richard II. Her sister Philippa married Geoffrey ${ }^{*}$ Chaucer.

Sydenham, Thomas (1624-1689). English physician. The founder of modern clinical medicine, his studies at Oxford were interrupted by service with the parliamentarian forces, but from 1655 (though he did not obtain a licence to do so until 1663) he practised as a physician in Westminster and was thus able to study the fevers arising from the marshes of St James's Park. The great plague (1665) provided another exacting test of his medical skill. As his fame grew he got to know John *Locke, Robert *Boyle and other scholars and scientists of the time. He recognised that the physician's task was to assist nature in its constant efforts to eliminate morbid matter or render it harmless. Thus his task was to study the disease in relation to the particular patient. Some of his descriptions (e.g. of gout, based on his own symptoms) are classics of medical literature; convulsions of children are still known as Sydenham's chorea. He was not afraid to do nothing if he felt that he could not render effective help, and his prescription of fresh air, few coverings and a light diet for fevers was almost revolutionary.
Sydney, Thomas Townshend, 1st Viscount (17331801). English politician, born in Norfolk. Grandson of 'Turnip' *Townsend, educated at Cambridge, he was a Whig MP 1754-83 and a critic of the American war. As Home Secretary and Colonial Secretary 1782-83; 1783-89, he was a patron of Arthur *Phillip. When the first settlers reached New South Wales (1788), the capital was named for Sydney.

Sydow, Max (Carl Adolf) von (1929-2020). Swedish actor. Educated at the Royal Dramatic Theatre School, Stockholm, he had a long stage career, then appeared in 114 films, 11 directed by Ingmar *Bergman.

Syme, Sir Ronald (1903-1989). British historian, born in New Zealand. His The Roman Revolution (1939) was a powerful analysis of how *Augustus seized power and crushed dissent while preserving a republican facade. He became Camden professor of ancient history at Oxford 1949-70, and wrote biographies of *Tacitus (2 vols, 1958), *Sallust (1964), and The Augustan Aristocracy (1986). Considered to be the greatest 20th-century historian of ancient Rome, he received the OM in 1976.

Symington, William (1763-1831). Scottish engineer. He made early experiments in applying steam power to ships and patented (1801) a horizontal directacting steam engine that he fitted to the tug Charlotte Dundas on the Forth-Clyde canal. This was the first effective steamboat but, though it towed two coal barges 19 miles in six hours, its adoption was rejected for spurious reasons. A further plan to introduce steam-powered tugs on the Bridgewater Canal ended in disappointment when the 3rd Duke of Bridgewater died (1803). Symington died in poverty.

Symonds, John Addington (1840-1893). English man of letters. His Studies of the Greek Poets (1873) was followed by the notable The Renaissance in Italy (1875-86). He translated Benvenuto *Cellini's autobiography, and the sonnets of *Michelangelo, whose biography he also wrote (2 volumes, 1893). He wrote several volumes of poetry, and studies of Ben *Jonson and *Shelley.

Symons, A(lphonse) J(ames) A(lroy) (1900-1941). English writer. He was remembered almost solely for an astonishing piece of literary detection, The Quest for Corvo (1934), which revived interest in the eccentric novelist Frederick *Rolfe, Baron Corvo.

Symons, Arthur William (1865-1945). British critic and poet. By his translations and studies of *Baudelaire and by The Symbolist Movement in Literature (1899) he was largely responsible for introducing the work of this French literary school to English readers. His other books include The Romantic Movement in English Poetry (1909) and several volumes of essays and poems. In 1909, he suffered a psychotic breakdown, which reduced his output for two decades. 
Synge, John Millington (1871-1909). Irish playwright, born near Dublin. After living in Paris (1895-1902), where he met *Yeats, he returned to Ireland and made several visits to the Aran Islands, studying folk speech and culture. This study provided him with the setting for his plays, the first two of which, In the Shadow of the Glen (1903) and Riders to the Sea (1904), brought him into close association with the Abbey Theatre, Dublin. There followed The Well of the Saints (1905) and his great comedy The Playboy of the Western World (1907). His tragic verse-drama Deirdre of the Sorrows was unfinished when he died. His influence upon succeeding Irish playwrights was immense.

Skelton, R., The Writings of J. M. Synge. 1971.

\section{Syngman Rhee see Rhee, Syng-man}

Szálasi, Ferencz (1897-1946). Hungarian fascist. An extreme Hungarian nationalist (curious because his ancestry was Armenian, Slovak, German and Hungarian), in 1935 he founded a fascist party, renamed Arrow Cross in 1939. Installed in power by the Germans in October 1944, the Arrow Cross regime murdered many thousands of Hungarians (mostly Jews) and Szálasi was executed for war crimes.

Szell, George (1897-1970). Hungarian-American conductor, born in Budapest. A juvenile prodigy as a pianist, he made his debut as a conductor in Berlin (1914) and became a protégé of Richard ${ }^{*}$ Strauss and Arturo ${ }^{*}$ Toscanini. Chief Conductor of the Metropolitan Opera, New York, 1942-45, he directed the Cleveland Orchestra 1946-70 and raised it to the first rank, also making many recordings.

Szent-Györgyi (de Nagyrápolt), Albert (18931986). Hungarian-American physiologist, born in Budapest. Educated at Semmelweis and Cambridge universities, he is credited with isolating Vitamin C and explaining the citric acid cycle, for which he received the Nobel Prize for Physiology or Medicine in 1937. Active in the Hungarian Resistance during World War II, he entered Hungarian politics briefly after the war, but migrated to the US in 1947.

Szigeti, József (1892-1973). Hungarian-Jewish violinist, born in Budapest. Encouraged by *Joachim, ${ }^{*}$ Ysaÿe and ${ }^{*}$ Busoni, he toured with *Melba, worked closely with *Bartók, and was admired for his fine intellect. He lived in the US during World War II and died in Switzerland.

Szilard, Leo (1898-1964). Hungarian-American physicist, born in Budapest. He studied in Germany, lived in England from 1934 and the US from 1937. He wrote pioneering papers on information theory (1929) and the theory of nuclear chain reaction (1934). He drafted *Einstein's letter to President *Roosevelt (October 1939) which led to the 'Manhattan Project' and nuclear weapons. He worked with *Fermi in Chicago on the original 'atomic pile' and on developing the atomic bomb, although opposing its use against civilian targets. Professor of biophysics at Chicago 1946-53, he had extraordinary insight into a variety of scientific areas but did little sustained research or publication.

Lanouette, W., Genius in the Shadows. 1993.

Szymanowski, Karol Maciej (1882-1937). Polish composer. Director of the Warsaw Conservatoire 1926-28; 1930-32, his early works are individual, despite their eclectic romantic blend of influences (*Wagner, Richard ${ }^{*}$ Strauss, ${ }^{*}$ Scriabin, ${ }^{*}$ Debussy, ${ }^{*}$ Ravel). Later studying Polish folk music strongly affected his compositions. His works include his three symphonies; piano and chamber works, e.g. The Fountain of Arethusa for violin and piano; operas, e.g. King Roger (1926); two violin concertos; and Stabat Mater for soloists, chorus and orchestra. A victim of homophobia, he also suffered from tuberculosis and died in Lausanne.

Szymborska, Wisława (1923-2012). Polish poet. She won the 1996 Nobel Prize for Literature for her elegant, subtle but penetrating verse, hailed as Mozartian by enthusiasts. Volumes of her poems include Views with a Grain of Sand (1995). 


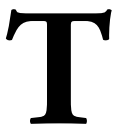

Taaffe, Eduard von, Graf [Count] (1833-1895). Austrian administrator. Of Irish descent, he was a lifelong friend of the Emperor ${ }^{*}$ Franz Joseph and became Prime Minister of Austria 1868-70, 187993. He proposed concessions to the Czechs in return for support against the Hungarians.

Tacitus, Publius (or Gaius) Cornelius (c.55-120). Roman historian. Born in the reign of ${ }^{*}$ Nero, he became proconsul of Asia under ${ }^{*}$ Trajan and thus lived through seven of the reigns which he described. Of his undisputed works Agricola was a eulogistic account of his father-in-law, especially interesting for its account of Britain; Germania was a first-hand account of the country and its people; The Histories (14 books, of which No. 14 and part of 5 survive) relate the events of his lifetime from the death of Nero (68) to that of Domitian (96). Even better were the Annals (16 books, with most of 1-6 and all of 11-16 extant), which cover the earlier period from the death of *Augustus (14 CE). Tacitus was a shrewd psychologist but where his prejudices were involved (e.g. against ${ }^{*}$ Tiberius) he becomes unreliable and unfair. He aims to be an exact recorder of events, which, however, he sometimes misinterprets. In striking contrast with the rotundity of *Cicero's period is Tacitus' terse, epigrammatic style which adds dramatic intensity to the episodes he describes.

Syme, R., Tacitus. 1958.

Taft, William Howard (1857-1930). 27th President of the US 1909-13. Born in Cincinnati, Ohio, son of Alphonso Taft (1810-1881), briefly Secretary of War 1876 and US Attorney-General 1876-77 under President ${ }^{*}$ Grant, he studied law at Yale and in Cincinnati. He was a judge of the Ohio Supreme Court 1887-90, US Solicitor-General 1890-92 and a judge of the Court of Appeal 1892-1900. Following the defeat of Spain by the US and the acquisition of the Philippines, he was president 1900-01 of the commission sent to the islands and the first Governor-General 1901-04. His friend Theodore *Roosevelt appointed him Secretary of War 1904-08 and secured for him the Republican nomination for president in 1908, which he won overwhelmingly on the first ballot. He defeated William Jennings *Bryan comfortably and in his inaugural address (1909) declared that henceforce the status of AfricanAmericans would become the responsibility of the states, in effect renouncing the principles for which *Lincoln fought the Civil War. His conservatism and lack of initiative alienated Roosevelt who sought the 1912 nomination himself. After Taft's renomination (significant but with many abstentions), Roosevelt then ran as a third party Progressive candidate, splitting the Republican vote and ensuring victory for the Democratic nominee, Woodrow *Wilson. Professor of constitutional law at Yale 1913-21, he was appointed by President ${ }^{*}$ Harding as Chief Justice of the US Supreme Court 1921-30, becoming the only person to have headed two branches of the US Government. He is also remembered for his huge bulk (about $170 \mathrm{~kg}$ as president).

His son, Robert Alphonso Taft (1889-1953) was a US senator from Ohio 1939-53. As conservative as his father, he sponsored the controversial TaftHartley Labor Act (1947) to curtail union power. $\mathrm{He}$ first sought the Republican nomination for president in 1944 and 1948: in 1952 he lost narrowly to ${ }^{*}$ Eisenhower. The most effective conservative of his era, in 1957 he was voted by a US Senate committee as one of the five greatest senators ever. His son, Robert Alphonso Taft, Jr (1917-1993), a lawyer, was a US Congressman 1962-84; 1966-68 and Senator 1971-76.

Taglioni. Italian ballet family. Filippo Taglioni (1777-1871) choreographed about 40 ballets. His best known, La sylphide, to music by Jean Schneitzhoeffer, was premiered in Paris in 1832 and toured extensively as the prototype modern romantic ballet. His daughter Marie Taglioni (1804-1884), born in Stockholm, made her reputation in $\mathrm{La}$ sylphide, and created the popular ethereal style, with wispy costume, dancing on points, and elevation. She later taught in London and died in the south of France. Her brother and niece were also famous dancers.

Tagore, (Sir) Rabindranath (1861-1941). Indian (Bengali) poet, short story writer, philosopher, artist and composer, born in Kolkata (Calcutta). His very rich family was part of an unorthodox Brahmin community, which allowed a liberal attitude to religion and life. Largely educated by his brothers, he studied briefly in London, and founded (1901) at Bolpur in Bengal a school for the reconciliation of western and eastern educational thought. Later at nearby Santiniketan, he established an institution to guide the rehabilitation of village life and a seat of international culture. He first became known as a poet outside India with Gitanjali ('Song Offerings') and was the first non-European awarded the Nobel Prize for Literature in 1913, for 'his profoundly sensitive, fresh and beautiful verses'. (The original Bengali loses much in English translation.) In the natural beauties of earth and sky, the love of children and his mystical experiences (upon which rather than on theology his religion was based) he found the inspiration for his poems, into the original Indian versions of which he introduced much metrical experiment. His works were translated in several languages, he travelled extensively through Asia, Europe and the Americas lecturing on Indian philosophy and religion and was an international celebrity. He composed more than 1,000 songs and became a painter in later life. 
He opposed imperialism, but thought India could learn from the west, for example, in science, law and democratic politics. He corresponded with *Gandhi from 1915 until his death: they agreed on broad issues but disagreed on tactics. Tagore disliked communalism and nationalism and promoted science, while Gandhi wanted a return to traditional values.

Knighted in 1915, Tagore renounced the honour after the Amritsar massacre (1919).

Bose, A., Rabindranath Tagore. 1958; Sen, A., The Argumentative Indian. 2006.

Taine, Hippolyte Adolphe (1828-1893). French historian and critic. He established the principle of applying scientific method to the analysis of history and literature. He first gained recognition with a study of * La Fontaine in 1853. His most famous work, still unfinished at his death, was Origines de la France contemporaine. He was made professor of aesthetics at the École des Beaux Arts in 1864. His studies of history reveal a pessimistic view of society and its development.

Takemitsu Töru (1930-1996). Japanese composer. Influenced by *Debussy, ${ }^{*}$ Stravinsky, ${ }^{*}$ Messiaen, ${ }^{*}$ Cage and ${ }^{*}$ Boulez, his music had a striking individuality while attempting to merge elements of Western and Eastern traditions. He was a prolific composer of orchestral, chamber and piano works.

Takeshita Noburu (1924-2000). Japanese Liberal Democratic politician. A Diet member 1958-2000, and originally a member of the *Tanaka faction he was Finance Minister 1982-87, Prime Minister 1987-89. He was a powerful influence behind the scene, regarded as corrupt but skilful at avoiding prosecution.

Talaat Pasha (Talât Paşa), Mehmed (1874-1921). Turkish politician, born near Edirne. A leader of the 'Young Turks' movement, he was Minister for Finance 1914-17 and Grand Vizier (i.e. Prime Minister) of the Ottoman Empire 1917-18. He and ${ }^{*}$ Enver Pasha bear primary responsibility for the Armenian genocide from 1915 in which between 0.8 and 1.5 million were killed. He was assassinated in Berlin by an Armenian, with the tactic approval of British, German, Turkish and Russian intelligence.

Kieser, H.-L., Talaat Pasha. Father of Modern Turkey. Architect of Genocide. 2018.

Talbot, (William) Henry Fox (1800-1877). English experimenter. Educated at Harrow and Trinity College, Cambridge, he was elected FRS in 1831 and became a Whig MP 1833-34. Assisted by Sir William *Herschel, he worked on techniques to fix the images produced by a camera obscura, and his first photograph using a negative of paper impregnated with silver chloride dates from 1833 and is essentially the photographic technique still in use. $\left({ }^{*}\right.$ Niepce and ${ }^{*}$ Daguerre produced single images on metal plates which required long exposure and could not be reproduced.) In 1841 he succeeded in making positive prints and published the first book of photographs, The Pencil of Nature (in parts, 1844-46). By 1850 he had laid the foundations of modern photography by overcoming the need for long exposures. He also carried out useful investigations on spectra and showed how to distinguish certain elements by their spectral lines. He was also one of the first to decipher the Assyrian Cuneiform scripts from Nineveh.

Gernsheim, H. and A., The History of Photography. 1969.

Talleyrand (Périgord), Charles Maurice de, Prince of Benevento (1754-1838). French diplomat and politician, born in Paris. From a noble family in economic decline, he suffered from a congenital limp that prevented an army career and led him to enter the Church. Combining a dissolute life with theological studies, he became Bishop of Autun in 1788. During the Revolution he was President of the Constituent Assembly (1790), supported the Civil Constitution of the Clergy and resigned his bishopric. He lived in Philadelphia 1794-95. When the Directory came to power, his friend *Barras made him Foreign Minister, a position he held 1797-1807, under Directory, Consulate and Empire, and again 1815-16 under *Louis XVIII. He used his keen and subtle intelligence to consolidate by diplomacy the victories won in the field. Among the treaties he negotiated were those of Luneville (1801) with Austria, of Amiens (1802) with Great Britain and of Tilsit (1807) with Russia. Soon after Tilsit he resigned as Foreign Minister, apparently in disagreement with *Napoléon's policies in Spain and Portugal. He remained, however, at the centre of events and accompanied Napoléon to the Congress of Erfurt (1808). Here, convinced that the policies of his master and the interests of France were increasingly divergent, and being by no means neglectful of personal advantage, he entered into secret relations with Tsar *Aleksandr I and the Austrian statesman, ${ }^{*}$ Metternich. Thereafter he played a double game. After Napoléon's fall (1814) he headed the French provisional government, and at the Congress of Vienna defended French interests with consummate skill. His last important post was that of Ambassador 1830-35 to Great Britain under *Louis Philippe. In the negotiations about the future of the Netherlands his views in favour of creating a neutral, independent Belgium prevailed. $\mathrm{He}$ was almost certainly the father of the painter ${ }^{*}$ Delacroix and grandfather of the politician *Morny.

Bernard, J. F., Talleyrand 1973; Orieux, J., Talleyrand. 1974.

Tallien, Jean Lambert (1769-1820). French Revolutionary politician. He first became prominent as a printer of Jacobin broadsheets. As a member of the 
Committee of Public Safety he was sent to Bordeaux (1793) to institute the 'Terror'. There he met his future wife, whom he saved from the guillotine. Later she became known as 'Notre Dame de Thermidor' because of the prominent part she played with her husband during the rising of 9 Thermidor (28 July) which resulted in *Robespierre's downfall. Tallien's importance soon declined and he died forgotten.

Tallis, Thomas (c.1505-1585). English composer, probably born in Kent. Little is known of his early life but he may have been organist at Waltham Abbey from 1538 until its dissolution (1540). At Canterbury Cathedral 1540-43, then at the Chapel Royal 154385 , he became joint organist $1575-85$ with his pupil and business partner William ${ }^{*}$ Byrd. Despite their Anglican appointments, like Byrd, he remained Catholic, but composed for both the Catholic (Latin texts, polyphonic) and Protestant (English, chordal) liturgies. They collaborated in obtaining (1575) a monopoly for printing and selling music and music paper and in publishing in that year a volume of motets, of which they were joint composers. Tallis' huge output consists almost entirely of liturgical music, including the Lamentations for five voices and the motet Spem in Alium Nunquam Habui ('I have never put my hope in any other...'), written about 1570 for eight choirs of five voices, a 12-minute work of extraordinary complexity, gripping drama, tension and serene beauty. Fantasia on a Theme of Thomas Tallis (1910) was composed by Ralph *Vaughan Williams.

Doe, P., Tallis. 1968; McCarthy, K., Tallis 2021.

Tamayo, Rufino (1899-1991). Mexican Expressionist painter. Influenced by pre-Columbian and popular arts forms, as well as *Picasso and *Braque, he lived in the US and was recognised as one of the most important modern Mexican artists.

\section{Tamerlane (or Tamburlaine) see Timur}

Tammany (correctly Tamanend) (c.1625-1701). American Lenni-Lenape chief. Chief of chiefs of the Turtle clan of the Lenni-Lenape nation in the Delaware-Pennsylvania region, he negotiated seven land agreements with William *Penn. Tammany Hall, founded (1789) as the Tammany Society of Columbian Order, a patriotic political club, was named after him. Later, as the headquarters of the Democratic Party organisation in New York City, it won a bad reputation for the methods of corruption and intimidation by which it was alleged to secure votes.

Tan Malaka (1894-1949). Indonesian Communist leader. A Sumatran, he was a co-founder of the Indonesian Communist Party (PKI) in 1920 and asked the Comintern to endorse the Pan Islam movement. After 1922 he spent many years in exile under a variety of names. His career parallels ${ }^{*} \mathrm{Ho}$ Chi Minh's. He returned to Indonesia in 1942 and worked with the Japanese. In 1948 Moscow denounced him as a Titoist. He founded the Murba (Proletarian) movement, began guerrilla warfare against Soekarno and the Dutch and was shot by the army.

Tanaka Kakuei (1918-1993). Japanese politician. Educated at a technical college, he began his own construction business at 19 , became a member of the Diet 1947 and Secretary-General of the Liberal Democratic Party 1965-66 and 1968-71. As Prime Minister 1972-74 he initiated closer links with China and promoted proposals for remodelling the Japanese archipelago. Accused of taking bribes from the Lockheed Corporation, he resigned as Prime Minister and faced a lengthy trial from 1976. Convicted in 1983, he was sentenced to four years jail, fined \$US2.1 million, and then released on appeal.

Taney, Roger Brooke (1777-1864). American jurist, born in Maryland. Andrew *Jackson appointed him Attorney-General 1831-33, Secretary of the Treasury 1833-34 (the first presidential nomination ever rejected by the Senate) and Chief Justice of the Supreme Court 1836-64, being confirmed over the objections of ${ }^{*}$ Clay, ${ }^{*}$ Calhoun and ${ }^{*}$ Webster. He was the first Catholic appointed to the Cabinet or to the US Supreme Court. Taney broadly supported increasing Federal power at the expense of the states. However, he is best remembered for his decision in the Dred Scott case (1857) that, under the US Constitution, African-Americans 'had no rights that the white man was bound to respect; and that the negro might justly and lawfully be reduced to slavery for his benefit. He was bought and sold and treated as an ordinary article of merchandise and traffic, whenever profit could be made by it'. As a result, African-Americans had no right to sue in the courts and Congress could not exclude slavery from the territories. Taney had been an opponent of slavery as a young man, then became its defender. However, he remained loyal to the Union during the Civil War.

Taneyev, Sergei Ivanovich (1856-1915). Russian composer and pianist. A pupil of Nikolai ${ }^{*}$ Rubinstein and close friend of *Tchaikovsky, he taught ${ }^{*}$ Rachmaninoff, ${ }^{*}$ Scriabin, ${ }^{*}$ Medtner and ${ }^{*}$ Glière at the Moscow Conservatorium. He was a pioneer in studying early composers, including *Josquin, *Lassus and ${ }^{*}$ Ockeghem, and wrote a textbook on counterpoint. His most performed works are the two String Quintets (cello, 1901; viola, 1904) and Piano Quintet (1911). Sofya Tolstoy became infatuated with him.

Tang. Chinese dynasty which ruled 618-907, marked by a golden age in the arts and a liberated role for women. The Tangs claimed descent from ${ }^{*} \mathrm{Lao} \mathrm{Zi}$.

Tange Kenzo (1913-2005). Japanese architect. Educated at Tokyo University, where he became professor of architecture 1946-74, he designed buildings for the Tokyo Olympics 1964, Expo '70 
at Osaka, the Hiroshima Peace Centre and major projects in Italy, Yugoslavia, Algeria, France and the US.

Tapies Puig, Antoni (1923-2012). Spanish artist, born in Barcelona. He studied law and was selftrained as an artist, holding his first one-man exhibition in 1948. He turned from Surrealism to abstraction, working in mixed media, combining glue, paper, cloth, cardboard, plaster and wood, and won an international reputation. In 2010, King *Juan Carlos created him a marquess.

Tarantino, Quentin (1963-). American screenwriter and director, born in Tennessee. His films include Reservoir Dogs (1992), Pulp Fiction (1994), Inglourious Basterds (2009) and Django Unchained (2012).

Tardieu, André Pierre Gabriel Amédeé (18761945). French politician. A journalist who wrote mostly on foreign affairs, he became a deputy in 1914 , fought in World War I and assisted *Clémenceau in the peace treaty negotiations. As founder and leader of the Republican Centre Party, almost continuously in ministerial office 1926-32, he was Prime Minister 1929, 1930 and 1932.

Tarkington, Booth (1869-1946). American popular novelist. He is mainly remembered for the novels of life in the Middle West which were dramatised into successful plays or films. e.g. Monsieur Beaucaire (1901) and The Magnificent Ambersons (1918) which won the Pulitzer Prize and was later filmed by Orson *Welles.

Tarquinius Superbus, Lucius (c.564-505 BCE). King of Rome 534-510 BCE. Seventh and last of the semi-legendary kings of Rome, his reign and that of his father Lucius Tarquinius Priscus (616578) represented a period of Etruscan domination, interrupted possibly by the intervening reign of Servius Tullius (who may, however, also have been Etruscan). Tradition assigns the cause of Tarquinius' expulsion from Rome to the anger caused by the rape of the beautiful Lucretia (Lucrece) by his son Sextus, but it was more probably due to the tyranny of his rule which was remembered so vividly that 'king' became a hated word and the title was never adopted even by the all-powerful rulers of later days. An attempt by Lars Porsena (commemorated in the legend of Horatius) to restore Etruscan supremacy failed.

Tartini, Giuseppe (1692-1770). Italian composer and violinist. The greatest violinist of his time, and the first to play with a ${ }^{*}$ Stradivarius, he founded his own school (1726) in Padua. The best known of his surviving compositions, mainly for violin, is the Sonata in G Minor ('The Devil's Trill': c.1740), inspired, he said, by music played to him by the devil in a dream. He wrote on acoustics and is known as the discoverer of 'resultant tones'.
Tasman, Abel Janszoon (c.1603-1659). Dutch navigator. Sent on several voyages of exploration by van ${ }^{*}$ Diemen, Governor of the Dutch East Indies, he discovered Tasmania (1642), which he named Van Diemen's Land, and New Zealand, Tonga and Fiji (1643). On another voyage (1644) he entered the Gulf of Carpentaria (previously discovered) and went on to explore the northwest coast of Australia.

\section{Tassigny, Jean de Lattre de see Lattre de Tassigny, Jean de}

Tasso, Torquato (1544-1595). Italian poet, born at Sorrento. Son of Bernardo Tasso (1493-1569), author of Amadigi di Gaula and Floridante, he studied at Padua, where he wrote his epic Rinaldo. In 1565 he went to Ferrara where he served first Cardinal d'Este and then (from 1571) his brother Duke Alfonso II. In 1573 he published a pastoral play, Aminta, the sensuous atmosphere of which was repeated in his great epic of the 1st Crusade, La Gerusalemme liberata (1575). In the following year, partly because of objections to his epic by the Inquisition, he showed signs of persecution mania. For a scene of violence (1577) in the presence of the Duchess he was briefly imprisoned. Given a refuge in a Franciscan monastery he fled to his sister but in 1579 was back in Ferrara. After renewed outbursts of frenzy he was again imprisoned, this time for seven years. The legend repeated by ${ }^{*}$ Goethe and ${ }^{*}$ Byron that the sentence resulted from his love for the Duke's sister has no basis in fact. Released in 1586, he was received by the Gonzagas in Mantua but soon began a wandering life, working intermittently on Gerusalemme conquistata, a revision of his earlier epic, from which many of the loveliest passages were removed. Among his other works were his 'discourses' on poetry, his letters and an unsuccessful tragedy, Torrismondo.

Brand, C. P., Torquato Tasso. 1965.

Tate, Sir Henry, 1st Baronet (1819-1899). English merchant and manufacturer, born in Lancashire. As a young man employed in a sugar refinery in Liverpool he patented a device for compressing and cutting sugar into cubes. The profits from this enabled him to set up his own company, Henry Tate and Sons. In 1897 he established the Tate Gallery, to which he gave his own collection of paintings and $£ 80,000$.

Tate, Nahum (1652-1715). Anglo-Irish poet. He wrote the libretto for *Purcell's opera Dido and Aeneas (1685), a metrical version of the Psalms (1696) and, almost certainly, the hymn While Shepherds Watched Their Flocks By Night (1702). His version of King Lear (1681) practically ousted *Shakespeare's original until 1840. Poet Laureate from 1692, he also wrote Panacea, or a Poem on Tea (1700).

Tauber, Richard (Ernst Seiffert) (1891-1948). Austrian tenor, born in Linz. He sang in opera and, increasingly from 1925, in light opera (e.g. Lilac Time) and films. He was also a noted exponent of 
*Schubert's songs. He composed several songs and the musical comedy Old Chelsea. In 1940 he was naturalised as a British subject.

Tavener, Sir John Kenneth (1944-2013). English composer. He taught at Trinity College, London, divided his time between Britain and Greece, became a Russian Orthodox convert in 1977 and wrote works for the Russian and Greek liturgy. He disclaimed his earlier works. Later compositions include The Protecting Veil (cello concerto, 1989), which was frequently performed, The Repentant Thief (clarinet and orchestra, 1991), Song for Athene (1993), The Veil of the Temple (2003).

Taverner, John (1495-1545). English composer. He composed his best music before 1530, while choirmaster at Cardinal College (Christ Church), Oxford. His Masses (notably Gloria tibi, Trinitas and $O$ Western Wynde) show him to have been a strongly gifted precursor of English polyphonic masters of the later 16th century. He played a fanatical and active part in the suppression of the monasteries instituted by *Henry VIII. The greatest choral composer of his time, six of his great Masses have now been recorded.

Tawney, Richard Henry (1880-1962). English economic historian, born in Calcutta (now Kolkata). Educated at Rugby and Oxford, he was a Sergeant in World War I and a social worker at Toynbee Hall in the East End of London. A lecturer at the London School of Economics 1917-31, and a Fellow of Balliol College, Oxford (1918), he became President 1928-44 of the Workers' Educational Association. A Christian and a non-Marxist socialist, his studies of English economic history (particularly of the 16th and 17th centuries) include The Acquisitive Society (1926), Religion and the Rise of Capitalism (1926), Equality (1931) and Business and Politics under James $I$ (1958). He was professor of economic history at the London School of Economics 1931-49.

Taylor, A(lan) J(ohn) P(ercevale) (1906-1990). English historian, born in Lancashire. Educated at Oxford, he lectured at Manchester 1930-38 and Oxford, where he was a Fellow of Magdalen 193876. Taylor was a controversial figure, devastating in debate and with mastery of sources, incisive in style, witty and argumentative in manner, determinedly paradoxical in approach. He described his own politics as 'extreme views held moderately'. His involvement in television lecturing and popular journalism aroused deep professional prejudice despite the strength of his published work, e.g. The Habsburg Monarchy (1941), The Struggle for Mastery in Europe (1954), Bismarck (1955), The Origins of the Second World War (1961), and English History 1914-45 (1965).

Burk, K., Troublemaker. 2000.

Taylor, Dame Elizabeth (1932-2011). English film actor in the US. Famous as a child star (National appeared in many vapid romances, later gaining a reputation as a dramatic actor, e.g. in Cat on a Hot Tin Roof (1958), Butterfield 8 (1960) and Who's Afraid of Virginia Woolf? (1966), winning an Academy Award for the last two. She married the film director Mike Todd, the singer Eddie Fisher, Richard *Burton (twice), a US senator and three others.

Taylor, Frederick Winslow (1856-1915). American industrial engineer. He wrote Principles of Scientific Management (1911) which applied technocratic modes to industrial practice, setting scientific standards, such as time-study and cost-benefit, to measure efficiency. Opponents of 'Taylorism' thought that his methods increased alienation and dehumanisation in the workplace.

Taylor, Jeremy (1613-1667). English author and clergyman. He attracted attention as a preacher, became chaplain to ${ }^{*}$ Laud and ${ }^{*}$ Charles I and (1638) was rector of Uppingham, Rutland. In the Civil War he was a chaplain with the royalist forces, was taken prisoner in Wales, became chaplain to the Earl of Carbery (1645-57) and Bishop of Down in Northern Ireland (1661-67). His theological works, of which The Liberty of Prophesying (1646), Holy Living (1650) and Holy Dying (1651) were the most influential, were written in a style combining simplicity and splendour. They reveal him as a moderate and tolerant Churchman ready to limit matters of faith to what is found in the Bible and the Apostles' Creed, leaving a large area in which a Christian was entitled to think for themselves. Such teaching, which provided a basis of belief for later evangelical Churchmen, was supplemented by Ductor Dubitantium (1660), a vast work on moral theology aimed at formulating distinctions between good and evil.

Taylor, Zachary (1784-1850). 12th President of the US 1849-50. Born in Virginia, son of a planter who then settled in Kentucky, he joined the army in 1808, lived in Louisiana from 1825 and gained a national reputation in the frontier fighting in the second Seminole war, earning the nickname 'Old Rough and Ready'. Sent to Texas by President *Polk (1845) to defend the frontier against Mexican attack, he was present when an exchange of shots led to the Mexican War (1846-47). His victory at Buena Vista (1847) was the decisive and culminating episode. Despite having had no political experience (and having never voted), he defeated Winfield ${ }^{*}$ Scott and Henry *Clay to win the Whig nomination for president in 1848 , and won election over Lewis *Cass and Martin *Van Buren. Although a slave owner himself, he took the commonsense view that California (acquired from Mexico) should, if it chose, enter the Union as a free state. He died of an unspecified stomach complaint and was succeeded by Millard *Fillmore.

Tchaikovsky, Pyotr Ilyich (1840-1893). Russian composer, born at Kamsko-Votkinsk in the Urals. As a boy he was hypersensitive and abnormally 
dependent on his mother; her death when he was 14 affected him for the rest of his life. After being trained for the law, for which he was unfitted, at 21 he began to study music under Anton *Rubinstein at the St Petersburg Conservatoire. In 1865 he became professor of harmony at the Moscow Conservatoire, founded the previous year by Rubinstein's brother Nikolai. In his early works, e.g. the Symphony No. 1 (Winter Dreams, 1868) and the fantasy-overture Romeo and Juliet (1870, revised 1880), he was influenced by the ideals of the nationalist group of Russian composers led by *Balakirev. The strongly Russian flavour of *Tchaikovsky's early music (often based on folksong) was now gradually superseded by a cosmopolitan idiom in which his preference for the French over the German masters became apparent. He met *Berlioz, Johann ${ }^{*}$ Strauss, *Brahms, *SaintSaëns and ${ }^{*}$ Mahler. Partly to squash speculation about his homosexuality, he married (1877) a former pupil Antonina Milyukova, despite their complete incompatibility. He left her after a fortnight but the episode caused insomnia, hallucinations and a deterioration of his mental stability. He toured from 1877, partly for his health, journeys largely financed by a rich widow Nadezhda von Meck (1831-1894) who settled a generous annuity on him. They corresponded from 1876 to 1891 but never spoke: on two accidental meetings they passed in embarrassed silence. He conducted in Paris, London, Hamburg, Leipzig, Dresden, Berlin and Prague, and took holidays in Italy. He lived at Klin, near Moscow, from 1885 and visited the US in 1891, giving concerts in New York, Baltimore and Philadelphia.

He composed eight symphonies, including the unnumbered Manfred (1885) and the incomplete No. 7 (1892). The most performed are Symphony No. 4 (1877), No. 5 (1888) and No. 6 (Patetitčeskaja, 'passionate' in Russian, mistranslated in the West as Pathétique: 1893), his last, and most emotionally intense, work. His major ballets Swan Lake (1876), Sleeping Beauty (1889) and Nutcracker (1891-92) remain in the repertoire of every company. His Piano Concerto No. 1 in B Flat (1875) has challenged every virtuoso and contains some of his most effective keyboard writing. The Variations on a Rococo theme for cello (1876) and the Violin Concerto in D (1878) are masterpieces. He wrote the Serenade for Strings (1880), a powerful Piano Trio (1882) and the Souvenir de Florence (string sextet, also arranged for string orchestra, 1890), many superb songs and less successful piano solos.

His emotionalism and rhetoric, which both attracts and repels, is demonstrated in the fantasy overture Romeo and Juliet (1869), the symphonic fantasy Francesca da Rimini (1876), the 1812 Overture (1880) and Hamlet (1888). Of his 10 operas only Evgeny Onegin (1878) and The Queen of Spades (1890), both based on *Pushkin, are performed outside Russia. He died, supposedly of cholera, but possibly by suicide, in St Petersburg and was buried there.
Weinstock, H., Tchaikovsky. 1943; Brown, D., Tchaikovsky: A Biographical and Critical Study. 4 vols, 1978-93; Poznansky, A., Tchaikovsky. 1993.

Tcherepnin, Nikolai Nikolaievich (1873-1945). Russian conductor and composer. After studying under *Rimsky-Korsakov he was attached to the Mariinsky Theatre, St Petersburg, then working with *Diaghilev's Ballets Russes, and later with Anna *Pavlova. Principal of the Tiflis (Tbilisi) Conservatorium 1918-21, he moved to Paris. He wrote music for Diaghilev until 1914 and in 1918 became principal of the Tiflis conservatoire. He wrote two operas, but was best known for his ballet music which showed a mixture of traditional Russian and modern French influences.

Tecumseh (c.1768-1813). American Shawnee chief, born in modern Ohio. Helped by his brother Tenskwatawa, 'the Prophet', he enforced order and discipline, and, above all, forbade all intercourse with the white settlers or any cession of land without consent of the Indian peoples as a whole. He fought on the British side with the rank of brigadier-general in the War of 1812, among the causes of which were alleged British intrigues with the Indians on the USCanadian frontier. Near this frontier Tecumseh was killed at the Battle of the Thames (Ontario).

Tucker, G., Tecumseh: Vision of Glory. 1956.

Tedder, Arthur William Tedder, 1st Baron (18901967). British airman, born in Stirlingshire. Educated at Cambridge, he joined the colonial service, transferring to the army (1914), then the RFC (1916), becoming a pilot. Director-General of research and development at the Air Ministry 1938-40, he became RAF Commander-in-Chief in the Middle East 194143, Allied Air Commander in the Mediterranean 1943, and Deputy Supreme Commander of Allied Forces in Europe 1943-45, under *Eisenhower. He greatly disliked *Montgomery. Promoted Marshal of the RAF in 1945 and created a baron in 1946, he was Chief of the Air Staff 1946-49 and Chancellor of Cambridge University 1950-67.

Owen, R., Tedder. 1965; Tedder, A. W., With Prejudice. 1966.

Teilhard de Chardin, Pierre (1881-1955). French geologist, palaeontologist, Jesuit priest and philosopher. He was closely involved in the 'discovery' of Piltdown man (1912-13) which may have been intended as a scientific joke rather than a serious hoax. After serving in World War I as a stretcher bearer, he became professor of geology at the Institute Catholique, Paris, in 1918. He lived in China 192346, made palaeontological expeditions into Central Asia and worked on the Peking man excavations (1929). In his writings he tried to reconcile Christian theology with science and developed the concept of 'cosmic evolution', leading to the ultimate 'Omega point' and the second coming of Christ. He lived 
in France 1946-51 and the US from 1951 and died in New York. Forbidden to publish during his lifetime, he achieved great posthumous fame with his The Phenomenon of Man (1938-40, published 1959 ) but his reputation has declined as rapidly (and mysteriously) as it rose in the 1960s.

Cunot, C., Life of Teilhard de Chardin. 1965.

Te Kanawa, Dame Kiri (1944- ). New Zealand soprano. Part Maori, she studied in Auckland and made her London debut in 1970, followed by New York (1974) and Milan (1978). Especially successful in ${ }^{*}$ Mozart, ${ }^{*}$ Verdi and ${ }^{*}$ Strauss operas, she made many recordings and several films. She received a $\mathrm{CH}$ in 2018 .

Telemann, Georg Philipp (1681-1767). German composer, born in Magdeburg. Self-taught, he abandoned the study of law to become Director of the Leipzig Opera (1702) and later the Hamburg Opera (1732-38). He declined the post of Kantor at the Thomaskirche, Leipzig, in favour of his lesser known colleague J. S. *Bach. Telemann was almost certainly the most prolific composer of all time, writing 40 operas, more than 600 orchestral suites, 44 passions, 12 complete sets of services, over 1,000 cantatas and many chamber works and concertos. Bach and *Händel admired his music and Händel, especially, borrowed heavily from it. His works have sometimes been dismissed as tuneful, ornamental and lacking in dynamic tension, however, with renewed interest in his music, the admiration of his contemporaries appears well-founded.

Telford, Thomas (1757-1834). Scottish engineer, born in Dumfriesshire. Son of an Eskdale shepherd, he worked for several years as journeyman mason, using all his spare time for engineering study. After superintending dockyard construction at Portsmouth (from 1784) he was appointed surveyor of public works in Shropshire and built his first bridges in 1792. His Pontcysyllte Aqueduct and Canal (17951805), 18 kilometres long, in north-eastern Wales, became a World Heritage site in 2009. Other great achievements in a career during which he built some 1,200 bridges and 1,000 miles of roads, were the London-Holyhead road (including the Menai Straits suspension bridge, 1826) and the Caledonian Canal (1803-17). Elected FRS in 1827, he was the first President of the Institution of Civil Engineers.

Rolt, L. T. C., Thomas Telford. 1958.

Teller, Edward (1908-2003). Hungarian American physicist, born in Budapest. Educated at the Karlsruhe Technical Institute and the universities of Munich and Leipzig, he was professor of physics at George Washington University 1935-41, Columbia 1941-42, Chicago 1946-52 and California 195371. He worked on the atomic bomb during World War II and later, as assistant director of Los Alamos contributions to physics by his work on, e.g., the structure of matter, cosmic rays and magnetohydrodynamics. Known as the 'father of the hydrogen bomb', first tested in 1952, he was a hardliner in the Cold War and an opponent of Robert *Oppenheimer.

Jungk, R., Brighter than a Thousand Suns. 1958.

Temple (Black), Shirley (1928-2014). American actor, businesswoman and diplomat, born in Santa Monica, California. A prodigy, she appeared at 31/2 in her first film, The Red-Haired Alibi (1932). In 1934 she made 10 more (including Little Miss Marker and Bright Eyes), winning a special Academy Award. Her skilled acting, singing and dancing, accompanied by curls and dimples, made her an international phenomenon. By 1938 she was Hollywood's No. 1 box office attraction, spinning off Shirley Temple dolls, dresses and colouring books. By 1940 her juvenile career was in decline, but she made occasional films and television programs until 1960. She became active in Republican politics and was Ambassador to Ghana 1974-76 and Czechoslovakia 1989-92.

Windeger, R., Shirley Temple. 1976.

Temple, William (1881-1944). English Anglican prelate. His career closely followed that of his father Frederick Temple (1821-1902), headmaster of Rugby 1858-69 whose views were suspected as radical and unorthodox. He became Bishop of Exeter 1869-85, of London 1885-96 and Archbishop of Canterbury 1896-1902. William Temple was headmaster of Repton 1910-14 and became Bishop of Manchester 1921-29, Archbishop of York 192942 and of Canterbury 1942-44. Deeply influenced by the ideas of Charles *Kingsley on Christian Socialism, he worked to link Christian thought with social and economic reconstruction. He was President of the Workers' Educational Association 1908-24 and became, 1943-44, first President of the World Council of Churches.

Iremonger, F. A., William Temple. 1948.

Temple, Sir William, 1st Baronet (1628-1699). English diplomat and essayist, born in London. Educated at Cambridge, he negotiated the marriage of ${ }^{*}$ William of Orange and *Mary (Stuart) and tried to persuade ${ }^{*}$ Charles II to accept the idea of Cabinet government. Jonathan ${ }^{*}$ Swift was his secretary at Moor Park, Surrey. He married Dorothy *Osborne, promoted the English landscape garden movement and wrote eloquent essays.

Templer, Sir Gerald Walter Robert (18981979). Son of a general, he served in France, Italy and Germany during World War II. As High Commissioner in Malaya 1952-55 he defeated the insurgency by the Malaysian Races Liberation Army. Chief of the Imperial General Staff 1955-59, he founded the National Army Museum, London, in 
1960 and received a KG in 1963. He is the only field marshal known to have been wounded in action by a grand piano.

Templewood, Samuel John Gurney Hoare, 1st Viscount see Hoare, Samuel John Gurney, 1st Viscount Templewood

Tendulkar, Sachin Ramesh (1973- ). Indian cricketer, born in Mumbai. He made his test debut in 1989, retiring in 2013 after playing in 200 test matches. By 2012 he had scored 100 centuries, for an aggregate of 34,000 runs, and was often ranked as second only to Don *Bradman. He was appointed to the Rajya Sabha, India's upper house, 2012- .

Teniers, David (1610-1690). Flemish painter. Like his father, David Teniers the Elder (1582-1649), by whom he was trained, and under the influence of Adriaen *Brouwer, he painted mostly genre pictures tavern scenes with soldiers gambling or brawling, a village festival, alchemists, witches etc. He worked in Antwerp and later Brussels, was court painter to Archduke Leopold, and compiled an illustrated record of his collection of pictures.

Tenniel, Sir John (1820-1914). English draughtsman. He joined the staff of Punch in 1851 and in 1901 retired after 50 years as the leading political cartoonist. He became even better known as the illustrator of Lewis *Carroll's Alice in Wonderland and Through the Looking Glass. He was knighted in 1893 .

Tennyson, Alfred, 1st Baron Tennyson (18091892). English poet, born at Somersby, Lincolnshire. Son of a clergyman, his family had a history of manic depression, obsessions and/or fits of rage. At Trinity College, Cambridge, he met Arthur ${ }^{*}$ Hallam, who became his greatest friend and whose sudden death (1833) evoked his famous elegy In Memoriam (published anonymously in 1850). Some of his juvenilia had already appeared in print and a volume published in the same year as Hallam's death contained his first successes such as Oenone, The Lotus-eaters and A Dream of Fair Women. A further collection (1842), including Morte d'Arthur (the genesis of Idylls of the King), Locksley Hall, Ulysses and such famous lyrics as Break, Break, Break, confirmed his reputation. A state pension of $£ 200$ (1842) per annum relieved immediate financial anxiety but it was not until 1850 , when he succeeded *Wordsworth as Poet Laureate, that he felt free to marry Emily Sellwood, to whom he had been engaged for 17 years. By now his poetry became a source of wealth. As Laureate he had to write poems to commemorate great events (e.g. Ode on the Death of the Duke of Wellington and The Charge of the Light Brigade). Maud (1855) was read or recited in every drawing room; of Enoch Arden (1864) 60,000 copies were at once sold. (Richard *Strauss set it in 1897 as a melodrama for narrator and piano.) In 1854 Tennyson began to live at Farringford, his house at Freshwater in the Isle of Wight, and he began to build his second home near Haslemere in 1868. Meanwhile, he had found inspiration in the legends of King Arthur and his Idylls of the King were appearing in steady sequence (1855-89). Of his verse plays the genius of *Irving managed to make something of Becket (1879), but the others, e.g. Queen Mary (1876) and Harold (1877), were among his least successful works. He received a peerage in 1884 .

Tennyson was so prolific and the demand from his public so great that much that is trite and second-rate appears in his Collected Works; his skills, his complete mastery of versification and the lilting music of his lines, turned opinion against him when a later age equated roughness with sincerity. He was capable of deep emotion, as In Memoriam and many other poems show. His approach was not primarily intellectual but he brought to the problems and discoveries of his day a philosophic outlook and a somewhat scientific mind. In 1890 he declaimed some poems on wax cylinders, now available on CD and YouTube. His son Hallam Tennyson, 2nd Baron Tennyson (1852-1928) was Governor-General of Australia 1903-04.

Tennyson, C., Alfred Tennyson. Repr. 1968; Thorn, M., Tennyson. 1992; Levi, P., Tennyson. 1992.

Tenzing Norgay (1914-1986). Nepalese mountaineer. He first climbed as a porter with an expedition to Everest in 1935. In 1952 he reached $8600 \mathrm{~m}$. and in 1953, in John *Hunt's expedition, he and Edmund ${ }^{*}$ Hillary reached the summit $(8848 \mathrm{~m}$.) He became President of the Sherpa Association.

Ullman, J. R., Man of Everest. 1955.

Terborch (or Terburg), Gerard (1617-1681). Dutch painter. He spent much of his time as a young painter in travel. One of his finest pictures (now in the National Gallery, London) portrays the delegates to the peace congress of Westphalia which ended the Thirty Years' War (1648). By 1650 he was back in Holland and perfected a type of genre picture, nearly always of small size, depicting scenes in which one or more figures, usually ladies, are reading, writing, playing music etc. in rooms appropriate to the elegance of their attire. Soft and delicate colour harmonies characterise his work.

Terence (Publius Terentius Afer) (c.190-160 BCE). Roman comic playwright, born in Carthage. Taken to Rome as a slave, he was educated and freed by his master. He achieved great success with Andria (166), the first of six plays, all extant. His others were Hecyra (The Mother-in-law, 165), Heauton Timorumenos (The Self-punisher, 163), Eunuchus (161) on which the first English comedy, Ralph Roister Doister was based, Phormio (161), Adelphi (The Brothers, 160). All were based on Greek originals, Hecyra and Phormio on plays by Apollodorus, the rest derived from *Menander. 
The stock situations and characters of ancient comedy were later again revived by ${ }^{*}$ Shakespeare and ${ }^{*}$ Molière. Terence was famed for use of polite colloquial speech.

Beare, W., The Roman Stage. 3rd ed. 1965.

Teresa of Ávila, St (also known as St Teresa of Jesus: Teresa Sánchez de Cepada y Ahumada) (1515-1582). Spanish nun. She entered a Carmelite convent in Avila (c.1526) and had lived there over 20 years, much troubled by ill health, before she left to found, after considerable opposition, a convent governed by the original, stricter rule. St Joseph's Convent at Avila was the first of 15 established during her lifetime for 'discalced' or barefooted Carmelites (a separate order from 1580), for men as well as women. Despite this immense practical activity her books are among the most famous examples of mystical literature. The Life (1562-65) is a spiritual autobiography, The Way of Perfection (1565) provides guidance for her nuns, The Foundation (from 1576) tells of her work in establishing the new convents, and The Interior Castle (1577), perhaps her most illuminating work, is an account, written with all the conviction of her rich experience, of a contemplative life. Minor works too and letters, vivid, witty and wise, help to reveal one of the most attractive personalities of religious history. She was canonised only 40 years after her death. St Teresa in Ecstasy (in Rome) was one of *Bernini's greatest sculptures. General *Franco kept her mummified hand on his desk.

Teresa of Calcutta, St (formerly known as Mother Teresa: Anjezë Gonxhe Bojaxhiu) (1910-1997). Albanian Roman Catholic missionary, born in Üsküp (now Skopje), then in the Ottoman Empire. She joined the order of Sisters of Loreto in 1929. As principal of St Mary's High School, Calcutta, she founded the Missionaries of Charity in 1950 and, through this organisation, founded 50 orphanages and refuges for the destitute in India, notably the Pure Heart Home for Dying Destitutes. She was awarded the Pope John XXIII Peace Prize in 1971, the Nobel Prize for Peace in 1979, and the OM in 1983. The Order was established in other countries. In 2003 she was beatified by Pope *John Paul II, and was canonised by Pope *Francis in 2016.

Muggeridge, M., Something Beautiful for God. 1971; Egan, E., Such a Vision of the Street. 1986.

\section{Teresa of Lisieux see Thérèse of Lisieux, St}

Terfel, Sir Bryn (Bryn Terfel Jones) (1965- ). Welsh bass-baritone. In 1992 he made his debut at Covent Garden, Salzburg and Vienna, and was soon recognised as a ${ }^{*}$ Mozart specialist as Figaro and Don Giovanni. Later roles included Wotan in *Wagner's Ring in New York and *Verdi's Falstaff. He also recorded popular songs.
Terry, Dame Ellen (1847-1928). English actor. She achieved immense success as a Shakespearian actor and was *Irving's leading lady 1878-1902. She married three times, first and disastrously to the painter G. F. *Watts (1864). The theatrical designer E. G. ${ }^{*}$ Craig was her son by Edward Godwin, an architect. She had a long 'paper courtship' with G. B. *Shaw. Other members of her family won fame on the stage: her brother, Fred Terry (1863-1933), who created the part of Sir Percy Blakeney in The Scarlet Pimpernel, her granddaughter Phyllis Neilson-Terry and her grandnephew John ${ }^{*}$ Gielgud.

Manvell, R., Ellen Terry. 1968.

Tertullian (Quintus Septimus Florens Tertullianus) (c.155-c.225). Latin theological writer, born in Carthage. A convert, he became a presbyter of Carthage, but little is known of his life. Of his 31 surviving works one of the greatest was Apologeticus (197), written to defend Christianity against charges that it was immoral, useless and dangerous to the state; it warns Roman officials that the blood of martyrs provides the seeds of growth. A second series deals with practical subjects: attendances at theatres and games, idolatry and extravagance in dress etc. are condemned; chastity and fasting are among the virtues praised. In his theological works he claims that true doctrine is handed down through apostolic succession and cannot be assailed by argument. $\mathrm{He}$ further stresses the ascendancy of faith over reason by such paradoxical assertions as his saying that a subject of belief 'is certain because it is impossible'.

Barnes, T. D., Tertullian. 1971.

Tesla, Nikola (1856-1943). Serb-American electrical engineer, born in Smiljan, Croatia. Son of an Orthodox priest, he was educated at Graz and Prague and migrated to the US in 1884 . He worked briefly with Thomas *Edison and, from 1885, with George *Westinghouse. Edison was deeply committed to the use of direct current (DC); Westinghouse and Tesla saw greater efficiency and economy with alternating current (AC). In 1888 Tesla invented the first AC electric motor, substantially in the form still in current use, and this was the most important single development in the Electric Revolution. He sold his patents to Westinghouse and set up his own laboratories. In 1891 he invented the Tesla coil, an air-core transformer used to produce high voltage in radio (and later television) equipment. He improved the transmission of AC over long distances and was the first to demonstrate that the earth is an electrical conductor. Tesla did not patent most of his inventions and died in poverty, bitterly disappointed not to have received a Nobel Prize. Elon *Musk's luxury electric car (2010), minor planet 2244 Tesla, a moon crater and a rock band were named for him.

Hunt, I. and Draper, W. W., Lightning in his Hand: The Life Story of Nikola Tesla. 1964; Munson, R., Tesla. Inventor of the Modern. 2014. 
Tetrazzini, Luisa (1871-1940). Italian singer, born in Florence. She made a great name for herself as a coloratura soprano, mainly in Italian opera, and commanded huge audiences in virtuoso recitals throughout the world.

Thackeray, William Makepeace (1811-1863). English novelist, born in Calcutta (now Kolkata). Soon after the death of his father, an official in the East India Company, he went to England (1817) where he was subsequently looked after by his mother (later portrayed as Helen Pendennis) and his stepfather (afterwards transformed into Colonel Newcome). From Charterhouse ('Grey Friars') he went to Cambridge, where prospects of wealth encouraged idleness, travel (after failure to get a degree) and a half-hearted study of art and law. The disappearance of most of the money through the failure of a Calcutta agency (1833) forced him into activity. Unable to sell his pictures, he took to journalism in 1836, the year when he married Isabella Shawe. In his first period of writing appeared The Yellow-plush Papers (1840) in which Thackeray, in the guise of a footman called Yellow-plush, dilated with good-humoured satire upon the social follies and foibles of his time. Fraser's Magazine, The Times and Punch were among the periodicals that accepted his work. In 1840 his wife showed signs of insanity. After trying to cope with an increasingly impossible situation he was forced to part from her and place her under control. She lived for another 50 years but never recovered. The effect upon his work was to soften its asperity and introduce a new note of pathos. The Great Hoggarty Diamond (1841) and the Punch series (1846-47) later published as The Book of Snobs are among the numerous writings that preceded the publication of his best novels. The first, Vanity Fair (published as was then the custom in monthly parts, 1848-50), tells of the manoeuvres of the clever adventuress Becky Sharp, in the days of Waterloo. Henry Esmond (1852) is the story of a disputed inheritance in Ireland with a background of *Marlborough's war and Jacobite intrigue. Its sequel, The Virginians (1857-59), continues the hero's story in America; Pendennis (1848-50) returns to Thackeray's own time with several autobiographical passages. The Newcomes (1853-55), in that it purported to be written by Pendennis is aligned with the earlier book. The later novels show a marked decline. The best known of his miscellaneous writings include the delightful children's story, The Rose and the Ring (1854), and two series of lectures collected as The English Humorists of the Eighteenth Century (1853) and The Four Georges (1860). In 1860 he fulfilled an ambition by becoming editor of the Cornbill magazine. As a novelist, Thackeray had the same taste for melodramatic plots as *Dickens but his stories are more tightly constructed; while his characters move within a narrow range, his humour is more astringent than that of Dickens and his compassion less evident. This was partly due to the unhappiness of his domestic life, which, as the years passed, made him increasingly sensitive to personal slights.

Carey, J., Thackeray: Prodigal Genius. 1977.

Thalberg, Irving Grant (1899-1936). American film production executive. After a sickly childhood, he developed secretarial skills and became head of production at Universal Studios and, from 1924, at Metro-Goldwyn-Mayer (MGM). Known as 'the boy wonder', he was the subject of F. Scott *Fitzgerald's novel The Last Tycoon, and married the Canadianborn actor Norma Shearer (1902-1983).

Thales (c.640-c.550 BCE). Greek philosopher, born in Miletus, Asia Minor (now Turkey). Regarded as one of the 'seven wise men' of Greece, he was held to be the first of the philosophers because he sought to explain the universe rationally rather than by mythology. The tradition recorded by *Aristotle that Thales believed that all things are made of water is probably based on an attempt by him to give a rational explanation of an ancient myth. It seems likely that he was a merchant and that in his travels in Babylonia and Egypt he acquired the mathematical knowledge that enabled him, e.g. to predict the solar eclipse of 585 BCE.

Thant, U (1909-1974). Burmese diplomat. After working as a school teacher 1928-47, he entered the public service in Burma and became the trusted advisor of Prime Minister U *Nu. In 1957 he became Burma's permanent representative at the United Nations, and on the death (1961) of Dag *Hammarskjöld was made Acting Secretary-General of the organisation, then Secretary-General 1962-71.

Tharp, Twyla (1941- ). American dancer and choreographer, born in Indiana. She worked in New York with her own modern dance troupe, performed extensively in film television and in her own ballets, often based on popular music e.g. Hair, and *Sinatra songs.

Thatcher, Margaret Hilda (née Roberts), Baroness Thatcher of Kesteven (1925-2013). English Conservative politician, born in Grantham, Lincolnshire. Her father, a strict Methodist, owned two grocery stores and was a local councillor and mayor. Educated at Kesteven and Grantham Girls' School, at Somerville College, Oxford University, she studied chemistry under Dorothy *Hodgkin, and worked as an industrial chemist 1947-51. She was active in Conservative student politics at Oxford, and became deeply influenced by the economist Friedrich von *Hayek. In 1951 she married Denis Thatcher (1915-2003), a former oil industry executive, and became the mother of twins (1953). She studied law at Lincoln's Inn and was called to the bar in 1953. Conservative MP for Finchley 1959-92, and Parliamentary Secretary to the Minister of Pensions 
and National Insurance 1961-64, she was appointed Secretary of State for Education in Edward *Heath's Cabinet 1970-74. In February 1975 she was elected leader of the Conservative party (defeating Heath). In the general election of May 1979, she defeated James *Callaghan's Labour Government to became Britain's Prime Minister 1979-90, the first women to hold the office.

Her election destroyed the Keynesian consensus dominating British economic policy since the 1940 s and her enthusiastic adoption of von Hayek's paradigm was a turning point in political economy in the West, soon followed in the United States by ${ }^{*}$ Reagan, in New Zealand, by Roger ${ }^{*}$ Douglas and in Australia, in modified form, under Bob *Hawke. (Coincidentally, in 1979 dramatic changes were initiated by Pope *John Paul II, *Deng Xiaoping in China and the Ayatollah *Khomeini in Iran.) Like Khomeini, she had a conviction of infallibility, scepticism about 'progress', commitment to absolutes and an invoking of the Manichean contest between Good and Evil. Paradoxically, she showed no interest in gender-related issues.

Mrs Thatcher urged a commitment to 'Victorian values', of self-help, rejecting the 'nanny state' (a coinage by Iain ${ }^{*}$ Macleod) as intrusive and all encompassing, inhibiting personal choices about education and health, insisting that lower taxes would stimulate economic activity and job creation. She was deeply hostile to trade unions and seemed indifferent to high unemployment. She began a major program of 'privatisation', selling off public assets: schools and hospitals, even prisons, to be run as trading enterprises. She 'outsourced' policy advice to consulting firms, bypassing public servants. She promised to eliminate 'feather bedding' and phase out tariffs. She promoted 'deregulation', arguing that market forces would require higher ethical standards. (The banking crisis of 2008 challenged that assumption.) The changes occurred with little public debate: as the acronym TINA put it, 'There is no alternative.' She described her supporters as 'dries' and her opponents as 'wets'. She often resorted to populism in her campaigning and was strongly supported by the *Murdoch press.

War with Argentina over the Falkland Islands (AprilJune 1982) was the most controversial act of her first term, but the economy began to recover and she won a second term with a large majority in June 1983. In October 1984 she survived an assassination attempt when the IRA bombed a Brighton hotel during a Conservative Party Conference. In June 1987 she became the first British Prime Minister since *Palmerston to win a third consecutive election.

She had a major role in persuading President Reagan to collaborate with *Gorbachev. British politics moved sharply to the Right in the era she dominated and Tony *Blair's New Labour was distinctly Thatcherite.
She remarked, notoriously, in 1987: 'There is no such thing as society. There are individual men and women, and there are families.' Personal enrichment displaced the setting of social goals, and all values could be measured. Often called 'The Iron Lady', she alienated many colleagues with her imperious style, increasing opposition to closer involvement with the European Community and the rigidity of her commitment to neo-classical economics, leading to significant regional unemployment. Increasing preoccupation with the immediate and material had a crowdingout effect on community values and the concept of 'the public good'. She was forced out by colleagues in November 1990 and replaced by John *Major, after serving 11 years 6 months and 25 days, the longest single term since Lord ${ }^{*}$ Liverpool. She received the OM in 1990, the US Presidential Medal of Freedom in 1991, a peerage in 1992 and became LG in 1995 . Her husband received a baronetcy in 1990. She wrote two volumes of memoirs, The Downing Street Years (1993) and The Path to Power (1995). She suffered debilitating strokes after 2002 and had a ceremonial funeral at St Paul's Cathedral.

Young, H., One of Us. 1989; Campbell, J., The Iron Lady: Margaret Thatcher. 2 vols, 2003; Harris, R., Not for Turning. 2013; Moore, C., Margaret Thatcher: the Authorized Biography. Vol. 1, 2013, Vol. 2, 2015, Vol. 3, 2019.

Theaetetus (417-369 BCE). Greek mathematician. He studied under Theodorus of Cyrene and at the Academy with *Plato. None of his writings has survived, though we have adequate accounts of them from other sources. Plato wrote a dialogue about him (the Theaetetus) and he is the principal character in The Sophist. One of Theaetetus' main contributions to mathematics was the development of a proper classification of irrationals (irrationals in mathematics had only recently been discovered). *Euclid also notes that he was the first mathematician to write upon the five regular solids. It is possible that he discovered the octahedron and the dodecahedron, though it is much more likely that these figures were earlier known to the Pythagoreans. Theaetetus undoubtedly set out the theory of the construction of the solids probably in much the form used by Euclid in book 13 of The Elements. Scholars have debated how far Euclid simply reported Theaetetus' work in several of the books of The Elements (e.g. Book 10). There is no way of knowing. Euclid attributed some of his theorems to Theaetetus.

Themistocles (c.523-c.458 BCE). Athenian soldier and statesman. During the Persian Wars he recognised the importance of a navy for Athens, having secured the banishment of his rival *Aristides, he made use of the opening of a new seam in the silver mines at Laurium to raise the total number of ships from 70 to 200 . When the Persians forced the pass of Thermopylae, the 'gateway' to Athens on the north, he persuaded the citizens to take refuge with the ships 
and himself directed the strategy by which the Persian fleet was destroyed at the Battle of Salamis (480). In the next year the Persians were forced to withdraw. Arrogance soon cost Themistocles his popularity and his anti-Spartan policy threatened Greek unity. Banished from Athens, he went first to Argos and then, after accusations of intrigue with the enemy, to Persian territory, where he was generously received.

Theobald (or Tebaldus) of Bec (c.1090-1161). Anglo-Norman cleric, born in Bec, Normandy. A Benedictine, he was Abbot of Bec, then chosen by King ${ }^{*}$ Stephen to be Archbishop of Canterbury 1139-61, becoming the patron of Thomas *Becket, who succeeded him.

Theocritus (fl. c.280 BCE). Greek poet, born at Syracuse. He visited Cos and then Egypt where he attracted the notice of ${ }^{*}$ Ptolemy II Philadelphus. He perfected the type of poem that came to be known as an 'idyll', a short sketch or scene in dramatic form usually taken from country or village (but sometimes from town) life. His poems were much imitated by later 'pastoral' poets and one provided a model for *Milton's Lycidas.

Theodora (c.500-548). Byzantine Empress 527-48. Probably born in Cyprus (or Syria?), daughter of the bear trainer at the hippodrome in Constantinople, she was an actor and courtesan before becoming the mistress of *Justinian I and, in 523, his wife. She proved a valued advisor and her courage helped to save the throne during the faction fights of 532. There is an outstanding mosaic of her in St Vitale Cathedral, Ravenna.

Browning, R., Justinian and Theodora. 1971.

Theodorakis, Mikis (1925-2021). Greek composer, playwright and political activist, born in Chios. He worked in the Resistance during World War II, was deported for his political activity during the civil war 1947-52 and studied with *Messiaen in Paris. He was extraordinarily prolific in a variety of forms, including seven symphonies, a Requiem, chamber music, the ballet Antigone (written for Margot *Fonteyn), songs, choruses, an opera and 22 film scores, including Zorba the Greek, also a ballet. He was a member of the Greek Parliament 1964-67, 1981-86, 1989-93, imprisoned 1964-67, left the CP in 1986 and was Minister without Portfolio 1990-92.

Theodore (1816-1868). Emperor of Ethiopia 185568. Originally a brigand named Kassa, he fought his way to supremacy and showed considerable talents as a ruler though prone to unpredictable violence. Taking the absence of a reply to a letter sent by him to Queen *Victoria as a slight, he seized the British Consul and other Europeans. Eventually a British force was sent under Sir Robert ${ }^{*}$ Napier. When Theodore's stronghold of Magdala was taken, he shot himself.
Theodore (Theodor, Baron von Neuhoff) (16941756). German adventurer, self-styled 'king' of Corsica. The son of a Westphalian nobleman, he led a life of adventure and political intrigue. In 1736 he landed in Corsica with instructions he had received from the Austrian Government in 1729 to investigate the causes of a rebellion there. On his arrival he was crowned King and proceeded to issue coins and acquire revenue by selling knighthoods in his 'Order of Deliverance'. This not proving enough, he left to seek foreign aid, but after two attempts to return had failed he settled in London, where he was imprisoned for debt and died in Soho.

Theodore, Edward Granville (1884-1950). Australian Labor politician and director, born in Port Adelaide. The son of a Romanian (Teodorescu) father and an Anglo-Irish mother, he left school at 12 , worked in mines, then became a union organiser in Queensland and state president of the Australian Workers' Union (AWU) 1913-16. Queensland State MP 1909-25, he was Treasurer 1915-19 and a reforming Premier 1919-25. In 1922 the Legislative Council was abolished and Queensland became the first place in the then British Empire to end capital punishment. A Federal MP 1927-31, in the *Scullin Government he was Treasurer 1929-30; 1931-32, stepping down at a critical time to answer allegations of bribery about mining leases in Queensland. This damaged Labor's campaign to meet the impact of Depression, as Theodore was the strongest figure in the Government, with the clearest economic strategy, paralleling the ideas of *Keynes. Theodore's reinstatement as Treasurer in January 1931 provided Joseph *Lyons with a reason to defect from the ALP. Jack *Lang hated him. He became a director of mining and publishing companies and during World War II directed the Allied Works Council 1942-44.

Fitzgerald, R., Red Ted. The Life of E. G. Theodore. 1994.

Theodoric (known as 'the Great') (c.454-526). King of Italy 493-526. Son of the ruler of the Ostrogoths, he was educated in Constantinople and in 488 was urged by the emperor Zeno to lead his people to regain Italy from the German mercenary *Odovacar who had made himself king. Theodoric succeeded, after four years of confused fighting, only by inspiring the treacherous murder of his opponent. Setting up his court at Ravenna and proffering only the most nominal allegiance to Zeno, he consolidated and enlarged his kingdom and entered into friendly relations with the Franks and other peoples of Europe. He showed unusual religious tolerance and, though he had to take large areas of land to provide settlements for his 200,000 Ostrogoths, he ruled with prudence, making use of many of the old Roman institutions and paying special attention to the preservation of the splendour and dignity of Rome. 
Theodosius I (known as 'the Great') (c.346-395). Roman Emperor 379-95. Born in Spain, son of the Count Theodosius who had protected Britain from raids from Scotland, he was summoned by ${ }^{*}$ Gratian to be his co-emperor. In this role he restored law and order in the Balkans by providing the barbarians with land in return for their service in the Roman army. On the death of Gratian he maintained Valentinian II in power in Italy until his somewhat mysterious death (492). Despite his ability, Theodosius, who had been baptised (480) and condemned any who rejected the decisions of the Council of Nicaea, could be fiercely cruel. Having pardoned rioters in Antioch, he punished a similar outbreak in Thessalonica by a massacre (390) in which 7,000 perished, an act for which St ${ }^{*}$ Ambrose insisted that he make public atonement in Milan Cathedral. He was succeeded by his sons Honorius and *Arcadius.

Theophrastus (368/373-c.287 BCE). Greek naturalist and philosopher. Taught by *Plato and *Aristotle, he inherited the latter's library and manuscripts and carried on his school at Athens. Most of the 224 books he is said to have written are lost, including the series on zoology, but books on plants, stones and fire are among the survivors, which also include the Characters, a book on moral types which may not be wholly his work.

Thérèse of Lisieux, St (known as 'the Little Flower' or St Thérèse of the Infant Jesus) (Marie-FrançoiseThérèse Martin) (1873-1897). French nun. Daughter of a watchmaker, at the age of 15 she entered the Carmelite convent of Lisieux, where she spent the rest of her short life and died of tuberculosis, complicated by her self-inflicted privations. L'Histoire d'une âme (1898), an account of her experiences, quickly established her cult throughout France. She was canonised in 1925, made patron saint of France in 1944 and in 1997 became the youngest Doctor of the Church.

Theroux, Paul Edward (1941- ). American novelist, essayist and travel writer. Educated at the University of Massachusetts, he taught in Italy, Malawi, Uganda and Singapore. His novels include Saint Jack (1973), Picture Palace (1978), The Mosquito Coast (1981), Doctor Slaughter (1984), My Secret History (1989) and Chicago Loop (1990). His acidly witty (and controversial) travel books are The Great Railway Bazaar (1975), The Old Patagonian Express (1979), Riding the Iron Rooster (China: 1988) and The Happy Isles of Oceania (1992).

Thiers, (Marie Joseph Louis) Adolphe (1797-1877). French politician and historian, born at Marseilles. He went to Paris (1821) and became known by his Histoire de la Révolution (1823-27) which revealed his opposition to *Charles X's regime. He supported the revolution that brought *Louis Philippe to the throne (1830), was elected a deputy and became Minister of the Interior (1832) and Prime Minister (1836). The king's refusal to intervene in the civil war in Spain soon forced his resignation. He returned in 1840 but his government fell when Great Britain and her allies thwarted his attempt to sustain the seizure of Syria from the Turks by ${ }^{*}$ Mehemet Ali, the Egyptian viceroy. For the rest of Louis Philippe's reign he vigorously opposed *Guizot's right-wing government, while writing his Histoire du Consulate de l'Empire (1845-62). He supported Louis Napoléon in the first stages of the revolution of 1848 but turned against him when he made himself Emperor as *Napoléon III (1851). He was expelled from the country and spent the next 12 years on his literary work. A deputy again 1863-70, he was the only major politician to oppose the Franco-Prussian war and, on France's defeat, negotiated peace with ${ }^{*}$ Bismarck. Pending any decision to revive the monarchy he was elected (February 1871) 'Chief of the Executive Power' and suppressed the Paris Commune brutally. In August 1871, he was elected first president of the Third French Republic, resigning in 1873 in conflict with the ultra-conservative legislature.

Bury, J. P. T. and Tombs, R. P., Thiers 1797-1877. 1986.

Thistlewood, Arthur (1770-1820). English conspirator. Having lived in America and France, where he imbibed revolutionary doctrines, he enlisted others to join him (1820) in an attempt to murder the members of the British Cabinet, while at dinner. The plan was betrayed and the plotters were arrested at a house in Cato Street (after which the conspiracy was named). Thistlewood and four others were hanged, five more were transported.

Thomas, St ('twin', T'oma in Aramaic, Didymus in Greek) (d.c.75 CE). Christian apostle, his personal name may have been Judas. From his reluctance to accept the fact of the resurrection without tangible evidence, originated the phrase 'Doubting Thomas'. Tradition relates that he became a missionary in India. The 'Christians of St Thomas of Malabar' claim to have been founded by him and a shrine (rebuilt in 1547 by the Portuguese) near Madras is said to indicate his place of martyrdom. He is Portugal's patron saint.

\section{Thomas Aquinas, St see Aquinas, St Thomas}

\section{Thomas (of Canterbury), St see Becket, St Thomas}

Thomas à Kempis (Thomas Hammerken) (13801471). German Augustinian monk and mystic, born at Kempen near Cologne. He seems to have spent his whole life at the monastery of Zwolle (now in the Netherlands) and there wrote in Latin The Imitation of Christ, which was published posthumously (1486) and, in its many translations, has proved probably the most popular of all devotional works. Its four books relate in simple and sincere language the progress of the Christian soul to perfection, its gradual dissociation 
from the human world and its eventual union with God. Its authorship has also been attributed to Jean Charlier de Gerson, a French theologian.

Thomas, Albert (1878-1932). French Socialist politician. He was the foundation Director 1920-32 of the International Labour Organization (ILO) set up under the auspices of the League of Nations by the Versailles Peace Treaty of 1919.

Thomas, Dylan (1914-1953). Welsh poet, born in Swansea. He moved to London in 1932 and published Eighteen Poems in 1934, followed by Twenty-five Poems (1936) and The Map of Love (1939), the last containing prose as well as poetry. The Collected Poems appeared in 1952 . His poetry, rich in vivid and highly original imagery, technically ingenious, frequently obscure, has been highly praised as part of a 20thcentury neo-romanticism. He achieved immense posthumous success with his radio play Under Milk Wood (1954), a brilliant evocation of a day in an imaginary Welsh village. It later proved successful on stage and screen. He also wrote the autobiographical sketches Portrait of the Artist as a Young Dog (1940), and an unfinished novel, Adventures in the Skin Trade (published 1955). His death, hastened by excessive drinking, occurred in New York during a lecture tour. His wife, Caitlin Thomas (1914-1994), wrote an autobiography of great poignancy, Leftover Life to Kill (1957).

Fitzgibbon, C., The Life of Dylan Thomas. 1965.

Thomas, Norman Mattoon (1884-1968). American socialist, born in Marion, Ohio. Educated at Princeton, he became a Presbyterian minister 1911-31, joined the Socialist Party in 1918 and ran for President of the US in every election from 1928 to 1948. His highest vote, 882,000, was in 1932 . Despite overwhelming defeats at the polls, he had the satisfaction of seeing his program adopted by Democrats and Republicans.

Thomas, R(onald) S(tuart) (1913-2000). Welsh poet, born in Cardiff. He was an Anglican priest in Wales, living remotely but writing poems of great simplicity and intensity, e.g. 'A Marriage', 'Via Negativa' and 'The Bright Field'.

\section{Thompson, Sir Benjamin see Rumford, Count von}

Thompson, Dame Emma (1959- ). English actor. She won Oscars for best actress in Howard's End (1992) and best screenplay in Sense and Sensibility (1996). She married Kenneth *Branagh in 1989 and left him in 1995.

Thompson, Francis (1859-1907). English poet, born at Preston, Lancashire. Having abandoned his medical studies he went to London, where he lived in direst poverty and misery relieved by opium until rescued by Wilfred and Alice Meynell, who sent him to hospital and subsequently watched over him through years of ill health. Of his works, which were preponderantly religious, The Hound of Heaven, contained in a collection of poems published in 1893, is best known. It tells how the poet in his flight from God is pursued and overtaken. Its style is reminiscent of 17 th-century poets, e.g. ${ }^{*}$ Crashaw.

Thomson, James (1700-1748). Scottish poet. Intended for the ministry, he went to London to seek his literary fortune and achieved recognition by The Seasons (1730), originally published separately, beginning with Winter (1726), in Miltonic blank verse. His Alfred, a Masque (1740) contained the song Rule, Britannia. Thomson used the forms of the classical age to which he belonged but some of his rapturous descriptions of nature in The Seasons presaged Romanticism.

Thomson, James (1834-1882). British poet, born in Scotland. Brought up in poverty, he tried various careers, including that of an army instructor from which he was dismissed in 1862 . He went to London where he lived a lonely life, made worse by the use of stimulants and drugs to relieve illness and melancholy. Friendship with Charles *Bradlaugh enabled him to contribute to the National Reformer, for which he wrote his most famous poem, The City of Dreadful Night (1874), in which London is pictured as a city of despair. He attached the initials B. V. (Bysshe Vanolis) to his name.

Thomson, Sir Joseph John (1856-1940). English physicist, born in Manchester. Educated at Owens College and Trinity College, Cambridge, he became Cavendish professor of experimental physics at Cambridge 1884-1918 and Master of Trinity 191840. He discovered (1897) the electron and deduced that cathode rays consist of these sub-atomic particles. This work laid the foundations of modern atomic physics. He invented (1911) positive-ray analysis and showed that the naturally occurring elements are mixtures of isotopes. He won the Nobel Prize for Physics (1906), received the OM (1912) and the Copley Medal (1914) and became President of the Royal Society 1915-20. Eight of his students became Nobel Laureates.

His son, Sir George Paget Thomson (1892-1975), won the Nobel Prize for Physics (1937) for discovering the diffraction of electrons by transmission through crystals jointly with the American physicist C. J. *Davisson who had made the same discovery by a different method. He was professor of physics at Aberdeen 1922-30 and at Imperial College, London 1930-52, and knighted in 1943.

Thomson, G. P., J. J. Thomson and the Cavendish Laboratory in his Day. 1964.

Thomson, Virgil (1896-1989). American composer and critic. His works, notable for their economy and simplicity of style, include symphonies, sacred choral music and two operas with libretti by Gertrude *Stein. 
Thomson of Fleet, Roy Herbert Thomson, 1st Baron (1894-1976). Canadian newspaper proprietor. After small beginnings as a seller of radio equipment, he acquired radio stations and newspapers in Canada, breaking into the British market with the purchase of the Scotsman (1953). His greatest single acquisition was the *Kemsley Newspaper groups (1959) which included the Sunday Times. He became a British citizen in 1963 and was given a peerage in 1964. The Thomson Corporation bought The Times, London in 1966, selling it to Rupert *Murdoch in 1981.

Thoreau, Henry David (1817-1862). American poet, essayist and mystic, born in Concord, Massachusetts. His birthplace became the centre of his life: he returned there after graduating at Harvard, where he added a love of the classics, especially of ${ }^{*}$ Homer, to that of the English poets whom he already knew. His first book, $A$ Week on the Concord and Merrimack Rivers (1849), intertwines philosophy and observation. From Concord he went into a twoyear retreat in a cabin which he constructed at Walden Pond. The record of that experience, contained in his most famous book, Walden (1854), remains an American classic. It tells a story interesting in itself and is important as a study of nature, but its greatest significance is derived from the revelation of his own idealistic faith. Nor was his faith a matter of theory only, he preferred prison to paying a poll tax to sustain the Mexican War. Essays such as Civil Disobedience (1849) provided texts for *Gandhi and many other fighters for liberty. Much of his later life was spent in travel and nature study in Canada and the area round Cape Cod. He returned to Concord to die.

Harding, W., The Days of Henry Thoreau. 1965.

Thorndike, Dame (Agnes) Sybil (1882-1976). English actor. Her first successes were with Annie Horniman's repertory company in Manchester and in 1908 she married the actor (Sir) Lewis Casson. At the Old Vic, London (1914-18), working with Lilian *Baylis, she was effective in *Shakespeare and as Hecuba in *Euripides' The Trojan Women. *Shaw wrote St Joan (1924) for her and she played the title role 244 times in its first London season. She received a DBE in 1931. She appeared in 15 films, toured widely and continued to play in old age, making a hit in a revival of Arsenic and Old Lace (1966).

Trewin, J. C., Sybil Thorndike. 1955.

Thornhill, Sir James (1675-1734). English painter. He is best known for the decorative murals he painted for *Wren's hall at Greenwich, for the dome of St Paul's Cathedral and for great baroque houses such as Blenheim. His portraits included one of the criminal Jack Sheppard. Knighted in 1720, he was appointed history painter to the king in $1728 .{ }^{*}$ Hogarth became his son-in-law (1729) and they collaborated in a conversation piece of the House of Commons (1730).
Thorpe, (John) Jeremy (1929-2014). English Liberal politician, born in London. Educated in the US, Eton and Oxford, he became a barrister and television journalist. Liberal MP 1959-79, he became Leader of the Liberal Party 1967-76, which won 6 million votes in the election of February 1974. In 1979 he was tried (with three others) with conspiracy to murder Norman Scott, who had been blackmailing Thorpe about his homosexuality. All four were acquitted but Thorpe's career was destroyed.

Thorvaldsen, Bertel (1768/70-1844). Danish sculptor. He spent most of his life in Rome and came to be recognised as the chief exponent of neoclassicism after ${ }^{*}$ Canova. Modern taste has rebelled against the smooth perfection of his style but his contemporary success was immense. Among his patrons was ${ }^{*}$ Napoléon, who commissioned a frieze of *Alexander's campaigns. He left all his unsold works, religious and classical, to his country and they are collected with casts of many other of his important works, in the Thorvaldsen Museum, Copenhagen.

Thrale (Piozzi), Hester Lynch (née Salusbury) (1741-1821). English writer, born in North Wales. She had learning, vivacity and charm, but was unsuitably married to a wealthy Southwark brewer. At her country house at Streatham she entertained a lively, intellectual circle including Samuel *Johnson. The house became his second home. He was outraged when, three years after her husband's death (1781), she announced her impending marriage to Gabriel Piozzi and later lived happily with him in Wales. She published a book of anecdotes about Dr Johnson (1786) and his correspondence with her (1788).

McCarthy, W., Hester Thrale Piozzi. 1986.

Throckmorton, Francis (1554-1584). English conspirator. He became entangled in plots to restore Roman Catholicism in England and to bring *Mary Queen of Scots to the English throne. Caught in the act of writing in cipher to Mary, he was tortured and executed. He came from a family long distinguished in public affairs: his uncle, Sir Nicholas Throckmorton (1515-1571), served Queen *Elizabeth well as Ambassador in France and Scotland. Elizabeth Throckmorton, daughter of Sir Nicholas, was ladyin-waiting to Queen Elizabeth but was disgraced for marrying Sir Walter *Raleigh.

Thucydides (c.470-400 BCE). Athenian historian. Naval commander in the Peloponnesian War, for his failure to capture Amphipolis (424) he was forced to live in exile for 20 years. He then wrote his famous unfinished history of the war which carries the story as far as 411 . The first book is introductory and discloses his own methods of impartial record. The remainder contain in chronological sequence narratives of the summer campaigns alternating with accounts of diplomacy in the winter months. An exception to this method is the interpolation of speeches said to have 
been made by the characters concerned but in reality expressing the author's summing up of the situations. Lucid, impartial and often writing with restrained passion, Thucydides created the greatest historical work to survive from the ancient world.

Romilly, J. de, Thucydides and Athenian Imperialism. 1963.

Thunberg, Greta Tintin Eleonora Ernman (2003-). Swedish climate change campaigner. A student, from 2015 she devoted herself to climate activism and called on world leaders to act courageously. She attracted enemies but won international awards for her blunt advocacy.

Thurber, James Grover (1894-1961). American humorist, born in Columbus, Ohio. He worked on the New Yorker for many years and won fame with his essays, stories and drawings, the last especially noted for the originality of their anarchic humour. Among his favourite subjects were dogs, dominating women and the pathetic little men whom they owned. Sometimes his cartoons accompanied his text, sometimes they stood alone. His publications include My Life and Hard Times (1933), Men, Women and Dogs (1943) and a later work, The Years with Ross (1959); Harold * Ross being editor of the New Yorker. Thurber suffered from deteriorating sight, the result of an accident as a boy.

Kinney, H., James Thurber. 1995.

Thurmond, J(ames) Strom (1902-2003). American politician, born in South Carolina. A lawyer, he became Governor of South Carolina 1947-51 and ran for president in 1948 as candidate of the Dixiecrat (States' Rights) Party, winning four states. A US senator 1954-56; 1956-2003, he joined the Republicans in 1964 and, in December 2002, became the first centenarian to serve in the Congress.

Thutmose III (Thothmes) (d.c.1450 BCE). Egyptian pharaoh 1504-1450 BCE. Until 1482 he shared power with his stepmother ${ }^{*}$ Hatshepsut then proved to be probably Egypt's greatest ruler. He led 17 campaigns into Asia, conquered Syria and Mesopotamia, extended Egyptian trade, built temples and erected many obelisks. He raised Egypt to its greatest power and was a skilled horseman and archer.

Tiberius (Tiberius Claudius Nero) (42 BCE-37 CE). Roman Emperor 14-37 CE. Son of a high priest and magistrate Tiberius Claudius Nero and ${ }^{*}$ Livia Drusilla, later wife of *Augustus, he was adopted by his step-father, whom he succeeded. As early as 15 BCE he had shown his abilities as a soldier on the Alpine frontiers and later he achieved further successes in Germany, his troops by 9 BCE having reached the Elbe. To further Augustus' dynastic scheme he was now forced to divorce his wife Agrippina, whom he loved, and marry the Emperor's widowed daughter, Julia. Partly in anger, partly to conceal Julia's notorious profligacy, Tiberius withdrew to Rhodes. This act cost him the favour of the Emperor by whom it was misunderstood. However, the sudden death of his two grandsons left Augustus no choice: Tiberius was recalled, adopted (4 CE) and acknowledged, as his colleague and heir. During the first eight years of his reign he showed his old efficiency, though he also appeared pedantic, austere and suspicious. From 23, however, he fell more and more under the influence of the ambitious and unscrupulous *Sejanus, prefect of the imperial guards. In 26 Tiberius retired to the island of Capri whence stories of unspeakable and improbable orgies (he was nearing 70) drifted back to Rome, where Sejanus, now in undisputed control, exercised a corrupt tyranny. In 31 Tiberius roused himself to organise with his usual skill the downfall of Sejanus but in his last years he was embittered and disillusioned. Outside Rome and in the provinces his reign was remembered as one of prosperity and enlightened rule. The ministry and crucifixion of *Jesus Christ occurred during his reign.

Tibullus, Albius (c.60-19 BCE). Roman poet. A friend of *Horace, his love poems and those descriptive of the countryside are tender and charming.

\section{Tichborne Claimant, the, see Orton, Arthur}

Tiepolo, Giovanni Battista (1696-1770). Italian decorative painter, born in Venice. The finest exponent of the late baroque or rococo styles in Italy, his pictures were often contrived to enhance architectural effects by being allowed to 'escape' from their frames or the spaces where they were assigned. From 1733 to 1750 he flooded the palaces and churches of northern Italy with examples of his work, sometimes aided by assistants (including his sons), who, however, had no hand in the oil sketches from which pictures were worked up. Outstanding is the festive and theatrical Banquet of Cleopatra (1743-44) in the National Gallery of Victoria. In 1750 he was commissioned to decorate ${ }^{*}$ Neumann's architectural masterpiece, the Warzburg Residenz in Germany, for which he produced some of his greatest work. His last years (from 1762) were spent in Spain, decorating palaces in Madrid and Aranjuez, where the light and airy atmosphere of earlier work is carried to the point where his pictures seem to dissolve in light.

Morassi, A., G. B. Tiepolo: His Life and Work. 1955.

Tiffany, Louis Comfort (1848-1933). American glass designer. Son of Charles Lewis Tiffany (18121902), a jeweller who established Tiffany \& Co. in 1853, he invented 'favrile' (iridescent) glass and developed an ornate art nouveau style for lampshades, jewellery and decorative windows, combining glass and metals.

Tiglath-Pileser III (d.727 BCE). King of Assyria 745-727 BCE. Like his namesake Tiglath Pileser I (1114-1076 BCE), whose conquests, however, 
proved ephemeral, he overcame Babylon and became its king in 729. He occupied Syria, Phoenicia and Palestine. He was an able strategist, preferring blockade to invasion, an efficient administrator and a formidable archivist.

Tilden, Bill (William Tatum) (1893-1953). American lawn tennis player. Distinguished by his great size, he was the leading amateur player of the early 1920s. He led the US Davis Cup team to seven straight victories (1920-26). After an intervening period of French domination (Jean *Borotra) he again won (1930), at the age of 37 , the singles title at Wimbledon. In the following year he turned professional. His career was destroyed by disclosure of his homosexuality.

Tilden, Samuel Jones (1814-1880). American lawyer and Democratic politician. A protégé of Martin *Van Buren, he became a successful corporation lawyer and made a fortune in assisting railway development. He managed the presidential campaign of Horatio *Seymour in 1868 . He broke with the Tammany Hall faction in New York in 1871 and built a reputation as a reformer. Governor of New York State 1875-76, he won the Democratic nomination for President in 1876 on the second ballot. He won 51 per cent of the popular vote but the Republican candidate, Rutherford B.*Hayes, secured a one vote majority (185 to 184 ) in the Electoral College. The Democrats challenged the results in South Carolina, Florida and Louisiana, where under 'Reconstruction', 'carpetbaggers' from the North were able to manipulate returns. An Electoral Commission was set up in 1877 which, by a majority of one, awarded all the disputed votes to Hayes. Democrats accepted the result on condition that Federal troops were withdrawn from the South and Reconstruction ended. Tilden hoped to be nominated again in 1880 , but the Democrats in New York were deeply split and turned against him.

Tillerson, Rex Wayne (1952- ). American engineer, business executive and government official, born in Texas. Educated in Texas, he worked in the Middle East for ExxonMobil and became its President and CEO 2006-16. He joined the *Trump Administration as Secretary of State 2017-18, but his views on climate change, free markets, international co-operation and negotiations with Iran and North Korea were disregarded. He was dismissed by Trump in March 2018.

Tillett, Ben(jamin) (1860-1943). English trade union leader and Labour politician. Having organised the Dockers Union (1887) he remained its General Secretary until it amalgamated (1922) with the Transport and General Workers Union; he was closely associated with the famous strike of 1889 . He was Labour MP for North Salford 1917-24 and 1929-31.
Tillich, Paul Johannes (1886-1965). American theologian, born in Germany. He left Germany in 1933 and taught at the Union Theological Seminary in New York 1933-54, Harvard 1954-62 and Chicago 1962-65.

Tilly, Johann Tserclaes, Count of (1559-1632). Flemish soldier, born in the castle of Tilly in Brabant. He had fought for Spain and against the Turks before entering the service of Maximilian, Duke of Bavaria (1610). On the outbreak of the Thirty Years' War (1618) he commanded the armies of the Catholic League. He gained early successes at Prague and in the Palatinate and forced Denmark to come to terms by his victory at Lutter (1629). He succeeded *Wallenstein (1631) as Commander-in-Chief of the imperial armies and those of the League, but in 1632 was routed by ${ }^{*}$ Gustaf II Adolf at Breitenfeld and in a second defeat was mortally wounded.

Timoshenko, Simeon Konstantinovich (18951970). Russian (Ukrainian) marshal. He was Commissar for Defence 1940-41 until *Stalin took the job and made him Commander-in-Chief in the Ukraine 1942. He was blamed for failing to halt German advances and was shunted to the sidelines.

Timothy (Timotheus) of Ephesus, St (c.17-c.97 CE). Greek-Jewish bishop and martyr, probably born in Lystra (Anatolia). Son of a Greek father and Jewish mother, he became the associate and travelling companion of $\mathrm{St}^{*}$ Paul in his missions. The first bishop of Ephesus c.64-97, he was stoned to death there. The Epistles to Timothy in the New Testament, with that supposed to be addressed to Titus, are called the 'pastoral Epistles'. On grounds of style and content, modern critics have rejected Pauline authorship, but the personal details suggest that they have a basis in letters written by St Paul, though probably enlarged and adapted for his own purposes by a later editor.

Timur (Timur Lenk, Timurlane: called 'the Lame') (1336-1405). Turko-Mongol conqueror, born near Samarkand. Said to have been descended from ${ }^{*}$ Genghis Khan in the female line, despite being crippled from birth he took advantage of a period of Muslim anarchy to establish his rule in Samarkand by 1369, and assumed the title of Great Khan. For the rest of his life he followed a career of conquest with extreme brutality in war but with firm, just rule over conquered territory and with an appreciation of the arts. By 1385 he was master of all central Asia: his armies had conquered Persia, Georgia and Armenia, had defeated the Tartars and marched as far north as Moscow. He invaded India (1398), sacked Delhi and founded a sultanate which later grew into the Moghul empire. After overrunning Syria he smashed the Turkish army at Ankara (1402). He died while preparing to invade China. Among English plays inspired by his career are *Marlowe's Tamburlaine the Great (1590) and Nicholas* Rowe's Tamerlane (1702). 
Tinbergen, Jan (1903-1994). Dutch economist. He served on the staff of the Central Bureau of Statistics at The Hague, 1929-36 and 1938-45 and between 1936 and 1938 he was engaged in research on commerce for the League of Nations. He was director of the Central Planning Bureau at The Hague 1945-55, and professor of development planning, first at Rotterdam and then Leyden universities until 1975. He shared the first Nobel Prize for Economic Science in 1969 with Ragnar *Frisch for their work in developing econometrics. His brother, Nikolaas Tinbergen (1907-1988), an experimental zoologist, taught at Oxford from 1949 and was professor in animal behaviour 1966-74. He wrote The Study of Instinct (1951) and Animal Behaviour (1965) and shared the 1973 Nobel Prize for Medicine with Karl von *Frisch and Konrad *Lorenz for their pioneering work in ethology.

Tinbergen, J., Developing Planning. 1968.

Tintoretto (Jacopo Robusti) (1518-1594). Italian painter, born in Venice. Son of a dyer (hence the name by which he is known), except for short visits he seems to have spent all his life in Venice. Here with his wife and children he lived happily, respected for his piety and increasingly renowned for his work. His fellow Venetian, *Titian, in whose studio he worked for a time, and ${ }^{*}$ Michelangelo, were the strongest influences on him but mainly he was self-taught. In his earlier works, many of them mythological, he continued the ideals of the High Renaissance but as the Counter Reformation proceeded and he became more and more absorbed by religious themes he gradually became the most robust exponent of the style loosely called 'Mannerism'. In his St Mark series (1548) the thunderous atmosphere, the glowing and insubstantial architecture, the perspective effects produced by design and lighting, exemplify the vigour and inventiveness of Tintoretto's grand operatic manner. His greatest undertaking was the decoration of the Scuola de San Rocco in Venice. In the Doge's Palace he executed an enormous Paradise, in which the milling, over-crowded figures are manipulated with the control of a master choreographer. His portraits of the celebrities of his day are much less spectacular and rely upon characterisation more than upon the splendour of the garments. His last pictures at San Giorgio Maggiore, especially The Last Supper (1591-94), show the final culmination of his colour techniques.

Tippett, Sir Michael Kemp (1905-1998). English composer. A late developer, in striking contrast to *Britten, he studied at the Royal College of Music and was musical director of Morley College, London (1940-52). He was jailed as a conscientious objector in 1943. The Elizabethan composers and *Purcell as well as later influences, e.g. *Stravinsky, *Hindemith and jazz, all contributed to his highly individual idiom, notable for springy rhythms and for 'long-breathed' melodies that are woven into an elaborate contrapuntal texture. His works include four symphonies, a Concerto for Double String Orchestra (1939), a Piano Concerto (1956), string quartets, operas to his own libretti The Midsummer Marriage (1954) and King Priam (1962) the oratorio A Child of our Time (1944), and the cantata The Vision of St Augustine (1966). In the Concerto for Orchestra (1963) he constructs the movements out of consecutive sections each associated with a certain group of instruments. He was knighted in 1966, given the $\mathrm{CH}$ in 1979 and the $\mathrm{OM}$ in 1983.

Kemp, I. (ed.), Michael Tippett. 1965; Soden, O., Michael Tippett: The Biography. 2019.

Tipu Sultan (Fateh Ali Sahab Tipu) (1750-1799). Indian ruler. Son of ${ }^{*}$ Haidar Ali, from whose French officers he acquired his military skill, he became Sultan of Mysore on his father's death (1782). The peace (1783) between Great Britain and France, to which he as France's ally adhered, gave him time to consolidate his rule, but in 1789 , moved by an almost obsessional hatred of Britain, he invaded the protected territory Travancore and, as a result of the retaliatory war by Britain, lost half his territory (1792) and had to pay a huge indemnity. As he continued to intrigue, however, the war was renewed (1799), he was quickly driven back into his capital Seringapatam, and was killed when the city was stormed after two months' siege. Tippoo was fanatical and cruel, but as a ruler showed great industry and (e.g. by a new currency and calendar reform) interest in his country's welfare.

Tirole, Jean (1953- ). French economist. He taught at Toulouse University, winning the Nobel Prize for Economics in 2014 for his work on market power and regulation, and on taming powerful firms.

Tirpitz, Alfred, Graf von (1849-1930). German admiral. He commanded the East Asia fleet, based on Tsingtao 1896-97, before his appointment as Secretary of State for the Imperial Navy (1897), becoming the driving force behind the successful campaign for a greater German navy. $\mathrm{He}$ was dismissed (March 1916) because his demand for ruthless submarine warfare, adopted later, was considered premature. He thus missed the Battle of Jutland. He founded the Fatherland Party and was elected to the Reichstag 1924-28.

Steinberg, J., Yesterday's Deterrent. 1965.

Tiselius, Arne Wilhelm Kaurin (1902-1971). Swedish chemist. Appointed professor of biochemistry at Uppsala (1938), he became known for his application of electrophoresis to the analysis of proteins, especially serum proteins. He also adapted chromatographic techniques to the analysis of colourless substances. From its foundation (1946) he was President of Sweden's State Council for Research in Natural Sciences. He won the Nobel Prize for Chemistry (1948). 
Titian (Tiziano Vecellio) (c.1488-1576). Italian (Venetian) painter, born in Pieve di Cadore. Apprenticed to a mosaicist at nine, he entered the studio of Giovanni *Bellini and later studied with *Giorgione, who influenced his early work. However, an independent style is already apparent in the first of his famous works, Sacred and Profane Love (c.1515) a work, despite its allegorical subject, of human realism. From this time his technique steadily developed. Experiments are made with figures in action, pyramidal shapes and diagonals become the compositional bases of several of his works, and significance is given to the main figures by use of light and shade. From 1516 to 1530 the series of great religious pictures, including the Assumption of the Virgin (1516-18) and the Madonna with Members of the Pesaro Family (1519-26), are matched by equally great mythological paintings for Alfonso d'Este, Duke of Ferrara, e.g. Bacchus and Ariadne (1521, now in the National Gallery, London). By then the richness of his palette, with its bright reds, blues, greens and golden browns, sometimes used in contrast, sometimes to build up an almost sculptural effect, had established him as one of the boldest colourists so far known. In such works and in his portraits he is said to have 'liberated' colour, a further sign of freedom being the broad brush strokes with which it was applied. For much of the decade that followed (1530-40) he worked for the emperor, ${ }^{*}$ Charles $V$, portraits of whom and the members of the court, kept him busily occupied. One of the best of the emperor himself (now in the Prado, Madrid) shows him full length with a dog. Portraits of Pope *Paul III and other members of the Farnese family reveal a growing power to probe the character of his subjects. From 1556, when Charles V abdicated, Titian's principal patron was his son, *Felipe II of Spain, for whom he painted a series of 'poesies' Diana and Actaeon, The Rape of Europa, Perseus and Andromeda etc.- - similar in subject to the earlier mythological pictures but painted with much softer, almost iridescent colours. Titian continued to paint to the end of his life, his last work being an unfinished Pietà intended for his own tomb. Titian's painting is warmly emotional and sensual. He was no intellectual and attempted no superhuman scale of effect. His painting techniques were developed by *Rembrandt, *Rubens and *Velázquez, with whose greatness his can be compared. He died very rich and has been called 'the first artist tycoon'.

Hope, C., Titian. 1980; Hale, S., Titian. 2013.

Tito, Josip Broz (1892-1980). Yugoslav politician and marshal, born in Kumrovec, Croatia. Son of a locksmith, he was conscripted into the AustroHungarian army in World War I, was taken prisoner and remained in Russia to serve in the Red Army during the Civil War. Back in Yugoslavia he helped to form the Communist Party and took the name 'Tito'. Imprisoned (1928-34), he became active in the interests of his party in Paris and Central Europe, recruiting for the Spanish Civil War. Secretary-General of the party from 1937, he returned to Yugoslavia in 1939 and in 1941, after the Germans had overrun the country, became a leader of partisans whose task was to harry the occupying forces.

This brought him into conflict with a rival resistance leader, General *Mihailovich, who was acting in the royalist interest. Eventually the Allies decided to give Tito, the more active of the two, full support. This enabled him, after the German defeat, to execute Mihailovich, to exclude King * Peter and to establish a Communist state. He was Prime Minister 194553 and President 1953-80. In 1948 Yugoslavia was expelled from the Cominform for adopting nationalistic policies (i.e. for rejecting Russian dictatorship). Eventually relations became less strained and in the following years Tito maintained an independent Communism at home, opened trading relations with the west, and kept a clever balance between the rival groups or powers who dominated Europe.

Auty, P., Tito. 1970.

Titus (Titus Flavius Vespasianus) (39-81 CE). Roman Emperor 79-81. Elder son of the emperor *Vespasian, he was a brilliant soldier and, after his father's elevation, quickly brought the Jewish rebellion to an end by the capture of Jerusalem. He became virtual co-ruler with Vespasian and on his succession not only delighted the Roman populace by his magnificent displays but won esteem by firm, just rule and by his discouragement of flatterers and informers. His popularity was threatened only by his passion for the Jewish Berenice (the Bernice of Acts xxv), whom he had brought to Rome but soon dismissed. He completed the Colosseum and did much to help the survivors of the tragic eruption of Vesuvius (79).

Tizard, Sir Henry Thomas (1885-1959). English chemist. Educated at Oxford, he worked on aeronautical research in World War I and, later was Rector of the Imperial College of Science and Technology 1929-42 and President of Magdalen College, Oxford 1942-46. He chaired the Air Defence Committee 1935-40, became the great advocate of radar and clashed with Churchill's advisor, Lord ${ }^{*}$ Cherwell. He opposed saturation bombing of German cities and became Chairman of the Advisory Council on Scientific Policy 1947-52.

Tobin, James (1918-2002). American economist. A Keynesian, he was Professor of Economics at Yale 1957-88, won the Nobel Prize for Economics in 1981 and proposed the 'Tobin tax' on global financial transactions.

Tocqueville, Alexis de (1805-1859). French political writer, born in Paris. He came of an aristocratic family, studied law, and in 1831 visited the US with Gustave de Beaumont to investigate the penal system and wrote the extraordinarily vivid Du Système pénitentiare 
aux Etats-Unis (1833), with a long appendix on the Australian system. Writing and an incursion into French politics occupied the rest of his life. He became a deputy 1839-48, Foreign Minister June-October 1849 and in 1851 was imprisoned for opposing the coup d'état of Louis Napoléon (*Napoléon III). In his two well known books La Démocratie en Amérique (1835-39) and L'Ancien Régime et la Révolution (1856, 1859), he concluded that by abolishing aristocracies (with their inborn protection of the rights and privileges of the different social classes), the peoples both of France and America had sacrificed liberty for equality, that demands for economic equality must necessarily follow those for social equality and that the final result must be authoritarian, centralised rule. His arguments were given point by the rule of *Napoléon I and Napoléon III in his own epoch, and his foresight justified by the centralising tendencies of modern democratic governments.

Brogan, H., Tocqueville. 1973.

Todd, Alexander Robertus, Baron Todd (19071997). British chemist, born in Glasgow. As professor of chemistry at Manchester 1938-44 and then professor of organic chemistry at Cambridge 194471 , he made a notable contribution in the fields of vitamins and drugs, particularly in the elucidation of nucleotide structure, and synthesised ATP in 1948. He chaired the Advisory Council on Scientific Structure 1952-64, won the 1957 Nobel Prize for Chemistry, and received a life peerage (1962), the Copley Medal (1970) and the OM (1977). He was President of the Royal Society 1975-80.

Todd, Sir (Reginald Stephen) Garfield (1908-2002). Zimbabwean (Rhodesian) politician, born in New Zealand. A missionary and teacher, as Premier of Southern Rhodesia 1953-58 he introduced reforms to education and labour laws that challenged white minority rule and he was displaced. Originally sympathetic to ${ }^{*}$ Mugabe, he denounced him as corrupt.

Todleben, Eduard Ivanovich (1818-1884). Russian soldier. He developed a genius for military engineering and won international fame for his defence of Sebastopol (1854-55) during the Crimean War. In the Russo-Turkish War (1877-78) he was put in charge of the siege of Plevna, which he eventually captured.

Todt, Fritz (1891-1942). German engineer. He shared with ${ }^{*}$ Hitler a taste for the grandiose, and undertook much of the constructional work under the Nazi regime (e.g. the autobahns) and the Siegfried line. During World War II, squads of the Todt organisation were most effective in keeping communications open and in bringing factories back into production after bombing attacks. Minister for Armaments and Munitions 1940-42, he died in a plane crash and was succeeded by Albert * Speer.
Toer, Pramoedya Ananta see Pramoedya Ananta Toer

Togliatti, Palmiro (1893-1964). Italian Communist leader. While a student at Turin University he made a study of socialism. In 1926 he became Secretary of the Italian Communist Party (a post he retained until his death) and in that year went into exile and lived abroad, mostly in Moscow, for 18 years (from 1935 as secretary of the Comintern). He returned to Italy (1944) after *Mussolini's fall, and joined Badoglio's Cabinet. He built up the Italian Communist Party to be the second largest party in the country and the largest Communist Party in Western Europe. To secure support he compromised on Communist doctrine to the extent of recognising Roman Catholicism as the state religion and the Lateran Treaty by which the Vatican City became an independent state.

Tōgō Heihachirō, Marquis (né Tōgō Nakagoro) (1848-1934). Japanese Marshal-Admiral. Of samurai descent, he joined the navy in 1863, trained with the RN in England 1871-78, travelling extensively, including Australia. In command of the fleet during the Russo-Japanese War 1904-05, he succeeded in bottling up the Russian Pacific fleet in Port Arthur and then (May 1905) in annihilating (in the Tsushima Straits) a relieving fleet sent from Europe. He received the British OM and GCVO in 1906 and mentored the future emperor ${ }^{*}$ Hirohito.

Tóibín, Colm (1955- ). Irish novelist, essayist, travel writer and editor, born in Wexford. Educated at University College, Dublin, he held chairs in New York and Manchester and spent much time in Spain. His books include Homage to Barcelona (1990), The Sign of the Cross (1994), The Master (2004) and The Testament of Mary (2012).

Tōjō Hideki (1884-1948). Japanese general and politician. Of Samurai descent and son of a general, educated in Europe, he became head of the secret police and Chief of Staff of the Kwantung Army in Manchuria 1937-40. He was Minister for War 194044 and Prime Minister from October 1941 until July 1944, resigning after US forces occupied Saipan, an air base within striking distance of Tokyo. Identified in wartime propaganda as the main Japanese war criminal, he was tried by an international war crimes tribunal and hanged in Tokyo with six others.

Tokugawa. Japanese dynasty. The family controlled the shogunate (hereditary military dictatorship) which, although nominally subject to the Emperor, ruled in reality, from *Ieyasu in 1603 to ${ }^{*}$ Yoshinobu in 1867 .

Tokugawa Ieyasu (1542-1616). Japanese soldier and shōgun, born in Okazaki. He assisted Nobunaga (d.1582) and *Hideyoshi in overcoming the feudal nobility, and after the latter's death (1598) succeeded in establishing in his own Tokugawa family in the 
hereditary Shogunate (nominally subject to the emperor), which lasted until 1867. Shōgun 1603-05, he retired to Shizuoka, but maintained absolute power until his death, ruling through his son, Hidetada. He fought in 90 battles. At first he At first he tolerated the Christians, but, hearing how in other lands the entry of Jesuit missionaries had led to Spanish and Portuguese conquest, he expelled or executed them. He adopted and applied Confucian syncretism to absorb the apparent contradictions of Buddhism and Shinto. For foreign trade he relied on the English and Dutch, and kept William *Adams at his court as advisor on shipbuilding and navigation.

Tokugawa Yoshinobu, Prince (né Matsudaira Shichirōmaro, later Akimune; known as Keiki) (1837-1913). Japanese shōgun, born in Edo (Tokyo). The last of fifteen shogguns in the family, on succeeding his cousin in 1866, he attempted some reforms to strengthen the shogunate and expand linkages with France and Russia. However samurai from the Satsuma, Chōshū and Tosa domains raised an army to force him to relinquish power in favour of the Meiji Emperor (*Mutsuhito) and in November 1867 Yoshinobu abdicated. Although promised a share of power, he was soon stripped of rank and retired to Shinzuoka. He fathered 26 children by his wife and concubines. In retirement, he devoted himself to archery, hunting, painting, photography and cycling, adopted Western dress and was created prince in 1902 .

Tolbukhin, Fyodor Ivanovich (1885-1949). Russian soldier. In World War II, having made his name as a general at Stalingrad, he became commander of the army that swept through the Ukraine (1943), reconquered the Crimea, Romania and Bulgaria (1944) and finally (1945) Budapest and Vienna. He became a marshal in October 1944.

Tolkien, J(ohn) R(onald) R(euel) (1892-1973). English writer and philologist, born in Bloemfontein. He was professor of Anglo-Saxon 1925-45 and of English language and literature 1945-59 at Oxford University. His academic work on early and medieval English texts was highly regarded, but he achieved popular success in fiction. His interest in language and mythology enabled him to create a world with its own cultures, languages and beliefs. The Hobbit appeared in 1937 and the more sophisticated The Lord of the Rings in 1954-55. It speedily attracted a cult following which persisted, especially after the success of Peter *Jackson's The Lord of the Rings film trilogy, The Fellowship of the Ring (2001), The Two Towers (2002) and The Return of the King (2003).

Toller, Ernst (1893-1939). German-Jewish playwright and poet. He was imprisoned for taking part in the Communist rising in Germany after World War I. His plays, e.g. Man and the Masses (1921) and The Machine Wreckers (1923), reflect his revolutionary opinions. He also wrote poetry and autobiographical works. He lived in exile after *Hitler's rise to power, and committed suicide in New York.

Tolstoy, Aleksei Nikolaievich (1882-1945). Russian writer. A distant cousin of Lev ${ }^{*}$ Tolstoy, he went abroad after the Revolution but returned (1922) and soon became well known for science fiction like that of H. G. *Wells. His The Road to Calvary (1945), describing events before and during the Revolution, won a *Stalin Prize. His patriotic play about Ivan the Terrible was a great success during World War II. His best work was an unfinished historical novel, Peter I.

Tolstoy, Lev (Leo) Nikolaievich, Graf [Count] (1828-1910). Russian novelist and moral philosopher, born in Yasnaya Polyana. Brought up on his mother's family estate of Yasnaya Polyana ('Bright Glade'), in Tula province, $190 \mathrm{~km}$ south of Moscow, after the early loss of both parents he was privately educated until he went to Kazan University (1844-47) to study law and languages. A life of ease and mild dissipation followed, but in 1851 he joined the army and from 1853 took part in the Crimean War. This inspired The Sebastopol Stories (1865) which, together with the autobiographical sequence Childhood (1852) and its two sequels, established him as a writer. Life in St Petersburg did not attract him, and he travelled over much of Europe. From 1862 he settled down with his young wife, Sofya Andreyevna Behrs (18441919), became the father of 13 children, and applied himself to the management of his estates, establishing peasant schools on the pattern of those he had seen abroad, attending to the problems arising from the emancipation of serfs and filling the role of a humane and forward-looking landlord. To this happy period belong his two most famous novels.

War and Peace (1865-69) gives an epic account of Russia's conflict with *Napoléon between 1805 and 1813. It pulsates with life, driven by inexhaustible energy, proclaiming human complexity, with characters full of contradictions. About 580 individuals appear, 167 of them historic figures, including *Napoléon, Tsar *Aleksandr I and Marshal ${ }^{*}$ Kutúzov. But despite the complexity, the story is easy to follow.

The outstanding characters are Count Pierre (Pyótr) Bezúkhov, Prince Andréi Bolkónsky and Countess Natásha Rostóva. Pierre inherits wealth, but is tormented by contradictions and injustice and devotes himself, tirelessly but not always successfully, to making sense of his world. He is an observer rather than an activist, often indecisive, plagued by selfdoubt. Prince Andréi, born into a military dynasty, is thoughtful and philosophical, drawn into active service against his better judgment. There have been tragedies in his personal life. The beautiful Natásha, romantic and impulsive, breaks hearts and vacillates. War and Peace is the longest of the great Russian novels, running to 560,000 words. The 
work went through endless revision, and Countess Tolstoy copied the complete manuscript seven times. He made 33 attempts to write a novel on the life of *Peter the Great, but gave up in frustration.

Tolstoy's genius for reaching the heart of women (although not in real life) is shown in the other great novel, Anna Karenina (1874-76). Anna Karénina, married to a workaholic bureaucrat, Count Aleksei Karénin, and mother of Sergei, falls in love with Count Aleksei Kirillovich Vrónsky, a cavalry officer, dashing, handsome, shallow and rich, and goes to live with him. Anna and Vrónsky have a deeply asymmetrical relationship: she is shunned by society, loses access to her son, gives birth to a daughter Anna, while Vrónsky gives up nothing-he continues to socialise, gamble, drink, flirt and he leaves her alone with the child. The most powerful writing in Anna Karenina is based on the triangle of Anna > Aleksei (Karénin) > Aleksei ${ }^{2}$ (Vrónsky) and the tensions arising from family, duty, divorce, custody, desire.

The novel ends with the inevitability of a Greek tragedy. Anna, maddened, confused and despairing, after the collapse of her relationship with Vrónsky, is driven to the Moscow railway station and on the way experiences an astonishing stream of consciousness in which she absorbs sharply etched images of the world she is about to leave. Once at the station, in revenge against Vrónsky and to annihilate herself, she hurls herself under a train.

Tolstoy had always been troubled by inner conflict. His eager acceptance of life and his zestful response to the demands of natural instincts conflicted (as is apparent in his books) with his reactions as moralist and reformer. About 1877 the conflict became acute and he emerged from the struggle as a kind of solitary prophet, revered even by his opponents.

There is a striking parallel between Tolstoy and *Wagner. As artists, each was a genius, with staggering achievements. But in every other area they were cranks. Tolstoy was reactionary and violent as a young man, then became increasingly eccentric in his judgments, finally repudiating all artistic expression, whether in music or literature.

Vladimir *Nabokov wrote: 'Most people approach Tolstoy with mixed feelings. They love the artist in him and are intensely bored by the preacher ... [But] Tolstoy is homogeneous, is one, and the struggle which ... went on between the man who gloated over the beauty of black earth, white flesh, blue snow, green fields, purple thunderclouds, and the man who maintained that fiction is sinful and art immoralthis struggle was still confined within the one man.'

His teachings, set out in What I Believe (1883) and What Then Must We Do? (1886), amounted to Christianity stripped of theology and he called himself a 'Christian anarchist'. The Gospel in Brief (1896) was an attempt to reconcile the four synoptic
Gospels. He denounced all authority and all violence, even in resisting evil. (*Gandhi corresponded with him from South Africa about this, and set up a Tolstoyan commune and school.) Albert *Schweitzer's concept of 'reverence for life' was deeply influenced by Tolstoy. The philosopher Ludwig *Wittgenstein was another Tolstoyan. To reconcile his life with his teachings, Tolstoy became a vegetarian, refused to exploit the services of others and tried (1895) to renounce all property rights in his estate and book royalties. The family quarrels that ensued were of such intensity that they embittered his last years. He was excommunicated by the Synod of the Russian Orthodox Church in 1901.

Tolstoy would have been the obvious choice to receive the first Nobel Prize for Literature in 1901, but he was not nominated, presumably for failing to meet the requirement in Alfred *Nobel's will to have produced 'the most distinguished work of an idealistic tendency'. Instead, the award went to the French Parnassian poet René *Sully Prudhomme. However, Tolstoy was nominated for the Nobel Prize for Peace in 1901, 1902, 1909, and for Literature in 1902, 1903, 1904, 1905, 1906.

Tolstoy's late novels were The Death of Ivan Ilyich (1886) and Resurrection (1899). His short stories include What Men Live By and What Shall It Profit a Man? (1885), and How Much Land Does a Man Need? (1886). Father Sergius (1890), The Kreutzer Sonata (1899) and Hadji Murad (1896-1904, published posthumously in 1912) are novellas. However, his reputation as a novelist, perhaps the greatest in all literature, rests on his famous two works.

Tolstoy had a cranky, totally dismissive, attitude towards *Shakespeare, accusing him of arousing 'irresistible repulsion and tedium'. He had an irrational hatred of King Lear because in his last years, when he tried to renounce his wealth, rank and possessions, he was living Lear's life. George * Orwell wrote an important essay, 'Lear, Tolstoy and the Fool'. Tolstoy became increasingly critical of his two masterpieces, and dismissive of all high art forms.

In his last decades, Tolstoy became an international celebrity. He appeared in many newsreels. His estate at Yasnaya Polyana and house in Moscow attracted pilgrims from all over the world and he conducted a large correspondence with disciples. His death, in 1910, at the stationmaster's cottage at Astapovo, after he had run away from home, was recorded by the world's newsreel photographers but he refused to see his wife.

Steiner, G., Tolstoy or Dostoevsky 1959, rev. 1967; Troyat, H., Tolstoy. 1965; Parini, J., The Last Station. 1990; Wilson, A. N., Tolstoy: A Biography. 2001; Bartlett, R., Tolstoy. A Russian Life. 2010. 
Tombaugh, Clyde William (1906-1997). American astronomer. Essentially self-taught, he worked at the Lowell Observatory, Flagstaff. Arizona (1929-43). In February 1930 he identified the 'planet X' which Percival *Lowell had hypothesised from 1905 . This ninth planet of the solar system was named Pluto. Tombaugh took his first degree in 1936 and became a professor in New Mexico 1955-73. In 2006 Pluto was reclassified by the International Astronomical Union (IAU) as a 'dwarf planet'.

Tomlinson, Ray(mond Samuel) (1941-2016). American computer programmer. Recognised as the implementer of email (electronic mail); the first system operated from 1971, first on the ARPANET system, then it became universal with the Internet.

Tompion, Thomas (1639-1713). English clockmaker. Both his father and grandfather were blacksmiths, which may have set his mind to working in metals but cannot account for the extraordinary skill and artistry he brought to his craft. The first clocks for Greenwich Observatory were built by him (1676). For *William III he made a clock that would strike the hours and quarters for a year without rewinding. Survivors of the 650 clocks made by him now fetch very high prices. In addition he made about 5500 watches, including some of the earliest to be fitted with balance springs.

Tone, (Theobald) Wolfe (1763-1798). Irish politician. Having become convinced that only independence would bring about Roman Catholic emancipation and overcome the many injustices of British rule, he formed the Society of United Irishmen (1791) and in 1795 left the country to seek help in America and France. He accompanied the French invasion fleet (1796) and after its failure returned to Ireland with a small squadron to aid the rebellion of 1798. Defeated and captured by the British, he killed himself in prison while awaiting execution. His journals show him to have been a man of good nature, gaiety and wit.

Tooke, John Horne (1736-1812). English politician. His father's name was Horne, and he added the name Tooke (1782) at the request of a rich friend of that name. He became a clergyman as a young man but spent his life in political agitation, at first on behalf of John *Wilkes, but after a quarrel he formed (1771) the Constitutional Society to agitate for parliamentary and economic reform. In 1777 he was imprisoned for raising money for American troops 'murdered' at Lexington (in the War of American Independence). He filled the time by writing The Diversions of Purley (published 1786 and 1805), which, amid much philological, metaphysical and political comment, pointed to the need for studying Anglo-Saxon and Gothic. His attitude when the French War opened caused him to be tried for treason (1794), but he was acquitted. After two failures to enter parliament he was elected for Old Sarum in 1801, but unseated, as a clergyman.

Torquemada, Tomás de (1420-1498). Spanish inquisitor. A Dominican friar, having become confessor to Queen *Isabella easily persuaded her and King *Ferdinand I (jealous of the rich Moors and Jews of Castile) to ask the pope for the Inquisition to be established in Spain. In 1483 he became the first inquisitor-general, and centralised and organised a campaign of torture hitherto unparalleled. $\mathrm{He}$ was largely instrumental in the expulsion of the Jews (1492).

Torricelli, Evangelista (1608-1647). Italian physicist and mathematician. He succeeded (1642) his former teacher ${ }^{*}$ Galileo as professor of mathematics at the Florentine Academy. He demonstrated (1643) the first man-made vacuum (soon known as the Torricellian vacuum) in experiments with a long glass tube inserted in a trough of mercury. This also proved that the weight of the atmosphere was equivalent to a column of $760 \mathrm{~mm}$, and became the principle of the mercury barometer. He also discovered the law (now known as Torricelli's Law) governing the flow of liquids through small holes.

Torrigiano, Pietro (1472-1528). Florentine sculptor. He had to leave Florence after breaking *Michelangelo's nose in a fight. He worked in the Netherlands (1509-10) and then went to England, where he did some of his best work, notably the tombs of Margaret Beaufort, *Henry VII, and his wife, Elizabeth of York, in Westminster Abbey.

Toscanini, Arturo (1867-1957). Italian conductor, born in Parma. Trained as a cellist, he made his debut as a substitute conductor in Rio de Janeiro in 1886 and quickly rose to prominence. He premiered *Puccini's La Bohème in Turin (1896). He was Chief Conductor at La Scala, Milan 1898-1903, 1906-08 and 1921-24, at the Metropolitan Opera, New York 1908-15, and of the New York Philharmonic Symphony Orchestra (1928-36). As a protest against fascism in Italy and Germany he left Europe in 1937 for the US, where he created and conducted the NBC Symphony Orchestra until his retirement (1954). His repertoire revealed a remarkable catholicity of taste and included not only the German and Italian classics, but composers as different as *Debussy, ${ }^{*}$ Elgar and *Sibelius. This, combined with an astonishing musical memory, deep insight into a composer's meaning, scrupulous (sometimes rigid) fidelity to the score and the driving energy of his interpretations, made him an outstanding (if controversial) conductor. He never performed the music of Gustav *Mahler, his great rival as a conductor.

Sachs, H., Toscanini. 1981. 
Toulouse-Lautrec, Henri (Marie Raymond) de (1864-1901). French painter and lithographer, born at Albi. Descended from an ancient family of southwest France, a fall from a horse broke his thighbones, and he was crippled. Left only 1.55 metres (61 inches) tall, he felt cut off from his family, sought refuge in art and went to Paris in 1882. There, in the cafés and cabarets of Montmartre (e.g. the Moulin Rouge) he found the subjects for his pictures and drawings-dancers, singers and prostitutes-as well as circus and racecourse scenes. He shared the gay, grotesque, dissipated life of those he painted and developed a sympathetic insight into their character. The main influences on his style were Japanese woodcuts and the work of *Degas. In the last decade of his life he mastered lithography and his work in that field had an important influence on the development of poster art.

Joyaut, M., Henri de Toulouse-Lautrec. Repr. 1968.

Tourneur, Cyril (c.1575-1626). English dramatist. His fame rests on two plays, The Revenger's Tragedy (printed 1607) and The Atheist's Tragedy (printed 1611). The greater is the first, a dark, tightly woven intrigue of blood in which the Machiavellian protagonist becomes as corrupt as his opponents. It was very influential on the contemporary theatre.

Tourville, Anne Hilarion de Colentin, Comte de (1642-1701). French sailor. Having made a name for himself against the Turks and the Algerian pirates, he fought the combined Dutch and Spanish fleets (1677), but his great triumph came (1690) when, commanding the French fleet that was aiding the exiled *James II against *William III, he won a dramatic victory over the Dutch and English near Beachy Head. For a time he commanded the Channel and anchored in Torbay. However, he suffered complete defeat when convoying the invasion fleet intended to bring back James II, with the loss of 16 men-of-war in one of the longest naval battles of history (19-24 May 1692). Despite this he was made a marshal of France.

Toussaint l'Ouverture, Pierre Dominique (c.17461803). Haitian leader. Born a slave, he managed to acquire enough education to read French works on *Caesar's and *Alexander's campaigns. The military and diplomatic lessons thus learned he was able to put to good account in the slave rebellion of 1791 from which he emerged as the most important man in the island. When France, then in the throes of revolution, abolished slavery in her colony (1794) he returned there, held the Spanish and British at bay and made himself Governor-General for Life under a new constitution (1801). He would have liked to come to terms with France but *Napoléon Bonaparte, now in control, sent a force against him. Toussaint surrendered (1802) and was taken to France, where he died in prison partly from the hardships inflicted on him. He was a remarkable man, a firm, just and usually humane ruler, though often sharp-tongued and a natural intriguer.

James, C. L. R., The Black Jacobins: Toussaint L'Ouverture and the San Domingo Revolution. 2nd ed. 1963.

Tovey, Sir Donald Francis (1875-1940). English musician and musicologist. Reid professor of music at Edinburgh University 1914-40, he was acclaimed for his Essays in Musical Analysis (6 volumes 193537). Also a pianist, he composed concertos for cello and piano, chamber music and an opera, The Bride of Dionysus (1929). He was knighted in 1935.

Grierson, M., Donald Francis Tovey. 1952.

Townes, Charles Hard (1915-2015). American physicist. He won his $\mathrm{PhD}$ at the California Institute of Technology, then worked at the Bell Telephone Labs, and held chairs in physics at Columbia 1948 61, MIT 1961-67 and CalTech 1967-86. In 1953 he built the first 'maser' (microwave amplification by stimulated emission of radiation) and by 1958 he had worked out the theoretical basis of an 'optical maser', using highly concentrated visible light; this was the 'laser' (light amplification by stimulated emission of radiation'). In 1964 he shared the Nobel Prize for Physics with A. M. *Prokhorov and N. G. Basov for work in quantum mechanics. Masers and lasers became indispensable scientific, medical and industrial tools.

Townshend, Charles, 2nd Viscount (known as 'Turnip Townshend') (1674-1738). English diplomat, politician and agriculturist. He became, on ${ }^{*}$ George I's accession, Secretary of State in the Whig ministry which crushed the Jacobite rebellion of 1715. In 1717 he was briefly Lord Lieutenant of Ireland, but soon was back in office in London, and in 1721 was again Secretary of State, sharing power with his brother-in-law Robert *Walpole. His interventionist foreign policy alarmed Walpole because a close alliance with France would divide Europe into two potentially hostile leagues. Forced to resign (1730), Townshend spent his retirement studying and improving agricultural methods on his Norfolk estates. His introduction of the Norfolk fourcourse crop rotation - wheat, turnips (or other roots), barley, and grass or clove-gained him his nickname.

Townshend, Charles (1725-1767). English politician. Grandson of 'Turnip' *Townshend, educated at Cambridge and Leyden, he was a Whig MP 1747-67 and an epileptic. One of the most brilliant and wayward of 18th-century parliamentarians, he was a thorn in the flesh of any ministry he opposed and equally dangerous to any ministry he joined. In most of the Pitt-Newcastle combinations during the Seven Years' War, he joined and left *Bute, and assailed ${ }^{*}$ Grenville over the question of John ${ }^{*}$ Wilkes. His greatest capacity for harm was seen when he became 
Chancellor of the Exchequer (1766) in the ministry dominated by *Pitt (by then Earl of Chatham), who was, however, so ill that he could only sporadically exercise authority. Thus able to ignore the known wishes of his leader, Townshend, in his anxiety for revenue, introduced a bill to tax all tea, glass, paper and several other products entering American ports. This measure precipitated the events that led to the American War of Independence.

Toynbee, Arnold (1852-1883). English economic historian. His great and influential work, The Industrial Revolution in England (edited by Alfred ${ }^{*}$ Milner and published posthumously in 1884), was originally composed as a course of lectures at Oxford. Its title popularised the term 'industrial revolution' to describe the social and economic changes that transformed British life in the late 18th and early 19th centuries. He gave vigorous support to adult education and did much social work: Toynbee Hall in Whitechapel, London, was built in his memory.

His nephew, Arnold Joseph Toynbee (1889-1975), was a historian, the range and scope of whose work exceeded even ${ }^{*}$ Gibbon. Educated at Winchester and Balliol College, Oxford, he worked in the Foreign Office during both World Wars, taught at London University as professor of Byzantine and Modern Greek language, literature and history 1919-25 and research professor of international history 192555. His A Study of History (12 volumes, 1934-61) analyses the growth and decay of past civilisations and contends that their survival depends on their response to internal and external challenges. He supports his arguments by a mass of illustrative material, fascinating in itself and indicative of his astonishing industry and receptivity of mind. He was awarded a $\mathrm{CH}$ in 1956. Critics complained that he selects examples that support his argument but neglects those that appear to counter his main thesis, and his reputation diminished after his death.

Toyoda Sakichi (1867-1930). Japanese inventor and industrialist. In 1897 he invented an automatic power loom and the Toyoda Automatic Loom Works, set up in 1926, became the centre of a diversified industrial empire. His son Toyoda Kiichiro (1894-1952) established the Toyota Motor Corporation at Koromo (now Toyota City) and the first model Toyota car was produced in 1937. By 1955 Toyota was the world's third largest producer and by 1990 had plants in 22 countries.

Tracy, Spencer (1900-1967). American actor. Originally intended for the priesthood, he became a stage actor, starting in tough guy roles, and made the first of 72 films in 1930. He won two Academy Awards (1937, 1938), received seven more nominations and co-starred in eight films with Katharine *Hepburn, his lover for many years.
Traherne, Thomas (1637?-1674). English religious poet. Educated at Oxford, after some years as a country rector he spent the rest of his life as chaplain to Sir Orlando Bridgeman, Lord Keeper of the Seal. Most of his work appeared after his death and two books of poems were found and printed in 1903 and 1906. Centuries of Meditations, written in musical prose, was printed in 1906 and Poems of Felicity in 1910. His Thanksgiving for the Body showed that he had not the mystic's usual fear of the senses.

Margoliouth, H. M. (ed.), Complete Works of Thomas Traherne. 1958.

Train, George Francis (1829-1904). American eccentric, born in Boston. He pioneered prefabricated buildings in Victoria during the Gold Rush (1853), began the first horse-drawn tram system in Liverpool (1860), and was co-founder of the Credit Mobilier scheme in the US (1863), making and losing millions of dollars. He travelled round the world in 80 days (1870-71), claiming to have been the original of Jules *Verne's Phileas Fogg, ran for president (1872), went to jail 15 times and was certified insane.

Trajan (Marcus Ulpius Traianus) (c.53-117). Roman Emperor 98-117. Born in Italica (near Seville), he was a distinguished soldier, consul under ${ }^{*}$ Domitian and was eventually adopted as heir by the emperor *Nerva. As Emperor he overcame Dacia (central Romania) in two campaigns (101-02 and 105-06) and colonised it with Romans, but his Parthian conquests (113-17) proved ephemeral. His exploits are carved on the column that bears his name in Rome. He was a wise and moderate ruler, as is shown by his fair-minded letter to *Pliny about the treatment of Christians. He arranged the succession of his kinsman ${ }^{*}$ Hadrian.

Trastámara. Spanish dynasty (*Isabella)

Traven, B. (Benick Traven Torsvan) (c.1890-1969). American novelist, born probably in Chicago. Of Swedish or German descent, he kept his identity a close secret, lived in Germany, using a variety of names, including Otto Feige and Ret Marut, and moved to Mexico in 1924. He was an anarchist, deeply opposed to capitalism and imperialism. His novels, published in German, included The Death Ship (1926, translated 1934) and The Treasure of the Sierra Madre (1927, 1934).

Travers, Ben (1886-1980). English playwright. He was a prolific writer of 'the Aldwych farces', most having long runs in London, using the actors Ralph Lynn, Robertson Hare and Tom Walls. A Cuckoo in the Nest was first produced in 1925, Rookery Nook in 1926, Thark in 1927 and Plunder in 1928. There were 24 films based on his plays: the last, The Bed Before Yesterday (1975), was a major success.

Tree, Sir Herbert Beerbohm (1853-1917). English actor-manager. The half-brother of Sir Max *Beerbohm, he was lessee-manager of the Haymarket 
Theatre (1887-97), where he achieved one of his greatest successes, Trilby (1897). Profits enabled him to build Her Majesty's Theatre where, for 20 years, he provided lavish productions of *Shakespeare and other plays (Carol *Reed).

Treitschke, Heinrich von (1834-1896). German historian, born in Saxony. He completed his education in the liberal atmosphere of Leipzig and Bonn Universities, but in the Austro-Prussian War (1866) he completely identified himself with Prussia. When a series of academic appointments had brought him (1874) to Berlin he shared *Bismarck's vision of a united, nationalistic Germany under Prussian leadership. This bias permeates his great History of Germany in the Nineteenth Century (1879-94). Despite prolonged and accurate research, its literary brilliance, and its excellent chapters on the cultural and social achievements of the lesser states, the book provided an armoury of justification for the Prussian militarists who were planning for World War I. He wrote several other volumes of historical and political essays. His usefulness as a member of the Reichstag (1871-84) was much hampered by deafness.

Trenchard, Hugh Montague Trenchard, 1st Viscount (1873-1956). English soldier and airman. A colonel in the Royal Scots Fusiliers, he had fought in South Africa before taking up flying and joining the RFC. In World War I he commanded the British air forces in France and his persistent advocacy brought into being the Independent Air Force and the beginning of strategic bombing. He was Chief of the Air Staff 1918, 1919-29 and became (1927) the first Marshal of the RAF. The RAF was largely the creation of his strategic insight and organisational planning. He was Commissioner of the Metropolitan Police, London 1931-35 and received the OM in 1951.

Boyle, A., Trenchard. 1962.

Trevelyan, Sir George Otto, 2nd Baronet (18381928). English politician and historian. His father was an Indian civil servant, his mother, Harriet, a sister of ${ }^{*}$ Macaulay. He was a Liberal MP 1865-86 and 1887-97 and Secretary of State for Scotland 1886; 1892-95. His books included The Life and Letters of Lord Macaulay (1876), The Early History of Charles James Fox (1880) and The American Revolution (1899-1914). He was awarded the OM in 1911.

His son, George Macaulay Trevelyan (1876-1962), was Regius professor of history at Cambridge 192740 and master of Trinity College 1940-51. His works include a remarkable trilogy on the life of Garibaldi (1907-11), England under Queen Anne (1930), and English Social History (1944), which achieved a great popular success. They read well and were highly praised in their time as literature and history, but his judgments were both cautious and conventional and he left no followers. In 1930 he received the OM. The Trevelyans were the only father and son so honoured until the Duke of ${ }^{*}$ Edinburgh and Prince ${ }^{*}$ Charles.

Cannadine, D., G.M. Trevelyan. 1992.

Trevithick, Richard (1771-1833). English engineer, born in Cornwall. Largely self-educated, he worked as a mining engineer and invented (1798) a pumping engine driven by water pressure. More important was the high pressure steam engine (patented in 1802) which he applied to both road and rail transport. For the latter, to win a bet, he used the Penydaren tramway on which he gave several demonstrations. The engine was also used for a dredging machine when he was working on a tunnel under the Thames (1806). He went to Peru (1816) where his engine was introduced in the silver mines and for a time served as a military engineer under *Bolívar. When he returned after 11 years' absence he was almost forgotten, and when he died while working at Dartford he had to be buried at the expense of his fellow workers.

Trevor-Roper, Hugh Redwald, Baron Dacre (1914-2003). English historian. He studied at Christ Church, Oxford, and taught at the University 1936-80. During World War II he served in military intelligence, which commissioned him to investigate the circumstances of *Hitler's death, published in 1947 as The Last Days of Hitler. He wrote comparatively little but his books covered a very wide range and were highly praised, e.g. Archbishop Laud 1573-1645 (1940), The Gentry 1540-1640 (1953), The Rise of Christian Europe (1964) and The Jesuits in Japan (1968) and A Hidden Life; The Enigma of Sir Edmund Backhouse (1976). He was best known as a critic and a devastating analyst of other historians' deficiencies. He became Regius professor of modern history at Oxford 1957-80 and Master of Peterhouse, Cambridge 1980-87. He married a daughter of the 1st Earl *Haig. As a consultant to Rupert *Murdoch, he gave initial credibility to diaries attributed to Hitler (1983), then repudiated them.

Sisman, A., Hugh Trevor-Roper. 2010.

Trimble, (William) David, Baron Trimble (19442022). Northern Ireland politician. A lawyer, he was an Ulster Unionist MP 1990-2007 and, as leader 1995-2005, was a moderate supporter of the 1998 Peace Plan. He became First Minister of Northern Ireland 1998-2002 and shared the 1998 Nobel Peace Prize with John ${ }^{*}$ Hume.

Trocmé, André (1901-1971). French clergyman. Pastor of the Reformed Church in Le Chambonsur-Lignon, he organised a network that saved 5,000 Jews by smuggling them into Switzerland, and was recognised by Israel as 'Righteous among the Nations'.

Trollope, Anthony (1815-1882). English novelist, born in London. Son of the writer Fanny *Trollope, he had an unhappy childhood because of the 
harshness and extravagance of his irresponsible father, a failed barrister. Educated at Harrow and Winchester, after a short time in Belgium he became a clerk in the GPO, London (1834); but after a breakdown he was sent as a deputy postal surveyor to Ireland, where hunting, marriage and steady promotion made a new man of him and he began to write. (He is also credited with the invention of the red pillar box.) In 1859 he returned to England and settled at Waltham Abbey which he left (1871) for Montagu Square, London. With a happy domestic life, with his novels and with official journeys (e.g. to Australia, South Africa and America) to provide subjects for travel books, he was content. The more important of his novels fall within two series. The 'Barsetshire' series, which comprises chronologically The Warden (1855), Barchester Towers (1857), Doctor Thorne (1858), Framley Parsonage (1861), The Small House at Allington (1864) and The Last Chronicle of Barset (1867), is mainly concerned with clerical intrigue in the cathedral town of Barchester and reveals to the full his great gift of characterisation (e.g. Mrs Proudie, the Bishop's vulgar but masterful wife). For the second series, which is political, Trollope gained some firsthand experience when he stood unsuccessfully as parliamentary candidate for Beverley (1868). The books are concerned with the fortunes of Plantagenet Palliser (Duke of Omnium) and his wife Glencora, and once again the interplay of character and motive is enthralling. The best known of this sequence are Phineas Finn (1869), Phineas Redux (1874) and The Prime Minister (1876). Trollope's other novels include The Claverings (1867) and The Eustace Diamonds (1873).

His autobiography (1883) revealed the almost coldblooded persistence with which he wrote his daily quota of 2500 words before breakfast; he admitted the strength of the money motive and recorded that by 1879 he made $£ 68,93917$ s. $5 \mathrm{~d}$ from his books. Such methods and motives suggest lack of spontaneity and it is true that his style is at times pedestrian but the characters are so vividly brought to life that interest is sustained. After a period of neglect, Trollope won new popularity, especially after successful television series based on his novels. In March 1993 he was reinterred in Westminster Abbey. He was the most prolific of all major English novelists (even more so than Samuel ${ }^{*}$ Richardson) with 47 to his credit.

Sadleir, M., Trollope: A Commentary. Rev. 1945; Glendinning, V., Trollope 1992.

Trollope, Fanny (née Milton) (1780-1863). English writer. Her Domestic Manners of the Americans (1832) caused great offence in the US but sold well in Britain. She had extraordinary energy, lived in Florence from 1843 and published more books than her son Anthony *Trollope.
Tromp, Maarten Harpertszoon (1598-1653). Dutch sailor. His father was captain of the frigate Olifantstromp (hence the name), killed in an action against pirates, and the young Tromp was a slave in Morocco for two years. He joined the Dutch navy, was captured again and became a slave in Tunis. On his release, he was steadily promoted and in 1639 defeated a Spanish fleet off Flanders. In the AngloDutch War 1652-53, there was an evenly matched struggle with ${ }^{*}$ Cromwell's soldier-admirals ${ }^{*}$ Blake and ${ }^{*}$ Monck for command of the narrow seas. From encounter to encounter (over a score in all), fortune veered. In May 1652, Blake, with only 15 ships, had the best of a fight with 40 ships under Tromp, but only six months later it was a triumphant Tromp who, according to legend, sailed down the Channel with a broom at his masthead to show that the English had been swept from the seas. Yet, in February 1653, a three-day battle in which Tromp showed his usual courage in defence of a large convoy, cost the Dutch nine warships and 30 out of 200 merchantmen. In the last desperate encounter fought off the Dutch coast at Scheveningen, against the English under Monck, Tromp lost 30 warships and was killed.

Trotsky, Leon (Lev Davidovich Bronstein) (18791940). Russian revolutionary politician, born in Yanovka, Ukraine. From a middle-class Jewish family, he was expelled from Odessa University and joined the Russian Social Democratic Labour Party (1896). Exiled to Siberia 1898-1902, he escaped and lived in London 1902-05, where he took part in the 1903 RSDLP congress. When it split, Trotsky joined the Mensheviks (minority faction). In 1905 he returned to Russia to become President of the first Soviet in St Petersburg but was again arrested, once more sent to Siberia and repeated his successful escape. At the outbreak of World War I he went to Paris but, expelled (1916) for pacifist and revolutionary propaganda, eventually reached New York. After the Revolution of March 1917, he returned to Russia and, after being arrested by the provisional government, joined the Bolsheviks and with ${ }^{*}$ Lenin organised the November revolution which brought them to power. As Commissar for Foreign Affairs November 1917-March 1918, he negotiated the Treaty of Brest-Litovsk with Germany and as Commissar for War 1918-25 virtually created the Red Army, directing it with strategic brilliance in the Civil War. His policy of 'permanent revolution', based on the contention that Bolshevism could not survive in Russia unless revolutions were stirred up in the west, was not, however, accepted by the majority of the party. When Lenin died (1924), he lost a power struggle against ${ }^{*}$ Stalin, partly because his brilliance as writer and orator made him suspect, and being Jewish was a negative factor. But he also exhibited an uncharacteristic passivity. Trotsky headed various opposition factions but was expelled from the party (1927) and was ordered to leave Russia (1929). From Turkey he travelled widely and at the same time built 
up dissident Communist groups, some of which long survived his death. In the official Communist Party, 'Trotskyite' became a term of abuse applied to anyone whose loyalty to party decisions was in doubt. In 1937 Trotsky settled in Mexico. In August 1940 he was murdered with an ice axe by Ramon Mercader, alias Jacques Mornand, alias Frank Jacson (1914-1960?), a Spaniard whose mother was the mistress of a NKVD general. Released from jail in 1960, Mercader flew to Prague and disappeared. Trotsky was a brilliant and prolific writer whose works include The History of the Russian Revolution (3 volumes, 1932-34) and The Revolution Betrayed (1937).

Deutscher, I., The Prophet Armed: Trotsky 1879-1921. 1954; Deutscher, I., The Prophet Unarmed: Trotsky 1921-29. 1959; Deutscher, I., The Prophet Outcast: Trotsky 1929-40. 1963; Howe, I. (ed.), The Basic Writings of Trotsky. 1963.

Trudeau, Edward Livingston (1848-1915). American physician. As a sufferer from pulmonary tuberculosis he benefited from the air of the Adirondacks and established the Trudeau Sanatorium there (1884). He was the first in the US to isolate and study the tubercle bacillus.

Trudeau, Pierre Elliott (1919-2000). Canadian politician and lawyer, born in Montréal. From a rich business family, he won a law degree at Montréal University, and after brief army service undertook further study at Harvard, L'institut d'Études Politiques in Paris and the London School of Economics. Called to the bar in 1943, he was associate professor of law at the University of Montréal (1961) and became a member of the House of Commons 1965-84. Parliamentary Secretary to the Prime Minister 196667 and Attorney-General 1967-68, he was elected Leader of the Liberal Party in 1968 and held office as Prime Minister 1968-79 and again 1980-84. One of his main preoccupations was to satisfy the aspirations of French-speaking Canada without destroying the federal system. He became a QC (1969), was appointed CH (1984) and CC (1985), and wrote extensively, including Memoirs (1993). His son, Justin Pierre James Trudeau (1971-), born in Ottawa, won degrees from McGill and the University of British Columbia, was a teacher and acted on television. Elected to the House of Commons 2008he became Leader of the Liberal Party 2013- and was Prime Minister 2015-, when the Liberals won an absolute majority, defeating Stephen *Harper, despite having fallen to third position in 2011.

Trudeau, P. E., Federalism and the French Canadians. 1968.

Truffaut, François (1932-1984). French film director. Critic and publisher of Cahiers du Cinma from 1954, he worked as an assistant director to Roberto ${ }^{*}$ Rossellini in 1956 and directed his own films from 1957. His study of childhood, Les
Quatre-cent Coups, won first prize at the Cannes Film Festival in 1959. He was thereafter recognised as the leader of the French 'New Wave' of realist cinema, which deliberately dispensed with accepted formulae in the structure of film stories.

Crisp, C. G., François Truffaut. 1972; Truffaut, F., Les films de ma Vie. 1975.

Trujillo Molina, Rafael Leonidas (1891-1961). Dominican dictator. He graduated from the military academy in 1921 and by 1928 he had risen to be Chief of Staff. He was President of Dominica, 1930 38 and 1942-52, but he remained in total control ruling through nominees (1938-42), and in 1952 was succeeded by his brother Hector Trujillo. His rule was bloody, especially the Parsley Massacre of October 1937 in which more than 25,000 ethnic Haitians were slaughtered. While enriching his own family he pursued a conciliatory policy towards the US, and provided a firm administration that brought social and economic benefits. He created national parks and suppressed illegal logging. Within six months of his assassination the last of the Trujillo clan had left the country. From 1936 to 1961 Santo Domingo, the capital, was known as Ciudad Trujillo.

Truman, Harry S. (1884-1972). 33rd President of the US 1945-53. The initial ' $S$ ' represents the names of his grandfathers but has no other significance. Born on the family farm at Lamar, Missouri, despite bad eyesight which prevented his entry into West Point Military Academy, he served as an officer in World War I. In 1922 he was a partner in a Kansas City haberdashery which failed in a recession. He insisted on paying all creditors in full, which took 12 years. He studied law but did not qualify, and entered politics as a Democrat. He presided 192634 over an administrative court in Jackson County for controlling expenditure on construction. As US Senator $1935-45$ he became well known through his chairmanship 1941-44 of the Committee for Investigation of the Defence Program. He replaced Henry *Wallace on the Democratic ticket, was elected as Vice President (November 1944) and succeeded to the presidency on Franklin *Roosevelt's death (April 1945). Acting on advice by Henry L. *Stimson, he took responsibility for dropping atom bombs on Hiroshima and Nagasaki, news of which came when he was attending the Potsdam Conference (July-August 1945) with ${ }^{*}$ Stalin and ${ }^{*}$ Churchill (later, *Attlee) to plan the division of Germany. In March 1947 the 'Truman Doctrine' offered political and military aid to nations resisting Communist influence. With George *Kennan and Dean *Acheson he developed the policy of 'containment' of Communism. The *Marshall Plan, announced in June 1947, provided massive economic aid to war-ravaged European nations. As Cold War tensions increased, Stalin rejected an offer of Marshall Plan assistance to the Soviet bloc. 
In November 1946 the Democrats were heavily defeated in elections for the 80th Congress and Truman faced a Southern challenge for nomination in 1948. The Democrats split three ways, with J. Strom *Thurmond, on the right, standing as a 'Dixiecrat', Truman taking the middle ground and Wallace, on the left, running as a 'Progressive'. Thomas E. *Dewey was the Republican nominee. Truman travelled 48,300 kilometres in a 'whistle-stop' railway tour across the nation, making 315 speeches. He won an unexpected (but comfortable) victory, with Electoral College votes from 28 states. In 1949 the North Atlantic Treaty Organization (NATO) was established and the 'Point Four' program provided technical assistance to the Third World. However, *Mao's victory in China caused a violent anti-Communist reaction in the US (exacerbated by the ${ }^{*}$ Hiss and ${ }^{*}$ Rosenberg trials), contributing to the rise of Joe ${ }^{*}$ McCarthy and Richard *Nixon. When North Korea invaded the South (June 1950), Truman sent in US troops, under Douglas *MacArthur, supported by a UN mandate. He dismissed MacArthur (April 1951) for publicly proposing a military strike against China, which was thought (wrongly) to have initiated the Korean War. This provoked a huge political reaction in the US which soon subsided. In 1952 the US tested the world's first hydrogen bomb. Truman's domestic policy, the 'Fair Deal' aimed to promote racial harmony and help the poor. He declined to stand for re-election in 1952 and secured the nomination of Adlai *Stevenson, who then lost to ${ }^{*}$ Eisenhower. He wrote Memoirs (1955-56). His reputation grew after his retirement. In 19 Presidential ranking lists by historians and political scientists, Truman scored No. 6 in the aggregate.

Truman, M., Harry Truman. 1973; McCullough, D., Truman 1992.

Trump, Donald John (1946- ). 45th President of the United States 2017-21. Born in New York, he was the son of a property developer of German descent, and a Scottish mother. Educated at Wharton College in the University of Pennsylvania, he owned hotels, casinos and golf courses, became a beauty pageant impresario and won a national reputation on television for his brash optimism, propensity for stunts, and natural aggression as the host of The Apprentice 2004-14. He founded the now defunct Trump University in 2005. In June 2015 he announced his candidature for the Republican presidential nomination. His populist appeal to nationalism and occasional racism and misogyny was successful with voters in primaries, but threatened the Republican establishment and alarmed America's allies. He won the Republican nomination for president in May 2016, after defeating 15 rivals. In November 2016 he beat Hillary *Clinton, winning 30 states, and a narrow lead in the Electoral College, with a popular vote of 63 million, 2.8 million behind Clinton's. Only 55.7 per cent of those eligible actually voted. Trump was the oldest and the richest person to be elected President, and the only one without experience in government or the military. Twitter was his preferred mode of communication. He described himself as 'a very stable genius' with a 'very, very large brain'.

He developed a close relationship with Saudi Arabia and Israel, had a wary respect for Russia and North Korea, and was dismissive of leadership in Canada, France, Germany and-until Boris *Johnson became Prime Minister - the UK. He withdrew the US from the Paris Climate Accords, insisting that 'the future belongs to patriots'.

In December 2019, the House of Representatives voted to impeach President Trump on two counts: (i) abuse of power, in applying pressure on Ukraine that unless Joe *Biden's family was investigated military hardware would be withheld; and (ii) obstruction of Congress, by refusing to allow witnesses who had been subpoenaed to give evidence. In the ensuing trial, the Senate voted narrowly against calling witnesses or examining documents, and voted to acquit (5 February 2020) on party lines, although Senator Mitt * Romney voted guilty on the first count.

His response to the COVID-19 pandemic (2020) was marked by denial, confusion, delay, false claims and the attribution of blame elsewhere. The 'Black Lives Matter' demonstrations after the death of George Floyd in Minneapolis intensified racial divisions.

Trump campaigned vigorously in the 2020 Presidential election, which was marked by record voter turnout. Although defeated by Joe Biden, Trump's model of authoritarian democracy won 74.2 million votes $(46.9 \%)$. He refused to concede defeat, insisting that the election had been stolen, urging his supporters to 'fight like hell'. Courts (even with judges he had appointed) refused to intervene. On 6 January 2021, when Congress was certifying the results of the Electoral College vote (Biden 302, Trump 232), the Capitol was attacked by hostile crowds numbering between 8,000-10,000, resulting in five deaths, and the building went into lockdown. Trump broke with Vice President Mike *Pence for having declared Biden as President-elect.

The House of Representatives voted on 13 January 2021 to impeach Trump for incitement of insurrection'. This second impeachment was the first in American history. However, trial in the Senate was postponed until after Trump's term ended. On 13 February the Senate voted 57 to 43 to convict, but under the Constitution a two-thirds majority (67) was required, so Trump could claim vindication. His former Senate leader and close collaborator Mitch *McConnell voted to acquit on technical grounds, but then denounced Trump's actions as 'disgraceful'.

Trump's base continued to dominate the Republican Party and he kept open the option of running for President in 2024. Meanwhile, New York State initiated proceedings against Trump for taxation fraud. 
Barred from using Twitter, his preferred medium, in 2021 he established the Truth Social app.

He refused to concede that he had lost the 2020 election, discounted the Congressional investigation of the 6 January 2021 attack on the Capitol and, in November 2022, announced his candidacy for President in 2024.

In the three major presidential surveys conducted by US historians and political scientists between 2017 and 2021, Trump was ranked 44, 42 and 41.

Woodward, B., Fear: Trump in the White House. 2018; Wolff, M., Fire and Fury: Inside the Trump White House. 2018; Siege: Trump Under Fire. 2019.

Trumper, Victor Thomas (1877-1915). Australian cricketer. His batting achievements included 3163 runs in test cricket, of which 2263 were made against England. His greatest performance was 300 not out made in 1899 against Sussex at Hove.

Mallett, A., Trumper, 1985.

Truss, Liz (Mary Elizabeth) (1975- ) English Conservative politician, born in Oxford. An Oxford graduate, she became an accountant, MP 2010-, Secretary of State for the Environment 2014-16, the first female Lord Chancellor 2016-17, and Chief Secretary to the Treasury 2017-19. She voted 'remain' in 2016 but became a Boris *Johnson loyalist. Secretary of State for International Trade 2019-21 and Foreign Secretary 2021-22, she defeated Rishi *Sunak for the Tory leadership in September and became Prime Minister September-October 2022. Two days after her appointment, Queen *Elizabeth died. Her proposed major unfunded tax cuts caused a rebellion in the financial markets and her sudden U-turn lost her all credibility. She was the shortestserving Prime Minister in British history (49 days).

Truth, Sojourner (c.1797-1883). American evangelist, born in Ulster County, New York. Born a slave and given the name Isabella, she was freed in 1827 , became a touring evangelist and a passionate campaigner for abolition of slavery and for female suffrage.

\section{Tsai Lun see Cai Lun}

Tshombe, Moïse Kapenda (1919-1969). Congolese politician. An accountant who owned a chain of stores, after the Belgian Congo became an independent republic (1960) he declared the secession of Katanga, the copper-producing province, and was its first (and only) President 1960-63. The Congolese Prime Minister Patrice ${ }^{*}$ Lamumba called for intervention by United Nations troops, but French and Belgian mercenaries intervened, Lumumba was captured and executed. UN forces ended the secession in Katanga in 1963 and Tshombe fled to Spain. However, in 1964 he was recalled and appointed as Prime Minister of the Democratic Republic of the Congo by
President *Kasa-Vubu but was dismissed in October 1965. Kasa-Vubu was then overthrown by General *Mobutu. Tshombe fled to Spain again, but he was later hijacked and kept as a prisoner in Algeria, where he died.

Tsiolkovsky, Konstantin Eduardovich (18571935). Russian physicist. Originally a school teacher (hampered by extreme deafness), he carried out fundamental research into aeronautics, constructed the first 'wind-tunnel' and by 1895 was writing about space travel. From 1898 he was predicting (with a high degree of accuracy) future space exploration in rockets using liquid fuel. The launching of Sputnik I (1957) was timed to coincide with his centenary.

Tsvangirai, Morgan Richard (1952-2018). Zimbabwean politician. A Shona tribesman, after leaving high school he worked as a miner and became active in the trade union movement. He was leader of the Movement for Democratic Change, he contested the presidency against Robert *Mugabe in 2002 and 2008 , and in a power-sharing arrangement with Robert *Mugabe became Prime Minister 2009-13.

Tsvetaeva, Marina Ivanovna (1892-1941). Russian poet, born in Moscow. Her father was a professor who founded the Pushkin Museum of Fine Arts. She observed the Revolution and the following famine, lived in Paris from 1922, returning in 1939, but was ostracised. Her husband was executed in 1941, her daughter was jailed as a spy and she hanged herself (although it could have been murder). Her lyric poetry, most written in exile, was published in 1961 and championed by Vladimir *Nabokov and Joseph *Brodsky. Minor planet 3511 Tsvetaeva was named for her in 1982 .

Tswett, Mikhail Semenovich (1872-1919). Russian chemist and botanist. Inventor of the important chemical technique known as chromatography, he showed (1906) that plant pigments dissolved in petrol could be separated by means of their differential rates of absorption by powdered calcium carbonate in a vertical glass tube. This method of analysis has since been widely developed.

Tubman, William Vachanarat Shadrach (18951971). Liberian politician. A lawyer, judge and leader of the 'True Whig' party, he was elected President in 1944 and re-elected six times, dying in office. He attempted social, economic and educational reforms.

Tuchman, Barbara (née Wertheim) (1912-1989). American historian, born in New York. A journalist, she twice won the Pulitzer Prize, with The Guns of August (1962) and Stilwell and the American Experience in China 1941-45 (1971). Other books include The Proud Tower (1966), A Distant Mirror (1978) and The March of Folly: From Troy to Vietnam (1984). 
Tudjman, Franjo (1922-1999). Croatian politician. During World War II, he became the youngest general in *Tito's partisans, was a fervent Marxist, then an academic, teaching history at the university of Zagreb. He was expelled from the Yugoslav CP in 1967 for his advocacy of Croatian nationalism. In 1989 he founded the Croatian Democratic Union, was elected President of Croatia 1990-99 and declared its independence in 1991. War with Serbia, the fourth in 90 years, broke out with massive loss of life, only token intervention by the UN and an ineffective response by the European Community.

Tudor (ap Tewdwr). Welsh dynastic family that ruled England from the accession of *Henry VII (1485) to the death of *Elizabeth I (1603). Its links with the English royal line were established by the marriage of Owen Tudor (né Owain ap Maredudd ap Tewdwr) (1392-1461) to *Henry V's widow ${ }^{*}$ Catherine of Valois; he was defeated and beheaded at Hereford at the outset of the Wars of the Roses. Henry VII's claim to the throne rested, however, upon the marriage of his father Edmund Tudor, son of Owen, to Margaret Beaufort, granddaughter of John Beaufort, one of the legitimised children of *John of Gaunt and Catherine *Swynford.

Tudor, Antony (né originally William Cook) (1908-1987). Anglo-American ballet dancer and choreographer. He trained in England but worked in the US from 1940. He was a driving force in the American Ballet Theatre, linked with *Balanchine as a creator of modern ballet.

Tukhachevsky, Mikhail Nikolaievich (1893-1937). Russian marshal, born near Smolensk. From a noble but impoverished family, he joined the army in 1911 and was a prisoner-of-war 1915-18. He supported the Bolsheviks in 1918, commanding the Red Army in the Caucasus during the civil war, and becoming Chief of Staff 1925-28, Deputy Commissar of Defence 1931-37, under *Voroshilov, and promoted to marshal in 1935 . The SS fed misinformation to the NKVD that Tukhachevsky had conspired with *Bukharin and the Germans, and this fed *Stalin's paranoia. Tukhachevsky was arrested, tried and summarily executed, together with eight other generals. His wife and two brothers were also shot. In 1957 he was rehabilitated by ${ }^{*}$ Khrushchev.

Tull, Jethro (1674-1741). English agriculturist. Called to the bar in 1699, as a result of the enclosure system, which by bringing large acreages under direct control of landlords encouraged more scientific agriculture, he turned to farming. He invented a seed drill (1701), and his advocacy of planting cereals and turnips in rows instead of by broadcasting the seed was of the greatest importance in improving yields. A prolonged tour of Europe enlarged his knowledge, among the things learnt being the value of the cultivator in aerating the soil and allowing access of water. His practices were explained in Horse-hoeing Husbandry (1733).
Tunney, 'Gene' (James Joseph) (1897-1978). American boxer. A skilful tactician, he fought 68 professional bouts and lost only one. By defeating Jack Dempsey, he became world heavyweight champion (1926) and retired undefeated (1928).

Tupolev, Andrei Nikolaievich (1888-1972). Russian aeronautical engineer. Educated at the Moscow Higher Technical School, in 1922 he became director of the Central Aero-hydro-dynamic Institute. He fell into disfavour with the authorities in 1938 but was reinstated in 1943 . He was responsible for over 100 aircraft both civilian and military. The Tu-104 (1955) was the first jet transport to provide a regular commercial service for passengers. The Tu-144 ('Charger') was a supersonic transport (SST), first flown in December 1968, just before the AngloFrench 'Concorde'. It had serious design flaws and after spectacular crashes was grounded.

Turenne, Henri de la Tour d'Auvergne, Vicomte de (1611-1675). French soldier. A grandson of ${ }^{*} W i l l i a m$ the Silent (Prince of Orange), after his father's death he was brought up in Holland as a Protestant. $\mathrm{He}$ returned to France in 1630 and soon showed his military abilities during the Thirty Years' War. In 1641 he was given the supreme command and in 1643 was rewarded for his conquest of Roussillon from the Spanish by being made a marshal of France. He ended the Thirty Years' War with triumphant campaigns in Bavaria and Flanders. In the civil wars that ensued he at first joined the Fronde, but later was reconciled with the regency government led by *Mazarin, and thus found himself opposed to his great military rival ${ }^{*}$ Condé. From a period of confused fighting Turenne emerged victorious, while Condé, a declared traitor, crossed the frontier and took service with Spain. The contest between the two men continued with Condé leading the Spanish army, Turenne the French, and was only finally settled when Turenne, after overrunning much of the Spanish Netherlands, finally, with the help of a force of ${ }^{*}$ Cromwell's Ironsides, defeated Condé at the Battle of the Dunes (1658), which led to the surrender of Dunkirk. Peace followed (1659) and when hostilities were resumed (1667) Condé had been pardoned and taken into favour by *Louis XIV. In 1668 Turenne turned Catholic. In the war (1672) with Holland, soon joined by the emperor Leopold and other allies, the two great commanders campaigned in concert. In the winter of 1674-75 Turenne fought his last and most brilliant campaign in Alsace but in the spring, while reconnoitring the imperialist position near the defile of Sassbach, he was struck by a cannon ball and killed.

Weygand, M., Turenne: Marshal of France. 1930; Longueville, T. and Lloyd, F., Marshal Turenne. 2007.

Turgenev (or Tourgeneff), Ivan Sergeievich (18181883). Russian novelist, born in Oryol. Brought up on the family estate, he quarrelled with his masterful and neurotic mother about her treatment of the serfs. 
After a university education and a short time in the civil service he achieved his first popular success as a writer with A Sportsman's Sketches (1847-52), a series of delightful rural sketches. In 1843 he fell in love with Pauline *Viardot (née Garcia), a famous singer then visiting Russia. She was married but, moved by a hopeless but enduring passion, he followed her around from place to place in Germany and France. He even maintained a friendship with her husband and collaborated with him in the French translations of his works, sometimes even sharing their home. This barren love affair may explain why so many of the men in Turgenev's books are such emotional weaklings. Turgenev was on bad terms with *Dostoevsky, ${ }^{*}$ Tolstoy and other Russian contemporaries. After 1856 he spent much time in Paris, where he was a friend of *Flaubert, *Zola, *Daudet, the *Goncourt brothers and Henry *James. He died near Paris.

His most important novels, among which are $A$ Nest of Gentlefolk (1859), Fathers and Sons (1862), a story of political conflicts between the generations, and Virgin Soil (1876), belong to a series referring to social and historical developments in Russia between 1830 and 1870. These were criticised both by the progressives and the reactionaries although much admired outside Russia. Of equal or greater fascination are the short stories, love stories, tales of the countryside and of the supernatural. Here the fastidious elegance of his style can be appreciated at its best.

Schapiro, L., Turgenev: His Life and Times. 1978; Pritchett, V. S., The Gentle Barbarian. 1977; Figes, O., The Europeans: Three Lives and the Making of a Cosmopolitan Culture. 2020.

Turgot, Anne Robert Jacques (1727-1781). French economist and administrator. Having abandoned the idea of a Church career, he lived in Paris in the midst of the great intellectual ferment of which *Diderot's great Encyclopédie was the symbol. Turgot's interests were mainly economic and in his writings on the subject, especially in his advocacy of free trade, he anticipated the work of Adam ${ }^{*}$ Smith. As intendant of Limoges (1761-64) he was able to put theory into practice: by substituting a money tax for the corvée (the compulsory road-labour of peasants dating from feudal times) he greatly improved communications; and by establishing free trade in corn, by stimulating the porcelain industry and encouraging new ones he transformed the Limousin from one of the poorest into one of the richest regions of France.

On the accession (1774) of *Louis XVI he was called upon to do for the country what he had done for the region. As controller general with the watchwords 'no bankruptcies, no tax increase, no loans', he began by making stringent economies, including the suppression of some 32,000 government posts. The measures which followed-abolition of the corvée, free trade in corn (followed by bread riots), and a minor land tax on nobles and clergy_-produced such a selfish outcry from those adversely affected and the privileged classes in general that Louis lost his nerve and in 1776 Turgot had to resign. His declared conviction that the alternative to far reaching reforms was revolution was soon borne out.

Turing, Alan Mathison (1912-1954). English computer scientist, logician, mathematician and cryptographer, born in London. Educated at King's College, Cambridge and Princeton (where he worked with Alonzo *Church), he published a paper 'On Computable Numbers, with an Application to the Entschiedungsproblem' (1937), referring to a challenge about the 'halting problem' made by the German mathematician David *Hilbert. This proposed a formal theory of how a universal computer would work, embodying the logic of all future computing machines. During World War II, he worked as a cryptographer at Bletchley Park, Bucks., and produced a device (the 'bombe') that cracked the German Enigma naval codes and was decisive in winning the Battle of the Atlantic. In 1943 he worked briefly in the Bell Labs with Claude *Shannon. Reader in mathematics at Manchester University 1945-49, he worked on the Manchester Mark I computer, investigated artificial intelligence and morphogenesis (mathematical biology) and became FRS in 1951. Convicted, in 1952, of an 'act of gross indecency' with a young man, he accepted chemical castration as an alternative to imprisonment and committed suicide by eating an apple laced with cyanide. In 2009, Prime Minister Gordon *Brown made an official apology about Turing's treatment. He received a posthumous royal pardon in December 2013 and in 2021 his head appeared on the $£ 50$ banknote.

Hodges, A., Alan Turing: the enigma. 1983.

Turnbull, Malcolm Bligh (1954- ). Australian lawyer, banker, writer and Liberal politician, born in Sydney. Educated at Sydney University, and a Rhodes Scholar in Oxford, he became a journalist, barrister and merchant banker, leading the 'Yes' campaign in the failed 1999 referendum on a republic. Member of the Australian Parliament 2004-18, he was Minister for the Environment and Water 2007, under John *Howard. He replaced Brendan Nelson to become the Leader of the Opposition 2008-09 until deposed, narrowly, by Tony *Abbott, on the issue of climate change. Minister for Communications 2013-15, he defeated Abbott in a Liberal Party room ballot and was Prime Minister 2015-18. Internal tensions over energy policy, climate change and resentment over same sex marriage led to a party coup in August 2018. Turnbull was forced out but ensured that he was succeeded by Scott *Morrison, and not the hardright candidate, Peter ${ }^{*}$ Dutton.

Manning, P., Born to Rule. 2015; Turnbull, M. B., A Bigger Picture. 2020. 
Turner, Frederick Jackson (1861-1932). American historian. Professor of history at Wisconsin University $1892-1910$ and Harvard 1910-24, he was the proponent of the 'frontier school' of American historiography, arguing that pushing back the frontier created the essential and distinctive elements of American society, culture, politics and the economy.

Turner, John Napier Wyndham (1929-2020). Canadian politician and lawyer, born in England. Educated at the University of British Columbia, he was a Rhodes Scholar at Oxford, became a lawyer in Montréal and a Liberal MP 1962-76; 1984-93, serving as Attorney-General 1968-72 and Minister for Finance 1972-75. In 1975 he resigned over policy differences with Pierre ${ }^{*}$ Trudeau, became active in business, and was nominated to succeed him as party leader and Prime Minister of Canada, June 1984, although he was not an MP or senator. In September 1984 his government was overwhelmingly defeated but Turner remained as Opposition Leader until 1990.

Turner, J(oseph) M(allord) W(illiam) (1775-1851). English painter, born in London. His father kept a barber's shop in Maiden Lane, Covent Garden. He was sent to the free school at Brentford and in 1789 gained entrance to the Royal Academy school. His first money was made by selling sketches in his father's shop and colouring engravings. With his savings he made sketching tours and also worked with his friend Thomas * Girtin, whose style in watercolours influenced him greatly. His first Academy exhibit was shown in 1791. His early oil paintings were influenced by Richard Wilson and *Claude Lorrain but after going to the Continent (1802) he came to admire ${ }^{*}$ Titian and ${ }^{*}$ Poussin. Elected ARA in 1799, he became RA in 1802. By about 1810 he had fully developed the technique that made him famous, showing the subject of his picture, whether a natural phenomenon, mythological figures, or-in accordance with the romantic vogue of the time- an ancient building, through cascades and explosions of light and colour. He sometimes painted direct from nature but usually in the studio, where an astonishing visual memory enabled him to reproduce almost exactly the original scene. He would execute a subject, e.g. Blois, as watercolour, gouache and oil (Blois on the Loire, c.1829). They were often reproduced as etchings or engravings, as in the series Rivers of England (1823-27) and Rivers of France (1833-35) which popularised his work. He visited France, Italy, Switzerland and Germany several times, and his best paintings include many studies of Venice. Among his greatest works are Burning of the Houses of Lords and Commons (1834), The Fighting Téméraire (1838), The Slave Ship (Slavers Throwing Overboard the Dead and Dying, Typhoon Coming On), (1840) and Rain, Steam and Speed-The Great Western Railway (1844). Despite prolonged attacks by the leading art critics of the time Turner was supported by the Royal Academy and, to his surprise, by John *Ruskin and above all, by
Lord Egremont of Petworth, with whom Turner often stayed and where some of the best of his pictures are still exhibited. He took a keen interest in photography, and J. J. E. Mayall took a daguerreotype portrait of him in 1847. In his old age Turner lived as a recluse in Chelsea under an assumed name and there died. $\mathrm{He}$ was buried in St Paul's Cathedral. He left $£ 140,000$, more than 300 oils, 20,000 watercolours and 19,000 drawings to the nation, many exhibited in the Tate Gallery, in extensions built by Sir Joseph *Duveen (1908) and Sir Charles *Clore (1987). Until the 20th century his works were more admired in Europe than in Britain. Rome from Mount Aventine (1835) sold in London for \$US47.6 million in 2014.

Lindsay, J., J.M.W. Turner: his life and work. 1966; Walker, J., Turner. 1976; Wilton, A., The Life and Work of J. M. W. Turner. 1979; Hamilton, J., Turner. 1997; Hermann, L. and Harrison, C., J. M.W. Turner. 2000; Moyle, F., Turner: The Extraordinary Life and Momentous Times of J. M. W. Turner. 2017.

Turner, Ted (Robert Edward III) (1938- ). American broadcasting executive. He inherited an advertising agency from his father, moved into radio and television and in 1980 founded Cable News Network (CNN), a global 24-hour newscast, which reached its highest penetration during the Gulf War (1991). The immediacy of CNN's coverage not only influenced reporting but policy outcomes and, by breaking down frontiers, illustrated Marshall *McLuhan's concept of 'the global village'. Turner won the America's Cup for yachting, owned the Atlanta Hawks and in 1991 married the actor Jane *Fonda. He sold CNN to Time-Warner, gave \$US1 billion to the UN for an environment fund and was the biggest landowner in the US.

Tussaud, Marie (née Grosholtz) (1760-1850). Swiss modeller. Founder of the waxworks that bear her name, she learned modelling in Paris from her uncle, J. C. Curtius, whose wax museums she inherited (1793). She prepared death masks from heads severed by the guillotine. Having separated (1800) from her soldier husband she established her exhibition in London, first at the Lyceum Theatre and then (1835) in Baker Street. The move to Marylebone Road was made in 1884 after her death.

Tutankhamun (Tut-ankh-amun, originally Tut-ankhaten: regnal name Nebkheperure) (c.1341-c.1323 BCE). Egyptian pharaoh of the XVIIIth dynasty 1332-23 BCE. He was son of *Akhenaten (and one of his sisters), and, after two short reigns by family members, succeeded, ruling through his high priest (and, later, pharaoh), *Ay II. Akhenaten had tried to impose a form of monotheism, with Aten as the one god. Popular and priestly opposition had rent the kingdom, and under the young pharaoh the country reverted to its former polytheism, with Amun as a principal god. He died at 18 or 19, after a reign of six years, possibly of gangrene, after the fracture of 
a leg, probably compromised by malaria. Despite his youth, the many weapons and warlike images found in his tomb suggest that he sought to be a warrior king. His tomb was found undisturbed by Howard *Carter (funded by Lord *Carnarvon) in November 1922 and the artefacts (5398 objects), notably the golden death mask, iron-gold dagger and six chariots, are magnificent. They have toured internationally but are normally housed in the new Grand Egyptian Museum, Cairo.

Desroches-Noblecourt, C., Tutankhamen. 1963; Hoving, T., Tutankhamun. 1978; James, T. G. H., Tutankhamun. 2000.

Tutu, Desmond Mpilo (1931-2021). South African prelate, born in Klerksdorp. Of Xhosa and Motswana descent, he became a teacher, then an Anglican priest (1960), and studied in London. Bishop of Lesotho 1976-78 and Johannesburg 1985-86, he was General Secretary of the South African Council of Churches 1978-86. He received the 1984 Nobel Prize for Peace and was appointed Archbishop of Cape Town 1986-06. He chaired the Truth and Reconciliation Commission 1995-98. He was awarded the Templeton Prize (2013) and an Honorary CH.

Twain, Mark (pseudonym of Samuel Langhorne Clemens) (1835-1910). American author and humorist, born in Florida, Missouri. His father was a Virginia lawyer who had moved west to seek a fortune by land speculation but died poor (1847). The boy, who had a casual upbringing in Hannibal, Missouri, where the river provided many scenes for his later books, became a journeyman printer. After some years of wandering, he visited New Orleans and became a pilot on the Mississippi (1857-61). His later pseudonym was derived from the leadsman's cry indicating that the water was two fathoms deep. The Civil War ended this chapter and he joined his brother in Nevada to prospect for gold. But soon his early humorous writings began to appear. He was encouraged by Artemus *Ward and in his writings for the San Francisco papers by Bret ${ }^{*}$ Harte. A commission to visit and write about the Sandwich Islands was followed by a lecture tour in the east which proved a great success. A Mediterranean tour resulting in Innocents Abroad (1869) established his fame. Having married Olivia Langdon of New York State (1870) he settled down as editor of the Buffalo Express but was fortunately encouraged by friends to draw on his boyhood memories of life on the great rivers for Tom Sawyer (1876) and his masterpiece Huckleberry Finn (1884). In later life, as well as having to submit to much ceremonial and hero worship he dissipated his energies in foreign travel. A Tramp Abroad (1880) records a European walking tour and business ventures which sometimes involved heavy losses. Meanwhile, and partly to recoup himself, he continued to write with industry and versatility. The burlesque A Connecticut Yankee in King Arthur's Court
(1889) is sometimes very funny; Personal Recollections of Joan of Arc (1896) reveals a long-felt devotion to this historic heroine. Others, e.g. The Stolen White Elephant, show his satirical gifts. He went on a roundthe-world lecture tour (1895-96) and visited Australia and New Zealand. He will always be remembered by the books which owe their inspiration, vigour and freshness to the river lands of his childhood. His journalism was powerful and incisive and he attacked the conventional wisdom with zest and courage.

Kaplan, J., Mister Clemens and Mark Twain. 1966; Twain, M., Tales, Sketches, Speeches and Essays. 2 vols, 1992.

\section{Tweedsmuir, 1st Baron see Buchan, John}

Tyler, John (1790-1862). 10th President of the US 1841-45. Son of a governor of Virginia, he became a lawyer, congressman 1816-21, Governor of Virginia 1825-27 and US Senator 1827-36. Supporting States' rights he joined the new Whig party formed by President *Jackson's opponents. In 1841 he became Vice President to W. H. *Harrison, on whose death, a month after inauguration, he succeeded as President. His term of office was rendered largely ineffective by the party split created by the conflict between the national policies of Henry ${ }^{*}$ Clay and the belief in States' rights favoured by the president. It was marked, however, by the *Webster-Ashburton Treaty (1843), which resolved difficulties with Great Britain and the annexation of Texas (1845). Tyler sought re-election in 1844 but soon dropped out and endorsed James K. *Polk. In 1861, he supported the Confederacy when the Civil War broke out but soon died.

Tyler, Wat (or Walter) (d.1381). English rebel and popular leader. In the Peasants' Revolt (1381) he led the Kentishmen, who with the men of Essex converged on London to present their demands, of which the main one was the abolition of serfdom and the crippling poll-tax. Three days and nights of burning and looting had already occurred when, at a conference with ${ }^{*}$ Richard II at Smithfield, Tyler, acting as spokesman, was struck down by Lord Mayor Walworth. He was killed in the subsequent scuffle; only Richard's courage in taking over the leadership of the peasants saved the situation. The gesture was a token one, however, and few of the rebels' grievances were met or their hardships lightened.

Tylor, Sir Edward Burnett (1832-1917). English cultural anthropologist, born in London. A Quaker, he left school early and did not attend a university. Suffering from tuberculosis, he went to Cuba and Mexico (1855-56), and with the ethnologist Henry Christy (also a Quaker) explored Toltec remains. Anahuac, or Mexico and the Mexicans (1861), Primitive Culture (2 vols., 1871) and Anthropology (1881) were important in developing evolutionary concepts and analytical techniques to civilization. 
Tyler became professor of anthropology at Oxford 1896-1909 and influenced James *Frazer and John Lubbock (*Avebury).

Tynan, Kenneth (Peacock) (1927-1980). English critic. Immensely influential, he wrote for the Observer and the New Yorker, worked with Laurence *Olivier at the National Theatre and arranged the sexually explicit revue Ob! Calcutta! (1969).

Tyndale, William (c.1494-1536). English Biblical translator, born in Gloucestershire. He graduated at Hart Hall, Oxford, and later at Cambridge came under the influence of humanists such as *Erasmus (one of whose works he translated) and the religious reformers. He mastered eight languages, and translated directly from Greek and Hebrew. Having set his heart on biblical translation but having failed to get patronage in London he went (1524) to Hamburg, to Wittenberg (where he met ${ }^{*}$ Luther) and to Cologne. Here he began printing his New Testament but, forbidden to proceed, fled to Worms. Of the edition there printed (1526) and smuggled into England, almost all copies were destroyed. His later works were published at Antwerp and they included translations of the Pentateuch (1530), Jonah (1531) and New Testament revisions. The section Joshua-II Chronicles was left in manuscript. Both in his marginal notes to the biblical books and in his many theological works he revealed his Lutheran doctrines and attacked papal supremacy. He engaged in bitter controversy with Thomas *More. In May 1535 Tyndale was lured out of the 'English House' on a pretext by an appalling opportunist, Henry Phelips. He was arrested and, after 16 months' imprisonment at Vilvoorde, near Brussels, convicted of heresy by an Imperial court. Despite sporadic efforts by *Henry VIII to save him, he was strangled there and his body burned at the stake.

Tyndale's translations were incorporated (without attribution) in the 'Matthew Bible' (1537) and the 'Great Bible' (1539), both publications being secured by Thomas *Cromwell.

His superb use of the words and rhythms of the English language is enshrined in the Authorised Version of the Bible: about 84 per cent of the New Testament, and 76 per cent of those books in the Old that he completed, is his work. His influence on written English was comparable with Luther's on German. His monosyllabic style is at its best in 2 Kings iv:8-37.

Daniell, D., William Tyndale. 1994; Moynihan, B., William Tyndale: If God Spare My Life. A story of martyrdom, betrayal and the English Bible. 2002; Bragg, M., William Tyndale. 2017.
Tyndall, John (1820-1893). Anglo-Irish physicist, born in Ireland. Son of a policeman, he worked as teacher and draftsman, then studied at Marburg, worked for years on polar diamagnetism and became (1853) professor of natural philosophy at the Royal Institution in London, where he later succeeded (1867) *Faraday, whose biography he wrote, as superintendent. In 1859 he identified the role of water vapour, $\mathrm{CO}^{2}$ and methane as key factors that absorb and emit radiation within the thermal infrared range ('the greenhouse effect') and in determining atmospheric temperature. Interest in glaciers and meteorology turned him into a mountaineer: he was among the first to climb the Matterhorn, and made a first ascent of the Weisshorn (1861). His other researches concerned heat, sound (lighthouse sirens) and light (the 'Tyndall effect': the imitation of the blue of the sky by passing a beam of light through a cloud of very fine particles). A very prolific writer and active populariser of science, he supported ${ }^{*}$ Darwin and was deeply sceptical about religion. He died from an accidental overdose.

Jackson, R., The Ascent of John Tyndall. 2018.

Tyson, Edward (1650-1708). English anatomist. Best known for his Orang-Outang of 1699, describing the anatomy of a primate (actually a chimpanzee) brought back from Malaya. Tyson saw the specimen as halfway between a man and an ape, a link on the Great Chain of Being. Fierce debate continued throughout the 18th century as to whether such higher primates were really forms of men, or of monkey, and whether man gradually shaded into the primates, or whether there was a sharp distinction.

Tzara, Tristan (originally Samuel Rosenstock) (1896-1963). French poet and essayist, born in Romania. In 1916 in Zürich he founded the 'dadaist' movement, using random assemblages of ideas, words and objects, and became a Surrealist by $1922 \mathrm{He}$ later joined the Communist Party and the Resistance.

Tz'u Hsi. Dowager empress of China see Cixi 


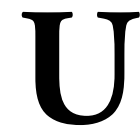

Uccello (= bird), Paolo (né Paolo di Dono) (c.1397-1475). Italian painter, born in Pratovecchio, Florentine Republic. He worked as a boy in *Ghiberti's studio, and was later in Venice and Padua as well as Florence. In most of his paintings he is preoccupied with problems of perspective which he worked out by mathematical means. This is evident in the wellknown fresco The Deluge done for S. Maria Novella in Florence. He won contemporary fame for three panels of the Battle of San Romano, painted for the Medici palace in Florence, but now dispersed. He was one of the first to draw plants and birds from nature, a sign of the spirit of innovation that marked the Early Renaissance.

Pope-Hennessy, J., Paolo Uccello. 2nd ed. 1969; Borsi, F. and S., Paolo Uccello. 1994; Hudson, H., Paolo Uccello. 2008.

Uchida, Dame Mitsuko (1948- ). Japanese-British pianist, born near Tokyo. Trained in Vienna, she became a great specialist in ${ }^{*}$ Mozart, ${ }^{*}$ Beethoven, and ${ }^{*}$ Schubert. She also toured, recorded extensively and taught.

Udall, Nicholas (1505-1556). English playwright and scholar. He was headmaster of Eton from 1534 until dismissed and imprisoned for misconduct (1541). He translated a number of classical and scholarly works but is remembered as the author of the earliest extant English comedy, Ralph Roister Doister (c.1553), inspired by *Plautus and *Terence and written in doggerel verse.

Ulanova, Galina Sergeyevna (1910-1998). Russian ballerina, born in St Petersburg. Her father was an artist, her mother a dancer. Prima ballerina assoluta in her time, she danced with the Kirov Ballet 1928-45 and the Bolshoi 1945-63, was held up as an icon by the Soviet regime and highly decorated but not allowed to travel until 1956 when she led a visit to London. *Prokofiev wrote Romeo and Juliet for her. After 1963 she taught at the Bolshoi.

Ulbricht, Walter (1893-1973). German politician. He joined the Communist Party in 1919 and was a member of the Reichstag 1928-33. On *Hitler's accession he went to Moscow, but after the collapse of Germany in World War II he reappeared in Berlin and was Russia’s principal agent in East Germany. In 1946 he became first Secretary of the Socialist Unity Party formed by the merger of the Communists and Social Democrats. On the formation (1949) of the German Democratic Republic (East Germany), Ulbricht was one of the three deputy premiers, but virtual ruler of the country. In 1960 when the presidency was abolished on the death of Wilhelm Pieck, Ulbricht became Chairman of the Council of State. He retired in 1971.

Keller, J. W., Germany, The Wall and Berlin. 1964.

Umar I (Umar ibn al-Khattab) (c.581-644). Second caliph of Islam 634-44. Born in Medina, he succeeded *Abu-Bakr, and maintained the discipline and control of his armies as they advanced to the conquest of Syria, Mesopotamia (Iraq) and Egypt. He was the first caliph to be known as Commander of the Faithful. His descendant Umar II (Umar ibn 'abd al-Aziz) (682-720), ninth Umayyad caliph 717-20, was born in Aleppo and ruled from Damascus. He imposed the 'ordinances of Umar' by which restrictions (e.g. of dress) were placed upon Jews and Christians.

Umayyad (Omayyad). Arab-Muslim dynasty, established by ${ }^{*}$ Mu'āwiyah I during the civil wars that followed the death of *Uthman, and which dominated Islam 661-750, ruling from Damascus, until overthrown by the Abbasids. An independent Umayyad dynasty ruled in Spain 756-1031.

Umberto I (Humbert) (1844-1900). King of Italy 1878-1900. Son and successor of *Vittorio Emanuele II, he was poorly educated, hugely moustached and largely kept out of the affairs of government. His reign included the war with Ethiopia, ending with a disastrous defeat at Adowa (1896). Having escaped several earlier attempts on his life he was assassinated at Monza by Gaetano Bresci, an Italian anarchist from New Jersey.

Umberto II (Umberto Nicola Tommaso Giovanni Maria di Savoia) (1904-1983). King of Italy 1946. Son of ${ }^{*}$ Vittorio Emanuele III and grandson of *Umberto I, he married (1930) Princess Marie José, a sister of King *Leopold III of the Belgians. He became King after his father's abdication in May 1946, but in a referendum held in June a majority voted for a republic. Umberto left Italy 'temporarily' but in 1947 a ban was placed on his return or that of his descendants. He died in Geneva.

\section{$\mathbf{U} \mathbf{N u}$ see $\mathbf{N u}, \mathbf{U}$}

Unaipon (né Ngunaitponi), David (1872-1967). Australian inventor, writer and preacher, born in Point McLeay. From the Portaulun branch of the Ngarrindjeri people, he became a bootmaker and, from 1924, was the first Indigenous author to be published, with books on Aboriginal legends. $\mathrm{He}$ invented a sheep shearing tool that applied rotary motion, but despite being widely adopted he received no royalties. He is commemorated on the $\$ 50$ banknote.

Unamuno y Jugo, Miguel de (1864-1936). Spanish-Basque philosopher and writer, born in Bilbao. He became professor of Greek language and literature at the University of Salamanca 1891-1901 
and rector 1901-14, 1915-24, 1931-36, being removed three times for his political stances-in favour of the Allies in World War I, against *Primo de Rivera's dictatorship and against *Franco's extremism. A pioneer existentialist, in the sense that he tilted against dogmatism and hypocrisy, he was a modern Don Quixote, the hero or anti-hero whom he came to regard as the symbol of the nobility and tragedy of man (see Life of Don Quixote and Sancho, 1905). Yet even such a generalisation was alien to him as he propounded no general system and was above all an analyst and critic. His longing for eternal life and his realisation that reason and scientific thought stand as bars to the acceptance of immortality are the theme and substance of The Tragic Sense of Life (1913) and other of his numerous poems, essays and novels. His passionate love of Spain was shown not only in his books but in his political opinions and acts. $\mathrm{He}$ became known outside Spain for his opposition to the dictator ${ }^{*}$ Primo de Rivera and the monarchy. $\mathrm{He}$ returned triumphantly from exile when the republic was formed but was soon as disillusioned with the new Socialist regime as with the old, though he strongly protested against the Falangist state foreign intervention in the Civil War.

Undset, Sigrid (1882-1949). Norwegian novelist. She was the daughter of a well-known antiquary who inspired her fascination with medieval Norway, the setting of several of her best novels culminating with Kristin Lavransdatter (3 volumes, 1920-22) and Olav Audunssön (1925-27) for which she was awarded the Nobel Prize for Literature (1928). Treating the characters and themes with modern realism she brought a remarkable sense of conviction to her picture of life in 14th-century Norway. Of her many contemporary novels, the tragedy Jenny (1911) is among the best known.

Updike, John Hoyer (1932-2009). American novelist and critic, born in Pennsylvania. Educated at Harvard and Oxford, he was a staff writer (195557) on the New Yorker, which published many of his poems, short stories and essays. His novels witty and inventive, explore human tensions arising from conflicts of flesh v. spirit, freedom v. responsibility in a rapidly changing world of family life in the United States. His novels include Rabbit, Run (1960), The Centaur (1963), Couples (1968), Bech: A Book (1970), Rabbit Redux (1971), A Month of Sundays (1975), Marry Me (1976), The Coup (1979), The Witches of Eastwick (also filmed, 1984), Roger's Version (1986), Rabbit at Rest (1990) and Memories of the Ford Administration (1992). He won Pulitzer Prizes in 1981 and 1991. He became the chief book critic for the New Yorker and published collected reviews: Hugging the Shore (1984), Just Looking (1989) and Odd Jobs (1991).

Begley, A., Updike. 2014
Urban II (Eudes (Odo) de Châtillon) (1042?-1099). Pope 1088-99. Born in France, he became prior of the abbey at Cluny, then ${ }^{*}$ Gregory VII appointed him as Bishop of Ostia 1080-88 and papal legate to Germany 1084-85. In 1095 he proclaimed the 1st Crusade at the Council of Clermont. He followed this up with letters, sermons and exhortations, the result being the capture of Jerusalem (1099) and the establishment there of a feudal kingdom.

Urban VI (Bartolomeo Prignano) (1318-1389). Pope 1378-89. Born in Naples, he was a canon lawyer, Archbishop of Bari 1377-89, conscientious but obstinate. In the year of his election the College of Cardinals, claiming that they had chosen Urban under pressure from the Roman mob, chose *Clement VII. The latter went to Avignon, where he was recognised by France and her political associates, while Urban remained at Rome. So began the Great Schism (1378-1417), with two rival popes competing for the allegiance of Christendom.

Urban VIII (Maffeo Barberini) (1568-1644). Pope 1623-44. Born in Florence to a powerful merchant family, as papal envoy to France he showed his diplomatic ability and was created cardinal in 1606. As Pope he was led by fear of the Habsburgs to support ${ }^{*}$ Richelieu and the German Protestants in the Thirty Years' War. He befriended writers and scholars and only reluctantly sanctioned proceedings against ${ }^{*}$ Galileo. Extremely able, but a shameless nepotist, he appointed three of his family as cardinals. He improved Rome's infrastructure, consecrated St Peter's (1626), reformed the liturgy and encouraged missionary activity.

Urey, Harold Clayton (1893-1981). American chemist, born in Montana. He studied in California and in Copenhagen with *Bohr. He discovered (1931) deuterium, the heavy isotope of hydrogen, and this led almost at once to the commercial production of heavy water. He subsequently worked out methods for separating the heavy isotopes of carbon, oxygen, nitrogen and sulphur. He won the Nobel Prize for Chemistry in 1934. He was professor of chemistry at Colombia 1934-45 and Chicago 1945-58, then continued research at La Jolla, California. His work in separating isotopes was essential in the development of the atomic and hydrogen bombs. In 1953, with Stanley *Miller, he explained the creation of amino acids. Urey campaigned for an international ban on atomic weapons, wrote extensively on geochemistry and the development of the solar system, and consulted for NASA.

\section{Usama (Osama) bin Laden see Laden, Osama bin}

Uspensky, Gleb Ivanovich (1840-1902). Russian novelist. His themes are generally concerned with the impact of industrialisation on peasant life treated realistically as in The Power of the Soil (1882). Depressed by social conditions, he committed suicide. 
Ussher (or Usher), James (1581-1656). Irish prelate and scholar. Famous for his calculations of biblical chronology, he arrived at the long accepted date of 4004 BCE for the Creation. He was ordained in 1601 and appointed professor of divinity in Dublin (1604), Bishop of Meath (1621) and Archbishop of Armagh (1625).

Ustinov, Sir Peter Alexander (1921-2004). English actor, producer and playwright. Of Russian descent, he first appeared on the stage in 1938 and soon became well known for his versatility and skill in a wide variety of roles both on the stage and in films. Among his plays the most successful were The Love of Four Colonels (1951), Romanoff and Juliet (1956) and Overheard (1981). He also produced operas, was an active Ambassador for UNICEF, wrote an autobiography Dear Me (1977) and My Russia (1983).

Ustinov, P. A., Dear Me. 1977.

Utamaro Kitigawa (1753-1806). Japanese graphic artist. The first great artist of the ukiyo-e ('floating world') school, his works illustrated everyday scenes in Japanese towns. His prints appeared in book form, e.g. Insects, Types of Love and Book of Birds and Flowers. His striking use of colour, especially red and gold, and his sensuous portraits of women were much admired by European collectors. He was followed by *Hokusai and ${ }^{*}$ Hiroshige.

Uthman (Uthman ibn Affan) (c.575-656). Third caliph of Islam 644-656. Born in Medina to the *Umayyad clan, he was the first of his rank to accept Islam and married an unnamed daughter of ${ }^{*}$ Muhammad. A council chose him as a compromise to succeed ${ }^{*}$ Umar as caliph. He published an authorised version of the Qu'ran, reducing the influence of scholars who preached their own variants. Rebellions broke out in Egypt and Iraq, the army opposed him and he was murdered.

Uthman (Othman or Osman) I (c.1258-c.1326). Turkish ruler. Regarded as founder of the Ottoman empire, named for him, he established a sultanate in northwest Anatolia about 1300. Within a century the Ottoman or Osmanli Turks had conquered Anatolia and Bulgaria, confining the Byzantine Empire to the enclave of Constantinople until its fall in 1453.

Utrillo, Maurice (1883-1955). French painter. The adopted son of Miguel Utrillo, a Spaniard, his mother, the French painter Suzanne Valadon, encouraged him to take up art, partly to combat the alcoholism of which he was a victim at an early age. The pictures that won him fame in the 1920s were much influenced in their colouring by the Impressionists, notably *Pissarro, but his freshness of vision resulted from an almost naive affection for his subjects, mostly the narrow streets of Montmartre and little French towns near Paris. Success and his way of life soon dimmed his powers and many of his later pictures display an exaggerated style almost like caricature. Collectors have been embarrassed by the frequent forgery of his works.

George, W., Utrillo. 1960.

Utzon, Joern (1918-2008). Danish architect. A pupil of Alvar *Aalto, he won (1956) an international competition for designing the Sydney Opera House. Construction began in 1957 but, after major disputes with the construction authority, he resigned in 1966 and returned to Copenhagen. The external sail configuration was completed in 1967 (after a 10fold escalation in cost) and the opera house complex opened in 1973. He became an honorary AC in 1985. 


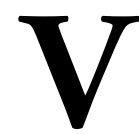

Vacquer, (Louis) Théodore (1824-1899). French archaeologist, born in Paris. As *Haussmann destroyed medieval Paris, Vacquer rediscovered structures from Roman Lutetia and secured their preservation.

Vajpayee, Atal Behari (1924-2018). Indian politician, born in Gwalior. A Brahmin, he was a Member of Parliament 1957-2009 and Leader of the Bharatiya Janata Party (BJP). Prime Minister in May-June 1996 and again 1998-2004, he led a multi-party conservative coalition.

Valdivia, Pedro de (c.1500-1559). Spanish conquistador. After taking part in the conquest of Venezuela and Peru, he was sent by *Pizarro against Chile. At the head of 175 Spaniards and some Indians he set out in 1540, crossed the desert without loss and founded Santiago. Almost immediately the Indians rose in rebellion and the Spaniards had not only to defend themselves but to grow food to live on. When rescued two years later they were in pitiable plight, but Valdivia carried on and then, with his appointment as Governor of Chile confirmed, proceeded to the conquest of the south. Soon after founding Concepcion, Valdivia and other towns, he was defeated and killed by the local Indians.

\section{Valens see Valentinian and Valens}

Valentinian (321-375) and Valens (328-378). Roman emperors (from 364). After the death of Jovian, Valentinian, acclaimed by the troops, made his younger brother Valens co-emperor with responsibility for the Eastern provinces. Meanwhile, Valentinian, having reorganised the administration, ruled with savage justice in the west, kept the German Alemanni at bay, restored Roman supremacy in Britain and Africa, and was campaigning in Hungary when he died from a burst blood vessel.

In the lower Danube, pressure from the Huns in their rear had caused the Goths to seek safety within the imperial territories. Weak and indecisive, Valens hesitated whether to welcome them as allies or resist them as foes. Eventually he turned against them and near Adrianople, in one of the most decisive battles of Roman history (378), he was defeated and killed.

Valentino, Rudolf (Rudolfo Guglielmi di Valentia Antognollo) (1895-1926). Italian-American film actor, born in Castellanata, Puglia. He went to the US in 1913 and in such films as The Sheik and Blood and Sand became the romantic ideal of girls of the 1920s. He died at the height of his popularity and his funeral was the occasion for the display of mass grief and adoration. He wrote a book of poetry, Daydreams, in 1923.

Brownlow, K. and Kobal, J., Hollywood - the Pioneers. 1979.

\section{Valera, Eamon de see De Valera, Eamon}

Valéry, Paul Ambroise (1871-1945). French writer, born in Sète, near Marseilles. Son of a Corsican father and Italian mother, he settled in Paris (1892) and wrote graceful pictorial poems that show the influence of his friend ${ }^{*}$ Mallarmé. For nearly 20 years from 1898 he published no poems but devoted himself to mathematical and philosophic studies. When he resumed writing poetry it was in an entirely new style. La jeune parque (1917) is a harmonious but difficult poem dealing with feminine 'consciousness' in symbolic and philosophic terms. Valéry's prose works include Soirée avec M. Teste (1896), an analytical selfstudy of the inner workings of a human mind, and many essays on aesthetic themes, e.g. Eupalinos and L'Âme et la danse (both 1924). Valéry was elected to the Académie française in 1925 and in later life his lectures at the Collège de France became well known. He was working on a version of Faust when he died.

Mackay, A. E., The Universal Self: A Study of Paul Valéry. 1961.

Valla, Lorenzo (1406/7-1457). Italian humanist scholar, born in Rome. He spent some years moving from university to university before settling in Naples under the protection of Alfonso V. A defence of *Epicurus, in which he maintained that satisfaction of the appetites was the chief good, provided a warning of controversy to come. He went on to prove that a document 'discovered' in 1440 and purporting to be a transfer of the temporal power of the emperor to the papacy was a recent forgery. By similar critical methods that became the basis of later historical research he refuted the contention that the Apostles' Creed was in fact the joint work of the apostles. Saved from the Inquisition by his protector Alfonso, he became (1447) secretary to the humanist pope Nicholas V.

Valerian (Publius Licinius Valerianus) (c.200-260?). Roman Emperor 253-60. Born to a senatorial family, he persecuted the Christians, and made his son ${ }^{*}$ Gallienus co-ruler, dividing the empire. Valerian took the eastern empire, was defeated by the Persians and became the only emperor to die in captivity.

Valois. French dynasty which ruled from the accession of ${ }^{*}$ Philippe VI (1328) to the death of *Henri III (1589). The county of Valois was bestowed (1285) by Philippe III on his third son Charles, who founded the family, which was thus a junior branch of the Capetian line. When the main dynastic line 
failed under the miscalled Salic Law, by which the succession could not pass to or through females, the crown passed to the house of Valois.

Van Allen, James Alfred (1914-2006). American physicist. Professor of physics at Iowa State University 1951-85, he was a pioneer of space research with rockets and artificial satellites, and investigated cosmic rays. He discovered (1960), from the results of the first communications satellite (Echo I) sent up by the US, a belt of radiation that surrounds the earth (and is now named after him).

Vanbrugh, Sir John (1664-1726). English dramatist and architect. Grandson of a Flemish refugee, he failed in the wine business, worked in India, and was arrested and imprisoned in France as a suspected spy (1690). On his release (1692) he returned to England and quickly established a reputation as both playwright and architect. His first comedy The Relapse (1696) was followed by The Provok'd Wife (1697). His third play The Confederacy was staged in 1705 at the New Opera House in the Haymarket, which he had built, and managed in partnership with ${ }^{*}$ Congreve. Three years earlier he had produced grandiose designs for Castle Howard, the Earl of Carlisle's Yorkshire seat, and in 1705 was commissioned to build the even more spectacular Blenheim Palace for the Duke of *Marlborough. Despite frequent quarrels with the duchess, Sarah, over the plans and the enormous expense, he succeeded in creating the most splendid and by far the largest example of English baroque. He became Comptroller of Works in 1702 and was knighted by *George I. His last play, The Provok'd Husband, was unfinished at his death.

Holland, N. N., The First Modern Comedies. 1959.

Van Buren, Martin (1782-1862). 8th President of the US 1837-41. Born at Kinderhook, near Albany, New York, he became a lawyer and was prominent in state politics. His wife died in 1819 and he never remarried. A political manipulator of great skill, he established the first political 'machine', in New York and was known by his supporters as 'The Little Magician', by detractors as 'The Sly Fox'. He became US senator 1821-28 and Governor of New York state 1829. When his friend Andrew *Jackson became President (1829) he chose Van Buren to be his Secretary of State 1829-31, Minister to Great Britain 1831-32 and Vice President 1833-37. The Autobiography of Martin Van Buren (1833) is illuminating on the development of party politics in the US. Jackson's influence secured him Democratic nomination and election to the presidency in 1836. Van Buren was the first president born as a United States citizen. He opposed the extension of slavery but opposed its abolition in the South. Despite skilful handling of a financial panic, in 1840 he was defeated for a second term by William Henry *Harrison. In 1844, at the Baltimore Convention, he sought re-nomination for president, but failed to win the two-thirds majority required and withdrew. $\mathrm{He}$ emerged from retirement in 1848 to run unsuccessfully for the presidency as a 'Free Soil' candidate. Van Buren was also known as 'Old Kinderhook', from his hometown. The abbreviation 'OK', which first appeared in print in 1839, was popularised in the 1840 presidential election by the Democratic OK Club.

Lynch, D. T., Epoch and a Man: Martin Van Buren and His Times. 1971.

Vance, Cyrus Roberts (1917-2002). American lawyer and administrator, born in West Virginia. Educated at Yale, after naval service he became a New York lawyer in 1947 and in 1957 was appointed special counsel to a Senate subcommittee. He became General Counsel to the Department of Defence in 1961, Secretary of the Army in 1962 and Deputy Secretary of Defence 1964-67. He was the president's special envoy to negotiations for peace in Cyprus (1967) and Vietnam (1968). President Carter made him Secretary of State in 1977 and he resigned over the Iranian crisis in 1980. With David *Owen he was the joint UN mediator in Bosnia 1992-93.

Vancouver, George (1758-1798). British naval explorer, of Dutch ancestry. As a youth he sailed with Captain ${ }^{*}$ Cook on his second and third voyages 1772-75, 1776-79 and later he was commissioned to lead an expedition to northwest America, partly to settle a territorial dispute, partly to explore. On the voyage out he went by the Cape route to Australia, where he explored the southwest coast, and thence to Tasmania, New Zealand and Hawaii. He spent three years (1792-94) on the American coast during which he circumnavigated Vancouver Island (named by the Spaniards after him) and made an accurate survey of the coasts of what are now California and British Columbia.

Vanderbilt, Cornelius (1794-1877). American financier, born in New York. Known as 'the Commodore', as a boy he established a ferry service from Staten Island to New York which expanded until he controlled several shipping lines. He then turned to railways, and after a series of financial battles gained control of the New York Central Railway and many other lines. He amassed a vast fortune and used part to found the Vanderbilt University, Tennessee. His granddaughter Consuelo Vanderbilt married the 9th Duke of Marlborough.

\section{Van der Walls see Waals, Johannes Diderik van der}

\section{Van der Weyden see Weyden, Rogier van der}

Van de Velde. Dutch family of painters. Willem van de Velde the Elder (the Elder) (1611-1693) painted large pictures of ships and sea battles, usually drawn in black paint or Indian ink on a white ground. In 1672 he and his elder son, Willem van de Velde (the Younger) (1633-1707), were in London where they remained as official marine painters. Several hundred marine paintings are attributed to Willem 
the Younger, who is held to be among the greatest masters in this genre. Many of their paintings of sea fights were made from sketches done on the scene of action and sometimes under fire. Adriaen van de Velde (1636-1672), the younger son, painted gentle Dutch landscapes with figures and grazing cattle.

\section{van Dongen, Kees see Dongen, Kees van}

Van Doren, Carl (Clinton) (1885-1950). American editor and biographer. He taught at Columbia University and won a Pulitzer Prize for Benjamin Franklin (1938). His brother Mark Van Doren (1894-1972), poet, teacher and critic, won the 1939 Pulitzer Prize for Collected Poems 1922-38 and also taught at Columbia. His son Charles Lincoln Van Doren (1926-2019), also a Columbia teacher, achieved unwelcome celebrity in a scandal involving the television quiz 'Twenty-One' (1958).

Van Druten, John William (1901-1957). American playwright, born in England. His exploration of adolescence Young Woodley (1928), first made him known. His plays include Bell, Book and Candle (1950), and I am a Camera (1951), a picture of interwar Berlin based on Christopher *Isherwood's stories. He became a US citizen in 1944.

Van Dyck, Sir Anthony (1599-1641). Flemish painter, born in Antwerp. Son of a well-to-do silk merchant, he was a prodigy in art, by 1617 one of the chief assistants of*Rubens with whose work, especially his portraits and religious subjects, Van Dyck's work has been often confused. Van Dyck was invited to England for the first time in 1620 but stayed only a few months. From 1621 to 1627 he was in Italy (Genoa, Rome, Sicily, Venice), and with *Titian as a strong influence, he perfected a style of aristocratic portraiture which remained fashionable for 150 years. After winning a great reputation among members of Genoese society, he returned to Antwerp where, working in friendly competition with *Rubens, he found an overwhelming demand for his portraits. In 1632 under pressure from ${ }^{*}$ Charles I he returned to England, where he remained for the rest of his life and painted many portraits of the sad and solemn king, of his family and of the great men and ladies of the court. The glittering clothes, the texture of the materials, the perfumed hair, the jewelled accessories, the very dogs and horses, combine to give a romantic effect. The draughtsmanship is sure and true (his etched heads are superb) and the characterisation convincing. As a court painter he has had few equals.

Strong, R., Sir Anthony Van Dyck. 1972.

Vane, Sir Henry (1613-1662). English parliamentarian. Son of Sir Henry Vane (15891655), Secretary of State 1640-41, he became a diplomat, lived in Boston 1635-37 and was Governor of Massachusetts 1636-37. Member of Parliament 1640-53, 1659-60, he 'leaked' information purloined from his father to John
*Pym which led directly to the impeachment and execution of *Strafford. After Pym's death he became *Cromwell's main parliamentary supporter, took part in the creation of the New Model Army (1644-45) and the settlement of Scotland (1652-53). Under the Commonwealth he was a member of the Council of State. Disagreement with Cromwell brought a temporary eclipse but after his leader's death he was again active. After the Restoration, he was the only man apart from the actual regicides to be executed.

Vane, Sir John Robert (1927-2004). English pharmacologist. He shared the 1982 Nobel Prize for Medicine for research on prostaglandins and related biologically active substances, and advocated the use of aspirin in inhibiting heart disease and stroke.

\section{Van Eyck see Eyck, Hubert van and Jan van}

\section{Van Gogh see Gogh, Vincent van}

Vanier, Georges-Philéas (1888-1967). Canadian soldier and diplomat. Trained as a lawyer, he practised in Montréal. In World War I he won the DSO, MC and bar. Afterwards he held a number of official posts, culminating with that of Minister to France 193940. During World War II he served on the Defence Board in Ottawa and as Minister Plenipotentiary to seven exiled European governments exiled in London, returning to Paris as Ambassador 1944-53. He was the first French-Canadian to serve as GovernorGeneral 1959-67. His son, Jean Vanier (1928-2019), a philosopher, established L'Arche International, a network of 158 communities for the intellectually and physically disabled, in 38 countries. Once regarded as a candidate for potential canonization, his reputation was damaged by well-documented evidence of sexual abuse of women.

Van Loon, Hendrik Willem (1882-1944). Dutch-American historian and biographer, born in Rotterdam. He emigrated to the US in 1903, studied at Cornell, Harvard and Munich universities and, after a period as a war correspondent, wrote a series of books that aimed to explain the world and its complexities to both children and mystified adults, illustrated by himself. All were enormously successful: they include The Story of Mankind (1921), The Story of the Bible (1923), The Story of America (1927), The Home of Mankind (1933), The Arts of Mankind (1938), Van Loon's Lives (1943) and the autobiographical Report to St Peter (1944).

\section{Van Rijn, Rembrandt see Rembrandt}

Vansittart, Robert Gilbert Vansittart, 1st Baron (1881-1957). English diplomat. As Permanent Undersecretary for Foreign Affairs 1930-38 he expressed to his political superiors his misgivings about ${ }^{*}$ Hitler and his policies. These warnings went unheeded and he was shunted off as Chief Diplomatic Adviser to the Foreign Secretary 1938-41. He retired in 1941.

Colvin, I., Vansittart in Office. 1965. 
Van't Hoff, Jacobus Henricus (1852-1911). Dutch physical chemist. One of the founders of physical chemistry in its modern form, he held professorships at Amsterdam 1877-87, Leipzig 1887-94 and Berlin 1895-1911. In 1874 he proposed the theory that the four valencies of the carbon atom are directed to the corners of a regular tetrahedron, thus establishing the field of chemical structure now called stereochemistry. In 1887 he established his theory of solutions, which is the basis of present-day knowledge of the subject. He showed that the osmotic pressure of a dilute solution is equal to the pressure that the dissolved substance would exert if it were a gas occupying the same volume at the same temperature and pressure. Other studies included reaction velocity and thermodynamics. Van't Hoff was awarded the first Nobel Prize for Chemistry (1901).

\section{Vanzetti, Bartolomeo see Sacco, Nicola}

Varadkar, Leo Eric (1979- ). Irish politician, born in Dublin. A Catholic of Indian descent, he was a successful medical practitioner, gay, MP 2007- , Leader of Fine Gael 2017- and Taoiseach (Prime Minister) of Ireland 2017-20. Fine Gael ran third in the February 2020 election, but there was no agreement on an alternative leader so he remained as a caretaker Prime Minister until June. During the COVID-19 pandemic he returned, part-time, to practice then, in a coalition with Fianna Fáil and the Greens, became Deputy Prime Minister 2020- .

Varèse, Edgard Victor Achille Charles (18831965). French-American composer, born in Paris. He lived in the US from 1915, experimenting with quarter tone music, percussion and electronics.

Vargas, Getúlio Dornelles (1883-1954). Brazilian politician, born in São Borja. A lawyer and cattle rancher, he served as Federal Finance Minister 1926-27 and Governor of Rio Grande do Sul 1928-30. He ran for the Presidency in 1930 in a notably corrupt poll, just after the Great Depression hit Brazil: the army intervened to remove the declared winner Júlio Prestes and installed Vargas as 'interim President' 1930-34. The 1930 coup marked the end of the 'Old Republic', in which power alternated between two oligarchies (known as café com leite politics). He adopted much of the corporatism of ${ }^{*}$ Mussolini in Italy and *Salazar in Portugal, combined with interventionist economic policies similar to *Roosevelt's New Deal. Vargas continued as President 1934-45, using emergency powers to over-ride the Constitution and stay in office, ruling as a dictator from 1937 in his 'New State' (Estado Novo). But he had some popular support and was known as 'the Father of the Poor'. Despite having shown some sympathy for the Axis, the US induced him to take Brazil into World War II on the Allied side, but afterwards had to give way to constitutional demands. He resigned (1945) but remained leader of a reformed Labour Party and was a Senator 1945-51.
After a free election, he was again President 1951-54, but the rise in the cost of living soon dimmed his popularity and when a group of officers gave him the choice of resignation or exile he shot himself.

Dulles, J. W. F., Vargas of Brazil, a political biography. 1967.

Vargas Llosa, Mario (1936- ). Peruvian novelist. Educated in Lima and Madrid, he became a journalist and broadcaster. His novels include The Time of the Hero (1963, translated 1966). Conversation in the Cathedral (1969, 1975) and Aunt Julia and the Scribbler (1977). He was the candidate of the Freedom Party for the Presidency of Peru (1990), losing to Alberto *Fujimori. He was awarded the Nobel Prize for Literature in 2010.

Varmus, Harold (1939- ). American medical scientist. He shared the 1989 Nobel Prize for Medicine with Michael Bishop for their work on cancer-causing genes and became director of the National Institute of Health 1993-99.

Vasarely, Victor (1908-1997). Hungarian-French artist. He worked in Paris from 1930 and became a pioneer of op art with geometrical abstractions which were much reproduced. He won the São Paulo Biennale Grand Prix in 1965 and was represented in museums throughout the world.

Vasari, Giorgio (1511-1574). Italian art historian, architect and painter, born in Arezzo. Though he gained considerable contemporary reputation as an architect (e.g. of the Uffizi in Florence) and as a Mannerist painter (e.g. of overcrowded battle scenes in the Palazzo Vecchio), he is remembered for his book The Lives of the Artists (in full The Lives of the Most Excellent Painters, Sculptors, and Architects, 1550), containing the biographies of the Italian painters of the previous 300 years. Despite considerable inaccuracy and bias it is the only source for much of the material, is full of lively anecdotes and shrewd comment. A revised and enlarged edition appeared in 1568.

Ruben, P. L., Giorgio Vasari. 1996; Rowland, I. and Charney, N., The Collector of Lives. Giorgio Vasari and the Invention of Art. 2017.

\section{Vasco da Gama see Gama, Vasco da}

Vasks, Pēteris (1946- ). Latvian composer. Son of a Baptist pastor, he became a violinist and composer, influenced by ${ }^{*}$ Lutosławski and ${ }^{*}$ Penderecki. Describing his work as 'food for the soul', he composed three symphonies, a violin concerto, 'Distant Light', two cello concertos and much chamber and choral music.

Vauban, Sebastien le Prestre de (1633-1707). French military engineer. Orphaned and destitute, he joined the army and served under *Condé, having gained (1655) an engineer's commission in the 
army of the King. He was primarily engaged in the taking and making of fortresses. He also developed the socket bayonet and ricochet fire. In the Spanish Netherlands (Belgium) (1672-78) he conducted 17 successful sieges, reducing Maastricht in 13 days by an approach by parallels, a method he introduced. In the decade between the wars (1678-88), he constructed the magnificent series of frontier fortresses which were effective until they fell under the attack of German howitzers in World War I. Already a general, he was appointed Marshal of France in 1703. Twelve 'Fortifications of Vauban' were inscribed on UNESCO's World Heritage List in 2008.

Vaucanson, Jacques de (1709-1782). French inventor, born in Grenoble. He invented the first allmetal lathe, and created a series of elaborate automata, the most famous of which was 'The Digesting Duck' (1739).

Vaughan, Henry (1622-1695). Welsh religious poet. In 1647 he began practising medicine in his native Brecknockshire. He began writing secular poetry (Poems with the tenth Satyre of Juvenal Englished 1646) but after a religious conversion (c.1648) wrote only devotional verse and prose mediations. His religious poetry, the best of it in Silex Scintillans (1650) and Thalia Rediviva (1678), owes much to the influence of George *Herbert. In his natural descriptions and some of his thought (e.g. the nearness of a child to God, based in a belief of a life before birth) he seems to presage *Wordsworth.

Durr, R. A., The Mystical Poetry of Henry Vaughan. 1962.

Vaughan Williams, Ralph (1872-1958). English composer, born in Gloucestershire. Son of a clergyman, his mother was related to the ${ }^{*}$ Darwin and *Wedgwood families. He studied at Trinity College, Cambridge (where, in 1901, he took a Mus. Doc.), the Royal College of Music under *Stanford and *Parry, in Berlin with *Bruch (1897-98) and in Paris with *Ravel (1909). However, the turning point came with his discovery of English folksong (1905) and of the Tudor polyphonic tradition. His Fantasia on a Theme of Thomas Tallis (1909), probably his best work, shows the influence of both Church music and Ravel's orchestration. His song cycle On Wenlock Edge (1909), to poems by A. E. *Housman, remains in the repertoire, as do many songs, hymn tunes and folksong arrangements. He wrote nine symphonies between 1901 and 1958, of which No. 4 (1935), a stark and violent work, marks an abrupt change from his romantic and lyrical style. He wrote several operas, including Hugh the Drover (1914) and The Pilgrim's Progress (1951), many choral works, The Lark Ascending (rhapsody for violin, 1921), and the ballet Job (based on *Blake's etchings, 1931). He received the OM in 1935 and continued composing until his death.
Vavilov, Nikolai Ivanovich (1887-1943). Russian geneticist, born in Moscow. A Mendelian, from 1914 he travelled incessantly to collect varieties of wheat, other cereals and potatoes from their natural habitat, establishing in Leningrad the world's largest 'bank' of genetic variation in crops. From 1936 he was attacked by his former protégé T. D. *Lysenko, arrested in 1940 and starved to death in a labour camp. He was posthumously rehabilitated. Minor planet 2862 Vavilov (1977) and a moon crater were named for him.

Pringle, P., The Murder of Nikolai Vavilov. 2008.

Veblen, Thorstein (Bunde) (1857-1929). American economist and sociologist, born in Wisconsin. Of Norwegian descent, he learned English at school, won a PhD at Yale, taught at Chicago, Stanford and Missouri, and had a broken career because of marital difficulties. He wrote several successful books. The Theory of the Leisure Class (1899) is an analysis of the psychological motives for the business class in an acquisitive society. His style was astringent and witty, the concept of 'conspicuous waste' was one of his creations. Others works include The Theory of Business Enterprise (1904) and The Engineers and the Price System (1921).

Vega Carpio, Lope Félix de (1562-1635). Spanish dramatist and poet. As a young man he took part in the Spanish expedition to the Azores (1583) and sailed with the Armada (1588). He was also secretary to the Duke of Alva, the Marquis of Malpica and the Marquis of Sarria. He had many love affairs, was twice married and had several illegitimate children. His sensuousness is reflected in his love poems, and in this, and the religious poetry which was written in his periods of remorse and his charitable gifts to the Church and poor, there is a dichotomy that makes his writing more immediate and personal than that of many of his contemporaries. He had great literary prestige during his lifetime, which was, however, marred by tragedy, including the death of two wives, the blindness and madness of a mistress, the abduction of a daughter and the deaths of two sons.

After 1588, his dramatic production was huge and generally sensational, and approximately 500 pieces (including entremeses and autos) survive of approximately 1500 . He was the master of the Comedia in three acts, full of action and sentiment but not noted for individual characterisation or powerful situation. His plays are roughly (1) 'cloak and sword' plays comedies of intrigue, complicated aristocratic love stories such as La discreta enamorata, Noche de San Juan, and Maestro de Danzar, and (2) plays on Spanish history or legends, such as Peribnez, Fuenteovejuna and El ultimo godo.

Lope de Vega is critically praised for his neatness and inventiveness of plot, his lyricism, his sympathetic and unpatronising portrayal of the peasant characters of his plays, and his charming lovers. He also wrote many 
poems, religious and secular, a pastoral novel Arcadia (1581) amongst others, prose, a mock epic about cats and an autobiographical novel La Dorotea (1632).

Veidt, Conrad (originally Hans Walter Konrad Weidt) (1893-1943). German actor and director, born in Berlin. He made his stage debut in 1913 and from 1916 appeared in 119 films, notably as Cesare the somnambulist in The Cabinet of Dr Caligari (1919), The Thief of Bagdad (1940) and as Major Strasser in Casablanca (1942). He left Germany in 1933 and became a British subject.

Veil, Simone Annie Liline (née Jacob) (1927-2017). French administrator, born in Nice. She survived concentration camps at Auschwitz-Birkenau but her parents and a brother died. She served at the Ministry of Justice 1957-65, first as an attaché and later (from 1959) as an assistant. She was Secretary-General to the Conseil Supérieur de la Magistrature 1970-74 and a member of the French Broadcasting Administration 1972-74. She achieved wide popularity and recognition as Minister of Health 1974-77, Minister of Health and Social Security 1977-78, Minister of Health and Family Affairs 1978-79 and Minister for Social Affairs, Health and Towns 1993-95. She promoted the cause of women's rights in the family, for easier access to contraception and legalising abortion. Elected as MEP 1979-93, she was the first elected President of the European Parliament at Strasbourg 1979-82. She won the Charlemagne Prize in 1981, was appointed Hon. DBE in 1998, elected to the Académie française in 2008 and awarded the Grand Cross of the Legion of Honour in 2012. She was interred in the Panthéon in 2018.

Velázquez, Diego Rodriguez deSilva y (1599-1660). Spanish painter of Portuguese descent, born in Seville. At the age of 14 he began to study under Francisco Pacheco, an indifferent artist whose daughter he married. At first working closely from life, he painted genre scenes, such as kitchen interiors, with figures and objects in realistic detail. The strong contrasts of light and shade recall the chiaroscuro of ${ }^{*}$ Caravaggio, then becoming popular in Spain. In 1622 and 1623 Velázquez visited Madrid where he painted his first portrait of ${ }^{*}$ Felipe IV, which led to his appointment as court painter and to other more or less honorific appointments as his reputation grew. ${ }^{*}$ Rubens visited Madrid in 1628 and his influence enabled Velázquez to go on a two-year visit to Italy (1629-31), which resulted in a softening of the harshness of his early style: colour began to show in the shadows, light and space became his preoccupations, whilst the range of subjects was enlarged. He resumed his position as royal painter on his return. In his royal portraits he avoids flattery but the infantes and infantas have freshness and charm despite their elaborate and formal clothes. Velázquez was an assiduous courtier, eager for royal favours but his treatment of his masters is unsparing. In his only surviving battle piece, the Surrender of Breda (1634-35), the chivalrous compassion depicted in the attitude of the victors to the defeated gives a humanity to the picture almost unknown in paintings of this kind. Where he is less inhibited by his subject, e.g. in his pictures of court jesters and buffoons (notably the moving Calabazas, 1637, in the Prado), he is at his most effective in combining realism with interpretation of character. The loose brush work of the views of the Medici Gardens, two of his rare landscapes, indicate a stylistic development to which his second visit to Italy (1648-51) may have contributed. To this last period belong the masterpieces The Toilet of Venus (The Rokeby Venus, painted in Italy, his only nude, now in the National Gallery, London), the outstanding portraits of his mulatto slave Juan de Pareja (1649, New York), Pope Innocent $X$ (1650, the subject said 'troppo vero'), Maids of Honour (Las Meninas, 1656, in the Prado, Madrid), voted in 1985 as 'the world's greatest painting' by an international panel of experts and The Spinners (Las Hilanderas, 1657?, Prado). Velázquez was a rapid but not very prolific painter: of 125 canvasses confidently attributed only 98 survive. He founded no school of painting and his genius was unknown outside Spain until the 19th century. Among painters deeply influenced by Velázquez were ${ }^{*}$ Manet, ${ }^{*}$ Picasso, ${ }^{*}$ Dalí and ${ }^{*}$ Bacon.

Brown, J., Velázquez: Painter and Courtier. 1985; Bailey, A., Velázquez and the Surrender of Breda. 2011; López-Rey, J. and Delenda, O., The Complete Works of Velázquez. 2019 edition.

Venizelos, Eleftherios Kyriakou (1864-1936). Greek politician, born in Crete. He was prominent in the rising of 1896 against Turkish rule, and after limited self-government was conceded, became Crete's Justice Minister 1899-1901; 1908-10 and Prime Minister 1910. Summoned to Athens, he had broken terms as Prime Minister of Greece 1910-15; 1915; 1917-20; 1924; 1928-32; 1933. He was the prime mover in building up the Balkan alliance which resulted in the wars of 1912-13 against Turkey and Bulgaria. The aim of Venizelos' life since boyhood, the union of Crete with Greece, was now achieved. World War I led to a deep rift between King *Constantine (who was married to the German Emperor's sister) and his pro-Allied Prime Minister. Venizelos eventually felt himself obliged to set up a provisional government at Salonica (1916) and there were two governments in Greece until the Allies forced the deposition of Constantine (1917). Venizelos led the Greek delegation at the Paris Peace Conference (1919) but was defeated at the election of 1920 (when Constantine was recalled). After the Greek defeat by the Turks in Asia Minor (1921-22) the monarchy was suspended in 1923 but Venizelos remained (except briefly) out of office until 1928. Defeated in 1932 after a successful term during which he had done much for the economic reconstruction of the country, he returned to Crete, where he took part in an unsuccessful revolt against the restored monarchy (1935). Forced into exile, he died in Paris. 
Ventris, Michael George Francis (1922-1956). British architect and scholar. While practising as an architect he pursued his self-imposed task of interpreting the ancient Mycenaean writing known as Linear Script B. His conclusion that it was an early form of Greek writing gradually gained general acceptance. In collaboration with John Chadwick of Cambridge University he wrote Documents in Mycenaean Greek (1956). He was killed in a motor accident—possibly as suicide.

Vercingetorix (d.46 BCE). Gallic (Avernian) chieftain. Defeated by Julius *Caesar at Alesia $(52$ $\mathrm{BCE}$ ), he was taken in triumph to Rome and executed there. He is celebrated in the French Asterix comics.

Verdi, Giuseppe (Fortunino Francesco) (1813-1901). Italian composer, born at Roncale, near Parma, four months after his great operatic rival Richard *Wagner. Son of a village tradesman, he studied under the local organist. A friend and patron, Antonio Barezzi, a rich merchant (whose daughter Margherita he married in 1836), supported his early musical education. The Milan Conservatoire refused to admit Verdi (as he was over age for admission), and he continued his training in Milan with Vincenzo Lavigna, a repetiteur at La Scala. After Verdi's daughter (1838), son (1839) and wife (1840) died, he sank into depression. However, friends persuaded him to return to composition, leading to his first major success, Nabucco (Nebuchadnezzar) (1842). Ernani (Venice, 1844) followed and then Macbeth (Florence, 1847), in which Verdi developed a strong melodic style ideally suited to the dramatic episodes of the plot.

Verdi's genius combined popular appeal, with vocally attractive arias beloved of amateurs and record collectors, with, in later decades, growing sophistication and psychological penetration. His most performed operas are Rigoletto (1851), based on Victor *Hugo's Le roi samuse, an immediate success which has never left the repertoire; psychologically complex, intensely dramatic and superbly scored, Il Trovatore (The Troubadour, 1853), a complicated story of jealousy and vengeance, and La Traviata (The Fallen Woman,1853), drawn from the play $L a$ Dame aux camélias by *Dumas fils.

Shakespearean in his range, Verdi was a skilled writer (including excellent letters) and sometimes his own librettist. Don Carlos - the French title, Don Carlo in Italian (1867), based on a drama by *Schiller, is his longest opera. Set in France and Spain in the 1560 s, it is a powerful psychological study of family conflicts (with Oedipal hints of incest), dynastic rivalries, personal frustration, freedom v. authority and religious fanaticism.

The achievement of dramatic 'truth' (verismo), now Verdi's main aim, made such demands on acting ability that the virtuoso singers, so long the mainstay of opera, were deprived of their dominance.
Un Ballo in Maschera (Rome, 1859) and those that followed, including I Vespri Siciliani (Paris, 1867) was not immediately recognised. Aida (Cairo, 1871) was commissioned for the opening of the Suez Canal.

He bought an estate at Sant'Agata, near Busseto in 1848 and later became a major landowner. He spent some time in Paris, visited St Petersburg (1861) and London $(1862,1875)$. He lived with the soprano Giuseppina Strepponi (1815-1897) from 1849, married her in 1859 and generally lived happily ever after, although he had other amours, even in old age.

Verdi played a symbolic political role and the letters of his name became a political acronym for the unification movement (Vittorio Emanuele Re D'Italie). An ardent patriot ('a Liberal, but not a Red'), he was elected as a Deputy 1861-65 in the national parliament and Senator (from 1874) but rarely sat. He wrote some religious works, including the Requiem (1874), dedicated to the memory of Alessandro *Manzoni, and Four Sacred Pieces (published 1898) including Ave Maria and a Stabat Mater.

Of his three Shakespearean operas, Macbeth (1853) had a libretto by Francesco Piave, while for Otello (1887) and Falstaff (1893), the librettist was the composer and poet Arrigo *Boito, whose work rivals Lorenzo * $\mathrm{Da}$ Ponte or *Wagner. Iago's aria in Act 2 of Otello, 'Credo in un Dio crudel ...' ('I believe in a cruel God ...') is a dramatic masterpiece, but not using Shakespeare's words. Falstaff, first performed in Verdi's 80th year, a work of genius with words and music at the highest level, is drawn largely from The Merry Wives of Windsor. The action proceeds at breakneck speed in a variety of genres-farce, inner reflection, betrayal, joy and reconciliation. Among the greatest passages in Falstaff are Ford's chilling aria 'È sogno o realtà? ('Is it a dream or reality?') in Act 2, and the finale, an exuberant fugue 'Tutto nel mondo e burlà ...' ('Everything in the world is a jest ...')

Verdi died in the Grand Hotel, Milan, leaving an estate worth \$US40 million (in 2013 values). *Schoenberg and ${ }^{*}$ Stravinsky admired Verdi. His reputation continues to grow. Of his 27 operas, more are in the international repertoire now than at his death: all are available digitally.

Phillips-Matz, M. J., Verdi. 1993; Conrad, P., Verdi andlor Wagner: Two Men, Two Worlds, Two Centuries. 2011; Wills, G., Verdi's Shakespeare. 2011.

Verlaine, Paul (1844-1896). French poet, born in Metz. At 17, after leaving the Lycée Condorcet, Paris, he became a clerk in the municipal service and was already writing poetry. Soon, as a contributor to Le Parnasse contemporain, he mixed with such poets as *Leconte de Lisle, Catulle *Mendès and *Mallarmé. His first volume, Poèmes Suturniens (1860), won moderate praise; the next, Fêtes galantes (1869), was a more mature work evocative of the elegance of the 18 th century in which it was set. His courtship of 
his 16-year-old bride Mathilde Mauté is recorded in La Bonne Chanson (1870), but in 1871, having met the young ${ }^{*}$ Rimbaud, he left her and their infant son to spend a year of bohemian wandering with him in Belgium and England. In Brussels (1873), Rimbaud threatened to leave him. They quarrelled, Verlaine shot him in the wrist and he was later arrested and sentenced to two years' imprisonment. While in prison he wrote Romances sans paroles, in which the meaning is almost submerged by the music of the words. On his release he became a schoolmaster, and in a mood of religious penitence wrote Sagesse (published 1881). Back in France (1877) he continued to teach for a time, the poems in his Amour (1888) were inspired by grief at the death of a former pupil whom he had adopted as a son. Despite growing fame he had difficulty in making a living and his works progressively deteriorated. His critical writings, e.g. Poètes maudits (1884), short stories and lecture tours were not remunerative. Alcoholism and illness brought him to poverty and squalor, though his friends and admirers, and even the state, rallied to his help at the end.

Richardson, J., Verlaine. 1971.

Vermeer, Johannes (or Jan) (1632-1675). Dutch painter, born in Delft. He spent all his life in his birthplace where, in 1653 he joined the Guild of St Luke as a master painter. Except for a famous View of Delft (1658-60) and a very few portraits and other pictures, he painted mainly interiors, where a single wall and a tiled floor provide backgrounds for the harmoniously composed figures in the soft serene light pouring through tall windows, lighting effects over which he gained a supreme mastery. The figures, mostly young women, appear singly or in very small groups and confirm by their attitudes and occupations the pictures' moods. It is likely that he used a camera obscura to assist with proportions and to capture tonal changes. Vermeer was popular in his own day but was then almost forgotten until the 19th-century revival after 1866 by the art historian Theophile Thoré. A slow worker, only about 35 of his paintings survive. *Proust thought View of Delft 'the most beautiful painting in the world' and other masterpieces include The Milkmaid (c.1658), The Little Street (1658), Girl with a pearl earring (1665) and Girl with the red hat (c.1665). Vermeer can be recognised by the monumental and spacious effect he gives to small rooms by sitting close to the model, by his characteristic dark blues and warm yellows and by the occurrence in picture after picture of the same small objects painted with the same meticulous detail. Such idiosyncrasies provided an opportunity for the forger Hans van ${ }^{*}$ Meegeren in World War II (although as Vermeer's work has become better known, it is hard to see how the forgeries could have fooled anybody). Vermeer cared little for commercialism. At his death his baker held two of his paintings for unpaid bills, and his wife, declared bankrupt, could not retrieve them. The microscopist ${ }^{*}$ Leeuwenhoek, an exact contemporary, was his executor but it is uncertain if they were friends.
Gowing, L., Vermeer. 2nd ed. 1970; Wheelock, A. K., Vermeer. 1981; Wheelock, A. K., Vermeer and the Art of Painting. 1995; Steadman, P., Vermeer's Camera. 2001.

Vermes, Geza (1924-2013). Hungarian-British scholar. His family converted from Judaism, but his parents died in the Holocaust. He studied in Paris and Louvain, became a Catholic priest, worked on the Dead Sea Scrolls but left the Church in 1957. Reader 1965-89 and professor 1989-91 of Jewish studies at Oxford, his books include Jesus the Jew (1973), The Changing Faces of Jesus (2001) and The Authentic Gospel of Jesus (2004).

Verne, Jules (1828-1905). French novelist, born at Nantes. Originator of 'scientific' romances, he wrote a long series beginning with Five Weeks in a Balloon (1863) and including Twenty Thousand Leagues under the Sea (1870) and Around the World in Eighty Days (1873). Their enormous success, based largely on their plausibility, inspired H. G. *Wells and later writers of science fiction. He lived in Amiens from 1872. His lost novel Paris in the 20th Century was published in 1994.

Evans. I. O., Jules Verne and His Work. 1965.

Vernier, Pierre (c.1580-1637). French mathematician and soldier born in Ornans, FranceComté. After working as an engineer for the Habsburgs in the Spanish Netherlands, he became captain of the chatêau at Ornans 1622-38. In 1630 he invented the auxiliary scale named for him. By using the vernier to subdivide the smallest divisions of an ordinary scale he greatly improved the accuracy of linear and angular measurements.

Veronese (Paolo Caliari) (1528-1588). Italian painter, born at Verona. Though the titles of his pictures, e.g., Marriage of Cana (1563), Feast of the House of Levi (1573) etc. are religious, the episodes depicted are removed in time and place to contemporary Venice. In architectural settings of unparalleled magnificence, emphasised sometimes by his experiments in false perspective, he sets the men and women of the aristocratic world in which he moved, brilliant in silk brocades and glittering with jewels. He had to appear before the Inquisition (1573) for introducing dwarfs and jesters into biblical scenes but he claimed the artistic privilege of a decorator. Though he was a contemporary of the Mannerists his work is nearer to that of the High Renaissance. Most of the paintings went to adorn the great palaces of Venice and Rome.

Orliac, A., Veronese. 1948.

Veronica, St (1st century CE?). Legendary saint. According to tradition she was a woman of Jerusalem who offered her veil to Jesus to wipe the sweat from his face while he was carrying the cross to Calvary. His features, so it was said, were miraculously imprinted on the fabric and the picture survived 
and was eventually brought to Rome. A naturalistic explanation suggests that the name Veronica is derived from the cloth itself vera icon ('the true image').

Verrocchio (Andrea di Michele di Francesco Cioni) (1435-1488). Italian painter and sculptor, born in Florence. He took his familiar name from Giuliano Verrocchi, the goldsmith who was his first teacher, but like so many of the great Renaissance figures he worked with almost equal facility in all the arts and crafts. Not only was he a painter and sculptor but he showed his skill as a metal worker and wood carver. He succeeded (1467) *Donatello in the service of the *Medici and among his many tasks were the making of tournament armour and carnival masks. There are notable differences between him and his predecessor: Donatello's statue David is an idealised naked youth, Verrocchio portrays him with sword and armour. Among his pupils was ${ }^{*}$ Leonardo da Vinci who is said to have painted the angel on the left of The Baptism (now in the Uffizi, Florence), one of Verrocchio's few known paintings. At his death he was still working on the equestrian statue of Bartolomeo *Colleoni, a magnificent portrayal of the great and arrogant Venetian mercenary.

Verwoerd, Hendrik Frensch (1901-1966). South African politician, born in Amsterdam. He went to South Africa as a child, was educated at Stellenbosch University, to which, after further study in Europe, he returned (1928) as head of the Department of Sociology and Social Services. He edited Die Transvaaler, a new Afrikaans daily, 1938-48, then became a senator. In 1950 he became Minister of Native Affairs in the Nationalist Government and strictly applied the apartheid policy of racial segregation. This he continued when he became Prime Minister 1958-66. In 1960 South Africa decided by referendum to become a republic, and the decision was put into effect (1961) when South Africa left the Commonwealth. An English settler had attempted to assassinate him in 1960, and in September 1966 he was stabbed to death in the House of Assembly at Cape Town.

Vesalius, Andreas (1514-1564). Flemish anatomist, born in Brussels. He studied in Paris and Louvain before becoming professor of surgery at Padua University, where he had just (1537) taken his degree. His publications were based on the works of ${ }^{*}$ Galen, but by carrying out dissections (a revolutionary practice at that time) he was able to point out many errors. His greatest work, De humani corporis fabrica (1543), was enriched by superbly engraved illustrations. Upset by criticism, Vesalius burnt his books and became court physician to the emperor ${ }^{*}$ Charles V and his son *Felipe II of Spain. He died returning from a pilgrimage to Jerusalem.

O’Malley, C. D., Andreas Vesalius of Brussels 1514 1564. 1964.
Vespasian (Titus Flavius Sabinus Vespasianus) (9-79 CE). Roman Emperor 69-79. Born near Rome, with no particular social advantages he slowly climbed the military and official ladders until he had become Consul (51) and a senator. He took part in the conquest of Britain (43) by the emperor ${ }^{*}$ Claudius, and at the time of*Nero's suicide he was fighting the Jewish rebels in Palestine. While ${ }^{*}$ Galba, ${ }^{*}$ Otho and ${ }^{*}$ Vitellius were contending for Nero's vacant throne he remained at his post, but when his legions proclaimed him Emperor (July 69) he left his son *Titus in Judaea and marched on Rome. When Vitellius died defeated, there was no further resistance and having had suppressed a revolt on the Rhine the empire was at peace (71). His reign was one of prudent consolidation, he lived simply, restored the empire's finances, patronised the arts and began the Colosseum. He was succeeded by his son Titus who established the Flavian dynasty.

Vespucci, Amerigo (1451-1512). Italian merchant adventurer and navigator, born in Florence. He was immortalised by the adoption of the name America, first applied to South America in maps (1507) by Martin *Waldseemüller. An agent of the ${ }^{*}$ Medici at Seville and a successful man of business, he was given the task of fitting up the royal fleets that sailed in Columbus' wake. He claimed to have made four voyages between 1497 and 1504, two in Spanish service, two for the Portuguese. However, it is more likely that he made only two. In the first, 1499-1500, under the command of Alonso de Ojeda (1465-1515), he sailed along the north coast of Brazil, observing the mouths of the Amazon and Orinoco, visiting Trinidad and Haiti. (They supposed themselves to be off the coast of India.) In the second voyage, 1501-02, commanded by Gonçalo Coelho (1451/4-1512), he returned to Brazil, named Salvador and the site of Rio de Janeiro (January 1502), possibly observing the Rio de la Plata and parts of Patagonia. Pilot Major of the Commercial House for the West Indies, Seville 1508-12, he was probably the first to propose that the Americas were not part of Asia. The wide currency given to his accounts of his voyages (a German translator even mentions 'America' i.e. South America, as being called after 'its discoverer Americus') ensured that his name, not 'Columbus', was inscribed on the first maps of the New World.

Vianney, St Jean-Baptiste-Marie (1786-1859). French priest, known as 'the curé of Ars'. A holy innocent, renowned for his devotion, he was the parish priest at Ars, near Lyon, 1818-59. Credited with many miraculous cures, he was beatified in 1905, canonised in 1925 and became the patron saint of parish priests in 1929 .

Viardot, (Michelle Ferdinande) Pauline (née Garcia) (1821-1910). French mezzo-soprano, pianist, teacher and composer, born in Paris. Daughter of Manuel ${ }^{*}$ Garcia and sister of Maria *Malibran, she studied under her father and Franz ${ }^{*}$ Liszt, married Louis Viardot and ran an intellectual salon in Paris. 
Renowned for her acting, she became the mistress of *Turgenev and premiered *Brahms' Alto Rhapsody (1869)

Kendall-Davies, B., The Life and Work of Pauline Viardot-Garcia. 2 vols, 2003, 2012; Figes, O., The Europeans: Three Lives and the Making of a Cosmopolitan Culture. 2020.

Vickers, Thomas (1833-1915) and Albert (18381919). British industrialists. The two brothers entered a Sheffield steelmaking firm, and gradually control passed into their hands. Decisive steps that led to their becoming ranked among the great armament makers in the world were the taking over (1897) of the Maxim, Nordenfelt Company (*Maxim) and the Naval Construction and Armament Company of Barrow-in-Furness. A wide variety of armament from machineguns to battleships (and aeroplanes after the brothers' deaths) was made by the firm, known (from 1911) as Vickers Ltd.

Vico, Giambattista (Giovanni Battista) (1688-1744). Italian philosopher of history. A professor at the University of Naples and historiographer to ${ }^{*}$ Charles III of Naples, his major work was Scienza Nuova (1725, revised 1730,1744$)$. A critic of $*$ Descartes and an antiUtopian, he rejected the idea of uniform laws in history and promoted cultural pluralism, arguing that all national history is shaped by individual differencesgeography, climate, anthropology, language, institutions, ritual, art and custom, often expressed in myth. To Vico, knowledge was not a science but a deeply subjective human process. He opposed rational absolutism, 'the vaunting of judgment without context, applying abstractions without reference to realty or history'. Interest in Vico was revived by ${ }^{*}$ Michelet, ${ }^{*}$ Weber, ${ }^{*}$ Croce, ${ }^{*}$ Yeats and ${ }^{*}$ Berlin. He also influenced James *Joyce.

Bergen, T. G. and Fisch, M. H., trans., The Autobiography of Giambattista Vico. 1944; Berlin, I., Vico and Herder. 1976.

\section{Victor Emmanuel II and III see Vittorio Emanuele II and III}

Victoria (Alexandra Victoria, née *Welf-Este, by marriage von *Wettin) (1819-1901). Queen of the United Kingdom of Great Britain and Ireland, Defender of the Faith 1837-1901, Empress of India 1876-1901. Born in Kensington Palace, London, she was the only child of *George III's fourth son, Edward, Duke of ${ }^{*}$ Kent and Strathearn, and of Victoria of Saxe-Coburg, sister of ${ }^{*}$ Leopold, later King of the Belgians. She became queen on the death of her uncle, ${ }^{*}$ William IV. Another uncle, Ernest Augustus, Duke of *Cumberland, became King of Hanover, where its succession laws did not allow a woman to reign, ending the common sovereignty of the two countries. During the first years of her reign the young queen found a friend and political mentor in her Prime Minister,
Lord *Melbourne, but after her marriage (1840) to her cousin *Albert of Saxe-Coburg, her husband became the dominant influence in her life.

Victoria bore nine children between 1840 and 1857. She doted on the eldest ${ }^{*}$ Victoria (Vicky), but had a stressful relationship with Albert Edward (Prince of Wales from infancy, then ${ }^{*}$ Edward VII) and some others. She was physically and emotionally remote, but obsessively controlling. She inherited haemophilia from her father, was a carrier but not a sufferer, and transmitted it through her daughters Alice and Beatrice and son Leopold.

Prince Albert's influence was important in foreign affairs, where his interventions, generally prudent, and aimed at the liberalisation of the European monarchies, sometimes provoked friction with her foreign ministers, especially *Palmerston. The network of royal relationship which played an important part in international affairs during the 19 th century was greatly extended as their children reached marriageable age.

She was interested in and sympathetic to India (but never visited) and in 1858 wrote deploring 'a bloody civil war' and promising that Indians would be 'placed on an equality with the subjects of the British Crown' and was angered that these promises were never kept. Early Indian nationalists regarded Victoria with affection.

The Prince Consort's death in December 1861 shattered her happiness. She remained in complete seclusion at Windsor until 1864 and did not open parliament in person until 1866 . Only the tact and flattery of her Prime Minister ${ }^{*}$ Disraeli induced her to emerge: his proposition that she be proclaimed as Empress of of India (1876) greatly pleased her, but power was in the hands of her often ruthless administrators.

Between 1840 and 1882, she was shot at on eight occasions, but each incident was bungled, silly or the result of derangement.

Victoria's distrust of her eldest son and her long refusal to allow him any part in public affairs did serious damage to his character. For the other great Prime Minister of her reign, *Gladstone, the queen had respect but no affection: 'he speaks to me as if I were a public meeting'. In her last years, the public identified her with the nation's great achievements during her reign. The Jubilee (1887) and the Diamond Jubilee (1897) celebrations revealed the extent of her popularity and even veneration. Although neither intellectually brilliant nor highly imaginative, she had much shrewdness and common sense and, despite her identification with 'Victorian morality', her judgments were usually charitable and kind, and she was racially tolerant. Oddly, she was fiercely opposed to votes for women but sympathetic to Alfred *Dreyfus. If her taste was no better than that of the majority of her subjects, it was certainly no worse. During her reign, 'constitutional government' in the modern 
sense was fully developed. She did not conceal her opinions, often showed bias (especially towards the Conservatives in her old age) but never acted against formal 'advice'. Her reign restored the crown's prestige and became a symbol of public service and imperial unity. A voluminous correspondent, few women have revealed themselves more fully than she did in her letters, thousands of which have been published.

She was the longest reigning British monarch until 9 September 2015 when *Elizabeth II overtook her.

Buckle, G. E. (ed.), Letters of Queen Victoria 18621885, 1926-28; Buckle, G. E. (ed.), Letters of Queen Victoria 1886-1901. 1930-32; Longford, E., Queen Victoria. 1964; Wilson, A. N., Victoria: A Life. 2014; Baird, J., Victoria the Queen. 2016.

Victoria (Victoria Adelaide Mary Louisa von Hohenzollern, née von Wettin) (1840-1901). German Empress and Queen of Prussia 1888. Eldest child of Queen *Victoria and Prince *Albert, styled 'Princess Royal' 1841-1901, known in the family as 'Vicky', she was trained in politics by her father. Her marriage (1858) to the future emperor *Friedrich of Germany, who shared her views, gave promise of a They had eight children. However, he died of throat cancer (1888) barely three months after his accession. She disliked ${ }^{*}$ Bismarck, was curious about *Marx, and her enormous correspondence with her mother (nearly 8,000 letters) survives. She became estranged from her son, Kaiser *Wilhelm II, and lost all influence. She died of breast cancer.

Pakula, H., An Uncommon Woman: The Empress Frederick. 1995.

Victoria, Tomás Luis de (Tommaso Ludovico da Vittoria) (1548?-1611). Spanish composer. His output was entirely of religious music. The two settings of the Passion and nine Lamentation lessons contained in his Holy Week Office (1585) and his Requiem Mass for the empress Maria (published 1605) are of special importance. His work superficially resembles that of ${ }^{*}$ Palestrina but he had a more pronounced sense of harmony and key relationship.

Vidal, (Eugene Luther) Gore (1925-2012). American novelist, essayist and dramatist, born in West Point. He grew up in a political family, served in World War II, ran for Congress and was an acidulous and penetrating critic. His novels include Myra Breckinridge (1968), Burr (1973), 1876 (1976), Creation (1981), Lincoln (1984), Empire (1987), Hollywood (1989) and Live from Golgotha (1992). United States: Essays 1952-1992 (1993) confirmed his encyclopaedic range. Palimpsest (1995) was autobiographical.

Vidocq, Eugène François (1775-1857). French criminal and detective. Son of a baker, he started his career by robbing the till of his father's shop. After a period as a circus acrobat and (as a supposed savage) in 1796 he was sentenced to eight years in the galleys for forgery. He escaped to join a gang of highwaymen, whom he handed over to the police. Accepted now as a police informer he became (1809) head of the 'Brigade de Sûreté', which he may have founded himself. His success as a detective was regarded as marvellous until it was found that he organised many of the burglaries he 'discovered' and in 1825 he was dismissed. His Memoirs (1828), possibly spurious, contain as much fiction as truth.

Viète, François (1540-1603). French mathematician. Son of an attorney, he studied law, and began his career as an advocate and a councillor in the parlement of Brittany. As a Huguenot, he was banished from court during the reign of ${ }^{*}$ Charles IX but restored to favour by ${ }^{*}$ Henri IV. One of his greatest political services lay in decoding enemy messages during the war against Spain. Viète was one of the first to advocate algebraic rather than geometrical constructions in mathematical proofs. He introduced many key technical terms into algebra, such as 'coefficient' and 'negative', and pioneered the technique of using letters of the alphabet to denote unknown quantities. $\mathrm{He}$ was principally concerned with algebra as a practical tool and most of his own work in the subject was geared to solving cosmological and astronomical problems. He was deeply involved in calendar reform. When Pope ${ }^{*}$ Gregory XIII proposed a major reform of the calendar (by making 15 October 1582 follow immediately after 4 October), Viète was one of the sternest opponents of the new Gregorian calendar (although his own astronomical calculations were incorrect).

Vigée-Le Brun, (Marie) Elisabeth Louise (17551842). French painter. Daughter of a portraitist who trained her, she married the artist, critic and dealer J.B.P. Le Brun. She painted *Marie Antoinette more than 20 times, left France on the onset of Revolution (1789), then lived in Italy, Russia and England. Her subjects included Emma *Hamilton, Lord *Byron and Madame de ${ }^{*}$ Stal.

Vigeland, (Adolf) Gustav (1869-1943). Norwegian sculptor. Under a unique agreement, Vigeland was provided with a studio and a livelihood on condition that he hand over all his work to the Oslo municipality, which in turn promised to exhibit them in perpetuity. The result is an array of robust and realistic nudes in single figures or groups in a beautiful setting in the Vigeland Park, Frogner, in Oslo. The influence of *Rodin is apparent but both the merits of the work and its symbolism (clearly linked with the life cycle) have provoked much controversy.

Vigny, Alfred Victor, Comte de (1797-1863). French Romantic writer, born in Loches. After serving in the army for 12 years, an experience that inspired Servitude et grandeur militaires (1835), he became one of the leading figures in the Romantic literary movement. His Poemes antiques et modernes (1826) show the influence 
of *Byron. The *Scott-inspired Cinq-Mars, a novel of the reign of *Louis XIII, appeared in the same year. Chatterton (1835) a play written for the actor Marie Dorval, for whom he cherished a jealous love for years, is considered his masterpiece. He had married (1825) Lydia Bunbury, an Englishwoman, but the marriage was not a success. He was no more fortunate in public life. His attempt to enter parliament (1848-49) was unsuccessful. These failures are reflected in the pessimism of his work. After his death the philosophic poems Les Destinées appeared in 1864, while Daphne, concerned with the struggle between Christianity and what he considered a new paganism, was published only in 1912.

\section{De la Salle, B., Alfred de Vigny. Rev. ed. 1963.}

Villa, Francisco (1877-1923). Mexican bandit and revolutionary. After escaping from peonage he became a bandit and was nicknamed Pancho Villa. His aid in the revolution of 1910-11 helped *Madero to overthrow Porfirio ${ }^{*}$ Diaz. Later he came into conflict with his previous allies and Villa was obliged to flee to North Mexico where he operated as a rebel until 1920. An American punitive expedition under General *Pershing was sent against him (1916) after the murder of several Americans but failed to take him and caused much ill feeling in Mexico. Villa, a daring and impulsive fighter for social justice, became a popular hero.

Villa-Lobos, Heitor (1887-1959). Brazilian composer. One of the first South American composers to win international recognition, he was largely selftaught. Most of his vast output, which includes operas, symphonies, chamber music and piano music, is influenced by the style of Brazilian folksong. The Chôros, for various instrumental combinations, blend Brazilian, Indian and popular elements and the suites entitled Bachianas Brasileiras fuse Brazilian melody with the manner of ${ }^{*}$ Bach.

Villars, Claude Louis Hector, Duc de (1653-1734). French soldier. One of ${ }^{*}$ Louis XIV's most famous generals, in the opening stages of the War of the Spanish Succession his bold efforts against the Austrians were constantly foiled by the hesitant obstinacy of his ally, the Elector of Bavaria. In 1705 he conducted a masterly defence of the northeastern frontier of France against *Marlborough, and, after forcing his retreat, captured the Allies' reserves of food, equipment and artillery in Alsace. He was equally successful against Prince *Eugène (1708). He was wounded at Malplaquet (1709) but, after Marlborough's recall, he more than held his own until the Peace of Utrecht (1712) brought the war to an end.

Villeneuve, Pierre Charles Jean Baptiste Sylvestre de (1763-1806). French sailor. One of *Nelson's leading antagonists in the Napoléonic Wars, he was a captain at the Battle of the Nile and managed to save his own ship and two frigates in that disaster (1798). Chosen by ${ }^{*}$ Napoléon to play the leading part in the strategy to gain command of the Channel for long enough to enable him to invade England, Villeneuve slipped out of Toulon early in 1805 and joined by a Spanish squadron from Cadiz, reached the West Indies in May. Nelson followed. Villeneuve doubled back, but after an encounter with the British off Ferrol, he decided that the remainder of the plan to rescue the ships blockaded at Brest and then enter the Channel was impractical; he turned south to Cadiz where Nelson found him. Anxious to redeem himself before a successor could arrive, Villeneuve sought battle and at Trafalgar was defeated and captured. Released in 1806 he killed himself on the journey to Paris rather than face Napoléon's anger.

Villepin, Dominique de (1953-). French diplomat and politician, born in Morocco. He served as Foreign Minister 2002-05 and Prime Minister 2005-07.

\section{Villiers, Barbara see Cleveland, 1st Duchess of}

Villiers de L'Isle-Adam, Auguste, Comte de (18381889). French writer. He dedicated an early volume of symbolist poetry, Premières poésies, to de *Vigny, but is chiefly remembered for his prose works, late Romantic studies in the fantastic and the macabre. The best known are Contes cruels (1883), short stories in the manner of *Poe, the novel L'Eve future (1886), and the play Axël (1885). Both his plays and novels suffered because they were used to display ideas rather than to represent the development of character.

Wilson, E., Axel's Castle. 1931.

Villon, François (1431-c.1470). French poet, born in Paris. Of obscure parentage, he was brought up by Guillaume de Villon, a priest who lectured in canon law. After graduating in the Sorbonne he continued the irregular life of his student days. In 1455 he stabbed Philippe Chermoye, a priest, to death in a brawl, fled to the countryside, joined a band of criminals and learned the thieves' argot in which he later wrote ballads. He returned to Paris (1456) but continued his criminal life and took part in a robbery at the Collège de Navarre. In 1460 he was under sentence of death at Orléans for an unknown crime, but he was released after an amnesty. Another amnesty, this time to mark a visit by the new king, ${ }^{*}$ Louis XI, saved him again in 1461 . He returned to Paris (1462) only to be imprisoned once again for the old Navarre robbery. He was freed through the influence of Guillaume de Villon, but a street brawl, at the cost of another life, again brought a death sentence. This sentence was commuted to 10 years' banishment from Paris. Nothing more is known of his life.

Villon used medieval verse forms but the individuality of the poet's voice, the intensity of his feeling, his perception, and surprisingly if his life be considered, a strain of religious devotion, have given his work a permanent appeal. The poems are variously ribald, urbane, boisterous, and penitent, learned and coarse; 
they revel in life and are preoccupied with death. The major works, Le Lais or Petit Testament (written 1456) and Grand Testament (1461), comprise poems interspersed with ballads. In addition (apart from ballads in argot) there is the grim Ballade des pendus (written under sentence of death) which ranks with the Ballade des dames du temps jadis with its famous refrain 'Mais où sont les neiges d'antan?' ('But where are the snows of yesteryear?').

Villon's work was first printed in 1489 and a critical edition appeared in 1533. A period of neglect intervened but, in the 19th century, French scholars made serious studies, and several English poets, including * Rossetti and ${ }^{*}$ Swinburne, chose pieces for translation.

Bonner, A. (ed.), Complete Works of François Villon. 1960.

Vincent de Paul (originally Depaul), St (1581?1660). French priest. Son of a peasant in the Landes, he was ordained in 1600 . There are various versions of the story of his being captured by Moorish pirates and sold into slavery at Tunis. He escaped to Rome and the French ambassador there sent him on a confidential mission to ${ }^{*}$ Henri IV of France, where he became chaplain (1610-12) to Marguerite de Valois, Henri's wife. Later, as tutor to the family of the general in charge, he had an opportunity to show his compassion for the convicts condemned to work in the galleys. By 1633 he had acquired enough influential friends to set up two charitable orders, the 'Priests of the Mission' (or 'Lazarists', after the Convent St Lazare in Paris where they were established) for men, and the 'Little Sisters of the Poor' for women. Hospices for the old, the poor (La Salpêtrière) and foundlings were also started and missionaries dispatched abroad. He was canonised in 1737. The lay Society of St Vincent de Paul, founded by students in Paris (1833), has spread through the world.

\section{Vinci, Leonardo da see Leonardo da Vinci}

Vinogradoff, Sir Paul Gavrilovich (1854-1925). Russian-British historian. After settling in England (1901) he was appointed to a professorship in jurisprudence at Oxford in 1903. His outstanding contributions to medieval history include Villeinage in England (1892), The Growth of the Manor (1905) and Outlines of Historical Jurisprudence (1920-22).

Vinson, Frederick Moore (1890-1953). American jurist. A US Congressman from Kentucky 1923-29 and 1931-38, he served as a federal judge 1938-43, director of the Office of Economic Stabilisation 1943-45, and as *Truman's Secretary of the Treasury 1945-46 before his appointment as Chief Justice of the US Supreme Court 1946-53.

Viollet-le-Duc, Eugène Emmanuel (1814-1879). French architect. Talent as a draughtsman combined career. He was employed by Prosper *Mérimée at the Commission des Monuments Historiques to carry out a robust restoration of decaying buildings, beginning at Vézelay with the Madeleine Abbey (1840), followed in Paris by Sainte-Chapelle, Notre Dame and Saint-Denis, the medieval fortress-city of Carcasonne, and Saint-Sernin in Toulouse. His works included a 10 volume dictionary of architecture and a six-volume dictionary of furniture.

Virchow, Rudolf Carl (1821-1902). German pathologist. Professor of pathology at Würzburg 1849-56 and Berlin 1856-1902, his Cellular Pathology (1858) became the standard text in the new discipline. He became a progressive member of the Reichstag 1880-93 and an opponent of *Bismarck who once challenged him to a duel.

Ackerknecht, E. H., Rudolf Virchow: Doctor, Statesman, Anthropologist. 1953.

Virgil (Publius Vergilius Maro) (70-19 BCE). Roman poet, born near Mantua. He was given the best education but did not take the usual course of entering public life. After some years in the country writing poetry, he went to Rome and attracted the friendship of *Maecenas. His earliest known works are the Eclogues or Bucolics (c.37), pastoral poems modelled on those of *Theocritus. In the four books of the Georgics (completed 30) he uses graceful poetical techniques and verbal artistry in a series of didactic poems on agriculture, olive-growing and vine culture, stock-raising and bee-keeping. His greatest work is the Aeneid published after his death, a national epic that tells the story of the flight of Aeneas (a minor prince in ${ }^{*}$ Homer) from defeated Troy, his stay at Carthage with Queen Dido, and his final settlement in Italy, where his descendants were to found the Roman nation. The Aeneid stems from Homer and uses Homeric mechanisms but differs completely in being the product of a sophisticated society rather than of the heroic semi-barbaric world of Homer. A main weakness is in the character of Aeneas himself. The fine poetry is there, the resonant verse, the romantic episode (e.g. that of Dido) but the hero remains something of a dull prig. From the first the Aeneid was used as an educational work and it was natural that this use should survive the change to Christianity. In the process Virgil emerges in the role of a prophet and in the Middle Ages passages of his works were held to contain prophecies of Christ's coming. In the Divine Comedy, Virgil appears as *Dante's guide through Inferno. From the 15th century until the 18th, the Aeneid was regarded as a model of epic form.

Visconti, Gian Galeazzo (1351-1402). Italian nobleman, Duke of Milan. He sprang from a family which from 1262 (when Ottone Visconti had been made Archbishop), gradually assumed ascendancy in Milan. Gian Galeazzo, who had succeeded his father in Pavia (1378), and dispossessed his uncle in Milan 
(1385), concentrated the family power in his own hands. By uniting Milan with the neighbouring cities into a single powerful state, he gained the title of Duke from the emperor. He married his daughter Valentina to the Duke of Orléans, an alliance held to justify the future claims of French kings to the territories of Milan.

Visconti, Luchino, Duca di Mondrone (1906-1976). Italian film director, born in Milan. Member of a noble Milanese family, he worked with Jean ${ }^{*}$ Renoir as an assistant director, then went to the US. His first film Ossessione (1942) was mutilated by Fascist censors but marks the beginning of the Italian neo-realist school. His 16 films had varying success but the best were regarded as masterpieces: Rocco and his Brothers (1960), The Leopard (1963), The Damned (1969) and Death in Venice (1971). Visconti, also a successful operatic producer, was murdered by a young lover.

Servadio, G., Luchino Visconti: A Biography. 1982.

Vitellius, Aulus (15-69 CE). Roman Emperor (69), one of four in that year. Sent by *Galba to command on the lower Rhine, he was proclaimed Emperor by his troops and, after the defeat and death of ${ }^{*}$ Otho, hastened to Rome. His gluttony, extravagance, cruelty and inertia in the face of *Vespasian's army advancing from the north left him with no friends. When his enemies entered Rome he was killed by being dragged through the streets.

Vitruvius (Marcus Vitruvius Pollio) (c.80/70-c.15 BCE). Roman architect and engineer. His celebrated 10 book treatise, De Architectura is virtually an encyclopaedia, and, as it is the only Roman work of its kind to survive, Vitruvius had enormous influence on the architects of the classical revival from the late 15 th century, when the work was first printed, to the 18th century. The famous drawing by *Leonardo, Vitruvian Mani (1490), incorporates his ideas.

\section{Vittoria, Tommas see Victoria, Tomás Luis de}

Vittorino da Feltre (1378-1446). Italian educationist. From 1425 he directed a school at Mantua under the patronage of Marquis Gian Francesco Gonzaga, whose children were among the pupils. By combining religious instruction with physical training and classical studies Vittorino aimed at producing the Renaissance ideal of a complete, balanced individual. The school provided a pattern followed by the many succeeding humanist educators.

Vittorio Emanuele II (Vittorio Emanuele Maria Alberto Eugenio Ferdinando Tommaso di Savoia) (1820-1878). King of Italy 1861-78 and of SardiniaPiedmont 1849-78. He succeeded his father ${ }^{*}$ Carlo Alberto as King of Sardinia (and ruler of Savoy and Piedmont), and became the first king of united Italy. He showed military skill in the vain struggle against Austria (1848-49), and, when his father abdicated in his favour, continued by political and diplomatic means to support the cause of Italian unity. His chief instrument was the great minister *Cavour, with whom he often disputed but whom he always finally supported, even when it meant the surrender of his historic Savoy territories to France to gain the support of ${ }^{*}$ Napoléon III in the coming struggle. His reward came when, after the French victories (1859) of Magenta and Solferino, only Venice was left to the Austrians (this came to Italy as a reward for alliance with Prussia in 1866). Vittorio Emanuele, free to move south, was welcomed everywhere and having won the reluctant adherence of ${ }^{*}$ Garibaldi was proclaimed King of Italy. Turin was his capital until 1864, then Florence until the French garrison, left to maintain papal rule in Rome, was withdrawn during the Franco-Prussian War (1870-71). Throughout his reign, both of Sardinia and of Italy, he reluctantly observed the practice of constitutional monarchy. Crudely anti-clerical, bellicose in manner, and a great slaughterer of animals, his private life was disorderly and the description 'father of his country' no mere figure of speech. He died of malaria in Rome and, being excommunicated, was buried in the Pantheon.

Mack Smith, D., Italy and its Monarchy. 1989.

Vittorio Emanuele III (1869-1947). King of Italy $1900-46$. He succeeded on the assassination of his father ${ }^{*}$ Umberto I. Diminutive, he was an expert numismatist and, for a member of his dynasty, widely read. He reigned as a constitutional monarch without serious problems (although he used his influence to ensure that Italy should join the Allies in World War I) until the rise of *Mussolini and the 'march on Rome' (1922) caused him to take the decision which eventually proved fatal to his dynasty. He chose (against parliamentary and military advice) to give a constitutional appearance to an unconstitutional act by inviting Mussolini to become his Prime Minister. This made the king an accomplice (even if at times an unwilling one) of the Fascist dictator. He gave active assistance in the conspiracy that led to Mussolini's downfall and arrest (1943), but his countrymen could not forget the past. Vittorio Emanuele retired from public life (1944) after appointing his son *Umberto Lieutenant General of the realm and abdicated in 1946. He died in exile in Egypt.

Vivaldi, Antonio (c.1675-1741). Italian composer and violinist, born in Venice. He was ordained (1703) but turned to music (1709). For many years he conducted the concerts at the Conservatorio dell'Ospedale della Pietà in Venice, a music school for orphan girls whose concerts enjoyed great prestige. He wrote operas and choral works but his fame rests on the large number of concertos that form the bulk of his output, for example the 12 concertos of L'Estro Armonico (1712). Many are for violin but he wrote examples for other instruments and for various instrumental combinations; several were transcribed by J. S. *Bach. Vivaldi was a great violin virtuoso and 
had considerable influence on violin technique and on the concerto. Vivaldi was forgotten after his death until a revival that began in the 1930s.

Kolneder, W., Antonio Vivaldi: His Life and Work. 1970.

Vives, Juan Luis (Ludovicus Vives) (1492-1540). Spanish humanist. The dedication of his translation of St Augustine's Civitas Dei to *Henry VIII brought an invitation to go to England as tutor to Princess * Mary. His disapproval of the royal divorce was punished by imprisonment. From 1528 he lived and taught mostly in Bruges. His De Disciplinis (1531) became one of the best known books of guidance on humanist studies, and his psychological observations in a commentary (1528) on a work by ${ }^{*}$ Aristotle (De Anima) show a remarkably modern outlook.

Vladimir I, St (c.956-1015). Russian ruler, Grand Prince of Kiev c.980-1015. Eight years of civil war broke out on the death of his father, Sviatoslav, until Vladimir defeated his brothers, imposing his rule from the Baltic to the Crimea. He forced Russian conversion from paganism to Greek Orthodoxy, according to legend having first considered Catholicism, Islam and Judaism.

Vlaminck, Maurice de (1876-1958). French landscape painter. Of Belgian descent, an admirer of van ${ }^{*}$ Gogh, he became a friend of André ${ }^{*}$ Derain, with whom he joined the revolutionary group known, because of its violent use of strong colour, as the 'Fauves' ('wild beasts'). This period of his development lasted until 1907 when he came for a time under the influence of ${ }^{*}$ Cézanne. His later, more realistic, work lacks the earlier force. As a young man Vlaminck was well known as a racing cyclist.

Vlaminck, M. de, Paysages et personnages. 1953.

Vogel, Sir Julius (1835-1899). New Zealand politician, born in London. He migrated to Victoria, then to New Zealand (1861) and in the same year founded the Otago Daily Times. He entered parliament in 1862 and as Colonial Treasurer he made bold proposals for the financing of immigration, railways and other public works by large loans. His policy as Premier $1873-75$ and 1876 led to the abolition of the provinces (1876).

Volstead, Andrew Joseph (1860-1947). American politician. A lawyer, he was a progressive Republic Congressman 1903-23 and supported liberal measures. He gained national attention as sponsor of the act (known as the Volstead Act) which made detailed legislative provisions for the enforcement of the 18th Amendment to the US Constitution-the prohibition of the sale of alcohol. The act was passed in 1919 despite President Woodrow *Wilson's veto. It was abrogated by the repeal of prohibition (1933).

Volta, Alessandro Giuseppe Antonio Anastasio, Conte (1745-1827). Italian physicist. Professor of from 1815 he directed the philosophical faculty at Padua. He isolated methane in 1776, used 'marsh gas' in lamps, developed the 'electrophorus' to generate static electricity, became the rival of *Galvani and was awarded the Copley Medal in 1794. He discovered that electrical effects could be brought about by contact between two dissimilar metals, and he invented the simple battery or 'voltaic pile' (1799). $\mathrm{He}$ also investigated electrification by friction, and invented the electrophorus and the condensing electroscope. He is commemorated by the name volt given to the unit of electromotive force.

Voltaire (pen name of François-Marie Arouet) (1694-1778). French writer, born in Paris. Epitome and genius of the 18th-century Enlightenment, son of a notary, he was educated at the Jesuit college of Louis-le-Grand but soon found congenial company in a lively young set of sceptical aristocrats. He declined to study law and after a year spent in the country studying history returned to Paris. Accused of lampooning the regent, the Duke of Orléans, he was sent to the Bastille where he changed his name to Voltaire (supposedly an anagram of his name, Arouet l(e) j(eune), and revised his first tragedy, Oedipe (1718), a great success. Publication of an epic (La Ligue) was forbidden because it championed *Henri IV's efforts to establish toleration, but it was secretly printed and later revised and reissued as L'Henriade (1728) in England where Voltaire had been allowed to go (1721) after further confinement in the Bastille. In England he was lionised by the fashionable and literary worlds (*Bolingbroke, *Walpole, ${ }^{*}$ Swift, ${ }^{*}$ Pope and ${ }^{*}$ Gay) and was influenced by the ideas of *Newton and *Locke. After his return (1729) he wrote several more plays, and a history of the Swedish king *Charles XII which (with a later one on the age of *Louis XIV) initiated modern historical methods. Most controversial were his Lettres philosophiques (1734) in which his praise for the constitution, tolerance, and scientific achievements of England implied a criticism of France. From the storm this raised he found shelter at the home of Émilie, Marquise du Châtelet, at Cirey-sur-Blaise near the Lorraine frontier. Here he stayed for 10 years writing more plays (of which Alzire, 1736, is regarded as one of his best), two philosophical letters and other works. By 1736 *Friedrich II ('the Great') of Prussia was already trying to persuade the great literary lion of Europe to grace his court but it was not until after Émilie's death (1749) that he eventually succeeded. Voltaire lived in Berlin or Potsdam (1750-53) but the vain writer and the authoritarian king were ill at ease. He moved to Colmar (1753-54), then divided his time between Geneva and Lausanne. Finally in 1758 he made a permanent home in France at Ferney, near the Swiss frontier. In 1755 his mock epic on Joan of Arc, La Pucelle, appeared and in 1760 his best known work, Candide, in which Candide travels in the company of futilely optimistic Dr Pangloss (a satire on ${ }^{*}$ Leibniz) who, however great the injustice and intolerance encountered, can only reflect that 
everything is for the best in the best of all possible worlds. *Diderot and d'*Alembert persuaded Voltaire to write many articles for their Encylopedie, author and book alike contributing to the great revolution of ideas that preceded the political upheaval. Not only was much of Voltaire's later work propagandist but he took practical steps (e.g. in defence of Jean ${ }^{*}$ Calas) to right injustice. His belief in tolerance is summed up in his phrase 'I may disapprove of what you say but I will defend to the death your right to say it.' In February 1778 he was triumphantly received in Paris, but the excitement was too much for him at his age (84) and he died of uraemia in May.

Peyrefitte, R., Voltaire. 2 vols, 1985; Goldzink, J., Voltaire: La legende de saint Arouet. 1989.

Vonnegut, Kurt, Jr (1922-2007). American novelist. Educated in science at Cornell, he served in World War II and was a prisoner of war in Germany. His novels, written in a 'hip' humorous style, reminiscent of some science fiction, deal with the threats to individuality in a technologically obsessed society and include Player Piano (1952), Slaughterhouse Five (1969), Breakfast of Champions (1973) and Slapstick (1976). He was also a prolific essayist.

Voronoff, Serge Abramovich (1866-1951). FrancoRussian surgeon, born in Shekhman. Working in Switzerland, he gained considerable notoriety in the 1930s with experiments designed to prolong human life by grafting animal glands, especially those of monkeys, into the body.

Voroshilov, Klimenty Yefremovich (1881-1969). Russian political soldier. A sheetmetal worker, he joined the Bolsheviks in 1903, led Red Army guerrillas against the Germans 1918, defended Tsaritsyn (later Stalingrad, now Volgograd) in 1919 during the Civil War and worked closely with *Stalin. He became Commissar for Defence 1925-40, a Politburo member 1926-60 and Marshal of the Soviet Union (1935). However, he failed during the war with Finland (1939-40) and the German encirclement of Leningrad (1941), and *Stalin dismissed him. On Stalin's death he became President of the USSR 1953-60, but lost any influence after 1957 when his attempt to dislodge *Khrushchev failed.

Vorster, Balthazar Johannes (1915-1983). South African politician and lawyer. A founder of the proAxis Ossewa Brandwag ('Oxwagon Guard'), he was interned 1942-44 for opposing the war effort. In 1953 he entered parliament as an extremist National Party member, becoming a deputy minister (education, arts and science, social welfare and pensions) in 1958. He was Minister of Justice 1961-66, and was noted for a stringent application of apartheid law and traditional Boer principles. This also characterised his term as Prime Minister 1966-78. In 1978 he resigned and was elected President. In 1979 disclosures concerning the involvement of a former Cabinet minister, Connie
Mulder, in improper use of public funds for party propaganda led to his resignation (1979). Despite his hard line on racial issues, he cultivated trade and diplomatic links with black African states.

Voysey, Charles Francis Annesley (1857-1941). English architect and designer. Influenced by the work of * Pugin and the Arts \& Crafts movement, he was a successful designer of wallpapers, fabrics and furniture.

Voznesensky, Andrei Andreivich (1933-2010). Russian poet. Trained as an architect, he greatly admired ${ }^{*}$ Pasternak, ${ }^{*}$ Mayakovsky and the symbolists, was denounced by *Khrushchev as 'modernist' and attacked the Writers' Union for its ineffectual opposition to censorship. Six volumes of his poems have been translated into English.

Vries, Hugo de (1848-1935). Dutch botanist and plant geneticist. Born of a wealthy and long established Baptist family, his interests, even at school, tended towards natural history, and his early research was on plant cells. He spent part of the 1870s working for the Prussian Government on cultivated plants such as sugar beet, potatoes and clover. He was professor of plant physiology at Amsterdam University 18771918. He is best known for work from the 1890s on plant inheritance: how hereditary characteristics were passed down had been a source of immense debate within evolutionary theory. In his two major books, Intracellular Pangenesis (1899) and Die Mutationstheorie (1901) de Vries argued that inherited characteristics were quite separate individual units each of which had its own separate gene bearer. De Vries called this bearer a 'pangene'. Pangenes combined in fixed ratios to breed either true or mutant forms as de Vries showed with his own extensive experiments on hybridisation. He made use of ${ }^{*}$ Mendel's writings, and came to the conclusion that mutations could be preserved because the information for them was contained in fixed, transmissible genetic material. He believed that evolution occurred by quite large 'steps' (corresponding to mutant forms of pangene), though this notion won little favour with the scientific community.

\section{Vries, Peter de see De Vries, Peter}

Vuillard, Édouard (1868-1940). French painter and lithographer. A member of the 'Nabis' ('prophets') group, influenced by ${ }^{*}$ Gauguin, and a friend of *Bonnard, he developed the style called 'intimism'.

Vyshinsky, Andrei Yanuarevich (1883-1954). Russian lawyer and politician. He became public prosecutor (1931) and was soon notorious for the rancour and vindictiveness with which he conducted state trials, notably in the 'purges' of 1936-37. From 1943 he became active in foreign affairs and was *Molotov's successor as Foreign Minister 1949-53. As a delegate to the United Nations he often attacked western policies with the same vigour as he had shown in the Soviet courts. 


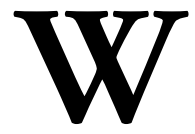

Waals, Johannes Diderik van der (1837-1923). Dutch chemist. Poverty delayed his progress so much that his doctoral dissertation was not published until 1873. In one of the most important papers of its kind ever published he pointed the way to all modern methods of gas liquefaction. Receiving immediate academic appreciation he became (1877) professor of physics at Amsterdam, where he had a great reputation as a teacher. He won the Nobel Prize for Physics (1910).

Wagner, (Wilhelm) Richard (1813-1883). German operatic composer, born at Leipzig. His father Friedrich, an actuary, died in 1813 and his mother married the actor and painter Ludwig Geyer, leading to speculation about his paternity. He grew up in Dresden, returning to Leipzig in 1827 where he attended the Nikolaischule and studied with Christian Weinlig, cantor of the Thomaskirche, J. S. *Bach's old job. His musical career started unhappily with immature compositions and ill paid conductorships of small orchestras, e.g. at Königsberg and Riga. In 1836 he married the actor Minna (Wilhelmine) Planer (1809-1866) and their relationship was marked by frequent separation and misunderstanding. (There were no children.) In Paris (1839-42) he was forced to keep himself by hack-work while trying to gain support for the operas he was writing. Rienzi (1842) was a great success at the Dresden opera and in 1843 Wagner became Director of the Court Orchestra. Der Fliegende Holländer (The Flying Dutchman, 1843) and Tannhäuser (1845) were less well received.

Wagner was now becoming involved in revolutionary politics. As a result Lohengrin, which had been written in Paris, was refused by the authorities. He supported Mikhail *Bakunin's attempt at revolution in Dresden (1849) and, when this failed, was exiled from Saxony until 1862, taking refuge in Switzerland. ${ }^{*}$ Liszt came to the rescue (1850) by staging Lohengrin at his small theatre at Weimar. Wagner conducted in London in 1855 and 1877, was received both times by Queen *Victoria and had a major success in Moscow and St Petersburg in 1864.

Wagner was shaped by many influences: Greek, Icelandic and Teutonic mythology, *Aeschylus, medieval legend, the romances of *Gottfried von Strassburg and *Wolfram von Eschenbach, *Shakespeare, *Beethoven, *Grimm's fairy stories, ${ }^{*}$ Feuerbach, ${ }^{*}$ Schopenhauer, even Buddhism. By his innovations he altered the course of operatic history. In his essay, 'The Art Work of the Future' (1849), he propounded the idea of Gesamtkunstwerk ('total art work') as a synthesis of all the art forms, on a Michelangelesque scale, with music, poetry, dance, mime and scenic effects, all of equal importance, a concept that anticipates the development of cinema.
He abolished the classical structure of opera with arias and recitative links and substituted a continuous dramatic narrative. Following *Weber's practice, he broke with tradition by concentrating the thematic material in the orchestral accompaniment, Beethoven being his model for the development of this material. He went far beyond his predecessors in the expansion of orchestral resources and development of chromatic harmony. Few composers have been so slow to gain contemporary recognition or have been the subject of such bitter controversy.

In 1848 Wagner had begun working on the libretto of the cycle Der Ring des Nibelungen (The Ring of the Nibelung), comprising Das Rheingold (Rhinegold, 1853-54), Die Walküre (The Valkyries, 1854-56), Siegfried (1856-57, 1869) and Götterdämmerung (Twilight of the Gods, 1869-74). He described The Ring as a 'stage festival play'.

The Ring is essentially symphonic, and Wagner's argument is long and interrelated, with the orchestra playing the role of *Freud's 'Id' (instinctive unconscious desires), sometimes as Greek chorus. The text (short fluid lines without rhyme) and music are seamlessly integrated. Jean ${ }^{*}$ Cocteau described Wagner as writing 'music for the entrails' and he often seems to bypass the brain and go straight to the viscera. His psychological insights foreshadowed Freud to an uncanny degree. His use of a recurrent theme (leitmotiv - 'leading motif') to denote a person (for example, Siegfried), place (Valhalla) or a concept (Redemption), gives the drama unparalleled intensity and evokes powerful instinctive reactions.

In The Ring, unlike the operas of *Mozart, *Rossini, ${ }^{*}$ Verdi, ${ }^{*}$ Bizet, or ${ }^{*}$ Puccini, it is rare to have individual choruses, solos, duets, trios, and so on, which lead to tumultuous applause, stop the action on stage, and can be performed as excerpts in concerts or on records. Wagner has more in common with Shakespeare and *Strindberg: his context is central, not showstoppers such as 'Nessun dorma' or 'The toreador's song'.

The heavy mythology and cast of gods and demigods are only metaphors: The Ring's gods are not transcendental - their characteristics are exaggeratedly human. The subject matter of the tetralogy is making sense of human existence with the struggle for selfunderstanding and fulfilment in a materialist, postreligious age, confronting the problems of hatred, violence, greed, pain, fear, frustration, duty, failed marriage and unattainable love. Ultimately, the world of the gods is destroyed. Humans have to create a new world.

The Ring works its way through gigantic themes: love v. power/wealth, love v. law, man v. nature, being divine v. being human, feeling v. understanding, sexual taboos. The tenderness of Wagner's depiction of the desperate needs and frailty of humans is compelling, but his work depicts power, violence and rage as well. 
Having completed the first two operas and part of Siegfried he interrupted the enterprise to write Tristan und Isolde (1859), a story of doomed love, the conflict between passion and duty, set in Brittany. Wagner created a new sound with the 'Tristan chord' (F, B, D\#, G\#) which begins the work and recurs constantly. Isolde's 'Liebestod' ('Love Death'), which closes the opera, has an incandescent beauty. Even for Tristan there were long and daunting delays before the enthusiasm of King *Ludwig of Bavaria enabled it to take place in Munich in 1865.

Since The Ring would require a special theatre for its performance, Wagner knew that production must be distant, and he was always in debt. Tristan was followed by Die Meistersinger von Nürnberg (The Mastersingers, 1868), the complex story of a 16th-century song contest in Nuremberg, involving the politics of art and the role of professional guilds, also written to promote German national sentiment in music and as a strong rejection of the French operatic tradition. These two operas were conducted by Hans von *Bülow. Cosima Wagner (née de Flavigny, later known as Cosima Liszt) (1837-1930), daughter of Liszt and Countess Marie d'Agoult, was married to von Bülow but had two daughters by Wagner, and lived with him at Tribschen, near Lucerne, from 1868. The birth of their son Siegfried (1869-1930) was celebrated by the Siegfried Idyll for orchestra. They married in 1870 and lived at 'Wahnfried', Bayreuth from 1872.

Wagner created a new sensory ambience at his Festspielhaus (Festival Theatre) in Bayreuth, which he planned in detail to be equipped by its size and mechanical arrangements to house the production of The Ring, with all the lavish scenic effects, aerial flights and elaborate transformations in which he took such delight. With the help of *Nietzsche and others he succeeded, and it was opened in 1876 with the production of the whole Ring cycle. The listener/ observer/participant is placed in the womb-like dark while the orchestral sound, sets and lighting create an emotional world, an all-enveloping environment. Wagnerian sound, style and use of the leitmotiv influenced cinema profoundly.

Parsifal (1882), Wagner's last opera, based on Parzival, a 13th-century epic poem by *Wolfram von Eschenbach, was described as Ein Bühnenweihfestspiel ('A Festival Play for the Consecration of the Stage') and until 1914 operatic performances were embargoed outside Bayreuth. (However, the New York Met defied the ban in 1903.) Parsifal, set in the castle of Montsalvat in northern Spain, is the most ambiguous of Wagner's operas and perhaps the most beautifully scored. It uses Christian symbolism obliquely and its major themes are innocence and redemption. Parsifal (tenor), for whom the opera is named, is a 'perfect fool, enlightened by compassion', with the shortest singing role of any major character. Gurnemanz (bass), a venerable knight, has the longest role, essentially as narrator.
Montsalvat is the sanctuary for the Holy Grail and, until it was stolen by the evil, self-castrated, magician Klingsor, the 'holy spear' which pierced Christ's side. Amfortas, leader of the Montsalvat knights, is seduced by the mysterious Kundry, a female equivalent of the Wandering Jew, loses the spear and receives an agonising wound that will not heal. Kundry is Wagner's most complex character with seven different aspects in her nature. Parsifal, who resists Kundry, retrieves the spear, uses it to heal Amfortas and succeeds him as leader of the knights.

Wagner died suddenly at the Palazzo VendraminCalergi in Venice, not yet 70 , and was buried at Bayreuth. His character was deeply unattractive: he was egotistical and disloyal; he lived on friends, whom he often alienated by ingratitude; he was sybaritic and extravagant. He kept his first wife in a torment of jealousy (e.g. of Mathilde Wesendonck, who inspired his Isolde). He gave genius a bad name. He was deeply anti-Semitic, although Jews had been among his strongest artistic and financial supporters. However, The Mastersingers contains ample evidence of the humour, humanity and attractive high spirits to which contemporary accounts bear witness.

Cosima Wagner directed the Bayreuth Festival Theatre until 1906, when Siegfried, a moderately gifted composer and conductor, succeeded. On his death in 1930 the directorship passed to his widow Winifred (née Williams) (1897-1980), an English born traditionalist and ${ }^{*}$ Hitler sympathiser. (Hitler identified himself with Bayreuth and the Wagner family.)

After World War II, the Bayreuth Festival was revived by the sons of Siegfried and Winifred Wagner. Wieland (1917-1966), a producer and stage designer and Wolfgang (1919-2010) were joint directors 1951-66, and Wolfgang was sole director 19672008. Wieland's austere, anti-romantic productions were controversial and his work has been abandoned at Bayreuth but retained at Stuttgart.

Magee, B., Aspects of Wagner. 1988; Millington, B. (ed.), The Wagner Compendium. 1992; Müller, U. and Wapnewski, P., Wagner Handbook. 1992; Conrad, P., Verdi andlor Wagner: Two Men, Two Worlds, Two Centuries. 2011; Ross, A., Wagnerism. Art and Politics in the Shadow of Music. 2022.

Wagner-Jauregg, Julius (1857-1940). Austrian neurologist. He graduated in medicine at Vienna University and quickly rose to become a professor at Graz (1889). His early work was largely concerned with thyroid deficiency. He also made the controversial proposal that to prevent cretinism iodine should be introduced compulsorily into the manufacture of common salt. His later work was concerned with the treatment of psychotic ailments by fevers artificially produced. Among the various fever-producing agents tested, tuberculin was used with success in the treatment of general paralysis of the insane. During 
World War I, however, he coped with this disease more effectively by inoculating patients with benign tertian malaria. For his researches in this field he won the Nobel Prize for Medicine (1927).

Wahhabi, Muhammad Ibn Abd al- (1703-1792). Arab theologian and religious leader. He founded a militant sect, fundamentalist, puritan and deeply hostile to the Shiites. Wahhabism is the dominant Muslim influence in Saudi Arabia.

Wahid, Abdurrahman (widely known as Gus Dur'elder brother') (1940-2009). Indonesian politician. A Muslim cleric, tolerant and pluralistic, he was Leader of Nahdlutah Ulama (NU). Despite suffering from strokes and partial blindness, he was elected as President of Indonesia 1999 until impeached by the People's Consultative Assembly and removed (July 2001). *Megawati Soekarnoputri replaced him.

Wajda, Andrzej (1926-2016). Polish film director. His many films included Man of Iron (1981), Miss Nobody (1996) and Katyń (2001).

Wakefield, Edward Gibbon (1796-1862). English colonial theorist, born in London. After holding diplomatic posts in Turin and Paris, he was imprisoned in Newgate (1827-30) for abducting an heiress, and while there studied colonial government and outlined his views in A Letter from Sydney (1829). He proposed 'systematic colonisation' by free settlers (no convicts) with some capital, land to be sold at a 'sufficient price' to ensure that labourers did not buy their own farms until they had accumulated assets. To test his theories the South Australia Association was formed to found a new colony in that area, but before this had taken place (1836) Wakefield ended his connexion with the promoters. He formed (1837) a similar Association (which became chartered company in 1841) for the colonisation of New Zealand. In 1838 he went with Lord *Durham to Canada to advise on the use of crown lands and was elected to the Lower Canada House of Assembly (1842). In 1839 he had encouraged the dispatch of the first group of settlers to New Zealand. In 1849 his book $A$ View of the Art of Colonisation appeared. Meanwhile settlements had been made in New Zealand under the auspices of the Company and in 1852, after a constitution had been enacted, he went there himself. He was a member of the first assembly of 1854 and died in Wellington. *Marx cited Wakefield in Das Kapital.

Waksman, Selman Abraham (1888-1973). American microbiologist, born in Ukraine. A naturalised American from 1916, he was professor of microbiology at Rutgers University, New Jersey 1930-56. After examining a great many microscopic organisms from soil, he isolated two powerful antibiotics (a term of his coinage) - the highly toxic antimycin (1941) and, relying on the research of Albert ${ }^{*}$ Schatz, streptomycin (1943) which was effective in treating tuberculosis. He was assiduous in denying any credit to Schatz and won the Nobel Prize for Physiology and Medicine (1952) as the sole discoverer of streptomycin.

Waksman, S. A., My Life with the Microbes. 1954.

Walcott, Sir Derek Alton (1930-2017). St Lucian poet and playwright. Professor of English at Boston University 1981-2007, his Homeric epic poem Omeros (1990) describes the impact of European conquest on indigenous cultures and helped win him the Nobel Prize for Literature in the Columbus quincentenary year 1992 .

Waldheim, Kurt Josef (1918-2007). Austrian diplomat. Although his father was anti-Nazi, Waldheim joined the SA and lied about the extent of his service in World War II, including intelligence work in the Balkans. In 1945, he entered the foreign service and became counsellor and head of the personnel division, Ministry of Foreign Affairs, 1951-55. He was an observer or representative to the UN 1955-56, 1964-68 and 1970-71. In 1960-64, he served as Director-General of Political Affairs at the Austrian foreign ministry, and was Minister for Foreign Affairs 1968-70. As Secretary-General of the United Nations 1972-81, his leadership over two terms was ineffectual. He was elected President of Austria 1986-92 after a bitter election campaign, in which his wartime record and complicity in anti-Semitism aroused international criticism, and some official boycotts.

Waldo, Peter (or Pierre) (d.1210?). French religious reformer. A rich merchant of Lyons, he gave up his wealth and formed a band of itinerant preachers. His followers (known as 'the Poor Men of Lyons' or the Waldenses), rejected the sacramental claims of the priesthood and said that every man may exercise priestly functions if moved by the spirit. The sect was rigorously but intermittently persecuted by popes and rulers throughout history (e.g. in 1655, provoking Milton's sonnet 'Avenge, O Lord, thy slaughtered saints'), but it has survived in isolated parts of France and Italy.

Waldseemller, Martin (c.1470-1521). German cartographer. In 1507, in Dieppe, he published a world map that clearly identified a New World, distinct from Asia and first used the name America (for South America), from the navigator Amerigo *Vespucci. By 1513 he had concluded that Vespucci's claim to priority was exaggerated but it was too late to substitute Columbus' name.

Wales, Jimmy Donal (1966- ). American internet entrepreneur, born in Alabama. Educated in Alabama and Indiana, he worked in Chicago, and later relocated to London. In 2001, assisted by Larry Sanger, he founded Wikipedia, a free online encyclopaedia, far larger, more comprehensive (and controversial) than any other reference works, and which has essentially put traditional encyclopaedias (such as Encyclopaedia Britannica) out of business. 
Wałęsa, Lech (1943- ). Polish politician and trade union leader. A shipyard worker from Gdansk (formerly Danzig), a practising Catholic and Polish nationalist, Wałęsa was sacked in 1976 for his anti-government activity. He became a cofounder in 1978 of the Baltic Free Trade Unions, an underground movement. In 1980 he led a strike of shipyard workers in Gdansk which aroused massive public support and international sympathy, and led to the founding of the independent trade movement, 'Solidarity', which sought significant political concessions from the Polish Government. The imposition of martial law in December 1981 led to Wałęsa's arrest and imprisonment for 11 months. He was awarded the 1983 Nobel Peace Prize, elected as President of Poland 1990-95 but defeated by Aleksander *Kwaśniewski in November 1995. His name is pronounced 'Varwensa'.

Walewski, Alexandre Florian Joseph Colonna, Comte (1810-1868). French diplomat, born in Walewice. Son of *Napoléon I and his Polish mistress Marie Walewska, he served under his cousin *Napoléon III as Ambassador in London 1851-52, Foreign Minister 1855-60, Minister of State 186063 and finally President of the Legislative Assembly 1865-68.

Waley, Arthur David (original name A. D. Schloss) (1889-1966). English orientalist and poet. Although he never visited China or Japan, he published outstanding translations of Chinese and Japanese classics, notably The Tale of Genji (1925-33) by *Murasaki Shikubu, and received the CH in 1956.

Wallace, Alfred Russel (1823-1913). English naturalist, explorer, geographer, and social activist, born in Wales. Trained as a surveyor and builder, he turned to natural history and explored with Henry William Bates (1825-1892) the Amazon basin (1848-50) but his collections were lost in a shipwreck on the way home. He investigated (1854-62) animal and plant life in the Malay archipelago. Influenced by *Malthus, but independently of *Darwin, to whom he communicated his ideas, he developed the theory of natural selection. Their joint work was read to the Linnean Society in 1858. Their views were not, however, identical. Wallace did not believe, for example, that natural selection alone could explain such changes as the loss of human hair. He thought too that the male adornments required to provoke sexual selection by animals would conflict with other requirements for the 'survival of the fittest' by natural selection. In 1859 he proposed what is still called 'Wallace's Line', the faunal boundary between Southeast Asia and Australia, running through Indonesia and wrote the important treatise The Geographical Distribution of Animals (1876). He campaigned for socialism and spiritualism and, oddly, against vaccination. A pioneer of bio-geography, he became preoccupied with human activity as a factor in environmental degradation, such as deforestation and soil erosion, and wrote about the possibility of life on other planets. He was awarded the first Darwin Medal (1890), elected FRS in 1893, received the Copley Medal (1908) and the OM (1908).

Severin, T., The Spice Islands Voyage. 1997; Fichman, M., An Elusive Victorian: The Evolution of Alfred Russel Wallace. 2004.

Wallace, David Foster (1962-2008). American novelist, short story wrier and essayist, born in Ithaca, New York. He grew up in Illinois. His novels The Broom of the South (1987), Infinite Jest (1996) and The Pale King (incomplete, published 2011) are marked by irony masking deep despair and he became a cult figure. He hanged himself.

Max, D. T., Every Love Story is a Ghost Story. 2012.

Wallace, (Richard Horatio) Edgar (1875-1932). English author. An orphan, brought up in poverty, he joined the army and later became a sporting journalist. An immense literary output, mainly of thrillers, include the bestselling novels The Four Just Men (1905) and Sanders of the River (1911), and successful plays, e.g. The Ringer and On the Spot.

Wallace, George Corley (1919-1998). American politician. An army sergeant in World War II, he then took a law degree from Alabama University. As Governor of Alabama 1963-67 and 1971-75, he became a notorious opponent of desegregation. Nominally a Democrat, he backed Barry ${ }^{*}$ Goldwater for president in 1964. His wife Lurline Wallace succeeded him as Governor (1967), but died in office (1968). As presidential candidate of the American Independent Party in 1968 he polled 13.5 per cent of the vote and won five states in the South. In May 1972 he was shot in Washington DC, by Arthur Bremer, and paralysed, but in 1982 he won election for a third term as Governor of Alabama 1983-87.

Wallace, Henry Agard (1888-1965). American politician, born in Iowa. His grandfather, also Henry Wallace (1836-1916), founded the journal Wallaces' Farmer (1895); his father, Henry Cantwell Wallace (1866-1924), succeeded as editor and served as US Secretary of Agriculture 1921-24. H. A. Wallace also edited Wallaces' Farmer (1924-33) and developed high-yielding strains of hybrid corn (maize). Franklin D. *Roosevelt appointed him Secretary of Agriculture 1933-41, and he was Vice President of the US 194145 , but lost the 1944 nomination to *Truman because major party figures were apprehensive that Roosevelt would soon die (as he did). Wallace was Secretary of Commerce 1945-48 until dismissed by President Truman for attacking the government's foreign policy. He ran unsuccessfully for the presidency (1948), winning only 2.4 per cent of the vote, as candidate for the Progressive Party which, in 1950, he denounced as a Communist front. He supported US involvement in the Korean War but opposed 
NATO and the Vietnam War, endorsed *Eisenhower in 1956 and *Johnson (reluctantly) in 1964. He made a fortune developing high egg-yielding chickens.

Wallace, Lew(is) (1827-1905). American soldier and author. He served in the Civil War as a Major General, was Governor of New Mexico 1878-81 and Minister to Turkey $1881-85$. He is remembered, however, as author of the novel Ben Hur (1880), set in the time of Christ. It was one of the most successful books ever published, and the basis of several lavish films.

Wallace, Sir William (Scottish Gaelic: Uilleam Uallas) (c.1270-1305). Scottish patriot. He emerged from obscurity as the leader of the Scottish national resistance to the pretensions of the English king, *Edward I. After early successes he inflicted a major defeat on an English army at Stirling Bridge (1297) and, advancing rapidly, devastated England's border counties. Against this threat Edward moved in person and gained a decisive victory at Falkind (1298). For a short time Wallace maintained a guerrilla struggle before making his way to France, where he tried to enlist support, and possibly visiting Rome. He was back in Scotland in 1303 but was betrayed (1305) to the English by Sir John Menteith, was taken to London and hanged, drawn and quartered.

Wallenberg, Raoul (1912-1947). Swedish diplomat. He served in Hungary from July 1944 and was responsible for saving the lives of 70,000 Jews. He was taken prisoner by the Russians in January 1945 and disappeared. Following reports that he was still alive, an international 'Free Wallenberg' campaign was mounted. KGB archives, released in 1992, indicated that Wallenberg had died violently, in custody, in 1947.

Bierman, J., Righteous Gentile. 1981.

Wallenstein (or Waldstein), Albrecht Eusebius Wenzel von, Duke of Friedland and Mecklenburg and Prince of Sagan (1583-1634). Bohemian soldier. He came of a noble Czech family, and added to his family wealth by marrying a rich widow. Converted from Protestantism to Catholicism, he raised troops privately in support of the cause of the emperor ${ }^{*}$ Ferdinand II in Bohemia against *Friedrich of the Palatinate at the beginning of the Thirty Years' War. From the land of the defeated Protestant nobles he added still further to his own estates until his duchy of Friedland (he became Duke in 1623) became an almost independent state. In 1625 he was made Imperial Commander-in-Chief, quickly restored the situation in Hungary and Silesia, and advanced to the Baltic, gaining the duchy of Mecklenburg as a reward. Held up, however, by the siege of Stralsund and unable to carry out his intention of building a fleet he made peace with the Danes. Meanwhile his arrogance and his pretensions to act as a separate ruler roused the jealousy of the traditional Catholic nobility, and in 1630 Ferdinand found himself compelled to dismiss him. Wallenstein retired to his duchy of Friedland, but the emperor, dismayed by the victorious campaign of *Gustaf II of Sweden, was forced to recall Wallenstein, who after preliminary success in Bohemia and Saxony was defeated by the Swedes at Lutzen (1632). Defeat was more than compensated for by Gustaf's death. In 1633 Wallenstein was strangely inactive, he was negotiating both with Catholics and Protestants, with the probable aim of imposing a peace which, under nominal imperial rule, would leave him supreme. Ferdinand, aware of these manoeuvres, had already signed an order of dismissal when Wallenstein was murdered by a group of officers.

Mann, G., Wallenstein. 1976.

Waller, Edmond (1606-1687). English poet. Related to John *Hampden and Oliver *Cromwell, his wealth, already considerable, was increased when he married an heiress (1631). After her death (1634) he courted without success Lady Dorothy Sidney (the 'Sacharissa' of his poems). He served as MP 1621-43, 1661-87. After joining the opposition, he veered in his allegiance and engineered the 'Waller plot' to enable *Charles I to seize London (1643). For this he was banished, but in 1651 was reconciled with Cromwell, to whom he wrote a panegyric. He contrived to remain in favour under ${ }^{*}$ Charles II. As a poet he was important for the development of the heroic couplet but is better remembered for such charming lyrics as Go Lovely Rose.

Chernaik, W. L., The Poetry of Limitation: A Study of Waller. 1968.

Waller, 'Fats' (Thomas Wright) (1904-1943). American jazz composer and pianist, born in New York City. He influenced jazz technique, especially 'stride' piano playing. His best known numbers are Ain't Misbehavin, Honeysuckle Rose and Squeeze Me.

Kirkeby, E., Ain't Misbehaving. 1966.

Waller, Sir William (c.1597-1668). English soldier. He served in the Thirty Years' War and fought for parliament in the English Civil War, but after a series of successes in the south and west, was defeated at Roundway Down (July 1643). Convinced that the latter was due to the unreliability of his troops, he helped to found the New Model army ( ${ }^{*}$ Cromwell), but as an MP surrendered his command (1645) under the Self-denying Ordinance. As a Presbyterian he opposed Cromwell and the army extremists: he favoured a settlement with ${ }^{*}$ Charles I, and later conspired for ${ }^{*}$ Charles II's return.

Adair, J., Roundhead General. 1969.

Wallis, Sir Barnes Neville (1887-1979). English aeronautical engineer. He trained as a marine engineer and later became designer in the airship department of Vickers Ltd. He designed the airship R100 but is most remembered for the bouncing bombs used against the Möhne and Eder dams during World War II.

Morpurgo, J. E., Barnes Wallis: A Biography. 1972. 
Wallis, John (1616-1703). English mathematician, born in Ashford, Kent. Educated at Cambridge, he studied medicine but was ordained as a clergyman. Savilian Professor of Geometry at Oxford 16491703, his most important work is the Arithmetica infinitorum (1655) which paved the way for the introduction of calculus and the binomial theorem. $\mathrm{He}$ introduced negative indices and our present symbol for infinity $\infty$ (the lemniscate). He was an expert in cryptography and had an astounding memory. Among many other works he wrote Treatise of Algebra (1685). He was among the founders of the Royal Society and collaborated with Isaac *Newton.

Walpole, Horace, 4th Earl of Orford (1717-1797). English connoisseur, art historian and man of letters, born in London. Fourth son of Sir Robert *Walpole, he left King's College, Cambridge, without a degree and took up valuable sinecures arranged by his father. Distraught after his mother died, he went on the 'grand tour' of Europe 1739-41 with his friend Thomas * Gray, the poet. He never married and was probably asexual. A Member of Parliament 1741-69, he took no active part in politics. In 1747 he bought a house near Twickenham and devoted many years to transforming it into the fanciful 'little Gothic castle' of Strawberry Hill; he spent most of the rest of his life there, establishing a private press. His letters, witty, graceful and with a love of gossip, are now regarded as his most important literary work and have been published in 80 volumes. They provide a valuable firsthand account of polite society and of such events as the *Gordon riots. Of his other writings the most famous is The Castle of Otranto (1764), an early and influential 'Gothic novel'. In 1791 he inherited the earldom from his nephew. He invented the term 'serendipity'.

Lewis, W. S., Horace Walpole. 1961; Ketton-Cramer, R. W., Horace Walpole: A biography. 1964; Mowl, T., Horace Walpole: The Great Outsider. 2010; Sabor, P., Horace Walpole: The Critical Heritage. 2013.

Walpole, Sir Hugh Seymour (1884-1941). English novelist, playwright and critic, born in Auckland. Son of an Anglican bishop, he was educated at Cambridge University, and achieved early success with $\mathrm{Mr}$ Perrin and $M r$ Traill (1911), a psychological study of a schoolmaster. He served with the Red Cross in Russia 1914-17 and The Dark Forest (1916) courageously revealed his homosexuality. He had an unrequited passion for the Wagnerian tenor Lauritz * Melchior. He wrote 40 more novels including The Cathedral (1922), Portrait of a Man with Red Hair (1925), Rogue Herries (1930) and John Cornelius (1937), studies of *Scott, *Trollope and *Conrad and much criticism. He was satirised as Alroy Kear in *Maugham's Cakes and Ale.

Walpole, Robert, 1st Earl of Orford (1676-1745). English Whig politician, born in Houghton Hall, Norfolk. Third son of a Norfolk landowner, after the death of his brothers the inheritance came to him.
Educated at Eton and King's College, Cambridge, he was an MP 1701-12, 1713-42, then created Earl of Orford. Under Queen *Anne, he was War Secretary $1708-10$ and Treasurer to the Navy 1710 , but resigned with his colleagues when the Tories came to power (1710) and he had to await the accession of *George I before returning to office. He was First Lord of the Treasury and Chancellor of the Exchequer 1715-17, 1721-42, sharing leadership with his brother-inlaw Viscount ${ }^{*}$ Townshend until 1730, then Prime Minister in all but name. (The king was frequently absent, English politics bored him and he spoke the language poorly: all three factors aided development of the Cabinet system.) Walpole was little interested in foreign affairs and left the handling of them to the King and Lord ${ }^{*}$ Townshend while he concerned himself with the domestic situation. After Townshend's retirement (1730) his position was even stronger and he had powerful support from Queen *Caroline. In 1721 he handled the South Sea Bubble crisis coolly and thereafter, in a long period of peace, built up British prosperity by retrenchment (involving a dangerous neglect of the armed services), by establishing a sinking fund and by lightening taxation. He kept control of parliament by the traditional method of bribery ('every man has his price'), the awarding of honours and contracts, with subtlety and skill. Jealousy made him secure his own position by keeping potential rivals, e.g. ${ }^{*}$ Carteret, in the background. A Cabinet of second-raters was the inevitable result. Consistently isolationist, he tried to keep Britain out of European wars by a policy of appeasement. The 'War of Jenkins' Ear' broke out with Spain in 1739, leading on to the War of Austrian Succession in 1742; he opposed both. He resigned after a hostile vote (1742) and retired from politics. Even *Macaulay, who praised his 'prudence, steadiness and vigilance' admitted that 'he was content to meet daily emergencies by daily expedients'. His major collection of paintings was sold to ${ }^{*}$ Catherine the Great and became part of the Hermitage Museum in St Petersburg.

Plumb, J. H., Sir Robert Walpole. Vol 1. 1956; Vol 2. 1961.

Walpurga (or Walburga) St (d.c.780). English abbess, born in Wessex. With her brothers (St) Willibald and (St) Winebald, she founded a double monastery at Heidenheim, now in Baden-Würrtemberg. She was confused with Waldburg, a fertility goddess, and the eve of 1 May, 'Walpurgis night', is, according to German legend, a time when witches hold their sabbaths and sacrifice to the Devil.

Walser, Robert (1878-1956). Swiss novelist, short story writer and poet, born in Biel. He worked as a clerk and had long periods of illness and isolation. His short stories have a hallucinatory quality and were admired by ${ }^{*}$ Kafka, ${ }^{*}$ Hesse and ${ }^{*}$ Sebald. His works were first translated into English only in 
the 1970s and The Assistant (tr. 2007), The Tanners (tr. 2009), and Berlin Stories (tr. 2012) are good ones to start with.

Walsingham, Sir Francis (1530?-1590). English diplomat and Secretary of State. He lived abroad to escape the troubles of *Mary's reign but, when *Elizabeth succeeded, his abilities were discovered by *Burghley and in 1570 he was sent as Ambassador to Paris. After his return he was appointed Secretary of State (1573). His main task was to gain information of links between the powers on the Continent and Roman Catholic conspirators in England, whose object was to murder or dethrone Elizabeth and replace her by *Mary Queen of Scots. To achieve this he maintained a body of spies which (though far from being comparable to a modern secret service) kept him closely informed of the comings and goings of conspirators. Letters were intercepted and decoded but subsequently delivered to give a feeling of false security to his victims, which enabled him to arrest them at their most unguarded moments. Exposure of the ${ }^{*}$ Babington plot which clearly implicated Mary and led to her execution was among his notable successes. Walsingham was a patron of the arts and letters and supported voyages of exploration and colonisation but was so ill rewarded that he died in poverty.

Walter, Bruno (Bruno Walter Schlesinger) (18761962). German-Jewish-American conductor, born in Berlin. Trained as a pianist, he conducted at the Vienna Imperial Opera 1901-12 as a protégé of *Mahler whose Das Lied von der Erde (1911) and Symphony No. 9 (1912) he premiered. General music director at the Munich Opera 1913-22 and the Gewandhaus Orchestra, Leipzig 1929-33, he left Nazi Germany for Austria, where he helped to shape the character of the Salzburg Festival and became artistic advisor to the Vienna State Opera. On the annexation of Austria by Germany (1938), he sought refuge in Paris and then in the US, where he became a citizen in 1946. Walter's repertoire was wide but he excelled in interpretations of *Mozart and Mahler. He promoted the career of Kathleen *Ferrier and made outstanding recordings with her.

Walter, John (1739-1812). English publisher. Having acquired a printing office (1784) he founded the Daily Universal Register (1785) which he renamed (1788) The Times. Under his younger son, John Walter II (1776-1847), it developed into a great national newspaper. John Walter III (1818-1894) continued the family association.

Walter the Penniless (d.1097). Burgundian knight. With *Peter the Hermit, he led the march across Europe of the enthusiastic but undisciplined body that set out in advance of the organised armies for the 1 st Crusade. Having crossed the Bosphorus they were all but wiped out by the Turks at Nicaea.
Walther von der Vogelweide (c.1170-1230). German minnesinger. The greatest of medieval German lyric poets, after several vicissitudes at the court of Vienna he became (c.1215) court minstrel to the emperor *Friedrich II, who rewarded him with an estate. As well as songs, he wrote maxims which have a strong political flavour. He enriched the art of the troubadour by introducing into his songs not only the conventional gallantries of courtly love but the more natural affections of the less high-born.

Taylor, R. J., The Art of the Minnesinger. 1968.

Walton, Izaak (1593-1683). English author. As the owner of a shop in Chancery Lane he came to know John *Donne, in whose parish it was. Thus brought into contact with ecclesiastical and literary circles, he was asked by Sir Henry *Wotton to collect material for a preface to a proposed biography of Donne. This started him on a literary career that led to his writing biographies of Donne, *Wotton, *Hooker, *Herbert and Bishop Sanderson. In 1644 Walton retired to rural Clerkenwell and there wrote The Compleat Angler (1653, enlarged 1655), a rhapsody on the joys of fishing (with concealed advice for living in troubled times), containing verses, anecdotes and pastoral descriptions.

Bottrall, M., Izaak Walton. 1955.

Walton, Sir William Turner (1902-1983). English composer, born in Oldham, Lancashire. As a chorister of Christ Church, Oxford, he received some formal training of his precocious talent. The early Façade (1923), a setting for reciter and chamber ensemble of poems by Edith *Sitwell, was suffused with a wit that dominates the overture Portsmouth Point (1926) and the outer movements of the Sinfonia Concertante (1928 revised 1943). In the Viola Concerto (1929), probably his masterpiece, the wit deepens into a violence that contrasts with a new vein of romantic melancholy, a change of mood that was to become characteristic. The cantata Belshazzar's Feast (1931) is notable for the savagely brilliant orchestration, representing the sufferings of the exiled Jews, and for choral writing of Handelian splendour. This was followed by the Symphony No. 1 (1935) and the Violin Concerto (1939). A String Quartet (1947) and a Violin Sonata (1950) preceded the unsuccessful opera Troilus and Cressida (1954), Symphony No. 2 (1960) and Variations on a theme by Hindemith (1963). He composed music for films, e.g. Laurence *Olivier's Henry V, Hamlet and Richard III, and two coronations, Crown Imperial (1937) and Te Deum (1953). Later works include a comic opera The Bear (after *Chekhov, 1967), a Magnificat and Nunc Dimittis. Knighted in 1951, he received the OM in 1968. He lived in Ischia from 1956 and died there.

Walton, S., William Walton: Behind the Façade. 1988. 
Wan Li (1916-2015). Chinese government official. A teacher, he became an administrator in the CCP, worked with *Zhou Enlai and ${ }^{*}$ Deng Xiaoping, was persecuted 1966-73 during the Cultural Revolution, restored, dismissed again in 1976, and then rose steadily with Deng. He was Chairman of the Standing Committee of the 7th National People's Congress 1988-93 and promoted non-political interests including tennis and bridge.

Wang Hongwen (1934?-1992). Chinese Communist politician. Of unknown background, he was apparently well-educated, became a textile worker and rose to power in Shanghai during the Cultural Revolution. As a protégé of ${ }^{*}$ Mao Zedong he was a Politburo member 1973-76 and third in the Chinese Communist Party hierarchy. He was forced out in October 1976, attacked as one of the 'Gang of Four', tried in 1980 and sentenced to life imprisonment.

Wang Wei (courtesy name Mojie) (701?-761). Chinese poet, musician, painter, calligrapher, born in Shanxi. An outstanding artist of the Tang dynasty, he was a Zen Buddhist and civil servant. None of his paintings survive, but 400 poems are attributed to him, the most famous being 'Deer Park', a beautiful but elusive quatrain. *Mahler quoted from Wang Wei in Das Lied von der Erde.

Weinberger, E., Nineteen Ways of Looking at Wang Wei. 1987/2016.

Warbeck, Perkin (c.1474-1499). English pretender to the throne, born in Flanders. He was persuaded by the Yorkists to claim that he was *Richard, Duke of York, the younger of *Edward IV's sons believed to have been murdered in the Tower of London. In 1492 he was 'recognised' by Edward IV's sister, Margaret, Duchess of Burgundy. After an unsuccessful landing at Deal, Kent (1495), he went to Ireland and then to the court of *James IV of Scotland, where he was married to Catherine Gordon, the Earl of Huntley's daughter. He next sailed to Cornwall, failed to take Exeter by siege, fled and eventually surrendered to *Henry VII. He was imprisoned in the Tower of London and after an attempt to escape and alleged involvement in a plot with Edward, Earl of Warwick, he was tried and executed.

Warburg, Emil Gabriel (1846-1913). German physicist. He carried out extensive experimental investigations of electrical conduction in solids, liquids and gases. His work on spark discharges in rarefied gases led on to the experiments by ${ }^{*}$ Franck and G. L. ${ }^{*}$ Hertz on electron collisions. He later moved in the direction of photochemical studies and confirmed the fundamental law of the quantum nature of light absorption formulated by *Einstein. Warburg was a celebrated teacher. During his 10 years at the Berlin Physics Institute he trained about a fifth of the productive German physicists of the next generation. His son Otto Heinrich Warburg
(1883-1970), born in Freiburg, was a chemist who became an outstanding pioneer in biochemical methodology. His work on respiration in tissues, identifying enzymes that consume oxygen and absorb light in cells, and explaining the role of haemoglobin in capturing oxygen and putting it to work, won him the 1931 Nobel Prize for Medicine. Before viruses were understood, he rejected the germ theory of cancer, identified metabolic changes as a major cause and helped to establish that vitamins are components of enzymes. He directed the Kaiser Wilhelm Institute (later renamed for Max *Planck) in Berlin from 1931. Although half-Jewish, Warburg was allowed to continue his research throughout the Nazi regime but had to refuse a second Nobel Prize in 1944.

Ward, Artemus (pseudonym of Charles Farrar Browne) (1834-1867). American humorist. He was famous for his lectures in the US and England, and for his contributions, quaint and misspelled, to American and English publications, including Punch. His humour was one of the classic American variety, the shrewd plain-speaking of the ostensibly 'simple' man.

Ward, Sir Joseph George, 1st Baronet (1856-1930). New Zealand politician, born in North Melbourne. He was the last in the line of Liberal prime ministers who, from 1870, brought New Zealand through its great period of social and economic development. An Irish Catholic, with only primary schooling but a voracious reader, he was MP 1887-97, 1897-1919, 1925-30, surviving bankruptcy in 1897. His first term as Prime Minister 1906-12, was ended by an election defeat, but he returned (1915) to join his opponent, W. F. *Massey, in a coalition during World War I; both were present at the Paris Peace Conference (1919). They loathed each other. Ward was again Prime Minister 1928-30.

Ward, Mary (1485-1645). English nun, born in Yorkshire. In 1609, in Saint-Omer, she established a religious congregation for women, the Loreto Sisters (Institute of the Blessed Virgin Mary), actively participating in the world, influenced by the organisation of the Jesuits. She faced strong opposition in the church hierarchy. The order was suppressed in 1631 , but revived in 1703 . Nevertheless, she travelled throughout Europe establishing schools.

Ward, Mary Augusta (née Arnold) (known as Mrs Humphry Ward) (1851-1920). English writer, born in Tasmania. At the age of five she returned to Britain with her father, Thomas Arnold (1823-1900), brother of Matthew *Arnold, who became co-editor of the Catholic Dictionary (1883). His daughter, who married (1872) Thomas Humphry Ward, an Oxford don and art critic, was also preoccupied with religion and the best known of her books, Robert Elsmere (1888), studies the hero's struggle with religious doubt. She was friendly with leading intellectuals and contributed to periodicals as well as writing 25 novels, 
three plays and nine non-fiction works. She supported higher education for women and was secretary of Somerville College, Oxford 1879-81. Although a keen social worker and one of the first seven women appointed magistrates (1920), she actively opposed women's suffrage.

Huws Jones, E., Mrs Ward. 1973.

Warhol, Andy (né Andrew Warhola) (1928-1987). American artist and film maker. He was a leading exponent of pop art in the 1960s using household objects, such as Campbells' soup cans and sculptures of Brillo soap pads. He also produced multiple image photographic silk screens of subjects including Marilyn *Monroe and the electric chair. Later he made 'underground' films, some of which lasted as long as 25 hours. These included Chelsea Girls (1966) and Blue Movie (1969). His New York based 'Factory' became a fashionable studio and centre for the artistic avant-garde and eccentrics of the 1960s and early 1970s. His Silver Car Crash (Double Disaster), a serigraph, sold for \$US105 million in 2013, while his Shot Sage, Blue Marilyn (Marilyn *Monroe, $1964)$ set a record for 20th Century art works at \$US195 million in 2022.

Gopnik, B., Warhol: A life as art. 2020.

Warlock, Peter (pseudonym of Philip Arnold Heseltine) (1894-1930). English composer. A critic and editor under his family name, he became obsessed with the occult, adopting the name Warlock. He wrote a biography of *Delius, and was a friend of *Yeats and *Bartók. He composed about 150 songs, in which the predominant moods are Elizabethan jollity (many were settings of Elizabethan poems) and sensuous melancholy, e.g. The Curlew (1923), a setting for tenor and chamber ensemble for poems by Yeats. He also wrote choral and orchestral works, e.g. the Capriol Suite for strings (1926). He died of gas poisoning, a probable suicide.

Warne, Shane Keith (1969-2022). Australian cricketer, born in Ferntree Gully. Regarded as one of the greatest spin-bowlers in the history of cricket, in the Australian Test team 1992-2007, he played in 145 test matches, took 708 test wickets and was also an effective batsman and serious carouser.

Warner, Harry Morris (né Hirsz Mojżesz Wonsal) (1881-1958). American-Polish-Jewish film producer, born in Russian Poland. His father, a shoemaker, migrated to the US in 1889, then lived in Canada briefly. Harry Warner and his brothers Samuel (Szmuel), Albert (Abraham) and Jack (Jacob) formed (1923) the motion-picture company Warner Brothers. He produced (1929) The Jazz Singer, the first talking picture. Although conservative Republicans, they supported Franklin D. *Roosevelt, and produced films that mobilised public opinion against the Nazis, e.g. Casablanca (1942).
Warner, Sir Pelham Francis (1873-1963). English cricketer. As captain of Middlesex and England for many years and as one of the most attractive and informed writers on the game, he occupied an important place in the history of English cricket.

Warner, P. F., Long Innings. 1951.

Warren, David Ronald de Mey (1925-2010). Australian inventor. He studied in Sydney, Oxford and Melbourne, worked for the Australian Aeronautical Research Laboratories, and in 1953 developed a prototype of the 'black box', a flight data recorder, now universally adopted, but then dismissed as pointless, especially in his native land.

Warren, Earl (1891-1974). American lawyer and Republican politician. He served as Attorney-General 1939-43 and Governor 1943-53 of California. In 1948 he was Republican candidate for Vice President, on Thomas *Dewey's ticket, and in 1952 sought the Presidential nomination. The newly elected President *Eisenhower appointed him as Chief Justice of the US Supreme Court 1953-69. His activist court made liberal decisions that changed the US far more than Congress or the presidency by ruling against segregated schools (1954), securing legal protection for accused persons, redistributing state legislative districts, striking down censorship laws, and emphasising civil liberties and the right to dissent. His commission of enquiry into President *Kennedy's assassination (1963-64) was attacked as inadequate and its conclusions criticised. Warren was a favourite whipping boy for right-wing extremists.

White, G. E., Earl Warren. 1982.

Warren, Elizabeth Ann (née Herring) (1949- ). American Democratic politician and lawyer, born in Oklahoma. Educated at Houston and Rutgers, and originally a teacher, she became a specialist in bankruptcy law and held chairs at universities in Texas, Michigan, Pennsylvania, and then Harvard. A Republican until 1996, she was a US Senator from Massachusetts 2013- . In 2016 she was encouraged to seek the Democratic Presidential nomination but backed Hillary ${ }^{*}$ Clinton. She announced her candidature for 2020 in February 2019, but although passionate, articulate and intelligent, polled poorly in the primaries and withdrew in March.

Warren, Robert Penn (1905-1989). American poet, novelist and critic, born in Kentucky. He studied at Berkeley, Yale and (as a Rhodes Scholar) Oxford. He won a Pulitzer Prize in 1947 for his novel, All the King's Men (1946), based on the life of Huey ${ }^{*}$ Long, and made into an award-winning film. In 1958 he won a second Pulitzer Prize for Promises: Poems 1954-56. 
Warren, (John) Robin (1937- ). Australian pathologist, born in Adelaide. He shared the 2005 Nobel Prize for Medicine with Barry *Marshall for their work in identifying Helicobacter pylori as a cause of peptic ulcers.

Warwick, 16th Earl of, Richard Neville, 2nd Earl of Salisbury (known as 'Warwick the Kingmaker') (1428-1471). English nobleman. Son of the 1st Earl of Salisbury (d.1460), he claimed the Warwick earldom (1449) through his wife's rights. He owned so much land and wealth that he was able to hold the balance in the Wars of the Roses. At first he joined the Yorkist faction and after the death of its leader, *Richard, Duke of York, was able (1461) to supplant *Henry VI by Richard's son, *Edward IV. Edward was not the man, however, to submit tamely to a power behind the throne, and when Warwick secretly married (1469) his daughter Isabel to the king's brother, George, Duke of * Clarence, Edward was strong enough to force Warwick and Clarence to take refuge in France, where a reconciliation took place with Margaret, *Henry VI's queen. As champion of the Lancastrian cause Warwick now returned to England, compelled Edward in his turn to leave the country, and reinstated Henry VI. In March 1471 Edward landed in Yorkshire, was joined by his repentant brother Clarence, and met, defeated and killed Warwick at Barnet. Warwick's younger daughter Anne Neville (1456-1485) married the future *Richard III.

Kendall, P. M., Warwick the Kingmaker. 1957.

Washington, Booker Taliaferro (1856-1915). African-American educationist, born in Virginia. By becoming (1872) a janitor at the Hampton Normal and Agricultural Institute he was able to work his way through the course and graduate (1875). He then began to teach, and interested himself in educational methods. In 1881 he became principal of a school for African-Americans at Tuskegee, Alabama, and made it a centre of black education. His writings, e.g. his autobiography Up from Slavery (1901), aimed to promote racial understanding.

Washington, George (1732-1799). 1st President of the US 1789-97. Born at Bridges Creek, Virginia, he was the eldest of his father's six children by his second wife, there being already four children in his first family. His father was the grandson of John Washington, whose family home was at Sulgrave, Northamptonshire, England, and who had emigrated (1656/7) to Virginia, where his domains had been enlarged by his successors. After his father's death (1743) George, then aged 11, came under the guardianship of his elder half-brother Lawrence, with whom he lived at Mount Vernon. Here he came to know Lord Fairfax and his brother, who was Lawrence's father-in-law. The brothers took George under their wing, encouraged him to educate himself in their large library and, by sending him to survey their own outlying land, enabled him to become (1749) a public surveyor. The deaths of Lawrence (1751) and his daughter soon afterwards gave George the ownership of the Mount Vernon estate. In 1751 he had been appointed Adjutant General, with the rank of major, of the provincial militia, and in 1753 was sent on a dangerous mission (described in his Journey to the Ohio) to the French commander, 600 miles distant, to warn him against encroachments upon British territory. The warning being disregarded, Washington accompanied General Braddock on the disastrous expedition of 1755 and showed great skill in rallying the routed survivors. On his return he was given command of all the Virginian forces, but the subsequent fighting in which he took part was of only minor importance. In 1758 he was elected to the Virginia House of Burgesses, where his contributions to debate were marked by common sense rather than eloquence.

In 1759 he married a rich widow Martha Dandridge Custis (1732-1802). At Mount Vernon he lived as an affluent country gentleman, became an expert and enthusiastic rider and performed many public duties. He steadily improved his estate, amounting to 2300 hectares, with 200 slaves, and magnificent gardens laid out in the French style. He accepted, without approving, the institution of slavery but his slaves were freed on his death.

The events that preceded the War of American Independence found Washington firmly on the side of the colonists. Despite the dissolution of the Virginia House by the British Government for its support of the Boston resistance to taxation without representation, the burgesses continued to meet elsewhere and Washington was chosen as a delegate to the two continental congresses (1774 and 1775) summoned to decide on future action. The second was interrupted by the outbreak of hostilities, and Washington, one of the few with the necessary military experience, was made Commander-in-Chief of all revolutionary forces. Assuming the leadership just after the American defeat at Bunker Hill (June 1775), he began the enormous task of recruiting, training and equiping, necessary to match his troops on equal terms with the British and German regulars. A new vigour and determination were soon apparent, but though the British were driven from Boston (1776) Washington's attempt to hold New York against * Howe failed and a year of varying fortunes (1777) culminated in the defeat at Brandywine. Having overcome a movement to deprive him of his command, Washington emerged from the hardships of wintering at Valley Forge (1777-78) with a hardened, better trained and much more efficient army, unitedly devoted to its leader. The tide finally turned when France entered the war and it was the surrender of ${ }^{*}$ Cornwallis at Yorktown (October 1781) to a combined attack by French ships and American troops that virtually ended the fighting, though formal acknowledgement of independence awaited 
the Treaty of Versailles (1783). Washington was no great strategist but, without the patience, courage and willpower of his formidable personality, victory could have scarcely been achieved.

The war over, Washington returned to Mount Vernon. He was elected as President of the Constitutional Convention meeting in Philadelphia May-September 1787, when delegates from 12 states (Rhode Island having failed to send delegates) hammered out a Constitution. Once ratified by the states, an election was held for members of the Electoral College in December 1788-January 1789 who would choose the first President and Vice President. Only six states had a popular vote, with a strikingly low turnout $(43,782$ in total), four more sent delegates chosen by the state legislature, and three did not participate.

The Electoral College cast all 69 votes for Washington who was inaugurated as President of the United States in April 1789. (There were 11 candidates for Vice President. John *Adams won comfortably.) Washington chose his administration from all factions and only his force of character could hold together, even temporarily, men of such different outlook as Thomas *Jefferson and Alexander *Hamilton. Jefferson eventually went into opposition with the loosely organised Democratic-Republican Party. In 1792, the Electoral College unanimously re-elected Washington, but the Vice Presidency was contested, with the Federalist Adams defeating the DemocraticRepublican George *Clinton. Among Washington's most important decisions was keeping the United States neutral in the war between England and France. He refused a third term of office. Henry *Lee's words, contained in the Resolutions in the House of Representatives at the time of his death, remain his finest epitaph: 'First in war, first in peace, and first in the hearts of his countrymen'. His will directed that his slaves should be freed on his wife's death: among the Founding Fathers he was the only slave owner to do this.

In 1976, he was promoted 'General of the Armies of the United States' as part of the Bicentennial celebrations. In 20 major studies by historians and political scientists ranking US presidents, Washington scored No. 3 in the aggregate, behind Abraham ${ }^{*}$ Lincoln and Franklin *Roosevelt.

Freeman, D. S., George Washington. 6 vols, 1948-54; Knollenberg, B., George Washington. 1965; Perry, J. A., Allison, A. M. and Skousen, W. C., The Real George Washington. 1991; Chernow, R., Washington: A Life. 2010.

Wassermann, August von (1866-1925). German bacteriologist. After practising as a physician for some years he became (1902) a professor at the *Koch Institute for Infectious Diseases at Berlin and in 1913 was given the direction of a new institute of experimental therapy. He is best remembered for the also worked to provide antitoxins for immunisation against other diseases, e.g. diphtheria, cholera, tuberculosis.

Waterhouse, Alfred (1830-1905). English architect, born in Manchester. He designed several important London buildings, e.g. the Natural History Museum, St Paul's School and the Prudential building in Holborn, and Eaton Hall, Cheshire for the Duke of *Westminster.

Watson (né Tanck), (John) Chris(tian) (1867-1941). Australian Labor politician, born in Valparaiso, Chile. Son of a German sailor lost at sea, he was brought up in New Zealand and became a printer. After serving in the New South Wales Parliament 1894-1901, he was a foundation member of the Commonwealth Parliament 1901-10, the first federal leader of the Australian Labor Party 1901-07 and the first Labor Prime Minister April-August 1904. He was (at 37) the youngest Australian Prime Minister, and the first Labor leader of a national government anywhere in the world. He broke with the ALP over conscription (1916) and went into business.

McMullin, R., So Monstrous a Tragedy. 2004.

Watson, James Dewey (1928- ). American biologist, born in Chicago. One of the radio 'Quiz Kids', educated at Indiana and Chicago Universities, he worked with Francis ${ }^{*}$ Crick in Cambridge on establishing the structure and function of DNA (deoxyribonucleic acid) and published the joint findings in Nature in 1953. In 1962 he shared the Nobel Prize for Medicine with Crick and Maurice *Wilkins. He wrote The Double Helix (1968), a lively account of the DNA discovery. He was a professor of biology at Harvard 1961-76, director of the Cold Spring Harbor Laboratory 1968-93, and its President 1994-2004, and of the National Centre for Human Genome Research 1989-92. Awarded the US Presidential Medal of Freedom in 1977, he was appointed FRS 1981, received the Copley Medal in 1993, and became an Hon. KBE in 2001. After 2004, he faced sharp criticism for his views about alleged genetic deficiencies of Africans.

Watson-Watt, Sir Robert Alexander (18921973). Scottish physicist, born in Angus. Educated at St Andrews University, he worked for years as a meteorologist. As superintendent of radio department of the National Physical Laboratory in Teddington, he convinced military and political leaders of the possibility of applying to the location of aircraft the known principle of range-finding by the reflection of radio waves (1935). The main figure in the development of radar (an acronym of Radio Detection and Ranging), he led the team that developed this idea into an important defence weapon for World War II. He was elected FRS in 1941 and knighted in 1942.

Watson-Watt, Sir R. A., Three Steps to Victory. 1958. 
Watt, James (1736-1819). Scottish engineer, born in Greenock. Son of a merchant, after an apprenticeship he became instrument maker to Glasgow University, where he used a workshop for engineering experiments. Here he devised (1765) means of improving the steam engine, notably by the addition of a separate condenser and a steam jacket. The reduction of wastage would, he estimated, cheapen steam power by about 75 per cent and thus make its use economic throughout industry. Delay in the construction of a full-size engine was overcome when Watt eventually obtained the backing of John Roebuck of the Carron Ironworks. Roebuck sold his interest to Matthew *Boulton of Birmingham, and it was there that Watt successfully completed his engine (1775). Taken into partnership by Boulton he continued to make improvements. To transform the reciprocating (i.e. to and fro) motion into a rotary movement he devised a 'sun and planet' gear. He invented also the two-cylinder engine, the double-acting engine and a centrifugal governor for controlling speed. In another field he invented a copying press which, by eliminating handmade copies, greatly reduced office work. The unit of electric power, the 'watt', was named after him.

Watteau, (Jean) Antoine (1684-1721). French painter, born in Valenciennes. He grew up in a border town and was in contact with the Flemish tradition. He went to study in Paris (1702) but continued to paint in the Flemish manner until he made his permanent home in Paris. While living there (1712-19) he introduced a new and highly sophisticated style in accord with the artificiality of court life. Subjects are the serenade, the dance, the whispered conversation, the picnic; shimmering gowns in a pastoral setting, a nostalgic transposition of the aura of the sweeter classical myth into the terms of Watteau's own day. Paintings like the Embarkation for Cythera (1717) are among the masterpieces of baroque art. To these subjects he brought techniques derived from a study of *Rubens' work and his own acute observation. In part, too, the pictures represent a dreamlike escape from reality. He died of tuberculosis from which he had long suffered and for which a visit to England (1719) was a vain attempt to find a cure. His last masterpiece, Gilles (1720-21), a pierrot in white (and a self portrait), is in the Louvre.

Watts, George Frederic (1817-1904). English painter and sculptor, born in London. He gained wide popularity, mainly through reproductions of allegorical pictures such as Love and Death, Hope and Mother and Child but his best work is in his portraits (*Russell, * ${ }^{*}$ Disraeli, * *Shaftesbury, *Tennyson, *Gladstone, ${ }^{*}$ Manning, ${ }^{*}$ Carlyle, Ellen *Terry), 54 of them in the National Portrait Gallery, London. His first marriage (1864) to the actor Ellen Terry, then barely 17, was dissolved. Elected RA in 1867, he twice declined a baronetcy but was an original member of the OM (1902). He also created monumental sculptures e.g. Physical Energy (1902). Watts thought of himself as the English *Michelangelo. Posterity has not agreed, although he had some influence on Henry *Moore.

Watts, Isaac (1674-1748). English hymn writer. He was a nonconformist pastor in London, constantly handicapped by ill health and from 1712 he lived with and was cared for by Sir Thomas and Lady Abeny. He wrote a metrical version of the Psalms and was a most prolific writer of hymns, among the best known being $O$ God, our help in ages past, When I survey the wondrous cross and Jesus shall reign whereer the sun.

Waugh, Evelyn Arthur St John (1903-1966). English novelist, born in Hampstead. Son of a publisher, he was educated at Lancing College, Sussex and Hertford College, Oxford. He taught unhappily at three schools (1925-27), material he turned to advantage in his first success, the novel Decline and Fall (1928). His marriage to Evelyn (he called her 'she-Evelyn') Gardner broke up in 1929. In 1930 he published a satire on Mayfair, Vile Bodies, and became a Roman Catholic. Journalism followed and the first of several visits to Africa which inspired the novels Black Mischief (1932), A Handful of Dust (1934) and Scoop (1938). He wrote a notable biography of Edmund ${ }^{*}$ Campion (1935) and married Laura Herbert in 1937. He joined the Royal Marines in 1939 and served with the commandos (and Randolph ${ }^{*}$ Churchill) in Yugoslavia 1944. His World War II experiences produced the great trilogy Sword of Honour (Men at Arms, 1952, Officers and Gentlemen, 1955, Unconditional Surrender, 1961). Brideshead Revisited (1945) was a popular and critical success, later a television series. The Loved One (1948), also filmed, was a biting satire on the Californian funeral business. The Ordeal of Gilbert Pinfold (1957) was a savage self-portrait of a Catholic novelist, hallucinating on pills and alcohol, fighting against paranoia and despair. One of the great stylists, Waugh's work was distinguished by wit, cynicism and a firmly reactionary view of life, sustained only by his family and pre-Vatican II Catholicism. His son Auberon Alexander Waugh (1939-2001) was a polemical journalist, novelist and critic.

Stannard, M., Evelyn Waugh: The Early Years: 190339. 1986; Stannard, M., Evelyn Waugh: The Later Years: 1939-66. 1993; Hastings, S., Evelyn Waugh. 1994; Eade, P., Evelyn Waugh: A Life Revisited. 2016.

Wavell, Archibald Percival, 1st Earl Wavell of Cyrenaica and Winchester (1883-1950). English field marshal, born in Colchester. Son of a major general, educated at Winchester and Sandhurst, he was widely read, an enthusiast for poetry and mastered several languages. He served in India 1903-09. In World War I he was in Flanders (losing an eye at Ypres), Russia and Egypt. Commanderin-Chief in the Middle East 1940-41, his brilliant campaign of December 1940 resulted in the conquest of Cyrenaica and the capture of 130,000 Italian 
prisoners. ${ }^{*}$ Churchill then directed Wavell to divert forces from North Africa to Greece (April 1941), a doomed campaign that enabled the Germans to recapture Libya and threaten Egypt. Churchill never forgave Wavell for his own strategic blunder. He was appointed Commander-in-Chief, India, 1941-43 and Supreme Commander, Allied Forces in the Southwest Pacific January-March 1942 when Japan invaded Indonesia, Malaya and Burma. Churchill reluctantly appointed him as Viceroy of India 1943-47, with a viscountcy. ${ }^{*}$ Gandhi and ${ }^{*}$ Nehru had been interned in 1942 when their 'Quit India' campaign began, but Wavell released Gandhi in 1944 and Nehru in 1945, despite Churchill's objections. His plan for British withdrawal from India, seen as defeatist by the time, was rejected by both Churchill and *Attlee, but in retrospect looks to have been more practical than *Mountbatten's impulsive strategy and there would have been fewer deaths during the transition period. Wavell was recalled from India and promoted to an earldom. He was buried at Winchester College.

Connell, J., Wavell, Soldier and Scholar. 1964; Wavell, Supreme Commander, 1969; Lewin, R., The Chief: Field Marshal Lord Wavell. 1980; Close, H. M., Attlee, Wavell, Mountbatten and the Transfer of Power. 1997; Schofield, V., Wavell: Soldier and Statesman. 2006.

Waynflete, William of (c.1395-1486). English scholar and prelate. He had been headmaster of Winchester for 11 years when (1441) he was called upon by ${ }^{*}$ Henry VI to organise his new school at Eton, of which he became provost when it opened (1443). He became Bishop of Winchester (1447) and founded Magdalen College, Oxford (1448).

Webb, Sir Aston (1849-1930). English architect. $\mathrm{He}$ was best known for the new east front of Buckingham Palace, as well as the Victoria Memorial and Admiralty Arch which distinguish its ceremonial approach. He designed large extensions to the Victoria and Albert Museum (1909).

Webb, Mary (née Meredith) (1881-1927). English novelist, born in Shropshire. Her best known works are the novels The Golden Arrow (1916) and Precious Bane (1924), which won the Femina Vie-Heureuse Prize.

Webb, Sidney James, 1st Baron Passfield (18591947) and Beatrice Webb (née Potter) (1858-1943). English socialists and sociologists. Sidney was educated in London, became a civil servant (1878) and a barrister (1885) and was an active member of the Fabian Society from 1884. Beatrice was the daughter of a wealthy industrialist, assisted Charles Booth in an investigation of London working-class conditions and had written The Co-operative Movement in Great Britain (1891) before she married Sidney in 1892. He was a member of the London County Council 1892-1910. Their careers were a literary and political collaboration. They visited Australia in 1898. They sat on many royal commissions, e.g. on trade union law, the coal mines, and the Poor Law (for which in 1909 Beatrice produced a notable Minority Report), and they helped start the London School of Economics (1895) and the New Statesman (1913). Their works on social history were of great importance e.g. The History of Trade Unionism (1894), English Local Government, (10 volumes 1906-29) and The Decay of Capitalist Civilisation (1921). Sidney became a Labour MP 1922-29 and served under MacDonald as President of the Board of Trade 1924 and Secretary of State for the Dominions and the Colonies 192931. After visiting the USSR (1932), the Webbs wrote Soviet Communism (1935), a thorough but excessively admiring account. Sidney received the OM in 1944.

Cole, M. and Drake, B. (eds), Our Partnership. 1948.

\section{Webber, Sir Andrew Lloyd see Lloyd Webber, Andrew, Baron Lloyd Webber}

Weber, Carl Maria Friedrich Ernst von (17861826). German composer, born in Eutin. Son of a musician, he was a cousin of *Mozart's wife Aloysia Weber (1759?-1839). In the hope that he would become a youthful prodigy he was sent to study music under Michael ${ }^{*}$ Haydn (brother of Joseph). After his first post as conductor at Breslau he entered the service of the Duke of Württemberg, where he and his father were expelled for debt and dissipation. To his early period belong his only two symphonies (of little worth), two tuneful concertos (and one concertino) for clarinet and strings and the operas Sylvana (1810) and Abu Hassan (1811). He was director of the Prague opera 1813-17 and directed German opera at Dresden 1817-26. Here he succeeded in checking the dominance of Italian opera and in establishing the school of German romantic opera with its emphasis on the supernatural. His own contribution comprised his three mature operas, Der Freischütz (The Freeshooters, 1821), Euryanthe (1823) and Oberon (1826). Only Der Freischütz has remained popular, but their colourful, dramatically apt orchestration, the occasional use of leitmotifs and a new structure of the overture (based solely on themes from the opera itself) influenced *Wagner profoundly. Weber died of tuberculosis while in London for the production of Oberon at Covent Garden. Of his other works, one remains outstandingly popular, his piano waltz Invitation to the Dance (1819), to which the orchestration by *Berlioz and, later, by *Weingartner gave a fresh brilliance.

Warrack, J., Carl Maria von Weber. 1968.

Weber, Max(imilian Karl Emil) (1864-1920). German sociologist and philosopher, born in Erfurt. Son of a civil servant, educated in Heidelberg and Berlin, between bouts of disabling illness, he held chairs at Freiburg and Heidelberg and wrote voluminously on social subjects, some of his most valuable work being concerned with the categorising of social groups. Politics as Vocation (1919), a collection of lectures, argues that leaders must have 
three qualities: passion, responsibility and a sense of proportion. He identified three different styles of leadership: 'charismatic' (*Mussolini, ${ }^{*}$ Hitler, *Trump), 'traditional' and 'legal/rational' in a work published posthumously. His best known work, The Protestant Ethic and the Spirit of Capitalism (1920), an attempt to explain the link between the two halves of his title, was influential in Britain and the US. He died in the influenza pandemic.

Bendix, R., Max Weber: An Intellectual Portrait. 1962.

Webern, Anton (Friedrich Wilhelm von) (18831945). Austrian composer, born in Vienna. He studied composition with ${ }^{*}$ Schoenberg, whose methods he adapted to his own purposes. After conducting in Danzig, Stettin and Prague, he directed the Vienna Workers' Symphony Orchestra 1922-34. His orchestral works include a Passacaglia and two symphonies. He also wrote songs and two cantatas dating from World War II. The Nazis banned his works and forbade him to teach, but he had some sympathy for *Hitler. After liberation he was accidentally shot dead by an American soldier, Raymond Bell. In his compositions (most of which are very short) Webern, who developed Schoenberg's principle of serialism by dividing the series into small cells and extended the serial principle to instrumental timbre, has had important influence on postwar composition (including *Stravinsky's late works).

Wildgans, F., Anton Webern. 1966.

Webster, Daniel (1782-1852). American lawyer, orator and politician, born in New Hampshire. $\mathrm{He}$ practised law first in his native state and then in Boston, where, with legal skill and with magnificent eloquence, he argued cases involving major constitutional issues. Elected Member of the House of Representatives 1813-17, 1823-27, in the second period he was the principal spokesman in Congress for the administration of President John Quincy*Adams.

Webster was one of the greatest of American orators. His speech on the bicentenary of the Pilgrim Fathers (1820), his two Bunker Hill orations (1825 and 1843), on the supremacy of the Union (1830), and funeral orations (e.g. John *Adams and *Jefferson, 1826) demonstrate his mastery of phrase and superb gift of matching style with content.

US Senator from Massachusetts 1827-41, 184550 , he was prominent in creating the new Whig Party (1833), but never secured the presidential nomination. He twice declined nomination as Vice President $(1840,1848)$ and in both cases the incumbent president died. He supported William Henry *Harrison in 1840 and served as Secretary of State 1841-43. The Webster-Ashburton Treaty (1842), with Britain, defined the US-Canadian border and ended the slave trade on the high seas. Although strongly opposed to slavery, in the interests of preserving the Union, Webster worked tirelessly to secure passage of the Compromise of 1850 which retained slavery in the South but prevented its expansion to the West. He became Millard *Fillmore's Secretary of State 1850-52, dying in office.

Webster, John (c.1580-c.1625). English dramatist. Many of his plays were written in collaboration, notably with ${ }^{*}$ Dekker and ${ }^{*}$ Heywood, only three, in fact, of the surviving plays are known to be his independent work: The White Devil (1612), The Duchess of Malfi (c.1614) and the much less important The Devil's Law Case (1623). The first two, based on Italian originals, vie with *Shakespeare's work in tragic intensity, but the characterisation is cruder, the range of emotions narrower, and humour, except in its grimmest form, is lacking. Webster's poetry, however, occasionally touches greatness.

Bliss, L., John Webster. 1983.

Webster, Noah (1758-1843). American lexicographer, born in Connecticut. Educated at Yale, he became a teacher, journalist and political writer, publishing the famous Webster's Spelling Book in 1773. A Compendious Dictionary (1806) and An American Dictionary of the English Language (2 volumes, 1828) helped to standardise American English.

Scudder, H. E., Noah Webster. 1971.

Wedekind, (Benjamin) Frank(lin) (1864-1918). German dramatist, born in Hanover. Conceived in the US, he became promoter, cabaret performer, poet, actor and director, and wrote many expressionist plays that anticipate the work of Bertolt *Brecht. The best known are Earth Spirit (1895) and Pandora's Box (1904), in which the central character is the courtesan 'Lulu'. G. W. *Pabst filmed Pandora's Box and Alban *Berg composed the opera Lulu.

Wedgwood, Dame (Cicely) Veronica (1910-1997). English historian. Educated at Oxford, her books include The Thirty Years War (1938), Oliver Cromwell (1939), William the Silent (1944), The Trial of Charles I (1964) and Milton and his World (1969). In 1969 she received the OM.

Wedgwood, Josiah (1730-1795). English potter. Descendant of a family of Staffordshire potters, in 1759 he started his own business in Burslem. He eventually succeeded in developing for large-scale manufacture the hard white earthenware already made in Staffordshire and possessing many of the qualities of porcelain. His improvements to body and glaze were made by introducing china-clay and china-stone, then recently discovered in Cornwall. Apart from this utilitarian product, Wedgwood became famous for his 'jasper ware', generally pale blue or green and, to accord with the classical taste of the time, adorned with a frieze of Greek figures embossed on it in white. For these decorative pieces, made nearby at his new works (1769) called Etruria, 
he employed many artists, notably *Flaxman. Wedgwood was an enlightened employer who did much to improve education and living conditions of his men. Charles *Darwin was his grandson.

Mankowitz, W., Wedgwood. 1953.

Weelkes, Thomas (c.1575-1623). English composer. He wrote Church music, music for keyboard and for viols, but is at his most original in madrigals, regarded as among the finest of the Elizabethan School.

Wegener, Alfred Lothar (1880-1930). German geophysicist, meteorologist, polar researcher and geologist, born in Berlin. He studied at Heidelberg, Innsbruck and Berlin and, before World War I, taught at Marburg. From 1910, following the ideas of Eduard *Suess, he developed his theory of Continental Drift or Displacement. Empirical evidence for this seemed to be the close jigsaw fit between coastlines on both sides of the Atlantic, and palaeontological similarities between Brazil and Africa. But Wegener had strong convictions that geophysical and geodetical considerations would also support a theory of wandering continents. As to the cause of the displacement he looked to tidal forces and a 'flight from the poles'. Wegener supposed that the Mesozoic had seen the existence of a united supercontinent, 'Pangaea'. This had split apart into Laurasia and Gondwana. During the Cretaceous, South America and North America had split, but not till the end of the Quaternary had North America and Europe finally divided, or South America split from Antarctica. He died on his fourth expedition to Greenland. The South African geologist Alexander du Toit supported Wegener, but it was the development of paleomagnetism by P. M. S. *Blackett and others in the 1950s that provided conclusive evidence for continental drift. Craters on Mars and the moon, and an asteroid (29227 Wegener), were named for him.

Georgi, J., 'Memories of Alfred Wegener', Continental Drift. 1962; Greene, M. T., Alfred Wegener. 2015.

Weil,Simone (1909-1943). French social philosopher and mystic, born in Paris. Daughter of a rich Jewish (but agnostic) physician, she was a youthful prodigy and studied philosophy, literature and science. She taught philosophy in provincial lycées, worked for a year in the Renault factory (1934-35) and as a cook for an Anarchist group in the Spanish Civil War (1936-37), also writing for socialist journals. She was severely burnt in Spain, suffered from acute migraine and contracted tuberculosis. In 1938 she had a series of mystical experiences, became absorbed in Catholicism and, although she did not enter the Church, was instrumental in converting others. She wrote an important short essay, The Iliad, or the Poem of Force (1939). She left France in 1942 for the US (via Casablanca), then went to England to work for General *de Gaulle. Suffering from tuberculosis, she refused to eat and died in a sanatorium in Kent. The posthumous publication of her books aroused intense critical interest. They include Waiting on God (Attente de Dieu, 1951), The Need for Roots (L'enracinement, 1952) and Notebooks (2 volumes, 1956). Between 1992 and 2012, 2500 scholarly works on Weil were published.

Weill, Kurt (1900-1950). German American composer. A pupil of *Humperdinck and *Busoni, his best known work is Dreigroschenoper (The Threepenny Opera, 1928), a modernised version of *Gay's Beggar's Opera with libretto by *Brecht, who also collaborated with Weill in later works, equally harsh and satirical in character, e.g. Happy End and The Rise and Fall of the City of Mahagonny (both 1929). These works are deliberately 'popular' and jazz-inspired in idiom, and in them Weill shows himself as much a political and social satirist as a musician. In 1933 he was obliged to flee Nazi Germany, settling (1935) in the US, where he produced music for plays and a folk opera, Down in the Valley (1948). He married the singer and actor Lotte *Lenya.

Weinberg, Steven (1933-2021). American astrophysicist. Educated at Cornell, Copenhagen and Princeton universities, he held chairs in physics at the University of California (Berkeley) 1964-73, Harvard 1973 and Texas 1982. He wrote the bestseller The First Three Minutes (1977) and shared the Nobel Prize for Physics 1979 with Abdus Salam and Sheldon Glashow for their research on unification of the weak force and electromagnetic interaction between elementary particles.

Weinberger, Caspar Willard (1917-2006). American administrator. He served as US Secretary of Health, Education and Welfare 1973-75, became general counsel to the Bechtel Corporation and was Secretary of Defence 1981-87.

Weinberger, Jaromir (1896-1967). Czech composer. Chiefly remembered for his opera Schwanda the Bagpiper (1927), in 1938 he left Czechoslovakia and eventually settled in the US.

Weingartner, (Paul) Felix von (1863-1942). Austrian conductor, composer and critic. He studied at Leipzig and then under *Liszt. As conductor, he held posts in Berlin, Munich and Vienna where he was *Mahler's successor at the Imperial Opera 1907-11 and elsewhere, and became well known by his foreign tours. His compositions, which include operas, symphonies and chamber music, lack individuality. He wrote books on *Beethoven's symphonies and the art of conducting.

Weismann, August Friedrich Leopold (1834-1914). German geneticist, born at Frankfurt-am-Main. He studied medicine at Göttingen, and practised at Rostock and then in Frankfurt. He became professor of zoology at Freiburg in 1873. During the 1860s he carried out detailed microscopic investigations into insects, crustaceans and embryology, though 
difficulties with his eyes eventually put a stop to this work. Weismann is best remembered for his 'germ plasm' or chromosome theory of heredity. He grasped the centrality of the transmission of 'information' in biology. Within evolutionary theory there was deep disagreement as to how constant features and variations were passed on by inheritance. ${ }^{*}$ Darwin had early favoured 'pangenesis', the theory that all characters were coded together in the genetic material. Other biologists had stressed the inheritance of acquired characteristics. Weismann launched a full-scale attack on this latter theory. His own experimentation had convinced him of the totally separate existence of genetic cells (germ cells) from body cells. He believed in the reality of an unbroken line of descent between the germ cells of successive generations, punctuated only by mutations in those cells (whereby evolution occurred). He argued that the hereditary material is contained in 'chromosomes'. Fertilisation takes place by the bringing together of chromosomes from two individuals, and variation resulted from the combinations of different chromosomes that occurred. Weismann's essentially genetic theory of the action of evolution was wrong in detail, but essentially underlies modern genetic theory.

Weiss, Peter Ulrich (1916-1982). Swedish-German writer, born in Babelsberg. From a Czech-Jewish family that left Germany in 1934, settling in Sweden in 1939, he became a painter, documentary film maker and Marxist social critic. His best known work is Marat/Sade (1963, in full The Persecution and Assassination of Jean-Paul Marat as Performed by the Inmates of the Asylum of Charenton under the Direction of the Marquis de Sade), first published in German, which was staged in many countries and made into a powerful film (1967) by Peter ${ }^{*}$ Brook.

Weizmann, Chaim (1874-1952). Israeli chemist and politician, born in Motol, Belorussia. Educated in Berlin and Freiburg, he lectured at Geneva (190004 ) and was a reader in biochemistry at Manchester 1904-16, becoming director of the Admiralty laboratories 1916-19. He pioneered biotechnology by using bio-organisms to extract acetone from maize. This was of enormous importance in making explosives during World War I and attracted the interest and friendship of A. J. *Balfour. The Balfour Declaration (1917) promised the Jews a 'national home' in Palestine. Weizmann was President of the World Zionist Organisation 1921-31, 1935-46, of the Hebrew University, Jerusalem 1932-50, and first director of the Sieff Research Institute (later named for Weizmann) in Rehovot 1934-48. He served as the first president of Israel 1948-52. His nephew, Ezer Weizmann (1924-2005), was a general in the Israeli air force, served as Minister for Science 198892, urged a settlement with Israel's Arab neighbours and became President 1993-2000, resigning over accusations of accepting gifts from businessmen.
Weizsäcker, Richard von (1920-2015). German politician. Educated at Oxford, Grenoble and Göttingen, he served in World War II and became a lawyer. He was a CDU member of the Bundestag 1969-81, governing mayor of West Berlin 1981-84 and President of the Federal Republic of Germany 1984-94. His eloquent speeches on the implications of war guilt attracted international interest.

Welby, Justin Portal (1956- ). English cleric, born in London. Educated at Eton and Trinity College, Cambridge, he worked in the oil industry until 1989, then followed a late vocation into the priesthood, becoming Dean of Liverpool 2007-11, Bishop of Durham 2011-13 and Archbishop of Canterbury 2013- . Doctrinally, he was a cautious conservative.

Weldon, Fay (née Birkinshaw) (1931- ). British author. Educated in New Zealand and Scotland, she was a prolific author of novels, plays, short stories, children's books and criticism, and an accomplished broadcaster. Her books include Praxis (1978), Life and Loves of a She-Devil (1983), Letters to Alice (1984) and Habits of the House (1984).

Welensky, Sir Roy (Raphael) (1907-1991). Rhodesian politician, born in Salisbury. Of Lithuanian-Jewish and Afrikaner parentage, at 18 he became heavyweight boxing champion of Rhodesia. He worked as a barman and engine driver and, having gained a reputation as a forthright and belligerent trade union leader, first entered the legislature of Northern Rhodesia (Zambia) in 1937. He became a member of the Executive Council (1940) and founded (1941) the Northern Rhodesian Labour Party. He took part in the discussions (1950-51) which led to the formation of the Federation of Northern and Southern Rhodesia with Nyasaland. He joined the new federal government as Minister of Transport (1953) and succeeded Godfrey ${ }^{*}$ Huggins (Viscount Malvern) as Prime Minister 1956-63 and was bitterly disappointed when the federation ended in 1963.

Welensky, R., Welensky's 4000 Days. 1964.

Welf-Este (or Guelph-d'Este). German dynasty, originating (like the ${ }^{*}$ Hohenstaufens and the ${ }^{*}$ Hohenzollerns) from Swabia. The Welfs (known in Italy as ${ }^{*}$ Guelphs or Guelfs) were allies of the papacy and contenders for the Imperial throne in the 12th and 13th centuries; their traditional rivalry with the *Ghibellines (who opposed secular papal power) led to constant instability. The Welfs formed dynastic links with the d'Estes of Ferrara and became rulers of Bavaria 1070-1180, and later Brunswick and Hanover. The dynasty also provided a Holy Roman Emperor (Otto IV) and a Russian Tsar (Ivan VI). The family name (never used) of Britain's Hanoverian dynasty from 1714 to 1901 was Welf-Este. 
Welles, (George) Orson (1915-1985). American film and theatre director, producer, writer and actor, born in Kenosha, Wisconsin. The son of a successful inventor and a concert pianist, he was orphaned at 12 and had a peripatetic childhood punctuated by short bursts of education. At 16 he made his debut as an actor with the Gate Theatre, Dublin and was strongly influenced by the Anglo-Irish actor-director Micheál MacLiammóir (1899-1978). After some years in touring companies, he founded the Mercury Theatre, in New York (1937) with John Houseman (19021988) and this led to innovative stage, radio and film productions. His realistic radio production (1938) of H. G. *Wells' War of the Worlds caused a sensation and even some panic. His masterpiece, the film Citizen Kane (1941), which he wrote, directed and acted in, was a thinly disguised and controversial biography of W. R. *Hearst, the newspaper proprietor (with some elements of R. R. McCormick). Many film historians regard it as the greatest American film. Welles was 25 when he made it. His second feature The Magnificent Ambersons (1942) also used the Mercury stock cast, but not Welles himself. He directed and acted in the films Macbeth (1947), Othello (1952), Mr Arkadin/ Confidential Agent (1955), Touch of Evil (1958), The Trial (1962) and Chimes at Midnight/Falstaff (1966). None of his later films made money so major production houses were unwilling to back him. He was forced to earn money as the narrator of many film and television productions of dubious value. Welles' influence on European and American film makers has been enormous. His film roles for other directors include Jane Eyre (as Edward Rochester), The Third Man (Harry Lime), Moby Dick (Father Mapple) A Man for All Seasons (Cardinal Wolsey), Catch 22 (General Dreedle) and Waterloo (Louis XVIII.) His semi-documentary $F$ for Fake (1975) was highly regarded. His ashes are buried in Ronda, Spain.

Higham, C., Orson Welles. 1985; Welles, O. and Bogdanovich, P., This is Orson Welles. 1992; Callow, S., Orson Welles. The Road to Xanadu. 1995.

Welles, (Benjamin) Sumner (1892-1961). American diplomat, born in New York. Educated at Groton and Harvard, he began his career (1915) as Secretary to the US embassy in Tokyo and later specialised in Latin American affairs. He supported Franklin *Roosevelt politically, became Assistant Secretary of State 193337 and Undersecretary 1937-43. During World War II he played a leading part in the negotiations that led to the signing of the Atlantic Charter (1941). Roosevelt essentially bypassed Cordell *Hull and used Welles as his foreign policy instrument until forced out by a gay sex scandal, complicated by heavy drinking.

Welles, B., Sumner Welles. FDR's Global Strategist. A Biography. 1997.

Wellesley, 1st Marquess, Richard Colley Wellesley (originally Wesley), 2nd Earl of Mornington (1760-
Eldest son of the 1st Earl of Mornington, whose Irish title he inherited (1781), his younger brother, Arthur, became Duke of ${ }^{*}$ Wellington. Educated at Harrow (expelled) and Eton, he read classics at Christ Church, Oxford and was a British MP 1784-97, a strong supporter of ${ }^{*}$ Pitt and a Commissioner of the Indian Board of Control 1793-97. The East India Company appointed him as Governor-General and Commander-in-Chief of the Presidency of Fort William (Bengal)_for practical purposes British India-1797-1805. His goal was to eliminate French influence in the sub-continent and extend British rule. He first dealt with the Nizam of Hyderabad, whose French-trained forces he contrived, by diplomacy and a display of force, to disarm without firing a shot. Next he turned against *Tipu, Sultan of Mysore, who was killed at the storming of Seringapatam (1799); Mysore was virtually brought under British rule. For the remaining years of his rule Wellesley was engaged in a prolonged struggle with the Mahratta confederacy, in which the victories of his brother played a decisive part. In 1803 came the end of French political and military influence in India and the Mughal Emperor Shah *Alam II was taken into British 'protection'. Before British rule was consolidated, however, Wellesley, whose annexationist policy alarmed some of the Company's directors, was recalled. During his tenure of office the small strips of British-held territory had been enlarged to become the foundations of an empire. Estranged from his brother for decades, he had two unhappy marriages and left no legitimate children. Created baron (Great Britain) in 1797, he was aggrieved at being only awarded an Irish marquessate, which he called 'a double gilt potato' (1799); he was later consoled by a KG (1810). He later served as Foreign Secretary 1809-12 and Lord Lieutenant of Ireland 1821-28 and 1833-34. He wrote excellent letters, deplored the decisions made at the Congress of Vienna (1815) and was sympathetic to Catholic emancipation.

Butler, I., The Eldest Brother. 1973.

Wellington, 1st Duke of, Arthur Wellesley (originally Wesley) (1769-1852). Anglo-Irish Field Marshal and politician, born in Dublin. Son of the 1st Earl of Mornington and a younger brother of the 1st Marquess *Wellesley (whom he much disliked), he first gained an army commission in 1789 but did no regimental service until war with France broke out (1793). He served in a futile Dutch campaign (1794) but his first opportunity for distinction came when he was serving in India, where his brother was GovernorGeneral. He successfully restored order after the fall of Seringapatam and held an independent command in the Mahratta wars. His greatest triumph was at Assaye (1803), where the Mahratta army was shattered. He returned to England (1805) and married Lady Katharine Pakenham (1806), a miserable union for both. A Tory MP 1806-09, he was Chief Secretary for Ireland 1807-09, interrupting his term to command the expedition sent (1808) for the relief of 
Portugal. Despite early successes, including the Battle of Vimeiro, he was superseded, and not responsible for the much criticised Convention of Cintra by which the French were allowed to withdraw rather than surrender. In 1809 he resumed his command in Portugal, which the French were again invading. He gained a victory at Talavera, which earned him the title Viscount Wellington and enabled him to take up a secure position in the prepared lines of Torres Vedras. Here, after checking the French at Busaco (1810), he stood firm against *Masséna's advance. In 1811 he was strong enough to advance in turn, but had to await the fall of Ciudad Rodrigo (January 1812) and Badajoz (May).

Though he then captured Madrid he had to retire and winter in Portugal once more. Rapidly advanced to Earl (February) and then Marquess (August) in 1812, he received $£ 100,000$ from parliament. In 1813 , promoted Field Marshal, with the French forces depleted to replace *Napoléon's losses in the Russian campaign, he advanced across Spain and after the victory of Vittoria (July), forced the enemy to retire to France. Wellington followed, and after winning the last victory of the Peninsular War at Toulouse (April 1814), heard that Napoléon had abdicated four days before. He was created Duke of Wellington and parliament voted him $£ 400,000$ to buy estates. He was discussing peace terms at the Congress of Vienna (1815) when he heard of Napoléon's escape from Elba. Wellington was placed in command of the allied army of the Netherlands and, though Napoléon succeeded in dividing his opponents, defeating the Prussians at Ligny and checking the British at Quatre Bras, it did not prevent Wellington, with the help of *Blücher's Prussians in the later stages, gaining his final victory at Waterloo (18 June 1815). Parliament granted him a further $£ 200,000$ as there were no more British honours to give, although Spain, Portugal, France and the Netherlands conferred titles.

Commander-in-Chief of the Allied Armies of Occupation in France 1815-18, he returned to England to enter political life as Master-General of the Ordnance 1818-27. Temperamentally ill-equipped for this, he had constant friction with ${ }^{*}$ Castlereagh and ${ }^{*}$ Canning until he resigned and became Commanderin-Chief of the forces 1827-28, 1842-52. As Prime Minister 1828-30, his term was made memorable by the passage of the Roman Catholic Emancipation Act (1829), on which he was surprisingly open. On the death of *George IV, an election was held in August 1830: despite a narrow Tory majority in the Commons, Wellington's government lost a vote and the Whig, Earl ${ }^{*}$ Grey, committed to Parliamentary reform, became Prime Minister. Wellington's increasingly strident, sometimes irrational, opposition to Grey's Reform Bill made him deeply unpopular and earned him the soubriquet 'the Iron Duke'. Ultimately, he urged his supporters in the Lords to abstain from voting against reform, as he feared the risk of civil disturbance and threats to the monarchy, He voted against Jewish emancipation in 1833 . Wellington was again briefly Prime Minister November-December 1834, served under *Peel, as Foreign Minister 183435 and Leader of the House of Lords 1841-46 and became Chancellor of Oxford University 1834-52. His photograph (1844) by Antoine Claudet is the earliest taken of a British Prime Minister. His burial at St Paul's Cathedral marked the English nation's ceremonial farewell to one of its greatest military leaders. Wellington had an austere nature but there was a gentler, more humane side to his character and he was a man of complete integrity and great shrewdness who, though little loved, commanded universal respect.

Longford, E., Wellington - the Years of the Sword. 1969; The Pillar of State. 1972; Holmes, R., Wellington: The Iron Duke. 2003; Muir, R., Wellington. The Path to Victory 1769-1814. 2013; Muir, R., Wellington: Waterloo and the fortunes of peace, 1814-1852. 2015.

Wells, H(erbert) G(eorge) (1866-1946). English novelist, historian and scientific prophet, born in Bromley, Kent. Son of a professional cricketer and failed shopkeeper, he endured poverty and illness, worked first as a draper's assistant, then became a teacher, and, with the aid of scholarships, graduated BSc at the Royal College of Science (1890). His first publication was Text-Book in Biology (1893). Developing the same genre as Jules *Verne, he wrote a series of novels now described as 'science fiction', including The Time Machine (1895), The Island of Doctor Moreau (1896), The Invisible Man (1897), filmed 16 times, The War of the Worlds (1898), dramatised for radio in 1938 by Orson *Welles, When the Sleeper Wakes (1899, revised as The Sleeper Awakes, 1910), The First Men in the Moon (1901), The Food of the Gods and How it Came to Earth (1904), The War in the Air (1908), The World Set Free (1914) and The Shape of Things to Come (1933). These novels anticipated tanks, aerial warfare, lasers, moon landings, an atomic bomb, television, email, voicemail, communication satellites, the world wide web and genetic engineering.

Acutely conscious of class distinctions ('We're in a blessed drain pipe, and we've got to crawl along it until we die'), his writing asserted a Utopian view that adopting rational scientific planning and humanistic world view could transform human life. (He was unduly optimistic about the benefits of an information revolution.) He regarded himself as a democratic socialist, was active in the Fabian Society 1903-08, wrote the powerful tract The Misery of Boots (1907), but fell out with the *Webbs.

In Love and Mr Lewisham (1900), he pioneered use of the word 'sex' to describe human activity, not as a classification ('male sex') and he was an energetic practitioner. Until old age, Wells philandered tirelessly. Ann Veronica (1909) is based on his relationship with Amber Reeves (1887-1981). The best known of his many lovers were Elizabeth von *Arnim and Rebecca *West. 
Wells, like *Dickens, who was a significant influence, wrote novels in a variety of styles: social, comic and autobiographical. Although he retained his belief in scientific planning, he was too much the born novelist to be bound by dogma. He disdained the stylistic graces of Henry *James and professed to regard writing as a utilitarian means of expressing his ideas.

The novels of his maturity include his own favourite Kipps (1905), Tono-Bungay (1909), The History of $\mathrm{Mr}$ Polly (1910), Boon (1915), Mr Britling Sees it Through (1916) and The World of William Clissold (1926). His characters came to life, moving mostly in the lower middle class, where boundaries were changing quickly with new opportunities, hopes and challenges. He was also a prolific writer of short stories and essays.

He supported World War I to defeat militarism and proposed a 'League of Free Nations'.

His most successful later book was The Outline of History (1920), 'an attempt to reform history teaching by replacing narrow nationalist history by a general review of the human record'. The Science of Life (1930), written with his son G. P. Wells and Julian *Huxley, was a bestseller. He also wrote the important Experiment in Autobiography (1934), and social and political works. In 1934 he interviewed *Stalin but was more sceptical about the USSR than *Shaw or the *Webbs. In 1939 he began a campaign for recognition of universal human rights, which had been ignored for a century, and his book The Rights of Man (1940) had a significant influence on Franklin *Roosevelt's exposition of war aims and led to the Universal Declaration of Human Rights (1948). He had once been an advocate of eugenics but lived long enough to witness the horror of its application by the Nazis. His last years were pessimistic and he concluded that 'bomo sapiens in his present form is played out'.

Nominated four times for the Nobel Prize for Literature, craters on Mars and the Moon were named for him. It is claimed that he declined an offer of the OM.

MacKenzie, N. and J., The Life of H. G. Wells: the Time Traveller. 1987 rev.; Foot, M., HG: The History of Mr Wells. 1995; Lodge, D., A Man of Parts. 2011; Tomalin, C., The Young H. G. Wells: Changing the World. 2021.

Welty, Eudora (1909-2001). American novelist and photographer, born in Mississippi. Her novels and short stories about the Old South gained critical acclaim. She won a Pulitzer Prize with The Optimist's Daughter (1973) and received the Presidential Medal of Freedom in 1989.

Wenceslaus (Wenzel or Václav), St (c.911-935). Bohemian duke and Czech patron saint. He was the grandson of Borrivoj, a Bohemian chieftain converted to Christianity by the Byzantine missionaries ${ }^{*}$ Cyril and ${ }^{*}$ Methodius. An enlightened ruler, with a reputation for sanctity, he was assassinated by his brother Boleslaw and associates. The emperor *Otto I posthumously conferred the title of king. The English Christmas carol 'Good King Wenceslas' dates from 1853.

Wen Jiabao (1942- ). Chinese Communist politician, born in Tianjin. Trained as an engineer, and a protégé of *Zhao Ziyang, he was an able technocrat who became Premier of China 2003-13. Criticism of his family's wealth actually confirmed the success of China's adoption of capitalist norms.

Wenner-Gren, Axel (1881-1961). Swedish industrialist and entrepreneur. He owned Electrolux (manufacturers of household appliances), and controlled banks and newspapers, then moved into monorails and early computers. In 1939 he offered himself as a mediator to avoid the outbreak of World War II and became mistrusted on both sides.

Wentworth, William Charles (1790-1872). Australian politician, born near Norfolk Island. His father D'Arcy Wentworth (1762-1827), born in Ireland, brought up in Yorkshire, became assistant surgeon in New South Wales and his mother, Catherine Crowley, a convict. Educated at Greenwich, he crossed the Blue Mountains in 1813 in the first major inland exploration, then studied at Cambridge and in 1819 published A Statistical, Historical and Political Description of the Colony of New South Wales, the first book written by a native-born colonist. Called to the English bar in 1822, he returned to establish The Australian (1824), a newspaper that espoused the cause of convict emancipation. He was one of the most powerful speakers in the New South Wales Legislative Council and took a prominent part in the negotiations (1852-53) by which the colony gained responsible government. He lived in England from 1855 , died there but was buried in Sydney. His greatgrandson, William Charles ('Bill') Wentworth IV (1907-2003), Oxford educated, was an idiosyncratic Member of the House of Representatives 1949-77, distrusted by *Menzies, Minister for Social Sciences 1968-72 and for Aboriginal Affairs 1968-71, and an original thinker on rail unification, Aboriginal land rights and science.

Ritchie, J., The Wentworths: Father and Son. 1997; Tink, A., William Charles Wentworth: Australia's Greatest Native Son. 2009.

Werfel, Franz (1890-1945). Austrian poet, novelist and dramatist. Of Jewish parentage, his poetry, mostly written in early life, is characterised by a deep compassion for mankind. The themes of his plays were both historical and modern. He married Alma *Mahler in 1929. He was best known for his novels, especially The Song of Bernadette (1941), concerned with the origins of the Lourdes miracles, and Jacobowsky and the Colonel (1945), a comedy filmed as $\mathrm{Me}$ and the Colonel. From France, where he had 
taken refuge after the German occupation of Austria, he escaped on foot (1940) over the Pyrenees during World War II and eventually reached the US.

Werner, Abraham Gottlob (1749-1817). German geologist. He proposed a general succession of the creation of rocks, beginning with Primary Rocks (precipitated from the water of a universal ocean), then passing through transition, sedimentary and finally recent and volcanic. The oldest rocks were chemically deposited, crystalline and fossil-less. Later rocks were mechanically deposited and contained fossils. Werner's approach was particularly important for linking the order of the strata to the history of the earth and relating the study of mineralogy and geology.

Werner, Alfred (1866-1919). Swiss chemist. Professor of chemistry at Zürich 1893-1919, his studies on complex metal-ammonia compounds and other inorganic salts led him to formulate (1893) his coordination theory of valency. His postulation of 'coordination numbers' led to the discovery that inorganic as well as organic compounds have spatial structures. He thus laid the foundations of modern inorganic chemistry. He won the Nobel Prize for Chemistry (1913).

Wesker, Sir Arnold (1932-2016). British playwright, born in the East End of London. Of Jewish parentage, he found a setting for his play Chicken Soup with Barley (1958), part of a trilogy completed by Roots (1959) and I'm Talking about Jerusalem (1960). Among a variety of occupations, he was employed in a hotel, which provided a setting for The Kitchen (1961) and as a clerk in the RAF, Chips with Everything (1962). From 1961 until its ultimate failure in 1970 he devoted himself to running Centre 42, a TUC project for introducing workers to mainstream culture. Later plays include The Journalists (1975) and Caritas (1981).

Leeming, G., Wesker the Playwright. 1982; Taylor J. R., Anger and After. Rev. ed. 1969.

Wesley, Charles (1707-1788). English hymn writer. Brother and devoted adherent of John *Wesley, he wrote more than 6,000 hymns, including Jesu, Lover of my Soul, Hark The Herald Angels Sing and Love Divine, all Loves Excelling.

Gill, F. C., Charles Wesley. 1964.

Wesley, John (1703-1791). English founder of Methodism, born in Epworth, Lincolnshire. A member of an old family linked with that of the Duke of *Wellington, he was educated at Charterhouse and Oxford, and ordained deacon (1725) and priest (1728). Elected a fellow of Lincoln College he remained in Oxford to teach, and there he, his brother Charles, George *Whitefield and other religiously earnest young men began to be known as Methodists pledged to live according to the 'method laid down in the New Testament'. In 1735, when he crossed the Atlantic to go to Georgia under the auspices of the Society for the Propagation of the Gospel, he was still a High Church man but he became an admirer of the work of the Moravian Brethren and on his return to England made friends with their missionary, Benjamin Peter Bohler, who convinced him that to be a Christian it was not enough to believe in a body of orthodox doctrine but that a positive act of acceptance was necessary, resulting in living in union with and under the direct guidance of Christ. Such an instant conversion was experienced by Wesley himself at a meeting in London (24 May 1738): 'I felt my heart strangely warmed. I felt I did trust in Christ alone for salvation, and an assurance was given me that $\mathrm{He}$ had taken away my sins ...' This change meant an actual if not a formal breach with Anglicanism. As pulpits were refused, John and *Charles Wesley held vast open-air meetings, the first at Bristol, which some 3,000 attended. The rest of his life was a prolonged pilgrimage, during which time he rode 60-70 miles a day and is said to have delivered over 40,000 sermons. Most of his converts were people of the working classes, miners, labourers, artisans, for whom the ancient parish system, a formalised ritual and a clergy grown languid and genteel, provided little comfort. In these circumstances the Methodist movement grew in strength and as it did so doctrinal differences increased: ecclesiastical traditions could not survive the move into the open air; the apostolic succession was rejected; separate chapels came to be built. The year 1784, when despite the strongest protests from Charles Wesley, John ordained a bishop (Francis *Asbury) for America, is regarded as a turning point. Ministers in Scotland first, then in overseas territories and finally in England, were also freely ordained by John. From a vast literary output his Journal stands out as an impressive witness to his character and observation. Such a man had little time for private life, but a lack of tolerance and tact in dealing with women may explain his unhappy marriage.

Tomkins, S., John Wesley: A Biography. 2003.

Wessel, Horst (1907-1930). German Nazi agitator. Severely injured in a street brawl, he died after refusing attention from Jewish doctors. His senseless death was commemorated in the Nazi anthem The Horst Wessel Song.

West, Benjamin (1738-1820). Anglo-American painter, born in Pennsylvania. He went to Italy to study (1759) and in 1763 reached England. He soon became known for classical religious and especially historical paintings such as the Death of Wolfe (1770), remarkable at the time for the use of contemporary clothing. He also illustrated the Boydell Shakespeare. A foundation member of the Royal Academy (1768), he succeeded * Reynolds as President 1792-1820. 
West, Mae (1892-1980). American actor. She specialised in glamorous but witty and earthy 'sexbomb' roles and was noted for a voluptuous figure: the 'Mae West' naval life jacket was so named because, when inflated, it produced a similar effect.

West, Martin Litchfield (1937-2015). English classical scholar. Educated at Oxford, he was Professor of Greek at the University of London 1974-91 and a Fellow of All Souls College, Oxford 1991-2015. He published extensively on Greek poetry and philology including a comprehensive (and controversial) revision of *Homer's Iliad (19982000). He received the OM in 2014.

West, Morris Langlo (1916-1999). Australian novelist, born in Melbourne. Trained for the priesthood, his successful novels (several were filmed) include The Devil's Advocate (1959), The Shoes of the Fisherman (1963), The Ambassador (1965), Proteus (1979), The Clowns of God (1981), Masterclass (1989) and Eminence (1998).

West, Nathanael (né Nathan Weinstein) (19031940). American novelist, born in New York City. He wrote four novels The Dream Life of Balso Snell (1931), Miss Lonelyhearts (1933), A Cool Million (1934), and The Day of The Locust (1939), which, taken together, are a picture of disillusionment and an indictment of the American Dream. In his 'black comedy' vision of society, the common pursuits of happiness and liberty are inverted and seen as the paths of boredom, nightmare, neurosis and failure. He wrote film scripts for Columbia and RKO Pictures and was killed in a car crash in California at the age of 37, the day after his friend F. Scott *Fitzgerald died.

Reid, R., The Fiction of Nathaniel West. 1968.

West, Dame Rebecca (real name Cicely Isabel Andrews, née Fairfield) (1892-1983). British novelist, critic and journalist, born in Ireland. Trained as an actor, she adopted her pen name from an ${ }^{*}$ Ibsen character and wrote a long series of original and penetrating books, including studies of Henry *James (1916), D. H. *Lawrence (1930) and St *Augustine (1933), Black Lamb and Grey Falcon (about Yugoslavia, 1942), and several volumes reporting notable trials. She had a son, the writer Anthony West (1914-1987), by H. G. *Wells and was the lover of Lord *Beaverbrook.

Glendinning, V., Rebecca West. 1987.

Westermarck, Edward Alexander (1862-1939). Finnish sociologist. Professor of sociology at London University 1907-30, his many books include History of Human Marriage (1891), Origin and Development of the Moral Ideas (2 volumes, 1906-08), Ritual and Belief in Morocco (2 volumes, 1926) and Ethical Relativity (1932).
Westinghouse, George (1846-1914). American inventor. He had no academic training as an engineer but after taking part in the Civil War he went to work on the railways. He invented (1867) an automatic brake worked by air pressure and formed a company to manufacture it. Later he applied the same principles of air pressure to the movement of signals and points. $\mathrm{He}$ also devised gas and water meters and a system for safely transporting gases over long distances. He took out over 400 patents. Nikola *Tesla worked for him (1885-88) and in 1888 Westinghouse bought all his patents for the alternating current $(\mathrm{AC})$ electric motor. At his workshops in Pittsburgh he also manufactured electrical equipment, including generators to utilise power from Niagara Falls. His campaign for the use of alternating current for the distribution of electricity was ultimately successful.

Westminster, 1st Duke of, Hugh Lupus Grosvenor (1825-1899). English nobleman, born in Cheshire. From an old Norman family, claiming descent from ${ }^{*}$ Charlemagne, which married well, he was educated at Eton and (unsuccessfully) Oxford, becoming a Liberal MP 1847-69. The richest man in Britain, he owned much London property, including Mayfair and Belgravia. He inherited a marquessate in 1869, was awarded a KG in 1870 and in 1874 received the last non-royal dukedom from Queen *Victoria on *Gladstone's nomination; the reasons are obscure. In 1886 he broke with Gladstone over Home Rule for Ireland and became a Liberal Unionist. His horses won the Derby four times. He opposed cruelty to animals but was an expert shot, supported Florence *Nightingale and advocated cremation. His grandson, Hugh Richard Grosvenor, 2nd Duke of Westminster (1879-1953), known as 'Bend Or', a magnifico, gambler, hunter, racehorse and yacht owner, served with ${ }^{*}$ Milner and ${ }^{*}$ Roberts in the Boer War, was a 'die-hard' (*Halsbury) in 1911 and won the DSO in World War I. He developed estates in Scotland, South Africa, Canada and Australia, married four times and was a disagreeable figure in English society. His cousin, William Grosvenor, the 3rd Duke (1894-1963), was kept in seclusion by the family.

Westmoreland, William Childs (1914-2005). American general, born in South Carolina. He served in World War II, Korea and Vietnam, and was a soldier out of central casting. As US Commander-in-Chief in Vietnam 1964-68 he believed that huge increases in troop numbers (and bombing, which exceeded World War II totals) would defeat North Vietnam by attrition: in fact, the US suffered the worst military/ strategic defeat in its history. He became Chief of Staff of the US Army 1968-72.

Wettin. German dynasty. First prominent in the 10th century in Thuringia, the conferment of the electorate of Saxony on the Margrave Friedrich (1423) confirmed the family's supremacy in that area. It was weakened, however, by a territorial 
partition between his grandsons: Ernest, founder of the Ernestine line, obtained the electorate and the larger part of the territory, while the Albertine line, stemming from his brother, was given the rest. The position was reversed during the Reformation. The Ernestine line, which provided *Luther's strongest princely supporters, was deposed by ${ }^{*}$ Charles $\mathrm{V}$ and the Albertine line substituted. Its members were also kings of Poland (1697-1704; 1709-63). After the fall of the Holy Roman Empire during the Napoléonic period, the elector of Saxony took the title of King. Meanwhile the Ernestine line had split into a number of branches, one of them that of Saxe-Coburg, from which sprang ${ }^{*}$ Leopold I of the Belgians, *Albert, Victoria's Prince Consort, and the kings of Bulgaria. Although Wettin was the family name of *Edward VII and ${ }^{*}$ George V (until 1917), British courtiers thought it sounded 'unsuitably comic' and the cumbersome 'Saxe-Coburg-Gotha' was invariably used.

Weyden, Rogier van der (de la Pasture in French) (c.1399-1464). Flemish painter, born in Tournai. Probably a pupil of Robert ${ }^{*}$ Campin, identified as the 'Master of Flémalle, he was appointed city painter of Brussels in 1436. Whether or not he actually visited Italy in 1450 (as supposed) is uncertain but his Entombment (Uffizi) certainly has affinities with Italian art. For the most part he worked in the Gothic tradition of the van ${ }^{*}$ Eycks, but the figures, with the folds of the garments emphasised, and characters of the subjects more boldly defined by expression and gesture, give a more dramatic effect, sometimes at the expense of observed detail. Among his most characteristic paintings are the Adoration of the Magi (Munich), Last Judgment (Beaune), Entombment of Christ (Florence) and the magnificent Descent from the Cross (Madrid).

Beenken, H., Rogier van der Weyden. 1951; Châtelet, A., Van der Weyden. 1999; De Vos, D., Rogier van der Weyden: The Complete Works. 2000; Campbell, L., Van der Weyden. 2004.

Weygand, Maxime (1867-1965). French general, born in Brussels. His parentage was uncertain (even to him), but his mother may have been *Metternich's daughter Mélanie. He joined the French army in 1886 and was deeply opposed to Alfred *Dreyfus. As Chief of Staff 1914-23 to Ferdinand *Foch he made a great impression with his clear mind and quiet competence. He led the 'allied armies of intervention' (mostly French) in Poland 1919-20 and forced the Red Army back to the boundaries agreed on at BrestLitovsk. He was elected to the Académie française in 1931. Commander-in-Chief of the French Army 1931-35, in 1939 he was recalled to service as Commander-in-Chief in the Levant. He replaced *Gamelin as allied Generalissimo May-June 1940 after the German breakthrough, but was too late to retrieve the situation. He served as *Pétain's Minister for Defence 1940-41 and Governor-General of Algeria 1941-42. He was imprisoned 1942-46, first by Germans, then by the French.

Weygand, M., Recalled to Service. 1952.

Wharton, Edith (née Newbold Jones) (1862-1937). American novelist, born in New York. From a socially prominent family, she married in 1885, lived in France from 1907 and was divorced in 1913. Strongly influenced by Henry ${ }^{*}$ James, her novels include The House of Mirth (1905), the more realistic Ethan Frome (1911), The Age of Innocence (1920, a Pulitzer Prize winner, filmed by Martin *Scorsese in 1993) and Old New York (1924). Her writing was concerned with the lives of the rich, leisured, cosmopolitan Americans of her own class. Wit, irony and satire characterise her novels, with more than a hint of anti-Semitism. Her themes are ethical as well as social, and sometimes, especially when writing of the position of women, she achieves tragic intensity.

Louis, R. W. B., Wharton: A Biography. 1975.

Whately, Richard (1787-1863). English scholar and Churchman. At Oxford, where he obtained a fellowship (1811) he associated with *Keble, *Newman and *Pusey but held no extreme religious views. He became Archbishop of Dublin (1831). He wrote much but is remembered by Historic Doubts Relative to Napoleon Buonaparte (1819), a satire on rationalist criticism of the Scriptures.

Wheatstone, Sir Charles (1802-1875). English physicist. Like *Faraday, he had no formal education in science, but while apprenticed to his uncle, an instrument-maker, became absorbed in experiments in physics. This led to his becoming (1834) professor of experimental philosophy at King's College, London, an appointment which he held for the rest of his life. He was elected FRS in 1837, the year in which he patented the first electric telegraph with W. F. Cooke. Another invention of his was a clock for which polarised light was ingeniously used to measure time, but curiously enough he did not invent the socalled 'Wheatstone bridge' for measuring electrical resistance. The many other products of his inventive mind include the 'concertina'. He was knighted in 1868.

Wheeler, John Archibald (1911-2008). American theoretical physicist, born in Florida. A Professor at Princeton 1938-76, he worked on general relativity, explained nuclear fission, popularised the term 'black holes' and coined 'superspace' and 'wormhole', mentored Richard *Feynman and was a very effective communicator.

Halpern, P., The Quantum Labyrinth. 2017.

Wheeler, Sir (Robert Eric) Mortimer (1890-1976). British archaeologist and writer, born in Glasgow. Educated at London University, he was awarded an MC during World War I, then earned a reputation 
for excavating Roman sites in England and Wales, especially Verulamium, near St Albans (1930-33). Keeper of the London Museum 1926-33, he directed the Institute of Archaeology 1934-39. Rising to the rank of Brigadier in World War II, he directed the Archaeological Survey of India 1944-48, excavating the Indus Valley civilisation, especially Mohenjo-daro and Harappa (both in Pakistan). He held a chair in archaeology at London 1948-56 and popularised the subject with books, broadcasts and television. He received a $\mathrm{CH}$ in 1968 and was heavily involved with UNESCO. He remains a controversial figure in archaeology, a careful observer, but prone to rash judgments and a sexual predator with his assistants.

Wheeler, M., Still Digging. 1955.

Whewell, William (1794-1866). English philosopher of science. Son of a carpenter, educated at Cambridge, he became a clergyman, professor of mineralogy 182832 and of moral philosophy 1838-55 at Cambridge, and Master of Trinity College 1841-66. A polymath, he was a poet, wrote on *Plato, translated ${ }^{*}$ Goethe, published on crystallography, tidal movements and Gothic architecture, and coined many new words including 'scientist' (1834, originally a pejorative), 'ion', 'cathode', 'Eocene' and 'Miocene'. He worked on the refraction of crystals and built up maps of cotidal times, wrote on the works of *Kant and on the history and philosophy of science, but had no interest in experimentation and was suspicious of contemporary research. He died after falling from a horse.

Whistler, James Abbott McNeill (1834-1903). American painter, born in Lowell, Massachusetts. After a brief incursion into military life at West Point Academy and a short period with the Coastal Survey Department (where he learned to etch), he went to Paris (1855) to study art. From the 1860 s he lived mostly in London, and the Thames near his Chelsea home inspired some of his finest work. *Courbet's work in Paris impressed him most, but a later and stronger influence was that of ${ }^{*}$ Hokusai. In his famous Nocturnes, for example, he was more concerned with tone values than with the direct reproduction of nature's effects attempted by the Impressionists. Even his well known portraits of his mother and of Thomas ${ }^{*}$ Carlyle are studies in black and grey. A similar preoccupation with tone is seen in his Little White Girl hung at the Salon des Refusés in Paris (1863). Some of his best work is to be seen in his etchings of London and Venice. Whistler was slow to gain recognition, partly because of an angularity of character. Being extremely resentful of *Ruskin's criticism, he embarked on the famous libel suit (1878) in which he obtained a farthing damages. The trial is documented in The Gentle Art of Making Enemies (1890).

Whitaker, Joseph (1820-1895). English publisher. He founded The Bookseller (1858) and the Almanack that bears his name (1869).
White, Edward Douglass (1845-1921). American jurist. After serving in the Confederate army, he joined the $\mathrm{Ku}$ Klux Klan after the Civil War, becoming an attorney, law professor and judge in New Orleans. He was a US senator from Louisiana 1891-94 until appointed a justice of the US Supreme Court 1894-1910. W. H. *Taft then promoted him to Chief Justice 1910-21. A conservative centralist, critical of special interests and states' rights, he was the first chief justice from the 'deep South' and the first associate justice to be promoted.

White, Ellen G(ould, née Harmon) (1827-1915). American religious pioneer, born in Maine. Claiming visions from God, she became a central figure in creating the Seventh Day Adventist church, founded in 1863 in Battle Creek, Michigan. Adventists observe Saturday as the Sabbath, following the Jewish practice, and emphasise 'the second coming' (of Christ). *Arminius, the Dutch theologian, was a significant influence. A prolific writer, White's Steps to Christ (1892) was translated into 140 languages. She published hundreds of pamphlets and speeches. Adventist schools, hospitals, nursing homes and missionaries are now found in every continent. Adventists promote health foods, such as Weetbix, marketed (tax exempt) under the Sanitarium Health Foods brand. Adventists claim 20 million adherents.

White, E(lwyn) B(rooks) (1899-1985). American author. Educated at Cornell, he joined the New Yorker as a staff writer (1926), published volumes of essays, the children's books Stuart Little (1945) and Charlotte's Web (1952), and revised and enlarged The Elements of Style by William Strunk, Jr (1959).

Elledge, S., E. B. White: A Biography. 1984.

White, Gilbert (1720-1793). English clergyman and naturalist, born at Selborne, Hampshire. Curate of Selborne from 1751, his Natural History and Antiquities of Selborne (1789) records in prose of great charm his observations of nature. In 1885 , the Selborne Society was founded in his memory.

Scott, W. S., Gilbert White. 1950.

White, Patrick (Victor Martindale) (1912-1990). Australian novelist and playwright, born in London. His parents were Australian and, as a child, he lived in rural New South Wales. Educated at Cheltenham and King's College, Cambridge, he served in the RAF during World War II and returned to Australia in 1948. His play The Ham Funeral (1947) anticipated *Beckett's Waiting for Godot, but was not performed until 1961. His books include The Aunt's Story (1948), The Tree of Man (1954), Voss (1957), Riders in the Chariot (1961), The Vivisector (1970), The Eye of the Storm (1973), The Twyborn Affair (1979), and an autobiography, Flaws in the Glass (1981). In 1973 he received the Nobel Prize for Literature 'for an epic and psychological narrative art which has introduced a new continent into literature'. An original recipient of the 
AC in 1975, he returned it in protest after the dismissal of the *Whitlam government. He became a vigorous campaigner for causes, especially the environment, the republic and against nuclear weapons. His feuds were legendary, especially his breach with Sidney *Nolan.

Marr, D., Patrick White. 1991; Marr, D. (ed.), Patrick White Letters. 1994.

White, T(erence) H(anbury) (1906-1964). English author. He is chiefly known for a series of Arthurian fantasies which reflect his love of the Middle Ages and of traditional sports such as falconry taken up while he was a teacher at Stowe (until 1936). These tales, of which The Sword in the Stone (1939) was the first, were published as the trilogy The Once and Future King (1958).

Whitefield, George (1714-1770). English preacher. One of a large family left fatherless, he was a servant at Pembroke College, Oxford, where he first came under Methodist influence and worked devotedly among prisoners and the sick. Ordained as deacon (1736), he immediately attracted attention as a preacher. $\mathrm{He}$ followed John *Wesley to Georgia and on his return, to collect funds moved from place to place, preaching wherever he halted and attracting a huge following by his eloquence and sincerity. His Calvinistic doctrines on predestination led to a breach with Wesley and, though a personal reconciliation took place, each took a separate religious path. For Whitefield his followers built a large church at Moorfields, London, known as the Tabernacle.

Dallimore, A., George Whitefield. 1970.

Whitehead, Alfred North (1861-1947). English mathematician and philosopher. He studied and taught mathematics at Cambridge 1880-1910 and in 1898 published A Treatise in Universal Algebra. He collaborated with Bertrand *Russell in Principia Mathematica (3 vols, 1910-13), taught at University College, London 1911-14 and was professor of applied mathematics at the Imperial College 191424 . He became increasingly interested in philosophy and wrote several books attempting to link physical evidence into a philosophical scheme. In The Principle of Relativity (1922) he propounds an alternative to *Einstein's theory. A move to Harvard University (1924) coincided with the inclusion of metaphysics in his wide range of thought. The best known of his books in this field was Science and the Modern World (1926), others include Process and Reality (1929), the highly important Adventures of Ideas (1933) and Nature and Life (1934). Whitehead was awarded the $\mathrm{OM}$ in 1945.

Lowe, V., Understanding Whitehead. 1962.

Whitelaw, William Stephen Ian, 1st Viscount Whitelaw (1918-1999). British Conservative politician. A guards officer who won the MC, he became a farmer and MP 1955-83, serving as a minister under Edward *Heath 1970-74 and Deputy Prime Minister 1979-88 to Margaret *Thatcher. In 1983 he was made the first hereditary peer since 1964, although he had no heir, and also received a $\mathrm{CH}$ and $\mathrm{KT}$.

Whiteley, Brett (1939-1992). Australian painter, lithographer and graphic artist. He first exhibited in Sydney in 1959, London 1960, Paris 1961 and New York 1968, and his works are marked by extraordinary virtuosity and occasional savage satire. They included landscapes, animal drawings, self portraits and studies of the murderer ${ }^{*}$ Christie, ${ }^{*}$ Baudelaire, van ${ }^{*}$ Gogh, ${ }^{*}$ Rimbaud, Francis *Bacon and Patrick *White. He died of a drug overdose. The Olgas for Ernest Giles (1985) sold for \$AU3.5 million in 2007.

Wilson, A., Brett Whiteley. 2016.

Whiteman, Paul (1890-1967). American dance band leader. A close friend of George ${ }^{*}$ Gershwin, he stimulated interest in 'symphonic jazz', in which the performers did not improvise but played from written parts.

Whitlam, (Edward) Gough (1916-2014). Australian Labor politician, born in Melbourne. Educated in Canberra and Sydney, he became a barrister (QC), Member of the Australian Parliament 1952-78, Deputy Leader of the Australian Labor Party 1960 67, and succeeded A. A. ${ }^{*}$ Calwell as leader of the party 1967-77. In December 1972 the Australian Labor Party regained office after 23 years but without a majority in the Senate, and Whitlam served as Prime Minister until November 1975. He introduced sweeping changes in foreign policy (recognising China, self-government for Papua New Guinea), education, social welfare, medical benefits, law reform and equal opportunity for women. He reduced tariffs by 25 per cent, promoted the arts and film and set up an Australian honours system, changes which have essentially remained. In 1974 Senate rejection of legislation forced a double dissolution in which Labor won the House of Representatives again, but not the Senate. More legislation was rejected, wages, inflation and government expenditure increased sharply and unemployment rose to 4.4 per cent. Following the Senate's deferral (but not rejection) of supply, Whitlam declined to call an early election for the House of Representatives and, in an unprecedented act, was summarily dismissed by the GovernorGeneral, Sir John ${ }^{*}$ Kerr (November 1975), who installed Malcolm *Fraser as Prime Minister and, on his recommendation, dissolved the Parliament and called an immediate election. Whitlam was heavily defeated in the 1975 election, and again in 1977 . He declined a CH in 1977, but received an AC in 1978 and became Ambassador to UNESCO, Paris 198386 and a member of its Executive Board 1985-89. His books include The Whitlam Government (1985) and Abiding Interests (1997). By 2013 he had become the longest lived head of any government in the 
English-speaking world. His wife, Margaret Elaine Whitlam (née Dovey) (1919-2012), a social worker, played a major role in opening up social issues, especially gender equality.

Freudenberg, G., A Certain Grandeur. 1977; Whitlam, E. G., The Whitlam Government. 1985; Hocking, J., Gough Whitlam. 2 vols, 2009, 2012.

Whitman, Walt (1819-1892). American poet, born in Long Island. Son of a Quaker carpenter, he grew up in Brooklyn and worked briefly as an office boy, printer, journalist and teacher. Among other journals he edited (1846-1848) the Brooklyn Eagle which he made a platform from which to voice his anti-slavery views. At loggerheads with his proprietors, he left to enlarge his knowledge of America by a trip to New Orleans, from which he returned by the Mississippi and the Great Lakes. There followed a period of avid but unsystematic reading, from the Bible, ${ }^{*}$ Homer and the classics, to ${ }^{*}$ Shakespeare and writers such as ${ }^{*}$ Scott, ${ }^{*}$ Carlyle, ${ }^{*}$ Coleridge and ${ }^{*}$ Emerson. Apart from a vein of mysticism in his poems, attributable to his philosophic readings, the main result was an attempt to shed European influences and introduce a national literature suited to the free, robust, democratic American. He began the realisation of this purpose with the first publication of Leaves of Grass (1855), an attempt 'to put a Person, a human being (myself, in the latter half of the 19th century in America) freely, fully and truly on record' and 'to loosen the mind of still-to-be-formed America from the folds, the superstitions and all the long, tenacious and stifling anti-democratic authorities of Asiatic and European past'. At first a volume of 12 poems, Leaves of Grass grew with successive editions; the sixth (1881) contained 293 poems. In a final reprint (1892), two annexes added 95 short poems. His poetry is marked by irregular measures, long verse lines, strong rhythms and an incantatory style.

His greatest poems, all written in the decade 1855-65, include 'Song of Myself' (1855), 'Crossing Brooklyn Ferry' (1856), 'Out of the Cradle Endlessly Rocking' (1860), 'When Lilacs Last in the Doorway Bloom'd' (an elegy to Lincoln, 1865) and 'The Wound-Dresser' (1865, later set by John *Adams). (He had been a wound-dresser in a military hospital in Washington DC 1863-64).

The Civil War traumatised Whitman's family. After representations by ${ }^{*}$ Emerson, he secured a clerkship in the Department of the Interior but was dismissed (1865) because the Secretary disapproved of Leaves of Grass, and suspected Whitman of being gay. However, he was soon appointed to the Attorney-General's Department.

In England, Leaves of Grass was praised by *Tennyson, ${ }^{*}$ Ruskin and the *Rossettis.

In 1873 he had a paralytic stroke but gradually recovered from complete invalidism. From 1884 he lived in retirement in Camden, New Jersey, where he died. In addition to his poems, Whitman wrote several prose works including Democratic Vistas (1871) and the random jottings in e.g., Specimen Days in America (1887). Whitman was the first great poet to be distinctively American, but it is ironic that it has always been to the intellectual that his work has appealed rather than to the 'common man' for whom he wrote.

Harold Bloom described Emily *Dickinson and Whitman as 'the two great American poet-originals'. His poetry influenced *Lawrence, *Eliot, *Stevens, ${ }^{*}$ Lorca, ${ }^{*}$ Borges and ${ }^{*}$ Ashbery.

Allen, G. W., The Solitary Singer. Rev. ed. 1967; Loving, J., Walt Whitman: The Song of Himself. 1999; Stacy, J., Walt Whitman's Multitudes. 2008.

Whitney, Eli (1765-1825). American engineer and inventor, born in Massachusetts. He graduated from Yale College, and had been a tutor when a chance conversation turned his mind to the problem of separating seed and dirt from cotton fibre. The result was the 'cotton gin' (1793), a machine consisting of a wire-toothed drum that tore the fibre from the seeds, the fibre being in turn removed from the wires by revolving brushes. The use of a single machine to do the work of some 200 men revolutionised the cotton industry. Paradoxically, the gin made cotton production economically viable, it expanded exponentially in the South, 'King Cotton' displaced tobacco as the major employer, and greatly increased the demand for slavery. Owing to patent difficulties with the gin, Whitney won more prestige than money. One of the greatest figures of the Industrial Revolution, he is credited with the theory and practice of standardised interchangeable parts, which led to the concept of mass production. (He was not its originator, but an influential promoter.) He probably did not invent the milling machine. His creative use of accounts to secure government grants inspired accountants for decades.

Green, C. M., Eli Whitney and the Birth of American Technology. 1956.

Whittier, John Greenleaf (1807-1892). American Quaker poet, born in Massachusetts. He worked untiringly for the abolition of slavery, as political activist and journalist, writing pamphlets and editing abolitionist journals. His numerous volumes of poetry, especially those depicting New England life and legends, gave him great contemporary popularity and some poems are still recalled. Among them are Snowbound, The Barefoot Boy, and the ballad Barbara Frietchie.

Whittington, Richard (c.1358-1423). English mercer. Son of a Gloucestershire knight, he acquired great wealth in London, which enabled him to lend money to ${ }^{*}$ Henry IV and ${ }^{*}$ Henry $\mathrm{V}$, and, since he was childless, to bestow many benefactions on the city of London both before his death and by bequest. 
He was Mayor of London 1397-98, 1406-07 and 1419-20. The legend of Dick Whittington and his cat was first given currency in a play and a ballad in 1605. The only similarity between history and fiction seems to be that both Richard and Dick married an Alice Fitzwaryn (Fitzwarren).

Whittle, Sir Frank (1907-1996). English aircraft engineer and inventor, born in Coventry. Despite his small stature, he joined the RAF (1923) and soon began studying the problems of jet propulsion for aircraft. Having striven hard and long for official support, he at last found himself with a small team of craftsmen, fired by his own enthusiasm, installed in a small, ill equipped workshop and using every spare hour to turn his idea into a reality. He studied at Peterhouse, Cambridge 1934-36. At last (1937) the first successful gas turbine engine was made. Despite official indifference from the Air Ministry until 1939, by 1941 a Gloster plane fitted with one of Whittle's engines flew and achieved excellent results, but owing to the time required for manufacture, the jet-propelled aircraft played no effective part in World War II. In 1948 Whittle was awarded $£ 100,000$ and a KBE for his work, and became consultant to Rover, Rolls-Royce and BOAC (now British Airways) in developing jet aviation. He migrated to the US in 1976, taught in Maryland, and in 1986 received an $\mathrm{OM}$ and was elected FRS. He died of lung cancer.

Whittle, F., Jet. 1953.

Whitty, Dame May (Mary Louise) (1865-1948). English actor. She married the director Ben Webster (1864-1947). In 1918, she and Nellie *Melba were appointed DBE for their war work, the first female performers so honoured. She made three silent films, then between 1936 and 1948 played character roles in 33 'talkies', including Night Must Fall (1937), The Lady Vanishes (1938) and Mrs Miniver (1942). Her daughter, Margaret Webster (1905-1972), was a theatrical director, e.g. of Paul *Robeson in Othello.

Whitworth, Sir Joseph, 1st Baronet (1803-1887). British engineer and inventor. Founder of the Whitworth scholarships in engineering science, he is best known for his invention of a gun barrel with a revolutionary type of bore, and for the now standard screw thread named after him. He was created baronet in 1869 .

Whymper, Edward (1840-1911). English mountaineer. A wood engraver and book illustrator by profession, he is better known for his travels in Greenland (1867 and 1872) and for his mountaineering feats, including the first ascents of the Matterhorn (1865) when three of his companions lost their lives, and of Chimborazo in the Andes (1879).

\section{Wicliffe see Wyclif, John}

Widodo, Joko ('Jokowi') (1961- ). Indonesian politician, born in Central Java. Mayor of Surakarta 2005-12, Governor of Jakarta 2012-14, and a protégé of ${ }^{*}$ Megawati Soekanoputri, he was nominated as the Indonesian Democratic Party of Struggle (PDI-P) candidate for president in 2014. He defeated Prabowo Subianto by 53 per cent to 47 per cent and was President 2014- .

Widor, Charles-Marie (1844-1937). French composer and organist. He was organist at St Sulpice, Paris 1869-1934 and professor of composition at the Paris conservatoire. He composed 10 symphonies for organ and many orchestral works, and edited *Bach's organ music with his pupil Albert ${ }^{*}$ Schweitzer.

Wieland, Christoph Martin (1733-1813). German writer. Son of a pastor, he first wrote pious and religious poems but, after contact with the literary and social world, he began to produce a variety of elegant and witty works. From 1762 he produced the first German translations of *Shakespeare (all in prose except A Midsummer Night's Dream). Of his original works, the narrative poem Oberon (1780) is of particular charm. It is based on a medieval chanson de geste which relates the fantastic adventures of Huon of Bordeaux at the court of Babylon. More important, perhaps, is the novel Agathon (1766) the classical setting of which does little to disguise its autobiographical theme of a young man's reaction to the impact of experience and philosophy. In 1772 Wieland went to be tutor to the future Duke Karl August of Saxe Weimar and remained at Weimar until his death. While there he translated many classical texts and wrote opera libretti.

Wien, Wilhelm Carl Werner Otto Fritz Franz (1864-1928). German physicist, born in Prussia. As professor of physics at Giessen 1899-1900, Würzburg 1900-20 and Munich 1920-28, he carried out important studies on cathode rays, canal rays, and blackbody radiation. He discovered (1893) the 'displacement law' (Wien's law) which shows how the intensity maximum in the spectrum moves to shorter wavelengths with increase in temperature, so that the product of the wavelength at maximum intensity and the absolute temperature is constant. This law made it possible to determine the temperature of bodies such as the sun and stars by observing the distribution of spectral intensity. He won the 1911 Nobel Prize for Physics for 'discovering laws governing the radiation of heat'.

Wiene, Robert (1873-1938). German film director, born in Breslau (now Wroclow, Poland.) His film The Cabinet of Dr Caligari (1919), featuring Conrad *Veidt, was a highpoint of German Expressionism. Other films include Raskolnikow (based on *Dostoevsky, 1923) and The Hands of Orlac (1924). He left Germany in 1933 and died in Paris. 
Wiener, Norbert (1894-1964). American mathematician, born in Columbia, Missouri. A child prodigy who had enrolled by the age of 15 at Harvard Graduate School, he spent his late teens and early twenties trying out various approaches in mathematics, philosophy and zoology, before moving to the Massachusetts Institute of Technology (assistant professor, 1924, associate 1929, full professor 1932). He remained there until his retirement. Much of his early career was devoted to pure mathematics. He was concerned with harmonic analysis, and did work on Lebesgue integration and Brownian motion. The mathematical consequences of the laws of thermodynamics were worked out by Wiener. His most original work came after 1940 when he became absorbed in the development of computing machines. His penetrating analysis of feedback control in artificial intelligence systems led to interest in human intelligence, and to creative work in the general field of systems analysis. The science of communication and information opened up as a result of Wiener's probings. His Cybernetics was published in 1948.

'Norbert Wiener' in Bulletin of the American Mathematical Society, 72, 1966.

Wieniawski, Henryk (1835-1880). Polish composer and violinist. He ranked immediately after *Paganini and ${ }^{*}$ Sarasate as a great virtuoso and wrote many works to show off his prodigious technique, including two concertos, Legende, Scherzo-Tarantelle and Fantasy on Gounod's Faust.

Wiesel, Elie(zer) (1928-2016). American-Jewish writer, born in Romania. His mother and sister were killed in Auschwitz; he and his father survived Buchenwald. He revived the use of the term 'Holocaust' and wrote extensively about the wartime attempt to exterminate the Jews. He held chairs at Boston and Columbia Universities, received the Nobel Peace Prize (1986), the US Presidential Medal of Freedom (1992), Hon. KBE (2006) and many other awards. He campaigned for human rights in South Africa, Argentina, Bosnia, Nicaragua and Sri Lanka, denounced the Armenian genocide but was silent on Palestine.

Wiesenthal, Simon (1908-2005). Austrian-Jewish war crimes investigator, born in Poland. Trained as an architect, he was a Nazi prisoner 1941-45, worked to gather evidence for the prosecution of war criminals and founded the Jewish Documentation Centre in 1954. His agents tracked down Adolf *Eichmann in 1960 .

Wiggin, Kate Douglas (née Smith) (1865-1923). American author. She was a pioneer of kindergarten teaching before becoming a writer. The best known of her novels, Rebecca of Sunnybrook Farm (1903), gives a charming picture of New England life.
Wilberforce, William (1759-1833). English politician and philanthropist, born in Hull. From a wealthy Yorkshire family, after leaving Cambridge University he entered politics. He was first elected MP in 1780 and became a friend and supporter of *Pitt but, having been converted to evangelism (1784-85), devoted himself to philanthropic causes, e.g. the abolition of the slave trade, a bill for which he finally carried (1807) after 20 years' struggle. His next objective was the abolition of slavery itself. He helped to found the Anti-Slavery Society (1825) but, as his health failed, leadership of the movement passed to $T$. F. *Buxton. A month before the measure was passed Wilberforce died. He helped to found the Church Missionary Society (1798) and the Bible Society (1803), and he wrote A Practical View of Christianity (1797). His son, Samuel Wilberforce (1805-1873) was a High Church bishop of Oxford (1845) and of Winchester (1869). Though he opposed ${ }^{*}$ Newman and ${ }^{*}$ Pusey he did much to invigorate the Anglican Church, supported retreats and religious communities, Cowley (for men) and others for women, and founded Cuddesdon Theological College. His nickname 'Soapy Sam' referred to his equivocal position in several controversies. He was killed by a fall from his horse.

Wilbye, John (1574-1638). English composer. One of the leading masters of the English madrigal, among the longer and best known examples are Draw on Sweet Night and Sweet Honey-Sucking Bees.

Wilcox, Ella Wheeler (née Wheeler) (1850-1919). American verse writer. Extremely prolific, she was described by the London Times as 'the most popular poet of either sex and of any age'. Sentimentality was the key to her success.

Wild, Jonathan (1682?-1725). English criminal. Having gone to London (c.1706) from Birmingham, where he was a buckle maker's apprentice, he controlled a gang of thieves, whose loot he 'recovered' for its owners for a fee that he shared with his accomplices. Eventually, he was hanged at Tyburn. *Defoe related his exploits, which Fielding elaborated, to provide a plot for his satirical romance, Jonathan Wild the Great (1743).

Wilde, Oscar Fingall O'Flahertie Wills (18541900). Irish writer and wit, born in Dublin. His father, Sir William Wilde (1815-1876) was an ophthalmic surgeon, writer, archaeologist and philanthropist, his mother Jane Francesca Agnes Algee (1821-1896), a poet, Irish nationalist and suffragist who wrote under the name 'Speranza'. Oscar showed his brilliance at Trinity College, Dublin, and Magdalen College, Oxford, where he was influenced by *Pater and *Ruskin and won the Newdigate Prize for Poetry in 1878 and was regarded as the founder of the aesthetic movement which cultivated 'art for art's sake'. Wilde, notorious for his eccentricities of manner and dress, was satirised as 'Bunthorne' in Patience (1891) by 
${ }^{*}$ Gilbert and ${ }^{*}$ Sullivan. His first book of poems was published in 1881 and in 1882-83 he lectured in the US and Canada. In London he married (1884) Constance May Lloyd (1859-1898). Of their two sons, the younger, later known as Vyvyan Holland (1886-1967), wrote tirelessly to vindicate his father's reputation. In 1888 Wilde published The Happy Prince, a collection of children's stories and in 1891 a novel The Picture of Dorian Gray, an arresting study in the macabre. Meanwhile he had established himself as the most brilliant conversationalist of his day, coining epigrams and paradoxes which provided the main substance of his highly successful comedies: Lady Windermere's Fan (1892), A Woman of No Importance (1893), An Ideal Husband and The Importance of Being Earnest (both 1895). His play Salomé (1893), written in French, was refused a licence in London and became the libretto of an opera (1905) by Richard *Strauss. In 1895 the Marquess of *Queensberry, who objected to Wilde's intimacy with his son Lord Alfred ${ }^{*}$ Douglas, living and travelling together, left a card at Wilde's club accusing him as 'posing as a somdomite' (sic). Wilde imprudently initiated a prosecution for criminal libel against Queensberry but cross-examination by Edward ${ }^{*}$ Carson, the marquess' counsel, was destructive and the charge was withdrawn, leaving Wilde to pay heavy costs. Despite advice from his friends, including Bernard *Shaw and Frank *Harris, to leave for Paris, Wilde was arrested and charged with 'gross indecency'. In the first trial the jury disagreed, but a second humiliating trial resulted in his conviction and a sentence of two years' jail with hard labour. From his experiences of prison life came his long poem The Ballad of Reading Gaol (1898) and the bitter De Profundis (published posthumously in 1905). After his release he lived in Paris under the name of Sebastian Melmoth. Dogged by ill health and poverty, he died there and was buried in the Père Lachaise cemetery.

Ellmann, R., Oscar Wilde. 1987; Frankel, N., Oscar Wilde. 2017; Sturgis, M., Oscar. A Life. 2018; Mendelssohn, M., Making Oscar Wilde. 2018.

Wilder, Billy (originally Samuel) (1906-2002). American director, producer and screenwriter, born in Sucha Beskidzka, then in Austria-Hungary, now in Poland. He became a journalist and scriptwriter, arriving in Hollywood in 1933. He won seven Academy Awards for writing, directing and producing. His feature films include The Lost Weekend (1945), A Foreign Affair (1948), Sunset Boulevard (1950), Stalag 17 (1953), The Seven Year Itch (1955), Some Like It Hot (1959), The Apartment (1960) and The Front Page (1974). He was a major art collector.

Wilder, Thornton (1897-1975). American novelist and playwright. His novels include The Bridge of San Luis Rey, which won the Pulitzer Prize (1927), and The Ides of March (1940). His first successful play was Our Town (1938), followed by The Skin of our Teeth
(1942). Later he wrote The Matchmaker (1954) and A Life in the Sun (1955), a version of the Oedipus legend.

Wiles, Sir Andrew John (1953- ). English mathematician, born in Cambridge. He taught in Oxford and Princeton and won international acclaim for solving the problem of *Fermat's last theorem, with a partial solution in 1993, fully developed in 1995. He won many awards, an asteroid (9999 Wiles) was named for him and his work was celebrated in songs, films, television programs and novels.

Wilhelm I (Wilhelm Friedrich Ludwig) (17971888). German Emperor 1871-88, and King of Prussia 1861-88. He went to England during the revolution of 1848 but returned in 1849 to lead the army which crushed the insurgents. He was regent for his brother, *Friedrich Wilhelm IV of Prussia (by then insane), from 1858 until he succeeded him. When he became King he quarrelled with the Diet over the reorganisation of the army, and even thought of abdicating, but in 1862 he appointed *Bismarck as his Chief Minister, and thereafter he gave continuous, though not uncritical, support to his minister's triumphant policy by which, through wars against Denmark, Austria and France, Prussia was given a dominating position in Europe and became the hard core, around which the new empire was built (1871). Wilhelm, a good soldier and, though a reactionary ruler, an honourable man, disliked the newfangled imperial dignity thrust upon him as well as many of the means by which it was obtained, but he had neither the will nor power to quarrel with Bismarck to whom he owed so much.

Wilhelm II (Friedrich Wilhelm Viktor Albert) (1859-1941). German Emperor and King of Prussia 1888-1918. Grandson of the emperor *Wilhelm I and son and successor of ${ }^{*}$ Friedrich III, he was the 'Kaiser' of World War I. Unlike his liberal-minded father, he gloried in the traditions of the Prussian army and indulged in dreams of leading it to new triumphs. Though *Bismarck had been the hero of his youth he could not submit to the tutelage of anyone, however great. In 1890 he 'dropped the pilot' and thereafter Germany's destiny lay in the hands of its able but impetuous and unpredictable ruler. At home he chose ministers for pliability rather than wisdom, abroad he stirred antagonism as though intentionally. He even managed to bring Britain, France and Russia together by truculent interference in their concerns. To Britain, for example, his telegram of congratulation to President *Kruger on the suppression of the Jameson Raid was a deliberate provocation, while his vast naval construction could have only one purpose. Thus, when the murder of Archduke *Franz Ferdinand (1914) proved to be the match that fired World War I, Germany and Austria stood alone. Even Italy, the third member of the Triple Alliance, joined her enemies (1915). The German army fought at first with all its old brilliance and success but it was the 
generals not the Emperor who gained the plaudits, and when the tide turned it was remembered whose policy had brought disaster. Wilhelm fled to Holland when defeated Germany became a republic and lived quietly at Doorn, near Utrecht until his death. His first wife, Augusta Viktoria of Schleswig-Holstein died in 1921 and he married Princess Hermine of Reuss (d.1947). His son, Crown Prince Wilhelm (1882-1951), satirised as 'Little Willie' by British cartoonists, supported the Nazis from 1932.

Cowles, W. S., The Kaiser. 1963; Röhl, J., Young Wilhelm. 1998; The Kaiser and His Court. 1994; The Kaiser's Personal Monarchy. 2004.

Wilhelmina (née Wilhelmina Helen Pauline Maria van Oranje-Nassau) (1880-1962). Queen of the Netherlands 1890-1948. Born in The Hague, she was a daughter of King Willem III (1817-1890) by his second wife Emma of Waldeck-Pyrmont (1858-1934), who acted as regent for her daughter until she came of age (1898). In 1901 Queen Wilhelmina married Prince Heinrich (later, Hendrik) of Mecklenburg-Schwerin (1876-1934) and, after his death, generously paid allowances to his mistresses. The Netherlands had been neutral in World War I and in May 1940 when the Germans occupied the Netherlands, she left for London as part of the government in exile, made broadcasts and strongly supported the Resistance. She visited the US and Canada in 1942-43, was much admired by ${ }^{*}$ Churchill and was made LG in 1944 . She abdicated in favour of her only child, *Juliana, and wrote the autobiography Lonely but Not Alone (1959).

Wilkes, Charles (1798-1877). American naval officer. He led an exploring expedition to the Antarctic (1838-42) but did not land. Wilkes Land, in the Australian territory, is named for him. During the US Civil War, he provoked a diplomatic incident with the British by arresting the British mail steamer Trent (1861) and removing Confederate officials.

Wilkes, John (1727-1797). English politician. Son of a wealthy distiller, as a young man he was prominent among the members of the Hellfire Club who celebrated their orgies at Sir Francis Dashwood's residence, Medmenham Abbey. In 1757 he was elected MP for Aylesbury but in 1761 he became a violent opponent of Lord *Bute, Chief Minister of the young *George III. To this end he established a weekly newspaper The North Briton, in No. 45 of which he asserted that the speech from the throne contained lies put into the King's mouth by his ministers. He was arrested under a general warrant (soon held to be illegal) against authors, printers and publishers, but was acquitted on the grounds of parliamentary privilege. The government's next step was to obtain a copy of his privately printed Essay on Woman. Obscene extracts read out in the House of Lords caused its condemnation and, after a duel, was expelled from parliament for his 'No. 45' and outlawed. On his return (1768), though elected four times in succession for Middlesex, he was imprisoned for 22 months and not allowed to take his seat. 'Wilkes and Liberty' became the Radical catchwords. Wilkes, not born to be a martyr, was elected Sheriff of Middlesex (1771), Lord Mayor of London (1774) and in the same year took his seat in parliament without opposition. Meanwhile he had made his peace with the court and in 1780 was to play a prominent part in the suppression of the Gordon Riots. However, by his stands for the freedom of the press, and against arbitrary governmental action he earned the epitaph of his own composing, 'a friend of liberty'.

Thomas, P. D. G., John Wilkes: a friend to liberty. 1996.

Wilkie, Sir David (1785-1841). Scottish painter. He came to London in 1805, and won fame with his genre pictures such as Village Politicians (1806) and Penny Wedding, notable for their imaginative colour and sense of character. He was elected ARA (1809) and RA (1811). Later he turned (less happily) to historical pictures, e.g. The Preaching of John Knox. He succeeded *Lawrence as court painter (1830) and was knighted in 1836 .

Miles, A. D. and Brown, D. B., Sir David Wilkie of Scotland. 1987.

Wilkins, Sir (George) Hubert (1888-1958). Australian explorer, born in Hallett Cove, South Australia. After service as a war correspondent in the Balkan Wars (1912-13) he accompanied *Stefansson's expedition to the Arctic before joining the Australian Flying Corps in World War I. He was with the Quest during *Shackleton's last Antarctic voyage (1921-22). He was knighted (1928) for a flight from Alaska to Spitsbergen, one of several exploratory flights he made in the Arctic at this time, and in the Antarctic (1928) he led an expedition to Grahamsland. In 1931 he tried unsuccessfully to navigate the submarine Nautilus under the North Pole.

Wilkins, John (1614-1672). English scientist. Son of a goldsmith, he studied at Oxford, graduating in 1631, entered the Church, and became warden of Wadham College 1648-59. He took an early interest in science and his A Discourse Concerning a New Planet. Tending to prove, that tis probable our Earth is one of the Planets (1640) was probably the first use of 'Earth' as a planetary name. He worked tirelessly to avoid partisan divisions in science. A supporter of Oliver ${ }^{*}$ Cromwell, whose widowed sister Robina French he married in 1656, he was appointed Master of Trinity College, Cambridge, in 1659, but was removed at the Restoration. A foundation Fellow (1660) of the Royal Society, a member of the Council and one of the secretaries. He took great interest in machines and technological improvements. He speculated about the moon possibly being inhabited. His Mathematical Magick (1648) analyses the 
principles of machines; Mercury, or the Secret and Swift Messenger suggests telegraphic communication. Perhaps his most important interest lay in attempts to construct a universal, rational language, spelt out in his An Essay towards a Real Character and Philosophical Language (1688).

Shapiro, B. J., John Wilkins. 1969.

Wilkins, Maurice Hugh Frederick (1916-2004). British physicist and molecular biologist, born in Pongaroa, New Zealand. His Irish parents moved to Birmingham in 1922 and he studied at Cambridge and Birmingham. At Kings College, London, he worked on X-ray diffraction studies of DNA (deoxyribonucleic acid), had a tense partnership with Rosalind *Franklin and stimulated the interest of James *Watson and Francis *Crick. The first to hypothesise a double helical structure for DNA molecules, Wilkins shared the 1962 Nobel Prize for Physiology or Medicine with Crick and Watson 'for their discoveries concerning the molecular structure of nucleic acids and its significance for information transfer in living material'.

Wilkinson, John (1728-1808). English ironmaster, born in Cumberland. His improved methods for boring cannon led to the production of cylinders for high pressure steam engines and he worked with *Watt and ${ }^{*}$ Boulton. He provided the iron for Abraham *Darby's bridge at Coalbrookdale (1779).

Willard, Frances Elizabeth (Caroline) (1839-1898). American social reformer, born in New York. She became a teacher and was briefly Dean of Women at Northwestern University (1874). She was a cofounder (1874) of the Women's Christian Temperance Union (WCTU), its secretary 1874-79 and president 1879-98. Using the slogan 'Do everything', she organised petitions, demonstrations, lobbying and publication in her advocacy of female suffrage and for 'prohibition' of the consumption of alcohol, which both became law decades after her death. She organised an international 'Polyglot Petition' (1883) against the drug trade and became a socialist in her last years. A powerful speaker and writer, Willard has been accused — probably unfairly—of linking alcohol with African-American crimes, thereby condoning lynching.

Willcocks, Sir David Valentine (1919-2015). English choral conductor, organist and teacher. After distinguished service in World War II (winning an MC in Normandy), he was director of music at King's College, Cambridge 1957-73 and of the Royal College of Music, London 1974-84 and made outstanding CDs of *Bach, ${ }^{*}$ Haydn, ${ }^{*}$ Fauré and carol services.
Willem-Alexander (1967-). King of the Netherlands 2013- . Son of Queen *Beatrix and Claus von Amsberg, he was educated at Leiden University and on his mother's abdication became the first Dutch king since 1890 .

William (known as 'the Lion') (1143-1214). King of Scotland 1166-1214. He was the grandson of *David I and brother of Malcolm IV, whom he succeeded. Angered by the refusal of *Henry II of England to restore the disputed territories of Northumberland and Cumberland, he allied himself with Henry's rebellious sons but was captured at the siege of Alnwick. By the humiliating Treaty of Falkirk (1174) he was forced to do homage for his kingdom. From this obligation *Richard I's monetary needs for the 3rd Crusade enabled him to escape, but renewed war with King *John compelled him to make another large payment to obtain peace. Before he died he had brought the Scottish lords under firm control.

William 'the Silent' ('der Zweiger', Willem VII van Nassau-Dillenburg) (1533-1584). Stadholder of Holland and Zeeland 1572-84, Count of Holland, Prince of Orange. Descendant of the Counts of Nassau, he inherited (1554) their estates in the Netherlands and Burgundy as well as the principality of Orange (in Provence). His parents were Lutheran but at the insistence of the emperor ${ }^{*}$ Charles $V$, then holding court at Brussels, and whose page he became, he was educated as a Catholic. In 1559 he was made stadtholder of Holland, Zeeland and Utrecht by the emperor's son, *Felipe II of Spain, whom he served ably as a diplomat. He was horrified, however, by Spanish persecution of Protestants in the Netherlands. Failure to obtain an agreement which would secure toleration for all was followed (1567) by the arrival of the Duke of *Alba and the execution of Counts *Egmont and Horn. William, who had left the Netherlands in 1567 , realised that the time for compromise had gone and made plans for a rising against Spain. His first invasion (1568) failed but in 1572 he returned, aided by an alliance with the Sea Beggars (Gueux), a group of rebels who had taken to the sea and who, in 1572, captured Briel (Brielle), a port on the Maas. He founded the University of Leiden in 1575 . He maintained his struggle and in 1576, by the Pacification of Ghent, even managed to unite the northern and southern provinces against the Spaniards. Under Alba's more conciliatory successor, the Duke of Parma, however, the Catholic provinces were regained for Spain, but by the Union of Utrecht (1579) the northern alliance was confirmed and strengthened. Anxious for French help, in 1580 William induced François, Duke of Anjou and Alençon, the surviving brother of King *Henri III, to accept sovereignty of the United Provinces. In February 1582, when the Duke arrived, it was clear that he was deeply unpopular and resented being offered limited powers. In March 1582 William was shot in the face, but survived. William resumed leadership as virtual head of state but was 
soon assassinated, in Delft, by Balthasar Gerard, a Catholic fanatic. In J. L. *Motley's famous words: 'As long as he lived, he was the guiding star of a whole brave nation, and when he died the little children cried in the streets'. The Orange family continued as a dominant force in Dutch politics.

Wedgwood, C. V., William the Silent. 1944; Jardine, L., The Awful End of William the Silent. 2005.

\section{William I (Guillaume) ('the Conqueror')} (1027-1087). King of England 1066-87, Duke of Normandy 1035-87. Illegitimate son of Robert 'the Devil', Duke of Normandy, he succeeded his father as Duke (1035), but 12 years of fighting followed before he fully established himself. The Normans ('Norsemen'/'Northmen'; 'Nortmanni' in Latin) were the descendants of Vikings, who raided Normandy for decades and occupied it after 876 . *Rollo, the greatgreat-great-grandfather of William, became Duke of Normandy in 911. William married (1053) Matilda, daughter of Baldwin, Count of Flanders. His claim to the English throne rested upon a promise said to have been made (with no legal authority) by his cousin, *Edward the Confessor, while William was paying him a visit. He also seems to have obtained under duress an oath of fealty from ${ }^{*}$ Harold, who was in his power after being shipwrecked on the Normandy coast and his claim was supported by the pope. On hearing that Harold had proclaimed himself King, William prepared to invade and on 14 October 1066 won the decisive Battle of Hastings, in which Harold was killed. William himself was crowned at Westminster on Christmas Day but the conquest was not complete until 1070 . There was little devastation except in the north where resistance was strongest. * Malcolm of Scotland submitted in 1072 and, for a time, *Hereward the Wake maintained a pocket of resistance in the East Anglian fens. Once in control of the country, William proved himself a wise, just and resourceful ruler. He abolished slavery and curbed the tyranny of local barons by concentrating power in royal hands organised on civil, not military lines. (In the 17th century the term 'feudal system' was applied to his rule but it had no contemporary meaning.) By replacing Stigand, Archbishop of Canterbury, with *Lanfranc he brought the English Church into closer touch with that of the Continent, but he strongly resisted the authoritarian claims of papacy. In 1086 he ordered the compiling of the Domesday Book, which recorded the value of royal, baronial and Church lands and the distribution of the population. In his later years he had to contend with the intrigues of his half-brother *Odo, Bishop of Bayeux, and the disloyalty of his own eldest son Robert. After falling from a horse in Mantes, he died in Rouen and was buried in Caen.

Douglas, D. C., William the Conqueror. 1964; Bates, D., William the Conqueror. 2001; Hilliam, P., William the Conqueror. 2005.

\section{William I and II of Germany see Wilhelm I and II}

William II (Rufus) (c.1056-1100). King of England 1087-1100. Called Rufus for his red hair, he was the second surviving son of ${ }^{*}$ William the Conqueror, whom he succeeded as King. Normandy had passed to the elder son Robert, on which account the two brothers were in constant feud until the duchy finally fell into William's hands (1096), Robert having been forced to 'pawn' it to enable him to go on the 1st Crusade. William was ruthless and brutal, he quarrelled with his great archbishop of Canterbury, ${ }^{*}$ Anselm, but was an able soldier, held the barons in check and maintained firm if extortionate rule through his chief minister Rannulf*Flambard. He was accidentally shot while hunting in the New Forest by his companion Walter Tirel.

Slocombe, G., Sons of the Conqueror. 1960.

William III (Willem Hendrik van Oranje-Nassau) (1650-1702). King of England, Scotland and Ireland 1689-1702, Prince of Orange 1650-1702. Born in The Hague, the posthumous son of William (Willem) II of Orange and Mary, daughter of *Charles I of Great Britain, he was chosen stadholder of the United Provinces after the murder (1672) of*de Witt. A dour Calvinist, he brought the long struggle with *Louis XIV of France to an end by the honourable Peace of Nijmegen (1678), having meanwhile strengthened his position by marriage (1677) with the British princess * Mary, daughter of the future *James II. He formed (1686) the Grand Alliance to combat Louis' renewed aggression and, seeking fresh allies, was glad, therefore, to accept an invitation from England to intervene on behalf of 'English liberties' endangered by his father-in-law James II. He landed at Torbay (November 1688) with an army of 15,000 and quickly gained almost universal support. James fled to France, a Convention Parliament declared the throne vacant and in February 1689 William and Mary were proclaimed joint sovereigns. Resistance in Scotland was all but ended by the death of 'Bonnie *Dundee' at the Battle of Killicrankie (1689) and in Ireland he defeated James' army in the Battle of the Boyne (July 1690); all resistance ended after the surrender of Limerick (1691). William, his power limited by the Bill of Rights (1689), neither liked, nor was liked by, his new subjects and his popularity waned further after the death of Mary (1694). He refused to commit himself to a single party and his administration included politicians from both Whigs and Tories. The foundation of the Bank of England and the start of the National Debt were of more interest to future generations than to his own. In 1695, apparently through inadvertence, the licensing of printing presses ended, enabling the creation of newspapers and journals. An able strategist, William's principal aim was to contain French power. $\mathrm{He}$ won a decisive victory at Namur (1695) and the continental war ended with the Treaty of Ryswick (1697). Another continental war (of the Spanish 
Succession) was about start when he died. His horse fell at a mole burrow, he broke a collar bone and died of pneumonia. (Jacobites toasted the mole: 'The little gentleman in black velvet'.)

Baxter, S. B., William III. 1966; Claydon, T., William III: Profiles in Power. 2002; Troost, W., William III, the Stadholder-king: A Political Biography. 2005.

William IV (William Henry) (1767-1837). King of the United Kingdom of Great Britain and Ireland, King of Hanover 1830-37. Born in London, he was the third son of ${ }^{*}$ George III, created Duke of Clarence in 1789. His career in the navy earned him the nickname of 'the sailor king'. He became titular Admiral of the Fleet (1811) and the office of 'Lord High Admiral' was revived for him 1827-28. In 1811 he parted from his mistress, the actor Mrs Dorothea Jordan (17621816) with whom he had had 10 children. In 1818 he married *Adelaide, daughter of the Duke of SaxeMeiningen, but both their daughters died in infancy. On the death of the Duke of *York (1827) he became heir presumptive and in 1830 succeeded * George IV. As King he objected strongly to Earl *Grey's Parliamentary Reform Bill of 1832 but eventually promised to create as many peers as might be necessary to secure its passage through the House of Lords. He did not have to act on his promise because enough peers abstained to allow the bill to pass. His outspokenness and eccentric remarks (hence the description 'Silly Billy') were often an embarrassment to his ministers but he strictly observed the constitutional proprieties. He was succeeded by his niece, *Victoria.

William of Malmesbury (c.1095-c.1143). English historian. A monk, he compiled accurate and impartial histories, notably the Gesta regum Anglorum, the story of the English kings to 1128, continued in Historia novella (up to 1142). He also wrote accounts of the bishops and monasteries and a life of St *Dunstan.

\section{William of Ockham (or Occam) see Ockham, William of}

\section{William of Wayneflete see Waynflete}

\section{William of Wykeham see Wykeham}

William Arthur Philip Louis MountbattenWindsor, Prince of Wales, Duke of Cambridge (1982- ). British prince, born in London. Son of ${ }^{*}$ Charles, Prince of Wales and ${ }^{*}$ Diana, formerly Princess of Wales, second in line for the throne, he graduated from St Andrews University and became a helicopter pilot in the RAF. In April 2011 he married Catherine Middleton (1982- ) at Westminster Abbey. A royal prince, George Alexander Louis, third in line for the throne, was born in July 2013.

Williams, (George) Emlyn (1905-1987). Welsh actor and playwright. His successful plays included Night Must Fall (1935) and The Corn is Green (1941). He acted in his own and other plays including those of * Shakespeare and later his dramatised readings of *Dickens and Dylan *Thomas were widely acclaimed. His sensitive autobiography, George (1961), related the stages by which he emerged from a poor home in Wales to Oxford University and success on the stage.

Williams, Fred(erick Ronald) (1927-1982). Australian painter and graphic artist, born in Melbourne. He trained in Melbourne and London, evolving a spare, almost calligraphic, style that captured the strangeness and isolation of the Australian landscape. His Upwey Landscape (1965) sold for \$AU1,987,000 in 2006 and You Yangs Landscape 1 (1963) for \$AU2.9 million in 2013.

McCaughey, P., Fred Williams. 1980, revised 2008; Mollison, J., A singular vision: The art of Fred Williams. 1989.

Williams, Roger (c.1603-1683). American colonist. He emigrated (1630) from England to Massachusetts, but was expelled through the intolerance of its Puritan rulers. He then established the new colony (chartered 1644) of Rhode Island with complete religious freedom. He epitomised his views in The Bloudy Tenent on Persecution (1644) and many pamphlets, and also wrote $A$ Key into the Language of America (1643), a remarkable grammar of Indian languages.

Williams, Rowan Douglas, Baron Williams of Oystermouth (1950- ). Welsh cleric, theologian, poet and translator, born in Swansea. Educated at Cambridge and Oxford, he was ordained in 1978 and became Bishop of Monmouth 1992-2002, Archbishop of Wales 2000-02 and Archbishop of Canterbury 2002-12. His books include Grace and Necessity (2005), Dostoevsky: Language, Faith and Fiction (2008), and several volumes of poetry. Created a Privy Counsellor, awarded the Royal Victorian Chain and a peerage (2012), he became Master of Magdalene College, Cambridge 2013- .

Williams, Shirley Vivien Teresa Brittain (née Catlin), Baroness Williams (1930-2021). English politician. Daughter of the novelist and pacifist Vera *Brittain, she was educated at Oxford and Columbia Universities and became secretary of the Fabian Society 1960-64. Elected a Labour MP 1964-79, from 1966 she held junior ministerial posts, becoming Secretary of State for Prices and Consumer Protection 1974-76 and Secretary of State for Education and Science 1976-79. Defeated in 1979, she was a co-founder of the Social Democrats, re-elected as MP (November 1981) in a by-election, losing in 1983 . She went to the House of Lords in 1993. She married (1) the political philosopher Bernard Williams and (2) historian Richard Neustadt.

Williams, Tennessee (Thomas Laniel Williams) (1914-1983). American playwright. He first came into prominence with The Glass Menagerie (1945). This was followed by a series of major successes, most of them set in sordid surroundings in the Deep South in an atmosphere of impending tragedy with sex as 
a dominating theme. Among the best known are $A$ Streetcar Named Desire (1947, it won the 1948 Pulitzer Prize for Drama), The Rose Tattoo (1951), Camino Real (1953), Cat on a Hot Tin Roof (1955, also a Pulitzer Prize winner), and Sweet Bird of Youth (1958). He also wrote screenplays, short stories and novels.

Spoto, D., The Kindness of Strangers. 1985; Lahr, J., Tennessee Williams: Mad Pilgrimage of the Flesh. 2014.

Williams-Ellis, Sir Clough (1883-1978). Welsh architect and environmentalist. An innovative designer, conservationist and town planner, he was a prolific writer and propagandist who created the model resort village of Portmeirion, North Wales. He coined the term and concept of 'national estate'.

Williamson, David Keith (1942- ). Australian playwright, born in Melbourne. Trained as an engineer, his plays - several of them filmed - include The Removalists (1971), Don's Party (1973), The Club (1977), Dead White Males (1995), Don Parties On (2011) and Managing Carmen (2012). He was also a successful film script writer.

Williamson, Henry (1897-1977). English author and naturalist. He wrote successful books over a long period but it was by Tarka the Otter (1927) that he became renowned and is still best remembered.

Willingdon, 1st Marquess of, Freeman FreemanThomas (1866-1941). English Liberal politician, born in Sussex. Educated at Eton and Trinity College, Cambridge, he became MP 1900-06, 1906-10; Governor of Bombay 1913-19; and of Madras 1919-24. He served as Governor-General of Canada 1926-31 and Viceroy of India 1931-36 at the time of *Gandhi's civil disobedience campaigns. Created baron (1910), viscount (1924), and earl (1931), he was the last person raised to a marquessate (1936).

Willis, Thomas (1621-1675). English physician. One of the leading anatomists of the 17th century, and a pioneer student of the nerves and brain, he graduated BA at Christ Church Oxford in 1636, and turned to medicine, getting his MB in 1646. Willis practised medicine in Oxford, and in 1660 became Sedleian professor of natural philosophy. He was an early member of the Royal Society and in the 1660 s he moved his medical practice to London. His most important work is the Cerebri Anatome (1664), the best anatomical account of the brain yet published. He offered new descriptions of the cranial nerves and described cerebral circulation. Willis also pioneered the clinical and pathological analysis of diabetes. He produced accurate descriptions of many fevers, such as typhus and typhoid, and puerperal fever, making considerable contributions to epidemiology.

Willkie, Wendell Lewis (1892-1944). American lawyer and Republican candidate, born in Indiana. A successful lawyer, active in the Democratic Party until 1939, although supporting many of Franklin
D. *Roosevelt's social goals, as President of the Commonwealth and Southern Corporation 1933-40 he became an outspoken critic of New Deal business regulation. He joined the Republican Party only a few months before winning its nomination for president at the Convention in Philadelphia, on the sixth ballot, defeating Robert A. *Taft and Thomas *Dewey, after a campaign run by amateurs. In November he lost to Roosevelt by 22 million votes to 27 million. He attacked isolationists in his own party and provided strong support for US entry into World War II. After visiting China, Russia and Britain (1942) he wrote One World (1943), a passionate appeal for post-war international cooperation. In 1944 he polled poorly in Republican presidential primaries and withdrew his nomination shortly before his sudden death from heart disease.

Fullilove, M., Rendezvous with Destiny. 2013; Lewis, D. L., The Improbable Wendell Willkie. 2018.

\section{Wills, William John see Burke, Robert O’Hara}

Wills Moody, Helen (Helen Newington Moody Roark, née Wills) (1905-1998). American lawn tennis player. With Suzanne ${ }^{*}$ Lenglen she could claim to have brought lawn tennis for women up to modern championship standards, but unlike her rival she showed a 'poker face' whatever the fortunes or incidents of the game. She dominated the tournaments of America, England and France from 1923 to 1938.

Wilmington, 1st Earl of, Spencer Compton (16731743). English Whig politician. Son of the Earl of Northampton, he came from a Tory family but became a Whig and had a 40-year partnership (often uneasy) with Robert *Walpole. Speaker of the House of Commons 1715-27, he was Lord President of the Council 1730-42, and succeeded Walpole as First Lord of the Treasury (i.e. Prime Minister) 1742-43, although Earl ${ }^{*}$ Granville was the de facto leader. Regarded as a plodder, he died in office, unmarried.

Wilson, Sir Angus Frank Johnstone (1913-1991). British author. Known for short stories and for satirical novels, e.g. Hemlock and After (1952) and Anglo-Saxon Attitudes (1956), he also wrote literary biographies: The World of Charles Dickens (1970) and The Strange Ride of Rudyard Kipling (1977).

Wilson, Charles Thomson Rees (1869-1959). Scottish physicist. From 1895 he worked in the Cavendish Laboratory at Cambridge and held a professorship there 1925-34. He invented the 'cloud chamber' in which the behaviour of ionised particles can be observed and photographed by the tracks they make in supersaturated air. He shared the Nobel Prize for Physics (1927) with *Compton. Other honours included the Hughes Medal (1911), the Royal Society's Royal Medal (1922) and Copley Medal (1935) and a CH (1937). 
Wilson, Edmund (1895-1972). American literary critic, born in New Jersey. Educated at Princeton, he began as a journalist, then developed as a critic of encyclopaedic range, recognised as the greatest American man of letters of his time. He worked as Associate Editor of New Republic (1926-31), and was book reviewer on the New Yorker. In 1938 he married Mary ${ }^{*} \mathrm{McC}$ arthy, third of his four wives. His books include To the Finland Station, a study in the writing and acting of history (1940, a historical study of socialism until 1917), Memoirs of Hecate County (1946, short stories), The Scrolls from the Dead Sea (1955) and Patriotic Gore (1962, civil war literature). His literary criticism include Axel's Castle (1931), a definitive analysis of the Symbolists, The Wound and the Bow (1941) and an anthology, The Shock of Recognition (1943). His revealing journals, kept from the 1920s, appeared in five volumes.

Meyers, J., Edmund Wilson: A Biography. 1995.

Wilson, Edmund B(eecher) (1856-1939). American zoologist, born in Illinois. From a rich family, he studied at Yale, Johns Hopkins (PhD 1881), Cambridge and Leipzig. After teaching at Bryn Mawr, he held a chair at Columbia University 1891-1928. The study of cells preoccupied Wilson, gradually heading him to concentrate upon the problems of genetics and heredity. The Cell in Development and Inheritance (1896) was a pioneering contribution to understanding how cells work, especially the sex chromosomes. He was an enthusiastic supporter of Mendelian theory, and carried out extensive experimental research to work out the chromosomal theory of sex determination in detail. T. H. ${ }^{*}$ Morgan built his experiments on fruit flies upon these foundations. Wilson was concerned to depict the cell as a flexible, developing entity, and to chart the emergence of the cell as part of evolutionary descent. He was not, however, a wholehearted Darwinian, believing that ${ }^{*}$ Darwin had over-stressed the role played by natural selection.

Wilson, Edward Osborne (1929- ). American zoologist. Professor of zoology 1964-76 and of entomology 1976-96 at Harvard University, he investigated social insects. His book Sociobiology: the New Synthesis (1975) proposed a unified, but intensely controversial, science of social behaviour that applied to all species (including humans). He won Pulitzer Prizes with On Human Nature (1978) and The Ants (1990) and also wrote The Diversity of Life (1992).

Wilson, (James) Harold, Baron Wilson of Rievaulx (1916-1995). British Labour politician, born in Huddersfield, Yorkshire. Educated at Wirral Grammar School and Oxford University, where he later lectured on economics, he served in the ministry of fuel during World War II. A Labour MP 1945-83, he became, at 31 , *Attlee's President of the Board of Trade 194751 (the youngest Cabinet minister since *Pitt) but resigned in protest against increased charges for social services to help pay for armaments. Under *Gaitskell, Wilson was the Opposition's Shadow Chancellor and regarded as leader of the Left after *Bevan moved towards the centre. After Gaitskell's sudden death Wilson was elected Labour's leader 1963-76. When Labour won the October 1964 election, with 317 seats to 304 for Alec Douglas- ${ }^{*}$ Home's Conservatives, he became Prime Minister 1964-70. Inflation and unemployment levels were low, the death penalty was abolished, laws on homosexuality were relaxed and interventionist economic policies were modified. $\mathrm{He}$ resisted US pressure for Britain to participate in the Vietnam war but sent troops to Northern Ireland to cope with 'the Troubles'. Parliament was dissolved early and the ensuing election (March 1966) gave him a majority of 96. In June 1970 Labour was defeated when the Conservatives, led by Edward *Heath, won 46.4 per cent of the popular vote and a 42 seat majority. In February 1974, Labour won a four seat majority in the House of Commons (although the Tories led slightly in the popular vote) and Wilson became Prime Minister again 1974-76. In October 1974 Wilson called a second election, increasing his majority to 42 seats, with a 2 per cent swing. He resigned as Prime Minister in April 1976 (being succeeded by James *Callaghan), was made a KG (1976) and a peer (1983), then had a slow decline into Alzheimer's disease.

Pimlott, B., Harold Wilson. 1992; Ziegler, P., Wilson. 1993; Wheen, F., Strange Days Indeed. 2009.

Wilson, Sir Henry Hughes, 1st Baronet (18641922). British field marshal, born in Ireland. $\mathrm{He}$ commanded the Camberley Staff College 1907-10 and, as Director of Military Operations at the War Office 1910-14, developed close working relations with the French, especially ${ }^{*}$ Foch, and was the chief liaison officer during World War I. In February 1918 *Lloyd George appointed him to succeed *Robertson as Chief of the Imperial General Staff and he served until 1922. As a 'political' soldier he was viewed with suspicion by many army colleagues. He broke with Lloyd George, fantasising that he was under Bolshevik influence and saw himself as a potential ${ }^{*}$ Cromwell. Elected as MP for North Down in 1922, he was assassinated in London by two Sinn Féin gunmen.

Wilson, Henry Maitland Wilson, 1st Baron (18811964). British field marshal. After serving in the Boer War and World War I, 'Jumbo' Wilson (called for his size) commanded British troops in Egypt (1939-40), then Greece, Syria and Iraq (1941-42). He succeeded *Alexander in the Middle East command (1943) and from 1944 was in control of all Allied operations in the Mediterranean area.

Wilson, Kenneth Geddes (1936-2013). American physicist. Professor at Cornell 1963-88, he developed a theory of second order phase transitions in matter 
and received the 1982 Nobel Prize for Physics. He then devoted himself to studying education in schools.

Wilson, Pete (1933- ). American Republican politician. Mayor of San Diego 1971-83, he served as US Senator 1983-90 and Governor of California 1991-99.

Wilson, (Thomas) Woodrow (1856-1924). 28th President of the US 1913-21. Born in Staunton, Virginia, son of a Presbyterian minister of ScottishUlster ancestry, his parents owned slaves and supported the Confederacy. He grew up in Georgia. After graduating at Princeton University, he briefly practised law and studied further at Johns Hopkins University. Deeply influenced by *Gladstone, he became increasingly prominent in the academic world during the next 25 years. His The History of the American People (5 vols, 1900-01) characterised the Civil War as being about states' rights and mildly condoned the original $\mathrm{Ku}$ Klux Klan. Professor of jurisprudence and political economy at Princeton (from 1890) he became its president in 1902 . He instituted many reforms in the teaching system but his more liberal plans were rebuffed. In 1910 he was nominated as Democratic candidate for Governor of New Jersey by party bosses who hoped he would be easy to control, won election and served 191113. As Governor he instituted a full liberal program including Corrupt Practices and Employers' Liability Acts. In 1912, supported by party liberals he won the Democratic presidential nomination at Baltimore, defeating Champ ${ }^{*}$ Clark on the 46th ballot, with the support of William Jennings *Bryan. He was elected in November with 42 per cent of the votes, due to the Republican split between President *Taft and Theodore * Roosevelt. As President, Wilson continued his policy of reform (the 'New Freedom') with such measures as Workers' Compensation and Child Welfare Acts. However, he promoted segregation with the sophistry that separate development would avoid friction and direct competition between whites and African-Americans. Three Constitutional amendments were adopted during his Presidency: direct popular election of Senators (1913), prohibition of alcoholic beverages (1919), and votes for women (1920). After World War I broke out in 1914, Wilson maintained formal neutrality but indicated sympathy for the Allied cause. In 1916 he was re-elected, defeating Charles Evans *Hughes, with the campaign theme 'He kept us out of war'. However, Germany's disregard for common humanity and neutral rights shown by the torpedoing of the Lusitania (1915) and the sinking of several American ships and some explosions in US factories led to Wilson's successful appeal to Congress ('The world must be made safe for democracy') for a declaration of war (April 1917). Wilson soon asserted moral leadership of the Allies and in January 1918 set out his famous 'Fourteen Points', including establishment of a League of Nations, as the basis of a just and lasting peace. He attended the Paris Peace Conference (1919), the first time a president ever left the US during his term in office, but Wilson was gravely weakened (April 1919) by catching influenza during the great pandemic. The US had the highest principles but the least direct involvement and Wilson was soon outmanoeuvred by the advocates of a harsh peace, ${ }^{*}$ Clemenceau, *Lloyd George and *Orlando. The Treaty of Versailles (June 1919) imposed severe sanctions on Germany but endorsed the League of Nations. Wilson was awarded the 1919 Nobel Prize for Peace. However, he faced a significant revival of isolationist sentiment at home. He undertook a speaking tour in the midWest to support the Treaty, collapsed in Colorado in September 1919 and in October suffered a stroke from which he never recovered. The extent of his illness was kept from the public and conduct of affairs passed to Edith Bolling Galt Wilson (1872-1961), his second wife, and his secretary, Joseph Tumulty (1879-1954). In March 1920, the Senate voted by 49 to 35 to ratify the Treaty of Versailles, seven short of the two-thirds majority required. Thus the US never joined the League of Nations and Wilson's plan for international collective security was fatally weakened from the outset. Wilson retired in Washington, died and was buried there. He was a powerful influence on Franklin D. ${ }^{*}$ Roosevelt. Despite his tragic failures, in 20 Presidential ranking lists by US historians and political scientists, Wilson scored No. 7 in the aggregate, more recent assessments judging harshly his passive support for racial segregation.

Link, A. S., Woodrow Wilson. 1968; Berg, A. S., Wilson. 2013.

Winant, (John) Gilbert (1889-1947). American Republican politician. Governor of New Hampshire 1925-27, 1931-33, he was appointed by Franklin *Roosevelt as head of the Social Security Board 1935-37. He directed the International Labour Organization (ILO) in Geneva 1939-41 then became US Ambassador to Great Britain 1941-46, urging strong support for ${ }^{*}$ Churchill. US Representative to UNESCO 1946, and awarded an honorary OM in 1947 , he became profoundly depressed and shot himself.

Winckelmann, Johann Joachim (1717-1768). German archaeologist, critic, art historian and consultant, born in Prussia. Son of a cobbler, he had to struggle to obtain an education and it was only after 15 years as tutor and schoolmaster and much study that he realised his ambition of going to Rome (1755). He became a librarian in the Vatican and secretary to the great collector Cardinal Alessandro Albani. His History of Ancient Art (1764) and Reflections on the Painting and Sculpture of the Greeks (1765) were extremely influential in reviving popular interest in the art of Greece (which he never visited). He wrote extensively about the excavations at Pompeii and Herculaneum and has been called the 'father of modern archaeology'. *Goethe compared 
him to ${ }^{*}$ Columbus. A great writer and a profound thinker, he was stabbed to death in Trieste by a gay acquaintance.

Leppman, W., Winckelmann. 1970.

Windsor. British dynastic name adopted in 1917 when ${ }^{*}$ George V gave up his German titles. (The previous name was *Wettin, the family of Prince *Albert, but invariably described as *Saxe-CoburgGotha.) In 1960 it was announced that descendants of Queen *Elizabeth II and Prince *Philip, other than those styled princes and princesses, should bear the surname Mountbatten-Windsor.

\section{Windsor, Duke of see Edward VIII}

Winfrey, Oprah (Gail) (1954- ). American producer, television host, promoter, publisher, actor and philanthropist, born in Mississippi. Educated in Tennessee, she worked in media in Chicago. The Oprah Winfrey Show, on television, 1986-2011, had a major social, political and cultural impact, discussing sexuality, race, women's liberation, 'selfhelp', literature and values. Recognised as one of the world's most influential women, she was a strong supporter of ${ }^{*}$ Obama, and received the Presidential Medal of Freedom in 2013.

Wingate, Orde Charles (1903-1944). British soldier. He served as an officer in British army intelligence in Palestine (1936-39) but was repatriated for his proZionist activities. In Palestine he met and impressed *Wavell who sent him first to Ethiopia (1940) to organise guerrillas against the Italians and, in 1942, to India to conduct similar operations behind the Japanese lines in Burma. After careful training and practice, the first raid of Wingate and his 'Chindits' was made early in 1943 . When Wingate with some 60 per cent of his original force returned in May he had proved that a force could live and fight for several weeks sustained only by supplies hazardously brought by air. Now hailed as a hero, Wingate persuaded ${ }^{*}$ Churchill and ${ }^{*}$ Roosevelt to allow him to command a large force of more than 20 battalions, British, Gurkhas and Nigerians, which should be dropped from the air to form an enclave behind the Japanese lines. The drop successfully took place, but, while Wingate was returning from a conference to discuss subsequent difficulties and delays, his aircraft crashed into a hill and he was killed. Courageous and imaginative, he was intolerant of opposition but was able to win and sustain the enthusiasm of political leaders as well as troops.

Sykes, C., Orde Wingate. 1959.

Wingate, Sir (Francis) Reginald, 1st Baronet (18611953). British general and administrator. He served in India and Aden before being posted to the Egyptian army. His record there led to his appointment as Governor-General of the Sudan in 1899-1916 where he created an efficient administrative structure. As
High Commissioner to Egypt 1917-19, he was virtual ruler, collaborated with *Allenby in supporting the Arab revolt and began negotiations with *Zaghlul and the Wafd party.

Wingate, F. R., Wingate of the Sudan. 1955.

Winstanley, Gerrard (1609-1676). English 'leveller', born in Lancashire. A failed cloth merchant, in 1649, with William Everard he led a group of 'diggers' who asserted their right to cultivate wasteland at Walthamon-Thames and Cobham until dispersed by force and wrote six interesting tracts calling for communal ownership and the abolition of hierarchies. His Law of Freedom in a Platform (1652), dedicated to ${ }^{*}$ Cromwell, advocated a Communist society. He also wrote on religion and was a forerunner of the Quakers.

Wint, Peter de (1784-1849). English watercolourist. Of Dutch descent, he illustrated many aspects of English landscape and rural life. Among his paintings are The Hay Harvest, Nottingham, Richmond Hill and Cows in Water.

Winterhalter, Franz Xavier (1806-1873). German painter. He became famous for his royal portraits, e.g. of *Louis Philippe of France, *Napoléon III and the Empress *Eugènie, the Empress *Elizabeth of Austria, ${ }^{*}$ Leopold I of the Belgians and Queen ${ }^{*}$ Victoria, Prince *Albert and the British royal family.

Winthrop, John (1588-1649). American colonist. An Englishman by birth, a Puritan by religion, prosperous both as lawyer and Suffolk landowner, he sponsored the Massachusetts emigration scheme and went there as its first governor in 1630, an office which he held until 1633 and from 1637 until his death. Many of the social and political institutions of Massachusetts preserved his memory but the rigid Puritanism of the administration caused many to leave the colony. Winthrop's diary is an important authority for the early period of American history. His son, John Winthrop (1606-1676), a chemist and first American Fellow of the Royal Society, established the first iron furnaces in Massachusetts. He became Governor of Connecticut 1660-76.

Morgan, E. S., The Puritan Dilemma. 1958.

Winton, Tim(othy) (1960- ). Australian novelist. His books include Cloudstreet (1991), The Riders (1994, later a successful opera (2014), music by Iain Grandage, libretto by Alison Croggan), The Deep (1998), Dirt Music (2001), The Turning (2004) and Breath (2008).

Wiseman, Nicholas Patrick Stephen (1802-1865). Anglo-Irish cardinal, born in Seville. Of Irish descent, he was educated for the priesthood at the English College in Rome, becoming rector in 1828. Realising the way for a revival in England had been prepared by the Tractarian movement in the Church of England $\left({ }^{*}\right.$ Keble, ${ }^{*}$ Newman, ${ }^{*}$ Pusey) he went there in 1840 , 
became vicar-apostolic in London (1848) and in 1850 *Pius IX created him cardinal and Archbishop of Westminster, re-establishing the Catholic hierarchy in England after 292 years.

Withering, William (1741-1799). English botanist, born in Wellington. Son of an apothecary, he trained in medicine at Edinburgh University, graduating MD in 1766. Withering practised first in Stafford and then in Birmingham. He became an active member of the Lunar Society alongside Erasmus *Darwin, Joseph *Priestley and Josiah *Wedgwood. Withering is important in the history of botany for his $A$ Botanical Arrangement of all the Vegetables Naturally Growing in Great Britain (1776), which made early use of the Linnaean method of classification. He also performed useful chemical and mineralogical analysis, and translated Torbern Bergman's Mineralogy. His most original scientific work was his championing of digitalis, derived from foxglove, as a specific for diseases ranging from dropsy to heart trouble. A slightly querulous man, Withering spent the last years of his life in bitter controversy with Erasmus Darwin and his son.

Peck, T. W. and Wilkinson, K. D., William Withering. 1950 .

\section{Witt, Johan de see de Witt, Johan}

Witte, Sergei Yulievich, Count (1849-1915). Russian statesman. At first an official in the railway administration, he was appointed Minister of Finance (1892). He introduced various financial reforms, sponsored the building of the Trans-Siberian Railway and promoted industrial development. He lost favour and was dismissed (1903), but was recalled to negotiate peace with Japan (1905). The terms he secured in the Treaty of Portsmouth (1905) were more favourable than had been expected, and his reputation was enhanced. Created a count in recognition, he persuaded the tsar ${ }^{*}$ Nikolai II to sign the Manifesto of 1905 promising to set up a Duma (parliament) that had elements of constitutional government. He became Premier (1905) but resigned almost immediately when he failed to obtain the support of the Duma. He was followed shortly by the more conservative ${ }^{*}$ Stolypin.

von Lane, T., Sergei Witte and the Industrialisation of Russia. 1963.

Wittelsbach. German dynasty. It enters history in the 11th century, taking its name from a castle in west Bavaria. Later there were numerous branches, the most important of which ruled in the Palatinate and (eventually as kings) in Bavaria. From the former branch, through *Elizabeth, daughter of ${ }^{*}$ James I, stem the present British royal house and (after the failure of the royal Stuart line) the later Jacobite pretenders.
Wittgenstein, Ludwig Josef Johann (1889-1951). Austrian philosopher (naturalised British 1939), born in Vienna. His affluent family, originally Jewish, became Catholics in the 1830s, and his father Karl Wittgenstein (1847-1913) made a great fortune in the steel industry. Ludwig attended the Linz Realschule (*Hitler was a fellow student), the Berlin Technical High School and Manchester University where he studied engineering, working on aircraft engine design, which stimulated an intense interest in mathematics. At Cambridge he worked with Bertrand *Russell, and became acquainted with J. M. ${ }^{*}$ Keynes and G. E. ${ }^{*}$ Moore. In retreat in Norway in 1913, on the outbreak of World War I he joined the Austrian army as an artillery officer, was wounded, decorated and interned. In September 1919 he gave up his share of the family fortune to his siblings, choosing to live in austere penury, working at times as a gardener, (unsuccessful) primary school teacher, and aspiring architect. His Tractactus Logico-Philosophicus (1921), translated by Frank *Ramsey, presents a system usually described as logical atomism, comprising a theory of language and a closely related physical view of the world. Language is seen as basically made up of simple propositions, which are immediately meaningful because they picture (or have the same structure as) simple or ultimate facts. The Tractatus, notoriously difficult to interpret, also contains, among other doctrines, the view that the only meaningful assertions are either factual or strictly logical ones. It thus anticipates the central meaning of the theory of logical positivism. He returned to Cambridge in 1929, took out his $\mathrm{PhD}$ and became a Fellow of Trinity College 1930-36, 1939-51. He succeeded G. E. *Moore as professor of philosophy 1939-49. He engaged in critical debate with Alan *Turing. He published very little in his lifetime but left behind 20,000 pages of notes. Wittgenstein's last work, Philosophical Investigations, translated from German by his associate Elizabeth Anscombe, appeared in 1953. His lecture notes for 1933-35 were published as The Blue and Brown Books: Preliminary Studies for 'The Philosophical Investigations' (1958).

Philosophical Investigations rejects or modifies some of the rigidity about language and concepts in the Tractatus, eschews metaphysical speculation about ultimate facts and offers reflections on the nature of philosophy. Language is now seen to have a large number of functions, including promise-making and giving orders, for example. It is absurd, Wittgenstein argues, to assimilate all these to the business of stating facts. They are like games, which overlap in various ways but have no common character. Philosophy, he suggests, should be an attempt to clear up puzzles that have arisen, at least in part, through linguistic confusions. The concern of recent British philosophers with the clarification of concepts owes much to Wittgenstein's inspiration.

Three of his four brothers committed suicide. His brother Paul Wittgenstein (1887-1961) was a pianist who lost his right arm in World War I and 
commissioned works for the left hand from *Ravel, Richard *Strauss, *Prokofiev, ${ }^{*}$ Korngold, *Hindemith and ${ }^{*}$ Britten.

Fann, K. T., Wittgenstein's Conception of Philosophy. 1969; Monk, R., Ludwig Wittgenstein. 1990; Edmonds, D. and Eidinow, J., Wittgenstein's Poker. 2001.

Wladislaw. Four Polish kings. Wladislaw I (known as the 'the Short') (1260-1333, reigned from 1320) was instrumental in restoring the kingdom. Wladislaw II (Jagiello) (1350-1434, reigned from 1386), a grand duke of Lithuania, married the Polish queen *Jadwiga. He checked the power of the Teutonic knights and agreed to the conversion of the Lithuanian subjects to Christianity, Wladislaw III (1424-1444, King of Poland from 1434 and of Hungary from 1440) led two crusades against the Turks. The reign of Wladislaw IV (1595-1648, reigned from 1632) was one of internal turmoil and external wars.

Wodehouse, P(elham) G(renville) (1881-1975). English-American novelist and playwright, born in Guildford. From a family of dispossessed landed gentry, he was educated at Dulwich College, worked as a bank clerk, then began writing boys' stories. He moved to New York in 1909, lived there throughout World War I, and became successful as a musical comedy librettist (with Cole *Porter, George ${ }^{*}$ Gershwin, Irving ${ }^{*}$ Berlin and Jerome ${ }^{*}$ Kern), and author of humorous serials for magazines, featuring such characters as Psmith, Ukridge, Mr Mulliner and the Earl of Emsworth. He wrote 96 books and developed a unique prose style. By weaving his consummately stylish humorous fancies round a few brilliantly conceived characters (caricatures even when they first appeared) and by never seriously altering the character of his dialogue, he maintained an almost unparalleled popularity for more than half a century. Bertie Wooster and his omniscient manservant Jeeves (who first appeared in 1915) were successfully adapted for television. Among his best books were The Code of the Woosters (1938), Uncle Fred in the Springtime (1939) and Joy in the Morning (1947). His finest musical was Anything Goes (1934), written with Cole Porter. He lived in France from 1935, seemed oddly unaware that World War II was about to begin, was interned by the Germans in France in 1940, then held for a year in Belgium and Silesia. He made five wartime broadcasts for the Germans, evidence of extreme naivété, and never lived in England again. He became a US citizen in 1955 and was awarded an Hon. KBE just before his death. His admirers included W. H. *Auden, T. S. *Eliot, Aldous *Huxley, Evelyn *Waugh, George ${ }^{*}$ Orwell, Ludwig *Wittgenstein, J. K. *Rowling and John *Le Carré.

Jasen, D. A., P. G. Wodehouse: A Portrait of a Master. 1975; McCrum, R., Wodehouse: A Life. 2004; Ratcliffe, S. (ed.), P. G. Wodehouse: A Life in Letters. 2013.
Wöhler, Friedrich (1800-1882). German chemist. Trained in medicine he turned to chemistry, of which he was professor at Göttingen 1836-82. He was the first (1827) to isolate aluminium by reduction of its anhydrous chloride with potassium and he used similar means to isolate beryllium (1829). He was the first to make calcium carbide, from which he prepared acetylene, and he also improved the method of manufacturing sulphur. His synthesis of urea from ammonium cyanate by intermolecular re-arrangement (1828) disproved the theory that organic compounds could be produced only by living organisms. Many other examples of such synthesis followed, opening a new era in organic chemistry.

Wolf, Hugo (Philipp Jakob) (1860-1903). Austrian composer. He contracted syphilis in 1878 and became manic depressive from 1890 . His dismissal for insubordination while a student at the Vienna Conservatoire was followed by a period of precarious living. In the many songs he then wrote, the influence of $*$ Schumann is especially evident. As music critic of the Wiener Salonblatt (1884-87) he made many enemies by his savage attacks on ${ }^{*}$ Brahms and his circle and by his wholehearted support of *Wagner. His best known works are song collections: 51 settings of Mörike (1888), 20 of Eichendorff (1880-88), and 51 of *Goethe (1888-89). The Spanisches Liederbuch, 54 poems (1889-90) and the Italianisches Liederbuch, 46 poems (1890-91, 1896) set translations by Paul *Heyse. Wolf also wrote an opera, The Corregidor (1895) and the Italian Serenade for string quartet (1887). In 1897 he became insane and, after a brief period of recovery, ended his life in an asylum. His songs, among the greatest written, represent a unique blend of poetry and music into an organic whole, achieved by a close interdependence of the voice and piano parts and his own imaginative response to the written word.

Wolfe, James (1727-1759). British soldier, born at Westerham, Kent. While still a boy he adopted his father's profession of soldier and he was only 17 when he took part in the Battle of Dettingen as a regimental adjutant. He fought at Falkirk and Culloden (against the Jacobites) and on the Continent. After the opening of the Seven Years' War (1756) he was chosen by Pitt to command a brigade in *Amherst's expedition against Cape Breton in Nova Scotia. Hailed for the skill and heroism that led to the fall of Louisburg (1758) he was given command of the expedition sent to capture Québec and end French rule in Canada. He finally achieved success (September 1759) by the discovery of a steep unguarded path that enabled him to land his troops and scale the cliffs of the St Lawrence River unobserved. The armies met on the Plains of Abraham outside the city. Both commanders, the French general ${ }^{*}$ Montcalm and Wolfe were killed 
in battle but Wolfe lived long enough to hear of his complete victory. He was only 32, one of the youngest and most famous of British generals.

Grinnell-Milne, D., Mad is He? 1963.

Wolfe, Thomas (1900-1938). American novelist, born in Ashville, North Carolina. Look Homeward, Angel (1929) was the first of his mainly autobiographical novels, giving portrayals of life in a small Southern town. Of Time and the River was published in 1935, The Web and the Rock, You Can't Go Home Again and The Hills Beyond appeared posthumously.

Donald, D. H., Look Homeward: a Life of Thomas Wolfe. 1987.

Wolfe, Tom (Thomas Kennerly, Jr) (1931-2018). American journalist. One of the originators of 'new journalism', he wrote biting studies of contemporary American culture. His books include The KandyKolored Tangerine-Flake Streamline Baby (1965), Radical Chic and Mau-mauing the Flak Catchers (1970), The Right Stuff (1975), The Bonfire of the Vanities (1987, novel), and A Man in Full (1998, novel).

Wolfensohn, James David (1933-2020). AmericanAustralian banker, born in Sydney. Educated at Sydney University, from 1968 he pursued an international banking career in London and New York, and was President of the World Bank 1995-2005.

Wolfensohn, J. D., A Global Life. 2010.

Wolff, Kaspar Friedrich (1733-1794). German physiologist. One of the 18th-century pioneers of embryology, having studied at Berlin and Halle, he graduated in 1759. He served for a time as an army surgeon and developed a Berlin private practice. In 1767 he moved to St Petersburg as an Academician in Anatomy and Physiology. He researched there continuously until his death. Wolff's work in embryology challenged the 'preformationist' hypothesis (which held that the embryo contained in miniature all the parts of the adult-to-be, ready formed). Wolff adopted the counter position that the embryo contained as yet undifferentiated tissue. He tried to show that the growing tips of plants contain undifferentiated tissue which only gradually unfolds into the distinct parts, such as leaf and flower. This more 'evolutionist' account came to dominate the field over the next half century.

Oppenheimer, J., Essays in the history of embryology and biology. 1967.

Wolfit, Sir Donald (1902-1968). British actor manager. He made his debut in 1920 and his first London appearance in 1924. In 1937 he formed his own touring company and, through provincial tours and the lunchtime performances he gave in wartime, presented *Shakespeare's plays and other classical drama to audiences which would otherwise never have seen them. Clement ${ }^{*}$ Freud commented that ${ }^{*}$ Gielgud was a tour de force, while Wolfit was forced to tour. He played character roles in many films.

Wolfit, D., First Interval. 1954.

Wolfowitz, Paul Dundes (1943- ). American administrator, born in Brooklyn. Educated at Cornell and Chicago Universities, he was Ambassador to Indonesia 1986-89, Undersecretary of Defense 1989-93 and Deputy Secretary 2001-05. A leading 'neo-conservative' in Washington, he was an ardent advocate for the war against Iraq (2003) and George W. *Bush nominated him as President of the World Bank 2005-07.

Wolfram von Eschenbach (c.1170-1220). German epic poet and minnesinger. His love poems glorify married love and deep affection, in contrast to the tradition of courtly love where women are simply exploited. He wrote the epic Parzival, incorporating the legend of the Holy Grail and the inspiration for *Wagner's operas Lohengrin and Parsifal.

Wollaston, William Hyde (1766-1828). English physician and chemist, born in Norfolk. One of 17 children, he was educated at Gonville and Caius College, Cambridge. An inheritance from his brother enabled him to give up medical practice and devote himself to research, and he made a fortune from developing a method of making platinum malleable for conversion into wire and vessels. In 1801 he demonstrated that electricity produced by friction and from voltaic piles was identical and in 1802 observed dark gaps in the solar spectrum. Awarded the Copley Medal in 1802 and the Royal Medal in 1828, he was Secretary of the Royal Society 1804-16 and briefly President 1820. He discovered palladium (1803) and rhodium (1804), anticipated *Faraday in identifying electromagnetic induction but failed to demonstrate how it could be used. He devised a lens combination that eliminated aberration, and invented the camera lucida and the reflecting goniometer used to measure the angles of crystals. The mineral Wollastonite, a compound of calcium, silicon and oxygen, a moon crater and sites in Canada, Chile and Greenland are named for him.

Usselman, M. C., Pure Intelligence: The Life of William Hyde Wollaston. 2015.

Wollstonecraft, Mary (later Godwin) (1759-1797). English writer and feminist, born in London. After an unhappy and violent childhood, she worked as a governess and translator and, inspired by the French Revolution, wrote Vindication of the Rights of Man (1790), a rejoinder to Edmund *Burke's Reflections on the Revolution in France which anticipated Thomas *Paine. She lived in France 1792-95. Her Vindication of the Rights of Woman (1792), a pioneering feminist work, identified women as an oppressed class and called for legislation to guarantee equality of the sexes 
in society, law and education. She married William ${ }^{*}$ Godwin in 1796 and died soon after the birth of her daughter Mary (Mary Wollstonecraft *Shelley).

Tomalin, C., The Life and Death of Mary Wollstonecraft. 1974.

Wolseley, Garnet Joseph Wolseley, 1st Viscount (1833-1913). British field marshal. He held his first independent command in Canada where his administrative skill enabled him to suppress the Red River rebellion (1870) without bloodshed (Louis ${ }^{*}$ Riel). He took a prominent part in carrying out and extending *Cardwell's army reforms. His victory at Tel el Kebir (1882), by which he completely crushed the rebellion of *Arabi Pasha in Egypt, added still further to his fame, and he was created baron. In 1885 he arrived in Khartoum too late to save *Gordon, and he shares blame with *Gladstone's Government. Nevertheless, he was promoted to Viscount. He created the modern British army, was Commander-in-Chief 1895-99 and received the OM in 1902 .

Lehmann, J. H., The Model Major-General. 1964.

Wolsey, Thomas (1473?-1530). English cardinal and statesman, born in Ipswich. Son of a butcher (or innkeeper), he was educated for the priesthood at Magdalen College, Oxford, became chaplain to Henry Deane, Archbishop of Canterbury (1502), royal chaplain to ${ }^{*}$ Henry VII (1507) and Almoner to ${ }^{*}$ Henry VIII (1509). He had a common-law wife for a decade and fathered three children. Henry VIII liked and admired Wolsey (but later destroyed him), finding him useful for diplomatic missions. $\mathrm{He}$ advanced quickly, being appointed Bishop of Lincoln 1514 and an absentee Archbishop of York 151430 (never enthroned). He succeeded Archbishop William Warham to become Lord Chancellor 151529 and Henry's chief minister. Pope ${ }^{*}$ Leo X created him cardinal in 1515. An inveterate collector of ecclesiastical offices, Wolsey doubled up as Bishop of Bath and Wells 1518-22, Prince-Bishop of Durham 1523-29 and Bishop of Winchester 1529-30.

Wolsey became preoccupied with three projects: the creation of Cardinal College in Oxford (which survives as Christ Church); Cardinal College in Ipswich, his birthplace (long disappeared); and a huge tomb of regal splendour (unachieved). $\mathrm{He}$ employed the capable Thomas ${ }^{*}$ Cromwell as his agent in all three. A great patron of education, he was sympathetic to ecclesiastical reform despite his own obsessive pursuit of wealth and power, refusing to condemn heresy.

Henry's foreign policy aimed at maintaining a balance between the young *François I of France and the emperor *Charles V, who also became King of Spain. In Wolsey he found a skilful agent who was obsessed with the idea of making his master Europe's arbiter. At home too he aimed at making Henry supreme, only once summoning parliament and when he did so addressing the members in the most arrogant terms; a strengthened court of the Star Chamber kept the nobles in check. Thus his unpopularity grew and he depended entirely on royal favour. This was at first lavish and enabled Wolsey to build the magnificent palace of Hampton Court (which he later found it expedient to hand over to his royal master), but Henry began to have misgivings about his minister's growing power and did not support unreservedly his attempts to be elected pope. The crisis in their relations arose through Henry's domestic affairs. Queen *Catherine had borne Henry six children but only one girl (Mary) had survived. He needed a son and planned to annul his marriage on the grounds that, despite papal dispensation, it was an infraction of Church law to marry his dead brother's widow. With the agreement of Henry, Wolsey, as papal legate, summoned the king to appear before an ecclesiastical court. But these and subsequent proceedings were drawn out and indecisive, and Henry, blaming Wolsey for the delays, began negotiations with the papacy behind his back. The situation was abruptly changed when the troops of Charles V seized and sacked Rome (1527) and the pope was a virtual prisoner of Charles, Queen Catherine's nephew. Henry now realised that he could only gain his purpose-doubly urgent now owing to his infatuation with *Anne Boleyn-by a breach with the papacy in which Wolsey would be unwilling to assist. Wolsey therefore retired in disgrace to his see at York (1529). But his enemies at court were not to be appeased. Charges were made against him and eventually one of treason, which he was summoned to London to answer. On the way he fell ill at Leicester Abbey and there died.

Ridley, J., The Statesman and the Fanatic: Thomas Wolsey and Thomas More. 1982; Mantel, H., Wolf Hall. 2009.

Wong, Penny (née Penelope Ying-Yeng Wong) (1968- ). Australian Labor politician, born in Sabah, Malaysia. Educated in Adelaide, she became a lawyer, then Senator from South Australia 2002- . Minister for Climate Change 2007-10, and Finance 2010-13, she was Minister for Foreign Affairs 2022- .

Simons, M., Penny Wong. Passion and Principle. 2019.

Wood, Sir Henry Joseph (1869-1944). English conductor. With Robert Newman, he was co-founder of the famous Promenade Concerts in London which he conducted each year from 1895 to 1941 . They were given at the Queen's Hall until it was destroyed by bombing in 1941, then at the Albert Hall, and are now called the Henry Wood Promenade Concerts. He wrote My Life of Music (1938).

Pound, R., Sir Henry Wood. 1969. 
Wood, John (1704-1754). English architect and planner, born in Yorkshire. He is famous for his plans for Bath (from 1727), where he designed Queen's Square, North and South Parades and the Circus. His work, unfinished at his death, was carried on by his son, John Wood (1728-1781), who also built Royal Crescent and the Assembly Rooms.

Woodhull, Victoria (née Claflin) (1838-1927). American feminist, born in Homer, Licking County, Ohio. She became a specialist in magnetic healing, and was active in the spiritualist movement. With her sister Tennessee Claflin she became a successful stockbroker on Wall Street: they founded Woodhull and Clafin's Weekly which printed *Marx's Communist Manifesto. Although not entitled to vote, she was nominated for the Presidency of the US in 1872 by the Equal Rights Party. She advocated free love and had a tense relationship with other feminists such as Susan B. *Anthony. She lived in England from 1877, married a banker and edited The Humanitarian 1892-1901.

Woodward, John (1665-1728). English geologist, born in Derbyshire. Apprenticed to a linen draper in London, he studied medicine, becoming professor of physic at Gresham College, London, in 1692. He was a pioneer geologist, who set up the Woodwardian Chair of Geology at Cambridge in 1728, a theorist of the earth, a pioneer of stratigraphy, and an important collector of minerals and fossils. In his theory, An Essay Toward a Natural History of the Earth (1695) he asserted that the strata lay in regular order throughout the globe and that fossils were organic remains. Both phenomena he attributed to the effects of the Biblical Deluge, which he explained by the action and suspension of the Newtonian force of gravity. In his other major works, such as the Attempt towards a Natural History of the Fossils of England (1728-29), he sought to order all the British fossils into a collection and to provide a classification of mineral objects. Woodward had wide interests, and made important contributions to plant physiology and to Roman antiquities.

Porter, R., 'John Woodward', Geological Magazine. 116, 1979, pp. 335-43.

Woodward, Robert Burns (1917-1979). American chemist. Educated at the Massachusetts Institute of Technology, he was a chemistry professor at Harvard 1950-79 and became known as the father of synthetic organic chemistry. He succeeded in synthesising penicillin, terramycin, chlorophyll, strychnine, quinine, reserpine, vitamin B12 and many other substances. He received the 1965 Nobel Prize for Chemistry, was a Fellow of the Royal Society and a Davy Medallist.

Woolf, (Adeline) Virginia (née Stephen) (18821941). English author, born in London. Daughter of Sir Leslie *Stephen and sister of Vanessa (wife of
Clive *Bell), she married (1912) Leonard (Sidney) Woolf (1880-1969), printer, publisher and political writer. They established (1915) the Hogarth Press in Richmond. It was moved to Bloomsbury in the early 1920s and Virginia Woolf became a leading figure in the literary coterie known as the Bloomsbury set. Meanwhile she had begun her career as a novelist with the publication of The Voyage Out (1915). Her novels are difficult but rewarding. She seldom uses direct narrative but is most concerned with the inner consciousness of her characters expressed by internal monologue, while the emotional intensity and symbolism of her language are more typical of poetry than prose. But she is not over-serious and sometimes, e.g. in the fantasy Orlando (1928, filmed in 1992), shows an impish sense of humour. Among the most characteristic of her novels are Jacobs Room (1922), Mrs Dalloway (1925), To The Lighthouse (1927) and The Waves (1931). She was also a distinguished essayist and showed her interest in social changes affecting women in, e.g., A Room of One's Own (1929). Another aspect of her talent was shown by her biography of the artist and critic Roger *Fry. Deeply depressive, she drowned herself.

Gordon, L., Virginia Woolf. 1986; Lee, H., Virginia Woolf. 1996.

Woollcott, Alexander (1887-1943). American journalist. He became a famous dramatic critic in New York, respected and feared for his capacity to make or break plays. Later he won renown as a broadcaster and essayist. Sheridan Whiteside, the central character in the play (and film) The Man who Came to Dinner by George S. Kaufman and Moss Hart was based on him.

Woolley, Sir (Charles) Leonard (1880-1960). English archaeologist. Famed for his excavations of the site of the biblical 'Ur of the Chaldees' in Mesopotamia, after being assistant curator at the Ashmolean Museum, Oxford, he gained practical experience of excavation in Egypt, Syria, Nubia and at Carchemish in Turkey (assisted by T. E. *Lawrence). After being a prisoner of war in Turkey in World War I he spent 12 years from 1922 excavating at Ur (by then in Iraq). At the royal cemetery, evidence of human sacrifice at the burials of the nobles was found and rich accumulations of artistic treasures were uncovered. These are described in The Royal Cemetery (1934). His other works include Digging up the Past (1930).

Woolley, C. L., Spadework. 1953.

Woolman, John (1720-1772). American Quaker preacher, born in New Jersey. A farmer's son, he preached and wrote against slavery and published several religious works, as well as his Journal (1774, often reprinted). 
Woolton, Frederick James Marquis, 1st Earl of (1883-1964). British administrator, businessman and Conservative politician. He ran Lewis' department store, received a peerage in 1939 and was appointed from outside politics to be Minister for Food 194043. He devised an efficient rationing scheme in World War II and was Minister of Reconstruction 194345. He joined the Conservatives on their defeat in 1945, was appointed party chairman $1945-55$ and with R. A. *Butler was largely responsible for their return to office in 1951. He served as a minister again 1951-54.

Woolton, F., Memoirs. 1959.

Woolworth, Frank Winfield (1852-1919). American retailer. He was a farm worker until becoming a shop assistant in 1873. His first 5-cent store, opened (1879) in Utica, N.Y., failed, but a 5and 10-cent store started in Lancaster, Pennsylvania, in the same year became the nucleus of the vast international chain of shops that bears his name. The giant New York skyscraper, the Woolworth Building, for a time the world's tallest building, was constructed (1913) to house his central offices.

Wootton, Barbara Frances, Baroness Wootton of Abinger (née Adam) (1897-1988). English social scientist and economist. Educated at Cambridge, she lectured in economics at Girton College 1920-22, did research work for the Labour Party 1922-26 and was principal of Morley College 1926-27. Director of studies at London University 1927-44 and professor of social studies $1948-52$, she was made a life peeress in 1958 and wrote many books.

Wootton, B. F., Testament for Social Science. 1950.

Worde, Wynkyn de (fl. 1480-1535?). English printer, born in Alsace. He was a pupil of *Caxton, who in 1491 succeeded to his business. He made great improvements in printing and typecutting, and printed many books including The Golden Legend (1493), Morte D'Arthur (1498) and the third edition of the Canterbury Tales.

Wordsworth, Dorothy Mae Anne (1771-1855). English writer. Only sister and close companion of William *Wordsworth, her Journals show that she shared his poetic sensibility and his response to nature; her delight in natural beauty and sharp observation was a continuous inspiration to him. She had a nervous breakdown in 1829 and never fully recovered. Before her death she had become senile.

Levin, S., Dorothy Wordsworth and Romanticism. 2009.

Wordsworth, William (1770-1850). English poet, born at Cockermouth, Cumberland. The second of five children, he was closest to his sister *Dorothy; a younger brother, Christopher Wordsworth
(1774-1846), became Master of Trinity College, Cambridge. Their father, a lawyer, was psychologically remote but encouraged his children to read poetry.

William studied at St John's College, Cambridge from 1787 , graduating BA in 1791 . He was a great walker and his close observation of nature was on foot (or feet). Thomas *De Quincy estimated that he 'must have traversed a distance of 175 to 180,000 English miles - a mode of exertion which, to him, stood in the stead of wine, spirits, and all other stimulants whatsoever to the animal spirits' but observed that his legs, while serviceable 'were certainly not ornamental'. He walked through Switzerland in 1790, France 1791-92, 1802 and Germany 1798-99 and also visited Scotland, Ireland and Italy.

He was in France as it approached the height of the Revolution, and in Blois fell in love with Annette Vallon, who bore him a daughter. At first a sympathiser of the Revolution cause, after his return to England, Jacobin excesses and England's declaration of war with France horrified and confused him. From this condition Dorothy, by re-invigorating his love of nature, and his friend Samuel Taylor *Coleridge, by his philosophy, restored him to his vocation as a poet. His poetic inspiration, with its striking originality, was confined to a single decade 1797-1807, followed by a long, sad decline.

A legacy enabled brother and sister to move first to Dorset, then to Somerset, and in 1799 to Grasmere in the Lake District, where they lived at 'Dove Cottage' until 1808. Jointly with Coleridge he had already published Lyrical Ballads (1798), which marked a revolt from the highly wrought 'Augustan' style of *Pope and his successors and the return to nature for inspiration. He asserted that poetry should use the language of common speech, should express 'the spontaneous overflow of powerful feelings' and take its origin 'from emotion recollected in tranquillity.' He was a central figure in the Romantic revival which long dominated English poetry (*Byron was a scathing critic).

Coleridge and Robert *Southey lived nearby and, with Wordsworth, were known as 'the Lake Poets.' He married (1802) Mary Hutchinson, a friend from childhood, and she moved into 'Dove Cottage' with William and Dorothy. After several moves in the Lake District, Wordsworth and family settled in 1813 at Rydal Mount, near Ambleside. He reacted strongly against the impact of industrialisation on the landscape. Wordsworth referred to 'spots of time' in which a brief image or observation of an element in nature has a lasting psychological impact on the observer.

Gerard Manley *Hopkins wrote that in his 'Intimations of Immortality' (1804) Wordsworth had 'seen something' and that this insight or vision had 'given human nature a shock' and 'sent it trembling'. Wordsworth rarely refers to God in his poetry but he 
saw Nature as 'sacramental', analogous to the divine, with its own transcendence.

Wordsworth became Poet Laureate in 1843, succeeding Southey. In his last years he was increasingly Tory, Anglican and depressive, especially after the death (1847) of his daughter Dora.

The Prelude or, Growth of a Poet's Mind; An Autobiographical Poem (published posthumously in 1850 and named by his widow), largely completed by 1798 , still being revised until his death, is a huge work, 14 books in blank verse, autobiographical and relating the poet's aesthetic development. However, it has extraordinary flashes, including in Book X, an hallucinatory memory of the September Massacres (1792) in the French Revolution, with echoes of *Dante, ${ }^{*}$ Shakespeare and William *Blake. Its meaning is unclear but its emotional power and urgency is undeniable.

With unextinguish'd taper I kept watch,

Reading at intervals; the fear gone by

Press'd on me almost like a fear to come;

I thought of those September Massacres,

Divided from me by a little month,

And felt and touch'd them,

a substantial dread;

The rest was conjured up

from tragic fictions,

And mournful Calendars of true history,

Remembrances and dim admonishments.

'The horse is taught his

manage, and the wind

Of heaven wheels round and

treads in his own steps,

Year follows year, the tide returns again,

Day follows day, all things have second birth;

The earthquake is not satisfied at once.'

And in such way I wrought upon myself,

Until I seem'd to hear a voice that cried

To the whole City, 'Sleep no more.'

Wordsworth, W. (eds de Selincourt, E. and Darbishire, H.), Poetical Works. 5 vols, 1940-49; Gill, S., William Wordsworth. 1989; Gill, S., William Wordsworth: A Life. 1989; Davies, H., William Wordsworth: A Biography. 2009.

Wotton, Sir Henry (1568-1639). English diplomat and writer. After leaving Oxford, where he befriended *Donne (and later, *Milton), he became secretary to the Earl of *Essex, accompanying him on several expeditions. The Grand Duke of Tuscany sent him to warn *James VI of Scotland of a Catholic plot against his life, entailing a journey in disguise through Germany and Denmark. When James became King of England, he made Wotton Ambassador to Venice, serving intermittently 1604-23. Elected as MP in 1614 and 1625, he was provost of Eton 1624-39 and took holy orders in 1627 . He coined the aphorism: 'An ambassador is an honest man sent to lie abroad for the commonwealth'. His The Elements of Architecture
(1624), suggested adaptations of the Palladian style for English country houses and he also wrote many charming lyrics (Izaak *Walton).

Wouk, Herman (1915-2019). American novelist. A radio scriptwriter, he served in the US Navy. His bestselling novels include The Caine Mutiny (1951), Marjorie Morningstar (1955) and Youngblood Hawke (1962). The Caine Mutiny was also a play and film (starring Humphrey *Bogart as Captain Queeg, 1954).

Wouverman, Philips (1619-1668). Dutch painter, born in Haarlem. He studied with his father and probably Franz ${ }^{*}$ Hals. His brothers Pieter and Jan were also prolific artists in the baroque style. He is best known for his numerous hunting and battle scenes, the latter often distinguished by a conspicuous white horse in the foreground.

Wozniak, Steve (Stephen Gary, often known as 'Woz') (1950- ). American inventor and electronics engineer, born in San Jose. He worked closely, but not happily, with Steve *Jobs, in the development of Apple, Macintosh and a range of electronic products.

Wran, Neville Kenneth (1926-2014). Australian Labor politician. A Sydney barrister and QC, he was Premier of New South Wales 1976-86, National President of the Australian Labor Party 1980-86, Chairman of the Commonwealth Scientific and Industrial Research Organisation (CSIRO) 1986-91 and a merchant banker.

Wrangel, Pyotr Nikolaeivich, Baron (1878-1928). Russian soldier. Having served with distinction in the Russo-Japanese War and become a young major general in World War I, he succeeded *Denikin in command of the anti-Bolshevik forces in south Russia. He held out in the Crimea until November 1920, when he evacuated troops and refugees to the Balkans.

Wren, Sir Christopher (1632-1723). English architect and scientist, born in East Knoyle, Wiltshire. Son of the dean of Windsor, he was educated at Winchester and Wadham College, Oxford and won a reputation as a prodigy, anticipating *Newton's work on gravity. Professor of astronomy at Gresham's College, London 1657-61, he was a foundation Fellow of the Royal Society (1660) and Savilian professor of astronomy at Oxford 1661-73. He developed an active interest in architecture at Oxford and his first great building was the Sheldonian Theatre (exhibited as a model in 1663, carried out in 1669). A visit to Paris (1665), where he met *Bernini, was important in developing his style. Surveyor-General of London 1666-69 and of the Royal Works 1669-1718, he was working on the restoration of the old Gothic St Paul's Cathedral, when the Great Fire (1666) destroyed it and about two-thirds of the city. Although his ambitious plans 
for rebuilding London were not accepted, he was commissioned to design a new St Paul's and 51 city churches, of which 20 survive. He collaborated with his friend Robert *Hooke. Early plans for St Paul's were rejected as (i) too grandiose and (ii) too modest; building began in 1675 and was extensively modified as work proceeded. The great dome was begun in 1698 and St Paul's was completed in 1711. Wren's later work, especially the western towers of St Paul's, shows familiarity (probably through engravings) with Roman baroque. His secular work is almost equally famous; the new buildings of Hampton Court for all their magnificence conform to the domestic charm of the old. To the same decade (the 1690s) belong the Royal Hospital, Chelsea, Kensington Palace and the start of work on Greenwich Hospital. Earlier the perfect proportions of Trinity College Library in Cambridge had given promise of what he could achieve. Knighted in 1673, he was President of the Royal Society 1680-82 and elected as a Whig MP in 1685, 1689 and 1701, rarely (if ever) attending. He married twice, and a son by each marriage survived him. Buried in St Paul's, his modest grave is marked by the inscription: 'Si monumentum requiris, circumspice' ('If you seek a monument, look around').

Tinniswood, A., His Invention So Fertile: A Life of Christopher Wren. 2001.

Wright, Sir Almroth Edward (1861-1947). English pathologist. Professor of experimental pathology at London University 1902-46, he developed the first successful anti-typhoid serum and investigated parasitic diseases. He was the teacher of Sir Alexander ${ }^{*}$ Fleming.

Wright, Frank Lloyd (1867-1959). American architect, born in Wisconsin. He studied civil engineering for a year at the University of Wisconsin, was influenced by the writings of *Viollet-le-Duc, then worked in Chicago (1889-93) in the office of Louis *Sullivan. Between 1900 and 1910 he designed 50 houses in the 'Prairie style', emphasising low, horizontal proportions: the prototype of the openplanned house. The Robie house in Chicago (1909) is a famous example. His highly original style integrated engineering techniques into architectural expression, by use of appropriate materials and stressing the importance of a harmonious relationship between building and landscape. Wright had a turbulent and well-publicised domestic life. He built a famous house and work centre, Taliesin, at Spring Green, Wisconsin in 1911. (In August 1914 his mistress, two of her children and four others were murdered there by a deranged servant and part of the house was burnt down.) He built another home and school, Taliesin West, at Scottsdale, Arizona. His Imperial Hotel, Tokyo (1916-22), one of the few major buildings to survive the 1923 earthquake, was demolished in 1968. By 1930 his work, using natural materials and related to landscape, appeared to be eclipsed by the mechanistic 'International style' of *Le Corbusier,
*Gropius and *Mies van der Rohe, which he detested. He concentrated on teaching, then produced his greatest works. Among his masterpieces were the 'Fallingwater' house, near Pittsburgh (1936-37), the Johnson Wax Building, Racine, Wisconsin (1936-39) and the ${ }^{*}$ Guggenheim Museum, New York (195659). He designed about 800 buildings of which 484 were constructed and 433 survive. Wright was also a furniture and window designer and a prolific writer, particularly influential in Europe. He wrote a revealing (but wildly inaccurate) Autobiography (1932). His hero was *Wagner and his life had operatic overtones.

Gill, B., Many Masks. 1987; Secrest, M., Frank Lloyd Wright. 1993.

Wright, Judith Arundell (1915-2000). Australian poet. Born into a pastoralist family, she was educated at Sydney University, travelled in Europe, worked on the land and at the University of Queensland, and married the philosopher and novelist J. P. McKinney. She published 12 volumes of poetry, the first, The Moving Image (1946), establishing her in the front rank of Australian poets. She wrote her family history in Generations of Men (1959), edited anthologies, published criticism and was an ardent campaigner for conservation of the environment and Aboriginal land rights. She had an intimate relationship with the economist H. C. ${ }^{*}$ Coombs from 1972, which was only revealed after their deaths. Their letters to each other are moving.

Brady, V., South of My Days. 1998.

Wright, Thomas (1711-1786). English astronomer, born in County Durham. He became one of the most original cosmological and astronomical thinkers in 18th-century England. Largely self-taught, he set himself up as a teacher of navigation and pursued astronomical research. In 1750 he published his most important work, the Original Theory, or New Hypothesis of the Universe. This was primarily an attempt to fuse his own heterodox religious views with physical truth. He believed that the universe had a divine and gravitational centre, which was the abode of light. He saw the Milky Way as a thin shell of stars, and proposed the existence of a multiplicity of star systems, each with its own supernatural centre. He later published his Second Thoughts in which he suggested that the universe rather consisted of an infinite sequence of concentric shells surrounding the divine centre. The sky is one of those opaque shells. Stars he saw as pinpricks, letting light pass through from within.

Hoskin, M. A., 'The cosmology of Thomas Wright of Durham', Journal for the history of astronomy, i (1970), pp. 44-52.

Wright, Wilbur (1867-1912) and Orville (18711948). American aviation pioneers and inventors, born in Millville, Indiana and Dayton, Ohio, respectively. The Wright brothers were the sons of a 
clergyman, lived austerely and never married. They made and repaired bicycles in Dayton and became interested in gliding, after reading Otto ${ }^{*}$ Lilienthal's experiments. When they began to think of aircraft construction, they found themselves frustrated by a lack of scientific data. To overcome this they built (1901) a small wind tunnel to determine the effect of air pressure on wing surfaces. They invented 'ailerons' or wing flaps as controls and finally they designed and built their first aircraft, a machine weighing $340 \mathrm{~kg}$ (750 lb.) and powered by a 12 h.p. petrol motor. On 17 December 1903 they made what are generally regarded as the first successful powered, sustained and controlled flights at Kitty Hawk, North Carolina. The first flight, made by Orville in Flyer I, lasted for only 12 seconds but on the fourth the machine travelled 260 metres (852 feet) in 59 seconds, a speed of $48 \mathrm{kph}$ (30 mph). By 1905 Wilbur had remained aloft for 38 minutes in Flyer III. Incredibly, their achievements were never reported nor believed in the US and it was a successful demonstration at Le Mans, France (8 August 1908), which proved the sceptics wrong, making the brothers famous. In September 1908 Orville flew for 62 minutes; 8 days later he crashed, killing a passenger. The Wright Aeroplane Company was founded in 1909. Wilbur, who was the driving force, died of typhoid (R. W. *Pearse).

McFarland, M. W. (ed.), The Papers of Wilbur and Orville Wright. 2 vols, 1953; McCullough, D., The Wright Brothers. 2015.

\section{Wriothesley, Henry see Southampton, 3rd Earl of}

Wunderlich, Carl Reinhold August (1815-1877). German physician. He practised in Leipzig where he became professor. Among the earliest to recognise that fever was not a disease per se, but a symptom, he introduced the regular taking of temperatures and their recording on a chart. (The clinical thermometer he used was a clumsy instrument more than $30 \mathrm{~cm}$ long, which took nearly 20 minutes to register.)

Wundt, Wilhelm Max (1832-1920). German experimental psychologist. Son of a Lutheran pastor, he pursued a career in medicine, attending university at Tübingen, Heidelberg and Berlin, where he worked under *Du Bois-Reymond. He taught at Heidelberg until 1871, moving first to Zürich and then to Leipzig. After a generation in the shadows, his career blossomed. His laboratory became one of the great centres of psychological research. Wundt's approach to psychology was always physiological. He was concerned with response and reaction, with the speed of nerve impulses, and with the understanding of electrical impulses in the brain. His approach was frequently described as 'psychology without a soul', though he denied that his outlook was reductionist and materialist. Emil *Kraepelin was his pupil.

Boring, E. G., A History of Experimental Psychology. 1950 .
Wu Zetian (also Wu Zhao or Wu Hou) (624-705). Empress regnant of China 690-705, sole ruler of the Zhou dynasty, an interruption of the Tang dynasty. Born to a rich family, she became the concubine of the Taizong Emperor, married his son, the Gaozong Emperor, displaced her son the Ruizong Emperor, and was recognised as Empress regnant. She promoted Buddhism, erected many monuments, ordered exploration of central Asia and was ruthless with her (many) enemies. She was the only Chinese Empress regnant.

Fitzgerald, C. P., The Empress Wu. 1968; Clements, J., Wu. 2014.

Wyatt, James (1746-1813). English architect. Son of a builder, after studying in Italy he returned to England and worked in the style made fashionable by the *Adam brothers. From about 1780 he became a leader of the Gothic revival. He undertook restorations and extensions to eight Oxford colleges. The eccentric William *Beckford gave him a wonderful opportunity when he commissioned (1796) Fonthill Abbey; its 90 metre tower collapsed in the year of his death. (Rebuilt, it collapsed again in 1820). His restorations of Salisbury, Lichfield, Hereford and Durham are regarded as unfortunate. Nine members of the Wyatt family were architects. In $1796 *$ George III chose James Wyatt to restore Windsor Castle. However, the present appearance of the Castle is due to his nephew Sir James Wyatville (né James Wyatt) (1766-1840), who changed his name in 1824 to avoid confusion. Enormously prolific, a prefabricated hospital in Sydney (1790) was attributed to him.

Robinson, J. W., The Wyatts: An Architectural Dynasty. 1980.

Wyatt, Sir Thomas (1503-1542). English poet and diplomat. He was sent on diplomatic missions to France and the papal court, after which he privately visited many Italian cities, where he admired and absorbed their literary culture. His further career was interrupted by ${ }^{*}$ Henry VIII's suspicions about his relationship with *Anne Boleyn and he spent two brief periods in the Tower of London. He translated much of ${ }^{*}$ Petrarch and is credited with introducing the Petrarchan sonnet into English literature. His own lyrics were published after his death, in Tottel's Miscellany (1557). In the 20th century he has been recognised as a good, and even great, poet after centuries of critical neglect.

His son Sir Thomas Wyatt the Younger (1521?1554), a soldier, raised a rebellion to prevent Queen *Mary's marriage to *Felipe II of Spain and was executed when his plan failed.

Lewis, C. S. English Literature in the Sixteenth Century. 1954; Brigden, S., Thomas Wyatt. 2013.

Wycherley, William (1640-1716). English playwright. After some years in France and attending Oxford University, he went to London, where he lived 
a somewhat dissipated life while nominally studying the law. His first play, Love in a Wood (1671), was dedicated to the King's mistress, the Duchess of *Cleveland, whose patronage he won with that of the Duke of *Buckingham and of the King himself. The Gentleman Dancing Master (1672) was less successful, but his third play, The Country Wife (1675), was one of the most entertaining Restoration comedies. It was adapted by ${ }^{*}$ Garrick and has been revived in modern times. The Plain Dealer, written earlier but produced in 1676, was the last of his plays. He married the Countess of Drogheda (1679) but was reduced to poverty by lawsuits that followed her death (1681). *James II came to his rescue with a pension. In later life Wycherley became a friend of *Pope. His plays have been condemned for their bawdiness (a reflection of the taste of the period) but his wit and satire are indisputably brilliant.

Zimbardo, R., Wycherley's Drama. 1965.

Wyclif (Wycliffe, Wicliffe), John (c.1320-1384). English ecclesiastical reformer, born in Yorkshire. He is first mentioned in 1360, when, already renowned for scholarship, he was master of Balliol College, Oxford. He soon left to work in nearby parishes, which allowed him to maintain his links with Oxford. By this time he was known at court and had come under the powerful patronage of *John of Gaunt. In 1374 , the same year that he was presented with the living of Lutterworth, he was sent on an embassy to confer with the papal envoys at Bruges. The removal of the papacy to Avignon and its close connexions with the French crown had increased English resentment at papal exactions. Thus Wyclif, taking his stand on the authority of the New Testament, was voicing the popular view in denouncing the Church's right to interfere in secular affairs and in maintaining the state's right to withdraw ecclesiastical endowments. Supported by John of Gaunt, who wanted the Church's wealth for the French wars, Wyclif, whose aim was a return to apostolic simplicity, was able to evade episcopal and papal attempts to secure his condemnation. The scandal of two popes (1378) *Urban VI (supported by England) at Rome and ${ }^{*}$ Clement VII at Avignon, persuaded Wyclif to go further. He not only attacked the Church's corruption and the pope's temporal power, he also rejected the system of priestly absolution, penances and indulgences. To convince his followers that these lacked scriptural authority he organised, with the help of the Oxford scholars, a complete translation of the Bible from the Latin Vulgate to which he contributed a rendering of the Gospels and probably most of the New Testament. It was condemned and suppressed. Nevertheless, nearly 200 manuscript copies survive, suggesting that it was widely used in his time. So far his support had been widespread even in the Church itself, but when he attacked the dogma of transubstantiation and assailed the whole hierarchy the attitude changed. Condemned by a synod (1382) he had to retire to Lutterworth, where he died. His followers, contemptuously called 'Lollards' after a Dutch word meaning 'mumblers', were generally stamped out. Wyclif's teaching strongly influenced Jan ${ }^{*}$ Hus, the great Bohemian reformer, and the doctrines of both were condemned by the Council of Constance (1414-18).

MacFarlane, K. B., John Wyclif and the Beginnings of English Nonconformity. 1952.

Wyeth, Andrew Newell (1917-2009). American painter. His spare, sometimes unnerving, landscapes were extremely popular and widely reproduced. In 1963 President * Kennedy awarded him the Medal of Freedom for work 'which in the great humanist tradition illuminated and clarified the verities of life'.

Wykeham, William of (1324-1404). English prelate and patron of learning. He entered royal service (c.1347) and eventually as Lord Privy Seal and Lord Chancellor 1363-71 became the virtual head of the administration. Meanwhile his ecclesiastical progress continued and in 1367 he was appointed Bishop of Winchester. During *Edward III's closing years he fell into disfavour for supporting the parliamentary opposition but, with the accession of ${ }^{*}$ Richard II, he was back in office and was again Lord Chancellor 1389-91. During his long career he had amassed a great fortune with which he founded Winchester College and New College, Oxford. He also bore the expense of rebuilding the nave of Winchester Cathedral in the new Perpendicular style.

\section{Wynkyn de Worde see Worde}

Wyss, Johann Rudolf (1781-1830). Swiss writer. He wrote the Swiss national anthem and finished and published The Swiss Family Robinson (English translation 1814), which, originally written by his father for his children, quickly became a worldwide classic.

Wyszynski, Stefan (1901-1981). Polish cardinal. Bishop of Lublin 1946-48, he became Archbishop of Warsaw and primate of Poland 1948-81 and was created cardinal in 1953 . Throughout the period of Communist rule he maintained the Church's position with the greatest courage. Imprisoned 1953-56, by cooperating with the government where this did not offend the Church's dignity and conscience, he saved it from still greater interference. 


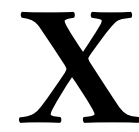

\section{X, Malcolm see Malcolm X}

Xavier, St Francis (Francisco de Jasso y Azpilicueta) (1506-1552). Spanish (Basque) Jesuit missionary, born in Javier, Navarre. He studied in Paris from 1525 and there met Ignatius *Loyola (1529) and was among the first members of the Society of Jesus. Ordained in 1537, in 1541 he made his first missionary journey to Goa in Portuguese India. From there (1545-49) he visited many parts of the East Indies including Ceylon, where he converted the King of Kandy. A mission he established in Japan (1549-51) endured for a century and attained great influence. He returned to Goa (1552) to organise a similar mission to China, but on his way there died of fever on the island of Changchwen (St John) near Macao. One of the greatest Christian missionaries, he became known as 'apostle of the Indies' and was canonised in 1622. As well as many interesting letters his writings include treatises on asceticism.

Brodrick, J., St Francis Xavier, 1506-1552. 1952.

Xenakis, Yannis (1922-2001). Greek composer, architect and mathematician, born in Romania, living in France. He fought in the Greek Resistance, then worked as an architect for 12 years with ${ }^{*}$ Le Corbusier, while studying composition with ${ }^{*}$ Honegger and ${ }^{*}$ Messaien. He was the originator of 'stochastic' (i.e. dependent on random variables) music, in which pieces were programmed with the aid of a computer.

Xenophon (428-354 BCE). Greek soldier and writer, born in Attica. A pupil of *Socrates at Athens, he wrote several books about him, e.g. Memorabilia, that reveal a much more conventional personality than that portrayed in *Plato's works. Xenophon's greatest experience as a man of action took place when (401 BCE) he joined the army of the Persian prince ${ }^{*}$ Cyrus in revolt against his brother King *Artaxerxes. The death of Cyrus (400) left 10,000 Greeks marooned in Persia. Xenophon placed himself at their head and led them on the long and hazardous march across Asia Minor made famous by his Anabasis. Next he joined the army of the Spartan king Agesilaus, an act regarded as treasonable by the Athenians, who decreed his banishment. During his exile he lived in retirement at Scillus near Olympia, where he devoted much time to writing, and at Corinth. It is known that the banishment decree was eventually repealed but the exact date and manner of his death are uncertain. His other works include Cyropaedia, a kind of political romance in which Cyrus I of Persia fills the role of a model ruler, and Hellenica, a continuation of the work of Thucydides from 411 to
362 BCE. All Xenophon's books are written in a clear, straightforward style and his historical works reveal a gift for narrative and an objective search for truth.

Miller, W., et al. (eds), The Complete Works of Xenophon. 1960-68.

Xerxes I (Greek form of Kshajarsha) (c.519-464 BCE). King of Persia 485-64. Son and successor of *Darius I, having crushed revolts in Egypt and Babylon he continued his father's preparations for an invasion of Greece. In the spring of 480 his great army began to cross the Hellespont (the Dardanelles) by a bridge of boats, an operation said to have taken a full week. No resistance was encountered during the march through Thrace until the Spartan king *Leonidas and his famous 'Three Hundred' made their heroic stand at the Pass of Thermopylae. When Xerxes reached Athens he found that the population had taken to the sea. Seated on his throne above the straits between Salamis and the mainland he had the humiliation of watching the destruction or dispersion of his ships. Fighting in Greece ended with the defeat and death of the Persian general Mardonius at Plataea 479. Much of Persepolis (Takht-e Jamshid) was built during his reign. Xerxes spent the rest of his reign in peace until his murder by the traitor Artabanus (see also *Ahasuerus). His grandson Xerxes II (d.425 BCE) was murdered after ruling for 45 days.

Xi Jinping (1953- ). Chinese Communist official, born in Beijing. Son of the party veteran $\mathbf{X i}$ Zhongxun (1913-2002), he became a party official in Fujian and Zhejiang provinces and in Shanghai. He became Vice President of China 2008-13 and ${ }^{*} \mathrm{Hu}$ Jintao's presumed successor. General Secretary of the Chinese Communist Party and Chairman of the Central Military Commission 2012- and President of China 2013- , he represented the fifth generation of leadership since the Revolution. He argued for free trade, globalisation, action on climate change and strengthening legal institutions, while maintaining the CCP's total monopoly on political power. In 2018, the Chinese Constitution was changed to enable the President to serve more than two terms, a demonstration of Xi's dominant leadership and in October 2022 the CCP elected him for a third term, unprecedented in the post ${ }^{*}$ Mao era.

Brown, K., CEO, China. 2017; Rowell, R., Xi Jinping. President of China. 2018.

Xia. Chinese dynasty, the first, possibly legendary, said to have been founded by $\mathbf{Y u}$ ('the Great') around 2200 BCE, displaced by the Shang about 1700 BCE. Archaeological and documentary evidence about the $\mathrm{Xia}$ is dated centuries after the presumed date of their rule.

Ximenes (Jimenes) de Cisneros, Francisco (1436-1517). Spanish prelate and statesman, born in Castile. He completed his education for the priesthood in Rome, but though he received a papal 
nomination as archpriest for the Spanish diocese of Toledo, the archbishop refused to admit him and held him in prison for six years. After his release he retired to a Franciscan monastery where he gained such a reputation for learning and the austerity of his life that Queen *Isabella of Castile appointed him her confessor (1492). Three years later he became Archbishop of Toledo and in this dual capacity exercised his great talent for affairs of state. Eventually, Isabella having died (1504), and with her husband and co-ruler *Ferdinand of Aragon often absent in Italy, her daughter and heiress Juana mad and her sonin-law *Felipe I (aka Philipp of Burgundy) dying in 1506, the influence of Ximenes (cardinal from 1507) became almost paramount. Much of what he did, and especially the centralising of monarchic rule and his financial management, was beneficial. The capture of Oran in Africa by an expedition (1509) financed and led by himself reduced piracy but his continued persecution of the Moors (in defiance of the promise of religious tolerance which led to the capitulation of Granada) did irretrievable harm. After the death of Ferdinand (1516), Ximenes became regent and fully maintained the royal authority, but on his way to meet his new sovereign, Carlos (afterwards the emperor ${ }^{*}$ Charles V), the great minister died. Apart from his political achievements, Ximenes was a great patron of literature and the arts. He refounded the university of Alcalá de Henares and published at his own expense the great work of Spanish scholarship known (from Complutium, the Latin name for Alcalá) as the Complutensian Polyglot Bible.

Xuantong (Hsuan T'ung) emperor see Puyi 


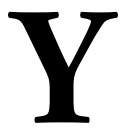

Yacoub, Sir Magdi Habib (1935- ). Anglo-Egyptian cardiothoracic surgeon, born in Belbis. Working in the US, Africa and London, he developed new techniques for heart and heart-lung transplants, achieving exceptional survival rates and winning many awards, including the $\mathrm{OM}$ in 2014.

Yadin, Yigael (1917-1984). Israeli archaeologist, soldier and politician, born in Jerusalem. He joined the Haganah defence force in 1933 and was Chief of Staff of the Israeli army (1948-52), professor of archaeology at the Hebrew University (1963-77 and 1981-84) and Deputy Prime Minister (1977-81). He carried out valuable work on the Dead Sea Scrolls, excavated Hazor (1955-58) and Masada (1963-65), and wrote several books.

Yagoda, Genrikh Grigorievich (1891-1938). Russian (Jewish) Communist official. He used the OGPU (United State Political Directorate) to raise forced labour for *Stalin's first Five Year Plan and became head of the NKVD (Peoples' Commissariat for Internal Affairs) 1934-36. He was shot as a 'Rightist' in the 'Great Purge'.

Yakovlev, Aleksandr Nikolayevich (1923-2005). Russian politician. He was influenced by the ideas of Aleksandr *Herzen (whose family name was also Yakovlev, but no relation). Inside the CPSU he worked in the science, culture, propaganda and journalism departments, was Ambassador to Canada 1973-83, a member of the Central Committee 1986-90 and the Politburo 1987-90. A close advisor of *Gorbachev, he concluded that the party had no future and transferred his increasingly important support to *Yeltsin.

Yale, Elihu (1649-1721). British merchant, born in Boston, Massachusetts. He was educated in England, joined the East India Company and by 1687 was Governor of Madras. When the collegiate school of Saybrook, Connecticut, was moved to New Haven it was named after Yale (1718) in gratitude for a generous benefaction and, in 1887, renamed Yale University. It is regarded as the third oldest university in the US.

Yale, Linus (1821-1868). American inventor and industrial manufacturer. He invented various types of locks including those named after him.

Yalow, Rosalyn Sussman (1921-2011). American medical physicist. Educated at the University of Illinois, she worked on radioisotopes and radioimmunoassay methods in the Bronx and shared the 1977 Nobel Prize for Medicine for discoveries concerning peptide hormones.
Yamagata Aritomo, Prince (1838-1922). Japanese field marshal. Born to a samurai family, he became one of the influential counsellors (genrō) of the Meiji emperor ( ${ }^{*}$ Mutsuhito). As Minister of War 1873, he modernised the organisation and equipment of Japanese forces, based on the Prussian model. $\mathrm{He}$ defeated the Satsuma Rebellion in 1877 and was Chief of the General Staff 1878-82, 1884-85, 190406. Prime Minister 1889-91, 1898-1900, his power base was the army. He resented parliament, detested political parties and trade unions. He was a rival of *Itō Hirobumi and the architect of military control of civilian government. President of the Privy Council $1893,1905-09$, 1909-22, he was awarded the OM in 1906 and a GCMG in 1918. He was also an expert garden designer.

Hackett, R. F., Yamagata Aritomo in the Rise of Modern Japan, 1838-1922. 1971.

Yamamoto Isoroku (1884-1943). Japanese admiral. Trained in naval aviation, he studied at Harvard, was a naval attaché in Washington and rose to be Commander-in-Chief of the Japanese combined fleet 1939-43. Although pessimistic about the outcome of war, he planned the Pearl Harbor strategy (1941) to strike a knockout blow against US naval forces. He directed the Battle of Midway (1942) and died when his plane was shot down in the South Pacific.

Yamashita Tomoyuki (1885-1946). Japanese general. He led the conquest of Singapore in 1942 and conducted the Philippines campaign. His success was ended by a counter-attack of US forces under General Douglas *MacArthur, by whom he was captured and hanged (for authorising atrocities) in Manila. His execution is now regarded as grossly excessive and vindictive.

\section{Yang Jien see Sui Wendi}

Yang Shangkun (1907-1998). Chinese politician and soldier. A member of the CPC from 1926, trained in Moscow and a veteran of the Long March 1934-35, he rose through the party apparatus but fell out with *Mao and was imprisoned 1966-79. He then rose with *Deng, although his approach to market reform was more cautious, became a Politburo member (1982) and President of the Peoples' Republic 198893. His brother Yang Baibing (1920-1913) was a general in the People's Liberation Army and another conservative who suppressed the Tiananmen Square demonstrations (1989).

Ye Jianyiang (1897-1989). Chinese marshal. He joined the Communist Party in Germany in 1924, was close to ${ }^{*}$ Zhou Enlai and ${ }^{*}$ Deng, controlled the PLA and arranged the coup of October 1976 which overthrew the 'Gang of Four' and put Deng in power. 
Yeats, Jack Butler (1871-1957). Irish painter, born in London. Brother of W. B. *Yeats, he became a book illustrator and later a playwright who devoted himself to oils after 1915. He was regarded as the greatest Irish painter of his time.

Yeats, William Butler (1865-1939). Irish poet and dramatist, born in Dublin. Son of a barrister, John Butler Yeats, he was born into a Protestant family and, like his father and brother Jack Butler *Yeats, studied art. However, by 1889 he had published his first book of poems, Crossways, and soon became one of the leaders of the Irish literary movement. He was closely associated with Lionel Johnson, Katherine Tynan, and G. W. *Russell and took part with Lady ${ }^{*}$ Gregory in the various dramatic ventures that led to the opening of the Abbey Theatre, Dublin (1904). His lover Maude Gonne (Sean *MacBride) created some important roles. His early plays, The Countess Cathleen (1892, staged 1899) and Cathleen ni Houlihan (1902) contributed. Other plays included The Land of Heart's Desire (1894) and Deirdre (1907). Meanwhile volumes of his poetry were appearing in steady sequence. His early work was much concerned with Irish myth and folk lore, there were delicate romantic lyrics e.g. Down by the Salley Gardens (1889) and The Lake Isle of Innisfree (1892). Prose works, e.g. The Celtic Twilight (1893), evoked similar themes. In 1893 Yeats published an edition of *Blake, and the influence of mysticism, both the occult mysticism of the east and that of *Maeterlinck and the French symbolists, becomes apparent. The publication of a second collection of poems (1910) marked the beginning of Yeats' middle period, the twilight mists begin to disperse, imagination is tempered by reality, heroes of that violent phase in Irish history join those of myth. In 1917 he married Georgie Hyde-Lees (1892-1968) who was deeply involved in spiritualism and $A$ Vision (1925) provides insight into his sources of poetic inspiration. Appointed as a senator of the Irish Free State 1922-28, he supported ${ }^{*}$ Cosgrave's savage repression of Republican forces, indicated sympathy for ${ }^{*}$ Mussolini and Fascism and authoritarian rule and emerged as a public character. In 1923 he won the Nobel Prize for Literature. In his later works, e.g. The Tower (1928), The Winding Stair (1933) and the last collections, there is greater simplicity but at the same time greater violence, of ecstasy, but also of bitterness at the inevitable consequences of old age. He edited The Oxford Book of Modern Verse (1936), died in Menton, in the south of France, and was reburied in Drumcliff, Co. Sligo in 1948. Despite his great output of plays, essays, critical, philosophical and esoteric works, he is remembered now only as a poet, especially for his disturbing imagery e.g. in Second Coming (1919), Sailing to Byzantium (1926), Byzantium (1930).

Ellmann, R., Yeats: The Man and the Masks (1949, revised 1979); Donoghue, D., Yeats. 1971; Foster, R. F., W.B. Yeats: A Life. Vol. 1. 1997, Vol 2. 2005.
Yellen, Janet Louise (1946- ). American economist, born in Brooklyn. Of Polish-Jewish descent, educated at Brown and Yale, she taught in London and Berkeley, was Deputy Chair 2010-14, then Chair 2014-18, of the Federal Reserve. She became *Biden's Secretary of the US Treasury 2021- . Her husband George Arthur Akerlof (1940- ), a Keynesian, shared the 2001 Nobel Prize for Economics for his work on information asymmetry.

Yeltsin, Boris Nikolayevich (1931-2007). Russian politician, born in Sverdlovsk (now Yekaterinburg). He graduated as a construction engineer in 1955, joined the Communist Party in 1961 and was a party official in the Sverdlovsk oblast from 1968, rising to First Secretary 1976-85. He was brought to Moscow in 1985 by Mikhail *Gorbachev and made first secretary of the Moscow city party committee until his dismissal and humiliation in 1987 after he had criticised the slow pace of reform. He used his exile from administrative responsibility to organise a major public campaign against entrenched privilege, bureaucracy and economic inefficiency. In March 1989 he was elected to the Congress of Peoples' Deputies for the Moscow region with an unprecedented 89 per cent of the vote. Elected in May 1990 as Chairman of the Supreme Soviet of the Russian Soviet Federal Socialist Republic (RSFSR), this made him an alternative focus of power to ${ }^{*}$ Gorbachev within the Soviet Union. Lacking the encumbrance of the CPSU, Yeltsin became immensely popular, while Gorbachev, shackled by the party and his enemies within it, retained responsibility for economic reform. He was elected as President of the Russian Federation in June 1991 with 57 per cent of the popular vote. In August 1991, when hardliners staged a coup against Gorbachev, Yeltsin, supported by elements of the armed forces and KGB, led popular resistance in Moscow. The coup collapsed and Gorbachev returned to Moscow, increasingly dependent on Yeltsin. By December 1991, the USSR was dissolved and replaced by a loose federation, the Commonwealth of Independent States (CIS). The Russian Federation took control of the Kremlin and replaced the USSR in the UN Security Council. Yeltsin also became commander of the armed forces. He faced intractable problems in attempting to transform a command economy to a market economy and the Russian parliament was obstructive. Nationalism also became an increasingly powerful and disruptive force. In March 1993 he declared a state of emergency and ruled by decree, with strong support from President ${ }^{*}$ Clinton. In October his troops crushed a coup organised by the parliament. In December 1993 Russian voters approved his new presidential constitution but elected a Duma largely hostile to reform. Russia's invasion and destruction of Chechnya (November 1994-February 1995) was politically damaging, so were his eccentric personal behaviour and his health problems. He defeated the Communist candidate, Gennady *Zyuganov, by 
54 per cent to 40 per cent in the second round of the July 1996 presidential election. After repeated illnesses, he resigned suddenly on 31 December 1999.

Yersin, Alexandre Émile John (1863-1943). SwissFrench bacteriologist. He studied under *Pasteur and worked at the Pasteur Institute in Paris, where, with Pierre Roux, he did research on diphtheria serum. In Hong Kong he isolated (1894) bacillus for bubonic plague (Yersiania pestis) and prepared an effective serum for it (1895). He lived in Indochina from 1895 and set up branches of the Pasteur Institute in China (*Kitasato).

Deville, P., Plague and cholera. 2012.

Yesinin, Sergei Aleksandrovich (1895-1925). Russian poet. Of peasant origin, he celebrated 'wooden Russia' and attacked the impact of the iron age and urban industrialisation. He briefly welcomed the 1917 Revolution, and soon became a leader of the Russian Imagist poets. He become a heavy and destructive drinker, married the American dancer Isadora ${ }^{*}$ Duncan, visited the US, suffered a nervous breakdown and hanged himself. His poetry was popular, held in low regard by Soviet officials, but republished in the 1960s.

Yevtushenko, Yevgeny Aleksandrovich (19332017). Russian poet. His poems first appeared in the USSR in 1952. He quickly became the most prominent of the young writers who rejected 'socialist realism' in literature. He incurred much criticism for his poem Babiy Yar, which pilloried Soviet hypocrisy and anti-Semitism. *Shostakovich used Babiy Yar and four other Yevtushenko poems (including A Career, about Galileo) in his Symphony No. 13 (1962). He continued courageously to maintain his critical attitude in his autobiography, which was published in Paris (1963). His reputation fell sharply in the 1980s.

Yezhov, Nikolai Ivanov (1895-1939?). Russian Communist official. He directed the NKVD (Peoples' Commissariat for Internal Affairs) 1936-38, when thousands of 'Old Bolsheviks' disappeared in the 'Great Purge', disappearing himself in 1939. In 1956 *Khrushchev denounced him as a 'degenerate'.

Yirawala (c. 1897-1976). Australian Indigenous painter, born in the Northern Territory. Influenced by rock art around Oenpelli, he creatively reinterpreted ceremonial themes and became a Gunwinggu elder and 'clever man'. Praised by ${ }^{*}$ Picasso, and dubbed 'the Picasso of Arnhem Land', he became a teacher and retired to Croker Island (Minjilang) in 1959.

Holmes, S. L., Yirawala: Painter of the dreaming. 1994.

Yongle ('perpetual happiness': personal name Zhu Di) (1360-1424). Chinese emperor 1402-24, third of the *Ming dynasty. Fourth son of the ${ }^{*}$ Hongwu emperor, he displaced his nephew Zhu Yunwen after a brief civil war, transferred the capital from Nanjing to Beijing, drained, reopened and enlarged the Grand Canal, began construction (1406) of 'The Forbidden City' and sent his favourite *Zheng $\mathrm{He}$ on extensive voyages of exploration with large fleets. He designed the Porcelain Tower of Nanjing and commissioned the huge Yongle Encyclopedia. He created a spy agency, killed off many relatives and servants and was succeeded by his son Zhu Gaozhi, known as the *Hongxi emperor.

York, Henry Benedict Maria Clement Stuart, Cardinal Duke of (1725-1807). British cardinal and pretender, born in Rome. Younger son of James Edward *Stuart, he was created Duke of York in the Jacobite peerage by his father in 1725 , made a cardinal in 1747 by Pope *Benedict XIV and served as Bishop of Frascati 1761-1803. The last male in direct descent from the Stewart/Stuart kings, on the death of his elder brother Charles Edward *Stuart in 1788, he proclaimed himself as Henry IX. Impoverished by loss of property after *Napoléon's invasion of Italy, he was granted a pension of $£ 4,000$ by ${ }^{*}$ George III in 1800. He died in Frascati and was buried with his father and brother in St Peter's, Rome.

York, House of. English dynasty, a branch of the *Plantagenets descended, through Richard, Duke of *York, from Lionel, Duke of Clarence, second son of *Edward III. Yorkist kings were *Edward IV, *Edward V and *Richard III. Later the Duke of York became a common title in the British royal family, e.g. the kings ${ }^{*}$ James II, ${ }^{*}$ George $V$ and ${ }^{*}$ George VI. *George III's second son, Frederick Augustus, Duke of York and Albany (1763-1827), had a career in the army, fought in Flanders during the French Wars, and was appointed Commander-in-Chief 1798-1809; 1811-27, the two years break due to investigation of charges that his mistress had sold commissions. However, he is credited with effecting some significant reforms.

Green, V. H. H., The Later Plantagenets. 1955.

York, 3rd Duke of, Richard Plantagenet (14111460). English nobleman. Both parents were descended from *Edward III: his mother, Anne Mortimer, through Lionel, Duke of Clarence; his father Richard of Conisburgh, Earl of Cambridge (executed in 1415), through Edmund of Langley, Duke of York. He married Cecily Neville (14151495) in 1429; five of their 12 children died in infancy. He commanded English forces in France 1436-37; 1440-47 and was Viceroy in Ireland 1447-60. He became leader of the Yorkist faction against the Lancastrians, ${ }^{*}$ Henry VI becoming an increasingly hapless pawn. Yorkists were associated with a white rose, Lancastrians with a red. The "Wars of the Roses' (not a contemporary term, coined by Walter *Scott) began in 1455 when Richard's forces defeated the Duke of *Somerset, the king's protector, at a skirmish at St Albans. In October 1460, a truce 
was negotiated and Richard was recognised as Henry's heir, but - greedy and impatient-he refused to wait. Fighting resumed and in December Richard was killed at the Battle of Wakefield, Yorkshire. Two of his sons became *Edward IV and *Richard III.

Johnson, P. A., Duke Richard of York. 1988.

\section{York, Prince Andrew, Duke of see Andrew, Duke of York.}

Yoshida Shigeru (1878-1967). Japanese Liberal politician. A diplomat, he was Ambassador to Great Britain 1936-39 opposed extremist policies during World War II and was imprisoned (1945) until the Americans released him. He was Foreign Minister (1945-46) and twice Premier 1946-47, 1948-54, largely setting the pattern of post-war Japanese politics.

Yoshihito (regnal name Taisho, i.e. 'great righteousness') (1879-1926). Emperor of Japan 1912-26. Son of *Mutsuhito, father of *Hirohito, he was insane from 1921.

Young, Arthur (1741-1820). English agriculturist and writer, born in London. His father, a clergyman, owned an estate at Bradfield, Suffolk, which his son began to farm in 1763. As a farmer he was a failure, but he gradually gained success as an agricultural writer, basing his work on information gathered during a series of tours (from 1767) through the agricultural districts of England. In 1776 he went to Ireland where as estate factor to Lord Kingsborough he renewed his practical experience. Meanwhile he had begun to publish his observations, which, e.g. in Political Arithmetic (1774), extended to social and political comment. Elected FRS in 1774, he edited the periodical Annals of Agriculture (1784-1809), contributors including *George III (writing as 'Ralph Robinson'). He visited France in 1787 and 1789, observing the outbreak of the Revolution, which he deplored; his Travels in France appeared in 1792, expanded in 1794. Secretary to the newly formed Board of Agriculture 1793-1820, after 1804 his work deteriorated due to failing sight (total blindness by 1811), melancholia and religious obsession. Larger farms, enclosures of unfarmed land, the use of fertilisers, improvement of stock and secure tenure were among the things he advocated, supporting his arguments with statistics and surveys. The 'agricultural revolution' was in fact largely of his making.

Young, Brigham (1801-1877). American Mormon leader, born in Whitingham, Vermont. A carpenter, painter and glazier by trade, his life was completely changed when, in 1830, he saw the Book of Mormon and was later converted by a brother of the prophet Joseph ${ }^{*}$ Smith. In 1835 he became one of the 'twelve apostles' of the Mormon Church and after Smith's murder (1844) - the result of his claim of divine sanction for polygamy-he led his people to
Utah where he founded Salt Lake City. As President of the Church he was made territorial Governor (1849). Though deposed by the US government for adhering to polygamy he retained his hold over his co-religionists who under his guidance became a self-contained and prosperous community. He was survived by 27 wives and 56 children, to whom he bequeathed \$US2.5 million. The Mormons (Church of Latter Day Saints) renounced polygamy in 1890 .

Young, Thomas (1773-1829). English physicist and Egyptologist, born in Somerset. Trained in medicine in Edinburgh and Göttingen but interested mainly in physics, he was elected FRS in 1794 and became professor of physics at the Royal Institution 1801-03 and secretary of the Royal Society 1803-29. From 1801 he did much to establish the wave theory of light, particularly in attributing phenomena such as 'Newton's rings' to 'interference' between trains of light waves. He also put forward a theory of colour vision which was later improved by ${ }^{*}$ Helmholtz and explained the cause of astigmatism. He first used the term 'modulus of elasticity' in its modern sense, and introduced what is now known as 'Young's modulus' and was also the first to use the word 'energy' in the context of physics. An outstanding linguist, he attempted to decipher the inscriptions on the Rosetta Stone (*Champollion), and, following on the work of William *Jones, coined the term Indo-European (1813).

Robinson, A., The Last Man Who Knew Everything. 2007; Wood, A., Thomas Young: Natural Philosopher. 2011.

Younghusband, Sir Francis Edward (1863-1942). British soldier and explorer. As the culmination of a long period of difficult relationships and unsatisfactory negotiations, Colonel Younghusband, accompanied by an armed escort, advanced into Tibet (1904) and, after being attacked, reached Lhasa, the capital. An agreement resulted which marked the opening of Tibet to British trade. He explored and wrote about many parts of Central Asia and vainly tried to reach the summit of Everest.

Fleming, P., Bayonets to Lhasa: The First Full Account of the British Invasion of Tibet in 1904. 1961, repr. 1984; French, P., Younghusband: the Last Great Imperial Adventurer. 1994.

Yourcenar (de Crayencourt), Marguerite (19031987). French author, born in Brussels. She lived in the US from 1937 and became a citizen in 1947. Her Memoirs of Hadrian (1951), a critical and popular success, was followed by a novel on *Zeno, The Abyss (1968). She published a collection of Greek poetry La Couronne et la Lyre (1979) and in 1980 became the first woman elected to the Académie française.

Yousafzay, Malala see Malala Yousafzay 
Ypres, 1st Earl of see French, John (Denton Pinkstone)

Yrigoyen, Hipóleto (in full, Juan Hipóleto del Sagrado Corazón de Jesús Yrigoyen Alem) (18521933). Argentinian politician, born in Buenos Aires. A teacher by profession, he became (1896) leader of the Radical Civic Union party and in 1905 unsuccessfully attempted a revolution. After a change in the corrupt electoral system, providing for a secret ballot and universal male suffrage, he was elected President 1916-22, and, although splitting his party by his autocratic rule, he carried through considerable social reform. He maintained the neutrality of his country in World War I. In 1928, he was again elected President, but the ineffectiveness of his administration provoked a military coup and his deposition (1930).

Ysaÿe, Eugène (1858-1931). Belgian violinist, conductor, composer and teacher. He toured extensively, founded a famous string quartet, and wrote concertos and sonatas for violin.

Yuan. Chinese dynasty, also called Mongol, founded by ${ }^{*}$ Kublai Khan, which had its capital in Beijing (then called Dadu) and ruled 1279-1368.

Yuán Shikai (1859-1916). Chinese general, president and emperor, born in Henan. As a soldier, he gained the highest honours under the dowager empress ${ }^{*} \mathrm{Cixi}$ in her last years, proposed some modest reforms similar to Japan and Germany and was Secretary for Foreign Affairs 1907-08, falling from favour after her death. On the outbreak of revolution he was recalled to office, serving as Prime Minister 1911-12. He gained some success over the revolutionaries, but, backed by the Beiyang Army in the north, the best trained troops in the country, was soon playing a double game. He persuaded the imperialists to accept the necessity for the abdication of the young Xuantong emperor (*Puyi) and forced *Sun Yatsen, elected as provisional President, to resign in his favour. He was President of China 1912-15; 1916. In 1914 he issued a silver dollar coin ('yuan' = dollar in Chinese) with his image on it, which continued to be minted long after his death. He suppressed the National Assembly and political parties, but soon over-reached (possibly at the urging of his son) by restoring the monarchy and proclaiming himself as the Hongxian ('constitutional abundance') emperor (December 1915-March 1916). Confronted with the threat of civil war, defection of his own commanders and refusal of recognition by foreign powers, he was forced to abdicate. This 'loss of faith' probably contributed to his death from uraemia 10 weeks later, in Beijing.

Ch'en, J., Yüan Shih-Kai: Brutus Assumes the Purple. 2nd ed. 1972.
Yudhoyono, Susilo Bambang (known as SBY) (1949- ). Indonesian soldier and politician, born in Java. An army general, he was a minister under Abdurrahman *Wahid and defeated *Megawati Soekarnoputri to become President of Indonesia 2004-14.

Yukawa Hideki (1907-1981). Japanese physicist. While a lecturer at Osaka University, he evolved a theory of nuclear forces and predicted (1935) the existence of a particle (the meson) having a mass 200-300 times that of the electron. Mesons were observed in cosmic rays in 1936, but in 1947 these were found to be of a different type from those predicted by Yukawa, which were then observed. He became the first Japanese Nobel Prize winner when he was awarded the Prize for Physics (1949). In 1953 he was made director of the new Research Institute for Fundamental Physics in Kyoto, retiring in 1970.

Yunus Emre (1238?-1321?). Turkish poet. A member of a Sunni dervish sect, he was a travelling mystic and humanist, generally regarded as Turkey's greatest poet, having some parallels with ${ }^{*}$ Omar Khayyam.

Halman, T. S. (ed.), Yunus Emre and His Mystical Poetry. 1981.

Yunus, Muhammad (1940- ). Bangladeshi social activist, economist and banker. In 1983 he founded the Grameen Bank, dedicated to providing microcredit, without collateral, to impoverished people, especially women, to enable them to become economically independent. The 2006 Nobel Prize for Peace was jointly awarded to Yunus and the Grameen Bank 'for their efforts through microcredit to create economic and social development from below'. 


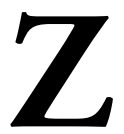

Zabarella, Jacopo (1533-1589). Italian scientist and philosopher. One of the major figures in the revival of Aristotelian studies, he helped purify, by humanist methods, Aristotelian texts of medieval glosses and inaccuracies. He recognised the fruitfulness of Aristotelian theological and organic approaches to the study of the living body and the practice of medicine. Zabarella wrote extensively on the methodology of science. He tried to show that logic was not so much a system complete in itself but rather a tool for investigation. In this respect he was probably instrumental in reorienting Aristotelianism away from rationalist metaphysics and in the direction of a more experimental approach.

\section{Zafar see Bahadur Shah II, Zafar}

Zaghloul, Saad (1859-1927). Egyptian politician. Born into a peasant family, he was educated at the al-Azhar University in Cairo, and became a lawyer, journalist, judge and Minister of Education 1906-10. He encouraged introduction of Western, secular civilisation in Egypt but sought to end both the nominal rule by the Ottomans and the British protectorate. In 1918, he founded the Wafd party, clashed with *Wingate and was deported to Malta (1919). Negotiations with *Allenby and *Milner led (after a period of exile in the Seychelles) to a degree of independence in 1922 and Zaghloul was Prime Minister briefly in 1924 .

Zaharoff, Sir Basil (1850-1936). Greek-French financier, born in Mugla, Turkey. Partly educated in England, he became an agent for the armaments manufacturers, T. V. Nordenfelt, Maxim-Nordenfelt and Vickers and acquired the sobriquet 'the merchant of death'. He was active in oil, shipbuilding and banking. He became a French citizen in 1913, worked with allied intelligence during World War I and was awarded a GBE (1918) and GCB (1919). He promoted the Greek-Turkish War (1919-22), owned the Monte Carlo casino, married a Spanish duchess and endowed university chairs in England, France and Russia.

Allfrey, A., Sir Basil Zaharoff. 1986.

Zahir Shah, Muhammad (1914-2007). King of Afghanistan 1933-73. He succeeded to the throne after the assassination of his father ${ }^{*}$ Nadir Shah and continued a policy of orderly progress. He showed considerable astuteness in using the rivalry between the US and Russia after World War II to secure aid from both for his country. He was deposed in a coup organised by his cousin.
Zamenhof, L(ejzer) L(udwik) (1859-1917). PolishJewish philologist, born in Bialystok. He practised as an oculist in Warsaw and invented Esperanto ['one who hopes'], the best known of the artificial international languages, publishing the textbook Lingvo Internacia (1887). He translated the Old Testament, Hamlet, and works by ${ }^{*}$ Molière, ${ }^{*}$ Goethe and Hans *Andersen. The first International Esperanto Congress was held in 1905.

\section{Zamora, Niceto Alcalá see Alcalá Zamora, Niceto}

Zamyatin, Yevgenyi Ivanovich (1884-1937). Russian novelist. A naval engineer, he served in England 1914-17, became an early left-wing critic of *Lenin's regime and had his works suppressed. He lived in Paris from 1931. An important antiUtopian, his novel We (1924) was a forerunner of *Huxley's Brave New World and *Orwell's Nineteen Eighty-four.

Zangwill, Israel (1864-1926). Anglo-Jewish writer. The best known of his novels and plays of Jewish life was Children of the Ghetto (1892, dramatised 1899). A philanthropist and keen Zionist, he organised the Jewish Territorial Organisation, which was a failure.

Zanuck, Darryl Francis (1902-1979). American film producer. He began his film career in the 1920s, writing scenarios first for the Fox Film Company and later for Warner Brothers, becoming an associate producer there. In 1933, he and Joseph M. Schenk founded 20th Century, and in 1935 they combined with the Fox Film Company to become 20th Century Fox. As head of production Zanuck was noted for his direct involvement with filming, picking good directors and letting them think for themselves. $\mathrm{He}$ moved to his own independent company in 1957, and retired in 1971. The last of the tycoons of Hollywood, his main concern was to tell a strong story and make money from it. His varied productions include The Jazz Singer, 42nd Street, Little Caesar, The Grapes of Wrath, 12 o'clock High, Cleopatra, and The Sound of Music.

Zapata, Emiliano (1879-1919). Mexican revolutionary. He led the first major agrarian revolution of the 20th century against ${ }^{*}$ Carranza, became a guerrilla and died in an ambush. He has been a folk legend ever since.

Zappa, Frank (1940-1993). American rock musician. Leader of The Mothers of Invention, flourishing mainly in the 1960s and early 1970s, his major records include Lumpy Gravy, We're Only In It for the Money, Grand Wazoo and Bongo Fury.

Zatopek, Emil (1922-2000). Czech athlete. Noted as a long-distance runner, between the Olympic Games of 1948 and those of 1952 he broke 13 world records in the 5,000 metres, 10,000 metres and Marathon. He was considered the best of his time. 
Zedillo Ponce de Leon, Ernesto (1951- ). Mexican economist and politician. He studied in the US and UK and became a banker, serving as a member of UNESCO's Executive Board 1989-93, Secretary of Public Instruction 1992-93 and President of Mexico 1994-2000. In 2000 the Institutional Revolutionary Party (PRI) was defeated after having held power since 1929.

Zeeman, Pieter (1865-1943). Dutch physicist. Professor of physics at Amsterdam (1900-35), he discovered (1896) the 'Zeeman effect', the splitting of spectral lines when a beam of light passes through a magnetic field. The effect was explained by ${ }^{*}$ Lorentz and led to the development of magneto-optics. Zeeman also demonstrated the existence of magnetic fields around the sun and the stars. He shared the Nobel Prize for Physics (1902) with Lorentz.

Zeffirelli, Franco (1923-2019). Italian theatre and film director. He began his career in the theatre, as an actor and designer, in 1945 . He produced his first opera (La Cenerentola) at La Scala, Milan, in 1953 and later worked at Covent Garden and the New York Metropolitan. His notable stage productions included Hamlet and Romeo and Juliet, both marked by keen perception of the author's intentions and vivid clarity in interpreting them. His films include Romeo and Juliet (1967), The Taming of the Shrew (1968), Othello (1986) and Hamlet (1990). He served as a senator 1994-2001 and was awarded an Hon. KBE in 2004.

Zeffirelli, F., Zeffirelli: An Autobiography. 1986.

Zeiss, Carl (1816-1888). German optical instrument manufacturer. He founded the famous firm at Jena, renowned for the precision with which lenses for telescopes, microscopes, field-glasses, cameras etc. were made. He was a pioneer of co-partnership.

Zelenskyy, Volodymyr Oleksandrovych (1978- ). Ukrainian comedian, screenwriter and politician. Born to a Russian-speaking Jewish family, he had a law degree, worked as an actor, screenwriter and producer and played the role of President of the Ukraine in a popular television series Servant of the People (2015). He created a party of that name and, campaigning on social media, heavily defeated the incumbent Petro Poroshenko, to become President 2019- . Pressure applied on Zelensky by Donald *Trump to provide military equipment in return for damaging information about Joe *Biden's family was the triggering factor in Trump's impeachment proceedings.

Zelenskyy sought Ukrainian membership of the EU and NATO. He emerged as charismatic and inspirational in leading resistance to the Russian invasion of Ukraine in February 2022. From the West he gained moral support, some weaponry but no direct military intervention. However, ${ }^{*}$ Putin was exposed for his cruelty and appalling judgment.
Zeno of Citium (335-263 BCE). Greek philosopher, born in Cyprus. He founded the Stoic system of philosophy, called after the Stoa Poikile ('painted porch') in Athens where he taught a modification of the Socratic ideals of virtue, endurance and independence.

Zeno of Elea (fl. c.450 BCE). Greek philosopher, born in Elea (now Velia), Southern Italy. He came to Athens with *Parmenides, of whom he was a disciple. According to ${ }^{*}$ Aristotle he introduced the form of argument known as 'reduction to absurdity'. A famous example of his method is his 'proof' that a hare can never overtake a tortoise, because by the time that the hare has covered the distance between them the tortoise will have made some small advance. When this distance, too, has been covered by the hare, another advance, however small, will have been made by the tortoise and so on indefinitely, there will always be a fractional gap between them.

Zenobia (fl. c.260-270). Queen of Palmyra in Syria. After the death of her husband Odenathus, Rome's ally against Persia, she ruled as regent for her son, established a brilliant court at Palmyra and increased her realm until she exercised power from the Egyptian frontier to the Black Sea. In 272 she revolted from Rome, her armies were defeated and her capital destroyed. Zenobia, in chains of gold, was led in the emperor *Aurelian's triumphal procession through Rome. She died in a villa at Tivoli.

Zeppelin, Ferdinand, Count [Graf] von (18381917). German airship designer. As an officer in the Württemberg army, he became an observer in the American Civil War and retired in 1891 as a lieutenant-general. He soon fulfilled a long-held ambition to construct a rigid and dirigible airship. This he first accomplished in 1900. In 1912 he made a 12-hour flight which stirred such enthusiasm in Germany that 6,000,000 marks were raised for him to start a Zeppelin Institute for their manufacture. In World War I Zeppelins made several raids on England but their hydrogen-filled containers made them very vulnerable and they played only a restricted role. After the war Zeppelins were used commercially on flights between Germany and North and South America, but the superiority of aeroplanes and a series of disastrous accidents, notably the explosion of the 'Hindenburg' in Lakehurst, New Jersey, in May 1937, led to their abandonment.

Zernike, Fritz (1888-1966). Dutch physicist. Professor at Groningen University 1920-58, he won the Nobel Prize for Physics (1953) for his work from 1932 on the phase-contrast principle in microscopy, which made it possible to observe transparent, colourless micro-organisms in the living state. 
Zetterling, Mai (1925-1994). Swedish actor and film director. Her most notable roles included Hedvig in The Wild Duck and Nora in The Doll's House (film). She directed Night Games (1966) and Vincent the Dutchman (1973).

Zhang Yimou (1951- ). Chinese film actor and director, born in Xi'an. His highly acclaimed films include Red Sorghum (1987), Raise the Red Lantern (1991), The Story of Qiu Ju (1993) and To Live (1994), all featuring the actor Gong $\mathbf{L i}$, and Hero (2004).

Zhang Zuolin (Chang Tso-lin in Wade-Giles) (1873-1928). Chinese war lord. In the lawless period following the downfall of the Qing (Manchu) dynasty, Zhang with some aid from Japan, managed to carve out for himself in Manchuria almost a separate state and ruled in complete defiance of the central government. His power was, however, already waning when, while retreating before a government force, he was killed by a bomb. His son, Zhang Xueliang (1901-2001), known as 'the Young Marshal', succeeded his father as ruler of Manchuria until forced out by the Japanese (1931). In 1936 he kidnapped ${ }^{*}$ Chiang Kaishek in the Xi'an incident and was imprisoned by the Guomintang in Taiwan 1949-61.

Zhao Ziyang (1918-2005). Chinese Communist politician. After serving as a party official in Guangdong province (1965-67), he was purged in the Cultural Revolution, rehabilitated and became First Secretary in Sichuan province 1975-80. A protégé of *Deng Xiaoping, he was Premier of China 1980-87 and General Secretary of the CCP 198789. He was dismissed from all posts because of his sympathy for the Tiananmen Square demonstrators and remained under house arrest until his death.

Zhdanov, Andrei Aleksandrovich (1896-1948). Russian politician. Son of a teacher, he became Communist Party Chief of Leningrad, succeeding *Kirov (1934-44) and was a Politburo member 1939-48. He organised the defence of Leningrad during the war, then emerged as *Stalin's favourite, chief party ideologist and promoter of the 'Zhdanov line', which chastised composers and writers for deviating from party orthodoxy.

Zheng He (Cheng-ho in Wade-Giles, also Jen Ho, originally $\mathrm{Ma} \mathrm{He}$ or San Bao) (c.1371-1433). Chinese admiral and diplomat. Born to a Mongol family, he became a eunuch in the Ming court and led seven great voyages of exploration for the *Yongle emperor (1405-07, 1409, 1411, 1413-15, 1417, 1421-23, 1433), visiting India, Ceylon, Persia, Java, Arabia and East Africa. His largest excursion involved 300 ships and 27,000 men and it has been speculated that Chinese ships visited North and South America, Greenland, Australia and New Zealand.

Menzies, G., 1421: The Year China Discovered the World. 2002.
Zhirinovsky, Vladimir Volfovich (1946- ). Russian nationalist politician. He founded the Liberal Democrats, a nationalist and xenophobic party that urged a return to Russia's tsarist frontiers, opposed market reforms, resisted Western cultural influence and called for more military spending. He contested the presidential election in 1991, running third to Yeltsin. In December 1993 his party won 25 per cent of the popular vote in elections to the Duma.

Zhivkov, Todor Christov (1911-1998). Bulgarian Communist politician. A printer, he rose through the Communist Party apparatus and became First Secretary in 1954. Premier of Bulgaria 1962-71 and President 1971-89, he was a devoted follower of Moscow. His daughter Liudmilla Zhivkova (19421981), educated at Oxford, began to liberalise arts and media policy, then died suddenly of a cerebral haemorrhage. Convicted of embezzlement and abuse of power in 1992, he was kept under house arrest until 1997, then published self-serving Memoirs. He was the longest serving party leader in the Soviet bloc.

Zhou. Chinese dynasty, formerly called Chou (WadeGiles). The Western Zhou were dominant in the period c.1100-771 BCE, the Eastern Zhou 770-256 $\mathrm{BCE}$ (in the time of ${ }^{*}$ Confucius and ${ }^{*} \mathrm{Lao} \mathrm{Zi}$ ) and the Northern Zhou 557-81 CE.

Zhou Enlai (Chou En Lai in Wade-Giles) (18981976). Chinese Communist politician, born in Kiangsu Province. Son of a bankrupt mandarin, he studied in Tokyo 1917-19, then in Tianjin, was active in the Awakening Society and was jailed for six months. He was in Europe 1920-24, mostly in France, but also visited Britain and Germany, working as a correspondent and political organiser. $\mathrm{He}$ returned to China as CCP Secretary in Guangzhou (Canton), working closely with the Guomindang and their Russian military advisors, then taught at the Huangpu Military Academy and was a political commissar with *Chiang Kaishek's 1st Army (1926). In 1927 he broke with Chiang, led an abortive rising in Shanghai, escaped with a price on his head and became a member of the CCP Politburo 1927-76, a record term. He worked in Moscow in 1928, then shared party leadership with ${ }^{*} \mathrm{Li}$ Lisan until another unsuccessful rising at Nangchan (1930) led to direct Russian political intervention in the CCP. He retreated to Jiangxi (Kiangsi) in 1931 and was a rival of Mao's until the 'Long March' began. He then deferred to Mao (1935), accepted his 'peasant strategy' and was a leader in the March. His wife Deng Yingchao (1904-1992) was one of only 50 women who survived the entire Long March. When the Japanese war began, he was the CCP's liaison officer with Chiang's HQ at Chongqing (Chungking) (1937-45). After the revolution, he was first premier of the Peoples' Republic 1949-76 and Foreign Minister 1949-58. Fluent in English and French, he was the best known figure of the regime overseas. $\mathrm{He}$ favoured greater technological change and closer 
links with the US to counter-balance Soviet influence in Asia. His position was strengthened by the 1973 Party Congress, then weakened by his own illness. Under *Deng Xiaoping his widow was elected to the Politburo (1978) and became head of the Chinese Peoples' Political Consultative Committee 1983-88.

Wilson, D., Zhou Enlai. 1984.

Zhu De (Chu Teh in Wade-Giles) (1886-1976). Chinese marshal and politician, born in Sichuan province. Son of a rich peasant, he took part in the 1911 Revolution against the Qing (Manchu) dynasty. He joined the army, rising to the rank of brigadier in 1916. He became an opium addict but, after breaking himself of the habit, was sent to Germany to study engineering in 1921. He joined the Communist Party in Berlin in 1922 and was expelled from Germany in 1926. He led the Nanchang rising against ${ }^{*}$ Chiang Kaishek (1927) and in 1928 organised an army with *Mao Zedong. He became Commander-in-Chief of the 4th Red Army from 1931. With Mao he led the celebrated 'Long March' from Jiangxi to Yan'an (1934-36). He commanded the 8th Route Army against the Japanese until 1945, was Commander-inChief of the People's Liberation Army 1945-54 and, after Chiang's defeat, became Vice President of the People's Republic 1949-59. He served as acting head of state $1968-76$.

\section{Zhu Di see Yongle emperor}

Zhu Rongji (1928- ). Chinese Communist official. Trained as an engineer at Qinghua University, he joined the CCP in 1949 and worked through the Shanghai party machine. He was Mayor of Shanghai 1988-91, then appointed Deputy Prime Minister 1991-98, with special responsibility for promoting economic reforms, especially the 'socialist market economy'. He succeeded ${ }^{*} \mathrm{Li}$ Peng as Prime Minister 1998-2003.

Zhu Xi (Chu Hsi in Wade-Giles) (1130-1200). Chinese philosopher, teacher and writer, born in Fukien province. As a civil servant under the ${ }^{*}$ Song dynasty, finally working at the Imperial court, he wrote four commentaries on ${ }^{*}$ Confucius (The Four Books, 1189) which became the basis of neo-Confucianism and were extremely influential in China, Japan and Korea, incorporating elements of Taoism and Buddhism, with a strong moral emphasis. His ideas became institutionalised and used as the basis of examinations for the civil service from 1313 until the 20th century. By then his thoughtful teachings had become fossilised.

Fung Yu-Lan, A History of Chinese Philosophy. 2nd ed. Vol. 2. 1953; Wing-Tsit Chan, An Outline and Annotated Bibliography of Chinese Philosophy. Rev. ed. 1969.

\section{Zhu Yuanzhang see Hongwu emperor}

Zhukov, Georgi Konstantinovich (1896-1974). Russian marshal. Son of a peasant, he served uncommissioned in World War I, joined the Red Army (1919) and rose steadily in rank, and was briefly Chief of the General Staff 1941. When the Germans invaded Russia (1941) he commanded the central front and as Deputy Commissar for Defence 1942-44 (under *Stalin) directed the defence of Moscow and operations at Leningrad (now St Petersburg). Promoted Marshal of the Soviet Union (January 1943), his encirclement of Stalingrad (now Volgograd) resulted in the surrender of Field Marshal Friedrich Paulus (31 January 1943), the first major German defeat. He commanded the successful Ukraine offensive. The Battle of Kursk (July-August 1943) was the war's greatest armoured engagement, both sides having more than a million men and 3,000 tanks, marking defeat for the German summer offensive. Zhukov led Soviet forces into Poland and Romania (1944), captured Berlin in the last days of the war, received the German surrender (1945) and commanded the Russian occupation forces (1945-46). Stalin, fearing his popularity, kept him away from Moscow but in 1953 the new Soviet leaders made him Deputy Minister of Defence under *Bulganin. As Defence Minister (1955-57), he backed *Khrushchev in June 1955 after a Presidium majority voted to oust him, helped organise a reversal by the Central Committee and was rewarded first with promotion to the Presidium, then (October) with dismissal since the counter-coup proved his strength as a potential rival. His Memories and Reflections appeared in 1969.

Zia ul-Haq (1924-1988). Pakistani general. He rose to the rank of Lieutenant General and was appointed Army Chief of Staff by Z. A. *Bhutto in 1976 . In July 1977, Zia took power as President and martial law administrator, and Bhutto was executed on a murder charge in 1979 . He was killed in a plane crash.

Ziegfeld, Florenz (1869-1932). American impresario born in Chicago. He was renowned as a showman with the lavish production (1907) of the Ziegfield Follies, from whose chorus line many dancers, later well known, started their stage or matrimonial careers. Showboat (1927) was among his many successes. He worked with Jerome *Kern, Irving *Berlin and W. C. *Fields.

Ziegler, Karl Waldemar (1898-1973). German chemist. He was best known for his observation of the Ziegler Catalysts (e.g. titanium trichloride) which produce stereospecific polymers leading to greatly improved industrial plastics. He shared the 1963 Nobel Prize for Chemistry.

Zieten, Hans Joachim von (1699-1786). Prussian soldier. A brilliant trainer and leader of cavalry, his exploits in the War of the Austrian Succession and the Seven Years' War made him a national hero. In the latter he was made a cavalry general on the battlefield 
of Liegnitz (1760) and by his dash won acclaim at Prague, Leuthen and Torgau. In his old age he was in high favour with *Friedrich II ('the Great').

Zinoviev, Grigori Evseyevich (né Hirsch Apfelbaum, later Ovsei-Gershon Aronovich Radomylsky) (18831936). Russian revolutionary politician. He left Russia (1908) and lived abroad with *Lenin, as a Bolshevik propagandist. He was a foundation member of the CPSU Politburo 1917-26, President of the Third International 1919-26 and Party Chief in Leningrad 1921-26. He had become notorious in British politics when the publication (1924) of a letter, allegedly by him, urging the supporters in Britain to prepare for violent insurrection, contributed materially to Ramsay *MacDonald's electoral defeat. After Lenin died (1924), party leadership was held by a triumvirate of * Stalin, ${ }^{*}$ Kamenev and *Zinoviev. As Stalin moved towards one-man rule, Zinoviev allied himself with *Trotsky and was expelled from the party in 1926 . Re-admission followed recantation but he was never again secure and was executed with Kamenev after condemnation in the 1936 treason trials. Kirovograd was named Zinoviesk after him between 1924 and 1936. He was 'rehabilitated' in 1988.

Zinzendorf, Nicolaus Ludwig, Graf [Count] von (1700-1760). German religious leader. By sheltering the persecuted Moravian Brethren on his estates. he enabled a revival to take place. His visits to England (where he came to know *Wesley), America and elsewhere greatly extended their influence.

Žižek, Slavoj (1949- ). Slovene philosopher and critic, born in Ljubljana. Educated at the University of Ljubljana, he was exceptionally versatile and a charismatic presenter as a celebrity philosopher, fluent in five languages, teaching in Ljubljana, Switzerland and London, a prolific writer and enthusiastic participant in conferences and television. Especially interested in Marxism, psychoanalysis and film theory, he declared a commitment to the elusive Communist ideal. His books include The Sublime Object of Ideology (1989), The Ticklish Subject (1999), The Parallax View (2006), First as Tragedy, Then as Farce (2009) and Living in the End Times (2011).

Zoë (Porphyrogenita) (c.978-1050). Byzantine Empress 1028-50. 'Born to the purple' (as her name indicates), she was the daughter of Emperor Constantine VIII. She had a tense relationship with her sister Theodora (980-1056), who was coempress 1042 and sole empress 1055-56. Zoës three husbands Romanos II, Mikhaēl IV and *Constantine IX, were crowned as co-rulers. She was involved in the deaths of the first two.

Zoffany, John (c.1734-1810). German painter. Resident in England from c.1758, among his early patrons was David *Garrick for whom he painted Garrick in 'The Farmer's Return' (1762) and similar works. From $1766{ }^{*}$ George III commissioned royal portraits and conversation pieces and in 1768 he became a founder member of the Royal Academy. During a visit to India (1783-90) he found exotic subjects to extend his range. Although not a great painter, his works attract by their liveliness and glitter.

Millar, O., Zoffany and his Tribuna. 1967.

Zog I (Ahmed Bey Zogu) (1895-1961). King of Albania 1928-39. Before becoming King he had been Premier 1922-24 and President 1925-28. As King he was forced to rely on Italian support but he became irked by his dependence. As soon, however, as he tried to assert himself, *Mussolini ordered the invasion of his country. Zog took refuge abroad and was never able to return.

Zola, Émile (Édouard Charles Antoine) (18401902). French writer, born in Paris. After his father's death (1847) he was brought up in poverty at Aixen-Provence, where at the Collège de Bourbon he became a great friend of ${ }^{*}$ Cézanne. His first novel, Thérèse Raquin (1867), a psychological crime story, established a new trend in fiction. Soon, however, he became deeply concerned about social evils and planned a series of novels relating the effects of environment on a single family (Les RougonMacquart) and intended to be an indictment of *Napoléon III's regime. The empire had, however, collapsed years before the novels began to appear. This resulted in serious anachronisms as in Germinal (1885), where child labour in the coalfields, long abolished, was assailed as though it were one of the contemporary evils with which the novel was concerned. Other well known novels of this series include L'Assommoir (1877) on drunkenness and Nana (1880) on prostitution. His works lack humour, but their realism is impressive and few have evoked more convincingly the sordidness and stresses that accompanied the growth of industrialism. An exception was $L a$ Débâcle, a vivid story of the catastrophe of the Franco-Prussian War. Zola also made a name for himself in critical journalism and in 1898 made a sensational incursion into public affairs with 'J'accuse', an open letter to the French president which forced reconsideration of the celebrated *Dreyfus case. Also an excellent photographer, he accidentally gassed himself.

Wilson, A., Emile Zola: An Introductory Study of His Novels. 2nd ed. 1965; Rosen, M., The Disappearance of Émile Zola. 2015.

Zoroaster (c.630-c.553 BCE). Persian prophet. Little is known about him except that in middle life he appears to have converted a King Wishtaspa (Hystaspes) and to have lived and preached under his protection. His teaching postulates a contest between Good, personified as Ormuzd, and Evil, unmentionable by name but represented by the evil spirit Alriman and Asmodeus (wrath). The tradition of Zoroastrianism is maintained by the Parsees and their 
sacred writings, the Ayesta. These include the Gathas, philosophic poems almost certainly attributable to Zoroaster himself. In Thus Spake Zarathustra *Nietzsche makes Zoroaster the spokesman of his own ideas.

Zoser (Djoser) (c.2686-2613 BCE). Egyptian pharaoh of the IIIrd dynasty. The first major ruler of Egypt, he established his capital at Memphis (near modern Cairo) and created an efficient administrative system. His chief minister was *Imhotep. He built the first great pyramid, a six-step stone structure intended as his tomb, at Sakkara.

Zuckerberg, Mark Elliott (1984- ). American entrepreneur and programmer, born in New York. Educated at Harvard, in 2004 he became the cofounder of Facebook, was a billionaire at 23, and in 2018 was worth \$US66 billion; by then Facebook had 2.2 billion users (more than the total number of Christians). Facebook was the most significant element in 'social media', which involved feedback loops, addictive behaviour, alienation, loss of privacy, withdrawal from civil discourse, disinformation and disregard for rational analysis, based on evidence. Facebook sold personal data of 87 million users, contributing to corruption in the 2016 US Presidential election.

Zuckerman, Solly Zuckerman, Baron (1904-1993). British anatomist, born in South Africa. Educated at Cape Town and London universities, he carried out research on the anatomy of monkeys and apes, and became professor of anatomy at Birmingham 1943-68. He advised the RAF against the saturation bombing of German cities during World War II and was chief scientific advisor to the British Government 1964-71. He was Secretary of the London Zoo 1955-77 and received the OM in 1968. His books include Star Wars in a Nuclear World (1987) and Monkeys, Men and Missiles (1988).

Zukerman, Pinchas (1948- ). Israeli violinist and conductor, born in Tel Aviv. He studied in Israel and New York, and was mentored by Isaac *Stern. He toured and recorded extensively, began conducting in 1970, directing orchestras in the US, UK and Canada.

Zuma, Jacob Gedleyihlekisa (1942-). South African (Zulu) politician, born in Natal. He had no formal education, but became active both in the African National Congress (ANC) and the Communist Party. He was imprisoned on Robben Island with Nelson *Mandel, then worked with exiles in Mozambique, leaving the Communist Party in 1990. Deputy President of South Africa 1999-2005, he was elected leader of the ANC in 2007, defeating Thabo *Mbeki. After being acquitted of rape, corruption charges were dropped. Zuma was elected President of South Africa 2009-18, with a comfortable margin, being by the UK. He faced constant charges of rape and corruption, living in grandiose luxury, and in 2017 the ANC leadership was won by Cyril *Ramaphosa, who forced Zuma's resignation (February 2018). Charged with corruption on an industrial scale, he was convicted and sentenced to prison but released on medical grounds, pending appeals. A polygamist, Zuma had four living wives in 2022.

Zurbarán, Francisco de (1598-c.1664). Spanish painter. He worked mostly in Seville and in Madrid, but though he painted at the court of *Felipe IV, his best work is found in his religious works and especially in pictures of single figures-saints and ascetic monks-at their devotions. The naturalism of his Spanish contemporary ${ }^{*}$ Velázquez and the chiaroscuro of *Caravaggio are clear influences. His Still-life with Lemons, Oranges and a Rose (1633, Norton Simon Museum, Pasadena) has an extraordinary ecstatic quality and is his most reproduced work.

Sona, M. S., The Paintings of Zurbarán. 1953.

Zweig, Arnold (1887-1968). German writer, born in Silesia. His most famous work was The Case of Sergeant Grischa (1927). He left Germany to live in Palestine in 1934, returning to East Germany in 1948.

Zweig, Stefan (1881-1942). Austrian writer. Having gained an early reputation by his translations from English and French, he wrote a number of biographical essays, published in groups of three, e.g. *Balzac, *Dostoevsky and *Dickens (1910), ${ }^{*}$ Casanova, ${ }^{*}$ Stendhal and ${ }^{*}$ Tolstoy (1928). He also wrote plays, short stories, essays and memoirs, e.g. The World of Yesterday (1943). He left Austria in 1934 and, after some years in England, reached Brazil where he and his wife committed suicide in despair at the condition of the world. His collection of musical manuscripts is in the British Library.

Prochnik, G., The Impossible Exile. Stefan Zweig at the End of the World. 2014.

Zwingli, Huldrych (or Ulrich) (1484-1531). Swiss religious reformer, born in Wildhaus, Sankt Gallen. After graduating at Basle University he became a parish priest at Glarus, and having served as chaplain in Italy denounced the mercenary system. In 1516 he moved to Einsiedeln, and denounced the superstitions connected with that place of pilgrimage. His wider influence, began with his appointment (1518) as preacher at the Great Minster in Zürich. Having persuaded the civil council to forbid the entry of indulgence sellers and the enlistment of mercenaries, he went on to preach that only those acts definitely forbidden in the scriptures need be regarded as sinful. Thus it was decided by the council that meat could be eaten in Lent, and other changes, e.g. the removal of images from church, were made after public discussion and debate. Eventually (1528) after a great disputation at Berne the Ten Theses of the Reformed Church were adopted. Meanwhile 
monasteries had been secularised and a communion service substituted for the Mass. In 1524 Zwingli's own marriage was announced. An attempt by Philip of Hesse to bring German and Swiss Protestantism into accord failed at the Colloquy of Marburg (1529), Zwingli's belief that the Communion should be only commemorative being in conflict with *Luther's sacramental doctrines. But the Roman Catholic cantons of his native Switzerland were the immediate threat. Although a treaty between Romanist and Protestant cantons had been signed in 1529, the Catholics attacked Zurich territory and at the battle of Kappel (October 1531) Zwingli, once more a chaplain with the troops, was killed. He was the least dogmatic of the great reformers. His urge to reform the Church sprang not from striking religious experiences but from his studies of the Scriptures.

Potter, G., Zwingli. 1978; Stephens, W. P., Zwingli. An Introduction to His Thought. 1992.

Zworykin, Vladimir Kosma (1889-1982). American electronics engineer, born in Russia. He migrated to the US in 1919, investigated the photoelectric effect and, while working for the Westinghouse Electric Corp, developed (1924) a primitive electronic television camera, the kinescope, based on the cathode ray tube. Westinghouse showed little interest and in 1929 he joined RCA. By 1938 he had perfected his 'Iconoscope' which superseded the method of mechanical scanning devised by ${ }^{*}$ Baird. $\mathrm{He}$ also worked on an electronic microscope with far greater magnifying power than optical instruments. Zworykin was called 'the father of modern television' (Philo *Farnsworth).

Zyuganov, Gennady Andreyevich (1944- ). Russian Communist politician. A teacher from the Orel region, he became Chairman of the Executive of the Communist Party of the Russian Federation 1993- , a Duma member and a presidential candidate, losing to *Yeltsin in the elections of June-July 1996. He also ran for president in 2000, 2008 and 2012, in the last polling 17 per cent against Vladimir ${ }^{*}$ Putin. 